adams 220.4 


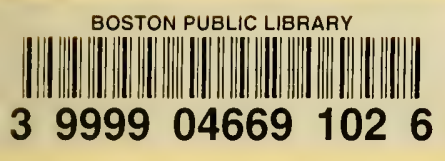





\section{$\begin{array}{llllll} & \text { J A } & \text { C } & \text { O } & \text { B } & \text { I }\end{array}$ \\ Z A B A R E L L \\ P A T A V I I, \\ D E}

REBVS NATVRA-LIBVS

$\perp A B R I X X X$.

Quibus Quxitiones, quxe ab A R I $\mathrm{T}$ T 0 T E L IS Ile terpretibus hodie tractari folent, ac. curate difcutiuntur. .

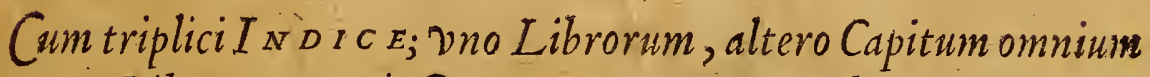

Librorum,tertio Rerum omnium notatu dignarum, qua toto Volumine continentur.

E D I T I O P O S T R E M A. 



\title{
EPISTOLA NVNCVPATORIA.
}

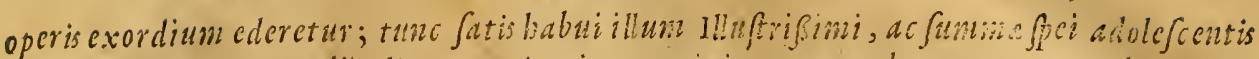
Alexandri peretti Cardinalis, nepotistui patrocinio comnendare, tanaten de ciictionis mex pignus, donec totum ab folutum opustuo conpectu diginius redderetur. IJocigitur vo fortunatum indicandun eft, quod ei boc tempore in lucem exire contigerit. quonact:m fit te Orbiregendo prafectum à D E O Pontificem; tum Philofopbun fapientisimum, maximumque Pbilofophorum fautorem; tum Chriftiana pietate, vitaque integritate, o. omni virtutum genere cumulat ißimum, à quonunc Chrifriana Reßpublica enpurgatam $\int e$ omnifcelcre non absque admiratione confitetur, of gloriatur. Fortunatißinum erit, $\sqrt{i} a-$ te bilariter exceptum, dignumque tuofanore redditum fuerit, impar quidem illud pre fua, autborisque bumilitatedignitati tue, of cum ea minime comparabile, fed à tuatamen fanctitate non contemnendum: quum illius vicibus apud nos fungaris, qui fe bumilia omnia benignovulturepicere palam profeffus, eafe elaturum, \& Jublimia redditurum pollicitus cft. Hac egoopinione, ac $\beta$ e ductus, Tue Beatitudini bos frudiorum meorum fructus dedico, atque confecro, aliosque omnes, qui à me fortaße edentur:etenim, vt opto, ita \& perote diu apud nos futurum fuperftitem, idque DEVM OPT. MAX. ad totius Chriftiane Reip. Salutcm, of felicitatem effe iuffurum. Ouod vt velit, eunk. toto corde precari, atque orare nunquam definam. Vale.

Pataü̈ pridic Calend. Octobris,

M. D. $X I C$.

\section{Hunilimus feruus}

\author{
JACOBVS ZABARELIA.
}

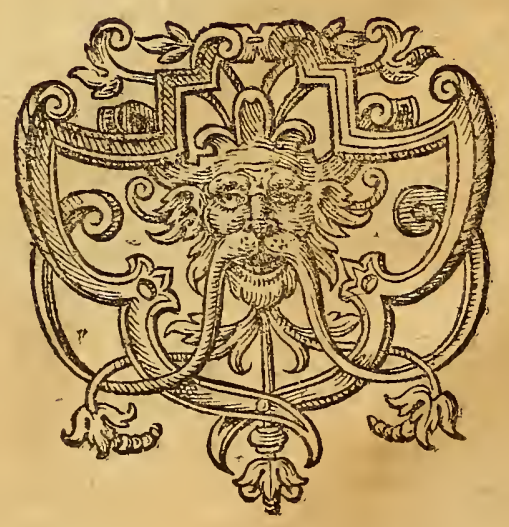

REVE- 

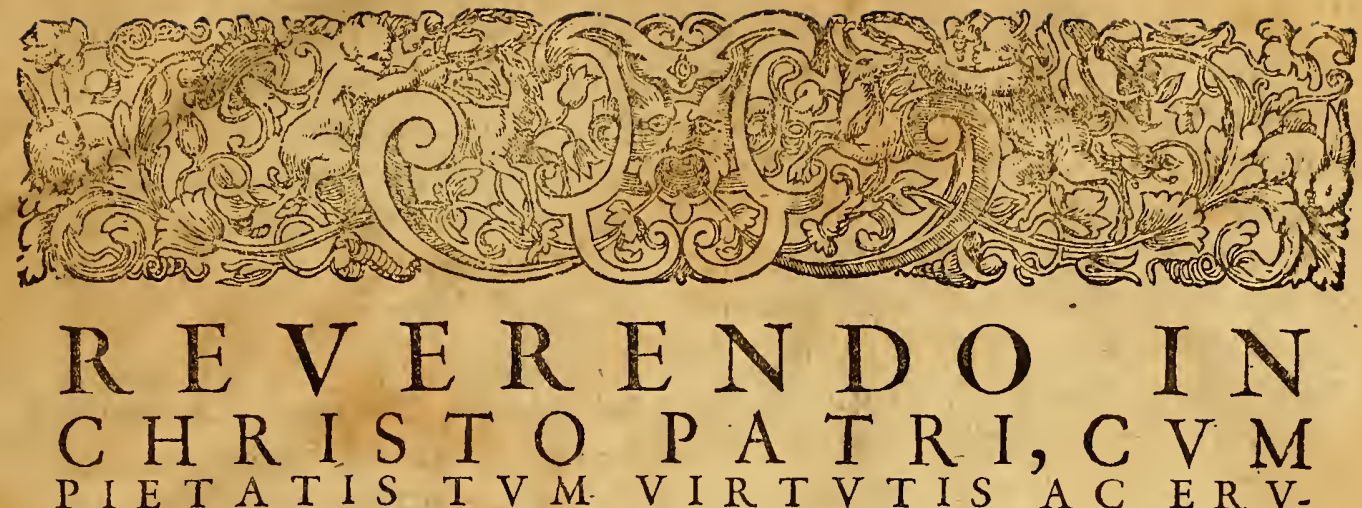

DITIONIS LAVDE PRESTANTISSIMO DOMINO LVDOVICO: Cœnobij Gengenbacenfis Abbati digniffimo, Domino fuo reuerenter ac fubmiffe colendo,

S. P. D.

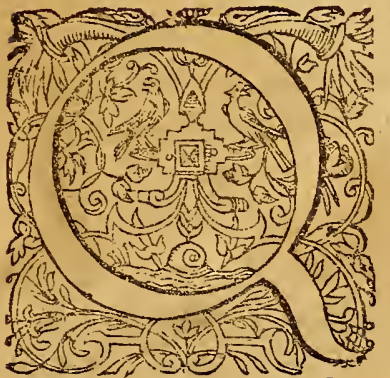

VoD ad res alias prædicatione dignas adhibetur prouerbium, Reuerende in Chrifto Pater: vino vendibili bederấfupensá nibil opusefje: id cgo doctinimis $J$ A COB I ZA B A REL E, illuftris olim Comitis, \& in Academia Patauina Profefforis primarij lucubrationibus iure accommodari poffe arbitror: Quis enim in omni doctorum in uenitur numero, qui non exiftimet, dinini huius Viri monumenta, quotquot lucem afpexerunt, non habend a folum, verum etiam diurna nocturnaque mạnu effe verfanda omnibus, quicunque ad interiores genuinæ Philofophiæ receffus penetrare fefe cupiunt. Declarant hoccum multa paffim in libris doctiffimorum hominum preclara de hoc Viro IIluftri edita teftimonia : tum vero inprimis quadam infinita \& infatiabilis cupiditas, qua plerique Mufarum alumni in præcipuis Germaniæ noftræ Academiis erga ipfas eiusdem lucubrationes mirabiliter funt incenfr. Etenim Logicorum eius operum volumen quum primum in Italia effet editum, tanto doctorum omnium cum applaufu fuit exceptum: vt exemplarium numero emptorum multitudini non refpondente, altera ftatim in Germania editio fit adornata : qux \& ipfa tamen ardentem illam ftudiofi popelli fitim haud omnino potuit reftringere. Itaque tertiam nunc eiusdem voluminis editionem qui vrgeant, omnibusque votis expetant, non fane pauci reperiuntur. Hocidem pene vfucucnit poftea diuino illi de Rebus naturalibus operi, quod hic Auctor poftremum, \& quafi cygneam quandam ante obitum cantionem emifit : Nam \& illud, quum itidem in Iralia primum lucemafpexiffet, diftractis quafi in mo- 


\section{E PIST. DEDICA TORIA:}

nento exemplaribus omnibus, Joannes Baptifta Ciottus, Bibliopola Venetus Germanis quibusdam Typographis fuo recudendum xre tradidit. Quo fane facto \& magnum ille opera meritus eft pretium : \& exi. miam à doctis quibusque viris noftra nationis reportauir gratiam. Qux. quum ita fefe habeant, Renerende Pater, \& iftorum feriptorum cum præftantia tum vrilitas fic manifefta fit, \& nota omnibus: vt toties iam repetitx corundem cditiones fudió $x$ iuuentutis explere defiderium ne. queant : haud me peccaturum in publica conmodaratus fum : fi poftremum hoc volumen, in quo Rerum naturalium non minus accurate quam perfpicue explicatur obfcuritas, meo fumpt u recufum,cum.fudiofis Philofophia, cxterisque per Germaniam viris doctis communicarem. Quapropter re diligenter ponderata, \& propofitis ob oculos infinitis vitIt atibus, qux ex hoc labore ad literarum \& Philofophix ftudiofos promanare pofent, negotium aggrefus fum; atq; vt effet liber quam emendatifimus, \& pretio à Studiofis xquiore comparari, \& formâfatis commodâtractari poffet, quantum quidem in me fuit, procuraus. Proinde, omnibus bonis viris \& candidis huiusmodi rerum $x$ ftimatoribus hoc meum qualecunque ftudium gratum \& acceptum effe futurum plane confido. Prafertim, quum prxter illam meam de multorum ftudis, totaque Germania benemerendi voluntatem, non nullorum quoque bo. norum \& veræ Philofophix amantium virorum crebræac pene quotidianæ voces ad hancobeundam prouinciamme fint cohortata.

Quod autem inclytan Tuam Dignitatem, Reuerende Pater, hîc compellare, \& eidem hunc nobilifimi Philofophi de Rebus naturalibus Tractatum, meis fumptibus toti quafi Germania reftitutum, peculiariter as Ceorfim infcribere voluerim; nec prorfus nulla, nec etiam leues, vti arbi. tror, mihi caufe fuerunt. Nam, vt multas nunc alias latere patiar, primum. mihi certe hocmeum in adornanda noua huius Auctoris editione confilium, aduerfus maleuolorum infultus potenti aliquo muniendum fuit prafidio: quod profecto nec tutius quxrere, nec certius apud aliũ quenquam inuenire me poffe fum arbitratus. Satis enim iam eft perficuum; conftatque inter omnes, Te non folú literarum ac literator um omnium Patronum acfautorem effe eximium : fed etiam cruditâ.doctrinâ, \& ele. ganti torius Philofophiz cognitione ita excellere: vi in toto hoc Rhen iractu, \& Diøcefi Argentinenfi ex iis, qui tecum in pari dignitatis gradu funt conftituti, aqualem habeas neminem. Accedit deinde \& illud, quod, quum Reuerenda Tua Dignitas coemendis plurimisoptimisque 2uktoribus pro inftruenda veftri Cœnobij Bibliotheca, fingularem fæpe numeroerga me declarârit beneuolentiam ac liberalitatem: miki quoq: tandem de aliqua grati animi \& obferuantiæ erga Reuerendam Tuam Dignitatem fignificatione cogitandum fuerit. Quam fane clarius me 


\section{EPIST. DEDICATORIA.}

non poffe prebere exiftimaui, quam tali aliquo muncreliterario, \& boni fcriptoris dedicatione. Placidōigitur vultu, Reuercnde Pater, pro folita Tua crga pias Mufas humanitate \& amore, Philofophica hæc de Rébus naturalibus Commentaria fufcipito: \& cum perpetux mex erga Tuam Reuerendam Dignitatem obferuantia, tum grati animi \& voluntatis promptre monumentum ac fymbolum efle permittito: meque, quod reuerenter \& fubmifsè peto, in illorum harere numero patere, qui Reuerendæ Tuæ Dignitati fefe quam commendatifimos effe exoptant. DEuM Op T. MAx. toto pectore oro, vt Reuerendam Tuam Dignitatein ex moleftis \& doloribus diuturni iftius morbi liberatam, \&omnibus corporis \& anim bonis anctam, quam diutilime faluam \& incolumem confes. uet. Bene \& Feliciter Reuerenda Tua Dignitas valeat. Argen. torati die ?. Febr. Anno à $C$ H R IST o nato M. D. X C VIL.

R. T. Digw。

Subrsiffe ac reucrenter colens

$\mathbb{Z} A Z A R$ V Z ETZNER Bibliopola Argentinengis. 


\section{N D E X L IBROR V M, S I V E T I T V O R V M C I QVE L.I BRO huius VOLVMIN is prafixorum.}

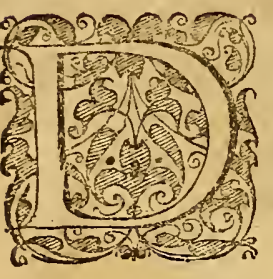

E Naturalis foientia confritutione liber vnus.

De prima rerum Materia libriduo; primus quidem pag.t. Alter autem

De Natura liber vicus.

175

De Innentione aterni Motoris libervnus.

231

De Natura Celi lioer vnus.

De Moru ignisin orbem liber vnus.

269

291

308

De Motugrauium \& leuium libri duo: prior

Altervero

De Conftitutione indiuiduiliber vans.

373

De Communirerum generatione \& interituliber vnus.

De Rerctione liber vmis.

De Miftione liber vnicus.

De Oualitatibuselementaribus libri duo; vnus quidem Alter autem

De Regionibus aeris libellus.

De Calore caleftiliber vnits.

557

De Mifti generatione cinteritalibritres.

581

primus.

Secundus.

582

609

T'ertius.

656

De Fartitione Anime.

227

765

837

856

De senfu agente.

Devifulibri duo: prior quidem Altervero.

De Mente bunanaliber vnicus.

De speciebus intelligililibus liber vnus. 


\section{I $N$ D E X}

\section{CAPIT VM OMNIVM, Q V $Æ$ IN SI N G V O QVO QVE LIBRO E X P L I C A N $T$ V R.}

Libri de Naturalis fientice conftitutione, Capita 42.

Onfilij ratio,cap.r. pag.r.

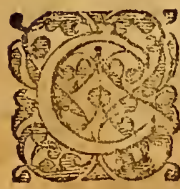

De fubiedto totius fcientix natusalis, opinio vera, cap.z.3

Hicpl ures aliorum fententizad bonũ fenfum trahuntur, cap. 3. 7 .

Confutatio fententizillorum, qui aliquod naturali corpore communius fubieEtum ftatuerunt,cap. 4 .

\section{II}

Confutatio fententixillorum, qui aliquid naturali corpore anguftius fubiectum ftutuerunt, cap.s.

12

Defisicio ac partitio fcientir naturalis, cap. $\sigma$. 16

De fubiecta librorum Phyfica aufcultationis, cap. 7 .

19

Diuifio librorü Phyficze aufcultationis, c.8. 20

Deprimo libro Phylicor. \& eius connexu cum fecundo, sap 9

$2 \mathrm{~L}$

Quod corpus naturale non fit commune vniuo-

uocum, fed an.lógum,c.ro. 24

Qunmodo dao priores libri Phyficorum fint de principis, e.r.

27

De expofterioribus libris Phyficx aufcultationis,, .Iz.

$3 E$

De fede librorum de Coelo, \& de eorum fubieEto vera fententia.c.13.

Sententia Alexandri de fubiecto librorum de Coelo,c.14

Diex $x$ fententix confutatio, א.15.

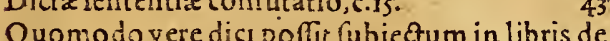
Colo effe mundum, s.i 6 .

Quod meîius fit disere fubiectum corpus fim. plex, quam mundum,cap.17. $\quad 46$

Solutio argumentorum pro Alexandro adductorum, cap. 18 48

Aliz aliorum fententiz de fubiecto librorum de Coelo,cap.ro.

SI

Defubiefto, \& deloco librorum de Generatione \& interitu, aliorum fententix, earumque re. probatio,cap.zo.

Defubięto lib. de Generatione fententia propria,tiusq; declaratio, cap.2I

56

Difficultates contra pradictum fententiam, \& earum folutio, cap. 22 .

s8:

Ratio ordinis librorü de Coelo, \&lıb. de Generatione, \& difficultatum folutio, sap. 23 . $\quad 6$ -

De fubięto, \& loco trium librorum Meteorologicorum,cap. 24

Desatione ordinis, \& infcriptionis librorumMeteorologicorum cap. 25 . 75

Defubiceto quartilibri Meteorologicorum plu- res aliorum fententiz cum ipfarum confut 2 . tione,cap. 26 .

De fubiecto quarti Meteöroiogici opinio vera, \&: refponfio ad argumenta contraria, cap. 27. 73.

De loco quarti Meteorologici,cap.28. 80

De infcriptione quarti Meicorologici, cap. 29 . $8 \mathrm{r}$

De foffli ibus \& metallis, eorumque tractatione, cap.30.

82

Partitio totius tractationis de animantibus, caf. $31 \quad 89$

Diuifio \& ordo omnium librorum de animalibus iuxta propriam opinionem, cap. 32 , gt

Qual is debeateffe tractatio de fanitate \& mos bo in fcientia naturali,cap. 33 . 99

Comparatio librorum de hiftoria animalium curn reliquis libris de Animalibus, cap. 34 . 102

Latinorum opinio de locolibrorum de Anima, Ex eius reprobatio;cap. 35 10

Solutio dubii quod Ariftoteles de eadem re $\{x$. pius agere videatur, \& aliorum dubiorum ad ordinem pertinentium, cap. $36 . \quad 110$.

Nonnullorum opinio de locolibrorum de Generatione animalium, \& eius confutatio, cap. 37. $\quad 113$ Quodnam fit fubiectum ftatuendum in orationibus: \& in fingulis libris deanimabus opinio propria, cap. 38 :

117

Opinioillorum, qui dicunt fubiectum in lib. de Anima effe animam, \& eius confutatio, capa 39.

IIg.

Opinio illorum, qui dicunt fubiectum in lib. de Animaefle animal, \& eius confutatio, cap. 40. $\quad 126$

DePlantis, \& earum tra Clatione,cap.4r.

Deperfectione frientiz naturalis , ac de eius ordine,cap. $\mathbf{4}^{2}$.

I3L

Libriprioris, de primarerum materia,

\section{Capita 15.}

PRocemium operis, caf. T:

Peduobus principiis contrariis, cap.2. ${ }_{134}^{133}$

Deinuentione prinz materiz,cap. 3 . $\quad 136$

De modis, quibus ad priri a materiz cognitionem duci poffumus, opiniones aliorum, capa 4. 137 .

Declaratio vera fententize de cognitione materia,cap.s. $\quad 138$

De duabus prime materiz noticnibuss, csp. 6. r42:

De priuatione, \& de privationis, ac noticnis: difcrimine, cap. 7. 


\section{Y D EX}

De prituationead materiam relata, cap. 8. isI

De potentia materix quid́a sit, cap. $q$

De Juplici materizerotentia, cap. yo.

Qunodopotentiavniuerfalisad materiam fo habeat in prima rotione asceptam, cafp. 11. 160

Dubia aduerfus ea, quze dicta funt, \& corum fo. lutiones, cap. 12.

Quemodo potentia vniuerfalis ad materiam fe habeat in fecunda notione acceptam, cap. 13. 168

Depotentia particulari, quomodo ad materiam re habeat, cap. J4. 171 Quznam potentia aetui opponatur, cap.15. 171

\section{Librifecundi, de prima rerum materia, Capita 21.}

Ententia Scoti deasiu entitatiwo materize, \&e $\checkmark$ eiusargurnenta, caf. .

Confutatio opinionis Sco:i, cap. 2.

Declaratio quarundam diftinctionū ad omnes foluendas dufficultates, cap. 3 , 194

Collectio totius veritatis quing: afrertionibus, cap. 4.

Solutio argumentorum Scoti, cap.5. $\quad 187$

Contrarix fertentix de prima materia, an it perfequanta, cap. 6 .

Argumenta Thom aduerfus opinionem Auerrois de quantitate interminata, cap. 7. 192

Argumenta pro Auerroe, ad comprobandam quantitateminterminatam, cap. $\delta . \quad \$ 93$

Scntentize duerrois declaratio, \& confirmatio, iaf. 9.

Reprobacio praui fenfus, Aueroi à nonnulis atrrbuti, cap. 10 . 598

Solutio argumentorum pro Thoma adductorums, cap. II. 200

An primasmateria fitcorpus de genere fubitan-, ti $x$, opiniones varix, cap.rzo. 20 ;

Argumentallorum, quidicunt primam materiam efle corpus per formam corporeitatis zterman, cap. 13.

206

Dicta fententix impugnatio, sap. 4 . 208

Argumenta loannis Grammatici, ad proban. dum, quod prima materia fit trina ipfa dimenfio, cap. 15 .

218

Argumenta contra Ioannem, ad probadam primam materiam fecundum fe non elle corpus, qux eft communis opinic, cap. 15. 213

Proprix fententiz declaratio, \& comprobatio, cap. 17.

214

Eiufdem fententiz confirmatio explurium antiquorum Phiiofophorum authuritate, cap. 18. $\quad 213$

Diftnctio trium acceptionum corporis, \& cuiurdam dubij folurio, cap. 19.

Solut1o orn nium argumentorum pro aliorum opinionibus ad ductorum, sap. 20 .
A P I I I M,

Epilogus onnium, quz deprima materia dicta funt, cap. 2 !.

\section{Libride Natura, Capitag.}

$\mathrm{Q}$ Vid fit natura, cap. I. 231 An natura fitprincipium motus actiuum. an pafliusm, opinio Auicennx, \& eius confutatio, cap. 2.

Opinio Simplicij cum argumentis, cap. $3 r^{-}-234$

Confutatio fententix Simplicii, quod anima non fit natura, cap. 4.

236

Confutatio opinionis Simplicii, quod natura fit principium motus paffiuum tantum, cap. s. 238

Quod natura fit principium motus tum actiuum, tum pafluum, \& quid vtrunque fit, cap. 6.

239.

Qux fit natura, \& quomodo materia, \& quomodo forma fit naturz, cap. 7 . $24 \overline{8}$

Obiectiones aliquorum aduesfus ea, qux dicta funt, \& earum folutio,cap. $8 . \quad 245$

Solutioargumentorum \& pro Avicenna, \& pro Simplicio adductorum, cap. 9.

249

Libride inuentione terni Motoris,

\section{Capita 7.}

A $\mathbb{a}$ in ineniencum dari fubfartias à ma: 1 terizabiunctas,alio mesio vi poltimus, quam motu, cap.x.

253

An ex fclo zterno moru poline dernonftrari fubftantix à maceria al iunesz, an etiam ex motu abfolute, cap. 2.

254

An demonitrare zternos morores ex xterno motupertineat ad naturalem, an id primum Philofophum, opinio aliquorwm cum eorum argumentis, cap. 3 .

257

Opinio Auerreis, quod ad folum naturatem pertineat probare motcrem xternum, * elus argumenta, cap. 4.

259

Verizatis declaratio, cap.s. 260

Quod demonftratio fit nominanda à medio, \& reiectio defenfioniszduerfaciorum, cap, б. 264

Refponfio ad argumenta aduerfariorum, cap. 7 .

\section{Libri de Natura Coii, Capita 1\%.}

Isendorum propofitio, cap. r. 260

DVarianpuniones de materia Coli, cum argumentis Thom \& \& Ezidij, cap. $2 . \quad 27 x$

Commenis confutatio fententix Thomx Ágidii, cap. 3.

273

Propria confutatio opinionis Thomæ, cap. 4 . 276

Propra confutatio opinionis Fidip. cap. So 277

Declarario \& comprobatio opinionis Auerrois, cap.6.

Gracorum opinio de materia Cceli, cap.7. 23 I

Diftinctio duplicis formx, cap.\&.

Solutio 
I N 0 I $X$

Solutio argumentorum Thomx \& Egidij, c. 9. 284.

Dubia, qux oftendunt, in coelo non effe materiam, \& variz hac de re feneentix, cap. 10.286

Quomodofit in coelo natura, \& quomodo coeIi motus dicatur maturalis. cap. 11 .

288

\section{Libri de Motuignis in orbem, Capita 10.}

Poponitur quaftio \& folutio Conciliatoris,

Impugnatio eiurdem fententix Conciliatoris. cap. 2.

Multorum communis opinio, cap. 3. ibid

Argumentatio Zimara contra communem fertentiam, cap. 4.

293

Impugnatio fententix, \& folutio argumentorum Zimarx, cap. So 294

Aliorum argumentatio contra eandem com? munem fententiam, \& ipforum opinio, cap. 6.

296

Dietx fententia confutatio, cap. 7.

397

Veritatis declaratio de motu ignis in orbem, c. 8.

299

Collectio errorum aliorum, cap. 9 .

301

Frror multorum in declarando motu Planeta. rum diurno, \&: totus yeritatis conslufio, cap. 10.

\section{Prioris libri, de Motu grauium ó lo- uium, Capita 17.}

Delaratio \& partitio dicendorum, sap. ${ }_{508}^{\circ}$

Dux antiquorum fentëtix, de motoregrauium \& leuium, \& earum confutatio, cap. 2: 309

Opinio dicentium elementa externum tantum haberemotorem, \& eius comprobatio, cap. 3.

310

Opinio dicentium elementa moueri à propriis formis, \& cius comprobatio, cap. 4. 311

Quid ea de re dixerit Auerroes, cap. 5 . 313

Senfus opinionis Auerrois fecundumaliquos, \& cius reprobatio, cap. 6. . $\quad 3^{14}$

Opinio Scoti \&2liorum plurium, cap. 7 . 316

Recentiorum argumentatio contra Scotum, \& eorum opinio, sap. 8.

317

Impugnatio fententizerecentiorum, s2p.9.ibid.

Nonnullorum opinio de motu clementi in vacuo, \&asius confutatio, cap. $10 . \quad 318$

Diftinctio poteritix \& a gentis, cap. Ir. $\quad 321$

Declaratio quinque propofitionum, quibusto. ta rei veritasconcluditurs cap. $\$ 2$.

Confideratio opinionis S.coti, cap. 13. 329

Conciliatio omnium diAtorum Ariftotelis, \& Auerrois; 2.omnis diffrcultatis folutio c. Ifte 332.

Cur motus grauium \& leuium fit velosior in fine, quam in principio, plures aliorum fenrentix, cap. is.

Opinio vera, \&reius declaratio; cap. 16.
A P I T 4 M.

Solurio oriencis cuiufdam difficultatis, cap. $17^{\circ}$ 340

\section{Secundi Libri, de Motu grauium or leuium, capita 10.}

I) Eubiectoprino motus corporis milti, qui dicitus: fecundum praulens elemertum, cap. $I_{0}$.

Demotoremiftiopinio Latinorum acromina-

-lium, sap. 2. 344

Di Ex fententix confutatio, cap. 3. $\quad 346$

Vera fententia de motore mifti, cap. 4. 350

De forma mifti, an fit fupperaddita formis elc. mentorum, Zimarx opinio, \& argumenta, cap. s.

Difta fententiz confutatio, \& verz fententiz declaratio, cap. 6 .

Solntio argumentorum $Z$ imarx, cap. 7. $\quad 358$

An motus mifti factus fecundum preualens elementum fit fimplex, an miftus, opiniones aliorum cum eorum argumentis, cap. $8, \quad 368$

Yerz fententia declaratio, \& comprobatio, 2 liasum vero confutatio, cap. $9 . \quad 364$

Conţariorüargumentorum folutio, c, 20, 373

\section{Libri de Confritutione indiuidui. Capita 11 .}

Thoomium libri, cap. I. 373

1. Partirio dicendorum. \& accidentia non porit conficuerefingularitatem, cap. $2 . \quad 376$

Opinio Thoma, \& fectatorum, \& corum argumenta, cap. 3 .

377

Dikiz fententiz \& Egidii impugnatio. sap. 4. 379

Dro decláanda veritate fundamenta jäciuneur; sap. 5 .

385

Duabus. propofitionibus tota rei yéritas declara. ratur, cap. 6.

382

Alia nonnullorum opinio, \& eius reprobatio, $c_{\text {. }}$ $\%$ 385

Opinio Scotide duplici forma; \& duplici materia, \& deprincipio fingularitatis, cap. $8 . \quad 387$

In.quo fenfu opinio Scoti defendi poffit, \& in quanon poffit, , c. 9 . 388

Solutio argum ert orum à Thona; $\alpha a b$ aliis áb. uerfari is adductorum, cap. 10.

390

Iibri de Commonirerum generationé

So interitu, Capita 11.

Propofitio dicendorum, cap. I. 394

1 Quod plures effe poffint fubftantiales forma in eodem compofitio, cap. 2. 395,

Quodaliqua fubftantial is forma feruari polfit. in genito, quzeadern fuserat in corrupto, 6 ; 399

Solutiodifficultatum, quzex definitione generatiomis oriuntur, \& ipfius definitionis decla. ratio, cap. 4.

$40 z$

Quod eadem definitio fit generationis, \& quo modo generatio vnius lit corruptio alterjus cap. so 408

Tubia. 


\section{N D E X C A P I T U M.}

Dubia aduerfus ea qux dicta funt, \& eorum folutio, cap. 6.

4 II

An idenumero accidens poffit in genito remanere, quod fuerit in corrupto, contrarizaliorum fententix, \& eorundem argumenta, cap. 7.

414

Confutatioopiniónumaliorum, cap. $8 . \quad 416$

Declaratio veritatis, ac difficultatis folutio, c.9. 418 .

Cur poft rei interitum aliqua eius accidentia feruentur in genito, aliqua vero non feruentur, cap. 10.

42 I

De caufis generationis \& interitus, cap. Ir. $\quad 422$

\section{Libri de Reactione; Capita 8.}

Icendorū propofitio, ac declaratio, c I. 425 tigurienta, quz reactioni refragantur,c.2. 428 .

Variz aliorum fententiz, \& earum confutatio, cap. 3 .

Quid fit agere, quid pati, quid reagere, \& quid repati, \& curreactio fit necefisria, cap. 4. 432

Quid fit refiftentia, \& vade proueniat, c. $5 . \quad 436$

Collefiototiusveritatis de reactione in motu alterationis, cap. 6.

$44^{2}$

Dereátionein motu locali, cap. 7 . $\quad 445$

Contrartorum argumentorum folutio, cap. 8. $4+8$.

\section{Libri de Miffione, Capita 13.}

Iftionis definitio, \& difficultates qua ex iN1 pra ormuntur, cap.I.

Au connza opinio, \& argumenta, cap. $2 . \quad 453$ Auerrois opinio, \& aduerfus Auicennam diffutatio, cap. 3.

Scrti opinio \&argumenra, cap. $4 . \quad 456$

Aliorun Latinorum opinio \& argumenta, cap. 5.

Latinorum difputatio aduerfus Auerrois fundamentum de formis clementorum, cap. 6 . 458.

Dctentio opinionis Auerrois, \& declaratio veritatis, csp. 7.

460

Quod ra. quze hactenus declarata eft fententia, A : ierrois tuerit, cap. 8.

Cuntirmatio pixdicta fontentiz ex dicturum Arifotclisconfideratinne, cap. 9. · 467

Confimatio eiuldem fenteniz authoricate G ac rum. interpretum, cap. $10 . \quad 470$

Solutio argumentorum pro Auicenna adductorum, cap. II.

Solutioargumentorum Scoti. cap. 12.

473

Solutio argumentorum Thomz, \& aliorum

Latinorum, cap. 13.

\section{Prioris libri de Qualitatibus elemen- taribus, Capita 9.}

DRopofitio, ac pariinodicendorum, cap. I. 48 I Quomodo ad elementa fe habeant primz qualitates, cap. 2.
Dedefinitionibus quatuor primarum qualitatum, cap. 3.

Dubia aduerfus veritatem prædictarum definitionum, \& corum folutio, cap. $4 . \quad 485$

Quomodo primarum qualitatum dux dicanturactiua, \& dur pafiiur, cap. 5 . $\quad 490$

Curpalfiua qualitates non patiantur ab actiuis, nificoniunct $x$, cap. 6.

Cur Ariftotelesnōalıter definierit primas qualitates, quam ve definitit, cap.7. , 494

De caufis primarum qualitatum in elementis, opinio aliorum \& eiusreprobario, cap. 8.500

Opinio propria, \& eius declatatio, cap. 9. 504

\section{Secundi libri de Elementaribus qua- litatibus, Capita 9.}

$A \mathrm{~N}$ in quolibet elemento ambx qualitates fint fumm $x$, an poffit altera efre remiffa, cap. I.

507

Dubia aduerfus ea qux dietafunt, cap. 2. Sis

Dictorum dutrorum lulutw, car.3. 516

Anfyrrbolre clementorum qualitates differant fpecie,necne; aliquorum opinio \& argumenta, cap. 4. $\quad 527$

Dietx fententix confutatio, \& probatio contra : - riz, cap. 5 . 528

Prodeclaranda veritate, \& contrariis argume étis foluendis fundamenta iaciuntur, cap. 6. 530

Contrariorum argumentorum folutio, c. $7 \cdot 539$

De modo, quo ex duobus contrariis elementis tertium medium generatur, quaftiones dur, \& folutic prioris, sap. 8 . 534

Sulutio pofterioris quaftionis, cap. 9. $\quad 539$

\section{Libri de Regionilusacris, Capita 9.}

Vot fint, \& quales regiones aeris, cap. I.
s4r.

Duvum de mediaaeris regione:folutioaliquo. rum, \& foluticnis impugnatio, cap. 2 . $\$ 43$ Aliorum opinio, \& eiusconfutatio, cap.3. $\quad 544$ Aliorum praterea opinio, \& eius confutatio, $c$. 4: $\quad$ ibid. Opinio Alberti, \& eius confutatio, cap. 5. 545 Fundamenta iaciuntur neceffaria pro declarationeveritatis, cap. $6 . \quad 546$

Vera fententiæ de aeris qualitatibus declaratio, \& com robatio, cap. 7. , 550

Dietzrententix confirmatio per omnium difficultatum folutionem, \& per expericntiam, cap. 8.

553

Quod aliorum opiniones aliqua exparte verxe int, \& alıqua ex purte falix, cap. 9.

\$5S

Libride Calore Colefti, Capita 11.

A Stra non ideo calcfaccre, quedignea fint, A cap. $\mathrm{r}$. 556 Suntentia Arift. quomodo Coclum per motum calctaciat, cap. 2 . $\quad 558$

Quomodo motus generet calorem, cap. 3. 559 Dubitatio contra Ariftotelem de modo, quo 


\section{$I N D E X . C A$ A I T U M.}

Colum calefacit per motum, \& prior folutio Alerandri, \& eius reprobatio, cap. 4.562

Altera Alexandri folutio, \& ciusimpugnatio, cap. 5 .

ibid.

Alia Ariftotelis defenfio ab Auerroe adducta, cap. 6 -

Quod refponfione Auerrois Ariftoteles nō defendatur, sap. $7 \cdot$ !

Verx fententiz, \& opinionis Auerrois declaratio, cap. 8.

Dubium de partibus elementi ignis, \& eius fo. lutio, cap.9.

Delumine quomodo calefaciat, cap. 10.

Quis fit calor diftinctus cœleftis, cap. 11 .

\section{Primi Libridemiftigeneratione,} interitu, cap. 10.

$\mathrm{P}$ Rocmium libri, cap. I. Definitio generationis mifti, cap. 2.

Quomodo fit intelligendum adiuarum quaIitatum dominium in duas paffiuas, cap. 3. 585

De actionefrigidi in generatione mifti,aliorum opiniones \& argumenta, cap. 4.

Vera fententia de actione frigidi \& eius declaratio, cap. 5 .

Refponfio ad argumenta recentiorü, cap. 6. 594 .

De modo action is, quo dure actiux agūt in duas pafliuas, cap. 7 .

595

In quo differantmiltio \& generatio mifti, aliorum fententia \& argumenta, cap. 8.698

Confutatio pradictarum opinionum, \& veritatis declaratio, cap. 9. 600

Solutio argumentorum Erafti \& Mercenarij, cap. 10.

\section{Secundi Libri de mifti generatione, interitu, Cap. 16.}

0 Vomodo fiat mifti corruptio, qua putrefactio dicitur, cap. 1.

Qunt modis miftum interire poffit, cap. 2. 6II

Quomodo putrefactio dicatur interitus naturalis, fententizaliorum, \& earum confutatió, cap. 3 .

Verafententia \& eius declaratio, \& quorundam dubiorum folutio, cap. 4 .

618

Definitio putredinis \& definitionis declaratio, cap. 5 . $62 \mathrm{I}$

Opinio recentiorum, quod predicia putredinis definitio fit cauralis, \& eius cófutatio, cap. $\sigma$. 6.23

Quodnam fitambiens, cuius cal or eft caufa putredinis, cap. 7 .

625

Quomodo putredo tum à calorealienó, tum à proprio frigore fieri dicatur, cap. $9 . \quad 626$

Quomodo calor extraneus in calorem naturalem ageré, \& corrupere ip um dicatur, cap. 9. 629

D. claratio illorü verborum (in vnoquoq; humido 2 in definitione putre dinis, cap. 10. 634 .
An detur alia putredinisfpecies, qux fub definitione pradicta cótinæatur, opiniones aliorurn,cap.11.

Dietarum opinionum confutatio \& argumentorumi folutic, cap. 12.

Aliorum fententiz de putredine fecundumpartess, \& earum confutatio, cap. 13. $\quad 642$

Opinio vera de fpeciebus putredinis, ac de putredinefecundum partem, cap.14. 645

An putredofecundum partem fit interitus formæ fub ftantialis, an fit mera alteratio, alio. rum fententia \& argumenta, cap. $15 . \quad 649$

Propria fententia, \& pradictarum confutatio, \& argumentorum folutio, cap. 16.

652

\section{Tertï Libri de miftigeneratione, interitu, cap. 10.}

$D \begin{gathered}\text { Efinitio putredinis à Galeno adducta, } \\ \text { aliorum rententiz de illius comparatio. }\end{gathered}$ ne cum definitione Ariftot. \& earum confu. tatio, cap. 1 .

656

Collatio definitionis Galeni cũ definitione Ariftotel is, \& obiectiones contra definitionem Galeni, cap. 2.

658

Alia ab aliis adducta putredinis definitio, o $e$. ius reprobatio, cap. 3 .

6GI

Dubia, \& aliorum obiectiones aduerfus definitionem putredinis ab Ariftotele traditam, cap. 4 -

662

DiEtorum dubiorum folutiones, cap. s. $\quad 664$

Dubium de putredine vini, \& aliorum folutiones, earumq;impugnatio, cap. $6 . \quad 672$

Fundamenta neceffaria ad propofitum de aceto dubium foluendum, cap. 7. $\quad 675$

De qualitatibus vini, cap. 8 . 677

Solutio propofitz difficultatis de aceto, \& de vini putredine, cap. 9: $\quad 678$

An Galenide aceto fententia modoaliquo defendipoffit, cap. 10 . $68 \mathrm{x}$

\section{Libride facultatibus anima, Cap. 13 .}

D Ropofitio ac diuilio dicendorum, cap. I. 1. 6.84

An facultates ab effentia anim $x$ diftinguantar $r_{r}$ opinio Ssoti \& Gregorij Ariminentis, cum eorum argumentis, cap. 2 :

685

Opinio Thoma \& Egidii, \& eorumargumenta, cap. 3:

688

Vera fententia, \& eiusidecláratio, cap. 4. 690

Contrariorum argumentorum folutio, cap. 5 . 693 :

Dediftinctione facultatum anim $x$, inter $f e d u x$ aliorum contraria opiniones, sap. $6 . \quad 696$

Argumenta pro opinione Latinor ü, cap. 7.698

Argumenta pro opinione Auerroiftarum, cap. 8. 699.

Vera fententiz conclafio, â contrariorum argumentorum folutio, cap. $Q$.

706

Defaculatibus animaregetancis, cap.ro. 712 


\section{IN D E X CA P I T II M.}

Dubia defacultatibus anime vegerantis, \& eo-

rum folutio, cap.r.

Defacultatibus a nimzentientis, cap. 12. 719

De facultatibus animæ rationalis, cap. 13. $\quad 724$

\section{Libridepatifione anima, Cap. 15.}

Ropofitio ac diuifio dicendorum, cap. I 728

Deprima quaftionis intelligętia,cap. 2.72 ?

Opino Platonis de diftributione partium animix, cius confutatio, cap. 3.

730

Albertiopinio \& argumenta, \& opinionis confutatio, cap. 4 .

732

Vera fententia, \&eeius declaratio, cap. 5. . 734

Refponfio ad argumenta Alberti, cap. $6 . \quad 736$

Galeni argumentatio contra Ariftot. de merhbropracipuo, cap. 7 .

738

Fundamëta prodeclaratione veritatis, cap.8.74I

Solutio argumentorum Galeni, \& contraillum argumentatio, cap. 9.

742

De Anima partitione fecundum quantitatem, opinionesaliori, \& argumenta, cap. 10. 752

Verafententia, \& eiuscōprobat1o, cap. 1I. 754

Contrariorum argumentorum folutio, $\mathrm{sa}_{\mathrm{i}} \cdot 12$ 758

An anima fecundura omnes fuas facultates fit infingula fartecorporis, aliorum fententia \& argumenta, cap. 13 .

760

Vera fententia, \& eius declaratio, cap. 14, 762

Contrarior ü argumentorum folutio, cap. 15.76/3

Libri de Accretione ó nutritioné,

$$
\text { cap. } 25 .
$$

Vot modis fumaturaccretio, \& qua con-
ditiones adaccretionem propriedictam requirantur, cap. I-

765

Quomodo fiat in viuentibus accretio, \& quze mutationes ad eam faciendam concurrant, cap. 2.

767

Qunmodo ex materia extrinfecus accederte 1 di, quodaugetur, maiorem quantitatem, \& maiorem locum acquirat, dua aliorum contrarizopiniones, cap. 3 .

760

Opinio vera, \& eius comprobatio, cap. 4. 770

Solutio argumentorum, qua contra extenfionem addu eta funt, cap. 5 .

771

Solutio quzftionis, cur in adultis ceffet accretio, cap. 6.

772

In quanam mutatione fit accretionis effentia conftituta, opiniones aliquorum, \& earum corfutatio, cap. 7 .

7.75

Aliorum opiniones, ac earum confutatio, cap.s. 777

Vera fententia, \& eius declaratio, cap. 9. 779

De duplifi quantitatis incremento, \& duplici raritate, cáp.10.

782

Aduerfantiüargumẽtorum folutio, cap.11. 787

Quomocio ad a ccretionem fe habeant alia mutationes, qua in ea fiunt, cap. Iz.

790
Quomodoidem nimcromaneatid, quodargetur, dua contrariz opiniones, \& difficulta. tes, quibus vrgentur, cap. 13.

792

Quomodo omnibuspartibus eius, quod augetur, fiat additio magnitudinis, pluresalior um fententia, cap. 14 .

794

Verafententia, \& eius comprobatio, \& contraria confutatio, cap. Is. $\quad 796$

Dubia contra veram fententiam, \& eorum iolutio, cap. 16.

Qunmodo in accretione dure pofteriores conditiones feruentur, cxip. I7.

sos

De duplici vinentis materia, 1 \& de nurritione qunmodo fiat, k quid fit, sap. 18, 807

Quornobionateria, \& eius partes in accretione maiores frant. cap.r. $\quad 808$

Quod non omnes partes nateriz extendantur, \& quomodo alimenti quantitas quantiati reinutritzadiungatur, cap. 20.

812

Qulomodo forma, \& eirs partes fieri matores dicantur, cap. $2 \mathrm{t}$.

814

Confutatio opinionum alic rum in intellig $\overrightarrow{\mathrm{e}} \mathrm{t}$ is partibus materia, \& partibus forma, cap. 22. 316

Analiqua fit materize pars in viuente, qux non fluat, fed eadem per totam vitam feruetur, cap. 23 .

818

Quomodo, \& qua ratione compolitumaugeatur. cap. 24.

823

Collectio omniü caufarum accretionis, \& nutritionis, \& perfe \&x ambarum definitionis conftitutio, cap. 25.

828

\section{Libride senfuagente, cap. 11.}

D Ropofitio as partitio dicendorum, cap. r. l 831

Argumenta ad probandum, quod prater obieEqum derur aliudagens, à quo fpecies ferfibilis producarur, cap. 2.

832

Suefani \& Buccáferrei opinio: \& eius confuratio, cap. 3 .

834

Recentiorum opinio, \& eius confutatio, cap. 4 . 837

Vera opinic, \&e eius declaratio, cap.s. $\quad 84 \mathrm{E}$

Contrariorum omnium argumcntorum folutin, cap. 6.

844

De fentiendi actu, à quonam agente producaIur, varisealicrum fententia, cap. $7 . \quad \$_{4} 7$

Omnium dietarü opinionuma cōnfutatio, cap. 8 . 849

Deactione fenfus vera fententia, cap. $9 . \quad$. 851

De modo, quo fenfus in fentiendo agit, cap. ro. 852

Qund argumenta aduerfus alios adducta pradicta fententia non cfficiant, cap.Ir. 855

Librorum duorum de Vifu, fed prioris,

Cap. 13.

Popolitio ac partitio dicendorum, cap. $\mathbf{x}$. Deco, 


\section{N D E X C A P I T U M.}

Decoloris natura \& generatione, cap. 2. 856

Deperfpicuo, cap. 3 .

Quod lumen non fit corpus, cap, 5 .

Varix fententix de lumine, an fit ens reale, an intentionale, \& quid fit intentio, cap. 6 . 859

Declaratio \& comprobatio veritatis de natura luminis, cap. 7.

De inftrumento vifus, cap. 8.

An lumen requiratur admedium, an ad coloremilluminandum, opinio Auempaces \& argumenta, cap. 9.

876

Auerrois \& Alberti fententiz, \& argumenta, cap. 10.

877

Vera fententia, \& cius declaratio, ac comprobatio, cap. xI.

Solutio argumentorum pro Auempase adductorum, cap.12. - 83,1

Solutioargumentorum Auerrois, cap. 13. $\quad 884$

\section{secundi Libri de Vifu. Capita s.}

E modo, quo fiat vifio, opinio Democriti,

1) \& confutatio, cap. I.

Argumenta_Galeni contra fententiam Ariftotelis, cap. 2.

Platonis \& Galeni opinio, \& eius declaratio, cap. 3 .

890

Sententix Galeni de modo vifionis confutatio, cap. 4.

Alia aduerfus $G_{3}$ lenum argumentatio ab oculi fubftantia, cap. 5 .

900

Confutatio fententiz Galeni de oculo, quod fit igneus, cap. 6.

$=904$

Nonnullorum conciliatio Platonis \& Galeni cum A riftotele, \& eius reprobatio, cap.7.907

Solutioargumentorum Galeni, cap. 8.

910

\section{Libri de Mente bumana,}

$$
\text { capita } 15 .
$$

Rocmium libri, cap. s.

1 Quaftio, an anima rationalis fit forma hominis, \& quaftionis declaratio, cap. 2. - gr6

Declaratio opinionis Auerrois, \& aliorum dicentium aninıam rationalem non effe formam hominis, cap. 3 .

918 .

Aliorum contraria opinio, quod anima rational is fit vera hominis forma, cap. 4. $\quad 921$

Argumenta pro opinione Auerrois, quod aniina rationalis non fit forma hominis, cap. 5 . 923

Dictze fententiz confutatio, \& alterius contrariz comprobatio, cap. 6 . 925, Quodpradicta fententia Arifrotelis fuerit, cap. 7 .

$9.3 \pi$

Varix Auerroiftarmm cuafiones, \& carum impugnatio, cap. 8.

938

Solutio argumentorum pro Auerroe adductorus, cap. 9.

942

Auerrols as Themiftii opinio de intellectus $\mathrm{v}$ -

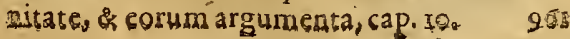

Pradictx fententiæ confutatio, cap. Is. $\quad 964$. Solutio argumentorum Themiftii \& Auerrois cap. 12.

Quid fit humana mens ratione fuz operationis, cap. 13.

Error D. Thonæ, \& feetatorum \&̇lexandri de intellecu confiderato in tertio librodeanima, cap. 14.

Anima rationalis perfect fecundum Arift.definitio, cap. 15.

\section{Libri de fpociebus intelligibilibus,}

\section{Capita 9,}

Ropofitio disendum cap..

979

Duæ Latinorum contrariz fententiz, \& earum deslaratio, cap. 2.

Prioris fectzargumenta adprobandum fpecies impreffas, cap. 3.

Argumenta pofterioris fectz ad probandum, non darifpecies impreffas, cap.4. $\quad 2.85$

Error vtriufque feetx, \& quod neceffarium fit fpecies in intelle etu imprimi à phantafmatibus contra polteriorem fectam, cap. 5. 986 Quod fpecies impreffa pracedere intellectionem poffunt, nec poft eam feruari, contra priorem fectam, cap. 6 .

993:

Confirmatio eiufdem fententiz teftimon:o Ariftotel. \& reiectio interpretationis Scoti, \& collectio erroris omnium aliorum, cap. 7 . 297

Quid fit habitus intellectus, à quo intellectns diciturin habitu, cap. 8.

1000

Omnium vtriufque fectx argumentorum confideratio \& folutio, cap. 9 . 1004

\section{Libri de Mente agente, Capita 16.}

$P_{1007}^{\text {Ropofitio ac difpofitio dicendorum, cap. I. }}$

De officiis inteilectus agentis varize opiniones, cap. 2. $\quad 1003$

Dikarum opinionum confutstio,cap.3. 1009

Vera fententia de aftione intellestus agentis; cap. 4 .

1012

Ầnintelleçus agens iungatur phantafmatibus in phantafia exiftentibus, an in intellectu patibili receptis, cap. - . 1013

Deabfractione, an fiat ab intellectu patibili, an ab agente, cap. $\sigma$. 1016

Solutio dubii aduerfus ea qua diata funt, cap. 7 . Ior:

Collectio officiorum intellectus agentis, feptem propolitionibus, cap. \&. $\quad 1020$

Quid fit intellectus agens, variz aliorum fertentia, cap. 9 . $1.02 \pi$

Confusatio omnium cpinionum eorum, qui. dicunc intellectum agentem, \& intellectum patientem effe ynam \& eandem fubftantiam, eap. 10. IOÂz

Quod neceffarium fit intellectum agentem effe formasm abiunctam à materia per ef- 


\section{N D X C A P I T U M.}

fentiam, cap. $\mathrm{r}$.

1025

Qundintellealus agens non poffit effe vlla inrelligentia prateullas, quo mouent colestes o:bes, cap. 12.

1028

Qitod intellcetus agens non poffit effe aliaincilligentia, nifi ominium prima, cap. 13. 1030

Pradicte fententia confirmatio teftimonio $\mathrm{D}$.

Thomx, cap. I4.

1033

D.bia, \& aliorum argumenta, qux pradictz fententia videntur officere, cap. Is. $\quad 1036$

D. Atorum argumentnrum folutio, cap. I6. 1037

\section{Libri de Ordine intelligendi, Capita. 14.}

Rdinum diftinctio, \& dicendorum propofitio, cap. I. 104 I Opmio \& argumenta illorum, qui negant fingulare ab intelletu cognofci, cap. 2. 1041
Diefrententix confitatio, cap. 3. $\quad 1044$

Contrarioum argumentorum folutio, cap. 4. 1047

Quod fingulare ab intellectu prius cognofcatur, quain vniuerfale, cap. 5:-

Ioso

Declaratio quaftionis de ordine intelligendivniuerfalia, cap. 6.

IOS4

Scoti opinio \& argumenta, cap. $7 . \quad 1055$

Thomz opinio \& árgumenta, cap. 8. 1056

Genuæ opinio, \& prædictarum opinionum conciliatio, cap. 9.

1056

Zimarx \& A chillini opinin, cap.ro. 1059

Noftra cognitionis diftinctio, cap. If. IO59

Quodnam fit primum cognitum, cognitione

actuali, originali confura, cap. 12. $\quad 106 t$

De primo cognito cognitione habituali confu\{a, cap. 13.

1068

Contrariorum argumentorum folutio, cap. I4 107I

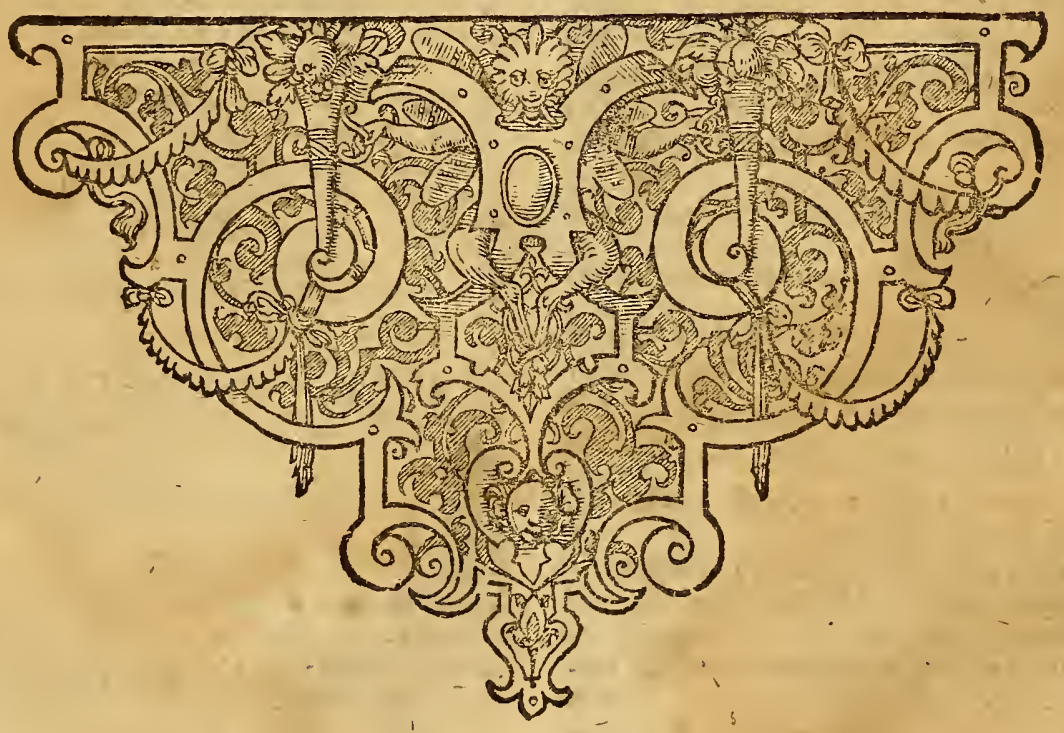

J A C O- 


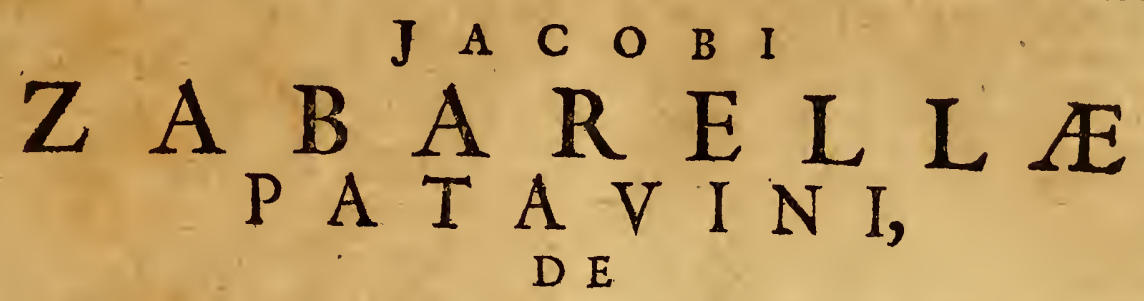

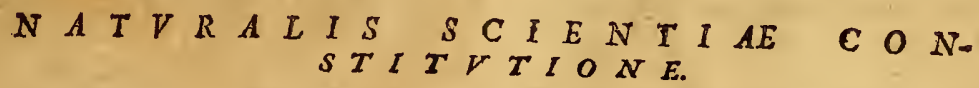

Confilïratio. Cap. I.

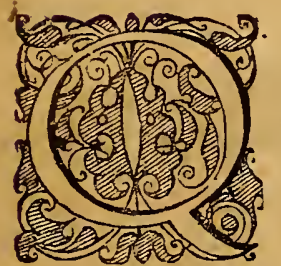

Visquis in naturalium rerum confideratione fruetuofe verfaturus eft, debetante omnia ipfius naturalis difciplin $\boldsymbol{x}$ naturä \& cōditionem cognofcere;praterea vero\&cius diuifioné in partes, \& iprarum partium ordinem, propriosque fingularum fcopos non ignorare. Nam fi artificiofa cius fcientix fabrica bene intellecta, ad ordinatam rerum naturalium contemplationem acceda mus, longe melius atque facilius abditas rerum cau$f_{2}$, intimaque naturx arcana penetrare apti fumus; vt è contrario ea ignorata, fatis magnum indefruetum percipere nemo poteft. Tradidere quidem eam ŕciētiam prifcis temporibus conplures, fed in eo munere ita excelluiffe creditur Ariftoteles, vt nemo in hac philofophix parte non modo illi praferédus, fed ne comparandus quidem cum eo effe videatur; quod quidem omnium \& antıquorum , \& pofteriorum ad hxc vsq; temph ora Philofophorum confenílo comprobauit. Tot enim viri præclarinimi \& Græci, \& Latini, \& Arabes in interpretandis naturalibus Ariftotel is libris ætatem confumpferunt, vt cognouiffe omnis pofteritas videatur, non poffeab humano ingenio excellentius tradi natu. ralem philofophiam, fiquidem tantum honoris nefie naturalibus Auicennæx, aut Galeni libris, neq; magni Platonis Timro habitum effe certum eft. Quoniam igituriam pridem concepta hac opinio, poftea quafi per manus tradita ad hanc vsque tempeftatem peruenit, \& vsque adco inualuit, vt nunc illi, qui naturalem philofophiam difcere cupiunt, null o nifi Ariftotele doEtore vtantur, \& in omnibus philorophantium Gymnafiis, ad vnius Ariftotelis naturales libros declarandos interpretes etiam magnis ftipen. diis ftatuantur, non paruun opera precium fa-
A Cturum me effe exiftimaui, fi Galenum imita. tus, qui de artis medica conftitutione libellum conf'cripfit, ego quoque vniuerfeab Ariftotele fcriptx, naturalis philofophiz ftructuram \& artificiü declarauero, \& ea, qua alij fingulos Ariftotelis libros interpretaturi, fparfim, \& feparatim prafati confueuerunt, in vnum ipfe congeffero,eiusque difciplinx vnitatem, naturamg; \& partes, \& harum artificiofam difpofitionem B omnium pofuero, fic vero \& quam alias Logics artis ftudiofis operam præftiti, eandé nunc Philofophis quoq; praftitero: vt enim tunc de Lagicis rebus fcripcurus, ante oninia de ipfus Logicz natura, \& partibus dicendum effe iudicaui; ita nune de rebus Naturalibus volumen, Deo fauente, propediem editurus, in primis Naturalis fcientix naturam, \& fabricam a me hoclibello explicatam, ta nquam praludii, ac propararionis loco cunctis Anifotelicx theorixe ftudiofis C exhibebo. Quanquani enim non defuere, qui ante me tale quoddam onus fufcepiffe vidètur: nam fcripfere aliqui de ordine librorum naturalium, aliqui etiam profationes in onnes A riftotelisnaturales libros compofuerunt; attamen, vt diuerfe funt hominum fententix, fpero non defuturos, quibus hiclabor meus non fuperuzcaneus fore videatur; nam vbi ita ab aliis cognitam rei veritatem reperere, vt nil à me addi poffribam, \& tanquam eius relator \& interpres nitar faltem eam reddere clariorem; vbi vero nihil, in quoacquiefcere poffim, abaliis dictum inuenero, non dubitaboaliquid ip fe novi, quod mihi ratio perfuaferit, in mediumadducere, $\&$ aliis ad judicandum proponere : nec defpero meahxc fcripta aliquid effe vtilitatis habitura, nam $f i$ aliis fortaffe non proderunt, auditoribus faltem meis non paruo ea vfui fore, meque ipfum magno labore leuanduin per ea effe non dubito: quum enim in has patria Academia naturalem philofophiam publice interpreter, 
obidque cogar quotannis fingulos Ariftotelis libros declaraturus non parum temporis conte-

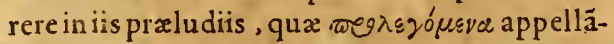
tur, eo poithac labore fuperfedebo, maiorem in ip $\{0$ Ariftotele declarando progreflum facturus: maximum certe tunc faciam, çum cæteri omnes à me erunt editi librinaturales. In iis enim difpurationes omnes, qubus examinandis folemus in quoquolibro feriem dictorum Ariftotelis interrumpere, tractand $x$ à $m$ eis ftudioforum vfum \& excutiend $x$ funt. Interea exigiun hoc magni laboris exordium accipiant : quod quanto eis gratius, atque vtilius fuerit, tanto me ad totum abfoluendum opus promptiorem \& znimatioremreddet.

\section{De Subiecto totius Scientio Nater alis opiniovera. Cap. II.}

Scienorrat:

xibr. ale

Iribses

precogn

subiediz

fcientix

natura-

is.
Q Voniam in primis cognof cendum eft quid fit difciplima naturalis, quod quidem ad elusgenus attinet, fatis apud omnes conftat, eam effe fcientiam fpeculatiuam, quum eius fcopusnon fit operari, fed fcire res naturales; propria igitur differentia inquirenda eft, qua ipfam conftituat, \&abaliis fsientiis feiungat; fumitur autem cuiusque fpeculatiux fcientiz differentia à proprio fubiecto, hoc enim vnum propriam cuiusque fcientiar naturam conftituit, feparatque ab aliis omnibus; videndum igitur eft, quodnam fitproprium fubiectum totius naturalis philofophix:nec fubiecti nomine intelligo quamcunque rem confideratam, fecundum guam acceptionem etiam principia \& accidentia fubieki poffunt appellari fubiectum; fed hac nimis lata fignificatione reiecta, proprie fubiectum accipimus, quale in r. lib. Pofteriorum it atuit Ariftoteles in qualibet fcientia contemplatiua, nempequod à principiis, \& affectionibus diftinguatur, cuius condition es iam funt à me diffureinoperibus logicis declarat $æ$ : vidicntur quiden res naturales, qua fub hujus difciplinæ confiderationem cadunt, numerari ab Arittotele in initio tum 2. libri Phyfic aufcul.tum 3. de Ccelo, fcilicet colum, elementa, mifta, animalia, ftirpes, \& horum fpecies, in horum enim omnium confideratione verfatur Philofophus maturalis : fed hoc cognofcere non fatis eft; quũ enim fcientia naturalis vna fit, \& vnitas fcientiz fumatur ex vnitate fubięti, oportet res omnes naturales prodictas fub vnum al iquod genus re- $F$ ducere, quod eas omnes compleetens dicatur fubiefum ynum totius naturalis philofophix, \& ipfi tot1 adxquatum. Hoc igitur quodnam ftatuendum fit, interpretes Ariftotelis fuperioribus temporibus non confenfermat, fuitque inter eos maxime controuerfum : fed hac tempeftate videntur omnes in hanc fententiam conueniffe, quod corpus vniuerfe fumptum, quod \& coleftia \& inferiora omaia complectatus,
A quatenus naturale, hoe eft, quatenus habens in feipfo naturam, qua motus principium effe definitur, fit commune fubiectum totius fcicntia naturalis : quam fententiam ego absque dubio veram effe cenfeo, quum \& Ariftotelis teftimonio fatis claro, \&efficaci ratione comprobetur. Quum enim fubiectum fcientiz duabus partibus conftet, re confiderata, \& modo confiderandi, vt in operibus logicis dictum eft, fitque in hac feientia res confiderata corpus, $\boldsymbol{x}$. de $N$ $B$ modusautem confiderandi, quatenus habens in tur. Log. feprincipium motus, iuxta conımunem, quam $\mathscr{F}^{\circ}$ lib. de veram effe diximus, opinionem, vtramque ab pracogs. Ariftotele apertepronunciată legimus : nam in initio, \& libro fecundo Phyfic. \& 3. de Colo, fola corpora nominat vt fubiectum philofophix naturalis, fed clariffime in principio libri primi de Cceloafferit, fcientiam naturalem verfari in corporibus, \& horum principiis \& affectionibus: nam praterquam quod aperte nominat C corpus vt naturalis fcientix fubiectum, 1liud idem affirmat, dicens principia \& affectiones corporum in hacfientia confiderari, fiquidem. id fubiektum eft, cuius principia \& affectiones quxruntur. Quodautem modus \& ratio confiderandi corpus non fit, nifi vt habens in fe principium motus, afferit clare Ariftoteles in principio libri fecundi Phyficorum, dum inquit res naturales à non naturalibus diftingui per hoc potiffimum, quod quatenus funt naturales, habent in feipfis principium motus, quod quidem aliis non competit, nifi per accidens: famnum enim \& quodlibet aliud corpus artificiofum, habet quidem in fe principium motus, non tamen per fe, quianon vt artificiofum, fed quatenus materiam habet corpus naturale, vel lignum, vel lapidem:atqui certum eft vnamquamq; rem abaliis diftingui per formam, non per materiam; igitur habere in fe principium motus eft inftar form $x$; \& eft formalis ratio fubE iect, qua corpus phyfiologix fubicctum abaliarum fcientiarum fubiectis feparatur; etenim vt artes mittamus, qux verfantur in corporibus, Mathematicus quoque, qui contemplatiuus eft, corpora contemplatur, non ea tamen ratione, quatenus habentinfeprincipium motus, quia hoc folius Philofophi naturalis pro: prium eft. fedalius apud Ariftotelem locus eft; hoc mirifice confirmans, is que confideratione dignus eft, quoniam à multis perperam intelligitur; locus eft contextu 7 r. libri fecundi Phyfi-y corum, vbi Ariftoteles inquit: Quxcunque mo ta mouent, funt phyficaconfiderationis; qua cunque vero non mota mouent, non amplius: fed ea Ariftotelis verba difficultatem faciunt, quoniam primus motor aternus mouet, \& eft immobilis, tamen eft phyfica confiderationis, quum de ipfo agatur in lib. s. Aufcul. phy- Cómunis fic. Dubium hoc folent alij ita foluere: primus expofitio motor eft phyficx confiderationis, quoad qua-

\author{
Declara \\ tiotext. \\ 7r. fec $\tilde{s}-$ \\ di Pbyfico.
} Subasorfues 
ftionem an fit; quod enim exiftat, oftenditur à Philofopho naturali ex eterno motu, at non eft phyficx,confiderationis, quoad quxftionem quid fit, fic enim ad Metaphyficum pertinet, fed Confut hac folutio non eft confona verbis Ariftotelis tie. fequentibus, qui ftatim rationem afferens, cur non fit phyficx confiderationis, ita fubiungit [non enim infeipfis babentia motum, aut principirsm motus mowent, ed immobilia funt ] itaque fi hac communis folutio vera eft, oportet æque in ommbus validam effe rationem Ariftotelis, vt quicquid non habet in feprincipium motus, non fit phyficx confiderationis, quo ad quid eft: licebit ergo ita argumentari: motus, locus, tempus, \& alia accidentia naturalia non habent in fe motum, aut principium motus, ergo nõ funt phyfic $x$ confiderationis quoad quid elt; quod fi caullando dicanr Arıfotelem de folis mouentibus loqui, verum quidem iftudeft, attamen ratio Ariftotelis fi in his eft efficax, debet pariter in omnibus habere efficacitatem: imo veroneque in mouentibus omnibus locum habet, nam calor \& frigusagint \& mouent, nec habent in feprincipium motus, fequiturergo hæc non effe phyficr confiderarionis quoad quideft; falfa tamen effe conftat hre omnia confequentia. nam accidentia naturalia cognof cuntur à Philofopho naturali \& quod fint, \& quid fint; quod autem nō habeant in fe principium motus, manifeftum eft, quia hoc proprium eft corporum naturalium, accidentia vero naturalia non dicuntur habere naturam, fed effe à natura, vel feVeraex- cundum naturam, vt diciturin lib. 2. Phyl. Hac
pofitso. fpondendum: Phyficus conliderat \& fubiectum fuum, \& principia, \& affectiones eius, quorum trium confiderationes in quo difcrepent, iam Lib. de declaratumà nobis eft in operibus logicis: AriPracogn. ftotelesautem in memorato loco non loquitur abfolute de phyfica confideratione cuiufcunque rei, fic enim ratio, quam adducit, idonea non effer, fed loquitur de folius fubiecticonfideratione, \& de illo, quod à Philofopho naturali confidereturvt fubiectum, non vt affectio, neque vt principium; itaque illud tantum à Phyfico vt fubiectum confiderari dicit, quod in feipfohabeat motum \& principium motus, ita "vt quicquid huiurmodi eft, in ea f́ientia confideretur vt fubiectum, quod vero talenon eft, non poffit in ea habere locum fubiecti ; per hoc tamen non ftat, quin poffit in ea vel vt princi- $F$ pium naturale, vel vt naturale accidens confiderari; tollitur itaque omnis difficultas, quia primus motor immobilis, quum non habeat in fe principium motus, non eft confiderationis phyficx vt fubiectum phy ficum, per hoctamen non ftat, quin à Phylico pofít confiderari ve principium; fic motus, locus, calor, frigus, \& alia accidentia naturalia, quum non habeant infeprincipium motus, non poffunt effe fubie.
A Atun phyficum propricacceptum, funt tamen accidentia phyfica, \& quatenus talia funt, cognofcuntur à Philofopho naturali \& quod fint, \& quid fint. Hoc idem confirmant verba Ari- Declaraftotelis in contextu 73. eiusdem libri, vbi ait tzotex. [duofuntprincipta motsentiaphyfice, quarumal: terum non est phyfoum, quia non habet princi. Physa. pium motus in eip $\int 0$ ] nam quomodo dic1t alterum effe mouens phyfice, nec tamen effe phyficum? certe nullus alius effe poteft fen fus verbo B rum Ariftotelis, nifi quod eft principium phyfi. cum, \& ita à Phyfico poteft vt principium confiderari, ficuti reuera confideratur, at non eft fubiectum phyficum, quia non habet in fe principium motus: hæc eft huius difficultatss tut 1 fima folutio. Quoniam igiturratioilla ab Ariftorele adducta nil aliud probat, quam non cöfiderari à Phyfico vt fubiectum, quicquid non habet in fe principium motus, manifentum ent rationem formalem fubiecti fcientix naturalis apud Ariftotelem hanc vnam effe, quatenus habens in fe principium motus : per hanc enim vnam feparat Ariftotel. fubiectum phyficum ab eo, quodnon eft fubiectum phyficum : illud autem, quod habet in fe principium motus, non eft nifífubftantia corporea, vt afferit Arifonteles in contextu 4.lib. 2. Phyfic. nullum igitur aliud ftatuendum eff fubiectum totius fientia naturalis, nificorpus naturam habens. Ip a quoque naturæ definitio hoc idem teftatur; nam D conueniens erat, vt in ipfo huius fcientix initio fubiecti definitı proponeretur, hæc autem fa. cile intelligitur, fr folum intelligaturnomen naturæ: definitur ergo natura, non vt principium fubiecti, fed vt fubiectum, hoc eft, vt ratio formalis fubiccti, ex qua intelle fa ftatim apparet quid fit corpus naturam habens, ideo Ariftotel. ftatim poft definitionem naturæ fubiungit definitionen habentis naturam, quod totius naturalis philofophix fubiectum eft. Ratione E quoque hoc comprobatur; illudenim ftatuere oportet fcientiz fubiectum, cui omnes conditiones competunt, quas Ariftoteles in Pofteror. Analyt. dixit in cuiusque fcientix fubiecto poftulari; at hre competunt omnes corpori naturam habenti quodita oftendimus: Conditio- Canditi nes fubiecti, vt exiis libris colligimus, \& vt inßnes fubre. operibus Logicis declarauimus, hæ funt; fub- $a i$. iectum debet effe pracognitum, \& quid no- Lib. do men fignificet, \& quod fit; debet omnibus, Tribus qux in icientia confiderantur, fubftratum ef $\mathrm{e}$, precogn. \& ipfum nulli ineffe; debet habereprincipia, \& accidentia demonftranda; ac denique debet toti fcientix effe adxquatum, ita vt neque eam excedat, neque ab ea excedatur, hoc autem eft, omnes partes fcientix in eius confiderationeverfari, \&ipfum in nulla fcientia, nifi in illa fola, tractari poffe. Corpus autem naturam habens precognof citur quid nomen fignificet, fic quidicn eitis declaratio tanquam totius fcien- 
tia principium proponitur ab Ariftotele in ini- A tio totius naturalis nhilolophre: notiffimum etiam eft quod fit, \& nithil co notius eft in fcientia naturali, per quod poffit demonftrari, idque Ariftoteles ipfeproteftatur in contextu 6. eiuldem 2. Phyf. quod habeat principia, \& accidentix, qux de ipfo demonftrantur, ita manifeftum eft, vinulladeclaratione indigeat: nulli etiam ineit corpus naturale, quumipfumper fe exiftat, fedipfum omnibus in naturali fcientia confideratis fubftratum eft: nam fi diligenter omnia, qux in ea fcientia tractantur, percurramus, nihilinueniemus, quod non eius principium aut accidens fit, nempe vel ipfius communis generis, vel alicuius fpeciei. Eit etian toti fcientix adæquatum, quum enim tractari fubiectum nil aliud fit, nifi cius principia, \& affectiones inueftiga ri, nulla certe huius fcientiæ pars ef, in qua de ipfo non agatur; fiquidem nulla efr, in qua non agatur de principio, a tut de accidente aliquo corporis naturalis: nulla eft etiam alia fcientia, in qua agatur de corpore naturali quat enus naturam habet, \& inqua eius principia, \& accidentia quatenus talia confiderentur: fola igitur, ac tota fcientia naturalis eft de corpore narurali, quatenus naturale eft: hocigitur eft totius huius fcientia fubiectum adxquatum.

\section{Hic plures aliorum fententia ad bo- num fenfum trabuntur. Cap. III.}

Ententiahxcex aliarum confiderationeconSirmatur; quicunque enim aliud quidpiam huius fcientix fubiectum ftatuunt, ii vel idem dicunt, quod corpus naturam habens, vel fal$D$. Tho fum dicunt; tres hac in re inuenio opiniones mas. probabiliores, quxad verun fenfum trahi poffunt. D. Thomas in principio primi Phyficorum inquit, fubiectum effe ens mobile, vetans ne dicamus corpus mobile, ea ductus ratione, quod Ariftoteles in 6. eorum librorum probat omne mobile effe diuiduũ, quod eft probare, omne mobile effe corpus, quare fi corpus mobile fubiectum effet, probaretur fubiectum in fcientia fua, quod dicendum non eft. Idem tamen in initio primi libri de Cœlo inquit, fubie-

Albertsis ctum effe corpus mobile, qux etiam Alberti, \& aliorum complurium fententia fuit: viditenim tandem $D$. Thomas llius argumenti fui vani- $F$ tatem, quialicet in 6 lib. oftendatur omne mo'bile effe diuiduum, non ob id probatur dari corpus mobile; tum quia non idem eft effe diuiduum, \& effe corpus; fiquidem linea \& fuperficies diuidux funt, nec tamen funt corpora; tum maxime quoniam non eadem eft propofitio, datur corpusmobile, \& omne mobile eft corpus, quum illa fit omnibus notifima, hac dubia, \& ab aliquibus negata, qui animam per
A fe mobileni effe dicebant: quamobrem fuc concedatur, fuse negetur animam, imo \& res omnes per fe moucri, non minus hac eft manifefta, datur corpus mobile; non hanc igitur probat Ariftoteles in eo 6. libro, quemadmodum fi quis probaret omne album effe hominem, non ob id probaret dari hominemalbum, quum hac fit manifeite vera, illa manifeite fa! fa. Scotus vero fubiectum ftatuere videturfub- Scotas. ftantiam naturalem; ita vt tres extent opinio-

$B$ nes, quum alii ens mobile, alii corpus mobile, alir fubftantiam naturalem fubrectum efre dicant, at $f i$ has bene perpendamus, non differunt niff nominibus; quum enim rem confideratam alii ponant ens, alii fubftantiam, alii corpus, modum vero confiderandi alii mobrle,alii naturale, tamenfifano modo verba eorum fumantur, eandem dicunt rem confideratam, \& eundem confiderandi modum, quncirca Ariftoteles quoque variis in locis fubicetum fcien-

C tirnaturalis his omnibus modis nom inauit. Illi igitur, qui dicunt modum confiderandi effe, vt mobile, per mobilitaten vel intelligunt aptitudinemillam ad motū, quxeft accidens, \& qualitas quædam; vel intelligunt principium internum, vnde hre aptitudo, \& motus ipfe fluit: fi qnaiitatem intelligant, in difficultatem neo quidem iudicioiniolubilem incidunt; quum e. eim huius mobilitatis caufafit ipfa rebus natutalibus infita natura, demonftrari poterit à prioD ri modus confiderandi de re cófiderata per medium naturale in ipfa fcientia natura!i; corpora namque funt mobilia, quoniam habent natisram, ficautem fubiectum in fcičtia fua per caufam demonftraretur, quod omiro abfudum eft. Reftat igiturvt nomine mobilitatis inteliigant internum motus principium, nemsenaturalitatē, fue naturam ip fam, vitecs putcintellexiffe.ita vt nifíaliudapud eosigrificet mobile, quan naturam habens. Qui verc modumcon-

E fiderandi effe dicunt, quânaturale, clarius id fi- Natz:4 gnificaffe videntur; tribus enim modis accipi le dis:poteft naturale: primo fumiturpro effentiali, iss triquemadmodum etiam natura pro effentia fil- plicitermitur, vt quum dicimushancefferei naturam, \& hoceffeilli naturale: fecundo modo fumitur naturale proomnire pertinēte ad Philofophum naturalè, fic materia prima dicitur principium naturale, \& motus dicituraccidens naturale, \& res naturalis:tertiofumiturftrictius proeo, quod in fehabet naturam, hoc eft, internam quandam propenfionem ad recipiendum motum; huiufmodi autem funt fola corpora, fic enim nec materia, nec motus eft naturalis. Illi igitur qui vel ens fubiectum effe dicunt, vel fub tantiam, vel corpus, quầ naturale, non pofiùnt nifi tertio modo fumere naturale; primum enim omnino abfurdum effe manifeftum eft; fecundus vero omni artificıo carens, ac puerilis effet: quicquid enim fubiectum effe dicamus quatenus 
quatenus naturale, hoceft, quatenus pertinens $A$ ad Philofophum naturalem, fubicti nomine complectimur omne pertinens ad $\mathrm{Phlo}$ ophum naturalem, quoniam ab eo, quod eft quatenus ipfum, ac de omniefficax femper, ac neceffaria eft illatio; omnia igitur \& principia, \& accidentia naturalia fpecies iubiecti erunt, proinde nulla erunt fubiecti principia, nulla accidentia ab ipfo fubrecto diftincta; id que effet accipere fubiectum late pro omni re confiderata, quam acceptionem nimis rudem, \& à noftro inftituto alienam effe iam diximus. In tertia igitur fola fignificatione fumptum effe ab illis naturale manifeftum eit ; fed clarifima omnium eft appellatio modi huius confiderandi, fi dicamus quatenus naturam habens, feu quatenus habensprincipium motus, fic enim omnem vitamus ambiguitatem, \& errandi occafionem, quam fortafie præbere poteft 1 lla dißtio, naturale, proptervarias, quas com nemorauimus, huius vocis fignificationes. Hunc igitur confiderandi modum fi omnes ftatuunt, neceffe eftrem quoque confideratam eandem ab omnibus poni, \& fub ftantiam, \& ens ab eis accipi pro corpore: etenimomne habens principium motus in feiplo corpus eft, idem ergo eft ens habens principium motus, \& fubftantra habens principium motus, ac corpus; quemadmodum ens rifibile, fubftantia rifibilis, animal rifibile idem fignificant, nempe folum hominem. Rectius elt tamen dicere corpus, quam fubftantiam, vel ens, propterea quod in fientiis contemplatiuis debet modus confiderandi effe æqualis rei confidarat $x, v t$ alibi declarauimus; oftendimus enim nō pugnare inter fe hæc duo, modusconfiderandi eit $x$ qualis rei confiderat $x$, \& eft anguftior, illamque coarotat; æquales enim funt, quatenusfuntres quædam, qux extra animam exifunt, nullum enim extra animam datur cor. pus, quodnon habeat in feprincipium motus, \& nullum datur habens in fe principium mo-E tus, quod non fit corpus : attamen fialterum vt res fumatur, alterum vero vi modus, rem modus cuaretat, non vt rem, fed vt confidarabilem ; corpus enim eft confiderabile non modo vt habens naturam, fed etian aliis modis: poteft enum mente concipi abiunctum ob omni aptitudine ad motum, \& confiderari tantummodo yt quantum, qux eft confideratio Marhematica: hocautem eft manifeftiffimum in itlis fcientiis, iu quibus idem effe videtur $F$ modus confiderandi, ac res confiderata, vt in Metaphyfica, in ea namque fubiectum effe dicimusens, vt enseft, in quo dicto effet abfurditas, \& nugatio manife fta, nifi modoaliquo. ensreftringeret ens, reftringit enim nonvtres, fed vtnsodus, fiquidem vt res non modofunt xquales, fedism; at acceptum ens pro relatius pates, ro ens acceptum pro modo, ens namque . con tum omnia complectitur,
\& nihil excludit, nam \& mobile, \& naturale, \&e magnitudo, \& numerus ens eit; fed quodlibet tamen horum, fi fumatur vt modus confiderandi, nullum aliorum continet, \& ea omnia excludit, nam conliderare vt ens, non eft confiderare vt mobile, neque vt magnitudinem, \& è conuerfo, confiderare vt mobile eft quidem cófiderare ens, ad noneft confiderare vt ens: ens igitur, quod omn ia continet, reftringiturab hoc modo confiderandi, quatenus ens, quum ab B hoc cxteri omnes modi excludantur; ratioque huius eft, quoniam materiæe eft amplitudo, \& indeterminatio, formæ vero diftinétio, acdeterminatio; quoniam igitur res confiderata locum obtinet materi $x$, modus autem confideranditenet locum form $x$, neceffe eft vtens acceptum pro reconfiderata latius pateat, quam ens acceptum pro modo confiderandi , \& $2 b$ hoc coaretetur. Dico igitur rem confideratam, \& modum confiderandi debere effe xqualis ambitus, quatenus res quædan funt, fieenim feruatur effentialis connexus, néque per hoc ftat, quin res confiderata reftringaturà modo confiderandi : quocirca melius eft , fubiectum fcientix naturalis ftatuere corpus quatenus naturam habens, quam fubftantiam, aut eas quatenus naturam habens, quia habere naturam eft accidentale quiddam fubftant: $x, \&$ enti, nifi dicamus itriete fumi fubftantiam, \& ens pro folo corpore. Quum itaque Ariftote$D$ les variis in locis loquens de fubiecto fcientiæ Arifonatural is modo ipfum vocet corpus, modo fubftantiam, modo ens, vel eft inconftans, vel per. lizc omnia folum corpus intelligit: fic etiam quum modum confiderandi modo ftatuat quatenus mobile, modo quatenus habens principium motus, \& quietis, necefle eft vt per mobile iutelligat idem, quod naturam habens: nam in puincipio primi libri de Coelo inquit, fcrentiam naturalem verfari in corporibus, in principio autem tertij libri dicit eam verfari circa fubftanias, intelligit autem corporeas, quia ftation eas recenfens fola corpora nominat: \& in primo contextu librifexti Metaphy ficorum inquit, fcientram naturalem verfari circa talem fub tantiam, in qua eft principium motus, is quietis ; fumit enim fubitantiam non omnem, fed talem, nempe illam tantum, qux corporea eft, hxc enim fola habet in fe principium motus: attamen in calce eiufdem contexius inquit, Philofophum naturalem confiderare ens mobile, per mobile intelligens idem, quod habens principium motus; \& pertale ensillud idem, quod prius perfubfantiam corpoream. Sic Auerroes in principio quarti Metaphyficorum inquit, ens mobile effe fubiectum fcientix naturalis, in primo autem libro de Colo, commentariis 2. \& 5 . inquit fubiectum fcientix naturalis effe corpus; in fua autem Prafatione in primum Phyfico. 
rum ing̨uit fubiectum efferes fenfiles quatenus transmutabiles, quæ verba fignificant corpus quatenus mobile, fed ftatim declarans, quid intelligat per mobiles, fubiungit, id eft, quatenus in feupfis habent principium motus \& quiet is; fumit igitur mobile pro habente principiun motus. Notare autem poffumus, Ariftotelem \& A . uerroem de fubicito naturalis fcientix loquentes, appellatione corporis vfos effe in libris nasuralibus;inMetaphyficis vcro appellatione fub. Atantix, \& entis, ha namque voces pertinent proprie ad Metaphyficum; intellexit tamen folum ens corporeum, \& folam fubftàtiam corpoream, rtprediximus.

\section{Confutatio fententia illorum, qui aliquod saturali corpore communius Jubie- ctum ftatuerunt.Cap.IV.}

Ylorum fententias, qui aliquod naturali cor1 pori zquale huius fcientix fubiectum effe dizerunt, ad rectum fenfum trahi poffe iam oftendimus : nunc de eorum quoq; opinionibus, qui nullam defenfionem recipiunt, aliqua breuiter dicamus : hi in duas fectas diftincti effevidentur;aliqui enim cömunius aliquod corpore narurali, aliqui etiam eodem ftrictius fubiectum ftatuerunt: quem vtrumque errorem explodere oportet. Primum quidern non defuerunt, qui ens mobile fubiectu m effe dicentes, palam profefi fint, fe id fumere vt latius patens, quam corpus mobile;fiquidem non fola corpora, fed materia quoque, \& forma mobiles dici variis modis pofiunt : corpus quidem dicunt effe fubiectum motus, materiain effe primam radicem, as fundamentum omnis paffionis, quia pati eft propter materiam, \& moueri eft pati; formam. veroefle terminum motus : itaque corpus dicunt effemobile fubiectiue, materiam fundamentaliter,formam terminatiue;proinde matejiam, \& formam non modoeffe principiacorporis mobilis, fed etiam effe fpecies enticunobilis, quod eft xquatum fubiefum totius f fientix naturalis. Huius fententia vanitatem fola nominis fignificatio declarare poteft, mobile enim. non dicitur aifi id, quod eft fubiestum motuss materiaper fenon mouetur, fiquidern id, quod mouetur, actu eft, vt inquit Ariftoteles in quinto Phyficorum; fed mouetur materia per accidens, nempe dum mouetur corpus, cuius pars eft, quare foli corpori eft attribuendus motus. Multo minus mouetur forma co modo, quem ifi fingunt, nam terminare motum non eft moweri,imo adueniente term ino ceffat motus. Sed nil cerce ineptius effe potelt, quarn dicere, quicquid cum motu coniunctum eft, feu quidquid relationem aliquam habet ad motum, mobile effe, fic enim quicquid à naturali Philofopho confideratur, fpecies erit entis mobilis, proinde
A fpecies fubiecti:onnia igitur locum fubiceti habebunt, nulla dabuntur principia, nulla accidentia à fubiecto fcientiz diftincta. Praterea quemadmodum motus maxime proprie, ac pracipue dicitur de motu locali , fecundario de aliis; ita locus vt terminus motus localis magis dicetur terminatiue mobilis quam forma, qux generationis, feu al terationis terminus eft: attamen nihil ab Ariftorelealienius eft, quam locü dicere mobilem, quum aperte afferat effe prorfus im. B mobilem. Tempus quoque tanquam numerus motus mobile erit: fed quid magis erit nobile, quam motus ipfe? Vaniffima igitur eft hrc fententia , \& abfona ration, ac docrinz Ariftotelis à nobis antea declaraiæ. Sed non minus a. liena eft à verbıs Thom $x$, quem ifti fe tueri pro. fitentur; nam in principio primi libri de Coelo dicit folum corpus effe fubiectum fcientianaturalissininitio autem primi Phyficorum, vbi dicit ens mobile, declarat etiam fe per mobile c nilaliud intelligere, quam habens in fe principium motus : quoniam igitur omne habens in fe principium motus corpus eft, videtur ab ip a potius nominatione corporis, quam à re abm horruiffe eo in loco Thomas, eo ductus argumento, cuius poftea leuitatem fe cognouiffe indicat in Prafatione primilibri de Ccelo. Pates igiturnihnl latius patens corpore mobili ftatuendum effe fubiectum naturalis philofophiz; nil enim, quod non fit corpus, habet in fe prin$D$ cipium motus; \& nihil, quod principium ma tus infe non habeat, poteft in hac fcientia haberelocum fubiecti iuxta fententiam Ariftotelis, fed folum vt principium, vel vt accidens corporis naturalis locum habere poteft in naturali philorophia.

\section{Conj'utatio ententia illorum, qui aliquod naturali corpore anguftius fubiectum fatuerunt. Ca.p. $V$.}

Liquivero in contrarium errorem inciden- Fonnt.

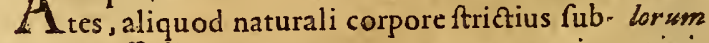
iectum effedixerunt, nempe corpus generatio- opinio. ni \& interitui obnoxium, hoc moti argumento: Argsmés illud effe fubictum totius fcientix naturalis, ith cuius principia in primo Phyficorum libro qua - r $* m$. runtur; at quaruntur ibi princspia rerum tantum caducarum, tefte Ariftotele in contextu 68.eius.libri; ergo ha folx funt fubiectum, quaF re coelum iuxta horum opinionem non confideraturà naturali vt fpecies fubiecti, fed vt fubięti principium. Alij vero nec collum, nec ele. menta fubiecto fcientiz naturalis contineri nia exiftimarunt, fed fubiecturn ftatuerunt corpus naturale miftum, cujus \& colum, \& elementa principia funt: videntur hi codem ferme argumento moti in hanc fententiam venıffe, elementa enim, \& colum eiusdem ordinis effe viden- 
videntur, \& vt eiufdem ordinis corpora ab Ari- A enim competit effe mobile, feu habere in fe ftotele confiderari, nam in libris de Colo zque confiderantur vt fimplicia corpora, è quibus mundus conftat, deinde tn libris de Ortu, \& interitu æque vt principta miftorum, colum vt efficiens, elementa vero vt materia; quarefi colum in fcientia naturali vt principium confideratur, elementa quoq; vt principia fubiecticonfiderari dicendum eft. Quum autem hi rem confideratam dixerint effe alij corpus naturale caducum, alij corp us naturale miftum.in modo tamen confiderandi confenferunt, dicentes illud confiderari quatenus mobile, hoc eft, quaConfuta- tenus habens in fe principium motus. Sed erratio Geri- runt vtrique in vtrifque, in re quidem confidemque - rata, quoniam fi colum \& elementa non copinionis. gnofcuntur à naturali Philo fopho, nifi vt principia, fcientia naturalis manca \& imperfecta eft : res enim naturales eo modo funt cognofcend $x$, quo funt, \& quem locum háabent in natura, eundem habere in noftra cognitione debent; atqui in natura non folum funt principia aliorum, fed funt etiam abfolute naturalia corpora fine vlloaliorum refpectu, \& per feexiftunt, nec minus etiam deftructis omnibus miftis exifterent: funt igit ur cognof cenda à Philofopho naturali, tum vt aliorum principia, tum fecundum fe vt naturalia corpora, proinde vt fpecies fubiecti: idque expreffe notatum ab Asimpli- uerroelegimusin primo \& vltimo Commentario tertii libri de Cœlo, vbi dicit perfectam fim. plicium corporum notitiam in his duabus tracrum cor porum tractario duplex. ctationibus effe conftitutam; vna, qua confiderantur vt naturalia corpora, \& vt fubiectum, qua ratione tractantur in quatuorlibris de $\mathrm{C}$ lo; altera, qua confiderantur vt aliorum principia, qualis eft eorum tractatio in libris de generatione.Sed quis non videat huius dogmatis abfurditatem ? tractari enimvt principia, eft tractarialiorum gratia, hocautem de cœlefti faltem corpore abfurdiffimum eft, id enim dicere propteralia exiftere nefas eft, exiftit enim præcipue propterfe, fecundario autem propteralia; eft igitur etiam per fe cognoscendum, attamen à nullo per fe cognofcetur, nifi dicamus, à Philofopho naturali, nulla namquealia fcientia eft, in qua colum vt naturale corpus confideretur, aut confideraripoffit. Patetautem ea confiderantibus, quxab Ariftotele in libris de Colo dicuntur, competere omniaiis corporibus perfe \& abfolutefine vllo miftorum refpe- $F$ ctu ; \& propria ipforum accidentia ibı de ipfis demonftrantur tanqquam de fubiecto: quare dubitandum minime eft, illa corpora in libro de Colo ve fubiectum confiderari. Peccârunt etiam hi in modo confiderandi, quem talem adiecerunt, vt propriam ipforum fententiam euerterint: dicentes enim fubiectum effe corpus caducum, vel corpus miftum quatenus mobile, dicunt omne mobile effe fubieftum, cricunque principium motus, illud neceffe eft, ipfis etiam confitentibus effe fubiectum philofophix naturalis:non fola igitur mifta corpora, neq; fola c2duca, fed etiam elementa, \& colum in fcientia naturali habent locum fubiecti, quum fine per fe mobilia corpora, \& habeant fingula in fe ipfis principium proprij motus naturalis. Hunc igitur errorem in adiiciendo modo confiderandi committunt, quod spfum amplioren ponunt $B$ re confiderata; fic enim pugnantia dicunt, \& ide fimul affirmant, \& negant; nain colum, aut etiam elementa negant in fcientia naturali habere locum fubiect, idque pofteaafirmant, dum di. cunt modum confiderandi effe quatenus habés in fe principium motus, fic enim dicunt, omne habens principium motus effe fubiętum fcientix naturalis. Ad argumentum autem iftorum, quodex tactatione primi libil Phy ficorum fu mengus quodex tractatione primi libii Phylicorum fu. mentum mebatúr, videntur $a l_{j j}$ ita concorditer refpon- refponfro dere, principia de quibusin primolioro Phyfi- aloorzoma corum agitur, proprie fumpta non competunt nifi rebus caducis, at improprie, \& proportione quadam celo quoq; accommodari poffunt ratione motus localis, in quo tria illa notare porfumus, fubiectum, \& duos contrarios terminos, nempe à quo, \& ad quem. Sed hæc communis Reponfit refponfio me co quidem iudicio vera nó eft : nam nis conmateria \& forma confiderantur ab Ariftotele futatia. tum in primo; tum in fecundolibro Phyfico- Mazerice rum, diuerfis tamen modis, in primo vt princi- Eform piagenerationis corporis naturalis, in fecundo confideviprincipia motus \& quietis, fecundum quam ratiodzo confiderationem competit eis nomen natura. ples. QuoJigitur cœlo aptari eadem principia poffint, concedendum eft, prout confiderantur in fecundo libro, fed non prout confiderantur in primo; nam ficuti in interioribus corporibus dicimus formam effe propriam naturam vniuscuiusque, \& principiū proprij motus naturalis, ita in Ccelo eft propria natura, qua eft proprij motus principium, \& proportione refpódet form qux in corporibus caducis eft principiū motus, ob id definitio naturæeft communis omnibus naturalibus corporibus, tam caducis, quam $x$ ternis. At in primo libro confiderantur eaden principia,refpectu ipfusmet náturalis corporis, nempe vtprincipia, ex quibus naturale corpus generatur, \& conftat, qux confideratio non poteft aptari colo, quia Cœlum apud Ariftotel em ex his principiis genitum non eft, neque ex iis conftat ;ideoque Ariftoteles in contextu 68. 6 ius libri aperte dicit fe de principlis loqui rerum tantummodo naturalium, qux generationi \& interitui obnoxiz funt. Quod vero dicunt eadem principia poffe Colo accommodari refpectumotus localis, nihil eft,fiquidem non ea confiderat Ariftozeles in primo libro vt principia motus, fed vt principia corporis naturalis, qux confideratio nullum habet locum in

$$
\text { A } 4 \text { Colol' }
$$


Calo; imo neque concedendum eft poffe ea- A demprincipiaaccommodari motui locali, prout in primo libro confiderantur, fiquidem aliud eft moueri,aliud eft generari, \& fieri:eft enim motus à pofitiuo in pofitiuum, generatio vero à priuatiuo in pofitiuum; ideo alij motus præter localem poffunt diuerfis modis \& motus, \& generationes vocari, vt aquæ calefactio diciturmotus alterationis, quatenus eft à frigido in calidum, dicitur etiam generatio, quatenus eft calidi exnon calido; fed motus loca- B lis non recipit appellationem generationis, nif: adnodum improprie: nee dicere folemus id, quod loco moue tur, generari, vel fieri, nifi maxime impr prie; licet Ariftoteles in contextu 24. libri 8. Phyfic hunc loquendi modum difputandi tantum gratia, \& ad conuincendum magis aduerfariorum errorem vfurpauerit: ratioque huius eft, quoniam generari, ac fieri proprie dicitur, quando acquiritur forma aliqua inhærensilli quod mutatur, eaque effe non poteft, nifi in vna trium categoriarum, nempe fubftantiæ vel quantisatis, vel qualitatis, hæ namque folx funt res abfolutx, qux poffunt appellari formæ; at locus eft res externa, qux non poteft vocari forma rei motx, à qua poffit motus vocari gencratio; id vero, quod vocamus $\mathrm{Vbi}$, refpectum habet ad locum externum, nec eft vereabfolutum, quod poffit vocari forna; ob id Latini motum, qui eft ad locum, ab aliis omnibus diftinguere folent, tan-. $D$ quam à motibus ad formam. Quoniam igitur principidin primo $\mathrm{Phy}$ ficorum ea ratione confiderantur, quatenus funt principia, ex quibus aliquid generatur, \& $\mathrm{fit}_{2}$ idque manifeftum eft in definitione prim $x$ materix, \& in toto fere co primo libro, vaniflimum eftid, quod illi dicunt, ea poffe accommodari motui locali; eaque fuitcaufa, curvideamus Ariftotelem aliarum omnium mutationum, tam fubftantialium, quam accidentaiium exempla tuliffe in illo libro, eafque omnes confideraffe; de motuautem locali ne verbum quidem feciffe, nec vllum vnquam eius exemplium attuliffe in declarandis tum principiis contrariis, tum fubicAta materia. Maxime autem atteftatur huic veritati in contextu63. eius libri ${ }_{2}$ vbi perfectamfaciens enumerationem omnium, qux dicantur ficri fiue fecundum fubftantian, fiuc fecundumaccidentia, vt perfecta inductione colligat hanc vniuerfalem; in omnibus, qua funt, $F$ necefiaria eft fubiecta materia omnes mutationes recenfet, tum fubftantiales, tum accidentales, \& tum ab arte, tum à natura factas, fola tamen excepta mutatione fecundum locum. cuius nullam facit mentionem, quoniam illi non conuenit verbum, fieri, feu generari. $\mathrm{Pa}$ tet igiturcommuneın hanc folutionem falfam. Refponfoe effe, proinde argumentum non effe folutum. propria. Vera huiusargumentifolutio poitea masifelta. erit, quum de ordine librorum, ac primi libri Phyficorum cum fecundo connexione loquemur, nunc breuiter dicımus id non poffe negari, in illoprimo libro agi de principis corruptibilium tantum, fed negandain effeillam maiorem: illud eft fubiectum, cuius principia in primo Phyficorum libro confiderantur: puto enim cum Auerroe verum initium totius naturalis philofophiz fumendum effe à fecundo libro Phyficorum; primum vero fuiffe antepolitum propter noftram faciliorem cognition em, non quod reuera ad eos libros pertinuerit. Itaque ad cognofcendum generale fubiectum totius fientiz naturalis fpectare debemus, quid in feentix naturalis fpectare debenus, quid in fe- lis, $2 n-$ quid in promo; in illis autem feptem manifeftum eft agi de cómunibus, quæ fimiliter competunt omnibus naturalibus corporibus, tam caducis, quam xternis, fecundum quandam analogiam, definitio naturæ, \& habentis natuC ram competit etiam colefti corpori; tractatio de niotu, motum quoque Coli complectitur; de loco agens Ariftoteles in quarto libro docet etiam, quomodo Coclum fit in loco; rractatio autem de tempore magis etiam ad Colum pertinere videtur, quam ad alia, fiquidem tempus eft numerus, \& affectio motus iolius coleftis; aternus vero motus, qui in octauo libso declaratur, vel eft motus generaliter acceptus, vt multi dicunt, fub quo etiam coli motus (quod negare fatuum effet) contineatur; vel eft folus coleftis motus, non quidem vt proprius Cœli, fed vt motus vniuerfi, qui omnes moris continet, vt rectius putauit Auerroes. Omnia igitur, qux in iis fptem libris traetantur, funt communia cunctis naturalibus eorporibus, eo modo, quo cōmunia effe poffunt, nam corpus na. Corpuss turale late acceptum non eft vniuo cum genus, natsurequod vnius naturx fit, quo fit, vt qua inferio- le non eft ribus corporibus communia cum Colo effe vi- Snizso-

E dentur, non fecundum eandem rationem eis cum, incompetant, fed fimilitudine quadam, \& analo- fracap. gia. Ex illorum igitur feptem librorum confi- 10 . deratione efficacius argumentü fumitur, quam exprimo, ad oftendendum quod corpus naturale complettens omnia, \& coleftia, \& inferio. ra corpora, fit commune fubiectum totius fcientix naturalis.

\section{Definitio ac partitio Scientia naturalis. Cap. VI.}

Q Voniam teta fcientia natura à proprio. fubiecto pendet, cognito fubiecto philofophix naturalis, facile eft eius. definitionem ex iis, qux dicta funt, colligere: dicimusigitur philofophiam naturalem effe fcientiam contemplatiuam, qua naturalium corporuni, quatcnus principiun motus in fe habent, peifectam cognitionē tradit; perfecta autem fu's-
Secüdus Pbyfic.

est initiumpthilofophia natura- 
iecti cognitio, quum fit finiscuiusque fcientiz $A$ Inlib de fpeculatiux, in cuobus confiftit, vt alibideclaTrabus rauimus, in principiorum \&accidentium illius pracogn. fubiecti cognitione: quare natural is fcientia fcopus nullus alius eft, quam cognofecre principia corporum naturalium, \& eorundem accidentia per fuas caufas. Ex hac definitione haurire poffumus veram totıus fcientix diuifionem in partes præcipuas, \& aliorum errores in ea partienda deprehendere. Multos audiui hac pri-

De disi. fione opinisiolsorum. mum diuifione vtentes : aciurus Philofophus naturalis de naturalibus corporibus, eosü prin-

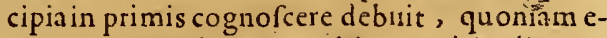
nim ex principiorum notitia cognitioaliorum pendet, debet quisque alicuius rei cognitionem indagaturus, ante onmia nofle eius principia; fcientia igitur naturalis in duas principes partes diuiditur, vnam priorem, quæ eft de principi is corporuin naturalium, eaque octo Phyficxaufcultationis libris continetur ; al teram pofteriorem, in qua agitur de corporibus ipfis naturalibus, quorum illa principia funt, eaque contunct reliquos omnes libros naturales, quorum priRation- mus eft liber de Colo. Diuifionem hanc ex
pinionis ipfrus Ariftotelis verbis defumunt, nam in inipinionis ipfus Ariftotelis verbis defumunt, nam in ini-
pradicts. tio Phyficorum inquit, feprimo locoacturum pradicts. tio Phyficorum inquit, feprimo locoacturum
effe de principiis rerum naturalium, in initıo autem libriprimi de Colo afferit, fe tuncprimum naturalium corporum tractationem aggreffurum; octo igiturlibros Phyficx aufcultationis nullum aliud dicunt habere fubiectum, nifi principia corporis naturalis, cım quibus coniuneta effe debuit tractatio de eiusdem consmunibus accidentibus; ipfum autem corpus naturale non in illıs, fed in aliis fequen! ib. libris fubiectum effe, eiusque tractationem incipere à Confuta- primo libro de Colo. Hanc fententiam ego atio. lias, quum philofophiam publice interpretari cepi, fatis inter noftrorum temporum Philofophos yulgatam, ab iisque receptam, atque defenfam inuenis probare tamen eam nunquam potui, quia puto abfonam effe rationi \& doctrinæ Ariftotelis Pofterioriftica, propterea remper llam efficaciter impugnaui; nunc vero. pauca aduerfus eam dicere fatis erit, tum

Lib.2. de quod fatis multa à me dicta funt in operibus Metbod. logicis, tumetiam qnod audio defertam nunc c.IG. EG effeà pluribus, qui quum antea ipfius defenfo4.6. de resextiterint, in veriórem fententiam, de qua Pracogn. mox dicemus, poftea venerunt, ita vt pluribus ca.5.6.7. in eam inuehi nullum operæ pretium fore vi1. Ratio. deatur. Itaqque nunc paucis agentes dicimus, non poffe de fubiecto aliquo agi, nifi agendo deprincipiis, vel de accidentibrs. eius, nam in his tantum. duobus tota feientia verfatur: ab. fonum igitur eft rationi, quod dicaturagi prius. de principiis corporis naturalis, poftea vero in aliis libris de ipfo naturali corpore, led ipfamet de principiis tractatio eft actu tractitio de cor4. Ratio. pore naturali. Sed vt boc etian cis condone-
A mus, quid de accidentibus dicimus? in his enim vti non poffunr ea ratione, qua de principiis vtebantur: non eft enim neceffarium agereprius de accidentıbus rei, quam de ipfa reagatur, ino potius varıffimumeft talem tractationem moliri, fiquidem acc:dentia funt naturấ pofteriora fubiecto, nec por̂́rum ad eorum demonftrationem accedere, nifi fubiecto iam cognito, abfurdum igitur eft id, quod illi dicunt, agi prius in libris Phyficorum de consB munibus accidentibus corporum naturalium, poftea vero in aliis hbris agi de $1 p$ fis corporibus naturalibus. Pratcrea docuit Ariftoteles in primo libro Pofteriorum, accidentia pro. pria generis non effe fpeciebus atribuenda, fed iplemet communi generi, fin minus, fophifticam tradi cognitionem; atqui accidentia, \& principia, quæ in libris Phyficæ aufcultationis tractantur, communia lunt, \& competunt omni corpori naturali : in libris autem

C de Colo, \& aliss omnibus fequentihus, non agitur de coipore naturali in genere, fed feparatim de feciebus eius fingulis: ergo fillis attribuit Ariftoteles accidentia, qua in libris Phyficæ aufcultationis tractantur, fophiftice tradit cognitionem accidentium naturalium; tangitur autem ratio hæc ab Auerroe in fua Prætatione in primum librum Phyficorum. Hac igitur opinione reiecta, ego puto accipiendam effe Auerrois in dicto loco, \& Latinorum

D communem fententiam, qui putarunt tractåtionem de corpore naturali diftingui debuiffe in duas partes pracipuas; quum enim corpus naturale cognofcendum proponatur, tum fecundum conimunem rationem, quatenus genus quoddam eft latifime patens; tum etiam fecundum proprias fingnlarum fpecierum rationes; \& ordinc doctrina fit prius de genere agendum, quam de fpeciebus; oportuit fcientram naturalem in duas partes diuidi; in parE tem communcm, qua de ipfo genere fit, primumque in fcientia locum occupet, \& partem propriam, fiue particularem, in qua defingulis fpeciebus tractatio fiat; pars igiturcommunis continetur ofto libris Phyficx aufcultationis, in qua docet Ariftoteles ea, qua omni corpori naturali communiter competunt: altera ve. ro pofterior pars continet reliquos omnes libros naturales, qui propter fpecierum muliitudinem., ac diuerfitatem plurimi, atque diftincti funt, quorum diuifio \& ordo in fequentibus declarabitur. Nulla igitur-diffenfio eft in partibus huius diuifionis, quum omnes confentiant duas effe primas huius frientiæ partes, \&: vnam contineri octo libris. Phyfica aufcultationis, alteram vero reliquis omnibus: fed in ratione partitionis tota controuerfia pcfitaeft, alii namque dicebant, priorem partem efle debuiffe de principiis corporis naturalis, pofteriorem. yero de ipfismet corporibus naA. 5 turali.
Vera di$2 i j \sqrt{20} \int c x-$ entisa na taralis. 
turalibus. Nosvero cum Auerroe, \& Latinis dicimus prioren partem effe debuiffe de ipfo communi genere corpore naturali, pofterioren vero de ipfius fpeciebus; cuins partitionis mentionem fecit Aucroes etiam in initio fuæ Epitomes primi libri de Colo, \& in initio primi Metcorologicorum. Talemque etiam artis Logicæ partitionem apud eundem legiinstio mus in fua Przfatione in primum librum Po2. 66. de fteriorum, eamque nos in logicis libris nottris Naeur. declarauimus.

exion

\section{Defubiecto librorum Pbyficáaufculta- tionis. Cap. VII.}

$\mathrm{E}$ $\mathrm{X}$ his, quæ modo diximus, patet eandem effe difputationem de prima librorum naturalium partitione, ac defubiecto oeto libroAior:m an Phyfica aufcultationis; ill enim, qui pri6ince. mam huius fcientix partem dicunt effe de principiis corporum naturalium, dicunt etiam nullum aliud in ea parte fubiectum effe ftatuen. dum, nifi ipfa principia; cuius opinionis falfitatem iam demonftraumus. Nos vero cum Latinis dicinus illud idem, quod in to a fcientia fubiectum effe dicatur, in his quoque octo libris fubięum effe ftatuendum, ita vt, quum rota fcientia fubiectum habeat corpus naturaJe, hocidem in fua maxima amplitudine confideratum in his octo libris fubiętum effe dicaobiectio tur. Aduerfus quam fententram vaniffima eft Vicomer obicatio Vicomercati, qui dicit, idem ergo erit oati. fubiectum totius fcientiz \& partis, fiquidem tota fcientia fubiectum habet corpus naturam habẽs, \& liber Phyficorum fimiliter habet fubie fum corpus naturam habens, quod quidem (inquit) eft fruftra multiplicare corpus naturam habens. Sed huius obiectionis folutio fa-

solutio Corporis xatura lis triplexaceeptio. cile ex iis, qux dicta funt, colligitur; nam corpus naturam habens tribus modis accipipoteft: vno modo proipfo folo communi genere, abfque fpecierum confideratione; fecundo modo pro fola omnium fpecierum collectione; videntur enim fimul fumptæ omnes æquipollere generi; tertio pro ambobus fimul, pro communi genere cum tota fpecierum fuarum collectione. Dicimus igitur curpus naturale primo modoacceptum, fubrectum effe in folis octolibris Pbyficz aufcultationis: fecundo autem modo in reliquis omnibus libris, præter prædictos;tertio demum in tota f́ientia, qux continet \& octo Phyficos, \& alios omnes; non eft igitur idem fubiectum totius fcientiz \& partis, quum non eodem modo confideratum ponatur fubiectum in octo Phyficis, atque in feientia tota; ino neceffarium omnino fuit his modis naturalia corpora confiderare, ad fcientia huiusperfectionem \&.integritatem; nam fi $\mathrm{fe}_{\mathrm{e}}$ cundum propriastantum rationes, quibus difGdent, paturalia corpora sognofcerentur, im-
A perfecta cognitio effet, quia cognofenda etiam funt fecundum communem rationem generis, in quo conueniunt; qux namque generi competunt, non funt de fipecicbus demonftranda, fed deipfo communıgenere: \& è conuerfo imperfecta fuiffet fola generis, cognitio fine cognitione Specierum; confufa namque \& rudis fuiffet rerum naturalium cognitio ratione tantum communi, in qua conuenunt, ignoratis propriis fingularum naturis \& proprietatibus.

B Vtraque autem confideratione difciplina naturalis perfecta; \& integraredditur: nec ob id fit, vt totius $f$ cientix naturalis non vnum fit fubieEtum: quanuis enim plurimæ fint naturalis corporis fpecies, tamen fat eft generis, fub quo omnes colligunt ur, vnitas ad fubiecti, \& fcientia vnitatem conftituendam. Magis autem videntur aduerfarii hac difficultate vrgeri, dum dicunt non agi de corpore naturali, nifi in libris de Colo, \& aliis fequentibus; quum enim in nulC lo eorum librorum agatur de communi genere, quod vnum eft, fed de fpeciebus, qux funt quam plurimæ, non fatis tueri poffunt huius difciplinæ vnitatem; imo \& mancam, atque inperfectam eam reddunt, dum eam tractatione communis generis deftituram effe volunt. Eorum autem ratio, quam initio adduximus, nullius eft moménti, \& fufius loluta à nobis eft in operibus Logicis: quum enım fubiectocuiufqua fcientix confituto ftatim oriatur du$D$ plex authoris confilium, fiue intentio, nempe agendi de principiis, ac de affectionibus eiufdem fubiccti quo fit, vt agere de principiis, vel de affection, rei fit in 1 lla re verfari vt in fubiecto; certe fententiam noftram confirmat potius, quam infirmet dictum Ariftotelis, quando inquit, agendum primo loco effe de principiis, fic enim nil aliud indicat, quam fcopum \& intentionem effe agere primum de primis principiis: fubiectumigitur eft illud, cuius ea princiE pia funt; funt autem principia corporis naturalis communis : hoc igitur eft fubiectum, quoniam huius principia quæruntur. Quod vero in initio primi libri de Coelo Ariftoteles dicat fcientiam naturalem verfari in corporibus, non ob id alferit, fe tunc prim um aggredi tractationem de corpore; fed fignificat fe tune primum aggredi tractationem particulare de fingulis corporibus naturalibus, idque dicit, vt occafionem fumat declarandi præftantiam vniuerfi, de quo in eo libro locutus erat.

\section{Dinifio librorum Pbyfice aufcultatio- nis. Cap. IIX.}

Q Voniam diftum eft ofto libros Phyfica aufcultationis fubieftum habere corpus naturale ampliffine fumptum, \& adhuc abiunctum à fpeciebus fuppofitis; fubiefto a'stem alicusus fcientix, feu libri conftituto, oritur duplex
Ratio

mitatis fientia nos:uras. lis. Solutio rationis aduerfa riorsm. Lib. 2.de Method. c. 16.8 lib. de pracogn. casp. 5. 6. 7 । 
duplex authoris intentio in eo libro, nempea- A gendi de principiis, \& de accidentibus illius fubrecti; neceffe eft duplex effe Aruftotelis confilium in his octo libris, proinde eos prima diuifione diuidi in duas partes, in quarum vna priore agatur de principiis corporis naturalis; in altera vero pofteriore de eiufdem propriis accidentibus; in his enim duobus confiftit perfeeta tractatio de corpore naturali in genere, eaque omnia \& principia, \& accidentia, fi ipfius propria funt, neceffe eft vtfint communia corporrbus omnibus naturalibus. Huic horum librorum diuifioni in duas partes atteftatur partitio illa trita \& vulgata, quam apud Grxcos 1nterpretes Iegimus; horum enim octo librorum alios dixerunt effe de principiss, alios vero de motu, nominatione motusalia quoque naturalis corporis accidentia complectentes ; certuin eft enimnon de folo motu, fed eriam de toco, de tempore, de infinito, de continuo in his libris agi, eaque omnia accidentiain principio tertijlibri ab A riftotele confideranda proponi, fed quia principem locum inter accidentia naturalia tenet motus, \& plurimun de motu agitur in iis libris, non abfque ratione fit vt à parte \& maxima, \& præcipua, totam de communibus accidentibus tractationem appellemus de motu, probandaque ent Græcorum interpretum appellatio, fi modo ea, quam diximus, ratione vfi funt. Sed quinam libridicendi fint de principiis, \& qui de motu, controuerfia inter cofd em fuit, nam Simplicius, \& Adraftus dixerunt quinque priores effe de principiis, tres vero poifteriores de motu: Prophyrius autem, \& Ioannes Grammaticus quatuor priores de principiis, quatuor pofteriores de motu. Attamen plures recentiores in hac opinione, qux verior eft , confenferunt, quod duo tantum priores fint deprincipiis, reliqui autem fexde motu, aliisque accidentıbus corporis naturalis. Hancigitur declarantes, aliarum fimulfalfitatem detegemus; prius quidem confiderabimus, quid in primo libro, \& quid'in fecundo agatur; poftea quidem in alis fex; quum enim hi octo librifint de rebus communibus, videntur modo quodam totam fcientiam naturalem fua virtute complecti. proinde digni funt, in quorum ftructura declaranda diutius, quam in plerifque aliis, immoremur.

\section{De primolibro Phyficorum, E eius connexu cum fecundo. Cap. IX.}

Dubzum IFFICVLTATEM primo loco facit der. lib. Rhy. primus liber, in quo de caducorum tantum corporum principiis, vt ante diximus, agitur, non de principiis corporis naturalis viriuerfe fumpti, de quibus potius agendum effe videbatur ; fiquidem de illius principiis.agi oportet;
A quod libri fubieatum eft; atqui fubiectum eft non corpus caducum, fed corpus habensnaturam, quod \& caduca, \& aterna corpora complectatur; adde quod fecundus lıber, \& alij fe. quentes funt de rebus communibus, qua ad coclum quoque extenduntur, vt fupra oftendimus; quomodo igitur primumaliis anteponens A riftoteles particularem tractationem antepofuit vniuerfali : Res hæcplena eft dificultatis, solut qua per aliorum refponfionem, quam antea re- dróg.j.

B futauimus, non tollitur; ego igitur non verebor propriam hac in re proterre fententiam, ad quam inueniendam excitarunt me Auerrois verbain calce poftremi commentarijillius primilibri. Videtur enim Auerroes huiufce rei veritatem non ignoraffe, aut filtem fub nube vidiffe: ibi namque interpretans vltima illa Ariftotelis verba rurfus alowd princoperum capientes dicamus] duas affert expofitiones, fed in altera priore non acquiefcens, quippe quæ manifefte C vana \& ablurda eft, alteram poftea adducit, dicens, Ariftot.intelligere aliud doetrinæinitium, qnoniam reuera initium huius fcientia fumendum eft à fecundo libro: Cuius quidem diki nullam Auerroes rationem adducit, qua dignofcamus, num huiufce rei intima penetrauerit, dictum tamen veriffimum eft , \& firmififimis nititur fundamentis, propterea quod nullum eft fcientix naturalis cenuenientius initium, quam à definitione fubiecti, \& à declaratione huius D nominis, Natura; idque Francifcus Vicomercatus, inftar Caipha infcius confeffus eft in principio fuorum commentariorum in illum fecundum librum, dum inquit ita. effe praclarum; \& m.gnificum illud fecundi libri initium, vt totius naturalis philofophix exordium effe queat: enumerat enim ibi Ariftoteles præcipuas naturalis corporis fpecies, in quibus verfaturus ef?, deinde ftatim naturæ nomen declarat, in quo tanquam in communi confiderandi ratione ilE laomnes conueniunt, fitque vnum totius fcientiz fubiectum corpus naturam habens. Quid igitur de primo libro dicemus? eftne $2 b$ ec locoalienus, \& in eo perperam ab Ariftotelepofitus? abfit vt hoc dicamus, quim potius: miro cum artificio fit ibi ab'Ariftotele ante fecundum librum collocatus, ita vt fit vere primus liber 'Phyficz aufcultationis, qui vero fe-. cundus dicitur, fit reuera fecundus \& eum ftatim fequatur. Dicimus igitur duo effe initia D 140 fmbs 7 fcientix naturalis, vnum, quod ipfa fecundum inttaf $c$ e fe difciplina illa poftulauit, alterum vero ob entia na. noftram meliorem cognitionem; ip $\mathfrak{f a}_{\text {qui- }}$ turalks. dem fecundum fe fcientia naturalis requirebat, vt à definitione fubiecti exordium fumeretur, quemadmodum diximus; hac igitur ratione fecundus liber eft initium fcientix naturalis, incipit enim ab enumeratione rerum mturalium, \& à definitione corporis naturalis latufline fumpti, quod \& caduca, \& aterna cor:

\section{Vermase instizue fientie netura. lis est 2. Pbypes.}


pora compleetatur; hujus autem ita accepti, nulla erant effendi principia, ideo nulla eiusmodi principia tractari potuerunt, fed principia tancum cognitionis, vt mox declarabimus, inter qux piricipem locum tenet declaratio no. prior ra- minis Natura. Sedpropter noftram meliorem tio cur is cognitionem coactus eft Ariftoteles primum 1.Pbyf. libium anteponere, \& ab co totam fcientiam incipere anlpicarl,idque duas ob caufas ; vna eaque praoporteat. cipua,fuit propter cognofendam naturam; ad inielligendum enim quid fit naturam habens, $B$. non modo intelligere oportebat quid fit natura, fed etiam quanam fit, nec fatis erat cognofere naturam efie principium motus infitum ipfinaturali corpori, fed nofcendum etiamérat, qiodnam fit illud, quod in phyfico corpore inexiftens, dicatur principium naturalis morus in co; ob id Ariftetelés ftatim poft declarationem nature, \& habentis naturam, difputationem aggreditur, an hoc principium motus fit materis, vt prifci Philofoph voluerunt, an forma, vt ipfe Ariftoteles exıftimauit; neceflarium igitur omnıno erat nouife prius naturalia corpora ex materia, \& formaconftare, quod quidein ex primo libro cognouimus, vt polfemus intelligere naturam, qua eft principium mo tus, formam potius efic, quam materiam; alioqui non opus eratab illis principsis aufpicari, quum manifeftum fit ea non effe naturalis corporis principia vniucrfe fumpti, fed generationis, \& generabilis corporis tantummodo, quo fit vt ad libros potius de generatione, \& interitu, cornm conlideratio pertinuer it ; idq:1e in illorum librorum exordio Ariftotelcs ipfe teftatur:proponit enim confiderandas caulas generationis, \& interitus communiter omnium, qux natura generantur, \& intereunt, hx autem non funt nifi ill $x$ exdem caufx, qux fufe in primo Phyficolum confiderate fuerant, de guibus iternm loquitur, fed ftrietus in primo de Generatione; horum igitur generationis principiorum tractationem Ariftoteles in Poferior primo Phylicx aufcultationis anticipauit pro. ratio. huius ordinis tractationem, quæ ipfa quidem per fe fortafie Ariftotelem non mouiffet; fed alteripriori adiceta aliquid potuit afferre momeist ; nam fi antiquos Philofophos fpectemus, prima generationis principia apud cosomnium naturalium corporum, nullo excepto, principia crant, fiquidem colum ex iisdem $F$ principiss, è quibus cæetera corpora conftare arbitrabantur. Quoniam igitur illud certum, ftatutumque eft, fi naturale corpus vniuerfe fumptum, communia fux conftitutionis princi ia habuiflet, ab is omninoaufpicandum fuiße, A A iftoteles qui nondnm docucrat colun efle corpus xternum, nullaque habere generationis principia , nulla vti poterat excuiatione, cur à primis generationis princıpiis ordiretur;

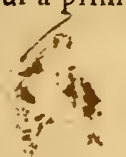

A ab his ergo voluit incipere in primo libro Phyficæaufcultationis, \& iis quiden vt principiis generabilium, non ita tamen vt conftitueret aliqua naturalia corpora non effe generabilia , quü potius è contrario fúpicari deberemus omnia effe generabilia, fiquidem extabant alıorum fententıx, qui dicebant, colum non minus, quam reliqua, corpora, generationi \& interitui obnoxium effe. Ob id exprofello ab horum principiorum tractatione aufpicatur Arifoteles in primo Phyficorum, eamque in Proomioillius libri proponit, eaque vtitur ratione, quod ex principlorum notita oninis aliorum cognitio pendet; quarailo de omnibus naturalibus corporibus inceiligenda e\{t, fi omnia funt generabilia, non de omnibus autem, fi non omna, hoc autem iam diximus nondim effe ab Ariftotele declaratum. Sed tueri etiam fortaftis abfolute poffumus, adomnium prorfus rerum naturalium notitiam conferre llorum principiorum C cognitıonem, quatenus illorumprincipiorum cognitio neceflaria erat ad cognolcendan naturam, qux in fecundo libro declaranda es at, vt communis colo, \& inferioribus corporibus, vt antea dicebamus.

\section{Quod corpus naturale non fot commune vniuocum, fei analogum. \\ Cap. $X$.}

D $\mathrm{S}$ D dignum confideratione hic eft id, de $S$ quomultidubitarunt ; quum enim corpus naturale late fumptum non it uniuocum, fed analogum, id autem vocarifoleat analogum, quod multa contineat ordine quodam; vnum prius, alterum vero pofterius, dubium eft, de quonam corpore dicatur prius, \& de quo po1terius, num prius de ccelo, polterius de caducis corporibus, an è conuerfo. Videtur quidem multis, Colo prius competere naturam, \& no-

E men corporis naturalis, deinde vero infeioribus corporibus, quoniam Calum \& nobiliffimum omnium corporum eft, \& aliorum càufa: quare videtur primum inter naturalia corpora locum fibi vendicare. Hæc tamen fententia mihi quiden femper dubia vifa eft, nam fi $\mathrm{Coe}$ lum propter fuam nobilitatem effet magis naturale corpus, quam corpora caduca, oporteret eadem ratione hominem magis, quam lapi$\mathrm{dem}$, effe corpus naturale, \& magis, quam afinum, efle animal, quod tamen dicendum non eft; quemadmodum enim fpecies generis vniuoci funt alix aliis nobiliores, peridtamen non ftat, quin participatione generis fint xquales; fic etiam hic dıcendum videtur, Colum fecundum propriam rationem effe aliis corporibus nobilius, nec ob id fierivt fit magis, quam alia, naturalecorpus, quum poffit elle nubilius, \&e $x$ que naturale, acilla, aut etiam minus, quam illa. Si vero quia eit caufaaliorú, effet magıs na-

\author{
Confuta- \\ tio.
}


turalecoipus, oportcret elementa magis effe natualia, quam nifta, \& magis hominem generantem, quan hominem genitum, quod tamen dicere non pofiumlis: quanum enim flius fit à patregenitus, non eit tamenhomo à patre, fed à fua forma, hacenim fola êt xquata ratio humanitatis: 1ta etram clementa fun: caufe nijftorum, non jtamen hac ratione habent $\mathrm{mi}$ fta naturam, quod ex clementis corfrent, fed quia formam fuam habent, qua vere eft natura; nam etiam anima eft natura, \& principium morus, st cit forma addita formis elementorum: fic etiam dicendum êt, Columefiecauram effeAtricem inferiorum corporum, hæc tamen finguia non ex ratione dicinaturalia, quod à colo fint genita, fed per proprias formas; fingulum igitur naturale corpus per feiplum habere naturan dicitur, non peraliuá, licet vnumalterius opini caufa dici poffit. Ego puto ad huiufcerei depropris. clarationem neceflarium effe intelligere quid Analogü fitid, quod folet vocarianalogum,nam opinannon eft i- turmuli, analogum effeid, quod ab Ariftotede quod le in principio 4. Metaphylic. vocatur ab vno, ab.sno, fiue advnum; decipiuntur tamen, quia iniis, fue ad quaabvno, fcuad vnum dicuntur, eft pendenGnum. tia necelfaria aliorum ab vno, quatenus talia funt: accidentia namque ea ratione funtentia, quatenus inhærent fubfantix, quæ primario dicitur ens; \& fana omnia ideo dicuntur fana, quia referunturad corporis fanitatem, qua finis eít: at vnum analogianil aliud eft, quam vnum proportione, etiam fi nulla fit pententia aliorum ab vono. Huius exempla plura legimus apud Ariftotelem in libris de Animalibus, vt membrum illud, quod in animali principium, \& fons vitæeft, vnum eftanalogia,non enim id in omnibus eft cor, fed vel cor, vel quid cordiploportione refpondens, nam in animalibus fanguineis eft cor, in aliis vero, qua fanguine carent, eft quiddamaliud, quod in iis eo munerefungitur, quo in fanguineis cor; de pracipuo itaque membro loqui polfumus, tanquan de vno per analogiam, nulla tamen eft pendentia interilla, qua fub hoc communicontinentui, neque enim proportionale cordi in carentibus fanguine ideo fuo munere fungitur, quia pendeat à corde fanguineorum, neque cor ab illo pendet, fed folum habent quandam cōuenientiam virium, feu muneris, qua dicuntur, idem effe fecundum analogiam : legimus etiam aliud exemplum manifeftum apud Ariftotelem $\mathbf{F}$ in contextu 87 . Fecundi Pofteriorum, vbi dicit idem effe officium offis in animali habente os, quod fpinæin pifce, \& fepæi in fepia, proinde os, fpinam \& fepæum effe vnum analogia, non *orpes vnum vniuoce. Sic dicendum puto de colponö eft ab ra complectitur, vinum enim eftanalogia, quoGno, fed niam vt hxc inferiora habent in fe naturam, enalogĭ. qux eft internum principium motus fingulo-
A lum nathralis, ita in calo quoque princiation intcrnum fui motus efie dicinus, non quidin emidem rationis, fed illi proportionequadin ref ondens: habere autem in feprincipina motus, nec calo competit per inferion corpora, nec his per Colum, fed cullibet natuali corpori competit per feipfum, proinde ranum cit quxpere cui pris's competat, cui pofterius, quum minime necefarium fit in analogis taLenoorünen effe; quamobiem corpus natulale B non refie appellatur communeab vine, fet ad frim, fed focandum eft commune analoguis quimadmocum è contraito ens nor pioprie Ensman vocailiranalogum, fed rectius dicitur efle com- eft anamuneab vno. Illud praterea notarevolo, quod logam. hac in renon parui efm onenti, tantum abeffe rt habens naturam prius fignificet Calum, po- Habere fterias vero inferioracorpora, quod multiopi- naturá. nantur, ve potius meo quidem iudicioinferiori- compet if bus competat prius, Coclo autem pofterius, non prius in$C$ quidem fecundum rem iplam, hoc enim iam ferrorilegauimus, fed fecundun nos, \& rationeco-bus, pofe gnitionis noftrx, quoniam enim familiaria no-riuscalo. bis funt hac caduca corpora, in quibus verfamur, \& quorum compolitionem exmateria \& forma iam in primo libro cognouimus, hxc pracipue refpexifie Ariftotelem in defnitio. nenaturx putandum eft. vt tale motus principium Calo quoque, quod remotius, \& ignorius nobis elt, poftea accommodemus. Hoc in D dicant tum verba pofita indefnitioneña:uræ, qua fortafie alibiop portuniore occafion ferpendemus, tum fejuens illa Ariftoieliedifutatio, an materia, an potius forma fit 19 fis 1 ei natura: loututur enim ibi Ariftoteles ce is, qua ex maceria \& forma confant, nec ob id excluditu-Colum, quia etí materia \& furma compontionen non habet, tamen \& materix, \& form $x$ conditior.cs redolet; materi $x$, quatenus cficorpus, form: vero, quatenus exifit aE E.u; haber igiti: aliquid proportione refpondens form $æ$, cuoceftineo principium motus, $v t$ in caducis copporibus forma, hoc autem quomodo fere Eabeat, alibi declarabimus. Hinc ortum habuife puto nonnullorum errorem, qui dixere, fub naturæ cefinitionenaturam colicam non contineri; nam hi id quidem viderunt, quod manifefum eft, Ariftotelem præcipue caducorum corporum naturam refpicere; atid, quod profundius erat, conflium - artificiumque Ariftotelis non penetrarunt, qui colo quoque aptari voluit definitionem naturx: hoc enim tum ratio, quaim tetigimus, perfuadet, tum tota feptem librorum tractatio declarat: adde vero \& Ariftotelis verba fatis clara in contextu s. libri primi de Colo, vbi repetens definitionem naturæ in fecundo Phyficæ auf́cultationis traditam, inquit omnia naturalia corpora effe loco mobilia, propterea quod habent naturam, qua 
eft motus principium : deinde ftatim motum localem diuidit in rectum, \& circularem, \& miftum: itaque afferit motum in naturæ definitione iam acceptum colefti quoque motui communem fuiffe: fed res manifeftior eft, quam ve pluribus verbis, aut longiori difputatione indigeat.

\section{Ouonodo duo priores libri Phyficorum fint de principiis. Cap. XI.}

Ex $\mathrm{X}$ iis, qux hactenus dicta funt, cognofcere poffumus, quomodo duo priores libri Phyfic aufcultationis fint de principiis: vera
Opinio

D. Tho-

m\&.

Solutio. enim eft opino $D$. Thom $x$, qui dicit agi in primo libro de principiis rerum naturalium, qux effendi principia vocarifolent; in fecundorutem de principiis fcientix naturalis thoc eft, de principiis cognofendi. Sed huus dieti decläationcm D. Thomas nullam adducit, qua intelliganuus, ipfum hulufee rei rationem \& artificium Ariftotelis penetrafe, efiet enim abipfo gurerendum, cur tam diuerfis exordiis diftineta fint ab Ariftotele principia rerum naturalium à principiis fcientiæ naturalis, quı dicuntur cognitionis principia, prefertim quum in untio primi libri contrarium afferuiffe videatur; $\mathrm{d}$ cens enim aufpicandum effe à primıs principiis rerum naturalium, propterea quod ex eorum notitia omnis aliorum cognitio pendet, fatetur eadem effe rerum naturalium, \& cognitionis principia: cuius quidem dubitationis quam folutionem $\mathrm{D}$. Thomas attulifiet, \& quam huius furdiftinctionisrationem effe exiftimauerit, ego quidem nefcio: púto autem cam effer rationem, quam antea tetigimus. nam principia effendi, qua omnium prorfus rerum naturalium principia effent, nulla confiderari poterant, quia nulla erant; fed à principiss tantum cognofcendi aufipicaripoterat Ariftoteles, quod in fecundo libro fecit; fed quoniam hac cognofci non poterant; nifi prius saducarum faltem rerum principia nouiffemus, licet horum confideratio adalium potius huius fcientix librum pertinuiffet. Ariftoteles melioris doctrinæ gratiâ ftatuit anteponere primum librum, in quo prima generabilium principia declara ret, eumque à lecundo feiunxit, fumens in fecundo altius exordium, quia primus ad fola generabilia, fecundus vcro ad omnia penitus naturalia corpora pertinebat. Quod autem dice- F batur, principia effendi effe enram cognofcendi, verum id quidem eft, at non reciprocatur: \& longe diuerfa funt principia cognofcendi tantum, ab iis, quæ \& effendi, \& cognofcendi principia funt; de quibusıd poflumus notare, quod licet vt effendi principia non lunt nifi rerum caducarum principia, tamen vt principia cognofcendi poffunt omnium rerun naturaliu un principia diç̇ ; conferunt enim ad tra-
A ctationem fecundi libri, ficut antea diximus: Cæaterum vt primum librum tandem omittamus, reftatvt defecundo doceamus, quxnam /at de cognitionis principia in eo confiderêtur. Pri-prancipien mun quidem dubitare non poffumus, maxime is cogniomnium præcipuū cognitionis principium effe ticnis. declarationem nominis natur $x$, eamq: non effenifi principium cognitionis; quum fit tradita per effectus pofteriores, per motum \& quietem. idque notauit expreffe Auerroes in commenta.

B rio 44. libri 2. Pofteriorum; non enim definitur ibi matuta vt principium cotporis naturalis, fed vt racto formalss ipfius fubiceti córporis naturalis, declaraturque per refpectum ad accidentia pofteriora; patet altem declarationem nominis fubienti inter omina cognitionis principia prımum fibi locum vendicare, ideo in fecundo libro prima omnium efre debuit traftatio de natura, qua doceamur quid fit \& quæ fit natura, quod ibi preftat Ariftoteles ad contex-

C tum vfque is. Quoniam autem ficuti res ab aliis rebus diftinguitur per propriam formam, ita qualiber fcientia abaliis per modum confiderandi, qui forma locum obtinet; ideo declarata ipfa ratione formalı proprii fubiecti, Arifroteles per eam, nempe per internum princi. pium motus, quod vocatur natura, reparat naturalem fcientiam à Mathematicis: idque fimilitèr eft cognitionis prencıpium; fiquidem tollit difficultaté de ip fo huius fcientia proprio fub$\mathrm{D}$ iecto, qux in- huius difciplinx ingreffu turbare aliquem poterar. Et quoniam dixerat Ariftoteles tormam effe rei naturam, Ideo declarare etiam voluit, qualis debeat efe tractatio de forma in fcientia natuali, \& ad quos vfquefines extendasur, idque ve phyicam trątationem feiuingeret à metaphyfica. Hæc igitur omnia in ipio fcientixi initıo fuiffe declaranda, vt cognttionis principia, faltem vt qux dirigentia feu praparantia dicuntur, manifeftum eit. Sed fe- Qualio E quens de caufis tractatio aliquid videtur babe- tract a re difficultatis, \& digna eft aliqua confideratio- tio de ne: nam' qualifnam fit, \& curab Ariftotele in- carsfis. ftituatur, videtur non fatis ab aliis fuiffe declaratum: funt qui dicant Ariftotelem in principio opinis primi libri profeffum, fe de principiis, de cau- alegusofis, ac de elementis rerum naturalium loquutu- rwro. rum, id poftea itaeffeexequutum; egit in primo libro de principris, in fecundo autem de elemèntis, \& de caufis; de elementis in tractatio. ne de natura, quoniam natura eft internum principium morus, quod proprie dicitur elementum; tandem de caufis in hac, de qua loquimus, de caulis tractatione. Qua fententia in eo tantum eit probanda, quod dicit in primo libro agi de principiis, in reliquis omnino reprobanda, de caufis namque \& de elementis nor in fecundo libro agitur, fed in eodem primo; fiquidem in prino Iibro Arifteteles idem prorfus fignificatit iis tribus vocabulis; prima nam- 
que interma principia rerum naturatium, $\propto$ primxcauf $x$, \& maxime proprie elementa vocantur, idque manifefte teftatur tota primi libri tractatio, in qua Ariftoteles eadem principia indiftincte appellat modo principia, modo caufas, modo el enienta : fed nihıl repugnantius eft rationi, quam dicere tractationen de natura effe de elementis; nani materia \& forma non yocaintur elementa refpectu motus, \& quietis, \& accidentium confequentiam, fed folum refpeetu corporis naturalis, cuius funtprim $x$ internæ partes; non funt igitur elementa quatenus fubeunt appellationem naturæ, quæ refpicit motum \& quietem; fed quaten us funt ma teria \& forma, \& partes corporis naturalis, quod ex cis generatur \& conftat. Nec minus errant in tractatione de caufis; ea namque non eft illa, quam Ariftoteles in inirio primi libri propofuerat, fiquidem de illa quidem traftatione, qux in primo libro habetur, jicere poffumus, nos per eam cognouife primas caufas rerum naturalium; fed de illa qux habetur in fecundo libro, nihil tale dicere poffumus; per eam enim nullas cognofcimus rerum naturalium caufas, ex quarum notitia aliorum cognitionemadipifcamur; patet enım agi eo in loco de generibus tantum, modifque caufarum, non de caufis vilis affectuum naturalium. Certum autem eft tractationem de generibus caufarum non ad naturalem Phlofophum, fed ad Metaphyficum proprie, \& modo etiamaliquo ad Logicum pertinere;nam cognofrere demonftrator debuit, fi demonitrare eft à caußa rei procedere, quanam canfarum genera in demonftratione locum habere polfint : ideo de his aliqua dicunturab Ariftotele in libro fecun. do Pofter. Analyt. Quomodo igitur de generibus caufarum agat in fecundo phyficæ aufcultationis Ariftoteles, confiderandum eft, hos enim fatis abaliis explicatum effe non video. Sumitur (yt arbitror) huiufce res declaratio ex Auerrore infua Præfatione in pofteriores Analyticos, \& in comment r6. librifecundi Phyfic, \& in initio fuorum comment. in lib. I. dc Parti bus animalium, vbi inquit duo cffe genera regularum logicarum; aliz namque funt vniuerfales, \& ad omnes difciplinas vniuerfe conferentes; aliæ voro proprix, \& ad vnam aliquam difciplinam peculialiter attinentes; de illss agere ad Logicum in quit pertinere, de his vero minime, fed cuiuf́que dif́ciplinx proprium id munus effe; nam illa, quaad omnis demonitrationis coftructionem. generaliter attinent, in PoAterioribus Analyticis tractari ab Arifotele debuerunt; fed illa, qua ad foles pertinent demonftrationes naturales, non in Logica, fed in ipfamet fcientia naturali declaranda funt;non enim debet Logicusad particulares, ac proprias fingularum fcientiarum conditiones defcende$r_{1}$ nec docere qualis effe debeat demonfiratio
A naturalis, \& qualis Matematica. Eam igitur caufarum confiderationem, qux in fecundo Phyficorum habetur, ego Logicam effeputo, eamque reftrictam ad fientiam naturalem, \&.faciendam in ipfamet difciplina naturali : quum enım inlibro fecundo polter. docuifiet Ariftoteles, ex quibufnam caufis conftrui demon tratio polfit, docet in libro 2. Phyficor. ex quibufnam caufis demonftrare debeat Philofophus naturalis, \& declaratis caufarum gene-

B ribus oftendit demonftrandum ipfi effe ex ominibus, maxime vero ex fine, propterea quod natura quicquid agit, propter finem agit. Hanc effe Auerrois mentem, patet legentibus prædictam eius Profationem in Pofteriores Analyticos, vbi exemplaferens huius Logicæ particularis nominauit exempli gratia librum fecundum Phylicorum, \& primum de partibiss an:malium; putauit enin hac effe principia cognitionıs in fingula difciplina, per qux moneamur, qua methodo in ea difciplina progrediendum fit: nec dico hanc effe Logicam rebus naturalibus applicatam, quæ vtens, fine in vfu pofita vocari folet; nam huiu fmodi effe totam fcientiam: naturalem certum eft, nō folum aliquem ynum: eius fcienti librum; fed dico effe logicam docentem, fed propriam fcientix naturalis, ideoque in naturali fcientia traditam, non in libris Analyticis. Illa vero de cafu \& fortuna tractatio, qux in eo fecundolbro habetur, annexa eft tractationi de caufis; vt autem eius ratio cognofcatur, fcendum eft, tractationem illam de caufis duas habere partes, vnam, in qua declarantur folummodo genera, \& modi caufarum; alteramvero magis pracipuam, qux incipit in eo contextu 70 . in qua Ariftoteles adid, quod fibi propoluerat, applicat ea omnia, quæ dixerat, quippe docet effe per omnia caufarum generademonfrandum infcientia naturali, maxime vero per fine", tandernq; in calce libri oftell-

E dit neceffitatem in rebus naturalibustribuen. dam efle marerix propter finem, non fini propter materiam, quxantiquorum fententia erat, dicentium, effectus naturales fieri ex materia. necelfitate. In hacigitur poftrema parte, in qua docet Ariftoteles, ex quibus caufis debeat Philofophus naturalis quarere fcientiam rerum naturalium, non loquitur de cafu, \& fortuna, fed potius excludit huiufmodicaufas, dicens, effectus naturales vel femper eodem modo fe habe-

F re,vel faltem vt plurinum, proinde nullum eorum referri poffe in cafum \& fortunam : fed in altern parte priore, in qua declarat genera, \& modos caufarum, vt quid omnes fint intelligamus; declarat etiam quid fint cafus, \& fortuna: quum enim in has caufas referantur ab hominibus multi effectus, eaque locum habere vidinnzur folum in rcbusnajuræ, debuit Arittoteles,docere quid fint. Docuit itaque eas effe catfas per accidens, \& reduci ad genus cauf ef

\section{Decafs E for twna.}


ficicuntis; \&. has ratione explęuit țractationem de caufis, quantum ad naturalem Philofophum potuit pertinere, nec ob alium fcopum, nifi vt tandem doceret, in quas caufas fint referendi effectus naturales, vt perfectam eorum fcientiam adipifcamur. Sed nimium fortafte prolixi effe videbinur, vt in magnam molem crefcere noftram hanc naturalis fcientiz fabricam oporteat, fi in omnibus Arftotelis libris tantam facere moram fatueremus : fatigitur fit in ipfis naturx primordiis fcientixque huius vniuerf principiis diutius inftitife, quonia m principiorum confideratio, etfi mole parua eft, virtute tamen eft maxima, quum totam modo quodam fieritiam complectatur, in reliquis libris fatis erit artificium \& ordinem perfcutari, dimiffa fingularum rerum confideratione.

\section{Defexpofterioribuslibris Pbyfica aufcul- tationis. Cap. XII.}

Q Vod autem reliqui fexlibri fint de motu, aliisque accidentibus corporis naturalis, tum trątio ipia tractat, tum Ariftotelis verbateftantur in initio tertiilibri, vbiaflerit fe de his tractaturum, tan quam de communibus ab. Error cidentibus rerum nitura!ium. Quare falfa eft Grecorž Grxcortum fententia, quitertium, ¿ quartum, inftatue dis lebris deprisaci pios.

Ratio ol lorum prima. Ratiofe csnda.

principis. Friuola tamen vtraque ratio eft: ad Solutio alteram enim priorem dico, Arifotelem 1 bi reprimera fpicere cognitionem motus an fit, qux confutionis. fa dicitur; fed non cognitionem quid fit, qux dicitur diftincta, qualem in eotertio libro tradit; dicensenim ignorato motuneceffe effe ignorare naturam, non id fignificare vult, quod plerique exiftimarunt, tractationem de motu ibi effe inftituendam ad intelligendam definitionen naturæ, fiquidem fi abfque illa non porfet intellig! definitio natur $x$, debuifet omnino Ariftoteles prius motus, quam naturæ definitionem tradere \& declarare: fed volens fo, lummodo fignificare Ariftoteles magnum connexum, quem motus habet cum natura, quo fit, vt naturali philofopho neceffarium omnino fit agere de motu; fumitignorationem motus, qux opponitur cognitioni motus confu$f_{x}$, quam habent on:nes homines, \& inquit: Statuas ignotum effedari motum, videbis natuı an cognofcı nullo modo pofíe; \& reutra fi bene naturx definitionen expendamus, faci-
A le intelligemus eã fatis à nobis intelling ner ?nlam motus cognitionem confufam, necpoftulare diftinctam illam, qux in tertio libro traditur; qux , fi bene confideretur, nihil confert ad intelligendam definitionem naturæ; videmus etiam Ariftotelem in illo tertio libro tanta cum diligentra indagare, acdeclarare definitionem motus, vt dicere cogamuragi ibi de motu propter fe, non propter definitionem naturx; nifienim ibide motu agitur propter fe, vbifumma B cum diligentia definitur, non viden quo alio in loco dicere poffimus de motu agi in philofo. phia Naturali; hocidem de loco ac de tempore dicendum eft, de quibus agitur in quarto libro: fed in eodem tertii libri initio Ariftoteles affe. rit, fe de his omnibus, ac de aliis locuturum,vt de communibus accidentibus corporum naturalium; quare dubitandum non eft, tertiuns librum \&alios quinque fequentes effe de accidentibus corporis naturalis late accepti. AdalC teram rationem dico, Ariftotelem eo in loco non ipfum perfefumptum tertium Phyficorum vocare deprincipiis, tanquam diftinctum à libris de motu; fed totum volumen de Phyfica aufcultatione à parte eius pracipua nominae de principiis : fic etiam quandoque totam Metaphyficam vocamus diuinain fcientiam, \& dicimus quartum diuinorum, quintum diuinorum, tamen neuter horum, fed folus duodecimus eft de rebus diuinis: fic Ariftoteles in context.40.8. Phyfic. fextum librum vocat de natura, licet omniū confenfione is in libris de motu numere. tur, non in libris de principiis; totam enim prxcedentium librorum congeriem appellat de naturn, non illum fext:im feorfum acceptum, De ipfa autemillorum fex librorum difpofitione, acde ordine eorum communium accidentium multa dici poffent, qux confulto omittimus, ne hac noftra theoria in magnum nimis opus excrefcat : fatis in prafentia lit aliqua beruiter tan$E$ gere, quxad confilium inftitutum que hoc noftrum magis pertinere videntur.Imprimis id vo- C\&r de lo de quintolibio adnotare, agi quidem in eo de fpeciebss fpeciebus motus, eas tamen adlibros Phyficx aufcultationis non pertinere, vel faltem non omnes; de motu enım latiffime accepto, atque et - 5.labre. iam de motu locali vniuerfe fumpto, qui omnibus naturalibus corporibus comımunis eft, in iis tantum libris agi potuit; fed de al teratione, de aceretione \& imminutione, ac de generaF tione, \& interitu; quum folis caducis corbonbus competant, mon ibiagendum erat, fed in $/ 1$ bris de generatione, vbi etiam manifeftam harum omnium mutationum tractationem legımus; quxigirur déhis dicuntur in libris Phylicxaufcultatsonis, non propter fe dicuntur, fiquidem is noneft locus, in quo de hisagatur, ted propter cognitionem gencris, de quo ibiagitur; cu. ius rationem declaro hoc exemplo; Si fit cognofcendum animal genus cognitione quătum Solutio
fecunde
retionsio :. 
Cöfus fum fieri poffit diftincta, neceffe eft vtquum fit tocognofce- tum quoddam confufurs, cognof́catur per core confis- gnitionem partium ( hoc enim eft diftincte cofo EF in- gnolcere; confufe autem cognofcere, eft condiftin- tutum cognofcere vt confufum, hoc eft, fine coItc, qrid gnitionepartium) quoniam igitur animal duo fet. habet partium genera, oportet ipfum ratione omne gev vtrarumque dittincte cognofcere, primum quinusest - dem habet partes effentiales, hoc eft, attributa duplice per fe primimodi, qux eius definitionem conratsone ftituunt; deinde habet partes fubiectas, nempe côfufum. Species à fe contentas : per propriam igitur definitionem cognofcetur aniznal diftincte vno modo, fed manebit confufe cognitum altero modo, nifialiqua fpecierum notitia habeatur, non quidem diftincta, \& perfeeta vt fpecieruin, fed pudis faltem atque confufa : neceffarium enim eft ad perfectam notitiam generis, aliquam fpecierum diftinctionem faltem ruditer, \& pingui Minerua cognofcere ; proinde rudis \& impeifecta fpecierum cognitio confert ad diftinctam cognitionem generis, quatenus genus eft, \& tanquam genus confiderandum proponitur. Itaque per definitionem motus traditam in tertio libro eognofcitur quidem motus diftincte fecundum priorem rationem, fed tamen confufe notus manfiffet fecundum alteram, nifi ipfius fpecies modo al iquo nouiffemus; ipfa autem fecies fecundum proprias rationes diffinet $x$ cognofcend $x$ manent in alio libro; nam in libris de generatione declarabuntur per proprias definitiones, \& per propriascaufas; motus tamen localis 12 tifime acceptus non tractaturinalio loco, nifi in libris Phyfisa aufcultatinnis; qux enim in is de motu abfolute dicuntur, funt prescipue intelligenda de locali, rui proprie, ac primario con!petit nomen motus.

Dubsum de traictes - tionemoress.

Solutio. Inz r.lib. de Meth. Es in 4 . pologia.
Polict autem alicui difficultatem facere illa, quam in iis libris cernimus, interruptio tractationis de motu, nam in prima parte tertij libri agit de motu, atque eius defintionem tradit; deinde vero agit de infinito, docetque quomodo detur in rebus natural ibusinfinitum, \& quomodo non detur ; poftea in quạrto agit dilıgenter de loco, de vacuo, de tempore; in quinto autem reuertitur iterum ad agendum de motu, de eius fpeciebus, atque oppofitionibus ; cur igitur non vna, \& continuata tractationetotum de motu fermonem abfoluit: Soluitur tota hæc difficultas ex iis, qux alias de doctrin $x$ ordine fcripfimus; quum enim ratio ordinandi fumatur femper à noftra meliore, vel faciliore cognitione, illa femper funt anteponenda, quorum cognitio vel neceffaria, vel vrilis fit ad reliqua cognofcenda ; exhoc igitur fonte facile eft rationem haurire ordinis ab Ariftotele feruati in his libris; quod quidem nunc paucis verbis abfoluam, alias fortaffeidem diffufius declaraturus. Quoniam igitur cognitio definitionis, \& nacurz motus non pendebat ex aliorum pradi-
Atorum accidentium notitia, \& motus principemlocum tenet inter accidentia corporis naturalis; debuit ante omnia Ariftoteles in initio tertii libri declarare naturam motus, \& eius definitionem adducere: at agere de fpeciebus motus,ác de eius oppofitionibus, ac de ipfius differentiis non commode poterat, nifi prius de infinito, de loco, acde tempore pertractaffet: ea enim fpecies motus, qua dicitur motus localis, melius intelligitur intellecta natura loci, quum B praferrim locus refpectu motus localis habeat rationem caufre finalis : cum tractatione autem de loco coniuncta effe deburr tractatio de vacuo, fiquidem nil aliud fignificat nomen vacui, quam locum fine corpore. Tractatio etiam de tempore pracedere debuit ea, qux de motu dicuntur in quinto libro, fiquidem in eo quinto fir rxpe ment1o temporis, pracipue veroin declaranda notus vnitate, quam fine temporis notitia cognofcere perfecte non poffumus. His omnibus pracedere debuit tractatio de infinito, qua in tertiolibro habetur, quia fi daretur corpus actu infinitum, de medio rolleretur \&e motus localis, \& locus, \& tempus: de his ergo fermo fieri non poterat, nifi prius oftenfum firiffet, non dari in natura infinitum corpus. Adde etiam quod cum moru coniundtionem \& affinitatem quandam habere videntur reliqua predicta accidentia, ideo Ariftoteles, qui de motu plurima in his libris diesurus erat, voluit D declarata definitione motus vniuerfali ftatim illorun omnium confiderationem abiolucre, \& poftea ad motum reuerters, omnia qua de ipro dicenda manebant, ordinatim pertraetare. In fextoautem libro agitur de continuo, de quoo- De G. lib. mninoagendum erat rquum fit commune accidens corporis naturalis; \& quia fimulcum corporis continuitate confiderat ibi Ariftot. etiam motus ac tem poris continuitatem, ideo non potuit agere de continuo, nifi poft cognitionem E motusactemporis traditam in tertio, quarto \&e quinto libris, erant etiam in quisintolibro trádita definitiones continui \& contigui, quas Ariftotel. in inttio fexti libri refumens manifeftam facit eorum duorum librorum inter fé connexionem. De feptímo libro nil videtur dicen- De $7 . l 6 \%$. dum prater id quod à multis dicitur, eum effe veram proparationemad octauura ; maior enim pars theorematum, qquat tractantus in feptimo; tractantur iterum in octaro: ideo Eudemus in F horum librorum interpretatione dimifit feptimum vt fuperuacaneum, fed tamen Simplicius \& Alexander animaduerterunt oftendi quidem in vtroque libro eadem theoremata, at non effe-vtrobique easdem demonftrationes ; etenim in feptimo funt leuiores ac faciliores, in octano autem validiores, exquifitores \& effentialiores. Putarunt igitur Ariftotelem de rebus altifimis, ac difficillimis in octauo libro fcripturum voluiffe prius easdem in fepti- 
moleuiter adumbrare, \& rationibus faciliori- A brum de motu. Sed difficultatem facere videbus planiorem nobis viam reddere ad aliarum profundiorem intelligentiam; hocidem defeptimolibro fenfit Auerroes, vt apud eum legere poffumus in initio octaui. Ip fe quoque A rifto. tel. hocidem teftarividetur in vltimis verbis fexti libri, proponens enim confiderandum, an detur in rebus naturalibus xternus motus, figni. ficare videturfeptimum librum effe modo quodam partem octaui, \& effe de xterno motu; eft enim de xterno motu, fi ominia qux in eo fcribuntur, ad aterni motus cognitionem, qux in octauo librotraditur diriguntur;id autem quomudo fit, non eft nuftrum in prentia confide-

De 8. lib. rare. In ipfo autem octauo libro fi hoc vnum effe Ariftot.confilium ftatuamus, agere de zterno motu, vt eg's quidém omnino afferendum effe arbitror,clara eft huius confilij ratio, \& eius libri cum pracedentibus connexio: quum enim apud A riftotel. in corpore naturali perpetuus, \& inceffabilis exiftat motus, de hoc tanquam de accidente Phylici corporis vniuerfi agendum in his libris fuit, eaquetractario in tota de motu zractatione poftremum locum habere debuit: quum enim egiffer prius abfolute de motu, deinde etiam de motu, quatenus eft continuus, agendue manebat de moto, quatenus eft xternus, idque in octauolibro fit, quem fi totumlegamus, videbimus eum intelliginon poffe nifi is omnibus intellectis, qu $x$ in aliis pracedent $i-$ bus librisdeclarata fuerant; fupponit enim co. gnitum iam effe motum, \& infinitum \& locum ax tempus, \& continuum, vinon abfque aliqua ratione aliqui in hunc errorem inciderint, $v t$ dixerint pracedenteslibros fuiffe $a b$ A riftotele fcriptos propteroctauum. Altera quoque eft ratio, cur octauus hber poftremus omnium effe debuerit, alij nam que funt de rebus vniuerfalibus, hic vero eft de aterno motu, qui vnus continuus fingulariseft;idque Ariftoteles fatis clare pronunciauit in contexru 40. eius octaui, dum dixit pracedentes libros fuiffe vniuerfe de natura, hoceft, de rebus naturalibus in vniuerfali; hoc enim difcrimine feparansálios ab octauo, indicat octaum effe de re natural fingulari: neque ob-id alienus eft hic liber à libris Phyficz zurcultationis, fiquidem funt hi omnes libride rebus communibus, fed alii funt de rebus corrmunibus pradicatione, octauus vero eft de communibus non pradicatione, fed extenfio ne \& anbitu; nam motus in orbem, cuius in o- $F$ staus libro demonftrarur aternitas, non con. fiderarur ibi vr Coli, fed vt omnium rexum naruralium motus. Hocefre puto Arifotelis confilium in octauo libro, vnde patet eurn iure numerase in libris de motu, \& ita cum appellat Ariftutel. in context. 14. primilibri degeneratiose, vbi disit, fe de motoreimmobili egiffe in primisfermonibus de motu, \& in contexr. 7 r. priari libride Colo hunc librum citans yocatlitur tractatio de primo motore immobili, quie in eo libro habetur, qua multos in hanc fenrentiam traxit, quod confilium A riftot.prxcipuum fit agere de motore $x$ terno; agat autem de $x$ terno molu propter motorem, vtex eo ducat nos in cognitionem primi xterni motoris. Sed abfque dubiodecipiuntur, quia motor imınobilis non eft confiderationis Phyficz, vtafferit Ariftotel. in contexr. 71. \& 73. fecundi PhyficoB rum,ideo deilloagitnon propter $\int e$, fed propter zternum motum:quum enim accidens non cognofcatur, nifi per fuan caufam demonftietur, caufa autem xrerni motus xquata fit primus mororimmobilis, neceffarium fuit agere de $x$ terno motore, ve per eum perfecta haberetur cognitio zterni motus; totaigitur tractario dicenda eft de zterno motu, etiam illa qua eft de xterno motore, quia id dicitur confiderari, cuiusprincipia \& caufre quxruntur, vr air Arifto-

$C$ tel. in principiolibr. 12. Metaphyficorum. Sed tota hac in re difficultas tolletur, fi cognouerimus difirimen phrlofophi naturalis \& Meta phyfici in confideratione fubitantiarum à materia abıunetarum; in hoc enin non videntur omnes confenrire. Sunt qui dicant difcrimen cónfiftere in diuerfitatc attributorum, alia nanque earundem artributa cognofcere Meraphy- one ab. fici eft, alia vero Phyfici;quod enim fint fubtan- fradtotix, \& à materia abiunctx, \& actus puri , \& mo- rum. ueant vt finis, aliaque eiufmodi, confiderar Metaphyficus:quod autem fint xterni motores immobiles, cognofcitur à philofopho naturali ín octauo libro Phyficorum. Alijetiam dixerunt hanc effe differentiam, quod à phyfico cognofcuntur, quoad quxftionem an fint, à Metaphy. fico autem quoad quaftionem quid fint. Sed o. mnemalium erroem ipfa veritatis cognitio declarabit. Ego puto veram \& præcipuam differentiam, aqua alize, fiqua \&u precipuam diffe- opine

E effe,qux ex verbis Auerrois colligitur in poftemo commentario primi libr1, \& ex verbis Ariftorelis in contextu 73. fecund1, motores xterni confiderantur à Metaphyfico vt fubiectum, à Phyfico autem non vt fubiectum, fed vt principia affeetionis naturalis ; fimile difcrimen affere Ariftoteles in fecundo libro inter Pbyficuin \& Mathematicum in earundem rerum confideratione; dicens quantitates Mathematicas à Mathematico confiderari vt abiunctas menteà materia naturali, proinde vt habentes locumfubieeti ; à naturali autem vt funt affectiones corporum naturahum; quum enim tria hxc tantummodo in qualibet icientia confide rentur, fubięum, principia \& affectiones, fufficierieffima eft duarum fcientiarum diftintio in eiufdem rei confideratione, quim dicimus, earn in hacfcientia habere locum fubiest $i$, in 1 lla vero ve affectionem, vel ve principium confiderari. Quonian igitur motór 3
Aligmerum opsnso do premo motore. Confures rio. $D i f c r$. men Pby face, ह5 Meta,by friencoEderatiAliquorum op:nio. Alinopio. nio. Opinis
Sera. 
ternus non confideratur à naturali nifivt principium \& caufa zterni motus, tota illa confideratio eft refpectiua, vocandaque eft de $x$ terno motu, quia de caufa loqui quatenus eft caufa, eft de eoloqui, cuius eft caufa. Ex his patet prioris opinionis falfitas, nam fi xierni motores confideranturà Metaphyfico ve fubiectum. neceffe eft omnia eorum attributa, nullo excepto,à Métąhyfico cognofci; munus enim cuiufque fcientia eft ómnia penitus fub rubiecti propria attributa cognofcere, fin minus, ea perfecta frentia effe non poteft; omnia igitur diuinorym entium attributa, quatenus talium entium atrributa funt, ad Metaphy ficum pertinent, nullum ad Phyficum, ideo videmus Ariftotelem in 12. Metaphyfic. non folum docere entia ill a efle fubftancias abiunctas à materia, \& purosactus, fed etiam effe aternos motores immobiles : philofophus autem naturalis, qui entia illa non confiderar ve fubiętum, fed vt caulas moius, non indiguit omnium illorum artribuiorum confideratione, fed quorundam tantummodo, fine quibus cognofcere non poterausus caufam xterni motus: confiderar igitur, primum motorem effe abiunctum à materia \& penitus immobilem, nonvt ipfius aterni motoris fecundum. fe cognitionem adipifcatur, fed vt perfecte cognof cat caulàm cur in corpore naturali aternus eft motus; quum enim motor fit à materia abiunctus, non laborat, proinde poteft mouere perpetuo. Ex his col- D ligimus yeram effe hanc propofitionem; Metaphyficus cognofcit entia abitracta efe xternos motores, \& hanc; Phyficus cognof cit entia abftracta vt xternos motores, quia tota eius confideratio eftrefpectiua, \& quatenus funt principia ; fed hanc effe falfam, Metaphyficus confiderat entia abftracta, vt xternos motores, fic enim Meıaphy fico attribuimus folum confiderationem refpectiuan, \& excludimus omnem aliorum atributorum confiderationem. Patet E Error fe- eriam errorfecundzopiniónissillud enim quod cunde $a$ - adducunt, difcrimen verum eft, fed fecundapinionis. rium adducunt, prætermiffo primario; ratio enim cur Metaphylicus cognofat de zternis motcribus quid fint, eft, quia eos confiderat vt fubictum; qualibet enim fcientia debet proprii fubiecti quidditatem cognofcere: Naturalis vero, qui non confiderat cos abfolute, fed refpectu motus, non potuit illorum effentiam confiderare; ea nam que abfoluta eft, \&ad eum pertinere non potuit, latis igi tur habuit inuenire quod fint; quid autem fint, ignorat, ideo nec fubftantias efle cognofcit, nec actus, nec illa, qux folus primus philorophus contemplatur. Dicere igirur polfumus, tractarionem de primo motore in 8.lib. tum prima riam effe, turz fecúdaram; quatenus enim fumitur vt pars-quxdam tractationis de aternó motu, primaria if: quoniam primaria eftractatio tota de atıno
A motu; quatenus autem xternus motor fumitur, vt quoddam diftinctum ab xterno motu, fecundarıa dicenda eft, quia inftituicur propter $x$ ternum motum. Deillius autem ociaui libri ftruetura \& artificio, quod certe eft maximum, plura dicipoffent, qux nunc omittimus, fatis effe arbitrantes vniuerfalem librorum conftructio nem exponere; illam vero, qux fingulorum librorum propria eft, its qui libros ip fos interpretandos fufcipiunt, relinquendam effe cenfeB mus. Hac igitur funt, qua tractantur in his octo libris Phyfica aufcultationis, in quibus cauédum eft, ne diuerf́a fubiecta quxramus, quod alıqui faciunt; vnü enim \& idem ii omnes fubiectum habent corpus naturale, $\mid a t$ ITime accepeum; eorum autem inter fe difcrimen non in fubiecto confiftit, fed in varis fcopis, feu intentionibus circaidem fubieeturn, vt in praceden. tibus declarauimus. Hoc fignificauit Ariftoteles per infriptionem illam, Phyfica aufcultaC tionis, qux ad eius, quod modo diximus, comprobationem breuiter declaranda eft; duo librorum genera ab Ariftotele feripta effe conftat; vnum exquifitumacfcientiale, in quoipf $x$ rerum naturx penetrantur - \& effectus per fuas

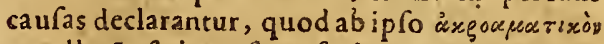
appellatū eft, hoc eft, aufcul tatorimrs, eo quod ad philorophos, \& literatos viros', qui cius aufcrltatores extiterant, huiufcemodi libri fcripti intelliguntur. Alterum genus, quodilli ab Ariftotele contraponitur, eft id quod ab ipfo in vltimo cap. primi libri de Moribus vocatur

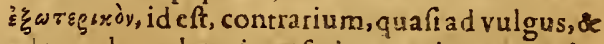
ad populares homines foriptum, in quo resleuirer, \& pingui Minerua tractafitur; eilufmodi erant $\mathrm{ii}$, quorum ibimentionem facit, extrarij de anima libri, qui nunc non extant; nam ii. quos habemus, librı de Arimafcientiales potius, atq;aufcultatorijfunt appellandi ; e os etiam extrarios libros fignificafle videtur Arift. in contex. 54. primilibride Anima, vocans $\tau$ r's $^{\prime} c^{\prime}$ robvẽ $\lambda \leq \gamma$ opéves $\lambda$ órys, id eft, in communi habitos fermones, quafi ad populum, nō ad fcientes. Caterum fi id aufcultarcritu eft, quod modo diximus, manifeftū eft non diftingui hoc no. minetos octolibros abalis Arift. İbris tū naturalibus, tum fupernaturalıbus, $q u ', \Phi$ lciētiales iunt, non minus appellar: merentur aufcultatorij; reftat igitur vtinilla dict:one, Phyficaconfiftat diftinetio horum ceto librorũ ab aliss, fiquidem alij libri'naturales funt quidem $\&$ jpfi denatura, nō tamen vniuerfe de natura, fed par ticulariter dealıqua huius, velillius rei naı ura; hi foiifunt ablolute de natura, \& de vniuerfa nat ura, idec hi foli per excellentiam funt appel-

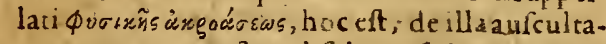
tionc, qua vnıueife \& abfolute eft de natura.Eft igitur in his omnibus commure fubiedum ftatuenúm corpus naturam habens laiffime acseptum, non ad aliquam fpeciem reftringen-

Notasts. quorum errorem. De anfors
perone. $i^{-}$ (1)

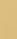

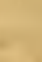


dum; de fpeciebus autem funt cateri, qui mox fequentur, libri natural es, ad quorum omnium ordinatam confiderationem nunc nobis accedendum eft: nam de octo libris Phyficx aufcultationis ea qux hactenus dick funt, fufficiunt.

\section{De sede librorum de calo, do de eorum fubiedo vera Jententia. Cap. XIII.}

Equitur altera fcientia naturalis pofterior Dpars, in qua fpecies corporis naturalis orrum varietate in plures libros diuifa eft, quorum primus confenfuomnium eft liber de Colo, in quatuar libros diuifus: hic quum in fcientsa naturali fecundum lecum obtineat, \& $\mathrm{fta}$ tim fequat ur octo libros Phyficaz aufcultationis, non poreft aliud habere fubiectum, quam primam naturalis corporis fpeciem, cui poit generis cognitionem primus debeatur locus: $C$ hac igitur quanam fit, non difficile eft videre fi primam generis huius divifionem nouerimus; hanc autem ipfemet Ariftoteles facit in initio primi libri de Colo, vbiexfecundo $\mathrm{Phy}$ Prime ficorum repecens definitionem corporis natudivific alis, illud fratim diuidit in fimplex \& mittum, corporis naturalis.

Conexio lib. de Caelo cis lib. Pby66 .

Corpus fimpiex eft corn mune walogis. \& proportione quadam dicuntur fimplicia cor-
Cur de pora, quoniam quodibet horum eiufimodi
celo pri- eft, vt exaliis prioribus corporibus non conftet: seelo pri- eft, ve exaliis prioribus corporibus non conftet: tur, quä batur; quum enim fit ita notx exiftentiz, vt de elementis. diuifionemque hanc âclarat ex diuificne motus in firoplicem \& miftum. De fubiecto igitur librorum de Calo clarum eft Ariftoteils reftimonium, qui ita videtur hos libros cum libris Phyficxaufcultationis cónectere, quum in illis acum fit de corpore naturali generaliter fimplex \& mifum, \& ordine doftrinz fit prius agenduin defimplici, quam de mifto, neceffe cit fubiectum hibrorum de Colo elfe corpus. naturale fimplex; quod quden ipra quouue tractatio confirmat;agitenim primo loco Ariftoteles de corpore fimplici communter fumpto in initio primi libri, vbi de hoc communia. nalogo pauca quzdan dicit, qua de eo dici poterant; ipfr namque tanquam fubiecto ateribuit propriam affectionem, motum fimplicem. qux illi competit propter fimplicem naturam: quemadmodum enim abfolute accepta natura caufaft motusabfoluteaccepti, ita \& natude hoc communi dicipoterar, ideofatim Arinem defcendit, fpecies autem eius funt Coeluin ox quatuor elementa, qux, quum in nullo com\& proportione quadam dicuntur fimplicia corpora, quoniam quodlibet horum eiufmodi non egear ex aliorum corporum declaratione innotefcere, $\&$ a d eius nacuram declarandam faaccepto, \& hoc prima parcitione duidacur in ra fimplex fimplicis motus eft caufa : nil aliud ftoteles ad ordinatam fpecierum confideratiomuni vniuo co conueniant, fimulitúdine tamen tis fit rudis illa aliorum corporum connitio. quam fenfuperiepimus, nulla facilioris doctrinæ ratio congit Ariftotelem de elementis prius agere, quam de Colo; ordinem igitur fermauit naturz \& nobilitatis, Colum enim \& nobilius eft inferioribus corporibus, \& nacuia prius, quia illorum eft caufa; nifi etiam dicamus ordinem ita feruari facilio ris noftra cognitionis; cognitio enim coleftis corporis, quod leuia \& grauia omnia ambit \& concinet, non parum conferre viderur ad cognitiónem illorum, qua à ad ipfium teı minctur motusleuium, \& ab ip fomotis grauium incipere intelligatur; adde quod mo:us grauium ad medium effe dicicur, motus autem leuium à medio, at medium incelligi non poterat non intellecto extremo, nec centrum non intellecta peripheria; omnes igiturob caufas videturde Cœlo prius agendun fuiffe, quam de elementis. In ipfa autem coli tractatione ordi-Ordo tra nem feruat Ariftóteles côuenientifimum, quia ctarzons quum in cuiufque fubiecti cótemplatione duo, de Coelo. nec plura, cognofcenda proponantur, primum quidem elus natura \& effentia, deinde vero proprictares, \& accidentia, quzab ea emanant, ante omnia naturam Coli declarac in primo libro ad contextum y fque $3 z$. poftea vern in tola fequente primilibri parte, atque in toto fecuncia accidentia coleftis corporis contemplarur: in primo quidem illa, qu $x$ licet naturam coel in iequantur, in totum tamen mundum redusidants ita vt Colum habeant fubiectum prátipum. mundum vero fubiectum-adaquatumis yornde de toto mundo ab Ariftotele denonitianur, eaque tria funt, finitudo molis $s_{2}$ vnitas, fompiternitas: in lecundo autem illa, qua anon redundane in vnuerfum, fed Coelum habent fubicatum adrquarum, cuiufmodi inist fex illædifferentiz politionis in Colo, dextrisn, finftrum. furfum, deofum, ante, \& retro; necnon varieqas motuum, \& aftrorum, \& orbium, eorumque E ordo, \& figurá, \&aliz, qux in eodem librotraetantur, nōfunt enim hîcomnia fingillatim recenfenda, quum faris fit totius tractationis rationem intellexiffe. Id folum nō eft filentio prź- Trą̧ at. tereundum, in poftrema fecundilibriparteagi de Terra de terra, non quiderr vt de elemento graui, fic sn 2. lib. enim de ipfa agiturin 4. libro, fed quatenus refpectu Coeli locum centri obtinet, adeo ve illa quoque traftatio modo quodam de Coelo effe dicatur: quemadmodum enim tractatio de cenF tro, quatenus cenrrum circuli eft, pars quadam eft r ractationis de circulo, fiue de circuli peripheria, ita \& ibi tractatio de terra pars quadam 4.66 . tractarionis de Colo effe intellige ca eft. In duobus autem pofterioribus Iibris agit Arift.de reliquis fimplicibus corporibus, de grauib. \& leuibus, qux funt, ignis, aer, aqua, terra, hac enim ibirractäur vt grauia, \& leuia, fumitq; ibiArift. grauitate \& leustatem pro formis elemëtorum, nö quodreuerafut formas sunt enim qualitares, 
Pel quialatentibus form is fumuitur earum loco accidentia hre confequentia, per qua moucntur clementą loco, \& in propriis quarquc locis fua integrant mundum; hac ent enimpropria clenctorum confidcratio in icrtio \& quarto libris de Colo, vt poftea declarabinzus, quateuusfint grauia, \&leuia, hoc eft, quatenus funt fimplicia corpora, quorum fimplices naturas infequmtur fimplices motus naturales, per ciuos propria loca occupando mundintegritatem coultitumnt. Sed de corum duorum librorum tractatione plura dicemus in fequentibus,tunc prafertim, quum loquenurde fubiefto librosum de Generationc, \& interituinune pauca hre dicere volumulis, vt ante onmiaintelligatur, quænam fit vera fententia de fubiecto, \& de rractatione quaruor librorum de Coelo; nodo expendendx funt aliorum hac dere fententix, vt cum $i j$ difputando veritatem clazriorem reddamus.

\section{Sententia Alexandride fubiecto librorum de Colo. Cap. XIV.}

$\mathrm{H}$ $\checkmark i c$ fententia repugnant maxime fectatores Alexandri, qui (ve Simplicius refert) aliud opinari vilus eft de lubiecto hoi lim librorum : dixit enim Ariftotelem 'in his agere de Mundo, ac de fimplicibus corporibus, quxipfius partés funt:quam fententiam alij quieum poftca fequuti funt, itaintellexeruni, vt rubiectum fit mundus tantum, non fimplicia corpora; quum hec vt principia mundi, \& propter mundum confiderentut, exijs enim tanquam ex materia mindus conftat; non ipfa per fe vt Primsm -fubiectum libri. Huic opinioni multa videntur argumé- argunenta fuffragari, primun quidem argtttxm pro mentantur ex inf criptione, quum enim hi hibu Alexaninfcribantur de Coeto, vel fumitur ibi Coelum profolo calesti corpore, vel pro mundo toto, itroq; enim modo afferit Arift.in contex.96.1.i. bri fumipoffe Colum; atqui pro iolo quinto corpore accipi non poteft, fic enim manca, \& imperfecta eflet inf́criptio, quum non de folo quinto corpore, fed etram de quatuor elementis agatur in hislibris; fumitur itaque Colum pro mundo, proinde fubiectum eft mundus. Secundo fumunt argumentum àtracatione ipfa. nam totus primus liber eft de Mundo, nempe de eius finitate, de vnitate, de æternutate. Tertio ex verbis Ariftqui fape Colum vocat primum clemētum,vt in context.9r.primi libri, \& in initio tertij : quoniam igitur nomen elementi refpectium eft, elementum cnim eft alicuius elementum, videndum eft cuiuinam elencntum poffit vocari ipfun colum; refectu quidem miltorum nor poteft elementum dici, quia miftum non conftat ex Colo vt ex materia: relinquitur ergo vt refpectu folius mundi poffit vocari elementum, iquidem omnia quinque fim. plicia corpora finc matcria mund ; quoniam i-
A gitur calem debet we Coli, \& aliorusn "nuor corporum conlideratio, neculice ft, ti Ccelum confideratur materiamundi, elementa quoqivt materiam nundi confiderari, omna igitur fimplicia corpora ve princspia fubiedti in his libris confiderandur, non vt fubic daun. Ine aliudargumentum colligunt, quod erit or cins quartı!n;illud eft fibbect' $' m$, cuius principia \& accidentia quaruntur, illud vero non eft fiubieEcuin, chius non quarütur principia, \& affestiones; atqui princił ia, \& accidétia nuandi, nö finpliciun corporum,tractanturiul libris de Coclo; ergo fubiectum eft mundus, non fimplicia corpora:maiorpropofitio manifefta eft, minor probatur; agitur in tribus polterioribus libris de quinçuc implicibus corporibus, qux sît principia mundi materialia, in primo autcm lib.açitur de accidentibus müdi, onnes igitur hi quatuor libri funt deprincipijs, ac deaccidentibus mundi: deprincipijs autenr fimplicium corpoC rum manif eftum eft nōagi in his libris, Cơlım emm nulla habetprincipia, elenrentorum vero nulia tractantur principia in his libris de Colo. Argimentantur etiam contra Simplicij fententiam hocpacto: fi fubiectum hormm libronm effet corpus fimplex, deberet Artfot. in libris de Ccelo omnia, qua ad fimplicia corpora pertinent, pertractare, \&docere omnia corum accidentia ; hoctamen non facit, quia folas motrices elénentorum qualitates confiderat; de alips. D vero, quxaliteratrices dicuntur, ne verbum quidemfacit, dcijs enim loquetur in libris de Generatione: non eftigiturhorum librarum fubiefum corpus fimplex. Poftremo pro fua opinione hoc argumento vtuntur,agendum omninoetat de mundo in philofophia naturali, crgo nifíin libris de Coelo fubrectü fit mundus, minca \& diminuta erit f́cieitia naturalis ab Ariftot. fcriptá, nullus enim in ea alius locus relinquetur,in quo agi dicatur deip fo mundo vniucrio.

E Hancigituferitentiā quifequintur, alia vturtur ratione in horum libror.ordine declarandos $d$ quirione in horim libror.ordine declarando; disis liquum enim in hocomnes confentiant, quod brorum libri de Col'o fequanturftatum ofto libros Phy - fecunficrealfultationis, duplicem huius ordinis ra- dosaz * tionem affignant : alij namque dicunt, in libris lios. Phyfica anicultationis afum eft de principijs corporis naturals, fequebatur vt'de ipfis corporibus naturalibus agerctur, fed quia totum nobis prius offertur cognof cendum, quam par$F$ tes, eft enim nobis notias partibus, vt dicitur ir context.quartofrimilibri Phyfic. ideo m libris de Coelo agendum primo loco eít de mundo vniuerfo, vt poftea de fingulis erus partibus ordinatimagendo tota naturalis fientia abfolueretur: quod quidem Arifto tel. feciffe videmus, nam poftiractationem demundoagit primum de fimplicibus corporibus, poftea de miftis onuibus \& generatin \& fingillatinn. Alij vero dicunt fubictum fuifle in librs thyfica aufcub.
Drist-

tisise $a r^{-}$ crisuerb. twro.

Quin:thin ar gumertwin. Vltmiz a) tuire.

\section{-}


tationis eorpus naturale late fumptum, ì quoquum ad eius fpecies tranfeñdum efiet, primo loco dicendum fuit de tota earum congerie; qua vocatur mundus. poften vero de finguils.

\section{Dicte Sertentic-confutatio. Catp. XV.}

$\boldsymbol{S}^{\mathrm{E}}$ Ententia hxe an reuera Alexandri fuerit, ego quidem dubius fum, quum enim commontarios Al exandri non habeamus, ex is qux à Simplició referuntur, nó liquet ita fenfife. lexandrum, vt eius opinio ad refium fenfim quen mox confiderabimus, trahi nequecat; quemadmodum fi ita lenfit, rt eicxteri attribuunt, defendi nullo modo poteft: primume-

Primu asgurs: trem.

Secundis argamí term. $111 \mathrm{~m}$ aduerfus eum fic argument or cum Simplicio, fi f copus Ariftotel.in his libris effet agere de müdo vniuerfo, ant equam de fingulis cius partibus ageret; ergo mundum hic confideraredeberetperfectum, nec ex fimplicibus moło, fed ex mifts quoquecorporibus conftanteis, hoc enim ommino probaret aduerfariorumratio , fi modo aliquid habet efficaciatis; tam fi cognito corporenaturali communi, feu cogntis prin- ci is offertur primo loco cognofendum totum, deinde partes fingul $x$, \& liæ quxpoftca ab Ariftot.conideraburitur, crunt \& fimplicia corpora \& mifta, non video cur fecundum ip fain cortm rationem non fieritarte omniaconfiderandum vniuerfum, vt ex his omnibus corporibus conttans, hocenim cfiet te toto mundo azere; quemadmodum \& Plaro in Timro, \& auctor libelli de Mundo ad Alexandrum videnturmundum confiderafieatiamen de mundo yt mifta complectente ipfis quoque confitentibus non agitur in libris de Colo, nonstigitur confilitum Arift. in iis libris agere de Mundo: reurera cnim mundus nó êt vinum quiddam eilismodi quod perfecte in vno libro tractare potuerit, quum non fit vnius nature, fed ex diucrfarum naturarum corpoibus fit conflatus; quamobrem perfecta totius mundi tractatio habetur in tota philo[ophia natura]i, quum in hoclibro agatur de fimplicibus corporibus, in alio de mittis generaliter, in aliis vero de variis fpeciebus; fic enim cognitis partibus dicitur totus mundus effe cognitus, fed non totus fimul in aliquo libro ve vnum quoddam fubiectum cognofcendum. Preterea fecundum hancopinionem nullus eft conueniens tranfitus à libris Phyfica aufcultationis ad libros de Colo, neq; enim vt à prumis principiss ad mundum, fiquidë illa non funt mundi totıus principia; neque vt à cosporenaturali late ascepto ad mundum, quia numudus non eft fpeciesaliqua corpor is naturalis, fed omnium fipecierum congeries, ordo autem art ficiofus, quem propofuit Arift. in procemiofrimi Phificorum, eft vt ab vniuerfalibus ad particulara pregrediamur, \& à ycinere ad

A fpecies. Adfunt etian plusa Ariftot. teftimonı fententiam noftram comprobantia: nam in initio primi libri de Colo ineipit agere de corpore fimplicigeneraliter, deinde ad ipecies tranfit à colo incipiens, viantea diximus. In poftrema parte primi libri loquituritife de ternitaic mü di, dende in principio fecun di libri concludurs illam iam oftenam xternitatem, tribuit eam folicalefticorpori, quaficam demonftraffe de mindo, fuer it eam de coelefti corpore demon-

B ftralle, illudenim folum apud Arift. eft radix $x=$ terniatis, fiquidemideo reterns eft muidus, quia Colum eft xternum: quare de accidezibus nind agere in primo libro eft agere de Culo. quia illa omnia accidétia folam Coeli natıram confequunrur. Intio etian tertiilibrireceniens Anft.ca qux in duobus prioribus libris traetata crant, non dicit fe egife de Mundo, fed de folo coletticorfore, quod vocit rimum elemen. tum. Sic in initio x. Metcor. commemerans ta C qux in pracedenibus libris tractancrat, non di. cit fe in libris de Colo egiffe de Mundo, nec vila proríus mundi mentionefacit, fed dicirdecoleftibus corporibus, \& de quatuor elenentis actumefle in his libris; nec vilum apud Arif́tot. comperiemus locum, n quo afierat, fe in libris de Calo egitre de mundo.

\section{Quinodo vere dicipoßit, fubiedum inli- bris de Cuelo effe Mundum.} C.p.X.XVI.

CEdmemorate fententix a fitas clariorredSdeur, fideclaraurinus, quomodóadrestum fenfum opinio de mundo redigi poilit, huius enim comparaticne error allortm gata. lium fenfum acceperunt, manieitiffimus erit. Mundum húnc corforeum duobus modis fumi philofophi omnes concedere videntur, quum enim nomen mundi fignificet'quoddam perfiE ctum \& abiclutum, duplex in eo perfectio notar1 poreft, vna molis leu quantitatis, altera qualitatis feu formæ;1lam vocarent Latini noftri extenfuam, hançintenfuam : rationc quidem quantitatis \& extenfionis perficitur, \& abfoluitur mundūs à quinq; fimplicibus corporibus, à miftis enim non integratur mundi moles quatenus mifta funt, fed quatynus conftant ex fimplicibus tanquam ex mareria; quare enami mulla efrent mifta, perfequs tamen hacratione F müdus diceretur, exomni enim conftaret cuitutate, \&omnem locum adimpleret; ideo A ritt. dixit mifta non alium habẹre locum, quam illum qui eis connenitratione elemenți praralét1s in miftione fingulorun ; rarione aut $\mathrm{m}$ forma \& perfectionis fecundum interfionem acceptæ, mundus non ì folis fimplicibus, corforibus dicutur perfectus, fed etiä i miftis ommibus, nam prxter elemêta adięetx funt mirtis proprix fingulori formx, in quibus omuibus, carumque pliciter. $-$ 
ordine ita ef mundiperfectio conltitula, vt vina fublatadefineret mundus elle forectus \& ornatus. Ad molis igitur mundi integritatem fola fimpliciapertinent, ad ornatum vero \& ad abfolntam perfectionem etram mifta. Inter omacs autem qui mundim efle horum librorum fubiectum dicunt, hoc comtenit, quod mundus confideratur hic vt ex folis fimplicibus cöftansy non vt ex miftis; attanin fi poft libros l'tyficxe aufcultationis prius offerebatur nobis totum cognofccndum quam partes, à toto ordiendım erat azcepto potius fecundo modo quam primo, ficut antea confiderabamus.- Primo autem modo acceptus mundus nil aliud retera eit, nifi quinquefimplicia corpora fic ordina:a, vt graue fubiftet leui, \& grauitus minus graui $\&$ id, qnod nec grauenecleue eft, alia omnia intra fe contineat \& complectatur : itaque de quinque fimpliciun corporum naturis loqu, per quas fingulaproprios, \& ita, vt prædiximus, inter fe difpofitos occipantlocos, eft de mundo loqui, quum nilaliud fit mundus, niliilla fic ord nata.

AievanQuamobrem fi ita intellexit Alexander fibieEum effe mundum, vtfubiectum fintipla fintplicia corpora, quorum congeries eft mundus, vera eft eius fenientia idque videntur ipfius verba à Simplicio relata fignificare, quando dixit conflium Ariłtot. effe agere de mundo \& fimplicubus corporibus, vt coniunciua pro declaratiua fumatur, \& fenfus verborum fit, fcopus cit mundus, hoc eft, fimplicia corpora, ex quibus conftat mundus : hæc enim etiam Aucrois opinio fuit, qui quumaliquando dixerit fubieEtum horum librorum effe mundum, ve legimus inprincipio fux paraphraleos, \& in poftremo Commentarii tertii librisnon ob id dixit (quod multidicunt) fimplicia corpora non vt fubiectum tractari, fed vt principia mundi, hoc enim nil poteft ineptius, nil falfitis excogitari, quandoquidem prius oportuiffet Arift. defimplicibus corporibus agere quam demundo, fi illa vt mundi principia confiderarentur i quonian cuiusq;rei cognitio ex principion ituorum cognitione acquiritur, nec poteft res, iis ignoratis bene cognofci ipfi tamen dicunt, agi prius de mundo, quam de fim licibus corporibus, quodfecundum eorum fententiam eft omuino abfonum rationi : at putaut fiucroes fimplicia corpora confiderarivt fubie ¿tum librí,nō vt pruncipia fubiecti, vapertifime apud eum legimus in prima Comment ario libri tertii de Cœlo, vbi primum inquit confilium Arift. effe agere de partibus mundi fimplicibus, nee ob id intelligit fimplicia corpora confiderari yt principia tmundi: nam poftea feipfum declarans inquit demonftrar i ip forum accidentia per f caufas, fubiefum autem eft illud, de qua accidentia per fuas caufas demonftrantur, ea igitur corpora vult ibi habere locum fubient. Le. ginus etiam ibidem agud Auerro eno yerba has

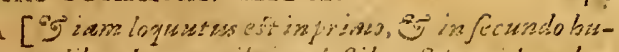

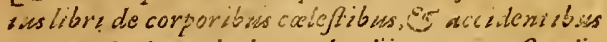
corum; Gult modo dicere de alics givar inor fimplocibus, qua rect a mouentur ] fic enim dicit, accidentia coleftis corporis tractata fuille in prim \& fecundolib.de Colo: quarcnonputauit primumlibrim ita effede accidentibus mundi,vt non fit de accidentibus Cocli. Denumautem in calce ciusdem conmentarii fententiam fuam clariffme profert, \& aliorum errorem patefacit

B Auerroes, dum difinguit confiderationem elementorum, qux habeturin libris dé Generatione, ab ca qua habetur in libris de Coelo, his verbis: [in libro de Generatione non confiderat elementa,nifipropter confederationem miftorum generabilium Es corruptibilium; bic autem confideratea in quantüfunt partes mundi, bic igitur c'afiderat ea in quare um funt fubsectum, ibi vero sn gieantumfunt principia.] Itaq; apud Aucroem confiderare elementa vt partes mundi, non eft

C. caconfiderare vt pruncipia fubiecti, fed eft ea confiderare vt fubiectum libri, fiquidem parte; integrantes non diftinguuntur reà to to, fed funt idem quod illud; quare confiderare mundum vt conftantem ex fimplicibus corporibus, \& con iderare fimplicia corpora ve funt partes mundi, idem est : proinde fubiectum dicere mundun, idem eft ac dicere fimplicia corpora effe fubiectum:eaque Auerrois opinio fuit, quiin eodem dizto Commentario tum dixit elementa in libris de Colo confiderari vtpartes mindi, tum etiam dixit confiderari quatenus funt fimplia.

\section{Quod melius fit dicere fubiect um corpus fimplex, quam Mundum. - Cap.XVII.}

TON eft autem ignorandum, quod vnum 1 nomine mundi, \& nomine fimplicis corporis idem horum librorum flibiectum denotetur, attamen longe melius, \& artificiofus loquimur dicentes corpusfimplex, quam dicentés mundum. quia licet eandem vtroque modo rem confideratam exprimamus, non æque tamen modum confiderandi exprimimus, qui eit quatenus fimplex, non quatenus mundus: quod oftendo, fumens ab hoc dubio occafio $=D$ witum. nem, quod quum egapluribus eruditis virisiam obrulerim, neminemreperir, quiidbenefolnerit: dubium tale eft: Sentcntia nunc eit pluF rium philofophantium, quod tota fcientia naturalis fubieftum habeat adxquatum corpus naturale, quatenus nat urale eft; hicis aque confiderandimodus debet elle proprus icientix naturalis, \& illi adrquatus, ita vtnulla fit alia difiplina, in qua aliquid confideretur quatenus naturam liabens, nec vlla fit ferentia naturalis.pars, qux alia ratione confideret aliquid nifi vt naturale, feu naturam habens; quum igitux in libris de Colo agatur, feu de 
47 do, fu deColo, \& de Elementis, qui lminia tunt corporanaturalia, neceffe elt ea confidcrari hacfolaratione quatenus naturalia corporafunt; atqui efficax illatiofemper eft à quitenusipfum ad te omni; igitur quemadmodü fi homo quatenis aft aumal, ientit, necelfe eft vt omne animal fentiat; itafilla confideranturvt naturam habentia, necelfe eft ibidem conliderari ommianacuram habentia, proinde omnia naturalia corpora in libris de Coto fubic tum erunt, tum limplicia tum mifta; is hoc ảubium non minus in quolibęt alio libro Scicntix Naturalislocum habet, quam in libris dé Colo, caufa enim abourdit atis elie videtur, quía fic ponitur modus contideiandiamplor re confiderita, nam latius pater quatenus naturale, quam elementa, quam anmalia, quam itipes. ciuare dum dicimus aliquod horum confideraii vt naturale, in prædictum abfurdum incidinus, vt dicamus ibi confiderari omne naturale; quod fi dicamus confiderari non vi naturalc, fed alio modo, ea confideratio non pertinebit ad fcientiam naturalem, quia fub modo confiderandi fcientie naturalis non continebitur. Vera huivis dubii folutio meo quidam illlicio in hoc confiltit, quod quemad modim ses confidcrata communis primum eft, deinde ad varias fpccies coarctata, fic \& modus confidesustes sandi, hor enim omnino confitendum elt, fi modus confiderandi debetefie aqualis reiconfide:atx, vt antca dicebamus; quoniamigitur fubiectum in tota fcientia natuali vnum eft, corpus naturale; idque primo locotratandum proponiturvt commune genus, deinde ad vaias ipecies ordinatum coarctatur, nec obid plura funt fubiecta, fed vnum, fiquidem fpecies omuesin communi genere vnitatem recipiunt; modus quoq; confiderandi vnus eft totam fientiam amplectens, quatenus nasuram habens, ita tamen vt prius fumatur natura communiter, \& indiftinete in libris Phyfice aufultationis, deinde cuiufq; naturalis corporis propria natura, qux huius proprii motus ptincipium eft; confiderantur igitur in libris de Coclo fimplicia corpora, quatenus proprias habent naturas, quæ propriorun! fimplicium motum caula funt ; fimplicis autem motus caufa eft natura fimplex : eft itaque futicetum corpus fimplex vt naturam fimplicem habens, non vt abfolute. naturam habens, fic cnim requereturamplioremeffe modum confiderandi re confiderata, \& alia indeemanarent abfurda, quxin dubitatione tacta fuêre, qux omnia in quolibet libra naturali euitamus, dum naturam reftrictam fu. minus ad corpusillud naturale, quodin quo. quolibro dicarur confiderari, Sic ctiam fertiatur ille doctrinæ ordo, \& artiliciofus progreflus ab vniuerfalibus ad particularia, quem propo. fuit Ariftotcles in lrocenio primi Phyficorum à corporc naturali latiflume accepto ad lingulas
A cius fpecies, quatenusproprias fingulx habeit naturas, que propriorum motuum funt principia ; talis enim rcuera eftapud Ariftotelem con fideratio omnium corporum naturalium in totaphilofophia naturali. Hunc igitur artificiofum progreffum fertuamus, dum dicimus fubie. ctum in libris de Calo effe corpus fimplexquae tcnus fimplex, feu mundum quatenus eft ominium fimplicium corporum congeries, fic enim dicimus quatenus naturam habet fimplicem: Bon fic, fi dicanns fubiectum effe mundum, feu fimplicia corpora quatenus mundum conftituunt; muludus enim non ef fpecies corporis naturalis, fed cft potius omniü naturalium corporum ạggregatio, neq; vt mundus eft, habeta. liquam propriam naturam, vel proprium aliquem motum, fed folum habet propias naturas fingulorum corporum, \& proprios fingulorum motus: quarefitota feientia naturalis verfatur in corpore nalurali quatenus habet in fe C naturam, qux eftpincipium motus naturalis: non poicftia contiderare mundum vniucrium, vteius confideratio fit feitunda à confideraione fingulorum corporum è quibus mundusconftat. Simmaigitur hochit; nomine mundi fruificari poliefatemur rem in libris de Coloconfideram, fed mundum conlidcrandi omnino negamus nomine mundi figniticari polle. Adde Nomes quodappllatiomundiambigutare non caret, müdiest poieftenim nonmodoid, quodex fimplicibus aquino. corporibus conftat, ted ctiam id, quod omnia cum. proŕfus cos pora cótinct appellarimundus; $1 \mathrm{mo}$ \&ै rertun omni tam corporalium, quam ıncorporalum colleçtonem poffet quifpiam nomi1) mundintelligere; hæa atuem liçet vnü mundum contituant, nonita tamen vnum, vt fubvnam fcientiam cadere aptus fit. Quodigisur melius fit fubiection ftatuere corpus naturale fimplex, quam nundum,manifeftum eft.

\section{E Solutioargumentorum pro Alexandroad- ductorum. Cap. $X I I X$.}

$\mathrm{R}$ Eftat, vt quantum roboris habeant argumenta pro Alexandro addueta, videamis. Ad pirmum cx mifcriptione acceptum, pofumusbifariam refpondere; primum dicere poffumus, nihil effe abfurdi, ficolum in hac inferiptione pro folo quinto corpore accipiatur, non eit enim neceflarium, vt inferiptiones

F librorum femper fumantur ab omnibus rebus confideratis : quum folcant efle arbitiarix, \&e interdum etiam à nullius rei confiderate nomine fum comperiantur; ve Mctaphylica ficappellata, non eftà rc aliqua confidersta, fedab ordine doetrinxrefpecu fcientix naturalis; eadem etiam vocatur feicitia diunia, licet parna tantū cius pars fit de rebus durinis, fic cnimappellatur à folaprxcipua re contiderata qualis ê. fet êtinfriprio librorum de Coclo; fi Coclü pro. 
folo quinto corporeasciperetur: fic libri quoque Metcologyci inferibuntul abiis tantum, qure in fublimi fiust, non ab is, qux gignuntur interra, licet talia plura in eifdem libriscon. fiderentur. Secundo dicere pofinm fumi tiz ca inferiptione Coclun pro mutudo vniucrfo, idque fententix noftre minime refragari, quimm nos quoque afferamus tractari in his libris vniuerfum, hoceft ; fimplicia corpors, quoum collectio eft mundus vnucrfus; lic autem fumpta eflet inferiptio àre confiderata, at non a modo coníderandi, neque id abfurdum eft, quum aliqux inferiptiones ne ì re quidem confiderata fumptx apud illuftes auctores comperiantur, fed ab aliquo extrinco, vt predixi. mus, quocirca nil roboris habet argumentum adfecsn hoc. Adfecundum iam patetrefponfo exiis, disern. quxantedicta funt; dicumus enimprimum librum effe de Coclo, vtipfe Ariftoteles afferit in initio tertiı libri, \& in initio primi Metcorolog. nam accidentia Mund, qux in primo libro tractantur, primo competunt Cuelo, indeque ad vniuerfum-mundum redundant; ideo volens ca attribucre Ariftoteles mundo, vt fubiecto adxquato, cognouit nullum effe locum eis conuenientiorem, quam cum librum, in quo de cœlefti corpore agitur, ob id eo:um tractationem

Fide lib. aggreffus eft ftatim poft declaratam quinticorApol.c.2. poris naiuram, qua de re alio in loco vberius loquitifumus, quum noftram de doetrinæordine fent entiam abaliorum obirectationbus tueAder- ricoaAt fuimus. Terti argumenti folutio futirm. mitur ex verbis Simplicii, qui dicit Colum non Cus calü idco voceri elementum. quia lit materia mun. Socetur di, fed quia et fimplex, quam refponfionem veelemen - riflimam elfe demonitro; quum enim Ariftotetwm les in iis libris \& Coelum \& alia quatuor fimpliciacorpora elementa vocer, confiteri cogimürea omnia eadem ratione elementa appel, lari, itaque fi Ccelum refpectu mundi elementum dicitur, oportet etiam reliqua dici elementa refpeôtu mundi, hoctamen ita eft falfum,vt nihilfalfius, nam legentibus totum terium librum de Colo, partet ea nunquam vocari clementarefpectu mundi, fed femper refpectı miftorum, ipfa namquevocat Ariftoteles elementa corporum, \& in de finitione elementi, quam ibi tradit, hoc manifeftilfimum eft; igitur neque Cuelum dicitur elementum refpectu mundi, fedperillorum fimilitudinem, qum enim fint eiufdem ordinis quatenus fimplicia funt, \& conditio clementi fit vt fit fumplex, Coilum dicitur elementum quatenus eft fimplex ficutil-

tror ne la, qua vere funt elementa miftorum. 'Miror antium autem, quodalıquin gareaudeant necefiarram slemen- effe elementi conditionem ve fit fimplex, \& dirum de- cant requirifolum vt fit homogeneum, \& ex eo bere effe catera conftituantur, nam manifefte repugniant fim, iev. Ariftoteli, \& incidunt in fententian Anaragosxin contextu, 33. illius tertil libriab Ariftote!e
$\Lambda$ reprobanu, inquitenim non onene homorencum cifelementmin, vicancm, do os, fedid folum, quod in res fpecic dinerfas refoluinon pucR, caroautem relolutur in ignem. a quam, arem, \& téram, poindscaro non eftemen. tum: vult crogo A tiftotelesnon cife clementum. nili id, quodeft fimplex, idque ciam apertea ferit in cup.3.hb.5. Met.phyfic. vribividere clt. Confrmaturautem hec Simplicii, ac noftra refponfióteitunonio Ariftotelis in primo MetcoB rologic. cap. 3. \& 4. vbi Coslun finilitervocat primum elementum; ibı nainque cartum el non vocari Cuclum clcmentum refpefu m:mdi, qum in is libris non aliatatione confid:retur Coelum, nifivt ca afa coum, que in 1 fesriore mundofint; itaque non aliaratione dicitur elementmm, nuti quia cffimplex. Ad qual- $A d$ qu tum neganda eft minor propofitio; a 1 proba- ium. tionem autem negamus mundum habese alia accidentia preter illa, qux propria funtalicaC ius fimplibis corporis nam llla qux in primolibro tractantur, naturam Cueli confequmntur: mundum vero habere principia negaadum omanoef, quanquam enum cx fimplicibus corporibus conitat tanquam expartibus ; 3 ex materia, taiis tamen materia non dicitur principium reı, nifi ei forma fuperueniat, quemadmodun membrisanimalis fuperuenitanima, quo fit vt partes animalis tum fint partes integrantes, tum efentiales, nempe materia, quix ab anjma fipcrueniente perficitur; talem autem formam nundus non habet; quarevanum eft id quod illi dicunt, fumplicia corpora vt mundi principia confiderari, quod ex eo quaque oftenditur, quod non tractantur antea accidentia mundi; yt traetanda effent, quia prius funt cognofeenda principia res, deinde accidentia coniequentia. Zuod vero dicunt, principra fimplicium corporum non confiderari in libris de $\mathrm{C}_{\mathrm{c}}$ 1o, falfum eft, licet enim Collum non habcat E principia, habet tamen propriam naturam, qua declaratur in primolibro,caque tractatio eftinftartrakationis' principionum Coli, non enim jia. aliain ob caufam quxruntur principia rei hahentis principia, nifivt eius natura \& effentia gुnofatur. Quatuorautem el ementa habent quidem principia, m.teriam \& formam, fed de materia nil dici poterat præter illa qux in primo Phyficorum dicta erant; deforma vero diAtum quidem eftinilloprimólibro, fed folım communiter \& generaliter, reftabat igitur dicendum de propriis elementorum formis iuxta promifum Arittot. in poftremo contextu illius prims libri Phyficor. idquefaciendum erat in libris de Colo,fed quoniam hr funt incognitx, \& nomine carent, Artitoteles accepit propristatesloco formarum, nejpe grauitatem \&leuitaten : quare negari non poteft formas elementorumin libris dc Calo confiderari: paet eitiul ibi deciarar, proprios cormm notus it

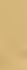

,

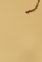

$x$
(n) 

rropras quetes, aliaque eorundem accidentia: A tim de mobiliad vi, hoc inaque fubiefum eft Lí grsiz munt. Adquintum negandum \& conféquens, rwise. \&evtrationegationis apparcat, retorque prius contra aducriatos argumentum ficspotefit confidurari mundus, vi côftans ex omnibus \& fimplicrbus, \& miftis corporibus, qua ratione propric dicitur mundus \& perfectus $\&$ ornatus, ergonifi in aliquo libro f́cientiznaturalis ita conideretur mundus:philofophia naturalis manca \& diminuta erit. Si hoc argumentum non eft eficax, argumentum quoque aduerfarorum nihil haber eficacitatis; ratio autem eft, qusa mundus non eft ita vnum quid, quod feorfum âartibus fuis cognofci debucrut vel potuerit; fed cognitio partium eft cognitio mundi; dum igitur cognof́cimus omnia fimplicia corrora, ciamfi nullam totius tractationem faciamus, cognofcumus mundum; quia mundus eft fimpliciacorpora fic ordinata : fic etiam dum cognoicumus ommia naturalia corpora \& fimplicia \& milta, cognoficimus m:undum altero modo acceptum, proinde nulla alia requiritur múdi coníderatio prater confiderationem par-

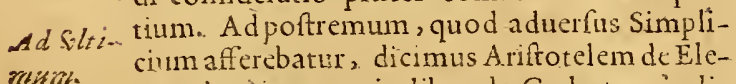
montis agere tum in libris de Coelo tum in libris de Gineratione \& interitu, cum hoc tamen difcrimine, quod in libro de Calo ea confiderat abfolute it corpora naturalia, in libris al:tem de Generatione ve principia miftorum. Quoniamigitux qualitates motiux competunt elementis vt funt natural ia corpora, absque vllo miftorum refpectu, alteratuz: autem eis datre funt yc fint principia miftorum, Ariftoteles harum q̨ualitatum tractationes feuunxit, \& motrices confiderauit in libris de Celo, quæ maxime videbanturidonex, vt pro elementorum formis fumerentur, quia per has formx elementorum edunt immediate proprios maturales motus ${ }_{2}$ qui eis competunt prout fuint corpo- $\mathrm{E}$ ra nattralias alteratiuarum autem confideratio fuit ricieta in libros de Generatione: qua de te. pofteafisfusloquemur.

\section{Alic aliorum fententia de fubiecto lifre- rum de.Calo. Cap.XIX.}

A LI \& quoque fuerunt aliorum fententixe de fubiecto horum librorun, quas non erit ab rebreuiter expendere, \& andefendi poffint, confiderare. I atiniomnes fubicctum ftatuffe videntur corpus mobile ad vbi , hác mots ratione; Libri Rhyficeantrcultationis fubiectum habucre mobileabfolnte acceptum, hoc autem. prima dinifione diniditur in mobilead v $b_{1}$, \& mobileadformam; quoniam igitur: motus ad locum eft onnium motum primus, rationi confonum fuit vt poft cognitionem corporis, fet catis mobilis abroluts fumpti, ageretur ftabanda maxume eft, quod putarunt Aritot.n libris Naturatibus ordinem ferualfe ab vnituerfalibus firbicctis ad particnlacia, az in libris Phyfi$c x$ aufcultationis egific de genere ipfo fubieeto, poftea vero in alis libris agere de fpeciebus. Sed quod de fubiecto horum librorum dixerunt, admittendüm non eft, nifi ad bonum fenfum trahatur, qui etriam videtur quibusdam $B$ ipfortm non fulfe incognitus, vt videre eft in quxftione Ioan. Magiftri, doctoris Parifienfis, Scotità non pipernendi. Vrgetur primum hac opinio hardificultate, quod corpustocomobilenon folius hbride Coelo, fed omnium librorum natıralium fubieĉum eft, fiquidem omne naiurale corpus tam fimplex quam mi. ftum, eft loco mobile quod fi generalıter accipiatur corpus loco mobile, videtur potius ad libros Phylicæa aúfcultationis pertinere cius cŏC. fideratio, quumid omnia proríus naturalia corpora fua amplitudine compleztatur. Hoc illi videntes adiecerunt fimplex, \& dixere corpus fimplex quatenus mobile ad vbi, effe fubiectum librorum de Crelo. Sed hoc dicentes in alias non minores angufuas inciderunt, modumenim confiderandi ampliorem fecetunt re confidera:a, quod nullo pato faciendum eft, fie enim fieret ve non folum fimplex, fed etiam miftum, ox omnenaturale corpus in libris de Ceelofubiectum effet, fienim quatenus loco mobilc; ergo onne loco mobile, vt etiam antea dicebamus. Sed hoc quoque illi animaduertentes diftinxcre mobile ad vbi, \& dixere feillud tantum intelligere, quod fimplici motufit mabile. Artamen nequeper hocomnem difficultatem fuitulerunt nammobilicas eft accidens corporis naturalis, i medio naturalidemonitraripoteft à priori, nam corpusinaturale elit mobile, \& loco mobile, quianaturam in fehabet, qua eft E principum motus; a cr corpus fimplex eft mobile motufimplici, quia naturam fimplicem ha. bet, non poteftigitur mobilitas fratui ratio formalis.fubiecti m fcicntia naturali, feu in aliqua etusparte,quin fubiectum po!fit in fcientia fua. demonftrariper caufam, demonftrabiturenim pars formalis departe materiali, quod quidern abfurdiffimume eit. Vt igitur hane quoquie difincultatem effugerent, tandem dixerunt ic non. fumere mobilitatem veafiectioné, fed lozo in F terni principii, à quo emanat iplapropenfio ad motum, principium autem eft naiura, dicunt itaque le per mobile intelligere naturale, fen naturam habens, \& per mobile motu fimplici naturale fimplex, feu!na:uram habens fimplicem, quze opinio noftraeft, lic enim fubiectum ftatumintcorpus. maturalefimplex quatenus naturam fimplicemlaben.s. Si qui vero fententiam illam non fic intelligunt, ii prædietis difficultatibus anco' quidemiudicio fic rrgentur, vt defenc.

\section{Ditia}

fentétie, imprión tio. io.

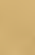

. 
defendinon pofint. Iamblicus autem \& Syria- .A ftantem, nullaidonearatioapparet, cur poft co-

Opinio Iamblici Es syria ni. Confuterio. nus dixcrunt, confilium Ariftotel. cfle agere de coelefti corpore, nonde elementis, de his enım agi in his libris fecundario, \& propter Corlum. Cux rententia præter illa, qux aduerfus camà Simplicioadducuntur, hoc quoque argumento falla efle cognofcitur, quod elcmenta hunt corfor a naturalia digna per fe cognitu à philoto phonatuali, non minus, quam Colum; quocirca non folum aliorum gratia tractand du funt à natuali fed etian propter fe. Quoniam igitur in liuris de generatione confiderantur vt piincipia miftorum, necperfedaibi ct corum confideratio, fiquidem particulætantumnodo elementorun, que fub gencrationem cadunt, ibi confiderantir, non integritatesupfonm ; delidembit in fientia naturalitractatio el ementorum abioluta \& inftituta propter ipfamct eleméira, talis enim nulla eft, niti illam dicamus quec habetur in duobus poiter ioribus de Cuelo libris. Quicontiahan iententam alia videre cupt, Simplecum legat; fiperwacancum enim eflic exiltimaui. omna que hole de re hic a Sirnplicio dicuntur, in mediumadductre. Defubreto igiturlibrorum de Colo, \& curin feientia naturali lecundum locum obtineant, hæc difta iunt.

\section{De fulięto, do de loco librorman ie Genera- tione o interitu, aliorun fententia, earuinque reprobatio. Cap.XX.}

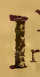
Nter omnes conftat, duos libros de Gene. Eratione \& interitu ftatim poft libros de Coelo collocari, proinde tertinm in hac fientia locum obtinere : ideo fr ratione duce inuenerimus, quidnam primum poft fimplicium corportm cognitionem nobis cognofsendum proponatuI , manifefum erit horum libronum fubiectum, \& prædictiordinis ratio. Multorum fententia firit, quodiubiectum horum librorumfit Generatio \& interitus, quum Ariftotel. in ipfo eorum libro um initio hunc tanquam fcopum fibi proponat, de Generatione \& interitu loqui. Hanc fententiam nos alibi reprobauimus, \& oftendimus, generationem \& interitum efle quidem fcopum \& intentionem Arift in his libris : at fubicetum dici non poffe, quum funt accidentia \& affectiones corporun naturalin m, \& in iifmet librisvt arrectiones in fubiezto inhrrentes tractentur ab Ariftot. quæraturque ibian fint, \& à priori per fuas caufas demonftrentur de fubiecto, quod quidem nullo pacto fieri poffet. fi ipf $x$ eorum librorum fubiectum effent. Sed neque ordinis horum librorum vlla ab his adduci recta rat io poteft, quirm enim ipfi dixerint, fubiectum librorum de Calo fuife mundum viuterfum, yt ex fimplicibus corporibus congnisionem mundi fequat tir ergnofecendis generatio: quod fi quam ipliaducunt, ea italeuis eft, vt uon pollit in illa animus acquicfcere; mundus cum \& limplicia corpora fibfantix funt, genesatn vero acedens: cur 1 gitmpotil larum fubtantiarum notitiam foquantio hrec accidentianofenda, generatio, intentus, alteratio, accietio \& imminutio, nec potius aliz fubftantisenaturales, nulla (vt milii videtur)af-

I3 ferifimatiopoter: \& huius erroris ea una catfa extitife videtur.quod fubięum fcien ix $\mathrm{a} \bar{b}$ affectionibus \& abinentione; feuconflio aucturisnunditiaxerunt, fed hrec omnia confundintes verum do atrine ordinem, \& al tificio- famlibrorum ltucturam cognofere nequiueront; hancigiturfententiam vealibi à nobisexplotam in preentia dimittamus. Latini, qui in lib. Phylicraufcultationis fubiectum effe dixere ens, icu corpus mobile generaliter acceptum,

C deintein libr. de Coloprimam eius fpeciem, quxe ct corpus mobile ad Vbi, probabilicem ordinislibrorum rationem adduxere dicentes, fubiefum lib. de Generatione effe corpus no. bile ad tor mam, feu (vteorum aliqui malunt) corpus tranfmufabile, quod tamen meo quidemiudicioidem lignilicat, pronde totailloruminter fe altercatio de hac re inaniseft. Etenim qui dixcrunt mobile ad formam, nomine form $x$ intellexerc terminum motusab folutum $D$ addiffcrëtıamrefpectui ;in decen auteṇ fum: mi generibus tria tantmm funt., qux habeant naturam abfolntam, fubltantia; quantitas, \& qualitas, reliqua omniarefpectivam, ideo tres tâtum mutationes dicuntur efle ad for mam, gencratio, accretio, alteratio, de quibusagitur in libr. de Generatione: motus autem localis non eitad formam, non eitenim proprie ad locum, fiquidem locus non eft quid inhærens locato, fed extra eft, quare locatumn non dicitur acquiE rerelocam, fed potiuslocationsm, feu (vt vocant.) Vbi: proinde recte vocaturà Latinis interpuetibus motus ad Vbi. Vbi autem fignificat refpectum quendam locati ad locun, quare non eft proprie forma; i iaque diftinguitur motusad Vbi a motuad formam, qui complectiturgenerationens, allctionem, \& alterationem, \& tractaturin libr. de Generatione; quumigitur hunc cundem fignificare voluerint alij dicentes transmutabile, non video in quo difF terant trantinutabile, \& mobile ad formam. Sententia hæc majorem, quamaitera prius reiceta, probabilitatem habet, \& propius âd veritatem accedit, nam hi corpus aliquod naturale fubrectum hortm librormm. ftaturunt, non affectionem, vt 1 lli; ratione quoque ordinis potiore vtuntur, nam ordine doctrinz confiderandum prius eft mobile generaliter acceptum, quam ejus fpecies, \& inter has prius mobile ad Vbi, quain mobile ad forman, quoniam

\section{Latina- risin ops. nio dis $\int$ ubieta libr.de Ginera-} tione. Quid fit mobile aifformasim. Triasüt predicanenta abjoluta.
Miltorit Precom 


\section{De fibiecto lib.de Gcheratione fententia propitiaseiafque declaratio. Cisp. XXI.} tereccdum ob rationem a nobis tactam fupeyius, quin de fubicito libro de Colo loqucremur, nam nobilitis ad formam eft accidens; quod per-cusiam naturalem demonfirari poteft, ficauten demonftraretur modus confideranki de re confiderata, quod eifet demonftrare fubicutum. Hitamen minišspeccant quam qui Aliorsm dicunt corpus generabile \& corruptibile fubie-prar Rum efic quatcnus generabile, \& comptibile, nam pratuquam quod ifti quoque generabilitatem, que eft accidens, modun confiderandi faciunt, in èum quoq; errorem labuntur, quod Confu- illun magis coareant, quam coaretandus efzatio. fet:dum enim corpus generabile fubiectum effe dicunt quatenus generation fubicitur, exciudunt alia omnia, qux in his libris confiderantur prestergenerationem \& interitum: neliusitaque alij dicebant; quatenus mobileadformam, ficenin modun confiderandianpliorem facientes, dicunt ipfum confiderarinon folum vt generationi \& interitui, fed etiam vtalterationi \& accretioni \& imminutioni \& miftioni firbijctur. Ob id tutius fortafe cft, nullum in finNotade modo có-gulis naturalibus libris modum confiderandi foderidia quxrere proter rem confideratam, quum id multis caufa erroris extiterit; fatis namque ef femelrationem confiderandi toti fcientixadxquatam inueniffe, qua eft quatenus habens naturam, dummodo fempernaturam intelligamus, vt antea in libro de Coelo annotauimus, nempe nö femperlate, \& indiftinse acceptam, fed ad illud corpus, quod in quoquo librotractatur, contractam, arque reltrictam. Quemadmodum enim in libris de Coelo fubiectum effe diximus corpus naturale fimplex quatenus naturam habens fimplicem, quæ eft principium proprij motus, aliorumque propriorum accidentium; ita $v$ bi fubiectum eflet animal, nullus effet aliıs quærenctus confiderandi módus, nifi vt habensnaturam, propriam felicet aninisalis quapropriorum motuum áx accidentium cau. fa eft. Sic igitur in quolibetlibro naturali quum primuminuenta eft res confiderata, hoc eft fub: icctum, quod materiale vocant, modus quo, que confiderandi inuentus eft , confideratur e. nim quxlibet fpecies corporis naturalis, quatenuspropriam babens naturam. Hoc admonerevolui, vtcommune preceptum eflet, quod \& in hoc, \& in alijs fequentibus libris obieruemus : fats enim eritin ingulis cognolcerefubiectum materiale, quod quidem in quoliber libro neceffe eft effe fpeciem aliquan corporis naturals: modus enum confiderandi idem femper rubandendus erit. Quod igitur ad fubrectum attinet libr. de Geneiatione, hac dealiorumfentcntijs dieta futcherant.
$\mathrm{V}$ $T$ ipfehac in re meam fententian proforama: cgo puto corpus naturale generationi \&' interirui obnoxium in his libris iubreên effe, ita tamen ve per hecrem folan confideratam fignificari intelligamus, non modurn confiderandi, hic enim temper fubaudiendus eft, $B$ quatinus propriam habct naturam; hoc quidemalij, qui hanc ipfam fententiam fequuti funt, non animaduertentes in magnas difficultates inciderunt; fed eas nos nullo negocio cuitamusill namque dum generabile \& compti. bilevt rarionem confiderandi fumunt, cxtera omna, quxin his libris tralantur, excludunt; nos autem per hxc fubiectum folum materiale denotantes, exprimeretanimuodo volumis, 'quam natualis corporis fieciem Ariftot. in his

C. lib.tractaturus fit, eandemqite fignificare poffemus dicendo corpus naturalealterabile, hoce nim cum corpore generabilireciprocatur; huic poftca xqua am confiderandi rationem adijcientes, quatenus propriam habet naturam, omnium, qux huịus corporis naturam infequantur, confiderationem amplectimur, nullumque cornm excludimus. Sed nondum propriam de fubiceto horum fibrorum fententiam protulimus, adhuc enim nō expreffimus, quidnam intelligamus percorpus generationi \& interitui obnoxium, quum 11 hoc ego ab aliorums opinione diffentian:referamigiturfutentiam meam, eanque quanta potero breuitate declarabo. Ante omna eft nobis hoc fundamen, tum iaciendum, quod quando dicimusrem aliquam xternam vel caducam effe, non refpicimus fpeciem, fed indiuiduum, nam fi fpecies fpectemus, omnes apud Anftotel. funtæternæ; proindenullares datur.qux fit vnquam interiE tura fecundum fpeciem:quoniam igitur rerumo alias dicerefolemuscadicas, \& mortales effe, alias vero perpetuas, certum eft 110 f femper indiuiduis folere tum aternitatem, tum interitumatribuere. Hocita conftituto, fi confiderare velimus, an naturalia corpora fint caduca, an eterna, tres corum gradusefle comperiemis, duos extremos, tertium medium : primus gradus eft coleftium corporum, quæapud Ariitot. xternapcintus funt tam fecundum fe tota F quam fecundum partes : alter eft miftorum corporum, quxíngula interitui obnoxia funt tam fecundum partes, quam fecundum fe tota : medum inter hæc locim elementa obtinenr, Elemët quafecundum partes quidem continuegune- gromodo rantur \& intereunt, at fecundum integritates fint ater fuasnec vnquam apud Arifot. fint genı, nec ned. vnquam interitura, proinde funt quatnor indiuidua seterna. Dedit autem náturaelemętišsas duas cötrarias códitiones propter duo muncra, quib'ss

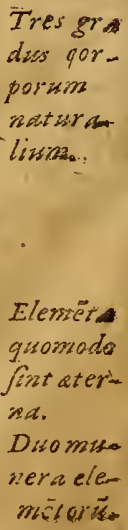


quibus ea in mundo fungi oportebat, tanquam Dusge própter duos fropos actines. ideoque dedit etnera qua jam eis duo genera qualitatum, tan ruam in ftruloutum menta, perqux duobus illis muneribus funge-lemen- rentur. Vnum munus fuit integrare hanc machicorwm. nam, qux vocatur mundus,primx nam que partes, è үuibus mundus conftat, funt quinçue fimplicia corpora, vt antea dicebamus;quod munus obeunt elementa fecuadum fetota, ignis enim totus fupremum locum implet, terra totum infin un, aer \& a qua medium; Colum vero hac omnia ambit, \& continet : huic priori muneri in feruiunt motrices quali ates, grauitas \& leuitas, quodilibet enion ipforum fuum locum occupat, vel ve graue, vel vt leue, vel vt nec giaue, necleue. Pact a utem elementa in huius muneris functione nuliam habere relationem ad mifta, fed abfolute exiftere ve corpora naturalia , etiamfi nullum miftum ex ipfis conftitueser ur. Alteruin munus eft vt fint materia corporis mifti, coque túrgunturnon am plitus iecundum ferotdfed fecundum particulas, tota namque commiferinon pollunt, led 1 ol $x$ particula commifceniur, \& contituurit mifum : propter hoc fecundum murss, quo elenenta répciunt miftuin vt ejus funcigia da um eft eis alterumgenus qualitutum, qua vocanturalreratıu $x$, quibus intcife agere \& pat1, \& mutart inuicem poffeit , liqudim exjlu, ibus, 1 sque contrariis naturis taunua ru ex nuateria non poterat vnum aliquod generari,nifillia \& alterari, \& generari, \& interire permutuam iater feactionera; \& palfionem apta crent, 3 icm atuo trangere, \& caitigarepolfent, \& in nztu:am vnam coalsicere: non func autem elementa apta iner fe agere, \& pati. niff per qualitaces alcerarrices, nimirum ve funt calida, frigıdd, huovida, \& lic ca. Sais autem per femanifetum eft tias qualiates ad prioris muneiv furetionem nibıl conducere, ficun neque ad poiterius ratunus conferunt qualitates motrices, modoenim ínt graua \& leuia, etiamfi fatwerentur, nec calica, nec frigida effe, nec humida, nec ficca, fatisioonea eícnt ad manendum quxque in locis fuis o \& ita mundum conftituendum. Sic etiam patetad elementorum miftionem non conterie grauitatem, \& leuitatem, quum fateri oporteat elementorum particulas in mifto non dittingui loco, fed qua a liber mifti particulam effe miltam. Ex his colligimus duas effe debuiffe in phrlofophia naturali diftinctas elementorum confideraziones ; vnam abfolutam, quam el ementa fecundum fe confideraren. tur vt corpora naturalia, fine vllo miftorum refpectu, eamque manifeftum eft Ariftotelem fe. ciffe, \& abfoluiffe in libris de Colo, vbielementa tanquam ipecies corporis naturalis habent locura fubiecti : al teram vero refpectiuam, pro. ut funtmate:iamiftorum, qua ratione tractan. rurab Arifto: ele in lib. de Generatione, proinde non vt fubiectuas, fed vt principia fubiecti, quat
A fuit Auerrois opinio in primo, \& vltimo Comment.3. lib. de Coelo, -Hæc fi vera funt, vtamur argumento Ariftotelis in princip. 12. Meraphyf. illud eft fubiectum, cuius principia confideranrur,atqui elementa in libris de Generatione tra- Subiectio ctantur veprincipia corporis mifti, ergo fubie- lib. de gcctum horum librolum eft corpus miftum: vide- neratio. turiué hoc mirifice confentaneum iis, qux an- ne est tea de librórum ordine diximus, quum enim corpus primo loco actum fit de corpore naturali late miftum. B accepto, idque prima partitione diuidatur in fimplex \& mifum, \& fimplexpracedat mifto, proinde fecuindoloco actum fit de corpore naturali fimplicin libris de Colo; fequividetur vt fratim tertio loco agatur de corpore naturali nifto in libris de Generatione \& interitu,vt mox in aliis libris naturalibus agendum maneat ordinatim defpeciebus mifti. Adde quod neceffarium omnino fuit de sinifto late accepto agere in aliquo libronaturali,idque manifeftum eft in nul-

C loalıo feri, nifi in libris de Generatione id fieri fatcamur, in quibus etiam videm us agi ex profeffo de mittione, \& degeneratione miftigeneraliter fumpti : de reifto igitur generaliter accepro, agit is libris de Generatione, de ipfius autem fpeciebus agetur poftea in fequencibus libris naturais bus, vt mox oftendemus.

\section{Difficultates contra predictam Senten- tiam, Ge earum folutio:}

$$
\text { Cap. } X X I I \text {. }
$$

CEN T E N T I A hacclarior \& manifeftior Siter, li difficultates, quibus maxime labefaEari videtur, de medro tollamus: videtur enim non folum miftum, fed potius corpus generabile, qu $¥$ delementorum, \& miftorum eft communegenus, fatuendum effe in his libris fub-

E iectum, idq; oftenditurprimum auctoritate $A$ riftot qui in initio z. lib. de Generatione propontt featurum de Generatsone \& interitu omnium, qua natura generantur \& intereunt; facit ergo fubiectum non miftum folum, fed omne corpus generationi \& interitui obnoxiusa. Prae secundü. terea illud eft fubiectum, cui primo compet unt affectiones, quarum declaratio eft fcopus au. Atoris in eolibro; at fcopus \& intentio Arift in iis duobus libris eft agere de Generatione \& in-

E teritu, \& de alteratione, vtipfe in eodem loco afferit, ha autem non primo competunt corporimifto, fed generiamplicri, corpori caduco: hocigitureft Iubiectum, non miftum folum: Tandem confirmatur, quoniam in fcientia pro Fertism cedendum elt à magis communibus ad minus. comumunia : at corpus caducum latius patet quam corpus miftum, \& eft genus vniuocum, de quom ulta dici poffunt; prius ergo agendum fuit de corpore cadus generaliter, quam de
Primum twini. argumen 
mifto; id tamen non fit vllo alio in loco, nifi di- A camus in libris de Generatione \& interitu. Huius difficultatis folutio mihi videtur in duobus, quaiam declarauimus, effe conftituta. Vnum tio mon eit, quod generatio non omnino competit eleomrino mentis, quoniam particulis tantum eorú com. competit petit, non ipfis totis; tota namque, vt diximus, elemétis. funt quatuor indiuidua, quæ fecundum quandam xquipollentiam feruantur xterna; quemadmodum etiam nauis dicitur eadem numero diutifime feruari, licet fxpe facta fit partinm B mutatio \& inftauratio, fiquidem nunquam tota fimul mutata eft, \& forma eadem manfit. AlGener - terum eft quod eo etiam modo, quo competit tio data elementis generatio \& interitus, competit eis eftele- proptermifta, quibus proprie \& pracipue commenis petit: quo fit vt primum fubiectum generatiopropter sis \& interitus primitate fcopi, \& intentionis mifta. nacura non fit nifi miftum; licet primum primitate adxquationis fit quiddam communius: poterat enim natura facere omnia fimplicia corporaxterna, fi nullum alium fcopum fibi propofuiffet, nifi ex is mundum conftituere, fed voluit ea fecundum partes effe mutabilia propter generationem miftorum, qua non poterant ex multiplici materia generari, nifi illa quoque generari \& interire poffet: quamobrem fi fcopum \& confilium natura fpectemus, dicere poffumus generationem \& interitum elementís comperere non proprie vt fubieto, fed potius vt principiis, \& ve materia generationis \& interitus corporum miftorum, quorum hec erat natura, vt generari, \& interire non poffent, niff proxima quoq; ipforum materia modoaliquo generationi \& interitui obnoxia fuiffet; propterea ipfa quoq; vocare poftumus fub. iectum primum generationis primitate originis. Hxc fuit abfque dubio Ariftorelis mens, qui in I. libro poftquam definitionem generationis \& interitus deciaraffet, \& mox de earum caufis aturus effet, fcopum \& confilium fuum in contextu 43. proponit his verbis: [Quonsam autem oportet primum de materia; $\mathcal{G}^{2}$ de bocatis elementis dicere ] etenim dictio [E] non eit coniunctiua, fed declaratiua, quia poitea nu]lamaliam materiam declaraturus erat, nifi materiam fecundam, qux funt quatuor el ementa ; de his ergo agendum proponit non tanquam de fubiecto generationis, fed tanquam de materia generationis; ipfa quoque elementorum tractatio, que infecundolibro habetur, eft eiufmodi: nam in initio fecundilibri quatuor primas qualitates vocat Ariftoteles principia ele-

Qualita-mentorum, quum tamen accidentia potius eletesfunt mentorum fint, \&alibi ab ipfomet Ariftotele princs- accidentia \& qualitates vosentur; fropterea pen ele- quod dum elementa abfolute confiderantur vt mento- naturalia corpora, ha funt reuera qualirates, rum. eorum formas nobis incognitas fequentes; at dum accipiuntur in fecundo munce, quo re- fpieiunt miftum, illæe eadem qualitates cuadunt formzelementorum, \& conftituunt rationem principii, quia funt rationes forpales, quibus elementa funt principia miftorum; neque abfurdum hoceft, \& notatur à Themiftio in 1 . Phyf.in fua magna digreffione, \& clarū per fe in omnibus rebus $\mathrm{eft}$ : quum enim homini quatenus eft homo, habere flium fit accidens, idq; feparabile; idemtamen eidem quatenus eft pater, effentiale eft; alia namq; $₫$ per fe conpetunt rei vt abfolute fumptr, alia eidem vt ad aliud relatz, Poftquamautem in eo fecundolibro docuit A. riftoc. quatuor primas qualitates effe formas elementorum vt refpicientium conftitutionem mifti, loquitur primum de generatione elementorum, poftea vero de generatione miftorum, $f$ gnificans generationem comperere primumelementis vt materix, fine cuius mutatione non compereret generatio mıftis, in primo etiam cōtextu eius fecundilibrirationem afferens, cur fit acturus de elementis, inquit, quia generatio \& interitus corporibus naturalibus ineft non fine elementis, aflerit ergofe de elementis afturum tanquam de materia generationis miforum; \& recte dicit [non fine] folet enim materia vocari caufa fine qua non. Hoc etiam legimus apud Ariftotelem in t. cap. urimi libri de Partibus Animalium, vbi dicit, [aer EG agua non n'ficorpoxi materiaest] particula namque elementorum vtinter fealteranturatq; mutantur, gratia miftorum funt, tanquam eorum materia quod etiam aperte protulitin 1. cap. fecundi eorundem librorum, vbi etiam dicit, quatuor primas qualitates effe materiam mifterum corporum, fcilicet quatenus in conftituenda proxima mifti matcria funguntur officio formz. Fuit praterea rationi confonum, vt quemadmodum $\mathrm{C} \propto-$ lum, \& elementa in libris de Colo fuerunt eodem modo confiderata vi corpora naturalia? quorum congeries dicitur mundus; ita in libris E de Generatione fimilis in eo fit ipforum omni. um confideratio, vt funt principiaaliorum:quoniam igitur manifefturin eft in fecundo libro de Generatione Coelum cônfideräri vi caufam generationis effeetricem, dicendum eft, elementa quoque vt materiam generationis conffderari. Sed fortaffe dabitur aliquando occafio hoc aperte demonftrandi, fi tantum vitz mihi Deus tribuerit,vt in libros Ariftotelis naturales (quod opto) poffim edere commentarios. Ad propoF fitas igitur obicctiones facile eft per ea, qua modo diximus, refpondere; ad primam enim quod Ariftoteles dicat initio primilibri, fe de omnium penitus, qux generantur \& intereunt, generatione \& interitu locuturum, id nobis non officit : cognnfcenda enim cft quxlibet res eo modo, quo reuera eft: quoniam igitur data eft elementis gerseratio a natura propter generacognofcenda eft, nempe vt competens \& elementis 
mentis \& miftis, fed elementis ve principiis materize, miftis vero ve fubsecto pracipuo in mente naturze wolientis generationem in rebus; neque enim negamus de omnium generatione in iis libris agi, quum pateat A riftotel. loqui \& de elementorum \& de miftorum generatione, fed dicimus agi de elementis vt de mate-

$2 d$ fecsn ria miftorum, qux Auerrois opinio fuit. $S_{i c}$ ad dswr. fecundam, quxelat, cui primo competunt affectiones, id fubiectum eft, dicimus generationem \& interitum, \& alterationem competere corporimifto vt fubiecto pracipuo, elementis autem vt matcrix mifti, quo igitur modo ineft rebusgeneratio, eodem cunfideraturab $A$ iftotel. in his libris. Sic etiam ad tertiam refpondemus, non efleabfurdum, neq; inufitarum, quod in codem libro \& de genere \& de fpecie agatur, de motu enim locali late accepto nonagitur nifin libris Phyficz aufcultationis, fiquidem is communiter co:npecitomnibus corporibus naturalibus, in iisdem tamen libris de eius quoque genere motu agi manifeftum eft: ficin libris de Coloagitur \& de fimplici corpore communiter, \& defpeciebus eius omnibus, ac de frngulis fepararim : fic in libris de Anima tum de anima generaliter, tum de fi: gulis animz partibus. In libris igitur de generatione dicimusagi \& de caduco corpore generaliter, \& de mifto generaliter, quia nullus eft alius liber naturalis, in quo vel de hos vel de illo agatur; fed hoc eo modo quem declarauimus, intelligendum eft, vt generatio ita in rebus ineffe cognof catur, vtreuera ineft, mifto vt rubiecto pracipuo, elements vt principiis, corpori autem caduco ví fubiecto adxquato, adeo vt definitio generationis, qux in primo lib.traditur, necelementorum propria fit, vt nonnulli dixerunt, nec miftorum, fed his omnibus communis, ita tamen ve pracipue in. telligatur eife miftorum, quibus proprie competit, elementis vero propter mifta, \& vt marerix miftorum.

\section{Ratio ordinis lib. de Colo, o lib. de Genera- tione, \& difficultatum Solutio.}

$$
\text { cap. } X X I 11 \text {. }
$$

$\mathrm{E}$ his qua hacenus dicta furt, triplex fu. Cmitur ratio ordinis horum librorum, vnde \& ipforum fubiect a facile difcernuntur : vna ett, quum in libris de Coelo actum fit de corpore naturali fimplici, fequitur vt in libris de Generatione agatur de mifto, fimplex enim \& natura \& cegnitionis ordine pracedit mifto. Altera ef, quum in libris de Calo astum fit de naturalibus corporibus zeternis, fequitur vt agatur de caducis, \& primo loco de ipfo caduco corpore generaliter acsepto, quod quidem fit in libris de Generatione, hoc autem quomodo fit intelligendum, iam dictum cot fuperius.
A Hoc non ignorauit loan. Grammaticus, qui in fua pretatione in libr. de Generatione inquie, elementa in lib. de Coelo fuiffe confideratave terna, in libr. autem de Generatione confiderari vt generationi \& interitui obnoxia; non funt autem xterna, nifi fecundum fe tota; nec funt caduca, nifiratione partium : innuit ergoconfiderata effe fimplicia corpora in libris de $\mathrm{C} \propto$ lo, quatenus fecundum fe fumpta mundum complent, in libtis autem de Generatione qua$B$ tenus corum particula in miftionem veniunt. Tertia ratio eft, quando eadem res cognofcen- Tertis da eft tum abfolute, tum refpectu aliorum, co- ratsso. gnitio abfoluta debct pracedere refpectiuam: quoniam igitur colum \& elementa erant co. gnofcenda tum vt naturalia corpora abfolute, tuin vt aliorum corporum principia, recte fecit A riftotel. qui in libro de Coelo ea confiderauit vt corpora naturalia, in libr. autem de Generatione vt principia generationis miftorum. Sed

C aduerfus hac aliquze difficultates exoriuntur, quas foluere nos oportet : primum quidem dubitare ali quis poffet non iniuria de ordine qualitatum elementarium; alteratrices enim funt natura priores morricibus, vt inquit Ariftosel. in 1. cap.. fecundi libri de Partibus Animalium, deriuantur enim \& entanant grauitas \& leuitas à caliditate, frigidirate, humiditate, ficcirate, quix ob id folx appellari folent primx qualitates; prius igitur debuit Ariftotel. de alteratrici$D$ bus agere, quam de motricibus; cur itaque contrarium ordinen feruauit? Ad hoc dicere poffe- Soluts se mus, librorum ordinationem non ab accidentibus fum endam effe, fed à fubiectis : quoniam igitur elementa fuere prius confideranda vt naruralia corpora abfolute, deinde vt principia miftorum, \& ad confiderationem abfolutam maximepertinent qualitates motrices;alteri autem refpectiua congruit confideratio alteratricium :ideo Ariftot. coactus eft præponere moE trices, prafertim quia ordo dostrina non fumitur neceflario ex ip fo ordine rerum naturali, fed ex noftra meliore, aut faciliore cognitione, Sed praterea dicimus fubitantiales elementorum formas, quibus elementa conftituuntur, \& fune corpora naturalia, priores effe natura omnibus qualitatibus : quoniam igitur grauitas \& leuitas in libris de Ccelo fumuntur loco formarum latentium, earun confideratio debuit præcedere confiderationem qualitatum altera-

F tricium; reuera enim grauitas \& leuitas in libris de Colo famuntur vt illorum corporum formz conuenientius, quam alteratrices qualitates, quandoqnidem forma elementorum mobis incognita edunt naturales motus \& quie Oynsos. tes permedias has aptitudines, qua dicuntur do ommes grauitas \& leuitas, nonper primas alteratrices quaizita. qualitates. Quamobrem qualitates motrices tes fint tum vt comperentes elementis fecundum an forma el run cöfiderationem abfolutam, tum yt accepra mientors 
proformis elementorum, priores natura funt $\mathbf{A}$ qualitatibus alteratricibus, qu $x$ nunquam fumuntur veforma elementorum, hoceft, loco formarum fubstantialium latentium : fed funt ipremetelementorum form $x$, non quidem for$m z$ tales, quibus elementa vt naturalia corpora conftituantur in fpecie, fedrationes formales, quibus elementa conftituuntur in effe refpectiuo, \& funt principia miftorum; quocirca horum

Dubium. confideratio omnino debuit efle pofterior. Aliud praterea dubium oritur, quod multos traxit in varios errores: Arstoteles in tertio lib. de $\mathrm{C} \propto$ lo confiderat elementa prout elemèta funt, \& definit elementum, at qui nomen el ementirefpectiuum eft, notat enim relationem ad nifta, qux exelementis conftat; ergo elementorum confideratio ibi non eft abfoluta, vt nos diximus, fed refpectiua: praterea in eodem libro oftendit elementa effegenerabilia \& corruptibi.

So'kt10. lia, ergo non ea confiderat vtaterna. Sicio equidem, multa abaliis dici in conferenda \& corineEtenda tractatione degeneratione elementorum, quamibilegimus, cum ea, qux poftea habeturinfecundolib. de Generatione; verum ipleomiffis aliorum fententiis, \& ab Ariftotel. fcopo in his libris, quem declaraui, non rece. dens, opinionem meam breuiter exponam \& declarabo: puto enim ita efle diftin ctas has duas trakationes, vt neque vna cum altera coniungi, neque dici cius perfectio, feu complementum poffit; carum autem difcrimen in hoc viAliud detur elfe conftitutum, quod aliud elt generaest gene- bilitas \& corruptibilitas elementorum, alitid eft
rabilatas ipforum gencratio \& corruptio actualis : genealiudest rabiliaquidem \& corruptibilia effedementafegenerabio. cundirn partes docuit Ariftotel. intertio lib. de colo, de ip forum autem generatione \& inreritu non egitnuli in fecundo de generatione, fed hor dicere nitil eft, nifi \& huius difcriminis \& $v$ triufque confilij Arifotel. rationem intelliga. mus, qua in hoc confiftit, quod in qua fciencia fubicatum aliquod confiderandum thatuitur, in ea neceffe eft omnia qua illi fubiecto per fe competunt, confiderare \& cognofcere, fecus enim imperfecta cst eius fubiecti cognitio; quoniam igiturperfe competit elementis effe generabila \& corruptibilia fecundum partes, neceffarium fuit vt in eolibrin quo elementa locum habent fubiefti, hoc quoque attributum, feu hac corum proprietas nof ceretur, idque notatur expreffe ab Auerroe in primo Comment. 5o libride Ccalo; idcirco toti elemento tribuitur ab Ariftotel.in 3. libr. de Colovefit generabile \& corruptibile, eft enim totius elementi aptitudo a proprietas, non poteft tamen ad actum duci in toto elemento, fed in partibus fingulis, eft igitur generabilitas elementi totus, generatio vero non totius, fed partum; illam conliderauit Ariftotel. in 3 libr. de Colo, hane vero in fecundo de generatione, haceniman non eft elementorum proprietas, ficuti neque hominis rifus, fed rifibilitas. - Ob id ego quidem non recte dicià multis cenfeo, quod A riftotel. Multor fermonem de generatione elementorum ince- érror. perit in 3 . librode Coelo, compleuerit autem in fecundo de generatione; quodenin in 3. libr.de Colo non agatur de generaticne, hinc cognofserenanifeite poflumus, quod alicuius accidentis tractarionem necelfe eit in his duobus confiftere, in cognofcendacius definitione, qua B fignificatio nominis \& ipla accidentis effentia declaretur; \& in cognof cendis eiufdem caufis, qua funt perfectio or complementum definitionis; atq̨ui definitio generationis latiflime fumpra non traditur ab Arittetel. nifi in primo libr. de Ortu \& interitu, arque ibi tanquam in proprio loco declaratur, elt que definitio nomi. nalis, fiue effentialis, quia caufas generationis non continet, nam eas poftea declarat Ariftot. in fecundo libro; qu um igitur in 3. libr. de Co-

C lo neque caula generationis, neque detinitio cognof catur, non video quomodo dicere aliquis porfit, agi in eo librode Generationcelementorum : agitur ergo ibi de plou um tantum. modogenerabilitate, cuius caufa nota iam eft in primolibro Phyfic.alia enim eft caufa cur cleméta fint generabılia \& corruptib:lia, alia vero cur actu generentur \& intercant; omnia igitur, qua in eotertio libro dicuntur ab Ariftot. de el ementorum generatione, \& interstu, is muD tuainter fe mutatione, deaptitudine, non de actu intelligenda funt, ibi namque generabilia, \& corruptibilia, \& inter fe mutablia effe ele. menta cognofimus, fed quomodogenerentur, \& inuicem mutenear, imo \& quid generatio in ipfafit, ignoranus. Quodigitur atcinctadelementorum mutabilitatem, qua eft corum pro. prietas naturalis fatis ea funt, qux dicusturab Ariftot.in3.lib. de Colo, \& ca fecundum téperfecta tractatio eft ratinne confilii Ariftor. quod

E eratelenenta fecundun le vi naturalia corpora confiderare, nec ofus ctat eam tractausnem abfolui in fecundo degeneratione; nifi quatenus dicere etiam poflumus quemlibet librum naturalem efle periectionem, "\& complementum aliorum pracedentium, qua finc illócientia naturalis manca, \& impertecta effet, imperfecta quidemelfet animalium cognirio in libris de Partibus Animalium, nili poltea in libris de Anima de ipforum forma fermotieret; auamen perfecta eft fecundum re tracta tio de partibus inlibris de Partibus, pertecta ıtidem fecunduni fetractatio de forma in libris de Anima: fic imperfeeta eft cognitio corporis naturalis communis \& confule fumpti in libris Phyfica aufcultationis, nifi aliféquantur librinaiu. rales in quibus fingula $\mathrm{f}$ pecies Phyficicorporis declarintur. In his ergo abioluitur tractatio corpous naturalis incepta in libris Phyfica aufcultationis, nec per hoc tamen ftat, quin ille- 
rum librorum, \& aliorum fingulorum tractatio $A$ fecundum feperfecta fit ratione proprij conlilij, \& fcopi Arift.in fingulo libro. Hocquiden mihi videt úr fatis comprobari teftimonio Arift. in coipfoloco, vnde illi quoque pro fe argumentum fumpfere, nam in context.24. fecundilibri de Ortu \& interitu Arift. aggredi volens tractationem de elementorum generatione his verbis vtitui [quoniam determinatü est prius qusodfimplicibus corporsbus exfe inuice generatio, dicendum eft quis modus adinucem tran mutationis] ipfenim putarunt Arift. dicere fe profequi tunc velle id, quod in tertio libro de Colo imperfectum reliquerat; at tamen fignificat A rift. tractationem illam in tertio libro de Cœlo pro occafione, \& pro ratione loci fuiffe perfectam , \& dicens agendum effe de modo illius tranfmutatonis indicat fe in tertio de Coclo folam declaraffe elementorum mutabilitatem, non tamen modum ipfum quofit, hocenim eft actualem elementorum mutationem confiderare: propofuit quidem Arift. in context. 56 . tertij de Colo declarandum modum, quo mutanturinuicem clementa, ipfum tamen ibinon declarauit, nifi ruditer, confutans in hoc antiquorum fententias ; eum enim declararenon poterat, nificonfiderando actualem elementorum mutationem, quod quidem ad eum librum non pertinebat. Dicere tamen poffumus refpeetu fcientia vniuerf $x$, imo \& ipfius perfectx elementorum confiderationis, ea, qua in libris de Ortu \& in teritu traduntur de elementis, effe perfectionem illorum, quæ dicta erant in libris de Colo, proptereaquod perfecta elementorū cognitio vtramq; tractationen 1 poftulabat; vnam, qua cognofcerentur vt corpora naturalia, qux habetur in libris de Colo;alteram, qua nof cerentur vt principia miftorum, qua habeturin libris de Ortu, \& interitu, vtraquetamen tractatio in feipfa perfectionem, \& complementum habet; quocirca poteft etiam illorū opinio verum habere fenfum, quem nos non improbamus. Quod autem haEtenus de generatione elementorum diximus, hocidé de cæateris omnibus quæ in 3. lib. de CoNota. qualis fit lo tractantur, dicendum eft, vt omnis difficultas tracte- tollatur, quamuis enim ibi A riftot. corporailla tio tertii vocet elementa corporū, \&definia tel ementum, lib. de ca- qux vox notare ad mifta relatione videtur, non to. obid tamen vt elementa, \& vt principia niftorum tractantur, fed tota illa tractatio ad illorum finplicium corporum vt fubiecti cognitionem referenda eft: fiquidem propter ipforum elementorum cognitionem ea dicuntur, non proptermifta, vt hanc quoque illorum proprietatem nof camus, quod funt elementa miftorum corporum, fic enim patet omnia in iis libris diciab Ariftotel. addeclarandas naturas, \& proprictates elemęntorum, nam \& de numero iplo- rum loquitur, \& de figuris, docetque elementa nullam habere propriam figuram, fed apta effe figuram recipere ab alio, tandem que de motibus naturalibus, qui eis competunt vt funt grauia, \& leuia, qux omnia a perfectam elemen. torum cognitionem pértinent ea ratione, qua funt corpora naturalia per fe cognofenda a philofopho naturali. Hoc antem, quod de tractationibus elementorum diximus, clarius fiet, fi aliarum quoque rerum exempla adhibea. mus. Motor aternus immobilis cognofcitur \& à Metaphyfico, \& phyfico, diuerfis tamen modis ; primus enim philofophus, quum Deum contempletur vt fubiectum perfe fcibile, debet omnia, quxilliattribuuntur, cognof cere, nempe qua in noftram notitiam venire potuerunt. in quorum numero eft quod xterne moueat, ideo fine huius cognitione manca fuiffet illa de diuinis mentib.tra tatio in prima philofophia. Phyficus veronon eum fcopum habet vt Deum velit cognofere, fed folum vult naturalia corpora, \& illa; qux eis competunt, contemplari, inter hæc eft motus xternus : vt igitur hanenaturalis corporis affectionem cognofceret, $\mathrm{CO} 2-$ Etus eft caufam eius indagare, quia fcire eft rem per caufam cognofcere, caufa autem nulla alia eft, nifi primus motor æternusimmobilis; eadem igiturprimi motoris conditio confideratur $V$ ide $f_{t}$ tum à primo philofopho vt proprietonferatur pracap. ditio fui fubiedi, \& eius cognitio pertinet ad perfectam cognitionem fubięt, etiamfinotet relationem ad effectum naturalem; tun à philofopho naturali vt conditio principi, à quo producitur æternus motus in corpore naturali, \& eius cognitio pertinet ad cognitionem hu. ius accidentis naturalis, Quas diftinctas tractationes optime fignificamus dicendo, Metaphyfici munus effe cognofcere fubftantias illas effe motores aternos; ad Phyficumautem pertinere eafdem confiderare vt motores aternos, E hoc enim Metaphyfico attribuere abfurdum effet ficut illud, philofopho naturali ; illud enim fignificatconfiderari vt fubieftum, hoc vero vtprincipium, Sic etiam fi quis quareret ad quam naturalis philofophiæ partem pertineat confiderare quod coleftia corpora fuo motis, \&lumine agant in hrc inferiora, dicere porfumus id pertinere ad duos diftinctos libros, ad librum de Cœlo, \& ad librum de generatione, fiue etiam fortaffe ad libros Meteor. di$F$ uerfis tamen fcopis; ad libr. quidera de Colo, quatenus ea eft proprietas corporis cœleftis, eitusque cognitio pertinet ad perfectam cognitionem coli, quodibifubiectum eft, ad aliosautem memoratos libros, quatenuspertinet ad cognitionem generationis, \& interitus, \& aliorum accidentium, qux à Colo producunturin hocmundo inferiore, ibi Colum prin- 
cipiilocum habet, non amplius fubiecti.Sic igitur dicimus, cognoficere quatuor illa corpora elfe aliorum elcinenta, petinuit ad'libros de Colo, vbilocum habent fubiecti; at illa confiderare vt elementa, pertinuitad librum de generatione, vbi confiderantur vt principia miftorum. Quodvero cum Ioanne Grammatico diximus, agi in libris de Colo de corporibus naturalibus zternis, fano modo intelligendum eft: non enim dicimustractari ibi elementa vt aterna, ita vt hace fit ratio confiderandi elementa in iis libris, huic enim repugnat Art ftoteles, docens ea effe geñerabilia \& corruptibilia; fed dicimus elementa, qux in libris de Cœlo confiderantur, effe indiuidua aterna, quoniam ibi fecundum fetotaronfiderantur; quamuis enim ibi Ariftot. oftendat effe generabilia, \& corru. ptrbilia, hac tamen generabilitas ad actum non ducitur., nifi in partibus fingulis : quare per hoc non ftat, quin fingulum elementum totum fit xernum. Quodigiturattinet ad libros de Or tu, \& interitu, hæc diata fint; poffenus etiam corum diuifionem in partes, \& artificiofam ftruturam confiderare, fed quiz in prafentia vniuerfalem tantummodo huius fcientix fabricam declarare ftatuimus, particularem finguiorum librorum diuifionem \& methodum ad commentarios, quos aliquando edere in animo eft, remittendam efle cenfemus: interim fatis erit, fifaltem voce in publici munerisfunAtone hanc auditoribus noftris operam praftiterimus; nuncad Meteorologicos libros accedemus.

\section{Defubiecto, ćloco trium librorum Metro- rologicorum. Cap. $X X I V$.}

Q Vum Ariftoteles in initio lib. 1. Meteorologicorum quartum locum in feientia naruvalı iis Iıbris tribuerit, collocans eos ftatim poft duos de generatione, \& interitu;id nobis laborandum relinquitur, vt huius ordinis rationem inquiramus: defubiecto igitur horum librorum dicendum eft, \& ratione duce confiderandum, quidnam poft libros de Ortu, \& interitu primum nobis tractandum proponatur.
Gracoris -pixio.

Tria ge- agenteimprimuntur in elementis. Qux fentenmerac ac ria videtur hacinnitiratione; duo accidentium cidentiz genera in elementis confiderari poffunt fed vsneleme- no diuifo in duo, tria oriuntur: alia namq; funt xis. ipfis elementis naturalia, quia proprias eorum.
A quum ab externo agente in elementis iam exifienribus generentur, non fenper ipfis inharent, \& feparari pollunt: naturalia accidentia duplicia funt, alia nam q ; eis competunt ve furt corpora naturalia, vocanturque motrices qualitates, grauitas, \& leuitas; de quibus egit $A$ ri. ftoteles in libris de Cœlo : alia vero data funtelementis, vt polfint effe materiamiftorum, dicunturque alteratrices qualitates, qux fuerunt confideratæin libro de Ortu, \& interitu. Reftat

B igitur vt in libris Meteorologicis tertium genus accidentium trątetur,nempeilla, quxinteruntur elementis abagente externo: horum enim tractatio poiterior effe debuit tractationealiorum, qua naturalia el ementorum accidentia effe diximus, \& videtur ipfe quoque A riftoteles in 1 . \& 2. cap. primilibri hunc frbu fopum in is libris proponere, vt legentibuspatet. Ratio igituror'chis manifefta eft, \& curlibri Meteorologici ftatim fequanturlibros de Ortu, \& interitu. Alii vero lubięum horum librorum ftatuerunt miftum imperfectum, quorum fententiam egopotiorem effe puto: quanquam enim prædictam Græcorum opinionem non improbo, fiquidemilla ad hanc modo quodam redigitur, rectius tamen hi dicunt, quam illi, vt mox veritate cognita intelligemus. Eft ante omizia

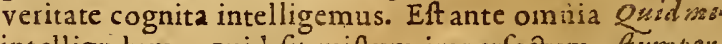
intellignidum, quid fit miftum imperfectum, frsmperidque clarum erit, fi cognofcatur quid fit mi- fectsem, ftum perfectum, fiquidem exaliquo huius per- E imper . fectronis defectumiftum imperfectum dici cer- fectums. tum eft. Miftum igitur perfectum dicitur, fi dux adfint conditiones, vna ad materiam attinens, altera ad formam; quod ad materiam artinet, debet ex omnibus conftare mifcibilibus; quod vero ad formam, debet effe facta vera eo. rum vnio, hoc eft, ex pluribus illis naturis natura vna, \& expluribusformis vna forma , fial tera conditio defit, imperfectam effe miftionem; \& imperfectum miftum neceffe eft, vtii E. quid non ex omnibus elementis conftet, fed ex pluribus, vel fi diftinct $x$ mifcibilium natura feruentur, nec prorfus in naturam vnam verfae fint : hanc autem imperfeftam miftionem infequitur durationis breuitas; nam ea, qux non perfecte funt mi fta, diu durare non poffunt; neque enim cometa plures menies durare aptus elfet, nifi en femper noua materia in fublime elata, quafi cōtinuum pabulum fuppeditaretur. Quomodo igitur hi libri fint de miftis imperF: fectis, facile intelligetur, fi breuiter, \& quantum prafens occafio poltulat, earum rerum, qux in iis tractantur, conditionem ac generations modum expofuerimus; de tribusautem tantummodo prioribus libris loquor, quartum enim poftea feorfum confiderabimus. Docet in initio eorum librorum Ariftotelesab aftrorum, potiffime autem Solis radiis calefacta ter?
Alionars opinsio. naturas infequuntur, proinde ab ipfis nequeunt feparari; alia vero non funt eis saturalia, fed 
r 2, \& aqua, duos ind e halitus generari, vnum ca- $A$ lidum, \& humidum, quem vocat vaporem, alterum calidum, \& ficcum, quem vocat exhalationem, feu fumidum halitum; quum enim proprium fit calidi rarefacere, partes aqua, rerumque madefactarum calcfact rarefiunt, \& in vaporem mutantur, quem medix effe naturæ inter aquam, \& aerem, ipfa nos experientia docet, quum in alterum duorum el ementorum facilime vertatur;nam ficalor in co perfeucret, nec ab aliquorefrigeretur, ita pergit rarefieri,vt fiat aer; fi vero quippiam frigidum, feu minus calidum offendat, à quo refrigeretur, denfatur, \& in guttas vertitur, fitque iterum aqua.Sic partes terræ calefaetx rarefiunt, \& in fumidam exhalationem vertuntur, qux eft medix naturæ inter terram, \& ignem; facilem enim in al teram duorum mutationem habet, nam \& facile accenditur crefcente calore, \& in ignem vertitur, nec enim aliud eft flamma, nifi hic fumus ardens; \& facile etiam in fuliginem terramque Duo ha- conuertitur, firefrigeretur. Duohi hảlitus funt bisus. materia eorum omnium, qux in tribus Meteorologicis libris ab A riftotele cöfiderant ur ; nam ex vapore in fublime elato, \& frigefcente generatur pluuia, ros, pruina, nix, grando, \& fi qua eiusgeneris alia funt; ex halitu autem ficco generantur venti, \& comet $x$, accenf $x$ trabes, ftellædifcurrentes, fulgura, fulmina, \& omnia, quæ in fublimi accenfa videmus : ex iifdem etiam halitibus in terra inclufis, nec erumpere valentibus fiüt fontes, flumina,terræ motus, lapides, \& metalla. \& fi qua alia funt huiufmodi. Videntur autem tum duo halitus prædicti, tum alia, qua exiis gignuntur, vocarı poffe mifta imperfecta, exceptis tamen illis omnibus, qux communi nomine folent appellari minera; hæc enim funt abfque dubio miftaperfecta, \& iprorum confideratio ad Meteorologicos libros non pertinet. Duo quidem halitus non ea ratione dicuntur mifta imperfecta, quod ex pluribus conftent elementis, fiquidem vterlibet ex vno tantum elemento genitus eft, fed quia duorum elementorum conditionibus participat, eft enim medium quoddam, quod oritur in tranfitu ex vno elemento ad alterum, fimplicem quidem habens naturam, \& formam vnam, fed qux diu feruarı nequeat, quin in alterum duorum, vel in aliquod aliud tranfeat; vapor enim humiditatem retinet aqueam, calorem autem aereum potius, quam igneum: quum enim in $F$ iis, qux diuidi poffunt, oport eat tranfitū prius per medium fieri, quam perueniatur ad extremum, calefaciens ignis aquanı generat prius caiorem mediocrem, qualis eft aereus calor, quam fummum, qui folius ignis eft proprius; neque eft vapor perfectum corpus, quod diu polit in fua natura confiftere, fed quiddam ge-
A nitum in medio tranfitu ex aqua in acrem, vel exaere inaquam; ideo nifi impediaturt tranfitus ex aqua in aerem, breui admodum tempore exiftit vapor, quia confeftim fiet $a e r$, ficq; in aeris denfatione fit vapor, \& illico, fiea mutatio absqimpedimentopergat, fitaqua. Hocidem dicimus de fumida exlsalatione, quæ generatur in tranfitu ex terra in ignem, manente ficcitate, fed frigore paulatim \& pergradus receder. te, \& adueniente calore; quare ficcitatem terre $B$ retinet, calorem autem adepta eft tantum, vt facto incremento poffit facilefieri ignis ; participat igitur duorum elementorum conditionibus, terræ \&ignis, nam aqua nihil habet, nihil etiant aeris, fiquidem propria maxime aeris eft humiditas; calor autem cum ficcitate coniunctus nó poteft aereus dici, fed potius ign :us; licet nondum fit ignis, quia forman ignis $n \rightarrow n-$ dum habet, ficuti nec formam terræ, fed mediam quandam, cum qua funtiun $2 x$ conditio:

C nesterræ, \& ignis, ratione quarum dicitur miftum quoddam effe, imperfectum tamen, quia duorum tantummodo elementorum conditicnesprafe ferens, \&ygenitum in tranfitu ex vno el en ento in alterum, nec nifi breuiffimo tẹmpore permanens. Qux vero exhis duobus halitibus gignuntur, funt quidemaliqua absque du. bio imperfecta mifta, vt omnia in fublimi ardentia, nam conftant ex igne, \& halitu terreo nondum confumpto, fic grando videturhabere conditiones terræ \& a qux; neq; facta eft in his vera miftio, qua eft naturæ vnio, fed potius congregatio mif́cibilium; tamen aliqua non videnturefremifta, vtpluuia, qux eft fimplex aqua, ficetiam fontes, \& Aumina; aliqua veromifta quidem, fed perfeeta, \& ea quidem diutifime permanentia, vt qux mineræappellantur, nifi w. traq; hac ea ratione velimus imperfecta mifta nominạre, quatenus ex halitibus, quos iam diximus effe mifta imperfecta, generari dicuntur.

Aliquitamenfuêre, qui negarunt dari aliquod miftum imperfeetum, quod non ex omnibus elementis conftet; nam \& in pluuia, \& in grandine, \& in aliis iam memoratis omnia elementa, omniumq; qualitatum commiftionem effe dixerunt; fic etiam in vtroq; ha!itu, fiquidem Ariftot.in 2. Meteorol. in cap. de Ventis, aperte di- Primuse cit, necficcum, nechumidum halitum ita ap-corsm pellari, quia fit fumme talis, fed ab exceffu; ne- arizum $\vec{s}$. que enim eft humidum fineficco, neque ficcum tusm. finehumido;fic etiam in 5.cap.primilib.inqúit, duorum halituum alterum effe magis vaporofum;alterū vero magis f pirituofum;vtitur enim diationem comparatiua, denotans effein vtroq; \& humidum \& ficcum, proinde \& calidũ \& frigidun, \& elementa omnia, licet vnusab exceffu secundio dicatur humidus, alter ab exceffu ficcus. Addüt argumëetiam rationem ad hoc comprobandum; nam $t u m$.

$$
C_{2} \text { vtrum- }
$$


vtrumque halitum calidü effe manifefium eft; $A$ non tamen fumme calidum: fic enim eflet ignis; at omnis remilfio tit per admiftionem contrarii, vt ait Ariftoteles in contex.19. quinti Phyficorum, igitur aliquid frigidi habet commiftum, fic nec fumme humidus alter eft, necalter fumme ficcus; funt ergo in vtroque omues. qualitates,proinde \& omnia elementa: quare non hacratione dicuntur imperfecta mifta, fed quod imperfeetam habent miftionen, nec diu

Impugra durant. Sedhorum fententia mihi non probatro. tur: \& caufam erroris elle puto, quod naturam \& effentiam rei ab exiftentianon diftinxerunt; prima materia non exiftit fine forma, tamen in fua effentia nullam formam habet: fic etiam non exiftit fortaffe elementum purum, vt multi exiftimant; \& vt dicendum maxime videtur: de duobus elenuentis mediis: per hoc tamen non ftat, quin poffint fingula elemēta in fua naturali puritate confideraris, vt ea confiderauit Ariftotelis in libris de Colo, \& $1 \mathrm{n}$ libris de Generatione; non enim ideo non datur pura, quia per fe exiftere, fi darentur, non polfint; exifterent enim non minus, quam commifta: fed quia impediunt fe mutuo, \& perturbat vnum. alterius puritasem, ob ecrum contaćum, actionemque mutuam, ac ob Coli motum ea. continue alterantem, a tque mutantem : quemadmodum igitur, licetpermifta fint elementa, \& appellentur fingula ab eo, quod maxime excedit, confiderantur tamen, \& cognofcuntur vt. habentia fuam naturalem puritatę;ita de duo. bus halitibus dicendum eft; non generatur enim ynus finealtero, tamen fi v trumque in puritate fux naturæ confideremus, al ter conditiones refert a qu $x$, \& aeris tantum, alter vero ter$r z_{3}$ \& ignis tantum: quod enim:vnusalterum femper hibeat commiftum, non eft quiaper fe exiftere vnus finealtero nequear, fed quia ob. terre, \&\& a qua commiftionem, \& propinquitatem non poteft Sol ficcum halitü educere, quin. educat \& humidum, neque hunc, quin edirat Adps- illum, Quanquam egoquidem huius fum opimum ay- nionis Ariftotelem hocafferentem nil aliud regumen- fDicere,nifiillud; quod frequentiffimument:ne-

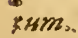
que enim negaffetcontingere poffe, vt alterius aliqua pars pura quandoque; \& cumaltero non commika extrahatur, quod videtur fenfiffe Vicomercatıs in interpretasione illius. cap. deVétis, in feciando libros dicens enim vix fieri poffe, vt puri extrahantur, difficultaten denotat, \& ra- ritatem, fed non impoffibilitatem. Prat ereat etiamfidicamus, non poffe vnum educi fine altero, non propterea fí, quin diftinet $x$ fint partes: vnius à partibusalterius.; ram contangune quidem fenutuo, \& apoofitzhrillis dicuntur, at fecundum fe fingul pur $x$ \& impermift $x$ funt idque folum fignificare voluit in pradictis locis:
Ariftoteles; quienim eleuatur vapor totus habet in le partes aliquas fumida exhalationis, ab exceffu tamen totus vocatur vapor; fic fumida tota exhalatio, qure attollitur, aliquas in fe habet vaporis parriculas, fed ab exceffu tota aupellatur fumida. Adrationem autem illorum $\perp d$ ecü. dicimus, non parum in le habere difficuliatis dum. id, quod illi fumunt, omnem remiffionens per admiftionem contrarii fieri, qua dere difputandi nobis fortaffe occafio dabitur in operibus. B naturalibus; fed efto nunc, vtilli volunt, dicin In lab. 2. mus tamen, nil inde contra nos fequii; ficcus e- de qualjnim halitus, dum in fua puritate accipitur, caio- tatibus rem fummum non habet, quia retinetaliquid elemenfrigoris terı è qua genitus eft, humiditatis ve- tartbus. ro nihil habet, quia fumme eft ficcus, quemadmodum \&ignis, \& terra fummam habentficcitatem, vtalio in loco oftendemus. Exipfius izitur qualitatibus nil aliud colligimus, nifi ip rum duorum elementorum conditionibus particiC pare, terra \& ignis: fic vapor calorem habct re. miffun, fimilenrq; cal ori aereo, qui mediocris eft, non fummum; aliquem enim gradum aquei frigoris retineat neceffe eft; humidus auten eft fumme, vt \& aqua, \& aer fummam habent humiditatem, in ipfa enim actione caloris folaris in aquam non labefactatur humiditasaqux, fed fola frigiditas; rarefitenim aqua, \& eius humiditas fir a ere cōtrarium humido, non eft eius proprius interD emptor, fed ipfum refoluit in humidũ tenuius; in vapore igitur nihil ineft ficci, quare non redolet nifia quæ \& aeris cōditiones; quod fi quid habeat ficci, non eft ratione proprize eius naturæe fedratione halitus ficci, qui cum eo commiftusattollitur, vt iam declarauimus. Sed redeamus vnde digreffi fumus, \& videamus, quod: nam fit mifum imperfecturn, quod in his lib ris fubiectum diximus effe ftatuendum. Duas hac in repoffumus proferrefententias : primum diE. cere polfumus, vtrumque halitun effe fubiectum, cui omnes conditiones competunt ; habet enim materiam, ex quagignitur, elementa ipra; habet effectricem caufam, calorem coleftem, qux in his libris confiderantur, \& ex quibus declaratur eius generatio, ficuti in aliis librisnaturalibus declarantur ab Ariftotele aliarum rerum naturalium generationes \& generatim, \& fingillatim : haber præterea affectiones. \& accidentia quamplurima, qua in his libris demonftrantur ab Ariftotele per fuas caufas;alia namque omnia, quxex his duobus halitibus gignidicuntur, non funtnifi horum halituum accidentia, vt cometa eft accenfio fumida exhalationis craffioris; pluuia eft denfatio vaporis, \& in aquam conuerfio in fublimi loco; idem funt \& fontes, \& Aumina, fed in terra: concauitatibus; grando eft eilifdem vapo-

Quodna
miftum
imperfe-
dumfit
borune
leb. Jub-
jectum.
primao-
pinio.


ris in fublimi congelatio \& fic de aliis omni- $A$ bus. Quoniam igiturvterque halitus eft corpus naturale per fe exiftens, quod habet propria principia, propriaque accidentia quamplurima, eaque cognitu digniffima, non abfque ratione factum videatur, fi late fumptum halitum fubicatum in his libris ftatuamus, videturque huic fententix atteftari Ariltotel. qui in initıo primi libri in primo, \& fecundo cap. proponit dehis omnibus Meteorologicis rebus agendum tanquam de accidentibus, \& affectionibus, \& declarandum propter quas caufas fiant, fic enim intentionem potius, quam fubiectum horum librorum proponere videtur., Declarat etiam in quarto, \& quinto cap. horum duorum halituum naturam, tanquam fubiecti, dequo poltea funt accidentia demonftranda ; eaque dici etiam poterunt accidentia elementorum, quo. niam hi halitus funt veluti elementa mutationem aliquam pafra, \& parum recedunt ab elementorum maturis; vnde colligimus, rete à Gracis dici fcopum Ariftotel. efle agere de affectionibus elementorum ; ficuti prodicimus, quanquam hoc dicendo intentionem potius Ariftotel. exprimunt, quam librorum fubieetum, fi modo hanc fententiam fequamur. Secundo dicere poffumus, vtmultis placuit, hos duos halitus non effe nifi proximam materiam miftorum imperfectorum, ipfa autem mifta imperfecta effeilla, qua ex his generantur, vt cometx, aliaque accenfa in fublimi, pluuia, grando, \& alia omnia, quxex duplici halitu, $f-$ ue in fublimi, fiue intra terram fiunt; in quo fenfu dicere omnes videntur, fubiectum effe miftum inperfectum, eo argumento, vt videtur, ducti, quod hrec accidétia eiusmodi funt, vt formx officio fungantur, dentque iis rebus nomen, ac definitionem, atqueita conftituere talia naturalia corpora videantur; nam accenfum halitum vocamus cometam, feu trabem, feu fulgur, \& aquam in fublimi loco genitam vocamus mutato nomine pluuiam; è cauernis a utem terre manantem vocamus fontem, \& fic de reliquis. De his igitur agi videtur tan quam de corporibus naturalibus, de duplici autem halitu tanquam de proxima horum materia, vtante dicebamus. Hanc fententiam fi fequamur, dicere poffumus, Græcos fubiectum horum librorum fignificaffe, dicendoaffectiones elemetorum; tales enim effe videntur affectiones; qux fugantur munere formx, ita vt corpora ab illis $F$ conftituta poffint in his libris habere locum fubiecti. Non defuerunt etiam, quivtramque fententiam coniungentes, dixerint fubiectum effe miftum imperfectum, late acceprum, quod \& duos halitus, \& omnia ex iis geriita complectatur. Ego vero etfi duarum predictarum o. pinionum vtramlibet defendi poffe arbitror, priorem tamen tutiorem effeputo, \& verbis Ariftotel is accommotatiorem, vt duos halitus dicamus effe fubiętum horum librorum, \& $\mathrm{m}$ fta imperfecta, quorum accidentia funt reliqua omnia, quxe in hislibris confiderantur. Quod enim hi dici poflint mifta imperfecta, \& parum recedant ab elementi natura, iam dictumeft; de aliis autem pleríque non facile hoc oftendere poffumus: nam pluuia, \& fontes, \& flumina, quornodo fint mifta imperfecta, nonplane viB deo, quum pateat hxc omnia éffe aquam. Neque enim magni momenti eft id, quodaliqui dicunt, eam non cffe aquam puram, red miftum quodda $m$, in quo femper apparent terrcx partes genitze ex halitu ficco inclufo in vapore, ex quo orta eft plauia : nam fi hoc adnitteremus, non daretur in vniuerfo elementum aqux; $\mathrm{fi}_{1}$ quidem nulla fortaffe datur aqua, in quanon fit aliquid terræcommiftum, \& aliquid caloris ab aftris ingenitum; onanis a gitur aqua effer mic Atum imperfectum. Hoc tamen dicendum non $e f$, quia licetafferamus aquam puram non da. ri, non ob id negamus aquam el ementarem ; $\widehat{A}_{1}$ quidem apud Ariftotelem non dicitur miftum, feu perfectum, feu imperfectum, nifi in quo tantus fit receffus ab elementi puritate, vt abiecto nomine elementialiam appellationem furcipiat if ve cometam non rectel appellaremus ignem, quia multum haberterrei halitus nondum confumpti; necterram, quum in eofenfiD bilem infpiciamus ignem : a t vbi tantus eft $v$ nius elementi exceflus; vi omnem cum aliis comparationem fuperet, feruatur in eo nomen elementi, idque haberi ab omnibus folet vt elementum, licet commiftx cum eo aliqux aliorum el ementorum particula, vel qualitates purum omnino effe non finant. Ideo nemo eft, qui dicat pluuiam, \& fontes non effe aquarn; aqua enim reuera elt, \& ita nominanda, à $m z$ gno, \& incomparabiliexceffu; quod autem fiE mul appellatur pluuia, id non tit ob alıquam fubftantiz varietatem, fiquidem nullum difcrimen norunt homines pluuiz, \& aliarum aquarum; fed propter modum generationis; illam enim aquam, qux in fublimi genita exnube in terram cadat, vocant homines pluuiam, quumtamen eius fub ftantiam nil aliud eife putent, nifi meram aquam; nomen igitur aqua feruatur, nomenautem pluuix adicctum, refpicit potius originem, quamipram eius corporis naturam, potiusque denotat effe miftum imperfectum vaporem, ex quo eft genita, quam ipfammet pluuiam. Adde quod proprium fubiecti munus eft vt de ipfo accidentia demonitrentur; horum autem, quz vocantur ab aliis mifta imperfecta, non proponit Ariftotel.accidentia indaganda,fed ipforum vt accidētium caufas inquirendas, per quas demonftrentur propter quid. 
Pnfiumus tamen fortaffe har dngmataconcilia- A re dicendoresiftas Afeteorologicas, quæ communitervocari folent mifta imperfeeta, vt cometam, \& grandinem, fubiectum dici horum librorunı, quatenus his nominibus fignificantur duo illihalitus,vna cunaffetionibus; cometa enim eft halitus liccus accenfus, grando eft vapor in aquaın, \& glaciem mutatıs; quoniā enim duo halirus ita his accidentibus permutantur,vt nomen etiam mutent, ideo appellătur iis nominibus, quaipfis ab accidentibus imponuntur, quum propria ipforum halituum nomina non feruentur; hacigitur fubiectum horuns librorü. dicere, eft duos halitus dicere, quatenus his accidentibus fubiiciuntur. $\mathrm{H} z \mathrm{c}$ omnia, quæ dicere hacin re voluimus, quisque confideret, \&c eam, quaprobabilior vifa fuerit, fententiam accipiat.

\section{De ratione ordinis, ơ inforiptionis librorum Mereorologicorum. Cap. $X X V$.}

GXhis, qua hactenus de fubiecto horum liHbrotum diximus,rationem ordinis, atq;infcriptionis defumere polfum us: quum enum fubiectum habeant miftum inperfectum, clara eft ratio, cur ftatim poft duos de generatione locandifint, proinde quattum in hacferentia locum obtineant, q́uemadmodum fupra dicebamus. Qúum enim in libris de generationeafum fit de corporemifto latiffime accepto, poftea vero fuerit ad eius fpecies deféndendum, qua funt perfectum, \& imperfectum miftum, fi harum altera ad alteram facilius nofcendam prodeffe nobis potuifet, de illa primoloco agere Arifi. debuir-

fet, vt conuenientem ordinem doctrin $x$ feruaret,de quo nos alias plura feripímus; fed quia $n$ utrius fpeciei notitia a dalterius cognitionem aliquidconferebat, debuit Ariftordinem naturæ generantis feruare, \& prius agere de mifto imperfecto, quod quidem facit in tribus hislibris Meteorologicis, qui ftatim fequuntur duos de Ortu \& interitu. Adde quodaliquis etiam docrinz ordo, faciliorq; dosendi ratio hoc poftulauit ; de miftis enim perfectis funt cseteriomnes, qui mox fequentur, libri naturales, qui funt quam plutimi, quorum omnium continuara debuit elledifpofitio, neque hac imperfectorum tractationeinterrumpi. Voluit igitur Arift. prius de miftis imperfeetis fermonem, qui breuis futurus erat, ab? oluere, yt poltea in folis perfectis miftis, quaprolixam tractationem poftulabant, confiderandis verfaretur. Hxc eft conueuientifima librorum difpofitio quire fumitur à fubie£ro, vtpriusłagatur de miftogeneraliter in librode Ortu, \& interitu; poftea de prima eius fpecie, mifto inperfecto, in tribus Meteorologiais, deinde vero de penfeatis, vt loco fuo dicemus. Cum hastamen pracipua ordinandi ratso-
A neconiun ta eftetiam ratio fumpea abelementis, \& ratio fumpta ab accidentibus el cmentorum, quas alij refpexilfe videntur; prima namq; (elementorum tractatio ca efic debuit, quaeft in libris de Colo, vt funt corpora natural ia ; fecunda yero illa, qua babetur in libro de generatio. ne, quatenus funt principia omnium m:ftorum generaliter;poftrematandem illa, qux habecue intribus Meteorologicis, ve funt principia miftorum imperfectorum, hocelt, vrleuen muraB tionem palia fubeunt appellationem miltorum imperfectorum. Sicinter tractationes accidentium elementarium (vt ante dicebamus cum a- In snitia liis) tertia, \& poftrema hac effe debuit, qua eft cap.z\&. de illis affectionibus, quxab agente externo $1 !$ latze extrahunt elementa modo aliquo à pro:prianatura. Qurod vero ad infcriptionem atti- Infersnet, ea fumitur à loco rerum confideraiarumi ptio.

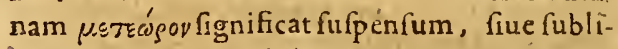
me, ideo tractatio de is, qua in Cublimi geneC rantur,vocata eft ab Ariftotel. Meteorologia. Si quis autem obiiciat, alıqua etiam in his tractari ex duobus halitibus genita, quænon in fublimi fed in cauernis terræ generantur, vt fontes, flumina, naria, terræmotus; ideoq; horum refpectu congruam eam infcriptionem non videri; direndum eft, fatis defendi huius in friptionis cógruitatem, fi à maiore faltēparte rerum con-solwrio. fideratarum fumptafit; maxima enim pars eorum,quæ exduobus halitibus fiunt, in fublimi D loco fiunt : arbitratia namque infcriptioneslibrorum effe folent : nec femper à tota re conifderata defumi, red quandoq; à parte præcipua, vt quando Metaphyficam vocamus fcientiam diunam:quandoque à parte maiore, vt quando fexpofteriores Iibros Pliyfic aufcultationis vocamus de motu; quandoq; etiam à nulla re confiderata, vtinfcriptio Metaphyficx, qux à doetrinæ ordine fumitur. Hac igitur Mcteorologicorum librorum infriptio fumpta eft à loco, in E quo fit maxima pars corum, quas ex duplici halitugenerantux.

\section{De fubiecto quarti lib. Metcorologicorum, pluresaliorum fententia, cum ipsarum. confutatione. Cap.XXVI.}

Q Vurn ca, quà no nobis hactenus dicka funt, ad tres tantum priores libros Meteorologicos pertinuerint, de quarto dicendum refat, quodnam habeat fubiectum, qua fit ratio infcriptionis, 2 quis fit eius locus inter libros narurales. Quod ad fupiestum attinet, cenfuir Defubie. Ioan. Grammaticus Ariftotel: in hoc libroagere ctoopmio velle de mineris, in quam fenteniam creden- $30 \%$. Gra dum eft 1 prum his argumentis induot um fuifte; matics, primo quia Arift. in yltimo capitc tertii lib. pausa dicit de mineris genesaliter, \& Jubinngit

Dubiums.

\author{
Solurio.
}


effe de cifdem dicendum etiam particulariter, \& fingillatins; hoc igitur exequitur ftatim in quarto libro; nullus enim alius eit liber Ariftotelis, in quo de mineris particulariter agatur, nifi hic quartus. Secundo, quia plura in hoc dicuntur de metallis, prafertim vero in contextu 48. fignificat igitur $A$ riftoteles hunc librum elfe de metallis, minerifque omnibus, qux intra terram ex duplici halitu fiunt. Tertio, Ariftoteles in poftremo capice husus libri proponit fe acturum de animalibus, \& plantis; nullum ergo fcripfit alium librum de nineris, nifi quartunı hune Metent logicum. Hæc fententia ab ipfamet huius librı uractatıone manifefte reprobatiur;ilId enim qux in hoc libro tractantur, aliis quoque competunt prater mineras; quare fubieetum effedebetaliquid communi us, fiue id fit corpus miftum perfectum, vt aliqui dixêre, fiue miftum perfectum homogeneum, vt alij; patet enim Ariftutelem in hoc libro non tantum mineralium exempla adducere, fed etiam aliorum miftorum homogeneorum, vt carnis, offis, nerui, quxanimantium partes funt; de mineris itaque agitur in hoe libro, non fecundum propriam rationem, \& prout funt lapides, \&e metalla; fed fecundum rationé communiorem, qua iunt miftaperfecta, vel mifta perfecta fimilaria. Eft etiam omnino rationi confonum, atque adeo neceffarium, ut quum miftum perfectum fimilare fit genus miner $x$, de quo multa dici, \& tradi poffunt, de ipfo prius fermo fiat, quam de minera, qua eft pecies, nullus tamen ante hunc quartum liber elt, in quo agatur de mifto perfecto fimilarishunc igitur de mifto potius fimilari effe dicendum eft, quam proprie de mineris Latinorum magna pars purârunt fubiectum huius libri effe nuftum perfectum vniuerfe fumptum, quod non folum mineras, fed etiam aliz omnia perfecta mifta, tam fimiları, quam diffimilaria complectatur. Et hac potiffimum ratione ducti effe omnes videntur, quod in libris de Ortu \& interitu actum eft fimpliciter de generatione, ac de generatione fimplicium; tranfeundum igitur erat ad dicendum de generatione miftorum, fed quum hre alia fint perfecta, alia imperfecta, \& imperfecta præcedant perfectis, ideo ftatim in tribus Meteorolog.actum eft de generatione miftorum imperfectorum; fequebatur igitur vt ftatim ageretur de mifto perfecto in vniuerfum; hoc igitur eft fubiectum in hoc quarto Meteorologico. Hre quoque fententia reprobanda videturjnam fi il. la omnia, qux in hoc libro tractantur, confideremus, proprie competunt miftis perfectis, fimilaribus, non diffimilaribus, nifi ratione fimilarium, qua eorum partes funt. Ip fe quoque Arifoteles fape in hoc libroafferit, fe de fimilaribus logui, prefertim yero in poftremo cap. ubi ait, fe de finilaribus dixiffe, \& proponit dicendum in fequentibus libris de diffimilaribus, qux funt animalia \& ftirpes. Preterea fi bene rem hanc perpendanus, de mifto perfecto vniuerfe fumptonil dici poterat, prater illa, qua in libris de generatione dieta funt communiter de omnimifto; illa namque etfi dicta de nifto generaliter, proprie tamen \&e perfecte competunt mifto perfecto, nec aliud dehoc communi dicendum relinquebatur. Alexander de huius liB bri fubiecto nil aliud dicit, nifi fcopum Arift.effe agere de actione, \& paffione quatuor primarum qualitatum; quum enim de his iam egiffet in lib.de Ortu, \& interitu, nunc agere vult de aliis fecundis qualitatibus, qux ab lllarum primarum inter fe actione \& paffione producuntur; ob id exiftimare videtur Alex.4. lib.effe immediate a diungendum z.de Ortu, \& interitu. Alexandri fententıam tueturad vnguem Francifcus Vicomercatus, nec enim aliud huius librifubicEtum ftatuit, nifi illud, quod cum Alexandro diximus; necà librorum ordine, quem Alexander: ponere videtur, recedit, fed eum enixe tuetur.Sed nos de huius libriloco potterius loquemur; nunc vero quod ad Cubięum libri attinet, dicimus approbari quidem Alexandri fententiam poffe de fcopo, \& intentione A riftotelis, fed nonde fubiecto libri; nitil enim aliud dicit, nifi elementa, \& primas eorum qualitates effe in hoc libro cōfiderandas vt principia, alias vero fecundas qualitates, vt effectus, \& vt áffeEtiones dimonftrandas; fed neceffe eft fubieEum effe aliquod, in quo ha fecund a affectiones producantur, \& de quo demon itrentur, idque eft miftum corpus vel omne, vel aliquod; poftea cófiderabimus, hoc igitur fubieftum huius libri ftatuendurneft. Qund veroab Alexandrodicitur, confilium quidem eft Ariftotelis, at non fubiectum, quale in prefentia quarimus.

E Defubiecto quartiMeteorologiciopiniove.
ra, dorejponfio ad argumenta contraria.
Cap. XXVII.
TTEram effe puto Olympiodori \& Auerrois Eram effe puto Olympiodori \& Auerrois olympiso
fententiam, quam alii complures fequuti dows. funt, qui huius quarti libri fubiectum ftacuunt $A$ wercorpus niftum imilare amplifime acceptun, roes, quod \&lapides, \& metalla, minerafqueomnes, \& partes quoq; homogeneas anima hum, \& ftir-

F pium complectatur. Similare autem corpus dici. citur, quando totius \& partis cuiuslibet idem eft nomen, \& eadem definitio, vt aurum, ferrum, lapis, fulphur,caro, neruus, os, lignum, cortex, pilus, \&alia eiufmodi. Sentētia hæc ex huius libri lętione facile copprobatur, omnes enim, qua in eo tractanturaffectiones, proprix funt affectiones corporum miftorí fimilarium, nec diffiraiC 4 lari.
Alexan: dri opinro. Canfutatio. $+$ Simitare quidi. 
laribus competunt, nifi quatenus competunt $\mathbf{A}$

fimilaribus, qu $x$ funt in eis, idque hunc librum legentibus ita manifeftum eft, vt nulla egeat declaratione; poffumus itaque fic argumentari ; iliud of fubiectum, cuius affectiones quaruntur, atqui corporis mifti homogenei affeEtiones hic declarantur, hoc igitur huius libri fubiectum eft. Hocidem confirmatur teftimonio Ariftotelis apertifimo; nam in contex. 42.48 . clare dicit, fe de fimilaribus corporibus, ac de ecrum affectionibus agere, nominatque ea omniafimilaria, qua fupra memorauimus, metalla, \& lapides, carnem, lignum, corticem, aliafque omnes homogeneas plan. tarum, \& animalium partes : in poftremo quoque contextu afferit fe de fimilaribus egiffe, proponitque poftea agendum de difrmilaribus $\mathrm{i}$ cuiufmodi funt in animalibus caput,manus, crus, \& catera membra; in plantis vero radix, ramus, fructus, \& alia eiufm odi : fumitur etiam ex ordine librorum argumentum, quod Solutro poftca confiderabimus. Reftat, veritate co-
argume- gnita, vt argumenta pro aliis adducta foluaargumercorum. Sd primis loan. Gräma. tici.

Adfecüdum.

Ad tersium.

Ad argumensum Lasinoris. mus. Ad primum Ioannis Grammatici dicimus, Ariftotelem in vltimo capite tertii libri proponere quidem agendum particulariter de mineris, non tamen fequi quod id exequatur in quarto libro, fed has de re poftea loquemur, quam libros ad mineralia attinentes confiderabimus. Ad fecundum dicimus no. minari quidem ab Ariftotele in hos libro lapides, \& metalla exempli gratiâ ${ }_{2}$ fed nominari etian carnem, \&cos, \&lignum; quemadmodum etiam in libris Phyfica aufcultationis fape exempli gratiâ nominantur elementar, \& coelum, \& lapis, \& homo, \& animal, nec ob id ea , quatenus talia, fubicctum illorum librorum funt, fed ratione communi, quatenus. funt corpora naturalia: quare \& hic nominantur minerx vt nifta homogenea, ficut eriam caro, \& lignum, fednon ob id agitur de his fecundum proprias rationes. Ad tertium negandum eft confequens; quamuis enim in vltimo capite proponat agendun de anima. libus, \& de plantis, non ob iddicit fe de his ftatim effe tractaturum, nec per hoc ftat quin interponi polfint proprii libri de mineris qua de repofterius loquemur.Ad argumentum Latinorum iam refponfum eft; diximus enim actum effe in libris de generatione de mifto vni. uerfe fumpto, eamque tractationem omnia. F que, qua ibi dicuntur, pracipue competere mifto perfecto, proinde nil manere dicendum de: mifto perfecto generaliter accepto, fed folum. de huius fpeciebus feparatim 2 inter quas primus locus debebazur mifto perfeke homogeneo, de quo agitur inhoc quarto libro.

De loco quarti Metcorologici. Cap. XXIIX.

$\mathrm{Q}$ Vod ad locum huius libri attinet, non defunt, qui Alexardruin fequentes dicant proprium eius locum effe ftatim poft duos de ortu \& interitu, ea dukti ratione, qua videtur $v$ ti Alexander : quum enim hunc librum exordiatur Ariftoteles ab elementis, \& ab eorum qualitatibus actiuis, \& paffiuis, de quibus loB cutus erat in fecundo de generatione, videtur hic liber immediate coharere cum illo fecundo, ita ut tertius de generatione nominari pof fit. Hac tamen fententia aduerfatur \& Arifto-Confutateli, \& rationi : Ariftoteles enim in ipro initio tro. primi Meteorologici recenfet ea, qux in libris Phyfica aufcultationis, \& in libris de Cœlo, \& in librisde Ortu, \& interitu tractata fuerunt, \& ftatim fubiungit fequi ut Meteorclogiam aggrediatur; nempe illam, qua eft de cometis, C de lactea via, ac dealiis, qua ibi nominat, qua manifeftum eft tractari in tribus Meteorologicis, non in quarto; de hoc enim ibi ne verbum quidem facit, itaque poft duos de Ortu, \& interitu, locat ftatim tres Metcorologicos, non quartum. In calce etiam ipfius quarti inquit, agendum effe de animalibus, \& plantis, non dicit de rebus Meteorologicis; quare abfque dubio Ariftoteles librum hunc poft tres Meteorologicos collocauit. Sumitur etiam ad D hoc comprobandum ratio exiis, qua in his omnibus libris tractantur; poftquam enim in libris de Ortu, \& interitu actum eft demifto latifime fumpto, quum effet ad fpecies defcendendum, prius de imperfectis miftis agendum fuit, de quibus funt tres priores Meteorologici, poftea de perfectis homogeneis, de quibus eft quartus; demum autem de perfeCis heterogeneis * qua funt animalia \& plantx. Credo tamen ad verum fenfum trahi pofE - fe verba Alexandri, \& alios fuiffe deceptos, qui talem ei fententiam attribuerint: erenim fpecies omnes eiufdem generis $x$ que cohxrent immediate fuo generi, vt animali xque homo, ac leo; necefle tamen eft in doctrina de vna prius agere, de alia pofterius, prout facilioris doctrina ordo, vel alia aliqua ratio po.ftulat. Quoniam igitur in libris de Ortu, \& interitu actum eft de genere, de corpore mifto vniuerfe fumpto, ac de elementis, corumque primis qualitatibus, tanquam de eius. principiis, cum hac tractatione immediate coharet tam tractatio de mifta imperfesto, quam ea, quas eft de mifto perfecto; attamen quum hac tractari fimul non potuerint, voluit Ariftoteles, ob eas , quas, fupra tetigimus. zationes de imperfectis prius agere, quam de. perfectis. Ad: hunc igitur fenfum, referenda. Opinio
Alexan-
diedelo-
co.
Confuta-
tro.

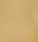


funt verba Alexandri, qui afferit quidem illa, qux ab Ariftotele dicūtur in initio huius quarti, cohxter ecum iis, qua traditafunt in fecundo de generatione; fed non inquit ob id quartum cife ftatim collocandum poft illum fecundum; neque enim negaffet etiam illa, qux in principio primi Meteorologici dicuntur, coh $x$ rere fimiliter cum iis, qua de elementis, primifque qualitatsbus in fecundo de generatione dicta'erant;imoid afferit Alexander, dum interpretaturinitium primi Meteorologici: dat enim cum Ariftotele quartum locum in f́cicatia naturali libris Meteorulogicis prioribus, in quibus tractantur ea, qua cōmem orat Ariftoteles in illo primo capite; nó igitur itaintelligenda funt cius verba in fua Profatione in quartum librum, $v t$ dicant hunc quartum effe allis tribus antéponendū. Olympiodorus tamen \& in initio huius quarti, \& in initio primi eã Alexandro fententiam attribuit, quam \& alii multi; atq: eandemab Amnonio receptam fuiffe teftaturimo non folum quartum librum, fed \& poftremum tertii libri caput, quod eft de mineralibus, inquit locandum effe ftatim poft fecundum de generatione, fecundum Alexandrum \& Ammoniũ. Ego vero de Ammonio quidem nil habeat, prxter id, quod de ipfo refertur ab Olympiodorojifd quodad Alexandrum attinet, non video cur non in veriorem fententiam eius verba trahi poffint : alios fortalle Alexandri libros vidit Olympiodorus, qui nunc non extant, in quibus fententiam illam clarius exprefferit Alexander. Ratio autem, qua vfum efle Ammoniü Olympiodorusast, nullius momentieft; dicebat enim, nifi quartus hic annectatur ftatim fecundo de generatione, diftracta, \& interrupta erit tractatio elementorum, qua continuata effe debuit. Ego enim dico, nec libros de generarationis. tione, nec quartum Meteorologicum dici poffe libros de elementis; quum entm in vtrifq; confiderentur elementa vt principia miftorum, eft in vtrifq; fubiectum niftum. Quoniam igitur. tres quo oque Met eorolog!ci. funt de mifto, coniuncta eft tractatio miftorum, eaq; optime dif pofita, figuidem ratio ordinandi libros Ariftot. a folis fubiectis fumenda eft, non ab illis, qux vt principia confiderantur; quanquam in tribus. quoque prioribus Meteorologicis dicere porfumus elementa vt principia tractari, proinde vel ficelementorum tractationem non interruptam, fed continuatam effe. Devltimo autem: tertiilibri capite poftea dicemus.

\section{De inf.riptione quarti Meteorologici. cap.. XXIX.} Vod ad eius, libri infcriptionem attinet, Ioannes Grammaticus cenfuit eum effe:
A perfe Meteorologicum, propterea quod eft dc mineris, qux ex eadem materia generantur, ex qua illa qux fiunt in fublimi; onınia namque qua in his quatuor libris tractantur, ex vtroque halitu genitafunt, proinde in eifdem libris tıafari omnia debuerunt ob banc conuenientaan in communi materia. Sed hac in foriptionis ratio approbanda non eft; iam enim oftendimus, librum hunc non effe de mineris, fed de genere communiore, fcilicet mifto perfefto hoB mogeneo; huiusautem materiam dicere non pollum us effe duplicem halitum; hrc enim cft propria fpeciei conditio, qua eft accidentalis generi : quemadmodum enim animalı accidit efferationale, quum deturanimal, quod rationale non eft; ita mifto fimilari accidit ex duplici halitu fieri, quum dentur plura mifta fimilaria, qua ex duplici halitu non fiunt; ideo dicerenon poffumus, quartum librum effe de iis, qux ex duobus halitibus fiune. Ego igitur di- Opinio

C cendum puto, librum hunc non efle per fe Me- Gera. teorologicum, neque enim de is eft, qux in fublimi fiunt, neque de iis, quxex duobus halitibus generantur: per hoctamen non ftat, quin aliis tribus annecti poflit, \& omnescommuni nomine vocari Meteorologicij quum enim sertum fit, eum ftatim poft illos effe collocandum; potuit Ariftotelesillumaliis tribus obaliquam rérum confideratarum connexionem adiungere, \& vnum ex omnibus volumen con: D. ftituere,-quod à maiori parte Meteorologịcum, infcriberetur. Num autem Ariftoteles hoc fecerit, vt feciffe videtur, an potius librum hunc $\mathrm{ab}$ aliis tribus difiunerit , tanquam non Meteorologicum, pauci momenti, mec quidem iudicio, id eft; fiquidem neutro modo abfurdum aliquiod fequitur; poteft liber is aliis tribus adiunctus, vocari ex ea coniunctione Meteorologicus; poteft etiam ab aliis trıbus przcedentibus diftingui, \& propria infcriptione appellari de mifta perfecto fimilari.

\section{De Foßsilibus; of Metallis, eorumǵ traction tione. Cap. XXX.}

E lapidibus autem, crererifa; foffilibus; ac: De metallis; qua omnia communi nomine folent appellari miner x; tres inuenio alio. rum fententias. Vna fuit Ioannis Grammatici, qui dixit de his agi in illo libro, qui vocatur quartus Meteorologicus -Hanc opinionem nos antea reprobauimus, oftendimufq; librum ilo lum effegeneraliter de mifto perfecto homoge- Confutaneo; quare defideratur propria traetatio de me- tio. tallo, ac defoffilibus. Alıam opinionem poite- Alia opio. riores plures fequuti funt, qui dixêre, nullam nio. aliam requiri tractationem demineris, praterillam, quas habeturin poftremo capite tertii. Me-

$$
\text { C: } 5 ; \text { teoro- }
$$
tro. Gera. Io.Grame matici.
Confuta-

Opinio - 
trovologicisproindeftatim poft quartum Meteorologicum fequilibros de animalibus Sententiam hanc his argumentis confirmant; priPrims mo conflium Ariftotelis in tribus Meteoroloargmë- gicis fuit agere de iisomnibus, qua ex duobus twm. halitibus generantur; in horum numero func mctalla, \& foffilia omnia; ergo hæc ad nullun alium frbrum pertinuerunt, quam ad tres Mereorologicos; proinde fatis ea lunt, qua ab Ariftotele fribunturin calce quarti Meteorologi-

securdia ci, necalius de his liberdefideratur. Præeterea aliquotita audiui argumentantes; Ariftoteles in quarto Miteurclogico fape nominat exempli $g$ a lapides, \& metalla; ergo fupponit factam pitus corum declarationem, \&, traetationem in tribus Meteorologicis. Confirmant teftimonio A iftotelis in calce primi capitis primi Meteorologiccrum, vbi poftquam recenfult omnia confideranda in Meteotologia, nil aliudinquit fupereffe confiderandum, nifi animalı, \& plantas: igitur fecundum Ariftotelem nullus prater Meter rologicos poftulatur liber de mine-

Qwartü. ris. Tandem confiderant Ariftocelis verba, in calce quarti Meteorologici, quibus proponit agendum postea de animalibus \& plantis : nullum ergo putauit ad huius fcientix perfectionemrequirilibrum de mineris; fiqudem hic, fi neceffarius effer, nullum haberet locum, nufi poft qiatuor Meteorologicos, \& ante omnes librosde animalibus, \& de plantis. Verum hi,ve
A verbis breuemillum fermonam cöcludit [ communitér de bis dictum eft, fingillatim autem con. fiderandum intendentibus fecundum inum grod. que genus] affirmat igitur confiderandum effe firigillatim delapidibus \& metallis, nofque ad particularem tractationem remittit, qux omnino neceffaria eft, fi haturalis fcientia debet effe perfecta. His ego argumentis duetus, opinio fequendum effe arbitror tertiam opinionem, Gera. quæ Auerrois eit, \& Olympiodori, qui putant B efle omnino neceffarian particularem, atque diftinctam tractationem de mineris prater illam generalem, qux habecur in vitimo capite tertii Meteorologici; nunquid autem de mineris fcripferit Ariftoteles preter vltimum illud caput tertil Meteorologici, incertum eft; fcript! m quiden effe ait Olympiodorus, fed, vt eg( arbirror, conie ftat potius, quam affeue ranter affirmet, quoniam Alexander in declaratione vltimorum verborum illius poftremi capitis cercii libri dicere videtur, proprium hune de mineris librum non ab Ariftotele fcriptum effe; fed ab aliis, preferrim vero à Theophrafto: Auerroes quoque in inicio primi Meteorologicorum, numerans ordinatim omnes libros naturales, inter eos locat librum de mineris ; fed poltea inquit ex nominatislibris aliquos ad noftras manus non peruenifle. Ego quidem, etfi non dubio neceffarios omnino effe libros de mineris ad huius f́ientix per$D$ fectionem, credo tamen potuifie contingere, vt eos nunquain Ariftoteles fcripferit; non fum enim in eo communi errore, vt putem necelle effe Ariftotelem ita perfectam tradidifie naturalem philofophiam, ve nihil quod ab himano ingenio inueniri, aut cognofci queat, pratermiffum ab co effe potuerit; illud quiden puto effe confitendum, Ariftotelem ita arrificiofe huius fcientiz fabricam, quam in pratentia declarandam fufcepimus, conE ftruxiffe, \& confeciffe, vt quanuis rebus ip fis, as materix ( $v$ ita dicam ) addi aliquid poffit. artificiotamen, \& forma nihil;ipfam enim fcientiam in omnes fuas partes diftribuit, eafque optime difpofuit, ita vt facile cuique fit, fi quid in aliqua parte defit, addere, \& addita in fatis quxque locis collocare: \& laxe omnia puto ipfummet fignificaffe in primo capite primi libri Meteorologicorum. Dicere igitur poffumus, frriptos ab eo fuiffe libros de forfilibus, \& metallis, qui portea perierint: dicere etiam poffumus, nullos effe fcriptos, fed fatis ei fuife illa, qux de his pauca fcriplit in vltimo capite tertii Meteorologicorum, ip fum: que in calce eius capitis fignificaffe, fe ho. rum tractationem aliis poftea abfoluendam reliquiffe; 'quod poftea preftitit Theophraftus, ac pofterioribus etiam temporibus $\mathrm{Al}$ - 
Locuslit de raineris.

\section{Dubism}

Solutzo a licrum. bertus Magnus, fcu quifquis ille fucrit , quii quatuor, quos habemus, libros diligenter, \& egregie feriplet de mineris. Vteunquefefe res habear, fiue fcrip fit Ariftoteles libros de unineris, fiuc non fcripfit, neceflarijomnino funt ad huius fcientix complementum, propriusque eorum locus nullus alius eft, nifi natim poft quartum Meteorologicorum, vt cenfuit Auerroes in initio promilibriMcteorologici, \& in vltimo commentario quarti, quam fententiam fequutus Albertus, librns à fe compofitos de mineris locauit Atatim poft quatuor Ariftotelis Meteorologicos, \& ante omnes libros de animalibus. Ratio autem huius ordins manifefta eft : quum enim in quarto Meteorologico agatur de milto perfecto homogenco vniuerfe fumpto, agendum poftea erat de fpeciebus : fpeciesautem huius funt foffilia, \& metalla o. mnia, \& illa, qua in animalıbus, \&planissinfunt, fimilares partes, vt caro, os, cortex, lignum; ftatim igiturquattum Meteorologicuin fequicur tractatio de mineris; nam reliquis fimilaribus nulla propriatraftatio conue. niebat; quum enim non ideo fint in rerum natura, vt per fe exiftant, fed vr animalium, \& plantarum partes fint, cognouit Ariftotel non effe alibi de his agendum, nifi in iis ipfis libris, in quibus de animalibus, ac deplantis ageretur: : nulla igitur erat fpecies miftı perfecti fimilaris, de qua feorfum agendum fuerit poit quarrum Meteorologicum, nili foffilia, \& meralla; poft libros autem de mineris, fequuntur ftatim libride animalibus, \& plantis, vbi \& de carne, \& de neruo, \& de ligno, $\&$ de aliis fimilaribus agitur, ex quibus tanquam ex materia conftant animantium partes diffimilares. Sed aduerfus ordinem memoratorum librorum oritur dubjum, quod mnultos turbauit : nan fi quartus Meteorologicus eft de mifto perfecto hom geneo vniuerfe fumpto, \& huius fpecies funt foffilia, \& me- $E$ talla, Ariftotel. de his agens in vltimo capite tertij libri, de fpeciebus prius egit, quam de genere, quod faciendum non eft, fiquidem vniuerfalia in doctrina fint particularibus an-

teponenda. Refponfio, qua ab aliis ad hoc dubium afferri folet, hzec eft; vniuerfalia funt anteponenda particularibus; nifi facilioris doArinz ratio in contrarium vrgeat; quoniam igitur fofflia, \& metalla ex duobus illis halitibus generantur, ex quibus alize omnes res Meteorologicx, facilioris doctrinx ratio poftulauit, vt Ariftoteles continuato fermone totam eorum, qux ex duplicï halitu generantur, tractationem abfolueret; ideo poft resomnes Meteorologicas voluit etiam de mineris loqui in illo vltimo capite tertij libri, \& ita particularia vniuerfalibus antepoluit facilio.
A ris doetrina gratia. Hac communis refponfio Confura. mihr quidem om $1 \mathrm{em}$ tollere difficultatem non rio. videtur : llam fi continuata tractatione agen. dum crat de omnibus iis, qua ex duplici halitu gencrantur, oporteret cotam quoque de mineristractarionem, qux defiderantur,interponi inter tertium \& q̨uartum Metcorologicorum, quod tamen nemo vnquam afferuit; omnes emim qui neceflariaon effetalem tractationen confeffi funt, eam poft quastum Me-

B tcorolngicorum collocarunr. Eft etenim hos confentaneum rationi, quia quum fpecies cognofici perfecte non polfit, ignorato gencre, poteft quidem rudis aliqua, \& imperfecta fpeciei tractatio tractationi generis anteponi, facilioris doctrinx gratia, qualis eft breuis illa tractatio, qux haberur in poftremo capite illius tertij hbri; fedperfęa traftatio nullo pacto, dum generis natura non eft perfecte cognita. . Licet igitur verum fit $\mathrm{id}$, quodilli diC cunt, ordinem doctrinx prasspuc refpicere noftram faciliorem cognitionem, difficultas tamen hxc non tollitur, quia non rectam, vel faltem non perfectam rationem adducunz huius facillioris doctrinx. Egoigiturdicendum puto, caputillud vltimum tertij lik rinon effe proprsk. trastationem de mineris, proinde non elle ab Ariftotel. antepofita particularıa vniuerfalibus, fed effe potius tractationem de duplici halitu, \& ibi inftitutam ad plenam ipfolum háli$D$ tuum cognitionem; quod quidem videtur fenrentiam illam confirmare, quod in tribus Mereorologicis libris duo halitus habent locum fubiecti, cuius accidentia quasuntur. Quemadnodum enim alias diximus uim xrerne movendiconfiderari tum in odtauo Phyficorum cb cognitionem aterni motus in corporenaturali, tanquam huius caufam; tum in duodecimo Metaphyficorum propter cognitionem fubitantiz à materia abiuntz, tanquam eius proprietatem, fiue attributum : \& in coelo"vim rutandi hac inferiora confiderari tum in fecundo de generatione propter cognitionem muxationis, qua fit in his inferioribus corporibus, cuius eft caușa; tum in libro fecundo de Calo propter ipfius $\mathrm{Car}$. li cognitionem, tanquam eius proprietatem : \& quatuor fimplicia corpora in libris: de generatione confiderari vt elenuenta miftorum; eadem autem in tertio libro de CaF lo vocari elementa, \& cognofci effe elementa miftorum, vtipfa fecundum fe cognofcantur, \& omnia corum attributa, quia effe elementa mifforum eft quadam aliorum corporum proprietaś : ita nunc dicendum vicetur; effe ducrum halituum proprietatem, vt ex iis hos, vel illud generari aptum fit Adt plenam igitur suorum halituum cognitio- 
nem,nonad cognitionem ipforum mineralium dicere voluit Ariftoteles pauca illa de foffilium, ac metallorum ex duobus balitibus generatione, feu potius generabilitate; reuera enim de eorum generatione nihil ex eo capite addifimus, quum ipfe generationis modusibinon declaretur; declarandus enrm eft in propriis libris, in quibus minera locum habeant fubieetianquam fpecies mifti perfectir homogenei, dno autem thalitus locunı ibi habent principiorum ; quim iidem in tribus Meteorologicis vel fubięi folummodo locum habeant, vel non minus fubiecti, quam principiorum. Hoc modo fublata effe videtur omnis difficultas. Reftat vt argumentapro aliiis prius adAd pri- ducta foluamus. Ad primum dicimus, non fagument pite terii libri de cognitione foffilium \& mealiorzm. tallorum; fatis quidem funt ad plenam duorum halituum notitiam, ipf autem miner non funt folum affectiones, qux duobus hali- $C$ tibus accidant, fed funt mifta perfecta, in quibus eft facta yera miftio, \& vera natura vnio: quatuor enim elementorum forma verfx funt in formam vnam fubfantialem inediam ab eis diftinctam; cater autem res Míteorologic $x$, quæe ex ducbus halitibus gigni dicuntur, non habent veram miftionem, nec formam fubftantialem prouenientem ex congreffu formarum elementorum, fed accidentia tantummodo funt duorum halituum, licet inftar formx effe videantur, quum dent rebus illis nouum nomen, faciantque appellari niuem, grandinem, pluuiam. De his itaque agendum eft in tribus Meteorologicis tanquam de accidentibus duorum halituum; at de mineris, quun fint mifta perfecta, aliolocoagendum eft; fatis quidem fuit in tribus Meteorologicis cognolcere duorum halituum aptitudinem. vtex iis generentur foffilia \& metalla, fed ipfrérecundum feibi fatis confure, \& suditer cognofcuntur, vt cuique rationis compotımaniteftum effepoteft: neque enim fatis eft conuenientia in communi materia, vt aliqua dici debeant ad candem fcientix partem pertinere; fed requiritur etiam conuenientia in forma , \& natura, \& in modo generationis ex

Adfecun illa materia. Secundum argumentum vaniffd:m. mumeft, quia quum genus non exiftat nif in fpeciebus fuis, folent fcriptores, dum agunt de genere, nominare exempli gratı fpecies : fic nominantur in libris Phylicx aufcultationis varix fpecies corporis naturalis, nec ob id fumunturvtiam perfecte cognitz, fed vt confufe no$t x$; neque etıam declarantur fecundum proAd ter. tionem generis, dequo ibi agitur. Ad tertium tosms.
A cap.prim1 Meteorologicorum, dico non effe 1 bi eius confilium omnia penitus enumerare, qux poit libros Meteorologicos tractanda manebant, fed fatis habuit aninıalia, \& ftirpes tanquam pracipua nominare, quorum cognitio maxime expetibiliseft, tum ob eorun nobilitatem, tum ob cognofcendi difficultatem, \& tractationis prolixitatem, qua plurimos libros poftulabit. Ad hocautem comprobandum fu. mo ex Áriftotele in eodem loco duplex arguB mentum : primum, quia non abfolute dicit fola animalia, ac ftirpes fupereffe, fed dicitfere abfolutam, ac perfectam fore fcientix naturalis traditionem; dicens enim [fere] indicat alia quoque effe traktanda, qux, vt minoris mo. menti, nominata non erant: præterea in illor. cap. ea tantum recenfuerat, qux in tribus prioribus Meteorologicis confideranda erant, de iis autem, quxin quarto, ne verbum quidem fecerat; itaque fi iftorum argumentatio efficacitarem habet, non minus excludit quartum Meteorologicum, quam libros de mineris: fenfus enim verborum Ariftotel. erit, quod poft tres Meteorologicos nil aliud tractandum manebit, nifi animalia, \& plant $x$; fubricuit igitur \& ca, quæ traetanda erant in quarto, \& mineras, tanquam res cum Meteorologicis magis coniunctas propter confiderationem elementorum, quxin horum omnium tractatione eft 0 . mnino neceffaria; \& fola rerum vere Meteorologicarum expreffione voluit etiam implicite complecti \& miftum perfectum homogeneum, dequo agendum erat in quarto: \& eius fpecies foffilia, \& metalla, de quibus in libris de mineris vel ip emet tractaturus erat, vel aliis tractandum relinquere ftatuebat. Hocidem confirmare orfumus auctoritate Arittotel in calcelibri delongitudine \& breuitate vitæ, vbi hæc verbalcyuntur [ Religumest confiderare de sweniute ${ }^{\circ}$ fenectute, $\mathcal{E}^{\circ}$ Gitro, E' morte, bres: E tis. finem babetit, gsoc de animals? merbodus] tacet tamen fanitatem \& morbum, de quibus poftremo locolibrum feripturuserat, vt in primo cap. libri de fenfu, \& Ienfil'sus propoluerat; fatis enim habuit aliqua precipua acciden tia nominare. Itaque teftimon s sifot.manifeftum eft argumentationem han nullius effe momenti. Ad poitremum argumentum fumptum ex vltim. cap. 4. libri dico, Ariftorel. ibi non proponere agendum ftatim de animanti. bus; fed folum dicereagendum effe de partibus fimilaribus in libris de animalibus; \& plantis: quoniam enim nominauerat in eo capite carnem, \& neruum, \& corticem, \& alia fimilaria, qux funt partes animalium, \& plantarum, qua credere poteramus propriam, ac feparatam tractationem poftulare, ideo inquit de his agédum effe poftea in lib. de animantibus vt ex horum 
cognitionenofcamus diffimilarespartes, \& ex A his tandem animalia ipla, \& plantas; led non dicit cffe de his ftatim agendum; 1deo Aucrroes ibi dicit defingulısillis fimilaribus agendū manere in tribus libris;in libris de miners, in libris deplantis, \& in libris de animalibus : hos enim omnes voluit Auerroes fequu quartü illum $\mathrm{Me}$ teorologicorum. Hæc dicere volui, vt oftenderem, non probari his argumentis nullum ab Ariftotele fcriptum efle librum de mineris. Attamennibil etiam abfurdi effet, fi diceremus Ariftotele \& in I. cap. libri 1. Meteorolog. \& in poftremo quarti ita efle loquutum, quod nullum de mineris librum forbere ftatuifet;per hoc e. nim non itat, quin poft 4 . Metcorologic. necerfarii fint libri de mineris, \& quin ipfemet Arift. nouerit cos ellic necelfarios.

\section{Partitio totiustractationis de Animan-. tibus. Cap. $X X X 1$. .}

Partitio cientice zatura'is fectunitit alioso.

?artitio ectsor.

Tisisific: ractati. nis de inenti-
$T^{\circ}$ Otam naturalium rerum trabtationem in: duas partes fecare multi folent; vnam dicunt effe de in animatis, quam hactenus percurrimus; alteram vero de animatis., quam mcdo. aggrefiuri fumus: diuifionem hanc ego quidem non refuto, in co tamen.corrigenda efle arbitıor, quodaltera prior pars-nó de inanimıs tan- tum fuit, fed-de is quoque, qua ipfis communia funt cū animatis, nam corpus naturale commune, de quo agitur in libro Phyfica aufcultationis, noin fola inanima; fed animata quoque complectitur; vt Ariftos. ibiin initio 2. libri teftatur; fic corpus mifturn, de quo in lib. de Or: tu; \& interitu: ficetiam miftun perfectu homogeneum; de quo in quarto Meteorologic. Reĉtus igitur dicemus, priore huius fcientiz partem fuife de iis rebus naturalibus, qua vel' inanimis, \& animatiścómunia, vel inanimatorum. propria funt, alteram vero, qux fequitur, de iis tătum effe, qux funt propria animatorum. Huius igitur partis feriem explicaturi, qua \& rerũ nobilitate, $\&$ varietate, \&e difficultare, \& librorum numero digna maxime eft confideratione, nos-facta priıs rerum cöfiderandarum diui:fione, \& partitionemlibrorum, \& ordinem, atq; difpofitionis artificium, \& fubiectam in fingulis materiam declarare nitemur . Totarequens pars, quæ ad viuentiapertinet; tres videtur præcipuas partes-habere deburfe; quum enimab. vaiuerfís ad fingula progrediendăfits primo loco agendum eft de ipfo viuente corpore generaliter accepto, ibiq; \& deanima communiter, \& de eius parte vegetali, qua animátia cuncta participant, \& de iis, qua eam confequuntur, pertraetandum: fecundo loco de animalibus tum. generatim; tum fpeciatim: tertio loco de plantis: fiue (vt Auerroi placuit) fecundo loca de:
A plantis; tertio de animalibus. Attamen Ariftoteles totam de viuentibus tractationem in duas tantum partes diuifit; vnam de animalibus, alteram vero de plantis; non quodillam, qux de vituentegenere eft, urxtermiferit, fed quia ob doctrinx facilitatem voluit eam cum illa, qux eft de animalibus, commifcere, adeo vt in libris de animalib. tum illa tractentur, quod funt animaliú propria;tum ctiam lla, quæ funt eis communia cum plantis;in reliquis vero,qui de plan-

B tisfunt, illa tantummodo, qux propria plantarumfunt, tractanda relinquantur. Rat1o, quæ Ariftotelem mouit, fuit, quoniam ilia, qux cōmuniter plantis, \& animalibus compet unt, diftinetiora in animalibus, proinde faciliora cognitu funt, in ftirpibus vero rudiora, \& oblcuriora, cuusimodi funt vegetalis animæ facultates omnes, \& operationes, \& organa. Quũ itaq; ocislatıfimus ille Philofophus animaduertiffet difficillimum effe hæc omnia cōfiderare in cor-

C. poreviuentecommuni, quod mente à fuppofitis fpeciebus abiunctum fumatur, ftatuit ob faciliorem doctrinam ea omnia confiderare in animalibus, vt proportione quadam in plantis eadem cognof cantur, quaderealias plura fcripfimus in lib. de Methodis, qux quum nec re- Lib. $r$. petenda hîc, nec ignorandi fint, inde petantur. cap. Glt. Ex his colligerepoffumus Auerrois errorē, qui opinis putauit libros de plantis effe libris de animali- Aserrobus anteponendos, quod plantæ naturam ha- is de liD beant fimplicioré, quamanimalia. Attamen de- bris. de ceptus eft Auerroes, quia fine cognitione eorü , plantis. qux viuenti corpori communiter competunt, Confutas non bene poterant ftirpes cognofci: non poteft tso. enim perfecte cogncici fpecies ignoratogene. re; ípfus autem viuentis generis, omniumin; ad ipfumattinentium tractatio cõmifta eft, quemadmodum dixinus, cum tractatione de animalibus; quamobrem neseffarium omnino fust libros de animalibus anteponere libris de plantis, idque Ariftoteles aperte teftatur. in calce libelli de longitudine, \& breuitate vita, vbi, afferit. fe tunc effe in libris de animalibus, pofterius autem acturum de plantis. Quod autem in libris de animalibus tractentur omnia quæ viuentibus omnibus communia funt, illa ipfatractatio declarat; in libris enin de anima: agitur, \& de anima generaliter; \&e deanima ve-getali; tanquam de viuentis corporisanima : \&: in iis libris; qui folent.yocari larui naturales, a-Fitur de vita, \& morte, de longitudine, \& breuitate vit $x$, acidealiis, qua communiter competunt omni viuenti: Sed clare hoc:teftatur. Ariftoteles in principio libri de Senfu; ó fenfilibus, vbi proponit fe acturum de aninalibus, ac de viuentibus omnibus, nec non de omnibus corum tum propriis, tum communibus perationibus: Erraruntetiam obid quidam al $i j_{2}$, 
qui omnia, qur dicuntur in libris de animali- A hus, tractari putârunt proptcr fola animalia, . non penpter ftirpes: fic enim errorem manifcftifím um attribuunt Ariltoteli, vt ea, quæ primocompetunt generi, confidcrauerit in fpecie; nempeea, qua viuenri primo competunt, attribuerit animali, quem errorem Ariftot.ipfeiam in $\mathrm{I}$. I b. Poferiorum damnauerat.

\section{Dinifio es ordo omnium librorum de Ani- malibus iuxta propriam opinionem. Cap. $X X X I I$.}

Q Voniam igitur ita de animalibus ordien-dum effe Ariftoteles duxit, vt in ipfis c inmunior quoque viuentis natura confideraretur, illud in primis confiderandum nobis proponitur, in quot partes, feu libros diuifa effe Jebuerit hæc de animalibus tractatio, \& quo ordine ii omnes libridifponendi funt. Eam igitur, quam effe putamus rei veritatem, totamque horum librorum feriem prius exponemus; deinde verofi qua aduerfuseam dubia ob aliolum opiniones digna confideratione efle videbuntur, ea ad exquifitiorem rei declarationem rrimo expendemus, atque foluemus. Dictum à nolibro de bis eft alias, perfectam cuiufque fubiecti coMeth. c. gnitionem in duobus confiftere, in cognitioGlt. Ein ne naturæ, \& propriorum ipfius accidentium; 1. de Pr\&-naturam autem, \& effentiam rei cognofcere cogn. non poffumus, nifi propra eius interna principia, ex quibus conftat, intelligamus; acturus ergo Ariftoteles vno, \& eodem difcurfu de animalibus, ac de viuente corpore vniuerfe, cognouit duas effe débuiffe huius tractationis partes; vnam, in quade internis principiis viuentium ageretur; alteram, in qua de accidentibus, \& operationibus confequentibus, tales duas partes habuiffe etiam tractationem de corpore naturali communi iam oftendimus; nam in duobus prioribuslibris Phyficreaufcul: tationisagiturde eius principiis; in fex autem pofterioribus eiufdem accidentia confiderantur. Quoniam igitur corpus animatum, \& animal ipfum principia habet interna, propriam materiam, \& formam, hæc fuerunt in primis confideranda; materia propria, ac proxima animalium funt eorum partes tum diffimilares, qux eorum membra dicuntur, vt brachia, caput; tum fimilares, vt os, \& caro; forma vero eft anima : primum igitur locum fibi vendicauit traetatio de partibus animalium, deinde de anima; his enim cognitis, iam plene cognita eft ipfa animalium natura; poftea vero agendum fuit de accidentibus, \& operationibus confequentibus, qux omnia Ariftoteles ordinatifime exequutus eft; qui praterea.asimaduertens, tractationem de animalibus magna yarietare ac difficultate refertam cfre, ftaruit ad maiorem doctrinæ facilitatem omnibus aliis libris anteponere libros de hiftoria 2 nimalium, in quibus \& de animalium principiis, \& de eorum accidentibus, \& operationibus ea, quz experientia, \& fenfu cognof ci po- lıum. tuêre, nobis exponeret, fine vlla caufarum redditione; vt poftea earundem rerum fcientialem tractationem fequentibus libris traderet. It2que libri de hiftoria funt praparatio quadam $B$ ad alios omnes de animalibus libros; tradunt enim cognitionem, quod ita fit; alii vero fequentes earundem rerum caufas declarant, \& docent propter quid; ideo illi iure fueruntappellati hiftorici, quum reliqui non hiftorici, fed fientiales potius fint appellandi. Videmus autem \& in libris de hiftoria eandem illam traEtationis partitionem, quam in aliis libris iam declarauimus; nam quatuor prores libri de hiftoria pertinentad principia animalium, non c quidem ad animam (hre enim infenfilis eft, nullaque de ipfa effe poterat hiftorica tractatio) fed ad folam materiam; agitur enim in iis quatuor libris hiftorice de animalium partibus, in reliquis antem pofterioribusagitur de operationibus, \& accidentibus confequentibus, ita vt pofterior illa hiftorix pars refpondeat poiteriori parti tractationis fientialis, qua poft libros de anima in paruis ( $v t$ vocant) naturalibus continetur; altera vero D prior hiftoriz pars refpondeat libris de partibus animalium, quibus in parte fcientiali primum diximus locim deber1. Si quis igitur quærat, an libri de hiftoria fint pars fcien. tix naturalis, dicere poffumus effe modo aliquo eius partem, \& aliquo etiam modo non efle; parsenim dici poffunt, quatenus ad aliorum cognitionem plurinsum conferunt, \& alii eorum intelligentiam prafupponunt; quare primi omnium librorum de animalibus

E funt libri de animalium hiftoria. Si vero eos tantum libros, qui demonftratiue fint fcripti, comprehendere velimus, libri de hiftoria non funt pars fientix nacuralis, \& hac ratione primi omnium librorum de animalibus funt quatuor libri de partibus animalium, quod etiam indicat magnum, ac prolixum corum librorum procmium, quod occupat totum primum librum; non enim librorum tantum de partsbus, fed omnium ad animalia perti-

F nentium librorum commune proomium eft, quo fit, vt illud dicendum fit initium fcientialis tractationis, de animalibus, vt cuique eum primum librum legenti, manifeftum effe poteft; videtur enim Ariftoteles peracta tota animalium hiftoria, aggredi tterum earundem rerum fcientialem tractationem, ideoque tam. prolixum proomium apponere voluife lihris de par- 
6.de deparibus animalium; tanq̨uam exordium tortious tius tractarionis de animalibus. Poft librosigitur de hiftoria ponendi ftation funt quatuorlibridc partibus anmalium, de quorum diuifione in partes non eft quod in preicntia dicamus: farrshit hocannotare, Arritutclem in is libris demonitratiue de partibus agere, quod in prioribus de hiftoria libris non fecerat ; fingularum enim partium caulas alfignar finales, nam finis a cuiusque partis eft propria operatio, \& proprium munus, ad quod lingulam partem tanquam inftrumentum ad hnem natura direxit ; funt enim omnes anmalis partes inftrumenta animz ad varias edendas operationes, inftumenti autem natura optime ex eius fine declaratur. Ex hac potifimum naturalis philolophiz parte fumit ars medica partem illam, qua phyfiologica dicirur, in qua de humano corpore, acde eius partibus fermo fit, quum Medico illas curaturo neceffara penitus lit earum cognitı; obid Medici, qui artificiolam, ac fructuoram facere volunt humani corporis anatomen, imitari Ariftotelem debent, nou sn libris de hiltoria, fedin libris de partibus methodice de ipfis partibus agentem : duo namque omnino cognolicenda lunt ad perfectam. ipfarum partium notitiam habendam; vnum eft proprium culusque parns officium, propriaque operatio; alterum vero; quod exillo deducitur, ea, quxe in fingula parte requiritur elementorum commiftio, \& primarum qualitatum temperies; horum enim altero ignorato, non poteit aliqua humani corporis pars dici perfecte cognita. Quatuor libros de partibus fequitur ftatim liber de animalıum incelfu, qui fimiliter de partibuseft; nempe de ills, qua pertinent ad motionem animalis, cuinsmodi funt crura, pedes, \& in aubusalz, \& alize eius generis; has enim partes fecernere volut Ariftoteles ab aliis, qux in quatuor libris, qui de partibus infribuntur, confiderarafuerunt, de quo partium difcrimine aliqua poftea dicemus. Librum de inceffu fequuntur libic de anima, qua poft confiderationem materia, animalium, quxin quatuor libris de partibus, \& in libro de inceffu habetur, fequitur vt ltatim agatur deforma, quod Arriftuteles preftat in libris de Anima. Hunc effe debere memoratorum librorum ordinem, tum ipfa, quam declarauimus, ratio demonftrat, tum clarum. Ariftotel. teftimonium confirmat: nam in primo capite fecundi libri de partibus anima. lium, \& in primo capit. libelli de inceffu aperic afferit, fe iam in libris de hiftoria docuif$f e, q u o d$ animalia ex iis partibus conftent; poftea vero dicendum effe, quamobrem ex is conftent, - \& earum caufas efle inquirendas ; inquit igitur libris omnibus de partibus, \& de-
A incefupraceffifelibros de hiforia. Oned attten liber de inceflu fequaturfation quaruor libros de parribus, teftatur Ariftotel. in poftremis verbis quarti de partibus dum inquir [ fequitur bo de part:bus snceffist animalsum sinferusentebuss differamus.] Demum in calce libri de inceffu inquit Ariltotel. [his sta determinatis, proxime fegutur, St agamus de Anima] eum igitur horum librorum ordinem effe volut, quem diximus. Non eft auteri filentio pretereindum illid, premode

B quodetiam in operibus Logicis tetigimus, dif- Meth. crumen librorum de A nima cum libris de parti- cap. Vhs. bus; in hisenim agitur de partibus propriisanimalium, in libris autem de Anima non de la animalium anima, fed de illa quoque, qua eft animali communis cum Ptirpe; nam in recundo libroagit primo loco deanima latiffimefumpta, poftea de prima eius parte; qua vegetabilis dicitur, qua vtraque trątatio non magis de animalıum, quam de ftirpium forma diC ci porelt; poftea agit de animr parte fenfibili, qux eft propria animalium; mox in tertio libro de parte rationali, qua eft hominis propria. Ratio autem huius difcriminis fumitur ex iis, qux antea dikta funt : Ariftotel. enim conftituit in animalibus confiderare non ea folum, qux ipfis proprie competunt, fed etiam illa, qux funt eis communia cum plantis; exordiens igıtur à materia proxima nullam inuenit communem animali cum planta, non potuit igitur D nifipropriam animalium materian confiderare, qux funt partes ipf $x$ animalium, nifi dicamus aliquas nutritioni, \& accretioni anima. lis inferuientes effe quadam proportione communes, quatenus alix eifdem nuneribus fun. gentes reperiuntur in plantis; at certe proprie, \& (vrdicunt) formaliter communes nul$1 x$ funt. Ad formam autem animalis confiderandam accedens, debuit omnis anim $x$, qu in animali infit, confiderationem facere; quo-

E niam iggitur in animalibus omnes in funtani$m æ$ partes, feu gradus omnes debuit eo, quem diximus, ordine confiderare; hoctamen non ita intelligere debemus, vt aliqui intellexêre, vt dicamus quamlibet animz partem tractari vt animalis; nam fi vegetalem animam confideraret vt animalis, id, quod primogeneri competit, attribueret fpeciei ; quam in primo Pofteriorum dixit fophifticarn effe confiderationem, \& nullam fcientiam parere. Quam-

F obrem ne vitium hoc Ariftoteli afcribatur, dicendum eftomnem quidem animam ab eo in animali confiderari, non tamen omnem vt animalis, fed tum animam late acceptam, tuhr: partem vegetantem-confiderari vt viuentis corporis, quod-in animali ineft; \& commune: genus eft animalis \& plantx, ita vt omnia quas. ibi dicuntur, \&.animali, \& firpi competere ins 
telligantur. Poft declarata animalium princi- $\Lambda$ pia, materiam, \& forma m, fequebarur vt Ariftoteles de accidentibus, \& operationibus ageret, quod fecit in iis libris, qui folent vocari Parui

Parut

nat wh:

les.

Lib. de $S \tilde{e}$

lis, हैen

flious.

Ordopar uorüna. twralsts. naturales; horum primum effelibrum de Senfu \& ienfilibus, manifeftum eft, quum in cius initio Ariftotel.totam fequentem tractationem cuin pracedentibus de Anima libris connectens, funmque infequentibus confilium aperiens his verbis vtatur [ Poftenquam de Anima dictum est fecundum feipfam, confequens est facereconfiderationem de animalubus, Grtanque bobentibus omnibus, que font propria. EF qua communes operationesif form Afferit igitur eum librum,\&alios fequentes fequiftatim poft libros de Anima; afferit etiam orerotundo, fe non de folis animalibus, fed \& de omnibus viuentibus locuturum; \& preterea afferit, fenilaliud effe tractaturum in fequenribus libris, quam operationes tum animalium proprias, tum viuentibus onnibus communes : quare mainfefum eft, illud effe commune proomium omnium partorum naturalium, quum etiam Ariftotel. ftatim nom inet cætera omnia, qux poft eum lifrum in aliis requéntibus confideranda funt. Horum igitur fequentium librorum ordinem inter fe, \& ordinisrationem declaremus; quod enimad ordinem ipfum attinet, is nullam videtur habere difficultatem, quum partimab Arift. ipio exponatur, partim communi alıorum confenfione concedi videatur. Primum enim poft libros de Anima efle omnium paruorum natıralium librum defenfu \& fenfilibus, \& Arifto. teles ipfe in eius libri initio tefatur, \& omnes fatentur: in calce autem eiufdem libri proponit agendum ftatim de memoria, \& reminifcentia; poftea fe quitur liber de Somno, \& Vigilia, \& alii cum eo connexi, nempe de fomnis, ac de diuinatione per fomnum; deinde poft hos, liber de communi Animalium motu, in cuius libelli fine Ariftoteles epilogum faciens corum qux $E$ priustractauerat, eo, quem diximus, ordine eos omnes libros difponit, proponitque ftatim agendum de generationeanimalium; librumigitur de motu ftatim fequuntur quinquelibri de generatione animalium. Tandem omnium pofremi ab omnibus collocantur libri illi, qui ad durationem animalis, viuentisque omnispertinent;ii autem funt, delongitudine, \& breuitate vitæ, deiuuentute, \& feneetrute, de vita \& morte, \& refpiratione, ac demum de fanitate, \& F morbo; hunc enim ordinem ab ip fo Ariftotel. fuiffe conftitutum patet tum in primo capite libri de Senfu, \& Senfilibus, tum in calce libri de longitudine, \& breuitate vit $x$, \& in inicio libri de iutentute, \& fenefiute. De ordine igitur horum librorum non eit dubit.indum, quan. quam de libris de Aninalium generationeali-
A qui, quorum dogma mox expendemus, aliam proferre fententim aufi funt. Nunc huius ordinis rationem nos confiderare oportet, quum enim in aliquibus neceffarius omnino fit ordo, ita vit alius feruari non potuerit, in aliquibus vero non neceflarıus, fed propter melius, nos ytriusque rationem cognofcere debemus. Ante omnia quum memoratarum operationumaliæ fint proprix animalıum, al lix cunctis viuentibus communes, non eft ignorandumid, de quo dif-

B fufus diximus in libr.de Methodis, accidentia propria fpeciei duplicia effe, alia namque o- Lib.r. mninofpeciei naturam confequuntur, non na- cap. 6 lt. turam generis, cuiufmodi eft ienfus, qui folam animalis naturam infequitur, non naturam viuentis; alia vero, quum abfolute naturam generis confequantur, tamen à propria fpeci ei natura ita ad certos proprios modos reftringuntur, vt fpeciei propria fiant, huiufmodi eft modus animalium; quum enim ab folute fumptus motus naturam abiolute fumptam infequatur, proinde primo competat corpori naturaligeneri, variistamen modis à naturis fpecierum reftringitur, \& fit proprius fiingularum ; motus enim fimplex proprius eft corporis fimplicis, \& motus animalium infequitur non amplius naturam abfolute acceptam, fed naturam animalis; aliqui etiam particulariores modi exiftunt, quibus fitalius hominis, alius equi, alius canis proprius motus: fic generatio abfolute accepta primo competit corpori naturali cadu$\mathrm{co}$, at aninali competit proprius quidam generationis modus, qui ipfius naturx eft confentaneus, \& dicitur generatio animalium, qux eft fpecies generationis late fumptr, ficutietiam motus animalis eft fpecies motus generaliteraccepti. Tria igitur funt accidentium genera, quxab Ariftotel.in his libris confiderantur, alia communia funt omnibus viuentibus, qux etiam vt viuentium, non vtanimalium, confideranturab Ariftotel.licet confiderenturin in animalibus; huiufmodi funt vita, mors, longitudo, \& breuitas vitæ, iuuentus, feneftus, fanitas, morbus; modi namque, quibus hxc communiteranimalibus, \& plantis competunt, confideratione digni extiterunt. Alia vero accidentia ita naturam animalis folam confequuntur, vt nullam cum natura generis habeant affinita. tem; huiufmodifunt fenfus, memoria, reminifcentia, fomnus, vigilia, fomnia, \&r diuinationes, quxper fomnum fiunt, de quibus fingulis libros ab Arift. feriptos habemus. Alia demum quum abfolute naturam communiorem confequantur, ab ipfatamenanimal is natura ita reftringuntur, vtanimal ium propriareddantur, vt motus animalium, \& eorundem generatio: proprii namq; modi, quibus in animalıbus fiūt, ita cognitu digni extiterunt, vt propriam tra- 
ctationem poftulauerint, quia iis ignoratis mã- A ca, \& imperfecta fuiffet naturalis philofophia. De his igttur proprios libıos fcripfit Ariftoteles, tanquam de accidenzibus propriis animalium, essque infcripfit de motuanimalium, de generatione animalium; nnn fic de morte, \& vita animalium, nee de suuentute, \&e fenedute animalium, quia bac vt omnium viuentium communıa accidentia confiderare voluit. Hxc omnaaccidencium genera quum in his libris tractentur, potuiffet Arıltotel. in hoxum tractatione ordinem leruare à magis vniuertalibus ad minus vniuerialıa. \& illa, quxviuentibus omnibus communia funt, aliis anteponere, poitea vero agere deillis, qux funt propria animalium, idque onmino facere debuiffet, fi melioris, aut facilioris doctrınæratıo hunc ordinem, vt in aliis plurimis folet, poftulaflet; quum autem nulla poitulauerı (cuius quidem rrimo de rei rationem nos in memorato locodiffufe de. Mech. ip. Glr. clarauimus) ideoque vniuerfalioraanteponere coactus ea ratione non fuerit; ftatuit non recedereab inftituto, voluitque ab iis exordiri, qua funt propria animalium, pofrea vero dealiss agere, qua viuentibus omnibus communia funt: quum enim vtraque hac in animalibus conftderare decreuiffet, ita eorum tractationes difpofuit, vt qux intimiora natur $x$ anmalis effeviderentur, ea prius tractaret, qua vero remotiora, pofterius. Quoniam igitur narura animalis nihil eft intimius fenfu, fiquidem animal per fenfum eft animal ; ideo ftatim poftlibros de anima primum locum inter omnes operationes Lib. de Sé tribuere voluit operationi fenfus, de qua agit in H, ESen librodefenfu, \& lentil, bus; vbi illud eft nobis ilibses. animaduertendum, nomen fenfus accipi folere senfess for tum proipfaanim $x$ faculta:e fenfibili, tum pro mirur, eius operatione; fenfus pro anima acceptus, Go pro fuit confideratus in libris de Anima; in hoc auenrma tem libro agitur de fenfu fumpto pro operatioGíproa- ne; \& ita infcribitur defenfu; de obiectis auberatio- tem fenfilibus ibi agitur propter operationem, me.- vt magis declaretur, quomodo immutetur orLib. de ganum ex eorum actione, vnde piodit operamemori tio. Librum de fenlu \& fenfilibus fequitur ftaGreminifentia Lib.deso mino, Es Cogstian

Libride fomnis, Esde ds irsinatio ne perfo. m.sm. omnes libri funt proprianimalium, quia ad folum fenfum pertinent, \& ea, quam diximus, $i$ prorum inter fe ordinatio neceffaria eit, quo. niam aliter difponi non potuerunt, vt manifefum eft. Hos omnes fequitur liber de commu. Lab. de ni Animalum motu, quia motus eft fenfupo-morusn: fteriorea, quam tetigimus, ratione, fenfusenim malswm. omnino infequitur animalıs naturam; motus veronon hanc, fed vniuerfe fumprans naturam infequitur: naturam au en anımal is confequiB tur modus potius ipfius motus, quam motus iipfe: non ita igitur intimus naturæ animal is eft modus vt fenfus : adde quod fenfus datus eft animali vt fit, motus veronon eft animali neceffarius vefit, fed vt conferuetur; conferuatur eni in per cibum, quem fibi quarit per motum; omnibusigiturlibris perfe adfenfum attinentibus, pofterior effe debuit liber de motu animalis; ob quam eandem rationem etiam quatuor libride partibus Animalium, quum fint de iis partibus, qux pertinentadanimalis effe, vel ad bene effe, praponendi fuerunt libro de Inceffu. in quo agirur de iss partibus, qux conferuntad motum, proindead conferuationem animalis. Poft librum de motu Ariftotel. itatim locat ( $v t$ prædiximus) libros de generatione Animatium Lib. de ge quamuis enim alia fortalfe ratione generatio \& neratsomotui, \& fenfui antepom potuiffet, tamen fi A- ze antriftot. inftitutum (pectemus, poitponenda fuit; malism. eft enim operatio animalis, quaneque ad cius $D$ efre, neque ad conferuationem pertinet, fed ad folam conferuationem fpeciei; poteft enım \&e exiltereanimal, \& diutifime conferuari, quod omni prorfus vi generandi fit orbatum: non eft tamen ignorandum, generationem alio modo refpicere naturam vnuerfalem, alio particularem;refpectu enim naturæ vniuerfal 1 s, qux præ caterıs quarit conferuationem fpecierum, pracipua magis eft generatio, quam motus; at fi particularem cuiuf que naturam fpeetes, ea præE cipue vult indiuıduum feruari, deinde vero fperiem; officium enim eft naruræ vniuerfalis, finem vltimum sebus, ad quen tendant, ftatue. re; naturx autem particularis, iufra quodammodo illus exequendo procedere ordine generationis, quem hic Ariftotel.refpexiffe videtur, primum enim vulr animal exiftere, deinde conferuariacdurare, donec ad $x$ tatem perueniat perfectam, in qua fit aptum generare aliud frmile, atque ita fpeciem conferuare; hac igirur ratione prior eft fenfus moru, \& morus generatione, quia propinquior, \& incimior $\mathrm{i}$ pfinatur $x$ animalis. Non defuere tamen, qui de loco libr. de Animalium orru aliud fenferint, quorum fententiam mox expendemus. polt libr. de generatione Animaliurn fequuntur illi omnes, qui quam ad viuintia omnia pertineanr, \& res tractent communes animalibus \& planris, qua remortores enle videntur à propria aisimalis natura, vt ante diximus, ad poitre- 
poftremum locumab Ariftot. reiecti funt; com-A tium feriem edoceremus; egotanen eo labore munia omnium viuentium accidentia funt lōgitado, ac breuitas vitæ, luuentus, fenectus, viL.b. de tō ta, \& mors, fanitas, \& morbus, de quibusagit Agytudire rift. eoordine, quiaddotrine facilitatea conGbreutit ferre vifus eft; prinum quidem locum fibi venGitc. dicare videbatur tractatio de longitudine, ac bretitate vita, per quam cognofceremus rationem.cur viuentium alia diutius, alia breuius viuant; hoc difcrimine cognito diftinguenda eft cuiufque duratio in partes, qua dicunturiuuen-

Zib. de in tus \& feriectus; ideo Arift. in calce libri de lonweritute, gitudine, \& breuitate vita, proponit agendum G fent. deiurentute, \& fenectute, acfimul de vita, \& Est. EF morte; coniunda namque ef horum omnium mor. tractatio, itavt de omnibus in eodem libro loqui cómmodiffimum effe Arift.iudicauerit;fed cum fermone de vita, \& morte coniunxit etiam tractationem de 'refpiratione, \& expiratione, qu.umuișanimalibus folis hxc competant, non. plantis, propterea quod animalia tamdiu viwunt, quamdiu refpirare, \& expirare poffunt: quum enim id facere nequeunt, moriuntur; itaque fermonem de refpiratione coniunxit cum fermone de vita; \& morte, \& haram tractationem cum tractatione deiuuentute, \& feneetute, in his enim æratibus viuere animantia dicuntur, \& earum omnium extremum mors eft; ideo poftrema omnium pradictarum eft tractatio de vita, \& morte, fquidem per mortem his omnibus finisimponitur. Poftremus omnium de a-

ciÉride nimalibus librorū eft liber de Sanitate, \& Mor-

finitate. bo, v. Ariftot.ipfe teftatur in primo capitelibri bo, v. A riftot.ipfe teftatur in primo capitelibri
de Senfu, \& Senfilious; baic vltimus debebatur locus, tum quia fanitas, \& morbus cognitionem. aliorum dictorum accidentium prafupponunt, tum exiam quoniam alia omnia iam memorata.pendent à fola naturas fanitas autem, \& $x$ gr1tudo \& à natura , \& ab arte : quo fit vt Arift. in 1. c. libri deSenfu, \& Senfilibus, \& in initio ipfius libride vita, \& morte dicat, traetationem hanc $\mathrm{E}$ modo quodam effe in confinio feientix naturalis, \& artis medic $x$, quum in ea definatphilofophus naturalis, \&ab ea incipiat medicus: quod quidenı quomodofitintelligendum, iä in mea

Z36.2.5.7 de doctrinæ ordine Apologia declaraui. Hunc igitur ego puto effe verum ordinem omnium librorum de Animalibus, \& ipfius ordinis rationem. Reftat vt in pradictis libris aliqua confideremus, \&raliorum de ordine fententias breuiter expendamus.

\section{Qualis debear efferractatio de fanitate $e^{\circ}$ morbo in fcientia naturali. Cap. $X X X I I I$ :}

$\mathrm{Q}$ Vum omnium de animalibus librorum ordinem expofuerimus, optaret fortaffe aliquis, vt etian finguli cuiufque libri tractacionis modum, diuifionem que in partes \& par.

fuperfedere conftitui, neopus hoc, quos brtate efe voluit, in magnam molem excreficat, quum prafertim hac in fingulis Arifturel. libris per fe quifque confiderare poffit; nobis igitur fatis fit vniuerfam ftructuram declaraffe. Sed traetario de fanitate, \& morbo poffulare videtur ve aliq̨iva de ipfa dicamus, quum enim folum eius libri initium habeamus; ipfa autem tota tractatio defideretur; quo fit vt videre nequeamus, quomoB do de Canitate \& morbo egerit Arifotel. \& quomodo horum tractatio naturalis à tractatione medica diftinguatur, non erit ab re, fi de hocnos aliqua diximus; \& quum pratermedicos nemo, tanquam philolophus naturalis de fanitate, \& morbo fcripta, qua legere polfinus, nobis reliquerit, noftram ipfi hac de re fententiam proteramus. Ego igitur quid fentiam, paucis exponam. Philofopho naturali de fanitate, \& xgritudine fcripturo, du o putoefle obferuandar C vnum pertinet ad fubiectum horum accidentium, alterum veroad eorum caufas; quond ad: fubiectum attinet, tribuenda funt omnia accidentia illi fubiecto, cui primo competunt, contra quam medici faciunt, qui \& fanitatem, \& morbum, \& multas operaicones, ip fasque organicas partes, qux hominicum multis aliis communes funt, vt hominis contemplanrur; qua in requum omni reprehenfione careant vt medici, at vt philofophi naturales admittendi non ef-

$D$ fent : itaque confiderare oporteret fanitarem. \&morbum vtaccidentia viuentis yniuerfe fumpti, ita vt son minus furpium, quam animalium fanitas, \& ægritudo confideraretur. Quod vero ad caufasattinet, non eft ignorandum, fanitatis, \& morbi caufas, quæ tractantur à medico, alienas effe à philofopho naturali, quum ad effectionem omnes pertineant, non ad fcientiam; hx autem funt, qua communiter à medicis auxilia , feu remedia appellantur, quorum inuentio, \& cognitio fcopus eft artis medicz docentis, eaque funt magna ex parte plantasum vires, \&proprietates: etficnim non inficior, debere philofophum naturalem in libris de plantis docerenaturas, \& proprietates plan. tarum, ad plenam rerum naturalium notitiam, \& ad perfectionem traditionis feientia naturaralis; dico tamen id in libro de fanitate, \& morbo minime effe faciendum; talium enim virium applicatio ad ipfum viuentis corpus faF nandum humani arbitrii eft; fitque ex habitu: artis: funt igiturà philofopho saturali cognofcendxplantarum naturz, \& proprietates propter cognitionem plantarum tantunamodo; à medico autem propter humani corporisfanitatem efficiendam, vel conferuandam. Quano. brem naturalis de fanitate tractatio deber effe vniuerfalıs, caufasque complecti vniuerfales, \& naturales; eft enim fanitas, propria cuiusque viuentis, feupartis eius temperatura, qua Canfafa-
netatis,
go morbs
non om-
nesperti
nent ad
naturat
lems. 
prouenit ex elementorum commiftione; \& huius quidem plurimz funt fpecies pro fpecierum viuentium, atque earum partium diuerfitate, fed particularem omnium temperaturarum confiderationem facere pertinet ad libros de partibusanimalium, \&ad libros de plantis; quarelibro de fanitatenil aliud reftat confiderandum, nifi vniuerfe quid fit fanitas', \& à quibus caufis pendeat; fic enim quid fit morbus, qui nihil aliud effe videtur, quam à pradicta viuentis naturali temperie receffio talis, qua $l x$ dat operationem; \& hui us receffionis caufas $v$ niuerfales debet naturalis philofophus declarare, veluti ambientem aerem, \& extrinfecus affumptum alimentum, à quibus pouffime viuentium corpora variis modis inceffanter alterantur, mutanturque temperaturæ naturales; quare fi eousque procedat mutatio temperiei, ve ladatur operatio, morbus eft; at particulariores variorum morborum caufas diftinguere ad medicum potius, qui curaturus eft, quam ad philofophum naturalem pertinere videtur; vt fortaffe idem de fanitate, \& morbo dicendum fit, quod de habitibus animi dicitur, hi namque tum vt funt habitus, tum vt affectiones; feu ( $v t$ vocant) difpofitiones, per voluntarias actiones acquiruniur, proinde non ad naturalem philofophum pertinet eorum confideratio, fed ad moralem; naturalis enim fatis haber cognofcere omnes animi facultates, in quarum numero illa eft, qua hos habitus acquirere apti fumus, fiue ea vna fit, fiue plures; habitus autemipfos fiue bonos, fiue prauos diftingere, \& cognofcere debet moralis, qui eft quafi medicus animi , \& particulares caufas, per quas gignüntur, declarare. Sic etiam debet naturalis philofophus cognofere hanc viuentis corporisaptitudinem, qua \& fanum effe poteft, \& $x$ grum, \& vniuerfaliter quid fit fanitas , \& xgritudo; particularesautem diuerforum morborum caufas, nec non eas, qux fanitatem conferuant, \& eas, qux lapfam reftituunt, ac fingulos morbos pellunt, cognofcere folius medici officium eft, hrc enim omnia effectionem refpiciunt. $\mathrm{Ob}$ id eam ego puto efferationem, cur dicat Ariftoteles tractationem de fanitate, \& $x$ gritudine effe quodammodo in confinio fcientiæ naturalis , \& artis medica; \& in ea definere naturalem fcientiam, ab ca vero medicam artem exordium fumere: definit enim Philofophus naturalis in vniuerfali confideratione fanitatis \& morbi, à qua exordiens medicus defcenditpoftea ad particularem morborum omnum tradendam notitiam, \& propriarum caufarum, tum à quibus producuntur finguli, tum per quas expelluntur, quippe qui affectionem molitur, hæc autem non eft nifi rerum particularium. Idem mihi videtur,aut faltem aliqua ex parte fimilis effe refpectus difciplinx moralis,ac ciuilis ad legislatoriam; nam in morali, \& in ciuili facultate de
A moribus, de virtutibus, ac vitiis, at que de fercndis legibus vniuerfalia pracepta traduntur;legumlatoresautem de omnibus, ac fingulis particularibus leges condunt, per quas in ciuium animis virtutum habitus gignantur, \& vitia expurgentur. Quamobrem ficut bonus medicus effe non poteft, qui non fit philofophus naturalis, ita nec bonuslegislator, qui non calleat moralem philofophiam : inter eas tamen illud intereft, quod medicina folam effectionem refpi-

B cit,philofophia natural is non effectionem, fed folam fcientiam; ciuilis autem, \& legislatoria. ambxabactionem dirigütur, quo fit vt vtramque liceat anima medicinam appellare, cum cotamen difcrimine, quod ciuilis yniuerfalia pracepta tradit, legislatoria vero defcendit ad particularia : aliudautem eft legislatoria, aliud iudiciaria, quar eft illa iurisperitia, quam profi- Iwripetenturilli, qui histemporibus Iurisconfulti ap - ricie. pellarivolunt, hanc enim legislatoria ignobi-

C liorem effe manifeftum eft, idque aperte teftantur Plato in Gorgia , \& Ariftuteles in primo librode arte Rhetorica ; eft enim fimplex quxdam peritia, quæ nec fcientia, necprudentia, nec ars appellari meretur, quum fine ratione fit, hane enim callere aliquis poteft absque vlla ciuilis, aclegislatorix cognitione; fed ita videtur effe fublegislatoria, vt empirica fubarte medicajempirica enim, quum rationem ignoret, ars nominarinon poteft, quum ars non dicaturnifi quæ cum rationeeft, vt inquit eo in loco Plato. De modoigitur, quo debet philofophus naturalis agere de fanitate, \& morbo, hrec mea fententia eft, eamque fignificare vifus eft Ariftote. les in fecun do libro de partibus Animalium,capite feptimo, vt quifque eins verba eo in loco perpendens animaduertere poteft.

\section{Comparatiolibrorum de biftoria animali- um cum reliquis de Animalibus.}

\section{Cap. $X X X I V$.}

C Eterum quum totam de animalibus tratationem in duas partes diuiferimus, vnam in qua folum quod ita fit declaratur, qux nouem libris de hiftoria Animalium continetur: alteram vero in plures requentes libros diuifam, in qua eor $\vec{u}$, qux in hiftoriis dicta erant, cauf $x$ afferuntur, \& declaratur propter quid : $F$ non erit abre, fi vnam cumaltera conferentes confideremus, cui hiftoriz parti quis liber refpondeat, quod quidem brcuiter præftabimus. Notare quidem in libris de Hiftoria poffumus earum duarum tractationum diftinctionē, quarum vna ad principia, \& ad fubftantıam animalis pertinet, altera vero ad accidentia; \& operationes, fed ruditer, necita diftincte $y t$ in aliis fequentibus libris, quos fcientiales effe diximus; neque id iniuria: fiquidem rudis \& hiftorica e-

\section{E}


narratio cam exquifitam-partium diftinctio-A nem, quam demonftratiua cōtemplatio habet, habereminimè potuit. Prim o quidem loco de De parti partibus animalium agi in hiftoris, ficut etian bus ani- in parte demonftratıua, manifeltum eft; nam malım. in prioribus quatuor de hiftoria libris pateragi deanimalium parcibus, idque Ariftoc.epilogo Triag ge-c.llegit in initio quinti. Sednon eftignorannera par dum, iriaeffegenerapartium in animali , alıa trum in namque pertinent ad effe, feu ad bene effe, de asmals. quibus agitur in quatuor libris, quide partibus animalıum inferibuntur; alıx ad motum, de quibus in libro deincetfu; alix demum ad generationen, de quibus in libris de generatione animalium : fed hac partium diftnctio in libris de hiftoria non admodum n , tari poteit; de primo quidem partium genere ag tur in primo, \& in fecundo, \& in poiteriore parte tertii, $\&$ in priore quarti, quare eam totam tractationem dicere poffumus, quatuor libris de partibus animalium refpondere: de parribus au. tem ad motum conterentib. nil feparatim dicitur in hftoriis, fed de his aliyua dicuntur fparfim in memoratis libris, vna cum alıarum prædictarum partium confideratione ; quare liber de inceffu nullam serram haber in hiftoriis fibi refpondentem partem: de partibus autem generationi inferuientibusagıt feparatim Aritot. in prima parte tertij, \& in eius libri initio de his dicendum proponit; quare pars illa tertij refpondet fcientiali harum partium tractationi, qux habetur in libris de. Generatione aniIibris de malium. Librisautemde animain hiftoriis nulansma la pars refpondet, quia nil de anima hiftorice sulla dicipoterat, tum quia anima infenfilis eft, quò pars re- fit vi, licèt de ipfius operationibus plura dici jpondet potuerint, qualenfu, \& expetientiafunt inuenin biffo. ta, de ipramettamen anima nihil, tum etiam riss. quia delllis tantummodò inftitui tractatio hiftorica poterat diftincta à fcientiali, quz caufam aliquam habent, ita vt de 1 is declarari poffit \& quod fint, \& propter quid fint: caufam habent partes animaliun finalem, cuius gratia funt: caufam etiam habent omnes viuentium operationes, vt patet; de his igituromnibus du. plexfieritractatio potuit ; vna hıftorica fine cófideratione caufarum;altera fcientialis per caufarum traditionem: aft anima in viuentibus caulam nullam habet, quia ipfa eft primaaliorum omnium caula; qui enim dicunt operationem effe anim $x$ caufam finalem, reiciendi omnino funt, nec tantum abfurdum fuit vnquam ab Ariftotele pronunciatum, qui femper pro eodem habuit dicere partes animalium efre operatio propter anmam, \& effe propter operationes, nes non canquam proper fincm; \& lemper animam $\mathrm{J}$. nus vociuit finem, fed non dixit eam habere tinem. arsirua. Quim : gitur anima caulam priorem non habe. at, duas, vecxtera, tractaciones non poftulaurs; idq; fortalle fignificare Arıft. volut in primo contextu primi libri de Anima, dum fcientiam illam appellauit hiftoriam de Anıma, non iolum enim denotauit enarrationem veram, quam lis effe folet in omni hiftoria, fed etiam figaticauit nullam deanima hiftoriam præceffifie diftin tam à f́cientrali crufdem tractatione, fed \& illam iplam effe fimal \& hiftoriam, \& exquifitan, quantum à naturali philof opho tradi poterat, tractationem de anima. Néque etianı puto ob aliam caúfam Aritorclein eodem in loco B hiftoriam de Anima $i \tilde{n}$ é: ftuntem elle iixilfe, nili quod in is Jibris tradituranima cognitio, qux omnium, qux in viuentibus funt, prima, ac ituprema caula eft: quoniam enim exquificilfima cognitio eft, quando effectus omnes ad primam, \& in eo genere fumman caufam, à qua omniapendent, reduxerimus, exquifitiffina eft hiltora illa de Anima, quia tradit cogationem animæ qux eft prima caufa omniuin qux in viuentibus conC liderari poifunt, ex culu; cognitione cognttio aliorum perfecta habendaeft; quamobrem per hoc non alıun dat Ariftoteles primatum libris de Anima, nifi an libris omnibus ad animantia pertinentibus; omnium enim qux in iis traduntur, perfecta cognitio pendet ex animanotitia, qux in libris de Anima traditur, qui obid principernilocum renent inter omnes libros de animantibus, videnturque in medio collocati tanquam rex in medio regni; qualis etiam videtur effelitus cordis in animali. $\mathrm{Li}$ bros de Anima Atatim fequitur liber de fenfu, \& fenfilibus, cuirefpondet tractatio de fenfibus in pofteriori parte quarti libri de Hiftoria: deinde tractatio de fomno \& vigilia, \& de fomniis in calce ciufdem quarti refpondet libris de fo. mno \& vigilia, de fomnis, \& de diuinatione per fomnum, fed libro de memoria, \& reminifentianulla feparata tractatio in libris de $\mathrm{Hi}$ ftoricarefponder; fparfim tamen in iis librisaljE qua ad has pertinentia dicuntur, vt in nono $\mathrm{li}$ bro de illa, quamalıqua a nimalia maiorens, aliqua minorem præfe ferre videntur,prudentia, feu fagacitate, variisque animalium moribus. Hos omneshbros fequitur liber de communi animalıum motu, cui propria tractacio in hi. Deme. ftoriis nulla refpondet, quemadmodum nec $t w$. libro de inceffu, fed fparfim aliqua dicuneur de motu, \& de partibusad motum conterentibus vna cum aliarum partium cunfideratione. qux in quatuor prioribus de hiftorialibris habentur, qui videntur refpondere omnibus fequentibus libris, qui funt à primodepartibus animalıum, vfque ad calcem libri de communi motu animalium, quen itatim fequunturlibri de yenerationeanimalium, de qua eaden incipir loqui Ariftet. in princi io quinti de hiftoria : quum enım operariones, qux tractantur ì l,bru de ienfu, \& lentilibus ad librum vfque de comanuni aniwalium motu; videantur ma.

\section{$\operatorname{Defenfu}$. $\mathcal{E}^{2} \int_{\mathrm{en} f \mathrm{~s}}$ libzss. Deform- no, Es: gilia, E de fom - nis. De me-} moris.

\author{
Demo.
} .

.


xime effentiales animalibus, \& cum corum fub- A ftantia valde coniunctx, fenfus enim pertinet ad effe ipfius animalis, motusautem eft cineceffarius ad eius conferuationem: ideo Ariftot. in quatuor prioribus de hiftoria libris omnia complexus eft, qux tum ad fubftantiam, hoc eft, ad partes animalium pertincbant, tum ad operationes cum ipfa fubftantia maxime-coniunctas, vt epilogorum finilitudo, \& inter fe refpoindétia dcclarat, $f c$. eius, qui eft in initio s. de hiftoria, \& eius, qui in fine libri de comuni motu. Nam in principio quintide hiftoria inquit [expofuipartes animalum omnestü intereores, tum extercores, at que etiam de ferf fu, de boce, EF defomno; reftat Gt corundem generationesperfequamur ] in calce autem libri de cōmuni motu huic fimilem epilogum legimus his verbis: [Departibusigetur cuins $\dot{q}_{3}$ arimalis, $\mathcal{E}^{5}$ de animas prateres de enfu, Es memoria, So motudiximus caufas, relequum autem est de generatione dicere.] Voluit itaque A rift.omnia, quxad hunc vsque locum tractauerat, refpondere quatuor prioribus libris de hiftoria, ita vt ftatim fequatur vtrobique tractatio de generatione, de qua in quinto, fexto, \& feptimo hiftoriarum libris loquitur, quibus refpondent quinque libri de generatione animalium in tractatione fcientiali. Quum enim generatio fitauimalis operatio ad extra, qua neque neceffaria eft animali vt fit, neque vt conferuetur, ficut ante oftendimus, proinde remotior ab animalis effentia effe videatur:A riftoteles in v traque tractatione feiungere eam medio epilogo voluitabaliis memoratis operationbus, qua maiorem cum fubfätią animalis affinitatem, \& coniunctionem habere videbautur. Poftrema pars tractationis de animalibus ea fuit, in qua tractantur commuDe Gota, nia accidentia a nimalium, \& plantarum, eaque s mor- omnia ad vitam, durationemque animantium 'e, pertinent, de quib us agitur in libro de Longitudine, \& breuitate vitæ, \& in eo, qui eft de iuuentute, \& fenectute, de vita, \& morte, \& refpiratione : huic toti parti refpondet oftaus de hiftoria liber, vbiagitur de animalium variis vitæ generibus, rationibusque viuendi; agitur etiam in eodem libr. de pluribus diuerfotuni animalium morbis, quæ pars refpondet libr. de fanita. te, \& morbo. Nono autem libro de hiftoria, in quo de moribus animaliū agitur, nullus in fcientiali tractatione liber refpondere videtur, de his enim fortaffe Arift. præter hiftoricam traditionem nihil habuit, quod diceret, nam morum nulla alia effectrix caufa afferri potet, nifi quod talis eft illorum animaliü natura, veluti fi ferocitatis, aut magnanimitatis leonis, aut crudelitaris tigris,aut ouis ftultitixcanfam quæiamus: finalis autem caufaplurium morum ita pet fe manilefta eft, vt fimul cum inforum morum enarratione exm exprimi ncecle fit;atinamque z̀ natura funt dituris in animal: ous yarij mores, \&
A inftinctus, ad ipforum animalium conferuationem, aut deficnfionen, vt prudentia quædam, \& aitutia, quan in pluribusanimalibus tum maiorem, tum minorem notare poffumus, \& alia multa eiusmodi, qua in nono illo hiftoriarum libro leguntur; nulla igit ur eorundem morum alia fcientialis, tractatio relinquebatur, quocirca fola hiftorica narratione Ariftoteles voluit effe contentus. De decimo autem hiftonarum libio ego quidem maxime dubiús femper fui, videtur

$B$ enim nec hiftoricis, nec frentialis dici poffe, quod enim non fit hiftoricus, ip fancteius libi tractatio declarat; in co namque declarantur caufx fertilitatis, ac ftcrilitatis, quæ tractatio nullo paeto hiftorica appellari poteft, quod cognofi ens Theodorus Gaża, qui reliquis nouem in Latinum fermonem conuertit, decimum hunc conuertere noluit, nec al iis noucn apponendum putauit, fed pornuslibris de generatione animalium inferendum, ficutapud eum legimus in fua in eos libros prefatione, vbi etiam coniderat cum librum 1 on integrum efre, fed fragmentum quoddam, cui manifeftum eft de. effe initium, quum incipiat à diatione aduerfatiua,nec vlla prorfus appareat eius continuatio, feu connexo cum iis, qua in calce noni libri dicta erant. Egoitaque in hoc Theodorifententiam probo, led non in eo, quod putat effe annectendum libris de generatione animalium, plura nam que in eo dicuntur, qux in is quoque li-

$D$ bristraltantur; non ef auten credendum earundem rerum declarationem bis in eisdem libris ab Ariftotel.fuifie fruftra repetitam. Adde quod librorum de genrratione tractatio fientialis maxime eft, qualis non eit ea, que in illo decimolibrohabetur; caufas enim iterilitatis, ac fertilitatis in folo homine confiderat qux tamen pluribus animalibus communes funt.Mos autem Ariftot. eft om nia attribuere illi fubie fo, cuiprimo competunt, quam folam effe fcienE tialem tractationein ipfe in pofterioribus Analyticis docuit : hoc autem diffrimen manifefte infpiciturinis, qua eadem \& in eo libro, \& in libris quoque de generatione traduntur; qux enim in libris de generatione dicuntur vninerfe de animalibus, ea in illo decimolibro in folo homine confiderantur. Hanc ob caufam ego arbitror, librum illum non elle f́cientialem, nec annedendum libris de generatione:videtur potius effe extra ordinem fcriptus, vt etiam alij

F plures, fiue ab Ariftotel. frue ab aliquoalio, \& medicinalis potius erfe, quam naturalis: nam medicimulta, qux pluribus animalibus communia funt, in homine folo, quem fanare volutt, coniderare confueuerunt; neque aliena ab hac fententiz funtilla, qurein eolibro fcibuncur, multa enim dicun:ut deauxilis terendis ferilitati, qurmedicinam potius fapiunt, quam philofophiam naturalem. 53 2ati-
Delibr. 10. debeo froria. Roria. 


\section{Latinorum opinio de loco librorum de Ani- ma or eius reprobatio. Cap. $X X X V$.}

$\mathrm{V}$ Eritate cognita de ordinc omnium librorum de animalibus, fequitur vt alıorum falfas hac in te fententias expendamus, ac reprobemus, \& aliqua exiis, quæ diximus exorientia dubia foluamus. Primum quidem Latini de loco librorum de anima aliam fententian fequuti funt, nempeillam, quam videturapprobaffe Auicen. in difponëdis libris fuis naturalibus : putarunt enini libris de anima primum locun deberi inter omnes libros de anımalibus, Arguméhos argumento ducti, quíod qui rem aliquam tiu Lati- cogniturus eft, debet primoloco iilius princinorkir. pia contemplari, eft autem anima principium animalis, \& omnis viuentis corporis; ab anima igitur totan de viuentibus tractationemexordiri oportuit;quocirca libros de anima fêxtum in fcientia naturali locum obtineredix crunt, ita vt ftatim fequatur libros de mineris, \& omniū ad Senters animantia pertinentium prumus fit. Sententia tia im- hæc iam reprobata à nobis eft pluribus Ariftot. pizgratzo teftimoniis, yui primum locum dedit libriz de hiftoria Animalium, fecundiun quatnor libris de partibus, tertium libro deInceffu, poft quem ftatim locauit libros de Anima: nuncautem rarione aduerfis eos vtemur, necalia, quamea ip fa, qua fuam ipfi fententiam comprobaruni: fis enim vno, \& eodem labore \& veram fententian confirmabimus, \& eorum argumenturm Solutio foluemus. Dicebant ipfi, à principiis rei confiargume- -dirandx ordiendum eft, nos vero hoc idem sorwss. confitentesita argume tamur:partes animaiium funt principia, funt enim materia animalium, ergo a partibus inchorandum eft, proinde primi funt libri departibus, nam \& priores delifitoriahbros departibus effe manifeftum eft. Itague controuerfiaint egra manet inter materiam \& formam, idque nobis in prefentia excuriendum proponitux, quum cognofenda fit cuiufque rei naturalis \& materia, \& forma, de vera An isma- prius fitagendum. Illi quidem, qui in ordine serie, an doctrinx ipfan rerum narunm fequendam a forma femper effe putant, dicerent materian femper fat ordzé- efie anteponendam, tanquam natura priorem dum. forma ; prius enim propria cuiufque rei mate-
Aliarum ria ftaruenda eft, quam ex ea edicatur forma; Confio. idque videtur Ariftotelafferere in primolibro sis. - de partibus Animalium. Sed horum fententwæ illa, quæ in primo Phyfic. habetur,materias, ac form $x$ confideratio manifefte refrngatur: ibi namque acturuts Ariftotel. de internis princi-m. piis corporis naturalis, prius oftendit efle duo principia contraria, quæ formalia principia vocari folcut, deindevero ex cor um notitia ducit nos in prime materiz cognitionen'; itags prius ibi agi de forma, qram de materia, manife ttum: eft. Neque eft quod aliquis dicat primums il -
A lum librum de materia effe, fecundum vero de forma, \& ita prius agi de nuateria, quam de forma; craffus enim hic error eft, \& a nobis antea reprobutur: de forma enim, \& de materia quatenus funt forma, \& materia, hoc eft, quatenus funt principia conftituentia corpus. naturale, non in fecundo libro agitur, fed in piimo; eaque tractatio in primo libro perfecta eft: in fecundo autem libro eadem principia tractantur reipeEtu accidentium, motus, \& quetis, quorũ prinB cipia fime, qua ratione non dicuntur amplius confiderari vt forma, \& vt materia, fed ve natura.Ideo alienifhıma à veritate, \&ab Ariftorele eft illorum interpretatio, qui in vltimo contextu primi libri, quando $A$ riftotel.ait $f e$ pofterius de phyficis, \& caducis formis acturum, dicunt $\mathrm{fi}_{\mathrm{i}}$ gntficari lequentem tractationem de naturain lecundo libro: : reuera enim nil aliud fignificare vult Ariftotel. nifitractationem de propriis fingulorumnaturalium corportum formis habenC dam in reliquis libris naturalibus; quum enim in eo primo libro formam communiter tantun acceptam confiderafier, ibi foluere volens tacitam quaftionem, inquit de prima omnium formarum fiue vna fit, fiue plures, ad philofopbum naturalem loqui non pertinere, fed de formis folis naturalibus, dequibus quum communiter egifet in eo primo libro, reftabat de fingulis feparatim dicendum in reliquis huius frcientiallibris,fcilicet de formis elementorum in libris de elementis, de formis miltorum in libris de miftis, de formis animantum in libris de animan. tibus; fic enm tractatio fignificatur de formis. quatenus formæ funt, qualis non eft ea, qua in fecundo libro l'hyficorum habetur de natura, ve etiam manifefte oftendit.locutio Ariftotel.in. plurarinumero,de formis enim fe acturum pollicetur, quum in eo primo de forma egiffet, \& in fecundo aeturus effet adhuc de forma late. fumpra, quatenus eft natura, fed non de forE mis, quia totailla tractatio eft ynuerfalis. Illud igiturverifimum eft, vbi de materia, \& deforma naturalis corporis: aetum eft, ibi prus de forma actuns effe, quam de materia prius enim. oftendit omne, quod fit, ex contrariis fieri, eaque duo effe, vnum nobilius, qux eft forma, alterum ignobilius, qux eft priuatio; poftea vero ex anutatione, quafit de contrario in contrarium, oftendit dari pracer contraria tertium principrum fubie Aum. Egoigiturab iis; quralıbidemonftraii, non recedens, dico ha- opmio bere qudem materiam, \& formam, inter fe. ordinem naturalem, vtait Ariftotel. in primo: cap. fecundi departibus Animalium: nam ordine gerverationis naturæ materia prior eft, ordine autem intentionis natura forma eft prior, quia materia eft proprer formam; attamen ordo doctrin $x$ non fumiturab ordine natur $x$, fed à noftra faciliore, aut meliore $\operatorname{cog}_{\text {gai- }}$ tiôe: pbi igitur forma eft rotior, \& cius cognitio: c.ord:- 
confertadenorofcendam materiam, agendum prins efi deforma, quam de nuateria; vbi vcro materiacit nuiso, lid materia prius, quam de forma cit agendum. Ob id A rift.in primo $\mathrm{Phy}$ ticor. agens de prima rerum matcria, qux quum fit ens mera poteftate, maxime ablcundita nobis eft, ac difficillima cognitu, prius egit de forma, quia nun poterat prima materia cognofci, nifi ex mutatione, qux eft de priuatione ad formam,vel de forma ad priuationem: contra vero in libris de animalibus egit de materia animalium, quam de forma, quoniam partes animafium, qux funt eorum proxima materia, fenfiles funt, \& notiores, anima vero in/cnfilis, \& ignotior, \& eius confideratio ardua, multisque, ac magnis difficultatibus referta eft, vt Arittot. ipfe teftatur in prooemio librorum de Anima; eaq; fuit Ariftot. mensin primo libro departibus Animalium, quandodixit agendum prius effe de materia, quam de forma, non enim ea tantum ratione ductus eft, quod materia fecundum ordinem nature dirigi' ur ad formam, fed quodan malium partes, 11 bene cognitze fint, cognutionem anima facilioren reddunt, idq; potiffimum refpexit, quarído ibi dixit effe de animia agendum, fed prius effe dicendum de materia:hoc autem fignificauit A riftot.in if fa animx definitıone, definit enim animam per corpus organicum : hoc eft, variis organis preditum : ad plenam igitur eiusintelligentiam plurimam cốtert coznitio partium organicarum, quam A. rifoteles tradit in libris de partibus ; non enim cognofcimus quod fint organn, nifi fingularum officia intellexcrimus, hac autem in libris de partibus declarantur. Caternm etiamfinec partium notitia ad animan cognofeendam, neque cognitio ansme ad cognitionem partium aliquid conferret, debuiffet tamen.A rift. de partibus prius agere, quam de anima, quia hoc magis confonum eft ordini compofitiuo, quo fcientiam naturalem fcribere conftituerat : omnis enim generationis-ordo compofitiuus eft, materia vero prior eft forma ordine generationis; idcirco hunc ieruat Ariftot. in tota fcientia naturali, nifi quando facilioris doetrinæratio contrarium ordinem poftulat, quod rarum eft, idq; factüeft in primo Phyfic. vt modo dicebamus. Poteft aurem folum ipfum procemium librorum de partibus oftendere illud efie initiü tractarionis de animalibus, \& libros de partibus pracedere libris de anima, vt cuiq; illud legenti manifeftum effe poteft.

\section{Solutio dub ï quod Ariftoteles de eadem re fepius agere videatur, \& aliorum dubio- rum ad ordinem pertinentium.}

cap. XXXVI.

Po Oteft etiam ex iis, quæ dicta fúnt, colligi folutio dubitationis, qua torquere multo-
A rnm animos poffet. videtur enim Arifot. pluri- Dubium bus in locis egiffe de vna \& eadem re; nam de fenfibus agit accurate in fecundo libro de ani$\mathrm{ma}$, curigitur cortum tractationem repetinit in libro de lenfu, \& f́cn'ilibus, vtroque cnim in loco agitur de operatıone fenfuum, qux in vino, \& codem loco decluranda videbatur; fic de motu animalıum egit $\&$ in fibro de incelfu, \& in tertio deanima, \& inlibro de communi animalium motu; vidcbantur tamen omnia, qux ad nio-

B tum animalispertinent, finul vna tractatione explicanda fuiffe. Huius difficultatis folutio in eo, quod fupra declarauimus, conftituta eft, dixinus cnim totam tractationem deanimalibus in tres partesdiuifam effe; in vna agiturde materia animalium, in altera de forma, in tertia de operationibus \& accidentibus confequentibus; quum igitur in his tribus partbus diuerfie fint fcopi,nullum abrurdum eft, fi in iis omribus dealiqua eadem re agatur propter di-

C uerfosfcopos, in libris quidem de allma nullus alius eit A.riftotclis fcopus, quam naturam animedeclararejquod fi de operationibus quoque plura dicit, idfacitvt per eas nos ducat in cognitionem anim $x$, ficutiipfe faciendum effe dixerat in context11 33. fecundi libri, non quod confilium eius fit ibi ipfarum fecunảum te operationem cognitionem tradere; idque effe fignificauit in principio libri de fenfu \& fentilibus, quando dixit fe egife de anima fecundum D feipram, poftea agendum efie de operationibus: quoniam igitur de operationc fenfuum in fecundo libro de anima locutris ẹrat non propter fe,fed propter cognitionem partis anima fenfibilis, ideo de cadem fcribere voluitlibrum de fenfu, \& fenflibus, in quo iprius fecundum fed operationis perfectam notitiam nobis traderet: ideo fi in eo libro aliquam ip fius anima mentionem facit, non amplius eam confiderat fecundumfeipfam, fed propter cogniitionem oE perationum, quarum eft caufa, in fols enmm libris de "Anina vere dicinus iplam fecundum feipfam animam, eiusque nattiram declarari, hic enim folus eft eorum librorum fcopiss. Sic de motu dicendum eít, in libro enim de inceffu nullusalius eft fcopus, quam deciarare partes inftrumentales, qux snotui animalium inferuiunt, quod fi despra quoque operatione ibi fit fermo, non eff propter ipifus motus cognitionem, fed propter notitiam partium organicarum, motus enim eft earum caufa finalis, per quam ipfa partes cognofcendæ funt : in tertio autem deanima libro non eft Ariftotelis confilium declarare ipfum aninalium motum, quomodo, \& à quibus caufis fiat, fed folum facultatem animæ mouricem, qux declarari non poterat fine ipfius motus 'confideratione; reftabat igitur ve de motuageret fecundū feip fum, quod facit Ariftoteics in libello de communi Animalium motu, bi hisuias operationis cognitio 
tra dirurper fuas caufas; quoniam igitu omnis tråtatio nommaturabeo, quod/u gratia traEarur, non abco, quod propter aliud, ideo non de eadem re funtilla tres, quas diximus, diftinctæu uationes, tcd in libro de incefu agıtur de paribu organcis inferuientibus motu, in tertio autem libro de Anima agiru de facultate animæinotrice; demum in libello de motu agitur deipto net motu, non igitur idem fruftra Dubbum reperitur. Sed dubitare adhuc aliquis hacin re poteft : nam fiverum eft id, quod modo diximus, debuerunt omnes operationes, quæ un libris de Ansmaconfiderate fuesant propter animam cognofeendam, iterum confiderari propter fe in faruss naturalibus, quod tamen factum fulfe nonvidemus, pluresenim funt operationes anima, quarum lacta eft mento in libris de anima, de quibus tamen nullum habemus proprium tractatum in partuis naturalibus, vtoperationes intellectus \& phantafir. Soluetur hac in re omnis dubitatio, fi artificium Ariftorelis, quod fortafie nemo conliderauit, declarauerimus : quum igiturnecelfarium Ariftoteli fueritad tradendam cognitionem facultatum anima loqui de eins operationibus, cognouit effe in his hoc difcimen, quod aliquaDiferimeneperation is

enime. rum exactifima cognitio requircbatur ad cognofcendam aliquam animæfacultatem, quales fuerunt humana mentis opcrationes; non poterat enim mentis noltræ natura bene declarari, nifi per exquifitam operation um omnium-D declarationem, quam pollicerı videtur Aritoteles in primo context.tertij libri, dum proponit declarandum, quomodo fiat intellectio; de huius igitur partisoperationbus non opus fuit alıquideorfum feribere in paruis naturalibus: aam diligens illa operationum tractatio, etfí propteranimx notitiam facta, vtramque fimul operam prafticit, necalıd de his dicendum relinqubatur. Aliquarum autem operationum. xudis, \& imperfecta coguitio fatis erat ad declarandam aliquam animx facultatem, quales fuêre operationes externorum fenlium; ideo ad perfectam iplarum fcientiam tradendam debuis propriam harum tractacionem inftituere in paruis naturalibus, ideo icripfit librum de fenfu, \& fenfilibus, in quo melius declaràs obiectosum fenfilium naturas, perfecte docet, quomodo if fxoperationes in organı fenfunm iāt. Sic ctiam cognoutt rudem motus notitiam tatıs fuiffe ad declarandasorganicas partes in libro de incufu, \& ad declarandam vim animæ motricem in tertio libro de Anima, ita ve motns iple imperf ede cognitus relinquerctur, idco de hac ipla operatione, vt plene cognoficertui, icribere voluit librum de cómunı motu animalium, in quo ex cmmbus caulis motus in animalı tam propinquis, quam remots tradit nobis p, rectan firentian huius operationis; funtautum caud cus remotx appetitus, \& Icnlus, \& in-
A tellectus, qux iam declaratx fuesant in lib. 3. de Anima ; propinque viroorgana ipla corporea, qux declarata crant in libro de inceflu; has 1 gitur omnes caulas Ariftoteles accommodat ad declarandum, quomodo in animalibus fiat motus. Alix demum fuere operationes, quarum nulla declaratio, ant mentio ad animam cognolcendam requirebatur, de his igitur ne verbum quidem tecit Arritotcles in librus de Anima. led integrum in hisfermonem remifitad 5 paruosnaturales; huiusmodi fuerunt memoria, \& reminifcentia, \& fomnus, is vigl 1 lia, $\hat{x}$ fomnı, \& alia accidentı, quorurn proprij ractatus lcguntur in parais naturalibus, quum nulla corum tacta fit mentio in libris de Anuma, quoniam ad anmam cognofcendam nihil cor:um contideratıo conferebat. Hac ıgitur norma vtétes, omnem huiuscemo di dificuliatem paruo negotio tollemus. Caucnádum etiam eft, ne ob aliqua Ariftotelis teftimonia de librorum dif-

C poittione in errorcm ducamur, nam fi eius verba legamus in cap. 11. quaru libii de partibus Anumalium, bis in eocapite aiferitle ian tractafle de partibus motui inlertientibus, quare lufpicari pollumus librum de inceliu precedere quatuor libris de partibus, velialtectle m verbis Arritotelis repugnantiam; nam un poltremis verbis libri quarti de partibus proponit ie ttatim acturum de partibus ad inotum pertinenibus, \& in calce ibbride inceflu inquit, 1etam egifie departibus tum alis, tum iis, qux ad motum conserunt, \& proponit agendun ftatim de anima : poltponit igitur librum de incefli libris de partibus, quod euam indicat prolixa illa prafatio librorun de partibus, vtantea conliderauimus. Sed nulla eftrepugnantia in verbis Ari- Sslwio. ftotels : nam illa quide, qua ab co in initio, vel in fine librorum ad ordinelibrorum pertinentia fcribuntur, certam tidem taciunt deipla librorum ferie, ac dispofitione; nam ti in inutio libri

E tanyuam per eplogum referat ex, qux antea tractata iunt ; absq, dubio dicendum eit ea prutus fuilfe tractata; \& in calce libri ti de aliqua re proponat agendum, aperte ligniticatur, non lolum agendum; fed itatim in libro fequence agendu,ficuti verbailla in fine libri de incellu aperte indicant,agendum ftatim effe deanima:Led 1 lla, quxin medio libiorum dicuntur, nullam certa.11 ndem de librorum ordinetaciunt, quando nöordinis lignificandi graı ia ab Arittoncle pro-

F teruntur,fed lolum caura cilandi, teu nominandralıquem librum;quod quiaem a liis in re manitefta exemplis follimus com robare: in primo cap. libii de interpretatione iaquit, fide conce ptibus anima dixife in libis de Anima, quum tamen lota logica osdine doctrinx pracedat totam fcientiam natu ale:in 4.cap. ciusde

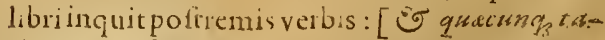
lium cotrafophiftecas derexmusinusmus impariznotates If oitca intertiolignacn o ciusdem lib. cag. 65 
cap. fecundo dicit: [ dicium ussem de bisest in Topices ] verba igltu. illa prateriti temporis vi-

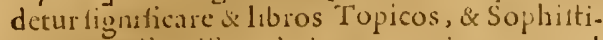
cospracelitic libro de interpretatione, quod cft manneteralíum: alia quoq; plura cinsmodi Joca cuniderare pollemus, qua contulio onitittimus. Credudum igutur cit, non coden ordine fcriptos eflic ab Arritocelc ommes fuos libros, quo iplo voluit cos efle diponendos:fortalle enim prus libros de Anima leriplit, \& toram etiam naturalem philotophian, quam Logıcam; voluit tamen Logican p. acedere toi narurali philulopha: lic tonalle prius Topicos, \& So. phifticos librosicriplit, quani librum de interpretatione, bunc tamenillis pracedere volut; nam quxin primo cap. primi Topicortum Icribuntur, videntur teftari,iam aftun effe de fyllogitmo, \& demonttratione, quibus omnino pracedere debuit liber de inccipretatione: maiorein fidem iacere potelt locuio Aristot.perverbum futuri tempors, lignificat cnim rractationem illam faciendam ettepoiterius, led tamen ad ortendendum quod immediate pofterus fit de ca re agendir, nil prorius efficacilatus habet, nifs lit in poutre: is verbis libri, liculi dixumus de vltimıs verbıs librı de incelfu, qua significant cile tharm agendum deanima. Dicimusitaque Aritote efortalle prins abioluere voluifie breuem illum tratta um de partibus attnunubus adincellim, vt pootca $n$ librss departibusalias confideraret, in qubus erat diutius moratuus, ob idque in capite illo vndecimo quarii de partibus dixill e; ic iann effe locutun de farubus ad motum conferentibus; voluilie tanein ordine doetrinæ libros de partibus præcedere libro de incefiu, it alia fimiora Arritotelis teitimonia, \& ratio ipla declarat.

\section{Nonmullorum opinio de loco libroram, de generatione animalium, ó eius con- futatio.}

\section{Cap. $X X X V I I$.}

$\mathrm{N}^{\circ}$ Onnulli fierunt, quilibros de animalium ortualio in loco ponendos cfie exiftimarunt,uon in eo, in quo nos plurium aliorum fententiam fequentes cos collocaumus : putarunt enim locandos efle ftatim poit quatuor libros de partibus, \& ante librum de inceffu; motiauprimum tem hunt tali argumento. Tria funt partim geneargumen ra inanimali; aliz nanq; pertment ad effe anithm sllo- malis,alix ad motum, alix ad generationem, de quibus Ariftotel. manifefte proponıt agendum in initio primi libri de generatione animalium, inquit cnim fe iam dixiffe de aliis anımalium partibus, fupercfie autem agendum de partubus generaioni inferulentibus, quarum tractatiouem lbi ftatim aggredirur; atqu omnes an.enalis partes locum habent materix reipcetu amun , quemadmodum igitur de alis partibus
A agioportuit prius, qu.rm de anima,ita ctiam de his, qua ad genera tuncm pertincut, eadencnim tho ommbus ratio viget, quod de matcria animalium prius agendum erai, quan de forma; itaq: libride generatione animalıin tanquam libri de partibus poncindi innt ante libros de $A$. muna inter alios libros dep rubus Animalium. Adducume ctian teftimonim Ariftot. in poftrmis verbis quartilibride partubus, v bidicit conlequens efle agere de partibus generationi inieruicnibus. 7 anden confiderant verba $A$ B liftot.in quar o libro de partibus cap.4.10.11. \& 12. vbinquit fepoftea degeneratione animalum locuturum, qua eandem fententiam confirmare videntur. Sed ezo contiarian kententiam; quam antea declaraui, \& quam plures tuentur, lequendam elle arbitror. Vtigitur huitus verituten cognot cam us, fcire debemus Ariftotelem non ita de animalium gencratione cgiffe,vt egir de motu; qui cnim confiderare oportherit \& operationem ipfam, \& organicas parC tesiplinferuientes, Arrit. in duobus, duftuctis, \& leparatis libris egit de motu, \&de partibusad motum conferentibus; non fic de generatione; ob maiorem enin commoditatem, acficilitatem doctrin decreuit in eilde libris, quide generatione anımaliü un fcribuntur, \& de ipla generatione, \& de partibus ei inferuicntibus agere, quia cognouit peıfeetam earú cognitionem hoc poftulate: hoc igitu dubıam seddidit corū libiorum ledem, nam ratione partum ad geneD rationem pertinemium, locandividentur ante libros de Anima cum aliis libris departibus; ac ratione ipfius generationss, qua eft operatio quadem conlequens, videnm ponendip oft libros de Anima iner paruos naturales. Hæc autem tractarionem cönuntio un is librisita manirefta eft, vt à nullo negetur, \& proponit etiam ipfarn A tiftut. in quartulib. de partibus cap. 4 . viait dicendum elle de partibus generationi inferuientibus, quibus mas differt àtomina fed

E quoniam de ipła quoq; generatione dicendum eft, melius efle vt hæc conlideratio ad eum locun remittatur. Ex quibus Aruftorelis verbis non folum colligimus, confilun eius suifie fimulagere \& de generaitione, \& departıbus; fed etiam iplum indicaffe, melius efle totum tractatum locare poft libros de Anma inter paruos natuiales, quam ante inter libros de paitibus: ad quod comproband um habemus etiam illud Aritt. clarifimum teltmonium in qumo F librodegeneratione animalium, cap.ivbialie. rịte de visu egitie prius quum de ien !ibus ageret,atque etram pirus, quunde anma. necion etiam in cap. $7 . \checkmark$ bi dicit, fede voce priliselie locutum inlibris ce Anima, \& in libio de 1 enfu, \& feninlibus, fic enim locat libios de generatione poit libros de Anima, a poit libium de icnfu \& fenfilibus. Idem etiam oltendunt verba Ariftotelis in frima cap prim libri de
Secundio aigumen twms. Tertivm argumen t Hirt. Opiniomis confis tatio. 
generatione animalium, quxe magna confiderur : vnum, quod, quum de cæereris animalium purtibusiam locutus efler; reliqum eft dicere de partibus generatıoni inferuientibus; alterum quod, quun quatuor fint caufa, \& de tribus animalium caufis dictum iam fit, materia, forma, \& fine, dicendum eft etiam de caula efficiente, ho mo enim hominem generat, \& equus equum, vtcauía effeetrix. Ex priore colligo argumentum efficax contra aduerfarios, quum enim $A$ : riftoteles teftatur, fe ram egifle de cxteris partibus, \& folas relinqui coninderandas partes ad generationem pertinentes; ergo omnes alijlibride parribus funt anteponendi libris de gencratione, etiam liber de inceffu; nan fi fecundum aduerfarios locarentur libri de generatione antclibrum de incelful fallo diceret Ariftoteles fe iam egifre de aliis partibus, \& folas fuperefle partes generationi inferuientes; atqui locari nō pofiunt pott librum de incefín, nifi etiam poft libros de Anima collocentur, librum enim dc inceffuftatim fequuntur libri de Anima, vt Ariftoteles in calce eius libri teftatur; afferit ergo Ariftoteles libros de generatione libris de Anima pofteriores effe. Exaltero autem dicto duo validiffima argumenta fumo: vnum eft, afferit Ariftoteles fe docuife tres animalium caulas, \& inter eas formam ; atqui forma eft anima, ergoalferit, fe egiffe de anima; quare libri degeneratione fequuntur libros de Anima; alterum

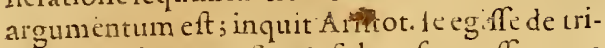
busanimalitim caufs, \& folum fupereffe agere de caufa efficicnte; manent autem tractanda partes generationiinferuientes, has ergo non putat Ariftot.vocandas effe materia manimalis; hine fumitur ratio totius veritatis, \& errons aduerfariorum, \& confilij Ariftotelis in horum lbrorum difpofitione; materia enim refpicit formam, proinde illa dicitur materia, qux ad formam recipiendam dirigiturà natura. Quare, $f$ bene cōfideremus, 11 æ quidem partes, quæ pertinent ad efreanimalıs, de quibusagıtur in q̨uatesfint materia animal is twor libris de partibus; \& illæ, quxpertinent ad conferuationem animalis indiuidui, de $q$ ibus agitur in libro de inceffu, merenturnomen materix; fed non ill $x$, qua ad neutrum conferunt, fed ad folam conferuationem fpeciei, de quibus agitur in libis de generatione animaliūis quum enim hæ neq; ad recipiendam animam, neq;ad eam conferuandam necefiaria fint, nullo pacto videntur eam habere rationem ad animā, quam materia habetad formam. Quamobren recte $A$ riftot.cenfuitharum confiderationem non effe confiderationem materizanmalis, fed potius caufe efficientis, nam per has animal generat aliud fibifimile; quum reliqux partes non modo fint cauf $x$ effectrices inftrumentarix operationum, fedetiam materia, fine qua ves non resiperctu anima, yclnon conferuaretur. Nec tamen ob id dicendum eft cum aliquibus, li- Aligra bros de gencratione animalium effe de princi- rumerpiisanimalium, \& hoc nomiue locandos effe ror greod ante libros de Anima, aut faltem ftatim polt li- lib.de gebros de Anima; nain agere de generatione ac de ncrat eius caufis, eft quidem modo aliquo agere de font de caufaeffectriceanmalis; fed præcipue ett agere princen deoperatione pofteriore, partes enim genera- $p \ddot{y} r$. troni inferuientes, etfi locum habentcau $x$ efficientis refpectu animalis geniti, tamen refpectu B generantis, cuius partes funt, non funtiplius animalis effectrices caulaz, led operationis pofterioris, qux eft generatio alterius fimilis. Quonianrigitur confiderat ibi has partes Ariftot. in animali generante, nō in animali genito, præcipua eft tractatio generations tanquam oper:tionis confequenus, fecundaria vero etian cau$f x$ efficientis, quia confequitùrvt eaden fit cōfideratio caur cffectricis refpectu animalis gemiti feu generandi, qua eft conlidcratio operaC tionis anmalis generantis : nec diffimilis eft ea tractat1o aliis, qux habentur in paruis naturalibus, nam in iis quoque operationes animalium declarantur per luas caulas, qux funt potiflmum ipra animalium inftumcntales partes, vt in is libris videre eft. Iure igitur Ariftoteles in epilogo in calce libelid de communi animaliun unctu, foft cum locat fram libros de gencratione: quim enum commilenent cum riactatione generationis, tractitonum famm taci-

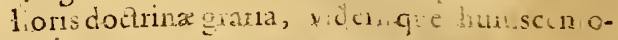
divartes non anisecitm hiercin nomen riaterix in anma:1; feuli ad aliqued caux zeris fint esucusdx, reuluci po ul ad cauram eifecticcm, idco toian 11 aćation,m lucaull inter paucos natuaies foft hibrum de commeni motu anmalım. Ad argumenta illorum facile eft ref ondercad pimum enm iam patetrefponlio, nam nesallus purtes gencrationi infer uientes habcie locum materix. Sed pirterea

E hoc etram daso, nil el,eablurdi,fi Ariftotelesad maiorem doctrun e raciliatem ricififet harum partium conideraionem in paruos naturales, quum foleat modo praponere materiam forni $\boldsymbol{x}$, modo forman materix; quippe qui ordinem naturæ tunc folum feruat quando ordini melioris cognitionis noftræ confentaneus, vel faltem non contrarius eft; fed cum femperdeSpicit, quando melios, aut facilior cognitio noftra contrarium ordinem poltulat. Ad lo- Adfecus

F cum A riftot. in calce quarti libri de partibus, drsm. dicimus cum efle mendolum, quia vbi dicitur [generation $]$ legendum eft [inceffiri] quam corum verbortm emendationem nunc communts omrium confenfus comprobauit, \&e ita in onnibus codicibus Ariftotelis, qui pofterioribus tenyoribus funt excefi, recepta eft hac corretio; \& ea non admiffa, effetcontradictio iniolubilis corum verborum cum 1]lis, qua leguntur in Epilogo in calcc libri de 
communianimalium motu : effet praterea ctiam nugatio in verbis Arift.qui quando in calce præcedentis libiri propoluit rem in fequêti confiderandum, non iterum eam proponit in principio fequentis, ita vt his ponat eandem eorunden libröm connexionem; quare fi in calce quarti de partibus dixiffet; quum de reliqus partibus dixerimus, dicamus de partibus generationi inferuientibus, non recte hoc itatum repeteret in initio prima degeneratione, quum dicat; poftquam de cxteris animalium partibus dictum eft, reftac vi dicanus de iss, quá geneAd tevti- rationi inferuiunt. Adverba autem Ariftotel.in cap. quarto, decimo, vndecimo, duodecimo eiuldem quarti libri, dicimus ea non fignificare quod ftatim fit agendum de partibus ad generationem pertinentibus, fed folum . quod portea dé his erit agendum jimo \& verbo illius capitis quarti nortrx opinioni fauent; inquit enim elfe etiam agendum de partibus generationi inferuientibus fed quoniam deipla quoque generatione agendum eit, ideo congrum eife, vt ha- $C$ rum partium confideratio ad eum locum differatur; denotat igitur diftantem ab eo loco librum, in quo de generatione, ac de partibus ad eam attinentibus fermo fiat: quod etiam indicat modus loquendi Ariltotelis in initio primi de generatione, dicensenim, quum de cæteris animalıum partibus diktum iam fit, denotatremotam ab eo loco effe aliarum partium tractationem, vt totum illud primum caput bene confiderantibus manifeftum efle poreft.

\section{Quodnam fit fubiectum ftatuendnm in o- mnibus, ó in fingulis libris de Anima- libus, opinio propria.}

\section{Cap. XXXVIII.}

$\mathrm{H}^{\mathrm{\Lambda}}$ Actenus declaratum a nobis eft, quæ fit: Ceries omnium illorum librorum, qui vocantur de Animalibiss, \& quid in fingulis traetetur ab Ariftotele; reftat vt de corum fubiecto pioprie accepto aliqua dicamus, quum enim ain lib. de lins oftenfuin à nobis fit, non omnem rem conPrecog. fideratam fubiectum effe proprie fumptum, fi. quidem Aritt. dixit non modo fubiectum confiderari in fcientia, fed etiam principia, \& affectiones fubiecti, qux, quum a fubiecto diftin-guantur, non poliunt.proprie appellari fubiectum; ideo non fatis eft cognouiffe quidagatur in fingulis lib is de Animalibus, fed videndum: etiam eft, quodnam in iis fubiectum ftatuédum fit, in hoc igitur confiderando hunc ordinem. feruare côftitui; primo loco breuiter exponam. quidnam ego hacin re fentiam, deindealiorum Sisbiect ü fententias cum argumentis in mediumefferam, atque perpendam. Mihi quidem videtur, facilem explicatu rem efle, fi vera illa funt, qux diximus in libro de pracognitis; nam fi id lemper fatuendun eft fubiectum, cuius principia, \&
A affectiones quaruntur, in libris autem de Animalibus tractantur principia, \& affectiones non folius animalis, fed onnis viuentis corporis, neceffe eft fubicetumonn nium fimul corum librorum effc non folumanimal (nö effet enimadcquatum) fed corpus animatum latiflime acceprum; quamuis enim appellentut libri de Animalibus, quia confiderantur omnia in animalibus, non eft tamen ab hac fola appellatione fumendum fubiectum : quandoquidem appellationes, \& inferiptiones librorum non femper à

B fubiegtio funumutur, fed quandoq; a parie fub. ic et precipua, quandoque etiam ab aliqua re extraneajfed tirmis nitimur fundamentis, fi à rebus ipfis confideratis fubiectum colligamus. Quoniam enm in animalinon folam animalis propriam naturan, fed etiam naturam vıuentis in eo infitam Ariftot. contemplatur, \& viuentis quoque principia, \& a fifectiones confiderat, \& hxc omnia ore rotundo dicit effe communia animali cum planta, ve videre cot \& in libris de Anima, \&in paruis naturalibus, certe fubiectum. adrquatum non folum animal eft, fed corpus animatum latiffime acceptum, illud videliter, quodeft fpecies mifti ex elementis conftantis; nam Coelum quoque eft animatum, fed de eo non agitur in his libris, neque de anima Coeli agitnr libris de anima, vt ipfa librorum feries indicat, \& vt Ariftotel. deciarat in procniolibrorum de partibus Aninalium, \& quid afferere audent, ita craffa ignoranria laborant, vt o-

$D$ mniprorfus confutatione indigni fint: Mea igitur fententia hæceft; fi omnes fimulaccipiantur libri, \& de animalibus, \& de plantis, fubiectum adæquatum eft corpus animatum confiderandium, \& fecundum amplitudinem fuam, \& fecundum proprias rationes fpecierum,nempe \& animalis, \& plantæ:fi yero feclufis libris de plantis folos fumamus libros de animalibus; fubiectum erit corpus animatum vt confiderandum \& in fua maxima hatitudine, \& fecun--

E dum propriam naturam animalis; id enim certum eft, nonagi de corporeanimato communi, nifi in libris de Animalibus, neque eft abfurdum, quod in eifdem agatur de genere, \& defpecie, quæ animal dicitur; quum id in aliis quo-que libris naturalibus factum effe viderimus;in libris autem de plantis fubiectum: erit planta? vt confideranda recudum propram rationem.. In fingulis autem libris facile eft fubiectum in-uenire luxta normam à nobis traditarn in lihro. dePræcognitis; quum enim eorum librorum nullus fit, in quo non tracteturvel principinm, vel accidens aliquod feu animalis, feu animati corporis, illud in fingulo fubiedurn ftatuendum eft, suius vel principium, vel accidens confideretur; yt in quatuor libris de partibus animalium fubiectum eft animal, quia materis animalis ibi tractatur; in libro autem de inceflu fubiectum eft animal, non tame
$\mathrm{NecCe}$. lum nec anima Coeli in lab. de animalibusconfederatur it Sicbiertis in lib. de partibus. omne; 
omne, fed illud folum, quod talis motus parti- A cepsfit, fi quod cnim-commune nomen haberemus, quo omuia exfe mota animalia compleeteremur, illud ftatuendum effet fubiectum \& in libro de incefli, \& in lib. de communi animalium motu, quiribide huius partibus agitur, hic vero de huius propria operatione: haceadem ratione dicentum eft in libris de Auima Subrcä̈ fubięum effe corpus animatum vniuerfe fuminlab. de pum, quodomnia viuentia mortalia compreanima. hendat, quia ibi de huins forma agitur' non de fola animalis forma; detinitur crim anima efle actus primus, \& forma viuentis corporis : co igirur modo confiderat ur, quo defnitur, nempe vt principium formale viuentis corporis. Quoniam igitur illud eft fubiectum, cuius principia confiderantur, null um aliud effe poteft eorum librorum fubiectum, nifi corpus animatum; hoc idem de fungulis alijs libris dicendum eft, id enimcuius principilim, vel iccidens confideratur, fubiectum in fingulo dicendum eft, fue fit corpus animatum commune, fue animal, fine aliqua fpecies animalis: certum enim eft iis ominibus librisabfolui totam tractationem \& de viuente communitér accepto, \& de animalibus tum generatim, tum fpeciatim confideratis. Hac igitur norma quisquis vtatur, errare meo quidem iudicio non poteft in dignofcendo cuinsq; librifubiecto.

Opinio illorum, qui dicunt fubiectum in libris de Anima effe animam, or eius confutatio. Cap. XXXIX.

$S^{\mathrm{E}}$ Ententia bac noftra maxime confirmabirur,fi breniteraliorum errores, quiablac norma recefferunt, aperuerimus: nobis quidem fat is erit confiderare, quid alij fenferint de fubiecto librorum de Anima, qui inter omnes de animalibus libros principem locum tenent:nam errore aliorum in iis libris detecto, facile cuiq; crit \& illa, quxin aliislibris errata fuerint, deTres oy:- prehendere. Tres inuenioillorum opiniones de nz:nes de fubiestolibrorum de Anima:vna eft, quam nos fubiecto fequimur;quod fit corpus animatum, hāc enim lib. de a- folam verameffe puto, dummodo fano modo, nima. quem poften exponam, intelligatur.Secunda eft plurium recentiorum, qui fubiectum horum librorum dicunt effeanimam ipfan. Tertia demum nonnullortm, qunec corpus animatum, Primum necanimam, fed animal volunt effe horum liargrmen brorum fubicetum; hanc igitur vtramquenos tü ponen confiderare oportet.Illi, quilubiçum dicñt eftiumani feaniman, argumentanturptinum ex inferimara fub ptione; infcribuntur libru de Anima, ergo nulrectum. lumaliud in is fubicatum ftatuendum eft, 11 ifi Secundü an ma.Secundocx verbis Arift. in mitiolibid de argyrazen fenfu, \& finflibus;ibi enim dicit, fe animam cō. tum.
A nonvt principium fubicti; quæ enin confiderantur vt principia, non cōfiderantur fecundum feipfa, fed alterius gratia. Tertio dicunt,illud eit fubieatum, quod in principio fcientix definitur, at in initio fecundi libri de Anima definitur ani--tum. ma, \& magna cum diligentia inquiritur, ac declaratur eius dénitio ; corporis autem animati definitionemnullibi in is libris comperiemus, ergo non corpus animatum fubiectum habent, fedanimā. Quarto, illud eft fubiectum, per quod B fcientiafiue totalis, fiue partial ss diftinguitur ab aliis:at per animæ confiderationem diftinguunturlibri de Anima à cunctis alis libris naturalibus, non percorpus animatum, hoc enim etiam in pluribus aliis libris fubiectum eft, imoin omnibus fimul libris de Animantibus; dun igitur fubicetumadxquatum quærimus librorum de Anima, nullum eit ponendum, nifianima ipfa. Tandem dicunt, anima habetomnes conditiones, qux in fubiecto ficntiarequiruntur,

C ergoeft fubicetum:probant affumptum; anma habet fpecies, vt patet, habet affectiones, quas Arift.in context. 3. primilibri proponit confiderandas; habet etiam principıa, quod quidem ipfi variis modis oftendunt, in hoc enim non cörentumt;aliqui dicunt, anima habet faltem principia cognitionis,nempe fuas operationes, ex quibus crignofcitur ; alij confugiuntad caufamagente, qur animam educit de poteftate materix ad actum, hac enim principium quoddam ipfins D an mæ dicı foteft; alij demum dicunt animam habere propriam naturam, ac definitionem, qux inftarprncipijeft, quum per eam multa accidentia de ipia anima demonftrari poffint. Huius fententiæ falfitas tum ex iis, quæ antea dixim us, tum maxime exis, qux fripfimus de præcognitis, manifefta eft,nunc igitur paucis agemus; primum quidem iam diximus animam definiri ab Ariftotele vtprincipium, \& fape in iis libris appellari principium, \& caufam viuent is corpo-

E ris; patet igitur eam vt principium confiderari. Præterea cilælibet res ita eft cognofceinda, vt fecundum propriam naturam eft, nce alio modo; atqui anima in rerum natura non per fe exiftit fecundim Ariftotel.imo effentialis conditioanimxeft, vt fit perfectio, \& forma viuentis corporis, ergo non poteftalio modo cöfiderari, aut cognofe1, nifi ve formale principim corporis viuentis. Iratcrea fi anima, non corpusanimatum, ftatuatur fubiectum in libris de anima, nulF lus erit liber, in quo dici polit conliderari corpus animatum; hoc autem dicereabfurdumeft, quia corpus animatum ef fpecies corporis naturalis, fine cuius tractatione mancä necerle eft elrenaturalem philolophiam; confequens aute probatur, quia qua ratione dicimus, fubicetsi in librus de anima non alic animatum corpus, fed

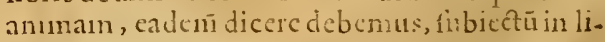
bris de partibus nullü eflc, nufripfranctanimaliii partes; fe in lib.defenfu, \& fenfilib. nil alind

\section{Tertius. argume.

\author{
(1)
} argurtĩ twm.

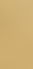

Quintis


effe ftatusndum fubicetum, nifi fenfum ipfum; fic in libello de motu nil aliud nifi motuni; \& in libris de generatione animalium nil aliud, nif ip ram nituralium generationem: nam quum nibil fit animaio corpori intimius anima, qua eit eius forma, li de hacagere non eft agere actu de corpore animato, mulro minus agere de materla, aut de operationibus, erit agere de corpore animato; in nullo igıtur librofubicetum ita. tuerc potfumus corpus animatum; quod fi dicant hoc effe fubiectū in omnibus librisfimu! fumptis, vanum ceste, ac rilu dignum hoc eft, quomodo enim fubiectũ in omnibus ftatui poteit, fi eorum nullus inuenitur, in quo dici poffir iplum conliderari? Sed huius erroris ratiopetaturex libro noftro detribus pracognitis. Argumenta autemillorum facile foluuntur: primun, quod abinfcriptionefumitur. nullius roboris eft, quia non fèmper infcribunturlibrià fubiecto, librizutem de anima infcribuntur ab intentione, non à fubiceto; quid autum interfit inter fubieftum, \& intentionem, legatur in libris de Præcognitis, vbi diligenter id declarauimus. Ád fecundum dicimus, A riftotelem non ideo dixiffe animam fuiffe confideratam fecundum feipfam, quod voluerit eam in libris de anima effe fubiectum proprie acceptum, fed folum ad differentiam aliorum fequent $\bar{u}$ librorum; quum enim in iisagendum fit de operationibus confequentibus, quarum caufa eltani$\mathrm{ma}$, neceffe erit in iis facere anim $x$ mentionem, quia effectus nō cognof cuntur nifi per fuas califas; fed non erat ibi confilium ip fam fecundum feanimam cognofcere; fed accidentia perillam; an in libris de anima nulla fuit alia Áriftotelis intentio, nifitradere cognitionem ipfiusanima fecundum feipfam. Audiui tamen aliquos ita argumentantes, fi confideraretur anima vt principium fubiecti, ergo non fecundum feipfam; quemadmodum vbi tractatur yt caufa operationum, ibi non tractatur fecundum feipfam. Quzargumentatio, etfi non modo vulgata eft; fed etsam recepta; vana tamen eft, \& in dex magnx crcitatis, qux ex eo prouenit, quodnon diftinguuntintentionem à fubięto; ipfum enim fubiectum nullibi tractatur, nifi dum fingilla. tim ea tractantur, qux declàrare eft confilium, \& intentio authoris, quo fit, vt: quicquid tractare eft intentio aurhoris, id fecundù fe ipfum, \& propter feipfum, tractari dicarur, licet vt fub. iecti principium, vel vt affectio tractetur. $Q$ ra... re cognitio anım quxritur propter feipiam, \& : quxritur ad habendam cognitionem corporis animati; hæc enım qux aliss duo diuerfa.atque etiam repugnantia effe videntur, idem reuera funt; ipram enim fecundum fe a nimam cogno: fcere volunius, \& cam cognofcere eft cognofcere corpus animatum, hoc eft, aliquid corporis anımars s eft enim eius forma. Sic etiam dicimus, un libro de motu aninalium, intentro.
A nem effe cognofrere morum animalis, \& eum quxri propter feipium, quia eft per fe dignus cognitu, \& iplam cognnfere eft cognolicese corpus animatum; neinpe aliquil ipfius, hane eius ojerationem. Rem igitur confideratam aliud eit referre adintentionen1, alind eft referre. ad fubiectum libri.nam fiad fubiectum librı referatur, \& ipfa fit intentio authoris, dicitur fimul propter feipfam confiderari, \& propterco. gnitionem fubiecti, hocenim idem eft. Sicigi-

B tur in libris de animacōideratur anima fecun. dum feipfam, quiaipfam cognofcere eft inten. tio, nec dirigiturad aliam principaliorem intentionem, licet conferat etiam plurimum ad notitiam reliquorum; at fi aliquidad intentio. nem referatur, \& propter illam dicatur confide rari, tunc non amplius confideratur fecundun feipfum, quia non eft intentio authoris; ficconfideratur anima in parius naturalibus propter operationes, quas cognofcere eft intentio in iis C libris, ideo in illis non cófideraturanıma fecun. dum feipfam, quum ibi non quæratur anima cognitio, fed operationum perillam, illxigitur fecundum feipfas dicuntur confiderari: quicquid enim confiderare eft intentio, \& confilium authoris in aliquolibro, id femper fecundum fepfum confiderari dicendum eft. Ad tertium Adter. negamus vtrumque confequens. Vnum erat;a - sium. nima definitur, ergo anima eft firbiectum: quod quidem eft vanumargumentum; nam in I. PhyD fic. definitur materia, nec tamen eft fubiectum, fed principium, \& definitur vt principium; fic definitur in 3. Phyf. motus; nes ob id eft fubieEtum, fed affectio fubiecti, \& definitur,vt affeCrio; quum igitur principia quoq; \& accidentiá definiātur in fcientiis, inualida prorfus eft 1 fta argumentatio, quum prafertim in definitione ipfa anim $x$ appareat eam definiri, vt principium. fubiedt, non vt fubiectum habens principıa.Alterum confequens erat ; corpus animatum non:

E definitur in libris de anima, ergonon ef fubieEtum: quod fimiliter negandum eft, poffumus cnim hocargumentum torquere contra aduerfarios, imo contra Ariftotelem fac; in nulla parte feientix naturalis definitur corpus animatum, vel animal, vel aliqua fpecies animalis; : ergonullum horum eft fubiectum inaliquolibro. naturali, fiue vno, fiue pluribus. Sólùiturautem . argumentum; quia eft quidem fubiectum in fcientia pracognofcendum quid fit; non tamen

F. femper expreffe definien dum; nam docuit Arifto teles in primo libro Púferiorum; defpici quandoque expreffi jnem : præcognitionum, quando res per fe confpicua, ac nora eft; fi igitur loquam ur de pirecognitione quid nomen : fignificer, de qua ctian Ariftoteles in eo libro loquitur: non thir opas expreffe fumere quid fignificet nomenviucntis; vel nomen ansinalis, vel nomen th mis yula horum omnium fignificatio notillima per fe omnibus est; fat 
Cap. 8. igitur eft, fi mente præcognof catur, vt inlibro de prxcognitis declarauimus: fi vero loquamur de definitione perfecta, non eft neceffarium hanc effe pracognitam; pofunt enim interna principia, qux eam conftituunt, ignota effe, \& inueftigari, \& denonftrari. Solet igitur A riftoteles indagare internaprincipia ignota corporum naturalium, nec tamen ex is conflatam corum definitionem exprimere, fed nobisielinquere, vt leui negotio ex principiis ab eo declaratis definitionem perfectam conftituamus cuiufque corporis naturalis, vt viuentis corporis, \&anımalis, \& fpecierum animalis. Sic etiam in primo libro de Colo declarat conditiones effentiales coleftis corporis, qux in noftram cognitionem venire potuerunt, fed relinquit, vt ex llis nos definition em illius corporiș côftruamus, dicentes, effe corpus naturale, nec graue, nec leue nec generationi, nec interitui obnoxium, necalterabile, nec a ugmentabile, fed folum in orbem mobile, fic de aliis multis diAdquar- cendum eft. Ad quartum dicimus, maiorem
tum. propofitionem veram femper effe de fcientum. tiis totis; fcientia enim qualibet tota ab alia qualibet diftinguitur per fubiectum, vt fcientia naturalis à Geometria, \& vtraque hæc ab Arithmetica; fed non femper veram effe de partibus cufdem, nam partes quidem aliqux eiufdem fcieritix diftinguuntur per propria fubiecta, qux funt diftinctx Species fubiecti totius, vt in fcientia naturali libri de mineris à libris de animalibus; aliqux tamen partes non diftinguuntur per fubiecta, quum verfentur in eodem fubiecto, fed diftinguuntur folum per diuerfasintentiones circa idem fubiectum, nt octo libri Phyficz aufcultationis in eodem fubiecto verfantur sorpore naturali ; diftinguuntur autem inter feper varias tantum intentiones circa idem fubiectum; nam in duobus prioribus intentio eft agere de principiis corporis naruralis. in tertio autem agere de eius affectionibus, motu, \& infinito, in quarto de aliis accidentibus, loco, \& tempore, \& fic dereliquis : fic dicendum eft delibris de anima, refpectualiorum librorum de animalibus; nam in corpore anımatoplurima erant confideranda, quorums numerus, \& varietas plures etiam diftinctoslibros poftulauit, quare diuerfis intentionıbus difinguuntur, non diuerfis fubiectis; nam certum eft, corpus animatum commune effe fubicctum \& in libris de anima, \& in libro de longi- $\mathbf{F}$ tudine, \& breuitate vitz, \& inlibro de vita, \& morte; varix tamen funt in his libris intentiones Ariftetelis, quia in corpore animato plura erant confideranda \& principia, \&accidentia; latis eft igitur, fi libride anima ab aliis fecernantur per hanc propriam inten:ionem, qux eft declarare formale principium corporis animati in nullo enim alio libro, intentio eft agere de forma corporis animati, nifi in libris de ani-
A ma. Advltimum argunentum negamus ani- Adbltimam habere omnes conditiones, qux in fub- mum. iecto fcientix requiruntur: primum quidem, quod habeat fpecies, hoc nulliuseft mouenti: quoniam etiam fi non haberet, perid tum non ftaret, quin poffet effe fubiectum in aliqua par te fcientix; etfinon in fcientia tota : quod vero anima habeat principia co modo, quo fubiectunı debet habereprincipia, falfum eft, vt ipforum aduerfariorum inter fe diffenfio declarat;

B quod enim aliqui eorum dicunt, animam habere principia cognitionis, fuas operationes, vam num eft; hoc nam que eft pocius dicere;animam effe principium, quan habere principia; proprium enim eft principiorum incomplexorum, $\mathrm{vt}$, fi lateant, demōftreturà pofteriori perfuos effectus;oftenditur enim in r. Phyfic. prima materia ex mutatione, nec ob id vllus vnquam di$x$ it materiam habere principia, eanamque dicuntur principia fubiecti : ex quibus de ipfodeC monftranturaccidentia à priori, non à pofteriori. Non minus vanum eft id, quodalii dicunt, animam habere caufam agentem, à quaeducitur. de poteftate marerix ad actum; namagens educens formam, non dicitur ob id effe caufam formx , fed compofiti ; \& forma in illa eductione locum habet cauf $x$, non effectus: præterea hocetiam condonato, nullx per talem caufam demonftrantur affectiones anima, imo ne confideratur quidem talis caura animxin libris $D$ de anima; quid autem abfurdius, quam dicere animam effe fubiectum, quia habet principia, quum talium principiorum nulla vnquam fiat mentio in libris de anima? Maiorem probabilitatem habetid, quod dicunt, animam habere principia, nempe fuans naturam, ac definitionem : fed nequehac dicipoteft, nam concedimus quidem fubiectum quandoque fimplex ef$\mathrm{fe}$, \& nullam in fe habere compofitionem, vt fupra de Colo diximus, quod in libris de $\mathrm{C} œ l \circ$ E habet locum fubiecti; eius enim natura, quæ ibideclaratur, inftar principii eft; fed hoc non poffumus de anima dicere; quum enim certum fit definiri in fcientia non modo fubiectum, fed etiam principia, \& affectiones fubiecti, omnia hac dicuntur proprias haberenaturas, ac definitiones, nec tamen ob id omnia funt fubiectū; fed quum hæc diuerfis modis in fcientia confiderentur, vt dictum eft in libro de præcognitis, \& eo modo confiderentur, quo definiuntur, fpectanda eft definitio fingulorum, vt videamus,an definiatur vt fubiectum, an vt principium, an vt affectio, ad quod difcernendum iam in memorato libro pracepta tradidimus, qux inde petenda funt; ipfa certe anim $x$ definitio aperte declarat, animam vt principium fubiecti definiri, \& confiderarí, non vi fubiectum. vt antea declarauimus. Cxterum etiamfi fateremur, animam habere principia, non ob id fieret, vt anima effet fubiectum; namaffectiones quoq ; fua prin- 
cipia, \& fuas caufas habent, nec ob id funt fubiectum in fcientia. Maioris igitur momenti eft poftrema conditio, qua reuera eft maxime onunium propria, \& neceffaria fubiecto, vt affecriones habeat; id enim proprie fubiectum dicitur, quod habet affectiones, \& eis fubiacet, \& de quo illædemonftrentur : omnilso igitur negamus animam hoc modo habere affeetiones. Quod autem illi dicunt, Arift. in procmio primi lib. de anima fx pe vocare affectiones aninıx; \& in tertio contextu proponere confiderandas affectiones anım , nihil nobis obeit, quoniam verba illa funt ita intelligenda, vt Arift. dicat, animam habere affectiones, \& operationes ab ipfa prodeuntes, fed non vt ipfi inhærentes, fic autem nō dicit,animam effe earum fubiectum, fed effeipfarum principiun, quod \& nos fatemur, imo clara in hoc eft fententia Arift. in context. 64 primi lib.de Anima, vbi dicit, omnes animxoperationes effe attribuendas toti animato corpori, non animre, nec dicendum effe animam irafci, vel contem plari, fed hominem anima; hr igitur omnes funt anımati corporis tanqua in fubiect , \& funt animæ tanquam cauf $x$, \& principij: Ideo rifu digna eft nonnullorum diftiratzo, qui locum illum expendentes, $-\&$ oftendēre omnino volentes, anima nn habereaffectiones, \& ita poffe effe fubiectum in libris de anima, dicunt poffe duobus modis intelligi, affeEiones effe ipfius anim $x$, vno modovrfubiecti recipientis, quod folum ibı Ariftotel. negat, altero modo vt origınis, à qua producuntur, qua ratione non negat, imo fxpe afferit animam habere affectiones, qua fit, vt hx poffint de anima demonftrari, quum fintaliquo modoaffectiones ipfius. Sed hoc dicentes, propriam ipfiopinionem euertunt, \& in noftram veniunt; nil enim aliud dicunt, quam animam nō effe harum. affectionum fubiectum, fed effe principium, atqui certum eft, affectiones non demonitrari de fuis principiis, à quibus producuntur, fed de fubiectis, in quibus inherent, per fua principia; dicere igitur affectiones effe anımz vt originis tantum, eft dicere cas non de anima demonftrari,fed de corpore animat o per animam. Preterea noneft ita pingui Minerua intell igendum dietumillud Arift.in 3: context. primi libride anima,vt dicat declarandas effe affectiones animæ in libris de anima,vt intelligere ibi omnes vidëtur; etenim in libris de anima nil aliud declatar Ariftot.nifi ipfam animæ naturam, \& effentiam, vt ipfemet teftaturin initiolib.defenfu, \& fenfslibus; fed de affeetionibus anim $x$ fignificat. effe agendum in paruisnaturalibus, non in libris de anima; quod fi qua mentio fit in libris de anima: affectionum anim $x$, ea fit propter effentiam anima, \& cuiusque facultatisanima cognofcerdani, non vt ipfre operationes animz ibi no. fcantur; quemadmodum in pracedentibus diffúfe declarauimus.
A opinio illorum, qui dicunt fubiec?urs inlibro de Anima effeanimal, os eirs confutatio. Cap. XL.

Onfideranda manet poftrema opinio illo-
rum, quidicunt, fubiectum in libris de anima effe animal.Hi ad hanc comprobandam vtun Primum tur prinum authoritate Anffotelis, qui in fe cirgumecundo contextu primulibri deanima inquit, ani- tumipro

B mam effe principium animalium, \& in primo bacopins capit. primi libri de partibus animalium ait fe one. poftea locuturum effe de anima, quaanimal tale eft; itaque teftatur, fe de fola animalium anima. acturum efle;atqui id fubiectum eft, cuius principia quaruntur, animal igitur eft fubiectum, non corpusanimatum vniuerfe fumptum. Præterea ficargumētantur; deillius formaagitur in secundz libris de anima, de cuius materia prius actum eft argumen eft in libris de partibus;at in libris de partibus a t tumb.

c ctum eft de folaranimalium materia,non de materia fitirpium; ergo in libris de anima fimiliter agitur defola animalium forma : minorem iam nos conceffimus, nam perfe manifeftum eft in hbris de partibus agidefolis animalium partibus; naiorem probant auctoritate Ariftotelis in primodepartibus animalium, vbidicit agendum effe deanima, \& eius gratiaagendum prius effe de materia, qux funt partes animalium; quāobrem fi de partibus agitpropteranimam, neD ceffe eft, ve de eiusdem anima loquaturin libris. deanima, de cuius materia lo quatus eftin libris. de partibus. Hre támenfententia falfa eft, \& omnino reiicienda ; quod enim in fecundo libro de anima agatur de anima vniuerfe fumpta a $g$ aros. poftea de animx parte vegetante, itamanifeffum eft, vt id negarenemo poffit; ea autem vtraquetractatio communis eft plant1s, \& animalibus; ergoibi de omnium viuentium anima agitur,non de animalis folius. Quod fi dicant, eam: E quidem aninz partem omn viuenti competere, de ipfa tamen ibiagi propter fola animalias \& vit contracta ad aninialia, hoc teftimonio pri. mum Ariftotelis reprobatur, qui in ea parte exempla fape fumit à plantis ; \& definitionem quoque anima in plantis declarat; deinde etiam ration e; quia fi ita effet, fophiftica effet illa! Ariftotel is confideratio, \& qualem ipfe iam vitiofam effe docuerat in primo libro Pofteriorum Analyticorum; ibi enim dixit, omnia effe F attribuendailli, cuiprimo, \& quatenus ipfum competunt, \& ea, qux funt generis propria, in ipfo effe cognof cenda, nonin fpecie, neque in fpeciebus ormnibus; vt zqualitas angulorum: duobus rectis non inxquicrure, fed in triangulo: fic etiam Auerroes in fuo procemio in primo. libro Phyfic dixit, quod confiderare primam: materiam vt materia animalis, vel vt hominis;. nonfaceret propofitiones vniuerfales, \& quatenus ipfum, fed effet, vt oftendere aquilate: 
rum habere tres angelos xquales duobus re- A ctis. In huncigitur errorem incides et Ariftotel. fi ann am lace fumptam, \&animam vegetalem, qux primo competit a nimato corporı, iplevt folius animalis animam confideraret, feuviad animal coar atatam. Neque etiam dicere poitunt, eam confiderari pracipue propter animalia ; plantis autem attribui fecundario, \& animalium gratia; nam vnaquaque res ira eff cognofenda, vrieft; anima vero vegetalis eft forma $x$ que à planta, atque ab animali participata ; fecus enim non effet viuens genus vniuocum; quoniam igitur non minus planta quam animal: fed $x$ que ac animal, hacanima participat, xque etiam in vtrifque cognofcenda eft. Præterea manca effet naturalis philofophia,fi in folis animalibus hane anima partem cognoferemus, non in plantis : nec dicere pofune, Ariftotèlem de hacagere in libris deanima propteranimalia, \&e iterü in libris de plätis prepter plantas:fiquidem nullam legimus huiusanıma tractationem in libris de plantis, fue ab Auftotele,fiue à Theophrafto icriptis:imo fi Ariftoteles, vel aliquss alius hoc pacto duas eiurdemanime trautationes feciffet, vnam in animalibus, alteram in plantis,perperam tecıffet, magnaque reprehenfione dignus extitiffet; tum quia id, quod primo competitgeneri, non refre oftenditur de fpecie, neque de fpeciebus omnibus;

Cap. de errorio

bus.

alpre. mumar. gumenstam. vt Ariftoceles afferit in primo libro Pofteriorum, quemadmodum antea dicebamus, tum etiam quia non eft iteranda eiufdem rei tractatio, quando femel pro omnibus, multoquemelius, tradi poteft, vt notat Aucroes in dicto fuo proamio in primum $\mathrm{Phy}$ fic. imo Ariftotel. ipfe in primo de partibusanimalium. Soffumus etiam huius dogmatisfalfitaté videre in libris de longitudine, \& breuitate vitz, de iuuentute, \& defeneftute, \& de vita, \& morte; vbi Ariftoreles proficetur, fe hæc omnia communiter confiderare in an imalibus, \& 1 plantis, quia reuera funt $E$ communia accidentia omnis viuentis; tametfi enim proprij modi, quibus hac plantis.competunt, reiiciuntur ab. Arıftorele in libros de Plantis; fer hoc tamen non ftat, quin hac omnia, prout xque omni vuents, competurt, in iis libris confiderentur. Quamuis etiam Arsfoteles in calce libri de. Longitudine, ac bi euitate vitx afferat cos effelibros de animalibus, nil tamen hounubs officit; fatemur enim, A: ifto teJemin animalibus confiderare ftatuiffe tumilla $F$ quæ anınaiilint propria funt; tu nilla, qua funt illis comn unia cum lantis, hxctumen femper atuibuere vuents. qued in animali ineft, non animali quacinus ett anum.i, licut Anato. miftrea, qu in hos mduiduo homine contemplancur, non vo huws hun inis contemplantur, fidve hominss. Rcía vt a illorum argumenea relpondeamus. Ad rianillw, yuod

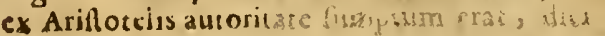

mus Ariftotelem in procmio primi libride Anima, \& in proamio librorum de Partibus animalium, folis animalibus animam attribuere, proponereque de animalium anıma agendum, quia nondum improbauerat antiquorum fententiam, qui fola putabant anımalia viuere;eam enim poftea contutat in calce prinilibr. de Ani$\mathrm{ma}$, vbi oftendit, etiam in plantis vitam ineffe. Confiderandum praterea eft, Aruftotelem id

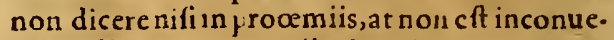

B niens aliqua in procmiis dici pingu! Minerua, \& aliorum fententiam potius, quam veritatem refpiciendo, quando al orum opinio eft vulgata, \& nondum reprobata:at in 2. libr. de Anima, vbi Ariftoteles ferio, \& fecunám mentem propriam de anima loquirur, nıl vnquam tale có. periemus, led in inueitıganda, \& tradenda, \&e declaranda definitione animæ, femper dicit earn effeviuentis corporis tormam, nunquam dicur folius animalis; \& in cont 36.37 . illis 2 -lib.

Coftenditanimam effe viuentis corporis caufam vt formam, \& vt finem, \& vt effearicem, non dicit folus animalis; fic etiam torum tractatum de parte vegetalı fil legamus, nunquam videbimus Ariftotelem illam anima partem foli animali attribuere fed femper viuenti generi communi animalis, \& plantz. Mirum certe eft, quod illi proosmia potius Ariftotel is refpicere voluerint, quam ipfammet traetationem, in qua Arıftoreles veritatem declarat, nihil que oratorie dicit, fed omnia docendi gratia . Ad alterum argumentum fumēda eft refponfio ex iis, qua antea dictafunt; quum enim in libris de Anumalibus tractentur \& illa, qux animalium propria funt, \&illa, quz funt illis.communia cum plantis, non poffumus ita argumeniari, ve dicamus, hic liber eft defolo animali.ergo \& itle alius:iam enim oftendimus, aliquos effe de folis anımalib. aliqu os de viuentibus omnibus communiter, vt afferit Arift.in initio libri de Sensu, \& fenfilıbus; quoniam ergo prius de matersa, quam de forma dicendum effe sudicauit, \& vtramque confiderare voluit in animalibus, ideo materam confideıaut propriam anımaliun, quia nulla erat propinqua materia communs anımali, \& plantæe, formam autem cöfiderauı vrcomin unem, quia in animali ineft pais quædam anımx, qua eadem etiam plantxpartucipant; qua de rediffutius loquuti \&umus in libis de Methodis.

\section{De plantis, o earum tractatione. Cap. $X I I$.}

Tbros cmnes de animabus iam à nobis Lcontidcrates lequintur tandem lib. de plantis, quimfoenta r a uirlspolirimus locumienent: quum cnim derchusiranimatis a-

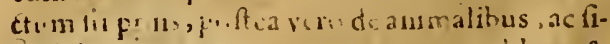
mulcicis oi lunciomminaasimalibus, \& 1.ans! /. co, v: agerctur de flan- 
tis, fecundum propriam rationem, qux diftingututur ab animalibus; in his igitur libris fubicetum eft planta vt conlideranda, \& generaliter, \& fingillatim, fer üdum omnes fpecies fuas, ficut Aritoteles propofuit in calcc capitis primi libıi Metcorologici. Duo autem de plantis confideranda funr, fubftantia promum, deinde operationes \& proprictates confequentes, qualis fuit etiam animaliun conideratio; ideo Ariftotel in duobus libris de llantis agir primo io. co de partibus plantarum; ficut etiam primo locoegerat de partibusanimalium, poftea vero de piantarum gencrarione, ac decarum proprietatibus. Exquifriorem plutarum tractationem tradidit Theophraftus, qui Ariftotelem deanimalibusagentem imitarus, diltinxitplantarum conliderationem in hiltorican, \& fcientialem; extant enimnouem eius libri de hiftoria plantarum, \&einitium decimi; deinde alii fex libride caufis plantarum; in quibus feruatordinemab Aritolcle feruarum in declaratione animaliuí; nam primo loco de lubitantia plantarum agit, dcclarando partes tum homogeneas, tum heterogeneas; deinde generationis \& accidentium conlequentium declarationem ptofequitur. Notare autcm pofiumus in is \& Ariftorelss \& Theophaiti sibr:s, plura efle de plantatum viribus medicinalibus dieta: fed Theophraltus non folum fparfim has plantarum vires confiderat, fed de his peculiariter agendum proponit in decimo libro hiftoriarun, licet eius libri initium tantum habeamus, reliqua defiderentur;hoc dico ad comprobationem eorum quir fupra dixi, loquens de anitate \& morbo: vires enin \& proprictares plantarum medicinales cognofcendr funt \& à Medico \& à philofopho naturali, diuerfis tamen fcopis; Medicuseas cōfiderat, dum fibi proponit fanitatem recuperandam, vel conferuandam ; philofophus autem naturalis easinquirit, vt plenam habeat cognitionen plantarum, quæ funt fpecies corporis naturalis, ideo id ei facere non conuenit in libro de fanitate \& morbo, fed folum in libris de ubtum. plaitis. Nolo hic filentio praterire dubium quoddam; quod quidem aliis leuifimum effe videtur, mihi vero non ita leue, fed ardutim femper vifum eft: quum enim in tractatione de animalium fubitantia Ariftoteles \& materiam \& formam animalium declafaucrit, priusenim egit departibus anmalium, poftea de anima; queratur, curagens de fubftanria plantarum \& $\dot{F}$ ipfe \& Theopliraftus folas partes plantarum confiderauerit, deforma vero ne verbum quidem fecerit. Ad hocomnestefponferent, non opus fuiffe loqui de anima plantarum, quia de hac iam plene dictum erac 11 fecundo libro de Anima, nempe de parte anina vegetali, quia fo. mpugar la videntur planta viuere. Hxc tamen relponfiomihi videtun non omnino tollere dinicultaem; anima enim vegetalis, de qua agiur in li-
A bris dc Anima, mon eftpropria plantarum forma,fed eft propria viuentis, quod communc genus eft animalis \& plantæ, nee per cand diftinguitur planta abaninali. Cunniam igiturnecetle cft confiteri plantam ab animali diffire per fubitantialem aliquam forman, quæ lit propria plcnte; fiquidem per matcrian res non differunt; qua autem per fola accidentia differunt, non differunt fpecie; omnia atitem qure funt propria plantarum, tractanda funt in libris

z de l'lantis, agendum omni no erat de forma plátæx, qux plantam feparat abanimali; quare difficultas viger. Egobreuiter dican, quid hacin Repponfico refentiam, diffulius poftea de hoc loquuturus, propras. in operibus naturalibus. Ego quidem nunquam in eo multorum errorefui, vt diccrem, anmam vegetalen confituere plantam; animam vero fenlibilen conftituere brutum, fed credo vegetalem conftituere viucns, quod eft gremsplant \&aninalis; \& animam fenfibilem conftituere animal; quod eft genus brutorum \& hominis; plantam vero ab anmali differre puto per propriam formam, \& brutainter fe, $\&$ ab homine per proprias fingulorum formas. Vnde aliud maius dubium oritur; nihil enim poteft elle pre. ftantius anima, quod \& ipfum non fitanima, forma vero pecies eft nob lior, quam forma generis; quareforma propria equi nobilioreft quá anima fenfibilis, \& forma propia planta eft nobilior quam ani ma vegetalis : plur!mæ igitur alia dantur animæ prateril las, quas Ariftoteles in libris de Anina declaraut. Sed de hoc loquemur in operibus naturaibus, nunc fat is fit hane dificultatem tetigifle. Ad dubium autem prius propofiti fatis eft, fi in prafentia dicamus, nullam fieritractationem de forma fropria planta, quia hæceft incognuta, vltim enim differentı ac proprix fubftantialés formeplantarum, \&animaliñ ignorantur, negaritamen 12 on polfunt, E rifi in boc abfurduni incidanus, vtdicamus, plantam abarimali, a plätas interfe, \&ainima. lia intcr fe differre folisaccidentibus; fed de hoc alibi. Quodautem libri de plantis fequi debeät Qund lilibros deanimalibus, dupliciratione, eaqucian bizdeplä in pracedentibustacta, demonftratur: vna eft, tis $\int \mathrm{egu} a$ quia in libris de animalibus traetntur omnia tur $Z_{\text {s- }}$ illa qux pertinentad corpus viuens, quodeft bros de planteg genus: quoniam igitur cognitrojpeciei nimalsprafupponit cognitum 1 am effe genus, neceffe bus. elt vt libru de plantis fin: pofteriores libris de animalibus; nam fi præcedcre ftatuantur, de planra agetur, ignoratogenere, \& ignorata animavegetali, qua viuentia omnia dicuntur viucre; qquod quidem dicendum non eft. Altera ratio fumitur ex is qua funt propria plantarum; haccnim quú midiona - froinde igriotiota fint in plantis quamilla, qux is inanimalibus proporitone refiondent, faculius cogñofcuntur in plantis polt cognitione animalium; ideo mulı plantarum partes \& ab Ariftorele 
\& à Theophrafto declarantur per animalium partesiam cognitas, \& qquum nominibus careant, vocantur is nominibus, qua funt propria partiun anımaliun, ob quandam proportionalem répondentiun \& officii fimilitudinem; videmus enim ibiconfiderariin plantis carnem \& venam, aralia eiufnodi, quæ dicuntur proprie de animalibus : haec igiturindicant, libros de animalibus iam pracelfife, quum Ariftoteles ac Theophraftus his nominibus vtantur, vt inn declaratis in animalibus. Quare tractatione plantarumabrolutur tota natural is philoro. phi2, quum hxc poftremum obtincat locum; quod etiam fignificauit Ariftoteles in calce primi capitis primi libri Meteorologicorum, vbi dicens agendum poftea effe de an imalibus \& de plantis; prtus animalia nominat, pofterius vero plantas.

\section{De perfectione Scientic naturaliss, ac de eius ordine. Cap. XLII.}

TAturalis difciplinze ftructura, \& partium Nomnitim feric ita declarara, id vnum confiderandum reftat, quxrere aliquem poffe, an 3usp. 5.30. perfectam rerum naturalium lcientiam ab $A$ riltorele traditam effe dicendum fit, an non perfectam. Mihi quidem videtır, ficut antea quoque distum eft; perfectam, \& non perfectam dici polfe; nam perfecta eit, fi ipfan forman, hoceft, fabricam, \&artificium lpectemus; fed imperfecta, ratione materix \& rerum confideratarum; multr nam q; funtres naturales, quas non confidera uit Ariftotel. \& mult $æ$, quas non nouit; attamen fi harum quoquenoritiam affequeremur, non obidalio ordine, alioueartificio tradere naturalem feientiam oportere fed manente fabrica; arcificioque A rift: diceremus, fcientiam naturalem earum rerum additione perfectiorem reddi, quoad materiam, non quoad formam; plurima namq; cum dealiis rebus, tum maxime de animalibus, \& de plantis addi pof. fent, qua ab Arift. dita non funt; fed facile cirque effet, adiectis fingulis propros inlibris Ariftotelis locosaffignare;ordine tamen \& artificio Atiftotelisnonimmutato nec labefactato; vifi. diceremus, nullos Arif: fcripfife proprios libros de mineris; facile fuit Alberro Magno, qui eos compofuit, illosadderelibris Ariftotelis, \& polt quatuor Meteorologicos, quameormmedem efle diximus, collocare. Sed dicere praterea poffimus, naturalem philofophiam ab Ariftot.fcriptam eciam ratione materix; acrerum cognofcendarum perfectam, \& cmnibus numeris abfolutam efe, finonaetu, faltem virtute; quandoquidem credendum omnino eft, non folum pretermiffa ab Arift fuiffe multa, quoniam ip fi fierunt incognita; fed omiffa etiamab ipfo pina fuiffe, qure nouit, fed fcribere nol uit;nam cerrum eft, nullum ab Ariftotele foriptum fuife librum, yel tractatun de hominis rifibilitate, aut
A de hinnibilitate equi, aut de his fimilibus; tamen fundamneta, acfemina quædam ab eo iakta effe, vnde emanare etiam lllorum, quix non feripfit, cognitio poteft ; iis enim. qua nos Aniftote: les docuit adsuti., poffumus alia multacontemplari, \& in eorum notıtian duci. Quamobrem id mihi denaturalıbus Arift.libris dicendum videtur, quod ego dicerefolitus fum de Geometricis, \& Arithmeticis ab Euclide fcriptis : Etenim multa funt Geometrica \& Arithmetica B theoremata, quxab Euclidedemoniftratanon funt, demonfrantur tamen ab alis inipla librorum Euclidisinterpretatione; nec ob id macam \& imperfectam vocare debemus Euclidis Geometriam vel Arithmeticam; nam fiomnia, qux de magnitudinibus, ac de numeris demoisftrasi poflunt, demonftrare Euclides volurfet, creuifet ab que dubio volumen in immenfum quod quidem Lectorem facile au ertere ab illius lectione potuiffet : fatis igitur ei fult, præcipua

C quiadam theoremata demonftrare, ex quibus poiteaaliorum plurimorum, qua fubsicuit, imo omnium, qux excogitari pollunt, demonftrationes deducerentur: iciunt enim omnes eruditi Mathemątici, nullũ effe Geometricum theorena, cuius demonftratio ex libris Euclidis, tanqุuã ex v berrimo fonte, nófacile hauriatur;eañque puto fuiffe caufam, cur Euclides libros fuos Eleméta appellauerit, quafi fundaméta \& prin. cipia, ex quibus aliaplurima deduci poffunt, tū $D$ in illa ipfa difciplina, tum in ali is \& fcientiis \& artibus quibus interdum vfus rerum Mathematicarum neceffarius eft. Dicere igitur poffumus, imodebemus, friptos effe tanto cum aro tificio ab Euclide librosillos, yt in.iis Mathematic $x$ difciplinx perfes $x$ \& int cgr $x$, fi non aetu, faltem poteftate \&. vurtute contineantur. Hocidem de naturali philorophia ab Ariftotele tradita dicendum efle videtur: quí enim ea, qux funt pracipua, de rebus natur $x$ docueritz. E alia reliquit, in quorum notitiam ex illorum, qux fcripfit, confideratione duci poffumus. Itaque perfeetam dicire poffumus ab Arifotele friptam effe naturalem philofophiam, etiam. ratione rerum cognofcédarum;omnium enim, qua humanum ingenium affequi poteft, cognitonem tradit aut actu, aut faltem virtute; id que fortaffeipfemet fignificarevoluit in calce primi capitis primi libri Meteorologicorum, dum ait, agendum manere de animalibus, \& de plantis F tum vniuerfe, tum fingillatim, quoniam his declaratis, finem fere habitura elt totius naturalis fcientiatraditio;inquit enim [fere] rum propter quartum Meteorologicuin, \& proprer libros de mincris, quos non nominauerar, tum etiam ad fignificandum, fe. non actu perfeetzm naturalem fcientiam traditurum, fed virtute tamen perfectam, quremadmodum diximus. Ordinem autem totius fcientix counpofinum effe manifeftum eft , idque à robis accurate
Cur E cledis 1 brs So centis Elengen: 
6. 2. declaratom eft in libris de Methodis; ibi enim diximus, progreffum totius huius difciplinæ rationi fubicetı effe a magis vniuerfalibus ad mi . nus vniuerfalia, â corpore naturali ad fimplex, $\&$ ad miftum late fumptum, ab hoc ad imperfeEtum \& pertcetum \& ab hoc ad inanimatum \&c animatum, \& ab hoc ad animalia, \& plantas, ac tandem ad horum fpecies : fed quia hotum fingulorum confiderancurordinatim \& principia \& accidētia, ideo ratione principiorum eft pro-
A greffio à primis ac remotiffimis principiis ad propinquiora, ac tandem ad proxima fpeciebus naturalibus; \& à fimpliciorıbus ad concretiora : nam interna principıa corporss naturalis lale fumpti, fimpliciora funt intern is principiis mi-fti, quatenus miftum eft, \& hæc fimpliciora in ternis principiis animalis, quatenus animal eft: hæcautem eft condiuo ordınss cópolitiui, caq; ad fcien iam rerum confequendam omnino neceffaria, vt in memoratis libris declarauimus.

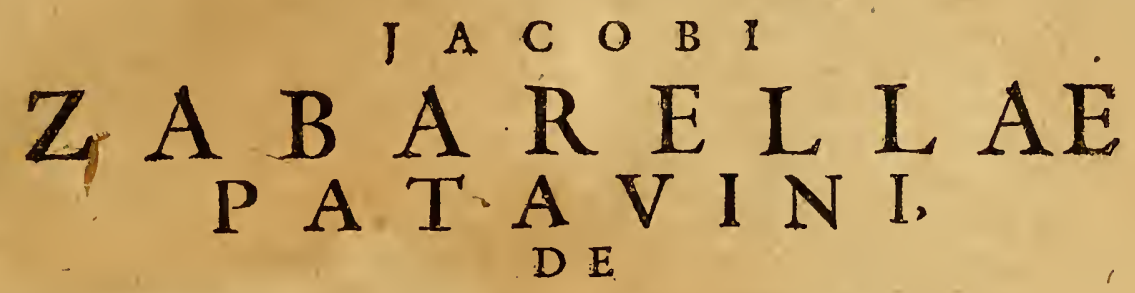

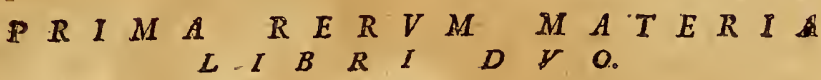

L I B E R $P$ R I M V S.

Procmium Operis. Cap. 1 .

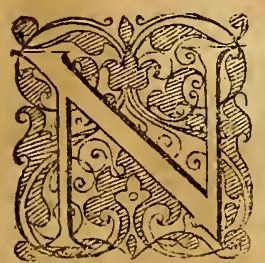

Ihil effe videtur in rebus naturæ oblcurius, \& cognitu difficilius prima rerum materia, de qua in 1. libro Narural. Aufcultat. Ariftoteles artificiofifime pertractauit : plurimum ettam ad fententiam naturalem confert ipfrus cognitio, quum in ipfomet. eius difciplina limine idem clara voce teftatus fit, nullam ignoratis naturæ frimordiis, rerum naturalium cognitionem haberi à nobis poffe.Hæc ego coniderans, aliquod me operzpretium facturum exiftimaui, fi arduas, qua hac de re exiftunt, quxftiones, magnafque difficultates; qux negotium faceffere omnibus folent, proviribus explicare tentauero ; \& ea, quxe iprephilofophando excogirate potui, in commune cōferens, aliifq; expendenda relinquens, $F$ nifus fuero veritate, \& Ariftotelis de prima materia fententiam (fi poffim) reddere clariorem. Eritetiam hac noftra concemplatio non inutilis propteralia principra, de quibus ob eorú inter fe mutuum refpectum aliqua dicere neceffarium erit, nec non de merhodo, qua nos Ariftoteles ad corum omnum cogririonem perduxit; hacenim ad plenam prim marurix notitiam confiderare oportebit. Ordinem veio eum feruabo, quo in omnibus vit folıus fum, \& qui elt naturx noftr maxime confentaneus; ea cnım. quafaculiora cognitu funt, quæue exactiorem.
D aut faciliorem reddere aliorum cognitionę pofo fint, femper anteponam, eliam li ipfarum rerum naturals ordo, quo exiftunt (quod quidem hac in re frequenter euenturum (cio) alius effe videatur. Aliorum fententias, \& dicta in mediune adducere non curabo, nifi quando rem ita poitulare exiftimauero, in if $q$, vtar ea, qua Philofophum decet tum libertate, tum ingenuitate: nam \& illa, qua falfa videbuntur, refutare, \& qux vera effe putauero, recipere \& approbare; E \& fectarorem me aliorum facere non verebor, vt folo veritaris amore ductum me effe omnes intelligant, \& fateantur:

\section{De duobus Principiis contreriis. Cap. $1 L_{3}$}

Vum prima rerum naturalium principia apıd A tift. tria fint, duo contraria, \& tertiun. lubięum; erat quidem fubiectum natura prius cōrraris : fed quoniam 1 gnotius offerebatur, \& ad eius notitiā neceffaria erat principiorum contrariorũ cognitio, A rift. primo loco de sontrariis egit, poftea vero de fubieta materia: ad principia cótraria cognofcenda laris fuit inductio, quippe qux minus abı́co lita \& facıliora cognitu erant; a. materiam aūt inueniendaim efficaciore initruméto opus fuir, demonftı arioneab effectu, ad quam etiam Arist. magno cum artificis, magnoq: verberum appara:u progref- Multorin I us eit: qui vero dicunt, principaa con raria pro- error in b.iri ab Aritor. demontratione à priwri in con- textu tex 42 . libri c. Payti aufcult. ii non b. ne logica $\$ 2 . x$. didicerunt, fiquiden is eft iyllogifmis quidam Pbyfic.

$$
\text { E } 2 \text { Diale- }
$$


Dialecticus; qui rihil demonftrat, quum ex A definitionequidditatiua principipobet prima contraria cli principia rerum, quod eit piteresludidem, quod probandum esat, yt in Log cis libris often lum à nobis eft; proinde ratio illa vi Dialcaticandmitti poteft, qua vt dènonftratiua abique dubio vitıofa eft, Ratione igitur naurali Ariftotcles nulla alia vtitur, nifi inductione; ex fingulis enimqux funt, colligit hancr niucralem; omne quod fit, ex fuo contuariofieri, \& ita cuiuslibet rei principia elfe duo contraria, vnum recedens vocatum terminum à quo, alterum vero accedens vocatum teminum ad quem. Contraria autem anpel. lauit non contrarietate vera, fed ea oppofitione, qua eftinter habitum \& priuationem : quum enim ownis generatio fit tranfitus de non effe ad effe, \& omnis interitus fit tranfitus de effe ad non elle, necelie eft, alterum contrarium effe nobilius, alrerum vero ignobilius; \& vnumeffe habitum quendam, \& formam, à qua res habet vt fit; alterum vero illius forma priuationem, quæ fignificat, non efle illius rei cum poteftate ad formam oppofiram; \& quamuis videatur generatio effe trāfitus à forma ad formam, vt fi ex aqua generaturaer; non enim poteft aliqua forma recedere, quin alia forma accedat, id tamen non eft perfe, nec quatenus eft generatio; generar enim dicimus id quod non eft, quare per le generaturaer ex mon aere, peraccidens vero ex aqua, accidit enim illinon aeri, ex quo fit aer, ve fit aqua. Generari autem \& interire dicimus propric quidem \& abfolute fubfantias, accidentin vero minus proprie, \& (vt vocant) fecundum quid: mam frex aere aqua generetur, aquā fier. fimpliciter dicimus; fivero aqua ex frigida fiatcalida, nonfinpliciter dicimus aquam fieri, fedaquam ficricalidam; vnde colligimus, eanMítatio dem mutationem in accidentibus vocari poffe yacci- \& generationem \& motum provarijs confidedentilus rationibus: illam enma aque calefactionem gefecarz nerationem appellare poffumus, quatenus fit foteft $\mathcal{F}$ calidumex non calido, formatum ex priuato; motus et cuatenus autem eft tranfitus à frigido in caligenera- cum, à forma ad formam, \& (vt vocant) ì pofitio Sari- iluo ad pofitiuum, èatenus vocatur motus;idco is modir. Ariftoteles ins.lib. Phyfic, diftinguens generationem à motu, dixit morum effe de fubiecto in fubiectum; generationem yeso de non fubicto in fubiectum, \& interitum de fubiceto in non. fuicetum; fume do fubicetum pro: termino pofit.uo, \& non fubiectum protermino priuatiuo. latet igitur, principia generation is cuiufquerce efle duo contraria, qua de ratione generationis. eft,vt id q̨uod generatur, tranfeat de non efle ad effe: \& de ratione in teritus eft, vt id quod interit, tranfeat deeffe ad non effe; fiquidem nil aliud eft generari, quam prius non effe, poftea elfe; \& nihlaliudeit interire, quam prius elie poftia. vero non efic.
De Inuentione Prime Materia.

$$
\text { cap. } I I I \text {. }
$$

Ognitis principiss coñtrarijs, Ariftoteles ad Qprmam materiam inueniendam ita progrcilus eft: copprt dubitando oftendere, duo contraria ad rerum generation cm non fufficcre, proinde fubiectam contrarijs materiam fatucndam efle, tanquam tertium principium: qux

B materixprobatio dialectica \& infirma eft; nam ex fact in contrarias partes argumentatione colligere fubirciendam effe materiam, vt aduerfantia illa argumenta concilientur, eft probabiliteracdialectice rem prebare, abfq; ilid ex natura rei ducta ratione; propterea cam ab effectu notiore demonftrare aggreffus eft hune in modum; propofitũ illi erat oftendere, dari primam materiam fubiectam generationi fubitantiali, quandoquidem de fubiecto mutationis acci-

\section{-} dentalis nullü dubium erat; videmusenim ce-
ram exinfiguracione figurä accipere, \& aquam ex frigida fieri calidam; non ita apparet fubiectum generationis aeris ex aqua, quoniam infenfile \& ablconditum eft, \& videtur aqua tota interire, \& tota acris fubfantia generai ex nulla præexiftente materia, ideo Ariftoreles ex accidentali-mutatione duxit nos ad idem cognofcendum ingeneratione fubfantiali, quu enim tandem vfuruseffet hac demonftratione $a b$ efDectu; rbi eft mutatio fubfantialis, ibieft materia illi fubiecta, àc in corpore naturali eft mutatio fub ftantix; ergo in codem eft materia tali mutation fubiecta, vidit Ariftoteles minorem quidem propofitionem manifeftameffe, fed maiorem efle incognitam \& aliqua declaratione indigere, ita vt à notioribus ad ignotiora piogrederetur, generationem viniuerie fumptam ante omnia fibi confiderandā propofuit ; quum enim id, quod communius eft, notius nobis fit, E facilius cognofcitur fubiecta materia in generatione latifime accepta, qux \& illam, quæ fit $\mathrm{ab}$ arte, \& illam qua à natura, fiue fubftantia. rum fue accidentium, communiter amplectstur; quam peculiariter confiderata materia folius mutationis fubftātialis: voluitergoprimum inductione probare hanc vniucralem; in omni generarione fubiectum requiritur; \& confiderare cept in accidentibus omnibus id effe manifeltum, ve ex corum confideratione idem proportionequadam in fubfantis quoq; neceflarium efle cognoferemus; hacen eft vis inductionis dem onftratiu, yt ex aliquorum particularium enumeratione in lucem prodeat predicati cum fubicto eflentialisconnexus, inde cognofcamus ita elle in reliquis; femperenin ex co quod predicatio elt $f$ er fe, licet inferre cã efle deomm; licigitur Ar iftorcles à generatione accidentum pregrediens ad cam, qua eft lubdtantiarum, tidem ex his perinductionem colligit hanc 
git hanc vniuerfalem, in omni generationene- $A$ ceffarium eft fubiectum, fub qua deinde fumit peculialiter de generatione fubftantiali hanc maioré, vbi generatio fubftantialis, ibi eft fubięa materia, \& facit demonftrationem illam ab effectu, quam fupra memorauimus. Hac methodo in uentameffe ab Ariftot. primam rerum materiam in r. lib. Phy ficx aufcult. eum librum bene confiderantibus manifeftum eft.

De modis, quilus ad Prime Materia cognitionem duci poffumus, opiniones aliorum. Cap. IV.

$\mathrm{O}$ Væri folet, quotmodis in primæ nateriæ cognitionem duci poffimus; ad hoc quid alif dicant, paucis referam, poftea quid ipfe fentiam, declarabo; plui ibus videtur Ariftuteles multis modis primam materiam manifeftaffe; vnus legiturin contextu 8. libri 7. Metaphyfic. vbi pernegationem declaratmateriam, dicens; Materia non eft fubftantia, necquantum, nec $\mathbf{C}$ quale, nec vlla aliarum Categoriarum, fed horun omnium fubicctum. Alij vero duo modi legunturin s. libr. Phyfic. vnus per mutationem fubftantiæ, quem iam expofuimus; alterper analogiam, quam tangit Ariftoteles in context. 69. eiufdem libri, fed illa analogia non eodem modo ab omnibus intelligitur. Scotus intelligit relationem ad formam, vt apud eum legimus in 2. Sent. diftinct. 12. quxition. r. fic etram Thomas interpretatur in Opufculo 32 . \& alii complures Latinorum:quum enim actus fit ratio cognofcendi, \& forma fit actus, rationi confonum eft, primam materiam per formam cognofci. Sed Graci \& alij melius locum illum interpretantes, intelligunt analogiam non ad forman, fed ab fubiectum fenfile mutationis accidentalis; vt enim fe habet $x$ s ad totum compofitum arte factum, vt ad ftatuam, ita prima materia fe habet ad fubftantiam compofitam; quemad modum igitur $x$ antequam fiat ftatua, non eft actu ftatua, red poteftate, ita prima materia antequam formam accipiat, non eft actu ens vllum, fed omnia poteftate: hre eftillius loci vera interpretatio ; analogia enim eft proportio, qux quum fit fimilitudo rationum, non poteft effe inter duo, fed eft inter quatuor, quia ratio eft inter duo, quare dum duas rationes inter fe comparamus, \& fimiles effe dicimus, quatuoor terminos confideramus, vel tres, fi vinus bis fumatur, \& teneat locum duorum; dicimusenim, quaternarium ad binarium habere rationem duplam, fic duodenarium ad fenarium habere rationem duplam; quum ergo eadem vtrobique fit ratio, dicimusita fe habere duodenarium adfenarium, vt fe habet quaternarius ad binariúm, eaque vocatur analogia; fic ergo ibi Ariftoteles dicit, 'ita fe habere primam materiam ad fubftantiam compofitam, ut fe habet materia artefact ad ipfum compofitum arcefa-
Atum, \& ita per hanc analogiam cognofcitur prima materia, quia proportione refpondet fub iecto mutationis accidentalis. Aliqui tamen locum illum confiderantes dixerunt, Ariftotelem ibiloqui de cognitione effentix ipfius materix, non de cognitione exiftentix; quum enim dicat ['tabac adfubftantiam, $\mathcal{F}^{\circ}$ id quodest, fo babes] ignificat primam materiam iam inuentam vt exiftentem, \& confiderans folam eius naturam, inquit eam cognofci per analogiam, videlicet

B quodfecundum fe nihil eft actu, fed omnia poteftate, ficuti etiam res ad ftatuam fefe habet: præterea inquit ibi Ariftoteles, materiam effe Grsntì: per analogiam, quare de perfeeta materix cognitione loquitur, perfecta auten eft diftincta, qua cognofcitur effentla, \& quid res fit. Hæc funt, qux ab aliis de modis, quibus ad materix cognitionem duci poffumus, diata inuenio.

\section{Declaratio vera fententia de cognitione Materie. Cap. V.}

$\mathrm{V}^{\mathrm{T}}$ pateat, quidnam recte ab aliis dicatur, \&e quid non recte, ego in hac re fententiam meam proferam; puto inprimis verum effe id, quod Auerroes afferit in Commentario vlim. r. liber.Phyfic. quem poftea multi in hocfequutifunt, nullam effe aliam viam, qua ad primæ materiæ notitiam peruenire poffimus, nifilllam Via, qua D vnam, qua Ariftoteles in illo primo libro vfus coginoficeft fumptam à mutatione fubftantiali; etenim tur dari hoc vno medio oftendi poteft primã materiam materi $\vec{a}_{\text {. }}$ dari, \& nullo alıo; vanaigitur eft Auicennæ \& a- Gna esz. liorum fententia, qui putant materiam poffe a lio medio demonttrari à primo Philofopho; quodenim dicuntaliqui de modoillo, qui habetur in context. 8.liber.7. Metaphyfic. eft error manifeftus, quoniam aliud eft via ducens ad inuentionem materix, aliud ệt via ducens ad coE gnofcendam effentiam materixiam inuent $x$, aliud demum eft ipfus fententixiam cognitæ fignificatio \& expreffio per definitionem; iam enim inLogicis libris oftend 1 mus, definitionem non notificare effentiam rei latentem, fed aliquem effemethodum, qua quid res fit notificar tur, idq; effe notificare ipram definitionem: itaque negatio, qua Ariftoteles in dicto locovtitur Declara. ad materix naturanı fignificandam, non eft via tio mate. duceñs ad materia m cognofcédam, nec ratione ric per

F exil exiftentix, nec ratione effentix, fed eft potius negatioconclufio illius progreffus, quo effentia mate- nem.qua rix notificata eft; poftquam enim quid fit mate- lis. tia nobis innotuit, optime ei us effentiä eo modo fignificamus per negationem : hoc autem Effentias clarius fict, fi confideremus, qua via fit notifi- materice c.ta materia natura \& effentia; hanc viam ego cognof $i$ non aliam effe puto, quam illam analogiam, de tur per qua Ariftoteles in context us 69. libri 1. Phyfic. analogiloquutus eft; poftquam enim materiam dari am. 
perfubstantize mutation em inienimus, confideranus eam ita fe habere ad res, qua ex ipfa fiunt, vt fe habet xs ad ftatuam, cuiuseft materia; \& quum ratioxis ad ftatum nota fit, inde colligimus, qux fit ratio prim $x$ materix ad res qux cxca fiunt; xs enim antequan formam ftatux accipiat, non eft actu ftatua, fed poteftate : quoniam igitur eadens eft Primæ materix ratioad res omnes, qux rris ad ftatuam, materia quoq; non erit ulla ex rebus actu, fed omnes poteftate; hæc eft definitio materix per talem analogiam cognita, quam profert Ariftot.in illo context.8. lib.7. Metaphyf. nec potuiffet ibi effentiam materix ita per negationem lignificare, nifi prius peranalogiam prxdictam cognouifet hanceffe materix effentiam; hoc tamen maiore eget confideratione, \& infequentibus diligentius expendetur; in prafentia hoc dixille fat is fit, illam expreflionem effentia materix per negationem non effe viam ducentem ad cognitionem effentir marerix, fed efre potius conclufionem illius via; fic enim exprimitur effentia materiæiam à nobis inuéta \& cognita per analogiam, hoc eft, per proportionalem fimilitudinem, quam habet cum fubiecto fenfili mutationis artificiof $x$. ob id optime eos fenfiffe arbitror, qui dixerunt, Ariftot el em in illo context- $\sigma 9$. effentiam materix precipue refpexiffe, dum dixit materiam fcri per anlalogiam, \& fignificaffe, nullam effe aliam viam, qua cognof ci poffit quid fit materia, nifi hanc analogiam; quifquis enim bene verba illa Ariftotelis expendat, animaduertet Arftotelem denotaffe folamanalogiam ad cognofcendam materize eflentiam nos ducere ofje: idquerationiconfentaneum eft, quum enım materia fecundum fe non fit actu, non poteft perfe mouere intellectum, fed folum peralia, qux actu funt, quorum ipfa fimilis eft: quod etiam Platofignificauit, dicens, materiam cognofcia nobisadulterina quadam cognitione, nec per rectam infpectionem, fed per obliquam; dum enim fenfilem materiam fpectamus, ex ea huius quoqueinfenfilis matcrizenaturam iudiArasio- camus. Negandumtamen propterea effe non giaetiaz putoid, quodillinegant, etiam ad exiftentiam aderzfte materixinuenieridam fuifevtilem, imo \& nesiam $m$ ceffariam talem analogiam, quod quidem ita teria co- declaro : certum eft, nullum effe medium, quo grofen- primamateriaignota demonftretur exiftere, nidam Sti- fi folam mutationem fubftantialem per demōis 6 \$7. ftrationem ab effectu, qua vfus eft Ariftotelesin primo libro Phyficæ aufcultationis, eaque eft fententia Auerrois clara in commentario vltimoillius primi libri, qua etiam ratione validiffima comprobatur: nifieniminterire aquam, \& in aërë mutari videremus, nulla ratione cogno feere poffemuscorpora hac ex materia \& forma conftare, fed fimpliciapenitus effeputaremus; fic honirem \& equuim, \& reliqua omnia corposanaturaliaj ca naunçue fi ætenna cfiè, \& nun-
A quam interireinfpiceremus, itayt nulla nobis effe cogiaita fub?tantix mutatio, nullam prorfis cognofcere poffemus compofitionem materix cum forma : hancigitur ex mutatione fiab. ftantia in aliam fubltantiä cognof cimus; quum enim interire aquam, \& ex ea gigni aërem videamus, cognoficimus neceffarım effe alıquod vtrique fubitantia commune fubiectum, quoniam 1 omni accidentium mutatione videtrıus idem fubiętum cōnune fub terni form $x$ geni-

B t $x$ \& form $x$ interempt $x$, \& nullä fieri mutatione contrarij in contrariü fine ali qua vtrifq; contrariis fubiecta materia. Hinc patet vanam effe illorum confiderationem, qui dicunt materiam cognofci per formam, feu per relationéad formam, nifillud idem quod nos dicimus, fe fignificare vellefateantur: nä fíntelligant, materiam cognofci per formam vt aduenientem \& rece-
dentem, dicunt cognofciper mutationem fubftantix, quod nos quoqueafferimus; fic enim C per formam, non prout eft actus \& ratio cognocendi, fed prout accedit, acrecedit, \& prout elt mutabilis, materiam cognofcimus;at fi fubftantia omnis naturalis aterna effet, dicere per formam, quatenus eft actus, materiam cognofi, ridiculum effet; performarm enim cognofcitur ipfurnmetcorpus, cuius eft forma \& actus, \& perfectio,per eam etiam cognofcunturaccidentia confequentia:at certe ipla materia nunquan per formam cognofceretur, fiomnes rerum naturalium formæaternæ, \& immutabiles eflentQuum autem hoc vnum medium,mutatio fubftantix, nos in materix cognitionem ducere potuerit, neceffaria tanı ê fuit etiam analogia : nam fuit quidem fola mutatio medium in demonftratione ab effectu, nec vllo alio medio vti poteramus, attamen illius demonitrationis pro. pofitio maior non poterat nifi per analogiam declarari, alioquin ignota manebat:quod enin vbi eft fubftantix mutatio, ibi fit fubiecta mate-

E ria,ignotum offerebatur, \& exaccidentium mutatione ab A riftotele declaratum eft, vt legimus in context. 6z.libr..1 Phyfic. Hocautem eft analogia vti, \& dicere, vt generatio domus, \& generatio ftatux materiam habent fubiectam, ita \& animalis generatio \& plantæ debet haberemateriam, quxad plantan \& animal eam habeat rationé, quam habent lapidesad domū \& $x$ s ad ftatuä, hoc eft, qua fit fuftentaculum ipfus mutationis de contrario in contrarium; fic enim locum illum interpretatur Aucroes ibidē, \& hoc pacto ad demonftrandam materize exiftentiam vtitur analogia: haceadem vtütur etiam Arithmetici practici in inueniendo numero aliquo ignoto; tribus enim numeris conftitutis, quorum primus ad fecundum certam habeat rationem, quxrunt quatī, ad quem tertius eandem rationens habeat; \& dicunt, fi quatuor dant oEto, ieptem quotnam dabunt? \& inuetsiunt, dare quatuordecimiideoaduertendur cif, nos ron- 
trariis modis analogia vti ad exiftentiam, \& ad effentiam materi $x$ declarandam : nam in declaranda exiftentia fupponimus notam rationem contrariorum ad fubiectum, \& materiam qux. rimus, ad quam fit eadem ratiocontrariorum degenere fubitantix, quod diximus etiam Arithmeticos facere, dum quxrunt al tquem numerum ignotum: at in declaranda effentia fupponimus vtrobique materiam notam, \& quatuor term inos notos; quarimus autem perfecte cognofeererationem prima materix ad compolitum naturale; eam cnim prius leuiter cognofcebamus, \& in cius diftincta cognitione confistit cognitio ellentia materix. Qund vero aliquidicunt, poffeprimam materiam lune mutatione probari medio Metaphyfico fic; datur purus actus, ergo datur pura potentia, vanum ett; Dialectica enım \& probabilis eftratio, qua nihil habet neceffitatis; fumitur enim a loco il10 Toptco, qui dicitur ab oppofitis; nam quum opponantur potcntia \& actus, feu relatue, feu alio modo, videtur vno exiftente neccfirium elfe, vt al terum quoque exiltat; attamen fi qua eft relario actusad potentiam, ea non eft cuiuslibet actus, fedillius tantum, qui potentiam adimpleat: actus enim fubfiftentes nullam habent relationem ad potentiam; actus vero non lubfiftentes, qui materiam informant, non pofiunt efle cogniti, dum materia ignoratur; quitquis enim materiam neget, is compofitionem quoq; materix \& formx inficiabitur: quare nullius momı ñti hxc eft ratio, qux fumitur abactu: quod fi dicant eius vim in hoc efie conftitutam, quod necelfe eft dari vtrumq; extremú latiudinis entis, vt purum ątü, ita \& puram potentiam, hoc qunq:infirmum elt; dicam enim polfe quidem iubliftere actum purum, at puram potentiam non poffe fubfiftere, ideo que non dari; ratio igitur nul aliud probat, nifi dari duo extrema entis fubfiftentis, perfectiflmum \& imperfeEtiffimum, quodquidem nemonegaret, dicam autem perfeEtiflimum fub fiftens effeDeum,imperfectirfim ì vero terram, vel aliud quidpiam, eaque effe duo extremalatitudinis entis fubliftentis: quare patet, rationem hanc non effe neceffarian, fed probabilem, cui alian fimilem legimus apud Ariftotelem in contextu 37. libri 8. Phylic.ad probandum motorem immobilem, vt plures interpretes eo in loco animaduerterunt. Vt igitur omnia, qux dixinus, paucis colligamus, iumma hac eft:primam materiam dari, nullo al io medio oftendi potuit, quam mutatione fubftantix perdemonftrationem $a b$ effectu, fed eius demonftrationis propofitio maior declarata eft per analogiam \& fimilıudinem pandam cum muratione accidentiü, quæe fenfile fubiectum babent: dcinde inuenta matera. eius effentra norificaiur pér analogiarn, quam habet cum fubiedofenfilı mutarionis accidentalis: hac dernum effentia ita per analogiam coA gnita exprimitur, ac fignificatur definitione illa
pernegationem tradira, quam legimusin contex. S.l.b. 7.Metaphyficorum.Sed quia diximus. analogiam cōferre nobis tum ad eflenriam, tum ad exiftentiam materix cognofcendam; eft an:maduertendum, non eandem prorfuseffe analogiam: nam in declaranda effentia materiam fupponimus, \& dicimus eam proportione refpondere fubiecto mutationis accidentalis; at in declarand a exiftentia fupponimus mutatioB nem fubftantiæ de contrarjo in contrarium, \& dicimus eạm proportione répondere mutatio. ni accidentali, vt ficut illa habet fubicctum, ita \& hunc habere fubiectả materiam colligamus.

\section{De duabus prima Materia notionibus.}

$$
\text { , Cap. VI. }
$$

$\mathrm{Q}$ Voniam autem primæ materix "conditio. nes confiderandas nobis propofuimus, C noulint ignorandxdu ill $x$, quas vocant, primæ materizenotiones à Themiftio declaratæ in r. lib. Phyf.aufcult. in fua magna digreffione; 4 enim pro diuerfis materix notionibus, feu confiderationibus, condition es quoque diuer $f x$ ip fi attribuend $x$ funt. Inquit enin Themiftius duas elfe confideration es materix; vnam abfolutam, quatenus êt ens, qux prima notio dicitur; alteram refpectiuam, quatenus eft aliorum principium, quæ vocatur fecunda notio: quemadnodum igitur homini aliaattribuuntur, quatenus homo, alia, quatenus eft pater; fic etiam materiæ alja funt attributa fecundum primam eius notionem, \& prout eft ens, alia vero iuxta fecundam notionem, quatenus eft principsum, \& refertur ad alia, dum enim eam fecundū fe con. fideramus, attribuimus einegationem omnium formarum, nec non dimenfiones \& quantita. tem; in fecunda vero notione confideratx attribumus priuationem, quæ eft tertium princiE pium rerum naturalium, \& potentiam recipiendi formas; nam quidquid fit, fit ex materia priuata, \& potente formam, qua caret, recipere, qux poftea diligentius à nobis confiderabuntur. Sed hac, qua de duplici materianotione dicuntur, multis dubia vifa funt, \& mihi quo. que non paruam difficultatem fecerunt; expo- $t r$. nenda igitur breuiter funt ea, qua hine inde hac de dipoftint, ve veritas cognofalir, hac de re dicipofiunt, ve veritas cognof caitur, tersa 20 quoniam ad illa, qux poftea tractanda funt, tronzm. hæc confideratio non parui eft momenti, Primum quidem videtur, nullam dari primam materiæ notionem, propetera quod materia non eft fpecies aliqua enuis fubfiftens, \& ab aliis rebus diftincta, fed ea tantum ratıone eft ens, quatenus eft aliorum materia, \& principium; fic enim non eft aliquod ensà rebus difincrum, led eftres omnes poteftate: quoniam igitur in prima materia rebus omnib. fubiicienda non fut natura cófilium, eam vt rem guanE 4 dain 
damconftituere, fed vt ipfarum rerum princi- A fecundum dici,vt caput dicitur effealicuius capium, \& vtid, ex quo omnia fierent, \& conftarent, non habet materia locum in rebus vt fpecies ent is, fed ve pars, fiue vt principium fpecierum entis; vnumquodque autem ita eit confiderandum \& cognofendum, vti eft; ergonulla alia datur materixconfideratio, feu notio, nifi hac vna refpectiua, prout eft principium rerum. Patet autem hoc exaliis rebus, quibus reuera hx duæ rationes competunt; nam elemento. rum in fcientia nattrali duplex eft confideratio, quia duplicem habent locum in riatura; primum quidem fecundum fe confiderata, funt fpecies corporis naturalis, \& fecundum hanc abfolutam confiderationem tractantur in libris de Coclo: deinde funt principia miftorum, \& hac confideratione refpectiua poftea tractanturin libris de Ortu \& interitu : Itaque fi materix quoque hx dux notiones feu confiderationes competerent, dur etiam ipfius tractationes extarent, vna abfoluta, quam tamen non videmus, altera refpectrua, quam folam habemus. Praterea fi materia etiam fecundum fe confiderari poffet $v t$ ens, eam confideraffet Arritotetes. hoc modo in libris Metaphyficis; attamen. hoc in iis libris non videmus, quin potius videmus contrarium;nam definitio materix, quam legimus in contextu 8. libri 7. videtur ei competere infecunda potius notione, quam in prima, definitur namq; ibi materia per refpectum, quem. habet adres omnes, fecundü quem dicitur earum principium: nam inquit Arsfoteles eam nec effe fubitantiam, nec quantum, nec quale, nec vllam aliarum Categoriarum, fed omnium fubiectū, hoc eft, materiam ex qua omnia fiunt; dicere enim eam effe fubiectum omnium, eft dicere effe omnia poteftate, \& ita ibi int erpretatur. Auerroes, hocautem eft eam effe omniū principium; quare nulla dari videtur materix conff-

srgumë deratio. in primanotione. In contrarium autem. tatiopro ita poffumusargumentari; materia eft fubftanprima norione materis. put, at non fecundum cffe, quia fi elt lubitantia, neceffe eft vt propriam naturam habeat abiolutam, cui poftea relatio fuperueniat: fic igitur neceffe eft effentiam materiz effe abfolutam, quo fit, vt hoc modo, cognofci etiam materia à nobis poftit ; quicquid enim eft, cognofcibile à nobis eft; itaque materia in prima quoq; notıone confiderari \& cognofci poteft. Hoc ipfa argumentoductus, poft longam cöfiderationem,

B cognouiveram effeThemiftii fententiam de duplici materix notione, vidique rationem diffi. cultatis hac in re illam effe, quain Themiftius quoq, animaduertit; nempe abfconditam naturam, \& debilem (vt ita dicam) entitaté ipfus materix; quum enim prope ad nihil accedere videatur, licet fit aliquid, \& fubftantia, non porfurnus nifi magna cum difficultate abfolutam eius natura m comprehendere, nec videmus fine relatione ab alia eam poffe concipere aninıo, ac C contemplari;poffunt tamen illi, qui. mediocri ingenii acumine funt præditi, fi efficaciter in ea figant oculos mentis, abfolutam eius naturam. penetrare, \& apprehendere. Clarior res fiet, fi solutio contrariaargumenta foluerimus. Ad primum argumé refponfio patebit, fi ipfum etiam contra Arifto- rorü con telem ita retorqueamus, confilium naturx in trapridando animalibus capite non fuit, vt effet fpe- mam no cies entis, qux per fe exifteret, fed folum vt ef- tionem. fet pars aninalis, quod vere eft fpecies entis; er-

D go nullaalia est capitis effentia; quam qua in illa relatione confiftit; eftigitur caput vere relatiuum; quod tamen A riftoteles negauit, dicimus igituir caput effe fubftantiam fecundun fe, \& hac ratione habere naturamabfolutam, bane tamen fubftantiam factam effe à natura propter animal, \& vt effet parsanimalis, ideoq; nullam dari confiderationem capitis abfolutam in fcientia naturali, tanquam corporis naturalis, qu $x$ non fit propter animal ; tota enim eft animalis E gratia, per hoctamennonftat, quin in ipfa animalis confideratione fint cognofcenda omnia atrributa, qux capiti, vt eft fubftantia, \& fine vllo refpectu competunt, vt caput perfecte cognofcatur, veluti eius ftructura \& temperies. neque per hoc fiet, quin tota eius cognitio animalis gratia quæridicatır, imo \& ipfius animalis effe: fic de materia dicendum eft, etenim confilium naturæ in ea ftatuenda non fuit vt effet fpecies entis exiftens diftinata ab aliis, fed folum vt effet pars, \& principium, \& inchoatio omnium entium, ideo tota materix confideratio eft propter fubstantiam compofitam, ad cuius plenam cognitionem requiritur etiam ve ipfa materix effentia fecundum fe cognofcatyr. quemadmodum ad perfectam animalis not. tiam requiritur, vt caput etiam fecundū fe fumptù abfoiute confideretur \& cognof catur: comparatio autem elementorum cum materia non eft conueniens, quoniam elementa funt ctram corpora 
corporanaturalia, \& fpecies entis completre fine vlla ratione ad mifta, quare datur elemen. torum eonfideratio abfoluta, qua primario eft propter $f e$, non propter mifta, at iplius matcriæ datur quidem confideratio abfoluta, fed ea cft proper fubltantiam compofitam, \& in hoc confiftit multorum error, quod non cognouerunt fubftamias à natura conftitutas propter aliud, confiderari etiam, \& cognofci abfolutefecundum fe, ita tamen vt tota llla confideratio fit propteraliud; vbiautem confideretur ab Ariftotele prima mareria abfolute, in fequentibus dicemus; dabitur enim poftea occafio hac de re fufus ac diligentius loquendi, vbi manifeftius fiet id, quod modo diximus, materiam confiderari poffe non folum in fecunda, fedetiam in prinia notione. His duabus mnteriæ notionibus Themiftius duo materiz nomina $2 c$. commodat; vocatur enim \& materia \& fubieEtum, \& habet quidem vtrumque nomen relationem adalia, fed tamen nomen fubiecti magis conuenit materix in prima notione accept $x$, nomen autem nuateri $x$ nullo modo, fed folum in fecunda notione, quia notat refpectum \& relationem ad formam futuram, \& ad compofitum, quod ex ea generandum eft, quare includit ea priuationem \& potentiam, \& fignificat materiam, quat enus eft principium aliorum, quod in illa mutari poteft, \& fierires fingul $x$ : at. nomen lubiect denorat refpectum ad formam prafentem, nec fignificat motum, \& dicit naturani quandam diuerfam ab eo, cui. fubiicitur; quare etfi potent fignificare materiam etiam in fecundanotione, tamen magis eam fignificat in prima, quia non fignificat eam vt principium generationis, fed vt ens quoddam rebus omnibus fubfiratum. Quoniam igitur materia plura habet attributa, qua à nobis cum diligentia funt confideranda, \& eorum aliqua ei competunt in prima notione, aliqua vero in fecunda. notione acceptæ, nos à facilioribus ordientes. ea prius confiderabimus, qux atriouuntur materix in fecunda notione, deinde veroilla, quæ in prima: fic enim etiam Ariftoteles prius in $\mathrm{Phy}$ fisis materiam confiderauit, vt principium rerum naturalium, poftea in Metaphyficis de eadem loquutus eftabfolute \& fecundum primam eius notionem:attribuuntur autem materix in. fecunda notione accept $x$ duo potiffimum, priuatio \& potentia; de his igitur. \& quid fint, \& quomodo ad materiam fe habeant, cum diligentia declarabimus , \& primum depriuatione loquemur, qua non folum propter materiam cognofcenda eft, fedipfa etiam propter fe, quumab Ariftotele fit numerata in principiis generationis, tanquam tertium principium à materia diftinctum.

Ie Priuatione, ơ de Priuationis ac negationis difcrimine. Cap. VII..
A Ciendum inprimis eft, prinationem quam Ofatmit Ariftoteles tertium principiuns rerum naturalium, \& generationis terminum à quo, interitus vero ad quuem, non effe illam vniuerfalem abfentiam omnium formarum, per quam definitur materia ab Ariftotele in contextu 8. libri 7. Metaphy fic. illa enim eft pura negatio, non eft principium, ex quo res fiant; hoc enim dato, fequeretur omnibus formis vnans numero priuationem opponi; fequeretur et-

B iam, priuationem aternam effe, qua vtraque in 1. lib. Phyfic. aufcultat. negantur ab Ariftotele, qui ibi docet, cuilibet formx propriam opponi priuacionem, fed non vnam omnibus; inquitenim album fieri ex non albo, neque ex omnitamen non albo, fed exnigro, vel medio, fignificans illud non album fumendum effe; non vt negationem, fed vt priuationem; neque effe $p u-$ ram abfentiam albi, fed talem, qua coniunEtum habens aliquem alium colorem notet po. tefatem ad album: in contextuautem 82. inquit, priuationem in materia interire, idque eft confentancum tationi, quia contrarium in ad. uentu fui contrarii recedere \& interire neceffe eft, nec ninus priuationem in aduentu for$m x$, quam formam in aduentu priuationis. Negat1o igitur omnium formarum in materia non eft iila priuatio, qua apud Ariftotelem eft tertium principium resum naturalium: \& in hoc differunt negatio \& priuatio, quod negatio eft pura abfentia forma, priuatio autem eit neceffario coniunzta cum quadam forma praceden. teformam generandam, cui illa priuatio opponitur, \& conftituente in materia potentianirecıpiendi illam formam; $v t$ in Deo eft quidem negatio albedinis, at non priuatio, quia non eft ibi potentia ad albedinem; in corpore autem nigro vel. rubeo eft priuatio albedinis, nempe abfentia albedinis cum potentia ad 1 llam. Hæc quifquis confideret, \& illa, quæ de priuatione: ab Ariftotele dicuntur in primo libro Phyfica aufcultationis, is facile cognofcet, priua- Priuatio tionem cuiufque formæ neceflario effe con- femper iunctam cum aliqua qua dam ftatuta forma, fi- babet for ne qua non diceretur effe illius forma: priua- mantatio; nón enm omnis abfentia albi dicitur pri- liam cōuatio albi, fed illa tantum, qux fit coniuncta iuncta.. cum aliquo alio colore; quod fignificauit Ariftoteles, quando dixitalbum fierinon ex omni: non exalbo, fed exnigrovel medio. Hoc idem in fubftantialibus formis dicendum eft, priuatio enim form $x$ humana non eft qualibet eius. abfentia; non enim ea, qux eft in lapide, fed ea que eft coniuncta cum certa quadam forma, quæ eft formahumani feminis, hacenim fola eft quaconftituit propriam priuationem oppofitam forme humanx, \& poteñtiam pro ximam ad eam; nam. fi in lapide effe diceretur priuatio: formæ liumanx, qux eft proprium principium generationis hominis, pofiet ex

$$
\text { E } 5 \text { lapio. }
$$

Prikationis 6 negationis diferi men.

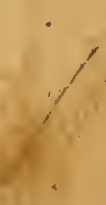
Priuatio
emper
babetfor
mama-
liamcö-
iunctä..

.


lapide homogenerari: ob id quum priuatio fe- A cundum fe fir nihil, fignificarifolet nomineforn « coniunetr qurlibet propria cuiufque formapriuatio, qua alioqui nullum ex fe nomen habert: legimus hoc in contextu $6 z$. libri primi Phyficor.vbi Atiftoteles.fignificare volens propriam materiam, ex qua res qualibet generatur (propria autem eit, qua habet proprian illius reigenerand $x$ priuationem) dixitgenerari plantas, \& animalia ex femine, non enim fumpfit ibifemen vt contians ex materia \& forma, led vt conftans ex materia \& priuatione refpeEu flantx, vel animalis generandi; quamuis enim femen per fuam formam fit femen, itavt dicentes femen dicamus formam, tamen ibi Ariftoteles nō fumit formam feminis vt formam, fed vt fignificantem propriam fibi annexam priuationem form $x$ animalis, vel plant $x$, quidsriwat 80 quid enim fit, ex materia priuata fit. Ex his colef gruodä ligimus, dici polfe abfque vlla abfurditate, prinoodo uationem illam, quam Ariftoteles ftatuir terforma. tium principium, \& terminum generatronis à quo, effe fubftantialem formam alieri forma contrariam, vi priuationem forma humana effe furmam human feminis; hx namqi ea ıantum ratione dicuntur contraria, quod fimul in eadem materia exiftere nequeunt, \& vna alteram peliit, neceffarso enim forma hominis aduenens materia formam leminis pellit, \& cum forma feminis eft neceffario coniuneta priuatio formæ hominis, \& poteftas proxima recipiendi, eam. Hoc certe verishmum eft, fi fano modo intelligatur, non enim dicimus formam feminis fecundum fe, \& quatenus eft forma, effeforma humanz priuationem, fed per quandan necefiarium comitantiam, quia neceflario habet comitantem abfentiam formæ humanæ, cum potentia proxima ad eam: itaque priuatio formaliter eft abfentia formx, \& eft nihil, fed per neceffariam comitantiam eftalia forma, à qua folet priuatiocuiufquerei propria nomina- E ri; dicimus enin, ex cibis fanguinem fieri, \&ex fanguine carnem, \& ex femine hominem, vel plantam, nil aliud perhrc denotantes, quam proprias fingulorum materias priuatas, ex qui-

Declara- bus funt. Hoc fignificauit abfque dibio Aritio con- ftoteles in contex. 15 . lib. 2. Phyfic. quando ditex. 15. xit, priuationem effe quodam modo formam \& l.6m 2. naturam, iure enım dixit [quodemmodo] quia Plyyficor. priuatio non eft effentialiter forma, fed per comitantiam, vt dißtum eft. Hoc etian fignifica- F uit Auerroes in 3 tractat. Epitomes Metaphyfic. cap.12. \& hanc eandem iententiam tribuit

Alexan der a Simpli: sio confutatur. Alexandro Simplicius in contex. 58 : lib. 1. Phyfic. \& eam refutauit, quia ip̧am non inte!lexit, inquit enim. Alexandrum dixiffe priuationem fignificarcalteram formam pofituam : aduerfus quam fententiam ita argum curatur: fi id verumeffet, fequeretur priuationis efte aliam pịuationem, \& illius aliam, \& fic in infinitum; at confequens falfum eft, quoniam priuationi opponitur forma, non alia priuatio ; confequentia autem patet, quia forma feminis eft priuatio form hominis fecundum Alexandum, atqui forma feminis habuit ipfa quoque fuam priua tionem, igttur priuationi opponeretur ptiuatio. Ego aute miror, quomodo Simplicius in hanc Alexandri fententiam ita fit inuectus, quū ipfemet in memorato contex. 15. hanc fequutus fit, \& locum illum A riftotelis optime interpreta-

B tus, dicens priuationem effe formam, quatenus habetaliam forman coniunctam; quire vel fui immemor fuit, vel A lexandrum non intellexit; ipfiusautem argumentum nihil roboris habet, nam forma feminis poteft duobus modis confiderari, vno modo vt forma, qua femen eft femen, altero modo vt refpicit formam hominis generandam; primo nodo dicitur oppofita priuationi fux precedenti, non formæ humanx, quia fic non eft priuatio, fed forma; fecundo autem modo opponitur form $x$ hominis, non $v t$ formalteri form $x$, fed vt priuatio form nore cnim opponitur ei quatenus fecundú fe eft forma, fed quatenus habet annexam, \& comitantem priutionem forma hunanz; primo quidcm modo eit terminus generationis ad quem, quia ex fangune fitemen, fecundo autcm modo eft teiminus generationis à quo, quia ex femene fit homo; staque necforma eft formaliter priuario, nec ptuano formaliter eft forma; led per niceffariam connexionem tum forma elt priuatio, tū priuario eft forma : quandu.jgirus Simplicius att, forma femıni, habet fuā priua onè,ergo pliuation is eft pruatio, negandũ eft cöiequens, quia forma femınis habet fuam priuationé, quatenus eft for ma, nō quate. nuseft pr uatio qqnatenusaũi eft priuatio, non habet pruationé oppotitam, fed formam; quare idem diuerfis ra ionibus eft forma, \& priuatio, \& terminus generarionis tum à quo, rum ad quem, $\mathrm{e}$ d non eiufdem genciationss : male igitur à Simplicio carpuur Alexander, cuius fententia veriffima eft, \& ean apud iptum Alexandrum claran legimus in 2. lib. Natural. quxft. cap. I1, quoniam autem in eadem materia hactria coniunctarunt, forma leminis, priuatio form $x$ humana, \& potentia proxima ad eam, in his nullus eft or do temporis, fed eft ordo natu 2 , nam foma feminis eft natura prior aliis, conftituit enim tum propriam form $\mathrm{hu}$ manx priuationem, tum poteftatem proximam recipiendi forman humanam, quare \& a. mica videturform $x$ humanæ, \& inimica; amica quidem, quatenus facit propenfionēad formam humanam; inimica vero, quatenus conftituit proprium contrarium formx humanx; quo fit, vitipla for nia feminis dicatur humanx forma contraria, \& hominem ex femine fieri fit apud Arstotelem fieri contrarium ex contrarbo: non fis dicesitur contraria forma honi-
Defenfio
Alexan.
dri.
Solutio
arg. Sum.
pircy.

$-$ 
nis, \& forma lapidis, quia non pellit vna al tera decodem fubiecto, nec vbi vna definit, incipit altera : hrec enim elt contrariorum conditio, quam pulcherrime notauit apud Platonem Socrates in Phædone, dicens, contraria effe modo quodam inter fe consunota extremitntibus, ita vt definente vno incipiat alterum. Ex his colligimus, erraffeillos, qui dixere duplicem effe priuationem; vnam remotam, alteram propinquam; in lapide quidem efle remotam priuationem forma hominis, in femine vero propinquam: quum enim non contingat vt ex lapide homo fiat, Ariftoteles non dicereteffe in lapide priuationemillam, qux eft generationis hominis principium, \& terminusà quo, fed in folo femine, ex quo immediate fit homo. Hac igitur ratione contrarietatem pra feferunt forma leminis, ac forma hominis, quanquam vere contrariz non funt, nempe quatenus fimul in eadem materia exiftere nequeunt, \& vna habet coniunetam priuationem alterius, \& quando definit, incipit altera: non eadem autem rationè eft forma \& a mica, \& inimica alteri form $x_{2}$, fed inimica eft fecundum fe; quia quum fit forma, non poteft imul cum altera forma exiftere in materia;amila vero non fecundum fe, fed ratio ne qualitatum, quas habet coniunctas, hromamque materiam illam praparant ad formam hominis recipiendam;retinet enim femen qualitates quafdamillius animalis, à quo defluxit, quæ faciunt vt materia non poifit aliam formam recipere, quamillius animalis, velfemen in elementa diffoluatur, fi quid prohibeat animal generarii ; hoc fortaffe refpexit Ariftot. in fecundo libr. Natur.aufcult. quando dixit, in femine animalis ineffe illius animalis naturam, non quidem viformam, fed ve artificem:fed hæc confideratio à prafenti locoaliena eft; fat eft, fi exiis, qux dieta funt, habeamus, quodpriuatio, etfi formaliter fumpta; nihil eft, tamen connotat formam, qux dicitur forma contraria, idque reDeclara- fpexit Ariftoteles in contextu is.libriz. Phyfic, iso cont. proponens quaftionem illam, \&infolutam di15. l,6.2. mittens, an in generatione fubftantiarumpriuapbysc. tio denotet etiam contrarium pofitium formægenerandx : nam priuatio, qux formaliter accepta eft oppofitum forma folum priuatiue, notat etiam contrarium pofitiuum, quatenus connotataliam formam coniunctam, fed quia in formis fubitantialibus non eit vera contrarietas, qualis eft in accidentibus, ideo Ariftoteles ibi iure dubitat, an forma pofitiua, quæ cum priuatione eft coniundta, fit vere contraria for$m x$ generand $x$, necne, reuera cnim non eft ibi contrarietas, fed fimilitudo tantum quxdam Priuatio contrarietatis. Si quis autem definire priuationis defo- nem velit, affignari ipfius poteft definitio talis: nitio. priuatio eft contrarium, ex quo recedente res it, fiue, priuatio eft abfentia form $x$ in materia cum potentia proxima ad eam: vtroque enim.
A modoiam dicimus, nam in eo ex quo res fit, necelle ef inefíe potentiam proximam adillam, \& in quo inef potentia proxima ad.rem, exeo res fit; fic contrarium form eft ip fa formæab. fentia coni uncta alteri form $x$, qux hacratione vocatur contraria. Hinc pater ratio, cur priuatio form $x$ humanx appellarinon poffit illa eius formrabfentia, quze eft in lapide, ficuts aliqui dixerunt : oportet enim non folum effe cum illa abfentia alıquam potentiam in illa ma B teria ad formam hominis, fed etiam potentiam. illam effe conftitutam à forma coniuncta cun illa abrentia, quod quidem de forma lapidis d:cere non poffumus, quia nulla ibi eft particula; ris propenfio ad formam hominis, fed folum. illa vniuerfalis poteftas, quam materiafuapte natura habet refpectu omnum formarum, nou qux formam ipfam lapidis confequatur; igitur illa abfentrahumana form non ef priuatio, fed potius negatio: hoc fignificauit A uerroes in C. Comment. I6. libr. 5. Metaphylic. dicens, potentiam eatenus effe priuationem, quatenus eft praparatio; non eft igitur prauatio form $x$, nifi vbi eft præparatio ad eam. Sumitur ex hisratio differentix à Themiftio adduct $x$ in fua digreffione inter priuationem \& negationem ; inquid enim latius patere negationem, quam priuationem, quia negatio nullam qualitatem in materia ponit quatenus eft negatio, priuario autem reddit mareriam qualem quatenus neceffario annexam habet aliam formam, qua materiam afficit; neque vllo pacto attribui poteft priuatio ipfi materix nud $\&$ inaffectx, fed formatx, \& quali, quemadmodum dictunt eft: negatio vero, quam nuilam fomam, nullam qualitatem inmateria poftulet, tribuitur primas materix fumptzin primanotione abfque vila alicuius form $x$; autaffectionis confideratione; quando enim dicimus eam effe naturam materiz, vifecundum fe non fit fubftantia, nec E quantum, nec quale, necaliud ens determinatum, hor eft, vtrullam fibi formam, feuftaturam naturam prafcribat; declaramus natts. ram materiæ per negationem, non per priuationem; quin potius repugnat natura priuationis, vt fir abfentia vniuerfalis omnium formarum: qua in re multi deceptifunt, qui priuationem à negatione diftinguerenefciuerunt, in quoerrorevideturfuiffe Plotinus in 4. lib. 2. Enneadis, plotini cap.14. dum Platonem tuerinititurabobiectio-erromin ne Arifterelis; quum enim Ariftoteles Plato- nondat nem reprehendat, quod materiam cum priua- fringrzétioneconfuderit, quafidemfit, non folum re, de nega fed etiam ratione: Plotinus oftendere volens tione materiam \& priuationemidem effe etiam ratic- prizane, inquit materiam definiri per infnitum, \& fons.. hoc fignificare priuationem; proinde priuatio. nem elfe ip fammet effentiam materia : fed vol cacus videre poteft, hanc non efie prinationean illam, de qua Ariftoteles in primo ibr. Phyfica aufsul? 
aufcultationis loquitur, \& quám itatuit tertium principium rerum naturalium; fed efle negationem yniuerfalem omnium formarū, per quam ipfe quioque Ariftoteles in 7. lib. Metaphy f. materiam definiuit,vt etiam cenfuit Themiftius in fua digreffione prædicta, \& Alex2n. 2. lib. quxit. natural. cap.7. quare mani feftu $\mathrm{m}$ eft, Plotinum in ambiguo laboraffe, \& pro priuatione negationem lumpfiffe, idque eft clariffi mum cuique eum librum legenti, quare tota ip fius aduerfus Ariftotel. disfputatio inefficax \& vana eft. Quid igitur fitpriuatio, quxeft tertium principium generationis, manifeftum eft. Deforma vero prout eit principium corporis naturalis, nil dicendum relinquitur preterilla, qux dicta funt; eft enim terminus generations ad que , ex quo tanquam actu \& perfecticje, \& ex materia res conftat; vberius autem deipfa loquitur diuinus Philofophus, ideo pauca de hac dicuntur ab Ariftotelein primolibro Phyficx aufcultationis; in fecurido autem plura quiden de forma ac de materia dicuntur, quatenus refpiciunt motum, \& appellantur nomine naturæ : fed hxe eft alia confideratio, ideo in prafentia dimittatur.

\section{Depriuatione ad Materiam relata. Cap. VIII.}

$\mathrm{P}$ Rivationedeclarata,confiderandum êt, quomodo ad materiam fe habeat priuatio, nempean fit de effentiaipfius materix, an materix accidat; agit hac de re Themiftius in fua digreffione, \& ad vtramque partem argumentatur:primum probst priuationem non effe de effentia materix hunc in modum; fi priuatio effet de materixeffentia, materia in aduentu formæinteriret, quum priuatio tuni intereat, vtpote contraria forma. Quod autem fit de effentia materix, ita probat; effentia materix in poteftate confiftit, ip faigitur poteftas eft de elfentia ma- terix; at cum poteftate eft neceffario coniuncta priuatio, nō enim diceretur habere poteftatem, mifi careret actu, itaque etiam priuatio eft de efprivatio fentia materix. Ad foluendam hanc difficultanon est tem diftinguit Themiftius duas materix notiode effen- res, quas ante declarauimus, \& tandem inquit, tinma- priuationem-non effe de effentia materix, nec terix. in prima,nec in fecunda notione accept ma enim notione materianec formam, neccöpofitum refpicit, fed eft natura quxdam abfoluta, quare nullam habet potentiam, proinde nec priuationem; illa namque vniuerfalis abfentia omnium formarum non eft priuat1o, red negatio, qux non eft quidem ip fa materix effentia, fed per eam tam en eflentia materiz declaratur; qux propter exilem \& abfconditam eius naturam declarari aliter nequit : in fecunda vero notione accepta materia habetquidem potentiam \& priuationein, \& priuatio eft ei neceffaria ad generationem, non eft tamen de eius effentia; quod enim fit ei neceffaria, patet, quia nifi materia effet priuata, nihil ex ea generaretur, nifienim priuationem form $x$ haberet, neceffario formam ipfam haberet; iam igitur res effet, quare nullum haberet locum generatio: attamen non eft inaterix neceffaria priuatio tanquä de ipfius effentıa, fed tanquam natura quxdam alia alij naturæ accidens, habet enim mater ia poteftaten recipiendi xque formam ac priuationem, B quocirca vtraque materix accidere dicitur, \& extra eius effentiam effe, quum inter eat vtraque in materia, \& materia fine vtralibet effe poffit: eft igitur priuatio tanquam accidens materix, accidens tamen neceffarium, nec ablolute neceflarium, fed propter generationem, quacunq; enim priustione conftituta poteft materiaefle fineilla,attamen neceflarium eft, vt materiaillam priuationem habeat, fi ex ea debeat res illa, cuius eft priuatio, generari; neceffarium enim C eft vt quidquid generatur, generetur ex materia priuata.Sed qua de poteftate materixà Themiftio dicuntur, egent exquifitiore examine, \& pofterius confidcrabuntur;illa vero, qux de priuatone dicit, vera \& manifeftafunt; quum eninı priuatio apudAriftotelem fit tertium generationis principium à materia diftinct ủm, nō poteft ipfius materiæeffentiam conftituere; quod Ariftoteles ex eo oitendit, quod materia leruatur in re genita, nec vnquam interit; priuatio a utem in aduentu form recedit, quare aliud eft terminus generationis à quo, aliud eft fubiectum communevtriusqueterminideferens mutatio nem; dicereautem priuationem effe neceffariä materı propter generationem, nihilaliud eft, quam dicere, materiam effe quiden generationis principium, at non folam, fed alia quoque principia poftulari, fine quibus ex fola inateria nihil generaretur; præftant eninı fingula propriam operam, led lingulum requirit operama

E liorum, quare omnia principia in generatione requiruntur:eadem autem ratione dicere poffemus, materiam effe neceffariam priuationı pro. - pter generationem,quoniam expriuatione fine materia nihil fieret; fic neceffaria eft materia form $\&$ \& forma materi $x$, nullum tamen horum princıpiorum eft de effentia aliorum; quæ igitur depriuatione à Themiftio dicuntur, manitefta funt. Exhis autem, quæde priuatione diximus, corollarium quoddamcolligimus, quod F licet videatur implicare contradictionem, veriffimum tamen eft: prima materia, ex qua res omnes naturales generarentur, debuit effe äTrot (G, hoc eft, omni qualitate, \& omni forma carens, debuit etiam clie affecta, \& formata, \& qualis; nam diuerfa refpiciendo verum eft $v$ trumque, dum enim materiam in prima notione fecundum fuan effentiam confideramus, dicinus cam effe ürobor, nonquodita line vlla affe- 
affentione cxiftat, fed quia in eius effentianulla $A$ forma, nulia qualıtas inc ft ; lic cum folann materia chintu un tipectanus, \& quanus limper formata, \& qualis exiftur, dicimus tamen, omnë forman, \& omnem quilizatim die extra materia cflentiam, quar millam inciuditaffeetioncm, \& ne potentian quidem ipiam, vl poitea dicemus: at fi materiam in fecunda nocione, \& vt principium cftiumamus, oportet cam efle formatan, \& quale, quia necelle eft inetle ipfiprinationcm, \& potentian, fi dcbeat ex ea quip- B piam generari priuatio autem habet neceifaro coniumctam alian formā, ita vt modo quedam forma vocari polfet, ficut etram A riftotelesap. pellauit:exmateria igituin nuda \& penitus inafect:l, li darettr, nil gencrari poiset, neq; enimapra eflet ad futtinendam actionem agentis, neq; habcret prinationem, quamipla adgenerationem neceflarian efic cum Themiftio dixinus.

\section{De Potentia Materia, quid fit. Cap. $I X$.}

Po Oft priuationem confideranda eft materia potentia, qua nun quam à priuntione feiungi videtur; de hac duo declaranda proponuntur, vnum quid ipfa fit, alterum vero, quomodo ad materiam referatur, videlicet an fit de efientia materiæ; an in fit ei vt accidess. Vt videamusquid fit potentia, diftinguendre funt inprimis nominis fignificationes: potentia duplex eft, vt ex Ariftotele colliginus quinto Metaphyficolum, contextu 17. \& nono Metaphyficoinf fecundo, vna actiua, al tera pafiliva, ad quarum alteram reduci onnem potentiam neceffe eft; aut enim dicimusagens poffe agere, nut patiens poffe pati: tribuimus quiden etiam effectibus potentiam, non tamen ab his duobus diftinctam; dicimus enim effectum effe poteftate, quando nondiu eft actu, efle tamen potef, quia cft in potentia actiua agentis, \& in potentia paffitu materix, quaretuncnil aliud fignificamıs, quam dari caufas, ì quibus produci poteft. Sciendumpreterea eft, vtramque potentiam fumi. duobusmodis, yt Ariftoteles docet in libro de Interpretatione; proprie namque fumitur pro illa potentia, qux præcedit actum tanquam illi. oppofita, \& ip foadueniente interit; improprie autem quandoque fumıtur, \& (vt inquit ibi Ariftoteles) xquitioce pro illa potentia, qux eft fimul cum actu, vt fi dicamus, Coelū pofie mo- F ueri, \& Deum poffenouere; mproprian enim effe hanc acceptionem, patet ex iplis efrects; non enim dicinus effictum effe poteftate, nifi quandononeftaktu, quare ét materia \&agens tunc propriedicuntur habere potentram, quando non habent actum fiue patiendi, fiue agendi. Nos in præfentia loquimur de fola potentia paffiua, talis cnimeft materix potentia, \& de proprie accepta, quæ præcedit actum; materian cnim cófideramus antequain recipiat formam, ấ quærinus, quum potentiam babcat recipicndi, quidnam fit ifta potentia : talemenim Ariftoceles quoque in 9. Metaphyfic. conficlerat, \& in contextu s. incipit reprobare lententian Megaricorum, qui nulllan exiftere potentian diccbant, nili quando cft actus, vbi Auerroesinquit, hocafferere effe deftruere omnen potentram: quoniam exiftente actu non eft reuera potentı. Hanc plurimi confiderantes, Mulrorä \& eius naturam ficrutantes, dixerunt, eam ef opinio de fesabfolıtum quiddam, \& refpectiuum, fed porétice, vt abfolutum non diftingui ab ipfamet matc- quedfot. rix effentia, necefle aliqund ipfi materix fupe:additum, nifi vt refpectiuum, \& ita potentiam, prout a fubfantia naterix diftinguitur, effe in categoria relationis, \& inter potentiam \& actun effe relationem realem, non tantum rationis: hre enim efie videtur propria huius vocis fignificatio,quxnil aliud notat, quam quod-

C damrefpiciens actum. In hac fententia videturfuffe Aucroes, qui 9. Metaphy fic. II. inquit, potentiam \& actum opponi relatiue, quod etiam ita oftendit, quoniam pnum definitur per alterum, qux efí relatorum propriaconditio; hocidem apudeum legimus in Epitome Metaphyfica, tractatu 3. capite 4. Thomas au. Arghtcm adprobandum potentian materis, dum mé. Thofumitur pro abfoluto, à fubftantia materix ms. non diffingui, hoc argumento vtitur: potentia \& actus funt in eadem categoria, atqui 2 ctus, quem porentia materiz refpicit, eft fubftantia, ergo etiam potentia debet effe fubfantiaj non eitigitur nifi materia ipfa. Hans fententiam, etfi omnium ferè communem, ego nis repreprobare non poffum, credo enim poteftatem batio. 0 cmnem tam agendi, quan patiendi tfie in ca- mnis potegoria qualitatis in fecunda fpecie; quum e-tentueft nimin ea pofuernt Ariftoteles potentiam natu- in fectnralem, nec vlla detur alia potentia preter a- da dpecie E ctiusm, \& pafiuam, oportet aut vtramque, qualataaut alteram conftituerefecundam fpeciem qua- 7 is. litatis; legentibus autem abi Ariftotelem pater;ipfum in illa fpecie locare tam agendi; quam patiendıpotentiam ; omnen igitur potentiam cenfuit effe in fecundafpecie qualitatis. Huic fententix videntur quidem nonnulli recentioresfublcripfife, fed nqque eam firma ratione comprobarunt, neque omnino in ea perfiftere vifi tunt, quum modo dixerint, potentiam materix effe qualitatem: fecund $x$ fpeciei, modò effe relatiuum, \& nihil notare abfolutum fupperadditum fubftantix materix, qux fuit aliorum communis opinio, vtprediximus. Nobis igiturnitendum eft (li fieri poffit) huiufce ré intima penetrare, \& ralida ratione veritatem demontrare. Primum quiden ticere aliquis tortallepoffet, Arritotelem in cap. de qualitace non abiolute omnem agends ac patiendipotentiam in fecunda fpecie collocalle, fed
Propria opinio. 
foim posentiam facile agendi, \& potentiam $A$ non facile patiendi, non enim idem eft currere,

Orenis

popentia efinfe. ardaspeaie gueEratis. acbene currere. Sed hoc dicinon poteft, quia differentia fecundum magis \& minus non v2riat fpeciem, multo autem minus poteft virriare genus, quare fi potentiabene agendi eft qualitas, ctiam potentia agendi abrolute debet effe qualitas: afferit etiam hoc Ariftoteles 9. Metaphyf contextu 2. dum diundit potentiam agendiabfolute, \& potentiam bene agendi, fic etiam potentiam patiendı : atqui velpartitur genus in fpecies, vel declarat eiufdem ipeciei differentian fecundum magis \& minus, \& vtrumuis dicatur, in eodem genere ponitur potentia agendi, \& potentia bene agendi. Adde quod potentia refertur ad actum, ergo vt fe habct actusad actum, ita potentia ad potentiam, atqui in eadem categoria eft actus currendi, \& actus bene currendi, ergo etiam potentia currend, \& potentia bene currendi debent effe in eadem categoria. Praterea inquit ibidem Ariftoteles in defuitione potentix bene agenci contineri definitionem potenti $x$ agendi, \& in defnitione potentiz bene patiendi, cótuneri definitionem potentix patiendi, funt igitur ciufdem generis potentia agendi, \& potentia bene agendi : guando enim duo ita fe habent, ve visum fit de quidditate alterius, necefic eft ea in eodem genere efle; eftautem potentia agei:d1 de quidditate potentix bene agendi, ergo fi vna eft qualitas, etiam altera debet effe qualtas. Si quis auten quærat, cur A riftoteles in fecunda fpecie qualitatis non expreffit, nifi porentiam bene agendi, ratio in promptu eft, quoniam in eo libro noñ exquilite de decem fum mis generibus loqui voluit, fed pingui $\mathrm{Mi}$ nerua pro adolefcentibus, ideo ixpedinitis difficilioribus faciliora in medum adduxit; quum igitur hic exceffus, quo aliquam potentiam dicimus effe bene agendi, faciat eam euidentiorem, ita vt inde fumatur nominatio; curforem enim dicimus non onnem, qui currere aptus fit, fed eum tantum, qui bene currere pofit, ideo Ariftoteles folius potentia bene agendımentionem fecit, fed non ob id negauit eam potentiam tum agendi abfolute, tum patiendi effe in fecunda fpecie qualitatis, hancenim eius fententiam fuiffe iam demonftrauiQuodpo- mus. Sedadprobandum non poffe potentiam têtıa $\mathcal{G}$ \& aftum effe vere relatiua, vt eft communisoatturnon pinio, non poteft eficicacius argumentum fu- $F$ fontrela mi, quam ex propriis conditionibus relatiuo. trua. rum; relatiua enim funt fimul narura, \& vtrouis pofitoalterum neceffario ponitur, \& vtrouis ablatnalterum necellario aufertur; at pof:tâ potentiâ, non ponitur actus, neque actu pofito, ponitul potentia, imo è contrario dum potentiam ponımus, auferinus actum, \& dum ponimus actum, anferimus potentiam, nam adueaiente actu otentia interimitul; eigo non lunt relatiua; reuera enim fi potentiarefpicit actum, refpicit iplum vt non exiftentem, quæ eft conditio contraria conditioni relatiuorum, qux eft vt vno exiftente alterum quoque exiftat: dicere igitur cogimur, potentiam effe primo quiddam abfolutum, cui refpectus aliquis fuperueniat. Sumitu praterea ab actu argumentum efficacifimum: nam fi potenia idco eft vere relatiuum, quia refertur ad actum, oporter non minus actum, quam potentuam effe in categoria relationis; hoctamen eft manifefte falfum; actuscrion eft maxime in categcria fubftantir, \& nullam notat relationem ad potentiam, licet potentia referatur ad actum; at eorum, qua vere funt relatiua, debet reciproca effe relatio, illud autem -quod multos decepit, fuit (vt ego puto) quædain fimilitudo, quum enim pocentia \& actus fint oppofita, putarunt eife relatiuam oppolitionem, quam tamen fit alia o, politio : eit enim ( $v t$ ego arbitror) op. puficiopiluatiua, nam potcnia feinper habet annexam pruationem act.s qua ratione opponitur actui: imo videnı ur di $n$ re ipfa effe pctenria \& priuatio, diftungui aurem ratione, ab v ra.iber enım hxc duindenot entur; abien tia actus, \& a tisudo ad lllum: fed differ unt. quod potenna prir o notat apti.udincm, ie cundo connutat abientiain, prua 10 allem primo notar abienuam, fecundo aptitudinem : tione. potentiaigiturratione abientix connotat $x$ opDonitur actui, vt priuatio habicus. ai ratione aptitudinis primo fignificatæ, eft qualitas fecundx ipecie, nec videtur hac iatione efle oppofita actui, led potius fimslis \& amica, quum notet propenfionem ad illum. Non videtur $a b$ hac iententia alienus Auerroes, nam in Com-Auerrois mentatios.lıb.3. Metaphyfic. inquit, potentiam fentéfja. \& acturn opponi inter $1 i$, deinde hanc oppolitionem declaratus, fubiungit, ea non poffe effe fimul, quia fe mutuo intetimunt, quare non puE tat effc oppofita relatiue, nam relatiua non fe, mutuo deftrunt, fed potius licmutuo ftatuunt, atque conferuant. Ett etiam con íferandum id: quod Auerroes dicit 12. Metaphy licorü, Connment. 37. afum cognof ci per le, potentiam vero per afum, quod etiam ex Arutotele \& Auerroe colligimus nono Metaplyyficorum vigefimo; fed quis non videat, hoc non computere relatiuis, fed elle provriam conditionem eorum, qua priuatiue opponuntur : nam priuatio cognofcitur, ac definitur perhabitum, fed non nabitus per priuationem, vt ait iden Auerroes in fua pratatione in librum Potteriorum, qux conditionon apraur alıcui alsi oppofitioni, nifi pruatiuz: nam contradictorium non pendet à fuo contradictorio, neque definitur per illnd, fimiliter neque contrariun per fuum contraritum, relatmum autem pendet quidem à fuo correlatıuo, \& per ipfum defrn isur, led ea pendentia eft mutua at $q$; reciproca: in fola op-

Potentice Eg a tus opponuntisporan

\author{
inctravas
} Potentio Epritia $t<0$ jisnt sdem re. E diffe. runt res. tione. Auerroi 
pofitione priuatiua ef pendentia non reciproca, pendet tonim priuatio ab habitu, inon habitus à primatione, itaque fi potentia \& atus op:nuntur; \& potcutia pendet ab actu, nonactus à potentia, non potest cormm oppolitio elle alia, quam prituriua. Sed profert etiam clare hane fententiam Auerroes 5. Metaphylic. 19. dicens potentram habere coniunctam priuationen, kationc cuius opponitur actui; \& 9. Mctaphyfie. Commentario 3 vbidubit: [potentiafognificat aliquem modum prisurions ] sin in tio fui Commentiaris un librum de Sonmo \& vigilia inquit: [id,quodest in potéten,est prouario eives, grodest in actu ] in Ep:rome Metaphyfica tractacuprinıo, vbiagit de potentia \& actu, dicit potentıam elledespecicbus priuationi : in his igi ur onmibus locisclaraefle videtur Auerrois fententia, qued potentra opponatur atuinonalio modo, quam vtpituatiohabitu. Cxterum quidad Auereoem dicemus,aliisin locisalferentem eacf feoppofita relatiue? non eft credendum, Auer rorem fibi contradicere, fed porius dicédun eft relatiua efre duplicia, al ia fecundum effe, qux funt vere relatiua, \& proprie conftitumt categorian relatiuorum; alia vero non.fecundum effe, fed fecundum dici, qux non funt reuera in categoria relationis; fed inalis; q qux diftinctio eftipfufmet Ariftotelis in cap.de relatiuis; vera quidem relatiua nil habent abiolusi, fed tota ipiorum effen tia pofita cft in relatione ad aliud; at relatiua fecundum dici funt illa, qux reuera non funt in genere relatiuotum, fed in aliquo alio, menstamen ea referr, \& dicit effealterius, eaque vocatur elatio rationis, vt qquum dicinsus caput effealicuius caput; \&in hacrelatione euenit, vt ynum dicaturad aliud, nec tamen è conuerfo illud ad hoc, qua de reloquitur Au rroos in Epitome Metaphyfica, tract. 1. dumagit de relatione. Dico igitur Auerroem ponentem potentiam \&actum inter relatiua, ron intelligete aliam relationem, quam fecundum dici, \& fumere late at que improprie nomen relationts, vt etiam fumit in Epitome Metaphyfica tract. 3.cap. 4 . vbi dicit hancrelationem effe in omnibus predicamentis, \& feri abanina, ira yt fiamima non effet, hac quooue relatio non eifet: Ariftoteles quoque in context 6 . libroprimo de Anima dicir, potentiam \& actum amplectiomnes categorias, \& in ommbus locum habere; \& ibi Aerroes inquit elie difierentias entis, quoniam qualıbet categoria diuiditur per po- F tentiam \& actum; at fi edlient y ere reiariua, non poffent effe in on nibus generibus, neque etian effet conueniens fumere-verarelariua vt differentias diuidentes aliquod genus, fumirurenim Ielatiuum in definitione fiu correlatui, at difresentia non poteft fumi in definitione alterius oppofitæ differentia. Patetigitur Auerroem exiftimalfe, potentiam \& actum eif relatiua feoundun dici, \& habererelationem non realen,
A fed rationis, quum fiatabanima, ideoquehanc relationem non effereciprocam, refertur criin potentia ad actum, fed non actus ad potentiam. Sunt ctiam notanda Auertois verba loco predicto, qux funt hxc [attus Es porencia yuamuis fint oppofota.funt tamen ex relatisis] nain dictiones ill a adtucranies, quamuis, \& tamen, indicant alio modo effe oppofita, quam relatina, quamobrem aliis quoque in locis, quando $A_{2}-$ ueıroes ait ca efle oppolita, non intelligit relari-

B ue, red aliquo alio modo. Sententia igitur mea eft potentiam materix fumi \& pro ahioluto 2 pro refpectiuo, non ita tamen, ve fumpta pro abioluto fit idem, quod ipfamet materia, fed fit qualitas diftincta abeflent an ma: erix, cui fuperu:nit rclatio rationis, qua mës noftra eam refert ad actü, fed non actum ad potentiam, vt iamoftenfum eft. Argumentum aus em Tlion $x$, quo probat potentram fumptam proabfoluto effe ipfammet matcriam, debile $\in$ ft, abutirurenin C illa propofitione Ariftotelis, potentia \& actirs in arg. The codemgenerefunt, qux vera quidem eft, dum mo. potentiam \& actun atribuimus effectui; nam homo, qui nunceftactu, \& antea erat poteftate, non folum genere iden eft, fed etiam numero: fic quxlibet alı res eft eaden numero, dum poteftate eft, qux poitea fit actu; fed hor minine verum eft, fi potentialecindunfe \& formaliter accipiatur, quátitas enim peraccretionem acquifita actus quidam êt, ad quem res aucta $D$ poteftaten prius habebat, illa tamen poteftas non erat quantitas, neque eft ipfum fubsectum potens, illudenım eft fubftantia; quum ıgituraEus quantitatis fit quantitas, potentia tamen ad eum non fit quantitas, ctiam porentia materix poreft efie qualitas, licet actus, quem refpicit, fit in categoria fubftantix; vel in aliqua alia; dicere quidem poffumus, potentiam ratione priuationis connotatæeffe per quandarn reduE ctionem in eo genere, in quo eft habitus oppofitus, at certeipfa aptitudo nil aliud eft, quam qualitas fecundrefocciei, quemadmodum diEtum eft: qua vero pro Thoma hac deredicuntura Iauello in fua prima quxeftion.9. Metaphỵ. ita leuia funt, vt commem orari non mereantus.

\section{Deduplici Materia potentia. Cap.X.}

$\mathrm{N}$ Atura potentia ita declarata, antequam confideremus, an fic de effentia materia, nec ne, diftinctionem nolfe oporcet, tum duplicis ellentialis, tum duplicis potentix, quæ primæmateriæ attriburifolet. Ellentiale Effentiafumitur duobus modis, ve Auerroes docet in le esta droCommentario trigefimo primo prims polte plex. rorun, alia namqque funtartributa effentialia vt effentiam fubreti conftituentia, alia vero vt fubiecti effentia m'confequentia; idem alis verbis dicamus, alia de rubiceto p1zdicantur 
per fe primo modo,vt rationale de homine; alia per fe fecundo modo, ve rifibule de homine, ideo accidentia propria yocantur cfentialia, nonvt cflentiam fubiecti conftitucntia, fed vt eam có-

Potentzs fequentia. Potentia vero materix duplex eft, matere vna vniuerfalis, alteraparticularis, \& eft fatis disfiex. trita \& vulgata diftinctio: potentia vniucrfalis eft propenlio materixe ad omnes formas indiftincte, ideo dicitur libera \& indifferens ad oppofita, hre enim eft conditio potentix paffure, vt fit xque apta ad vtrumque oppofitum rect- $B$ piendum; hanc indifferentiam mult fignificare folent dicendo, potentiam aque receptiuam form $x$, ntquı oppofitx prinationis, fic loquitur Alexander in lib. 2. Natural. quxft. cap.7. ¿ Autrroes 1. Phyfic.comment.79.mulci etiam eam figmficant dicendo potentiam recipiendi omnes formas $x$ qualiter : 1 ed vtrique idem dicunt per diuerfu, \& endem fignificant materis potentiam, quarocatur, vniucrfalis;iam enim diximus, priuationemeffe for mã quatenus eft coniunta cum quadan forma, qux per fimilitudinem yocatur contrira; qua mobrem dicere, nuateriam babere potentiam reque formam hominis, atque eius pruationem reciprendi, eft dicere,potentian recipiondifomam hominis, \& formam femuis, feuformam hominis, \& for-

Priwatio mam cadaueris; num duplex eft priuario, vt ait displex. Simplicius in context. 58. libr. 1. Phylic. vna, qux formamprecedit, \& eft terminus generatronisà quo;altera, quæ formam infequitur, \& eft terminus ad quem que coniuntam habet aliquam. formam; quo fit vt formæ humanx contaria dicatur \& formafeminis, \& forma cabueris, qualiscunque hacelie ftatuatur:quoniam igitur quxlibet forma locum habet priuations se pectu form $x$ aduenturx, dicere potentiam ad formam \& ad priuationem, eft dicere potentiam ad omnestormas; ita Auerroes loquitur in libro fuode Sub. ftantia orbis, cap.r. dum inquit, materiamper hanc potentiam vnuterfalen recicipere omnes formas; priuationes enim non nominat, quia hre cum formis contraris coniunctx funt; \& Dubium. hac eft maxime propria loquutio, per quam nonleue eft; quum enim hrc potentia vinuerAppeti- fals fitlle appetitusmaterix, de quo loquitur tesmate Ariftoteles in parc.si. libro primo Phyfic. eferisequed. nim naturalis propenfio matertzad tormas indiftinete, ideo quemadmodum potentia materixæque eft ad formamatquead priuationem, ita videreturetiam appetitum materix $x$ que ad formam \& ad prinationem dirigi, quod tamen dicendum non eft, quia pruatio nec bonum nécappetibile eft, quum fit turpitudo, vt 1 bı $A$ solutio. riftotelisant. Sed dubium hos peres, qua diximus, facile tollitur : nam potentia materire eft indifferens ad formam \& priuationem, id elt, adformum, \& adformam contrariam; \&
A appetitus materize fimiliter, prinationem enim matcria appetit, non vt priuationem, fed vt alceram formam; quamuis enim ip fa per fe priuatio non fit appetibilis, eft tamen appetibilis forma, cui iuncta eft: dum igitur dicimus, per potentian viniucrfalenı, materiam efle aptam recipere omnes formas, omnem hac in redifficultatem enitamus, in quam videmur incidere, dum dicimusformam \& priuationem. Potenciam hanc viniuerfilem manifeftum eft $x$ ternam effe apud Aritotelem, qui materiam xternam efle voluit; quum enim non onnes fimul formas materia recipiat, fed viam tantum modo pof aliam, remanet fenperin materia poreftas, \& propenfio ad alias formas, quas non habet, quare materia nunquam eft fine hac potëtiavuiueriali. Potentiavero patticularis ea dicitur qua matcria ita lianc formam refpicit, venon alias, feim ngis hanc, quam alias; hæc autem otenti corrtatio $\&$ determinatio non fit à natura materix, fi. qudem hac xque omnes formas appetit, \& apta eft recipere; fed fit abagente it m materiam preparante ad hanc forma mirecipiendan, vt no fit apta reciperealias:fit etian a forma prafente, feu ลे qualitatrbus eam infequentıbus, iamenim diximus cum forma humanifemisis qua dam effe coniuncas qualitates, que materian reddunt magis aptam recipere fomam hominis, quam formam lapidis; lacigi u: potintia particularis dicipur, quia rafplestal quareftatut in $\mathrm{D}$ forman noinalias. Hancrotentiannon polle xternam efiemanifentum eft, quia interitnecef- $p$ a fario in aduentu for næ, quarcinus cft particularis potentia illam tantum forman reipscians Quonian igiturin materia pi teft vtraque hac putentiacontiderari, virnq cum materia eft conterendatum 11 prinn, tum in fecunda notione accepta, vevidcan us quonodo vtraquc ad materian tetratur.

E Ouomodo potentia vniuerfalis ad Materian fe babeat inprimanotione acceptan.

\section{Cap. $X I$.}

$T$ Otam huiufece reiveritatem ego quidem in tribus dictis confiftere arbitror, qux fingillatime referam, \& comprobabo. primum hoc eft: fi printamateria in paima notione, \& fecundum popriam libltantiam confideretur, poF tentavinuerfalis patiendinon eftei efentialis, vt effentian cius conftituens, fed eft ei efrentialis, vt efientiam confequens : priorem huius diEti parrom probarefacilecft, nullum enim accidens poteft cffe de effontia alicuius fubfantia, arqui potent ial eftaccidens, materia vero fubltantia, ergopotentia non poteft ellentiam materix conffitucre: fed illud annotare debemus, eflentiam matcrix quanjoque nomine potentia fignilicari, fidtunc nonfumi poter- 
tiam pro aptitudine, qua eft qualitas, redpro A libri de Subftantia orbis, quando dixit matemateria ipfa, quam imperctam effe fignificare volentes, potentiam appellamus; ficut et. iam in alis rebus effentiam occultiorem folemus nomine proprictatis euidentioris fignificare; at potentia proprie fitmpta pro aptitudine ad formam, quum fit qualitas, non eft de effen-

- tia materix.Addo etiain al terum argumentum: materia votatur apta, \& potens, hoc autem eft, habens aptitudinem, \& potentian ; ergo non eft ipfamet potentia \&aptitudo; nihil enim dicitur habere feipfum, nec poteft de codem predicari concretum \& abfractum. Q odautem hac potentiafit effentialis materia, vteffentiam confequens, ficuti rifibile dicitur cflintiale homini, probatur conftitu to hoc fundamento fumpto ex Ariftotele libro nono Meta. phyficorum, contextu 2. patieft propter rateriam, \& omne patiensideo patitur, quia materiam habet, hinc fit vt form $x$ materiales (vt ait ibi Auerroes) patiantur per accidens, nempe propter materiam, in qua lunt, formæ veroà materia abiunctx fint omnino impatibiles; idem lcgimus apud Ariftotelem libroprimo de Ortu \& Interitu, particul. so. itaque fic argumentemur; prater materiam quicquid patitur, propter nzteriam patitur, ergo foli materix perfe competit pati, neceffe eft enim omne tale peraliud reduciad aliquodper fetale, \& illud eft perfe tale, per quod alia funt talia; quoniam ıgitur potentia paffiua competit aliis propter matcriam, competit materix perfe;veligitur perfe primo modo, vel per fe fecundo; at non primo, vt modo oftenfum eft, ergo fecundo, quocirca hæc potentia eft proprietas materiæ manans ab interna eius natura, quemad. modum ex natura hominis rifibilitas, Hanc fententiam fignificauit Auerroes multis in lo. cis: nani in illo Commentario fecund olibri noni Metaphyficorum inquit, in definitione omnis potentix paffiux fumi potentian primæ materix, indicans primam materiam efle reuera primam radicem omnis patibilitatis. In Commentario etiam feptuagefimo nono libri. primi Phyficorum inquit, nec forman; nec priuationem efle de natura materiae, fed vtramque illi accidere, ipfam autem materiam efre quafi compofitam ex effe, \& non effe; per hac fignificans potentiam materix liberam, \& $x$ que refpicientem oppofita habere effentialem connexum cum naturamaterix, non quod infit ei perfe primo modo, non enim dicitabfolute niateriam effe compofitam exhac potentia ad effe, \& non effe, fed effe quafi compofitam, quia non includitur $h x c$ potentia in natura materix, fed eam confequitur vt proprietas, proinde incft ei perfe fecundo modo. Clarius hocidem fignificaut Auerroes in primo capite riam fubftantiarı per poffe, \& potentiam elle cius differentiam fubftantialem; quem locum multi perperam intellexerunt. Marcus Antonitus G:nua Prxecptormeusdicebat Auerroem funere potentiam improprie pro ipfamet ma teria, \& nilaliud fignificare dicendo materian fubftantiari per polle, quim imperfectionem naturæ materix; fic etian Thomas inquit, potentiam fumi pro abfoluto, \& fignificare ipfain B materiam; fic etiam Gandauenfis potchtiam pro fubiecto potence, \& abfrastum pro concerto: hoc autem modo fumptam potentiam certum eft non folum effe de effentia materiæ, fed effe ipfammet materiam. Attamen hxc non poteft effe Auerrois mens in eoloco, qui ftatim fubiungit, hanc potentiam effe diuerfam à natura fubiecti, quod fubftantiatur per ipfam, quarenon fumit potentiampro ipfamet materia. Aliiverodixerunt, Auerrocm fumerema. $C$ terian in fecunda notione, quatenus enim eft principium rerum, eatenus potentia eft de effentia materix. Sed neque hrc interpretatio conueniens eft, quum eum locum legentibus Confitam pateat, Auerroem loqui de materia in prima notione, dicit enim materiam effe vnum ex entibus perfe exiftentibus, \& de eius effentialoquitur abololute confiderata. His ergo expofi- Expofatio tionibus reiectis, melius eft, vt dicamus Auer- Gera.
roem intelligere, poientian effe offentialem roem intelligere, potentian effe effentialem D materia in fecundo mododicendiperfe, \& eitus proprietatem; per quam natura materiz declaratur: quia ve idem Auerroes docet in fecundo pofteriorum, commentario vigefimo, \& in quarto de Colo, conimentario quadragefims, fumuntur quandoque proprialoco differenti2rum ad rei effentian-declarandam, quando differentia funt ignotz: fic igitur dicit Auerroes potentiam hignificare naturam mater $x$ loco differentix contituentis; \& ne credamus E effe reuera de effentia naterix, fubiungit potentiam effe diuerfam à matura materiz, quafi admonens eam effe proprietatem, non differentiam fubftantialem. Ad hunc fenfum trahenda funt verba Simplicij in contextu 82. libri primi Phyficorum, dicentiseffentiam materix conftitutam effe in ipla potentia; fic etiam verba Alexandri in fecundo libro Quxfionum naturalium, capite feptirno, quando dicit omnem formam, \&omnem pritationem acci$F$ dere materix, quia natura materia eft conftituta in potentiareceptiua omnium formarum, \& omnium priuationum, intelligit enim potentiam effe proprietatem, per quam fumptam loco differentix ipfa materix eflentia declaratur. - Hocetiam fignificauit Ariftoteles in particula octuagefima prima libriprimi Phyficorum, quando dixit materiam aopetere formam confio.
tio. QuomodomateriafirbPancieturper $p \theta \iint \hat{e}$. Ex;ofice Genua.

Confutatio. Expofitio 
fecundum fuam ipfiusnaturam, is namqueap- A fit quiddan diuerfum àmateriæ effentia, vtair petitus eft iffa materix potentia recipiendi omunes formasindıftincte, quxineft materix feappeti- cundum cius naturam, quia ipfam infequitur en mate vt proprictas, quemadmodum homo dicitur rs.e efferifibilis fecundum propriam naturam, quia propriam naturam hominis infequitur rifibilitas.

\section{Dubiaduerfusea, que dicta funt, Er eorum folutiones. Cap $X I I$.}

A Duerfus éa, qux modo dicta funt, dubia A qurdam oriuntur, qua foluere oportet.

rimsm Primum quidem;fi potentia vniuerfalis effet ef-

wósuss. fentialis materix in fecundo modo dicendiper $f e, \&$ in ea inhæreret neceflario, \& ab ea inceparabilis eflet, hoc tamen falfum videtur, nam Themiltius in fua digreffioneinquit, materiam inprima notione non habere potentiam, igitur

secsndšs porentia effentiam materizenon infequitur. Alterum dubium eft : potentia opponitur aftui, crgo perit adueniente actu, non eft igitur xterna, neque neceffario in materia in heret, proin-

Irrtism denullo modo eft illı effentialis. Tertium dubium:diximus fupra cum Themıftio, materiam in prima fua notione ä750.01, id eft, expertem omnis qualiratis, ergo non habet potentiam, quia fi eam haberet, effet qualis, quum potentia

Qsartiz. fit qualitas. Quartum dubium eft: non videtur verum id,quod diximus, potentiam effe materix proprietatem, per quam declaretur natura materix, loco differentia ignota, nam Ariftoteles 7. Metaphyfic. contex. 8. definit materiam abfque vlla potentiz rientione, igituretiam fiAdpri. nepotentia natura materisedecla ratur. Adprisism re- mum horum dubiorum disuntaliqui, TheniSponfso ftium loqui de potentia particulari, hanc enim eliortss. materia non habet in prima notione accepta, \&c inc eadem refponfione fecundum quoque du Confuta- bium foluiarbitrant ur. Attamen difficultatem
non tollunt, quia legentibus Themiftij verba non tollunt, quia legentibus Themifti verba
manifeftum eft, eum negare in materia etiam potentram vniuerfalem, difinguit enim primam materiz notionem à fecunda tânquam ahfulutam à refpectiua, vtraque autem potentia notat refpectum ad actum, ergo fi materia in prima notione nullum habet refpectum, nulhm etian debet habere potentiam, necvniuerfalem, nec partıcularem, itaque dubium viget. Egoaliter dico, fubiectum poffe abftrahimen-

tura teabaccidente proprio, \& effenriali, licer non reipfa, nam accidens proprium eft re infeparabilè fuo fubiedto; quamuis enim non poffit re feparari ab homine rifibilitas, concipi tamen poreft naturahumana non concepta rifibilitate; fic igitur potentia eft infeparabilis à materia, quum cius effentiam infequatur, tamen quum Auerroes in primo capite libri de Subftancia o:bis, \& materia fit priornatura fuis proprietatibus, poteff confiderari materixeffentia mente abiuneta à potentia; hoc igitur vult denotare Themiltius, quando dicil materiam in printa fua notione non habere potentiam, nimirumipram fecundum fe conlideratam materixe efentiam, non includerepotentiam, quemadma dum \& hominis effentia non inclidit rifibilitab tem; hanceffe Themiftijentem pates 1 pfitis verba confiderantibus, inquit enisn [ bec res, gurm bocamus materiam, cst quoddam fubiectum, cuss accedit in eius natura St fit receptaculum oppofotorum ] quum enim dicat [accidit] denotat potëtians effe accidens materıx; quum autem ditat [in euss natura] fignificat effe accidens effentiale, quod habet connexionem cum natura materix : inquit pratesea Themiftius ibidem, non effe facile ita materiam, \& eius efC fentiam abfolutam abftrahere mente à potentia , \& ab omni refpectu, effe tamen poffibile, fi quis efficaciter nitatur, \& aciem mentis exacuat, fic autem fignificat potentiam effe reuera infeparabilem à materia: nam fi effet feparabilis, nullo negotio poffet effentia materix fine potentia confiderari, ipfe tamen inquiteffe admodum difficile, quialoquitur de mentaliabftractione. Ad fecundum dubium, vtin prafentia concedamus potentiam hanc vniuerfalem D opponi actui, hoc enim poftea diligentius expendetur, dicimus tamen eam non opponi huic Potent formx, vel illi, fed vniuerfo generi formarum Gniner. materialium; obid quum materia non poffit fi- lis non mul recipere omnes formas, fed vnam poft a- ponitu. liam, fequitur non poffe vnquam impleri totam form hanc materix porentiam, proinde nec interire vnquam, quoniam in materia habente hanc formam feruatur potentia recipiendi alias omnes: neque eft quod alıquis dicat, in omnibus. E fimul fumptis materix portionibus inefle acts. omnes formas; fiquidem nunc de effentia materia loquimur, quamobrem ea, qua de ipfa dicimus, cuilibet etiam portioni competere debent, nullum in hoc difcrimen eftrotius materix, \& partium; totam enim materiam habere ormes formas, effet ita habere, vt tota à qualibet forma informaretur, proinde \& portio quxlibet ab omnibus fimul formis, non ve pars vnam formam haberet, \& alia aliam, pez $F$ loc enimnon interit potentia, fed aterna feruatur in omnibus materiz portionibus, quoniam in qualibet portione eft vna tantum forma , \& potentia ad a lias omnes; quare eft à materia infeparabilis hæc potencia vniuerfalis. Prxterea vt etiam admittamus illud effe habere omnes formas, tamen non effet habere omaes.indiuiduas, fed omnes fecundum fpe- 
cicm tantum, mancretigitur in materia pote- $A$ ftas recipiendi faltem alias indiuiduas pofterius aduentaras; non igitur interit potentia vniuerfalis. Adtertium dicimus duplicem effe qualitatem ; vnam, quareftringit, \& coarctat materiam ad ftatutam, ac certam alicuius rei naturam; alceram vero, qux nullam coaratationem materixfacit : quando igitur Themiltius \& Alexander dicüt, materiain fecundum propriam naturam effe êtrolov, quod etiam ex Ariftotele colligimus in context. 54 . primi Phyficorum, intelligunt expertem earum tantummodo qualitatum, quæ materiam coarctent, atque determinent : cuius ratio eft, quoniam omnes for$m x$, \& omnes qualitates certam entis naturam determinantes continentur fub obiecto adxquato prim $x$ materix, quo fit vt nulla harum poffit effe effentialis materix, neque vt conftituens, neque vt cunfequens, nulla enim determinatio poteft infequi naturam onaterix : quod fial qua forma, fiue fubftantialis, fiue accidentalis, comprehenfafub obiecto adxquato prima materix effet ipfi effentialis, non poffet amplius materia aliquam aliam recipere, quoniam intus apparens prohıbet alienum, vt dicitur in quarto contextu teruj lib. de A nima, quam rem optime declarat Plotinus in quartolibro fecundx Enneadis, cap.8. fed qualitas, qux materiam non coaretet, neque ad aliquam certam naturam reftringat, non continetur fub obiếo adxquato prim $x$ materix, ideo poteft absque vlla repugnantia attribui materix vt effentialis, nec reddit eam qualem illa qualitate, quam omnes Philofophi relpesêre, qui materiam ä7rosoveffe aferlierunt : huiusmodi qualitas eft potentia hæc vniuerfalis; qux tantum abeft vt materiam coar ctet ad aliquam certam naturam, vt potius eam reddat liberam, \& aptam ad omnes indiftincte recipiendas. Ad quartum fumptum ex contextu oetauo feptimi Metaphyficorum, refpondere poffumus, eam non afferriab Ariftotele vt definitionem materix, neque enim elus confilum ibi eft materiam definire, fed folum dubitandi gratia oftendere materiam effe rei effentiam, quod poftea reprobaturus erat, \& oftenfuruseffentiam effe formam: at quoniam illa, qux ibi dicuntur de materia, dicuntur ad modum definitionis, \& $2 b$ Ariftotele vt vera proferuntur, \& ita ab omnibus vt vera recipiuntur, etfi confequens, quod inde infertur, materiam effe rel effentiam, falfum eft, ideo nc's quoque eam vt definitiouem quandam materix recipientes, aliter efponfso foluere duandam materıx recipientes, aliter lequa- lis cum Auerroe dici poffe Ariftorelem in ea
umb. definitione non ombifle poreuriam defintione non omifille potentiam, quod enim Aritoteles dicit [est enom gueddam, de quo fingula borum predscantur.] Auerroes ita vide.
A tur incerpretari, vt dicat, his verbis fignificari potentiam recipiendi omnes formas, quandoquidem non alia ratione eft fubređum, quam perpotentiam patiendi: attamen ca neque $A$ uerrois mensett, neque Ariftotelis ; Auerroes - Confuca enim non illa pradicta verba Ariftotelis interpretatur, fed declaratalia precedentia : quum enim Ariftoteles dicat, materiam non effe quid, nec quantum, nec qualc, nec aliud vllum ex decem generibus. Auerroes ad horum verborum B declarationem, quafi rationem adducens inquit [quoniam est in potentia ominia ifta, $6 t d s-$ ctum est in Pbyficis ] qux verba profert'Auerroes ex feipfo, non vt contenta in definitione $A$ riftotelis, ipfe vero Ariftoteles absque dubio in ea definitione potentram non accipit; fed effentiam materiz abftrahit à potentia, \& à refpectu, quum dicat materiam effe omnium fub. iectum, cui us effentia diuerfa eft ab effentiis omnium rerum : nam dicere materiam habere C potentian ad omnia, eft potius eam dicere omnia, quam effe quid diftinctum ab omnibus; ergo dicere eam effe quoddam ab omnibus diuerfum, eft non confiderare potentiam:dubium igitur viget, \& à nobisaliter foluendum eft. Ego puto folutionem perendam effe ex Themiftio Refpons so in fape memorata ipfius digreffione : quume- Gera. nim dicat, materiam in fua prima notione non habere potentiam, \& dicat difficile admodum effeita materiam concipere animo fine vllo reIpectu adalia, non effe tamen impoffibile, fi quis aciem mentis efficaciterintendat, figniGcat vtilem quidem effe potentiam ad materiz effentiam fignificandam, non effe tamen necelfariam : illi enim qui magno ingenj acumi. ne praditi funt, ducentur quidem in cognitionem effentix materix per poțentiam, fed eam poftea concipient etiam non confiderata potentia, \& in fua prima notione absque vllo refpectu adalia : $1 l$ i vero, qui non ita valent ingenio, non poterunt quidem materix effentiam compleati finepotentia, quarefícit formas, \& vtenturpotentia loco differentix, poterunt tamen non ignorare potentian effe accidens, cui fubef ipfa materix natura ab illo accidente diftıneta, licet naturam illam vt abfolutam, \& fine illa potentia concipere nequeantadeo, vt fi perpotentiam definiant materiam, intelligant fe fumere potentiam loco differentix, quam penetrare cognitionenon poffunt: vnde colligimus, necefie effe ad primz materix cognitionem, hoc ordine progredi, vt primo loco eam cognofcamus vt materiam, hoc eft, in fecunda notione, \& prout referturadalia i poftea vero, fi poffinus," ad primam quoque eiu's notionem perueniamus, \& eius fubitantiara absque vllo refpectu conremplemur, quocirca in primæ materiá inF a ueft- 
Quarue, ueftigatione primus labor eit Phyiofophi natuconzrde- ralis, qui non alio modo eam cognofcit, quam rescones vt principium generationis corporum naturaprama lium, atque etiamvtmodoaliquoprincipium muteris. motus \& quietis in eifdem corporibus: dux alix fuperfunt prima materix confiderationes, ad primum Phylofophum attinentes, vna quaterius eft principium quoddam, \& pars fubftantix compofita, non confiderata ipfius generatione, qua confideratio habetur in 7 . \& 8 . Metaphyfic. nec poteft effe fine potentia: nam docere non poffumus, ex forma vt effentia, \& ex nateria ve vehiculo neceftario vnum compofitum exiftere, nih cognof camus materiam habere potentiam naturalem, qua refpicit formam, qua eit actus, \& ita ex poteftrte \& actu vnum fieri : altera eft confideratio materix abfoluta, de qua modoloquebamur, quam etiam attigit Ariftoteles in illo feptimolibro in loco pradicto: fed pauca de hac erant dicenda, quoniam res ita funt à Philofopho cognofcenda, vt fecundum naturam funt, materia prima eft in rerum natura; non $v t$ fpecies entis, fed vt principium, \& vt materia fpecierum entis, quia fi confilium natura fpectemus, materia eft propter alia, non ptopter $f e$, ficut etiam antea dicebanus; de materia igitur agit Ariftoteles in prima phylofophia propter fubftantiam compofitam, dum de huius effentia loquitur, tangit tamen ibidem etiam naturam materix abfolutam; idque facir in contextusllo octauo feptimilibu, vbi hoc notare debemus; res omnes poffe de materia prædicari vt poteftate, at non polfe vt actu, poteft enim \& affirnari, \& ne-

Q.somo-

do áe $m A$

teriapia

dicenthr in

res o-

mnes, एद

gromido

xсgёंиr. gari materiam efle res omnes, affrmari quiden vt poteftate, negariautem vtactu; fed huiufmodi affirmatio declarat nıateriam in fecunda tantum notione, \& in refpectu confideratam: ideo nullam eius mentionem fecit Ariftoteles in ea definitione, fed folius negationis, qua dicimus materiam nullam effe ex entibus, hac enim negatione fignificat ibi Ariftoteles prima materix naturam in prima notione, quium dicat eam effe quiddam diuerfum à rebus omnibus; fed necrederemus, materiam nihileffe nifi hancrerum negationem, quim difficile fit eius naturam affequi, ideo fubiungere 1 bidem voluit, materiam non foJum non effe aliquam ex rebus, fed neque effe carum negationes (quod effet effe nihil) vt inde cognofceremus huic rerum omnium negationi aliquod pofitiuum fub effe, qux eft ipfa. materiz natura, licet explicatunon facilis, iden per eam definitionem non cognofcimus renera quid fecundum fe fit materia, fed potius nุuid non fit, cognofcimus tamen cife fubltantiam quandam fubicetum omnium rerum n2turis, qux ab his, \&ab earum negatione diuerfa
A eft; cognofcimus igitur eam effe aliquid fubftans, \& quadillud non lie, fed non cmniliso quid fit. Per affirmationem vero declaratur materia in fecunda notione accepta, idque fit in primo libro Phyfica aulcultarionis, dum dicitur materiam effe prinum fubiectum, ex quo res fiunt, fic enim figuificatur eam fieri res omnes. Confiderandum autem id quoque eft, Ariftotelem in slloprimo libro diftinguere à materia priuationem, de negatione autem nihil dicere, B contra vero in feptimo Metaphyficorum, diftinguere negationem à materia, de priuatione autern ne verburn quidem facere propterea quod materia in prima notione non habet priuationem, fed negationem tantum, in feçunda vero notione priuationem, \& Ariftoteles in illo. 8. contex. feptimi Metaphyfici rrateriam in prina tantum notione confiderat, in primo autera Phyfico in fecunda folum. Per hxcigiturfublataeit, nu fallor, omnis difficultas-

\section{C}

Oumodo potentia vniuerfalis ad Materiam se babeat in Jecunda notione acceptam. Cap. XIII.

$\mathrm{D}$ Eclarato primo dieto, fecundum fequi- secsin. tur, quod tale eft : fi materia fumatur in destum. fecunda notione, seprout eft principium rerum. potentia yniuer falis ineft ei per fe in primo modo dicendi per fe, \& eft illieffentralis vt rationale homini; huius dicti ratio fumitur ex verbis Theminii in digreffione pradicta, vbi inquir; alia competunt homini fecundum fe confiderato, \& quatenus eft homo, alia ve relato ad aliud, \& quatenus eft.pater; nam habere filium eft illi accidens vt homini, idque feparabile, fed eidem vt patrieft effentiale: fic etiam albedo accidit homini fecundum fe fumpto, fed eft de eius effentia, quatenus eft homo aibus, quialo. cum forma obtinet, qua eft homo albus; non eft enim inconueniens, quod accidens fit de effentia fubftantix, non fecundun fe acceptre, fed fecundum aliquam aliam confiderationem. Materia igitur fecundum $\int$, \& fecundum propriam naturam confiderata, potentia vniuerfalis eft accidens eius proprium, \& eflentiam ipfius confequens, vt iarn demonfrauimus; fed confiderata materia prout refertur ad alia, \& vt eft principium rerum, potentia vniuerfalis eft eius conditio neceffaria, tanquam eius naturam conítituens, quemadmodum effe rationis participem eft conditio neceffaria homini vt fit homo, \& eius naturam conftituit; proprius enin modus, quo materia eft principium rerum naturalium, confiftit in hac potentia vniuerfali, qua eft apta recipere onines formas, itavt diccie polfumus, potentian pati- 
endi effc rationem formalem principii materialis; effentia enim materix eft fecundun naturam prior hac potentia vniuerfali, quia fubicEtum eft natura prius accidentc proprio, \& eft tanquam ciuscaufa; ipfa vero potentix ratio, $f$ bene confideretur, eft natura prior ratione principij materialis non enim quia materia ef principium materiale, ideo habet potentiam patiendi, fed è contrario, quia habet potentian patiendi, ideo eft principium materiale potentia igitur vniucralis eft velutiforma \& racio materix, quatcnus eft materia rerum, hoc autem eft quatenus adalia refertur vt principium : hoc fignificauit Ariftoteles in fecundo libro de Ani.

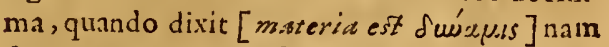
fumpta materia, vteft principium, quomodo fumit eam Philofophus naturalis, poteft vocari potentra in cafu recto, quia potentia eft cius ratio conititutiua. Eft autem animadiertendum, non idem de prituatione, ac de potentia dicendun effe: nam priuationem funındo:eo modo, quem declasauimus, pruatio eff necerfaria materix propter generationem, non vt conditio materix ad recipiendum, fed vt terminus generationis à quo, ob id prituatio eft tertium priucipium diftunctum effentıalıter à matcria ; nam in generatione alio officio fungitur materia, alia priuatio; \& proprius eius modus, quo dicitur principium, longe diuerfus eft $\mathbf{a b}$ eo, quo materia principium dicitur : at potentia non eft terminus generationis, fed eft folumb conditio neceffaria materix, vt fit materia, propterea hæc non conftituit quartum principium, fedeft ratio conftituens prircipium marorale teriale. Idcirco erraffe mihi videntur nonnulorune $\mathrm{li}$, qui priationis neceffitatem in eo fitam efproua-fe exiltimarunt, vt fit necelfaria propter materis ne-riam, hoc argumento ducti, quod ex materia Sstate. non priuata nihil generari polfet : hoc autem dicentes videntur prinarionem ponere incer conditiones, materiale principium confituentes, quo fieret vt priuatio non effet tertium principium, ficutetiam de potentia modo dicébamus. Quamobrem dicendum potius eft, prinuationem effe primum neceflariam propter generationem : tanquam eius terminus à quo, quia de ratione generationis eft, vt non effe pracedat cife; deinde vero efre neceffariam materiæ eo modo, quem antea declarauimus, nempe quoniam principia præitant fibi mutuamoperam, \& quemadmodum exmateria finepriuatione nihil generaretur, ita neque ex priuationefine materia, neque ex duobus principiis vtcunque acceptis fine tertio. His igitur duo. bus modisfe habet potentia vniuerfalis ad materiam, vt egoarbitror, \& per hæc multæ difficultates foluuntur. Sententiam autem noftram teltimonium aliquorim comprobaffe videtur,
A qui duo hac dicta, corumque difcrimen non intelligentes, ea tamen vtraque protulere, tanquam ab ipfa veritate coacti : nam quatuor 12tiones attulerunt, cur hxc potentia fit effentialis primx matcrix; vna eft, quoniam manat immed rate à natura materix; fecunda, quod per eam effentia materix ad forman dirigitur; tertia, quod ex matcria \& forma fit vnum tanquam ex potentia \& actu; quarta, quoniam hxc potentia ponitur loco differentia fubftantialis $B$ ad declarandam naturam materiæ, qux aliter declararinon poffet. Hac omnia verafunt, fi bene ac diftinete intelligantur: nam primus \& quartus modi referunt primum dictum no. 1trum, quoafferuimus potentiam refpectu materix in prima notione acceptæe effe proprietatem confequentem eius naturam, \& fumiloco propria differentix ad declarandam materix naturam, quam fine potenta diccre quidem poffimus quid materia non fit, fed non re. uera quid lit: fecundus vero ac tertius modi referunt fecunduin dictum noftrum : nam effentia matcria ad formam respiendam dirigitur, dum materiam vt princeith confideramis : dirigituralltem per potentiam tãquam per rationem formalem, quodifticonfitentur, dum dicunt, per eam : non enim recte diceretur, per potentiam, fipotentia effet folum quoddam confequens; fed hoc conuenienter dicitur, fi potential eft quoddam prius, quod caufx locum obtinet; idem êt fenfus tertij modi : nam in eo quoquemateria vi principrum fumitur, proinde eft ei effentialis hac potentia iuxta primum modum dicendiperfe; difcrimen, folum eft, quod in lecundo illorum modo materia confideratur vt principium generationis corporis naturalis, qux eft confideratio Phyfica; in tertio autem vt principium fubtantix materialis, quæ eft confideratio Metaphyfica, \& viroque muE perationem formalem. verum dixerunt formalem. Hi ergo in omnibus cisefientialisnt, diftinetionem tamen duplicis efientialis non animaduerterunt, fed ea confuderunt, \& tanquam vnum \& idem pronun-
ciartint.

\section{Depotentia particulari, quomodo ad $\mathrm{Ma}$. teriam fe babeat. Cap.XIV.}

F Dmum tertium dianm eft; potentia par-Tertium ticularis eft accidentalis materix, tam in dictam. prima, quam in fecunda notione acceptæ, fumendo accidentale pro eo, quod diftinguitur ab vtroque effentiali, hoc eff, quod nec primo, necfecundo modoeft perfe; hocita probaripoteft: illud, fine quo aliud effe poteft, \& eft, accidentaleilli ent; at fine potentia particu- primo lars poteit matcra exiftere, \& exiftit, tum vt

$$
\text { F } 3 \text { ens, }
$$


cns, tum vt principium rerum; igitur hæc poten- A ria eft ei accidentalis, tum in prima, tum in fecunda notione accepta: maior propofitioclara cft,minor probatur: potentia particularis eft illa, quxhanc tantum formam refpicit; $\mathrm{tt}$ formam hominis, nonalias; atquifine hac particulari potentia exiftere poteft materia vt principium aliarum rerum, \& exiftit actu, priufquam hanc potentiam particularem recipiat; patet enim non elle in ligno potentiam particularem ad forman hominis; quoniam igiturpotentia hæc particularis non vna eit, fed plures pro formarum multitudine, fine qualibet exiftere poreft materia, proinde nulla talis potentia eft

secundat materix ellentialis. Praterea hac potentia nec ratio. primo, nec fecundo modo dicendi perfe in materia ineft, ergoeft illi accidental is: confequentia eft Ariftorel. in context. 32. libri primi Pofteriorum : antecedens facile probatur : nam fi hæc potentia ineflet materix perfe vel primo, vel fecundo modo, materia nullam formam recipere poffet, neque enim illam, ad quam potentiailla refertur, neque aliarum vllam; non illam, ad quam refertur, quia recepta forma potentia periret; tollitur eniw potentia in aduentua actus-attamen interire potentia non poffet, quia quicquid ineft perfe vel primo, vel fecundo modo, id neceffaria, ac femper ineft: non etiam alias, quia adnullum earum effet peculiariterpræparata, fed adillam folum; non poteft autem materia aliquam formam recipere, niff prius ad eam recipiendam præparetur, \& habeat potentiam particularem refpectu illius. Tertia Prxterea materia fuapte natura eft libera, \& inratio. determinata, \& xque refpiciens. omnes formas; ergo nihil determinatum poteft eius effer kiam vel conftituere, vel confequi; quare neque hxc potentia particularis, quum fit determinata ad refpiciendam hanc vnam formam, nonadalias; patet igitur hanc determinationem, \& coarctationem non prouenire à natura materix, fed ab aliquo alio, vt ab agente, \& àforma præfente, qux refpectu forma aduerturæ locum habet priuationis; hæcenim particularis potentia illa eft, quam antea diximus effe cum priuatione coniun tam: fiquidem potcntia vninerfalis negatione potius iuneta eft, quam priuationi. Non eft autem igrioraldum, duo in hac potentia particulari effe confideranda, vnum ipfam potentiam recipiendi formam quatenus potentia eft, alterum vero. illam determinationem \& reftrictionem ad hanc vnam formam refpiciendam, \& non adalias: quatenus igitureft potentia patiendi, rarenus infequitur naturam materix, \& ita illi eft effential is; fed quatenus eft determinata, \& co. arctata, eatenuseft eiaccidentalis, nec proneait à natura matariz, fed ab alio, vt dictum eft.
Hac igitur potentia corruptibilis/eft, quia necelle eitaccedécc actu eam interire, ideo de hac loquitur Auerroes in Commentario feptuagefimo primilibriPhyficorum, quandodicit, potenciam non effe de ellentia materix, eo argumento vtens, quod quum in aduentu forma hac potentia intereat, mataria fimul interiret, fi potentia effet 1 lli effentialis; hre enim Aucrois ratio de potentia vniuerfalinihil robors haberet, quum illa nunquam intereat : lianc et1am B relpenit Simplicius in contextu quinquagefimo oetauo eiufdem libri, quando dixit potentiam effe accidentalen materix; quare hanc potenriarum qifinctionem dubia multa foluuntur.

\section{Quanam potentia actui opponatur. Cap. $X V$.}

Vum duplex fit potentia, confiderandum
manet, an varaciue opponatur a tui, an alresiolum : depotentia particulari clara res eft, habet enim priuationem conitunam, ratione cuius opponitur actui prsuatiue, vt dictumeft fupra. Devniuerfali vero potentia dubium eft, Poten, ea nam que non cum priuatione, fed cum nega- Gnike: tione eft coniuncta, quamobrem non poteft a- lis non Etui opponi vt ptiuatio habitui, fiverum eft id, ponitu quodantea diximus, potentiam opponi actui actus. ratione priuationis annexæ: præterea hæc po$D$ tentia, quum perpetua fit, \& nunquam intereat -nón recedit in aduentu form $x$, non eft igitur contraria forma, fi cum ea manet in materia. Quapropter huius egofententia fum, potentiam vniuerfalem non opponi atui, fed de fola particul ari id verum effe, quod fupra de oppofi. tione potentia \& actus dictun à nobis eft; potencia namque vniuerfalis non refpicit reuera formam, fed potius uniuerfam formarum omnum collectionem, feu earum infinitam reE ceptionem, quo fit ve nunquam tota impleatur, proinde nunquam intereat, fiquidem interire potentiam inl aliudert, quam totam adimpleri, quod de hac diciminime poteft. Hus potensix fimilis eft potentia contmuiad diuifionem infinitam, qux nunpuam ad perfectum actum ducitur; fed a dimperfectum, qui cum potentia femper est commiftus : hac eft A uerros fententia in 9. Metaphyf.coinment. 11. vbi dicit potentiam continuı ad diuıfionem infinitam, \& porentiam prim $x$ materi $x$ ad infinttas tormas, e+iufdem ellerationis, quia nunquam ad completumactum ducuntur, fed ad incompletum, qui nunquam feiungiturà-potenta: idem leginus apud Auerroen in Comment. 79. libri octaui: Phyficornm, vbi dicit non dari potentiam acti . uau materialem infinitam, daritamé paffrnam infi- 
infinitam, hæc enimeft potentia primæ materiæ, qux ab ipfa materia nunquam feparatur, licet eialius femper; \& alius actus adueniat: fed in illo Commentario vndecimo libri noni Metaphyficorum clare dicit, porentiam hanc infinitam, \& perpetuam, qux eft in prıma materia, non elleillam, quærefpicit atum; nam potentia, qux ad actum refertur, eft illa, qux opponitur actui, \& in aduentu aetus deftrustur. Нæc igitur potentia vniuerfalis non opponitur aEtui, fed quando restringitur, \& contrahitur ad recipiendam aliquam certam formam tunc fit oppofita illı formx, quia iam facta eft particularss . i\& iuncta priuationi propriz illius for"6ium ma. Ex his lumitur folutio cuiufdam dubii, quod multis negotium faceffit, cuius mentionem facit Achillinus in primo fuo libro de Elementis dubio 13. \& Loannes Gandauéfis in quxftione 25. libri primi Phyficorum, id que tale eft: in fugula portione materixineft potentia recipiendiformas numero intinitas, iuxta Ariftotelis fententiam xiernum mundum fatuentis, quoniam igitur fingulo actui propria potentia refpondet, iequitur efre in 1 lla materia par icula potentias numero infinitas, \& ita dari numerun actu infinitum, quod nullo modo alierendum eit Gandauenfis nefciens dubium hoca!iter foluere; concedit effein illa nuatcria potentias infinitas, quodeft ablurdum manifeftum, ideo \& qux ab iplo, \& qux ab Achillino hac de re dicuntur , quum vana prorfus, \& inutilia fint, dimittantur. Ego vero conftanter negandum puro, effe in illa materia potentras infinitas, dico enim vnam effe potentiam vniuerfalem, per quam materia refpicit indiftincte omnes formas per omne futuum tempus aduenturas: potentias vero particulares elic quidem infinitas, prout refpiciunt actus numero infinitos, at non fimul omnes exiftère in eadem materia: fingula namq; huiufinodi potentia cum prituatione eft, \& cum propria praparatione ad talem formam, non poteft autem eadem materix particula efle fimul ad omnes formas recipiendas peculiariter præparata, nam dicere ad onnes æque præparatam, eft dicere ad nullam, \& omnino negare in materia potentiam particularem : hæc igitur potentia in cadem materia vel vna tantum elt, vel plures, non tamen unfinitx, fed paucx, vt in femine humano eft potentia particularis, \& proxima ad formam honuinis recipiendam; eftetiam in eodem particularis potentia recipiendiformas elementorum; poteft enim tumin hominem conuerti, tum in elementa diffolui; at sulla ibidem eft potentia particularisadalias formas pofterioribus temporibus aduenturas; vt ad formam auri, vcl ad formam lapidis, licet fieri polfit, ve diffoluto femine in elementa, ex iis poftea gereretur lapis, vel autem ad illas igitur tantummodo formas materia habet potentiam particularé, quas ftatim poft illam, quam habct, recipere apta eft, hæ autem plures quidem effe poffunt, non funt tamen omnes, neque infinitx. Patet igitur potentias particuta. res, qux refpiciant infinitas formas, effe qui-

B dem infinitas, non tamen fimul omnes exiftere in eadem materia, vtin argumento fumebatui, fed vnam poft aliam aduenire, ficut etiam for$m \approx$ vna poft aliam de materia educuntur; funt, igitur eo modo infinitx potentix, quo etiam formæ funt infinita, nempenon actu, fed potethate, \& fucceffione, quod quidem non eft abfurdum; fic enim etiam contunum habetpoteftatem, vt in partes diuidatur fuccelitone infinitas; quam continu potentiam fi vnam efC fedicamus, quxrefpiciat infinitam diuifionem, ea refpondebit potentix vniuerfali prime materix tefpicienti indiftincte omnes formas, \&e infinitas per infinitam fucceffionem aduenturas, licet ipfa fit vna, illæ vero infinitæ.Sed Gan- obiectio danenfis videns hanc folutionen1, qux ex con- Gradafideratione potentix vniuerfalis fumi poterat, uenfis céeam nititurreprobare, \& inquit: fi vila nume- tra folsturos, ergo fi hæc ad acturin redigatur per vnius forma aduentum, neceffe eft vt fimul rediga. tur ad actum refpectu omnium formarum, \&e itanccelfe eft, vtadueniente vna forma; adueniant omues, \& infinitx eodem temporis momento. Hæc tamen argumentatio vanifima Solutio eit, quia nos neganius hoc abfurdum fequi, \& obiectroin hoc ipfe deceptus eft, quod. fuppofuit po-nis. tentiam materix penitus adimpleri per vnius forma receptionem, quod quidern de potentia vniuerfali falfum effe afferımus, ea E namque non vnam tantum formam refpicit, fed omnes, 1 deo vna recepta in materia, non adimpletur tota potentia, fed remanet refpiciens alias; fola autem potentia particularis adimpletur per vnius form $x$ aduentum, fed hxc illam vnam formam refpiciebat, non alias, ideo non eft neceffarium, finul cúm illa forma alias omnes formas aduenire: argumentum igitur Gandauenfis nih 1 roboris habet, \& folutio noitra prædicti dubii firmiffima, $F$ ac tutiffima eft: poteftautem quifque ea, quæ
hactenus diximus, bene confiderans, \& prædictis diftınctionibus vtens, alia, quoque, qux hac de re exiftunt, dubia facile foluere.

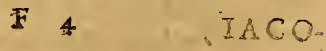




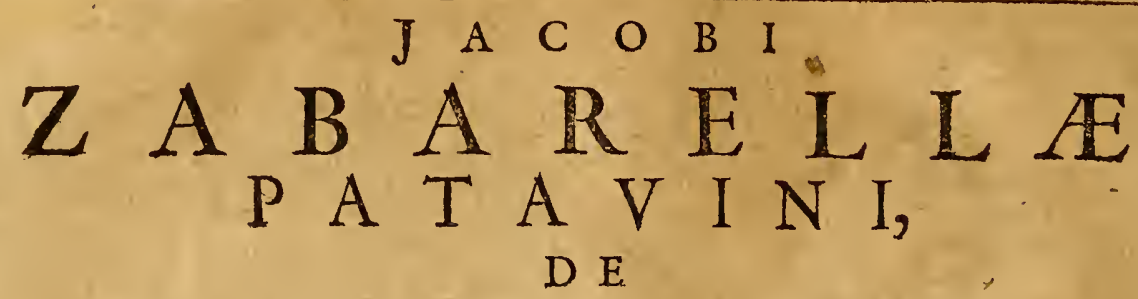

\section{$\begin{array}{lllllllllllllllll}P & R & I & M & A & R & E & R & V & M & M & A & T & E & R & I & A .\end{array}$ I I B E R S E C N D V S.}

\author{
Sententia Scoti de actu entitatiuo Ma- \\ teria, o eius argumenta. \\ Cap. I.
}

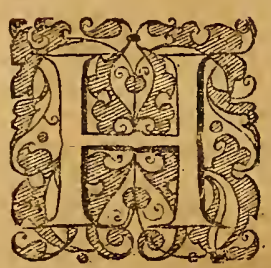

Actenus ea confiderauimus, qux prima rerum materiæ,vt ad alia relaı $x$ competere vidētur, fequitur vt illa tractemus, quæ ad primam elus notioné. $\mathrm{B}$ pertinent, atque illi fecundum fe fumptxattribui ab aliis folent, qux eo difficiliora funt, quo migis abfcondita, ac tenuis, atque exilis eft peimæmateriænatura; hincenim fit, vt longe facilius fit eam vtad alia relatam, quam vt ab. folute acceptam contemplari. Dioauten funt, qua cōfideranda proponūtur, \& de quibus magina effe folet inter Philofophos.difceptatio ; vnum, an prima matcria fecundū fuam naturam actum aliquem habeat, al terum vero, an fit per scotious - fe corpus. Actum in materia ponit Scotus libro nio. 2. Sententiarum, diftinet.12.quxft. I. \& 2. quem Duspoté vocat actum entitatiuun : \& huncdeclarans intice apud quit duas dari potentias, proinde \& duos a tus scetum. illisrefpondentes: vnam: vocat potentiam fubiectiuanı, qux tribuitur materix; hæc enim. potentiam habet, vt omnibus formis fubiiciatur, ideo huic potentiærefpödet åus formalis. qui eam adimplet: alteram potêtiam vocat obiectiuam, eaq; tribuitur non cau $x_{2}$ fed effectui; effectus enim quinoneft actu, effe tameri potert. dicitur effe in potentia obiectiua refpectu fuaxum caufrum, à quibus producipoteft, vt ante mund creationem dicimus mundum fuiffe in pozentia obiectiua opificis, à quo produci poterat, feci non in potentia fubiectiun, quia nulla pracrat materia, ex qua mundus, generatur, fed ex nihilo creatus eft: homo vero antequam generetur, dicitur effe in potentia tum obiectitua refpectu agent is, à quo produci poteft, $t u m$ fubiectiua refpectu materix, ex.qua poteft generaxi. Potentix huic obiectux refpondere inquit
A actum entitatiuū, quando enim res eft altu producta, \& iam habet efle actu extra fuas caufas, tunc dicimuseam habere actum, non quidem formalem, fed (vtipfe vocat) entitatıūu,talem igitur actü habuitprima materia quã primum à Deofuit producta, fine vilu ope formu, \& ita fecundum propriam natuian, \& fecuidum primam luam notıoné habet adtun entitatis proprium, \& abactu formali, quem poftea recipit, diftinctum. Haceft Scoti fententia, quam ipfe Primss. pluribus argumentis confirmale sititur, quorü argume - primum, quod ex his, qux modo diximus, col- tis Scot. ligitur, tale eft:id quod actu reperitur extra firas caufas, habens entitarem realcm diftnitam ab entitatibus omnium aliarum rerum ${ }_{2}$ eft ens actu, \& habet aftum entitatiuum: at materia eft huiufmodi, vt patet; ergo habet per fe actil entitatiuum. Secundo fic argrumentatur: fi mate- Secund. rian on habetactu entitatem realem diftinctam ab cntitate forma, compofitum non poteft dici compofitū, fed eft fimplex, quia non dicitur cōpofitum, nificonftet ex re \& re, \& vtraq̨; res fit actuin illa compofitione. Tertium fumit argu- Tertiun mentum ex modo loquendi; dicimus enim materiam effe actu princspium pes fe rerun naturalium, ef̂e actu materiam, efle a tu fubictam forma; eft ergo ensåtu; nam fi detur oppofitum, non erit actu principium, neq; a tu nate ria, neq; actu fub forma. Quarto, materia apud Arifotelem eft id, ex quo proxistente, \& inD exıftente res funt, ergo exiftente; atqui exıitentia dicitabum, ergo materia eit ens actu. Por- Quintž fumus. eriam fententiam Scoti confirmare ailthoritate Themiftii in digreffione pradicta, vbi inquit, materiam in piima fua notione effe aliquid, \& effe actu. Hocitademonitrato, infert secunda inde Scotus alteram hanc conclufionem: quum conclufat materia actū entitatis habeat, poteft etiam per Scorion feactu exiftere fine vlla forma, quod multisargumentis probat. Primo fic : pofitiuum abfolu- Pramum E. tum diftinetū ab alio abfoluto, \& natıra prius. illo, poteft abfq; repugnantia line illo exiftere: at materia eftens pofitium abfolutum diftinctum à forma \& prius omni forma tam acci- 
dentali, quan fubftantiali; ergo materia fine vlla forma exifterepoteft: maior propofitio clara eft ex difcrimine abfoluti \& refpcetiui ; relpeetjum enim vt fit, requirit fuum correlatium, abfolutum yeronórequntit aliquid alıd, quare fine alio cfie poteft; patet êt minor, quia materia eft ens pofitium, \& abfolutum, quum fit fubftantia, \& eft natura prior omniforma, nam inquit Arift.in parric. 52 . libri 1. Phyf. fubiektum pecundis eft natura prius predicato. Secundo, materia comparata cü fingula forma poteft exiftere fine illa; ergo etiam fine omnib. fimul fumptis, qua fi vnamrefpicit contingenter, omnes quoque rertium contingenter refpicit. Tertio, fi materia non poflet exifterefine forma, prafcriberet $\mathrm{fib}_{1}$ formam, ergo aliquam ftatutam formam; at hoc fal fum eit, quoniam materia nullam fibi certam formam prafcribit : confequêtiam probat, quia id, quod libi præfribit genus, certam quoque aliquam fpeciem illius generis neceffarıo fibi præicribit; fi quid cnim effentialiter eft animal, eit neceffario aliqua certa fpecies animalis. Quarto, ad huius fententix confimationem adducere pofiumus Simplicii \& $A$ ucroois teftimonium : nam Simplicus in cōtexı $5 z$. libriprimi Phy'icorūinquir, materiam efle porreperfeipfam, formam vero nö polfe. Auerroes autem in primo capite libride Subftantia orbis dicit, materiam éfe actu vnum ex entibus per fe exilten ibus. Qurre confiteri manifefte videntur Simplicius \& Auerroes, primam materiam olfe per fe actu exifterefine vlla forma.

\section{Confutatio opinionis Scoti. Cap. II.}

$\mathrm{H}$ Æc Scoti fententia prumo quidem afpecu fpeciem quandam veritatis habet, at $f i$ bene confideretur, falfa eft, tum fecundumAriftotelicam, tum fecūdum veram philofophiam; Ton da vanū enim eft, alium atum ponere præter forsr alsus malem, quodoftendo tum exactus, tum ex pocraspre tentia confideratione, vade etiam Scotus ad or for- probandum actum entitatuura argumentum. ialem. fumebatiante omnia dicere debet Scotus, an atctus en Cus entitatiuus fit aliquid, an nihil; nam fi nitatist hil eft, ergonondatur; fi vero aliquid, videnciü. aproba- eft quidnam fit: igitur ne ipfum cum actu for.o. mali confundamus, confideremus illum, qui attribuitur prim $x$ materix, quize fecundun $\mathrm{fe}$ nullum habet actum formalem; actus igitur, quem in prima materia Scutus ponit, fi eit aliquid, vel eft fubftantia, vel accidens; accidens quiden effe non poreft, quia fecundum Scotum nol aliud eft actus entitatiuns, quam entitas talis, entitas autem matcrix nil aliud eft, nifi materia ipfa; non poteft ergo actus enti tatiwus materiæeffe accidens, nifi materia fit accidens, quod quidem Scotus nun diceret; eft ergo fubftantia: atqui fubltantia fecundum Ari-
A ftotelem diuiditur in materiam, \& formam, \& compofitum; forma quidem efie non poreft, quum Scotus : diftinguat maxime actum hunc entitatiuum ab actu formali, multo minus eft aliquod compofitum, quia fequeretur in entitate materix efle compofitionem materix cum forma, \& a fum hunc non efe nififormalem, quorum neutrum concederet Scotus: fi vero eft materia, vel eft materia natcrix; \& ita materia conftaret ex alia materia; vel eft ipfamet mate-

$B$ ria, quod omnino confitendum eft; quemadmodum enim ens homo, feu entitas hominis. nilaliud eft, quam homo, ita nil aliud eft entitas materiż, quam ipfamet materia; hanc igitur cntitatenı actum appellare, ita vanum eft, vtne mente quidem concipipoffit, quum potius naturæ materix contrarium nomen omnes lhilofophiattribuerunt; nempe nomen potentix, \& dixcrint elus naturam in hoc effe conftitutam, vr fit ens poteftate, poteftas autem opponitur actui, quare quam materia fit fimplex, fieius natura caeit, vt fit potentia, eadenı not poteft efle actus; quam in fententia Scoti a burditatem opime notauit loannes Bacconius in difrin i. 12. I1b. 2.Sententiarum. Vel enim potentialitas materix eft actualitas, vel fi re diftinguunt ur, natura materix nō eft fimplex, quum pervtram que materix natura denotetur. Illud quoq; apud Ariftotelem aperte legimus in contextu 2. libii.z. de Animz, vbi matcriam dicit effe potentian; \& in contextu 8. libri 7. Metaphye ficorum, negat de materia omnem determinationem entitatis: : illud igitur quod non eft aliquod ens.determinatum, quomodo poteft vocari ens actu? clara eft etiam fententia Arifotelis, quod ens diuidaturper potentiam \& aAum, \& in omni categoria lit potentia \& actus, vt. videre eft in libro tertio Phy fi corum: part. 3 . \& 6. \& in 1ade Anima, partic. 6. igitur fi datur E ens poteftate, quomodo-omne ens debet actum denorare? eft igitur hic altus commentum Scoti; quod enim materiam appel. Tet ens, concedimus, fed non ob id eft dicenda cris actu, quum fecundum fe non fit ens, mifi potefta: te, imo neque proprie dicatur ens, vt antea oftendimus, \& vt Ariftoteles dixit, red principium \& materia entıum, fiquidem non eft in rerum natura tamquam fpecies aliqua entis, neque habetcertam vllam naturam fpecialem, fed F: folum eft quoddam inchoamentum fpecierum. entis - quum igitur materia talis fit; eam appellare actum, quatenus eft ens, \& fingere hunc effe diuerfum ab actu formali, arbitiaria eft appellatio, qux omni ratione caret, poffemufq; eadem ratione materiam appellare afinum, ac dicere nos afinū fumere infignificatione diuerfa ab illo afino; qui eft fpeciesanimalıs: quin potius rationi confon $\bar{u}$, ac neceffarium elt, dari in

$$
\text { F s: rebus, }
$$


rebus aliquid, quod fit pura poteftas, nihilque $A$ in fe habeat actus, vt lit idoneum rerum omnium inchoamentum, ficuti refte confiderat Ioannes Bacconius in loco pradicto. Sed porentic actus hic efficacitcr etian reprobatur per reobiectiws probationem potentix obiectiux, quam Scoreproba- tus excogitauit: nos enim apud Ariftotelem ise. duas tantum potentias inueniemus, actiuam \& paffiuam, vt patet in nono Metaphyficorum, \& duostantum, primum \& fecundum, quos ponit in initio fecundi libri de Anima, quos ad duas illas potentias optime refert Thomas in quxftione prima difputata, dicens, potentiam paffiuam referri ad actum primum, quia materia eft receptiua form $x$; actiuam autem referri ad operationem, quæe eft actus fecundus : \& ficuti primo dictus eft actus de opcratione, poftea vero traductum eft nomen etiam ad formam; ita primo dici nomen potentix de actiua, deinde attributum effe etiam paffiux: \& ficuti nihil paritur; nifiratione potentix paffux, ita nihil agepenifi rationeactus primi ; nam pati eit materix, agere autem formx, foli namque form potenria actına attribuitur. Potentia igitur objectiua nihil effe poteft $a b$ his duabus diftinetum, idque facile oftenditur : nam fi dicamus hominen, qui nondum eft genitus, effe in potentra obiectiua, quxrendum erit, in quonam ea potentia adhæreat, quum adhuc homo non fir; certe nilaliufiref́pon deri potet, nifi eam effe in prima materas hominis enirn generandi nihil tunc exiftit, nifi materia, qux ip fius pars futura eft; atquj potentia in materia non alia ineft, quam fubiectiua; quare potentiailla obiectiua, quahomo poteltate effe dicirur, nilaliud eft, quam poientıa fubic ctiua; nam dicere hominem elle in potentia obiectiua, eft dicere materiam habere potentiam recipiendiformá hommis, imonilaliud eft poteftate homo, nifi ipfamet materia. Idem etiam de potentia actiua confiderare poffunus: quando enim dicitur, mundum, antequam crearetur, fuiffe in potentia obiectiua refpectu agentiś; tunc non fignificamus potentiam aliquam exiftentem; quim enim tunc mundus nibil fit, nihil etiam eft ifta potentia, prout mundoattribuitur, quia nihil exiftit in quo recipiatur;ideo fi bene illa potentia confideretur, nil fignificat lecundum fe, nifi non rcpugnantiam termınorum, hoc eft, negationem impoffibilitatis, \& veritatem huius propofitionis: poffibilc eft mundum creari; talem autem potentiam non effe aliquid reale docet Ariftoteles in contextu decimo feptimo libri quinti Metaphyficorum; vanum igirur eft, hanc potentiam, quæ nuhil eft, nifi ens rationis; t tatuere vt te diftinctam ab illis potentiis, quæapud Ariftotelem fintentia realia: eft tamen hæcpotentia obicctiua aliquid real e; dum fumitur vtidem, quod potentia actiua; quandoenim dicinus mundum effe in potentia obiectiua, fi quid reale fignificamus, id non eft nifi ipra potentia actiua Dei, ita ve dicere mundum fuifre tunc in potentia obiectiua, nihil aliud fignificet, quam Deum habuiffe tunc potentiam actiuam creandi mundum, potentia autem Dei Deus ipfe eft; igitur nihil reale refpondet illi potentix, nifi Deus ipfe, cuius eft potentiz creatiua; nihil ergo eft illa potentia B obiectiua re diftinctum à potentia actiua. Hinc colligimus, conuenientius dici, effectum, quando nondum eft, effe tamen poteft, effe in potentsa paffiua materix, quam in potentia actiua agentis; quo fit, vt etiam conuenientius diceretur in poentia obiectua refpectu materix, quam refpectu agentis; quum enim vtroque modo aliquid $\mathrm{p}$ fi effectui attribuamus, inaniter id attribuimus, quatenus ille effectus nihil eft: vanum ergo eft atribuere mundo potentiam obięiuam refpectu opificis, dum ipfe mundus nil penitus eft, quum nulla prorfus mundi parspraexiftat: at fi diceremus hominem generandum prexiffere in potentia obiectiua, id eft, fubiectiua materix, rectius loquelemur; matetia enim preenifit, quafutura eft parsfubitantix hommis generandi, pro. inde poteftate homo iure appellatu; aligno igitur modo tunc bomo exifit, cui attribuamus ve fit in potentia obiectina, fed quia homo ille non eft nifi matera ipla, nil aliud eft potentia obiketiua, qua tribuitur homini quan ipła potentrafubiefiua nareriz, wt antedictuin eft, Ex his'ig't1r paict, petentiam obicet uam nibileffe dittinctumab yctiua, \& a pafiua, \& omnia a!gunenta, que a fectarcribus Scoti pro fux opinonis defentione adducuntut, vana \& fophifica funt: ea quidem multa funt, fed in prefentia fatis fit duo in medium afferre. E Vnum eft,potentia fubicctiua materix vna eft: potentix vero obiektiux, qux effectibus at- Scotiffas. tributuntur, funt plurimx; nam dicimus ho- rem. minem effe in poten tia obiectiua, refpectu ma- Primum terix, ficafinum, ficlapidem, \& alias res; plu- argumerimx igitur fint potentix obiectiux effecti- trm. bus attributx, vn:3 autem cit potentia fubiectiua materix, ergo re diftingtuntur: fic potentia actiua vo in agente eft, obicktiux autenl plures, quia plures effectus ab codem a$F^{-}$gente produci poffunt. Alterum argumentum eft: fubiectum generationis eft re diftinctum $a b$ vtroque termino, ideo fi generetur aer, terminus à quo mutationis illius eft aer poteftate, terminus auten ad quem, eftaer actu, igi, tur nareria diffinguirur à termino à quo, ergo \& potentia fubiectiua $2 b$ obrectiua, nam lubiediua attribuitur materix; obiçtiua autem termino à quo. Sed v.trumg; argumentum 
Solutio primi.

solistio fecouds.

Soless aizus formalis reCondet Gtrique borentic Cecundin Ariftor. leuifimumeit. Ad primum cnim dicimus;nil A aliud per lludoftendi, nili poicutian actuan candem, quxrefpeou ipfus agentis via eft, fieri multiplicem, yt relatam ad plures effictus, quos producere poteft; fic potentiam partiuam, qux relpetu materix vis eft, reciphendiomacs formas, fieri multiplicem vtrelatam advarias formas, quas refpicit; cft igitur eadem potentia re, qux fit plures fecundum rationen. Adfecundum dico, terminum à quo gonerationis formaliternon effe dërem poreftate, fed potius non aerem, id eft, pruationem, \& non effe tp fius acris : \&: quamuis priuatio connotet poteltatem ad aeren, illa tamen poteftas eft conditio materix fuscetr, vt antea denonftraumus, non terminus à quo generationis, qui, eft tertium principium à fubrecto diftinctum: igitur potentia aer eit potius ipfa materia, quam priuatio, \& resita manifefta elt vt mirum fit, quod illi fint aufi his cauillis tenebras offundere veritati; quum enim Ariftoteles trum principiorum neceffitatem collegerstex necelliria difturctione duorum contranorum tcrminorum: à quo, \& ad quem, \& fibiecti tertii, quod vtrifque fub fternitur, ifti terminum à q̨uo, cum fubiecto confuderunt, dum potentiam attribuere termino à quo, quum potius fubicto., vt cius neceflaria conditio, attribuenda fit. Quoniam igitur manifeftums eft, non dari potentram obiectiuam diftinctam re ipra ab actiua, \& à paín ua, fequitur vanum effe etiam actum entitatiuum ve diftinctum à formali:quum enim ex potentia illa obiectiua induxerit Scotus huius actus neceffitatem, ea fublata hunc quoq; actum corruere, vel ab actu formali non diftingu neceffe eff; rettera enim non datur aîus actus, quam formalis; \& hic vnus refpondet omnipotentix, tamactiux, quam paffiux: de paffiua quidem concedit Scotus, ega vera de actina queque oftendo, tum iuxta Ariftotelis fententiam tum fecundum veram philofophiam;apud Aritotelem clarum eft, materiam effe aternam, \&nullum effeagens, à quo fit vnquam creata, vel creari poffit; nunquam igitur materia fuit in potentia obiectiua fecundum Ariftotelis opinionem, qui putauit nullum dariagens tantæ potentix, vi poffit totam rem producere abfque vila mat eria prafuppofita, fed folum ex praexiftente materia : quamobrem nil remanet, quod $\mathrm{ab}$ aliquo agenté produci poffit, nifi fola forma; hanc enim educens de potentia materix præexiftentis, lic rem producere dicitur: quemadmodum igitur potentix palfinx, ita etiam actiux.nullus refpondet alıus actus, nifi formax lis, neque aliud eft obiectum vtriufque potent1x, nili actus to tmalis : nam quælibet res actu exiften', exiftirper formam; hanc igitur producens agens dicitur rem ipram producere; for- mam enimequi, velafini de potentia materix educere, eft equum vel if finum produccre, \& è conuerfo equum producere, eft formam equi de matcria educere; hoc fignificauit Aucroes libro octauo Meraphyfic. comment. 15. dicens, agess nonlargitur multirudinem, fed perfectioucm, \& hibro vindecimo Meraphyfic. comment. 18. agens reuera non congregat duo inter. fe, forman, \& materiam, fed ex materia praB educit; qua verba perperam interpretatur Scotus in predicta diftinctione 12 . libr.1. Sententiarum, quxeftione 1. cötrarium enim habenus fen. fum illi, quem eis ipfeattribuit : nam agens largirctur multitudinem, fitotam rem produceret: cuius nulla pars prius exfritiffet; fic enim augeret rerum numerum, quia producerat rem illam, qua prius non erat; nec video, quomodo hoc negare poffit Scotus, \& afferere id non efle multiudinem largiri; fed materia iam exiC ftenti á aliqguam formam amittendi, aliam formam tribuere non eft numerum rerum augere, fed perfectionem mutare, \& materix tribuere nouam perfectionem loco alterius amiffa perfectionis: congregare autem diceretur, fi materi.m \& formam feparatim prius exiftentes cōiungeret, fic enim nihil produceret;folam igitur formain producit, qux eft perfectio, \& 2Eus vtrique fimul potentix refpondens. De ipfius ergo Ariftotelis fententia nullum effe duD biumpoteft. Maiorem veritatis fpeciem habet opinio Scoti fecundum Chriftianam Theologiam, quxdocer, prmam materiam vna cumaliis rebus à Deo futfe creatan ; quoniam enim, antequam crearetur, erat folum poteftate, neccffarium videtur, vt itatim creata extiteritactu, tanquam ensaliquod ante reecprionem formx, \& ita habueritex feactum entitatis, fed non actum formalem. Attamen fic quoque, fi res bene intelligtur, opinio E Scotifalia eft: nam proprie loquendo, materia non fuit a Deocreata vres quiadam fedpo- confur ranon fuit a Deo creata veres quædam, led po- creats, tius rebus concreata, quia non eft aliquid per fed côcre* fe determinatum in lpecie, fed eft inchoa- ats. mentum omnium fpecierum corporalium; non fuit igitur ita creata, vt nuda, \& abfque vlla forma per aliquod tempus extiterit, fed folum fub forma, vt optime Thomasfenfit; nifus præcipue arguniento, quo Auerroes ytitur in commentario duodecimo libri fecundi phyficorum, fi materia prima exifteret fine forma, fequeretur, id quod non eftactu, effeactu; qux efticontradictıo; quoniam igitur fecundum Theologos, Deus facere non poreft, vt duo contradictoria fint fimul vera, hinc Tho mas colligit, Deum non potuiffe creare materiam primam exiftentem fine forma, quia ti exifterct, iam haberet determinatam naturä, pro-
Agexsio largitur moltitu$\operatorname{dine}$, fed perfectio nern.

Prasia in corpresatio scots. Idem of:é ditur fe. cundum Theologe cm Chris: ficnana. Materias
monfuit
creats,
fed côcrs.
ats.. - 
in de \& actum formalem, quum tamen fuapte $A$ natura nullum habeat actum formalem nullamque naturam determinatam. Alio quoque argumento idem confirmari poteft : agens enim potens totum aliquen effelum producere, nifi impediatur, producit perfectifimum, quantum producere poteft, hanc maiorem propofitionem negare Scotiss non poteft, quum frepe ea vtatur: at Deus à nullo poteft impediri, ne quamlibet rem perfectifimam in genese fuo producat; quamlibet igitur perfectam produxit; ergo non materiam nudam, quia materia eft imperfecte res omnes: quare materinm frimo nudam creare, \& illi pottea formam inponere, repugnat perfectioni diuinæ, qux imminueretur, hi Deus prius imperfecte res crear. $f(t$, poftea vero formas imponendo perfectionem indidiffet: res igitur primum abfolutifimas, ac perfectifimas produxit, proinde nateriam non informem, fed fub formis. Ex his igitur patet, obięum potentiæ creatiuæ Dei nunquam fuife materiam, fed formam, id eft, , res ip fas vt formatas; hac enim idem funt apud eos,

Idea prima mate ris.

Contra

fecund:

conclisero

rem Sco-

tr.

\section{Wulla}

forma

fererica

generica lem,crgo mulu munus Iolamatcrizeltapta per

potect. feexifere:confequentia cttatis manifefto, quia

dare exi- fi aliqua dereminata nururx accedcntes if $f$

fotram. materix adhuc non pollunt rem actu exilten-
A tem conftituere, multo minus id præftare fine illis nuda materia poteft ; clarum etiam antecedens, nam anima nutritiua, \& anima fenfibilis funt form fubfantiales, qux fecundum Ariftotelem in fecundolibro de A nima, funt actus primi corporis naturalis, \& conftituunt hocaliquid, nec tamen poffunt tribuere exiftentiam, quemadmodum nulla alia forma generalis fine forma fpeciali, quia non datur viuens, quod non fit alıqua ftatuta fpeciesanimalis, velltirB pis, nec daturanimal, quod non fit aliqua certa - fpecies animalis. Videtur etiam hocaflerere Atiftoteles in 2. contextu 2. libr. de Anima, dum inquit, materiam fecundum fe non effe hoc aliquid, nam fi perfe exifteret, vt Scotus putat, effet fubstantia indiuidia demontrabilis digito; igitur max me effer hocaliquid, quod Ariftoteles negat. Quod fi afferat Scotus, feidnon dicere iuxta Ariftotelis fententiam, fed folum fecundum veram philofophiam, confiderata omnipotentia Dei,fic quoq; falfum dicit:fi quicé à Den nil effici poteft, quod implicet contradiEtionem; implicatautem hoc, quia fi materia exifteret aEcu fine vlla forma, iam neceflario haberct determina am \& actualcm naturam; hocautem repugna! narur $x$ nater $x$; hxcenim à Deo eft creata talis naturx, vt muliam habeat in entibus determinatam naturam, fed recipere poffit omnes rerum naturas; irag̨uefi Deus id taceret, faceret id effe actu, quoinon eft actu, quod Anerross argumentun tuit \& Thom $x$ in r. part. Summa, quæit. 66.ait.1.

\section{Declaratio quarundam diftinctionum ad omues joluendas difjicultates. Cap. I I 1 .}

D planam veritatis intelligentiam, omniA unsque dubsorum folutsonem, quadam funt notandx diftinationes. Primum quidem ratio erroris Scoti, ac rotius hac in re veritatis, E ex hac diftunctione fumi videtur: ens feu entitas fumi poteft duobus modis, nam \& effentiam, \& exilietiam ignificare poteft; dum enim ens pro genere rerun omnium fumitur, effentiă fignificat, nam animal quoque fignificat effontiam hominis, \& aliarun fpecierum fuarum; dim autem fumitur pro exiftentia, nonfignificat genus, fed accidens quoddam intentionale, vtalias dixmus in initio 2. Pofter. exiftentia enim eft quoddamadditum ellentix: quo fit, vt plura requirantur ad exiftentiam tribuendam, quam adellentiam reiconftucudam;effentiam enim propriam quilibet res habet per fe iplam, at non qualiberes afta eftperfí sp fancexiftere, fed multa funt, quxalio egent, perquod exifint: momen ergo entitatis ambigum eft, \& icum proefientiąiumi poreft, tum pro exiftentia
Entitas

Sismitur Eqproen ifientia Eproes rentik. (n) 
quodacceptionum difcrimen manıfeftum eft in A cadem propolitione, qux eodem temporevera eft vno modo, \& altero falfa: vt hrec propofitio; cometa eft ens, nunc dum nullum exiftit comera, falla eft, fumendo ens proexiftent:a; vera tanen eft, fumendo ens prn genere: ficut hac quoque vera eft; come ta ef halitus ficcus in fublini accenfus, etiam nullo exiftcnte comcta; hac enim folam comet $x$ effentiam exprimimus, nihil dicimus de exiftentia. Nomen quoque actus multifariam fumifolet, frimitu enim \& proforma, \& pro effectu formx: islifor proforma quidern fumi manifeftum tif, quum isurs. formadicatur actus, vt videre eft in initio fecundi libri de Anirna; quando autem formam vocamus âtum, nihilaliud fignificam us, quam perfictione propriam, qua aliquid in fpecie feu fibalter1a, leu infima conftituitur; hoc auten non fit finereftrictione, ac determinatione, necefie cnimelt omnem form.nn, fiuegeneralem, fue fpeciulem sötraheremateriantad alıquam cercun naturam, ix efle rei peifcetionem, \& actum. S:mi:urauiem pro effictúlorma, quando lumitur pro siftentia, properea quod actus exiftendi non eft forma, fed effectus forma, gulm forma proprinm munus nt, rem exiftentem conftituer, non quidern onsus forma, fed folum form vitima, จุu ad nullama: liam forman dirigicur; calis enim forma iuncta. reaii materix, conltituitrem fingul areso per fe. exifientem: vtramqueacceptionem funnl com-

$x$ ali. id disco rijt$t$ plexus eft Aritateles in z: contextu 2. libri de. Anıma, dicens, hocaliquid; nam hos aliquid. non folum fignificar fingulare exstens, ac demonftabile, fed euam determinatam naturam; quia forma vtroq: modo facir hocaliquid; tum enim materiam contrahitad ceram quandam fpeciem entus, tum etiarn conftituit fingulare exiftens, cim hoc tamen difcrimine, quodillud omnis forma preftat, hoc vero fola forma vltimafpeciei; propriam enimnaturam omnis forIna conftitui, t tam generalis, quam fpecialis; exiftentiam autem actu non onnis forma præ.

- bet, fed fola vltima, quia hac non eget alia for s ma. Sumiturautem nomen actus non modoad. denotandã exiftentiam rei fimpliciter acceptæ, vt quum dicimus, equum aqu effe, fed etiam ad fignificandam exiftentiam rei complerx, id eft, $d$ veritatem propofitionis: dicimus enim, chima. ra eft actu non ens, qua eft vera enunciatio, nec alius eft eius fenfus, nifi quodvera est hæc pro. pofitio, chimara eft non ens, ob id ex ea non licet inferre, ergo chimrra eft actu, neque enim chimera eft; ficut. Ariftoteles docet in libro de Interpretatione; quum enim de non ente porfit aliquid vere enunciari, non licet ex veritate enunciationis inferre eius fubicctum. effe ens quia poteft efre non ens.

\section{Collectio totius veritatis quinque affer-} tionious. Cap. IV.

$\mathrm{F}^{\mathrm{X}}$ his aliqux afertiones, feu conclufiones Ededicuntur, per q̧uas tota rei veritas de. clarsta, \& contraria argumenta foluuntur, funique omnes vel per fe manifefta, velfatis demonftratx per ea, quz hactenus dicta funt. Prima eft: fi entitas fumatur pro effentia, ma- prema teria habet propriam entitatem diftinctam $a b^{\circ}$ conclufso $B$ entilate formx: nemo enimeft, qui ignoret aliam effe materixeffentiam, alia in form $x$; quá enim fit fubftantia, propriam effentiam habeat neceffe eft. Secunda affertio eft: fi entitas pro exiftentia fumatur, materia non habet entitatem propriam, fed folius compufiti proprium eft exiftere; materia vero, \& forma coexiftere potius compofito, quam exiftere dicurtur ; materia quidem, vt quæ exiftentiam recipit, forma verovt qux dat: haciam 'isit antea demontrata: nam finon omnis forma exifentiam habet per fe; non enim forma generis, fed fola forma vlima fpeciei, quatenus confituit rem exiften$t \in m$, exiffere per fe dicitur, multo minus materia apta per fe cftexiftere, fed eget forma, qua illi exiftentiam largiatur. Tertia conclufio eft: primamateria fecundum fe non habet actù pri- cöclufio. mo modo fumprum : ratio huius clara eft, qroniam ita habere actum eft habere determinationem, \& contractionem ad certam naturam, D hac autem non fit nifi à forma: fola igitur forma eft actus, quare fi materia fecundum fe nullam habet formam, manifeftum eft, eam fecundumfeactum ita acceptum non habere. Quarta.conclufio eft: fi fumaturactus fecundo modo pro eo, quod eft actu exiftere, que forma effectum effe diximus, materia prima non perfe eft actu, fed performam, qua ipfam perficit, \& conftituit hocaliquid; hre facile probatur,nam exiftentia infequitur formam, eampue non omnem, fedpriftantem, \& perfectam, quare necefario prafupponit atum primo modo acceprum: idque cuilibet confideranti manifeftum eft; nihil enim poteft exiftere, cuius non fit determinata natura, fecus enim ne mente quidem concipi, aut fingi alicuius rei exiftentia poteft; quoniam igitur materia fecundum fe non eft aliqua determinata natura, multo. minus exiftit acu fecundum fe, fiquidem plura ad exiftentiam requiruntur, quam ad de.. F: terminationem certa natura; hanc enim omnis forma præbet; illam vero fola forma vltimæ fpeciei. Quinta demum conclufioex his omnibus deducitur talis: materia prima in fua effentia nullum continet actunz; fed folam potentiam, itatamen, vt nomine potentix non qualitatem fignificemus, fed fubftantiam quandam, qua eft fons, fe radix huius quali- secunia cóclutio.
Quarta
coclufoo.

Qusnta cocinfio. (1)

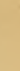


tatis, nempe fubftantiam quandam imperfe- A etifimam, incompletam fecundum fpeciem, \& inchoamentum omnium fpecierum, nam huiulmodinatura latis congrue videtur potentix nomine fignificare: hac clare oftenditur Ariftotel is teftimonio in multis locis;nam in fecüdolibro de Anima, contextu fecundo inquit, materiam fecundum fe non effe hoc aliquid, quodfignificat eam non habere vllam certam saturam, nec vllam determinationem in fpecie, \& addit ipfam efle potentiam. Sic feptimo Metaphyficorum contextu octauo inquit, materiam non effe vllum ex entibus determinatx natura, fed fubieftum omnium, quare fententia Ariftotelis eft, materiam non effe modo vllo ens actu, nomen enim actus notat determinationem, qux aliena eft à natura materix: guare vanum eft $S$ coti inuentum, quod omne ens, quatenus eft ens, fit actu, quandoquidem fecundum Ariftotelem non omne ens eft astu ens, fed datur etiam ens poteftate, cuiufmodi maxime eft prima materia, cui fecundum propriam naturam nulla conuenit a ppellatio actus; Forinus quod etiam Plotinus optime demonftrat in s. libro 3. Enneadis, cap, 4. \& 5 .

\section{Solutioargumentorum Scoti. Cap. $V$.}

DEr hecfacile eft foluere argumenta Scoti. Ad pri. Ad primum enim dicimus, fi encitatem pro mesin. eifentia fumar, negandam effe maiorem; non enim quicquid habet realem entitatem, id eft, effentiam, id habetactum entis, fedaliquid eft, cuius effentia fit pura poteftas, qualem materia naturam effe iam diximus: fi vero entitatem pro exiftentia fumat, negamus minorem; fic enim $A \dot{a} f \bar{c}$ - materia propriam entitatem non habet. Ad fedam. cunducicimus, fi entitas pro eflentra fumatur, totum effe concedendum; nom fi materia effentiam propriam ab effentia form diftinEtam non haberet, vtique id, quod materia \& forma conftat, non effet compofitum, fed fim plex, quia non conftaret ex re \& re: fivero entitas pro exiftentia fumatur, neganda eft confequentia, quia nec forma, nec materia exiftentiam propriam habet extra compofitum, fed $v$ naeft cópofiti exiftentia, qua å materia \& forma exiftant, nec ob id to tü dicitur fimplex, fed conftat exre\& re. Dico præterea tantū abeffe. vt hoc argumento oftendatur, materiam habere actumaliquem, vt potius demonftretur,nullum habere actü, qnandoquidem ex duobus actibus non fit vnum, fed ex poteftate, \& a $\& u$, vt ait $\mathbf{A}$ riftoteles in contex. 7 lib.2. de Anima, \& fufius in $7 . \& \$$. lib. Netaphyf.igitur fo compolitü tanquam vnum ex materia \& forma conftat, \& forma eft aftus, neceife eft materiam non effe aadter. trswor. atum, fed potcfatem. Ad tertium negare por- fumns confequentiam : quando enim dicitur, materia eft actu principium, nil aliud denotatur, quam veritas huius propofitionis; materia eft principium, vinde nonlicet inferre, ergo materia eft aetu per feipfam: poffumus etiam omnia concedere; nam materia eft actu principium, \& eft 2 ctu fubiecta form $x$, \& eft actu ens; non tamen ex fe, fed per formam; dicere enim materiam effe actu principium, \& dicere effe principium actu exiftens, idque vere di-

$B$ citur, aetu nam que exiftit, at non per fe, fed per formam; nullus enim actus competit materix fecundum fuam naturam; in omnibus autern qux competunt materix fecundum propriam naturam, fi dicuntur illi inefle actu, actus ille non eft fecundum naturam materiz, fed merito form $x$. sicetiam ad quartum omnia concedimus : non poffet enim materia exiftere, vel praexiftere, nifi exifteret, \& nifi effet actu ens; eft autem actu ens per formam, nunc quidem C per formam huius compoliti, prius vero per formam alterius. quod interiit. Sic etiam di. cendum eft ad Themiftium in digreffione dicentern, materiam in fua prima notione effe aliquid, \& efle aqu, quod etiam apud Simplicium legimus in contex. 58 . lib. 1. Phyficorum; nil enim aliud fignificare voluerunt; nifi materiam habere proprā effentiam diftinctam ab effentia form $x$, \& eam actu exiftere diftinctam ab effentia form $x$, ita tamen vt exiftere ilD licompetatperformam; non enim fumunt ita materiam in prima notione, vt ftatuant eam fine forma exiftentem, fed materix fub forma exiftentis effentiam confiderant, \& dicunt effe propriam quandam materix effentiam exiftentem fub forma; exiftere namque materiam, \& ipfam materize effentiam; qualıcunque ea fit, aहu exifterenemo negat, dicimus tamen eam non per fe, fed per formam exiftere. Alia quoque Scoti argumenta facile foluuntur, quibus E oftenderenititur, poile nateriam abfque repugnantia exiftere perfe, fine vlla forma. Ad primum neganda eft propolitio maior; ea namque fome $\mathrm{Sa}$ vera eft folum de efientia rei, acdemental $\mathrm{ab}$ - ti. fractione, at non de exiftentia actu, ac de feparatione reali: fi quid enim eft abfolutum prius natura altero abloluto, id ab illo non pendet fecundum effentiam; idro niente concipi, \& abftrahi ab illo poteft, ideft, definiri \& confiderariabfque illius conlideratione; non eft tamen neceffarium, vt ctiam exiltere actu line 11 lo porfit; aninal enim eft abfolutum, \& natura prius omnibus fpeciebus fuis, ncc ab id aptum eft fine illis ommbus exiltere actu fed roium poteft den̂nuri, \& confiderariablqque lla allarum confideratine: fic e:iam fubicenm eft naturapius accidence proprio, vt homo rilibihate, \& eft ens abfolutum, quo hit, vt poifit méte ab ftrahi à rifibi.

\section{Ad qua trm. \\ Ad gess Exm.}


rifibilitate, \& definiri fine illa, non tamen line $A$ illa exiftere poteft. Sic igitur materia, quun fit fubftintia, eft quiddam abfolutum, prout abfolutunr diftinguitur à relatiuo, \& eft natura prior onnibus form is, quocirca effentiamaterix à forma non pendet, \& mente abftrahi poteft abomni forma, non tamen re ipfa exiftere actu fine forma, multa enim requiruntur ad exiftentiam rel, qua non requirunturad effentiam conftituendan. Pacet itaquefalfam effe masorem Scoti. Ad probationem auteng, quain fumit à difcrimincabfoluti, \& refpectiui, dıcimus hoc difcrimen in eorum effentia effe conftitutum, quemadmodum ab A riftotele declaratur in libr. Categoriarum : nam relatiui tota effentia confiftit in relarione ad aliud, quo fit vt relatiuum nequeat definiri, aut confiderari, aut cognofi fine fuo correlatiuo; abfoluti autem effentia nullum habet refpectum ad aliud; hoc corum difcrimeneft, in alis non necelfe eft vt differant: nam fi exiftentiam fpectemus (de hac $C$ enim nunc fermoeft) relatiuum non poteft exiftere, nifi etiam fuum correlatiuun exiftat ; hoc enim in relatiuis efr neceffarium; at non ob id fit, vt contraria effe debeat omnium abfolutorum conditio, quia non in hoc eft pofitum eorum difcrimen, fed daturabfolutum, quod fine alio abfoluto exiftere poteft, vt homo fine equo; datur etiam abfolutum, quod fine alio abfoluto non poteft exiftere, etiamfi eo fit prius fecundum naturam, vt animal fine fpeciebus $D$ fnis omnibus : fic igitur materianon poteft exiftere fine omni forma, non eft tamen relatiuum, fed abfolutum, \& omniforma prius fedfecass cundum naturam. Ad fecundum neganda eft confequentia; quia enim fi materia exiftere poteft fine qualibet forma feorfum, poteft etiam exiftere fine omnibus coniunetim acceptis. Ad probationem aurem dicimus, materiani fecundum fuam effentiam refpicere contingenter tum fingulam formam, tum omnes fimul fum. $E$ ptas; non fic tamen fecundum exiftentiam; vt enim exiftat, refpicit quidem contingenter fin. gulam formam, at formam abfolute fumptam non refpicit contingenter, fed necelfario; quia neceffaria eft illi forma ad exiftendum, non quidem hac, veliila, fed forma indiftincte. Argumentum itaque Scori, fi quid habet robo. ris, habet folum de effentia materix, quia fi: nulla forma feorfum accepta de effentia matefix eft, vtique nes cmnes limulfumpta: fic etiam fi non eft de effentia oculi color aliquis feorfum acceptus, patet neque omnes fimul fumptos de effentia oculi efle; tamenfecus effde actuali vifione; oculus enim vt videat, refertur contingenter ad fingulum colorem, quia poteft videre fine fingulo, fed non contingenter refersur ad vniuerfum genus colorum, hoc enim ef: eius obiectum adrequatum, nec poteft oculiss videre, ni colorem aliquem: fimiliter obieEtum adxyudium, ad quod recipiendum direEta eif prisna materia à natura, vi eviliac, eft totumgenus forrwarum, non forma hac, aut illa,ideo line fingula exiftere poteft; at non fine forma abfolute: ficetiam dicimus, animal genus refpictre contingenter fecundum fuam effentian, "\& fingulan fpeciem, \& omnes fimul, quia f snt omnes extraeffentiam animalis; attaB men ratione fux exilłentix refpicit quidem contingenter firgulam, omnes autem necelfario, quianon poteft exiftere fine omnibus. E2dem refponfione tertium quoque argumentum folutur: nam illa Scoti propofitio ; quicquid fibi prafcribit genus, prafcribit etiam fibicertam aliquam illius feciem, vera eft tan. tummodo de effentia, nam quicquid fecundum effentiam fuam prafcribit fibi genus, id eft, eflentialiterinilloeft, neceffe eft, ve fit determinate aliqua fpecies illius generis, vt quicquid effertialiter eft animal, eft neceffario aliqua fpecies animalis; at non eft vera de determinatione extra effentiam; oculus enimadoperandum determinat fibi colorem abfolute, at non fibi determinat aliquam certam fpeciera coloris, fic propria.aliqua affectio animalis præf cribit fibi animal genus tanquam fubicctum proprium, \& 1 lli neceffarium ad exiftendum, non tamen fibi præf fribit aliquam certan fpeciem animalis, fed aliquam indiftinete; fic igitur prima materia vt exiftat, præferibit fibi formam abfolute fumptam, \& genus ipfum: formarum, nec tamen oportet vt fibi prafcribataliquam ftatutan formam. Quare hac Scow ti argumenta funt potius cauilli, quam folida rationes, qux vel demonftrent, vel perturbare hac in re aliquem debeant. Ad Simplicium $A d q a b s$ autem in contextu 52 : libr. 1 . Phyfic. dicentem; tumb poffe materiam effe per feipfam, minime vero formam, dicimus, Simplicium non accipereperfeipfam efreproco quod effexifterefine forma, fedibifumere effe per feipfum, prout - diftinguitur ab.eo, quod eft efle in alio, vt: in fubiecto; hic enim eft fenfus confentaneus verbis \& fententia Ariftotelis eo in loco, \& verba ipfa Simplicij húnc manifefte fignif. cant, inquit enim, materia poteft effe perfeipfam, contraria vero inharent in alio, itaque: effeper feipfum nilaliud ibi fignificat, quam non ineffe in alio. Ad Auerroem autem in primo capite libri de Subftantia orbis dicentem. materia eft vnum entium exifrentium per $f e$, di. cimus, non eam effe Auterrois mentem, vt dicat: materiam fine forma exifere poffe,fiquidem id. aperte negauit in libro fecundo $P$ hyfic. aufcultationis, commentario 12: fed de fola materiz: effentia: ibi Auerroes loquitur, eamque diciz:
Adtanto towas: 
eflediftinctam tum à forma, tủ à potētia ;quare his verbis nil aliud fignificare vult, nifi pri, mam matcriam liabere realem effentiam diftinet am ab effentia formx, \& ab effentiis omnium rerım, quod etiam A rift. dixit in context. 3.11 b.7. Meraphyf. fxpe à nobis citato.

\section{Contraric fententia de prima Materic, an fit perfequantia. Cap. VI.}

Cerpus displex.

\section{C} ONSIDERANDVM manet, an prima cit corpus; vnum, quod effe dicitur fupremum genus in Categoria fubfantiz; alterum, quod eit fpecies quanticontinui, \& nilaliud eft, quam trina dimenfio, longitudo cum latitudine ac profunditate; ideo huius confiderationis duz erunt partes; vna, an ipfa fecundum fe fumpta prima materia fit corpus de genere fubltantix, a liera vero, an fit perfe quanta, hoc eft, longa, lata, ac profunda ; illa quidem eft fecundum naturam prior, quum fubstantia fit prior quantitate, nos tamen facilıoris doctrinzerdınem fequentes, ab liac pofteriore ordiemur, quoniam ablque huius declaratione difficilis admodum, atque ardua altera contemplatio foret. Sunt hac in re dux contrarixopinjones; -vnaAuerrois, ad qua $\mathrm{m}$ accedere videtur Simplicius in contextu 69. libriprimi Phyfic. \& Ioan. Grammaticus in Awerrois hor.1r. contra Proclum; altera Thom opsris de nitus contraria.Auerroes in comment. 63 . lib. I. frima multeriat quati: toute.

Opjisso 2 home phyfic. \& in calce 2. tract. Epit. Metaph. \& in r. cap. libri de fubintantia o: bis, \& aliis in locis affe rit priman materiam fecundum $f e$, \& ante receptionem forma elf quantam, \& habere tres dimenfiones, longitudinem, latitudinem, \& profunditatem, tanquam accidens perpetuum, \& infeparabile, eas tamen nullis certisterminis circumfcriptas, fedinterminatas, qux poftea à diuerfis formis varios terninos recipiunt, provt variz naturalium corporum naturz requirunt; adco vtintereunte per receffum formx corpore aliquo naturali, dimenfiones non intcreant, fed earum tantummodo terminideftruant, $r$, \&alijaccedant, qui ab alia adueniente formaprafribuntur, Contrariam fententiam tuetur Thomas, quipluribus in tocis, præfertim vero in npufculo 32 : nititur oftendere, nullam elle in prima materia quantitatem aremam, fed o mnes naturilium corporum quantutates infequiformas, \& à formis tribui, proınde generari \& interire, ptout ip fx quoquenaturales formæe oliuntur, \& intereunt. Plotinus quoque huius fententıx fuiffe videtur, qui in libro quasto fecundae Enneadis ofrendit, frimam materiam elie tecundum fepenitus nicorporcan, i carereomnidinenfione, fufcipereauticm comes djmenfiones a foma. Albertus quoqueinltb. de quatuor Coxuis, \& in 3, Metaphyll tract. 2.cap.à.

A ponit quidem in prima matcria formam quandam fubftantialem xternan, quam vocat ipfe inchoatione formarum, alij vero formam corporeitatis; at corporeitatem de genere quantitatis in prima nateria nullam ponit coxternam ipfi nlaterix, quia putat præter primam materiam, \& formam illam cotporeitatis nilaliud effe in natural corpore zerernum, fed omnia generationi \& interirui obnoxia effe. Hoc idem fenfifle vid turAuicenna, vt colligere poffumus B ex primo fure fufficientia, cap.2.\& ex 2. tract. Metaphyfico, cap. 2. ponit enim un frima materia formam illam corporeitatis de genere fub. ftantix coxternam materix, fed nullam ponit corporeitatem de genere quanritatis aternam, idque eft quod Auerroes dicir in 1. cap. libri de fubltantia orbis, Auicennam non diftinxiffe dimenfonesinterminatas à términatis. Sententia hac pluribus argumentis defenditurà Thoma in præátito loco, \& alıa quoque ab eius fectatoribus in confirmationem adducuntur, fid nos ea tantum, qux eficaciora eflevidentur, aliis omillis, in mediumafferemus.

\section{Argumenta Thome adtuer us opinionem $A$ - uerrois de quantitate interminata. \\ Cap. VII.}

$P$ Rimum ita argumentatus Thomas, aut quantitas interminara eadem eft numero cuaterminata, aut funt dure diftincta:f eadem, ergo acsidentia rei pracedent rem tempore infinito; nampropria hominis quantitas pracedet infinito tempore ip fum hominem, fi eaden numero eft cum quantitate materiz interminata quæ poniturefe æterna, fed confequens adueriatur Ariftoteli, qui in context, 4 , libri 7.Metaphyfic. inquit, fubftantiam accidentepriorem cfie \& natura, \& cognitione, \& tempore: fequeretur etiam eandem efíe hominis quastitatem,

$E$ \& formicz; uam vtraque eft idem quantitati interminatr; qua autem funt idem alicuitertio, ea inter feidem effe neceffe eft; fi vero duæ fin diftincte quantitates, ergoquantitas in eodem corporeerir bis, fiquidem quantitas interminata nunquam perit; quare dabitur penetratio dimenfionum, quam omnes Ihilolophi negant. Secundo, fi darctur lixc quantitas in- secundin tominata zterna infrima materia, ens potethate ellet fubiectum accidentis, quod ab Ari-

F itotele negaturins, Phylic, \& ab iplomet Auerroe in comment. 63. 1.br. 1. 1 bi dicit, fubiectum accidentium elle ens a $9 u, \&$ ex materia \& forma conftans; fic enım iplum diftinguit à fubiefo formarnm lubfianralium, quodeft ens poteftare. Tertio, prius eft die fimpliciter, Tertim quan cîe fecundum quid; at formalubftantialis dat eflesinpliciter, ascidens autem omne primum $+\pi m$. 
dat effe fecundum quid, ergo forma fubltantia- A lis precedit omnia accidentia in materia; quod fi quantitas interminata procederet formam fubftantialem, hacprius daret ipfi materix effe fecundun quid, quam forma fub ftantialis det artï. cidem effe fimpliciter, quod eft abfurdū. Quarto, fequeretur, id quod eft vnum per accidens, pracedere illi, quod eft vnum perfe, hoc autem fimiliter abfurdum eft, \& communi omniun confenfioni aduerfatur;dicunt enim, id quod eft per accidens, neceffario prefupponere id, quod eft perfe: confequenria probatur, quoniam ex fubiecto \& accidente fit vnum peraccidens, ex materia autem \& forma vnumperfe, prius zu. temerit vnuni conftans ex materia, \& quantitate interminata, quam vnum conftans ex msteria, \& forma fubftantiali. Cuinto, vel he dimenfiones interminatx effentrales funt primx materix, velaccidentales; fi effentiales, ergo prima materia effet effentialiter quantitas nō fubftantia; fi vero accidentales, ergofeparabiles, proindenon aternx. Sexto, fequeretur, quatuor effe frincipia rerum naturahıum, non tria tantun, quoniam huic quantitati interminatz competerent omnes conditiones, qux fecundum Ariftotelem in primis principiis poftulantur:quum enim aterna fit, non fit ex alio, neque ex reliquis principiis, \& ex hac omnia funt; qux autem funt huiusmodi, ea funt prima princip12; quamobrem principia quatuor erunt, forma, priuatio, materia, \& quăritas interminata. Septi- D mo, per hanc quantitate interminatam materia vel fit aetu diuidua, vel poteftate, quorum neutrum dici poteit : non enim actu, quia facta aetu diuifione materix, diftingueretur eius pars ab alia parre, hoc autem effe non poteft q quia omnis diftinctio fit à forma, materia verofecundum $f e$ eft prorfus informis; fi vero poteftate, ergo hac quantitas interminata fruftra eft, quia materia etiam fine hac eft diuidua poteftate, fitque port-

ea aहtu diuidua per aduentum forma. Poitremo, fi daretur hac qquantitas interminata, ea effet in aliqua categoria , at in nulla effe poteft, ergo non datur:nam fi in aliqua Categoria cft,certe eft in Categoria quanti, in hac tamen noneft, quum $A$ rift. in capite de quanto dicat omne quătum fignificare certam, acterminatam rei quantitaten!, quantıtas igiturinterminata in Categoria quanti non eft; ergo in nulla.

\section{Argumenta pro Auerroe ad comprobandam quantitatem interminatam.}

\section{Cap. VIII.}

$\mathrm{F}^{\mathrm{X}}$ altera parte pro Auerroe valida arg廿num Ementanondefunt. Primum fumitur ex ipfa umen rei natura: quantitas non eft generabilis, ergo non generatur, ergo zterna eft : affumptum probatur, quia nullum eft agens, à quo generai poffit; non enim à forma, nec ab alia quan-
A titate, necab vlla qualitate; non à forma, quia forma fecundum fe non eft quanta, nec diuidua, ergonon apta ad producendam quantitatem s proterea quantitas poteft mente abftrahi ab omni forma naturali, ergo eft natura prior formis, crgo à nulla forma produci poteft, quia non poteft caufa efre pofterior fuo effectu : non à quantitate, quia quantitas non eft actiua : non etiam à qualitate, quia omnis quulitas eft natura pofterior quantitate, quare eius caufa effe non poteft. Secundum argumentum, quo pre-seexnds. cipue innititur Auerroes, tale eft : fi prima materia nō effet fecundun propriam naturam quanta, Id, quod ex materia \& forma conftat, non poffet efle diuiduum, fed effet inftar puncti indiuiduum : quod probatur furmptis ex Ariftoteleduobus fundamentis: vnum fumitur ex colltextu 18. libr. s. Metaphyfic. vbi inquit, diuifionem, \& diuifibilitatem effe propriam quanti, \& nihsl effe diuifibile, nifi quantum vel merito C quanti, itavt folum quătum fitperfediuiduum, cxtera vero per quantum : alterum fumitur $e \mathbf{z}$ context.2. lib. 6. Phyfic.vbi Arittoteles ait, non fieri quantum, neque diuiduum expluribus indiuiduis ; nam fi decem millia punctorum firuul iungantur, non fiet ex eis nifipunctum vnum; his ita conftitutis, fic argumentor:fi materia prima ante receptionem formæ fecurdum fuam naturam non eft quanta, ergo per prius fundamentume eft indiuidua ; atqui forma quoque fecundum fe indiuidua eft, vt omnes dicunt; ergo per pofterius fundamentum neceffeeft id, quod ex ambabus conflatur, effe indiuiduum; nam $\mathrm{fi}$ ponatur diuiduum; conftabit diuiduum exzon diuiduis, \& quantum exnon quantis, quod Āriftoteliaduerfatur: nec poteft aliquisad hoc confugere, vi dicat Ariftotelem loqui de partibus tantum integrantibus, proindehoc argumen. to de folis partibus quanti integrantibus oftendi, quod debeant effe quanta, non de partibus E effentialibus, de quibus in prafentia fermo eft; nam fibene rem confideremus, eadem viget ratio in omnibus partıbus, è quibus totum acta conftet; qualefcunque enim partes fint, neceffe eft fi omnes fint indiusdure, ve totum diuiduum effe non poffit: praterea non haber la cum hxc partium diftinctio, quando fumantur vt indiuidux, vt ibi fumit Ariftotel. dum ait ex non quantis, \& non diuiduis non feri quantum; dum enim fumuntur vt indiuidux, $F$ non poffunt dici integrantes; dictum igitur $A$ riftotelis eft vniuerfe verum, ex pluribus non quantis vtcunque compofitis non poffe fieri quantum. Neque etiam dici poteft forma, lice: ipfa quanta non fit, caufam tamen effe quantitatis, ita vt eam propria rei quantitas infequatursetenim indiuifibile non poteft effe caufa diuifibilitaris: praterea eadem difficultate dictum quoque illud Ariftotelis $\nabla r g e r e t u r$, dicere namque poffemus, licet nulla partium diuidua fit, 
taren vel excarum alioua, vel faltem exearum sulleftione prodire quantitatem in toto con-

Terizun iuncto. Tertioargumento fic Auerrois opinio comprobatur : fi quantitasinteriret, haberet cötrarium; quicquid énim interit, à fuo contrario interimitur ;atqui non habet quantitas contrarum, vt legimus in libr. Categar.ergointerire

Quiviti non poteff. Quarto, idem confirmaturfumpto ex Ariftotele hoc fundamento in z. lib. de Ortu 3 interitu; in elementum habens fymbolā qualitatem facilior eft alterius elementi mutatio, propterea quodilla fymbola qualitss noninterit,fed eadem feruatur in genito, qua fuit in corrupto; huius autem ratio $\mathrm{e} f$, quoniam accidentiaconuenientia formægenerandz, \& illi neceffaria non debent de materia pelli, fi inea iam infunt,imo neque poffunt pelli, quandoquidem non pellitur aliquidà fimuli,fed à contrariv : eadem itaque ratione argumentemur : quantitas \& extenfio eft neceffaria ormibus corporibus naturalibus, \& communis eft conditio omnium formarum naturalium, vt in materia extendantur;non debet igitur, neq; potefinterirequantitas; ergo zterna ef, \& foli ipfus terminimu-

Qs $n t z$. tari \& interire poffunt Tandem id confirmat Auerroes teftim onio fenfusiquando enim exaqua generaturä̈r, videmus quantitarem aquar nonperire,fed potius ad aiorem molem, \& ad nouosterninos ampliores extendi; ipfa igitur quantitas in omnibus manetincolumis, \& foli eius terminimutantur prout diuerf naturales

sextsm. forma variosterminospoftulant. Videnturetiam omnes, etiam aduerfarij, hoc confiteri, dum dicunt formam extendi ad extenfionem materix, \& fieri diuiduam diufione materiz;fic enim affrmant materiam fecundum fe diuduam effe ante forma receptionem : dicunt praterea accidentium omnium alia admateriam pertinere, alia ad formam, \& qualitates quidem adformam, quantitatem veroad materiam, quodef ipfam Auerrois fententiam approbare.

\section{Sententic Auerrois declaratio do con-}

$$
\text { firmatio. Cap. IX. }
$$

10 Vum egoveram hac in te effeputem op:nionem Auerrois, ductus tum argumentis piaistctis, tum Ariftotelisaliorumque authoritate, vt mox oftendam, ante omnia optime declarandam effe hancfententiam arbitror; quia ipfa bene intellecta viderur fuam veritatem patefacere, \& contraria argumentafacile diluere. Dico igicur huiufcerei veritatem in hoc potifimum fundaméto confiftere, quod quum cuiufq; rei quantitas fitterminata, hac nec fo-

Qumo- lam materiam infecuitur, nec folam forman, doquan- fedvtramquefimul, nam quantitas ip fa feclufis rotas mse mence omnbusterminis à fola matcrizenatura teriam emanat, \&: eft eiuspropiletas inherensipfiper mequa fefecundomodo,ficuthominirifibilicasjtermisur.
A tenus qualibet forma certos quoldam, ac proprios terminos pofulat; hoc certe ex ipía lo. quendi confuetudinefatis comprobatur; idem enim fignifscarevi cemur dicendo magnitudine, \& corporeum, \& niaterislc, \& has dictiones $\{$ pe, vtidem fignificantes confundimus, dumà rebusincorporeis bos corporeas, \& materiales fecernerevolumus; fic autem denotamus à natura materiz prouenire, vtres dicantur \& magnitudines, \& corporca.- At ftatuere terminos maonitudini eft folius form $x$ oficiü, quia nutl a dematio à materia prouenire potef, \& ra tu tioniconfonum eft, vt forma, quemadmodum feqast. naturam ipfam materix coarctat, \& ad certam forma. fpeciem contrahit, facitq; hominem, \& equum, \& afinum; ita etiam quantitati materia, qux fecundum feterminis caret, certosaliquos fines largiatur. Duplicesautem terminos forma pra. fat, externos, \& internos; externi funtilli, qui non funt degenere quantitatis, vt figura, quaef $C$ inguarta fpecie qualitatis, \& nil aliudeft, nifi in fuarta fortum quanti inter fe concentus, harmonia; internivero illi funt, quifuntde gesere quanti, \& certam quanti fpeciem confituunt, vtbicubitur, tricubitum. \& huiusmodi: vtrofque terminos quãut bet; at quantiatem ip fam prebere non poteft, quia frcuti forma hominis non poteff fire materia hominem confituere, ita neque tantum facerepotef, nifi in materia giuanta, \& extenfa $D$ recipiatur, quumipla fecundum fe formanon fit quanta, neque diuidua: de qualitatibus vero fecus eft; ha namq;incorporea per fe funt, \& indiuidua, qua tribui à forma poffunt, quia materiafecundum fe his omnibus caret. Hunc colligimus, formam \& materiam fibi mutuam operam praftare : forma enim qua fecundum feindiuidua eft, recipit à materia extenfionem, \& quantitat em; materia vero fumit à forma terminos fua quantitatis: hancvericatem confiteri omnes videntur, infcijtamen, \& ab ipfametre ad ita loquendum inducti, dum in gymmafis frequenter dicunt, formam extendi ad extenfionem materiz; fic enim afferunt propriam materia efle extenfionem, forman vero eam accipere àmateria: dicere tamen poffumus, nonmo- Mater do formam extendi ad extenfionem mate- exten riz, fed etiam materiam ad forma extenfio-turaa nem extendi, verum enim vtrunque eftalia \& exten alia ratione; illud enim verum eft de extenfione nem fo abfolute accepta, quam forma fumir à materia, ma, hoc autem de limitibus, as furibus extenionis, forma nam eoufq; materia extenditur, quoufg; forma extenj prafcribit, \& imperat: fimiliquajam ratione di- $3 s m m$ cere folemus tum equostralientes currim, tum teriß. etiam aurigan tantum itiueris peregiffe; csyus quidem abloluteloquendo; ipfi enim innt, qui ambulant, non auriga, aurigan velo tarquan eum, qui certos limites, ac fines tuneri tatuit, quum equinullum sibi certum termium from

ponants 
ponant, proinde tota hac deccrmmatio tribua- A turaurig Hanc fententian colligit Allerroes ex Ariftotele in contextu rs. libio 4. Phyficorum, dicente locum videri efle materian, quatentrs eft magnitudinis dimenfio, fquiden materia eft dimenfio magnitudinis; vocat autein ibi magnitudinem Aritoteles eam tantum, qux terminata eft, certamque habet quantitatem, dimenfioneṭu vero Grece diktam fiásnues vocat ip \{am materia quaniratem, feclufis terminis; quumigitu dicat Ariftoteles, locum ea ratione videriefle materiam, quatenus eft dirnenfio, abfque dubio nateriam per fe disnenfam point, quim prefertin poítea materiam hanc dimenfam diftinguat à forma, dicens cam lub forma contineri tanquam fub luperficie, ac termino; forma enim dat terminos extenfioni materix, materia vero fuapte natura quanta, \& extenfia eft, imo Ariftoreles ibieam vocar dimenfionem ipfam: quamobrear refte ibi Altcroes colligit ex Ariftorele materiam per fe habere dimenfiones interminalas, qua necre necimaginatione feparari i materia poffunt; quod quidem verifinum eft; dum enim mente materiam fine formis concipim us, fieri non poteft, vt eam non quantam imaginemur, fed necellario imaginamur quantam, ac veluti valam quandam magnitudnem, nullifque certis terninis cirsumlcript ta idque Arifoteles co jp fo in loco fatis clare pronunciare videtur, dum inquit; fi à corpore arioneantur terminus, \&affectiones, nil remanet, nifi matcria, non enim dicit, fi amoucatur quantitas, fed dicit, fi amoueatur terminus; quare putat proprias, \& naturalem materia effequantitatem, at non terminos. Tabatos A- lem materiam fignificauit Chaos rilud Anaxaascagoa. gorz corporeum, in quoomnia ineffe dicebat; efterim materia moles quadam indiftincta, in qua infunt omna, non quidem actu, vt Anaxagoras dicere vifus eft, fèd poteftate folum. Plotinus quoque eiuftem rententia fuit in 4. lib.2. Ennead. licet es contraria opinio at tribui foleat: ibinamque longo fermene oftendit rateriam fecundum fe incorpoream effe, \& quantitatem non habere, fed aperce etiam declarar de quanam quantitate lo quuatur; de fola enim teımihata loquitur, vt omnia cius exempla teftantur; dicit enim quantitatem infequi formam; quoniam aliam quantitatem forma hominis poftulat, aliam forma bouis, aliam forma canis, quarum nullam materia in fe habet; igitur hoc tantum ex Plotino ibi fumi poteft in cap. 8. eitus $\mathrm{l}$ b. idque nos non inficiamur; fed in cap.r. manifefte ponit in prima materia quantitatem interminatam, quum dicat materiam effequandam veluti molem, ac dimenfionemvacuam, \& declaretnon effealiud hancyacuitatem, quam negationem terminorum, feu inteminationem; vnde colligit materians effe molem, \& non molen; molem quidem; quatenus extenía eit, non
A molem vero quatenus non eft terminata; expo nit etiam ibidum Platonis de materia prina fen- Plato. tentiarn, qui non dixit eam magnam, neque dixic paruam, fed vocauit fimul inagnum \& paruum, vt tum quantam fignificaret, tum interixi. naram ix aptam indiftinete ad quofcunqge terminos fulcipiendos: praterea in cap.o.volins oftendere Plotinus elementa ex materia \& forma conflare, inquit; fi elementa effent fola fo:ma fine materia, qnomodo magnitudiners ac B molen haberent? molem igitur, ac magnitudi nem corporibus à materia prouenire, \& mate riam infequicenfuit, non formam, folos autem terninos tribuia à for ma.

\section{Reprobatio prauifenfus, Aüerroi à nonnul- lis attributi. Cap. $X$.}

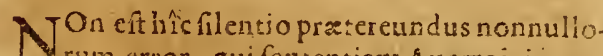
Nrum error, qui fententiam Auerrois in pra. uum fenfum trahentes, in eam poftea inuecti funt; putâunt enim has dimentiones intera: inatas apud Auerroem effe illas, quze actu exiftunt extranimam, dicique interminatas ratione terminorum prafcribendorum à forma generandajimenfiones entm qua funfin femire humano, etfi proprios termulos habent, dick 23 . men poffunt interminatx refpectuterminorum tribuendorum à forma horninis a duētura, qॄes noudum habent; qua ratione exifterent actu

$D$ interninatzextra aninam, quatenus carentes terminis forma generanda. Sedab hac fenten. Confut w tialienifimus $A$ uerroes fuit, qui nunquam äi- to. xit, dimenfiones interminatas exiftere actu ve interminatas, fed in commat. 15 . lib.4. Phyfic. \& in salce 2. traet. Epit. Metaph.aperte dixit, has dimenfionesinterminatasion effe actuales, fed potentiales; interminatas enira intelligit, non Verus ratione terminorum tantum forma generanda, Senfos. fed rationeomnium terminorum, qui à quali-

E bet formaprafcibi poftunt, imo etiam eorusa, quashabent à forma prafence: quamuis eniui exiftant vt terminatz, \& nunquam ve intermınate, termnos tamen non ex fe habent, neque ex propria natura materix, fed à forma; quare non ideo dicuntur interminatre, quod reperianturvnquam fine terminis, fed quia fecundum propriam materiæ naruram, quam infequuntur, nullos certos terminos habent prefcriptes: fic enimiplam quoque materiam dicimus fecūF dum refle informem, \& onniadu carentem, quamuis femper habeat formam, necp ofic vnquam exifterefine forma: nil enim aliud per hoc fignificare volumus, quam naturam materia nillam fibi certam formam prafcribere. Quemadmodumigilurdum folam materizeffentiamfpectamus, camque mente $a b$ actu exiftend abiungimus, in formem pentus elfe dicimus; dum auten cădeıs vresiftentem confideramus, dicimus iemper fife formatain : fic ctiam eius quan-

G a tita-
Pyateres C. Cos atrribist2s siverros: Confut
to.
Ferws
Engses. 这 
titatem dum fecüdum fe fumptam refpicimus, interminatam vocamus, quia fecundum fe nullis certis terminis eftaddieta; dum autem ea!ndem vtåtu exiftentem refpicinus, femper hilbere terminos dicimus, \& nunquam exiftere aftu fine terminis; fiquidem ponere eam actu exiftentem v't interminatam, effet ponere actu magnitudinem infinitam, qux darinullo modo poteft : non igitur eam vocamus interminatam, quod terminorum negationem requirat, fed quia terminos, quos habet, \& quos habere poteft, non à $f e$, neque à natura materia prafcripros habet, fed ab alio, nempeà forma terminante; ob id Auerroes has dimenfiones materix vocat potentiales, non actuales, quia interminat $x$ non exiftunt actu, fed dum mente à terminis abiunguntur, cognofcuntur effe fecundum $f e$ interminatz, \& poteftatem haberequofcunq; terminos recipiendi; hoc igitur modo intelligendum eft id, quod Auerroes dicit, quantitarem hanc interminatam non exiftere actu, fed poteftate; non enim negat eam exiftere, fed folum vult eius imperfectionem, atque interminationem fignificare, quia nullum ex propria euant $;$ - natura terminum habet. Non eft etiam ignothes in-randum, quantitatem interminatam non differcermina-re numero à terminata; eadem enim eft, quax taef ea. fecundum fe terminiscarens, eos poftea fumit dem $n$ - à forma, \& fit terminztajideo idem eft vtriufque zero cū fubictum inharentix, nempe ipfa prinamaterms- teria, at nöeft 1dem fubiectumattributionis, feu ata. denominationis; nam interminata attribuitur materiz, terminata vero toti compofito: fimili ratione etiam imagoà pictore leuiter adübrata. non differt numero ab ipfa iam abloliata, fed folum vid, quod prius poteftate, atque imperfectum e्ft; poftea vero fit actu, atque perfectum.

\section{Solutio argumentorum pro Thoma addu- ctorum. Cap. XI.}

d' pri- $R$ Eftat xt contraria argumenta, quapro Tho mum. I ma adducta funt, foluamus. Ad primum dicimus, quantitatem interminatam eandem effe numero cum terminata : quando aurem infertur, ergoaccidentia rei praceduntipfam rei fubstantiam temporeinfinito, dicimus, fi fuma. tur quantitas, ve hominis propria, \& ve humanis cerminis circumfcripta, neganduin efle confequens, quia hxc, quatenus talis eft, non pramceffit hominem; fi vero fumatur: quanticas abfolute, feclufis terminis, negandam effe falfitatem confequentis, quia ficuti materia hominis fecundum Arstotelem præceffit hominem tempore infinito, ita quantitas illa ve interminata praceffit per infinitum, nec ob id vllum abfurdum fequitur, quia non propterea aliquod hominis proprium pracedit bominem; fiquidem materia non eft magis hominis materia, quam aliarŭ rertım; ad probationem vero fumptamex Ariftotele, quiin coutex. 4 libri $7 . \mathrm{Me}$ -
A taphyf.dicit fubftantiam effe acciden bus priorem naturâ, connitione, \& tempore, nul !ri inul tadicunt, \& lecus ilie magna difficultare nov caret, quiade temporevidetur dietum Ariftotclis falium efe : nam fi hoc intelligamus de proor a qualibet fubllantia, refpectu ascidentium fuo- ciderst. rum, non eft tempore prior an nibus fuis asci- bus. dentibus, nō enin ascidentibus propriis, quum hæc fimul orianturcum fubiecta fubftantia, ve fimul cum homine rifibilitas; fivero iateil gaB tur etian de omnibus accidentibus tar illius rei, quamaliarum,adbuc falfum eft; dantur enim fecundum Arifrotelem accidentia xtenna, qualia funt accidentia Corli, qua funt tempore priora ommibus fubftantis caducis, \& nullam habent fubftantiam temporepriorem, ne ipiam quidem fubftantian Coeli, quum \& ip fafint $x$ terna; ideo locus ille multerum aniroos tortit, qui variis modis illum nixi lunt interpretai; ego pro uccafione bî́ pauca quadam dican; C idtamen prámonere velim, argumentum lioc non nagis nobis, quam a duerfarns obeffe: vit enim-fecundum Auerroem pon vitetur accidens tempore prius forma fub ftantiali, queci $A$ riftot.aduerfatur, ita fecunchurn Thorazu ponitur quantitas rei fimul oriricuin forma, qued firailiter Ariftoteli dueriutup, quia fi ditum 1]lud Ariftot. verum effe debcat, cporu accidens nec prius tempore exiftele, quam fubitantiam, nec fimul cun illa, red pofterius tempore;omitD tere igitur poterant aducr arijargu mét un hoc, tanquam abeo, de quo nuns agitur, alienum, quum ad aliam quandam difficulsatem pertineat, nec minus Thom a, quan Aucrois. fententiam oppugnare videatus. Agir hac de re $\mathrm{Zi}$ mara in theoremate nono, \& reprobat interpretationem à Scoto adductam in 2.qua ft.jib.7.Metaphyf.vt ibılegere poffumus:affert etiam expofitionem $A$ uerrois, quam nec approbat, nec re. E probat, fed aliam ipfe propriam adcurit, qua ipfomirum in modum placuit: Auerrois quidirm fententia eft, Ariftibi loqui de fibftantiis tantum caducis, acde earum accidentibus, non de aternis, quare ceffat dubium de accidentibus. Coli, inferiorum autem corporum accidentia omnia habent fubstantiam tempore priorem; vel enim fubftantia compofita, quarillis fubie¿ta eft, pracedit ea tempore, vel faltem prima mareria, qux illius fub ftantix pars eft, quantitas. vero materiz interminata non exiftit vt interminata, fed femper fub terminis, nec differt numero à terminata; quum igitur Ariftot.ibi loquatur de accidentibus, qua extra animam a. Qu exiffunt, refte dicit omnia effe tempore pofteriora fubftantia, in qqua inhærent; fic dubıum

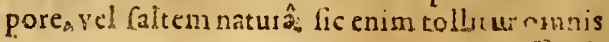
foluitur fecundum suerroem. Zimara vero inquit, verba illa Ariftot.ita efre inteliigenda, vt coniunctio pro difiunctione fumatur, \& fenfus. corum fit, fubstantia eft accidente priorikel'temdificul-
Expofi: tio $Z$ inare.

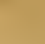

Expofe-
tio -1-
yerros.

1
Expofi-
tio $Z$ i-
mare.


difficultas : nam quantitas interminata non eft comparanda cum compofito, fed cum prima materia, qux ipfius fubięum eft inharentix, \& attributionis; materia vero prior illa quantitate eft, fi non tempore, faltem natura. Ego quidem alias Auerrois folutionem fequutus lum, quum viderem, folutionem Zimarze non fatis accommodari verbis Ariftotel. qui coniunetione vtitur, non difiunctione : fed quum poftea folutionem quoque Auerrois diligentius confiderauerim, vidi eam quoque non carere difficultate, quandoquidem non eft obfcurum, Ariftotel. eo in loco loqui de fola fubftantia compofita , \& hanc vocare fubftanciam, \& dicere priorem accidentibus natura, \& temporenempe accidentibus fuis, non accidentibus alienis, de quibus nihil certum ftatui poteft, quum accidentia hominis fenioris pracedant tempore fubftantiam alterius hominis iunioris;itaque non videtur effead materiam confugiendum, qux accidentibus prior tempore efle dicatur, fed oftendendum, quomodo fub ftantia compofita tempore prior fit onmibus accidentibusfuis, hoc eft ilis, qux ipinmettanquam fubicctoattribus folent, fi verba illa A rift. eũ fenfum habent, quem aduerfarii nobis obiiciunt;id tamen necipti, nee alius vllus oftendere potis eft, quum fit manifeftum, quamlibet fubftantiain compofitam aliqua habere accidentia neceffaria, qux fimul cum illa, non pofterius, oriuntur, ve propria cuiusque quantitas, \& alia complura ; huncigiturfenfum falfum effe certum eft, nec verbis A-
riftotel.attribuendum. Quamobrem quum ego rem hane diligenter conliderauerim, femperque cxiftimauerim, quxrendam femper effe ante omnia cuiusque rei veritatem, deinde slla cognita, ad eam, fi fieri poffit, verba Arift. trahenda effe, non è contrario, quod multi faciunt; viderim autem häceffe manifeftiffimam huiusce reiveritatem (etiamfi id non affereret Arift.) fub. ftantiam effe natura priorem omnibus accidentibus fuis, non omnibus tamen tem pore, fed ali quibus; dicendum cenfui, neceffe effe vt Ariftot. vel hocidem dicat, vel falfum dicat: quod hoc idem dicat, tueri polfumus, fi ipfam quidem $\mathrm{Zi}$ maræ fententiam recipiamus, quam dicere porfumus non ab eo fuifle inuentam, fed ab ipfa. met re oftendi omnibus, ac patefieri; verborum tamen Ariftotel. meliorem interpretationem adinueniamus, conftat enim interpretationem Zimarxillisaccommodari non poffe, quum A. riftotel. non difiunctione vtatur, fed coniunEtione, fitque arbitraria expofitio, \& fatis impropria lotutio coniunctionem accipere pro difiunctione. Propterea ego dico,defendi poffe fenfum illorum verborum etiam coniunctum, nempe vt Ariftotel. hoc folum dicere velit, fubftantiam effeaccidentibus priorem, vtcunque id fir, poftea vero modos declaret huius prioritatis, \& dicat priorem effe his omnibus modis , ra- tione, cognitione, natura, actempore, non quidem femper his omnibus fimul, fed modo a mnibus, modo aliquibus, fat enim eft, fi hi o. mnes fint modi, quibus folet fub tantia effe accidente prior, nec alius detur preter hos:|fic nos alias fumus interpretati verba illa Arift. in definitione naturx [morsos Equiet is] vt coniunatio non pro difiunctione fumatur, red pro coniunEione, nec ob id dicere oporteat, naturam in quolibet naturali corpore effe caufam vtriufq; $B$ hocigitur modo conueniens eft loquutio coniunctiua, inconueniens autem difiunctiua': quemadmodum enim natura non eft caufa alterius tantum, fed vtriufq;, ita hic dicêdum non eft modum, quo fubitantia eft accidinte prior, effe aut hunc, autillum, fed effe hosomnes, tametfinon fimul; accidens enim nullo illorum modorum poteft effe prius fub ftantia fibi fubieEta, imo neque fimul, nifi temporefolum; fubftantia vero omnis eft fuis accidentibus prior C \& definitione, \& natura, \& cognitione diftincta, etenim hi modi reip $f_{2}$ in ideni cadunt; tempore autem prior eft multis fi̛is accidentibus, quibufdam tamen fi non eft prior, non eft faltem pofterior, fed fimul. Hanc effc puto mentem Ariftotel. eo in loco. Ad argumentum igitur dico, quantitatem terminatam referendam effe ad fubitantiam compofitam, cuivt fubiecto attribuitur, interminatam vero nö ad compofitum, fed ad materiam; itaq; fat effe, fi, vt compofitum D quantitateterminata, fic materia quantitate interminata fit prior, fi non $t \bar{c}_{\hat{c}}$ ?ore, faltem natura: quantitatem autem interminatam comparare cum compofito, \& illo prioré dicereabfurdum eft, perinde enim eft ac dicere, accidentia buius hominis effe tempore priora fub tantia alterius hominis, quodincongruum eft, \&alienum ì mente Ariftot. eo in loco, qui fubftantiam cum fuis tantum accidentibus comparat, non cum alienis, imo necvllam fubftantiam ibi confideE rat, nifi compofitam, \& perfeetam, \& nulla accidentia, nıli terminata, \& actu cxiftentia : quod veroaddebatur, ergo eadem effet hominis quätitas, ac formicz, negandum eft; quoniam axiomaillud, qux funt idem alicuitertio, funt idem inter $f e$, verum eft comparando inter fe illa, qux funt actu ; fed non eft verum, fi fiat comparatio eius, quod eft poteftate, cum co, quod eft actu, quia hæc non ommino funtidem, fed differunt per poteftatem, \& 2ctum; lignum enim eff poteftate idem numero lectus, qui poftea eft actu,eft etiam illud en im lignum arca poteftate, \& eadem arca numero qux poteft ex eo fieri actu, nec propterea fequitur vt arca fit idem quod lęus : lic materia prima eft idem quod homo, qui ex ea fieri potelt, cum hoc tamen difcrimine, poteftate, \& actu; \& eadem materia eft idem quod equus, qui poteft ex ea fieri, nec ob id homo eft Idem quod equus, nifi fic intelligamus, eadem materia eft poteftate G 3 homo 
homo \& poteflate equus, ita vt effeidem in eo tantum confiftat, quod eff poteftate, fed non in co, quod eftactu: fic igitur quantitas interminata prima materix eft poteftute quantitas liominis terminata, \& poteflate q̨uantitas formicx) quoniain apta eft recipere vtrofque termisdfecux nos, fed hiinterie non funt idem. Ad fecundum dum. argumentum dicimus, fubiectum accidentium terminatorum, acperfectorum effe ens aĉu, \& de his tantum loquuntur Ariftotel. \& Auerroes, non de accidentibus interminatis, qux poffunt Adter. habere fubiefium ens poteftate. Ad tertium
trum. funt qui refpondeant, primam materiam exfe habere effe fimpliciter, non à forma, propterea quod habetpropriam exiftentiam: fed hanc opinionem nos antea confutauimus, \& oftendimus primam materiam non per fe exiftere, fed performam, qux confrituit hoc aliquid. Nos igitur dicim us, aliud cfie exiftentiam, aliud effentram, \& vtrouis modo hi fumant effe, argumentum nihil habere roboris.. Nam fi intelligant effe effentix, non fequitur, quod effe fecundum quid fit priks, quam effe fimpliciter; ipfa enim mareriæe effentiaindererminata prior eft, quam effentia quantitatis interminat $x$ : fi vero effentiam fumant $v t$ determinatám per formam, quodappellari folet effe fpecificuin, hac comparanda eft cum quartitate terminata ipfam infequente, non finterminata, qua foli prima materiz comparăda eit; forma vero fubftantialis dans rei effe fimpliciter, id eft, conftituens ipfam in aliqua fpecie fubftantia prior eft quantitate confequente, qua non dat rei effe fimpliciter, fed effe fecundurn quid; quia confituit eam in categoria accidentis. Si vero effe pro exiftentia accipiatur, hanc dare poteft fola forma fubftantialis, quare nequit aliquod accidens formam pracedere, quod vllo pacto rei prabeat exiftentiam: itaque nullum modum video, quo fit prius effe fecundum quid, quam e?fe fimpliciter; nam quantitas interminata non dat effe fecundum quid, quod fit coarfatum ad aliquam certam quantitacem, hoc enim vtique effet abfurdum, nempe rem effe prius dererminatam fecundum f́peciem aliquam accidentis, quam in fpecie villa fubftantirs; at quantiras interminatadat quidem materia effe fecūdum quid, fed indeterminate, \&r eo prius eft effe materiz fubftantiale, quod fimiliter eft indeterminatum : quoniam igitu r prius eft in materia elfe fubftantiam, quam effe quantam inter- $F$ minate, effe vero determinatum, quod tribuitur ¿े forma, eft prius omni accidente terminato, quod tribust effe fecundum quid, manifeft ŭ et, nunquaim effe prius effe fecundum quid, quam dd gaar eife fimpliciter. Ad quartuns cöcedimus, ex matиm. teria, \& quantitare intermmata fieri vinum per accidens, quod prius eft compofito conftanreex materia \& forma, \& vnoprrie; fatis enim eff, $f$ illud ynum per accidens uabeat priorkan fe fal-
A tem fubftantiam materiz, qux dicipoteft vnum perfe, prout diftinguitur ab vno per accidens: videtur itaque hic cauillus in hoc confietere, qued comprarat quantıtatem interminatã cım forma, cum qua non debet comparari: congrua enim fit comparafio forma fubftantialis acquifit $x$ cum accidentibus fimiliteracquifitis, qux his omnibus, vt antea diximus, prior eft, \& primæ inaterix apud Arift. æternæ cum quantitate interminata fimiliter æterna, \& eius naturam $B$ infequente, proinde pofteriorefecundum nacuram. Similis fuit deceptioin argumento præcedente, à quo hoc parum difcrepat. Ad quintum dicimus, quantitatem interminatam neque effe effentialem materize vt per fe in primo modo dicendi perfe, neque etiam penitus accidentalem; fed eife ill effentialem vt per fe in fecundo modo dicendiper fe, effentiam enim materix infequitur quantitas, ficut effentuam hominus riibilitas; quarenec $f_{p}$ arabilis eft à materia, nec ma- $A d \int e_{i}$

C teria eit effentialiter quantitas. Ad fextum dicimus, quantıtatem hanc interminatam nō poffe quartum rerum prıncipium appellari, neque ex eares fieri, parua enim \& incongrua eft hrelacutio, res funt exquantitateinterminata; fed folum dicımus, ex duobus contrariis, \& ex fubiecta materia res fieri;ex materia enim \& forma fiunt res, \& conftant; ex priuatione autem fiunt tanquã ex terminoà quo: ratio autem eft, quioniam hac fingula proprias habent principij raD tiones, forma vt terminus, ad quem mutatio tēdit, \& vt fuo aduentu rem conftituens; priuatio tanquam terminus, à quo recedit, in omni mutationeneceflarius;maceria vero vt fubieetü.deferens mutationem, \& in re genita permanens: ipra vero fecundum fe quantitas interminata nullam habet principii rationem, fed eft conditio quxdam materiz, qux fubiici non poteft, est $q$ ss nec fuo officio funginififit quanta : fic etıä ma- skmp terix potentia, de qua ante loquutifumus, nul- cepiss E lam habetpropriam rationem principii, fed efî gener. conditio conftituens principiū materiale; quan- onis. titas vero dics poteft eiuldem conditio, non tamen vt conftiruens, fed vt fine qua non. Ad reprimum dicimus, incongruam effe interrogationem, an per quantitatem interminatam materia fiat actu diuidua, an poteftate, fiquidê dtuiduum, feu diuifibile fignificat manitefte poteftatem, nóactuın;nam diuifibile vocamus non id, quod actu diuiditur, fed quod habet pote!t? tem vt diuidatur; nifi fortalle dicant actu diuifibile effe id, quod habet poteltatem proximam vt diuidatur.poreftate autem druifibile, id, quod haber poteftarem renıotiorem; quoniam enın agens non agitnifi in fubiecto bene preparato, \& idoneo ad recipiendum, ideo illud fubiectum, quod nondum eft bene præparatum, dici poteft habere patiendi poteftarem remuciorem; veficeram dicam us diuiduä efle, \& ferrum. diuiduum, fed ceram actu, ferrum veropotefta- 
te: cera namque diuidi ftatim poteft, ferrum autem non ftatim, fed a liqua adhibita praparatione. Hoc igitur modo fi intel ligant actu diuifibile, \&diuifibile poteftate, dicimus primam materiam, quum fit per fe quanta, habere primam radicem, \& rationem precipuam diuifibilitatis, \& ita fieri diuduam, non tamen a ftate; diftat enim aliquantum à diuifione, \& praparatione indiget, quia diuidi prafupponit rem effe actu, id enim quod won eft actu, non eft aptim fuftinere actionem agentis:oportet igitur materiam prius fieri actu per formam, vt recepta forma fit diuifibilis actu, feu poteftate propinquiore; quare per quantitatem interminatã materia fit diuifibilis poteftate remota : quod vero illi dicunt, ergo illa quantitas eft fruitra, quia etiam fine illa eft materia diuifibilis poteftate, hoc negandum eft; dicimus enim materiam fine quantitate diunduam dici non poffe, hoc eft, nec actu, nec poteftate, quia neq; à forma,ncque ab vlloagente poteft quantitatem recipere, nifi eam habeat fuapte natura, quare i- nunquam fiet diuidua. Ad poftremum argumentum dicimus, quantitatem interminatam effe in categoria quanti; quũ enim quxlibet categoria diuidaturperpoteftatem, \& actun, vtinquit Arift. in context. $\sigma$. primi libri de Anima, \& in context.3.\& 6.tertii Phyfic. eft quidem pracipue in categoriaillud, quod iam eft actu,idq; refpiciens Arift. in cap. de quanto dixit, quantum effe illud, quod denotat certam rei quantitatem, per hoc fignificans, folum quätum terminatum effe proprie, ac directe in categoria quanti; attamell non negaret etiam quantitatem interminatam pertinere ad eandem categoriam, $\&$ in ea effe per quandam reductionem, \& fecundario: fic etiam in categoria fubftantix non folum eft homo actu, \& perfectus, fed etiam homo poteftate; nam prima materia eft poteftate homo, \& poteftateomnia, \& ponitur in categoria fubftatix per reductionem, tanquam omnium fubftantiarum inchoamentum; ideodicere folent, fubftantiam compofitam, \& actualem proprie, \& precipue in genere fubftantiz collocari, materiam vero \& formam, qux funt fubftantix fimplices, in eodem effe fecundario, \& tanquam partes fubftantiz compolit $x$.

\section{An prima Materia fit corpus de genere jubfantia, opiniones varia.$$
\text { Cap. XII. }
$$

T-Aetenus oftenfum eft, primam materiam Heffe per quantam, \& ita effe corpoream quatenus habet tres dimenfiones, qua confttuunt corpus de genere quantitatis; confiderandum-reftat, an fecundum propriam naturam, \& antéaduentum forn de gentre fubftantix. Hac de re tres ad furamum inuenio aliorum fententiás. Prima eit il-
A lorum qui in materia ponunt formam quan- Prima odam fubitantialem eternam, quamalii vocant piria inchoatiuum formarum, alii formam corporcitatis, à qua habent omnia naturalia corpora vt fint corpora, ita vt ea fit natura communis refpondens corpori, quod eft fupremumgenus in categoria fubftantix; fententiam hanc fequiztus eft Auicenna in primo fufficientix cap.2. \&c in 2. trątatu Metaphyf. cap. 2. \& Albertus Magnus, \& Linconienfis, \& Ioannes Gandauenfis,

B . \& Auguftinus Sueffanus, \& meis temporibus M.Antonius Genua preceptor meus, qui oftendere nifus eft, dari hanc formam infeparabilem à prima materia, \& ab Arift.fignificatam nomine priuationis tãquam omnium formarum imperfectiffimam. Secunda eft fententia, quam tueturIoannes Grammaticus in lib. fuort. con-opinio. tra Proclum, vbi oftendit primam materiam fecundum fe effe corpus, quia eft ipfamet trina dimenfio, ita vt trina dimenfio in materianon c fit accidens, fed fubftantia, \& nil aliud fit fubAtantia ipfa materiæ, quam triplex dimenfio, longitudo, latitudo, \& craffities. Tertia eft opj- Tertia nio communis, in qua videntur cateri omnes opinso. philofophi confenfiffe, quod prima materia fecundum fuam naturam non fit corpus corpo. reitate fubftantiali, fed illa folum, qua eft de generequantitatis, quum fit per fe quanta, vt iam demonftrauimus; corpus enim de genere fubftantix dicunt effe illud folum, quod ex maD teria \& forma conftet. Ego vero his omnibus Duart fententiis confideratis, atque reiectis oftendam of inso primam materiam in fua prima notione, \& in propria. fuz naturæ puritate acceptam nil aliud effe, quam corpus de categoria fubftantia, non quidem per formamillam ziernam, quam prima illa feeta tuetur, neque quia fit idem quod trina dimenfio, vt Ioannes Giammaticus; fed quia fecundum propriam fuam naturam eft corpus fubftantiale fimplex, trinæ dimenfioni fubieE ctum: \& quemadmodum non dubito, quin hac fententia primo ipfo afpectu à plerifque $\pi d c^{\prime}-$

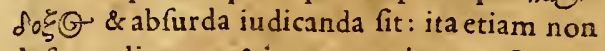
defpero, literatos \& ingenuos viros, poftquam ipfa veritatis fundamenta perceperint, aut in noftran fententiam venturos, aut faltem iudicaturos, me non temere, fed valida \& efficaci ratione ductum, in hans fententiam veniffe.

\section{Argumenta illorumi, qui dicunt primam Matcriam effe corpus per formam corporeitatis eternam. Cap. $X I I I$.}

ZXPENDENDA primo loco eft illorum Hopinio, qui primam materiam dicunt effe corpus per formam fubftantialem illi perpetuo inherentem, \& infecarabilcm : hi plurubus ad hanc comprobandam argumentis nituntur, fed nos reliquis amiffis duo tanG. 4 tum 
tum precipua in medium afferemus, quorum A eam requirant; igitur nec debet, necpoteft for. confideratio ob ea, qua mox dicenda funt, mar rimum gno nobis vfui futura eft. Vnum eft, nifi hac argumé- forma admittatur, dabitur creatio ex nihilo, aum. imoilla, qux folet vocarigeneratio, creatio erit: confequens eft falfum non modo apud Arifto. telem, fed etiam apud Theologos noftros, qui negant, naturam poffe aliquid creare, quum hoc ad folum Deum pertinear; confequentiam ita probant; forma, qux producitur, tota producitur,nulla fui parte prafuppofita, at id, quod totum producitur, nulla prafuppofita fui parte,creari dicitur, ergo forma creatur; hacautem forma admiffa, qux fit omnium formarum inchoamentum, creationem formarum vitamus, quia bac forma ab agente elaborata ad varias perfectiones ducitur, \& fit forma fpecifica mosecundü do huius rei, modo illius. Secundum argumenargkmém tum tribus nititur fundamentis, qux illi ante t*m. omnia ftatuunt;primum eft, veram effe fententiam Auerrois in Porphyrium in cap. de fpecie, quod fuprenum genus vniuocum in categoria fubftantix eft corpus, quod fola caduca corpora complectatur; fecundo fumunt genus vniuocum id folum dici, cui refpondeat extra animam aliqua vna communis natura, qux à plıribus fpeciebus aque participetur, nec fit fola vox pluribus naturis communis, hac enim ambigua, ,eu xquiuoca dicitur; tertio accipiunt, non poffe talem communem naturam, à qua in rebus exiftente fumatur vniuocatio, effe nifi formam, hxc enim effe videtur Auerrois fen. tentia in 2.Phyfic. Comment. 28.\& in 1. Metaphyf.17. \& in 7. Metaphy .43. \& in 8 . Metaphyf. 6. \& in 2.tractatu Epitom. Metaphyf. cap.13. in his enim omnibus locis inquit, partes omnes definitionis effe formas; genus quidem effe formam vniuerfalem, differentiam vero effe formam particularem: his jactis fundamentis ita argumentantur, corpus; quod eft fupremum genus in categoria fubitantix, eft vniuocum genus omnium caducorum corporum, ergo ei refpondet in rebus aliqua vna forma ab omnibus talibus corporibus participata, datur igitur formacorporis,fiautem datur, ergo æterna eft; quia quicquid in reintereunte ineft, quod etiam in re generanda ineffe neceffarium fit, id non debet. interire, fed in re genitaidem feruari ; at corporis natura nulli rei generand $x$ repugnat, imo eft omnibus neceffaria; crgo interire nunquam debet, fi verum eftid, quodab Ariftotele dicitur de fymbclis elementorum qualitatibus in 2 . libro degeneratione; nam fi mutetur aqua in aerem, inquit Ariftoteles humiditatem aqua non interire, fed eandem in aere feruari, quum a mbo fint elementa humida; imo non folum non debet interire, fed neque poteft interire, quicquid enim interit,à fuo contrario interimitur; at for$m z$ corporis nulla eft contraria forina, quum omnes eam complectantưr, imo \& necelfario

ma corporis vnquam interire.

$$
\begin{gathered}
\text { Dicta fententic impugnatio. } \\
\text { Cap. } X I V .
\end{gathered}
$$

A Duerfushancfententiam, quum iam fit ab Aomnibus explofa, pauca dicere fatis erii; impugnat eam nultis in locis Auerroes difputans contra A uicennam, qui eam rutatus eft, prafertim vero in Comment.63. primi Phyfic. B \& in Epitonse Metaphyf.tractatu 2. cap. vltimo, \& vtiturargumento tali : fi in prima materia effet hac forma aterna, fequeretur, non poffe vl lam aliam formam in materia recipi,fed fola ac- $\mathbf{s u m}$. cidentia, quoniam per hanc formam materia fieret ens actu; enti autem actu non poteft aliqua fubftantialis forma aduenire, fed accidentia tantummodo; nulla igitur dabitur fubftantix generatio, fed fola mutatio in accidentibus. Verum alıqui Auerroiftx huius fententix fe. Soluti C Etatores facile effe exiftimarunt, non modo hoc aligue argumentum foluere, fed etiam oftendere A- rum. uerroem eiufdem fuiffe opinionis; dixcrunt enim dip plicem effe forman fubftantialem, $v$ nam fpecificam, \& (vt eorum vocabulo vtamur) vltimatam, qux eft forma vltima fpeciej;
vt hom inis, equi, bouis; alteram vero comnunem \& generalem, qua non fpecies infima conftituitur, fed genus aliquodvt forma corporis, forma viuentis, forma animalis; huiufmodi forma non poteft exiftentiam tribuere, fed fola forma fpecifica id facere poteft, propterea quod forma generalis dat quidem actum, fed imperfectum, \& cum poteftate commiftum; at forma fpecifica dat actum perfectum , \& nulia alia for$m a$ indigentem ad exiftendum: dicunt igitur, $A$ uerroem nō negaffe formam corporis aternam in prima materia, fed eam pofuiffe vt generalem, non vt fpecialem, ideoque Auicennx fen. tentiam reprobaffe, qui talem formam tanquam fpecificam itatuebat, quod ex ipfomet Auerr. argumento colligitur: nam fi materia habeat aliquam formam generalem, non impeditur ne aliam formam recipere queat, fed folum fi habeat formam fpecificam; idque afferit manifefte Auerroes in Commentario 17.primi Meta. phyf. vbi dicit materiam prius recipere formas vninerfales, \& imperfectiores, poftea vero particulares, \& perfeetiores; itaque argumentum Auerrois de fola forma fpeciali efficacitatem habet, non degenerali, materia enim habens formam fpecialem non poreft manente illa aliam formam recipere, fed fola accidentia; at form generali poteft alia forma fubitantialis fuperuenire, quareper formam corporis generalem non tollitur generatio. Sed hi neque A. Solsten. uerrois, neque Auicenna nentem penerrarunt. nis im. Auicenna quidem facuus fuiffet, fi pofuiffet in prgnaprima materia formam fpecificam aternam, rio. quonsodo enim poffet materia effe libera ad

omnes

Formo diples

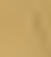

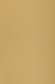

$-$


omnes formas recipiendas? \& quomodo non fuit pofita ab Auicenna vt general is, fi fuit ab eo appellata forma corporis, \& corpus eft generalifirm um in catcgoria fubftania? ? nullau certe formam putauit Auicenna effe generalem, fi formam corporis generalen efle negauit: talem igitur opinionem de forma generali xterna attribuit Auerroes Auicennx, camque refellit, idqueaperte legereapud eum poflitmus in fecundo tractatu Epitomes Metaphyfica, capite vltimo;quare ipfenullam in prima materia formam xternam admifit, nēque vt fpecialem, neque vi generalem; oftendamus igitur, quo modo contra hanc formam argumenium Alieirois fit efficaciffimum, \& eorum folutio vana fit: negari certe nonpoteit forman hancaut effe effentialem materix, aut extraneam, quamuis ci fenper inharentem, quamamodum \& alix form $x$, quxadueniunt naterix, \& ab ea resedunt, extranex illi effe dicuntar: fi dicant effe extraneam, ergo materia ad eam fe habet vt potentia paffiua fed potentia paffiua. vt ait $A$ riftotelesin 9. Mitaphyf. eft potentia contradictionis, \& xque refpiciens oppofita ; ergo matera \& habere \& non habere hanc formam poterit; atqui potentia naturalis non poteft effe fruftra, fed neceffe eft vt aliquando ad actum ducatur; ergo materia erit aliquando fine hac forma, ficut etiam exiftit fine qualibet alia; non eft igitur xterna forma hxc, fed neceffe eft ( $f$ datur) vt interire poffit, \& habcat formam contrariam, à qua alıquando pellatur de materia , iuxta dictum Ariftotelis in libro de longitudine \& breuitate vitæ, fieri non poteft, quin materiam habens habeat contrarium, obidque o. minis forma materialis interitui obnoxia eft. Quamobrē cognouit Auerroes hanc formam non poffe ftatui xternam, \& fimul extraneam. naturæ materix; fed ex neceffitate poni effentialem materix, dum ponitur illi coxterna; hoc igitur conftituto, argumentum Auerrois eft efficaciffimum, quando dicit, ergo nulla daretur fubftantialis generatio, fed fola alterátio, quia materia ita formata non poterit aliam formam. recipere, huius enim ratio fumitur ex Ariftotele in 4 contex. 3 . libri de Anima, vbi dicit, intus. apparens prohibetalienum, \& ibi Auerrois ait, omne recipiens debet effe denudatum à natura recepti; quod quidem dictum non ita intelligendum eft, vt recipiens aliquain formam carere omni forma debeat, hoc enim. falfum eft etiam de intellectu noftro poffibili, dequo ibi Ariftoteles loquitur; is enim habens aliquam rerum cognitionem, poteft aliarum quoque: rerum notitiam adipifci,imo ex principiorum. cognitione in conclufionis. fcientiam ducitur, tantum adeft vt eam recipere prohibeatur; fed. fenfus verborum Ariftotelis. hic tantum eft; 1 lud, quod eft proprium receptiuum alicuius generis receptibilis, non debet intus, id eft, in lua
A effentia includere aliquid illius generis; mens igitur noftra debet fuapte natura effe expers omnium cenceptuum rerum cognofcendarum; \& quodlsbet aliud receptiuum debet in fua effentiacarere toto genere fui proprii obiecti, ad quod recipiendum dirigitur, quia fi quideius in fua efientia contineat, aliud amplius recipere prohibetur; quare totum genus obiectum debet fuo receptiuo cffextraneum, \& nihil eius poteft illi effe effentiale: de conceptibus vero $B$ extraneis \& aduentitiis id minime verum eft; vnus enim vel plures in intellecturecepti nö prohibent nealii recipiantur; ob id non dixit Arift. omne inharens vtrunque, fed dixit intus apparens, ideft, infitum in ipfa effentia recipientis, facere ne reliqua eiufdem generis in co recipi poffint. Sic igitur non ignorauit Auerros, loquendo de formis materix extraneis \& aduentitiis, aliquam formam receptam non impedire ne alice recipiantur; nam tantum abeft, vt forma vniuerfales, \&imperfedtiores materiam prohibeant receptione aliarum, vt potius eam praparent, \& aptam reddant, imo \& neceffarix illi lint ad al ias perfectiores recipiendas : at $f i$ in ipfa materix efrentia inclidiponeremus formam aliquam de genere formarum materialium, ea eflet abfque dubioxterna;fed fiue generalis, fiue fpecialis poneretur, ómnino materiam ims. pediret, nevllam a liam formam recipere poffet, \& itanulladaretur fub ftantialis generatio ; quaDe argumentum Asuerrois optimum eft de forma, qua fit de effentia materiz, qualem cogno: uit effe ex neceffitate formamillam corporis apud Auic. dum xterna effe ponitur:hanc effe $A$ uerrois mentem clare legimus in Com ment.79. primi Phyfic. vbi dicit, fi materia in fua natura: effet formata, non reciperet alias formas ; iure enim dicit in fua natura, quianon putauit im:pedimentum fieri nifiabilla forma, qux de ma.terix effentia effe ftatuatur. Præterea cōtra ean-

E dem opinionem poffunusita argumentari: vana eft omnis forma, qua formx officio nō fungatur, huiufmodiautem eft hac forma corparis; etenim quum forma officium fit materiam: reftringere, \& coarktare, hxc tamen nullam materix coarctation em facit, quia ad nullam determinatam naturam eam contrahit, fed eam: relinquit in tota fua amplitudine, \& in vniuerfali poteftate recipiendi omnes formas, imo neque ip fam corporis naturam cöftituit, quia mox: oftendemus ipfammet materiam fua natura, \& abfque hac forma egregie illa omnia praftare quorū gratia illi. formam hanc aternam introduxiffe videntur, nam fufficit fola materix na:tura ad vitandam omnem creationem;, \& ad faciendam vniuocationem couporis; fruftra igitur hac forma ponitur, qua nullo form rofficio: fungitur; quo etram fit, vt etiamfi daretur, nullo argumento cognofci à. nobis poffet, quum ob. nullum forma oficium necefiaria, atque aterG. 5 ba fit;
Secandis argumeזหm. 
na fit; nam in rebus cognofcimus materix \& form compofitionem, dum manente materia formam interire, \& aliam generari confideramus; at fi forma aliqua ftatueretur æeterna, nulla effet ratio, quaillam materix cum forma compofitionem mente penetrare, \& cognofcere vnquam poffemus: quo argumento ego vti foleoctiam aduerfus eos, qui dicint Coleftecor. pus ex materia \& forma conftare, qua de re alibi Tertium loquemur.Poffumus etiam 1 ta argumentari, hæc arounze- forma corporis aut eit reipfa diftincta à forma rism. fpecifica, vt hominis, vel equi, aut fit vna \& eadem cumilla; fi diftincta, ergo aduerfarii ipfomet fuo argumento vrgentur, quoniam nö euitatur creatio formæex nihilo, etfi enim hæc forma antehóminis generationé fupponitur; forma tamen hominis diuerfa eft ab illa, \& tota producitur, proinde creatur, quia forma corporis non eftparsaliqua form $x$ humanz. Si vero tit vna \& eadem forma, ergo formz fubitantialesintenduntur, \& renitttuntur; quia fi forma illa imperfecta perfici debet, oportet modo magis, modo minusintendi eius perfeetionem, proit diuerfi funt rerum natura, \& perfectiones: fequitur praterea formam hominis, \& formam equi effe eandem fubftantiam, quum veraque fit hacforma corporis perfectionem adepta; nam fi quid eiadditum eft, quo differant, id vel fubftantia eft, vel accidens: fi fubftantia ergo forma eft quid compofitum, \& ex diuerfis fubftantiis conftans, quod minimedicendum eft; fi vero accidens, ergo homo \& equus accidentali tantum differentia difcrepant, quod eit abfurdiffimum. Hac igitur fententia reiicienda eft. Soluenda effent argumenta pro hac opinione prius adducta, fed hæc poft veritatis declarationem, \& comprobationem clarius, ac firmius foiventur.

\section{Argumenta Ioannis Grammatici ad pro- bandum, quod prima Matcria fit trina ipja dimenfio. Cap. $X V$.}

Con Onfideranda eft fecundo loco opinio Ioannis Grammatici, qui in libro 11. contra Proclum niticur demonftrare, primam materiam natuta fua efre corpus, non quidem per formam aliquam, fed quia nil alıdeft, quam trina dimenfio, adeo vt trina dimenfio fit ipfa prima materia, ex qua omnia fint; hac eadem fententia Stoicorum fuit, \& hanc fequens Ioan - F nes refutat efficaciter opinionem al iorum', qui materiam fecundū fe in corpoream penitus effe cenfuerunt, nec fentertiam tantum fuam argumentis comprobat, fed confiderat etiam, ac joluit argumentaaduerfariorū. Vtitur ipfetriPrimum bus argumentis, quorum primum eft : illud ftaargumc- tuendum eftprirum materiale prencipiun otsm. mnium rerum natialium, ad quod nos ducit ratio Arift.in r. lib. Phyfic. aufcultationis fum-
A pta àgeneratione fubfantiali, atqui ratio illa nos ducit ad corpus, ergo prima materia eft corpus: maior manifefta eft, minor probatur: in generatione omnium corporum naturalium tria requiri Ariftot.oftendit. duo contraria, \& fubiectum tertium; horum autem nullum $æ$ ternum eft, nifi fubiectum, nam contraria fe mutuo interimunt, quofit, vt nihil in hoc mundo inferiore xternum fit, nifi prima materia; atqu fola corporis natura in hoc mundo inferiore nun-

$B$ "quam interit, quia præter hanc reliquz omnes res oriuntur, \& occidunt, \& fit qualibet ex non tali, \& mutatur in non talem, vt homo ex non homine, \& in non hominem, \& fic dereliquis; corpus vero in non corpus, aut ex non corpore nun quam mutatur, nullum enim corpus interit quatenus corpus, quum fimiliter in genito maneat natura corporis, fit enim homo ex non hòmine, corpus tamen ex corpore, q̨uare corpus non interit; idque non abfque ratione, nulla enim res naturalis abhortet à corpore, nec vllum habet contrariū, nec vilı repugnat natura corporis, imo eft omnibus necellaria; quare nce debet, nec poteft interire: quoniam igitur fola materia in rebus inferioribus aterna eft, xterna autem eff natura corforic. fequiturnit aliud effe primam materım, quaarm corpusipfum, $\&$ id, quo corpora hac omnia dicuntur corpora. Secundo fic Irannes argunentatur: prima nateria talis eft ftatuenda, per quam idonea reddatur caufa cffectuım naturalium, \& contrario non ef ponenda talis, ex qua non poffic effeEtuum naturalium ratio id oneaaltignari; at po. nendo materiam incorpoream, nulla aliquorum effectuum naturalium reddi ratio poteft, quorum tameh optima affignatur ponędo materiam corpoream; materia igitur corporea eft ponenda: minoritaprobatur: certum eft inter particulas elementorum efle fratutam quan. dam rationem, feu proportionem, yt ex tanto

E vnius tantum alterius generetur, non plus, neque minus; vt fi ftatuta quadam aquxportio fumatur, quz in aerem mutari debeat, Itatuta etiam eft aeris quantitas, quz ex tanta aqua gignipoteft, nam fi quantumcunque aeris ex ea fieri diceretur, poffet etiam ex minima aqua particula generari quæuis magna aeris moles, quod tamen non videmus; huius igitur proportionisnulla afferri ratio poteft, dum materia ponitur incorpoica, ipfa enım forma aqux non poteft effe caufa, vt ex ca tantus aergeneretur, quia lhæc in aduentu forma aeris interiit; fed neque forma aeris, quia certum eft, a eris naturam non poftulare eam fratutam quantitatem, quum \& cum maiore, \& cū minore feruari poffit; materia quoque, fifit in corporea, non poteft effe caufa huus proportionis, quia fi fecundü fe nullam quanitatem, nullamq; extenfioné habet, fed omné extéfionem ab alio recipit, 1 ta poteft ad maiorē, vsad misosem quantitatem ex-
Secundi argume. tim. sendi 
tendi. At fi materia fecundum fe quanta, \& cx tenfa penatur, clarahuius proportionis caufa adducitur; nam tanta materia, qua eft in aqua vniusollx, quum fecundum fe pofit extendi, quia corpuseft, habet etiam certam extenfionem refiectu forma aëris recipiendx, ita ve fi illa aqua in aerem mutanda fit, tamen aẹris quantitatem ex ea generari oporteat, non maiorem, neque minorem : prouscnit enim hoc ab illo refpectu, qui eft denfitatis aquæ ad raritate acris, fed is refpectus non poteft hoc efficere, nifivtriq; eadem materia, vel faltem $x$ qualis lubrtssm fternatur. Tertium argumentum loannis eft: gumen fi prima materia quanta, \& extenfa non effet, inim. diuifibilis effet; hoc tamen eft falfum, quia videmuseam in multas portiones diuifam fub diuerfis formis exiftere; eft igitur diuidua, proinde corporea fecundum propriam naturam.

\section{Argamenta contra Ioannem ad probandum primam Materiam fecundum fe non effe \\ Corpus, qu.e eft communis opinio.

$$
\text { Cap. XVI. }
$$

Po contraria fententia, qua ponitur mate$P$ Ro contraria fententia, qua ponitur mate-
ria fecundum fe penitus incorporea multas contra ferationes loannes adducit, \& eas fingulas foluit: nos vero in prefentia ipfas tantum rationes propon emus, fimulque alias, qua contra eum à pofterioribus philofophis adducuntur, poftea vero \& argumenta ipfa, \& Ionnnis folutiones diligenter expenderisus. Primum quidem Ioannes contra fe ita argumentatur: quandocun que corpus aliquod perit, experientia docet, fimul eius dimenfones interire, \& quando generatur corpus aliquod, fimul videmus in eo generari nouas dimen fiones, necvl. lam in ho c mundo inferiore videmus dimenfionem zternam; at materia aterna eft, ergo non habet dinenfiones fecundum propriam natucundis ram. Secundofic; dimenfiones funt effentialigumen ter in categoria quantitatis, ergo fi materia effet m. iplametdimenfiones, effeteffentialiter çuantitas, hoc tameneft falfum, quia materiact fubAtantia. Tertio, fequeretur, materiamnonefie informem, \& in ffectam, cuiufmodieam pofuerunt omnes philofophi, nam effe trinam dimenfionem, \& effe quantam, eft effe affectam, \& haberepropriam quandam naturam. Quarto, fi materia effet corpus, aut effet finitum, aut infinitum; at neutrum efle poteft, ergonullo modo eit corpus;non eft corpus infinitum, quoniam infinita moles non datur; nes finitum, quia íc materia effet propris terminis circumfcripta, yuod dicendum non eft, ponenda enim eft maceria nullis certis terininis alligata, fed li-

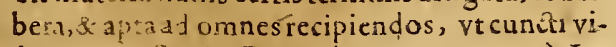
dintul conficri. Præter hres argumenta à Ioantreconira ic al tucta, etram alia complura à poltwo ibus affruacur, ad probandum pro mam materiam fecundum fuam fubftantiam corpus dicinon poffe: fed quoniam magna covum pars nullam efficacitatem habent, vt ipfimet fatentur, ideo cateris oniffis, duo tantum proponam, in quibusilli magnamvim faciunt. Alrerum profitentur fe ex Plotino accepiffe is 4.libr.2. Ennead. quod tale eft : aliud eft quantum,a!iud quãtitas, fic aliud eft magnum, aliud ipfa magnitudo; fimiliteraliud eft corpus, aliud corporetas: nomen enim concretum fignificat B quiddam diuerfum ab eo, quod fignificatur per nomen abfractum; quantum enim fignificat id, quod ha'set quantitatem; magnum fignificat id, quod habet magnitudinem; corpus fignificat id, quod habet corporeitatem : atqui nihil dicitur habere feipfum, habēs enim debet êfe aliud ab eo, quod habetur; itaque fi prima materia eft corpus, habet corporeitatem, proinde eft quid diuerfum à corporeitate, \& à magnitudine, ergo non eft ipfa corporeitas, \& magnitudo, fed eft

C fubiectum corporeitatis, \& magnitudinis; non eftigitur dimenfiones fed fubiectum dimenfionum; proinde fi inente ab eisabltrahatur, erit fecundum fuam naturam penitus incorporea. Deindeargumentum fumunt exverbis Ariforo qui \& in G. Phyficzaufcultationis acens de corpore, \& in 2: libro eiusdem operis, \& inprincipio primi ac tertij de Colonumerans corpora naturalia, nullam primæ materiz mentionem facit;fed fola compofita, qux ex materia \& forma D conftant, corpora vocat; materiam igitur non putauit effe corpus, fed folummodo caufam internam, \& primumprincipium corporum naturalium. Præterea fape Ariftotel-quatuor elementa vocat fimplicia corpora, quoniam, etfi ex materis \& forma conftant, tamen fimplicia. funt vt corpora, quum exaliis fimplicioribus. corporibus non confintantur: at fi prima materia corpus effet, non bene elementa vocarentur fimplicia corpora, çuia daretur corpus fim: E plicius elementis. His igitur omnibus Ariftot. teftimonis oftenditur, primam materiam fecundum fuam naturam non effe corpus. His: moti argumentis recentiones omnes afferunt, materiam non habere aliam corporeitatem, quam illan, quzeft accidens decatégoria quäth; fib btä1iam vero ipfius nulla ratione poffe dici: corpus, fed effe fubftantiam incorpoream ; qua: fuit tertia opinio à nobis propofita ab initio.

\section{Propriafententia declaratio, oo comprom butio. Cap. XVII.}

Q VVM hactenus omnes aliorum ferrtentias expofuerimus, fingulorumque arguisenta retulerimus, iam ad veritatis declarationem accedendum eft. Ego puto pri- opinio mam materiam fecundum propriam naturam, proprias. \& feculfa comn! torma die corpus de catego:

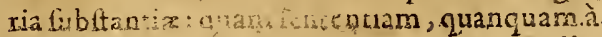
mullo 
nullo recentiorum receptam, nitar \& ratione, \& antiquorum philofophorum teftimonio comCorpses ef generadijss mum.

Primum argumethm.

probare. Illud inprimis manifeftum eft, \& ab ipifímet aduerfariis conceffum, corpus latiflime complectatur, efle fupremuni genus vniuocum in cacegoria fub tantix; huic neceffarium eft $v$. nam aliquam naturam communem refpondere ab omnibus caducis corporibus xque particiacceptum, quod cadica corpora omnia \& fola patam, vnde fumatur huius fummi generis vniuocatio, \& ratio corporis in cun tis corporibus inferioribus; quemadmodum in alis cuufdem categorix generibus \& fpeciebus infpicimus: ratio enim qua viuens ef viuens, \& qua ef genus vniuocum, eft anima vegetans; has quicquid participat, in genere viuentis conftituitur: ratio, qua animal eft a nimal, \& qua eft vniuocum, eft a nima fenfibilis:fic ratio, qua homo eft homo, \& commune vniuocum, eft anima rationalis. Ratio igiturcorporis in quonam eft conftituta? quodnam eft illud, quodin rebus natura exiftens facit eas effecorpora de categoria fub. fantiz? certe neceflari um eft, vt omnia corpora vna \& eadem ratione fint corpora, ficuranimalia omnia habent à fenfu vt fintanimalia: hæc ratio corporis neceffe eft vt fit vel materia, vel forma, vel nexus form $x$ cum materia, vel ascidensaliquod. Accidens quidem dici non poteft, quoniam accidens non eft aptum fubftantize effentiam conftituere. Forma aliqua dici non poteft, iam en im reiecimus illorum fententiam, qui formam corporis $x$ ternam in interia ftatuebant, eaque his temforibus ita cftà communi omnium confenfu reprobata, \& explofa, ve fuperuacaneum fir, aduerfus eam aliquid pr $x$ terea dicere, fed pro comperto conftituendum fit,nullam dariformam corporis. Reftat igitur, vt ratio corporis vel fit materia, vel nexus form $x$ cum materia ; illi quidem, qui \& forman corporis negant, \& materiam fecundum fe incorpoream effe dicunt, in folo nexu formx cum materia rationem corporis conftitutam etfe arbitrantur; proinde, nec materiom folam, nec for mä folam, fed ip farum cōpofitionem effe rationé omnis corporeitatis, vt quicquid matera \& forma conftat, id corpus effe dicatur: hreplurimorum Latin orum, \& omnium recentiorum fententia elt, quam fi falfam effe oftenderimus, fola materia relinquetur, qua omne corpus dicatur corpus, \& quae fit natura communis abomnibus inferioribus corporibus xque participata, qua refpondens corpori fummo generi in categoria fubltannize faciat illud effe vniu ocum. Primum igitur contra illam communem fententiam itaargumentor: ex componentubus incorporeis non poreft compolicum prouenire corporeum, atfecund um ęos non munus rateria quam forma eft incorporea, compolitum igitur non poteft effe corpus : maior clara eft, quianeutrum componentiuin potest alteri da- re corporeitatem, quum ipfum eam non habeat; quare nulla ratio apparet, cur corum nexus polfit facere corpus, imo ratio adeft manifelta, curnon poffit. Prxterea ratio, à qua fumitur vniuocatio cuiuslibet fiue generis, fiue fpeciei, debet effe natura aliqua fimplex, qux 1 lli extra animam refpondeat, vt patet omnia confiderando: nam ratio viuentis eft fimplex forma, anima nutriens; fic ratio animalis eftanima fenfibulis;fic ratio hominis eft anima rationalis; fic B ratio equi eft forma ipfa equi,fic dico dealiis omnibus; vtamur igitur argumento tali :magis videtur raio, qua homo eft homo, effe compofitio, vel natura aliqua compofita, quam ratıo corporis, quia fpecies maiorem habet compofitionem, quam genus; attamen ratio hominis non eft compoficio aliqua, fed fimplex forma; ergo multo ninus ratio corporis debeteffe cōpofitio, fed deber effe aliqua natura fimplex, atqui nulla eft in rebus fubitantia fimplex, nifi

C forma, \& materia ;ergo duasumaltera ftatuenda eft ratio corporis: forra quidem ftatui non poteft; vel cuiusque propria, qux Specifica vocatur, quorum neutrum dici poteft; nam generalem corporis formam iam refutauimus, camque ipfi quoqueaduerfarij non admittunt; forma vero fpecilica facit quidem tale corpus, at non facit abfolute corpus, nam à for ma ignis habet ignis vt fit tale corpus, nerıpe ignis, fed non ve ab$D$ folute fit coıpus; fic animal à fenfu habet vefit tale coipus, quod animal dicitur, non vt omnino fit corpus; quandoquiden omnis eiusmodi forma materiam reftringit, eaque reftrictio repugnat natura corporis, quod coaretandum non eft, fi cuncta naturalia corpora complecti dcbeat : praterea ab vna forma prouenit vnum effe, non plura; ergo fi forma animalis dat effe animal, non poteft eaden dare effe corpus: adde quod ratio hrc vniuocationis, de qua in E prafentialoquimur, vnatantum, \& adaquata effe debet; quare fi ratio corporeitatis confifteret in forma animalis, folum animal effet corpus, vel omne corpus effer animal, fic dico dealiis fingularum fpecierum fiue fpecialiffimarum, fiue fubalternarum propriis formis : fi enim ali qua earum daret effe corpus, fimiliter qualibet aliarum daret effe corpus, quod quidem abfurdum eft; quia nulla iftarum effet adxquataratio, qualem in prafentiaquxrimus, F à qua tanquam vna vniuocatio corporis defumatur : quod fi dicant, aliam corporeitatem prouenire à forma animalis, aliam à forma lapidis, vt illa folis animalibus det vt fint corpora, hre vero lolis lapidibus, iam non erit corpus genus vniuocum, quum non vnailli in rebus natura refpondeat, fed alta ratione hxe res dicatur corpus, alia veroilla, ve enım cor. pusfit vniuocum, oporter vnd \& eadern ratione omnia dicicorpora. Quoniam igitur ratio cor. poris

\section{Ratio 8 rionis deberef fefim. plex.}

\author{
(1)
}

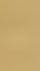

$-$ (

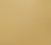


poris nequeaccidens aliquod efre potelt, neque forma vlla, nec compolitio foruix cum materia, telinquitur earn null.um efle aliam, nififo-

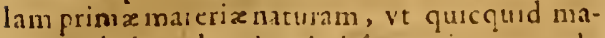
teriaru habet,abeadem hiubéat, vetit corpus de carcgoria fubstantix; reucra enim in corpore, ve cômuni genere conuenire nilaliud eft, qum contuenire in participatione ciufdem materix; quare niaturianonmodo corporea eft, fed corpus inlum, quod in categeriarubftantix fummum gemus ponirur, idouc fignificare vifus est Ariforeles in contextu if primi libride Oitu \& interitu, quando dixit, materiam liberamad undī oppolita efle relutigenus. Arguncntumetiam ssze- funcrepoflumus à corpore de genere quantstats: quum enin duplex fit corpus, vnum de categoria lubłtantix, alcerü de categoria quanii, exnatura vnıs duci polfumus un cognitionem naturæ alterius, nam accidentia funt cuidentiona lubltantiis; idio corpus de ginere quanti, yidelicet trina dimenlio, eft eusdentius corfore de generefubitanciz, \& ex eo \& in huius notitiam perucnire folfumus, quum vnum ab altero infeparabile fit; nam corpus vllum de catigoria lubitanize dari, quod dimenfiones non habeas, neque polisbile, neque ( $v t$ mihi videtur) excogitabile eft: fed neque rrina dimenfio elle poteit abfque fubftania corporea, in qua inbareat, accidons enim fine fubiefto exiftere nequit; fubftintiis autem incorporeis di. menfiones non inefit manifeftum eft, folis, $\mathrm{gi}-\mathrm{D}$ turcorporeis; quidergoaliud dicese polfusmus, quam lubftantiale corpuse feillam. fubtätram qux tribus dimenfionibus fuhsecta efíetenim fubitantiam, qux dimentiones non habeat, nemo yocarec corpoream, \& eam us qua infinitres dimenfiones, corpoream omnes vocant; videtur namque nomen corporis precipue dimenfiones fignificare, \& inde factim effe vt fubieEtum ab eo nomen fumplerit, \& fit appellaium corpus de categoria fubtantize quodinilalud eft, quam fubitantia trinz dimenfioni fibbe. cta ; hac fi ita vera fint, vt negari non porlint, tali argumento v tanur : illud eft primum corpus de categoria fubftantiz ordine originis, à. quo primo emanat corpus de categoria quanti, \& in quo prisooinharertanquam proprium: illius accidens; at prima materia: eft primum fubiectura corporis de caregoria quanti, idque ex iplius materix natura primo emanat; ip fai igitur materia eft primum corpus de caregoria: fubftantix. Maiorem propofitionem modo declarauimus, minor vero fuit antea diffufe, \& abunde demonftrata.. Clariffimum certe hoc: eft,ita mihi quidem res ip fa loqui videatur:quia. fi materiam mente contemplemur abiunctam: à formis, nil aliudiconcipere poffumusnifi corpus quoddam vaftum, \& indiftinctum, \&. molem quandam vacuam, vt dicebat Plotinus: at. formam duni fine materia, confideramus, con
A cipimus $\nabla t$ quoddam incorpereum, \& indiuifbile, quod foftea in materia quanta extendatu: : q $\operatorname{lod}$ li ali tanto funt ingenii acumine pradui, vt valeant ipfam quoque materiam incosporamimarinari, egotamen (ve meam rudita: non folum à natura corporis abiungere mente naturam mateiize nequeo, fed eandem effe puto naturam colporis, \& naturam materix, hoc enim \& ratio, \& res ipfa mihi efficaciter. E perfuader.

\section{Einfacm fent cntia confarmatio ex plurium. antiquormm philojophorumin auctori-}

tate. Cap. XIIX.

Ententiam harc multorum auctoritate conSirmare poffumus. Primum qquidem non du ito, in eader fuife Plotinum, idque manifitum eft legentibus quartuoa librum z. Enveadi;, cuius verba aliqua ante confiderauimus, quum de dimenfionibus materix loqueremur, reliqua apud ipfum aliis legenda relin. quo: materiam enim corpoream abfque dubio ponit \& figuificat itafe habere fubftatiam materix ad dimenfiones interminatas, vt corpus perlectum fe habet ad determinatas, \& neceffarium effe vtdirnenfiones inhæreant fubftantix corpole $x$, interminat $x$ quidem, \& potentiales: corporiundeterminato, \& porétiali, quxe tt prima materiznatura; terminatæ vero, \& ątua. les corpori determinatx naturæ:, \& actuali, \& perfeto; reuera enim neque corpus de categoria quanti exiftere poteft fone corpore decategoria fubftanira, neque hor fineillo. Alexandex: quoque in fecundo libro quaftionum naturalism, cap. 3. apertedicic, materiani, quafecundum fe omnis qualitatis, \& figuræe eft expers, ef fecorpusfineactu. Hæc eadem fententia Simpliciifisit, qui in primo Phyficx aufcultationis, cõtextu fexagefino nono probare nititus, matexiam efí corpus indeterroinatum, \& potentiale, \& vtitur foc argumento:illud, per quod: differunt materialia ab immaterialibus, eft ipfa materia; at per nolem, \& corporeitatem differunt materialia abimmaterialibus; ergo materiaprimaeft corpus; qua Simplicii argumentatio eft op tima, \& eandera vfus eft Ariftoteles in 2 . lib. Phylica aufsultationis ad inuefigandum quid fitnatura, \& in fecundo de anima ad indagandum quidifit animas illud enim eftnatura. per quod naturalia à non naturalibus diftinguuntur; \& illud eft anima; quo differunt animata ab inanimatis, ficigitur, iliud eft materia, quo differüt materialia ab immaterialibus. Adducit etiam Simplicius locum Ariftotelisà nobis antea confideratum in 4. Phylic aufcultationis part: 15. vbi Arift.dicit, matexiam effeextenfionem quandam \& molem : neque dicere pof fumus; Simplicium eo modoidintellexife, quo loancs Grammaticus intellexit, Iowpe mate:
Alexander. Simplicrizs. 
riam efre ipfasmet dimenfiones, etenim ipfe in contextu 22. primi libri de Colo eam Ioannis opinionem impugnat; quarenon de dimenfio$n$ bus loquitur, fed de ipfa materize fubftantia dimenfionibus fubiecta, \& ad liunc fenfum locum illum Ariftotelis trabit; fed argumentum quoque illud Siraplicii, quod expoluimus, ad fubftantiam materia pertinet; qua enim ratione Ariftoteles effentiam declarat \& natura, \& anima, ê̂dem Simplicius declarat effentiam materia, eam que dicitnil a li ud effe, quan corpusindeterminatum, quare non poteft intelligere materiam corpoream corporeitate accidentali, quia hac enentiam materizenon conftituit, neg̨ue per hanc primo differunt fubitantia materialesab immatcrialibus: fed quifquis in somorato loco verbasimplicis legat, aperte videbit, eura de fubftantia inzteriz loqui, \& 10. Gram cam probare effecorpus. Sed \& Ioan. Grammamatis $\%$ tici opinio fententiam noftram confirmat, nam aliorum omnium proxine ad veritatem loan. nes'acceffit; vidit enim fub nube veritatem, neque eam ita eft affequutus, vt fe prorfus ab errore immunem feluatrerit; nam cognouit fubfiantiam materix effe corpus; fed quianon diftinxit corpus de categoria quanti à corpore de categoria fubftantiz, vnam putauit effe corporeitatem, quz in dimenfombus conffitit, eamque in componitis accidens effe dixit, in materia vero effe fubftantrais, \& iplammet fubftantiam ateriz, quum potius debueritex dimenfionibus, \& corp reitateaccidentali duciad cognof́cendü fublitantiale corpus illis fubictum, \& ab illis diuerfum; quem errorem notafie videtur Auerrocs in calce fecundi tractatus Evjtomes Meta phyfica, quando dixit, aliquos exiftimafle co:poreitatem, qua eft in prina materia, efle iubftantiam: itaque fi Ioannes dixiffet, primam materiam ita effe corpus de categoria fubltancire, vt effet fubitantia dimenfionibus fublecta, nonvt effet ipfrmet dimenfiones, nihil effer, in quo eum reprehendere hac in repofremus; in hoc tamen eius confefionem accipimus, quod dicit primam materiam effecorpus de categoria fubtantiz, quod nos quoque affeAser. rimus. Auerroes quoque idem fenfit, vt oftenros. derepoffumusmulta eius diata perpendendo in varislocis: primum quidern confideranda funt duo Auerrois dicta, qua pugnare inter fevidentur, eam in 3. Metaphyf. Comment. 1r. \& in 8. Metaphyfic-vltimo, \& in Epitome Metaphyficà Geszer'a tracta. 2. cap. 13. in quit, genera effe compofita, \& fint $c \bar{D}^{-}$exmateria \& forma conftare: contra vero in $z$. pofira. Phylicz aufcultationis Commentario 28. \& in primo Metaphyfic. 17 . \& in 7 , Metaphylicosum 43. Ex in octauo Metaphy ficorum 6 . \& in endem Joco Epitomes Metaphyfice dicit omnes partes definitionis effe formas, genus effeformam vniuerfalem, dıffeı étiam veroclie formain parsiculareín; quæ due dicta contraria videntur, quia fi genus eft forma, non poteft ex materia \& forma confarc: non funt tamen contraria, quia fimul vtrumque verum eft; diuerfisenim modis genus dici poteft \& forma, \& materia, \& conftans ex forma \& materia; ipfum quidem fecundum fecompofitumeft, conftat eniua animal ex forma animalis, \& materia illi foimz fubrefa, ideo eriam Alexander in fecundolibro quaftionum naturalium, capite vitimo dicit,a-

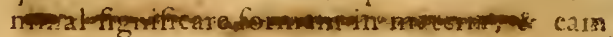

B forwam vocat communem; hinc aum fume modo matcria, modo forma appelletur:ủum enim confideramus ipfum efie talem per formam, non permateriam, dicimus genus fignificare formam; animal enim non per materiam, fedper forman fuam efi anjmal, \& ita fignificare dicitur formam vniverial $\mathrm{rm}$ : verum qua animal refpectu formx fyecific locur habet materiæ, ideoanimal efis humine tanquam materiz, vt ait Porphyrius in capite de differentia, licerfecunduin fe fit perforias animal, \& licet ex materia \& forma conftet. $\mathrm{C}_{2}$ terum Auerroes quando in memorat is locis inquit, generá effeconipolita, excipit folum general.fimum quod dicit efie timplex, quum a ninia iubaitena genera fint conpofita, vrode colligit generalifimum non habere detinitio nem: que A uerrois fententia de fupremogenere eftratinni maxime confentanca quia clle fupremum genus, \& ex materia \& forma confare implican contradsctionem, \& fimul exiftere nequeunt, nam omne habensfornam informantem, \& refringentem ipäm materiàn, habernceffriodiffentiam conitituentem, proinde etiam nec frario habet genus, quare non potelt clit fupremum : itaque fi omnegenus ex materia \& formaconftare dixermus, procedimus in infinituming nerbus, nec ad fumn:um vnquam peruenicnus. Quun igitur manif:fum fit, Auerroem putafic tupremum genus vE niuocum in categoria fubfantia efle corpus, idque dicat effe fimplex, neceflarium omnino eft, ve fit vel fola forma, vel fola materia; forma fola efle non poteft, quia forma fola non patitur, nec recipit, fuminum autem genus paribile maxime eft, \& recipit onnes interiores differentias diuidentes, ficuti matersa recipit forma: adde quod fieffet forma, non efiet forma abiuncta à materia, fed forma materialis, effet igiturforma in materia, ficut alia quoque infe. riora genera, quare non effet fimplex,neq; fupremum, ficusiden omnisforma haterialis materiam pralupponit, vtpote natura priorem : reftat ighur vi lit fola materia, caque eft Auerrois fententia in pradieto loso Epromes Metaphyf.

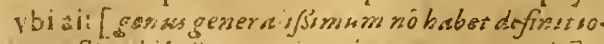

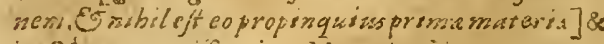
in Cónenr. 43. feptims Metaphyi inquat, genera diftingui inecr fe quatenus a lia funt fimiliora form $x$, alia veromateriz, quī n. officiü form $x$

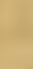
a

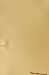


fit coaretare, ac diftinguere, fequitur vt inferioregenera tanquam reltrictiora, \& diftindiora magis habcant rationem form $x$, fuperiora vero, \& coinmuniora magishabeaut rationem materix; reuera enim genus inferius in categoria nobilius, ac perfectius eft generefuperiore, ei nam que tanquarn inateria forma to faperaddit, quareadillud cam habet rationem, quam forma habetad mareriam, \& pertectio ad perfectibile, \& actus ad poteftatem : quamobrem necefirium videtur, vt, quoniam ad genera fuperiora afcendentes, quanto magis afcendimus, tanto ad materialion, \& magis potentialia tranfimus, neque in infinitum acendimus, definamus tandem in fupremo, quod fit para materia, hac enini nilil in genere fubltantix potentialius,atq; imperfectius datur: recre jgitur Auerroes dixit generalitionum effeproximum, \& finilimum prima materix, \& efle fum plex, genera vero fubalterna habere cornyofitionem, atque ex materia, \& forma confrare. Cxterum quarere aliquis poffet, cur Aucroes dixerit, corpus fupremum gemis efie proximusn prima nateria, nec dixeritelfe materism ipfam, fi nil aliud fignificat nomen corporis, nitipfamet materiam. Ad hocfacilis erit refponlio, fi materiz \& generis turn difcrimen, tum conuenientiam intellexerimus: loquitur hac dere Alexainderin fecund.libr.naturalium quxftion ua, cap. vlim. fed ea qua ab ip fo ibi dicuntur, adeoleuia funt,vrad propofitum nihil conferant; furmit cnim Alexander genus logice potius, quam naturaliter, rempe vt eft in animo, \& vecatur vniuerfale poft multa, non vt fignificat naturam communem, qua extra niman in rebus exiftit, diciturque vniuerfale in mulcis: ficautem facile ipfituit generis \& materia, difcrmenconfiderare;nos vero non de conceptiancanimi loquimur, fed deipfare, quae extra animain conceperigenerisrefponder, \& quarimus quetrodo genus hoc, realis hxc naturabipla aseria diftinguatur. $R+m$ bancdodulime, ac protundiffine declarat Auerroes in 6. Commeniar. 8. Meraphyfic. \& docet materiam, \& genustic idem re, fed ratione diftinguijanirial inum quod cít in fpeciebus, eftum matcria, tum gerus fpecierum, genus quidem, quasenus eft id, qrod re fpondet conceptui in animo exiftenti, \& ita fumitur ad modum totius; materia vero, dum fumiturad modun partis; fi enim fumatur vt hominis pars effentialis, hoc modo non ef hominis genus, nec de homine prædicatur, quia nulla pars de fuo toto predicatur in cafu redo, \& nullum totura eft fua pars, proinde pofiuzaus dicere non effe veram banc propolitionem, homo eft animal, dum fumirur auinal vemateria, \& pars hominis, homo enirs noneft fua materiapatet igiturantmal acceprun ă no jug partis effemateriam hominis, uon gen as : fr vero fumarus animal non vepars bominds, fed ye to-
A tus homo poteftate, \& coufufe confideratus? liac propolitio eft vera, homo eft animal, \& animal lumitur pro genere, pars ad modum totius? non ad nodum partis; ideo Ariftotel. in contex. 3. \& vltim. 8. Metaphyficorum dixit materiam \&: formam idem fignificare, cum difcrimine tancnaecus \& poteftatis; nam materia hominis eft potifate idem homo, qui poftea pes forman fit hemo actu; \& Auerroes dicit, materiam. non predicari de compofiro quarenus eft eius B materia,fed quarenus cft eiusgenus, \& fumitur ad molum totius, nempe vt eft poteftate totum compofitum ;eadem ergoeftres, qua alia raticnevocatur materia, alia genus. Ad hanc generis \& materix conuenientiam refpexit Arift. in context.54 primilib.de ortu \& interitu, quando dixit matcriam efic veluti genus, \& in eodem librincap. deaccretione, dum materiam fxpe vocauir genus commune. Hrc omnia, quxin animaliconfiderauimus, fi fupremogeneri cor-

C poriapplicemus, tota rei veritas de prima materiainlucem prodibit ; corpus enim fignificat iplam pimam rateriam, \& iff tanquam generi ailaliud in rebus refponder, nifi päma materia, fed fumi potef corpus a ad modum partis, a ad rsodurn totius; vtrefpectu elersenti corpus eft tum ateria, tum genus; eit enim genus ynis quatenus eft poteftateignis, \& totum ignem fignificat confire, materia vero quatenus eft altera pars fubltantiz ipfius ignis, qux D potentiam habet recipiendi formam, per quam fiat 1 gnis actu, quaratione corpus non eft genus ignis, nec de iplo pradicatur in recto, fed eftipismet prina materia, nempe corpus nulla differentia conficuente coarctatum, fed fimplex, comni carens compofitione ;ideo eadem differentia vocatur diuifiua refpectu generis confiderati quatenus eft genus, hoc eft, quatemus ef? totum quoddan commune; \& vocatur confitucius, dum idengenus confideratur vt illifub-

E ftratum tanquam materia, qua à forma perficitur. Pofium us autera ex ipfá elementi natura fumere pro hac fententia argumentum validum : nam fiab aliqua fpecie auferatur mente differentia conftituens, remaner natura communior, qua vosaturgenus, vt fi dematur ab homine rationalitas, remanet aniaial, \& fic de fingulis; ignis autem ex prima anateria, \& p:opria forma conftat, ideo fi propria ignis differentia, quaipfius forma eft, auferarur, rema. F net eius genus, atqui ablata forma ignis nil remanet nifi prima materia, ergo prima materia eft genusignisinon eftautemaliud ignis genus, nificorpus, ergoprima materia eff corpus, nec reuera dicere aliud poffumus;ignis enirn \& ignis. eft, \& abrolute corpus, habetautem ì fua forms yt fit ignis, quare non habet ab esdem ve fir corpus hoc igitur habetà materia, quünibil in igne

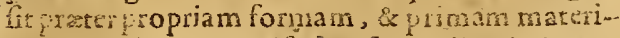

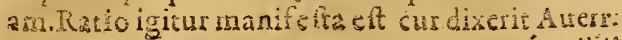


nibil efe prime raterix propinquius, quam generaliffimum, nec dixerintgeneralillinum effe corpus a ipfammetmateriam; quamuis enim eadem res lo modo- fit, alio tamen modo dicitur matera rerum oest genzes mnium, aliogenus generaliffimumres omnes generals complectens : dum enim fumitur ad modum Sumum, partis, eft prima omnium rerum nateria, qux alsomo - eft poteftateres oxnes \& fit fingula resper redoesf pri ceptionem forma ; dum autem lumiturad moma mate dum totius, 8t vt confufcomnia complectitur, ria.

Notaa-

lia Auer

rois Ger

$6 a_{2}$
A folas elementorum formas nominare, non quod neget corpus effe genus etiam miftorum, fed quia materia primum recipit formas eicmentorum, deinde per eas etiam formas miftorum, ideo fatis habuit formas elementorum no. minare, ad quas materia cft immediate propenfa. Praterea aduertendumeft, Auerroem non ab qque artificio dicere corpus efle fupremum genus vniuocum, quod reperiatur in indiuiduis fubftantix, nec dicere in categoía lub.

B ftantia, quia ipfum confiderat non pront eft conceptus anımi, \& vniuerfale poft multa, fed prout eft natura communis extra animam exiitens in indiuduis, \& illi conceptui refpondens, qua dicıtur vniuerfalein multis; per hanc enim fit, ve corpusfit genus vniuocuin, ficut antea dictum eft. Ex his obiter colligere porfumus Latinorum errorem, qui diftinguunt genus fhyficum à genere prædicamentali, quod vocant genus logicum; genusenim phyficum in C quiunterfe genusfubiectum, id eit, materiam vnam; genus autem logicum effe genus pradicabile, quareputant fub ftantian æernam, \& fubftantiam caducam in genere phyfico non conuenire, quia communem materiam non habent, ideoque dicunt has fubftantias differre inter fe plus quam genere, nempe phyfico, conuenire tamen in genere logico, hoc eft, in vno communi conceptu vniuoce pradicabili de o. mnifubftantia tam xterna, quam caduca : qua $D$ fententia iureà Zimara refelliturin Theorem. 62. quoniam hac duo genera re diftinguenda non funt, quumnon detur vnum finealtero, \& fint vnum re, duo autem ratione; nata genus predicabile non poteft vocari viniuocum, nifi ei e:tra animam vna communis natura refiendeat, proinde vanus eft illeconceptus, cui nulla refponceat in rebus communis natura; propterea rubftantux à materia abiunda, \& corpora caleftia, \& corpora inferiora nullum habent E gere non quidem formam aliquam in prima materia diftınctanı à formis element orum, fed naturam inclinationis aduenientis prinx $\mathrm{ma}$ teriz, qux eft veluti genus formis elementorum, quaratione fi Auicenna intellexit materiam effe corpus (inquit Auerroes) diatum eius verum eft, ita me Diiament; ö hincinfert itatım corpus effe ampliffirnum genus vniuocum? quod in indiuiduis fubftātiæ reperiatur. His Auerrois verbis tora reiveritas puicherrime, \& apertiflirae continetur; nam concedit Auer.materiam effc fummum genus in categoria fubftantix, fi modo fumatur vt genus, id autem eft, s fi fumatur vt inclinata ad formas elementorum, quod eft eam fumere ad modum totius, \& quateruspoteftate eft ipfa elementa tota; vnde colligit corpuš effe genus vniuocum, cui refpondet in rebus vna communis natura, qux eft natura primz materiæ; hocigitur modu non negat Auerroes materiam effe corpus, idque ita aperte, ve nullus cauillandi losus relinqui vidcatur. Notandumautem eft, Auerroem ibi communegenus pradicabile vniocum; quum crim in materia non conueniant, in nulla communinatura participata conuenirepofiunt, fed fupremum genus in categoria fubfantia vniuocum eft corpus fola inferiora complectens; quia hre communi materia participant, à qua hac vniuocatio prouenit. Volo etiam ad noftra fententiz comprobationem verba quxdam Thomx, \& Caictaniadducere: quum enim Thomas in prima parte Summa, quaft, s5. nxs. articulo tertio dicat in Deo tffe ideam prima materize, non tamnn aliam ab idea compofiti, ibi Caictanus quarit, cuiusnam compofiti idea fit idea primx materix iuxta Thome fententiam;- \&c refpondet hanc effe ideam corporis, quod eft genus in categoria fub ftantix: vel igitur veritatem lianc cognouit Caietanus, corpus de categoria fubltantix effe ipfammer inateriam naturam, vel ipfa rei veritas iplum ad ita la quendurn induxit. rum quaftione vltima gloriatur. Ponitur etiam
clare tota hac veritas ab A uerroein 2. tractatu effe corpus, duobus modis id poffumus intelli
gere; primo, ve fit corpus per formaza corporis quo quidem modo quifquis dicat materiam effecorpus, decipitur, quia materia fic non eft 
Diftinctio trium acceptionum corporis, on cuiusdum dubij Jolutio. Cap.XIX.

$\mathrm{V}$ Eritate ita declarata, ac demonftrata, vt ommia aduerfantia argumenta facile foluantur, fciendum eft, cos pus de categoria fubftantir accipi duobus modis, fed altero in duos dinilo, tres orimtur : primum enim fumitur procorpore perficio, \& exiftentire actum perfe habente, quod quiclem non modo eft corpus, fed etiam talc corfus, \& certealicui naturæ alligatum, \& hocexneceffitate eft compofitum cxmateria \& forma conftans : quæ prima acceptio dicipotelt pracipua, \& prima primitate euidentix, ac perteetionis: fecundo modo fumi poteft corpus pro corpore indeterminato, \& nulli certæ natura alligato, quod fit tantum modo corpus, fed non tale corpus, id qq; fignificat ptimam matcriam; \& hxc quoque acceprio dic1 poteft pracipua \& prima, icd alio modo, nempeprimitate caulx \& originis: hic modus duidi poteft in duos: vnus eft, vt nomine corporis fignificetur materia fumpta vt materia; non vt genus, nempe confiderata ad modum partis, \&

de nullo naturali corpore perfecto pradicata in recto, qux dicetur fecunda corporis acceptio; alter vero eft, vt fumatur materia vt genus, \& ita nomen colporis fignificabit corpus fecundum fe indeterminatum, fed poteftate determinatuni, quatenus eft poteftate omnia naturalia corporaperfecta, \& de iis prædicatur, \& fumitur ad modum totius, ita vt vera fit hæc enūciatio; homo eft corpus, qurerit tertia acceptio corporis. Hac diftinctione multas difficultates foliemus : nam if primo modo fumatur corpus, fatemur primam materiam ita corpus noneffe, quippe qux non eft perfectum corpus, fed eft tamen ratio, \& inchoatio omnis corporeitatis in rebus, ex qua omnia corpora lublunaria dicunrur corpora, licet nonfit corpus aftu per fe exiftens, \& nobiseuidens: fecundo tamen, ac tertio modo materia dicipoteft corpus, fcilicet imperfectifimum, \& nulli certæ naturæ alligatum,vt iam dictum eft. Soluturautem per hæc quoddam exoriens dubium: nam dicere folent fubftātias pofitas in linea media categorix fubftantix effe folas compofitas, quum fubftantia fimplices in lateribus potius, qua $m$ in linea media collocentur; quomodo igitur corpus, quod eft fupremum genus, poteit tfie fimplex, quum in linea media continea tur ? ad hoc dicere pollumus effe quidem compofitas omnes fubftantias, qux in media categorix linea ponuntur, nempe omnia genera \& lpecies, fed vino excepto generalifimo, quod ex necefitate eft fimplex, vt antea \& Aterrois teftmonio, \& ratione demonftrauimus: quod vero dicitur fubftantias fimplices in lateribus effe ponendas, verum elt de folis formis, non eft verum de materiajmanteftum enim eft in lateribus folas diffe-
A rentias poni, qux non funt nifi form $x$; genera vero, qux refpedu fpecierum locum habent materix, in linea media colocari:qur vero diceret, materian in altero latere locandam effe, ridiculum fe omnibus preberet, quia fic diccict cam fungi officio differentir, quod repugnat penitus nature materix, qux neccertam reinaturam confinuere, necsem à re diftunguereapia eft : nullusigitur in categoria-fubfantixe relinquitur matcrix conueniens locus, nifi qui fit-

B premus omnium in media linea eft, quatcus materia eft corpus, \& cummunifima natura participara ab omnibus in illa categoria, \& de omnibus pradicata, in qua om nia conuenitut. Dicere tamen etiam poffumus hoc quoque firprenum modo aliquo effe compofitum : quan quam enim fecundum fuam naturam fimplex eft, poteftate tamen eft compofitum, quatenus eft poteftate omnes fur fpecies, quarum quxlibet ex materia \& forma confat: fic antem in Nota orC gradibus categoriz fubfantiz optimus ordo feruatur; nam fpecics infirma eft actu compofi-gradibus ta, neque in ea remanet poteftas vlla a dialo- presticarem compofitionem, quia iam habetvltimum mati actum; genera vero intermedia compofita qui- fubfandem funt, fed actu imperfecto, \& mifto cum po- to. teftate, \& aptitudine ad alium præfiantiorem a, ctum, \&adaliam compofitionem : reftatigitur vt fupremsim genus fit compofitum poteltate folum, non åu; quia fi effet actu compofitum, non effet fupremum, fed aliud fupra fe genus haberet. Hoc igitur modo prima materia locatur in media linea cat gorixiubfantix, \& locum habet fupremum, \& diciur corpus, idque fimplexfecundum propriam naturam, potefiate tamen compofitum, quiapoteft quarnlibet fpecierum fuarum formam recipere, \& ita ad quamlibet contrahi, \& fieri tale corpus.

Solutio omnium argumentorum pro aliorum opinionibus adductorum.

\section{Cap. $X X$.}

Eliquum-eft ve omnia trium dictarum 1. fectarum argumenta foluamus. Prima fecta ad probandam in materia prima formam illam corporis aternam, vtebatur primum tali argumento; nifi hec forma detur, fiet creatio cx nihilo: adhoc neganda eft confequentia: ad probationem autem dicimus, productionem effe compofitoattribuendam, non forma; id enim F quod propriegeneraridicitur, nōeft forma, fed com pofitum; ideoad euitandan creationem fatis eft, fi compofitum exprxfippofita materia producatur; forma vero non eit ens perfe completum, quod produci dicatur, fed eft perfectio alterius qux fi tora producitur, non ob id creatur, quia ad euitandam eius creationé fatis eft fi præfipponatur materia, è qua educatur: quod hoc modo creatio nó enitatur, ne ipfi quidéaduerfarii cà euitare polsút, vt fiupra conlide-

\section{Ad pre- mevin pro foriside coriorei. tatis.}


tauimus, quando argumentum hoc aduerfus A qualitas, in igne autem fubftantia, quia eft forcosletorfimus: neceffectim eft if res aliqua fit generanda, vt producatur ab agente noua pertectio, qua prus non fuerit, itaque haccreabitur, filla eft creatio; non eft tamen s reatio, quia fic agens non producit rein aliquam nouam, dum de poteftate materiz formam educit, fed potius rei, quæ praerat, nouam pelfictionem largitur; hac autem apud Ariftotelem eftgencratio, noncreatio, quia prefupponitur materia, ex qua educaturforma : deforma quidem $\mathrm{B}$ biuncta à maseria argumentum effet efficaciffimum; hæc enim fi ab agente produceretut, vtiq̨ue crearidiceretur, vtnos Chriftiani afferimus, Angelos olma deofuiffe creatos, \& humanns animas quotidie à Deo creari, ron de poteftate matcria educi; fed huiufmodi produEto Ariftoteliconnita non fuit. Ad fecundum argumentum, quim dicitur, corpus eft genus vniuocum, ergo illi vna realis natura refpondet, concedimus hoc: quum vero additur; hæc eft formacorporis, hoc negandum eft; negamus enimtertium illıd ab iis iactum fundanentum, quo ftatuebant, rationem valuocationis femper efle formam; fatcmur quidem cum Auerroe, genus efle formam vniuerfalem, fed excepto folo fir?remogenere, quod eft fola materia; ipfam enim Auerroes iam exprefle excepir, vtiamoftendinus; per materiam enim faris fuperque feruatur id, quodilli dicunt, nam hec noninteritraquam, quia nulli reinaturali corporis naturasepugnat; patet igitur, folam primematerianatuam \& vitale creationem formarum, \& corporis vniuocationem conftituere; cuius natura in rerum generatione \& interitu nunquam interit, quia eft omnibus neceffaria. Ioannis au-

Adarghmentalo Graneanteci. tem Grammatici argumenta folutione nonegêt; iis enim nil aliud oftendıtur, nifinateriam effe corpoream, \& haberetrinam dimen fionem ab ca infeparabiem, quod nos quoque afferimus:at non probant materiam efle eflentialiter trinam dimenfionem: ideo fi confequens hoc ipre exiis argumentis deducat, negandum eft? in. $\mathrm{m}$ eft quidem matcria corpus trina dimenAdarg. fioni fubiectum, fed non eft ipfamet trina di. troopini nenfio. Confiderasda manent argumenta pro one com-tertil fecta, qua omnino negat materiam effe musi. fublantiale corpus, fed incorpoream penitus elie dicir; horum aliqua ab ipfo Ioanne contra fe adducta \& foluta funt aliqua vero ab illius fententıæ feetatoribus propofica, quæ omnia exAdpro- pendenda à nobis funt. Primum Ionnis ab muspre- ipfomet optime foluitur, dicendo in interitu

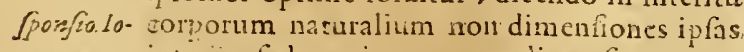
ennis. interise, fed teminostantum dimenfionum, ve Adfecun nesiandeclerauinus. Ad fecundum refpondet disya re- loannes, dimenfiones in corporibus perfeetis ponfso Io- eficiaccidentia, fed in ipfa materia effe fubftani wrms. tiam, id que non effe abfurdum, quum etiam in. aliishocidem videamus;nam calorin miftis efí na ipfa ignis. Hec Ioannis refponfio omnino rencienda ef, quum intitaturfalfo fundamento, quod porfit eadem resin hoc elfe accidens, \& in illo fubitantia; id enim quod fecundum propriam naturam eft quantitas, vel qualitas, 110 n potert non vique eandem conditionem feruare;nec video qui fieri poffit, vt calor idem in mi. fto manens, qui in elemento fucrat, non mutet fpeciem, mutet tamengenus, hoc enim ne imaginabile quidemett. Nos igirur dicimus,argumentum hoc contra Ioannem effe efficacllimum, \& infolubile, fed nobis non officene, quippequi nonafferimus, fubstantiam materix effe ipfasmetimenfiones, fed dimenfiones dicimus effeaccidens, \& proprietatem infequentem fubftantiam materix, \& abilla diueriam. Ad. tertium negat Ioannes falfitatem confequen. tis, \&longo fermone nititur demonftrare, materiam debere effe affectam, fi ex ea debeant 0 . C mnia fieri, quiafi eflet penitus informis, \& inaffeeta, effetnihil, \& exprimi nullo modo pofet : fatetur igitur, materiam dici modo quodam. affectan atque formatam, dum dicitur effe trina dimenfio, neque hoc repugnare natura $i$ pfius materiæ, qua non debet effe nihil, fedaliquid. Hac Ioannis refponfío melius eft declajanda; ipfe namque non videtur rei veritatem plene fuife affequutus, ideo nee bene eam exprimere potuit: duobus modis folet acipi nomenforma; vno modopro illa, quæeft altera. pars componiti, \& informat materiam; altero modo pro quidditate \& ef Centia curufque ręi $: \mathrm{fi}_{1}$ ue compofitz, fue fimplicis ; primo igitur modo materia eft informis, fed non. fecundo; quum enim omnis forma materiam informans refringat ipfam, \& reddat alligatam alicui certrenaturæ, omnis talis forma ip fa materiæ cf fentiarexpers e $j$ debet, \& ita eft informı; habet tamen formam fecundo modo, quia habet

E propiam effentiam, \& proprium quid cf, vt nos antea demonftrauimus; fiquidem non debet effe nibil, fed aliquid; \& hre materiæeffentianon eft alligata alicuı certæ nasuræx, quare non repugnat materix hoc modo forman ha. bere : affecta etiam potelt effe materia, dunmodo non tali affectione, fen taiiaccidente, quo eius natura coarcterur, \& ailigata figaificetur; at trina dimenfio interminata non coarctat materiamadvllam cerram natuam, quum fit acE dicen's communifimum, \& necefiarium omn: corporinaturali, per quodmateria manet libeya ad omnes formas indiftinete recipiendas. Quodigiturdici folet, materiam ficundum effentiam fuam effe informem, \& imaffectam, id ita intelligendum eft, vt folum negetur eam habere talen formam, vel talem affectionem, per quam materia ad sertam aliquam naturan reftringatur. Ad quartum Ioames optimerefpondet, uatesiā elficsundum fe corpusinfinitum, ROS

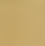


non quidem infinitum acu, quia tale infuitum nondatur, fedinfinitum per mentalem abftractionem à finibus ac terminis; femper enim eft aetu fub terminis, \& finita; fed quia fecundum propriam maturam nullos fibi certos fines prafcribit, ca ratione vocatur corpus infinitum, hoceft, non ex feipfo finitum, qua de re antea plura diximus, quum de materix dimenfionibusloqueremur. Hxc funtargumenta à Iohanne contra fi adducta, \& foluta, quibus tertia illa fententia comprobatur, quod materia feyusn cundum fe incorporea fit. Soluenda manent alia argumenta à recentioribus adtecta, ad eiuf$\mathrm{dem}$ icntentize confirmationem. Ad primum fumptum à corpore \& corporeitate, tanquan ì concreto, \& abitracto, dicimus nomine corporis duo in prafentia poffe fignificari: vel enim vtrumque fimul corpus denotamus, vnum de categoria fubftantix, alterũ de categoria quanti, fimul iuncta, hoc eft, fubftantiam quantam: vel folam fubiectam fubitantiam abfque dimenfionum confideratione : fi primo modo fumatur corpus, vtique aliud eft corpus, aliud corporeitas; corpus enim dicitur tocum coniunctum, corporeitas vero folas denotat dimenfiones, qua in illo habent locum forma, licet ex eis \& fubftantia fubiecta non fiat ynun nifi per accidens; in tali autem vno aliud eft quidditas, aliud eft id, cuius eft quidditas, vt ait Ariftoteles in contex. 20. lib. 7. Metaph. \& ita aliud eft corpus, aliud corporeitas; corpus enim fignificat fubftantiam quantam: corporeitas vero folam quantitatem. At fi fecundo modo - materiam dicamus corpus, fubftantiam fimplicem dicimus, qux eft vnum per $f e$, quare corporeitas nilalud fignificabit, quam ipfammet effentiam materix; quærere igitur an differant corpus, \& corporeitas, eft quxrere,an in eo, quod eft vinum per fe, differat quidditas ab habente quidditatem Arift. quidem in 7. Metaphyf.contex. $20 . \& 21$. inquit ide efle quidditatê, atq; habens quidditatem, nempe in eo, quod fit vnum per $f e, f e d n o ̈$ in vno per accidens: tamen in 3. lib. de anima, contex.9.\& in r. de Coelo 92. dicere videturaliud efre quidditatê, aliud habens quidditatê. Sed hac de re nobis in præéntia dıfputādum non eft: fatis effe debet, fidicamus, quando materia hoc modo vocatur corpus, ita fe habere corpusillud ad corporcitatê; vt Colum ad Cœleitatem; nomine enim cæleitatis fignificamus ipfam Coli quidditatem, fiue fit idé quod $C_{\wp}$ lum, fiue non idem; ita igitur nomine corporeitatis quidditatem materix fignificamus, quia ponimus materiam effentialiter effe corpus : $v$ trum autem illa corporeitas differat ab habente corporeitatem, nihil ad rem, quia neq; id afferere, neq; negare nobis obeft, dú fumitur corporeitas pro ipfa materix effentia diftincta à dimenfionibus; quioniam ad nos non attinet quxerere, an differant quidditas, \& habens quiddita-
A ten, prefertim in fimplicib. fubfantiis, cuiufmodi \& Colum \& materia ptima effe ftatuuntur. Poftremú argumentum, quod ex verbis A - Ldfextus riftotelis in variis locis fumitur, facile foluitur quod enim fxpe naturalia corpora numerans nullia materix mentionem faciat, hoc certe nihil eft; folet enim A rift. fola corpora perfeeta, \&e actu exiftentia cnumcrare, quia cum horü numeratione fimul materia numeratur; qui materian on fit aliud corpus ab his perfectis corpo-

B ribus diftinctum, fed fit liæc omnia, quia nunquam reperiturnifi formata : fic neq; genus aliquod exiftit extra fpecies fuas, proinde carum numerationedicitur numerari, vt in illis apud Ariftotelem locis notare poffumus; nominat enim in corporib. naturalibus, ftirpes, \& animalia, non tamen nominat viuens conune earum genus: quid igitur?nominat ne ibi omnia vituentia, an non omnia? abfq ; dubio nominat omnia, licet non nominet viuens genus, quia omnium C fpecierum nominatione numcratum, \& comprehenfum genus effe intelligitur: it:1que dicendum eft, non nominari ibi corpus, quod eft omniū genus materiam primam fignificās, quia fat eft omnes eius fpecies nominari, in quibus generis natura comprehenditur: effet quidem mancus Ariftot. fi in illa emuneratione ali quam fpeciem nö nominaffet, aliis eiufdē generis nominatis: quoniam vna in aliis non continetur; fed nominans oés fpecies omiffo genere, mancus dici uon poteft. Elementa vero folentappellarifimpliciacorpora refpectu aliorum perfectorum, \& a fu exiftentium corporum : mifta namp; in elementa difoluuntur, hæc vero non amplius in alia, qux perfe exiftant aftu; 1taque dicuntur fimplicia comparatione omnium inter fe fpecierum corporis, non comparatione generis: idq; ita eft manifeftum, vt puerilisadmodum hac argumentario dicenda fit; etenim dimiffa ét hac noftra de prima materia opinio-

E ne, nonne fecundnm oés communeeft elementorü genus corpus: nonne quodlibet genus fpecie fua fimplicius eft, quĩ fpecies præter genus differentiam habeat adiectam; igitur fi efficax corum argumentum eft, datur etian fecundum ipfos corpus fimplicius elementis, quod eft eorum commune genus: quare ab ipfis quoq;aduerfariis foluendum eft argumentum, quum eis non minus, quam nobis officere videatur.

\section{Epilogus omnium, qua de prima Materia dicta funt. Cap. $X X I$.}

$\mathrm{H}_{\mathrm{a}}^{\mathrm{s}}$ Ec omnia, quæ de prima rerum materia à nobis declarata fuêre ordine feruato à notioribus, \& facilioribus cognitu ad ignotiora, ac difficiliora, fi epilogo colligere velimus ordine natur $x$ fcruato, ab ipfa materiæ natura, \& fubftantia ordiemur, deinde ad propriętates, qux ab ea emanant, \& infeparaH 2 biles 
b:les funt, \& ab his demumad ea, qux ipfi ma- $A$ teria accidunt, \& funt ab ea feparabilia, progrediemur: dicemus enim, primam materiam liza pte natura effe corpus de categoria fubftantire indetcrminatum, nulli terre nature alligatum, \& aptĩ omniafíter, quod fignificat corpus generaliffimum in categoria fubftantix, \& iprum vnitocum effefacit; ideo in ipfa materix natura nullus actus ineft, fed eft fubftantia quxdam indetcrminata, poteftatem habens recipiendi quemlibet actum. Ab hac materiæ natura duæ $B$ proprietates emanant, qux ab ipfa nunquam feparantur: vna eft quantitas nullum fecundum fe terminum habens; prima enim radix $\&$ fons à quo in rebus naturalibus quantitas, ac dimenfo deriuatur, eft ipfa natura materiæ : altera vero eft poteftasilla vniuerfalis recipicndi omnes formas indiftincte; qux fi ad maceriam referaturvt abfolute, \& in prima notione acceptam; eft proprictas erus naturam confequens: fi vero confideretur materia cum refpeetil ad alia, \& vt principium, \& materia aliorum eft, hæc eadem poteftas vniuerfalis de effentia materixe eft, quia eft ratio formalis; conftituens primum materiale principium. Denum accidunt materia priuatio, \& potefas particularis, quæ cum pri uatione eft coniuucta; priuatio enim connotat alteram formam, qua eft generationis termunus àquo; quare in aduentu form recedit \& fimul étian interit poteltas particularis, quxillam tantummodo formam, qux acquifita eft, refpiciebat: ha itaque neque de effentia materix funt, neque eam confequuntur, fed ei prorfus accidunt, \& ab ea poffint feparari. Hoc tamen in his omnibus eft difcrimen, quod folapriuatio meretur nomen principii diftincti à princip1o materiali, fed non quantitas, neque potentia materix; nam priuatio propriam principii rationem habet, diftinctam à 1atione materialis principis; eft enim terminus generation is à quo, \& eft illud non effe, quod ex neceffitate omnem generationem pracedit; ratio autem principii materialiselt, vt fit fubiectum generationi, quod idem maneat fub vtroque contrario termino: quantitas vero \& poteC ftas materixnullum habent propriam principii rationem, fed funt fubiect materix conditio. nes neceflari, ideo nullum principium à materiali principio diftinctum conftituunt.

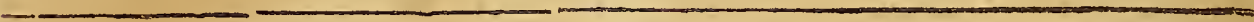 \\ Z A B J A P A T A V I I I

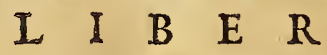 $D E \quad N \quad A \quad T \quad V R A$.}

\section{Quid fit Natura. Cap. 1 .}

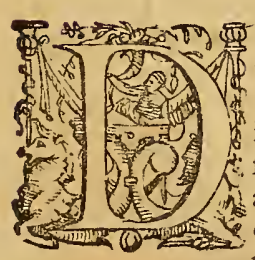

E rebus maturalibus diffure ac diligenter acturus AriFoteles non abfque ratione in ipfomet naturalis philofophize limine de natura agere conftituit, quandoquidem nihil eft naturalius natura ip $\{2$; \& affirmare etiam abfque dubio poffumus, totum philofo- $E$ rophi naturalis negotium confiftere in contemplatione natura, quod Ariftoteles ipfe figniticauit, dum frequenter eam difciplinam vniuerlam appellauit fcientiam de natura. Quoniam igitur magni momenti eft, imo \& fummopere neceflarium philofopho naturali nomen naturæ intelligere, de hoc ego aliqua dicere, \& qux ab Ariftot. in 2. Phyf. hac de re traduntur, quum prafertim ab aliorum opinione diffentireme p'sa ratio cogat, quantum in me eft, expianare cŏftitui. Duo autem funt, in q̨ıo-
D rumconfideratione in tota hac mea difputatione verfaturus fum; vnum eft, quid fit natura; al terum vero, quanam fit. Quid fit natura, ab $A$. riftotele declaratum habemus hac definittone; Natura eft principium motus \& quictis in eo, in quo primo ineft, per $f e$, non peraccidens:in qua definitione verba fingula, \& multa, qux fatis trita atque vulgata funt, confulto præteribo; id potiffimum cenfeo effe animaduertendum, na- Natura turam in rebus naturalibus caufam effe motus, est castnō folum in eo ipfo corpore, in quo ine tr, quam $\sqrt{a}$ mrots. immanentem motum vocant, vermm etiam in $\mathcal{E}^{3}$ in et alio, \& extra, quem tranfeuntem appellant; $m 0-$ dem, $ह 5$ tus enim ignis à medio prouenit ab ipfa ignis in also. natura, tanquam ab interno principio, \& dicitur operatio immanens, quonian in ipfomet igni recipitur:at calefactio, qua extra ignem alind aliquod corpus incalef fit, qure dicitur operatio tranfiens, non minus prouenit à natura ignis; ficutenim ignisper fuam naturāa afcendit, itaper fum naturam calefacit alia: Ariftatutem per folas operationes imumanëtes definire natu- 
rum voluit; nempe per motum \& quietem in co ipfo corpore, in quo natura ineft; non quod negau erit eiusdem operationes tranfeuntes; negari ctenim non poflunt, fed quia pertranfeunies non diftinguitur natura ab arte, neque declaratur quid fitnatura, quum ars qquoque fit principium motusrecepti in alio : quoniam igitur nature proprium eft, motum per le producere in illomet, in quoipfa ineft, corpore, neque id vnquam competit artı,nifi per accidens, videns $A$ riftot. per hosoptime declarari quid fit natura, \& diftingui naturs $m$ ab arte, perhoc folum, negleetoaltero, naturam definire con Rrituit; nee tamen negaret naturam effe principium, \& caufam motusetiam inalio. Eft igitur natura perfe principium motus in eo,in quo ipfa eft: proinde naturaleillud effe intelligitur, quod tale in fe principium habet, hoc eft, internam propenfionem ad motum; quare is quoque motus vocatar alicui corpori naturalis, qui proueniat ab interno principio, hoceft, qui frat cum interna propenfione illius corporisad talem motum.

\section{An Nàtura fot principium motus actiuum, an paßiuum, opinio Auicenne, of eius confutatio. Cap. 11 .}

Thac nature definitione plura effent confiIderanda, qux miffa facimus, quia tumab interpretibus Ariftotelis declarantur, tum etiam fortaffis aliquando à nobis declarabuntur; fi datum fuerit vt in libros phyficos poflimus edere commentarios; nuncillud explicandum $e f t, c u-$ ius potiffimu gratia hæc de natura fcribere conftituimus, vtrum in hac naturx definitione principium motus fir intelligendum actiuum, an paffium; de hoc enim non i jem omnes fenfif- Ari- fe videntur. Aricenna putauit, actiuum tantum a pri-principium intelligendum effe, $i d$ enim videtur $m$ atr- fignificafie Ariftot. quiftarim poftallatam hanc definitionem feparansper eam naturalia à non naturalibus inquit, artefacta non isabere in feipfisfactionisprincipium, quum igitur per hoc feparet naturalia à non naturalibus, vult naturalia habere in fe actiuum principium motus, nam rsndü. factionis principium non eft nifi actiuum. Confueuitetiam Ariftotelescaufam effectricern appellareprincipium vnde motus; credibile ergo eft in hac definitione principium motus fumi proprincipio adiuo. Hectamen fententia non eft confona verbis Ariftotelis, qui pofteainquit, non folam formam, fed etiam materiam dici naturam : materix autem nullam tribui poffeaCionem certum eft, fed paffionem tantummodo; non poteft igitur materia efie principium motus nifi paffium , proinde in ea definitione neceffe et lignificari etiam principin pastiuum.Praterea Ariftotel. in context. 32 . lib. 8 . inquit, elementa habere in fe principium motus rimsn sm. icsonitis sinse-$$
\text { quir }
$quit
A non actiuum, fed pafiuum, \& loquitur de ipforum motu naturali, ergo putat, naturam effe etiam principium motus paffiuum. Sumitur ef- Tertisom lam contra Auicennam argumentum à coelefti corpore, in qun negare non pofumus, inefe nataram vt internum principium motus, quí colo dicitur naruralis, id enim afferit Ariftoteles manifefte in context.s. libr.s. de Coelo; attasaen nulla eft in eo corpure natura, qux fit acriuum principium motus, $\mathrm{e}$ ed folum, qux eft principium paffiuum, rtalio in loco demonftrabimus; ergo fatendus eft, naturam effe princi- in lobr. pium motus paffium, quia hoc negatonon ef de rocen. fet in Colo natura, proindenon effet Colum racels. corpus nuturam habens, nec fpecies corporis naturalis,neque motus Coli poflet vocari naturalis, quxomnia veritati \& Arifoteli aduerfantur,quare huicennzopinio reiicienda eft.

\section{Opinio Simplicü cum argumentis. Cap. 111 .}

CONTR A vero Simplicius pluribus in loCis, przertim vero in context. 16. libri z. Phylic.\& in procmio librorum de anima dixit, naturam non effe motus principiuta a ctiusum, fed folum paffium, \& in hoc feparat naturam abanima, ņuam fub natura contineri, \& naturam effe omnino negat: ideo non defuere qui Siaplicium accufauerint inconftantiz \& con- Contratradictionis, quoniam in r. context. libri fecun- dict 10 in di Phyficorum, declaransillam naturalium cor berbis porum propriam conditionem, quod habent in Simplsfeprincipium motus, expofuit principium acti- $c i j$. uum : fedipfemet Simplicius fe ab hoc crinuine vindicauit, ilam poftea in expoficione context. 16.eiusdem libri afferuit, le antéa pingui Minerua effeluquatum; quocirca ibi diligentius rem hanc perpendens, ftatuit naturam effe reuera principium motus pafiuum tantum, non act$E$ uum; \& ad hoc probandum tribus argumentis vtitur. Prinoum eft: fi natura dicatur princi- Prusum pium motus actiuum, non diftinguetur natusa a guméabanima, quum anima fit principium motus a sus sine ciuum, \& boc fitproprium animz, vt ait Ari- plscij. ftoteles in contextu 29.Irbri octauiphyficorum, quoniam igitur anima non eft natura, \& ea eft propria anim $x$ conditio, non eft eademattribu. enda naturx: Vtitur etiam autoritate Arifto. Secsno telis, quam fupra aduerfus Auicennam adduxi- dsm.

F mus, in cont ext. 32. eiufdē octauilıbri, vbidicit, grauia \&leuia \& inanimata omnia habere infe. principü motus paffrum tantum nō act 1 uum: quaredum conftituimus, feparandam effe naturam ab anima, \& naturale ab animato, clarum effe videtur illud Ariftotelisteftimonium, quod natura non fit principium motus actiuum, fed paffium tani umxodo. Tandem per- Tertism pendit Simplicius, in definitionenatur $x$ Arift. telein vi verbo pafhuo, nō verbo actiuo, quum

\section{Defenfin.}




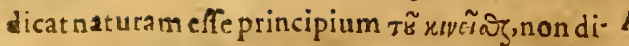

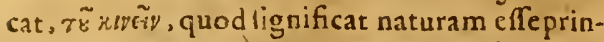
cipium patiendi, non principium agendi. Quoniam autem validirtimum effe putauit Simplicius ad fuam opinionem tuendam argumentum illud, quod fumitur à difcrimine natur $x$ \& animz, hocipfe ftabilire voluit, \& pluribusargumentis oftendere nifuseft, animam non effe naturam, vt apud eum legere poffumus tum in 1. \& in 16. contextu libri fecundi Phyficorum, tum in fuo procmio in libros de anima. PriPrimum mumargumentaturà definitionibus natur $x, \&$ argumen animis fic: quorum diuerf $x$ funt definitiones, iltas, quad la interfe diuerfafunt; atquialia eft natura de4asma finitio,alia aninıx; nam anima eft actus corpo$x *$ is ris naturalis organici, natura vero eft actus non nsthr. corporis organici, atque heterogenei, fed potius fimplicis, \&omogenei; ergoneque natura eft anima, neque anima eft natura, proinde reipfa diftinguuntur natura \& anima, quare etiam na-

scossdis. turale \& animatum. Secundo ex eadem definitione animz fic quoque argumentatur : Arifoteles dicit animam effe actum corporis naturalis, ergo putat animam effe actum fuperadditum corporinaturali, proinde fuperadditum etiam naturx;itaque fignificat animam non effe

Tertism naturan. Tertio inquit: anima eft caufa motuum oppofitorum, \& ad omnes partes indiftincte tendentium; natura veroeft caufa ftatuti alicuius motus, \& ad vnam tantum partem, non ad contrarias, vt terra eft naturaliter propenfa ad defcendendum folum, \& ignis ad afcendendum;anima igitur non eft natura, quum diuerforum motuum caufx fint anima \& natura.

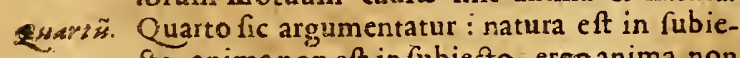
Eto, animanon eft in fubiecto, ergo anima non eft natura : maior eft Ariftotel. in contextu 4. librifecundi Phyficorum, vbi dicit, naturam femper effe in fubiecto ; minorem ita probat, anima rationalis eft xterna, \& immunis à nexu simplroü materia, ergo non eft in fubiecto. Alia quoque refponfio argumenta adducit in memoratis locis Simpliadplures cius, qux quoniam vnica folutione omnia cor-bief:io ruunt, omittenda exiftimaui. Nifus eft etiam mes. Simplicius foluere difficultates, quibus fuam oAdprt- pinionem vrgeri opinabatur. Primum quidem mam. Alli offcere videbantur verba Ariftotelis in initio 2. Phyfic. vbi in corporibus naturalibus nu meratanimalia, \& ftirpes; dicens enim animata effe naturalia, afferit etiam animam effe naturam. Sedad hxc refpondet Simplicius, animata ibi vocari naturalia, non quatenus animam habent, fed quatenus conftat ex elemendefesn tis, \& funt grauia \& leuia. Vidit pratereacodem anm. in loco Ariftotel.nominareaccretionen vt motum à natura prodeuntem ; attamen hxe cef propria animatorum, \& fir ab aninea, ergo putat $A$ riftoteles animam effe naturam. Ad hoc quoque refpendet, Ariftotelem non nominare motum accretionis vt proprium animatorum, fed vt latc asceptum, \& inanimatis quoque competentem, quia adhuc dubium erat, quibus infit ille motus, multi namque exiftimabant eum igni quo que competere; qua fententia fi admit. tatur, non prouenit ille motus ab anima, fed à natura illius elementi. Prxterea videbatur ei refragari dictumillud Ariftotel. in contextu 8o. tiam. libri fecundi Phyfic. araneus propter aliquem finem telam texit, \& hirundo propter aliquem finem nidum facit; quum enim hoc dicat Ari.

$B$ ftotcles, vt oftendat naturam agere propter $\tilde{\mathrm{f}}$ nem, afferit animam effe naturam, quum manifeftum fit, operailla prodire ab anima. Ad hoc refpondet Simplicius, dicens exempla illa non effe reuera ad propofitum accen:modata, \& Ariftotelem fumere exempla animatorum pro exemplis naturalium; negari tamen non poffe, melius furfe accipere exempla in operibus naturx, quam in operibus animx; quoniam ad fcopum Arift.magis fuiffent accommodata.

\section{Confutatio fententic Simplicü, quod Ani- manonfit Natura. Cap. IV.}

TIE Simplicii opinioabaliis impugnatur, Hneciniuria; quia falfa eft, \& Arifoteliaduerlatur; \& quia in duobus demonftrandis po. tifimum laborauir Simplicius; nempe naturam effe principium motus paffiuum tantam, \& animam non effe naturam ' nos vtriufque fal. fitatem feparatim oftendemus, ab hoc pofteriore ordientes. Primum quidem adfunt contraSimplicium pradicia Ariftotelis teftimonia; Impsen ad qua ipfe non reete refpondit. Quodenim tio pro. primo loco ait, Ariftotelem in initio libri fe- ma ref $p$ cundi Phyfic. animata vocare naturalia, non forrir.

- quatenus funt animata, fed quatenus grauia \& leuia; hoc certe vanifimumeft : quia vnumquod que eft tale per fuam formam, non per fuam materiam, quo fit, vt apud Ariftot. quun. dicimus Colum, vel bominem, vel equum, dicamus formam, forma autem animatorum eft anima, materia vero elementa; nominans ergo Ariftotelesanimata, refpexitformam, qua eft anima : quod fi putaffet, animata effe naturalia ratione tantum elementorum, è quibus conftant, animata nominare non debuiffet fed fatis fuiffet, fola elementa nominare, fi fola funt perfenaturalia, \& alia omnia perilla. Quodveroad fecundum refpondet Simplicius de motu accretionis, falfum eft : quoniam Ariftoteles non folam accretionem nominat, fed etiam do. contrariam imminutionem, at igni non competit imminutio, qua dici poffit motus naturalis , \& factus ab interno principio, fed animatis tantuminodo; in his ergo folis confiderat Ariftoteles accretionem, \& imminutionem, vel faltem hic conon excludit; neque enim verifimile eft, Airtotelem loqui fecundum mentem tantum aliorum, non lecundum mentem pro. 
priam; imo etiam fi loquatur fecundum mentem aliorum, fumere debet accretionem late, vt competit etiam animatis, hac enim augeri nemo negauit; atque adeo euidentius omnibus eft animata augeri, quam inanimata, quum illud oinnes affirment, hoc vero non omnes: non eft ergo credibile, Ariftotelem id excludere, quod eft omnibus manifeftum, \& id folum accipere, quod eft obfcurius; quamobrem vel proprie fumit accretionem vt folis animatis competentem, vel faltem communiter vt competentem omnibus, quibus competere poteft, feu proprie, feu improprie, ita vt accretio animatorum nullo pacto excludatur : hrc autem in viuentibus non fit à formis elementorum, red ab anima; quare fententia Ariftotelis eft, quod anippugna ma fit natura. Ad tertium quoque acceptum o ter- ex contextu 80.eiufdem libri leuifsima eft Sima. plicii refponfio, imo nec vllo pacto recipienda, quum fit potius impugnatio Âriftotelis, quam verborum eius loci interpretatio: nam fianima non eft natura, \& Ariftoteles pro natura animam fumit, quum naturam fumere deberet, nullius roboris eft 11 la Ariftotelis argumentatio; probat enim animam agere propter finem, non probat naruram, quod probandum erat. Sed ibi confiderans hacomnia Simplicius, tandem veritate codetus concedit Ariftotelem animam vocare naturam. Clara praterea eft fententia Ariftotelis in contex $7.2 \mathrm{in} \mathbf{1 3}$. eiufdem 2.libri, vbi dicit : fi effodiatur lectus, ita vt germinet, producet lignum, non lectum, \& cam inquit efle operationem natur $x$, eft tamen operatio anim $x$, quare animam vocat naturam. Hoc idem fumitur ex Ariftotele in contextu 27. libri 8. Phyficorum, vbi ait, animalia habere in fe principium fui motus, eumque dicit fieri à natura, nec aliud principium confiderat, quam 2 . nimam; ergo animam vocat naturam. Idem confirmaturalio Ariftotelis teftimonio in 1. libro de Partibus animalium, cap.1. vbi concedit animam effe naturam; quamuis enim de men. te dubitet, an fit natura, \& principium motus, de nutriente tamen, ac de fentiente ani$m x$ parte non dubitat eas effe prineipium motus, \& nomine natura participare, vnde colligit pertinere ad philorophiam naturalem loqui de aliqua faltem anima; vult igitur alilisa ra- quam faltem animam effe naturam. Sumitur quam faltem animam ex ipfa natur $x$ definitione argumentum validifsimum cõtra Simplicium: cui enim competit definitio, de eodem prædicatur etiam nomen definitum; atqui an im $x$ competit definitio naturx ; negari enim non poteft animam effe principium motus \& quietis in eo, in quo primo ineft, per $f e$, non peraccidens; igituranima eft natura. Id autem quod Simplicium in errorem duxit, fuit multiplex fignificatio huius vocis natura; fumitur enim tribus modis. Vno inodo amplifsime pro effentia rei, qua ratione
A etiam rebus fupernaturalibus tribuimus quandoque nomen natura; dicimus enim naturan Natzara Dei, id eft, effentiam Dei ; qua fignificatio a famisur nos in prafentia non pertinet. Secundo modo triplicin fumitur natura ftrictiffime pro quadam facultate coarctata, \& reftricta ad alteram tantum parsem oppofitionis, prout diftinguitur à facultate cognofcente, qux poteft agere vtrumalibet contrariorum : hoc modo natura diftinguitur abanima, \& naturale ab animato, imo

B ex aduerfo ci opponitur, quia naturale in hoc fenfu fignificat inanimatusu. Tertio fumitur natura modoquodam medio, prout fignificat totum genus rerum variabilium, ac musabilium; \& ita naturale fumitur pro mutabili quo. modocunque, natura vero pro interna propenfione ad mutationem. Simplicius ergo fecundam fignificationem accepit, quum tertiam po. tius accipere debuerit; patet enim Ariftotelem ita acceptam naturam definiuiffe, qux animam

C quoque complectitur; non enim definiuit naturam vt oppofitam facultati cognofcenti, fed vniuerfe vt fignificat internum principium motus, cuiufmodi effe animam quoque manifeftum eft, quum ei competat definitio naturx, ficut prædiximus.

\section{Confutatio opinionis simplicü, quod Na- tura fit principium motus paßiuum tantum. Cap. $V$.}

Vodvero attinet ad alterum Simplicii di- Crimess Etum, de quo pracipue fermo eft in prafent 12 , nempe naturam effe principium motus tums. paffium tantum, hoc videtur fatis effe reprobatum ex ipfamet confeffione Simplicii : quum enim ipfe afferat animam effe principium motus aftiuum, nos vero iam oftenderimus, animam effe naturam, \& ei competere definitionem naturæ, manifeftum eft, naturam effe prinE cipium motus etiam actium. Sumitur exiam secess. ex Ariftotele argumentum contra Simpliciu as dism ex iis, quæ dicuntur in libro fecundo Phyfic. à feptimo contextu vfque ad is. ibi enim docet Ariftoteles formam effe precipue naturam, \& magis, quam materiam;fed form $x$ eft agere, \& materix eft pati; ergo natura eft principium motus actiuum, quia non poteft forma effe natura, quin fit principium actiuum mocus. Praterea Ariftoteles in tertio contextueiufdem li-

F bri declarans definitionem nasurx à fe traditam, in quit fe dixiffe[per $\int e, \mathcal{E}^{5}$ non per accidens] propterMedicum fanantem feipfum : quia l1cet ars quoque videatur effe principium motus in eo, in quo eft, id tamen eft per accidens, non per fe; Cola autem natura eft per fe principium motus in eo, in quo eft: at certum eft Medicum effe principism actiuum fanationis, fiue in feipfo, fiue in alio; ergo etiam naturam intellexit Arift. effe principium motus actiuum, quia 
nifi hoc affet, nô oportebat excludere Medicum frastem feipfum, quonam ex co nullun dubium oricbatur, quum Medicus lit principium Quarsü. actiuü,natura verólol um pafiuum:postea yero etian clarius A rift.ibidem dicit, arte fâta non habere in fe factionis principium, vt etiam ante pro Auicenna fententia confiderauimus; affirmari autem de naturalibus vult id, quod de arte factis negat; ergo cenfet naturalia habere in fe Alsorzm actiuum motusprincipium Sunt etiam quiconargumé- tra Simplicium adducant verba Arift. paulo antsmi con- te à nobis confiderata in contex so.eiufdé libri, tras Ssm- quädo dicit ; araneus propter aliquem finem teftscrm. Lam texit, \& hirundo propter aliquem finem nidum facit; hac enim dicit ad probandum naturam agere propter finem, ergo afferit naturam effe principium motus actiuum, quandoquidem araneusagendo texit telam, \& hirundoagendo. Reffonfro facitnidum. Hanc tamenobiectionem vidit co Simplo. ipfo in locosimplicius, \& ad eam refpondit, Acir. riftotelem non intelligere naturam effe verea-. gentem, fed modo quodam coadiuuare actionem; nam paffua quoque propenfio ationem agentis quodāmodo adiuuare dicitur, quamuis. mpugna non propricagat. Sed hac Simplicii folutio vatis re- nact, licet argumentumillorum debile fit, \& föfons. facilem habeat folutionem, quam Simplicius. nonvidit: Simplicii quidem refponfio quod fit. vana, manifeftum eft, quum pateat hirundinem.

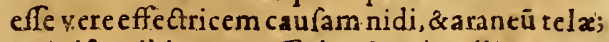
\& Ariftot.ibi veram efficientiam intelligat, qua agens efficital iquid propter finē;fins enim mouet efficiensad agendum, non mouet materiam, quare fi philofophus probat naturam agere pro pter finem, fumit naturam vt vere agentem ; \& mirum eft, quomodo hoc eufus fit negare Simrefpenfor plicius. Argumentum ause aliter foluendum: ar eft, quiareuera nullam habet efficacitatem adgomme- uerfus opinionem Simplicii:iam enim diximus, Lior. Ariftotelem non négare naturaatione in alio, quätran feuntem appellant, nectamen per hanc. definire naruram voluiffé, fedper folam immanentem: dicere ergo debebat Simplicius, nil 2 liud hoc argumento oftendi, nifi maturam effe. principiū actuum operationum tran feuntium; has tamen adidefinitionem naturx nun perticere, neque ob id probari, quod etiam motuum immanentium natura fit caura effectrix: Arifto teles enim, ad probandum naturam agere propter finem, fatis habuit accipere actiones natua ræa tranfeuntes, per quasid facile demonftratur, rec opus habuit confiderare operationes im. manentes, perquasnaturam definiuerat.

\section{Quod Natura fit principium motus tum as. ctiuum, tum paßiuum, ó quid vtrun- que fit. Cap. VI.}

$\mathrm{P}$ Er ea , qua hactenus. \& contra A uicennam. \& contra Simplicium dicta funt, fatis. vide-
A tur effe demonfratum, naturam effe principium motus non modoactuum, vi futaut $\mathbf{A}$. uirctina, nec folum pafiuum,ve Simplicius, icd \&actiuum, \& palfium, vtalii somplures exi- Air ârunt. Sed.veritas marafelier fiet, fi decla rauerimus,quid fit tum actiuum, tum pafísum - principium motus : de acti uo quidem principo clara res effe videtur; illud enim à quo efficisur piü morus, dicitur adiuum motus principiun, ve fort. - in animalibus anima; hoc enimfigurficauit $\mathbf{A}_{-}$

B riftor.in 81,b. Phyfic. aufcult. quando dixit animalia à feiplis moueri, hoc eit, internam habere caulam effectricen fui motus; fic eriam, fi elementa à formis fuis mouentur, vt multi pusant, formx clementorum funt actiua principiamotuum naturalium. De pafiuo autem principio non ita manifeltum eft, quomado fit intelligendum; quum enim potentia pafliua fit oppofito rum, nec magis apta perfe fit vnum, quam alterum recipere,poteit tanien ab aliquo ita reftrinC gi, \&coarctari, vt fiatapta ad vnum, non ad alterum recipiendum; vt potentia pafíua raateria refpicit quidem contranas formas aqualiter,attamen dum fit particularis, \& vnam täıum formam refpicit, non ob id definit effe potentia pafirua, propterea quod non ab ea prouenit hac determinatio, fedabaliquo alio: dnbium ergo oritur, an natura vt principitum motus paffium fumenda fit potentia libera recipiendi aque $\mathrm{v}$ trunlibet oppoftum motum, an potius reftricta, \& contracta ad alteram tansum recipiendum, vt exempii gratiâ,an in el emento graui fit natura vt principium motus paffium, æqque apta moueri ad medium, atque à medio; an potius ad determinatum motum recipiēdum propenfa, vt ad motum defcenfionis, non ad motum a fcenfionis. Plurimi (vt ego video) priorem fenfum accipiunt; dum dicunt, materiam in rebus naturalibus effe principium reotus paffiuum, formam vero a tiuum, nam certum eft E materiam habere poteltatem patien di liberam, \& aque refpicientem contraria, nec magis vnum, quam alterum; quare ficut $x$ que apta eft. recipere omnes formas, ita. \& omnes motus. sedhanc communem fententiam egoquidem confus recipere nunquam potui ; ipram enim, fi. ita ru- tio. diter, \& inconfiderate accipiatur, vt eam alii videntus accipere, magne \& manifefta abfurditas fequitur, quod ominis motus erit naturalis, etiamille, quem contranaturam, ac violentum. appellare folemus; nam fi terra proiecta afcendat, negari non poterit, quin ille motus dicaturilli corpori naturalis ratione faltem principii paffiui; fic omnes motus artificiofi erunt na. turales, vt motus nauis per aquam, \& motus lignorum; quando ab artifice claborantur; quamuis enim non fiant $a b$ interno prinsipio actiuo, fed ab externo, tamen principiurn pafsiulim internum habent, quia prima materia ad omnes motus recipiendos aque apta eft secuir-

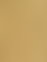


dum propriam naturam. Quoniam igitur hac diccrenefas eft, fateri opoucce, principium motus paffium, quod dicalur natura, non effe accipiendum liberum, $\stackrel{a}{*}$ contrarios motus $x q u e$ reipiciens, féd coarkatum ad vnum ît atutü motum recipiendum, qui folus dicatur illi rei effe naturalis; hocex Airfotelc fumitur manifefe in contextu 32. lib.8. Phylicolum; quam enim prius diftinx Ientum ab corundem motu naturaii, loquens ibi de folo naturalininquit, grauia \& leuia habere in feipfis principium motus paffium tan. tum, non actiuun; paffiusm autem intelligit refpectu v nius tantum motus, qui dicitur naturalis, nonrefpectu contrarii, quem violentum effe, \& ab externo principio fieri iam dixerat; quoniam igitur Arift. ibi negat violentum elementi motum fieri modoviloab interno principio fiue actiuo, fiue paffiuo; motum autem naiuralem inquit habere internum principium. palliuu mantuz, \& ea rationedicinaturalem; manıfeftulimum ef:paffun principiun ab Ariftotele intelliģirefrietum aú vnum centũ tum, qui fol ts âic tur naturalis cuiquereis non principium gaflisum hberum, \& anceps ad recipiendos contrarios motus:fic enim fieret, vt etiam motus, quem ibi vocat violentum, haberet internum principium paffitum; \& ita id, quodeft contra naturam, effet fecundum naturam, quod minime dicendum eft.

\section{Qua fit Natura; \& quomodomateria, \& quomodo forma fit Natura. Cap. VII.}

$\mathrm{V}^{\mathrm{T}}$ omnis hac in re difficultas tollatur, \& Weritas perfpicua fiat, declarandum eft, quodnas fit in corpore naturali principium: motus; quod vocamus naturam, fic enim alte. rum initio à nobispropofitum manifeftum reddetur; quum enim iam docuerim us, quid fit natura, confiderandum relinquitur, quanam fit ; id enim non ita, ve pleriqueputant, facile explicatu eft, fed plena res difficultatis; nam Âriftoteles dicere videtur, tam formam, quam mate. riam effe naturam, eam que fententiam nunc 0 .mnes fequuntur; attamen fi vera illa funt, qua: modo diximus, non apparet, quomodo materia poffit vocari natura; fiquidem natura certum quendam; ae ftatutum motū: refpicit, quiq dicitur naturalis;materia vero eft libera, \&xqueapta ad'contrariosmotus recipiendos; hoc autem fi dixerimus, fola forma erit natura, quo $d$ Ariftoteli aduerfarividetur, dicenti, imateriam. quoq; effe naturam: praterea vero fequetur, na-. turam effe principitm motus actiuuum tantü ${ }_{2}$, quia forna eft agere, materix vero pati; quomodo igitur dicere antea potuimus, naturam effe principium motus etiam paffiuum? \& quomodo Arift. in contex. 32, lib. 8. P hyfficorü; h०c: idem manifefte afnrmauit? ab hoc mihi videnturplures in huncerrorem dueti fuiffe, vt putauerint \& materiam \& formam effe naturam, \& formam quidem effeactiunn principium motus, materiam vero pafiuum. Ego autem ptro cos in hoc effe deceptos, \& fecundum Arifote-sola for. $\mathrm{lcm}$ !olam formam effe naturam, \& principium mu eft motus tam actiuum, quam paffium; tuan quia perferamatëria fecundum fe libera eft, \& $x$ que apsa ad ,ura. oppofitos motus patiedos, nec dici doteft prin-

B cipium alicuius determinati motus, ita vtnon alterius illi contrarii; tum etiam quia, quum $r-$ 113 fit omnium materia, fequeretur, om nium rerum naturalium ynam \& eandem effe naturam, quod tamen vult Ariftoteles: quum enim non vrus \& ide fit rerum omnium naturalium mo. tus naturalis, natura quoq; non debet omnium vna \& eadem effe, quod etiam ex verbis Axiftotelis in lib. z. Phyficx aufcultationis fat1s aperte colligilur; etenim cenfuit naturam, de quaibi c loquitur, non effe quid vnum \& idem numero in cunctis rebus naturalibus, fed commune folum predicatione, quia vult vniufcuiufquerei propriam \& peculiarens effe naturam, qux non fit aliarum rerum natura; idque perfe manifeftum effe videtur, alia nam que eft hominis natura, alıa equi, alia leonis; fignificauit hoc Ariftoteles in contex. 11. \& 12. eius libri. Jicens vramquamque rem tunchabere fuam naturam, quando eft zetu, non quando poteftate; non di-

D ceret enim hoc Ariftoteles, nifi propria cuiufque rei effet natura:Præterea in contex. s. eiufdem libri declarans, quomodo accidentia naturalia dicantur effé fecundum naturam, inquit [Gtigniferrifurfum ] loquitur ergo de propenfione a d proprium naturalem motum, qui non eft idem in omnibus, proinde neque eius principium idera eft; quocirca etiam in definitione natura fumendus eft mocus-non pro quolibet: indiftincte, fed proille tantum, quii. fit cuiusliE bet rei motus naturalis. Ex his poffumushanc: rationem colligere: vnius rei vna debet effe natura, non plures, quemadmodum vnius rei.vnus: eftactus; non enum diceremus naturam ignis, naturam terræ, naturam hominis, nifi cuiufque rei. yna effet natura; attamen fi tam materiam quam formam effe naturam rei Ariftoteles exiftimaffet, dux effent ynius rei-naturæ; quodi nullo pacto dicendum eft. Duo.igitur ànobis declaranda funt, vt omne hac in re dubium tol. F latur vnum; quamodo forma fit principium: motus \& actiuum, \& paffiuum; alterum veroj quomodo dixerit Ariftoteles materiam ef: fe naturam; fi fola forma eft natura. De forma Quomoquidem; quod fitprincipium motus paffuum, do forma fatis eft manifeftum ex memoratis Áriftotelis princapiverbis incontext. 32: lib. 8. Phyficorum; quum umpuß;enim dicar; elementa habere in feprincipium usm fit. motus paffium tantum, non actuum, non. poteft mfin formam intelligere; nam fir mate- 
riam intelligeret, relinqueretur formam elementinaturam dici non poffe, \& nullius motus principium effe formam; \& preterea vnum \& eundem effe omnium elementorum motū naturalem, ficut vna eft om nium materia: attamen falfa hac omnia funt; neq; enim dicendum eft, formam elementi non efie naturam, \& nullius effe motus principium, quum A riftot. in lib. 2. Phy fic. dixerit, magis naturam effe formá, quam materiam; neq; omnium elementorum vnus \& idem eft naturalis motus, nifi dicamus, quemli. het motum indiftinete cuilibet elemento. effe naturalem, \& nullum effe violentum, quod quidem iam diximus Ariftoteli eo in loco, imo \& omnium confenfioni manifefte aducrfari : queniam igitur neceffarium eft, confiteri, formam elementi efle naturam, \& magis eriam naturam, quam materiam, \& Ariftoteles ibi dicit elementum non habere in re principium motus, nifi paffusum, afferit ab fque dubio formam effe principium motus paffium : huius autem ratio fumitur ex iis, quz ante dicta funt; quum enim principium paffiuum hic non intelligatur refpectu cuiufcunque motus indiftincte, fed refpeetudeterminati motus, qui folus dicatur naturalis, \& omnis determinatio proueniat à forma, neceffe effe formam dici principium paffuum motus, quatenus materix potentiam coaretat, qua fecundum fe libera erat; \& facitpropenfionem a d certum al iquem naturalem motum, ita vt non ad alium : etenim à quonam habet ignis propenfionem ad recipiendum motum afcenfionis tantum, non defcenfionis? non à materia, quia materia eft zque propenfa ad omnes motus; ergo à fola forma; fola enim forma ignis reftringit potentiam materix paffiuam ad motum à medic, qua fecundum fe $x$ que omnes motus refpiciebat: principium ergo paffiuum recipiendi huius determinatimotus eft forma quatenus actuans, ac determinans materiam: \& hoc eft quod ait Auerroes in 3. lib. de Collo, comment. 28.\& in 4. de Colo 22. forma mouet quatenus eft forma, mouetur autem quatenus eft in materia; quum enim for$m x$, quatenus eft forma, officium fit agere, materix vero pati, forma, quatenus eft forma, eft principium motus actiuum, \& eadem eft etiam principium paftium, quatenus eft in materia; quia cum proprium materix fit pati, quicquideft in materia, eft patibile propter materiam: alia igitur ratione forma eft actium principium motus, alia paffium; idque fimiliter dicimus; habere locum in omnibus naturalibus corporibus materia \& forma conftantibus; in animali enım cerum eft animam efie principiun actiun proprii motus animalis, quum ab anima moueatur animal, fed neceffe eit eandem arimam effe etiam principium pafíum elufdem motus : quia fi quzeatur, cur animal fit naturaliter propentum ad fecipiendum determinate motua progreffionis, nil aliud refponderi poteft, nifi quia eft añmatum; ipfum enim corpus feclufa anima non habet naturalem propenfionem ad illum motum, fed ideo cam habet, quia habet animam: fie de aliis naturalibus corporibus dicendum eft etiam de elementis, nam (vt inquit ibi Auerroes) forma elementi mouet vt forma, \&e mouetur vt eft in prima materia, qua de re alibi eft à nobis difputandum: propterea principi- Inlib. um motus actiuum, \& pafiuum non poffunt motse feparari, in his faltem inferioribus corporibus $u i u m$ (de Colo enim fortaffealiud dicendum eff) vbi lezszs? enim eft compofitio materia \& formx, ibs ne- Princ ceffe eft formam tum determinare materiam, \& $4 \mathrm{~m}$ a ita effe principium motuspaffiuum, quatenus wam eft in materia; tum etiam effe principium acti- $p$ as $\beta$ sh uum eiufdem motus, quatenus eít forma, quia non $p \circ$ formx eft agere. Quod vero ad materiam atti- funt $f$ net, totius difficultatis folutio fumitur ex ipfo- rars. C met Arift. in context. $11 . \& 12$, lib. 2. Phylic. \& in quom 5. Metaphyf. materiam enim dicit effe naturana, do ma non quidem fecundum fe vt alteram naturam à rea $\int_{2}$ forma diftinctam, fed vt eandem: quoniam e- nats nim in context. 3. \& vlt. lib. 8. Metaphyf. inquit Ariftoteles, materiam effe idem poteftate quod forma actu; ideo materia eatenus eft natura, quatenuspoteftatem habet recipiendi formara qua eft reinatura: quemadmodum enim quium dicimus lignum rude effe arcam poteftate, deinde performam fieriarcam actu, non dicimns propterea duas arcas, fed vnam \& eandem numero, quix prius erat poteftate fola in materia, deinde fitactu per formam; ita denatura dicendum eft; vna enim eft vnius rei natura, non dux, fed naturam rei poteftate fignificamus per materiam, aftu autem performam: ob id Ariftoteles in contextu illon. lib, 2. Phyfic inquit, $y$ num quodque dicitur habere fuam naturam, quando eft actu, non quandoeft poteftate, tunc E enim poteitate habet fuam naturam, non actu; \& quia magis eft res, quando eft actu, quam quando eft poteftate, ideo poitea fubiungic, magis effe naturam formam, quam materias, hoc eft, magis performam: quam per materiam fignificari naturam rei, eadem tamen natura per vtramque fignificatur, vt prædiximus : in hoc igitur communis aliorum error confiftit, quod putant materiam per fe effe naturam, \& ita duas effe diftinctas naturas in eadena re, forF mam \& inateriam; reuera enim materia non perfe eft natura, fedper formam, \& prout poteftatem babet recipiendi formam, qua eft ipfa rei natuta: quam fententiarn clare legimus apud Ariftotel. lib, s. Metaphyf. context. s. vbidicit formam effe illam, qua proprie dicitur na ura; materiam vero fuiffe quidem ab antiquis dictam to:am rei paturam, attamen non alia ratione effe naturam, nifi quatenus eft fufreptiua formx: hac igitur ratione ma- 
teria eft principium motuspaffium, non ta. men à forma diftinctum; fiquidem dicentes, ma. terian effe principium paffiuum, quatenus eft per formam determinata ad talem rei naturam, \& dicentes, formam effe principium paffium, quatenus materiam determinat, vnam \& eandem naturam dicimus, \& idem principium motus paffiuum, non duo, quoniam fola materia won haberet hanc determinationem, qua dici poffet principium paffium huius ftaturi motus, fed eam habetà forma ; \& viciffim forma non poteft effe ratio putiendi, nifi quatenus eft in materia:ad hunc fenfum trahenda funt verba A.riftotelis in context. 21. \& 22. libr. 2. Phyficorum, quando dicit materiam $\&$ formam effe duas naturas; non funt enim dux diftinctzenatur $\boldsymbol{x}$, fed duz eiufdē natural is corporis partes, quarum vtraque dici poteft natura, fed forma ąu, materia vero poteftate, \& forma primario, materia vero fecundario, ie per forman. Credendum etiameft, Arift. hoc dicentem refpexiffe anciquorun fententian, quilolam materiam naturam effe dicebant, materian enim vocat naturam, quatenus ab antiquis ip fa fecundum fe appellabarurnaiura, atquéadeo tota rei natura. Pitet igitur, naturam in rebus naturalibus fecundum Ariftotelem effe formam; hrecenim perfe, \& quatenus eft forma, eft actuum principium motus, \& eadem vt materiam determinans eft principium motus paffium, quod idem fignificamus, dicendo materiam vt à forma determinatam; neq; enim materia fine for$\mathbf{m a}$, neque forma fine materia eft principium motuspaffiuum; patibilitas namque eft materix, determinatioautem patibilitatis, vt hune potius motum refpiciat quarm illum; eft folius formx. In colefti autem corpore quomodo ib. de fit natura, alibi confiderabitur: nunc quid fit natura, \& quznam-fit, vniuerfaliter intellexiffe fatis eft.

\section{obiectiones aliquorum aduerfus ea, que dictaJunt, do earum Solutio. Cap. VIII.}

T $F$, quze haktenus diximus, clariora redHdentur,fi quafdam obiectiones, qua à nonnullis afferuntur, foluerimus. Scotus in fecund. Sentent. diftinct. 18. diligenter loquitur de natura, \& inter cztera hoc veriflımum fcribit, principium motus pafiuum non effe folum materiam, fed etiam formam : in hoc enim longe melius fenfit quăm alijplurimi, qui fatis inconfiderate loquentes dicunt, formam effe principium aftium, materiam vero paffiuum: optine etiam hocdeclarat Scotus, fumpto exemplo grauitatis lapidis, qux tanquam forma accipitur; eft enim principium paffuum, \& caufa vt lapis fit receptiuus talis mocus, qui eft ad medium, propterea quod ab eadera forma
A qua rcs habet vt fit, habet etiamaptitudinem recipiendi narurales eiusdem rei affectiones: certum autem eft, Scotum exiftinaffe formam elementieffe etiam aAtium principium motus naturalis in elemento, vt mox alio in loco oftendemus;ergo fententia Scoti eft, formam effe'\& actiuum, \& paffiuum principium motus; quod quidem effenon poteft, nifidıuerfis rationibus,ve nos antea declarauimus: quare in hoc optime, meo quidem iudicio, fenfit Scotus. Sed B id, quod de materia ibi dicit, mihi dubium eft, necpolfum eius fententiam fequi ;inquit enirn rateriam fecundum fe effe naturam, proindeomnem motum, qui iuxta materix aptitudinem fiat, vocandum effe naturalem; hanc enim propofitionem tanquam axioma quoddam ftatuit ; quxliber mutatio dicirurnaturalis, quando $\mathrm{pa}$ tiens mutatur, vt fecundum naturam aptum eft mutari: hinc infert, generationem effe mutationem naturalem, quia materia fecundum

C propriam naturam eft apta ad omnes formas indiftincte recipiendas; frc etiam alterationem efementi effe mutationem naturalem, quia tunc elernentum mutatur, vi fecundum naturam a'ptum eft mutari; has igituromnes mutationes inquit effe naturales ratione principij paffuri tantum, non ratione actiui ; hoc enim absque dubio externum eft. - Et quia obiicere aliquis poterat motus artificiofos, qui hac ratione effent 1uaturales, quoniam fimiliter fiunt à prinD. cipio paffuo interno, quare nulla effet diftinctio inter motus naturales, \& motús artificiofos:ad hoc refpondet, negando motus artificiofos fieri ab interno principio paffiuo; inquit enim materiam naturalem, qux in rebus arte factis ineft, non habere aptitudinem ad reciprendas formas artificiofas; proinde dici non poffe in mutatione artificio fa rem mutari, vt fecundum naturam apta eft mutari ; quare illa non eit mutationaturalis. Hanc Scoi fenten-Nonnut

E tiam alii plurimi fequati funt, fed inter cate-lorum ros nonnulli, qui de natura diligenter fcripfe- argmmen: runt, doctrinam hanc Scoti prorfus approban- twm. tes, confutantillorum fententiam, qui putant naturam effe principium motus aktiuum tantum, non pafiuum, proinde folam formam effe naturam, \& aduerfus eos hoc argumento vtuntur. Si has fententia admitteretur, fequeretur nullam generationem effe mutationem naturalem, fiquidem nihil feipfum gene-

F rat; fequerctur etiam alterationem elementorumnon effe naturalem, quum femper ab externo agente fiat: attamen fatentur omnes, ge: nerationcm effe mutationem naturalem, idqueafferit Ariftoteles in primis verbis primi libride ortu \& interitu; naturaliter etiam alterari mutuo elementadicimus, \& has omnes mutationes certum eft vocari naturales ratione princip i tancusa paftiui, non ratione actiui, \& ratione folius' materiz, non ratione formz: Horum 
Horum igitur \& Scoti fententiafi vera eft, iam materia eft per fenatura, non per formam : nam fi fierialiquando potest, vt fola materia ine ope formafit principium motus, qui ob eam folam dicatur naturalis, certum eft, materiam fecundum fe efle naturam, falfam autem efic opinionem noitram, qui dicimus, materiain non effe naturam, nifi per formam; nam fi vera fentencia noftra eft, oportet núquam materiain dici principium motus paffiuum, niff ferma quo oque fit eiufdem motus pafliuum principium; quo fir,vt rerum generationes \& alterationes elemcntorum, vel à forma quoque tanquam à principio prouentant, vel non videantur dici polfe mutationes naturales; contra vero, fi illorum fententram fequamur, à fola materia tanquam à prin. cipio paffuo funt mutationes vere naturales. opinio- Sed horum fententia vrgetur maxime ea diff. nis smps cultate, quam antea tetigimus ; nam fecundum gnatro.

eam fequerctur, motum violentum effe naturalem, ratione faltem principij pafirui, quod eft $C$ materia; non enim ad id cōfugere poffune,quod de fornis artificiófis imaginarifunt, quippedicentes, has nullo modo produci ex intermo principio, feu actiuo, feu paffiuo; etenim de motu violento hoc dicere non pofiunt, quoniam materia ipfis quoque confitentibus naturalen habet potentiam recipiendi onnes formas natucales, \& omnia accidentia naturalia confequentia formas, idque afferit etiam Ariftoteles in context. 8. libr. 7. Metaphyfic. dicens materiam $D$ effe fubiectum receptiuum omnium categoriarum: atquiafcenfio eft inotus naturalis, \& materia pocentiam habens naturalem recipiendi formam ignis, habet etiam potentiam naturalem recipiendi morum a feenfronis; ergolapide furfum proiecto, moius ille eft fecundum naturam,refpectuprincipij pafiui, quod eft materia; nan materia, quas eftin lapide, habet potentiam tum recipiendiformam ignis, tum afcen-

Matera dendi. Sedillud quoque, quod de formis artibabet po- ficiofis dicunt, dubium eft; negant enim matecentiam riam refpectuillarum habere potentiam natumaturalé ralem; attamennon video, quomodo eas recirecipien- piat, fi recipiendi poteftatem non babet; negadifor- reenim potentiam recipiendi, eft dicere non efmasarti fepoffibile ve recipiat, atcui id, quod non eft fics.jas. potibiletieri, nunquam fit; quomodo igilur eas recipit: Negare igiturnon debent in materia naturalew potentiam recipiendi etiam for masartificiofas, quum eas recipiat actu. Nos igitur fi in materia aptitudine, qua omnes formas recipere poffe dicitur, difcrimen aliquod

potentia inuenerimus fortaffeomnem hac in re difficulmateris tatem rollemus, \& corum errorem manife fum adfor- reddemus. Inprimis illud à nemine negari pormas ba- fevidetur, materiam magis, \& principalius reborgra- Spicereformas fubftantiales, \& ad eas inaiorem dos. habere propenfionem, quam ad accidentales: materia formam appetit vt perficiatur, \& fiat actu, quum fecundum le non fic ensaliquod determinat $x$ naturx ; perficitur autem \& conttituitur, \& recipit effeactu à forma fubftantiali, non abaccidente aliquo ; ergo potentia materix formam fubftantialem primario refpicit, accidentia vere fecundario; itaque fi fecunù Ariftotelem dicendunı fit, quisnam fuerit $f c_{\text {. }}$ pusnatur $x$ vniuerfalis in ftatuenda rerum ima teria, certe is præcipuus fuit, recipere formas

- fubftantiales : quod idem fecundum veram philof phiam dicere debemus de opificis confilio in rerum creasione, nas pracipue eam creauit, vt fubiectum receptiuum formarum fubitantralium; fed quia neceffe crat, vt accidentium quoque receptisa effet, plura namque accidentia formam neceffarso infequantur, plura ctiam ab externis caufs inducuntur, ad qua omnia recipienda aptam effe materiam oportuit, ideo debuit materia habere potentiam naturalem vniuerfalem recipiendi omnes formas, tam fubftantiales, qæam 2ccidentales. In accidentibus autem hoc pofumus difcrimen notare, quod a lia à natura, \&à caufis naturalib. inducuncur, alia vero à nobis per liberun nofra voluntatis aibitriuta operantibus ; cuius. modifine omnes torma arificiof bis per habitum artis producuntur in mate. ria naturali: quanquam igiturcredenduri non eft, natuam vniuerialem in ftatuenda materia has refpexife, negari tamen non poteft, materiam iam conftitutam effe praditarn na. turali porentia recipiendi etiam formas artificiofas, ita ve de materiz aptitudine illud idem dicendum effe videatur, quod nos alias in libro noftro de natura Logicx, de vitilitate Lo. gicadiximus: Logica enim à Philofophis, ơ Philofophiæ tantum gratıa producta eft: primario quidem propter Philofophiam conternplatiuam, fecundario tamen etiam propier 2E Etıuam, fed non propter artes effectrices; attamen producta Logica inuenta eft vtilis ad omnes difciplinas, etiam ad artes ozones tradendas \& addifcendas : producta igitur eft Logica primario confilio propter Philofopham contemplatiuam, fecundario autem etiam propter actiuam; quod autem ad altes quoque omnes vtilis effe comperiatur, id euenut ex ipfius Logica natura, non ex connilio Philofophorum, qui Logicam genuerwut, idI eoque propter corum intentionem : fic igitur de prima materia, ac de eius aptitudine naturalidicamus; aptirudinem enim habet naturalem recipiendi omnes formas, \& omnia accidentia, fed formas fubftantiales ex intentione natura prmaria, accidentia vero naturalia ex intentione fecundaria; at formas artificiofas prater intentionem natur $x$, уи $x$ non harum gratia dedit materize potentiam pafiuam, attamen naturam materiz liberam huius enim ratio euidentiflima eft, quoniam 
confequitur neceffario, vt eius potentia paffua fit vniucifalis, proinde ve formas quoque artificiolas recipere apta fit : habet igitur anateria potentiam naturalem recipiendi etian has, licet cam habeat preter intentionem naturæ vniucrfalis. Si hoc verum eft, ve eft verifhunam, fententia illonun de materia reircienda eft,nam eam hoc abfurdun fequitur, omnem notum feu artificiofum, feu violentum dici pofe natuz ralem ratione principii pafiui; quia quum materia fuapte natura fit apta recipere omnes motus, his omnibus motibus mutantur res, prout fecundumnatutam, cluæeft materia, aptæ funt mutari: fed quum id fit manifefte abfurdıffmum, cogimur confiteri, non effe veram propofitionem Scoti, nifi refpiciendo naturam, qux eft forma; tunc enim eft mutatio naturalis, quando tes ita mutatur, yt Secundum naturam, hoceft, formam fuam apta eft mutari; nam fi folam materiam fpectemus, omnes motus nullo exclufo effent naturales. Id co ad illud, quod degeneratione, \& de elementotum alteratione ill obiiciunt, affeueranter dicimas, has non effe mutationes naturales, prout in libro fecundo Phyficorum in tradenda definitione naturæ fumitur motus naturalis; hos enim decepit ambiguitas huius vocis naturale: quoniam enim ia m diximus, naturam effe caufam motus tum immanentis, tum tranfeuntis, ideo vterque eorum dicitır naturalis, quatenus fit à natura, \& à cau-, fa naturaliter agente; fic enim motus fulmunis \& venti, \& turbinis funt motus naturales, nempe à caufis naturalibus productı; tamen illis corporibus, in quibus infunt, non funt naturales, fed violenti: in definitione autem naturx non fumitur alius motus naturalis, quam ille; qui prouenit ab interno principio, \& caufam habet in eo ipfo corpore, quod mouetur; ideo generatio, imo etiam interitus ab A riftotel evocatur naturalis, in initio libri dc Ortu \& interi. tu, quia fiunt à caufis naturalibus, \& à natura ipfa; at fi fumatur mutatio naturalis pro illa, cuius principium eft injillo ipfo corpore, quod mutatur, hx lon funt mutationes naturales; fic nequealterario elementi eft motus naturalis, fed potius contra eius naturam; fi enim aqua calefiat, non minus violentus illi is motuseft, quam motus afcenfionis; vt enim hic eft ad contrarium locum, ita ille eft ad contrariam qualitatem; in illo enim fubiecto neque atiuum horum principium ine ft, neque pariuum, quale antea declarauimus, id eft, cum determinata propenfione ad hunc tantum motum, non ad alium recipiendum :in animalibus vero; qux conftant ex contrariis naturis, dari poteft alteratio, qux fit hoc modo naturalis, \& facta ab interno principio etiam actiuo;

quam fententian ex Auerroe colligimus in 5 . Commentariolibriz. Phyficorum.
A Solutioargumcntoruin \& prosuicenna, os prosimplicio adductorum. Cap. IX.

VEritate declarata, reliquum eft, vt que initio attulimus \& pro Auicenna, \& pro Simplicio argumenta folnamus. Primum pro A uiccnna fumebatur ex Ariftotele in principio lib. 2. Phyficevbi naturalia à non naturalibusper hoc feiungere videtur, quod naturalia habent B in feipfis principium actum motus. Ad hoc dicimus, id Simplicio quidem refragari, non nobis;non enim dicinus naturam elle motus principium tumadiuum, tum paliuum; quare nihil mirum, fi dicat Arifoteles, naturam efre principiumactium; per hac enim non negat effe etiam principium paffuum:ratio autem cur ibi exprimat actiuum, non pafiuum, ett, quia comparat naturam cum arte, vt artem excludat; \& feparet à definitione naturæ; ars enim non eft arte factorum principium paffuum; fed actium folum, ideo vt congrua fit comparatio, fimit A riftoteles naturam quoque vt principinas afium, \& oftendit artem effe principium motus in alio, non in eo, in quuo eft, nifiıd contingat per accidens, naturam vero effe per fe principinm actirum motus in eo, in quo eft. Adalicrum argumentum dicımus, folitum quidem elie A ritotelem caufam effeetricem ap- Ad fecüpellare principium motus, fed quandoque et- dum.

D iam communi appellatione omnes caulas appellare principia, vt in primo Iibro Phyfic. aufcult. manifeftum $c$ ft, materiam ab Ariftotele frequentervocari principium: quapropter nomen principii in definitione naturx, poteft etiam paffum principium fignificare. Ad primum Simplicii dicum ian eft, anımam non ita dıftingui à natura, vtanimanon fit natura, fed plecÿ. vt fpecies difinguitur à genere: quare in eo qirodeft effe principium motus eft actium, \& E paffuumi, non differt anima à natura: quod autem Ariftot.in lib. 8, Phyfic. dicat, proprum effe animatorum mouerià ieipfis, id fano modo eft inteligendum, qui à nobis alibi declarabitur: Ad fecunduin fumptum ex Ariftotele in contex. 32. eiufdem 8. libri longa opus effet confideratione, quam ad alium opportuniorem locum remittimus, vbi oftendemus, etiam grauia \& leuia modoaliquo habere in fe actiuum principium fui motus naturalls; forma enim ele$F$ nenti mouet vt forma, \& moueturvt eft in materia; neq; Ariftoteles abfolute ibi negat grauia \& leuia moueri à feipfis, fed negat eo modo, quo à fe mouentur animalia : fed de hoc aIibi; pro prefentiautem occafione fatis etiam eft fi dica. mus, da to etiam quod natura elementi fit prin cipium motus paffiuú tantummodo, nã tamen eiufmodi effe omné naturam, fed aliquam da ri, quæe fit etiam aEtiuü principium motus : quire argumentun fumptum à natura elemento-

\section{Adpri-} mit Ari: cerne. 
rum inefficax eft, quum non probet de onni A seder- natura. Ad poftemum argumentum, quod r.sm. Simplicius fumit à verbopaffiuo in definitio. ne natur $x$, dicimus leuem effe confiderationem; quia verbum pafiuum non fignificat naruram non elle principium actium, quandoguidem omne mouens eft principiun \& cautfa, vt mobile moueatur; quocirca dicere etiam ibi Ariftoteles poteft, naturam efie principium åiuum \& caufam, vt naturale corpus moueasur: cur autem malueritibivti paffuo verbo, quam action, ratio eft, quia fi actiuo vfus eflet, fignificarepotuilet motum tranleuncem, \& in alia corpore teceptī, per quem non fuifer bene declaratum quid fit natura; igitur cum artificio vius eft verbo paffiuo, vt fignificaret motū receptum in eodem corpore, in quo natura ineft; fenfus ergo illorum verborū eft; natura eft princrpium per $f c$, vt illud, in quo natura ineft, moueatur \& quiefcat; neque per hoc ftat, quin natura fit principiü motus açtiuum. Ad alı quoq; argumenta, quibus oftendere nitebarur Simplicius, animam non effe naturam, facile eft reAdtri- fpondere. Ad primun dicimus, nil aliud perilmét Sim-lud oftendi, quam nö 1 dem elreanimam, ac naplicis turam, quod nos quoq fatemur, quemadmograd a dum etiam dicimus, non idem effe hominem, \& nima nö animal;neq; eandem effe vtriufque definitiofot natse- nem; per hoc tamen non fare; quin homo fit ras.

A.jectufpeciesanmalis, \& ei competat aninalis definitio, tametfi non vt popria definitio hominis; alia igitur eft naturæ definitio, al ia anima, quoniam natura latius patet, quan anima; anima enim eft fpecies quxdam naturn, fed de anima predicatur \& nomen, \& defintio n.tura, ficuti cuuslibet generis \& nomen, \& definitio predıcatur de fpecie: quando auté Simpliciusinquit, natura eft a tus corporis fimplicis, \& homogenei, negamus hanc effe definitionem natur $x$, imo \& vniuerfe prolatım falfum effe dicimus, \& nihil tale protulit Ariftoteles, fed dixit naturam effe interitum principium motus \& quieiis; hæc autem, etfi non eft definitio animæ,prædicatur tamen de anima, quemadmadun definitio animalis dehomine prædicatur; anima igitur eft natura. Ad fecundum dicumus, animam non effeactun fupcradditum corpori naturali ozganico, vt Simplicius imaginatur; fiquidem in definitione animæ non fumitur corpus naturale organicum fecluáa anima, fed inclufa, \& quatenuseft animatum; ficuti quum dicimus, anima rationalis eft forma hominis, non intelligimus cam effe actum quendam howini fuperadditun, quoniam fine ipfa nors eliet hono, red dicimus cfle illum formam, as illam perfectionem, qua homo conftituitur,
\& eft homo: fic etian dicimus, animam vniuerfe fumptam efle actum illum, quo corpus naturale organicum conftitutur, quafi dicamus, anima cft actus primus, quo corpus naturale animatum tale eft, idem cnim eft ani. matum, quod organicum, fic autem patet naturale reftringi ab animato, \& animatum effe fpeciēnaturalis. Ad tertiun negamus id, quod Simplicius afiumit, naturam efle caufam vinius tantum determinati motus, \& ad vnam partem

B tancum, ita ve non motuum oppofitorum; fic c. nim fumit fecundo modo naturam nimis ftricte prout ab anima diftinguitur: nos atutem dicimus, naturam hicaccipi latius, prout complectitur omnes formas naturales, tam quæagunt contrarios motus, quam quæ vnum tan= tum: dummodo enim fint internæ caufr motus, conuenit eis nomen natura, \& fic anima eft natura. Adpoftremum neganda eft illa minor, anima non eft in fubiecto; dum enim fumimus efle in fubiesto, prout competit etiam forma fubftantiali, \& fignficat inhærere in materia, \& illam intormare, fic omnis forma naturalis eft in fubsceto: itaque fianma in materia inhæret, \& eaminformat, \& dac effe cospori animato, abfque dubio anıma eit in fubiecto, \& eft talis corperis natura, neque hoc negaret Simplicius, faltem de anima nutriente, ac de fentiente; quum enim probet de fola rationali, de alis concedere videtur quod fint in fubiecto, proinde \& natuas appellaripoffe; quare ipfiufmet argumento eius fententia relellitur: de anima vero rationali non eft in præfentia difputandum, id folum dicimus, fi ea quoque eft forma materiam informans, \& dans effe honuni, vt ego omnino dicendum effe arbitror, eam quoque dicendam effe hominis naturam: fi vero non informat, vt aliqui arbitrantur, non eft natura hominis; fatemur enim nomen naturæ non complecti nifi formas naturales materiam informantes, \& ipfa corpora naturalia conftituentes, hx namque funt fingulorum corporum natura, \& in eıfdem principia motus \& quietis; de his omnibus nomen naturæ pradicari dicimus, non de formis à materia abiunctis per effentiam, hæ namque nullius corporis fumt naturæ; idque fignificare voluit Ariftoteles in cap, r. librir. de partibus animalium, quando dubitauit, an de omni anima agere debeat philofoplus naturalis, re-

$F$ fponditque agendum ei effe de illa faltem, qua animal tale elt, hoceft, quæ conftituat-animal, feu fpeciem alıquam animalis; omnis enim forma materianireformans eft natura, \& rractanda à philofopho saxurali.

(n)




\section{$\begin{array}{llllll}J & A & C & O & B & I\end{array}$ \\ Z A $\underset{P A}{\mathrm{~B}} \underset{\mathrm{T}}{\mathrm{A}} \mathrm{R} \underset{\mathrm{V}}{\mathrm{E}} \mathrm{L} \mathrm{I}, \mathrm{L}$ \\ L $\quad I \quad B \quad E r$}

DE INVENTIONE

Anfld inueniendum dari fubfantias à materia abunnctas, alio medio pti poßsipuns quam motu.Cap.1.

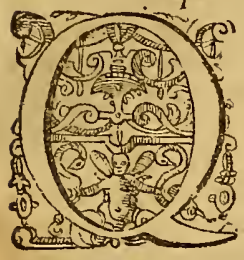

Vum Ariftor.in 8.Phyfic.aufcultationis libr. exæterno Calimotu demonftauerit dari xternum motorempenitus immobilem, \& abomni materiaabitietum, tres indequxituncs exortx sür, in quarum folutione controuerfix non leues inser philorophos exiftunt, de quibus aliqua nunc breuiter dicere conftituimus; hac pramilla proteftutione, nos hac de re fecundum principia philoiophix Arift. effeloquuturos, \& illam tantum fubltantiartum à materia abiuncta rum notitiam, quam via naturali adipifcimur, cunfideraturos, omıfía penirus earundem cognitione, quam reuelatione diuina \& lumine fupernaturali accepimus;veriffimam illam quidem, fed Arift. cuius dicta interpresanda fufcepimus,prorfis abfconditam. Harum quxftionum prima eft, an ad cognofcendum dari fub ftantias à materia abiunctas, al io medio vti pofimus, quam motu, an potius neceflàrium fit hoc medio vti, neque aliud detur ad eas demonftrandas idoneum. Hanc vt breuiter abfoluamus, fententia Auic. fuit, quod prater motum habeat primus philofophus alia plura media ad Deum notificandum idonea, veluti fidicamus; daturens ex alio pendens, ergo daturaliquod primum, quod no pendet exvlloalıo;nifi enim detur, erit progreflus in infinitum, quod minime dicendum eft: id autem, quod à nullo pendet, \& eft omnium primum, Deus folus eft. Vel fic:datur perfectum, \& perfectius, ergo datur perfectiffimum, quod nil alitt perfectur effe potcit, hocautem non eft nifi Deus ; \& confequens eft manifeitum ob eandem rationem, ne fiat progreflus in infinitum. Vel etiam fic: daturbonun, \& datur melıus, \& adhuc alind melius,ergo datur optimum, quo nihil eft melius, idiq; eft folus Deus. Et eiusmodi aliis pluribus medris demonftrari idem poteft, vt confiderantibus manifeltum eft. Quam Auicennz fententiamnor defuere, quipofterioribus temporibus fequuti. ita - fint. Enm reprobat Auerr. nec iniuria, pluribus. in locis, in r.Phyficaxaufcultationis, Com. ylt. \&

\section{AETERNI MOTORIS.}

A 26.2.lib.\& in tert.oetaui, \& in 12. Metaph. Com" 5.\& in 4. difputatione contra Algazelcm, qui eiusdem fententix fuit.Inquit Auerr.nullam harum rationum aliquid habere neceifitatis, fed leues ac probabiles omnes effe; quia licet oftendatur dari ens à nullo pendens, dariens optimum, ac omnium perfectiffimum, non propteren oftenditur id effe à materia abiune en $\mathrm{m}$, \& incorporcunn:quare illi philofophi, quorum mentionem facit Plato in Sophifta, qui ptater res B corporeas \& fenfiles nil aliud exiftere concedebant, dicerentillud fummum \& optimun, \&e perfectifimum, non elfe niti Coelum, nec vllum praterillud darialium Deum ; quare nifi ad motum Coli confrgramus, \& dicamus Coelum opinis perpetno moueri, \& quicquid mouetur,moueri Gera. ab alio, \&̊ omne corporeum effe mobile, nec dari progreflum in infinitum in mouentibus \& motis, nunquiam ad cognofsendas via naturali fubitantias à materia abiun

C Igiturabsque confideratione motus conicetare quidem aliquid de illis fubstantiis poffúmus, fed certam earum habere cognitionem ninime poffumus:qnod Ariftot.1pfe lignıficauit, qui ad harum fubltantiarurn inuentionem nullo alio mediovfus ett, nifi æernomotu, vt tum in 8 . phyfic.aufcultationis libro, tum in 12. Metaphyr. videre eft.

Au ex folo aterno motupoßint, demonfrari fulftantice à materia abiuncter an etiamex motuabfolute.

Cap. 11 .

Voniam igitur ex folo motu duci pofuQmus in cognitionem fubftantianum à materia abiunctarum, fecunda quaftio oritur, an ex aterno tantum motu, an etiam ex motu abfolite fine confideratione eternitatis ad earum notitiam peruenire pothimus. Non detunt qui di- opinio cant, etiam ex motibus nouis absque zeterno aliquoE motu perueniri poffe in cognitionem æterni rtom. motorisimmobulis, nam bacquoque via vfus effe videtur Arift. in S.lib. Phy fic. aufcultationis longo progrefuad cont. vsq; 44.exeo n. quod qui icquid mouetur, ab alio molnetur, nec datur proceilus an infinitum, collegit neceffarium effe dari primuin mouens isnmobile; quod a nullo alio moueatu:, idq; incorporeun efie oportere, Confutan quia.fiefet corpus, non poffet non effe mobile. tro. 
Ego tamé eos decipiarbitror : quoniam fi hune Arifto:el. difcurfun confideremus, manifeftum eft, pereum nosnon duci ad alium mutorem immobilem, quam late acceptum, quianimas quoque animalium mortaliun complectatur; immobiles enim fint, quatenus non fitur perfe mobiles, quum incorporex fint, fed tamen lunt peraccidens mobiles; neque perid fit, quin dicantur motores primi uuxta oidinem mouenDefenfio tium effentialen. Sed hocilli videntes confite illorwm. tur Arift. ad demóftrandum ñotorem arernum vnituerfi hunc difcurfum non applicaffe, quippe qui fpreut hanc argumentationem, quoniam alia efficaciore ab xterno motu defunpta ibiden ftatim vfurus erat; poterat tamen hac quoque vti,fi voluiflet, \& abfque confiderationerternitatusex folis motibus nouis, \& ordine mouentium, \& mobilium nos duceread primum xternum motorem vninerfi penitus immobilem:hoc igitur ipfi declarare volentes, \& Ariftotelis argumentatıonem conficere, quam ipfe/vt aiunr) abfoluere neglexit, ita argumentantur: fi difcurfum Ariftot.aptemus ad motum vniueri, abfque dubio mueniemus peruenrendum effe adprinum motorem immobilem, iuxta ordinem mouentium effentialem; quum enm moucatur Colum, neceffe eft vt ab alio moueatur, \& vt pertueniatur tandem ad primum immobile; fed hocpetendum eft, an it æternum necne; nam fidicaur efle xternum, iam id habemus, quod quxrinus; fi vero non xternum, ergo aliquando interiturum, ergo ab aliquo agente interimente, illud igitur non eft primum mouens, fed habet motorcm priorem, cuitis contrarium conftitumus, iam enim oftendimus, ipfum efle primum : \& ad ipfum duxinus tanquam ad primum ; itaque manifeftum eft, fi primus motor ynituerf nullum extra fe habet inotorem prio$\mathrm{rem}$, eum à nullo interimi polfe, proinde efle $x$ ternum. Eo itaque Ariftotelis difcurfu ex folo motu abfque-confideratione atcritatis ducimurad cognofcédum, prinum vnituerfi motoren, non modominobilem, fed etia m xternum

Confut $\alpha$ - e1 Te. Verum hac horum argumentatio, fi bene tiv. perpendatur, nihil habet efficacitatis: primum enim id certum eft, qulod ipfi quoque non inficiantur, Ariftot. tali argumentatione v fum non effe, neque ad alud eo úf curfu nosperduxifle, quãad oftendēdum dari mototem im mobilem lateacceptum, quianimas quoquc animalium comprehendat: quod lieandem illam demonfirationemad aternitatem quoque primi motoris vniueri aptare potuifler, idabfque dubio fecillet, \& fiam de xtcrno motore fencenriam hac quoq; ratione confirmale volufilet; quanquam enim ratio fumptaab aterno molu efficacior aut euidentior eft, tamen hac quoque, fi neceffitatem aliquam habet, ipernendin nonesat; confueurt, enim Ariftotel. cumsatione deaonftratiua alias puoque minus efficaces in
A confirmationem adducere; hoctamen nonfecit, quia cognouit rationem hane ad demonftrandum xternum vniuerfi motorem aptari minime pofle : vt igitur pateat illam, qua ifti vfl funt, argumentationemefle infirmam, \& Ariftotele indignam, declaremus breuiter, quomodo ea facile folui polfit. Illi igitur poft quam inuenerunt dari motorem immobilem, quxrunt an motor immobilis viniuerfi æternus fit, an corruptibilis : ad hanc interrogationem diB cameffe corruptibilem, \& aliquando interiturum, tanquam non ditter $x$ conditionis ab hin. mabus animalium mortalium; ideoque non alio modo interiturum, quam quo animalium a. nim interire dicuntur, nempe ob neceflàiam fequelam ex interitu corporis, in quo inhærent; id enim quod proprie interire dicitur, animal eft, anima vero non per fe interit, fed interit interennte animali; dicam itaque cum multis antiquis philofophis, Coelumex elenentis conC Atare,feu elie naturæ elementaris, proinde genitume the, \& interiturum, tum Colum, tum mîdum vniuerfum, quum conftet ex contrariis, \& omne ex contrariss contans interire aliquandonecelle fir; dicam iraque, ex interitu Coli necefarso fieri vtanima quoque morrix intereat, quia licet hac contrárium non habeat, tamen ex fubiecti corpons miteriru ex neceffitate deliceret, quum fit forma nuaterialis, quales funt anm $x$ animalium; animam humanam

D femper excipio, de cuius immortalitate ve fecundumveram Theologiam certillimi effe debemus, itanon defuere qui fecundum principia quoque philoroplia Arrfotel.idem exıftimàdum efie cenfuerint; nostamen de hoc nihil in præfentia ftatuimus, quum ad id, de quo loquimur, mhil conferar, \& hatis nobis ad hane noftram argumentaionem fit in folis bruto. rum animabus id, quod diximus, intelligeread illorum de primo motore errorem liac finilitu. E dine declarandum. Hac igitur dicentibus nobis, vt dicere, poteramus, Ariftoreles fuam il. lam argumentationem ad mororem aternum oftendendum aptare minime poterat, prefertim quia Cæleftis corporis naturam atque impatibilitatem nondum declarateras, hane enim poftea oftendet in primo libro de Calo, nec aliunde argumentum tumens, quam à motu in orbcm, cuinullus eft contrarius motus: quando igitur hi dicunt, fi primus motor vni$F$ verfi eft corruptibilis, ergo non eft primus, negandum eft confequens; ad probationem autern, quum dicunt, corrumpetur à motore priore, hoc quoque eft negandum; non enim ex eo quod eft compribilis, requiritur motor prior, à quo corrumpatur, fed quum fir incorporeus, \& lorma corporis, fails, caulix eft ad ipfum interimendum corruptibilisas corporis, cuins aft forma; corpus autem ipfum, quum fit elementare, fuo contrario lædi 
\& interimi potéf.Patet igitur, inanem effe hanc A corum demonftrationem, quod (vt diximus) auctoritas A riftotel . qui ea non eft vfus, manifefte confirmat;ideo enim eam fpreuit, quia inefficacem, \& vanam efle cognouit. Ex motu igitur abfolute accepto absque confideratione $x$ ternitakis nilaliud oftenditur, quam dari primum motorem vniucrfi immobilem eo modo, quo anim $x$ animalium trutorum funt immobiles, hoceft, nou per fe mobilem; quod autem nec per fe, nec peraccidens mobilis fit, proinde à materia abiunctus, \& impartibilis, \& infatigabilis, \& fempiternus, id ea ratione non oftendi tur; quapropter nullum aliud philofopho naturalimedium relinquitur ad demonftrandum primum motorem 'acernum, nifi motus xternus; quando enim fumimus motum vniuerfivnum \& eundem numero $x$ ternum effe, ftatım inferimus, eum ab vno tantum motore totum produci; quare neceffe eft, motoremillum effe infatigabilem, \& fempiterium.

\section{An demonfrare atemos motores ex aterno motu perineat ad naturalem, an ad pri- mum philofopbum, opinio aliquorum cum eorum argumentis. \\ Cap. I I I.}

IIs ita conftitutis, poltrema oritur quaftio, Hquum ex folo arerno motu poffint fubAtantix à materia feparatæ demonftiari, an hrec demonftratio dicenda fit Metaphyfica, an naturalis, hoceft, an eam demónftrationem formaread Metaphy ficum, an ad maturalem pertineat; quum enim videatur huius dem on ftrationis medium efie naturale, quafitum vero $\mathrm{Me}$ taphyficum, hinc lis non parua orta eft, an applicare medium quafito, \& hanc dem onftrationem extruere fit officium primi philofophi, an naturalis; ob id quum vtraque pars fectatores lrabuerit, in hos potifimum omnes laborarunt, vt oftenderent, demonfrationem fumere conditionem, \& nominationem, illi quidem à quæfito, hi autem à medio. Magna pars in ea fententia fuit, quod ea demonftratio fit Metaphyfica, \& vfi funt his præcipuis argumentis. um Primo,finis demonftrationis, \& fcopus demonmen frantium eft cognitio maioris extremi, quod quafitųm vocatur, non cognitio medij, ergo non à medio, fed à quafito eft nominandade- $F$ monftratio; in hacautem qquxfitum eft Metaphyficum, nam fubftantix à materia abiunctæà folo primo philofopho confiderantur; ergo eft Metaphyfica demonftratio. Secundo, ille dicenclus eft aliquo medio vri, quiillo indiget; atquillle, cuius eft quafitum, eger medio adillud demonfrandum; demonftratio igitur formari ab eo dicitur, cuius eft quafitum, nonab eo, cu- ius eft medium, is enim ca demonftrationenen eget; ergo pradicta demonftratio extruitur à primophilofopho, non à naturali : confirmatur etiam maior propofitio-teftimonio Ariftot. in context,86. primi Pofteriorum, vbi inquit perfpectium debere fua theoremata demonftrare per media accepta ex Geometria, quandoquideın ip re perfpectiuus eft qui talibus mediis eget : confirmatur preterea auctoritate Ariftotel. in context. 102. eiusdem libri, vbi ait, conB clufionemillam Medicinalem; vulnera orbiculata tardius fanantur, demonftrari medio Geometrico, non medio Medicinali, quia Medicus non cognolcit nifi rem ita effe, Geometra veromedium prabet ad demonftranduni propter quid;certum autem eft,ad Geometram non pertinere eam demonftrationem formare, ea namque non indiget, \& nihileffet abfurdius, quam dicere Geometram aliquid de vulneribus demonftrare; folus igitur Medicus, cuC. itus eft quxfitum, eo medio ytitur, quiaipfo indiget. Tertio, quxnio an fit, eft quxltio an Tersium contineatur fub ente; ens autem quatenus eft argumen ens, eft Metaphyficx confiderationis; ergo tum. quxrere an fint fubftantix à materia abiunctr, \& demonitrare quod fint, eft officium Metaphyfici. Quarto, Ariftotel. in primo contex. Owartü 6. Metaphyficorum inquit, eiusdem effe difci- argumen plinz declarare an fit, \& quid fit, arqui Meta- tum. phyficimunus eft declarare quid illæ fubftantix fint, ergoad eundem pertinet demonfrare etiam quod fint. Tandem adducunt plura Quint $\bar{s}$ Ariftocel. teftimonia, nam in fecund. context. argumen tertij libri de Colo hæc vciba leguntur [aliqua tum. effe entiumpenutus immobilia, magis efs alterius, quam nutwralis confiderationis $]$ ergo magis ad Metaphyficum, quam ad naturalen afferit pertinere ofendere q̨uod detur primus motorimmobilis. Et in primo libro de ortu \& interitu context. $55 . \&$ in quarto de ortu animalium, capite vltino, \& in tertio Metaphýy ficorum contextu fecundo \& in fexto Metaphyficorim ter tio, \& in feptimo Metaphyfic. 5 . \& in vadecimo Metaphyficorum, capitefecundo, 2 in initio tertizSummz, inquit Metaphyficum verfari in fubftantiaimmobili, \& aperte dicit effe adhuc immanifeftum, an talis fubftantia detur, idque effe pofterius demonftrandum: fignificat ergo fe id non derronftraffe in oftauo Phyficorum, qui omnes pradictos libros pracedit. Praterea hoc idem confirmatur ab ipfa tractatione duodecimi Metaphyficorum, vbi aperte ea demonftratiolegitur, qua ex aterno motu oftenditur dari motores immobiles, qui funt fub-

ftantiæ à materia abiunctæ; has igitur demonftrare, ad folum primum philofophum pertinet. 
opinio Auerrois quod ad folsm natiralem pertineat probare motorem atermin of

$$
\text { ciusarguments. Cap. IV. }
$$

Ontrariam opinionem, quodilla demonftratio fit naturalis , \& à naturalı philofopho extruatur, efficaciter tuetur Auerroes in primo Fhy ficorum, Comentariovltimo, \& in fecundo Phyficotum 26. \& in 8 . Phyfico.um tertio, \& in duodecimo Metaphyficorum quinto, \& inquarta difputatione contra Alegazelem, prims:m to, inquarta dim potiffim um argumento duetus, quod fubargzsmen iectum in fcientia luanec à priori nec à polte-
tism.

teria abiunetx in Metaphyfica locum habent fubiecti, ergo à Metaphyfico demonftrari non poflunt, à folo igiturphilo fopho naturali. Confirmat hoc Auerroes exipfa Ariftotelis tractasecusndz tione. nam demonftratio zterni motoris ex engsmen terno moto, quamuis legatur in duodecimo tisin. Metaphyficorum, tamenfufius, ac diftinctius in oktao Phyficornm explicata legitur; hinc enim colligitur, proprium eius demonftrationis locum effe octauum librü Phyficorum, in duodcs cimo autem Metaphyficorum eam breuiter repeti vt demonftrationem naturalem: hæc certe eft fententize Auerrois valida comprobatio, nā fi ea demonftratio Metaphyfica effet, non poterat prácccupari in nafur ali philofophia, in qua res ad Metaphyficam attinentes incognitz ad-huc effe ftatuuntur; fed quum Metaphyfica fit aduiifenda poft philofophiam naturalem, po- tuit Metaphyficusad doêrinæabundantiam \&z claritatern repetere breuiter demonftrationem naturalem iam prius in octauo phyficorumexPrimusm truetam, \& intellectam. Illivero, qui hanc Aargumen verrois fententiam poftea fequiti funt, ad eam t:sm A- comprobandam nixi funt oftendere"; omnem werrob- - demöftrationem fumerenominationem à mefarum dio,non à quafito; hocigitur probant \& ratioqrod de- ne, \& Ariftotel.teftimonio:ratione fic; medium monftes-eft materia, ex qua conftituitur demonftratio, t:0 a me- ergo quale eft medium, talis eft demonftratio disonoms appellanda, quoniam in hac demomftrationis nerus. materia tota eius efficacitas, \& yis nothícaciua confiftit; neq; obeft id, quod dicere aliquis poffet, res non à materia nominari, fed à formajetenim verum hoceft in fubftantiis, qux ex materia \&- forma conftant, quoniam ibi forma eft differentia conftituens; at in accidentibus materia locum habet differentiz, forma vero genesis, ix his perfimilis eft denionftratio, cuius natura conftitu ta eft in materia neceffaria, non in forma fyllogiftica, qux eft ei communis cum siricrtid alis fylogifmis; fcientia vero conclufionis qux conslif to fitæ eft quidem fins demonftrationis conftrumis, est tism enda, at demonftrationis iam confructa non ent finis, fed potius effectus naturam medii coss-
A fequens, ita ve pro diuerfis medü conditioni. bus diuerfa conclufionis f́cientia proueniat, $1 \mathrm{~d}-$ que docet Ariftoteles in 1. Pofterior. cap. to. \& oftendir ex diuerfis conditionibus medij va rias demonftrationis fpecies fieri ; non eniar materix tantummodo locum habet in demonftratione medius terminus, fed etiam efficientis, cui totam conclufionis fcientiam acceptam ferimus. Præterea Ariftotel. in context. 5 \&. eiufdem primi Pofteriorum loquens de tranfitu $B$ ègenere in genus inquit, non poffe Arithme ticam demonftrationem aptari ad demonftranda accidentia magnitudinum, atqui certum ef?, accidentia magnitudinum conftituere conclufionem Geomerricam, ergo illi aptare Arithmeticam demonftrationem nil aliud effe'po. teft, quam vt1 medio Arithníetico ad eam demonftrandam; Ariftotelès igitur Arithmeticam vocateam demonftrationem, cuius folum medium fit Arithmeticum, tota vero conclufio Geometrica : \& paulo por in codem capite dicit, non effe Geometrix demonftrie, contrariorum vnam effe feientiam, qux eft conclufio Metaphyfica, neque duos cubos effe $\mathrm{Y}-$ num cubum, qux eft conclufio A rithmetica: itaque fi fieret hacdemonftratio, effent fecundum Ariftotelenì demonftratio Geometrica, \& folus Geometra, cuilus eft medium, de mōftrare diceretur, licet conclufio ad aliam fcientiam pertineat. Patetigitur, demonfrationem à folomedionominari, quo fit vt demonftratioxterni motoris ex aterno motu, quum medium habeatnaturale, vocanda fit naturalis, \& ad naturalem pertineat, etiamfi conclufio fit Metaphyfica.

\section{Veritatis declaratio. Cap. $V$.}

Nhac magnaaliorum inter fealtercatione ego, ve meam fententiam proferam, cenfeo E quidem falfam omnino effe priorem fententiam illorum, qui dicunt hanc, de qua loqui; mur, demonftrationem éfie Metaphyficam, veram autens effe Auerrois opinionem dicentis eam effenaturalem, \& ad naturalem philofophum pertinere; tamen ipfos quoque Auerroiftas puto aliqua exparte fuiffe deceptos, isque fuit vtriufque contrarix fettz communis error-, quod putarunt demonftrationem illam habere medium naturale, \& conclufionem Metaphyficam; quod ego monftrum effe arbitror, \& Hermaphroditumà doctrina $\mathrm{A}$ riftotelica, \& ab Auerroe quoque ipfo alieniffimum: quanquam igitur optimum effe Auerroiftarum argumentum arbitror, quo oftendunt, demonftrationem femper à medio nominari, fuperuacaneum tairien illud effe puto , \& costrarix opinionis yeram confutatio-

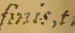 nis.} $a_{0}=c^{2}$ derror. Aratis Secur a.gur titm. 
nem in hoc tantum effe conftituendam, quod falfum eft id, quod illi pro comperto fumunt, conclufionem propofita nobis demonftrationis effe Metaphyficam, quod quidem Anerroift $x$, quum negare debuerint, concefferunt : hoc igitur fi oftenderimus, patebir totam demonftrationem effe naturalem, proinde vanam effe difputationem illain, an demonftratio à medio, an à conclufione fit nominanda. Inprimis ex iis, qua in primo Pofteriorum Analyticorum dicuntur de tranfitu è genere in genus, oftendere facile poffumus, non dari apud Ariftotelem hanc monftrofam demonitrationem, qua ex medio naturali conclufio Metaphyfica colligatur, imo indignam prorfus effe nomine demonftrationis ; nam ibi A riftoteles aperte dicit, non poffe ex medıo alicuius fcientix conclufionem alterius feientix demonftrari, quoniam is effet tranfitus de genere in genus; \& in cont.6. vtiturhis exemplis; Geometria non poteft demonftrare, contrariorum vnam effe fcientiam, neque duos cubos effe vnum cubum; illa eft Metaf hy fica conclufio, bæc vero Arithmetica; hocautem quid lignificet, iam dictum eft, figniffatenim demonftrari exnedio Geometrico conclufionen Metaphyficam, vel Arithmeticam : neque enim coníderat ibi Ariftoteles, in qua [cientia id fiat, fed ab folute confideratam vitiofom efle eam demonftrationem putat, fue in Geometria, fue in Metaphyfica intelligatur, quia naturam demóftrationis confiderat, non locum, in quo fiat; non enim ita négat eam fieri debere in Geentetria, ut consedat in Metaphyfica, neque ita negat in Metaphyfica, ut concedat in Geometria, fed abiolute eam reicit vt vitiofam : huius enim probandi-vim habetratio illa quam ibi adducit in contextu 59. qua hoc fundamentri nititur, quod $a$ media, \& qurfita debent in fubiecto fcientix äfrus per fe \& effentualiter ineffe. Non eft autem, butio- quod aliquis dicat illud effe vitiofum in demōin o- ftratione propter quid, de qua ibiagitur, non in is fpe-demonftratione à pofteriori, de qua in prafen- de- tia loquimur; etenim dem on ftratio ab effectu mfra- non minus habet propofitiones per $\{$, quam mis. demōftratio propter quid, quum ex iifdem terminis, ac propofitionibus ytraque conftituatur, vt Ariftoteles docet in contextu 96.97.98. eiufdem primilibri, \& vt nos demonftraumus in libro noftro de fpeciebus demonftrationis; $f \mathrm{~d}$ in contextu quoque 55. eius libriafierit Arıftoteles demonftarionem à figno tradere cognitionem eius, quod efr perfe. Quumigituradreiiciendum tranfitum de genere in genus Ariftoteles. hoc folo argumento utatur, quod demonfrationis propofitiones omnes debcnt effe per $f e$, \& habere prædicationem effentialem, nec effe eft in demonftratione ab effeatu tranfitum hüc
A non minus effevitiofum, quan in demonftratione propter quad. Quoniam ergo ita fe habet Gcometria ad Metaphyficam, ut ferencia naturalis ad eandem Metaphyficans, eft enim vtrobique refpectus f́cientize particularis ad $\mathrm{r}$ niuerfalem, \& omnium reginam, vitiofum autem eft apud Arifotelem ex medio Geometrico conclufionem Metaphyficam demonftrare, fimiliter iudicandum eft vitiofum, ex medio naturali oftendere conclufionem Merapiny?i-

B cam, vbicunque id fieriálcatur; non eft igtus: Ariftoteli tribuenda talis demonftratio, quam ipre in libris Analyricis vitiofan, \& nomine demonfrationis indignam elfe docuit. Sed am in propofita nobis zterni motoris demonftratione hoc offendamus: certum eft, fi talis cit demonftratio,vt oftendat conclufioneri Mela- 2ustis phyfican ex medio naturali, fiéri in ea debe-far dennre hanc illationem, datur in corpore naturali fratso C xternus motus, ergo dartur lubftantiz à materia abiunctre per elfentiam; atımen nullibi motoris. apud Ariftotelem talis argumentatio legitur, eaque elfet eriam parum efficax, vel faltem nein euidens, quoniam fubftantiz illa immateriales, quatenus tales funt, nullam cum motu a finitptem habent; quod fi quam habent, habent ve xterni mocores, non vt fubftantia im. materiales; fic enim refpectus caufa ad efteeturignificatur, ideoque effentialis eft term:norum connexus; non poteft igirur alia fieri illatio, quain hæc, datur zternus motus, ergo datur etiam motor aternus; hacantem eft ab?que dubio conclufio naturalis, quia motorem vt motorem confiderare eft cinfiderarevt caufam motus, \& pertinetad fcientiam naturalen, cuius propria eft motus confideratio, \& cognitio per fuas caufas, \& omnium habentium aliquam relationem ad motum; primus atstem philofophus confiderat quidem fubftan-

E tias immateriales effe motrices, at non eas confiderat ut motrices, quemadmodum in libro de naturalis fcienriz conftirutione aliàs declarauimus, Vt igitur communis erroris ratio cognofcatur, fciendum eft ex Auerroein Comment. 26. fecundi Phyfic. duplicem effe cognitionem fubitantiarum immaterialium, vnam confufam, quod fint, alteram diftinctam quid firt, quantum à nobis lumine noftro naturai acquiri poteft; traditio cognitionis confuft pertinet ad folum philofophum naturalem, al. terius vero diftunetz ad folum Metaphyficum: naturalis enim ex æterno motu demonftrat eas darı, ngon quidem vt fubitantias immateriales, fed folum ve æternos motores; poftea vero Metaphyficus hanc conclufionem à naturali dem,nitratam accipiens, ex ea progreditur ad inueftigandas illorum motorum conditiones efientiales, ix pertinentes ad cognofendum

I 2 quid
Captz:。

Disples:

cogiti: 0

rib, $7=2$ tiarianz epparaztitrismo turtism. 
quid fint; ex eo enim quod xterne mouent, co- A gnofcit cos effè̀ matcria abiundes, quia nulla facultas materialis poteft mouere perpetuo; ex en autem quod funt immateriales, cognofit cffe fubftantias incorporeas, \& actus puros, \& intelligentes, \& catera, qu $x$ ad declarandam diuinarum mentium eflentiam à Metaphyfico confiderantur. Hoc apud Ariftotelem legimus in contextu 73. fecundi Phy ficorum, vbi ait duo effe principia mouentia phyfice, quorum alterum non eft phyficum, quia eft imsnobile; rult $B$ igitur primum mouens mouere phyfice, \& ita phyficum efle quatenus eft mouens, nam omne habens relationem ad motum, quatenus tale, phy fica eft confiderationis; quatenus igitur eft principium motus, phyficum principium eft; at quatenus fecundim fe fumitur vt fubiectum cognofcibile, fic non eft phyficum, fed Metaphyficum, quia eft immobile; hec idem fignificat Ariftoteles in contextu 14. primi de ortu \& interitu, vbi inquit: [ de motore immobili, grod detur, dictumeft in ermonibus de motu, at de ipfodeftinguere,sdeft, difinctepertractare, eft prioris philofo bre ] afferit ergo fuife confufe cognitum in oftauolibro Phyfica aufcultationis; atqui nil aliud eftrem fimplicem confufe cognofere, quam cognofcere quod fit, nec aliud eft eam cognofcere diftinde, quam cognofere quid fit; quare teftatur fe in octano Phyficorum oftendiffe quod fit. Caufa ergoconmunis erroris fuit horum duorum progreffum confufio, \& eorum acceptio tanq̨uam vnius, quo per motum xternum demonftretur dari fubrtantias à materia abiunctas, fic enim videtur ex medio phyfico conclufio Metaphyfica demonftrari: quod fi progreffum hunc partirentur in duos, \& dicerent, naturalem ex sterno motu demonftrare aternum dari motorem, poftea vero Metaphyficum hanc conclufionem accipere à naturali demonftratam, \& ea conftituta inueftigare \& numerum, \& condi. tiones efientiales aternorum motorum, vtcognofcat quid fint, \& inuenire eos, effe fubftantias ab omni materia feparatas, nullum errorem committerent. Illud quoque ad eos decipiendos non parum valuit, quod viderunt demonftrationem exiftentix zerni motoris legi, \& in octauo Phyfica aufcultationis, \& in duodecimo Metaphyficorum; atq; itidem confiderationem attributorum effentialium non modo in duodecimo Metaphyficorum habe$\mathrm{ri}_{2}$ fed etiam modo aliquo in calce octaui Phyficorum; attamen rei veritas ea eft, quam ali-

Lib. de Regref. caj. G.
A clufionem accipere; \& eam vt à naturali demonftratam conftituere, tamen ad clariorem doctrinam voluit etiam repetere totam demonftrationern, idco demonfratio aterni motoris, quan in duodecimo Metaphyficonü legirnus, ponitur ibinon vt Metaphyfica, fed vt phyfica, \&vt repetita, \& nutuo accepta à naturali: fic etian confideratio impartibilitatis primi motoris, qua legitur in caice octaui Phyficorum, eft mutuo accepta à Metaphyfico ob rationem à me alibi declaratam: ob idbreuis; acrudis ibi eft ea confideratio, fufior autem, \& exquifitior in duodecimo Metaphyficorum, quemadmodum è contrario demonftratio exiftentia fufior, ac diligentior eft in 8. Phyf. breuior autem in 12. Diuinorum. Hac eft harum tractationum vera diftinctio, non quam aliqui faciunt, qui $d^{3} \hat{h}^{2}$ cunt dernonftrationem xterni motoris tum à naturali, tum à Metaphyfico fieri, communiorem tamen à Metaphyfíco, parciculariorem à C naturali: ego enim non video, quomodo illa fit communior, quam hæc, quum fiat vtraq; ex $x$ terno Coli motu; nam fi medium vtrobiq; eft idem, neceffe eftidem effe quxfitum, \&eandem demonftrationem. Hanc, quam expofui, puto effe hujufce reiveritatem, ideoque fruftra fieri eam difputationem, andemonfratio fit à medio nominanda, an à quxfito; propterea quod in omni demonftatione, qua fit vera demonfratio, \& fciētıam pariat, necef̂́e eft medıum, \& $D$ conclufionemad eandem fcientiam pertinere.

\section{Quod demonfratio fit nominanda à me- dio, o reicectio defengonis aduerfario- rum. Cap. VI.}

Cretum quia Auerroiftz ad fententiam Auerrois tuendam probare nituntur, vt pradixumus, demonftrationem effe à medio nominandam, \&argunentum fumunt ex Ari-

E ftot. in 1. Poferior.contextu 6o.declaranda breuiter eft fententia Ariftot. eo in loco, vt videamus, quid reuera inde contra aduerfarios colligi pofit, nec locoillo abutamur, ficutiabuti videntur Aueroiftx putantes, Ariftotel. afferere demonfrationem dari conclufionis Metaphyfica, ex medio Geometrico, vel naturali, eamque non à conclufiore, fed femper à medio effe nominandam. Nos igitur dicimus, non effe hanc Ariftotel.mentem, neque ipfum vnquam F talis demonftrationis conftruetionem admifif$\mathrm{fe}, \mathrm{fed}$ potius dicere eam non dari, quia vitiofa eft: hoc tantum inde colligere pro noftra fententia poffumus, Ariftot. ibi in contex. $58.8 \mathrm{c}$ in $60 . t a l e m$ vitiofam demöftrationem femper nominare à medio; nam fi oftendatur conclufio Arithmetica, vel Metaphyfica ex medio Geometrico, eam rocat Ariftot. Geometricam debi declarauimus, fcientix namque mutuum fibi auxilium preftant, \& Metaphyficus egens demonftratione primi motoris, eamque facere ipfe non potens, fumit ip ram à philofopho naturali; \& quum ei fatis fuiffet folam conmon- 
monftratiouem; is etenim, qui demonftrare, \& id vitium commitrere diceretur, Geometra effet, quia tota vis demonftrationis in medio confiftit, \& ille demonfrat, qui medium prabet, videturque res ipfaperfe maninefta, nam conclutioni verbum actuum non conuenit, fed pafiuum, non enim demonftrat conclinfo, fed demonftratur; medium vero demonftrat conclufionem, quia eft caufa effectrix fcientix conclufionis. Veraigitur \& firma confutatio fententix aductfariorum hre efle debet, quod non eft verum id, quod affumunt, denonitrationem xterni motoris ex aterno motu habere conclufionem Metaphyficam, habet enim naturalem, ficuti etiam inedium, pronde tota eft naturalis : quod fi etiam concedatur conftitui talem demonftrationem, ea non effet demonftrario appellanda, quia non feruaret præcepta neceffaria demonftrationi, neque cor ditionibus demonftrationis prædita eflet ; fed vitiola quxdam effet oftenfio, vt fapediximus: quilifiunque autem effet, vocanda effet naturalis, \&ille, qui æternum motorem monftrare diceretur, effet philofophus naturalis, non Metaphyficus, quia medium eft natutale : omninoigitur decipiuntur aduerfarii , quia hæc demonftratio non elt vocanda nifi naturalis, cuiufcunque etiam dicatur effe conclufio: Qux vero ab illis ad fui defenfionem adducuntur, vana pentus, \& ridicula funt. Prımum quidem id, quod aliqui dicunt, nominationem demontrationis fumi quidem abfolute à medio, fed fecundum quid fumi etiam à quxfito, ego prorfus non intelligo, necipformet puto intelligere : quim enim apud Ariftotelem eiufdem effe generis debeant conclufio, \& medium, vana redditur hæc corum diftinctio; locum autem haberetin fola vitiofa dem onftratione, quam diximus non effe demonftrationem, nec dari vnquam pofle in aliqua difciplina : quod fi etiam eis, hac omnia condonaremus, iam ipfi fatentur, demonftrationem, de qua nunc loquimur, effe vere naturalem; nominandum enim vnum quodque eft abeo, quod illi abfolute, ac primario competit, non ab eo, quod fecundum quid, \& fecundario. Vanum etiam eft id, quod aliqui dicunt, effe quidem à medio nominandam demonftrationem, fed, applicare medium quxfito effe illius officium, cuius eft qurefitum, quamobrem demonftrare fubftantias dari à materia abiunitas eft munus Metaphyfici, cuius eft conclufio, tametfi medium eft naturale: miror enim quod hi non animaduerterint, nil alind effe applicare medium quxfito , quam demonftrare, proinde hanc applicationem, effe ipfammet demonftrationem, eft igitur in eorum verbis repugnantia manifefta, dum dicunt,
A demonftrationem effe vocandam naturalem fedapplicationem fierià Metaphyfico, nequealiquis eft iudiciolus vir, qui hoc non confiteatur. Ariftotel, quoque non folum dixit demonftrationem" ex medio Geometrico effe Gcome. trican, fed etian Geometræattribuit vt fit ille, qui demonftrat; ipfe crgo eft qui applicat medium quafito, fi ipfedemonftrat. Aliqui etiam dicunt demonftrationem hane habere medium naturale, \& conclufionem MeraphyfiB cam, nec obideffe vitiofam, quoniam fcientia naturalis eft fubalternata Metaphyficx, in felentiis autem fubalternis Ariftotel. aferuit non efle vitiofum ex nuedio alterius fcientix conclufionem alteritus demonftrare. Sed hoc o- Confuramnium vanifimum eft quum falfum fit id, tio. quod affumunt, alias fcientias effe fubalternatas primæ philofophiæ, quod nos alias demonftraumus in librode Præcognitis : fed hoc etiam conceflo, nil tanen aliud inde fumere porC funt, quam pofie accipi medium ex Metaphyfica a demonftrandam conclufionem Geometricam, vel naturalem; at non è conuerfo: nam id quod Ariftotel. conceffit in fubalternis, fuit, vt fumatur medium, feu principia ex fcientia fubalternante ad demoriftrandas conclufiones fcientiæ inferiorss fubalternatæ, at non vt ex fubalternata fumantur principia ad demonftrandam cōnclufionem fcientıæ fuperioris fubalternantis, imo hoc aduerfatur conditioni, \& naturæ talium fcientiatum. Præterea Ariftoteles in context 1160 . prim 1 Pofterior. aperte dixit, non licere Geomeur demonftrare conclufionem Metaphyficam, ergo eadem ratione non licebit naturali conclufionem Metaphyfican demonftrare; fiue fint fubalterna hx fcientix, fiue non fint. Vana igitur funt omnia, qux ab aduerfariis ad fe tuendos dicuntur.

$$
\begin{gathered}
\text { Refponfio ad argumenta aducrfario- } \\
\text { rum. Cap. VII. }
\end{gathered}
$$

Q Vereft vt aduerfariorum argumenta fol- Adpris Suamus. Ad primum dicimus, medium, \& mum. maius extremum effe eiufdem generis, proinde vanam effe difputationem, ab vtrodemonftrationis nominatio fumendaft, quum fit eadem ab virolibet: fed etiamfi diuerlorum generum effe ftatuerent ur, noninanda effet demonftratio à medio, quia fcientia maioris extremi licet demonftrationis conftruend $x$ finis fit, conftruatx tamen non eft finis, fed effectus confequens nacuram termini medii, in quo tota demon trationis efficacitas conftituta eft, ficut antea dixinus. Ad fecundum refpondemus,illum, Adfecun qui medio ad demonfträdum aliqùd indigeat, dum. eo quidem vti, fi eiuspioprium fit; non tamen defengio.
Aliorum 
fiftalientum, quianon eft transeundum de genere in genus; quocirca lipponendum in ea feientia sllud eft quun? medium propritum ad ildemonfundum ibi nullum habeaur, alieno zutcm vti non liceat; quare illa abfolute $q$ idem conclufio vocabitur, quia demonftrabiliseft, fed in ea fcientia crit fuppoficio, \& principium indemonftrabile, vt incontextu feptuagefimo octauo primi Pofteriorum Arifot. a Terit;adde, quod folus naturalis eget illo medio, quum adipfun folum pertincat demonftrore dari aternum motoren, quum lixc fit esnclufio naturalis; quare Metaphyficus non eget medio, fed eget fuppoftione conclufionis nituralis, ficut antea declarauimus. Ad confi. mationem autem fumptam ex Ariftotelein c ntext. ofuasyefimo fexto eiusdem libri ian $x=$ Pponfum eft, dicimusenim Ariftotel. id concidere in fubalternis tantum, at fientiam naturalem, \& Metaphyficam non efle fubalternas: quodfietiam fubaltemas effe concederemus; locus tamen ille aduerfarius minime fnifragaretur; quoniam Ariftotel, dicit effe media aran ferenda de Geometria fuperiore ad Perf)eluam inferiorem, fed non dicit è contuerfo; non enim dicerer ex Perfpectiua poffe fumi mediure ad demonfrandam conclufioncm in G :ometria fimliter; inque nec medium matsrale fumi poteft ad demonftrancin conclufionem Metaphyficam, fi naturatis eftubalternita Metaphyficr. Ad aliam confirmationem ex contexiu 120. eiusdem libri acceptam, refponfio fumenda eft exvera illius loci interpretatione, quæin Commentariisnoftris legatur, ea autemin hoc confiftit, quod Ariftotel. nil a-

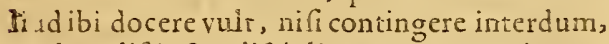
$\mathrm{v}$ : dux diftinetre difciplinx opem contribuant a perfeftiorem fcientiam habendam eiusdem conclufionis; nempe quando vna teftimonium fenfusadhibet, quodita fit, alteravero caufam \& propter quid adducit; aćeo ve fi quis fimul Geometra, ac Medicus fit, is perfectam ficientram habeat quod vulnera orbiculata tardius Linantur; non tamen propterea vult Medicum quatcnus Medicus eft, eam conclufionem demonfrare permedium Geometricum; fed debet Medicus effe contentus cognitione quod fit, quam per experientiam \& fenfum comparauit ; imo Geometra potius; cuius eft medium, debeteam demonftrationem extruere, non támen yt vulneris, fed abfolute vt circulí, ita vt tota demonftratio Geometrica fit. Ad tertium dicimus; fallax argumentum effe, id่que inde manifefte deprehendi, quod Ariftotel. etiam in fcientia naturali fæpe quærit an ailErs fum: quid fir, necne, vtan fit vacuum, an fit infinicum, verdupli an fitprima materia, an fir generatio, \& alia siser.
A duobus modis funi, rno modo pro generc; altero modo pro exiftentia, quzefi accidens rei ; quaftio igitur entis accept pro genere Metaphylica eft, quoniam ita acceptum cns eft atcributum tranlcendens, at quatio entis fumpti pro exifentia non eft neceffirio Metaphyfica, fed exirtentia corarenta, \& refricta ad rem naturalem eft quiftum natirale; quum prafertinn non fit accidens aliqued reale à re diftinctum, proinde non fit funcn$B$ da ve maior extremitas in demonfrationé, vt complures imaginaniur : omnis enim demoiaftratio tres habere debet reales teriminos, it in hac, de qua loquimur, oftendere pofiumis. in ea enim neneft iple motor fubictum, exiftentia vero predicatum quafitum, fed maior extremitas eft motor xternus, minor corpls naturale, medium motus aternus, \& conclufio colligirur non de fecundo adracente, fed detertio. feilicet, corpus naturale habet C moioxem xternum: hocigitur argumentum eft caullı!s manifefus. Ad quartum refpoisfio fumenda elt ex Ariftotel. in context. trige- tum. fimonono, fecund. Polter. nam duplex eft cognitio, yuodres fi: ; via perfecta, qua habctur per elentiala, a per caufam; altera imperfecita, qua habetur peraccidentaiia, \& finecamfa; 2 teandemigitur fientiam pertinet cognofcereperfefe q̨iodres itt, ad quam pertinetcognofere guid lit ; \& ita folus Meraphyficus. perfeere cognofcit dari fubltaintias à materia abunctas; at pbilofophus naturalis coznofcit, quod fint quatenus funt motores cogintione imperfecta, \& cōfufa, qux hab eripoteft etiarn ab eo, qui non cognor cat, quid fint. Adverba Anftotel. infecund. context. rertiilibride Calo facilis eft refponfio : nam immobilitas primi motoris denotat abftraction em à materia; \& cít eius conditio effentialis, quam cognofcereeft primi philofophi, quia pertinet ad cognofenE dum quid eft, à naturalıautem leniteriangitur in octauo libro Phyfisæ aufcultationus, quantum oportuit ad xreinum motun cognoticendum, ficuti notaumus in libro noftro de Regreflu; quum igitur Ariftotel.ir memora to loco vtatur dictione comparatiua, eiusverba nobis non officiunt: inquiens enim magis elfeprimi philofophi quam Phyfici cognolcere primunı motorem immobilem; nó negateun cognofcietiam modoaliquo à naturalı, qui hanc $F$ conditionem confiderat, vt conditionem $x$ terni motoris, non vt fubltantiz à materia. abiunctx. Ad reliqua omnıa apud Ariftotel. loca ajuerfus nos adducta dicimus. Ariftotel. recte dicere ignoias adlu uc efle fubftantiasimnobiles, quoniam in 8. Phyfic. non Jemonfrauit primum motorem effe fubfan a inmabilem, fed elle motorem penitus immobilcm. quare 
quare ibi ignoramus eum efe fubfantians: non A lofoplon naturali, \& docere hunc effe fubfancft igitur mirum, fipluribus in locis poft s. Phyficor. dicat Arifot.ignorari adhuc,an deturaliqua fubitantia immobilis, idque efle pofterius demonftandum; nam in folo 12. Metapliylicognnfcimus dari fubltantias immobiles, qum ibiprimum doseat A ritotel primum motorem immobilcm efiefubitantiam, quod prius ignorabatur. Chuendum tamen elt, ne perperam hocintelligentes in errorem labumur: nonenim ita ibi dimonitrat dari fubtantias immateriales, vt ea fit demonftratio exiftentize iprarum, led itavt per hos ellentia potus, quam exifentia, declararidicatur, fiquidem exiftentia non demonitratur nifi à philofopho natusali, non quidem quatenus funt fubitantix, led quatenus xterni motcres: quamobré id, quod dicimus, Metaphyficum demonftre dari iubftantias immarevales, cft fano modo intelligendum ne inpevt dicamus Metaplyficum accipere xternum motorem demonftratạm à phitiam abiunctam à materia per effentiam; \& ita rotam exiftentix demonftratione naturali philofopho attribuamus, fiquidem eædé funt lubAtantice immateriales, que in s. Phyfic. vecantur xterni motores; Metaphyfico autem atribuamus totam dechationem conditionum effentralium eorundem motorum, quarum vna hac eft, eos eflic fubftantias, que à naturali ignorabatur. Iure igitur dicit Ariftos. poft 8. Phyícor.

B ignotum effe quod dentur fubftantiximnobiles, fed nunquam divit effe ignótum dari motoresimmobiles, imo in contex. 14. primi libride ortu \& interitu afferit hoc effe notum, \& in 8 . Phy ficor.declaratum, effe tamen diftunctius declarandum in prima plilofophia quod veruin 12. diuinorum legatur demonftacio $x$ terni motoris ex reteno motn, iam diximus eam effe naturalem ibi ab Ariftotele repetitam ad doctrinz abundantian, \& ad maiotem claritatem.

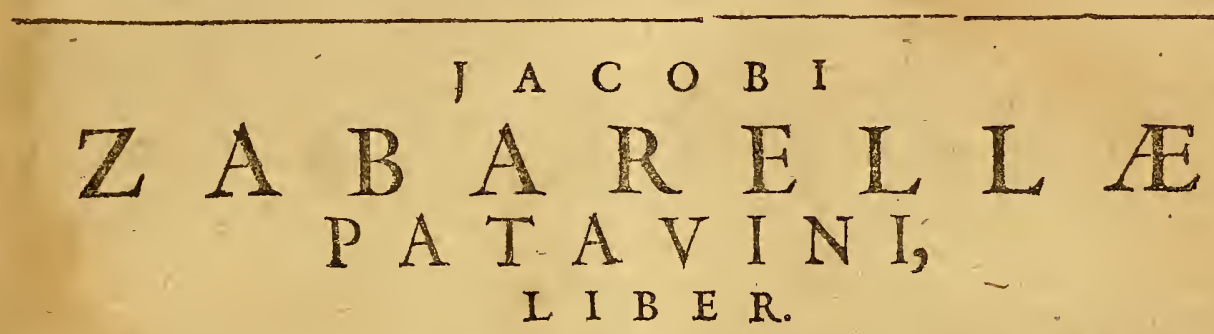

\begin{abstract}
D E N
Dicendorume propofitio. Cap. 1 .
\end{abstract}

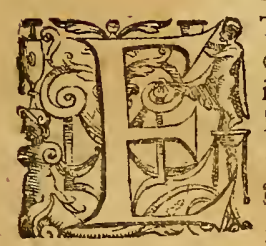

Tfi ita abfcondita nobiseft coeleftis corporis natura,vt ipfe quoque fummus philofophus Ariftot. fola conditionum fiblunarium negatione eam declarare potis fuerit; attamen ea est eius præeftantia, atque nobilitas, vt vel rudis, \& imperfecta ipfus cognitio expetibilior lit, quam exquifita, \& perlecta aliarum rerum ignobiliorum, ficut idem anferuit Ariftot. De hac igitur niti debemus ea cognofcere, iifque effe contenti, ad qux peruenire humana ratio poteft ; quod me mouit vt de illo corporealiqqua fcriberem, eaq; pracipue tangerem, qux magis dubia funt, \& apud interpretes Arift. controuerfa; vtxes obfeurriflimx aliquid, fi polfem, luminis, \& claritatis a fereré. Vt autem $F$ intelligatur, quibus de rebus fit nobis propofita difputatio, vtq;illa, qux dubıa funt. ab iis, qua furat manifenta, fciungantúrante omnia nemini
D dubium effe arbitramur, Ccelū effe animatım, \& conftar ex mente motrice, \& corpore moto, fiqquidenanimatorĩ proprium eft moutere feipfa: vt in 8. Phy fäufcult. lib. Ariftot. docuit. Illud quoq; abomnibus concedi videtur, animam itlam motricem non effe formam Ceeli, nec dare Coelo effe, fed motum folum, proinde nó informare orbem, fed illi regendoaffiftere, ficuti naui nauta affittit, orbis enim abfq; illius ope per fe exiftit atu; quod fiperillamexifteret, \& $a b$ Lizima

E illa conftirueretur, non poffet fecundum Anft. ceele mona ab ea motreriperpetuo, quoniam nulla forma informateriam informans poteft fempiterno motu mast or mouerejadde quod fimensilla infor.naret orbe bem. effet eius natura, \& fubitantia pars: quare onnnino fuiffet ab Arift. declaranda in libris de Coelo, quam tamen declarationem in is libris non leginuus. Quon:ă igitur ad illius corpor is fubftantiam contituendam mens illa motrix nihıl confere, iure Ariftot. in libris de C randa cius corporis natura, nullam anme coeleft is contiderationem fecit ; quip pe quni cognout can ad fablimiorem dufiplinam pertine. $r e$ \& phlofopho naturali fatis effe naturaluum 
corporum naturas, \& accidentia contemplariNosıgıtur Ariftot. imitati coleftium menuum confiderationem miffam prorfus faciemus, \& foluts coleftus corporis naturam perueftigare nitemur; duoquc poriflinum tractabimus: vnum, an illud corpus fecluia mente motrice conftet ex materia, \& forma, qua spium tanquam partes conftituant : alteram vero, quxnam fit illius natura, id eft, quodnam habeat mo: us principium internum, à quo eius motus dicatur naturalis, ita vt ei quoque competere pollit definitionaturæab Ariftotcle in 2. Phyfic. tradita, his enim intellectis nil videtur fuperefle, quodad Coli naturam , \& fubftanciam declarandam pertinere videatur.

\section{Varice opiniones de materia Coli cum ar- gumentis Thome do Aegidï. \\ Cap. I I.}

Onfiderandum primo loco eft, an coClefte corpus ex materia \& forma natesiam informante conftet, ita vt ab illa forma babeat vt fit actu, \& materia illi fubiecta habeat potentiam ad effe. Durhas in re opiniones extant, vna Thom \& \& \&gidij afferentium corpus illud conftare ex materia, \& forma informante, altera Aucrois, quiid conftantiffimenegauit, \& oltendere nixus eft, colefte cor. pu seffe fimplex, \& actu per feipfumabsquevlla compofitione materiz cum form ; qua de xe in libello, quem de fubftantia orbis infcripfit, diligentifime difputaut. Prior fententia in duas diuifa eft: Thomas enim \& Egidius in co diffentıunt, quod gidius putat materian colefti formæ fubiectam, \& materiam horum corporum inferiorum eiusdem effe naturæ, \& rationis; Thomas vero hoc negat, \& ait materiam Coli effe diuerfa rationis à materia inferiorum. Horum azgumenta omnia in medium afferre operæpretium non eft, ea nam- E que tum apud eos, tum in difputationibus alio. rum pofteriorum, quæ multæ circumferuntur, legi poffunt, fed nobis quadam præcipua conPrimus fiderare fatis erit. Thomas primo loco probat, argumé- id in quo conuenit cum Egidio, coelert e cor*um Tha- pus ex materia \& forma conftare, \& hocargume. mento vtitur:omne, quad extraanimam actu exiftit, aut eftactus, aut habens actum, at orbis coleftis. feclufa anima motrice exiftit actu,vel igitur eft actus, vel habensactum, atqui actus puius non eft, fic enim non effet corpus, fed fornia fola abiuncta à materia, quod dicendum non eft, ergo eft habens actum, eft igitur in Colo preter formam aliquid aliud, quod quidem non effe nifi materia, nil enim dicinus. habere actum, nifi id, quod ex materia \& forma scusadu conftet. Probat deinde Thomas. illud in quo ab
A eoco diffidet $\approx$ gidius, materiam illam efle di uerf $x$ rations a materia inferiorun: Coclum $2^{-}$ pud Aritotelem eft ingenitum, \& incorruptibile, ergo eius materia non habet anuexam priuationem, nec potentiam ad alia m formam;nifi ad folam formam Coeli, ita vt obiectum adxquatumillius potentix fit fola forma Coli, qux illam totam adimpleat, \& materia formam illam recipiens dicatur totum fum obiectum recipere; eftigitur diucriarationis à materia in$B$ feriorum, hacenim nullam potef forman recipere, qux fit ei perfectio integra, \& totum genus obicctum receptibile, fed omnis forma, quam recipit, eft pars obiect a daquati; quo fit, vt ill materia neceffario relinquatur potentia recipiendi alias formas, proinde omne habens. talem materiam dicatur habere contralum, ie fit corruptibile, ficur A riftoteles dicit in libro de longitudine \& breuitate vitx. Fgidius vero primum fententiam fuam ita declarat, vteam fentés C ablioc Thomæargumento vindicare videatur, deinde ad eam probandam argumentatur: inquit Colum \& inferioracorpora ex endem materia conftare, neque ob id fierivt Colum fit corruptibile; quandoquidem duo funt formarum genera, qux in hac materia recipiuntur;a. lia enim forma contratiam formam habet, quare materna illi fubicta poteftatem habet recipiendi formam contrariam, \& resilla necefiario eft corruptibilis, cuiufmodi funt omnia corD pora inferiora; alia vero forma contrario caret, qualis eft forma Cocli, ideo materia illi fubiecta non habet potentiam recipiendi aliam formam, fatiatur enim ab illa forma totusillius. materia appetitus, totaque potentia, quo fit vt illa materix portio fitperpetuo fub illa forma \& nullius interitus capax fit: quamuis igitur Colum, \& inferiora habent endem materiam. \& inferiora funt corruptibilia, Colum tamen. poteft effe incorruptibile, hoc enim diferimen prouenit à ratura formarum, quum Colum ideo fit incorruptibile; quia forma fua non habet formam contrariam; inferiora vero fint corruptibilia, quoniam eorum form $x$ habent con. trarias formas. Probat hanc fententiam Egidius pluribus argumentis, ego vero aliis dimiflis, vnum tantummodo quod pracipuum eft adducam, idq; tale eft : omne indiuiduum fenfile, \& per fe exiftens ex materia \& forma conitat, corpus coelefte eft eiufmodi, conftat F igitur ex materia \& forma; minor propofitio eft per fe nota, maior vero, imo \& argumentum totum Ariftotelis eft in contextu 92. primi libri de Coelo, vbi hanc ipfam maiorem exprefleproferens, ex ea colligit, alud effe remipfan abfolute fumptam, vt Colum, aliud efle eandem vt fingularem, vt hoc Coelum; Colum enim abrolute prolatum fignificat for- 
nım, at hoc Colum fignificat forman in ma- A tcria, Ariftotelcs igiturapertedicit Coelumex nuatcria \& for ma conftare, \& hac ipfa ratione vticur, quoniam eft indinidumn fenfile; atqui nulla nuate ia formx fubftantiali fubftans furt, coguita Anftoreli, nifiprima illa materia, quae in primo librollhylicorum ex mutatione lubftantix inuenta eft, \& qua omnia corpora inferiora participant; igitur materix forma Cocli fubiecta eiufdem eft rationis cum materia corporum inferiorum.

\section{Communis confutatio fententic Thoma do AEgidï. Cap. III.}

$\mathrm{H}$ E dux fententix tum communibus, tum propriis vrgentur difficuliatıbus. Primum quadem fimul amba impugnari poflunt in eo, in quo conueniunt, videlicet cœle fte corpus fecluia mente molrice ex maicria \& forma conftare, nam ex Aiffotelis progicllu in primo libro Phyrica aufcultationis manilefte colligimus non potunfe primam materiam nobisinnolefcer, nifi per mutarionem fubitantix, hxe enim iola nos duxit in cognitionerin compofitionis materra cum forma; quia quam videamus fieri ex aqua aerem, \& formam aqux interire, forman vero aeris generari. cognofclmus efieneceflarium, ve priter formam aliud quoddam in aqua 11t, quod pofrea feruetur in aeregenito, fiquidem non poteft aer fieri ex ni. hilo; conftat ergaaer ex mareria, qux prxfuit, \& exforma, qua nuperaceeffit: 1 taque vbi nul= In eft fubitantix mutatio, ibi nullam materix cum forma compofitionem cognofere pofiumus. Cali autem fubitantia apud Ariftotelem immutabilis eft, ergo etiamfi reuera ex materia \& forma conftaret, nos tam en huius compofitionis nullam habere cognitionem poffemus, quippe eo medio deftituti, quo vno in talem cognitionem duci poffumus, ideo reete Auerroes dicit in r. Pliyfic. Comment. vlt. \& 2.Phyfic 22. \& 4. Phyfic. 38. primam materiam non poffe denonftrai, nifi à philofopho naturali, nec alio medio, quam mutatione fecundum fubftantiam; vnde colligimus, inefficacem effeillam Thomæ argumentationem, aut eft actus, aut habens anum, vt poftea in folutione declarauimus: nam fi validum hoc argumentum effet, certe Ariftotel. in primo $P$ hyficorum fatis paruo negotio poterat primam materiam inuenire dicendo, corpus naturale, vt lapis, vel eft actus, vel habens åtum, at non eft actus, eigo habens actum, ex materia igitur \& forma confat: led nouit Ariftot. nihil habere roboris. Prarerea vtcurique dicatur colelte corpus materia \& forma conftare, fit necefiario vt lit corruptibilc $c_{2}$ am fi materiam habet fub forma, necefle eft materiam illam refpectuillius form $x$ habere potentiam pafliuam, qux fit potentia ad efle, fiqudem torma dat effe, atqui omuis potentia paffisa eft potentia contradictionis, igitur eft potentia etiam ad noneffe: idque afferit clare Ariftotcl. in calce libri de interpretatione, \&clarius in nono Meraphyf.vbietiam in contex. 37 . inquit, non effe in Colo potcnriam, nifi ad vbi, cognouit enim non poffe in Coclo effe materiam cum potentia ad effe, quin infit etiam potentia ad non efic, 1 deoque Coelum fir corruptibilc. Idem confumat defnitio potentix paffiux, quam legimus in quinto Metaphyf. contex.17. \& nono Metaphyf.2. potentiapafliua eft principium vt res tranfmutetur ab alio quatenus eft aliud, quoniam igitur hoc effentiale eft potentix paffiux, debet omni tali potertix competere' fed oannis mutatio eft ab oppofito ad oppofitum, à non effe ad effe, vel ab effe ad ncn etle, onme igitur habens potentiann paffuam eft corruptubile : quod fi quis dicat effe quidem. in Colo potentiam ad effe, fed aquiuoce dictam; quæ non faparatu ab actu. de qua loquitur Aristoteles in calce libride interpretatione, hoc certe nihil eit; quia licet fit cumactu, tamen nobis fatis eftutendiffeean effe poffe fine actu, quum fit potentia contradictions. Pofu- Qusat mus etiam ad hoc confirmandum fumere argu- argume. mentum ex verbis Ariftotel. in 2. Metaphyfic. tum. context. $30 . v b i$ dicit, motores Colorum debeD re effe fine materia, \& hanc affert rationé, quia debent elle lubftantix fempiternx; confiderandum enim eft, Ariftotelem non dicere, quia debent monere perpetuo, fed dicere, quia debent efle tibftantix lempiternæ; fignificat ergo necellarium efie, fi effent in materia, vt effent corruptubiles: eadem itaque ratione argumentemur de forma Coli; nam fi de hacargumentumAriftorelis inualidum eft, de méibus quoque motricibus eft inualidum; igitur neceffe eft E formam Celi effe corruptibilem, quam fit in materis, \& huius rationem iamadduximus receptiuum enion dirigitur à natura ad proprium receptibiledifinctum ab eoeffentialiter, quia nihil recipit fe, igiturneceffe ef vt refpiciat illud tanquam potentia libera, \& aque refpicicns vtramque partem contradictionis. Si vero Thomas dicat, Ariftotelem ibi negare folam materiam inferiorun, qux eft materia generationis, \& de hac validum effe argumentum, quia forma inharens in tali materia non poteft effe fubitantia fempiterna; vanum hoe eft, fic enim debile, \& mutilum manebit argumentin Ariftotelis; co namque oftenderetur. motores Colorum non effe in tali materia, qualem obtinent inferiorum corporum formx, fed non abfolure oftenderetur; effe abomni materia abiunctos, hoc autem aduerfa-

\section{Tertisms argume- tesirn.} $-$ 
tur confilio Ariftot. quirmituerfam demonftra - A tionem facere vult, \& oftendere motores C.olorum ab omniprorfus materia effe abiunetos, nullo enim pacto concedere eos effe formas, colcftem materam informantes, nimirum pio pter naturam potentix pafux, quam diximus xque refpicerevtramque partem contradietionis : quod vero illi dicunt, formam Cocli fariare cotnm materixappetitum, \& totam eivs potentiam adimplete, repugnat proprix conditioni potentix paffur, hanc enim non adimplent nififorma contrarix, haautem fimul effc non pollunt: quare femper manet in materia potentia recipicndi formam contrariam; eaque potentiaquim fit naturalis, non poteft ef ic fruftra, fed aliquando duceturadacun .Po: fumls etiam contra hanc fententiau hec argumento vti : fi Colum proter animam motricem habet etiam formam informantens, certe illa forma eft natura, proinde eft principium alicuius motus, at nullius morus poteft efiefrincipiun, crgo talis forma in Coelo ponenda non eft: confequentiam probare non oporet, clia enim ert apud Ariftotelem in fecundo Phýficnrum; necvllus eam negare poreft, quia iorma materiam informans, \& conftituins corpus aliquodnaturale, eft neceffario 1llius corporis natura, \& principium naturalis motus 1 neo; abconum enim eft rationi, formam aliquam efie otiofam : confequentis autem falizas facile oftenditur, nullus enim in Colo datur motus, nifi circularis; huius autem caula effectrix eft nens illa abiuncta à materia, non forma informans materiam Coli; crgo n: 1lus remanet motus, cuius caufa pollit efle rlla Q oma; ef igitur

Solutio Thomifarkats. otiofa, \& nullius motus caufa. Sed menini me aliquos Thomiltas audiuiffe ad hoc relpondentes, naturam ab Anftotele dici principium motus non folum actiuum, fed etiam pafriuım, ideoquefoiman Coeli eatenus efie naturam, үuatenus eft principium motus paffuum, cifinon eft principium actiuum; hoc enim videtur Ariftoteles deformis quoque elementorum protulifie in contextu z2. octaui Phyicer. cum dixit elementahabere in fe principiu moimpes- tus, non quiden agendi, fedpaticndi. At hoc golutio dici non poteft, neque eis hrc cum elementis Solutioass. frram maxime confimat, vt mox patebit tum cx iis, qux de Cosli natura dicturi fumus, tum etiam maxime ex iss, qua poftea dicentur de grauium \& leui um notu; tunc pauca pro occafione dicere fais erit : certum eft, officium form $æ$ effeagere, materixautem pati, imo nec formam pur fe pari, fed per accidens, \& propter materiam, cui iunctaeft; raque abfurdiffimum ent, ponereformam, qux nihilagat, fied patiatur folum: quod vero ad elementa attir net, cenfuit Ariftoteles, elementum ea ratione
motum recipere à gencrante, quatenus generans dans forman, dat etiam motum, qui eam confequitur; ideo elementum, fimulatque eft genitum, fibi fufficiens eft ad fe mouendü ab fq; ope generantis, dummodo à 1 ullo impediatur: quianulla eft alia generansis motio, quam producto forma; ea anem cellat exiltente for quano ma; tunc igitur motus elementiformaminfe- me. quitur vt cauram, non generans, quod nil am$B$ plius agit: quamobrem negars non poteft (id. que nos alio in loco fufus demonftrabinus) formas elementorun efle apud Ariftotel.ciam principia motus adtua, eft enim repugnantißfmum natura forma vefer fepatiatur, necaliquid agat, leu vt per accidens patatur, perfe veronec agat, nec patiatur, led lit otiofa : ferma igitur Cceli, quam illi ponunt, longe deterior let formis elementorum, fi folum patcerur, quum illscetianagant: vel fi velint, Coclum in C hoc fimile efle elementis, oportet fuperuacaneam efle montem illan notricem : quemadrodum enis: genitum jam elemertun, vimoueasu, non eget amplius generante, quia motus naturalis Iolamipfís 10 maninfequırur; ira quum Columnunguan fit genitum, fodarud Ar te temperabtolutum, \& perfedum extucrit, deberet moius in crbom in/equitormam illam jan cxittentem; necind:g re intelligentia ma. trice, quematimocium elententum gentumion D eget amplins goneante; vel iginirfuperuacanea eit nens illa motrix, yél forma Cail et ignobilior formis elementorum.

\section{Fropria confutatio opinionis Iloma. Cap. IV.}

$\mathrm{V}$ Rgeur etiam viraque fententia propriis inifularibus: nami Thomatopino, giod Colum conter ex materia \& fom eans inE formante, qua maturia lit diuerfa à materia infenorum, eft alienifina ab Ariftot. qui præter p:i man materian, ex qua inferiora corpora cótant, nullam aliam materiam cognouit qu $x$ hábeat potentiam recipiendi forman de genese fubfantia dantem elfe; nam in r. libro Phy= ficaaufcultationis primam rerū materiam inuenit, prater hanc nullamaliam in libris fuis viquam confiderautiergo nulla fuit Ariftot.cognita: adde, quod fi Coclin talen materiam habcrer; debuiffet naxime Ariftotel.eam confiderare in prima parter. lib. de Coelo, vbi Cosli naturam fibi declarandam propofuit; ibitamen apertenegat Coelum habere matcriam; quod fi folam infeiodum matcrian ibi negare in $\mathrm{Co}$ lo dicatur, omnino tamen exprimere debuit aliam in Colo effenateriam diserfam à materia inferiorum, fitalem matcram in Coloefle exi- 
ftimaut; attamen nullom huiusmodı materire A quum poffit recipereetiam formam Cocli; crit

mentionem eo in loco ficit. Vii pirterea aducrfus Thomam pollimusargumento Rtgidij: materia illa Cocli, fi fecundum fe abfq; Cocli forma confideresur, non eft nifi pura potentia,

- quia uullum in fe actum includit, en iggurur ipfamet materia corporum inferiorum, quiapusa potestas à pura poteftrte nullo difcrmmine diflidet, fi puidem diftinatio fit abzetu, vtait Ariftotel. in context. 49. Fentinu Mitaphyfic. Nec dicere Thomas poteft, earum difcimen in hoc cife conftitutum, quod illia habet potentim ad folam Culiforman, hxc vero adreliquas omnes; nam omnis coarotario, \& onnis determinatio fita forma, quare nccefle eft vt materia C.oli habeat in fe aliquid aftus, à quo eius potertia ita contrahatur ad hane formam, ve non ad alias, à pura enim potentra nou poteft hæc determinatio fieri : vel igitur materia Coeli eft ipfamet inferiorum maicria, fi eft pura poteftas;veleftactu perfintam fine forma: fed quifquas hoc dicat, faceri etiam debet, materianil. lim inullan forma indigete fed fuapte natura effe acti, qua eff Auarois opinio, de qua mox dicemus. Illudpraterca abfurdum hanc fententiam confequitur, quod quim in aliis generibus caufarumina tantum detur prima in fin. gulis, in caufa materiali duæerun primæ, quod dicenjum nor eft, fed quum vnum tantuin fit abfolute primum mouens, \& vna prima forma, \& vnus vltinus omnium rerum finis, vnam quoque priman materiam efie dicendum eft, nouplures.

\section{Propriaconfutatio opinionis Aegidii. Cap. $V$.}

Ententia quuoque Rggidii facile reptobatur. Drimum enim non mus ex hac, quam umé- ex opinione Thomz, ima etiam multo magis, infertur, Colum effecorruptibile, quod in dcetina Ariftot.et manifefte falfum : deducitur confequens ftatuto hocfundamero, quod à nemine erudito viro negari poteft, cuilibet potentiapafiux refpondere in natura proprium, \& ipfr requaium obiectum, ad quodilla per fè natura dirigatur, vidicere folemus potentiam vifium habere proprium obiectum non quidem album, vel nigrum, fed vniuerfum genus colorum, hoc enim illi refpondet tanquam proprizperfectio proprio perfectibili ; quæien dum igitur ex Ægrdıeft, quoduam fit proprium ob. iectum potentix palfure materize \& ip i adiequatum; nanfi eiuldem rationis eft nuteria Cóli, \& materia corporum nferiorm, vt ipfe opinatur, certepropriun e us obieerun non eft fula forma Coli, quir polit materra alias quo formassecipere; nec folx lorma inferiorum, igitur proprium, \& exquatum obiectum quod primum refpondet potentix paffix materix; vniucrfum genus formarum matcrialium, quod omnes \& Cocli, \& inferiorum corporum formas complectatur : hoc conftituto, ficargumentemur: potensiarecepiiua non expleturipartealkqua fui obiecti, fed toto ipfo obıcto adæquato. ergotorma. Collinon poteft totam materix poreniam adimplere, proinderemanet in materia poteftas recipiendi alias formas, caque eit potintia naturalis, quanon poteft effetruftra, fed aliquando ducenda eft ad actum; exgo neceffe eft Coelum aliquando effe interiturum $;$ ideo verifimum eft Auerrois dictum in Comment. 20. primi libri de Coelo: fi Coelum conftaret ex materia \& forma non habente contiarium, natura feciffet aliquid fuperuacancum, \& firutra, nam forma illa contratso carens, feruaretur perpetuo in illa materia, quare materic poreftas recipicndialias formas fiuftmefiet: nequealicuius momenti eft id, quód dicit Egidi:ss, forman Coli ob fuam magnam perfectionem explere totam materix poteftatem; nam potentia refpiciens totum gents non poteft expleri fola parte àiquaillius gene. ris : ratioquehuius verifinz affignari poteft, quoniam id, quodalicui naturale, arque effentrale eit, non poteft ab vllo extranco variari, a immuiari eflentialis autem eft pfi materix po. tentia libcra ad omnes formas; ideo etiarnf forma Coli fecundum fe carens contrario, \& incorruptibilis ftatuatur, nón ob id potis eff materix naturam immutare; quamobrem duo. rum alterum requi neceffe eft, aut diffonaiz tiam efle in rebus natura, nec fibi conuenienter refpondere formam, \& fubiectam ma teriam, led inanem prorfus, \& fuperuacuam effe materiæ naturam, \&e aptitudinem naturalem; aut conceffa, vt omnino concedenda $t \in \mathbb{t}$, E ea confonantia, Cxlefte corpus aliqu:n to ef. fe interiturum, pellique eius formam poffe à forma contraria, inxta Ariftotelis fertentiam claram in lib. de longitud. \& breute vi $a$, materam habenti nécefle eft habere contraism, giuo fit, vt omme habens materiam fit corruptibile: fic etiam in primo librode ortu $\&$ interitu, contextu 22. \& 43. inquit Ariftotel. ea, qua mutio agunt \& patiuntur, conueniunt in materia, \& è conuerro illa, qua in materia conueniunt, neceffe eft vt mu:uo inter fe patiantur, \&agant, \& víns materia polfit altcrius forman recipere. Et in contextu 138. primi libri de Colo, inquit Arift. materism habere poteniam ad oppofita, \& effecaufam viresfit; \& non fir, qilo fit, ytomne habens materiä pof fitnon efe- Qund autem fillum fit, \& abionum rationílid, quod Rigidius dicit, formam Coli ob fuams

\section{$\operatorname{Re}$ Poinfo Aegidis. Confutas- tio.}


obfuam nobilitatem fatiare totam potentiam, A totumque appetitum materix, hoc argumento oftendi poteft; quia hocidem euentre debcret inaliistormis, vt forma nobilior vices gereret omnium formarum iguobiliorum, \& expleret totam potentiam ad eas; igitur forma hominis expleret totam materix potentiăadomnes inferiorum faltem corporum formas, proinde homo quoque effet incorruptibilis, quod tamen mo quoque effet incorruptibilis, quod tamen
sesundü falfum efle videmus. Vtor etiam contra $s_{-j}$ -
argumen dium tali ratione: fi materia Coeli, \& materia rrm. inferiorum cademeft, \& eiusdem rationis, ergo competitei definitio prim $x$ materixab Ariftot. tradita in calce primi Phyficorum, itaque materia Coli eft primum fubiectum, ex quo fital1quid,proinde cx ea generarialiquid pote 1 t, quare Co.lum eft corruptibile; debetenum definitio lla effe talis, quae matcrixeffentiam declaret, proinde om ni materix competere debent slla, qux in ea definitione fumuntur; nec dicendum eft, priman materiam ibidefiniri prout eft in corporibus tantum inferioribus, qua fic definiretur peraccidentalia, quod minime dicencum eft:quoniam igitur conditio effential is materix cft, vt ex ea portitaliquid generari; neceffe eft Coli quoque materiam eadem conditione $p a r-$ ticipare: attamen habemus clarum Ariltotel. testimonium in r.Phyfic.contextu $57 . \& 68 . \mathrm{vbi}$ afferit, fe de caducarum tantummodo rerum materia loqui : quoniam igitur C.olum cenfuit effexternum, non potuit exiftimare materiam Coeli, \& mat eriaminferiorum eiusdem eflenaturæ, \& rationis; ino etiam aperte negauit effe in Colo materiam, vt legere poffumus in context. 20.libri primi de Coelo; quare fententia agidii in philofophia Ariftotel. concedi non poteft.

\section{Declaratio \& comprobatio opinionis Auerrois. Cap.VI.}

FX horum dogmatum confutatione manet Eprobata opinio Auerrois, quam veram effe puto, quod orbis Coleftis fit corpus fimplex, non conftans ex marcria \& forma, ca vero tantum ratione cx materia \& forma conftet, quaterus intelligentia motrix dicitur forma, orbis verodicitur materia, quænon haber potentiam adeffe, fed folum advbi; quam fententiam fequutus eft Scotus in 2 . Sentent. diftinitione it. quxitione prima : hanc diffufe declarat Auerroes in fuo libro de fubfantıa orbss, \& eam fat is manifefte colligimus ex Ariftot.pluribus in locis, mąm in contextu 138. primilibride Colo, inquit, materiam effe caulam vt res fit, \& non fit, quod idem dicitin r3. primi će generatione: mateiam igiturpreditam potentia ad effevult haberepotentiam etiam ad non effe; quomam ca cit natura potentix paffiux, vt fit potentia contradictions, \& monftrum eft in philofophia Ariltotelis, ponere materian, qux habeat potentsam ad dimidiam tantum contradictionis, ad folum efle, non ad non effe : neque eft quod aliquis dicat, Ariftotelcm ibi loqui de fola materiainferiorum, nam vnituerfe de materia loquitur, quum agar ibı de mundi ætcrnitate, qux pracipue in Coli æternitate confiftit. Clarjus etiam Ariftoteles octauo diuinorum contextu

$B$ duodecimo, loquens de cognitione rerun ex cognitione caufarum fuarum, inquit, effe res cognofcendas percaufas, quas fingular habent, $\&$ in eis numerat caufarn materialem; fed ftatim Colum excipitdicens non omnes fubftantias naturales habere materiam, quia fubftantiz naturales xternx vel non habent materiam, vel non talem, fed folum loco mobilen : nullam i. gitur aliam materiam in Coclo concedit, nıfi qux locotantum fit mobilis, hrecautem eftens actu, quia non moueturnifid, quod actu exiftit : at materia, qux recipit ad formam fubitantialem \& cuius poteitas talem forman refpicit, non dicitur loco mobilis, \& hanc ibı Ariftotel. in Colomanifefte negat; imoetiamfi cam ibi non expreffe negarct, omnino negata intelligeretar, fifolum nodonominara non lisffet; quü enim loquaturibi Ariftotel de rerum cegn tioneper onnes fuas caufas, non reete feciffet, fi inter coleft is corporis caufas hanc quoque materiam non nominafict. Sed clarillmia eft Arifotel.fententia in 9. Mictaphyfic. context.17, vbi aperte dicit, omnem potentiam paffuam effe oppofitorum, ideoqnenullam in Coelo effe po tentiam patiendi, nifi refpectu morus localis. Et 12. Metaphylic. context. 10. inquit, omnia, qua mutantur, habent materiam, fed diuerfan); nam \& fempiternorum, qux loco mobilia funt, eft materia, attamen nongenerabilis, fed vnde quo, idct, mobilis de loco ad locum:omnem enim materiam putauit habere priuationem coniunctam ; privatio autem in Coclo nulla no- Inz Ca. tari poteft, nifi ratione loci, quia Sol in hoc loco est pr exiftens habet priuationem alterius loci, \& po- wario tentiam exiftendi in illo. Qunum igitur folam sone loco mobilem materiam in Colo Ariftoteles cr. ponat; loco autem non moueaturnifi id, quod eft atu, \& Coeleftis orbis fit id, quod mouetur; absque dubio putauit Ariftoteles, nullam in F. Coclo effe aliam mareriam, nifiorbem ipfum, qui eft materia per fe actu, neque cx alı materia conftat.

\section{Gracorum opinio de materia Cali. Cap. VII.}

H $\approx C$, quam diximus, Auertois opinio. $H$ Gracorum quaque fere onanium fuit, 
firecte corum verba intelligantur; in is enim $A$ errare facile poffumus, nifi liac diftinctione vtamur: Colum duobus modis accipi poteft; vel enim luspitur Coclum animatum, hoc eft, orbis cum anima eius motrice; vel furnitur folus orbis, feclufa anima: quando igitur Græci dicunt, Colum ex materia \& forma conftare, femperaccipiunt Coclum animatum, \& orbem vocant materiam, animam vero yocant formam; \& matesiam illam dicunt loco tantum effe mobilem; orbem vero feclufa anima nunquam dixerunt effe compofitum, fed fimplex corpus, \& materiam fimplicem effevoluerunt, nulla ex parte ab Auerroe in hoc diffentientes; nullam enim materiaın fubftantiali form $x$ fubiefam Graci cognouerunt, nifi qux poteftatem habeat libernmad oppofita, quam Ariftotulis fententiam fuife diximus; talis aucm potentia in Coclo ponı non poteft, quin Coclum interituiobnoxium fátuatur; talem igitur materiam Colum non habet, luxta Gixcorum fententiam. Poflem plura eorum dicta confiderare, \& oftendere hanc eorum fuiffe opinionem, fedeuitandx prolixitatis gratia, dimifin verbor!1m ip forum confideratione, fatis erit in prafentia notare quxdamapud cos pracipua loca, qua quisque per felegere, \& confiderare poteft. Theopliraftus, referente. Simplicio in $\mathbf{I}$. Aus context. lib. 1.Phyfic. abfolute dixit,omnia naturalia ex materia \& forma conftare, quod de fol is inferióribus, quorü principia in libro primoPhyficorum quæruntur, intelligendum eft: quod li Coclo quoque dictum illud aptari velirnus, eo modo, quempradiximus, eftintelligendurn, vt orbem vocet materian, animam veromouentem vocet formam; hocenim apud Græcos interpretes manifeftum fuit, \& nullus corum dixit, orbem, feclufa anima, alım for-

an- mam habere. Alexanderlibro r.quatenatural. cap. 10. \& 15. inquit; efle in Cuelo materiàn di ucrfærationis à materia inferiorum, \& idem intelligit, quoci Ariftot femper intcllexit, nempe materiam loco mobilem, \& orbem ipfum $\mathrm{Coz}$. leitem: idem de Alexandro colligitur ex verbis Simplecij in z.Phyficorum contextu 69. \& in 2. de Colo, 17. \& 4.1. idem legimus in commentariis Metaphyfic. lub Alexandri nomine editis. Jibro 9.comment.18. \& libro 12. comment. 2. \& 20. \& 34.iuxta Alexandri partitionem, vbicor. pus ipfum, quod in orbem fertur, inquit effe materiam, \& clementum, quod materia infe.. riorum corporum proportione refpondet; moorem vero immobilem inquit effe ipfius $\mathrm{C} \propto \mathrm{li}$ formam. Hac eaderis. Ammonij fertentia fuit in calce quarti fegmenti libri de interpretatio. ne; \& Themiftij in 3. contextulibri 3. Phyfic. \& clariusinzo. lib. 1. de Colo, vbi fententiam A. riftotelis declarans, dicentis Colum neque ma-
A teriam habere, neque contrarium, inquit $\mathrm{C}$ colefte corpus nullum habere rubiectum : Coclun enum dun vt animatum fumitux, habet fubie. ctum, nempe orbern animse colesti fubftan. tem; at corpus ipfum coclefe feclufa anima, quodibiab Ariftotele confideratur, nulluma. liud, ex quo conftet, fubiefum habet:quare manifefta ibieft Themifti fententia, imo \& Ariftotelis; qui coleftis corporis naturam ibi ex inteitato declarat. Simplicius manifent flime hanc simpli-

B Iententiam fequutus eft, yt apude um patet in li- cres. brom. Phyfic.68.\& in 2. Phyfic. 7r. \& in 8. Phyfic. 70.\& in 1.de Coclo 5. \& 20.8 22. Lamblicus quuc- Iamblaque in lib.deMyfteris Aigypriorum aperte dicit, cus. Colum efle fubftantiam timp licifirnam, \& 0 mnimateria \& forma compolitione carentem. Oiympiodorus in Procmio libri 4. Meteorolog. Olympioinquit, Coclum \& clementa effe compofita: fed dorus. non intelligit fecundum eandem compofitionem;nam Coeli compofitionem denotat effe ex orbe, \& anima mouente. Michael Ephefius Ale- Michael xandrifectator in 1.cap.1. lib. de partivusanima. Ephefius. lium inquit, nullam effe in coslo materiam, nifi 10. Grarm loco mobilem. Solus Ioannes Granmaticusali matzcus. ter ferfire videtur, fed eius fententia non eft digna coufideratione; nam Ariftotelis de Coclo opinionemimpugnauit, \& oftenderenixus eft, Colum effe naturx slementaris, \& corruptibile,tettatur c'eloanne Simplicius 8. Ihy ficor.79. a lib.r.de Coelo 72. quod dixeriz, formam Cocli D. haberepriuationem oppofitam : contrarium iamenafierere videtur in lib.r. Phyf. 68. fed quam deferathac in re Ariftotelem, nulla eft nobis ipfius.liabenda ratio, qui hac de re iuxta principia philofophir Ariftotelis difputandum propofuimus.

\section{Diftinctio duplicis forme. Cap.IIX:}

T illa, qux-in contrarium ad du Ea funt, argumenta foluantur, fciendum eft, formam feu caufam formalem fumi duobus modis.: ac. Forma cipitur enim vno rnodo pro illa forma, quix eff diaplicin. altera pars compoliti, \& re diftinguitur à mate- terfumi. ria, in qua inhret; hac ratione corpts $\mathrm{Cos}$. tur. lefte, feclufa anima mounte, nec formam habet, nec nateriam, nempe qua fint dux partes re diftineta, ex quibus iunctis Coclefte corpus conftituatur : altera modo fumitur forma pro effentia, feu quidditate rei, omnis enim res habeteflentiam propriam, \& proprium quid eft; hos modo etiam coelefte corpus feclufa anima. habet formam, hoc eft, eflentiam propriam. Harum igitur duarum acceptionum illud eft difcrimen, quod priori modo accepta furma diftinguitur.re a materia, \& à compofito : quemadmodum enim aliud eft forma, aliud materia, ita aliud cft forma, aliud forma \& materia fi- 
An qusd nul iunet $x$. At de forma accepta pro quiddidst.ss ab tate fecus eft; quandoque enim fola ratione dieodefire- finguuntur qudditas, \& id, cuius eft quiddigratur, tas, quandoque etiam nullo modo; in illis ecasus ef nim; qua funt abiucta ì materra, idem prorquidits. fus eft quidditas, atqüe id, cuius eft quidditas; tas. suumenim non habeant effe fenfile, fed folum elle intellectile, in his quidditas ab eo, cuius eft quidditas, necre, nec ratione diftinguitur : in habentibusautem materiam, vbi neceffe th raticut diftingui effe fenfile, \& tfie intell ctile, diftir guitur etiam ratione quiddisas ab eo, cuius eft quidditas, retamen iṕa idem funt, vt Ariftoteles docet in libro feptimo Metaphyficorum, contextu 20. \& 21. nam quidditati hominis ail al iud in rebus reffondet, nifi homo ipfe: nil nim aliud eft quidditas hominis, quam formahominis in materia propria, \& eam fignifi. camus per hominis definitionem, quanco dicimus, homo eft animal rationis particeps ; differunt autem fola ratione, quia dicitur homi. nis quidditas, quatenus mente concipitur, \& intelligitur, homo autem extrá animam exiftens, qui fingularis, \& fenfilis eft, dicitur non quidditas, fed habens quidditateni; eft enim res demonftrata \& reftricta ad has conditiones, hic \& nunc, \& ad accidentia, (vt vocant) indiuiduantia, qua infequuntur nexum hunc realem formæcum materia; fingularium enin effe dicuntur ipfa quidditates; nec, quia idem fint homo \& hominis quidd ditas, nugation em committimus, dicendo hominem habere quidditatem, quafi dicamus iplum habere fepplun; etenim advitandam nuzaticnem, \& rmnem abfurditatem, fulficit dittinctio rarionss : patet hoc in definitione, $\&$ definito; eft enim idem re homo, atque hominis dcfinitio, tamen dicinus hominem habere definitionem, nec vllam nugationem committimus, quia differun ratione. Quoniam igitur coinm eft indiurdum materiale \& fenlile, \& demonftratum, neceffe eft vt ratione diftinguantur Colum, \& Coeli quidditas, idque fignificauit Ariftoteles in contextu nonagefimo lecundo, libri primi de Ccelo, dicens Coclum effe formam, \& hoc $\mathrm{Coe}$ lum effe formam in materia; non enim accipit ibi formam proea, qua eft altera pars compofiti, fed pro quidditate rei materialis, qux aliud eft ve fenfibilis, aliud vt intellectilis; ideo quando abfolutedicimus Colum, dicimus rem intellectilem, \& quidditatem ipfam; quando autem dicimus hoc Coelum, dicimus rem fenflem, ac demonftratam, proirde quidditatem in materia, \& id quod appcllatur habens coridditutcm, nam hoc Coclun, fenfleeft iu, crivis eft forma accepta pro quiddisare: id $<0$ non eit ignolandurn, Ariftotem ibi, filti nomine forma non tntelligit illam, qux eft altcra pars

A compofiti, ita nec nomine materia materiam illam intelligere, qua eftaltera compofiti pars diftıncta à forma; fed nonine forma rem ipfam totam intelligerevt habentem efle intellectile, \& nomine materize eandem rem vt habentem effe fentile, ac demonftrabile; ita vt hac duo nomina, forma \& materia, ibi fignificent quidditatcm, \& habens quidditatem, qua idem funt re, ratione autem diftinguuntur: eft autem trita apud Ariftotelem hrc materia acceptio, vt Mat

$B$ materian firmatron pro ea, qua fubicitur for- ctia mx, \& ex qua fitaliquid, fedpro fubftancia ip la m/t: corporea extra animam exiftente, \& fenfili; pro hoclegere apud Simplicium poffumtis in pri- $\beta$ an molibrodeColo, contextu 22. \&: 92. cuiuover- dem ba hic recenfere operæ pretium non eft. Ob id frat non ablque ratione Graci interpretes in libro fecundo Phyficorum, contextuvicefimo fexto, \& feptuageimo primo Colum vocant mate- Col: riam formalcm, of formam materialem; ent e- $e f$,

C nim materia quadan actu.perfeipfan, \& participat inodo quodam ium mateize, tum for- mal, ma cònditionibus, forna quatenus eft actu per forn fe, materia vero quat, nus ef corjoreum, \& mat fenfile; quamobtem eft res intellectilis, quate- lis. nus eft forma; \& resicnillis, cimatenus eft materia; \& ct materia habens lormam, \& forma, in materia, ablq̨: rea i difinitionc inaterix. \& forma; quare app Hlari joetet \& habens formam, \& bábens narenam, cxlola ditucriene ratioD nis, quam rnoce diclaranous.

$$
\begin{aligned}
& \text { Solvitio digumntorkm Thond es } \\
& \text { A. gidid. Cap. IX. }
\end{aligned}
$$

A Reumenta Latuncrum, qua antea adduA mus, per ca, qua asodo dicta funt, fac1lcfoluuntur; namad argumentum Thema fi $A d$ f maior propofitio lano modo inrelligatur, dici-mü nus totuni conced' poffe; nam maior erat; o- me me guod extra arimam actu exiftit, autefi ar gasm Ctus, aut habens actum; in qua fi fumatur actus $1 \mathrm{rm}$. lata fignifcatione, prout complectitur \& for. mam, quaeft altera pars compofiti, \& formam pro efientia acceptam, vera eft propofitio:per eam tamen non oftenditur, Colum effe conlpofitum, fed rolum oftenditur, Coelum habere aetum altero disorum modosum, ntmpe vel formam, qua eftaltera pars corrpofiti, vel formain pro quidditate acceptam : fi verofumatur F actus proprie pro forma, quæ eft altera pars compofiti, neganda eft illa maior; dicimus enim dari aliquid, quod neque eft talis forma, nequetalcm formam habens; huiufnodi enim efie dicimus coclefte corpus : quare in fufficiens eft hxc Thomx diuifio, quum dicit, omne exiftens vel effectũ talem, vel habere taléactum: quod fi dicat, fe in hoc argursento no ellentian refpi- 
refpiccre, fed exiftentiam, qure eft quiddam ad- A ditum effentix, adluc eadein refponfionevtemur; ficut enim forma efteffentiarei, ita dat etiam atu exiftere, nec magis forma parsaltera compofiti, quam propria quidditas rei fimplicisjnam corpus coilefte eft matcria exiftens per fe, quoniam ex fua natura proprium habet complementam, quo exiftit atu fine ope alicuiusexterni : quoniam igitur Coelum eft indiuiduum actu exiftens, debet effe aut purus actus, aut habens actum, non eft autem actus, ergo habens actum, non quidem formam re diftinEam à materia, fedpropriam effentiam, \& proprium complementum, quo fine alicuius ope eft aptum perfe actu exiftere; intelligo autem proprium complementum, non ratione óperationis, fed ratione folius effe; quemadmodum. enim nauis noneft apta per feoperari fune nauta, itanec Colum fine anima mouente; attamen exiftit nanis per leipfarm fine openata ; fic igitur \& orbis Coleftis talem habet naturam \& eflentiam, vt firealicuius adininiculo perfe exifatactu. Patetigitur, hoc árgumento non oftendi, calefte corpus conftare ex materia \& forma re diftinet is : nam fi hoc ita probari poffet, facle Ariftotelifuffet in primolibro Phyfica aufcultationis demonftrare, naturalia corpora exmateria \& forma conftare, dicendo, 0 -mne quod extra animam antu exiftit, autelt actus, aut habens actuminon fuiffet tamenargumentum Ariftoteledignum, quia vanum eft, vt oftendimus. Sic etiam foluendum eft argumentum, q̨uod Thomıftx fumunt ex A ifturele in contexiu 12. libri odaui Metaphyficortum, vbi dicit, Coclum habere materian, fed non talem, qualem habent inferiora corpora; lic enimf grificare videtur, Coclum efic compofitum, \& exmateria, \& forma conftare, quohiam nihil dicitur habere feipfum; quare fi Coelum habet materiam, non eft fimplex materia. Nos vero iam dixımus, tritum \& vulgatumefe in philo- $E$ fophia hunc modum loquendi, hoc habet hor, etiam absque redlidifinctionehubentis, \& rei habitx, ficuti quando dicimusaliquid habere definitionem. Dicere etian pollumus, Colum, quatenus eft animatum, effe vere compo. fitum, \& ita haberemateriam \& formam re difindtas; habet enim mentem mosentem, qua eft inftarforma, \& orbem, qui eft inftar materiz: quare nullius roboris eft argumentum hoc. cis- Ad alteram vero partem argumenti Thom Tho non eft opus refpondere; hoc enim conftituto, quod orbis coleftis non fit compofitus, fed fit materia per fe afu exiftens, concedimus efie materiă diuerfærationis à materia inferiorum. Ad argumentum Fegidij fumptum ex context. 22. libri primide Coelo, fi formam fumat pro. quidditate, \& materiam illi refpondentem; fic- ut antea declarauimus, dicimus totum effic concededun:quianeceffe eft, vt omne indiuidutum fenfile habeat fuam quidditatem, ratione diftinctam ab habente quidditatem, quod ibi vocatur materia: at fi intelligat formam \& materiam, 'jux fint dux partes compofiti re diftinEtas, leganda eft propolitio maior;non eft enim necefiarium, vtomne indiuiduum fenfile conftet exmateria \& forma ie diftinctis, neque hoc vultibi Ariftoteles, ve cuilibet eum locum \&e B fcopum philofophi confideranti manifeftum effe potclt: hocigiturargumento non oftenditúrid, quod Eigidius probarevult.

\section{Dubia, que oftendunt, in Colo non effe $\mathrm{Na}$ - turam, óvariie hac de re fenten- - tic. Cap.X.}

Vipereft, vt confideremus, an in Coelo fit naStura, \&: tale principiun motus, vt Coelum quoque fub definitione naturæ contineatur: norl videturres hac carere difficultace, fi vera illa funt, que alias denatura diximus; nam fi natura eft fola forma, materia veroperfe non eft natura, fed folım quatenus habet poteftaten recipiendi formam, qua eft natura, hoc eft, quatenus efidem poteftate, quod forma actu, non videtur Coelum habere naturam; nam intelligentiam, à qua mouetur, non poffumus naturam appillaré, quum fit abiundta à materia, naD tura vero cuiusq; rei dicatur propria eius forma, çuxipfam conftituit, \& materiä informat $q_{\text {qué- }}$ admodum enim nauta nō dicitur natura nauis, ita nec anima Coeleftis dici poteft natura Coli, fed eft fupranaturam : obid Arift. in 4 . context. lib.z Phyficorum, dixit naturam femper effe ins fubiecto, forma enim naterialis inharet fubieat $x$ a teria, quan informat,acperf́picit : anima vero Coleftis non eft in orbe vt in fubiecte, quum fit fubftantia per.fe exiftens, \& abiuncta à fubftantia orbis, licetilli gubernando affiftens. Sed neque orbis videtur polte appellari natura, quim lit fimplex materia, fi fola forma et natura, materia vero per fe non eft natura, fed per formam, quam refpicit; orbis enim nullam refpici: formam, à qua recipiat effe, fed eft materia actu per fe ipfam: quoniam igitur materia fine formanon poteft appellari natura, non videtur orbis disipoffe natura Coli, nulla igitur in Caloeft natura; hocautem fi verum eft, inde infer-opin:o de $F$ ri videtur, motum Coeli noñ effe naturalem, cerstism, quum à natura Colinon prouseniat. Ob id non mot,um defuero, qui dixerint, neque motum Coeli effe Cols $30 n$ naturalem, neque inefle in Colo naturam; qua effe na- Alberti \& Scoti, \& Durandi opinio fuit: alij turalem: vero naturalem quidem effe motum Coli, \& opinis ds in Colo naturam effe afferuerunt, diuerfam centrum, tamen ab illa, qure in libr. 2. Phyfič definitur: Colžnon proin: cortsnes s: 
$\int s i b d e f-$ nitsone natura.

\section{Opinio}

Gera. proinde fub ea definitione naturam colicam non contineri. Quibus auten argumentis $v$ rrąue fecta nitatur, non referam, quia funt quamplurima, \& ea legere quifque poteft apud Ii:nediftum Perexium in libr. fio de principiis, vbi \& ambo has dogmata rite confutantur, \& omnia eorum argunenta tum diligenter exponuntur, tum etiam optime folutuntur; nam illa qure $a b$ aliis recte tradita funt, libros noftros transferre, vt aliorum feriptis volumén noftrū excrefcat, conflii noftri nö eft, prafertim quando idfieri non poflet abfque magna fermonis prolixitate, quodvtique hac in re contingeret. Omilla igituraduerfus cos difputatione, nunc fatis nobis fit hanc tanquam veram, \& dilis Arift. confentaneam fententiam fatuere, motum Coli efle naturalen, \& in Colotalem effe naturam, qua fub natura definitione ab Arift. in 2 . Phyfictradita continearur per quanda $m$ fimilitudinem, \&analogiam, qua Gracorum interpretum, \& Auerrois opinio fuirieanque ex Aritot. hatis manifefte fumimus in context. 5 . lib.1.de Ccelo, vbirepetens definitionem naturæ in 2. Phyf. traditam, motum in illa accept um diuidit in rectum \& circularem; quarealferit in Colo effe naturam, \& internum principium motus: prætereain eo 1 . lib frequenter motum circularem inquit effe quinto corpori naturalem, \& ab eius natura prodemitem In i.quoque context. 3.libri de Ccelo, nominat Colum inter corpora naturalia; at naturale eft id, quod naturam habet; quare fecundum Ariftot. in Colo eft natura, eaque talis, cui competat definitionaturæ, quam in context. 3 . libr.2. Phyfic. aufcult. Ariftot. tradidit. Hocigitur conftitut 0, modum tantummodo confiderare oportet, qu o in $\mathrm{C} \propto-$ lo natura ineft; quum enimnon eadem prorfus ratione, qua in corporibus inferioribus, fit in Colonatura, multi in eum erroren ducti funt, vt dixerint, naturam in Coclonon ineffe: hoc igitur eft à nobis in præfentia confiderandum.

\section{Ougmodo fit in Calo Natura, is quomodo Coeli motusdicatur naturalis. Cap. XI.}

\section{$\mathrm{T}$} Ota huiufce rei difficultas tolletur,fi decla. rauerimus, quomodo proportione quadarn,ac fimilitudine Coelefti corporitila, qua de inferiorum natura alibi diximus, accommo dentur. Quoniam igitur natura in his inferioribús eft forma, quædiftinguitur re àmateria ; \& quatenus eft forma, eft principum motus actiunm, \& quatenus eft in materia, eft principium motus palfuum, quia facit in materia propenfionem ad talem motum recipiendum, non ad alium; mategria vero fecundum fe nullum refpicit determinatum motum, quum aque fit apta
A ad omnes, fed coarctatur à forma, \& fitpropenfa ad ftatutum motum recipiendum, \& hac ratione eft principium motus paffiuum, non per re, fed per formam, ita vt non duo principia motus paffua dicamus, fed vnum, dum dicinus formam vt in materia, \& materiam vt tali forma praditam; ideo hac eadem principiain coleft corporequarere vanum eft, vbi neque eft forma materiam informans, neque materia aCtuata, feu perfeeta à forma. Attamen quum

B illa materiaiam fit actu exiftens, \& ad certam naturam coarctata, ac deterninata, non quidem per formam, red per femetipfam; de hac idem dicere polfumus, atque etian debemus, quod demateria inferiorum performam actuata alibi diximus; fi enim materia fecundum fe ad nullum ftatutum motum propéfa eft, red æque ad omnes, ita vt nullus motus ei yiolentes dici polist; quatenus vero à for ma perficitur; \& coartatur, ita, properifionem adipifcitur ad cerC tumaliquem motum, nonad alium, fiquidem talis propenfio non poteft nifi ab actu prouenire: fic materia Cocli, quum fitiam perfedeterminat natur $x$, propenfionem labet ad recipiendum folum notum in orbem, nonaliquem alium, \& ita eft principium motus paffiuum; quod idem denotarnus, dicendo propriam $\mathrm{C} \propto-$ liforman, hoceft. quiddiatem, effein coprincipium motus pafium, prout eft quidditas materialis, ita ve illa pofit appellari natura D Coli, qua Codum eft naturaliter mobile inorbem. At principium motusactiuum internum in Colo nullum eft; quum enim in his inferioribus forma fecundum fe, \& quatenus eft forma, fit princiyium motus actiuum, in Ccelo autem nulla fit forma re diftincta à materia, non eft in Coelo principium motusactiuum, quod in ipfo infitum fit, quia neceffe eft, redifinctam effe formam à materia, fi forma debeat vim habere mouendi: folum igitur paffuum internum

E motusprincipium in Coclo eft;fed quia nullum patiens ducit le de poteftate ad aftum, ideoque in $C$ omn parienti affignatum eft à natura aliquod agens, à quo patiatur, data eff Coló́ anma motrix tanquam externum principium quod natura Coli appellatinon potef, cum illo tamen ita conueniēs, vt tanto motu fit apta moucre, quanto orbis eft aptus moueri, quod for gnificauit pulcherrime Alexander in 34 context. libr-12. Metaphyfic. dicens, eundem in Colo effe motum anim $x$, \& natura, \& animam mouere per mediam naturam; quod poftea declarans inquit, naturam in Colo efie aptitudinem, \& propenfionem quandam ad certum motü recipiend um; ab anima vero tribui ipfum tranfeundi acitum, ad quem orbesfunt pernaturam procliues: fic enim dicit in corpore colefti infitam elle propenfionem recipiendi quen- 
dam ftatutum motum, hæcautẽ eft principium motus paffiuum, \& hanc folam vocat naturam Coli, eamque diftinguit ab anima, tanquam à principio quodam externo, ì quo orbis non re. cipit effe : quumergo diftinguat in Cocloaniman à natura, \& animam dicateffe principium actitum, naturam vero pafluum, absque dubio nullam in Coilo naturä ponit, nifi qux fit principium motus pafiumm; quoniam aninualla non eft Coli naturajquod enim anima animalis mortalis dicatur eiusdem effe natur $x$, id fit, quia eft forma informans materiam, \& dans elle animaliatanima Cosli, quum non det effe Coelo, illins natura appellari non poteft:ad fignificandum autem proportioncm magnam, ac perfeatm conucnientiam motoris cum moto, \&e principij actiui cum paffino; dixit Alexander, eundem effe in Colo motum animæ, \& naturæ, quia eodem motu natura Coli facit ipfum aptú moxeri, quo anima eftapta mouere. Hoc idem

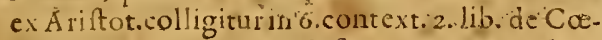
1o rbidicit, aninam coleftem mouere Coelum co mont:, quod ip fum eftaptum natura mouedi; qua i i liter moucet, quam ipfum fitaptū moueri, mocusille effet violentus, \& aninia in mouendo tatigaretur, quia natura Coli repugnaret, quod mortalibusanimalibus euenir : naturam ergo Coli vocat Ariltequitdam diftinctum abanina motrice, \& eam dicit effe paffium tantum principium, à quo habet orbismaturalem propenfionem, vt tanto motu moueatur. Ex his rationem colligere pofumus erroi is Durandi, qui in z.libr. Sentent. diftinet. 14 . quart. 2. efficaciter tuetur, motum Colinon effi naturalenn : id enim, qnodeum in errorem duxit, fuit, quod folum refpexit principium motus actuum, quafi natura nunquam fit principium paffiuum, fed femper actium, quod tamennegatur expreffe ab Ariftotele in contextu 32 . libr.8. Phyfic.quum igitur principiumactiuum inotus Coli fit anma Coeli, qux non eft forma dans effe Coclo, quales funt anim an amalium mortalium, ipfe conftanter negauit motum Coli fieri à natura; \& eius fententia vera eft de principio actiuo, quia motus ille non habet tale principium actiuum, quod Coli poffit vocari natura. Eft igitur colefti corpori cum his inferiozibus \& fimilitudo aliqua \& difimilitudo: fumi-
A lia namque in eo funt, quod vtraque habent Stmilits principium motus paffum internum, quo do, ac propenfa funtad ftatutos quosdam motus rec1- dissimsli piendos, qui folifunt eis narurales, \& hocin v- tudonatrisque cft materia vt atuata, feuforma vt in rurs camateria : diffimilia autem funt, quoniam in his licsm inferioribus materia acuatur performamredi natur 1tinetam abipfa, matera vero Cocli per feneti- mferio. pram eftactu, \& per fe eft talis determinatz na-rwm. tur $x$ hincalterum difcrimen oritur, quod in his

I forma eft etiam principium motus actutum, quim fit rediltincta à materia, in Ceelo autem -aetusille non poteft efreprncipium actium ciusdem motus, quum non fit rè̀ materia diftinctus; quamobrem indiguit Colü externo principio a quo moucretur, ficuti naus habet propenfionem, \&aptitudinem ad motum naugz tionis recipiendum, fed eget motore externo,à quo mo:scatur. Motus igitur Colieft verenatualis, quonian uterum eius principium in

C Coloeft, idque fatis eft vt ille motus dici poffit naturalis; quoniam Ariftoteles in detinitione naturx inditinete accepit principium motus, feu actuum, feu paffunm. Ratione autem prin- Motus cipij aetui motus Coeli non eft naturalis pro- Cols rapric loquendo, fed fit à pincipio fupernaturali; tione tamen per quandam fimilitudinem dici poteft principÿ hac quoque ratione naturalis; quoniam antma stisu, Coli, etfi non eft Couli natura, mouet tamen ad non est modum naturz, \& licet fecundum fuam fub- natsinaftantiam non fit res naturalis, eft tamen prinei- lis,nif pium naturale, quia quatenus eft mouens, eft fectundü caufa effe Aus naturalis, \& ita pertinens ad fciē-fimilatus tiam naturalem, quod fignificauit Arittoteles in dimem. contextu 73. diceris, ccelcites motores moucre phyfice, non effe tamen res phyfens. Poffumus autem hac dere Auerroem legere in Comment. 9.1.hb.de Colo; vbi omnino negat animam coeleftem efle Coeli naturam, nifi fecundum quandam fimilitudinem, quatenus.ita mouet calefte E corpus, vt forma materialis, quavere eft natura, moutet corpora inferiora :-renera tamen inquit, folam Coli materiam, vt per fe aetuatam, effe naturam Coeli appellandam, \& principium motus pafiuum tantum, quemadmodum nos modo declaraumus, qui hacin re Auerrois fententiam ad vnguem fecuti fumus.

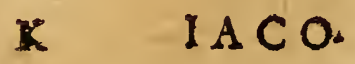




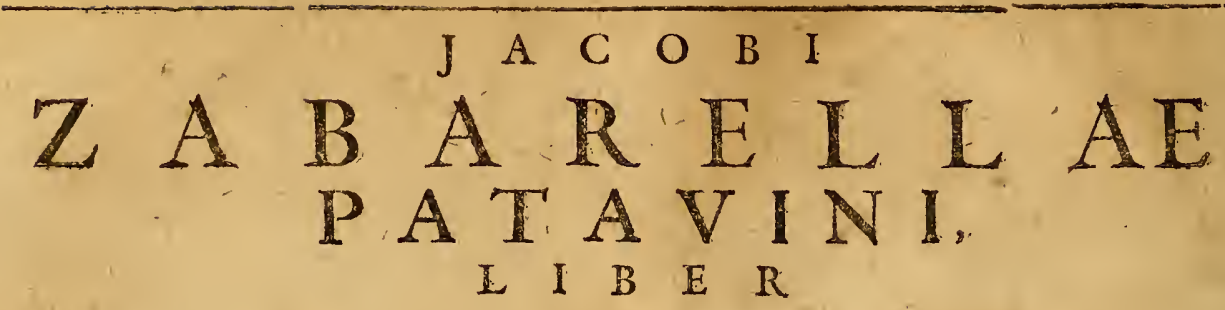

\section{DE ALOTV I GNIS IN O R BE M.}

proponitur quaftio, do folutio Cons. ciliatoris. Cap. I.

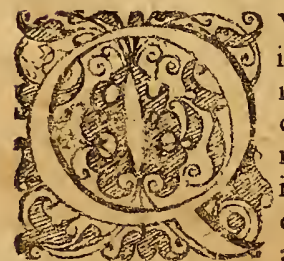

Vum totum elementum ignis \& magna etiam aèris pars à Colonin orbem circumuoluatur, ve ait $\mathrm{A}$ riftotin in libr. Meteorol. idque fiat perpetuo fecundum Arift. qui mundum xrenum effe exiftimauit: fitque motusille-igni, \& aëri prater naturam, quum fiat ab externo principio; dubium maximum deeo apud omnes fectatores Arift. ortum eft, quomodo motus, qui prater naturam eft, poffit effe perpetuus:quandoquidem Arift.1i is: context.1. lib.de Calo, dixit ea, qux funt præter naturam, citiffime interre; vade fumitur vulgata illa propofitio, nullum violentum poteft efle perpetuum , quam etiam aperte pronuntiauit Ariftin cont.17.lib.2. Difficultas hacnon leuis eit \& interpretibus Arift.nagnum negotium faceflit, quum pugnare inuicem vidéätur hæ duæ: propofítiones; nullim violentü eft perpetuum; \&, ignis perpetuo fertur circa mediü:1 dco multi. ad hanctollendàn difficultatem varia dixerüt.

Sessien-

tra. Conciliate-

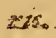

Primum argusmen toskid.
Conciliator in differentia 14 . confiderans propofitionemillam, nuilum violentum eft perpetuum, inquit, nullam ex ea oriri difficultatem, $\sqrt{z}$ intelligatur.cum hac limitatione, nifi habeat catifam perpetuantem: per hocigitur foluit dubiumde motu ignis inobem; dicens motum illum \&rviolentum effe, \& perpetuum : quia caufam habet fur perpetuitatis, nempe motum Coliperpetumm fecund um Arift at nifi caufam haberet perpetuantem, vique motus ille, qum fit prater naturam, non polfecefie perpetuus.

\section{Impurgatiofententia couriliatoris.

$$
\text { Cap: 1: }
$$

2. Ed doctifrmas ifte vir nihil reuera dicir Wuod hane difficultatem tollat, quum rem declaretper femetipfam: docerenim Atrfot. in ritio 2.lib.Polteriorum Analyticorum, onnem quaftionem efle quaftionem caufa: quarere enim an res aliqua fit, eft quarere an detur caufa

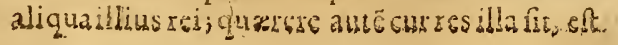

$A$ quærere quanam fitilla caufa: vt quxterean: Luna obfcuraretur, eftquærere an caufa aliquáa detur obfcurationis Lunæ; quærere autem cur Luna obfcuretur, eft quærere quanam fit illa: caufa : omnis igitur quæítio eft quxftio cauf $x_{2}$ etramilla, quaquarịtur an res fit; fiquidé quicquideft, caulam aliquam habet, qua eft: quando igiturquarimus, an detur aliquod violentum. perpetuum, quxrimus an deturaliqqua caufa perpetuitatis violenti, fiverum eft id, quod ab Arift. $B$ ibide quæítionibus traditur,ideo quando Conciliator inquit, effe tunc violentum perpetuum, quandocaufam habet fux perpetuitatis, perindẹeft ac fi dicat, dari tunc violêtum perpetumu, quando datur violentum perpetuum; feutunc dari caufam vt violentum fit perpetuum, quando daturcaufa vt violétum fitperpetuum:quare Conciliator ad hanc difficultatem nihil reuera dicit, fedpropofitionem prædictam limitat per femtiplam. Praterea fi hac folutioadmittatur, sech

C nullius momenti iedäitur ratio Arift.in contex. dism 87. lib.2.de Coelo: quando enim rationem ad ducens cur motus Coli fit naturalis,inquit, nifi ef- fet naturalis, nóporfetefreperpetus, quia nuilum prater naturam ef fempitenum; rationem hancfacile foluere poffemus, dicendo motum Cocli effe prater naturam, perpetuum tamen, quiacaufam habet aternam fuæ perpetuitaris: Sed huius yiri error twanc clare in ficietur, quandorationem cognouermus, cur neqleat vioD lentum perpetuari ; nam fi repuguat violento. perpetuitas, nulla eft caúa, quaxipfum perpe. tuare polfix.

Multorum communis opinio. Cap. III." E S. T. communismuliorum fentencia, quod dubium hoefolvatur per diftinctione violent1:duplexenim eft vioicntum; vnum quod eft contrarium naturali, \&ininicum naturæ illius ¿ei, cui diciturviolêtü;alterum vero, quod neq; $p l e s$. z naturale eft, neq; contrariú natura, fed medium inter hac: dicunt igitur propoficionen illam A: rift.nullum viotentum eft perpetuum,veram ef le de illo violento, quod eft contrarium naturali, culusmodi effencgät motum ignis \& aeris in orbem; hunc enim inqui unt,neq; natural em tffe his elementis,neq; contrarilim natura ip forum,

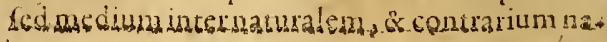


turx, proinde poffe cffe perpetuum. Hune motum medium inter naturalem, \& vere violen= tum pofinit Aucroes in comment. 20. lib. 3. de Calo, \& in z. Meteoroloz. cap. 2. vbi dicit, motum ignis, \& aeris circa medium non efle naturalem, neq; violcntum, fed medio modo ic habere: huncetian pofuit Thomas in contex. 10. lib. 1. deCoclo, dicès motum ignis in orbem nee effe fecundum naturam, nec contra naturam, fed fupra naturam. Einfdem ctiam mentionem facit Simplicius paffim in libris de Colo, vt ibi videre eft, ei us enim yerba non refero.

\section{Argumentatio Zimare contra communem fententiam, do eius opinio. Cap. IIV.}

A Duerfis hanc com munem opinionem aliqui inuehuntur. Primum quidem Zimarain fuo Theoremate 19. vbi omnium negat motum illum mediun inter naturalem\& viomum lentum, j̧fumq; enertere nititur. Obiicir primo wmé- authoritaté Ariftotelıs, qui nullibi mentionem huius mediifecit.neq alium motum cognouit, quam naturalem \& violentum, fumendo violentum, pro co, qui.eft contratius naturali; nam in 7. lib. Phyfic.afcult.inquit, omnem motum vel ab interno, vel ab externo principio fieri, \& illum efe naturalem, hunc autcm viclentum, quem etiam diuidit in pulfionem, traftione $m$ vectionē, \& vertiginem. In 3.etiam lib. de Moribus ad Nicomachum, definiens Ariftoteles violentum, inquiteffe illud, cuius principium extra eft; quareoinnis motus factus ab externo principio apud A rift. eiufdem eft conditionis, \& eo-

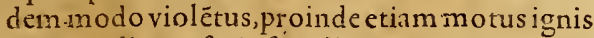
mdis. circa medium eft eiufmodi.Praterea in contex. 76. \& 77.lib.r.de Coelo, probare volens A riftot. vnum tantū effe mundum, inter alia fundamenta hoc ftatuit, omnia, quæ mouentur, aut moueri naturâ, aut violentiâ ; at fi tertius ille mediusmotus daretur, ratio illa Ariftot.facile folui poftet, negando hanc effe fufficientem enumerationem, v targumentum illud A rift. confiderantibus manifeftum eft. Hacigitur fententia reiecta, propriam ipfe profert, quz eft, per fe nuillum violentí poteft effe perpetuum, per ac cidens tamen poteft violentum perpetuari ; intelligit autem perfeillud, quod eft ex confilio\& intentioneagentis, per accidens vero, quod pr $x$ ter agëtis confiliū: quoniam igitur(inquit)nuli. $F$ la caufa fibi ptoponit efficiendumeffeetum violentum, qui perpetuo duratsrus fit, ideo per fe nullum datur viol entum perpetumm;n, $\mathrm{m} \mathrm{Co-}$ lum quoq: dum mouetur, \& ignem mouet, 11 on id fpectat, vt ignem perpetuo circumfcrat, quare non perfe effectum illum perpetuum producit; circumuoluitur tamen ignis perpetuo præter conlilium agentis, ideo q: per accidens: quia yuum oporuerit in ipfocali conta etu effecl:-
A mêtumignis, asciditigni hxe neceftitas, vt fimul cum Coelo circumferatur:pet fe igitur nullum violentum eft perpetuum,peraccidens tamen poteft aliquod violentum perpetuari.

\section{Impuguatio fententic, do folutio argumen- toruanzimara. Cap. V.}

$\mathrm{H}^{2}$ Fe Z Zmara opinio recipienda non eft, \& maxime refellitur ea ipfa ratione, qua no-

B tus videtur Ariftoteles ad dicendú, nullum violentum poffe effe perpetumm : nulla enim alia ratione magis ductus effe videtur, quam hac, quia violenrum eft contrarium nature, contraria vero inter fe pugnant. feq; mutuo interimere nituntur' neceffe eftigitur, vrid, quod eft cótrarium naturæ, illam oppugnet, \& illa contra perpetthrepugnet, quia qualibet res nititur fc conferun- $2 m$. re: \& ea pugna non poteft effe perpetua, quoniam alterum cötratiorum tanden vincere, ac pellerealterum neceffe : vel enim ipfa rei naturaid, quodi ipficontrarium eft, tanden repet lit, vel fuccübit, \& à contrario oppugnante opprimitur, atq; interimitur; horì autem vtrūlibet eueniat, nō poteftilla violentia perpetuari, quum vel ipfa tollatur fupera to cótrario, vel in natura interempta, definatillud effe contra naturam, quū nulla amplius eiufce rei natura exiftat: hoc reficiens A uerroes in commen. 7.lib. 2. de Coelo, dixirnō dari violentum ab̧ą; naturalı; quia neceffe eft, vt id, quod eit preter naturam, præfupponat ipfam naturä: quoniam igitur non poteft al iquid dici contrarım naturæ, nifi exiftente illa natura, fieri nullo modo potê̊t, vtalig̨uid violentum, \& contratium natur perpetuetur; fiquidem pugna, vt diximus, non potef effeperpetua. Si hac eft vera ratio, cur Primura nullum violentum perpetuari queat, fententia argumieZimarx deferidinon poteft: qurum enim apud tumcon$E$ ipfum non detur motus medius, fed omnis mo- tra $Z i$ tus vel fit fecundū naturam, vel cōtra naturam, masamo motusignis in orbem, quum fecundum naturam dici nequeat, quia fit ab externo, non ab internoprincipio, eritergo contra maturam;itaq; vel à natura ignis tandem expelletur, vel ipram oppugnabit, ac perimet; at qui repellinō poteft, quum fiatabagente rteno, \& impatıbili; ipre igitur tandé fuperabit, a c perdet naturam ignis, fi eft illi contrarius; fieri enim no poteft,vt ignis fub illa affectione fux natui contraria feruasi perpetuo poffit:perempta autem ignis natuta motus ille non poteft amplius dici violentus, \& præter naturamigni, imo neq; appellari amplius poterit motusignis, nuilo exiftente igni; perpetuus igitur molus ille effe non poteft, fi eft contra naturam ignis : quod fi inficietur $\mathrm{Zi}$ mara, motum illum pugnare cum natura ignis, \& illi clle contrariun, ian fatetur motuni me- dim, quam negauerat : quida enim eft motus nedius, nif ille, quit neque à res natura proue-
Notara itonem cur nul. lum Gio. lenturiz polste efle 
nit, nequeille contrarius! vanum etiam eft ilSecund $\bar{x}$. lud, quod Zimaradicit, motum ignis in orbem perpetuariper accidens, quia: præter confiliun mouentis nam vt ei condonemus, motum illum efe preter, agcntis confilium, non ob id políbilis redditur eius perpetuatio, hi eft, contrarius nature ignis; nam ratio nunc à nobis adducta dcmonftrat neceffarium eifc, vt vel natura ignis fuccumbat, acpereat, vel motum il lum repellat, tanquam fibi contrarium: nullius igitur momenticf confilium rgentis, quia fiuc ex eius confilio, fue prater eius confilium circumferatur ignis, non poteft perpetuo circunduci, fi molusille eft ipfus naturæ contra-

Tertium fius. Patet etiam opinionem hanczimara cuertereargumentumi A if totel is in contex. 1s.lib.r. de. Colo, \& in 17.tib. 2. quando dicit; motus Cocli eft naturalis, quia nullum præet naturams: eft fepitcrnum : folui enim poffet argumentum hoc, dicendo motum Colli effe præer naturam, xternum tamen, quia perpetuatur per

Quart $\tilde{2}$. accidens, \& praterconfilium mouentis. Sed reuera nullo pacto admittendim eft id, quod $\mathrm{Zi}$ mara dicit, circunductionem ignis fieri præter confilium mouentis, nifí etiam dicamus, cæleftra corpora regere per accidens hac inferiora, \& hocregimen effe prater illorum conflium: hoc tamen minime dicendum eft, quia ( $v t$ Auerroes a it in comment. 17. lib.r.de Colo) gubernare inferiorem müdum eft finis colectium corporum, faltem fecundarius, quodidem etiam ex A iftotele fumitur in fecundo capite libri prmi Meteorologicorum, \& quisquis hoc neget, negat neceflarium rerum ordinem, \& connexum in vniuerfo: quum igitur neccflarium omnino fit his inferioubus gubernaria fu Ferioribus, à quibus \& producuntur, \& conferunntur, neceffe eft vt ex naturaconfilio, non prater confilium, inferiora corforn è fuperio. rịbus moueantur, atque regantur : peculiariter autem de duobuselements igni \&acreibidem cap. 4 . ab. A rifte tele hoc decl iratur, dum dicit elementa calida à motu Ceeli habere calorem. \& ita conferuari nifi enim circumerreturignis ¿ $\mathrm{C} x \mathrm{clo}$, non poffet eius natura feruari; taque fi notus ille in orbem coffertat naturam ignis,vt. mox declarabinus; Colcfitim auren corpo-. rum finis eft regcre; \& confcruare hacinferio: necede eft exeortm conlilio feri vt ignis perperuocirca medium feratur, quarenon eft per:

ddpris mum 2 : maraargumert*m. accidens, vtZimara dicit. Adargumenta Zimarae facile eftrefpondire; dico cnim Ariftotelem in 7: Phyficorum lata:fignificatione fumerc mo tum violentum pro onmi notu, qui fiat ab exa terno principı ; idco ibi nomine violenti non. folum illeintclligitur, qui eft conrrarits natur moti,\&cum cius repugnantia,fed etiam ille, quifit nequerep:ignante, neq; vim conferente mobili, qualis eft in igne motus in orbcm; quaproptci concedamillum seduciad tractionem.
A vel ad vertiginem. Sic etiam in 3.lib. deMoribus: fumitur latéviolentum pro omni habëte principium extra, quamobrem ea definition e comprehenditur non folum motus contrarius natur $x$, fed etiam ille, qui intcr.naturalem \& natur $x$ conuatium medius eft. Id circo non eft igno. randum, qued proprie loquendo latius paret violentum, quam contra naturam; nam violentum vocaturid omne, quod fit ab externu principio abfque vlla ope naturre recipientis;at con- ram.

B tra naturam cicitus illud folum, quod eft in imicum raturx, proinde eft cun repngnantia patiètis; in viu tamen eft pofieum, vt fimmatur violentum proeo, quodeft contraritum natur \& \& hac duo id m fignificent. A rglimentum quoq; fumptum ex contex.76.77-lib. I. de Colo, leue eft, quoniam A rift.in to to libro illo de lolis fimplicibus motibus loquitur:quarc exhis folis:argunentum fumit ad mundi vintatem probsndam; fimplexatutem motus non poteft efleme. Not: C. dius inter naturalem, \& contrarium nautu fed frmpi. neceflario yel naturalis eft, vel natura contin- no po ruus, vt in eorum librorum intepretatione de- efje $n$. monftrauimus: motus autem ignis circa me- as int dium non eft limplex, redmitus; vt A werroes natu ait, \& vt confiderantibus manif eftum eit: quum less i enim non fiat ablq; confufione, ac pertubatio- conts: ne partium, non teruartu;in his perperua $x q u i-2 m m a$ diftantia à centro mund: $r e c t e$ igitur $A$ riftord $-r a$. xit omnia; qux mouentur, nempe fimplici mo-

D tu, aut moueri natura, aut cótra naturam. Vana igitur eflc argumenta Zimaræ, maniteftum cit.

\section{Aliorum argumentatio contra candem: communem Jententian, dipforum. cpinio. Cap. VI}

A Lii vero hanc eandem communcm fententiam alia ratione oppugnarenituntur: nam motum quidem illum medium, quem neE gaut Zimarat; ipfi concedunt; tamen dicunt, illam Ariftotelis propofitionem, nullim viclentum effeperfetuum, de hoc quoque veram effe non folum de illo, qui eft contrarius nurura, ita vernuerle vera fit de o:mni motu, qui non fit fecundum naturam : fiue enim fit contrarius natura; fiuemedius inter naturalen; \& contrarium naturalr, non poreftelle perpetuus; cum hoctamen difcrimine, quod de $11 l o$, qui eft contratius naturali, abfolute, \& ab fque vlla diftin"Etione dicendum eft, ipßum non polieperpetuaris rationamque iann a nocis adducta hoc demonftrat, quonian perfeucrancibus in pugna duobus conirains, necefiedt, vi randem alterum deficiar; at que inccumbat: de motu autem medio, pum on eif cutrarius naturali qualis eft motusignis inorbem, dicunt nor abfolu:c veramelle propofitionem, led cum quadam diftnctione: poreft.n. contiderari duobus modis. vno modave rchatis adigne, in quo in eft; quos- 
niamenimeft prxter naturam ipfius ignis, hac $A$ ratione notat quandam extrancitatem à ftatu naturalij neque eft aptus perpetuari, quia tale nihil eft perpetuum; altero modo confiderari poteft vtrelatus ad caufam, à qua producitur; quum enim producatur à Colo, \& fit ipfemet Coli motus, qui cum elementis per contaEtum communicatur, hac ratione poteft effe perpetuus; quoniam enim naturxignis non eft contrarius, neque illi repugnat, neceffe eft, fi Coclum femper mouetur; vt ipfe quoque ignis femper moueatur; fiquidem fieri non poteft, quin Coclum tangens ignem circumferat ipfum perpetuo,fi ipfum quoque perpetuo circumfertur. Comprobant hi hanc fuam opinionem confiderando ea, qux dicuntur ab Ariftotel. in context. 17. libr. 2. de Colo, vbi dicitur motus Coli effe fecundum naturam, quia eft fempiternusinullum enim, quod fit prater naturam, eit fempiternum : fumit autem ibi Ariftoteles praternaturam late, prout complectitur etiam illud, quod non eft contrarium naturæ; quia ra. tio, quam ftatim ad hoc probandum fubiungit, non minus de hoc probat, quam deillo, quod eft contrarium naturæ; namaffert Ariftoteles hanc rationem, quiaid, quod eft præter naturam, eft pofterius naturali; hæc autem eft communis conditio vtriufque violenti, quia naturale eft prius omniaccidentali, tam eo, quodeft contrarium, qua in eo, quod nö eft contrarium: quemadmodum enim dicere non poffumus aliquid effe contra naturam ignis, nifi præfuppofita ignis natura; ita nec fupra naturam, nec vllo modo preter naturam; nifi eam ipfam naturam præfupponamus.

\section{Dicte fententia confutatio. Cap. VII.}

$\mathrm{H}$ A NC fententiam ego ab Ariftotele alienameffe puto, veram autem communem multorum opinionem, à qua ifti recefferunt. Primum quidem videntur incidere in fentenriam Conciliatoris, quam ipfimet confutauerant: nam dicere nullum productum ab externo princupio effe perpetuun fecundum fe, poffe tamen à fua 'caufa perpetuari, eft dicere, nullum violentum effe perpetuum, nifi caufam aliquam habeat fux perpetuitatis, qux Conciliatoris opinio fuit.Prxterea quando dicitur, motū ignis in orbem effe per fe corruptibilem, quærendum ab eis eft, qua potentia dicant ipfum effe aptum deficere, an naturali potentia, an logica: fi dicant naturali,neceffe eft vt aliquando definat motus ille, quoniam potentia naturalis non poteft effe fruftra, fed neceffarium omnino eft eam aliquãdo duciad actum; non poteft igitur ab vlla externa caula perpetuari, ficuti non poteft Colum facere, $y$ hic equis feruetur eternus, fi naturalem' betportian ad interitum : fi vero dicant potentia logica, ve dicere videntur, ab hac non poteft ille motus nominari corruptibilis, quonianı à potentia logica non fumituralicuius rei nominatio, fedab atu; homo enim quatenus eft animal, habet potentiam logicam vt fitafinus; dicimus enim homini quatenus animali non repugnare effe afino, non tamen obid licet homincm appellare a finum, fed vocatur homo, qua eft actu homo: ficitaque nec motum ignis in orbem pofumus ex potentia logica vocare B corruptibilem, fed ab actu eft vocandus $x$ ternus, quum reipfa æternus fit. Ariftotelesigitur non recte loqueretur, dicens omne violentum effecoruptibile, fi daretur aliquod violentum xternum : ipra quoque Ariftot. verba indicant, ipfum non potentiam logicam refpicere, fedaEtum, quum dicat [Gidentur quafunt preternaturam, cotißsme interire] nam verbum qaiveras fignificat apparere, \& effe euidens, quod id, quod eft prater naturam, cito interit; itaque denotat $C$ in omniviolento neceffarium effe, vt naturalis potentia intereundi ducatur aliquando ad actum. Efficaciffimum quoque argumentum contra hancfententiam fumitur exiisipfis Ariftotel.verbis in context.17.lib.2. de Collo, è quibus eifdem hi quoque argumentum fumprerunt: quum enim Ariftotelesibiquoque dicat, nullum præter naturam effe perpetuum, non poteft intelligere aliud prater naturam, quam id folum, quod eft contrarium naturali; quod $D$ oftendo tum ex ipfo Coclo, de quoibi Ariftoteteles loquitur, tum ex eius motu, quem folum ad confiderat, tum demum exargumento quod promum quidem fi Coelum ipfum confideremus, non poteft cius motus dici fupra naturam; quum enim aliud $\mathrm{C} \propto l$ lo fuperius corpus, à quo motus ille cum Coelo communicetur, non cognofcamus, non poteft ille motus nifi contra naturam effe fi non eft fecundum naturam : $f_{i}$ E vero motum Coli peetemus, de quo folo ibr fermo eft, is non eft nifi fimplex; ergonifi fit naturalis, neceffe eft vt fit contrarius naturæ; quia motus fimplex non poteft medio modo fe habere, fed neceffario vel naturalis eft, vel contrarıus naturali : ratio quoque ab Ariftotel. ibi adducta declarat ipfum non de alio præternaturam motu ibi loqui, quam de illo, qui eft contrarius natura, in quit enim, id, quod eft prater naturam, effe pofterius naturali, \& effe quendam exitum, feu remotionem à ftatu naturali; atquires è fuo naturali ftatu non remouetur, nifi per pugnam, nec pugna eft fine contrarietate; loquitur ergo de illo motu, qui eft contrarius naturx: quod autem ratio illa $\mathrm{A}$ riftotelis aptari non poffit motui ignis in orbem, vtiftiimagipantur,moxluce clarius oftedemus, \& totam rei veritatem patefaciemus; is enim reuera neque pofterior motu ignis naturali dici poteft, nequeremotio ignis è propria 
natura:horum igitur epinio recipiendanon eft: A attamen commutus quoque fententia, in quam. ift inuecti funt, non vacat omnino reprehenfione, vt mox veritate cognita manifeftum fiet.

\section{Veritat is declaratio de motu ignis in orbem. Cap. VIII.}

$\mathrm{V}$ Thuiufce rei veritas plene intelligatur, fciendum eft ex Ariftotel. in 4 . Phyficorum, \&e in 4 . de Coelo, fublunaria corpora effe in loco, \&

$\sec s$ resoest cover:iscobeo $r$ x:m imperfedio xem.

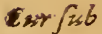
Calocon ferserwor ignis. locum requirere ob eorum imperfectionem : propria enim, quam habent, interna perfectio ad corum conferuationem nō fufficit, fed egent conferuante externo,proind e eft eis neceffarius locus; ad huncigitur fingula mouentur fuapte natura, quia cupiunt conferuari ; terra, fi in fuperoloco fit, deorfum fertur \& \& centrum petit; ignis in hacinfera parte genitus fertur propria vi ad concauum orbis L unx, quia non hic, fed ibi conferuatur: ideo Ariftoteles in context. 22. \& 23. lib. 4. de Cœlo inquit, grauia \& leuia ferriad proprium locum, tanquam ad perfectionem, \& formam; locum enim iure formam vocat, quia inftar form eft, quum fuppleat id, quod forma interna preftare non poteft; $h x c e n i m$ dat rei ef: fe, \& ipfam conftituit, fed ipfa per fe non poteft eam diu conferuare; locus autem tan quam altera forma externa, pervim, quam habet, conferuatricem locati, conferuat rem in fua naturali cóftitutione: hinc colligimus, locum effe quiddam natura prius locato, \& eius caufam, vt afferit clareA riftotel.in 4. Phyfic.quum fit tanquam caufa motusad locum, \&eipfius locati conferuatrix: fed confiderandum eft, quanam fit hxc vis conferuatrix, quam inefie loco dicimus: tria quidem inferiora el emenda fi f pectemus, dicere poffumus, vim hancin fymbola qualitate confiftere, vt Ariftotel. in dicto locolibriquarti de Colofignificare videtur: at de igne fecus fefe res habet; non enim poffumus ad fymbolam qualitatem confugere, quum nulla adfit fymbola qualitas, quæ coelefti corpori communis cum inferioribus dicipoffit: eftautem Ariftot. fententia, Colum in hæcinferiora non agere, nifilumine, \& motu; quare ûagendo in ignem conferuatipfum, neceffe eft vt vel lumine agat, vel motu vel ambobus fimul:átqui lumine non poteft, quia radij ftellarum non videntur operari, nifi in hac inferiore mundi parte, in terra \& in aqu2, \& hac infima aeris regione; propterea quod non agunt, nifi percutientes, \& fracti, \& reperculfi, \& quodammodo duplicati, recta enim progrediendes vel nullam, velinfenfilem vim agendi habent ; patet enim mediam aeris regionem extranfitu radiorum Solis non caletieri, fed manere valde frigida $m$, quia radijà terra repercuffi, iftuc non perueniunt : eadem igitur ratione in elemento ignis nilagunt radij , quod ignem omnium corporum calidiflumum son- reruare polfe videatur; folus itaq̨; motus relinquitur, quo ignem à Colo conferuari dicamus: ea ̨̧; cft tentêtia Arift. clara in lib. r. Meteor.c. 4 . vbidicit, elemeeta calida effe calidà motuCooli, $\& a b$ eodem conferuari in fuo naturali calore: motus enim rapidiffimus vim habet diffipandi, attenuandi, \& rarefaciendi,proinde \& calefaciendi; motus enim per attenuationem \& attritionem partium gignit calorem, vt A riftot.ait in context, 42.lib. 2.de Colo:idque ab Auerroe ibi B optime declaratur, qui etiam dicit, notum effe perfactionem calidi, qux propofitio maleintellecta, plures turbauit;fed om nia dubia folnimus dicend o eam effe fumendam, non in fenfu formali, fed in caufali; motus enim dat perfectionem calido, quatenus eft calidum, quiacalorem conferuant, qui fine motu non feruareturiradix enim formalis omnis caloris in hoc mundoiaferiore eft elementum ignis, qui omnium calidiffimus eft, \& fubigne aer pofitus eft mediocriC ter calidus; catera vero omnia per horum participationem funt calida : hxc autem elementa non conferuarentur calida, nifi per attionem cxleftem;ignis enim(vt inquit ibi A verroes)nifi moueatur, extinguitur, ac perit : in Epitome quoque Metaphyfica, tract. 4 - cap. 13. inquit $A$ uerroes, elcmentaproducta effe ex necelfitate à magno motu; quia proprium eftmotus facere calorem, \& huncinfequiturlevitas, quæ eft ignis natura: priuationem autem coleftis motus infequitur frigus, \& grauitas. Ignis igitur elementorum calidiffimus à Colo in fuo naturali ftatu conferuatur per motum in orbem, qui cum ipfo 1 gne femper 2 \& abfque vlla interm iffione à Colo communicatur: vnde coligimus motum illum ignis non fimplicem efle, fed $\mathrm{m}$;ftum, vt antea dicebamus: nam fi effet vere fimplex, \& nullum partiumafcenfum, vel defcenfum haberet, nulla earum attritio fieret, proinde neque calor; quum igitur attritio ibi, E \& calor fiat, miftum effe motum neceffe eft: Colligimus ptæterea rationem, cur motus ille fit medius inter motum ignis naturalem, \& motum contrarium naturali : etenim non eft naturalis, fumendo naturalem pro eo, qui fit ab interno principio; non eft etiam ita præter naturam, vt naturam oppugnet, ac lædat, quum potius eam foucat atque conferuet; fed eft modo aliquo fimilis vtrique: quatenus enim non ab. interno principio fit, fed ab externo, eatenus fimilis eft motui violento, ea tamen eft violentia ad conferuandum illata, non ad interimerdum, ficuti quando pater vim infert filio, vt erudiatur, \& addifcat: quatenus vero eft conferuatiuus naturæignis, quæ fine ipfo non conferuaretur, ea ratione videturpotius appellandus fecundum naturam, quam prater naturam; nam externum quidomeft eius principium, fed t.1le, quodad conferuandum ignem efficit iliud, quod ipfa ignis natura fibi praftare potis non 
eft ; quoniamilli formx nulla alia vis data eft à $A$ natura,nifi mouendi à medio ; fimplex eni m natura vnum tantum motum efficere apta eft, non plures;ob id motus ignissin orbem à quibusdā vocatur potius fupra naturam, quam fecundum naturam, vel prater naturam; eft enim quoddam excedens naturam ignis, amicum tamen, atque conferuans. Ab hac aut em noftra fententianon videnturalieni fuiffe illi prifci Philofo. phi , qui dixêre, motum elementorum natura-

s]corì tètsa motu mento lis. lem effeillum, quiin orbem fit; viderunt enim hoc motu elementa fuperiora conferuari, \& particulas ignis apud nos genitas ideo a feendere, vt cum toto ignis elemento circumducta conferuentur:ex hoc enim iudicarunt, magis effe przecipuum in elementis motum in orbem, quam motum rectum, quum viderent eum elementis competereiam integram fuam naturam, \& perfectionem obtinentibus, rectum vero in illis nó dari,nifi vt conftitutis in ftatu inperfectionis, \& exiftentibus extra fua loca naturalia; ideo cnim dixerunt naturaliorem effe igni motum in orbé, quam motum rectum, propterea quod quando ignís ad locum fuum peruenit, totamque fuam perfectionem adeptus eft, definit rectà moueri, \& folo in orbem motu cietur,absque vlla intermiffione. Arift. vero rem hanc diligentius confideraffe videt ur:nam conftituta definitione naturæ, quam in initio lib: 2 . Phyf.legimus, non potuit alium motum appellare elementis naturalem,quamillum, quiab interno principio prouenit, qui eft folus motus rectus;nec bb id nega uit motum quoque in orbem effe elementis alio modo naturalem, quatenus eft cóferuatiuus naturx, fed fignificare vifus eft, hunc rectius vo. cari fupra naturam, quam fecundum naturam, vel prater naturam, vt colligimus ex 4 . cap. lib. I.Meteorolog. vbi dicit el ementa calida conferuarià motu circulari,quo participant:in 4.etiam libro de Cœlo, dicens elementa mouerı ad locū fuum tanquam ad formam, hocidem fignificauit;mouetur enim fingulum elementum ad elementum continens, à quo per fymbolam quali. tatem conferuatur; ignis vero fertur ad orbem Lunæ, \& ad concauum Coeli; tanquam ad fymbolam qualitatem, quam Colum habet, non quidem vt formam, fed vt virtutem; eft enim virtute calidum, quatenus vim habet efficiendi in elementis calorem per motü $;$ illucigitur ferturignıs, táquam ad conferuans, quia conferuare calorem, eft ipfam ignis naturam conferuare.

\section{Collectio errorum omnium aliorum.}

\section{Cap. IX.}

TEc igitur eft illius motus conditio, quo Hignis à Colo circumuoluitur, non plene (vt videtur) ab aliis declarata: nam fi aliorum fententias bene perpendamus, omnes in aliquo defeciffe videntur. Primum quidem deceptus eft Conciliator, non diftinguens motum hunc à cxteris; quos appellare folemus violentos , \& contrarios naturæ. In eundem errorem incidit etiam Zimara, negans motum hunc mediun Errorz;. inter naturalem, \&contrarium naturali, \& pu- maik. tans omnes motus, qui non fint naturales, eiusdum effe conditionis, \& eadem ratione dici vio. lentos;quum ex huins motus conditionibus pateat; eum neque effe naturalem, neque contr. riumnatur , fed medium, \& aliqua ex parte fimilenı vtrique, quofit, vt non contineatur fub B illa Ariftotelis propofitione, nullum violentum perpetuum, quü hic poffit effe perpetuus, quippequi non eft contrarius naturæ ignis, neque illam oppugnat. Errárunt etiamilli pofteriores, qui motum hunc medium concedentes, dixêre
veram de hac quoq; effeillam Arift. propofitio. nem, quatenus ipfe fecundum fe denotat quan dam extraneitatem, ratione cuius ei non conuenit perpetuitas: hi namque ignoraffe videntur, quomodo hic motus fit dicendus medius, \& id C folum fpectantes, quod huius motus principiü extra eft, dixerunt eum igni \& aeri extraneum, \& accidentalem effe, \& hac ratione corruptibilem : quafi vero omne externum fit accidentale rei, cui externum dicitur; quod quidem eft manifefte falfum; dux namque funt caufx exter$n x$, efficiens \& finis, qux tamen ad rem, cuius funt cauf $x$, habent efrentialem refpectum, \& de illa per fe predicanturiuxta quartum modum dicendi perfe. Quum igitur hic motus fit inD ftumentum quoddain caufr fuperioris ad hre elementa conferuanda, \& hacratione fit caufa effectrix conferuans initrumentaria, non eft motus extraneus, id eft, accidentalis, fed potius neceffarius; proindeceffatratio, qua coci poffitper fe corruptibilis. Errarunt etiam iftiabutendo argumento Ariftot. in contex. 17. lib.2. de Cœlo, quod fi bene intelligatur, nullum habet locum in motu ignis in orbem: nam reddens ibi rarionem Ariftot. cur id, quod eft prxter natu-

E ram, non poffit effe perpetuum, dixir, quia eft pofteriusillo, quod eft fecundum naturam, \& eft egreffio, \& receffus à ftatunaturali; at motus ignis in orbem non eft huiusmodi; non eft enim pofteror motu ignis nat urali, imo neque igneipfo; quatenus enim eft caufa conferuans naturam ignis, apta etiam ignem generare, $f$ ibi ignis non effet, eatenus eft prior: fi vero conferatur cum motu ignis à medio, absque dubio eft illo prior tanquam caufa finalis; nam ignis F ideo fuperum locum petit, vt ibi cum toto elemento circumuoluatur, \& ita à loco conferuetur, quum ipfe propriis viribus fe conferuare nequeat:propterea id, quod dici folet, elenenta ad fualoca moueri, vt in illis quiefcant, \& ita quie- Qüses tem effe finem motus eorum naturalis, fano gyomodo modo eftintelligendum; eft enim abfolute ve- $\int 2 t$ caufa rum de terra, cuius conferuatio confiftit in pri-finalis uatione motus coleftis qui ad locum infimum motzes. non peruenit, ideo ad eum locum fertur ter-

$$
\mathrm{K} 4 \mathrm{ra}, \mathrm{Yt}
$$

Error aliortum pofteria. rum.

\author{
$r$
}


ra,vt ibi omnino quiefcat;idque protulit clare A ter cxcum, \& videns, de quo vtroque génere Ariftoteles libr.primo Mcteorologicorum,cap. 4. dicens elementa frigida conferuari per immobilitatem, hoc eft,per quietem in loco fuo, \&iemotionem à motu colefti: de igne autem, \& de aere non ef abfolute intelligendu $m, f e d$ potius fecundum quid; nam poit motū à medio quiefcit ignis refpeetu illius motus, quia definit afcendere, \& in fuo loco manet, abfolute tamen non quiefcit, quia mouetur in orbem, vt conferuetur, \& nifi moueatur, extinguitur. Paret igitur, huic motui non competere priorem conditionem motus præter naturam, quam ibi-Ariftotelesadduxit; non eft enim pofterior motu ignis naturali, fed multo minus ei-competit altera; tantum enim abeft, vt motus ille fit receffio igais à fua natura, \& ipfi læfionem aliquam inferat, vt potius naturam ignis fouear, atque conferuet, qux fine ipfo periret. Manifeftiffimŭ ergoeft, Ariftotelem eo in loco fumere prater naturam pro eo tantum, quod eft inimicum, \& cōtrarium naturæ; hoc enim diftrahit rem à fua naturali conftitutione, \& ad interitum ducit, quia pugnat cum natura rei;ob id negat Ariftot. hocpoffe effe fempiternum: \& italocum illum interpretatur Auerroes; fic etiam in contex is. lib. r. de Coelo Ariftoteles non dealio violento motu loquitur, quam de illo, qui eft contrarius naturæ; folus enim ibi confiderat fimplices mo tus, qui non poffunt effenifi naturales, vel contrariinatur $æ$, ficut an tra diximus: motumigitur medium inter naturalem, \& contrarium naturali Ariftot, in ea parte non confiderat, quia hic non poteft effe nifi miftus, dequo ibinon eft fermo, huiufmodi autem eft motusignis in orbem, quare de hoc Ariftot. nunquam loquitur, quando in libris de Colo dicit, notum præter Error naturam non poffe effeperpetuum. Communis opinionis quoquefententia, in quam illi inueeti funt, \& comms- quam nos verioren effe diximus, non penitus nis. errorevacat; nam in eo quidem veriffima eft, quod ponit motum medium inter naturalê, \& contrarium naturali, \& talem effe afferit motumignis circa medium, \& ad hunc non extendi propofitionem illam Ariftotelis, nullum violentum eft pespetuum, fed de folo motu contrario naturæ fuiffeab Ariftot. pronunciatum : in toctamen hi quoq; defeciffe videntur, quod fine vlla motus medii diftinctione, \& abfque cognitionepropriarum huius motus cōditionem eam fententiam protulerunt; nam abfolute dicentes propofitionem Ariftot. in mots medio locum non habere, fic putarunt fublatam effe hac in re omnem difficultatem; quamobrem quo pacto motus ignis in orbem fit medius, Medisum non videnturintellexife. Nos autem dicimus, onter ex- medium inter extrema duplex effe; ynum per trema participationem extremorum, quale eft tepiof du- dum inter calidum \& frigidumzalterum perneplex. gationem extremorum, cuiufmodi eft lapis inmedii fi inditinete pronuncient, ipfum potfe effe pcrpetuum, falluntur, quia motus medius per participationem extremorum non potet elle perpetuus: fi quid enim itafit víolentum, \& praternaturam, ve non fit extrente contrarium naturali, fed mediocriter, tan quam medium per extremorum participationem, hocaliquam habetcontrarietatem cum natura; proinde neceffe eft, vt pugna fiat naturæ cum illo, \& tândem $B$ alterum fuccumbat, \& pereat; nam fummecalidum læditur non folunzà frigido, fed etiamà tepido, \& 2 b hoc diftrahitur è fua natura: ideo in hoc quoque locum habet ratio Ariftot. pra. dicta, quoniam neceffarium eit, vt pugna fat, non folum ertremi cũ extremo, fed etiam cum medio:idcirco illa propofitio, nullum violentum eft perpetuum, vera eft de omni violento, quod fit contrarium natura, fiue extreme fiue mediocriter, quia vtrumque naturam oppuC gnat. De medioautem per negationem extremorum propofitio Ariffotelis vera non eft, nee de eoprolata fuit, quoniam argumentum A riftotelis de hoc nullam habet efficacitatem; talis autem eft motusignis in orbem; non enim conftat ex afcenfu, \& defcenfu, fed eft folummodo circa medium; proprié namque afcenfus dicitur, quando ignis à locoalienoad locum proprium tranfit, ifque eft ipfi motus naturalis; fic defcenfus propie dicitur, quando ignis tranfit à loco proprio adalienum, \& hic eft ta violentus, vt fit contrarius naturæignis, \& eam ladat: extreme quidem contrarius, fi defcendat ad locum terra, mediocriter vero, fi ad locum aeris; fed neque in loco terra, neque in loco aeris poteft ignis diu conferuari, quia in vtrolibet detineturviolenter, \& cum lafione natura; nam etiam locus aeris eft igni præter naturam, licet mediocriter; conftat enim quodammodo ex conditionibus loci naturalis, \& loci extren!e E contrari, quum fit extra proprium locũ ignis, fed non fit ab eo valde remotus. In fphæra autem propria quum circumfertur ignis, licet is non fit motus in orbem fimplex, qualis eft motus Cali, fed cum agitatione acperturbatione partium, non eft tamen cum mutatione loci naturalis, fed cenfendus eft folummodo circa medium, non ad medium, neque à medio: quamuis enim fiat ibialiquis afcenfus $s_{3}$ acdefcenfus partium, ratione diftantix à centro, nullus ta$F$ men fit afcenfus, vel defcenfus ratione qualitatis \& virtutis; quia totus ignis in fuo loco manens circa medium voluitur; nifi fortaffe aliqua eius particula aeri propinqua ad locum aeris demitiatur, quod quidem fit peraccidens; nam fcopus illius agentis coleftis in hoc inferioris mundiregimine eft elementum ignis conferuarepermotuni, nonaliquam eius partem interinere, Hic autem motus, licer medius inter naturalcm, \& contrarium natura dicatur fer ne- 

pugnanda, fed potius motui naturali in ea conferuanda: hoc igitur multi nō intelligentes,nullaq; diftinftione in hac re veentes, non penitus huiufce rei veritatem affequuti effe videntur.

\section{Errormultorum in declarando motu plane- tarum diurno, of totus veritatis con- clufio. Cap. $X$.}

$F^{X h o c, ~ q u e m ~ c o n f i d e r a u i m u s ~ e r r o r e, ~ i n ~ a l i-~}$ Eum fimilem illimet inciderunt, de quo pauca in prafentin dicere neque inutile, neque à $C$ propofita nobis contemplatione alienum erit; quxri enim folet, qualıfinam fit motus ille, quo errantes fpharx dicuntur à primo mobili circumduci : quum enim planetæe duobus fimul motibus ferautur; vno aboccafu ad ortum, alii tardius, alir velocius, qui dicuntur fingulorum proprius, ac natural is motus, altero dutem huic contrario, quem aftrologi diurnum appellant. quoniam fingulus planeta femel in die naturali, hoc eft, tempore horarum viginti quatuor totum circuitum peragit; hunc etiam vocant motum raptus, quia inferiores fphæræ à fuprema qux primum mobile dicitur, rapiuntur $a b$ ortu. ad occulum, \& iterum ducuntus ad ortun; de hoc diurno motu, quiplanetis violentus effe videtur, \& contrarius proprio eorum motui naturali, dubitāt multi, ficut etian de motu ignis in orbem dubitârunt, quomodo poffit effe perpetuus, fi nullum violentum, vt Ariftotel. dixit, poteft effe fempiternum. Refpondent, de hoc idem dicendum effe, quod de moru ignis in orbem, nam hic quoque eft medus inter naturalem, \& violentum, quare eadem ratione poteft effe perpetuus. Sed hi decipiuntur, quia magnì. eft horum motuum difcrimen, quod ipfinö cognouerunt: omnia namq; coleftia cor pora tantæ funt perfectionis, vt fuapte natura feruentur: xterna apud Ariftot. abfq; vlla ope conferuantis externi; ideonon funt in loco, quemadmodum in 4 lib. Phyfic auicult. Ariftoteles docet, propterea quod locus proprie fumptus corporibus imperfe tis datus eft ad corum conferua. tionem, idcirco fi quid in eis ab agente fuperiore imprimitur, id iure vocatur fupra naturam. qualis eft in igne, \& in aere motus in orbem, de: quo hactenus loquuti fumus, quum nuilum $h u$. ius motionis principium in his elementis infitum fit. At motus planetarū diurnus non eft huiufmodi, fed eft vere naturalis, \& ab interno
A principio proueniens, quemadmodumaliâs declaıaimus, in Coclo effe naturain, \& principiü motus intcrnum; quomodo autem hoc fit, legere apud Auerroen poffumus in commen. $\{2$. \& 7 1.lib.2,de Coclo, \& in 44. lib. 12. Metaphyl. \& clarius in 3. difputatione cōtra Algnzelem in folutone 28 . dubii, vbi rem hane doctiffime decłarat, eam $;$; nos in præfentia paucis perftringemus. Inquit Auerroes, motum diurnum negue violentum effe planetis, neque proprium fupse-

B $m x \int p h x r x, v t$ Aftronomividenturafferere, fed elre notum naturalem totius coleftis globito. tum enim Coelum eft velurianimal quoddar magnum, fphxræ autem funt tanquam varia meinbra illius anımalis: quemadmodum igitur motus, quo totum animal progrediendo mouetur, etfi in corde primum habet principium, eft tamen naturalis, \& toti animali, \& cuilibet eius parti, adeo, vt dum ambulat animal, dicaturille motus effe naturalis, non folum toti animali, fedetiam oculo, prater hunc autem habet etiam oculus proprium motum, fic manus, \& brachium, \& fingula alia membra : ita de Coelo dicendum eft: motus enim diurnuseft naturalis motus totius globı Coeleftis, ideo etian planetis fingulis eft naturalis tanquam partibus illius totius, quemadmodum ambulatio anima. lis \& oculo, \& manui eft naturalis : proprii autem planetarum motus funt eo modo naturales, quo proprius oculi motus, \& proprius moD tus manus dıcitü illi parti naturalis : primus aüı Primus motor, quiapplicatur dicitur mouendo orbifu - motor.e,z premo, inillo quidem diciturrefiderevt in parte motor tonobiliore; ficutirefidet anima in corde anima - tius. lis, tâmen non illius tantum orbis eft motor, fed. viuerfi globi cœleftis, \& ille motusiurevocatur motus totius, quia phara omnespropenfionem habent naturalē; non minus ad illü motum, quam ad proprios motus fingularü. Motus ergo diurnus eft motus naturalis, etiam fungulis.

E inferioribusfphrris, quatenus funtpartesilirus magnianimalis. Aftronomi vero, qui cœleftiū. corporünaturam nōpenetrant, fed fol aś quantitates, pingui Minerua rem hanc confiderantes, eum vocant motum raptus quafi primus. motor folam fupremam fphzram moueat, \& ab hac cateræ inferiores violenter rapiantur; id tamen minime verum eft, fed primus motor eft. totius globi motor, mouentur enim oés fph $x$ tx,\& to tus fimul coeleftisglobus à primo omniú motore, \& ad motumillum habent omnes naturalem propenfionem: idq; fignificauit Arift. in contextu 40. lib.12: Metaphyfic vbi motum: diurnum diftinguens à motibus planetarum, non eum vocat fuprema fphæræ motum, fed: vocat motum totius, co namque mouetur \& to. tum Colum, \& totıs fere inferior mundus; alios autem coeleftes motus vocat particulares, \& priores fingulorum planetarum, quià propriso fingulari fparaum motoribus effriun-

$K$ s. tur: 
tur: idemenim difcrimë in motoribuseft, quod $A$ benstamen fimilitudinemcum vtroque extrein motsbuseffe diximus, nam primus motor eft motor vniuerfalis, quia totū mundum mouet, proinde ille motus vocatur vniuerfalis, \& totius mundi motus; fingulæaüt fph rire citra primam proprios habēt motores, \& propriis fingula feruntur notibus, quos fimiles effediximus moti-

Colledio torizs Gerita is. bùs proprijs membrorum animalis. Errant igitur illi, qui dicunt eiufdem effe conditionis motum diurnum in fplraris errantibis, $3 \mathrm{c}$ motum iguisin orbem:nos enim dicimus, motum diurnun effe omnibus fphæris verè naturalem, motum verò ignis in orbem iam diximus non effe ita naturalem, vt proueniat $a b$,interno principio, fed effe fupra naturam ignis, eam tamen conferuare, vt antea dictum eft; ob id ille motus vocatur medius inter naturalem, \& contrarium naturæ, nö quidem medius per participationem, fed per negationem extremorum, ha- mo: quo fit, vt tum naturalis, tum violętus alia, \& alia ratione dici poffit, \& poffit effe perpetuus, quia neque extrem è neq; mediocriter contrarius eft natur $x$, nec modo vllo eã oppugnat, imò ad ipfiuscōferuationéneceffarius eft ; \& eft motus nō fimplex, fed miftus, folü enim colü motu inorbem fimplici moveri aptũ eft:de hoc igitur non loquitur Arift. quando in 1. \& in 2.lib. de Colo inquit, nullü præter naturä poffe effe perB petuum; quia non refpicitaliud præter naturam nifi illud, quod vel extremè, vel mediocriter fit contrarium naturali; de boc enim vera eft illa. propofitio: nullum, quod præter naturam fit, poteft effe perpetuum:fic ergo fublata effe videtur hac in re omnis difficultas. Alia de illo ignis motu dicenda effent, qua ad eum librum remittimus, in quo de calore à Colo in his inferioribus producto fermonem facturi fumus.

\section{$-1$

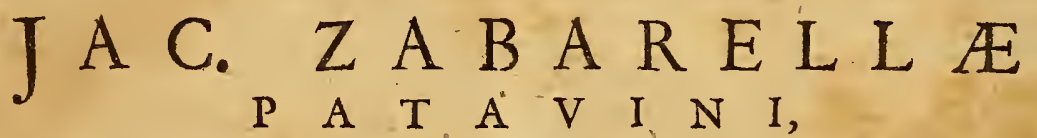

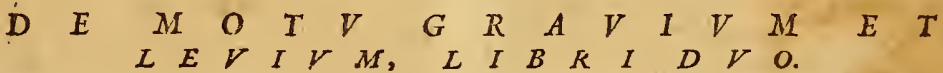 L I B E P R I M U S. \\ Declaratio, or partitio dicendo- rum. Cap. 1.

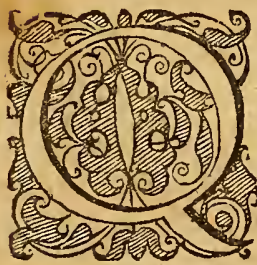 \\ Vumilla, qua ab Ariftot. de grauiū, ac leuium mo- tu variis inlocis dicuntur, difficultate non careant, \& interpretibus occafio- nem controuerfandi pra- buerint, ego hac de re a- liqua feribere, \& fenten- tram meam in medium proferreconftitui, vt A- riftot. dieta, de quibus adhuc magnx alterca- riones exiftunt, clariora, fi fieri poffit, reddan- tur. Vt aüt intelligatur, quid nobis in præfentia confiderandum proponatur, fciendun eft, gra- uuum, ac leuium appellatione non fola elemen- ta, fed mifta quoque omnia comprehendi; nec minusanimata, quam inanimata; grauia enim a ut leuia hæcomniafunt, \& eo motu cientur, quo elementaipfa moueri cernuntur, etenim a- nimal non modo progreffionis motu naturali ter mouetur quatenus animal eft, fed etiam de- fcendit naturaliter, fi exalto loco demittatur, quatenus eft graue, \& ex elementis conftans. A- riftor. igitur quando de grau ũ, ac leuium ıno- tu loquutus eit tum in 8 . lib. Phyfic. aufcult.tum in quarto de Colo, etfi elementa præcipue re- fpexit, tamen miftaquoq; complexus eft, qua- tenus grauia, acleuia funt, fatis enim habuit in \\ C initio r.lib. de $\mathrm{C} œ l o$ cos admonere, mifta, dum vt grauia, vel vt leuia mouentur, moueri iuxta illius elementi naturam, quod in fingulorum miftione proualet aliis: quare quum neceffe fit, in quolibet mifto aliquod el ementum cateris praualere, neceffarium etiam eft, eundem effe cuiuslibet mifti naturalem motum, qui eft ele- menti in fingulo dominantis. Quamobrem ea, qux de grauium, \& leuium motuab Ariftot.di- cuntur, grauibus omnibus ac leuibus cópetunt, $D$ fed primario elementis, miftis vero per elemen. ta, è quibus conftant. Cæt erum miftorum mo- tus propriam habet difficultatem, quomodo ex vnius elementi imperio proficifi dicatur, id. circo nos vt diftinctus, ac facilius progredia- mur, noftram hanc difputationem in duas par- tiemur: primum enim grauia, \& leuia abfolute confiderantes, fed el ementa pracipue refpicien- tes, declarabimus, à quonam motore mouean- tur, etenim totafere hxe difficultas in motore \\ E confiftit, fimulque aliqua huic confiderationi annexa dubia foluemus : fecundo loco mifta quatenus mifta, hoc eft, quatenus ex grauib.ac leuibus conftantia confiderabinus, \&declarare nitemur, à quonani moueantur, vt fententia A- riftot. intelligatur dicentis mifta moucri iuxta elementum cateris praualens in miftione fin- gulorum: his enim intellectis, clarū erit, à quo- nam motore grauia nmnia, \& leuia moueantur, tum fimplicia, tum mifta quatenus mifta funt.}


Due antiquorum fententia de motoregra- A uium \&o leuium, or earum confutatio. Cap. II.

Nprimis igitur confiderandum proponitur, à quo nam grauia, \& leuia moueantur motibus corum naturalıbus, nam de violentis in præfentia non loquimur: Hac de re plures antiquorum philofophorum fententix extiterunt, quas omnes commemorare operæpretium nō $\mathrm{eft}$; duas tantum, quarum confideratio ad ea, qux dicenda funt, conferet, breuiter expendemus. Aliqui dicere, elementa ad fua loca moueri à Coulo, quod notu fuo rapidiffimo illa pellit proculà fe; quo fit, vt quo grauiora funt, colongiuspellantur; terra omnium grauifima adremotiffimum centrilocum propellitur;aqua minus grauis ad locum proxime fuperiorem \& alia deinceps; itaque Coli motu perfeu erante, detinetur terra tota in centro, \& crtera omnia in locis fuis, itavtabeis recedere nequeant. Sententia C hxc, qux Empedoclisfuit, abfona eft rationi, vt Ariftotel.probat in calcelib. 2. de Coelo;fic enim motus elementorun ad fua loca effent violenti, quun tamen communi omnium confenfionecenfeantur naturales. Quiefcerent praterea violenter in locis fuis, fi ad ea yılenter mota effent, igiturnon poffent in eis manere perpetuo, quia nullum violentum poteft effe fempiternum, fed interire ea tandem oporteret, quia contrarix effent locorum vires nacurisipforum element orum, fi violenter in iis detinerentur. Praterea rationem quidem aliquam hi videntur adducere, cur grauia defcendant, fed nullam, cur leuiaafcendant : de toto enim elemento ignis cur minime omnium propellatur, poteft ex horum dictis ratio aliqua colligi, fed de ipfius partrculis, qux apud nos gignuntur, cur afcendant, nulla ratio apparet; ideo hæc fententia dimitt2tur. Alij vero dixerunt, el ementa à fuis locis moueri, quoniam locus vim habet attractricem, à qua trahıtur fingulum ad proprium locum.Hæc opinio daos poteft haberefenfus; vel enim dicunt, locum attrahere \& mouere tanquam fine $\vec{e}_{\text {; }}$ vel tañquam efficientem, nā finis quoq; dicituz mouere agens, ad agendum : fi igiturdicant $v t$ finem, concedi poteft, fed is eft motus improprie, ac metaphorice dietus, de quo in prafentia non loquimur, fedde efficiente eft nobis inftitutas difputatio:quod fi intelligant locum mouere vt caufam effectricem, falfa penitus eft eorum fen-tentia; oportet enım vel tunc moueri à loco elementum, quando iam in 1 llo eft, vel quando abeftabillo,quorum neutrum effe poteft; quando. enim elementum in fuo loco eft, non mouetur, fed quiefcit; quando autem eft extra locum, non poteft ab comoueri, quoniam ommis actio fir per contactum, \& omne mouens debet fimul effe cum moco,nunquam igitnr poteft elementam à loco fuo tanquam ab efficiente moueri. opinio dicentium elementa externum tuntum babere motorem, oc eius comprobatio. Cap. III.

N 1 vltihac in re eam fententiam fequuntur; N1quam proferre videtur Arifotel. in context. 32. oftaui Phyfic. 2 in 24. \& 25. quarti de Coślo, à qua ne latum quidem vnguem recedere volunt :ibı Ariftot. aperte dicit grauia \& leuia motibus fuis naturalibus non ab interno moto-

B re moueri, fed folum ab externo, eumque duplicem effe dicit; quum enim mouere fit rem ducere de poteftate adactum, \& duplex fit ele- Duples mentipoteftas, duplex etiam eft motor, à quo in elem mouetur;primum quidem dicitur graue habere to poten-. poteftatem ad naturaliter afcendendum, quia tia ad dum eft graue, noh afcendit, eamq; vocant po- motum. teftatem effentialem, quia non afcendere competit graur effentialiter, \& per $\int e, \&$ quatenus eft graue; fed fi mutetur graue in leue, vt fí ex rerra genereturignis, tunc ftatim afcendit açu, nifi ab aliquo impediatur; itaque moueri tunc dicitur à generante, à quo factum eft ex graui leue, dans enim formam, dat omnia confequentia formam : quoniam igitur à generante accepit leuitatem, quam prius non habebat, ab eodem accipit etiam motum 11 li form $x$ conuenientem; furfum ergo fertur, quoniam àgenerante factum. eft lèe, quod prius erat graue: al tera eft afcendendi poteftas in elemento iam leui, quando ab $D$ aliquo impeditur ne afcendat, vt quando ignis in infero aliquo loco inclufus non fertur furfum, fed poteftatem habetafcendendi, quan vocant poteftatem accidentalem, quia per fe competit elemento leui effe in fuo loco, vel ad. illum ferri, fi extraillum fit; quare fi extra fuum locum fit, nequead eum moueatur, id ei accidentale eft; $a b$ hac igiturpoteftate accidentali: adaftum duciturà remouente impedimentum, $\mathrm{vt} f \mathrm{vas}$ a ereplenum in fundoaqua detineatur E viabaliquo faxo fuperpofito, \&aliquis remoueat faxum; afcendit aer, \& ab illo moueri dicitur, à quo abducum eft impedimentum. Nullum igituralium motorem habent grauia \& leuia, nifi externum, nempe vel generans, vel remouens impedimentum: haxe omnia ab ipfomet Arift.in diatis locis proferuntur, qui etiam in octauo illo Phyfic. expreffe in hoc diftinguit grauia \& leuia ab animalibus, quod grauia \& leuia non à fe mouentur, fed femper ab externo. F motore,animalia veroà $f e, \&$ à motore interno, nempe ab anima : fed rationem quóque addit Ariftad hoc comprobandum : non poteftidem Primsss fecundum idem agere \& pati, quia idem fecun- ergmen dum idem effet fimul poteftate $\&$ actuergo non sum. poteft idem mouere fépiptum, nifi duas habeat: re diftinctaspartes, vnam mouentern, alteram. veromotam, quemadmodum in animali videmus diftingui aninam mouente à corpore motojin elemento autem bac diftinetio locum nos 
habet, non poteft enim diuidi nifi in primam materiam \& formam, \& vt concedatur forniam pothe mouere, materia tamen non eft apta per fe noueri, ficuti neq; mouere: vt enim omne mouens debet effe actu, ita etiam omne, quod mouetur, debet efie actu, vt in s. l'hyf. aufcultatio$n$ is A rif.docet: igitur materia neq; eft apta moucre, neque moueri per fe:quare elementum diSec ur dü uidinon poteftin partem per femouentem, \& urg.rmé- lartem perfemotam. Addit etiam aliam ratiotmis. nem Arift. talem: id, quod fe mouet, fiftit ctiam ie, \& mouet fe contraris motibus; ad elementum neq; fifere, neque contraris motibus moliere feiplum poteft;ergo non à fe no ouetur:itaque videtur de hac re nō efle dubitandum hanc Arift. fententıam fuifre, quũ eam \& aperte proTertium twlerit, \&pluribus etiam argumentis comproargame- bauerit. Magnietiam mnmentifunt verba Arift. sism. in calce pradicti contextus 32. octaui Phyfic. vbi foluere videturtacitam quantam obiectionem: nam dicere aliquịs poterat, fi elementa ab externo motore mouentur, cur ergo motum illum vocas naturalem? eft enim potius vocandus violentus, fiquidem motus naturalisille eft, qui fit interno principio: refpondet ibi Arift. grauia \& leuia habere in fe principium motus paifiuum, non'actiuum; aptitudinem enim internam, \& propenfionem habent, vt moueantur ftatutis quibufdam motibusad propria loca , \& hac tatione motus ipfortm dicuntur naturales; mouentur tamen non à $f e$, fed ab externo motore; quamobrem fatis eft principium motuspafiuum, vt motus grauium, \& leuium dici poffint naturales. Huic igitur fententix complures adamuffim ita adhrient, vt omnino inficientur, grauia \& leuia internum habere motorem.

\section{opinio dicentium clementa moueri à pro- pritiformis, of eius comprobatio. Cup. IV.}

$F^{X}$ altera parte alij putant elementa à fuis Eformis moueri, \& ita motorem habere internum : ad quam fententiam tuendam multa, Primum eaque fatis valida ex Arift. argumenta fumunargumé- tur. Primum quidem ex initio z. Phyfic.tale artwm. gumentum fumitur: forma elementi elt nat ura, ergo eft principium motus:aflumptū patet, quia omn is forma naturalis, \& materiam informans debet appellari natura, \& alicuius motus principium, ergo eft principium motus actiuum ; nam proprium formaeft agere, materiæ vero pati: nequite eft quodaliquis dicat, forman elenienti effeprucipium motus pa!fium tantummodo; quia proprium folius materix ent pati, forma vero nond icitur per le pati,fed folun ratione matcri $x$, in qua eft;inquit cnim Arift. in contex. 55 . librir. de Gen ratione.fi quis effet à materia abiunctus calor, isnihil pateretur's ergo ii forma
A elemétieft principium motus pafiuum, id non eft per fe, fed ratione materix, neceffe eft igitur concedere etiam propriam eius operationem, qux eft agere, vt nomen ipfum fignificat; forma enim dicirur actus ab agendo; ablurdum auten effet negare form propriam operationem, \& eam tătum illı tribuere, qux ei competit rationematerix. Confirmaturteftimonio Ariftot.2. Phyfic. context. 4 . vbi natur $x$ definitionem declarans per difcrimen naturalium, \& artefa-

B etorum, inquit, astefacta non habere in feipfis perfe factionıs principium: quum igitur hoc dicat ad differentiam naturalium, vult naturalia habere in feipfis per fe principium motus effeEiuum: elementum autem eft corpus naturale, ergo debet in fe habere principium motus actiuum, idque non poteft effealiud, quam fua forma. Idem oftenditur argumento efficaciffimo, quod eft Scori, \& Gregorij Ariminenfis: effectus atu exiftens debet habere caufam actu exiften-

C tem, vtait Ariftot.in centext 38. fecundi Phyfic. quod quidem potiffime verũ effe debet deillo effectu, cuius effe confiftat in fieri, cuiufmodi eft motus; quum igitur motưs grauis defcendentis fit effectus actu exiftens, caufam deber habere aliquam coexiftentem actu; hæc autem nulla prater formam effe poteft, vt oftenditur à fuffi. ciente enumeratione: vel enim eft generans, vel remouens impedimentum, vel Colum, vellocus naturalis, vel aliquid internum; alıud enim D ne fingi quidem poteft, à quo tanquam efficiente ille motus fiat : at generans effe non poteft, quia hoc non agit amplius, imo neque agere poteft; quum non amplius tangat, \& poteft interiiffe, quando graue defcen dit; quare vel nullo modo coexiftt illi motui, vel non coexiftit vt caufa: idem dicendum eft de remouente impedimentum, huius enim actio in fola impedimenti remotione confiftit; remoto igitur impedimento non agit amplius in graue defcendens,

E ficut etiam de gencrante dicebamus : non eft etia m Colum, qua fuit Empedoclis opinio ab Ariftotel. reprobata, vt prædiximus : neque locus naturalis, quiaiam dictum eft, locum mouere quidem vt caufam finalem, atnon vt efficientem, qualem in præfentia quximus : nulla igiturillıs motus caufa relinquiturilli coexiftês, nifilliufmet corporis forma. Ad hocauten argumentum corroborandum maxime conferunt illa, qua ab Ariftot.in 2. Pofter. Analyr. de caufa F. \& effectu traduntur; inquitenim effectus prateriti caufam effe præteritam, prafentis præfentem, futuri futuram, actu exiftentis actu exiftentem, poteftate exiftentis poteftate exiftentem:quare dum effectus exiftit, necefie eft, caufam quoque fimul codem modo exiftere. Sumi. tur præterea argumentum validum ab experi- argumes entia : nam fi iam exiftuns graue no fit in fuo lo- $t \mathrm{~km}$. co, nequeadillum motiearur, poftea vero moueatur, \& quæramus, à quonā motore mouea. 
tur, vi:łentur illi cum Ariftotel. refponfuri, à remoucte impediucntum: at vero per hocipfum oftenditur noucri a feipfo; nam fi ftet aliquandin graucinace alligatum filo, \& fupenfum, poit ten verofua ponderofitate filum frangat, \& deorfum firatur, certum est filä finfe inpedinentum, idque a nulla alio fublatum finile, nifi ab iplomet graui deoflum premente per fuam grautuatem, non po.ctt antem graue remoucre impedmentum, nifi ipfum moueatur prius feu tempore, leuialtem natura, quianullum moués corporeum potist mouere aliüd, nifi ip fum noucattr, gran: igitu prius monet feipfun, deindecum motmn nfequiturfactio fili, qua-re à propria virtule mouetur: idqilim liter de omubus grauibus, \& leubus dicendum eft, cadem cnim elt om aium mar ura, conditio. $\mathrm{H} x \mathrm{c}$ argumcnacerie efficacifima funt; ideo multi Lanciontentiam receperunt, camque acerime tutatifunt,grania \& lcuia à fuis formis moueri, veScotus 2: Sentent. diftinct 2. quxit. 10.\& Gre$A$ - gorius Armincnfis 2. Sentent.diltmet. 6.quxit. en - 1. artic. 3. vbi de hacre fufffime difpurat, \& omues aliorum fententias diligenter expendir; \&e loames Gandauenfis, \& Zimara, \& alii recentiöres complures. Res igitur difficultate nó caret, qüum ex altera parie habeamus teftimonum Ariftotelis clarum, quod grauia \& leuia non moueanturà fe, neq; habeant motorem internum, fed externum, exalcera vero extent argumenia validilfma ex 1 ffits i $_{1}$ ftot.principi is $D$ deiumpta, quxdemonitrare videntur grauia \&e leuia à fuis formis moueri:quanobrem mö abf-. que ratione vtraque contraria opinio viros gra-uilimos fectatores habuit.

\section{Ouid de bac dixerit Auerroes: Cap. $V$ :}

A Verroes quoque vidètur hac in re dubiAus fuifie, quum non idem vbique dicere, $\mathrm{E}$ vidcatur, ita vtuon ab fque ratione Scotus in lo. co pradicto afferere potuerit, nilil certi ex $A$. uerrois verbis defumi poffe; nec defuerunt alii, qui aliqua ex parte Auerroem fequuti; aliqua: etiam ex partecius fententiam reiecerunt. Nos igitur breuiter ea referemus, quæ.ab Aueroe variisin locis dicantur, \& repugnantias, qua A.uerroi attribuuntuir $a b$ aliis, vt appareat; re hane: fumma plenam effe diffcultate. Auerroes in 8. Phyfic. in ea parte, in qua Arititoteles de grauiū, F. \& leuium motu fermonem facit, nilalihd dicere: videtur, quamillid idem,quodibiabariftote-:le dicitur, elèn chtum mouetiper fe à generante, a fe autem non noueri; \& in Commentario ₹०. ratıonem affesens, cur nonà fe,myoueatur, in quit, non moletur à fe; quia nondiuiditur, in motorem, a 11sotum; materia enin quum fit ens merapoteftare, neque mouetur per $f e$, negue motlet. At in primo Commentario 2. Phy-
A ficoì. clare dicit Auerroes clementum moueri fe. quoniam habet principium motiuum in feipfo; \& in Comment. 7r.quarti Ppyficorum in : quit, mouens in elemento eft forna, motum autem eft materia, \& ita elementum diuiditur in motorem \& motum: idem legimusaccuratius ab A uerroe explicatum in libro 3. de Coelo, Comment. 28. qui præcipuus locus eft, in quo hac de re differuit, \& fententiam fuam profert Auerroes; inquit enim motorem in elemento B elfeformam; motum vero. effe.non materia nudam, fed materiam fornatam; ideft; totum ipfum compofitum, fic enim elementum vere dicitur in feipfo habere principium motus \& aciuum; \& pashuum; nam v troque munere fungitur forma vt duobus modis accepta, mouct cnim vt forma; moueturautem vteft in materia, \& vt materiam perficit; non eftenim inconueniens, quodidem dicatux \& agendi ratio, \& patiend, vtalio, \&alio modo acceptum. Sed difC ficultatem auget aliud quiddam, quodibidem ab Auerroe dicitur, atque etiam in Commentarìo 71. quartillhyficorum; nam explicare volens modum, quo elementum à fe nouetur, inquit, moueri à feipfo peraccidens, non pet $\mathrm{fe}$. idqueira déclarat: graue defcendens mouet primo aerem medium vt caufa, deindé ad motum aeris cedétis mouetur etiam graue, quare à primoad vltimum mouetur elementum à feper accidens; comprimit enim aerem, \& per fe illum mouer, deinde ad motum aeris iplum quoque mouetur : vtitur auten ad hoc declarandum exemplo narure, qui dum nauim perfe nouer; fipftum quoque mouet per accidens; mouet enim primo nauin, non fe, fed motum nauis confequitur vt ipfo quoque noucatur. .

\section{Senfis opinionis Auerro is fecundium ali-: quos, ó, eius reprobatio.

$$
\text { Cap: V V T }
$$

12 Oftremum lioc Alierroiș dictum magnas: pofteriorum altercationes excitauit : quorun aliqui eam fententiam féquëtes quod graue \& leue à folo generante molieantur,à forma: veronequaquam, dixerunt Auerroem optime: fenfife, ideoque fententiam fuam A uerrois au. ctoritate confirmarunt: loquens enimA uerroes : de gratiitim; \& lểum motoreper fe ;à nulloa. lio ea moueri dixic;nifi à generante; quod Ari- . ftot: quoque pronunciaut ; à fe autem moueri : conceffic, non quidem per fe, fed per accidens; quæ Ariftotelis quoque fententia fuit, qui ait: graue, \&léue moueri per accidens à remouen- te impedinentumingemouens autem effepoteft: non modó aliquid externum, fed etian.ip fum- met graue, \& $\}$ èue, quemadmodū fupra dé graui : filim rumpente dictü eft graue namqiper vim : à generante fufceptan rumpit filì, quo fụfpé. fum erat, \& à quo impediabatur. ne defcende- 
ret, \& ftatin rupto filo deorfum fertur; ficetiam aer fubftans inpedit aliquantŭi \& aliquam refiftentiam facit defcenfui grauis, debilem tamen, quam graue lacile fuperat, \& remouet aerem impedientem, \& ita per remotionem impedimenti moueturà feipfo peraccidēs, tanquam à remouente impedinsentii, perfe autem à nu1lo, nif ì generante, vt etiam Atift. dixit: itaq; hi concluduntoptimam efic Auerrois opınione m, sefie eam ipfam, quam ipfimet tuentur, Sed opiasis- hacfententia, etfi magnam habet veritat is fpe- $B$ mis repro- ciem, falfa tamen eft, nec Auerroes, fi ita lenfit, batso. defendivllo modo poteit; impugnatur autem fenfus hic à Gregorio Ariminenle, \& ab aliis, qnocirca fatis nobis crit; pauca tantun, qux präipua funt, aduerfus hanc fent ëtiam in meFrinum dium adducere-Primum fic argumentor: graue aigrume - moutet aerem per fe, ergo eft caufa motus aeris, turs. igitur ipfum quoque graue mouetut, nam inotiens cerporeum non poteft mouere, nifi ipfun quoque moueatur: quoniam igitur motus grauis eft caufa motus a eris, necelle eft vt priorillo fit, fi non tempore, faltem naturâ, ergo in illo priori naturâ mouctur graue fine vllo aeris motu; ron ergo ad motum aeris mouetur graue, fed potius aerad motum graus; graue igitur à fe noueturimmediate; quare etiam per le, quia nö per medium aelis motum, idque ita clarum effe videtur, vt nullam defenfionem recipiat; prius enim debet moueri graue, qquam aer, quia non alia ratione monct aerem, nifi quatenus

Secundü argumetum. premit, \& ad centrum tendit. Confirmatur hoc: quia motus grauis defeendentis eft motus naturalis, motus autem aeris à graui eft violentus, quum fiat ab externo principio; at motus violentus non poteft effe prior motu naturali, fed Tertism eft potius pofterior, \& ipfum infequitur. Pra. argumé- terca onne per accidens debet reduci ad aliturs. quod per fe, ergo fi moneturgraue à fe per accidens, debet ab alıquo moueri per fe, à quo 1 gitur, nifi à feipfo? dicere enim non poffunt ab aere moto, qui illud fecum ferat, hoc enin falrum.effe inm oftendimus, quum motusacris infequatur potius motum grauis, quamefíciat.

Refponfio Zimara veroad hoc refpondit: graue monere Zsmara. nerem, \& iplum prius molieriper fe, non tamen àfe, fed à gencrante : attamen ad generans confingere non eft fais tutum, quia hoc non coexiImpugna ftit defcenfui grauis: quare aliam cius, motus tio. caufam excogitate oportet, ficut antea dicebamus, quoniam omnia iam adducta argumenta $F$ hanc Zimarx refponfiónem relellunt. Id vero, quod diximus, morum aeris efie polteriorem ip fo grauis motu, chrum eft cullibet confidetanti, neque id deber aliquis inficiari, aer enim non nouet graue defcendens, nequeiplum lecumfert defcedendo, fed potius cedit graui defendenti; quum enim refifter illius de centui non peffic, ab eo monetur, sx pellicur. Exemplum cuoq, naturæ \& H.. uis, quo Aucroes vti-
A tur, refragatur huic opinioni, \& id, quod modo diximus, confirmat: natura enim mouetur qui= dem motu naugation is cū naui, qquam mouct, fed tamąn nó poteft eam mouere, nifi prius moueat feipfum alio motu, \& eo quidéper fé ; nou enim moueret nauim, nifi prius fua meebra moueret, \& per ea mota moueret nauin, neceffaritum enim eft, vt mouens corporeum moucat alind perfui ipfus motum : fic ergo etram graue non poteft aerem mouere, nifi iplīi motu priore moueatur, fiquidem per fium motum mouet aerem; moueri auten dicendum eft à fe, fir recta eft Auerrois comparatio, quia etiam natura primo mouetur a $f \mathrm{e}$; deinde nauim mouet. Ex his igiturpatet, fenfum hunc, quem illi atribuunt Auerroi, defendi nullo modo polfe.

\section{Opinio Scoti, \& aliorum plurium. Cap. VII.}

C Isargumentis moti alii complures, quum 1 eundem fenfum verbis Auerrois atiribuerint, ab eius fententia receficrunt, vt Scotus, \& Gregorms Ariminenfis, \& aliciui pofteriores, qui dicunt elementum mouers à feiplo, non per accidens, vit licere videtur A tierroes. led per le: ac quia hoc dicences oltendere debucutur quomodoclumenium diuda.tu in prom mouentem, \& partennotam, in has declisando non

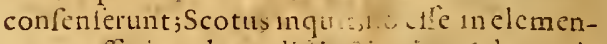

$D$ to neeffarian hanc ditinctionem, \&hac vtitur ratione: duplex eft agens; vnum vnïrocum, quod etiam formale appellatur, quia per formā, quā habet,agiit;alterum vero $x$ quiuocii, quod etiam virtualeappellatur, quia non performam agit, fedper virtutem, vt Colum calefacit tanquam agens virtuale, etenim non per calorem, fiquiden caloren nó habet, red per vim produ. cendicalorem, qua præditumeft : agens igitur formale nóporeft agere in feipfum, quin quum iam habeat formam non poteft cam amplius recipere; çuamobrem neceffe eft $v t$ fit re diftunAtunı à patiente:at agens virtuale poteft abfque vlla repugnantia agere in feiprum, quum enim non habeat formam, quam ef aptum producere, recipere eam poteft: prius enim habeat actü virtualem, fed potentiä tormalem, quare poteft à feipfo recipere actum formalem, quem non habebat. Quioniam igitur forma elementi eitagens aquiuocum reipectu motus localis, \& elementum habet potentiam formalem, quia eft aptum recipere motum 1llum, potert abry: vlla ablurdıtate à virtute fua productiua recipere motú formaliter. Videturautem hac Scoti dithinctio etia ab Auerroe poni alis verbis, quando in Commenti28. Iib. 3. ae Calo nquit, lipis mouet fe quatenus eft aftu grauis, \& mouciur qquatcnus eit pócentate interius; nam dicere actu graue, eft dieere habens actum virtualem, hoc eft, virtutem producendi notum defcenfio- 
ris; dicere autem poteftate in infero loco, eft di- A cére potentam formalem, nam locus proprius. inftar forme eft, quangraue per futuin motum sfaturalcon adipifcitur. Eft igitur Scoti fententia , clementum à feipfo moueri, hoc eft, à fua forma, idyue non peraccidens, fed per lénec requiri diftintionem realem motoris \& moti. propterea quod elt agens. xquiuocum, quod absque vlli abfurditate poteftagere in feipfum.

\section{Recentionm argumentatio cötra Scotum;} cócoram opinio. Cap. VIII.

A Duerfus hanc Scoti fententiam quidan: poftenorcs intehutur hoc potifimum argumento, quodea admifla ruit progreflus Arift. in s. Pliyfic.ad inueniendum primum motorem immoblen; is enim nititur necefrario eofundämento, quicquid mouetur, ab alio monetur" lioc autem de medio tollitur dicendo, poffe idé molucri à feipfo absque reali diftinctione mouentis \& mont;nam adueriarius diceret deueniri quiăem in mouentibus 2 motis randem ad primum, led id fimplex effe, \& à feiplo moueri, quia elt agens xquiuocum; habelis actum virtualem, \& porenriam formalem:tota igitur 1lla. Arift, argumentationos ad folum Coelum duceret, quod non fecus ac elementum, diceretur. à feipfo moueriabsq; diftunctione mouentis \& mon:ficitaq; de inueniendo via naturali aterno motore immobili effet penitus defperandum, $f$ wullam habemus aliam viam, nifi ex xterno motu,v talibi demonftraumus. Ipfi igitur aliter dicunt, effe in elemento realem diftirctionem. moucntis \& moti, licet fubrecto nō feiungantur; ctenım forma eft mouens, materia vero eftid; quod mouetur;forma nam q; eft actionis principium, materia vero omnis paffionis:lic ergo fub latam effe arbitrantur omnem difficultatem, quum ita pareat graue \&.leue à fe molteri per: $f e$, non per accidens, vt exiftimauit Auerroes:-

\section{Impugnatio fententia recentiorum. Cap. IX.}

E GO vero de Scoti quidem fententia pofterius dicam, ea namque fortaffe proxime omnium ad veriratem acceffit. Quod vero ad hos recentioresattinet, puto cos penitusaberraflein. Hac Scoti impugnatione, quoniam eorum opinio vel falfa eft, vel in idem cadit cum fententia Scoti, quam reprobarunt; nam eft quidem materia radix omnis paffionis, ipfatamen per fe non fufficit, ve fitidonetrm fubiectum motus; quia id, quod mouetur, debet effe actu, vt in 5 :Phyraufcultationis Arifotel.docet. Vt veroetian concedamus, materiam habere poteftatem recipiendi motum, ex hac tarnen non nagis a." feenfum recipiet, quan defcenfum : quare quod graue habeat determinaiam propenfionem ad defcendendum, hocent materia prouenirenon

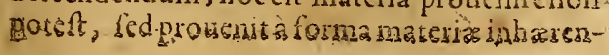

te; nam eft quiden materix pati , fed determinatc pati locpotius, quam illud, à forma elt. non à matcria:cogintur itaque dicere, non matcrin folam, fed totum compofitum primo mot!m illum recipere, \& forman effe rationem recipiends : atqui eadem forma eft ctiam mouens, ergo mo:ıens \& motumre nō diftunguuntur:qux Seotifententia fut, atq i etiam Auerrois dicentis, forma elementi mouet vt forma, \& moueturve eft in materia; grauc namque deor-

B fụn fertur, quiaelt graue, non quia matcriam habeat; ergo vt tali motu, non alio, moueatur, non à materia luabet, fed à grauitate, qux eft etram mouens; nec ablurdum videtur, quod eadem forma fit fimul ratio agendi, \& ratio patiendi,principium morus \& actiuum, \& pafiuü. varis modis confiderata, ficut alibi declarauimus. It aque fi hi recentiores intelligant, materiam effe motan, hoceft, materiani vt formatam, quodeft dicere totum compofitum,eorum: C fententia non differt à fententia Scoti \& Auerrois, fed eis difficul tas integra manet, quomoda ideffe poffit fine reali difcrumine mouentis \&. moti : quod fintelligant, materiam effe perfe. motam, falla omnino eft corum fententia, tum: quia nec abfolute materia eft per fe mobilis, nee: ad hunc ftarucum motum habet determinatan: propenfionem:adde quod Ariftot.aperte ne $e^{2 \mathrm{c}} \mathrm{at}$, elcmentum dinid 1 in partem mouentem, \& parten motam; cui fenrentia ift manifefteadue D santur,dum hæc dicunt.

\section{Nonnull orum opinio de motu clementi.iz" vacuo; deius confutatio, cap. $X$ :}

$Q^{5}$ Vum autem Auerroes in memorato Com: ment. 71.quarti Phyto præeterid, quod modo confiderauimus, dicat ctiam nullam in vacuo,fi vacuum daretur, fieri poffeelementi motun , iidem pofteriores in hoc quoque Auerrocmseprehenderunt, imo etiam exproferro $\mathrm{A}$ Inftotel hocidem dicentem; hoc igiturin prafentiabreuiter confiderare, preterquam quod. iptum per fe non parum eft vitile, \& intellectu dignum, non eft eriam; vt fortaffe viderur, à propolito aliemum, fed ad fequentia conferet, \& illi: quoque in hacipfa de motu gravium \& leuium difputatione fermonem de hoc facere voluerunt. Auerroes igitur ibi ex Ariftotel. fumit, ne-"Atiftot. cellarium efie lenum ad motum elementi,pro- है Auer pterea quod continuitas in motu à refiftentia rois opiprouenit, at in elemento nulía mobilisad ino- jzo de torem internarefiftentia eft;ideo externa requi- motu ele ritur, fi debeat fiericontanus morus; mediun monti in: enim plenum refítit alrquantum elemento mo Gabro. , to, \& ita facir continutarem; quamobrem fi daretur vacuum, elemenum in eopofitum non movereter, fed momento temporis ad locum faum wanfet, qui non efet motus, fed mu- 
tatio fubita:qua in re Atterroes A uempacem reprehenditdicentem, $2 \mathrm{~d}$ morum elementinon effe neceffarium medium plenum, quandoquidemetiam in vacuo, fi daretur, fieri elementi motus poffet, isque continuus.ob internam reRecentio fiftentian. Aduerus Arift. \& Auerroem hrerescon- centiores infurgunt, \& aperteprofitentur, Arift. trasrt- nō cognouifle qux fit refiftentia in motibus elefot. mentorü,imo \& multa falfa dixifle in 7 . Phy fic. pe proportionibus in motu: adnerfus qux 1 p f plura adducunt experimenta, quibus fe cognouiffe teftantur fallas effe illas proportiones, \& hanc falfitatem proceffife ex hoc falio fundamento, quod forma clementi mouens iptum non habetà mobili aliquam internanı 1 fiften. tiam, fedfolum externam à mediopleno. Ipfi igitur fequentes opinionem Anempaces ibiab Aueroe reprobatam, quam etiam fequutus eft Scotus. Refiftentiaduplex.

Scotus 2.Sentent. diftinct. z. quxê.y. dicunt, duplicem efferefiftentiam in motu elementinaturali : vnam externam; \& accidentalem, qux.fit à medio pleno, \& facit vt tardior fit motus in pleno, quam eflet in vacuo: alten m verointernam, \& effentialem, qua elementum motum refiftut form $x$ mouenti, ita, vt etiam in vacuo, fi daretur, fieret continuus motus : rationem autem armobilerefiftat fux formæ mouenti, dicunt effe quod mobile eft continum, \& fpatium quoque continuum; repugnat autem continuo tranfeunti per continatum effe eodem momento in omnibus fimul partibus illius continui, fed neceffe eft vt tranfeat prius per vnam partem, quam per aliam : hac igitur eft neceffaria refftcntiainterna, ex qua fieret vt elenentum in

Impugna vacuopofitum continue mouerctur. Ego vero

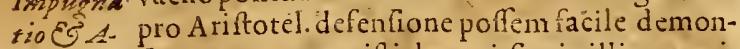
rifzot.de- frrare, quantum ifti decepti fint in illis experifenglo.

Omisis refifentrafit ab atiu. iffi imaginantur de illo interna, \& effentialirefi- mentis, qua aduerfus Arift. adduxerunt, renera proportionibus in motu; fed quoniam alienum hoc efet à noftro inftituto, onirtendum in præfentia ef, licet ipfi dur de motore graui um\& leurum difputationi id inferere voluerint ; fed fi quando datum nobis fuerit in libios Phyficos edere commentarios; diligéter hac de re loquemur : nline de eo, quod ad rem magis pertinet. pauca dicere fatis erit. Dico falfum elle id, quod ftentia mobilis, nulla enim in elenento effepoteft; quod autem de elen: ento dicimus; id de omni inturali corpore, quod vt graue, vel vt leue moucatur, intelligendum eft: ratio autem eft, quoniam omnis refiftentra fitab actu, potentia enim non reffetit, quum fit aptitudo indiftirate refpicicns oppofita ; fed aetus eft qui refiftitaction alterius contrarij actus, fiquidem non fit actio, nifiab actu : non poteft igitur efie interna refiftentia, nifi vbieft duorum actuum compofitio, vt in animali, quod etiam in vacuopofitum (vtibidem ait Aucroes) continuo motu
A moueretur, obinternam refiftentiam corporis grauis ad animam mouentem: fic etiam videmus prouiam generationi alterationem effe motum continuum, ob refiftentiam qualitatis contrarix ad contrariam; at in illuminatione nulla eft fucceffio, quia nulla refiftentia, quia lumen non haber contrarium; quare illuminatio êtıam magni fpatij fit tota fimul fubito, non in tempore aliquo. Quoniam iguru in elemento vnicus eft actus, nulla in eo effe poteft interB na refiftentia; niri dicamiss eandem elementi formam fibimetrefiftere;nam dicere non poifumus, elementū refiftere fux formx, nifi per f̂u actum, hic auté eft íorma ipfa $;$ fic igitur diceremus; formā fibiipfi refiftue, quod ne imaginari quidem pofiumus. nulla igitur eft reffifentia elementi motiadformam mouentem, fed potius fumma confenfio, quum eadem fit ratio agendi, krecipiend, fi çnim ad illum ipfum recipiend:m moum it elementum propenfum, C quem apta eft efficere forma, non poteft elemenum moum refifere fux forma monenti; igitur opinio Arritocel. vin eft, 2 racioni confentaneanon tamen neg mus in mo: elementi internam refifentiam per accidens; de qua folterius loquimur, fed bltm negamus reliftentram fer ie, qualcm ifti ponum, ain li poftto elemento in vacuo inefet refiftentsa interni, e.1 non polfer effe nifi perfe; at iefitencia per accidens non foteft habere locum, niff in mcdio pleno, vi mox confiderabimus. Pectant tiam iftrinafferenda ratione huius refrftentia; tum quia datovacuo illud non potefteffe quantum, nechabere partes, quum absque fubiecta fub. ftantia quantitas nonpoffit exiftere; tum quia hoc etiam conceffo adducunt non caufam pro caufa, nil enim aliud dicunt, nifi impofisbilitatem confequentis, quam nos quoque confitemur,fed hxc fimul effe poteft cum veritate confequentir; dicimus enim, cfle impoffibile ita E transferri mobileper omnes partes fpatij quanti, te codem monento fit fimul in ominibus; hoe tamen neceffario deduci ex vacui pofitione, proinde validam effe hanc confequentiam, fi elemétuṇ effetin vacuo, ad locum futum tranfiret fubito, \& absque vlla fucceffione; quia quandoagens à nulloprohibetur, \& nibil cr refeftit, necelfe eft fubitam fierimutationem, vitin illuminatione videmus. Poffumus autem hoc confirmare ex argumentatione Aritotel. in context.79.oftaui Phyfic.vbific argumentatur: $f$ in magnitudne finita ineflet vis motrix infinita, moueret fubito non in tempore, propterea quod finiti ad infinitum nulla eft proportio, proindenulla refiftentia moti ad motorem:at $\bar{i}$ dicerelicet, nou fequitur, quia quantum non poteft tranfire lubito perifpation quantum, quun non polfit fimul eodem momento elle in omnibus eius partibus, argunentalio il ia Ariftot.leddcretur incfficax;ett tamen efficax, quia 
confequens, licet fit impoffibile, deducitur ta- A ftimo; Arift. enimiduastantumillas ibiconfidemen ex illo antecedente, \& valida eft confequé. tia. Quodfi eximpoffibilitate confequentis liceret inferre confequentix praurtaten, tolleretur penitusargumentatio per ductionem ad incommodum, per eam enim infertur confequés imporfibile vt impoffibile, efficaxtamen effe poteft.confeque etiajfed hoc magis eft manifeftum, quam vt pluribus verbis indigeat. Patet igitur, hos in refutanda opinione Scoti, \& iis, quzab Arift. $\&$ ab Auerroe dicuntur 4 . Phyfic. 7 I. multifariam errafre. De ipfa vero Scori fententıa pofterius dicemus, quum noftram hac de refencentiam proferemus.

\section{Diftintio potentia ó agentis. Cap. XI.}

rauit, quoniam hx fol $x$ ad eius fcopum conferebant, fed tertiam, quam ego nunc adiiciam, non negaret, quum fit per fe manifeftiflima; quoniam enim de illa poteftate loyumur, qu $x$ dirigiturad actum, actus, quem vtraque illa potencia refpicit, nullus alius eft, nifi motus ipfe, ibi namque Arift . confiderat potentiam ad motum in elemento quiefcente; ideo quando iam mouctur, tunc ductam effe dicit vtramque poB tentiāadactum, quem refpiciebat;fic enim graue aut leue tranfiuit denon moueriad moueri, \& terminusad quem illius tranfitus eft motus ipfe: at quando elementum aku mouetur, negari non poteft ipfum effeadhuc in potetia, non tamen amplius ad motum, fed ad locum fuum, fiue ad fuum vbi, quo adhuc nón potitur actu; patet enim hoc ex definitione motus, in qua di., citur motū effeactum imperfęum eius, quod poteftate eft, quatenus eft poteftrate:intelligiteC nim poteftatem nonad motum, fed ad termiuum \& finem ipfius motus: quum igitur in aliis duabus poteftatibus, \& earum duetione ad actum,terminus ad quem, non fitalius, quä motusipfe,ac quem ex quiete tranfit elementum; in hac tertia poteftate, feu ei.ss ductionead actum, terminus ad quem, non eft amplius motus, fed locus, vel qualitas, vel aliud quippram, ad quod tendat morus: hrcigitur fit prior diftinctio. Al. rera vero eft, quam Scotus ponit in fua quxf. Agens 56. Pofter. Analyt. qua tamen in hac difputatio-duplex. ne non eft vfus, quum maxime ea vtidebuiffet: efficiens duplex eft; vnum, quod cum tranfmutatione efficit, \& quartum caufr genus conftituit, quod ab Ariftotel. vocari foler principium vnde motus, quia femper cum motu efficit; huic proprie dita efficienti competit definitio potentixactiua ab Arift. tradira in 9. Metaphyfic. potentia acti ua eft potentia tranfmutandi aliud prout eft aliud, tale namque efficiens requirit E neceffario patiens diuerfum, quianihil poteft mutare feipfun, \& ducere de poteftate ad aAtum : hoc efficiens habet à patientealiquam refiftentiam, à qua fucceffio in motu prouenit, quocirca iure vocatur ab Arift. caufa vnde motus :alterum eft efficiens, quod non per tranfmutationem efficit, fed per folam emanatio. nem effectus ab eo, quafi ip fo non operante effeatus fponte fua illud infequi videaturjtale effciens elt in corporib. naturalibus forma refpe-

F ctuaccidentium, \& proprietatü confequentium in eadem re: iccirco dicere Logici folent, rationalitatem effe caufam effectricem rifibilitatis in homine, non quidem tranfmutantem, quia non agit rationalitas in hominem faciendo exnon rifibili rifibilem; fed fine vllo motu, fine vlla tranfmutatione, quum primum eft rationale, ftatim confequitur vt fit rifibile, ita vtrifibilitas à rationalitate $a b$ fque vlla mutatione emanare videatur; ob id hoc improprie dicitur efficiens, I redu- 
redu: tur tamen ad caufa!n efferticem conuenientils, quam ad aliud caufa gents.

Decluratio quinque propofitionum, quibus tota rei veritas concliditur.

\section{Cap. XI1.}

TIs fundanentis iactis, totam huiufce rei Iveritatem in quinque propofitionibus puto cffe conftititam, quarum prima hac eft. Si loquarourde prima elementi potentia, qua eft Primacó ad motum, \& effentialis appellarifolet, ab hac singio.

sectsinde. sorciarso elementum ad actum dúcitur à folo generante; \&hociden intelligi volumus déomni cörpóre, quod ut graue, vel ut leue moueatur, ficutetiam ante ad monuimus : hxc apud A riftotel.clara eft in 8. Phyfic. \& in 4 . de Colo iam memoratis, \& per le etiam fatis manifefta eftinam efteffentiaJe graui non afcendere, nec poteft hunc motum. recipere, nifi à generante quod mutet ipfum in leue, fic euim dans ipfi leuitatem, dat etiam confequentem afcendendi facultatem : patet autem non poffe graue in hac poteftate exiftens ducere fead actum, \& dare fibi motum afcenfionis, fed indigere generante. Omnia igitur, qua ab Ariftotel.in prædietis locis dicuntur, nil aliud probant, quam hancprimam propofitionem, atque etiam fecundam, quam mox fubiungemus, has enim nemo eft qui inficiari poffit, quum manifeftum fit, non poffe graue aut leue ducere fe de non moueri ad moueri, fed mouente externo indigere. Secunda igitur propofitio eft: fi loquamur de fecunda porentia ad motum, qua accidentalis vocatur, vt porentia afcendendi in elemento leui, quando impeditum nonaficendit, ab hac ada atum duciturà remouente impedimentum : hans fimiliter ponit Ariftotel.in memoratis locis, neque vllus ett qui cam negetinam graue iam exiftens extra locum fuum, liad eum non moueatur, neceffe eft, vt alituo detineaturimpedimento, quod remouere iplimmet non poteft, ideo eget agente externo, quod remouendo impedimentum ducat $\mathrm{i}$ plum de quiete ad motum. Tertia propofitio eft: fi confideremus tertiam potentiam in graui aut leui exiftente extra fuum locum, nec impedito, qux eft potentia ad locum, quens non ob: rinet, de hac ad actum ducitur, \& ad furm locum mouetur per fe à fua forma tanquaria $b a$ : gente per folam emanationem. Harc fatis demonfratur argumentis ante adductis, ad quz nullam ego refponfionem video; fed comprobaripraterea poteft alioargumento fumpto ex iis, qua ab Ariftotel.in contextu 8 2.oftaui Phy"fic. dicuntur de motu proieforum; non purat enim canfam illius motus effe manum proiici'entern fed vult efie neceffariüaliquod mouens; quod comitctur illum motum \& illi coexiftat; ideo caufam refert in partes aeris, per quas prosectum fertur, vt ibi videre eft, fimiliter igiturin. motunaturalinon fufficit generans, quusm non
A coexiftat motui; neque vlla huius difcriminis rario in his adducipoteft, quam enin ratiunc $m$ haber proiiciensad rem proiectam, eandeni ha: betgenctans ad elementum genitum, nempe quantum attinet ad motum localem; varum yue enim dat patienti motionis initium, fed moncre ad finem vfque ipfius motus non perleuerat. Quemadmodum ergo fecundum Aritt. non la. tis eft dicere proicctum moueri à proiiciente, ita nec átis eft dicere, elementum motu naturali moueri à generante. Ideo notandi maxime funt varii Aristot. fcopi in prima eius octau libri parte, \& in capiteillo poftremo, nam diuerfa refpiciens variis etiam modis de eadem re loquutus eft : In prima namq; parte confiderabat primum principium motus in vnaquaque re, $\&$ primum mouens, à quo res ducirur de non moueriad moueri, quoniam fropus ibi eft primum vniuerfi motorem inue ftigare: loquens igituribi de motu grauiuns \& leuium tum naturali, tum violento, non confiderat aliud mouens, quam externum, quod rem taducit de non moueri ad moneri, quale eft generans refpectu motus naturalis, \& proiicens refpectu motus violenti: quocirca ibi nullum alium mororem tribuit motis violenter, quamillum, qui proiecitinam aliun pofteriorem motorem, qui poftea coexiftit motui, ibi Ariftot non confiderat, propterea quod ad eius fcopum non conferebat; ob quam eadem rationem neque elementi forD mam ibi confiderat vi mouentem motu naturali, quia non eft motor primus, fed prafupponit motorem priorem, quia rem tranfulerit de quietead motum; in poltremoautem eiuldem libri capite non amp!ius loquitur de primo morore rei proiect $x$, fed de proximo, \& adaquato. coexiftente, fiquidē primus motor proiectorum iam manifeltus erat, nemo enim ignorat proiicienten effe primum motorem; fed motor proximus ignorabatur, ideo ibi docét proiectum

E mouerià diuerfis aeris partibus vna poftalian: ficigitur etiam in motu naturali negare Ariftot. nonpoffeteffe neceffarium moués proximum, \& coexiftens, quod non poteft effealiud, quam propria forma; generans enim eft caufa prima \& remota,vt confideräri manifeftum eft. Praterea lapis furfum proiectus per vinı, poftea deorfum ferturpernaturam, à quo igitur moue tur? non à proiiciente, quiaidem non poteft effecaufa fimul contrariorum motuum; non à gencrante, q̨uoniam huius actio iam olim defít ante longum tempus, \& fortaflis ante mille annos, imoetiam fortatie generans iam olim interiit; à fola igitur fua forma tuncnaturaliter mouetur. Polfumus etiam ad hanc fententiam cōfirmaidam fumere argumentū ex Arift. in meniorato cont. 3.x. oftaui Phyl.qui abaduertariis fumra cun, efficacia pro leadducitur ; nā ibi dicit qudē Ariftot.gua uia \& leuia mouen per fe à ge nerāte, jed quarit ctiam propter quid ad fua ioca moueall- 
tur grauia \& lcuia : \& refpondet his ver bis [cost-

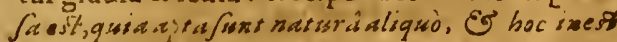
graus [G lous effe ] quum enim quzítio proper quid fit quxftio proxım \& immediatre caufx, rion refpondet Ariftot. generans effe caufan cur moucantur, quia gencrans eft caufaremota, per quam non fatisfieret quxftioni propter quid; fed refpondet ipfammet elementi naturam caufameffe illius raotus, earaquc ipfius efienciam effe; atqui hac eit forma, itaque fecundum Ariftotelem forma grauis, aut leuis eft proxima caufaillius motus. Hoc idem notare poffumus in context. 24. lib. 4. de Calo, vbi Ariftot.eandem quxftionem facit, propter quid ferturignis furfum, \& terra deorium; ad quam fimiliter, imo \& clarius refiondet, quod hac in feipfis habent mutationis principium; \& in hoc diftinguit hxc mobilia moru naturali à fanabili, \& augmentabili, qux mutantur ad fanitaters, \& ad magnitudinem ab externo principio; intellıgit autem à principio actiuo ; ergo vult propriam elenśenti naturam effe principium actiuum fui motus naturalis : quod videtur etiam fatisclare pronunciaficin contextu 84 . fecundi Phyfic.rbiinquit, naturalia effe illa, qux abaliquo in feipfis principio continue mota perueniunt ad aliquem finem, afferereergo videtur, omnia naturalia moueri ab interno principio actiuo, non inferiora corpora refpicit, in quibusid vniuerfe verum effe arbitratur. Confirmatur etiam hic fententia per ipfamet aduer fariorum dicta:declarantes enim, quomodo generansfit motor grauium \& leuium, dicunt, generans dat formam; dat igitur etiam motum, quia dans formam dat etiam ornnia confequentia formam mediante forma: hoc enim eorum dictú fi fal fum fit, nullam eorum opinio defenfionéhabet, generans enim non dabit motum: fiautem verum effe concedamus, per illud ipfi veritatem confitentur, \& in noftram fenteniden tiam veniunt. Primum quidem dubia eft eius or- dieti veritas, quoniam accidentia formam cona $\bar{c}$-fequentia duplicia funt, alia habent efle permaeria nens, vt rifibilitas in homine, \& calorinigne; ady- Iia vero habent effe fluxile, cuiufmodi eit moa. tus: deillis igitur, qux habent effe permanens, clara res effe videtur; nam agens vna \& eadem actione; qua dat formam, dat etiam hæc formam confequentia, vt generans hominem dat eadem actione formam, \& rifibilitatem confequentem, licet hanc permediam formam : at de motu fecus eft, generans enim dans elemento formam, non dat eaden actione motum, quia ceffat generätis actio in primo elf́ forma, quod eft vltimum non effe ipfius motus, fiquidé motus nondūeft, fed poltea erit, quando generans non ampliusaget; generass ergo dans formam non dat eadem actione motum confequentem. Sed admittamus dieti huius veritatem, admitti enimpöt in hocfenfu, quia dan elemento for. mam,dat vim moricen fui ipfus; at hoc dicere, eft dicere formam effe motricem element, quare hoc ipfí dicentes veriiatem aperte cöfitentur : dum enim dicunt, confequentia form am, ta. tentur motū elementi infequi formam, proinde effe effectum forma : quodetiam clarius affirmant, dum addunt, mediante forma ; fic. n. fatentur, generans non efle caufan ímmediatám. quum intercedat forma, perquam mediam generans dat graui \& leui notū: reEtifime etiam B vtunturilla dictione [confequentia] fic. n. ipfa veritate ducti dicunt formam effe motus efreetricem peremanationem; à taii nan q; efficiente ita emanat effectus, vt iplum infequatur ficut vmbra corpus absq; vila transniutatione; alind enim elt motum producere, aliudeft rem pro- Alivad ducere cum motu \& transmutatione; efficiens est proquidē transmutans producit rem cū motu, ideo dacere generans producit motum elementiper muta-motum, ronem fubitantialem; at forma elementi pro- aliud est C ducit motum tanq̨um rem confequentem, nec rem proproducitpertransmutazionem. Quodvero ali- ducere qui ad fetuendos dicunt, formamnon effecau- cim mofam effectricem, de quain prafentia loquimur, tw. fed porius effe caufam formale, falfun eft; quia forma eft quidem caufa formalis corporis naturalis, at accidentiu non eit caufa formalis, fed effectrix,yt etiam de anima afferit Arift. in contex. 36. fecundilibri de anima; nec video, quomodoaliquis fanæmètis dicerepoffit, formam D compofitieffe formam etiam acridentium. Sed his caufa deceptionis füit, quod non cognouerunt efficiens per emanationem ratione faltem dıftinctum à caufa formali ; naus forme vtrennq; Nota de competitvariisrefpectibus : alius enim eft cau-agete fandi modus, quo forma elementicft illius cor-per ema. poris caufaformalis, qua ipfum in fpeciecon-natione. ftituit, \& alius, quo eadem in eodem corpore motum naturalem producit. Videtur antem Ariftoteles ipfe hoc efficientium difcrimen pulcherrme fignificaffe inillo contextu 32 . octaui Phyfic. nam efficienti transmuzanti accommodatverbum $\pi 0 i \tilde{i} y$, \& de hoc loquens dicit: graue \& leue non habere in fe principium effectiuum motus, fed lolum paffium, effectiunn enim habet extra fe, à quo ducitur de quiete ad motum : efficienti autem per emanationem ac-

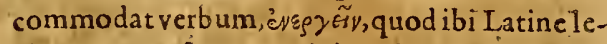
gitur, agere, feu operari ;inquit enim, graue \& leue agere ftatim, \& operari ; \& ita illis attribuit attionem ex fe turic, quandoiam ceffauit effeCtio agentis externigenerantis, vel remouentis impedimentum: multo tamen manifeftior eft Graci verbi fignificatio, nam maxime pro-

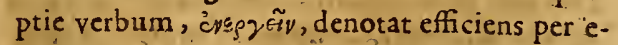
manstionem; fignificat enim exire ex feipfo in actum, \& in operationem ă natura manantem; poftquam céffauit effectio generantis, vel remouentis impedimentum. Quarta pro- 
pofitio eft, in motu naturali grauium \& leuium, A riæ \& form $x$. Talisaurem diftinctio partim rea requiriturnecefla rio, ve non penitus fit re diftınCtum mouens à moto : hac ex tertia propofitione deducitur, \& eam confequitur ex necelititate, nan: agens quidem tranimutans rem de poteftate ad actum eft neceflario diftinctum re à patiente, quia nihil ita in feipfum a git, fic enim effet fimul poteftate $\&$ åtu fecundum idem, vt argumentatur Ariftot. in contex. 40. illius octaui libri, quoniam ibi loquitur de foloagente

Agentix peremazationé artioeft immanens. tranfmutante: fed agens per emanationem non poteft effere diftinctũ à patiente; à forma nam. que accidentia confequétia emanant in eodem compofitio formato, non in aliquo externo; extra vero agit forma non aliter, quam trafmutando; quodc!arum eft per inductioné, dicimus enim, formam hominis effe caufam rifibilitatis, effectricem per emanationem, non ita tamen, vt dicatur homo diuidi in corpus \& animam, \& anima efficiat rifibilitatem, corpus vero feclu, fa anima eam primo recipiat, fed totum compofitū animatum recipit primo hanc proprietatem, \& quatenus eft animatum; proinde anima eft tum agens, tum ratio patiendi, diuèrfis tamen modis, nam agit vt forma, recipit autem ve iuncta materix: fic à forma ignis emanat in ipfomet igni fummus calor, qua eft ignis proprietas, non itatamen, vt fola materia patiatur, quia materia informis non eft idoneum fubiecum caloris, fed totus ignis dicitur fubiectum caloris vt tali forma formatus; eadē igitur forma agit vt forma, \& recipitvt eft in materia hæc autem eadem percalorem infequentem agit extra fe in alia per tranfmutationen, dum resalias calefacit \& vrit. Sic igitur etiam de motu elementidicit Auerroes 3. de Coclo 28, forna elementi mouet vt forma, \& mouetur vt in materia; nam mouere tribuitur foli form $x$, tali autem motu moueri tribuiturilli corpori, vt ab ea forma conftituto. Ex his autem patet, in motu elementinon poffe diuifionem fieri in partem per fe mouentcm, \& partem per fe motam; quia per fe monens eft forma, per fe motum eft totum compofitum, quod eandem formam complectitur: attamen ibi quoque notari poteft aliqua diftinctio realis; quum enim compofitum conftet ex materia \& forma, diftinguitur reà forma ratione materix, qux eft diftincta re à materia, $f e d$ ratione form non re diftinguitur, fed ratione, quatenus aliud eft forma vt forma, aliud eft forma vt in materia : idque relpexit $A$ uerroes in 4. Phyfic. Comment. 7I. quando dixit elementum diuidi in motorem \& motum, quatenus motor eft forma, \& motum eft materia; non enim abfolute dixit materiam perfe moueri, nam in Comment. 28. inquit, id quod mouetur, effe totum elementum; fed fignificare tantum voluit illam, qux ibi notari poteft. mouentis \& moti realem diftinctionem; ea enimelt, qux fumitur à reali diftinctione mategerite per emanationem; quia vbi fola forma fine materia fuam edit operationem, ea non poteft effe nifi forma abiunda à materia, cuius actio eft ipfius fubfantia; quare nullus ibinotari poteft effectus ab cfficiente diftunctus, proinde neque efficiens appellari ea ratione poteft; vt igitur effectus emanans fit ab efficientediftinCtus, tamouam accidens infequens formam vt B caufan, neceffe eft materiam quoque adeffe, qux formata tali forma illum recipiat, \& ita faciat aliquam realem diftinctionem: contra vero non poteft omnino effe diftinctio realis, q poteft quidem agens agere in aliud extra fe per tranfmutationem, \& ductionem de poteftatead actum; at per emanationem non poteftagere in aliud, quia effectus emanans non poteft nifi in co ipfo recipi, à quo emanat, hccenim fignifi. cat verbum emanare; eaque eft diftinctio ratio. C nis, quā fignificauit Auerrocs dum dixıt, fornı elementi mouet vt forma, \& mouetur vt in materia ; non catur igitur effectus à forma emanans, \& ab ea diftinctus tanquam à caufa, nifi in rebus materialibus, nec poteft ibi effe prorfus realis diftinctio agentis \& patientis, fedparim realis propter materiam, \& partim rationis propter formam. Poftrematandem propofitio hac eft;i motum elementi redigere velimus ad notorem per veram cfficientiam, \& pertranfmuta-

$D$ tionem, elemētum mouetur à feipfo vtabagente tranfmutante, non tamen perfe, fed per accidens:hæc per folam reiconfiderationem manifefta redditur; nam graue defcendës mouet aerem, qui ei cedit, quare motum aeris confequitur vt graue deorfum feratur, non enim moueretur graue, nifi fubftans a er, vel aliud eiufmodi corpusilli cederet, à primo igitur advltimŭ moueturgraue à feipfo per accidens, quia per aerem mediū qui primo mouetur à graui. Eft au-

E tem notandus in motu grauis \& leuis hic ordo,fi nō temporis, faltem natura: primum quidem moueturclementum à fua forma per fe, tanquam ab agente per emanationem, ab eanamque emanat immediate motus naturalis in ip fo. met elemento, non per medium aerem, \& nifi graue primofeipfum moueret, nö premerst aerem: fecundo totuni graue, non forma eius, per fuum motum mouet aerē tanquam agēs tranfmutans; fic enim agit in aliud, \& ibi adeftperfeF. Cta realis diftinctio mouentis \& moti, \& refiftentia patientis, à qua in motu fucceffio prouenit ; iam enim diximus, nullam effe in elementi motu internam refiftentiam, fed externä folum, quia in mouendo per emanationem nulla poteft efferefiftentia, nifi diceremus, eandem formä fibimet obfiftere, quod nullo pacto dicendum eft:tertio ad notumaeris mouetur etiam ipfum graue, \& incedentis aeris locum fubintrat; \& ita fit vt graue à feipfo moueatur tum per 
perfe, tum peraccidens; per fe quidem ratione $A$ ornnia eius dieta verafunt, vt mox confiderabiefficientix per emanationem, qux ordine naturæ prima eft, peraccidens vero ratione officientix per tranfmutationem, qux eft poftrema, \& pcraerem medium, \& cum refiftentia moti ad motoren, quam etiam Scotus declarat in 2. Sentent.in diftinct. 2. quæít. 9. ad quartum : prima enimactio tranfmutans eft ipfius grauis in aerem, non in fe, eam autem confequitur vt etiam graue moueatur, hoc enim non moueretur, niff prius aer mouerctur: ideo non eftignorandum, modum hune mouendi fe per accidens, reduci ad remotionem impedimenti; quando enim graue defcendit, renouet aerem impedientem, \&sita mouet fe per accidens; fic etiam Ariftotel. dixit à remouente impedimentum moueri rem peraccidens, quia per mediam remotionem impediméti:refpectuautem ipfius impedientis dicitur mouensper fe, quia per fe \& immediate mouetimpedimentum, fecundarioatem confequitur, vt res quoqueimpedita moueatirr; fic igitur graue defcendens remouet perfe a erem, quo fit, vt ipfum quoque fe per accidens moucre dicatur, quia per fubitanis a eris en- remotionem. Ex his colligimus, effein motu eter lementi aliquam internam refiftentiam. non mo quidem perfe, vtaliquos putaffe iam diximıs, fed folum per accidens : dum enim graue motum à fua forma mouetaerem medium, \&aerilli refiftit, neceffe eft vt ipfum quoque refiftat formx mouenti;tota tamen refiftentia prouenit àrefiftentia externi aeris, ipfum enim graue per fe fux formanon obfi fteret, fed quoniam aliud corpus ipfi refiftit, cogituripfum quoque refiftere fux form $x$, peraliud ergo refiftit, non per fe, \& eo magis refiftit, quo magis aliud illi refiftul, quod prouenit ex ma1ore medii corporis denfitate. Hanc cffe puto veram.fententiam, \& to tius huius difficultatis folutionem, \& Ariftot. atque Auerrois verbis, imo \& ipfi terum naturæ maxime confentaneam.

\section{Confideratio opinionis Scotï. Cap.XIII.}

$\mathrm{Q}$ Voniam fupra diximus, Scotum hac in in re proxime omnium ad veritatem accellile, nunc veritate cognita, videamus quid bene, \& quid non bene ab eo dictum fuerit. Primum quidem, quod dixit, elementum per fe mouerià fua forma; optime dixit; quod etiam dixit, id effe abfquereali diftinctione mouent is \& moti, verifimum eft: \& in hoc maxinie probandus eft Scotus, quod id cognouerit, quod alii non viderunt, nifif folus Auerroes; quu dixit formam elementi mouerevt formam, \& moueri quatenus eft in materia : in eo tamen defecit, quodputauit Auerroem hac inre.inconftantem fuifie, \& nihil certi ex eius yerbis fumi poffe; nam Auerroes hac in re fibi femper conftitit', \& mus.In afferendaquoque fux fententix ratione puto Scotum defecife; imperfectam enim rationem adduxit confugiens ad agens æquiuocum : nam licet omne agens per emanationem fit æquiuocum, non tamen conuertitur; datur en!m agens xquiuocum, quod non peremanationem, fed extra fe per tranfmutationem agit, curufmodi eft Colum refpectu corporum inferiorum; in talibus autem agentibus Scoti ratio

B locum non habet, quia nihil poteft tranfinutare feipfum, \& quod poreftate habet, tribuerefibi actu, nifi habeat partem per fe mouentem, \& partem perfe motam : quodenim non fufficiat actus virtualis, \& potentia formalis, vt poffit aliquid mutare feipfum', clarum eft in multis; nam vinumeft virtute calidum, quum habeat vim calefactricem, \& habet potentiam forma. lem, quum fit actu frigidum, \& poffit fieri calidum, attamen non poteit calfacere feipfum: motus etiam fecundum Ariftotel. generatcalo. rem, quo liquefcit plumbeus mucro fagittre, non ita tamen, vt primo calfaciat mucronem ipfum, qui mouetur;fed mucro per modum agit primo in aerem, \& ipfum atterendo accendit, poftea ab eo accenfo ipfe poitea calefit; itaque fagitta mota habet actum caloris virtualem, \& potentiam formalem, quia eit apta calorem, quem non habet, recipere, tancin non poteft immediate feipfum calefacere permotum; non $D$ eft igituridonea ratio, eftagens æquiuocum, \& habet poteftatem recipiendı formaliter, ergo poteft mutare feipfum:huius auten deceptionis ratioeft, quouian aliquid habens potentiam formalem, potettquidem fimul habere actum virtualem refpectu aliorum, in quæ agere poteft, at non refpectu fui ipfus; puta dicere refpeetu fui ipfius eft implicare contradietionem, vt aliquando confideraui in declatando context. 40. octauiphyfic. quando enim agens naturale aptum eftagere, \& habet patiens prefens, nec impeditur, exneceffitate fir actio; ergo fiagens poteft fibitalem formam tribuere, iam eam habet, nec poteft effe in potentia formali, quia femper fuit fibiipliprefens quoigitur momento habet actum virtualem refpectu fuiipfius, eo, dem momento neceffe eft vt habeat etiam aEtum formalem, nifi impediatur: quod fi impediatur, habet quidem potentiam formalem, fed F non habet actum virtualem, quia non poteft remouere impedimentum, \& feducere de potētia ad aहturn, vt patet in graui detento per vim in aliquo fuperoloco; non habet enim per fe actum virtualem, i.vim mouendi feactu, fed eget auxilioagentis externi, quod remoueatimpedimer,tum:dum igiturimpedımeritũ viget, haberquídem potentiam fornalem, fed non habet perfecte actum virtualem; dum aüt habet perfecte actum virtualem refpectu fuiphius, tüc habet necelfario actum formalem, non poteft igitur ba- 
bere perfectum actum virtualem lefpênu fui i- A pints, \& fimu! potentiam formalcn. Nielior itrquceft ratio, quam nos attulinus, non requiritur diftinctio partis monentis, a partis motx, quia eftagens per folam emanationem: quamuis enim hoc non fit nifi agens $x$ quiuocum, ratio tamen non eft quia fit aquinocum, fed quia per entanationem agit; quoniam agens per emanationem fimul eft cum effectu, nec habet actum virtualem cum potentia formali, fed cum actu formali, quoniam in feipfum agit, quum emanare effectus non pollit, uifiniplomet fubiecto, in quo eft caufa, à qua emanas: hre igiturvera ratio eft, cur in graui \& leui non requiratur realis diftinetio partis per fe mouen tis \& partis perfe mot $x$, non quam Scotus adduxit. Viget praterea contra Scotum ratio alJata ab allis ; admiffa enim Scoti fententia ruit progreflus Arift.in 8. Phyficorum ad inneniendum primum motorem immobilen; namaduerfarius diceret, deueniri ad primun, cuodidco feip fum nouer abfque diftinctione modoris \& moti, quia eftagens æquiuocum;idque rationi confonum videretur, quoniam agens xquiwocun eft natura prius agente vniuoco; nullus ergo daretur motor inmobilis...

\section{Conciliatio onmium dictorum Ariftotelis, \& Aurrois, Eomnis difficultatis folu- tio. Cap. $X I V$.}

Drea, qua hactenus diatafunt, omnisdiff1 cultas tollitur, \& omnia tum. Ariftotel. tum Auerrois dicta optime conciliatur. Auerroes enim modo dicitformam elementi effe mouentem, \& materiam effe motam; modo dicit formam effe mouentem, \& eanden formam quarenus eft in materia effe motam, quod declarans. inquit, totum elementum formatum mouerià fua forma; quandoque etiam dicit el ementum femouereper accides, quia peraerem medium, vel peralıudeiufmodi corpus: \& hac oninia vera funt: quaindo enim dicit materiam effe moran, non intelligit proprie materiam moues $i_{\text {, }}$ quumalibi dicat elemetum totum effe id, quod mouetur, fed folum fignificarevult diftinctionem aliquam realem mouentis \& moti, ficut antea declarauimus: \& quando dicit, formam effemouentem \& elementum effe motum, iirtelligit per emanationem, \& perfe, non peraccidens: quandoautem dicit elementum mouerefe per accidens, hoceft, peraerem medium, intelligit vt mouens per tran Imutationem; fic enim mouerenon amplius formæ tribuit; fed compofito; forma enim mouet elementum per fe tanquam moucns per emanationem; ip fum autem elementum per tranfmutationem mouet perfe aerem mcdium, \& per eum mouet etiam feipfum per accidens, quæ onnia iam fuere à mobis fufe declarata ; quare nulla eftin dictis A- uerrois repugnantia, nulfa inconftantia. Sicet$\mathrm{i} a \mathrm{~m}$ in diats A riftotelis : nam fecundunt principia philofophiz Ariftotelis fateri oportet formum clementi efe naturam, \& principium actiuum motus proximum, \& xquatnm, vt argumenta prius adducta denronftrint; at in octaiso Phyficre aufcultationis libr. de hoc Arif́totel: non loquitur, fed de primo mouente, ad quent reduci quem libet motum neceffe eft, nam fcopus ibi eft inuenire primum vniuerfi motorent. B xternum $\alpha$ immobilem; forma vero elementi non poteft dici primus motor refpectu fui mo: tus, quoniam pendet à gen erante, à quo eff́producta, \& à quo hanc neceffariam legem accepit vt tali motu moueat, non alio; generans enim talem ipfam produxit, vt eam neceffario infequercturad ftatutum locum propenfio, ip fa igitur fui motus imperium non haber; fed ita mouet, ve ei mandatum eft à generante externo; quare non eft primum fui motus principium. c nec poteft dare elemento motum poft quietem, red pendet à generante, tanquam à primo principro:non fic animalium anima; quamuis enim ipfa quoque fecundum fuum effe pendeat à ge。 nerante, non tamen fecundum motum illum ${ }_{2}$ quo an imal ab ipfa nouetur íoco, non ełt enim producta talis vt eam neceffario infequatur certus aliquis motus, fed eft producta libera ad mouendum, \&non mouendum; \& ad mouendum etiam contrariis motibus; habetigituripa imperium fui motus, \& traducerepoteft corpus animalis de quiete ad motum, proinde refpectu fui motus poteft appellari primum mouens. Ex his etiam rationem colligimus, cur mouens loco per: emanationem non poffit effe primum mowens; nam tale mouens non eit nifi forma materialis, eaque rei inanimatr, \& nil aliud eft emanare, quam per neceffariam quandam naturalem deriuationen prodire effectum ex caufa diuerfum ab illa; ideo eft etiam fine cogni-

E tione, quia vbi eft cognitio, ib r eft imperium moltendi, \& non monendi; quocirca ab anima cognoficente ron dicitur emanare in animali motus, fedpotius efficicum mutatione de nor moueri ad moueri, \& ex anima imperio: à for. ma vero inanimati emanat ftatutus quidam naruralis motus, non alius; nempe ille, qui ei affignatus eft à generante externo; quod formam cum hac lege produxit, vt tali moueret motu; nonalio; ob id Ariftoteles in libro octauo Pliyfic. generanti tribuit prinas in motu inanimati: quamuis enim proximum eius mouens fít forma, hæc tamen non eft primum mouens, fed in illa motione pendet ab imperio externi mouentis proris, quod refpiciens Ariftoteles in contextu 32 .illius libri dixit, graue \& leue habere in fe principium motus paffiuum, non actiuum; eftenim paffium, quatenus non eft pri$m \tilde{u}$, fed pendet à principio priore, à quo dicitur pati, quatenus ab eo recipit inuiolabilem legem. 
mouendi tali motu, non alio: feu dicamus, omnem formam materialem effe principiü motus paffiuum, vt aliâs in libro de Natuta declarauimus, proinde non effe mirum, fi Atiftotelesforman clementi dicat effe principium notus pafliuum, negat autem efre principium actiuum; quia in ea parte non vocat actium principium. nifi illud, quod primum fit, \& in mouendonon pcndeat ab alio. Nobis igitur non officit argumentum ab aliis adductum contra. Scotum: nam fi nobis obicianr per hane no- B ftram fententiam deftrui Ariftotelis argumentationem in libro octauo Phyficorum, ad imueniendnm primum motoren immobilem, quia dicere aduerfarius pofet, primum feipfum mouens iffe mouens per emanationem, proinde non rcquiri diftinctionem realem mouentis \& moti, quum à femctipfo mouteatur: ad hoc dicimus, nullum motorem per emanationem poffe dicı primum, quo fit, yt quum adhunc peruenimus, is neceffario pendeat à motore alio priore, quarc non poteft efle, nifi forma materialis, ficut modo dicebanıs : quando igitur conftituimus, pertentum effe ad primum feipfum mouens, hoc non poteft fe mouere per emanationem, quia fic non effet primum, idque locum habet etian vniuerfe confiderando motil, abfque propria confideratione motus æxterni, \& $x$ terni motoris vniuerfi; quod fi hunc fpeEtemus, multo minus nobis officit obiectio pradicta, quoniam à motore per emanationem non poteft rternus motus fieri, nec talis motor potefteffe aternus.

\section{Cur motus grauium \&lenium fit velocior in fine, quam in principio, plures alio- rum fententic. Cap. XV.}

$F$ A eft veritatis natura, vt per eius cognitio. Enem omnes, quæ in re oriuntur; quxftiones foluantur: quoniă igitur dubitari maxime folet de eo, quod ab Ariftotele dicitur in contex. 88 . libri r. de Colo, grauia \& leuia velocius ferri in fine motus, quam in principio; fi oftenderimus nullam adduci poffe huius effectus. idoneä caufam, nifi fateanur grauia \& leuià fuis formis moueri, magnam certe huius fententiæ comprobationemafferemus. Quxritur itaque, quænam fit caufa, vt motus grauium \& leuium naturalis in fine vclocior fit, quam in principios plureshac de re aliorum fententix extiterunt, guas a pud Simplicium legere poffurnus, tum in memoraco loco prumi libri de Colo, tū in contextu 76 .libri octaui Phy ficorum. Vna fuit opinio Hipparchi, qui caufam effe dixit remotionem maiorem à principio violento. nam fi lapis furfum proiiciatur, motusille violentus maior eft in principio, \& continue minor fit; do-
A necpenitus definat, \& tunc incipit lapis fuapte natura defecend cre, fed in principio tardins, quia retinet adhuc aliquid illius violentix, à qua litie proicetus; hrcenim motui naturalı aliquam refiftentiam facit;quanto autem magis defcendit, tanto fit velociormotus, quoniamilla violentia fomper imminuitur, \& naturx lap is minus obfiftit : tandcm igitur in fure velocifimus eft motus: iraque quun primum eft proicctus lapis,videmus in principio violentiam præualere nasurx, \& hunc exceffum continue minorem fieri, donecnatura incipiat præualcre violëtiæ, quod eft,dum incipit lapis deorfum ferri,fed tunc tardus eft motus; quia paruus eft exceflus nature, fed quanto magis deicendit, velocior fit motus, quia quanto magis remouetur à principio violento, tanto magis præualet natura ipfi violentix, in fine igitur velociflime mouetur, quia tuncremotiffimus eft à principio violento. Ad-Confutsuerfis hancHipparchi fententiam Alexander, \& tio.

C cum eo Simplicius hoc argumento ufi funt, guodifta caufanon eft vniuerfalis, neque in o. mubus locum habet; quo fit, vt dicinon poffit huius effectus caufa; vi enim admit taturde 1 lo motu naturali, quem præcefferit motus violentus, vel etiam violenta quies, at certelocum non habetin graui \& leui extra funm locum genito, \& ftatim absque vllo impedimento ad eum tendente: nam fi aqua in fublimi generetur, fimulatque eft genita, deorfum fertur, \& D maiorfemperfit eius motus velocitas, licet nullam prius impreffam violentiam habuit; fiquidem nec motus vllus violentus, nec violenta :quies praceffit , nec vllum affignari poteft principium violentum, quandoquidem generans dedit potius aqux naturams quam, illi violentum dici pollit : caufa igitur incrementi velocitatis.non eft illa, quam Hipparchus attulir, quum non habeat locun in omnibus. Aliam. tangit Simplicius nonnullorum opinionem,

E quod caufahuius effectus fit medium per quod fertur graue, velleue: quun enim in illo motu oporteat medium fcindi,facilius fcinditur paucum, quam multum: quando igitur lapis defcendit, fubftat ei in principio multum aeris, proinde magis obfiftit lapidi defcendenti, ne feceturab co \& tardior fit motus; poftea vero quando lapis fuo loco propinquior eft factus, fubftat ei parumaeris, proinde minus ei refiftit, acfacilius fcinditur, ideo tunc velocior fit motus. Aduerfus hanc fententiam vtitur Simpli- Confutacius authoritate Ariftorelis, qui in contextu 88. 230 . libri primi de Colo inquit, hoc velocitatis incrementum fieri ob incrementum grauitatis-; nam ficaufa eflet me dium, vtilli dixere,Arifoteles non veram caufam artuliffet, quare ea fententia verbis Ariftotelis confentanea non eft. Alexander tamen (vt in dicto loco Simplicius refert /nifus eft oftendere, horum opinionem non pugnare cum opinione Aiftot. \& admit-

$$
\text { 、 } \approx \text { I } 4 \text { ti:of- }
$$

Alioruse opinio. (2) Confutia
t3o.

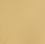

$+$


tipoffectiam iuxta Ariftotelis menten, fed hoc apud Simplicium in dicto loco legaur ; non eft enim operepretim in boc tempus confumere, quum certum. fit, eam fententiam falfam effe; namprater Simplicii obiectionem alia quoque ratione falfitas eius oftenditur; fi enim duo grauva paris grauitatis \& magnitudinis in aere firfpenfa ponantur, fed vuum à terra diftans centum cubitis, alterum vero decem cubitis tantum, \& prius demittaturillud, quod cétum cubitis diftat, exactis autem nonazinta cubitis, demittatur etiam alterum. vt per decem reliquos cubitos fimul def cendunt, certum eft, at q; experientia comprobatum, non $x$ quale $m$ fore in illis decem cubitis vtriufque velocitatem, fed velociùs mouebitur illud quod à remotiore loco defcendit; tamen fíidonea abillis caufa affgnata effet, oporteret ea duo grauia xquali velocitate defcendere in iis poftremis decen cubitis, quum $x$ qualis aer vtrique fubftet: patet autem fecundum hane fententiam nullam porfecaufam adduci, cur graue à remotiore loco defcendens maiorem ictum faciat, quam defcendens à propinquiore, na $\mathrm{m}$ vtrobique deberet $x$ que velox efle motus, qui per fpatiü xquale ftatim præceditioumproinde \& iatus æquaSım licti:lis, quodtamen verum nō eft, \& aduerfatur exEF Ale- perientix; quare hæc opinio reiiciatur. Simpli$x a n d r$, cius \& Alexander caufam huius effectus effe diES Tho-. cunt; quia elem étum, quo magis appropinquat me opi- fuoloco, \& fuo toti, eo magis roboratut, \& valinio. dius fit, \& perfectiorem formam adipifcitur; \& c̀ contrario, quo remotiusà fuo loco eft, eo magis: debilitatur, \& formam haber imperfectiorem. Hanceandem fententiam. Thomas quoq; fequi videtur in interpretatione illius context. 88. lib.1: de Colo inquit enim, elementum fuo loco appropinquansabeo confortari, \& ex ea confortationemaiorem fieri elementi vigorem, \& grauitatem, velleuitatem, eaḿq caufam effe, cur motus.velocior fiat. Sed Ariftoteles quoque hanc ipfam fententiam fignificare in memorato loco vifus eft, dicens augeri elementi grauitatem; vel leuitatem, dum loco fuo appropinquat; \& inde fieri, vt etiam velocitas motus augeatur: Quod vero ad Simplicium attinet, ipfe quidem videtur in contextu 76. libri 8. Phyficor.plures \& varias afferre huius effectus caufas, fed non ob id inconftans dicendus eft; propterea:quodill $x$ omnes in hunc ipfum, quem retulimus, fenfum cadunt; \& quas ibi vt plures adducit, eas poltea in ibror: de Coelorefert vt vnam: quod enim elementa fuis locis appropinquantia roborentur $\mathrm{ab}$ eis, vel à fuis totis, vel formam perfectiorem confequantur, vel grauitatem, vel leuitatem maiorem, vel validiora fiant, hacomnia apud Simplicium \& Alexandrum idem fignificant, vt videre eft apud Simplicium in pradicto88. contex.1.lib. de Colo: vbi etiam notaredebemus, ipfum, quam-
A uisprædictam fententiam Arifto teli attribuat, videri tamea poltea de ea dubitare, dum dubitat de ipfoeffectu, quem ibi Ariftoteles vt mannfeftum conftituit; inquit enim Simplicius, tum ipfum fecundum fe effectum dubium elre, quia difcernere non pofumus, quod motus elementi fiat in finevelocion; tun etiam dubium maxime reddi ratione cauf $x$, quam Ariftoteles adducit; fiquidem inquit, id fieriex incremento grauitatis, kel leuitatis: hoc tamen non eft cla.

B rum; nam hoc dato, oporteret corporis pondus effe maius, quando eft terræ propinquū, quam quando eftremotum, \& in fublimialıquo loco pofitum: attamen in librandis lanceponderibus hoc non experimur, fed idem inueniemuseffe eiufdem corporis pondus \& prope terram, \& in fublimi locolibrati; nam fi prope terram inueniatur effe decem librarŭ, tantundem effe com. perietur etıam in loco à terra valde remoto, nifi forte pro Ariftotel. defenfione dicamus (in quit C Simplicius )effe quidem difcrimen aliquod in illius ponderis libratione, fed illud eft inlenfile: videtur itaque fignificare Simplicius, dubium effe effectum, quem Aritoteles pro comperto 1umit; fed eoadmitro, non effe aliam eius caufam, nifillam;qux modo rclata e:t, nempcadeptionem perfections form $x$, \& maioris vigoris, dum elementum fuo loco appripinquat. Sidreuera dubiū Simplicī etıam illa caufa ad-sente miffa vanum eft: vt enim condonemus, maio- confa D rem effe grauis corporis granitaiem prope terram quam in fublımi loco, iplumque à loci fü propinquitate roborarijtamen certum eft, idem temper inueniri debere eiufdem corporis pondus, fiue prope terram, fiue procul à terra libretur, proinde negandum efle illam confequentiam ; fi idem corpus maiorem habet grauita. tem prope terram, quam procul, ergo non 1 dem in u? niretur eiuldem corporis pödus in iis duobus locis: certü enim eft, in librand is lance ponE. deribus duo ponderain confiderationé cadere; altero namq; vtimur pódere noto, ex quo in altera partelancis pofito alterius ponderis quxfitam quantitatem cognofcamus; in vtroq; igitur pondere eade ratio viget; eten im fecundum Simplicij rationen, oportet prope terram effe. atque maioren vtriufque grauitatem, \& procul àterra æque minorem: quŭ igitur vbiq; eadem feruet ur ratio noti pond eris ad igno tum ; neceffarium eft, vt vbique eadem ponderis quantitas $F$ inueniatur, quia vbique idem manet eorum $x$ quilibrium; non eft igiturvalida Simplicii ratio; proinde eius dubitatio vana eft, fiquidé etiam admiffa caufa ab ipfo, \& ab Alexandro adducta, neceffe eft idem vẹique pondus inueniri. Coterum quia prædicta Simplicii contra Ariftotelem dubitatio locum non habet, nifi illa caufa conftituta, vanius reddetur eius dubrum, fi oftenderimus, caufam illam nullo paeto.admittenéam efle.. Primum quidem. vrge-

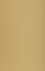


tur ea fententia difficultate illa, qua alios quoq; vıgeridıximus; nam oporteret idem graue per idem terræ propinquim fpatium moureri endem velocitate tum à propinquo loco, tum à remotiffimo demiflum, proinde \& xqualem ictum faccre: tamen contrarium experiuntur; idem enim homofupra terram exiftens_i à lapide percutiatur defendente de loco tribus cubitis fuperiore, minorem ictum fentiet, quan fi percutiatur ab eodem defendente de loco fuperiore viginti cubits : per tres igitur infimos $B$ cubitos velecius mouetur la pis à remotiore loconefcendens, quam à propinquiore: tamen fi vera effet fententia Simplicii, deberet idem lapis effe entufdem grautatis , \& moueri aqualivelocstate à quolibet loco demiffus, quonım in eadem diftantia à centro deberet eademelfe per, featio formx, \& ea tem roboratio, \& idem vigor. Praterea quando dicunt, formam elementi fieri perfeniorem, videndum eft, quidnam performam intcllizant: vel enim formam fubftantialem perfectiorem tieri dicunt, vol aliquodacidens ormam in lequés, formam quidem fibltantialem riddi perfectiorem, \& intendi, eft vaniffimum ticcre, quia hae nee intendi, necremitri poleft; hac autem integra manente, neceffe eft proprielatcs quoq; eam confequentes fer lari inte gras, \& eandem fierioperationem, nempe eandem effe eiufdem corporis. gratitatem, \& eundem motum pir idem medium, quum non adfit aliquod agens à q!o talem mutationem pati poffit; attio namque omnis per contactum fit; quare lapis deicendens neque à locoluo roborari poteit, neque à ids terra tota, ad quam tendit, quum ab his nondum tangatur. Durandus in z. lib: Sentent. diftinet. 14. quaft. I. refert caufam husus incrementi velocitatis in minorem refiftentiam medii, conftituto eodem interno principio: inquit enim medium graui defcendēti minus lefiftere in fine motus, quam in principio, ideoq; motü in fine effe velociorem : minons au tem refiftentix caufam effe inquit, quod aer propinquior terr eft minus leuis, quam aer fuperior, ideo. minus nitıtur contra motum grauis defcendentis. Hxc fententia proxime quidem ad veritatem accedere meo quidem iudicio videtur, attamen non omninoprobanda eft, quia nö idoneam rationem adducit minoris refiftentiæ me-dii: non enim ob naturæ fimilitudinem, vel dif: fimilitudinem fit maior, vel minor medii refi- $F$ ftentia, ita vt mediun grauius minus refiftat graui defcendenti, quam medium leuius; fed propter denfiratem vel raritatem, quando diuerix funt mediorum natura; feu propter motum, vel quietem, quando eadem medii natura. conftituitur; qua de re mox diffufius loquemur. Videtur etiam ratio hæc Durandi contrarium oftendere:nam fi acr inferior minus eft leuis, eft igitur grauior, quā aer fupcrus, ergo etiam den.
A fior; quare magis refiftet graui defcendenti, quä acrlcuior, qui ctiam eft rarior : ob hanc igitur rationem debcret elemęti motus naturalis tardior ef? e in finc, quam in principio; hoc tamen \& Ariftoteli, \& experientix aduerfatur.

\section{opinio vera, do eius declaratio. Cap. XVI.}

Nhac difficultate ego fequendam puto multorum fententiam, qui dicunt, prxecentem motum effe caufam maioris velocitatis motus fequentis; hinc enim fit, yt continue crefat velocitas motus, \& in fine fiat maxima: quoniam initio debilis. ac tardus fit motus, quem alius motus non praceffit; in fine autem velocior, quia alius eam praceflit motus. hoc ita fere habere experieniin docet : fi quis enim pellere, vrgere ac percutere ren aliquam velić, vehementius id facit, fi prius moueatur, quam fi nullus C motus pracedat; ideo quando vehem enterper. cutere aliquem volumus, manum prius retrahimus, vt maiorem ictum faciamus: \& in haftiludio haftas currendo frangunt, quas fine curfu non fiangerent; naturalinamque inftinctu ducimur, vt à remotiore loco motum inchoemus, quando maiorem in fine perculfionem facere voiumus. Hinc fumitur ratio, cur fi duo æ үue grauia defcendant, fed vnum à loco remotioie, alterum à propinquiore, \& confide$D$ rentur in aliqua æequali diltantia à centro, vnum velocius altero moueatur; velocius cnim mouetur illud, quod à fublimıore loco defcendit, quia præcedens eius motus maior fuit, alterius velo minor. Hac abfque dubio eft huius effeEtus caula, fed in hac tamen acquiefcere non poffumus, nifi huius quoque cauf $x$ caufam cogilof camus; fcire namque oportet, cur prece-. dens motus fit caufa maioris velocitatis motus fequentis; fic enim proximam reicaufamcoE gnofcemus, qua cognita, omne hac in re dubiū. tolletur, \& intelligetur, quid fignificare A rifto -teles voluerit, quando dixit, motum in fine effe. velociorem propter incremëtum grauitatis, vel. leuitatis. Mihi-quidenıvidetur, caufam hane colligi poffe ex iis, qux in contex.82. lib.8, Phyficor. ab Ariftotele dicuntur demotu proiectorum : licet enim ille fit violentus motus, \& tar-dior in fine, quam in principio; tamen fi ea; quæ ibide violento dicuntur', applicemus naturali, fortaffe omnem hac ill re difficultatem foluemus. Docet ibi Ariftoreles proicetum moueri ab aere, hoc eft, à partibus aeris ordine difpofitis: quando enim manus proiicit lapidem, pellitur primum à lapide prima: aeris pars lapidi proxima, \& hæc pellit aliam partem fecundam, \& illa tertiam, \& tertıa quartam; eftautem aer elementum facillime mobile, \& agitabile in fuo loco;idcirco ea vi percufus magis mouetur, qua lapis, \& pracurrit ifti lapidi : poftquam igitur à

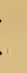

Sextentia Arifotelis de motu proiecterum. 
proiicientedimiffus eftapis, fertur ab his ateris partibus motis, qux funt illi tanquam vehicuJum; fed tardior femper fit motus lapidis \& in fine tardifimus, propterca quod lapis mouet primam aeris partem, \& eiden dat vim motricemalerius fecund $x$ partis, debiliorem tamen, quam infe labeat: fic etiam prima aeris pars mouet fecundam, \& datetiam illi vim pellendi tertiam, fed debiliorem, quam habeat ipfa; fecunda mouet tertiam, \& eidem dat viin, adhuc tamen debilıorem, monenti quartam fequentem; adeo yt propter contmuam imminutioncm facultatis motricis, deueniarur tandem ad aliquam aeris partem, qua ita dcbiliter moueat aliam fequentem, vt nullam ei impertiatur vim mouendialiquamaliam partem; illa igitur eft vitima pars mota, qua nullam aliam monet: quumiraque ab his ita notis aeris partibus feratur lapis, tardius mouetur in fine, quam in principio, \& tandem definit prorfus motu illo moueri, quando peruenit ad poftremam moti aeris partem; \& caufa huius imminutionis velocitatis motus eft, quia pofteriores partes aeristardius monentur, quam priores propterea qued à primo illo motus principio remotıores funt; quum enim primum mouens fit extrinum, partés ab eo diftantes tardius mouenrur, ptopinquiores autem velocius, quia maicrem abeo vim mouendi recipiunt. Hæc igitur apud A riftotelem caufa eft, cur motus violentus tarcior fit in fine, quam in principio, licet multis dubia videatur: fed de hoc in prafentia difputandum non eft, fatisenim eft, habrre hacin re opinionem Ariftotelis, vi cognofcamus, quid de motu naturali idem philofoplius fenferit. Sihæc omnia confideremus, colligere ex iis porfunus, quod fi naturalis quoque el ementorum motus à folo externo motore fieret, idem in co contingere deberet, quod in motu proiectorum : nam fi rarioilla de violento motu ab Ariftotele adduct vera eft, vera etiam effe debet de motu naturali; pars enim vltina motus naturalis, tanqua mi diftanti or à primo monente, deberet efle tardior, cuius tamen contrarium afferit Ariftoteles, dicens effevelociorem: vult igitur grauia \& leuia moueri à propriis formıs, tanquam à motoribus proxumis; fic enim fit, vt graue defcen dens noô remoueatur magis à principio mouéte, quia fecum fert motorem fuum, \& eum vbiq; præfentem coniunetum habet $a b$ initio motus ad finem. Hac tamen rationedeberet motus grauis defcëdentis effe tous $2 q u e$ velox, quoniam eadem natura mouens cundem ciufdem corporis motus facit; ergo fi crefcit continue velocitas motus, necefle eftaliquam effe huius differentixe extemam caufam, enmque efe medium, per quod fitmotus, vt acrens, rel aquan: quun enin oportetà corpore medio aliquam fieri refiftentiam, graui defcendenti, ac leui afcendenti, hanc fioftenderimus in
A initio motus maio:em ere, in fine vero minorem, ratio manifefta erit, cur in principio tardiorfit motus, \& in fine velocior. Certum eft,ac per experientiam comprobatum, vnam quam: que rem facilius moueri per mediũ quiefceus, quam permedium aduerio motulatum, fed adhuc facilius permedium, quod ad eandem partem feratur, quam per quiefcens; nauis enim velociffime fertur per flumen fecundo fluxu。 tardius peraquam quiefcentem, fed tardinime $B$ aduerfus fluxum am his: ftatuamus igitur lapidemin aere defcendentem, fubftatilli in initio illius motus primn aerss pars quiefcens, quam vi mouere incipit lapis defcendendo, quia refftentiam ei aliquam facit; non poteft autem prima aeris pars premi, ac deorfum pélli, nifi fimiliter pellat ac noueat fecundam ei fubstantem partem, lapis igiturad fecund um a eris partem perueniens, inuenit eam motam, \& ad eandem partem, nempe deorfum; ergo velocius in C ea defcendit, quam in prima quiefcente; quum autem velocius defcendat in fecunda, quam in prima, necefle eft vt tertiam magis premat, quam prius Cecundam preflerit: tertia igitur deorfum premitur vehementius, ac velocills, quam fecunda; ergo quando peruenit lapisad tertiam, in ea mouetur velocius, quam in fecunda, quemadmodum \& nauis qux fecundo flumine moueatur, eo velocins mouetur, quo velocior fit fiuxus amnis: velociusautem Iatus

D lapisintertia, quam in fecunda, magis premit quartam, quam prius tertiam preflerit, ideo quarta velocius deorfum pel itur, quam tertia, \& ita lapisad quartam perueniens mouetur per eam velocius, quam fer tertia $m$; $\&$ ta deinceps; quamobrem augerur femper velocitas motus, $\&$ in fine eft maxima; non tamen quod grauitas, feu vis lapidis motrix frat maior; hæc enim eadem manet, fed quia continue imminuitur refiftentia medii, proinde augetur exceffus vir-

$E$ tutis motricis ad refiftentiam aeris, qui ab ea mouetur, \& ita velocitas motusaugetur: quod fi. graue \& leue non à fua fotma, fed ì morore tantum externo mouerentur, id euenire non debcret, vt in violento motu non euenit, quum. igitur incrementum hoc velocitatis motus proueniat eximminutione refiftentia, me tii, hæc autem idefficerenon poffit, nifi conftitita eadem vi mouentis, necefle eft fateri, elemen. tum moueri à propria forma; fic enin fit, vt

F motor fit femper æque propinquus moto ab initio ad finem motus, at fi motor effet externus, fieretetiam femper remotior, proinde motus continue debilior, ac tardior ficret, nec vlla ampliusratio fumi pollet à refiftentia medii, vt nuillan fuñi videmus in motu violcnto, quare idem prorfus in motu maturali eueniret, quod cuenit inviolento; eflet enim tardior in fine, quara in principio Exhisautempatet:recte in Durd co fenfifie Durandum, quod caúam incremcti dus. 
yclocitatis retulit in imminutionem reffentix medii, fed un co defeeifle, quodnon idoncen racionem idduxit imminutions refiltentiz, ficut anpea demonftramisnus.

\section{Solutio orientis cuinfdam defferittatis. Cap. XVII.} Ollenda hic eft difficultas mon leris, qua rrgeri hac fententia noftra viderur : nam fi ex fola ceffentix medii imminutoneprouenit incrementum velocidatis motus, non exincrenento grauitatis, vel leuitatis corporis moti ergofalfum dixit Arittin context.8s.libr. ride Calo, vi aperte inquit, crefcere velociraicm motus propterincrenentum gratritatis, vel

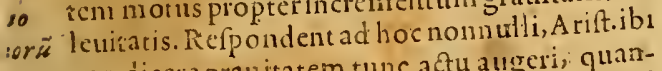
non dicere grautitatem tunc actu augeri, quandoatgeturvelocitas, fallim enim diceret; red quia loquitur demotu elementi, quiftatuatur infinitus, ideo dicit, eo pofito fequi vt augeat ur velocitas in infinitum:quod quiden fieri pollet, grauitas quoq; pofferin infinitum augeri:quum enim velocitasad grauitatem fe habeat, vit effectus ad caufan, fi poffibile eft incrementitm velocitatis in infinitum, eft etiam polfibile grauitatis acle leuitatis. Sed hacrefponfio mihiprobarinulla ratione poteft: quia liabfolute ex incremento velocitatis non licet inferre incremerrtum grauitatis, vell leuitatis, non video, vnde tum ifti fumant, quod ex incremento velocitaris incrementum infinitum : iniki quidem videzur potius contrarium colligi; nam fi ex actu id non infertur, ergo neque expoteftate inferri poreft.Ego igitur refpondendum puro, grauitatein fumi poffe duobus modis: quum enim fit qualitas quadam \& propenfio ad inferum locum, quam confequitur hic effectus, hac operatio, ad. eum locum moueri; ideorccipi poteft tum fecundumfeproactu primo, tum pro operatione, \& åtu fecundo;ficutietiam fcientia fumi poteft tum prohabitu, tum pro fpeculatione: priori modo acceptam grauitatem certum eft augeri non poffe, eandem enim feruari neceffe eft, dum eadem natura, \& forma feruatui, fic etiam dico delcuitate; fedaltero modo accepta augeri, ac minui poteft, \& dlcitur granitatio potius, quam grauitas: quum enimnilaliud fit, quam cxceffis irtutis nootricis fupra reliftentiam nedii, vnde fit defcenfus, \& preffio tubitant is corporis refiltentis hic maior fit, dum refiftentia imminutur; de hacigitur loqucbatur in prædicto loco Arift. maior cnim velocitas motus non prouenitexincremento grauitatis primo modo ac, ceptre; fiquidem 'ea crefecere in eodem corpore minime potef, fed exincremento grauitationis, hoc elt, exceffu virtutis mouet is ad refiftenrian medii mori, hic enim augeri poteft, \& huius in crement un eft caufa incrementi velocitar tis motus:fic igitur nil aliud ibi Arift. dicit, quá illud ipfum, quod nos diximus; nil enimaliud efr huius grauitatis, vel leuitat!s incrementum, quamimminutio refiftentix medii, \& ex co prouenit incremè um velocitat is motus, tanquan effectus ex caufa. Ip fa vero grauitatis, ac leuit?tis diftintio, quampofuimus, tum per fe nzanifecta eft, tumab A rift. pofita: nam grauitatem pro granitatione fumimus; quando dicimus, graue in fuoloco non eft graue, id eft, non gravitat, necpremit deorfum : primo enim modo falfum diceremus; quoniam elerientam graue habet vbiq; naturam graus, etiam in loso fuo, obid Ariftin context. 26: \&27. lib. 4. de Colo, fumit priore modo grauitatem \& leuitatem, dum dicit, leuiffimum effeid, quod omnibus fupereminet, \& grauifimum id, quod omnibus D fubftat;fic enim etiam in locis firis dicit effe grauifimumarque leuiffi mum : in context. autem 29. \&30. eiufdem libri fumit grauitatem \& letitatem fecundo modo; dun dicit lignum vinius tatentiin aere maiorem habere grauitate $\bar{e}$, quám plumbum vnius librr, contravero in aqua rem fele habere; fumit enim grauitatem pro operationé, qux notat réfpectum ad externa corpora, per, qua fir motus, eo namque refpeetil variato etiam grautitas yariatır, non quidem natura ipfa, f d grauitatio: dicit etiam in contex.illo 30 . omnia elementa in fuis locis aliquam habere grauitatem prater ignem; namaer quoque in fuo loco exiftens facilius deorfum pellitur, quam furfum, quia magis grauitat, quam leuitat; attamen fecundum eius naturam magis eft leuis, quam grauis.

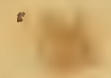




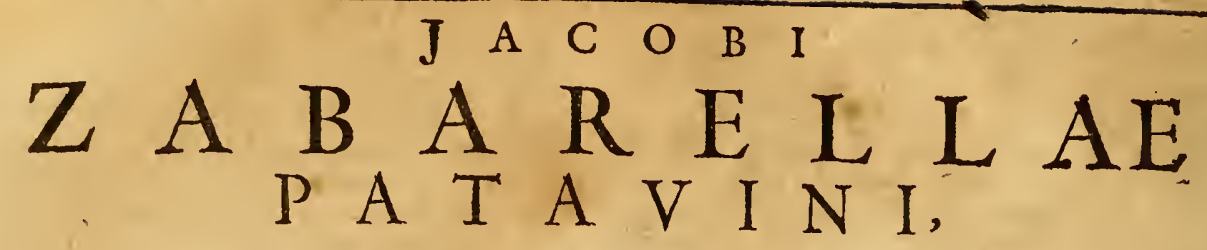

DE MOTV GRAVIVM ET LEVIVM.

\section{I B R S E C N D V S.}

De fubiecto primo motus corporis mifti, qui dicitur fecunditm praualens elementum. Cap. I.

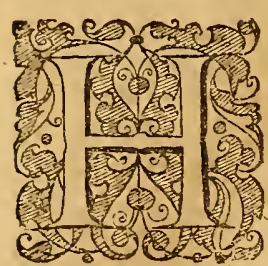

Actenus grauia \& leuia abfolute confiderantes, 0 ftendimus, ea internum habere motorem;reftat de mitis perpendendum id, quod Arift. dixit in intio 1. libr. de Coclo, ea moueri iuxta elementum aliis praualens in miftione; in hoc enim tria funt, qure quum difficul tate non careant, funt fingillatim confideranda : primum eft, quodnam fit primum fubiectum huius motus, quo dicitur mi ftum naturaliter moneri iuxta dominans elementum; fecundum, à quonam motore hic mo-

3

Opinto

Ioannis

Ganda. benfis. tus fiat, tertium demum, quál isnam fit, an fimplex,an miftus. Quod ad primum attiner,'ioannes Gandauenfis videtur exiftimaffe, primum fubiectum, cui talis motusineft, effe elementum, quodin miftione excellit, ita.vt in eo primo recipiatur motus, poftea vero confequatur, $v t$ ad motum elementi preualentis totum fimul miftum moueatur, non quidem pofterius tempore, fed natura, \& hac ratione miftum fecundum praualens elementum mouen dicatur. Confurta- Sententia hrec ob duas rationes reiiciend̄a eft. t20. Primum quiảem, fielementum dominans effet primum fubiectum, quodillo motu moueri di- D ceretur, oporteret illud effe actu in mifto fecundum fium effe fpecificum, quona am operatio præfupponit rem effe, nec poteft effe fubicitum motus, niffid, quod fit actu : confequenstamen fecundum ominum Arift. interpretum opinsonems falfume eft;nam fi.Latinosfequamuri,dicentes elementa in miftione penitusinterire, \& folis eorum vires feruari, ,non poffumus dicere aliquod elementum in mifto effe primum fubiectum motus, quum nullius elementi fubftantia feruetur : fiverofequamur Auer. dicentem elementa in mifto manere caftigata, \& refrąta, \& modo quodam medio inter actum \& poteftatem, adhucnullum clementum in mifio aptum eft perfe moueri, quia nulliū manet in fuo actu fpecifico; 110 enim mancnt amplius ignis, aer, aqua, terra, fed medium quoddam ex iis confa-
A tum,qua de realibi fufius differemus: nunc fatis fit, fi dicamus Auerrocm exiftimaffe, quatuor elementorum fubftantiasnon manere in mifto; quia fi manerent,non effet facta miftio, qux eft plurium naturarum vnio ; poffimusque hanc fententiam apud Auerroem legere, in commentario 57.116.3. de Coelo. Praterea fialiquod ex elementis ita poteft actu feruari in mifto, vt fit idoneunf fubiectum motus, ergo \& reliqua omnia:quanquam enim illud excellit, tamen deB. bent omnia eodem modo manerein mifto, vel omnia perfecta, vel omnia fracta, vel omnia a. Etu,vel omnia poteftate, fic autem fieret, vt motusillius miftinon magiseffet dicendus viatura. lis refpectu elementi praualentis, quam violen. tusrefpectu aliorum; perinde enimeffet, ac fi quis pilæx plumbex vtren acre plenum alligaret, \& in aquam proiiceret; defcenderet enim, \&e -ille defcenfus effet plumbo naturalis, fed aeri violentus : attame motuscorporis mifti, de quo in prafentia loquimur eft apud omnes vere náturalis, \& ne: pre quidem Gandauenfis concederet, eum effe alia ratioue natural $\mathrm{cm}, \&$ alia violentum. Dicendum igitur eft, motum mi fti, qui fecundum praualens elementum fieri dicitur, ipfimet mifto tanquam primo fubiecto inhærere, quumipfum folum, \& vina cius fibftantia exiftat actu perfecta, \&.fítidoneum fubiectum motus.

\section{De motoremifri,opinio Latinorum ac nominalium. Cap.II.}

$\mathrm{D}$ E motore autem mifti maior dificultas exiftit; forma namque elementidominantis non poteft effe motrix, vt eisdem argumentis - oftenditur; quemadmodumenim nullum elementum ita actu manet, vt fit aptum moueri, ita nulla elementaris forma ita feruatur, vt fit apta mouere: fiquidem non minus in motore, imo $E$ fortufe magis quan in eo, quod mouetur, requiritutr vt fit actu. Sed neque forma mifti vide. tur effe pofle huius motus effect rix; nam fi dicamus motum 11 lum effe fimplicem, is nö videtur poffe fieri, nifi à principio fimplici, non igitur à forma milthi ; fi vero dicamus, effe motum miftü, quomodoArift. ē attribuit el em êto dominăti? natura.n.clementi fimplex eft, quare nō videtur 
effepoffenifi fimplicis motus caufa, \& principium. In hac difficul tate, qua non leuss eft, Latini, qui putant, clementorum formas in mifto :- penitus aboleri, nullam elementarem fornam dicere poffunt effe huius mo tus caufam: fed nequeformam mift ; quum enim hxc apud eos ex illis conflata non fit, fed ab illis penitus diuerfa, non poffet motus ab ea productusattribui elemento præualenti, \& dici factus fecundum pradominans. Quamobrem ad qualitates confugiunt. \& dicunt ex elemëtorum comniftione quandam oriri qualitatem vergentem ad qualitatem elementi praualentis; eamq;effe huius motus effectricem caufam, qui hac ratione fecundum elementum dominans fieri di- citur. Albertus autem Saxo, \& Amadeus, \& alii - nominales, in eo quidem cum his confenferunt, quod caufam effectricé huius motus non formam effe dixêre, fed qualitatem, nam formas elementorum fimilitcrinterire penitus exiftimâtunt; at in co diffensêre, quod putârunt non ab vna qualitate moueri niftum, quod dicitur moueri fecundum prædominans, fed modo $a b$ vna, modo ab alia, modo eriam fimul à pluribus. Ad hanc fuam fententiam declaran. dam duo inprimis fundamenta ftatuebant; $v$ num ex Ariftotele acceptum in 4. lib. de Colo, quod graue in fuo loco non grauitat, \& leue in fuo loco non leuitat, hoceft, neq; mouetur, neque mouet; mouentur autem, \& mouent tunc
folum, quando funt extra propria loca. Alterũ vero, quod graue \& leue tunc fecundū naturam 8. locatum efle dicitur, quando eft fupra grauius, \& infra leuius : quare fi vas aliquod repletum aqua, cui oleum fupernatet, in elemęro ignis poneretur, illud ol eu effet naturaliter collocatum; quoniam haberet fupra fe ignem le uio $\bar{e}$, \& fub o. fe aquam grauiorê. His.iactis fundamentis tale cla exemplū tingebant: fit miftum habens quinq; gradus ignex qualitatis, tres aerex, tres aquex, tres terreæ, certū eft, dominari in eo mifto igneă. $E$ qualitatem, tamen non femper ab illa mouebitur; nam fi ponatur in igni, defcendet, quia praterquam quod illi gradus ignis in loco ignis funt otiofi, ipfis etiam preualent nouen gradus elementorum grauiorum. qui tunc dominantur, \& agune; quando autem ad elementum: aeris perueniet, in illo quoq; defendet, tunce. nim gradus aeris in fuo loco erunt otiofi, \& fex. gradus elementorum grauiorum proualebunt: quinque gradibus ignis; quando autem ad aquam peruenerit, tunc gradus aquei in $10 \mathrm{co}$ aqux erunt otiofi, quare non mouebunt; in aqua igitur non defcendet, fed potiusafcender, quo. niam octo gradus elementorum leuium tribus. terrx gradibus praualebunt; quamobrem niftum illud quiefcet inter aerem \& aquam, quod. oleo, \& aliis fimilibus contingere videmus : in tali igitur mifto dominatur quidem abfolute ignea qualitas, non tamen ab ea femper moue-
A tur miftum illud, quoniam ratione diuerforum locorum, in quibus ponitur, variantur qualitates elementares dominantes, at que mouentes. Hinc duo corollaria colligebant. V num eft, dari miftum, quod motu fuo naturali tardius moueatur in fine motus, quam in principio: hoc autem ita oftendebant: fit miftum habens duos gradusignis, duos aeris, tr es aqua, quinque teri'ze, \& ponatur in loco ignis, defcendet primum velocilfime, quia deorfum mouebitur à decem B gradibus aeris; aqua \& terra abfq; vlla refifentiagraduum ignis, qui in fuo loco nó refiftunr; deingde quand o erit in aere, tardıus mouebitur, quiá vis motrix imminuetur, \& refiftentia augebitur, tüc enim mouebunt foli octo gradus terræ \& aqua, \& duo gradus ignis refiftent, gradus autem aeris in fuo loco erunt otiofi; tandem quando ad aquam peruenerit, in ea tardiffime defcendet, nam vis motrix 2 dhuc magis erit imminuta. fiquidem foli quinq: gradus terre moC uebunt; gradus enimaqua in locoaqux erunt otiofi; refiftentia vero aucta erst, quia refiftent quatuor gradus ignis \& aeris. Alterim corollt secundus rium eft, dari aliquod miftú, quod tardius mo- corollaueretur in vacuo, quam in pleno: hocinillo co, rim. dem exemplo declarabant: nam fi totus aerislocus vacuus effe ftatuatur, motus illius mifti per locum illum tardior fiet, quam prius in loco ignis, propter pradictam cuufam; nam in ilio vacuo gradus aeris erunt otiofi, \& gradus ignis refiftent defeenfui, qui prius non refiftebant, \& gradus mouentes pauciores erunt, nempe octo, quum prius fuerint decem.

\section{Dicte fententie confutatio. Cap.11I.}

Ententia hac vana eft, \& prorfus abiiciSenda, Primum quidem peccant errore communiomnes, qui putant motum mifti, qui dicitur fecundum elementum praxualens, non fieriab aliqua forma fubftantiali, fed à qualita:te relicta ab elemento praualente, fiue vna, vt alii Latini dicunt, fiue pluribus ; vt nominales : hi namque non vident, nonfatis effe qualitatem, fed faciendam effe refolutionem in formam tanquam in caufam primam; fola enim. forma eft natura \& primum principium motus, . Neceffe qualitas vero nö eftnatura, necprincipiuramo- ef crizftus, nifi fecundarium, \& vt inftrumentum for que natu mx: quare velint, nolint; coguntur dicere, for- ralis moF mam aliquam effe primum principium illius twprimotus; ea autem effe non poteff forma elemen - mis prit ti, quurn apudeos formze elemeniares penitus. cipitum aboleantur; fed neque forma mifti, hasenim effeforquum fit diuerfa penitus.fecundum cos a for-manamis elementorum, quomodo poterit fimpli-liquam. cem motum efficere, \& qui fecundum praualēs fubftanelement üfactus dicatur? fed aliorum cốparatio- izalem. ne multo deterioreftopinio nominaliüs, dicenciü; i dem miftú mouerì à pluribus qualitatibus
Premum corollarismi. 
dominantibus, necfemper ab eifdem; fic enim dicunt, qualitates elementorum omnes feruari integras, proinde diftinetas, \& pugnantes inuicem, ac refiftentes, quod eft omnino abfonsm rationi. Sequitur etiam motum mifti fimul effe raturalem, \& violentum; qui enim ratione huus qualitatis eft naturalis , idem rationealterius cif violentus. Praterea eadem natura, qua eft principium motus, eft etiam principiw quietis, vt inquit Ariftoteles in libro z. Phyficorum, in definitione natur $x$, \& in contextu 23.lib.8. idque eft per fe manifefum, quia eaden terra natura eft caufa motus ad medium, \& quietis in medio; attamen fecundum iftos al ia eflet caufa motus naturalis, alia quietis naturalis : nam fi thiftum habeat decem gradus terræ, \& decem ignis \& aeris fimul fumptorum, aqua vero vnum, illud in aere \& in igne defcendet, eruntque principia illius motus gradus terr \& aqux; idem in aqua quiefcer, quia non plus poflunt g) adus terra, quam gradus elementorum leuium, quum totidem fint, \& gradus aqux in 10 coaqux eftotiofusjitaque illius quietis in aqua non erit caufa ille gradus aqux, quum fit vnis, \& fupereturabaliis, \& fit otiofus; neque etiam gradus terræ; qui fuerunt principium motus, dicipoterunt çaufa illius quietis, fed potius aquilibrium graduum terr $x$, \& gradu um elementorumleuium. Ob id fequeturetiam, non pofe elementum dominans facere, vt miftum in loco illius elementi quiefcat, licet etiam maximus illius elementi fit exceflus; qu oniam in loco fuo nullam haber vim refi ftendi aliis elementis, etiamfi plurimi infint eius gradus in illo mifto. Preterea fequetur, dari pofie miftur, quod ftet in aere fufpenfum, nec moucatur furfum; neque deorfum : nã fi habeat decem gradus ignnis, quinque aqua, \& quinque terr $x$, aeris verovnum, illud in aere necalcendere, nec defcendere poterit, fed fufpenfum manebit; \& idem conringet, fi gradus aeris ponantur quotcunque; omnes enim in locoaeris erunt otiofi. Sequetur etiam, variata plurimum proportionelmifcibilium, eundem tamen fieri motum, nam miftum habens feptem gradus ignis, vnumaeris, fex aqua, duosterra, defcendet in aere, afcendet in aqua, \& quiefcet inter aercm \& aquam; hoc idem continget, fi habeat feptem aeris, vnum ignis, fexterra, duos aqua; \& pluribus etiam aliis modis. Hzc \& alia ciufmodi plurima abfurda hanc fententiam, qua abfurdiffima eft, fequuntur. Radix autem huius erroris fuit, qux etiam totius veritatis fundamentum eft, vnde omnes had in re cauilli foluuntur, quod ifti ponunt in mifto inanimato plura actu principia
motus, diftincla inter fe, \& contraria, quum tamen omne tale miftum fit corpus naturale vnum, vnam habens naturam, non plures, \& vnam tantum qualitatem ratricem;ideo recte dicit Zimara in fuo Tlicorsmate $\sigma_{2}$. \& alii de
A hoc errore loquentes, praciata ab his fica exempla commentitia effe, \& impofibilia; çaufa namque impoffibilitatis ea eft, quam diximus, quia nulius gradus vnius eiementi remanet in mifto diftinetus à gradibus aliorū; neque vlia di ftincta qualitas, cui qualitates aliorü refiftanc, ac reluetentur: fed ficut omnia elementa confpiraucrunt in vnum, \& facta eft ex pluribus natutis naturavna; ita multa concrariz qualitates facta funt vna qualitas abliq; vila repugnan-

B tia, vel difinctione gradut; præterquam qued illa vna natura magis refert vnius elenıenti naturam, cuamaliorum, nempe illius, quod in miftione prasulet aluis, nulla vero ibi eft propenfio ad motum, nifilla, qux eit elementi dominantis, reliqua namq; elementa reddita funt,ita obtcniperantia irsifcuo inius, vt ad nullumalium motum inclinent; ille autem motus ref $\hat{p}$. cit vnum quicndam ftatutum in mundolocum, qui natureill cum talis elementi imperio conC ueniens fit: fi lecus fit, non eft facta vera miftio: qux eft mifcibilium vno: quemadnodum enim fi quatuor homines iterfacturi controuerfarentur, \& vnusire vellet ad orientalem partem, alius ad occidentalem, alius ad aquilonë, alius ad auftrum, deinde oft pugnarn concordesfierent, \& vnıus ientētıam fequerentur, nulla amplius inaliis effer propenfio eundi ad alias partes, fed orines vnanimes ad illam vnam tenderent, quam ille pracipit, cuius fententia pra-

$D$ ualuit; ita in tribus elementis fuccumbentibus non eft anplius adalios contrarios motus propenfio, prafertim qu ü eorure natura non feruetur actu, imonec dominantis elementi natura aftu fernetur; vna enim eit mifti natura, qua magis retinet virirs clementicóditiones, quam aliontum, ce cius naturam refert, quoad motum localem, quo ad prafcribendum fibi certum aliquem in sirundo licum: obid notandus eft modus loquendi Ariftotelis in initio 1. lib. de

E Colo, quinon dixit, miftü moueri ab elemento dominante, fic enim fignificare potuiflet illudelementumactuineffern mifto, \& effe actu moueus; fed dixit, moueri iuxta el ementum dominans; quum enim mifū magis huius, quam aliorum, naturam præ fe ferat, moueri etiam illo motu, qui elementi dominanti conueniens eft. Ex his patet, omnia, qua ab his dicuntur, falfa effe. Primum enim eorum fundamentum verum quidem eft de elementis per fe actu exiF ftentibus; perfenamque exiftens graue inlo- $m$ co fuo non grauitat, nec leue in loco fuo leui- co tat: fed de elementis in mifto non eft verum, ti quia ibi non eft difinctum leue à graui, vel gráue à leus:fed vna eft mifti natura, qua vel grauis, vel leuis dicitur, iuxta naturam elementi praualentis. Alterum vero eoram fundarncntum $f$ non modo de elementis in mifto, fed de eif $m$ dem etism feparatis, \& per fe exiftentibus fal. co fum eft; nam in mifto non funt eleraenta actu, th

qux 
qux cum propriis eorum locis, aut cum alicnis $A$ comparari polfine: noi cnin dicere polfumus m lapide terrzadherente ignem non effelocatumiecundum naturarn, quod fib aes e fit pofi tus, fit ensm ficret vt nullum miftum poffet 112 turaliter effe locatum, quoniam ratione vnius tantum elementi locatum effetfecumdum natu$\mathrm{ram}$, fed ratione aliorum prater naturam. In elementsisquoque feparatis id falfum eft, nam fi in vtre fit aqua, cui aer lupernatet, \& ponamus vtrem in locoignis,non eft verum id, quodilli dicune, aerem illum effe naturaliter collocatum, quodfupia fe habeatignem, \& fub feaquamifed erit preter naturami locatus, quia non eritin loco fuo naturali, \& fibi à natura proforipto, qui eft totius aerislocus. Falfa eriam funt omnia illa ab eis conficta exempia, vtprediximus; qua non daturin mifto illa contrariarum qualitatum dißtinctio, quam ipli comminif́cuntur. Peccant deinde in priore corollário;nam declarantes, quomodo graue, vel leuetradius mouezur in finc motus, quam in principio, confiderant graue \& leue, quzetranfeant perdiuer 1 a elementa, \& ita putant fe aliqua ratióne labefaetarefententiam Ariftotelis, dicentis, notum grauium \& leuium naturalem velociorem effe in fine, quam in principio : attamen nil noui per hoc in medium adducunt, neque id negaret $A$ rifóteles ; faterctur enim lapidem defcendentem prius peraerem, poltea per aquanı, tardius peraquam defcendere, quam per aerem; quid ergo ablconditi colligunt hoclio corollario, quod etiam ruftico cognitum non fit? Ariftoteles enim, quando dicit, motum naturalem grauinm \& leuium velociorem efle in fine, quam is principio, loquicur de motu fáto per vnum \& idem medium, yt per folum aerem, vel per folam aquam, non per diuerfa : redipfi in afferenda ratione huius fus euidentifimi corollarii manifeftiitime decipiuntur, hancenim fununt ex pra moti corporis natura, quum à folo medio externo fumenda fit; quum enim non fint in milto llil diuerfi gradus, quos fingunt, ratio, quam adducunt, falia eftinecalia eit eiss effecrus ratio afferenda, quam maior denfioris medij refiftentia, quam rarioris; hincenim fit, vt tardius defcendat lapis per aquam, quam per aerem. Falfum tandem eftalrerum quoqueco rollarium, quia non datur vacuum in natura, neque fi daretur, motus per illurn tradior fieret; quinimo nullus prorfus fieret motus, fublata o- F mni refiltentia medii, nififorte mutatio fubita: ob id Ariftoteles purauit necefiarium oranino effe medium plenum ; fi debeat fierı motus grauium \& leuium, ficutante dicebauns. Viderur etiam ex horum dictis oftendi poffe. quod graue vel leue in vacuo pofirum nulio modo moueretur, nec locum mutaret $i$ pfi tais corpora hac tunc moueri aiunt, quando non funt fecundum naturam locata, tunc autews non. fecus- dum nituram locata effe dicunt, quando funt fubaliquo grauiore, vel fupra aliquod leuius;atqui corpus in vacuo pofitum nec eft fub grauio. re,nec fupra leuius, quum \& fupra \& infrafe habeat vacuum, ergoper ip fam horummet definirionem non cit prater naturam locarum, proindenon eft, cur locum nutet, fi tunc folum, quando eft prater naturam locatum, corpus quodlibet loco mouetur.

\section{Verasententia de motore mifti.}

\section{cap. IV.*}

$\mathrm{E}$ $X$ iis, qux hactenus aduerfus alios dita funt, colligividetur, nullam aliam in mifto efic effectricens caufam motus, qui iuxtapr $x$ ualens elemencum fieri dicitur, nifi ipram mifti formam, qux eft eius natura \& fola fatui poteft principium motus naturalis in eo: ad hanc autem veritatém cognof́ndam, \& multos erro C res euitandos, anmaduertere oportet, vanum effe degrauium ac leuium motunaturali verba Mifum if isa for. manats raliter mouetwr facere, nifi praftituto fine ipfius motus; is au, tem eft locus naturalis, ad quem fingula fuapte natura feruntur: quemadmodum igitur in confiderando fingulorum elementorum motu 10 . cum prius conftituimus, cuius naturali appetitu duata mouentur, fic de miftorum quoq; motu, qui ex dominante elemento prodire dicitur, faciendum eft; prius enim alfignandus eft cuiD que mifto naturalis locus illi conueniens ratione grauitatis, vel teuitatis, vt poftea facilius de eius niotu, ac de motore, à quo promenit, fermonem faciamus: quoniam enim neceffarium eft' quolibet mifto genito, vt eiftatimafignetur proprius, \& naturalis in nuundo locus confiftens in fatua quadam diffantia à Colo, \& à centro; neceffe etiam êt, vt vbicunque mifum extra fuum locum ponatur, ad eum mouearur fecundum propriam naturam, \& in co folona* turaliter quief́cat, quot idem in fimplicibus. corporibus infpicimus; vnus autem locusnaturam vnam indicat, cui ille conueniens eft, $\checkmark-$ rus enim locus vnius eft natura conferuators ab illaigiturvna, \& eadem natura mouetur miftum ad locum fuum ex quolibetalio loco: neque eft quod decipiamur, videntes idem mifum motu naturali nodo afcendere, modo de. fcendere, ytoleum defcendere in a ere, afcendere in aqua, \& credamus ipfum non femper ab. eodem, fed à diuerfis principiis moueri, vt dicebant nominales ipfum deorfum ferri à gradibus. qualitatum e'ementoium grauium, furfumveroà gradibus leuium; fed vna eft oleinatura. qua ipfum in aqua afcendere facit, \& in aere defcendere, quia fic eundem femperpetitlocura fum naturalem, qui eftinter aerem \& aquam, \& ad huec mouetura fola propria forma, fueafcendendo, fure defcendendo:hoc aurem ira fefe habere, demonfrant duo elementamedia, aex

enim: 
anim naturaliter $\&$ defcendit in igne, $\&$ afcendit $A$ inaqua: quid ergo dicemus? Suntne etiam in ä̈rediuerfa afcenfus ac defcenfus principia ? certe eriam nominales faterentur, vnum tantum effe in acire princigium motus, quum fit corpus fimplex, \& unam habeat vim motricem naturalem; idem igitur de oleo \& de omni mifto, quıod vt graue, vel vtleue moueatur, dicendum eft. In itatuendo autem loco mifti naturali principes partes fibi vendicatillud elemétum, quod in ea miftione aliis preualet; eius enim naturam ma-

- gis,quam aliorum redolet ipfum mifum, \& ratione el ementi dominantis alfignatur cuilibet mifto locus naturalis, ad quem nacura! iter mouetur $a b$ omnibusaliis locis; ob id videmus, diuerfa naturalia loca, diuerfis miftis elle affignata, propter dominantis elementi varietatem: qua fit, vt alia mifta defcendant in aqua, \& in terra quiefcant; alia in aqua afcendant, in aëre vero defcendant, \& ita quiefcant inter aërem \& aquam; alia etiam in aëreafcendant, vt exhalationes, quxplurimum in fe habere videntur ignez naturx. Nullum ergo in hoc difcrimen eft inter elementa \& mifta, quatenus grauia,vel leuia funt; fingulis enim aflignatus elt in mundo locus naruralis, ad quem mouentur ex omnibus aliis locis, isque vel magis, vel ninus à Coelo remotus pro maiore cuiufque grauitate, velleuitate. Sed de elementis dubitare aliquis

Disbissm

demots elemento rssm me -

diorsum.

Solutio.

Vrates specres motres in dicatur ifine. poffet, quomodo idem corpus fimplex duos, \& eos quidem contrarios, habere poffit motus naturales; aer enim in igne naturaliter defcendit, \& in aqua naturaliter afcendit; quum tamen Ariftoteles dixerit in primo librode Coelo, vnius fimplicis corporis vnum tantum elle motum naturalē, \& contrarios inter fe effe motus, à medio, \&ad medium. Ad hoc ego dicendum puto motum naturalem grauium \& leuium iudicari eiufdérpeciei, aut diuerfarum fpecierum à fine, hoc eft, à loco naturali, a d quem tendit; hic enim vnus quum fit, indicat \& naturæ, \& motus vnitatem:igitur afcenfus aeris in aqua, \& defcenfus in igne non funt fpecie diftincti mo. tus, fed numero; quia ad eundem tendunit naturalem locum, \& ab eadem fimplici natura proficifcuntur. A rift. autem quando dixit, motum à medio diftinguifpecic à notuad medium, femperlocorum diftinctionem conftituit, proinde \& naturarum; aerisautem vna eft natura, \& ea fimplex, ficut etiam aqua; non enim quod fit tum grauis, refpectuignis, tum leuis refpectu terræ \& aqua, ob id duas habet naturas, fed vnam habet fimplicem, qux compaiatione duorum elementorú diciturleuis, \& comparatione ignis dicitur graus. Hocidem de miftedicen. dum eft, quatenus eft grali ,aut leuejnarn youm

tantum habet motum natuiales, quern ob

id Ariftotel attribuit elemento praualenti in eius miftione:

$$
\text { *** }
$$

De forma mifti an fit fuperaddita formis elementorum, Zimara opinio, or ar-

\section{gumenta. Cap. $V$.}

Q Voniam autem dictumeft, miftumà fua torma moueri, non bene intelligi poteft, qus nodo hic motus attribuatur natura elementi praualentis, nifi alia noua quxitio foluatur, ad id, quod declarandum propofuimus, maxime pertinens: dubium enim eft, \& apud in$B$ terpretes Ariftotelis controuerfum, an forma mifti fit forma qurdam re à formis elementorumdiuerfa, \& illis fuperaddita, an potius non fitillis fuperaddita, fed fit ipfrmet forma elementorum caftigat $x$ fract $x$; qux per miftionem euaferint val forma : huius quidem rei declaratio poftulare videtur,vt de miftione loqueremur; de hac autem agi non poteft abfque con. fideratione primarum qualitatum, quxalteratrices vocantur; at nos non de his, fed de motricibus tantum in prefentia loqui conftituimus, ideo diligentem de miftione difputationem ad alium locum remittentes, de ipfa nunc prooc. cafionetantum, \& ratione motricium qualitatumbreuiteragemus, vt videamus, quomodo ex elementorum commifione vnum in mifto remaneat principium motiuum fecundum naturam, quod dicatur grauitas, velleuitas, ita vt motus ille fieri dicaturiuxta elementum in miAtione praualens. Zimara in fua tabula fub liter C. in declaratione illius propofitionis [casfefmplices exiftentes in re non compofot a funt [nititur oftendere formam miftieffe quintam formam re diftinctam à quatuor formis elementorum fractis \& caftigatis, \& illis fuperadditam, quam fententiam alii quoque poftea fequutilunt; ad hanc comprobandam multifariam argumentantur. prinium fic; elementa ad formam mifti eam habent rationem, quam materia habet ad formam, eam enim recipere debent; ergo forma mifti dirtinguitur re à formis elementorum, \& eft eis fuperaddita ; forma namque non poteft effe pars materix, in qua recipitur; proinde miftum ita ex elementis conftarę dicendum eft, vt ex vna parte ftatuantur elementa formata, tanquam materia fecunda, exaltera vero parte forma mifti fuperueniat elementis formatis, tanquam diftincta re à formis elementorum. 'secundo, forma mifti non effet addita formis elementorum, conftaret effentialiter excorporibus, quia forma elementorum non funt feparabiles à materia; quoniam igitur ab?urdum eft, fi formam conftare excorporibus, non poteft forma $\mathrm{mi}$ fti conftare ex formis elementcrum; quia ex hisconftarenon poteft, quin conftet etiam ex materia. Teltio fequererur, non minus formam mifi, quam formas elementorum intendi ac remtti porte, ficutividemus etiam colores miculios non ninus, quam extremos, intendi atque 
atque remitti, confequens tamen falfum eft, quia omnes confentiunt, formas subfrantiales, faltem miftorum, non recipere magris, vel mi7. nus. (uarto, Aritotel.in context. 30). libr. z. de Anima, difputans contra Empedoclemunguit, formas elementorum nonpofle in mifto fimul confifterc, nifiadlitaliud quoddam, quod $e_{a s}$ contineat ; etenim line hocignisad fuperiora elabcretur, aqua efflueret, terra centrum petere nitectur : crgo quum elementa ab aliquo contincrioporteat, ne inuicem feparentur,necelle $B$ eft, aliquan effe formam in mifto pratef for. mas elenientorum, quare forma miftieft for\%. misclementorum fuper addita. Quinto, quam habet rationem anima ad formas elemento. rum, eam \& formá mifti habet ad eafdem; at aninsa cx formis elementorum conflatanon dicitur, led illis fuperueniens; ergo etiam forma mifti eft fuperadditaformis elemétorum. Tandem hane lententian confirmant authoritate Auerrois multisin locis: 13am lib. 7.Metaphyfi- $C$ corum comment.ro. inquit Auerroes, compofitum eft aliquodadditunı aliud à componentibus, vt caro non eft terra \& ignis, redaliquod additum, quemadmodim hxefyllaba Ca.non eft C. \& A.fed quid additum. Item s. Meraphyfico rum 6 . inquit, effe in compofito naturam additam xaturis componentium, Et l. Metaphyfic. 12. res, quix ex elementis generantur, differunt eflentialiter ab element1s. Et 12. Metaphyfic. 22. inquit, formas fimplicium effe alias a formis compofitorum. Et primo de Anima 77. ait, effentix \& formæ rerum neceife eft vt fint fuperadditæ elementis. Et primo de Generatione 84. illud quod generatur ex mifibilibusinmiftione, eft aliud ab eis. Per hrcergo oftenditur, forman mifti effe fuperadditam formis elementorum.

Dicta ententia confutatio, ơ vera fenten-
tia declaratio. Cap.VI. $1 \mathrm{G}$ O veriorem effe arbitroraliotum opinio-

E nem, qui dicunt, formam miftinon efreadditam formiselementorum, tanquam rediftinctam ab illis, fed effe formam ex earum congreffu orientem; ita vt qux erant quatuor forma, in vnam migrauerint, qux eft forma mifti. Hancfententiam antequam comprobare, \& errorem Zimaræ demonftare nitamur, illud admonere volumus, noftram hanc difputationem locum non habere iuxta Latinorum fenten- F tiam, quidicunt elementa nullo modo iemanerein mifto; nam fi elementorum form in miftione penitus abolentur, vt upfi putant, vanum eft quarere,an forma mifti fit addita, an non addita formis elementorim : fed conftituta Aucrrois opinione, cuius veritatem alibi demonftraturi fumus, quod forma elementorum modoa- liquo feruentur in mifto, quan Zimara qquoque \& alii, quibus cum in prefentia difputanus, $\mathrm{c}$ quut funt, opportun: cficonfideratio, an formaniftifit addita formis elementormin mifto, an non addita. Declarandum antc omnia Notatxe eft, in quo differat fententid noitra i fentevtia quobec

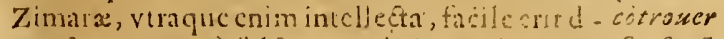
gnofecreveram à falía : quando giturdicimu, fia fit: $\overrightarrow{\theta-}$ formas elementorum modo aliquo manere in fitwr. mifto, fiucintegras, fiuefractas, \& caftigstas, hos poteft tres haberefenlits. Primuseit, vt dertelementis elle fuecificum, ficutante miftionem dabant, ita vt maneant quaruor dífinctx form $x$, \& quatuor elementa feruent fum efle fpecificum, fueprefectum, fue imminutum, \& à perfecto differens folum fecundum magis \& minus : qui primus lenfus omninoreicienduseft, vt alibi, quum de mifione loquemur, apertiffime demonftrabimus : nune eum hac via rationerefutare fatis eft, quod it hocefie, naturamift non eliet una, fe:i qua. tuor diftinctre, qua ad quatuor diftuctos motus inclinarent, vt contingere videmus in mifo imperfecto, in quo non eft facta vera ria ftio, fed plurium elementorum nazura feruantur: quo fir, vt non moueaturvno fimplicimotu ; quia licet vnum elementum in to preualeat catetis, illa tamen non obediunt, fed iepignant quantum polfunt; fic etiam fieres vt naturalis motus mifti noin femper fieret iaxta ele$D$ mentum præualens, fed quandoque contingeret, vtalia tria fimul fumpta plus polene, quam illud foluni, ficutinominales dicebant. Hic igitur fenfus dimittatur; quia Zimara, \& alii, qui eius fententiam fequuti funt, hunc, vt ego arbitror, non accepernint. Alins eft fecundus fenfus, quodin mifto maneant form elementorumcaltigat $x$, \& fract $x$, non tamen amplius vt quatuor form $x$, fed $v$ f fact $x$ vna, \& ad naturan vnam redact $x$, quæ magis referat elementi præEalentis naturam, quam aliorum, \& huic fornix fuperueniat propria mifti forma diuerfa $a b c a, v t$ formalapidis, velformaauri; hac aurem ratione dux effent form $x$ in auro, vna orieas ex commiftione, \& vnione formarumelementorum, altera vero illi fuperueniens, qux dicitur forma mifti : hune fenfum accepiffe videtur Zimara, qui dicere non poteft formam miftieffere diffinctam à formis elementorum, quæ maneant quatuorin mifto, fed quæadvnitatem redact $x$ fint; quia fi quatuor naturæ elementorum feruarentur, non effet facta miftio; \& clara eft Arifotelis fententia in capite poftremo libri primi de Ortu \& interitu, in miftione non exiftere amplius aliquod mifcibilium, fed quoddam medium : fic ıgitur dicere formam minti efle fuperadditam formis alementorum, eft dicere faperauditam form is mifiso 
mitionis prodeunti ex congreffu formarume- A lenentorum. Tertus d:inum etf fenfits, qus folus, vtegoarbiror, verus elt, quod in mito perieto quatuor form celencutorum ita inuicom trangantur, Srenitantur, vt in vnam quintam formum coalcicant, qux neque vna aliqua earum lit, neque omnes fimul, neque etiam ita illis fuperaldita, vere ab eis diftinguatur, fed vt idem re cum illis, quoniam illæ quatuor fun factie vna, nam feruatis quibusdam gradibus fingularum, plurisui tamen vnius, quxe prxulere dicitur, exis omnibus prouinit iorma quxd.un media, quæ diciur forma minti ita vt qux prius erït quatuor, \& dabant effe ignem, \&aerem, \& aquam, \& terram, pofted fit vna, que det effe antrum, \&adifinguatur ab eis formaliter, quia aliam fpeciem conftituit; at non realiter; quia ch illex iplæ quatuor ad vnitatem redakti per mittionem, \& conftituit mcdium qualdam fipecic differens ab extremis, qua de re diligenter loquuturi fumus in libro de mi-

Frms minisp.st simest a.ditts, partim non add:teformis elemen-

roriss. ftion: Hunc igitur tertiun fenfum fi accipiamus, dicere polfumus, formam mifti tum cfe additam formis elementorum, tum non additam: addita enimeft, quatenus non eftillarumaliqua, fed alia quinta forma, \& aliam fpecicm conftituit; atnon eftaddita, quatenus nan funt præter illam form elementorum in miito, nequenlia forma ex earum congrelfi exoriens, fed hxcipfa elt forma proueniens ex congreffúformarum elementarium, ita vt pr $x$ ter hanc nulla fit in milto alia forma; quem fenrerefen. fum fi zimara accepifet, eius fententia damna-
tentre co ri nullo modo pofet. Huncigitur probare, ise tentze co ri nullo modo pontet. Huncigitur probare, is Ë impro mun quidem fecundum hans opinionem tuer Gatioost- non pofiumus, id quod Ariftoteles dixit, mi mionis $Z$ - ftum moucri iuxta elementum preualens : fic mara. einum argumentari poffumus; fi in mifto inanimato funt duæ form $x$ re diftinct $x$, vna oriens. ex congreflu formarum elementorum, qua diraturforma miftionis, altera vero huicfuperaddira, qure fit forma huiusmifti, vt auri, ergo vtraque eft nutura, \& principium motus, qua omnis forma e ft natura, proinde \& principium alicuius motus naturalis ; ànaturisatem diuesfisnccefie eft diuerfos naturales motus prouenire; quinam igitur funt in mito inanimato hi duo narturales motus? nullum ego video præter illum.vnum, quo miftum iuxta praulens elementum moueri dicitur; \& hic fin forman miftionis, in qua vnum ex elementis præualet, refuratur vt in caufam, ergo forma mifti huicfu. peraddita nullius eft motus principinm, proinde otion eft : at fi referatur in formam mifti, quo: modo dicetur fieri iuxta preualens elementum, fi bxe cla redifinca ab omnibus formis ele mentorum? quarenon foffumss amplius tueri veritatem dicti Arifloteles, quod mi fum 1 uxta eleníentum proualens moueatur; imo forma miftionis, qur in fecontinet vim elementi do. minantis, eliet otiofa, \& nullius motus principium, quod quidem nullo modo dicendun eft : hou autem confirmatur argumento fumpto ab anima, qua eft vere addita formis clem:ntotum, id eft, form miftionis ex cartum congrefiu prodeunti; quoniam autem est vere fuperaddi-

B ta, \& reabillis diuerfa, ideo diuerfi ctiam motus eft princifium, itavtneutra illarum lit otiof, nan anima eft principium motus progrefionis, forma vero miftionis eft principium motus dominani elemento conuenientis, quo mouetur animal naturaliter, fi ab alto loco demittatur: hocidemigitur euenire debere in mifto inanimato, frcius forma effet eodem modo fuperueniens form $x$ miftion is, \& reab illis diftingueretur. Nonnullitamen huins argumentivim niC tuntureffugere, dicendo ynum quidem tantummodo effe in mifto inanimatomotum naturalem, fed ad hunc producendum vtramque formam concurrerc; nam forma mifti eft mouens, \& ipli motusille attribuitur, mouet autem iuxta legen libi prafcriptam i praulente elemento, se ita ab vtraque forma ille motus modo aliquo proficifcirur: Sedhrecdefenfo vana cit, quia duo mouentia ré diftincta non poffuntad ciusdem motus productioncm concurrere, nifí $\mathrm{v}$ num fit mouens principium, alterum vero feeundariu!n, \& inftrunentale; eft ergo ab his quærendism, vtra duarum formarum fit agens primarum, quun dicere vtramque habere $x-$ qualem primatum in eiusde motus productione, \& fecundü idem caufægenus, fatuum onnino fit, \& à philofophia prorfus abhorreat: fi dicant formam mifti effe mouens primarium, formam veropraualétis elementi etle nouensinftrumentariü, necefle efi, nrotum illum efie mim E ftü,quod tamenipfi omnes negant; putantenim effe fimplicem: confequentia probatur teftimo nio Arift.in contextu $33 . \& 4.1$ libri odtani Phyfic vbidicit, mouens primarium magis mollere, quam mouens inftrumentarium, \&penes 11 ud effe totum imperium ipfus motus; fiquidem mouensinftrumentarium non vi propria mouteredicitur; fed vi ei tributa à mouente pracipuo: quoniam igitur mouens primarium eft formz mifti, qux formx miftionis fuperaddita eft, \&e ab hac prouenire non poteft nifi motus miftus, necefre eft, vt motus i talis formre imperio productus miftus fit: pugnant ergo inter fe hac duo, formam mifti ell mouens præcipuum. \& mouere iurtalegem fibi prercriptan à forma clementi dominants; liocerim eft omninoabionum racioni, quum inserare, \& legena 
prxferibere fit primarii agentis, non fecundarii : fi vero dicant, formam elcmenti dominantis, feu (quod idem eft) formam miftionis, qua illam continct, cfic moucus primarium, formam vero mifti cffe mouens fecundarium, in maiorem incidunt absurditatem; quia principatus cftilli forma tribucndus, qua continct alias, \& rem in fpecie collocat, quan Latin forinan vlcimaru appellare confueuetunt; hancesim $f i$ in eadem re alix formæ precedant, cas refpetu illius locum matcriz tenere necefie cft \& ab illaregi, \& illius imperiu obtcmperare:quum igitur formx clementorum (vt ipfi contitentur) iencint in mifto locum materix, \& ad formam mifti fuperadditam dirigantur tanquam ad perfectionem, alienum penitus eft à latione, quod carum fit motum imperarc, forma vero nifti earum imperio fubiecta fit. Sed conuincuntur etiam aduerfarii fuis iptorum dictis, nam corum aliqui tali exemplo rem hane declarant: anima fenfibilis fungit ur officisanimx $\gamma$ egetantss, quam in fe continet, \& ipfius of pirationes edit; ita igitur \& forma mifti contiact in fe formas clementorum, \& editoperatio-s nem elementi dominantis. Hoc tamen exemplum corum fententia refingatur; nam anima fenfibilis non folum officiis fungitur animavegetantis, fed pratur illa habet etiam ipfa proprias operationes, \& propra munera, quamobrem etiam forma mifti pratcrquan quod efficit motum proprium elementı dominantis, a lium quoque fuum proprium motum efficere dcberet, \& co magis, quo apud hos eft re diftincta a formiselementoruni, anima vero feníbilis non eft se diftincta à vegetante; quocirca congria quoque efteorum comparatio, nam fi putant, animam fenfibulem non efe un aninali formam re diftinctam à vegetante, nullum inde argumentum fumi poteft de forma nifti, \& de forma elementi dominantis, quas re diftinctas effe arbitrantur: \& mirum certe eft, quod fornatum numerum concedant in niffo inanimato, quem in viuente negant, quum potius è contratio fefe res habere videatur; patet igitur hanc comparationem officere eorum opinioni; quemadmodum enim anima fenfibilis conrinet in fe naturam \& vires anima vegetantis, nec eft illi fuper addita tanquam re diftineta; ita etiam forma mifti in fe continet forman clementi dominantis, proinde nion eft addita formis elementorum, quæ eft lententia noftra. Poflunus hocidem confirmare authoritate Aneriois, qua ipfi quoque vuntur; nam in Comment.67. lib. 3. de Coelo inquit [ forma

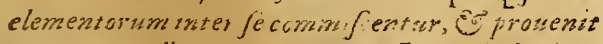

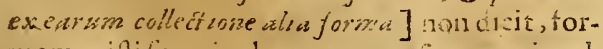
man miñiformis elementorum fuperuenire ab cis diueriam penitus, 1ed ex earum collectione
A alian formanuprodire; eft enim renera alia forma, quia neque eft torma ignis, neque acris, neque aqux, nequx terr $x$, nec tanen eft reabillis d: fincta in nufto, quum fintille ipf $x$ fact $x$ vna: poftea vero adhuc imagis hoc Jeclarat A uerrocs hac finilitudine [ficusi qusmalbedo, EJ nogredo comuifentur, fiunt cx eis muliscalores medii), non poteratenim aptior fieri comparatio; quia calor medius differt fpecic ab extromis, ex quibus conftat, nec tamen eft eis fuperadditus, ve B rediftinctus ab illis; reprafental cnim aliquos gradus albedinis, \& ali quuos nigredinis, qui tamen conftitumt alım fpeciem coloris diterfam ab vtrifque, necillis litperadditam, fed eos in fe continentem; \& ex eisinterne conftantem, vt ait clare Auerroes in libr. primo Plyýícorum, comment.56.\& in quinto Phylicor.comment. $\sigma$. 19.45. \& 52. Preterea in 10. Metaphyfic Comment.23. inquit Auerroes [impojsuble est, ft in Curnos compofito fint dus partes equales, fed oportet alte-politit das

C ram cffe dominantem, cui artribuatur format ri miftis quibus verbis optime Auetroes totam rei veri- ex elemē tatem declarat; inquit enim, non duri miftum tis aguaconfans ex elementis aqualibus : \& hanc ra-liter. tionem adducit, quia debcteffe aliquod, quod fungatur officio formz; eft autem formæ offcium continere, \& vnire, \& operationibus imperare; oportet igitur vnum ex elementis in miftione aliis prenalere, vt $11 \mathrm{li}$ attribuatur pra. togatiua forma, \& fungatur officio forma continendo alia, ficuti dicebat Ariftoteles aduer. fus Empecoolem in contextu 39. libriz. de A. nima: Atque apud Aucroem non eft opusalia forma diuerfa à formis elementorum, qux illis fuperueniat, vt eas contineat, quoniam hoe munere fungitur forma elementi præualentis; continet enmm alias, \& cohibet, \& fibi obedicntes reddit, imo fit vna forma cum illis : a forma igitur mifti exoriente ex congreffu formarun elementorun cum imperio vnius, prouenit motus naturalis ipfus mifti, qui hac ratione dicitur fieri fecundum naturam elementi in ea miftione pracualentis.

\section{Solutio argumentorum Zimare. Cap. VII.}

$\mathrm{V}$ Eritate declarata, fuper eft, vt argumen ta pro Zimara adduleta Ioluamus. Ad primú refpodebat $M$. Antonius Genua Praceptor meus, miftum polfe cōfideraritum in fieri,tum mum $r$. in facto effe: \& quando cöfideratur in herı, cius fonfro materiam effe quatuor elementa perfecta, \& in Genwa. tegra, diriguntur enim ad formam mifti; \& hac ratione formas elementotú effe partē matèrix, nec habere locun formarefpeitu mifti : ficto autem mifto formas elementorum tenere lo cum formz, non quidem vt elementorï forma 
funt, nam quatenus tales, non remanent, fed A perit, neque eftamplius forma illius mift; ete. ve fuut factrova forms, qux cft forma minti. f. Spon- Hanc refponfionem cgo quidem uon reluco, fionis de fed clariorem reddens dico, non eodam modo clararso, clementa manerefub forma mifri, quo prima materia fuppolita eft forma clcmenti, quod ex alio genitum fit; nam prima materia, quum fit vna, feruat maturam fuam integram fub quali. bet forma ; aft elementa, quum fint plura, \& interfecontraria, non poffint integra manere in Elcmen - mito; nqque etiampenitus intercunt, fed cotaguo- rum forma renanent fracta inuicem, is cafrimodoma gar , adeovt perierint fecundum aliquos granewnt in dus, \& fecundumaliquos fint feruati, \& hi mijfo, F $^{\circ}$ quum int ijdem rein mifto, qui prius fuerunt guomodo in elementis integris, fatis idoneam miftimatesnicreit rian conftumn, qux hacratione in mifto genito remanere dicitur, nempe fecundum realitatem gradum remanentiuns. licet ratione graduum in mítione deperditorum deftrueta it prior illa formalitas, qua dabant effe fpecificum ipfismet elementis, \&alia formalitas genita, qua dant efle mifto; \&. ita ratione nouæ formalitatis locum habent form $x$, ratione autem realitatis fermatæ dicūtur effe par's materix: fed hac dere in libro de miftione fufus differemus.

-1d/ecus. Adfecundum negarda eft confecientia; nam dum. factamiftione; confrar quiciem corpus ex corforibus, at non forma ex corporibus, fed potius ex pluribus forms, qua euaferunt forma In miftio vna necerfe eft crin tres fumul fieri commine tres ftiones, valm plurium corporum, qua funt Griones corpusvum, aliampluriunfomarum, quæ fiunt. fiuntvat forma, tertam demum contrariarum qualitatum, quæ finul contemperatæ faciunt vinam qualitatem mediam, qux dicitur temperatura mifti, \& retinet aliquid' omnium. elementarium qiualitatum, fed plus illarum., qux funt qualitates elementi præualentis; quia etiam tota mifti natura propinquior, ac fímilior eft natura elementi dominantis: , quam:natu1 isaliorum: liocigiturargumento non probaturformam mifti conftare cx corporibus, fed folum commiftionem formarum fieri non pof$f_{e}$, quin corpora quoque commifeantur, propteres quodillz forma: non . Peparabiles à materia- Ad tertium fimiliter negamus conferium. quens; \& rationegationis eft, quoniam natura mift confiftit: in indiuifibili:, nec: poteft intend 1 , vel iremitti, nifi inteseat, \& res alia: gene. retur: \& \&uiailla intenfio, vel'remiffio fit cum interitu form mifti, \& cum conferuatione graduum formarum elementorum, ideoattribuenda eftilli, quod feruatur, non illi, quod perit; quamobrem fola formz elementorum intendi, vel remittidicuntur; quarum: funt illi gradus, qui remanent, non forma mifti, qux confiftit in indiuffibli, à quo vtcunque declinans: nim formalitas nec intendi, nec remitti potef, realitas vero intendiur quidem ar queremitte. tur, fed hxcintenfio, vel remiflio aturiburut formis, elcmentorum, non formæmifti; fed de localibi. Adquartmm dicimus, rrgumentum illud Ariftotelis efficax efle contra Enspedoclem, at non contra nos, Empedocles cnim elementa in mifto ponebat feruantia fuas naturas integras, \& fuos actus fpccificos, \& propriaseB dentia operationes, loquens enim de vituentium nutritionc dicebat, ignem afcendere ad fuperiorem animantium partem, \& eam nutrire, terram vero: defcendere ad alendam partem inferiorem; ideo Ariftoteles reate dixit, elemenı indigere formanliqua continente, \& coercente ip fa, ne feparentur:nos vero non dicimus, elementain milto manere integra, \& proprias.edereoperationes difanctas, fedin aliam naturam: C. tranfiiffe, \& omniaita confpiraffe, vtad vnum. \& eundem motum: propenfafint propter obefientiam: quam imperanti elemento catera præftant,quoniamillinon amplius repugnant:: (idcirco non egent aliquo continente, quum à dominante elemento fatis contineantur, \& illi. abediant in.petendo loco naturali i hre fuit Auerrois opinio in Comment. 23. decimi Meta. phyficor. à nobisantea confiderato, vbi inquit, non dari miftum ex elementis xqualiburs; fed oportere vnum eorum pranalere aliis, . cui attribuatur forma; fungitur enim officio form 2 . quia continet alia: qux Auerrois ratio optima eit ad demon frandunz, non darimiftum ex elcmentis aqualiter conftans, \& fumpta eftab hoc forma pricurario munere, quod eft continere; neceffe eft enim aliquod efle continens, \& $\%$.. niens; hocautem nullum:effepoteit, fixquales. fint in mifo clementorum vires : non diceret. aurem Auerroes hoceffe neceffarium, fi putaretformam miftieffe fuperadditam formis eleE mentorum; lixc cnim fatis formæofficio fun geretur, \& formas elementorum contineret. etiamfi effent aquales. Credoetiam ad noftram. fententiam comprobandam fatis roboris haberealiud argumentum; quo vfuseft A uer roes in Comment. 7..lib. r. de Coelo; ad probandum non dari miftu m æquale: inquit cnim, fi daretur miftum $x$ quale., quiefceret in quocunque locoponeretur, quare nullum habcret motum naturalem: tale autem.corpus inrerum natura nunquam.vidimus. Confeqnentia m.unifefta eft perea, qux fupra diximus; antequam enim de naturalialicuius corporus notu loquamur, necelle elt vt ei ftatuamus cercum in mundo locumnaturalem:, quem naturahter petat; hic autcm ftatuinon poreft, nifi ratione elementi. -praualentis, . ergo fielementa in mifto xquaLiacfent , nullusci locus alfignari poflet, quia. 
non magis hic, quam ille; iccirco maneret miftum in quocurque loco poneretur, ad nullum enim locum ex fe mouereturid, quod nullum habere poneretur certum locum naturalem: itaque fi vnun ex elementis prouleat aliis in misto, fecundum illudaffignabitur ei locus in nundo, ad quem moueatur, quare penes elementum doninans eft imperium motus naturalis;proinde hoc fatis eft ad alia continenda, \& adfatuendum motum natural em, neque opus eft alia forma fuperueniente formis elementorum: :ex his igitur patet, argumentum hoc pro opinione Zimarz nihil habere efficacitatis. Ad

n- quintumargumentum neganda eft fimilitudo; anima enim eft forma nobilifima vere fupcraddita formis elementorum, hoc eft, forma miftionis orienti ex earum congreffu, non fic formu mifti inanimati : quod quidem ex motibus confequétibus manifeftuma eft, anima enim éft principium motus diuerfi penitus à motu elementi dominantis, \& vtrumque niotum vide. mus in eodem antmali ineffe vt naturalem; at forma mifti inanimati non efficit alium motum, quan illum; qui conuenit elemento præualenu; hæc igitur non eft addita formis elementorum ; anima vero eftaddita, \& re ab illis diftincta. Ad verba antem Auerrois in omnibus memoratis locis patet refponfio ex iis, qua ste dictafunt. Anerroes enim dicens formam mifti effe quid addiı un , \& quid diftincuun à formis elementorum, non intelligit realiter diftinatum, fed formaliter tantum ; non enim fignificare vult effe additam noun formam, qux fit in mifto prater formas elementorum, fed has ipfas in v nam formam trăfiiffe, quax eft mifti forma;non amplius élementorum, ita yt fpecie differat miftuni ab elementis om nibus \& diuifim, \& corrunctinı acceptis ; nám cato non eft terra, necignis, nec a mbo fimul, fed quixdam alia fpecies, qux diftinguitur effentialiter ab elementis; hoctantum fignificant omniallla Auerrois verba, fibene conliderentur.

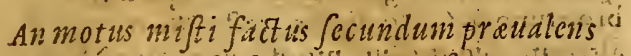 elementum fit jimplex, an miftis, opi- niones aliorum cum eorum}

\section{argumentis.}

\section{Cap. VIII.}

T. Andem confiderandum manet, an motus mifti, qui iuxta praualens elenentum fieri dicitur; fit fimplex,an miftus. Tres hac de re opinionè éxtant :-yna fuit Sueffani, quem alij nonnulli fequuti funt, quidixerunt nullum talem motim effe fimplicen, fed feniper efle miftum: alia kuic contraria, qux plurimorum communis fententia eft, potiflime autem à Simplicio, \&\& ab Anerroedefenditur, quodomnistal is motus fit fimplex; \& hanc ego quoque veram effe exi- Tertse ftimo: tertia demum aliquorum, qui dicunt opinio. falfam effe vtramque vniuerfalem propofitionem, veram autem hanc vtramque particularem, motus mift fecundum preunlenselementumaliquis fimplex eft, \& aliquis miftus. Afferam igiturin medium argumenta, quibus alias duas opiniones alij tuentur, deinde veritate declarata, ca ominia foluam. Primam fententiam Proprs.

B quod omnis talis motus fit miftus, probät Suef- ma opefanus \& fectatores multisargumentis. Primu m nione pri à caufn ipfius motus tale argumentum fumunt : mum arvbieft elementum dominans, ibı funt etiam a- gismenlią, quibús dominatur, dominans enim notat re- twm. fpectum adilla ; adfuntergo' in mifto omnium elementorum naturæ, ergo ex his ómmbus conftans natura mifti mifta elf; \& qualis eft natura, talis eft motus, quiab ea producitur, ergo motus ille miftus eft; magis tamen vergens ad motum elementi dominantis, quam ad motus aliorum, quemadmodum etiam natura illa fimilior eft naturæ element i dominătis, quam naturis aliorum. Secundo ficargumentantur à fubiecto: Secundz̃ quale eft fubiefum motus, talis eft motusipfe, argumen atqui huius motus fubiectum miftum elt, hoc thm. enim fupponitur, ergo motus eius naturalis miftus elt ; eaquefententia Arifot. fuit in context.7. lib.r.de Collo dicentis, fimplicium corporum fimplices funtmorus, miftorum autem mifti. Tertio id ita confirmant: fi hic milti mo- Tertium tus fimplex effet, fequeretur, eundem produci argumen effectum à tali fecundum quid, \& à taliabrola-tum. te:confequens falfum eft; quia debiliter calidum non poteft tantum calorem efficere, quantum efficitid, quod eft fumme calidum : confequentia probatur, quia terra eft elementum, \& fimplex corpus, 2 abfolute grauis, ideo producet effectum conuenientem corpori abfolute graui, nempe motun fimplicem; miftum auE tem non potefteffe abfolinte graue, fed folum fecuindum quid ergo fi miftum, in quo terra præualeat, fimplicí moti mouleatur, eodem mouebiturmotuid, quod eft giauefecundū quid, quo terra, quaeeftabfolute, acfumme grauis; neceffe eft enin, vt licet in mifto terra praualeat, eius tamen grauitas remittatur ex commiftioné el emeniorum lenium; itaque à tali fecundum quid, \& ab abfolute tali idenı effeetus producetur, quod eft omnino abfonum rationi.

Confirmat auctoritate Aucrois in Comment. Quntio 7. libr.r. de Colo, vbi.interprétans verba illa A-argumes riftot. [mouer autem fecundum prewalens] in-tum ab quit, Arift. occurrere tacito dubio: quum enim auctors. dixiffet, motum mific corporis effe miftum, ob- tate. jicere quispiam poterat quosdam motus, qui licet fint miftorum corporum, fimplices tamen fuxt, ideo inquit Anerroes, A riftot.refpondere, 
motusillos videriquidem fimplices, nōtamen A co propofitam, quod omnis motus corporis elle:caufan autem,cur fimplices effe videantur, efre snius clementi exceffum, ad cuius naturam magis vergitillius corporis motus, proinde videtur effe fimplex, quum tamen non fit:propterca ifti hunc putant effe fenfum illorum Ariftot. verborum corporis nifti miftus eft motus, fit tamen fecundum el emëtun præualens, ideo eius motui finulioreft, quam motibus aliorum. Sim. plicium quoque in hanc fententianı trahunt, qui dicit in corporibus miftis tot effe principia nows, quot funt illa, ex quibus conftant, \& adducit etiamverba Alexandri dicentis miftorum corporū miftos effe motus, quia plura motus principia in eis infunt : quod quidem poteft etiam colligi ex Alexandro in primo eius l, bro de Anima,cap.2.vbidicit : formas miftorum effe modo quodam affectas à formis mifcibiluum, qua fin. gulxad communem formam aliquid conferüt, vnde multæ varietates contingüt : fignificatigitur miftorum corporum non fimplices effe mo-

Tertic tus, fed miftos. Alia vero fententia dicentium fectar - aliquem mifti motum factum fecūdum præuagsmenta lens elementumeffe fimplicem $\&$ aliquem effe miftum, ab eisita probatur : primum quidem probant aliquem effe fimplicem vtentes teftimonio Arift. in context. 8. libriprimi de Colo, quod etiam fenfu' $\&$ experientia confirmatur, paret enim lapidem non minus fimplici motu deorfum ferri, quam terram : quod vero aliquis motus mifti fecundum præualens elementum ractus miftus fit, fimiliter teftimonio fenfus cognofsidicunt; motus enim turbinis, venti, fulaninis, \& aliorum fimilium, eft motus factus fecundum præualens elementum, \& eft miftus, vt patet, illa enim pluribus elemétis conftant, quorum vnum aliis validius eft, ob id eius motui fimilior eft illius mifti motus; quo fit, vt dicatur fieri fecundum element um praualens, miftus san en absque dubio eft. Quoniam autem in illo contextu 8. videtur Ariftot. hanc vniuerfalem propofitionem proferre, notus miftifecundum praualens eft fimplex, dicunt ipfi veram quidē effe hanc vniuerfalem, omnis motus fimplex mifti corporis eft iuxta elementum præualens; red conuerfam effefalfam, omnis notus corporis mifi fecundum præualenselementum fimplex eft, quum motus turbinis, ac ventifit miftus, quare hxc non eft vera, nifi vt particularis; non igitur hanc voluit ibi fignificare Ariftot.fed alteram conuerfam, qux etian vt vniuerfalis vera eft, vt pradiximus.

\section{Vera Sententic declaratio, of comprobatio, aliarum vero confutatio.}

Cap. IX.

F Go vero vtramque fententiam falfam effe arbitror, veram autem aliam fecundo lomifti factus fecundum clementum præualens fimplex fit ; cuius contrariam prima feeta tuebatur,contradietoriam verotertia. Ad ver $æ$ ıgitur fententix comprobationem, \& aliarum reprobationem, eft ante omnia cognofcendum, qua conditiones ad fimplicitaten motus re. quirantur, \& cur motus al iquis dicatur fimplex, \& aliquis miftus. Sunt qui dicant, tres conditiones ad fimplicitatem motus poltulari, nemB pe \& fpatij, \& naturæ, \& mobilis fimplicitatem; ob id putarunt non poffe corpus miftum fimplici motu moueri, propterea quod neque fub. iectum, neque caupa fimplex eft. Sed hi, quum absque diftinctione loquantur, decipiuntur: aliud enim elt conditiones quarere neceflarias nes: adalicuius rei effentiam conftituendam, aliud tus $/$ t eft quxrerecaufas qux ad eam producendam placis requiruntur; nan effentia eclipfis confiftit in open priuationeluminislunx, caufa vero eam pro-liorn ducens eft terræ interiectio, ficconditiones ef - Conf fentiales, qux ad hominis effentiam conftituen- tio. dam poftulantur, funt eius caufre interna, materia' \& forma propria; ad hominem autem generandum requiritur Sol, \& alter homo: fic igitur de motus fimplicitate dicendum eft; ipfa enim fimplicis motus effentia in fola fpatij, feu linex fimplicitate confiftit; quisquis enim motus per fimplicem lineam factus ftatuatur, is absquedubio fimplexeft, cuiuscunque fit cor$D$ poris, \& à quacunque caufa productus: at fi quæratur, quænam caufxad fimplicem motum producendum poftulentur, fi de fimplici motu naturali fermo fit, dicere poffumus, re. quiri fimplicem naturam, proinde \& fimplex corpus., nam fimplex natura corpus fimplex conftituit : at fi abfolute fimplicem motum confideramus;, nec magis naturalem, quam violentum, is produci poteft etiam à natura fimpl. mifta; poteft enim fagitta exarcu, \& plumbea Geoles E pila ex bombarda furfum pelli per fimplicem tws. lineam, isque erit motus fimplex violentus : quod manifefte fignificat Ariftotel.paffim in libroprimo de Coio dicens, rectorum motuum alterum cuique elemento effe naturalem, \& alterum contra naturam : cenfuit igitur dari fimplicem motum etiam violentum; hic autem non fit neceffario à natura fimplici, neque neceffario in fimplici corpore: fed quum videatur raro, \& per accidens euenire, ve fiat in aliquo F corpore motus fimplexviolentus, \& id folum fit confiderandum, quod eft per fe; idcirco dicendum eft, motum fimplicem naturalem aptum effe produci folum à natura fimplici, proinde $\&$ in fimplici mobili ; natura enim eft principium motus in eo, in quo eft, \& omne corpus, cuius natura fit fimplex, fimplex eft: fimplex autem linea quænam dicendafit, confideran-

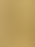


dum eft, nam. fi mathematice loquamur, for- A taffe omnis recta linea, \& omnis linea circularis poteft appellari fimplex; mifta vero, cuins pars aliqua recta fit, \& aliqua circularis : fed phyfice confiderando fecus eft; dum enim linean confideramus refpectu notus, qui per cam fit, aliqua datur recta linca, qux vocanda eft mifta, \&c fimiliterali qua circularis', qux miftact; dicimus igitur fimplicem effe naturaliter illam lineam, per quam factus motus non conftat ex recto \& circulari, fed vel rectus tantummodo eft, vel tantummodo circularis ; circularem autem y oco illum, qui fiat circa folum mundi centrum, non circa quoduis circuli centrum; ita vt ille motus, per quem non varietur moti corporis diftantia à centro, fed femper $x$ que ab eodiftet, circularis fimplex nuncupandus fit: 1 ectusautem firplexille fit, qui fiat per rectam lineam à centro mundi ductam, feu afcendendo, feudefcendendo; fimplexenim dicitur, quia nihil ei refpondet in Colo, nifi punEtum;lic enim eft vel meia acceffio ad centrum, vel meia recefio ab eo, fine vllotranfituad latera, quod effer mouerietiam circa medium :at motus omnis per rectam lineam factus non à centro mundiductam miftus eft, conftat enim exrecto, \& circulari ; ex recto quidem, quatenus neceffario fit cum acceffuad centrum, vel cum receffu à centro; ex circulari autem, quatenusilli rectrlinex refpondet in Colo al iqua peripheriæ pars, nulla enim à mundi centro du- D cta recta linea poteft per vtramque illius linex extremitatem tranfire, fed neceffario dux diftinct $x$ linex recta à centro per duas illius extremitates ducentur, qux fuss extremitatibus aliquam peripherix partem in Colo intercipient, qux toti illius motus fpatio refpondebit; \& hacratione motus llle dicetur etiam ex circulari conftare : fimiliter quilibet motus per circularem lineam factus, qui non fit circa mundi centrum, miftus eft; quia conftet ex motu circa medium, \& receffione à medio, feu acceffione ad medium: ynde colligi obiter volumus, motus aftrorum factos per eccentricos orbes, vel per epicyclos, quos aftrologi ponunt, fi darentur, non effe fimplices, fed miftos, non folum enim circa medium funt, fed continent etiam accelfionem ad medium, \& receffionem à medio, qua ratione conftant etiam ex motu recto : inifti funt etiam animalium motus, \& turbinis, \& fulminis, \& venti, \& F alij ejusmodi, quia funtacceffus, vel receffus refpectu medij, vna cum tranfitu ad latera, cui relpondet circuli pars in Colo. Colligimus etiam ex his nonnullorum errorem, qui mótum miftum intelligunt1llum, quiconftet vel ex recto \& circulari, vel ex recto \& recto, vel ex circulari \& circulari jnam exafcenfu, \& de- fcenfu eundem motum conftare ne imaginari quidem poffumus, nıfi dicamus, candem rem prius afcendere, poftea defcendere per eandem fimplicem lincam; fed hic non eft motus $\mathrm{mi}-$ ftus, funt potius duo diftincti motus, \& vterque fimplex : ex circulari etiam \& circulari non Mifzio datur miftus motus, quia miftio non dicitur eo- eft rerïs rum quæ funt eiufdem naturæ, \& fpeciei, fed fpecse difolum corum, qux funt diuerfarum natura- uerfariz. rum : praterea li intelligant motus erraticorum ideo effe muftos, quod fiant per circulos eccentricos, id concedemus, fi modo tales circuli dentur; fed ea erit miftio ex circulari \& re- Morus cto, ficut antea dicebamus, non ex circulari \& planetacirculari; fi verocum perpetua æquidiftantıa à rum noz centro confiderent folum duos eorundem a- estmeftrorum oppofitos motus, decipiuntur, quia fut. hre non eft miftio, quum feruetur vna fimplex conditio, quod fineacceflu, vel receffu, refpectu medijeft foluni circa medium, obid etiam Calis motus, etfinon percirculum, fed potius per helicem fit, fimplex $\in$ ft: quamobrem dicinus nó darialium miftum motum, quam conftantem excirculari \& recto, eaque eit fententia Ariftotelis clara in contextu s. Libri primi de Colo; fic enim duarum fpecie diftinctarũ conditionum miftio fieri dicitur. Quis igitur fit fimplexmotus, \& quis miltus, \& in quo confiftat tum fimplicitas, tum miftio ipfius, manifeftum eft: fimplicitas enim iudicatur ex fimplicitatelinex, perquam fit motus, hxc autem iudicaǐur ex fimplicitate fitus refpectu cētrimun$\mathrm{di}$; fimplex enim eft fitus line quando o mnes partes funt à centro fimiliter $x$ quidiftantes, itavt totus ille motus fit circa medium; vel quando funt ita pofitzpartes refpectu centri, venulla eis peripleria pars in Colo refpondeat, fed fit vel mera acceflio ad medium, vel mera receflio à medio. Quoniam autem dictum eft, fi motú tantum modo natural em con-

E fideremus, caufam motus fimplicis effectricem effenaturam fimpilcê, mifti vero miftam; confiderandum eciam eft, quanam fimplex natura dicatur, \& qua mifta, vipoltea rationem habeamus, cur fimplex natura fimplicem motum efficiat. Dubitareprimum de hac re non abfque simp les rationealiquis polfet: quum enim cuiufque rei natur natura fit forma, \& omnis forma fit fimplex, 'o- quanam innique carens compofitione, videtur dicen- fot. durgeffe, omnem naturam effe fimplicem, proinde nullam dari naturam miftam. Dicimus igitur, omne formam effe hacratione fimplicem, quoniam ex pluribus naturis non conftat; alia tamen ratione dici pofle miftam; nempe fi alias formas, vel aliam in eadem ma teria præ fuppo- nat:licanina diciturnarura mifta, quia præfupponit priores fe in ea dé materia for mas elementorum, quain mediam formam migraucrunt M 4 redi-
Verd apsnio de motis mifto.
- 
re diftinctam ab anima; cuius quidem miftio- A feendereperbreuiorem : hæc autem rátio non nis figra cfle videmus varietaten virium anjmr, \& organorum in corpore animato illis viribusinferuientium; \& motus quoque ipfe, quo anınıl ab anima monetur loco, miftus ef, quia conftat ex recto \& circulari : forma vero clementi eft natura fimplex, quia nullam priorem formam in matera prafupponit, fed ip fa in prima materia immediate inhret, \& corpus ab ea conftitutum finplex dicitur; quemadmodum id, quod ab anima conftituitur, miftum eft, quoniam anima præfupponat neceffario cöcur frm - grefum, \& commiftionem elementorum. Sed plex na- quum ex his pateat, non eadem ratione natuturafim- ram dicifimplicem, qua motus dicitur fimplex, plicem fed alia, \& alia; nam fimplex natura dicitur, mıгиm quæaliam priorem in eadem materia non præafficiat. fupponat; motus autem fimplex, quia non conftet ex recto \& circulari: cognofcenda eft ratio, cur à natura fimplici fimplex motus proue. niat, fi non eft eadem vtriufque fimplicitas. Dicimus igitur, talem effe fublunariū corporum naturam, vt egeant confertuante externo, fine quo non conferuarentur: quum autcm fublunaria dico, fimplicia prafertim intelligo, quia hac fingula fatutum habent in mundo locum naturalem, quem appetunt, \& in quo quiefcen-

M:Paba bent locis ratione fimplecium. tia conferuantur, \& mundum complent, mifta vero non fibi præforibunt in mundo locum quatenus miftalint, fed quatenus ex eifdem, qua mundum implent, corporibus conftant; ex illius enim elementi natura, quod in miftione aliis prxualet, prafcribitur mifto locus in mundo; exmotuigiturelementiad proprium locum cognofcere poffumus, qualis fit eriam mifti corporis motus, \& in quofit fimilis motui elementi, \& in quo ab eodifcrepet. Elementum ad fuum locum mouetur, vt conferuetur, fiquidem non in quouis loco conferuaretur, quum diuerforum locorum diuerf $x$ fint naturx, \& vires; harum autem differentix non aliundefumuntur, quam ex varietate diftantix à Colo, quo fit, vt per lineam rectam à centro mundi ad Colum yfque productam. omnes locorum differentix denotentur: elementum igitur extra fuum locum exiftens neceffe eft vt per hanc vnam lineam fuum locum petat, proinde non alio motu, quam fimplicit. ctenim natura nunquam abundat in fuperuacaneis, fed in vnaquaque re id, quod optonum eft, facit, nec patitur aliquid effe fruftra: elementum igitur exiftens extra fuum locum ad illum tendit, per lineam breuiffimam, nifi impediatur, hac autem eft reeta à centro mundi ad Coelum vfque protenta; nam $f i$ per aliam quamcunque moueatur, mouetur per longiorenı, quod dicendum non eft, quia fruftra per longiorem lineam defcendit graue, fi poteft demagis in fummegraui, \& in fumme leui, cuä in duobus elementis mediis locun habet; imo ét in omnib.miftis tum inanimatis,tũ animatis, qua vt grauia, vel vt levia moueri dicantur: quú enim itatutus fingulis fit locus naturalis, grauia autem, \& leuia omnia locum fuum petant vel ad centrum accedendo, vel recedendo à centro, necelfe eft vt om nia per breuiffimam lineam ferantur naturaliter; breuifima autem $B$ eft, vt diximus, ea fola, quxà centro inundiducitur, eaque eftetiam fimplex ; igitur etiam mifta dummouenturvt grauia, vel ve leuia, non alio motu mouentur, quam fimplici; mifta vero inánimata manifeftum eft non haberealiun motun natuialem, nifi illum vrum, quo it grauia, vel vt leuia mouentur; horumergo naturalis motus necefario fimplex eft, nec poteft efle miftus; hunc autem attribuit Ariftotel. clemento praualenti in vniufcuiufque miftioC ne, quia iuxta elementum praualcns afignatur cuique locus in mundo naturalis, quo affignato non poteft corpus vllum adillum tendere vtgraue, velvtleue, nif motu fimplici. Hxc igirir eft ratio, cur natura fimplex fimplicem inotum producat; hac enim non mouet, nifi per grauitatem, \& leuitatem, proin. de per folam fimplicem lineam: nacura autem mift quum affignatum habeat in mundo locuin ratione elementi in ea dominantis, mouet etiam iuxta illius elementi naturam, quam prafe fert; ideo mouet potius ratione fimplicinatis, quam ratione compoftionis, quia catera elementa iam funt facta obedientia vni præualenti, neque funt principia aliorum motuum, neque reluctuntur: natura igi- $N_{a}$ tur mifti media quodammodo eft inter formam m elementi, \& animam ; nam anima eft forma vere mifta eo mado, quem diximus, prafupponit enim in materia formas elementorum præ.

E cedentes, tum in fua generatione, tum poftquam eft genita; forma vero elementi nul lam aliam formam in materia prefupponit modo vllo vt habentem locum marerix, fed folum vt habentem.locum priuationis, quia ynumgeneratur ex alio; at formamiftionis in fua quidem generatione prafupponit formas elementotum, quarum realitates refpectu illius tenent locum materiæ, fed poitquam eft genita, nullam habet præcedentem forman in F materia, fed ipra immediate, \& fole in materia hæret, quia nulla ibi eft alia forma, eo quod ipfa non eft fuperaddita formis elementorum; fed eft 11 læmet factre vina; quocirea hacratione eft fimplex, \& mouet motu fimplici, quia praualentis elementi naturam reprafentat, \& mouet per præualentem grauitatem, vel leuitatem, qua funt principia fimplicia, \& proprix elem en- 
clementorum qualitates, proinde non aptre moucrenifi fumplici notu, quia per folumfin. plicem lincam, ficut dictum eft. Id autem, quod de fimplici motu diximus, poteft per motum miftum animalium confirmari; hic enim foluseft miftus naturalis, quum onnesalii mo tus mifti fint violenti, \& fit à natura mifta quatcnus mifta eft; datus cnim eft animalibus quoque motus propter eorum conferuationem, aJia tamen ratione, non énim -vt conferuentur à loco, red vt idoneum fibi alimentum quxrant; videmus autem hunc quoq; motum perlineam brevilfimam fieri, quia nilil eft fruftra in naturaicquus enim famelicus cibum intuës ad eum per breuiffimam lineam mouetur, non per flexam, \& longiorem, nififorte impediatur; hic tamen motus non eft fimplex, quia non ex fola linex rectitudine, feu breuitate fimplex motus iudicatur, fedex eo quod fiat per lineam à centro mundi ductam, \& fiat vel à grauitate, velàlenirate, qux funt princivia fimplicia, \& m. naturam fimplicen denotant. Hinc fumitur folutio cuiusdandifficultatis : quum enim ignis aque conferuetur in qualibet parte concauilunæ, vićcturille ignis, qui apudnos generatur, non minus trantire pofie ad illam partem concauilunx, qux eft fupra antipodas, quam ád illan, qux eft fupra nos, quum veraque fit aque. conferuatua naturæe Ignis; cur ergo non tranfit ad iilum partem loci iui, quæeft fupra antipo-

io. das? Nusautem dicimus, ignem quidem non magis hancpartem illius loci appetexe, quam alım, fiquidem eaudem vim omnes habent conferuandi ignem; led qua adlocum fuum mouctur per lncam breuillumam, ideo cam tantum partem petit, quélippra nos eft, non illam,quæe eft fupra antipodas, ad quam fimoueretur, neceffe effet, vt priusad mundi centrum defcenderet, \& ita recederet à parte loci fui propiuquiore, quod quidérepugnat natur $x$ ignis. pinquiore, quod quidérepugnat naturæ ignis.
Notareauten hicpofumus, ominem localem s na motum naturalem ab appetitu fieri, fed dupli'is cem effe, quiaduplex etia m eft appetitus; vnus. ap- eft naturalis, qui fine cognitione eft; alter vero. animalis, \& cum cognitione : appetitus natura-
lis proprij loci eft grauitas, \& leuitas, \& ineft st. primo elementis, deinde per el eméta etiam miftis, \& femper motum fimplicem efficir, quia. hac funt principia. fimplicia, nam animal quo. que, fi naturaliter moueatur vt graue, fimplici motu mouebitur, quoniam à principio fimpli: ci fimplex motus prouenit : appetitus autemanimalis infequitur animam, ideo non eft fimplicis motus principium, fed miftínon eftenim appetitus loci conferuantis, cuius differentix fumantur ex varietate diftantia à Colo; fed eft appetitus alimenti neceffarij ad vitam conferuandam, cuius indagationon fitnifi per mo.
A tum miftumjà natura igitur wif qua quatenus mifta eft, non proucnit motus nifi miftus. De mo- Motus tu autem Coclialia ratio cit: quamuis enim fiat cali a ab anima cognofente, fimplex tamen eft, quia principio fiat à principio tum actiuo, tum paffiuo fumme fimplosi. fimmlici; anima cnim mouens fimplex maxime eft, orbis quoque eft corpus fimplex, \& quum non fit elementaris naturæ, nihil habet grauitatis, aut leuitatis, quare nec accederead centrum poteft, nec ab eorecedere, fed folummodo cirB ca ipfum ferri; hic autem eft fimplex motus, quiavnius tantum eft conditionis, vt prædiximus, $\&$ is fimplici natur $x$ Coclimaxime conueniens, cuins fimplicitas fumma ex eo iudicatur, quod nullius motus præter illum eft capax, neque vt maturalis, neqie vt violenti : at elementum minoris eft fimplicitatis; quamuis enim vnum tantum habeatmotum naturalem, capax tancn cftetiam contraria tanquam violenti. Per Errorpre hac vtriusque fect er or oftenditur : errauit e- me fecta.

C nim prima fecta dicens nullum miftimotum effe fimplicem; etenimiam oftenfum eft, neceffarium effe vt motus mift, quifit fecundum praualens elenicntum, fit fímplex, quia omnis motus factus per grauitatem, vel leuitatem, eft per lineam finplicem, eaque eft feńtentia. Ariftotelis.lara in contex. 7. \& 8.lib.r. de Coelo, vbi profert harc propofitionem vt vniuerfalem, mo. tus mifti naturalis fimplex eft,-quia eft fecundum elementumpræualens, omnisigitur motusfactus fecundun praualens elementum eft fimplex: vanifima autem eft in eo loco interpretatio Sueffani dicentis Ariftibi tollere quan- saeffare dam obiectionem; nan dicerealiquis poterat, error.

- fi \& afcenfus \& deféfus eft motus fimplex, mifti autem corporis niftus eft motus, ergo miftú. neq; afcendere, neque defcendere: ad hane igiturinqut Arift. refpondere motum miftifemper effe miftum, effetamen furfum, vel dcorfum fecuadum quandam preualentiam, at non fim. E - pliciter, quoniam eft quidéfimiliormatuicleménti præualentis, at non eft omnino furfum, nec omnino deorfum. Sed huius interpretationis vanitatem ipfa verborum Arift. feries declarat; nam pracedentia verba erant hac. fimplex. motus est fimplicis corporis ] deinde ftatim hac: requuntur [etenim ficompojiti fuert, fecundum proualens erit] ]eft ergo fenfus; et en im fi fimplex. motus fuerit mifticorporis, erit fecundu præualens elemëtum; de fimplici etenim motu;vt paF. tet, hac omniaxerba proferuntur : fuit etiä hac fententia Simplici \& Auerrois, vt paffim in ip forum Cămentariis librorū de Calo legere poffumus : ideo mirandum profecto eft, quomodo aduerfarij udeant ho rum interpretu. verbapro feadducere. Experientia quoq; hanc fententiam confirmatinam rdificatores vtuntur. linea perpendicularifimplisi, quam inueniwat per plum.

$$
\text { M. } 3:- \text { bum }_{2}
$$


bum, vel lapidem capiti funis alligatun ; hac $A$ enim funt mifta corpora, \& ad centrum feruntur grauitate elementi proualentis, perlineam perpendicularem, qua fimplex eft, omnis enim reeta linea ad centrum protenta fimplex eft. Parietes quoque $x$ dificiorum, nifi ad perpendic:lum fint fabricari, durare diu nequeunt, fed aliquando cadunt, \& per lineam perpendicularem deorfum feruntur: \& omnino docet experientia, non minus mifta grauia, quam elementa per fimplicem lineam defcendere: quapropter illorum fententia fenfui quoqueaduerfaBrror tur. Tertia vero fecta errauit, quia non animadsertise ferta. uetit, pofic duobus modis elementum in miftoaliis dominari : vno modo in mifto perfecto, vbi eft facta vera miftio, \& alia elementa vni obediunt; quare vnum ibi eft principium motus, non plura, nec vlla adeft repugnantia, obid motusille eft merenaturalis, \& fimplex: altero modo in mifto imperfecto, $v$ bi non eft factavera miftio, neq; naturarū vnio, fed ibi funt plura elementa feruantra proprias naturas, \& inter fepugnantia:ideo fi vnum præualcat aliis, dici quidem poteft dominans, fed improprie, quia reliqua non funt domita, fed reluctantur; ideo non omnıno talis motus prouenit, qualem elementi dominantis natura poftularet, led mifus, magis tamen ad illum vergens, quam ad motus aliorum; ibi ergo funt plura principia motus, non vnum, proindenon lim lix motus prouenit, fed miftus; non fit enim a fula grauitate, neque à fol 2 leui tate, $f$ ed ab virifque fiınul agentibus, tanquam à duobus principis; neque eo modo, quo aerdefcendit in igne, $\&$ afceindit in aqua, idem enim eft motus, quia ad eundem locum fit, \& ab eadem natura aeris. qux́ dú cift in igne, dicitur grauitas, dum autem eft in aqua dicitur leuitas, quare eft motus penitus natura- lis : at ille nó eft motusnaturalis, fed potius violentıs, nulli nam que el ementorum ibi exiftentium eftmerenaturalis: quod fi ctiam concederemus, efle elemento dominanti naturalem, licet hoc minime verum fit, at negari falte non poteft effeviolentum cæteris: de tali igitur mo. tu non loquitur Arıft. in principio 1,16 . 1. de $C_{0}$ lo, quando dicit, miftum moucri iuxta elementum praualens; fed loquitur de motutantum naturali proinde de motu perfecti tantum mifti, vbi vnum elementum primo modoalis pr ualeat, hoc eft, facta vera miftione, \& fublata emnirepugnantia aliorum elementorum.

\section{Contrarium argumentorum folutio. Cap. $X$.}

Adpri- $\mathrm{R}$ Eliquum eft, vt contraria argumenta folmüssef. R uamus. Ad primum Suefañ dicimus, nafans. turam miftam efficere quidem motum mi-
A fum, fi moueat quatenus eft mifta, \& eiufmodi diximus effe animam, qux eft vere addita formis elementorum : fed fi natura mifta moueat non vt mifta, fed ratione naturæ fimplicis in miftione præualentis, facit motum fimplicem; quia nonalia ratione mouet, quam ratione grauitatis, vel leuitatis, qux funt principia fimplicia: ad de quod forma miftions, licet in fua preductione præfupponat formas elementorü, tamen poftquam elt producta, nullä habet in maB teria præcedentem formam, fed ibi fola adeft abfque alia forma; quare eft principium motus fimplicius, quum fit tanquam fimplex forma. Ad fecundum fimiliter dicimus, corporis mifti, quatenus eft miftum; non eife motum nifi miftum; fed quando miftum mouetur non vt miftũ, fed ratione fimplicis in miftione praualentis, tunc mifti corporis fimplex eft motus; moueturautem ratione fimplicis, quādo mouetur vel vt graue, vel vt leue, hx nam q ; funt proprix elementorum conditiones, qua iplis cōpetunt per elfentiam miftis vero per participattonem. Ad tertium dicimus, veram quidem efle illam propofitionem, tale fecundum quid non potest eundem effectum roducere, qué producit tale abfolute, fed aduerionos ca absti; nain idem effeotustlle dicirur. quin om nibusent idem, \& in nullo difcrepat, \& hac sationc idem produci nö potelf à ral cernifie, quiproducitura fiomne tali; poteft tamen product idem fecundum aliquam cenditionim, ficundum aliam vero difcrepans, neque hoceftabludin; ipfivero ita eam propofitionem fumunt, quafi effectus produetus ab eo, quod eft minus tale, debeat in omub. differre ab cffectu, qui produciturà lumme tali, fic autem falia eft: dico igitur omnia, qux mouentur vt grauia, vel vt leuia, moueri motu fimplici, hocenim eft neceflarium, vt ante demonftraumus, etiamfi alia fint minus grauia vellenia, alia vero magis; fed difcrimen ef-

E fefolunin locis, adqux mouentur, maior enim grauitas mouet ad locun centro propinquiolen, minor vero ad remotiorem à centro: fallacia autem huius argumentideprehenditus confiderando elementum aqu $x$, \& in eo argumentum contraaduerfarios retorquendo, nam aqua eft minus grauis, quam terra, ergo eorum argumento oftenderetur, aquam motu fimplici moueri non poffe, fi terra mouetur motu fimplici, quæ eft fumme grauis, propterea quod miF nus talenon poteft eundem effectum producere, quë producit inagis tale: atcamen certum eft aquá effe corpus fimplex, \& mouerí æque fimplici motılac terram, differentiam autem in locis efie conitrtutan:nam locus, ad quem mouetur terra, eft centro propinquior, quam locus, ad quem mouctur aqua, proinde non eft idem motus, fed duo fpecie diftinati; difcrimenigitur ma- 
tur maioris, aut maioris gratritatis, velleuitatis, A nullam facit differentian in fimplicitate mo. tua fed folum in locis naturalibus, ad qux mouentur corpora, non poteft enim minus graue cundem habere locum naturalem, quem habet magis graue; hocigiturargumento oftenditur, non poffe miftum moueri ad cundem locum, ad quem mouetur clenicntum fimplex, quod fit fumme graue, vel fumme leue, fed non oftenditur, non poffe moueri motu fimplici, quum po. tius neceffarium fit vt omne graue, \& omneleue, quatenus tale eft, fimplici motu moueatur. Hoc etiam confirmatur ea ip fa comparatione, qua iftimet vtuntur:agens enim minus calidum non poteft eundem calorem pioducere, quam poteftagens calidius, id eft, non poteft afiequi cunden terminum, ad quem; nam calor acqui rendus, eft terminus, ad quem illa al teratio tendit, itaque fi, rite eftacienda comparatio, fumēduseft etiam in motulocaliterminus, a quem mobile tendit, hic autem eft locus; quars non ad eundëlocun mouerinaturaliter poteft, id, quod eft minus graue, ad quem mouelurid,quodeft magis graue; at non elt neceffarium vedifferant etiä in modo motus, fimplici namq; motu hæc omnia mouentur: adde quod differunt etiam hi motus maiore, ac minore velocitate, quiaid, quod grauius eft, magis fuperat refiftétiam me. dij, quamid, quod eft minus graue, quanquam enimaliqui hoc inficia ri audent, tamē adeftaduerfus cos teftimonium Arift.in cont.6.lib.4. de Colo, vt videre elt : fatis igitur nobis eit, fi motus rei minus grauis differat in plurib. à mosu rei grauioris, at mon eft neceffarium, vt in o- mnibus differant, quodillihoc argunento oftenderevoluerunt. Quod vero aduerfarij nitantur Aucrois teftimonio, certe vanum eft; quum clarum fit, A terroem exiftimaffe, motü mifti factum fecundum prxualens clementum cfie fimplicem, vt apud eum legere eit in Conmentario 8. \&12.lib.1. de Cuclo : quod vero ex Auerroc fumunt in Comment. 7. erufdem libri, ctiamfi admittatur,corum tamen fententix non fuffragatur, ctfi Aucroesmentem Ariftotelis in B iis verbis non eft affequutus: putauitenin Aritotelem ibiloqui de motu quorundam miftorum imperfectorum, vt turbinis, \& venti, qui fimplex cffe videtur, necicuera eft;quum tamen Ariltotel. loquatur de motu mifti perfecti, qui vere eft fimplex:fed admifla etiam Auerrois fententia, qua fecundum fevera eft; motus enim turbinis, ac venti miftus eft;non ob id afferit $A$ uerroes motum mifti perfecti factum fecūdum elementum praualens miftum effe, fed hunc

C fimplicem effe arbitratui.Illa etiam, qux à Simplicio, \& ab Alexandro dicuntur, nobis non officiunt: quando enim dicunt, miftorum corporü motus finıplices effe nō poffe, fed effe miftos, confiderant mifta put mi fta funt; nā præcipue refpiciūt animata, quæ vere funt mifta, vt antea diximus; à natura enim mifta quatenus milta $e f$, non poteft nifi miftus motus prouenire : at non dicerent motum mifti factum fecundum elementum.præualens, hoc eft, ratione grauitatis,vel leutatis, miftum effe, im o aperte affirmat Simplicius hunc effe fimplicem. Adillavero, quxà fenfutertia feła fumebat, refponfiopater exiis, qua dicta funt.

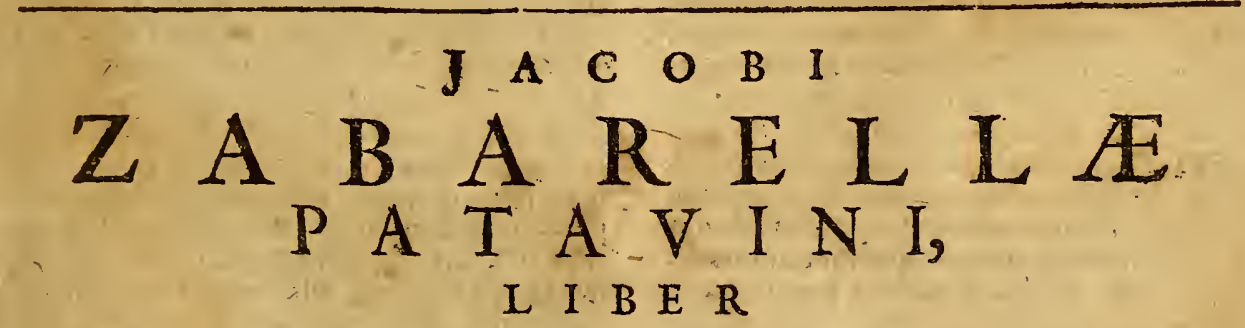

DE

'Procmium libri. Cap. I.

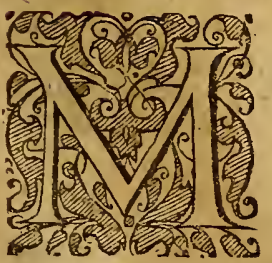

A GNA eft inter philo. fophos altercatio de fub ftantia indiuidua , à quonam cōftituatur, \& reddatur hæc: nam \& antiquiores Latini de hacre acerrime certauerunt, \& his quoque temporibus pofteriores philofophi de eadem controuerfantur, ita vt ad hunc vfque diem fub iudice lis effe yideatur, nec paruū operæpretium facturus fit,
E quifquis eam diremerit, \&huiufce rei veritatem omni fublata difficultate patefecerit : attamen ego quum de rebns naturalibus fcribendum mihi propofuiffem, dimittenda prorfus hac difputatione non parum cogitaui, quum videren, eam ad naturalem philofophum minime pertinere, fed abfque dubio ad Metaphyficum; ideoque vererer, ne talia ipfe tractans obnoxium me eidem crimini redderen, quod plerifque aliis obiicere folitus fum : quum enim multi \& in Ariftotel. interpietando; \& in philofophicis libris confcribendis alienas à propofito 
pofito difputationes inftituere foleant; \& tum A ea, quxad Metaphyficam attinent, tractare diffufe in fcientia naturali, tum qux ad naturalem, in Mcraphyfica, tum etiam qua ad contemplatiuas fcientias, \& ad Logicam pertinent, cum moralibus commifcere, \& variis alis modis diuerias difciplinas coaceruare non dubitauerint, haud quaquam in hoc Peripatetici, neque artificij Ariftotelis imitatores; ego ab hacphlofophandi ratione me abhorrcre lemper profefius lum, \& ab extraneis quxtionibus proponen- $B$ dis, ac diligenter excutiendis abftinui, nifi obiter, ac ls uiter aliqua tangere occafio me forte coigerit : ob id, quum indiuidui conftitutioneri, quam noftri indiuiduationem vocant, à folo Mctaphyfico declarandam effe animaduerterem, eam prorfus miflam facere decreueram, ne libris naturalibus librum Metaphyficum connumerare viderer. Attamen quum confilium hoc meum pluribus ftudiofis expofuifien, enixe me illi rogarunt, à propofito defiftens, hac quoque de re ficribere, ineamque fententiam exponere diligentervellen. Egovero cofacilius, vt eorum precibus obtemperarem, adductus fum, quod confiderại, me non fcientiam up fam naturalem vna ordinata tractatione tradendam, fed feparatos, diftinctofque inter fe libros fcribend os fufcepiffe; proinde iatisfore, fi lectoresadmonerem, vt librum hunc, fi non ve, naturalem, at faltem vt Metaphyficum legerent, quemadinodum ego quoque illum ad priman philofophiam pertinere profiteor, adque proteitor. Adde quod ad inftitutum quoque mcum vilem fore hans difputationem animaducri : qunmenim cocontilio friberede rebusnaturalibus conftituerim, ne in publico obeundo muncre, quo in Academia patria fungor, certos Atiftot lislibros narurales quotannis interpretandi, prolixis difputationibus declarationcm verborum, fenfurmque Arrtotel. quod antehac facere me oportuit, amplius interrunıpercm, fed mongum in ea progreffum facerem; in vfu autem pofirum fir,vi qui prinum librum. de Cuclo interpresandum fufcipiunt, omnes difpusationem iueant de ratione fingularttatis, ociafionem à verbis A rift. nacti in varticula 92. eiufdemlihri; rectius me facturum effe exiltimäui, magisque \& aliis, \& mihi fatisfacturum, $f$ ferpcis hanc operam praftitifem, -quam fivel voce id exéquendo furiem verbotum Ariftotelis alienis conternplationbus", quam ne propriis quidem interrumpere me amplius velle profeflus fun, interumperevoluifiem; velvtrumque recuiando \& mulcorum defiderum negligere, \& hunc feulaboren, feu certamen detrectare viderer.- Scribam igitur, \& in hac maxima controuerfia, poftquamaliorum opiniones diligenrer expendero, quid ipfe lentıen- dum putem, in medium proferam, at que rem hanc ab omni difficultate, ac dubio vindicare nitar.

Partitio dič̈dorum, foaccidentia non posfe conftituere fingularitatem. Cap. II.

A Ne omniaintelligendum eft, de quonam A quaftio nobis propofita fit: quum cnim duplex exiftat fub ftantia indiuidua, vna materialis, altera abiuneta à materia, de hac dubitare minime poffumus, quin fuapte natura, fit hæc; quum enim ita fimplex fit, vt necfubitantialium partsum, nec fubftantix cum accidentibus compofitionem habeat, quippe qux nullius accidentis eft capax, necefre eft eam fie$m$ ind iuiduam per feipfam, \& in illa eandem effc - vnitatem fpeciei, ac numeri : ob id Anft.in context.92.lib.1. de Coalo, de fola materiali fub tanCia eampsopofitionem protulit, aliud eft $\mathrm{C} \propto l \bar{u}_{\text {, }}$ aliud eft hoc Colum \& quam Colum dicimus formam denotanus, quum vero hoc Colum, formam miftam materix; proindefiguificauit, in fubrtantia materialialiud effe formam vt forma eft,alkud effe formā cum materia, \& formam quidem vt forma eft, fpeciei rnitatem conftituerefignificans, formam vero vtiunctam materiæ facere vnitaten numeralem. Deindiuiduaigitur fubftantia materiali confiderandum nobis D proponitur; à quo reddatur hxc, loceft, qux. nam.fitinterna ratio fingularitatis, à qua fit, ve indiuiduu fit indiuiduü, \& dicaturhoc: ex eo autë orta eft hac,in re difficultas; quod tria funt in huiufnodi indiuiduo, quibus fingulis hæc prærogatiua tribuipollevidetur; autenim materia ettratio fingularitatis, ita ve permateriam indiuidum fit hoc, vel forma, vel accidentia. A ccidentia videturafferuiffe Prophyrius in cap. E de Sperie, quando dixit, fingulare illud efle, cuiusaccidentia ómnia fimul collecta non poffunt in aliquo alio reperiri fic enim fingulariatem per accidentium collectionem definure vilus eft, \& hanc ipfus hationem fatucre. Hec tamen F fententra accipienda effe non videtur, neque credendum, id voluife Prophyrium : nam fub-poff. ftantia eft fecundum naturä prioraccidentibus : effé ideo dari oportet in categoriafubitantra fubftă fing tiam indiuiduam, qux ab accidentrb. non pen- tat. deat, sein illo priori naturæ fit aliquid difunctū ab accidentibus omnibus, quo hic homo eft indiuiduus homo, a deo vt illa accidentia fingulairitatem confequantur potius, quam cöftituant : - quare nö id retpexifle videtur Prophyrius, vt afferret veram rationem fingulariatis, ied lignum tant rumodo, quo cafignificarcul, adducere fat is habuit. Neq; 1 gitur accidens vllü, neq; accidentiū omniū collcetıo eft vera ratio fingularitatis. 
Opinio Thome, of featarum, \& cortum argumenta. Cap. III.

$\mathrm{R}$ Elinquitur, vt vel ì materia, vel à forma indiuidum fit hoc, \& vraque fententiafeatores, \&argumenta pro fe habet: Thomas enim \& in memorato loco libri primide Colo, \& in opufculo 29. \& in part. 1. Summx quxit. 3. artic. 2. \& 3. \& aliis quoque in locis, inqutut, materiam figmatam id clt, deterninatam, plincipiun ctle fingnlaritat is; huic con im iuncta forma fit lingulaus, \& dicitur forma huius materix: fed non faris expelit Thomas, quidper materiam fignatam intellexerit, quo factum eft, $v$ t non eandem illi fententiam: attribuerint $c x$ teii, qui eum hac in refequi voluerunt : aliqui cnim dıxêre, materiam. fignatam: fignificaremateriam quantam determinata quantitate, camque efferationenfingulatitatis:, quam fenten2. tiam pluribus argumentis comprobarunt. Pri$m$ mum quidem ratıonem fingularitatis effemacn: teriam probant teftimonio Ariftorel. in contex. 12. quinti Metaphyfic. vbi dicit vnum numero clfe id, cuius materia êf vna, fic enim dēfinıt vsitatem numeralem non per forman, fed per materiam, quoniam igitur slla eft ratio fingularitatis, per quam ipfa fingularitas definitur, definiturautem per materiam, dicendum eft mabis teriam effe id, quo indiuidum eft hoc. Hoc en idem fignificauir Ariftoteles in contex.y2: libri primi de Coclo, dum inter Colum, \& hoc Colum hanc differentiam itatuit, quod Colum formam fignificat, hoc autem Colum forman cum nateria : cenfuit ergo illi dictioni, Coelum, refpondereformam, illi autem particulx, lioc, refpondere materiam, proinde indiuiduum non pes; forman efie hoc; fed per maym teriam. Hoc autem confirmatur: quia forma. zer rem potius vniuerialem fignificat, quan particularem, vtibiclarearlerit Arritoteles dum di- E cit, Colum vniuer fale fignificare formam, \& ibi Auerroes inquit, formam efie fubiectum vniwerfalitatis, id eft, effe obiectumillius vniuerfalis, quod mente concipitur : hoc idem denotatuit Ariftoteles in prædicto contextu 1z. quinti Metaphyficorum, quando declarans quxnam fint vnum fpecie disit, vnum fpecie ea funt, quorum ratio eft yna, ratio autem apud Ariftotelem fign ficat formam; putauit itaque Arriftotel.formam facere vnitatem fpeciei, non vnitatem indiusdur. Prærerea indiulduum pcr: illud fit hoc, per quod ab alirs ditinguitur, at-qui per forman: non difting uitur ab aliis in-diuidus eiusdem fpeciei, etinim illi, qux dif-: ferunt forma; differunt: fpecie, ideoque Græci formam \& fpeciem vno \& eodem vocabulo, ثิ£ज्ञ vocant; igitur non per. formani indiui-
A duum fitlonc. Hoc idem teftatur Arifotclesin Qtient contextuzs. feptimi Metaphy ficorum, dum in- argurnen quit; Socrates \& C.rllias differunt propter ma- turn. terian, idcm antem funt fpecic; atquidifferune perillud, per quod fimneluc \& hic; per materi.rm igitur fiunt lingulares, performam vero continiunt, \& in eadem fpecie conftitutuntur. Sic igitur patet, materiam eflecaulam fingtlaritatis. Qund autem id preftet materia cum sextum quantitate determinata; ita probant: fubftantia argumen

B fingul.nis eft illa, qux ncque in fubiecto eft,ne- tum. que de fubreelo prædicatur, \& abaliis oinmbus diftuneta eft; has autem omnes conditiones habet per materiam quantam, ergo materia quanta eft idonca ratio fingularitatis : minorem probant, quia materiarecundum fe neque in fubiecto eft, neque de fubiecto prædicatur, rationc au-

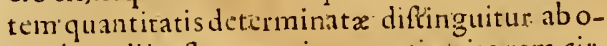
mubuts aliis; ftatuta enim quantitas ita rem cilcumfcibit, vteam à cunctis aliisfeparet, \& hac C pofitaponiturabsque dubio fingularitas, \& ablata aufertur; fi namque certam quantitatem res habeat, iam eft fingularis, \& è conuerfo fi eft fingularis, certam habet quantitatem : nam fi ligurumaliquod diuidatur:, expartitione vnius quantitatis duæ oriuntur, \& duo ligna fingularia, quæ dum coniuneta \& continuata erunt, vnum numero crat lignum', quoniam vna erat quantitas; in materia igitu cum quantitate determinata confiftit fingularitas. Verum hi, qui D hanc fententiam tuentur, videntur aliqua ex parte recedere $a b$ opinione Thomæ: dicunt enim, duslicem effe quantitatcm; vnam interminatam, qux eft æterna in materia, quod quidem omnino negaut Thomas; alteram vero terminatain, quainfequiturferman, \& vtransque ad conftituendam ingularitatem conculrere: quoniam quantitas unterminata rałix eft, \& origo primadiufionis, per eam enim matera eftin multas partes diuijua ad multa fingulaE. riaconfituenda; terminata vero prxbet actum indiuifionisin $\mathrm{fe}$, \& duifionis ab aliis ; quare exequitur; ac perficit ipfam vnitatem numera-$1 \mathrm{~cm}, \&$ prebetaitum fingularitatis. Sedilli-qui. penitus Thomam fequuntur, \& negaint quantitatem interminatam, alio modo intelligunt materiam fignaram, vi. Cardinalis Caietanus in Caiesatractatudic Ente \& eifentua : inquit enim , ma- nus. teriam fignatam fignificare non materiain cim quantitate, fed matcriam cum potent 1 a proxiF: ma ad hanc determinatin' quantitatem; ita' vt non ad aliam;nam agensdum in materiam agit pro educenda forma, femperipfam reddit propinqtiorem illiform $x$ recipiend $x$, \& illideterminatrquantitati, adeovt intermino generationis illa materianon hab at potentian adaliam quantitatem, neque ad aliam formam, nifi at hancfingularë; hanc igitur materiam fignz- 
tam, inquit Caietanus effeillam, quxà Thoma A dıcisur elle principium fingularitatis.

\section{Diatefententic, \& fententie AEgidij im- pugnatio. Cap. IV.}

P ROhuius fententix confutatione plura legere apuid Scotum pollumus in 2. Sentent. dief. s. quæft.4.\&s. vbi cfficaciter oftendit, ncque materiam, nei]; quantitatem effe pofferationem fingulariatis; plura ctiam apud Ioannem Bacconium 2. Sentent. diftunet.11 . artic. 2. nec non 3. Sentent. diftinct. 12 . Sed ego in prefentia quædam pracipua argumenta, qubus illius opinonis falfitas demonftratur, brewiter

Confuratiofenteria Tho$m e_{\text {. }}$

Aegidÿ

fentetis. Confistacio. adducam. Neceffe eft dum materiam quantam ponimus principium fingulartatis, vt ei hoc competere dicamus, vel quatentis eft materia, vel quatenus eft quanta, ita vt vel ipfius materiæ naturam,vel quantitatis dicamus effe rationem, qua induiduum conftituitur; neutrum tamen dici poteft: non materia, quoniam illud, fer quod Socrates hit hic, eft ctiam illud, quod diftinguiturab aliis; at per matcriam nulla res ab aliadiffert, quum materia fecundum fe fit $v$ nanumcro, \& in omnibus cadem; ergo materia fecundum fe non cftillud, per quod Socrates fit hic. Pratcreaindiuiduum, quum per fe cxiftat, fummam habet perfectionem, "\& fupremumactuns: quia quanto magis in categoria defcendimus, tanto magis ad perfeetionem , \& ad actum tranfimus, adco vt indiuiduum habcat actum fupremum, qui in illa categoria ha beri pofit: quod ab ipfo quoq; Thoma alferitur in prima parte Summæ quæft. 3 .artic. 4 . vbi dicit ; effe eft actualis addita effentiz, \& ad eam referturvt actus ad potentiani : contra vero materia fecundum fe fummam habet imperfecionem, \& meram porentiam absque vilo aहtu: ergo nullo modo ftatui poteft xquata, \& immediata ratio, qua indiuduum eft hoc, fed necefle cft materiam ab aliquo alio reftringi , \& aftuari,vt fiat propria huis indiuidui; quareillud aliud dicendum erit principium fingularitatis, non materia, idque mili videntur omnes concedere, quum nemo dixerit, materiam nudam hoc munere fungi : relicta igitur materia, illudaliud confiderare oportet; patet enım illos qui ponunt matcriam vt quantam principium fingularitatis, absque dubio non materiam, fed quantitatem dicere elle fingularitatis proncipium, qux eft Egidij fententin in luis Quodlibetis, quaft. 11. Sed neque hoc dici potelt, quoniam antea oftenfun clt, nullum accidens poffe farui principium fubltantix fingu, laris, hac enim in categoria fubitancix in fum um medix line $x$ gradum obtinet, de qua fecuncix fublantixperle, \& cflentialiter pradicantur; quocirca non poteft in illo gradu conftitui per aliquodaccudens, quoniam non poffetefienif vnumperaccidens, qum ex fubftantia \& accidente conftaret, quare non poffet de co fecunda fubftantia pradicari perfe. Debet igitu dari fubftantia indiuidua, qua fit vnum per fe, \& prius omni accidente, ita vt feclufis per intcllectun accidentibus omnibus, fit per fe fubftantia indiudua. Preterea ipfam fecundún fe quantitatem confiderando, oftendo cam non $B$ pofie ftatui racionem fingularitatis : vel enim fumiturinterminata, velterminata, quorum neutrum dici poteft : non interminata, quia dum cft huiusmodi, nondum efi hoc indiuiduum, etenim indiuiduum tunc incipit effe hoc, quım à forma termi natur quantıtas; itaque $f i$ quantitas interminatafaceret hoc, indiuiduum effet autequam fieret, \& antequam liaberet proprietares (vt vocant) indiuiduales, quibus diftinguiturabalıis: adde quod quantitas inC terminata xterna eft apud Arifotelem in prima materia, \& eadem manet in corrupto, qux fuit in genito, ergonon facit indiuiduum hoc; nam indiuiduum, quatenus eft inditiduum, eft ab aliis omnibus feunctum, ac feparatum. Nequequantitas terminata, hæcenim pralupponit formam, à qua terminatur, \& fit hæc:igitur formæ potius eft tribuenda hac prerogatiua, vt pir cam jndiuiduum fit fubiantia fingularis in illo priorinaturx, quodante quantitatis ter-

D minationem confideratur. Præcerea fi quantitas terminata effet pracipua ratio fingularitatis, ego nunc non efiem idem homo numero, quin pueritiafui ; neque idem in pueritia, qui fui in infantia; hrec enim augetur, \& mutatur, necmanet eadem numeró, gqnare neque idem indiuiduum, quodab ea confrituidıcitur. Caietani quoque opunio defendinon poteft, quí dixit, non materiam cum quantitate, fed materiam cum potentia prosıma ad determina-

E tam quantitatem effe principitim fingularitatis; nam fi fecundum fe, \& in fux naturxpuritate materia fumatur, indifferens, \& communis eft; quare non poteft conltituere hoc, \& iplum ab aliis feparare: fi vero fumatur ve co arctata tta ad recipiendam hanc quantitatem, venon ad aliam, necelfe oft, vt ab aliquolit coaretata, idque potius dicendum erit principium fingularitatis, quamipia materia; confiderandum ergo cet, quodnam fit illud: nam fi rite F philolopharivelimus, eft potitus forma, quam quantitas; matera cnim a forma reftringitur. \& primum habet potentiam ad lorman, dein: déad quantitalenıper fo:man, q̨u sniam hæe terminaca quantitas siffequitur ornam : mirumitaque elt, cur vur die dicere malitrit, macuan cum potentia ad hane quant tatcm, quam cum potentiad hanctorman, clic prin- 
cipium finfularitatis; fiquitem mareria forma $A$ pdutefentian, \& cet quiddamadditum ipfief- ctusad. prinorefuicir, deinde quantitacm, \&aliancidentiaperforman.,

\section{prodeclaranda veritate fundament.s iaciuntur. Cap. $I$.}

\section{DER ea, qux hactenus difa funt, videtur fatis} cffedemonftratum, necmaterian, necaliliquod accidens, fiuc rnum, fiuc plura, neq; materiam cum aliquo, vel aliquibus accidentibus pofli ft:tui principium fungularitar is : rclinquituir, ve hoc nonalnunde peti pollit, quam it for111: à qua omnis diftinctio, \& omnis determinatio pionenit. Ad hanc fententiam complures accederc vififunt, non tamen codem modo, nequcerian fatis claram ipfam reiverutatem reddiderunt. Ego igitur peripicutatıs, acbreuitatis gratia inprimis huinice rei verutatem aperire nitar , deinde confiderabo, quomodo alriab ea modo aliquo defecerunt. Sciendum ante onunia eft, non candem elle quaftionem de multitudine indiuduorum fub eadem fpecie, ac de finguloitum vnutate numerali : ac diftinctione inter fe; multitudonamque indiuiduorum norat imperfetionem, \& prouentt à diuifione materix; vnitas antem numeralis, qua dicitur indiuifum in fe, \& diuifum ab aliis, notat perfectionem, quia prouenit ab actu, \& à perfectione rei, ideo tribuitur à forma; nam formæ officium eft detcrminare, \& conftituere hoc aliquid, vt D in quit Ariftoteles in 2. context.lib.2.de A nima: $\vec{y}$ munus etiam forma eft fepararc, a difinguere rem ab alis, inquit enim Ariftotel. 7. Metaphyfic. context. 49. aetus eft qui feparat \& diftingut : propterea Auerroes in prima difputatione contra Algazelem in folutione octaui dubii dicit, caufa multitudinus numeralis eft materia, caufa vero diftinctionis in multitudine numerali eft forma. Sciendum præterea eft, quod, quum form $x$ officium fit dare efle, \& actum rei, hoc effe duplex eft, proinde \& duplexactus, $v$ num eft effe effentix,alrerum eft effe cxiftentix: quare actus quoque fumi poteft tum pro gradu efientix, quem tribuit forma, fiquiden forma animalis conftituitanimal, forma vero hominis hominem; tum proactu exiftentix extra animam, quem itidem forma tribuit; idque puto Ariftot.intellexiffe in 2. context. libr. 2 . de Anima, quando dixit, formam effe qux facit hocaliquid, credo enim ibiample fumi hoc aliquid pro omni determinatione,fiuc ad cffentiam, fiute ad exiftentiam pertinente, nam determinare, \& actuare eft folus form $x$ officium. Dico praterea, maius elte dare exiftrentiam actu, quam de reefrefpecificum, aeffentian conftituere; pluraenim requiruntur ad exiftentian, quam ad elfe etiam rei conftimendam; nam exinteria prafup- fentir, quodiplence Thomas in loco predito dosesef aflert hisverbis;uffe efi actualitas formæ; forma fensian enım dicit potentialitatem antequam ponatur in cffe, idco elle comparaturad effentiam, ficut actus ad potentiam;ob id videmus formamanimalis, \& quamlibetaliam forman generalem, conftituere propriam eius reicffentiam, vt effentiam animalis, vel plante, tamen tribuere non porle exiftentiara actu fine ope formx fpe-

B. cific $x$, qux fola tum effentiam conftituit fpecici, tum facst rem actu exiftere; maius igitureft tribuere exiftentiam actu, quam efrentian rci conftitucre; quare liad formam pertulet effetztian conftitucre, multo magis ad eam pertinere debet tribucre exiftentian actu: quamobrem nec materia, nec aliquod accidens poteft exiPentix aitum tribuere, quum enim cffentiam fubftantiænon conftituant, minus tribuere exi. ftentiam poffunt, per locum à maiori. HocigiC turvtveriffimum, \&e frmiffimum dicendorum fundamentum ftatuendum nobis eft, folam formamtum effentiam conftituere, \& rem in fpecie collocare, feu fubalterna, feu fpecialiffima; tum exiftentiam actu extra animam tribuere; \& harum difcrimen illudefle, quod dixamus.

\section{Duabus propofitionibus tota rei veritas de- claratur. Cap. VI.}

$\mathrm{H}$ I s ita conftitutis, dicimus, totam huiufce rei veritatem duabus propofitionibus contineri, quarum vina conceditur ab omnibus, altera vero eft maxime controuerfa. Prior hac eft: presna forma vt effentiam rei conftituens non dat vni- conclattatem numeralem, imo in ea tanquam in cont- $f 0$. muni effentia conueniunt omnia fingularia; quia fi funt eiufdem fpeciei, eandem hab: re debent effentiam aque cum ipfis omnibus communicatam: hoc modo forman confiderauit

E Ariftoteles in contextu 92. libriprimi de Colo, quando dixit, Colum vniuerfale fignificare formam, \& ibi Auerroes dicens, forma eft fubiefum vniuerfalitatis:nam effentia, \& quidditas ietum vniuerfalitatis:nam eft nifi vniuerfalis. Altera propofirio eft: forma fpecifica quatenus dat exiftentiam actu, qua eft quiddam additum eflentiz, dat vnitatem numeralem, \& fingularitatë, \& feparat indiuiduum hocab aliis. Hre licet in controuerfia pofita fit, tamen fi diligenter confideretur, F fatrs manifefta efle videtur; nam forma fecun. - dum fe fumpta, \& quatenus eft forma, eftreieffentia, \& quoddam vniuerfale, quod fecundum. fuam naturam vel ef communicabile pluribus, vel non eft communicabile:forma quidem materials eft fecunduin fuam naturan communicabilis, at forma abiunea per éfentiam à materia eft fuagte natura incommunicabilis:

\section{Esefen tiam, हु exiften- tiam iris. buit.}

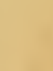

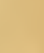

secund conclufoo. $r$

\section{Forme} materia lis fecron. disen fistis nat 3 rane c.2 6.20 
munica-

bolis, for.

$m \times x$ sere

abfras.

asinco-

wuszist.

bilis. non cnim caufa eft mareria, cur forma fit communicabrlis, fed fecundum propriam naturam

- Lorma yel communicabilis, vel incomunica. biliseft; ideo quia nuxima eft confonantia in rebus, natura tribut formze cōmunicabilimateriam diuiduam, in qua pluribus comimuncaretur, form vero incommunicabili talem materiam aflignare non oportuit. Quoniam igitur de materialı forma nuns fermocit, ea fecundum te eft communicabilis pluribus; fignificat enim effentiam, in cuius participatione plura indiudua comeniunt: fed eadem vtextra animau cxiltens, non poreit elle nifi vna numero, \& facere indiuidum hoc, quia nihil exiftit, nuf fingulare;ab co igitur necelle eit fingularitatem tribui, ì quo tribuitur exiftentia, hxc auten tribuitura forma, ergo à forma tribuitu fingularitas, non à materia, qux non ex le habet cxiftentiam : errorisautem caufa multis extitille $\$ 1$ detur, quod forma ad exiftendum eget materia, in qua recipiatur, ideo putarunt materian efle caufam fingularitatis; non eft tamen caula, fed conditio, fine qua non, quia forma non dat fingularicatem nifi vt exiftens, exiftere autcm non poteftine materia; neque ob id dicendum eft,

Materi formam habcreexiftentiam à materia, fedpoest exz- tiusmateriam habercexiftentiam à forma; nam fentice formadomina quodammodo eftexiftentix, \& caufa it fola datexiftentiam, materia vero eft minitra fine qua quxdam, qux formam fuftinens illifamulatur non.

Vnum

dicotur

quetsor modis. vt exiftat; tali igitur famulatu adiuta forma exifit, \& exiftens conftituit hoc indiuiduum difinctum ab aliis. Quod autem materia vnitatem numeralen tribuere nequeat, ita oftendere poffumus: vnitas numeralis, de qualoquimur, cit ynitas pofitiua at materia fecundum fe non eft un numero pofitite, fed lolum prisutiue, fit autem vna numero pofitiue a forma; ergo non a materia, fed à forma fir ynum numero pofiriue, non poteit enim materia tribuse compofito id, quod ipfa fecundum fe non ha bet. P'rterea hocidem oftendere poflumus ar gumento efficacifimo: vnum dicitur quatuor modis, vtait Ariftoteles in context. 12. libr.5. Metaphyfic. vnum analogia, vnum genere, vnum lpecie, vnum numero, fed maxima omaium eft vnitas numeralis, quia infert alias; nec inferturab llis; id enm quod eft vnum numero, eft eriam vnum fpecie, \& vium genere; at noneft receffarium, fieft vnum genere, vt fit $v$ num fpecie, vel numero; neque fi eft vnun fpecie, vt fit vnum numero, maior enim vnitas continet in fe minorem, nou è conuerfo; itaque ficargumentenur:id quod minorem vnitatem tribuere nequit, minus poteft tribnere maiorem, ergo quod non poteft tribuere vnitatem fpeciei, id minus poteft tribuere vntaten numacrijatqui nec materia,nec accidens vllum, nes
A accidentia plura, nec materia cumaliquo accidentepoteft conftituere vnam fubftantiam fpecic;minus igitur poteit facere vuam numero;nil igitur remanet nifi forma, qux diuerfis modis accepta conftituat \& vnum fpecie, \& vn!ım numcro; forma enim humana quatenus effentia hominis $c$ f, f pecicm vnam facit, \& eft ratio conuenentia omnium indiuduorum hominum inter fe, nec vllum in is difcrimen ponis; eadem yt dans homini extra animā actu exiftere, quod

$B$ elt diftinctum quoddam ab effenria, \& ci additum, conftituit wam num ero, \& eft ratio diftinction:s indiuiduoium inter fe. Hæc Auerrols fententia fuit, qui in prima difputacione contra Algazelem in jolutione octani dubijdixit, caufa multirudinis numeralis eft materia, fed caura diftinctionisin multitudine numerali eft forma; -nam multirudonotat imperfectionem, \& prouenit à matera diftinctioautern, ac determinatio à forma, nec poteft fieri, nifià forma, \&ab $C$ actu : hac tamen Auerrois verba referens $Z i-$ mara in fuo theoremate 97: viderur ea aliter le. gille, nempefic, caula conuenientix in multitudine numerall eft forma; tamen in codicibus emendatifimis non legimus, conuenientix, fed diftunctions : \& quamuis vtrumque vere dici poffí, quemadnodum antea declarauinus, tamen rectins leginr diftinctionis, ỵmm conuenientix; qua non loquitur ib: At:croes de fpecrei vnliate, led de vnirareindiuidui, \& de multiD tudineinduiduorum. Hanc eandem fententiam apud Auerroem legimus in 2. Conment. libri 1ccundi de Anma, ybideclanans dictum 1llud Ariftotclis, forma eft, qux facit hocaliquid, inqui, forma eit, perquandiudum fit hoc, fed clarus in 11 trio Commentatii noni eiufdem librihacapud Aucrocon ferba leguntur: [Indiuiduñ none st indwudum,nififer formami quia non est un diudu $\tilde{u}, n i f i$ quat enus est ens actu, $G^{\circ}$ est ens udtuper fsam fir wan, non per fuam maE terism] ccitsnonpoluit Ancroes clarius exprimere fentum lubus noftræ pofterioris propolitionis; accipit cnim ens actuproco, quod actu exifut, \& confiderat formam vt dantem exiftcntiam actu extra animam, \& hacratione allerit indiuiduum fieri hoc à forma, non à materia. In Connnentario etiam 9o. libri primi de Anima,1nquit Anerroes, omne, qnodeft vium, eft vnum per fuam forman, non per firm materiam; omncm igitur vnitatem cenfuit Auer$F$ roes à forma tribui, nec poffumus hac in re de cius opinione dubitare.

\section{Alia nonnullorum opinio, do ciusrepro- batio. Cap. VIII.}

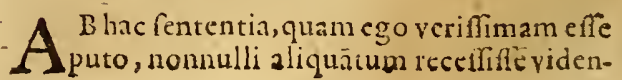


tur: qui confiderantcs, non fine materia confti- $A$ zu tui indiuiduum hoc, dixere, nec folam materam nec folam formam effe caufam fingularitatis, fod finul vtramque; quatenus enim hre dux fubftantiales partes extra animann exiftentes coniunguntur, eatenus confituuntindiui- duum hoc. Hoc antem dicêtes mihi quidem videnturproximead veritatemaccelfifle, fed aliquantum ctiain ab ea reccliffe: quod cnim materiam neceffariam effe dixerint in conftitutione indiuidui, in loc optime eos fenfife arbitror, fed in co defecites, quod zque materix, ac formx primas in hoc munere tribterunt; quim potius dicendum fit, folam forman effe primam, \& xquatam caufam fingularitatis, materiam vero caufam quandan fecundariam, \& fine qua ron, quatenus famulaturforme ad exifiendum, \& ad conftituendum hoc aliquid. Hoc videtur fatis à nobis fupra effedemonifratum; poffumus autem id magis declararc, \& oftenderenitentcs propris corum fundamentis šex eo enim quod ipfi de effentia confitentur, pofinmus de exiftentià optime argumentari "effentiam \& quidditatemafieruntipfieffe folam formam, qua in re optime fentiunt ; \& folum formann conftituere fpeciei ynitatem, non materian, formam tamen non fine mate tia ; materia cinim eft neceffarium fundamentum, \& vehictllum quidditatis, quoniam hominis quidditas eft quide m forma tantum, non tamen forma per fe fola exiftens, fed forma, cuius eft neceffaria conditio ve fit in tali materia : ideo ille, qui hominem rniuerfalem per folam formam definire, effentiam hominis non exprimeres, licet fola forma fit effentia ; fed definiendus eft homoper formann in tali materia, idque traditul clare ab Ariftotele in Proomio libri primi de Anuma. Hoc idem de exiftentia dicenduñefe, nam absque dubio à fola forma tribuitur, fimulque vinitas numeralis, non à materia; fed materia eftneceffaria conditio forma ad cxiftendum, nam forma fi materiam realem habeat, in qua hareat, facit rem actu exiftentem, \& rram numero ab aliis diftinctam: quemadmodum igitur,licet materia fir quidditati neceffaria vt vehiculum, ob id tamen non fit, vtetiam materia fit quidditas, neque per id ftat, quin quidditas fit fola forma; ita neceffaria eft extra anim. am materia ipfi form $x$ ad confriturendum indiuiduum, neque per id ftat, quin fola forma confticuat ipfum, quum folius formæ officium fit determinare, \& conftituere, licet præeftare hoc nequeat fine famulatu materiz. Concedimusigitur, materiam \& ad effentiàm, \& ad exiftentiam effe neceifaram yt conditioncm, fine qua non, hanc tamen in praferntia non quærinus, fed quærimus immediatain, \& æquatam caufam fingularitatis, quam
A dicimus effe folam forman. Caterum ne ob vniuer. ca, qux diximus, aliquia in etrorcm labatur, fele Eु non eft ignoranda differentia inter vniuerfale, fingulde\& fingulare in comprehendenda materia: reclisuerquum cnimucceffariafit materia \& vinieifali, fos mods quod fignificat eflentiam, \& fingulari, quod ex-atmatetramimam exiftit, hoc tamen difcrimen ha- riamfe bent, quod vniuerfale mareriam complectitur habert. ve conditionem neceffariam, at non vt partem; quo fit ve materia no fit effentix pars, fed folum $B$ neceffaria conditio, \& fundamentum: fingulare vero materiam complectitur etiam vt partem, fiquidem fubftantix indiuduxe extrannimam exiftentis dux funt partes, materia, \& forma; difcrimen hoc exprimerc voluit A riftotel. in contextu 92. libri primi de Cólo, quando dixit Coclum vninerfale effe forman, hoc autem Celum effe forman cum materia mittam; quamuis enim colum non habeat materix \& forma compofitionem, habet tamerí peranalo. giam, \& fimilitudinem, quatenus haber quidditatern in materia fenfili: hoc etiam idem fignificaulit, in 9.context. lib. 3 . de Anima, vitibi videre efthoc tamen iis, qux modódiximus, minime refiagatur; aliud enim eft indiuiduum, aluad eft indiuiduans, indiuiduum quidem ex materia \&e formaconfat, tanquam partibus, at perhoc non ftat, qquin ndiuiduans fit fola forma, cui famuletur materia tanquam caúa fine qua non; eadem igitur materia indiuiduato eft pars, indiuiduanti autem non pars, fed conditio. Prztérea vero non eft ignorandum, ficuti forma Materia duobus modis fumitur, ita materiam quoque dupleciaccipiduobus modis: ficut enim forma tun vt ter feme effentia rei fumiur, tum vi prabens exiften- turrefpe tiamactualem, ita necefle eft, materiam quo- cäuforque duobus muneribus fungi, quatenus formæ ma. ytroque dicto munere fungenti famula tur: vno igitur modo fumitur materia pro neceffario fundamento quidditatis, nulla habita ratione actualis exiftentix extra animam; fic accepit materiam Ariftoteles in Procenio libri primi de Anima, quando dixit, omnem formam naturalem effe definiendam per materiam, fic enim etiam homo vniuerfal is eft forma in materia, non tantum homofingularis, fed confideratur tunc materia vt animo concepta fub effentarei, non vt aqu exiftens extra animum. Altero modo fumitur materia it aetu exiftens extra animam fub forma, \& per forman, eaque folet ab Ariftotcle appellari materia fenfilis, quia performam eft facta fenfilis, quemad. modun etiam per formam exiftit, \& per formam eft hxc fingularis; \& hæc omnia dicere, eft dicere compofitum indiuiduum exiftere, \& effe hoc per formam, non tamen fine materia ;quonian enim materia non existit, nifi yt facta hic homo, vel hic equus, vel aliqua a- 
lia res; ideomateriam exiftere, eft compofitum A exifter, a Ariftoteles nomine materix linfilis fignificale folet materian vt exiltentem extra animam, proindeipfun compolitum, quod per formam exiftit : attamen dum materam cxiftcntem diftingumus à toto compofito, ca $\mathrm{c} ? \mathrm{f}$ quidem ipfus counpofiti pars, icdtalis pars, qua fingulariatem non tribut, fed potius ab alio reciptt, ncmpe à forma; nificatenus materiam quoque facere fingularitatem dicamus, quatenus famulatur form $x$ conftituenti hoc aliquid, hoc eft, quatcmus caula fecundaria, \& fine qua non, \& in hoc illos defecifle dicebamus; quod enim ad formam attinet, nos ab eorum fententia non recedimus.

\section{Opinio Scotide duplici forma, do duplici materia, deprincipiofingularita- tis. Cap. IIII.}

Cotus de hac re loquitur in 2.libr. Sentent. 3iftinet. 3. \& eam fuffinme tractat feptem continuis quæftionibus, vbipluresalionum fenrentias refutat, quas nos quoque refinatuimus, videlicet rationem fingularitatis eflematctiam, vel quantiatem, vel alıquod aliud accidens, vel materism cum quantitate : fententiam autem. qua ftatuiturformam elfe fingulariatis princi. piun, \& quam nos veram effe arbitramur, non confutat:quarevideturad hanc potius accefiffe, \& reucra eius opinio ad noftram facilime trahipotef, vt mox confiderabimus; hancipfe declaratibi in q.5. fed clarius in Quodlibetis, q.

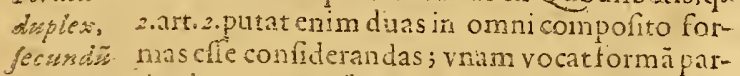
scousm. tis,alteram veroformam tolius, id eft, formam, qua eft pars, \& formä, qua eft totum; $13 a m$ formam partisinquit effe illam, qua eft altera pars copofiti, vt eft in homine rationalitas; formam vero totius inquit effe totam quidditatem hominis fumpti. in abftracto, nempe humanita tem; plitatenimetiam materiam effe partem quidditatis, itaythumanitas nonfolum notet formamhominis, fed formam \& materiā fimul complectatur: \& quoniam materia \& forma referuntur inuicem, proind oportet tot modis $\%$.

Maserise dicplex. fecundis sct:sys. nầ dici, quot dicitura!tera; ideo his duabus formis duas dicit refpondere materiàs, quas fimiliter vocit materiau partis, \& materam totius: materiamenimpartisinquit efle illam, qux eft alcera pars compofiti, \& fibjicicur formæ partis, \&ad eam refertur: materiam vero totius refpõ. dere aitforma totius, eam g; vocat differentiam indiuidualem, reuentitatem indiuidualem, qua coaretat forman totins, id eft, quidditatem; $a-$ mnis enim quidditas eft ynimerials, \& coarefatur in ipra entitateindiuiduali; qua mobrem cnatas indiuidualis habec.lacums masterizo, qua: a refpondet format totins, \& vocatur à Scotiftis. hachcicas, quandicunt effe principium fingularitatis. Sed videns Scotus aliquem ipli obiicere pofie, \&: quærere quidnam fit hae differentia indiuidualis: nam fieftaliquid, neceire eft $v e$ rel hit fubitantia rel accidens;accidens ante efie nonforeft, quia ians vnueric hanc fententian Scotus confintalerat, quod aliquod accidens poffit efle ingularitot is principilim; ied neque fubetätia, qua lic lequeremer indiuddua eiusdens

B f peciei differe inter le per differentian lubthantialen, quod Porplyyrius ne gaur , inoidonnes negant, fic enim different undiuidua, non. folum numero, fed etian fpecie; quare relinquitur, ve fit nihil; foluit hanc difficultatem, dicens, differentam indiuidualem non elle accidens, fed quiddam prius omni accidente aducniente, neque ctram effe fobftatian re ditrnctan il differentiafpecifica, neque vllam aliam rem illi additam, fol folum efealiam realitaten jquod. fignificare vićctur,non effe aliud ens, feu aliam rem, fidalium quendam nodum eflendi,per quemres dicitur lingularis: propter ea quando. Ariftoteles libr.s.Metaphyficortim., content.12. inquit vnum numero efle, cuius naterna eft $\%$ na, Scotus dicit, A riftotelem rbi inrelligere, non: maleriam partis, fed materamtotius, \& hane effe illam hrcheitatem, ac differentian indinidualem, quzeft fingularitatis principium : hane. interpretationem adducit'scotus, tum in illa. quaft.6.tum in commentariis stuis in librum 1 ]lim; \& hanceandem attulit Ioannes Bacconius. in 3. Sentent. diftinct, 12. dum tueri voleas corum feutentiam, qui dixerunt formam elre principinm froulariatis, foluit argumentum, quod. excoloco Thomiftaccipiunr, ad probandums. illud effe officium materiz; inquitenim materiam ibi nō fignificareillam, qua eft altera pars compoliti, fed totumipfum compofitum fenfr. le, quodextra animam non existit. Sicetiam quando in 1. lib. fe Coclo Arifo dicit, Culum ef-

E feformam, hoc autem Colum effe forman cum materia, inquir $S$ cotus, formam 1 b! fumi proformatotius, id ett, pro quıdditate, \& materiam promateria totius, qux qudditatem refuringit; hoc cnim modo Colum yniuerfale ef forma, hocautcm Cotlum eft forma commifta materia, id eft, quidditas in re finguları.

\section{In quo Jenfu opinio scotidefendi poßit. d in quanon poßit. Cap. IX.}

T. IEC Scotifententia vel vana \& commen1 titia eft, vel eft ipramet opinio noftra, quod forma fit principium fingularitatis, ina: alio enim. fenfu defendi $110 n$ potest. Prinums quiden quod ad fundamentum Scoti 2t! sat, quo ftatuit diplicem cife forman, id c- 
a- muino negandum cft, nifi funo modo intelliga- A tur: nam fi intelligat, duas cffe formas ic di-

i- ftinclas, lationalitatcm \& humanitatem in homine, idminime eft concedendum, quim vina,

\& \& eaden forma lit, \& verague eandeun figniticethominis quidditatem, quapen eft forma \& 'materia, fed forma in materia: neque cuim rationalitas, neq; humanitas materiam continet vt partcm, fed folum ve vehiculum, s conititio. ncm necelfarian; admitcre tamen poniumus, eas differre fola ratione, quia rationalitas matc- B ruim connotat implicite, humaniras vero ex piclle, notat enim formam humanam in tali materia, quare in hoc fonfin admittere polfumus fundanconcum Scoti; quemadmodum et-

$d$ - iam concedere pollumus forman hominis, \&

if- quidditatem hominisdifferre ratione, vt cadem voceturforma, prout extra animum habet elle

8. reale, \& quidditas, prout in animo habet elfe cognitum; at non ob idfunt duæ forma, quiavinalteram reprafentat; vt cquis in animo; \& equus extra animam non duo equi funt, fed $_{\mathrm{y}}$ -

fit nussalter cnim eft imago alterius. Materia vero

totius, quam Scotus ponit diftincîn ì materia partis, nil aliudeft quam iprum compofitū exua animun exiftens; quod if se materianí nominare vult, 1 on eft appellatio abfurda, quum ipfe quoq; Ariftoteles aliquando nomine materix intelligat iplum compofitum, quod extra nimumactu exiftit, ieu (quod idem eit) materiam ipfam vr exiftentem; non enim aliter exi- D ftit, quam formata; \& fic eft ipfummet compofitum exiftens, quemadmodum nos antea dicebamus. In hoc igitur fenfu fundamétum à Scoro iactum de duplici forma, \& duplici mareria approbandum efle céfemus, praterquam quod nateriam, quam ipfe vocat parris, negamus effe partem quidditatis: fed hocad propolitam nobisconfiderationem non attinet; ideo de eo in - prefentia difputandum non elt. Quod veroad po- ipfam Scoti opinionem attinet, quum ipfe dicat, principium fingularitatis effe differentiam inditidualem, feu hrcheitatem, videndum eft, quidnamper hæc intelligere poflit: materiam quidem vt partem compofitinon intelligit,iam enim hanc lententiam confutauerat ; nequeac cidens aliquod, fiue materiam ipfam, vt aliquo accidente coarctatam, quia hoc quoque reprobaucrat: reftat igitur vt intelligat vel iplum compofitum, vel formam : videntur quidem verba fignificare compofitum, quod exrra animam exiftit, fed hoc eft potius indiuiduatum, quam caufa indiuiduans; \& illa, qux ab ipfo vocatur hrcheitas, fi ipfam nominis vim fpectemus, eft reueia idem, quod fingularitas, quix eftille ipfe effectus, cuius quæiimus caulam, nec poteftallignari vt caufa fui ipfius; affertigi sur effectum pro caura; caufain yero pprais, quam quærimus, nou cxprimit; quocirea hac nobis inuckiganda relinquirur. Necefe eft igitur vt forman intelligat: led neque hanc poreit intelligerevt quidditatem, vel parcen quid tita tis; quonian iplic aperte dicit, hase differen. tian indiuidualcm, feu hachertaicm efle coira quiddiraton, eq quicidam aủirmm quidistati, ergo antelligir fomam ve exiftentcuevtra animan, iam cnim diximus, exiftentiam efie quid additum clientix. huic igitur fenfui optimeaptantur omna diata Scoti; fic cnim prizcipium fingularitatis nó enitnoua differentia inhftantialis adueniens fpecicitanquamn notin chs, fed noua cntitas (vt ipfe dicit) hoc cft, noutus modus acciprendi forma:1, \& noutun ciufdem form $x$ munus; forma enim vi cit formin, cit litferentia fpecifica: vt vero extra animan: cxiftens, eft differentiaindiuidualis, quáacit hoc, non poteft enim exifterenifiv hac; \& quia cxifteręnequit fine talimateria, n qua recipiatur, ideoid, quod a forma conftituitur, cft hoc fingulare exiftens, \& cxmateria \&e forma cóftans, quod a forma cóftituitu:, \& fit hocaliquid.S6Otus igitur vel formam dicir effe principiun fingularitatis, vel nihil dicit : cgo quadem arbitros ipfum fub nube veritaten widifie, ideoque non expretie, \& clare spram protulifie: quod ensm. ad hanc potius fententiam tiverit inclinatus, id. maxime oftendit, quod in fin tam prolixa de hacredifputatione, in qua alias omnes fententias diligenter impugnat, non videmus hanc, quam nos fequimur, de forma opinionem ab eo fuife impugnatam: non eft igitupræter ra. tionem, quod ei hac fententia aitribuatur.

\section{Solutio argumentorum a Thoma, \& ab a- lis aduerfaris adidictorum. cap. $X$,}

$R$ Eliquum $e f t$, vt aduerfantia argtmenta, $\mathcal{L} d$ prim quæ initio adducta funt, foluamus. Pri- mum ars mum crat argumentum Thomifarum ex Ari-gumenftotcle acceptum in contextu 12 . libri 5. Mta- tum. phyficorum, vbi definit vnum numero non per formam, fed perfolam mareriam, dicens vnum numero elle cuius matcria eft vna: ad hoc dico, non effe ibi confilium Ariftotelis exprimere æquatam rationem fingularitatis, fed folum propriam conditionem vnitatis numeralis, vt à fpeciei vnitate diftinguitur: quamuis enina caufa vnitatis numeralis fit forma, tamen quia eadem eft etiam caufa vniratis fpeciei, non poterat Ariftoteles eandem afferre vtcaufam vtriufque vnitatis; quonam igitur caufam vnitatis fpeciei dixerat elf formam, quamvócauérat rationem, quia illam acceperat, quatenus eft effencia rei, ideo vt errandi occafionem auerteret,- non attulit formam vtcaufam vnitatis nume$\mathrm{N} 2$ ralis, 
ralis, fedattulit condicionem illam, quan for- A ma requirit ad exiftendum, frquidem non fa. cit vnum numcro, nifi vt exiftens; matcriam igitur nominauit, fine qua non conftituitur à for. mavnum numcro; conftat enin indiuiduum cx forma \& materia, tanquam partibus, \& materia eft facta vuaper formam, quia forma iun. cta materix extra animam, facit vnum numero:per hocautemdiftinguitur vnitas indiuidui ab vinitate fpeciei; ñam vnum fpecici fit à fola forma, quatenus eft forma, neccontinet materiam nifi ve vehiculum forma: at vnum numero fit à forma exiftente; exiftit autem in materia, \& fic facit vnum numero, cuius pars eft matcria:hocita fefe habere oftendo arguméto manifeftiffimo; peto $a b$ aduerfariis, quando Ariftoteles dicit, quorú materia eft vna, quonam modo intelligat materiam vnam, an priuatite, 2n pofitiue; priuatue intelligo per mentalem ablationem omnium formarun; fic autem intelligerc ibi Arrftoreles non poteft, quonam materia hoc modo nullum in diuiduum conftituit, nec magis facit hunc hominē, quam hunc cquum; fed hoc magis eft manifeftum, quam vt probatione vlla indigere videatur; itaque neceffe eft, vt dicamus: intelligendam effe matexiam vnam pofitue; atquinon eft materia per fe vna politiue, fed per formam fit vna, quia forma eft, qua facit hocaliquid, vt ait A riftoteles in 2. contextu libri fecundi de Anima; ergo patet notralium effe fenfum verborum A riftotelis, quam hune; vnum numero eft, cuius materia eff facta vna per formam; quare pracipuaratio huius vinitatis ablque dubio forma eft, fed Ariftoteles conftituens tanquam notum, quod forma facit hoc alliquid, folam cöditionem expreflit, quamrequirit forma, vt hocmunere - fungatur, conditio autem eft, vt ei famulatus materiz, in qua exiftat, fuppeditetur; fic autem scotz re-apparet difincta ratio vnitatis numeralis à raforzso. tione vnitatis fpeciei. Scotus vero ad nocidem argumentum refpondit, Ariftotelem ibinonntelligere materian partis, fed materiam totius, proinde non oftendi matetiam partis effe cauIoass. Bas fam fingularitatis, quod fe oftendere putarunt conis re- ris Bacconiirefponfio, qui dixit, Ariftotelem
sonfio. nominemateriænonillam intelligere, qua eft fubicat formx, fed totum compofitum exiftens, quod ab eo frequenter materia fenfilis appellari folet. Sed hæ folutiones non videntur diuerf $x$ adnodiab ea, qua nos vfi fumus: quoniam materia vna pofitiue facta performam, elt ipfummet compolitum, quemadmodum antex dicebamus: noltratamen refponfio magis exprimit rationem illius dicti Ariftotelis, quam $1 d$ fecü- horum refponfiones, vt confiderantipatet. De. dusa. inde argumentum fumebast ex Aniftotels in

contextu 92. libriprimi de Colo, rbi dicit $\mathrm{C} \propto$ lum die formam, \& hoc coelum efie formam cum materia ; proinde fignilicase videtur, $\mathrm{C}^{\circ}$ lum conftitui hoc ì materia, non à forma. Nos autem dicimus, non can cffe Ariftotelis men. tem, vt dicat, Colum effctórmam, ầ hoc Ca:lum per materiam conftitui, fed potius denotat, tam Coelum, quan hoc Coelum fignificare formam, diuerfis tamen rationibus confideratam: Colum enim fignificat formam vt eft forma, \& eflentia, hoc autem Colum denotat formam vt exiftentem cum materia fenfili, \& confituentem hocindiuidnum, cuius dux funt partes, forma, \& materia, à furma tamen fola conftituitur, materia vero eft id, quod tanquain fubiectum recipit hauc artion en form $x$, quam recipit etiam totum compofituni, tanquain denominatum: non eft tamen hoc ita de Coelo intelligendum; vt dicamus efle in eo materiam \& formam rediftinctas, fed folum ratione diftim ctas, eft enim corpus fimplex, quod alia ratio. ne dicitur forma, aliaratione materia; fit autem hoc, \& diftinguitur ab aliis per proprium actum, proinde quatenus eff forma, 1101 quatenus eft materia; \& eft forma materix mifta, quatenus exiffit cum vtraque conditione, tum form $x$, tum materix, quemadmodumalio in loco declarauimus. Scotus autem \& Ioannes Bacconius aliter refpondere videntur, dicendo matetiam fignificare totum compofitum exiftens: fed ea refponfio noltra difcrepare non videtur, ficutpaulo anteconfiderabamus. Ad Auerroem autem ibi dicêtem formam effe fub. iectum vniuerfitatis, dicimus eum ita loqui, \& effentia; fic enim eft vniuerfalis; vt patet. Ob id etiam A riftoteles in contex.illo 12.libri quinti Metaphyfic. dicit vnum fpecie effe illa, quorum ratio eft vną, quia fumit formam, prout eft rei effentia, quæ folet ratio appellari, fic enin

E facit vnum fpecie. Ad aliudargumentum dicimus, ea, quæ differunt forma vt effentiam confituente, vtique fpecie differre; aft $11 \mathrm{ll}$, qux difinguuntur performam vt exiftentem extraanimam, non eft neceffe vt fpecie differant: indiuidua namque eiufdem fpeciei per formas primario diftinguūtur, quia dıftinetas fingula formas habent, has autem cum materia miftas infequiturplurium ascidentium collecto in fingulo indiuiduo, qua illius indiuidui propria F eft: \& dicere quidem polfumus, per talem accidentium collectionem diftingui indiuiduum hoc abillo, non tamein primario, fed fecundario; quemadmodum etiam dicere poliumus, per rifibilitatem differrehominem a brut is, eft enim quiddan polterius, quod primaram differentiam infequitur. Ad Ariftotelem autem in contcxtu 28. Jibrifeptimi Metaphyficon unz, disımus 
*- dicimus illudidem, quod de contex. 12. libri s. paulo antediximus, non effe mentem Ariftotelis ibi exprimere primariam rationem diftinctionis Callix \& Socratis, fiquidem certum ct, nos non per materiam differre, fed id folum re. fpexiffe, vt rationem adduceret diftinftionis indusiduorum diuerfam à ratione conuenientix corundem : quoniam igitur ibidem dicit eos conuenire in fpecie, \& forma, dicere non debuit, cosdem differre per formas : fed materiam expreffit,id ent, materım fenfilem, qua extra a. nimam exiftit per formam, \& eft fimul condi. tio, fine qua non exifterct forma; qrocirca forma eft, quz cum materia cxiftens feparat hunc hominem ab illo. Ad poftremum argumentum, de quantitate, refpondemus, negandam effe propofitioncm maiorem, nifi addatur, primo: veri enim eft fi talis proferatur; illud, quo prim pofito ponitur fingularitas, \& diftinctio huius indiuidui ab aliis, \& quo primo ablato, aufertur, c ft fufficiens principium fingularitatis; $a b$. folute autem prolata falfa eft, nam etiam rifibili politaponitur homo, \& ablato aufertur, nectamen rifibilitas eft prıncipium cöltitutium hu-
A manitatis, propterea quod non primo pofito" necprimo ablato: vera autem exiftente maiore falfa cti minor, qua dicitur, pofica mat eria cum quantitate terminata ponitur indiuiduum, \& ablata a u fertursnon primo pofita, nec priaro ab. lata, fed primo pofita forma actu exiftente ponitur indiuiduum, \& primo ablata aufertur ; formam enim exiftentem infequitur terminatio quantitatis, qux eft quoddam infequens fingularitatem, at non contrituens; \& quamuis per B cam fecernatur hoc ab illo, vt quantum à quanto, non tamen vt fubftantia, à fubftantia, fed per folam formam : illud autcm, quod dicunt, indiuiduum habere à materia, veneque fit in fubiccto, neque de fubiccto pradicetur, negandum eft, quia eft petitio principi $\}$; illud enim quod facit veindiuidus m de fubiecto nō pradicetur, êt illudidean, quod facit ve fit hoc, negamus igitur id effe materiam : in fubiecto autem non effe competit omnifubftantia, tum vniuerfali, tum C particulari; quareà quasunq; fumat indiuiduum hanc conditionem, nihil ad nos; quare hoc argumentum nihil habet effi-

cacitatis.

\section{J A $A$ C \\ Z A $B$ A $P$ A T A V
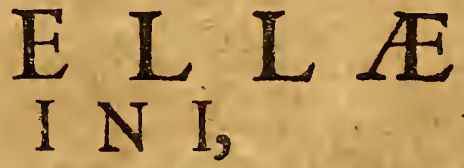 I I B E R}

\section{$D E \cdot C O M M V N I$ R $E$ R $V M M$ G E N E R A T I O- N E E E T I I N T E E R I T V.}

Propofitiodicendorum. Cap. I.

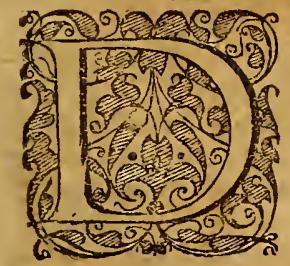

E communi rerum gencratione loquens Ariftoteles in duobus libris de Ortu \& interitu, imprimis effertiam cius fignificauit per definitionem illam, generatio eft mu. tatio totius, nullo fenfili remanente, vt fubiecto eodem;deinde vero in $z$. libr. ipfius Generationis caufas declarauit : \& quamuis cam definitionem tanquam notam propofuerit, vel faltem tanquam leui declaratione indigentem, quum fit definitio nomina. lis; plures tamen poftea ex e2 ortz difficultates ipfam obfcuriorem ; quam reuera fit, reddidiffe videntur, quum multi, vt aliqua fua dogmata tuerentur, fenfum Ariftot. extorquerc aufi fint:
$D$ confiftit autera potiffime difficultas in illa diEtione, totum, quukn enim dicat totum interire, \& totum generari, fignificare videtur nihil rei corrupt $x$ remanere in genita; attamen con. tingere videtur, vt in re genita aliquid ferue. tur, quod prius fuit in corrupta: dubium igitur hacde re ortum eft, quod nos in prafentia confiderare decreuimus, idque duplex: vnum quidem an aliqua fubftantiz pars remaneat; al. terum vero an aliquod idem numero aecidens. B Quod autem ad fubftantial es partes a ttinet, certum eft, eas non poffe omnes comprebendi ea diâione, totum; quoniam fi ita interimi totum intelligeremus, id eft, omes fub ftantix partes, oporterer primam quoque materiam interire, \& ita interitum effe nihilationem rei, quod quidem dicendum non eft : materia igitur excepta, interpretes ad folam formaun difputa. tionem direxere, vt fit quaftio, an aliqua fub.

$$
\text { IN Atantialis }
$$


ftantialis forma feruetur in genito, quz prius fucrit in corrupto: quam quaitionem aliis quo. que verbis protulerunt; quarendo an in generatione fubftantialiad primam vfque materiam refolutio fiat; boc enim nibil aliud eft, quam nullam prorfus formam fed folam materiam remanere. Cum hac autem difficultate alix quoque non leuis momenti coniunctx funt, nempean hre generationis definitio ad omnia penitus fublunaria corpora extendatur, an ad aliqua tantum, \& an folius generationis definitio fit, an etiam interitus; \& demum an generatio vnius fit alterius corruptio, \& è conuerfo, \& quomodoidfit intelligendum. Nosigitur hxe onınia diligenterexpendemus, vt mox ad accidentium confiderationem tranfeamus, 2 c poftmoduan de cà ufs generationis, \&interıtus, quaz minus difficultatis habere videntur, aliqua dicamus.

\section{Quod plures esfe poßint Subftantiales forma in eodem compofito. cap. I I.}

AETERVM quia prima quaftio locum onon habet, nififtatuanus, plures fimul fubftantiales formas in eodem compofito exiftere poffe, etenim hoc negato vana redditur difpucatio, quum neceffarium fit vna exiftente forma in compofito, vt eo interewnte fiat refolutio in materiam primam; ideo hac de re prius aliqua dicere oportet: quamuis enim ad Metaphyfic. potius quam ad Natural $\mathrm{em}$ hac difputatio pertinere videatur; tamenfi \& naturaliser, \& frictim tractetur, non inutilis, neque à proTemëta pofitoaliena efle iudicabitur. Quoniam igitur G mifta tres effe videntur naturalium corporum grasnanima dus, qui fub prafentem confiderationem ca\&nä $\$ a n$ - dunt, elementa, mifta inanima \& viuentia; de *um for- elementis quidem, quod vna tantum forma mam ba- conftent, manifeftum eft, \&à remine vnquam lezy. negatum : ego vero de miftis quoque inanimatis idem dicendum effe arbitror; quandoquidem forma mifti,vtalibi dictum eit, non eit addita formis elementorum, neque reab eis diflinsta, fed quatuor ipf $x$ elementorum form $x$ per miftionem in eam vaam migrarunt; ideo in misto inanimato vna tantum forma ineft, quz niftionis forma nominarifolet, nec diftinguitur re à formis elementorum- De corporibus igitur inanimatis omnibus, tam fimplisibus, quam miftis, ego quidem huius fententix fum, corum quódlibetex primamateria, \& vnarantum forma conftare; difcrimen autem effe fo-

anx: Sorsents tlures. funsfor. lam in modo generationis, ficut alibi declarauimus. De corporibus vero animatis diffentio penitus à negantibus multitudinem formarum in quolibet viuente; credo enim in his exnecefdate glures formas inefle:primum quidem foc. mammiftionis, qua prouenit ex congreffu formarum elementarium, neque eadem eft in fingulis animati corporis partibus, fed diuerf $x$, prout varia funt diuerfarum partiun temperatura; alia namque eft forma miltionis in carne, alıa in rierwo, alia in offe: prater hanc habentanimam tanquam formam additam form $x$ miftionis, \& re diftinctam ab illa: poffet ctiam confiderari, an partes anima fint in eodem viuente diftinct $x$ forme, an vna tantum, quæ variis $\mathrm{fa}_{2}$. $B$ cultatibus praditafit; fed hoc à prafenti conffderationealienum ef, \& ad propofrtum nihil conducit: fiue enim vna in quolibet viuente infit anima, fiue plures; certum eft, vnum \& cundem effe earum omnium interitum, fiue receffum à corpore, nec fieri poffe, vt vna fublata remaneant aliz; ideoadalium losum hanc confiderationem remittemus; fatis in prafentia effe $F$ arbitrantes, animam tanquam formam vnam, \& formam miftionis in viuente corpore confi-

C derare: hârumigitur duarum realen diftinctionem oftendere multifariam poffumus. Primum quidem argumento ab ip fa reinatura deducto: forma enim nobilior nobiliorem, \& elaboratio- $d$. rem materiam poftulat; anima igitur, qux eft $m$ forma nobiliffuma, non debet hærcre immedia- $A_{i}$, te in materia prima, ficut forma elementi, fed $P$, in materia magis elaborata, qualis eft materia formata formis elementorum, hoc eft, forma in miftionis, qux ex eis prouenit. Hocidem con-so D firmatur argumento fumpto à motu natura. $\mathrm{ji}$ : in animali enim duo funt diftincti naturales motus; vnus, qui fit ab anims , \& progreffio dicitur, cuius fpecies funt ambulatio, natatio, volatus, \& fi qua alia funt; alter vero, qui fit iuxta elementum praualens; fi enim de turri animal demittatur, defsendit motu recto fimplici, quem nemo diceret effe violentum, fiquidem ab interno principio fit, neque eft minus naturalis, quam fi terra deorfum feratur, idque aperE teafferit Ariftotel. in contextu 27. libri octaui Phyficorum; hi auter funt duodiftintt, \& inuicem pugnantes motus, ergo non ab yno prin. In cipio fiunt, fedà pluribus, proinde à pluribus $N_{A}$ formis, quizomnium naturaliusa motuũ principium eft forma; hac enir proprie natura dicitur,vtalibi dernonftrauimus: hunc autem animalis defcenfum naturalem attribuere animz ita vanum eft, vt nihil vanius effe queat, quum potius repugnet animx, quam eam infequaF tur; patet enim, eius principium effe grautit tem, qux eft санfa laboris, quem animalia in progrediendo patiuntur, quoniam interna grauitas deorfum trahens repugnat motui anima: quo fit, vt progreffio fit moius violentus corporranimalis, quatenus graue eft, quamuis fit ci naturalis, quatenus eft animatum, vt ait $\mathrm{A}$ riftoseles in sodem loso. Ob id non eft admis. 
tendum, id quod aliqui dicunt, animam animalis fungi omnibus muneribus inferiorum formarum, \& efle principium omnium naturalium motuum in animali; difcenfus enim, qui à grauitate prouenit, nó fit ab anima; quum 8: dormiens animal cadat, \& cadauer quoque eodem motu feratur naturaliter. Sumitur etiam ad hoc comprobandum efficax argumentum ex Ariftotele in contextu 28. \& 29. libri o. ctaui Phyficorum, vbidicit, fola animalia mo. ucre feipfa, quiadiuiduntur in partem per fe 8 mouenters, \& partem perfe motam; anima namque eft mauens inftar nauta, \& corpus in. ftar nauis eft motum: quodquidem de inanimatis dicere non poffumus, quia non diuiduncur nif in primam materiam \& formam, materi i vero neque mouens dici potent, neque per femota; ratioautem eft, quia tam id, quod monet, quam id, quod moetur, debet efle actu; de mouenteclarum eft, quia omne agens agit per ąum; de motu autein habemus teftimonium Aristotelis clarum in quintolibro Phyfica au. feultationis, vbi hocditcrimine feparat id, quod mouetur, ab eo, quod generacur, quod id, quod mouetur, eft actu, id autem, quod generatur, non eft actu, fed po eftate: quicquid ergo à feipfo mouetur, debet habere duos in re diftintos actus, proinde duas formas, ita vt vna fit furma mouens, altera vero materiam informans confttuat corpus per fe mobile; oportet ignur animal diuidi in animam, \& corpus alia forma formatum; fecus enim non diuideretur in partem mouentem, \& partem perfe motam : quod fi vtroque officio fola anima fungi diceretur, ita ve fola ratione diftinguerentur mouens \& motum in animali, vtaliquidicunt, hoc ider deinanimatis dicere poffemus, quod tamen ibi Ariftoteles negat, qui omnino vult realem effe deberediftinetionem mouentis \& moti, fi quid debeat mouere fejpfum eo modo, quo $t \bar{u}$. animal feipfum moutet. Praterea videmus, non codem interitu animam \& formam miftionis interire:anima enim interit per mortem, qua eft caloris vitalis, atque infufi extinctio; forma vero miftionis interit pei putredinem, qua eft eductio caloris elementaris à calore ambientis, dux igitur diftinct $x$ form $x$ in corpore vist\%. uente funt anima \& forma miftionis. Hoc idem plura accidentia teftantur, nam odores \& fa. pores formam miftionis infequuntur, non animam: quum enim in demortua herba, vel planta iden feruetur odor, qui in viuentefuerat, eandem formam infequitur \& in viuente, 2 in demortua; non igitur animam, fed folum forman miftionis. Hac omnia quifquis bene confideret, negare nois audebit, duas in viuentibus diftunctas formas; fi autem duas finul effe nun repugnat rationi, nec quatuor,
A nec centum repugnabit fimul effe in eodem; quare non eft neganda in philofophia malticudo formarum in codem compolito. Illud au. tem, quod maxirac huic fententiz aduerfari, de multos mouiffe videtur, eft, quod qualibet res conftituitur, \& fufcipit effe à forma; vnius autem rei vnum tantura eft effe, quare vnius rei vna tantum eff forma, non plures; ideo Auerroes quoq; in commentario 63. libri prim i Phyficorum inquit, quicquid aduenit illi, quod eft B actu, eftaccidens; quoniam ergo per formam res fit actu, non poteft forma alia forma fuperuenire, fed fola accidentia. Nos vero ad hac fa- Solutio. cile refpondemus; dicimus enim, licet vnius rei vnum fit effe, per hoc tamen non ftare, quin ea. dem resfit \& corpus, \& mifrum, \& viuens, \& 2nimal, \& homo, licet aliud fit effe hominem, aliud fit effe corpus, \& catera, qux dicta funt, fi enim idem effet effe miltum, \& effchominem, omne miftum effet homo:igitur fano modoin- Quomo. telligendum eft dictum illud; vnius rei vnum do brises tantum eft effe; quum enim aliud fit effe gene- rei Gnai rale, aljud vero effe fpeciale, poteft vna res ha- jof effe, bere plura effe generalia, non tamen plura fpe- $\mathcal{E}$ qusocialia, fed vnū cantummodo; poteft enim idem mode indiuiduum effe \& corpus, \& animal, \& hono, plista at non poteft fimul effe homo, \& equus: hos fignificauit Auerroes libro primo Metapbyficorum, commentario 17. quando dixit materiam prius recipere formas vniuerfales, deinde per easrecipere etiam formas proprias, \& particulares: quoniam enim forma generalis oificio materiz fungitur; eft enim tanquam praparatio materix adrecipiendam formam fpecialem, ideo à fola fpecialı forma res fumit nomen, \& effe; hac igitur vna tantum effepoteft vnius rei, non plures, quia vnius rei vnum eft effe. Quamobrem per dictum illud, vnius rei vnum tantum eft effe, excluduntur illa form $x$ folum, qux non funt fubordinata, nec vna eft prapa. E ratio ad aliam recipiendam, cuiufmodi funt forma hominis, \& forma equi, \& aliz fpeciales forma; at non excludun ur forma fubordinat $x$, quarum fola vltima fungitur officio formæ \& perficit omnes alias, qua cum prima materia conftituiunt materiam proximam, \& propriam ipfi vltimx forma, hxc enim alias continet, \& vnum tantum compofitum con. fituit, quoniam, vt ait Ariftoteles in contextu feptimo libri fecundi de Anima, exactu \& poF teftate vnúm fit: quando igitur ex prima materia, \& omnibus pracedentibus formis conftituitur vna quadam materia poteftatem habens recipiendi vltimam formam, ex hac, \& illis omnibus vnum fit, fi verum eft dictü illud A rift. ex actu \& poteftate fit vnum. De hoc igitur vltimo, ac fpeciali aetu loquitur Auerroes in commentario 63. libri|r. Phyfic. quando dicit, quic$N+$ quid 
quidaduenit ei, quod eft actu, accidens eft; quum enim talis actus non habeat poreftacem recipiendi alium actum, ex illo, \& alio actu non fieret vnum; ideo quicquid aduenit actui fpeciali, eft accidens; at forma generali poteft alia fubftantialis forma fuperuenire, quia non folum eftactus, fed coniunitam habet poteitatemadalium actum, eft actusgeneralis, \& poteftatem habet recipiendi actum fpecialem perfectiorem.

\section{Quod aliqua fubfantialis forma feruari poßit in genito, quaeadem fuerat in corrupto. Cap.III.}

Deme. TI's ita conftitutis, ad propofitame quaftio. tha ele. 1 nem facile eft de mutua elementorum in. menter mstatio. refolutionem fieri penitus in materiam primam, ne. fi vnatantum in elemento eft forma, quoniam De muta hacfublata manat fola materia. In miltis vero tione $m$;- inanimatis res non videtur earere difficultats: firinansmati.

nam fi in mifto forma elementorum non funt penitus interemptx, fed manent fecundum aliquos gradus; qua de re tunc fufius loquemur, quum de miftione differem us ; non videtur fie. ri prorfus refolutionem in materiam primam, flue miftum in aliud miftum mutetur, fue in elementa diffoluatur $r_{2}$ fue ex elementis per mifionem genererur; his enim omnibus modis fit mutatio, non in tora forma, fed in folis gradibusquibusdam formarum elementarium, ita vt aliquibus feruatis, \& aliquibus muratis alia forma fiat, \& mutetur fpecies; manet ergo materia cum aliquot gradibus formarum elemêtarium, proinde ron fit refolutio in materiam primam. Artamen firem diligentius expendam us ; disendum eft, in his quoque ad primam vsque materiam fieri refolutionem; quia fi grad us formarum elementarium in mifto effent aliquid re diAinctum à forma mifti , \& hac, intereanpta, illi cum materia feruarestur, iam mifti forma effes addita formis clemétorum, quz manerent poft interitum mifti : at nonita fefe res habet, gradusenim formarum elementarium in mifto $a b$ ip 2 mifti forma non diftinguuntur, fed fimul huncli cuadunt forma mifti, adeovt prater formam mifti nil aliud in mifto fit, nifiprimamaeria; quare fi ex eo mifto generetur aliud mifcum, in eo fimifiter nil aliud eft prater formam propriam, nifi prima materia, qua fola illam formam przceffit : dicercautem gradus aliquos. formarum elementarium, qui funt in hac for: magenita, prafuiffe etiam in forma corrupta; mil aliud eft, quam confiderareillarum forma. zum conuenientiam * inter fe, \& cum formis clementorum, qua modoeft maior, modo mi-

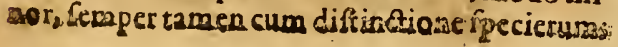

A at non efe ponere aliquid prater formam genitam, quod præfucrit in corrupto, quum ifti gradus non fintaliquid ditinctum à form a genita fed fint illimet, qui pervariationem menfur $x ; \delta^{2}$ proportionis euadunt alia forma, \& aliam fpeciem conftituunt; fed hoc clarius fiet, quism de miftioneagemus. Quod ficontendere etiam aliquis velit, hos manentes gradus effe aliquid, quod præfuerit, \& ita prater primam materiam aliquid, quod prafuerit, remanere, id meo qui-

$B$ dem iudicio nullius eft momenti, quum Arifto. teles nunquam dixerit, neceffarium effe, vt in fubftantiz mutatione omnes fubftantiales partes prater primam materiam intereant, fed folum dixerit, mutari forma in fubftantialem, qua rem conftituit, \& in fpecie collocat: fic a utem fola realitasaliqua formarum elementariū manere diceretur, at non formalitas; hane enim mutarineceffarium eft, \& ita fpeciem variari; quandoenim talis eft mutatio, vt fpecies varieC tur,vtcunqueid fiat, ea femper appellatur mutario fub ftantialis ; quemadmodum è contraris non poteft dici fubftantial is mutatio, vbi nulla noua fpecies eft facta : parum igitur refert, vtro modo dicamus, dummodo quorrodo feres habeat, intelligamus; nihil enim preter primam materiam manet, quod fit re diftinctum à forma mifti genita, \& à forma mi fi corrupta, fed manent gradus elementares, qui reipfa non funt abillis diftincti, amiffa tamen vna formalitate aliam formalitatem fubierunt, \& aliam fpeciem conftituerunt. In mutatione autem fubftantiali animatorum, non poteft in primam materiam refolutin fieri, quia poft viuentis inreritum remanet forma miftionis cum prima materia ; quare etiam in generatione credendum eft generari prius formam miftionis, fiue vnam, fiue plures, deinde poft quandam merabrorum ftatutam formationem animan aduenire : quamuis enim hoc in generatione viuenE tis occultius fit, quam in eiusdem interitu, afferendusa tamen effe videtur, idem euenire in generatione, quod in interitu fatis eft confiderantibus manifeitum. Quod eninapoft receffum nimx mancat aliquandiu forma miftionis, ofté. ditur duobus his fundamentis conftitutis: non idem eft interitus animx, ac form $x$ miftionis: \& forma miftionis non poteft in toto corpore interire, nifi prius intereat anima. Racioprioris furdamenti eft, quam fupra tetigimus, quia duplex inviuente eft calor; vaus elcmentaris, qui Giose eft calor temperátur ; alter vitalis, qui infequitur animam, de quo loquitur Arift. in lib. de Vita \& morte, \& in z. de Ortu animalium, cap..3. vbi aperte diftinguit calorem animalium, quem celeftem \& prolificum vocat, à calore elementari, qasem appellat ignesus, \& deftructiuum affe dicis snon prolificum: kowsm autem duo. 
rum cal orum non poteft eadem effe deftructio, nam calor elementaris non corrumpitur nifi per putredinem, at corpus animalis non putrefcit totum, durante vita animalis; adiectus enimcalor vitalis calori elemerinari magram reddit calorem, qui non potelt educi à calore ambientis; ideo vitalis calor non interit per putredinem, fed eius corruptio mors eft: poftea vero hoc per mortem extincto, remanet calor elementaris, qui vitali calore defitutus, educitur à calore ambientis, \& ita poft mortern cor- $B$ pus interit per putredinem. Ex hisalterius quoque fundamentiratio colligitur: non folum.n. diftindi funt borü duorü calorum interitus, fed vnus eftaltero pofterior tempore, \& illum neceffario prafupponit; quoniam enim vierque interitus fit poft alterationem preuiam, proinde non fubito, fed in tempore; corpus autein nen putrefcit, nifi poft mort cm: ideo forma mifionis non interit, nifi fof recclium animx: interitus ergo viaentis, qusi vocatur mors, non eft refolutio in materiam primam, quia prater materiam remanet in eo forma miftionis eadem, qua in viuente fuerat. Quod vero aliqui dicunt, in viuent is interitu nullam miftionis formam manerc, fed ftatim generariformam nouam, qux yocatur forma cadameris, id nullo pacto admitterdum ef: neque enim datur forma cadaueris, neque iliud, quod nos cadauer vocamus, eft vnum per formam aliquana $v-$ nam, qua totum informetur, iam orne inaniwatum hom ogeneum eft, quum fit proprium animatorum, vt lint heterogenea, \& organica, vt in definitione animx manifefturn eft; quare inamanati corfuris nulla efal ia forma, nifi forIma miftionis, qu oritur ex congrefu forma rum elementarium cum ftatuta quadam men. fura, \& proportione, qua pro fpecierum diser, fitate variatur. Quoniam igitur partium cadaueris non eadem eftremperies, quod ex eo ma-

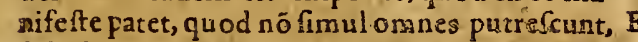
fed aliz citias, alize ferius, varize etiam in cadawere funt forma miftionis, proinde cadauernon eft vere vnum corpus, fed eft pluriamcorporum congeries, quorum fingulum homogeneum eft, \& per propriam miftionis formam conftituitur, peraliam caro, per aliam neruus, per aliam os, a reliqua : erat quidem corpus vnum, quando erat animatum, quia tuncanima partes corporis omnes continebat, \& informabat, \& totics: veram vnitatem conftituebat; fed poftea hac forma deftitut $x$, diuerf manferunt, neqialiam. labent vnitatem, quam cötinuitatis, fiue cenactus, ex qua fit, vt cadauer foleamus appellaie vnum corpus; refpicimus vero praterea etiam viuens, quod praceffit; quum enimillud: fuerit vere vnum, cadauer quoque illius hocrefectu vnum vocars confuesimus, quatenus a vnius viuentis materia fuit. Illudetiam quod aliqui ad fuam fententiarn tuendam commenti funt, vanum prorfus eft, \&r omni ratione caret; dixerunt enim nomulti ex variis illis cadaueris partibus compofitis vnam prodire formam $\mathrm{mi}$ ftioniscommunem, qua cadaueris forma appellatur. Sed hoc dicentcs, fignificant fe ignorare quid miftio, \& quid forma miftionis fit; in miftione enim oportet mifcibilia diuidi mutuo in partes minimas, \& ita inuicemalterari, vt definant effeid, quod erant, \& frant vnum quoddam tertium medium quodammodo interilla. quod in cadauere non euenit, non enim dhitdunt femutuo in pastes minimas caro, \& os, \& nerus, fed integra manent, nec commifcentur, necproprias naturas amittunt; caro enim manct caro, \& os manet os, \& fic religua: 0mnes, nempe vatione folius forma nilifscsis: nam fi animan ?peatemus; \& officium, quo fungebatur caro, vt inferuiret anims, hac ratione. non remanet fortaffe câro, nifi zequiuoce : geso - niam igitur ba amnes partes integra manforunt, \& proprias fingulz naturas fersawerint, nulla eft facta earum inter fe miftio, qua ad vnam omnes naturam redacta funt: nullaigirur ibi eft vnatotius sadaueris forma, fed pluxes, quar ex anim $x$ receffu diftinct $z$ manfer unt, qu $z$ pritis ab Anima in vnum colligebantur; neque. aliam affignare caufam poffumus diuerfitatis ac generationis earum, nifi animam; hrec enim. D propter fuana nobilitatem pluribus facultatibus. pradita cit, \& apta varias edere operationes, quarum grariá natura ipfi varia inftumenta fubminiftrauit, vt ad varias operationes edendas variis inftrumentis vteretur, quorum varias. effe oportuit remperies, \& commiftiones elementorum : quoniam igitur animæe gratiâ partes viuentis forcitz funt varias formas miftionis, nulla effe poteft caufa:diuerfitatis harum: partium in cadauere, nif hsec vna, quod illas: eafdem miftionis formas retinent in cadauere, quas prius.in viuente obtinebant. Ex his igituri: patet, poft viuentis interitum formannaliquam fubfantialem feruari, imo \& plures, qua cadem in vimente prafuerant.

\section{Solutio difficuliatum, ause ex definitione generationis oriuntur, of ipfins defi- astionis declaratio:}

cap. 1.7.

F Ac, quxe modo diximus, clariora fient; $f$ Ldubia quasdä, qua ex generationis definitione oriuntur, foluerimus. Primü quidem diffi- - . 36 bü. cultatéfaciunt verba Arif dicentis generatione: effe mutationé totius; nam fi rotum interit\& totum aliud generatur, quomodo dici potef ali.

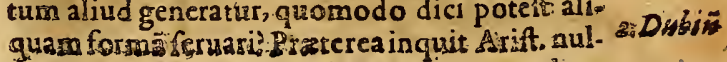
A 5 lumes. 
lum ides fubiectum fenfile remanere in genitn, quod fuerit in corrupto; at cadauer fiuc vna, five pluribus formis formatum dicatur, eft futiectum fenfile; itaque fi illa formx miftionis etiam in viucte prafuerunt, remanet idem fub2. Dubsü iectum fenfile, quod Ariftoteles negat. Illud quoque omnibus nor partum negotium faceffit, quod non datur alicuius rei interitus, q̨ui nö fit alterius reigeneratio, vt aperte Ariftoteles dixit; generatio autem non dicitur, nifi aliqua noua forma adueniat materia; quomodo igicurfitinteritus viuentis abfque alterius rei genetatione? vel; fi dicatur cadauer generarı, quomodo fit generatio fine vlliús fubitantialis formx aduentu? iam enim diximus, nullam no. prims uam formam cadaueri aduenire. Prima diffidubii fo- cultas apud Zimaram tanti fuit, vt eum dicere lusto $Z_{t}$ - coegerit, definitionem generationis non effe mare. nifi generationis elemencorum, quum in ca fo. la intereat totum, \& rotum generetur, \& in primam materiamréolútio fiat; non fic in mistis, quia form $x$ elemétorum remanent in mifto genito, \& poft mifti interitum feruantur; quare definitio illa generationis non axplectiur generationem miftoram: hoc apud eum legere Confura- polfumus in theoremate vigefimo.Sed bac in re t3o. deceptus eft Zimara. Ariftoteles enimgeneraErrer tionemibi definit ampliffinefumptam, quxoZımar mnem \& fimplicium, \& miftorum generatioin defini- nem comprehendat, vt ipfe in eius lib. Prafasione $g$ - tione expreffe propofuerat; quum enio nullam nerat16- aliam generationisdefinitionem in iis duobus mi. libris legamus preter illam, qua in contextu 23. libri primi habetur, dicendum omnino eft, eam effe maxime amplam, \& communen generationis definitionem; quod etiam exempla, quibus ArIftotelesibi vtitur, teftantur; nam \& fimplicia corpora, \& mifta indiftincte, nominat Ferafo- ad eam definitionem declarandam. Sed res malstio. nifefta fiet, fi dubium, quod $\mathrm{Z}_{1}$ mara foluere nequiuit, foluerimus. Dicimus igitur, cam diktio. nem, totum, in ea definitione fumi coniunctim tantum, non difiunctim; non enim fignificare voluit Ariftoteles ita interire totum, vt omnes partes nulla feruata intereant: quod patetargumento furo pto à prima materia; hac enim eft pars fub ftantix totius, nec tamen interit, fed eadem feruatur, attamen oporteret hancquoque interire, fi fenfum illum, quem cenfuit Zimara, verba Ariftotelis haberent : fed totum ibi fignificat integritatem fubftantix cuiufque corporis naturalis, quat ex omnibus partibus conflata eft, fedporiffimum conftituitur ab vltima forma, qux omnes alias continet, ideo ab Ariftotcle in contextu gr. libri 2 . 'hy ficorum, forma vocatur totum, quoniam res integritatem, conftituit: quemadmodü igitur interire, ac deftrui qุuaternarıum numerü dicimus, fi vnitate fub-
A lata maneat ternarius, quoniam destructa eft il. la integritas, \& alia eft facta numerifpecies; ita ex vnius fubftantialis partis interitu totū com, pofitum interire dicimus, \& aliud totum generari, quia fitalia fpecies corporis naturalis: fed quoniam in mifto omnes fubitantiales partes ita funt ordinat $x$, vt qualibet pracedens ad fequentem dirigatur tanquam materia ad formam, \& poreitas ad actum, proinde dirigitur materia ad formam generalem, \& hrec ad forB mamfpecialem, \& vltimam, qua rem in fpeciecollocat; nec poteft pofterior exiftere fine priore, prior tamen exiftere poteft fine polteriore: hinc fit, vt fublata forma aliqua generalineceffefit, alias omnes fequentes auferri, vl. tima tamen auferri poffit , manente aliqua alia priore; qua mobrem neceffe eft, vtin onni fub. ftaniali interitu pereat forma vltima, qux fpecifica dicitur, \& alı fpecifica exoriatur, \& fic totum intereat, \& aliud totum generetur, id eft, $C$ aliud compofirum fpecie differens ab eo, quod inierist : hunc effe fenfum verborum Ariftotelis, alia cius verba declarant, quar in cuntextu tceimo eiusdem l:bri leguntur, vbialiis verbis eandem affert generationis definitionem nominalem: quod enim in vicefimo tertio dicit, totum mutarun totum, ill wd in decimo dicit, mu. tariexhoc in hoc; patet autem eam dict.onem, hoc, apud Ariftoteicm fignificare fubitantram compofitam, qux exird nnimam per fe exiftit aD atu :quare nil alıud in definitione generationis denotarc Ariftoteles voluit, quam hoc compofitum intciire, hoc aliud compofitum generari, quod nihilaliud eft, quam mutari vltimam formam; hoc enim mutata, etiamfinihil aliud mutetur,mutari tamen totum dicitur, \& fieri 2 liud compofitum. Elt etiam trita ac vulgata res in philofophla,generationem \& interitum proprienon tribu forma, fed toti compolito, idque ex vitim $x$ form $x$ aduentu generari; hoc E igirurrefpiciens Ariftoteles dixit totum interire, \&aliud totum generari: quare manifeftum eft, definitionem illam generationis aque omni generationicompetere, tam miftorum, quam fimplicium. Colligims etiam ex his rationem, cur Ariftotelesibi vti volueritilla dictione, totum; idenim fecit, vt generationem ab alteratione feiungeret; quontam in alteratione non mutaturaliqua fubftantix pars, proinde totum integrum manet, mutantur autem fola acciF. dentia, qux tolum non con ftituunt, neque eius partes funt. Secunda quoque difficultas facile tollitur, fi bene verbailla Ariftotedis intelligamus, neque ea peruertamus, vtalıqui faciunt, quidicunt effe legendum [Gifsubiozo eissdem] propterea, quod Grasa verba vtramque conuerfionem patiuntur; ducti autem funt hoc argumëro,quod fil legamus [ins fubrecte eodem] nuga 
tio eft in verbis Ariftotelis : quandoquidemetiam abfque illa dictione, codem, idem fenfus fignificatur, proinde fatis fuiffet dicere, nullo manente fenfili vt fubiecto. Sed ifti dum Gra ca Ariftotelis verba perpendunt, non animaduertunt illa hane conuerfiones non recipere;

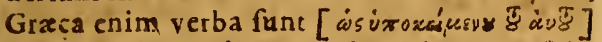
fed quamuis nos dicere Lasine foleamus, fub. iectum huius, quia voce illa, fubiectum, quie perfe participium eft, nos etiam vt nomine vtimur; Graci tamen, qui non fumunt participium, nufi vt participium, non conftruunt participium illud i $\pi$ oxsímeyov, nifi cum datino: qua-

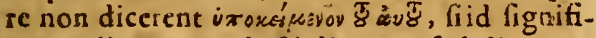
care vellent, quod ifti dicunt, fed dicerent, i่ iftos dicere debullict:patetigitur verba Ariftot. conuertionem illam non recipere. Sed fenfus quoque eam lectionem non patitur: fi enim legamus [ non manente Gllo fenfrls br fubrecto infdem ] dictio illa, elurdem, non poteft fignifica re nifi eiufdem form $x$; at quomodo eandem formam dicere poffumus, fi non eadem eft forma in vtroque termino generationis, fedalia, \& alia? corumauten ratio friuola eft quia fuiffet quidem fenfus idem verborum A riftotelis, etiam abfque illa dictione, eodem, red obfcuzior, ideo ad maiorem declarationem voluit eam Ariftoteles adiicere, fic enim fenfus clariffimus redditur, quo omnis tollitur dificultas; quum enim nomen fubiecti fit relatiuum, \& refpiciat formam, feu quicquid aliud in fubiecto herere dicatur, neceffe eft, dum dicimus fubieAtum idem, vt ad duas formas fubiectum referamus, \& denotare velimus, idem duarum for marum effe fubiectum ; non fatis ergo Ariftoteli fuit dicere, nullo manentefenfili, quia vt ipfemet ibi declarat, poteft fubfrantialis mutatio fieri etiam manentealiquo fenfili eodem, quod fuit in corrupto, vt quando in generatione elementi manet fymbola qualitas; ideo adiecit [Grfsubiecto] id eft, quod ita maneat, vt fit fubiectum form $x$ acquifit $z$, non vt fitaccidensaliquod reigenitz; fed vt clarius mentem fuam fignificaret, adiecit etian: [ $6 t$ fubiecto eodem] filicet refpeetu vtriufque form $x$, ita vtillud idem, quod fubiacet form $x$ acquifit $\boldsymbol{z}$, fuerit esiam fubiectum formz deperditz; reuera eniz in nulla fubitantiali generatione poteft idem:ra commune fubiectum remanere, nifi fola prima materia, quzz non eft fenfilis, resqueita clara eft, vt non fit alicui dubitandum; quod qui$\mathrm{dem}$ in viuentium mutatione fubfrantiali, in qua minus notum effe videtur, declarare nune libet, yt hoc idem in omni prorfus fubftantiali mutatione verum femper effe intelligamus: oritur animal, \& in cadauer mutatur, confiderandum $\mathrm{c} f$, quanam dua forma fint, quas huius mutationis terminos ftatueredebeanus, ita vt vnam dicamus interire, \& alieram generari: certumeft, terminum à quso, qui recedit, effe animaso; terminum vero ad quem, qui accedit, effe formam cadrueris, hoc eft, conge. riem illage plurium formarum miftionis quam antea declarauimus; hanc igit ur denotando per formam cadaueris, dicimus eam in hac mutatione locum bebere terminiad quem, \& huic nullum aliud fubiectum fubfternitur, nifi priB ma materia ; fic ergo tollitur omnis difficulias, nam remanet qujiern cadauer fenfile, quod idem in viuentcerat, fed non remanet yt fubiectum idem vtriufque termini; nam prius erat quidem fubiectum termini à quo, nempe ani$m x$, quia forma miftionis in viuente locum tenebat fubiektx materia, animx namque fubftabat; recedente autem anima, non obtinet amplius fubiecti locum, fed forma, \& termini ad quem: quod enim nune vocamás cadaC uer, illud prius in viuente erat altera pars compofiti, \& materia fubiecta animx; nunc vero non eft amplius materia alicui forma fubiceta, fed eft totum compoficum conftans ex prima materia, \& forma miftionis; ergo remanet quidem idem fenfile corpus, quod in viuente fuerat, at non remanetyt fubiectum idem vtriufque zermini : quamobrem. fi diligenterconfideremus, quodnam fir idem communefubiefum Aliorux forma cadaueris \& anim $x$, nullum inueniem us error $:$. D nifi primam materim. Alii.quoque fuere, qui- definit:bus difficaltatem fécerunt formz elemento- onegenzerum, qux conftituunt fubieftum fenfile, ele- rasions. mentum enim eft corpus fenfile, \& in mifto feruantur vt fubiecti locum tenenties, quo fit, vt in generatsone mifti ex alio mifto maneat idem fubiectum fenfile fub vtroque termino, quia manent formxelementorum, proinde el ementa ipfafub vtraque milti forma : ideo ifti hac moti difficultate aliam adinuenerunt verboE rum Ariftotelis interpretationem, quam non refero, quia nimis obscura, \& violenta eft, prot inde nulla confideratione digns; folum dico; nullam nobis difficultaten facere debere formas elemetorum, quoniam hac non confttuunt aliud fubiectum fenfile nifi elementa, vel miftum, quando per miftionem ad maturz vnitatemredacta fint, fed vtroque modo locum habenttermini, fiù quo, feuad quem, non fubiecti ; illi vero exiftimantes elementorum 3 formas vt elementa conftituentes manere in mifto diftinctas à forma mitti, \&cilli fubiectas, is laqueos inciderunt, quibus fe explicare nequiuerunt: mens aureas Ariftotelis, \& pradietorum verborum fententia ea eft, quam diximus, \& ficintelle 2 z , omnem difficultatem tollit. Non eft autem ignorandum, in eadefinitione geserationis, verba illa [nullo fenfili remat 
mente Gefubied. oodem ] effe declaratiua pracedentium : quamuis enim ad feiungendas generationem ab altcratione fatis fuilfet dicerc tof 5 mutari in totum; attamen ad id clarius fignificandum, adiecit Ariftotel. [ rsollo fenfols manonte Gofubiecto eodem ] fcil. viriul ique teimini; hocenim euenit, quando tolum mutatur in totum:neque hoc ablurdum ef in definitione nominale, ficut etiam notare poffumus in definitionc primz materia in calce r. libri Phyfic. \& in definicione natura in initic libr. 2. vbiad maiorem declarationem ponjaturverba iden fignifiantia: ideoalim quoque notare portumus corundem errorem: dixcrunt enim gencrationem definiri ab Ariftotele \& per fubiectum, \& perterminum, quum tamen nihil in ea definitiene dicaturab Ariftotele de fubiecto, nifineTerty gatiue. Soluenda mance poftrema difíncultas, dubÿfo. quomodo in interitu mifidicatar grnerari calusis. daver, nulla adueniente nouaforma, fi eadem cadaueris. forma prafuit in viuence, tanquam forma miftionis fingulas viuentis partes confticuens. Hanc igiturioluentes dicimus, nullam quidem nouam fubltantialem formam accedere in viuentis interitu, quando cadauer generatur, perinde tamen effe', acfin noua forma accedat; forma enim miftionis in viuentenen fungebatur officio forma, refpectu ipfus viuentis totius, fed potius materix; fubla ta autem anima incipit eadem forma miftionis fungi officio forma, a corpus illud in fpecie conftituere : $q$ uod quidern ex eo patet manifeftifime, quod f pecie differunt animal, \& cadauer; illud enim fpecies eft viuentis corporis, hoc autem minti inanim ati m mutataergo fpecie factum eft aliud coroprfitum 2 aliud totum, quia fi ab vltirna forma compofitum conftituitur, necefie eft ex diuerfitate vltimarum formarum conftituentium varia etiam compofita exoriri, \& ecrum varias efQuemo - fe definitiones; viuens quidem confturuitur ab do forma aninsa,cadauerautem à forma mifionis, \& hæc cadake- tametfi prafuit in viuente, non tamen ipfum $r \dot{s}$ f $-n o$ - conflitucbat; quiatunc formie officionon funwafor. gebatur: quemadmodum fi mortuo Rege ferma. uus aliquis fiat $R e x$, is erat prius etiam $R$ ege viA diferimen in forma antionis notare poffumus,
quod dum in viuente eft, non eft formafpecifica, fed commeunis, o generalis: eadem autem in cadauere euadit fpecifica, \& fpectem fuecialihlmam conftituit; prius enim in viuente confticurbat ipfum fub genere mifto, \& reftringeba. tur $a b$ anima, tanquam à forma fpecifica; oftea vero quandonon amrlius ab anima coaretatur, Epeciern conitituit ipecialiffimam, \& poteft exi. $\int P^{2}$ B fica.

\section{Quodeadem definitio fit generationis, of interitus, \& quomodogeneratio vnius fit corruptioalterius. Cap. $V$.}

VT ANA ego quidem femper exiftimaui quorurdam diffutationem, an generationis definitio ab Ariftoiel tradita competat etiam interitui, multo autem vanius id negare quum Ariftoteles aperrifime illud afirmet; inquit enim in contextu 23. [quando artem sotum matetur] quibus verbis cxpreffe fignificatur potius interitus, quam generatio; deinde exempla adducens inquit [ ex fmine fangsos, ex aguat aer, ass ex aere a is $^{\text {[ }}$ [poltea vero dicit] genera tso sam hoc te'e, husus autem corruptso ] mutatio enim ynius fubftantix in aliam necefte eft $v t v$ nius fi corruptio, alterius vero generatio; hoc idem dixerat prius in context. 10. his verbis [est enim gener at io fmplex. Eo interitus, quando musat wan fuerit ex boc in boc ] 11 la enim dictio, hoc, fignificat indiuiduam fubtantiam; dicit ergo vnam fubftantiam interire, \& aliam generari; quare eadem dicta definitio \& generationis, \& interitus difinitio dicenda eft. Quoniam autem hui usce rei ratio confiftit in illa propofitione, generatio vnius eft corruptio alterius, quam legirrus in contex. 17.eiufden libri, nun crit ab re, fillus propofition is fentum, in qua plurimi decerifunt,aliquantum confideremus:ccrum eft Ariftotelem loqui de generatione \& interitu rim compoliti; hoc enim propric dicitur generari, \& interire, non forma, neque materiajideo dictum hoc duobus nititur fundamentis; Vnum eft, quod prima materia non poteft nuda exiftere materia exiftere: fine vlla forma, fequereturid, quod, non eft actu, effe actu, imo \& uari cns aliquod quod non effet vilum ens; ex hoc priore fundamendo infertur, vnius rei interitũ eflenecelfarioalterius res generationem; quum enin interitus'fiat per forin zeceflum, necefleet forma recedente vtalia for ma adueniat, fi materia fine forma exiftere nequit : alterum vero fundamentum eft, quod dur forma fpecifica non poffunr fimul cile in eadem materia; \& huius ratio eft, quianon poteft aliqua res effe frmul

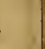

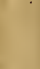
fine vlla forma; ratio autem huius eft, quia fi

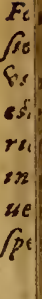
uente, at non erat vt Rex, ideo fi quzrat quif. piam, an fit creatus nou us Rex, necne, dicendum abfque dubio eft, effe nouum Regem creatum mutatum que effe Regem : fic igitur in viuentis interitu eatenus noua forma acquiritur, quatenus qux prius erat tanquam conditio $\mathrm{ma}$ terix fubftans form nobiliori, nunc incipit effe forma, \& compofiturn conftituere \& imperare: hacitaqueratione dicimus animatum intertre, \& generari cadauer, \& ita totum mutati; res enim ipfa loquitur, \& quilibet cam diligenter confiderans, deberet veritatem infpicere, a nulla difficultate perturbaci. Illud quoque 
fub diuerfis vltimis fpeciebus catcgorie fub- A fantic, vt non poteltaliquid cife fimul homo \& equus, neque effe limulacr \& aqui ; $\mathbf{x}$ hocautedn poficiore fundanento infertmr generationem vnus efie neceflario altesius interitum, nam vna adueniente forma, allam recedere necefle eft; ideo dicilolet, naturam primano generationcm velle, fecundarioatrem intertum, quia non poteft remaliquan generare, nifi aliam nnterimat. Ex his ctiam rationen colligimus, cur dicum illud Arifotelis, q:um de fubftantiis femper verum fit, non fit tamen femper verum de accidentibus, quod Aritoteles ipfe afferitin context!1 20. illius libri primi, rationamque eft, quoniam duo prædica furdamenta in formis accidentalibus locum non habent; quoniam enim abhis materia non recipit effe, fed iam a ctu eft per formam fubitantralem, ideo potcit accidens aliquodrecedere à fubiedo; line alıcuius accidentis aduentu, quod emenit, quando aecidens non habet contrarium, ciufmodi eft lumen; recedit enim lumen, \& nullum aliud accidens illi materiæ aducnit : poffunt etiam plura accidentiā fpecie differentia hærere fimul in eodem fub. iccto, idem enim poteft effe dulce \& album fimul, quare non eft neceffarium vt vno adueniente alia eiufmodi recedant: in folis ergo fubftantiis neceffitatem habet hac Ariftotelis pro. pofitio, generatio vnius eft interitus alterius, \& interitus vnius cft alterius generatio; \& intelligitur de generatione \&interitu compofiti, quod ab Ariftotele in definitione generationis hoc, feu totum vocatum eft. De hac autem propofitione quærituran ita fit intelligenda, vt vna \& eadem numcrofit mutatio, qux dicatur huius rei effe interitus, \&illius generatio, an potius dur fint mutationes; nec fatis liquet, vtrü duorum fit afferendum: nam fi vna effe mutatio dicatur, ergo contrarium crit idem fuo contrario; interitus enim eft generationi contrarius: fi ve- E ro dux, ergo vna eft altera, quare corruptio vnius non eit generatio alterius. Videntur omnes dicere, duas effe mutationes, non ynam. Ad obrectionem vero aliqui dicunt, propofitio$n$ nem Ariftotelis ita effe intelligendam, generatio vnius præfupponitalterius interitum, feu infequitur alterius interitum:alii vero rem dili. gentius confiderantes, \& videntes eodem momento vnam formam recedere, \& alteram aduenire, dixerunt intcritum non pracederetem- $F$ pore generationi, fed narura, \& è contrario generationem pracedere interitui ratione fcopi, \& intentionis naturæ; quoniam natura præcipue vult generare, nec alio conflio interimit, nifi vt aliam rem genere; per hxc tamen non fare, quin tempore fimul fint generatio vnius, \& corruptio altẹcius, idque refpicientesalii, di- xcrunt vtendum cfeverbo, comitari, generationem enim vnius reicomitatur interitus alterius rei, ita vt hic fit fenlius propofitionis Ariftotelis, generatio vnius reiconiundum habet alcerius rel interitum, \& interitus vnius reiconiunetam habet altcrius generationem. Ego vero hac onuna vana cfle exiftimo, \& eos onnes cliedeceptos in co, in quo confenferunt, quod dux fint mutationcs, non vna; puto cnim vnam numcro clfe mutation cm, qux duorum termiB nortum refpeetu dicatur intcritus vnius, \& alterus generatio: fi cnim ignis in aquam agens, eam mutct in aerem, erit interitus aqua, \& genemtio aeris, vna tamenerit mutatio, 2 facta ab vno \& eodemagente, \& per vnam \& eandem aetionem, etenim ignis calefaciẻs vertitaquam in aerem; ab vno autem, quatenus eft vnum, non prouenitnifi vnum; \& reuera ita fe res habet; omnis enim motus, \& omnis mutatio eft à termino ad terminum, nec fieri potent, vt aliqua C detur mutatio, qux duobus terminis conclufa non fit; neque per hoc ftat, quin vnus fit tranfitus ab hoctermino ad illum, ifque dicatur frmul effe vnius termini amifio, \&alterius acquifitio, \& hoc negare mihi quidem fatuum efle videtur: confpici autem poteft mañifeftiffimum in motu locali; nam fi defcendat lapis de fumma turriad imam, tranfit à loco ad locum, \& vnus numero eft motus, qui dicitur receffio ab altero loco, \& acceffio ad alterum;nec

$D$ folum eftrnus, fed etiam fimplex, qui in plures refolui non poteft; patet enim omnes in eo conditlones inefie, quaad vnitatem motus numeralem requiruntur; eft enim ynius mobilis, $\&$ in vno tempore, \& perfpatium vnum, \&à motore vno: quod igitur de motu locali negare non poffumus, id de alis motibus inficiari vanum eft; it.ique fi muteturaqua de frigore in calorem, vna numero eft calefactio, \& vnus numero motus, \& quia alteratio vocari poteft modo aliquo etiam generatio (vt dicunt) fecundum quid, idem numero motals eft intcritus frigidi, \& generacio calidi; cur ergonon idem dicendum eft de mutatione fubftantiali? vna enim eft mutatio aqux in aerem, qua eft aqux interitus, \& a eris generatio. Ad argumentumautem antea adduetum in promptu eft refponfios nana

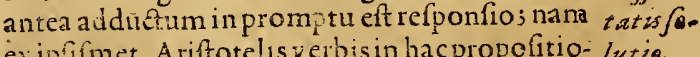
ne defumitur, \& confiftit in illis dietıonibus, vnius, alterius nam efr quidē contrarius interitus aquæ generarionı eiuldéaquæ, proindeñon potelt eadénumero mutatio effe fimuleiufdem rẹi \& generatio, \& interitus; attamen eadem numero mutatio interitus aqux, \& alterius rei generatio abfque vlla abiurditate effe poteft: fic etian de contradictoria oppofitione, qua maxima onnium eft, dicere Ariftoteles folet, negationem enim affrmationiopponiait con-
Confutam t10 rajentetia decia ratio. 
tradiftorie; non tamen quamlibet cuilihet; fed ciufdem de codem, \& fecundum idem, huic enim affrmationi, homo eit animal, hre negatio non opponitur, lapis non elt animal, ino neque huic, Ethiops eft albus, opponitur hac, sthiops non eftalbus, nifi fecundum cafden partes intelligantur; quum crgo dicat Ariftoteles interitum vuius, \& generationem alterius, nulla in his eft contrarietas, quare eadem nutatio refpesil dinerforum eft generatio, \& interitus fonul, ; va enim eft mutrtio. realiter, quæ variis rationibus \& generatio, \& interitus appellatur : hæc antem rationis diuerfitas oritur ex vtriufque termini dupiicitate; iam enim aliâs dixımus, cum qualivet fubstantialiforma efle coniunctam alterius forme pritationem, quia efle vnius rei, eft coniunfum cum alteriis rei non effe, \& cum poteftateadillud; quando igitur ex aqua fit aer, terminus aे quo duplex elt, cffeaqux, \&e noneffe acris, fic etiam terminus ad quem duplex eft, effe aeris, \& noneffeaqux: illa igifur mutatio, quum vna fit, generatio dicitur, quatenuseft de non effe acris ad effe aeris, \& dicitur interitus, quatenus eft de efle aqux ad non effeaqua: at quia cuiufque rei nominatio fumitur à pofitiuo, non à priuatuo, fcilicet à forma, non à priuatione coniuncta, ideo mutatio illa dicitur aquz in aerem, \& ita duo termini pofitui exprimuntur, quorum vnius eft generatio, alterius vero interitus : ita cnim loqui Ariftotelem manifeftum eft in declaranda generationis defuitione prædita. Non eft igitur dicendum, ytaliqui dicunt : duas efie diftinctas numero mutationes, generationem viuius, \& interitum alterius, vnam tamen \& eandem ippecie, quatenus vtraque continetux fub mutatione fubftantiali; fed potius dicendum eft, vnam effe numero mutationem, qua duabus rationibus \& generatio, \& interitus dicirur; Ariftoteles autem voa definitione vtramque complexus eft, qua rexlem conuenicntram refpexit. qua eft via numero mutatio, non differentiam rationis, qua diftinguuntur: quoniam enim fecernere yolebat mutationem fubftantize ab alteratione, eam definiuit tanquam vnam, nam reipfa yna eft, dixitque efle mutationem totus, fel totius in totum; poftea vero fignificare volens conprehendi hac definitsone \& generationem, \& interitum, dixit, eft huius generátio, illius vero interitus : quod fivtranque definire vell enas, quatenus differunt ratione, diceremus generationem effe mutationem de non effe ad effe, interitum vero efle mutationem de whe ad non elle, fed hoc ibi Ariftoteles, yt per fe

manifettum, exprimere acglexit.
A Dubia aduerfus ca, que diata funt, do eorum Solutio. Cap. VI.

I Z A quam declaraui, eft huiufce rei ve1 - ritas, \&ententia Ariftotelis, vt egoarbithor: qua manifeltior reddetur, fi quafdam difficulates folleriutus;omnium enim folutioex iis, qux dicta funt, colligi facile poteft. Prima diffcultas eft: in interitu animalis nitil generatur, quianulla noua, forma acquiritur, liqui-

B- dem formacadaueris eft illa ip fa forma miftio. nis, quxin viuente prafuit; ergo daturalicuius contptio, qurantíns eft generatio. Secundo ex comparatione generationis cum aliis lpeciebus mutationis lumitur argumentum tale: vt fè habet accretio ad immunitionę, ita generatio fe habetad interitu, funt. nt. hrinter le contrarix mutationes, ficut ille inter fe; atqui accretio vnus non eft imminutio alterius; ergo neque generatio vnius eft corruptio alterius:

$C$ fic etian $a b$ alteratione argumentari poffumus, nain calefactio viius non eft sefrigera tio alterius: fic etiam à motu locali, quoniam afcenfio vaius non eft alterius defcenlc. Tandem oritur dubium ex milti generatione 3 ex elementis : vel enim in milto remanent formæ elenentorum, vel non remanent; fire. manent, eigo generatio mifti non elt alicuius corruptio: li vero non remanent, ergo generatio vinius non eft alterius corruptio, fed po. titis, plurium. Ad primam difficultatem fumenda elt refonio ex iis, qux antea dicta funt: neymus enim id, quod aftumitur, anımalis iurertum nullius generationem effe, nam dicinus effe generationem cadaueris, hoc eft, miti iranimati, ficuti prædiximus quum autem obicitur, nullam nouam for-, mam produci, lami diximus, hoc non omnino verum effe, nam forma miftonis ea ratione produc dicitur, quatenus incipit fungi offi-

E cio forme, quum prius functa eliet officio materix; prius enim non conftituebat compofitum, neque illi nomen largiebatur; pottea vero incipit fung officio forma, quod exco patet, quia fpecie differunt cadauer, \& animal. Ad fecundam neganda eft fimilitudo, quamuis cuim aliqua ratione lint fimiles, vt quatenus funt mutationes contrariz, tamen non funt in omnibus fimiles, habent enim potiffime difcrimen illud, quo diffidet generatio

F à motu; nam de generatiòne verum cif dictun Ariftotelis, at nen de motu, quemadmodum manifeltum eft in iifdem mutationibus, à qui . busudubium fumebatur, nam fi conliderentur, non vt motus, fed yt generationes; eis propufitio Ariftotelis acconmodabitur, ytfi calefietio fumatur vt generatio calidi, eadem muta tatio dicitur etam corruptio frigidi, fic etiam

ii accie 
fiaccretio fumarur ve generatio maioris quanritatis, eildemerit interitus quantitatis minorns; verum ficonfiderentur vt motus; non potert idcm motuscfictimal duo concrarij motirs, ve in dubiratione dicebatur : ratio altem lutus difcriminis elt, quoniam licet in boc connchtant genentio, \&motus, quod funt de pofitio impolitium famen in co differunt, qubd now tits cit de politiuo, quatenus eff pofitium, generatio autem eft de pofitiuo, non quatenus eft pofitium, fed quatenus habet coniunctum priuatiumm, nam terminus à quo primarius generationis homins ele priuatio formæ hominis; tefnunus autem à quo fecurdarius ciusdem generationis eft femen; hincautem patct- v trunique terminum generation is efli duplicem ; proinde in omni generatione quatuor teminos in confiderationem cadere, q: 10 fit, vt variis ratioaibus eadem mutatio dics politit \& huius generatio, \& illius corruptio; terminiantem motus funtambo fimplices, ac perfe politiui, ett enim omnis motus de lubiecto in fibiectum, vt ait Ariltot.in s.libr. Phylic aufcultan.id eft, de politiuo in pofitium, absque vlla confideratione termini priuatiui: quocirca locum un moru non habsea duplex confideratio, qua locum habet in generatione, quum duo tantum terinini in confidéntioncm cadere poflins; quöfit, vt non polfir eadem mutatio efle'fimul duo contrarij motus, quia hoc dato, idem fecundum idem effet duo cötraria fimul, feu ellet fibimet contraritum, quod ne imaginari quidem polfumus. Ad poftrenum dubium dicimus, formas elementorum quateuts forme elementorum funt, non feruan in mifto, proinde elementa eatenus interile, quatenus definunt effe id, quod erant; quare generatio mifti eft elementorum interitus Quod vero dicebatur, generationem vnius hoc: pacto efie interitum plurium, hoc nihil refert: quianon ideo dixit Ariftotel. vaius \&alterius, vt fingul.rem numerum denotarer, ad excludendum pluralem, fed vt realem tcrminum fignificaret fue rnum, fiuepluties; quare non negat exinteritu plurium pofregenerari vnum ; \& e contrario poffe ex interitu vnius plura generari, quod euenit indifolurione mifti: hx nam q; omnes mutationes fub hac propofitione comprehenduntur, generatio vnius eft cormptio alterius, \& comptio vnius eftalkerius generatio. Quodigiturvera fit liac propofitio, \& quomodolitintelligenda, exhis, qua hactenus diximus, manifeftum eft : vnde etiam patet ratio, our defintio generationis ab Ariftotele addusta interitum quoque complectatur ; ratio enim st, quoniam eadem numero mutatio \&

gencratio, \& incritus dicîuly. refpectu diuerfo

ธแ13:?
A An idem muncro accidens popit in genito

rcmanere, quod fucrit is corrupto, contris ria aliorum fententice, or corundem argumenta.

Cap. FII.

$\mathrm{H}$ Actenus in generationc \& interitu formas fubitantialcs confidcrauimus, reftat vt accidentia guoque confideremus; \& magnum B illud dubium foluerenitamur,an in fubftantiali mutatione pofit in genito aliquod accidens feruari, gqnol idum numero fucrit in eo, quod interit. Hac de re contrixiz extiterunt philofophorum fententix : alij namque penitus negarunt, polfe aliquod idem numero accidens in genitoremanere, inter quos Petrus Pompo-netij op 8 natius in lib. ́ito de nutritione, \& accretione ef- $n \neq 0$. ficaciterhanc fententiam tuetur; nitütur autern Argumé hi potifimun hocargumeuto: fi idem numero tumpons accidens remanere dicatur, alterum duorum pozast ij. abfurdorum fequi neceflè eft, aut accidens idem. numero migrare è fubiecto in fubi ectum;ant omnia accidentia immediate harere in prima materia : nam fi fubiectum accidentis effe dicatur totum compofitum, quod exmateria \& forma conftat, certe fit accidentis migratio, mutato enim compolito fubieftum accidentis mutatur; quare idem numero accidens migrat è fubiecto in fubiectum, quod ab omnibus philofophis mpofibile efle cenfetur:quod fiad vitandan migrationem dicamus, fubiectum accidentis non effe totum compofitum, fed folam materiam, in aliudabfurdum incidimus, quod facimus accidentia omnia hærere immediate in mateila prima, quod Aliftot aduerfatur, qui in context.24. libr. 1 ' de ortu, \& interitu in q̨uit, ac. cidentia haberefubrectum fenfile, \& ificontex. 8. Feptimi Metaph. inquit, materiam prius recipere formas fubftantiales; noftea vero accidentales;quare exiftimanit fubie tum accidentis effe compofitum conftans ex materia, ¿̇ forma fubftantiali.Auerroes quoque in Comment. 63. 1. Phyf.hoe difcrimen fatuie inter formas fubftantiales, \& accidetia, quod fubiectum formarum eft enspoteftate; fubiectum auten accidètium eftensactu:vult ergo formas fib ftantiales inharere in materia prima, accidentiavero non in materia, fed in compofito, quod ex materia \& forma conftat. Econtrario antem illi dixerunt, Aliorwa polle idem numero accidens feruari in genito; côtrariz quod fueritin corrupto:quam fententiam \& te- opinios. ftımonio fenfus, \& ratione, \& auctoritate Arif. comprobaruntínenfus enimiudicat éandem numero figuram, \& eandem cicatricem manere in caçauere., qua in yiuentefuit, e q; eft omnium hominum conmunis opinio. Ratio quoque id soufirmat, nā fi in cadautere alı eff cicatrix, non 
illamet, quxinviuente fuit, dicendum eft, à $A$ quonam agente fucrit imprefla, oportet enim in puncto temporis imprefram fuifle cadaneri, quod ne imaginabilequidem eft; quum prefertim nullum appareat agens, à quo imprimi potuerit. A riftotcles quoque in contextu 24. primide ortu \& interitu affirmat, in mutatione aqux in aerem feruari eanden perfpicuitatem, \& eandem humiditatem, \& aperte fateturpolle in genitoaliquod idem fenfile accidens remanere, folum autem negat remanere pofie v obtinens locum fubiedt; \& in context. 34 . lib. . inquit, in elcmentis fymbolam qualitatem habentibus, faciliorem clle mutationem, propterea qnod fymbola qualitas eadem manet in genito, qua fuit in corrupto. Hanc fententiam. plures fequutifunt, Gregorius Ariminenfis in fecund.Sentent.diftint.1z. quiztion. 2. articul. 2. \& Marfilius, \& Buccaferreus in libro primo de generatione. Pater igitur vtramque opinionem maximis vigeri difficultatibus, \& in iis foluendisalij pluximum laborarunt:Pomponatius cnim in libro fuo prædikto volens hxc, qux à fecunda fect adducta funt, foluere, fe tamen explicarenon potuit, \& multa vana dicere coaetus cit, quæ non funt digna confideratione, neque elt in is tempus conterendum; nam cuique ea legenti manifeftum fiet; vel deferendan efe eiusiententiam vel melius contraria argumen-

Aliorum ta foluenda.Marfilius vero \& Buccaferreus prarefpongio adsargumentim Pomitosatiy. dictum argumentum confiderantes, quo alterum duorumabfurdorum inferebatur, vel accidens migrare de fubiceto in fubrectum, vel accidentia ominia inhærere immediate in materia prima, migrationem accidentis confelí effe penitus impolfibilem, vt eam evitarent, negarunt alterius confequentisabfurditaten, \& dixerunt accidentia immediate inherere in prima materia, tanquam in communi fibiecto omnium formarum tam fubftantialım, quam accidentalium. Ad Ariftorelem autem dicentem accidentia habere fubicetum fenfile, \& ad Auerroem dicentem accidentia habcre fubicatum ens actu, dixerunt, eos ibi loqui de fubięto denominations, non de fubiceto inhælentix; compofitum enim effe accidentium fubiectum denominationis, at primam materiam efle corundem fubiestum inharentix. Ad illud autem, quod ab A riftotel. dicitur in leptimo Metaphyficorum, de ordine in formis à materia recipiendis, dixerunt, enm effe ordinem recipiendorum, non ordinem recipientis : quod enim ad materiam attinet, ip fa xque apt a eft recipercimmediate formam accidentalem, atque fubftantialem, fed forme ip re recipicnd $x$ hunc ordinem poftulant; forma nam que fubitantialispixcedit natura accidentalcn, \&eforma acsidentalis præfupponit receptam fubfantia- lem: \& hrec caufa eft, cur fubicctum nominationis, cuiaccidentia attribui folent, fit totum compofitum, quia forma accidentalis recipitur poft receptam fubstantialem; at verum fubicctum, in quo immediate recipiuntur omnes formatam fubituntiales, quan accidentales, eft prima materia. Hac funt præcipua, quæ de hac reab aliis dicuntur, breuiter tunc à me relata, alia namque plura in prolixis difputationibus le. gere qutisque potett.

\section{Confutatio ofinionum aliorum. Cap. VIII.}

N hac fumma dificulate ego puto, falfam oImnno efie priorem fententiam, alteram autem veriorem; ftandun enim eft teftimonio fenfus, qui iudıcatidem numero effe accidens, quod in genito remanet, \& prius fuit in corrupro, idque inficiaripertinacis prorfus hominis

C efrevide.ur: defenfionem tamen, quapoftior fecta vtitur, approbareminine pof̂n ; quam enimfoliendum fitillud aliorum argumentü, quo inferebāt, velacciduns migrare de fubiecto infubiectum, yel in prima materia immediate inhærere, illi quidem recte re, onderuni negando falfitatem pofterioris membiadmifa ta:fitateprioris, nempe dicendo mofibilem effe accidentis migrationem de fubiesto in lubiectum, ted accidentia omnia un prina materia tanq̨uam in fubsecto inharere, proinde remanente eodem accidente in re genita nullam ficri migrationem, quim idem accidetis fubtectum remaneat, nempceadem portioprimæ materix. Sed quia huic fententix refiagari videbantur Ariftorelis, \& Alicrois verba varris in locis, 1fti ad foluendam omneu difficultatem vir funt duabus diftinctionibus, quarumneutram ego probare poffum, quiam per eas difficultas hize non tollatur. Frior enim diftinctio fubiecti in

E fibiectum inharentix, \& fubiectum denominationis, feu attributions, vera quidem per fe eft, fed ad rem non pertinet : nam qu.undo Arift. \& Aucroes dicunt accidentia hábere fubięu fenfile, \& ens afu, id dicunt ad diftinguenda accidentia à formis fubttanialibus, qux non habent fubiecum fenfile, neque ens actu; atramen per hanc illorum diftingtionem non fecemitur accidens à forma fibftantiali, fiquidem tam accidentia, quam forma fimiliter fecundum eos inhærent primæmatcriæ, tanquam lubick o inharentix, \& habent tun compofitum vt fubiectum denominationis, fet attributionis ; forma enim lapidis inhæret quidem in pruma materia. not tamé forma materix nommatur, fed forma lapidis;nuodidem de onnbus formis fubftantialibus noware oitumus, quxlibet enim attributul compolito, non prim $x$ materia: itaque fi Arift. 
A riftot. \& Auerroes dicentes accidentia habere fubiectum fenfile, \& ens actu, intelligunt rubieaum denominationis, non feparant per hoc, vt feparare volunt, accidentia à formis fub ftantialibus, quum ipf $x$ quoque habeant fubiectum denominationis ens actu, \& fenfile, quia omnis nominatio fit ab actu, \&e ipfamet materia nomen fumere folet ab actu, quem recipit. Altera verodiftinctio eft prorfus reiicienda; dum enim dicunt, ordinem efle formarum recipiendarum, at non materix recipientis, in duobus peccant: quia diEtum hoc tum falfum eft, tum etiamf adnsittatur, difficulitem non tollit:falfumenim eft, quia nihil eft fruftra in natura, nec datur aliqud potens pati, vel fieri, quin ditur etiam agens potens illud facere, \& è conuerfo; quarenon datur receptiuum fine receptibili,nec receptibile fine receptiuo, fed eft fumma confonantia in rebus natura, qux nuhil patitur effe fruftra: ergo fi in formis eft hic naturalis, ac ne. ceffarius ordo, vt priusrecipiendz fint fubftantiales, pofterius vero accidentales, neceffe eft, eundem concedere ordinem etiam in materia recipiente, vt prius appetat recipere formas fubftantiales, portea veroaccidentales;idque elt etiam maxime confentaneum natur $x$ prim $x$ ma teriz, id enım quod materia áppetit, eft cffeacu; non fit autem actu nifi à forma fubftantia li, hanc igitur prius ac magis appetit: oportet enim ( $v t$ mododicebanus ) matcram ita formarum receptionem appetere, $v t$ form $\approx$ ipf $x$ aptæ funtrecipi, at non funt aptze recipi, nifi hoc ordine, vt priusrecipiantur fubftantiales, deindeascidentales; ergoeodem ordine debet materia appetere earum receptionem, quocirca idem elt ordo form a rum recıpiendarum, ac materiz recipientis. Preterea etizmfi admittamus ordinem hunceffe in formis tantum recipiendis, non in materia recipiente, perhoc tamen prafens difficultas non tcllitur, vi illi eam tolli arbitrant ur ; puant enım fi is ordo in ipfa materia fratuatur, non effeamplius materiam fubieCum immediatum accidentium, quod ipli omnino tueri contendunt, attamen idem fequitur etiam pofito ordine in formisrecipiendis; quia fi in his eft hic neceffarius ordo, vt form $x$ accidentales non polfine immediate recipi in materianta, fedrequrant receptas prius formas fubftantiales; ergo fubiectum in quo in. hrealut, requirunt confans ex materia, \& forma fubftantiali, proinde in compofito imme- $F$ diate inharent, non in prima materia. Quum ig!tur ita manifeftus in to mis hic ordo fit, vt -negarinequeat, nec poltic etiam negari in materia recipiente; aliam defentionem adducere opertet, \& alia ratione of tende:e, q omodo hic oidotum formarum recipiendarimi, tum materia recipientis non tolią, quin fubectum immediatum omnum fonnarum tam fubitantialium; quam accidentalium it iplamet prima
A materia, quod quidem nos preftare pro viribus enitemur.

\section{Declaratio veritatis, ac difficultatis folutio. Cap. IX.}

V T hac in re veritas cognofcatur, ftatuendum ante omnia eft illud, quod apud 8 rift. legimus in contextu ss. lib.1. de ortu \& interitu, \& tulius in g. Metaphyfic. poteftatem patiendi, quam noftri potentiam paffiuam appellant, effe B prim $x$ materix propriam, neque alicui competere nifi perillam; ideo in illo context. 5 s. Arift. inquit, fi daretur calor à materia feparatus, is n!hil vtique pateretur; prater materiam igiturnihil patitur perfe, fedquiquid patitur, permateriam patitur; quare forma non eft perfe patibilis, fed quatenus eft in materia; \& ipfum quoque compofitum patitur quiden, ac recipit, non tamen quatenus ex materia \& forma confans, fed folum quatenus habet materiam: quapropteriure Ariftotel.7. Metaphyfic. context. \&. dixit, materiam effe fubiectum omniume categoriarum, quum folius materix officium fit recipere, \& pati. Caterum etfi materia eft fubiectum omnium formarum tam fubfrantialium quam accidentalium, negari tamen non poteft, eam efle aptam eas recipere ordine çuodam, ita vt eo ordine percurbato non reciperent.1rprius enim recipit fubfiztiales formas, pofte2 accidentales, \& inter fub ftantiales vnam $D$ prius, quam aliam; aliqux enim funt, qux vt recipiantur, requiruntalias prius receptas, vtanimanon recipitur in materia, nifi prius formata formis elementorum, \& inter ipfas quoque animx partes al iquis eft neceffarius ordo, qui à nobis alio in loco opportunius confiderabitur: hoc autem eodem ordine, quo forma funt aptx recipi, ipfa quoque materia eftapta eas recipere, nec minus eft recipientis ordo, quam recipiendorum, ficut antea aduerfus alios dicebamus.

E Per huius tamen ordinis conititutionem non ftat, quin proprium materiæ fitpati, \& ipfa fola fit receptaculum omnium formarum : itaque dicere cogimur ad omnem tollendam difficultatem, aliud effe fubiectumrecipiens, aliud effe conditionem illi neceffariam ad recipiendua ; forma enim fubftantialis eft quidem conditio necertaria materize ad recipiendas formas accidentales, atnon ob id ef rubiectum recipiens, nec parsrecipientis; quod quidem etiam in aliis notare poffumus, qualitas enim non recipitur in materia, nifi poft receptam quantitatem, quantitas tamen non fungitur officio recipientis, fed eft folum conditio neceffaria ad reci piendam qualitatem; fic igitur forma fubftantialiseft necefiaria materiæconditio, fi debeat $\mathrm{ma}$ teria recipere formas accidentales, fola tamen materia eft fubiefum recipiens; ideo mauens in cadauere cicatrix, qux in viuentefuerat, non migrat defubiecto in fubiectum, quia manente

\author{
Aloudef \\ Subsedtis \\ recipies, \\ alisdes? \\ condatio \\ necefJa- \\ riand \\ recipsensi- \\ dirase.
} o eadem 
endimportione primamateria, quxeft prima r.dir nmnisreceprions; non dicitur mutatum fubiectum; fedilidemaccidensad aliam materiaportionem tranfiret, illa vtique effer migratio, quam philofophi omnes impofibilem effe exiftimarunt; ea enim non aliter eftintelligenda, quam cum tranfitu ad aliam portionem primæ materix. Poffumus autemad hoc com. probandum yti tali ratione: illud eft fubiectum inhærentix omniumaccidentiam, de cuius potécia educitur quodlibetaccidens; atçuı omnia accidentia, qua generantur, educunturdepotentia folius materix, non de pnrentia compofitivt exmateria \& forma conftantis; ergo fola materia eft fubie ctum, in quo accidentia omnia inharent: maiorclara eft eo fundamento conftituto, quodform $x$ in materia inhærentes educuntur de materia, non inducuntur, quod in philofophia Ariftotel. omni prorfus dubio caret, vel faltem id nemo inficiabitur, de quo fubiecto forma aliqua educi dicatur, in eadem etiam inhærere: minor fic probatur : ignis calefacitaquan, \&sita calorem educit de potentia ad actum; vel igitir depotentia a quz prout eft aqua, vel de potentia folius materiz, quzinaqua ineft; non primum, quia dicere aquam, quatenus eft aqua, eft ducere ratione forma aqu $x$, qua aqua eft, hrcautem repugnat calori, ac renititurcalefacienti, quia calor inimicus eft natura aqua, ergo nullam habet naturalem aptitudinem recipiendi calorem, fed hanc habet folam materia, qux eft apta recipere omnes formas tam fubftantiales, quam accidentales. Sed

Distism. obiiciet aliquis, quomodo igitur forroa aquz dici poteft conditio neceffaria materizad recipiendum calorem, ficuti paulo ante dicebamus? recipit enim aqua calorem, nec reciperet nifi materia illa iam haberet formam fubftantialemi non habet autem aliam, quam formamaqux; hæc igitur tum inimica eft calori, tum eft conditio neceffaria materiæadrecipiendum calorern, qua videntur inıplicare contradiftio-

solutio. nem. Ad hoc dicimus, aliud effe fubietum recipiensaccidentia, aliud effe caufam à qua accidensproducitur, vel emanat: calor non confequitur quidem naturam aqua vt cauram, quum ab externa caufa producatur, habet tamen in aqua fubiectum receptiuum ipfius; materia enim, qua eft in aqua, eft per fe receptiua caloris, ficutionniumaliarum formarum: fed quia non poteft recipere formam accidenta. lem, nifi prius receperit fubftantialem, forma. aqua hanc operam praftat, vt abfolute eft forna, nonvtaqua forma; quum enim quaibet portio materiz fit zque apta recipere omnes formas, ideoomne cotpus mundi huius infenoris eft capax caloris vel vémici, vel vtinimici, hoc enim eft illi neceffarium propter materinm, quam habet : vt igitur materia poffit calosem recipere, fatis ei eft qualibet forma fpecif-
A ca, etiamficalor fit illi form inimicus, quælibet enimfoma q̨ เatcnus materımperficıt, \& eam reddit ens actir, facit etian receptiuam \& caloris, \& firgoris quatenus fubiefum rec1piens, recipcreauten cogitarabagente externo, etiamfi forma it.uftantialis, quam habet, tali accidentirepugnet. Poceft eciam hacfententia confirmariauctoritate A riftotel. in pradicto context.8. feptimi Meiaphyficorum, vbi do dicit: primun eniminquit, materiam effe fi:bieB Ctum omnium categoriarum, proinde receptiuum ornium formarum tam fubftantialium, quam accidentalium, \& perhoc ipfus materiaz naturam deforibit : deindevero dicit, materiam prixis recipere formas fub trantiales, poftea accidentales : priore igitur dieto fignificat acciden. tıa omnia in prima materia inherere, proinde materiam effeper fe eorum omnium fubiedum inherentix; fi enim hoc non per fe materix competeret, definiretur ibi materia per accidenC talia:alrero autem pofteriore denotat, formas fubftantiales effe conditionem neceffariam 'naterix ad recipièndas accidentales, non effe țamen fibiectum recipiens, quonian recipiendi officium iam ipfi materix attribuerat. Sed aduerfus hunc ordnem dubitare quispiam poffet: forma enim fubfrantialis non educitur de mate. ria, nifi poft praiam alterationem, ergo non minus requiritreceptas iä formas accidentales, quam ipfe accidentales requirantreceptas fubD fantiales;non eft crgo in receptione formarum receffariusille ordo, quem ibi Ariftotel. ponit, nempe vt prius forma fubftantiales, quam accidentales in materia recipiantur. Ad hoc dicimus, aliud effe receptionem forma in materia, aliud effe eius productionem, feu cductionem : forma fubftantialis pro fuí inhxrentia in materianon requirit inh rentiam form accidentalis, fed folum profui eductione de materia re. quirit formas acsidentales vt praparationes : at

E forma accidentalis prefupponit pro fui inharentia inhrentiam form fub ftantialis, quod quidem in illa ipfa præuia alteratione notare poffumus; non enim in materia nuda fitaltera. tio præuia, fed in materia formata, habet enim tunc materia formam corrumpendam, qux prius inhret materiæ, quam accidentia, quæ in illam materian pro eductione forma generan$\mathrm{d} z$ introducuntur; forma namque ilia prasedens, licet accidentibus illis inimica fit quateF nus eft talis forma, tamen quatenus abfol ute eft forma, facit vt materia politacciłentia illa recipere, quemadmodum de calefactione aqua antea dicetamus. Adverba igitur Ariftotel. \& - Auerrois, qua fuperiusadducta funt, arbitror fisefierefpondendum: auando Ariftotel. dicit, ascidentia habere fubiectum finfile, \& Auerroes inquit accidentia habere fubiectü ess actu, non folum fubieftum inharentia refpexerunt, fed agfiegatura exco, is conditione necella- 
ria ad recipiendum : per hoc enim diftinguuntur ab accidentibus form $x$ fubftantiales, quod ha non requirunt receptas prius accidentales, at accidentales requirunt prius receptas fub ftantiales, \& hacratione habent fubiectum fenfile, \& cns aftı; id tamen, in quoproprie recipiuntur, eft prima materia, quare hac manente non dicuntur migrare de fubiecto in fubiectum; qua forma fubftantialis eft quidem miediatrixinter - accidens \& materiam, nontamen ita mediatrix, - vefit medium fubiectum, vel pars fubrecti recipientis, fed folum tanquain conditio materix vt recipere poffit. Admonere tamen volumus, hac de illis tantum accidentibus, qux in materia generantur, effe intelligenda, non de illis, qua nunquain à materia feparantur; nam quantitas interminata infequitur prima materix naturam, nec requirit forman fubltantialem vt in materia recipi poflit, fed potius è contrario eft necuffria conditio materix proreceptione forma lubitanialis; forma namque per fe indiuidua eit, \& omni-quantitatecarens, quare yt diuidua fiat, indiget materia per le quanta, in qua extenfionem fulcipiat. Sic igitur patet primam miteriam.efe fubiectum, in quo omnes formz ram fubitantiâles, quam açcidentales inhærent: idque Anerroes a erte afferit in 1 . Comment lib. 1 de ortu \& interitu, dum inquit idem efle iuviectu generationis \&alterationis. Quare curlibet ea, quædisimus, confiderant facile eft omilit Arrftotelis, \& Anerrois dieta conciliare, \& eorum verba ad rectum fenfum trahere, \& omnia hac in re dubia foluere.

\section{Cur poft reinterit na aliqua ciusacciden- tan feruentur in genito, aliqua vero non feruentur. Cap. $X$.}

$\mathrm{Q}$ Vxrere aliquis poffet huius difcriminis rationem, cur poft rei interitum aliqua eius accidentia in genito remaneant, aliqua vero non remaneant : quxitio hrcaliena fortaffe videbiturà prefenti contemplatione, quum fatis fuiffe videatur oftëdere, quòd poffint aliqua remanere: ideo breuiter dicimus, effe confiderandam cau fan, à qua fingulumaccidens pédet, ex diuerfo enim refpectu accidentis ad fuam caufam hoc difcrimen oritur : nam aliqua accidentia funt, qux exiftere nequeunt non exiftente caufa, ideo hæc non poffunt fublata caufa feruari,in horum numero funtilla omnia, quorum natura confiftit in fieri, vt ambulatio, loquutio, intellectio, fenfus, nutritio, accretio, \& huiufmodi omnesoperationes anima; ideo nulla harum remanetpoft viuentis interitum, quia fublata eftanima, qux earum caufa erat: aliquorumatitem natura conftituta eft ( $v t$ vocant) in facto effe, \& horum alia exiftere poffunt etiam non exiftente caufa, cuiufmodi funt omnia arte facta, remanent enim etiam interempto arti-
A ficc: alia vero cum fua caufa reciprocantur, \&e ca fublata non remanent, vt odores, \& faporcs; certam enim quandam primarum qualitatum temperiem confequuntur, qua deftructa nequeunt feruari:hacigitur in alicuius rei intcritu remanele neceffe eft, fi eorum caufa interierit: contra vero interire, fi eorum caufa interierit: ideo fapores \&codores aliquarum plantarum etiam poft plantz interitum manere folent, quia infequuntur formam miftionis, quæ remanct B poit animainteritum, fedhimet poft putrefactionem illorum corporum non feruantur,quia per putredinem foluitur miftio, fublata autem. forma miftionis manere non poffunt. Si vero pollint exiftere etiam non exiftente caufa, hac poffunt etiam fublata eorum caufapoft rei interitum feruari, dummodo non repugnent formagenerand $z$ : vt figura eft accidens animati corporis, ix animam infequitur, vt figura humana animam humanam: fed quia exiftere poC teft etiam fure anima, \& in rebus inanimatis, quum fit terminatio quanti, \& quantitas primum infequatur naturam materi 2 , ideo remanet in cadauere, quia corpus inanimatum nulli cert $x$ figur $x$ addiêum eft, \& nulla ei figura repugnat:fic cicatrix remanet, quia eft quxdam figuræ vitiatic: In mutatione vero aqua in aerem non rersanet quantitas aqua, fed deftruitur; quialicętaeri quantitas $1 l$ la non repugnet vt abfolute confiderato,fiquidem poteft effe a er tan$D$ tæ quantitatis, attamen illi repugnát vt ex tanta aqua genito; quum enim aer fit elementum rarius aqua, neceffeeft in mutatione aquxin aerem, vt etiam quantitas aqua in maiorem mutetur: quando igitùr accidens ab que fua caufa exiftere poteft, \& formx generanda non repugnat t um vt abfolutx confiderat $x$, tum vt relatz ad formam pracedentem, quæ interiit, poteft idem numero accidens in re genita remanere, quod fuit etiam in re corrupta : \& hæc pauca $E$ hac dere fufficiant.

$$
\begin{gathered}
\text { De caufis gemerationis, do interitus. } \\
\text { Cap. } X I .
\end{gathered}
$$

Mnia, qua hactenus diza funt, ad declarandam generationis naturam, ac definitionem pertinuêre, vt quid generatiofit intelligatur; reliquun eft, vt de caufis generation is \& interitus aliquadicamus, quas Ariftot. quoq; polt traditam generationis definitionem in eifdem F libris perueftigauit. Quem autem quatuor caufarum genera fint, de tribus dicendum eft, materia, efficiēte, \& fine,quia de formaiam diximus; nulla namq;alia eft generationis forma, quam Formo ipfius effentia, quxper definitionem iam decla- generaratam fignificatur; eiufmodi enim ea defritio tionis. fuit, quam effentialem, feu nominalem vocari, Maters $\&$ in demonfratione locum maioris extremi generaobtinere iam in lib.Logicis diximus. Materiam tzon: genęrationis duplicem Ariftet. in iis libris tra- duplex. 
dit : vnam maxime communem \& remotam, qua prima materia dicitur; qua quum apud $A$. riftot. fecundum fuam fubftantiam zterna fit, nec polfit exiftere fine forma, necefle eft vtrecedence vna forma recipiataliam, \&ita in:eritus vnius rei fit alterins reigeneratio, proinde caufa non eft folum vt generatic effe poffit, fed etiam vtpoffit perpetuari:altera eft propinquior materia, nempe quatuorvocata corporum elementa, de his enim tanquam de generationis materıa Ariftotel.in iis libris fibiagendum propofuit, vt videre eft \& in contextu 43 . lib.r. \& in initio fecundi : qua de re nes difputandum in præfentia eft, nec plura dicenda; fatis enim in libro de naturalis f́ientix conftitutioneoftendimus, corpus mittum effe id, quod pracipue generationi \& interitui obnoxiū dicitur, elementa vero in is libris confiderari vt principia generationis, nempe vt materiam generationis miftorum: non enim aliam ob caufam Ariftot.in illo 43. context.propofuit agendum de tactu, de actione \& paffione, ac de mirtione, nifi quia elementa non funt materia mifti, nifi prout in $\mathrm{mi}$ ftionem veniunt, \& ad naturz vnitatem rediguntur; quocirca de miftione prius agere oportuit: fed quia non comraifcentur inter fe elementa, nifi per mutuam actionem \& paffio$n e m$, ideo de actione \& parione agendum etiam prius fuit, quam de miftione: \& rurfus quia non agunt inter $f e$, niff fe tangant, iden de tactu agere prius oportuit, quam de actione \& paf. fione; quare clara eft Ariftotelis fententia, quod de elementis agitin iis libris, tanquam de maeeria generationis mi ftorum : ideo fi quaratur, quodnam generationis akinterirtus primum fub. Fromum iectum fit, dicendum eft, primum primitate fuksefiz fcopi \& intentionis natura effe corpus miftum; genar - fed primum primitate ad rquationis effe comsiossis mune illud, quod \& mifta omnia, \& elementa quacha fit.

Efficiess carrageseratiowis.
A crim per illum Sol, \& aftra modo prepinqua puntionofito verticali, modoab eodem remota ferantur, caufa funt harum varietatum ; candein enim rem modo generant, modoperinüt, quia modo calcfactinit \& magis, \& min!ts, modo effimper nimian remotionea compra hac inferiora coclefti calore deft teuta relinquit,preinde inceritus caufe funt. Caula vero final s generationis eft conferuatio fpecierum; quã enim apud Ariftotelem illud fir naturx vniuerfalis pracipuum confilium, vead huus mundi tum perfectionem, tum ornatum fecles ornates feruentur zetern $x$, ideoillas, çtarum natura in codem indiuiduosternitatem non patitur, reternas feruare ftatuit per continuam \& perfeuerantem generationem, vtinterempto locinduidun aliud eiufdem fpeciei generetur, \& ita in pluribus faltem indiuduis zernitas fpeciei fernetur per generazionem incofracem, ob menuratas callfas. Illudauten hacin le eft fummopere anotandum,aliud affe, ablolure alicuis rei caifas, qur plures effe poffunt, confiderarc, flidit efie, aquatam caufum quxrere, propers quan res eft; hac chim uon poteft vnius : nif vna efe, vt Ariftoteles docet in liorofecundic Poffer. Analyt. \& vt nos in operibus Logicis diffure declarzuimus. Quum autem Ariftoteles non foleat alicuius rer caufarn adducere, nifi zquatan: qua fatisfaciat quar fioni propter quid, dubiun orisi poteft, quomodo duobus in locis caufam perpetuitatis generationis aliam \&aliam attulerit:nam in libro primo de ortu \& interitu qu 2 rens, cur generatio fit perpetua, caufam inquit effe naturam prima materiz, qux quum exi- $n$ ftere nequeat fine forma, \& aminla vna forma accipiat aliam, quo fit, vt interitus vaius reifit alterius rei generatio, facit vt generatio nunquam deficiat: in fecundo autem libro caufam huiufmet perpetuitatis non amplius in materian refert, fed in motum Ccli æternum, qui E facit in hocinferiori muadogenerationemperpetuari. Sciendum igitur eft, ut etiam in operibus Logicis diximus, caufas quidem ynius rei plures effepofferemotas, \& non æquatas, fed earum tamen quamlibet effe proximam, caufam alicuius effectus, nempe vel alicuius communioris, vel eiufdem alio modo confiderati : vt prima materia, quum fit ens mera potefate, non potef facere vt generatio fit, proinde non eft cius zquata caufa; pofita enim materia, non $\mathrm{cx}$ qua neceffitate ponitur generatio, fed eft caufa fine cars qua non, agensautem generans eft caufa gene- ner rationis xequata, pofito enim generante, genera - nis tio ponitur, \& ablato aufertur; cum coautem quo ef coniuncta cauf $x$ finalis confideratio, quia $x o n$ propter aliquem finem generat:alıatamen ratio- $A l$. ne etiam materia eft zquata caufa generationis; quum enim aliud fit poteftas, aliud fit actus, neque eadem fit caufavtriufque, ve rifibilitatis, \& rifus; ideo vt generatio effe polfit, caufa eft ma- ct wo. 
teria $v t$ autem actu fit, caufa eft agens generans; eadem autem eft caufa generation is vniuerfe fumptx, ac perpetuitat is generationis; quxenim facit vt generatio fit in rebus, cadem facit yt inceffantir \& perpetno fit;iccirco aliud eft perpetuitas generationis, aliu d eft ciusdem perpetuabilitas : perpetuitatis quidem caufa eft motus Cocli, fed perpetuabilitatis æquata caufa eft materia, quum no:a mifit effe caufa actus, fed fo. lum poteftarss, polita enim materia, perpetuitas generationis non quidem ponitur, fed poffibilis eft, perpetuatur autem ab agente'; \& rationi confentaneum hoc eft : quum enim agens agat quatenus eft actu, \& materia patiatur quatenus eft poteftate, conuenienter caufam actus in agens referimus, caufam vero poteftatıs in materiam, \& ambo hac fuerunt nece faria in naiura, vt nihil effet fruftra; inam fruftra daretur agens, cui nullum refponderet potens pati, \& fruftra poneretur materia pati potens, nifi affignatum illi effet agens, à quo pateretur. Sed quum \& agens indigeat materia, in quam agat, \& viciffim materia egeat agente, à quo patiatur, agens tamen nō appellatur caufa fine qua non, fed fola mareria; appellatio enim cauf $x$ fine qua non, folicaufxe
A fecundarix conueniens eft, nempe illi, qux inferuiat alij cauf $x$ principaliori, cui pracipueattribuatur effectus, \& qux abfoluteillius cauf dicatur; principaliorautem eft actus poteftate; ideo abfolute caufa alicuius rei illa effe dicitur, qux facit vt res fit actu, deinde veroalias miniftrantes caufas fpectando dicimus illam id pra. ftare non fine aliarum minifterio, præterea illis conuenit appellatio caufx fine qua non: quum igitur materia fit mera poteftas, \& ipfa per $\{e$ niB hil producat, non poffumus agens vocare caufam fine qua non; quia fic iam itatueremus, mareriam per fe producere, \& illi primas in ea productione tribueremus : fed quum agentis nomen fuo formali fenfu actum producendi fignificet, huic afcribimus productionem effeÊus, \& ei primas tribuimus, dum dicimus, $\mathrm{i}$ pfum agerenon fine materia. Forma verogenerationis, qux per eius defint tionem fignificatur, effectus potius eft, quam caufa; eft enim declaraC-tio nominis, quze in demonftratione ponitur vt maius extremum, cuius caufa quxritur, quemadmodum de accidentibus omnibus alias in operibus Logicis declarauimus.
Curma-

reriads-

cater

$\cos \sqrt{x} \hat{e}$.

ne juas

non.

\section{JA C. ZABA R E L L $Æ$ $P$ A $T, A \cup$ I $N$ I, Liber}

\section{DE REACTIONE.}

Dicendorum propofitio ac declaratio. Cap. 1.

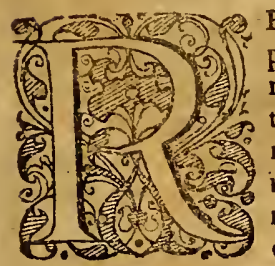

EACTIONEM in corporibus naturalibus fatis manifefte pofuit Ariftot. tum in 3. Phyfic. cont. 8. ac 16. dum dixit omne mouens Phyfice in mouendo moueri, tum in primo de ortu \& interitu 53. dicens omnia, qux conueniunt in materia, agere \& pati inuicem; fed in modo declarando tanta ineffe videtur difficultas, vt plurimi fententiam Ariftotelis tueri non vclentes, ad varios 〔enfus, eosque ab Ariftotel.alieniffimos illam trahere, \& extorquere coacti fint: ob id licet multas hac de re difputationes aliorum habeamus, prafertim vero librum doctifimum petri pomponatij, cuius quidem viri iudicium ego femper plurimi fecj, adhuc tamen nen videtur fublara effe hac in reomnis difficultas, idque me mouit, vt de ea breuiter aliqua fcriberem, \& illa qua Philofophando excogitare potui, ad communem
D ftudioforum vilitatem inmedium proferrem. Hac igitur de re feripturus, non tempus teram in referendis omniurn aliorum dietis, fiquidem tum apud cos legi poffunt, tum etiam inlibro Pomponatij, in quo omnesaliorum fententiz diligentilfimerecenfentur \& expendūtur:fed lila folum adducam, qux ad veritatis declarationem conferre videbuntur, \& qux vel ab aliis tacta effe non viderim, vel tacta quidem, fed ita obfcure,vt explanatione indigeant.Ante omnia E vt nomen reactionis, de qua nobis in prafentia difputatio propofita eft, intelligatur, dicimus reactionem effe retributam quandam mutatio neni, qua id, quod patıtur, renitituraduerfus agens, \& illud com mutat, dum ab illo mutatur, adeo vt \& agens pati, \& patiens agere modo aliquo dicatur. Quoniam autem plures funt mut2tionis fpecies, quartio hac neque in mutatione fub ftantiali, neque in accretione, atque imminutione locum habere vllum poteft, nifi E quatenus ha coniunetam habent alterationem: generans enim ab ipfomet genito viciffin nec generatur, necinterimitur in ipfogenerandi a tu, necmodo vllo fecundum formam fubO 3 ftan.
Reattio gussafit. 
ftanrialem labefactatur, quun hac indiuidua A videntur; quorum aliqua præcipuz, quze rei defir, nequecintendi, aut remitti poffit: fieneque augens dum auget, augeturab illomet, quod augetur. Eftigitur præcipuc hredifputatio inftituta de motualterationis, \& modo aliquo etjam de motu locali, an agens à patiente vicifin patiatur: quum enim alteratio fir in qualitate, qua intendi ac remitti poteft, quæritur, an agẽs alterans al teretur modo aliquo à patiente, \& obsundatur, vt an calidü agens in frigidum patiatur fimul à frigido, ita vt eius calor in illa actione remittarus:non eft autem quaftio de agente remoto, fed deproximo tantum, \& quodconseniat in materia cum patiente, ipfemet Ariftotel. in memoratis locis nos expreffe admonet; nam egens remotum non eft cum patiente coniunctum, ideo nihil ab eo recipere poffe videtur: fed nequeagens proximum, quod non conueniat in materia cum patiête; nam Colum fi.mmediate agere aliquid dicatur in his inferioribus, non patitur vicifim ab eis, quianon conueniuntinmateria, neque ipfum capas eft illarum qualitatū, quas in illis producit, quum fit agens (vt vócant) zquiuocum \& virtuale. Loquimurpraterea de agente per $f e$, non de agente per accidens, quale eft agens per antiperiftafin j nam calidum refrigerat, nec propterea viciffim calefit: nequeloquimur de actione fpiritali, feu dealreratione perfectiua; qualis eft fenfus, \& intellectio, quoniam in hacnon fit vlla zeactio, nee de ea vnquam aliquis dubitauit, quum manifeftum fit obiedta, qua \& fenfum \& mentem mouent, non poffe fimul effe fentienisa, \& intelligentia in ill omet a ctu, quo mouere dicuntur. Non eft etiam quattio de mouente per Metaphoram dicto ficusi quum finis mouere dicitur, vt cuilibet confideranti patet: neq; enim Ariftoteles vnquam tale mouens refpexit, quando dixit omnemouens phyfice in mouendo moueri. Ef igiturpropofita quxftio de altesatione materiali, an agens per $f e$, \& proprie diaum, \& patientiproximum, \& cum eo in materia conueniens, dum in ipfum agit, ab eodem repatiatur. De motu etiam locali dubium efr, quoniam Arift.de hoc maxime loqui videtur in 3. Phyfics aufeultationis, dum inquir, omne mouens Phyfice in mouendo moueri; \& aliis quoque in locis, quos poftea perpendemus, expreffe reactionem ponere videtur etiam in motu locali:propterea de hoc quoque aliqua nobis dicenda erunt, iisdem tamen conditionibus $\$$ conftitutis, quas dealteratione fituimus, loquimur enim de mouente per $\int c, \&$ proximo 2 dienti, \& comueniente in materia cum illo.

\section{Argumentaqua reactioni refragan-} tur. Cap. II

Tálem, qual'em diximus, rêactionem, nrulIt ta funt argumenta, qua de medio toilere clarand occafiosem dabunt, in medium afferemus, reliqua apud alios legenda dimittemus. primum eft argumentum, quo vtitur Burlæus in context.8. tertii phyficorum; ftaluit in primis fundamentum, quod fumit exAuerroc in Com - $t$. mentar. 71. quarti Phyfic. quod etiam apud $A$ riftotel. clare legitur in libro de motu animalium, actio non prouenit nifi à victoria, \& exceffu agentis refpeetu patientis; \&ex eoitaa:B gumentatur: fi dures furnantur, in quibus a: ctio \& paffio effe de beat, vt portio ignis, \& portio aqux, hx vel $x$ quales habent vires, vel inxquales, fi æquales, neutrain alteram aget, quia neutraalteră vincit; fi vero inæequal es, illa, qux validior eft, in alteram aget, fed viciffim $h x c$ in illam non aget, quoniam, vt modo conftiturum eft, \& vt per $\int e$ manifeftum effe videtu; debilius. $s$ in validius agere non poteft. Seçundum eft ar. gumentum Calculatoris tale : pofita reactio-

C nefequeretur idem moueri fimul duobus contraniis motibus, \& fimul intendi ac remitti fecundum eandem qualitatem, quod omnino ab. furdum eft : confequens autem deducirur; quia fi ignis aquam calefaciat peraerem medium, \& ab eadem aqua refrigerari dicatur, neceffe eft vt aermedius timulab igni calefiat, \& ab aqua refrigeretur, proinde vt eius calor fimul intendatur, acremittarur: praterea fic quoque idem confequens deducitur; figat ignisetıam abf$D$ que medio in aquam, neceffe eft vtpars ignis propinquioraqua prius repatiatur, \& refrigeretur ab aqua, quam pars remotior; illa igitur pars erit minus calida, quam pars remotior, quare calefietab.illa, nam minus calidum refpectu calidioris eftinftar frigidi; \& vna alteri contiruata eft, itaque pars illa eadem ignis fimulab aqua refrigerabitur, \& calefiet ab alia eiufdem ignis parte. Tertio, data reactione fieret vt agens nunquam poffit reddere patiens fi-

E biomninofimile:hocautem eftabfurdum,quia nullum aliud effe videturagentis confilium, \& fcopus, quam fibifimile patiens redderexonfequens probatur; quia fi ftatuatur agens calidum vt quatuor, \& patiens frigidum vt duo, fcopus illius agentis eritillùd patiens reddere calidum vt quatuor, hunc tamen non affequetur, fed frufrabitur; quia in illa actione \& reactione calor agentss remitretur, \& fies calidum folum vttria, deinde vero etiam vt duo, in fineigiturillius pugna non erit amplius calidum vt quatuor, quocirca nec reddere poterit patiens calidum vt quatuor, quia nihil agit fupra fuarum virium gradum. Quarto, fint duo agentia contraria, vt ignis, \& nix , \& ignis polfio calefacere per diftantià decem pedum ad lummurn, nix verorefrigerare pofint perdifantiam duorum pedum tandummodo, igitur ti quatuor pedibus diftare inuicem ftatumntur, aget ignis in niuem; nec repatietur ab illa, quare

non 
non omneagens naturale in agendo repatitur. Poftremo, li talis reactio daretur, idem fecundum idem, \& refpectuciufdem effet fimul poteftate \& actu, quod nullo modo dicendum cit; nam fi agar ignis in aquam, \& ipfam calefaciendo ab ea viciflim retrigeretur, aget quatenus calidus, proınde quatenus eft actu, fed à frigido patietur etiam quatenus calidus; ergo eadenı ratione, quacalidus eft, \& aget: \& patietur, \& fimul erit actu, \& poteftate.

\section{Varia aliorum fententia, fo earum con- futatio. Cap. 11 I.}

Vamuis \& verba Ariftotelis tum in memoratis, tum in plerifqne aliis locis fatis apcrte reactioné ftatuant, \& teftimonium fenfus eandem confirmet; videmus enim contingere, vt fi quis manu calida rem aliquam frigidam apprehendat, tum eam calefaciat, tum fimul $a b$ eadem refrigeretur : tamen argumenta prædıcta apud complures tanti nomentı fuêre, vt eós coegerint ab Ariftotelis lententia deuiare, \& in al ras opiniones, qux omnes, \& earum inpugnario legi poflunt inlibro Petri Pomponatii, ego alıquas, breuiter referam. Dixcrunt quidam, vt horumargunentorum vim effugerent, dari quidem reactionem, vr Ariftoteles afferit, non tamen fecundum eandem contiarietatem, fed fecundum diuerfas, ita vit polfit ignis agens in a.juam vt calidus in frigidam, ab eadem repati vr ficcusab humida, at non vt calidus à frigida, quia fi calor ignis praualeat frigori aqux, agere tantū potêt ignis in aquam, non aqua in iginem, per contrarietatem calidi \& frigidi; fed is tunc eueniat vt humiditas aqux prapolleat liccitati ignis, reaget aqua in igrem vt humida in ficcum, iedab codem vt à ficco no patietur, quoniam à debiliore in validius actio 2- fierinon poteft. Sed hac rententia \& experientix, \& Ariftot. \& rarioni aduerfatur: nam experientia ( $v t$ modo dicebamus) docet fieri reactionem fecundum eandem contrarietate ; nam fi quis manu calida rem frigidam apprehendat; fimul eam calefacit, \& ab ea refrigeratur; ita fi ferrum ignitum in aquam frigidam iniiciatur, calefacitillam, \& ab eadem refrigeratur, qua eft reactio fecundum eandem contrarietatem. Hoc idem fignificauit Ariftot. in locis pirdietis, fi bene iplius verba perpendantur: fed alius cit locus omnium clariffimus in 4 . lib. de ortu 2nimalium, cap. 3. vbi dieit omne agens in agendo repati, \& tum de motu locali, tum de alceratione hrcexemplafubiungit, vt pellens pellitur, \& calefaciens refrigeratur; ponit ergo in alteratione reaktionem fecundum eandcm contrarietatem. Ratio quoque, quam loco fuo confiderabimus, hocidem demonftrat;nuncattem ê fatis fit argumentũ funere à miftione, non poffet enim fieri miftio fine reactione fecundum cam contrarietatem: quia fi ad miftionem con-
A grederenturignis \& aqua, \& ignis rationecaloris agerct tantum, non pater etur, calor cius maneretinteger; fic etiam integra feruaretur huniditas aquix, fi aqua per humiditatem itaageret in ignem, vt ab eius ficcitate non pateretur; quare ad mediam tëperiem qualitates elementorum non redigerentur, proinde nulla miftio fieret. Aliqui vero alij vt experientix \& verbis opini Ariftot. fatisfacerent, ad loc confugerunt, quod aliorsm reactio eft quidé primo fecundum diuerás con-

B trarietates; fed fecundario, \& per quandam fequelam eft etiam fecunduneandem contrarietatem: finamque ignis per calorem agat in aquam vt frigidam, \& ab ea dem vt humida repa tiaturvt ficcus, labefa\&tatur fimul, \& imminuitur etiam calorignis per quandam fequelam ex. labefactatione ficcitatis coniuntax; calefacit igituraquam, \& ab eadem refrigeraturfecundario, quatenus imminutionem ficcitatis confequitur imminutio caloris. Sed neque hoc de-

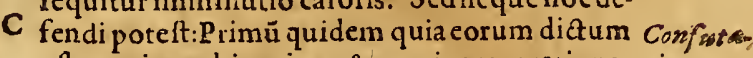
eft omnino arbitrarium, \& omni carens ratione; $t i \theta_{0}$ nulla enim adeftratio, curad ficcitatis imminutionem labefactetur calor, fiquidem calor non poftulat neceffario ficcitatem, quum pof. fit $x q u e$ exiftere cum humiditare, vtin aere patet, qui eft nacuraliter calidus \& humidus : deinde quia nulla daretur reactio inter elementa fymbolam qualitatem habentia, nam fi aervt calidus agat in aquam vt frigidam, non poteft abeadem repativt ab humida, \& quumipfefit humidus;non eft igiturverum id, quod Ariftot. dicit, omne agens Phyficum in agendo repati. Non eft etiam dicendum, Ariftot. in predictis locis hoc intelligere: quando enim dicit calefaciens refrigerari, non poteft intelligere nifi per fe, quoniamilla, qux funt per accidens, in difcis plinis non confiderantur: hoc etiam patet in exemplo motus localis adducto ab Ariftotel. nam dicit,pellens pelli, quod quidem non poteft efle peraccidens, fed per fe, \& primo, quia ne fingi quidem poteftalia loci contrarietas, fecundum quam illa reactio fiat; quare etiam quando dicit calefaciens refrigerarı, intelligit per $\int e$ \& primofecundum eandem contrarietatem. Hac o- sueffans mnia quidam alij confiderantes, \& tueri volen- opinio. tes reactionem per fe fecundum eandem contrarietatem, confugerunt adreactionem priuatuam, pofitiuam enim nullo pacto admittere voluerunt; pofitiuam reactionem ipfi vocant, quando \& calidum agitinfrigidum imprimendoaliquid caloris, \& frigidum eodem tempore viciffim in calidum imprimendo aliquid frigoris; priuatiuam autem reactionem vocant illam, qux in fola patientis refiftentia confiftit, \& hanc1fti folamadinittunt, quia licet hoc calidum fit validius hoc frigido, $\&$ in ipfum agat, nec ab eo aliquid recipiat, ipfum tamenfrigidum aniequam deftruacur, refifit a liquandiu, \&retardatactionem calidiagentis, 
quodlibet enim nititur feconferuare quantum poceft:ted politiuam reastionem impoffibilem effe dicunt: quam fententiam tandem fequutus eft Auguftinus Sueffanus in fuis Comment. in 2. Phyfic. vt videre eft in context. 11. eius libri, vbifatetur fe hacin re fententiam mutaffe; Swejpaxs гонитёi>m. quum enim in lib.r. de Ortu \& interitu pofitiuam reactionem tutatus effet, inquit, fe poftea eam fententiam deferuiffe, \& ductum effe hoc potifinum argumento, quia fi agens eft tant $x$ potentix, vt pofit vincere, \& deftruere penitus aliquod patiens, àebet etiam tantam habere vim, qua fufticiat ad fe defendendum ne abillo aliquid patiatur; quodquidem argumentum in idem cadit cum primo à nobis antea aduerfus reactionem adducto. Sed huic fententix, vt antea diximus, \& experientia, \& ratio, \& teftimonium Ariftot. refragantur. Quod enim ad experientiam attinet, vana elt Suef́rani fuga, quum dicit aquam feruentem non effé calidam, fed videricalidam proptervapores in ea exiftentes; boc enim dicere eitnegare aquam poffealtera$z i$, quod manif eite repugnat communi philofophantium confenfioni, omnes enim concedunt clementa poffe eti am alterari ad cötrarias qualitatesabfque mutatione fub?tantix: quemadmodum igitur aer feruata fubftantia fia poteft \& calidus \& frigidus fieri, fic etiamaqua'; pro. pterea negandum non eft, ipfam quoqueaqux fubitantiam à ferro ignito aliquid recipere caloris, quem poitea confequatur conuerfio tenuiorum aqux partium in vaporem: $f e d$ firgumentum ab aqua ad aerem transferatur; nullus Sueffano locus confurgien di relinquitur, vt confideranti manifeftum eift; Similiter vanum eft id, quod ipfe dicit de glacie apprehenfa manu calida, negat enim fieri fimul veramque actionem, \& inquitrefrigerari prius man um à głacie, poftea verotanfmitti abanima nouos fpuritus, à quibus glacies calefit, \& ita non codem temporcactionem \& reactionem fieri, fed diuerfis. Attamen nemo eft qui non videat veram q; fieri limul; ftatim enim calefit glacies à nıanu, quod \& fenfu cognofcitur, \& ratione comprobatur: quia fi glacies retinens frigus fuum non calefit à manu calida, minus poteft calefieri poltea à manu refrigerata, \& credendum eft, fpiritus calidos internapotius petere, quam ad manum. tranfmitti, dum ftatuitur integrum manere glaciei frigus. Nitıturetiam Suefranus foluereargumentum, quo fupra vfi fumus à miftione ac- I ceptum- \&inquit remiffionem qualitatum elementarium in miftione non fieri ex mutua earü. interfe actione, acreactione, fed fieri ab agente generante miftum, aut ab aliquo colefti influxu ; nam cenfuit Arif.ipfas elementares qualitates effe proximum agens in miftione: \& ve cócedamus, ab aliquo etiam externo poffe mifum tanquam ab agente proximo generari,negari tamen in philofophia Peripaterica nullo
A modopoteft, ex mutua etiam elementorum actione poffemiltsonem abfolui. Quod vero de influxu dicit, ita vanume t, vt confutationem non mereatur, certū enim êt; influxus ab Arift. nö admitti, neq ;ipfenet Sueffanus id, quod dicit, intelligit: nam fi mpliciter ad influxum confugereabfque vlla ipfius safluxus declaratione nil a liud eft, quam dicere id fieri ab aliqua cau$f a$ qu $x$ ignoratur. Clara etiam funt A rift. verba antea memorata;Arlftot. enim non dicit patiess B refiftere tantumagenti, fed dicit calefaciens refrigerari, qux eft ab que dubio reatio pofitiua. Prætereavti poflumus contra Sueffanum tali argumento: fi reactio, quam Ariftot ponit, non eft intelligenda, nifi priuatiua, fequeretur das $i$ reactionem etiam inter illa, qux non conueniuntin mareria, vt inter Colum, \& inferiora corpora, etenim hær quoq̣; refiftút actioni coeleitium, \& eam retardant refiftendo; aqua enim refiftit omni calefacienti, non folum igni, fed etiam Calo: quare fi dicere liceret caletaciens refrigerari à patiente satione folius-refiftentiæ, qux dicatur appellari refrigeratio, etiam $\mathrm{C} œ$ lum dici poterit à corporibus inferioribus per refiftentiam refrigerari : hoc tamen nemo fana mentis diceret; \& confequens apud Ariftot. eft manifefte falfum, qui omnino negautt corpora inferiora in Colum reagere, \& in contextu 53. lib. s:de Ortu\& interitu aperte dixit, nullam d2rireact $10 n e m$ inter illa, qux in materia nō con$D$ ueniunt. Exhisigitur patet, negandam nullo pacto effe reactionem pofitiuam, fed folum cogitandum, quomodo difficultates, qua illam demedio tollere.videntur, foluendatint.

$$
\begin{gathered}
\text { Quid fit agere; quid pati, quid reagere, or } \\
\text { quid repati, do cur reactio fit ne- } \\
\text { ceffaria. Cap. IV. }
\end{gathered}
$$

E

Voniam igitur omnes hæopiniones falf funt, \& in eas 11 li inciderunt, quoniam argumenta à nobis.antea adducta foluere nequiuerunt; nos in eolab orare oportet, ve pofita ve. rareactionepofitiua per fe fecundum eandem contrarietatem, vt cam Ariftor. pofuit, omnia aduerfantia argumenta foluamus. Ante omnia declarandum accuratius eft, quid fit agere, quid pati, quid reagere, \& quid repati, \& quot modis dicantur.hac omnia qquatenus fecundum qualitates confiderantur, nam pracipue de alF teratione eft nobis propofita difputatio. Agere eft mouere ad contrariam patienti qaalitatem, fic pati eft mutari ad contrariam qualitatem, hanc autem non ea ratione dicituragens inprimere, feu tribuere parienti, quod illaminducat, red quod educat de poteftate ad: actum; non enim dicendum eit, calidum agens tribuere patienti fuummet calorem eundem numero, fiquidem non poteft accidens migrare de fubieato in fubiectum; fed per calorem, quem $h$ abet, educit 
educit alium calorem fimilem de poteftate patientis ad actum, \& hoc modo dicitur imprime$d *$ re contrariam qualitatem. Hre autem actio fu. mi poteftduobus modis, vno modo pro impreffione alicuius gradus qualitatis abfolute,altero modo pro actione perfecta, qux eft cum viAtoriaagentis aduerfus patiens. Exemplis res clartorfiet. Aliquis manu calida parvam glaciei particulam apprehendit, certum eft glaciem illam in initio non folum calefieri à manu, fed etiam è contrario manum refrigerare, \& in ea producere aliquid frigoris ; ad hoc enim oftendèdum ita fufficiens eit teftimonium fenfus, vt quisquis id inficietur; is fenfu indigere dicendus fit : procedente autem actione abfumiturglacies, \& totum eius frigus deftruitur à calore manus fuperante: dum igitur atio fumitur pro impreffione alicuius gradus qualitatis, tum manus agit in glaciem, tum glacies in. manum; at fi totam ab initio ad finem actionemillanı \& paffionem fpectemus, manus potius, quam glacies, vocabitur agens, glacies vero patiens, quiacalor manus frigus glaciei fuperauit. Quandoigitur cum Arittot.dicinus, aEtionem non fieri nifi ab nnaquali fuperante, id rio intelligendum eft de tota \& completa actione, tio- quxeef cum victoria agentis, fed non de qualibet actione indiftinate; quando enim: in contrariorum pugna vnum debet alterum vertere in fuamnaturani;id.facerenon poteft; nifi prae- ualeat, \& maiorem habeat vim, quam alterum; attamen fi initiu m tantuns actionis, \& pugna confideremus, negare non pofiumus, etiam debilius agere invalidius, vt modo de parua glacie dicebamus; etiamfi in fine pugna; totum glacieifrigus à calore manus victum fit : hoc nifi concedamus, cogimur in hoc abfurdum incide. re, quod plures inani ratione coacti confiteri aufi funt, quod. fi duo contraria æquales vires habentiafumantur, \& vrum alteriapponatur, vt portio ignis, \& portio aqua, quibus \& inten-fionis graduum, \& magnitudinum habita ratione æqualesprorfus fint vires, neutrum aget in alterum; hoc enim dicere eft abfurdum manifeffifimum: qui cnim fieri poteft, vt duo extreme contraria attiua \& paffiua inuicem fecundum propriasnaturas, \& femutuo tangentia ita otiofa.maneant; yt neutrũ in alterum agat? fieri quidem non potef:, vtalterum vincat alicrum; \& in fuam naturam conuertat, neceffarinm tamen eft vit pugnent, \& in fe inuicem agant, idą; negare eft miftionem penitus de medio tollere, ficutanteadicebamus: quando enim vnum contrarium tanto exceffu praualet alteri, vt mutet illud in fuam naturam, tüccertum eft, non fieri. miftionem, ficurait Arift in calce lib. I de Ortu \& interitu; fed quando viribus quodammodo. xquantur; id eft, vel æquales habent vires, vel. non tanto difcrimine inzquales, vt vnum poffit alterum penitusin fuam naturam mutare 2 tunc
A mutant fe mutuo, ac diftrahunt à propriis à natuis, \& transcunt in vnam quandam naturam mediam, hxcenim eft miftio. Sicitąque dicendum eft, quando in fine purgna vnum verist alterum in feipfum, necenc cuim eft, $r$ in principio ag.unt infe mutuo, licet vnum debiliter, alrcrum autem vehementius : nam in miftione quoque hoc cuenit; quim enim vium mifcibilium validius fit, magismutat alıa, quam muteturabillis ; quo fit, vt illud medium, quod per B miftionem generatur, magis ad eius naturam vergat, quam ad naturas aliorum. Huiusceautem iei vera ratio ea eft, quam A riftot. adducit in contex.8.\& 16.3. Phyficorum : caufa enim, cur multa inuicem agant \& patiantur, eft, quia fingulum eft fimul poteftate \& actu, refpectu diuerforum; id enin, quod eft frigidumactu, eft poteftatecalidum, \& id, quod eft actu calidum, eft frigidum poteftate, contraria namq; verfantur in eodem fubiecto; \& vbi vnum eft actu, ibi C. neceffe eftalterum efle poteftate : quoniam igitura gere eft form $x$, pati vero eft materix, \& res agit quatenus eft actu, \& patitur quàtenius eft poteftate, neceffe eft, vtadmoto agente a $\varepsilon_{t u}$ tali.ad patiens poteftate tale fiat actio: quando igituradmoueturignis aquæ; neceffe eft vt actu calidumagat in calidum poteftate, \& vt actu frigidum agat in frigidum poteftate, vt etiam in contex.77.lib.r.de generatione Ariftoteles dicit:nec refert. dicere, alterum altero valentius effe: D hoc enim facitquidem, vtinfine pugnz vnum alteri fuccumbat, fed per hoc non ftat, quin antea debilius quoque agat in alterum, quodvalidius.eft:vt fi ignis in aquam agat, \& validior effe ftatuatur,neceffe eft, vt tum ignis tanquam actu calidus agat in 2 quam vt poteltate calida $\mathrm{m}$, tum aqua tanquam actu frigida agat in ignem vt poteltate frigidum; materia enim, qua actu fub caloreeft, poteftate habetrecipiendifrigus, \& materia, qux eft actu fub frigore, poteitatem E. habet recipiendi calorem: etenim fi ignis per fat reaformam fuam \& ageret \& pateretur, vtique nul- cionem la fieri reactio pollet, quia frigus aqux non pof- fier. fetagerein calorem ignis protentiorem; at non itafefe res habet, ignis enim non per formam patitur., fed per formam agit, per materiam veropatitur : quoniam igitur à nulla forma, ànulla qualitate materia abhorret; fed actiam habet poteftate recipiendi omnes; ideoatta eft pati etiam à debiliaqux frigore, quum ipfafit friF gida potestate:quamobrem necefle eft $v t$ in initio pugna remittaturtum frigus aqux per actionem ignis, tum calorignis per reactionem aqux, magis tamen remittatur frigus aqux, quia ignis vchementiusagit;ideo perieuerante pugna augetur continue excefliis caloris ignis ad frigus aqux, \& fempervehementior fit actio, debilior autem reactio; quia neceffe eft tamdi u reaćtionem durare, quamdiu durat a ctio ; nan actio túc ceffat, quädo patiens omrino fuccubuit agenti,

\author{
Ratio \\ cxs ne- \\ cefiariz \\ (1)
}


tunc autem reactio ceffat, quia dum patiens habuit alıquid virium, quamuis id minimum fuerit, perillud neceffe fuit ve reageret tanquam 2 etu tale in agens tale poteftate:neque dicendum eft, åtionem agentis fieri cótinue debiliorem, quod perrepaflionem vires agentis imminuantur, propterea quod fi imminuuntur agentis vires, magis imminuuntur vires patientıs, proinde vehementior femper fitactio, quia cref́cit continue exceffus virium agentis ad vires patientis: incomparandis autem inter fe agentis, ac patientis viribusnon fola attendenda eft intenfio graduum, fed etiam extëfo magnitudinum, in maiore enim corpore vis maior ineft; ideo contingere poreft vt contrarium remiffius vincat alterum contrarium intenfius propter exceffum magnitudinis: nam multum vini extinguit paruum ignem, licet vinum fit minus frigidum, quam ignis calidus, \& minus humidum, quam ignis ficcus. . Ex his igitur patet, fi atio fumarur ample pro impreffionealicuius gradus qualitatis, non fieri actionē ignis in aquam abrque eiufdem aqux reactione in ignem, nec manum per calorem agere in glaciem apprehenfam, quin glacies quoq; perfrigus eodem tempore in eandem manum reagat: fi vero totius pugnæ finem, \& alterius victoriam fpętemus, manifeftum eft, manum dici agentem, \& glaciem patrentem; neque hac ratione poteit tieri reactio, quia eadem glacies non poteft fimul vinci \& vincere; \& in hoc fenfu verum eft dicum Ariftotelis \& Auerrois, actio non fit nifi ab inæquali fuperante; non poteft enim agens cōuertere patiens in fuam naturam, nifi illo validius fit; remittitamen, \& obtundi poteft etiam vàlidius à debiliore. Reactio igirur nil aliud eft, quam attributa feu reciprocata actio; fi namque hoc in illud agere dicatur, illud in hoc dicetur reagere, fic repaffio eft reciprocata paffio : funi autem poffunt tum late, tum ftriete; late enim fumuntur, dum nullo confiderato difcrimineagentis \& patientis, vtrum ף; dicimus reagere, \& vtrunque repati; proprie vero, quando id, quod in actioneprincipalius eft, \& vincit,vocaturagens, alterum autem vocaturpatiens fic enim patienti reactio attribuitur, \& agenti repaffio:ficut enim alterum folum vocatur agens, quatenus principalius eft, ita reliquū, tanquam, debilius, vocatur reagens; \& è conuerfo hocidē vocatur patiens, agens vero principalius repatiens potius dicitur, quam patiens, ita vt reagere proprefignificer fecundarioagere, \& repaufecundario pati. Principalitas tamen, ex qua alterumpotius, quam alterum, folet appellari agés, duplex eft: vel enim folumagendivigorenł refpicimus, \& ita id, quod validius eft, vocamus abfolute agens, id autem, quodinualidius, abfolute patiens; vel folam intentionem, feu fcopum attēdimus in appellandoagente; yt quando aquam igni infundimusad illum extinguen- dum, aqua dicituragens, \& ignis patiēs, etiamfi quandoq; contingat vt aqua infufanequeat ignem extınguere, fed ab illo potius abfumatur: tunc igiturfirefpiciamusid, quod eft validius, ignis diceturabfolute agens, \& aqua patiens; fi vero confilium, fcopumq; infundentis; aqua diceturagens. \& repatiens, 1 gnis vero patiens, \&e reagens: hoc fpeetaffe videtur Arift. in lib. 4.de ortu animalium, cap. 3. dum dixit contingere quandoq; vt agès magis repatiatur, quam agat;

B nam fi magis repatitur, inualıdius eft; fed tamé vocatur agens ratione fcopi, \& intentionis, fecundum quam debeat effe validius. Sic igitur patet quid fitagere, quid pati, quid reagere, \& quid repati, \& quot modis dicātur, \& cur neceffe fit agens proximum repati, \& patiens reagere: $r a-$ tio namque eft, quoniam agens non folum eft atu ratione propria qualitatis, fed eft etiam poteftate refpectu contraria; ideo neceffe eft yt in agendo ab illa repatiatur. quia neceffartum C eft vtid, quod eit poteftate tale, patiatur abeo. quod eft actu tale, fi illi adiungatur.

\section{Quid fit refiftentia, \& vnde proueniat. Cap. $V$.}

Onfiderandum praterea eft quid fit refiCitentia, qua de re maior nos difficultas manet, quum multi multa dixerint, nemo taD men eam plene declarafie videtur. Pomponatius in libro fuo de reactione probare contendit refiftere non elfe agere; neque elfe pati, fed folum effe impedire ne agens agat in idin quodagete nititur, hoc auten vel ablulute, \& perfeete, vel aliquatenus, \& (vt aiunt) fecundum quid:nam fi digito ferrun premamus, ferrum perfecte refiftir, quia nulla ex parce comprimitur; fiveropremamus ceram, comprimimus quidem, fed cum aliqua mora, quo fit, ve aetio illa retardetur modo magis, modo minus, pro maiore, vel minore refitentia rei preff $x$, quximperfecte, \& fecundum quid refiftere dicitur, quatenus non tinit fe ftâtım pelli, \& moram aliquam, ac difficultatem modo maiorem, modo minorem in illo motu ponit; nil igituraliude et refittentia, quam impedimentum. $\mathrm{H}_{x \mathrm{c}}$ Pomponatii fententia à polterio ribus improbatur, quodignotum per ignotius declarare videtur; dicit enim refiftere eife impedire, fed adhue sectso F dubium manet quid fit impedire, fi neque eft agere, neque pati. Hanc difficultatem vidit quidem Pomponatius, fedfeab ea explicare non potuit: quumenim ad hoc declarandum multa dixerit, tamen ex elus dictis nor apparet quid fit impedire, cuum ipfe non declaret in quanam categoria ftatuendum fit; dum aute in quo genere impedinzétum fit ignoramus, ipfius quoq; Recen refiftétix genusignoramus, ignorato autem rei rum genere nihil de ipfius rei effentia noffe poffu- nio. mus : 
mus. Quidam recentiores refiftentiam redigunt $A$ ad fecundan fpeciem qualitatis, qure dicitur porentia, vel inpotentia naturalis:nam refiftentia, quam ferrum facit fecanti, nil aliud effe videtur, quam impotentia naturalis patiendi ab. agente fecare nitente; \& dicere fcrrum refiftere fecanti, idem videturac dicere, non poffe, feu - non facile poffe fecari, quemadmodum paleam non refiftere igni eft facile pati ab igni. Sed hxe fententia, quanquam primo afpectualiquid habet probabilitatis, tamen fi bene perpendatur, vera non eft;quoniam non idēeft potentia agëdi,atq; agere actu, nec potentia paciendi, ac pati actu:nam potentia agendi , \& potentia patiendi eft in fecunda fpecie qualitatis;fed actu agere, \&e actupati, non funt qualitates, quum manifeftum fit hxc habere proprias categorias actionis \& palfionis:ita potentia refiftendi, poteft vocari qualitas fecund $x$ fpeciei , eft enim potentia nö patiendı; at actus ipfe refiftendi non eft qualitas, fed quodtamalıud, \& videtur euitarí non poffe quin fitagere, vel pati, vt voxipfa fignificare videtur. $O b$ id recentiores quidam hac $m$ confiderantes dixerunt, refiftentiam effe in cao- tegoria actionis, \& pro hac fententia adduxe1/- runt verba Ariftotelis in memoratis locis, prafertim quarto de ortu animalium, cap.3. vbi di- cit calefaciens refrigerari. Sed ifti refiftentiam. cum reactione confuderunt, nam pofitiuam reactionem effe actionem quis negare poteft, videnturautem ipfimet fuam fententiam cuertere, \& errorem fuum patefacere, dum in illis, qua agendi vim nor habent, afferunt dari refiftentiam, eamquenon effe amplius in genere actionis, fed in fecunda fpecie qualitatis, qua dicitur impotentia naturalis : dum enim fatentur dari refiftentiam fine aliqua actione, fatentur etiam. effe quiddam diuerfum à reactione, itaque etiam in illis, quar reagunt, aliud eft refiftentia, aliud reactio, proinde non poteft refiftentia po$\mathrm{ni}$ in sategoria actionis. Quidam vero alij recentiores reprobant quidem \& ipfi fententiam. Pomponatij, tanquam nondeclarantis quid fio refiftere, tamen ipfi poftea in eundemierrorem labuntur, multa enim dicunt pertinentia ad dosendum cur fiat refiftentia, fed in quonam genere fit, non declarant; quare adhuc quid fis ignoramus. Nobis igitur confiderandum.ma. , net quid fit refiftere, nam cognita eius efíentia facilius poftea erit caufam inueftigare, $\&$ adducere. Credo efiftentiam in nulla elfe categoria directe, neque etle aliquid pofitiuum, fcd priuatiuum, proinde per reductronem tantum effe in generibus actionis \& paffionis; ef enim priuatio quxdam actionis \& palfions., vt confiderantibus poteft effe manifeftum ; quia nil aliud eft agenrirefiftere, quam non patiabillo, proinde \& ipfum agens non agere, fi pertecte illi refiftatur neagat; vel fi quadantenus tantum illi refifatur, eft non facile pati, pronde agens nos. facileagere: eft igitur per reductionem proprie in categoria paffionis, \& relpectu agentıs eft etiam modo aliquo in categoria actionis. Pro pompona presea optime naturam refiftentiz declaraftet $t \ddot{y}$ defisPomponatius perverbum, impedire, fi declaraf- dous. fet quid fit impedire, \& dixiflet effe quidpriuatiuum, non pofitiuum;nam dicere parietem im:pedire ne Sol me calefaciat; non eft dicere aliquid pofitiuum, quod infit parieti, fed folum eft diceremenon pati à Sole, \& Solem in me non B agere: fic dicere nimiam diftantiam impedire ne ignis aliquis mecalefaciat, eft dicere diftantiam loci facere priuationem actionis in igne, \& paffionis in me:hoc id ë dicendumelt de illo, quod non.fit penitus impediens, fed fecundum quid, vt confideranti patet. Quoniam igitur refiftentiaimpedimentum quoddam eft, vt recte Pomponatius dixit, impedimentum autem eft priuaponatius dixit, impedimentum autem eft priua-
tio, quod ipfe videtur ignoraffe; confideran- Quafir dum eft, vndenam proueniat hoc impedimen- carnfa rec tum, quod vocatur refiftentia, quandoquidem fifserts priuationes quoque caufam aliquam habent. Certum eft, materiam non poffe huius impedimenticaufam effe: nam fi refiftentia eft priuatio paffonis, natusa atitem materize eft primaradix, \& prima caufa omnis paffionis, non poteft eadem effe caufa impediendi paffionem, fed potius promptiffima eft ad quodlibet patiendum. Relinquitur vt caufa refiftentix fit forma, qua in re concordes effe omnes videntur, fed in modo diffident:aliqui enim confiderantes effe offi-, Aliqu*cium forma agere, neceffarium effe putarunt, rum opivi quantum actiua qualibetforma eft, tantum no. fit etiam refiftitiua ; quam fententiam fi admit- Confur teremus; fequeretur debuiffe ignem iampri- tio. dem omnia confumpfife, \& inignem mutaffe: quum enim maxime omnium fit actius, fi effet etiam maxime omnium refiftitiuus, nulla: afferri poffet ratio, cur non fint omnia in ignem. mutara: quonsam igitur ad feruandum ele: E mentorum xquilibrium pro ipforum conferuatione neceffarium fuiffevidetur, vt maxima: actio cum minima refiftentia coniungeretur, \& maxima refiftentia cum minima actione, idcoalij dixerunt, in qualitatibus elementorum duos effe ordines inter fe contrarios, vnum acionis, alterum refiftentix : \& in actione pri mum locum obtinère calorem, qui maxime omnjum qualitatum eft aftiuus, fecundum vero frigus', tertium humiditatem, quartum demum ficcitatem, qua minime omnium ef actiua. Huic contrarium fatuunt ordinem refiftentix, ficcitatem enim maxime refiftere dicunt, alıquanto minus humiditatem, adhuc minus frigus, minimam autem refiftendi vim obtinere calorem. Mihi tamen vidssur hacfententia vrgeri eadem diffictltate; $\mathrm{fe}-$ queretur enim fimiliter ignem iampridem omnia confumere debuifie, quum per calorem fir marime astiulus. \& per ficcitatem maxi-

\section{Alorums opinio.}

\section{Cosfinstipe} tio. 
me refiftitius : quamuis enim non percalorem -A nem : quod declarane exempioillius, qui glarefiltat, tamen fatis elt li relitat per ficcitatem, ne ab alis elementis mutetur; inon facitenim calor ne refiftatper ficcitatem, ficut etiam ficci12s, quu in parum actiua fit, non propierea facit ne per calorem maxime agat; attaraen videmus ignen, etfi maxime ficcum, minimam tamen reliftendi vim habere:igitur non rete in ficcitate conftituitur maxima refiftentia. Alia multa, opises quxabaliis dicuntur, omitto, quoniam omnia propria. apud Pomponatium, \&alios legi poffunt: dicam quid upfe fentiam; \& aliqua aliorum dieta recipiendo, aliqua etiam, qua ab aliis dieta non funt, adiiciendo, nitar huiufce rei yeritarem red. dere manıfeftam. Refiftentiam prouenireà forObinio a ma, vtmultidicunt, omnino confitendum effe liguoris. matbitror ob rationem ante adductam; fed vanam effe puto nonnullorum additionem, qui dicunt refiftentiam fieri tum à forma, tum ab annexis, hoceft, ab affectionibus, \& accidentibus fubiecti, qux funt coniuncta cum forma, nam ab his quoq; fit refiftentia; vt ignis in ferro magis refiftit, quam extra ferrum, idquenon propter formam ignis, fed propter denfitaterm nuaterix; ficterra propter denfitatem maxime refiftit aliis elementis; dantur igituraliqua accidentia in fubiecto patiente, qux faciunt vtillud Confuta- zgre patiatur, \& agenti refiftat. Ego autem ar:10. biror foli forma effe refiftentiam attribuendam; accidentia enim vel infequuntur formam, vtdenfitas terr $x$, vel illi penitus accidunt, yt denfirasigni exiftentiin ferro: de illis quidem; qu $x$ formam infequuntur, claia res eft, forma enim vt non agit extra, nifi per accidentia medı, ita neque refifticastioni agentis externi, nifi per ascidentia confequentia:dicere igitur $h x c$ refiftere agenti, eft dicere formam per hacjactio enim magis eft tribuenda primario agenti, quam fecundatio, vt ait Ariftotel. in context.33. 8. Phyfic. quia caufa fecundaria non per vim propriam agit, fed per vim caufx primarix. Si vero accidentia formam non infequantur, fed extranea fint, ab his non fit-refiftentia, nifi per accidens ; perfe enim femper fit à forma, vt in exemplo ab his adducto notare poffumus; denfitas enim ferri nihil conferret ad refiftentiam ignis, nifi ignis fuapte natura refifteret extinguenti: quoniam igitur præcipuum refiftens eft forma ignis, denfitas autem ferrifacit vt in parua illa mole fit conftipatum multum ignis, \& àmulto igni maior fitrefiftentia, quamà pauco,ideo denfitas facit vt ille ignis magis refiftat; proindenon perferefiftit, fed peraccidens, quatenus facit vt ibi fir multum ignis, qui fecundum propriam naturam refiftit; in multo enim quan in pauco major visineft, vt agendi, ita \& refi. ftendi. Aliurs quoque errorem mihi videntur iftimer committere, dum declarant, quomado forın a faciat reliftentiam; dicunt enim formam refiftereagendo, scius refiftentiam efle actiodio retur inimici rciiciat, agendoenim reliftit \& illa actione vires etiam inumici obtundit: fic crgo \& quando agit ignis in aquam, dicitur aquarefiftere, \& actionem ignis retartare, quatenus reagendo minuit calorem ignis, refiftritenim dum vires agentis reddit debiliores: quum igitur hæc refiftentia fit actio quadam, hinc colligunt, de hac actione verum elle id, quod al iqui dixerunt, quamlibet formam tantam habere B vim refiftendi,quantam habet agendi. Sed meo quidem iudicio hoc nulla ratione probandum eft, quia fic non diftingueretur refiftentia à reaCtione pofitiua; diffinguitur tamen, quia refiftentiam concedunt omncs, reactionem non omnes; quocirca illi, qui talem reactionem negant, negarent etiam refiftentiam in in tali reaEtione conftitui, quum refiftentiam concedant. Praterea hanc non poffum us appellare refiftentiam, nifiper accidens; quia per fe \& priC monon eft nifiactio, hancautem confequitur vt imminuatur proportio agentis ad patiens, ita. vt minus agat: quare hxc improprie vocatur refiftentia, vt ait. Pomponatius in cap. s. fect. 2 . liv bri fui; non enimimmediate refiftit paciens agenti, fed quatenus obtundendo eius vires $a b$ co minus paritur:addequod non femper verum cft id, quodipfi dicunt, per hanc reactionem imminui proportion em agentis ad patiens; imo frequentius euenit, vt augeatur;nan fi agens fit validius patienti, augetur ifta proportio, quia magis imminuitur ab agente vis patientis tum actiua, tum refiftitiua, quam à patiente imminuatur vis agentis per reactionem. In to præterea decepti funt, quod non videruat alium magis proprium refiftendi modum, quo forma abfque vllaactione refitere dicitur, isquenon fuit omnibus incognitus; vt apud Pomponatium legere poffumus : aliqui enim confidesarunt quamlibet formam habentem contra-

E rium præditameffe duabus viribus, qux confundendx non funt, eft enim tum actiua in contrarium, vt calidum in frigiduni, tum fuiipfius conferuatiua, \& fe conferuare nititur quantum potelt, ideo conatur ationem agentis non admittere, \& vel omnino impedit ne agat, vel faltem quadantenus actionem eius retardat, \& hac ratione refiftere dicitur, ctiam nulla eius reactione confiderata: huius igitur impedimenti nulla alia eft afferenF da caufa, nifi ipfa forma natura, qua fe conferuare volens, non ftatim admittit actionem agentis, à qua neceffe eft imminui ipfius vires, ac tandem etiam deftrui : hæc proprie refítentia dicitur, propulfatio q̨uxdam actio nis abfque vlla reactionis confideratione, \& propulfatio talis, guse non habet aliud effe, quam priustiuum; eft enim tantummodo actionis non admiftio, fiue non pallio, \& infequitur naluram formx nitentis fo confer- 
uare, \& cft diucrfum quiddam à reactione; quod quidem illi, qui dixêe, non dari pofitiuam reactionem, fed priuatiuzm, cognouiffe videntur: etfi enin in co funt reprehendendi, quod pofitiuam non concefferunt, in hocranen optime fenlerunt, quod hanc abilla differe exiftima. runt, \& quod hans vocarunt priuatinam, quia reuera nil aliud eft refifentia, quam priuatio, licet pofitiuam forma naturam infequatur. Dif. ferreauten à reactionerefiftentiam teftatur experientia, qua exiam oftenditur falfitas fententixe illorum, qui dicunt quamlibet formam haberc tantam refiftendi vim, quantapn aze di, terra enim magnam vim refifterdi habet, quia in ignem etiam iniecta, non abfumitur, agit autem debilitcr; ficesterra, ve lapis, plurimum refiftunt, parum autem agunt; contra veroignis piurimum agit, parum refiftit, quia facilc extinguitur: p2ter igitur res non tantam habere vim lefilendi, quantam habent agendi; patet etiam da-ivimrelifendi, qux nor eit vis a tiua, fed a1:a quredam fine actone: hoc autem factum eft à natura, propter rerum conferuationesl, quia fic feruatur zqualitas virium in rebus actiuis \& pafius; qux non is eo conliftit, ve aquas agendivires habeant; fed vt quantum hrecaetuueft, tantum lit lla refifticiu, vt quantu a Aiuus eft ignis, tantum eit terra refilizima, \& quantum a, ctiua terra, tantum reffftiuus ignis: fic igizur feruantur, nec vnum ab altcro ablumitur, nifi quum portiones ita inxquales fumŭtur, vt propter maiorem quantitatem alterum babeat maiorem agendi vim, quam alterum refittendi, tunc enim praualet, ac deftruitillud. Obaliam quoque rationem non debuit quodlibet aquas habere vires ad fetuend $\bar{u}$, \& ad alia opprimenda: quemadmodum fcribit Ariftoteles in libris de Partibus animalium, narura nihil, facit fu. peruacaneum, obidq; dedit finguloanimali vnum tantum inftrumentum ad fe tuendum,non plura, vt equis pedes pofteziores, bobus cornua, canibus dentes, \& aliis alia; fuperuacaneum enim fuifet equis dare etiam dentes ad mordendum idoneos: hoc idem de elementis, ac de miftis inanimatis, qux elementorum naturas redolent, dicendum eff; hac enim omnia fe conferuant, vel deftruendo alia, vel aliis opprimere nitentibus refiftendo, \& corum actionem non recipiendo, qua dua cōditiones nulli frmul dataz funt fumm $x$, fed vana tantū fumma, vel duz mediocres: terra enim maxime refiftit actioni externa; fed minimam agendi vim habet, contra ignis plurimum agit, minim2m habet refiftendi vim, elementa vero media virumque babent mediocriter; videtur tamen aqua plus agere, quam refiftere, \& aer plus refiftere, quam agere: \& horum omnium caufa (vt cgo-arbitror) non in fingulam elementarem qualitatem referenda eft, qua in re plures decepti funt, dicentes calidum cffe maxime atiuum, fiscum
A vero maxime refiftitiun, \& alia fimiliter; fed cotafo in varias primarum qualitatum coniugationes, moioris calidum enm cum ficro magnam agendi vim EF mimchabet,minoren cum humidsividetur enim hu- res refimiditas vires caloris obiundere, nec poffe pari ftenide fummum calortm, contra vero frigus raggis a- quzratm gitcum humido, quam cum ficco, ideo magis it. eit actiua aqua, quanteira: fic calidum cuara ficco parum refiftit, cum humido multum;contra vero frigidum cum ficcoplurimum refiftir,

B cum humidominus: has autem omnia dicentes, dicimus formas clementoru in \& agere, \& refificre per medias qualitatis, que eas infequuntur, ficut antea dicebamus. Neque eft in. quam pratermittendum id, qued antea monuimus, naicre $n$, \& minorem tum actionem, tum refifentiam non folum.à naturarum diuerfitate prouenire, fed etiam à diuernis quantitatibus eiufdem naturx; magis enimagit, \& magis etiam retiftit maior terra, quani minor, \& maios C ignis, quam minor : ideo fieri potelt, vt $g$ lusa gat magna terra quam paruus ignis, qura muttiplicantur vires per quantitatisincrementum, licet gradus non intendatur, idem enim eft gra. dus caloris in magno igni. atque in paruo: nec dicerefollumus, in maiore effe maiorem calorem, fi vterq̨ue eft fummuscalor, fed dicere tamen poffumus, in igne maiore effe plus saloris, quam in minore; ideo alicuius patientis vires minor ignis fuperarenon poterit, maior tamen poterit, nam fi quantitas duplicetur, crefcit proportio, \& fittanquam duorum ad vnum, qua priuserat tanquam vnius ad vnum, fi prius $x$ quales vires hab bant; ficutififtres fint homines xqualis roboris inter $f e, \&$ corum duo inuicem pugnent, neuter alterum vincet, fed fi duo fimuliundi pugnent cum tertio, facile eum fuperabunt, quia plus roboris habent duo fimul fumpti, quam vnus.

\section{E Collectio totius veritatis de Reactions in motu alterationis.} Cap. VI.

FX his omnibus, qua hactenus declarasa Erunt, poffumus duabus affertionibus colligere, quid fentiendum fit de reactione in motu alterationis, quarum prior hae cft: Si acfio fu- prima matur pro fola imprefione gradus, necéfe eft cöclusio. in omni al teratione reactionem fieri patiëtis in agens proximum, dummodo, cóueniant in ma-

F teria, \& conuenienter propinqua fint, \& fecurt dum quantitates cómenfurata. Huius ratio clara fumitur ex iis, qua dica funt : quandoenim appropinquat patienti habenti aptitudinem recipiendi eandem qualitatem, quam illud agere poteft, neceffe eft, vt actio fiat: quando igitus calid̄̄ frigido conuenienter appropinquet, neceffe eft vtrumque in alterum agere, quia contraria verfantur in eodem fubiecto, \& id, quod eft actu calidum, eft poteftate frigidum, $\alpha$ il- 
1ud, quod eft a f̂u frigidum, eft poteftate cali- A dum, vtrumque igitur ab altero pati necefice eft; ficut enim vtraque qualitas actiua eft, ita fub. jectum vtriufq; eft xque vtriufque receptitum, « dum habet vnam antu, poteft à contrariapa. ti, \& eam recipere: neque eft quodalıqu is obi iciat, ynum effe validius altero, hoc cnim facit quiden, ne vtrumq; poffit alterum penitus vincere, quia fi vnum vincit, neceffe eft al terū vinci, non vincere; at non facit, quin etiam id, quod inualidius eft, antequam victum penitus, ac deftructum fit, imprimat aliquid in alterum validius, quum habeat qualitatem aftiuam: \& alterium habeat materiam paffuam, \& receptiuan illius:imprimi autem gra dus frigoris nen potef in fubiecto calido, quin aliquem caloris gradü extinguat, \& ita alterius calorem obtüdat; ideo neceffe eft, vt agente calido etiam valıdiore in frigidum, obtundatur, 2 c remittatur agentis calor, etiamfi in fine pughix totum frigus fit defruendum:hacautem omnia intelligenda funt, $C$ adiectis conditionibus memoratis, nempe vt fint propinqua, \& impedita, \& quantitatibus commenfurata: quoniam enim in quantitate maioreineft vis atiua maior, ideo fi vnum nimioexceffu alterum fuperet, nulla fit reactio; $v t$ fi in ignem fornacis ardentem iniiciatur palea, credebile eft eam abigne ftatim abfumi, fine vlla reactione, ob virium inxqualitatem incomparabilem; ideo has omnes conditiones cnnftituiffe Ariftorelem credendum eft, quando vniuerfe dixit, omne agens naturale conueniens ih materia cum patiente in agendo repati. secunda Aitera afferto eft: Si actio fumaturpro pertecórlufio. Eta pugna duorum inter fe cum victoria alterius, reąio pofitiua impolfibils eft: quonsam ita fumendoreactioneni, nomen reactionis implicatcontradictionem, quum fieri non poffit, vtaliquod deftruat aliquod aliud, \& abillo viciffin deftruatur, ita ve \& illud perfecte mutetus in hoc, \& hoc in illud, vt fi agant iuuicem portioaqua, \& portio aeris, reactio quidem fiet accepta pro impreffione gradus, at non properfecta victoria; nam fi validior fit aer, tandem mutabit aquam in aerem, nee fieri poteftivetiam ille idem aer fimsl in aquam mutetur: ob eandem rationem antea dicebamus, reactionem in mutatione fubftantiali non pofe locum habere, nifiratione altcrationis prauiz; in hac enim fit reactio fumpta pro impreffione gradus qualitatis: fed in eductione forma fubftantialis ne imaginari quidem reactionem aliquam poffumus; agens enim interimit fubito for, mam patientis, nec poteft ipfum quoque eodem momento interimi abillo; hoc enim effet remanere vtrungue integrux, \& vtrunque intenfie, qua eft repugnantia manifefta: \& eadem ratio vrget in alteratione, qux fumatur pro perfecta vetoria agentis: de miftione autem alia ratio cft; nam milcibiliainterimunt quidem fe mutuo, neutrum tamen mutat alterum in fuam naturam, qualem mutationem nos in prafentia confideramus, fed mutantur amboin aliam quandam naturam mediam diuerfam ab vtrifque. Cisterumea, qua hactenus diximus, vrgeri videntur difficultate non parua, qux multos conturbauit: nam fi agant in. uicemaer \& aqua, validior autem fit aer, \& tandem vincat aquam, ipfe quque aer in fine pugnx manebit ob aqux reactionem debilitarus; B ergo finem quoque pugnx fpectando mutila eft reactio, \& mutua vietoria; fiquidem etiam aqua vicit aerem aliqua faltem ex parte, quum extinxerit in aere gradum alıquem caloris naturalis: oporteret itaque naturam aeris in fine pugnx integram feruari, fi verum effet id, quod diximus, non effe victoriam mutuam. Vt du bium hoc, \& alia qunque plura foluantur, fciendum cft, non effe neceflarium, vt ex qualibet reniffione qualitatum elementarium fiat remiffio etiam forma fubfantialis; quoniam remiffio forma elementaris non poteft fitri, nifi cum ipfus elementi interitu, at qualitatis remifie fier pot $\mathrm{ft}$, etiam integra manente elementi natura: etenim fi intra quoldam terminos fiat intenfio, vel remiffio qualitarum naturaliuminelemento, fe r a integra maner;quod fi intenfio vel remifiomodum excedat, forma quoque deftruitur, \& micrat in forman mift, fi mutua fict remifio omnium formarum elcmentarino ; vel muatur wum elcmerizum in aliud, fialteris forma feruetur, alierius verodiftuarur: tuncenin in eirngnto fuccunsbente, tansa cft facta qualitatum remillio, vt foima queque fit remifia, proinde neceffario intersent: in elemento autem praualente, atque sincencerinorfacta ef naturalium qualitarumrem: ffis, quare forma \& natura elementi feluata ct integra; nam fi hrequoque intereat, miftio fit, vı modo dicebamus, \& forma eE lementares migrant in vnam formam mediam, qua eff mifti: isaquefin miftione mutarionem form $x$ fubstantialis, qux alteration is terminus eft, attendamus, negare non poffumus, in miftione mutuam effe omnium mifcibilium viEtoriam, quatenus quodlibet eft à fua natura difractum obactionem aliorum: quodlibet igitur \& vincit, \& vincitur fecund um partem, licet enim in omni miftione vnum element um aliis dominctur, victum tamen illud quoque effe F dicitur, quatenus non feruat amplius fuam naturam, fed in naturam mifti migrauit; fed hæe poftea, quum de miftione loquemur, manifeftiora fient. Ex his colligimus, fecundam noftrum affertionem non efle omnino veram de miftione, quandoquidem manifeftumeft, mif́tione abfoluta, omnia elenenta agentia \& patientıa interijffe, quia omnia à fuss naturis diftracta funt, \&: modo quodans omnia funt vina, liscr modo quodam dicere pofiumsts, 
vutum aliquod ipforum vicifle, ad cuius naturam magis vergit illud miftum; \& hac rationc dicerepoffumus, non effe victoriam muruam, quatenus'non poffunr plura elle pracualentia, fed eft vnum rantummodo. Poriffime autern locū haberalfertio noftra extra miftionem, quando duo contraria agunt inuicem, \& alterius natura feruatur: nam fi duo elementa nuiccmagant, \& patiantur, \& alterius forma aboleatur, alterius vero feruetur integra, certum eft, hoc folum perfectim victoriam obtinuife ratione form $x$ fubftantialis, rationc autem qualitatum fi non omnino perfeetam, quia ipfum queque eft debilitatum, faltem modo aliquo victoriam obtinuit, \& fecundum gradus, quiz minus eft debilitatum, quam alterum contrarium, quod ill fuccubuit: non eft igitur itaintelligenda viEtoria ve vincens nullo dicatur afiegtum effe de. trimento; hoc enim minime dicendum eff; fed vt fit çuidem paffum aliquam remiflionem, fed minorem, quam alterum quod victum effe dicitur: hoc igitur modo victoriam intelligendo cum refpectu ad alserum, quem refpectum victorix nomendenotare videtur, non poteftinutua effe victoria agentis \& patientis in tota pugna: dictun autemillud Ariftotel: \& Auerrois, actio non fit, nifiab inxquali fuperante, non'eft intelligendum fumendo amplifime nomen a: ctionis, féd in illa tantum actione verum eft, in quaalterum dicaturagens, alterum vero patiens; hrec enim nominatio fit ab exceflu, \& defecu virium, dum totam eorum pugnam refpicimus.

\section{De Reactione in motu loculi. Cap. VII.}

( Onfiderandum manet, quomodo in mou locali reatio fiat; hancenim ponere manifefte vifus eft Ariftotel.in 4. libr.de Animal. ortu, cap. 3. dum inquit, pellens pellitur; \& in 3.Phyfic. context. 8. ac 16. vniuerle de omnibus pronuntiafe videıur, prafertim vero de motu locali,omne motiens phyfice in mouendo moueri : videtur etiam resipfa fatis manifefia, \& per experientiam comprobata; nam fi trabs erecta ftet, ita vtleui in eam facto ictu cadere porfit, \& faxo, vel pila lignea percutiatur, cadit trabs, \&c pila repercutitur, quare pellens pellitur abillo ipro, quodab eo pellitur; ficeriam in ludo pilarum in menfa videmus pilam percutere aliampilam, \& illam pellere, \& ipfam quoque $F$ pelf́entem pelliadaliam partem ex eodem ictu, neque refa fuum motum profequi; duo quoq; gladij fe mutuo percutientes, fe mutuo fecant č obtundunt, imo hoc idem euenit alterofolo percutiente, altero autem quiefcente; ferra etiam fecans lignum, non fecatur quidem ab illo, hebetaturautem, proinde reparirur aliquid $a b$ illo eodem ligno in illa eadem actione. A tiarnen dubium oft, an ita fit in omnibus: Ariftoteles.
A enim de omnibus vniuerfe protulife videturin. 3. Piylic. dicens, omne mouen 3 phyfice in mouendonouetur; \& in 4 . de Ortu animal. cap. 3. locidem dicit, \& addit, exceptoprimo. In multis tamen hoc verum efenon videtur; nam liomo hominem pellit, nec ab eo pellitur, manus moutr baculum, nec motecturà baculo. Videtur dicipolle, onne mouens corporeum moueri quidem, non tamen neceffario moueriabillomet moro, fed vel ab illo, velabaliquoalio, vel $B$ criam à femetipfo; qua ratione propofitio Ariftotclis vera elt de omni mouente corpóreo, etiam de Colo; mouet enim inferiora, \& muuetur necelfario ; licet non ab ipfismet inferioribus;fic pellenspellitur, non tamen ab illomet, quem pellit, fed à feipfo, quatenus non poffet illum pellere, nifi ipfe mouererur: hocfignificare videnturverba Arrftotelis in loco pradicto 4 , de Generar. animal. dum vniuerfe de omnibus dicit, orme mouens mouetur, \& excipit folun primum, quod eft immobile; quarevult Coelum quoque hac propofitione comprehendi: prxterea addit [morualigwo] quafi dicens, vel moueturà moto, vel ab aliquo alio; fatis enim eft, fi omne mouens corporeum motu aliquo moucatur dum novet. Veruntamen fi exempla. ab Ariftotele ibidem adducta perpendantur, $f$. gnificat mouens moueri à moto, nam dicit [ pellerispellisurquodammodo, Eq quodpremst, reprsmitur: ] imo etiam aperte ibl dicit Ariftoreles, D nouensmoueri, \& repatiab ipfomet patiente: quare dicendum viderur, Ariftotel. loqui præ- Notagzo cipue de illis monentibus, qua conueniunt in modo s: materia cum motis; in his enim mouens moue- motndotur à moto,nempemonens propinquum \& cor- cali reporeum:hoc quidem in illis, quorum antex ex- atro emplaacculimus, manifeftum eft; in aliis vero, fiat. in quibus dubium videtur, ita pôtef́t declarari. Sitipatium A. B. in cuius medio fit punctum, C. pellat aliquis alium abA.ad B.neceffce efovt pelE lendorentias refiftentiam, qua repellitur quo. dammodo, \& motusilie eft compofitus, cont ftans modo quodam ex'pulfu \& repulfu, quia. nifille, qui pellitur, refifteret, pellens ranto quodam fuo conatu eum ad B. vfque pelleret, fed refiftentia facit, vt illo conatu non pellat, nifivfque adC.quare motusille conftat quodam modo ex duobus contraris motibus, quia perinde eft, ac fi pellens pellat alterum vique $\mathbf{a d}$. deindeabillo repellatur à $B$. ad $C$ víque, vincit enim primuspellens, ideo maior eft motus: ab A. ad B. quam à B. ad C. quamobremibiillud idem contingit, quod in alteratione cont tingere dicebanus : ficut enim calefaciens dicitur refrigerari, non quod caloren fimui cum frigore habeat, tanquam duas qualita. tes, fed quod calorem habeat remifiorem, quamprius; ita hicnon dicinas fiesi forfum , hos dios motus, vnum pullionis ab A. ad B. alcrum repulfionis à $B$ ad $C$. fed vaum, qua 
etiam folus apparet, $a b A$. ad C. hic enim eft, quipraualet, \& eft ininor, quam effet fi pellens non repelleresur; qui enim deberet cfic ab A.ad $B$ effolum ab A. ad C. \&e e?t veluti motus miftus ex duobus contrariis motibus cum dominio vrius, qui fit à primo pellente, tanquam validiore:hoc fignificauitin dictoloco Ariftot, dicens [pellenspellitur qteodammods] son enim abfolute dicit pellens repelli, quafi retro pellatur: fic enim non diceretur pellens, fed pulfus; fed quia quum reuera pellat, eftinilla pulfione repulfioaliqua adinifta, qua facit,ne tanta fit pul. fio, quantaeffet fine illa repulíone: in preflione autem clarior res eft, premensenies (inquit $A$ rifot.) reprimitur, quia fi áigito rem aliquam premimus, ab illa vicifim reprimitur digitus: fi verogladiofecemusaliquid, non fecatur quidem viciftim gladius, obtunditurtamen, idsirco inquit ibi Ariftotel. [motualsquo]indisans non effenecefiarium, verpafio fit fecundun eandem fpeciem, feu modum motus, fed elle neceffarium, vt aliquo mo:u repaziatur, \& al iquam mutationem recipiat etiam mouens à motu. De Celo autem mouente hac inferiora verum quidemeft illud Ariftotelis dictum, non tamen omniizo, neque co modo, quo de his inferioribus mouentibus, fed modoaliquo, quatenus non mouethxc inferiora, nifi ipfum cusoque moueatur, etfinon abillis; ob id Ccelum quoq; comprehendi videcurilla vniuerfali Ariftotelis propofitione in lib. 3. Phyfi.omne mouens phyfice in mouen do mouetur:at de mouentibus inferioribus verum eft etiam intellectum de reaatone;moucns enim repatitur aliquidab ipfomet moto; \& huius rationem affert Ariftoteles in context.53.lib. 1. de Ortu\& interitu, quia cònueniunt in materiajetenim qua in materia non conueniunt, ea agunt quidert, fed non repatiuntur:ideo quando Ariftoteles lib. 4 de Ortu aninalium, cap.3.inquit [excepto primo] quodimmobile eliefignificat, ca verbaintelligi porfunt de primo mouente corporeo, quod Celum eft; quum enim precedentibus verbis expreffe dixiflet, omne mouens moueri vicifica a patiente, \& moto,pofea excipit Colum, quod vocat immobile, id eft, non ab his inferioribus vicifim mobile, ita enim agit,vtab his non repatiatur, \& hac ratione vocaturimmobile.

\section{Contrariorum argumentorum Solutio. Cap. VIII.}

Adprimumar. gumen. twm.
A naturam fuam; hoce nim facere minime poteft, nifi praualeat patienti; per hoc tamen non ftat, quin durante pugna patiens quoque reagat in agens, etiamfi non vincat illud; quia reaction non debet effe cum victoria, proinde fub illa Arifto. telis propofitione non continetur, quoniam pa. tiens non eft abfolute nominandumagens, fed folum reagens, quia eius natura mutanda eft; alterum vero, cuius natura eff fermanda, nominaturabioluteagens, etiamfi repatiatur, \& ex

E pugna debiliterur:ficigituragensappellari non potef, nififuperet, eaque eft mens Ariftotelis in illa propofitione, vt mauifefum eft illa confiderantibus, qua ab ipfo dicuntur de miftıne in context. 88. \& 89. Irb. r. de Ortu \& interitu: ibi namque duo ponit genera aetionum; vnum, quando patiens mutatur in naturam agentis, tanquam dom inantis; alterum, quando verumque mutacur quodammodo in al cerum, vt in mitione fit; neutrum enim remanet, fed C medium diuerfun ab veroque : funt autem ibi notanda Ariftotelis verba, qui vtrumque vocat dominans, non alterum determinate, propterea quod non remanet determinate natura alterius, fed vtrumque ex natura fua diftractum eft $a b$ altero; vtrumque igirut vincit, \& vtrumque vincitur;quareilla non eft tal is pugna, in qualterum polite determinate rocari agens, \& alterum patiens, quum neutrius natura feruetur; proinde huiusmodiantio non comprehenditur D lub illa propofitione Ariftot. \& Auerr. actionon fit, nifiab inæquali præualente, feu (vtlatini noftriloquuntur) a proportione maioris inæqualitatis : primum ergo hocargumentum nullius eft roboris : ideo argumentum quoque Sueflani, quod diuerfum ab hoceffe non videtur, facile foluitur; ipfe enim dicebar, agens de- $g^{\text {um }}$ bet elle alıdius patiente, ergo quantam habet suse
potentiamagendinillud, tantam etiam habere dsbet fe defendendi, ne ab eo alıquid patia$\Sigma$ tur; dicimus enim negandum effe confequens, \& ratio negationis manifeftạ eft, tum quiaagen:agitratione forma, patitur autem non ratione formx, fed rationc materix: quum igitur ftatuantur conuenire in materia, neceffe eft vt agens quoque aliquid patiatur ob rationem antea declaratam; tum etiam, quia etiam folam formam fpectando iam oftendimus, non xquas in fingula re effe vires agendi in aliam, \& refiftendi", feu defendendi femetipfam: F quisquis ergo ea, qux antea diffuie declarauimus, bene confideret, facile intelliget, argumentum hoc nihil habere efficacitatis. Se- $d$ f cundum argumencum, etfi multis arduum vi- dum fum eft, leuifimum tamen eft, ac facile foluitur. Primum quidem dicere poffemus, illud adrem non facce, fiquidem loquimur de agente corporeo, \& proximo patienti ; quare dun fu. mitur ignis a aqua cum aere medro interpofi. to,neciguis agit immediate in aquam, necaqua in ignein, 
in ignem, fed ambo in acren medium: quod fi illi quærant, quomodo poffit idem aer fimul caIefieriab igni, \& refrigerariab aqua, haceft alia difficultas, qux ad præfentem confiderationem non pertinet, loquimur enim de reactione pat1entis in agens proximum; ideo id fol:tm effet nobis confiderandum, an aer ille in ignem reagar, vel etiam in aquan, namignem \& aquam effe duo diftincta agentia.manifeftum eft. Dicimus tamen, hanc queftionem, fine oportuna cfic dicatur, fue importuna, facillime folui \& nilil in fe habere difficultatis : man fi qus fimiliter quxrat de aqua feruentifima, qux cum aqua frigidifima commifecatur, quomodo porfint duo contraria fimul effe, nempe magnus calor, \& magnum frigus, refponfio in promptu eft : duo contraria integra \& perfectain codem fubiectofimul exiftere nequeunt; atfiacta, \& mutuo caftigata, 3rad vnam mediam qualitatem redacta, poffunt fimul effe in eodem, ficut ibi pater; nam tota illa aqua neque frigidifima amplius eft, neque feruentiffima, fed tepida. Sic igitur ad argumentum dicendum eft : aer ille medius \& calorem ab igne recipit, \& frigus ab aqua. non tamen $v t$, duas qualitates diftinctas contrarıs, fed yt vnam mediocrem ex vtrifque prouenientem; ignis enim in illum aerem agit per calorem, tamennon tantum caloris imprimit, quantum deberet imprimere, quia caftigatur, \& remittitur à figore, quod eodem tempore imprimitaqua; fic etiam aqua non tantum frigoris imprimit, quantum imprimere deberet, quia caltigaturà calore, quem imprimit $i-$ gnis; $a b$ vtrifque igitur contratis agentibus fimul patitur idem aer medius, non tamen recipir duas qualitates contrarias extremas, tanquam diftinctas, fed vnam mediocren, qua ex earum commiftione exoritur; agens enim non agit nifi in patiens aptum ad recipiendum; maiorem igitur calorem imprimeret ignisillein illum aeren, fi nulla tunc aqua in eundem aeren ageret, fed propterillius a qux actionem non ita eft aptusille aer ad recipiendun calorem ignis, ficuti effet, fi nulla in eum aqua ageret; \& e contrario non eft ita aptus ad recipiendum ab aqua frigus, vt effet, fi nullo tunc igni pateretur, ita. que ex vtriufque actione qualitas vna media in. illo aere prouenit, qux in parte igni propinquo re magis vegit ad calorem, in parte autem propinqua aquæ magis vergit ad frigus. Hoc idem dicendum eft de igni-immediate agente in aquam; pars enim aqux propinquior ign agenti recipit maiorem calorem, quam parsremotior, quare hæc refpectu illius habet rationem frigidi: igitur necefle elt, vt calor partis propinqux remitratur aliquantum à frigore partis remotioris, \&ita minus caloris recipiat pars illa propinqua, quam fi non haberet coniunctam aliam aqux partem remotiorem : quo fit, vt magis; ac citius calefiat ab igni parua aqux por-
A tio, quam magn q; ctenim magna iuuatur à pertibus diftantioribusabigne agente, quæ fouent partes propinquiores, \& faciunt vt illæminus patianturab igni, \& magis illi refiltant, propterea etian pars remota recipit aliquid caloris ì partepropinqua, ficuti viciffim pars propinqua recipit ab ea aliquid frigoris; hocautem dicere, eft dicere, totam aquam recipere calorem ab igni, ita tamen vt in to ta fic vnica qualitas media, quæ in parte igni propinqua magis ad caloB rem vergit; inparte autem remota migis vergit ad trigus: haceit verifima huinsargumenti folutio.Aligui tamenaliter folmunt:dicuntenim, Alsorume nó pofiedı́tingui illius aquxpartes, fed aquam refponfo. totam pariab illoigni, taoquam corpus vnum continutm, \& totam etian reagere in illum. Sed experientia docet, hancrefponfionens non Impuelle tutam; ego enim vidi carbonem accenfum, gratio. cuiluspartem quandam particula aqua extinxerat, munentibus cateris carbonis partibusac$C$ conís, à quibus poftea parti extinctz priftina accenfio eft reftitura : patet igitur, partem eius- dem continui propinquiorem ageńi magis pa. ti, qua m reliquas, \& ab illis quoque aliquid re- Alioruss cipere, quod illinegant. Suntetiam quiadar- refponfro. gumentum de aere medio refpondeant, effe quidem abfurdum dicere duo contraria fima! in eodem recipi vt fixa \& permanentia, atnon effe abfurdum vetranfeuntia,cuiulimodifunt in illoaere medio calor, \& frigus; funt enim in träfitu, quia calor tranlitab igniadaquam peraerem medium, \& ita frigus ab aqua ad ignem. Hac tamen refponfio probanda non eft: quo- Impuniam de accidentibus quidem fpiritualibus, à gratio. quibusilll decepti efle videntur, verum eft id; quod dicunt, fiquidem pendent ab agente, à quio producuntur, non à fubiecto, in quo recipiuntur; ideo per eundemaerem medium fimul tranfeunt fpecies contrarioruin colorum, neque fe mutuo vitiant, yel remittunt, nequeinter fe commifceri dicuntur:at de materialibus qua. litatibus verum non eft, hæ namque non porfunt peraerem medium tranfire, quin fe mutuo lædant; imo \& fix in eoremanent vel longo, vel faltembreuitampore, vtin cubiculo remanet calefactus aer etiam port ignis extinctionem;non pofuntigitur fimul in eodemaere re, cipifummus calor, \& fummum frigus, ita $\vee t$ vtraque maneant fumma : quareabiicienda eft hæcrefponfio, \& altera fumenda, quam prius adduximus. Ad tertium argumentum ncgan. dum eft confequens; fcepus enim agentiseft, fibiaffimilare patiens quantum poteit, ideo fi ex pugna fit debilitatum, affimilat fibi patiens, fi non omnino, falrem ex parte; non igitur fine suo fruftratur, fed eo potitur velperfecte, vel ex aliqua parte : imo neque dicendum eft, hunc effe natur fcopum, quem ifti fingunt, in actione \& paffione rerum naturalium inant. matarum; nam fi naturæ confilium eft, vtignis P vertat

\section{dilere}

twum. 
vertatperfectcaquam in igncm, of vt aquavertatperfecte ignem in a wam, necpoteftuatura finefuo fruftrari,veillidicunt, quomodopotelt duoshabere contrarios fopos; quos fimul alfequinullopacto poteft? num fi ise? fnis horun duorum elenentorum, inecefie eft, yt aitero faltem natlira fruftectur. Dicendum igitur potius eft, nature vniuerfalis, quromnia regit, non hunc efle fcopum, fed potius vt agant mutuo, \& patinntur, \& fe mutuo obtuidat, \& v'num alrerius vires firangat, propter ipformm confer uationem, \& propter generationem miftorum: quod finaturam cuiusque rei propriam fpectenus, lcopus quide hums ignis ett, vertere illam aqum perfecte in ignem, led illius quoq̧ a quæ fcopus eft vertere hunc ignem perfecte in aqua ; fiuttrari ígirur, \& impediri, qquid abfurdi elt, quum id necefiarium fit ob repugrantiam contrarij : hoc enim fi mutari penitus non finit, vtiturque fingulum viribus fuis, \& nititur, quantum potelt fic conferuare, \& contrarium oppugnare; idque fi facere nequeat, non dicitu: firo tine fruftrari, quia alıquid agit, etiam quando agit in contrarium validius; ve! fi aliquam eff fruftrationem concedamus, at faltem natura vniuerfalis, vti diximus, non fruftratur. Falfum. praterea eft, quod nunquam polfit agens perfecte alfimilare fibi patiens; quia fiaer muter aquam in acrem, \& maneat in qualitatibus debilitatus, in forma tamen fubftantiali manet integer, \& in talem aerem mutatit illam aquam: quod fin calore lefus ef aliquantum, \& manfit minus calidus, quam conueniat aeri, reftituitur tamen ei priftinus salor à circumftantibus zeris partibus, \& ab actione coleft: quare et-
A iam aer exaq1a i!h genitus vertitur tandem perfecte in acrem. Leuifimam eigo eft argumentum hoc, quia hec omnia in natura continger recefie eit, yt agens quandoque mutct patiens perfectein fuam naturam, quandogu: imperfecte, quandoque etiam inutare nequeat, quandoque etiam mutetur ab illo; hac enum o. min eueniunt ex lege natura vniuerlalis, qua ftatuit hac ommia polfe contingere : quomam igitur proprix fingularum rerum naturæ fubdiB tafuntlegibus naur vnuerfalis, frutratio ef femper referendiad naturam vniuerialem;qu1ua fi natura particularis non poteft fuan actionem perficere ob repugnantiam contrarij, non eft frustratio, gua natura yniuerfalis talem robus natum tribut, yt hoc euenire porlit, imovt amuino lit necefarim, ve id pollit contingere; $l i$ enim nüquam poffet accidere, nulla licret actio inter elenenta, vel vnum verteret alia omnia in fuam natiram : efiet autem hocpotus modo C fruttratio, quamillo, quia rés, ć carum vnuer. fitas non conleruaretur, coinferuatio autem rerum eft f́popus præcipuus naturæ, vniuerialis. Ad quartum, concedimus, nulhm fier reactionem, vbi nimia diftantia loci prohibetne fiat: Ad quintum, negandum eftconfequens; non enim in reactione idem fecundum idemagit, \& patitur : fed ignis.agit, quatenus calidus; patitur autem, non quatemus calidus, fed quatenus eft poteftate frigidus; agit enim per formam, \& patitur per materiam, vt antea diximus. Quare. omnia hæc argumenta, \& alia eiusmodi commenta Latinolum vana funt, \& facile foluuntux. per ipfam rei confiderationem, quia nutuntur oppugnarerem manifertam.

\section{$-\longrightarrow$

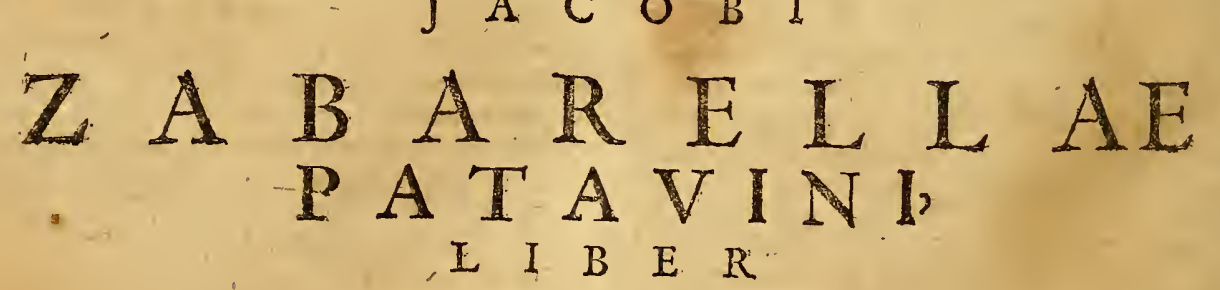 \\ $D E \quad M I S T I O N E$.}

Miftionis definitio, \& difficultates, qusex ipja oriuntur.

Cap. $I$.

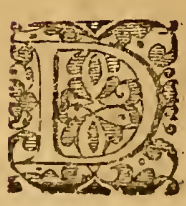

Ifficillimum femper fuitintelligere, guid fecundum Ariftot. fit niniftio, de quin nunc feribere cōftituimus; 1dque difcordia inte:pretum, ac difceptatio declarat, gutum multx, \& contrarixab his
E fententix Ariftotel attribuantur, \& ad hanc ys: que diem hac altercatio perduret: orta autem eft hac in re difficultas ex iis, qux ab Ariftot. in calce r.lib. de Ortu \& interitu de miftione traduntur, \& exipfametionis definirione, quam Arift. tandem colligit in poftremis verbisillius libri, dum ait, miftro ct mifeibilinm alteratorum vnio:repugnantia namque effe videtur in hac definitione; quia, quum dicat,altesatorum, aec dicat, corrugtorus, indicat illa q̧ux com: 
mifcentur in miftione non interirc, fed remanere in mifto, quod idem denotat etian nomen miftionis, vt confideranti patet; fi enim commifentur, ergo non interent; fed ibu paulo ante ipre quoq; Arift. aperte dikerat, muifisibilia nö in erire, fed feruari : contrarium auten fignificat illa vor, vnio, qux abi non denetat metam cogrigationem, fịtuiden hanc fententians iam Aritut.reprobautrat, fed pnionem natuarum, ita fex plurib. naturis vaa natura oriatur : itaq; fi plures milcibilium nature, quz prius erant, non exiftur amplius, fed ina quadam alia fa-

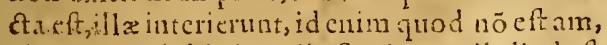
plius, abfq; dubiointeriit, fiquidem nil aliud eft interire, quam definere efie; fed hocexpreflectiam protulerat ibidem paulo antea Ariftoteles, dicens, neutrum mifcibilitim remanere, fed generabi quoddan tertium ab illis diuerfum. Hac igitur de re elt nobis in præfentia difputandum, vomni, fi feripolfit, difficultatefublata, definitio miftionis clara \& perfpicua reddatur; quā bene intelligere non poflunsus, nifi ea, qux tetigimus, dubra foluantur: hec autem duo funt potiffime: vnumde formis elementorum, an feruantur in mifto, afterum deorundem qualitatibus, quas in præentia ftatuimus"inon effe formas elemétorum, fedaccidentia confequentia. Repugnantia autem pradicta traxitalios in varias opin̄iones, quæ mihi videntur quatuor effead fummum, eafg; fingillatim cum earum argumentis nos confiderare oportet, poftea vero rei veritatem declarare nitemur, ac denique omnia aduerfantia argumenta foluémus.

\section{Auiccnne opinio or argumenta. Cap. 1 .}

D Rima eft Auicennx fententia ab Auerroe 1. relata, \& confutata in comment. 67.hib. 3.de Colo: putaut enim Auicenna formas elementorum remanere in mifto integras, \& nulla ex parte lafas; qualitates vero manere quide, non tamenintegras, fed caftigatas, \& fractas ob mutuam inter fe actionem \& paffionem. Ad hanc fentenciam comprobandam vius eft hoc potiffimum argumento: certum eft formas elementorum manere in mifto; hoc enim indicat ipfung miftionis nomen, \& fuit ab Ariftotele aperte afGrmatum, dum in contextu 84 . lib. 1. de Ortu \& interitu dixit, neque ambó mif́cibilia interire, neq; alterum, fed remanere vtrunque, \& in 88 . dixit guttam vini non admifceri multr aqua, quin gutta deftruitur: yult igitur omnia mifcibilia feruari in mifto, quum neget illa, quæ non fernantur, commifceris atqui feruari res non dicitur, nifi mancat forma eam conftituens; manere igitur debent formæ elemétorum : fed $h x$, quim fint fubftantiales, non poffunt intendi, neq; remitti; neceffe eft igitur, fi manent, vt integramaneant. Qualitates yero intendi, as rt-
A mitti poffut, quare nccefe eft, vt frangantur mutuo exrim excellentix, \& fiat qualitas via media, qux eftemperatura mifi. Secundo, fu. Secundü mitur imins fentcntire cófirmatio ex definitione miftonis, miftionamq, (vtinquit Aritut.) eft mifcibiliumaltcratortin vinio; non dixitautcm, corruptorum, fedalcratorum, coruptio cnim cft lubiantix, altcratio autem refpicit qualitates; vult igitur Arifoteles formas clementorum fuu urintegras, \& folas qualitates

B permutuam alecrationem remitti. 'Tertio, funitur arginentum ex Arifotcle in contex. 3. lib. s.Metaphyfic vbi definiens elementum dicitclie id, ex quo nnexiftenteres fit, vult igtur clenchta inexiftere, proinde remanere in $\mathrm{Co}$, cuius funt elementa; at non remanent, nift ipforum formx ferucntur; itaq; feruantur in mifto forme elententorum, Quirto, Arifoteles in Quartz̃. contex. 67. lib. de Cocilo, difputans contra Platonem, doset elementa non habere fignran aliquam propriam, \& hoc argimento vtitur; quia fi haberent, remancrein mifto non poffent: quü igitur confequens hoc putet Ariftoteles effe ab furdü, putat eleméta remanere in mifto. Cuin - Quint $\vec{s}$. to, Arifroteles in initio r.lib. de Colo inquit,mifum mótueriab elemento præualente; vult igitur elementa manere in mifro; praulens enim elementum quonedo moueret, nifi effet actu? hocautem fi remanet, ergo etiam reliqua, quibus dominari, as praunleredicitur. Sexto, nifi sextum. $D$ elementa feruarenturin mifto, miftio à generatione \& interitu non differtet; quia nilaliud effet mifto, quam generatio mifti, \& interitus e-

lementorum. Poitremo, miftum in elementa sestims. diffoluitur, nam Ariftoteles in contex. 84 . lib.r. de ortu \& interitu inquit, mifcibilia poffe iterum fepararià mifto ; ergo ex eis dum cóftat âtu m ftum;exeisdem enim res con tat actu; in qux diffoluitur. Quoniam igitur manent elementa in mifto, necefle eft, vt eorum forme feruentur $E$ à quibus conftitui el ementa dicuntur.

\section{Anerrois opinio, Oे aduerfus Auicen- nam 'd? putatio. Cap. III.}

$S$ Ecunda eft Auerrois opinio, quam apud eum legimus in comment. 67. lib. 3. de Colo, vbi dicit, tam formas fubrtantiales elementoF rum, quam qualitates manere actuin mifto, fractas tamen omnes, \& caftigatas, \& ad mediocritatem redactas; ideo de qualitatibus confentit Auicenna, fed de formis diffidet; cenfuit enim fotmas elementorum, licet fubtantiales fint, in hoc tamen ad accidentium naturam accedere, quod poffunt intendi, atque remitti, proinde funt quodammodo media inter formas fubftantiales perfectas, \& accidētia. Auicenna vero quia putauit formas elementorum neq inten-
Tertiun 2

\author{
vintis.
}

Sextum. 
di, net, remittipofe: \& vidit Ariftot. dicenrem A miscibuls in miftionenon inserire, dicere conctus eft, formas remancre integras, aduerfus quam opinionem Auerroes multifariam arguTrimsm mentatur. Primum fic. filorma clementorum argume- mentatur. Primum feruanturintegr $x$, crgo etiam qualitates, quotum.

Secundü. cadem eft ratio de vno gradu qualitatis,ac de alio; ergo fi poteft forma clemenri exiftere fine aliquo gradu fuarum qualitatum, poteft fimiliter existerefine alio, quocirca \& fine omnibus; B hoc tamen eft impofibile, neque aliquis diceret formam elementi feruari poffe, deftuctis penitus omnibus gradibus fuarum qualıtarum.

Tertium Praterea fequeretur generationem mift effe alterationem, quia quicquid aduenit rei actı exiftentiper forman fpecificam, eft accidens: igitur fi formx elementorum funt in mifto integræ, \& dant cffe fpecificum fecundum fpecien fpecialifimam, accedens forma mifti non poteft effe nifi accidens, vel, fi nulla mifti forma: formis elementorumfuperuenire dicatur, miftum non effet vnum; quia id, quod conftituitur. à pluribus formis fubftantialibus diftinctis, \& ejufdem ordinis, \& fpecificis, non poteft efre $\mathrm{v}$ -

Duart $\tilde{u}_{0}$ num. Sequeretur. etiam. fecundum Auicennam, nij aliud effe:miftionem, quan congregationem, quem miftionis modum reicetum elle ab Ariftot.certum eft: probatur confequens; quia î formæelemëtortum integræ, ac perfect $x$ manent, non poffunt finu \& eande materia particulam, hoc enim de formis fub ftantialibus non fubordinatis, red eiufdem gradus, ne-imaginabile quidem eft, quia non potefteadem particula effe fimul iginis, \& a:qua, oportet igitur vnam materı particulam f. rmaignis informari,aliam forma acris,aliam forma aqux, \& aliam forma tetræ; \& has particulas fetangere inuicem; quarenon erit miltio: nifi fecundum tactum, qux eft congregatio. Si-

puintzu. mul etiam. fequeretur, non quamlibet mifti particulam efre miftam, aliqua enim particula effet purus ignis, aliqna purus aer, \&. fic de reliquis:attamen cenfuit Ariftoteles talem effe debere miftionem yt qualibet mifti particula miOpinio. Ata fit. Has omnes difficultates putauitfe euiAnerrois tare Auerroes, ftatuendo formas elementorum poffeintendi, \& remitti, \& frangi, \& caftıgari, ita $v$ : ex omnibus fiat vna forma media: fic enim. non funt amplius, plures forma fpecifica, fed vna, quam infequitur etiam qualitas vna me- $F$ dia oriens ex congreffu \& mutua alteratione, \&: caftıgatione excelléntiarum qualitatū. el ementarium. Sic etiam non fequitur, generationem cfie alterarionem, quia fit noua forma fubltan-tialis ipecifica, quxeft formamifti; \& elemen-ta non feruant amplius nomina; ac definitiones; ac species, quum per illam caftigationem iam defierint efle ignis, aer, aqua, terra. \& totum inceperiteffeaurum vel ferrum, vel aliud eiufmodi; hoc autemad faluandam generatio nus nuturam fatis cte, quum nouí efie fubitantiale acquiratu, \& noua fpecies fiat. Similiter non fiquitur amplius, miftionem effe cögregationem, quia form non funt amplius quatuor, fed funt factx vaa, qux fola informat quamlibet materix particulam; quare non eft congregatio, fed potius natur $x$, ac fubltantia vnio per mutuam clementorüalterationem. Sic tandem fit, vt fingula miftiparticula mifta fit, quoniam in qualibet ineft eadem forma miftionis; quamobrem feruatur ét mifti vnitas, quam lecundum opinionem Auicenix tuerinō pollumus.

\section{Scotiopinio ó argumenta. Cap. IV.}

$T$ Ertia eft opinio Scoti, quam apud eum legimis in 2. lib. Sent. diftiret. 15. putauit Scrtus \& formas, \& qualitates tlementorum in miltione pentus interire, \& nouam mifti formam generari, \& nouam qualitatem, qux eft temperatura mifti:quod autem dici folet, miftú conitare ex elemētis, id inquit ita efre int elligendum, quod forma mifti habet quandam fimilitudinem. \& conuenientiam cum formis elemētorum, quemadmodum nediū habet. quan. dam conuenientiam cum extremis, ex quibus conftre dicitur:fic propriam mifti qualitatem dicit effediucrfam à qualitatibus'elementorum, D: \& æque fimplicem, acillas, dici tamen ex illis conftare propterfimilitudinem, quam cum illis omnibus habet; quam fimilitudinem, \& conuenientram inquit Ariftotelem fignificaffe, quando dixit, remanere in mifto virtutes mifcibiliü, non ipfamifcibilia actu: putauit igitur Scotus nec formas, nec qualitates elementorum vllo modo remanere in.mifto, id eft, neque integras. neq; refractas: in qua opinione Thomam quoque fuille recentiores. Philofophi arbitranrur, quod. ego.falfum effe exiftimo, quum Thomas hoc in loco fententiam fuam praferens aperte dicat, formas quidem elemëtorum nullo modo fernari, fed penit us interire; at qualitates manere remiffas \& ad mediocritatem redactas: Cæterum parum refert, quid hic, quid ille fenferit, fatis nobis eritipfas per fe fententias, cuiufcunq; fuifle dicantur: expendere, Præcipua argumenta, quibus vtitur, vel vti poteft Scotus, hæe funt: Primum quidem de fornis fubftantialibus ita argumentatur: non funt multiplicanda entia fine neceffitate; at nullanos neceffitas cogit, vt in mıfto ponamus quatuor formas elementoriu, fed fufficit vnamiliti forma; ergo illæ in nifto ponendx non funt: minntem fic probat: non eft neceffarium, cas ponere proptcr operationes, quia miltum habit opcrationes proprias fpecie diftinctas ab operariombus elcmenroruni \& confequentes folam mifti forman : neque propter qualitatcs, nam qua'itas cuiulqque mifti:diffurt: 
fert fpecie à qualitatibus elementorum, \& fatis à forma mifti prouenis, at que feruatur, nec formis clementorum eget: neque demum propter gencrationem, quia tam forma mifti, quam forma clementorum habent enticatem fufficientem, yt poffinteffe termini fux gin :rationis, ix in lioc forma mifti non eget formis elemento rum, nifitanquam terınino à quo, hic autem in generatione mifti recedit:igitur in mifto non remanent forma elementorum. Secundo, fi formxelementorum feruarentur in mifto, miftum non effet vnum; plares enim formæ fpecifica conftituunt plura indiuidua de categoria fubftantix. Tertio, quamlibet fou mam fpecificam confequitur propria quantitas ; ergo fi quattor form ze elementoruas feruanturin mifto, crunt in codem plutes fimul quantitatcs, quodeft impolfibile. Quarto, duo termini generationis, à quo, \& ad quem, fimul manere non poffunt; at forma mifti, \& form elementorum fe raurus refpiciunt vt termini generationis oppofiti, quum ex elementis generetur triltum, \& exmifto elementa; ergo non poffunt in mifto form $x$ elementorum manere cum forma mifti. Quin. to, fequeretur non effe verum illud Ariftotelis dietum, generatio vnius eft corruprio alterius, quia quando generatur niftum, nihil interiret, fi elementa non intereunt. Qund autem etiam qualitates elementorum penitus intercant, 0 . ftenditur duobus argumentis. Primo, quia qualitates infequuntur formas, ergo quod de formis dicitur, idem de qualitatibus dicendum eft; atqui fornsas nullo modo feruarioftenfum eft; iz ergo neque qualitates feruaripoffunt. Praterea, fi deftructis formis qualitates manerent, accidens idem numero migraret de fubiecto in rubiêtum; fubiectum enim ascidentis eft compofitum ex materia \& forma confrans, quod deleta forma diciturinterire, \& adueniente alia forma dicitur alind compofitum generari; ergo mutatur fubiectum fub iifdem accidentibus; fi qualitates elementorū in mifto remanent, hxc autem eft migratio, quam impoffibilem effe 0 mnes $P$ hilofophi cenfuerunt.

\section{Aliorum Latinorum opinio of arga- menta. Cap. $V$.}

Varto fententia eff, vt mihi videtur, cxterorum Latinorum, qui de formis eleme torum Scoto confentientes dicunt, eas nullo modo feruari, neque integras, neque refractas; fed in qualitatibus ab eo difcrepant, has enim putant in miftoremanere fractas, \& ad mediocritatem redactas: tuetur hanc fententiam aperte Marfilius in r. libr. de Generat. \& ad eandem accedere videntur Thonas, \& Egidius, \& eam fequitur Ludouicus Buccaferreus, \& alii nonnulli recentiores: pio hac opinione, quantum ttinet ad formas fubfantiales, faciunt illa ca-
A dem argumenta, qux pro Scoto adducta fuere; de qualiratibus vero hi nituntur duobus potilf:mum argumentis : vnumex Ariftotele fumunt Primers in contexiu 84 . libri primi de Ortu \& interitu, v- argemen bidicit, mifcibilia non manere actu in mifto, vt $\vec{t} u m$. corpus \& album, neque etiam interire, fed feruari ip forum vires; quum enim dicat ea non manere actu, fignificas formas non feruari, etenius per formam res eft actu : quum autem dicat $m a$. nere mifcibilium vires, fignificat feruari quali.

B tates, nam fi hr quoque penitus interirent, nil vtiq; de elementis feruaretur in mifro, quo modo igitur manere dicerent ur eorum vires? alterun tinuile argumentum accipiunt ex aliis ver. bis A riftot clarioribus in 2. lsb. de Partibus ani- Seeunmal. cap, t. vbi dicit, tres in animali effe compo- dwm. fitiones; \& eatum primam effe ex iis corporibus. quz à nonnullis el ementa vocantur, fcilicerterra, aqua, aere, igni; fed ftatim fubsungit, melius foriafie effe, fi dicanus, corpora conftare ex viC ribus elementorum, quatm ex elementisipfis, \& virium nomineftatim afferit feintelligere qualitates elementares, quas etiam exprefle nominat, calorem, frigus, hum iditatem, \& ficcitatem, quas in quit effe materiam miftorum, quumex his conitent omnia nuifta; ceter as veroomnes qualitates inquit effe pofteriores, \& ab his deriuatas, proirde non efle materiam corporum, nempeleuitatem, grauitatcm, raritatem, denfitatem, \& alias eiulmodi : igitur claraaft Ariftot. $D$ fententia, quod clementa remaneant, non fecundum formas fubitantiales, fed fecundum qualitates; hxa aut $m$ quum fint contrari $x$, non poifunt fimul exiftere integramanentergo fracta \& rersuffe: fic igiturconditiones miltionis optime feruantur, mifcibilia namque actu in mifto non manent, quia form non feruantur; maitent tamē eorum vires, quia fermantur qualitates caitigat $x$, \& fract $x$, quod fenfus quoque confirmat; fentimus enim mifta effecalida, E frigida, \& huníida, \& ficca.

\section{Latinor ü difputatio aduerfus Auerro is fun- damentum de formis elemento- \\ rum. Cap. VI.}

Q Voniam autem Auerrois opinio eo po. tiffimum fundamento nititur; quod form $x$ elementorum intendi, acremitti poffunt, \& hac ratione participant quodammodo conditione accidentium, Latini fundament ü hoc demoliri conantur, quoniam eo fublata, fententia Auerr. manifefte corruit. Themas aduerfus Aucroem duobus vtiturargumentis, quorum vnoimprobatillud, quod Auerroes ait, formas elemento- Priwura rum effernedias intér fubtantiam \&accidens; argsmose idq; tale eft: fi hoc effet verum, daretur medium -tura com inter duo cötradictoria, quod quide eft manife- tras - ite falfu $m$ : probatur confequés, quia fubftantia werroom. \& accidens coniundtam habent oppofitionem

$$
\text { I } 3 \text { affir. }
$$


affirmationis \& negationis, quatenus accidens cft in fubiedo, fubltantia vero non eft in fubie-

$\sec d \ddot{n}$. Cto. Altero autem impugnatid, quod Auerroes dicit, formas elementorum fufcipere magis \& minus, hoc pacto: fi id concederetur, eflet in fubstantia continuus motus, quod Ariftoteles negat in lib. s. Phyfic. fic enim formze elementorum effent diuidux fecundum gradus, quemadmodum etiam qualitates; quapropter acquiri poffent gradus poft gradum, qui effet verus mo-

Fersium tus. Tertio argumentanturalij: fi vera effet opi- B nio Auerrois. fequeretur etiam formas miftorum fufcipere magis \& minus : confequens eft falfum, vtipfe quoq; Auerroes confitetur : confequentiam ita probant: in compofitione thesiacx, \& aliorum fimiliun, illa qux commifcentur, non funt el ementa, fed mifta, quz omnia feruant in theriaca vires fuas, quemadmodum in mifto feruantur el ementor um vires;itaque oporteret mifta quoque theriacam ingredientia intendi, ac remitti fecundum formas fuas fub- $\mathbf{C}$ ftantiales. Et quia dicere ad hoc aliquis poterat, non effe validam confequentiam, propterea quod Ariftoteles in capite de Miftione loquitur de fola miftione elementorum, non de com miftione aliorum, proindeid, quod dicitur . mifcibilia manere in mifto, defolis el ementis intell:gendumeft: hoc ipfi inquiuntnon effe verum; quia ibi Ariftoteles de mí́tione loquitur vniserfe,non de illa tantum, qua eff elementor um; nam fi de fola elementorum miftione loquerecur,debuiffet priusde elementorum natura differere, poftea vero de eorundem commiftione; loquitur ergo de quorumlibet corporum miftione; proinde illa, quat ab Ariftotele ibi dicuntur, omni prorfus miftioni. competere debent.

wares. Quarto, fic argumentantur; omnis fubftantia quantumcunq; imperfecta, perfectior eft quolibet accidente, quantumlibet perfecto; atqui secipere magis \& minus notat imperfectionem, däturautem accidentia, qua non recipiunt m2gis \& minus, vt patet; ergo nulla fubftantia recipit magis \& minus; hocenim dato, fequeretur aliqua accidentia effe perfectiora aliqua fub-

esintis. ftantia, quod dicendum non eft. Addunt etiam 2uthoritatem Ariftotelis in libro categoriarum, vbidicit, proprium effe fubftantix non fufcipe-

slwito. remagis \& minus:ad quam, fi quis dicat Ariftotelem de compofita fubftantia loqui, non de forma, qux eft fub ftantia fimplex, obiiciunt ip fi mp "gna hoc dici non poffe; quia fi formx elementorum sio folw- fufcipiant magis \& minus, ip fa quaque elemensiossi. ta fufcipient magis \& minus; quum enim à fuis formis elementa conftituantur, neceffe eft, fi forma ignis fufcipiat magis \& minus, ignem quoquealiquem effe magisignem, quam alium Alsafo- ignem. Et quia videtur Auerroes refpondere, hass: Ariftotel-ibiloqui de formis tantum perfetis, non de imperfectis, quales funt forma clemétorum; taacrefponfionem dupliciter impugnät.
A Primo,quoniam Arift. ibide fubftantia genera- 1 liter loquitur, neq; excipit imperfeetam; quum $t$ igiturid, quod generi competit, debeat etiam $t$. competere cuilibet fpeciei, de fubftantis quoq; $p$ -imperfectioribus debet Ariftotelis dictum verum effe: adde quod Arift. in eo libro quando propriúaliquodadducit, quod non omni competat, folet expreffe admonere, id non omni competere; de hoc tamen proprio fubftantiz nullam exprimit exceptionem. Secundo, quia Ariftot.lib. 8.Metaphyfic.context.10. inquit fpecies efle vt numeros, proinde non fufcipere magis \& minus, quemadmodum neque numeri fufipiunt magis \& minus; quicquid enim alicui numeroaddatur, vel detrahatur, illa numeri fpecies deftruitur; quamobrem fi elementa funt fpecies corporis naturalis, non poffunt effe magis vel minus, fed fuam effentiam habent in indiuifibili conftitutam.

\section{Defenfio opinionis Auerrois, \& declara- tio veritatis. Cap.VII.}

$\mathrm{H}^{\boldsymbol{E}}$ funt aliorum de miftione fententia, \& cotius difputationis fumma ea eft, quam retuilimus : in qua confiderare quisque poteft, in quo huiuscerei difficultas fit conftituta. Iam ad veritattis declaratiónem accedendum eft : \&e quum hac in refta intelligentia fententix A. uerrois, quam folam veram effe arbitror, confiftat, notanda fummopere eft hxc diftinctio, quarn apud Auerroem legimus 1o. Metaphyfic. comment.23.\& 6.Phyfic. 32. \& 3. Metcorol. cap. de Iride, medium inter extrema, quod per parti- $p$ cipationem, feu per compofitionem extremo- $t i$ rum medium dicitur, duplex eft : vnum, quod $n \epsilon$ differt fpecie ab vtroque extremo, idque ait $A$. pli uerroes vocari proprie medium, cuiusmodi ent rubeum interalbum \& nigrum; de quo medio non eft verum dietum illud, transeuntiab extremo ad extremum, neceffe eft tranfire per omnia E media,vt Auerroes notat lib. 2. de A nima, com. ment.105.alterum eft medium, quod non differt fpecie abaltero extremorum; ve fi multo albo parum nigriadmifceatur, remitticur albedo, \& fit minus album, fpecies tamen non mutatur, quia adhuc vocaturalbum, licet min us album fit: hoc igitur dicetur medium quodammodo inter nigrum, \& purum album; improprie t2men, quia non eft nifialbum, \& de tali medio verum eft dictum illud; transeunti enim contiF nuo progreffuab extremo ad extremum, neceffe eft per omnia eiusmodi media tranfire: ideo proprie loquendo, inten di \& remitti, latius patet, quem fufcipere magis \& minus, quamuis ampla quadam fignificaiione accepta confundi foleant;remiffio enım aibi effe poteft, \& absq; pat variationefpeciei, \& cum tpeciei varuatione: at qua magis \& minus non variant 1 peciem, \& compa - gis rationem denotant incer illa, qux fint elusdem $n$ my fpecici ; op ortet enim vurumq; elle album, fi di- pere 
cere liceat ynum effe magis album,alterum vero minus album. Intenfio igitur \& remiffio elfe poteft duobus modis;vno modo fine variatione fpeciei, quod proprie dicitur fufcipere magis \& minus, \& ita remiffio conftituit medium, quod non differt fpecie ab al tero extremorum; al tero modo cum mutatione fpeciei, \& fic remiffio conftituit medium, quod fpecie differt ab vtroque extremo. Hac diftinctione conftituta, poffumus totam huiufce rei veritatem duobus diatis concludere. Vnum eft: fi intendi \& remitti fumatur priori modo, prout idem eft ac fufcipere magis \& minus, nulla fubftantia fiue fimplex, fiue concreta, fiue perfecta, fiue imperfeEta, poteft intendi,vel remitti : hoc modo intel. lexit Ariftot. in cap. de Subftantia, quando dixit proprium effe fubstantix non fufcipere magis vel minus; hoc enim de omni fubftantia, \& abfque vllius exceptione verum eft; neq; enim elenienta,neq; form $x$ elementorum hoc modo intendi, zut remitti poffunt, nec Auerroes vnquam dixit, elementorum formas hoc modo fufcipere magis \& minus, nec fortaffe vllus Auerroiftarum, fi bene confideraret, hoc affereret; omnis enim fubftantia habet fuam effentiam conftitutam in indiuifibili, nec poteft dici magis, vel minus; quocirca etiam ignis quum fit fubftantia,non poteit de hoc igni magis prxdicari, quam de illo, ita vt hic fit magis ignis, quam ille, idq; fignificauit Ariftot.8. Metaphyf. contex.ro. quil locus, quäuis ab aduerfariis contra nos adductus, fentétix tamen noftr $x$ mirum in modum fauet: inquit ibi Ariftoteles fpecies efle vt numeros, \& fub ftantiam, qua eft fecundum formam, non fufcipere magis vel minus, fignificarevolens, cuiufq; fubftantize efrentiam indiuiduam effe, nec dici poffe magis, vel minus:quoniam igitur non potêt ignis effe magis, vel minus ignis, \& ynun quodque à fua forma conftituitur, neceffe eft, vt neque forma ignis fufcipiat magis, \& minus ; quia fi forma ita intenderctur, \& remitteretur, neceffe effet, vt ignis quo que diceretur magis \& minus ignis, quod Ariftoteles negat, túm in dicto loco, tum in lib. Categor. cap. de Subftantia : in hoc igitur fub. Atantia à qualitate diftinguitur, quod qualitas intendi acremitti poteft abfque mutatione fpesnda ciei, fubftantia vero minime. Alterū dictum eft: 45. fi fumatur intêtio \& remiflio altero modo,nem. pe cum variatione fpeciei, alicua fubftantia intendi \& remitti poteft : quamuis enim Ariftote- $F$ les dixerit, nullam fubftátiam poffe intendiaut remitti abfque mutatione fpeciei, quod vocatur fufcipere magis \& minus; non tamen negaret formas elementorum poffe remittilla remiflone, qua variatur fpecies: forma namque ignis poteft remitti, \& amittere aliquem gradum ; fed ea remifío mutat neceffario fpeciem, \& fit per admiftionemaliorum elementorum contrariorum, per quam alia quo q; elementa fimuliter re-
A mittuntur, \& exea remiffione, definunt effe ignis,aer,aqua,terra, \& fit noua fpecies, vt caro, vel aurum, quod reete ab A riftotele vocatum eft medium, \& diuerfum à mifcibilibus, quia eft tale medium, quod differt fpecie ab extremis. Huius dicti ratio confpici facile poteft,confiderando qualis effe debuerit natura illorum corporum, qux effent materia aliorum; debuerunt enim effe talia, vt eorum fornı variis modis remiff $x$ poffent euadere form $x$ omniū miftorum, B \& horum omnium fpecies conftituere: a deo vt omnes miftorum form $x$ (animam femper excipio, qux eit formaladdita formis elementorum) reipfa nihil aliud fint, quă gradu saliqui omniū formarum el ementariü, diuerf $x$ tamen formaliterà formis elementorü, quia non amplius conftituunt elementa, fed mifta, \& dant aliud effe fpecificum:hoc nifi fateamur, nullam poffumus afferre rationem cur magis elementa dicantur materia mifti, quam miftū mifti, nec magis ele-

C menta dicerentur materia hominis, quam femen materia hominis, \& homo materia cadaueris:nam fi formx el emétorum in miftione penitus interirent, ita ex eleme tis generaretur miftum per interitum formarum elementorum, vt expane fanguis per interitum form $x$ panis, \& ex feminehomoper interitum formafeminis, \& exhomine cadauer per interitum form $x$ hominis: nec fatis eft id, quod aliqui dicunt, qualitates elementorum remanere, \& hacratione dici D elementa manerevt materiam mifti ; certum enim êt, quamalibet rế conftitui'à fua forma fubftantiali, non à qualitatibus, quare nó ob id manere elementa dicuntur, dum forma fubftantiales penitus deletreftatuuntur : preterea hoc et-iam dato, nulla adinuc norari poteft diffimilitu. do interelementa, \& miftum, ex quo aliud miftum generetur;nam fape videmus, in mifto genito manere aliqua accidentia, qua fuerunt in mifto corrupto,vt in fanguine accidentia aliqua E cibariorum, so in homineaccidentia aliqua feminis, neque propterea dicitur manere in homine femen, tanquam eius materia.Neq; et:am fatis eft cum nonnullis dicere elementa manere in mifto, non actu, fed poteftate, quatenus porfunt iterum generari elementa ex eodem mifto: nam $f i$ ita inte! ligeretur id, quod A riftot.dicit, mifcibilia in mifto manere poteftate, non minus etiam miftũ maneret poteftate in alio $\mathrm{mi-}$ fto, quod ex eo generatur: nam fi ideo funt in pane elementa poteftate, quia poteft panis in elementa mutari, eadem ratione erit in pane caro, quia poteft panis mutari in carnem; imo co magis diceretur in pane ineffe caro poteftate, quam el ementa, quo facilior eft tranfitus à medio ad medım, quam à medio ad extremum; quodidem de qualitatibus dicendum eft; facilor enim debet effe tranfitusà temperie ad temperiem, quam à temperie ad qualitatem extremam: quoniam igitur cōfequens hoc Ariftoteli $\mathrm{P}_{4}$ aduer- 
aduel fatur, qui dixit,mifcibilia ita poteftate in- A ftere nequeat; fed quum ipfa forma fit ennftitu. effe in mifto, vt poffint iterum feparditheq; dixit inefie hoc eodem modo etiam miftis in $\mathrm{mi}$. fto, recefle eft fateri elementa ita remanere poteffate in mifzo, vt feruent aliquid a tus ; rema. nent enim cum amifínone fuarum excellentiarum, id eit, remanent aliqui gradus formarum elementarium, \&aliquiinterierunt, ita vt forma mifti realiter nil aliud fit, quam collectio plurium graduü fornarum elementarium, quibus acceffit noua formalitas, coituerunt cnim in naturam aliam diftinctam formaliter à naturis elementorum: \& hanc elementorum realitatem in miftis omnibus manentem refpicicbant illi prifci Philofophi, quidicebant, omnia funt aer, omnia funt aqua, vel aliud aliquod elementum, vel etiam plura, quxab ipfis principia reAiso mo-rum efle Atatuerentur. Propterea notanda maxido ele-meefthacdifferétia : dicimus hominem exelementa mentis ficritanquam exmateria, dicimus etiam fsta ma- hominem fieri ex femine, tanquam exmateria; tersa bo- fed nomine feminis nil aliud denotamus, quam missi, a- primam materiam cum priuatione; fic cnim filso modo gnificare volumus materiam primam, qua fit femen ef tacta hominis propria per pritationem, peculiamatersa riter oppofitam formx humanx, fignificatam homins. nomine forma coniuncta, qux efíforma ferrinis, \& conftituētem proprumm terminum à quo generationis hominis, qui in aduëtu formæ humanx recedit fimul cum forma feminis coniunata at quum dicimus hominem ex elementis generart; dicimus materiam fecundam remanentem in homine genito, ita ve non folum prima materia, fed etiam elementa dicantur mo. do aliquo remanere, quatenus manent fractro \& caftigata ipforum forma; manent enim aliqui ipfarum gradus, \& aliqui etiam recefferunt. ex qua remifsione interiit formalitas elemento. rum, \& accefsit alia formalitas, qua eft mifti,didiso mo- uerfa abilla. Ex his etiam colligimus,aliam effe do farma remifsioncm formarum elementarium, aliam remstt $\vec{n}$ qualitatum;nam qualitates recipiunt magis, \& twe alio minus, proinderemitti poffunt veraq; remifsio. gualss- ne, etiam illa, qua non variat fpeciem;aer enim ses. quandoque eit magis, quan doque eft minus calidus, \& tam intenfior, quam remifsior calor vocatur calor aereus, \& eft eiufdem focciei; non fic forma aeris, hxc enim remitti quidern poreft, non tamen ita; vt ferueturaer, çuoniam amiffo aliquo gradu, non eftamplius forma aeris, fed facta elt formalicuius mifti : ideo non eft ignorandum, non ex omni remifron equalizatis el ementaris fier remiffionem forma fubftantialis elementi; nam fi femper remiffionem qualitatis remifito foum $x$ infequeretur, elerx éta ex qualabet leui alteratione interirent, nec poffent diu conferuari : quamobrem ob eorum. conferuationem decreuit natura forınă cuiusl:bet elementi nó ita cfe alligatam certo cuidam: qualitatis graduifibi uaturali, vt abique illo exita in indiuifibili, \& ftatusum habeat grad a qualitatis perfecte natural em, non tamen ob quem. jibet receflum ab illogradu remittitur forma, quod eTet interire elementum, fed ad fui conferuationem forma requinit qualitatem non in indiuifibıli conftitutam, fed in quadam latit udi. ne certs quiburdam terminis conclufa ; idque maxime apparet in duobus elementis mediis, potiffimum yero in aere; nam eius calor poteft B norabiliter intendi, \& remittiabfque vlla inten. frone, velremiffione forma fubftantialis: at $f_{i}$ preter ftatutos latitudinis terminos intendatur, vel remittatur, neceffe eft formam a eris interire. Ignis vero vix aliquam admittit fuarum qualitatum reniffionem,cum qua poffit exiftere; aliquam tamen admittere dicendum eft, quum fit neceffarium, vtipfe quoque, dumagit, repatiaturabfque forma fux interitu.Patet igitur, non ornnem remiffonera qualitatis in elemento faC. cere remiffionem form $x$, quia remiffio formx femper eft cum elementi interitu, at qualitatis remifio non femper. Sed aduerfus hoc poffet 2 liquis obiicere argumentum illud, quo fispa diximus vfum efle Aueroem contra Aurennam: nam dicebat Auerroes; fiforma elementi ans pateft integra feruari, ablatoaliqun gradu fua cöt. qualitatis naturalis, ergo etiam ablato alio, pro- usc inde \& ablatis omnibus, quia de quolibet grad u eadem eft ratio: hoc igitur codemargumento D videtur oftendi poffe, formam elementi nó por. fe integram feruaricum remifsione qualitatis, quoniam huius cötrasium voluit A gerrues hoc argumento demonftrare. Egovero hac in refum in opinione multorum, qui putant argumétten hoc $A$ uerrois aduerfus Auicennam nibil habere roboris, ficet fententia illa Auicenna falfa fit jetenim inefficax eft ratio à diuifis ad coniractum:potef quidem exiftere forma elementi fire quoliber gradu qualitatis feparatim accepto, E. fed nō proprerea fine omnibus fimul, vt aerfortaffe feruari potef fine vno, vel fine duobus gradibus fui naturalis caloris, at non fine tribus; quemadmodum famnum quadrupes fabit fine vno pede, \& quolibet vno ablaro ftabit, quia de fingulo eadem eft rario, dummodo quilibet feorfum accipiatur, manentibus aliis; fed duob.ablatis,non amplius ftabit. Nifi pro Auerrois de- Defer fenfione dicamus, ipfum loqui de remifsione graduum qualitatum extra ftatutos linites, hoc to da F enim conftituendum videtur iuxta opinionem rox. Auicenna: quia fi formis elementorum integris feruatus (ve ipfe dicit) non funt tamen elementa, fed eft genitum miftum, videtur effe neceffarium, ve dicat, qualitates efle frantas extra latitudineru naturalem: \& hac ratione verum eft id, quod Auerroes dicit, eandem effe rationem de vno gradu, ac de omnibus, riempede vno, qui fit vltra limites naturales; quoniam eft contra clensenti naturan \& csicedere vno, \& excedere dua 
reduobns, \& omnibus excedere, quia nullo horum modoferuari clemécun poteft: Itaq; fi hoc intelligat A uerroes, potelt eius argume êtum de. fendi.A uerroifte vero abfq; dubio decipiuntur, putantes argumcutum illud abiolute quoq; validum effe, quum fit inerus cauillus.

\section{Quodea, que badenis declarata eft, fen- tentin, Auerrois fuerit. Cap. VIII.}

T Oc modo, quem hafenus declarauimus, 1 defenditur optime opinio Auerrois, caque fola veracit, dum fic intelligitur, quod autem Aueroes itaintellexerit elementa in mifto $m a$ nere frata, \& formas elementares caftigatas cum mutatione fpecici, non eft quod in demonftrando laboremus; efc enim clariffimum legentibus commentarium illnd 67 . lihri 3 . de Calo, cuius verba non referimus, led alis confideranda relinquimus. Notandus etiam eftalius a)ud Auerroen: locus in comment. 23. lib. 10. Misaphyfic. vbiduo illa mediorum genera ponit; vnum, quod ab aitero extremonoudiffert fpecie, fed folum fecundum magis \& minus 3 alterum vero, qund ipecie differ ab viroque extremo: deindefubiungiteffe bi motum, vi eft magis, \& minus. vbiveroomnia media differunt fpecie ab extremis, 1 bi-non effe motum, ex hisautem duabus propofitionibus col. ligitur in fecunda figura hac conclufio, ergo vbi omnia mcdia differunt pecie ab extremis, ibi non eft magis \& minus: quoniam igitur rsifa omnia ab Ariftotele vocantur media inter clementa, \&ab elementis fpecie differunt, fententia Auerrois cf; élementa non recipercmangis \& minus, fed intendi \& remitti cü variarionc fpeciei: fic igiturintelligenda funt ca, quz alibi dicuntur ab Auerroe, prafertim in comment.67. lib. 3. de Colo, vbi etiam notare poffumus obieftionem, quars contra fe affert, \& eius folutionem; obiectionnim efilla vulgata; fequeretur formas fubftantiales recipere magis \& minus, quod Ariftot. aduerfatur: folutio autem Aucrois non illa eft, quam ci multi tribuunt, vt excipiatformas elementorum tanquam imperfectas, \& afferat eas recipere magis \& minus: non enim conecdit Auerroes eas. recipere magis \& minus, fed veritatem declarans imquit, ex admiftione formarum elementarium prouenirealiam formam, ficutlex commiftone albi \& nigrifiunt multicolores medii : fic a utem fignificat formaselementares remiti ea tantum remifione, quæ fpeciem variat, non illa, quæ facit minus rale in eadem fpecse; iam enim dixerat in alio à nobis notato loco, vbi media differunt fpecic ab extremis, ibi non effe magis \& minus; differre autem niftà ab elementis fpecie afferit aperte Aucrrees, dum ait, ex aùmifione: formarum elenentarium provenirc aliam for-
A mam, quod ctiam clare dicit, vtens exemplo colorum : nan colores medii differunt fpecie ab cxtrearis, vt alias in comment. 32. lib. 6. Phyfic. ipfemet dixerat: quoetiam in loco inquitmedia hac differentia fpecieabextremis non effe nifi finita numero, fic enim patet, neceffarium effe, vt fini: fint fpecies miftorum, nec polfint effe infinita. Rationem autem cur formx eleementares itapoffint intendi \& remitti, \& $\mathrm{mi}^{\mathrm{i}}$ grarc in formas miftorū, refertAuerroes in ha3 rum formarum imperfectionem, dicens eas in hoc fimiles effe accidentibus quodammodo; non furt enim ormnino fimiles quum non recipiant magis \& minus vt accidentia, fed folum quatenus modo aliquo intendi acremittipoffunt, quod uon competit aliis formis futfan, tialibus. Hxc eft abfq; dubio opinio Auerrois, \& ip farei veritas, quam ego diu exiftimaui nullum Auerrortarum a fequntuz fuife; quum enim vfi non fint ea difinatore, qua nos vfifuC mus, \& ea quidemngn à nobis inuenta, fed ab ipfo Auerroe pofita, non potuêre fe penitus à magnis difficultatibus explicare, nec plene Auerrois fententian tueri: fed quum mihi \&ipla reinatura; \& confideratio yerborum Ariftot elis \& Auerrois bancfententiam fuggeffifet, res enim pene ipfa log̣ui videtur; poiteacontigit, yt quuin de hac re publice in Patauina Academia differuiffem, quidā difripulus meus valde erıditus, \& ex Carmelitana familia religiofus, lztus ad me accedēs dixerit, eandem fuiffe fententiam Ioannis Bacconii Dottoris fui, \& locum 1o. Bacnotawit, quemifateormeantca non anizaduer- coriss. tiffe; quanquam femper Bacconii fcripta libentínime legi, \&illius viri do frinam plurimi feci: quum igitur fratim locum illü auide legifferm, qui eft in lib. 3. Séntent. diftinks. 16. non potui non eius funmum iudicium roximopere ad. mirarimon poteft enim melius, aut exquifitius huiufce reiveritas declarari, quam ibideclareturà Bacconio, qui ea in $r e$, vt in alis quoq; facerefolitus eft, foidifime philofophatur, \& ex ipfa rei natura veritaten petit. In pradicto autem loco ipfe non modo diftinctionem illam mediorum, qua apud Auerroem clare legitur, ad huiusquxftionis folutionem applicuit, quod cxteri Auerroifta non fecerunt; fed etiam vfus. eft eifdem vocibus, quas ego adrem hanc declarandam excogitaueram, reàliter, \& formaliter; realitatem enim eandem formarú elemen. tarium inquit effe in clementis, \& in mifto, fed diuerfas formalitates, prout varias fpecies conftiturut : \& ne eandem rew farerivideatureffe clementun:, ac miftum, inquit, non effe in mifto realitatem formarum elementarium, fed effe in mifto realitatem candem, qua fuit realitas formarum elenchtarium; eanem enim reseft, qux fuirelenenta, \& nunc eft mifum, fed mitata ef formalitas, proinde etian fpecies, qux onsia verifime dicuniur.

$$
\text { I) Confir- }
$$


Confirmatio pradiate fententia ex dictorum Ariftotelis confideratione.

cap. IX.

Ane, quam declarauimus, Ariftot. fuiffe fententiam, oftendere facile poffumus varis in locis ipfius dicta confiderando. Primum quidem illa, qua dicuntur in poltremo capite libri primi de ortu \& interitu, huic foli fententix atteftantur: nam in contextu 89 . inq̨uit, $\mathrm{mi}$ fcibilianon mutari alierum tantum in alterum, fed v́rumq; in al terum, ita vt nonalterumipforuin generetur, fed medium, \& commune; medium enim \& commune non appellaret, nifialiqua ex parte retineret vtriufque naturam; \&e hoc commune inquit effe a liud, \& differens fpecie ab extremis: hrec autem non habent locum, nifi iuxta opinionem $A$ uerrois à nobis declaratam; quî enim fieri potêt, vt fimul aqua mutetur in ignem, \& ignis in aquam, ita vt id, quod generatur, nec fit ignis, ngc aqua, fed quid medium, in quo amboilla feruenrur, nifi co, quem pradiximus, modo? miftum enim differt fpecie ab igni, \& ab aqua, \& participat gradibus naturx vtriufque, quum tamen ipfum fit vnius tantum naturx. Inquit etiam ibi Arifoteles in contextu $\$_{4}$. mifcibilia nec omnino remanere ficut corpus album, qux integra penitus coniunguntur; neque etiam interire, fed feruare vires ipforū; vires autem intelligit realitates formarum elementarium, qux fecundum aliquos gradusferuantur; nam itatim fubiungit; inde fieri ve poffint iterum feparari, nam adiectis cuilibetillis gradibus, qui abiuncti fuerant, fufcipiuntiterum priftinam formalitatem, \& dicuntur ex mifto el cmenta generari, hoc enim faci lius eft quam formalitarem, \& realitatem tctam elementi produci, ficuti quando ex aqua generàtur ignis;nonenim diceret Ariftoteles ignem commintum fuiffe aqua, \& poftea feparatum, quia nihil form $x$ ignis in aqua inerat; $E$ nec poteft vlla aduerfariorum feu proterutas, feu cauillatio reete interpretari verbum illud, feparari; non enim dicuntur feparari, nifi illa, quz ita erant coriunea, vt modo aliquo ineffent actu; nec Ariftot. aliunde colligit ea polfe feparari, nifi ex eo, quod dixerat,mitcibilia non pentus interire: fed adhucclarius loquitur Ariftoteles in contextu 48. libri fecundi, dum ait; quando in duorum elementorum congreffu $\mathrm{v}$ num eftabfolute actu, \& alterum poteftate, non eft miftio, fed huius generatio, huius vero interitus; at quando neutrum omnino interiit, fed modo aliquo calidum factum eft frigidum, \& frigidum eft factums calidum, \& neutrum eft aCu abfolute, fed tranlist vtruinque in quoddam medium, tunc eft miftio: non vult igitur Arift. clementa in nufto ita efie poteftate, vinihil reti neant fui actus, fed ita poteftate, vt etiam actu; nonpolfunt aüt effe actu, nail per fuas formas;
A quare putauit Ariftot. formas elementorum aliquo modo feruari in mifto; \& ibidem aperteinquit, elementa in miftione folas amittere excellentias fuas, \& frangi, nec penitus interire. Illud autem eft femper animaduertendum, Ariftotelem fornus elementorum non aliis nominibus appellare, quam nominibus fuarum qualitatum: ideo quando in iis libris qualitates nominat, non eft credendum, eas vt accidentia à for$m$ is diftincta nominari, fed fumi loco formaB rum, quiaformæ elementorum per has qualitates agunt extra fe: quando enim Ariftoteles dicit, elementa fy mbola facile mutari inuicem, $v t$ aquam in aerem, mutato frigido in calidum, \& manente humiditate; fi intelligamus in folis qualitatibus mutationem fieri; ita ve non in formis fubftantialıbus, non erit generatio, qualem vult Ariftot. eam mutationë effe, fed fola alteratio; nifi enim mutetur forma fubstantialis a. qua, non fit aer, fed manet aqua, licet facta ca-

C lida; formas igitur præcipue refpicit Ariftoteles, \& inquit has non penitus interire, fed folü excellentias fuas amittere. Propterea etiam primocàpit. librifecundi de parribus animalium, quando dicit, miftum conftare potius ex viribus elementorum, quam ex elementis'ipfis, \& vires inquit effe calidum, frigidum, humidum, \& ficcum, per hec non intelligit nifi formas elementorum, \& fignificare vult elementanon remanere fecundum fuum effe formale, quum iam per miftion em fuas formalitates amiferint, \& ita non ex elementis proprie loquendo conftare miltum, fed potius ex corum viribus, hoc eft, ex realitatibus formarum elementarium, quae aliam formalitatem fufceperunt: hocautem ibi eft manifeftiffimum, quum Ariftoteles dicat, calorem, frigus, humiditatem, \& ficcitatem matriam effe miftorum corporum; nam fi hæc vt accidentia accipiantur, uici non poffunt materia corporum, quia materia non eft nifi fubftantia, proinde milta non ex his qualitatihus vt ex materia conftare dicuntur, fed ex ipfa fubftantia elem entorum, qux ab corum formis conftituitur: quod fi etiam qualitates dicuntur for$m x$ elementorum, quatenus conftituunt elementa vt elementa funt, id tamen non eft nifi prafuppofitis formis fubftantialibus; has enim fi abiungamus, euanef cit officium qualitatum, qux non amplius materiam miftorum conftituunt. Confiderandum praterca eft, tum in eo $10 c 0$, tum in contex. 34 . libri $x$. de ortu \& interitu Gracum nomen, Júvapers, quo ibi Ariftoteles vtitur, vbilatinus codex habet, virtutes, feu vires; nam dúvacess, fignificat etiam propriam rei naturam, fignificatetiam poteftatem, qux refpicit actum; quare optime vfurpatur ad lignifcandas formas el ementorum fraetas, \& poreftatem habentes actotam fuam perfectionem. Per hac èt optime declaramus modum, quo Arift. is 11 o poftremo cap.lib.I.de ortu \& interitu mi- 
ftionem fieri ftatuit : inquit enim mifcibilia primum debere fe mutuo diuidere in partes paruas, ideog; oportere ea effe li quida,vel aliq̨uod faltem ipforum, vt poffit aliorum partes penctrare, \& ita diuidiac diuidere in paruas partes; nec dicit in minimas, quia id verum non effet, neq; enim abfolute minimum intelligi poffet, neque minimum naturale, nam minimum ab. folute non datur, quum omne quantum fit diuiduum in infinitum;minimum veronaturale datur quidem, vt ait Ariftot. in I. Phy fic $x$ a ufcultationis difputans contra Anaxagoram, \& eft il. lud vltimum, in quo poteft forma feruari in diuifione cuiufq; corporis naturalis; eft enim neceffarium perueniread paruam particulam, qua vlterius quidem diuidi poteft ve quanta, at, fi diuidatur, non poteft forma amplius feruariin talia igitur minima fi intelligeremus diuifionem milcibilium fieri in ipfa miftione, oporteret $x$ quales femper inter fe effe portiones omnium mifcibilium, fcu eandem in omnibus miftis effe illorum menfuram, \& proportionem inter fe, quod minime verum eft; fed oportet vnum aliis dominari, variu mque effe dominium, \& variam elementorum proportionem pro diuerfis miftorum naturis. Facta igiturmifcibilıum diuifione mutua in partes paruas, neceffe eft, yt propter qualitatum interfe contrarietatein fiat inter ip fa actio \& paffio mutua, per quam elementa fe mutuo frangant, \& ad inediocritatem redigant; quod quidem poffumus cum Ariftotel in duobus mifcibılibus confiderare, id enim pluribus quoque accommodari poterit;itaque fi generandum fit miftum, quod fex gradibus referat naturam terra, duobus autem naturam aeris, fiet actio mutua inter particulas terra, \& particulas acris, \& aernaturam terra, quam in ofto gradibus confiftere ftatuimus, imminuet duobus gradibus, ita vt fex gradus terra remaneant; terra vero tanquam praeualens detrahet de natura aeris fex gradus, vi duo tantum relinquantur; \& fic tam particula terræ, quam particula aeris erit facta eiufdem natura, quia v traqua redolebit fex gradus naturze terr $x$, \& duos natura acris; \& fingula nec terra amplius erit, nec aer, fed quiddam medium, vtaurum : hacigitur ratione qualibet pars mifti eft mifta; qualibet enim pars eft aurum, neque cft amplius aer terra appofitus, fed \& aer, \& terra mutata in aurum setinens ex parte naturam terr $x$, \& ex parte naturam aeris; qunniam vtriufque clementifor$m x$ fract $x$, \& caftigatx migrarunt in formam mediam, qux eft forma auri. Sic etiam qualitates fe mutuo caftigant, \& fit qualitas vna media, qua cuiufq; mifti temperatura appellatur. Praterea confirmatur etiam maxime hacféntentia perea, qua ab Arift. dicuntur in cuntexr.10.8. Metaphyfic. quem locum aduerfarij contra nos adduxerunt; inquit enım fpecies effe ficut numeros, quia numero dempta vaitate maneat $3-$
A lize vnitates realiter, fed mutata eft formalitas, $\&$ facta alia fpecies numeri : quemadmodum ig itur numeris detractio, \& additio fieri potelt manentibus iifdem realiter vnitatibus, qux relinquuntur; fed mutata fpecie numeri; ita formz elementorum intenfionem, \& remiffionem recipiunt, ita tamen vt mutetur formalitas, \& fiat alia fpecies, licet aliqui earundem formarum gradus feruentur; quod eft feruari realıtat ē graduum formarum el ementarium, fed formalita-

B tem, ac fpeciem mutari: quod idem in numeris euenire videmus ; propterea ad rem hanc declarandam maxime accommodatum eft exemplum numerorum, quod ibi ab Ariftotel.sonfideratur.

\section{Confirmatio eiufdem Sententia auct oritate Gracorum interpretum. Cap. X.}

7 Andem fententiam Alexander \& Ioannes Alexan-

EGrammaticus fequuti funt. Alexander e. der.

C nim in libello fuo de miftionedeclarans quomodo miftio fiat, inquit, mifcibilia inter fe mutuoagunt \& patiuntur; fed neutrum interimit alterum penitus, quia prius definit poffeagere, quam prorfus verterit alterūin naturam fuam; quare miftio eft mutatio quxdam fine interitu: non vult igitur Alexander elementainterire, \& aperte dicit ea non amittere nifi excellentias fuas, $q$ eft remanere fracta, \& hebetata: poftea dicit miftum non effe aliquod ex mifcibilibus, fed effe illa omnia poteltate: nifi igiturinuicem pugnent Alexandri dieta, fignificat elementa amittere fuas formalitates, \& fuum effe fpecificum; quia fi hoc setinerent, iam miftum effet actu ignis, \& aer, \& aq̣ua, \& terra, feruare tamen fuas realitates, hoceft, non prorfus interiiffe: nam poitea quoque declarans quomodo maneant poteftate in wifto, inquit, funt poteftate, quoniam exiguo egent auxilio, vt recuperent naturam fuam; quum enim non tota fit aE miffa, fed folum hebetata, poffunt per additionem eius, quod amiffum erat, re dire in fuam naturam integram, propterea (inquit) nonomino generatione \& interitu indigent vt feparentur, fed mutatione aliqua. Itaque arbitratur Alexander formas elementorum non effe in mifto penitus poteftate, ficuti in prima materia, \& ficut in femine humano eft poteftate forma hominis; fed poteftatem intelligit, qux coniunctum habeat aliquid actus, at non integrum aF etum: ideo hanc integritatem poftea cquiri dicitper illam mutationem, qua miftum in elementa diffoluitur, eamque non effe omnino ges nerationem, fed mutarionem quandam, qua eft Miftio, dimidiata quxdam generatio : non eft autem i. Fo mifti gnorandu, qualis fit hac mutatio, qua miftum defjoluin elementa diffoluitus, \& qua ex elementisge- tiseft neratur miftum, ne forte opinemur, eam non in mutat st fubltantia, fed in folis accidentibus mutatio- $\int_{2} b f_{\text {ans }}$ nem effe qux dicituralteratio;quinimo eft fub- rablis. 
ftantialis mutatio, nequead aliam mutationis fecien redigitur, quam ad gencrationem \& interium : nam fi horum corporum formalitates fo: femus, eft perfecta seneratio, \&xperfectus iisteritus, nam penitus intereunt in miftione fornialitates elementorum, \&produciturn oua formalitas, qua eft mifti; vel interit formalitas mifti, \& generantur formalitates elementorum, quando miftum inelementa diffoluirur : at firealicatem tantummodorefpiciamus, non eftperfelta generatio, nec perfectus interitus, quemadmodum antea declarauimus : idquerefpexit Alexander, quando dixit effe dimidiatam generationem, imo \& Arift.iple, quando in capire de miftione dixit, mifcibilia non penitus interire, red al iquo modofertari. Notat autem ibidem Alexander quoddam fumma animaduerfione dignum, atqueverifimum : quoniam enim dicente Ariftotele mifcrbilia polfe ex milko iterum feparari, criderealiquis poterat clementa redire eadem numero, qua prius in miftionem

Elemëta nonfepserantur $\dot{a}$ motroes dem numere. gueprous eraet.

venerant; ideo nos monet ea non redire penitus eadem, fed alia fecundum numerum, cadem autem lecundum fpeciem tantum; quum enim proprias formalitatesamiferint, \& defierinterte ignis,aer, aqua, terra, hacrationeinterierunt; id autem, quod fem el interiit, iuxta opinionem Ariftotel. non poteftidem numeroviquam redire: igitur quando itcrum feparantur, redeunt eadem fecunduan fpeciem, idq; fatis facıliter, quia non totá fuam naturam, id eft, non toiārealitatem amifcrunt. Ex his colligere poffumus, non ead -melfe hancfeparationem elementorum ex mi to, atque illam, gua ex meracongregatione dicunturaliqua feparari abfque rlla mutatione, vt quando ex aceruo rritici grana feparantur: hacenin eadem numerofunt, facta feparatione, qux prius in compofitione, \& ante compofitionem erant, quia nulla eft facta naturarum mutatio; \& el ementa feparanturà mifto, in quo non oninino erant a $\mathrm{au}$, proinde feparantur cum alteratione, quanon efiabfolute in arcidentibus, fed eft dimidiata quadam generatio, tilem enimalterationem Ariftotel.in definitione miftionis intellexits non enim fieret naturarum vnio, \& plurium reductio ad naturam vnam, fi feruatis penitus formis fubftantialibus in folis accidentibus mutatio feretinon pofunt igirur el ementa ex mifto ita feparari, vt redeant eadem numero, quz in miftionem venerunt. Eiufdem fententia fuit abfque dubio Ioann.

50. Cram. Grammaticus in interpretando capite de miftione in calce libr.2.de ortu \& interitu:ibi enim in contextu $8 z$ declarans quomodo mifcibilia fiut poseftate in mitto, inquit, non funt peritus poteftaterefpetia tus pirmi, quemadmodum quando dicimus aquan efiepotiftate aerem; neque funt poteftate refpectu fecundi actus tancummodo, ficuti quando dicimus, Gcometram dormienten geometrizare poteftate,
A quum habeat actum primum perfectum ; fed tertio modo medio, vt quando dicimus Geometram ebrium habere poteftatem geometrizandi, nam habet qุuidem a tum $\mathrm{fr}^{\mathrm{r}} \mathrm{mum}$, id eft, habitum Gcometrix, fed obfuicatum, \& ispuratum, ideo non perfecte geomeirizas: fie elementa funt in milto fecundum actum impuratum, quiconiunctam habet poteftatem adipifcendifuamintegram perfectionem. Hoc idem dixit Ioannes in context.84.vbictiam aperte afB ferit,elementain miftionennn totam fuam formamamirtcre, fed folum excellentian $2 x$ complementum fux forma, proinde remancre in mifto forras elementorm in completas, \& im. perfectas : elementa igitur fecundum Ioann. Grammaticum non penitus poteftate in mifo funt, fed \& a Ecu, \&foteftate, quatenus naturam fuam non perfecte feruant. Deinde etiars in contexiusq. inquit, mifcibilia non prorfusinterimerefe muruo, fed folum frangere mutus

C excelientias fuas, ita vimedium quoddarn remaneai, qued ex parte redolet naturam fingulorum; quam Arift. quoque fententiam fuifie sam" oftendimus:quajropter de Gracorum opinione none?dubitandum.

\section{Solutioargumentorum pro Auicenna ad- ductorum. Cap. XI.}

TTEritate declarata, omnia aliorum aduerD fantia argumenta foluenda runt; \& primo loco illa, qua pro Auicenna adduximus. Ad primum igirur concedimus; formas elemento rum manere in mifto: fed gquum dicit, non poffunt intendi, autremitti, quum fint fub ftantiales, ergo manent integra, negamus antecedens; iam enim docuinus quornocio intendantur, ze remittanturforma elementorum, \& quomodo neq;intendi, neq̧; remutti poffint. Ad fecundum dicimus, Ariftot. non ideo dixiffe, alteratorum, $E$ quod putauerit miftionem efle meram alterationem in accidentibus absque vlla fubftantix mutatione, fed quia fi dixifer, corruptorum, perfeetum mifcibilium interitum intelligere potuiffemus; quodaduerfaretur iis, qua prius dixerat, nempe mifcibilia non interire, fed leruari ia mifto maluitergo dicere, alteratorum, ad fignificandam alterationem cum aliqua mutatione fubftantia, fiquidem absque hacnon fieretilla vnio, quam effe ipfam miftionis effentiam lam

F diximus. Ad tertium \& ad quartum dicimus, omnia effe concedenda ; is enim oftenditur elementa manere in mifto, fed non oftenditur manere integra. Ad quintum petenda eft refponfio ex is, qua foripfirmus alias de motu grauium \& leuiumillud enim, quod Arift. dixit, miłkū mo ueri iuxta elementü præualens, non ita eft intelligendü.vt forma elemĕti praualëtis disazur in. tegra effe in mifto, \& ita actu mouere miftu ; fed intelligendum eft, nō clle in mifto aliud moués, 
nifr ipfam mifti formam; qux magis redolet forman clementis preualetis, quamahorum, idco co motu mouct, quo illa : hoc ergo fignificauit A riftot. qui non dixit miftum à præualente elemento moucri, quafi miftum, feu eius forma fit moucns; fed dixit moveri lecundum praulens clcmentum. Ad fextum refpondemus, mintionem, \& gencrationem mifti dillerre quiden ratione, fed re idem efle; non poteft cnim vera mide ftio ficri, quin mifti generatio liat: quomodo autem differant ratione, al bi confiderabimus : nunc fatis eft fidicamus, miftionem vocari rationeg galduum mif́cibilium, qui leruantur, vocarlatem interitum elementorum, \& generationem mifti ratione graduum deperditorum, fic enim eft generatio mift, \& deftructio forma-

ti- litatum elementorum. Ad poftremum dicimus: nilaliud effe diflolui miftum in elementa, quam clementa facile recuperare gradus deperditos, propterea quiod non omnes gradus intericrunt: ex hocigitur nilaliud in ferrur quam non fuille in mıfto elensenta integra, fed fracta; ficut enim diffoluitur miftum in elementa per amifforum graduum recuperationem, ita generatur miftum ex elementorum compofitione per eorundem graduum amiffionem.

\section{Solutio argumentorum scoti. Cap. XII.}

$\therefore \quad-\quad D$ primum Scoti negamus fequi id, quod Aiple infert, multiplicari entia. fine neceffitate: fequeretur quidem, fi cum nonnullis diceremus, formam mifti effe additā formis elementorum, \& re diftinctam ab illis in ipfo mifto; at nosafferimus, folam miftiformam fufficeread miftum conftituendum, \&ad omnes operationes edendas, fed ad hanc effe neceffarias formas elementorum, quum fit idem re, quod ill $x$; proinde illis penitus fublatis nulla mifti forma porfit exiftere: tanta igitur eft neceflitas formarum elemētarium in mifto; quanta ipfus formæ mi. fti, quum har non diftinguatur.re abillis, fed fit illæ omnes ad vnitatem redactx per miftionem. d.ü- Ad fecundum negamus confequens, nam formæelementorum non manent in mifto vt qua. tuor form $x$; fed vt fact $x$ vna, fiquidem mùltis realitatibus aduenit vna formalitas, proinde miftum eft vnum:- Ad.tertium. fimiliter negamus confequens; nam poft clementorum congreffum non funt amplius in mifto quatuor quan-titates, red vna ex omnibus facta eft; quid au. tem abfurdi, fi ex pluribus quantis coniunctis: vnum quantum fieri afferamus? vtautem omnis fallacia deregatur, animaduertendum eft, quantitatem infe qui naturam materix \& illi effe coxuam;terminos autem quantitatis cuiq; rei præfcrbi à luaforma: quoniam igiturin miftrone perierunt formalitares el ementorum \& vna mifti formalitas producta eft, factum etiā eft ynum
A quantum ex quatuor materix portionib. quantis timul iunctis, quibus vnici termini funt præfcripti à forma, qua vna tantum êt, non plures, nempe forma nifti : quum igitur vnici fint termini totius illius quantitatis, vna cft quantitas. Sed imaginatus eft $S$ cotus, nos dicere formas clementorum manere in mifto integras, \& cum eis manere proprios terminos à fungula forma tributos fux portioni materix: quod quidem nos non dicimus, quia neque verum, neq̧; ima $B$ ginabile cft. Ad quartum dicimus, totum effe ginable cet. Ad quartum dicimus, tocum effe Adquar concedendum;nam form elementorum prout tum. clementorum form $x$ funt, in generatione mifti funt terminus à quo, nō terminus ad quem; nec poflunt funul ellecum formamititi, quia non potelt eadem res effe fimul miftum \& elemēta : terminos igitur generationis oppolitos fimul exifterc non dicimus; quamuis enim eadem fit realitas formæ mifti, \& formarū elementarium, diuerlextamen funt formalitates, \& hoc fatis eft ad diftinguendos generationis terminos, à quo, \& ad quem; liquidem termini funt ipf $x$ formaE materix portio maneat, qux in elementis fuit, ad fecundū acceptum ex primo capire fecundi $A d$ feç̋litates, quæ nunquam fimul exiftunt. Ad quintum negandum eft confequens: quum enim in generatione mifti intereant formalitates formarum elementarium, \& ita definant conftituere elementa, \& incipiant conftituere miftum differens fpecie abelementis, generatio mifti eft interttus elementorum; pereunt enim for$\mathrm{m} x$, quatenus form $x$ elementorum funt, \& fubeunt nouam formalitatem, \& ita fit alia forma. Adprimum de qualitatibus patet refponfio ex Ad fexiis quæ dicta funt, negamus enim, formas ele- tum. mentorum penitus interire: quare fi ita mane$r e, v c l$ non manerc qualitates debent, vt form $x$, qualitates quoque elementares in mifto fract $x$, \& caftigata remanent. Ad alterum negamus confequens: quum enim fubiectum, in qtio accidentia inhrent, fit prima materia, vt aliàs demonftrauimus, \& in mifto eadem qualitates non migrantin aliud fubiectum, fed potius idem earum fubiectum remanet. Sed eo inualidius hoc argumentum eft, quo nos dicimus formas quoque fubftantiales aliquo modo feruari, quocirca ne fingi quidem poteft migratio vila accidentis defubiecto in fubiectum.

\section{Solutio argumentorum Thoma, \& aliorum Latinotum. Cap: XIII.}

A D primum Thome fumptum ex verbis-A-Ad priA riftot. in contex. 84.lib...de generarione, \& mum. de partibus animaliū, dicemus, omnia clle con-dism. cedenda; quatenus oftendunt q!ali ates feruari fiactas, \& caftigatas, \& ad vnam mediam reáaCtas: fed q'iatenus oftëderefe putat, formas erementorü fubftantiales nullo modo feruari, negamus eam effe mentem: Arift. dì ait vires cle-
montogamus eam effe mentem Arift. du-ait vires cle-
mchto-

\section{Adquin tum.}

\section{Adept: mum.}

In libr.

de communire. rumgenorat. 
menerum manere, ve velit folus qualitutes fer- $\Lambda$ unulinc form is : iam cnim divimus, perviresefomentommbilignificari gradus fommumefemcntarum remanches, hoe eft, icoldtules fermansfubalia lommlitate, viantea locosil.

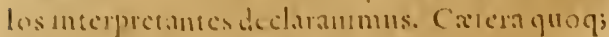

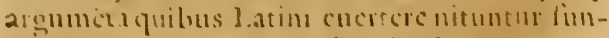
damen nun Ancrois de fomis clenentemen, ficilefoluments. Ad primum com, quo Tho-

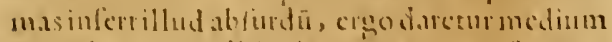

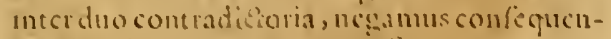
tiad probatoncmatem pollimus cmu haccifereodicie, Auersom nom flanereformas

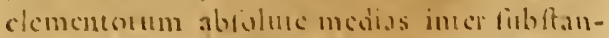

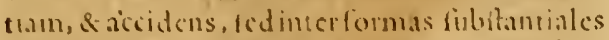
perfitas, \& acidentia : has:atem non funt contraditoria, ỵonim inter accidinnia, \&

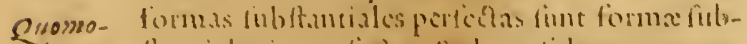

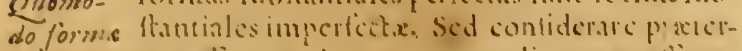
elemerro capollimms, Aucrocm non dicenecas ciöcreswor font re micdias, fot dicere, quili medtiss : mullum meilis. coim d.utur medinn inter fibltantism, siacsidens ; nec forma clementorum ita dicuntur medix, velintmedixper puticipationcm,

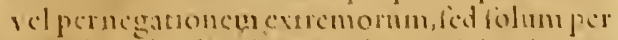
quandam fimiladincm, fen participationem

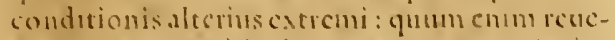

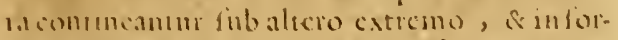

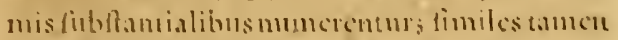
fum accidemibus in hac comdutionc, quod modostiquo intenduntwr, acemitnum, ctinon ommino ve accidenua, stracconditione ipra

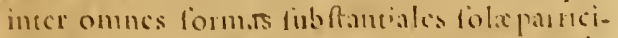
pant. Ad fecundum Thomx, quo illud alud abfudum infercbsur, crego infubitantiadanstur conemuns motus, nomulimeremiorestefondent, hocnon licqui, popteren quad lidchat ficilems motus, nonfolum reyuirtur toformo intendatur, \& scmittotur, fidetian velubictum fit cus actu, ficut ait Auftotel.in s. Phylic. fubicitum ante forma clementicit prims nutc-

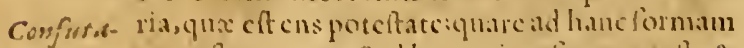
ro. donct motus. Scilhexchonliovana cit, \& mullomodo clt aduntecndum id, quodifticonccimut, darimutationcun concinnams fecundum

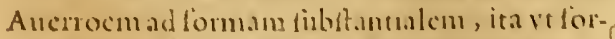
m.1 dementi acquiratur paulatim, \& per gradus, s in tempore, ficut ctt.m qunlitatess quod quidcm Aucross nunquam cócederet, qui ptl-

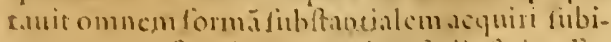

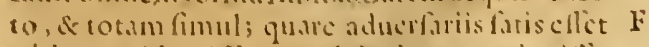
ad hoe cuidentilimum ahlurdum nosduxilli. Adde quad hoc concediono videtur negari pol:-

1 di cum efle scrum molum, ellot cnim a forma

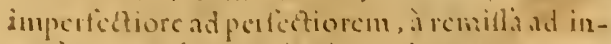
tentam: s: tolomutationi ommino competeret defuntionousin 5. Phylic. tradu, it culque

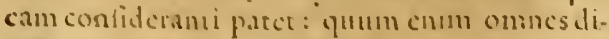
cant, gencrationem list cadelinitione non con-

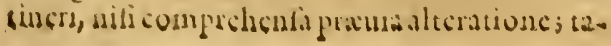

men fecundum iftos definitio illa competeret acuerationiaceptex ctiampro fola introductiosic formx libstantialis, quod quicénullusphi-

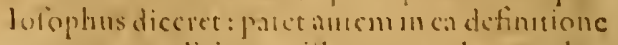
non pou conditioncu ifl.m, quodmotns h.1-

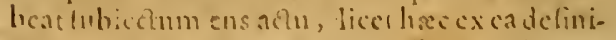
tione colligitur, quxcmus delinito $11 \mathbf{2}_{2}$ nan

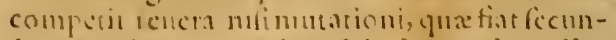

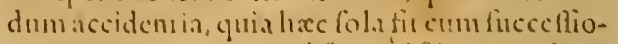
nc, 总 intempore: quod ficun ifis concedere. B mus, ctian forme fubftantials introductionem hoemodo per fincedlioncm ficri, ranmm.

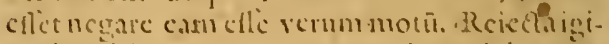
tu hac foltutione, noscamaciperedebcums, quamponit,ac de chant optime lomucs Baiconus inmemonato loco: eft cnim neginda confémontia, propterca quod mullus ditur in firbftantialcusmotus, quo forma clementi pau-

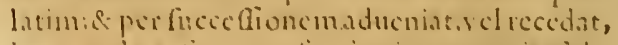

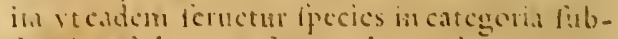

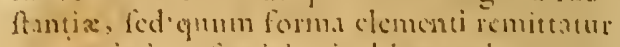
cum varatione fecici,cuinslibet gratus mutatiocte variatio fpecici, \& fingulus gradus, quo aducniente, yol recedente genetsur dementum, felmiftum, adusnit, fcurccidit non in tempore, fid fitbito, spoft alterationcin prexni:un, quxceftrens motus : mam in finc altera. tionistie moncoto tomponisacentio, ict remofio illiusgratus, gux cft gencratio finbita, D necpotedtapellarinomsidaucm quad Tho-

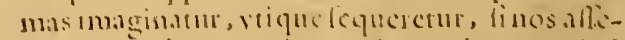
reremus, formamelomentintend, \& remitei

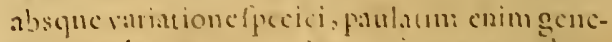
rarcur clementum, \& pars fomar accederet poit aliam pantem men fipeciom ciusdem clomonti : fiel quum fingula mutacuogradus that momentolcmporis poit pratuan alecrationem intemperetafim, \&insllomomente dicatur acedere illa formalitas, qua res conftiutur,

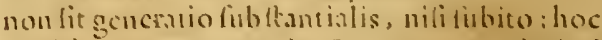
figniticanit Aucroes in Comment.23. decini Nctuphyficormm, quando dixit, vhic ct magis

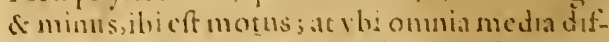

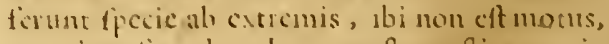
quonian lingulum horum cft conftitutum in

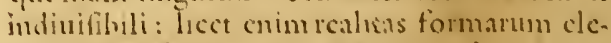
mentasium fie diuidua in gradus, in singulis tanen gradibus confitmut nowar fomplitates,

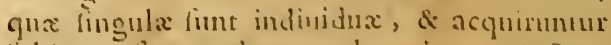
fubito post pracedentem alterationem tactam in temporc. Adtcrtimn; quando aliidicibant, crovo formx miltornm intendi, \& remeti pot: fent; negnatum eft confequens : dicinus enim, mull.n dari propric ditam mittonesu, nifi dementosum, theriaca icro yel non la, het vesanmiftsonem, vel li haber, cacte mflio clementorum, non miftorum theriasm instredicntium, hac enim conttabint ex clsmenus, \& cormm formse conftubant a realscatubs formarum cloucmarium, hocett, cail. 
hai gradibusfermatis fub formalit:remifti \& $A$

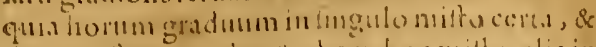

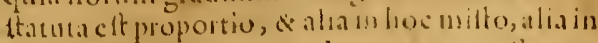
illo, deo ex plurim multomm compolime varatur proportio, \&e prosenit alud unituma: \& quia cmurge mumalis comorisformalita i liue fimplicis, fucmiftimdiusdua elt, nec potedt intonli, velemitu, nilimecrimaturicahtas vero diuidun clt in varios gradus, \& eit procipus clementorum, miturum vero per particpantionem ideo folis formis clemetorm attributur intenfio, e remillio, non om is mutormm, quia maturaftatuit elementa ve materam mitionum, non mitum ve materiam milii; \&elcmenta funt nutseria mistontum rationc fuac realit.nis diuidurpergmdus, quonim linc tali dinifibilitate non pollent effe materia mifiomm : hoe videtur fignificalle Ariforcles in context.illoso. was- libri ofan Meraphylicor. gusm antea con-

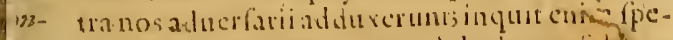
cies efle licun numcros : quod declarans lublum-

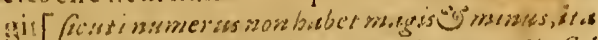

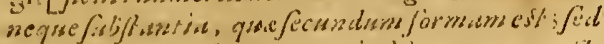

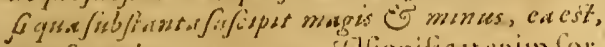

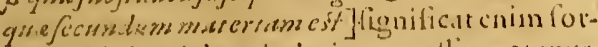
man fubrimutialem induicluam elli quatenus cfiforma, \& chlomua \& humpodi liurt ctian formx clementorun quatenus confuttunt clementa, nec datur ignts, qui dit magis ignis, quam alius ignis : feed cademelementa clutrenus fumt materiamiftorm, \& ratione realitatis fuamm formarum abiunctrencute abomi formalitate, intenduntur, \&enctrunturlufciprendo varias formalitates : dcuocatcrgorbi $\mathrm{A}$ -

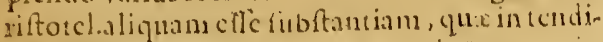
tur, ï remitrtur - funnit com magis \& muth in amyla fignificatione pro qualibetintentionc 36 rennitione, \& talem fubftantiam inq̨ut cllicillam, quxe ct materia, dum conlideratur ve materia, talia autem funt clementa quatcus funt matcriamistorum, fintaucm matriatione realitatum diatum formarum, icdnon rationc formalitasum. Hocausem, quod de elencentormm miftione disimus, pollumus cxcmplo declanare, crallo quidem, acrud, led ad propofitum fatisaccommodato: fit ftatua cqu tullilis exal1ro,argento, \& xre limul colliçuatisia comittis, in qua lit plus auri, \& minus alios uns, lit alta ftatua bouis exciftem metallis, 10 qu!a tamen lit plusagenti, \& minusaliorum; litalıa

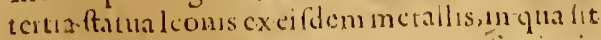
plus xris, quamaliortus; na ve varex fintin is ribus figuris menfure, \& proportiones hortim netallorum : deinde colliquinur itcrun wes iille flatux, \& cx tota illa materia lias tatua vina homins, decturne homoille fufilis cunbtare $\mathrm{er}$ equo,bouc, \& leone, an ex auro, argento, \& anc? cercex his metallis commiltis conlt itc disctur, cum alia tamen proportione, \& diteria à proportionibus qux dustunt in tribusilhs tha-
A tuisbrutorum; ficigitur theniacaconftarepro-

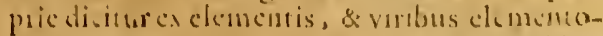
itu1, \& diucrams haber emperiom qualiber

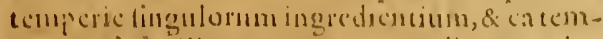

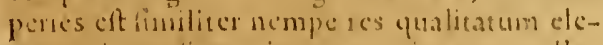
uncunatum, ficut chiam temperies ombes bllorum lingrulosum: atio ctlim ad hoc compro-

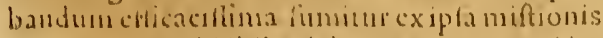
natura; num mifcibiliadebent sgere, \& pati in-

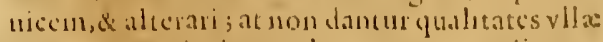
13 acture precer'primas clementares qualitate, qua alteratreces dicuntur; ideo li in theriacol te veramittio, qua derenon cet prafémia difpu-

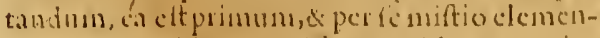
tormu, non miltorum, niliperatecidens; contingit cnim vet 10 griadus fingulatum formanm lementavium ad muttionem deloti line per illa corporanifta, ficuti contingit ve al lata matcria ad conthitucusam homus itamam fierit mat teria cqui, bous, \& lconis. Dicimus igitur omncm miftioncm propric aceptan, cui competat definitio miftionis ab Ariftor cl. tradira, ef-

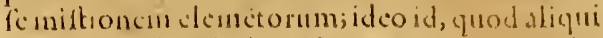
dicunt. Ariftotel. de mittioneagentem non fo. lam clemenormm mitionem confjerare, fed quimulibet indiftucte, admitti poteft, dummodo concedant omnem veram miftionsm, y $140-$ runemente corporma fir, reduci ad miftionem sementortum commifentur cnim inter fe alia corpora per vires element.1es, cx quibus conftant; quarechementa fola fum per liemifciblia, alia veroper elementa, qua in fe contincent;nane ex elementis confture omma nilta fatis per fo manifenticet, \& legiturclare apud Aristotcl. in lib. . de ortu\& interitu, ì context. 4 6. víque ad 5.o.dum loquatur de generatione miftorum: pa-

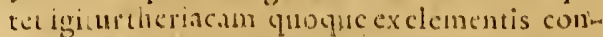
ftace, cius miltioncm, fi gua eft, à virbus clementorum elfefactam. (Onodautemallidicuat, di A riflotel. ibade fola clementortum miftione loqueretur, de clemeries prius agete, quande mitionc dibullict; hoc om nino elt ncyandum. \& forct aduerlus cos arginacintrom torques: quemadmodum cum tiola clementa fint micibiha, nceetlarium apucl cos efet agere prius de clementi; quandemiftunc;ita fiplua fint milcibiliapreter elcmenta, vt upfiptant, de itlis ommbus ub candem ratuonem crat prius agendam, quam de miftionic. Decimus igiturad mi.tionis cognntoneny fatis tintfe rndem quandau \& confillum mifibilium notitiam pex yuridan vauerfales conditiones, nequeorus fuildeditunete prius agere de elementis ; lict id poltex Aritorel facte in libro lecundo, de ex ca clemenom un tractationc colligmus, folis eincmis competce conditions milcibilumi prius tactas in iapice de nultione, quoniam cuim tir miftio per qualutates aturs is pathinas, qux vicicutur connmunter coperces \& clcmentis, \& miftis, ita yomitio cllic videatur \& fimpli- 
fimplicium, \& miftorum corporum : ideo docens poftea $A$ riftoteles qualitates illas effe proprias clementorum, \& illis compctere por éffentiam, miftis vero per participationem fignificat folaclementa sfepropric, \& perfe milcibilia, catera vero per elementa, è quibus conftant. Sumitur etiam horum confirmatio ex is , qua dicunturab Ariftotele in context.43.primi libri; ibi namque proponens de miftione agendum, nullam alian huius tractationis rationem adducit, nifi quia oportet de elementis agere tanquam de meteria muftorum; aflerit ergo fe de miftione agere velle propter elementa, proinde el ementorum tantummodo elie proprie dictam miftionem : \& potius cenfuit, cognitionem miftonis effe neceffariam ad confiderationem elementorum prout funt materia miftorum, quam è conuerfo perfectam elementorum cognitionem requiri ad cognitionem miftionis, ficut ifti in argumento fumunt. Neque turbare nos debent exempla,quibus vius eft Ariftoteles agens de miftione, "vifus enim eft fignificare nifta quoque effe mifcibilia, fed rudia exempla funt, \& fats habuit Auftoteles, fi perilla propoitum declararetur; \& talibus exemplis folitus eft paffim in fuis iibris vti, quia manifeftiora, \& faciliora intellectu funt; iis antem exemplis aliqure tantum miftionis conditiones declarantur, vt debere mifcibilia efle liquida, \& fe mutuo diuidere in paruas particulas; ad has enim conditiones declarandas fatis erant etiam exempla miftorum : at ṕracipua illa conditio mifcibilıum, quod debeant effe atiua inurcem, \& paflua, elementorum propria eft; nec miftisalia ratione competit, quam per elementa, è quibus conftant. Quartum argnmentum leue prorfus ac twm. puerile elt: datur enim res aliqua perfectior abfolutealia re, imperfectior tamen eadem re fecundum aliquam conditionem;vt afinus, quum fit fubftantia, eft ab folute perfectior, ac nobilior motu Coli, \& luce Solis, qux accidentia funt; attamen hxcapud Arifotelem ratione atcrnitatis, qux eft conditio nobilis, funt nobilioialafno, qui mortalis cft: quare ipfimet aduerfarij dicerent, afinum illis accidentibus nobiliorem effe fimpliciter loquendo, fed illa effe afino nobiliora fecundum quid : fic etiam prima matei ia, quum apud Ariftotelem æterna fit, eft nobilior ratione huius conditionis, quam forma, \& quă compofitum; tamen ab folute loquedo eftigno- bilior, \& imperfeetiorillis.Sic ergo dicımus, formas elementorum effe abfolute nobiliores quolibet accidente, quia fubftantiam conftiruunt, \& in fpecie collocant, quodaccidentia prattare
A non poffunt; poffetamen aliqua accidentia ha. bere aliquam conditionem nobiliorem, vt fi qua fint, quanullo modointendi, aut remitti porfint:nam poffe intendi \& renitti noratimperfeEtionem : talia itaque accidentia fecundum hāc conditionem nobiliora dici pollint formis ele. mentorum, fedillæ funt ipfis abfolute nobilio. res. Plura etiam eiusmodi in rebus videmus; nam multa bruta hominibus praftant robore corporis, vel efficacitate vifus, vel aliqua alia B eiusmodi conditione; homo tamen abfolute loquendo eft omnium animalium præftantifimus, quandoquidem aliis pluribus, \& illis quidem nobiliflimis conditionibus, brutis omnibusantecellit. Adauctoritatem autem Ariftin $\mathcal{A d}$. libro categoriarum dicentis proprium effe fub tum ftantia non recipere magis vel minus, ego quidem alienam ab Auerroc arbitror efle illam refponfionem, quam ei attribuunt plures Auerroifta, nempe vt Autroes dicat Ariftot.ibiloqui C deperfectis tantum fubftantiis, proinde non negare fubtlantiam aliquam imperfectam fufcipere magis \& minus; hoc enim fi Auerroes diceret, in errore eilet : quia quod lıbet efre fubftantiale indiuiduum eft, neque recipit magis vel minus, etiamfi répectualiorum perfectiorum imperfeEtum dicatur ; idque vt verum eft de omni cumpointo in categoria fubftantiz tam fimplici, qua mifto, ita etiam de formis concedendum eft; ne. queuni enim forma recupere magis vel minus, qun ipra quoque compolita dicaniur magis vel minus ialia: quamobrem non opus eft acuerfa. rios in hac refponfione impugnanda laborare, ego enim eam penitus reiciendam arbitror, vt ab Ariftot. \& ab Auerroe alienifimam. Dico igitur Ar1ftot. ibifumere magis \& minus pro eo quodeft intendi vel remitti fine rariatione fpeciei, quæ, vt antea diximus, eft propria acceptio; hoc autcm nulli fubftantize feu perfectr, feu impeifect $x$, feu compofitre, reu finplici competere $E$ poteft; idque legentibus verba A riftot. manifeftum eft : red non ob id negat A riftot. poffe aliquam fubfantiam intendi, \& remuti cum mutatione fpecici, fiquidem hancintenfionem, ac remiffonem ibi non confiderat; quum prafertim huic fententiz atteftetur dietum $A$ riftot. in context.10.octaui Metaphyficorum,vt anteconfiderauimus : fpecies enim fimiles efle dicit numeris, quibus additio, ac detractio fieri porelt cum mutatione fpecrei; fed qualibet numeri species indiuidua eft fecundum effentiam, neque poteft en fieri additio, vel detractio, quin deftruatur, \& alia numerifpecies oriatur. 


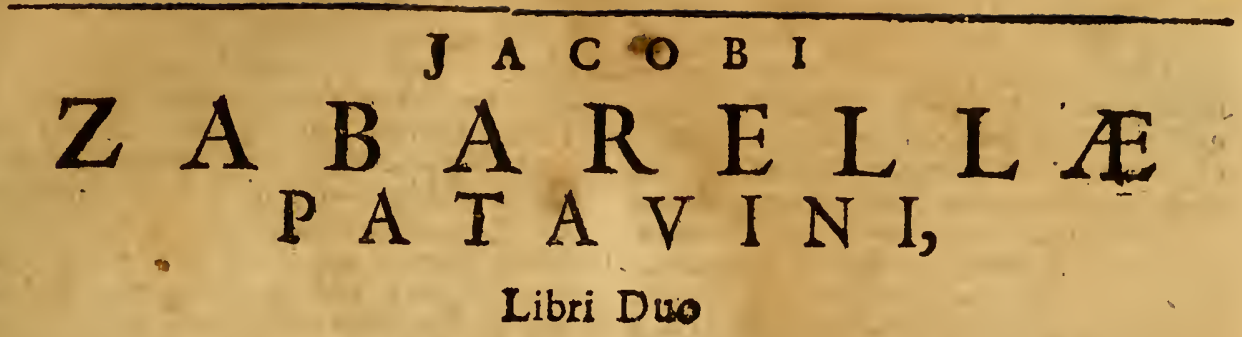

\author{
- e Q \\ $M E N T A R I B V S$.
}

\title{
L I B E P R I M S.
}

propofitio, ac partitio dicendorum. Cap. 1.

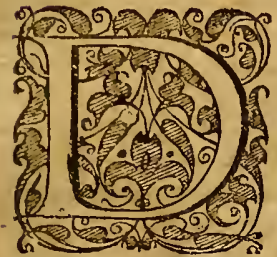

Ictum à nobis eft alias, quatuor fimplicium corporum, qux elementa vocantur, duo effe munera in mundo, proinde etiam in philofophianaturaliduas corundem effe confiderationes, vnü prout naturalia, \& fimplicia corpora funt, qux pergrauitatem, \& leuitatem proprios quaq; locos in mundo occupant; al terum vero quatenus miftorum principia \& elementa funt, \& per quatuor primas qualitates, quxalteratrices vocantur, in miftionem venientia cōftituunt miftum. Sed illa quidem, qux ad priorem eorum corporum confiderationem attinent, fatis à nobis tractata fuere in colibro, quem de grauium, \& leuium motu confcripfimus, nuncalteram, qux multis magnisque difficul tatibus referta eft, adgreffuri fumus, \& elementa confideraturi, quatenus element2, \& principia miftorum funt: \& quoniam, vt Arift, docet in initio lib.2. deortu \& interitu, corpora hæc eo munere funguntur per primas qualitates, quarum inter fe actione, \& paffione abfoluitur miftio, \&generatur miftum; tota de his qualitatibus hæc difputatio noftra futura eft; his enim optime declaratis, cognita erunt elementa, quaten us principia miftorum, \& elementa funt. Tria autem funt, qux de his confideranda nobis proponuntur: primo enim loco videndum eft, quid fint hx, qux prima qualitates appellantur, \& harum definitiones quæab Arift traduntur, expendend $x$, deinde vero de earum caufis, vnde elem entis proueniunt, agemus;ac demum quafdā quæetiones, de qui bus alij maxime difputare, \&controuerfari confueuerunt, ad has qualitates pertinentes propote nemus, atq; foluemus;in horum enim plena inat. telligentia confiftere arbitramur perfectam elementorum cognitionem, quatenus miftorum
A principia, \& el ementa funt: quorsodoantem $\mathrm{ex}$ horum congreflu genereturmifum, ad alium locım opportunius confiderandū remittemus.

\section{Quomodo ad elementa fe babeant prima} qualitates. Cap. 11 .

Vum dux fint, quas modo diximus, elementorum cöfiderationes in naturali philolophia, duobus etiam modis ad elementa fe- Qualutahabere primas qualitates alibi oftendimus:nam res non. B fiabfolute elementa vt naturalia corpora confi - funt forderentur, hæi non funt eorum formæ fub ftantia - meleles, fed accidentia confequentia de genere qua - mentolitatis, quod probatpluribus argumentis Achil- rum. linus inl1b.3. de el ementis, dubio4. fed hreconfideratio à prafesti noftro inftitu to aliena eft: $\Upsilon_{\mathbf{L}}$ vero eadem vtelementa rifterem ascipiantur, exdem funt ip forum elementorum conftitutrices forma, quia fine his corporailla non effent elementa miftorum. Non eftautem ignoranC dum, primas has qualitates ab Arift.in libr. 2.de ortu \& interitu \& formas, \& principia elementorum., \& materiam elemestorum vocari, \&e quandoque etiam appellari elementa; \& materiam miftorum: quatenus cnim in generatione elementorum hxqualitates funt ptaparationes materix profingulorum elementorum formis educendis, eatenus vocantur ab Arift. materia elementorem in б. contex. illius lib.z. nampreuia difpofitiones faciunt materiam propriam, \& preparatam ad recipiendam formam : dum autem elementa confiderantur vt genita, \&iam exiftentia, hæf funt form ipforum conftitutrices, quia faciunt vt fint el ementa miftorum, \& hac eadem ratione ipf $x$ qualitates $a b$ Arift. etiam elementa vocantur;nam fxpe in appellatione confundere folet formam cum compofito ab ea conftituto : ideo quum hæ qualitates elementa conftituant, ipf $x$ quoq; hacratione ele. menta vocãtur, veluti, fi quis ani mã humananı E homine appellaret: hæc legere poffumus apud Arift. in cont.7.\&16.eius 2 .lib.vbi has qualitates recat indiftincte \& elementa , \& formas elemé- 
torum: \& principia conftituciua elementorum: caliem iocat etiam materian miltorum in collo libr.2. de pastibus animalium, quia dum conttituuntelementa, materiă miftorum conftıt uunt; quaigitur refpeetu elementorum funt forma conftituentes, \&dantes elementiselferefpectiuum, quo dicuntur materiamiftorum, exdem refpectu mifti dicuntur materia, quia totum elementum ita $a b$ his conftitutum materix locum habet refpectu mifti. Hre igituromnia fecundum varias confiderationes verafunt, nec puguant intei $f e$, cognita enim veritate non difficilc eft varia Arift. dicta, qux difcrepantia videntur, conciliare, \& ad rectum fenfum trahere. His igiturdeclaratis, ad primarum qualitatum definitiones, qux ab Arift. afferuntur, confiderandas accadamus.

\section{De definitionibus quatuor primarum qua- litatum. Cap. III.}

$\mathrm{O}$ STENDERE volens Ariftot. quatuor primarum qualitatum duas effe adtiuas, calorem, \& frigus, duas veropalfiuas, humiditatem, \& ficcitatem; in medium affert earum definitiones, in quibus id manifeftum eft, ut legere poffumus in context.8. \& 9.lib.2.de Ortu \& interitu: funt autem definitiones tales; calidū eft quod cógregathomogenea, feu quod fegregat heterogenea, ut hom ogenea congregentur; frigidum vero eft, quod indiftinete omnia congre-

Defini: ysofrigidis. gat, tam homogenea, quam hererogenea; congregare autem, \& fegregare eftagere; quare ex his definitionibus patet has duas qualitates effe actinas : humidum vero effe dicit id, quod non eft terminatum propriis terminis, fed facile tcrminaturalienis; at ficcum è contrario, quod - terminatum eft propriis terminis, alienis vero non facile terminatur; terminari autem eft pati; idcirco hredefinitiones declarant has duas qualitates effe paffivas. Videnturautem hæomnes definitiones fatis effe manifeftæ; nã in urina hypoftafis fecernitur à partibus aquofis, \& eft fignum bonx concoctonis, qux fit à calore; fic ¿utem feparantur illa, qua funt diuerforum generum, \& finul congregantur omnia, quxe ejufdem generisfunt, in fundo enim congregantur omnes partes terreftres, in parte autem fuperiore omnes aquola : ita in vino fervefcente fecernuntur à calore partes terreftres à tenuioribus: fic fi in aliqua cera indurata commıftifint lapil$i$, \& pale $; \&$ cera per calorem liquefiat, congregantur in fundo omneslapilli, in fuperficie vero omnes palex fupernatant, \& in medio mayent omires partes cer $x$ feparantur igirurà ca- Joreheterogeneaj'st homogenea cōgregentur. Contrà verồ à firigore manifeftum cft omna 'congregari indiftincte, tam homogenea, quam heterogenea; Gcut enim calidi eft rarefacere, va-
A defit feparatip corum, qux funt diuer forum gè nerum, ita frigidi eft condenfare, $\&$ conftipare: quare ficera à trigore condenfetur, omnia, qux in ea funt, coniungun: ur, ut prædicti lapilli, \& palca cum cera commilti; nam fi onnia hac commilceantur, fuperuenicns frigus eaconjm1git \& facit, vt congregnta \& coniuneta maneant: fi aqua turbida congelecur a frigore, $c j$ junfte manent cum aqua partibus particula terræ, donecà calore congelationem folvente B fegregentur: lic ve1o etiam cera pura cóngregabitur a frigore; proinde frigus conden fando cójungit omnia tam homogenea, quam heterogenen, qua commilta elle contingat. Duarum quoque palfiuarum definitiones latis manifeftrefunt : humidum enim quum fit fluxile, proprios terminosretinere nequit, led facile recipit alienos; figuratur enim facile à continete, \& figuram ejus recipit, ut in vafe vide nus aquam, vel acrem facilime ad figuram vafis figurari;

C Aluitenim ftatımad omnes partes continentis, \& ita recipit terminos alienos : contravero ficcumjam eft terminis propriisterminatum, fed alienos non facile recipit; nam fialiquodvas iniiciantur lapides, non figurantur ad figuram $\mathrm{vafis}$, fed propriis terminis terminati manent. Sic ergo(inquit Arift.) exharum qualitatum definitionibus apparet calorem \& frigus notareaptitudinem ad agendum, humidiratem vero \& ficcitatem notare aptitudinem ad pauendum. Hæc funt, quxibi de his dicuntur ab Arift. quæ eadem poftea repetuntur in initio 4. Meteorol. Sed aduerfus hæc magnæ oriuntur difficultates, qua ad hanc vfque diem omnibus negotium faceffunt, \& aliqux etiam qux à nemine tacta vnquam fucre : dubia enim occurrunt primo loco aduerfus veritatem harum definitionum, quatenus abfolute confiderantur ut prædicata quadam, qux his qualitatibus attribuuntur; deinde verodubium videtur, quomodo effentiam

E harum qualitatum declarent, \& fint earum de. finitiones; quum enim munus definitionis fit exprimere effentiam definiti,non apparet quomodoper has harum qualitatum eflentia exprimatur, ita $v t$ aliter definiendx non lint: hxc igitur vtraque confiderare oportet; quum vtraq; dubia effe videantur; vnum, an competane his qualitaribus ; alterum, an effentialiter competant, \& earum definitioucsappellandx fint.

F Dubia aduerfus veritatem pradictarum de. finitionum, or eorum Solutio.

\section{Cap. IV.}

A Duerius harum definitionum veritatem Amulta dubia ab interpretibus Ariftorel, proponuntur. Plimum quidem aduerfus definitinnem calidi : nam cera \& pix fi fimul à calido colliquentur, ita commifcentur, yt feiungi 
iungi amplius nequeant, ita ctiam ftannum, \& plumbum; fic multa ab aromatariis per calorem ignis commifcentur, qux non poflunt amplius teparari ; ergo calidum congregat, \& coniungit illa, qux funt diuerforum generum: contrariumtamen afferuit Ariftoteles dicens cali-

37. dum fegregare heterogenea. Dubitatur etıan de frigido; quia tempore hyemis fit emiflio lachrymarum à frigore, ergo frigus fegregat heterogenea, quod Ariftoteles negauit: fic fanguis c̀ venis eductus refrigeratur, \& partes cius terreftres fundum petunt, aquof $x$ fupcrnatant, purior autem fanguis in medio manet, itaque a trigore fegregantur heterogenea, \& 11 la eaden videntur à calore congregari potius, quam fegregari : nam illa exdem languinis partes heterogenex prius erant commiftx, \& cōfule, dum fanguis erat in venis; à calore igitur commifentur, \& congregantur, poftea vero fegregantur à frigore: calidum igitur congregat heterogenea, trigus vero ead em fegregat: igitur Artitoix. teles in vtraque definitione falfum dixit. Dubitant præterea de definitione ficcl; dixit enim Ariftoteles ficcum effe terminatum propriis terminis, alienis vero non facile terminari: attamen contrarium contingit in igni, qui maxime ficcus eft; terminatur enim facillime termihis continentis, necretinet terminosproprios; quapropter igni conuenit potius definitio humidi, quam detinitio ficci. Sic etiam cinis \& puluis facile terminantur à continente, proprios au. tem terminos non facile feruant: falfun igitur dixit Ariftoteles in definitione ficci, dum contrarium afferuit, quum hxe fint corporatica. Vt hrecdubia, \& alia eiufmodi omnia foluantur, ftatuendum pra cateris eft fundamentum hoc: poteft aliquid alicui competere per ic, \& effentialiter, cuius tamen oppofitum eidem competat, fed peraccidens; vt calido nihil nuagis perfecompetit, quam calefacere, tamen qaandoque calidum refrigerat, ficut etiam figidum calefacit, fed per accidens, vt euenit in antiperiftafi; neque per hoc tollitur, quin perfe dicatur calidum calefacere, \& frigidum refrigerare: fic igitur per fe competitcalido etiam rarefacere, \& extenuare, hæc enim eft caloris natura, \& exhoc fit vt homogenea congregentur, heterogenea vero fegregentur, nifi quid aliud prohibeat: quare hæc omnia perfe competunt calido, licet eidem quandoque competat per accidens vt congreget heterogenea, vt contingit in cera, \& pice duin colliquantur; fco pus enim natura caloris effet feparare picem à cera, fed propter conuenientiam naturx, \& fimilitudinem liquationis fit vt fimul colliquat nequeant feparari, hæc enim continentia prohibet, ne calidum praftet fuam operam naturalem: quareper accidens congregat heteroge-
A nea, quum potius ea congreget quatenus vergunt ad naturam homogencorum, nempe ratione conuemientix, \& fimlitudinis, quam inter fe habent. Hoc enim contingit in suultis ré. bus, qux ab aiomataris per colliquationem commifcenrui; fedipfi pratetea adicicunt com-, miftionem artificiofam, qux impedit feparationem hetcrogeneorum, fegregarentur en!m frequëter res heterogenex exactione caloris, qua tamen prohibentur fegregaripercōmıftionem B artificiofan baculo factam; fedetiam fine hac poffunt per accidens congregai $i$ ob conuenientiam in modoliquationis, ficuti dictbam us de cera \& pice: fic etiam fannum, \& plumbum ob liquationis fimilitudinem à calore commifcentur, \& coniunguntur; at plumbum, \& cera nor ita commifcerentur, fed fegregarentur, quia difimilem habent liquationem, cera enim facilius, plumbum verodifficilius liquef cit.Potef etian alia ratione calıdum heterogenea per ac-

C cidens congregare: quatenus enim res aliquas indurat, dum partes tenuiores refoluit, vt in lus to contingerevidemus, eatenus etiam facit vt res craffiores, qux remanent, etiam fi diuerforum fint generum, maneant tamen congregat $x$; quia crafities, ac durities, in quares ill $x$ conueniunt, impedimento eft earum feparatio. ni. Confiáerandum praterea effalia competerecalorivt fecundum propriam naturam agenti, alia eidem competere, vt agenti infrumentario, \& gubernato ab aliquo agente primario: quoniam enim actio pracipue attribuituragenti primario, ideo poteft a calore aliqua actio prouenire, qua lit preter ir $r$ ins ralna: natu. ram, fed fecundum naturam \& ces

tis primarii, à quo regatur calor: $\beta 2$

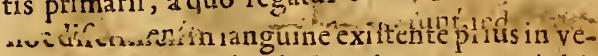
nis, deinde ex venis eductio, de quonunc dubitabamus: dum enim fanguis eft in venis, regit ur ab anima, quare tunc calor agit ex intentione a anima, non exintentioneproprix naturæ; nam fi fecundum propriam tantum naturam ageret, vtique heterogenea fegregaret, quod manifefte facit poltquam eft eductus è venis, nam terreftres partes fund um petunt, aquof $x$ fupernatant, prioi autem fanguis in medio loco inanet; fit enim feparatio hac à calore, quem ad- huc feruat fanguis, non à frigore; quia fi ftatim eductus fanguis omni calore deftitueretur, videremus ipfum ita condenfari, vt illa omnia in eo commifta, \& coniuncta manerent abfque vlla feparatione; agit autem tunc fanguis propriis viribus, neque eft amplıus fubiectus imperio animx, ideo eius calor feparat heterogenea: qui idem quando in venis inclufus fanguis continebatur, quanquam maior, atq; intenfior calor erat, non fegregabat heterogenea, quia obtemperare cogebatur imperio animx, qux Q 2 vult 
vult ex tota il!a maffa fanguinea omnes cor- A lantur, partesautem terreftresnon ita facilereporis partes nutrire, \& illan vertere in fubstana : tam animalis: fic dicimus de vrina, $f$ cparantur enim in ipfa partes heterogener à calore, nos de frigore, nam vrina egreditur calida, vt manifeftum elt; dumautem erit in vefica, vel fimiliter partes terreftres ad fundum defeenderunt, \& poftea in eniffione funt commifte cum vrina, vel etiam ab anim regimine prohibetur aliquantum illa fegregatio ob vtilitatem animalis. Ad horum autem cöfirmationem confiderare poffumus motum localem nutrimenti, in eifdem viuentibus corporibus; nam alimensum, quod fua natura eft gr.ue, \& naturaliter defcenderet, mittitur tamen ab anima etiam ad fuperas corporis partes: ficut ergo anima imperarepoteft grauine defcendat, \& facere vt afcendat, ita etiam poteft imperare calido fegreget heterogenea, nifi vbi ipfamet anima hancfeparationem molitur; nam per vafa huis kfui alfignata fegregantur aliqua partes finguinis aquoliores adrenes, terreftriores vero aliqux adlienem, fed alix taméin venis manent commift $x$ cum fanguine, quas natura non vult fegregari:patet autem in eodé fanguine c̀ venis educto ide contingere de eius motu, quod de calore disebamus; eductus enim fanguis quum ab animzamplius non regatus, non moueturnaturaliteralio motu, quam defcenfus;agit enim tunc fecundum propriam naturam, Guemadmodum etiam eius calortunc imperio anunxabfolutus incipit agere fecundum natusam fuam \& heterogenea feparat. Ex his igitur manifefum eft, competere poffe quandoque alori xt congre in theierogenea, nequeperhos arre, quir cidem per fe competat vt fegreget heterogenea; hac enim nan congregat nifiper

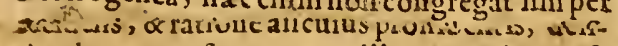
miendx autem fisnt res perilla, qux eis per ff competunt, non per ea, qua per accidens. Sic dicendum eft de emiffione lachrymarum à frigore; fitenias per accidens, nam per fe frigido competit conftringere, \& condersfare, hocaustem per fefacit congregationem omnium indiftincte; quod fi in illa conftrictione eueniat vt a. Niquidhumoristenuis exprimatur, id' fit perasGidens, \& prater intentionem frigidi agentis, quod quidem per fe folim congregationé molitur, quia fit pes fe congregatio ex conftrictiaac; fed propter differentiam, qua eft inter craffum; \& cenue, fit per accidens expreffio partium tenuiorum, \& earum à crafis partibus f egregazio, talis namque eft emifro lachrymarum à frigore: fic ctiam diccbamus, fieri etiam quandoque à calido condenfationem, fed per acciders, y. quando calor litum indurat; quum enim per fe compent calido rareficere, rarefiunt in luto gartes aquol $x_{2} \&$ in vaporem ssfolutx exhafoluuntur, ideo indurat $x$ manent, quoniam humore deftituuntur: calor itaque perfe cxtenuat aqueas partes, \& eas feparat i partibus terreis, fed facit per accidens vt partes terreæ maneant duricres. Adaliavero dubia adducta aduertus definitionefieci refpondet de igniloan. Grammaticus, flammam, qux eft in fornase, non facileterminari, fcu figuraria figurafornacis, quia

B \& conquiefcitin fornace, vraer, fed erumpit, \& afeendere nititur, atque fi id facere nequeat, extinguitur; terminos quoque proprios haber, nam habet figuram pyramidalem; quare illi competit detinitio ficci. De cinere autem \& puluere negat Ioannes corpora hre elfe ita fluxilia, vtcorpora humida; non enim ita locum adimplent, \& perfeete figurantur à continente, vtaer, \& aqua, \& alia humida, qua ftatim à continenterecipiunt terminos \& figuram, \& petfeate omnes continentis partesatungunt, quo fit, C vt cinis \& puluis habeant etiam figuram propriam, \& eam retineant, quando coaceruantur, aceruus enim propriam habet figuram. Sed has Io:unnis folutiones ego quidem penitus approbare non poffum. Quod enim de igni dicit, ipfum non facile termınari à continente, admitti poteft, quia nulla reuera ftabilitatem babe: flamma in fornace; totum yero elementū ignis. terminaturquidem à coleftis corporis fuperficie, fed cum maxima partium perturbatione, \& inftabilitate. Sed illud, quod dicit, flammam. has: bere propriam figuram, nulla ratione admittendum videtur: id enim propriam habere figtram dicimus, quod ftabilitatem habet, cuiuf-

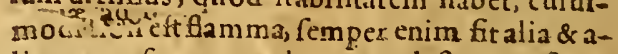
lia, nequeferuatur eadens: quod fi quans figuram habere vid s, candem habet etiam aqua weicendens, quando ex aliquovafe effunditur, qุuj̃ tamenfit corplis humidum, quod Ariftnegat habere terminos proprios: quocirca diff-

E cultasintegramanet. Poffumus igituraliter dubiurafoluere dicendoconditiones humido at- Solut tributasab Ariftot. videri quidem modo aliquo fera etiam igni, quificcus eft, competere, fed id efSe peraccidens; fit enim propter partinm tenustatem, y.t facile terminarialieno termino videatur, non propter ficcitatem, quum non om feco id competat; itaque hoc ei competit, quatenus eft tenuis, non quatenus ficcus; quo fit, v.t non perfecte ei competat, ficuti perfeate competit humido; quatenus enim ef humidum, eatenus fluidum eft, nec poteft retinere proprios cerminos, \& facile recipisalienos. Sed dignum: Alief confideratione eft id, quod pro huius dubii fo- Iwtso. lutione dicitus ab Auerroe in initio fux Epitom.4. Afeteor.eaq; mihi videtur omnium sutifima elfe refponfio: inquit Auerroes $A$ rift. defaribere bas qualitates per gnafdam proprie:-

calcis. 
tates, qux competunt clementis prout elementa funt, \& prout in miftionem veniunt, ac refpiciunt productioncm mifti miftio auten omnis cclebratur terra, vel prope terram, propterea quod ibi commode fit miftio, vbi adfunt omma clencrita; adfunt autem omnia apud terram, vbi manifefte fit trium clementorum inferiorum contactus, \& partes quoque ignex tum fupra terram, tum in terra gentex ab actione colefti: preterea in omni perfecto inifto terra prxualet, \& illi adhibetur aqua ad compagem facicndam, decinde acr \& ignis propter calorem, vt cuftigatus à frigore terrx \& aquæ regat, \& modcretur ficcum iunctum humido, \& miftionemabloluat, miftum enim recipit à calore teruinos propter humidum, \& retinet propter ficcums : igitur fifacile vel non facile terminari confiderentur in ficco \& humido vt acceptis in conftitutione mifti, tollitur omnis difficultas: Ariftolel. cnim definicus ficcum refpexit prexcipueficcum terre, quod cum a calido \& frigido teminari debeat, requirit ad miftionem humidiaquei, vt poffit facile terminart: ignis autem videturin miftionem venire potius vt calidus, quam vt fiecus; v tenim eft calidus, agit,ac moderatur; vtaute'm eff ficcus, non fungitur' nifi officio matcrix, fed condenfatus, \& adiunctus ficcoterreo paruam admodum molem adiicit, \& parum matcrix mifto fuppeditat, quoniam ad paruam quantitatem reftringisur ficcum igneum dum adiungitur ficco terrco: quare totum fcreilludficcum, quod eft materia mifti, terreum eft, vt expreffe dicitur ab Ariftoteh.in context. 49. \& 50. lib. 2. de ortu \& interitu. Sententia ergoAuerois eft, non effeneceffarium, vt hx defcriptiones veræ fint de qualitatibus elementorum, prout in funt elementis fecund um $\mathrm{fe}, \&$ abfolute confideratis, fed folum prout in miftionem veniunt vbi ficcum humido iunetum debet à calido terminari ; in miftione autem totum ficcum terreum cft propter mágnum terr exceflirm, \& illi adiunctum aliquid ficciignei non liabct amplius tenuitatem, quam habet ignis per fe, \& ab aliis élementis. feiunctus: quoniam igitur Ariftotcl. accepit has qualitates vt productionem nifti refpicientes, in productione altem mifti totum ficcum iam eft factum folidum, ac difficulter ab alio terminabile', quia per magnum exceflum eft ficcum terrcum, \& illiadiunctum parum ficci ignci eft factum craffum, ac denfin; de hoc ficco veramaxime eft definitioficciab Ariftotel.allata, \&omni carcns difficultate, neq; neceffariun eft, vt accommodetur elementis vt fimpliciter, \& extramiftiode nem confideratis; quum præfertim traditx fint clementis hæ qualitat es propter cöftitutionen mifti, non prout funt abfólute corpora natura-
lia,ficut alio in loco demonftraumusi hancelle
A puto veriffumam folutioncm difficultatis; qux de ficcoignis oricbatur. De cuncreautem, ac de pulucrepreter id, quoda Loanne Grammatica. dietumeft, addere nos poffunus, cinerem feu pulucrem non effe vinum corpus continum, fed cögeriem particularum terrs minutifhmarum; promde mirandum non elle, fi videantur facilius terminari continente, quan ficcumaliquod continumum, quod fit vere vnum corpus; hxc cnim funtmulta corpora colleda, ficuliat

B cenus frumenti, in quo difunsta inuicem funt grana, quo fit, vt fluxum aliquem habcani,per quen recipuntaliquam figurationem à continente : at fi conglobctur, \& conftipcturaceuus pulucris, ita, ve fiat vnum corpus, non amplius recipiet facilc terminos ab alio, fed proprios terminos habebit, acretinebit.

Quomodo primarum qualitatum duse di-. cantur adiua o dua paßiua.

\section{Cap. V.}

Dbium pretereacitillud, quod Arift. di1 cit tum in pradictu loco lib.z. de Ortu \&e interitu, tum in initio 4. Metcorol. caloren \& frigus effe qualitates atiuas, humiditatem vero \& liccitaten cffe paffitas; huic crim fententixe aduerfanturilla ; qux \& in prımó, \& fécundo de Ortu\& interitu libr. dicuntur: 1 n primo quidem. docuit Ariftot. contrarium agere in fuum contrarum, \& pati à fuo contrario agit ergo \& ca-

D liduminfrigidum, \& frigidum incalidum, \& patitur frigidum à calido, \& calidum à frigido; crgo hre dux qualitates non folum acti uxe, fed etiam parfux funt:fic etiam humiditas \& ficcutas, quum fint contrarix, agunt inticem, ac patiuntur; ergo non modo paffice funt, fed etiam actiux; agit enim \& hunsidum in ficcum, \& ficcum in humidum:in fecundo autemlıb. docuit, quodlibet clementumà quolibet clemento patiratione contrarietatis, \& aliquod pati abaliE quo per vtramque qualitatem, ncmpe fi vtramque habeat contrariam vtrique, vt patitur aqua ab igni, \& ignis ab aqua : aliquo vero patiabaliquofecundum altcram tantum qualitatem, videlicet fi altera conucniant; patitur ergo \& aerab igni , \& ignisab acre: atquinon poffunt pati ratione caloris, quum ambo fint calidi; quare patitur act ab igni vt humidusà ficco, \& i gnis ab acre ve ficcus ab humido; igitur etiam ficcum \& humidum funt actiua in fe mutuo, non folum paffiua: fic terra \& aqua agurstin fe mutuo, at non fecundü frigus, quum in co conueniat, ergo ratione ficcitatis \& humiditatis. Marfilius \& aliinonnulli hanc difficultatemita foluunt: omnes hr qualitates funt actiux, \& o- opinso mnes palfiux, vt Arift. in memoratis locis fignificauit; fed calidum \& frigidum funt magis actiua, quam humidum \& fiecum; \& è cōtrario hrec 
funt magis paniua, quam calidum \& frigldum: hoziritur connidirans A a itotel. pir comparationem dixit du, as effe atiuas , \& duas paliuas, ulett, diase efe mavis acturas, duas vero magis paflimas. Sed hrec fentenii à multus recentioribur reprobatur, necini liria; patct enim Aritt, has comparatione non vti, fed ablolite loqucndo lias vocareactiuas, illas yero pafiunas. Preteren oftendit hoc Á riftotel. ex enrim defi nitiomnibus:at in definutionibus catidi \& frigidi fola actiolignificarur, de pa Fionenihil dicitur; fic in definition,bus humid \& fieci ne verbum quidem de actione fit, fedfola praflio tangirur: Adite quod dum duas vocar actiuas, \& duas parfiuas, non confiderat aftionem contrarii in contrarium, vt ca'idi in frigidum, fed totius contratatis c.l一d \& frigidi in toram contrarietatem humidi \& ficci; ícaurem patet calidum \& figidum effe folum atius, humodum vero \& ficcum partiua folum, quia nemo vnquun divit humidum \& ficcum agere modo Vllo incalidum \& frigidum: itaque dictum Ariftotel. non eft comparatium, quia comparati. uum prefupponitpofitium; quod hic dici non poteft; fatum in m eflet dicere calidum \& frigidum magis agere in huniidum \& ficcum quiam hxc in illa, quum hrc in illa nullo modo agant: neque enmu dicendurm eft, calidum \&: trigidum magis agere inuicem , quan' humidum \& ficcum inuic m, quum Ar ftotel. (vt diximus) non confideret actionem contraria in contrariam, fed totius contrarietatis in totam contrarietatem. Prxterea non pollumus dicerecalidum \& frigidum effe magis actiua inuicem, quin dicanus efe etiam magis paifiua: etenim dum vnum agit, alterum patitur : quare fi in clligantcalidum \& frigidum magisagere inuicım quam hunidum \& ficcuminuicem, \& hac magis pati, qquam illainucem, eft ia cornm fententia repugnanua manifefta, \&infolubilis.

dicrum Hacigitur reseata videntur creteri omnes hanc opizizio. difficultatem foluere dicendo has omnes qua: litates efle actiuas, \& om ones pafluas, dum confideranturin implicibus fecundum fe fumptis : at dum con ideranturrefpectu mifri; \& prout ad mifti generationem congrediuntur, duas effe actiras tantum, \& duas tantum paffuns: Ariftot igitur quando divir omnes efle actuas, \& ounnés pafuas, confideranit eas in fimplicibus corporibus frout mutaniur inuicem, abique vilo mfrom refpeetu aqua enim in teriamagit humectando, terra vero in a quan exaccando, ytindubitatione dicebatur: quando auten diait duasclle actiuas tantum, duas vero tanzumpaffiuas, confidenumt ens in clements vt congreciientibus ad generationem mift: quare fcundum varias conliderationes verum eft $\mathrm{v}$ trunģue : fumunt autcin hans folutionemex
A Ancroeininitio 4. Meteorol. \& ex Iodn. Grammatico in context.8. Lib.z.dcGeneratione. Múai tamen videtur hec communis folutio aliquam pati difficultatem; quiain miftione quoque ac miftigeneratione necelle eft onnes agere, e omnes pati : quum enim in miftione oporteat fieri inifcibilium diufionem in minutas partes, \& caruminter fe attioncm, qua ad mediocritatemledigantur, neceffce eft particulum fitcam exiccare particulam humidam icista fe pofitan, 3 \& vicifím ab. eadem humêtari, \& calidam ì friçidarefrigerarı, \& frigidam à calıda calefieri: oportet igitur omnes ageie, \& omnes pati, vt contraria omnes fe mutuo obtundant, \&:totum ad uaturam median redigatur, quare difficultas 1ntegra manet; quomodo enim in productionemilti, quam refpexic Ariftotel.dicens duas actiuas elfetantummodo, \& duas pafluas, verum eff dietum 'hoc, fi eriam in productione mitti omnes agunt; \& omnes patiuntur? non e1t

C ergodiftinguenda harum qualiatum confideracio in fimplicibus \& in miftis, quodillifaciunt; fed melius eft, vt hac diftinatione vtamur. A Eio harum qualitatum duplex eft; vna vniuo$\mathrm{ca}$, qua eftapta fingula gignere imilem, quod facerenon poreft, nif fuan connariam interimendo; altera vero xquiuoca, qua producunt fecundas omnes qualitates, \& ipiam quoq; mifti naturam diuerfam à naturis elementorum. Priorum actione exercent hæo omnes qualitates non folum in fimplicibus, fedetiam in mufts, \&e hac ratione omnes funt actiux, \& omnes paffiux, quxlibet enim fuam contrariam deitruer e, \& fimilem producerenititur; quare humdum quoq; agit in ficcum, vt ipfum interimat, \& producat humidum, \& è contrario ficcum agit iı humıdum,vt ipfum perimat, \& generet ficcum. Alreram vero pofteriorem actionem exercent in miftis tantum, eaque eft pracipua elementorum operatio prout elementa funt; huius enim E gratia data eis eft à natura altera prior actio. quia line illa hanc pofteriorem exercereminime potuifient : ratione igitur huius fecundxeRionis, quam nos æquuocam appellauimus, Ariftotel.duas tantum ątiuas vocat, calorem \& frigus; duas, vero pafiuas tantum, humiditatenz \&liccitatem; hæc enum non eft amplius actio contrarixin contrariam, ted tanquam artificis in materiam ; ficcitas enim \& humiditas nullam habentvim actionis æquitoc:e, qqua ăgendo aliquod diuerium producar, fed funt conditiones conftituentes misteriam aptam ad patin endum à duabus å̊u , tanquā ab artifice elaborite: calor enim ne fecundas qualitates, nec miltum produceret agedo in folum humidum, velin folum ficcum, ied m humidum cum ficco. coniunctum ; iple aut calor non debet clle fumznus, fic enimigneus, as dsitrustuus effet, fed dibsth 
d. bet cfe remiffus, \& caftigatus ì frigore, \& modomagis modo mums, prout dinerfe miftorum naturx, \& diucrefectende qualitates requirunt : hacıgitur ratione calor \& frigus funt folum actiux qualitates \& locum habent arificis, lumiditas vero \& ficcitas funt lolum pafiux, quia conftitunt fubiefzam materiau ad paticrd um idoneam : 1 oc modo tollitur omnis difficultas, \& hanc fententiam fignificant Auerrois verba in x.comment. 4. Meteorol. fi bene perpendanu ; non enim diftinguit actioncm harum qualitatum in fimplicabus ab actionc carundem in miftis; fed productionem timilis, qua funt agentia vniuoca, a productione alicuins diuerfi, qua funt agentia requiuoca.

\section{cur paßiua qualitates non patiantur ab a-} ctiuis,nifi coniunctie. Cap.VI.

in $\mathrm{A} x$ his fumitur folutio ciusdem dubij, quod Extrbarealiquem poffet: quando chim ma. terixaptrad patiendum adiungitur agens", neceffe elt vt actio fiat; qumm igitur quodlibet elementum vnam habear qualitatem actiuam, \& alteram paffinam, deberet quodlibet agere in feipfum; ignis enim vt calidus deberet agerein feipfum,vtuccum, \& ficreliqua omnia clemen-

o. ta.Sed folutur, quia materiaidoneaad patiendum à duabus acti uis non eft iolum liccum, nec folum humidum, fed ambo cóiunictas id eo dur actiux non poffunt in paffuas agere, nifi m mifto, quod conitat ex ficco \& humido: quisquis enim nout quid fit congelatio, nouitetiam non poî́:a yuampuram, fi daretur, ab vllo frigido congelari, fedideo congelari aquam, quod habet aliquid terræ compuiftum, \& ira conftat ex humido \& ficco: quodidem dereliquis omnibus dicendum eft:loquimur autem de talı aftione, qua producantur fecunda quaiitates; nam pati polfe etram elementum implex à implici, vt inca dienmeft, nou inficiamur. Huic taner iolutioni videntur verba Ariftot.aduerfari, wm qux legunturin 1. contex. 4. Meteor. vbi dicit rbis humidum, \& ficcum parià duabus actiuis, tum ote vtraque fimuliuncta, tum etiam alterum fep.rratim acceptumine al tero: ideo yerba illa ma-gnam interpretibus difficultatém fëcerunt, qui varias interpretationes afferendo fignificarunt nagnam effe illius loci obfcuritatem; quum præierimillarum interpretationum nulla, fi beneperpendatur, ita fatisfaciat, yt in ea polfit animus acquiefcere: eas igitur ego all is confiderandas relinquam, \& illam adducam, quam puvo. to efle fllius loci veram interpretationem. Credo Ariftot.dicenterm hamidumfecundum fe, \& fiecum fecundum fe, non intelligere el : menta vere fimplicta, \& pura, qualia an dentur ambigitur, fed un hoc fequi comnnem loquendiconfuetudinem;etenim nomine elemenci appellare
A folemusid,in quo magnusillius el cmëti fit $c x-$ cellìs, quia reliqua in co cömifta non animad"mertimus:aquan cnim \& nıris, \& funiorü, $\forall$ ocamus aqum, hectpuranon lit, \& dicims a q iam congclari, quóniam corpus illid non alio nomine apellomus, quan aquam, propter magnum a yuxescollim; quamuis ron congelárecur, nuli a! iquid ecrre commultum liaberct: hoc igiturab Ariftor. ibrvocaturhumidum feB cundum les\& iccum lecundum le, hocelt, teria \& a qua , qurnobis videntur clie clementa puraj quoniam in aquanon vid :mus com niftum ficcum, \&in terra non animaduertımushumiditat:m admiltum: fic igiturliccum fecundum le, \& humidú lecundun le appollatelementa, qua crediutur efle limp!icin, propter magnum alicuus elcmenti exccffum; mifta vero corpora, qux non elemen: i nomineappellantur, quonia manifefte funt mifta, vocat conftantia ex ficco \& humido : inaq; fi fpectemus id, quod apparet, videntur ficcum \& himidun tum conmn fa, tum feparatim accepta pati à duabus actiuis; attamen fecundum rei veritatem non patiuntur nificonuneta. Confirmantautem maxime hanc noftram fententam illa, qua de putredine elementorum dicumturab Arift. in contex. s. eiusdem libris inquit enim omnia elementa putrefere,excepto igni, \& exprefle nominat teran, \& aq!am, \&aercm : atamen quisquisintelligat qud putredo fit, is cogno feet cam foli miD fto competere, quum nilaliud it, quam miti difolution in elenenta, è quibus conitabat; eft enim proprius mifti interuus, quatenus miftum eit, quielemento vere fimplicicompeterenullo modopotett bifiolui namque in componentia nonpoteft id, quod implexcft: vocat igiur ibi quoque Aritt. clemenia suxtacommunem hominum appellationem, quia propter magnum illius elementi excefium nominibus elementorum appellariconfueuerunt;putrefcunt tamen, E. quia reuera iunt mifta, nam fi vere fimplicia exifterent,putredini obnoxia non elfent : ita igitur dicendum pidetur etiam in $\mathrm{I}$. coniex, ciusdem libri, A rifotelem dicentem humidum foltum, \& ficcum folum, non rem ip anisefpreere, fed folam loquendi confuetudinem.

\section{Cur Arifieteles non aliter definiuerit pri- mas qualitates, quam vt dejeniuit... Cap. VII.}

F CEterum quia definitio non folum eiusmodi clle debet, vt illa, quxin ea fumu.2tur, vere pradicentur de definito, fed vt fre:1tiam quoque ipfus perfecte exprimat, hxc qua que in prefentia conliderandun eft; dubitare enim non asquie rationealiquis pulfet, ne per has definitiones cllentia primarum qua:i. tarum exprinatur; fic enim déniri videntur 
non mode per pofteriora, fed ctiam peracci- A dentalia;nan primaria operatio calidi eft calefacere, ficutifrigidi refrigerare; at congregare homogenea, \& heterogenca, fint operationes fccundaria, sremotx, qux à calido, \&à frigido non exereentur, nifi per med̉ias primarias, dalefactionem, à refrigerationem; effeotus auten! remotus videtur efle accidentaliṣ fure caumf $x$; quum per alium priorem efrectum producatur; non poteft igitur illius caufx effentiam dcclarare : Ariftoreles ergo vel per priora definire primas qualitatés debuit, vel fi per pofteriora \& per effectus definire voluit, debunt faltem definire per proximos \& primarios, non

Pöponatijfolts tio.

\section{Verajo-} lutio. per remotos \& fecundarios. Pomponatius in unitio libri quarti Meteorologicor. ad hoc dubium refpondet, Ariftot. ibi fic definire primas qualitates, quạa in illo libro eaș confíderat,prout refpiciunt mifum \& generationem, mifti; fecundum hancenim conliderationem non fuiffet conueniens illas definireper primas operationes, quie funtcalefacere, \& refrigerare, quum has edant non minus in fimplicibus, quam in maiftis; eas igitur definire voluit per fecundas opcrationes, quas edüt in folis miftis; hre namque funt prinçipaliores refpectu conftitutionis mifti, quam calefacere, \& refrigcrare, licet iftæ fint illis principaliores origine. Hinc coltigit Pomponatius difcrimen illius quarti Meteoro$\operatorname{logici}, \&$ duorum deOrtu \& interitu in elemen. tis, \& eorum quali tatibus confiderandis ; in lib. enim de Ortu \& interiț confiderauit Ariftotelesprimaš qualitates, prout edint operationes fuas in fimplicibus, non in miftis; in quarto auten Meteorologico,prout operantur in miftis, non in fimplicibus : quo fit, vt in libris de Ortu \& interitu dicamus, primam operationem calidi effe calefacere, \& frigidi refrigerare, \& humidi humeetare, \& ficci exiccare, quoniam ibiomines funt actilix, \& omnes paffiux: in quarto autem Meteorologico dicamus, priman operationem calidinon amplius effe calefacere, fed potius congregare homogenea, quoniam hxc eft magis pracipua in conftitutione mifti. Per hancigitur operationem definiuitibi, Arift. calidum, \& alias qualitates fimiliter: quoniam aliter eas definire conuenit in quarto Meteorologico, aliterin libris de Generatione. Hancreponfionem ego quidem aliqua ex parte probo, fedaligua ex parte probare minime pollum: quod enim ad dubium ipfumattinet, veram ef fe folutionem puto; quia quum definiantur hæ qualitates vt principia miftorụm tum materialia , tum efficientia, recte definiuntur per effectus pofteriores, nomen enim principij refpectiuum eft, \&r notatrelationé adéffectus , quorum eft principium, proinde per humc.refpectumilla omnia, qua vt promcipia definiuntur, definiridebent; talem videmus efle definitionem primamaterix in calce primi Phyficorum, \& nature in intto fecundi, \& animæ in principiofecundi de Anima : quum autem per effectus pofteriores ibi definiri debuerint primæ qualitates, vbi vt principia confiderantur, \& horum effectuum plures fint gradus, refte ctram factum eft vt definirentur perillos effectus, qui fpectāt productioném mifti; per caleffactionem B vero non recte fuifet definitum calidum, neq; perrefrigeratiónem frigidum, quoniam $h x 0$ perationes à calido \& frigido eduntur non minusin fimplicibis, quam miftis;ręte igitur fuit definitum calidum per cōgregaționem homogeneorum, \& frigidum per congregationem omuium indiftincte, quoniam itre operationes refpiciunt miftum: hæc izitur eft dubij folutio optima atque firmifluma... Sed quando Pomponatius hinc colligit difcrimen quarti Met eorologici, \& duorum de Ortu \& interitu in primarum qualitatum confideratione, meo quidem iudicio egregie decipitur; quia nonaliter definiuntur primæ qualitates in fecundo de Ortu \& interitu, quam definiantur in initio quarti $\mathrm{Me}$ teorologici, fedeodem prorfus modo vtrobique; imo in illo quarto h h definitiones non omino exprimuntur, fed imperfecte tanguntur, tanquam diligentius traditæ priusin fecūdo de Generatione, yt in proprioloco : quamvis enim in lib. de Ortu \& interitu confiderentur etiam D primæ harum qualitatí operationes, quæ funt. calefacere, refrigerare, humectare, \& exiccare, quia fine his aliæ fecundæe operationes produci non poffunt; attamenquando vult definitiones affignare primarum qualitatum in contextu 8. \& 9; librifecundi : Ariftoteles nulla facta: mentione de primis earum operationibus, definit eas perfecundas folas, quizmifti generationem refpiciunt, vt ipfemet Pomponatius confiteturjinquit enim calidum efle quod con gregat.

E homogenea; frigidum vero, quod inditincte congregat omnia, tam homogénéa quam heterogenea; deinde humidum, quod non habet. propriosterminos, \&alienis facile terminatur; \& ficcum, quodeft propriis terninus terminatum, nec facilerecipitalienos : quaxerdem definitiones tanguntur etiam in initio quirti Meteorologici:: ex his ergodefinitionibus, \& ex ipfiusmet Pomponatij confeffione colligimus \& elementa, \& primas qualitates confiderari F. Wrobique, yt principia miftorum, neque in hoc confiftere corum librorum difcrimen, fed in alịo,quod confiderarenon eff prxfentis cótemplationıs, fẹd fuit à nóbiș cum diligentia declarạtum alias , dum publice in Patauna Academia 4.illum Meteorolog. interpretaremuritaq: mirand ü profecto eft; quo modo l’öponatius dicateffealiter defuniedas primas qualitates in li- 
bris de Ortu \& interitu, alitcrin 4. Metcorolo- A gic: quum tanen nulla in libris de Oru \& interitulegatur larun qualitanm definitio, nif quam liabenus in contextu 8. \& 9. libri fecun. di, quam. eandem legmus in initio libxi quarti Meteorologicorum, qux indicat virobiq; confideration m cum refpectu, \& rclatione ad mifta. Vt igituradid, de quo fermo erar, redeamus,prima operationes primarum qualitatum: funt quidem origine principaliores fecundis operationibus corunden : alia ramen rationc nö fint prxcipux, fed ipfis fecundx funt principaliores, nimirum in mentc \& intentione naturx nolients generationem mifti; dum enini miAt a refpicimus, primxoperationes ad fecundas inm: tanquam adfinem diriguntur. Sed alia de his difficultas oritur, quam confiderare oportet: quum enim fecundx prinatum qualitatum operationes piurina fint, cognof cendum eft, cur non per alias, fed per folas memoratas A riftot. definire eas voluerit; calidi nam que fecundre operationes funt.\& congregare homogenea, \& terminare, \& indurare, \& mollire, \& liquare, \&. alix plures : cur ergo Ariftotel. potius per con. gregationem homogeneornm, quam peralias cillidum definiunt, quum aliæ quoque fimiliter miftum refpiciant? fic etian de aliis primis qualitatibus dubitare poflumus. Ad hæc dico,non potuiffe Ariftotelem per aliquam aliam fecundam operatıonem primas qualitates definire, nifiper has, per quıas definiuut : nam fi alias calidı operationes confideremus, pernullam illarum-fecernebatur.calidum à frigido, fed per hanc vnam, qux eftegxegare heterogenea, vt hom ogenea congregentur: nam terminare, indurare, mollire, hum ectare, exiccare \& fi qux alia funt, non minus frigido atrribuuntur, quam calido, licet variis modis; etenim quxà calido indurantur, acterminantur, ea molliuntur,ac foluunturà frigido; \&cilla qua indurantur,acterminantuxà frigido, ea molliuntur , \&. foluuntur à calido:pernuliàn ergo iftarum poterat calidum à frigido, \& frigidum à calido feparari : poterant quidem feparari perprimas operationes; qua funt calefacere; \& refrigerare; fed ha non répiciunt miftum, quum competant elèmentis etiam in fe mutuo agétibussimo \& abfuda talis definitio videretur; effetenim quodamunodo idem perfemetipfum definire : adde quod pereffectus porteri ores definire primas qualitates conueniens non effet, nifi vbiconfiderandx proponuntur ve principia mifto. rum. Separari etiam poterant per rarefacere, quod eft proprium calidi, \& immediate infequiturcalefaetionen, \& per condenfare, quod: eit proprium frigi di, \& immediaterefrigeratiorem infequitur fed neque hæc refpiciunt miitun, guiaetiam in actions slementorum mu- tua absque vllo refprectu ad mifta fit rarcfactio, \& condenfatio; calidum cnim in aquam agendocam rarefacit, \& in vaporcm acrensquc conucrtit; figidum vero in acrem agendo con denfatiplum, \& vertitinaquam : non potcrantergo per has operationes, qua non relpicimt miita, bene definuri prim $x$ qualitates, vbi crant confiderandx it principia miftorm. Hacigitur norma fi femper vtamur, crrare non poflumus:primæ qualitates vel déiniuntur vefecin-

B dum ic, \&abfolute confiderat $x$, vei vtprincipia miftorunı; fi fecundum fe, \& abfolute, non percffectus polteriores funt definiend $x$, fed per canfas priores, quum fint accidentia à catifis, quas mox confiderabimus, pendentia; quapropter hoc modo pernullam operationem eas definire cöunenit: fiv vero vt miftorū principia confiderentur,per effectus qui dem pofteriores definiendx funt, fed perillos tanrum; qui refpiciunt miftum, cuufmodinon. funt calefacere,

C retrigerare, rarefacere, \& condenfare. At quia proprium calidi eit per rarefactionen fegregare inucem illa; quæfunt diuerforum generum,idque non infequitur aliam rarefactionem; quam illam, qurefit in mifto; ideo calidum à frigido recte feparatur per fegregationé heterogeneorum, quam infequitur.congregatio homogeneorum, quum hxc operatio fiat per folam rarefactionem, \& extenuationem; qur eft propria calidi , \& ipfum diftinguit à frigido : fic etlam frigidum recte definutur.per congregationem onnium, tam homogeneorum; quam heterogencorum, quum hæc fiat per condenfationem, \& conftrictionem, qux eft propria frigidi, \& ipfum diftinguit à calido.Paterigiturnullam efle operationem calidi, vel frigidi, per quam melius definiri potuerint, atque a feinumcem difingui, quan per has, per quas Arift.calidum \& frigidum definiuit. . Deficco autem \& humido longe clarior res eft: quum enim hafint qualitates paffux, \& receptiu omnium actionum calidi, \& frigidi; conuenientifime definiuntur ? perhas patibilitates, quia per lias fignificatur. primarium harum officium in productione mi-. 17i: curenim miftum conftare debeat ficco, \&: humido terminandis, atque regendis à calido, \&-frigido, nulla eft al ratio, nili quaficcum foiù non facile terminos reciperet abactiuiş quia ficcum non facile terminatur ab alio; a diecrum érgofuithumidun; yt cum ficco commiftum redderet totun facile terminabile ab actiuis: facilis ergo terminatio habetur merito humidi, idque eft præcipuum munus hinidi in miftione : contra yero, quia folum humidum, etfi faciléterminos abalio recipit, non tameneos retinet, quia labitur , ac diffuit: ideo necefaria fuit committio ficci ; per quod termini iam: pes humidumrecepti retinerentur: vt ergo of- 
Ficium humidi in miftionceft facere, vt tẹrmini facile recipiantur, ita ofricium leci eft faccre, vt receptretineantur, \& conternenrur: refe igitur hadur pantux qualintes definiuntur in contex.9.lib.z. di Ginentione, per operam; quam preftant in contiutione mifti: vnde collizere folimmusid, guodantea diccbamus, conliderariprecipue in his definitionibus ficcū terreum, Ehumidum aqueum, quorum ea funt orficia in miftione, vt if femet Ariftote! es docet in eo

zabium fecundolibro. Sedalia exoritur quxltio, ex cuius folutione mirandum profecto erit, quä belle omnia confonentyeritati, quum etim quatuorprime qualitates lint accidentia, \& caufas habeant priores, per quas etiam definiri poterant; cur Ariftoteles nusquam inuentur eas in defininiffe; fed femper co modo, quem de. claramimus,per effectus poftcriores? huius dubij itullam apud alios folutionem vnquam vidi, imo ne tetigife quidem alıquis dubium hoc

Solwtio. videtur. Solutio autem nulla, meo quidem iudicio,afferripoteft, nifiilla, quam alias expofui fure in libro de Naturalis feicntire conftitutione : furt enim à philofopho naturali cognofcendares narurales, vt funt i natura conftitutæjeleméra autem prodıcta funt à nacura, tum ve fint naturalia corpora mundum complentia, tum vt fintrincipia miftorum; iden debuit Ariftoreles diftinctis in locis ea his duobus modis confiderare:non fic animam; hæc enim nonita eft in rerum natura, vt fit ens per fecompletum in fpecie, fed vtcomplèmentum, \& perfeetio alterius fit, nempeformale proncipum corporis animati; ideo Arifoteles nullibi cam confiderauit abfolute vt ens quoddam, led folum vt principium ipfam definiut, proinde pertefpectum, \& relationem ad corpus animatum. Sic eigo de quatuor primis qualitatıbus, dicendum eft,non funt enim alia ratione elementis tributie à natura, nifi fropter milta, \& vt per eas elementafine principra niftorum: idcirco Ariftoteles refoiciens conilium natura in his conftituerdis, non al to modo cas confiderare, ac definire volut, nifi ve fint principia, \& ve refprciunt miftum; hicenim folus fuit naturæ fcopus in tribuendo elementis quatuor primas qualitates; \& hoc modotantum, nonalio, Aritoteles cas confideralfe fatendum elt, niil cecivel pertinaces fimus: ob id in contextu 8. \& 9. hbri 2. de Ortu \& interntu in adducendis harm qualita:um definitionibus denonate efienualem ciseffohne refipertum ad multa; dicensenim calidum \& frngidum ita appellari, quia funt aciua, humidumvero \& ficcun ita dici, quia funt pailiua, indicatii jpamet rocabula hanc refrectum fignificare. Hatsc vanam ego viderepoun huits quationis folutionem; illi vero qui negant clementa, \& primas qualitotes in
A libris deOrtu \& interitu vt miftorum principia coniderari, \& Cententiam ilham Auerrcis, \& noitram non recipiunt, aliam refponionem, fi. poilunt, inueniart.

\section{Deculfis primarum qualitatum in elemë- tis opinioaliorm, \& eins reproba- tio. Cap.VIII.}

Q Voniamaurem prima qualitates, vt prædiximus, accidentia funt; accidentia verǒ o.

B mnia caufam alıquam extra fe habere necef́ce eft, à quo producantur, eamque veh in eodem fúbrecto, vel extra; hanc nos contiderare \& congnofcere oportet; quum alıquidin fe haberevidcatur difficul atis. Ariftot. enmm in lib.1. Meteor. cap.4. dicere videtur, elementa recipcre has qualitates à Colo; proprerea quod aer, \& i-gnis, cum circumferantur, accenduntur, \& calida rèdduntur, quia motus calové producit; terravero, \& aqua propterimmobilitatem frigida C manent, hoc ett, quoniam illo motu non participant:hoctamen Arifor. ditum onmbus negotium facelfit, quia fi hrequalirates funt elementismaturales, \& eorum naturas confequuntur, non ergo eis tributunrurà Colo, vel ab vlla alin externa cauía fí cnim a Cocli motu aer \& ignis calorem reciperent, non conlequeretur calorpropriam horum elementorim naturam: ob id Gracipradicta Ariftot. verba confiderantes', ad alium fenfum ea traxerunt: quum enim Ariftot.ibi d̂cat, totam hanc inferioris mundi materiam efiepoteftate calidam, \& frigidam, \& humdam, \& ficcam, actu auten tilem reddi à motu, \& inmobilitate; ipfi talem corum verboritinterpretationem adintenerunt, elementa caldda habent poteftatem vt finnt frigida, \& elementa frigida funt poteffate calidai quáre omnia elementa quum fint actu prodira aliquibus qualitatibus, poteftatem habent contrarias qualitates recipiendi:quod vero Ariftot. ait $\mathrm{E}$ [fit talis, Es est, a moits, Ev immobilitate] ipfi nonde Culi mótu intelliguñt, fed de ipforum elementorum mutua interle mutatione, vr fenfus fit; dementim frigidum tit calidum à motu, id eit,à mutatione illa, qua mutatur in calidum ; \& clementum calidum fit fimiliter frigidun à motu id elt, áb illat mutatione, qua vertiturin frigldum : elt alitem feu calidun, fen frig:tum abimmoblitate, id eit a priuntione talis mutationis, \& à perfeucrantia in fuo calore, vel frigor: \& itaclumenta fingulis cas, quas iam habent, qualitates retmenr per immobilitatem, id elt,guando non muantiur in aliud; illis vero contraras, quasion habent, reci iuntpermiltaione, cal crationem : hane Grocorum len-

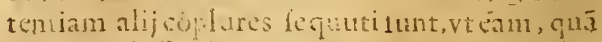
dnimus, dilichliatem y harent. Est tamenalienilluma elt à verbis, \&u cólio Arít. co in loco, \& 
omnino verba illicum fenfum habent, quem antea diximus, \& quemipfreiceruft; :am id, quod utti dicunt, non elementis totis, fed de corum tantum particulis verum eft; nonenim mutantur ţota, fed partıcula, idq; fit cti.um abfque vlla Cueli conlideratione; nam particula ignis mutat particulam aqux, tanquam agens proximum, nec fitilla mutatio à Cuclo, nifite abagente remoto, \& vniuen fali. Ariftautem ibi loquitur de elementis totis, \& de ipfortun vniterfitatibus, \& totam hanc inferionis mundi materianivt patientem \& gubernatam comparat cum Colo, rt agente, \& gubernante prosimo: confideratigitur totam hanc materiam omuibus naturis lecundum fen:łaram, quæ totam hunc infertorem nundum complet, \& inquit can efie poteltate calidam, \& frigidam, \& hismidam, \& ficcam, retu autem 1 ecspere has qualitates ì Coclo, nempè motu Cueli, \& à niga.roncillius motus; quod etiam bi declaratapertilime, dum inquit; quum Cuslum feratur ciculo, pats inicrioris mundialli propanqua accenditur,\& calida redditury roculautem a Coelo in medio mun dipolitum eft id, quod grauilfinum acfrigidifimum eit : Ipience igitur Ariftotel. declarii quem mocum, \& quam immobilitatem intelligat, nimirum motum Coeli in orbem, quo participant duo lementa fuperiora ignis \& aer, \& eins negationem in duobus elementi a Coelo remotis, terra \& a qua, teftaturqॄ: ie non de particulis elementorum loqui, quæ inuicem mutantur, fed de eorum vninerfitatibis, quarum dux à Colo cricum fertintur, quoniam illi propınqu fartucipant motucirculari, vnde calorem adiprl cuntur; dua vero eo motrimmobiles manent, quoniamita fune remง:æà Cœlo, vtnoncircumuoluantur. Efiet etiam iùa iflorúm lententuäincongìu \& inepta admódnn Ariftotelis loquitio ; ridiculum enım eft dicere aquam fieri calidam a motu, quando mutatur in elementum calidum; non enim ab illa mutatione fit calida; fied à gencrantce, quod dansfor mam datomnia contequentia fornam. Sed multo vanius eft, dicereaquam. cile frigidnmabimmobilitáte, \& ignem \& aczem élie calidosab.immobilitate, hoc eft, quod in elémentum contrarium non mutentur : inepriffima enim ef hrec loquutio; quoniam ignis mon idco elt calıdus, quod non mutetur in corpus frigıdum, fed quia eft ignis. Elt etiam aliena ea interpretatio à copo, \& à confilio Ariftotelis in eo loco , \& importunifinta ea fent entia : nam Anftotel, iam quæftionem propofuerar de vnineritatibus elemetorum ignis \& acris, quomojo ob virios eorum litus refpectu Cøh, 1eu varias fubitantias à Coelo, diuerfas etiam qualiktes, \& naturas adepta fint; vt per huus quxstionis difiolutionem intelligeremus etian dif
A crimen trimn reotontm aeris ratione primarum qualitatum; à quo infitutoalicum penitus cit confiderare mutationem particulatium elementorum inuicem, quæadillud nihilconducit. Hoc autem culibet eum locum bene confidcranti ita manifeftum eft, vt mirandum fit quomodo tot preftantes viriad eam fententian veiba Ariftocelis extorquereaufi fint; fed videntur in illud abfurdum incidifle, vtaliam difficultatem, quam abfoluere nequiucrunt, efB fugerent, caque eft, quam nos paulo ante tetigi$m$ is, qui ficripoffit, vt prinx qualitates fint elcmentis naturalis, \& ipiorum formas confequantur,fit tributnurullis a Coclo. Ideoalii,vt hæc.vúnqueabiurda vitarent, aliam illorum verboruminterpretationem cxcogitarunt: dixerunc enim harum qualitatum fingulam poffe in clementis duplicem confiderari inempe tün naturale, quxpropriam elementi formam confequitur, tum aduentitiam, quxe eidem elemento uribuiturab actionecolefti, vt in igne duplex fit caló, vmus naturalis, \& infeparabilis, quicmanat à propria ignis natura, alteraduentitius, quem reciput ignıs è motu Oocli, dum circumducitır: de hociğitur loquitur in dieto loco Ariffotel.quando dícit, corpus mnndi hríus. Coelo propinquum circumuolui, \& accëdinnon enim loquitur de naturali ignis calore, fed huic prxfupponens refpicit folum calorem aduentiD timm, qui in duobus elementis, igni, \& aere gencratura motu Colípreter calorem curundem. eicmentorum natnralem: ficut enim dúo elementa frigida præter'frigus ipforum natuale? recipinnt etian aliquid calorisab actione caelefti per radios, tanquam diftinetam yualitatem abcoum frigorenaturali; fic de duobus e-. lementis calidis dicendum eft, ea præier cálorem naturalem reciperealiumextrancum calorem à Cosli motu. Hæcilli dixere, \& itaputa-

E runt fe omnem hacin re difficultate fuftulife, quod vtinam praftitifent:nobis enfin nihilamplius laborandum hac in refuifet: at certeverba Ariftotel. hancinterpretationem nó recipiunt, inquit enim totam hanc inferioris mundi materiam elfe poteftate calidam, \& frigidam, \& humiciam, \&uficcan, actuatem talem fierià motu, \& abimmobilitate, nullum igitur calo rem elementis tribuit, præterillum, quem à mo tu Coli recipiunt: praterea quale frigus in eleF mentis confideratibiAnftotialen etiam debet: confiderare calorem, quia eadem effe debet harum omnium qualitatum?, quas ibinominat, confideratio; atqui frigus confiderar naturale, fiquidem. Coelum agendo non refrigerat; fed; potius non agendo, quare dum dicit, frigidnimum in inedo confifere-naturale refpicat fri- gus, quum pi ’ertim fuperlaciuo vtatur, quias nö datur fumme calidum, aut fumme irigidum

\section{Confut of tio..}

inis: 
nifi naturale:adde quod adiicit, \& grauifimum, loquiturautem de grauitate naturali, ergo \& de naturali frigore, proinde etiam de calore clementorum naturali : quam fententiam clare apud Auerroem leginus, in comment.94. lib.de Colo, rbidicit [remotio a motu circulari dat quitcm, frigiditatem, Eg grasitatem, ficurpropinguitas dat motum, calorem Eleuitatem ] quæ verba non poffunt intelligi, nifi de qualitetibus naturalibus, \& in elementis totis, non in

Cöditioeorum particulis. Sumitur autem huius fen nesloci tentia validifima confirmatio, ex confiderationeloci, cuius conditionesin 4. libr. Phyficx aufcultat. ab Ariftotel. egregie declarantur: locus enim non modo continere locatum debet, fed etiam conferuare pervim, reu facultatem, quam habet, illius conferuatricem, in qua eft præcipue loci natura conftituta; nulla enim afferri ratio poteft, curad locum fuum ferantur corpóranaturaliter, nifi hac van, vt in eo conferuentur, indita enim cuique rei ì natura eft propenfio adfe conferuandum, quantum poteft: quapropterilla, qux plenam feconferuandifacultatem non habent, externo conferuante, quem locum vocamus, indiguerunt, ipfum ipfum igitur naturaliter appetunt, vtabillo conferuentur; neque enim propria cuiufque rei natura rem moneret ad fuum locŭ,nifi in illo conferuaretur; quoniam vniuerfe in omnibus, in quibus caufa effectrix proptèr finem agit, finis Sola ele-precipua caufa eft, \& eo ablato efficiens illud mental lo: non efficeret: hæc quum loci natuta fit, manifecüGere ftumett, fola elementalocum propriefuimptum babent. haberc; miła nam que omnia locum in mundo habent ratione elementiin corum miftionc præ. ualentis, iuxta quod habent etiam motum naCaleftis nonfint inloco.

turalem, qui eis competit quatenus grauia,aut leùia funt; coleftia vero corpora non fuñt proprie in loco, licet enim orbes inferiores à fuperioribus contineantur, non ob id in loco funt, quia ab eis non confertlantur, quum ob exorum perfectannaturam conferuante externo nó in. äiguerint:folis igitur elementisper fecompetit locus, miftis vero per paticipationem elemétorum, at Calo(vtinquit Arılt.)peraccidès, quod quomodo intelligendum fit, cōíderare, ad nos in præfentia non attinet; fed quum dequalitatibus elementatibus fermo nobis propofitusfit, a elcmenta fuapre natura ad fuoslocos ferantur, \& in eis quiefcant, vtconferuentur, cognofendum eft, qurnam fit facultas conleruatrix, F qux in locis elementorum inefle dicitur: de inferioribus quidem elementis dicere poffumus, conferuari lingulum à fuperiore ratione fymbolæq qualitatis , \& in hac confiftere vim conferuatricem elementi locati; fed hoc de ignis loco dicere non polfumus; quonian in mulla qujlitate conuenitignis cum $\mathrm{C} \propto l o$, cur igitur in con-
A cauo Coli conferuaturignis? certe non poten alia ratio afferri, nifi hæe vna, vt in orbem voluatur, fic enim conferuatur, quia nifi moueatur, extinguitur: attamë fi cum illis diceremus; igne à Coli motu non reciperealium calorem, quan extraneum, proprium vero eius calorem ita formam ignis infequi, vt illi à Coelo non tribuatur, non ellet cur ad Colum mouteturignis, fiquidem cius conferuatio confiftit in conferuatione propriæ qualitatis, non in adeptione qualitatis B extranex; imo calorille extraneus ad ignem ita fe haberet vt calor febrilis ad coipus animalis, qui excedens gradum naturalem inimicus animali eft, \& eius deftrubtius potius, quam conferuatiuus ; itaque tantum abeft, vt fponte fuperum locum petere ignis deberet, vt potius illum fugeret, vt pernici ofum, \& hoftilem. Præterea fententiam hanc magnumaliud abfurdum fequeretur; daretur enin calor caloreignis maior \&intenfior, quod communi omnium confen-

C fionifalfumelle exiftimatur; afferint enim omnes, fumme calidum maturaliter efle ignem, neque polfe exiftere fine fummo calore, proinde non dari calorem intenfiorem calorè ignis naturali, confequens autem facile oftenditur; quum enim Ariftot. dicat corpus Colo propinquum accendı \& calidún red di à motu Colli, hoc ipfintelligunt, non de calore ignis natura. li, quem dicunt iam ex fe ignem habere rfed de aduentitio:igitur fecundum cos Ariftot diceret ignem accendi, \& calidiorem reddi, quam per femetipfum erat.

\section{opinio propria \& cius declaratio. Cap. I $X$.}

Q Voniam igitur ne grare nitllo modo porfumus, Ariftoter.in eo loco de naturalibus elementorum qualitatibus loqui, id nobis relinquitur declarandum, quomodo naturales clementis dici poffntilla qualitates, \& corum E naturam confequi, fi tribuntur elementis à Cælo. Nosigitur dicimus, non pugnare inter fe hæe duo, quamuispugnare videantur : quatuor enim primæ qualitates, quæ \& elenentis \& miftis omnbus in funt, fiue extrema, fiue ad mediocritatem redactx, quæ dicuntur niftorum temperaturæ, non ea ratione dicuntur fingulis corporibus naturales, quod eorum naturas ita confequantur,vt confequitur effectus caufam à 'qua producitur, adeo vt formaignis producere in igni dicatur fummum calorem; hoc enim dato, non egeret elementum cöferuante externo, proinde ad locum fuum non moneretur naturaliter: fed ea ratione naturalés dicun tur, quia ipfa elementorum nature has qualitates requirunt, \& fine his exiftere nequeint; dant tur tanen illis à Colo, \&ab eodem conferuartur, \& earum confruatio eft confertiatio natura ipfo.

\section{Prim qualis tis qu modo. tisna rales: a Cal proue. ant.} rแม1 
rum clementortm ; in locoenim proximo cœlefti motni conficuatur igni fummus calor, \& cum co ipfamet ignis natura, quemadmodū fi ibinon ellet ignis, gencraretur ab illo motu in illa materia lummus calor, \& forma ignis; ita igitu datColın igni fummum calorem,vt det etiaın iplam ignitatem ; itaq; fi bene confideremus, primæ qualitates, fue fumm , fiue caftigate tum in elementis, tum in miftis omnibus pracedunt genetatione formas fubftantialcs, quia funt præuix præparationes pro eductione formarum, \& tribuunturab agente externo alterante, \& generantc fingulam rem; non igitur ab ipfarei forma proueniunt: naturales tamen cuique rei funt, quia conuenientes natur $x$, imo \& neceffarix; ctenim fine his propria cuiufque mifti, \& elementi natura non conferuaretur,ficuti neg; generaretur fine pracedente harum aduentu in materia: hoc fignificauit A.riftoteles in 6. contextulib. 2. de Ortu\& interitu, dum cattfarum materialium feriem exponens dixit effe $C$ primo loco materiam primara nudam, \& prorfus informem, fecundo autem loco effe materiam preparatam primis qualitaribus, tertio demum loco iam eflè elementa ipfa, ignem, ae$\mathrm{rcm}$, aquam, terram, qux funt propinqua materia omnium miftorum. St quis igitur quxrat an primx qualitates fint formis elementorum priores, an pofteriores; dicendum eft, \& priores \& pofteriores effe varijs rationibus, nam origine, \& generationis ordine pricres abfque dubio funt, ficuti prauize difpofiriones funt generatione priores forma Yiubftantiali, ad cuius eductionse diriguntur: fed natura pofteriores funt, quatenus funt accidentia, nam accidentia funt fubstantiis pofteriora; \& quatenus funt effeetus, form 2 vero funt cauf $a$, non quidem effe' Exices caufx, fed finales; nam qualitates in materia producunturformarū fubbttantialium gratia, \& ad eas tanquam ad finem diriguntur, ficut ctiam conferuantur in elementis à Cœlo, vt ipfa elementa conferu entur;ita vt caufa harum qualitatum finalispropinqua fit elementonum con-. ftitutio, remota vero, \& vltima fit productio miftorum, nam elementa conftituuntur propter mifta, \& vt eorum materia fint. Sic igitur dici poffint qualitates confequi formas elementorum, quatenus forms funt earum caufa fina: les: ipfac vero qualitates, etfi funt praparationes proeductione formarum, non ob id caufa formar um dici poffunt, fed effectus tantum: polte- $F$ jiores, quum accidentia fint natura pofteriora. fubftantiis: quare dum fimul in elementis exi-

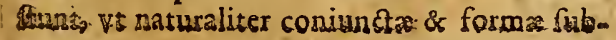

A ftantiales, \& proprix qualitates, formx tamen priores funt, qualitates vero pofteriores, \& ita dicunt confequi formas elementorum, quum. prafertim, vt modo dicebamus, formarum \& educendarum, \& cōferuandaruu gratiâ tribuantur elementis à Colo. Hrec igitux fuir Anftotelis mens in memora to 4. cap. Iibri 1. Meteorologicorum, quando dixit, totam hanc inferiorem materiam lecundum fe effe poteftate calidam, \& frigidam, \& humidam, \& ficean, afuautem B talëfievià motı Coli, \& ab immobilitate: hoc idem in primoeiufdem libri capite figuificauit, dam dixit,omnem huius elemêtaris mundi vir: tuten à coclefti motu gubernari; idque rationi confonum maxime eft: totum enim hunc elementarem mundum ad Calum referri putandum eft, vt materiam ad agens, proinde ex fe nihil habere, nifi poteftaté, quicquid autem aetus habet, 1dia Coclo recipere : quemadmod enina fi gener ari aliquando elementa vniuerfa, \& talia fieri copiffent, à Colo effent genita per harum: qualitatum productionem; ita quum Ariftot. nunquã inceperit generatio, ea continueà $C \propto-$ lo talia reddi, \& conferuari dicendum eft, quod in memoratis locis Ariftot. fignificauit: neque per hoc ftat, quin frimæ qualitates fint elementis naturales, \& eorum naturam confequentes; hoc enim verum efteomodo, quum deçlarauit mus, non v.t à plerifque intelligi folets putant $\mathrm{e}$. nim qualitates prou enire ă formis, vt tà caufis ef-

D. ficientıbus: quod quidétanquam rude dictum, \& exempli gratia prolatū, admitti poteft; prodire enim videntur à formis per. quandam emanation $\bar{e}_{\text {, }}$ eueratamen non efficiuntur à fotmis $s_{»}$, fed (vt dixit Ariftoteles) à Colo, tum qualitates gratiaformarum, tum formæ per qualitates; de poteftate materize edu cunturad actum : nodus tamen difficultate non caret, quomodo enim à Coli motu calor generetur, dicere facile pofiumus, de frigore autem non ita facile, $f$ ed de ficco \& humido difficillimum: ipfe namq; Ariftotel es in prædidto capite 4. libri 1. Met eorologicorum afferuit quidem elementa à motu $C$ ce: li, \& ab immobilitate reddi, \& calida, \& frig : da, \& humida, \& ficca; fed de calido, ac frigido tantum id declarauit, de humido autem \& fic-

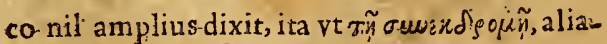
rum qualitatum ficcum \& humidum nominaffe, calidum vero \& frigidum precipue refpexilfe videatur: fed quid de hac re dici polfito ex is, qux in progreffu dicentur, intelligetur.

Deipfarum igitur primaram qualitatum.

matura, \& saufis, hæc, qua dictu.

funt, fufficiant. 


\section{A $\mathrm{C} \quad \mathrm{O}$ B I \\ $\mathrm{Z} A \underset{\mathrm{P} A \mathrm{~T}}{\mathrm{~B}} \underset{\mathrm{A} V \mathrm{I} \text { N I, }}{\mathrm{R}} \mathrm{L} \not \mathrm{E}$ \\ D E}

$\begin{array}{llllllllllllllll}2 & V & A & L & I & T & A & T & I & B & V & S & E & L & E- \\ & & M & E & N & T & A & R & I & B & V & S . & & & \end{array}$

L I B E R. S E C U N D U S.

An in quolibet elemento ambe qualitates fint fumma, an poßit altera eße remiffa. Cap. I.

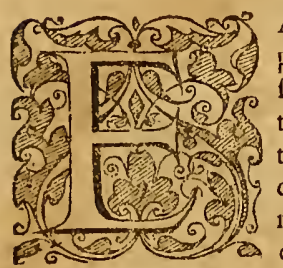

A omnia, qux in libro precedente dicta à nobis funt, ad primarum qualitatum definitiones, \& naturas. \& caufas declarandas pertinuerunt: nunc ad multas de eifdem, \& arduas quxitiones, de qui- opinio aleguorums. bas omnes Philofophi controuer fari forent, expendendas, atque foluendas accedendum eft. Inprim is quarunt interpretes Arift. an in quolibet elemento ambx qualitates fint fummx, an remiffa, an vna fumma', \& altera remiffa, \&e hac dereacerrime di/putant; alii namq; vnam tantuim dixere fummam efle, alteram vero remiffam, nitentes verbis Ariftot. in contextu 23 . lib. 2.de Generatione, vbi dicere videtur, ignem effe magis calidum, quam ficcum, \& aerenu magis humidum, quam calidum, \& aquam magis frigidam, quam humidam, \& terram magis ficAliorum cam, quam frigidan. Contra vero alii locum ileötraria lü aliter interpretantes putârunt vtramq; fumopinio. mam, \& extremam in quolibet elentento effe debere, ea ducti ratione, quod remiffio qualitatis fit peradmiftionem contrarix, proinde miftionem prefupponit; at elementum eft corpus fimplex, nullam habens miftionem; ergo neutra qualitas in elemento poteft effe remiffa:aliis quoque \& hi, \& illi argumentis vtuntur, quorum aliqua in progreflu confiderabuntur, aliqua etiam tan quă leuia, \& inutilia miffa fient: cońftitui namque breuibus agere, nec totam hanc difputationem in medium adducere, fed Irota de ipfam rei veritatem, fi fieri poffit, explanare, ac oracta- manifeftam reddere. Ante omnia id notare vosione pri lo, quod meo quidem iudicio eft veriffinum, limarum cetabaliis nonanimaduerium, nihil hac de re qualita- poffe ex Ariftot. colligi in libro 2. de Ortu \& insusm in 2. teritus non enim ibi clementa libi confideranda lib.deGe-
A proponens qualia actu exiftunt, ipforum qualitates inquirit, fedà qualitatum confideratione incipiens fumit inprimis quatuor ipfas primas qualitates effe elementa \& materian corporum miftorum, id eft, effe formas conftitutrices elementorum, deinde faciens quatúor illarū coniugationes, docet ab his quatuor el ementa conftitui, vnum à calido \& ficco, aliud à calido \& humido, aliud à frigido \& humido, aliud à frigido \& ficco, nil adhuc dicendo de corporib. quiB bus hx differêtiz feu coniugationcs cōpetunt: nam ipfas el ementorŭ conftitutrices differêtias confiderans, eas prius abftrahit à confideratione corporii, quubus insunt, \& eas ipfas elementa appellat, vt norare poilum in in conter. 16. libri 2. deinde vero his differe tiis declaratis, applicat eas primis quatuor corforib. it ibidé videre eft: patet igitur alienum effe à coniflio $A$ riftot.eo in loco cöfiderare, an illis quatuor corporib. infint hx qualitates fummx, an remifize; tales enim applicat piinis corporibus, quales prius fecundumfe defumptas cölideraucrat; at abfolute\& indiftincte primas qualita tes cöfiderauerat, $a b f$ que vllo difcrimine inten $f x, \&$ remiff $x, \& a b f q ;$ côfiderarione graduum fingularū, \& folum docuerat calidum \& frigidū, \& humidum, \& ficcu effe primas qualitates, \& ad corporum elementa conftituenda idoneas:quemadmodum igitur vanü effet in ea parte quærere an fiumat calıd $\breve{u}$ fumm $u$, an calidum remiflum, \& fic de reliquis, quĩabfolute, \& abfq; hoc difcrimine eas qualitates confideret; ita vanũ pofter eft facta earum applicatione ad quatuor pruma corpora, quxrere an in is exiftant fumm $x$, an remiff $æ$; quandoquidē confilium Arift.in eolib.eft folam cöfiderare differentiam elemı éti calidi, \& el eméti frigidi, \& ita ficci,\&humidi:quod quidē maxime cōprobatur perilla, qux poftea ibi dicūtur de mutua elementorū nutatione inter $f e$; in habentibus.n. fymbolam qualitatéinquit facilem effe mutatione ĕ, quia vna tantū qualitas mutatur in fua mcötrariam, altera vero manet, vt fí mutetur aes in ignem, mutatur hunsidum in ficcum, fed calidum 
calidum manet; attamen certum eft, non eundem elle calorem in aere, \& igne, prout reve-
ra exiftunt extra animam; quilquis cnim fenfu non eget, pro comperto liabebir aerem efle minus calidum, quam ignem, proinde non porfe in ignem mutari, niî facta quoque mutatio ne de minorecalore in maiorem : led quoniam Arifotel. difcrimen looc, quod in eadem qualitate penes varios gradus attenditur, ibi non refpicit, fed id folım, quo fecernitur contraria à fua contraria; ideo dicit manere calorem, \& mutari humidum in ficcum : revera enim dum graduum differentiam non fpectanus, non polfixmus nifi dicere corpus, quod interiit, fuifle calidum \& hunidum;illud vero.quod genitum eft, effe calidum \& ficcum. Difficultatem quidem aliquam tacere poflunt ca, qux prius in eodem libr. dicuntur ab Ariftotele de elementis à context.16. ufque ad 23. fed fi bene confiderentur, \& fcopus Aritotelis ea dicentis intelligatur, his, quæ modo diximus, minime officiunt: ibi namque non vult aliquid primaria intentione de elementis docere, fed folum dubia quxdam, qux turb.re nos poterant, remouere : primum enim dubitare poteramus de aere, cui calorem \& humiditatem jan attribuerat, quum ip frum quandoque fentiamus frigidum, \& quandoque etiam appellamus ficcum, quia videmus corpora quanduque refrigerari, \& quandoque exficcari abaere: ad hancigitur difficultatem tollendam monerenos Ariftoteles voluit varietatem, qux in elementis extra animam exiftentibus eu enit ab externiscaufis; ob id notauit duo elementa extrema, terram \& ignem, effe magis fincera, dito vero media effe minus pura, \& ita mifta potius, quam fimplicia, nec penitus affecta fuis qualitatibus naturalibus $;$ videmus enim quandoque aquam ex terra prodire valde calidam \& ferventem, quemadmodum quoque interdum fentimus valde frigidam : voluit igitur Ariftoteles nosintelligere elementa ibi confiderari vt naturaliter conftitita, \& vt abftraeta quodammodo ab his varietatibus, qux ipfis yt exira animam exiftentibus contingunt. Obid excludit etiam in ea partem ignem hunc noftrum, \& glaciem; qua quum ex nihil generetur, propter caloris, acfirigoris exceffum, dubitare poteramus, quia propter eundem exceffum digna maxime effe videbanturnomine elementi; attamen elementum non videtur dici poffe id, ex quo niliil generatur. Áriftotel. igitur ibifignificat, illa non efie elementa, nee fimplicia corpora, properea quod non habent excellum ratione graduum; quia nihil datur calidius igne clementari, neque glacies eft frigidior, quam elementaris; led habent excer. lum operationis tantummodo, quil propter nuaterize denfitatem fit, vt validiusagaits calc-
A faciendo, \& refrigerando. Ex qua dixerat, primas qualitates efle elementorum conflitutrices differentias', \& duas cuiliber elementoattribuerat, anbigere etiam poteramus, quomodouna \& cadem differentia poflit duo fpecie diftincta corpora conftituerc, vi calorignem \& aerem, \& frigus terram \& aquam, \& humiditas aercm \& aquam, \& ficcitas terram \& ignem; ideoad hoe dubium tollendum in context. 23. dixit, unam in unoquoq; elemento effe magis pracipuam, $B$ id eft, magis affinem natura illius, \& intimiorem,quam alteram : hoc fignificare ibi voluit Arittot. fed nonalteram elfe lummam, alteram veroremiffam, vt multiLatinorūpcrperam arbitrantur, non enim dicit Arift. ignem effe magis calidum, quam ficcum, fed effe magis calidi, quam ficci, vtalii recte an imaduert crunt: quare colliginon potelt, ignem non effe fumme ficcum, fed folum maiorem habere affinitatem cum ignis natura calorem, quam ficcitatem. C His auten difficultatibus fublatis, Arift. agere incipit de inutua elementorum mutatione inter fe, nec vllam facit mentionem intenfionis, vel remiffionis harum qualitatum, fed eas, vt pr $x$ diximus, abfolute, \& fecund nm proprias naturas confiderat. In eo igitur libro locum non habet hxc difputatio, an qualitates el ementorü fint fumm $x$, an remiff $x$, quia tractario illa eft quodammodo abftracta ab hacconfideratione; fed locum potius habet in libris Meteorolog cis, ubi confiderantur qualitates, qux elementis extra animam actu exiftentibusinfunt, qux varia funt, quia multas ab externis caufiz varie. tates recipiunt; nec femper elementa funt affecta fuis naturalibus qualitatibus, profertim duo elementa media, maxime vero omnium zer : ideo fecunduin hanc confiderationem duplex oriri quxftio poteft, una de qualitatib. quas hre corpora extra animam exiftentia habent actur, qux à præfenti inftituto noftro aliena eft, fed E cam tractabimus poltea, fumpta ab aeris qual:tatibus occafione, de quarum difcrimine mox loquuturi fumus,altera vero, quam in præfentia conliderare nos oportet, quxnam qualitates fingulis elementis conueniant in fua perfecte naturali conftitutione, fiquidem de qualitatbus.elementaribus, hoc eft, elementa prout elementa funt conftituentibus, dicendum in prafentia nobis propofuimus, quum enim aer mo do calidior, modo frigidior effe videatur, cognitu dignum eft, quis çaloris gradus aeri contu niens, \& perfecie naturalis fit, an fummus, in remıffus, fic dico de creteris elementis, ac de eorum qualitatibus, quod eft à nóbis in præfentia confiderandum. Proferam igitur breuiterfententiam meam, eamque comprobare nitar: poftea vero, fi qua aduerfus eam difriculiates ob a liosum opiniones exiftere videbuntur, eac disfobe 
diffolıam. Quoniam autem harum qualitatum dux funt actiux, dux vero paffure, nec vtrifque, vt egoputo, eadem ratioaccommodaDequals tur, de vtrifque feparatim dicemus. Primum tastrbess quidem dccalore \& frigore quod à Colopenactuss, deant per motum circularem, \& per eius motus gasbrs proationem, iam difun eft : ea igiturfi Arfofint fon-tel. \& vera fententia eft, inden ecelfario colligi, ma, $\vec{C}$ tur, in folo ignifummum calorem ineffe, \& in gusbess folaterra funmumfrigus, induobus autem eleremsfis. mentis mediis verumquerenitfum, in aereremufum catorem, in aqua vero remiffum frigus, \& has efle his omnibus naturales qualitates; nam fi à Coloper motum generatur in his corporibus calor, neceffe eft in proximo corpore fummum generari calorem, quum in eo fiat motus velocifimus: quoniam igirur in hoe mundoinferiore nullum corpus igne velocius. circumtertur fatendum etiam eft, 1 ihil dari calidius, \& nihil rarius igai; fed igne calore, ac tenuitate omera inferiora corpora fuperare: pro ximus enime mium eft Colo mouendi, \& maximum onnium circuitum peragit ; aer vero quum naturaliter fub igne locetur diftantiorà Colo, ita vt minorem taciat circuitum, \& tardius moueatur, non poteft tantam habere raritatem, nectantum calorem. quantum habet $i$ gnis, fed remiffum habeat necefle eft, eu mque vt libi naturalem, nempe vt naturaliter conuenientem illi corpori, quod natura fub igne ftatim locare conftituerit : quinam auten fit caloris gradus exquifite aeri naturalis, non facile eft dignofcere, fed id folum ftatuere poffumus, calorem aeris naturalem noneffe fummum, fed remifum; qui quum \& maior, \&minor effe poffit, manente aeris natura, alıquis tamen eft gradus, qui eftaeri naturalifimus, etfi eum certa aliqua ratione ftatuere nemo poteft, hanc, quam modo adduximus, effe certam demonftrationem à caufa rei æquata defumptam, nranifeftum eft: nanifi nzodusin orbem in hacinferioris mundi vniuerfitate eft caura caloris per rarefactionem, \& attritionem, \& naturale aeri eft fub igni locari, \& tardius igni moueri: non poteft aer ex motu in orbem confequi fummum calorem, fed remiffum, isque eft a eri naturalis: quocirca miranduns profecto eft, quiomodo id negare multi audeant, \& afherant, aeris quoque calorem naturalem fumm um effe; nam hi præterquam quod rationi aduerfantur, fenfus quoque teftimonio refragantur; etenim etiam tunc quandoaerem calidiffimumappellamus, vt $x$ fito tempore, certum eft minorem efle aeris calorem, quam ignis, quum in eo animalia degant, \& viuant, quxin igne viuere nullo modo poffent. Quodautem ad hocaliquidicunt, caJorem quide in aeris maximum, \& fummum effe, à nobis tamen non fentiri propter humidita-
A tem coniunctam, quanon finit ipfum fumme calefacere; hoc certe vanum eft, \& gratis prolatum, quia fine ratione, imo vero aduerfus rationem : ab humiditate enim contrarium potius oltenditur; nam li reque fummus in aere eft calor, atque in igni, debet efficacius agere cum humiditate acris, quam cum frecitate ignis, propterea quod aer igni denfior eft, idem autem calor in materia denfiore magis calefacit, quam in rariore, vt ferrum ignitum magis vrit, quam B flamma : fed manifeltum eft hos abuti confideratione humiditatis, nec veritatem confiterivelle, quam ex humiditate deductam peruertunt \& in prauum fenfum trahunt; nam fi bene confideremus, ea eft humiditatis natura, vt tam alorem, quam frigus obtundat, \& neutrum finat effe fummum, ficut poftea confiderabimus : itaque humiditas aeris non facit ne calor aeris, q̨uum fitfummus, fummecalefaciat; fed facit ne fummus efie poffit : caufaigitur, curaer non vrat, eft, quia non eft fumme calidus : cau fa autem, curnon fit fumme calidus, duplex eft: vna fumiturab agente, quod facit ne fit fumme ca. lidus, agens autem eft defectus velociffimi mo. tus, caufa. n. caloris motus eft, caufa vero remiffionis caloris, hocelt, defectus à gradu fummo, eft defectus velocitatis in notu, ex quominor attritio fit: altera vero caufa fumit ur à materia; humiditas enim eft qualitas materialis, \& paifiua, qux facit ne aer poffit effe fumme calidus; D ficalias diximus caufam perpetuitatis generationis effe motum Coeli vt agentem, caulam airten perpetuabilitatis eiufdem effe naturam primæmaterix; ex eo igitur quod aer tun remotior à Coelo, quamignis, tum humidus eft, colligimus eum ninus igne effe calidum, proinde non effe fumme calidum. Idem confirmatur ex confideratione fecundarum qualitatum, qux infequuntur primas; in aere enim minor eftraritas, \& minor leuitas, quam in igni, ergo \& minor calor; nam \& raritas, \& leuitas calorem infequitur. Quod vero ad aquam attinet, obeandem rationem neceffe eff, vt fummefrigida non fit; validum enim effe puto argumentum Thom $x$, quando dicit, terra eft omnium frigidiffima, quoniä maxime omnum diftat à principio; \& fonde caloris, aqua vero $\mathrm{m}$ nusfrigida, quod minus diftat, proinde calore aliquo, licet debiliffimo, participare videtur, ita vtcalidiflimms onnium fit ignis, aer ca$F$ lidus quidem, fed minus, aqua vero frigida, fed nonfumme, tandem terra fummefrigida, nee detur aliquid frigidius terra: hoc autem confirmatur figno manifeftiffimo, fumpto à fecundis qualitatibus, qux infequuntur primas: nam frigus facit grauitatem, ac denfitatem; at terra eit omnium elementorum grauiffina, atque denfifama; ergo etiam omnium frigi- 
diffimai aqua vero non cft fummegrauis, quare neq; fumme frigida. Quonians aulem bas qua: litates obtinent el ementa à Coclo,nemperntione fitus quem habent refpeetu Coeli, \& fitus, quem tingula habent, eft fingulis naturalis, quatenus talia funt; fatendum eft eas, quas modo dixinus, efrefingulis elementis qualitates naturales. Multo maior in paffuis qualitatubus 6. difficultas ineft, quum ex fitu \& diftantia à $\mathrm{Co}$ loịdicari minime polfunt : nanr fi propinquitas ad Coclum daret ficcitatem, dicere poffemus, humidius effeillud, quod à Colo diftantius eft: id tamen dicerenon poffiumus, quum \& ficcus fit ignis, qui Coclo proximus eft, \& ficca terra, qux om nium remotiffima; fed neque humiditatis caufa cit propinquitas, quum ignis fit ficcus, neque remotio, quum fit ficca terra. Mihi quidem dicendum videtur, qualitates paffiuas iudicari ex atiuis : quum enim funt qualitates materiales, \& neceffe fit oinnem huius inferioris mundi mateian vel humidam cfle, vel $C$ ficcan, proinde ex materix neceifitatc prouenire videantur, non quidem altera feparatim, quum hæc tota materia ita fit apta ad humiditatem, vt ad ficcitatem recipiend am, fed ambz coniunctim, hoceft vel vna, velaltera; pendent iftr quoque ab actione Coelefti, quat enus materia hre fecundum fe non habet nifi poteftaten recipiendi humiditatem, vel ficcitatem : et deternimatio prouenit $a b$ actiuis, non quod paffux fint effectus actiuarum, fic enim non effent primæ qualitates, fed fecundr: $\&$ confi deranti patet, ficcum non poffe dici effeetum caloris, quum terra, qux eft frigidifima, ficca fit, nequeetıam firgoris, quum ignis fit ficcus, \& calidiffinus : fic humiditas neque à calore prouenit, quum aqua fit launida, neque à frigore, quum fit humidus aer: non fic de fecundis qualitatibus dicere poffumus; nam fi quis fiiniliterdiceret, durum neque effe effectum caloris, quum metalla indurentur à frigore, neque frigoris, quum calor lutum induret, proinde vidern etiam durum, \& molle efieprimas qualitates;nor reeta eft confideratıo: quia durum, licet neque ad calidum, nequead frigidun reducatur, reducitur tamen ad ficcum, \& molle ad humidum,tanquam ad qualitates materiales priores, proinde ficcum \& humidum funt primx qualitates, vt paffur, \& materiales;non fic durum \& molle, quum habeant alias paffiuas priores, à quibas pendent, tanquam à materia. Itaque fi humidin \& ficcum pendent modoaliquo à calido \& trigido, per hoc non fat, quin fint ptimævt paffiuæ, fiquidem non habent aliaspalinus priores; vt Ariftotel. confiderat in 2. lib. de Ortu \& interitu; imo funt omnes zque primæ, hæ quidem vt pafiux, illæ vero vtactiux; 2 pendentia quoque earum mutua eft, quemad no is agente, a 410 claboratur, tum viciffim agens à
A materia, quæ nifi aptitudinem habeat, facit vt agens fit impotens adagendum: quod quidem notare in his qualitatıbus poffumus; quamus enimcalidum \& cum ficco, \& cum humido poffit cxiftere, \& frigidum finilitcr \& cum ficco, \& cum humido, \&vicifim ficcum tam cum calido, quam cum frigido, \& humidum tam cum calido, quam cun frigido; tamen \& paffiur legemaliquam præfcribuntactiuis, \& aliquamactiuxpaliuis, vt non omnino hre cumillis cxi-

$B$ ftere, fed ftatutis tantum quibusdam modis poflunt; humiditat $\mathrm{cm}$ enim obundere $\&$ calo$\mathrm{rem}, \&$ frigus confiderantibus manifeftum clt, proinde nec cum fummocalore, nec cun fummo frigore exiftete poffe; ficut c̀ conuerfo nec fummus calor, nec lummum frigus poteft exiftere cunr humiditate : huius autem ratio ab ftere cunr humiditate : huius autem ratio ab gue cum
Alberto \& à Thomaadducitur talis; quoniam fummo fummus calor totam humiditatem abfumit, frigore of fummum autem frigus, quim maxime con- feposit. ftringat, exprinit \& expellit omnem humiditatem : quam quidem rationem ego non improbo, filano modo intelligatur: non eft enim intelligédun ignem vt calidum agere in feipfun, \& in fe totam humiditatem abfumere, \& terram vtfrigidam cōtringerefeiplam, \& omnem humiditarem expellere: hocenim in miftis tan tummodo locum habet, vbi dux actiux agunt in paffiuas fimul innctas, \& eas elaborant tanquain artifex materianısin fimplicibusvero non fit huiufmodiactio, etfi quodlibet babet vnam qualitatem actuam, \&alteram pafiuam; fed exeo, quod in miftis videmus, colligimus tale quiddam in finplicibus, qux eorum principia funt, contingere, nempe cum fummo calore nullam exiftere polfe humiditatem, itidem nequecum fummofrigore, proinde \& in igni, \& in terra fummam elle ficcitatem abfque vllo penitus gradu humiditatis : \& rationi confoE nū fuiffe videtui, vi duo extrema elementa habcrent xtranque qualitatem extrenam, ita vt ignis fit fumme calidus, \& fummeficcus, \& terra fumme frigida, \& fummeficca, idqueafferit de igne Auerroes exprefre in commentar. 67. lib. 3. de Coclo, dicen1s, ignis non eft ignis actu, Siccitas nifi cum caliditate \& ficcitate, qux funt in fun- Ebsumsmo. Obaliam quoque rationem neceffe fuit \& ditasin ignem \& terran habere fimmam ficcitatem: omszobs quoniam fi bene confideremus, qualitates paf.elemét is fiux non pofint effe in fimplicibus, nifilun-funt fum $m x$, \& eas dicereremiffas eft pug:antia dicere; ma. quia non poffunt remitti, nifi peradmiftionem fux contrarix; necdatur corpus alıquod remiffe humidum, nifiper commitionem corporis ficci, neque remiffe ficcum, nifiper commintionem humidi;onne igitur remiffe humidum,vel remiffe ficcü, necelfario eft miftum, nec poteft effefimplex; itaq; arbitror criam aere $\&$ a quam effe fumme humida, dummodoaccipiāıur fimplicia, \& in fua perfecte naturali conftitutione. 


\section{Dubitaducrfus c.t, qua dict if futt. Cip. $I 1$.}

. Desbri. F ac dificultares, queaducrfus ea cxifterevidentur, futtulerimus. primo locodibium oritur concra id, quod de aere \& aqua diximus: contrariorum enim caden debetefie conditio; at igniratione qualitatum contraria eft aqua, \& ierre aer, ergo ficum in igne, tum in terra a mbx funt qualitates fuma, debent fimiliter \& in aere \& in a qua effe omnes funma; fecus.n.tion plene

a.Disbs.s. contraria eflet aqua igni, nec aer terræ. Secundo dubitatur, ob illa quæ dicunturab Artitotele lib. 2. de Generatione, context. 23.ibi enim dicí, furgulnclemēo rram qualitatem pracipuecompetere; alteram vero minus, acfecundario; piltat igitur vnam tantum effe fumman, \&alteramelfe remillam : quodratione quoque confirmatur, lumpta à definitione ad definitum;cui enim magis competit definitio ficci, illud eft magis ficcum; at definitio licci magis competit ficco terrx, quam ficco ignis ; terra namque eft difficillime terminabilis termino alieno, ignis verofacilius; ergominus efficcusignis, quam terra; non igitur funme ficcus: fic definitio humidi magis conuentt aeri, quam aqux, quia faculiusterminatur alicuis terminis aer, quamaqua quum tenuior \& fluxilior fit, aqqua vero craffior; ergominus humida aqua eft, quam aer,

3.Dxós.s. non igiturfumme humida. Præterea experientia docet, magis aquan refrigerare, quam terram,ergo aqua eft frigidior: falfum igitur eft id, quod diximus, terram effe frigidifimam, aqunn vero non fumme frigidam, quum potius contrario feferes habere videatur, \& terra fit reniffe frigida, aqua vero fumme : quapropter credendum etiam eft hoc fignificare Ariftotelem in prædikto loso voluiffe, quum \& rationi 2. fenfuiconfentaneum effe videatur, nempe igisem efle fumme calidum, fed remifféficcum, terram fumme ficcam, fed remiffe frigidam, 2 quam fumme frigidam, fed remiffe humidam: idque confirmatur confefione noftra de aere, quem fafti fumus effe fumme humidum, fed reniffe calidum; igitur fi deacre verba Anftotelis fic intelligimus, vt dicat eum effe fum me hūidum, non fumme autem calidum, eodem modo de aliis clementis ea intelligere debemus, vt afferat fiingulum liabere vnaun qualitatcm fumman \& alteram remiffan. Præterea qucun-

- Duburi que in aliquo el ementorum ponunt qualitatem aliquam reniffam, vrgeri maxine videntur 1lla, quam antea tetigimus, trita ac vulgata difficultate: remiffio non fit, nifi peradmiftionem contrarix qualitatis;ergo fi element um aliquod al iquam habet qualıtatem remifinn, non poteft cfie fimplex, fedeft mifum:quonamighitur ftatutum iam anobis cft, fermonem efle in profenun de elementis purisatguc funplicabus, ctiam-
A fi talia extra auimam non reperirentur, opor $t c t$, fi funt fimplicia, vt fint etian expertia omiris miftionis : nullant ergo habere debēt qua. litatem remillàm, ve fibi naturalem. Alıa quoque pluradubua aduerfus communem onuium conlenfonem à Ltinis afitunturatg ; fol unntur, q'ı orũ aliqua difficiliora confideranda funt. Primum quidé omines fatentur terram effe fun mc ficcan : at tamen fi hoc effet, oporteret nul. lim in terracfe humiditatem;ergonull 2 m teria

B habere coutinuitatem, quoniam ad compadionem \& continuationen partium requiritur liunidulas, vt ait Ariftotel.in libr.2. de Generat. consext. 49. Præterca humiditas ab aere facile feparacur, quum quandoque fit ficcus, \& manifeite exficcetalia corpora: fed non facileabaqua, perit enim aqua, fi ab ea auferatur himiciditas; ergo a jua est humidior aere: \& ex hos duo colligunturjvnum, quod aer non eft funme humidus; alterum, quod aquæ eft intimior, atque effentialior humiduas, quam frigiditas: id enrm intimius eft, quod minus poteft iepararijat ab a. qua lacile feparaturfrigus, quum polfit fierı calida, non ita facile humiditas, ve patet; falfum igivurafferit Arift.lib.2. de Generatione, context. 23. dumait, intimiorem açuz cfle frigiditatem, quam humiditatem.

\section{Dicrorum dubiorum folutio.}

\section{Cap. I 1 I.}

Rima dubitatio tanti apud aliquos fuit, vt so La ducti crediderint neceffa rium effe, vtino- pr mnibus elementis omnes qualitates fint fum$m æ:$ attamen apud me ratio illa nuilius momentieft natura enim nox ideo has qualitates. elementis dedit, quia clementa debuerint effe contraria: nam fi hocita effet, fortafisaliquid roboris ea ratio haberet; fed è contrario quoniam qualitâtes elementorum conftitutrices, contrarletarem inter fe habent, ideo factum eft,

E vt elementa fintinter fe contraria : quonians igitur hr qualitates infunt fingulis elementis tales, quales corum naturis conueniunt, ideo elementa talem contrarietatem ex his qualitatibus afequita funt, qualem affequi potuerunt rationefitus, \& refpectus, quem ad Colum habent; igni enim contraria eft a qua contrarietate extrema, ratione ficcitatis \& humiditatis, at ratione calor is a frigoris non extrema; quonia F 2 qua non eft fumme frigida, \& fatis eft, li extreme opponatur hac ratıone terra igni, quum fit fumme frigida, \& ignis fumme calidus : \& hoc tant um frobare ratio illa videcur; fi enim dàturelementunı fumme calidum, debuit etiam darifumme frigidum, talis autem non eft aqua, fed terra: quodautem dicitur contrariam maxime effe aquam igni, idideo dicitur, quia oppofita illi eft fecundum vtran fue qualitatem, quod de terra dicere non poff nus; fic dicinius contrariun terræ, tfic actem, quin oppo- 
fitusilli eft fecundum vtran q: qualitatem, licet terræ vt frigida magis contrarius fit ignis, quam aer, quum ignis fit calidior acre, \& taliselementorum contrarictas fufficiéns atque idonea ad miftorurw conftituriōem fuit, nequciliam effe contrarictatem oporturt. Confirmaturhoc $\mathrm{cx}$ coffideraitone qualitatum notricium : nam opponitur quidem ignis a qua, vt leuis graui, non tamen extrema oppofitione, quum aquanon fit lumme grauis, led maxime oppontur terra, qux grautrimac ft infequiturautem leuitas calorem, \& grauitas frigus; ergo extreme contra rius eft ignis terrat vtrigida, non fic aqux, quủ hxc non fit extremefiigida: neguenim ratiosi confentaneum eft, vt elementum exiremun elementomodio opponatur extreme, fed extrenum extremo; extremum autem contrarietaten calidi \& irigidimfequiturfimilitudo in ficcitate, quia, viprædiximus, nec fimmum frigus, nic lummus calor vllam patitur humiditatem ; quapropter debuêreambo el ementa ex-. trema eni lumme ficca. Adaliam difficultatem, qur fumitur à definitionibus humidi \& ficci, petenda eft refponfio ex is, qux fupra de his defintionibus diximus; dum enim has qualitates ita definitas in fimplicibus fecundum fe fumptis confideramus, in dificultates pene infolubiles incidimus; dum autemeas elementis aptam!ıs, vt congredientibus ad productionem miftu, omna dubia fiacile tollimus; qum enim ex ficco \& humido tanquam ex materia generetur miftum, illud eft prxcipue ficcum terreum, vt antea cum Ariftotelediximus, paruam enim molem adiicit fíccū igneum ob elus maximam raritatem; hoc igitur ficcum facit, ve mifum terminos proprios habeat, atque reti neat; fed quia oportet, vt prius cos terminos recipiat, necaptum eft purum liccum cos recipere, quum difficulter alienis terminis terminctur, indiguit humıdo tum coniungente partes ficci, tum faciente, vt termini facile recipiantur; pa- E tetautem non minus idoneum ad hoc munus efie humidum aqueum, quam humidum aereum, quare definirio humidi vt hane operam miftioni præftanis non minus competit humido aqueo, quam humido aereo; ino maxime competit humidoaqueo ob eandem rationem, quam deterreo \& igneolicco tetigimus; plurimum enim humidı aquei in miltione requiritur: quoniam aqua propterfuam craflitiem magis humectat, quam aer, qui propter fuam te- $F$ nuitatem non ita hreret corporibus, \& partam molem mifto abiicit, quemadmodum etian de igni diximus: dum igitur \& aqux \& a eris humiditatem in miftione confideramus, magis aptari videtur definitio humidi hum do aqueo, vtpote ad compagem, \&ad termınatione magis conferēti, vt non abfq; ratione Thomasin contex. 23. libii a. de Grneratione dixerit, aquam effeaere humidiorem, fi modo hoc ipfe refpexit:
A exnim humidum aqueum in miftione magis fungitur offecio hunidi, quā hu midum acrum, quemadnodum \&eficcum tereum in miftone magis fungitur officio fircı, quā ficcum igneum, retica tamen nec aqua eft ob id iudicanda humidioraere, necaer humidioraqua ; predicticenim differentin eis competit peraccidens, ratione dentitatis aqua, ac tenuitaris aeris, qua nrultos decepit : alij namq: confiderantesacrem effe facilime terminabilem, dixéreipfum elle hu$B$ midiorem aqua, ve Aucroes 1. Cantic. comment. is. vbi inquit, aereft humidionaqua, licet aqua magis humcetet; quum tamen hócilli competat ratione tenuitatis, non ratinne humaditacis ; quo fit, venon fit iu licandus ace bumidior, quam agua; hoc eliam manifertius fit miftonem confiderantibus;ve prediximus: id. co quum hocab Aueroe annotatum habeamus in intio fux Epitomesin 4. Meteorolog. videtur Aunroes in I. Cantic, velfuorim dictorum immenor futile, vel pingui Minerua efle loquutus, \& vt ivicdicus potius, quam vi Philof́ophus, quemadmodum Medici in omnibus facere confueuerunt: hocidem dicendum videtur de alia apud Auerroem repugnantia; nam in comment.67.lib.3. de Colo inquit, ignem effe. extreme calidum, \& extreme ficeum, hoc tamen negarevideturin I. Canric. loco pradicto, dum dicit terram elle ficciorem igni. Allj autem è contracio videntes aquam magis humectare, quamaerem, 1 quosum nu niero Thomas fuit, dixêre aquam cife aere humidiorem, quum tamen hoc illicontingatperacidens, nemperatione denfitais, non racione humiditatis: dum enim elementorum ve fimplicimmaturas contfideramus, non poffint effe ufi vel limme humida, vel fummeficca, vt in pracedentiblis di-ximus, \& vrmagis in fequentibus altendemus; neceffe enim eft aquan \& acrem habere fummam humiditatem, jicet aeris tenuitas indicarevidutur ipfum elie humidiorem dum defi. nitionem refpicimus; \& è contrario craflities ayux faciat, vt cam putemus humidiorem, propter efficaciorem operationem, quiamagis humeclat, quamatr. Fincidem dicendum Solutio eftadaliud Jubium de frigore terræ; quod enim aqua magis refrigerct, est per accidens, quia proptermaiorem tenuititem, \& propter humiditatem haret magis comoribus, quam terra; hac etiam ratione uages sa penetrat, proinde \& magis sefrigerat, non quod frigidiorfit fecun-Solstio dum gradum. Sed omnium difticillima eft alia snofequens dubitatio, quonodoqualitas aliqua mnis ro. in elementis pofit effe remifia, fi elementa fim- misizo fiplicia efie ftatuuntur, quum remiffio fiat perad-atper ad miftionem contrasix qualitatis, proinde \& per muftiono illius corporis admiftionemindevidetur colli- cotrarii. gi,nullum corpus habens qualitatem remiflam Alexaneffe fimplex. Alexander hane difficultatum con- dre opifiderans, eamfoluit, negando omiren rem $f-n$ " 
fionem fieri peradmiftionem contrarij, vtapud $A$ reritia, qua eft fecundum magis \& minus, forcumlegere poflumus in 2. lib. Q:rat. natualium, cap. 17. \& fape in fuis commentariis in libros Meteorologicos, prafertim vero capite 4 . libri 1.in commentario fuo 13 . wh aferit ignem efexeniste ficcum, aeron remille calidum, aquam remifle humidan, \& terram remificfigldam, quod etian dicit in libro 1. Quaitionum maturalium, cap. 6. nimirum illi fententiæ adharens, quam fignificare Ariftotelis verba videntur in contextu 23. libriz. de Generatione; negat tamen remi flione hanc effe ob admiftionem contrarij, \& inquit, peream non fare, quin puraacfimplicia elementafint; hoc tamen quomodofefe habeat, non declarat, neque aliąuam Awer- eiusrationem adducit. Auerroes quoq; in comroes. mentario 15:libriz. de Cọlo inquit, nō omnem remifionem fieriper admiftionem contrarij, \& citat Alexandrum, fed nil aliud hac de re dicit; ideo in eorum dictis acquiefcere minime pofitumus; nobisenim \& aliis omnibus tributntibus. alicuselemento qualitatem aliquan remifam vt illinaturalem, neceffarium elt oftedere, quomodo fit remiffa absque admiftione contrarix: Latino neque Latinorum aliqui difficultatem tollunt, rü opinio dumdicun alteran qualitatem in elemëto effe remiflan, non per admiftionen contrarij, fed per diftantiam à fummo gradu; hoc enim dicentes; nihil reuera dicunt, quiun rem declarentperfemetipfam; remiffo enim qualitstis nil.aliud êt, quāidifantia à gradu fummo, 1deo non apparet, quomodo hanc diftantiam ponere fitnon ponere admiftonem contrarii, fed neceffarium videtur, vt à fummogradu diftet quálitas per contrariz admiltionem; vel declaranduneft, quomodofineadmiftione contrarix id openio. Gieri poffit. Egoigiturdicam, quid hac de réfenpropria. tiam, \& feorfum actiuas \& paffiuas qualitates Qualita-confiderando prius oftendam, quomodo dux tes acts- afiux in duobuselementis mediis fint remifa ancle- $f_{x}$; poftea vero cur pafiux in omnibus eleantis medsis fintremifje. Frigus mentis fint funumx. Quod ad actiuas attinet, fciendum eft, eam effe trigoris naturam apud Ariftotelem.vt fitpriuatio quadam caloris; id enin clare legimus in fecundo libro de Ortuanimal. cap. 4 . \& in 1. Meteorolog cap. 4 . vbi inaf prssar qnit, ex defectu motus circularis calorem fatiocalo- cientis duo elementa: manere frigida, quare ris. vult folam prituationem caloris in materia apta calefieri, effe frigus; vel faltem dicendun eit, frigus effe quidem fecundum fe qualitatem.po- $F$ fitiuam, fed oriri expruarione caloris, proinde refpectu caloris habere locum priuntionis, qua

In lib. de de re alio in loco diligentius loquemur. Illud calorece quoque eft in memoriam renocandum, quod. leffi. aliâs in libro de Miftione diximus, tun qualitates, tum formas elementorum intendi, ac remitti poffe, non tamen eadem prorfus remiffione; nam qualitates. remitti polfunt etiam absque variatione fipeciei, \& cum illa tantum diffemaveronon polfunt remitti, nifi cum variatione fpeciei; quo fit, vt non onnis renifio qualitatis faciat in elemento remifionem forma, fed fape alterentur elementa fine aliqua fibfaniz mutatione; propterca fífumatur alıqu portio aquæ, quxpura ac inplex effe flatuatur, eapoterit calefieri manente integra \& illz. fa eius forma; quamobrem frigus naturale remiltetur, neque ob.id frabit, quin aqua fit puB ra, ac fimplex : vnde colligere pofumus contrarij argunenti vanitatem ; putant enim nulti non poffe qualitatem elementarem efle rëmifiam fine commintione fubtrantix elementi cum alia fubftantia; decipiuntur tamen, qiia poteft remitti qualitas, etian cum admiftione graduum contrarix qualitatis, feruata tamen puritate ac fimplicitace fubftantix elementi : hocigiturfi verum cft, non eft in qualitatibus natululibus elementorí impofíbile exiftimani-

C. dum vt fint remiffx, demusetiam cum permiftione contraria qualitatis, absqua vlla tamen remifione, velmifitione fibftantia:argumento fnt qualitates motricis, qua inter ie cortrarixicunt grauitas \& leuitas; num iecusum $\mathbb{A}$ riftotclem nec aqux granitas, nec a $4:$ i. as

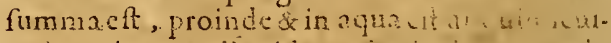

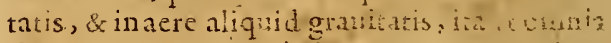
elementa grautatein habeant, c..ce! on a

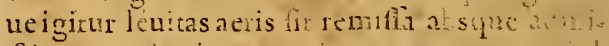

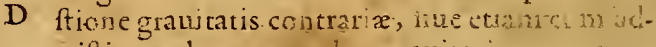
miftione alicums gratis gizmita is non ploptered in aelis fubfancia pontur alinia miftio, neq; ab id fit quin aerfecundun fuam lubfantiam fit corpus fimplex, \& elementum, cum illạ qualitate remiffa. Sed age, confiderenus an qualitates elementorum fint remilixperadmiftionem contrarij, \& qualis fit illaremifiv : vtuntur multi exemplo luminis,nec male, fi modo illud exquifitius expenderent; limen enim

E non habet contrarium pofitium, quiatenebra. nihileft, nifi mera priuatioluminis; videmus tamen modo inteníus, modo remiffius in eodem aerelumen fieri, quare fit remiffio absque contrarij admiftione, \& perfolam ablationem graduum, quam 1 lli vocabant diftantiam à gradufummo: huiusce igitur rei qux eft perfemanifefta, ego hancefie rationem exiftimo, quod lumen eft qualitas diuiduaper gradus, \& habet. priuationem oppofitam nonfolum toti qualitati fimul fumptx, fed etram fingulis gradibus, ita vt detur, tenebra tum exquifita, quxeft totius luminis perfecta priuatio, tum etiamimperfecta., quæe eft priuatio alícuius gradus, non onunium, proinde coniun ba clim gradualiquo luminis : vbi namque eft parum luminis, ibi eft. etiam priuatio aliorū.luminis graduum.; eamq̣; appellare miftioné luminis cü tenebra, etfinon omnono conuenit; admitti tamen poteft, fi intelligatur efle pofitiui cum pi iuatiuo, non cum poficiuo. 
pofitiuo. Hacidem diceremus de remiffione $A$ caloris per frigus, fi frigus effet mera priuario, qualis eft tenebra; fed quum fitaiiquid poítiuum infequens priuationem caloris, negare non poffumus, caloris remiffionem fieri per commiftionem alicuius gradus frigoris, fi modo ea eft miftı appellanda; nam miftio eft proprie corporum, non qualitatum: fed vtcunque remiffionemillam nominemus, certum eft, remiffum calorem effe non poffe, nifi quando adfuntaliquigradus caloris, nec tamen adfuntomnes, red aliqui abfunt; \& quia hacaliorum graduumabfentia eft il orum priuatio, quam neceffario conitantur gradus aliqui frigoris; fiquidem vt priuationem caloris infequitur frigus, ita priustionem aliqu orum graduum caloris infequuntur aliqui gradus frigoris ; ideo in omni remiffo calore infunt gradus caloris cum gradibus frigoris, nec obid funt dux qualitates, fed vna mediocris ex gradibus vtriusque pronenien s, qux dicitur vel remıfius calor, vel remilfum frigus: fi enim gradus caloris excedant, vocatur calor remiffus, fi veroexcedant giadus frigoris, vocaturremiffum frigus, faltem fi mulcum excedant: quandoque enim rem aliyua: vocamuscalidam etiam cum debili calore, quodeuenit ob calorispraitantizm, \& frigoris imperfeation cm, atque ignobilitatem, qua fit ve locum labeat priuationis refpectu caloris : ideoq; nominatio fumatur à gradibus caloris, quando dignofc in realiquis calor poreft : nequeabfurdum eft dicere in eadem qualitate fimul exifteregradus caloris cum gradibus frigoris, nulla enim eft repugnantia, dummodo tarutam latitudinern non excedär fimul fumpti : quod optime declaratur à Marfilio in fua qualtione de hacre in lib.2.de Ortu \& interitu. Talē igitur dicimus effe naturaliterin aere calorem remiffum, \& tale in aqua remiffum frigus, nempe cŭ aliquo graducōtrariz qualitatis absq; villa fubitantix miftıone: imonec duæ qualitates dicuntur effe cōmiftx, fed vna eft, qux refpectu maioris caloris eft inftar frigoris, \& refpectu minoris eft calor refpectufrigoris. Perhocigitur non ftat, quin aer \& aqua cum his qualitatibus naturalibus remiffis effe poffint vere fimplicia corpora, \& eleimenta, ficuti etiam funt cum motricibus qualitatibus:nec video quid ex hoc abfurdi fequatur, nec cur ita aduerfus hanc fententiam clament illi, quinegant vllam elementarem qualitatem (3. naturalenı poffe effe remiffam.Sed vt de actiuis qualitatibus explicatu facilis res effe videtur, ita 6. difficilis eft de paffiuis, fateorque hanc magnopere ańimum meum conturbaffe, referam ig'tur breuiter quid hac in re milhi negotium facefferit, \& quid ego dicendum effe exiftimem : iam dixi, parfuas qualitates in omnibus elemertis effe fummas, nec poffe in elemento fimplici effe remiffas : vt hoc crederem, duplex me ratio induxit; yna, quod ha non ex propinquitate, \& di- ftan ia à Coloproueniunt elementis, quandoquidem \& ignis eft ficcus, qui Colo proximus eft, \& terra ficca, qux oinnium remutiffima: neque etiam omnino funt ex materix neceffitate, quia tota hac materia ita eft apta ad humiditatem, vt ad ficcitate $m$ recipiendam; quare neutra harum qualitatum materiam neceffario confe. quitur:diceretamen poffumus, cas prouenire \& cx neceflitatematerix, \& fimul ab actione cœlefti, quatenus coelefti actione conftituta oritur B huic materia neceffitas vtalıa fit humida, \& alia ficca.idque à natura ideo factu m eft, vth $x$ effent conditiones materix, ex qua poffent mifta omnia generari : quum igitur non ex differentia diftantix à Coelo hx dux qualitates proueniant, vnde colligi poffit eas effe in alio fummas, in alio remiffas, rationiconfertaneum eft, vt hx in omnibus el ementis fint furnma: dum enim $\mathrm{fta}_{\text {- }}$ tuitur,fermonem effe de elementis vere fimplicibus, qua ad mifta tanquam materia diriganC tur, fimplices, ac puras in fingulis effe materiales qualitates credindum eft, fimplicibus enim corporibis, quatenus funt materia miftorum, conueniunt qualitates materiales implices, nố permift $x$, aut impur $x$; non fic de actius dici potẹt, funt enim porius formales qualitates, quam miteriales; quia form eft agere; \& pendent inmediate ab actione colefi per pr pinquitatem, vel diftantiam horum corporum refpectu Coli. Alteraveroratio eft, quonian in qualitaD tibus a tiuis, qux formalcs dicendafunt, remiffio prouenit ex earum mutua atione, etiam absque vlla permiftione corporum, id eoque potefaqua fecundum luam fubftantiam efic fimplex, quxtamen recipiat abigni calorem, ita vt naturale ipfius frigus remittatur:atin palfus, quas um munus aon eft agere, fed pati, non poteft remiffo fieri nifi percommiftionem naterix humidæ cum materia ficca:quod quidem etiam infecundis qualitatibusnotari poreft;nam E fi corpusalbum propenigrum corpus ponamus ita vi fe tangant, nulla fiet eorum colorum re. miffio per actionem, quoniam-talem agendi vim non habent; at finigrum corpus cum alio corpore albo permifceatur, vi atramentum cura lacte, fietvtriusque remiflio, \& medius aliquis color orietur: egovero de hum ditate \& ficcitate plurimum dubitaui, numaliquam vimagen. Nosa de di habeant; dum enim rem iplam confidera- Nozione mus, non videtur remitti humiditas ex contai pafase F Au ficci ; nam fi in aqua fit duriffimus ac ficcif- pajus
fimus lapis, non fiet lapidis inaquam a tio talis , qua humiditatem aqua remittat, ficuti neque humiditas aqua remittet ficcitatem lapidis, nifi eius fub ftantiam penetret, \& fein illam ita infinuet, vt commifio fiat; adeo vt quxnam fichumiditatis, aut ficciratisactionon fatis appareat: hoc idem confirmasur ex confideratione veiborum Arifotel. dum harum qualitatum naturas declarat ; femper enim eas vocat paf- 
fuas, necvnquamvllam agendi vim is tribuit, A tenus contrariafunt; itavtactionem vniuocam tur in libr. s. de Ortu \& unteritu, tum in 4. Meteorolog. \& eas pervim patiendi definit, nulla prorfus actionis facta mentione. Ex altera tamen parte Ariftoteles aliquando innuere vifus eît has quoq; vim aliquam agendi habere; nam in lib.z.de Ortu \& interitu, quando loquitur de nutuainter fe el ementorum mutatione, inquit in habentibus $\int \mathrm{m}$ bolam qualitatem tranfitum de vnoelemento in aliud facilem efre, quoniam altera qualitas manet, \& altera in contrariam mutaturjvt fi in terignem \&aerem pugna fiat, \& vincatur humidum à ficco manente calore, $\mathrm{mu}$ tabitur aerin ignem, fi vero vincatur ficcum ab hussido, mutabitur ignis in aerent: tribuit ergo Ariftoteles actionem alıquam etiam ficco, \& humido; quum enim ibi locum habere non videatur actio caloris, quia ambo funt elementa calida, nulla remanet actio inter duo illa eleweta, nifiratione humiditatis \& ficcitatis ; hanc Ariftotelis fententian fi faluarepotuiffem, audacter afferuiffem, nullam prorfus his duobus qualitatibus vimagendi ineffe: quodenim ad mifta attinet, facile videbatur onnem exficcationean, \& onnem humectationem attribuere calori \& frigori, quum calor per diffolutionem humidi exficset, of frigus per humidi expreffronem, \& expulfionem exficcare mifta corpora videatur. Ad illum autem Ariftotelis locum videbatar poffe refpoderi, mutationem aeris in ignem fieri ob actionem caloris ignei; quum enim ignis a ere calidior fit, agit in illum tāquam in frigidum, \& reddensfumme calidum, facit etiaco fumme ficcum, quia fummus calor nihil tolerarepoteft humiditatis: \& hac fententialegi poteft clara apud Alexand in lib. r. quaft. natur. c. 6. vbi dicit in elementishabentibus fymbolam qualitatem fieri mutationean non in vna Iantü qualitate, fed in ambabus; quamuis enim propter contrarietatem videatur in vnatantum mutatio fieri, fit tamen exiam in altera fecundum intenfionem \& remiffionem. Sed hacrefponfio, quanquam vera eft fecundum $f e$, nö eft tamen tuta, neq; in ea potui conquiefcere, quia itam dixi Ariftot.in co libr.2. de Ortu \& interitu allam graduum differantiam in primis qualicatibus confiderare; quare nullam poteft in igni \& aere differentiam calloris refpicere, fed folam conuenientiam, qua ambo funt elementa calidajiden aperte dicitin illa pugnaaeris cum igne vincivel ficcum ab humido, vei humidum à fic$\lessdot \mathrm{O}$, caloremanente; proinde vultactionem efre humidi in ficcum, \& ficci in humidum. Hac igitur refponfione reiecta, tanquam infirma, nos antea, quum de hacre loqueremur, ad hoc confugimus, quod humidum \& ficcum funt paffiua tantum; prout confiderantur in generatione iniftorum, \& in productione fecundarum qualitatum; dum autem fumunturvt fe mutuo refpicicotia, vimaliquam agendiinuisem babēr, qua-

habere, fed nullam aquiuocam videantur: attamen hoc quoquenegare ann dubitaffem, fi tueri verba illa Ariftotelis potuiffem, quandolo. quitur de mutatione in elementis fymbólā habentibus qualitatem; ibinamq; aperte attribuit vim agendi etiam ficco \& humido: adde quod ad hoc confitendum aliquis etiam ipfius rei refpectus, \& experiētia me compulit; aliqua eni funt, in quibus Medici vim agendiper exicicaB tionem, \& per hünectationem manifefte deprehenderunt, quam in calorem vel frigus referre minime poffumus. Quoniam igitur ego tum à cauillis, tum à nouis dogmatibus, qux certis fir isque fundamentis non innitentur, abhorrere foleo, tandem his omnibus contrariis argumentis cöfideratis tutiffiman effe fentẽtiam putaui, fi diceremus humidum \& ficcum habere quidem ali quam mutuo agendi virm, fed ita debilem, vt vix dignolei à no bis queat ; quo

C fit, ve tardifima fit eorum actio, nec nifi poft longum tempis mutecurab humido ficcum in humidum, velà ficco bumidum in ficcū ; quum è conirario celerrima fit calidi, ac frigidi actio inuicern, \& manifeftiftime à nobis digno fcatur, asfentiatur. Quoniam igıtur debiliffima eff, atque tardiffima actio humidi in ficcum, \& ficci in humidum, proinde non apta ad eorum remiffionem faciendam, nulla ratio manet remittendi humidiratem corporis, vel ficcitatem, nifi per corporum commiftionem:aftelementafimpl.c12 effe ftatuuntur, quatenus elementa funt, no i permifta; igiturneceffarium effe videtur,ve qu $x$ ficca funt, fummam habeant ficcitatem, \& $q$ ir humida, fummam humiditatem : quare in his duabus paffuis qualitatibus validum effe argumentum puto, remiffio nō fit, nifí per commiftionem, ergo hx qualitates nen poffunt effe remiffx. Hæc meafententia eft, quamaliis expendendam \& corrigendam relinquo. Ad aliud $ง$ E dúbium deterr $x$ ficcitate fumptum ex contex. 49. lib.z. de Generat.dicinuus, Ariftotelemibi de miftorum tantum continuitate \& coniundtione parcium loqui, ad hanc enim faciendam neceffaria eft humiditas;atnon eft neceffarım vificcorum quoque elementorum partes per humidum coniungantur \& continuentur, hocenim dato fequeretur, nec terram, nec ignem effe cammeficca, fed effe ambo continus per commiftionem humiditatis, vel, fi qua ftatuatur eo-

F rum particula fumme ficca, eam effe prorfus indiuiduam,quod quidem nemo afiereret:quoniam igitur elementa ficca funt fpecies corporis naturalis, \& omne corpus eft continuum, fateri oporetet ea ex propria natura habere continuitatem, quatenus prima materia eft per fe quanta. longa, lata \& profunda, fed indeterminate, $a$ forma aurem cuiufque rei propria terminos recipit, vt alibı declarauinus : in folls igitur mifts locum habct id, gatiod ibi Arifotel. dicit; Qนu 
quam enim miftio fiatex diuifione mifcibilium $A$ in paruas partes, proinde ficcū in minutas partes diuidi oporteat, neceflarium fuit humidüad carum partium coniunctionem, \& totius continuitaté. Ad aliud de humiditate, qux facile feparari videtur ab aere, non ita facile ab aqua, de aere quidem dicendum eft eú humiditate nun. quam carere; nam fi hxc ab aere auferatur, non foreft effeacr; quod autem quandoque ficcus eflic, \& res exficcare videatur, id non per fe eft, fed per accidens; halitus enim ficcos habet à terra exhalatos, quibus quandoque ita refertus eft hic aer nofter, ve per eos exficcet alia corpora; poteit etiam vtcalidus facere humidi refolutionem in aliis corporibus, quod euenit in is, qua putrefcunt; nam ab aere externo calido educitur calor naturalis miftorū corporum, cum quo fimul humidum euaporat, ita vt ficcum fine humido relinquatur; per accidens igitur fit vt acr exficcet, quum id faciat vt calidus, non vt ficcus, femper cnim habet fuam naturalem hu. miditatem, ratione cuius eft al ienis terminis facillime terminabilis, \& propriis terminis earens, per hoc igitur non oftenditur aerem effe minus humidum, quam aquam. De ipfa autem aqua cur facilius ab ea auferatur frigus, quam humiditas, multa dicuntur abAlexandro in lib. I. Quaft. natur. cap. 6.digna enim confideratio$a$ ne res eft, cur fi intimius naturx aqua eft fri18 - gus, quam humiditas, ablato tam e frigore maneat aqua, ablata vero humiditate intereat, nec poftit effe aqua fine humiditate: hanc difficultatem an foluat ibi Alexander, aliis confiderandum relinquo; mihi quidem videtur per eius dieta difficultatem non tolli, quia id, in quo potiffimum eius folutio confiftit, non tangitur ab A- lexandro. Eoigitur dimiffo arbitror hoc difcria- men ab actiuarum \& paffiuarum qualitatum ffi- differétia prouenire: quoniam enim actiua funt - an formales, \& omnino ab agente externo produ$r$, cuntur, paffiuz autem funt materiales, \& $\max -$ gis proueniunt à materia; ideo difficilius auferuntur elementis paffiux, quam actiux: idque non in fola aqua, fed in omnibus elementis verum eft, formam enim mutare, \& delere, \& producere vis narurx poteft, fed materiam deftrue-re, vel producere haudquaquam poreft: ob hoc igitur immutabiliores in elemétis funt paffiux qualitates, quam actiux; abaqua enim non po. teft auferri humiditas, nifi aquaintereat, frigus magis auferri poteft, quia poteft aqua calefieri, idcirco agente etiam igne in a quam facilius tol. letur a qua frigus, quam humiditas, ftatim enim mutataquam inaerem, quis facile mutat frigidum in calidum; non itafacile humidum in ficcum; quod fi facilius mutaret humidum in ficcum, quam frigidum in calidum, primo loco mutatet ignisaquam in terram, non in aerem; fic ab aere feparari humiditas non poteft, quin aer intereat, calor autem magis auferri $a b$ co poteft, quum quanúoq; frigidiffimus effe iudicetur. A terra quoque difficilius ficcitas aufcrtur, quam frigus, quod paretagente igne in terram; mutat enim primo loco inexhalationem, in qua ficcuiterreum feruatur, frigus auten interiit, \& factum eft corpus caliduun. Ignis vero difficillimc patitur feu caloris, feu ficcitatis remiflionem, ideo hoc diferimen non ita in eo manifeftun eft. Ad dubium igitur dicimus, verum quidem effe id, quod affun itur, difficilius B feparari humiditatem ab aqua; fed ex hoc non inferri aquam efleaere humidiorem, fiquidem dicimusipfi quoq; aeri hocidem cötingere, neque etiam inferrihum fditatem elle intimiorem naturxaque, quam frigus, proptcrea quod hoc non ideo euenit, quod humiditas fit aqux effentialior, fed quia e e conditio materialis, \&e qualitas paffua, qux in omnibus eft difficilius feparabilis, quara actiua; neq; credendurs ef A rift. attribuenté cuilibetelemento vnam qưaC titatẽ potius, quä alterä, fignificare per hoc voluiffe vnam effe magis connexam cum el ementi natura, quam alteram: fed ne crederenus vnum elementum à duabus finul condutionibus zquo cóftitui, tanquam à duabus formis, ideoalterius qualitat is principalitatem introduxit, eam q: iudicauit ex operationibus primarū qualitatum, ex quibus earum definitiones acceperat; vis.n. calefaciendi, \& attenuandi maxime in igne ineft, vis refrigerandi maxime in a qua, qua magis $D$ refrigerat, quam terra: difficultas autem recipiendi ab alio terminos maxime in terra confpicitur, id co maxime videturficciras in terra ineffe, è contrario autem fácilitas recipiendi abalio terminos maxima in acre eft, propterea cū aeris natura maxime conuenire exiftimauit humiditacem, licet nö minus hurada fit aqua: fic igitur fublataeft, ni fallor omnis difficultas, quü non. ex eadem ratione fumatur facilitas, vel difficultas feparationis qualitatis ab elemento, asque E ipfius qualitatis principalitas, feu maior conuenientia cum natura ipfus elcmenti.

\section{An fymbola elementorum qualitates diffe- rant jpecie,necne, aliquorum opinio o argumenta. Cap. $1 \mathrm{~V}$.}

Q Vxeri praterea folet, an fymbolz elementorum qualitates fint eiuldem vltima fpeciei, an fpecie differant ; vtan cslorignis, \& caloraeris diftinguäturfpecie nec ne, fic frigus terre, \& frigus aqux, fic bumiditasaqua, \& humiditasaeris, fic demü ficcitas terra, \& ficcitas ignis. Hac de re legi apud alios poffunt difputationes prolixz, prafertim apud Marfilium in 2. lib, de Generat.ob id ego paucis agam, \& pracipua quadam, aliis dimifis, in medium afferam. Non defuêre qui dixerint lymbolas qualitates senten differrefpecie, quä fententiam plurimisargu-tia alsmentis côprobarunt, quorū pracipua hac funt. quorü.

$$
\text { R } 4 \text { Primum }
$$


1. argü. Primum qquidem, vel qualitates funt forma elementorum, vel funt accidentia confequentia formas: fi form: ergo fpecie differunt, quia compolitorum fpecie differentium neceffe eft formas effe fpeciediftinctas; etenim nifi fpecie differrent, certe comnofita differenria fpecie non confutuerent : fi vero funt accidentia confequentia formas, id em fequitur, quia diftinetas fpecie formas diftıncta etian rpecie accidentia z.argum. confequuntur. Praterea fieffent eiufdem fpeciei, eafdem etiam ederent operationes; at diuerfas edunt, ergo non funt ciufden fpeciei.falfitas confequentis probatur, quia humiditas aerea ignem non extinguit, fed potius nutrut, patet enim flammam in aere non extingui, a quea vero humiditas extinguit ignem; ergo he dua humiditates non eafdem edunt operationes, differunt ergo fpecie; quod auten de humiditate dicimus, idem de alis quoque omnibus dicendum eft; ergo pradicta omnes non funt eiuf-

3.argum. dem fpeciei. Tertio fic argumentantur: calorem inf quitur leuitas, frigus vero grauitas; $\mathrm{er}$ - go quod de motricibus qualitatibus dicitur, ide de alteratricibus dicendum eft; atqui non ezdem en leuitas a eris \& ignis, neq̣; eadem grauitas terr $x$ \& aqua, quum ad duerfa loca naturaliter tendant; ergo neque caliditas ignis \& aeris eadem eft, neq; eadem firigiditas terræ \& aqua. Quartocalor ignis requiilt iccitatems, neq; cffe poteft cum humiditate, contra vero calor aeris requirit humiditatem, nec poteft effe cum ficcitate, ergod:fferunt fpecie; fic de aliis quos.argum. que qualitatibus argumentaripoffumus. Quinto fi eiufdem fpeciei effent humiditas aquæ, \& humiditas aeris, ita vt in mutatione aqua in $2 e-$ rem eaden numero humiditas feruaretur; accidens idem numero migraret de fubiecto in fubiectum, quod abfurdum effe omnes confite extur.

r. argum Sexto argumentantur à fimili : in miftıs calores fpeciedifferunt, alius enim eft in afino calor, alius in homine, quum alias in hoc, alias in illo operationes edat; fic etiam calor febrilis differt fpecie à calore naturali, vocatur enim à Medicis innaturalis, \& contrarius naturx ; natursle autem, \& innaturale ciufdem fpeciei effe non porfunt, quod ipf $x$ quoque eorum operationes declarant, calor enim naturalis caufa eft naturalium operation um, febrilis vero eft illis impedimento;ergonon funt eiufdem fpeciei;hoc igitur idem in fimplicibus quoque dicendum eft,

7.argu. quod in miftis videtur effe manifertum. Confir- $F$ matur haxc fententia auctoritate A lexandri, qui in lib.r. Natural. quxft.capite 6 . dicit aliam effe aeris humiditatem, aliam a qua $\&$ alium effecalorem ignis,alium aeris. Auerroes quoq; in fua Paraphraf 4. Meteorologic.inquit, frigiditas eft fecundum duas fpecies, vnaeft frigiditas terra, altera eft frigiditas aqua; itaque aperte dicit eas differre fpecie; $\&$ hoc idem de aliis omnibus röfiterineceffe eft, ergo omnes fymbolx qualita-
A tes fpecie diftingunntur. Iohannes etiam Grammaticus in conrex.24. libri 2. de Ortu \& intentu inquit, calor aeris, \& calcrignis non eft ilem fecundurn fpecien, puiduitigitur omnes iymbo. las qualitaies differre fpecie.

\section{Dicta fententic confutatio, of probatio contraria. Cap. $V$.}

B Clunt, ita vt conmmunem appellare poffimus, quam ego quoque veram efie arbiror, alteram vero pradictam falfamietenim conltanter cred o omnem calorem effe vnius \& eiufdem fpeciei fpecialifima, fic \& onne frigus, \& 0 mnens humiditat $m$, \& omnem ficcitatem, nec differre, nifi fecundum magis \& minus. Hancopinionem confirmare, \& contrariam réfutare mulis argumentis poffumus:quorum ego illa, quæ validiora videntur,adducam; reliqua apud - Marfilium \&apud alios legantur. Prinsum fumitur argumentum validiffinum ex harū qua. litatum trąatione, qux in 2.lib.de Generar.ha- betur: nam fi opinio contraria vera effet, non quatuor effent prima qualitates, fed octo fpecie diftinctse, nempe calorigneus, calor aercus, frigus aqueum, frigus terreum, humiditas aquea, humiditas acrea, ficcitas terrea, ficcitas igriea : attamen Ariftotelesnon offo effe dicit, fed quatuor, neque ofto earum definitiones adducit, fed quatucrtantum; atgai ilia, quibus eadem aptatur definitiol funt eiufdem naturz, proinde \& eurdem fpeciei;quare fymbolx qualitaies fpecie non diftinguuntur. Hoc videntes aduerfarii refpondent, oftendi hoc argumento al, fymbolas qualitates effe eiufdem fpeciei fubalterna, fed non eiufdem fpecialifim $x$; nan Ariftoteles appellat quatuor, \& vt quatuor definit, quatenus differunt fpecie fubalterna. Sed hac sol refponfio admittenda non eft, quia fecundura wis E eam Ariftoteles in iis definiendis-ac declarand is pug mancus fuiffet, non fatis cnim fuit communes sio. \& generales, in quibus conueniunt, definitiones adducere, fed propriis quoque definitionibus erant definiendas, quibus fignificarentur proprizearum natura, \& propriz vires, quatenus fecundum fpecicm vlrimam diftincta funt. Catera quoque omnia, qux ab Ariftotele de $2 . a r$ primis qualitatibus sbi dicuntur, præfertim quiz à textu vigefimo quarto vfque ad trigefinum manifeftifime atteftantur veritati : ait enim in habentibus fy robolam qualitatem tranfitum \& mutationem effe faciliocem, quam in non habentibus, \& hanc racionem adducit, quoniam in non habentubus mutatio fit duarum qualitatum in duas: vt fi mutanda fit aqua in ignem, $0-$ portet \& hurridum in ficcum, \& frigidum in calidum mutari; ar in habenribus fymbolam, $n: u$. tario fit vnius tantum in vnam, alteraenim temanetivt if ecutandus fit aerin ignem, fic folum niuta. 
mutatio humidi inficcum, calnrauten manet: quare putat A riftoteles eundem non modo fp:cie, fed etiam numerocalorem nantere in $ı$ gni genito, qua futt in aere corrup to: qupd non idem jpecie ellet calor in a ere, \& in igni, opoteret $\mathrm{Ca}_{-}$ lorem quoque mutali, \& perire calorem aereum, \& generari igneum; quare hac quoque mutatio ellet duarum in duaś, quod Arifore. les ncigat: a d hoc tamen aduerfarii refpondent, nil aliud ibi fignificare Arifotelem velle, nifi faciliorem effe nutationem in babentibus fymbolam qualitatcm, qua facilius eft acreum calorem mutare in igneum, cuinoneft contrarius, quam calorem in frigus, quod eicontrarium eft: fed has refponfio vanilina eft; nos enum non modo id, quod de hacfacilitate Ariftoteles dicit, fed rationem quoque, quam adducit, expendimus: ron enim illam affertratronem, quam llli comnunifcuntur, fedhane, quod facilus eft vnam mutare in vam, quam duas induas, quare in vnam tantum qualitate gu- mutationem fieri afferit. Praserea docet ibi4\%. dem Ariftoteles, quomodo ex duobus eicmentis perfecte contrariis tertium medium generetur, \& inquit exigne \& aqua poffe vel terram, vel aeren generat i; nam fiaqua frigus, \& ficcitas ignis intercant, generatur aer, quia remanent calorignıs, \& aqu $x$ humiditas, quibusaer conltirutur; fi veropiræualeat frigus a quu calori gnis; \& ficcitas ignis humiditatiaqua, ita vt ignis calor, \& aque hu iniditas intereant, terra generatur, quia remanet $2 q u x$ frigus \& ignis ficcitas, q̨u é firoul iunctx terram conftituunt; purauit crgo Ariftoteles eandem effe \& fpecie, \& numeroficcitatem terrz \& ignis, fic calorem ignis \& acris, fic frigus aquat \& terra, fic humiditatemaquz \& aeris; nam fi different fpecie, diatum Ariftotelis verum non effet; remanens enim ficcitas ignis non conueniret terrz, nec frigus aqua remanens conueniret eidem terr $x$, fedaliam ficcitatern, quam igneam, \& aliud frigus, quam aqueum, terra poftularet. Alia argumenta ad hocidem probandum legi poffunt apud Marfilium, ideo illa miffa facio; hocvnum adiicere volo, quod meo quiden iudicio magni momenti eft, ex fundamertis antea iactis, ac ita. bilitis defumptum: fi calor in elementis à Cœlo \& generatur, \& conferuatur, nec alio modo, quam per motum, \& per lumen, nećeffe eft eiufdem fpecieieffe calorem om nem elementarem; tum igneum, tum aereum; ab vnaenim caufa, \& codem modoagente idem effectus prouenit; fumptaigitur ratione à caufa efficiente oftenditur omnem calorem in elementis effe eiufdem natura: quare de aliis quoque qualitatibus hoc idem dicendum eft, quum eadem in omnibus ratio vigeat; vel enim omnes fymbolx fpecie - differme, vel nulla huius fentens 1 fuiffe Auerroem \& Ioannen Grammaticum paiet legentibus eorum Commentarios in eara partem, $\mathrm{vbi}$
A etiam ex iis, qqux à Ioanne Grammatico deAlenandre referuniur, ruanifeltumeftidem fenfille Alexandrum : eorum autem ves ba non affero, quadilucida funt, \& quifque ea legere \& iniclligerefacile potef; nequecit de Ioanne dicendum, quod fibi ipfe contradixerit, vt eialiqui atribunt; ipfum enim huic crimini obnoxiuar non elfe poitea oftendemus.

\section{Prodeclaranda veritate, \&ontrariis ar- gument is foluendis fundamenta iaci- untur. Cap. VI.}

$\mathrm{V}^{\mathrm{T}}$ omnis hac in re difficultas tollatur, \& contraria argumenta foluantur, notand um eft, fy mbolas qualitates, et fí f́pecie nö differūt, duas tamen habere differentias, quas confiderare nos oportet. Vna eft, quam recipiunt prout referunturadaliud: quum enim calor fit caufa fecundaria, \& in trumentalis; qua aliquod pri-

C mariumagens veitur; diuerfus calor dici poteft ratione diuerforum vtentium; ideocalorignis, \& caloraeris, quum fecundum propriam eî́entiam fint eiufdem fpeciei, tamen prout infequitur hicformam ignis, ille vero formam acris, ibi per calorem agere ignis dicitur, hic vero aer, diftincti calores dicuntur, \& modo quodan Tpecie differentes, non quidem proprie fpecie fecundum fuam naturam. (ed quatenus formas fpecie diltinctas iniequuntur: hac igitur rationealius effe dicitur aeriscalor, alius ignis; tunc enimnon ipfam fecundum fe caloris naturam fpectamus, fed aeris \& ignis, quibus attribuitur : fic etiam diximus, primas qualitates effe praparationes materiz ad varias formas recipiendas ; ideo eadem qualitas prout in diuerfis mutation bus dirigitur ad diuerfas formas, differens fpecie dici poteft, non quidem fecundum fe, fed refpectu formarum fpecie differentium, ad quas dirigitur. Altera differenria eft, quam $E$ ifta qualitares habent quidem fecundum $f e$, non tamen talem, quad iuerfas fpecies confti. tuat; ea autem eft differentia fecundum magis \& minus, feu fecundum intenfionem \& remiffionem, qux omnium philofophantium confenfione non variat fpeciem; hac differentia diftinguitur calor aeris à calore ignis, quiaille remiffior eft, hic vero intenfus, \& fummus, fpecie tamen ob id non diftinguuntur; \& hoc quandoque fignificamus, dü dicimus, alium effe in aere calorem, alium in igni, hoc eft, alium \& alium caloris gradum: quum enim denotare velimus differentiam fecundum magis \& minus,non dicimuseas differre fpecie, quum certum fit differétiam fecundum mâgis à minus fpeciem non variare. Ex his aliud quidda m colligimus, quod magnoperenotare debemus: quáuis enim proprie fumẽdo dıfferre fpecıe, lignificet differre natura \& effentia, tame éfumitur interdü ímproprie ad denotandan folü differ ențana accidésaI $s$ - lem,
Aliacōpetunt calorifecundiam ce $\operatorname{con} / i-$ derato, alia bt est infrumentam primarii agentis: idem in. fra, $c .7$.

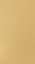


lem, requendo communem quandam loquendi confuetudinem, \& hominum exiftimationem, dicerenam q; folemus varias effe fpecies aqua, \& varias terr $x$, quum tamen fit folum differentia aceidentalis: \& hoc legimus clare apud Ariftot. in I. cap. 1. Meteorologic. vbi confiderandas proponit diuerias fpeciesterra, quum tamen terra fit f́pecies vltima, qux in alias fpecics diuidi minime poteft: quoniam ergo plures habet terrazccidentales differentias, has vocat $A$ riftot. fpecies terræ, iuxta confuetıd ine loquendi dicimus enim aliam effe terram petrofam,aliam arenofam, aliam cretofam, \& has vocamus varias fpecies terrz, licet non proprie fint fpecies. Sicigitur dicere etiam folemus fpecies caloris, \& fpecies frigoris' quamuis hæqualitates non habeant fpecies; refpicimus enim non quidem ip farn cuiufq; qualitatis effentiam, fed accidentales \& extraneas differentias, qua à diuerfis fubreetis, \& à variis rerum naturis defumuntur:atpropriz harum qualitacum naturæ, \& vires eædem in omnib. funt; omnis enim calor calefacit, \& difyregat heterogenea, \& congregat homogenea, \& foluit congelata, \& extenuat,abfq; vlla prorfus differentia,præererillam, qua eft fecundum ragis \& minus; intenfior enim calormagis atq; efficacius hac omnia praftat, quam remiffior, vt experientia declarat.

\section{Contrariorum argumentorum folutio. cap, VII.}

Adpri Tls declaratis, non erit difficile contraria maicm.

rum qualitatum coniugatio, eaque non potef $2 d$ fecis- cum alio elemento communicari. Ad fecundum. dum dicimus, duplices effe primarum qualitatum operationes, \& alias eis competereprout habent propriam agendi vim; alias vero vt inftumentis precipue agentis, vel etiam ratione zliorum accidentium, quz cum illis coniuneta funt. Illx igitur operationes, qux ipfis compecunt perfe, hoceft, quarenus vim agendi, vel patiendi habent fecundum proprias naturas, funt exders, nec diftingurntur fpecie, fed folum fecundum magis \& minus; calefactio e- $F$ nim, \& extenuatio, \& congregatio homogeneorum, \& aliz omnes operationes à calidoper fe prouenientes, ita comperunt calori aeris, vt calori ignis, licet calor igneus efficacius, \& magis hæc præftet, acreus vero minus'; fic de aliis dicendum eft: iiden ergo effectus à fymbolis qualıatıbus proueniunt, cum difcrimine tamen fecundum magis \& minus, præterquam q̨uod vbialıquaoperatio non abfolute à qua-
A litate aliqua prouenit, fed à certis gradibus illius qualitacis; pauciores enim gradus ad illam operationem edendam apti non crunt, vt calor omnis calefacit, quia calefacere competit calido, quatenus eft calidum abfolute: at vrere non competit omnicalori, fed igneo tantum \& fusmo: ex eo igitur quod calor igneus vrit, aereus vero non vrit, non infertureos differre fpecie, fed folum infertur differre fecundum gradus, quia vere non competit abfolute calori quarenus eft calor, fed ftatuto gradui quatenus eft talis gradus: hoc idem dicendu eft de operationibus calidi quatenus eft inftrumentum primariiagentis; ex harum enim diuerfitate non infertur calores differre fpecie, fed folum infertur aggentia præcipua, qua calore vtuntur, fpecie differre. Ad argumentum igitur, quando cicitur humidum aqueum non nutrire ignem, fed porius extinguere, humidum vero aercum non extinguere, fed nutrire, dicimus, . nil aliud effe nutriri ignem, nifi obiectam aliguam materiam accendi, \& in ignem mutari; fed potifimum deillis dicitur, quorum muta- tio in ignem facilior eft; quocirca nutriri ignem humido aereo, quale eft in olen, non fic humido aqueo, eft in ignem mutari facilius res acreas, quarn res aqueas; hoc autem quid mirum; quum magis refifat, \& cum igni pugnet aqua, quam aer? fciendum autem eft nutriri ignem fubitantia ipra, qua in ignem vertitur, non ac$D$ cidentibus; quare nō proprie dicitur nutriri humiditate, fed humido corpore, quod in ignem vertatur: imo iccum quoq; corpus eft in ignem mutabile, vt lignum aridum, quare etiam ficco nutritur ignis; humiditas autem per fe, \& quaten us eft humiditas, cuiufcunq; fit corporis, eft contraria ignivt ficco, propterea neceffario pugnat cum igni omne corpus humidum, \& agit \& repatitur; quarenon fecundum propriam na. turam ei competit vt nutriat ignes, fed continE git humido vt prodiuerfitate accidentium connexorü vel magis, vel minus pugnet cü igni, ita vtaliqua facilius vincātur ab igni,alia difficılius, \& aliz etiam vincant \& extinguant igné; humiditas enim aqux coniuncta eft cũ frigore; quare magis refiftit igni, \& magis in ipfum agit, quam humiditas aeris, qux cum calore coniuncta eft; praterea vero \& cum maiore denfitate, quare magis agit in ignem, quum prafertim denfitas illa faciat fuffocationem ignis, \& prohibeat euentationem, quo fit, vt ignis extinguatur; hoc a:1tem etiam oleum praftat, quando in nimia quantitate fuperfunditur igni, fuffocat enim \& extinguit; nam omnis humidi. tas per.fe habet vim humectandi, \& ladendi ignem, at per accidens ratione aliarum conditionum coniunctarum euenit vt alia magıs, aliaminus lædat, ita vt quz minus lædit . \& facilius a billo vincitur, dicatur ignem nutrire; in operationibusigitur fingularŭ qualitatum cōfi- 
derare femper debemus, an ab eis proueniant fecŭdum propriam carum naturam, an propter aliquid aliud, hoc eft, vel ratione agentis pracipui, vel ratione aliorum accidentium coniunctorum; nam fi à qualitate proueniant fecundum propriam eius vim \& naturam, hæ in omnibus funt exdent fpecie, nec differunt nifi fecundum magis \& minus: at fi competant illi qualitati non fecundum fe, fed per aliquod al.u, , offunt differre fpecie; nectamen inde inferrs poteft, qualitates fpecie differre, vt modo de nutritione ignis dicebamus : fi enim nutrire ignem fignificat mutarifacile in ignem, contrarix erunt operationes, nutrire, \& non nutrire, proinde \& fpecie differentes, nec tamen indicabunt humidum ab humido differre fpecie, quia non competunt humido fecundum propriam natuiram, ficut modo declarauimus. Ad tertium à leuitate, \& à grauitate acceptum neganda eft confequentia, alferimus enim non eiusdem effe fpecicileuitatë aeris, acleuitatem ignis, quum nihil aliud denotent, quam refpectum ad itatutumlocum naturalem cūrelationeadaliá corpora : quoniam igitur alius eft locus ignis, alius zeris, alia ctian eft huius, alia illius leuitas; $h \mathfrak{~}$ ius autem difcriminis ratio, \& ad confequentize probationem refponfio eft, quod leuitas; qux eft ignis, \& leuitas, quaz eft aeris propria non infequitur abfolute calorem prest calor eft , ficut antez de vftione dicebamus, neque indicant diuerfosfpeciecalores, fed diuerfos caloris gradus: quod fi leuitas ignis propria infequerctur non calorem fummum determinate, fed calo. rem abfolute, vtique argumentum effet efficar; oporteret enim, fialia eft aeris leuitas, \& fpecie differens à leuitateignis, aliam etiam effe fpeguar ciem caloris. Ad quareum dicimus calorem i-
gnis confideratum quatenus eft calor, neq; fiecitatem determinate requirere, noque humiditatem, quoniam calor vt calor eft, xque cum vtraque exiftere poteft ; requirit ergo frecitatem. non ipfe per fe vt eft calor, fed vtigneus, \& vrin19in- fequens formamignis. Ad quintum fumenda
eft refponfio ex libro noftro de communi rerum ortu \& interitu, vbi diximus, non effe migrationem de fubiecto in fubictum, quando cadem prima materix portio remanet. Ad fextum dicimus, omnem calorem tam fimplicium quam miftorum corporum, effe per fe ciusdem fpeciei, necdifferre nifi fecundum magis \& minis ca nus:per accidens tamen, \& per relationem $2 \mathrm{~d}$ afure liud poffe etiam dici diuerfarum fpecierum vi 7:, f- calorem equi, \& calorem afini, quatenus hic e. implis- qui eft,ille vero afini; fic dico de calore febrili, \& calem naturalis in naturali, quarenus referüturad pro isci. priam naturan illius anımalıs, cui conueniens eff tantus calor, maior vero non eft conueniens, fed inimicus, \& deftructiuus : at fecundum pro. prian effentiam, \& quateuus funt calores, non differunt fpesie : quod ex eo patet, quodetiam idem caloris gradus, \& iden numero calor, huic rei eft naturalis, \& alii rei eft prater nat uram, neque obid fitvt idem numero calor fit duarum fecierum, hoc enim ne cogitabile quidem eft. Ad verba autem Auerrois \& Alexandri refpondemus, eos nil aliud per ea denotare voluiffes, quam accidentalem calorum differentiam. recundum quam folent appellari fpecies variz caloris; quod quidem pluribus rationibus, quas B antea expofuimus, euenire poteft:quod einim ea fuerit Alexandri \& Auerrois mens, patet in aliis enrum verbis, qua antearetulimus, \& hoc nifi concelferimus, wanife ta eft in ipforum diatis repugnantia \& contradictio: hac ratione videtur etiam Ioann. Grammat. à verborum fuorum repugnantia poffe vindicari, licet eius verbapluss habere videantur difficul tatis; nam in context. 24. lib. t.de Ortu \& interitu, manifeftum eft loannem craffa Minerua loqui, quum is non fit proprius locus, in quo de hac re fermo fiat; fed volens ibiinterpretarı verba Ariftotelis pofita in definitionegencrationis, confiderat an in mutatione elementiin elementum fymbolum eadem qualitas maneat ; vs eadem humiditas, \& cadem perfpicuitas in mutatione aqua in aerem, \& inquit non remanere eandem, quia hiw miditas aqua, \& humiditas aeris fpecie differunt; fed poftea femetipfum corrigens fubiungit vel effe fpecie diftinctas humiditates, vel faltem numero: nil ergo certi hac de re ftatuit, fed indiftincte loquens dicit, vel effe fpecie diftinctas, vel eiusdem fpeciei, folo autem numero differentes : num autem hoc verum fit, non eft prafentis contemplationis; fatis enim nobis in prafentia eft,fifpecie non diftinguantur, neque hoc certe fsatuat lo an. Grammaticus.

$$
\begin{gathered}
\text { Damodo,quo ex duobus contrarijs elementis } \\
\text { tertium medium generatur, quaftiones } \\
\text { dua, o folutio prioris. } \\
\text { Cap.VIIL. }
\end{gathered}
$$

A I A quoque multos rurbauit ad primas A qualitates pertinens difficultas, propter il. la, quæ in z.lib. de Ortu \& interitu de his ab A rifotelefcribuntur; loquitur enim ibi de mutua elementorum generatione, \& tria docet : vnum, quod in elementss in altera qualitatum conuenientibus, qua fymbolavocant, facilior eft tray fitus ex vno in aliud,vt ex aqua in aerem, qu in habertibus vtramque contrariam; qut fit nim aqua \& aet in humiditate o onueg int, fit folum mutatio de frigido in calidurg alterun veroeft, quod in elementis in nera qualita vnius tc conuenıentibus difficilior ef in alterum, vt aqua in ign a duas generari: tertium derm um eft, ex daobus elementis contraris tertum medima generari, vo ex aqui 
\& igniaerem,vel terră, \& exaere \& terra ignem, A rium omnino eft,vt omnis mutatio ab aliquo a. vel aquam; fi enim aqua intereat humiditas manentefrigore, ignis vero calor manenteficcitate, fit terra; fi vero è cótrarioaqua frigus pereat manente humiditate, \& ignis ficcitas nia. nentecalore, generatur aer; fic etiam congredien ibus terra \& aere, generatur eoden modo vel aqua, vel ignis : de hoctertio Ariftotelis diEto dua quaftiones oriuntur, quarum non facilis eft fofutiojvna eft, à qunnamagente $h_{2}$ c mu-

Pror gerafico. peflerser graftio. tatio fiat; alteravero, an in tali mutatione dux qualitates ita intereant, vtalix duæ contrarix generen:ur, an duæ intereant, \& nulla generetur, fed fatis fint vnaalterius elementi feruata qualitas, \&altera alterius ad tertium elementum confituendum:de his ego fententiā meam

Solutio breuiter proferam. Priorem quiden qualtiopriorir. nem expendens, non parum dubitaui nealiena prorfus effet ab Ariftotelis confilio in eo libro, quum in evelementa, \& primas qualitates, vt pradiximus, cum quadam abftractione coufideret, \& effentiam potius, quam exiftentiam refpiciamus ; nam certum eff in mutasione acris in ignem non modo de humido in ficcum $m u$ tationem fieri, fed etiam moío quodam de frigido in calidum, quia minus calidum refpeqtu calidioris inftarfrigidi of in agendo, \& in patiendo: quemadmodum igitur non confiderauit Ariftoteles differentiam gradium in fingula qualitate, fed folum fingulas abfolute refpexit $v$ t conditiones elementorum conftitutrices; ita neque à quo agente mutatio el ementorum fiat. confideraffe videtur, quum in eaparte in folitis materialıs caufa tractatione verfari videatur: antequam igiturdoctat, quomodo ex elementis fiat mift generatio, docere voluit, quomodoclementi txelemento generario fiat, qux in illa mutationecontingant : ideo tria illa confiderauit, qua antea d cebamus, quia competunt prius qualitaribus abfolute confideratis, etiamfi reipla nunquam euerice dicerentur; dum enim duas comiungariones qualicatunı penitus contrarias confideramus, illis feundum fefuniptss cópetit vt deftructa vna qualisate in vna coniungatione, \& vnainaltera, dize remaneant qualitates, aliud elementum teriumab illis diuerfum conftituentes; num alutem reue. ra hoceueniat, \& quonamagente fiat, nonvidetur ibi Ariftoteles confiderafle, ficuti non nfiderauit an dentur omnia elementa pura, at se fimplicia, licet ea vevere fimpliciain eo $F$ libreresper acceperit, quum tamen ipla fortaffe nulibi fimplicia \& pura comperiantur: quodigin rad mentem Ariftotelis attinet, ego quidem ab' ac opinione quam modo retuli, Altera nonfumalience. Sed ne itigerehuitice res dif-
fulutso ficultatem, \&:aliwuma: comersris. ficultatem, \& alicun a gumenta iones videar, quum fratcrim lc-ura tiabear abfolute in elementorum crintideratine quaftio hacde caufa agente mutationis praticta, quia nccefa. gentefiat, pauca de hac redicam : communis eft omnium ferefententia, ab ipfifmet clementis inter fepugnantibus tertijelementi generationem fieri,vt agentibus inuicem aere \& terra , 2e. rem vthumidum agere in terram, \& eius ficcitatem interimere,terram verovt frigiưum agere in acrem, \& eiuscalorem extinguere ita vt manente terra frigore, \& aeris butwitite, aqua fit genita, cuius ha dua qualitates conftitutrices B lunt. Sed nonnulli recentiores in hanc communem fententiam acerrime inuchuncur, ducti duotus porifiram argumentis. Vnum eft, quod in ea eft repugnanta manifefta: nam fi terra aerem fuperetfigore, neceffeef vetiam ficcitate fuperet, quia non potef vna qualitate vincere, quin vinsat etıana'tera. Secundo dicunt, hoc etiam dato, nontamen poteftex is duobus tertium elementum generari;quia neccfe eft vtilla duo, quum lint contrasia, repati c antur inagendo, \& licet frigus terræ præualeat caloriaeris, \& tandem if lum extinguat, fierita. men nos poteft, quin frangatur, \& remstatur à calore aeris; manens ergo remiflum frigus aquam conftituerenon poteft, quum hac debeat elic fumme frigida; fic neccfic cft vt agens humiditas a cris in terra ficitatem repatiatur ab illa, \& remittatur; remilim igitur humidum non conftituet aquam, quz debetefiefumme humida : quoniam igitur dua qualitates vincentes, \&remanentes non pofiunt effe nifi fraca \& remifi $x$, in omnibus autem clcmentis debent ormes qualitates efic fummx, fieri nunquam potefert ex duobus elementis hocpasto inuicemagentibus tertim elementuin genere. tur. Hac igitúr opinione reiecta aliam ipfi excogitarunt, disereque agens clie tertium illude. lementum generandum, hoceft, allud eiuf́lem fperici: quando enisn exterra \& acue generaturaqua, alıa aquáltagens, qux caloremae-

E ris, ce liccitatem teria incerimens, verrit illaduo in aquan fibi fimiem: fic fe omnem euitafe dificulatcm exıftinarunt. Fgovero alienam effe puto ab Ariftotele eorum fententiam, \& communem opinionem fequendam; Ariftote les enim in tota illa parte tria femperconfiderat, nec plura, in tribus illis mutationibus de. clarandis, videliceragens, \& pariens, \& id quod ex corum actione gencratur : vel enim vnun elementura eft agens, \& aliud ab eo patitur, \& mutatur in naturam agentis, idque vel facrlius, quando in vna qualitate conueniunt, vel difficilius, quandoin neutra, vel vtrumque eftagens, \& vtrumque patiens, id eft, $v$ trumque ex parte vincit, \& ex parte vincitur, proinde neutri fimile elementum generatur. fed tertum ab vtrifque diuertum ; ita vt dicendum omnino lit, friftatclens vel nullum ibi ftatureagens, quoniam ad lllam confideracionew minime pertinet, ficut antea dice-

bamus; Prim
recen
rum.
gume
tumi
trac
mune
Sentes
drm 2.
gum. .

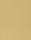

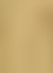


bamus; velidvt manifeftum prefupponere, \& ne verbum quidem ad illud declarandum facete; nam fi in aliisduabus mutationibus dicere volimus quodıan fit agès, niI aliud dicere poffumus, nili vnum clementum cffeagens, \& murace alterũ in fuam naturam, frue furr fymbola, fiec no fyubolı; criso in hac quoq:tertia mutatıone dicendū eft, vưum q clementū eflè agens: \& murarealterum, non tamen infeipfum, fed in alind tertium elementĩ. Praterea quando duo elemcnta, yt ignis \& aqua, mutantur fecundum iftos ab aere agente, quxro an duo illa fe tangant, necne: fidican tnon fe tangere, illa non crit duorum clementorum mutatio in tertium elementum, qualem Ariftoteles ibi confiderat, fed dux mutationes erunt ctiam loco diftuctx; ibienim abaere agente ignis in aerem vertetux, hic vero ab acreagente mutabirur aqua in aeren, ideoque dua crunt aeris generationes diftineta: fivero fe mutuo tangere ignis \& aqua dicantur, quaro an agant inuiccm, an otientur, \& folum ab aere agente ambo patiantul'; quod oticntur dicere fatuum eft, quî.cnim fier poteft, ve duo contraria fe mutuo tangant abfque vllaincr fe actione? fi vero agant inutuo, vt cmnno fateri cogimur, neceffeeit vt hxc cornm mutua actio tanquañ efricasior, atque celerior preueniat actioni aeris in illa; videmus enim guttam aque feruari multas horas antequam à circumitante aere, quanuis magno, in aerem mutetur, aer cnim eit tard $x$ actionis; fic in ferro accenfo fertiatur ignis aliquandiu, antcquam à circumftanfe acre extin guatur; fed actio aqu $x$ in ignem, \& igns in aquam celerrina eft; igitur antequam illius agentis aeris actio àbfoluatur, \& murentur duo illa in aerem, praueniet interitus alterius duor.um, quod in alterum mutabitur, vel in tertium ex mutua ipforumatione, vt in aerem, quæe eft vera fententia: quare nunquam continget, vt ex aqua \& igıi generctur terra à teira agente, vel aerab aerengente, quod tamen alleritur manifefte ab Aritotele in memorato loco. Quamobrem ego cum aliis arbitrdr tertium elementum oriri ex mutua duorum in fe actione, \& hoc Ariftotelem prefuppofuife, at non expreffiffe; quia, vt diximus, non hoc fibi confiderandim eo in loco propofuerat, fed elementa vt materiam generationıs niftorum; ideoque iudicaffe de eorum inter fe mutatione prius effe dicendum idvero, quodipfidicunt, cgo quidem euenire pofle non inficior, fed pertinet potius ad alias duas ab Ariftotele ibi tactas mutationes, nempe-adillam, qua fymbolum elenentum mutatalterum fymb̧olun in fuam naturam; nam fi eo modo, quem ipfi ftatuunt, ab aere agente mutentur ignis \& aqua in aerem: crunt dua mutationes elementi in fymbolim, vna ignis in acrem, altera aqua in aerem: tortha vero ab Ariftot adiecta mutatio mift quo.
A dammodocxaliis duabus ellevidetur, eft enim actio contrarii in contrarium penitus, fed eft mutatio in fymbolum refpcetu vtriufque. Ad il- Refponsio lorum autcm argumenta facile eft refpondere: ad pri. quam cnimilla Ariftotelis confideratio fit ab- mumarftracta à modo, quo exiltunt clementa actu, \& gumen fpectet illa folum, qux compctunt eis ratione tzsm re. propris natux, nogui non poteft, fi clemen- centsor tum calidum \& ficcum pugnet cum frigido \& humido, fieri poffevt calidü fuperetfrigidum, B \& vt ficcum fupereturab humido, vnde generabitur elemētum calidun \& humidum : ticri autem id pofie manifeftum eft, confiderando colum naturas fccundum fe; calidum enim \& fuperare frigidum, \& à frigido fuperarraptum eft; fic humidum \& vincere poteft ficcum, \& ab eo vinci:quocirca ftatuentes calidium fuperare frigidum, \& humiéum fuperare ficcum, non dicimus aliquid feri, quod nequeat ficri, red rem poftibilếdicimus fecundü proprias harú qualitatū naturas: quod confiderädoelementa prout âtu exiftunt, aliquid fit, quod id euenire prohibeat, ficut etiam impeditur elementorum puritas atque fimplicitas, nihil refert, quoniam ibi Ariftoteles hoc non confiderat; quare prior illorum ratio nhiliroboris habet: adde quod etiarn cófiderando el ementa prout actu exiftunt; fierifortalle poteft vt vnum vna qualitate vincat aliud, altera vero ab eodem vincaur, fi verum eft id, quodomnes fere conficentur, non ealden efle harun qualitatum vires in agendo, atque in reiftendo; ficenim fieri poteft, vt vna elementi qualitas fuam contrariam vincat, altera vero fit imbecillior fua contraria : :pro diuerfis ctiam elementorum, inxqualibufq; portionibus: \& inter fe proportionbus multx eis contingere varietates poffunt, \& id, quodin tanta quantitate fuperat aliud, in minore fuperabitur ab.illo, velfecundum alteram, vel etiam; E fecundum vtramque qualitatem. Sed prior fo- Adfecun lutio verifimaactutifinra eft; \& illa eademfe-dur.n. cundum quoqueargumentum tollitur, iam enim diximus, iilam Ariftotelis confiderationem effe abiunetam à confideratione graduum: qualitatum; quod fi abiectio iftorum valida effet, non minus Ariftotelem \& cos quoque ipfos. vrgeret: quando enimiuxta primum, vel fecundum mutationis modum mutari contingat elementum aliquod abalio fiue fymbolo, fiue non: F fymbolo, neceffe eft frangi, \& remitti in illa pugna qualitatem agentis vincentem, vel ambas. vincentes, proirde neq; elementum agens manet ampliuspurum, neque generare poteftele. mentum fimplex, \& habens vtramque qualita! tem fommam; quia nihilagit fupra proprias vi. resquare eorum argumentum friuolum eft.

\section{solutio pofterioris queftionis. Cap: IX..}

$\Gamma^{N}$ folutione autem alterius quxitionis poLiterioris: diffenfifie videntur Ioannes Gammacisus. 
maticus, \& Alexander, vt idem Ioannes refert in cxpolitione contex. 27. libri 2. de Ortu \& inAles:an - teritu.Alcxander etian exiftimauit in illo condriopi- sariorum elementorum congreffu duas qualinio. tates interre, \& nullam generari, vt agentibus inuicem aqua \& igni, interire \& ignis ficcitatem manente calore, \& aquze frigus manente humiditate, \& ita fine productione noux qualitatis aerem generari, quia fatis eft calor ignis feruatus;o humiditasaquæremanensadaerem conftituendum:putauit etiam Alexander vnum numero efle acrem illum, quihoc modo ex aqua. \& igni congredientibus generatur, non duos. ro.Gram. Sed Ioannes Grammaticus vtrumque Alexanopinse. dri di Eum mpugnat : primum quadem inquit, necefiarium effe, vt cum duarum qualita tum interitu fiat duarum cōtrariarum productiơ; dum enim in igne ficcitas interit, fierı nō poteft, quin loco ficcitatis producatur in illa materia humsditas ; fic dum aqua frigus deftruitur, produci calorem necefle eft ; nullus enimalius eft hasum qualitatum interitus, nifi productio contrariarum : hincloannes alterius quoque dicti impugnationem lumit; fi namque ignis ficcitas feruato calore interit, \& ibi producitur humiditas generatur ergo exillo igni aer; fic fi aquæ frigus mainente humiditate deftruitur, \& ibi calorproducitur, ergo exilla aqua fimiliter generatur zer; duo 1 gituraeres dilfinoti numeio generantur, vnus exigni, alter ex aqua, ficutilleıgnis, \& illa aqua numero diftíngu ebantur. Ego

Error $A$ - vero puto alterum quidem Alexandri dicum Lexandri falfum effe; \& veram in eoeffe Ioannis fententiam, fed alterum efle verum, \& in en ref 1 lendo Ioannem effe deceptum, vtreate in vtroq;nonnullirecentiores exiftimarunt. Prioris diati Alexandrifalfitas ita manfefta eft, vt vix credibile fit id fenfiffe Alexandrum : in illa enim materia portione, qux in ign erat, ne imagınariquidem poffumus, ficcitatem interimi, quin humiditas generetur: quod fi quis dicar, fatis efle humiditatem aqux remanentem, vtreddatur humida etiam materia illa ignis, in magnü abfurdum incidet, quod accidens idem numero migrabit defubiefto in fubiectum, hoceft, de hac materix portione ad alinm portionem. qua eft veramigninio:hac igitur fi nullo modoeft concedenda, alterum duorum fateamurnecefre eft; vel nullā humiditatem manere in materia ignis, poff defruitionem ficciratis, fed folum ibiefle caloremabsq; humiditate, \& absque ficcitate, \& itactiam in materia aquæ manerefolam humiditatem fine frigore, \& fine calore, quod nullo pazto dici poteit, quia fic nec ignuserit in aerem mutacus, quumaer non modocalidus efie debeat, fedctiam humidus, nec aqua crit mutata in aerem, quia ad aerem confituendum nor fatis eft humiditas, fed etiam calorrequiritur" ve" confitedumeft, \& in materia humiditateis perempta ficcirate, 2 in materia
A aqux interiiffe frigus per productionem cal oris, \& ita tum ignem, tum aquam in aerem tranfiiffe.Inaltero autem dicto probādam efféarbitror Alexandrifententiant, quscquid aduerfus eum dicatIoannes Grammaticus:quamuis enim duo fint diftuncta numero indiuidua, imo etian ipecie, ignis ille \& aqua, \& duas diftinctas materix portiones habeant; tamen exduabus illis coniunftis materiebus vna fit materia, cuius vna pars priusin ignerat, altera veroin aqua; in v$B$ na igitur illius totius materix parte calor ex igni remanfit, \& ficcitate perempta genita eft humiditasjin al tera vero parte humiditas rcmäfit exaqua, \& fublatofrigote $\mathrm{ct}$ genitus calor; quare totailla inateria cit fáta aér vnus-numero, non plures. Hoc autem verum effe oftenditur eo argumento, quod fi duo diftincti numero acres geniti effe dicerentur, non effer is modus generationis elementorum tertius abillis duo. busdiftin\&us, fed in idem caderet cum primo, C nempe cum mutatione elenenti in elementum fynbolum; duæ namque effent diftinct $\&$ reparata mutationes, vna ignis inaerem, altera aqux in aeren, ficutetiam antea aduerfus alos coníidurabarsus : oportet ergo ex duobus ele. mentus vnum numero genergrielementum tertiumperilorum congrefium, \& ita efletertium generaionis modun medium quodammodo inter illosduos; fimilisenim ff prino quatenus utrumqueintereuntium elemencorum mutaturin fymbolum, id enim quod generatur, eft fymbolum refpecu veriusque; fecundo autem fimilis eft, qquatenus duo pugnantia elementa funt contiaria fecundum ambas qualitates, \& quatenuseft duarum qualitatum interitus, \& duarum produetio; cum hoc tamen difcrimine, quod in fecundo duarum interitus, \& duarum productio fiebatin eadem portione materix, in hoc autentertio fit in duabus; in vna enim interit vna qualitas, \& contraria generatur, in alte:

E ra verointerit altera qualitas, \& contraría producitur:hincloannes Grammaticus recte colligit rationem, cur primus modus facillimus omnium fit, fecundus difficillimus, tertius vero medius, hoceft, difficilior primo, fed facilior fecundo: eft enim primo difficilior, quoniam in primo vnius tantum qualitatis perimprio eft, in tertio antem duarum; fed fecundoeft facilior, quia duns fimul qualitates pellere, ó duas fimul contrarias generare in eadem materia difficlins eft, quam in diuerfis materix portionibus, hoc eft, in vina portione vnam qualiratem interimere, \& inaltera fimiliter vnam; facilius enim eit vnam tantum deftruere qualitatem, quamduas; \&aciliu duas feparatas, \& in diuerîs materix portion:bus exiftentes, quin duasfinul in eadem materix portione. Hxc de his dicenda efle exifimo, \& ita omnem tolli difficul tatcm.

I A C O. 


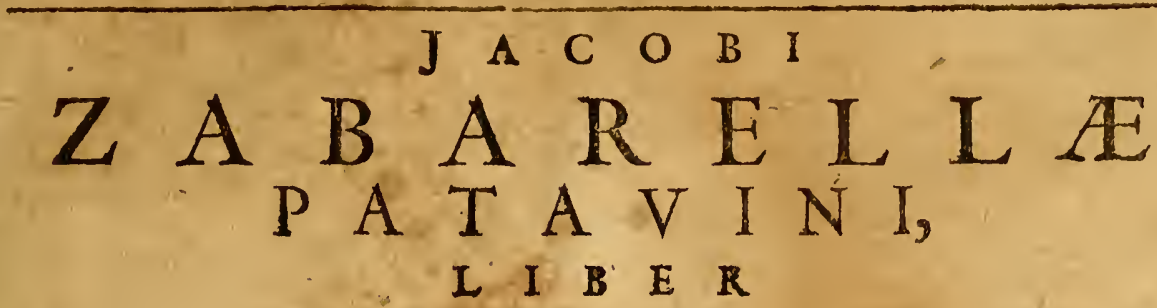

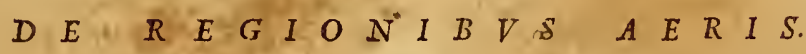

Ouot fint, \& quales Regiones aeris. Cap. I.

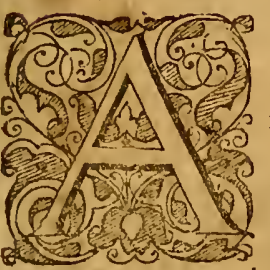

E $R$ in duas regiones diuifus effe videtur ab Arift. in c.4-libr.r.Meteorol.qqux fuperficie fphrica per fummitates montium circumducta diffinerx effe intëlligantur;f fedcodem coniderentur,tres ab co aeris regiones ftatumtur, variis qualitatibus profitum varietate difrepantes : de quibus nunc aliqua dicere ad explanandam Ariftot. fententiam conftituimus. Quum igitur terra ob exuperantias montium perfecte rotunda non fit, imaginatus eft Ariftot. eam redditam perfecte fphæricam à fuperficie fphxrica per montium fummitates circumacta; totum enim illa fuperficie conclufum corpus perfecte rotundum eft, tametif non folam terram continens, fed \& aquam, \& partemaeris illam, quæ altitudine cacumina montium non excedit: totum igitur fuperficie illa fuperiorem aerem, qui mole maximus eft, fuprenam regionem appellauit, eunque dixit calidun effè motu inceflante, quo à Cœlo continue circumfertur,nullis eum montibus.impedientibus; aut retardantibus. Alteram vero inferiorem aeris parten in duas regiones diuidi manifefte fignificaùt, dum dixit, in fuprema regione nubes non cogi, propterea quod non poffunt cogi nifi à frigore;calor enim vaporem difgregat, nec cogi in nubem finit; fupera autem regio calida eft, \& præterea inceffantem habet motum in orbem, à quo vaporis condenfatıo impeditar, quia motus difgregat, \& rarefacit : led neque in infera regione ob eardem rationem cogi nubes poffunt; ea namque, yt ipfe ibiafferit, calida redditur à radiis folaribus qui in terra fracti rcfiliunt, \& aere hunc noftrú calefaciunt; igitur à calore ibi quo que coudenfasi vapor prohibetur:quoniam igiturneq; in fupera, neque irrinfera regione cogi queuntnubes, quum vtraq; fit calida ; coguntur tamen manifefte in fublimiloco, median inter illas duas regionem dari cenfuit Ariftotel.ita vt rotus acr, qui pradieta fuperficic concluditur, in duas regicnes diuidatur, vran inamam, ir qua
A nos degimus, alteram vero fuperiorem, quzad llam luperficiem definat, \& media fit interfupremam, \& infimam:lıze autem partitio à radis refractis, atque refilientibus defumitur: quum enim in terra fractiafcendant, alicubi tamen definant, ceffetque \& extinguatur tandem omns eorum $\nabla$ is, ybifinis eft infim regionis, \& initiu medix; qux nequeà motu calefit, figuidem infra pradictam fuperfiçiem locata vel nullo, vel debiliflimo in orbem motu participat; nequeà

$B$ radiis, quum ad eam partem non perueniant. Differunt inter fe hæregiones, \& quantitatibus \& qualitatibusinam fuprema maxima omnium eft, eandemque femper, \& inrmutabilem quantitatem feruat, ytpote certis, \& immobilibus limitibus contenta;initium enim fumit à memorara fuperficie, \& à montium fummitatibús; definit autem ad principiū loci ignis, aliæ vero du \& multo minorenimolem obtinent, \& eam nö femper eandenı, fed modomaiorem, modo niC norem;nam æfituo tempore infima regio maior eft, quam tempore hyemis ; contra vero media eft maior hyeme, minor auten $x$ ftate : ratio huius difcriminis eft, quoniā zetate Sol fublimior, \& puncto noftro verticali propinquior incedit; hyeme vero humilior, \& ab illo pücto remotior: quo fit, vt $x$ ftate radij terram percutiant adangulos rectos, vel rectis propinquiores, proinde \& vehementius percutiant, \&ad fublimiorem locum refilientes afrendant; contra vero hyeme D obtufiores, \& acutiores angulos faciant, \& obliqué admodun :erram percutiendo debilem faciuntictun, \& debilem reflexionem, \& ad parum fublimem locū afcendunt: 'quamobrem $\mathrm{fi}$ in fima regio eousq; proténditur, quousq; radij: reflexialcendunt, ea angufior hyeme eft, aftate autern amplior; media vero regio hyeme ampla eft, quia magnum fpacium in erponitur inter finen infimæ, \& initium fupremæ; xfate autem

E Qualt tat ibus autem differunt, quoniam fupre- Regronis: ma calida eft propter notum in orbem, infima qualit calida propter radios, media vero frigida, vtpore: tes. vtraque caloris productrice caufa deftituta: fuprem a quoque propter motum, \& propterignis propinqultatéficcior, feu minus humidaeft ; intima hurnidior propter vapores, qui a terra exha. lati continue per ẹm afcendür,àquibusisd e me
Singularim regionum gisalsias tes: 
media quoque regio humidior redditur, quum A ad eam lati ibidiutius maneant, \& in aquam etiam vertantur.Hxc igitur funt harum regionum difcrimina à nobis nunc leuiter, ruditerque relata,ea que ex fituum ducrfitate, variaque à $\mathrm{C} œ-$ lo diftantia orirı manifeltum eft.

Dubium de media aeris regione, folutio aliquormm, So folutionis impugnatio. Cap. II.

Ed de media aeris regione dubium non leue Soritur, quod confideratione dignum eft; quoniam eius folutio ad alias quoque regiones, \& earum qualitates melius cognofcendas, non parum confert: quum enim aer fit natuialiter calidus, iure dubitatur, quomodo aermedir regionis poflit effe frigidus, præfertins magno, ac perpetuo frigore; num id, quod alicui naturale \&effentiale eit, infeparabile ab illo effe folet,vel nonabsque illíus interitu feparabile; gitur fieri non poffe videtur,vt aerille, qui medianr regio- $C$ nem impler, pofit in illa violenta, ac preter naturamaffectione diu perdurare; quomodo igitur manet perpetuo frigrdus? difficultas hac ita omnium animos torfit, vt adlinc nihil dictum effe videatur, in quo plene animus acquiefcat. Quatuor ego hac in re aliorum fententias, \& Prima huius dubijfolutiones vidi.Atiquinon recedenopinso. tes à verbis Ariftot. in 4. capit. lib.1. Meteorol. quæ antea retulimus, nullam illius frigoris aliam caufam adduxerunt, quan quod aer ille vtraque calorem faciente caufa deftituitur; neq; enim circumferturyt aer fuperus, fiquidem impediturà montibus necircumfluat, quum prafertim ob magnam eius à Coelo diftantiam debilis ad eum perueniat motus; nequead eum vfque radija terra refiliunt; quare vtraque caufa Coufuta- deftitutus manet frigidus. Sed hi non tollunt two. dificultatem, qua integra nianet:fienim aer eft fecundum effinian calidus, deberet femper elfecalidus: vel firefrigeretur, non deberet porfeferuariaer. Pizterea opinio hace ea diffenltate vrgetur, quxper omnium philofoplantium oia circumfertur: effectus enim pofitiuus caufam debet haberc pofitiuam, nö priuatiuam folum frigusautem non eft mera priuatio caloris, fed qualitas pofitiua, quare caufam aliquã pofitiua un habre debet; at fecundum illos non habere nifi priuatiuam, dicunt enimnullam aliamillius frigoris effe caufam, quam defectum duarum caufarum caloris, qux eft caufa pruatiua, F hoc autem effe abfurdum concedere omnes videntur; quamobrem hi \& præfentem difficultatem noil foluunt, \& in aliam maiorem videntur incidere.

\section{Aliorum opinio, cin eivs confutatio. Cap. I 1 I.}

Srcunda A Lij dixere, aerem illium medize regionis efopenio. vaporibus aqueis, \& frigidis, quiadillum continue afcendunt, \& ibialiquandiu manent, \& in aquam vertuntur, quæ frigida eft, \& locum il. lum perpetuo frigidum reddrt. Verum hi quoque nec difficultatem tollunt, necillius frigoris idoneam canfam addacunt; difficultas enim integra adhuc manet, quomodo poffit illeaer effe perpetuofrigidus, fi aer eft naturaliter calidus. Non eftenim verum id, quod dicunt, quia vaporis naturam inquit Ariftoteles efle calidam \& B. humidam, \& vaporéfurfum duci à calore; quaread mediam regionem vapores perueniunt ca- lidiactu, non frigıdi, nifi potefate; quomodo igiturà vaporibus poteft locusille refrigerari? imo à contrario potius fefe res habere videtur, à frigorenamque iliius loci vapores refrigerantur, idque Ariftoteles clareafferit in primoMeteorologicorum, capice de Nube, inquitenim vaporesilluc ceruenientes refrigerari à loco,itaque vult locü prius effe frigidum, quam vapor refrigeretur; non ergorefrigerant locum illum vapores, fed potius ab eo reftigerantur. Præterea euenit quandoque tit aer ferenus maneat longum tempus, vt duos, aut tres menfes, absque -aliqua pluuia, velnube, quo tépore à nullo vapore fit frigidus ; relictus itaque fuæ naturæ potirideberer fuo naturalicalore, ficutaqua calefacta, fi dimitratur naturæ fux, ad naturale frigus reuertitur: propterea fi poft tres illos menfes peteret eum locum vapor, non deberet amD pliùs àloconllo refrigerari, quum iam locus lit calidus; hoctanien non euenit, quia poft dıuturnas ficcitates afcendens ad eum locum vapor calidus refrigeratur; eft ergo locusillefrigidus, non propteralios pracedentes vapores, fedfuapteuaum, velobaliquam aliam caufam. Præterea Ariftoteles in c. 4. lib.r. Meteorolog. nullam aliam caloris aut frigoris elemeniorum caufam affignauit, nifi radios \& motum, \& immobilitatcinj motu enim dixit clementa caloE rem recipere, atque ctinm à radiis aftrorum ${ }_{2} a b$ immobilizate vero frigus.

\section{Aliorum opinio, or eius confutatio. Cap. I.V.}

A Lij, ut hancdifficultatem tollerent, adan- Ter A tiperifalin confugerunt, \& hanc dixerunt opis effe caufam frigoris illius medix regionis ; circumfeptus enumaer ille à fuperiore aere calido F propter motum, \& ab inferiore calido propter radros, fit frigidus per antiperiftafin, \& per frigoris confipationem. Sed reque hacfententia re-conf cipienda eft, fi bene confiderenus quid fit anti- tio. perifafis;nt enim antiperifalis, quando alterum contrarium ab altero obfeffum intenfius, rift ac validius fit ob virium collecti onem, propter- gusd, ea quodvures vnitx, atq; collect $x$ maiores redduntur ; igitur oportet aerem illü medium prius elle frigidū: fic enim poftea per circumobfiften- 
tiam caliải frigidior redderetur : quarēdum igitur ab illis ctt an acrille ante antiperiftafin calidusfit, an frigidus;nam fi eft calidus, nullum ibi locum habet antiperiftafis, quoniam vniri, \&e conftipari frigus non poteft, vbin on eft frigus;fi vero frigidus, difficultas integra manet, à quonam lit tacius frigidus, quum fuapte natura fit calidus; nec poteft eius frigoris caufa referri in antiperiftafin, quum prius trigidus effe tatuatur, quate fiat antiperiftafis : quare fententia hacrericiatur.

\section{Opinio Alberti, \& eius confutatio. Cap. $V$.}

A Lbertus, \& alij complures in hane fentenAt.am venerunt, calorem, \& frigus in elementis diplicia effe, nempe vel ve qualitates na:u ales, vel vt aduentitias \& accidentales;natural es enim funt, qux naturas elementorum confe yuuntur; aduentitix vero, qux proueniüt ex actione coleftis corporis per lumen \& motum, vel ex priuatione motus ac luminis. Dicüt igitur acrem infirwa regionis effe dupliciter calidum, tum enim calore naturali \& infeparabili, quem ex fe habet, tum etiam calore aduentitio, quem recipit à radiis Solis reflexis, quo fit, vt calidior fit, quam aeris natura requirat : aerem vero fupremæregionis fimiliter effe duplicicalore calidum, vro naturali, altero accidentali, quem à continuo in orbem motu adipifcitur: hunc etiam dicunt bumidum effe humiditate naturali, fed ficcum ficcitate aduentitia, quam recipit ex ignis propinquitate, aerem vero infima regionis humidum effe duplici humiditate, vna naturali, altera accidentali, quam à vaporibus à terra afcendentibus recipit. Aerem vero wedix regionis dicunt effecalidum calore tantum naturali, qui ei competit, quatenus eft aer, at non calore aduentitio, quia vtraque caufa calorem faciente deftitutus, remanet in fuo ftaru mere naturali, nec alium haber calorem, quam naturale $m$, qui debilis eft, \& denfarionem vaporis, a c conuerfionem in nubem, \& in aquam impedire non potef. Hi autem omnes, qui hac dicunt, coguntur afferere A riftotel. inc 2.3. \& 4 . lib. r.Meteorologicorum, lo quentem de elemétorum qualitatibus, vtà Colo productis, \& de el ementis, vt à Coloalteratis, \& gubernatis, folas confiderareaduentitias qualitates, non qualitates naturales: quando enim dicit, totum hüc inferiorem mundum effe ueluti materiam poteftate calidam, \& frigidam, fieriautem actu tas lem à motu, \&ab immobilitate, neceffe eft vt di. cant ipfum loqui de calore rantum, \& frigore aduentitis, non de naturalibus; ignis enim fecundū fe non dicereturpoteftate calidus, quum fit actu calidus proprio calore, fed dicitur tamen poteftate calidus fecundum iftos, refpedus caloris aduentitij , qui ci fuperuenit ex motu
A colefti; ob id aerem quoque fuperiorem dicens effecalid um \& ficcum , non potuit nifi aduentitiam hum ditatem refpicere, quia nou negaffet in illo acre humiditatem naturalem, salium quoque calorem naturalem; fic et iam dixit, ae. rem inferiorem effe humidum propter vapores, quia tefpexit aduerititiam humiditatem, quam à vaporibus recipit. fic igiturneceffe eft, vtilli dicant Arift. in to ta illa parte folas confideraffe qualitates clementorum aduentitias, non qua.

B litates naturalcs. Sed hrec quoque fententia coxfase multis vrgeturdifficultatibus. Primum enim sio. contra eam habemus argumentumillud vulga. tum, \& à magna Phslofophorum partereceptú: non poteft à caufa priuatiua prodire effectus pofitiuus fine vlla caufa pofitiua ; frigus ergo accidentale medix regionis, quum fit qualitas pofitiua, non poteft prouenire à fola priuatione duarum caufa rum caloris, fed alia illius frig oris caufa a fferenda effe videtur. Praterea valde du-

C bium eftid quod iftidicunt de duobus contrariis fimul exiftentibus in eodem fubiecto; vt de humiditate naturali, \& ficcitate aduentitia in aerefupremæregionis, \& de calore naturali, \& frigore aduentitio in aere regionis mediz: quxrendum enim eft an calor naturalis à frigore illoaccidentaliremittatur, necne;fi enim remittitur, ergo ille aer non eft naturaliteraffectus, fed prater naturam; quomodoigiturperpetuo talis feruatur? fi vero non remitritur, ergo duo con. D traria fimul exiftunt perpetuo in eodem fubiecto abfq; vlla actione, vel paffione inter fe; quod eft abfurdum manifefum. Pixterea fiaerille eft frigidus frigoreaccidentali, calidus vero ca. lore naturali, ergo eit minus frigidus, quam aqua; hac enim fecundum eos vtroque modoeft frigida, ergo non eft aptus gen erare a quam, quia nihil agit vltra proprias vires ; id enim quod fr1gidum eit in quarto gradu, non poteftaliud redderefrigidum in odtauo, qua mobrem non pofE fet in media aeris regione pluuia generari.

\section{Fundamenta iaciuntur necelfaria pro declaratione veritatis.} cap. VI.

Ihi quidem ob adductas rationes nulla M dĩearum opinionum ita fatisfacit, vt in ea conquiefcam; ex fingulis tamen aliquid veri fumitur, quod ad veritatis cognitionem F conducit, vi poitea veritate declarata confiderabimus: fed prius neceffaria quædam fundamenta iacienda, sc ftatuendafunt. Primoloco Elemenin memoriam reuocandun, ac fummopere an- terum notandum eft id, quod alibi fufius declaraui. Eprema mus, aliud effe primas qualitates, \& elementa rom que ipfa confiderare in fux naturz puritate \& fe-litarum cundum ipforum effentias cum abftractione à duplex modo quo extra animam exiftunt actu, aliud cons $/ 8 d s$. cf ea confiderare vtactu exiftentia; non enim ruit. 
femper habent fuam naturalem puritatem, \& $A$ fuas qualitates penitus naturales, imo dubium apud multos eft, an detur aliquod elementum purum : fic etian de huniani corporis temperazura dicere Medicifolent ; nam confiderare quidem polfunt qualis fit perfecta, \& exquifita humana tempcratura; fed an hec in aliquo hominedetur, dubitant, imo \& afferuntaliqui, eam in nullo reperiri : talis cl ementorum, \& elementarium qualitatum confideratio habeturab Ariftotele in 2. lib. de Ortu \& interitu, ad cuius dilucidationem fcriptus eft à nobisliber de QuaJitatibus elementaribus : in libris autem Meseorologicis quum docere Ariftoteles velit ea, qux elementisactu exiftentibus ascidunt, illa confiderat, qualia extra animam exiftunt, ideo dicit aerem fuper $x$ regionis calidum effe $\&$ ficcum obignis propinquitatem, infer $x$ calidum \& humidum, media vero frigidum \& humidum;multa enim funt, qua cxtrahunt clemena à fua naturali puritate, prafertim duo ele- $C$ menta media maxime veroaerem de quo iuxta hanc confiderationem loqui inftituimus; verfatilis enim eft naturx, \& videtur exiftere etiam Jub contrariis quaTitatibus, quoniam ad certos vfque terminos. poteft à fua naturali conftituzione recedere, \& vergere ad vtrumlibet extremorum fubitantialiforma feruata, \& manente natura aeris; ob id Ariftoteles in contextu 54. libri primi Phyficorum dixit, comparatione aliorum elementorum conuenient 1 us aerem ftatui primam rerum materiam, minus a utem conuenienter aquam, minime vero ignem;etenim etiam aqua videtur effe ancipitss nature, quum. polfit \& frigida effe, \& calida, fed magisaer ; de aqua enim nemo vnquam dubitauit cam effe naturaliter frigidam, at de aere non ita clarum eit: Stoici namque ipfum quoque fuapte natura frigidum effe dixerunt; Ariftoteles, vero rationem fequens, qux ex primarum qualitatum coniungatione deducitur, aerem naturalitercalidut effe pronunciauit, licet gradum caloris exquifite fibi consenientem non femper habeat, fed modo maiorem, modo minorem, ita vt quandoque ob magnum recefium à fuo naturali calore frigidus ctiam foleat appellari. Praterea ftatuendum eft id, quodalias demonsumonto ftrausimus, omneselemétorum qualitates, quarum qua lefcunque eas appellemus, fiue naturales, fiue
lit ustes sritusnz- aduentitias, \& extraneas, à Coloproduci, vel. sur is a permotum, vel per lumen, vel perpriuationem
salo. non. loquimur autem nunc de elementorum particulis; etenim non negamus aquam ollx ca. Icfieri ab igni, \& aerem, quiin camino eft ab. igni calidum reddi, non à Coclo; fed de vniuer. fitatibus elementorum loquinur, 2c de magnis carum partibus, quarum dif́crimen non ar liunde fumitur, quam à relatione ad Ccelum, ficuti quum aerem totim in tres regiones par. timur, \& aerem infima regionis in duo hem ifpharia, veletiam in plures terraplagas, quas. variis modis Sol refpiciat vt propinquus, vel remotus; ha namque omnes à Colo varias quali. tates adipifcuntur, qua vel funt fingulis ele. mentis exquifite raturales, vel à naturalibus recedentes, idq; modo parum, modo etiam multum, ita vt fint etiam quando que ita prater na. turam alicuius eleméti, vt fub illis qualitatibus diu feruari nequeăt, vnde mul tre elementis muB tationes contingunt, vt omnibus manifeftum cit:harum igitur omnium qualitatum, \& affectionum caufam actionem coeleftem effe diximus. Tertio loco illud ftatuimus, quod mirum quidem fortaffe videbitur, fed tum ab Ariftote- $n$ le clare afferitur, tum rationi eft maxime confentaneum, frigus non habere caufam xquiuo-ag cam, fed priuatiuam tantum, nam ex pruatio- $C_{2}$ ne caufarum gignentium calorem producitur tin frigus: de caufa quidem yniuoca non negamus à frigido generari frigidum, \& à calido calıdum; fed dum caufam primam \& pracipuam quarimus, qux vocatur $x$ quiuoca, calidum omne produciturà Cœlo perlumen \& motum, frigidum verooritur exprisatione vtriufque actionis cœle ftis;id enim, in quod neutro modo $\mathrm{C} \propto$ lum agit, manet neceflario frigidum : hoc fuit aperte ab Ariftotelepronuntiatum in memorato 4. cap. lib. 1. Meteorologicorum, quando di. xit elementa frigida effe frigida ex immobilitate; \& laudandi quidem in hoc funt interpretes Ariftotelis, qui in fola ipfius authoritate non acquiefcentes, de hoc dicto dubitarunt, tanquam rationem quoq; exquirentes, quod quidem illi, qui veri Philorophi effe volunt, in 0 . mnibus facere deberent ; fed in eo defeceye, quod rationem non inuenientes, dicum Ariftotelis in cas fententias extorferunt, quia ve. rum \& clarum corum verborum fenfum defendere nequiuerunt: nos autem dicimus, illa Ari-

E ftotelis verba non haberc alium fenfum, quam illum ipfum, quem habere videntur; de frigore enim elementorum etiam naturali loquens ibi Ariftoteles ait ipfum produci à coleftis motus priuatione, ita vt illa elementa, qua in orbem: a Colo non aguntur, frigida maneant, nifi 2: liquid caloris à radiis aftrorum recipiant. Hoc autem non eft ita ab/urdum, vt fortaffe videtur, fed confentancusn naturx huius qualitatis, qua vocatur frigus: fi enim calor \& frigus

$F$ funt primz qualitates, non pofiunt in hoc inferiori mundo habere aliam qualitatem priorem, à qua producantur, fed producuntur, \& conferuantur à Coelo; at Colum fua aetione nongeneratnificalorem, eft enim calor qualitas multo nobilior, qu ad frigus refertur, tanquam habitus ad priuationern : quanquam enim frigus habet naturam pofitiuam. tamen. refpectu caloris habet locum priuationis; ideo Sisuti calor prouenut ab actione ceslesti, ita à 
priuatione actionis coleftis oritur frigus: quo- $A$ niam enim nullum eft corpus huius inferioris mundi, quod harum duarum qualitatum expers effe poffit, calor autem prouenit ab actione coelesti, neceffe eft, vt frigidum fit, quicquid coelefti actione participare non pöteft; neq̨; ob id dicimus; frigus confequi ipfam inferiorum corporum naturam, iam enim Ariftoteles dixit, totam hancinferiorem materiam non' $e f f e$ fecundurn fe calidam, vel frigidam actu, fed poteftate folum, actu autem talem reddía motu in orbem, \& ab eius priuatione: quare feclufa actione colefti, neceffe eft, hanc inferiorem materiam nec calidam effe, nec frigidamı; fed conftituta actione cœlefti, oritur in hoc inferiori mundo neceffitas caloris \& frigoris, \& vttiufq; quali tat is generatio pendet à Coelo, \& habet vtraq; relationem ad Coclum; illa enim qux colestem actionem recipiunt,calida fiunt; qux vero non recipiunt, illamanent frigida, quia non effe calidum, eft effe frigidum: hac fuit Aritotelis mens in illis verbis, quam fequens Auerroes lib. 2. de Coelo, comment. 94. dixit, remotio à n:otu circulari dat quietem, frigiditatem, \& grauitatem ficuti propinquitas dar motum, salorem, acleuitatem: $\&$ in Epitome Metaphyfica, tract. 4. cap, 13. inquit, elementa ex neceffitate funt producta à magno Ooli motu, quia motus generat calorem, quem infequitur leuitas, priuationem autem motus infequitur oppofitum, fcilicet frigus, \&gra uitas: quemadmodum enim in fubiecto apro neceffe eft vt priuatio adueniat, recedente habitu, ita in corporibus inferiorsbus necefle eft, vt vbinon eft calor, ibi fit frigus; quia frigus veI eft priuatio caloris, vel qualitas necefiario infequens priuationem caloris; \& quum fit prima qualitas, nullam in his inferioribus priorem habens, non eft prater rationem fi in hac fola contingat, vt habeat caufam priuatiuam, quamuis habeat naturam pofitiuam: in aliis vero fecundis qualitatibus hoc euenire non poteft, quum enim proueniantomnes ex actione harum primarum, neceffe eft, vt earum qualibet habeat caufam pofitiuam. Habemus etiam aliud Ariftoteles teftimonium in s. Meteorolog. cap. de Nube, vbi dicit, vaporem in media aeris regione refrigerari, tum à loco, tum quia calor, à quo elatus eft in fublime. ipfum derelinquit, putauitigitur ad frigoris generationen fatis effe, fi calor recedat: in z. etiam lib. de Ortu et interitu inquit,per acceffum Solis ad nos generationem fieri; per receffum vero, interitum; atqui Sol non agit nifi calefaciendo,\& Solërecedere nil aliud eft, quam non agere, \& fux actionis beneficium non conferre; fed etiam abfque Ariftotelis teftimonio experientia, \& refmetipfa declarat prafentiam Solis calorē generare, abfentiam vero frigus abfque vlla alia caufa: quare ex priuatione actionis soeleftis.producitur in hos mundo inferiori fri- gus, ficuti ex ipfa actionecalor, ita vt omnis virtus huius mundiinferioris à coeleftibus corporibus regatur, \& gubernetur.

\section{Vera ententia de aeris qualitatibes de- claratio, ou comprobatio. Cap. VII.}

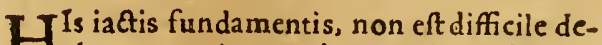
Hclarare omnium regionú aeris qualitates, \& carum caufas adducere: quamu is enim determinata fit aeris natura, \& ftatutz eius qualitates, \& earum gradusilli perfeetenaturales, \& talem aerem apta fint cocleftia corpora fua actione producere, \& conferuare; attamen ex aliorum elementorum contactu, etex variis fitibus refpeetu Coeli, recedunt partes aeris à naturalibus fuis qualitatibus intra quofdam terminos, ita vt poffit vel diütius, vel breuius aeris natura feruari, vel etiam nequeat feruari, fed in aliud eC lementum mutetur. Primum quiden certú eft. fuperam aeris regionem calidam reddi à motu; sircumagitur enım inceffanter à Coclo, quum nulli montes impediant; fed quia nō tantus ibi fit morus, qnantus in fupremo loco, ideo nec tantus calor, fed minor \& remiffior fit, eumque credere poffumus effe aeri naturalem: A riftoteles autem in 4. illo cap, lib. Meteorolog. dicere widecur eum aerem effe ficcum, quia fimul accipit duo elementa fuperiora, ignem \& aerem, tanquam ynum corpus; adde quod pars quoq; illus aeris fublimior, qua igni propinqua eft, vergit ad ignis naturam, \& refpectu inferioris aeris ficca appellaripoteft. Infimæ autem huius noftrzeregionis aerabfque dubio cálidus eft, \& humidus, vt ibi Ariftoteles ait; nam calidus fit à Colo tum per motum, tum maxime per lumen à terra refractum, fed à motu debilifínum calorem recipit, à radiis au tem validiorem : qu od enim motus Coeli ad terram vfque perueniat, Motus

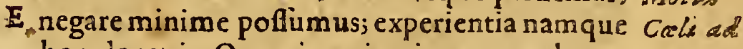
hoc docet in Oceani nauigatione, qux longe terrame celerior fit ab orientali parte ad occidentalem, $6 / g_{3} p e-$ quam ab occidentali ad orientalem, quod indi- neerat. cio eft aquam Oceani participare motu in orbem, \& circumagi ; quare \& aer omnis circurnuoluitur, fed ita tardo motu, vt parum caloris in eogenerari poffit;calorem enim generat non omnis motus, fed qui validus \& velox fit; hic autem tardus eft, tum propter magnam à $\mathrm{C}_{a-}$ f lo diftantiam, \& minorem circuitum, tum etiam propter montes, qui fi eum non omnino prohibent circumferri, faltem retardant, nec finunt motum effe velocem: ideo quando Ariftoteles aflerit, motum circularem ad hanc aeris partem non peruenire, non abfolute hoc negat, fed folum negat de motu valido \& aptoad gignendum notabilem calorem; tali namque motu fertur fola fupera aeris pars, qua ob id eft valde caliclaj media vero \& infima debilem motum

\section{regeo quali: se.}

Itsims regeo gralis fit. netrat. 
motum habent, à quo nos nifi debilitimum calorem adipifcuntur:teftatur autem boc Ariftotel. in I Meteorog. in initio capitis de $\mathrm{Nu}$ be, vbı dicit, terran! calefieri tū à radiis, tum ab ea, qua defuper eft, caliditate; necefic enimeft, ve aer medix, \& infimaregion is ex contactú infimi aeris calidi, \& motı recipiat aliquid \& caloris \& motus: fed nifialium hic aer nofter calorem haberet, frigidus admodum effet, calidus autem valde redditur à rad, is aftrorum, przcipue vero Solis, à ıerra refractis, vt expericntia declarar: quando enim radii vehementeragunt, magnum fentimus calorem, vt $x$ friuo tempore, hyeme autem longe minorem, \& quandoque etiam frigidifimum aerem hunc iudicamus, quoniam tunc à radiis quoque debiliter calefit: ideo infima hxcregio non vbique eft aque calida, neque om nibus temporibus, fed modo magis, modo minus, pro temporum ac loco. rum diuerfitate, qua fit, vt radii vel validius, vel debilius terram percutiant: eft przterea humidus, tum fecundum propriam naturam, quum fit aer, tum quia defert continue vapores humidos, qui ab aqua \& à terra madefacta exhalantur;ab his autem non fit aer humidior, quam fecundum fe efiet, quippe quim fuapte natura fit humidifimus, fed humidior fit re. fpectu noftri, quoniam habens vapores aqueos aptior eft ad humectandum: nam experientia docet, humiditatem aqueam magis humectare, quam bumiditatem aeream, nec tamen a- $D$ qua eft humidior aere, fed id fit propter aqua craffitiem, qua facit, vt magis hareat corpori-

Medias regio juals. bus, proinde magis humeetet. Media vero regio frigida eft, \& humida, non tamen extreme. frigida, fed refpectu naturx aeris, qux maio. rem calorem poftularet;illa enim regio aliquid habet caloris, fed parum, neque eit penitus frigida, quia corpus illud non poffet effe frigidifimum \& effe aer; teftatur autem eius raritas, ac leuitas ipfum effecalidurn, quia omne rarum eft calidum; \& omne leue eft calidum; fed frigidus vocatur comparatione fuperioris, \& inferioris aeris, qui funt calidiores. Prouenit autem ei \& calor, \& defectus maioris cal oris, vnde frigidus vocatur à Colo; quoniam, vt antea dicebamus, omnis calor, \& omne frigus in elementis à Cœlo prouenit; calorem quidem aliquem adipifcitur à contactu fuperioris a eris calidi, \& à motu aliquo, debili tamen, quo participat:adde, quod tranfeunt etram affidue perillam regione exhalationes calid $\boldsymbol{x}$, fuperam regionem petentes, à quo tranfitu illa parsaliquid cal oris recipit. Defectum vero maıris caloris habet ex defectu duarü caufarum facientium calorem: neq; enim ad illam partem perueniunt radii à terra repercuffi, neq; ita à Ccslo circūfertur, vt fuperus aer : quamuis igitur acris natura fit calida, feruatur tamen in elementis naturalis calor à Coelo, proinde vbi aeractionem coleftem nö recipit, viddicet rec motum in orbem, nec lumen repercufluin, neceffe eft vt calor natutalis deficiat, \& ille aer fit minus calidus, quam aeris natura exquifite perfecta requirat; aden ve vel diu poffit aer feruari fub illa qualitate, fi concedamus eam effe intia terminos latitudinis naturalis; vel faltem ali. quanditi, fi fit extraterminos, nil enim ex hoc fequiturabfurdi; fed ficuti aqua feruens feruaturaliquandiuaqua, tametfi preterfuam natuB ramaffecta; ita aer quoq; fub nimio frigore feruari aliquandiu poteft, antequam intercat. Ex his colligere poffumus, mediam illam regionē efle idoneam caufam generationis nubium, \& pluuix: quamuis enim ratione motus debiliorem habeat calorem aer infimus, quam aer medius, tamen adiectis radiis aer infimus fit aere medio longe calidior: quando igitur vapor calidus \& humidus ex aqua calefacta genitus in fublime fertur, fouctur primum, \& conferuatur à calore radiorum in hac infima aeris regione, ideo feruatur leuis, \& a fcendit, donec radiorum repercuflio, et afcenfus ipfum comitatur; fed quandoadmediam regionem peruenit, deferitur à calore radiorum, \& incipit à lo ao refrigerari, tranfit enim à calidiore ad minus calidu um lo. cum, quirefpectu calidioris eft inftar frigidi, \& prafta toperam frigıdi,itaq;condenfatur va \& in nubem vertitur, \& iterum in aquam, \& deorfum fertur. Notandum autem iummopere eft, non à folo illius loci frigore a quam ex vapore generari:aer enim ille eft minus frigidus, quã aqua, quum fit actuaer, quare non poteft agere vltra proprias vires, \& aquam generare, licut antea dubitando dicebamus; fed vaporcalidior fumit principium refrigerationis atque denfationis à loco frigidiore, \& incipit tendere ad fuam priftinam aqux naturam; quare incipit vti viribus propriis, \& propria natura adiuuante redire in aquam; fuit enim aqua, qux poftea à calore fuit aliquantum diftracta à fua nistu$\mathrm{ra}$, \& in vaporem conuer fa; ideo quando vapor accipit primum mutationis impetum à loco frigid ore, \& refrigeratus condenfatur, roboraturque in natura propria, confert etiam proprias vires, \& tranfit iterum in aquam; hincautem fit, vt in aquam mutatus, frigidiorem adhuc reddat locumillum, quemadmodum etiam vi num generofum in ventriculo eft prius actu frigidum, \& accipit à ventriculocalorem, poftea F vero propriis viribus vtens, fit calidior ventriculo: \& retribuit 1pfi maiorem calorem, quarm ab eo acceperit: vnde colligimus, aliquam etiam effe caufam pofitiuam frigoris medix regionis, non tamen primariam, fed fecundariam; quū enim locus ille primum fit frigidus ex priuatione duarum caufarum facientium calorem, ob idq; aquam ex vaporegeneret, fit et1am frigidiorabaquain eo genita: quod quidera nos. in hocquó: infimo aereexperimur; nam poit 
cafun pluuix, vel grandinis fentimus aerem, perquem tranliuit, rérigeratum.

\section{Dict e fententia confirmatio per ommium difficultatum fo!utionem, \&o perexpe- ricutiam. Cap.VIII.}

$\mathrm{H}^{\mathrm{N}}$ E c, quam declarauinus, fententia cxco maxime cófirmatur, quod per cam onjes, quas anteatctigimus, difficultates folumntu'; id enim, quod poillimum onnes conturbabat, erat, quomodo ille aer poffit efic trigidifimus, \&perpctuo durare in il a affectione fibi violenta,ac præter naturam : nos aut cm dicinus, non cffelocun illum extremefrigidum, fed aliquid haberecaloris, efle autem írigidum inferioris aeris conparatione, eamque elfe idoneam caufam generationis nubium, \& plutix;num autem ille debilis calor contineatur intratcrminos lacitudinis caloris aeri naturalis, non eft facile iudicure, fed vicuñú dicamus, nihil abfurdi fequitur.fi enim pradict is terminis contineri ftatuatur, non clt dubitandum, quomodo cum illo debili calore poffit aer durare, quum fit naturalis; videmus enim hominen quoque diu viucre, licet non habeat humanam temperaturan exquifite perfetam, \&aturalem, fatis namque eft, fi fit intrateminos latitudinis naturalis, quamvis recedens ab exquifite perfeeta: fi vero dicamus calorem illunı adeo debilem efle, vt terminis caloris aeri naturalis non concludatur,concedimus illam qualitatem effeaeri preternaturam, \& aeren illum frigidioren elie, quam acris natura patiatur,p:oinde fub illa qualitate feruari diunon pofle, \& poft tempus aliquodicnari, \& in aquan conuert $i$ : quodenim dicinus de eius perpetuo frigore, non ad aeren illum tanquam ad fubiectum idem numero, fed potius ad locum eft reficrendum, ineft enim perpetuum frigus illiloco, fed 11 on eidem acrinumero, fiquidem interitaliquando, \& in aquam vertitur, \&: ad cundem locum alius aer fuccedit, à fupera, vel abinferaparte, ne detur vacuum, isque aliusaer fimiliter abillius loci frigore in aq̣uam mutalur: inefieautem frigus illiloco dicimus, non quidem illi ipatio, quod absque contento corpore nihil eft, fed corpori fpatium illud occupanti : nam ob talem fitum, respectumquead Colum, necefie eft, vt quodcunque corpus locum illum occupet, ita afficiatur;itaque fi idem numero aer perpetuo locum illum admplere perfeueraret, dubium vrique maximum effer, quomodo id, quod eft prater naturam, polfit efle perpetuum; fed quum non idcm fibitemper exiftat acr, fed alius, \& alius, \& ab illius loci natura patiatur, atq; mutetur, hoc eft, à Ccelo, dum locum illum orcupat, nulla pofiumus vrgeri dificultate. Illud quoquc dubiun folutum iam eft, quomodo ille acr poffit yaporem mutare in aguam, \&agere vltra pro-
A prias vires : datenim vapori prinum mutationis impetum, quippe ontitrigidior eft, fed poftca vapor vtituretiain propriis viribus; \& quum omnis calor in clenucne is a cocleftr actione confirue! ur, is autem locus non fitaptus ad tantuma calorem conferunisdum, quantus aeri conueniens eft, neceffe eft, ve tandim vapor ille in a qu. veratur, quum in aerem vertiminime polfit. Illud quoque, quod dubrum \& incredibile videbatur, elrcetum pofitiuun habcrecaufim pri-

B tantuan, diximus in frignere \& pofibile, \& necellarium fuif: ; 8 huius ratiose m alduximus, quamrepetereoperapretium non êt. poffumus autem etiam per experientiam id, quod dximus, comprobaremihienim cótigit, id quod etiam aliis pluribus contigifie audiui, vt alcenderem ad fummitatem viquemontis Veneris, qui omnium in l'atauinoagroaltiffimus eft, ibi per totum diem habui aerem fermifimum, fed in ra circiter medium montis videbam nubes, qux me vifione vallium prohibebant, vefperi autem poftquam deillo mote defendi, inueni factam co die in infera parte magnam pluuiarn. quum in montis cacunnine nihil pluifet; exeo mellexi me tranfife per medism aeris regionem, in qua eft tacta pluuia, nectamen eam fenfi frigidilimam imovt vixaliquam animaduertidifferentiam frigidioris \& calidioris aeris:nam xftuun tempus erat, \& pro xftino temporeeran veftitus, nectamentantum Irigori, quod meladeret, ex eoloco percepi; pars igitur ille non ettabfolute frigida, fed folum compararioneinferi aers calidioris. Magnum qnoque veritatis teft monium prabent ftllationes aguarum:vidcmus enim eroris in ftllicidio exifentibus, iup:ófito igne vaporcm eleuari, \& in operculum ftillicidiuncidentem condenfari, \& in aquam mutari; atramen fi operculum illid manu tanganius, valdecalidum éf, \& quandoque $\mathrm{E}$ ita calidum, vt manu tangentes tolerarecaloremillum nequenus; quienim fieri poteft, ve quin fit calidum, mutet vaporem in aquam, fi facere id non poteft', nifi refrigerando? Jicêdum igitureft operculumillud, licer calidum, frigıdi tamen opcram praftare refpectu vaporisafcendentis calidioris ob fuppoficumignem; a re igi tur calidapoteft per condenfationem aqua generari, quia dum agit vt minus calida agitvt frigida; quarenon eft necefíarium, vt aermedia $F$ regionis, fidebeat vaporem in aquan mutare, fit frigidislimus, fed fats eft filit minus calidus, quam inferus aer, \& quā vapor, qui pèrinferum acrem elatus, ad mediam regionem perducitur.

\section{Quodalior ̈̈ opiniones aliqua ex parte vere fint, daliqua exporte false. Cap. IX.}

Tlud q:oque hanc fententiam confirmat, 1 quodalix, quasantea memorauimus, ficum
Expe rentra.

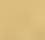

.


hac conferantur,aliquid videntur habereveritatis, ita verteri omnes huius fententix nofira

7.Senten- peritatem contitcri videantur. P'rimum quidem

ra. illi, quidiverenredian regionem effe frigidam, quoniam vraque caufacalorem faciente deftiruitur, omnium ferifimam fententiam protulerunt, fed eam non declarant 's, nec rationem vllamafferentes, cur effectus hic pofitiuus caufam habeat tautummodo priuatiuam, dubiam maximehancrem reliquerunt; nihil etiam de medir regioniscalore diserunt, itavextreme frigidam elle videantur exiftimafe : nos vero aliquem effeillius partis calorem oftendinus, debilem tamen, \& rum ipfius cal oris, tum debilitatis , quxe frigoris nomine fignificari folet, caufam adduxinus; eamp; omnino in Colum retulimus. Alii vero, qui illins frigoris caufam

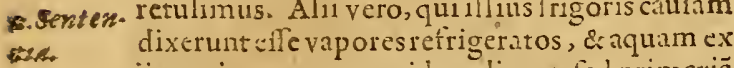
iis genitam, verum quiden dixere, fed primariă caulam prætermittentes lolam fecundarian attulerunt : prius enim quam à pluuia genita locusille refrigeretur, frigidus eft ex defectu illaIum duarum caufarum, \& prius yaporem retrigerat, quam à vaporerefrigerctux. Opinio all*asten- iemaliorum deantiperiffafifal fa quidem abfó tur. lute eft, quoniā ca concelfa nullus calorabigni, $\&$ abaere lupero ad nos perueniret, cuius contrarium A rit.pronunciauit:prztereafecundum iftos maximum eflet illius regionis frigus, \& ibi poffet grando generari, quod negauit Arift. dicens eam gigni in infera regıone per antiperiftafin, non in media; quare in media anti periftafin ficri nō putauit:videntur tamen isti modo quodam veritatem fignificaffe, \& fimilitudine quavlam deceptinoméantiperiftafis v furpafle ; nam frigidam effe partem illan conftituunt, hoc eft, \& iupero \& infero aere minus calidam, proinde comparationeillorum frigidam; hoc atatem dicere, eft eam dicere defti tutam, tum notu in orbem, à quo pars fupera cal efit, tum tradiis à terra xefraftis, à quibus pars infimacalida redditur;
A quandam igitur relationem aeris medii ad fuperum \& ad inferum cognonerunt, quam minus recte antiperiftafin appellarunt, quum potius con para:ionem appeliare deúncrint;reucra cuin medius acr comparazione aliorune ft frigidus, nonantiperiftafi. Tandem ad rectum fenium trahipoteft fententia Alberti: nam fi intelligit in aere medio effe duas difinctas quali. tates, calorem naturalem manantem à natura aeris, \& frigus aduentitium prouen icnsa defe.

B ctu gaula um calorem facientiún, reiiciendana efie elus fiententinmarbitramur, quiacalor \& frigus non poffunt fimul exifere in eodem fub. iectovt dua diftinet $x$ qualitates; quemadmodumetiamfi \& in fupero, \& in infero aere dicar effe ducs calores numero diftinetos, vnum na turalem, alterumaccidentalem, falium dicit, quia duo accidentia eiusdem fpeciei numero dittincta non poffunt fimul effe in eodem fubie* cto, \& omnis calor;atque omne frigus in vniuc1C fitatibus elementorum atque in magnis eorum: partibus prouenit à Colo, nec periditat, quir: dicanturefie elementis qualitates naturales. $A$ z fi intelligatin aere medio vnam tätum efle qualitatem, qua quum abfolute fit caloraliquss, dicaturtamen frigus comparatione fuperi \& inferi aeris, proinde eadem fit qualitas re, qua fola ratione diftinguatur, vera eft cius fententias gquemadmodum etiam admitri poteft id, quod de fupero, ac de infero aere dicit, fi intelligat ac.

D rem habere vnum tantummodo calorem nu. mero, eumque ì Colo accipere, qui tamen râ. tione alicurius gradus dicatur acri naturalis, id eft, exquilite conueniens nature acris : at fecurdumaliquem gradum excedat tarminos perfeete naturales, itavt fit idem nuniero calor, duo autem dicantur fecundum rationem; in hocenim folofenfit vera eft Alberti fententia: num autem ipfe ita fenferit, duburm eft, idque cgo affeuerare nonaudeo, fedalis eius verba perper E dentibusconfiderandum relinquo. 
difputare in prafentia velimus; fatis enimabAriftotele explofa eft tum in 1. lib. de Coeio, dum oftendit Colum non effe naturæ elementaris, fed corpus quintum nulli interitui, nullique alterationi obnoxium; tum in r. Meteorolog. vbi aliis quiburdam argumentis ad eam reprobandam vfus eft. Dumifla igitur naturacoleftium corporum confideratione, quæ à noftro præfenti inftirutoaliena eft, fig̣iidem de folo calore à ceclétibusproducto, dicendum nobis propo. fuimus, fignus quiburdam manifettiflimis contenti erimus, quibus oftenditur, non idco attra calefacere, quod ignea fint. Primum quidem fi Sol effet inncus, \& hac ratione.calefaceret, non minus in hyeme calefaceret, quam in $\approx$ ftate, Quia propter Coli rotunditatem Sol in omnibus Coclipartibus rque diftat à nobis; quare fine fublinior incedat, yt in xitare, fiue humilior, $v$ t in hyeme, eundem facere calorem debe. ret: qionian, vi in hoc igni noftro experimur, eadem eiuldem igni, dittantia eundè calor cm facit, refque ira eft nimilefta, v tomni dubio cạreat: quod in in radiorum repercaffionem productionem caloris refuranus, clara eft huius temporm dicrimins ratio, vt mox oftendemus: adde quod ti Sol effet 1 gneus, deberet Aitrologorum opmione magis calefacere in hyeme, quam in aftate, quia in hyeme propinquior nobis eft, quium fit in per: $\mathrm{g} x 0$, in reftate autem. remotior, quum lit in apogxo, quan vocant augen. Praterea fi Sol effetigneus; ideoque calefaceret, media acris regio, tanquain illi propinquior, magis calefieret, quam hæc intima, qux remotioreft; quare nulla a fferri ratio pofo fet generationis nubium in media regione : 0 portet enim vaporem afcendendo tranfire de aere calıdo in frigidum, fi debeat condenfarı, \&e in nubem verti,nec vlla fieret der.atio, fi à frigidioread calidiorem tranfiret. Sumitur etiam ra. tio validiffima ab experientia, quia videmus radios Sol is tranfeuntes per ampullam accendere ftuppan in altera parte politan; cuius rei nulla ratio fecundum eam opinionem adduci poteft, \& cur fine ampulla ftuppam non accendunt? nam fi Soleffet igneus, deberet etiam magis calefacere, nullo interpolito corpore, à quo aliquod fieri calefactioni impedimentum neceffe eft, vt in igni noftro experimur; nam per inter. pofitum vi.rum tranfit quidem ad nos lumen ignis, at non i ranit calor: fed fi Solem dicanus calefacere per lumen, ratio maniferta eft, quo. F niam in ampulla, \& ill vitro cauo multi radii cengrediuntur, ó fiunt rnus radius; ideo qui difperfi debiliorem vim habebant, ii coniuncti \& initi ma gnamadipif:ütur, \& accenùunt propinquum aerem, \& per illum etram fri pam. Exhis \&aliis eiulmodi prater argumenta qua ab Ariftotele afferuntur, manifestifimè oftenditur aftra non effe ignea, nec formaliter calida, fed virtute tantummodo, calida quia funtaptaj
A producce in aliis calorem: quomodo erga producant, quum calida non fint, id nubis ir prefentia conliderandum proponitur.

\section{Sententia Arifotelis, quomodo calum per motum calefacint. Cap. II.}

CI Ariftotelem legamus, tü ilì contex. 42 lif. z. de Ceclo,turn paffim in r. Meteorol.duo ab co ponunturmodi, quibus coléftia corporacalefaciunt hxcinferora: vnus per motum, alter verò per lumen, \& radios; quem vtrumque declaraturi ordicmur à moru. Declarans Arriftoteles in memorato loco rationem, cur à Coli motu iu his inferioribus calor generetur: eam totam in Solis corpus referre videtur: in çuit enim corpus folıdumdifgregare fuo motu, \& accendere aciem, fi duabus conditionibus preditum fit; yna, vt fir prope ipfum aerem; al tera, vt celerrime moueanur : nam fi remotum fit, non poteftaeremà fe longediftantem calefacere; fi vero fit propinquum, \& tarde moueatur, fimiliter non calefacit: oportet igiturvt \&e propinquum fit, \& velocifime moueatur : has duas conditiones coniundtm asceptas folum Solem inter omria aftra obtinere, inquit Ariftoteles: nam Luna proxima quidenr eft inferiori nundo, fed tarde mouetur, quia paruum circuitum facit; catera vero aftra celerrime quidem mouentur, quum magnum ambitum, magnumq; fpatium eodem temporeperagañt, quo Luna paruum; at nimium diftant à corporibus inferioribus; fed fol vtrifque conditionibus fuf'ficientereft praditus, fatis enim propinquus eft inferiori mundo, \& fatis veloci motu circumfertur: putat autem Arift. orbem Solis effe ordine fecundum, \&atimfupra Lunam collocatum, ita vt fupraSolem fit Mercurius, \& fupra Mercurium quarto loco Venus, deinde Mars \& solsc laco Iuppiter, \& Saturnus; fed Aftronomi certis obferuationibus inuenere Solem, non fecundo lo co, fed quarto effe pofitum, nempe fupra Lunam, \& Mercurium, \& Venerem: attamen $A$ riftoteles, fus 1lla opinione conftituta, quod Sol fit flatim locatus fupraLunä, ex hoc cius pofitu probat Solem efle fufficientem caufam calo. risin hocinferiori mundo per motum, quum \& fatis illi propinquius fit, \& fatis velociter mouea tur, quæ amba fimul iunctre conditiones nulli a ftro prater Solem competunt : facereautem videturAriftot, in predicto loco talem fyllogifmum; motus velocifimus folidi corporis per aerem factus difgregat, \& accendit ipfum; Sol autem eft corpus folidum, \& fatis propinquum acr, \& celerrme mouetur; ergo difgregat \& accenditacrem, \& ita caloren generat fuo motu. Huitusatiocinationis vrraq;prop ofitio magnis difficul laribas vigetur, idco vtramq; feparaim nos confiderate oportet.

$$
\mathrm{S} 4 \text { Quomo- }
$$


QHomodo motus gencret calorcis.

$$
\text { Cop. III. }
$$

Q Vod ad masoren propofitionem atinet, cius veritas omni dubio caret; espericn. tia namque docet, motum celeren generare calorem, \& Ariftoteles loc tanquan manifeAlsorkm ftum pronunciauit; tum in contex. 42 . lib. 2. óniro- de Coelo,tumińcaf.4. lib.r. Asctcorol.Seúratio iass. non ira maniferta cft, \& cie hac inter Pliilofophos non parua eft controus fia: alii namqi diConfuta- cunt hoc competere motui abfolute, quxtenus $\therefore 0^{2}$ eft motus: alifiveronon quatenus eft motus fed quatenus eft localis motus: vtriq: tamen decipiuntui, quia facere caloresu neq : motus abfolute fumpti, neq localis motus naturam confequitur; fienim per fe id competeret motui, vel per felocali motui, oporteretper regulam logicá onni motui cōpetcre, vel omni locali, quod tamen lalfum eft; nōomnis.n. motus, neque omnis motus local is caloré generat: nan fi quid tard o motu feratur, 11ullü generat caloré, pruterea nici folidŭ, ac durum fit, etiă fi velociter moueatur, non facit calorem, ficut experientia declarat, \& vt afferit Ariftot. in memoratis locis.

opsno Iropterearętius aliî́ntiunt, qui dicūt notum fera. faccre calorem, non perfe, fed peraccidens, hoc eft, non primario, \& quatenus eft motus, fed per siud, \& fecundario; tuncenim calorem facit, quando rarefacit, extenuat, \& atterit partes aeris, rt ibi Arift.ait; quocirca motus per rarefaErioners, \& attritioncm generar calorē, hoc eft, perillas conditiones, per quas excenuat, katterit; quum enim non detur corpus arius aere, n1fi inns, necelfe eft, quando aerà vehementı motal cöteritur, i rarior fit, vt tranfeat in naturam ignis. Sed difficultas hinc magna oritur, quam aii non confiderarunt ex his enim colligi videtur, attritionem effe calcris inumediatam caufam: cuia fimotus nō perfe, fed perattritionem calefacit, Attritio igitur per fe caloris eft caufa, hoc tamen non videtur dicendum, quoniam è contrario videmus motum effe caufam tenuitaris, \& raritatis; agcns enim calor in aquam, extenuat iplam, \& in raporem conuertit; atquı nö potelt calor efle saufa attenuationis, nifi effeEtriv; fic etian fiattenuatio fir caufa caloris, non poteft efienifi effectrix ; ergo dur res erunt fibi mutuo cauf $x$ in eodem gencre cruf $x$, quod nullo modo dicendum eft. Dibium hoc non leue eft,nectane ab aliquo fuit adnimaduerfum, licet quotidic experiamur, calorem \& raritatem fe mutuo confequi ; nm omne extenuatum fit cal:durm, vel, fi erat calidum, fit calidus, \& è contraro id, quod calefit, rarius actunuius cua-

sulutio. dit; qura ha dux qualitares fe nutuo producere vilentur. In hac difficultate ego dicendum puco, calori, tanquam primequalitati, principem efie locum tubuendum, proinde iplum ef-
A feefferricēcaufam raritatis, ac tenuitatis, fed non rartatcm elie caufam caloris : credendum enim eft, primum qualiatem efle caufam fecti$\mathrm{d} æ$, nō fecundam prim $x$, quod pofiumus etiam argumento à contraris defumpto comprobare: fic cnim calidum ad raritatem fe habet, vt frigidumad denliatem : contrariarum enim caliarum contrarios oportet cffe effectus, fed fripidum denfitat is eft cau $\{$, non denfitas eft cauia frigoris: fimiliterigitur non eft raritas caula cirloris, fed calor caupararitatis. Ad argumentum autem addueum in contrarium, quo oftendi vi= debatur raritatem effe caloris caufam, propterea quod motus non per fe calcfacit, fed per rirefactionen, dico calorem, \& :aritatem le mutuo confequi, vt caufan \& effeetum reciprocabiles, duni confiderantur in fimplicibus, de his enim loquimur, non de miftis, quorum alia eft ratio, ob contrariorum elementorum concurfum; igiturvbicaufa \& effectus reciprocantur, C quemadmodim pofita caufa ponitur effectus, ita \& effetu pofito ponitur caula, nec propterea fit, vt effectus frt caufr fux cauf $x$, fed eft præparatio ad eam in fubiecto recipicndam : quındo cnim agens vult formam aliquam fubitantialem introducere, pritus materam preparat accidentibus connenicntibus formx inro áucen$\mathrm{d} \&, \&$ his receptis, aduenit forma, nec ob id runt caufi formx, fed porius effictus 111 an conlequentes: quoniam igitur in clementis raritas eft effectus caloris, calor enim extenuat, \& rarefacit, eftetiam materiz praparatio ad calorem introducendum, ficut etiam calor eft profaratio materixadreciptendan formam elementi calidi, neq̨; obideft caufa formx: quando igitur dicebamus, motum facere calorem per rarcfaCtionem, non intelligebamus rarstatem; ac tenutatem effe caloris proximam caufam, fed potius effectum \& pripatacionem ad calorem Tecipiëdum:caufxautem caloris funt illx conditiones, qua adiunctr motuifaciunct morus atterat, nempe foliditas mobilis, ac velocitas motus, \& fi quaralix funt, que faciunt vt motus rarefaciat, \& atterat; non enim folus motus attenuat, fed motus cum itatutis quibufdam conditionibus, ficuti dictum eft. Illud praterea hac in re eft annotandum, prædictas conditiones, quas requiridiximus, vt à motu calor produca tur, non fufficere, nifi in illo quoque corpore, F per quod fit motus, \& in quocalor eft generandus, fit aptitudo ad calorem a mosn recipiendum; etenim agensnonagit, nifi in patiente ad recipiendum idoneo: corpus igirur, per quod fit motus, oportet elle tenue, \&rarum, \& naturaliter calidum; quia fi denfum fit, impedit mobile, ne velociter moueatur, eique ita reliftit, vt nequearmotus tamram habere veloct:atem, quanta adartes fum coryus illud requiritur; fi enım fagittiab areu enittatur per aquai, non calcht aqua, nceplumbeus mucio liquelicit; 
ugitur el emento calido, ne ramo auget motus calorem, \& raritacin; at alem nto frigido, ac denfo nü poteft caloum la rgiri, fed agente validiorcopus eftad inutandam fubftantiam illius clementifrigidi inclementum calidum, vt igneo c.lorealterante a quam, \& nutsite in vaporcm; quia motusinon poteft folus facerc hanc mutationem: hinc rationem colligimus, cur Ariftoteles in predidis locis folum aer cm nominauit, in quofactus motus generatc calotem pollit: in quit enim atteri zercm à mott velocicórporis folidi, \& it.l accendi; in aliis vero denfioribus elementis id ob rationem pradičam fieri nó poteft; ignem autem nō nom na uit, quia nihil dari potcit rarius, aut calidius igni, proinde motus rapidiffmus poteft quidem igniconferuare calorem, \& raritatem, fed calidiore aut rariorem facere non potelt; idcirco totum el cmentuignis à motu Coliconferuariafterimus, quodfuneillo motunon conferuaretur: led quianon eft ita manifelta caloris conferuntio in habente fummum caloré, vt eft generatiofumm caloris in non habente fummum, ideo Ariftotcles tacuit ignem, ơ folum,zerem nominzut in declarando quomodo à motu calor genererur; nos vero indecolligere debemus, iden efficere notum eriam in igni, quialicet calorem ci dare màiorem non poffit, generare tamen calorem dicitur, dum continue ipfum conferuat. Per hac foluitur dubium de àqua fluminis velocifime so- fluente, qua tamen ex eo motu non fit calida, 3t. imo a qua ftagnante, \& quiefcente frigidior eft: folutio enim eft, quod aqua eit corpus naturâ frigidum, ac denfum, quare nor poteft à motu cilorem recipere; non eit etiam tanta illius motus vclocitas, vt atterere propinquum aerem poffit, neque ip fum aqua cur us durum, ac folidum eft, qualead atteredum acrem effe oporterer: \& quamuis motus ille dicatur velocifimus refpectu aqure, qure eft minus agitabilis, quam aer, tamen refpectu aeris eft motus tardus, ideopotius contingit, ve propinquus aer à. contactu aqux frigefcat, quam ab eius motu calefiat: quod vero, quiefcens aqua fit calidior, quam mota.id non tit propter quietem; quies einim ad calorem gnerandum ajta per fe non eft, red quia firmius recipit actionem agentis calefacientis, fcilicetpercultionem radiorü Solss, \& tangitaerem calicun contiguum, quam aqua fluens; hxc enim dum fluit, non expectat actioncm acris agentis, quiefcens vero eam ex- $F$ - peetat, \& inagis ricipit. Non eft autem quod de animalidubiiemus, quomodo caletiat ex motu, non tamen per attritionem; nos enim in prefentianon de viuentibus, fed de inanimatis Joqumur, nempe demotu veloci corporis folidi peracrem facto, \& de hocfoloAriftot. loquiturinpredictsslocis vilegentious manifefum eft : animal vero alia ratione calefit ex notu; quum enim omnis actio in animali per fpiritus
A abfoluatur, ambulanie animalitranfeunt fprrítus ab intcrnis partibus ad axternas, ideo ex magno fpirituü concurfu extcrnxan malis partes incalefeunt, fed non per attenuationem, per hanc enim in foloace fitcalor ex motu veloci corporisfolidi, vt dictum eft. Poffumus autem cx las, qua diximus, fumercinterpretationem illius propofitionis Auerrois in comment. 4.2 . lib.z. de Colo. Moruseft perfectioralidiquatenus eft calidum; eft enim yera non formali-

B ter, fed caufaliter, motusenm non eftactus, \&. forma caloris, fed eft productiuus, \& conferuatiuus caloris; inquit autem, quatenus eft caludum, quoniam ea eft caloris elementaris natura, vt a motu pendeat, \& conferuecur, tanquam à caufa prima, vt Ariftoteles fignificauit libro primo Meteorologicorum, capite quarto, quando dixit elementa calida habere calorem ì notu, frigida vero ex immobilitate elfefrigida;ideoignis fua natura calidus fuperum locum C petit, vt ibià Colo circumuoluaiur: notareautem in iis verbis debemus, Auerroem non dicere, quatenus motus, fed dicere, quatenus calidum, quia de motu fallum dixifet: quum enim non omnis motus faciat calorem, ideo nō qua-

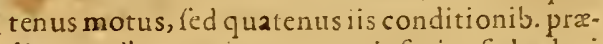
ditus, quibus attrinonem aeris faciat:fed calori per fecompetit generari ar conferuari à mosu. plurium enim rerum inter fe comparatarum ea eft códitio, vt huius ad illam refpeetus fit effen- In 2, lib.

tialis, illius vero ad hancaccidentalis, quemadmodum in libris Logicis diximus.

de Pro. pof.neref.

\section{Iubitatio contra Ariftotelem de modo, quo Calum calefacit permotum, é prior So- lutio Alexardri, \& eiusrepro- batio. Cap. IV.}

E $P$ Er hæc maior propofitio fatis, vt arbitror, declarata eft; in minore autem longe maio: difficul tasineft, eaq; tanta eft,vtvix Ariftoteles Argume defendipofie videatur; dixit enim folum cor- tsm conspus Solis elle fufficientem caufam generations tra dri. caloris in hoc mundo inferiore; quia fatis pro-fot. piuquum eft, \& fatis velociter mouetur.Sed hoc difficultate mantefta, \& ardua vrgerur, quia motus folidi cosporistīc tantum atterit, guando non modoprope eft, fedetiam tangit:omnis erim actio naturalis per contactum fit, vt ipie Arifoteles docut in 7.lib. Phyfica aufcultationis, \& in 1. de Ortu \& interitu; Sol autem non tangit inferiorem mundum, quia fecundum $A$ riftotelem eft interpofita faltem $\mathrm{ph}$ æra Lunæ, at fecundum Aftronomos interfunt etiam orbes Veneris, \& Mercurii; quomodo igitur Sol mundum inferroem caletacere poreft perattritionem, fi ipfum non tangit : poflet quidem per orbem Lunce calefacereinferiora, fi prius iprum Lunx orbcm calefactet, quemadmodim ignis $S$ s noiter

\section{Motss \\ efterfe- \\ aiogali.} di.

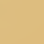
-
Pro.
necef.

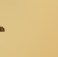


nofter per aerem medium in corporibus no- $A$ ftris calorem producit; at orbis Luna nullius caluris eft capax, nee vila pars coleftis corporis calefieri, aut refrigerari poteft; nulla igitur racione videntur hre inferiora corpora pofle à corpore Solis calefieri per attritionem. Videns

prior fo hanc difficultatem A lexander, nifus eft tueriAlatio A- riftotelem; \& duas refponfiones attulit. Vna uxandri eft, non inconuenit dart in natura aliquod agens, quod agat in extremum, quum illud non tangat, neque agat in medium, idque exemplo fatis noto confirmat: pifcisenin vocatus torpedo fupefacitmanum pifcatoris, dum adhuc retibusinclufus eft, nec manum pifcatoris tangit, necagit in rere medium, certum enim eft, rete non ftupefieri, neque effe capax ftuporis; fic igituretiam Sol per orbem Lunx medium caletacit inferiorem mundum, licet neq; ipfum

Confuta- tangat, neque orbem Lunæ calefaciat. Hæc Ario. lexandri folutio ab omnibus reprobatur, przfertimâ Ioanne Grammatico in capite quarto libri primi Meteorolog. \& ab Auerroc in commentatio 42. libri fecundi de Colo,nam aduerfatur Ariftot. in memoratislocis, qui voluit non pofieagens naturale agere in extremum, qun priusagat in medium, propterea quod neceffe eft omnem actionem naturalem fieri per contactum, Adilludautem quod de torpedine dicitur, inguutunt falfumefle id, quod Alexander ait, torpedinem in rete medium non agere; fiquidem neceffe eft inprimi in rete aliquam affetionem, qux poftea pifcatoris manum ftupefaciat; eaque an fitftupefactio, an aliquid aliud, non eft curandum ; fatis enim eft fialiqua affentio retibus imprimatur, à qua ftupefiat manuspifcatoris; eft enim fortafie refrigeratio vehemens, à quaretibusimprefla, ftupor in manu pifatoris generatur. Praterea (inquit Ioannes Grammaticus) quis afieuerare poteft, non imprimi in rece eandem affectionem, $11 \mathrm{cmpe}$ ftuporem? dicere namque retia carere fenfu non eft idoneam rationem adducere; fimiliter enim dicere polfemus, arbores in byeme non refrigerari, quia nonfentiunt.

\section{Altera Alexandri folutio, ó ciusimpu-} gnatio. Cap.V.

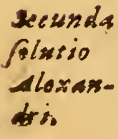

T. Fc Alexander confiderans, ad fecundam If refragabiliter veram illam Ariftotelis propofi. tionem, agens naturale non poteft agere; nifi tangat, proindénon agit in extremum, quin agat in medium, dixit nõ ef̂e faltem neceflarium $\mathbf{v t}$ in medium inprimat eandem affectionem, quam inprimit in extremum, fed fatis efe fi yel eandem inprimat, vel aliquam aliam; Sol igiturpoteft in mundó inferiore calorem producere per orbem Lunæmedium, in quo fi calo. cem nō producit, faltem producit aliquid aliud, producit enim motumiquare dicere pofumus, Solem in orbe Lunx efficere motum, \& per il. lum producere in inferioribus calorê. Sed neq; hac lolutio admitti poteft. Primum quidem poffumus negare Lunam moneri à Sole, nam fi depropriocius motu loǵ:amuin, moneturLu, na non à Sole, fed à motore proprio; quod ex eo etiam patet, quia Lúna eft velocior Sole: fi vero diurnum motum fpectemus, Luna non mone. tur à Sole, fed omnes orbes mouentur à primo

B mobili, feu potius ab vno motore primi mob: lis, à quo totus cocleftis globus tanquanı animal quoddam magnum agitur ab ortu adoc cafunn: adde quod A riftoteles in loco prædicto, quando dicit calefieri à Sole mundum inferio. rem, non intelligit à tota fphrra, fed à fola ftella Solis, harcenim inquit effe corpus folidĩ, quod perattritionem calefacit; Solisaüt ftella, quem motum in Luna orbem inprimat, ne imaginari quidem polfumus. Praterea q̨uando dicimus C agens in extremumagerectiam in medium vel candem affectioncm, vel aliam, non polfumus intelligere in medio produci affeetionem, nifi talem, quz fit tanquam agens proximum,ì quo producaiur affectio in extreno, quemadmodum de torpedne diximus; patet emm affici re. te táli affectione, que per contåum ftupefa. cere poffirmanum pilcatoris: fiue enim nota illa affectio lit, fue ignota, certum eft eam talem effe opoitere, alioquin integra maneret diffcultas, quomodoagens naturalepofit agere fine patientis contactu: nunc vero non eft ignotailla affectio, per quam apud Ariftotelem motus calorem eficit; eftenim rarefactio, \& attri. tio à motu facta; oportet igitur vel Solem extenuăre, atque atterese orbem Lunk, quod quidem dicere nó pofiumus, tel iili tribuere folum motum à guounferiora colpora asterantr: at neq̣; hoc dici poieft, quia mottis Lunx, fecun $\operatorname{dum}$ Ariftotelen, magis eft tardus, quam vt at* E terere, \& attririone producerc calorm polfit: quamobrem dum motum ip fum, quo fertur Lu* na confideramus, à quo is produci dicatur, ine. ptus eftiuxta Ariftotelis fententiam ad inferiora corporaatterenda: nil ergo refert confiderare, à quonam notus Lunx producatur, an à Sole, an ab alio, fed fpectanda tantummodo eft propria 1 llius motus velocitas, quam Ariftote les minorem effedicit, quam vt poffit per attritionem generarecalorem: itaque Sol neque pervelocitate motus Lune attcritinferiora co:pora, fiquidem illa inepta ad arterendum eft; neque per velocitate propriam, quoniam hanc cum Luna non communicat, neque per fuam velocitatem tangitinferiorem mundum, aut in ipfurm agit; fed à lola velociate orbis l,unæpa. tumur infiriora corpora motum, \& attritio. nem. Illud igirur, quod Alexander dicit cie mo. tu, qué Sol L.unx tribuit, nihil eft, quia vel -1ul. Jum tribuit, vel, fiid ei cödonemus, ineptumad calefas 
calefaciendum tribuit, alian vero excógitare affectioñcm non poffumus, quan Sol tribmat Lune, \& per quaminferiora corporaper attrilice tionem calefaciat. Simplicius quidem in cont. 1- zl. lib. 1. de Coclo attribuit Alexandrovt dixerit dro Solem calefacere inferiora corpora, qua prius calorem imprimit orbi Lme : fed hanc fententiam apud Alexandrum non legimus, eaqjion. eft confentanea opinioni Arifotelis, qui putauit coeleftia corpora expertia efle omnis alterationis, proindenec calorem, nec frigus recipere polle : preterea cenluit A riftotéles caloren à motuefici per attritionem, \& attenuationem; igitur fi motus Solis calefacit orbem Luira, necefreclt, ve extenuet, atqueatterat ip fum, quod quidem nullo modo dicendum eft: quocircaego adduci nen polfum, vt credam id vnquam dixirle, vel cëınffe Alexandrum, quod eià Simplicio a fcribitur. Patet igitur vanas effe Alexandrifolutiones, \&pereas fententiam Arift. non defendi, proundeintegram adhuc maneredifficultatem : quam conliderans Ioanu.Grammat. poftlongan diputationem cōtra Alexandrum tandem concludit, A rift. defendi non poffe, nec veram caloris caufam atrigiffe:ipfe vero fententram fuam proferens inquit, coleftia corpora calorem efficere, quia funt naturaliter calida \& ignea, maxime autem omnium Sol, vtapudiprum legere poffumus in memorato loco.

\section{Alia Ariftotelis defenfio ab Auerroead- ducta. Cap.VI.}

Alor Verroes in comment. 42. lib.2. de Coeloreprobata Alexandrif folutione, aliam ipre pro Ariforele defenfionem intienit: ftatuit: inprimis fundarnentum hoc fatis apud philofophos manifêtuń , omneen facultatem inateriafém diuiduám effe ad diuifion ean materize, proinde in maiori corpore ma iorem efie potêtran; \& in ninore minorem;idque ctiam ab. Ariftoteie expreffeponitur in poftremo cap. libri ófaui Phylicorum, hoc conftituto, inquit Aueroes, quando alicui corpori attribuimus vim moulendialiud corpus, eam dicimus illi inefic lecundum toram fux fubftantix profunditatem ; non tantum fecundum illam farrem, qua tāgit corpus motum; vt exempli gratia, orbis Lunz circunuoluens elemêtum ignis, non diciturillam vira habere in illa tantumpartê, qux et âd fü perficiein fuam concanam, fed in tota fua fubitantix profunditate, proinde quanto maiorem. habet profunditaten, tanto etiam maiorem vim motricem habet. Obeandem igiturntionem quam rotus co:leftis globus it tanquam corpus yınddam vnum, \& tanquam amal quoddan magnum, cuius motus eft tlle, qui diurnus dicitur, \& ab Arift. vocatur motns totins, guin tocus globus co motu mouetut, proprianit Gingulartm iphararum motus fint tainquans
A motus propriinembrorumanimalis;iceredebemusignem ia aerem non à folo orbe Lunz moucri, fed à tota omnium fphærarum congeriejin illa enim tota ineft tota viśmomendi infe. riorem mundum, quodetiam in Epitome Mctapliy fica trabtatu 4. cap.13.2pud Auerroem leginus; 11 fingulis autem partibus illius totins ineft pars tantum potentix ntotricis, non po. tentia tota, ideoq; fingula pars propriam fuamz illius facultatis partem contribuit, fiue ipfi tot

B fuefaltem parti inferiorem mundumtangenti parum enim refert, an dicamus fingulas Coeli partes toticolefti globo conuibuere fuas partes facultatis motricis, an dicamus, alias partes fuam potentiam contribuere illi parti, quatan. gitinferioren mudum, ytorbiLum; fatis nim eft fi intelligamus, totam illam vimmouendi inferiora corpora toti coelefti globo inf tàm effe,cius vero partem partiillius globi, \& in aliaquídem maiorem ineffe, inalia maiorem, C proillarum partium diuerfitate, prefertim pro maiore, vel minore illius materix portione, aut etiam denfitate: quoniam igitur itella eft pars orbis denfior, proindeplus illius corporis ha. bet, quam pars vbi non eft ftella, ideo plus et- iam facultatis motricis habetfiella, quam pars ftellam non habens : hinc fit, vt ftella Solis ma ximam onnium habeat potentiam, quia efto. mnium ftellarum naxima, \& lucidifima, pro. inde etiam denfifima, \& plurimum in fe illius $D$ materiæ contillens; magnam igitur potentiæ partem contribuit; ob idque illa pars orbis Lune, qua Solis corporifubitat, maiorem, quara alix, habet vim mouendi \& atterendi propin quacos pora inferioris mudi, quoniam ibi exercetur illa potentia, quam toti coelefti globo Sol contribuit. Quando igitur Arifoteles cor pori Solis afcribit facultatemattenuandi, \& ca- lefačiendi fubiedum aeren, notr eft accipien. dum(inquit Auerroes) ipfum folum corpus So. $\mathrm{E}$ lis tanquam agens abaliis fellis, \& orbibus f paratumifedintelligendum eft totan omnium. Ccolorum congeriem effe quafi corpus vnuma. contịum in quo infit vna tantum vis mouendinferiorem mundum, \& huius magnam partem contribura corpore Solis ob rationem pradiclam. Ieaque omne dubiun tollitur qquia noi eft necetiarium vi Sol agat prius in orbern Lunz mediun, quam in corpow inferiora; hoc enim fequebatur, dum Sol tanquam agens quoddam aborbc Lune feparatum accipicbatur: fed quum Sol non fit nif pars agentis contribuens toti magnam partem faculatis motricis, actio in interiorem mundus firper contactum, quia vnum eft totumagens, nerape totus coeleftis glóbus, à quo mundus hicinferior tangitur, vt ait Ariftoteles in z. cap. libri prin: Metcorol. huic autem totipartes omnes contribunt proms portiones factiltatis motricis, alia maiorem, alia minorem; neque in 
partibus vius agentis requiritur vt pars remo, tior à pat iente imprimat aliquid in partem propinquam, fed fatis eft ip fa potentix communicatio, dum id quod mouct, eft totum quoddam \& vinum, cuiurmodi efle coleftem globum di= ctume eft,

\section{Quodrefponfione Aucrrois Arifoteles non defendatur. Cap. VII.}

$\mathrm{I}$ N hac Auerrois folutione duo confiderand ${ }^{a}$ funtivnum,an per cam fatss A riftoteles defen datur, \& à pradica difficu'tate vindicesur; alterum, an ipfa perfe Auerrois funtentia vera fit. Quod ad Ariftotelem attinct, ego quidem arbitror eius verba hane defonfionem non recipere: n.mu fi folü ipfum Solis corpus fpętenus, cui tanquam agentifeparato vim totam mouendi. attribuamus, iam aperte fatetur Auerocs, can fententian defend non polfe, quia Sol inferiorem mundun non tangens, in ipfum agerenequit; ob id,lla, qux ab A riftotele dicunt ur, niritur Anerroes Soli attribuere confidetato tanquam pari to tius globicoeleftis magnam facultat is motricis partem contribuenti; attamen $\mathrm{h} \approx \mathrm{c}$ interpretatio verbis Arifotelis non congruıt, quóiam Ariftoteles ita attribuit Soli vin moundi, \& atterendi aeren, vtexpreffeexclu datomnes alias phrras, tum fuperores Sole, tum inferiores, proinde confiderat corpus Solis vt agens feparatum, nonvt partem agentisinam fi tolum globum putafee elfe mouentem, \& cale facientem inierioxacorp orafuo motu:Solem sutcm eflepartem plurimun illius potentir contribuentem, certe ascepiffet motum durnum, tanquam vaum totius globi motum, non vt multiplicatum, \& in plures diftinelum, prót in diuerfis orbibus recipitu, \& prout in Luna tardioreft, \& in fuperoribus remoriorabelementis, quam par it, in Sole autem fatis velox, \& fatis propinquus; hoc enim cit Solem confiderarevt agens quoddam feparatum, \& abaliis patibus Coeli diftinctum : at fecundum Auerrois confiderationem, in otus diurnus firmitur vt vulus totius globi motus, qui mundum mineriorem calefaciat per contacum, proinde per illam attritionem, qua fit à taintano? us velocirace, quinta eft in parte globi tangente, hæc autem eft illa velocitas, qua orbis Lune monetur. quamuis enim totum globum coleftem di comusatterere inferiora corpora per fui motus velocitatem, tamen hoc non efficitalia velocitas, quan illil, qu $x$ eft in inferioris müdı confinio, atque contadu; ab hac enim pronenit illa relocitas motus in igni ix nere, quxinciscalorem producit, \& ita illa dementaconferuat. itaque non erat conideranda prupria orb solis velocras diftinfanabalis rum ubium velocitate, ö ob idratio al Auenoe adducta non innititur propriæ velocitari, inecpropra propinqui-
A tatı Solis, fed denfitati tantummodo, à qua plurinu un virtutis tori globo contr:buitur; mullam entm refpicit velocitatum, vel propinquitatum differentiam, fed vinam tantummodo velocitatem confiderat, quir of totins flobi, \& vnam totius propinguiatem, qun tangit inferiorem mundum atratio ab Arifotel callata imnititur propinquitati, \& velocitat prepr $x$ corporis Solis, vidifinctr, àvelocitatibus, \& a propinquitaribus aliorum; neutram tamen conlide$B$ raredebebat, fi volebat fignificare totum globum elfe mouentem, \& atterentem: nam fecundum opinionem Auerrois, Sol eandem operam preftat in quacunque $C o c$ i parte collocetur, etiamfi in upremo oninium orbe eféfatuatur; vbique enim vim fuam eandem totiglobocontribut ; attamen fecundum cpinionem Ariftotelis, fi Sol remotior ab inferjor i mundo poneretur, non attereret, neq; calefacer't, quoniam ob eandem remotionem alios omnes fuperioC resorbes Ariftotad calefaciendum ineptos efe iudicauit, quare fententia Ancirois opinioni Ariftotelis non acconum odatur. Clara eriam funt Ariftotelis verba, dieent is [ fafficiens est hoc face re Solis latio tantum] nam manifefte alins orbes excludit, \& vult folum corpus Solis efic caufam caloris vt motorem feparam artamen fecundum opinionem Auerrois cxtera aftrab hocmunere non excluduniur, quia dum tumi. tult to: us globus vi vinum colpus motues, omnes D partes fuam virtus portione contr buunt, tum qux propinquxiunt, tum qux remotx; quum Arifoteles fingula afra ondidens vemouentra ceparaca, exch a omuia iuperiora Sole; vt ab in crior mundo n mis remora. Alia quoque d.ficulra eirerifiderurcin locoAr ftomeles, quod cumin queit onem pro orrufet decau huns culor s, quapud nos cit dincrat enmu principio capilis [propter quam ca fam fiat ca-

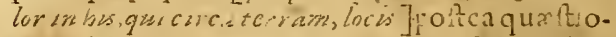
E nem foluens nitil de radis dicit, fed caufam huius caloris in folim colcftem notum refert, inquit en:mu [ ropter banc getur caufaperuerit adbunc locun caluditar] lignificans hü locum in quro nos degimus, quem tamen aliis in locis aferit calefiri etiamà radis, imomagis a radi s,quam à motu Coeli. Sed hoc folni iacile po. teft quum enim certum fit Ariftotclem non negale radios in hocaere inferiore calorem producete, in co tamen loco videtur folam cauiam F vuiucralen, dimiffa pariculari, adducere volunfie; nam a motu Coils produetus calor per totum inferiorem mundum diffunditus, \&adter ram vfque, \& eius intima peruenit; at ille, qui à radiis efficitur, eft in haciola inter aeris regione, obid hac canfoneglecta, Ariftoteles folun motuin coleftem conid raut quad quid pr $x$, dretan de mont dificultarem atiges : dusm enum radion confiderationem lechidimus, \& 10 lum notum coinlidcramus, non videturdetendi poll 
di poffe fententia Ariftotelis, dicentis, motum A te, quam ex illa, qux eft in orbe Lunx in munfolius Solis hunecalorem pai atcutionem producere; quum illi non accommodetur detinfro artificiofifima, quam exçoginauit Auerroes. Sed preter omnia, quxe hatenus dicta funt, nullum eit aduerfus Ariftrtelem efficacius argumentum, quam quodex ipfinfmet confeffione defumitur: ipfe enim exiftumatit fpharam Solisfeoundoloco, \&e itatim fuprafpheram Lunx effe pufitam, fpliaram autem Veneris in quarto loco nempe fupra Luna m, \& Solem, \& Mercurium : Venerem igitur ineptam cflc iudıcauit ad caiorem motu producendum; tanquaion nimis remotam, proinde confeflus eft quartum locum effe ab inferioribus nimiun diltantem, nec aptum ad ea atterenda per mocum: atqui inuentum poftea eft Aftronomorum obferuationibus, Solem in quarto locseffe, \& Luna, \& Mercurio, \& Venere fuperiorem; ergo neq; Sol adcalorem producendum idoncus eft, quia à corporibus inferioribus eit nimium remotus: nam fi Ariftotelis argumentum de Venere validum eft, non minorem de Sole habet efficacitatem, fi Sol reuera in eo loco eff politus, in quo Anftoteles Venerem effe exiftimauit. Ego igitur, quum aperte fatear menullam inuenire ratione potuifle, qua fententiam A riftotelis tueamur. quod mihi fortafle ob inf citiarn meam, atque ingenii imbecillitatem contigit, defentionem Ariftotelis aliis excogitandain relinquam; hrc enial dicere volui, non vi Ariftotelis fententiain impugnarē. fed vt slla dubia, qua mihi negotium faceifunt, in medium prof erës fignificarem, me eorum folutionem defiderare.

\section{Vera Sententia, or opinionis Auerrois de- claratio. Cap, VIII.}

Equitur vt qzomodo Colum fuo motu Salefaciat, confideremus, quando in fententia Arift. acçuiefcere minime pofiumus. Ege E quidem arbitror veriffimam effe Auerrois cpinionem, quam anteareculimus: quum enim Auerroes fententiam Ariftotelis, quani haetenus. expendimus, falfam effe cognouerit, eam tamen reuserentiâ ductus, impugnare non eft aufus, fed modeftius agens maluit Ariftotelem in alium fenfum trahere; ad quem tamen an verba. Ariftotelis trabi poffint, alii confiderent, illà nimirum verba, qux in calce 4. cap. r. Meteorol. leguntur, vbi Arifoteles rem hanc diftincte, \&e exquifite fe declarare profitetur, non enim inficior ipfum aliis in locis rudius de hac re loquéten attribuife productionem caloris colefti motui indiftin te, ñon motui Solis tantummodo. Quoniam igirur res per fe mavifefta effe videtur; patet enim totum elementum ignis, \& cum eoaerem à toto coleíti globo inceffan. ter circumuolui, \& ita calorem ex eo motu recipere per attritionem, neque ex alia velocita. di inferioris contactu; confiderandx nobis funt conditiones, qux in motu, vt atterat, requiruntur, \& oftendehdum eas omnes orbi Lunæ competere, ve argumentum tollamus, quo ductus Ariftoteles, orbein Linx ineptum adhoc effe iudicauit. Tres ad fummum conditiones poftulari videntur; vna, ve mobile fit prope rem atterendarn; altera, vt fit folidum; tertia demum, vt velociter moueatur:primam conditionem hîc B non defiderarisple quoque Ariftotel es confiteTres cödiriones ji debeat motis ca lefacere. turj patet enim torum coeleftem globum rangere mundum elementarem per orben Lunætanquam per partem fuam. Secunda quoque con- Calum ditio confiderantibus manifeita eft: neceffarium totü est enim eft colefte corpus folidum effe totum, \& Jobzdaminferioribus corporibus minime cedens; 'na m fi cederet, pateretur, quod dis édum non eft: quoniam ergo non eit aptum cedere vlli preffioni, folidum eft, \& idoneum ad fubiecta corpora c diflipanda fuo motu. Sed tertia conditio A riftotelis difficaltatem fecit, quia in orbe Lunzenon fatis velox effemotus videtur; affertio tamen illa Ariftotelis videcur probatione indiguifie, quum enim certum fit, velocifim um effe $L$ unze motum, quum quatuor \& viginti horarū tempore totum circuitum peragat, probandum erat: hanc velocitatem non effe tantam, qua atterere ignem, \& aerem, \& calefacere apta fir: nos enim non poffumus nifi iudicare motum illum,

D quamuis tardiorem in illa parte, quam in alus partibus fuperioribus, velociffimum tamen $e f-$ fe, \& a ptum ad atterendum, dum illum cum aliis, qui apud nos fiunt, motibus comparamus: frequenter enim experimur, ex motu, quo ferrum filicem percutit, atteri intermedum ae: rem, \& in ignem conuerti, nec tamen dicendum eft, motum illum effe motu Lunx velociorem, fed potius multo tardiorem: fic etiam dicendum eft, fagirı motū per aesem effe motu Lunatardiorem, tamen fatetur Ariftoteles plumbeos fagittarum mucrones motu accenfos col\&. quefcere:nam fi imaginaremur equum, vel aliquam aliam rem in fuperficie terrzadeo celeriter moueri, vr exactis viginti quatuor horis ad. lacum, à quo primo difcelift, rediret, nonne rapidifimum effe motum illum iudicaremus? nonne multo velociorem motu fagittæab arcu emiffiz? eo tamen ita ficto motu longe velocior eft motús Lun $x$ qu $\mathrm{ob}$ maximam à terF la diftantiam longe etiam maiorem circuitum, ac maius foatium co tempore peragit; quemadmodum in rota celerius mouent ur partes ad peripheriam fita, quam partes axi propinqux. quoniam illx eodem tempore maiorem circuitum perficiunt, quo hæ minorem. Negans igitur Ariftoteles tantam effe motus Lunze veloritatem, qux calefacere per at tritionem poffit, rem negare videtur ex aliarum rerum compa. ratione euidentiflimam, proinde non erat hoc abfque 
abfq̨; rationeproferendum, fed ea negatio ma. xime probationem defiderabat. Sed proter hane velocitatem, qux certe eft magna, magnum etiamadditmomentum maxima illa totius coc. leftis globi moles, atqueprofunditas: nam fi in maiori corpore maior agédi vis inct, vehementillimam reddi illam actionem ex magna fubftantia Cocli profunditate credẽdum eft, quum prefertim in eo innumerabilia aftra infixa fint, qua ob fuam denfitatem plus potenti $x$ motricis contribuunt, quam caterze partes; \& alia quidem maiorem, alia minorem, quarenus alia denfiora aliis funt: quo fit, vt maximam vim contribuat Sol, cuius denfitatem maximam omniü effe ex maxima eius luce iudicamus. Tanta igitur eft coelcfts globi in parte inferiorem mundum tangente velocitas, vt per fe apta maxime fit ad inferiora corpora atterenda, \& $\mathrm{mi}$ randum profecto ent, quumodo Ariftot. id negauerit; fedadiceta etiam magna totius globi coleftis nole, ac profunditare, fiquidem toti globo hac actio attribuenda eft, adhuc maior illius actionis efficacitas, ac vehementia redditur: quare dubitandum effe non videtur, totum globum coleftem perillam fui motus velocitatem, quxeft in orbe Lunx hxc inferiora tangente, caufam effecaloris in hocmundo inferiore per rarefactionem, \& attritionem.

\section{Dubium de partibus elementi ignis, \&o eius folutio. Cap. IX.}

Dubiพี.

C Aterum aduerfus ea, quz mododemonitrauimus, dubium magnum oritur, quod omnino foluendum eft ad plenam veritatis declarationem; quum prefertim non -magis fententiz huic noftra, quam opinioni Ariftot. officere videatu: :nanifi Coelum motu fuo velociffimoatterit, \& accendit inferiora corpora, \& ignem generat, feu cōferuat in proxima $\mathrm{C} \propto$ li parte; ego in partibus huius nuundi, qua lub polis, velcirca polos funt, nempe in illa parte. qu $x$ ab Aftronomis gelida zona dicitur, nō poteft effe ignis, quoniam ibi vel nullus fit motus, vel nimistardus: quare alterum duorum videtur effe concedendum, vel in fupero inferioris mundi loco, qui elemento ignis aflignarus' eft, ignem non effe, fed aliud frigidum corpus, quod quidem videtur effe abfurdum, quum illum fupremum locum non debeat alisd corpus occupare, quam ignis, vel, fi in totoillo loco fit iginis, exiftere ignem, \& fummum calorem, vbi non fit motus, aut non ita velox, ve poffitcalorem generare: qued fententiz noftre aduerfatur manifeftiffume, nec minus opinoni Ariftotelis, quicaufam caloris fupremi loci reculit in motum folius corporis Solis tanquam velociffimum, quum tamen Sol non feraturnifi per rorridam zonam, gux eft intra tropicos, \& fempes
A à polis remotiffimus fit : hine etiam fit vt folam fubiectam fibi acris, \& ignis partem poffit calidam reddere, nempeillam, qua fub torrida zana eft, non illam, qux eft fub polis in viraque gelidazona, qux necilli eft fuppofita, nec circumfertur, nifi tardiffimo motu; fi enim verum eft id, quod Ariftoteles dixit, calorem in elementis à motu $\mathrm{C} c$ li velocisfimo prouenire, frigus vero à priuatione 1 llius motus, non poteft lub gelidis zonis in ipfo Colicontactu effe ignis, quum B ibinon fiat motus, nifi tardifimus. Difficultas hac nulla efiet apud illos qui caufam caloris,ac frigoris elementorum referunt in ipfas corum formas, \& naturas: nam fi formam ignis infequitur fummuscalor, facis eft forma ignis fub polis locati, ad fuum naturalem calorem fibi conferuandum: fed hanc fententiam falfam o. mnino effe, \& Ariftoteli repugnantem alibi demonftrauimus, per hanc enim collitur penitus natura loci, \& vis confer'satrix locati, quam illi

Ariftoteles attribuit, \& motus elementorum naturalis ad fua loca, vt ibi fufus oftendimus. Hoc igitur fundamento conftituto, quod omnis calor in elementis à Colı moı u conieruetur, vet aperte Aiftoreles dixit, nicendum eft hanc difficultatem, fifieri polfit, de medio tollere. Ego quidem poltquam rem hane diligenter confideraui, in hancfententiam vent, in qua penitus acquacico, id quod dubium videtur, effe prorfusneccffariung, \& maxime, confentancum $D$ rationi fub polis enim, vbi non fit rocius velox, ignem cenferuari non foffe exiftimo, fed calore deßitutum refrigerari, grauefcere, \& in alıd elementum ratai , ac defcendere: quam enum ccelétis calor ad hxc quoque frigida elementa perueniens, ille profertine, qui à luminegeneratur, eacalefaciat, \& in halitus. vertat, qui continue à terra, \& ab aqua tanquam leues ad fupcram partemafcendunt, \& ibietiam ma. graexparte accenduntur, \& in ignem mutantur; debuit natura ad feruandum elemento. rum xquilibrium raticaem aliquam inuenire, qua in lupera quoque parte generetur frigus, \& vice verfa ignis in graue elementum mutatus deorfum feratur: nifi enim hoc tiat, iam ex continuo halituum afcenfu, afcenfione verfa effent onunia elementa in ignem, \& ignis ille, qui eft prope Lunam, immutabilis omni tenjpore duraret: quod quidem abfurdum fecundum hanc noftram opinionem non fequi$F$ tur; quum enim ignis qui fub polis eft, grauefcat, \& refrigeratus deorfum feratur, neceffe eft, ne detur vacuum, vt alius propinquus ignis ad cum locum implendum tranfeat, \& ibi aliquandiu maneat, \& fimiliter eius calor remittatur à natura loci, \& deorfum ferazur; ita vt hat in elementis viciffitedo, ac circularis generatio om nibus temporibus perfeueret, tanquam fluuius ad fuperna continue currens, atque inde recurrens; \& elementa grauia nun.

quare 
quam definant mutari in leuia, \&afcendere, \& leuia fimiliter in grauia, \& defcendere : \& quema dmodum media aeris regio, licet locus aeris fit, tamen ob eius fitum non poteft acrem diu confernarc quin frigefcat, \& in aquam mutatus defcendat; ita rationi confonum ef aliquam fub Coclocfepartem, qua licet fit locus ignis, ob motus tamen tarditatem nequeat ignem conferuare, quo fiat,vt ignis in aerem mutatus dcorfum feratur. Sic itaque omnis difficultas tollitur : fub polis enim non exiftit mfignis, is ta- B. men non in omnibus illius loci partibus diu feruatur, fed deorfum fertur, \& illuc alius ignis. tranfit ; fic enim in media quoque aeris regione non quiefcit nifiaer, etfi non diu ibiferuari potcit: ellet quidem abfurdum, fi in loco ignis corpusfrigidum itseffe poneretur, vt quiefceret; fed in loco ignis generari ex igne elementum frigidum, feuminuscalıdum, \& ftatim genitum recedere ab eo loco, non modo abfurdum non eft, fcd meo quidem iudicio eft fummoperc necellarium , \& patefaciens nobis artificium nacura in feruando in elementis xquilıbrio, \& viciffi udine ad ip forum \& totius mundi huius conferuationem. Hanc fenten am fignificare vifus eft Ariftot. in primo Meteorologicorum. Gap. 4. quando de duobus fuperioribus elementis, ac de ipforum locis loquens dixit [ $\mathcal{E} f \circ$. continueperfeuerat, boc quidem aere plenum exi. fens, boc awtem igni, $\mathcal{C}^{\circ}$ femper aliud, $\mathcal{G}^{2}$ alsud fic Grum quodgur spforum ] tota namque elementa illarefpiciens ait locum ignis effe perpetuo plenum igni, \& locum aerisaere, fed particulas vtriusque confiderans inquit femper vtrumque eorum mutari, \& aliud, at que aliud fieri; igitur neceflceft vt ignis quoque particula in aliude. lementum mutentur, \& hoc continue atque inceffanter fiat; fieriautemalio modo non poteft, quam eo, quem declarauimus. In partibus igiturfuperiloci, qui ignem continet, hoc difcrimen eft; quodaliqua tardiorem habent motum, quam vefummus calor, acfumma raritas gigni in eis poffit, ideo ibi nödiu feruatur ignis : fitas quidem fub polishas effe manifeftum eft, fedad quem vsque terminum protendantur, \& quibus limitibus à cateris diftinguantur, dicese nemo poteft : credendum eft, non procul à paruis circulis, qui polares dicuntur, has partes terminari, ibique incipere velociorem motum, \& aptum adignis conferuationem : quam partem fatis magnam effe putandum eft , \& complecti tum torridam zonam, tum duas temperatas, feu earum magnam partem, qux torrida zonz propinquior eft; ita vt multo maior fic illa fuperi loci pars, in qua ignis conteruatur, m. quam illa, in qua non conferuatur. St vero quis.obirciat : fub zona temperata fit tardior. motus, quam fub torrida, in qua eit maximus circulus aquinoctialis voratus, tarnen lub zoaa temperaiagencratur fungu, calcr. \& tum-
A ma raritas; proinde ibiconferuaturignis, atque etian gencraretur, fi ibin on effet;igitur fubtorridazona, vbivelocior fit motus, gigni deber maior raritas, \& maior calor, proinde \& corpus rarius, \& calidiusigni,ergo dabitur calor maior maximo, \& elementa eruntplura, quam quatuor, qua abfurda funt, \& nullo pacto concedenda. Ad hac dicimus, non dari in inferioribus solutis corpus rarius aut calidius igni; ideo vbiftatutus alıquis motusad generationem fummi caloris, \& ad ignis productionem idoneus eft, non obid velocior motus generabit aliquid calidius, a ut rarius, fiquidem nithil effepoteft calidius, aut rariusigni; fed vbi primum incipit motus effe ita velox, vt fummum calorem, atque ignem producere poffit, etiam vclociorillo cundem calorem producet, necaliud generabit, quam ignem.

\section{Delumine, quomodo calefaciat. Cap. $X$.}

$\mathrm{C}$ ONSIDERA N D M manet quomodo, lumen quoque fit caloris caura: quod enim. calefaciat, ita eft manifeftum, vt negarinon poffit;fentimus enim nos à radiis aftrorum, prafer:tim Solis, calefieri, \& quandoque ita vehementer, vt tolerare tantum calorem nequeamus: idco Ariftotel.pluribus in locis id confitetur, $v t$ in primo Metcorolog. c. 4. \& poftea in cap. de nube; in quarto etiam libro de ortu animalium,. cap. 2. afferit Lunam lumine crefcentem calidiorem effe, decrefcentem vero frigidiorem. Auerroes quoque in Comment. 42. lib.2. de Co1o, \& in cap. 4. primi Meteorolog. dicit reflexionem radiorum effe in hoc aere noftro caufam caloris, \& magis, quam motum Coli;imo dicit difcrimen caloris Solis in $x$ ftate, \& in hyeme ratione motus non effe fenfile, fed ratione radio. rum tantum ; caufam igitur caloris in hoc infimoacre in folos ferme radios Auerroes refert.

\& \& Arift.quoque hocidem fignificauitinillo 4 . cap. primi Meteorolog. quando dixit elementa Colopropinqua calida effe propter motum, remota vero manere frigida propter immoblitatem; hancigiturinferiorem partem, ad quam: motus Colinon peruenit, vel infenfilis peruenit, hacratione frigidam vocat, quoniam in ea. infenfilis à motu generatur calor; quicquid igiturfenfilis caloris in hac parte ineft, id totuatere in aftrorum radios referendum eft; idcirco quum aftra non fint ignea, ficut antea dictum eft, ratio \& modus quaritur, quo à radiis calon: generatur. Nonnull dicunt eam effe luminis fecaufam caloris, qua \& motus, nempe quia ras Opinio naturam, vt fit productuum caloris, proinde a: liam caufam quarendam non effc: in hactamen fententia non videtur animus acquiefcere, fed adhuc huiuscerei caufam defiderare: ob id cum aliis dicendum puto, lumen eadem rationc ef́refacit, \& extenuat, Gxtenuationem autem ne Gerk. wefacit, \& extenuat, oxtenuationem autem ne
cefra.

\author{
Aliges:- \\ rum ofi- \\ $n 10$. \\ Confuts:- \\ 580 . \\ Opinio
}


Opinso Gera.

ceffrioconfequiturcalor: \& quemadmodum $A$ morus in folo aere hoc praetat, vt ipıum reddat calidiorem, \&accendat, neque omnis motus, fed quimagnus, ac velor fir; ita etiam lumen in folo aereattritionem facit, neque quodlibet lumen, fed magnum, ac vehemens : experiencia enim docet, nullum à lumine candela aceenf $x$ produci calorem, ob eius luminis paruiratera, as debilitatem; imo necaftrorum, nec Solis lunen quamuis maximum effe videatur , produ. cere calorem videtur, vel faltem debilem admodum, \& infenfilem producit, nifi duplicetur, \& ita per duplicationem validiusreddatur; proiecti namq; radij Solis interram refiliune à terra refracti, \& in aere duplicantur, nimirum defcendentes, atque afcendentes, \& escradiorum incer fecollifione extenuatur aer, \& calidior fit : credendum quidem eft radios Solis etiam rectà proiectos, as fimplices aliquid caloris efficere; quomodoenim tantam haberent virs duplicati, fi nullam haberent fimplices? redadmodum paruam habere vim ex coconftat, guod fi magnam haberent, media quo gque zeris regio; per quan recà tranfeunt, valde salida redderetur, quum tanen frigida effe renfeatur, quoniam firplices tantum habet radios, quum regio infirna habeat duplicatos, à quibus valde calida redditur. 'Eft etiam in radiorum duplicatione magnum dificrimen, quad extemporis differentiis dignofcitur;nam in aftare magnus fit calor, in hyene autem paruus, ac debilis, \& codem tempore in al: qua regione maior, in alia minor; cuits difcriminis ravio hac eft; quando enim Solradios in terram proiicit ad angulos rectos, \& perpendiculariter, quiliber radius reflectitur in feipfum, \& idem firradiusafcendens, ac defcondens, ideo maxima fit collifio radiortum, \& aeris attritio, proinde \& vehemenriffums calor; quemanimalia perferre nequeunt; quando autem radiinonad perpendiculum cadunt, fed ad ançulus inzquales, obtufos, de acutos, minor fitcalot:cum hoctamen difcrimine, quod quanto redis propinquiores funt anguli, \& quanto afcendentes iadij funt propinguiores defcendentibus, tanto maior fir collifio, \& maior calor; contra vero qquando a d modum obtufi, \& acutianguliad terram fiunt, \& radijafcendentes funt à defcendentibus remotiores, minor fit collifio, ck minor calor, quod in hyeme euenit. Sclenim humilior incedens terram radiis fuis debiliter percutit, \& angulos valde obtufos, \& acutos facit; at in $x$ ftare fol fublimior fertur, \& pundto noftro verticali propinquior, ideo anguli funtreatis fimiliores, \& radij reflexi defcêdentibusprepinquiores: quod idem difcrimen ve in temporibus, ita in regionibus quoque diuerfis notari poteff. Quomodo autem lumen, quum fit accidens, moueri, \& percutere, \& refle- Ati dicatur, non eft in prafentia confiderandum, fed in iis, quar de anima, ac de fenfu vifus alio in loco dicemus, exactius declarabitur; nunc communi, \& receptaloquutione vtiliceat, dicendo lumen defcendere, \& reflecti, \& afcendere, id e. $\mathbf{n}: \mathbf{m}$ quomodo intelligendum fit, pradicto loco docebinus: reflexio autem luminisita manife. fta eft, vt negari nequeat; ego enim aliquando prope parietem à radiis Solis percufium ambulando non minorem calorem fenfi ex radiis à parieterepercuffus in oneafiniftra parte, quam ex radis me percutientibus in parte dextra inam B vtraque in parte fiebat percuffio, \& reflexio ra. diorum accendensaerem:in finiftra enim parietem percutientes refletebantur ad me, \& acrem calefacientes me quoque calefaciebant; in dextra vero mea parte percutiebant me radij Solis, \& à corpore meo refracti reflectebantur, \& aerem propinquum accendendo me quoque calefaciebant; \& hocidem alios plurimos animaduertiffe arbitror. Vbi vero absque refraEtione tranfeunt radij, \& nullam duplicationem C faciunt, vt in fupero, \& in medioaere, per quem vtrumque adinfirnum transmittuntur, an fiat à lumine illo recto calor aliquis, ineertum eft: credendum quidem eft aliquem fieri, ficut antea dicebamus, fed admodum debil em, quun regioaeris media etiam in magnis a ttibus frigidaefe cormperiatur. Quoniam autem dictum eft, magnum lumen caletacereper attritionem, quia extenuat arem, fi quis rationem quarat, cur ex:enuet, nulla (vt mini viáetur) afferspoD tcit nifi quod ea eft luminis natura, ve tenuem, ac fubtilem acrem reddat, effectus enim à fua caufa inmediare prodeuntis nulla alia afferri ratio poteit. Alud,quod de hasre dicam, non habeo, neque Arift. vsquam declarafie comperitur,qú jroodolumen calefaciat: quare fi nihil aliudeft quarendum praterid, quod modo diximus, videturidtanquam manifeftum, \& declaratione non egens dimififfe; fi quid vero aliud ad plenam huiusce rei cognitionem defideratur,

E non eft mihiverendum confiteri meillud ignorä́, quime nihil, aut paucafcire profiteor, quй fapientifimus quoque philolophus Arift. fe id nef cire tacite confelfus fit.

\section{Ouis fit calor cceleftis diffinct us ab ele- mentari. Cap. XI.}

T ERVM ex iis omnibus, qua hactenus dictafunt, magna oritur difficultas : nam fi F verum eft id, quod diximus, omnem calorem in hoc mundo infeiore produci à Colo per motum, \& per lumen. Onjnis igitur calor ratione fuz originis, \& fui principij poteft vocari coeleftis;atramen Ariftotel. in fecundolibro de Oituaninialıum capıt. tertio, duos videtur c2lores ftatuere, vnum coleftem, alterum elementarem : quos etiam inter fe diftinguit dicens calorem coeleftem effe prolificum, \& vitalem, el ementarem vero nö effe vitalem, fed po- 
rius vitx deftutioum : quod ex co oftendit, quonian ignis nullum animal genclat, at in feminibus animantium calor quidam ineft, qui clementaris uon eft, fed à collefti viruteproueniens, facitqueve fócunda fint femina: fic et iam in iıs, qux putrifcunt, gुenerant!ranimalia uon calore cl cmentari, tiquiden elementa vim generandi viuentia non liabent, fed à calore coclefti per huncinferiorem mundum diffu. fo ; afferit ergo Ariftotel. non omn cm calor cm à Calo prouenire, \& aliquem efie calorcm non coleftem, fed elementarem ; quum tamen in primo Metcorologicorum, c.4. dixcritomnem écmentorum calorem à Cælo produci, \& hianc rotam materian effe poteftate tantum calidam, \& frigidam. Auerroes quoque in lib. de Subftanria orbis, cap. 2. \& 12. Metaphyficor. Comment. as. duos ponit diftinctos calores, vnum calleftem, alterum elementarem: quare co ncedere non videtur onnem calorem efle coleftern. Difficultas hxc non letis eft, $\varepsilon$ multismagnū negotium faceffit, qui in declarando quis fit co leftis calor ab elementari diftinetus plurimum laborarunt; \&al ii di: 1os re diftinctos,penitusque diuerfos effe voluerunt, alii vero vnum \& cundem re, qui alia\&aliaratione tum coeleftis, tun elementaris dicatur: quorum difputationemego miflan faciam, \& fnim enitar hac in reveritatem declarare, cáetenim cognita, facile intelligetur, in quo alii defecerint. Sciend um itaque eft duo in his inferioribus efle genera formarum, quarum difcrimen ad hane noftram confiderationem pertinet, forman inanimati corporis, arnimam, qua ef forme viuentis: - formam inaninatipofumus elementarem formam appcllare, quoniam alias oftendim us formam nifti inanimati non effe re diftingnm à formis elementorū, fed effe collectionem plurium gradum omnium formarum elementarium vnam formam confituentium, quz non ef addita formis elementorum, fed eftillæmet, qua in alism formam migrarunt: anima vero Deft forma penius fuperaddita formis elemento rum, \& reab ilfss difincta. Hæigitur dur formo habentinterfe hanc finilitudinem, quod apta eft vtraque educi de materia à calore cœleftij Colum enim hancinferiorem materiam calefaciendo generat elementa calida; idem ex materia putiefcente gencrat animal, nec alio nodo, quam per calorem. Praterea Colum non modo generat ignem, fed datetiam illi facultatem calefaciendialia, \& generandialium ignem fimilem : ideo Auesoes in z. cap. Iibri fui de fubftantia orbis inquit, ignem non effè primum cilefaciens, quia eftetiam palfiuis, fed Ccelum efreprimun calefociens, quod agit, no patitur: idautem ficit ignis agendo per calorem, tanquiam per qualitatem confequuntem;
A iam enim diximus calorem efre quidem praparptionem materix pro educenda forma iznis. fed cil cdr:ta efe accidens pofterius forma; ita ve ficuti Colum fuo motn, vel lumine facit ca-

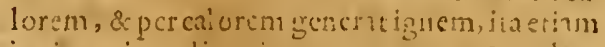
ignis genimsalium ign:m generet percunden caloremiproinde calor femperagut vtagens fecundarium, \& inftumcntile, quum fit inftrimenum, perquadagit tum Colum, tum forma ign is : hocidem in yiluntibus notarrpore?t,

B Cerlum cimimper calorem Ecneratuminal, \& pluribusanimalibus, ac firpibug dac cciam vim gencradi aliad fimile; nam in ferninbus tum aininalium,tum plantarum infitaeft vis prolifoci, \& principiun quodedamgeneratiunm, quod per calorem confequentem aptum eftgenerare alint finile. In cozuten difereparevidenturanima, a forma clementaris: ģuod forma elementaris producitur per caloren vicunque à Celogenitris, videlicetlen permotim, leu per lumenividenus en im radios Solis accendere, \& ignire ftuppan : aftanimanon peralium calorem ij Colo producitur, guam per eum, qui à radiis pro uenit; talis enim eft ille calor, à quo ex puttrefcenre materia animal generatur. His declàiais, vt cgomeamfententiam proferam, puto calorem cceleftem propric acceptum vt ab elementari diftinguitur, nulhom effealium, quá calorem vitalen, perquem a Coslo producitus anima, \& quiproductam animan confequitur, \& per quem anms in ferminibus latens th̆ quam artifex, generat aliud viués finile; calorem antem elemęarem elleillum, perquem educit un forma elementi calıdi, ant forma aliqua miftionis, : qui eam edutam infequitur, perquen illa.2git: quonim enim elem tntacalica videntur calorem haberevt accidens proprim, quod illis comperere dicitur per effentian, maxime antem igni, miftis vero omnibus per participa. E tionem; hincfanum eft vtcaloriftefic yocatus elementaris, calorem vero animalem quman habeant viuentianon perelementonum participationem, fed à natura quadam prefantiore, hanc referimus in Colum tançuan clementū quoddnmaliud omnes clementorum naturas fupereminens: \& quia in vinente genito calor hic vitalisinfequituranimam,quxeft forma diftincta for mis clementorum, \& eis multo preftantior; ideo Arift. 2.de Ortuanimalium, cap s.dixitefle $F$ in fentrbus principium vitale, quod proportione refpondetelemento ftellarum, id eft $\mathrm{Cos}$ lo, quod fol et ab Arift.vocari quintum elementum: quemadmodum enim Coelum percalorem educitanimä de materia, \&generatanimal; ita etiam principium vitale infitum femini generātanimal percalorem vitalem confequente, \& ita proporione refpondet elemento fiellarü,nempe elemento fupereninenti iaturas ele-

men. 


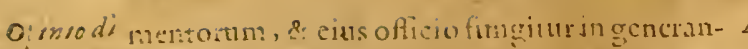

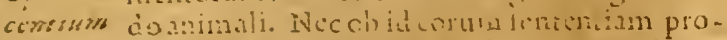
cotorem banus, qui colorcu cixleftem punan diuer-

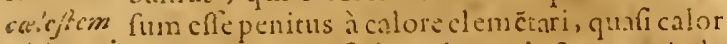
difirygu; clementarisnonf it à Coloproductas, proinde abeleme dictiut calori colefti non eli: contrasium fritsri. gus: imo han opinionem aburdifiman cffe Ci.juts arbinamu, qumm mani! eftum fit, \& experien530. tia comprobatum,ctiam vitalem calorcm ledi, dextingui a frigore, ve in concoutione ciborum figidorum clarifimum êf ; \&hoc idem aflicic Ariftotel.in lib.de luucntute \& finectuamnis te, rtibilegercpolfumus. Dicimus jgitur ocríor est mue:ucalorém llahereoriginem à Calcyvef $x$ essedim pediximus, proinde fecuncum feciusucm affe Secses. natura, \& fpeesei, nec aliam habere diferentian, quan diuerlorum gradum; fiquidem alius intenfior, alius remilior eft, dixiautem fecundumfe, quoniam aliud eft calcremconfderare fecundum propriam ipfius natusam, alind eft ivfum confiderare vt infrunentum a. gentis primarii, quod calore vtidicitur: nam fi ipfanlecundumfecaloris maram fpetemus, ina \& eademeft in omnibus; eft enim qualitas afiua, qux calefácitalia, \& extenuat, \& fegregat hetrogenea, vt homogenea congregentur ; ha namque funt piopria operationes caloris fecundum feconfiderati, ad quas edendas aptus eft omnis calorfeu vitalis, feu elementaMultar ris :-fed aliaplura funt caloris opera; qux ipfe sfficit ca- perfeprodiccreaptus noneft, fed ea pratare bornoper dicitur ve inftumentum agentis fuperioris: ficproprasm ut.enim in artibus videmuscalorem propria vi fim, fed aurum calefacerc, i liquarequatemus eftcalor,

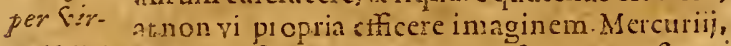
sutem a- red viartificis calore vtentis inftrumento;fic etgér ispri- jam in naturalibus notare poifunus ; nam vitamary. - lis calor aptus quidem eftpropris viribus calefacere, \&attenuarecibos, \&tenuiores eorum partes refoluere; at fanztrincm ex illis non vi propria generar, fed vixtute animæ vtentis calore, nam fi quiscliylum de animalis ventriculo ierrictum imponat olla, \& illi eundemmet cajorem fupponat, quem habetiecur, non tamen gencrabitur fanglis; quare in generatione fanglinis calor agit virtute animx, \&actionem ajum im adilam materiam traducit tanquam infrrmentum medium : hocidem dicendum eff de iilo animaliinteraues maximo, vocato ftruthiocamelo, cuius ventriculustanti roboris eft, F vt denoratum metallum concoquat, \& in nutrimentum vertat: fcribit cnim $A$ uerroes in quinto Collectaneorum, cap. 24. experientia compertum efle, exhibitun aurum huicanimali in cibum, \& paulo poft de ventriculo cius detraetum inuentum elle valdeimminutum, quum samcnabigniaurum nonabfumatur; calor 1 gisur 1 llius animalis absque dubio crt uzulto mi-
A noucalorictois, tamenabfumit aurum, gued abiunercedion ignisnon poatef ergononpropria virtucidlacu, ficd vituze anmx vtentis calore: quanuis igiturip fam fecurdum fe can fors inaturam conideriido, ca. vna \& cadem ftip eicisdem focici, tamen nagna difcrimia properagentiapriuraquxe calor vtinftrmezto ithintur, contingunt \& hocmulios decepit, qui illit, qua calor i competunt rationeagentis prioris, ipli fecundum fe confidcratoatribumnt, \& B difunguifpecieinter fecalures aflerunt:fic facile interpretari polfumus verba Ariftot. in tertio cap. fer undilibr.de Animalium ortu, qua à multisin praum fenfumtrainatui ; quumenim dicutibi Ariftorel. caloren feminibus 11 i- $b_{c}$ tum gencrandi animal vim haberes, proindenon. elementarentefie, fed colefem, acdiunum, fiquiden. calor igneus nullum animal generat; $n$ hinc collegeruist diftinctos effe fpecie calorin igneun, \& calorem vitalem : red deceptifunt, quia diuerfa quicem funt principra agentia, quæe calore vtuntur, fed upfa caloris natura eft ciusdem fpeciei: ignis enim non poteft animal generare, neque animam de materia educere percalorem, quia non poteft agerefupraproprias vires; at Colum, \& virus vitalis Coelo prom portionerefpondens poteft per calórem animal. generare; ita vt:fifumantul duanumero difrinEticalores, fed in gradu, \& intem ione omnino fimiles, quơrum vno forma elementaris vtatur, alteronutem vtatur immediate Colun vel a nima eius yices obtinens, hic generabit animal, ille vero nequaquam, fed folum generabit elenenum, vel miftum aliquod: calor enim elemétaris in miftioneagıtin ficcmm \& humidum, \& earegit, \& vnit, \& mifionemabloluit, \& formam mifti de materia educit; at non educit animam, hacenin egeragentéfupereminente nzturan elsmentarem, quale eit Colim, \& ani-" E ma,feı vitalis virtus Calo proportione refpondens;ideo Ariftotel.in memionto locoaferitomnem animam defors accedere, quarenus principiun actium non habet aliquod el crnétum, aut im elementarem, fed falefte, \& narura elementari praftantius $;$ contra quam euenit il formis elementaribus, hocelt, tam elementorum, quam miftorum omniun inanımatorum : in ipfa enim elementari mateia, exqua hæc corpora generantur; infitum eft abium principium, nempe calor elementaris à quo abroluitur miftio, \& cducitur forma mifti, tuemadmodum ctiam à virtute elemécari chlncitur de materiaforma clemefti, quaudo ab aliquo elenento conuertiturin nitum fuam aliud corpus': \& quamuss ad has guoque muationes concurat Colum vigens vniuertale, non tamenvt agens proximum, \& immednatum : nam

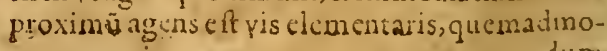


dum diximus. Sicigitur folui puto omnem dif- A ro; fed unus numero ef calor ex duobus confaficultatem: nam fi priman caloris originemrefpiciamus, onınis calor à Coclo proucnit, proinde omnis calor poteft liac ratione vocari $c(x-$ leftis; fed fi fecetemus agens prinarium, quod calore vt inftumento vitur, ll lud vel eft na tura elementi, \& ab hac vocatur calor elementaris, vel eft vis coclica, \& a b liac vocatur calor coele- ftis, ita tamen ye coleftem virtusum appellemus omnent maturam fuperiorem, \& preftantiorem 3. natura elementari; tatisenim eft nó folum ipfa. B so met Cosli matura, qua percalorem a fe genitum multa producit, led etrim anima, qua ob id vo- caturab Arilt. ptoportionerefpondens clemenid to ftellarum, quali cofteftis corporis locum ob$n$ tinens. Non elt autem ob ea, quie dieta funt, putandum in viuente duos effe diftinctos calores, ynuu clenentarem, al teram vitalem, fiquidem fieri non potêt vt in codé fubiceto fimul infint duo accodentia eiulden rpecici diftincta nume-

tus, etli pendens a duobus principis quemadnodum enim fi in eod e cubiculo fple leant noetu dux candela ardentes, ynum numero cit lumen in acre illus loci, licet pendeus à duabus lucibus fecundum gradus, adco ve altera candela extincta mınusluminis in illo aere inaneat; qua fecundumaliquotgradus prodibat ab via candela, \& fecundumaliquotabaltera: ita in viucute eft vuus numero calor conflatus ex duo-

B bus, nempe exciloreclementari, qui etian dic: poteftcalormiftionis, feu temp ratura, \& ex calore vitali animam conlequence ; ifque totus calor fecundum aliquos gradus prouerit à na turaclementorum calidorũ. fecundum aliquos vero ab aninia; ideo fublata anima remaner minor calor, folus cnim elementarts calor relinquitur, qui poftea inteit per putrdinem: fed hac de re, acde aliis ad animanti.n pertinentibus poftea opportunius dicenus.

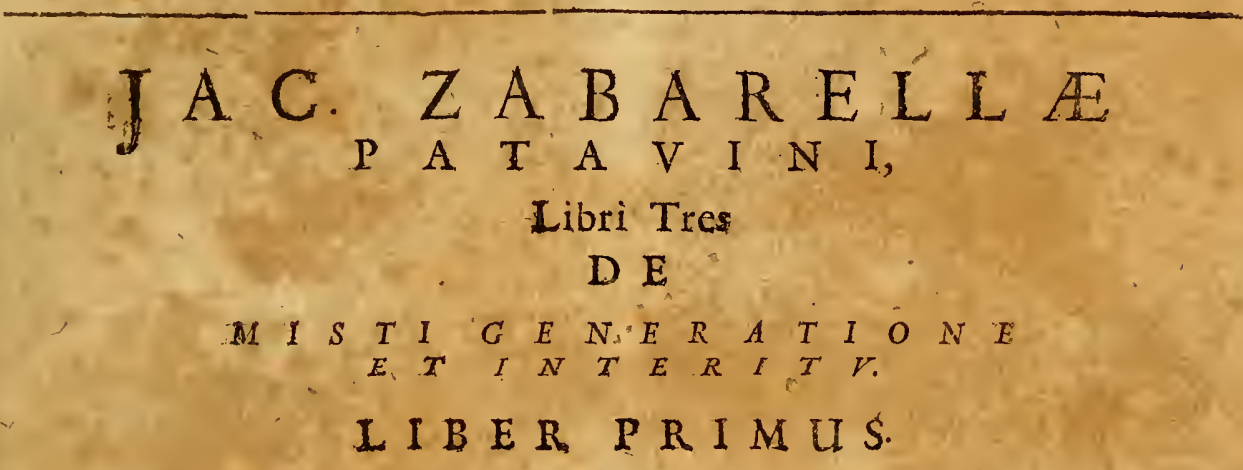

\section{Procemiun Libri. Cap. t.}

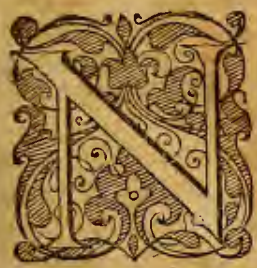

Aturalium corportum generationem \& interitum A. riftotelis in fuis librismul. tifariam confideraffe conftat; primum enim in duobus ac Ortu \& interituinfrriptig generationem \& interitumi ampliffime prout cosporibus omnibus fublumatibus indiftuncte competunt, tân :rimplicibús, quam miftis, \&2 his tam inanimatis, qum, viuentibus, fibi tractanda propofuit: fed quoniam varıænaturalis corporis fpecies varios etiam habent generationis modos, qubus inter . fe difting!nuntur, e ofque omnes cognofice oportet philofophum naturalem; ideo postea feorfum de fingulis docuit, quomodu elementa generentur, quomodo mifta, quomodo metalla, \& Lapides, quomodo animalia, \& plantz. Nos
$C$ in prafentia declarandum fufcepimus earngenerationem, quix mifo competit quatenurs mifum eft, \& contrariun illı interitum, qui vocatur putrefactio: rem énim cognitu digniffimam, ac difficultatis plenam, \&己 tum à philofophis, tum à medicis maximeagitatam effe videntes, aliquod fore operzpretium exiftimavinus, fi illa, qux de hac inuenire philorophando potuimus, ad ifudioforum vtilitatem, fi quam habitura funt, in medium proferreDus, \& res obfenrifrimes liquid luminis afferre pro viribus niteremur : quoniam auten hac de re fripfit egregie Ariftoteles in initio 4. Metiorolog. conabimur in hac noftra contemplatione ipfam Ariftot. in ea parte fententiam ex. planare, vt ea op time, fi fieri poffit, intellecta, poffimus omnia, que de hac re dieturi, acratione.ex natura rei deducta of enfurifumus, tanti quog; philofophi autoritate comprobare: qua vero de hocalii côplares, acerrime etiam inter E fe dilputantes \& altercantes confcripsêre; icum 
moderarionetangemus: illa enim qua vana \&
inurilia clie iuáicabimus, mira penicus faciemus, quxau:cmantyera, aut ad veritatem cognofcendam riliaforc arbitrimur, ea breuiter refermus, \&expcustonus: in omnibus autem itanos gerele niremur, ve omnes facile intellisycre poflint, nos nullocontronerfaindi, aut de trectandi ftudio, fed plilofophirac veritatis amore, \& communis vulital is gratia hanc difputatonem inftituife. A gemus autem prius de geheratione, cinfigaturam, ac definitionem declarabimus, omnefip; in ca orientes difficultates folucmus: deindeveroeadem metiodo loquemur feparatim de putredine : hocen im inter eft. interamplifime fumpram gencrationé, \& eam, quæ cuinf gue rei propria ct, quod late fumpta gencratio eft alterius rei corruptio; idcirco eadem defnitio Ariftor. generations, \& interitus naturam expreftit: non fic proprix fingularum rerum generationes; quamuis enim animalis generatio, quatenus eftabfolute generatio, fit alterius rei corruptio, non eft tancn corruptio alterius animalis;itanec mifti generatio eft neceffaro alterius mifti corruptio: cuins difcriminis ratio colligitur exillis dictionibus, ynius alterius; generatio enim vnius noin eft corruptio eiufden fecúndum numerum, neq; ciufdem fecundum fpeciem, fed al terius fpecie differentis, quocirca generatio animalis non eft animalis corruptio: diftuncas igitur tractationes, diftinEafq; definitiones poftularnnt generatio mifti, \& putrefactio, vtin 4 . Meteorol. videre eft, propierea quod generacio mifti non eit alterius putrefactio; ficetiam generation animalinm contraria eft mors, qux eftanimalium interitus; attamen A rift. in diuerfisetiam, ac feparatis libris wtramq; confiderauit, generationi enim animalium quinque abea inferiptos libros dicauit, de corum autem interitu egit in libello de vita \& morte; igiturnobis quog; feorfum de nufti geseratione, ac de eiufdem interitu agendum e?t.

\section{Definitio generationis mifti. Cap. II.}

G Eneratio mifti, de qua dicendum proTpofuimus, fpecies eft illius generationis, cuius definitionem in lib. t. de Ortu \& interitu talem legimus, generatio eft mutatio totius nullo fenfili manente vt fubicto eodem; genoniam igiturin definitione fpeciei eft fumendum genus, ideo Arift. quando in principio 4. Mcteorolog. generationem mifti definiens dixit effe mutationem, abfq; dubiotalem mutationem intellexit, nempe qua totum mutetur in totum; fubftantia nam q; elementor um mucaturin fubftantian miftipropria autem mateva mifti, quatcnus miftum êt; funt quatuore-
A lementa, quatenus humida \& ficcafunt ; jamenim diximus has efe qualitaces paffiuas, $\stackrel{\alpha}{\alpha}^{2}$ cöditioncsmateriales, quxpropran mizti materim confitidunt, miltum enim confacex quatuor alementis prout funt humida of fiech: $\mathbf{2}$ gensatiem proximum; vt alia renota, \& vniuerfaliangentia onittamus, furt duæ astua clemeatorum qualytates, calidum cnim \& frigidum contêperata agunt inficcum \& humidum, tanquam artifex in materiam, \& illa elaboran$B$ do, ecómifcendo, ¿x terminando educunt fornam milti, \& ita mifum generant: hoc enim difcrmine diffacre mifun, \& viuens alias diximus, quod miftum, \& omne inanimatü corpus à virtuce elementari tanquam agente proximo generatir; at anımatum non ab elenentári virtúte generatur; fed à virtute col efti, qua 'fenini infitach, ita vt in generacione viuentis onnes elementares qualitates locum habeant materia, agens aut em proximum fit virtus cceleftis, nempe calor vitnlis femini infitus, qui proportione refpondet elemento ftellarum : at in generatione mifti quatenus miftum efr, dux elementares qualitates, humiditas, \& ficcitas, materiamidoneam cóftiłunt, è qua educàcur forma niftisagens auten proximum funt dux aetiu eorundem elementorü qualitates firnal contemperara, calor, \& frigus: \& qua agës non agrt in materiam, nifilli dominetur, ita vt eam regere polit, ide of generandum fit miftü, opor$D$ tet actuas qualitates dominari pafhu is; illudq; dominium varium eft, \& varias habet rationes, fcu proportiones pro diuerfis miftorū naturis, exquadam enim itatutaproportione imperii actiuarum in paffuas generatur hoc miftum, ex aliaveroaliud;ideo finis generationis mifti eft ipfa mifti forma, ficut omnis generationis caufa finalis eft forma generanda. Has omnes cau- $D$ fas cxpreflit Ariftot. in definitione generationis $t$ mifti, qux ob id perfecta, \& omnibus numeris $r$ E abfolutadefinitio ef, nempe, generntio eft mu- $m$ tatio à virtutibus actiuis, quum rationero habuerint; exfubicata materia vnicuique naturá; deindehanc fatim-declarans inquit fubiceam materiam effé du ualitates parfiuas: nomi. ne igitur mutatio sfignificauit genus, quod form $x$ locum hab f filicet generarionem fubftantialem, qua in t lib. de Ortu \& interitu definita eft; duas fofuas qualitates fumpfit vt canfam effectrice of proximam; duas paffuas vt F imateriam, cauray autem firalem, quando ait [Gnicuiqua notid] forma enim, quact rei natura, eft finis gen arionis, \& propter eius eductionem fit $a b$ a firis elaboratio paffuarum: fenfus ergo hnius definitionis eft, generationifti eft mutatio facta à duabus actuis qualitatib. ex duabus paffuis tanquam ex matcria, quandoillax ad has easa habuerintrationem, ac fropostio- 
portionem, qux vnicuique form educcndx A commeniens cft ; alia namque, \& alia proportio requiritur pro diuerfis miftortum naturis, yt cöfiderantibus manifieftum eft.

\section{Onomodo fit intelliğ̈dum actiuarum qua- litatum dominum induas passi- uas. Cap. III:}

$M$ Vla in hac definitionead plomm eins intelligentiam expendenda, \& declaranda effent, fed quxadverborum fingulorum confiderationem, cormmque conftuctionem attinent, ea ad commentarios, fi quando à nobis edentur, remittimus; nunc illa tantum, qux ad naturam huius generationis declarandam pertinent, cum diligentia perfequemur. Primoloco de illa mione, fen proportione, quam habere debent acture ad pafliuas, dicendum eft: videtur quidem eam declarare fratim Arifto t.quando fubiungit [generant enim cullsdum Ef fingidü dominantia materia] indicat cuim talem effe debere rationem, vtastiux dominentur paffiuis; nifienim dominentur, regere, arque elaborare illam materiam nequeunt 3 quarenon fit generatio,fed potius inconcoctio, \& inquinatio, vt ibi Ariftotel. ait: fed dubium adhuc ert, quomodo hoc dominium intelligendum fit, \& de hoc multi multa dixerunt, prælertim vero Medici in prima primi Auicennx, quorum omnium fententix, \& dicta hicreferenda non lün, fed pauca pracipua breuiter tangere latis erit. Primum quidem aliqui parum confiderare loquentes dixerunt hoc dominium elfe intelligendum fecüdum intenfionem graduum, videlicet vt dux actiux palfuas vincant intenfione, velut $\mathrm{fi} d \mathrm{~d}$ ceremus fex gradus caloris vincere quatuor hilmiditatis. Sed hac fententia, fibene perpendatuy;yana, \& impofibilis efle cognof citur, quod alij plures aninaduerterunt, inter quos Ludouiças Buccaferreus, \& Petrus Pomponatius, qui in 4.Metcorolog. diffufam de liac re difputatıonem fcripferunt: en autem tribus potifimum fundamentis nititur, in quibus confentire omnes videntur. Primum eft, latitudinem cuilislibet qualitatis intenfiuam finitam effe; daturenim fummus calor, quo maior non datur, fic fummum frigus, \& fumma humiditas, \& fumma ficcilas. Secundum eft, omnes harum qualitatum latitudines efre $x$ quales, ita vt in quot gradus aliqua earum diuiditur, in totidem qua. libet aliarum diuidatur; proinde fi fummus calor fit ofto graduum, fic \& aliarum quxlibet, \& in fingula octauus gradus fit fummus. Tertium denigue eft, qualitates contrarias non poffe finul exiftere. Ex his tribus fuppofits colligunt omnem qualitatem fiue fumman, fue remiffom, haberefemper impletam totam octo graduum latitudinem : etenim fi fumn in fit cialor, erit octo graduum; fi vero remiffus, vt excmpligiatia, fex graduum tantum, necefle eft ve duos habeat frigoris a dmiftos, quare omnes fimul fumpri octo erunt: oportet cnim remif: fionem, feu abiectonem duorum graduum caloris,qui defunt, factam efic állobus gradibus frigoris;lic fi inaliquo fint quatuor gradıs fiecitatis, neceffe eft vin codem fint etram quatno humiditatis; fi vero quinque vnius, tres al terius B contraria: fed cum quatuor vnius cfie quinque alterius nullo modo pofinn, quia fic ad fummum nouem effent, \& totam latitudinem excederent; dum enim qualitatcs latitudinem non excederent, non funt contrarix, fed ad amicitiam, actemperamentum redactrefunt, fack emm eft vna qualitas, qux redolct exempli gratia tres caloris gradus, \& quinque frigor:s, eaque fi compareturcum altera habenre duos caloris, \& fextrigoris, inftar calidi eritrefpectu il-

C lins: fedquum finul innctx latitudinem excedunt, contrarice funt, \& fimul exiftere nequeunt; nam fi qunque infint gradus caloris, non pollunt effenifi tues frugoris, à quibus lint fraati, fen extincti trescaloris, qui defunt; nam fi quatuor efle dicerentur, quartus ibrefete integer, \& fine vlla pugna cum fúo contrario, 2 nullum caloris gradun remittens, quod impoffibile e!t; fed oportet quatuor gradus trigoris remittere quatuor caloris, \& itá quatuor tantum reliquos caloris inperefí, non quine le. Ob eandem etiam rationem fieri non potet?, it duarum contrariarum qualitatum gadus timul iuncti to tam latitudinem non adimpleant, ve fi quis diceret in aliquo effe quatuor gladus caloris \&ttes frigoris, qui feptem efient ad fummum : hocenim,eft impoffibile; quia quatuor gradus, qui defunt, caloris, non poningteffe extincti,niti à quatuor frigoris hon igitur tres tatrtum ibi funt frigoris, fed quatuor. His omni$E$ busitaconftitutis, de quibus hic difputandum non eft, quoniam vera omnia effe fatebitur quisquis ritephilofophari voluerit, falfitas pradietrententix facile oftenditur: vel enim intelligunt, duas actiuas fimul iunctas fuperare gradibus duas paîtuas itidem finuliunctas, vel. vtramque feorfum acceptam fuperare vtramque feorfumaccetam, quorum neutrum dici. poteft a nifi prius, quia per fundamenta iacla funt xquales; calidum enum \& frigidum fimul F iuncta ofto graduum erunt, totidem erunt et. iam ficcum \& humidum fimul iuncta, ergo illix has coniunctim non fuperant gradibus: non etiam alterum, quia fi omnes fint æquales, nulla aliam vincet, vt $f \mathbf{i}$ quxlibet ponatur effe quatuor graduum; fi vero ina quales, neceffe eft vincente calore paffiuas vt frigus vincantur $a b$ eisdem, non ergo dominari limul polfunt am-

$$
\text { T } 3 \text { baa- }
$$




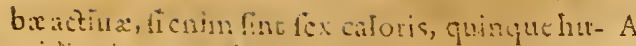
miditatis, fuestecita:s, vime quididucalor stramque paíitum fiparatin acepisan, fed frigusabvtraque viucetur, eritcnin disorum tantum gradum, deniyne per anines modos difcurendo inucnienus tieri nunquan pofie ve veraque actiua feparatin fupcret vtainque pafinam feparatimacceptani ; quare hac fenAliorum tintia reisciarur. Alii putarunt ommem vitari opinio. difficultatcm, firciecto frigore in folo calore perfitamus; dixcrunt ergo imperium qualitatum actuarum non eflc de frigore intelligendum, fed de folo calore, vnde collegerunt omnemiltum apid A riftorel. eff ab exceflu calidum, \&abexcefiu humidum : nitebancusau-

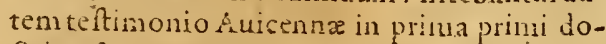
Etrina fexta, cap. 2. \& in fexto naturalium, vbi inquit frigidum non ingredi opera natura tanquamagens, fed omiam operationem naturx perficia calido, propterea quod frigus eficit priuationem motus, omnis aten operatio natuConfuta natura eftutilefrigus. "Sed de antione frigidi 640. nos poftealoquemur, in prefentia autem latis eftaduerfus hos ad duceretertimonium Ariftot. in context. 2 . quarti Metiorolog. vbi dicens

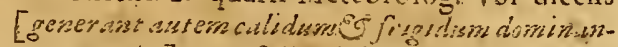
[eamateria] non foli caldo duminium atiribuit, yerun etiam frigido. In eo quoque decipinniur, quod dicunt omne mifun clic calidumexcefu, quum manifottin fic plura elle mitha exceffu frigida, ino \& frigidinima, vt metallojuon enim effent ita ind rrata, nifi à magna witgoris; multaetia plantre funt frigidilima temperatura, ve experientia docet:quanobrem rtainf concedamus, folum calidum agerepro generatione mifti, gradusautem frigolis, quotcuicue funt, whil agere, fieri tamen non poteft 'vt calidum fenper dominetur vtrique paffia: quonian multamifta comperientur, in quibus calorita debilisinfit, vt gradibus fupcretur ab aletra pafiuarum, aur etiamab vtraq; : difficultas foitur inegra maner, quale fit hoc aturtrum doninium in pafruas, q̧um prefertin videamus in aliquo mifto tantam eflehumidiro. tem, veitantam fiecitatem, qux fuperet gradibus \& calidum, \& frigidum feparatim acceptas gequeperid thare, quin il! ud fir vere as perfecte niftum.Ludouicus Buccaferrens pradiais mo.

Buscos-

ferreio.

pisiso.

Conjers-

taico. rus difficulatibas inquit, imperium qualizatum actianm non effe inteiligendum fecundum intcrionem, neque fecundum quantitatem, fed folum fecundim virtutem. Sed hac fententia mihi quidem viderur non carere diffscultase. na pervirtutem nilabiud intelligere yoteft, quam, potcnitamactian; sacautein non poteft malor, vel minor dici, nifi alteraduarun rationum, aut chun cx masowintenfome, aut ex maioie

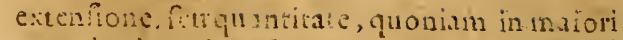

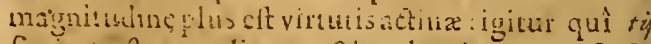
fieripotef v qualitates actux dominentur pal- se fuis lecundun virtutem, fi neque intenfione, neque quantitate excedunt: effe Domponatifententian, qux omnem datio ciniatem tollit, âd cam reduci potét opinio Buccaferrel, quiverisatem fub nube vidifle, fed eam nö ommu coinplexus elle videtur. Inquit Pomponatius, nö die necefiarun ve qualit.tes $B$ anturpanitias fiperent gradibus, fed poif'ed: rumalicrom, vtpote cilorem, licet humido re: miffiorm fecundam gradus, agere in humidumincenfins tanquam in materian, \& exers aliquid generart:vt aliquod calidum tribus gra: dibus potelt agere in matcriam habentem quinque gradus humidıatis, \& exea aliquam mifti forman educere; nam fi fermo effei de actione contrarijo contrarinm, vtiq; oporteretastons fuperaregradibus tum cŏrrarium, fecus cnima non feretactio:ideo dicere Latini noftri folemt, nullam fieriationem à proporioneminoris inxqualitatis, qua de realibidifferuimus; de has tamen in prafentian non loquinur, fed de actionein fubiectum materian; quum autem hac ne. materia debeat quibusdam cile conditionibus prædita, \& hælufipiantmagis, \& minus, inconyrtua, \& æqquitoca effet comparatio intentionis conditionum. materiz cura intenfone conditionum agentis. Dicendum igitur eft quamlibetmiftiformam de matera educendam certos palluarum qudlitatum gradus poftulare, \& cer-

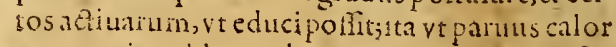
ca matria valdcrem hass generarenon poffit, fedilian, pollit : ditum igitur Aritot. non elf intelligenduniabiolute, vt feilicet action vincantpailiuas fecundum giadis, hocenim ofle non poffe ians ortandimus; fedeftntelligendum refpectu forma generand $x$ \& qn.mmm il. la poftulat, ita vt quando adeft illa proportio ar giarumad paffuas, qux proh hius form $x$ eduE Atone reciliriar; tunc dicantur actiux dominari paftuis:vt fiexempli graria ftatuanus oleum elle calidun quirque gradibus, \& humidum fex,plures funt gradus hunidiratis quam calo- $^{-}$ ris; conuemens tamen eft proportio pro eductioneformæolei ; \& ita dicitur cal or dominari humidisati, id eft, aptus elfe ad educendam de illatmateria humida forman olei, ita vefi mi. nor fumeretur calor, non poflet olei formam educere, fedaliam fortaffepofies, refpectu cu$F$ ins dicerenturactiux dominari pafiuis, at non reffectu-oles:hos denotauit Arif. indefinitione quando dixit [exfubiecta materis. Snicusig natura ] fic ening hignificaus proportionem lllam opins non elfe abfolute victorian ranone graduua nis, $B$ fed folum reipedtuformx generandx. Ad hune coufer

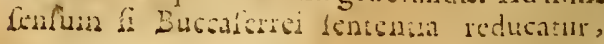
astinda 
defcolipotef;rempeffervirtutem inteligat A perfè frigido, nunq̨uam coneosionif peracpotciniamproductuan refiectu talis fomx, fal non abfolute, \&indinticte refpectu ommiumi ipieramen iroc non exprefrit.

\section{Dostione frigidion rencrationemifti, a- lonum opisionescongramenta. Cap. $1 \mathrm{~V}$.}

CAscrum ad plenam corum intelligntinam, qux ab Ariftot. \& à nobis dicta funt de astunum cunlitatum mperio inpalíuas,

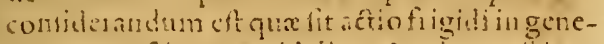
ratinis mift : nusu videlicet \& calor, \& frigus per fe agure dicantum, an foii calori tota actio vibuenda tit, nallafrigori, niti peraceidens:hate cnim de remagnxplifolophorum, 巟edico1 un difputationes \& contionetia exiftunt. Ante onmantintelignsur in quonam dificultas fitecnitima animaduertendune?t nos non de elemitigeneration loqui, patetenim elcmentun frigidum per frigus generarealind frmile, \& ita firgus che per ic aciuum \& eductuum fom ducmeditas. Neque de vinentium generationc loquimur, hancenim à íolo calore ab1o'ul afferit manifefte Arifoteles in libro fecundo de Oru animalium, cap.3. vbi foli calori calcfiatıribuit yim generand viuentis; dequa rcalio in loco difinfus lo qunti fumus. Logitimur antcm de fola mift, quatenus mifum cit, generatione, quod non eft nifi homogeneum: de forma namque illa, qux primum ex formarum elcmentarim commintione oritur, \& forma miftion s vocatur, non conftitut nifi homogeneum mifum, cuius gen:rationem in profentia confiderandum fuicepimus; etenim omne heterogeneum eftanimatum, \& ex pluribus taJibus homogeneis conftitutum, de quo hîc non loquimur : nec ob id defolo inanimato mifto homogeneo nunc fermonem facimus, fed abfolute de onini mifto homogenco fule animato, fue inanimato non enini folum de metalli, vel lapidis generatione fermo nobis propofitus eft: fedetiam carnis \& offis; ita tamen vthæe non vt animata, fed folum vt mifta nobis confiderainda proponamus, nempe quomodo in eis producatur non quidem anima, fed fola forma miftionis, \& quumodo cadem intereat, hacenim ratione hæc omnia eandem coniderationem fubeunt. De hac iq̣itur mifti homogenei quatenus talis generatione loquendo, non latis liquet quomodofrigidum ít a trisum. Auerois roes in fua paraphrafi in 4.Meteorolog. aperte dicit frigus non agere per fe, nifi corruptionem, ficti salor agit generationem, videtur cnim contrarionm agcutium contrarias effe debele operationes; quodin concoetione videmus, fit snim concostio à calido, inconco tio autcm

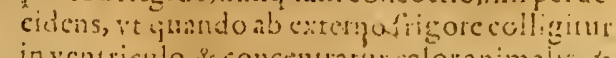

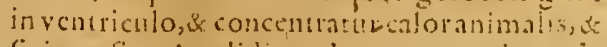
fit iutenfior, $\hat{Q}$ valitior ad concoytend:um : ic igiturad niffigencrationem conchrit lirgus it temperet, \& noderetur cillorcm, quia non 6mis caloraptuseft ad quamisbe furmane condam, fed dererminaus, \& vario modis icmilfus, prout fingula forma poftulat; frmmus antem calor eft aormprims mifti, nee po.ct B rem vllamgenenae, nifi ignem. Hancigitur $A$ -

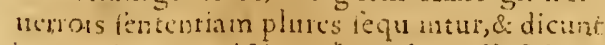

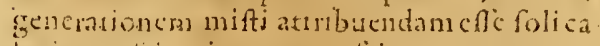
loit, non țigori, quonam frigusnongenerat, , aif per accidens, quatcuus caloren contemp: rat, \& moderatum reddir. Sententiam hanc improbant nonulli recontiores \& aduerfus eam tribusargumentis vmniur, Primum ex Anftot. fusum in $x$. contex.t. Mitecrol, $y$ bi du it frigu's C efie actíum non ca rancum ratione quatenu: caloré moderatur, fed quatcnus terminat, con-man.

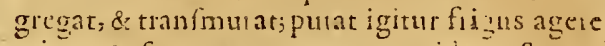
etiamperfe. non tantum per accidens. Secun- Secwade do fic argumentamur: frigusnonsemiltitcalc - arrosmëtem, nifireirigerando; at in generatione mitri txm. frigns non label lecü per refingentionem, ided peralias fecundas operationes, frgead generationem miltinon concurit firgus ve remittens caloren, gucmadino ratione muti locum habeivtremittens frigidi - Tertum tares: Tertioargumentum fununtàdifcrimi- arg smone miftionis, \&: generationis milti inan in mi- tsint. ftione intereuntexcclletix qualiratum elemeiarim, vt ait Ariftor.in calcelib.r. de Ottu \& interitu, \& in contex. 48. lib, 2. hoc autem non fit, hif peraktionem inter fe, \& mutuam renuisfionen qualitatúm elementarium contrariarū, nam \& calor remittit fiigus, \& frigus calorem, \& ficcitas humiditatem, \& humiditas ficcitatem:hrigitur mutuaremilio, \& contempera.

$E$ tionon in generatione fr, fed in miftione, quaniam in generatione non comparat Ariftoteles contrariam cum fua contraria, calorem cum frigore, \& humiditatem cum ficcitaic, fedambas fimul fumptas, calorem \&: frigus, cum ambabus fimul funptis, humiditate \& ficcitarc, ve agentes cum patientibus: hanc igitur efle inquiunt caułan communis erroris: quod nó diftinguunt miftionem a genera: ione miftijin fola enim miftione fit illa remifio mutua contra-

F riarum qualitatum quxin gene ratione nó confideratur, inqua ambæactıæ iam commifx, \& factramicx fuam operationem exercent in pafliuas: nö i gitur officium eft frigoris in generarione caloréremittere. His argumentis ducti ipfraliam fententiam tuentur, \&inquiunt generationem pofle dupliciter conffderari, vno mo do vi forma rubfantials introdubionem, al-

$$
\mathrm{T}+\text { tero }
$$

\author{
Il'or:m \\ recenico- \\ risopirio
}


tero modo cum prxuia alteratione; \& in formx quidem eductione dicunt nullam elle frigoris actionem, at in preuia alteratione non minus perfe frigus locum habere, quam calorem ; facit enim conftantiam partium, terminat, \& vnit humidum cum ficco, \& prrterea calorem cohiber, ac detinet intrinfecris, ne euanefeat : quocirca etiam frigusin generatione mifti aetionem per fe habet ratione preuia alteratioAliorsm nis. Aliiveroetiam maius quiddam oftendere opinso. volnerunt, nempe frigus in eductione forma mifti habereadionem per fe, \& vif funt hocarEorsm gumento;fi ponatur homo in acre frigidirlimo, argume- vel in frigidiffima aqua, ita vt ab illo frigore intwm. terliciatur, erit à folo frigore forma hominis interempta, \& educta forma cadaueris, ergo frigus per fe agit eductionem formæ.

\section{Vera Sententia de actione frigidi, \& eius declaratio. Cap. $V$.}

$\mathrm{E}$ Go, hac re diligentiffime confiderata, quam difficultatis plenameffe non inficior, veram effe arbitror opinionem Auerrois, quam complures fequuntur:fed ad perfectam veritatis declarationem oportet non folum bimembri diftinctione vti, vtilli fecerunt, fed trimembri;etenim cadere in confiderationem poteff \& alteratio prauia generationi, \& generatio ipfa mifi, quxeft eductio formæ fubftantialis, \& demum variæalterationes cōtingentes mifto iam conftituto, \& genito, quas Arift. in 2. contex. 4 . Meteor.propofuit in eo libro confiderandas, \& pofter etiam clarius propofuit in contex. I4- eiufdem libri, vt prouenientes ab actione duarumactiuarum qualitatum in duas paffuas. $V t$ giturab ip a generatione qux cductio form eft, ordiamur, concedere plures videntur eam à folo calido fieri, \& ad eam frigus per fe nullam operam contribuere, fed folū per accidens, quaxenus calotem moderatur, eun q; ad illam formam educendam idoneam reddit, fíquidem calorgeneratiuuseft, frigus vero corruptiuum:videmus enim Colum, quod ad omnium generationem concurrit, non agerenificalore, \& inreditu Solisad nos omnium rerum generationem fieri per calorem, in receffu autem corruptionem propterfrigus. Hanc fententiam ego veriffimam effe puto, fed dum bocdicimus, non video cur non idem dicere cogamuir de alteratione prauia generationi; quoniam calor non alia ratione formam edur it, nifi alterando ma- $F$ teriam, \& inducendoillas qualitates, quas forma fubftantial is ftatim infequatur: calor enim non agit nifi vt unftrumentum primarii agentis; quare e dustı form $x$ tribuenda potius eft agēti primario, qued calore vt inftruméto vtitur, qua ipficalorij preparatio yero peralterationem ca-
A. lori magisattribuëda eft, quia per eam fit poftea eductio forma: pugnantia igitur diceré videtur quifquis dicat à folo calore formam educi, præuiam veroalterationem fieriper fe \& à calore, \& à frigorc:fed res clarior fiet, fi modus declaretur, quo calor proforma introductione materiam prxparat. Certum eft mifti homogenei generationem confiftere in miftione perfeda humidi cum ficco, perfectam dico, quantum forma generanda requirit:fed hæc non poteft fieri, nifi a caloie; calor cnim extenuat, itavt mifcibilium particulæcommifceri poffint, nam alia forma maiorem humidi cǘficco permiftione, alia minorem poftulat, proinde alia maiorem calorem, alia minorem: hinc fit ve in aliquibus tanta fit permiftio. vt vix vnquam poffint ficcum \& humidum feparari; iden illa diutifime durant, quia putredini non ita obnoxia funt, vt alia; eiufmodi eft oleum, \& res a lix vifcớre, nā vifcofitas prouenit ex magna humidi cum ficco

c permiftione: validam etiam habent permiftionem metalla, præfertim argentum; \& aurū, quæ ob id,\& propter congelationem diutiffime feruantur: fic ergo generatio mifti confiftit potiffmum in extenuatione ficci \& humidi, vt poffint eorum particulæ commifceri, \& forma mifti educi, à folo autemcalore fit extenuatio, tị; à folo calore per fe fit præuia alteratio, non à frigore nifi peraccidens, fiquidem per fe frigus fac1t operationem contrariam operationi caloris, condenfat enim \& conftipat, \& hac ratione impeditextenuationem, \& in minimas partes diuifionem; quare per fe eft potius contrarium generationi mifti; peraccidens tamen ad eam confert quatenus calorem moderatur, id q; modo magis modo minus, prout cuiuff; mifti generatio poftulat: quantufcunque igitur calor fit, fue intenfus, fiueremiffus, ipfi foli perfeactribuitur \& generatio mifti, \& præuia ad eam difpofitio. hoc enim oftenditur ratione fumpta à fine: finiseft eductio fotmæ mift; hæc fieri E non poteftabfq; conueniëte commiftione humidi cum ficco, hæc non fit nifi perattenuationenı, \& hæc fit à folo calido, \& quælibet attenuatio à quodam ftatuto gradu caloris; igitur folus calorperfe, \& quatenus eft calor, tum formam miftide materia educit, tum prius materiam praparat peralterationem prauiam; frigus vero non perfe agit, fed folum contemperando calorem : hoc autem maxime confirmatur confiderando naturam, \& primam originem caloris, \& frigoris, de qua alio in loco fure loquuti fumus: quuns enim hæ duæ qualitates ex actione coelefti in inferioribus corporib. oriantur, cœleftis aūt actionon generet nifi calorem, frigus folam caloris priuationem infequitur, \& oritur ex priuatione actionis cœleftis, proinde refpectu caloris habet locu priuationis; quo fit, 
vt hix dux qualitarescommifte, \& contem e - A ratæagant fol:um virtute caloris in gencrandis miftis, \& in præparanda materia ad corum ge. ne rationenu, \& omne tempcramentum abfolute confideratum debeat vocari calor, licet comparatione calidiorispoffit frigidum appellari; quod idem de lumine, ac tencbris manifeftum cit: datur enim in aerc \& maius, \& ninus, \& minimum lumen, \& horum quodlibet vocatur lumen, non tenebrä, quia tunebra nihileft, nifi priuatio luminis; comparatione tamen maioris luminis folemusaerem minus luminofum vocare tencbrolum. In qualibet igitur calors \& frigoris temperie fol caloris gradus generatiui funt : quanues cnim poffint haberc commuftos plures frigotis gradus, ab eis tamen non impediuntur, quia iā ad amicitiam omnes redaati funt, \& facta eft qualitas vna, qux. refpectu generationis milti dicituriemifius calor: quod đi frigus e ft eleméti frigıdi generatiuñ, iamdiximus nos de fimplicium generatione non loqui; \& preterea ille eft potius vocandus interitus, quam generatio, vt Ariftoteles docet in contex. 18. primide Ortu \& interitu, quoniam interiit nobilius, \& genitum eft ignobilius elementum: fcdin mifti generatione videturnullam efféactionem frigoris, nifi ad contemperandum calorem, enque fuit Auerrois fententia, vt prædiximus, \& eandem videturfignificaffe Alexan.in contex. 4. 4. Meteorolog. dum inquit, id quod in miftione humidi cum ficcoagit, ac determinat, effe præcipue ipfum calorem; fic enim denotat, calidum primario, ac per fe agere, frigidumvero fecundario, \& per accidens, Hæc igitur dicta fint de actıone calidi \& frigidi in generatione mifti, \& in praviailli alteratione. At fi loquamu de miftogenito iam, \& conftituto, negari non poteft frigus agere etiam per $f e$; congelatio enim fit per fe à frigido, \& videtur frigidum tribuere vltimū complementum rei iam per calorem genit $x$, quatenus dat aptitudinem adactum fecundum; ad operationem, qux eft vitimum rei complementum: fed actum primum producere non poteft, quemadmodum diximus : id autem declarat Auerroes exemplo rerum artefactarum : faber xrarius volens ex ære aliquam figuram efficere, non poteft æri figuramillam tribuere, nuf liquefaciat metallum illud, neque hoc praftare poteft, nifi per calorem; fed acquifita figura opusillud confiftentiam non haberet, nec præberet quxfitam vtilitatem, nifi congelatetur, \& induraretur à frigore : ita enim illi qui efficere volunt enfem aptum ad incidendum, calore prius vtuntur molliente ferrum, vr poffit illam figuram\&illud acumen recipete; poftea vero intıngunt illud in aqua, vt à frigore duritiem confequatur; qua fat enfis ad pugnandum, \&adincidendum ido- neus: tale quiddam inquit Auerrocs euenire in natura. gencrat cnim netalla per calorem extcuuanı cma, \& duorü haliı um particulas commifcentem; fed poftca genito metal!o adicniens frigus indurat ipfun, \& dāt ei complementum, vt diu confeructur, \& vt ad humanos vfis aptum fit, fed non dat formam fub ftantialem, quia hac perfe educitur atione caloris, remiffi tamen à frigore, vt distum eft.

\section{B Refponfio ad argumenta recentiorum. cap. VI.}

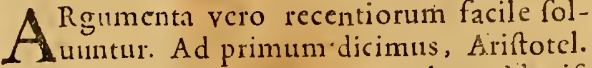
Rgumenta vero recentiorum facile folin primo illo contextu 4. Meteorolog. adduxifAd prinuwinfe exemplı gratia plures calidi \& frigidi operationes in mifto iam conftitito, tanquam manifeftiores (namillx, qux fiunt in generatione mifti, occultiores funt) has autem etiam à frigido perfe poffe fieti iam diximus, \& eft res claC rifrma, faltern in pluribus, quare non eft neceffe dictum Ariftotelis verum effe etiam in generatione mifti: quemadmodum enim necde calore tueri poffumus, quod femper agat per fe, quum fit manifeftum quandoque agere per accidens; fic defrigore fatis eft ad fententiam Ariftotelis tuendum, fi dicamus quafdam operationes ab eo fieri perfe; non tamen omnes.Ad fecundum dicimus. falfim effe id, quod affumunt, frigus in generatione mifti non habere locum retrigerando, fed folum fecundum alias fecundas operationes, dicimus enim è contrario potius lem fe habere; namin-generatione mifti frigus locum habet refrigerando folum, nempe moderando calorem, fed non fecundum alias feciundas operationes: quod quomodo fe habeat, mox clarius explicabitur. Ter- Adtertium veroargumentum ftatuit generationem trwm. mifti effe re diftinctam à miftione, quod neE gandum eft, quia re diftingui zon poffunt: quoniam igiturnon poteft fieri miftio abfque mifti generatione, neceffe eft, vt, fi in miftione frigidum agit in calidum, \& refrigerat; hoc idem fimul in generatione facerc dicatur; fed de hoc quoque pofterius dicemus, \& confiderabimus an differat miftio à generatione mifti, $\&$ in quonam differat, ibique oftendemus neceffarium effe in generatione mifti vt calidum agat in frigidum. Ad poftremum autem ar- $A d a r g u-$ gumentum ab aliis adductum ad probandum mentum frigus in ipfius quoque formæ mifti eductio- aliormm. ne agere per fe, puto optinam effe refponfionem, quam prædiatirecentiores adducunt; \& miror quomodo Póponatius in quarto $\mathrm{Me}$ teorologic. dubitatione duodecima dicat effe ita difficile argumentum hoc, vt neque ipfe foluere illud potuerit, neque Auerrois Tra$T$ is polinus 
polinuscius preceptor olin in Patauino gym- A nafio prorefiot crdinurus \& magni mominis vir.Dicoesin cuiditstecenoribus nullom in a. nimá'.s interitu nona for mă edici,fed manere

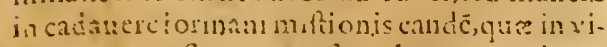
ventefuear, frue vmam, fiuc lures, \& for hane folam cadaucreonftitui: fed cam tunc prinum inciperctonm officio fungi,qun antca fub anima officio tanti materixtmgertur: quontam ifitur non negamus firgus per fecorrumpere, fiutcalor per ie gincrar, idco dicimus interem- B ptoanmali àfigorenulla tuife frigoris actionem, nifinterimedo animalfer deitrasionem forme, quxeft auma, thetan pet exriuctionem c.loris animalis; formà atitem nullam efie cduEtam, quxibi pius non fuerit; quare nil tunc operaturfigus, nifi itrerianu, inullam enim formam educit, quia nualla zunc cúncitur; proinde nec vilum facit preman alterationem eductioniformx. fed folum recentui forma animalis-

\section{De modo actionis quodue actina agunt in duappafituas. Cap, PII.}

\footnotetext{
C
} Ferum ex his, qua de actione frigidi haacenus diata funt, duæ magni momenti diffultates orimatur, quas ommino folucie oportct; rma eft de nodoationis, quo duraktiuxagere dicuntur in duas pafiuas pro gencratione mifti ; altera vero,an idem fint generatio mifti, \& miftio: his cnim explicatis arbicror $p$ a dictam generationis definitionem fatis manileftam fore. Prior difficultas oilturex hoc principio ab omnib. concelfo, qualitates actiua non eficiunt fecundas qualitates, feu fic cundas operationes, nifi per medias prumas: hoc enim 11 omnibus clarum effe videturnam firigidum non congelat, nifi prius refrigeret, nec calidum liquefacit, nifi per calefationem: finiliterfialias onnes in primo contex:4.Meteorolog.abArift. nominatas fecuńndas operationes pectemus, nulla illarum eft, qux non per calefactionem à calido, \& per refrigerationem à frigido produç̨t!̣r: hocıgituria constituto dicendun vicethir etiam in gueratione mifti duas actiuas edere omnes operationes per medias calelacionem, \& refrigerationcm, tam in præuıa altera-

Dubism tione, quam in eductioneformx: fed quomcdo hoc eflepoltit, non eft expliç:ar facile, å magnum dubium exsitat à nemine hactenus conlideratum, nedum folutum: quod quidem locum habet, non minus fi dicaturtrigidumagcre perfeingeneratione mifti, quam fi locum calidum; nam fi \& calorem, \& frigus perfe agere dicamus, de fecundas vtrung; operationes cotere, neceffe eft eas ediper primas, quo hevt idem corpus necticlit limul eoden tempore de iccundum easdem partes calefere, \& iefrigeriari, quod ne imaginabile quidem cft: quod fr quis dicat has duas gualitates non pignaze andius inter fief fed factaselic amicas, 1 in vnamelic taE.tm; non obid rollitu! difficultas : quicum ficri potelt ve hac caden citiali:a, fimul calcfa cicndo, \& refrigerando edat umnes fecundas opentiones, mulths, qume ad cilorem, tuns illas qua ad firghs pertinent? fi reo dicamus fquodiandemontratimus qualuatenu illam mediam progencrationemiftinonageie nifivt calorcm,adiuc diffenltate vigemuri man fi a calore nulla poteit fecundaria operation pronenire, nitiper calefationem medam, necefic eft calorem sllum xemitim, $\hat{s}$ a firgore temperatum non agere in ficcum \& humidum, hifi priuscaleiaciendo; nilantem caléit, nifi frigidum dise ftaiuxur; crgo idem eft fimul calidum, \& higidum, neque facta eft horum contemperatio, er anicitia, fiadhuc remanet pugna calidicum frigido, \& actio calidien irigidum

C cum reactione frigidim calidum : quod fi hoc concelio dicamus remittinterum caliduma frigido ficci \& hum!di, adhuc eadem difficultate laborenus; nam calor ita remifus non aget in ficcum, \& humidum, nifiper calefactionemperit ergo adhuc pugna caliuiticum trigido, \& fic in infinitum progrediemur. In hac difficulate, quim eam nemo confileraucrit, dicam ego $P$ quid fentiam. Cicdodiftinguendam eile pri- ru m.rum y'ralitatum action em, duplex cnim abs- lit.

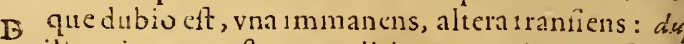
il:a enim qux eft contrarij in contrarium, eft est receffario tranfiens, quia nihil poteft ita agere in feipfum, nif fit fibi ipficontrarim, quod quidem eft impoffibile: led actio agentis in ma. teriam poteft effe immanens, jualem dicit Ar1frotin 2. Phyfica aufcultations dariactionem naturæ in rebus naturalibus: in feminibus cnim naturam inelle dicit non ve formam, led vt artificem, \& sn hoc differre naturam abarte; quod $E$ inarte arilexnon eft infitus matcria, fed extra eft at in matura ineft artifex in materia in quam agir, fic infemine humano ireft humana naturanoin t forma, fed va artifex, fic etian de aliis. Deso hiactionis modi notaripofiunt in generatione mifti: appolita namque elemena inu1cem necefle eft vt fer contrarias qualiates agaut \& patianturi\& fiat calefactio, \& refrigerat1o, \& humectatio, \& ex ficcatio; eaque eft actio tranfiens, quia nondum ell facta elementorum vnio, fec diftinelx adhuc fint eorum natura, \& vnum agit in illud tanquan conttarium in contrarium feparatum : quoniam autem naximamagendivim habent calidum \& frigidum, id:o abiolutur primo loco horum conemperatio, quatir qualitas vinamedia, qux vocians temperatus calor, quia joftcaggit in liccum ie humudum, yt illagliat, ac ceanuet pio torma mifí 
mitti eductione; \& hxc fecunda actionon poteft amplius ofle traniens, fid eft inmancins, quippe qunm xque omnibus clenentis mfit qualitas illamedia proueniens ex vnionecalidi efrigid: quarelizec vona ominum qualitas a git in eadchisclementa ve ficca $\hat{s}$ himida, \&e cet actio tanquan unfitiaticus in materiam, qualis illact?, quam in femine confiderauinus, led ron amplius vt contrarii in contratum : quan. docum qualitasilla medaagendo edit in ficco \& humido lecundas operariones, non amplius calefaciendo, ant refrigerando agit, fed fecundas qualitates producit non per primas, quo. niam agit atron: immancine, quaredigi videturatillam ationsm, qux per emanationem ficri dicitur, quapoteftaliquidagere in feipfum, vealiâs diximus de grauium \& leuium notore naturali:ideo deceptus eft Sueflanus dicens paffulas qualitates reagercinactius; reactiocnim non habet losum, nifi in atione tranfeunte, quzeft contrarij in contrarium, non in actione $C$ artificis vt agentis in materiam, qux nonelt vt in contrarium fed fit per quandam emanationem, quematimodum diximus. Deceptietiam funt alijnonulli recentiores, qui in fina inter fe alsercatione de genesatione nifti an fit 1 dem quod:muftio, hanc durum actionum diftin tio. nem non cognoneruat, fed communi confenfione afierueruat caloiem iam à firgore contemperatum terminare, \& vnire frecum \& humidum progeneratione mifti, idq; preftare per calefactionem: hoc autem minime verum ett, \& llud omnia pradicta abfurda confequuntur, nempe idem agere in femetipfum vt incontrarium, \& fimulefe calidum \& frigidum, \& eandern qualitatem calefacere fimul, \& refrigerare codem tempore eandem rem, \& calefactiones, atq̣; caloris remiffiones infinities multiplicari, quæ omnia abfuldiffima funt." Sccundæ igitur operationes, vt extehuatio, vnio, \& termiṅ rio paffuarum $a b$ actiuis fiunt, id eft, a calo- $\mathrm{E}$ réan temperato, tanquam vina qualitate media, fine calefatione, vel refrigeratione. Si quisautem objiciat, onnis atio in rebus naturalibus eft contrarij in conttaritm; hoc nos infician polfumus, nam agens aquiuocum non eft contrarium patienti, qualis eft artifex cuiusque operis artificiof, \& cuiusmodi funt plura agentranaturalia; Colum ersim agit in hac interiora, neque eftillis contrarium : lic duæaaiuæ qualitates funt agentia aquituoca quatenus in pafluis edunt fecundas operationes; quare non eft neecflarum ve aliqua bi infit contrarietas actiuarim cum pafiuis: fed dicere etian poflumus, id in omn elementari acione verumeffe au formaliter, aut (lic enim loquiliceat) fupporitite; actıo enina activarum in patiuas fi fomaliter noneft afio coninaj iis contrarium, faltempexpenit factumpriss

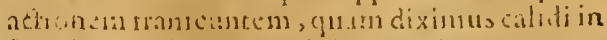
fiig dan, \& firgidim calidtm. Videnturatem hre ommatectum haberectiam in alies atiuarim qualitam opunasions in mifto iam ontintuo, vin lijactictionc; pracedcre namque upertet attoncull coloris ignei in metallun, guta lis calide in digidum, proindeactio touthens; ralis cum in iplo muto inm geniro mulla cxifter yoteft tanquam immanens, quia

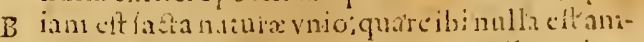

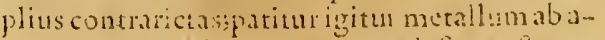
guncenteno, ab igni, \& prus calefit, poiteace colcutioncliquetit, \& canctali liquetactio non inliquiturnuncdiatc calorem ignis externum, fad calorem meialli inermum ab igne productum; quare patitur prinum inctallum vefrigidum ab igni calidoagénte acione transcunce, dinde calorem in merallogenitum infequitur liquefątio, tanquan actio immancns; \& per quandam emanationem edita, fed non per alixn mediam calefactionem : fic etiam tit mitalii congclatio ab externo firgore peripfus metafitei rigerationem, quam infequirut congelatio absque alia refrigeratione. Patet igitur primas operationes prmarum qualitatum-femper elle contrarij in contrarium, \& tranfeuntes; fecundas vero etfe actiones artificis in materiam, \& immanentes, proinde non efie contrarij in contrartum, nifi vt ante dictuni

$D$ eft: omnis igitux actio qualitatum elementarium vel eft contrarij in contrarium; vel prefupponitactionem-factam contrarijin contrariums quia? fecundx operationes prafupponunt primas, tam illa qux funt in milto iam genito; quan illa quia hunt proconttitutione, ieu generacione niffi : quare fublata efe videtur hac in reomnis difficultas. Sed fiendum praterea Dutzer. efi, aliam quoque dariactionem tranfeuntem, actzo ett. quænoneft contrarij in contrarium, fed fimi- $1 \mathrm{~mm}$ fms: lis in fimile, quoniam eius finis non eft genera: $\operatorname{lis}$ in $/ 2-$ re, vel deftruere, led conferuare; obid quum mule. conferuare fit agere, ea eftatio non contrarijin contrarium, fed imilis in fimile: exemplo res clarior fiet : generatur in caucinis terraurum hoc paeto ; ex duobus halibibusteferentibus naturas quatuor elementortim commiftis fit primo loco actio calidi irifrigidum, \& frigidi in caidum, vnde pronenit qualitas media, id ext calor mediocris agens pofea in F ficetum, \& humidum ; fed non perficerctur hæ acko, nifi calor ille conferuaretur, ne minuerelur, vei diflparetur; conferuatur igitur calor illeà calore coleiti, ita vt eandem fuam operationem aboluat: ita in foetu exiftente in vitro ineit calor internus pro generatione antmalis, fed iile dirliparetur, nili conferuaretur ì coloretominz founte, or italab fuluitur ge- 
neratio. Patet igitut duas effe actiones calidi tranfeuntes; vnam, qua agit in frigidum ad gencrandum calidum; alteram, qua agit in æque calidum adipfun conferuandum, quæ dici poffe videtur continua generatio eiufdem caloris: liac ratione Coclum eft agens vniuerfile in omnium fublunarium generationibus:qūu cnim In lib. de onmes calore abfoluantur, hic inagente partiCulore culari conferuatur a calore coleft, hocett, gecolesti. nito, à Coloper motum, \& perlumen, ve alio in loco declaraumus:hacigituratione virtuselementaris eff fecundarium agens, quia vel producta, vel faltem conferuata a virtute coleiti, tañquam ab agenteprimario, \& remotiore.

\section{In quo differant mijtio, \& generatio mifti, aiborum Sententia iurgumenta. C.lp. VIII.}

Equitur vt confideremus., an differant miSitio, \& generatio mifti, ac fi differant, quo differant. Fuit hac de re his temporibus magna controserful ner Th. Eraftun1, \& Archangelim Merccn.rum, vt ligerest in corum dilputationibus in publicumeditis deputredine. Eraftus enim idê prorfus effe dicébat generationem mifti, ac muiftionem, nec aliunde argumentunfumere videbatur, nifi ex ipfa vocum fignficatione, quam exemplis aliarum fimilium cófirmabat;nil enim aliud efle videtur miftio, quă mifti generatio,nec mifti generatio aliud, quam miftio, fiquidem ne imaginari quidem pollumus vnam exiftere fine altera: quemadmodum nil aliud eft redificatio, nifigenerat o fanguinis, nilaliud compofitio, nifi compofitigeneratio, \& fic de aliis omnibus, qur generantur, dicere Mercena poffumus. Contra vero Meicenarius demon-
m. ry. penitus, sargumentabatur potiflimum abcarum definitionibus : llla enim, quorum difcrepantes funt definitiones, diucria absque dubio funt; atqum diuerfa funt definitiones miftionis, ac generationis mifti, \& in duobus diftinctis locisab Arift.afferuntur, vt manifeftum eft; ergo non funt idem:patet autem diuerfas efle conditiones,per quas definiuntur; nam in miftione elementa à fe mutuo alemeridicuntur, quodnon fit, nifi per actionem contrarix quahtuatis in fuam contrarian, per quam fe mutuo contemperant, tum calidum \& ligidum, tum humidum \&. liccum, ita vt omnes ad mediocritatem redigantur; quimobrem in mistione locum non habetalterailla actio, qux eft duarum actiuarum in duas palfius, fed fola atio contrarix in contrariam; quo fit, vt in miftione onmes fintactiux, \& omnes fafiux: contra vero in gencratione mift inulla huius aetı onis condideratıo habetur, féd altcrits tantum; qqux cft duarum atuma-
A rum in duas paffiuas; hanc enim expreffit A rift. in definitione generationis mifti,nec vllam fecit mentionem alterius actionis, qua agit quxlibet contraria in fuam contrariam, fiquidem huius actionis nulla in illo 4. Meteorol. habetur confideratio. Præterea manifeftum eft (inquit $\mathrm{Mer}$ cenarius) hactria diftincta elfe, elementorum alterationem, \& vnionem, qua contrarix eorum qualitatesreprmuntur: deinde terminationen humidi cum ficco factam à duabus actuis ; ac

B denique productionem totius fubftantix mift; in primo quidem miftio confiftit, generatio autem inifti in fécundo, ac tertio, \& necelle eft prinu millud pracedere, nempe elemētorum iuxta pofitorum, \& le rangentium mutuam alterationem, \& qualitatum moderationem, qux dicitur vnio, deinde fieri teminationem palliuarm ab actius, quace eft proxina difpolitio ad fubstantix mifti productioncm, hoc cit, ad cductonem forma: tantum igitur abeft, ye miftio C-fitidem, quod generatio mifti, vt potius ean præcedat, imo ita prxcedat, vt ne fic quidem proxima difpofitio ad cam. Hæc funma eft totius ecrum argumentationis, fed præterea plurima etiam ab vtroque dicuntur ad alterius rationes foluendas: quæ non refero, quonian tædiolum admodum eflet totan corum prolixam dıpurationcm in mediū adducere, quum præfertum eam in eorum feriptis quisque legere pollit.

\section{Confutatio predictarum opinionum, G've- ritat is declaratio. Cap.IX.}

$\mathrm{E}_{\mathrm{p}}$ Go vtin re difficillima fententian meam proferam, à neutro penitus diflentio, ficut etiam neutripenitus aflentior; credo enim reliEis horum opinionibus, ve extremis,aliam medam accipiendam effe; qux mihi quidem omnen tollere difficultatem videtur; nempe vt E dicamus miftionem, \& milti generationem re ipla icemefie, ratione autem diftingui, neque alıud oltendi duabusillis contraris argumentationibus Erafti \& Mercenarij. Quoniam igitur \& in miftione, \& in generatione mifti \& lubftantiam, \& accidentia confidcrare necefle eft, fiquidem exelementorum fubftantiis fubftantia mifts conftituitur, idque non fit nifi per aetionem \& paffionem primarum qualitatum; ideo \& ratione fub ftantix, \& ratione qualıatum oftendo \& in miftione contineri generationem mifti, \&in hac miftionem, proinde eas effe idem re, fed ratione diffingui:quoniam enim diucrfareficiunt, douerfis modis definiedx funt: ficetian patebit ratio, cur miftiodefiniri debuerit in primo hbro de Ortu \& interin, milti autem genuratio non ibi, led in 4 . Meteorolog. Miftions definitio hes fint, miftio clt mufribi- 
fit liumalterntonm vinio: feu quia tona mifeionis natura confifit inilla dicliunc, vnio, hre quidlignificet, cōtidcrandum elt. Putaut Merma cenarius cam non liòniticare productionem vnius fub fanvie miti expluribus fubitantis mifubilitum; hace cum eft ipfamiftigeneratio, cui idem effe miftionem ire conedere noluit, fed fignificare folam congregationem elementorum iam diniforum in minimn, antequan plures iplorum naturs in naturam vam cóale-

ta. Font. Sed haceius fententia aductfatur Arifiotcli, qui eam vtantiquorum opinionem reprobasit; illi namque dicebant, miftionem nil aliudefe, quam congregationem, fen iuxta pone fitionem mifcibilum : quam dificultatem vi$\because$ dens Mercenanus, nifus eft cam effugere, or at liquam notare differentiam inter anciquorum, \& livam opinionem, quam Arif. fuilsc profeffus eft: dixitautem difcrimen confiftere in illa dictione, alteratorum; nam antiqui dicebant miftionem cfe diuifion cm mifcibilitum in partes miñimas, \& carım congregationeṇ, fed ntillam ipfartum inter fe alterationem confiderabant; Ariftoteles vero hanc confiderauit, \& voluit mifcibilia effe per mutuam inter fe $a-$ etionem \& pafionem ita alterata; vt refmetis contrariarum qualitatum extremitatibus fint omnes ad mediocritatem redactr: hrc igitur apud Ariftotelem eft miftio, in qua non includitur plurium fubftantiarum in fubotantian $\mathrm{v}$ nam mutatio, quæe non eft miftio, fed gencratio nifti. Sed hrecnon funt confentanea verbis $A$ riftot. eoin loco, vtbene confideranit Eraftus, dixit enim Ariftoteles mifcibilia per mitionem definere efleid; quod ante niftionem erant, \&c in naturam mediam tranfre, quam inquit effe quoddam iuosojespòs, vt ficuti qualibet aqua particula eft aqua, \& to ta éf aqua, ita illud qutoque \& totum, \& fingula pars habeat idem noman, \& candem definitionem; hoc tarren iuxta Mercenarii fententiam dicinon poteft, quia fi miftionis, \& vnionis nomen non fignificat $f_{2}$ ctam adhuc tranfitionem plurium fub fantiarum in fubfantiam vnam, fed folum qualitatum, qux erant contraria, temperamentum, integra igituradhuc mament in illo prioni, reu temporis, feu natura, omnes elementorum for: me, quum forma mifinondum educta fit; formisautem adhuc exifentib. elementa quoque exifunt, \& funt a dhuc ignis, aer, aqua, terra, yt erant prius; non igitur per miftionem deferunt I effe id, quod erant, quod tamen afferit Ariftoteles, neque totumillud eft iposouggoss, rt fimiliter afferit Arifoteles, fed potius eft dinimilium partium, quium carum alia fit ignis, alia fit aer, alia fit aqua, alia vero terra: cmnino igitur fateri cogimur naturam miftionis in pltırù fubfantiarum ynione pracipue confifere, hos
A $\dot{c} \Omega$ in carum mutatione in naturam, \& fubfantiamvaam; at productio vnius ubefantix mifit ex flur:bus clcmentorum cit abíque dubio ip\{a minigencratio; itaquedicioilla, vnio, in Verafer. dilinitione miftonis pofita miftigenerationcm tenssa. fignificat: quod etiam confirmare videur illud participiun prateriti temporis, alccratorum, quod finificat iam praccllific, \& à mifionc prefuponi mutuanullamalterationem peraetioncm, is pafionem contrarinim quaB litatm, neque in ca formaliter confifere miftionis natuan, red in ipfa fubitantiarum vnitione : quare Mercenarius proculdubio hac in relapfus eit. Alum quoque (rorem commififle videtur, quodafferuit raiftionem non precidere generationem mift tenupoie, fed folun naturấ ramen ex cius didis neceflario infertur pracedere etiam tempore, inquit cninn illum qualitatum contemperationem efre mifionem ip fam, quam non fatim fequitur generatio miC fti, fedintercedit atioduarm actuarumiam per miftionem contemperatarum in duas paffiuas iam inmiliter contemperatas, per quam a-

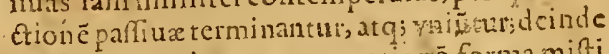
per hanc proximam preparatione forma minti edicitur. Quoniam igiturasio hacatiuarum in pafiuas non uidetur nifin tempore fieripoffe, dicere enim fubitan efferanum eft, necfortaffe conitabile, fateatur necefle eft, miftionem pracedie etiam tempore generationem mifti, nihilominus feu tempore dicat, feu matura, aduerfarur Arifoteli, ve confideraumus; quoniam in illopriori exítentibus iam formis ellementotum en fecundum Arifot. mitio vocari non poter, qui mitionem tunc elle voluit, quando eft genitum quoddam tertiú medium opooterses diftinctum à mifcibilibus: fic etiam è contrario negare non poffumus, in defnitionegenerationis mifti concineri raftionem; nil enim aliud eft generatio mift, nifi productio E fubfantix mifti ex elementorum fubfantiis; hacautem effilla ipfa vnio, que accepta fuit in definitionemiftionis, \& qur in defnicione generationis fignificata eft nomine träfnutationis': patel etiam in definitione generationis nominari qualitates clementorum \& actiuns, \& pafiuas: quocirca congreffus quoque elementorum in generatione mifti confideratur; hac coin eft mutatio quatu or fub fantiarü elementorum in vnam mifti fubfantiam: $\mathrm{cx}$ his igitur patcr, generationem milti, \& miltionem reipfa Costra idem effe, quod Mercenarius ncgauit. Quod Erafum atiem fecundum have ipfarm fubftantia confiderationein diffingunntur ratione, quod Erafus non vidit, ficile oftendo; eadem enim mutatis, qua ex elementis generatur miftum, dicitur \& miftio, \& generatio mifti, fed nlia, \&alia ratione: quum enim elementa fint terמinus 
minus à quo miftü vero fit terminus ad quem, nomen miftionis magis elcmenta refpicit, nomen autegenerationis magis refertur ad ipram miftum, vt voces ipfx délarant: nam miftio non mift eft, fedelementorum, nan enim, mífceri miftum dicimus, fed elementa, generatio autem ronelementorum, fed mift; non enim elementa tunc generātur, fed miftum, neque tamen eftaltera inealtera, mifti enim generario non eft nifi exelementis, neque bre ita vni- untur, quin generetur mifum: quocirca \& ge . neratio mifti fuit comprehenfa un definituone miftionis, fed confule, \& prout refpicit elementa, non miftum, cuitus nondum diftineta trấatio fiebat; \& viciflum miftio in definitione generationis miftituit comprehenfa, prout refpicitmiftum, non tamen exprefre, quia iam declarata prius ftatuebatur, quocirca in vtralibet definitionevtraque fignificatur, fed yna expreffe, alrera vero vt connotata. Hinc etiam oritur aliud earum difcrimen : quum enim mifćbilia partim feruar dicantur in-mifto, partim non lewari, fed interire in miftione, nomen generationis mifti refpicit elementa vt corrupta, fiq̨uidem generatio vnius eft alterius corruptio; nomen autem niftionis refpicir elementa. vt feruata, quemadmodum Ariftoteles in ea parRario d:- redocet, commifta enim dicunturilla, qu x non findto- penitysinterierunt. Ex his colligere poffumus nis tra- rationem diftinctions harum duaxum tractstationu tionum de miftione, ac de generatione mifti: D demfi- nam in libris de Ortu \& interitu Ariftoteles de one,ac de elementis agit, quatenus funt materia miftogenera- rum:quoniam igitur miftionis nomen refpicit tiane $m$ - rifitio propried icituripforum elementorum, \& fiti. bac funt nateria mifti nō alıter, quani vt in miAtionem veniunt; ideo conueniens, imo neceffarium fuit, vt in eo libro, in quo elementa vt niftorum principia confiderarentar, de miftione ageretur, \& doceretur quidid fit mif̣tio: hoc autem ipfius guoque Ariftot. teftimonio manifeftiflimo comprobatur.in I. de Generat. çontext. 43 . vbi dicit, quoniam de materia, \& de vocatis elements dicendun eft, ideo prius de iis, quxadilla pertinent, agere oportet: qunniam enim exelementis non aliter fit millum quam per eorum congregationem, qua eft miftio, ideo demiftione dicendum eft; \&́x quia mititio non fit fine mifcibilium inter fe actione \& paffione, ideo de actione quoque \& paffione eit agendum; \& quianon fit actio \& paflio, nifi per contactum, ideo etram de contactu agere oporter: propterea ftatim primo loco cgit decontactu, fecundo autem loco de actione \& paffione, terrio demum de miftione, deinceffatim in z. lib. aggreditur tractatione de elemenus tanquam demateria miftorum. Patet attem in definitione miftionis fignificari, nomine. $v$ nionis confufe generationem mifti porius ratone termini â quo, quam ratione fui ipius : licet enimilla vnio fir generatio mifti, modus tamen, quo fit, ibi non declaratur, nee declarandus erat, nifi in quarto Meteorologico: non poterat enim declarari, nifi feculiariter in mifto homogeneo, hoc enim primum generatur ex el mentortm commiftione, \& eft illius quarti libi proprium fubiectum; in libris aurem de

B Ortu\& interitu agitur vniuerfe de mifto abfque diftinctinne homogenei ab heterogeneo: quare illud etiam patet, definitionem generationis mifti in. Meteorclog. conuensentiffme tradi, quum fit propre mifti fimilaris, quod il. lius librifubiectum eft; in fecundo autemi libro de Ortu \& interitu videmus Ariftot. valde rudi. ter eguffe de generalione miftorum ; neq; ipfiụs definitionem ibitradidife, quoniam hoc facere non poterat abfque diftunctione homogenei ab C heterogenco, qua in eo libro vti conueniens non erar: definienda autem res ibi eft, vbidiftuncte eftdeclaranda, \& cognoficenda, non vbi confure, nil ergoaliud ibide mifti generatione docet Ariftot. nifi conftare miftum de bere cxa mibus elementis; de modo autem quoex is generatur, ne verbum quidem facit. Hactenus ipfas elementorum, \& mifti fubitantias confiderando, oftendimus, miftionem, \& miftigenerationem reipfaidem efle, fed ratione diftingui : reftat vtex qualitatum quoque confideratione idem oftendamus. Iam fxpe dictum ent, duplicem effe harum qualicatum inter fe actionem, a pafionem : vna eft, qua duæ contrariæ inuicemagunt, \& patruntur, qua ratione iam diximus, omnes qualitates efie atiuas, \& omnes paffiuas; altera veroeft, qua dux actiux iam fi. mul comtemperat $x$ in duas paffuas a gunt v traque continetur in vtraq; defnitione, cum hoc tamen difcrimine, quod qux in val ponitur exE prefie, eainal tera coniturimplicite; piriorenim actıo \& pafio miftioné præcıpue refpicit, ideo fuit expreffa in definitione miftionis; per illam cnim dictionem, alteratorum, fignificatur mutua elementorum actio per contrarias qualitates; hrcenim magis elementa refpicit: quam miftumgenerandum, altera vero actio implicite fuit connotata; quoniam vnio illa, quæ eft tranfitio plurium naturarum in naruram vnam, non fieret fine actione dunrum actuarum in F duas palfiuas, hæc aurem contra in definitionegenerationis exprin itur, quia magis miftum refpicit, quam elementa; prior autem illa implicite connotatur, quia non agerent'duæ actiua in duas paftuas, rifí per priorem actionem ellent contemperata: quocirca neceflaria omnin o ft vtraqueactio \& in miftione, \& in generatione mifti, qua non fit generatio mifti fure mi- 
fue mifione, necmifio fine mifri guncratio- $A$ ne: proinde funt dien re, ied different rutone, quatcons miftio refpirit elmuenta, generatio veromiftum: ob id mdefinitionc miftionis expinitur a! icra taltum actio, guamagrelencnta refpiest, in definsione atisem generations caprinitur altera, que mass reipicat milluis, quia per eam fit eductio formx mifit; fedaltera tanicn implicite includiturin $\mathrm{v}$ traque defintione, quep̧an viraque acto cft neceffara \& in miftione, $*$ in mifti generätione. Vt igitur hac omnia brenter, ac dis fincte complectanur., certum est \& in nuftione, \& in generatione hos duos terminos confiderari, elementa feparara, \& cadem faeta vnumi quoddam; in vttaque igitur. continetur totius progreffus ab effe eicmentorum ad effe mifti; ergo v traque contin t onnes partes huius progrelfis: biatem, fi bene corfideremis, trespracipue funt; nam dicendum eft tria ordinatini ficri in miftune, \& in miftigeneratione; primum eft alteratio mutua per adionem \& pafionem oinsum conrariarim qualitarum interfe; fectindum eft acio duarum actiunrum in duas paffiuas ; tertium eft productio mifti, qux perform eductionem fit, \& qux in definirione miftionis vocatur vnio : hocigiturtertium \& miftio eft, \& nift generatio, fed mitio dicitur reipectu mifcibulium, generatio autem refpectumifti; ideo in defintione miftionis exprimitur tertium sum primo, fed fecundum implicite connoratur, fine quo terium non effer; idque fit propterea quod primum rofpicit clementa potius, quan iniftum : at in definirione generatonis exprimii urertum cum fecundo, led primum implicite connotur, fine quo nec tertuns, nec fecundum ficret; guonian fecin.: dumrefpicit potius miftum; quan mificibilia: per-lixc tamen non ftat, quin in folo tertio conliftat \& miftion:s ; \& generationis ēffentia ; idque duobus modis confideratnm \& miftio, \& mifti generatio dicitur, reliqua yero duo iunt necefiarix difpofitiones in armbabus, fed vira magis elementa \& miftionem refpicit; altera vero magismiftum, \& generationen : quare patet Aritotel. \& in miftionis, \& in generationis definitione ponere voluiffe etiam prauian difpoitionem, eamque partim exprelle, partim implicite : ficuti diatum eft ; ex his enimomnibus clarum (nifallor) factum eft miftionem; \& mifti generationem re idem efie, fed ratione $F$ differre. Exhisautem duo maxime annotarida 3o colliginus, ne cum mults decipiamur. Vnum eft, miftionem nec tempore, llec natura pracedere generation mifti: huius ratio eft; quaniam ytraque confiftit in productione vnius natura fubstantialis, proinde in pottreno illorum
A trim, que memoratumus: quodfin folo primocfictmiftionis naturaconftiruta, quod tueri contendit Mercenarius, vtique non folum natura pracederet generationi, citod afleruit item Mercenarins, fed etiam temporc, quod aegalit quan quam ego quomodo id negare potucit, non videan; calidumenim \& trigidum besi fun contemperarionem abrolnunt, quipje qux maximam vim agendi habent; humidum vero \& ficcum, liseterdem.

B tempore agant inutem, \& patiantur; credendumtamen eft, noneodem temporefiam pugnam perficere; quumenim nimusactia fintr. quam ilianecefic ceft, vt tardius fumm cortanen. abloluant, idque etiam auxilo duam a thuarum sam contemperat arum; calor enim iantaEuss tempuratusagitinea, \& attenuat, \& ynit, \& titminat, \&ita adinuat, Eteorum quoque perfeca concemperatio fiat, prout poftulat forma mifts, qux in fine huitis totiuspreparationis C'momentotemporis educitur: quoniam igitur generatio miftin hac vltinatoraze eductione eft confituta, neceffe eft, fimiftio confiltit in contrariarum qụalithtum contemperationeantequin adtiux agant in pafiutas, qux Miécenarij lententia fuit, vt miftio tempore generationem pracedat : "quod etiam per ipfam mintionis definitionem confirmatur; nam fi virionem irteligamuscan Mercenario qualitalum contemperationemexalteratione, tumcertenondum eft genera io, quoniamadhuciorma mifti educta non eft: at fimclius fentientes dicamus vnionem efle vltimam illan forma mifti prodictionem id adhuc man feftius eft, quum Ariftoceles participio prateriti temporis vtatur dicens, altcratorum; fignifict enimalterationem iam pracellilic, vnionem vero fublequi in qua mintisnis naturaconfifit: digna etram confideratione fun illa Ariftotel verba in z. cont. 4 . Meteorolog. ad declarandam generationis definitionem adiecta [generint eñm calidum $\mathscr{E}^{\circ}$

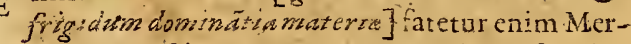
cenarus actionem contrariatim inter fe priorem efle actione duartm actiuarum in duas paifinas: quod Ariftotel. quơ que his verbis de. noiat, calido mam que \& frigido artribuit, $v t$ in pofiulas agendo generent miftum; atqui non agint; nifiprius fint coiztemperatæ per præcedentem pugnam inter fe: tuncenim non poffuntagere in pafituas, quoniam vma impediret actionem alterius; fed quando funt contemperatx, tunc agunt in paffius pingencratione mifti: confiderandum autem eit in eis dem verbis Arifotelem folicalido articulun appofu-

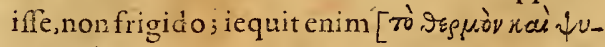
$\left.\left.x \rho u^{\prime}\right)\right]$ fignificans vnam efle qualitatem ex dua. bus contemperatis conftantem, quæ vocaripoteff fimul calidum \& irigidum : nam fi vtriq;ar. 
ticulum appofuiffet, vtramqque feparatim ngere fienificaflet, proindevt duas, quodminimeverun efict: piạs igitur dictum manteftum eft,

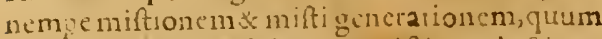
in illa cxtrenn lisbltantix mifti productione confiltant, limul effenon modo reriporc, fed ctLam matua; qua in re mulu crant, dicentes gुeserationcm nitit prefupponere multionem, tanq:am natura priorcm. Alccum vero eft: licet miftio \& gencratio miti fint fmul \& tcmpore, \& natura, propterea quod reipra idem funt, tamen quum ratione difting anatur, frior contideratione, \&cognitione efie debur mitio, quam mifti generarde : esurdem enin rci confit1.1 confideratio debet precedere diftinetans; quoniam igitur eadem mutatio confulus cognofcirur quatenus eft niftio, diftinetus vero quatenus eft mifti generacio; idco Ariftot prius can confiderare vuituit prouteft vnio refpecru clementortum mif́cibulum, pofteriusvero vetef generatioretjectunifti; proracnim funtconfideratienceleméta milto, quum furtprincipia mifti.

\section{Solutio argunentorun Erafti, \& Merce- narii. Cap. $X$.}

$\mathrm{R}$ Eftat vt \& Erafti, \& Mercenariiargunenta foluamus. Ad Eraftum fatisefie videtur, fi dicamus nilaliud á eo probari, nifi mifionem, \& mifti generarionem reipfaidem effe, hinc enim fit, vt vna fine alter exiftere nequeat: fatemur igitur omnem mitionen effe gencrationem miti, \& omnem mifti generationum chewifionemifed non ob id fit, veratione quoque finticin. Sed notare praterea pofunsus, nonidonca elle aliarum renum exempla, quxab Erifto addicuntur, Ideoquenegawam effe imilitudinem: nam idem prorfus eft rdificatio, atque ædium generatio, idem eft fanguificntıo, ac fanguinisgenerátio, ner dico folum re, fed etian ratione; quonian vtrumque nomen refpicit eunden terninum, quifieri dicitur, nempe terminum ad quem, ieutrum autem refpicit materiam exquajpopterea fic ctiam dicere poffemus idem elie ignitionem, \& genentionem ignis: fed roi expluibus vaum tht, \& mutatio fignificari poteft duobus voca. bulis; quorum vinun refficit illa plura, ex quibusialteum vetoreficitillud vnum, quod fit, necefie efl mutationem illan vi is duobus nominibusappellatam, vnam quidem \& eandem
A efle reipfa, fedmione diftinctam in duns;obid ex multús excmplis ab Erafteoadductisnullum cft ad propofitum accommodatum, rifi compofricio, atque compofiti generatio, diftingutuntur tamen ratione, quia iomen compofitionis refpicit illa plura, ex quibus vnum illud generatur,ill orm cnim efie compofitio dicitur, \& illa componidicuiztur nomen aitem generation is reipicis illud vuun, quod gencratur: hoc igitur iden de mifione, ac de milti generatione dicen-

$B$ dum eft. Ad argumenta vero-Mercenarii refpondete nititu Eraftus ex collatione inter fe defintionum miftionis, \& generationis milli, oftendens eandem ellevt:uiuque definitionis fignificationem, fed quinfatis leuis eft illa ipfus confideratio, inecintima iei penetrat, \& multis, ac magnis difficultatibus vrgetur, ego in ea referenda tempus non conteram : \& aliter ad Merceirarium refpondens dico, nil aliud oftendiex earum definitionum difcrimine, nifi mitioC nem, acmifti generationem rationediftingui; etenim qux racione difinguuntur, en difmctas definitiones habent, pro diuerfis enim eiufdem rei confiderationıbus diuerfx illi definitiones conueniunt, qux etiam diuerfis. in locis tradendrfunt, proutcadem res diuerfis in locis alio Eralio modo confideratur. Quzvero à Mercenario dicuntu: ad oftendendain realem quoq; diftnetionem miftionis, ac generationis mift, vana \& falfa omnia funt, \& a nobisiam negata, \& reprobata: quodenim in miltione non requiratur nfi contrariacum qualitatum inter fe actio, \& pafio ; \& contemperario, eamque vnio in defintione miftionis accepta fignificet, nee requiratur in mifione actio actinarum in paffiușs, \&-produtio torma mifti hac omria funt neganda, quoniam hac formæ productso fuit in definitione mifionis ab Arrftotele exprefla nomine vnionis: ficetiam negamus in generationemifti exelementis non recuiri primam illam acionem \& paflionem, que eft contraria1um qualitat um inter fe: fed hec omnia \& in miffone, seingeneratione miftirequiriafferimus, etfin earum definitionibus non æque ominia exprimuntur; quod quidem quomodo fe habeat, iam eft à nobis abunde in præredentibus declaratum. Quod igfiturad mifti gencrationemattinet, \& ad eiusdefnitionem, qun

Arifot in 4. Meteorologiconm addurit, declarandam, hxc, qua hactenus dicia funt, futticiant. 


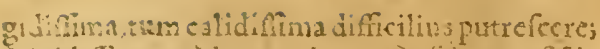
frigidinina quidem, quia ens in fir caloriambientis zu a

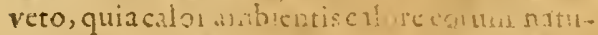

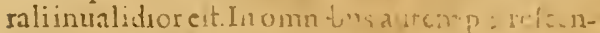

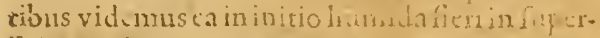

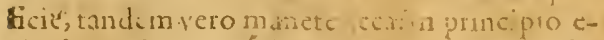
nim hamidumeritád cxcerian dum à liceo feparatur, fed quia continde ell worat, aique refoluitur; idcotandem remane: fimus, acrera, nempe fol:m ficcum ab himido deltisurum. Hecigitur \& alia mula, que mox confiderabimus, indicant co modo fieriputredinem, q Icm nuncexpoliumus.

\section{Quot modis mifum interire pofst. Cilp. II.}

Q Voniam autem Aritoteles in principio quarti Meteorolog. dixit, putredinem effe mift inteitum naturalem, eqque conbuftonem oppofuit vr interitum violentum, duo hic confideranda nobis proponuntur: vnum, an his tantum duobus modis nntenre miftum pofit, putredine \& combuftione, an etiam alis; alıerum vero, quomodo putredo dicatur Opinio Argento- interitus naturalis. Quod ad primumattinet, ris con- Argenteriusinquit Arilto:el. fuiffe deceptun, rir con- qui exiftimauit non darialum mifti intcritum, tra Ari- præter illos duos, qum tanen pluribus aliis fotekm modis inresire nuifum pofit, vt gladio, fufpenAcrec- dio, morbo, fubmerfione, \& allis multis Mcrnaris cen cenrius vero Ariftotelen tuerivolens, repreharir fen- hendit Argenterium, diccus non dari reuta atentin EE lium modum, preter illos duos ab Ariforel. defenjio Arjitotc dis. pofitos; proptcrea quod aliab argentério nominati non competuntritto, prournifumelt? fed fotius quatenus ef animatum; quaienus :nine ef mifum, nallus alius interitus illi com. petit, nifiputredo \& combuftio: huius tamen. rationcm nullam Mercenarius adduxit. Ego vero diffentio abvtroque. Cuod enimad Argenterii obiectionemattinet, en optime a Mercenario diluitur; quonzan illi modi, gutos pofuit A'rgenterius, funt proprii animatorum quatenys funt animata; neque eis. competunt qua. tcnus mifla fint; illenamque if mifti proprius interitus, quo tollinur miltio: at fipcrentanimal gladio vel morto, achucferuarur eadcm. miltio, quxpriss exat in viuente, quapropter: morsanimalis non eft enus corruptio vt ex clemontis conftantis, proinde Argenterius non o. ftendit alium dari modum incritus mifti vt conftantis ex elementis. In eo quoque decem. ptusent Argenterius, quod non vidit mifti, quatenus miftum eft, alium dari interitus modum, preter combuftionem \& putredinem; ideo Mercena. Mercenarius quoque laprus eft, dicens nullum riserror dari alium nodua Duo igitus in prafontia
A funtincbis ofendenda: vaum, qquod dẹtur a-

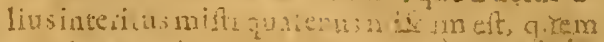

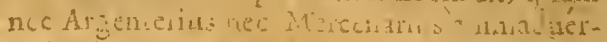

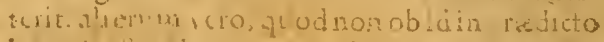

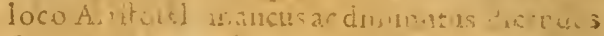

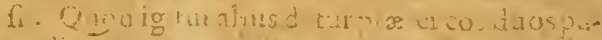

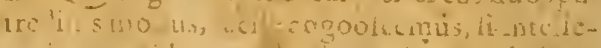

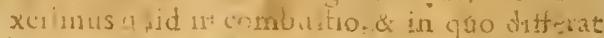

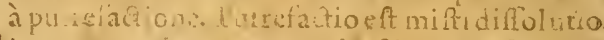
\{in oula lorelinenta, o mbuftio vero ét otius mi inuatu in hum rantumelcanentum, 1n.

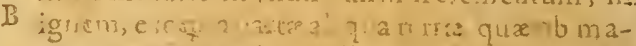

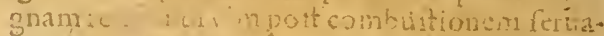
tur, ncotaferia woreigneo, thres amim cheris

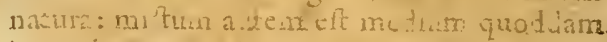

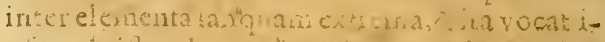

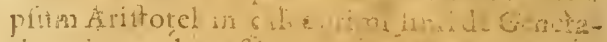

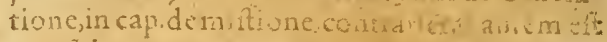

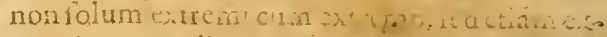
tremicum medio quo dit, ve heclium fatiat it ab acionevtriuslibet extremi ; combufto +gitweft mina à conzrario extremo : ideo siriftotel. in lib. de V ta \& morteinquit, violentua cfle illun intentala quifit a contrario: quan. wis enim ibi loquarur de cortaptiane aniza:0. rum, qux dicitur mors, \& lencinem tanquand interitum naturalen contraf onat ali is nisti:tibus tanquam violentis, quos licitifurit contrario, tameu hocidem locum irabet etiam inmifro quatenus miftum eft, en senim corritprio naturalis nou fit à contranio, fed poritis à

D fimili, putreiactio enim eft interitu riffiper comptionem caleris naruralis jaetsm a c. I re

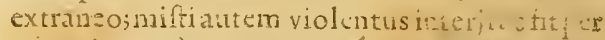
mutationemà eontratio, wédeconb. ionedi-

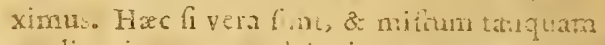
medium intermsturab igniranguam exiruno, $p$

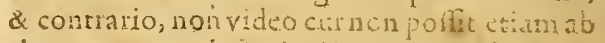

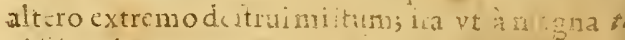
vi frigoris conuertaturtotum in vnuis cle thill. tum frigidum, vt in termam, neque in on in E lementa difolia ur: id autem, quod tio c.

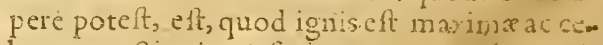
lerrima actionis, \& facile conutitis pluma miftain fuam naturam per combufium; trigita vero elementa non tantam agcnu fim obtia nent, nequeita celeriter miftun nụuant: attamenfiverum eft $i d$, quod firftotu docitn lecundo litro de Ortu \& interisu, poíl q ouliber clementum mutari in quodibet, nec mus is gnem inalia.quam alia in ignem; ferictian poE: teft, vt omnia elementa in mifto exiftentia nutenturin terram ob magnam vim frigidi agenris, \& condenfant is \& omucm caloren extin guentis:licet enim hoc fit minus facile \& minus. frequens, \& minus euidens, ratio tamen nus. cogit, vt hoc concclamus; quun piælercim id feralu \& experientia confirmetut, viderunt cnum.

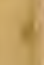


cuiusantea crat calor naturalis, \& ita cooperatur calori externo in educendo ad fuperficiem humido: putrefactio igitur sa ratione dicitus naturalss, quatenus fit mo do aliquo ab interno calore, non à folo externo; combultio autcm ab extcina tantumi caufa fit, calor cnim naturalis femper manet maturalis, neque ad comburendum mifum cooperatur igni combutenti. Hæc eft Alberti fententia, ipfe tamen non expreflis, quifnam fit ille defectus prancipii conferuantis miftionem, ob qquem calor naturalis. definit efle naturalis, \& cuadit igncus, \& contrarius; videtur autem hunc defeotum expreffiffe Buccaferrells, cuius opinio non videtur diuerfa ab opinione Alberti, inquit enm, calorem naturalem intenfiorem fieri ex actione caloris externi, \& ita auctum confumere humidum, euocando ipfum ad fuperficiem; fic enim calor naturalis definit effe naruralis, quoniam amittit eam proportionem, quam habere debet adficcum \& humidum proillius mifti conferuatione: ita igitur putrefactio partim elt naturalis quatenus ab interno calore fit, partim
Confuta- violenta quatenus fit ab externo. Sed hec fentoo. tentia non eft confona verbis Ariftoteles, qui, $v t$ in tota eius tractatione de putredine videreeft, nullam tribuit actioncm calori naturali. fed totam calori ambientis, à quo dicit deftrui calorem naturalem, proinde pati potius, quam agere: praterea luxta hanc opinionem oporteret calorem naturalem ita auctum, \& ynum. factum cum calore extranco agere immediate in humidum, \& facere ipfum cuaporare, attanien hoc non vult Ariftoteles, fed vult calorem. extraneum agere immediate in calorem naturalem ad ipfum educendum, \& per hocputrefactionem definit, poftea vero fubiungit, exeunte calore naturali humidum qquoque naturale cocuaporare; itaque vult enaporationem humidi effe quoddam confequens cxitum caloris naturalis, proinde non pati imme diate humidum à calore extranco. Nos tamen poltea, quum de putredinis natura loquemur, confiderabimus an opinio Alberti ad rectum fenGum trahi poffit: quantum autem adprefentem difficultatem attinet, certum eff Albertum. non idoneam rationem adducere, cur putrefactio ad differētiam combuftionis dicatur naEuralis; quia conceflo etiam eo mado, q110 Albcrtus putrcdinem fieri ftatuit, quem nos poft. ea diliggentius expendemus, non recte tamen. diceretur putredinem fieri ab interno principio; quia fi calor naturalis non. eft amplins naturalis, fed iunotus calosi cxtemo eft factus totus igneus, \& ininicus naturæe illius mifti, totus eit potius vocandus extrancus, quam internus illi mifto: adde quod in confideran. da cuiufque motus principio attendenda eft
A primacaufa ipfus motus; prima autem caufa etiam fecundum Albertum eft folus externus calor, qui primo loco agit in calorem naturalem; qunamobrem foli calori ambientis actio illa tota attribuendaeft, proinde fit ab exterio principio: vt autem fententia Alberti defendi polfet, oporteret externum \& internum caloren effe duo agentia xqualia 2 diftincta, non fubordinata; quiadum funt fibbordinata, adfcribiturtota actio agenti primario, ficuti diB ctumelt. Alia fuit opinso, quam in eodem lo. coimpugnauit Albertus, \& quam poftea Vicomorcatns fequutus eft, putredinem dici naturalem; quod à calore ambientis paulatim, ac fenfim fiat, combutionem vero violentam, quia fitceleriter, etenim opus nature non eft velox. Hanc fententiam Albertus refutat hoc argumento, quod modus rei infequutur xem, cuius eft módus, proinde caúa eins ellenon pac teft; fieri autem celeriter, vel tarde, cft modus, qui confequitur rem vel naturalem, vel violeı1tam; ergo non poteft effe canfa naturalitaris. vel violentix : prior igitur alia ratio efle debet, curactıo dicatur naturalis, vel violenta, deinde confequi, vt, elox vel tardafit. Aliam quoque aliorum fententiam reprobat ibidem Albertus, quam miflam facio, quoniam apud eum. legi potelt. Alij vero dixerunt, putrefactionem. dicinaturalem ratione interniprincipij, finon. D. ątiui, faltem patfiui; matera ęnim putrelcens vinu conferre dicitur, quatenus habet aptitudinem ad putredinem. Aducrfus hos Pomponatius in 4. Meteorologicorü hoc argumento viitur, quod per hoc non apparet difcrimen, quod quærimus, , putrefactionis \& combutions : fiquidemetiam combuftio babettale internum principium pafliuum, materia namqueilla naturaliter eft apta comburi, \& ita. vin conferre diciturnon minus, quam putrefactio: ego vero E alias demonftraui, vanum effe in iis, qux exmateria \& formaconftant, aliquıem motum vocare naturalem, ratione folius materiz tanquam principij paffus; fic enim fieret, vt nullus motus efiet violentus; materia enim habet aptitu。 dinem vit ad omnes formas, ita ad omnes motusindiftincte recipiendos; quaremotum lapi-. disfurfim proiectiliceret appellare riaturalem. ratione materix vt principij pafiui, hoctamen. nemo diceret. Ipfe autem Pomponatius in fua dubitatione 17. libri quarti Meteorolog. inquit $t$ putrefactionemefietum naturalem, tum violentam: quatenus quidem fit à principio externo, violentam efre; naturalem vero, quatenus miftum, fi fir naturadimit tatur, neque impediatur, hoceft, à nullo alio violenterinterimatur, fed finaturinterire fecundum communem curfum naturx, tandem interit per putredinem. Hanc lententian quidam recentiors impuconatse 
gnant, \& eam ctiam Buccaferreo attribaunt, quum tamen Buccaferreus (vt prodiximus) aliud fenfiffe videatur; ita autem argumentantur: quando dicitur miftum interire fux natura relictura, vel dicieur interire absque externo agente, vel ab externo agente, fi primum, id Ariftot. aduerfatur, dicenti putredinem fieri à calore externo; fi vero fecundum, nulla a p paret ratio, cur magis putredo, quam combuftio, fit interitus naturalis, quum tiat vtraque ab agente externo. Hxc tamen obiectio mihi videtur aduerfus $B$ Pomponatium, qui reucra huius fententix fuit, parui effemomenti : fiquidem ipfe palam afferit, non accipi hic naturale proeo, quod fit ab interno principio, fic enim fatetur putrefactionem non effe naturalem, fed violentam; fed accipipro eo, quod cft fecundum curfum narurz, nan hic talis eft, vt mifta dimifra fux natura intereant tandem per putredinem, non per combuftionem : fic enim putrefactio ad differentiam combuftionis videtur dici poffe naturalis. Sed praterea opinio, quam poftea iftimet recentiores adducunt, atque tuentur, mihi quidem non videtur ab hac Pomponatij opinione difcrepare : dicunt enim purrefactionem effe mifto naturalem, quatenus eit fecundum propiam mifti naturam, qua miftum eft; quum enim fit genitum per vnionem humidi cum ficco, aptum natura eft perire per diffolutionem, \& feparationem humidià ficco ob defectum c2loris continentis; vnumquodque enim natura- D liter diffoluitur in illa, ex quorum compofitione genitum eft: quoniam igitur miftum, quatenus eft mifum propenfionem habet, vt in ea, è qui. bus confat, diffoluatur, putrefactio eft ipfi naturalis, quatenus miftum eft : non fic combuftio, quia miftum prout eft miftum, non habet propenfionem vt intereat per conuerfionem in aliam naturam:addunt autem $h i$, poffe purrefaetionem alia ratione dici violentam, \& prxter naturam, quarenus rei naturam deftruit, nec fit fecundum intentionem naturz, quandoquidem cuiusque rei natura ab horret à fuo intericu. Egovero non video, in quo hac fententia differatab opinione Pomponatij : nam dicere putrefactionem competere mifto fecundum propriam eiusnaturam, \& prout miftum eft, idem videt ur, $x$ c dicere miftum dimiffum fux nat ura, non interire, nifi per putrédinem, \& ambo concedunt interitum hunc mifti ea ratione effe violentum, quatenus fit ab externo principio. Propterea ego puto vtramque fententiam effe obnoxiam cidem reprehenfioni : nam ad oftendendum quod putrefactio fit interitus naturalis, refpexerunt ambo propriam mifti naturam, iuxta quam confideracionem non poteft putrefatio dici mitto naturalis; quia fi per naturam intelligant materiam principiun motus paf- fiuum, in featentiam incidunt, quam amboreprobarunt, quod putrefactio ratione aptitudinis materix dicatur naturalis; fi vero formam intelligant, iamambo exprefre conferfi funt, putrefactionem effecontrariam, \& inimicam form z mifti, \& ipfius deftructricem; cft igitur po. tius contra mifti naturam, quam fecundum eius naturam : propereafallum eftid, quod illirecentiores dicunt, miftu habere naturalem propenfionem ad putredinem, imo vero propenfionem haber adie confertandum, quantum fieri poteft: quod vero $P$ om ponatius ait, miftum dimiffum lua natura non aliter, quam per putrediszem interire, idnon facit vt fecundum propriam naturam quarat putrefcere, fed folum fignificat eam efle eius naturam, qua nonpoffit tandem refiftere agenti externo putrefacienti; negari enim nullo modopoteft refiftentia mifti ad externum interimens : fic igiturnon videtur putrefactio effe milto naturalis.

\section{c}

$$
\begin{gathered}
\text { Verasententia, or eius declaratio, orquo- } \\
\text { rundam dubiorum Solutio. } \\
\text { Cap. } 1 \mathrm{~V} .
\end{gathered}
$$

D Ropter hac omnia, qua hactenus confideratafunt, ego puto non effe hic refpiciendam propriam noifti naturam, fed potius natu- Niture ram vniuerfalem, qua nilaliud eft, quam ordobniserrerum omnium, feu omnium caufarum certo falis. quodam ordine difpofitarum cum pendentia ab vno primo principio, vnde ftatuta fingulis rebus funt propria quadam leges, qux prateriri nequeunt; natura igitur propria mifti nollet putrefcere, nee modo vllo interire, at natura vniuerfalis itatuit eam effe interitui obnoxiam, \& tandem interire : fecundum hanc confiderationem dixit Ariftotel in initio r. lib. de Ortu \& interitu, interitum effe natural cm, id eft, fecundumleges naturz vniuerfalis, qua ftacuit omne E genitumeflealiquando interiturum : fed in context.3. lib.4. Meteorolog. confíleratio Arift. eft parricularior, quara ibijnam in initior. de Generat. etiam combuftio mifti dicitur interitus naturalis, quatenus eft rei corruptibilis, \& fit à caufa naturali, \& naturaliter agente. Sed quoniam prateripfum interitu natura ftatuit etiam modum, quo fingula res intereant, ideo hunc modum à natura conftitutum refpiciens Ariftot. in 4 Meteorolog. dixit combuftionea elfe interiF tum violentum, qux in principiolib. r. de Generat. dicebatur naturalis, quum ibi nulla modi confideratio habeatur. Tres autem ego inuenio Tribso modos vniuerfales, quibus ftatutum eff in natu-modseres ra res interire; vnus fimplicium corporum eft, 2 -en;erire lius miforum animateru, alius demum mifto natura rum inanimatorum. Simplicibus quidem hicformt. affignatus eft modus, vt per noutuaninterfea- 
ationem \& pafronem intereat, atque etiam per ationem coleftium corporum, quxidem poteft pervirtutem, quod elementa perform am. Animatis veroaffignatus eft modus per humidi naturalis confumprionem, factam à proprio naturali cslore, eaque mors dicitur, de qua agit $\mathbf{A}$ riftotel. in lib. de Vita \& morte; ideo ibi natura. lem vocat illam morten, qux fit pervltimam humidirefolutionem à calore naturali, qui ab. fumpto à fe humido tandem extinguitur; violentam vero mortem vocat illam, qua anteftatut:um tempus alio modo fiat, vt gladio, combuitione, fubmerfione, morbis, nam his omnibusmodis intereunt animantia prater naturam, hoceft, prater modum à natura eis conftitutum. Mifto a utem inanimato, id eft, prout miftum eft, \& cum abitraktione ab anima; fi fit animatum, afignatus eft à natura vniuerf́li proprius modus vt intereat perputredinem, qua nihilaliud eft, quam diffolutio in elementa; \& eft vere contraria generationi mifti, qux fit per elementorum commiftionem : his ergo vocarurab Ariftotel. modus naturalis, quia fecun. dum decretanatur $x$ vniuerfal is eft vt miftum ex elementis conftars, tandem in elementa diffoluatur; combuftio vero dicitur violenta, quia eft prater hancnatura legem, nam exignis actione violenta vertuntur omnia elementa in ignem, ideo ita eft miftio prater naturam, vtanimato. mors ex morbo, velex gladio: hæc eft abfq; dubio mens Ariftotel. in eo tertio contextu $4 . \mathrm{Me}$ teorolog. vt etiam ipfemer afferere videtur in context. 57. lib. 5. Phyfic. vbitam generationem, quam corruptionem diftinguit in naturalem \& violentam, \& inquit oppofitam effenaturalem generacionem violenta, \& naturalem interitum interitui violento; pofteadeclarans quxnam fit generatio \& corruptio naturalis, \& qua violenta,inquit naturalem effe illam, qua eft fatalis, id eft, fato determinata: nil enim aliudperfatum poteft intelligere, nifilegem à natura vniuerfali conftitutam de modo, quo quxlibet res genere-

Zompona เ̈̈ Erecentiorumfer. tentia ad ractü fenfum trabstur tur \& intèreat. Sententiam hanc Pompona. tius, \& recentiores illi fub nube viderunt, \& proximead veritatem acceffiffe videntü, quam etiam plene effent affequati, finaturam particularem ab vniuerfali, quam Ariftoteles in memora to loco refpexit, feiunxiffent; non enim dixit putrefationem effe fecundum mifti na. turam, fed fecundum naturam abfolute, nem. pe fecundum leges natura vniuerfalis: \& hanc proprie fignificat id, quod Pomponatius dixit, fecundum curfum nature, nempe yniuerfalis, feu etiam dicamus natura particularis, quatenus fubdita eft legi nature vniuerfalis, à qua mi. ftum, quatenus miftum eff, dirigirurad determinandum furm effe per diffolurionen in elegrenta, qua putrefadio disisur; Los ctiasa fi-
A gnificare poreft illa, quam recentioìs illi dixerunt, mifti, prout miftum eft, naturalis properfio ad putredinem; nonenim à propria natura dirigiturad putrefcendura, fed à conftiturione naturz vniuerfalis, quæ $\mathrm{tal} \mathrm{em}$ effe cius interitum ftatuit. Hanc puto effe rei veritatem, qua clarior fiet, fi quxdam aduerfus eam dubia foluerimus: quum enim plura ab interpretibus $\mathrm{A}$ riftotel. tanganturin 4 . Meteorolog. nobis pauca magis pracipua confiderare fatis erit. Dubi-

B tatur autemaduerfus id, quad dictum eft, putredinem effe interitum naturalem : fi enim putrefactio effet naturalis interitus mifti, quatenus miftum eft, deberet omnimifto competere; id enim quodalicui naturaleatque effentiale eft, omni competit, neque id negauit Ariftotel. in memoratoloco, quum aperte dixerit, putrefaetionem effe maxime commune contrarium generationis mifti, eft enim maxime cominu. nis, quia competiromni milto, quum ei sonpetat, quatenus miftum eft: attamennonvidetur effe omnium miftorum communis in:e1:tus, quod multifariam oftendipoteft. Primum $x$. quidem in climatibus extremis, qux calicilima \& frigidifima funt, non per putredinem in. tereunt mifta; fed in calidiffim is locis per combuftionem, idque eft illis locis naturale ; in frigidiffumis vero deftruunturà frigore, à quo ertiam prohibentur putrefcere, idque frmiliter eft illis locis natusale: non omnia ergo mifta per D putrefationem intereunt. Praterea metalla, 2. \& lapides compluresnunquam putrefcunt, vt aurum, \& argentum \& lapis adamas, \& alia:non eft igitur putrefactiomiftis fecundum naturam, quum non fit omnium miftorum communis interitus. Adhrc, \&alia eiufmodi fumenda eft refponfio ex Ariftotel.in loco pradicto: non pr enim dixit putrefactionem effe interitum maxime communem, quod voluerit effe neceffasium vt omnia mifta intereant per putredinem, I iam enim confefius eft aliqua per combuftionem interire, fed fignificare folum voluit omnia effe putrefcibilia, imo \& aliquando putrefcere, femota tamen omni violentia; nam fi praccupent interire violenter, non perucniuntad naturalem fux durationis finem, qui eft eis à natura vniuerfali conftitutus. Adillud ergo quod de locis calidiffimis \& frigidiflimis obiiciebatur, dicımus negari non poffe mifta à fummo calore, dà fummo frigore pervioF lentiam interimi, fed negandum etiam non eft illa eadem miffa effe putrefcibilia \& per putredinem effe tandem interizura, fiomnis violentia amoucatur, \& dimirtantur propriz natura : quod vero dicitur effe illis locis naturale $v t$ perfumnum calorem, vel perfummum frigus, res interimant, verum id quide $m$ eft, fed ita vt etiam igni naturale eft comb urere : quare fic- 
uti combuftio eft ea ratione naturalis, quatenus fit à caufa naturaliter agente, neque ob id fit, quin dicatur alia ratione effe mifto interitus violentus, quatenus non eft fecundum legem naturæe vniuerfalis; ita dicendum eft deillis, qux in locis calidifimis \& frigidifimis intereunt alio modo, quam per putredinem;etenim patiuntur quidem à caufis naturalibus, fed non inter eunt eo modo, quo natura ftatuit vniuerfaliter mifta effe apta interire, fcilicet per diffolutionem in el ementa; quanquam hoc naturx decrecum recipit impedimentum ob aliquam violentiam preoccupantem mifti interitum, ficuti etiam Ariftoteles dixit. Ad illud vero, quod de metallis, ac de lapidibus dicebatur, refpondemus \& aurum, \& argentum, \& adamantem, \& metalla omnia, \& omneslapides tandem neceffario putrefcere, \& in elementa diffolui, liceţ aliqua diutiffime durent: nifi enim aurum putrefceret, iam tanta effet auri copia congregata, vt omnia fere in a urum mutata effent, ip fum que vilis admodum effet pretii:putrefcereauten metalla cognofcimus ex ærugine, quam emittunt, eaq: in ferrocuidens eft, fed in alis quoque notari poteft; nam antiquum aurum, \& argentum cernitur coloratum colore obfcuriore, quam recens; fic de lapidibus omnibus dicendum eft; quarnuis enim diutiffime, \& multa quoq; annorum millia perdurent, tamen neceffario tandem per putredinem in elementa diffoluuntur. Sed clarior habébitur omnium huiufmodi dubiorum folutio, quando putredinis natura exactius declarata à nobis erit.'

\section{Definitio putredinis, ơ definitionis de- claratio. Cap. $V$.}

$\mathrm{TX}$ his, qua hactenus dieta funt, talem puEtredinis definitionem cum Ariftotele colligere poffumus, putredo eft corruptio proprii \& naturalis caloris in vnoquoqua humido à caloreambientis; quam effe perfętam, \& omnibus numeris abfolutam definitionem, ex eius, ac fingularum partium plena intelligentia manire feftum fiet, eft enim integra definitio, qua dicist turdemonftratio pofitu terminoruma differens: quod quidemaliâs in operibus logicis ruditer, vt ibi conueniens erat, declarauimus, dum hane definitioné vt perfect definitionis exemplum in medium adduximus; nunc vero eam xquifitius confiderare oportet. Quum igitur perfecta accidentis definitio tribus partibus conftare debeat, genere accidentis, fubiecto, \& cau$\mathrm{fa}_{\mathrm{a}}$ qui tres potifim $x$ demonftrationis termini funt, diximus fumi hic proprii caloris corruptionem, tanquam genus putredinis, quod eft in demonftratione maius extremum; deinde humidurn vt fubiectum proprium, quianon eft
A putrefcibile,nifid, quod eft humidum; tandem vero externum ambientis calorem tanquam caufam, qux eft in demonftratione medius terminus : fed vr hac omnia diftinctius explicétur. \& ipfa putredinis effentia ab effectrice cius caufa feiungatur, cognofere oportet in putredine ordinem à natura feruatum. Primum quidem locum calori externo tribuendum effe certum eft, ab hocenim corrumpitur calor mifti proprius, \& naturalis, corruptio autem caloris facit ve B humidum feparetur à ficco; itaque dicendum videtur, ipfam putredinis effentiam in hoc vltimoeffe conftitutam, reliqua vero effe caufas purredinis, ita vt effentialiter nil aliud effe putredo videatur, quam feparatio humidi à ficco, è quibus tanquam materia miftum conftabat, hxc enim eft in eleméta diffolutio, qux eft contraria generationi mifti : corruptio autem caloris naturalis eft potius caufa effectrix putredinis, quam effentia : quemadmodum enim in geC neratione mifti dux actiux qualitates funguntur officio agentis, quia calor à frigore contemperatus commifcet, vnit, ac terminat ficcum \& humidum coniuncta, ve antea in definitione generationis oftendimus, ita dicendum eft in interitu mifti, defetum caloris effe caufam putredinis effe atricem, non putredinem ip fam: fed quoniam eft caufa priuatiua, in qua animus non acquiefcit, propterea quod om nis priuatio caufamaliquam habet, proinde omnis caufa priuatiua habet caufam pofitiuam priorem, à qua pendet ; Ariftoteles hac non contentus exprimerevoluit etiam caufam pofitiuam externam, à qua fit proprij caloris corruptio, eaque eft calor ambientis; \& res per fe manifefta eft : quamuis enim certum fit, corruptionem proprij caloriseffe caufam vt humidum diffluat, \& à ficcoleparetur; tamen in hac caufa non quiefcimus, dumignoramus caufam pofitiuam, à qua fit b ec proprij caloris corruptio: attamen AriE ftot. non fine artificio in hac definitione fumpfitcorruptionem proprij caloris tanquam putredinis genus, qùo eius effentia fignificaretur; duo naniquerefpexiffe videtur, vnum vtbreuiffima effet definitio, alterum vt tribus tantū terminis conitaret, ficut etiam demonftratio: nam fi quatuor in ea terminos accepiffet, dubitare poteramus, an forte hec definitionon effet demonftratio fitu terminorum differens, quemadmodum in Pofterioribus Analyticis iam ip.e F docuerat: nam fi \& fubiectum in hac definitione expreffum fuiffet, quod eft corpus humidum, \&effentia, qux eft feparatio humidià ficco, \& caufa, qux eft proprij caloris corruptio, \& caufa cauf $x$, qux eft calor ambientis, quatu or termini in ea fumpti effent; qu ood vitare volens Arift. \& definitionem redder ebreuiorê, yno termino duos cōplexus eft; nam feparationem hü-

$$
V^{4} \text { midi }
$$


midià ficco, qua putredinis effentia eft, fub proprii caloris corruptione implicite comprebendit; hanc enim neceffario infequitur feparatio humidi à ficco; vt paulo antea Ariftoteles docuerat: dixerat enim putredinem effe humidi \& ficci feparationē prouenientem à corruptione propiii caloris fata à cótinente: \& hoc idem etiam poft allatam definitionem declarat illis verbis [exesnte ensm proprio calicto, cossaporat grodfecandum nesurum est humidum] fic enim monere nos voluit, corruptionem proprii caloris in definitione fumptaras effe, quatenus continetfeparationem humidià ficco: igitur proprii caloris corruptio denosat quidem per fe caufam proximam putredinis priuatiuan, fed connotat etiam eflentiam, quatenus complectitur humidi à ficco feparationem, qua ex neceflitate eam infequitur; \& $A$ riftot. hanc in definitiore accipere maluit vt effectum, quam vt caufam, quia caufam habet priorem pofitiuam, \& in detinitione exprefiam, cuius refpectu eft effectus, non caufa: itaq; hrec definitio tres partes habuit; corpus humidum tanquam fubiectum putredinis; corruptionem proprii caloris tanquam putredinis effentiam, \& tanquam effeftun, talem autem effectum, in quo includi intelligitur feparatıo humidi à ficcotanquam effectus alius pofterior, \& illum priorem neceffario infequens; as demum calorem externum tanquam caufam primam: eft igitur hæc perfecta definitio, \& demonftratio folo fitu diffe- D rens, quales oro nium accidentium perfectze definitiones effe debent.

\section{opinio recentiorum, quod pradicta putre- dinis definitio fit cartalis; or ciuscon- futatio. Cap. VI.}

TOn eft hic pratereundus quorundam reopinı Ncentiorum error, qui dizerunt. definitiorecersio- nem hanc totam effe caufalem, cuiufrodi eft $\mathrm{E}$ rum. illa, eclipfis eft obieftio terra, qua non exprimit effentiam rei, fed folam caufarm; licet in caloris naturalis corruptione concefferint includi feparationem humidi à ficco: negârunt enim effentiam putredinis effe ficci \& humidi feparationem, fed hanc quoq; effe putredinis caufam dixerunt; effentiam vero nulláa aliam efle, quam interitum form $x$ mifti, qui humidi à ficco feparationem infequitur tanquam caufam, ita vt calor ambientis fit caufa corruptionis proprii caloris, \& hac fit caufa feparationis bumidi à ficco, \& hxctandem fit caufa deftructionis forma mifti, qua eft formaliter putredo: quoniam igiturhuius deftructionis forma Ariftot. nullammentionen fecit, hinc collegerunt non effe definitionem formalem, fed cauralem, tradiram pertres illas ordinatas putredinis caufas.
A Sed hanc fententiam ego probare non pofím: quod enim caloris preprii corruptio fit caura putredinis, \& in fecontineat feparationem bumidi à ficco, nos quog; afferimus : proiudenon negamus caufalem efle definitionem, quantum attinet ad folum propriicaloris interitu : at humidi \& ficci feparationem puto non effe putrediniscaufam, fed effe ipfammet putrefactonis effentiam, \& deftructionem formz mitti : quod facile oftendo argumento fumpto à generatio. $B$ ne oppofita: nam fi generatio miftinil aliud eft, quam vnio, as terminatio humidi cum ficco, operantibus actiuis; ergo eiufdem mifi inceritus nil aliud erit, quam humidi ac ficci diffolutio, ex defectu actiuarum non valentium amplius imperare paffiuis: \& videtur cuilibet contideranti effe manifeftum, nilaliud effe mifti interitum, quatenus miftum eft, nifi eius in elementa diffolutionem. Sed foluenda eft dificulcas, \& quidem non parts momenti, qux hos mouiffe viderur:nam interitas mifti debet efle tubita,ac momentanea forma mifti deftructio, ficuti ctiam generatio mifti eft introductio forma mifti in momento temporis, nun in tempore facta; atqui feparatio humidi à ficco non in momento fit, fed in tempore, \& eft contirsia, vel faltem fuccefiua; exgo hac non puteft cife formaliteripfe miftn intericus. Solnutur mec iudicio hac difficultas fíc: generatio dusliciter acci pi pōt; vno modo pro vleiceo terrino, qui eft forma fubftantialis introductio fubita:altero modopro viá fizal cü termino, qữ nó eft momentanea, fed in tempore fit : his etiam eildem modis interitus aguoq; fumi poteftattamen propre \& generatio \& interitus pro folo termino fumitur, liceteriam fxpe fumatur pro termino củ tota præuia alteratione: fed nomen putrefactionis vicietur propriefignificare prauiam alterationé tendenté ad interitum fubftantix, \& ad diffolutioné miftijtuncenim rë putrefcere dicimus, quando eft in via ad perfectan diffol utionem, llon quando eft $f a \varepsilon z a$ diffolutio perfecta: quiodecianz Galen. fignificauit lib. n. Meth. c. 8. putredinem fic definiens; putredo eft mutatio ad interitum totius fubitantix putrefcentis ab. aliena caliditate;non enim dixiteffe totius fubftantiz interitum, fed mutationem ad fubftantia interitum. Quoniam igitur.purrefactio eft feparatio humidia ficco, qua non eft fubita, fed cum fucceflione fit; dicendum eft nen interire in primo esus. initio formam fubftantialem, fed eoufq; eam feparationem pracedere, vt tandem forma mifti momento iemporis deftriatur: neque eriam dicendum eft, deftructionem form $a$ mifti fieri folum poft totius huniidi feparationem à ficco. fed corrumpitur forma mi fri anteq̨:am remaneat terra, \& fimus: bec initur tria quodam temporis ordine fiunt; primum incipit fepara.

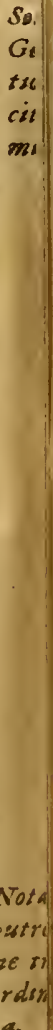


feperatio fieri humidià ficto, qux tamen adhuc eft $a$ bsque forma fubitantialis interitu, fedeft proparatio \& via ad eam; fecundo loco tanta eft facta diffolutio, ac feparatio humidi, vt forma, quum feruari amplius non pollit, fubito deftulatur, \& tunc feparata quidem funt inuicem humidum \& ficcum; quia non habent anplius illam miftionem, qua natura vnio dicitur, fed particula tamen verius q; fe mutuo tangunt, \& eif humidum aqueum contiguum ficut terreo, \& iuxt a pofitio quidem particularum, at non miftio, quia iam foluta eft naturæ vnio; tertio demum loco humidum illud à calore confumitur, hoc eft, vertitur in vaporem, \& exhalatur, ita vt nihil reliquum fit, nifi fimus ac terra, ve Ariftot.ait: qui non ideo hoc dicit, quod putetper hoc expriminaturam putrefactionis, fed vt per hoc tanquam yltimum remanés poft putrefactionem, \& ea pofterius tempore, cogno. famus putrefactionem effe feparationem humidi à ficco; quoniam videmus putrefcentia in hoc tandem definere ve remaneatterra, \& materia quxdam ficca, quum humor iam fecretus fit, \& in vaporem conuerfus euanuerit. Dicimus igitur putrefaetionem ab Arift. definirinon pro folo termino, fed vt viam quoque pracedentem complectitur; fic etiam eft formaliter feparatio humidi à ficco, qux in tempore fit : idq; A riftot.: fignificauit dicens proprij caloris corruptionē; calor enim eft qualitas, nec corrumpitur, feu euocatur, nifi in tempore, nec in prima eius imminutione interit forma miftifed poftquam to-' ta latitudo, intra cuius terminos forma mifti feruaripoteft, deftructa eft, tunc fubito interit forma mifti. Dignum autem confideratione eft; cur A riftot. in ea definitione ip fum mifti interitum non exprefierit, quũ tamen putredo fit mifti interitus quatenus miftum eft; fed hoc poftea quum de putredin is f peciebus agemus, confiderabimus, \& magno cú artificio ab Ariftot. factum effe oftendemus. Patet igitur, prædietam putredinis definitionem nó ef̂e mere caufalem, qualis eft illa, eclipfis eft obiectin terrx; fed effe definitionemperfectam, qua \& caulalem \& formalem continet; fic enim eft demonftratio pofitu differens, at fecundum illos effet folum medium, quod minime dicendum eft.

\section{Quednam fit ambiens, cuius calor eft caufa putredinis. Cap. VII.}

I Actenus itructuram definitionis putredinis $F$ 1 \& Arifot. in ea afferenda artificium confiderauimus, fequitur vt fingulas eius partes ordinatim expendarnus. A prima igitur caufa or. diendo, quam Arift a mbientis calorem effe ait. cognofendum eft quodnam fit intelligendum: ambiens, quod ruo calore sorpora putrefacito. Sunt qui dicant, haucnon effe aliud, quam ac-
A rem \& aquam, \&argumentum fumunt exipfo $\sigma^{2}$ arg Anftot. in eadens tractatione de putredine, vbi mantum. hactantum duo ambientia nominat. Hxctamé Confutafententia falfa eft, \& melius eft, vt communi in- sio. torpretum opinioni ad hreamus, qui dicũt ambicns effe vniuerfeintelligendum, vt conpleOtarur on ne continens, à quo res putrefieri poffit, iam enim dixerat Arıft. tria elema éta effe materiano igni ad putredinem faciendam; ergo vult etiam calorem ignis effe poffe caufam putrediB nisalioruan elemétorum: fic fi fanguis, vel alius Qwomohumor putrefcat in venis, ambiens putrefaciens do m ans non eftaer, aut aqua, fed eft circumitäs caro, feu malibses parsalia folidior, q:iz calore extranco, \& mo- humores dum excedenteaffecta, efficit in humoribus pu-putretredinen tanquam caufa quadam externa, qux fant. naturalem humorem calorem educit, \& ita putredinem efficit:fic quando exobftructione, vel prohibita tranfpiratione fitin animalium corporibus putredo, vapores ab humoribus exhalati, C quum difflarinon pofint, ibimanentes calefaciunthumores, acputrefaciunr tanquam externa quadam caufa; ob eandem enim rationem fit etiam lactaminis putrefactio multo facilior, atq;celerior, fi latamen in aceruum congrega tur,propterea quod vapores intrinfecus exhalati, quu m nequeant difflari, funguntur officio externicalidiputrefacientis. Argumentum autem Argume illorum nullius roboris eft: Ariftot.enim in illa t\& foluparte exempli tantum gratia nominat aerem, $\& 5$

aquam, non quod hac fola nomine ambientis comprehenfa effe volucrit, ita vt catera omnia excluferit : curautem hac potius nominauerit, quamalia, non absque ratione íd factum eft; ibi namqi; Arift. pluribus fignis cam putredinis definitionem confirmat, quæ ó mnia fumuntur $a b$. iis, qux in aere, \& in aqua putrefcunt, tanquarm à anifeftioribus : figna enim non dicuntur nifi illa, qua manıfefta funt; à putredine autem humorum in corpore animalis nullum fignum E accipi potuit, propterea quodilla, quz in animalium corporibus accidunt, occulta funt: non eftigitur mirum, fi A rift. ibi nominet folum aerem \& aquam, dum varia figna defumit ab illis. rebus, quz in his duobus elementis manifefte ob. corporis ambientis calorem putrefcunt.

\section{Qusomodo putredo tum à calore alieno, tum a proprio frigore fieridicatur. Cap.VIII.}

Ed al ia nobis de putredinis caura maior diffiSiultas proponitur:quum enim A riftot ftatim poft allatam putredinis definitionem dixerit à duabus fimul caufis putredinem fieri, à calore alieno, \& frigore proprio, confiderädum eft, quomodohocintelligeredebeasus.. Plures.recen- Recentiores idita intelligunt: calor a mbientis incipit tiorum 


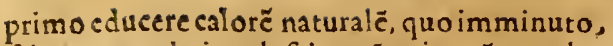
frigus naturale inualefcit;quũ enim nŏ extrahaturfrigus, fed folus calor, frigus feruat propriü gradum, calor autem imminuitur; ergo proprium frigus inualefcit fupra calorem proprium ipfius mifti, \& incipir ipfum excellere, aduuans in hoc calorem externum vtaltera caufa pofitiua: quare euaporatio caloris naturalis duas habet caufas potitiuas, calorem externum euocantem, \& internam frigiditatem expellentem, tametfi origine \& tempore prior cit calor externus, qui primo incipit calorent naturalem educere, \& facit vt internum frigus incipiat inualefcere. Ex hoc praterea eorum aliqui colligunt non effe cam, quam diximus, perfectam definitionem, \& in hoc omnes decipi; fed abfolui poftea ab Ariftotele definitioné, quando adiicit etiam frigus proprium tanquam alteram putredinis caufam; ctenim in definitione perfecta debuit vtraque caufa no. minari, \& frigus proprium, \& calor alienus. Confusa- Egovero hxcomnia falfa effe exiftimo. Er pritio. mum quidem id, quod de frigore dicunt, nequerationi,nequeAriftoteli confentaneum eft: exiftente enim ad huc mifto, \& nondum corrupto, vna eft cius natura, \& vna temperies; quarenon funt ibicalor \& frigus tanquam dux diftinctx qualitates, fed eft vna qualitas media, qua aliquibus gradibus calorem redolet, $\&$ aliquibus frigus, caque dum gradus caloris euoca.xur, magis ac magis tendit ad frigus, donec taidem miftum intereat; non eft igiturverum illud, quod dicunt, frigus feruare proprium gradum; quum enim ex priuationecaloris frigus neceffario oriatur, neceffe eft vt cum caloris imminutione fiat incrementum frigoris: quocirca non recte dicitur eundem effe frigoris gradum immutabilem, quiimminuto caloreidem feruetur. Sed maxime falfumillud eft, quod dicunt, gradus frigoris agerein gradus ealoris ad eos expellendos : nam exiftente adhuc vnione non poteft frigidi in calidum actio fieri, quum adhuc fir vna tantum qualitas media, qua imsautacur continue, \& fit magis vergens ad frigidiu, necab vlla alia actione, nifi caloris externi euocantis calorem naturalem:quo fit, vt quum, calor temperatus à frigore terminet, atque continear humidum iunctum ficco, idem calor debilitatus reddatur impotens ad continendum; proinde humidum diffluat, \& feparetur à ficco. Praterea primaria operatio frigoris eft refrigerare, ergo internum frigus mon potef pofitiue agendo pollere calorem, nifi refrigerando: ergoidem corpus refrigerabit feipfum, quod di-

Fera fen cerc vanim eít. Frigus igitur proprium non tensia. poreft efie caurapofiusua, yuz calorem expellat, fed eft caufa priuatiua, \& mera priuatio caloris producta à calore ambientis, qux non
A agit in calorem, fed in humidum tanquam cau. fa priuatiua; corpus enim ex defectu caloris eft frigidum: quare non poteft amplius ab ea qua. litate nimis ad frigus vergente contineri humidum, ne diffluat, \& à ficco feparetur. Hoc fignificauit A tiftoteles, quando poftallatam definitionem fubiunxit [quare quonsam ob indigentiam patisur calidx, isdrgens ast em tali Girtute frigidum amme] confiderandum enim eft, quodnam dicat Ariftoteles effe patiens, \& hoc quid-

B nam patiatur: certe miftum eftid, quod patitur, patitur autem putrefationem, \& hancnon po. teft intelligere Ariftot. effc proprii caloris corruptionem, fic enim afignaret idem vt caufam fuipfius; quia fenfus elfet, patitur corruptionem caloris ob indigentiam caloris : fed neceffario intelligit ficci \& humidi diffolutionê, qua eft putredo formaliter accepta ; ex quo polfumus intelligere hanc in illa definitione neceffario contineri, quum ex eanunc ab Ariftot.hoc deducatur: fenfus ergo illorum verborum eft, quare quoniam miftum patitur diffolutionem humidi \& ficci propter priuationem proprii caloris, omne autem calore priuatum frigidum eft, a mbx vique erunecaufe purredinis, \& frigus proprium, \& calor alienus : non igitur dicit frigus proprium effe caufam refpectu corruptionis proprii caloris, fed refpectu feparationis humidi, \& caufam quidem priuatiuam, quia pro eodem hic fumit frigus proprium, \& propriicaloris priuationem, \& ex priuatione caloris infert frigus proprium, tanquanı declarans vnam \& eandem caulam priuatiuam prodeun. tem à caufa externa pofitiua, quæeft calor ambientis: inquit enim [indigens calore frigidum omze] nondicit, indiget calore propter frigus expellens, fed dicit, ea ratione dicitur frigıdum; quatenus eft calore priuatum: \& reete inquit [indigens] defeetum indicans non cuiufuis caToris, fed proprii \& naturalis; fic enim mittum fit indigens tanquam re fua, qua eft priuatum: patet igitur Ariftot. nullam tribuere frigido ationem refpectu caloris, fed folum refpectu feparationis humidi, quum dicat, patitur ob defectum calidi, hoc autem eft frigidum, ita vt eadem putredinis caufa priuatiua lignificerur per frigidum, ac per defeetum propriicaloris, cuilus caufa caufa prior eft calor ambientis. Ex his colligimus, falfum etiam effe id, quod corumaliqui dicunt non effe completam putredinis definitionem, nifi addatur altera caufa, qux eft frigus proprium : nos enim dicimus definitionem, quam declarauimus, effe perfeetam, \& in ea comprehèdi frigus proprium tanquam caufam priuatiuam, qux eft effectus caufx primarix; nam dicerecorruptionem propriicaloris, eft dicere incrementum frigoris; quare nulla amplius additione opus eft, lied potius declaratione, 


\section{9}

de Mifti Generat. \& Interitu, Lib. I I. tione; illudenim, quod ab Ariftotel. poiftea de frigorefubiungitur, nilaliud eft, quan declara. tio, qua fignificatur contineri frigus in ez definitione vt caufam putredinis; locením colligit Ariftoteles exea hoc padto; omne priuatum calore eft neceffario frigidum, ergo fi priuatio caloris efficit putredinen, frigus efficit putredinem;primaria tamen caufa eft calor ambientis, fecundaria vero frigusproprium, id eft defectus proprij caloris: fignificat hoc dictio illa illatiua [quare] qua indicat Aritoteles fe non addere alıquid noui praterilla, qux in definitione funt pofita,fed ex illa inferrealiquid, quod in ea continebaturvirtute : quicquidautem ex aliqua definitione neceffario colligitur, id non poteft effe illius definitionis pars aliis partibus adic \&t , fed vel eft carundem declaratio, vel proprietas confequens : ideo verbailla [E putrefactio communis affectio frygoris proprÿy, ES caloris alsens] fenfum habent caufalem; non enim fignificant putredinem effe affectionem calıdi \& frigidi vt fubiectorum, fed vi caufarum, à quibus efficitur. ficut ctiam in libris de anima fape Arift. dicit affectiones anima, id eft, qux producuntur ab znima : ficigitur patet proprium frigus non addi ab Ariftot. vt alteram caufam corruptionis caloris, vtilli exiftimarunt, fed vt declarationema ipfiusmet priuationis caloris; Ariftot.enim fic exprefe ex definitione colligitid, quod implicite folum in ea continebatur.

\section{Quiomodo calor extraneus in calorem natu- ralem agere, of corrumpere ipfum dicatur. Cap.IX.}

Q Voniam autem dictum à nobis eft, corruptionem proprij caloris ita effe intelligenaum, vt etiam propriihumidi feparationem complectatur, eamqueà calore ambientis fieri; confideratione dignum eft, an calor externusagat prius in calorem naturalem, \& ipfum educat, deinde eductionem caloris eductio humidi confequatur, an è contrario prius agat in himidum, deinde per quandan neceffariam confequutionem calor quoque naturalis vna cum humido exh letur : nec foluitur dubium dicendo educi fimul vtrumque, adhuc enim difficultzs manet, vtrius eductio fit fecundum naturam - prior. Sunt qui dicant, calorem externum non midum, hocmotiargumento; quod nonagit fimile in fimile, neque corrumpitur fimile à fimili,quarenon poteft immediate calor in calorem agere, fed prius agit in humidum, deinde huius $m$ eductionem infequitur caloris quoq; naturalis eductio. Alij.verv öicunt, à calore externo educi prius calorem naturalem, deinde confequi vt et-
$A$ iam humidum educatur; qua communior, ac verior fentētia cft, \& tum $A$ rift.teftimonio, tum ratione comprobatur. Arift. eni m poftea codem in locodicit [exeunte exim proprio culido coeunporat quod fecundü nuturam est bumidum] vult igitur exitum proprij caloris priorem effe faltera natura, deindeper quandam confequutionem humiduin quoque naturale exire, \& euaporare. Adeft etiamratio; quia non eft neceffarium ve amoto effectu amoueaturcaufa, eft tamenne$B$ ceffarium, yt amota caufa amoueatur effectus, pendet enim effectus ex caufa, non caufa ex effectu; arqui calor naturalis in mifto eft caufa coniunctionis humidicum ficco, vt Arift. dixit, ergo neceffe eft vt exitum caloris naturalis infequatur feparatio humidi à ficco, non fic neceffarium elt vt exitum humidi infequatur exitus caJoris naturalis ; in multis enim videmuscontingere, vt fi exiccentur à putredine proferuentur. \& diutius durent: cur igitur calor euaporet, now C pótve caufaafrignari euaporatio humidi; quia neq; eft caufa, neq; hanc neceffario caloris euaporatio confequeretur. Hancigitur \& calidi, \&e humidi eductionem ita intelligere debemus, vt prius tollatur cau\{a, deinde vero effeetus, \& caloris eduetionem eductio humidi confequatur. Ob id antea diximus, nullam effealiam putredinis effentiam, quam feparationem humidi à ficco,proprijautem caloris corrupticnem effe potius caufam putredinis, quam ip famnet putre-

$D$ dinem;etenim generatio quoquemifti fuit coniunctio humidicum fisco, calor autem in ea locum habuitagentis. Hinc autem colligimus validam confirmarionem eorum, qua de actione frigidi in mifti generatione antea diximus: ex eo enim quod folius caloris euocatio eft caufa putredinis, manifefte infertur folum calorem continere, \& vinireficcum \& humidum, \& per fegenerare miftünam fi frigus quoq; in generatione perfe ageret, \& continerec humidu coniundunt E cumficco, deberec etiatn frigoris corruptio, fet eductio effe caufa diffolutionis, \& putredinis; quod tamen Arift.nunquam dixit, fed folius ca: loris remotione caufam putredinis effe voluit. Poteft præterea illud, quod dicebamus, confirmari teftimonio Arsfot.in problem. 20.part. $2 \xi$ vbi rationem reddens cur ignis non putrefcat, inquit; quia refrigerari prius oportet illud, quod putredinem eft concepturum, ignis autem refrigerari non potef, fed femper eft fumme cali$F$ dus : notandaenim eft dictio illa [prizes] qux fignificat caloriś proprij, corruptionem, quam yocat refrigerationem, non effe formaliter putrefaAtionem, fed illi pracedere vt caufam, fin non tempore, faltem natura, ideo relin quitur nullam ordoneefre aliam effentiam putrefactionis, quam fepa- ture in rationem humidià ficco. Iraque in putrefactio- putréds-
ue hic eft natura ordo: salos ambientus cuocat
$n e_{\text {. }}$ calo- 
- calcrem naturalem, \& ita ipfun corrumpere dicitur, corruptione autern proprij caloris Q40. infequitur feparatio humidi à licce. Adargu-

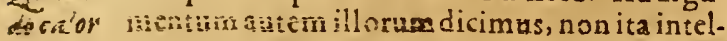
calorem ligi, calorem à calore corrumpi, vt contrerium corrum- deftruiturà fuo contrario, fic enim calidum à pat. frigido interimitur, non à calido; fed calorem coirumpi, ideft priuari mift um fuo calorenaturali à calore alieno ipfum euocante: non eft autcm abfonum rationi vt fimile ad fe trahat fium finule; etenim dum ipfum fecundum fe calorem confideramus, eff edudio caloris, non corruptio ; at refpelu mifti eft caloris deftruEtio, quatenus miftum fuo calore prisatur: quodautem frraileattrahatur à fimili, videtur effeper fe manifeftum, necprobatione indigere; vt enim contrariurn pellitur à fuo contrasio, ita rationi confonum tê $v$ timile attrahatur à fimili: 1 dque affererevidenturmedici demedicamentis purgantibus, purgancenim peratiraClionem ratione fimilis qualizatis. Proprieigitur calorem à calore non interimi confitemur, nifi quatenus poteft calidus agere in minus, calidum, fed tunc non vt in calidum agit, fed vt in frigidum; deftruit enimin eo gradum frigoris, non gradurncaloris : trahi tamen calorà caloSentox- repoteft, vt fimletrahiturà fursili. Sed yt hoc tia Al. Eeliusincelligatur, dignaeft confideratione Alberts'se bertifententia, quamipofteaalii pluresfequuti caloris funt: declarans Albertus quomodo corrumpanatura- tur calor naturalis à calore externo, notatealolis corru- rem naturalem agere poffe \& vt natural em, \& vt priore. caloremabfolute : nam in generarionemiftiagit ve naturalis, dumterminat humidum, \& iprum cum ficco cormifcet, \& coniungit cum ficco, quantumillius mifti natura requirit, \& has pafiuas qualitates continendo conferuat mifum : at in rofifinteritu idem agit non amplius vt naturalis, fed folum vt calor, proinde vt igneus, agit enim in confumptionem humi$\mathrm{di}$, \& diffolutionem miftietenim ambientis calor agens in miftum neceffe eft ve calefaciat, quia prima actio calidi ef cal efacere; hac igitur aetione calor naturalis intenditur, \& fit maior, ita vt fublata proportione ad pafiuas fiat præ, ter naturalis, \&e deftru\&iuus ; ob id deferitillud miftum, \& euaporat, \& fecum educit etiam huroidum; \& ita dicitur effe corruptus non vtcalor, fedvenaturalis; quia tune definit effe natuRecents- ralis. Hac Alberti fententia certe artificiofa ores con- eft, fed eam nonnulli recentiores impagnant tra Ab- hac ratione, quod apud Ariftotel. putrelactio berism. fit, quandoactua definuntireperare paliuis, \& ipfep liua actiuis dominartur; hocautem ef: fe non potest nif ab imminutionem caloris: quodeciars At iftot. manifefteligmficat, quan: do dicit putredinera fieri \& à calorealieno, è à frigore proprio, propterea quod omne primz-
A tumcalore eft frigidum : tantum igturabeft ve Ariftot. putet purredinem fieri per accretionem caloris in mifto, vt potıus aperte dicat eam fieri percaloris iminutionnem, quam etia appellat frigus. Egotamen cenfeoAlberti fententiam fano rnodo intellectam defendipolienon enix cocus firit Albertus, qui non viderit A riftot.dicentem fieri putredinem à frigoreproprio; fed fignificare veluit id,quod ipla rei natura, fi bene confideretur, nobis oftendit: in principio enim B quum externuscalor agat in miftum, necere eft $v t$ iftarta reddatur calidius, qrima nam que acio calidi tranfiens debeteffe calefactio, dicere auten duos numero diftinetos calores fimul in eadem re exiftere, vanum eftipfeigitur mifticalor exilla ationeintenditur, \& maior fit, \& hac ratione dicitur corrumpi, quia definit effeilli mifto naturalis, quum aniferit debitam proportionem ad paffuas refpectu natur illius mifti ; hiscigitur fit, ve delerat 11 lid, \& euapoC rer,ica resilla tandean fine calore maneat, \& frigida: in fine igitur putrefacionis rem manerefrigidam $m$ anifeftum eft;fed in initio quoque dici peteft frigida refpetu caloris naturalis, quexn non haber, ille enim quem habet, non eit naturalis, nec continet humidum iun tumfic. co; tuncigitur licet miltum illud habeat maiorem calorem, quami prius, non habet tamen naturalem, \& ita indiget calore vt naturali : quoniam igitur omne indigens calore eft ea ratione D frigidum, miftum dicitur frigidum vtcarens calore naturali: perhoctamen non feat, quin effe pofit calidius, quam prius, calorealieno, \&ad. uentitio; hocenim experientia, \& iatione, \& Ariftot. \& Galenı auetoritase comprobatur. ER perientia docet putrefentia in initio fiericalidiora, quak prius erant; aceruus enim tritici quando incipit putrefcere, fit calidior; ficaceruus lziaminis in principio putrefactionis adeo incalefcir, vt imporita qua gallinarum foueat $E$ non minus, quam calorgallina, ita vt inde pulli nafcantur : huius auten duplex efiratio; vna, quam paulo ante tetigimus, quoniam excalidi exrerni actione necefle eft $v t$ miftum reddacur calidius;altera, quia etiam abfque externi caloris confideratione calorinternus exiens fit maior, id eit,apparet maior, quia fit fenfilior: in illa namque el ementorum commiftione, \& contra. riarum qualitarum contemperatione, atqiamicitia videtur quodämodo contraria contrariam $F$ abfcondere, itavt neurra diftincta fentiacur; fed dum vna contraria abiungiturab altera, fenfilior fit;proinde videwr maior, præfertim quando excundo tranfit ab internis ad externa. ex boc autem fum poteft ratio differentis inter qualicures, qua vocari folentà medicis actua les, \& potentiales, feuvirtuales: dicunt eaim, firt vinuas \& piperhabere frigus actuale; fed calo. Ger. 
rem virtualem, tadu enim fentiuntur frigida, funt tamen naxime calefretiuajcuius difcriminis rationem quum ego frepe à pluibus medicis quxfitum, numquam tamen ab aliquo intelligere potui, ipfe autem arbitror eam fumi polfe ex iis, qux proxime dica funt: quamuis enim illa plurimum habeant caloris in fua temperatura, is tamen calor abfconditus eft à contraria qualitate cúi eft commiftus; fed fi ab aliquo externo calefiant, vt à ventriculo, excitatur ctiam calor internus, \& ei abiun tus calor extermus. reddit calorem vnum nagnum, \& valde fenflem, ita vt poftea illamaiorem ventriculo calorem retribuant, quam ab co receperint. Confirmatur autem 1 llud, quod modo dicebamus, per id quod ab Atiftotele affirmatur, \& ab ipfa experientia oftenditur de humido ; par enim ratio. eft, quum in putrefactione \& calidum \& humidum educanr: quemadmodum igiturilla; quæ putrefcunt, fiuntin initio humidiora, non quidem noua humiditate; fed quia humidum ab interms ad externa eductum, \& à ficco abiunctum fit fenfibus; ita exiens calor ad externa rei putrefcentis fenfilior: fit: illudigitur; quod putrefcit, in initio ve humidus eft fecundum Ariftot. 1ta etiam calidus; in fine tamen frigidum, \& ficcum fit, propter totius calons, ac to. tus humidi eluaporationem. Hocetiam tefta: tur clare Ariftorelesin 20. problem.part.25. diceus; mecelle eft vt id, quod putrefcit, fiatcalidiffimum, id eit, vtmagnum calorem fufcipiat propter propriis caloris increm êtũ à calore aunbrentis. Etin 3. part.problem. s.inquit, calorem naturalem quandoq; exiingui ob exceffum ab externo calore acceptum, vt in 11 lis, qui ì Solis ardore vruntur, \& in cbrii.s, qui quandoque ob. magnam ebrietatcm tremunt; tremor cnimille: proueuit à frigore, quoniam in illis calor naturalis eft $1 \mathrm{~mm}$ inutus exnimio exceffu caloris à potu; ex eo enim calor, qui erat naturalis, fit prater naturam, \& euapor:at; certum autem eft. illis ebriis in principio magnum effecalorem, fed dum definiteffenaturalis, euaporat, \& colpus frigidum relinquit. Galenus quoque in lib. fecundo de Temperamentis, cap.6.inquit illa, qux putrefcunt, calidiora fieri adfcintio calore, proprio autem frigidiora. Hoc igitur modo intellectaopinio Albertieft ratıoni \& experientix, \&. Ariftot..confentanea; quumi negari non. polfir putrefcentia omnia in principio fieri calidiora; neque per hoc fiet quin dici. poffint frigida ratione caloris naturalis, quo deftitumntur. Argumentum igitur, quo illi aduerfus Albercum vtuntur, facilefoluitur: fitenins putrefactio ex imminutione caloris ve natural is, quia definit effe naturalis, \& poftea etiam feparatu: à mifto; fed fimul etiam fit ex intenfione caloris gesutabrolute eit calor.
A Declarario illortin verborum, in vno quoq; hunido, in definitione putre.
dinis. Cap. $X$.

TActenus ca, qux ad ambientis calorem, Hik ad naturalis caloris corruptionem pertinent, declarauimus; reftat ve verba illa [in Grogusogue bumido I perpendamus : dubitare namque non abfque ratione polfumus, an per hxcintelligat Ariftot. humidum naturale, an omne humudum indifinute, feu naturale, feu aduentitum: quem enim dicat Gnogruog]videturoninem calorem ampicati, non folum naturalem, attamen fequentib.verbis videtur hæc interpretari, quando fubiügit [exunte enimprom. proo caldido, cocuaporat quod fecundum naiuram. est humidum ] intelligit ergo fo fum humidum naturale; idco féfum hanc omnes intrepretes receperint, vt Ariftot. dicens [in Gnoguog bu-Commumudo ]intelligatomme humidum naturale, non nis expeomuc abfoluce. Sed hacinrerpretatio mihinon fitio. parum dubia ent, potuifletenim Ariftot.in definitione quoq; dicere. in humido naturali, fi voluifiet; cur igitur poftea.dicit, quod. recundum. naturam eft humidum, in defintionevero dicit, vnum quodque humidum? Mihi quidem vi- Dubium detur huirufe rei declatatio fumi polfe ex cuiuldam dubii folutione, quod à nemine vidi fuiffe confideratun : videtur purredo effe eductio. non folum liumidi naturais, ex quo tanquam ex mareria conftat ipfa muft. fubtratia, fed etiam humidi aduenritsi, à quo non tit coniunctio partium; videmus cnim ligna arıda in $æ$ dificiis diutifime feruari fine putredine, \& multis feculis manere illafa;ea tamen. fi madefiant. \& ext erno humore humetentur, facillime putrefcunt ex illa humectatione; videcur igitur. putredo effe eductio etiam humidi.aduentitii: hos tamen non ef confonum rationi; quia fi E putrefactio eftinteritus contrarius generationi mifti, debet efféd diffolutio mufti in humidum \& ficcum naturalia, ex quibus genitumeft, \& conftats, fednon euaporatio humidi aduéti ii, quod: fubftantix pars non eft.. Si bene dubium hoc: Solutro. confideremus; nulla effepoteit alin eius folntio, nifihxc : calor ( $y t$ lam diximus) non ita corrumpitur, vt prorfus intereat, fed corrumpitur: illi. mifto, quoniam ab eo recedit; atqui recedere non poteft calor fine proprio interiru, gum ascidens idem numero non polit deferese proprium fubiectum, \& migraread aliud; neceffaria ergo eft calori.fubftantiahumida, in:
qua refideat, fi debeat educi, fic enim cum rubftantia humida: tanquam vehiculo calor. euatporat: in lignis ergo aridis nulla efthumiditas. nifi naturalis, \& ea quidem modica, per quam: coniunct fint partes, qua dicitur humiditas. olco\{2, suius fignum. manifeftim ab Alchimi. fris.ha- 
fis habenus,tullanim res eft ita fieca, \&arida,yt exea ipfi ol eum noneducant, hoc autem eductoremanet puluis inconiunctus, quia reparata eft illa humidias, qua frebat partinm conglutinatio; quum igitur hac interna, ac nsturalis lignorum humiditas dificillime extrahatur, ideo ligua arida non facile putrefcunt, quir non poteit calor folus cuaporare fine fubfantia humida; at fi eadem ligna extraneum aquofum humorem imbiberint, facile putrefiunt, quia ille faris eit it poffit cum eo tinquam rehiculocalor naturalis educi, ì calore ambientis : eductionem autem proprij caloris infequitur proprij quoque humidi eduetio, \& feparatio if ficso: quum enim proprio naturali calore deftituatur miftum, ita ve proprium humidum non habeat amplius calorem, à quo confineatur, difloluitur, \& fit leparatio humidi maturalis a ficco, qua eft putrelactio. Sunt igitur in lignis iliis confiderandæae diftnguendx hrduz humiditates;rna aduentitia, altera naturalis : aduentitir quidem eductio, feu eurporationon efletputredo, nificum ea calor naturalis edncerctur, fed ea eft folum occalio putredini, quia offertur cal ori vtrehiculum, ci quo calor educatur; hac igituraduentitij humoris eductio non eft putretackio, fed eft conditio, fine qua tunc calor lignorum naturalis non cxtraheretur; fed puzeractio eital terius propria humiditatis eductio infequens eductionem caloris naturalis; aliqua autem res adeo abundanthumidomaturali, vteo folo fine alio aduentitio humorelintaptifinzad putredinem, vt caro, iac, \& alia multa, in quibus hæc humiditatis diftinctio locum non habet, feu nullum nomentum facir. Ariftoteles igitur in deniniomne humidum compleeteretur quod fit vehiculum caloriad exenndum, ine fit naturale, flue aduentitium : non enim denotare per hæc verba voluitillud humidum, cuius à ficco fepa. ratio putredo eft, led conditionem lubiectiputrefcibilis, fine qua calór naturalis non educeretur; quia non datur hæc propriicaloris'orruptio, nifi in corpore humido, id eit, habente aliquan humiditatem fiuepropriam, fue aduentitiam : patet igitur verballa non ip 13 m pi«redinis erentiam lignificure, quæ et proprij inumidi cuaporatio, led folum fubiefum putzefcibile; nam ita communiter acceptum humidum non eftilid, cuíus a ficco fepantic fit fu- F tredo, effentia aute putredinis fubintuligitur, quia conteituta naturalis caloris corruptione. inlequitur neceffario feparatio humidi naturalis a icco; idque Aritorles iple ibidem peftea declarat dicens[exsunte enim propriosalico coes uaporat quodfcundumnaturame st humidum] hac igitur quum diximus, eft ratio cuŕbiex-

A primathum:dum naturale tanumasodo, prius vero in definition vniuerfe dinerit [m Gragus que humsdo] cóplectens etiam aduétitian: vnde patet lequentia illa verba [coeusporai qued focrindurn naturamest oums dum $]$ non effe desla.

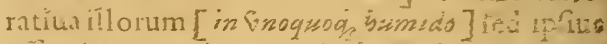
elfentix putredins, qure in detnitione coninebaturimplicitein is verbis [corratriopropry ey naturalis caloris] vult en mi po:-ea expreffenc a dmorere in hac corruptone propri a $a^{*}$ oris $1 \mathrm{n}$.

B cluamelí coeuaporationem hum - naluraIs qua exneceflitate illam conte zuitur.

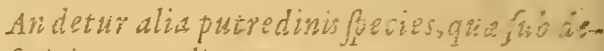
finitione pradiat inon contineatur, ofinionejaliorum. Cat K.

$\mathrm{D}$ Efinitione putredinis declarata, conf d - dumeit an hacomnem pronus ?ured.n. 3 modum comprehendat, an aliapured ${ }^{2}$ is i $\mathrm{De}$ cies detur, qux hac definitione non conciñeaC tur,vtnonatlirecentinres eviftmarurs; nem Thomas Eraftus, \& Archangelus Mercenarius, quum in hoc confenferint, duas effe puedin.s fecies, quarum alteritantum competàr detin: tiopredich, alteriveronequaquin, in hisramen fpeciebus fatucndis ditenierunt, a in e? feacerrime controueriatifunt, vt in eorum iteratis difpuationibus ac certamin bus edutis vi. dereeft. Qunniam igitur nounab vtroquedogmata hac de reirtroducta funt, \& Arittotattributa, noneritabrefi corum fententias aliquantü expendanus. Putauit Erıfus duas duarum diueriarum putredinum definitiones ab Arifoteleafferri in initio quarti Meteorologici, vnam priorem in contenuterio, alteram veropoteriorem in lexto : priorem quidem dixit miti, quatenus niffum eft, naturalem interitum, proinde vero contrariam generationi mifti, quum lit eius diliolutio in elementa, ex quibus genitum eit; s omnimitto pecelatian, nif prius contingat vtaliquo yiolento interitu mitrumpereat:ideoqueialeyocari ab Antoters interifum natualem, quia ht ab interno pris $=$ pio: nonenim a calore externo, fed potius ab interno \& naturali, liquiem proprius mitica. lor tandem abfumit humidum naturale, quod iilitabulum elit,quo fievtiplequoquecalor natualis pabuio deficutus tancem naradcai : haus igirur nutreus naturais, inquit Er?ftus, detinitionemafferrab Arilos tilem, futredóef finis interitus naturalis mifti quatenus miftum eit. Aleman vero pofteioremputredinis peciem divit violentim eife \& mo100211. fie iq àprincipio exteris, tame a caiore ... bi.nus, \& vocariao drat, nteritum lentud in fartem: quin per hancnon dilolutur pror 3 mitum inclententi, red inaliud niltum n +.t.

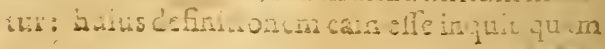


bulum; de folo enim ealore animali id verum eft, propriumque cft animatorum, vt corum calor humido naturali nutriatur, ipfumque tan dem abfumat, quxe eft viuentis mors per vltiman refolutionë, naturalis appellata; \& in hoc reftecarpit Eraftum Mcreenarius, liset uullam huiusce difcriminis rationem addusat:egovero hane efle puto rationem, quod calor naturalis duplicitcr accipi poteft, vino modo pro fola qualitate,alcero modo pro fubiedto quali ficuti folentmedici nomine caloris naturalis vitales firitus intelligere, qui funt primum fubictum caloris animalss: igitur quando dicimus calidum nutriri hunido tanquam pabulo, non poffumus fimplicem qualitatcin intelligere; non poteft enim humiditas in calorem verti,fed potius deftruiturà calore, quoniam nutririaliquo eft veitcre illud in fuam fubfantian; fic enim dicimus ignem ali combuttili, ideft, illud vertere 11 igncm : in animantibus igitur calorem vefilhumido rt pabulo non poteft intelligide calorc accepto pro qualinate, fed accepto pro spiritibus vitalibus, qui continue nutriurtur, dum vertunt lumidum in fuam fubtantiam; hxcautem humidi confumptio, \& exconfumptione nutritio, non fit, nifi ex actione fubltantix calidxinaliam fubftuntiam humidan; proinde non habet locum, nili in corporibus heterogeneis, qux confant expartibus dinerfanm naturarum, \& diterfarum temperierum; alia memque citnatura fpiritıs, alia fanguinis, alia carnis, lin offis, dicere igitur pofium us cirnem nutrir funguine, \& firitus nutriri humido in ew nub tantian contuerfo, \& hac rationenutiri calorem naturalem, id eft, conferuari per conferuatiónem firituum:aft vbi vna $\&$ eadem c? fubfantia homogenea cálorem habens, \& humiditatem naturalem, nihil eft vanius, quam dicere caloremali per confumptionem humidi naturalis:vna cnim eft natura, ac temperies mifti hómogenei, quarenon potelt agere in feipram: adde quod alor in nutsitione non agit nifi per mediam cllefactionem, ergo oporteret idem mifum calchacerefeipfum, quod dicendim non eft;ic enim elfet timul calidum \& non calidum, \&actu \& poteftatefecundum idem, quod ne imaginabil c quidé eit. lirærerea fi hoc verum efiet, etiã mifa inanimata egerent fumptionealmenti externi pro coniumpti humidi reftauratione, hoc tamcr nemo vnquam dixit: videmus enim multa mifta fine vllo affumpto alimento diutifime durare,vt metalla, \& lapides, \& oleum; in his ergo nulla proprij humidi confumptio fit. Dicendum crgo eft calorem têperatur in mifto continere, \& cóferuare humsdum iicco iunctum, tantum abeft vt abiumat ac perimat: ideo rede dicit Albertustalorem mifti, dum agit ve naturalis, confcrunc humidum, nẹe finere clabiac diffuere : non eltergo Arift.
A tribuenda hæc opinio, qux onsnino repugnat veritati : \& miror quomodo Eraftus in tantum errorem lapfus fit, quum prafertim modus ille loquendi A riftotel. non poffit definitionem $\mathrm{fi}$ gnificare; potius enim deriotat quæ corruptio lit putredo, quam quid firs \& fententia A rift.c it, quod illa putredo, qux eftinteritus naturalis, \& oppofitus generationi inift, fit à calore ambientis, eaque definitur in contex.G. illius libui,ve eft omnium interpretum opinio, quam tuetur B reete Mercenarius contra Eraftum. Poffumus autem aduerfus eum confidcrare etiam verba Arif.in contert.4.quando dicit [quare bumada primsm, deinde ficcatädem fiunt illa, quxpuirefeunt ] nam fecundum Eraitum dicere oporteret mitta femper magis exiccati, fi fempercalidum abfumit humidum: igitur quomodo dicit Ariftot.f utrefcentiafieri primum humida, deinde vero manere ficca?vidit hnedifficultatem Eraftus, \& illa verba ita eft intcrpretatus : mifta C putrefcentia habent in principio lummorem, \& humida funt, randem vero to to confunpto humido remanent arida. Sed hac non eft conue. niens interpretatio, quin non dicit Arift. ea effe humida, fed fieri humida ob ipfam putrefactionem, quum ante putrefactionem non efient humida, fiquidem per eductionem humidiad fuperficien, in extima parte redduntur humida in initio putrefactionis. Scd non refe etiam diceretur omnia mifta effe hu mida : quamuis enim omnia mifta habeant humorem in fua miftione, non ob id oninia denominantur humida;etenim non fit denominatio, nifi ab exceffu; vt lignumaridum vocamus ficcum, non vocamus humidum, licet aliquid habeat humidi in fua miftione: aliud ergoeft dicere omne miftu habere in fe humiditaté, aliud eft dicere omne miftum efle humidum:nam illud quidem verü eft, fed hoceft falfum. Mercenarius quoque in fecunda ab eo adducta putredine, quam fecunE dum partem vocauit, deceptus eft. Primú quidem non eft verum id, quod ait, hanc effe elementorum propriam putredinem : nam modus loquendi, quo Arift. in eo 5. cont. vtitur, fignificat hane niftis quoque competer e;inquit enim [propre dicitur putrefact $10 \mathrm{~m}$ is, qua fecundum parté intereunt $]$ poltea vero fubiungì [quapropter E putrefcut alia omia exceptoigne] \& ita colligit tria quoq; clemēta hoc modo putrefcere: non ergo folis el mintis hanc purredinem F attribucrat, nam dictio coniunctiun indicat cam aliis quoque compctere prater elementa hoc autem poftea manifeftum fiet, quü declarauerimus quid fit hæc putredo, quæ iecundum partem dicitur. Sed ipfanct Mercenarij de hac pu. treảine fententia videtur eflè abrona ratıoni, neque A rift.attibibucnda : nam fi putrefecre elementa dicuntur per alieni corporis adniftione. quod recedant à fua naturali puritate; ergo il- 
la tria elementa funt femper putrida, femperenim funt mifta, \& absque naturali finplicitatc: falfedo enim maris indicat miftionem cum halitu terreo, \& in acrefemper funt halitus à terra afcendentes, vel faltem frequentilfime; terra quoque in extima faltem parte, \& à centro remotiore apparet humefacta, \& cum aqueo humore commifta, attamen nec totam aquam maris vocamus putridam, nec terram madefaetam, nec aerem per vaporum commifionem puttefcere dicimus : non igitur in hac commiRione cōfittit natura putredinis, ita yt quicquid habetalienum corpusfibi commiftum, ea ipfa ratione dicatur putridum: id quidem verum eft, talem commiftionem in elementis effe putredinis caufam, fine qua non, quia nifi effent mifta, non putrefcerent; fed tali committione pofita non nece Tario ponitur putredo, caufa enim eft $v t$ fint putrefcibilia, fed non vt fint putrida; fic autem \& cxtera miftanon femper putrefcunt, funt tamen femper putrefcibilia, quum fint mifta. Praterea verbis Ariftot.aptari hac fententia nullo modo poteft, qui in eo loco de tali co:nmiftione ne verbum quidem facit;erat tamen omnino exprimenda, fi in hac ipfa conditione hxe fecunda putredo conftituta eft. Anftautem nil aliud dicit, nifialiqua fecundum partem putrefcere;at hos quomodo fignificare poffit commiftionem cumalio corpore, ego quidem imaginari non poffum, eft enim abfona rationi, \& incongrua hxc interpretatio ; at (inquir Mercenarius) declarat hoc Ariftot. quando fubiungit [qusm Separata fuerint à natura ]per tale enım commiftionem elementa remouentur à fúa naturali cóftitutione:fed hoc reuera nihil eft, quia feparari res à fua natura plurib. modis poffunt, non hoc vno,quem ipre ponit;nā \& quando elementü mutatur in aliud el ementü, feparari dicitur à fua natura; \& quando etiam al teratur contraria qualitate, vt quando aqua calefit, feparari modoaliquo dicirur à fua naturali affectione: nihil ergo in verbis Arift. elt, quod determinate cum extranco corpore commitionem fignificet, quum prefertim neque in pracedentibus de hacquippiam dixerit, neque in requentibus dicturus fit: hacigitur huius fecundx putredinis conditio apud Ariftotel.non legitur, quum tamen fuerit omnino exprimenda, fiper hanc fecunda putredo diftinguenda eft ab al cera priore. Reftat vt argumenta ab his addueta foluamus. Eraftus quidem pro fua opinione de priore putredine non alio argumento vfus effe videtur, quam confideratione verborum Arift in cont. 3.illius lib.4. nempe quando Arift. dicit eam effe naturalem corruptionem, \& vere contrariam generationimifti: fed ad hxciam patet refponlio ex iis, qua de eius loci vera intelligentia dixımus;cōtraria enim vocaturgenerationi mifti, quia eft mifti diffolutio in clementa; naturalis autem dicitur, non quod fiat ab interno princi-
A pio, fit enim à calore ambientis, fed quia fit fecund um legem naturx de modo, quo debeat interire miftum quatenus miftum eft. Ad primum Mercenarij dicimus, terram \& aquam, fi fimpli- $A$ tpri. ceceffeftatuantur, \& omni penitus calore care mis Mer. tes, vtique non poffi putrefieri; attamen putre- cenarÿ. fieri, quon iam aliquem habent calorem, finon naturalem, faltem aduentitium; is enim (vtaliqui reete dicunt) fivere intrinfecus non eft, eft faltem intrinfecasus, \& facit vt elementum fit a3 ptum putrefcere. Ad fecundum dicimus, totum effeconcedendum : nam fi fieri poffet vt aqua $A d \int c k n$ perfecte putrefceret, diffolueretur aqua in ele dum. menta fimplicia, proinde impura in puriorem; fed quia id fieri non poteft, ideo non fit perfecta dillolutio in elementa : cur autem fierinon poffit,poftea declarabimus, quando veram fententiam de hac fecundum partem putredine proferemus;vbi etiam oftenderius terram non modo fecundum partem, fed etiam perfecte putrefceC repoffe. Vtcumquefit, femper putredo eft corruptior rei putrefcentis fiue perfecta, fiue imperfecta: id eo fi putrelcit el emétum, putrefcit quarenus miftum eft; idque fi perfecte in fimplicía diffoluatur, non negamus impurum ea ratione refolui in purum; fi vero non perfecte diffoluatur, id non euenit, fed adhuc remanet aliquid impurum hóc tamen à nobis poftea magis de. clarabitur.

\section{Aliorum fententic de putredine fecundum partem, \& earum confutatio. Cap. XIII.}

$R$ Eatius igitur alii fenferunt, qui dixere $\nabla_{-}$ Rnam tantumeffe putredinem, qux eft proprij caloris corruptio à calore a mbientis; ita ve eiusmodifit tum illa, qux in context. 3. 4. Meteorolog. dicitur effe interitus naturalis, \& vere contrartus generationi mifti; tur illa, qux in E context. 5 . vocatur interitus fecundam partem. Sed antequam veram de hacre fententiam, ac mentem Ariftotelis declaremus, non erit ab re, fi pluies aliorumfententias de putredine fecundum partem breuiter expendamus; quia licet in eo omnes confentiant, quod hac non fit alia putredinis feccies, variis tamen modis hunc fecundum partem interitum intellexerunt. Plu- Latino. res Latini confijerantes Arifotelemibi dicere rum opiea, qux fecundum partem intereunt, effe fepara- nso.

$F$ ta à fua natura, de elementorum tantum purredine eum loqui exiftimarunt, \& dicere ea fepararià fua natura, quando ob commiftionem aliorum corporum fubftantix dicuntur à fua naturali puritate recedere, fiuntque apta ad pu. trefcendum; non enim putrefccrent, nifieffent milta, quum putredo fit diffolutio mifti in fim. plicia : fenfus ergo verborum Ariftotelis fecundum eos hic eft : elémenta, quando à fua natura recefferunt, ideft, quando facta funt quo- 
dammodo mifta, tune apta funtad putrefcen. confuta- dum. Sedhac interpretatio tum manca, \& imiso. perfecta admodum cft, quum eorum complures non declarent cur hac putredo appelletur fecundum partem : tum eciam fafa : quiafi modum loquendi Arifotelis perpendamus, non folis elementis attribuit hanc putredinem fecundum partem, quemadmodum antea aducrfus Mercenarium often dimus; fed poftea etiam demonftrabimus, miftis quoque eam putredinem, qua lecundum parten ab Ariftot. dicitur competere poffe. Notare autem volo hos in conlideranda in elementis miftione, quam dicuntıbi vocarı recefum à natura, mınus erraf$\mathrm{fe}, q u a m$ Mercenarium : ille namqi miftionem, \& impuritatemiofam elementorum formalites putredinem efiediscbat, quodomnino negandum eftifti vero non formaliter, fed antecedenter, quod quidem verum perfeef, fedabillis Ariftotel. verbisalienuminam fatemurguidem A riftot.prafupponere elementa effe rnifta quo. dammodo, fi dicbant puttefcere; fed negamus hocfignif́cari perfeparationem à natura- Al-

Alberti bertus vero fimiliter dixit putredinem ficun- pisziso dumpartem frlis elementisattribui, fed rationem quoque adduxit cur dicatur interitus fecuudum partern, dixit enim putredinem efle miftorum tantummodo: ideoque perfecta mifta putrefcere perfecte, acíecundum totum; at clementa, quianon funt perfectemiftafed imperfecte, dicietiam putref́cere imperfecte, acfeConfuip-cundum partem. Attamen in hac Alberti ra8io. tione manifeftum eft animum non acquiefcere: quamuis enim pusredo miftionem prafupponat, aliud tamen eft miftio, aliud putrefátio: quod igitur imperfteta in elemento fit miftic, non obid apparet imperfectam etiam eius putredinem effe, nifi de ipfa recundum feputredine declaretur quomodo fit imperfecta; imo nos p Atea oftendemus, tum perfecte mifta poffe imperfecte putrefcere, tum clementa, qua funtinperfecte mifta, quandoque perfecte putrefcere.

Alorem Aliqui putredinem fecundum partem intelleopinio. xerunt de parte quanticatis; vt quảdo pomi pars putrefcit, dum alix partes funt integra, eam vocant; utredinem fecundum partern; fic quando in aliqua corporis noftri partepropter vlcus fit fenies, eam dicunt elfe putredinem fecundum partem, nempe fecundum corporis noftri parConfusa tem. Sed hacinterpretationenefcioan alia pof230. fitcralfioracrudior excogitari; eadem enira eft putredinis natura, \& conditio, qua totum pomum, \& quapars pomi putrida dicitur: nam fi pars pomi in clementa peritus diffoluatur, etiamfi cxtera partes fane, å integre maneant, certum est perfefam elle cius partis putredine: new llum huius gifcrimen effe, \& illsus; qua cotum pomum puticfcit, nifi ratione quanntatis maituris, vel minoris, qux non facit differen-

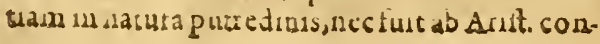

A fiderata. Probabilior videtur quorundamaliorum fententia, qui putarunt putredinem fecundum partem tunc dici, quando non toia mifti fub!tantia, fet particulz tantum tenuiores putrefcunt; qualem vini puttedinem effe dicunt; non enim tota vini fub ftantia putrefcit, fed particulx tantum tenuiores, \& a fuof $x$, qux fols euaporant, non totus humor vini : idque eo argurréto comprobant, quod illi qui vinum przeferuarevolunt ne putrelcat, coquütiplum igni, $B$ vt oésillx partesaquof $x$ exhalentur; ficenim vinū à putredine praferuatur. Vetum hi viden- $C$ tur quidepropius adveritatemacceffie, quam $t$ alı, fed ab ca tamen aliqquatum recefferunt: quum enim omnes putredo tiat per leparationerm partis à parte, nempe humidi à ficco, non ipfi parti educte actribuitur putredo, fed toti mifto; non enim purrefcere dicimus humidum pomi, fededuci, pucrefereautem ponum totum; quando igitur ag̨uofores vini partes in putrefactione extratuntur, non 1 lle dicuntur putrelcere, feu vinum totum, licet non lecundum totum, quia non totum humiduin feparatur à ficso: ea igitur fola debet addaciratio cu: alin̨idid fecundum partem tantuan putrefcst, quodnon torum humidum educiur, feJ pars eius tancum; arnon quod pass tantum aliqua putrefcat, nempeil'a, qua educitur; iraqu hi in difcrnenda putrefactione fecundum partem non videnturerraffe, fed folum in racione affe$D$ renda huius appellarionis; toti enim nifto ef attrıbuenda putrefa t: o, nó humido edueto: $: \mathrm{b}$ id fallum entid quod dicunt, non totum vinum putrefcere, imo totum putrefrit, quia abomnibus partibus euaporatproprium calidu.n cum humido;non tamen perfecte putiefcit:quaredicendum eit vinum totum putrefsere putredine imperfecta, \& nac rationedici fecunum partem interire. B.ccaferreus dicit Aruftotel. in eo $B$ loco, nec aliam purreduis Speciem adducere, re. nec eendem vt imperfictam, ied abrolute deo- mi mni putredine loqui, \& purredinem vuiuer fumptam declarare, acdicere omners putredinem effeinteritum fecundun partem tantum, nullam autem fecúủurs totum, prepterea quod eft fecundum calidura \& humidum tantum, non tecundum frigidum, \& ticcuminam à calore ambientis extrahirur calor tantum naturalıs, \& humidum naturale, non extra hitu frigidum \& ficcum : omnis igitur purrefictio eit corruprio fecundum partem . quia non eft iecundum onnes qualnates, fed fecurdinduas tantum. Hanc fenentiain maxime on 1311, m approbat Buccaterreus, \& eam inquir fuilie Alexandii, quod tamen minirnc veisis cit; quum praiertur fit vanifima interprerano, \&-indigr a dlexandro:túm cu ratiolse pradseten, quid putrefactio non astrisustur fol prarticuluesz, fed tcu misto, hos eniss disteur futeticri \& difo

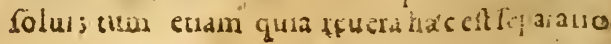


omnium qualitatũ, nam educere calorem non magis eft feparare calidum à frigido, quam relinquere frigidum feparatumà calido, hoc idem de humido \& ficco dicendum eft: quare hac fententia eft profus reiicienda.

\section{Opinio vera de epeciebus putredinis, ac de putredine fecundum partem. Cap. XIV.}

Tho quum hac in re à communi interpreLum iententiaarbitrer nō effe recedendum, \& vnam tantum dari putre dinis fpeciem, vnamque \& eandem omnis putredinis definitionem, omnis enim putredoapud Ariftotelem eft feparatio humidi à ficco ex propria caloris corruptione à calore ambientis, etiam illa putredo, qux ab Ariftotele vocatur putredo fecundum partem; tamen hos quoque erraffe exiftimo in hac intelligenda, \& fal fas effe omnes pradictas eorum fententias, vt modo demonftrauimus; declarandum igitur à nobis cft, quænam fit apud Arift. putredo fecundum partem, \& quomodo hanc abilla, qux fecundum totum eft, diftinguere videatur. Sciendum ita que eft eam, quam Ariftoteles definiuint, putredinem multas recifere varietates exdiuerfitate rerum putrefeentium, \& diucrfis earum miftionibus, \& naturis; quo fit ve diuerfis modis putrefcere res diuerfa vidiantur, propterea quod eadem cauf eundem effectum cum aliqua varietate producunt ob varias differentias fubiętorü recipieatium: vt exempli gratia eadem eft putredinis natura \& conditio, qua putrefit caro, \& qua pomum, \& qua ftercus; varii tamen funt horum putrefcentium odores, \& fapores, qu $x$ differentix oriuntur ex diuerfitate miftionum: fed hac tamen diuerfitas indigna eft confideratione, quoniam accidentalis eft, nec facit vt hoc magis, quam illud putrefcere dicatur; aque enim omnia pradicta diffoluuntur tandem in elemenra, \& nihil ex eis reliquum apparet, nifi terra \&e fimus, quanqquã per diuerfa accidentia ad hunc finem perueniunt: alix tamen maiores putredinum differentiz exiftunt, qux confiderari merutrunt, qua faciunt vt alia magis, alia minus putrefceredicantur, \& alia penitus, alia verofecundum partem tantum interice, $v t$ in memorato loco Aristot. admonet; attamen non funt ob id diuerfa putredinis f fecies, quia differentia fecundit magis \&e minus non variat fpeciem, fed potius varios gradus putredinis efficit, vnde aliarn maiorem, aliam minoré putredinem appellamus. Summa igitur, \& perfect a putred o ea eft, qua miftum penitus in el ementa difioluitur, ita ve nihil eis reliquum appareat, nifi terra: hoc modo putrefcunt caro, \& pemum, \& ftercus, \& alia omnia mifta, quæ folida, \& perexcetrum terrea funt; euocato enim proprio calore, humidum quoq exiftẽs educiturad externa, ibiq̨;
A tandem confumitur, ita vtremaneat terra ficca. Sed in illis, qua fluida, \& magno exceffu aquea putredo funt, non fit hacperfecta, \& integraputredo vt imperfe. in vino; quum enim in co infot plurimum hu- cta in midi, exparum ficci, fi per ficci quoq; eductio quibus nem fieri putredo polfet, vtique etiam hac fe-frat. cundum totum facile putrefcerent: fed quum ficcum eu ocari à calore nequeat, fed folum humidum educatur, idque ibi plurimum infit, id co non poteft educi totum, \& à ficco feparari; fed B primum tenuiores partes educuntur, quia facilior eft iprarum, quam craffiorum edueti 0 , ve in putrefcente videmus : eius enim ebullitio indicat tenuiores, \& aquofiores partes exhalari, ex quibus in fuperficie vini genitum infpicimus illum frt um, qui in om nibus fignum putredinis effe folet; attamen non omnino turc diffoluitur ex 1 lla actione vinum in elemèta, quia multo maior in eo ineft hum oris cepia, quum vt educi totus poffit, \& à ficco feparari: hanc igitur C putredinem Ariftoteles appellat interirum fe. cundum partem; nam miftum quatenus eft mifrum tunc dicitur fecundum totum, \& perfecte interire, quando penitus abrungitur humtdum à ficco; fed quando hac feparationon perficitur, tunc miftum quatenus miftum eft, fecundum partem tantum interiredicitur, \& fecundum partem diffolui, \& (vt inquit Arift) à natura, \& à fua naturaliconftiruticne recedere; vinum.n. putrefactum non omnino interiit qua$D$ tenus miftum, quia non eft in el ementa diffolutum, tametfí receffit à fua naturali temperie, \&e modo magis, modo minus, vt poftea confiderabimus : hactamen eft eadem putredinis natura, \& idem modus, \& ab eadem caufa proueniens, nempe à calore ambientis; cft enim omnis putrefactio eductio proprii caloris vna cum proprio humido à calore continentis, $v t$ in vini putredine manifeftum eft; idemus enim tantum tempore afiuo vina putrefcere, non

E tempore hyemali, quo aer effrigidus:quod autem de vino exempli gratia diximus, id dealis omnibusintelligi volumus, in quibus non perfecta fiat feparatio humidi à ficco, eam enim femper arpellandam effe, cenfemis putredinem fecundum partem. Tali putredine dixit Ariftot. elementa quoque putrefcere vno igni excepto; quarenus enim non funt fimplicia \& pura, fed permifta, eatenus tria el emenia putredini obnoxia funt: ignis veronone? putrediF nis capax; tum quia nihil fecum patiturcommilceri, quum omnia confumat, \& in fuam na'turam conuertat; tum quia calidiffimus omnium eif, nec datur aliquid ipfo calidius: quare interire quidem poteft, \& mutari à frigido in elementum frigidum, at non putrefieri; quia putrefactio eft corruptio proprii caloris, non à frigore alieno, fed ab alieno calore proprium rei calorem fuperante, Cæteraviro cleuentafunt apta ad putrefcendú, quia tust per-
Cur elemótapistrefcant. 
mifta: terra namque habet commiftum humoaftrorum; fic aqua habet cornmiftas exhalationes ficcas terreas, \& calorem fimiliter ex lumine aftrorum acceptum; \& aer habet commiftas exhalationes tum aqueas, tum terreas, \& habet calorem naturalem, qui caloreigneo debilior eft; idco funt apta materia putredini per interni caloris eduationem, \& feparationem humidi à ficco: videturautem de his elementis impuris, \& fua naturali fimplicitate carentibus alterum duorum dicendum effe: aut factam effe in ipfis veram miftionem, \& vnionem naturz; ita vt. portio aliqua terr $a$, licet vocetur terra, quia magno excefu terra vincit alia elementa in ca miftione, non fit tamen terra, fed miftum quoddam; ficetiam aqua, quam appellamus aquam: ficetiam aer; \& ita quatenus funt mifta, eatenus. effe obnoxia putredini: aut veram mifionem, \& naturz vnionem ibi non effe factam, quod eo nagis credo, quum Ariftot.in calce libri I. de Ortu \& Interitu dicat miftionem tinc effe, quando nullum mifcibilium manet integrum, quod quiden euenit quan do nullum nimio exceffu alia fuperat, quo fit vetranfeantomnia in naturam quandam media $m$, nec remaneat amplius nomen alicuius ex mifcibilibus: quoniam igiturin aqua nō.eft facta perfecta miftio, quum adhuc \& natura, \& nomen aqua feruetur propter magnum aqua exceffum in illa miftione; ideo calıdu \& ficcum, qux inexiftunt, non po. terunt quidem diciintern $x$ : \& naturales qualitates aqux, fed tamen ita funt permifta cum ipfa aqua fub ftantia, vt totum illud corpus putredini obnoxi um reddant; quamu is enim non. fint verseintrinfecx, funt tamen ( $v$ t bene aliqui dixerunt) intrinfecatæ illi elemento: quod idem dicimus de terra, \& de acre: hoc autem confirmatur ex eo, quodin miftis quoque conringere videmus; plura namque diu durarent fine putredine, fed quia aduenit eis humor aqueus extraneus, is facit vt cito putrefcant: $\mathrm{li}$ cet cnim nunquam dici poffit ille bumor effe illi corpori naturalis, \& intrinfecus, eft tamen ita intrinfecatus, v.t quamuis fit extraneus, per e $\vec{u}$. tamen res illa facile putrefcat, quemadmodum fupraconfiderauimus. Hxc autem fententia de putredine \& fecundum totum, \& fecundum. partem maxime confirmabirur, fi aliquarum rerum putredinem, de qua magis dubitari fo. let, diligenter confiderantes oftenderimus omnes purredines ad hanc vnam reduci, \& $\mathrm{vno}_{2}$. aceodem modoeas omnes fieri; cum eo tamen. difcrimine, quod alia penitus \& fecundum totum putrefcunt, alia vero fecundum partem

Qsemes doaqua pustrefisat. santum. Primum quidem confiderandum eft quomodo in tribus illis elementis locum ha. beat putredo: a qua putrefcit, quoniam infitum haber calorem, vt modo dicebamus, debilem. tamen, qui vincitur zे calore zeris ambientis
A ideoque educitur; quum autem calor fit accidens, \& nequeat migrare de fubiecto in fubiectum, non poteft educi, nifi cum aliqua tenui fubftantia, in qua inhreat, eaque eft parsaliqua humoristenuior, qux ad fuperficiem aqux cuocata facit ibi quandam teliculam, quaputredinis fignum elle folet; non poteit autem to. tumaqua humidum euscari, quia eft plurimum cum pauco ficco, ideo remanet adhuc in aqua plurimum humidi cum ficco terreo, eaque $B$ eft putredo fecundum partem, quia non penitus feparatur humidum à ficco; nec videtur hac putred o diffimilis putredini vini, cuius humor totus feparari à ficco non poteft ea vna actione, qua puitrefcere vinum dicimus in illa omnibus manifefta ebullitione, \& manife fte etiam ceffat, \& relinquit vinum iam putrefactum fecundum partem; nec tamen negamus materiam illam putridam interse etiam penitus, \& in el ementa refolui poffe, fed id poftea fit per alliam actio. C nem, \& non nifi perlongum tempus; tuncenim nil aliud cófideramus; quam illam vnam attio. nem caloris afiui, ex qua remanet vinum $p u$ trefactum fecundum partem, in illo enim ftatu. imperfectam effe pútredinem certum eft. Talis etiam efíe videtur aeris putrefactio: quando enim permiftum habeat plurimum ficca exhalationis, \& vaporis etiam aquei (nam aquea humiditas putrefcibiles maxime res facit, pro. pterea quod humidım, quod in mifto yt mate. ria requiritur, aqueum potifime eft, ficuti etiam ficcum eft potiffime terreum; hac enim duo elementa fubftantiam habent magis confiftentem, \& humiduma queum aptius eft ad conglutinationem, \& vnionem partium mifti, quam humidum aereum) poteft ab externo calore feu circumdantis ignis, feu ab aftris genito educi aeris calor naturalis vna cum aliqua humoris parte, qux erit imperfecta putredo, \& fecun. dum partem dicta, quia totus aeris humortam proprius, quamalienus non poteft ea adicneà ficco permifto feparari: ideo \& ante putrefaftionem, \& poft feruaturnomenaeris, quia non fecundum totum eft facta illius corporis diffoJut1o, neque omnis calor eductus eit; etenim fi remanet $a$ er, neceffe eft vt aliquid caloris in co remaneat: huius autem putredinis fignum apparet, quodaer fit turbidus, \& fitum generat in fuppofitis illi corporibus, ve in fuperficie terrx, \& arborum, \& xdificiorum, ad qua fitus tanF quan grauis defcendit; ideo quando turbidum, ac denfum effe aerem videmus, id fignum eft purredinis vel prafentis, vel futurz; indicaturenim permiftio multarum exhalarionum, qux: aerem putrefcibilem reddunt, prafertim tem pore $x$ ftiuo, aut verno, nam fine calore fuperante calorem proprium non fit putredo; purus, autem aer, \& nulli alii elemento permiftus. non poffet putrefere ficuti, neque aqua pus. ra; quomodo enim feparari poteft humidum 
à ficco, vbi nithil eft ficci? Partes autem terræ, qux permiftam habeant humiditatem aqueani, \& aliquid caloris, poffunt putrefieri a calore ambientis educente calorem illum intrinfecatua vnacum illo hunido nutrunfecato, ex qua puruactune teura illa fiet humbdor, \& apparebit etian in ea fitus, ficuein altis nultisputrefcentibus : ideo proxime videtur acecdire hæc putretactio ad cam, qux dicitur interitus fecundum to:um; quia poteft totus educi illeparuus calor, \& tous ille paruus humor, itaviemaneat tera pura ; eaque erit diffolutio in clementa limp!icia : fed nois elt ignosandum illan putredinem vocari poffe \& lecundum totum, \& fecudum partem ; quatenus enim reuera eit perfecta dillölutio in fimplicia; eatenus eft interitus fecundum totum, led ratione eius, quodapparet, dicitur fecundum partem tantum, id eft, fecundum accidentia; nam \& illud quod putrefeit, vocatur tern, \& id; quod ex putredine remanet, vocatur fimiliter terra; quare non videtur fubftantiá interinfe, fed folum efle al terata: neque hoc Arift. aduerfatur dicenti tria hacelementa fecundum partem putrefcere, quandoquidem non dicit ca fecundum parten tantum polle putreferesfed cx eo, quod dixerat; aliqua ita putrefcere, vt fecuudum partem tantum intereant, infert tanquam conféquens, tria illa elementa putrefcerepoffe:quia li putredo fecundun partem non daretur, fed folum fecundum totum, hoc fortafle non intuliffet, fed folam terram inter elementa putrefcere poffe afieruiflet. Talem effe puto in corporibus animalium illam humorum putredinem, ex qua febres oriunturà medicis putridæ appellatx: ficutenim putrefcuít in eisdem excrementa, yt patet ex corum fotore poftquam funt emilfa, ita etiam humores putrefcere poffunt, fedvt plurimum putredine fecundum partem; ficuti vinum, \& aquam, \& res liquidas putrefcere diximus : calefacti enim humores ab aliquo extraneo, vt nomine extranei intelligamus etran circun ftantes amimalispartes folidas, \& quedcunque aliud extra ipłam humorum fubitantiam exiften cós cŏfideretur, putrelcunt, quia proprius eorum calor; \& cum calore humidum educitur; fed quum fint Aluidi, vix poteit totum ipfortum humidum extrahi,vt dici poffit putredo fecundum totum, fed pars aliqua humidi educitur, non tota humiditas; quare non eft nifi putredo fecundum partem : poteft tamen aliquis humor exingenti putrèdine exarefcere tandem, \& (vtaunt) incinerari,fed id perrarum elt; imo nec videtur eousq; vita animalis polle produci, donec tota fit abfoluta putredo, fed mortem prauenire neceffe eft : hoctamenif concedamus, perfectam quoque, \& fecundum totum putredinsm efe fateanut oportetid ramch mon a amodum euenit, fedputreicunt humores fecundum partem, nec omino abiolutur diffolutio in elomensa:
A imo etian cocptam humoris putredinem compefcunt, \& cohbent fxpercmediis medici, bumoremq; illum priftinæ integritati reftitumnt, vt afferit Galcn. in arte Medicinali in eo cap. quadde communifima intentione curatiua in. fcrbitur; inqut enim concoctrone fierivthumorum putredo celietsproinderesalterari milnence fibltantia. Hace eit mea de vtraque put:edne opinio:puto enim non duas efe lpecies, $\mathrm{red}$ vrani,adquan omnium putrefcentium rerum $B$ putredines redicantur; hanc autem modo perfectan! effe, modo imperfectam, quuam Arift.dicitefle fecundum partem, patet enim imperfectam putredinem per hoc fignificari.

\section{An putredo fecundum partem fit interitus forme fubfantialis, an fit merd alteratio, aliorum Sententia, do argumen- \\ ta. Cap. $X V$.}

C CEterum ve melius hæc fecundum parUtem dieta putredo intelligatur, alia non paruı momenti difficultas nobis expendenda proponitur qux inter aliquos eruditos viros a. gitata eft, qui in hoc conlentientes, quod hæc fecuhdum partem putiedo fit alia putredinis fpecies, frat tamè hac quoque à caloreambiencis, acerrime difputant, an fit in folis qualitatibusalteratio, an potsus fit interitus formæ fubftantialișrei putrefcențis; habetautem locum D quaftio hrc etiam fecundum noftramopinionem; quum enim dicanus, putredinem fecindum partem non afle aliam putredinis peciem, fed eandem quando imperfecta eft; opportuna admodum eft quzetio, an per hanc imperfectam putredinem intereat forma nifti, \& aliud miftum generetur, an maneat eaden forma, \& in folis accidentibus fit facta mutatio: nec indigua perfe confideratione hæc res eft, an vinum putrefactum differat fpecie à reiplo iă integro, $E$ an non differat; certum enim elt non differre fpecie, fi forma fubftantialis feruata effe dicatur. Thomas Eraftus efficaciter tueri contendit Eraft: hanc fecundum partem puitredinem effe interi- optrio. tum form a fubftantialis, \& quatuorargumentis vtitur. Primum confiderar verbailla Arift. Primum [qum feparatafuerst i natura] qua fignifi. argmëcant, illa, quxita fecundum portem putrefcunt, $t 2 s \mathrm{~m}$. recedere à fua natura, atqui natura eft forma, ergo vult Ariftoftel. hæc fuain formam amitie-

F re. Præterea hanc vocatcorruptionem, non folet autem alterationi tribuere nomen corru- argumeptionis, præfertim vero hoc non debet facere in tum. illo initio 4. Meteorologici, in quo de mintige neratione, \& interitu fubftantialifibi agendumpropoluit; non poteft igitur intelligere, nifi form fubfantialis interitum; fed rocat inreritum fecundum partem, quia non eit diffolutio mifti in elementa, fed eit mutatio mifti in aliud miftum diuerfof fpeciei ; putauit enim X. 3 Er.- 
Enftus putredinem ibiin 6. context. definitam non cfle diblulutionem in clementa, fed effe mutationem mifti in aliud niftum \& hac ratione Tertim diciputredinem fecundum partem. Tertio Asugn. riftoteles dixit uia eleméta effe materiam igni, non ignemillis,at hocfalfum eflet de mera alteratione, frquidem ignis quoque alterari poteft abaliis elementis, proinde eft i!lis materia alterationis;ergo loquitur Ariftoteles dé mutatione fubitantiali. Tandem argumentum fumit ex illis fignis, quibus Ariftoteles definitionem putredinis poltea confimat; inquit enim excunte calido, humidum quoque coeuaporare, hocautem fubftantix deftructtionem fignificat;nquis enim animalia generari ex is, quxputrefcunt, atqui animalia formam habent nouam, \& diuerfam à forma mifti putrefcentis, ergo vult $A$ wercesacterifter hac purcedine formam fubitantialem
ris ofzris opssio. efle alterationem tantum:quod oftendit ftatuto illo fundament 0 , quod hæc fecunda putredo nil aliud, fit, quam corporis extranei cum elemento commiftio, \& ipfius elementi adulteratio quadam, hocenim conftituto nilaíud réuera dici poteft: fed quia nos iam hoc fündamentum fuitulimus, \& oftendimus hanc putredinem fieri à calore ambientis, non eft quod cum eoampiius hac de re loquamur. Nonnulli vero alii recentiores, qui de putredine aduerfus: Eraftum fcripferunt, prater cxtera in hoc quoque conati funt Erafti fententiam impugnare; \& oftende're hanc fecundam putredinem mon effe interitum formx fubltantialis, fed effe meramalterntionem, \& in folis accidentibus mutationem: quum enim ipfi quoque exiftimauerint hanc fe cundam putredinem fpecie diftingui ab alterz priore, hanc huius differenrix rationemattulcrunt, quod prior putredo eft fubftantix mifti perfectus interitus, hæc varo eft mutatio in folis accidentibus ab eadem tamen caufa proue-

Primum illorum argumé Trum.
A Eio generationi mifti non maxime opponatur, led potius putrefactio. Addere etram nos in confirmationem polfimus teftimonium Ariftorelis in r. cap. 2 , Poftcr. vbidiftinguens quaftionem fimplicem, an fit, à quaftione comple$\mathrm{xa}$, quod fit, dicit perillam quæurirem fimplici. ter, \& fecundum totam luam fibfantiam, per hanc vero quari folum partem : atqui perhane quxritur inharentia accidentis in fubiccto : evgo fecundum partem apud Ariftotelem idem fi-

$B$ gnificat, quod fecundum accidentia. Preterea (dicunt illi) videmus quandoque elementa, \& aliqua mifta ita putrefcere, vt non amittant formam fubfantialeni : putrefcit enim vinumadhuc remanens vinum, \& feruans nomen, ac definitionem vini: fic'putridam aquam adhuc vocamus aquan : experientia ergodeclarat, hanc fecundain putredinem elfe in folis accidentibus alterationem.

\section{Propria fententia, \&opradictarum confs tatior or argument orum folutio. cap. $X V I$.}

$\mathrm{E}$ $G$ o huiufeerei difficultatem confiderans tandem in hanc fententiam deueni; rclictis his duabus opinionibus extremis, tertiam mediam accipiendam effe; vt dicamus in hac imperfecta, \& fecundum partem dicta putredine neque neceffarium effe $v t$ forma fubfantialis intereat, quod putauit Eraftus, neque effe neceffarium vt feruetur, quod alin eius aduerfarii afferuerunt; dicimus enim onnem putrefactio nem qua ad diffolutionem in elementanon per ueniat, vocariab Arift.imperfectä, \& fecundum partem : in hactāmen dari gradus, vt aliqua ita Ieuisfit, vt resalteretur folum fecundum accidentia, forma vero fubfantialis non intereat, aliqua etiam fit maior, qua fubrtantialis forma perdatur, nec tamen in elementa diffolutio fiat, E fed mutatio mifti inaliam miftifpeciéjidemus fur enim quandoqj vinü leuiterpurrefcere, necde- dw finere effe vinü.quia quando putzedinis intum animaduertimus, \& aliquo remedio calorécohibemus ne euaporet, nee pergereputredinen: finimus, non eft facta in vino mutatio,nifi in accidentibus, proinde non definit enfe vinum ; fic quando putrefcere incipit in venis sanguis, poteft a dhibitis remediis reprimi illa putrefactio, ita vt fanguis priftinæ fuxnaturæ, \& integritati. reftituatur; quod quidem feri non pollet, if forma fanguinis interiirler; ram fecundum Aritoelem compofitum, quod perit,nunquam idem redit. Contra etiampotcft eiufq; progredi putrefactio, vt forma fubitantialis perimatur, \&c vinum non fit ansplius vinum, nifi æquiuoce ficuti quando cadauer hominem effe dicimus; fic etiam fanguis poteft itaputrefieri yt nonft am plius fangus, fed factus fit humor putriduscū quonon poteft animal ampjius yịuere: \& hos. 
putredinis gradus optime norunt medici, qui in febribus putridis hanc differentiam notare confueuerunt, vt in alia maior, in alia vero minor putredo fiat; vtroque autem modo vocatur putredofecundum partem, quia fine deftructa fit miltiforma, fiue feruata, dummodo non fit facta in elementa diffolutio, non pore it perfeeta putredo vocaii, "neque eft interitus, contrarius generationi mifti: \& huius appellatiouis duplex afferri ratio pōt,vna eft, vocatur fecundum partem, quia non eft abfoluta, neque ad finem du- B ata putrefactio; altera' eft, vocatur fecundū partem, quia eft fecuadum accidentia: eft enim neceffaria omnis purrefactionis feu perfect $x$, feu imperfect $x$ conditio, vt fit alteratio in accidentibus; nōeft tamen neceffarium vt in omni $1 \mathrm{~m}$ perfecta putredine forma quoque fubitantialis perdatu, fed quandoque perditur, quandoque eiam feruatur: quoniam igitur confucuit Ariftot. regulas femper afferre vinuerfales, rede feciffet ti omnem imperfectam putrefactionem $C$ vocafiet interitum fecundum accidentıa, qua hoc perpetuum ac neceffarium eft; de forma vero fubftantiali nullam certam regulam afferre potuit, quia hec quandoque perit, quandoque non perit. Non eft tamen ignorandum, iftam appellationem, fecundum partem, non habere hanc propriam fignificationem, vt fignificet fe. cundum accidentia; fed proprie denotare quiddam imperfectum, quod ex aduerfo refpondet ei, quod eft perfectum, \& fecundum totü: adeo vt alicuitis membri propriam agritudinem liceat appellare fecundum partem, non quidem vt fignificetur eam effe fecundun' accidentia, red vt ab illa, quæ totius corporis eft ægritudine diftinguatur; hoc enim nomen, pars, now habetproprietatem, vt fignificet accidens : alicratio autem fuit quand oque vocata generatio fecundum partem, quatenus accidens non eft tota res, fed aliquid rei; ideo quicquid eft aliquid rei; neque eft res tota, non video cur non poffit appellari pars, etiamfí non fitaccidens: hoc dico, quia, etfi defendi poteft quod Ariftoteles in memorato loco per interitum fecundum partem polfit fignificare interitum fecundumaccidentia, tamen ego puto hanc eius mentem non fuiffe; fed ipfum ea tantum ratione dixiffe fecundum partem, quatenus nō eft perfectus mi$f_{1}$ interitus; nam mifto prout eft miftum ille ir. teritus competit, quo in elemenra diffoluatur, nosi ille, quo mutețur in miftum diuerf $x$ fpe- $F$ ciei. Veritate declarata, fuper eft vt illorum argumenta expendamus atque foluamus. Ad pri-

$E$ - mum Erafti dicimus, receffum à natura non femper fignificare amiffionem formz fubftantialis, fed quandoque fumi poffe prorecefiu fecundum aliquem gradum a quatitatibus naturam rei confequentibus, quæ naturales, \& effentiales appellari folent; quod quidem in elementis manifeftu eft: putrefcit enim aliquando
A aqua, fed remanet aqua, dicitur tamen recedere à matura, 'quatenus aliquantum recedit à fuis naturalibus qualitatibus, nempe quas habebat quatenus erat miftum quoddam: Nam fi ì natura recedere femper lignificarct formæ fubftantialis amiffionem, omnia xque recedcr nt à natura, nec daretur maior, aut minor receflio; quoniam igitur manifeftum eft dari \& maiorem, \& minorem recelfum à natura, necefle eft vt he poffit in accidentibus quoque efientialibus confiderari. Ob id notanda maxime eft ratio, cur Ariftoteles imperfectam putredincm fignificare voluerit per feparationem à natura: ratio enim eft, quoniam perfecta putredo duos terminos habet; vnum, à quo; alterum, ad quem; terminus à quo, eft ipfa mifti natura, cerminus vero ad quem, funt naturæ elementormm, in quas mifiti diffolutio fit; vtrumque igiturterminum attingit perfecta putredo, res enim \& à natura recedit, \&_ad clementa peruenit: aft in putredine imperfecta poftremus hic zerminus non attingitur; nam recedit quidem res à fua natura fue pèr qualitates fibi contrarias, fiue etiam per a miffionem form $x$ imiti, at non peruenit ad diffolutionem in elementa: quemadmodum fi quis ab hac vrbe difcedens Romam proficifcatur, perfectum eft iter, fi Roman attingat; at imperfectum, fi maneat $B o$ noniæ, receffit enim à patria, \& Romam verfus profeetus eft, fed Romam non peruenit: Ariftotelesigitur reete ibi fecit, declarans imperfeatam putredinem per receffuni à natura, non per diffolutionem in elementa, licet per hanc potius declaretur natura putredinis fi modo ad eam perueniat; denotat igitur imperfectam putredinem ad hoc vltimum non peruenire, quum eam declaret per folum receffum à natura, \& dicat effe interitum fecundum partem. Ad fecundum dicimus falfum effe id, quod fu- Ad fecišmit Eraftus, nomen corruptionis apud Arifto- dum.

E celem non fignificare nifillam, quæ fecudum fubftantiam fit: \& miror quomodo non viderit ea, quain 2 . Phyfic. contex. 7.\& 8. \& in i. de Ortu \& interitu 18. \& 20. ab Ariftotele fcribuntur; ibi enim etian in accidentibus mutationem, generationem \& interitum vocat, non ta. men fimpliciter, féd fecundum quid, quod hîc dititur fecundum partem : quod vero inquit Eraftus folum fubftantialem mifti interitum ad quarti Meteorologici inftitutum pertinere, negandum eft; nom in eo quarto libro de piuribus mifti alterationibus agitur, qux noin funt fecundum fubftantiam mutationes : in primo autem eius libri capite non negamus confilium effe Ariftotelis agere de miftigeneratione, \& interitu fubftantiali; fed ad eandem fcientiam, \& ad eandem tractationem pertinere dicimus cofiderare id, q̨iod proprie, \& fumme tale eft, \& id, quod minus eft tale : ideolicet pracipue ibi agat de perfeita putredine, qua $x 4$ perfeCur pu-
tredorm
perfecta
socata
fetepa-
ratio a
natura 
Ferfçe orpotniturgeneration mif 1, tamen cö- A lidenarecian debutepurednem nuperlectam qua cit mifti intcritus lecundum patem; ideo cam titigir paucis verbis in s. contextu cius libri, \& itatim ad pertcon putredinem confiderandam reuerfus eft, \& culs definitionem tradidit, qux imperfetx quoq; putredini imperfecte \& fecundario accommodatur; fic etiam in primo libro Pofteriorum non defininit A riftot. demonftrationem ab effectu, fed lolum demonftrationepropter quid, of huires cordiciones do cuit; demonftrtionis autem ab cffectu fatis habuit notare defectum, \& cadicntiam à perfectiosdter. trum. ne dem on ftrationis propter quid. Tertium a:gumentum Erafti cōtra iprum manifefte retorquetur:inquir enim, fr Arift. dicens tria elemęnta efie materiam igni, non ignem illis, intelligeretalterationem, țlfun diceret, quia nō minus. ignis ab i!lis alterari potent quan alis ab igne; ego vero fimiliter dico, fi Ariftor inteligatfub. ftantialem mutationem, fallum dicit, quia non mints ignis ab aliis elemertis inerimi poteft, quã alia ab ipfo. Ad argumentüigitur rếpōeo, Ariftotelem neq; de alteratione elementorum ibi loqui, ne q; de eorum generatione, \& corruptione, qua fità contrario, fic caimetuam ignis abaliis \& alterari, \& deftrui poteft: fed loqui de fola: putrefactione, qua eft corruptio caloris. proprii acalorealieno; fic enim tria elementa: pat1 poflunt abigni, nonignisab eis, quum nihil'eo cnlidius fit. Ad vltunum dico, fallum effe id; quod fumit Fraftus; Aritatelem: in contex. 6. illius libridefinitionem adducere; non illius priorisputredinis, quam dixerat effe interitum mitti naturalem, Q illius generationi contrariü, redalteriuspofterioris, \& yiolenta; nos enim: dicimusdefinitionem illam prxcipue competere perfecte putsedini, quan A riitot. in 3.contex. dixerat elli interitum contrarium generationi mifti:propterea illin om na ligna, qua pooftea ad illius definitionis confirmanonem affe. runtur, cam potillime putedmen refpiciunt; imperfecta autem putredini competent modo aliquo, \& imperfecte, \& v t illi aptari pollunt:1 on eft autem ncceffarium, vt omna illa figna conueriant imperfect xutredini, \& fecundum pardex; darur enim putredo italeuis, ve nullum inea aninal generetur, èque eft mera alteratio, in qua non fit vila mutatio formz iub. Atantialis, nē̄; vllius formæ generátio. Ad conttaria vero argumenta, quæ ab Erafti aduerfariis a liducta funt, refponfio clafá fumiturex iis, qua hactenus diximus. Ad primum enim iam dictum eft, hanc putredinem ab Ariftotele appellarifecundumpastem eatantú ratione, quatenus non eft fecundun totum; qua eadem ra-

C. tione etiam generatio accidentalis folet yocari fecundum partem, quia non eft mutatio fecundum totum: Alterum veroargimentum, quod ab experientia fumitur, nil aliud probat, nifi. dari putrediné, quafit mera al teratio, per quāns. forma fub́ftantialis nó intereat, quod: nos quoqué confitemur; dicımus enim vinum quandoque ita putrefcere, vt forma miftionis feruetur: at non probathanc folam intelligere Arutotelem per interitum fecundum partem; dicimus D enim Ariftot. non hanctantum comprehendere; fed etiam illam; qua deftruatur forma fub- Atantualisy. dummodo non fiat perfedta difrolutio in elementa, fed fit mutatio in iliam mifi. fpeciem, nam hrcquoq; yocatur ibi ab Ariftotele interitus fecuncum partem.

\footnotetext{
-
}

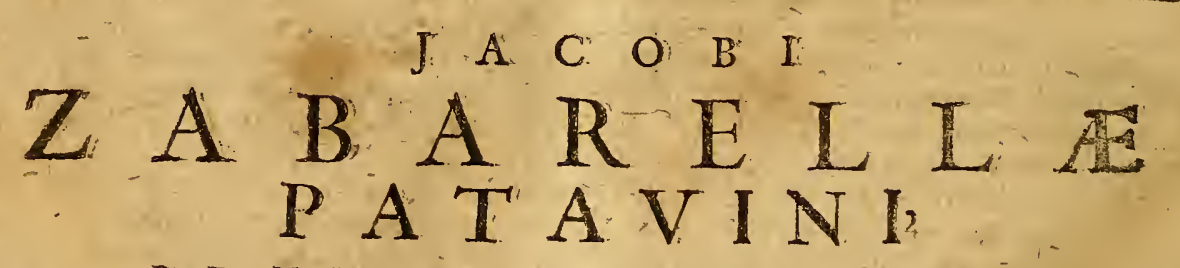

\section{E: II I S T I C C E N E R A TI O N E.T. IN.TERITV:}

\section{LIBER T E R T IVS.}

Definitione.putredinis ä Guleno adduct a, aliorum. Sententici de illius: comparatione. cum definitione Ariftotelis, G carum: confutatio: Cap: I:.

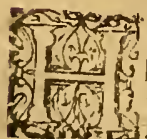

A Efenus ea, qua ab: Ariftotel: de: puttcidine dicta- funt; , percurrimus, \& eius fententiam, quantum per nos: ficri potuit; declaraumus: reftat yt:
Fi tum alias ab aliis traditias definitiones putredinis expendamus; \& cum hac, quam Ariftoteles. attulit conferamus, videamufque à quonam fit putredo optime definita; tum demun hanc Ariffotelis fentêtiam ab omnibus difficultatibus,, \& abaliorum morfibus vindicemus, \& fic quo- Pur. que ciusveritatem,confirmemus.. Confideran= $n$ is duprimo loco eft putredinis definitio; qumm nitid Galcnusaddusit in lib.11. Methodi, cap. 8.pro- Galc ponit cnim co in loco ex profeffo putredinis na- allat 
turan declarandam, \& talesm cius definitio$n c m$ atiignat, purrefactio eft nutatio ad colruptclan totus fubftantice putrefcentis ab cxtemacal ditate. Hane defintionem alii \& Philolophi, \& Medici, qui de pistredine loqumi funt, in eundem fenlum cadere exiftimamint cun iefinitione ab Arritotele sradia; difcrimen vero, fi quodeft, prium, ac leue efic : nos igitur ea, quxabaluśs de hac Gal. definutione dicuntur; breutes confidesemus, vt poftea ipfi guoq? propriam hac in re fententiam feramus.

a- Nonnulli recentiores dixenunt, eundem efre v-

pi- triuquedetinitions fenfum, fed eas in eo tan:

de tum differre, qund Galenus puĺre dinem pro terne mino acceptam definiult, quum otius fubitan-

F. tix comptionem dixcrit; Ariftoteles vero pro va innat termino, dixit ením corruptionem proprii caloris, quxeft via ducens ad fubttantix ineritum; qum tamen ambo idem fignificare voluerint. Sed hac fententia mihi non probatui $;$ h.mamq; in duobus peccalfe videntur: prino, quod hinum definition im difcrimen, quod reuera magnum eit, vt nos poftea oftendemus, ipfi non viderunt: de indequod hoc ab eis confideratum difcrimen reuera nullumeft : nam fi Galenus dixiffer putrediné effe totius fubftantixinteritum, vtiq; dicere poflenus eum definiuffeputredinemprofolotermino non comprehenfa viar, quxeit altcratio preuia; fed quum dixerit efle mutationé ad corruptionem,aperte dixit viam adinteritum, non interitum ipfum: itaq; non eft verum id, quod illi dikerunt, definitionem Galeni in hoc differre à definitıone: "um Axiftotelis. Alivero dixerunt, harum definitio-

num difermen in hocefle conftituum: quod. Aritot dicens putredinen effe corruptionem, putrefactum miftum-refoexis; Galenus vero dicens eile viam ad compionem, refpexit miftum femputridum, quod poteft redici ad benignum: igitur ifti cognouerurt Galenis fignificalie:vian ad termimm, quód ifti alteri negauevunt. Sethi quog in eo errâtun quod dixerunt Ariftrefpexifinifum put efreim : etenim lipipus nifti corruptionem dixiffet, vtique: admitti poffetifta conf́deratio; at no mifticorruptionem dixit, fed corrptionem proprit caloris, qux competitetiam mifro femiputrido; calor énimęumint qualitas, furcip: magis \& minus: quare educi potef à calore ambrentisalıquis gradus caloris naturalis 11 dicetur corruptio caloris, eii no to tius, nec tamen erit adhuc corrupta fubfantia. Videntur etiam ifti ini hoc fibicontradicere, quum prius dixilfent AriAtot.ibi definire vniuerfe omnem putredinem; tam perfectam, quam imperfectam; fic enim: necelle eft Arift.refpexiffe \& putrefactum mifum, \& femiputridim, ficutireuera debuit ab. folute putredinem definire; igitur faifum eft id, quod poltea dixerunt, Arift. definire miftü tantum putrefactum. Non eft etiam consedendum
A id, quodde Galcno dixermnt, neq; tantus error Galeno attribuendus oft, vt proponat abfolute naturam putredinis declarandam, poftea vero folius imperfectx putredinis definitionen adducat: finamy; ea defininio naturam putredins exprimit, deber pracipue compctere putrediri perficta, qux enim magis eft putredo, ea magis recspit definitionem putedinis: iraquecredendum ponius eft tam Galenum, quam Arift. abfolute \& vniucrfe putredinem definiuffe, ita vt definitio competatpimum perfeet $x$ putredini, Cecundario autens: etiam imperfectr;" ideo notandum in hoceft Ariftot artificium, qui licer Notaar prius dixiffet agendum clle de putredine, qua tificium eft mifti interus contrarius generationi eiufdem, tamen in definitione non dixit effe mifti: interitum, fed proprii \& naturalis caloris, quia fi interitum mifti dixiffet, non comprehendiffet illam. imperfictam putredinem, qua non eft: mutatio form $x$ mifti, fed in folis accidentibus altcratio: voléns igitur ea definitione omnem C putredinen vniuerfe completti, \& perfectan, \& imperfectam; non dixit effe fub ftantix interitum; fed folum dixit efie proprii caloris corruptionem; hac enim ef communis onuitum putredinum conditio pt propritis reicalor à caloreambientis cuocetur, fue totus, fue aliquis $i$ pitisgradus, \& quandoq; etram abfq; fubftantix:l retione. Sed praterea illud in horum fententia mihi videtur efle mirandum, quomodo potuerint eam Galeni definitionem approbare, D quum iam de Ariftot defiritione lo quentes dixiffent eam non eflcpesfectam, nifi \& calot extemus, \& frigus proprim, anctam dua diftineta carfx in ea exprimantui ginm enim lecundun eos Ariftoteles defintiomen à fé allatam abfoluat \& perfectam red dat : adiciens ftatini etiam frigus proprium, non video quomo do ipf, qui Medici funt; Galenum tueripolitint, quineq in ea definitione, neq polt allatam de-finitionem facit lilam propri-figoris mentio-

E: nem. Ex his ergo pateterrafe hos omnes in de: finitione. Galeni confidesarda; \& ea cum definitione Aritat. conterenda:

\section{Collatio defintionis: Galenicum definitio- ne Ariftoteits, olitections contra de- fintionem Gulemi. Cap. II:}

D Icam ego hac in re liberephiloroptandoquid rentiam, nec verebor dubia illa in medium additcere, quia me cogunt Galcni de-7 finitionem minus probare; \& eortum folutionem Medicis meditandam relinquam.. Quod: non bene fit à Galieno definita putiedo; often:do figno euidentiflinto; deinde eroris rationem adducam; \& quæ in ea definitione vitia'in-fint, confiderabo. Signum quidem manife fum - pratia definitionis elt, quod aliis quoque competit.præter putredinem; competitenim étiam $x=5$ combus:-
Arift. in definiti. one putredinis. 
combuftioni, quia cöbuftis eft mutatio ad corruptionem totius fubftantix corporex à colore extemo: neque recte Galenum tuentur illi, qui dicunt Galenum per illa verba, corporis putrefentis, excludere combuftionem, \& ab ea putredinem fcparare; hoc enim eflet putredinem à combuftione feiungere per femetipram, nō per aliquam effentialem differentiam; quemadmodum fi quis definiret hominem per animal bipes, deinde a h ominem ab auibus feparandum adderet humanum, dicens, homo eft animal bipeshumanum: fic enim nullam inter hæc differentiam poneret, nifi quod homo eft animal bipes, quod eft homo, auis vero eft aninal bites, quod eftauis : fic etiam hic fenfus effet,putredo eft illa mutatio ad totius fubftantix interitum à calote externo, qux eft putredo combuftio autem eft mutatio ad totius fubftanria interitum à calore externo, qux eft combuiftio: ponit igitur Galenus in definitione rem differentem; at differentiam, qua differt, non ponit: ideo in eum quoque errorem lapfus eft, quod in definitione definitum nominauit vt pattem definitionis, \& feparat ipfum à combuftione per femetipfum, quod quidem vitiofum eft, quia in definitione non eft ipfumdefinitum ponendum loco differentix: (ed dico praterea neq; fic putredinem à combuftione feparari; nam fi corpus putrefcens in ignem coniciatur, ita vt conburatur, 1 lla combuftio erit mutatio totius fubftantix putrefcentis corporis ad cotruptclam à calore externo: quod fi quis dicat contingere peraccidens vt corpus putrefcens comburatur, hoc nullius momenti eft; quoniam propria rei definitio non debet alii rei competere nec per fe, nec per accidens : fi enim contingerct per accidens, vtaliquod animal brutum effet animal rarionale, ea dici non poffet hominis definitio, neque effentiam hominis exprimeret: quoniam igitur definitio à Galeno adducta compétit etiam combuftioni, non poreft dici putredinis definitio, licet fit oratio qux vere de putredine prædicatur; quū præfertim cum putredine non $R$ atio de reciprocetur, ficut oftendimus. Vt igitur huius fectus in imperfectionis rationem cognofcamus, \& cur definiti- Galeai definitio effentiam putredinis non deone Ga- claret, nec feparet eam ì combuftione, confide. Lens. rand $x$ funt particul 2 illius definitionis, \& fingulæcum partıbus definitionis A rift. conferendx. Iam fape diximus, \& in lib. logicis fufe declaramus, in definitione cuiufque accidentis perfecta, tres partes neceffario poitulari genus, fubiectum, \& cạufam. Quod igitur ad fubiefum attinet. Galentis nullum proprium fubieEtum putredinis expreffit, nifi totam corporis fubitantiann, quod nimis anaplum \& comnune eft, neq ; in co vlla apparer ratio putrefcibilita. tis; Arift. vero hanc exprefit, durn dixit, in vnoquoq; humido, nam omne humidum eftputre ícibile, \& quatenus eft humidü, dummodo mi-

A ftum fit: primũ igitur hic defectus in definitione Galeni manıfertus ineft. Genus vero quod folet formā, \& effentiam definiti fignificare, exprimiturà Galeno valde commune, dum dicit mutatio ad cortuptelam; complectitur .n. omnem preuiam alierationem ad quemlibet fubftantix interitū ; \& quamuis huic addatur, à calore externo, comprehendit ēt combuftionem, vt iam oftendimus: Ariftoteles vero dixit, proprii calo. ris corruptionem, in qua contineri intelligatur B etian fcparatio humidi à ficco; hæc autem proprii caloris corruptio propriam naturaín putredinis exprimit, \& eam feparat ab omni alin corruptione, nulla enim datur alia proprii caloris corruptio, quam infequatur feparatio humidi à ficco, nifi putref.ctio: quod fi etiam caufa externa adiciatur, adhuc manifeftior res eft; nulla enim datur propric caloris corruptio à calore $\mathrm{m}$ bientss, nifi fola putrefactio; hic enim eft corruptionis modus proprius putredinis, in quopu-. C tredinis natura confiftit: quem quum Galenus in fua definitionenon exprimat, nec confiderare videatur, vanum eft dicere naturam putredinis per eam definitionem declarari: faltem fi traditam illam definitionem poltea explanaret, \& doceret quonam pacto ab extcrno calore mutetar ad corruptelan totarei fubrtantia, fortalie aliqua iatiose detendi ea derinirio poffets fed in eius definitionis declaratione Galenus in to1o 1 llo capite ne verbum quidem recit deeduD Etione caloris naturalis, vel de feparatione humidi à ficco, fèd folum affert rationem cur à calore externo putrefactio fiat, diftinguens calorem externum à calore proprio \& naturali, quia proprius internus calor eft potius rei corferuatiuus, exteinus vero humores inuadens eos perdit, quare à calore externo fit putrefactio, non à proprió calore: quod autem proprius calor ab externo calore extrahatur, Galenus ibi non confiderat, ideoque de eo, in quo E eftputrefactionis effentia conftituta, nibil penitus dicit; imo magnam errandi occafionem præbet, ita vt plures in eum errorem inciderint, vt dixerintaliudeffe putredinem Philofophorum, aliud effe putredinem Medicorum, \& humorum putredinem apud Medicos nil alind effe, quam effèruefcentiam, ac cxuftionem; reuera enim definitio à Galeno adducta combuftioni competit, quarenonabfqueratione factum eft, vt humorum puttedinen effe exuftionem quandam exiftimauerint. In caufa vero putredinis eatenus peccat Galenus, quatenus cauram af. fert remotam, \& accidentalem, ex qua non cogro of cimus quomodo fiat putrefactio; externus enim calor caufa eft corruptionis caloris naturalis, quam unfequituy feparatio humidi à ficco, \& hanc tandë inlequitur totius fubftantix corruptio, ideo Arift, caloré externü afferés vt caufam corruptionis caloris naturalis, affert ipfun vt caufam proximā, quia vi caufam effectus ab 
co imınediate produeti; Galenus vero cundem 'A affert vtcaufan remotam, quia vt caufam effectus remoti, nempe totius fubftantix corruptionis : Ignorato igitur effectu medio, non cognofeiturquid fit putrefactio, neque cognofcitu: modus, quo externus calor totam reifubftantım corrumpit, fiquidem poteft etiam intelligi corruptio per combuftionem, ino \& multo magis, quia is eft modus lōge euidentior, quem facile eft vt folum refpiciat quisquis eàn definitionem confiderat. Itaquefi Galeni definitio in demonftrationen mutetur, ea inullam fcientiam partet, quia medium erit maioris cxtremi catza remota, \& propofitio maior demonftrabilis; \& mediata erit : ea igitur definitione non dicitur quid fit putredo; quoniam neque proprium fub. iestum exprimitur, neque eflentia purredinis, neq; proxima reicaúa adducitur. Ego quidem nullam Galeni defenfionem inuenio; nifi dicamus ipfun non cam afferre vt defiuitionem putredinis, fed prafupponere iamab Arift.perfecte definitam putredinem, ideoq; pauca ill. de putredine dicere, v t nos reliqua iam ab A rift. dicta fubintelligamus. At fi eam vt definitionem putrednis rite traditam Medici recipiendam effe contendant, vt \& ipfi omnes, \& multi etiam Philofophi eam vt definitionem receperunt; ego quidem, quum nullam prædictarum difficulthtum folutionem videam, eam ex Medicis audire cupio, \& expecto.

\section{Alia ab aliis adducta putredinis defini- rio, Eo eius reprobatio. \\ CaP. III.}

Tonnullirecentiores, quifortaffe animad1 uerterunt definitionem purredinis à Galenoallatam complecti etiam combuftionem, voluerunt eam aliquantum coasctare, \& talem ipfi perfectam, \& omnibus numeris abrolutam putredinis definitionem protulerunt; putredo eft corruptio mifti fecundum totam fubftantiam proueniens à frigore proprio vala cum calore ambientis, alteram enim caufam addendo, frigus proprium, videntir conbuftionem a- exclufifie. Sed fi bene confideremus, hre definitio iisdem difficultatibus, quibus definitio Galeni, \&: fortaffe etiam maioribus obnoxia eft: de humido enim, \& de proprioputredinis fubiecto nihildicunt, nihil de corruptione proprif caloris, nihil de feparatione humidi à ficco, qux eft efientia putredinis, vt iam dictum eft; quare non expreflerunt proprium corruptionis modum, quo ab aliis corruptionibus putrefactio diftinguitur : fed praterea dicentes corruptionem totius fub ftantix, excluferunt putredinem imperfectam, qua non ínterinitst tota fubitantia ; cui quidem crimini non eft obnoxia definitio Galeni, qui dicens murationem ad interitum, imperfectam quoque putredinem com plexus eft; fiquidem tendere ad interitum res 2 liqua poreftad ipfum tamen non peruenire, fed preferuari : erran unt ctiam addentes frigus proprium tanquam alteran caufam per le agentem, hoc enim falfun effe iam demonftraimus; quem errorem non commifit Galenus : nihil præterca dicunt de corruptione proprij caloris ; quare calorem ambientisaccipiunt vt caufam remotan, ficut etiam contra Galen. confiderauimus. Præterca in eo reprehendendi effe videntur, quod rationem reddentes curà Gale-

B no, \& a fein definitione dicatui, fecundum totam fibftantiam, dicunt per hoc diftingui putredinem à corruptione nifti animati, qua vocaturmors; fiquidem mors non eft rotiusfubftantiz interitus, qutum remaneat cadauer, quod poftea interit,per putredinem. Hoc autem dicentes, videntur non confideraffe definitionem generation is vniuerfe accept $x$, quam Arift. tradit in cont.23. lib.1. de Ortu \& interitu, ibi namque dicit omnem mutationem fubftantialem C elfe mutationem fecundum totum ; quamob. rem fiomni generationi fubftantiali ea definitio debet competere, oportet etiam viuentis interitum effe mutationem fecundum totum; nam reuera ibi Ariftoteles non ideo dicit fecundum totum, quod velit omnes prorfus fubftantix partes interire, prima namque materia certe non interit; fed quia vlima forma deftruitur, quæx, quum alia onnia contineat, \& det rei effe fpecificum, ideo vocatur totum:patet igitur tam morten, quam putredinem effe totius fubftantixinteritum, vel neutram, quandoquidem in putredine relinquitur prima materia, qux fubftantix pars eft;imo etiarn fecunda materia modoalıquo relînqui videtur, quum per putredinem diffoluatur miftum in elementa, quxaliquo modo in ipfo inerant, \& ita illa, quæ fimul erant commifta, poftea feparantur : patet igitur in mifto folan mifti formam efle reficiendam, \& in viurente folam animam, cuius vtriufą; corE rupio dicitus corruptio totius fubftantix, tum mifti, tum animati:quum veriufqiauferatur effe fpecificum; quare ron minus mors, quam putrefactio, eft totins fubftantiz interitus;non igitur per hoc diftinguitur putrefactio à morte. Ex his ergo qux diata funt, colligimus definitiones putredinis ab aliisadductas maximis vrgeri difficul ratibus, quibus tradıta ab Ariftot. definitió ron rigetur: fed artificio plena eft, \& optime na turam, \& caúam putredinis exprimit, ita vt melius expriminon poffe videatur.

\section{Dubia, \& aliorum obiectiones aduer fus deffi nitionem putredinis ab Arift tra- ditam. Cap. IV.}

Equitur vt Ariftotelis definitionem, atque Sententiam ab aliorum obiectionibus, dur biisque eam oppugnantibus vindicenus ; \& fis quogisillius yeritatem, \& sa quı à nobis hactenus 
ctenus ad eam declarandam diąa funt, tandem confirmemus; magnum enim effe folet verita. tis indicım, quando om nia, quxaduerfus eam cuterevidentur, dubiaffar ile foluuntur: quoniam autem plura dubia ian à nobis in præcedentediputatione folutífunt, \&-aliorumplurum iolutiones, etfia nobisnon exprellix, tamenab omnibus facile ex dietis notris colligiportunt; nunc is prateritis, alia quadam, qux dıficiliora videntur, in medium affere mus. pri-

1. Dubi-

wins. mum quidem faifum videturid, quod Artitoteles dixit, putrefastionem efle mutarionen vere contrarian generarioni mifti etenim generatio eft mutatiovna, at putrefactio non elt vnamutatio, quum expluribus mutationibus conttare vidcatur, vnde etian fatum elt, vt multiabrolute negauerint putrefationcm efle mutationem ynam : quoniam igitur endem debet effe contraviorum conditio, noneft putredo generacioni contraria, quum generacio fit muxacio $\mathrm{v}$ na, putredo veroex pluribus conftet, fit enim primum proorii caloris corruptio, deinde huinidi propris euaporatio s- feparacio humidi à

2. Dubiй ficco, \& diflolutio mifti. Secundocbiicinntaliqui Arifi.illud idem, quod nos antea Galen.ob. iecimus; nam defnitio putredinis ab Arift. tradita competere videtur etiam cóbuntıoni, quo-

3.Dubiñ. niam etian combuftio ef proprii caloris corrufus definitionem putredinis, quia non omnis putuefactio à calore ambiëtis fieri videtur: qui enim onmis putrefactio fit interutus mifti, quatenus,miftum eft, proinde fit mifti in elementa diffolutio, omnisigitur diffolutio mifti in elementaputrefactio eft;atqui poteft miftum in elementa diffolui, etiam abfque actione caloris ambientis; ergo poteft aliquid putrefieri non à calore ambientis : affumptum probatur triplicitei. Primo fic: frmifum poneretur in vacuo:aliquando interiret, quia neceffarum eft, yt omae genitum poffit interive, \& aliquando intereat; \& it ex elementis genitum in elementa diffoluatur; at in vacuo nullus effet a mbientis calor; ergo putrefactio fieret non à calore ambientis. Prærercafinifum poneretur in centromund, vbinullus eft calor, putrefieret aliquando, non tamen à calore ambientis. Preterea miftun conftat cx contrariis, ergo ex fola contrariorum inter fe actione \& paffione diffolui, \& interite potef, ficigitur fiet putrefactio a principio in terno, ab interna pugna, non à calore a mbientis;ideo fxpe apud Aueroem legimus, natura4. Dubi- lia corporaideo interire, quia conftant excon-
sm. traris. Quarto dubitatur, \& eft obiectio Argen«in. terii contra A riftotelem : Si putrefactro eftinteritus contrarius generation fub ftantiali, debet. definiri corruptio fubftanix, vt defininit Galenus, 10 caloris corruptio, vt eãm Ariftoreles definuit, quum enim calor fit accidens, caloris corruptionon cit nifi alteratio; quare Anith. fibi
A aduerfatur, quum prius dixerit putrefactionem efle interitum vere contrarium generationi mifti; deinde verro dicat elfe corruptionem caloris, qua eft meña alteratio. Quinto obiicit iden Argenterius:courumpi eft pati,calor àtem non eft qualitas paffua, fed actina, ergo non reete dixit Arift.calorem corrumpi. Sextum dubium fatis tritum, ac vulgatum eft: caftanéx, \& nuces putrefcum intus, in extima autem parte nanēt illxix; ergo non fit putredo à calore a mbientis:

B quoniam ii ab hac tieret, oporteret pritus extimam partem, qua ambienti calido propinquior eft, putrefcere, quam intimam, qua etremotior: agens, enim non agit, nifi per contantum; quare prius agir in propinquum, quam in remotuní. Poftremo dubitetur ù multis qu $x$ in aere valde frigido frequencer putreñericununtur: nan: in hyene quoque 3 in magnis aeris frigoribus videmus \& lac, \& cones anmalium, \& herbas à folo feparatas, calia eicimodi putrefcere, quum tamen calidion illo are elle videantur; atqui ambientis calor, quan do eft minor caloremitt naturali, non ipfun incit, proinde educere eum non porest, ficut etiam A.rift. apertedixit; vel igirur hæc non deberent eo tempore putrefieri, feinon fit putrefactio a $62-$ lore ambientis.

\section{Dictorum dubiorum folutiones. Cap. Ir.}

$D^{-}-T^{T}$ has omnes difficultates ordinatim $[0]$ uamus, ad primam, orriffs iis, qux ab alıs dicuntur, nos breuiter dicimus \& generationem mifti, \& putredinem effe modo aliquo mutatio. nem vnam, \& modo etiam aliquo non effe vná: quum igiturfimiliter vtraque \& vna, \& non vna dici poflit, per hoc non frat quin vere contraria inter fe hæ mutationes fint : ipfa quidem mifti generatio fi maxime proprie fumatur pro fola fubftantialis form introductione, eft penitus

E vna mutatio : \& putrefactio fimiliter, fi pro fola formæ mifti deftructione fumatur, eftabiolute vna mutatio $: \&$ hoc potiffimũ refpicimus, dum dicimus eas effe inter fe contrarias; per vnam enim res incipit effe, qux antea non erat peralteram veroilla eadem res definit effe, qux prius erat: prouia veroad vtramque difpolitio fecundarium quoddam eft, quod ad fubitantix mutationem dirigitur; quare non ita exquifite confideranda eflevidetur, quia non elfneceffarium vt contraria eafdem prorfus habeant omnes cōditiones, fed vtalıquas habeant ealäen,aliquas etiam differentes, imo et ä contıarias a țamen quodadrnitatem, \& multiplicitatéattinet. cer. tum eft vtrang; acceptam pro fubitanti $x$ un tatione cü tota difpolirione prania, efie ccngeriē plurium mutationum- qux etian vocari põt mutarin vna, quatenus ad vnum finem tẻdit, ad fubftantix mutationem; quemadmodum enum videmus in animali plura efle diftincta mem- 


\section{5 de Mifti Gencrat. \& Interitu, Lib. III.}

bra, \& plures plures variis præditas tēperaturis, qux tamen omnia ad vnitatērediguintur ab vna vltima forma, quæe to: ü animatum reddit vnü; fimili quadā ratione plures ill $x$ mutationes, et fi fecundü fe plures funt, tamen refpectu vitimi finis, ad quem tendunt, dici poffinr vna mutatio, quoniam ab vno fine vnitaté recipiunt:fic igitur poffumus ét compreh éfa tota prauia difpolitio-

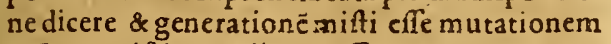
vnā, \& mifti putredinem effemutationē vnam: quod enim plures contineat mutationes, negari cérte non poteft; fit.n. primum atio calidiexterni , qua miftu calefit, poftea vero caloris naturalis euaporatio, \& eductio humidi, ̄̄ eft motus quidālocalis, \& humếatio externarü partium, ac demŭ totius exiccatio; quare oès mutationes, fiue totidem his contrarias in generatione mifti fieri non eft necef̂raü, ficuti ét non oportet vt in viuentis interitu fiant exdemillze prauiz difpofitiones, $\bar{q}$ fiüt in generatione eiufdem, neq;etiam vt totidem illis cótrariz, fed fatis eft $f i$ tinis vtriufque vnus fit, \& finis vnius fit cātrarius finialterius, \& to ta præuix difpofitionis cōgeries dicatur vna ex illius finis vnitate; fic. n. \& generatio mifti, \& eiusdem putredo eft fiin militer mutatio vna. Ad fccundū dubium multi cōcedunt êt combutionem efle corruptionem fprij caloris à calore externo, \& ad argument ii. hoc foluendura multa inania dicunt, đ̆ referenda non funt: egoputo non effe alio modo refpondendum, quam id conftanter negando; quoniam in combuftione deftruitur potius frigus àcalore, qu calorà calore: quum enim id $\mathscr{x}$ comburitur, vel fitfrigidum, v.cl habeat qualitarem mediam inter fummum calorem; \& fummum frigus, proinde fit minus calidum, $q$ ignis. \& refpectu.llius habeat lo cú frigidi, non alia ra. tione patitur, ٌ̆ vt frigidum à calido,agit,n.tunc ignis in gradus frigoris adeos corrumpendos. non in gradus caloris, \& in ea a ctione frigidum habet locum contrarij, humidum vero \& ficcum habent locum vel materiz patient is, velfmiliter humidum habet locum cötrarij, in quod: agit ignis vt ficcus, proinde patiens non patitur vt calidum, nec vt ficcum, fed vt frigidum, \& humidum:, \& perhorum deftructionern comburitur, atq; in ignem vertitur, eaq; eft adtio vehemens, \& violenta; quare com bustio nullo pacto. dici poteff corruptio cal oris à calore; fed frigidi: \& humidià calido \& ficco:in purrefactioneaūt. etfi calidum extern ù agit nrimum in patiens ca. lefaciendo, tamenagit etiam in calidū educendo; necalia ratione dicitur putrefactio, nifi quatenus agit calidum in calidum adipfum extrahend 'a', quod non poteft fieriactione vehementi,fed leni, \& fenfim facta: praterea Ariftot.ipfe: definitionem putredinis poftea declaransafierit illam proprij caloris cerruptionem complecti. $\&$ in fe continere feparationem humidi à ficco; asin combuftione non euapoxathumidum nec
A feparaturà ficco, fedabfuniturtotum, ficcum astem intenditur, \& fit ficcum igneum, quia amina elementa ibi deniq̨; mutantur in forum ignenı:eductio igitur caloris naturalıs, quam infequatur feparatio humidi à ficco, \& \& quz fiar à calore ambientis, non poteft effe combuftio, fed folum putrefactic. Praterea conditio neceffaria putredinis eft $y t$ fit in corpore humido, non ita. combuftionis, poteft enim terra puramutari in ignen1, qua crit combuftio rei nullatenus humi-

B dx:paretigitur definitionem putrefactionis non polfe dici definitionem combuffionis. Ad ter- Adtertiun dubium concedimis omnem diffolutio- tium. nem mifti in elementa effe puerefaktionem ${ }_{2}$ sed negamus fierialiter poffe talem diffolutionem. quam à calore ambientis. Ad probationes vero, ad primam dicimus, quod pofitum in vacuo miftum non corrumperetur, quamuis corruptibile fit:licet enim inconueniens fit, \& abfurdum, rem corruptibilem nunquam corrumpi,fequitur ta-

C. menex falfa \& impolfibilipofitione, eft enima impoffibile dari vacuum; quare non eft mirum, fi hoc pofito fequatur corruptibile nunquam corrumpi; \& alia fortafe plura abfurda;natura enim nihil fruftra facit, \& onmi corruptibili conftiruit proprium agens, àquo corrumpatus; tali autem: deftituitur miftum, dum in vacuo ponitur. Ad fecundam probationem dicunt multietiam ad. centrum mundi calorem aliquem perienire ex: actione colefti; à quo miftum fiibi effer, putre-

D fieret: fed hac folutio nititur.fundamento dubio, dum afferit ad centrum: mundi aliquid caloris peruenire. Idcirco ego aliter refpondeo. fiue illuc peruenist calor, fiue non perueniat. argumentum nullius roboris effe : nam fi dica. mus, nullum ibi effe calorem, non putrefceret. illudmilum, non quidem: quod euaderet in corruptibile, fedquia non putredine, fedalio, modo interiret; etenim à circumftante frigi-do deftrueretur interitu violento, cuiusmodi: E. eft etiam combuftio quemadmodim antea dictum eff: ficut enim combuftio miftum in ele menta non diffoluit, fed totum conuertitin $\mathrm{i}$ gnem;ita fummum frigus in centro mundi mu-tarettotum miftum in terram deftructis cate-riselementis, fednon facerer ipforum fepara:tionem, qua eftpurrefactio. Si vero in centro. dicaturefiealiquis calor, is yel vincet calorem. mifti naturalem, vel non vincet; de hoc enim. non eff difputandum, quoniam ad dubij, folu:F tionem nihil confert : fijgituryincet, ab eo putrefiermiftum, \& erirputrefactio à calore am bientis; fivero fitita debilis, vtnon vincat, vtin. prxfentia concedamus, ab co non foffe putre. dinem fieri, faltem aget in illud mifrum tan-quam contrarium, nempe tanquam frigidum: in calidum, \& ita deftruet: illud deftrustione: violenta, ficut ancea dicebamus. Ad tertiam: probationem dicunt aliqui, licet miftum conftet ex contraris, tamen inzernum eius frigus: 
nonagerc in calorem internum, nifi ipfi domineturinon dominaturaüt nifi cóftituta prius aEione calidi externi, à quo internus calor im= minuatur, tunc enim incipit etiam frigus internum agere in internü calorem, \& ipfum expellere; eft ergo necefiaria actio calidi externi, quia fine hoc non fit putrefactio. Sed hancfolutione ego probaren on poffum:iam enim oftendifieri ron poffe, vt frigus internum agat in internum calor $\mathrm{cm}$, \& fit caufa putredinis pofitiua; fed faca miftione iam eft vna qualitas media, non dux, qu $x$ inuicemagere polint, \& quarauis etiam ea media qualitas intendatur, vel remittatur, eft tamen femper vna vel ad calorem, vel ad frigus magis vergens, quz non poteft in feipfa habereagens \& patiens : vtaŭt ad hoc probandumargumento ex ore iftorum defumpto, dicunt enim frigus non a gere in calorem, quia illi non dominatur, quafi poffet in illu agere, fi maius illo effet; fi autem hos verum eft, ergo deberet calor, quem dicunt viribus fuperiorem effe, agere in frigus propriü, \& ipfum expellere, eadem.n. effe debet ratioactionis \& graduum caloris in gradusfrigoris, \& graduu frigoris in graduscaloris; fic igitur fieri nunquā poffet vt daretur miftum exceffu calidum, vel exceffu frigidum, quoniam al tera qualitas poi $\vec{e}$ tior deftrueret alteram debiliorem; hocautem dicere effer omnem miftionem de medio tollete, \& omne primarum qualitatum temperameium: vanum igitur eft id, quod illı dicunt, facto temperaméto calidi cum frigido poffe vnū agere in alterum, curo- etiamfi plusinfit vnius, \& minus alterius. Ego me con-igitur aliter ad argumentum dico, conftsre ex fransex contrariis nō effe in mifto rationem corrupuocontra$r i \dot{s i s}, f t$ corruptibile, nis, fed corruptibilitatis. idq; non ea ratione, it corrumpi pofit miftum ex con!rariorū, à quibus conftat, actione inter fe, fiquidem facta miftione non poffunt amplius inuicem agere: qquo fit, $v t$ conftare ex contrariis nil aliud fignifice:, quam effe genitum exiis, qux fuerunt contraria, in ipfo autem mifo non funt anplius contraria: fed eatenus dicitur fignificare corruptibilitatem, quatenus miftum conftans ex contrariis eft natura mediz inter extrema contraria; proinde fignificatillud habere extra fe contrarium, à quolrdi, atque int erimi poteft; nam contrarietas eft non folum extremi cum extremo, fedetiam extremi cū medio: quoniam igitur miftum eft medium conftans ex extremis, vt ait Arift. in calceprimi libri de Ortu \& interitu, ideo pati, ac deftrui potelt tum à frigidiore, tum à calidiore. Sic igitur eft intelligêdus Auerroes, quando dicit, omne ex contrariis conftans efie corruptibile, per hoc cnim fignificatur, illud habere extrafecōtrariusn, ì quo détruipoteft, ita yt abexterno agentepati, \& corrumpi fentAd quar per dicatur, nuzquam à feipfo. Quartum dusum. biũ facile foluitur per ca, quaze antea dicta funt, iam enim diximus non omnem putredinem ad
A interitum vsque fubfantiz peruenire : quanquam enim perfecta putrefactio eft fub tantix deftructio, non tamen omnis putrefactio eft perfecta : ideo Ariftor. licet in definitione putredinis pracipue refpiciat putredinem perfectam, qua eft corruptio caloris, quam infequitur feparatio humidià ficco, \& deniq; ctiam fubftantix intcritus; tamenita in definitione loqui voluit, vt imperfeetarn quoque putredinem complecteretur : quando autem dixit, putrefactioB nem elle intertum contrarium generationi mifti,perfedam putrefa\&ionem intellexit, quz eft deftructio fubfantix mifti : de hac enim pracipue loqui yolebat; ideo etiä in definition e hane pracipue refpexit, seam caloris corruptionem, qux ad fubsantiz interitum ducat, fed voluit etiam vtea definitio fecundario imperfectam quoq; cutredinemampletteretur. Ad quintum dicimus, leuilimam effe obiectionem, quialicet calor qualitas actiua effe dicatur, non ob id C dicitur effe impatibilis, \& incorruptibilis; quia licet agat in ficcum \&humidum in generatione mifti; ramen patitur etiam \& læditur à frigore, vt contrarium à contrario, ficut antea declarauimus: nunc autem non proprie dicirnus corrumpi calorem naturalem, fed extrahi, \& eciucià calore ambientis, vt fimileattrahitur à fimili: eftigutur calorin gencrando mifto aztius: , o multas etiam editoperatioñs in milto gerito; nec propterca fit vt fit impatbilis, nat \& deD ftrui poteft à liuo contrario, \& attra hi à fimili. Adfextum dubium de caftaneis \& nucibusrefpondentaliquicaul m huius effe, quoniansexterrus calor aperit excirsam partem caifanex, acnucis, vbiefrarior, de penetraitufacilior, \& ita fenetra: ad intimas partes pucrefaciondas. Sed laec Colutio probarda non eft; quia calor incorporevs $f$, neq: vt intimapenetret egetapertione, quum piafertim non migret de fubiccto infubiedurn, fed agendo producatalium E numero calorem in patiente; patiens autem, quum lit ynum continuum, calcfit \& in externis, \& in internis! artibus, fedmagis in externis, qua funt agenti propinquicres: quod autem in caftaneis, ac nucibus putrefactis appareast parua foramina in cortice, ic̀ non eft, quia calor externus agendo perforauerit, fed quia calor \& humorintimx partisputrefcentis euaporantes faciunt illud foramen, per quod exeunt; ideo intus in ea parte videmus relifum F puluerem, quod fignum putredinis eft, recedente enim humido ficcus puluis remanet:videmus ét genita ex ea putredine animalia, quia exiens calor fi refpectu cxeuntis humidi eam nancifcatur proportionem, quee fit conueniens refpeet: nature illius animalis, generatilludanimal, \& refpectu illius fit naturalis, quirefpediu mifti putrefcentis iam eft factus praternaturalis, \& deftructiuus : potuit igitur calor externus penetraic adinternas partes putrefaciendas etiam 
fine foramine, licet necefario foramen fiat ab interno humido cuaporante. Reiecta igitur ca folutione dicendum eft, calorem éxternum calefaccre tum extimam,tum intima m parten, \& magisetiam agere in exrinam, tanquam propinquiorean, quam in intimam, qux remotior eft; fed quum pars intima fit ad patrefcenduin aptior, quam extima, ideo purefritintima, dum exrimaadhuc feruaturincolumis; exrima enim mulroficcior eft, proinde minus putrefribilis, intima vero humidior, \& putrefcibilior; quoniam igitur agens nuagis agit in illud patiens, quod fit aptius ad actionemillam recipicndam, ideopriusputref́cit pars intima caftanex, ve aptior ad putrefcendum, licet ab agente remotior fit; extima vero pars difficilius putrefcit, quia propter ficcitatem magis refiftit agenti externo,tandem tamen ipfa queque putselcit, lea non nifi poft longum tempus; \& feinper multo prius quain pars rxtima, eft putref act a pas intimaproyter pratict im caufam. Poftremuin auten dubium nor leue ef, \& mulos maxime conturbatuit. Ad ip fum igit ur folutndum eft nobis ante omnia ftaturnam tangam veriffinums i lud idem.quaci dubum videbatur, \& ex quo hacipfa difficultas oneba:ur, nempe'putredinem à calore anbientis tunc folum fieri, quando ille mediocris, ze debilis eft, z fenfim agens; non fieri autem, quando ambiens eft calidilinum : patet autem loc per experientiam; e namres in ignem coniedta non putreicunt, ied vruntur; \& in zfareplura, qua ab aeris calore putrcfierent, fi exponanturra.jiis Solis, qui magnum caloren efficiant, non modo non pucrefcunt, fed etiam à putredine praferuantur. R2. tio auter huins difcriminis elt; quoniarn fi calor vehermenter agat, prius refoluit humidum quam calorem internam educat, quoniam internus calor non po:eft educi celeri, \& vehemeti actione, fed longa ac minus vehems enti : quando igituractio eft vehemens, praoccupat reioluerehumidum antequam internum calorem educat, ficautem res exiccata diutıus à putredine praferuatur: at fi atio non fitvehemens, fed lenta, prius educitur calor, \& eam eduationem infequitur humidi euaporatio, qua eft putredo; ob id folemus res exponere radis Solis, vt humidum, quod facirrem aptifimam ad purrefcendum, refoluatur ante proprif caloris eductionem, \& itares praceruetur. Illud praterea hicitre annotandum eft, maiorem, ac minorem agendi vim non folum áb intenfione graduu srouenire, fed exiam ab extenlione magnitudinis:nam. vt fapedaximus, in magnitudine maioremaior vis agendi inct, maior enim ignis magis calefast, quanu minor; idro multa agen ia, qux intenfioned bilia funt, exienfisonefunt valda : contraveroaliqus hicet pruana habednt extenfionem, vehementer tamen agunt, propter magnam intentionem: sumber
A tamen difcrimine; quod qua intenfiene funt $D$ f $f$ r valde efficacia, illa veliementer etram agunt $f C$ - mensucundum intenfionē, \& celeriter fuam actionem ter agës abfoluunt; qua veroextenfiune tantum valida Ga'bidsm funt,illa magnam faciunt actionem non quidem intenfise vivchementem, accelerem, fed vt lögam, \& diu $\mathcal{E}$ agans perfeuerantem, adco vetandem vincant, fed polt fo lidsen longum tempus, non celeriter,vt illa : taleagens exséfine. eft caloraeris, qui mediocriseft, nec vehementeragit, fed fenfim \& lente; quefit, vt calorem

B priaseducat, quä refoluat humidum, quare talis calor purredinem facit : ratio aút husus eft, quoniars omne agens corporeum in agendo repati neccfe eit, \& ex ea repasfione eius vires inaminuantur; fed vbiagens eft mole magnum refpe ctu patientis, ibi vel nulla, vel debilis admodum fit repaffio: illud enimagens repatitur quidew à patiente in fuis partib. illi propinquis, fed hr fouentur atque adiuuantur à partibus remotioribus;vtpartes aeris propinquaz alicui patiēti C patiuntur quidem abillo, fed adiuuantur à magna mole circumftant is aers , ita vi illarum vi res nullam imminutionem recipere, fed eadern feruari videantur; vires aüt patientis imminuütur continue, ac debilitantur, adeo vt ipfum tan. dem fuccumbereneceffe fit: hac igitur ratione longa \& perfeucrans actio agentis extenfione magni, quanuisintenfionedebilis, fit magna, \& valida, ita ve fuperet vim pacientis etiam intér: fone maiorem, \& hine fit vt tandem neceffaD rium fit mifta omnia à circumdante aerefupe: rari, as putrefieri. Hoc igitur quomodo in aere contingat, declarandum ef: eo enim intellecto manifeftum erit, cur multain aqua, \&c in tera, qux frigidiores aere funt, putrefcant:quod enim deaere dicemus, idaliis nmnibus'ambientibus accommodandum erit. Dubitari quidem de acremaxime poteit ob.ea, qux dicunturab Arif: in context. 10 . \& 1,4 . Meteorol.ibinamque dicit res frigidiffimas, \& res calidiffimas non putreCurtis aere 0 $m n i a-m ;$ Astpurre fant:

E fieri, propterea quod frigidiffima refifunt fuo. frigore calori aeris, faciuntq; ne abillo miftum patıatur; calidifimarum vero calor maior eít calore ambientis aeris, quare quum ab eo noa vincantur, educinon poteft: quamobrem fi fententia.illaA rift.vera eft, nihil inaere putrefcerc poffe videtur, vel falté pauca admodü putredina obnoxia funt;operter enim calorem aeris; fi patrefaceredrbeat, fuperare \& calorem \& frigus. mifti, quod quidem perrarum eft, vt fi dicamus F aerem elle calidum quinq;gradibue, miftūvero habere quatuor gradus caloris, \& quatuor frigorss; fed catera, qua vel frigus, vel calorem habeant maiorem calcreaeris, purefcere non potrunt; hoc tame dicendünon eft, fíc, uidē. purredo eft interitus mift quarenus miftuelt, proinde omn mifto cōpetrédeber. Dicoigitut Arit. to in loso denotare folú velle difficuliatemputrefeend 1 in reb.frigidifimis; \& in calidificnis, fed nōimpoltibilitatem, nam illas quoq̨; tạndépu- 
trefcere neceffeeft : quod exiactis fundamentis ita oftendo. Statuatur in adre aliqua res frigidiflima, ve metallum. quod à magno frigore eft congelatum, aer calidinr agit in illud per calotern: fed repatirurab eius trigore, ex qua mutua a etine necefie eft vt \& frigus metalli, \& aeriscalor imminuatur; at calor aeris fouetur, acreftituirur à magna mole circum fantis açris; adeo ve dicere poffimus à tota aeris molo metallu m pati, proinde calorem aeris nen imminu: ob magnum excellum magn!tudinis, imminui tamen irigus metalli:perfeuerante igiturpugn idiutifime, \&dccefcente frigoremetalli, acre autem feruante proprij caloris gradum, necefic eft ve tandem fiat in metallo caloris gradus fimilis graduiaeris, proinde foluatur congelatio, a c putrefiat metallum; fimilis enim calorà firnili ed ucitur, quvia vincitur à magnitudine molis:proinde metallum neceffario diffolueVicomer tur, arque putrefcer. Hinc colligimus riagnum catier- \& manifeftumefie erroremillorú, qui in quarti ror. Meteor. interpretatione dixerunt, putredinem efie propriunsinteritum animatorum, id eftillorum fimilarium, qua vel funt partes animatorum, vel exanimacis ortum habuerüt, ve carnis, fanguinis, laetis, vini, \&aliorum elufmodi;at metalla, \& ! spides non per putredinem interire; decepti enim funtob magnam iftor um refiftetiam, quam faciunt agenti externo; fed ratio, quomodo exporuimus, declarat neceflariü effe, vtilla quoquetandem putrefcant: Arift. etiam in eo lib. fatis clare docuit putredinern cfle interitum mifti quatenus miftum eft, \& e fe cōmune contrariü generationi mifti, proinde omne miftum effe putrefcibile, licet aliqua diutifine durent, vt metalla, \& lapides propter frigus refiftés calcria mbientis, \& ol eum, \&alia eiuimodi propter magnam vifcofitatem, qux indicat miftioné elementerum maximaro, \& exquiftiffimam, proin de difficilem reddit difolutionem. Si vero mitum fit calidifimum, vt piper, \& vinum generofum, neceffe eft vtaer tanquam minus calidus agat in illud vt frigidus in calidum, 3c vt cot:tinua, \& perfeuerante actione paulatim imminuatillius calorem, ipfe auté ob dictam caufam feruet proprium fux qualitaris gradum; igitur necefic eft imminutionem caloris mifti eoufa; procedere, vt tandem ad gradum fimılẽ guadui aerisredigatur, \& tunc à calore aeris ambientis extrahatur, \& miftumillud diffoluatur:ideoilla, quz mediocrem habent calorem, \& caioricontinencis fimiliorem, citius putrefcunt, nifi propter magnum elementorum committioné diuCur rn a- tu us feruentur. Exhis poffumus facile intelligequaÉ in re, curetiam in aqua, \& in terra tandem ormia rerra om mifta putrefcant: quum enim \& in terra, $\&$ in ansa me. qualiquidcaloris infir, necefe eit vtex diusurfrass- na, \& incelfante actione tandem imminuatur trofcant. feu calor, feu frigus mifti, \& redigaturad fimile caloris gradum, atque putrefcat; longa enim \&
A perfeuerans actio, \& nunquam debilitata, licet intenfione fit debilis, \& fenfim fiat, tamen extenfione eft maxima, ac fi tota fimul collecta cōfideretur, validifima: quare neceffe eft vt mifta omnia tandem diffoluantur, atque putrefcant, quum effugere nequeant actionem ambientis vniuerfalis, nimirum el ementorum, præfertim veroaeris. Quod vero Arift. dixit, tria elementa $D$ effe materiam igni, itavt eciam ignisambiens de putrefacere pollit, id fano modo intelligendum

$B$ eft : tangens enimignis non putrefasit, fed prit obeius vehementifimam actionern; at fi ita agat, vt minus vehemens einsactio fit, velurifi à patienteremotioragat per aliud corpus medıĭ, ve per aeren, tunc poteft putrefacere: ideo videmus multa, quxigns noftro propinqua ponun. tur, putrefieri à calore ignıs debilius in illa agēte; qua tamen, fi in ignem ip fum coniicerentur, ftatim comburerentur neq; eft quod aliquis dicatea à propinquo aere putrefieri, non ab igni; C nam putrefiunt quidem ab aere, $f$ ed vtabagente fecundario, ab igni autem vt primario, à quore. cipitaerillum calorem, per quem putrefacit. Dubium de putredinevini, or aliorum $\int_{0}$ lutiones, earumque impugnatio. cap. VI.

Ed alia maior difficultas nobis expendenda, Sac foluenda proponitur; quam \& ob id, \& quoniam prolixam de hacfacere tractationem oportet, feorfum ab aliis confiderare conftituimus; eaque eft de vino putredine: quum enimillud fit nobis maximelaborandü, vt omnia, qua putrefiericernuniur, ad vnam \& eandem putre. dinis naturam reducantur, nitendum eft etiam vini purredinem declarare, \& oftendere quomo. dofub definitione putredinis iam à nobis tradita ac declarata contineatur; quod quidem non fatus manifeftum eft:id enim, quod hac in re dubium nıximum facit, eft conuel fio vini in aceE tum, quam complures dicunt efle putrefactionem: quumenim alio etiam modo vinum putrefcere temporc xeftatis videamus, quädo propterambientis calorem incalefcit, \& ebulliēdo fitputridum, \& vappa, \& hxc omnium prorfus confenfione fit vini putrefastio; cognof cendum eff, qualis fit illa alia viniputrefacio;qua vinum non fit vappa, fed acetum: \& quid inter has duas mutationes interfit: tota autem difficultas confiftit in declarando, quomodo vinum mutetur F in acetum. Galenus in 4. Lib. de Simplicibusmedicamentis inquit vinum habere quatuor partes:primum enim habet fxcem terream, qux fundum perit; fecundo habet partem illam, qux flos vocarur, \& primum quidem fupernatat, deinde eriam ipfa fundura petit ; tertio habet partem aquofam toti vino commiftam; actandem habet ip fammet vini fubftantiam: vinoautem efferuefcente inquit illam a queam partem pracipue feruefcere, \& tunc florem fupernatare, 
fed hune queque ceffante fermefcentia fundum petere, ybi fax fubfidit: declarans igitur Galenus contrerfonem vini in acetum, inquit cam efieputredinem, non quidem totius vini, fed paitis rantum lammidioris, \& a yuofa, qux cum fubitantia vini eft commifla, adeo vtea putrefcentc, \& euaporäte, id, quod remanet, fiat acetum, remanet autem ip fa vini fub? Rătia cum innminutione etiam proprij \& naturalis caloris faeta à caloreambientis, quifimul aquofas partes purrefacit, \& proprium calorem fubltantia vini imminuit, quofit, vt vinum reddatur figgldius; certum enim elfingidius flle acctum viro, ideo inquitibi Gulen. acetum cfe quodammodo vinum mortuum. Hinc Galeni fententiam nonnulli recentiores $M$ edici, quorum etiam ancea meminimus, penitus fequentes, ac declarazes, dixeruntacetumnos effe yocandum putridum vinum, id enim falín effer, propterea quodea noneft perfectaputredo, fed ferundum partem folum;liquiden non ip fa vinifubfantiaeft putrefacta, fed fola aquofiores partes, portio autem vinofa non ef putrefacia licet ex putrafactıoue portionis aquora redita fit frigidior. Et quia Gal.ibidem dicit, acetum viquoque calida prædıtūefie, idifificinterpretantur : exilla partis aquofaputrefactione generatur fitus, qui toti fubfantix aceti commilcetur, \& facit ipfum participemalicuius caloris : idque dicunt à Gıl. ibidem fignificari, quando inquit acetum calorem vininaturalem perdidiffe, fed alium caloremadfcititium exputredine acquifurfe, nempe ex commiftioneficus : hoctamē ego quidem apud Galenuminon vidi, qui huius commiftionis fitus isullam mentionem fecit; fed folum di: xit acrimoniam aceti prouenire ex calore extraneo, quem ex putredine contraxit acetum. Hec fententia, vtmihi videcur, magnis vrgetur. diffcultatibus quas bieuiter referam; \& quum foluereipie nequean, Medicis foluendas relinquam. Primum quidem, fi ipia quoque vinifub ftantia, suamillivinofam portionem appellant, pruprium caloremamifit, non video cur nonilla quoque fit dicendaputrefacta, fi putrefactio eft corruptio caloris naturalis, \& corruptionem calorisnaturalis à calore anbientis infequitur neceffario reparatio humidi à ficco : igitur fecundum iftos illa eft putrcfactio fecundum totum, quia ficnecefarium eft vt non folum aquof a partes, fed etiam vinof $x$ putrefiant: quod fi dicant non effe pucrefactionem fecundum totum, quia non totum humidum euaporat, fed pars eius tenuior; quodnam erit difcrimen aceti, \& vini putridi, quodvocatur vappa? nullum certedifcrimen apparet, quia neq; illius vini pu tridi, quod vappa dicitur, totum hutniduns euaporaut ; ipfitamen dicunc hancefe putredinem fecundum totum, \& inde fieri vtabfolute voceturvinum putridum, acetum veronon dicatur putridum vinumpropter rationem pradictam;
A attamen neceffeef vel vtramquefimiliter effe putredinem lecumdum totum, vel neursam. Sed neqi refedicilur, parten vinilumidiorem pu-

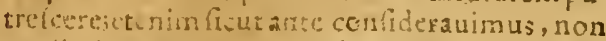
altributur pureto parri hunida enôporanti, fed totimifo: quare fi cxomnibus partibus integrantibls parsaliga humidi euaporer, totum putrefceredisitur; quia roilattribuitur putrefaEtio, \& totum ab co nominaturnon humidum foltun cxiens. Similitergeritur dicenda eft purre-

B fatiofecundurn partem, vel firnilicrfecundum to:um, \& vini lis accima mutatin, \&s vini in vappam; proinde per veranque firilite: vinum eft rocădum putcécens, vel putridum, quodillinegant. Qund vecodefitudicunt, vanü eft, \& gratispronuntiatum; nemoenim vnquam vidı fitum in aceco genitumeffe, \& commifum toti fublantix vinincq; eizmelt credibile, quiafitusredderet acetü turbidum, \& frauifaporis : attamen faje videmus aretum limpidu, \& trans-

C parentifimum, quod ctiam iucúdurt omnibus habatfaporem. Elt etian confideratione dignü, quod in vera vini putrefactione videmus ebullitionem fieri, qua indicat manifefte euaporationem humidi at in conuerfione vini in acetū nihul talevidemus, quare ibi nullum putrefafionis indicium apparet:quarmobrem necefice nagnam cife differentiam inter vinum putridum, \&aceturn : fed boc poit ca diligentius coniderabimus, \& oftendemus mutationem vini in ace. D tum rullomodoeffe putredinem appeliandam. Nonnullos autem alios audiuidicentes vinum fisorum effe animarum.anima vegetante, ldenque con opinio. uerlonem in acctum eflc mortem vini ex interitu anime, putrafioniom vero efe corruptionem vini quatenusef miftum, non quatenus eftanimatum; ideo hi peritus négant acetum elfe vinuan putrefactum. Sed hat renten- Confutatia, licctpropeacedere ad Veritatem videatur, tio. ipfataméfecrndum feveranon eft: omais enim

E anima eft a cus corporis organici, atque neterogedei ar vinumnon ef organicum, fed homngeneum : illud $\mathrm{n} \mathrm{m,} \mathrm{quod} \mathrm{G}$ alemus dixit de quatuorillis vini partibus, non facis vinum effe heterogeneun; fed folum deñotar effe nifum, a conftare ex elcmentis : igitu in vinononeft anima, quianou potef anima refidere vbinon funt organa ipfi inferuenia adedendas operationes animales : 11 ulla etim in vino apparet vegetantis animx operatio; neque enim augetur, F nequenutritur, neque omnisoalimentum tumit,neque generat fibifinile; quare etiam ex operationibus manifeftum eft, nullam in vino animam inefre: pratereavidemus quidem in aliis viuentibus huncvtrumgue interitum, mortem - \& putrefactionem; fed femper in is omntbús mors tempore pracedit putrefactionem, videmus enim non putrefierianimalium corpora, nifi poft mortem : ifc igitur etiam in vino accidere operteret, non deberet enim putrefieri, 
nifiprius morcetur, hoc eft cenuerfum effet in acerum: hostamen nonvidemus, imoexperinur contrarium, putielcit enim vinum antequam vertatur in acetum, fistum autem acetum non putrefcit, fed diutilime feruatur.

\section{Fundanenta neceffaria ad propofetum de acetodubium foluendum, Cap. VII.}

$\mathrm{F}$ G o vt in re difficilima fententiam meam Eroferam, quum in aliorum didtis acquiefeere nan poluerim, poftlongam confiderationem in hanc opinionem deueni, quod neceffe fitconfiteri ia vino cuos calores, \& duas humiditales, vt hincdifcrimen fumamus vini putrefacti, \& aceti; omnino enim negandum puto,acetum efie vinum purrefąum, \& vinum muta-

Oprrio

Alberti

de dupli

ci culcre

Gins.

$\$ 30$.

\section{Galeni}

openende di duplici

calore en glantis.

Prepria opiziso de duplics calore Sint. ri in aceium per putrefactionem. Daplex humidum ponit Albertus in quato Mereurologico. rum cap. 10 . deinde etiam duplexcalidum inc. 15. fed in horum conditionibus declarandis mihi videtur Alberti fententiam non omnino effe approbandam : quodenim ad cslorem attinct, ipfe dicit efé in vino duos calores, vnum natutarem, alterum loci, vbicreuit vitis, qui eft infufus à calore magno Solis, \& hunc dicit effe acci-

A tionem haurirefolfimus. Certum eft, in qualibet animato duos infpici interitus naturales, te. pore etiam diftinetos, mortem, \& purredinem: \& vtramq;icn fuit Arift. effecorruptione on caloris naturalis, mors enim naturalis eft abfurnytio calcris vitalis à feipfo petabfumtionem husidinaturalis : poft mortem vero remanens corpus interit per putredinem, qua eft corruptio caloristemperaturx. qui continebat, acterminabat humidum com miftum ficco: onne igitur

$B$ viuens duos habet calcres, vnum animalem, qui infequitur aninam, alterum elementarem, qui eff calortemperatura, \& poft mortem remanct: fed hoc tamen eff fano modo intelligendum; non cnirn ciedo exiftere poffe in eodem fubiecto duos calores tanquam duo diftinéta indiuidua eufdem fpeciei, fed vnum effe calorem intenficrem exvtroq; conflatü; ita vt dicere durs, nilaliud fir, quam dicere duo diftineta principra à quibus profuunt plures caloris gradus, quarn exaltero tantum; ita vefinul iuncti confrituant vnum numero calorem intenfiorem, qui fecun: dum aliquos gradus eft calor elementaris, fe. cundum reliquos vero eft calor vitalis. Poteft autem hos o time declarari exemplo luminis: fi enim nceturno tempore locus aliquis à dua. bus fimul candelisilluminetur, maius ab iis lumen prodit, qua $\mathrm{m}$ abaltera fola, nam vna extincta remanet in eodem loco minus lumen; atramen accentis fimul vtrisq; non dicimus inillo D eodéaere duo diftin cta lumina ineffe, fed vnum numerolunen, inrenfius ramen, quam id, quod exvna tantum candela pronentret; ex yna enim. candela prodeunt aliqui gradusillius luminis, acexalterarelıqui, \& ii onnes finul iuncti confrituunt vnum lumen intenfius. Quod veroad humidum attinet, Albcrtus in loco pra dicto inquit dari in miitis corporibus duplex humid u-: Vnum, quoddicitur continuans, à quo fit partium coniundtio;nam fi abfque vlla humıditate effent penitus ficcx, effent omnes difiunctz;nullum igitur eft corpusita durum \& exiccatum, quod non habeat aliquid humidi coniungens partes inter fe : idio Alchimifta ex quolibet quantumuis arido corpore oleum ed ucunt, humidum enim continuans eff craffum inftar olei; ideo recte etiam à quidufdā vocatur humidum oleaginofum exaereo, \& ex aqueo humidoconftans. Alterum miftorum humidum vocatur ab Alberto hunidum quafi nurriens: idque eft huF midum aquofum, quod ineft mifto prater continuationem partium, \& facilerefoluitur, quum fitaqueum; oleaginofum veronon facile, quia craflius eft : ideo quando volumins aliqua mi fta à putredine praferuare, curamus vt vel fale, vel igni, vel Sole exiccentur, vt euaporet humidum aqueum, quod eft caufa facilis purrefa. ationis, fic enim diu feruatur incolume. Notare vtrumque hunidum poffumus in carnibus anımalium mortuorum; nāex bunide aqueo. 
facile putrefcunt, fed eo confumpto diudurant, quia manet folum alterum humidum, quo partes coniunguntur: ideo non abfq; ratione humidum aqueum vocatum eft ab Alberto quafi nutriens, quia in animali viuente difperfum eft per fubftantiam carnis tale humidum ex alimentis genitum, quo fubotantia carnis nutriatur, idq; nec penitus extraneum eft, necpenitus naturale, fed medium quodammodo inter extraneum, \& naturale; eft enim aliqua ex parte affimlatum naturali, at non penitus affimilatum : in carnibus igitur animalium iam viuentium thumidum hoc vere dicitur nutriens; fed in carmbus animalium mortuorum nó eftamplius nutriens, fic neque in aliis miftisinanimatis, in quibus prater humidum coniungens fit etiam humidum aqueum extraneum : ideo hoc ab Alberto vocatum eft non abfolute nutriens; fed quafi nutriens, hoc eft, fimile humidealimentali in viuentibus, quod eft vere nutriens.

\section{De qualitatibus vini. Cap. VIII.}

$\mathrm{H}$ Is ractis fundamentis, declarandx ante 0 . Innia funt qualitates vini. Dicimus igitur in vino, quum à viuente corpore defluxrit, ineffe duos illos calores, quos antea declarauimus; vnum elementarem, feu temperatur $x$ : alterum vero animalem; quamuis enim non fit animatum, tamen potelt fecum ferre calorem ab anima fibiinfitum, \&. im reffum; quod quidem aliarum rerú exemplo manifeftiflimo compro. bare pofiumus: femen enim tă animalis, quarn plante fecundum Ariftot. in initiolib. 2. de Ortu ani malium nó habet animam åtu, âttamen ab anima iam accepit vimgeneratiuam alterius. fimilis, quam in 3. cap. eius 1 bri, dicitnil aliud effe, quam calorem vitalem, quem diftinguit à calore igneo \& elementari; ita vt in generatione viuentis primum moués fit animal, reu planta, vnde femen defluxit, femen vero fit eius infrumentun quod pervim ab eo receptam, videiicet per calorem vitalem generat alterum animatum fimile: quum crgo in femine fit calor vitalis pratercalorem elenentarem, cur non idem dicere poliumus, imo debemus, de vino, quod fimiliter ex animato corpore defluxit? habet igitur vinum duos calores, hoc eft; vnum exduobuscōflatum, ficutide lumine diximus, qui magnus, \& intenfus eft, vt experientiadeclarat: ifquen nconfiftit in indiuifibsli, fedin quadam latitudine, \& eft modomaicr, modo minor, prof pecierum varietate, atg; etiam pro diuerfitatelocorum; in locis enim culidioribus, vbi Sol maicrem efficit calorem, vina calidiora nafcuntur, ifque non eft exiernuscalor, fed potius naturalis, \& connatus $1 l ! !$ vino; nam ex calore loci fit, vt tuni calor vini vitalis, tum clementaris, qui ambo naturalem vini calot é con ftituunt, maior, atqque intenfior fit.S. cetıam negare in vine non poffumus duplicem illam hu- niditatem; \& eam aperte ponit Galen. in libro $D$ us bupredıcto; dum diltinguit in eo fubftantiam vi medssanofam, \& fubftantiam aqunfam : vinofa enim tcsinsi-

fubstantia habetillud humindum, quo fir soniī $n$. ctio partium; humidum vero aquifum eft illud, quod ex alimento contractum eit : dü enim vua erat viti coniuncta, ad eam conflucbat humoraqueus, quonutriretur; feparata ergo vua à vite retinet adhuc humorem illum aqueū, qui nondü in vini fubstantian conuerfus erat, neq; amB pliusconuertitur, quia vinum noneft amplius animatum:hocautem humidum a queun, quod in vinoremanet, eft illud, quod in coetrone vini confumitur, \& quando vinum feruet, \& quan. do igne coquitur, abfumitur humidum illud aquofum, \& remanet folum alterum humidum, quod ipf vini fubftantix intimius eft: \& inde fit vt totum vinum dulcius reddatur, quia confumpto humido aqueo remanet fola vinifubltan. tia, \& eiús humidum vere narurale, quod quum

C per concoltionem fit in fubftantiam conucrfum,dulcedincm facit; quia omne concoctum, vtinquit Arift. dulce eft.

\section{Solutio propofit a difficultatis de aceto, do de vini putredine. Cap. IX.}

$\mathrm{F} X$ his, qua de duplici calore, ac de duplici Hbumido dicta funt, fumi poteft propofita ditficultatis folutio, \& differentia inter acetum, \& putridum vinum; ex ẹo enim calorum \& humiditatum difcrimine, neceffe eft multas in vino contingere varietates. Quoniam igitur iuxta Ariftotelis doctrinam certum eft, putrefactio. nem non effe cuiuslibet calıdi, \& cuiuslibet humidieductionem, fed folius calidi' elementaris, \& illius humidi, à quo partes hạbent compactionem, \& continuationem; corruptionem autem caloris vitalis non effe putrefactionem, fed potius mortem, quum non ab eo calore contineatur humidum iun atum ficco: \& fimiE liter eduetionem humidi, quod alimentale, feu extraneum appellabatur, non effe putrefactioncm, quum adhuc remaneat humidum continuans, quod cum ficco ef commiftum, \& niaxime propric vocatur naturale: idco fi in vino euaporat folum humidum aqueum manente humidum coniungeate, tantum abeft vt illa fit vini putrefactio, vt potius fit à putredine praferuatio; hinc enin: fit vt vinavetufta non am. plius putrefcant, qquia nesefie elt verontinue eF uaporethumidum viniaquofum excalore tum ambientis, tum proprio, quare femper magis ac magisexiccatur vinum, quo fit, ve vetuftius vinumi tánquam ficcius minus fit aptum ad putrefocndum : \& experientia docet maximum periculum putrefactionis vini efle prima aftatefequenteipfius confeetionem, ea namque elapfa fi fanumisemaneat vinum, altera feçuen. te xftate ron putiefcet : vinum autem continue cuapolâre ita eft manifêfum, vt proba- 
tione non egeat, atq; etian id tieriabfq; putredine; etenim cuaporat folum humidum aquo. fum, nōalterum ol eäginofum, proinde nöfoluitur miftio : fimiliter fi Colus vini cnlorvitalis intereat manente calore elementari, ea non dicetur putrefictio vini, quoniam eam non infequitur folutio miftronis. At inquies: Si exinterizuilliuscalorıs, quèn vinum cont raxit ab anima, non fit putrefåtio vini, fiet ergo mors, vinum igitur dicetur mori, quo nihıl abfurdius: qued enim noö eft anımatü, ei mors nō cöpetit, $\sqrt{\mathfrak{L}}$ quidē mors eft interitus caloris vitalis cü jofius quoq; anima interitu, vel receffu à corpore, in vino aút iam diximusanimam non ineffe. Re-

solutio. fpondeo interitum folius caloris vitalis in vino non pofie quidem proprie vocari morté, quum nullus eum fequatur aninze interitus, fiquidem vinū non habet animam; poffe tamen per qua!?dam fimslitudinem dici mortem, ita vt vinum pofiquarn vitalem calorem amifit, perfirnilitudinem dicatur mortuu , propterea çuod viuentia tuncdiclintur mori, quando vitali calore deftitumtur: Hac omnia fi admittantur, vt mihi quidem admittenda efle videntur, facilem reddunt propofita difficultatis folutione: arbicror enim dicendum effe asetum fieri per interitum calcris vitalis manente calore elesientari, proindefine feparatic ne humidi continuantis a ficco; putridum àu yinum fier per corruptionem caloris temperatura; feu elementaris, quam infequiturfeparatio humidi continuantis à ficco, qua eft putrefactio: hoc enim ita efle ex eo maxime comprobatur, quod his admiflis ratio faci. le redditur omniū, qua vino côtingere cernuntur; vinum enim dilutum, astenuedebilem habetcalorem, \&plurimum hurudi aquei, facile igiturputrefcit, quia non facile refoluirur tantú humidum à calore tum ambiêris, tum proprio, ideo manet in vino multī humidiaquei : quod facit, vt debilis calor facile educatur à calore ambientus, qui totum fimul calidum euocans, $E$ tam vitalc, quä elementare façit vt humidü quoque continuans feparetur à ficco;id q; non tit nifi cü ebullitione, quod ef putredinisindicium manifeftum. Vinum aũt merum;ac generofum ficcius eft, \& minus habet aquei humoris, ideo no ita facile putrefcit, fed porius acefcit: nam fi. abambientecalido fiat euaporacio caloris vita. lis, qui in vino eft, eam nōinfequitur feparatio humidi coniungentis à ficco, propterea quod non abillo caloreterminantur pafiuz, $f \mathrm{ed} a b$. elementari, qui poteft remanereillafus; quia fi folus educaturcalor-vitalis, calor elementaris remanens cet valderemiflus, proinde ibı eft plurimum frigoris, \& parum caloris, quare frigus. illud, quummagnum fit, refiftic calon ambientis, \& ob hanc caufam acerum non purrefcit, quum prafeitim adfitetiam defectus humidiaquei, à quo, fi adeffet, facilis putrefacto redderetur, ficut antea declaraumas; quoniam igi-
A turacetum amifit calorem vitalcm, \& caret humido aquofo, non amplitus putrefcit, quia eit valde frigidum, \& refitit fuo frigoreculori àmbientis; tanto auten minus refiétit, quancoplus habeat hum oris aquofi: ideo actun factuns ex vino tenui, ac diluto facilius purrefcit fropter eius humiditatem aquofam, quam facurn ex vino generofo, quod dutifine feruatur.illud enim omnino conftituendum nobis eft, non facilem effe putredinem, vifolumadeft humiB dum continuans fine humido aqueo abiunoto: ideo oleum etfi valde humidum eft, ronfacile $C$ putrefcit, quia illud eft humicum totum olea- $t$. ginofum, \&: cum ficco efficacifime commiitum, vnde illa vifcofitas oritur, quafacit ne humidum illud poffit à ficco feparari: humidiffimum autem effe oleum ex co conftat, quod exceflu acreurn, \& aqueum eft, ve ait $A r: f t: 2 t$. in contex. 4I. 43. \& 48. quarti Meteorolog. Confarmant etiam $1 d$, quod de vino diximus, ea qua ibidem dicuntur ab Arift. in contex. 52 . 4 53 . inquit enim vinum efle aquex natura, c exceli valde aqueum, proinde eriam excefli frigidum, fed calidum effe ob alienam calidita em: alienara enim intelligit calidicatearimal $\mathrm{cm}$, quam vinum fecum tulit, propterea quo anizia, \& ornne infequens animain eft quoddam luperadditum rifto confiderato, quateous mitium eft, \& hac rationedici potentienum relyectu miftions. Dum igitur confiderat Anftut vinum quatenusef mitum ex clementis, qua eit eius confideratio in illo quartolib. rcete dicit aqueum effe, \& frigidz temperatuxa, \& parum habere caloris, reddi aute can calidum à calore vitali, \& quandoque etiam calidifin um, vi ratione loci calidumillud intenfius redditur. Secundum hancigitur fententiam optime illi loquuti funt, quos Galenus ait dixifie a cetum effe vinum mortuum; fic enim diceremelius eft, quam dicere effevinum putrefactum: idq; confirmatur teftimonio Ariftot. paffim in eo 4 lib. vbi exempla fape adducens miftorum, de quibus is liber ef, nominat vinum, \& acetum tanguan fpecies quafdam mifti; quod non faceret, fiacetum effet vinum purrefactum, çuia nominatione cuiuslibet mifti lignificatur quoddam in fpecie fua completum per propriam formam nifionis:at putrefactum, quatenus eft putrefactum, norat imperfectionem, \& receffum rei. à proprinnatura, \& progreffionem ad diffolutionem in elen êta; proinde indignum eft, quod nominetur: vt miftum. Si veroilli, qui dicunt Quo. acetum effe vinum putrefactum, dicerent hanc cetü efle differentiam inter acetum, \& vinum vere nonf putridum, quad minoreft aceti putredo, huius med. autem maior; hrc fententia \& experientia, \& cratt rasion aduerfatur: in omnibus enim videmus pert minorem pueredinem effe viam ad maiorem, ctum ita ve facilius fitvt magna putredine corripiatur id, quod aliquantum putrefere copit, quam 
id, quodadhac putrefcere non incepit : \& ratio A hoc idem confirmat, facilior enim tranfitus eft à medio ad extremum, quam ab extremo ad extremum; deceretergo acetum facile putrefcere, fi ineo,vt illi dicunt, eft inclioata putredo; attamen acetum non putrefcit, feu difficillime puerefcit: \& experientia docet vinum facilius fieri putridumantequam fiat acetum, quam fi mutatum fit in acetum : non poffumus ergo dicereacetum elle vinum mediocriter putrefactum. Confirmatur etiam hæc fenteritia noft ta ex 1 lla acetigeneratione, quam arte molimut;curamus enim ve velà Sole, vel ab alio mediocrite: calefacienteincalefcat vinum, vt calıdum visale exhaletur, \& humidum aquofum abfumatur; fic enim fitvt remaneat folus calor elementaris , \& humidum continuans, qux eft aceti natura; eft enim exceffu aqueum; \& valde frigidum, quia parum habet caloris in fua mittione; fed eft absque dubioperfectum miftum, vt disit Arift. in memoratislocis, non corpus putridum, feu puarefcens, vt Medici arbitrantur.

\section{An Galeni de aceto fententia modo aliquo defendipoßit. Cap.X.}

VErum qquia Galenus Ixpe dicit acetum exvinocffe genitum per putredinem, nempe ex putrefactione humoris aquei cum ip fa vini fubftanria commifti; etfi nos dictum hoc non admoduna approbamus, dignum tamen confideratione ob Galenı auctoritatem effe cenfemus, an id modo aliquo defendi, \&adrectum fenfum trahi poffit. Ego quidem arbitrorillud admittı poffe,fi per quandam follum fimilitudinem, non vt proprie dictum intelligatur: quemadnodum enim illa, qua vere putrefcunt, per proprii caloris corruptionem putrefcunt, proinde ex diffolutione proprij humi di, \&à calore a mbientis;ita acctum ex vino genitum eft pèr corruptionem caloris, \& refolutionem humidi à calore ambi . entis:attamen magnum eft horum difcrimen; nam in definitione putredinis non aliud calidū, neque aliud humidum confideratur, nifi elemétare, \& eft putre dinis conditio vt humidum non immediate patiatur à calore ambiëtis, fed prius patiatur calor naturalis , \& educatur, deinde illam caloris eductionem infequatur proprij hu midi diffolutio : poteft quidem aliquo violento interitu, vt antea diximus, vt combuftione deftrui fimul totum miftum fine præcedente eductione caloris; fed in terituillo naturali, qui vo- $F$ carur putredo, non poteft miftum diffolui, nifi prius educatur calor naturalis, qui humidum \& ficcum coniuncta cōtinebat : dẹ humido namq; continuante loquor, non de aduentitio, quod diximus per quandam fimilitudinem appellari nutriens feu alimentale, ideo videmus ligiana arda diutilime feruari, etiam in magnis $x$ ítious, \& in locis calidifimis, ne vnquā educi humidum continuans, nili prus educatur calor naturalis continens. At fialteriusealoris, \&alterius humiditatis vini corruptione confideremus, nempe caloris vitalis, \& hamidiaquofi, quod dicebatur quafi nutriens, aliter fefercs habet;nä humidum $1 l l u d$ nōidco refoluitur, quia prius vitalis calor fit corruptus:proinde eius luumidi eua. poratio nö infequitur corruptionem caloris vitalis, fed fit im mediate ca calore ambientis, ab ea enim inmediate \& enocatur calor vitalis , \& refoluiturhumidum aquofum, \& per æxe etiam

B fine exhalatione caioris vitalis folum humidú aquofum confumitur:quo fit, vt vinum maneat calidius, cuiusmodi eft vinum vetuftü , eft cnim maxime exiccatum, quia refoluta eft illa humiditas aquofa, quam prius habebat; quam enim hxc obtundat actionem caloris, hacconfumpta - vinum efficacius calefacit, 'quia efficacius agit calor cum ficco, quanm cum hunido: quod fi contingat, vt fimul cum humidiaquofi refoluC tione,vel poftillam, calor quoque vitalis exhaletur,fit ex vino acetum; quare huius generatio longe diuerfa eft à putredine: nam in putredine neceffe eft prius educi calorem naturalem. deindefierifeparationem humidi; atin generatione acetinon fit refolutio humidi ex euaporatione calidi, qua hæc non iniequituralicuius caloris corruptionem in vino, fiquidem à neutro calore dicitur contineri ; imo quum illud humidum fuerit induetum abanima nutritionem moliente, patitur potius à calore vinianimali, \& confumitur, quam contineatur \& regatur:quanquam enim in vino anima non remanfit,fed folus calor vitalis , \& humidum illudalimensale attractum prius ab anima nutritıonis gratia, tamen feruatuilcum illo calore hæc vitalis conditio vt confumat humidum ; non quidem ita, vt nutriat vinum eactione, non enim nutritur amplius vinum; fed quia refoluitur ab co calore humidum illud, \& fimul etiam à calore ambientis, à quuo non educitur calor vita-

E lis progeneratione aceti, nifi prius multum humidiaquofi fuit refolntum : ideo videmus ex vino nor o non facile ficri acetum, fed ex vino vetuftiore, cuius humidum aquo fum fit aliqua exparte relolutum : differt igitur generatio aceti à putredine, quod in generatione aceti non fit refolutio humidi ex eductione caloris, fed fit immediate à calore ambientis, \& fimul à calorevitali adiuuante eius confumptionem, vt prædiximus. Eftigituracętum genitum modo qujam fimili putrelactioni, quiacalor educitur \& confunitur humidum ; non efi tamen reuera putrefactio, qua non educiturcalor elementaris, fed folus animalis, neque huius edu. Etionem infequitur euporatio alicuius humidi , fedpotiuspracedit; poltquam cnim vinum eft exiccatum per eua orationem humidi quod vocatur quafi nutriens, tunc per exhalationem calidivicalis generatur acetum: quare patet 1 n generatione acetinó difolui mifum quatenus ' 3 miftum 
miftum eft, quia ficcum eft humidum temperaturanon feparantur inuicen, fedmanent conimnda. Sunt autem hre omnia confentanea naturæ \& qualitatibusaceti, qux \& perexperienOudita- tiam notx funt, \& à Galeno: declarantur in præsesaceti. dictolib.4.de fimplicibus medicament.eft enim - acetum frigidum, \& humidum aitu, ied facultate exiccatilum, quia per confumptionem humidialinentalis redditum eft ficcius, quam vinum;neque ita humectat, quia receflit huñiditas aquola, illa vero qux eft temperaturx, eft maxime commifta cum ficco, per corruptionem auten caloris vitalis factum eit trigidum.eft etiam acre, \& mordax (vtait Galenus) ex tentitate fubftantia, qua fit penetratium ; fingulas enim animalis partes penetrat, \& per frigus conftringit, \& ita mordicationem facit : qux interdum tanta eft, vt fit cum dolore, nempe fi tanta fiat fingularum partium conftrictio, qnæ faciat disjunctionem contmuitatis, fic enim dolor fit : dicere etiam videtur Galenuś, illam acrednem $C$
A prouenireà calore extraneo, quem contraxíacetum ex putrefactione, fiquidem omne putrefcens amittit calorem proprium, \& acquri! alienum : quod Galcni dictum admittcre poti:mus in eo lentu, fecundum quem dwinus we-

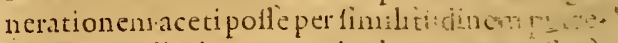
dinem appellari : qum cuim hac quoque fiuk aे calore ambientssambiens autenion pofit pat1entis corp oris calorem educere, quin finul in- ducat aliquid caloris extrancimullum eft abfu-

B dum, fidicamusacetī alıquid extranei caloris accepifle ab actione ambientis, \& ab eo adeptum efle illam acrimoniam;ita vtacrmonam calori extran eo attribuamus, mordacitatem autem frigori conftringenti ; vere tameu putridum dici non poteft acetum, ficut antea oftendimus. Hoc pacto ego puto folui poffe hac in re omnen difficultatem : fi quis autem aliquid probabilius inuenerit, eius fententia fubfribere non recufabo.
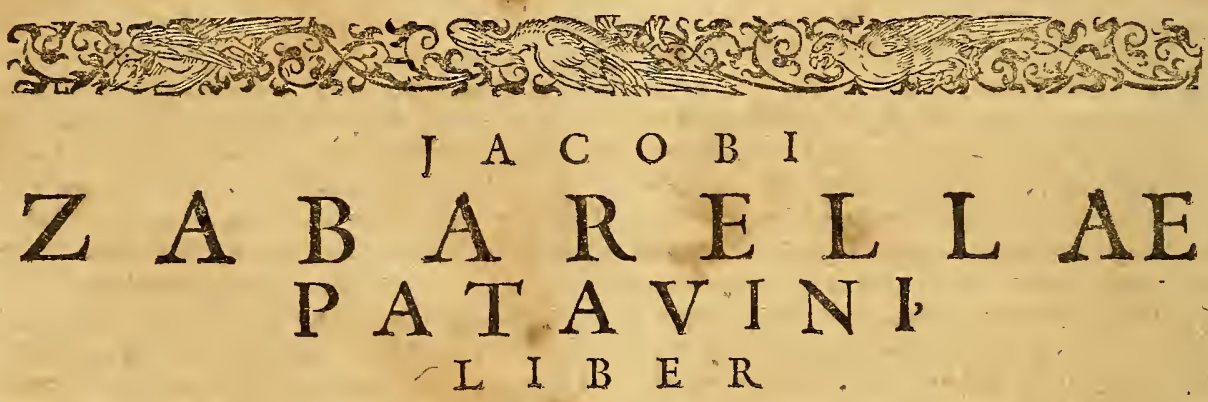

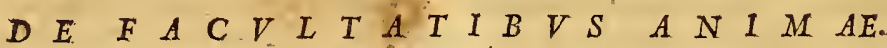

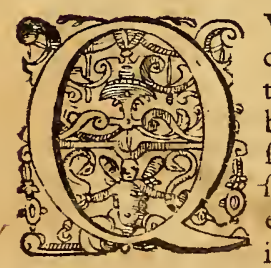

Vum animx naturam declarandã fufceperit Ariftoteles in tribus de Anima libris, nequealia ratione confideratam, quam prout cau\{a, \& principium aliorum eft, duas cius traetationes in iis libris ab eo factas notare

Duacon- poffumus : quoniamenim anima tum corporis fideratio animati principium eft vt forma ipfumi confines ani- tuens, tum operationum vt effectrix;per vtrummain querefpectum declarare voluit quid fit anima. lib. de Priusetenim eã definiuit per refpectum ad corAnsma: pus animatum, cuilis eft forma, dicens eam effe primum actum corporis naturalis inftrumentalis;qua communi definitione omnem animam. complexus, fignificauteam eflè omnisanimz. conditionem, \& naturam, vt fit actus, de perfeEcio, qua corpus viuenś conftitutur, \& in pecie collocatur. Dindevero candem confiderare ftatuiretiam proutrefpicit operationes, quemadmodum in context 33 . lib. 2 . videre eft; \& de fingulaanim $x$ parte $a b$ eoloco ad finem vsque lib. 3. hac ratione diligentifime pertractauito.
D Quod igitur ad priorem animx confideratio. nem attinet, eam nos in prefentia ad eos, quilibros Ariftot.velvoce, vel feripts interprete tur, remittimus : quum eorum officum fit $A_{i}$. ftot.verba, \& ipfan animxdefinitionem, \& fingulas eius particulas dèclarare: fed \& nobis al a In li fortaffis occalio dabitur, qua aliquid de ca def- - men. nitione dicamus: nune de altero anima reffe - bum ctuquadam, quæ prolixiorem difputationem poftulare videntur, quam vंt in commentaris E exponiconueniat, fcribere conftituimus: quum enim plures operationes animx fint, quarum edendarum naturalifacultate præditam effe animam conftat; inde factum eit, vtrefpectu diuerfarum opinionum diuerfas etiam tacultates philofophiomnes animæ attribuerint. Quum igitur Ariftotcles in libris de Anima folitus fit animam, \& eius partes facultatum nominibus appellare: nam certumeft, vegetatiuum; ferifitiuum, matiuum, appetitiuns, intellestium,

F \& alia eiusmodinomina facultatum effe, \& vaxias operationes refpicere : illud nobis confiderandum proponitur, de quo folent philofophi noitri controuerari, quomodo ha facula 
tates tum ad ipfam animx fubftantiam, tum ad fe inuıcem referantur : quæritur enim, an à fubfantia anim $x$ diftinguătur,an potıus funt idem quod illa; quarıtur ctian, quo difcrimine ipf $x$ difcrepent inter $f e, \&$ quot lint: hrc igitur confideraturı ftatuimusimprımis, id, quod paulo ante tetigimus, nomen facultatisin præfentia à nobis fumi proprie prout refpicit operationem, \& fignificat potcntiam operandi, vnde Latini potentias anim $x$ eas appellate confucuerunr: quum enim potentia refpiciat actum, duplex autem fit actus,vt Ariftoteles docet in initio libri fecundi de Anima; atusprimus, qui eft forma; \& actus fecundus, qui eit operatio forma: duplex etram cft facultas; yna eft, quæ refpicit. actum primum, eaque eft materix potentia; altera vero, qux refpicit actum fecundum, \& eft poientia formæ, cuiufmodi funt facultates animæ, de quibus in præfentia formonem habituri fumus.

\section{An facultates ab effentia anima diftin- guantur, opinio Scoti, \& Greg. Ari- minenf.cum eorum argument is:}

Cap. 11 .

Confiderandum primo loco eft. an facultates diftinguantur reab 1 fa animæ lubftantia, an fit idem, quodilla: led ad omnem tollendam ambiguitatem, iciendumeft, polfe duobus modısınt llıgi id, quod Latini dicunt realiter differre: primum enim fumitur pro eo, quod eft differrelubiecto, vt quando cum Ariftot. dicimus, materiam \& priuationem non effe ditinctas re, id cft fubiecto, ficuti neque pomum \& albedo, quum fimul fint fubiecto, dift nguidicantur, icd folum ratione; altero modo Iumıtur pro eo, quod eft eft effe res diuerfa, \& f́cundü eflentiam dıftinctas, etiã animo non cogitance:fic autem dicimus materiam\& priuationem effe diftinctas te, fic etiam pomum \& albedinem; quum enim toto genere differant, maxime d cuntur diftinguire, hoc eff effentias habere diucrfas: quæftio autem præfens nullum habet locum iuxta priorem acceptionem, quum enim in codem viuente infint facultates, \& anima ip a, certe non diftinguuntur fubieEto; fed locum habet iuxta pofteriorem tantum acceptionen, quærimus enim quum fimul fint in eodem, an potentix fint quidreale diftinctum effentialiter ab ipfa animre fubftantia, an idem fint, quodilla. Scotus libro 2 . Sentent. diftint. 16. \& Gregorius Ariminenfis ibidem quaft. 3. nituntur oftendere potentias animæ elfe ipfammet animæ fubftantiam, qux, quum varias operationes refpiciat, variis etiam nominibus appellati folet, qua dicunturpotentiæanim $æ$, ptoinde hæ funt idem re, quod ipfa animx lubitantia; \& hanc féntentiam fequiur magna pars recentionum ghilofophorum.
A Contra vero Thomas exiftimauit, potentias openio effe qualitates fecunda fpecici manantes ab ef- Thoma. fentia anim $x$, proinde ab ca diftinutas re, ficut apud cum variis in locis legerc poffumus, præxfertim vero in 1. past. Sum. quı æit. 77. artic. 1. de in 1. Sentent. diftinet. 3. qux/t. 4. artic. 2. Hanc eandem fententian fequutus eft Aegidius in Quodlibcto 3. quæft, 1 I. \& Ioannes Gandauenfis in libr-2. de Anima. Pro fententia Scoti hrc abinfo, \& abaliis argumenta afferuntur. Primum eft: de quo dicitur definitio, de codem Primum dicitur \& nomen definir it atqui de furma prædi- ärgumen catur definitio potentiæ actilix. ergo \& nounen; tum Scoanima igitureft lux potentix : maior clara eft : $t i$. minor probatur aucto itiate Ariftor. in פ. Metaph. vbi potentiam actiuam ita definit, potcntia actiua eft principium trafmutandi aliud quatenus eft aliud, atqui forma eit inu úmodi principium, ergo forma eif potentia actiua. Se- Secundiu cundofic argumentantur: ficuti fe habet poten- argumé-

C tia paffua ad patiens, nempe ad materiam pri- $t \boldsymbol{w}$. mam, ita" \& potentia actua ad agens, nempe ad formam; at potentia materix pafiua eft materia ipfa ; ergo etiam potentia actiua eft ipfamet forma: probant fimilitudinem per ea, qua dicunturab Ariftot. in 9. Metaphyf.q: ær nunc ecenfenda non funt: affumptum autem ita probant;i potentia materix effec aliquid diuerfum à natura materix, effec accidens; ergo aliquod accidens in materia reciperctur ante formam $D$ fubftantialem, quod eft abfurdum. Tertio: fi cutife habet forma mere naturalis ad fuas operationes, ita eria m anima ad fuas; at forma merc naturalis cft immediacum principium fuarum operationum abfq; vlla potentia media ergo \& anima, null $x$ igitut funt potentix diftinctrab eflentixanimz, fed funt anima ipfa: fimilitudo eft manifefta, quia non debet anima effe minoris perfectionis, quam forma inanimati, imo debet effe maioris ; forma auten inanimati poteft exire in actum feeundum abfque vlla potentia media : quod probatur \& de lub. ftantiali forma, \& de accidentali : fo ma en:m fubftantialis eft natura, at natura eft principiü motıs immediatũ,vt dénotat dictio illa, primo, in definitione naturæ:talesetıā lunt forme accidentales, nā calor 1 gnis eft immediata cậ́a calefaciédialia finevlla potétia media, fic grauitas \&leuitas lunt caufre immediatze mouendi elementaad fua loca, igitur anima mulco mag:s F debereffe immediata caufa fuaum operationu. ergonon per potentias medias. Quarto,natura $Q$ sartis nihil fru itra facit, necabundat in luperuacane- arg uméis, atqui ipfa animx fubftantia fufficiens eft ad tum. producendas omnes operationes feclufa ope cuiuslibet extra fe, ergo fruftra ponuntur potentix ab ea diftinctre. Quinto, agens nun- Quintz̃ quam agit in extremum, quin prius agat in argumemedium, fi medium habeat; itaque fianima trm. effieit operationes per medias potentias, ne-
Tertium arginetwhe. 


\section{lacobi Zabareliz Patauini}

sexrum

srgi:mé-

לันms.'

abfurduni, \& inexcogitabiie. Sexto, fi potentix funt dinerfáabefléntia anım \& \& ab ea manët, ergo ab ea pendent vt à caufa, in quo igitur caufxgenere? certe $110 n$ vt a materia,nceqivt à fine, neque vta forma, vt patet, ergo vt ab efficiente; igituranıma aliquidimmediate producit, quod aduerfarii negät, producit cuim ipfas potentias:' quod fi dicñt has produci peralias potētias medias, procedinus in infinitum, quod dicendum

septimin non eft.Septino, finullum agens poteft immeargumen diate aliquid producere, fed folú per potentiam twm. mediam:ergo neq: ip fa potentia porerit immediate opxrationem producere, nifi peraliam po-

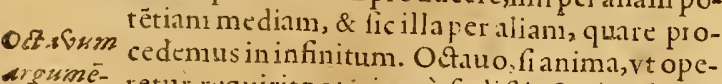
argumé- retur, requiritpotetiam à fe diftinctan, vel eam उसm. requirit ob funm perfectioné, ve! ob fuam imperfętioné; at neutro modorequirit, ergonullo jnon ob fuam imperfectionem, quia hoc pofito formaccidentales, quī fint imperfectiores, magis requirerent huiufmodi potentias, at non requinunt, vt ante dietum eft de calore, \& levitate ignis;nōetiam ob fuam perfectionem, quia fubitancia à materia absundx, ac Deus Worsm ipfe, quum fint perfectiorcs, magis requirerent,
argume- quodtamen dicendum non eft. Poftremo fenargume- tentiam hanc confimant auctoritate Ariftotelis in libris de Animain pluribus locis: nam in contextu 9. lib. z. in quit, fi effet oculus animal, potentia vifiua eflet forma cius, ergo potentia eft idem quodanima : deindein context.10. inquit. anima eí ficuti potentia inftrum étipoftea vero pafim in is libris ita potentias animæconfiderat, vt putet fe de ipfis anima partibus loqui dicit enim naturas, \& gradus animatorum ab his potentiis conftitui, quod falfum effet, $\sqrt{1}$ po, tentix effent qualitates; quoniam igitur vbiq; potentias cum anima ipfa confundit, non cenfuit eas effe alliquid præter ipfam fubftantiam anima, fed elfe ipfammet animam.

\section{Opinio Thome, \& AEgidï, do corwm argumenta. Cap. III.}

$\mathbf{E}^{\mathrm{c}}$ Contrarioautem ad probandum potentiàs animæeffe qualitates, per quas anima fuas operationescdat, multararguméta à Thoma, \& $2 \mathrm{~b}$ kgidio, \& à Iomne Gandauenfe afferumtur, vt apud eos videre eit, ego veropauca pracip̧ua leligam: \& quia fenecntian hanc yerios.em effe puto, afferam etiam refponfiones, quibusad fingula aduerfarii vtuntur, \& quantuna zrimum roboris habeant, confiderabo. Pimum arguargume méntum, quo opinio Thom comprobatur
zum. tale eit:potentia naturalis, feuapritudoadop. randum poniturabAlift.in fecunda fpecie qualitatis; at potcntixamim sunt apritudines naturales ad operandum, ergo fun etrentialiter in fecunda ipecic qualitatis;proindelunt re diftin etz ab anima, qux eft fubitantia. Ad ho6 sG.
Spondentaduerfarii, non omnem potentiam operandi poniabAriftotele in fecüda fpecic qualitatis, fed folam potentiam ad bene, feu facile operandum, vel ad facilerefiftendum. Sed hac refponfio nullius momenti eft, \& iam abunde teprobata à nobis fuit in libr. 1 . de materia prin. ma, quoniam differentia per magis \& minus non variat fpeciem, multo igitur minus potert variare genus: \& quemadmodum actus currendi non differt genere $\mathrm{ab}$ aetu benecurrendi, ita neque potentia currendi differt genere àpo. tentia bene currendi ; potentia enim répicit actum; quare vt fe habet actus ad actum, ita se potentıa ad potentiam, Sumitur etiam alıa huius confirmatio ex habitu, \& difpofitione, quæ fpecie non differunt, fed folum fecundum magis, \& minus fixum; quare neque potentia bene currendi differt fpecie à potentia currendi abfolute. Secundoita argumentantur:fi anima effet idem quod fux potentix, ipf $x$ quo q; potentiæ interle effent idem, quia quxalicui tertio funt 1dem, etram interfe fint idenr; igitur potêtia vifiua erit idem, quod potentia motiua, \&c quod potétia olfąiua. \& quod reliquщ omnes: hoc tamen nemo affereret, quia potentix funt plures, non vna. Ad hocalii refpondent, potentras an imx dupliciter confideratipofe, v ho modo fecundum internam rationem, altero modo fecundum externam: ideo fi fecundum internam ranonem confiderentur, totum argumentum effe concedendum, hac enim ratione omres funt ipfametanima, qux vna eft, \& hoc folum eoargumento oftenditur: fi vero confiderenturfecundum rationem externam, dictunt argumentum nihil habere roboris; quia quatenus eadem anima refpicit varias operationes, appellatur nominibus diuerfarum potētiarum ratione diuerforum refpectuum: quam fuam opinionem declarantes dicunt potentiam effeanimam ipfam, \& nibilaliuder fuperaddere, quam refpectum quendam, quoniam anima ef fubfantia quædam non otoofa, fed (vtaiunt) virtuofa, \& apta ad multifariam operandum; quare ifta aptitudo nihil aliudeft, quam anima ipfa vt refpiciens hanc, aut illam operationem. Sed contra hanc refponfionem ita argumentaripoffumus;illa aptitudines, qux fecundum externam rationem refpiciunt varias operationes, \& in quibus potentiarum difcrinen confiftit, vel funt aliquid, vel.nihils. fi nihil, nulla igitur erit potentiarum differentia, quare asgumentum contra eos viget: fi vero aliquid, vel funt fubftantix, vel accidentia; lubftantias quidem ncmo diceret: fic enim non porfent effe; nifi diuerf form $x$ fubftantiales; fi yero funt accidentia, ve revera funt, confideraradum eft, in quananı fint Categoria; in Categoria quidem relatiuorum poni non poffunt, quia non eft ratio, nifi interalia, qux finul actu ninto son est corim pasecnifi qui actu filium haheat, פ 40

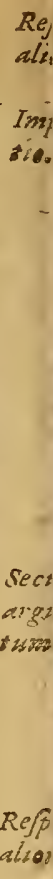


quo fit ve femper neceffrium fit vno relatiuorum exiftente alterum quoque exiftere; at in anima funt actu ifta facultates etian nulla exiftente operatione; neque dicere poffunt effe relationem rationis, quoniam etiam animo non cogitante habet anima potentiam videndi diftinctam à potentia ambulandi, nulla etian exiftente actu vifione, aut ambulatione: igitur hx potentix non habent effe refpeqtium, fed abfolutim; proinde in nulla alia Categoria ftatui polfunt, niff in Categoria qualitatis, vt confiderantibus manifeftum eft: itaque a duerfarii hoc dicentes veniunt in ipfammet opinionem Thomr; quodenim dicunt potentias omnesfecundum internam rationem idem effe, milaliud eft, quam dicere vnam efle anima fubftantiam, à qua omnes emanant: quuum autem dicunt eas diftingufecundum varios refpectus, fateri coguntut eas vel effe qualitates, vel.nullo modo diftingui, \& ita argumentum aduerfus cosvalidum effe. Alin quoq; ratione poteft eadem iplorum refpontio impugnari; nulla eft magis interna, feu magis effentialis confidera. tio, quam qux fignificatur per hanc duplicativam, quatenus: quod patet tutimonio Ariftotelis in r. Pofterior vbi docet hane effe pracipuan, \& fupreman conditionem; quxin propofitione faciat neceflariú, \& effentialem connexum;ergo nulia effe poteft intimior ratio potenti $x$ vifiux, quam qux fignificatur dicendo, potentia vifiua quatenus eft potentia vifua; ita- I que fi nulla eft magis interna ratio quam hæc, $\&$ potentix fecundum internam ratione omnes idem funt, fequitur potentiam yifiuam, quatenus eff potentia vifiua, effe potentian olfactiuam, \& potentiam ambulatiuam: patet igitur vanam effe eorum diftinctionem internx, \& externx, nifi intelligatur eo modo, quem diximus, nempe vnam effe animæ efféntiam potentias vero efle diuerfas aptitudines ad variasoperationes; \& externas dici, quia funt extraani- $E$ mx effentiam, quum fint qualitates eam infequentes, quarum fingula quatenus talis, abfoIutum quoddan eft, \& ab aliis diftinguitur:hoc videtur confiteri Ludouicus Buccaferreus, qui prædicta diftinctione vtitur; fed tandem veritate coactus afferit effentiam animx effe quoddam pruss, potentias vero efie polteriores, quod eft concedere eas diftingui à fubitantia anımæ Præterea aduerfusid, quod illi dicunt, animam effe fubftantiam quandam virtuofam, tali argumento vti poffumus ex eorum verbis defumpto: anima eft virtuofa, ergo non eft virtutes ip $f x$, quia neq; concretum poteft predicari de fuo abifracto, nequeabftractum de concreto; neq; enim album eitalbedo, neque albedo eft alba ; igitur fi anima eft ipf $x$ met potentix, fet virtutes, vtillidicunt, nō recte vocatur potens, feu virtuofa, velfi recteappellarur,aliud eft ip ia anma babens vidtutes, Gue potentias, \& aliud
A potentiæipfre. Praterea fic pro opinione Tho. Tertium mrargumcntari poffumus : potcntia operandi argumẽrefpicit actum, id eftoperationem ipfam, fed tum. femper nobilior, \& perfectior eft actus potentia ipfum refpicicinte; ergo fi potentia eflentialiter, \& fecundum internam rationen cffet anima ipfa, operatio, qux eit accidens, effet perfectior, quam anima, quae eft fubftantia. Aliud Quoztio quoque argumentum conitituere poffumus $\mathrm{cx}$ argumēa duobus, quxà Thoma vt diftincta ponuntur in tum.

$B$ predicto loco primi fententiarü: ficuti fe habet poffe ad effe, ita potentia ad effentiam; fed in anima differt poffe ab effe; ergo \& potentia $a b$ effentia; quoddifferat poffe abeffe,probat ibi Thomas ratione fupernaturali, qux aliena eft à noftra confideratione;nos autem id probare poflumus iatione naturali', quod eft aliud Thom $x$ argumentum in eodem loco: nam anima fecundum fuum effe refpicit totum corpus vt à fe formatum, \& conftitutum, at fecuudum C fuum poffe refpicit operationes, \& diftinctas eiufdem corporis partes tanquam inftrumenta, quibus ytitur ad operandum: hoc autem difcrimen in aliquo corporis noftri partenotare por. fumus; aliquis enim oculos habens cæcus eff, quare in eiuimodi oculo eft anima fecundum fuum effe, quia oculus eft animatus, \& habet fubftantiam anim in feipfo; non eft autem ibi anima feçundum fuum poffe, quia non potest operari, \& videre: quoniam igitur ibi eft fubftantia animxabfquepotentia vifua, aliud eft ipfa vifiua potentia, aliud eft fubftantia animz. Aliis quoq; argumentis vtuntur in memoratis locis Thomas, \& Egidius, \& Gandauenfis: qua quum infirmiorn videantur, dimittimus, præfertim quia apud eos Iegi poffunt.

\section{Vera Sententia, ơ ejus declaratio.}

Cap. IV.

$\mathrm{E}$ Go in hac cotroulerfia, licet magis ad Tho $m x_{\text {, \& aliorum pradictorum opinionem }}$ accedam, eam tamen penttus recipere non poffum, fed adhibedam ei effe puto quandam cor. rectionem; arbitlor enim totam huiufce rei veritatem in duobus dictis effe conftitutam: alte- Primu rum adueifus Scotum tale efit facultates animx dictum funt re diftinctix ab ipfa animx fubftantia, \& cosstro funt qualitates fecundx fpeciei:alterum vero Scos um. aduerfius Thomam, \& alios eft, facultates ani-secundio mæ non funt agentia media interanimam, \& diczum operationen, vtThomas, \& EEgidius exiftinia- contra runt.fed funt folummodo códitiones quxdam, Thom \& aptitudines animx ad operandum. Horum prius fatis probatur argumentis antea pro Thoma adductis, qubus reuera nil aliud oftenditur, nifi facultates effe qualitates ab anmm elfentia diftinctas;at non oftenditur eas effe agentia medialicut illi exiftimalle videntur. Alterum aute dictú probatur aryumëtis Scoti, eorum ni. plu. sacontia Thomam efficacifima funt inec folui I $s$ pofic 
polfe videntur,dum dicimus potētias effe ăgुen- A tia media interanimam, \& cperationen, fcdà nobis hoe negantibus faciline foluentur. $\mathrm{Vt}$ iritureritas clarior fiat, \& omniaduerfantia argumentafoluantur, notanda funt quadam. Fotensia Primoloco fiendum eft, potent am operandi oporande efle accidens quoddam mediun inter priuatiest meds uum, \& pofitiuum: quum enim notes priultiosminter nemadis, vidctur ellepriuatiuit potius, quam pofatises, politium, lion eft tamen pura priuario, fed cft Ë prsis quoddam resle, \& abfolutum, eftenim aptitutisum. do,acpropenlio quadan ad talemactum, quam Arifot. in genere qualitatis collocauit dite ete tanquam eius fpeciem:quod fi eflet mera prinatio, in nulla Caregoria poni poffer, nifi per reductionemiadeo vt hinc colligere polfumus, faculcatem operandi effe quidem rem quandam politiuam, \& abfolutam, led debilis admodun, omsis a- actenuis entitatis. Secundo loconotandum eft,
pititudo hanc potentiam fiue aptitudinem prefuppone. pritudo rein eadem re aliam naturam priorem, quam prasuppo retia inequatur : hoc autem fatis videtur confide. matur $\vec{i}$ rantibus elle manifeftum; quia omnis operatio pofirius. tit ab actu, quare aptitudo operandi, quī fit potentia, prafuppont neceffario prioren aliquam actualem naturam, à qua prouenit, \& poteft inductione declarari: nam potentia recipiendi omines formas, quxineft prins materix, ipian materiæ naturan infequitur; \& in elemçtis grauitas, \& lenitas nilalind funt, nifi potentiz naturales, quibus elementa propenfa redduntur ad dua loca naturalia, hrautcm ipfis elementorum formas confequnntur: alix quoque plures eiusmodi potentix naturales coniequuntur alia accidentia priora, vt illa, qux excmpli gratia nominantur ab Ariftotele in caip. de Qualitate; curlor crim dicitur, qui naturalem habet potcntiam bene currendi, fed hac necefle eft vt ab aliqua caufa priore proueniat, veluti ab optima partium corporis inter fepsoportione, vel à conueniente qualitatum temperie, feu à bona totius corporis habitudine, vel ab alin aliqua eiusmodi caufa, quæneceffario differt fpecieab ipfa potentia, \& quandoque etiam genere:nam fi dicatur effe temperies, ea vel eft in prima, vel in tertia fpecie qualıtaris, non in fecunda; fi verofigura, ea ef́t in quarta fpecie; quod fi dicatur elle fitus partium, diftinguitur toto genere ab ipfa potentia, quum lit in categoria poftionis : potentia vero primæ matcriæ differt ab ea toto genere, quum fit qualitas, materia ve-

posentia ro fubftantia. Tertio fcire opnrtet, tales po- st effe- tentias non alio modo pendere ab alia caura ctusper priore, quam yt à caufa effectrice: fed eam non cmana poffe effe effectricem propric dictam, quaeft troncm. per transmutationem, \& cum refifentia patientis, fod per folam emanationem ; emanatio enim dicitur,quandoabsquevlla refiftentia patientis, \&i fine vllo efficientis conatu ctlietus ipium infequitur quafi fjontefua, ticut vmbra corpus, quemadmodum alio in loco declarauimus. Quarto notandum eft, potentiam hauc naturalem, licet fit mo lo quodam media inter caufam, quam infequitur, \&: operationem, 110nefie tamen caufan mediam, fed caufamillam priorem effeimmediatam caufam operationis; vtfi quis actu currat, non dicimuspotenriam currendi cfle illius curfus proximam caufam, animam vero, fcu inftumenta, feu temperien, feu quodlibetaliud, à quo illa potentia emanaB -re dicatur, efle caufam remotan, red potius ploximam, \& immediatam : etenim potentia non eft caura operationis, fed folim aptitudo caufx ad operandum; quod poteft argumento pradicto comprobari": operatio enim fitab actu, non à potcntia, nifi prout potentia præ. fupponit aliam quandam aetualem naturam, à qua cmanat; illi igitur tribucnda efta tio, non ipfipotentir, qux non eft nifi conditio caufr ad operandum : patet autem hoc de potentia C paffua pima materia, cft enin cond to nıterna ad recipiendum, non ell tanten recipiens medium, non enım potenua recipit, hd in: teria immediate recipit: hoc idem in qualuatibuselemētorum notricibus maniteftum eft, grauitas cnim \& leuitas funt aptitudines, \& propenfiones naturales elementorum ad propria loca, proinde qualitates fecund $x$ peciei, \& omnium conicneione diftinctrà formis elementorum; nemo tamen dixit clementa moucri à grauiate \& leuitate tanquam motoribus à forma diftinctis, fed vt acceptis loco formarum latent1um : omnes enim, qui de motore elementi controuerfantur, vel à to ma mouerielementum dicunt, velàgenerante externo; nemo tamen dicıt à grauitate \& leuitate prout funt qualitates à forma diftin $x$; efle autcm qualitates teftatur A riftotcles in primo cap. libri fecundi de Partibus Animalium. Ex his colligere poffimus, debile effergumentum Egidij in præE dictoloco, quodindicat eum non fano modo hanc fententiam accepille, ac defendille: in quit enim, non poteft anima edere immediate operationes, quia eft natur $x$ nim is remotxab operatione, hitura autem non tranfit ab extremo ad extremü fine medio : anima quidem eft iubftantia, \& permanens; cperatio vero, line fit inmanens, fiue tranfiens, eft accidens non perma. nens; ideo conueniens fuit vt operatio ab animaproducerecur per mediam potentiam, quæ eft quidem accidens, fed permanens, \& ita medium inter condiriones extremorum. Videtur. enim confiderafic Egidiusid, quodab Ariftot. \& clarius ab Aueroe dicitur in libr. 8. Phyf, aufcultationis: motorem penitus immu abilem non pofe innuediate producere effictum nouim, \& mutabilem, niti per molorem medium, quipartim nuabulss, fartim immutabilis fit, cuiusmodi cit Colü, quodlecundnm fuivitantiam immutabile eft, fecundum locum ant mat-

ton-ile, 
tabile. Sed hec fimilitudo non omminopar, ginia primus motor agit in Coelum, \& Calum agit in liæc inierion, quare Coclum eft ages medum; at potentia non eft agen's medium inter opcra:ıonem, \& animam, neque eft miltumentum anima, fed conditio \& apcitudo ado eranduin, quxeius naturam infequitur peremanationem: argumentum igitur Egidij, licet irgenofum \& probabilefit,inecellitatem tancinon habet : mulla enim ratio prohibet quir anima, - qux eft fubftantia permanens, poflit cflenme$d$ diaca caufa accidentis tluentis. Poltremo notandum eft, potentias pronenire quidem ab anima vt ì principio, \& origine, non tamen in ea recipi vt in libiesto, fed in corpore anima:o : quemadmodum cnim operationes at tribuuntur animato vt fubiefto:anim $x$ vero vt principio, \& caufe, ita etiam potentix; totum enim animatum dicitur po.ens operari propter animan tarçuam caulam, à qua potentiæ emanant.

\section{Contrariorum argumcntorim folu- tio. Cap. $V$.}

Is ita conftiutis, nitendum eft ad arguH menia coniraria refpondere. Ad primum Scoti fumptum ex Ariftotele in 9. Metaphyfifiorum dicerepolfumus, Arift.ibinec definite foim potentiam, qux eft qualitas, nec folam formam ineporentia, fed totum coniunetum, hoc, ft, torman potentem, feu agens potens, $D$ hoc enim dicitur prencipium mutädialiud quatenus eft aliud.Dicere etiam pofiumus, eam definitionem compercre potentiæ, \& noméillud, principium, ibinon fignificare caulam agentem, fed rationem agendi; fic enim potentia aEtuneft pi incipium, id eft, ratio principij. Ad iu- fecundumnegamus potentiam paffuam efleiprammet materix fubftantiam, dicimus enim cam effe accidens manans à natura materix: ad probationem autem refpondemus non effe abfurdum, fialiqua accidentia indeterminata, \& potentialia in materia præcedant formā, quum ab his materia ad nullam certam naturam refringatur, $y t$ talıbi declarauimusjaccidentia quldem terminata non debent formam pracedere, quum eam infequantur; at potentia paffiua non eft huiusmodi, ied eft neceffaria materix vt poffiteffe rerum principium, \& recipere forma: olu 'Thomasautem in prædictis locis aliter hocasbo- gumentum foluit, quum concedat potentiam paffuam effe ipfammet fubftantiam materix: lednos alias hanc eius opinionem reiecimus: ideo ftandum putamus folutioni, quam nunc attulimus. Ad tertium ref́pondet in memoratis locis Thomas negando fimilitudinem quantum attinet ad formas accidentalcs, proptera quodnon itafe habet calor ad fuam operaticnem, vt forma fubltantialis ad fuam, calor enim coneft caufa primaria, fed agittanquam virtus
A fr mx, wam infequitur; qlare finilispotius cit por vis anime, quam anim $x$ p fi: itaque de formis Lubltantialibusnegarevidetur Thomas aliquan up farum agerefine potentiancdia, cui cgnaffentiendum puto; ac de accidentalibus fon miscius fentetiam non approbo; in co namque cratit, quod confefius eft potentiam efe agensmed lum inter formam, \& operationem; lioc cnim fi disamus, innumeris vregenur diflicultatıbus, vi antea dictum ct2. Ego igiturdcoB mmbus formis naturalibus, tamiublistialibus, quam accidentalibus vniuerle negandum effe puto, quodagantime potentia media tanquam ratione agendi; quemadmodum vuiuerfede omuibus allerimus,quod agant fine potentia me. diatanquam caufa media; ideo ve in plæentia admittamus dictionem illam, primo, in definitionc naturæ fignificare immediate, quod quidemfortaffe verum non elt, dicinus naturain producere mortum in codin corpore fine vlla C caufa media; neque per hoc ftare quin naturan infequaturpotentia motrix, per quam moueat non tanquan per caufammediam, fed tīquam perconditionem neceffariam: fic forman accidentalem actuam confequitur fua potentia, qua $\mathrm{ab}$ ea diffineta eft, vt calorem infequitur poten ia actiua qux eft in fecunda fpecie qualitatss, quum calor fit in alia fpecie: fed cauendumettne in fumendis formis accidentalibus Grausactiuis crremus, nan grauitas \& leuitas reuera tas, EF le nonfiunt actiux; \& dum aduerfarij ex his ar- ustas no gumentum fumunt, decipiuntur; nam form $x$ funt $a$ elementorum mouent elementa immediate, ctiws. grauitas autem \&leuitas non funt cauf media, lediunt propenfioues ad propria loca à formis emanantes, \& potenti $x$ naturales, quas $x$ quum eft ponere in fecunda fpecre qualitalis; quare grautatem \& leuitatem non infequunturalize potentix: \& id, quod dici folet, clementa moucri à grauitate, \& à leuitate, fano modo intelligendum eft, nempe ea molleri à fuis formis E. pergrausatem, acleaitatem, tanquam perpotentrasmouendi, non tanquan per caulasmedias. Ad quartum negamus animam effe a- Adqusr ptam operari per feipfam fine opealicuius exria tum. ellentiam ipfius, hoc enim manifefte falfum eft, etiam reicetis potentiis; eget enim anima corporess inftrumentis, fine qubus operari non poteft: fed vtcunque de aliis fefe res habeat, fat eft fi in præfentia dicamus, quando inquiunt, feclufo quocunque extra ipiam, is inF telligant feclufis potentis, eostalifum fumere; \& petere principium, nos enim dicimus ; nulLum agens polle agere lecluía potentia atiua. Ad quinum dicimus, eos fupponere poten-Ad quin tias elic caufas medias quod quidem nos ne- tur. gamus : de folis enim mediis, \& inftrumen alibus caufis verum eft 1 , quodiumint agensagere prius in medum, quam in extremum; at potentiasou fuat cauramedia, neque inftru- 
menta media, fed funt aptitudines ab ipfa ani- A mx effentia emanantes. Dicimus proterea ineptam, \& incongruam in hoc argumento loquutionem efle; ab anima enim tum potentix cmanant, tum operationes producuntur per potelltias, nectamen anima in potentas agere dicitur, nequein operationes. Ad fextum dictmus, nullum agens materiale pofferm mediate producere aliquid per tranfimutationem fine potentia media, atper emanationem poteft aliquis effcctus ab agente immediare prouenire; fic igitur potentix emanant immediate $a b$ effontianima,non peralias potentias. Ad feptimum refpondere alii debent, qui dicunt potentiam effeoperationum caufas proximas, at nobis, qui id negamus, argumentum non officit; non enim dicimus potentiam, prout eft quiddam diftinstum ab anima, producere operatio-

idoctaarmi. nem. Ad octauum dicimns potentiam infequentem, \& anime, \& formis naruralibus effe necefiariam, ob earum imperfectionem; nam formæà materia abiunctæagunt per efléntiam, ideo \& potentia , \& ipfamet operatio in cisidem eft quod elfentia; at formæ materiales ob fuam imperfectionem agunt per potentias ab effentia diftinftas, quum non poffint agere per effentiam : 1deo quandodicunt, ergo etiam formx ignobiliores agunt per potentias medias, hæc ominia concedimus. A d Ariftotelem autem, qui paffim in libris de Anima fumitpotentias pro ipfamet anmæeffentıa, dicimus, natiram animxe effe abfconditan, \& innominatan, ideo Ariftotelem eam fignificafie nomínibus potétiarum confequentium, quix nobis notiores funt; quum prafertim ibi confideret animam vt principium operationum, fic enim conuenientiffme vocari poteft nomine potentix ab ea emanantis: fic etiam in librus de Cœlo formas ele. mentorum nominauit per grauitatem, \& leuitatem, quia formæ non funt nominatx; ipfe tamengrautatem, \& leuitatem, quas ibidixerat efre formas elementorum, poftea qualitates effealierit in primo capitelibri lecund de Partibusanimalium. Ad hocautem confirmandum confidero verba A.riftotelis in context. nono librifecundide Anima, quæ ipfi contra nosad. duxerunt : ibinamque nor abfolutedicit, poten,iam vifizam effe animam, fed hoc conftituto, fi oculus eflet anmal totum, quiavidit potcntian vifiuam non effeanimam ipfam, fed effe accidens confequens a nimam, qua oculus in. F formatur: at qquia non per animam, fed per potentram vifiuam diftinguitur oculus ab aliis nembris, ideodixit; fi oculus effetanimal cotū, potentia vifua eflet anima eius; putauitigıtur fentia anim $x$, \& effe qualitates, quod nos quoqueafferimus; at non probant effe cauras medias: quare funtà nobis omnia concedenda.

\section{De diftinctione facultatum Anima inter $\int e_{\text {. }}$ dua aliorum contraria opiniones.}

Cap. V.

EActenus oftendimus facultates anim ab ipfa animx fubftantia diftingui vt accidentia a fuo principio, confiderandum reftat quomodoipfxinter fe diftinguantur tillud quidem manifeftum eft, earum differentiam as actionum difcrimine deriuari, ita vt qux eft $i$ prarum operationum differentia, eadem fit etian facul tatum, vtenim diftinguiturvifio à nutritione, ita \& vifua facultas à nutritiua : quisquis igitur nof'cat proprios fingularum operationum fines, \& vtilitaces, quarum gratıa funt à naturainftitut $x$, \& is operationum, \& facultaC tum difcrimen, quod à fine lumitur, optime intelligit, idque no ; anquan dificultate carens' alijs confiderand um relinquimus: fed alia eft $\bar{v}$ trisque communis difficultas, quam nunc confideraredecreuimus, de ipfarun tam operationum, quam facultatum principio, \& origine; quoniam enim funt qualitates ab ipfa animæ fubftantia manentes, ficut antea demonftrausmus, \& plures funt animæ tanquam plures forma fecundum ellentiam diftinct $x$, quod qui. $D$ dem concedere omnes videntur, mints erit illarum facultatum inter fe difcrimen, qux vnam $\&$ eandem anımæ fubftantiam infequantur; illæx vero, quæ à diuerfis animabus, tanquam à diuerfis principiis prodeant, maiore inter fe difcrimine diffidebunt. Eft igrtur inprimis confiderandum quæ fit animarum diftuctio in viuentibus, hoc enim declarato cognofeemus, quænam facultates vnain \& eandem form.m conlequantur, \& qux diuerfas. Dux hac

$E$ de re opiniones exiftunt, vna eft Latinorum fereomnim, altera plurium recentiorum, pracipue vero Auerroittarum. Latins non concedunt in coden viuente plures animas tanquam formas fibftantiales diftinctas, fed folum in diuerfis viuencibus; in homme enmm vnam tantum efle dicuut animz fubftantiam tanquam vnam formam, rationalem votatam; in quolibetbruio vnam tantum vocatam fenfibilcm; \& in qualıbet planta vnam vocatam vegetantem; \& has inter fe effentialiter differ:e tanquam formas diuerfas: quum autem in eodem viucnte vnam tantum effe animam fecundum fubfantiam dicant, illam praditam efie aiunt omnibus facultatibus animarum ignobilorum; it in bruto hon efle animam vegenantem; \& fentcencens veduas dittinEtrs formas, fed vinam tantunimodo proditam omnib. facultaubus, \& vegctantis animx , if fenticlis, led a pixfantiore nacultate apscllarifen- 
fibilen : fic in homine vnam tantum modo effe animain rationalers, quxpradita et tum propriisfacultatibus, tum illis omnibus que attribuuntur \& vegetanti, \& fentienti animx, fed à nobilioribus fuis facult atibus voratur rationalis, feumens, feuintellectus; ita vt cadem anima humana per facultarem rationslem inteiligat, \& fapiat, per fenlibilem fentiat, per veyetantem nutriat, \& augeat, \& generet alıud fimile. Secundum hanc igitur opinionem omines facultates animx in homine infunt, $k$ in eo vnum \& eandēanias fubitantiam infequuntur; prouk vero in diuerfis fpecievin č ibus confiderantur, adiuerfis animarum fubfantiis emanant: facultas enim fenfibilis, \& facultas nutritiua in bruto pendent ab eadem anima bruti, qua dic1. tur anima fenfibllis; fed fi ad differ ëria fpecie viuentia rcferatur eadem facultas, infequitur diuerfas animas tanquam diuerfas formás, vt facultas nutritiua in bruto infequitur anir à bruti, qux dicitur an!ma fenfibilis, in planta yero inlequitur animas planta, qux vocaiur vegetans, \& in homine animan humanam. qua dicitur rationalıs:ob id alrad effe dicunt anmam fenfibilem, aliud facultatem fenfibilem, fic aliudanimam nutritiuam, aliud facultatem nutritiuam; \& fenfibilem animam in folis brutis ineffe, non in homine, effe tamen \& in homine. a in brutis fenfibilem facultate $\vec{e}_{\text {in }}$ nutrituam aniruam in folis piantis inetie, non in animalibus, in omnibustamen \& plantis, \& brutis animalib. \& homine ineffe faculcatem nutritiuam. Hacdicentes illud meo quidẽ iudicio mirabile pronuntiare videntur, ornes facultates in eodem viuenteinfequi vnàm tảtım f rmam fubftantulen, fingulam vero facultatem in diuerfis vinentibus diuerfas etiam formas inlequi; proinde majus hacratione effe difciinen vnius facultatis in pluribus viuentibus quam plurium o. facultatum in eodern: HrecigiturLatinorum fentenzia eft. Plures autem Auerroiftz patârunt partem vegetantem, \& fentientem, \& intelligentem effe diftincras formas fubftantiales, etiam in eodern viuente, vt in homine; fic in bruto duas efle formas, fenfibilem, \& vegetantem; ita vteadem fit anima fenfibils in homine, \& in brutis, \& eadem vegetans in plantis, in brutis , \& in homine: fecundum quam opinionem fingu la facultas anime vnam \& eandem anima fubftantiam fernper infequitur, nunquam plures, vt facultas nutritiua folam animam vegetantem, fiue inplantis, fiue in brutis, fiue in homine confideretur; adeo vt in quo viuente fint ipfapartesanima, in eodem finc erian faculia tes Illarum partium propria, proinde in quo eft: potentia nutritiua, in eoden fit anima nutritiua diftincta ab aliis partibus animx, fi qux in eodem infint; \& in quo eft facultas fenfibilis. in eodem fit etiam anima fenfibilis. Dechacigitur controuerfia nos fecundum principia phi-
A lofophiz Arift. difputaturi, \& qux eius fententia fuerit inueftigaturi, veriusque opinion is argumenta feorfum referemus, deinde quid putemus fenfiffe Ariftotelem exponemus.

\section{Argumenta pro opinione Latinorum. Cap. VI.}

$\mathrm{L}$ Atini, quumad probandum non pofe is eadem materia plures fimul formas fubftantiales ineffe, pluribus argumentis vti foleant, \&e B horm aliqua ians in libro, quem de communi ierum generatione confcripfirus, confideraumus; nuisca tantum, quz peculiariter ad animam is eius fartes aftinentia adducunt, in mecium afferemus. Primum fic argumentantur: fruftra fit per plura, quod $x$ que ab bolui po- $x$. argum. teft per pauciora, atin bruto via anima fenfibi- Latinolis fifficit ad omnes edendas operationes animæ rum. vegetantis, ergofraftra in bruto ponitur anima vegetans diftincta à fenfibili: idem dicendum eft C inhornine de parte regetante, \& de parte fenfibili, qua ponantur diftinetz à rationali, frufra enim ponuntur, fi vna rationalis fufficit ad earum omnium operationes edendas. Secun- 2,argum do fi in bruto effent dux ill $x$ diffinet $x$ forma, vegetans, \& fenfibilis, \& in hominetres, vegetans, fenfibilis, \& rationalis, duobus interitibus nbnoxium effet brutum, \& homo tribus; diuerfanamq; forma diftinctis interitibus defruuntus, fiquidem vinus fubfantialis interiD tus vnius tantum fubftantialis forma defiructione terminatur; prius igitur interiret in bruto anima ferfibilis, deinde vegetans; fic in homineprius oporteret animam rationalem feparari, deindefenfibilem, actandem vegetantem: ter igitur homo moreretur, is brutura bis, hoc tamen nemo afferet. Tertio fi effet in homine $3 . a r g u m$. anima vegetans re diftincta à fenfibili, \& hacre diftinda à rationali, homo effer planta, \& effet animal brutum; quoniam anima vegetans, vt

E abalis diftincta, plantam confiruit, \& anima: fenfibilis, vt ab aliis diftincta, conftituit bru. tum. Quartoaliqui ita argumentantur: fi ani- 4. arg\%ma vegetans effet in homine diftincta ab aliis ment. partibus animz, non effet nifi communis, ackadem, quxin plantis eft; ergo: operationes quow que effent communes; qualis enim eft forma, talesfunt operationes : confequens tamen falfumeft, quia non idem eft nutritionis modus, quoalitur homo, \& quo planta ; fed modus nuF rritionis hominis eft hominis proprius, \& nutritio planta eft propria plantz; igirur etiam principium nutritionis humanae eft aliquid propritm hominis, proinde eft anima rationalis, nonalia communior; quare anima rationalis habetaltricem facultatem, \& alias omnes. Vuun- s.argsm. tur etiam maxime au Rtoritate Arifotelis in cötextu 31: libri fecundi de Anima, vbi dicit-vegetatiuum contineri in fenficiuo, ve triangulum in quadrangulo; at quadrangulum non habeta etu 
triangulum, ita vt fint dux diftind $x$ figurx, fed va tantum eft figura actu, qua dicitur quaòrangulum, \& cötinet triangulum virtute, non actu; ilcigitur non eft vegetatiuum actu in fenfituoo, effet autem actu, li effet forma diftineta, fed folmm fotefate, \& virrute, quia fenficiuum habet vim vegetatiuam, \& aptrm eit omnibus vegetantis anim muneribus fungi. His argumentis. \& aliis, qux mifa facio, nituntur cftendere, non poffein eodem animato effe pluresanimas tanquam diftirictas formas, fed vnam tantum fungentem muneribus aliarum.

\section{Argunchta pro opinione Aucrroifarum. Cap. VIII.}

In lib. de COntraria vero Auerroiftarum opinie,quam comsn: Cego Ariftotel. fuife abbitror, illis argurer.gent mentis maxime comprobatur, quibus alias

ra.cap.2. oftendimus animam, \& formam miftionis in codem viuente effe duas rediftinatas formas: quum enim in illis res ita manifefta fit, vt eam negare vanurs effe videatur, inde colligimus nihil effe abfurdi, fiplures quoque in eo: dem fimul exiftere formas afferamus; nam fi rationi \& rerum nacur $x$ non repugnat duas effe re diftinctas formas fub ftantiales in eadem $\mathrm{ma-}$ teria, certe neque tres, neq; decem, nequecentum fimulefferepugnabit: fed multis caúa erroris fuit fimilitudo partium anima inter $f e$, qua-multo maior eft, quam forma miftionis, $D$ \& animz; harum enım tanta eft difimilitudo, ve negari non pofie videarur cas effe duas diftineas formas, ficut eo in loco demonttrauimus: fed animarum interfe maior eft fimilitudo, vt in earum communi definitione manifeftum eft: omnis enim anima eft aetus corporis naturalis heterogenci, \& varisinftrumentis praditi: idcircomulti, quum animz \& forma

I. argum miftionis diftinctionem confo fil fint, eam tamen in partibus animznegauerunt. Sed bis a. E liquam poterat fidem facere de diftınctione animarü inter feilla continua, quam in nobis experimur, pugna fenfuscum ratione, quid enim ienfus appetit, ab eo ratio frequenter abhortet; \& quod ratio vult, id perfape fenfus fugit vt moleftū, ita vt eadem res rolefta fenfui, \& iucunda rationi fit, vel fenfui iucund 3 , \& molefta rationi:aliaigitur eft anim x fubfä ia, qua fentimus, \& alia, qua intelligimus, \& volumus: hoc argumento vtitur Galenus in libr. 5. de Kippocratis \&: Platonis decretis, ad probandurn diuerfas effe animz partes, rationalem \& concupifcibilem, \&irafcibilem; \& integrum ex Platone fumit in lib. 4 . de Republ. putatque effe ef-

Refponfro ficacifimù. Si quis autem dicar hoc indicarefo-

alsorum. Ium facultatum difcrimen, no animarum, proconfuta-pterea quod ha inuicem pugnantes facultates t:o refö candem anımam infequuntur: hoc certe ablursonn. diffimum eft, quia non pofiuntab eadem anima fubftantia prodire dua contrarix, \& inter fe pugnantes facultates, quarum vna alteri refiftere, \& ei impedimento effe \& praualere contendat: neq; eft quod aliquis nobis obiiciat facultatem motricem, qua eft apta mouere ad contraria loca, quia haceft quidem facultas libera,at dum ad hunc losum mouet, non meuet ad contrarium; fed fenfus \& ratio fimulecdem tempore mouent ad contraria, \& pugnant inuicem tanquam dua diftincta ficultases; quare nen reB ota eft comfaratio: nam facultas motrix yna tantum eft, qua contrarıa refpicit fine aliqua pugna cum feipfa;at apperirus fenfibilis, \& voluntas funt dux diftin âx tacultates, vt ipfimet aduerfarii concedunt, exq; inter fe pugnantes; quare unn poffunt ab una \& eadem aniwa fubftantia deriuar $r$, fed neceflarioà pluribus, ac diuerfis aninix partibus prodeunt: quod ne aduerfariis abfurdum, acrationi repugnans videretur, fatis illis erat confiderare difcrimen ma-

C nifeftifimum for $z$ miftionis \& animz in eodem viuente; quia, vt modo dicebamus, fi duas difinctas formas toleratnatura fimul in eadem materia, poteft eadern ratione \& tres, \& quatuor, \& plures tolerare. Sed ad majorem huius fententia cōprobationem libet nunc alia quxdam argumenta ad animam attinentia confiderarepraterilla, quæalıâsad probandam formæ miftions, \&ani $x$ diftinctione adduxim $u s: q u i$ autem flura videre cupit, islegat quxftionem Ioannis Gundauenfis 8 . lib. 7. Phyfic. vbi fufiffima dilputatione hanc fententiam tuetur. Primurs quidem adhanc fententiam lequen $: 2 \mathrm{~m}$ illud memax me mouit, quod forma fimplex eft effentia, o dat vnum tantum efie, son plura, qux igitur dat effe hominé, eadem non poręt dare efe animaligitur fi homo fer aninam $\mathrm{r}$. tionalem ef homo, non puteft per eandem effe animal, \& effeviuens, fed per rationalem eft ho. mo. per fenfibilem ett a nimal, \& per vegerante 2 : ef viuens: hoc fignificauit $d r$ itoteles, dum frequenter forman: appelluuit eflentıam, \& tò rísw; id quwd noftri quod qud eft feu quidditatem vocare confueuetun; ; alud namque eft quid ctanimal, aliud eft quid eit homo: abfur. daigitur eft aducrfasiorum fente etia qui dicunt, eandem formam effe fimul in eodé has omnes quid ditates, \& tributre firmul plura effe, \& eandem rem fimul in fpecie, \& in gencre collorare. Incidunt autem in alıud quog; abfurdum non s.arg minus grase: ficut en im dictint, plura effe $a b$ vna \& eadem forma tribui, ita etiam dicunt $v$ num \& idem effe tribui fimul à pluribus diuerfis formis; nam fecundum cos tam forma propria hominis, quam forma prepria equi, \& forma proprialeonis dat effe animal: hocautem tumipfum per fe cuilibet cólideranti abfurdü eft manifeftum, turietiam hoc argumento reprobari poteft: quiafi vnum, \& idem efle prouenit firsul à pluribus formis, ergo à fingulis prouenit 
uenit peraccidens, vt animalitas peraccidens à A tio. Egovero exi:s intelligere cuperem, quidforma hominis, per accidens à forma equi, \& à qualibet alia : illa enim eft alicuius caura per accidens, fine quaillud effe poteft; at qui ianimalitas exiftere poteft, ic exiftit adu fine forma humana; ergoab caprouenit per accidens, \& eadem racione à qualibet alia peraccidens, idque à nullorite philofophantenegari poteft. Ex hoc autem poffumus tale argumentum colligere: omne quodeft peraccidens, eft reducendum ad aliquodper fe, vt ait A rift.in 2. Phyfic. context. 66.67. ergo neceffe eft alian effe formamab omnibus fpecierum formis diftin tam, qux per fe tribuat effe animal, eamq; vnam \& candem effe in omnibus animalibus, proinde communem formam generis duftinctam effe à formis fpecierum:quod eo quoqueargumento confirmatur, quod fic feruatur vniuocatio generis, qua fecundumilloram fententiam feruarinon poteft; illa enim vere conueniunt in vniuoco, quibus vna aliqua natura communis, qua participent, refpondet, atquifecundum cos homo, \& bruta non participant aliqua eadem communi natura, qua fint animalia, fiquidem homo eft animal peranimam rationalem, equus vero eft animal per propriam equi formam,ergo animal non eft eis genus vniuocum; at fi in omnibus animalibus vnam \& eandem ineffe animz fenfibilis naturam fateamur, animalis vniuocationem optime feruamus : fic etiam per vegetantis anima participationem dicimus in viuente tanquam communi genere conuenire anirvalia omnia, \&. ftirpes, ideoque viuens effe illis omnibus genus nfo vniuocum. Ad hac omnia folent aduerfarij re30. fpondere, confugiendoad diuerfos eiusdemanim gradus, ideo hos diligenter confiderare *a- oportet;egoenim,vt libere dicam, quum exeorum friptis nunquam potuerim intelligere quid fint ifti gradus, non potui non fufpicaricos quoque, licet ad hos gradus confugiant, id tamen, quod dicunt, non latis inelligere. Vtigitur hac in re veritatem cognof camus, fuma mus exempli gratia animam hun ana m: bancilli dicunt vnam tantum effe \& vecari rationalem, \& dare hominitum effe hominem, tum effe animal, tum effe viuens, non tamen pereundem gradum, fed pergradum vegetabilem dare effe viuens,pergradum fenfibilem dare effe animal, \& pergradum rationalem dare effe hominem; $\&$ quanuis eafit formavna, \& diuerfa à forma equi, eam tamen in eo cum illa conuenire inquiunt, quod continet gradum fenfibilem, ficut illa; licet igitur in nulla vna communi forma conueniant homo, \& equus, conueniunt tamiea in eiusdem gradus fentibilis participatione: fic animalia, \& plantanullam habent communem animam, conueniust tamen in participatione eiusdem gradus vegetabilis, quem continentomnes tum arrimalum, tum ftirpium forma, \& bacratione feruatur loorum generum vaiuosana fint ifti gradus; quatenu's enim diftinatifunt, neceffeeft vt vel fub fantiz fint, vel accidentia : nam fi dicerent neutrum horum effe, dicerene effe nithil,proinde \& id, quod de his gradibus dicunt, nilil cffet, nulla enim ab is diftinctio, nulla vnituocatio prouenire poffet: accidentia au. tem dicinon poffunt, quia id, quod fubftantiam conftituit, non poteft effeaccidens : reftat igitur vt fint fubftantiz, \& vt fint plures diftinct $a$ forB mx,non poffune enim effe alize fubftátix, quam forms, fiautem funt form $x$;iam illincidunt in fententiam noftram, vt cuilibet eam confiderarti manifeftum eft:ideo mirum profecto eft, quomodo aduerfarij multas fimulin eadem nateria formas concedere vercantur, nec tamen yereátur dicereformam diftinctarn in varios fubftantiales gradus, quod quidem vel abfurdum eft, vel eft idem à quo ipfimet abhorrent:cur atutem abhorreant non video: etenimfif forma ef-

C fentcorpora, vtique vereri deberemus ne pluresfimulin eodem exiftere ponentes diceremus corpus à corporepenetrariffedquum fecundum fe incorporex, ac fimplices fint, neque aliud fit apud Ariftotelem forma, quam effentia, \& quidditas rei,non video quid abfurdi dicamus, dum ponimus plures fubordinatas quidditates in eadem re, quum pateat eundem hominem efie \& animal, \& viuens, \& hominem, qux plures. effentir colligatz funt earatione, quatenus vna ad aliam referturvt poteftas ad afum, nam ex poteftate \& actu vnum fit: dum igitur naturam, a conditionem forma diligenter cófideramus, cognofcimus nil aliud effe illos ab his pofitos gradus, ' quam formas ; idque Thomas verizate coactusali quando confeffus eft, vt poftea oftendemus. Praterea aliud abfurdum eorum opi- s.arguma nionem cunfequitur: dicunt enim rationalem, \&. fenibilem, \& vegetabilem in homine non tres formas effe, fed tres facultates vnius \& eiusderm

E formx, attamenharum fingula apud Arift. plures habetfacultates : vegetantis enim facultates funtnutritiua, accreţiua, \& generatiua; \& fentiétis vifua, auditiua, \& aliz plures; fic rationalis facultates funt intellecaus, \& voluntas; igitur facultas habet aliain facultatem, \& facultaterm facultates infequuntur; hoc autem dicere vanum: eft: foli nariq; fubftanția animastribuendum. eft vi habeat varias operandi facultaces, quum nilaliud fit facultas, quam potenria, feuaptitudoanim $x$ ad operandum: dicendum igitur ef vegetantem, fenfibilem, \& rationale in homine tres partes anima effe, \& tres formas, \& earura fingulam varis praditam effe facultatibus : $\&$ banc fententiam fignificauit Arift. in 1 c.libri de Auror:-

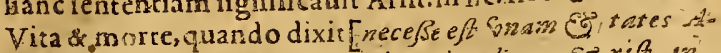

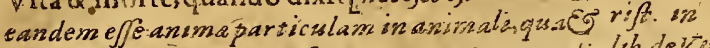

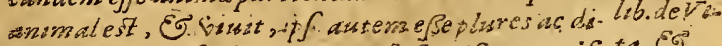
serfas ] nam effe ibi nun potcit fignificare, niff ta effencian, quare putauis eas encentialiter efle morta. 
diffinetas, licet exconnexu poteftatis, \&ąus $\Lambda$ homo vthominis pars, deindeverovthomoin. var ex eis anima fiat; nam fatim rationem fiubjurgens inquil [quia mon idem est efje arimal, E effermens ] fignificat ergo diftinctas eflentias, qux diftinctas formas denotant : in 2. eriam cap.

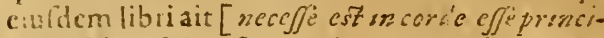

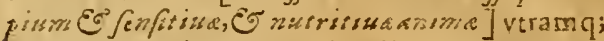
enim vocatanimam in animali, quarevult duas efle animas, non vnam, qux \& nutritiua, \& fenfitiua dicatur. Sed clarifime fignificauit hanc fententian Arifotel. in z. !ibr.de Ortuanimal. cap. 3. quando dixit, conseptumin vicro frius habcre animam regctantem, foftea recipere fenfibilem, quactania al, ac demumrationalem, qua eft homo: fic enim afferuit has effe diuerfas anim $x$ partes; neque ad id confugere aljIn 2. de quispotef, vit dicat Ariftotelem ibi ordinem Generat. naturx confiderare, non ordinem temporis, ansmat. nam Arifteteles manifeftifime de tempore loquitur, Br inquit, no ifmulherianinal, \& hoInserpre rainem, nes limul aninal, š eq̧um:ideo plures tatro ad-exaduerfariistoc videntes, \& negarn nonauLisrfaro- dentes, dixerunt Arifotelemibi non de ip fa arum. nima fubftutialoqui, fed de operationibus, \& harum tantus modo crdirem fignificare: anima namque humana momento temporis aducnit, non tamen fimul ett apta edere omnes operationes, fed prius editillas, qua ad partem vegetantem gertinent, deindeillas, quxadrenfiConfuta- bilem, tandemillas, qua adrationalem. Sed hac tio. interpretatioà verbis Ariftotel.alieniffima eft; ibi namque non de cperationibus, fed de ipfa fubfanciaanima loquitur: \& adco manifentum eft quafticnes ihiab Ariftoteleproponidefubfantia anime, nondeoperationibus, vtidnegare pertinacis admodum hor:inis effevideatur:clara eciam iunt verbailla [non from daimal

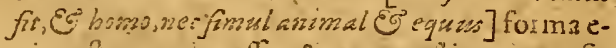
nim eft, qua dat effe, frem contituls, nec fit howso, velanimal ab operatione fed à forma.

Disbiwm. De hoc igitur non efivilo paeto dubitandum, fed alia potius dificultas ex ea Ariftotelis fententia oriti videtur: quia fi prius aduenit anima vegetans, deinde anima fenfibilis, actandem rationalis; formaigitur generis exiftit fine vlla forma fpecifica, ie daturgenus extra ommes fpecies fus ; fiquidern eritibi viuens, quod necert flanta, nec animal;deinde erit bi animal, quod non eit aliqua fpecies animalis; hoc tamen fal. fum videtur, \& communi omnium opinioni , \& rationi repugnantiffimum. Sed quifquis rem iffam, \& bi verb3 Ariftotelis bene confideret,

solstso facile hoc dubium foluet, Videcurdici poffe piror. conceptum prius viuere anima matris, quam proprian recipiat animam, proinde vinerctan-

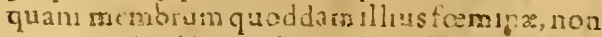

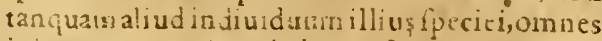
igitur parres anima habet vi fibi communicatas a furaina vterogerente; ideoque concepı us humanus fomper eit homo, prius quidem eft teger: fed hac tamen folutio non habet locum in 1 llis animalibus, qux pariunt ouum; anima! cnim quod ex ouo genctatur, fi prius animam vegetantera recipiat, vt A riftoteies omniso necellirum efledicit, ron poteft efreanimal per aumam atrmalis incubantis, quum fit feparatum:ideo fecundo dicerepoliumus, conceptum invtero effefpeciem.fpecialifinam, non qui- $\int b_{h}$ demperfectam, fed imperfectam, \& (vtaiunt)

$B$ inferi, non in in acto effe, conceptus enim humanus, quando accepit animam vegetantem, vel fentientem : eft homoin fieri, \& 1 n via; \& ita negandum eftconfequens, non enim fequitur darianimal, quodnon fitaliqua fpecies animalis; forma autern generis ibi exiftens abfque forma fpeciei reftringitur faltem abaccidentibus, $\&$ à difpolitionbus conferentibus ad formam fpeciei, ablis enim fitulla fpecies potefate prorima, quum ex eo concepun on polfitaliud aC nimal feri, quam homo:illudigitur, quod dici folet, forman generis non polle exiltere fine forma fpeciei, intelligendum eft dereperfecta, guc \& quaiamfit in facto effe, non dere imperfe- exiy cta, quireadhus fit in fieri, \&o in via, licet tunc fine. quoque dicatur modo aliquo reftricta ad ali- $m a_{j}$ quarm freciem, nempeab accidentibus \& dif- es. pofirionibus, vt dikumeft. Sedaduerfus ea,qua deillis gradibns diximus, förtaffe obiicere nobis quifpiam poffetrllud, quod nos alias de for D mis elementorum tutatifumus, eas habere varios gradus, ratione quorum intendi ac remitti pollint: fi ënm forma clementi, qua fimplex ett, plures hibet diftinctos gradus, curanima, quanon itáft fimplex, plures habcre gradus non potefinosautem ad liocdicinus, non eandem cfie rationem: nam forma elementi fim- Solu plexeft, neque habet atuplures gradus, quibus plura timul conftituat, \& det plua effe; dumenim conftituit aquam, nuliam aliam rem con-

E fítuirgrenieti tamenpoielt, er ita remifa conftitut vinum aliquod nistim tantummodo, vt aurum, \& definit aquan conftituere: atfesundumillos anima hominis habet fimul acta plures difinctos gradus, quibus fimul diuerfa conftıtuit, quum fimul det effe viués, \& effe animal, 8: cfle hominem; quo fit ${ }_{2}$ t per eaildem formam \& differat homo à brutis, er conueniat cum eis : nam rarione gradus rationalis eft differentia, qua diftinguitur homo à,brutis, rationeautem $F$ gradus fenfibilis eadem eft naturacommunis, in qua conueniunt lromo \& bruta; qux eft manifefta repugnancia in natura, imo de forma, qua apud Ariftotel. fimplex effentia eft, idneimaginabile quidem effe videtur: nos igitur non talem clementi formam effe ftatuimus; formam cnim aqua nun dicimus \& aquam, \& aurum eodem tempore conftituere, \& fimula. qua $m$ ab aliis corporibus diltinguere, \& effe rationem conucrientix inter illa eanden. Audde quod 
quod form elementorum remittūtur per gra- $A$ dus, $n$ on quatenus funt form $x$ conftitutriccs, fed quatenus funt materia, id eft, quateuus fuut conditiones materis miftorum, quad fignificauit Ariftotel. in context.10. 8. Melaphylic.alias à nobis declarato; aduerfarii autem tribumt anim $x$ gradus $v r$ fingenti officio form $x$, \& vt rem in fpecie conftituenti : quod A riftotcl. adnerfatur, qui in pradicto loco inquit formam, quatenus cf forma, efe indiufibilem:patet 1 gitur longe diuterfam efle gradum rationen in anina, \& in forma elementi : quod filta attribuant animæ gradus, vt nos formis elementorum, dicuntanimam intendi, acremitti poffe, ita vt anima raticnalis per remiffionem fiat anma fenfibilis, \& hxc perintenfionem, \& additionem gradus fiat rationalis, quod quidem ridiculum eft. Hane, quam hactenus demonftrauimus, fuife Auerrois fententiam non eft dubitandum: nain fxpe Anerroes dicit omnespartes definitionis effe formas, \& genus effe formam vniu erfolem, differentiam vero effe formam particularem : dicit etiam genus effe compofitum, \& ex materia \& forma conftare: quare putauit aliam effe formam, qua conftituiturgenus, \& aliam effe .qua conftituitur fpecies : legere autê de hoc Auerroem poffumus in comment.28. lib.2. phyfic. \& in 17.primi Metaphyf. \& in 1 .tertii, \& in 43 . Septimi, \& in 6 . \& vltimo oftaui, \& in Epitome Metaphyfica, tract.2. cap. $\mathbf{1}$. nobis enim in præentia in confiderandis omnibus Aucroois verbis non eft immorand um. Id folum Apud Alerroem eftnotandum, in comment. 42.libr. 7. Metaphyfic. Auerroem diceŕc genus non effe actu in fpecie, fed poteftate, fic etiam differentias remotiores poteftate effe in fpecie, non actu; fuam autem vltimam effe actu : hocenim Auerrois dietum ficraffa Minerua intelligamus, in errorcm labipoffumus: quia fi in homine non effet act u natura animalis, homonon effet aetru animal:quum igitur homo fit aftu animal, ineft actu natura generis in fpecie; proinde dictum. Auerrois eft lano modointelli. gendum: quoniam enim fola vl tima differentia tenet locumactus, ceteræ vero communiores, quxconftituunt fuperiora genera, locum habent poteftatis quatenus reitringuntur, ac dererminanturab ultima, eatenus dicunturineffe poteftate; fic enim etiam materia in compolito ineft poteitate, quin eft rub forma, \& ab ea perfi. citur,\&ad deteiminatam naturam contrahitur; vltima vero differentia nō amplius,ab alioper-" ficitur, fedperficitalia, id eo abfolute fungitur officio actus abfque poteftare, praterquam refpectu operationus; fed nos de primo tantumaetu, non de fecundo in præfentia loquimur: per hoc tamen non ftat, quin materiain compofito infit actu, \& differētiæ acforma communiores infint actu in fpecie; proinde \& natura generis, qux à propria eius forma conftituitul: Hanc igiturfuifle Aucroois fententian non eft dubitandum:led Auerrois verba, Gquxin pluribus locisleguntur, diligentifíme perpenduntur à loa. Gandauenfe in prædicta fua qureftione, quxomnia apud erm legenda, \& confideranda l'clinquo. Galenus quoque huius fententix fuit, in.5. Galenus. enim \& in 6. lib. dc.Hippoc. \& Plat. decretis, licet attribuat Arift. vt dixeriteffe facultutes tan-

B tum eiufdemanimz, ipfe tamenaffernt ef̂́ partes anime fpecie diftincas, non tanium facul. tates, idque proponit probandum in fequentibus libris,vtapud eum videreeft: quodautem in iudicanda A riftotel is fententia deceptus fit Galenus, ex eo patet, quod Ariftoteles in eotantumPlatonem carpit,quod eas loco [eparauerit, non in co quod fpecie diftinctas effe afleruent.

\section{Verafententia conclufio, \&o contrario- rum argumentorum Jolutio. Cap. IX.}

$\mathrm{H}$ Fe igitur omnia confiderans probabiliorem temper exiftimaui pluritm Auerroiftarum fententiam a quain tuendam funt nobisilla eadem fundamenta ftatuenda, qua alias in libro de Communi rerum generatroneiecimus, ac declarauimus: proinde hic repetenda non funt: id folumnotare volo, Arrfotelem in libris de Anima folitum effe totam anmarum colletionem in eodem viuente appellare animam totam, illarumatem fingulam appellare partemanimix: quum enim expoteltate \& actu vnum fiat, ex materia \& forma fit vnum, \& ex materia \& pluribus formis fit vnum; \& plures quoque form ita fubordinat $x$, inter fe colligatæe co nexu actus \& poteitatis dicuntur effe quodämodo forma vna, qux plures habet fubE itantialespartes, quas illi gra dus vocabant, dum formas appellareverebantur: huic igitur toti animæ omnes operationes attribuuntur ratione diuerfarum partiumideo Arift.in primis verbis 3.libr. de Anima hoc refpiciens dixit [departe autem anime, qua E cognofitanima, E⿺ fapit] totam enim animam yocat omniü animx partium collectionem in homine, qux per partem vegetantem dicitur nutrire, \& augere \& generare libifimile, per fenfibilem verofentire, \& per F rationalem contemplari, \& fapere: in aliis quoquelocis hunc eundem loquendi modum annotare polfemus, fed eum vnum tetigiffe fatis fit,quiaper illum alii omnes facileanimaduerti atqueintelligi poterunt. Alia quoque hac in re funt animaduerfione digna, qux mox in foluendis contrariis argumentis confiderabuntar. AdpriAd horum igitur folutionem venientes ad pri- mum. Z mum

\section{Quid fit \\ anima \\ totas \\ quid pars ani- $m x$. .

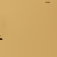


mumnegamus minorem, qua dicebaru, in $A$ bruto animam fenfibilem abst: vegetantefuificeread edendas omes gerationes anima vegetantis : dicimus enim nullam forman poffe operationescdere ad aliam formam pertinentes, proinde neceffarian elle n bruto animam vegetantam à fenfibili diftinctim, fic in homine vegetantem, \& fenfibilem difinctas a rationali. Ad fecundum regamus confequentam : ratioautem negationis eft, quonian, vtex Arift. colligimus in libro de Vita \& morte, cuiuslibet vifecun fruchio anim $x$ vegetantis, abque hac autem
dum. dxm. animx parte non pofiunt reliqux partes, fenfibilis, \& rationalis, in corporeremanere; ideò ex illius interitu alia quoque per neceffariam confequutionem limul intereunt, vel à corpore feparantur; vuts igitur eft viuentis interitus, \& vna mors, non plures : ueque ob id fit, vt vna \& cadem fit anima, qua eft homo, \& animal, \& viuens : quod enim non fit vna, fumitur argu- $C$ mintum à generatione, quum non fimul onines adueniant, fed prius anima vegetans, deinde fenfibilis, poftmodum vero rationalis, quæ fuit Arift. Cententia in 2. lib. de Ortu animal. cap.3. à nobis antea declarata: itaque à generatione vinentis fumitur pro nobis argumentum validifinum, ab interitu auten nullum; neq; enim pronobis, neque proaduerfariis, quum viuens om nibus fimulanima partibus eodem momento deftituatur. Tertium vero argumentum, vt libere dicam, eft puerile, \& philolophis indi. grum : quia li anima vegetans cōftituè tam a Ienfibilis brutum, vique fi homo has vt difinctas formas haberet, eilet planta, \& effet britum; redanima vegetans reuera non plantam conftituit, fed viuens, quod eft commune ginus animalis, \& plantæ; \& anima fenfibilis non brutuni conftituit, fed animal genus communc bruti, \& hominis; nil ergo aliud eo argumento oftenditur, nifi quod ii in homine fint 2wor süt hxtres diftincte forma, homo eft fimul viuens, forme in \&animal \& homo, hoc autem quis-negarepobomine, teft: ex his colligo neceflarium effe, vt quod. sot etiä funt formx in honune, totfintetiam inquoliinbrato bet biuto:ficut enim in homine eft anima veSunt. getans, qua eft viuens, \& anima fenfibilis, qua eft animal, \& rationalis, qua eft homo; ita in cquo neceffe eft prater vegetantem, qua eft viuens, \& fenfibilem, qua eftanimal, effe etiam propriam formam; fi enim folam fenfibilem haberet, non differret fpecie equus à fornica, fed folis accidentibus : hoc fignificauit AriftoQrelibes teles in 2. libro de Ortu animalium, capite 3. planta quando dixit, non fimulfierianimal, \& equum; duss ans lic enim afferuit peraliam formameffe animal, mas ba- \& peraliam effe equum: fic in qualibet planta ber.
A participatione omnesplant $x$, \& omnia anima lia conueniunt, effe etiam propriam formam, qua diftinguitur fpecie ab aliis plantis; nam $\mathrm{fi}$ per folam animam vegetantem omnes planta conftituerentur, non differrent fpecie lactuca, \& quercus; fed ha vltimie differentix funt nobis uncognitr, eas tamen dali fatendum eft, eafque efle vocandas animas: omnem enim formam nobilioremanima animam effe neceffarium eft; nobilior autem eft forma fpeciei,

B quam forna generis; ergo fi anima fentibilis, quxeft forma generis, eft anima; propria quoque equi forma, qux eft nobis incognita, eft anima: neq; abfurdum eft plurimas animarum fpecies conftituere, fiquidem aduerfarii quoq; id fatericoguntur; quumenim dicant, alian effe equi anmam, aliam afini, \&aliam cuiuf̣; fpecieianimalis, totanimas ponuts, fecundum ellentram difinctas, quot animalium, ac ftirpium fpecies funt : nifi dicant eiusdem cfiefpecici carnem \& equum, \& omnia bruta; quod fi dicant, eum iis difputandum nōeft. Sunt autem hac in re confideratione digna verba Thom $x$ in. prima parte Summa, quæft.so.artic. 4. ad primum, vbi inquit animalia bruta differre fpecie per diuerfos gradus animx fenfitiuz : deinde paulo poft ad fecundum inquit, magis \& minus, prout ex eiufdem form intenfione, ac remiffione proueniunt, nō vamant fpeciem; fed quatenus proueniüt à formis diuerforum graduun, fic variant fpeciem : fatetur igiturid, quod nos antea ex eius opinione colligebamus, has gradus anima fenfibilis effe diuerfas formas, \& vinā efle alia perfectiorem, cuiufmodi effectiam numerosalias cum Arifotelediximus : quare neceffe eft vt dicat animam fenfibilem effenaturam communem \& generalen ; varios autem eius. gradus efle diuerfas formas fpecificas, à quibus coaretatur, qua eft noftra fententia. Illud tamen eftanimaduertendum, duplices efie foec. E operationes forma fpecifica : etenm tum proprias ip fa edit operationes, quas non edit for- oper mageneralis, vtpropriahominis forma habet proprias operationes, contemplari, \& fapere, diftinctas penitus aboperationibus anima fenfibilis ; tum etiam coaretat, \& reftringit opera. tiones forma generalis, \& illius fpeciei proprias reddit : anima enim rationalis in homine vt vegetantem, \& fenfibilem coarctat, \& eas reddit humanas; ita \& eius operationes reftringit, \& facit hominem modo humano fentire, \& modo huniano moueri, \& modo humano Nut, nutriri, \& augeri, \& generare hominem, non in bi equum, neque animal commune, neque vi- ne ti uenscommune; ita vt nutritio in homine tum anim à parte vegetante, tum à rationali prouenire Geges dicatur; nam ipra per fc nutritio à vegetante te fit, prouenit, modusautem, \& coarctatio, qua hit i rat, nutritio nalio. 
nutritio humana, adicirur à rationali; quod $\mathrm{A}$ fi per rationalem animam intelliganus humanam animam tótam ita appellatam à parte 110. biliore, illiattribuunturomnes operationes tationediuerfarum partium, vt nutitio ratio ne partis vegetantis. In illis ıgitur, quas iguoramus, vitimis formis brutorum, \& frirpium, hoc fecundurn munus infpicimus; nempe coarctationcin operationum formarum generalium, fed proprias earum operātiones diftinetss ab operationibus formæ generis non cognofcimus, has enim finotas haberenus, $\mathrm{ex}$ is in formarum notitiam duci poffemus: vel dicendum eft, nullam effe earum propriam operationem, nifi coarctationem operationum forma generalis, hoc enim fortaffe linficit, ne ill $x$ nobis incognitx form $x$ dici poffint otio$f x$, \& operationibus carentes; fiquidem omnes operationes tribuuntur formæ lpecificæ, quæ alias omnes complectitur atque reftringit. Ex his fumitur etiam quarti argumenti folutio: quemadmodum non datur viuens, quod netr que fit planta, neque animal, ita neque nutritio communis datur, fed ómnis nutritio vel eft humana, vel equina, vel huius planta propria, vel illius: dicimus igitur; neque animam vegetantem, qux in honme eft, neque eius operationem effe communem; quoniam anima humana tum generales formas coarktat; tum earum operationes, facitque omnes effe humanas: quod auten anima vegetans, vel anima fenfibilis dicatur communis, id fit per mentalem ab. ftraktionem; nam fi eam mente concipiamus abiunftam $a b$ omnibus conditionibus refringentibus, eft communis \& eft illa eadem natura, qux in aliis viuentibus ineft; etenım non eft in rebus vniuerfale, nifi per mentalem abitractionem, quod fignificauit Auerroes in commentario octauo 1. Jibri de Anima, quan. do dixit, mtellectum effe qui facit vniuerfitain - tem in rebus. Poitremo loco adduxêre aduerfarii verbailla Ariftotelis in contexti 31 . fecun- di libri de Anima; vegetatiuum inest in fenfiti2. uo poteftate, ficut triangulum in quadrangu3r. lo: fed fi hac bene perpendamus, cognofice.de mus ea refragari potius illorum fentétiæ quam

a. fuffragari; confiderandum enim eft quid ibi fignificent ea nomina, yegetatiuum, \& fenfitiuum, an animas, \& fornas fubitantiales, an facultates animx, oftendo enim neutrum fenfum iis verbis accommodari iuxta eorum opinionem: formas quidem fignificare non pollunt, quia fecundum eos anima fenfibilis eft vna fimplex forma, in qua nulio modo ineft ipfa fubftantia animx vegetantis: fed neque facultates, quoniam fecundum eos anima fenfibilis habet actu omnes facultates, quas habet; vt enim habet actu facultatem fenfibilem, ita $\&$ nutritiuam \& generatiuam habet actu; atranen Ariftoteles denotat effe afu fenfitium, in quo fit poteftate vegetatiuum; reliquum eit, $v$ dicant nomen poteftatis bi non elépicerc a. Aum piimun, ncmpe vel formam, vel thculta. tem. fed operationcm, \& actum fectundum, ita vt nil aliud fignificet, quain vin, \& poteltarem edendi opcrationes attinentes ad vegetantem. \& vesborum fenfus fit hic, in fenfitiuo inett po. teftate vegetitiuun, id eft anima fenfitiua liaB betpoteftatem edendi onmes operationes animevegetantis. Sed hoc quoque ab Ariftotele alienum eft, quia comparatiocum figuris conueniens non effct, oporterct enim ita competere quadrangulo proprictates trianguii, vt animafenfibili ineft vis edendi operationes ani$m x$, vegetantis, id tamein dicere non poffumus, quia quadrangulo non competunt proprictates trianguli. Itaque fecundum illorum opunionem manifeftum eft, nullum effe eorum verborum conuenientem fenfum, fi illa bene perpendamus, nec fola eortim fuperficie velimus effe contenti. A tiuxta fententiam noftram facilis eft illorum verborum interpretatio:nam Ariftoteles 1 bin on de facultatibus loquitur, fed de ipfa fubftantia illarī partium animx, quum eas in contextu præcedente vocaffet animas, \& dixiffet non conuenre in aliqua vna communinatura vniuoca: idcirco resta eft earuin comparatio cum figuris, hæ namque diftinetæ funt fpecie, fed ordinem habent inter fe, \& præ cedens continetur poteftate in fequente, vt triangulum in quadraugulo; quomodo autem contineatur poteftate, poffumus in numeris confiderare, in quibusidmanifeftius eft; nam ternarius eft pars quaternarii, \& in illo ineft, $v t$. patet: neque per id ftat, quin quaternarius fit vnus numerus, vtendum enim eft illa diftinEtione vulgata, materialiter, \& formaliter; ternarius enim in quaternario ineft materialiter E folum, at non formaliter, fiquidem eft pars quaternarii, parsautem eft materia; formaliter vero non eft ibi ternarius, quoniam vna tantum eft ibi formalitas, qua vnus numerus fit, qui dicitur quatemarius; quoniam igitur res à forma conftituitur, \& vna tantum ibi eft formalitas, vna etran eft fpecies numeri, non plu. res, nec 1 bi eft ternarius vt fpecies numeri,fed folum vt pars quaternarii: fic de figuris dicendum eft: quadrangulum eft vna tigura, non plures, quia licet infit in eo triangulum, ineft tamen folum vtpars, \& materialiter, fed non formaliter, \& vt alia fpecies figuræ ; ducto.n. diametro, diuiditur qtad rangulum in duo triangula, quxillius partes funt:non igitur proprietates triangulin quadrangulo infunt, fediplamet ( $v t$ ita dicam) elus fubitantia in quadrangulo eit, quoniam area trianguli eft pars totius arex qta-

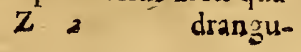


dranguli : ratio igitur clara eft cur dicatur trian- A gulum in quadrangulo effe poteftate, ineft enimvtpars, \& vt materia; materia autem in compofito ineft poteftate, quia fubitat fornix tanquam poteftas actui, à quo perficitur, ac deterninatur; quare ineft quidem triangudumin qua drangulo, fed determinaıur à formalitate quadranguli, tanquam materia à forma : hacratione antea dicebamus, genus \& differentias. remotiores in fpecie inefre poteftate, quatenus tenent locum materia:, fola vero vl tima differentia dicitur actu ine ffe, quia fungitur officio a\&us, \& formx, \& perficit, \& contrahit cætera omnia ad determinatam naturam, ficutoptıme declarat Auerroes in comment. 23. lib. 7. Metaphyfic. \& in Epitome Metaphyfica, tracta. 1. in cap. de Potentia \& actu. Quoniam igitur Ariftoteles animanstotam foletnominare ab vltima parte, qux continet alias tanquam forma materiam, \& actus poteftatem. , ideo vbi dua: partes anim $æ$ inelfeconfiderantur, vegetans, \&. fenfibilis, totam vocat fenfibilem., a qua dicit vegetanten contineri poteftate; vbi vero \& hæ, \& rationalis, totam vocat rationalem, \& hanc dicit continere alias poteftate: quamuis enim fint plures fubitantiales forma, tamen fola vl. tima datnomen torianim $x$, \& dicitur alias conxinere poteftate; quia illærefpectucius fungun. tur officio materia, ipfa veroforma. In prædiEto igitur loco fumitAriftotel es fenfitium eo modo, quo reuera exiftit, non exiftit autem fine animavegetante, ideo fumit tanquam animam totam, qux vocetur fenfitiua, fedcontineat etiam. yegetantem poteftate; id eff, tanquam determinatam abipfar, \& habentēlocum partis \& materiz: ea igitur rationeanima vegetans ineft poteftate in anima fenfibili, qua fecundum Auerroem antea declaŕauimus folam. yltimam differentiam effe actu in compofito, \& omnia continere, \& effe totum, reliqua vero omnia effe poteftate; \& effe partes: hxc eft il. litus locivera intelligentia,nequealium fenfum: illaverbarecipiunt; fic autem intellecta fauent uoftr opinioni, vt confiderantibus manifeftum: eft.

\section{De. facultatibus Anime vegetantis. Cap. X.}

$\mathrm{S}_{\mathrm{i}}^{A}$ A tis demonftratum eft ( $y$ arbitror) tres ef fe diftinctas animæ partes, etiam in codem yiitente; vegetantem, fenfibilem; \& rationalem; idq; rationi omnino confentaneinn eft, yt quod eft earum difcrimen fecundum proprias naturas, id perpetuum, acfemperidem fit, fiue illæ in diuerfis, viuentibus, fure in eodem: confiderentur. Quoniam igiturab harum fingula progriz facultates emanant; confiderandum bre. uitercit, quasnain, \& quot fingula facultates habeat, vt harum omnium numerum, \& differentiam quantum præéns occafio poitulat, $c 0$. gnofcamus. Vt à vegetante anima ordiamur, huic tres facultates attribuit Ariftoteles; altricem, autricem., \& gencratricem; has enim folas tanquam precipuas nominare fatis habuit, \& alias, quas Medici confiderant, tanquam fecundarias, \& illis minuftrantes in lib. de Anima commemorare neglexit, nempe attratricem, B retentricem, expultricem, \& concoctricem, êtenim fine harum minifterio hæc anima néque nutrit, neque auget, neque generat; iis autem tribus fublat is cxter corruunt, qua ipf $x$ per fe fine illis tribus praciputs viuenrinon profunt: at illa tres, licet ordinem inter fe habeant, \& v na ad aliam tanquam principaliarem dirigatur, fingulxtamen poffunt appellaripricipux, quoniam qux minus præcipua eft, ea exiftere etiam poteft; \& operari fine principaliore; al

C trix enim facultas dirigitur ad aufiricems \& ambre ad generatricem, nam generare aliud fimile eft huius animx operatio maxime omnium præ. cipua in mente naturæ vniuerfalis, quia confert immediate ad conferuationem fpeciei; huius gratia dedit vinentibus. facultaten. auctricem., qua augerentur donec ad perfectam $æ$ tatemperuenirent, ac debitam quantitatem adi pifcerentur, vt poffent aliud fimile generare; accretio igitur fuit penitus neceffaria viuenti-

$D$ bus propter generationem : quoniam enim femen à viuente abfiffum modicx eft quantitatis, \& viuentra omnia in principio parua admodum, proinde ad generantum inepta: oriuntur, oportuit ea augeri:, \& perfectam quantitatem confequi, tanquam neceffariam ad aliud funile generandum : accretio autem fier1 non poteft abfque nutritione, imo neque generatio; ideo propter vtramq; eft neceffaria nutritio, vt confiderantibns per fe manifeftum eft: fed quamuis

E; ad has nutritio dirigatur, \& illis inferuiat, tamen:ipfa quaque perfe exiftere poteft absq; illis, \& eft neceflaria propter conferuationem indiuidui, vt patet in illis viuentibus, quæ nō ampliusaugentur., neque generant; videmus enim plures homines effe natura fteriles, \& ad generandum ineptos, fic etiam pluraanimalia bruta; \& plures ftirpes, quibus, poftquam angeri defierunt, neceffaria eft nutritiovt feruentur.vsque ad tempus eis à naturapraficriptum; \& alias E- edere poffint naturales. operationes, quales funt in homine contemplari, \& fapere, \& alios regere, has enim: nobiliffimas operationes edere poteft homo: etiam ad generandum ineptus, \& quando non ampliusaugetur ; oportet igitur eum poft abfolutan accretionem diutius feruari harum operationum gratia; feruatur autem; \& quandoque etiam diutifime per nu. tritio. 
tritionem. Hx igitur tres facultates tanquam A præcipux ab Ariftot. nominatæ funt in fecundo libro de Anima, alix vero quatuor iseglect $x$, vel fub illis tribus implicite comprehenf $x$; quonianillæ tres abfque aliis fecundariis excrceri minime poffunt, \& earum minifterium neceffaro prafupponunt, \& continent, his auten tribus fublatis cæteræ auferuntur, quia funt prorfus inutiles, nihil autem eft fruftra in natura. Eft autem fummopere animaduertendum, non talemeffeordinem in his facultatibus, yt pofterior aliam prorem infequatur, \& dicat effe facultas facultat is, quod antea Latin is tanquam abfurdum obiecimus;non enim dicitur facultas habere aliam facultatem, fed fola animæ fubftantia dicitur omnes facultates habere, imo \&. omnes ean immediate infequuntur, non vna facultas aliam facul tatem:fed ordo in folis operationibus intelligendus cf, vna enım ad operandum præfupponit operationem alterius, yt à natura animæ vegetantis immediate emanant $C$ hx tres facultates, altrix, auctrix, \& generairix; féd generatrix non poteft operari, feu anima ipfa non potet perhanc facultatem generarealiud fimile, nifipraiuppofip prius operatione tumaltricis, tum auctricis facultatis: fic igitur dirigi vnam ad aliam dıcimus ratione operatinnun, fed non ratione emanationis ipfarum à fubftantia animæ; quod quidem etiam de facultatibus animx fenfibilis, quas poftea confiderabimus, eft intelligendum, hoc enim fencel annotaffe fatis eft. Hx funt vegetantis animx facultates, quas dum inter fe conferimus, \& earum inter fe ordinationem, ac pendentiam, quam modo declarauimus, confideramus, facile cognofcimus eas ab vna \& eadem anima fubftantia pronenire: at fi eas cum fenfibilisanima. facultatibus comparemus, tanta eft illarumab his difcrepentia, vt fatis a perte declaret eas à diuerfis animæ partibus emanare, quumillarum operationes ad operationes harum non dirigantur, neque illis inuiant, nifi quatenus animali ad vfum fenfuum neceffaria eft vitæ conferuatio, quam per nutritionem affequitur.

\section{Dubia de facultatibus Anima vegetan- tis, of corum folutio.$$
\text { Cap.XI. }
$$

Cæterum de his, qux modo dicta funt, dubia quædam oriuntur, qux ad colum iu. plenam intelligentiam foluere oportet. Primum quidem denutritione \& accretione dubitatur: ignis enim combuitıbilıalitur \& augetur, ergo hæ non funt proprix operationes animx vegetantis, proinde nec propria eius facultates altrix \& auctrix. Multo magis de generatione -dubitatur, quia neque omnibus viuentibus, ne- que folis competere videtur: quod non omnibus competat, manifeftum eft, plures enim hominesinfocundi, ac fteriles nafcuntur, fic alia plura animalia, \& plures ftipes; imoetiamaliqua fecundum totam fpeciem infocunda fint, vt muli, \&illa animalia, quæ ex putrimatcria generantur. Quod auten folis non competat, 3.Dubar. manifeftum eft in multis inanimatis, à calido enim generatur calidum, à frigido frigidum, ab igni ignis, ergo ctiam inanimata generant fibi fiB mile; quomodo igitur dici potelt hanc facultatem manare ab ipfa animæ vegetantis natura? nam fi id verum eflet, oporteret in folis viuen tibus, \& in omnibus hancfacultaten ineffe; idenim quod à propria alicuius rei natura emanat. neceflariun illi ıei eft;neque aliam naturam infequi poteft. Ad hac, \& primo ad primum de silurio. nutritione, \& accretione dicimusnegandum el- primi. fe eas com'petere igni, \& rebus inanimatis, quia proprie loquendo fola animata nutriuntar \& augentur: tres enim conditiones in accretione sola ankproprie dicta requiruntur, vt Ariftotel. docetin mata ne 1. Hbr. de Generatione \& interitu; vna eit vt ex triütur, materia extrinfecus accedente res augeatur; fe $\vec{E}^{\circ}$ aug $\vec{e}$ cunda,vt idem nunicro feruetur, id, quod augeri tur. dicitur;tertia denum, ve non folum totı, fed etiam fingulis particulis facta fit additio magnitudinis, ita vt omnes feparatim accept $æ$ dicantur masores fact $x$ : in 1 gnis autem incremento fola prima conditio adelie videtur, reliqux duæabrD que dubio defunt; quia nori manet idem numeroign is, qui auctus dicatur, $f e d$ fitalius, \& alius neque omnibus elus particulis fit additio ma. gnidutinis, fed toti tantummodo noutus ignis accedit; velutifi frufto ceræaliam ceram adiungamus, tota enim cera fit maior, at partes finguIx mullum faciunt incrementum. Ob eancem rationem neque nutritio proprie dictacompe. tatigni, quoniam conditiones prædıct etiam in mutritione requiruntur, quoniam neq; idem numero manet, iseque fingula particula nutriri dicitur; vera autem nutritio eft, quando omnium partium fubftantia reparaturatque inftauratur: igitur propriefumendo nutritionem, \& accretionein cum tribus memoratis conditionibus, fola viuentia nutriuntur \& augentur, $\&$ hæ funt proprix operationes anima vegerantis. Ad fecundum de generatione, qua Solutio non omnibus viuentibus competere videtur, fecundi. dicimus negari-non polfe plum effe viuentia; quæ nequeunt generare, fed hæc generandi impotentia, vel competit indiuiduis quibufdam, non totifpeciei, vel etiam fpeciei toti: $f_{1}$ quibufdam tantum indiuiduis competat, non toti fpeciei, id nullam deber difficultatem facere, quia certum eft res naturales recipere impedimentum prater conflium \& intentionem naturx; ideo ficuti contingit $v$ t hom o fiue 
oculis nafcatur, vel cum oculis ad videndam ineptis, ita contingere poteit vt nafcatur homo fteilis, feupropter nulam temperiem, feu ob alicuirs infrumenti defectum; hæc enim vocantur monftra, \& prater naturæ confilium faAa, in qubus concedendum eft effe aliquid fruftra. Sivero hæc impotentia competat toti fpeciei, jd eft, omnibus eius indiuiduis, id vel eft aliquo tantum tempore, vel omni tempore, \& femper; aliquo tempore, vt omnbus hominibus nullo excepto competit vt tempore pueritix, \& tempore fenectutis nequeant generare, \& in his non poffum us dicere organa effe fruftra : in puero enim non funt fruftra, quia fat eft $f i$ aliquando poterit generar e; neque in fene, quia fat eft fi aliquando generare potuit ille idem homo: per hocautem non ftat, quin faculras generandi infequatur anım $x$ vegetantis naturam : quod enim ad ipfam animam attinet, ea femper habet omnes vires fuas; fed quia ad eas exercendas plurium aliorum minifterium requiritur, ideo propter aliquem horum defectum fit quindoque vt aninal generare nequeat, cuiulmodi defectus in omnibus pueris, $\&$ in omnibus fenibus neceffario ineft. Vbi

CurmuSi. Ealigisst aileat animatbistren generent autem tota fpecies peromne tempus hanc impotenriam habet, maius dubium eft, quod quidem contingit in muls, \& in animalibus ex putri materia genitis: fed de multis dicere poffumus non efle mirum fi non generat, funt enim numerandi inter animalia monftrofa, quxpræter naturæ confilium fiunt; natura enim voluit equum coirecum equa, \& afinum cum afina, nonafinum cum equa: ficut igitur concedimus facultatem generandi, aut etiam inftrumenta: generacionis effe frutrain fomina fteril 1, \& \& in. viro infocundo; ita de tota mulorum fpecie dicendum eft, eos fruftra habere organa, \& facultatem generatricem, quum fint animalia monitrofa, \& aliquo vitioaffeeta ; obid non eft forcaffe eis affignanda propria pecies, quum nil aliud fit mulus, quam equus imperfectus, \& afinusimperfectus, vt ait Ioan. Grammaticus in. context. 34. libr. z. de Anima: vt igitur tu eamur. naturam nihil fruftra facere, fatis eff fi dicamus. equum perfectum, \& afinum perfectum generare fibi fimile : nam mulus, licet habeat tacultatam generatricem, quatenus habet animam vegetalem, habet tamen in partibusinftrumentalibus, vel in qualitatum temperie aliquem defectum, quifacitne illafacultas poffit exire in actum, \& ita facultas generatrix in mulo fit fruftra tanquam in animali monftrofo : quod. autem in mulo fit potentia generatrix faltem ratione fux originis, quxeft anima vegetans, cognofcere poffumus ex eo, quodfcribitur ab A riftotel.in 6. libr. de Hiftoria animalium, cap. 24. inquit enim, inuentam effe mulam pra.
A gnantem, fed eam non potuifie foetum perficere, \& edere prolem perfectam, hoc igitur eft fignum, \& veftigium quoddam facultatis generatricis infequentis animam vegetantem:inquit etiam in eodem cap. Arifotel. \& poltea in cap. 36. effe in Syria mulos \& mulas coeuntes, \& generantes prolem perfectam; fed adddit, eos non effe eiufdem generis cum his mulis noftris, fed habere tantum fimilitudinem faciei, propter quam apellantur muli, differre tamen fpeciè

B mulis genitis ex afino \& equa. Deanimalibus. vero exputri materia genitis dicendum eft, ea non efle quidem monftra, fed habere tamen naturalem quandam imperfectionem, quæin pedit faculratem generatricem ne exeat in a. ctum: euenit enim ixpe vtaliquid alicui competat ratione generis, quod tamen repugnet maturx fpeciei.j nam forma ipecies adueniens formægeneris., plura ill rupenddit, quxillam, \& eius operationes ad certos quofdam modos reC Atringunt, aliqua etiam demit, hoc cot, affert aliquod impedimentum alicui eius operationi ; $C_{2}$ quod hic dicere poffumus de his animalibus ex ta putri mareriagenitis : propria enim eorum for - tas ma facir in eorum ngtura talem petfectum, vt tio: potentia generatix non poffit edere fuam ope- ner rationem; 1 mo in his quoque aliquod apparet rep veftigium facultatis generatricis, quia (vtait A-rat riftotel.inlib. de Ortu animal. cap.ro.) hæc ani-Spec malia non carent omninoactu generandi, generant enimaliud, fedimperfectum, quod neque eft mas, neque focmina, neque eft eis fimile fecundum fpeciem; quarehabent aliquam generationem, fed imperfectam, quxad.lpeciem conferuandam non prodeft, indicat tameneffe ibi aliquam facultatem generatricem : \& hrc.

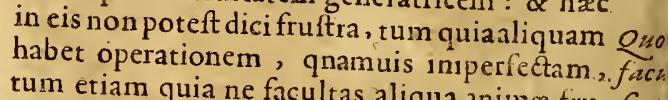
tum etiam quia ne facultas aliqua animx fru- fane ftra fit, fatis eft fi in aliquo viuente ducatur per- rats
fecte ad actum : finile enim etiam in fenfibus nonj notare pollumus; vbi enim eft anima fenfibi- frus. lis, ibi lunt omnes eius facutates, faltem vt in origine, licet non femper omnes yt in fubiecto; vt fi dicamus apes auditum non habere, habent quidem apes facultatem auditiuam ratione folum originis, fed propter natlram propriam habent aliquem defectum illis nat ralem, qui prohibet ne illa facultas poffit exiread actum : neq; obid dici potef, ibieffe fruF: Itra, quia quum infequaturneceffario animam fenfibilem, qux in omnibus animalibus æque inef, latis elt, ne fruftra effe dicatur, fi in aliquo anmli perfectam poffit edere operationem. Ad tertium dubium, quod generare fi- solüt
br fimile videaturetii) in igni, \& alis inanima-tertÿ.
tiscompetere, illud isem tis competere, illudiden dicendum ef, quod 
0: nim vtcunque gencrare fibi fimile eft propriam animæ vegetantis, fed modo quodan proprio ib: \& cum ftatutis quibufdam condutionibus, qux fot inanimatis competere non poffunt; propritus 7 autem hic modus tangitur à Thoma in r. part. so Suinmx, quxit. 78. artic. 2. ad fecundum, fed non perfecte explicatur: ipfe cnim dicit, genera. tionem fumilis in rebus inanimis fieri penitus $\mathrm{ab}$ extrinfeco, in viuentibus autem fieri quodam altiori modo per aliquid ipfus viuentis, quodeft femen, in quo eft principium corporis formatium, ideoque oporterealiquam effe rei viucntis facultatem, perquanr femen prapare tur; eamque effe vim generatricem : fed lianc Thomx refponfionem poftea veritate declarata perpendenus: nos dicimus differentiam in hoc elle conftitutam; quod ignis ignem generat agendo in aliam materiam extra fe, \& ex ea educendo aliam ignis formam; at viuens non ita generat aliud fimile, vt agat in aliam materiam extra fe, red largitur quodammodo alteri ali- C quid de fuamet materia, \& aliquid de fuamet forma cum facultate actiua, dum exhibet femen generationi : nam femen plātæ, dum eft in ipfa planta, eft animatum anima vegetante, qua etiam planta tota, \& ab ea feparatü retinet vim prolificam; \& alterius plantx generatricem, non quidem exalia materia, red ex illa ip ${ }^{2}$, quxeft in femine, quæ prius fuit portio quædam materix totius plantx, à qua femen prodijt ; feparatur igitur à planta aliquid depropria materia, \& aliquid de propria forma de facultate genêratrice, qux eft-agens proximum, à quo ex illa materia fitalia numero planta: huic proportione refpondet femen in animalibus; eft enim materia quadam abfifía ab ipfomet animali generante, retinens vim actiuam \& generatiuamalterius fimilis anımalis; femen enim humanum proprie dicitur totum illud, quod cunftat exfemine viri, \& men ftruo fanguine formi$n æ$, foletque appellari conceptus, \& eft fimile fem nnibus plantarum, quoniam habet infitam vim actiuam, qux, vt inquit Arift. in 2 . Phyf. eft ratura humana non tanquam forma, fed tanquam artifex, \& agens proximum; habet etiam in fe materiam, ex qua poteft homo fieri, nempe fanguinem menftrum fom inx: hæc enim fuit ratio diftinctionis maris \& fominx, propter eorum diuerfa officia in generatione: nam maris officium eft exhibere vim actiuam, \& generatiuam alterius animalis fimilis; fominæ vero exhibere materiam conceptui : quæ munera diftinxit oculatiffinus Philofophus Ariftoteles, neque illa confudit, quod Medici faciunt; dım dicunt \& femen viri effe matetiam foetui, \& foeminam quoq; femen vt actiua præditumemittere; ita vt \& virlle femen vrroque munere fungatur, tum agentis, tum mate-
A riz; \& focminarum fanguinem menftum exhibeat vt materiam generationis, tum femen præditum vi generatua; quod quidem fi verum effet, oporteret euenire aliquando it $f \propto-$ mina fine viri congreflu concipiat, quod tamen nunquam compertum eft. Sed repugnatifimum ctiam illud eft rationi, quia naturanon abundat in fuperuacaneis, nec propria rerum muncra confundit: quare fi ftatuit a mare prodire vim actiuam, à fomina vero materian,

B non debuit focm inæ dare femen cum facultate generatrice, neque virili femini materix ofícium tribuere: voluit igitur fominx officium efle exhiberconceptui materiam, ex qua à f́cultate actiua virilis feminis generetur alternm animal fimile; hoc genitum viuit prius anima matris, fed poftea viuit anima propria: quemadmodum etiam ramus in planta viuit eadem numero anima, qua viuit tota plarta, fed poftea auulfus fit alia planta numero, \& ita vetus illa planta generat alteram fimilem, largiendo aliquid de fua propria materia, \& de fua propriaforma. Hac igitur eftalterius fimilis generatio, quam Ariftoteles dicit effe propriam vegetantis anim $x$ operationem, cuius propria conditio eft, vt generans exhibeat aliquid de fua materia, \& aliquid de fua forma; nam in femine tum materia inef, tum vis quædam vitalis à forma viuentis proueniens, \& fungens officio agentis: hoc fignificauit Ariftoteles in libro de Vita \& morte, cap. I4. dum generatio- Quid fzt nem viuentis ita definiuit, generatio eft prima generaparticipatio animænutritiuæ cum calore natu- tio sizém rali; generans enim communicat aliquid de $t$ is. fua anima nuti itiua, quatenus exhibet femen anımatum, vt ipfe Ariftoteles afferit in 2. lib.de Ortuanimal. cap. 3. eft enim femen praditum facultate vitali, qux eadem in generante erat; fed fimul communicat aliquid de fua inateria, quia forma non poteft migrare de materia in $E$ materiam quare neceffe eft $v t$ viuens generans exhibeat portionem fuæ materix vna cum portione animre nutritiux, \& caloris fui naturalis; fit autem poftea alia numero anima, \& aliud viuens elufdem fpeciei. Inanimata vero ita generant aliud fimile, vt folam conferant vim actiuam in aliam externam materiam; at neque de propria materia, neq; de propria formaaliquid exhibeant, fed aliam numero furmam eiufdem fpeciei ex illa exierna materia educint. Illud autem, quod in memorato loco Thomas dixit, verum ent, fed ipfe materiam confiderare non videtur, quæ tamen in hac generatione eft maxime confideranda: inquit enim generationem animatorum effe penitus ab extrufeco, agensenim agit in materiam extra'fe, viuentis autem generitionem etre peraliquid ipfius viuenrs, ciliset p-r feZ 4 min 
suen: qux omnia vera funt; fea poftea dicens in fenine effe principium corporis formatiusm, videtur confiderare femenvt habens vim actiwam, non vt matcriam; attamen nif materiam quoque in femine confideremus, non. fatis apparetin hacfacultate actiua difcrimen, quo generatio viuentis $a b$ inanimati generatione $\int_{e}$ cernatur, fiquidem etiam inanimatum habet vim generatricem alterius fimilıs: fed res it a cla. ra elt. vromnino dicendum efle videatur eam Thom incognitam non fuiffe, quamuis eam non exprefferit. Sed illud quoque mihi dubium elt, quod ibidem à Thoma fubiungitur, oporterealıqum effe rei vitzentis facultatem . per quam huiúnodi femen prxparetur, eamque Nota in effe vim generatricem: etenim dux generatrifrzsente cesfacultates tî́c confiderari polle videntur, $v$ duas fer na, qua viuens generat femen; altera, qua fecultates mengenerataliud viucns fimile; iple quidem gcnera. Thomas fignificare videtur vim illam generatruces. tricem, qux fecundum Ariftot. eft præcipua facultas animæ vegetantis, effe prioré illam, qua femengeneratur: ego tainen puto effe potius alteram pofteriorem, quxin femine ineft ranquam artifex, \& ex illa materia generat aliud viuens; feminis enim generatio nil aliud effe videtur, quam concootio quædam vitimi alimenti,proinde non eft illa generatio alterius fimilis de qua in præfentia loquimur: neque ob id negamus effe in ipfomet viuente vim generatricem alt erius fimilis; nam dicendo eam in femine inefle, dicimus in viuente, à quo eft abfiffum femen, \& à quo hanc vim recepit: viuens igitur nonea ratione dicitur habere vim geneatricem, quatenus poteit ex alimento generare femen, fed quatenus femen in viuente genitum habct vim generatricem alterius viuentis fimilis. A lia plura de his vegetantis animæ facultatibus \& operationibus dici poffent, qux confulto omittimus, tançuamad fingularum facul tatum \& operationum diftinctam declarationem pertinentia: nunc enim confilium noftum eft geseralem tantummodo hárum facultatum parsitionem, \& enumerationem facere: hac eadem ratione de aliarum aninæa partium faculzatibus nunc aliqua dicereaggrediemur, aliâs. fortaffe de fingulis diligentius atque accura. sus loruturi.

\section{De facultatibus Anima fentientis. Cap. XII.}

Entientis vero animæ facultas induas clafOfes diuidi folent, in externos. \& internos fenfus: externi funt illi, qu ab obiectis ipfis materialibus patiuntur, iique funt quin. que, vifus, auditus, odoratus, guffus, \& tactus, deinternorū autem numero ambigitur, gูuı
A ab aliis plitres, ab aliis pauciores ftatuantur: ego duos proprie loquendo effe arbitror, fen. fun communem, \& phantafiam, à noftris ima. ginatiuam sppellatam; vel tres, fi memorsam addere velimus: fed quia nomen fenfus cognitonem denotare videtul, memoria vero non eft cognoficitiua, fed folum côferuatiua imaginum \& tanquam promptuarium imaginatiux; ideo dubium eft an memoriam liceat fen fum appellare: fed qualifcunq; fit, cèrtū eft effe vim quădam anima fenfibilis, \& poffe facultaten huius animæ nominari; quxinmediate inferuit imaginatiux; nam ex imaginatione imago imprimitur in organo memoratiua facultatis, quod eft proximū organo imaginatiux, \& eft tanquă liber apertus, in quo imaginatiua infpicere, ac veluti legere imagines fenfilium resum poteft: fed ipfa perfe memoria vim cognofeendi non habet, neque habere debuit, propterea C quod facultas cognof citiua non poteft fine cognitione recipete fpeciem; fpecies enim recepta nil aliud eft, quam cognitio ip fa, plura autem fimul cognofci minime poffunt, ideo facultatem illam, qux plura fimul retinereapta effet; cognitione carere oportuit, immediate tamen interuire cognitioni, \& hac tantum ratio. ne poffe appellari cognofcitiuam. Senfins communis ad quinque externos eam habet rationem, quam habet centrum quod vnum eft, ad quinque diftinetas lineas ab eo prodeuntes : eft enim tanquam ipforum radix atq; principium, \& comparat inter fe plurium fenfuá obiecta, \& illorum difcrimen cognofcit, non tamen operatur, nifi præfente obiecto ext erno, quemadmodum neque ipfi externi fenfus. At imaginatiua res quoq; abfentes umaginari poteft: etenim neceflarium quidem eft eam moueri prió mumabaliquo externo fenfu, fed poftquã $f e$. mel apprehendit, \& idolum impreftir in memo. E ria, poteft poftea illud idem frpeimaginari, etiamabsente obiect materiali. Preter hos vero ponuntaliquialios internos fenfus, vt xftimatiuam, \& cogitatiuam, feu ad ratiocinand um, \& difcurrendum à notoad ignotum in particularibus, feu ad ea comprehendenda, qux à fenfu cognofcinequeunt:vt ouis videnslupum, fentit folos colo:es, \& magnitudinem, \& figuram lupi; \& hæc omnia imaginatur; neq; tamen propter hæc fugit lupum, fed propter inimicitiam \& periculum, quod fimul cognof cit perfacultatem $x$ ftimatiuam, licet fub externum fenfum non cadat: ob hanc igitur rationem ponit hanc facultatem Thomas in 1. part. Summx, quxit. 78. art. 4. \& inquitappellari in brutis æetımatiuam; in hommeautem cogitatiuam, quia perfectius in homine, quam in brutis, prædictum munus exercet; etenim bruta res, quxà fenfbusnon apprehenduntur, non concipiunt per casum 
earum inter fe collationem, fed naturali quo. dam inftinctu, lomo vero per collationem ipfarum inter fe: idcoaccedere in hoc videtur Thomas ad opinionem Aucrois, qui præeter facultatem imaginatuam pofuit in homine cogitatiuam, cui tribuit vin affirmandi, es negandi, \& ratiocinandi. Ego vero hacin re arbitror nō efle ab Anft.recedendum, qui prxter fenfum communem, \& phantafiam, \& me moriam, non pofut aliam internam animæ fenfibilis facultatem, qux ad cognitionem pertincat; ctenim enuntiandi vinı, nutultoaute magis ratiocinandi \& difcurrendi propriam effe voluit folius animx rationalis, vtin . J 1 b. de Anima videre manifefte pollimus: vanum igitureft, \& ab A riftotelealıenum, ponere vllam anima fenfibilis facultatem ratiocinatricem, vel enunciatricem:ad concipiendas autem res fenfiles etian abfentes fufficit fola imaginatrix facultas, quare aliam ponere fupcruacaneum eft : a quoniam imaginatio fecundum Arifotelem eft motus ab externo fenfu factus, proinde nihil poffumus imaginari, quod prius in fenfu non fuerit; ideo multi confiderantes ficrialiquando imaginatio nem etian illorum, qux nun qquam fuere in fenfu, imo \& corun1, quæ nihil penitus funt (imaginamur enim montem aureurn, \& animalia monftrofa) alias facul ta tes, quarum id munus effe, introduxerunt. Attamen certum eft hæc o mnia proftari à fola imaginatina; phantafma enim fuitaliquando fub ienfu, faltem ratione partium fuarum feparatim, licet non ipfum totum, fenfu namque \& montem feorfum apprehendimus, \& aurum; quæ igitul fenfus feparata cognouit, hæc à phantafia coniunguntur, \& ita montem aureum imaginamur: fic etiam videmus magnitudinem montis, \& videmus animal, ideo magnitudinem cum animali coniungentes, imaginamur animal magnum inftar montis, \& alia eiufmodi: hac igitur ratione omnis imaginatio ortum habet à motu fa- $E$ cto $a b$ externis fenfibus: neque credendum eft eam enuntiare, quando imaginatur montem aureum; non enim affirmando dicit, mons eft aureus; fed abfque vlla enuntiatione duo componit, \& concipit fimplicia tanquam vnum. Quod vero aliqui dicunt de conceptu rerum, qux nullo modo fub fenfum cadunt, dignum cftaliqua confideratione; ouis enim fisgit lupum propter inimicitiam, quam nullo: fenfu cognofcit; fed naturali tantum inftinctur fic auis cognofert vtilitatem palex ad nidificandum; nce tamen aliquo externo fenfu illam vtilitatem percepit: ideo illi ducti funt ad ponendam facultatem reftimatiuan, diftinctan ab imaginatiua, vt Thomas in loco pradicto. Attamen, fi bene confideremus, non oportet ob id ponerealiam anima fenfibilis fa.
A cultatem diftineam ab imaginatiun; iucundiras enim \& moleftia non funraliquid in obiecto fenfibili inexiftens, fed funt paffiones quxd:um rem cognitam infequentes : nam in palea ineft quidem color, \& figura tanquam res quxdam, fed non inelt iucundutas, quam dicacur au is fentire, proinde incundicas slla in palea nilit eft; vifionenatem palex confequiturin aue perceptio iucunditatis, non quod iucunditas infequatur colorem palex fecundun $f e$, neque B naturam animx fentibilis fecundum fe, fed quia propriam illius animalis naturam infequitur ille naturalisinftinctus, quo percipit iucunditatem ex intuitu palex, inditus à natura, vt excitetur apperitus apprehendendi palcam ad nudificandum; fic ex vifioni lupi fit moleftia quxdam in oue, vt exciteturappetitus fugiendiad fe conferuandum, illa tamen moleftia in lupo nihil penitus eft: ideonotandum eft ex Arift. in In perce3. lib. de Anima, ì contex. 28. vfque ad 32. in ptrone C rerun fenfilium perceptione rria hxc ordina- Jofluz tim fieri: primum fentitur res à fenfu exterño treaorfub ratione obiecti proprii, vt color à vifu qua- dinatim tenus eft color: fecundo percipitur incunditas, fiunt. vel moleftia; fiuceadem res quatenus delectäs, vel moleftans, quia, yt diximus, nulla eft in ipro obiecto iucunditas, vel moleftia tanquam res fenfilis, fed obrectum in fenfu incundita- tem, vel moleftiam efficit per impreffionem fur fpecici; \& Arift. perceptionem obięti fub D propria obiecti ratione attribuit fenfui externo, perceptionem uero ilucunditatis, vel moleftix fenfui communu, qui eft cömunis radix, \& centrum omnium fenfum; idquenon fine ratione fecit, quia hac iucunditatis, vel moleftix perceptio non eft propria alicuius fenfus, fed omnium communis conditio indita à natura, propteranimalis conferuationem, ideoiure adfcribitur fenfui communi, qui eft commune principium omnium fenfuum externorum;ab hocigiturapprehenditur obiedum ab externo fenfu oblatis; \& fimul percipitur vt iucundum, vel vinoleftums tertio dem tum excitaturappetitus, qui in duos diuiditur, profequutionem, \& fugam; iucundum enim appetimus, moleftum autem fuginus; \& quia à fenfu communi offeruntur phantafizobiectafenfilia, quæ inea producunt phantafma, phantalia inaginatur ob. icfum tamprefens; quàm abfens, tum fub ratione obiecti, tum fub ratione delectantis, vel F molestantis, ideo fimiliter ex imaginatione obieatiabfentis excitatur appetitus prófequendi, vel fugiendi. Horum igitur trimm duo priorad eandem facultatem pertinent; nempe ad fenfum, yel ad phantafiam: idem enim eft animroperandi modús circa vtrumque, quum $f$ militer apprehendatur, \& cognofcatur verumque, feu à fenf́t commun, feu à phantafia li- 
cervnum ex altero; prius enim apprehenditur $A$ obiectum fub ratione obiecti fentilıs, deinde vcrovtiucunduin, vel moleftum; fed cum hoc difcrimine, quod apprehenfio obiecti fub racione obiecti pertinet ab Colute ad naturam fenfus quatenus eft fenfus, feu phantafir quatenus eft piantafia, idcirco animalibus omnibus competIt; fed apprehenfio eiufdem vt iucundi, vel moleftinonamplius ad fenfum pertinct quatenus eft fenfus, neque ad phantafiam quarenus eft phantalia, fed quatenus reftringuntur, \& coarEtantur à propriaforma cuiufque animalis; iam enim diximus proprian cuiufque forman coarctare forman generis, \& eius operationes cötraheread quof dam proprios modos, \& ad profrias cuiufque animalis conditiones: colorem igitur \& figuram palex omne animal vifu præditü videt, \& imaginatur; fed nō omne animal fercipit ex ea vifione iucunditatem, fedaliqua tantuin animalia, quæ egent palea ad nidificandum: hrc igitur apprehenfio rei vt iucundx $C$ competit fenfui illius animalis, non prout fenfus eit, fed vt determinatus, \& coaretatus à proprialilius animalis natura; fed quum hac fit nobis incognita, folemus eam nomine naturalis Facultas inftinctus appellare. Tertiū vero illorum trium, appetiti- quod eft prolequi, vel figere, ad aliam enufdem sa. anime facultatem, qux appetitiua dicitur, pertinere exiftımo; nec dicendum efle cum quibufdă vnam \&eandéanimæ facultatem effe fenfitiuī, \& appetitiūi, fed potius duas diftinctas, ficut oftendere nititur Thomas in r. part. Summx quaftione 78 . articul. I. quæ fuit etıa fententia Ariftotelis, fi bene perpendamus ea, quæab ipfo in fecundo libro de Anima, contextu 20. \& 22. \& 27. fcribuntur, \& poteft etiam itademonftrari: vbi dinerif funt modioperandi circa idem obiectum, ita vt variis modisanima ab illo obiecto immutetur, ibi diuerfa facultates iudicandx funt: quemadmodum vbi idem eft operandi modus circa diuerfa obicata, ibi vna E \&eadem eftfacultas animx iudicanda, eode enim modo operaturfenfus in vifione albı, \& in vifione nigri; ergo facultas vifiua vna eft: at-

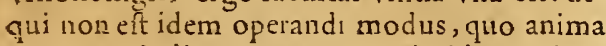
icntit \& iudicat, \& quo apetit idem obieetum: ergonon per vinam facultatem, fed per duas hæc duopræftat: minor probatur; quia fentire eft cognofere, \& fit per tranfitum obiecti ad animam; in cognitione enim obicetum quodanımodo ad animam trahitur, at in appetitu trahitur potius anima ad profequendum obiectum: quoniam igitur fenfus onnes, \& phantafia funt facultates cognofcentes per obicetı receptionem, diueı fa ab his eft facultas appetitiua, cuius operatio, quamuıs cognitionem obiecti prefuppponat, lion eft ramen formalitor cognitio, frd potius propenfio anima ad profequendum obiectum, quod prius cognouit: eadem igitur anima fenlibilis per diuerfas fuas facultates hæc omnia præftat; cognofcit enim cum fenfu, tum imaginatione, \& cognitionem infequiturappetitus profequendi, vel fugiendi. Exappetitu auten incitatur ad motum, vt quærat qua vtilia funt, \& fugiat noxia; ideo tandem hac eadem anima habet facultatem motricem, qua fuit animalıbus neceffaria ad ipforum coferuationen. Vt igitur omnes fen-

B fibilis animæ facultates colligamus, tres funt in ànimali operationes certo ordine difpofitx, cognofere, rem cognitam appetere, ac demum ad eam moueri: harum gratia datæ funt animali à natura plures facultates ad cognitionem quidem propter rerum fenfilium diuerfitatem non fatis fuit vna facultas, ideoplures in animalifunt facultates cognof citiua, quinque ex terni fenfus, \& tres interni, nempe fenfus communis, phantafia, \& memoria; licet enim memoria nó fit cognofcitiua, nullum tamen alıud habet officiun, quan infruiendi cognitioni; inferuit enim fuppeditando obieftun, quod in ea feruatur, vt ab ea moueatur phantalia: ad profeg̣ueudum autẹn, \& fugiendunı data animali eftacultasappetitiua: demum ad fe mouendum facultas nourix, hæc tamen nō omnibus ineft animalitus, fed perfectioribus; tantum illa nam que imperfecta animalia, quæ à .Gracis Góçute appellantur, non habent facultarem motricem, ficuti tribus quoque perfeEtioribus fenfibus destituta funt; \& duos tantum haben; tactum \& guftatum; ob id facultas motrix apud A riftotclem conftituit gradum viuentis diffinctum à gradu fenfibili; phantafia vero \& appetitus non conftituunt alium gradim : quouram enim quatuor graduum dittinEtionem Ariftoteles non aliunde accepit, quam ex maiore \& minore amplitudine, \& conm unitate, appetitus autē \& imaginatio funt xque communia, ac fenfus, quia vbi fenfus, ibi imaginatio, \&appetitus, ideo hæc non faciunt ǵradum viuentis dıftinctum à gradu fenfibili: at facultas motrix non omibus fentientibus ineft, ideo hæc proprium viuentis gradum conftituit; in quo funt animalia non omnia, fed perfectiora. Hæc de anima fenfibili, atque de cius facultatibus in prafentia dixiffe faus fit.

\section{De facultatibus anime rationalis. Cap. XIII.}

A Nimæ rationali tres facultates aliqui atAtribuunt, intellectum, voluntatem, \& memoriam; ita vt in intelięu res apprehendat atque cognofeat, voluntate ad eas profequendas trahatur, memoria vero conferuet. Aliqui vero memoriam quidem huic animæ adfcribunt, fed negant efie facultatem diuer- 
fam abintellectu, vt Thomas in r. partic. Sun1mr, quarit.79.aricul.7.Sed dememnria alio in loco oportunius difputabinus : nutnc latis tit breuiter dicere, duas tantum effe mentis noftrx n- faculiates, vnam cognoicendi, alieram appetendi, feuvolendi; nil cnim aliud eft voluntas, quam appetitus anim $x$ rationalis: quemadmodumenim cognitionem fenfus infequitur prote penfio ad obictum, que dicitur appetitus, \& ita néntis cognitionem proprius appetitus confequitur; quicn vt ab appetitufenfibili diftingue- $B$

7. rent, voluntatem appellarunt. Harum duaum facultalum difcrimen ex iis, qux paulo ante de fenlü diximus, manifeftum eft; aliud enim eft cognofcere, aliud eft rem cognitam appetere, \& longediuerfus eft operandimodus hic ab illo; nam mens woftra coginofcit patiendo \& recipiendo lpecies a phautafia, per quam receptionem dicitur fieri resıp/ $x$; obiectum igitur, vt cognof catur, ad animam ferri opottet, \& in earecipi: fed in volendo trahitur potius mens ad profequendum obiectum: quod etiam in fe diuerfitatem habet, nam cognofsitur quatenus ens, appetitur autem quatenus bonum. Ipra autem facultas cognof citiua vna tantum ftatuenda effe videtur, quia hxc animx pars non habet illam, quam alix, exorganis varietatem, quum nullo prorfus proprio organo $\mathrm{v}$ tatur; fed in ipfamet anima, non inorgano, fpecies recipiuntur, vinde fola ab Ariftotel. vocata eftlocusipecierum; \& ob id vnus tantum in ea notari poteft modus, quo ab obiect is immutntur, \& diciturrecipiendo fieri fingula. Eft autem confideratione dignum, quum A riftotel. in 3. libr. de Animadiftinguat intellectum practicum à ípeculatiuo, num hidicendi fint dux diftinefx faculrates, an vina \& eadem. Thomas. in quxftione pradicta, articulo vndecimo inquiteffe vnam \& eandem facultatem, \& hac vtitur ratione : id rquod accidit obicto fub ratione obiecti, non variat potentiam; at rebus; qux menteapprehenduntur, accidit ve dirigantur ad opus, vel non dirigantur ad cpus; ergo hac differentia non poteft varias potentias conftituere, fed.vna tantum eft, quæ res ómnes eodem modo apprehendit, \& harum alias adactionem dirigit, alias non dirigit, fed fimplicitex contemplatur: hoc fignificare vifus eft Ariftot. in context. 4:9. libri tertij de Anima, dum dixit, intellektum practicum à fpeculariuo diftingu fine, funt enim ambo coginofcentes eodem modo, proinde vnam \& eandem anima facultatem denotant, fed fpeculatinus. finem habet pfammet cognitionem, prafticus vero eam ad actionem dirigit : fcd quamuis ratione vltimi. finis diftinguantur , proximo tamen \& inmediato fine non fecernuntur, quia etiam intellectus prasticus habet proximum finem cogni-
A tionem veri in rebus agendis. Ego vero arbi-Confututror, intellefum practicum, \& fpeculatium, tio E duas notaretationalisanm $x$ facultates : quum opinio enim tria in intellectu practico confiderauerit propria Ariftoteles, quenadmodum etiam in fenfu; apprehenfionem rei, affirmationem, vel negationem bonvel mali; acdemum profequutionem, vel fugam: certum eft in duobus prioribus nullum intellectum difcrimen oriri, quoniaminillis non poteft intellectusalio nomine appellari, quam fpeculatiuus ; res cnim contemplatur per'vnam \& eandem fuan facultatem, qux intelleftiua dicitur, quia etiam bonum contemplatus, quatenus eft verum : in folo igitur tertionecefle eft horum difcrimen effe conftitutum, imo \& propriam intellectus practiciconditione e qua dicitur practıcus, in eo folo confiftere, vt nomen quoque ip fum declarat; nam in duobus reliquis cognofittantum, \& contemplatur, in tertio autem actionem reC fpicit, \& per hoc folum diftinguiturà fpeculatiuo, videlicet per propenfionem ad profequendum bonum, \& fugiendum malum, qua diciturvoluntas, \& differtab apprehenfione, quemadmodum dixumus : per hoc autem denotatur diuerfitas obiecti fub ratione obiecti, quialicerverum, \& bonum, vit ibi Thomas inquit, te idem fint, \& vnum in altero fit inclufrm, tamen differunt ratione, \& per has duas diftinctas rationes conftituunt duo diftincta D obiecta duarum facultatum; apprehenditur enim bonum, prout eft quoddam verum, appetitur autem non vt verum, fedv t bonum : quoniam igitur diftinctx funt obiectorum rationes, quatenus obiecta funt, \& diuerfi etiam modi operandi circa illas, non poffuntnifi duas animærationalis facultates fignificare, non tamenalias, quam eafdem duas, quas antea confiderauimus, intelletun \& voluntatem ; intellęus enim eft facultas apprehenfiua, \& coE gnofcitiua obiedi, vt veri; voluntas vero eft facultas profequutiua eiufdem, vt bon : ille igitur intellecsus qui dicitur fpeculatiuus, eft prior facultas, feu operatio prioris tantum facultatis, fine altera pofteriore; ille vero, qui vocatur praeticus, eft operatio vtriufque, \& eatenus notat aliam animre facultatem, quatenus eft operatio voluntatis, inso hxc eft propria conditio intellęus pracicici, qua diftinguitur à fpeculatiuo, quumina apprehenfione feu: veri, feu boniab eo non differat; fed hane præfupponens videtur effe formaliter electio, qua eft operatio voluntaris. Igiturintellectus practicus, \& intellectus fpeculatiuus eatenus duas animæ facultates fignificant, quatenus difcrimen dénotant intellętus \& voluntatis. Hanc. fententiam tuetur Ioann. Gandauenfis in qux: ftion. 39. libri tertii de Anima. Ad argumen-
Ad argus

Thome. 
rumatem Thomædicimus, deapprehenfione A gnificaturperintellectumfpeculatiuum; iam erei totum effe concedendum : quum enim poffit cognit1o tum dirigi ad actionem, tum non dirigi, acciditei vt dirigatur, \& accidit vt non dirigatur, proinde hæc 1unt apprehenfioni accidentalia dilcrimina, neepofiuntfacultates diuerfas conftituere, quü apprehenfio refpętu omnım rerum eodem modo fiat: obicetum quoq; quatenus apprehenditur, feruat in omnibus eandem obleeti rationem, quia etiamfi fit bonum, cognofitur tamen quacenus ens quoddam, cui vt cognofcibili accidit bonitas, illa prxfertim, qux eft reiagendx, quum hæc poffit effe tum bona, tum mala; \& tam bona, quam mala, quatenus apprehenditur, apprehéditut vt ens quoddam, \& quădoaffimatur efle bona, vel effer'a1a, cognofciturilla affirmatio vt vera. Perhoc igiturargumentum nil aliud oftenditur, nifi intellectum practicum in ipfa apprehenfione non denotare tacultatern diftinctamabilla, qua finim diximus, hosin apprehenfione nullam habere differentiam, nifi accidentalem, qux fumitur à rerü differentiis, prout diuerfar res funt, fed non prout habent ratıonem obięti. At fi tertiü intell eetus practici actum, qui electio eft, confideremus , mutatur ratio obiedti licet enim fit ens, eligitur tamen non amplius vt ens, fed vt bonum. Sic ergó neganda eft min or argunènti, quia nó ef amplius illi accidens, vt ad actionem

B referatur, fed neceffarium \& elfentiale:propria enin ratio obiecti voluntatis ef quatenus bonum; ficutpropria ratio obiedti intellectus eft quatenus ens, bonum auten eft per fe onnium humanarum a tionum fin : quoniam igitur in intellectu praetico fit prius apprehenfio, deinde profequutiojobiectum non eft idem in vtraque, quia mutatur ratio obienti ; apprehenditur enim vt ens, non vt bonum, appetitur autem non yt ens, fed vt bonum.

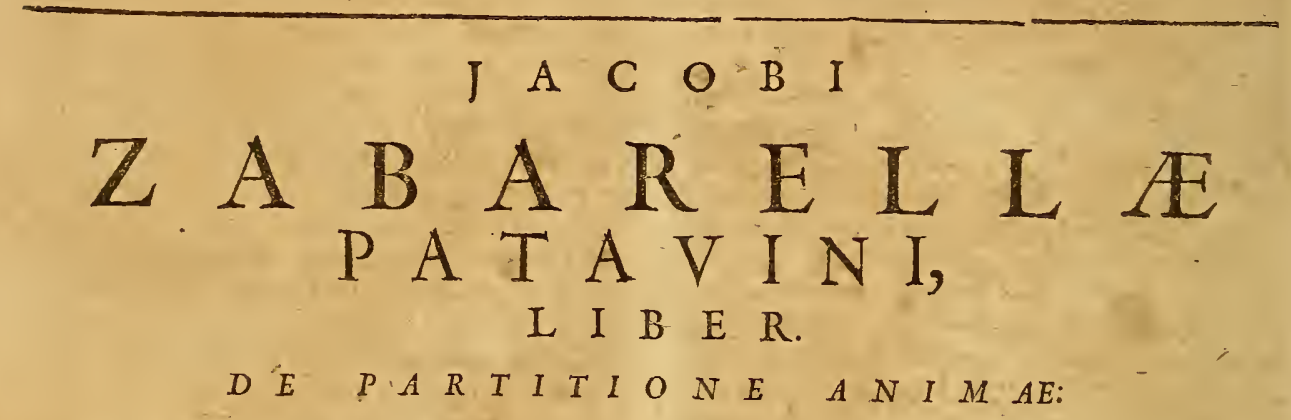

Propofitio, ac divifio dicendorum. Cap.I.

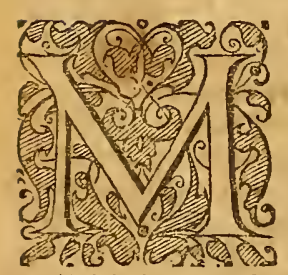

AGNA fuit inter prifcos Philofophos controuerfia de animæ partitione, atque eius diftributione per corpus, eaque à pofterioribus quoque agitata eft: folent enim tum Medicide hacredifpunterpretes Ariftot. tum tora in toto corpore infit, pars vero in parte, an potius tota tum in toto,tum in fingula corporis parte. Verum loan. Gandauenfis huius quæftionis ambiguitatem animaduertens, ti es eius acceptiones notauit, fecundum quas totam fuam difputationem in tres partes diftinxit, eumque alij poltea fequuti funt : easdem tetigit etiam Thonias in r.parte Sum m $x$, quxft.76. articul.s. nos igitur hac dere difputaturi, id rite factum effe aibitrantes, ad vitandam oblcuritatem eadem diftinctione vtemur ; ctenim certim eft,
C problema hoc poffe tribus modisintelligi: habet enim anima effenttam fuam; habet quantitatem quamuis peraccidens, quum ad corporis extenfionem extenfa fit; ac denique habet facultates diuerfas; ideo primum quxripoteft, an totafecundum effentian, \& in toto corpore fit, $\&$ in qualibet eius parte; fecundo an tota fecundum quantitatem fit \& in toto, \& in fingula parte tertiodemum, an anima tota, id elt, fecun. dum omnes facultates fuas fit non folum in to-

$D_{6}^{\prime}$ to,fed etiam in qualibet parte, an potius fecundumaliquam faculaatem fit in aliqua parte, \& fecundum aliam in alia: ideo dicere folent ani- Ans mam poffe tripliciter appellari totumitotum ef- pote, fentiale, totum quantitatiuum, \& toimm pote- placi ftatiuum, id eft, cum omnibus fuis potteniis \& appe facultatibus. Hunc itaque ordinen in hac no- totwi ftra difputatione feruabimus: primum de tota anima fecundum fuam fubftantiam; poftea de tota fecundum fuam quantitatem \& extenfioE nem; ac demum de tota fecundum facultates fuas, quid inxa Ariftotclis mentem fentiendum $f(t$, confiderabimus. 


\section{9}

$$
\begin{gathered}
\text { Deprima queftionis intelligentia. } \\
\text { Cap. } I 1 \text {. }
\end{gathered}
$$

$Q^{v}$ Vodad primam partem, ipfanque animx fubftantiam attinct, quum ante omnia intelligendum fit, quidram quxatur, non crit ab re, fi difficultatem à loanne Gandaucunte taAnm confideremus: ipfecrnim quamuis de hac le difoutet, fuamque fententiam proferat, tamen fubiungit, fibi hanc qua ftionem non probari, fed abfurdam videri: nam quarere, an anima tota fecundum eflentiam lit in qualibct parte corporis, an non tota, fed cias pais, eft confti tucre eam habcre partis cffentiales, quod minime verumeft; quonian anima, quum fit forma, eft fubitantia fimplex, \& nullas habet effentialespartes: non recte igitur appellatur tota, fi partes non habet, fed rectius diceremus nec totam, nec fecumdum partes in corpore, vel corporis partibus effe, quia neque partes liabet, neque poteft appellari tota. Nituntur multi variis modis qua ftioncm hanc ab ab fuiditate vindicare. Sunt qui dicant animam habere definitionem, \& partes definitionis, \& hac ratione habere partes effentiales. Sed hoc nihil eft, quoniam anima non per partes effentiales definitur; fedivt natura quxdam fimplex per effectus eam declarantes: proptereanemo vnquam dubitauit, an anima fecundum omnes fux definitionis partes fit in qualibet parte corporis, an fecundum: vnam definitionis partem fit in vna. parte corporis, fecundum aliam vero in alia; ideo quæitio fic intelleata abfurdiffima effet, proinde hoc modo problema $\mathrm{ab}$ abfurditate non defenditur. Nonnulli vero dixerunt, poffe in hac quaftione animam vocari totam; non ita tamen, vt fumatur totum refpectu partium, fiquidem anima, vt dictum eft, partes non habet; fed prout fumitur totum pro eo, quodeft perfectum:\& abfolutum; cui nihil deeft; ita vt quaftiofit,ananimafecundum fuam effentiam perfecta fit , \& in eo toto corpore; \& in qualibet eius parte. Sed neque fic conueniens eit quxftio, neque vllum locum habere poteft; quum enim anima fecundium omnium fententiam necintendi, necremitti polfit, fed fubftantiam habeat indiuiduam, non datur eius fubitan tia., nifi perfecta; \& integra; proindevanum eft quærere: an in: corporis parte fit perfecta animæ fubftantia: , an imperfecta; quum nullibi poffit effe imperfecta: Ego: vero, etfi arbitror Gandauenfem: reate: dubitaffe; \&. illum quxftionis fenfumita effe abfurdum:, vt nullum apud Philofoptios locum habere poffit ; alios tamen duos inuenio", fecundim quos digna quxftio eft difputatione, reque abrurda dici poteft. Vnus eft, vt.nomen partis pro parte fubiecta, hocelt, pro fpeciefumamus, nomenauten.to-
A trusproomnium fpecierum animæcollcetione' ficut Ariftot. frequenter in lib. de Anima vocat animam totam, \& partes anım $x$, ita vt quxftio fit, quum in coden viuenteplures incfe poffe animas ordine quodam difpofitas iam alibioftenderinus, tanquam formas fubitantiales d1ftinctas, num he locis quoque diftinguantur in corpore, an non diftinguantur, fic enim ad fubftantiam animæ quxeltio pertinct: quxritur enim, an huius animæ fubftantia vnam tantum:

B corporis partem occupet, illius veto aliam; quä fententiamab Arift. Plat.attributam effe manifeitum eft. Alter vero fenfis eft, conftituendo ipfas fpecierum animæ fubftantias locis diftinctas non effe, fed fimul omnes informare idem corpus, admitti quaftio poteft, fi appellationem totius, \& partium attribuamus non anima, fed corpori : reuera enim.non poteft anima vocari totum effentiale nec vllus vnquam dubitauit an anima tota fecundum: fuam effentiam fit in C fingula corporis parte, an parsaliqua effentix in vna parte, alıa vero pars in alia, hoc enim ne ex cogitabile quidem eft, quare de hoc difputare vanum effet; fed videtur fic poffe quxftionem proponi,eamque nihil in fe habereabfurditatis, an anima fecuudum fuam effentiam toti corpori adit, \& cuilibetcorporis parti;an potius alicui tantum parti corporis infit anima fe cūdum fuă effentiam, ita vt in reliquis partibus non infit, hoc enim in controuerfia pofitum eft, neq ; parD uumeft operæpretium id confiderare.

\section{opinio Platonis de diftributione partium: anima. Eo eius confutatio. Cap. III.}

Q Vum quxtio propofita intelligi his duobus modis poffit ; quod ad priorem attinet, certum eft eum ab Ariftotele Platoni fuiffe attributum; videlicet vt tres animx partes in E. corpore animalis in tribus diftinctis locis collocauerit, , concupifcibilem in iecore, irafcib1lem in corde; \& rationis compotem in cerebro: quanquam enim credi poteit, Platonem'nona nimarum, \& formarum fubftantialium' fed facultatum animx: diftinctionem intellexiffe; tamen Ariftoteles illiattribuit, , vt eas, tanquam diuerfas fubitantiales formas; ita y.tprædictum eft, locis.feparauerit in corpore animalis; \& Galenus quog; in s.\&. 6. libris de Platonis \& HipF pocratis decretis, diligenter Platonis verba confiderans nititur oftendere eamillius fuiffe fententiam: Huius igitur falfitatem oftendit:Arit-Confut as ftoteles, argumento fumpto ab animalibusillis tio op $z-$ imperfectis, qux in partes diuifa adhuc viuunt; nion is omnes enim quas habent, animx pattes in fin - Platonis. gulis diuifs partibus coniuncta ex earum operationibus cognof cuntur, fed.non:vnain vna

parte 
partc, alia vero in alia: quum enim infingula a- A tia, qua dicantur fingulapartes anime ita cife nimalis parte ab aliis feparata omnes operationes infpiciantur; vbi autem cft operatio, ibi \& facultatcm, \& ipfam anime fub ftantiam ineffe oporteat; onmes animæ partes in lingula anımalis parte reperirifatendum eft, proinde locis diftinctas nun effe. Prxterea fecundum hane fententiam oftendi non porelt quomodo animal fit vnum:quia vi funt tres diftinctre formæ fubftantiales non fubordinatæ, ibitria elle difinsta compofita manife ftum eft, ill $x$ autem anim non poffunt dici fubordinat $x$, quun diftinct $x$ locis effe ftatuantur, fed earū fingula ef forma fpecitica, conftituens proprium animatum fine aliis; vbi enim eft vna, ibi non funt alix:mos aute, qui dicimus has partes animæ non diftıngu locis, fed omnes fimul informareidẽ corpus, in hocabfurdum non incidimus, fedoptime animalis vnitatem reruamus; dicimus enim eas effe fubordinatas, 1ta vt vltima contineat omnes, \& fola det toti nomen, ac definitionem : vel igitur animalis vnitatem tueri Plato sion poteft, vel ad eam feruandam ftatuere cogituraliam vniuerfalem animam, à qua totum corpus informetur, \& vnum reddatur, ab hace. nimilla omnescontineri dicerentur; quemadmodum etiam nos dicimus plures effe in corpore animalis formas miftionis, easque locis feparatas, quia vbieft forma carnis, ibi non eft forma nerui, nec forma oflis, neque ob idrolli animalis vnitatem, quum fatis fit animaillis omnibus fuperueniens, \& eas omnes continens, ad vritatem animalis conftiruen dam: ob id dicimus Catauer cadauernon elreamplius vnum corpus, nifi per nonest contactum, quoniam animadeftitutum non hacorpus bet amplius formam vnam, quæ totum contifrum. neat, fed plures locis diftinctas: fic igitur animal ita, vt Plato pofuit, à tribus an i mæ partibus inuicem difunctis informatum noneft vnum, fed plura animata fe mutuo tangentia. Praterea manıfeftum eft, vt Arıftoteles in 2. de Animalibus oftendit, in illis tribus anima partibus naturalem, ac neceffarium ordinem ineffe: fenfibilis enim anima noneft fine vegetante, nec rationalis fine his ambabus; atqui irafcibilis, quam plato in corde pofuit, non efle nifi anima lenfibilis; concrupifcibilis vero, quam pofuit in iecore,non eft nifi anima vegetans, quum Medici q110 que eam in iecore, tanquam propria fede locare videantur; quomodo igitur in corde eft anima fentiens absque vegerante? quomodo in cerebro rational is absque aliis duabus? Sed ipf $x$ operationes falfitatem huius opinionis declarant : patet enim \& cerebrum, \& cor nurriri, proindeinits partibus quoque effe partem animx altricem, in quibus llato rationalen, \& irafcibilem collocavit : igitur non funt locis diftinat $x$, vt afferuit Plato. Huiusmodi ergo fentenin fingulis partibus corporis, vt locis diftinguantur, \& vbi yna cit, ibi non fintalix; falfa omnino eft, \& tum rationi, tum experientize re. fragatur.

\section{Albertiopiuio, or argumenta, do opinionis confutatio. Cap.IV.}

B Voniam igitur partes animx in animalis omnes fimul funt, \& folum ratione diftingum tui, vt Ariftoteles cenfuit, alrera, quam tetigimus, quæftio exoritur: quum tota anima fecundum omnes fpecies fuas fimul fit in eadem materia, an tota nnfit in alıqua tātum pracipuacióporis parte, non in aliis, an potius in toto animalis corpore, \& in omnibus eius partibus infit. Priorem fententiam accepit Albertus, vt apud eum legeré pollumus in lib. 2. de Anima, cap. 7. Ser C viafferit,animam fecundum fuam effentiam ac tia fubitantiam refidere in folo membro pracipuo, quod inquit effe cor, in aliis vero partibus ipfam aninx fubftantiam non ineffe, fed folum facultates diuerfas, qua ad illas à corde transmittuntur, Id o dicit cor elfe organum cffentıx animæ, alins autem partes effe organa faculiarum. Sen- r.a tentiam hanc probat Albertus pluribus argu- Ali mentis.Primo, fi in oculoefretanima fecundum fubftantiam fuam, crgototabi effetanimx ef.

$D$ fentia,pronde anima tota : quum enim fubltantiales partes non habeat, nccefle eft vt vbi eft fecundum fubftantiam, ibifit tota; igitur auulfo oculo tota anima auferretur, quare in reliquo corpore non remaneretanima; hoc taméfalfum effe videmus : ergoin oculo non eft fubitantia animx. Secundo, fi effentia animx in qualibet $2 . d i$ corporis parte ineffet, manus ab homine abfcif. fa deberet aliquandiu viuere: quoniam fi ibi effet fubftantia animæenon poffet forma illa fubi-

E to interıre, quia forma fubitántialis non interit fine præuia alteratione, quæ hon fit fubito, fed in tempore aliquo: confequens tamen falfum eft, quia manus abfifia ftatim mortua eft, neq; vila ibi notaripoteft preuia al teratio: igirur in manu non inerat fubftantia aninz. Tertio, fi offentia animæe effet in qualibet animalis parte, pars quælibet animalis effet animal; ybi enim eft animæ fubftantia, ibi perfecta \& integra eft; vbi autem eftanima perfecta, necefle eit illud

F perfectum animal efe. Tandem confirmatur 4 . hæc fententia auctoritate Ariftotel. in libr. de men Motu animal. cap. pen. vbidicit, animam non in omnibus corporis partibus ineffe, fed in vna tantum precipus, cui cxtera partes adnafcuntur, \& ea ratione participant vitā ; idque declarat excmplo Regis ad rem valde accommodato: Rex cnim non onanibus regni fui pas:vibus 
tibus adeff fecundam fubftantiam, fed foli regix, adalias vero partes tanquam ab illa pendentes transmittit vim gubcrnand per varios miniftrosfteos, \&iva regere dicitur nou folam regian, fed regnum totum:fic igitur in folo corde refidet anima fecundum fubfantiam fuam, non in aliis membris, fed ad illa varias faculatestransmittit ad varia ununera obeunda. Hxc Albertifententia admintenda noneft, \& iure à multiś impugunatur, præfertim à Thoma in $x$. part. Summa, quxft. 76 . articul.8. \& in quaftionıbus difputatis de anima, quixft. 2. artic. 10. \& in 2.contra gentes, cap. 72 . Ibi fentcntiam veriorem tuetur, nempe animam tanquam lubftantiam fimplicen, \& indiuiduam, ineficin qualibet corporis parte integram, non in folo niembro pracipuo. Poteft autem falfias opinionis Alberti multis argumentis offendi. Primofic, fi eflentia animx non adefiet cuilibet corporis parti, fequerezur non totum animal efle animatum; etenim partes omnes corporis prater partem pracipuam, quum animam non habeant, animatæ dicinon potliunt : nec defenditur Albertus, dicendo cæeteras partes effe animatas per virtutes, feu facul tates animæeo trăsmillas; quoniam illæ virtutes non funt nifi accidentia, quare non pollunt, fubitantiam conftitucre, \& dare efle materix: nam (vt inquit eo in foco Thomas) fi anima non effet in corpore nifi motor, \& rcetor, locum vtique haberet opinio Alberti, poffent enim cæteræ partes corporis ab illis facul tatibus moueri,\&regi per pendentiam à partepracipua, fed quia eft in corpore vt forma informans materiam, \& fubstantiale corpus conftituens, neceffe eft omues corporis partés efle animatas, \& ab ipfamet anima informatas. Prxterea vel putat Albertus facultates anima effe ipfammetanimxeffentiam, \& ab ennon diftingui, vel effe qualitates re diftin ctas à fibltantia anım $x$, vt nos alias demonftraumus; vtrumuis dicat, eius fentétia falfa eft; nam fi fint idem, quodanima ipfa, neceffe eft $v t$ in omnibus partibus infit fubftantia animæ, fi in eis funtfacul. tates anim $x$ : fi vero fint qualitates diftinct à fub tantia animæx, fimiliter neceffe ibi animan effé, vbi funt facultates, quoniam accidentiaià forma fubiecti emanantia non debent effe loco c’iftincta à forma; nam eiusmodi omnia emanànt in eodem fubiecto, in quo ineft forma, à 2. qua emanant. Sumitur etiam ex definitione anima argumentum contra Aibertum, inquitcnim Ariftoteles animam effe afum primum corporis naturalis organici, organicum intelligensillud, quod variis inftumentis præditum. eft, huiusmodi autem eft totum yiuentis corpus, non folum membrum prxcipuum, quia cor: dici quidem poteft organum, at non organioum, vit ibiab Ariftotele vocatur organicum:
A idque ipfemet Albcrtus fatetur, dum dicit, cor eflic organum eflentix anim $x$, cxtcra vero $m e m$. bia cfic organa facultatum : quod fi dicat cor effe corpus heterogeneum, ideoque ob varia parrium fuarum officia dici polle organicum; hoc cercenihil ef, quia non eiusmodreft membrum. pracipum in animalibus imperfectioribus. qux cor nor babent, fed aliquid cordi proportione respondens, hoc enim homogeneum, ac fimplex ctt,inde enim fit, vt illa animalia ctram $B$ in partes diuifa aliquandiu viuant : quare quum membrum pracipuum non in ommbus animalibus organicum appellari poffit, definititio auteni animx fit vniuerfalis, \& omnia viuentia complectatur, non poreft in ea definitionc organcum fignificare aliud, quam totum viuentis corpus: quum igitur huius dicat Ariftotel.animam effe actum primum, hoc elt, formam, qux ipfum conftituit,aperte fignificat animam: informare totum corpus, non folum membrum. C pracipuum: idque confirmant ca, qux ftatim ab Ariftotel.ibi dicuntur de plantis, inqquit enim plantarum partes effe organa, vt radicem, folia, fructum, \& pericarpium, quod denotat totam plantam vocari corpus organicum, própterea. quod his omnibus inftrumentalibus partibus prædita eft. Idem fignificauit A riftotel es in contextu 9.eiufdem libri, quandoargumentum fumens ab oculo dixit animam ita effe totuus animalis actum, \& formam, vt vifus eft actus oculi: vana enim effet ea Ariftotelis argumentatio, $\mathrm{f}$ : animanon totum corpus informaret, vt confs. derantibus manifeftum eit.

\section{Vera fententia, \& eius declaratio. Cap. V.}

$\mathrm{V}$ $T$ meam hac in re fententiam proferam, credo Albertum erraffe quidemaliqua ex parte;vt modo oftenfumeft, attamen aliqua etiam exparteveritatem attigiffe : vt enim abfurdum effe arbitror id, quod ait Albertus, animam fecundum fuam fubftantiam in fólo corde effe; Anzina ita \& contrariam fententiam, quod in omnibus est in ocorporis partibus æque refideatanima, falfam mnibus effe exiftimo: etenim fiomnes corporis partes partabass xquepracipue, \& absquevllo ordine animam corporis haberent, neceffarium prorfus, \& infolubile ef- ordsne fetargumentum Alberti ; oporteret enim ma- guodam. num à corpore feparatam viuere ali puamdiu; quod tamen non contingit:præterea fecundum hanc fententiam vana de membro precipuo difputatio redderetur, quia nullum in viuentis corpore membrum præcipuum vocari poffet; fiquidem nullo alio argumento præcipuum membrum iudicatur, nifi radicatione animae in eo quxe ex operationibus indagari folet: qquoniam igitur magna eft Philorophozam ac 
Medicorum difeptatio de membro pracipuo in corporeanimalis, concedere hi omnes videnturnon $x$ que in omnibus partibus vitrentis ineffe animam, fed radicari in aliquo membro. precipuo, kfab eo ad reliquas corporis partes diffundi, fecundum Ariftot. autem procipuum membrum in animalibus fanguineis cor eft, in aliis autem, \& in plantis pars aliqua cordi proportione refpondens; nos facilioris doctrinze gratia de folo corde loquemur, quod enim de hosdicemus, illud idesn de quolibetprasipuo membro in iis, quze cor non habent, intelligendum erit. De cordis quidem prinatu clara eft

Decordisfrimiat?. Ariftotel. fententia in libro tertio de Partibus animal. cap.3.4. \& 5.vbiab Auerroe in cap.4. res hrec difertiffime difpuțatur, nee non ab Alexandro in primo fuo lib. de Anıma, cap.vltimo, hos igitur in prxfentia conftututo, ex eo elicimus animam pracipue, ac primario refidere in corde, \& in eo effe tanquam in radice, à qua poftea diffunditur anima fubstantia ad vniuerfum corpus; primum enim quod generatur, eft cor animalis, \& in eo radicatur anima, poftea vero illi crter partes aggenerantur,ad quasftatim protenditur anima non tantum fecundum facultates, fed etiam fecundum effentiam, ad extenfionen esim fubieĉi corporis, animaquoque extenditur : hac igitur ratione habet anima in corde effe principale, in reliquis autem partibus habet elle participatum; quemadmodum etiam lumen in Sole habet efle principale, in aereautem habet effeperparticipationem, \& per deriuationem à Sole; quo fit ytaliguo folido corpore interpofito priuetur ftatimaer, yel pars eius aliqua fuo lumine, quia priuatur illa participatione, acpendentia a luce Solis. Sic etiam dicuntur resomnes habere effe per participationem primi entıs, quod folum habet efle per fe, \& elt ipfummet efle fubfiftens, ideoque fublato primoente; catera omnia ftatim redigerentur in nihil : hacigitur eadem ratione fi manus à toto corpore feiungatur, ftatim in ea vita omnis extinguitur, quia manus non habebat animam, nifi per continuam deriuationem à corCur ani- de, qua fimulatque deftituitur, definit efle animalaa sn- mata; contra yero cueinit in plantıs, \& animafecta, EV libus annulofs, in quorum partibus feparatis plearte ineft adhuc vita aliquandiu, propterea quodapost dusi nimaliailla pro corde habent humorem quenfronem dam intus per totam animalis longitudinem Giwant. nem recipentem;quo fit vt fi ita diuifio fiat vt in fingula parte remaneat aliqua pars illiushumoris, fingula pars aliquandiu yiuat, quum in re habeat portionem aliquam membri principalis : fic etiam plata in omni parte habetmenbrum præcipuum, in quo eft anma radicata, $f-$ ue id fit cortex,fiueradix (fiquidem in omni-
A busfere partibus habet radicem poteftate) fute quidpiam aliud; vnde fit vt pars ab aliis féincta viuerepoflit, \& fierialiqua planta per fe:ad in animalibus perfectioribus, in quibus eft cor, vel alud fimile, quod fit heterogeneum, \& certam figuram requirat, id nulla ratione fieri poteft, quia tale membrum præcipuum non eft diuiduum manente vita animalis. Hac eft reive ritas, quxip\{a per lé confiderantibus manifefta eft : quum enim anima duobus muneribus fun-

B gatur in corpore; vt Gracinotare folent; inlormat enim corpus, \& confituit animatum; deirde illosam informato, \& animato viturvt inftrumento ad operandum; facultates non refpiciunt corpus nifi vt organum, quo vtantur; non vtuntur autem, nifi animato; ideo præfupponuntipfum iam animatum, neque efle poflunt nifi vifit anima; facultates igitur à corde mif$f x$ fecundum Albertum ad alias corporis partes poflunt quidem reddere membrum aptum ad operationem, fed non poflunt facere mem brum animatum, hoc enim fola anina per fuä fubftanciam praftare poteft, imo neque a ptum redderepoffunt ad operandum, nifi prius conftituatur efle animatum, facultas enim præínponit anman, à qua non poteft effe feiuncta. Ex his coligimus alium quoque Alberti errorem : non reate enim dicitur cor effe organum eflentixanimx, cætera vero membra efle organa facultatum : organum enim non dicitur nifi refpectufacultatis, quia refpicit operationem, ipla vero animæ fibftantia quatenus eft forma, materiam potrus habere dicitur, -in qua recipiatur, quan organum. Ex his ergo patet animam fecundum fubfantiam fuam non in folo cordeinefie, fed in ommbus membris; non tamen in omnibus aqualiter, fed ordine quodam: n.n fi $x$ que in manu atque in corde ineffet anima, hoc eft, rque presipue, oporteret manum à $\mathrm{E}$ corpore abfcillam viuere aliquandiu, quod ta. men non videmus.

\section{Reßponfio ad argumenta Alberti. Cap.VI.}

$\mathrm{V}$ Eritate ita declarata, facile eft ad Alberti argum. refpondere. At primum neganda eft confequentia : quia licet in oculo fit anima tota fecundum effentiam, qúum ellentiam habeat undiuiduan, nec proprie appelletur tota, tamen non eft ibi tota lecundum quantitatem \& extenfionem, qua de repofterius lequenur, auulfo igitur oculo non tota fecundum extenfionem anima aufertur, fed remanct in aliis partibus corporis. Ad fecundum dicere poffenus comperrum efle quandoq; membrum aliquod abfcillum corpore pufillum tëpus viuere, vt ait Alexand.in r.lib. de Anima cap. vit. quandoque caput 
caput humanum à toto abfciffum vixiffe paruo $\mathrm{A}$ fed in fola parte precipua : fed hane refponquodam tempore; hoc enim non eft abfonum rationi, quia licet habeat animam deriuatam à corde, tamen quia ipfam animx fubitantiam infitam habet, fieri poteft vt non ftatim in eo anina extinguatur: fed aliter refpondemus, \& concedentes membrum abfciffum ftatim interire, dıcimus id fieri, quoniam in illo non eratanima radicata, fed à membro præcipuo deriuata; ob id enim fit, vt reparato membro non poffit amplius in eo effeanima; ficuti etiam delumine dicebanus ; negamus igitur.fequi quod manus abfciffa debeat viuere :-adprobationem autem, quando dicebat formam fubftantialem non poffe fine alteratione preuia interire, dicimus hoc effe verum ide forma totius compofiti, \& de forma etiamillius partis, in qua habeat efferadicatum, \& principale; at non deforma partis habente ibi effe participatum;illud enim non eft formanninterire, quum in aliis partibus eadem remaneat, fed eft potius illam partem per eam feparationem priuari participatione illius for. mæ; qux eadem remanet in membro præcipuo: ad hanc igitur priuationem dicimus non effe neceffariam alteration em prauiam, fed fatis effe feparationem à toto, \&cà membro præcipuo; per hoctamé non itat quin fieri poffit vtmembrum feparatum viuat paruo aliquo tempore, vt modo diccbamus, deindeftatim intereat fine vlla prauia alteratione; fiquidem hxc non eft ti- neceffaria, nifi vbi forma etiam fecumdun totam fuam extenfionem intereat, Ad tertium quoque fimiliter negamus confequens : \& ratio :negationis eft ; quia v talliquod vocetur animal, non fatis :eft fi habeat anima effentiam integram, hxc enim indiuidua eft \& vbi eft, ibinon poteft nifi integra \& tota effe; fed etiam oportet $\checkmark t$ habeat totam fuam materiam ; \& corpus integrum, in quo recipiatur: quum enim anima fit predita pluribus facultatibus, per quas apta eft plures edere operationes, requirit neceffario corpus varia obtinens inftrumenta, qux omnibus facultatibus correfpondeant;ideo licetin oculo infit anim $x$ effentia integra'; oculus tamen non poteft dicianimal, quianon habet ibi anima omnia fibi neceffaria inftrumenta, nequeintegram fuam materiam, cui adiuncta poffit animal conftituere; quare oculus non eft animal; fed pars animalis. Propterea negare etiam poffun nus animam inzoculo effe integram \& perfeEtam : quum enim fit effentialis conditio cuiufuis form $x$ vt recipiatur in tali determinata materia, proinde fit neceifaria animz conditio, vt fit in corpore tot inftrumentis prædito; anima, qux eft in oculo, ob hunc defectumion poteft vocariperfect. Ad Ariftotelemautem in calce libellide Motuanimalium Thomas in memorato locorrefpondet, Ariftorelem loquide fola facultate motrice, fignificans fe hanc concedere non in omnibus partibus inetle

fonem ego probare minime poffum; vel enima inteligit huius facultatis obiectum adxquatum, vel pracipuum, quod fit eius primum prin. cipium, \& tanquam radix : fi ad $x$ quatum, falfa eft eius fententia, quia vis motrix non infolo corde, fed in to to corpore ineffeconfpicitur: fi vero pracipuum; non defola motrice facultate, fed de tota quoque anim $x$ fubPtantia in afferere debuit, quum ibidicat eam in frngulis quoque B partibusin effe totam.'Nos igitur dicimus, Arift. Vera renil aliud ibinegare, nifi quod anima fit aquein forngso. omnibus partibus radicata, \& fignificare velle, eam in folomembro pracipuo habere effe radicatum; neque ob id negareanimam effe in omnibus membris fecundum fuam fubftantiam, \& habere in eis effe participatum. Comparatio autem cum . Rege 110 f fecundum omnes conditiones accipienda eft, fed fecundum ililam tantummodo, quod vnus eft locus principalis, in quo anima refidet tanquam in regia, quemadmodum vna eftvibs regia, in qua refidet Rex : in reliqnis autem non effet conueniens comparatio; nam anima, quum fit per fe incorporea, poteit fecundum fuam effentiam tota in qualibet part ineffe, non fic Rex, qui corporeus eft.

\section{Galeniargumentatio contra Arifto- telem de membropracipuo. Cap.VII.}

T. Ec fententia, quam modo expófuimus, eftrationi maxime confentanea, nam \&:animatum, \& vnum effetotumanımal oportet, non eit autem animatum totum, nifi in omnibus eius partibus ipfa arimx fubftantia infit, non in fola præcipua, vt putauit Albertus : ad vnitatem yero anmalis feruandam vnum tantum precipuum membrum eft concedendum, E in quo tota fit anima-radicata, \& à quo tanquam principio, \& fonte ad omnes corporis partes effundatur; fic enim \& vnumcorpus eft per omnium partium ab vna pendentiam, $\&$ a nima vna, quxex omnium dictarum partium congreffu con ftituitur: nam propter earum inzerfe ordinem, atquerefpectum fit vt vnaad aliam tanquam poteítas ad actum, \& tanquam perfectibilead perfectionem referatur, proinde vna ex his omnibus anima confurgat, cuius to. tius nomiuatio ab viltina tan quam ab actu defumatur, gua ratione vere dicete poffumus, $v$. nam effe in homineanimam, qux dicitır rationalis; fie vnam in equo animam equinam, \& fic de reliquis. At fecundum'Platonisopinionem, quamreiecimus, hoc dicere minime poffumus: dum enim partes animz'locis feparatx in animalis corpare ftatuuntur, vnaaliam non perficit, fed fingulaper fe perfecta anima eft, \& absque aliarum ope propriumanimatum cõftituit:

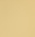

Confoutatio. 
quocirca animal non poteft vnum animatum $A$ apcllarised plura, ficut antea confideraumus. Prxterca iuxta omnium Phlofophorun fententiam animal, prefertim vero homo, paruus mundusappllarifolet:attamen hocfecundum hanc opinionem verum non elt, adeft enim hxc magnimonenti difimilitudo, quod in mago mundo vnum effe principem neceffe eft, vto mones conce fiffe videntur, ex cuius vnitate $A$. riftoteles multi vnitatem demonftrari afferuit; in auimali autem non vnus princeps, fed tres iuxta Platonis fententiam, quam Galenus quoq; fequutus eft, ablque dubio ftatuuntur: neque abfurditatem hanc euitat Galenus, dum cerebro principatum tribuit propter animain rationalem, qux in eo refider, \& praftantiffima omnium eft; etenim non penes folam nobilitatem attendendus eft principatus, fed etiam penes gubernationem, atque pendentiam : atcamen quid cordi cerebrum imperet, quid recinori, \& quomodo horum actiones iuffu cerebriaut eius virtute ad hæc trans miffa producantur, ne fingere quidem tota Galenı perrinacia, ac proteruitas poteft, quinımo ipfepalam faterur in z. acs. libro de Hippogratis \& Plazonis decretis, cerebrum \& cor proprias haberefunctiones, easque vtrumque abfque alterius ope obire; quod dicere eft confiteri neutrum actioni alterus imperare, aut vim aliquam contribuere, proinde neutrum poffe princeps membrum appellari. Verum quia veram hanc Ariftotelisfententiam demoliri prolixiffina difputationeGalenus nixus eft inlibris de Hippogratis \& Platonis decretis, non ab re fore iudicaui, fi prxcipua quædam, quæ ibi à Galeno contra Ariftot.afferuntur, breuiter referam \& expendam:qua muis enim non de membrorum primatu, fed de ani-

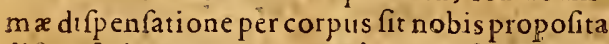
difpenfatio, attamen cum hac ita eft præcipui membri confideratio coniuneta, vt pentus omitti nec debeat, nec polfit:hac igitur de realias foiraffe fufius difputabimus, nunc eam cü moderatione tan gere fatis erit, \& quandum ad partium ånim $x$ diftributionem, de qua loqui,inftituimus, declarandam pertinere videatur. Galenus in memoratis libsisde hacre fuffifime difputataduerfus A riftotelem \& aduerfus Stoicos. Chryfippum prafertim, qui omnes vai cordi primatum attribuerunt, \& animam vniuerfam in eo tan quam loco præcipuo, ac membro principe refidere afferuerunt: ip fe vero \& eorum argumenta foluere, \& fuam opinionem compro. bare efficaciter nititur in feptem prioribus libris, \& in principio octaui : ita vt omnia ferme, quæ ab co in totailla patte dicuntur, ad hoc ynutu pertinere videantur. Sed go plurima illa. paucisper ftringam; omnia namqueargumenta qux tum à Galeno, tun à Chryfippo, \& aliis à nominumetymologia, ab exiftimatione, naturalique inftinctu hominum, atgue Poetarum auctoritate defumpta furt, \& à Galeno foluta, tanquan leuia, \& probabilia, vt ipfemer Gaienus a perte ibi profitetur, mifia penitus faciam; \& viloargumento contentus ero, in quopotifi me tanquam demonftatiuo Galenus imnititur à venarum, \& arteriarum, \& neruorum origine defumpto: quum enim horum trium minifterio abfolui omnes in animali operationes videantur, illud efie præcıpuum membrum, \& præcipuam anima fedem dicendun effe videtur, v-

B bi origo venarum, \& arteriarum, \& neruorum efle confpiciatur. Quoniam igitur Arift.horum omnium principium afferit elle cor, Galenus in hoc conftitutam effe totam controuerfiam exiftimans,petit fibi demon ftrari cor effe ' \& neruorum, \& venarum principium; nam hoc oftenfo conceflurum fe profitetur folum cor effe men:brum princeps \& in eo vno animam omnem re. fidere: fed quum ipfeperanatomen certo fe cognouiffe affirmet venarum principium non cor C effe, fed iecur, \& neruorü non cor,fed cerebrum; infolubile indeargumentum fumiarbitratur,ad demonftrandum tria effe precipua nembra, \& tres trium fpecierum anim $x$ fedes';argumentum autem tale eft : illud eft membrum præcipuum, \& animæ fedes, vbi eft principium venarum, \& arteriarum, \& neruorum; at principium, venarum iccur eft, neruorum cerebrum, arteriarum vero cor ; igitur tria funt membra pracipua, cerebrum, cor, \& iecur, in quibus tres partes aniD mx refident \& has non tantum facultates diftinctas, fed fpecies anim $x$ diuerfas \& formas fubitantiales effe affeueranter affirmat : in quo ego quidem ab eius fententra non recedo, fed in eo tantum, quod has effe locis feparatas, vt prædiximus, Platonem fequutus exiftimat: nutritiuam igituranimã , quam etiam naturalem partem v cat, Plato vero concupifcibilem, in iecore tanquam propria fede collocat, quoniam ibi principium eft generationis fanguinis, quo to-

E tum corpus alitur, \& origo venarum, qux fanguinem ad omnes corporis partes nurriendas deferunt; deinde vitalen, feu ira fcibilem in corde, vbi eft origo cal oris vitalis, qui per arterias. inde orientes ad vniuerfum corpus emittitur,ac: tandem rationalem, feu cognofcentem ponit in cerebro, à quo originem ducunt nerui omnes, per quos ad omnes corporis partes vis fentiendi, acvis mouen ditranfmittitur. Hoc vnum argumentum ex tota ea prolixa Galeni difputaF tione mihi expendendum defumpfi, quia cum. eius folutione coniuneta eft fententıx Ârift. validıfima demonftario; vno enim labore \& veritatis comprobationem, \&argumenti folutionematferemus.

\section{Fundamenta pro declaratione veri- tatis. Pap. VIII.}

TT clarior \& firmior difputatio noftra fit, quadam prius fundamenta, ac yeluti di. 


\section{$74 I$} de Partione Animx, Liber.

cendorum principia ftatuemus, qux vel funt à Galeno conceffa, vel ita manifêta, ve ànulloe da- rudito viro negari poffint. Primo loco aflumo cm. id, quodab Ariftotele diciturin contex.19. libri 3. deAnima agens eft præftantius \& nobilius materia patiehte : hoc a utem per fe manifeftum effe videtur; nam actus eft nobilior poteftare, agens autem agit quatenus eft actu, \& materia da- Patitur quatenus eft poteftate. Secundo accipio id, quod ab Ariftotele declaratur in 8. lib. Phyfica aufcultationis, in ordine agétium agens primarium effe praftantiusagente fecundario, \& inftrumentali; agens enim primarium vim agenditribuit agenti fecundario, quod fine primario nullam prorfus habet: hincetiam fit vt inter agentia fecundaria illud nobilius, ac principalius fit, quod eft prius, \& primario agenti propinquius : quod fi quis dicat primariū quoque agens egere fecundario, \& nihil agerefine illo, Id nihileft, neque in agente fecundario vllam preftantiam notat; primarium enimillo e- $C$ get vt miniftrante \& inferuiente, non vr agendi facultatem, ipfi largiente; at fecundarium eget primario, à quo vim agendi recipiat, qux tota in eo radicata eft: hæcomnia ita funt manifefta,vt quisquis ea neget, indignus fit, quo cum da- difputatio inftituatur. Tertio, fumoid, quod præcipuum Galenifundamentum eft neruos omnes oriri à cerebro, \& effe inftrumenta tuín fenfus, tum voluntarij motus. Quarto fanguinemalimentalem in iecinore gencrari, \& inde magnam partem ad reliqua membra nutrienda trasismittı per venas, fedaliquam etiam partem per venam caua $m$ ad cor, ibıque magis elaborari, \& ex co fanguinem tenuiorem, \& vitalem fpiritum in finiftro cordis ventriculo geneda rari. Quinto cum Galeno accipio fanguinem *m. deferri quidem à iccore ad cor per venam cauam, nontamenper eanden ad iecur remeare; fed duo tantummodo effe vafa, per qux fanguis ex cordeadalias partes emitraturivnum, quo ad pulmones ex corde defertur fanguis, quo nutriantur;alterum (qux arteria magna eft, $a b$ Ariftot. vena a orta appellata) quo ad omnes corporss partes vitalis fpiritus mittitur, \& cum fpiritu portio aliqua fanguinis puriffimi, ac tenuifida- fimi, quod vehiculum fpirituifit. Sexto fumo e $:$ m. cor efle fontem caloris in animali, quem calorem cum fpirituum fub fantia mit tit per arterias ad cunctas corporis partes, tanquam primum animæ inftrumentum; hoc Galenus afferit in lib. 7.de Hippocrat. \& Platon. decretis, \& res per fe clara eft : anima enim omnia facit percalorem naturalem, tanquam per primum eius inftrumentum; locus autem in animali calidiffimus confenfione omnium coreft; quamobrem ibi eft origo, \& fons omnis caloris animalis. Septimoloco ftatuoid, quod alibi fufius declaraui, duos in animali effe calores, feu potius duas caloris origines, y na origo eft amma, altera vero
A eft natura elementaris; in omnienim miftone- Duoceceffe eftaliquid inetre caloris propter elementa lores in calida, huic autem addirus calor ánimx vnum animals. reddit calorem intenfiorem, qui in diuerfis partibus varius eft, \& modo maior, modo minor ob temperierum varietarem; etenim in folo vitali calore nulla in corporis partibus diuerfitas oriretur, nifi fortaffe propter earum'maiorem, $\mathrm{rcl}$ minorem à corde diftantiam, fed propter diuerfas elementorum miftiones fit vt alia parscalidior, alia frigidior effe dicatur: Medici quidem foliti funt totum ex vtrisque conflatum calorem vocare cuiusque membri temperaturam, feu calorem temperatura ; attamen fi recte loqui velimus, debemus illumi tantummodo calorem, qui formam miftionis infequitur, $\&$ in corpore poft animalis obitum remaneat, vocare calorem temperaturx; alterum vero, quiconfequitur animam, nominareanimalem, fed to. tum exvtrisque conftantem naturalem cuiusq; membricaloremappellare.

\section{Solutio argumentorum Galeni, of con- traillum argumentatio. Cap. IX.}

Is ita conftitutis oftendo nullum princi1 patum iecinori attribui pofie, deinde idem in cerebro demonftrabo, vt offenfum maneat, folun cor effe membrum princeps, \& vniuerf $x$ $D$ anima fedem, vnde eriam argumenti Galeni foIntio defumatur: de iecoreita argumento: ie- Quod is: curin nutritione nullam alıam operam praftat, cur nulquam preparandi, \& exhibendi materiam, qua liom bus-, totum corpus alatur; agens autem conuertens beat prén hanc materiam, hoceft, fanguinem alimenta-cepatum. lem in fubstantiam, eft calor naturalis miffus à corde perarterias àd omnia membra, ergo facultatis altricis princepseft cor, non iecur: deductio confequentis manifefta.eft ex funda-

$E$ mendo à nobis jacto, agens eft pi incipalius ma. teria, \& cuilibet mediocriter in philofophia verfato, qui in nullius verba iurauerit, manifeftiffimum effe debet fuppeditationem materix ignobile officium effe, \& miniftripotius, quam principis, idque in artibus notare poffumus; nam ars illa, qux nauibus conftruendis folam materiam fubminiftrat, vilifima eft, eamque oemo architectonicam, feu artem principem Quaname appéllaret; aftilla, quæex illa materia nauim artes diF extruit, poteft architectonica nommari; \& ad-cant ur huc magis alia fuperior ars, qua huic praci-archtepit quomodo, \& qualem efficere nauim de-szonica. beat: ita arsilla, qux domibus $x$ dificandis materiam fuppeditat, ignobilis ef, nec poteft vocari princeps; ars autem æedificandi, qu $x$ domum efficit, magis poteft appellari ars princeps, quoniam ills im perat; fed multo magis ars alia, quæ nō facit, fed facıéti præcipit,nominearchitectonica dignanda eft, \& hosiolemus voca-

$$
A A 2 \text { rear- }
$$


Princi- rearchitectos; quoniam officium: principis èt A neris functione iecur non agat, nifiperfacultapro off- non occupari in aliqua actione particulari, fed crum. in aliqua tantum vniuerfali; qua fingulis miniftis propria: officia diftribuantur, ac principis auctoritas, \& agendi facultas communicetur .

Aliricis facultat is ös. Es pron cspium: eft cor.

Sanguis. duplex. Fàcultas igituraltrixin corde fita eft,vbieft fons caloris vitalis, \&à quo peromnia membra dif. ributo fit conuerfio fangunis alimentalis in fubftantiam : hocrefpexit.Arift. in lib. 3: de Partibusanimal: cap. 4: quuando gen erädi fanguinıs officium, cordi attribuit, non iecori, relpexit. enim(vtinquit ibi Auerroes) fanguinem illum, qui primus eft perfectione, \& intentione natu$r x$, non illum, qui folo generation is ordine primus eft: nam primus perfectione, \& naturæ cō. filio eft ille, qui generatur in corde, \& agentis, potius, quam mater: in to tius corporis nutritionelocum habet: ex eoenim generaturfpiritus, \&.idem vna cū f piritu per arterias ad omnia membra defertur; tãquam fecundariumagens, \& primum principis inftrumentum, à quo cum: omnibus membris communicato fanguis alimentalis, qui à iecinore per: venas prouenit in cuiufque membri fubitantiam mutatur: quid enim (qu $x$ fo) caufaefuit, vt natura ad Tingulanı corporispartem non folam: venam, fed cum vena contunstamarteriam mitti voluerit ${ }^{2}$ certe ea vna:caußa fuit; quia nutritio \& agens; $\&$ materiam postulat; materia nutritioni à.iecore $a d$ membra per;venas mittitur; agens autem nutriens.mittitur à corde per. arterias : quomodo igitur: al trix facultas agenti potius, quam materizattribuendaeft non secur, fed corinamima. lis nutritione eftinembrum princeps; iecur autem eft tanquarreius munifter; à quo \& cordi ad generandos $\{$ piritus, \& toti corpori materia ad nutritionem fuppeditatur, , nam etiam ad alias partes fanguinem mittere eft cor di materiam ad alendum fubminiftrare, quatenus eft mittere ad vitales fpiritus, qui à corde prodeuntes in omnibus corporis partibus exiftunt, \& agentis officio fungentes fanguinem à iecore miffum in fub-

Iecosis ftantiam vertunt:hocigituriecorisofficium inefficium dignum principe eft;idquetantumabeft vt corproncipe diattribuere conueniat; yt potius non effet cor indignz: dicendum princeps, fi eo munere fungeretur: est. adde quod (, vt aitin dicto loco Auerroes) hane. quoquefuam operam non praftatiecur; nifi virtute cordis : dicantenim Medici cur iecurarte. riis:referrum fits y per anatomen infpicere omospof unt vel'enimfruftia funt in iecore visales fpiritus per arterias, delati; fi iscur propria rantum:vircute farguinem generat; vel prabent iecoriactiuam facultatem; \& vitalem calorem, quofanguin emefficit; , quod quidem omnino cicend üeft, quianatura nihil fruftia facit: imperium igitur cordis.niniecureft manifeftiffinu quum \&.ıcaris officiū fit generaxe materiam, quz totum corpussalàtur, fed non tamenalere, ackertece in fubitatiams; \& in eius quoq ; mu. tem ipfi à colde communicatam; ita vt dicere poffimus etiam fanguificationem à fpiritibus fieri, qui à corde ad iecur mittuntur, quum ex cordis imperio, \& auctoritate iecur fanguinem generet. At (inquit Galenus) venarum origo, \& $N$ principium iecur eft: hoc autê, fi bene perpen- $\sigma_{a}$ datur, leuiffimum, \& nullius momenti ad id, de or quo difputamus, effe cognofceturi dietū enim hocambiguŭeft: quia vel intelligit principium B generationis venarum, vel principium difpenlation is fanguinis per eas, yel principium magnitudinis, licutidicere fol emus in itiul viæ, initium linex: fi primo modo intelligat, nullum inde argumentum fumi poteft; genitas enimeffevenas \& antecor, \& ante iecur credere poffumus, tanquam inftumenta, qux prius parare oportet quam pracipua membra his vfura generent tur, quemadmodum fi quis aduentü principis alicuius expectans aliqua prius neceffaria C. inftrumentaparet,vt accedens princeps is ftatim vai poffit: hocautem fi concedamus, nōapparet qux prirs venæ caux prius generan cœpcrit, an illa, qux eft prope cor, anilla, qux in iecore, \& nemo ex certa cognitione id affeuerare poteft credendum autem potsus eft; totamillam venam fimulfecundum omnes filas partes copiffe generari; non vnam eius partem prius quam alias: afferit etiam Galenus fe per experientiam in arboribus comperife iecur prius cordegenitum; quod fi admittamus, nil tamen inde aduerfus A riftot.colligi poteft:quanquam enim ego hoc non vidi, \& cogor de eo maxime dubitare, tamen dicere poffum, naturam voluif Se venas \&iecur cordi pragenerare tanquam ne ceffarios miniftros, quorum v fus cordi neceffarius eft : dicattamen Galenus an ante generationem cordis cognouerit iecur effe animatum, hoc quidem ipfe affeuerare non audet, neque fi affereret, vlla effet ei fides adhibenda; quia repugnantiffimum eft rationi : anima enim non poteftexiftere fine membro pracipuo.s in quo folo radicatur: quarefi foetus prius habet iecur, quam cor; non habet tamen animam nifi genito cordé; idè quando Ariftotelés dicit cor primum omniungenerari, dictum hoc faltem in comparatione membrorum animatorum defendi poteft cor:enim animatum precedit. 0 mnium aliorum: membrorum animationem, \&:prius eftanimatum, quam iecur..Si vero.inzelligat Galénus iecur effe principium difpenfarionis fanguinis per venas, \& has ratione.effeprincipium venarum; id concedimus de fanguine alimentali, \& materiali, hos enim dicimus generari in iecore, \& ab co primum tum । ad cor, tumad omnia membra perivenas tranfi-.xe: num artem ob'id fiat vt iecur. fit membrum princeps,iam fupra diligenterconfiderauimus: adde quod fi hac ratione effet princeps; mu-I to dignior: hacnomine ventriculus effet, à quo 
prius ad iecur materia alimētal is mittitar, quam à iecore ad alias partes. Tandem fi magnitudinis principium Galenus intelligat, negandum eft iecur effe initium venarum, fed tale eft folum cor, in quo folo eft conceptaculum fanguinis fine vena, quum vena caua per iecur tranfeat, \& in eo nullibi fit interrupta, ita venullum eius venzinitium in iecore notari poffit: quod ficonceptaculum aliquod fanguinis ibi effet prater venam, à quo illa ortum duceret, vtique ibi effe initium magnitudinis venarum affeuerare pof. femus. Non eft etiam alicuius momenti id, quod Galenus magna cum iactantia confiderat, fanguinem per venam cauamà iecinore ad cor permeare, fed non per eandem ad iecur remeare:hoc enim veriffimum eft, fed folum pertinet ad oftendendum principium difperifationis fanguinis alimentalis per 11 lam venam effe iecur, non cor ; at nihil probat de prncipio magnitudinis, quala licetper illam venam thuat fanguis à iecore ad cor, nee refluar à corde ad iecur, ob id tamennonfit, vt eius mag ritudinis initium fit iecur,quum in iecorenullum eius venx enirium notari polfit: ad hoc confirmatur ex conlidera. tione ven $x$ port $x$, per eam enım fluitumateria à mefenterio ad tecur, necrefluit à iecore per eandem : igitur $f_{1}$ ea ratio al iquid firmitatis haberet, eius vena initium non effet iecur, proinde non omnium venarum initium diceretur. Quod autem à Galeno dicitur, ampliorem effe venam cauam in iecilore, quam prope cor, debile ar- D gumentumeft, \& ab Auerroe folutum in memoratoloco: non omnia enim in fux magnicudinis initio maiora funt, fed in fingul is paitibus eam habent quantitatem, qu $x$ muneri $\&$ operationi conueniens fit ; praferum vbi initium magnirudinis non eft initium generationis, ficut antea de vena caua dicebamus: quoniam igitur initium difpenfationis fanguinis alimentalis per eam debuit in iecore effe, ideo conueniens fur vt in recore vena amplior effer; non tamen $E$ ibi eft eius magnitudinis initium, féd in corde, licer alsquanto anguftius fit. Qirod igitur ad iecuratemet, -non poteft illi facultatis altricis principas us atrribui, fed is foli cordia aitribuendus eft. Adargumentum autem Galeni facilereen fponjemus: namfídeperfecto languine loqua" mi mur, qui in nutritione fungitur officio agentis, re. negandzeft minor;non enim iecur eft hulius genera ionis principium, fed cor : fi vero alimentalem fanguinem, qui nutriti onis materia eft, in telligamus, neganda eft maior; non enim vbi hic generdiur, ibi eft anima fedes, \& membium 'princeps, quia mai erianı fubminiftrare ag enci eft potius ferul officium, quam principis; $q$ qum prafertim in hoc yuoque munere obcundo pendeat iecur à corde, fiquidem non fangusfi. caier, nifi beneficuo cáleris viualis ad ipium per arterias delati : de tecore igitur argunencuin Galeninihil concludic. Sedieque de cefebro: nam cerebram effe cognitionis, \& motus inftu- De cere mentum, non inficiamur; dicimus tamen nul- bro.

lam ibi cognitionem fieri, nifi beneficio firituum vita lium:qui à cordeilluc per arterias mittunt ur, vripfemet Galenus confiterur, afferit enimin libr. 7. de Hippocratis \& Platonis decretis, animal ex cerebri fectione nullam in fenfu \& motulafionem recipere, nifiad aliquem ce. rebri ventriculum vulnus penetrauerit:quum enion ventriculi fpiritu fintrepleti, inquit ex illius Spiritus exinanitione animal remanere ftupidum fine fenfu, \& motu ; poftea veroirerum refitui, quum iterum iidem ventriculifpiritu repleantur; \& huncà corde ad cerebrum per arterias mitti Galenus non negat: fatetur igıtur non in ipfa cerebri fubitantia vin fentiendi, ac mouendi ineffe, fed in folis fpiritubus, qui in cerebri ventriculis concluduntur: Ideo confiderans $\mathrm{Ga}$ lenusfpiritus reuera à corde pronenire, se ob id crederealiquem poffe vim omnem cognofienC dià corde tribui, ad hoc confugit, quod ip famet anima non in fpiritibus, fed in cerebri fub ftantia refidet, ita vt fpiritus non fint ipfius anima fedes, fed fint primum inftrumentum, quo anima vtitur ad fenfum, \& ad motum efficiendum. Mirandum profecto eft, quomodo, vt fuam fenrentiam tueretui, ad magnum hoc abfurduin confugerit : quum enim faceatur fub ftantiam cerebrinullum babere fenfum, \& detractam etiam non afferreal iquam animali noxam, nifi ad ventriculos vulnus perueniat; quomodo ad id induci potuit, vt diceret fubitanciam cerebri effe pracipuam animx fedem ? rationi enim con- Penraneum eft maximam fieri in toto animali lxfionem, \&omnium operarionum impedimetuin ex vulnere membri precipui, in quo ipfa animx uubftantia refidere vocatur : adde quod ce- Cerebrio rebrum eft omnium menbrorum frigidiffi- eftomnsmum, anima autem conuenientior eft locus ca- $4 \mathrm{mmem}$. lidus, quam frigidus ; tum quia nobılior portus brorum qualitas eft anima attribuenda, quam ignobi frigidiflior, qux priuationts locumtenet; tum qua ma- frmum. nifeftum eft animam omnes fuas operationes edereper calorem : neque alicuius momenti hac Galeni in re eft Galeni cauillus, dum inquit cerebrum causllus non effe frigidifinium, fed effe omni calido ae- contra recalidius; cauillus enim eft manifeftus, fiqui- Arifotedem neque Ariftorel. neque vllus alius ita vel lem. cœecus, vel proteruus fuit, ve cerebrum mil penitus habere caloris, \& abfolute frigidifimum efF fe dixerit ; fed folum comparatone aliorum membrorum animalis, prafertim autem vifcerum : quum enim omnia calorem habeant, mini num omnium habet cerebrum, \& hac rationefrigidifimum dicitur, quia minus calidun refpectucalddoris inftar frigidi eft, \& frigidi operam praftat. Dicendum igitur eft omnem fentiendi, ac mouendi vim non à cerebro fpiritibus, fed cercbrò̀ fpiritibus tribui, proin. de a corde, in quo primum generantur, \& à quo

\section{Error $G \dot{a}$ lens defe deano.}


ad omnes corporis partes perarterias deferun. Nerwerü tur: \& quoniam à fub ftantia cerebri omnes nerfubfätio ui tanquam furculi deducuntur, fiue ab ipfa-a cerebro mer, fiue à fpinali medulla, qua cum ea eft conest. iuncta, vt ex colore cognofici poteft, nerusenimalbus eft, tanquam ip fa cerebri fubfantia aliquantum indurata, partem tarien mediam tenuiorem, ac molliorem retinens, tanquam portionem quandam cerebri; id eo pro cerebro in cmnibus corporis partibus exiftunt nerui, per qurs cercbrum oficium fuum cum omnibus partibus cormunicat, fedin nulla tamen corporis parte confpicitur ner ulis fine arteria; quare firectaratıone vtivelimus, diceredebenus Cubftantizm cerebi, \& neruosefe inftrumentuin \& fenfutm omnium, tam internorum, quarn externorum, \& motus voluntarii, fpirirum autem vitalem efie inftumentum prius, \& i. or

$m$

rse-

150-

sis.

idem

atio

ani-

Git- frimo mouentı propiuquius; anima caim immediate vtitur vitali fpiritu, hic vtiturnerwo, \& tandem etiam neruus permufculum mout fingulas partes: cerebrum igitur eft inftrumentum fecundarium, quod vin recipit à fpıritıbus, fic nerui omnes, cum quibus hocminiftrandi mu nus à cerebro communicatur. Quod autemà Galeno dicitur, feito, vel conftricto nerwo ftatim mufculum motu priuari, nobis nonofficit; nam agens primarium, licet inftrumentis vim agendi tribuat, tamen vicifim etiam eget inftrumentis, ac miniftris ipfi à natura affignatis, ita vt fine illis agerenequeat: neque igitur fpıritus, nequeanima ipfa abfque nerrorum minifterio mouere poteft ficutineque neruifine anima, vel fine fpiritu vitali;fimiliter enim experimur confrieto, feu corsprefio brachio, vel crure, ita yifoiritus zefiuat ad interna, manere totum brachium, vel crus ftupidum fine fenfu, \& fine mota, quamuis neruos obtineat integros, idque etiam Gal.in 6 . eorum librorú confitetur: eff igitur neruus neceffarium animainfrumentumad fenfum, \&ad motum, fic etiam fp.ritus; in o magis quum immediate inferuiat primoagenti, \& per ipfum facultas neruisaba. nima tribuatur: quare neque abfque neruo, neque abfque vitali fpiritu edere anima has ope-

rgum. rationes poteft. Primatum autem cordis, \& pen$x$ Gal. dentiam amrium aliorum membrorum ab co e cordis faterur Galenus in illo 6. libro, dum inquitfo-

drimas\%. Iuminter omnia vifcera cor, fi eximatur, naturalem fuam functionem feruare, \& moueri: hoc enım dicens indicat cor à nullo alio membro pédere, fed haberein feanimam sadicatam, $c z$ tera vero omnia yifcera pendere à corde, \& ab co vim animalem recipere, quum feparata pri.. utio uenturfatim fuis functionibus. Exhis colligiumen mus foilutionem argumenti Galeni, quod à neral. de uorum origine furs itur:egoenim'gुu in nullius bro. verbaiuraui, fateor neruus à cerebro originem ducere, conceffa enim minore propofícione nego maiorem, non enim illud elt princeps mem. brum iudicandum, à quo nerui o riuntur, $\int e j$ potius illud, à quo criuntur fpiritus : nam rationi confonum eft ve nembrum princeps, \& pracipua animz fedesibi effe dicatur, vbi eft origo primi, ac pracipui infrumenti, quo animavti. tur, non vbi oriturfecundarium, \& à primo iaouéte remotius inftrumentum. Sed reftat tillud vnum refugium, ad quod fe Galenus recipit, illi adimamus: videns enim non poffenegari cere (pi) bri à corde pendentiam, dum conceditur fpiri- nson.

B tum, quiin cerebro eft, in corde generari, de inde ad serebrum mitti, hoc inficiariaufus eft, vtplurium ablurdorum ascuisulatione erroré fuum infigniorem redderet:dixit igitur duplicem effe firitum;vnum vitalem quifit in corde, al terum vero animalem, qui non in corde, fed in cerebro generatur, ita vt omnis cognitionis, \& voluntarij motus principium fit fpiritus animalis, quioritur in cerebro proinde pars a nima nobiliffi. manon in corde, fed in cerebro refideat: non C negat quidem fpiriura vitalem à curde ad cerebrum per aiterias deferri, fedinquit eum in arteriis effe vitalem, at in cerebro mutari à facultate cerebri in animalem : modum ctiam huius. mutationis declarans, ait fpiritum vitalem mitti primum à cordé ad illum reticularem plexum, quifub cerebro eft, \& ibi aliquantum elaborari, deinde ab eo per arteriasferriad ventr culos cerebri, vbiperfectius elaboratur, \& exquifitius concoquitur, \& mutatur in animalem.

D fed quifquis intelligat quid fit concoctio, cognofcethoc Galenidicto nil poffe pronunciari tio ineptius: concodtio enim fit ầ calore, quomodo igitur fpiritus vitales calidiffimi à cerebro frigidifimo concogui poffunt? at elaborantur (inquit) à cerebro, nos igitur confideremus quonam pacto elaborentur: certe nulla effepoteft alia cerebri elaboratio, feu actio in firirus, quam refrigeratio; necefle eft enim vir calidius à minus calido patiaturtanquam à frigido, at-

$E$ que refrigeretur; itaque refrigerantur fpiritus vitales in cerebro, \& huius refrigerationis caufa finalis, fcopusque naturz manifefus eft, fic enim ad cognitionem aptioresredduntur; nimius namque calorimpedimento eft cognitioni, quia calor motum \& agitationem efficit, cognitioautem quietem, \& 1tabllitatem requirit: teftatur hoc Ariftoteles in libro fecundo de Partibus animalium, cap. 10. dun ait calidioris fanguinis agitationam refringerefenfum; \&e F clarius in fecund. capize ciusdem libri, dum inquit fanguinem calidioren plus habere robo. ris, fed frigidiorem maiorelentiendi, atqueintelligendi vi effe praditum; \& paulo poft ibidem dicit effe fuis contrariisingeniofiora illa, qux fanguinem frigidiorem ac tenuiorem habent:quod autem ibi ab Ariftotele de fanguine dicitur, in Cpirituquoque locum habere deber, itavevitalis fpiritus, ifaliquantum refigeretur, aption ad fenfwa, \& ad omnen cogiutionen 
reddatur: iprequoque Galenus in lib. de Oculis afferit cerebrum calidius minus effe aptum ad $m$ contcimplationem. Ex his igitur patet, quodnanı cerebri officium fit, \& cur fuerit à natura conftirutum; cius enim officium eft, calorem fpirituum moderari cognitionis gratiâ, \& hanc ob caufamf ctum eft à naturafrigidủ, \& fatis magnamolis, in homine prefertion, qui maxime omnium ad cognofcendum, \& ad contemplandum natus eft, vt plus vitalis fpiritus contineret, atque ipfum refrigerando ad cognitionem idoneum redderet; quiafrigus ftabilitatem facit, calor autem agitationem, \& mobilitatem, - qua cogrititionem perturbat. Ad hunc fenfum fi trahamusilla, qua ab Ariftóéle de cerebro in di-cap.7. elusdem libri dicuntur, inanis redditur fno Galeniaduerfus Ariftot.exclamatio in lib. 8. de Víu partium:quodenim officium cerebrifit calorem cordis moderari, afferere absque vlla abfurdiratepoffumus, fi id fano modo intelliga- mus;quum enim fpiritus vitales fint primum a nimx inftrumentunı, \& in corde generentur, \& abeo ad orrnes partes mittantur, ad eorum calorem moderandum dedit natura animalibus cerëbrum, quod fuo frigore calorem f̧irituum, quilluc mitcuntur, imminuens, eos ad cogni. tioncm redderet aptiores; ob id fola fanguinea animalia, vtpote calıdiora, cerebrum habent, fola namque irigido illo mersbro ad mojerandun fpirıuum calorem indiguesunt. Vtigitur quanta fit cerebri preftantia, \& quis primatus, intelligamus, ita reetius, quam Medici faciant philofophari nos oportet: Princeps in regno fuo omnia agere dicitur, non quidem ipfe per fe, \& immediate omnia, fed pervarıos miniftros, quiab co variis muneribus preficiuntur, \& vim agendi recipiunt; cerebrum autem non omnia agit,non enim nutrit,neq; auget, neq; lifat ce mile generat, neq;ad hxc munera obeunda vim - pra vllani contribuit, neq; obeuntibus imperat; igi:tza. tur cerebrum nö eft membrum princeps, fed eft minifterquidam principis, omnium tamen minıftrorum nobiliffımus, cui operatio omnium praftantiffima commédata eft à principe, nempe cognitio, \& is, qui cognitionem infequitur, totius corporis, \& fingularum partium motus: at cor in nulla parriculariactione occupatur; fed in hac vna vniuerfali generandorum fpirituum vitalium, per quos tanquam princeps dicatur 0 mnes edere operationes; eos enim \& ad cerebrum, \& adiecur, \& ad omnes corporis partes mittit; per quos tribuitalis membris auctoritatem \& yim obeundi proprias fingulorum funAtiones, cerebro fentiendi, ac mouendi, ventriculo cmicoquendi, iecori fanguificandi, maninnisum busapprehendendi, \& ficreliquis omnibus; nultmb:o-lum enim membrum poteft fine fpiritu vitali impen-fiam actionem exercere : omnium ergo meminisa it brorumpendentia à corde, \& ipfius cordss prun. rde.
A cordetăquam membro prxcipuo fit animx fedes ftatuenda, \& ipfi cordi omnes operationes tanquam primo agendıat tribuend $x$, ita vt maxime omnium cor \& nutrire, \& fentire, \& imaginari, \& mouere, \& reliqua omniaperagere dicatur, quemadnodum rex noutt omnia, qua à miniftrisaguntur, eaque fuo imperio agere dicitur, quocirca non absque ratione ab Ariftotele fuit primum fenforium appellatum. Galenus tamen hac confiderans mirabili fubterfugio vfus $B$ eft, \&x vt cordiprincipatum fentiendi, ac mo uendi adimeret,cerebroq; tribueret, dixi duos in animali effet fpiritus, vitalem, quiin corde, \& animalem, qui in cerebro, non in cordegeneratur, \& hunc effe primum inftrumentum animx cognof centis, qux in cerebro refidet. Ego au- Confuta. tem miror, curnon plurimas fpirituum fpecies tio. intróluxerit : nam certum eft fpiritus à corde recedentes aliquam in aliis membris alteratio. nem recipere, frrefertim refrigerationem, ex maC iore enim receflu à fonte caloris neceffe eft $\mathrm{it}$ corum calor aliquantum inminasur, br prz. terea à propriis fingulorum membrorum tenperaturis multas recipiunt yarieiates; qu enim magis ad frigus vergit membri temperies, so magis remitt fpirituun caloremoporte:, maximevero in cerebro, quod (ve divimus) frigi$\mathrm{d} x$ admodum eft 1 emperatuix: itaq; ti has piajtuumalteratio fit diuerforum fpecte fpiritum generatio appellanda, dicendum eriz fpiritus concoctiuos non in corde, fedin yentriculo ex vitalibus à corde prouenientibus generari : lic fanguificatiuos ex vitalibus generari in iecinore, apprehenfiuos in manibus, lactificatiuos in mammis, carnificatiuos in pluribus membris, \& ficalios plurimos; non eft enim diuerfa ratio abea, qua Galenus dicit fpiritus cognofcitiuos, feuanimales, non in corde, fed in cercbro ex vitalibus generari:- quid igitur? dicemusne tot effe ipiritum fpecies, quot in diuerfis partibus operationes à fpiritibus fieri cernuntur? an pudebit nos itaphilofophari, \& huiusmodi fabulis veritati tenebras offundere, ad imprudentes homines decipiendos? nos igitur dicimus, differentiam fecundum magis \& minus non variare fueciem: \& quemadmodum aliâs In lab. de oftendimus omnem caloremeffe eiusdem fpe calore ciei, licet alius alio intenfior fit jita fpiritus o- colefts. mnes in to to animalis corpore eiusd em effe fpeciei, \& vitales vocandos, \& in folo corde gene.

F rari: quad fi à diuerfis operationibus eos variis nominibus diftinguere quispiam velit, \& illos, qui funt in manibus, apprehenfiuos appellare, qui vero in cerebro, animales, feu cognofitiuos, non probibemus, dummodo ratione iprius fpirituum fubftintix accidentalem effe differentiam fatearnur: fic autem plures quoque artifices videmus ad varia opera varios caluris gradus adhibere, prout fingulorum operu condutopoftulat; coguus enimin cabariis 60-

$$
\text { A A. } 4 \text { quen- }
$$


quendis, atqi condiendis modo plus, modo minusignis fubiicere confueuit, eadem tamen eit fpecies ignis, idem fpeciecalor, quo ad omnia Nota que v titur. Sed illud in artibus confiderandum eft, moda ani quod totam huiusce rei veritatem, \& Galeni erma perfo rorem patefacit : certum eft, calorem non dici lum calo remiffum, nifialiquos gradus frigoris commirem, non ftos habeat: quando igitur coquus remifro caper fri- lore vtitur, vbi res coquenda talem poftulat, 0 gus o- peratio illa fitne à gradibus caloris, an à gradimnes e- bus frigoris, qui remittere calore millum dicundat fuas tur? certe nemo eft, qui non gradibus caloris operafio- totam eam actionem attribuat: quod idem in ones. mnibus aliis artibus, quæ calore vtantur, manifeftum eft; quandoq; enim remiffiore, quando. que intenfiore vtuntur; femper tamen calore dicuntur vt $i$, non gradibus frigoris, nifi ad moderandum calorem. Sic de fpiritibus in cerebro exiftentibus, quos Galenus animales vocat, dicendum eft; remittitur enim corum calor à frigore cerebri, proinde à cerebro folos frigoris gradus recipiunt; at gradus caloris, quos retinent, habent à corde; operationes igitur animales, qua fiunt in cerebro, fiunt à gradibus calorisillorum fpirituum, non à gradibus frigoris, proinde à faculta te manante à corde, nrn à fa. cultate cerebri, nifi quatenuscerebrum frigore fiso, calorem fpirieuum moderando ita overam fuam praftare, \& $: d$ cognitionem conferre $d: c_{1}$. tur; termperatus enim ad eas operationes calor poftulatur, nontantus, quantus effet, nifi à ce. D rebro imminueretur. Hocita fefe habere manifeftum eft culliber conditsonem anima confi. deranti : quemadmodum enim coleftia corpora non fi igus faciunt, fed calorem, ita \& animam non frigus, fed calor infequitur, quem Arift. in libr. 2. de Ortuanimalium vitalem effe di itit, \& proportione refpondere el emento ftellarun:argumento funt corpora mortucrum; cadauera namque omnia frigidiora funt, quam viuentia, quia mors eft caloris vitalis extinctio, quem viuentia recipiunt ab anima : qüoniam igitur animam non frigus, fed calorinfequitur, licet non fummuscalor, fed moderatus; ideo ad omnes fed folo calore, vt in ftrumento, \& eo quandoq; maiore, quandoq; minore, prout qualibet actio poftulat; obidad calorem moderandum plura inftrumenta molita eft natura, potifime vero cerebrum, quod maxime omnium frigidam ha. bet temperaturam, vt calorem fpirituum modes. In amn;- ratiflimú redderet ob eam, quam diximus, caubus mem fam : per hoctamen non tat, quin anima ad obris pro mnes fuas operationes edendas calore vt inftrucorde est mento vti dicatur,idq;ab Ariftot. notatum legiarteria, autem inlibr.2.del'artubus animalium, c.7. Quale Ë pro ritem temperam ētum ex frigore cerebri, \& ijirituū vitalium calore fieri diximus, tale ex fpi. ritu arteriarum, \& neruo in aliis corporis partibus ficri exiftimädum eft, procorde enim in aliis

A membrisarteria eft. \& procerehro neruus : ideo non elat Galenolabcraidum in quacendo quo. modoperneruos fpistitas animal,s, quivim tentiendi, ac mowendi diferat, à cerebroad menbra mittarur, qua dereiafeptimo ll orum librorum inquit le dubitare, nee poffe aliquid certi Atatuere; etenirn furricu aniffo à cerebro membra non egent, quum Tais eis fit fpiritus vitalis à cordeper arterias delatus, qui neruis eam fa. cultatem impertiacur. De ipfa igituraniniz fub. B Itantia quomiodo, \& quo ordine fit per omnes corporispartes dı itributa, hac dieta fint.

\section{De Anime partitione fecundum quantita- tem opiniones aliorum, or argu- meita. Cap. $\dot{X}$.}

Equitur vt animam fecundum fuam quantiSatem, \& extenfionem confiderantes videainus, an vere fit extenfa per visiuerfum corpus, ita vt tora lecundum fus $m$ quantitatem in coto corporefit, non to:a in parte, fedpotius pars in parte; an potius tota etiam in fingula paste ef fedicatur. Sunt quidicant alias partes animz $A$ prater rational em elle extenfas ad extenfionem ru; materix, quia funt formx vere mateliam infor- nso mantes, \& ita quanlibet earum effe totam in toto, non totam autem in parte, fed partem in parte ; at rationalem negant effefirmam informantern, fed dicunt affiftere tantum homini, ficuti nautaaffitit naui, idedque non effe extenfam ad extenfionem materize, fed indiuifibiliter tum in toto, tum in fingula parce ineffe. Sed de hoc in prafentia dif utare eft ab inftituro noftroalienum : alibiopportunius confiderabimus, an fecundum Arittotelem omnis anima fit forma informans materiam, an non omnis. Nuncautem de fola anima informante fermonem facientes quarimus, an omnis anima, qux fit forma dans efle corpori viuenti, \& nateriam $E$ informans, fit quanta peraccidens, \& extenfa ad extenfionem materiz, ita ve fit psrs in parte, an potrus fit tota in qualibet parte. D. Thomas ops hacin re diftinctione vtendum effe exiftimauit; The nequeidem de omui anima effe afferendum : animam quidem plantarum, \& imperfectiorum animalium, quorum partes etiam ditis $x$ viuüt, dixit effe extenfam ad corporis extenfionem, \& itá totam in toto, fed partem in parte, idque-fignificaffe Ariftot. in contextu 20. lib.2. de Ani- ma, dicentem in hiseffe in toto vnam animam actu, fed plures poteftate, quam in parre feiun. cta ab aliis remaneat anima : perfectiorum autem animaliumanimam negauit effe extenfam, \& quantam, fed indiuilibilemefle dixit, \& nullo modo quantam, nec per fe, nec peraccidens, proinde in toto effe indiuifibiliter, ita vt tota etjam fit in fingula parte, fiquidem nullas habet partes, quum nec perfe, nec per accidens diuidua fit. Videturigitur D. Thomas exifinaffe animam 
animam non folum hominis, fed \& omnium $A$ perfectorum animalium, quorum partes fepararzen no viunt, effe ciufdem conditionis cum anisriabus coleftibus, nan \& illz fuis orbibus adfunt indiuifibiliter, ita vt fecundum fe totas adint etiam cuilibet parri orbis. Albertus aliqua ex parte à $D$. Thoma non diffenrit : in eo quidem difcrepat, quod de omni anima negat cum fecuudum fuam fubftantiam effe in oronibus parribscorporibus, fed dicit eam effe in folo membro precipuo, quam fententiam iam refutauimus:in eo etia m difcrepat, quod nullam viuentium diftınetionem facit, fed eandern in omnibus rationem vigere arbitratur: in co autem confentire $D$. Thom $x$ videtur, quod inquit omnem animam 1 lli parti, cui ineft, ineffe indurifibiliter, \& totam effe in toto, \& totam in fingula parte; ita vt in corde anima infit indiuidus, \& quantitate, \& partibus carens, proinde tota in qualibet cordis parte : ad hoc aut declarandum vtitur exemplo puncti in linea, eftenim inqualibet linex parte punctum, vbique tamen indiuifibile, neque extenfum per lineam $\&$ hoc exemplum accommodat Albertusad declarandamrationem, cur partes animalis infeeti retineant animam feparatx; quum enim id fignificare videatur eorum animam effeper corpus extenfam, ipfe hoc negans ait ita ibi animam ineffe, vt in linea punctum; vbicunq; enim notetur punctum in linea, , bi eft indiuifibile, tamen $f i$ in eo fecetur linea, duo puncta fiunt, - quia vtraque linex pars retinet punctum:fic igitur etiam in planta, \& in animali infecto anima, cui ineft, indiuifibiliter ine ft, feparatis autem partibus adhuc infingulis remanet eodem modovt indiuifibilis : hæc Alberti fententia fuit. Nos autem de eo, in quo à $D$. Thema Albertus difcrepat, nihil in praientia dicemus, nempe quod ipfa anima fubtantia infit foli membro pracipuo, iam in hoc Alberti fententian reiecimus; reftat igitur vt nunc de illo folum, in quo conueniunt, difputemus, nempean anima, qua fic form a vere informans materiam, poffit, indiuifibiliter, \&abfque extenfione meife illi, cui ineft, ita vt fit etiam totain qualibet parte yiuentis corporis ab ea informati. Referemus igiturinprimis argumenta, quibus hac opinio comprobari videtur, mox quidfentiendum fit confiderabinus. Pracipuum argumentum, quo inniti videtur Thomas, eft hoc: primo loco ipfe hoc difcrimen declaratanim $x$, \& form $x$ corpcris inanimati, quod forma inanimati codem prorfus modo fe habet ad totum, \& ad partes, neque vlla eft partium pendentia inter fe rationeform $x$, quum nulla dici poffit prasipua magıs, quam alix; anima vero longe diuerfo modo ad totum animatum, \& ad cius partes fe habet, variis enim inftumentis eget, qua omnia in toto corpore habet, fed non in fingula parte omna, hxcautem diuerfitas totius \& partium parua admodum eft in plantis, quia fi in ramo non funt actu omnia, quxe funt in tota arbore, funt faltem poteftate, ideo anima eft ibi extenfa per partes, \& ad corporis diuifionem diuidua: in animalibus autem infectis eft maior diuerfitas, quonianı anima in vna corporis parte non habet omnia neceffaria inftrumenta, nec actu, nec poteftate, tamen non tanta eft diuerfitas, vt anima non poffit in partealiqua feparata feruari modico faltem tempore; quocirca in his B quoque anima ad corporis extenfionem extenfa, ac diuidua eft: at in animalibus perfectis tanta eft totius, \& partiuen fingularum diuerfitas, $v t$ anima longe diuerfis modis ad totum, \& ad partes fe habeat; quiz in parte non folumnon habet omnia organa, fed neque aliquid habet, quod poffit eam per vllum quamuis breue tempus feruare poft feparationem partis à toto; ideo totitantun diciturproprie ineffe, non partibus fingulis, nufi quatenus cum omnibus comC municaturindiurititiliter: hoc ita declarato, fic Thomas argumentatur: illa forma, qux longe diuerfo modofefe habetad totum. \& ad parres, non eft extenfa, nequead corporis diuifionem diuidua; eiufmodi eft anima perfectorum animalium; ergonon eft extenfa. fed cuilibet parti indiuifibiliter ineft. Secundum argumentü pro Thoma à Caietano adducitur tale: de omni forma extenfa ad extenfionem materix verum eft, quod in maiori corpore eft maior virtus, \& in minore minor, fed hoc non eft verum de anima, ergo anima non eft extenfa : maior manifefta eft: minor probatur, quia homo aliquis minor eft validior homine maiore, \& animalia quædam minora multo validiora funt aliis maioribus; bos enim eft maiorleone, \& leo eft validior boue. Tertio inquit Caietanus: fi anima
effet extenfa per omnes corporis partes diuifi- 3 argü. biliter, maaus feparata à corpore deberetaliquandiu viucre, quia non polfet in manu interiE reanima fubitoabíque vlla prouia alteratione. Addere in confirmationé poffumus exemplum puncti in linea. quo veitur Albertus, \& Ioannes qtioq;Bicconius in 3. Sentent. diftinctione 18 , quemadmodam enim in omni parte linex ineft punctum indiuifibiliter, \& diuifalinea remanet in vtraque eitss parte punctun ; ita videtur de anima effeconsedendum, eam in fingulis corporis partibus indiuifibiliter, \& abfque extenfione inefle.

\section{Vera fententia, or eius comprobatio. Cap. $X I$.}

TJ ÆC Thoma opinio de animalibus perfeHatis, ve ego arbitror, eft ab Ariftotele aliena, itidem \& Alberti fententia de viuentibus omnibus, quod anima cui ineft, feu toti, fer parti pracipue, indiuifibiliter infit, at fine extensione; credo enim in philofophia Arifotelis tirmam \& irrefragabilem effe banc propofitioAA 5 nem, 
Omni: nem, omnis forma informăs materiam, \& conforma ftituens compofitum, eit extenfa ad extenfioinformăs nem materiz, proinde tota fecundum extenfiomateri- nem fuam in totoeft, non toto autem in parte, am exté- fed pars in parte; colligatio enim \& ynio form $z$ faest.

Argum. ex cortex. 7.lib.3. de Calo.

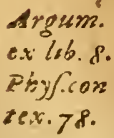

Argum.

Phis.con

78x. 78 . cum materiaad vnum compofitum côftituendum, hoc necefiario efficit, vt aque vtraque extendatur, \& in parte materı fit pars forma: per hoc enim diftinguitur forma informans à non informante, qux folum affiftat adregendum, ficuti nauta afiftit naui; hrc enim non eft aligata materia, neque per eam extenfa, neq; fpeciemconftituit per fuam prafentiam in materia, proinde nullas partes habet, fed cuilibet corporis parti tota ineft indiuifibiliter: fed forma conftituens cópofitum, \& ipfum in fpecie collocans, 2 dans effe cunctis illius partibus, neceffe eft vt ad diuifionem corporis diuidatur: ficut enim albedonon eft per fe quanta, neque diuidua, fed fit quanta, ac diuidua per accidens ratione matetiz, in qua ineft, vt ait Aritoteles in libro Categoriarum in capite de qualitate; ita denmni forma materiam informante dıcédum eft, nam eadem in omnibus ratioviget, pars enim informans vnam corporis partem non informataliam : \& quifquis illa omnia bene confiderer, quà Latinis dicuntur, ad probandum animam effe in qualibet parte totam, manifeftam in cor ū dietis ambiguitarem animaduerteret; de ipfa namque anima lubftintia verum eft id, quod dicunt: ficutenim tota, \& integra eft albecinis effentia in parce parietis, nec minus, quam in toto pariete; ita in fingula viuentis parte inefteflentia animz integra, non tamen tota fecundum quantitaté, quam per accidens adepta eft ex coniunetione cum corpore: quemadmodum etiam albedo in qualibet parietis parte, etfi tota inelt fecundum effentiam, non tamen ineft tota fecundum fuam extenfionem \& quantitatem; nam illa, qux in alia parteparietis ineft, in hac parte non ineft: hanc Ariftotelisfententiam fuiffe manifeftum eft in contex 7. lib 3. de Colo, vbidicit nullum diuifibile effe poffe in alıquo indruifibili, quaré neque in diuifibile in aliquo diuifibili toto, nempe idem numero indiuifibile, fed non diuerfa numero, vt diuerfa funt puncta in linea; quæ ab aduerfariis cnnfiderantur: etenim, vi mododicebamus, materix, \& form $x$ informantis coniunctio hoc neceffario efficit, vt vna ad alterius extenfionem extendatur. Sed clarifima eft A ri- F ftotel is fententia in contex.78 lib. 8. Phyfic.vbi ad oftendendum primum motorem nö tife formam matcrialem, fed abiunctam à materia, hoc fundamentum ftatuit, quod forma materialis diuiditur ad duifionem materix, itavt in parte materix fit pars forma, ron forma tota; cx quo ita constituto fundamento faciens diuifionem form $x^{7}$ ex diuifione magnitudinis, in qua eft: oftendit nullam formarn materialem
A poffe mouere perpetuo: at fi fieri poffet vt aliqua forma materiam informans fingulıs materiz partibus indiuifibiliter ineffet, \& in fingulis tota, illud Ariftotelis fundamentum euerteretur, \& tota illa argumentatio corrueret; nam dicere aduerfariusaliquis poffet, primummotoren effe formam materialem, non tamen extenfam ad materix extenfienem, proinde nullam eius fieripartitionem poffe, quis in fingula parte eft to:a. Aliqui tamen funt, qui licet hac $B$ in re fententiam noftram tueantur, tamen pu- al tant argumentum hoc aduerfus Thomam nihil habere efficacitatis: quia quum A riftoteles ibidicat, if forma materialis tanto tempore mouere potest, eius dimidium minore tempore mouebit, prafupponit talem effeillam formam materialem, qux in parte materix feparata ab alis partibus feruetur aliquandiu; dicere namque non pofiun us dirnidium illius form $\mathbf{z o}$ uere tantutempore, nifi ftatuamus illam in parC tibus à toto feparatis adhuc feruari; Thomas autem dicereı a iimam perfectiorū animalıum non effe eiufriodi, fed effe talem, qua in toro tancum inefie poffit, in parribus autem feparatis minime feruetur: quare argumentum nihil habet roboris aduerfus Thomam. Sed hac eorum confideratio mihu probarı nullo mody po reft: quia fi admittatur, fimıliter ratio illa Arifto-f telis corruit \& nullam prorfus vin habet ad demonitrandam primi mororis abiunctionem $D$ à materia; aduerfarius enim dicerepoffet, primum motorem effequidem formam materia: lem, fed talem, qua in partibus feparatis non feŕuetur, qualis eft anima perfectorum animalium. Egoigitur puto argunentum illud contra Thrmam ad mentera Ariftotelis declaran. dam efie optimum; quoniam Ariftotelisconfideratio coun loco eft vinuerfalss, \& abftracta ab hoc for narum marerialium difcrimine, quod aiı feruentur, alizenon feruentur in partibus à E toto feparatis: fed mencalem tantum diuifionem 1 bi Ariftoteles facit, ftatuens hanc effe communem conditionem, ac legem omnium formarum materialium, tam fubftantialium, quam accidentalium, vtin to:a materia fir forma tota, in parte auters materiz fit pars formx, hoc enim tanquam certum conftituens argumentum à partitione mentali, tuns magthtu-. dinis, tum formx in ea exiftentis, non à diuifione reali, quam ficripoffeftatuat; ficenim ratio nuilius momenti fuiffet, quemadmodum etiam prædicto fundarento de formarum extenfione non conftituto, nullam prorfus haberet efficacitatem. Id autem, quod multos in errorem traxit, fuit, quoniarn aliud eft formam ineffe in cuneris paitibus corporis, aliud ef eam remanere in iifdem feparatis à toto; nam in 0 . minibus partibus inefle eft commune omni form $x$ informanti materiam, at in fingulis remanere poft earum feparationem non onni- 
bus competit; viuentibus enim vel nullo modo competit, val imperficte; \& in his licet realem dusifione $m$ in partes cum forna conferuatione facerenequeamus, mentalcm talem poflumus, \& confiderare in haccorporis parte effe partem forma illi refpondentem, \& partem potentia motricis, ve ibiconfiderat Ariftoteles, nam potentix imminutionem fumerealiunde non peteft, quā cx partiticne extenfionis for $m x$, quam ibi pracipuerefpicit; nonenim deipfa tantum vt motrice probare ibi vult Ariftoteles abiunctionem à materia, fed ipliusmet motoris, \& $2 r$ gunentum fumtab eius partitione qux fit necellario cum partitione magnitudinis, fi eftin magnitudinetanquam informans; \& hancipfius particionem necefiario infequitur partitio et. iam facultatis motricis. Ad horum autem confirmationem fimile quiddam notareapud Ariftotelem poffumus in contextu 20 . libri fecundi de A nimz, vbi probare volens facultates anima non effe in animali diftinctas $10 c 0$, fumit argumentum ab anim libus infectis, quorum partes feparat $x$ iunctas recinentomnes anim $x$ facul. tates;nam certum eft Ariftotelem non de folis animalibus infectis id oftendere velle, fed de omnibus, nullo excepto; tamen argumentum. quo vtitur, non habet locum in animalibus perfects, quia in eorurn partibus feparatis nulla animz facultas feruatur ; facitergo in his mentalem tantum diuifionem, \& ex animalibus imperfectioribus oftendit idem effe dicendum inaliis perfectioribus:quod fo quis contendere vel let id nōeffet verum, nifi vbipoft partium fepa. rationem omnes anim $x$ pártesin fingula rem $x$ nere cernuntur, illa A riftotelis contra Platonem argumentatio vana redderetur; quia de folis infects animalibus probaret, non dealiis. Sic igitur patet validifirvum inde argumentum fumi ad Ariftotelis fententiam hac in re cognolcenc. dam. Ioannes autem Bacconius in 3. Sententra-

rum, diftinct. 18. artic.3. locum illum expendens veritatem fub nubeinfpexifie videtur, fed eam plene affequutus non eft; dixit enim argumenrum illud Áriftotelis efle efficax fecundum propofitiones phy ficas comranes, fednon effe efficax fecundum propriam confiderationem animz intellectiux; eft enim propofitio vniuerfalis in naturali philofophia, oninem formam dantemeffe materizextendi ad materiz extenfionem, fed hac non eit vera de anima intellectiua. Sed rectius philofophatus effet, fi dixiffet validum effe argumentum fecundum confiderationem vniuerialem, \& mente abiunctam aे. diuifionereali, illudque in omnibus, nullo excepto, locum habere ; fed non effe coareandum. adrealem particionem, quia fic inualidum redderetur, propterea g̨ıod neque de anima intellectiua, iseqi de plurium brutorum animalium. anima alquid iaberet efficacitatis, quum has fusta reali diuifone in maguirudinis partibus
A non feruentur. Quodautem lapfus fit Bacconius in istelligenda vi argumentationis Ariftorelis, patet, quia iuxta cius fententian ratio Arftorelis eft prorfus inefficax : nam aduerfarius dicerec

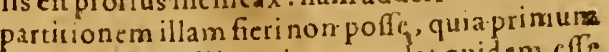
mouenseft intelligentia, qua dat quiden cffe coipori, \& hacratione eft formamaterialıs; diuiditamen non poteft, quoniam ad extenfionem magnitudinis exten $\sqrt{a}$ non eft; quamobrem non probaret Ariftotel primum motoremà materia B abiunctum effe:itaque firatio illa Ariftot. valida efle debet, eo modo, quem diximus, intelligends eft; fic enim elt validiffima, nempe co fundamento conftituto, quod omnis forma informās materiam extenfa eft ad materiz extenfionem. Praterea ad mentem Ariftotel. declarandam fu- Argum. mitur argumentum etiam excontext. $9.1 \mathrm{lib} .2$. de ex róta.c Anima, vbi ab oculo ad to tum animal argumen- 0.lib.2.de tatur, \& probatita fe habere partem anima ad srimu. totam animam; vt fe habet pars animalisad ani-

C mal totum; putat ergo animam habere partes fecundum extenfionem, \& in parte corporis partem anima ineffe, totam vero animam in toto. animali.

\section{Contrariorum argumentorum folu- tio. Cap. XII.}

D E T A T vtargumentapro Thoma \& aliis R adducta foluantur. Ad primum, in quo Tho- $A d$ pri: mas confiderat animam ad corpus rorum, \& mwm. ad partes diuerfis modis fe habere, dicere poffumus, argumentum hocprimo ipfo afpeetuipfiusmet fententiam oppugnare; videtur enim: rationiconfentaneum, vr forma, qua alio modo fe habeat ad tetum, alioad partes, alio etiam modo infit in toto, \& alio in partibus; quoniam igitur toti tota ineft, non debea fimiliter cuiqui. partiinefle tota, fed pars parti: ipfetamen exeo qued alio roodofe habet ad totum, \&e ad pas:tes, okendere nititur, eam eodem modo inefie E toi, sr cuibiberpart, nempeomnibus indiuifibiliter, quod quidem fundamentoab ipromec Thomaiactoconfonum effe nonvidetur. Sed Anim diligentius argumentum hoc confiderando, di- adcorcimusanimars ad corpus referriduobus modis; pus refer vno nodo, vteiss formazs, \& actum prinum, a tur duequo in fpecie conitituitur; altero modo, vt cor- bus mo. pore a le informato vientem tanquam infiru- dis: mento ad operandum, \& ve ci tribuentem aEtum fecundura : priore igitur modo dicimus animam eodem modo fe haberead totum, \& art partes, quatenus informat, ac perficit tum ro: tum, tum partesomnes; proinde minorem prspofitionem hacratione veram non effe, focveram efle fecundo modo: anima enira quaterus vtens non eodem modo re habet ad pareg fingulas, quo fe liabetad torum; in totocinim habet amnia organa nesefiaria, in fingulo autem membro non ornia : fed quam his duobus. Qficiis anima, ugatur in sorpore, tuar infor- 
mandi, tum vtendi, dicimus extenfionem ani- $\mathbf{A}$ tiuum, fit tota in qualibet corporis parte; hoc ma fequi primum folum officium, non fecundum, quia neceffe eft omnem formam informătem totum, \& partes, extenfam effe ad extenfionem xaterix, licet diuerfis modis v tatur toto, \& partibus : ad argumentum igitur dicimus, fi fus matur relatio animx ad corpus rarione informationis, negandam effe onoremsanima enim hac ratione ita fehabet ad partes, vt ad totum; fi veroratione vfus, \& operationum, negandä effe wainrê, quia etiamfi aliter fe habeat ad totum, \& ad partes ratione vfus, tamen dummodo eo. dem modofe habeat ad hac omnia ratione informationis, debet effe extenfa, \& ad corporis diuifionem diuidua : quare argumentum ThoAdfecsn ma prorfus in efficax \& fallax eft. Ad fecundum dum. dicimus, propofirionem illam, in maiori corpore vis maior ineft, effe intelligendam cateris paribus; non eft enim comparandus leo cum bo. ue, qui fpecie differunt, quia fic etıā dicere polfeæ, paruum ignem màg is calefacere, quä magnum aerem, neque tamen fequitur formas horum elementorum non effe extenfas: neq; com. parandus eft paruus homo, qui fit fanus. \& validus cum magno male temperato, \& male affecto; nam propter meliorem temperatupam; vel propter bonam valetudinem piterit effe validior homo paruus hominemagno, fed fi temperatura , \& alia omnia fint paria in duobus hominibus, magno, \& paruo, dico magnum hominem remper effe paruo validiorem, ¿ vniuerfe. in omnibus maioren effe vim in maioi icorpore, quam in minori eiufdem (peciei, \& cxteris oAdter- mnibus paribus exiftentibus. Adtercium fum. sism. ptum à manuabfriffa iam refpondimus, dủ aduerfus Albzrtum de anima fubitantia difputaAd quar uimus. Poftremum vero, qued fumitur à fimilitkm. tudine puncti in linea, vanum prorfus eft, quia $n$ ganda eft fimilitudo; non eft enim it a punctum in omnibus partibus linex, vt eft a nima in toto viuente corpore : punetum enim non eft in partibus lineas actu, fed poteftate, neque dat effe ipfilinez; anima yero dat elfe corpori animato vt eius forma, \& eft actu in illo, imo eft actus iplius:idco fi punctum eft in linea indiuifibiliter, non oportet animam effe in corpore indiuifibiliter, fed potius oportet eam effe extenfam ad extenfioncm materix. Praterea anima in toto corpore, \& in fingulis paribus vna \& cadẽ numero efíe dicirur, punctum vero noń idem numeroeft in omnibus linex partibus, fed lura, \& infinita, quare non eft idonea comparatio.

An anima fecundum omnes fuas facultates fit in fingula parte corporis, aliorum fentenria do argumenta.

cap. $X 111$.

Gperen huivs nofia difpurationis tertia $S$ ars, in qua confiderandum eftan anima vt totuan quoddam ( vt Latini vocant) potefraeft, an in firgula parte corporis habeat omnes fuas facultates fimul iunctas, an potius in fingula. parte vnam tantum habeat facultatem, vel plures, non tamenomnes, ita vt potentia vifiua fit in oculo, non in manu, neque in pede. Hac de redifceptario fuit inter expofitores Arifotelis, tum antiquiores, tum recentiores, nam vtraque pars fectatores habuit : alij namque dixerunt, in qualibet corporis parte omnes ineffe facultates,

$B$ alij vero hor negarunt. Hanc pofteriorem fen- 1.0, tentiam fequutus cft Albertus : quum enim putaueritanimam fecundum fuam effentiam non efle in omnibus corporis partibus, fed in vna tantum pracipua, necefie eft yt dicat tranfmitti ab ed ad alia membra varias facul tates, per quas membra inter fe diftinguantur, vt vifiuam ad oculos, olfact 1 uam ad nares, \& fic de reliquis, proinde non fimul effe omnes in eadem corporis parte, In hac opinione videcur fuifte Ioann.

C G ano matic. in interpretatione contedt. 20. libr. 2. de Anma, non quidem quod femper tacultates diue $f x$ diueilas corporis partes obtineant, fed quod non omnes fimul iureta fint in qualibet parte; vt fi dicamus effe in ligua facul tatem guftatiuam, \& faculiatem tactiuam, \& facultatem nutritiuam, at non facultatem vifiuam. Hanc fenentiam aliqui potteriores fequentes, ean pluribus argumentis probarenifi lunt, ea tament omnia ad huius vnius argumenti vin rediguntur; natura nihil fruftra facit, ergo vbi non poteft ficri operatio alicuius facultatis, ibi nec facultas iffa eire poteft, nan facultas gratia operationis eft; fruftra igitur ponitur, vbi tieri operacio non poteft; quod autem non in qualibet corporis parte fieri omnes operariones poffint, per fe manifeftum eft, neque enim in manu, neque in pedefit vifio. Sed ex ipfis quo. 2. at que organis idern oftenditur: quum cnim cuilibet facultatifint neceffaria propria organa cuique affignata à natura, fine quibus operarinon poteft, organa autem non poffint fimul effecomia in eadem corporis parte, non poffunt in eadem parte corporis omnes operationes fieri: ideo ex ipfis quvque inftrumentis argumentantur; vbienin non ineft inftrumentum cuique faculcatineceffarium ad operandum, ibineque faculras ipfa ftatuenda eft quoniam igitur in pedenon eft oculus, dicendum eft potentiam vifiuam in pede non cffe : quemadmudum \& è F conuerfo vbi facultas non ine ft, ibitruitra in. At, umentum poneretur ; nam in pede fruftra effet oculus, quumibi fa.ultas vifiua non infit; ideo natura non dedit oculum pedı, quia nihil vnquam fruftra facit. Confirmant teftimonio Ariftotelis in fecundo libro de Colo, context. quir quagefino v bi dicit; fi natura dediffet aftris facultarem ambulandi, feu progrediendi, vtique dediffet cis etiam infrumentum talis motus, figniticans non poffe in aftris effe banc facul- 
taten, quia ibi effet fruftra. Similiter in 3 . lib de Anima, contex. 44. inquit fi ftirpes haberent facultatem locomotricem, inftrumenta quoque ralis motus haberent, at inftrumenta non habent, ergo neque facultatem: quare apud Ariftorelem efficax femper ett argumentum hoc, non eft ibi inftrumentum talis operation is, ergo nequefacultas operandi ibi ineft. Ex alcera parte 11 lis, qui dicunt in fingula corporis parte effe omnes auime facultates; argumenta non 12. defunt, Primum quidem. vtuntur argumento valde efficaci: in qualibet corporis parte ineft. ipfa animx fub ftantia, ergo in qualibet funt omnes facultates: vel enim facultates funt idem cum anim $x$ effentia, velfunt qualitates eam infequentes; fi idem, omnino neccifarium eft, vt: vbieft anima, ibi fint omnes facultates; fi.vero. funt qualitateseffentiam anim $x$ confequentes : fimiliter oportet animam id qualibet parte corporiseffe his onmibus præditam; quemadmodum neceffe eft vbicunque eft Sol, ibi elfe lu-men, quod eum confequitur, \& vbicunque eft homo; ibi.effe rifibilicatem: neque eadem eft ratio de facultatt bus, ac. de organis; nam facultates; quumfint incorporex; poffunt in qualibet parteffimul omnesexifteresorganovero corporea fimuliexiftere nequeunt, quia non datur penetratio corporum , fed neceffario difiuncta funt. Confirmatur hac fnntentia teftimonio A riftatel is in contextu 20 . libri fecundi de Anima; vbi argumento lumpto ab animalıbus in feetis; oftendit facultates anim $x$ non diftingui loco, fed in fingula corporis parte ineffe omnes; \& quumibimultas nominet, nempemarricem, fenfibilem, phantafiam, "\& appetitum, vult vt idem de omnibus intelligamus,quoniam ea demonftratio non débet effe parcicularis, nam ftatim in contextu 21. inquit, dubium effe de facultate fpeculatiua; fed poftea in 22 : fubiungit, verum effe de cateris omnibus id; quod prius dixerat, eas locis feparatas:non effe, fed fola ra. tionefeparabiles. Eadem eft Alexandri fententia.in cap .vlt: lib: I. de Anina, vt ibilegere pof- fumus. Eandem fequitur Simplicius in context. rò. \& 20 iibri fecundi de Ánima, vbi quum eam Ariftotel, attribuat, aduerfus ipfam facit hanc: obie. Ationem: fenfus externi loco diftinet if funt, nam facultas yifiuanon eft in omnibuspartibus corporis; fed folum in oculis; fic olfaetiua in folis naribus; ficauditiua in folis auribus; ergo h $x^{-}$ facultates locis difiuncte funt: fed foluens in- $F$ quit nilaliud pertioc probari, quam inftrumenta corporea lócis diftinctà effe, at non facultates; : etenim ha in qualibeticorporis parte: in fiuntomnes; quoniam in qualibet parte eft ani-fffo. maa. Theniftus quoqi tum in calce prinyi libri । dé.A nima;tum in contextu 20 . libri fecundiclaredicitomnes animx facultates, quar in toto cospore funt; effe etiam in qualibet parte; fed folacasum organa effelocis diftinct $a_{\Sigma}$ quia funts
A corporea, nec datur corporum penetratio. Habemus etiam de Arifotelis fententia teftimonium loannis Grammatici, qui in contextu 2.0. Io.Gram lib. 2. de Anima, fatetur Ariftotelem exiftimaffe maticus. omnes animæ faculcates effe fimul iunctas in qualibetcorporis parte, licet ipfe in hoc ab Ariftorele diffentiat, $\&$ contraviam opinionem fequasur, ficut antea dicebamus.

\section{Vera fententia, or eius declaratio.. \\ Cap: $X I V$ :}

$\mathrm{I}^{\mathrm{N}}$ hac difficultate ego fententiam mediam liequendam effe arbitror, per quam videntur dux predifte contrarix opiniones, \& argumentationes modo aliquo inter fe conciliar: puto enim facultates anim $x$ in qualibet corporis parte omnes aliqua ratione ineffe; aliqua etiam ratione non ineffe: quum enim iam. dixerimus eas effe qualitates mutantes quiden ab anima vt à principio, \& origine, fed in corpore animaro receptas vt in fubiecto 3 dicendum videcuromnes in qualibet corporis parte omnes ineffe fecundum origine. 8 , fed nonfecundum facultafubiectum, ita vt per hanc diftinctionem origi- tes in fin naliter, \& fubiectiue (ficenim nobis in prefen- gulapartia more Latinorum loqui licent) omnis hac in te infunt redifficul tas tollatur; nam vifiua facultas eft in originafolo oculo, yt in fubiecto, fed originalitereft et- liter, at iam in pcde, etenim in pede eft anima', quam il- non fubla aculia sinfequitur; ita vt reciperet pes facul- iectime. tatem vifiuam, fi haberet oculum. Sentêtia hac ex.lpfarei confideratione fit manifefta, \& per eam prædicta contraria argumenta adrectum fenfum; \& ad conciliationem rediguntur: nam $f_{f}$ anima fuapte natura omnes operationes ede-. re apta eft; neceffe eft ve vbi eft effentia anims, ibifit etiam hre aptitudo, qux:ab:ea emanat, 8 . potentia, feu facultas appellacur; \& in hoc fenfú pofteriorisfectà argamentum efficax eft. E Sed quoniam faculiates in corpore animato recipiuntur, nihil autem in materia recipitur, nifi ad id recipiendum idonea, non recipitur in qualibet corporis parte facul tas vifiua; quia non omnis pars ad eam recipiendamapta eft; , fed folim oculus; \& hac ratione argumentum prioris : feetrvalidum eft; neque nos ad hanc noftram. fententiam comprobandam aliis argumētss vti : volumus, quamillifmet, quibus ali contratias . illas opiniones: tutati funt 5 patet en im ytram q: corum fententiam aliqua ex parte veram effe, fed quoniam ip fi hancidiftinctionem non ani-maduerterunt; ideadifcordes sin fuo cersamine: 10 . Ganperftiterunt: Hüicetiam noftras fententizatte- dawë/ss. ftanturyerba Ioannis Gàndauenfis in fua quxftione, dubius:enim eff; vtra duarum sontrariarumopinionum verior fit; \& ait vtramlibet. defendi poffes, \& veriorem quidem fibitvide. ri illam, quadicitur in omni corporis parte $0=$ mnessfacultates ineffe, fed-alterain effe appa- 
rentiorem: quũ enim de facultatibus iudicium A exnperationibus faciamus, ibitantum videtur effetacultas, vbi fit operatio; quocircahæe quoque Cententia defendi fine abfurditate poteft: itaq; vidit virille fub nube ipfam rei veritatem, led eam, quam diximus, diftinctionem ignorans fe explicare nequiuit. De facultatibus autem animærationalis, quas alibi declarauimusmanifeftior res effe videtur: quum enim hacanimx pars nullum habeat organum proprium, habet vbiq; fuas facultates; fed quia non potelt operari non operante phantafia, ideo ibi videtur intellectio fieri, vbi fic imaginatio; proinde fi in pede ineffet phantafix organum, ibidem etiam incellectio fieri videretur. Sed huius noftrx (ententix veritas clarior fiet, fo omnia ab aliis addueta argumenta diligentius expendamus, \& quantum roboris habeant, confideremus.

\section{Contrarium argumentorum folutio. Cap. $X V$.}

Adprimüprimosecta.

Qromodo innaeura/it aliquid fruftre.
Rrioris fectx argumentum erat: fi in quaPlibet corporis parte ineffent omnes facultates, ibi effent fruftra, quia fruftra eft facultas, cuius non poteft effe operatio: ad hoc dicimus totŭ effe concedendum, $f$ intelligant fubieftiue, hoc enim tantum eo argumento oftenditur; fi vero origmaliter, négamus confequens: fe, vt ibi eftanima, ibi fint originalter omnes eius facultates, quia non potert animx effentia non eit fons omnium facultatum fuarum; vt autem non fint fruftra, fatis eft fi in aliqua corporis parterecipiantur; quum enim organafint corporea, nec fimul effe, ac fe penetrare queant, neceffe fuit ea locis diftingui : à tota igıturanimx fubftantia, qux in toto corpore eit, quxlibet facultas emanat; recipiturtamen quxlibet in vna tantum parte, qua ad eam recipiendan apta eft, non in omnıbus:illi igitur, qui fic argumentantur, in eo errare vi dentur, quod partes animalis fumunt tanquam plura animalia, quum tamen omnes fint vrum tantum animal, in quo nulla facultas animæ fruftra effe dicitur, dummodo in aliqua corporis parte poffit fuam exercereoperationem. Si quis vero obiiciat cxcum ab ortu, in quo facultas vifiua fruftra effe videtur; dicendum eft non poffe omnino negari in natura id, quod eft fruftra: quod enim dicitur, naturam nihil fruftrafacere, intelligendum eft $F$ de effectibus vniuerfalıbus omnibus, nullo excepto, de particularibus vero non quidem omnibus; feu maxima exparte, propterea quod effectus naturx quandoq; impedimentum reci piunt, \& propter materiæ defectum aliqua pr $x$ ter confilium naturæ eueniunt; cuiufmodi funt ad probationem autem dicimus neceffariū fuif-
A oculiad videndum inepti. Vel dicamus id de o: mnibus vniuerfe verum effe fi intelligatur fecundum intentionē \& confiluum naturæ; quicquid cnim à nat ura fit fecundum eiusconfilium \& intentionem, id nunquam poteft effe fruftra.: Ad verba autem Ariftot. facile eft refpondere;vtique enim fruftra in Colo poneretur facultas ambúlandi, quum nulla in Colo pars fit, in qua recipi poffit:fic fruftra in plantis eadem facultas inellet, quum in nullaplantarum parte recipia-

B tur:at in animali nulla eft ipfiuscorporis pars, in qua fit fruftra facul tas vifiua; quia, quum in omnib. corporis partibus infit, tat eft, fi in ea faltem parte, quæ oculus dicitur, recipiatur; fed fi in pede quoq; effet oculus, ibi quoque fieret vifio, quum autem ibi non fit oculus, non ob id eft ibi fruitra facultas vifiua; quia fat eft, fi in oculo, quî in capite eft, recipiatur. Cōtrariæ quoque fectx argumentum nihilalıud probat, nifi, in qualibet parte effe facultates omnes origina-

C liter, fed non probat in effe fubiectiue: quia ficut fecundum Ariftot. ómnes operariones toti viuenti corpori vt fubiecto attribuend $x$ funt, non anim $x$, nifi yt principio, fic etiam facultates funt anim $x$, vt principii, \& originis, fed non vt fubiecti recipientis. Hoc figniticauit Arift. in contex. 9.lib. 2. de Anima, dicēs facul tatem vifiuam efle vt formam oculi, per eam enim diftinguit 0 . cul um abaliis membris, quafi alia membra eam facultatem non habcant; aliquẽ igitur dari noD dum oportet, quo in aliis partibus facultas vifiua non inst quare dicédum eft, eam in aliis non ineffe fubicctıue, fed folum originalıter. Qund vero in con tex.20. lib.2.de Anima Ariftot.dixit de animalıb. infectis, 1 d fano modo intelligendum eft:non enum dixiffet in vtraq; parte lacerre diuif $x$ feruari potentiam vifiuan vt in fubieEto, quum non fit in vtraque oculus; fed exillis facultatibus, qux funt fubrectiue in toto corpore, fatis habuit argumętum fumere ad proban-

E dum de omnibus, vt inde colligeremus, omnes in omnsbus partibus effe ratione animx, à qua originem ducunt, etfinon ratione fubiecti corporıs; nam per fe manifeftum eft, plures tacultaies fimul effe poffe in eadem corporis parte, etiam vt in fubiecto, non tamen omnes, quia non eft in oculo facultas odoratiua; attamen eam in omnibus partibus effe originaliter ratione ipfius anima, ex iis, qua dixımus, manifeftum eft. Ad hancfententiam trahi facile porfunt Alexandri, \& Simplicii, \& Themiftii dicta, qux antea retulimus; quod quidem aliis confiderandum relinquimus; fatis enim nobis eft, per cam, quam attulimus diftinctionem, omnia aliorum dicta ad verum fenfum trahi poffe, \& omnes aliorum opiniones conciliari. 


\section{J A C. ZA B A R E L L E $P$ A $T$ A V I N I, Liber}

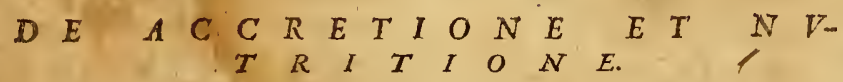

Quot modis fumatur accretio, or que conditiones ad accretionem proprie dictam requirantur. Cap. I.

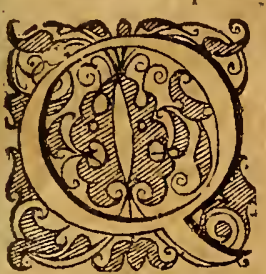

V.AM difficile atque arduum fit accretionis naturam penetrare, \& modum, quoviuentia corpora augentur, cognofcere tum resipfa declarat, tum doctiffimorumviro. rü, quide hacre fcripferunt, teftimonia confirmant; nam, vt nunc alios mittam, Petrus Pomponatius, qui duobus à fe editis libris diligentiffime, \& optime de accretione difputauit, non folum fe in eius cognitionen nonacquiefcere, palam, \& ingenue confeffus eft, fed etiam affeuerare aufus, nullum effe mortalium, qui poffit afferere fibi in hujusce rei inteiligentia effe plene fatisfactum. Hoc ego confiderans, \& illius viri, cuius eruditionem atque iudicium plurimi facio, exemplo \& authoritate ductus;neque detrectandam mihi propter difficulratem effe hanc difputationem eximaui,quod pufillanimi, ac philofophia indigni hominis effet;neque coanimo hanc fcribendi prouinciam fufcipere conftitui, quod mead plenam veritatis notitiam perueniffe putans, perfeetam eius declarationem polliceri me poffe confiderem, quod quidem arrogantiam fortafie, actemeritatem præfeferret : fed vt in re difficillima eam partem, qux cum minoribus difficultatibus coniun ta effe videbitur,accipiens, niteres quantum perme fieri poffit, prope ad veritatem accedere, acfi ipfam non prorfus attingere, faltem ad eam inueniendam alios magis excitare, \& fortaffis etiam iuuare bac me difputatione poffem. Scribam igitur \& qux fuerit hac in re Ariftot. Sententia, \& quid fentièndum fit, quanta potero diligentia perfcrutabor. Vt autem ad ea, qux obfcura, \& abfcondita nobis funt, inueftiganda à notioribus progrediamur, prius quadam ab omnibus conceffa, \& cognita de accretione tanquam dicendorum fundamenta conftituam, vt \&illa, qux nota funt, ab illis, qux in controuerfia funt pofita, diftinguamus, \& per illa ad reliquorum inueftigationem viam plamiorem reddamus. Ante onnia vt quam accretionem in prafentia confideremus, intelligatur,
A fciendum eft ex Auerroe in r.lib.de Coclo, com. 22.accretionem tribus modis fumi : quandoque Accretio enim fumitur proaggregarione, feu accumula- triplex: tione, vt quando cumulum fabarun augeri di. est. cimus per appofitionem aliarum fabarum ; \& quando aquam exaqux appofitione maiorem fieri dicimus : quandoque absque alicuius corporis acceflione dicimus aliquid augeri per folam rarefactionem, \& fic imminui percondenfationem absque alicuius particulée fubtractioB ne, quando enim aqua in aerem mutarur, quantitas maior redditur, quoniā aer eft rarioraqua, \& quando aer in aquă vertitur, fit minor quantitas, quia aqua eft denfior aere: tertio modo, qui maxime omnium proprius eft, fumitur accretio pro viuentium tantummodo corporum incremento, quum ftatim nata augeri incipiant, donec ad perfectam atatem, ac debitam fibi quantitatem peruenerint. De hac terria accre- Trescontione, aliss dimiffis, eft nobis propofita difputa- detiones C tio, \& hancyt ab aliis feparet Aritot. in I.libr. de GereacOrtu \& interitu, tres conditiones in ea poftulari cretiodixit; vna eft, vt exall qua extrinfecus accedente nis. materia res maior fiat; fecunda, vt id quod augetur, idem numero manear, poft quam auctum eft, quodante accretionem fuit; tertia dcmum, vt non modo totum maius fiat, fed etiam quaxlibet eius particula augeatur. Prim $x$ accretioni dux pofteriores conditiones non competunt, nā neq; idem numero manet fabarum aceruus, D neq; partes illius omnescreuerunt, quia fingulis granis nulla eft facta additio; fic per appofitionem aqui alia numero aqua eft facta, \& tota quidem aqua aucta eft, led fingulx eius particulæx nullum incrementum acceperunt : ad hunc. modum redigituraccretioignis; continue namque alius, \& alius numero ignis generatur, nec fingulis particulis additio quantitatis fievi dici- Qwal thr; perhasigitur duas conditiones hic accre- fit accre. tionis modus excluditur. Per primam autem 100 ignisom E conditionem excludirur fecundus modus; nam in mutatione aqux in aerem fit maior quantitas, nulla extrinfecus adueniente materia. Sed tertio modo fumpta accretio his omnibus conditionibus pradita eft:ram \& plantá, \& animal idénumero feruatur per totañ vitä, vt manifeftum eft; \& ex alimento extrinfecus affumpto. quodlibet viuens augetur, \& de mum nô folum to $i$, fed etram cuilibet parti fit quantitaris ad- 
ditio; ratio autem cur hxomnes conditiones coniunctim in viuentium accretione reperian. tur, eft, quia hæab interno principro augentur, \& exalimento non ex trinfecusappofito, fed introrfum recepto; hinc enim fit, vtad omnes partes augendas per totum viueintis corpus diftribuatur, necfolum totum maius fieri dicatur, verum etian partes omnes. Sed hæc omnia, \& tres prædictæ conditiones magis in fequentibus declarabuntur.

\section{Ounomodo fiat in viuentibus accretio, \& que mutationes ad eam faciendam con- currant.Cap.II.}

St præterea breuiter, \& pingui Minerua Eexponendum, quomodoin viuentibus hæc vera accretio fiat; nam Arsftoteles in 5. Phyfic. aufcult. accretionem ab aliis mutationibus feiunxit ratione terminorum, qui ex diuerfis categoriis fumuntur; generatio enim \& interitus eft mutatio de fubftantia in fubftantiam, alteratio de qualitate in qualitatem, latio de loco ad locum;at ipfa accret1o \& imminutio eft de quăitate in quancitatem: eft igiturinter has omnes murationes differentia effentialis, qux fumitur à terminis, hoc eft, à forma fluente; qux eft ipfa motus effentia, vtnos in tertij Phyficorum in-

Efentia estforms fluens. terpretatione demonftrauimus : attamenaccretio fierinon poteft fin multiplicio inniumalia: rum mutationum concurfu, vnde magna difficultas hac in re oritur; quumenimabfquemultis, ac diuerfis mutationibus fieri accretio nequeat, difficile eft cognof cere in quanam ex eis fit accretionis natura cōftituta: funtigiturordinatim hx omnes mutationes confiderandx, \& videndum perquas, \& quot mutationes, \& quo ordine alimentum ad augendas omnes corpo: ris partes perueniat, poftọuam intra eft receptum : hocautem confideremus in animalium perfeçorum accretione, qua nobis familiarior, atq; euidentior eft; poterit en in quifq; \& omnibus animalibus, \& ftirpibus hac omnia per quandam proportionem accommodare. Certum eft imprimis cibum in ore fumi, fidurus fuerit, conteri dentibus, qux contritio abaliquibns prịma concoetio dicitur : fed ea reuera non eft concoltio, fed potius praparatio ad primam concoctionem, quæ poftea in ventriculofit: cibus enim in ventriculo non coqueretur, nif prius liquaretur; liquariautem vêl $\mathrm{F}$ non poffet, vel agrepoffet, nifi prius effet in ore contritus: tranfit itaque ab oread ventriculum cibus, fitqueprimum neceffario motus ille lo. calis; in ventriculoautem fitprima concoftio, qua \& alteraturcibus, \& fecudum fubfantiam mutatur in fuccum, quià Græcis $\chi$ unòs dicitur; quare in ventriculo fit tum al teratio cibi, tum generatio, \& interitus; generatio quidem fucci, interitus ycro panis, vini, \& aliorum cibario-
A rum:d einde al io motu locali mouetur fuccus ad inteftina, \& ab his per venas nefenterij ferturad iecur, in quo iterum al teratur, \& fecundum fubftantiam mutatur, vertiturque in fangunem; fit igitur in iecinore tum alteratio, tum interitus fucci, tum generatio fanguinis: poftea loco:moueturfanguis, dum pervenas adomnia membra tranfmititur, \& ex venisperminutiffimos poros penetrat membrorum partes folidiores; nam omnes homogenex partes, vt caro,os,ner-

$B$ uus, minutiflimis poris refertæ funt, \& inftat fpongiæ fanguinem àvenis exugunt, ita vt pori fanguine impleantur; fit autem ibi tertia \& vltima concoetio, qua fanguis à calore naturalialteratur, denfatur, \& in fubftantiam fimiléconuertitur, vt in carnen, os, \& alias homogeneas partes; quare 1 bi fit tertioalteratio, \&.generatio, \& interitus, alteratio quidem 2 interitus fanguinis, generatio autem carnis, \& aliarum parti um;obid folet fanguis appellari vltimum aliimentum, eftenimper multas memoratas mutationes ita præparatum, vt iam poteftatem proximam habeat vt in rei fubftantiam contertatur : quod autem de fanguine dico, illud in animalibus fanguine carentibus, \& in plant is de quolibetalio homore, qui fanguini proportione refpondeat,intelligatur : in hac aũt poftrema mtatione, qua vltim. a limentū vertitur in fubftantiam, conftituta eft nutritionis natura, efte. $N$ i nim nutritio reparatio fub fantia, quacontinue qu refoluitur à calore naturali, per fubftantia fimilis aggenerationem : facta autem nutritioneadhuchumidum, quod ın carne, \& inaliis partibus eft, confumiturà continua actione caloris naturalis, \& ex ea confumptione:oriuntur iterum pori, deinde iterum fanguine replentur, qui iterum infubftantiam conuertitur, \& $\mathrm{nu}$ trit, \& hoc ad finem vfque vitæ inceffanter perfeuerat; animata enim nutriuntnr donec viuüt, vt Ariftotel. dixit in 1. libr.de Ortu \& interitu, \& in 2 . de Anima, \& quando nutriri ampilus nequeunt;neceffario moriuntur. fed in prima ata te non folum nutritio fit, fed fimul etiam ascrecio fingulorum membrorum, \& corporis totius; calor enim naturalis eft vehemens, \&:validus, \& plus conuertitin fubfantiam, quam confunsptum fuerit, vnde viuens redditur maius, quia plus materiæ pernutritionem adipifeitur, quam per actione caloris naturalis amiferit: propterea ita coniuncta eft cumaccretionenutritio, vt accretions naturam declaraturis neceffarium omnino fit etiam de nutritione loqui, \& quid nutritio fit, : \&quomodo fiat, cum diligentia confiderare : obid in hac noftra contemplatione nos non minus nutritionis, quamaccrerionis naturam, \& caufas perueftigabimus. Hac ifunt, qua tanquam manife fta ab omnibus conceduntur, nuncad reliqua, qux in contiouerfia funtpofita, progrediendum eft : \& quum tres conditiones yer accretionisab Ariftotel. pro- 
pofit $x$ fint, in iisqueomnibus magna infit diffcultas, de fingulis ordinatinı differendum.

Quomodo ex materia extrinfecus accedesto id, quod augetur,maiorem quantitatem. ó maiorem locum acquirat, dua alio-

rum contrarice opiniones.

Cap. I I I.

$P^{\text {Rimo loco difficultas oritur de adeptione } B}$ maioris quantitatis ex a limento exrrinlecus alluinpto:nam perilla, qux haetenus diefa funt, non apparet quomodo corpora augeantur: quia licet omnes pori fint noua carne repleti, \& nouo offe, \& reliquis homogeneis partibus, non tamen totum viuens eft tactum maius; poteft enim fortaffe caro dici maı or, quia plus ca:nis ibi eft, quam prius, fed non occupat maiorem locum, imo eundem, quem prius occupabat, proinde non acquirit maiores dimenfione's ; ficuti vas, quando eft aqua impletum non eft facturm maius, quam erat prius, quam aqua impleretur; fic etiam fpongia fi impleatur aqua, non fit maior,neque locum mutat: attamen Ariftoteles in contexr. 25. libr. x. de Generat. aperte dixit, id quod augetuir, locu m mutare, eo quod maicrem quanritatem acquirit, proinde neceife elt, vt tranfeat ad maiorem locum : op ortet igitur poft nutritionem fieri aliquam aliam mutationem, qua totum reddatur maius. Fiacin re dure 0 . piniones exiftunt. Vna communior eft, a cam plurimi fequuntur, quidicunt per stuernbri extenfionem fieri adeptionem maioris quantitatis, tum in ipfo membro, tum in toto viuente corpore; veluti fi fpongia manu conftricta poftea dimittatur, dimiffa enim extenditur, \& maiorem occupat locum: fic igitur caro, quando omnes eius pori funt repleti alia noua carne ex fanguine genita, extenditur, \& carefit, \& maiorem locum occupat;ita os, \& neruts, \& alizomnes fimilares partes : ad extenfionem aurem partiū omnium fimilarium crefcit membrum, proinde totum viuentis corpus maius redditur: hanc fententiam fignificare vifus eft Ariftot. in pradifu contextu 25 .quando dixit, illa qux augentur, mutare locum, ficut ea, qux extenduntur. Alterafententia fuit nonnullorum, qui ne$r$ garunt hanc extenfionem accretioni neceffariam effe, \& dixerunt partium, \& totius corporis incrementum fieri potius per pulfum, quam per extenfionem, vna enim parsaliam pellit, ac trudit, dilla aliam, quemadmodum in vinguibus fieri videmus. Ad hoc probandum, ac extenfio. nem reprobandam, tali argumento vif funt: contrariorum contrarix funt conditiones, accretio, atque imminutio funt contrarii motus; ergo debent contrariis modis fieri;itaque fiaccretio fieret per extenfionem , oporteret imminutionem fieri per contractionem, nam extenfioni con-
A tractio opponitur;attamen nemo dixit imminutionem tieri per contractionem, quia hoc nüllo pasto dicendum eft, ergoneque accretio fit per extenfionem. Praterca nullum connatum, \& vniforméc à feip fo moueri poteft, vt ait A riftoteles in context. 30. lib. 8. Phyf. at caro eft corpus vniforme, a homogeneum; ergonon poteft à feipía moueri; non poteft ergo exiendi, quia fi exienderetur,à feipfa extenderetur, \&ita à lc moueretur, quod ibı Ariftoteles negat.

\section{Opinio vera, do eius comprobatio. Cap. IV.}

A Rbitrorego veram effepriorcm opinionem, A quam complures fequuntur, \& extenfionem ascretioni penitus neceifariam effe, pulfum vero neçuaquâm, imo nullo modo fieri polfe:nam vngues itacrefcuntper pul fum, dum vna pars aliam peilit,, ed non dicuntur reuera augeri, quo . niam ad vnam tantum partem mouentur;illa vero, qu $x$ a ugentur, ad omnes fimul partes; pra. terea alimentum, feu excrementumillud, quod per vngues expellitur, non penetrat omnes vn. guium partes, fed vni tantum parti apponitur, proinde eft mera appofitio terrei excrementi, quodper viaguem emittitur, pulfione faka ynius partis ab alia, quare illa non poteft vocari accretio:at in vera viuentis accretione certum eft partes alimenti penetrare omnes corporis partes, \& augere totum corpus fecundum omnes firmul differentias politionis; non igitur per talem pulfum, qual is in vaguibus fit, hoce. nim dicere, eft dicere vnam partem \& pellere al. teram, \& abcadem pelli, quodne excogitabile quidem eft, quia fe mutuo impedirent ne vlla pulfio fieret, fiquidem fit pulfio, quando in vna tantum parte fit additio materix pellentis, qux propinquam partem pellat, \& illa aliam, fed non eandem, à qua i pla pellitur, qu fir, vt in pulE fuomnes parres ad eandern pofitionis differentiam tendant, ficuti viderrus in vnguibus; fed non ita fit in eo, quod vere a ugetur, hocercnitn mouetur ad omnes fimul differentias pofitionis. Praterea fi per pulfum accretio fieret, 0 porteret cicatricem in manu puerı factam tem. pore procedente pelli ad digitum, quod tamen non concingit: videmus enim cicatricem manere femper in eadem parte, cui fuit vulnus illatum, \& eum locum nunqquam murare. Perta$F$ lem igitur pulfionem accretio non fit, nifipulfionis nomine idem intelligatur,quodextên fio; reuera enimalium modum imaginari non pof. fumus, quototum membrum augeatbr, \& cum maioris quantiratis adeptione maiorem locum occupet, nili vt fongia prius manu conftr1Eta, poftea dimiffa extenditur, \& rarefit: ideo non eft ignorandum, in viuentecrefcente poros poriob propter duas fimul caúas generari, propter dusascan confumptionem humidi à calore naturali fa- fas fiunto

B B Etam,
Poferio. ris finterisconfís 4810. 2. Arget
ment. 
Etam, \&propter extenfionem; in adultis vero ex fola humidi confumptione poros exoriri, quia nulla amplius in eis cxtenfio fit: at in crefcentibusetiamfi nulla humidi confumptio fieret, necelfe effet ex fola extenfione poros generari.

$$
\begin{gathered}
\text { Solutio argunentorem, que contracx- } \\
\text { tenfioncm adductafunt. } \\
\text { Cap. I. }
\end{gathered}
$$

A Dargumenta autem aduerfus extenfionem Adpri- A adductafacile eft refpondere. Prius quidem mism. argumentum poteft contra aduerfarios ita retorqueri: fi accretio per pulfionem ficret, oporteret immintzionem fieri per attractionem, quoniara pulfioni contraria eft attrabcio, \& contrariorum contrariz funt conditiones : fed foluitur, quia non omnes contrariorum cond:tiones debent effe contraria, fed aliqua; \& hinc fit, vt locus argumentandi à contrario fit locus Topicus, qui probabilitatein aliq̧uam habet, at non necefitarem: dicimusigituraccretionem, acimminutionem effe motus contrarios, ideoque oporterevt ea ratione, qua opponuntur, contrarias etiam conditiones habeant: accretio igitur eft motus à minore quantitate ad maioImmins- rem ex materia cxtrinfecus accedente?, immisiogisd nutio,vero eft motus à maiore quantitate ad fis maiorem ex materix fubtracione; hx namque funt accretionis, acimminutionis conditiones contraria ab Ariftotele pofitz, quas negare non pofiumus: at his pofitis fequitur neceffario eas non poffe opponi etiam in modo, ficut illi imaginantur, nempe vt accretio fiat per exsenfionem, imminutio vero per contractionem; hac enim contrarietate confituta tollereturaltera illa oppofitio rationa materia accedentis, arecedentis, quam Ariftoteles pofuir, quia dicere contractionem eff fupponereeandem materiam feruatam, qua prius extenfa fuit; ha igitur dua contrarietates, vna permateriam additam, \& ablatam',altera per extenfionem ; \& contractionem, eiufmodifunt, vt ynalteram non patiatur, quare vna confitutu, non potefialtera poni; quia ficontrabiturmateria, ergonon eft fublata, fedeadem remanet in co, quod imminuitur, quod tamen Ariftoteles negat: quod fi materia in imminutione eft fublata, vtaffere. re debemus, cuiufnam volumus fingere contractionem? certe fi per fubtractionem materix quantitas imminuitur, nulla opus eft contraetione: imminutio namque refpęu accretioais locurn habetpriuationis, quatenus in accretione apponitur materia, in imminutioneautem demitur: quare id, quodimminuitux, priuatur fin matcria, feu partematerix: extenfio autem eft materia extenfio, nec poteft in vidfecun uente confiderarínemateria. Adalterumara...m.
A rum: nam Ariftoteles ibi non dicit homoge- $D$ neum \& viniforme à fé moueri non porfe, fed di- tso cit continuum non poffe ita à fe moueri, vt una te: pars alteram moueat, \& famit continuum pro- lib pric, \& eiuspartes fecundum quantitatem con- $P b$ fiderat; quare locus ille ad id, de quo nuncloquimur, non pertinet; non eniso dicimus vnam carnispartem extendiabalia parte carnis, tanquam à mouente, hoc eniz A riftotel. ibinegat; fed dicimus totam carnem extendi ab anima, $B$ proinde agens extcridens effe animam, nonz. liam carnis partera: quod fi omiffa cius loci confideratione ita argumentari velint, corpus homogeneum extendià fe non poteft, quia ficà feiplo moueretur; dicendum eft corpus homogeneum non pofte mouerefeipfum, dum fumitur homogeneum inanimatum, fue fit el emertum, fiue miftum; quun enım hoc non diuida. tur in partem mouentem, \& partern motam, non poteftà feipfo moueri,vtibi Ariftorel. confiderat; at fecus eft de homogeneo animato, quod eftaetu parscorporis heterogenci, \& organici, hoc enim przeter formā miltionis habez animan informantem, à qua tanquam à moucnte fit motusille extenfionis : homogeneum vero inanimatum habet fola formam elemen. ti,vel folam forman miftionis, ideo non pote? fe mouse co modo, quoanimalia ̀̀ fe moueri dicuntur; nam omne anima pradictum potef moueri à feipfo, id eft, ab anima ; quare etiam caro, fi habet animam, ab illa tanquam mouentè extendi poteft per calorem naturalem, tanquam per inftrumentum, feu agens proximum.

\section{Solutio queftionis, cur in adultis ceffet accretio. Cap. VI.}

$\mathrm{H}$ Ec, qux de extenfione diximus, maxime confrmantur, ex eorum confideratione, qua in viuentibus contingere cernuntur, propterea quod facile eft eorum rationem adducere, dum afferimusaccretionem per extenfianem ferijvidemus enim viuentianon femperaugeri, fed ad aliquod vique tempus, vt homoaugetur 2d atatem vfque adolefcentiz, poftea vero augeri definit; quodidem in cæteris animalibus, de in plantis omnibus contingere manifeftum eft: attamen videretur etiam in iutentute accretionem fieri debere, nam in iuuenc calor naturalis F validiffimus eft; poteft igitur \& multum alimentum in fubftantiam conucrtere, \& facere exrenfionem membrorum, fiquiden certum eft heccfieri ab anima per calorera naturalem: manente autenı eadem caufa, debet idem manere effectus; quoniam igitur manet eadem anima, \& calor naturalis eft vebensens, deberet etiam iuuenis augeri non minus, quam puer: eft igirurcognof cenda caúa, cur in adultis acsretio ceflet. Poffemus ad hanc quaftio- 
nem refpondere, adducédo caufam finalem accretionis : natura enim viuentibus accretionem dedit, vt poffent ad debitam fibi quantitatẽ peruenire, \& naturales exercere operationes; cte. nim viuentia ornnia nafcuntur admodum paruula, nec poffunt in initio fui ortus habere quätitatem fibi conuenientem, propterea quod omniaplantarum, \&canimalium femina necefle eft multo minora effe ipfo aniuali, vel planta generante,ideo tă animal, quam planta in prin. cipio fux generation is habet neccifatio paruam quantitatem, \& multo minorem quantitate totius viuentis perfecta: in animalibus vero, qua vtero gerunt, manifeftum eft fominam nō pofre fortum fibi xqualem geftare viero, fed longe minorem: quoniamigitur cum ea parua quantitate non poffunt viuentia omnes naturales operationes exercere, potiffime vero illam pracipuam, qux elt aliud fibi fimile generare; idco neceffaria fuit viuentibus accretio, per quam ad conuenientem cuiq; quantitatem peruenire poffent, \&idonea red di ad aliud fimile generandü ; hæceft accretionis caufa finalis, ex qua fumi poteftratio cur viuentia, quando cöuenientem fibi quantitatem funt affequuta, non am. plius augeantur; natura enisa nihil fruftra facit, led omna qux agit, propter finem agit: quoniam igitur accretionem viuentibus dedit propteraffequutionem perfectre quantitatis, neceffe eft, vthacacquifita ceffetaccretio, quia non eft a mplius neceffaria, acquifito fine. Sed in hac caufa finali non videtur animus acquiefcere, nifi alia quoque huius affectus caufa reddatur, quoniamnatura aliqué fibi finem proponens dirigit etiam certa aliqua media ad illiusfinis affequutionem; ideo fi puero accretionem dat. \& eam iuueni negat, neceffe eft iuuenimedia quoq; negata effe, perqux poffit augeri; fin minus, augetur etiam iuuenis, quia augendi officium eft anim $x$ vegetantis, qux fine cognitione agit, quocirca femper agit, nifi impediatur: $E$ quamobrem fi natura vult in iuuentute accre. tionem non fieri, neceffe eft, vt huicagenti impotentiam, vel impedimentumaliquod afferat, ne augere amplius pofft: hoc autenn impedime. tum non poteft efferatione ipfius agentis, quia ipfa animævis nunquan debilitatur, vt afferit Arift. in contex. 65. lib.de Anima, dumait [ $\int f e$ nex acciperet oculum susuens, fideret frut ouse. sis ] anima enim nunquam labefactatur, fep id, quod in fenio debilitatur, eft corpus, quovi in. ftrumento anima vtitur: non poteft etiam im. pedimentum oriri ex impotentia fecundarii agentis, qui eft calor naturalis: hic enim in iuuene validifimus eft, nec minus aptus ad avgendum, quam in puero. Reftat ve impedimentum fit in fubiecto recipiente, ita vt quando corpus augeri amplius non poteft, tüc définat accretio, quoniam agens non agit, nifi in fubieçis aptum d recipiendum:ratio autem, cur corpus iuuenis
A non poffit amplius augeri, eft, quia p̆cipua pars, quxaugeri dicitur, \&ad cuius incrementū crefcit totum viučtis corpus fecundum omnes dimenfiones, funtipfa offa: quumigitur omne viuens in principio fure generntionis fit valde humidum, \& molle, \& domabile, ofla qucq; tenera funt, \& ad extenfionem idonea; xtate autem prosedente neceffe eft, vt per actionem caloris naturalis ornnes corporis partes magis femper - cxiccentur, \& indureícant; ex cótinua enim hu- eur ab ofmidirefolutione à cal re omnes partes duriores flbus. \& folidiores redduntur, quod ipfa experientia docet; humidiorem enim \& molliorem effé experimur vituli carnem, quam bouis, \& bouis iuuenis, quam bouis fenis, \& offa quoq; duriora in bouc, quam in vitulo: quoniam itaq; accretio per extenfionem fit, neceffe eft vt tunc ceffet, quando offa ad tantam duritiem peruenerunt, vt extendi amplius nequeant; peruenire aūtad tantam duritiem neceffe eft, propter continuam attionem caloris naturalis, quemadmodum diximus: poffet quidem etiam in iuuene extendi carn, fed nö fit accretio totius corporis, nifi offa extendantur: huius autem fignū habemus manifeftiflimum, quia frpe contingit, vt ceffante accretioneincipiant iuuenes fieri carnofiores, \& impinguari; caler enim naturalis in illa atate valicus ac vehemens eft, \& multum nutrimentum in fubfantiam conuertit;ideo multü car. nis generat, non tamen dicitur a ugeri caro, neq; D ex carnis increméto membrum, vel corpus totura, propterea quod offa non extenduntur: totum igitur nutrimentum abundans in carnem $8:$ in pinguedinem conzertitur, nec poteft illa impugnatio vocari accretio, quia non fecundum omnes diranfiones in ciementum fit, non enim fecundülongitudinem, fecundum quam abfque offum extenfione accretio fieri nullo pacto poteft; puerosautem raro impinguari videmus, quia totum nutrimentum in totius corporis accretione confumitur; fed ceffante accrecione incipiunt impinguari, nifi à nimio coitu, ad quemadolefrentes, aciunenes procliues maxima fint, impinguatio impediatur; abundans enim nutrironture, fo totum per coitum cxcernatur, in pinguedinem conuerti non poteft: hinc fit, vtanimalia caftrata pinguia fiant, Cur ansdevtfeguentusin virili xtate pingues fieri ho- malia mines videámus, quam inadolefcentia, in iu- caftrata. uentute; nam in virili atateliberiorem habent pzngus$F$ vfum rationis, \& incipiunt abfinere à coitu; festr. adolefcentes vero itmmoderato vtplurimum $\mathrm{v}$ runtur coitu, quia concupiffentia potîus dit- Dwa cen cuntur, quam ratione. Ex his igitur colligimus, fa ce/faduas fimul ob caufas ceffare in viuentibusac-tionis an srecionem, ob materize necficatem, \& proper cretsofinem, ficutin 2. Polter. Analytic. in multis cō- nis:matingere Ariftoteles dixit, vt tum propter ma- tersoneteriæ neceffitatem, tum propter finem fiant; ceßstas finis enim \& fcopus naturze cit affequatio de. Efins. $\mathrm{BB} 2$ 
bitz quantitaris, \& husus gratia viuentibus accretionem dedit, ideo acquifico fine ceffat accretio, quia non eft ampli us neceffaria: fed quia maxima eft confonantia in rebus natura, ideo materia quoq; necelfitatem natura adiecit \& \& ft truit materiam tunc ineptam effead accretionem recipiendam, quande viuétia nŏ egent ampliusaccretione ad naturalia munera obeunda, \& ad omnes edendas naturales operationes:

\section{In quanam mutatione fit accretioniseffen- tia confituta, opiniones aliquorum, \& earum confutatio.}

\section{Cap.VII,}

$\mathrm{H}$ A ctenus declaratun à nobis eft, quot fieri mutationes oporteat, vt exalimento extrinfecus accedente viuentia corpora augeantur: fequituryt confideremus in quanam mutatione fit ascretionis effentia conftituta, an in omnibus fimul fumptis rnutationibus pradictis, an in aliqua earum tantummodo. Non defuêre

Aliquorum op: nio. Confutatso.

Int tan tis Gna

tantum

coscortso fit. qui dixerint accretionem effe omnium dictarum mutationum congerié: quam fententiam reprobar Marfilius in primo lib. de Generatione, quaft. 10 . idq; non iniuria, quoniam Ariftoteles cenfuitaccretionem effe fpeciem quaridă motus ab aliis fpeciebus diftinctam; quo fit, vt neque vlla exaliis fpeciebus, neque earum congeries poffit effe accretio, fed eius natura conftituéda fit in aliqua particulari mutatione, qua non fit alia vlla fpecies motus, fed fit folum accretio. Praterea illæ omnes mutationes, guas diximus, non modoaccretionis naturam nen conftitu unt, fed neque illi neceffariz funt: dux namq; illa priores concoetiones non funt neceffarix, nifi in animalibus; nimirum vt pereas prapareturalimentūad po Aremam concoctionen, qux in membris fit, recipiendam; primum enim oportetcibum conuerti in chylum, dein. de chylum in fanguinem, vt tandem fanguis in fubftantiam côuertatur, \& ita viuens augeatur : in plantis vero non fitnifi poftema hac tertia concoctio, qua alimentum vertitur in fubitantiam, \& huic proportione refpondet conuerfio, qu $x$ in animalifit, fanguinis in fub ftantiam; alimentum enim plantarum nulla praparatione indiget, quia planta ipfum à terra extrahütiam proparatum, \& aptum vt in fubftantiam coucrtatur, veluti fi animalia fanguinem extrinfecus traherent iam extra genitum, ita vt non fieret in eis a lia coctio, quam poftrema illa, qua fanguis in fubitantiam mutatur, affimilatio appellata, propterea quod vltimum alımentum, quod diffimile erat, redditur fimile, dum vertitur in fubftantian viucntis corporis: abfq; hac igitur affimilatione accretio nunquam fieri poteft; fieri tamen poteft fine aliis procedentibus mutarionibus, yt in plantis manifeftum eft, quare illa
A omnes ablq: dubio ipfi accretionis narurze extranex funt. Dux mutaticnes remanent, in quibus dici poffi: effe accretionis naturam conftitutam, \& in is tota huiufce rei difficultas pefita eft; vna eft hacmodo dicta afimilatio, qua eft vltimi alimenti in fubitantiam conuerfio; altera vero eft poftrema illa extēfio, qua dixirnus totum viuentis corpus maior $\bar{a}$ acquirere quantiratem, proinde \& maiorem locum : quum igitur in harum vtralibetaccretionis natura conB ftitu poffe videatur; duz contraria fententia ortar funt, \& veraque fectatcres habuit. Marfilius in fua quaftione pradicta priorem partem accipit; afferitenim nil aliud effe accretsonem, quam generationem partis fubstantix maioris parte confumpta; \& in hoc diftinguit accretionem à nutritione, quod nutritio folam fubftantiam refpicit vt reftaurandä, accretio vero quã. titatem; fubiecto tamen idem funt, vt Ariftoteles dixit in primo lib. de Generatione; quoniam C eadem mutatio eft, \& nutritio, \& accretio; nutritio quidem quatenus eft generatio fubitantix ad ipfum viuens reftaurandum, accretio autern quatenus generatur pars fubftantix maior parte confumpta: ideo inquit accretionem formalitergenerationem effe, diftinguit tamen in hoc accretionem à generatione, quod generatio proprie dicitur, quandoaliquid per $f e$ exiftens generatur, accretio vero, quando alteriaggeneratur: quo fit, -vt accretio fit potius aggereratio, quam generatio appellanda, quia eft generatio partis, quatenus eit pars. Quando igitur generatur pars maior parte confumpra, eam inquit Marfilius formaliter accretionem effe \& hanc fententia m probat duobus argumētis. P'rimofic: omnis conuerfionutrimenti in maiores partes partibus comfumptis in viuentecorpore ascretio ef, at illa aggeneratio ex vltimo alimento facta eff conuerfio in partes confumptis partibus ajores, ergo iila generatio eft ipfaE met accretio. Secundo ita argumentatur: illa mutaio, qua exiftente fecluís aliis omnibus accretio exiftit, \& qua non exiftente non exifit, et iplamet accretio; atqui generatio partium maiorum efthuiurmodi, ea namque exiftente augetur viuens, non exiftente autem, non augetur; ergo illa aggeneratio eftaccretio ip fa. Hac fententia magnis diffrcultatibus vrgetur. Primum enim cenluit Ariftoteles in accretıone non folum partes, fed etiam totum acquirere F maiorem quantitatem, vt videre eft in contex. 38. primi libri de Ortu \& interitu, imo vero accretiopracipue totum refpicit, non partes : at in illa aggeneratione maioris partis membrum non fit maius, nifi extendatur, proinde nectotum viuens fit maius: nam poris fanguine repletis, \& fanguine in carnem, \& alias partes homogeneas conuerfo, fingulis quidem partibus carnis, \& offts eft facta additio, fed niff fiat totius merobri extenfia nondum crefcit membrum; 
neque totum viuens : ergo illa aggeneratio non eft formaliteraccretio, quoniam ea pofita, \& aliis omnibus feclufis, non fit accretio. Confirmatur: quia in vera accretione totum mutatlocum, vt dixir Ariftoteles in contextu vigefimoquinto libri primide Generatione: at per folam aggenerationem maioris partis totum non $\mathrm{mu}$ tat locum, nili fiat extenfiu; ergo illa aggeneratio non eft formaliteraccretic. Paret etiam cuilibet diligenter confideranti, nullarn effe dif. ferentiaminter accretionem \& nutricionem, nifi membri extenfio affinilationem confequatur, quia etiam in nucrutione fit additio fubstantix gulantx fine extenfione membri; \& ad accretionem totius nihil refert fubftantiam illam adicetam maioien effe parte confumpta, nifi fequatur extenfio; fine hac enim totum corjus non fit maius, vt videmus manifeftifime in iuuenibus $\&$ in viris, qui carnofiores funt; generaturenim in eis plus carnıs, quam fuerti confumptum, nec tamen augeri drcuntur, quia nulla fitextentio membrorum. Prazerea Ariftoteles in s. lib. Phyficxaufcultationis per hocmo. tum à generatıone diftinguit, quod mo:us in tempore fregeneratio autem fubito, \& fub motuaccretionem ponit tanquam veram fpeciem propricfumpti motus, \& à generatione diftinaki; quare cen fet accretionem in tempore fier i, \& efle verum motum. At fecundum opinionem Murfilijaccreno tieret fubito, quum ipfe dicat accretionem effe formaliter generatione $\tilde{e}$; quare Marfilius Arifoceli aduerfarur in multis:primo dum inquit, ascretionem effe formaliter generationem, quum Ariftoteles dicat manifefte eas diftingui re, deinde dum ait accretionem fubito fieri, qua in Arsitoteles in temperefieri afferit; tum demum quod ponit fubiectum accretionis ens poteltate, quod forman vltimı alimentiamittens fuinit formam rei nutrienda, ve carnis, \& offis, A riftoteles autem putauitomnes morus haberc fubiectum ensactu, ad differentiamge: nerationis, cuius fublectum eft ens poteftate: patet igitur fententiam Marfilij defendi nö poffe, \& au Ariftotele alienaco eile.

\section{Aliorum opiniones, \& earum confuta- tio. Cap. VIII.}

HEc, qua aduerfus Marfilium adduximus, Haliqui confiderantes, in aliam fententiam inciderunt, quodaccretio non fit formaliter $111 \mathrm{a}$ aggeneratio, qua a fimilatio dicitur; fed fit illa exienfio, quz affimilationem confequitur:hane opinionem tuetur loan. Gandauenf. in quattios. ne fua decima libr. 4 . Phy fic. \& in quaftione feptima libr. 8. \& hac videtur multo probabilior priorellla opinione, quia fecundum hanc accretio eft verus motus, cum fucceffione, \& in temporefactus;extenfio enim fit in tempore, \& eft tranfitus ad folam maiorem quantitatem, nulla
A facta mutatione in fubftantia, ideo in ea manifefte appares accretionis, \& aliarum mutationum difcrimen. Proterea fecundum banc fententiam feruaturin accretioneid, quod Aritoteles dixit in context. 25. primilibride Genera. tione:id enim quod per extenfionem augetur, mutatlocum, \& ita mutat, vetoto manente in eodem loco partes de loco ad lucum moucan. tur, hrec enim in extenfione apertiffime confpiciuntur : at in conuerfione vltımi alimenti in B fubttantiam nequaquam; pattes enim locum non mutant, nec totum manens in eodem loco matorem adipifcitur.Vifus eft etiam A riftoteles in memorato context. 2s. hanc fententiam proferre; dixit enimilla, qua augentur, mutare locum eo modo, quo illa, qua extenduntur; puta. uit igitur, ea quz augentur, extendi, quare videturnaturam accretionis in illa extenfione confituiffe. Verum bac quoque opinio difficultatibus non caret, vt patet legentibus priorem librum Petri Pomponatij de accretione, \& nutritione, vbi tum pradiêtam Marfilij fententiam conlutat, tum hanc Ioannis Gandanenfis : ad uerfus quam in capite eius libri nono multifariam argumentatur. Primo fic: extenfio eft mo tus ad raritatem, eft enim rarefactio quzda $;$ raritas autem eft qualitas, non quantitas, vt ait $\mathrm{A}$ uerroes in commentario 84 . libri quarti Phyficorum, \& in 1s. libri feptimi : accretio autem eft motus a d quantitatem,non ad qualitatem; ergo non eit formaliter extenfio. Praterea fi natura accretionis in extenfione confifteret, reprehendendus effet Ariftoreles, quiin primo libro de Ortu \& interitudeclarare volensaccurate quid fit accretio; \& quomodo fiat, nunquam extenfionem nominauit, fed folum confiderauit aecretionem effe mutationem ad maiorem fubftantiam : quare videtur ad priorem poius opinionem fuife inclinatus. Praterea extenfio fit 2.argo etiam nulla adueniére materia, accretio autem ment.

E fit necefiario ex materia extrinfecus accedente, vt Ariftotelés docuit, dicens hanc materiam effein principio contıariam, in fine autem fieri fi milem;ergoaccretio non elt extenfio: quod au tem fieri poffit extenfio absque vlla accedente materia, patet in pongia. Argumentatur etiam ex eo, quod Ariftoteles dixit in contextu 41. primilibri de Generatione, a ccretionem, \& nutritionem effe idem fubiecto; fi accretio effet extenfio, non eflet idem fubiecto cum nuF tritione, propterea quodextenlio eft tempore pofterior nutritione, quare non poteft effe idem fubiecto cum illa. Tandem confiderat id, quod Ariftoteles dictin contextu 25. eiusdem libri: arge declarans enim quomodo illa, qua zugentur, locum mutent, vtitur fimilitudine, \& inquit, ficuti quz extenduntur : igitur lignificat accretiooem non effe formaliter ipiammet extenfionem, quia non debetaliquid declarari perfeipfum, neque comparari cum feipro: extenfi B B 3 - igitur
Pöporat. coners Gandawenfem. 1. argí.

\section{.}


igiturnonconftituit ipfamascretconis naturam A a rad arifotelem, fé́ cit quaddam ab ea diuserFamprafum, \&extrancurn. Iple igitur Fomponatius \{y opessso volens vitareablurda, qua vtramque dietä upisionem confequuntur, inquit accretionem neque effe generationem maloris partis, neque erfe extenfionem, fed elfe adeptionem maioris quantitatis, qux lierinon potefr abfq; aduentu confun quantitatis externa, \& quam requitur neceffa-
rio maioris locinscupatio. Sed hac dicens mihi videturad propofiram quxeftionem nihil dicefe: oronia enim qua dicit, vera funt \& omnibus manifefta, quia omnes concedunt accretionem effeacquifitioncm maioris quantitatis, \& fieriex materia quanta adueniente, \& cum loci mutatione : hoc igitur non eft id, quod in prafentia quxritur, fed quaftio noftra eif, in quonam confiftat hac maioris quanticatis acquifiuio; quum enimad accretionem faciendam plures. consurrere mutationes videamus, quarimus in quanam ex illis ipfa accretionis natura confi. 1tat, itavt illa dicatur effe mutatioad maiorem quantitaten: quum autem omnes mutationes, qux in accretione locum habent, iam fingillatim confiderauerimus, videtur vitari non poffe, quin dicamus accretionem vel in affimilatione confiftere, vel in extenfione, vel in ambabus fimul, \& hoc debuitipfe Pomponatius confidesare.

\section{Verafententia, o eius declaratio. Cap. $I X$.}

F $\mathrm{Go}$ in hac difficultate dicendum puto, acA retionem non in fola extenfione confifexc, neque in fola vltimi alimenticonuerfione in maiores fubftantiz partes, fed effentialiter continere vtramque, eft enim accretio mutatio ad maiorem quantitatem per motum extenfionis exalimento in fubftantiam conuerfo tanquam ex materia : vtramque conditionem pofuit manifefte Ariftoteles in primo de Ortu \& interitu, dixit enim accretionem fieri ex materia extrinfecus accedente; quare non in fola exrenfione naturam accretionis confiftere exiftmauit, fiquidem in hacnulla noux materixacceffio includitur, fed etiam in conuerfione alimenti in fubftantiam, ita vt hxc quoque in ipfa accretione comprehëdatur. Extenfionem quoque faris clare expreffit in context 25 . cius libri, quando dixit, illa, qux a ugentur, locum mutare, ficut illa, qux exrenduntur : cenfuit igıtur in accretıone fierițalem extenfionem, quaiem in fpongia, \& aliis ciufmedı fierividemus, vel faltein nivtum aliquem fimilem, quem proprer fi militudinem non porfumus nifi extenjionem appellare : \& quum marors lociadeptiofit coniuncta cum adeptione masois quanticatis, \& cam inieq:"arur, necelie cf, vi quersadmodum permotum extenfion/s masol licus acquiritur, vtast ibi Ariftot. ita percusdew maior quanti- tasacquira ur : itaquefi accetion is naturaconfiltu in adepcione nasoris quanticatis, manifefum eft cam fecundum Ariftotelem confiftere in extenifone. Hecfuit Auerrois fententia in comment. 38. eiufdem libri, voi áperte afferit accretionem fieri per extenfionem membrorura, cinilla extenfione foramina generari, quem. admodum antea confideraumus. Sic etiam fa. cile declaramusid, quod Ariftoteles dixit, accretionem efleidem fubiecto cum nutritione, $B$ hoceft, continere in fe nurrtionem, fedabea differreratione; nam fi folam extenfionem accretionem effe dicamus, id tueri nullo modo poffumus; at fi precedentem mutatis $n \mathrm{em}$ in fabstantiam eiadiungamus, dictum Ariftotelis clarune redditurinam in illa mutatione nutritio. \& accretio funtidem fubicto: quatenus enim mutarur fanguis in carnem, eatenus eft nutritio, qua folam fubftantiam refpicit, quum fit fubftant1a reparatio; quatenus vero mutatur in C carnem maiorem, eatenus eftaccretio, quannn fubftantiam refpicit, fed quantitatem, licet fubftantix mutationem neceflario' contineat, ve Ariftoteles fignificauit in contex. 41 . eiufdem libri,quando dixit, alimentum nutrire quatenus eft poteftate caro, a ugere autem quatenus eft poteftate caro quanta: polfumus enim ita argumentari ; ficuti fe babet caro quanta ad carnem; 1ta accretio ad nutritionem: at in carne quanta comprebenditur caro, igitur \& in accretione $D$ nutritio; ea tamer mutatio eft alia rationenutritio, alia vero accretio, \& fit vtraque eodem tempore, imo eodem remporis momento, fed differunt ratione, ficuti dicturn eft: fi veroextenfionem, quaillam mutationem infequitur, confideremus, maior oritur earum differentia; nam in nutritione, quatenus eft nutritio, nulla extenfio fit, in accretione autem neceffarium eft, vt membra extendantur; ideo ratione extenfionis accretio non eft fimul témpore cum

E nutritione, fed ef pofterior, idque omnino neceffarium eft: quia fi nutritio eft fubftantialis mutatio, nō in tempore fit, fed in temporis momento; accretio autem quum fit motus, ex neceffitate fucceffionem habet, \& in tempore fit id autem, quod in tempore fit, nonpoteft finul effe cum eo, quod fit lubito; eft autem ira neceffaria extenfio ad conftituendam accretionis naturam, vt, fi tiat fula in fubitantiam conuerfio, imo \& in fubitantiam naiorem, nec vlla fequaF turextenfio,non fitaccretio, fed nutritio fol um. vt patet in adultis.quandro carnofiores fiunt: il. lud ergo, quod dicitur, accretionem fimul effe cum nurritione, \& hac ratione effe idem fubieto, non eft verum de tota a cretione, fed de foloeiusinitio, quodex necellirate eft mutau $10 \mathrm{vl-}$ tims alımen: $i$ in masoremi fubltanriam; hisncautem poftea in lequitur cxtenfio, quxeft rempo. repofterior Jumllone; in $1 \%$ aus an intio continct ascrecio nutri ioncm, licet ab ca ditte- 
rat ratione, quia non ca rationédicitur accretio, quatenusnutritionem continet, fed quate. nus refpicit quantitatem, qux per fequenten maioris fub tantize extenfionem acquiritur. Si. quis autem obiiciat, ergoaccretio, non eft vnus motus, neganda eft confequentia, quia conucrfio in fubstantia eft fubftantialis mutatio, nempe geneiatio carnis, offis, \& fimilium; quare non eft motus, fed mutatio fubita, quzeft principium fequétis extenfionis, qua eft verus motus in tempcre factus ficuti punctum eft principium linea : quemadmodum igitur vna dicitur linea, licet duobus punctis terminata, atq; conclufa, \& ca puncta in ipfa linez definitione accipiuntur; ita vna accretio, \& vnus motus dicitur, licet terminü à quo, habeat fubitam mutarionem in fubfantiam, terminum autem ad quem, ipfam maiorem quantitatem in fine extéfronis acquifitam, qui vterq; terminus in ipfa accretionis effentia comprehenditur, ficuti duo puncta terminantia in definitione recta line $x$ : fropterea vera funt in accretione $h x c$ a $x$ bo diEta, accretio eft acquifitio fub ftantiz cum quantitate maiore, \& accretio eft acquifitio maioris quantitatis tantum : dum enim totam accretionem confideramus, ea vtrum q; terminum con. tinet, proinde ét nutritionem tanquam terminu à quo, non vt extraneū : proinde eft ad eptio fubAtantiz cum quantitate maiore, at fi motü à fine nominare velımus, \& à termino, ad que $\overrightarrow{\text {, accre- }}$ tio eft acquifitio quantitatis tantum. Seruantus autem hoc modo optime naturä motus, \& fucceffionem, imo \& continuitatem in ipfa accretione:nam fi accretio effet fola cōuerfio alimenti in fubftătiam, nulla ratione effet motus, neq; vllam fucceffionem haberet, quoniam illa conuerfio is mométo temporis fit; tranfitus aūt ad maiorem quantitatem, qui per extenfionem fit, eft verus motus, \& cōtinuus. Non eft aūt igno6): randum,motum accretionis in viuentibus poffe duobusmodis confiderari; poteft énim accipi pro toto cuiufq; viuentis incremento ab initio - fui ortus ad initiü vfq; xtatis confiftentix, quod quidem conftat exmultişnurntionibus, \& pluribus extenfionibus diftinctis; fecundo modo poteft accipi pro vna tantum particulari nutriti one cum vna extenfionc eam in fequente: primo modo accretio non eft vnus continuus motus, quoniam adeptio totius debitz quantitatis, qux fit in honineper totum tem pus vigintiannorū, non eft ita continuata, vt in qualibet par. ticula illius temporis fiat extenfio, \& acquifitio particula quantitatis illius; fed de toto co tempore fiunt plures interrupt $x$ \& diftinct $x$ extenfiones, inter quaspofitum eft tempus medium, quo nulla fit extenfio; poftquam enim facta eft in puero aliqua extenfio, definit puer extendi pertempusaliquod, nam iterum implentar fanguine foramina, deinde iterum fanguis ille mutatur in carnem, poltea vero fit alia membro-
A rum cxrenfio: st fecundo mado accepta accretrone pro vna raneum particulari extencíione, ea eft verus motus, vnins, e comsinuus: \& hac A- eser. uerrois fententia eft in commentario 6. libri 3. roes: Phyficorum, \& in 23. lib. 8. vbidicit motum accretionis non efle vnum continuum motii, fed efie compofitum expluribus motibus, \& pluribus quictibus:non eft enim admittenda aliq quo- Pressa rum interpretatio, qui videntes Auerroem ne- legisoriz. gare motumaccietuon effe vnum continum, incerpre.

B dicuntipfum accipere continuum pro perpetuo, tasio. \& lignificareaccretionem non eff: perpetuam, fed aliquando definere, nempe in initio atatis confiftentis: ctenim fenfus hic eft ab Auerroe alienus, qui feipfum declarans inquit non effe continuum, quia conftat ex pluribus notibus, \& pluribus quietibus ; igicur ron qua non fit perpetuus, fed quia eftinterruptus, negattotam vnius viuentis accretionem ad $x$ tatem vfq; confiftentem, efre vnum cótinuum motum: qua m:

C uis enim modo quodam dici polTit vnus ratione vnius fubietti, quod augeri dicitur, \& ratione fcopi natura, qua vnum fibi finem proponit, acquifitionem tanta quantitatis;reucra tamen non eft vnus continuus, quia natura non poteft vno conatu, vno tantum motu eam totam quantitatem affequ, ideo faltem acquirit partem poft. partens: quare totius quantitatis acquifitio non eft vnus continuus notus, led finguta pars per verum motum acquiritur, qui eit D vnus continuus; fcilicet vna particularis extenfio: hocmodo faluamus continuitatem, \& naturam motus in accretione, qua aliter faluari non poreft; in motu autem locali eft vera continuitas etiam fecundum totum, nam fi in fublimiloco ponatur lapis, ad cér rum viq; defcendet vno cótinuo motu abfq; vlla interruptione.

\section{Dedupliciquantitatis incremento, of $d u-$ plici raritate. Cap. $X$.}

Cexterum vt res magis intelligatur, \& 0 Cimnes difficultares tollantur, notanda funt quxdam : primum de quantitate, in qua videtur accretionisnatura confiftere; hanc enim Ariftótel. abaliis motibus per hoc diftinxst, quod eft motus ad quantitatem. Quantitas, vt alibi In libr.z. fufe dernonftrauimus, materia naturam infe-deprems quitur, \& eftilli cozua, \& ab ea infeparabilis; mateterminiautem omnes quantitatis præćcribun-ris.

F tur à forma; ideo ficuti quantitas materiam in. fequitur, itatermini quantitatis corporum naturalium infequuntur formam, \& à forma ipfi compofi otribuuntur; hinc fit vt neq; materia In reme poffit effe vnquam fine quantitate, neq; quan- sū gusstitas fine materia, ideoquenon poffit alicui rei titatis addi noua quantitas fire additione nolix ma-frerzoteria. Incrementum autem quantitas fer1 po- te, $a^{2}$ dus teft duobus modis, vt ex Autré colligimus in busmscomment. 84. libr. 4 . Phyficorum, vbide hac re dis.

$$
\mathrm{BB} 4 \text { dot: }
$$


doctiflime loquitur; vno modo fit maior quan. titas peradditioners nouz quantitatis, proinde \& noux materix, ficutiquum aqux pertionem alteru portioni adiungimus, fic enim maior aqua quantitas redditur: altero modo per folam atationem factam in forma, \& abfyuevllius materix additione ferimaior quantitas dicitur,vt quando aqua calefacta mutatur in aeré, maior enim fit aerıs quantitas, quã fuerit quantitas aqua; non eft tamen adiceta aliqua noua materia, neq; aliqua noua quantitas, quun enincadem feruecur matcriz portio, quastitas quoq; eadem feruatur; fed mutantur termini, nam propter formam aerisilla quätitasad ampliores terminos extéfa eft, diciturq̨i ea ratione facta maior, quatenus cadē quantitas per rarefactionem fubiecti exienfa eft ad maiorem locum occupandum, ita ve terminorum potius, quam ipfius quaititatis fit facta mutatio propter mulationem forme, quam termini infequuntur. .Duobusigitur modis fit tranfitus de minore quantitate in maiosem: aut enim manente eadem materia fit mutatio in terminis. quantitatis propter mutationem form $z$, ficuti quando aqua mutatur in aerem; aut fine mutatione formz res fit maior per acceffionem nouæ materiz, vt quū a qua aqua apponitur, dum enim nulla fitmutatio for m $x$, fierinullo modo potefivt magnit udoaugeat ur, nifi pernoure externx materix acceffionem : hic modus locum habet in accretione, de qua in prafentia loquimur; forma $\in$ nim rei augenda debet eadem feruari, vt moxoftendemus, fic enimidern nume. ro remanere diciturid, quod augetur; Ideo per acceftionem. externa materix nouam quantitatem afferentis fic viuentis corporis incremen-

Nota al- tum Colligere exhispoffunus quoddam alteterat o rationis \& accretionis difcrimen, \& difcriminis $n s, \xi^{\circ}$ rationem:alterationam q; non eget aliqua maaccretıc teria, ex qua fiat, fed folum habet fubiectum, in nis diffori quo fit, \& quod alterari dicitur; accretio autem men. non modo habet fubieftum, in quo fit, \& quod dicituraugeri, fed eget etiam materia externa, éx qua fiat: huius aurem ratio eft; quoniam alteratio eft motus ad qualitatem, quxinfequitur. naturam form $x$, non naturam materix; accretio vero eft motus ad quantitatem, qua materia, non forma, naturam infequitur; ideo fi noua qualitas inducenda fit, nonopus eft aliquam externam materiam accedere, fedilla ipfa materia fubiecta eft aptaad omnem qualitatem re. cipiendam, quia omnis forma, \& omnis qualia tas de poteftate materia educi poteft: fed quando abfquemutatione form $x$, \& eadem manente forma debet quantitas maior reddi, id fieri. nullo modo poteft, nifí per additionem noux: matcriz; quantitas enin ingenerabilis, \& incorruptibilis eft, \& lemper, ac neceffario in materia ineft; ideo fi manere debeat cadera fub. fantia, \& foruari eadem forma, non potefl fieri.
A maior quantitas, nifiperacceffionem noux ma terix, cum qua etiam noua quantitas aduenat. Secundo locoaliud quiddam notandum eft nó parui momenti : quoniam enim dictumeft accretionem fieri perextenfionera, qua eftrarefa. Etro quadam, fcrendum eft duplicem effe saritatem, \& duplicem denfitatem: quam diftinctionem ignorans $\mathrm{Z}$ inara in slla contradictione, qua ra notauit in Auerroe in comment. 84 . 1 b.4. Payficun errorem manifestifimum lapfus

B eft. Auerroes enim varis in locis de raritate lo. quens varia, \& interre pugnantia pronunciare vifuseft : nam in illo comment. 84 . inquit, rarum $\&$ denfurmeffe contraria in quanutate; tamen incomment. feq. 85 . aitraritatem \& denfitatem non efle de effentia quantitatis. In 7 . autem Phyfic. coinment.15. inq̨irt, rartatem \& denfitatem effe qualitates. Sedin r.Metaphyf. comment. 15. easdem locauit in Caregorialitus, qua videtur eciam Ariftotelis fententra fuife, in lib.

C. Categuriarum, cap.de Qualitate. At in comment.77.libri 8.Phyf.dixitıarefationem \&. denfationemeffe motus locales. Magna igitur eft horum locorum difcrepantia, quum Auerroes motũadraritatem modo dicat effead quantitatem, modoad qualitatem, modoad fitum, modo ad vbi. Soluens Zir ara dicit raritatem, \& défitatem effereuerain fola Categoria qualiatis: quandoautem Arift. \& Auerrocs eas 1- care videnturin Categoria fitus, inquit cos I qui iuxta aliortim opinonem, non fecundum mentem propriam: quod vero rarefactio dicatur motus ad quantitatem, vel ad vbi,inquit efe verum per quandam confequutionem; at non formaliter; rarıtate enim infequitur maior quantitas, proinde \& maioristoci occupatio : rarefactio igitur eft primario, \& effentialiteralteratio, \& motus ad qualitatem, per confequutionera vero \& fecundario eft etiam ad quantitatem maiorem, \& ad ampliorem locum;quare nulla eft repugnantia in Auerrois diEtis, quum omnia vera fint fecundum varias confiderationes. Ego autem nihil verià Zimara dictum effe arbitror, nifi illud vnum, quod de quantitate dixit:omnis enim rarefactio eft tranficus ad maiorem quantitatem, feu potiusad maiores terminos quantitatis, non tamen primario, fed fecundario, \& per quan. dam comitantiain, feu confequutionem; perfe autem, \& primo non eft ad quantitatem, fed ad aliquodaliud, quod inaior quantitas confequi-

F: tur. In reliquis autem puto deceptum effe $Z$ imaram, quia non animaduertit duplicem effe raritatem, 2 duplicem denfitatem; quarum vna eft proprie in Categoria qualitatis, quia confiftitin tenuitate fubftanti $x$; non in diftantia partium inter fe, \& eft de numero fecundarum qualitatum confequens calorem \& frigus, ve ait A. riftoteles in libro fecundo de Partib. anim. cap. s. \& Auerroesin 7. Phy fic. comment. 15. \& in 2. de. Gencrat. is \& ibiqem Iuann. Grammaticus 
in contex. 17. talis autem raritas, \& talis denfitas, funt illa, quibus dillideneclementa incer fe, acrem enim dicimus rarum, f: a quanidenlam, non quod partes acris diflcnt inuicern, \& habeant interpofitas vacuitates, reucra eluim nihil eft väcuiinaere, neq aliud inter cius partes eft interpofitu corpus: fid quad aertenuem habet fubitantiam, aqua vero craffam: patet autem prouenire ianc fubftantix denfiratem à fri. gorc, te rariatem à calore, \& han non cfle a frim, quam sllam, quz confiftit in enuitate fub-

- Ptantic; ideo Atrerroes in commenc.22. lib. 1. de Coclo de hacraritate loquens inquit moth mad - raritatem effealterationem, non quod murus pollit elle primario ad raritatem, fed quia primatio cht ad caiorem, quens confequicur raritas, actenuilas fibltanir; hanc autem confequitu etiam magnitudnis increnentum: quod confiderans A uetroes in illo comment. 34 . lib. 4. Pligic dixit raritatem \& denfitatem elacontraria in quantitate, guatenus raritatem confe quitur maior quantitas, denfitatem autem minor; hocen:m dicens refpexit id, quod fecundarium eft, non id, quod primarium, vt refe dixit Zimara : ideo in le querite comment. 85 . hoc declarans Aucroesaí denfratem \& raritatem nö effe effrntialiter in Categoria quantitatis. Aliera cframtas, quam non videtur animaduertife Zimara, qua non conffitit in tenuitate fubflantix, fed in difantia paltium inter fe; quemadmodum fongam rasm efle dicimus, qua partes habetinuicem diltanies perfpatium vacuras inteipofitum, non quiden vere vacuum, quod omnicolpr re careat, fed quodalio tenui, \& infentili corpore plenum eft; in fongra enim vacuas vocamus partes illas, in quibus aer eft inclufus: hxc raritas eft abfque dubio in Categoria fitus; nam diftantia, velpropinquitas par. trum interfe, nil : liudeft, yuam firus; de hac igitur loquutus eit Auerces in comment.15. lib. x. Metaphy f. \& Ariftot. in libr. Cutegor. in cap. de Qualitate: quam enim hacacceptio omnibus hominibus magis in promptu,atque euidentior fir, hanc folam Ariftoteles ibi reipexit, quia in co libro ftatuit ea tantum in medium adducere, quix notiora, \& commun hominum opinioni magis confentanea eflent; ideo negauit raritatem effe qualitatem, quod aleràmillam acceptionem vulgaribus incognitam effe animaduertit: ob id Auerroes quoq; ibiafieritraritatem efle in Categora fitus \& ibi Leui in fuis Annor. in Auerrocm expreffe notat duo effegenera $\mathrm{ra}$ ri, \& denfij ynum, quod eft in Categoria qualitatis; alterum, quod eft in Categoria fieus: \& hocidem fumirur ex Ioan. Grammatico in contex. 8. lib. 2. de Or:u \& interitu. In hosigitur deceptus eft $Z$ imara, quod dixit Ariftotelem \& A. uerroesat, quando raritatem in genere fitus collocarunt, iuxta alorum feitentiam effe loquurós; quum potius ex mente gropria.\& fecun-
A dum veritatem hoc dixerint, dum alteram hanc veriratem répexerür. In eo etiam, quod de motu l.)calidixit, lapfus eft Zimara: quando enim fporgia manu cóttricta poftea dimittitur, \& relaxaiur, rarefieri dicitur, nō itatamen, ve motus ille ficriprimo dicaturad raritate ; fiquidern ad fituns nof eft motus, neq; ad vllam aliam Categoriam irater quantitatem, qualitatem, \& vbi, fecundario tamen ad alias quoque fieri poteft motus, \& per mediam aliquam ex tribus pra$B$ dictis:igitur neceffe ve motus ille fpongia fit primo ail locum, mouentur enim partes ad diuerín vbi, qua poftea cófequitur varius illarum parium fitus interfe: non eft igitur verum id, quod Zimaia dixic, rarefastionem effe motum localem fecundario, \& per cófequutiones; eft quidein veruan depriore illa rarefactione, qua primario ent motus ad qualitate , fed deha" poiteriole falfun eft : quim enimnegarinon poffit, cam effemrtim quendam, ad nullam fpeC ciem motus reduci poteft, nifi ad localem;ef igitur motusille primario ad locum, fecundario vero ad fil um. Thlem effe certum eft illam raritatem, ad quam tendere videturid, quod augetur : tum enim extenditur, foramina exoriūtur, qua funt veluti partes, in quibus non ef caro, vel os, fed aer, yel vapor aliquisfimilis;patetenim perillam extëfionem non acquiri priorem raritatem, qux eff lubftantia tenuitas, \& qualitas, fiquidern fubltantia viue eris non fit tenuior, D quass prius erat; fed acquiritur raritas perillum motumaltero modo accepta, qualis eftraritas fporgia, ita tamen vt motusille dicatur fecundarioad fum primario autem ad quantitatem; namprimariusterminus \& fropus, que fibi natura proponit in illo motu, eft affequutio maioris quantitatis, hancautem confequirur mutatio ficus partium: ham mutato fanguine in carnem, in foraminbus caro denfa eft, quiaforaminbus caret, poftea vero extéditur, \& fit rara, dum icerum in ea oriuntur foramina, licet hac rarias non fit fcopus natur $e_{\text {, quemadmodum }}$ diximus: ino, fi beneconfideremus, dicerenon pofiums in accretione viuent is maiorem acquiri raritatem, fed eadem eft denfitas, \& raritas in principio, \& in fine accretionis; in principio enim caro dum habet foramina, poteftici rara, poftea verorepletis foraminibus fanguine, eo in carnem connerfo disi pote feriodo quodam denfior facta, dum foraminious caret; deF inde vero extenditur, \& rurfus foramina oriuntur, \& caroad prifinam raritatem reuerticur; quare nullatuns acquiritur maior raritas, fed fola quantitas per acceflonem :oja materiz. maior eft facta: reuera enim nulla ef qualitas, ¿ nullus alius terminas, quem per illar extentionem dicere pofiumis elle asquifitum, nifi iola maior quantitas, \& hac fola eft natura fopes: in' eo moru; cam poltca fecundario couleyultur maioris loci arquifitio, fedhacrō tute leate-
Adqua rarisate accretso tendas.

BB, s $\checkmark$ pls 
Lbe ex pus natura. Ex his colligimus difcrimen quod- A remfro $\mathrm{cm}$ dam inviuentis, \& in fpongix extenfone: nam eccresio extentio viuentisprimario ad quantitatein tenafit, dit, non ad vbi; at extenfio fpongiz eft motus Ls in frimarioad vbi, nonad quantitatem : nam ma. fpongra. jor quantitas duobus modis acqúritur, vno Masor nodo per additionem materix, altero modo gešstias perampliationem terminorum; in fpóngia exacgasri- tenfa acquiritur maior quantitas fecundo mocur dwo- do, fed non primo; in conuerfioneauiem fanare- guinis in carnem fit maior quätitas primo modi. do, at non fecundo, nifi fequatur extenfio: quod fi vtraq; fimulaccipiatur, tum conuerfio in fubfantiam, tum extenfio confequens, fit maior quantitas vtroque modo fimul, \& haceft accretionis natura: quare cius extenfio non eft omninofimilis extenfioni fpongia, licet per vtramq; eadem raritas acquiratur.

\section{Aduerfantium argumentorum folutio. Cap. XI.}

$\mathrm{V}$ ERIT A TE ita declarata, fequitur vt omnia prius adducta argumenta expenda. Adpri- mus, \& quantum roborishabeant, confidiremüMar - mus.Primo loco foluenda funtargumenta Marflï. - fili,quibus probare nitebatur, accretionem effe formalitergenerationem, id ef, conuerfionem in maiores partes. Primum erat:omnis mutatio alimenti in partes confumptis maiores eft accretio, at vltima illa ex alimento generatio eft huiusmodi, ergo illa eft accretio. Huius argumenti neganda eft maior; quia petitillud idem, quod probandum erat, \& idem eft fenfus maio-

$\Delta d$ ecun ris, acconclufionis. Alterum argumentum erat: dum. illud, quo exiftente eft accretio, \& quo non exiftentenon eft, accretio ipfa cft; at conuerfio illa vitimialımenti in partesmaiores eft huiusmodi; ergo eft accretio. Ad hoc dicimusnegandam effe minorem : nam ablata quide $m$ talı conuerfione auferturaccretio, quóniamabsq; lla fieri non poteft : non tamenilla conuerfiore pofita ponitur accretio, nifi etiam fequens exienfio po-

$A d$ argu natur, ficutantea demenftrauirous. Argumenta menta vero, qua aduerfus Mafiliura adducta funt, vacorera lida omnia funt, non quidem vt excludaturhxc Marfisiz in maiorem fubftantiam mutatio, fed vt ofenaddu- daturnon in ea fola confiftere accretionis natuca. ram,fed etiam in extéfione fequente, vt eacon. dd/ fiderantibusmanifeftum eft. Argumenta vero gumert. Ioan. Gandauenfis ad probandurn accretionem Garda- in extenfione cōfiftere,valida quidem funt, non senfes. tamen ad excludedam pricrem illam mutacionëin maiores partes; quia fine hac feruari qui. dem foffunt aliqua accretion is conditiones ab Arifotelepofita, non tamenomnes, quia non illa, qua dicitur accretionem fieri ex materia cxtrinfecus adueniente; fiquidem extenfic, dum fola confideratur, nuilam materiz acceffionem complectitur, quum fine hacextendi res poffit.
A Argumenta vero Pomfonati $3 d$ ofendendum $A d$ now in extenfionc accretionem ionliftere, facile $n$ w foluuntur. Primum erat : extentio eft motus ad poss raritatem, rariras eft qualitas, ergoeft motus ad qualitatem. Huius argumenti notare poffumus \& maiorem; \& minoiem : nam raritas, quæ per extcnfionem asquiritur, non eft qualitas, fed pofitio, vtantea dictum eft, ideo maior eit falfajeft etiam falfa minor, quia extenfio non eft primarioad hanc raritatem, fed ad maiores terB minosquantitatis, adillam autem raritatem fecundario, quareper hec non fat, quin extenfio fit motus in Categoria quantitatis. Præterea vt ci condonemus 1aritatem effe qualitatena. non ob id fit, vt extenfio fitalteratio; fiquidem non ad omnem qualitatem tranfitus eft alteratio, fed ad fol s primas quatuor qualitates, qua funt in tercia fpecie illius Categoriz;ideo neque motus ad raritatem illam, qua eft qual- tio. tas, hoc eft, partium tenuitas, eff ea ratione alC teratio, quod fit ad raritatem, fed quia eft primario ad câalorem, quem confiquitur raritas. Sccundum Pomponatii argumentum erat; if accrevio effet extenfio, reprehendendus Ariftoteles effet, qui de accretione agens, nunquam nominauit extenfionem. Ad hocdicimus Ari- $\mu d$ J itotelcm in ca tractationeveriatum effe folum dum in explicandis obfcurioribus accretionis conditionibus, has en $m$ declarareoperapretium e. rat; extenfionem vero declarare non oportuit; quia fatis manifefta eft, \& comprehenditur in tenfu formali husus vocis, accrecio; quia non pofumus aliomodo imaginarirotum fierima. ius, qumferextenfionern membiosum, id enim perpulfione m fici nulle modo poffe iam demonftratimus; guare nullus relinquitur modus, quo res crefca:, nifi hic unu per extenfionem. Ariftoteles tra ue hec tanquam notum - conftituens in reliquis declarandis veifatus eft, imoneque penitus orifit exten fionis nominaE tionem; nam incontex 25 . libriprinide Ortu \& interitu dixit, illa, qua augentur, mutare locum, ficut illa, qua extesiduntur;ita enim fignificauit accretionem fieri per extenfionea quzrendurn autem ex aduerfaris eft, vbinam Ariftoteles in eotractatudeclaret modum, quo totum id, quod augetur, tranfeatad maiorem locum; nam abfque subio nullibi hoc declaraust, fed defola affimilationeloquu tus eft: attamen certum eft, non per hanc folam fieri F tranfitum ad maiorem locum : onnino igitur reprehendendus eft Ariftoteles, qui neguede pulfione, neque de extenfione, neque de aliquo alio modo, quo maiorlocus acquiratur, loquutus eft, aliquem tamen effe modum opurtet prater conuer fionem a limenti diffimilis in fis mile: \&quamuis Arftoteles dixerit alimentum augere quatenus eff potentia caro quanta, mo. dum tamen non exprefit, quo totius viuentis quätitas maior reddatur:nos igitur dicimus rao. 
dum hune fatis tactum fuife in cont. 25. quando dixit, illa, qua augentur, mutare locun, ticut illa, quze extenduntur; fic enin fignificauit hoc fieri per extenfionem membrorum, \& de hoc tanquarn dere manifefta nil amplius dicere oportuit. Tertiumargumentum erat: extenfio fit etiam nulla aduenientematcria, accretio autem omnis fit exmater a adueniente, igituraccretio non eft extenfio. Huius facilis eft iolutio, ef enım paralogifnus ex maiore particulari in fecunda figura; nam darialiquam extenfionem concedimus, qua nullam materix accetionem prafupponat, fubtali tamen extenfione accretio non comprehenditur, quum neceffario confequatur nouz materia aggenerationem : quod fi maiorem vniuerfalem fumat, omnis exteafio fit absque vlla aduenicnte materia, neganda eft car mascr, quia falfa eft. Ad quartum argumentum, quod erat; fi accretio efíct extenfio, non effet idem fubican cum nutritione; neganda eft confequenia: ad probationemautem dicimus, nil $\mathrm{C}$ aliud hoc argumento. oftendi, quam accretioirso nem non efle idom penitus cum nutritione, " quod quidem nos concedimus, quoniam fecunem dum Ariftotelem non debent effe idem effentiaac- liter, fedidem fubiecto, \& differentes ratione: ne, conuenientraaurem, de difcrepantia in hoc confiftit, quod accretio complectitur \& conuerfionem in fubftantiam, \& extenfionem, qua maior quantitas acquiritur, \& ratione conuerfionis in fubftantiam dicitur idem re cum nutritione, non tameridem ratione, quoniam illa conuerfio eft alia ratione nutritio, alia veroaccretio; fedratione fequentis ext fionis differt etiam re à nutritione, quia eft tem pore pofterior : at quoniam accretio neq; eft fol a in fubftantiam mutatio, neque fola extenfio, ideo dum totam ac. cretionem cöfideramus, dicimus eam effeidem fubie to cum nutrit ione, quoniam nutritionem contínet, \& fine illa fieri non poteft; ratione autem differt, quia illa mutatio eft nutritio quatenus eft generatio carnis, \& eft accretio quatenus eit generatio maicris carnis cum extenfione fe. quente:\& hoc fignificare voluit $A$ riftot.quando dixit eas effe idem re, differre autem ratione.Pois: fremumargumentum erat: Arifteteles declarauit accretionem ex fimilirudu eco um, qua extenduntur, ergo putauit eam elle quid diuerfum ab extenfione; quia nibil comparátur cum feiplo, neq; declaratur per femeripfum. Ad hoc dicimus, varias effe extenfiones, \& diuerfos earum modos, proinde nō ef̂́e abfirduin, fi vnam 'per aliam declaremus, qued 1 bi Ariftuteles facit: fumit enim cam extenfionera, qux fub fenfum cadit, \& quāomnes vident, cuiusmodi elt fpongix exienfio, per carn declarat.quomodo illay qux augẽzur, locū mutent, figniticans ea qroq; per cxtentionemaugeri, qua non eft ienfilis, fed. mentecomprehenditur, à quoliber $m$ dú confderane, quis ce arsativ: guanobremexeo
A loco fumitur potius argumentum pro noftra o. pinione; quia fi id, quod augecur, locum mutat comodo, quo id, quod extenditur, cui dubium accretionem extenfionem quandam effe?ficigitur per extenfionem fenfilen, qua fine adueniente materia fit, declarat Arift. extenfionem in. tellestulem, qua fit ex acceffione seateriz : imo nec dicendunt eft, ynam extenfionem ibi peraliam declarari, fed mutation em loci corum, qua augentur,perfenfilen aliquorum extenfionem: B quarenon declarat idem perfemetipfum, fed potiusindicatilla, quxaugentur, ideo locuin mutare, quia extenduntur, ficuti illa, quxe extendi cernuntur, locum mutant: quare illius loci confideratio noftrafententia fuffragatur.

\section{Quomodo ad accretionem se babeant alies mutationes, que in ea fiunt. \\ cap. X II.}

$T$ RES ab Ariftotel. verzaccretionis conditiones conftitutas effe iam diximus; vnafuit, accretionem ex materia extrinfecus accedente fieri ; altera, idem numero ab initio ad finem vsque accretions feruari id, quod augetur; tertia demum, non modo totum, ied etiam partes omnes aliquod fufcipere magnitudinis increnentum. Ad harum primam declarandam ca, quar hactenus dicta à nobis funt, pertinuerunt:quomodo enim exaccedente materia corpus viuens augeatur, fatis ex iis, qua diximus. poteft effemanifeftum. Sequitur vtea, quac ad duas reliquas conditiones attinent, contideremus, \& difficultates, qua in ijs magna oriuntur. expendamus, ac foluerenitamur; vit his omnibus declaratis tandem perfectam tum accretionis, tum nutritionis definitionem colligars us: funt autem haduz conditiones ita inter fe connexz, vt coniunctim declarand $x$ effe videanturs. E vnam enim \& eandem effe rationem oftendemus, qua.\& idem numero manet 1d, quod proprie augeri dicitar, d omnibus eitis particulis aliqua fitadditio quantitatis; ideo prius difficultates, qua in vtraque conditione exiftunt, feorfum proponerrus; deinde vina, \& eadem contemplatione omnes foluere, \& veritatem fatefacere aggrediemur. Quodad alteram attinet, qua eft, ldem numeroid, quod augerur, $\mathrm{ma}$ nere, fcire oportet hanc non effepropriam acF cretionis cenditionem, fed ei cum omnibusa:liis motibus communem, qua omnes à lubltantiali mutaxione diftrnguunur; quando enim aliound in filis accidencibus niutatur manente fubitantia, idem numero fubic ftum fenfile maner, cui morus ille attribuitur: fed Ariftoteles hanc exprimere coactus eft; rumad multas excludendas improprie dictas accretiones, quas cum fubftantize mutatione coniuncta funt, ita vt asneadem numero lubitańtia in is maner 
dicatur, vtquando mutata aqua in acrem mo. A lescrefcit ; tum etian adfeparandas alias nuita: tiones, qux ad veram accretionem faciendam. concurrunt, ian enim diximus accretionĕ non fierifiuealterationis, \&: generationis, \& interitus multiplicienteruentu; fed harum omnium,

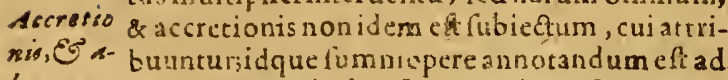
lsarsm accretionem abalis ferungeadam: fxpe enim mutaito- contingit, viqux eadem clle mutatio videtur, ns:rs, qua mulize fint, oumad d, ueifa fubiecta referuntur, cum tha vefiferrum aliquod quiefcens altero ferro moconinata to confricemus, is reffectu motieft motus loca fisne, non lis, refpectu aū quiefcent is non eft motus loca. icom est lis, fedalteratio folü, quia motuillo calefit;qui fubseçs.s. igicur vnuseffe motus videtur, duo iantita diftroti, về vno alter minime includatur : fic in vitientequando mutatur clylus in fanguinem, ea eft genematio, a interitus, non tamen ipfius viuentis, fed generatio fanguinis, \& interitus chyli: ficpoftea quando vertitur fanguis in car- $C$ nem, illa mutatio dum diuerfis fubiectis atribuitur, alia, \& al:a effe cognofcitur; nam refpectu languinis non eft nutritio," eque accretio, ledinteritus, quianeqi nutrirı, neq augeri mutatione illa fanguis dicitur fedinterire;refpectu autem carnis genit $x$ fecundim fe contideratze non eft nifi generatio; at sefictu torius viuentis neque alteratio eat, nequegeneratio, neq; interitus, fed nutritio, \& accret10: totum enim viuens neque alterari, neque generari, neque interiteilla mutatione dicitur, fed nutriri, \& augeri; proindetotum idem nurnero feruatur, non fic fanguis, neque caro, quibus non accretio, fed generatio, \& interitus atrribuuntur. Accretio igitur \& cum alteratione, \& cum generatione, \& cum interitu coniun ta ent; non tąrseneidem fubiecto haomnes mutationesafcribuntur, fed diverfis : fula nutritio tantam cum accetione affuicatem, a coniunitionem habet, vt eidem fubięto attribuatur; 11 am idém viuens cadem mutaicne \& nutrisi, augeri dicicur, licet variis ratiombus, ficut antea declarauimus : idco etiam id, quod nutriri dicitur, idé l: umero manet, non ficalind, qundin nutritione generatur, vel interit. Itaigiturfeparata abalis didi tationibus accretione per diuerla fubiecta denominarionis, nanitertum ert in ea idens numero feruariid, quodaugetur. Hoctum abiplo Arift. expreffe acceptum, \& abfque vlla probatione conftirurum eft, tum abomnibushomi. F nibusconceffum, tanquam perfe manifeftifimum; eandem numero plantam, \& idem numero animal per vnıuerfain vitam feruarı omnes homires exiftumare videntur.

Qucmodo idem mmero maneat id, quod algetur, dua contraria opiniones, edifficultaies, quibusvrgentur.

Gap. $X I I I$.
CAterum veresipfa manifefta perfe effeviUdetur, itavbícurifima eftratio, \& modus. quo id fit intelligendum. Dux hac de re contrarix opniiones exiftunt, quarum alteram $f e$ qui necelfarium omnıno eft; vtraque tamen cum maximis difficuleatibus eft coniuncta, \& vrraquelectatore habuit, at que habet. Vnaeft quam in libr. 1. de Generat. Marilius tuetur, \& Scotis in 4. Sentint. dittinot. 44. quxft. 1. \&alij complures, yui dicunt non manere per to:am

B vitam idem numero viuens, niff fecundü quandam xquiualinciarn, propterea quod in viuente non remanetper totam vitam cadem materia, neque eadern torma numero: de materia quidem certum eft; ca nam q ; continue fluir, \& alıa noua quotidie exaliment is aggeneratur : quare in homine fene non ett ea é numern caro, qua fuit in eod $\mathrm{cm}$ puerojeadem tamen eft recúdum xiquiualentiam, quia non tota fimul eft renoudta, led pars poit fartem: hoc ado etran incegritates elementorum exden maneredicuntur ranquam indiuidua zerna, qua teruantur eadern fecundurn aquiualenciaın lolum; in partibus enim fí continua ratatio, nō in to to fimul elemento : ficetiam nauis dicitureadem numerolongum rempus furuari, licer tandem omnes partes in ea fint renouatz; bodie namque mutatur temo,alio die malus. alio hac tabula, alio illa, adeove poft aliquod term pus fint omnes par. tes mutat $x$, \& nulla eà ü, quxinitio faßtx funt. remanferit,eande enim numero nauim dicimus remanfife per aquiualentian:at fi on mes fimul partes eodrn temporerenouarentur, nö eadem nauis elfe diceretur, fed eflet alterius numero diueifa generatio: quod autern demateria dicitur, idcm videtur efle necellario disendum de omniforma, qua de poteftate marerix fit edufta; forma crim materialisnon eft a fua materia feparubilis, \& ad materix extenfione extenfa eft; quareita eft pars form $x$ in parte roaterix, vt E tota forma in tota nateria : fluentibus igitur. parribus materix, necefie eft ve limul partes formz fluant, \& alize nouz partes cuin nou materia generentur, hoc eft, deslii,s poteftite cducancur. Qunniam igitur viaens eft viuens, k augetur petiliam anmz artem, quam altricm vucamus, hxc, quum fit furma materialis, fuit curn materialecund am partes, \& alix erus partesquotidie gencrantur: fisente cnim carne fecundun particulas, fluntetiam particula liuins anima cum particul:s carnis, \& quando fit mutatio alimenti in nouam carnem, generatur in illa particula carnssalıa noua anima particula, qua de lllius nattrix poteftate educitur. Sivigitur neque cadem numero materia. neque radem numero anima remenet abortu viuentisad finem vfque vita ipfius, led icmanetv traque per aquiualentiam. qua veray; lecunduni partes continue renouatur. Alzera cit opinio huic contraria, quam Al- 
io bertus, \& Thomas, \& alii multi fequuti funt, inns, ter quos Petrus l'oinponatsus in libro liso de acHer cretione eain efficaciter tueri contend 1 : quamPo- wis enim hi non parum diffideant in modo diiss. cendi, vt in difto Pomponatii labro videre eft, in hostamen omnes confentiunt; quod fola sasateria fecundum partes fluat, \& renouetur, ani-. ma vero vegetans non fluat, fed per totam vitam maneat penitus eadem numero tam fecundum fe totam, quain fecundum partes, \& adueniente noua materia extendatur ad eam informandam, \& animandam, fluente vero aliqua parte materiz non fluat cum illa, fed ad alias remanentes materia partes retrahitur. Hanc opinionem fequentes facile oftendunt, quomodo viuensidem numero per totam vitam feruetur: quum enim à forma, qux anuna eft, conftituatur, neceffe eft manente eadem forma, qua nec fecundum fetotam. nec fecundum partes mutata fit, vt idem iudicium maneat. Veraque cö- hxcopinio magnis difficultatibus yrgetur:nam in- fi hanc pofteriorem fequamur, \& dicaimus aniam mam tranfire ab vna parte materia ad aliam 7a. nupergenitam, afterimus formam materialem migrare de fubiecto in fubiestum, quod videtur, vi Biccaferreus ait, totam euertere Ariftot. philoiophiam;etenim Arifot. cenfuit formam materialem de poteftare materix educi, non in materiam induci, quum prius extra illam extiterit,vt fecundun hancopinionem afferitur. Ex ul- altera veroparte, ficum aliis dicamus animam cö- vna cuni materia fluere, \& in partibus materixe 2- exalimento genitis nouas anima particulas geam nerari, ita vt non eadem penitus anima per totam vitam feruetur, communi hominum exifimationi aduerfari videmur; omnes enim eandem numero plantam, idemqinumeseanimal ab ortu ad mortem vfque feruariarbitantur: cui opinioni atteitatur etiam co patio fpecierum in memoria, nam muita bruta animalıa d mortem vfque retinent multarumrerum fpeciesin memoria impretas; canes enim inuenti funt, qui quam multos annos à domino fuo abfentes fuerini, eum pofea vilum ftatim agnouerunt: quod non videtur poffecontingere, nifi eadem numero anima abfque aljquo fuarum partium fluxu feruata fit, nec Io- $^{-}$ lum per xquiualentiam eadem; facit enim $x$ quiualentia, vtanimal eandem rem acdifcere limiliter aptum fit, fed non vt eascem a $c$ u retineat : quodquidem oftenditur fimilitudine accepta à nauifecundum partes renowata, qua ipii quoq; vtebantur; nam $f_{2}$ quis in naui characteres aliquos imprimat, \& poft tempus aliquod mutentur, vna poft aliam trabes, \& tabul 0 mues illus naus, manebit quidern nauis eadem per aquiualentiam, fed characteres non Seruabuntur. Vtramque igitur opinianem maximis, \& vix folubilibus dificultatibus yrgeri maniteftum eft. auomodo omnibuspartibus eius, quod augetur, frat additio magnitudinis, plares aliorum fententia.

\section{Cap. $x I V$.}

$\mathrm{D}$ E relicua etiam conditione altercario ma. yna eft, quomodo qualibet cius, quod augetur, pars tiat maior: quum enim id, quod augctur, corporeum fit : proinde in infinitas pitrtes

B diuiduum, \& alimentum itidem corpusfit, non videtur fieripoffe vt omnibus prorfus corporis augendi partibus fiataccefio magnitudinis ex alimentoadueniente, quincoi pus à coipore penetretur, quod philofophi omnes imporlibile penitus effe exiftimarunt : ideo Arift. vt hoc ab. furdum euitaret, dixit cöditionem hanc de for $\mathrm{ma}$, non de materia intelligendam efle; ita ve quando dicitur, ftrarnibet partem rel crefcentis majorē fieri, id verum fit fecundum formam C tantum modo, non fecundum materiam : quod Arift. diétum magnas interpretum contruuerfias excitauit, quum dubium maxime fit quid Arift. intel!exerit per partes fecund ú formam; \& perpartes fecundum materians, \& varie huius dicti interpretátiones à multis excogitatz fint, ve videre eft in memorato Pomponaly hb. de Accretione, \& in quaft. Mariliji 12. lib. 1. de Ortu \& interitu. Aliquinomineformx animam intellexerunt, \& nominematerizcorpus, qua eft maxime propria, \& euidetılima harum vocum fignificatio: \& accretionem dixère attribui anim $x$, quoniam anima non lluit, fed cadéma. net tam fecundum fe totam, quam fecundü par. tes $a b$ ortu ad mortem viq;ipfi us viuentis, a $a$ mnes eius parkes fiunt marores fine vlla corpo rü penetratione, quia anima eft incorporea; ma. teria vetoaccretiónem nón attribui fecundum omnes clus partes., quia ha fant in cótinuo tis:xis, neq; eaden per totam vitani manent, neq ; E. nofunt omes maiores freripex ádition mäzeriß, guin corpus à corpore pensecetur, quod quidem feri rullomodo portif. Sedali, qui 2 opinio. qun modo materiam, fedetiam animam fecundur partes fuere exiftimañ, ad aiam borum. vabosum incerpretationer configere coati. funt; requecandem omncs atculerunt, fecin varias fentontias diuif fuat. Lliquerimcixeruntpartec fecundummáreiamincelligipares. homogerieas, qua funt materia hcterogencaI rum, patesatem fecundum formant effepartes hetcrogeneas: ha ramque ceram figuram. pofulane, ex ipfiusanimz proxima infu amenta funr, quocire his pracipue at ribuitur. accietio, \& homogezeis propreripras. Alijvero s.opinio. ¿ixerunt duplex in viuente corpore elie huri-

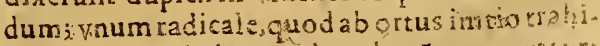
turialterum cibale, quad ex alim ëto geticuatur: aradicale nunquă.refolui, quoriam eius confumptioncm morsnecaffario infiquitur; cibale 
rero effeillud, quod ad humidi radicalis defen- $A$ fionem adiicitur, \& hoc folum fluere continue, \& renouari: partes igitur habentes humidum radicale putaruntab Ariftot. appellaripartes fecundum formam, quoniamanima in eis precique refidet; partes autem habentes humidum cibile vocari partes fecundum materiam, funt cnim veluti materia ad tutelam humidi radicalis adicata, \& in eis anima proprie non refidet, \& hæ continue refoluuntur, \& reftaurantur: quoniam igitur accretio attribuitur illi, quod Fermanet, non illi, quod Aluit, ideo Ariftot. dixitaccretionem fieri fecundum partes forma-

4. Opixio les, non fecundum partes materiales. Alii per formam intellexerüt totum animatum corpus, per materiam vero partes ipfius, quum Arift. in contex. 31. fecundi Phyfic. dixerit totum notare formam, partes vero materiam: quoniam igitur totum manet femperidem per xquiualentiam, partes vero funt in continuo fluxu; \& accretio ateribuitur illi, quod permanet, non illi, qued firit; ideo Ariftot. dicens accretionem fieri fecundum formam, fignificare voluit eam effeattribuendam toti, quod permanet, non partibus, cuoniam illa omnes Auunt, nempetam corporis, quarm anima partes, quum anima à materia feparari non poffit : ficigitur hi dixerunt, Arift. non intellexiffe materiam ab anima diftinctam, fed partes totius cōpolíti animati prout diltinguunturà tozo: ad hanc fentētiam acceffifle videtur Scotus in pradicta diftinct. 4 q quarti Sentent. qux ft. I. \&e hăc fequutus eft Fla minius Nobiliusin fuis Commentar. in libr. r. de Generat. 5. Opinio Marfil. aute dicit duplices effe viuentis corporis Marjelit. partes, alias porofas, alias non porolas, id eft, plenas, ceporofas vocariab Ariftot. partes formales, non porofas vero vocari materiales, propierea quod partes porofa fenfiles funt, a fenfilitas conuenitforma, partes autern non porofre infenfiles funt propter paruitatem, ideo atribuuntur materia, \& dicuntur materiales: gu $\overline{\mathrm{L}} \mathrm{E}$ igitur partes porola augeantur recipiendo alimentum intus, qua eft propiie dicta accretio; non porofe vero augeantur perfolam appofitionem alimenti, non per receptionem intus, quia fieri non potef penetratio colporum; his autem fit improprius accretionis modus; idcir. co Arift. dixitaccretionem fieri fecundum parres formales, qua funt partes porof $x$, non fecundum partes materiales, qua funt partes ple$n \approx$. Alii quoque alia dixerunt, in quibus omnibusrecenfendis conterendum effe tempus non videtur, quemadmodum neq; in fingulis modo numeratis fententiis refutandis; fatis enim fit cognouife quid alii dixerint, ve intelligatur, in quonam fit confituta huiufce rei difficultas: nunc veritatis derlarationem aggrediamur, ea enirn cognita facle, ac breue neçotium erir cognofere aliorum eriores.
Vera fentesitia, of cins comprobatio,

ó contraria refutatio,
Cap. XV.

A Risror egoveram effe illarum fententiam, Aqui dicunt animam vegetantem (de hae enim fola in prafentia loquimur) in omni viuente vnam penitus, at eandem numero $a b$ ortu ad finem viquie vitz illafam, \& incorruptam tam fecundum fe totam, quam fecun$B$ dum partes feruari, proindecumi corporis parriculis fluentibus partes anima non fluere; nihil.n. meo quidem iudicio varius, \& ab ạnim $x$ natura alienius ef, gै dicereparticulas anim $x$ cū particulis materiz cótinue fluere, \& alias nouas anima particulas de poteftate materiz ad actü educi:ad hoc oftendendü nallum adduci poteft efficacius argumentum, quam quod ex natua anim $x$ fur irur:illud inprimiscertum eft, Arift. in 2. lit. de Anima docuiffe animam effe formam corporis, non quitem cuiuslibet, fed organici, hoc eft, in varias inftrumentales parres diftineti, proinde heterogenci; \& per hoctanquam per conditionem effentialem definiuiffe animam, atq; eam ab inanimatorum formis diftinxiffe: hre namque, quum nullam inftrumentorum diftinctione requirant, formz funt corporum homogeneonm ; anima vero quam $v a-$ riis facultatibus pradica fit, varia etiam inftrumenta corporea poftulauit, quibus ad variasedendas operationes vererur. Quim igirur animalit heterogeneicorporis forma, necelrarium fuit, vt ordine quodam erans illius partesperficeret, a in vas prectpta refideret, in qua ortum habens, purea ab a cülins partibus comroun aretur, quemadmodum Arift.declaratin caicelibell de cómuni animalium motu, \& in terio de Parub. Animal. cap. 4.5 . \& 7. qua dere quum abunde iam loquuti fimus in libro, quem de părtitionc anima fripfinus, nunc eam fententiam breuiter referemus, \& tanquara ibi declaratam, \& confirmatam conftituenus. Docet in dictis locis Ariftot. animam in vno precipuo membro refidere, quod in fanguineis animalibus inquit effe cor, in aliis vero, \& in plantis aliud quiddam eodem munerefungens, \& cordi proportione refpondens; ideo quod nes nunc de corde dicenus, id de quolibet alio funili in aliis visentibus membro inelligendum erit. A corde igitur inquit Ariftot. pendere animalis vnitatem: quia animal eft vnüpropteranimam vnam; \& anima eft vna propter vnum principium, in quo primum oritur, \& in quo pracipue cor refidet, \& à quo ad alias omnes adnatas partes diffunditur ; fatim enim genito corde produciturineoanima pereduetionem de poteftate illius matcrix ad actum, deinde adnafcentibus cordi aliis membris ordinatim, anina ab illo principioad alia membra animanda protêditur: vtitur autcm ad hoc declarandü Arift. exemplo regis, 
regis, qui in fola vrbe regia refidet, fed potentiain fuam ad omnes regni partes gubernandas extendit; ita vt fiad eius inperium acced at aliquod aliud noum oppidum, ad illud quoque regis potentia extendatur, quemadmodum in pradictolibro noftro fufius declaranimus. Co. gnouit ergo Ariftotel. viuent is corporis tantam partium varietatem habcntis feruari vnitatem non poffe absque hoc ordine, \&illarum partium colligantia, qux confftit in earum omnium pendentia $a b$ vna pracipua, in qua fuit primus animx ortus;idque manifcfum eft fumpta à regno fimilitudine, non effet enim regnum vnum, nifi vnum regem haberet, qui in aliquo pracipuoloco refidens vires fuas ad cunctas alias partes extenderet. Ex his colligimus, duplicem effe mi- animaproductionem in corpore fecundum Arift.licet vnam proprie dictam, alteram verofa7. tis impropric: vna eft, qua fit in corde in initio generationis, eaque eft vere productio anima, \& generatio per eductionem forma de poteitate materixad a etum;neq; in vno viuente fit, nifi femel, quemadmodum vna taitum eft generatio cordis, nec poteft fxpiusiterari:altera vero eft, quando adnatis cordi cateris membris innafcitur in eis anima, non ramen amplius per eductionen de materia, fed perderiuationemà corde, a perinfluxum ab illo principio ad alia omnia, qua adnafcuntur, membra: quodautem in initiogenerationis euenit, illudidem poftea in aggeneratione, qux in nutritione per totam vitam fit, concedere debenus, fcilicet animam à corje a daggeneratas particulas deriuar $i$, nam cadem vtrobique ratio viget : fic.vero non prcprie dicimus animam, feupartem anim $x$ in aggeneratis partibus generari, nulla enim animz pars producitur, qux prius non fuerit, fed potius noua materia particula, qua prius non erat, aninize iam præexiftenti fubgeneratur. Hanc egofententiam fequendam puto, tanquam Ariftot.\& rationi magis confentaneam, quum alte- $E$ ram contrariam plura fequantur abfurda, eaque penitus infolubilia.Prinum quidem, fi de noua particula carnis nous anima particula educeretur, aninia effet primo actus corporis homogenei; quare non effet effeptialis conditio anima illa, quam Arift.in eius definitione aecepit, animan effe actum corporis heterogenei, fed etiam de fimilari corpore anima educeretur, \& anima quidem tota: alias namq; oftendimus effentiam anima effe totam, ex integram in qualibet corporisparte; qua enim anim $x$ effentia diuidua $110 n$ fit, neceffe eft vt ybicunque effe dicitur,ibi fit integra.Praterea fequeretur nullum effe in viuete pr xcipuum membrum, fed omnes corporispartes effe aque præcipuas; fiquidem pracipua pars non alia ratione rudicatur, quam ex primo animze ortu in illa, \& exprecipua esss fede, à quaad alias partesanima deriuatur, atque difunditur; quocirsa fiybique asina pri-
A tur, vbiqueeft membrum præcipuum; falfa igiturerit Ariftotel. fententia de prinatu cordis, quia fic omnis aliarum partium à corde pendentia tollitur; ab eoden enim res pendet fecundum conferuari, à quo pendet fecundum effe; quare fi in partibus corporis animafecundum efle non pendet à corde, fed in fingula parte eft primum educta de materia, neq; fecundum corferuari pendebit à corde. Quapropter fequerc- Tertıum tur etiam oportere quodlibet membrum $a b=$ - argumes

B nimali feparatum viuere aliquamdiu : nam fi membrum non habet animamà cordeinfluentem, fed in ipfo primum exortum, nulla efle poteft ratio cur feparatum membrumà toto non debeataliquamdiu animam retinere, quum fubftantialis interitus non fiat fine prasuia alterztione, qua non potef effe fubita, fed in temporefit neceffario:imo non folum membrum, ied etiam qualibet carnis particula feparata deberet ob eandem rationem aliquamdiu viuere, hos C tamen omnium confenfione falfum ett, \& experientia, acfenfui repugnat. Prat ereafequeretur etiam non vnam effe animam in vno viuente,fed plurimas; in fingula enim aggenerata carnis particula ineffet anima propria, \& feorfun ab aliis edueta de illa materia : idq̨; confirmatur perme moratum Arifi. diatum in 3. lib. de Partibus animalium, animal eft vnum propter animam ỳam, danima eft vna proptervnü principium, quod eff cer, in quo exoritur, \& in quo D refidet:nam fecundum illorum fententiam non vnum eft principium generarionis anime, quim. zque in finguia parte anima generetur, proinde non yna ef anima, neque vnum animal:fed prater Ariftotelisteftimonium id omnino confiteri nos ratio cogit:nam in tanta partium varictatenon poteft : otius vnitas fermari, nifi per colligantiam; nulla autem effe earum colliganzia poteft, nifiper naturalem ordinem, \& aliarum. pendentiam ab vna:quemadmodum ergo Arit. dicit vnum effe animal propter vnum principium generationis animz, ita fi plurafint'talia principia, plura quogue animalia in quolibet animali erunt, \& plura quotidie generabuntur. Hæc \& alia eiusmodi abfurda manifeftifima euitamus, fi cum Arift. dicamus eduetionemanina vegetant is de poteftate materizad anum femei tantum fieri, $\mathrm{d}$ in folo corde, feualio mebro, quod cordi proportione refpondeat, in initio generationis cuiusque viuentis, deinde ab $e$. F diffundianimam ad alias adnatas partes, ax per. totam yitam ad particulas materize ex alimento aggeneratas, nec poffe in alia parte prater membrum pracipuum animam de poteftate materia educi. Propterea optime illes fentire ouatiz arbitror, qui dicunt animam non ita effemate- argumen rialem,atque diuiduari, vtnon fit etiam imma- tsm. terialis, \& indisidua; eft enim medix natura inter formas penitus à wateria-abiunctas, \& formas materize grerfus immerias, qua funt for- 
mx inanimatorum; forma namqueà materia $A$ abiunciz omnino indiuiduz funt, \& nullam haben: quantiratem, quia nulilum habent $\mathrm{ma}$ terian : forme vero inanimstorum funtnecef. Gario zdiuc ctz quantitati materiz, in g̨u extenduntur, \& decerminatæ etiam gnantituti, \& determinata materia, fine qua exifter t nequeunt: forma crim; quze eft in hacaqquz particula, ita eft alligata huicportion matesia, 2 hinc dererminata quantitati, vtson pontextendi adinformandam aliquan aliam materiz portionem a diectam; fed fi aliqua materice portio adilciatur, qua debeat aque formam recipere, oporter deporeftate illitis aiterius mateis aliam aquz formam educi: anima vero medio modo fefe habet; nam eft quidem necefiario materia, de quantitati addicta, cuia fine materia, de ine quantibate efic nul!atenus po:ef: non eft tamen ita addi fa deternanatzmateriz, ac determinatre quantitati, vt non porfi mace ram guuantam mutare, Aalian, cuinharcat, fini adfribere, non ita zamen, vtpofit materiam, in qua eft, derelinquere fecundum rotutn, \& ad alism tranfire, quia fi rotafimul materia defruarur, perditur anima neceflario: fed fecundum partes, \& per fuscefionem, ranente foilicet eadem mareria per zquiualentiarn, vtantedeclariuinus exemplo natis, cuius partes diuenfis temporibus renouentur, non codem tempore omnes; hanc enim conferuationem eiufdem reiper aquiualentiam in ipfa quidem materıa \& in partibus corporis concedimis, at non in anima, cuius partes fluentibus materiz partibus minime flunt; eft enim anima forma nobilioris conditionis, \& magis eleuata, aclibera à nexu materix, quam form $x$ inanimatorum, qux nullum in materiam imperium habent, fed in ea prorfus immerf $\approx$ funt: anima enim, quatenus linemateria cfle non potent, materialis eft, \& femper extenfa, \& femper quanta, acdiuidua; fed quatenus $f$ uentibus materiz partibus ip $f a$ non fluit fed in remanentibus integra manct, de ad alias renouatas materix partes extenditur, redolet naturam formæimmaterialis, \& in diuidux. Hac fuit abfque dubio fententia Ariftotelis in context. 4r.libr.r. de Generatione, quando dixit, formam, fecundum quam fitnutritio, is accierio, effe formam quandam irmateriaIem, is materia tamen exiftentem : quam eius loci interptetationem à Latinis adductam o-
minu fequi debeinus reiecta altera Ioannis Giamarnacici, etfi nunc à multis recepta, in qua ço aliss dumeum locum publicedeclararem, wu is otzulabfu:da turis in Philotophia, tum ir. Gumatica exverboruta iriftotelis Gra-

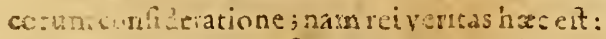
quun Ariftosel. griusforman eius, quodaugetui, armozfer, voluit aliquid dicere de bac formas, iccinúum quam nutritio, \& accretio fieridicisur fed getia forma hxc elt aniña vege- tans, quam in eo libro confiderare minime conueniens erat; ideo etiam ab animx nominatio. ne abftinere volens fatis habuit eam propria conditione circumfrerbere, \& fignificare, dicendo eam effe form:m immaterialem, materize tameninhxernsem, hxc enim non eft uifiani-

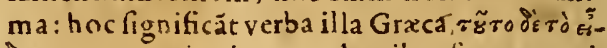
:3, quam enim in pracedentibus formam rei, $q u z$ augerur, nominanlet, idcirco $p$ oftea his verbis fubiunxit, hxc autem forma fine materia, $B$ nec lignificare potuit aliam formam, quam illam, quam iars nomine forma appellauerat; at fecunaum Ioannis Grammatici opiaionem oporreict formam in his ves bis efle pradicatum, ve fenfuseffet, hac aurem eft forma fine materia ; hoc ramen dicerenon polfumus, quia articulus oftendit formam ibieffe fubiectum, non predicatum: praterea diß̨o generis; quare non poteft ad a linenrum referri, quod à Grxcis farminino nomine rzo $\phi$ h̀ appe':latur: fed rnagis eft ea fententta ablusda, quam $v t$ in prafentia confutari mercatur, nam \& fecundum eam maxime impropria, \& incongrua eft Arift.loquutio, \& in multiplicem crorem,ac repugnantiam incideret Arift. fi id, quodeilo. atnes attribuit, fignificatevoluifier. Non porfum hic me continere quin dicam id, quod mihi eum locum confideranti venit in mentem, quod non credo Ariftutel.cogitafe, quanquamillud cogitare maxime debuit; fumitur enim ex eo loco, \& ex Ariftotel. confeifione argumentum aliquod, vel faltem coniectura de animx huma. n $x$ imm ortalitate: quum enim de anirsa vegetante, quxignobilıifima omnium a nimâru êt, loquens ibiArift fateatur eam effe modo a liquo immaterialem, eleuatam, \& liberam à nexu materiz, quia poteft laltem à part bus fux materize feparari, credendum eft animam fenfibilem multo eleuatiorê effe, fedmaxime nmnium animam rationalem ; proinde ita effe liberam à E nexu materix, ve poffit etiam à tota fua materia feplarari, fi aliz partes anim $x$ funt à partibus faltem fua materia feparabiles; co enin negace non haberet anima rationalis maiorem elcuationem, quam anima vegetans, quod non vicetur confentaneumefferarioni. Sedytadid, de quofermo erat, reuertamur, fumituretiam noftra fententix confrmatio $\mathrm{cx}$ is, qua dicuntur ab Ariftotel.in context. 3 б. ciufde mu libribibinam qua vtrem aqua fluente plenun comparans F cum corpore, quodaugetur, vtrifimietefle dicit formam eius, quod augetur,ag̨i z verc f tréci fimilean effemarerianı; fiquidem materiafenıper fuit, quemadmodum aqua illa per vtrem, manenie ransisvtre finc diquo fisxu, ficuriet. iam forma eiss, qu uodaugetur, non fluit. Similiter in sonext. 42. de imminurione lo quens dixit materiam, quantiratem minu, formāautern mancre; putauic igitur nullam forma partem cum fluertemateria fluce, fed tutam ani- 
mam remanere, \& ad reíquam materiam reftringi : nam fi fubftantiam quoque form $x$ in particulis materix fuentibus corrumpi, \& flucrecum materia exiftimallet; non potuifet vllum matcrix \& formæ difcrimen ftatuerc rationefluxus, vel permanentix, quoniam idem prorfus de vtraque dicendum fuillet.

\section{Dubit contra veram fententiam, \& eorum folutio. Cap. XVI.}

$\mathrm{V}$ Erum fententia hac ita magis difficultatibus vrgeri videur, ve multi eas folui nullo modo poffe arbitrăntes, hac reiecta, alteram, quan nos modo confutauimus, fequi maluerint: has igitur foluere nitendum eft, $v t$ f nobis non ita eas diluere datum erit, vt'omnes conquiefcant, id talt em preftemus,vt ii, qui mediocri ingenio præditi funt, \& rite philofophari volunt, dum eam cum contraria opinione contu$\overline{4}$. lerint, hanc cum minoribus difficultatibus coniunctam effe cognofcant, \& fateantur. Duo potiffimum dubı liult, qux maxima infirnare noftram hanc fentêtiam videntur. Vnum eft quod per eam ponitur forma migrare de fubiecto in fubiectum, quod \& de accidentibus \& de formis omnibus materialibus impoffibile prorfus effeomnes exiftimànt; quod autem hocfequatur,patet:nam fillla eadem numero anima, qux eft in carne vetere, tranfit ad informandam carnem nuper exalimento aggeneratam; \& illa eadem, qux erat in particulis mat eriæ confumptis, non fluxit cum illis, fed remanens contrahitur, \& reftringiturad alias materiæpartes remanen- tes,abfque dubio eadem numero anima migrat de fubiecto in fubiectum, Alterum dubium elt, quonian A rift.in lib, 1.de anima docuitanimam non efle per fe mobilem, fed folum per accidens ad motum corporis, nam in lib.6. Phyfi.aufcult. ofténderat fola corpora efle per fe niobilia:at fecundum hanc fententiam anima per fe moueretur, non ad motum corporis; quaido enim ad aggeneratā carnem extendıtur anıma. \& quan. do à parte carnis confumpta ad remanentẽ car. nis partem retrahitur, no poteft hunc tranfitum faccre, nifi loco moneatur; itaq; mouctur loco per fe, quia nulla corporis pars tunc loco mouetur, fed fola particülajanimæ locū mutat, quod̆ eft moueri perfe. Hre funt validiffimx obiectiones, vt multis videtur, qux fententiā hanc prorfus euertere, impoffibilem reddere videntur: ad quas quid dicipollit, proponitur nobis in pralentia confiderand um. Ego quidem arbitror priorem dubitationem non tanti effe momenti quanti eam elfe plures arbitrantur, quum ex 1plamet reloluno iumi videatur; migratio enim qua a phlofophis impolfibilis elle exiftimatur, eftilla folum, qua accidens, vel forma totum
A fuum fubiectum derelinquat, \& eadem numero adaliud tranfeat; fed dummodo forma torum fuum fubiectum non deferat, fed in eo maneat, poteftabfque vlla abfurditate ab vna eius parte ad aliam informandam tranfire: neque hæc dicenda eft migratio, $f e d$ quæda m nomine carens tranfitio, qua in nulla forma vel accidente ma. teriali cft admittenda, nifi in fola anima, ob eius .naturam aliquantum elcuatam, \& mediam, ficut antea declaranimus: in aliis igitur omnibus B formis, \& accidentibus naturalibus nullam fiue fecundum totum fubiętum, fiue fecundū partem fieripoffe migrationem concedimus; at in anima eft poffibilis, imo \& neceffarius tranfitus, ac diffufio ab vna corporis parte ad aliam: \&e huius difcriminis ratio ex eo : quod alıas declarauimus, fatis clara defumitur; nam cæteræp $\boldsymbol{z} z$ ter animam formæ naturales funt forma corporum fimilarium, in quibus eadem eft natura. $\&$ conditio totius, \& partis cuius libet, proinde. in ea forma participanda nullus eft in partibus ordo nat urz; folaanima eft forma corporis organici, \& diffimilaris, \& eius corporis partes, quar um magna eft varietas, informat, ac perficit certo quodam, ac neceifario ordine, vnam quidem primo, ac precipue, deindealias perillam, \& perderilutionemabilla;quamobrem neceffe eft vt $a b$ vila precipua viuentis parte ad alias partes anima diffundatur, \& hoc quemadinodum in prima totius viuentis generationis fieri certuni eft;ita in quotidiana nutritione eit concedendum; eaq; migratio, fi modo migrario vocanda eft, non eftimpoffibilis in anima, fed neceflaria, \& ipfi naturæa animæe maxime confona. Mutatis igirur perfucceffionem parribus viuentis, toto tamen corpore eodcm per $æ$ quiualentiam feruato, potefranima à membro præcipuo, in quo ett radicata, ad aggeneratas purtes proteridi, \& ita femper informare, atq i viuificare totum corpus, quud per totam vitam idem per $x$ E quiualentian feruaridicitur: quocirca ea non eft animæ migratio vocanda, quu in femperin eodem corpore feructur, neq̣; de illo toto ad aliud totum tranfeat: Hoc videtur conceffife in scoticon ter aduerfarios Scot. in prædiata quæent. 1. diftin. ceßsio. 44. quarti Sent. vbiaduerfusfententiă noftram ița argumentatur: quādo anima, qux eft in materia vetere, tranfit ad nouam materiam informandam, deferitne materiam veterem, \& ad nouam tranfit, an informat finul vtramque? fi primum,ergo nigrat de materia in materiam;fifecundum, ergo eadem forma perficit fimul duo perfectibilia, quorum vtrumque feparatim ac-. ceptumilli eft adæquatum:concedit igitur Scotus, fi lecundum ponarur nö efle migrationem, fed ex eo aliud abfurdum dedicit : ad quod tame nos facilerefpondemus:dicimus enim poffe duobus modıs intelligi animam corporis adæC C quari. 
quari.vno modofecundum quantitatem, alte- A 10 modolecundum proportionem fi ficundum quantitatem intelligat, vt intelligere videtur, anima nulli corporiadxquari poteft, quia non adrquatur nifi quantum quanto, anima vero perfe quanta non eft, proinde vanaeft quaftio de animæadrquatione cum corpore; eadem enim anima vegetans ita eft adrquabilis corpori formicx, ve corpori elephantis, velalicuius magnæarboris, quantitatem enm non habet, nifi quam recipit à materia, \& itaapta eft excendi in magña, \& in parua materia, quemadimodum etiam dicimus eandem animam ita adxquari coipori gigantis, vtcorpori Pigmai : argumentum igirur Scoti vanum eft, quoniam anima \& paruæ, \& magnæ materix adæquabilis eft, \& quando caro facta eit maior, non funcibi duo perfetibilia $\mathbf{a b}$ anima, fed vnum, quod prius erat minus, poftea eft factum maius, 1 mo totum viaentis corpus eft vnicam perfectibile: Wosagwo fecundum proportionem autem rectius dicimodo eni. musanimam corporiadæquari, feu potius corma dica- pusipfianimx; quum enim anima pluribusfasurcor- cultatibus pradita fit, túc corpus dicitur elle illi pors ada- adrquatum perféstibile, quando onnibusinquar3. ftrumentis prædium fit, quæad exercendasillas omnes facultates requiruntur; ideofi quis homo fine manibus, vel fine oculis nafcatur, 2nima non habet integrum, \& fibi adrquatum perfectibile, quia non poteft in illo corpore fuas omnes facultates exercere: fi igitur hoc modo Scotus intelligat adæquatum perfectibile, vanum fimilitereiusargumentum eft, quia nulia corporis pars eftanimx adx quarum perfectibi$1 e$, nec niembrum vllum, imo nect otum viuenris corpus, quando eft mitilatum, fed folum quando omnibus inftrument is præditum, quæ facultatibus omnibus animz refpondeant. Hoc igitur modo tolli facile puto priorem difficultatem, \& in hac folutione ego quidem pesilutio nitus acquiefco. Maioris momenti effe videnim corporis partead aliam tranfire eadem animanon poffe videtur, nifiloco moueatur. Ego quidem non abfurdam fore refponfionem puto, fi cum loanne Bacconio in diftinct. decimaoctaualibr.3. Sentent, diceremus, animam ad informandas aggeneratas partes tranfire non permotum; fed modo quodamalio nobis occulto, \& abfcondito; fateamur enim velimus nolimus, neceffe eft plurima fieri in natura, quorum rationem \& modum non intelligimus: quemadmodũ igitur fatui hominis ellet negareillain, quam videt, pluuiam defublimi.locodefcendere,quod modum generatıon is eius ignoret; itaingenui, ac vere philotophici aniMi eft humaniingenij infirmitatem, \& noftram. ignorantiam sonfiteri, qua fiequentifime fit.
A verertum manifefifinarmon caufas, \& modum generationis intelligentia non affequamur: dicere igitur poflumus aninum ad aggeneratara. partion informandan effundi absque motu; quis autem \& quatis ille tranfitus fit, nosignorare; hoc enim allerentes vel non erramus; vel multominus erranus, quam qui trantitum illum, hect per fe manifeftifimum, inficiariattdent, proptcrea quod modum, \& rationem eius non intelligunt. Sed fi quid hac de re dici. B poteft, illudeir,quod Pomponat. dicitin libro fito de accretione, cap. 15. eaque mihi videtur tuta, firmique refponfio, animam vegetantcina partion naturalem, partim immaterialem efle, vt Ariftotel. dixit in contextu 41. primi de Ortu \& interitu; quem locum Pomponatius optime intellexit: materialem quidem, quatenus de materia educta eft, \& eft neceffarioaddict materia quant $x$, fine qua exiftere non potelt; inmaterialem vero, quatenus tranfit fecundum partes eiusdem corporis ad informandam alinm. materiam fimilem, de qua non eft educta, propterea quod non eft ita aldicta ftatutx materiæ, vt ad aliam tranfire non polfit eo icilicet modo, quem in prooris dubitationis folutione declaravimus:quum igiturproten datur eo modo anıma à parte materix ad partem, hoc praftat, quatenusimmatenalis, \&indiuidua eft, non quatenus materialis, atque diuidua; id autem, quod immateriale, \& indiuiduum eft, vt locum. non occupat, ita nec loco mouetidici poteft: id. eo tranfitus illef non eft vocandus localis mo. tus, neque omnino motus, quia non mouetus? nifi id, quod corporeum eft; fed eit acceffio fubita reiimmaternalis. Obidne hacin re decipiamur, notandumeft aliud cfe mutationemalimentiultimi in fubftantiam, vt in carnem,vel in os, aliud effe exrenfionem, feu fluxum anima ad eam : mutatio quidem alimenti in fubftantiam eft verus motus, eft enim alteratio in centporefacta, quam infequitur etiam fubfantia mutatio, de qua poftea loquemur; fed extenfio anima ad illam aggeneratam partem fubita, ac momentanea eft, neque eft vocanda motus : itaque fola materia vere mouetur, ficuti fola vere locumoccupat; anima verovtin loco non eft; ita nec vere moueri dicitur, fed absque motu ad aggeneratam partem inibito extendi, ficuti rei immateriali \& indiuifibili conuenit vt extend2-

F turad aliă. Qüod vếó Arift. dicit,animam non effe per fe mobilem, intelligedum eft de anima totasquod quid'm respeviffe Airit. manifeftum eft, quunilli quo que philorophi, quorum ibi fententiam improbat, hoc folum intellexerint; non poteft enim anima tota fine corporis motu mutaclocuns, \& de toto fubiecto in totum aliud fubiectum tranfire, quemadmodum antea de migratione dicebamus, neque tota fei- 
pran mouere,vt illi philofophi diccrevififunt: fed manente anima in coćcm toto viuente exteŕfionem cins ad omnes aggenicratas partes animandas Ariftoteles non negauit, neque motum ani mæappellaret, fed foli materix, \& corpori motum attribueret; dicendum enim potius eft, nouam materiam mutariad recipiendam animam, quam mouerianimamad llam informandain, cuilibet enim aggeneratx partı iam adift anuma, qux in toto corpore exiftens $x$ que apta eft \& paruam, \& magnam nateriam informare. Hæc ad propolitas obiectiones dicenda elíc puto, \& profireor milii perilla ita effe latisfactum, vede hac re non dubitcm; quum enim réciflans isa lefe habere conftanter exiftimcm, démodo, quo id fiat, contentus efle volo eo, quod in re dificillima, \& fenfum max ime latenteaflequi; \& complecti humana ratio poteit: quisquis autem in his non acquicfcat, is debet vel confiteri fe concufa rei veritate modü ignorare; vel huncipfe inucnire, \& in medium proferre, veltandem fi à nobis diffentiens contrariam fenteintiam fequatur, ad illa, qux nos aduerfus eam attulimus, reipondere.

\section{Quomodo in accretione dus pofteriores cö- ditiones feruentur. Cap.X.VII.}

Ententia hacnoftra co argumento maxime Sconfirmatur, quod eam fequentes facile ferúam us duastllas accretionis reliquas conditiones; quodidem numero maneat id, quod augetur; \& quodomnibus partibus fiat acceffio magnitudinis, idq; verum fit ratione materix: prior enim conditio omni dubio caret, quia manente prorfus eadem forma per totam vitam absque aliquo fuarum partium fluxu rotum viuens id $\vec{e}$ manere dicitur, quia.vnitas indiuidui à forma prouenit, \& conftituitur. At fecundum illos, quidicunt partesanimæe cum partibus materia tuere, non video quomodo feruari hac conditiopoffit, tandem enim tota animx fubftantia erit mutata, quare non idem viuens feruatur: quodvero dicunt eandem manere per aquiualentiam, vanum eft, fiquidem materia quoque fic per æquiualentiam eadem feruatur, quare nill um eit in hoc materi $x$ \& form difcrimen: boctamen Arifot. aduerfatur, qui dixit materiam effe in continuo fluxu inftar aqux per $\mathrm{v}$ trem fluentis, formam vero manere inftar ipfius vtris ; deinde etiam dixit quantitatem imminui, fed formam mánere; fignificans concedi poffequantitatem forma fluere, at non ipfam formæ fubftansiam : folam autem formæ quantitatem fluere eft nihil formx fluere, quum fit quanta per accidens : \& nil aliud fignıficat, quan animam definere per illam pariem extendi, \& effe quantan perillam. Reliquzetiam $r$ conditio, licet maiore declarationc indigeat, $\mathrm{fa}$ -
A ciletamen fecüdum hancuoftram opinionem trosis $c \sigma^{-}$ incelligitur; contra vero, hac negata, nullum disso quo idoneum fenfum iecipit, vt conicetare quisque modo inporeft ex corum dillenfione, qui putantes ani-telliga. man quioque fecundum partes fluere, varias, tzr. quas aniea retulimus huiustertix conditionis interpretationes, easque omnes abfurdifimas, ve moxoftendemus, commenti fúnt. Hxc igitur antequam declaremus, tollenda eft propter illa, qux mox dicentur, quxdam ambiguitas, B quafortafisaliquem traherein crrorem poffet: quum enim repe nobis cont gerit in hac noftra - difputatione ve extenfionem nominaremus, animaduertendum eit duas effe, easque inter $r e$ valde difcrepantes, quarum antea meminimus, extenfiones, ne vnam cum altera confunda- Dreex mus; vna eft extenfio animx fubita ad partes :enforees fubftantix aggeneratas, altera vero eft totius corporis extenfio ad maiorem quantitatcm; \& in liac pofteriore diximus efle accretionis naturam conftitutam, non in altera priore, qux eft folius anim $x$ extenfio, \& potius vocanda effet defluxio, feu deriuatio virtutis animxad ommes corporis partes viuificandas: \& hæc etiam in vi-. ris, \& in fenibus fit, licet non amplius augeantur; dum enim per aduenientem materiam nutritur fenex, extendituranima ad illam aggeneratam materiam, nec tamen illa eft accretio. Quum igiruraccretio confiftat in ea, qux eft totius corporis extenfio facta ab anima per additionenı nouz materiz, \& Ariftot. dicat talem accretionem fier! fecundum omnes partes for$m x$, non fecundum omnes partes materia; ve hoc plene declaremus, trianobis confideranda proponuntur ad quafingulaaccretionem referanus, materia, forma \& compofitum. quum enim in accretione quodlibet horunı maius fiat, videnduin eft, quomodotum materia, tum forma, tum compofitum, tam fecundum fe tota. quam fecundum partes augeantur, \& cuinam ex his tribus tanquam pracipuo. \& $x$ quato fub. iecto accretio at tribuenda fit.

\section{De duplici viuent is materia, \&o denutritio ne quomodo fiat, or quid fit.}

\section{Cap. $X I I X$}

$\mathrm{V}^{\mathrm{T}}$ $T$ à materiz ordiamur, certum eft, ipfam acceffione noux materix maiorenm fieri: \& quia materiæ nomine non primam omnium materiam, remotam intelligimus, fed pro-Parses pinquam \& propriam, hæc duplexeft, \& vtra- Giusent is que augeri dicitur; nam \& heterogenex par diuplices, tes, qua membra vocancur, funt viuentis ma- Evotrius teria proxima, vt in animalicaput, \& pes, \& ma que sccr nus, \& in arboretruncus, \& ramus; \& homoge- tiocomnex funt materia hctelogenea $u$, ex carneenim pet it pri$\mathrm{CC}_{2}-\&$ ofle, mo. 
\& offe, \& nerro, \& aliis fimilaribus conftant animalium partes dillinilares: his ver isque partibus Arrftoteles accrenionem attribuit , \& verisque prino, alia tamen, \&calia primitate; primum enim augentur fimilares primitate originis, fed primum diffmilares primitate fcopi, \& intentionis naturæ, quum diffimilarium gr:atia fimilares fint à natura conftituta: quoniam igitur diffimilares non augentur, nifi quatenus fimilares, è quibus conftant, augentur, nos accretionem in fimilaribus tantum confiderabimus, \& has tanquan materiam viuentis, cui accretioattributur, accipiemus : \& quia ad hujus * materix reparationem nutritio pertinet, \& absque nutritione fieri accretio non poteft, de nutritione quomodo fiat, \& quid fit, breuiter dicemus, deinde ad declarandam huins materix ace cretionem progiediemur. Homogeneas viucntis partes continue confumi à calore naturali, \& in continuo fluxu effe iam diximus; ad hùus igitur materix reparationem fumunt viruentia alimentum, vtproparticulis confumptis in homogenearum partium fubftantiam conucttatur: hac igitur alimenti in fibftantiam fimilaris partis conuerfio nutritio dicitur, quæ nihil aliudeft, quam generatio partium materix fiNutritio milarium loco partum; qux effluxerunt, proquid ptereanutritio non eft mutationis fpecies ab aliis mutationibus diftineta, reducitur enim ad mutationem fubftantialem, quæ diciturgeneratıo \& interitus, ut fignificauir Ariftoteles in primo libro de Generat. partic. 41. dicens, nutritionem refpicere fubltantiam, \& in hoc diftingui ab accretione, qux refpicit quantitatem : $\mathbb{f}$ igitur fubftantian refpicit, generatio quædam eft, quia nulla mutatio ad fubitantiam tendit, nifi generatio; \& eft reuera geneiatio, fi absque animæ confideratione ipfam per fe homogemeam partem confideremus, yt carnem, \& os, tanquam compofitum conftans ex materia prima, \& fua formamiftionis, interit enim forna fanguinis \& generatur forma miftionis ; quare cft vera generatio carnis ita fumpta : at fi animam complectamur, differt modo aliquo à generatione nutritio; generatio enim eft mutatio ad form $x$ acquifitionem tendens, nutritio vero eft mutatio tendens ad acquifitionem materiæ fub praexiftente forma : anima namque nutrition i præexiftit, \& noua materix portio pernutrition égeneratur pro fuftentatione animx; ideo terminus ad quem, nutritionis, eft acquifitio materixefpectuanimæ, fed exclufa per confiderationem anima,terminus.ad quem, eft forma miftionis : fic igitur nutritio partim eft generatio partım differtaliquantum à generatione, fcilicet dum adhibetur confideratio animæ, quia non eft mutatio ad formam, fed ad mate. Liam; nififorte dicamus etiam ratione animx:
A effegenerationem quandam, quia eft mutatio tendens ad receptuvem animx, à qua incipit materia intormarin finenatritions, quum prius abea nou informaretur: eit igitur gencratioaliquaper aduenium formefubitantialis, qux eft anima, noneft tamen vera generatio, quo. niam anima de illius matenæ poteitate nō educitur,fed quum prius in aliis partsbus effet, poitea a eam partemadrectam extenditur, \& ita eft noua informatio cius materiæ ab anima, non

B. tamen noua illius forma eductionde poteltate materia:f quis vero obiiciat; non potelt materia ab aliqua forma informari, nifi ea forma de poteftate ipfius materizeducta fit : ad hoc dicendum eft, fatis effe fi forma illa fit educta de potentia vel illius, vel alterius materiæ, quod quidem de anima concedendun efle iam diximus, neque in generatione partium materix abfurdum dicendum eft, fedabfurdum effet in generatione totius inon poteft enim anima migrare à tota fua materia ad aliam totam, ficuti fupra declaraumuis in folutione argiumenti de migratione. Pater igirur, nutritionem efle aliquo modo generationem, quatenus aliquo modo eft viaad formam; \& aliquueriam modo differeà generatione, quatenus eit via non ad formam, fed ad materiain debentem fuftunere precxiftentem ormam, neque ad materiam totam, fed ad partes materix : ett igitur modus quidum generatiónis mproprius, quilicet onmino generationon fit, ad generationem tamen reducitur, quia ad iubftan!ix productionem tendit, vtcunque id fit ; etenim etiam materia eft fubftantsa, præferim matelia fecunda, \& formata, de qua nunc loquimur: videtur autem hoc fignificafle Ariftot.in contextu 39 .libri r. de Ortu \& interitu, quando dixit, nurritionem effe potius aggenera tionem, quam generationem, generatio enim vere eflet, ficaro perfe exiftens, \& feparata geneE raretur; fed aggeneratio eft, quando generatur. adiuncta alteri carni, \& vt pars totius; generari namque vt partem, eft generari vt materiam fub forma præexiftente, quia partes materiam fignificant: quoniam igitur tuncrefpicimus totum, quod non generari, fed nutriri dicitur; ideo nutritio non eft omunino generatio, quia refpectu totius viuentis, non eft generatio. Quidigiturfit ıutritio, diktum eft.

\section{Quomodo materia, \& ciuspartes in accretione maiores frant. Cap. $X I X$.}

Q VONIAM igitur nutritio eft acquifto partium materix loco partium confumptarum; fi maiotes confumptis acquiran. tur; idque in omnibus homogeneis partibus, pxafestim yero in oflibus fiat, tuncprater nu. 
tritionem fit etiam.accretio: quare negari non $\mathrm{A}$ alia forma informaretur quam à forma miftiopoteft materian quoque viucntis maivem fieri, \& per nour matepie additicuen augeri, vt carnem per camis agerencrationem, \&: os per aggenerationem puructiarum of Trs, idque ficriferrecetionemalimentintus iam enim diximus, partes onues homogencas pludimis effe refertas minutinmistoramnibus, per qui intropertranfit alimentum : eft ig $\mathrm{t}$ tur confide-randuin, quomoso \& tota marera, \& cins partesaugeantur, ve intelliganut. id, quod Arikotel. dixit, \& totum, is omnes partes aliquod recipere magnitudinis incrementum, idque verum cfle raione forme, non rationematcrix. Vt à materix confideratione ordiamur, fciendum ett, duo partiti genera efle in qualiber ftmilaripatc, quam in prafentia tanquam materian nobis confiderandain propofuinus; alize namque dicunum partes nuaiores, alix vero mia nimx: maiores vocantur illa, qua mos hant bent formina, per qua lunt adu diulix in mi-

es, noresitoramen enim, quod in carre eft, feparat quodanmodo vinam carnis paruculam ab alia; dichis maronbus partibus iden dicundum eft, quod de accresione totius, de qua no loquemur: minimas autcm canis partes voco illas, qua nullum amplius inna le foramen continent; neque has appel o miminas', qua non dentur alia minores quemadmodum difputari folet, an detur minima caro, qua non deturalia minor: led concido diuiduas efle in alias minores, proindc hac ratione no efie minimas; fed ea tantum ratione voco minmas, qua fingu. la eftindiuifa, nec habetactu porum per quem diucaatur, tta vt minima dicantur ratione acuss, led non ratione poteitatis; polfunt enim diuidi in minores, ied non lunt a ctu diuif a per poros: quod autem denturactu ha partes $\mathrm{mi}$ nimæex necefitate, confiderantibus manifeftum eft; quum enim finitus fit forminum numerus, necelfe eft dari duo foramina ta pro- $E$ pinqua, vt nulium babeantaliud foramen interpofitum, fed lolam maicizparticulam, vt carnis, foramine prorfus carentem, eamque nunc appello partem minimario. Si quis igitur quarat, an pars hac minima augeatur, dicendum efteam augeri quidem, non tamen per receptionem alumenti intus; quum enim intus nullum foramen habeat, nihitintra te recipit, quia non poterin eam ingredialimentum, nilfi fiat corporim pejetratio, ed periotam no- $F$ ux carnts appolitionem maiorfit; promde non habet proprie dictan accretionem, fed ean, qux fit per ajpoitionem extrinfecus; difcrepat tamen abilh ailarum rerum accretione impropria, qua per appóitionem fit, vt quando per frumenti appofitionem crefcit aceruus, \& cera perappolicionem ceræ : nam fí caro,à nulla nis, vique carnisad carnem appofitio, \& ills, qux eft cerá ad ceram, nullum difcrimen habsent; fed differentia eft penes animam : ctenim inparticula minima ca nis ineft anima, qux appofitum alimentum in nounm carncm conacrtit, \& ad eam poltea infomandain extenditur, at in cera priore nulla ineit vis mutan. di aliquid in ceram, ncque forma aliqua, quz ad appofitam nonam ceram exterdatur, idco B non elt accictio, fed mera appofitio: hæc autem minima partis accresio, licet fecundum fẹpfaum nón omnino fit vera accrecio,eft tamen vero accretio, quatenus illa particula conficicratar vt pars totius, quod intus recipiendo in fe alimentum vere augeri dicitur. Tota vero materla magis proprie dicituraugcri, quia non per folam appotitionem maiorfit, fed per receptioncm alimentintus, fanguis enim per foramina ingredicus intuma corpontis penetrat, quod C Iiguificanit Ariftotel in contextu trigefimo nonolibripræditi, quando dixitalimentum cum re nutrienda commifceri, hoc eft, per poros ad minimas vfque materix particulas penetrare; non enim veram illam miftionem intellexit, de -qua loquitur in calce eiufdem libri, nam in vera elemeatorum miffione intereunt fotm elementorum, quations migrant in formam ynars quintam diftincam ab eis; in accretionevr.ro fanguis per foramina ingretiens cum carne commifectur, deinde in carnem mutatur quare non eft veramiftio, quun fanguis intereat, caro antem maneat:fed non ob id fimilis eft mifioni aqua clim vino: 3 harum differentiam tetigit Ariftot. in eo contextu trigefimo nono: quoniam in milione aqua cum vino penetrant quidem partes aqua adminimas vfue vini particulas, fed non connertuntur in vinum, licet ita vulgaribus hominibus videatur, feruature. nim a qua curn vino commift, qua yinum non habet vim mutandiaquam in vinum at incarne vetere ineft vis couertendi commintum fangunem in aliam nouam caincm: hoc igitur modo tota materia augeturper receptionem alimentiintus; \& eodem modo augentur etiam partes maiores, ficut paulo ante dicebamus, quoniam hx quoque intus recipiunt alimen- tum perporos ingrediens: fed partes minime, quum nom habeant in fe aliud foramen, angentur folum per appofitionem alimenti extrinfecus, non per receptionem intus. Hac quum ita fefe habeant, facile eft fententiam Arift.interpretari, quando dicitacctetionéfieri fecundum omnes partes form $\ddot{x}$, non fecundum omies partes materix: de forma quidem pofterius dicemus, munc de materia facile eft dion Ariftotelis declarare per ea; quz modo diximu: materia namque eft per fequanta, \& per fe in 
infraitum diuidua, proinde partes habet infinit.15, non quidem actu, feś poteftate; igitur particula illa quam modo minimam vocabamus, reucra non eft minima, quoniam eft adhuc diuidua in alias, licet non fit setu dintifaper aliquod forameu, quum nul!un habere ítatuatur: Hancigitur partem ninimam appellemus A. \& quia diuidua eft poteftate in partes, has vocemus B. \& C. quando igitur ipfi A. apponitur alımentum, id toti minimxapponi dicitur totum fimul, red non feparatim pars cius apponitur ipf B. \& alin pars ipfi C. fed totum fimul toti A. quoniam igitur dicen do omnes partes materix, complectimur partes 11 las infinitas, in quas diuidua eft poteffate, ideo hoc refpiciens A riftot. dixt non omnibus materix partibus ficri ad :itionem magnitudins, non qu:ıd negaucrit materiam augeri, reuera enim \& tota materia, \& partes eius augentur per noux materix acceffionem, non tamen partes omnes; quia partibus omnibus in finitis, in quas diuidi poffunt partes minimæ, non eft facta peculiaris additio nutrimenti, fed folum toti minimx: \& huius fententix nuila eft alia ratio, nifi quod impoffibilis eft penetratio corporún, vt ipfe Ariftoteles fignificauit, argumentans in contextu 32 . $\&$ foluens in 35 . eiufdem libri; naim particulas alimenti inSinitas, in quas diuiduum eft, tranfre ad in finitas illas particulas, in quas corpus nutriendum disuidipoteft, ne imaginari quidem poffumus fine corporum penetratione, quam omnes Philofophi impoffibilem effe exiftimarunt. Altam quoque mationem multiadducunt, cur noth omnibus natcrix partibus fiat additio magitudinis, eamque funtant ex Ariftotele in context. 36. einfdem libri, vbi vtrem inquit fimilem efle form $x$, aquain vero inffuenteni, \& effluentem fimilem effe materix, qux eft in continuo flu$\mathrm{xu}$, neque femper eadem feruaur; hine igitur hane rationem fumunt: partes materix non femper exdem manent; quia flumt contimue. non igitur omnibusadditio fieri poteft magnitudnis, quoniam non manenti nihil addi poteft. Sciendum tamen eft, hanc non effe neceffariam, \& adriquatam rationem, cur non omnibus materiz partibus additio fiat , fed fumendam effe potitis vt confrinationem quandam ad vera rationis córoborationem idda. Etam; vt in illo exemplointelligeremus, non omnibus aqure partibus additionem noux aqua fieri, quoniamille fluxus eft continuus, \& par- $F$ tes noaremanent; at in illo, quod augetur, non omnino ita fe res habet; crederdum enim eft irterpolatas efrematerix fluxiones, quia non fit refolutio partis materite fine prouia alteratio"ne; quare datur tempas aliquod medium, in quo nibil refoluitur, \& nulla pars materia flnit; to igitur nadio tempore Aluxus nomimpediret
A quin onnibus materix partibus additio fieret, quía tunc nullus eft fluxus, fed impoffibilitas penerrationis colporum prohibetomni temporene id fiat: quod igitur dixitAriftoteles de materix fluxu, dictum eft potius ad intelligentiam illius exempli, nempe aquæ per vtrem Huentis, quam vit omnino ipfi accretioni accommodavetur tanquam vera ratio cur non omnibus materia partibus fiat ad ditio magnitudinis; fed vera ratio ea vna eft, quia fieri nullo modo poteft $B$ penetratio corporum.

\section{Quod non omnes partes materice extcndan- tur, \&́ quomodo alimenti quantitos quantitati reinutrite adiun-}

$$
\begin{gathered}
\text { gatur. } \\
\text { cap. } X X .
\end{gathered}
$$

${ }^{\mathrm{c}} \mathbf{Q}$ Vod hactênus de accretione nour mate. rix adveterem materiam oftendimus, id etiam de ipfius materix extenfione oftendere pofiumus qnemadmodum enim non omnibus materiæ partibus fit nouæ materiæ addifio, ita neque omnes materix partes extenduntur : etenim dictum eftantea, neceffarium effe in exten. fione, vt foramina oriantur; qux partem materix ab illa parte feparant; oportet igitur aliquam inter duo foramina particulam elle, qure integras maneat abfque vlladifusctione, camq; vocabamus partem minimam hoe itaque non extenditur, quia fi extenderetur, diuideretur ipfa quóque inalias per foramina, qux in ipfa fietent, quare non effent minima, vt effe ftatuitur: partesigitur maiores extenduntuir, \& rarefiunt; fed neceffe eit dari partes minimas, qux non rarefiant, neque extendantur, omnes enim extendi neque poffibile, neque imaginabile eft, effet enim omnes euanefcere, \& nihilati, \& continum efre actudiuifum in partes infinitàs, qua ne imaginar1 quidem poffunus. Ex his igitur manifeftum eft, veram effé Ariftorelis fententiam, quando inquit mon omnes materix partes augeri; nam tota materia maior fit, \& partes materiz maiores fiunt, non tamen omnes: idque oftendimus tum ratione additionis nonx materiaad matcrian veterem, tum etiam ratio. ne extenfionis; quia neque omnibus partibus additio fit, nequeadditione facta omnes extenduntur: Sed alia ad materiam pertinens quaftio hic oritur: quium enim \& accedens materia, \& illa cuiaccedit, quanta, \& corporea fit, quæritur an vna alteri in corporetur, \& qu!omodo id fiat, hoc eft, an noua materia amittat fiam priftinā quantizatem, fola manente quan- taro titatercterismaterix, an è contrario, maneat di a quuantitas goux, \& percat quantitas veteris, an

conacat 
maneat vtraque, an demum vtraque pereat, \& $A$ noua quantitas generetur vtramque materiam complectens, qux fuit Pomponatijopinio : nepi- gauitenim quantitatem interminatam coxternam materie, quam Aucrocspofuit, ideo putauit virusque materix, tum noux, tum veteris qquantitatem interire, \& nouam totiusaggregati quantitntem generari. Ego vero dimifia diputatione de quantitate corterna materix, qux $\mathrm{ab}$ hac noftra difputatione aliena eft, dica $\mathrm{m}$ brehuiter, conftituta huius rei veritate aliâs à me demonftrata, quidad propofitam quxftionem dicendum effe putem:ftatuens enim quantitatem materia ingenitam, \& incorruptibilem efle, \& fecundum Ariftotelem primæ materix coæternam; dico vtriusq; materiz quantitatem feruari, quemadmodum vtraq; materiæ portio feruatur:ficut enim ex duabus materiebus vna materia fit, ita ex duabus quantitatibus fic vnà quantitas , \& foli duarum quạntitatun termini mutantur'; quando enim ex fanguine nou caro generatiu, illa propriam habet quantitatem, id eft, proprios quantitatis term nos; ex illa igitur noure carnis quantitate, \& quantitate carnis veteris fit vna quantitas, \& neutra perit, fed folum noui termini generantur; quemadmodū fi duas lineas per extremitates in directum coniungamus, yna linệ ex duabus fiet, \& neutra illarum erit corrupta, fed duo tantum puneta eas terminantia corrupta crunt, vtraque autem linea manebit, quia manebit vna linea maiór ex duabus minoribus conftans : hocidem dicendum puto de quantitate eius, quod nutritur, \& augetur; nam vtraque quantitas manet, quxe enim prius erant duæ quantitates diftinct $x$, poftea manent vt partes ynius maioris quantitatis : nec propterea dicimus ita vnam materiam alteri incorporari, \& vnam quantıtatem fieri, vt vna alteram penetret, nulla enim fit corporum penetratio; fieret quidem; fi particula noux materix ita particulam veteris penetrarer, vt non perforamina ingrederetur, fed per partem plenam; fed pofitis foraminibus crebris, atque minutis, per quæ ingrediantur particulæ nouæ materiæ; non fitcorporum penetratio, ficuri neque quando aqua vino commifcetur, diuidunt enim fe mutuo in partes minimas, \& minima vnius non penetrat minimam alterius, fed illi cedit, \& ei fo. lum appofita eft. Quomodoergo materia, \& exus partes maiores fiant, diatum eit.

\section{Quómodo forma, \&omnes eiuspartes fieri maiores dicantur. \\ Cap. $X X I$.}

Equiturvt formam quoque viuentis, qua a. Snima vegetans eft, confideremus, \& oftendamus quomodo omnes partes formæ in accretioae maiores fiant, fisut Ariftot. dixit. Certum eft
A forman fecundum fc incorpoream effe, \& omni carentem qunutitate, quantā autem fieru per accidens, quatenus per materiam quantain extınditur,proinde non proprir quantitate effe quuan. tam,fed aliena: hinc ergo fft, vt omnes corporis partes penetrare absque vllabbfurditate porfit; nam eft quidem imporfibilis penetratio duor inuicem, quando virum q; eft per fecorporeum, fed incorporci cum corporeo non eft impolfibilis, vt in accidentibus cófiderare polfunus: nam B lactis albedo non eit per fe quanta, fed per accidens, \& ex lactis quancitate, per quam extcría eft; idco penerrat omnes lactis partes; neq; vITa cartum eft, quíx non fit alba ; non ita tamen pene- Qzomotrat, ve per foraminaingrediatur, fedperputes do omniplenas : quod quidem, li perfe corporea albedo buspar. effet, fieri nullo modo poffet : fic calorignis pe - tibus for netrat omnes ignispartes, ita vt earū qualibet, ma fiat quantulacunq; fitmatur, calida fit, neq; aliquis additzo. cft, qui hocinlicietur. Sic igituranima, quum nö lit per fe corporea, poteft omnes corporis partes penetrare, itavtnulla fit pars, qux non fit animata:hoc fignificauit Arrit.in contex. 4. lib.z.de Anima, quandodixit animä effe non poffecor. poreumaliquid, quia fi effet corpus, non porfet omnes corporis partes penetrare, quium pene. tratio corporum fit penitus impoffibilis; quare non omnes corporis partes effent animatr, adiaceret enim particula animæ parriculæcorporis, qua infe animamnon haberet. Hoc igitur fundamento, quod clarifimum eft, conftiruto, veritas diati Ariftot.facile declaratur:animam e. nin nuiorem fieri exmateriæ incremento negare non poffumus, quia fi fit quanta ex corporis quantitate, fit igitur magna in magno corpore, \&parua in paruo: hoc enimi dicere neceffarium eft, fi qualibet magni corporis pars eft animata: quoniam igitur viuentis tum materia, tum forma fit maior, non tamen ex additione \& materix, \& form $x$, fed folius materiæ; quum enim fola materia fuat, fola etiam materiandditur, \& additur verique, tum materix, tum formæ; materia enim per nouæ materix additio1ié m.sior fit, \& forma qưoq, fit maior, quia per maiorem materiam extenditur: hine fit neceffario, vt omnes partes forma crefcant, \& mulla fit, quxin accretione non fiat maior : quemadmodum enimànima facta eft quanta per mate. ruam, ita \& partes per materiam adepta eft, \& facta diuiduajextenduntur ergo omnes partes a-

F nimæad maiorem materiam, nec vlla cófiderari poteft eius particula, quæ nö extendatur : omnibus igitur anim $x$ partibus fit additio materiæ, \& magnitudinis" quia quum fit facta quanta, \& in infinitum diuidua fecundum fuam quantitatem, quanta manque eius particulam confideremus, illieft facta propriz magnitudinis additio, ea que proprium recepit ir.crementum : hoc

$$
\text { C C } 4 \text { enim }
$$

'Additio fit folius materis, nox for$\operatorname{manfit}$ tancen Gtreque, Ëmaieris, G. forma. forma. 
enim non offe abfurdum, fed potius necefrarium, fumitur ex fundamento iacto; quando:nim aliquid per fe quantun cum altero per fe quanto commifcetur, non poteft ommibus alterius partibus fierialterms additio finc corporum penctratione, qux in philofophia admitti non poteit; at fi alicem tantum fit per fe quantum, alterum veroper fe quantim non fit, potelt omnibus alterius partibus addiuo alterius fieri abfque vlla abfurditate, neque illa dicenda elt penetratio corporum, quimalterum non fit coxpus: quod quidem ita oftendere pofin. mus: quando duo inier fe coniuncta funt, vt A. \& B. nullum poteft effe difcrimen in coniunctionis modo ex eo quod dicatur coniungi A. cum. B. vel B. cum A. nam vtrouis modo dicamus, eadem eft eorum coniunctio, \& idem coniunctionis modus; quemadmodum idem prorfus hit, commifcendo phialam aqua cum phiala vini, ac commifcendo phialam vini cum phiala aque: eadem igitur fit \& animx cum corpore, \& corporis cum anima coniunetio, \& idem eft couiunctionis modus: atqui anima ita adiungitur corpori, vtomnesillius partes penetret, \& nulla fit corporis particula, quæ animam non habeat;non folum enim illæx, quas diximus, minimæ partes anumam habent, fed \& illarum particula, \& particularum particulx, \& demum ommes, qua in ea cófiderari poflunt: fic igitur etiam quaindo materia adiungi anima dicitur, neceffe eftidem fieri, \& cuilibet partiaaimæ aliquam materiæ particulam adiungi. quaniancunque partem fumamus; non ita tamen, vt re difinctas partes effe Rntuamus, hoc. erim fierinon poteft cum anim $x$ conferuatione w. eis, fed vt in toto exiftentes, fic enin Arifot. intellexit. Quomodo igitur non omnibus m.teria partibus, ted ominibus partibus forma. fiat additio magnitudinis, manifeftuin eft.

\section{Confutatio opinion alionum in intelli- - gendis partibus materice, os partibus forma. Cap. XXII.}

$\mathrm{V}$ Eritate ita declarita de partibus materix, \& de partibus. form $x$, ita. vt pateat quoConfut modo fit intelligendum id, quod Ariftoteles, sio $\int a c \bar{u}$. deoptniins.
A tam partibus materize, quam partibus form $x$ additionem fieri magnitudinis, ctim hoc tamen difcrimine, quod partibus forma cmnibus, partibusautem materixe non omnibus: vel igitur hi partes heterogeneas dicunt appellarpartes formx, homogeneas vero materix; vel hetero. gencas dicunc vocari formales, \& partes harum dicipartesformx, \& lta homogencas matelia. les, \& harum partes vocari partes materiz; quorum neutrum eft verbis. Ariftotclis confentaB neum: non primum, qiuia ficutiaugentu omnes heterogenex, ita \&: omnes homogenex, imo has primun fit additio materix, non lietcrogeneis, nif ratione-homogenearum, è quibus conftant; falfun igitur eflet Ariftoteles dictum, quin fignificaret non omnibus homogeneis additionem fieri. Sed neque fecundum, quia par, tes heteroǵenearum funt homogenex, ipf $x$, quamobreng dicere omnes hetcrogencaru partes fieri mares, eft dicere omnes homog neas; C quodtamen fecundum ipfos Ariftoteles negat, dum dicit non onines homogeneas, quas materix partes vocat, maiores tieri: huius igitur fentcintiafallitas manifeftifina c lt, quonım Ariftotelesnon dicitaccretionem magis forma attribui, qnam maten $x$, fed-dicit omnes partes formafieri maiores, partes vero materia fieri quidem maiores, non tamen omaes, cui fententix interpreta tio 1 lorum accommodari minime poteft, yt confiderantibus vetba Aritotelis in contestu 35.\& 36. primi libri de Ortu \& interitu manifefum eft. Alia quoque aliorucu interpretacio, qui hunidum radicale ab humido cibali diftinxerunt, reiicienda eft, quia ad- ti mila etiam hac humids diftinctione dictum Ariftotelis falfum effet : humidumenim radica- le, quiod ipfi immutabile effe ftatunnt, abqque dubiocorporeum eft; igitur -fi huius partes omnes fiunt maiores per.alimenti corporei acceffionemadomnes, fit corporum penetratio, E quamin eadem loco in contextu 32. \& 35 - Ariftoteles impoffibilem effe dixit, vt eam euitaret, ad partes formx confúgit ; per forman igitur non pollumus ibi aliquod corporeum intelligere, quoniam alimenti corporciad omnes penitusalterius corporei partes acceffio eft abeque dubia corporum penetratio. Sed hi decepti fint in afferenda ratione, cur non omnibus materix partibus, fieriadditamentum poffit; eam enim vnam refpexerunt, quia materia fluit; non alteram, qua à corporum penetratione fumitur, licet liæe potior fit, illia vero debilior, ficut antea diximus; ideo fatisfe vitare omnem. difficultatem exiftimârunt, fi. materiam aliquam non fluentem adinuenirent.. Sed ipra quoque per fe humidi diftintio, quam ponunt, nou parun dubia eft: qua de re tanquam icitudig!nifima, \& ad id, de quo agimus, plu- 
rimum conferente, poftca feorfun differemus, A \& eormm in hoc quoque croren patefaciea- mus. Non munus abiuida, \& ab A rifotele arr- linea cit dia interpretatio, quarn complures fequut funt, qui nonrixe forme totum ipfum viuens intellexerunt, nomine autem materix partes; quia totum fignificat forman, partes vero nateriam, \& totum nanct fimperidem, partes vero mutantury \& funt : crenim fi Ariftotcles folum dixiffet, attribuensiom cfe accretioncm non materia, fed forma, fortaffe admitipeorum opinio pollet, attamen non dixit hoc Ariftoteles, fed diftinxit partes forma à partibusmaterix, \& 1 llis omibus additamentum fieri dixit, his vero non omnibus: quare fi fecundum illos pares materian fignifieant, qitomodo feiunxit Ariftoteles partes; form tanquam figrificantes formam a partibus materiæ tanquan fignificantibus materian ? \& cur totam materiam non vocat forman, fed vocat materiam, fi fecundum cos totam fignificat formam? certefi nomine forma totum vt à partibus diftinguitur, intellexiffer, \& nomine materiz partes vt diftinguunturà toto, nequte dicere potuiffet partcs form $x$, neque totam niteriam, quia partes form fecundum. hos. fignificant materiam, tota vero materia quatenus eft tota fignifificat formam. Praterea fecundum hanc interpretationem deftruitur illa accretionis conditio, quam vult ibi tueri, \& à difficul tate vindicare Ariftotel. quod in vera accretione non modo totam, red omnes etiam partes maiores frant : quum enim huic obftare videretur: impofibilitas penetrationis corporum:, ipfe ad tollendan hane difficultatem dixit hoc efle verum de partibus forma; nor de partibus materiz: ifti vero féntentiam Ariftotelis, \& illam accretionis conditionem euertentes dicunt folum totum augêri, non partes. Denum opinio Marflii dicentis partes formæe effe partes porofas, partes vero ma terix efle partes plenas, abiurdifima eft; quia partes porofa nil aliud funt, quam ipfa foraminum fpatia \& vacuritates, proinde partes corporis appellandx non funt, quia nnn funt partes viuentis, quum entm fubftantiam in $\mathrm{fe}$ non contineant, fed aerem, vel vaporem aliquem: extraneum; vanum ergo eft dicere illis additamentum fieri in accertione viuentis quod. augeri dicitur, quum eius partes nō fint, $p$ roinde nee materix; nec formælocum teneant; $F$ nam fi debeat totum vinensproprie augeri, o portet eas, quæ vere eiuspartes funt, maiorıs: fieri. Sed \& hanc, \& alias omnes interpreta. tiones refutant fatis manifefte 1 famet Arifto telis verba, in contextu' 35 , prædicto : inquit enim accretionem competere partibus diffimiJaribus propter fimilares, è quibus illac contant
\& quxprimum augeri dicuntur; facirque eam partiun diftintionem, vt dimiffis diffimilaribus folas confiderit fimilares, in quibus illam, qux de corporum penceratione oriebatur, difficultatem tollat; \& obid ftatim fubiungit fimilares fingulas ex materia \& forma conitare, acdemum concludens drcit omnibus partibus form $x$ fieriadditionem, at non omsibus partibus matcrix : nomine igitur form ibi neque dufimilares partes figniticat, quum eas iam reB ieciffet;nequc humidum radicale, quum huius nullam mentionem feciffet; nę; torum ad differentiam partium: quum partes folas ibiconfideret, \& quomodoaugeantur doceatad prædictam tol!cndam dificultatem; \& quum formam sbi fumat vt partcm compofiti, nonvt compofitum totum, inquit cnim carncm ex naieria \& forma conftare, \& ftatim fubiungit, omnibus partibus formæ additamentum fieri, C Fed non omnib. partibus materiz: nec demum fignificat partes porofas, quum ha non fint viuentis partes, ipfe veto illam tantummodo formam, \& illam materiá intelligere polfit, è quibus conftare carnem, \& quamlibet aliam homogenean partem ploxime dixerat. Igitur non alian formam intelligit, quam animam; neque aliam materiam, quam corpusilli fubięum: ex his enim duabus con ftat caro animata; cuius ibi-Aritoteles accretionem confiderat, quum. in partibus fimilaribus quibus primo competit, eam confiderandam, \& ab ea remouendam iliam difficultaten fufcepiffet, qux de corporum penetratione oriebatur; hec enim folui nullo modo potefr, niff confugiédo ad aliquod perie incorporeum; quad omnes corpores partes penetrare fine abfurditate poirit.

\section{An aliqua fit materio pars in viusute; que non junt, fed eadem pertotanvitanjer- $\mathrm{E}$ uetur. Cap. XXIII.}

Citerum ad plenam eorum intelligenti Cam, quæ: de materia ac de forma eius, quodnutritr, \& augetur, dieta funt, confiderandum diligentius eitid, quod palo ante tetigimus an aliqua in viuente fit materix pars, qqu $x$ on fluat, neque à calore naturali abfumatur, fedeadem abortuad finem.vfque vitx immutata fertetur; an potins ita omnes materiz: partes fluant, vt poft tempus aliquod nullacarum, quaabortu: duetx funt, in viuente remaneat,quod eient aqua per vtrem fuenti; quod exemplo Ariftoteles-ad-declarandam \& form $x$; \& materixaccietionem vfus eft. Iam diximus aliquos exiftumalie, duplex effe humidumin viuente; vnum.radicale, quod durante vitanunquan confumitur, quia eius confumptio mors eft;alteví yero cibale, quod ex alimetis ad illiús C. 5 defen- 
defenfsonem quotidie aggenératur, \& hoccon-A tinuc Aluit, \& renouatur, neque idem permanet:

Aesan- fententiam hanc attribuit Aucrioes Alexandro der.

Argsm. in Comment.j8. primilibri de Ortu \& interitu, ¿ caudem f́quutus videtur loannes Gramma1.. Gram ticus, qui in eodem libro dixst neceflarium dari mac. aliquam materix partem, quenon Gitat, fed per totam vitam cadem permaneat; vifufqueeft tali argun ento: fi tota nateria Hueret, \& tota renomaretur, fequereturpone indinidum feruari $a-$ ternum, quia viuens haberet rmper materiam nouam, atque virentem : quare femper eflet in iumentute, \& numquan fenefceret :quam enum anima perfenium nop debilitetur, fi dicamus materam quoque tosam poffe renonari, nihul erit quod detrimentum aliquod pariatu; nullum igitur-decrementum in vinente fiet, nulla fenedus; cuius contrarium in omnibus viuen.
Argum. Alexan. $d r$.

\section{Anes. regs.} tibus experientia docet. Adeft etiamargumentum, quod Auerroes in pradicto loco Alexandroatiribuit: fi totamateria fuerct, \& tota renouáretur, fequeretur polfe forman materialem feparari à tota fua materia, quia fi à tota fua materia poteft hoc modo derelinqui per partem poft parté, ita vt tande maneat finevlla parte fuz materia, poteft ctiam à tota fimul materia feparari, eadem enim vtrobique ratio viget. Aliud quoque mirabile, \& vix credibile atribuit $\mathrm{A}$ lexand ro Auerroes in eodem loco, quod hac in re Ariftótel.reprehenderit, ac deferuerit:quum cnim Ariftoteles dixerit accretionem efle adfcribendam forma, non materiæ, hac ductus rationi, quia eftaitribuenda non illi, quod fuit, fed illi quod permanet, forma autem permanet, matei ia vero fluit continue, ita vt nulla eius pars eadem maneat, Alexander, vt ait Auerroes, dixit A riftotelem hoc de materia protuliffe fine vlla probatione, tanquain fequntum id, quod apparet, quum in ea animus acquiefcere videatur; falfum tamen effe hoc A riftotelis dictum, propterea quod datur etiāalıqua materiæ̌ pars non flueins, cui ob eandern rationem non minus, quam forma eft accretioattribuenda. Sed vbinam apud Alexandrum hoc Aucrroes viderit, ego quidem nefcio : nam fi Alexandrumlegamusin primolibro Natuial. quaft. cap. $5.8 x$ in poftrema parte libri fiside. Miftione, vbi de hacre loquitur, nihil tale comperiemus; fequifur enim in omnibus Ariftotel.\& inquit, materiam continue fluere fecundum partes, formam viro non fluere, fed eandem manere, \& per formam intelligit animam, vtnos intelligendam effe diximus, quam dicit ad masorem materiam extendi, \& ad minorem retrahi : de humido autem radiali; quod ron fluat, neverbum quidem ibi apud Alexandrum legimus, fed porius videtur in omaibus A ticroi confentire; nam Auerroes quoque in memorato locoalierit mate-

riam Auere, formam vero non fuere, fed eandem feruari : defenfionem autem A riftorelis in co putat effe conftitutam, vt-dicamus omnes prorfus materizpartes fluere, \& obid noneffe ipfi meteria attribucndan acciêtionem; fedin co quod nos anfea declarauimus, quod A riftot. non negauit matcriam; \& materia partes augeri, \& illis quoque additionem magnitudinis fieri, fed negauit omnibus partibus materixaddi. tamentum ficri; proinde illamaccrtrionis con-

B ditionem, quod omnes partes acigeantur, de partibus formz veram effe, non de partibus ma. teria : nequeper formam aliud sb intelligit $A$ uerroes, quamanimam, ficut etiam Alexander, quicquid multidicant, qui in alim fenfun ver. ba Auerrois trahentes inquiunt, Auerroem nomine form intellexiffe totum, it diftinguitura partibus, \& putalle partes quoque animævna cum materia partibus fisere; hoc enim ctiam Pomponatius Auerroi adfcribit in libía fuo de C accretione, \& nutritione. Sed non eft, cur in verbis Auerrois interpretandis immoremur: quanquam enim eaper fe obfcurifima, acdifficillima intellętufut, tamen quifquis ea cum diligentia legat, atque perpendat, deprehendere poterit eam, quemilli putârunt, Auerrois fententiam non fuille; fed Aucroem exiftumafie Ariftot.nomine formæ animam vegetante figuificafie, \& hanc nullo modo fuere, fed materiam folam fluere, ficutinos quoq; diximus. Sed mit$D$ tamus her, \& quicquid Auerroes \& Alextnder fenferint, ipfam fecundum fe, quam expendendani propófuimus, de duplici humido fentenriam, cuiufcunque en fuifle dicarur, confideremus. Hanc ego approbare nullo modo poffum: non ẹnim video, quomodo detur aliquod humidum, quod à calore pati, \& refolui nequeat, quum omne aliud humidum fit patibile à calore; quodnam igitur eft huius priullegium, vt fit impatrbile? proterea frid verum eflet, quomoE do tam parua materia, qua ab ortusinitio tra. hitur, diffundi poltea per tantam molem poteit, quantan effe videmus animalis perfecti \& plantæ: certe embryum eit valde partum connparatione perfecti animalis, \& parum humidi in fe habet; quomodo igitur poteft ea parua materia inconfumpta feruariad atatem vfque perfefam, \& cum tot tantıque mcmbris com municari? videmus etiam ex paruo admodum femine magnam arborem nafci; oporteretigiturin F illo fenine, feu in primo germine pullulante, quod valde pufillum eft, tocum hunidum contineri, quod inconfumptum ferueturad extremum vfque incrementum, \& per omnes magnx arboris partes diftribuatur, quod quidem incredibile eft. Hanc igitur de duplici humido fententiam reirciendam prorfus effe exuftimo. Quid ergo dicendum ? totane materia fecundum 
cundum partes ita fluit, vt in fenio mulla eitzs $A$ pars r cmaneat, qux prius in infante fucrit? hoc qioque mihi nó probatur, fed puto aliquam cife matcrix partem, qux à calore naturali confumitur, \& aliquam effe, quæ non confumitur: fed hane differentiam non ex co fumi, quod alia fit radicalis, alia verocibalis, \& ad- ucnitia; fed fumi exeo, quod alia pars eft humida, alia veroficca \& terreftris; humidum cnim à calore naturaliconfumitur, eft enim proprium ipfuts pabulun, pars vero terreftris remanet, quemadnodum etiam in is , qux comburuntur, infpicimus; toto namque humido confumpto ab igni, remanet cinis, qua eft pars terreftris, quam obcius maximam refiftentiam non poteft ignis abfumere: viuentia autem omnia in fui ortus initío humi diffima funt, procedente autem etate fiunt femper ficciora, quia calor confunit humidum radicale: \& quamuis adueniat humidum cibale reparans ipfum, atque reftaurans, tamen aduénit cum eo etram parsaliqua terreftris, qux poftea remanet cum terreftri parte ducla ab ortu, \& fcmper, atate procedente magis à calore naturali condenfaus tur, \& indurefcit: propteren Arittotel, in libel. i- de Iumentute \& fenectute dixit, nil aliudefe fencitutem, quam exiccationem, quouian humidum femper imminuitur, ficcum vero cref́it : ideo nifi morbi naturalem vit $x$ curfum intcrumperent, nec effe effet nos pertenire ad mortem naturalem, quæob totius humidi refolutionem fit : quando cnim corpora noftra per longam xtatem ad tantam duritiem, \& ficcitatem redacta funt, vt fint inepta ad operntiones, \& ad pabulum calori naturali præbendum. \& animam conferuandam, 'fit ex neceffitate bu mors. Dícinus igitur humidum radicale, feu naturale confuni a calore viuentis; neque illud folum, quod ab ortu trahitur, effe vocandum naturale, fedetiam illud omne, quod per totam vitam exalimentisaggeneratur; humidum $\mathrm{E}$ enim cibale conuertitur in fubftantiam, \& in humidum radicale, \& naturale; quum enim, mutetur in fimile naturali \& cum eo commi- fceatur, ipfum quoque fit naturale; \& vocatur radicalead differentiam humidi excrementitit, quod non eft idoneúm pabulum calori naturali. Sed praterea hocradicale, \& naturale hunidum fit femper impurius propter reactionem ciborum in facultatem naturalem, quoniam 2gens naturale in agendo repaticur; quare per continuam actionem in cibos corpora noftra redduntur impuriora', \& imbecilliora. Non eft igitur ponenda aliqua humiditas fixa, \& isscfolubilis, hoc enimnihil inanius pronuntiari poreft; quia omnehumidum eft refolubileà culore, illud quoq; quodab ortu trahitur, confumitux enim \& eger aliquo regarante, \& no- uum humidum frbminiftrante; id autem, quod non confumitur, cfi pars tereftis, tan quxab ortu trahitur, quam quxexcibis continueadiungitur. P’offumus autem ad huiusce reideclarationem vti fimilitudine fatis opportuna : in ellychnio lucerna vidcmus ignem nutriri donce attrahitur humidum olei, à quo proprium ellychnip humidum reparatur, quod quidem fine oleifuppeditatione cito ab igni confumeretur, fed propter continúam ignis abtionem peruenit ellychnium tandem ad tantam ficcitatem, vt nequeat amplius ignem conferuare: idque id. eo fit, quia ignis plus indurat, \& exiccat, quam ab olco humectetur, \& reparetur, \& ipfus quoque olei confumpti pars terreftris remanet cum terreftriparte ellychnij, quoniam ab igni non comburitur, fed remarret etiam contincto igni : fic in viuentium corporibus euenit; in fenio enim plus exiccationis, \& terreftris naturareceperunt, quam à cibali humido fuerit reparaC tum: pars igitur, qux in confumpta manct; non eft alıa, quam pars terreftris, quim refoluere calormon potent, teftimonio funt ofla, quæ etian poft mortem animalis diutifime durant, quoniam eorum temperatura magino exceffu terreftis eft; terra enim maximam yim refiftendi habet. Hae fententia Ioannis Grammaticifuit, qui in interpretatione context. trigefimi quinti primi libri de Ortu \& interitu, oftenderevolens formam non fluere, fed eandem nuD mero manere hocargumento vfus elt, quod neque matcria tora hnit, fed aliqua eft materix pars in fene, qux eadem fuit in puero; \& hanc inquit efle partem folidiorem, ac denfiorem; nempetcrieftrem, qux à calore non foluitur: \& ad boc confirmandum adhibuit fatis validum fignum, nam cicatrices in adolefcentia receptr remanent exdem in fenio, quod non effet, nifi aliqua materix pars eadem num ero in feneremaneret, qua in adolefcénté fuit : quod quidem argumentum fatis habet efficacitacis, nam proprum ficci ef figuram, ac terminos retineré, Sed alterum Ioannis argumentum, solutso cuitus fupra meminimus, reuera ad huius argumécomprobationem parum roboris habet : quan- ti Ioaro do enim inquit, finulla materix pars in fene feruata eft, qux in infante fuerit, ergo in- matic, diuduum effet immortale : polfet aduerfaşius hanc confequentiam negare, quia etianfitotam materiam fuere per partem poit pertem ciceremis, nos ob id fieret yt materiain fone femper virans renouaretur, ar ipfe femper in Gore iutentutis feruaretur : etenim etjam fi tota renouari ftatuatur, fit tamen fempe: impirior, propter reactionem ciborum, \& ciloris debilitationem ; calor enim, naturalis femper debilior fit, ob illam continuam reactionem, \& ob materix maiorem impu- 
ritatem; quarenecefie eft, vt tandem deficiat : ex ${ }^{-}$ hacigitur continua caloris debilitationefit, vt non ita perfête irmutare cibos, \& in finilicm fubltantian vertere calor pollit: quare etiamfi omaes naterix partes per fuccelionem renomarentur, necefe tameneflet animal fenclcere, solutio \& argumen Auerroe Alexandroattribúum in CommentawAlexa- 1 io 38 s.prediclo aliquid habctefficacitatis, ncmdrs. pe cumm diccbat if tota materia per fuccelíonem lenounetır, poffetanin a à 10 ra fua mate- $B$ ra feparar1:nam hacillatio nullam vim habet, quila tallacia committitur à duifis ad coniunEtum:ideo dicere aduerfarius poflet animam fi- / ne qualibet parte fure materiz feparárm fum pta pofte remanere, fed non fine omnibus fimul codem tempre fubtractis; talem enim elfe nzturam animxidiximus, vt determinet fibi certä snateriam fecundum totum, qux femper vna $2 x$ eadem foruerur per requilialentiam, fed non vt fibideterminet certas eius materiz partes, quo fit vt mutari point partes materix vna polt aliam diuerfis temporsbus, fed non tota fimul materia eodem tempore fub anima renouari. Patet igitur, rationem, cur in fencaliqua materix parsendem feruetur, qux in infante fuit, non effe ab ipfa anima fumendan; quiaetiamfi omnes materizpartes per fucceffionem vna poit aliam renouarentur, poffet anfma feruari, dummodo materia tota eaden feruaretur per æquiualentiam : féd rationem liumendamcife à fola matcriænacura, cadem enim materiz pars idco feruatur, quia denfa, nc terreftris eft, quam confumere calor naturalis non poteft.

\section{Quomodo, \& qua ratione compofitum augeatur. \\ Cap. $X X \perp V$.}

Accretio propitie est com pcfiri, nö formets zaci $m a$.

मeris.
H Actenus accretionem \& cum materia , \& $\mathrm{E}$ virique, \& earum partibus competat confider uimus: reftat vt eam ad ip fum quo que compofitum referamus, nempead totum viuens, quod excorpore vt materia, \& aninia vegetante vt formaconftare fatuitur. Primum quidem certum elt, compofitum efle proprim fubiectum, cuiprimo eft accretio attribuenda ; fiquidem, yt Aritoteles docuit in context. 67. primilibride Anima, omnes operationes anima fint totivi- F uenti atribuendæ vt fubiecto, non foli animæ, neque folicorpori :quamuis igitur propter ma gnum anima \& corporis difcrimen, \& propter cletationem à materia, powcrit \& in materia, \& in anima ficorfim accretio confiderari : tamen proprie loquendo, neque materia augetur, neque forma, ted compofitum ex vtrisque con-
A ftans eftid, quod augeturvt quod, materia vero, \& forma, vel ipfarum al tera vt quo, non vt quod, eftenm id, quo totum viuens aptum eft augeri, \& augetur:idco dubium non leue oritur. an forma, an materia fitin viucnte formalis ratio accretionis, hoc eft, an viuens augeaturatione materi $x$, an potuls rationc form $x$, \& qua tenus eitaninatum ; nam pro vtraque et raio. Videturprimum ratio formalis, curcorpus viuens augeatur,pctenda effè mareria, non abanima; quia tota accietionis natura in quantitate confiftu, quan eitus finis fit adeptio perfect quantitatis, quantitas autem eftpropria materiæ concitio, itaque augentur corpora, quatenus funt quanta, \& ita ratio formalis funitur à quantitate, proinde à materia: quod fi rationem formalem abanima funerenus, dicentes corpora augeri quatenus funt animata, eam ad fubRantiam potius, quam ad quanticatem referemus; fic autem tona accretionis natura tolC leretur, qua non ad fubltantiam, fed ad quantitatem dirigenda eft. Exaltera vero parte fi corpora dicantutaugeri quatenus quanta funt, fequitur omni quanto accretionem competere: confequeis eft manifefte falfurin, quia lols vi nentibus proprie dida accretio competit : confequentia autem facile probatur, quia valida fempureftillatio à quatenus ipfum ad deomni; quoniam igitur corporibus inanimatis accretio, de qua nunc loquinur, non competit, fed folis, acque omnibus ànimatıs; ergo quatenus funtanimata;non quatenus quanta : res igitur difficultate non caret; \& eam augent verba $A$ ueroois Commentario trigefrmo oftato prexdicto, wiinquit quantum augeri quatenus habet formam, quod eft dicere animam effe rationem formaleniaceretionis in corpore viuente, fed poftea etiam dicit formam augeri, nó prout eft forma, fed prout eft quanta, \& extenfa, quare videtur etian dicere rationem formalem effe E quantitătem. Whilop. quoqueibidem in digref: fione contextu 35 . oftendit accrecionem corporibus competere ratione forme; addit tamen, nouprout eit forma, fedprout eft forma quanta. Dignum ergo eft confideratione, quomodo hocferehabeat, \& quid hacin re fentiendum fit. Anteomnia ftatuendnn eft, quidnam fit id, quod quxrimus, vt hac in re omnem ambigui. tatem tollañus: diximus alias in libro de $\mathrm{Na}$ tura, duplex elle principum motus; vinum afiuum, à quo motus producitur jalterum faffiuum, quod facit in lubiccto aptirudinem, ac propenfioncm ad talem motumrecipiendum; nunc igiturnon quximus atium accretion is principium, nam illudanimam effecertum eit, à qua \& coquitur alimentum, \& in firbftantiam vertitur, \& membra ad maiorem quantitatem extenduntur: fed id, quod quxrimus, eft passic prin- 
pruscipium accretionis paffuun, illud fcilicet $A$ à quovuuns corpus aptum, arque propenfum redditur ad accretionis motum recipiendum; ideo hoc rectius vocaretur argumentabilitatis, quam augnentationis ratio formalis; nofque ipfum ita in prafentia apyellare liceat; nä̈ augmentabilitas fignificat potentiam, \& aptirudinem paticndi motum accrotionis. Si igitur verum eft id, quod in memorato libro docuimus, fornım cfle principium no:us, \& adtiunm, \& pafitum, diuerlis modis acceptam, nccerfe eft, vt dicamus animam vegetantem, quxe eft principum accretionis adiuum, efe ctiam pafiuum eiufiem motus principım; \& rationem formalem, qua corpus animatum, aigmentabile eft, eft enim augmentabile, quia eitanimatum, proinde omne animatum augetur, quia hoc ei competit, quatenus eft animatum, non quidem vt pertotam viam augeatur, fed per 1taturum quooddamà natura tempus, quemad- mołum antea declaranimus. Quumigitur hac ie- rei veritatis fit, nitendum eft dificul tatem tolleuâ re, qux ex quantitatis confidera.ione orrbatur: quoniam enim augeri nul aliud eft, quam majorem quantıtatem tieri : mon poteft augeri, nifi id, quod quant um effe ftatuatur, ideoque auginentabilıtas quantitatem poius, \& maceriani, quam formam confequi vidébatur. Sciendum igitur eft, anımam vegetantem, de qualoquinur, \& formam omnem materialem duas habere effentiales conditiones, qux" pugnareinter fe videntur, nec tamen pugnant; vna eit, quodfecundum fe non eft quanta, fed incorporca: \& indiuiribilis; altera eft, quod nei- ceflario requirit ftatutam materiam quantam, was per quam extendatur, \& fiat diuidua: neque boc extraneum, \& accidens effe ipf formx dicendumeft, quum A riftoteles in Proomio primi libri de Amma dixerit, hane effentialem omnis formamaterialis conditionem, proinde in cuiufque form definitione propriam materiam fumendam effe, fecus vanam, \& dialecticam effe definitionem, neque eius forma effentiam exprimere: non pugnant autem hæc inter fe, quafi dicamus effe effentialem conditioné form $æ$, vt fit \& diuid ua, \& indiuidua; quemadmodum enim non implicamus contradictionem, quando dicmus materiam poftulare formam, \& neceffario effe formatam, effentialiter tamen effe penitus informem, quia fie nil. aliud denotamus, quam materiam debere effe formatam, non habere tamen formam in fua natuta,fed extrinfecus eam recipere : ita etiam formam materialem dicimus debere ex neceffirate quantam \& extenfam effe, quantitatem tamen \& extenfionem non ex propria fua natura habere, fed ex materia in qua recipitur; ideo cflentialis eft conditio omnis forma ma- terialis vt fit in tali materia, vt in dicto loco Ariftotclesafferit. Ratio autcm horum omnium eft, quianec materia, nec forma eft cns per fe completum, \& in fpecie collocatum, fed vtraque dirigiturad cóftitutionem compofitisideo neutra ornes habet neceflarias conditiones ad fpeciem conftitutendam, fedaliquas fingula habet ex fe, aliquas ab altera recipit : materia ex fe habet quantitatem, \& naturæ corporex inchoamentum, nou terminos, \& actum, fed hxc

$B$ recipit a forma; contra vero forma eft termi, nus, \& complementum, fed eget materia recipiente \& fuitentante, \& quum dibedicile quanta \& diuidua, eiufmodi autem à feipfanon fit, requirit neceffario materiam quantä, per quam extendatur, ita vt per eam quanta, ac diuidua fiat : itague non dicımus conditionem effe forminecelfarian vt fit \& quanta, \& non quanta, \& firnul diuidua, \& non diuidua; fed dicimus necefiarium elfe, vt quanta ac diuidua fit, fiquiC dem compofitum, quod ab ea eft conftituendum, debet efre quantum, atque diuiduum; fed quum ipfa ex fenon fit huiufmodi, fieri quantan, ac diuiduam à materia, per quam extenditur, \& ita ad compofitum côftituendum tum materiam, tum formam ita concurrere, vt propriam viraque operam contribuat: hoc quum ita lit, non eft mirum, if formæ pro diuerfis fuis conditionibus diuerfa etiam aturbuantur; alia namque illi competunt ratione propriæ natuD. alia vero ratione illarum conditionum, quas recipit à materia, eft enim principium motus actiuum quatenus eft forma, non quatenus eft extenfa, \& diuidua per materiam, fed eft principium motus pafluum quatenus eft quanta, \& extenfa per: materiam, non poteft enim effe ratio recipiendi incrementum, niff fit quanta: propterea dicebat Auerroes in Cöment. 28 . tertii lib. de Colo, forma elementi mouet vt eft forma, \& mouetur quatenus eft in materiaj hoc ef, forma elementi eit ratio formalís cur elementum fit talimotu mobile, quatcnus eft in materia, in qua.fit, qunnta, \& conftituit corpus tali motu mobile quod autem dicit Aucroes de forma elementi refpeetu motus localis, idem dicendum eit de anima vegetante refpectu motus accretionis. Sed id, quod hac in re difficultatem faciebat, erat quod accretionis natura: in quantitate cófiftit, quare ratio augmentabilitatis videturà quantitate potius effe fumeda, F: quam a forma: quodetiam fignificaffe videntur Auerroes, \& Ioannes Grammaticus; dicentes viuens augeriquatenus habet formam; formam vero augeri quatenus eft forma quanta. Sed re bene intellecta onne dubium tollerit: \& Auerrois, \& Ioannis Grammatici fententia. vera effe cognofcetur: dicimus enim partiçulamillam, quatenus, guando hi dicunt forma m 
quatenus eft forma quanta, non denotare ratio- $A$ nem formalem, fed conditionem materialem ipfi formx neceffariam, \& fine qua non: fola enim formaelt ratio cur corpora fint augmentabilia, non quidem omnis forma, fed hxc, de qua loquimur, filicet anima vegetans quatenus eft anima vegetans; hac tamen id non præftat, nifi per materiam quantam extęfa fit: quod autem diximus de ea dictione, quatenus, confirmattr Ariftotelisteftimonio in contextuso. librifecundiphyficorum, vbi fumit, quatenus non pro ratione formali, fe pro cöditione materiali, quemadmodum alio in loco declaraui-

Sab lab. de tribss praceg. exp.12.

Lnima of ratso $\mathrm{q}$ formalis argmencabilitats, quar- minat; igituranima eft formale augmentabilirocft cc-minor ita probatur: quantum quatenus eft Litio mo- quantum, non alia ratione eft augmentabíle, cerialis. quam quia omni quanto rationequátitatis fieri additamentum poteft; hoc autem non foli animato competit, fed om ni prorfus quanto; eriam Iinex, ae fuperficiei; quare ille augmentabilitas, quxex fola quanti natura fumitur, nımis ampla eft, atqueindeterminata, neque eft propria folius viuentis; nos autem eam non ita amplam hic confideramus, fed determisatam, \& adcertum modum, qui viuentıum propritis eft, contractam atquereftrictam, nimirum per tres illas conditiones; vt exacceffione materix fiat; \& idem numero, maneat 1 , quod augetur; \& non folum totum, fed etiam omnes partes fecundumomnes dimenfiones incrementum recipiant; talem autem accretionem quifquis dicat quanto competere quatenus quantum eft, fatuus eft, quia fic diceret eam omni quanto competere: fatendum igitur eft, lianc proprie fumpteaccretionis determmationénon à quanto fieri, fed ab anima, proinde talem accretionem cōpetere quanto quatenus eft animatum: \& ita illius augmentabilitatis, quae dicit aptitudinem recipiendi accretionem iis conditionibus præditam, ration é formalem non eñe quantitatem, fed animam vegetantem; quantitatem vero effe conditionem neceffriam, \& finequa non, quoniam anima hoc non preftat, nifi junEa materix quanta: \& hoc Auerroes, \& Ioannes Grammatıcus lignificare volucruni, quandeargs- do dixerunt formais augeri quatenus eft forma qentr. quanta. Ad argumentum autem, quod antea ab accretionis natura fumebatur, facile eft refpondere: dicimus enim naturam accretionis à quantitate pendere tanquam à ternine, ad qu dimgitur, fiquidem ad quantitatem eft, non ad fubitantiam; fic autem, \& cuiuslibet motus natura fimiliter à termino iudicatur: fed aliud eft terminus, ad quem tendit, \& in quo definit motus, aliud eft formalis ratio fubiecti mobilis, qua eftreceptiuum talis motus; nim motus elementi ad fuum locum. fumit nominationem $B$ à termino, \& vocatur motus localis; at ratio formalis, qua elementum eft tali motu mobile, non eft locus, fed grauitas, \& leuitas, feu ipfa elementa forma; quatenus enim eft forma in materia, eatenus elt principium paffuum mo tus elementi naturalis. Sic igitur quantitas eft terminus, ad quem accreico tendit, \& in quo huius motus natura confiftit: ac ratio augmentabilitatis in iis, çux propric augentur, non eft quantitas, fed anima vegetans. Confideran. C dum praterea eft, tcrmiaum verx accretionis. ad quem, non effe quantitatem abfolute, fed pertectam quantitatem, vt ex Arifotele col. ligimus in tertio libro, Plíffica aufcultationis contex.s.periectio autem refpicitformam, \& à forma tribuitur; quare etianı ratione termini ratio augmentabilitaris eft attribuenda formæ, qum quantitas fecundum fe nec perfema necimpertecta dici poffit; forma enım, non quantitas, determ nat propenfionem ad perfeD ctam quancilatem.
Collectio omnium caufartm accretionis, do nutritionis, \& perfecte ambarum de- finitionis confitutio. Cap. $X X V$.

$\mathrm{F}^{\mathrm{X}}$ iis omnibus quæ hactenus diximus, colHigendx breuiter funt omnes accretionis \& nutritionis caufe, vt ex iis omnibus perfectam E vtrufqudefinitionem conftituentes in hactandem definamus, finemq; huic difficillimx difputationi imponamus. Habet accretio omnia quatùor genera caufarum, \& in fingulo genere plures, quod eam cognitu difficiliorem facit: has igttur omnes breuiter enumeremus. Forma accretionis eftipfamet eius natura, qux fignificatur per genus propriis cius differentiis, \& conditionibus coarctatum; genus quidem eft motus differétia vero videntur effe tres il-

F laconditiones ab Ariftetele pofitæ, \& iam, à nobis declarat : fciendum tamen eft primam conditionem qux fuit, vt ex adueniente materia accretio fiat, a d materiā potius, de qua mox loquemur: quan ad formam, pertinere; fecindam vero, quxerat, vnum numero manere id, quodaugerur non elle accretionis proprism, fed çömunem omni motui, grout motus à lubitan- 
tiali muratione diffinguitur' illud enin, quod fecundum fola accidentia mitratur, manente fubstantia, dicitur idem numero effe port motunı, quod ante unotum erat: Ariftot. autem has sonditiones non idea adduxit, quod omncs accretionis proprias efle voluerit, fed vtalias impropric dictas accretiones à vera accrecione fecerneret, quod quidem per has tres conditiones fatis commode prxftıtit, vıam igitnr fumpfit à materia : alteram à natura motus vniucrfe funpri,prout à generatione diftinguttur,fed tertiam $B$ apropria accreionis natura, quxe eft, non modo totum, fed omnes eian partes fecundum o. mnes dimenfioncs incrementum fufcipere; per hanc enim fignificatur illa membrorum extenfro, in qua diximus effe accertionis naturam conftitutain: quocirca hæc eft maxime propria accretionis differentia, quum fecunda omni motui cōmunis fuerit, proinde in definitione accretionis exprimenda non fit, $\mathrm{fed}$ fatis nom 1 narione motus fignificetur, prima vero fit accretioni communis cum nutritione: eftigitur forma, \& efientiaccretionis hæc, motus extenfionis ad Maiorem quantitatem \& totius, \& partium omnium fecundum omnes fimul dimenfiones. Materia duplex eft, vna ex qua, alterain qua : materiam ex qua, fignificauit Ariftoteles per primam conditionem, eaque eft.limentum qtood in principio eft contrarium, in fine autem eft factû́m fimile, \& in fubftantiam maiorem conuerfum : materia vero, in qua,fubiectum eft; quod aug eri dicitur, fed hoc ab Ariftotele in $p r i-$ molibro de Ortu \& interitu exprefliım nō fuit, id enim eft corpus anımatum quatenus eft an:matum; iam enım diximus animam effe rationem formalem, qua proprium fubiectum accretionis fufceptiuum conitituitur, in eo autem libro animam, \& animatum confiderare conueniens nonerat; fed hoc poftea declarauit in fecundo libro de anima: vtraque autem hæc materia prater conditiones accretiones formales in eius definitione tanquam differentia ponitur, quod fit in accidentum omnium definitionibus. Caufa quoque efficiens duplexeft; $v$ na primaria, quxe eitanima vegerans; altera infrumentalis, \& fecūdaria, quxe eft calor naturalis. Finis itidem duplex; vnus propinquus; alter vero remotus, ac magis precipuus : propinquus cft affequutio debitz quantitatis ; remotus fc-
A ro, ve viuens poffir exercere omnesoperationes vitx,fcd illam precipue, qux eftaliud fimile ge nerare. Exhis oinnibus caufis poffumus hanc vcræaccretionis perfectam, \& omnibus numeris abfolutam definitionem coñltituere: Accretio cfl molus viuentis corporis, quo to tim, \& omnespartes fecundum omnes fimuldmanfiones extendunturad maiorem quantitatem, tactus ab anima per calorem naturalem, ex aliméto intrinfecus affumpto; \& in maiores confumptis partibus partcs lubtantix conuerfo, vt ipfum viuens debitam fibi magnitudinem affequatur adéxercendas omnesoperationes vitz. Nutririo vero \& firbiecto, \& matcria, ex qua, \& effeetrice caufa tam primaria, quam fecundaria, ab accretione non differt, ideo Ariftoteles dixit as effeidem fubiecto; ex fine autem diftinguu- Forma tur, proinde etiam ex forma, \& propria narura: nutririo enim formaliter non eft motus, fed mutatio fubira, \& ad generationem potius reducitur, quam ad motum, vt fignificaust Ariftoteles, dicens cam tendere ad acquifitionem fubftuntix, non accidentis; quanquam non eftperfecta generatio, quia generatio eft via ad accquifitionem formæ, at nutritio eft via ad acquifitionem parrium matcrix, vt optime declarat Albert is in fuolibro de homine \& Petrus Pomponatius in capite decimooetauo prioris libri fui de accretione \& nutritione ; ideo videtur potius vocanta aggeneratio, quam abfolute geneD ratio:ficut antea declarauinus: quia non eit generatio refpectu viuentis, refpectucuius vocatur nutritio, fed folum refpectum partium materiz: hæc igitur elt propria eius natura, \& forma. Finis: Finis autem duplex elt, vnus propinquus, alter remotus, \& præcipuus: finis propinquus eft, vt matériæ partes reftaurentur loco partium à naturali calore confumptarum; qux reftauratio. adal terum principaliorem fine dirigitur,nempe ad conferuationem anim $x, 2 c$ durationem vit $x$

E vfqué ad tempus cuique viuenti à natura prafcriptum. Ex his igitur talem nutritionis perfectam definitionem colligimus. Nutritio eft aggeneratio partium materix in corpore viuente, ex alimento extrinfecus admoto, facta ab ani-Nutris. tionis dsfinitio. ma per calorem natural é; vt materia, quze effluxit, reftauretur, \& ipium viuens feruari poffit ad illud vfquetempus; quod eft ipfià natura pro frriptus?.

\section{Acerctio sis defini t20.} Nutritso tis mate rice, $\vec{G}$ officiens.

Forma.

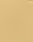

,

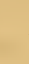




\section{J A C C O B I \\ Z A B A R E L L $Æ$ $P$ A $T$ A V I N I,

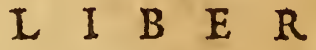

\section{$D E S E N S V$}

Propofitio,acpartitio dicendorum.

Cap. I.

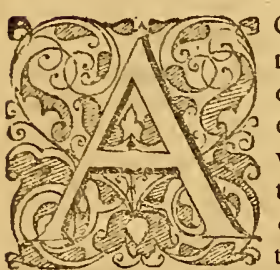

GENS Ariftoteles de mente humana in 3 . lib. de Anima, eam fenfui in eo finile effe dixit, quod vt fenfus feritiendo patiturab obiccto fenfili, ita \&'mens intelligendo patiturab obiecto intelligibili, proinde vt fe habet fenfus ad fenfilia, ita fe habet intellectus ad intelligibilia : ob id quum poftea præter huncintellectum patientem dixerit effe ad intellectionem neceflariun alterum intellectum agentem, iure multi dubitarunt, an prater fenfum patientem detur alius fenfus agens, qui fitill neceflarius ad fentiendum. Rem hanc ego confideratione dignam effe arbitra. tus, aliquid de ea fcribere conftitui, eo præfertim, quod occafionem nobis datura eft naturam fenfus, qux cognitud digniffima eft, declarandi; etenim de actione fenlus loqui inon poflumus, quin de paffione quoquic loquamur; quisquis autem intelligat quomodo fenfus agat, \& quomodopatiatur, is $1 \mathrm{am}$ ipfius naturam perfecte cognofcit. Quoniam autem res hxc à Latinis tum antiquioribus, tum recentionbus maxime agitata, ac diffufiffime difputata eft, vt tæadiofam legentibus fore hanc noftram difputationem oporteat, fiomnia, quxab aliis de hac re dicuntur, in medium adducere, \& perpendere ftatuamus; ideo ftrictius ageredecreuimus, \& corun, qux ab aliis dicuntur, pauca recenfere, quæ precipua effe, \& ad veritatem intelligendam conferre videbuntur, reliqua vero, vt quie apud ens legi poffunt, miffa facere: ita vt onmes intelligant, menon controuerfandi, fed veritatis quantum per me fieri poffit , declarand $x$ gratia hæc frribenda fufcepiffe. Ante omna non eft ignorandum, quxftionem hanc à Latinis propofitam, \& tractutam cfie tanquant fimplicem, fed poftea alij complures animaduerterunt eam haberedupliceun fenfum, \& 1 d duas effediuidendam, vt reuerneft: primum cnim comparari poteft obiectum fenilie cum fenfu,
A quiabillo patitur, \& quxrian obiectum fenfile egeatalio externo finul agente, feu ipfum adiuuante ad fpeciem in organum fenfus imprimendam, an folum obiectum agat, \& fpecienı imprimat: deinde vero facta fpeciei impreffione quxri poteft quodnam fit agens, à quo producitur operatio quam vtà fenfu pro facultate, feu pro animia ipfa accepto diftinguamus, liccat nobis fenfionem a pellare; cū enım alinıd fit imprimerefpeciem, aliud fenfionem, qux cognitio quædam eft, producere, necdicendum fit obieEtum reale effe productiuum cognition is in fenfu, aliud aliquod efic neceffe eft, quod impreffa fpecie promat operationem. Igitur nos quoque noftram hanc difputationem in duas partes diuidemus : in vna confiderabimus, an folum obiectum fpeciem imprimat in organum, an preter ipfum requiratur aliquod alind agens; deinde vero inqui remus, impreffa fpecie, à quonam agente promatur operatio, \& fenfio C producatur.

\section{Argumenta ad probandum, quod prater ob- iectum detur aliud agens, à quospe- cies Senflilis producatur. Cap. II.}

Q Vod adpriorem quæftionemattinet, vide- $p_{r}$ tur efle neceffarium præter obiectum fenfi-

D filc,al lquodagès, à quo fpecies fenfllis \& in medio, \& in organo fenfus producatur: nam obiectum fenfile eft qualitas materialis, eius vero fpecies eftaccidés ipiritale; at piritale nobilius eft materiali;ergo fi obiectum folum fincalioagente fpeciem produceret, ignobil ius produceret effectun nobiliorem, \& ageret fupra proprias vires : quoniam igitur agens debet effenobilius patiente; obrectum autem materiale non eft nobilius fpecic fux, quæ fjritalis eft, fediE gnobilius; non potef folum obicktum producere fpeciem, fed neceffe eft præter ip/um eflealiudagens nobilius, à quo pecies producatur. Confirmaturargumento fumpro ab intellectu: A riftot.cnim exultimauit plianiafna fol im non efle aptum ad fpeciem intelligibilem in intellectu 
leatu producendam, quia fpecies intelligibilis phaniafmate nobilior cit, idenque pretervhantafma effe neceffarium intelledum agentem , \&e pisaneafmatc, \& fucciencbiliorem, proinde po. tentem in intellectu producere fpeciem intelligibilem; poffuasus igitur fic argumentari : ve fe habet obicctum intelligibile adintellectum, ita obiecturn fenfile ad fenfum, vt ait Arift. in cont. 3.lib 3. de Anim 3, atqui intelligibile ad fpecie in intellectu producendam non lufficit fine ope al. terius intellectus, qui vocaturagens;ergo neque obiectum fenfile ad producendam fpeciem fenfilem fufficiens eft absque aliofenfu agente; vt igiturdatur intellętus agēs prxter intelleđum patientem, ita prater fenfun patientem datur lenfus agens. Praterea idem comprobatur teftimonio Auerrois, qui in Comment. 60. libr. 2. de Anima hifmet, $q$ ux modo add uximus, argumetis vtens oftendit effe neceffariam prater obie. ctum fenfile aliquam facultatem actiuam, à qua fpecies \{piritalis producatur, quum ab obiecto materiali produci non poffe videatur : tollit etiam ibiden refponfionem ad quam confugere aliquis poterat dicendo, rationem \& caufam fpiritalitatis fpeciei non effe ipfum obiectum niateriale, fed materiam recipiente $\vec{e}$, nempe medium, \& organum, in quibus recipitur fpecies, ita vt ex hoium recipientium natura fiat, veforma qux recipitur, fpiritalis fit. Sed refellit hoc Auerroes dicens efle magis contonum rationi, vtnatura effectus artuibı:azuragenti, quam patienti : agens enim agit performanı, \& patiens patiturper materiam; quare fpiritalitas lpeciei viderurpotius obiecto agenti artribuẽda, quam fubiedo recipienti; nullius igitur roboris refponfioeft, tkargument uni viget: quare consludit-Auerrees, efle neceffarium prater fenfum patientem ponere facultatem agentem, ficuti necelfarium fuit ponere intellectum agentem praterintellectum patientem: fubiungit autem Ariftotelem hoc dixiffe de intellectu, fed tacuiffedefenfu, quoniam occul tum eftinfenfu, ma. nifefum autem in intellectu.

\section{Sueffani, \&o Buccaferrei opinio, do eius Confutatio. Cap.III.}

H Fe multos coegerunt prater obiectum fenHile ponerealiud externumagens, à quo fpecies \& in medio, \& in organo fenfus producatur. Sueffanus enim refert caufam fpiritalitatis harum fpecierum in Deum, tanquam in cau. fam primam \& remotam, quxper medium ob. iectum materiale, tan quam per inftrumentum, producatfpecicm fenfilem: inquit enim quali. tatem fenfilem in aterialem pofie duobus raodis confiderari,vno modo lecundum fe, altero modovtinfrumentum Dei: \& fecundum fefumptan non producere nifi alia fara filem materialem, vt quum calor calorem efficit; vt autem
A eft inftruınereum Dei, producere effectum fpiritalem, fcilicet pervirtutem primiagentis fpiritalis, non per facultatem, feu naturam propriam: itaque concedere videtur Sueffanus colorem ffiritalem, qui eft in medio, effe nobiliorem colore materiali, à quo producitur : ideo ad tollendain difficultatem illam quomodo effeEtus nobilior $a b$ agente ignobiliore produci poffit, ad Deum coṇiugit, qui obıecto materiali tanquam inftruménto vtatur ad producendam B fpeciem fpiritalem:ad propofitam igitur quaftionem refpondet dari aliud agens prater obieftum fenfile, fed non darifenfum agentem; illudenim Deuseft, quem appellarefenfum non licet.HrcSutffanifententia recipienda non eft; quontam Deus eftrerum omnium, qua generantur, caufa vniucrfalis, nec aliter fecundum Ariftot.quam vt mouens Coelum; ipfum autem Colum in hacinferioranon agit, nifi per motum, \& per lumen; oftendere igitur Suefranus C debuit, quomodo Cozlum feu yer motum, feu perlumenagat in obiecta omnitum fenfuum, \&e ad fpecies fpiritales producendas iis tanquam inftrumentis vtatur; fic enım probabilius dici poffer Deum tanquam primam caufam, à qua Coclum mouetur, vtiobiccto materiali tăquam infrumento ad fpecieifiritalis productionem: id tamenneque dicere, neque imaginari aliquis poteft: fed Dcus per cole ett a corpora motu \& lumine agent1a res omnes inferiores producit, D \& fingulis proprias naturas tribuit, per quasedunt operationes proprias, \& fingulis conueniětes; quicquid ergo agunt qualitates fenfiles, id fecundum proprias naturas agunt, nequeilla 0 peratio eft Deoattribuenda, nifi vt cauf $x$ vniuerfali à qua pendet obiectum fenfile fecundum fuum effe, à quo omnes eius operationes proueniunt;ideo recte Thomas dixit in quaftionibus Agës na+ difputatisde potentia Dei, quast. 5. arsic.1. agen-tisale tia naturalia ron effe caufas formarum, quarum nonest E natura confiftit in facto effe, fed folum effe cau-casfafor fas productionis ipfarum; fierienim prouenit ma, fed abagenteparticulari ; proinde fubtracto agente prodssparticulari res definit fieri, at non definiteffe, fi ctconis eius natura confiftit non in fieri, fed in facto ef forma. fe, propterea quod eius effe pendet à Deo, non $a b$ agente parriculari, quocirca fubrate Deo omnia ad nihilü redigerentur; reete igirur $T$ ho. maspendentiam à Deo tribuit 1 llis, quorum natura confiftit in facto effe; quia cuiuslibet rei efF feeft per quandam Dei participationem, ficut etiam Arift.dixitın part.100. lib.1. de Colo, llis vero qua confiftunt in fieri, tribuit pendentiain ab agenteparticulari, quod non eft caufa reivt fir, fed folum vt fiar. Qu niam igirur hx, de qui- Species bus loquimur, fenfilium fpeciesnaturâm habēt fenjoles confitutam in fieri non in facto effe, nam in per- babent fpicuo fpecies coloris non elt fixa tanquam tan efje in fe - feata, fed fit continue, reatius dicunturab obic- ri,non on cio reali pencere, quam à Deo:quedetiam ligno $f$ atto eßse. $D D$ mani. 
manifeftilimodeprchendimus; fubirasto enim fubiecto materiali definit codem momento, \& euanefcit fpecies, \& imago eiustum in medio,tum in organo: quare probandum maxime videturillud Thoma dicturn, \& peripfum ratio crroris Sueflani declaratur. Non probotamen aliud eiufdem Thomedictum in eodem loco, art.8.nifi fano modo intelligatur: ibi enim dicit duas cffe naturalium corporum aहtiones; vnam fecundum propriam eorum naturam, quatenus ccrpera funt; alteram vero, prout participant conditionealiqua fuperiorum agëtium, \& fub. ftantiarum à nateria feparatarum, cuiufmodi eft productio fpecierum f piritalium in fenfu, \& in intellectu; hoc autem Thomxdiftum duos poteft haberefenfus;rnum vt intelligatipfa obiieta fenfilia non fecundum proprium naturam producere fpeciem fpiritalem, fed per virtutum eis infufamà fubftantiis fpiritalibus, ita vtilla operatio fit ipfisobiedtis potius fupra naturam, quan fecundum naturam; qui fenfus ad Sueffanifententram ascederevidecur, proinde reprobandus eft. Alterveroeft, vt intelligat res habere interfe aliquam fimilitudinem lecundum aliquas conditiones, non ita tamen, vt quicquid in aliqua conditione al teri nobiliorifimile eft, id habere illam dicatur abillo nobiliore, fed fit huiufmodi fecundum propriam naturam: qui fenfus admittendus eft; \& hunc fignificare videtur comparatio, quamibidem Thomas facit, quando dicit in quiburdam animalibus brutis infpici fimilitudinem quandam illius prudentix, quxhominis propria eft; nam fi intelligeretillam brutorum prudentiam non eis competere fecundum propriam naturam, fed vt ab hu. mana narura cum illis communicatam, \& illis quodammodo infufam, ita vt fupergrediatus naturam illorum animalium, vana prorfus, \& reiicienda fententia effet; quoniam illa prudentize fimilitudo infequitur propriā illorum brutorum naturam, neque h omo poteft 1 llius prudentiz causa, vel origo appellari: hocigitur. quod ibi Thomas dicit, ea tantum ratione verum eft, quatenus res omnes inuicem comparatr habent in aliquo fimilitudinem inter fe, ita vt foecies fpirital is obiectorum fenfilium dicatur modo quodam fimilis fubitantis fpiritalibus, non tamen ab illis producatur, fed à propria fenfiliun obiectorum natura, quzapta per fe diss st eftadtalem fpeciem, imaginem in medio \& pecier. in fonfu producendam. Adde quod illa cum faralium lublantius piritalibus fimilitudo parua admofirstali- dum en, \& prorfus aquiuoca, nil enim, quodetas, Es iurdemnarnra fit, poteft diuinis fub tantis, \&e lia.ssbftit his materialıbis idem sompetere : quare alia tiarum prorfus fjiritalitas eft in fubftantiis à materia immace - abiunctis per effentiam, alia in his fpeciebus rialsm. fenfilibus, qux licet non à materia, in qua recipiuntur, fed à producente pendeant, tamen exiftere abfque materia recipiente non poffunt.
A Vnde etiam manifeftius colligimus Sucfiani errorem: quum enım non eadem fit horum fpecierum fpirital tăs, qúx Dei, \& fubftantiarum à materia abiunctarum, fed penitus aquiuoce di$c t a$, vanum eft ob hanc folius nominis fimilitudinem referreillam potius in Deum, vel in fub. ftantias reparatas, quam in ipforum obiertorum propriam naturam, à qua producuntur. Notare etiam in eius fententia repugnantiam aliquam poffumus : nam fl obiecti materialis $d s$ B naturam dicateffe à Deo productam talem, qua fes fpeciem fusm fpiritalem in medro, \& in organo ss fenfus efficere poffet, \& hac tantum ratione caufam eiuseffe Deum; fic concedic id, quod eft ve. riffimum, fpeciem à propria obiecti natura produci, ficuti res omnes feruata earum pendentia à Deo proprias edunt operationes fingulis naturaliter conuenientes; hoc tamen ipfenegat, dum dicit obiectum non fecundum naturam fuam producere fpeciem, fed quatenus eft inC ftrumentum Dei:fi vero dicat productionem talium fpecierūab obiectis fierı non per proprias ipforum naturas, fed per duinam virtutem, fic alferit Deum effe earum caufam immediatam, $\$$ tamen ipfemet expreffe negat vt abfurdiffimum: in hoc igitur pugnanıa dicit, quia primum aperte norat Deumnon effe harum fpe. cierum caufam effectricem immediatam, fed remotam; deinde id declarans, \& eius rationem: referens in Spiritalitatem Dei, tanquam in cauD fam fpiritalitatis harum fpecierum, illud idem, quod nega uerat, affirmat; quum enim obiefí realis natura non fit fpiritalis, neceffe eft vtilla fpecierum fpiritalitas immediate proueniat à fpirtalitate Dei:vtrumlibet igitur dicat, fibimet aduerfatur. Nonadmodum diuerfa ab has fententia fuit opinio Buccaferrei, qui fimiliter dixit $f e$ prater obiestum fenfile effe neceffarium ali- $p$ in quod externum agens ad producendam fpeciem fpiritalem, non effe tamen fenfum agenté;

E red neque effeDeum, qux fuit Sueffani fentertia, fed effe coleftes intelligentias, feu Colum per virtutem intelligentiarum : aduerfus quam fententiam illa eadem dicenda funt, qua contra Sueffanum diximus: quodfiad lumen Buccaferreus confugiat, quod à Cœl o productū caura eft vifionis, hoc nihil eft; ad folum enim vifum. hocpertinet, non adalios fenfus: pi aterea non folum colefte lumen caufa eft vifionis, fed lumen etiam ignis, \&aliorum lucidorum; quare F perhoc non oftenditur, quomodo Colum fit caura productionis omnium fpecierum fenfi. But lium. Facit autem Buccaferreus ibidēadue: fus fer fe obiectionem deintellectu agente : quemad. modum enim ad productionem ipecierum fenfilium non requiritur fenfus agens, fed fufficit obiectum fenfile cum virture colefti, ita etiam intellectio feri poterit exactione phantalrmat per virtutem caleftem; quare non opuserit intelleetu agente. Dubium autem hoc non folum 
B.ıccaferreo, ac Sueffano officit, fed \& aliis o. A fit, illico fentit, \& cognofcitcalorem perillam mnib: etiam illis, qui dicunt a folo obiecto fenfili fpeciern fpiritale produciabfq; vlla prorfus opealicuius externi agentis : nam etiam aduerfushos dubitaripoteft, cur intellectus indigeat externoagente prater obięum, fénfus veronō indigeat. Refpondetad hoc dubium Buccaferreus, competere intellectui propter fuam dignitatem vt habeat in feipfonon modo paffuum, fed etiam actiuum fure operationis principium; fenfum vero propter fuam imperfectionem externo agente indigere prater obiectum fenfle: quod idem etiam à Sueflano diciturin eadem - fua difputatione de fenfu agente. Sed ifti hac fua refpófione declarant fe non intelligere quid fit apud Ariftot. intellectus agens, \& quodnam fit cius officium in noftra intellectione : quem eorum, \& multorum errorem alio in loco opportunius declarabimus, fimulq; huius difcriminis rationem afferemus, cur obiętum, à quo mouetur intellectus, \& illud, à quo mouetur fenfus, non fimiliter egeant auxilio externi agentis; hoc enim explicari perfectenon potelt, nifi declaratis tum officis, tum conditionbus intellectusagentis, de quo alibı differemus.

\section{Recentiorum opinio, Go eius confutatio. Cap. IV.}

TOnnulli recentiores confiderantes huiufce Nrei difficultatem in hoc effe conftitutam, quomodo obiecta fenfilia, quum fint qualrtates materiales, porfint fpeciem producere fpiritalem: neque eam aliter foluere valentes, non modo concedunt nullum obiectum fenfile porfeluapte natura fpiritaliter agere, fed etiami dicuitt non effe neceffariam fpeciern fpiritalem, nifi in folovifu: ideo hancfenfuum diftinctionem faciunt : vifio fierinon poteft, nifi per rece$m$ pionem fpeciei fpirtalis; id eo quum eam producere colormaterialis non pofit, eget agente ż- externo adiuuante, quod eft lumen;quare fpiritalizer a git non ex fua natura, fed ope luminis: in aliis vero quatuor fenfibus noneft neceflaria ad fenfionem fpecies fpiritalis, ideo eorum omium cbiecta materialiter rantumagunt, neque egent auxilio alicuius externiagentis: ideo 3 itti fententiam Auerrois refellunt, quiin Commentar. $97 . \& 10 \mathrm{i} .1$ b. 2. de animaperte dicit 0 mnia fenfilia fpuritaliter agere; ipfi vero dicunt folum obiectum vifus agere fpiritaliter, idque non per naturam fuam, fed beneficio luminis, cxtera vero omnia materialiter folum : idque in 3 iis omnbus fingillatim oftendunt: nam in tactu ह- manifeftum eftractiles qualitates nö facerefenfionem, nifiper corporum materialem contaहtum, quare ex neceifitate agunt materialiter; corpus enim calidum nö poteft effe contiguum corpori frigido, quin materialiter calefaciat; idco corpus illud frigidü, fi vi fentiendi praditum

ipfam actionem materialem, qua realem cale. rem recipità calido agente: fic etiam guftabile non fencitur, nifi in contactu lingux ponatur; ideo per illum conta etum agit macesisliter, \& afficit linguam faporemateriali, non fpeciealiqua fpiritali. Sonus quoq; eft realis motus partiumaeris, vt coargumento oftenditur, quod flante vento vehementi ferunturad aures noftras foni, quos non flante vento non fentireB mus, \& è contrariofi ventus fit aduerfus, repel. lit à nobis fonos, \& prohibetne ad aures noftras deferentur,proinde facit neaudiantur:fic etiam odores feruntur à ventis $a b$ vnaaeris parte $a d a$ liam; quo fit,vt modo magis, modo minus, modo etram nequaquam fentiantur: quod quidem non contingeret, fi odores effent fpecies fpuritales; nam fpecies colorum, quum fint fpiritales, non pelluntur à ventis; quare fi odores quoque effent fpiritales, nullam à ventis agitationem C paterétur; funt igitur qualitates reales,imo funt vapores corporei à corporibus od orabilibus exhalati, \& ad olfactum noftrum delati; quod pa tet in fuffumigiis, quia nifi eis a pponaturignis, qui vapores ex illis educat, non mouent olfaetum. Sed quoniam hac fententia videbaturad-Obsectis verfari Ariftoteli, qui aperte dixitenfile pofi- illurum tum fuprafenfum nullam facere fenfionem, cu- cötra fe. ius ipficontrarium afferunt : refpondent, non ob id fententiam illam Ariftot. labefactari, quo- Solutio.

$D$ niam A riftot.ibinomine obiecti fenfilis non in. tell exit vapores eduetos, fed corpus illud, è quo educuntur; quia fi vaporesad organum fenfus deferantur, fenfionéfaciunt, at fi corpus ipfum, à quo vapores exhalantur, ponatur in contaktu organi, nulla fit fenfio. Hrecfententia mihi pro bari nunquam potuit, quia \& rationi, \& Alift. adueríatur : quod rationi aduerfetur, facile intelligemus, fi cognoterimus, quomodo fiatactio naterialis; hocigitur declaremus in tactili$E$ busqualitatibus, qux raxime omnium materiales efie, \& materialiter agere videntur, id enim in aliis omnibus intelligendum erit. C 10 - Q remagerematerialiter nil aliudest, quam cale- agere facere; calefacereaurem nilaliudeft, quam in maseria pariētegenerarealiud numerocalorê, ze ipfum liser. educere de poteftate ad a ctum; non enim credendum eftignem agontem inlignum tribuere ill funmet calorm eundem numero, fed alium fimilem generare per edictionem de poteftate ad actum, hoccerte in philo lop hia Ita larum eft, vt à nullo negari dobeat; hoc igitur conftituto fic argumentemur : fi salor in fenfum tactusagit folum materialiter; ergoalum grod $\mathrm{s}$ numerocalorem in organo tątus producit, nó mnsa e en femetipfum eundē numero, fiquiden non po-falra in teft accidens materiale migrare de fubiecto in jenfusm fubiectum; ergofenfus tractus non fentitillud agant $p_{p} i$ calidu , quod tanquam obiectumagit in ipfum, rta.zfed alium numero diftinctum : quod quidém ter.

$$
\text { D } 2 \text { omni. }
$$


omninofalfum eft; quia fenfus quilibet fentire dicitur illudiden numero obiectú, à quo patitur, nōaliud fimife; confequentia auten manifefta eft, quia fenfusillud idem iudicat, \&fertit, quod recipit;ergo firecipit a lium numero calorem, alium numero iudicat. Imo fecundü eam fententiam fequeretur non isdicari, aut fentiri vnquam illumet caloris gradum, qui reuera in obiecto eft: quod ita declaro: fi ferrum frigidum coniiciatur in ignem, \& inde paulo poit extrahatur, certcaut nihil, aut parum caloris ab ignirecipit, quia re ftitit per frigus proprium:fic igitur etiam manus hominis, qua in hyeme fit valde frigida, tangensignë non lentict calorera ignis, fed multo minorem calore ignis, qua parum calorismaterialis cobreui tepore recipiet, quum ipta frigore fuorefiftat: hoc tam ç falfum effe experientia declarat; nam manus illa parum quiò calo tis materialis in illoparlio tempore recipit, fed tamen fentit, \& iudxcat maximum igniscslorem, \& eo maiorem iudicat, quo maior eff exceffus, at q̨; diftantia caloris-ignus à frigore proprio, fi verumeftud, quod Arıfot.dixit, tactum fentire, \& iuóicare tactiliuar qualitatum exceifus; patet igitur alium efie cals $\mathrm{rcm}$ materialem, qui tunc imprimitur ab cbiecto, alium effe caloren fpiritalem, qui fimiliterimprimiturab eodē, \& cognof citur fubito, quum hic cognofcatur maximus, illevero debilis recipiatur \& huius difcriminis racio eft; quia actio, feualteratio materialis, quum fit verus motus, \& alteratio corruptitia, nô fit fubito, fed in tem. pore,propter refiftentiam,vt diximus, contraria qualitatisjat fenfio eiufdem qualitatis ficfubito, \& finealiqua mora, quia eft alteratio perfeEtiua, ficut Arift. dixit, proinde fit peräionem fpiritalem, \& per impreffionem fpecici fipititalis, cui nihil eft contrarium, quod illi refiftst, \& ab ea pellatur. Przterea fumitur argumentum validum à fenfili communi, quantitas enim eft fenfilecommune, \& fentitur perfe, \& imprimit fpeciem fuam in organo ( hoc.na eft perfe fentiri) vel igitur materialiter agit, vel fpiritaliter:fi materialiter, ergo eft actiua, \& ita quantitas fimilem quantitaté producit, guod eft manifefte falfum, \& ab omnibus negatum; agit ergo fpiritaliter; quare integra manet difficultas, quam illi folvere nequiuerüt, quomodo, quú fit accidés materiale, pofit fpeciem Spiritalem produ. cere fine ope externi agentis; non enim dici pokefrillud efre lumen, quia, vt quātitas tactu fentiatur, non requirıtur lumen. Similiterà multis. fenfilibus propriis, qux materialiteractiuanon funt, argumentari poffumus; nam durü, \& molle, funt fenfilia perfe ferfutactus, ergo fi mate. rialiter agere dicantur, durum imprimit in carne duritiem realem, quod tamen verum non eft; caro enim nullam realem duritiem recipit. neq; durum eft aptum indurare, cogunrur igitur confiteri durum agere fpiritaliter: hoc igitur:
A fi in hismanifefun efr, nö eft nogandū in aliis, nams fapores quoq; non funt a kiuri matrrialiter, ideo corum actio in linguam non poteft $e f$ fe niff fpiritalis; quare hocidem dicerdum eft et iam de quatuor primis qualitatibus, quz lunt adin materialiter, quam enim eadem effe debeat ratio fentionis in ommb. in is pratertim, qua eodem funfu fentiuntur, neceffe eft vt ha quoq; prater adionem mattrialem producant ctiam lpeciem fpirtalem. Hacfuit Ariftot. Sen-

B tenria in contex.121. libr. 2. de Anima, dicentis fenfum effe fufceptiuum formarum fine materia: hoc enim fieri alio modo non porct te nifi recipiento fpiritualiter, quia forma materialis non poteft fepararià materia, ne qjaccidens materiale à fubiedo; quare fenfus formam materialern, qua eit in obiedto fenfili, recipere eandem numero abfque eius materianullo modo poteft at fpiritaliter pōt, quia recipit eius imaginem, quazilian repraientat, proinde dicitur

C dism eanden recipere per reprafentationem: iden locū illum optime declarans Aucroes inquit, fi fenfus resiperet formas fenfiles cum noteria, fequeresurfenfilia haberc idem eft in ani. ma, atq; extra animam, vtrubique enim haberent efferateriale, quod tamen fallumes, quid (inquit) in anima funt intentiona!iter, extra anirtam vero materialiter. Hro idem figitifeauit Arft. in erntex. $3 \%$. 1.6. 3 . de Anima, quando dixit, animam efle quodamnodo res umnes:

D quia res cmnesvel fenfilis funt, velintellectiles, anima veroperfenfum eft quodámodo res omnesfenfiles, per intellectum vero eff res oés intellectiles:fenfus autem fit res cmnes fenfiles, dum eas fpiritaliter apprehendit, certum enim eft ipfum non ficri iṕlamet fenflia materialiter accepta, quemadmodum neque intelleatus fit ipfamet intellectilia realia, fed recipit illa fpiritaliter, hoc eft, fpecies à quibus illa reprafentantur, \& ita fieri omnia disitur. Hinc fenten-

E tiam tuetur efficaciter Auerroes in Comment, 97. \& 101. lib. 2 de Anima, vide codore ita arguz $/ f$ mentatur: fi odor effet vapor corporeus, non $t$. poffet in loco remotiffimo fentiri, ve fentiuntur $r$. à vulturibus cadauerum remotifirnorum odores; etenim fieri non poteft, vt tanta vaporis quantitasabillis corporibas exhaleiur, qua ad omnes partestotum aerem impleat per decem, \& viginti, \& plusa millia pafium a quare son eft quiden negandum id, quod illi dicunt. vaporem aliquén à corporibus otorabilibus exhalari; fed neque negaripotef odores agere fpiritalıer, vt omria quz confiderauimus, argumenta demonttrant. Illud quougue de Arift. Fententia magnam fiden. facit, quod ipfe dixit fenfile pofitum fupra fenfum non facere fenfio. nem: quia null $2 \mathrm{eff}$ h tuius dictialia ratio poteft, nifi hac vna, quod interobiectum rinateriale, \& organü necefie eft ipeciem fpiritalë intercedere un tuedio; hoc enimnegato, nullam afferre ra- 
ionemaducrfarii pofunt, cur fenfili fupra fen- A Quemadnodum igitur vana effet quxftio cur fum pofito non fiat fenfio: quod enim illi de va. pore à corporibus exhalato dicunt, vanun eff; quia vaporis confideratio ad folum olfictus fenfirm pertmet, quum ipfi alicquid omnibus feufibus commune ad interpretanda Arift. verba adducere debuiffent, nam in aliis non per vapores eihalatos fenfionem ficri certum eft; fed arbitrarium quoq; eft hoc iplorum dietum, \& omnino carcns ratione: quume eni nodor habeatidem effe in tenur corpore vaports crhalati, quod habet in illo, à quo cxhalezur, in vtroq; enim habet effe matcriale; necelle eft vt cadem fit vtriufqueratio ad organum fenfus, \& venon minusillud corpus, à quo vapor exit quant vapor ipfe, mutare fenium ol factus per fuum realem odorem aptus fit.

\section{Vera opinio \& eius declaratio. Cap. $V$.}

$\mathrm{H}^{1}$ Is reicetis opinionibus, cgo accipiendam puto Alberti fententiam, quam \& alis plures fequut funt : inquit Albcrtus qualitates fenfiles talem habere naturam, vtmuliplicentin midio fpectem fuam fprritalem, proinde valnum efie quarerealiud externum agens, quium ad foeciern producendam ipfí fuapte natura fufficiant: huinfce autem rei rationem reddens Albertus dicit, omnem formam effe multiplillocatiuam fui ipfius vel realiter, vel fpiritaliter: quatuor enim prima qualitates veroque modo agunt; vt calor tum calorem realem in alia matcria producit, tum etiam fpeciem firital cm in medio, \& in organo fenfus tactus : relique vero omnes fenfiles qualitates, \& accidentia omnia fenfilia perfe, quum vim non habeant agendi realiter, faltem agunt fpiritaliter; vt quantitas, licet non fit actiria actione reali hoc eit, produEtua alterius fimilis quantitatis, fpiritali tamen actiua eft; quum enim fit de numero fenfilitium per fe,fpeciem fuä producit, quod non eft aliam quătıtarem prodụcere, fed fui ipfus imaginem, qux ipfammet reprafentat: fic dicendū cit de omnibus feufilibus per fe tum propriis tum cornmunibus. Duplicem hanc actionem diftinguës Albertus dicit aliud effe producere formam in matetia, aliud effe producere formam tantum: etenim producere formam in materiā elt materialiter agere, \& producerealterani fimilem formam materialem; forma enim materialis à materia ; in qua recipirur, pendet in effe, \& in conferuari, non ab agente, nifi folum in fieri; \& tali actione non funt actiua alia accidentia, quam folæ quatuor primæ qualitates, qux ob id actiux appellari folent: producercaút formam tantum non formam in materia, eff fpiritalem feciem producere; quia licet fpecies fit in aliqua fubiecta materia, ab ea tamem non pendet in effe, \& in conferuari, fed ab agente, à quo producitus. caloraliun caloremu matcriale producat, quum nulla huus productionis fitalia ratio, quam ipfinct calorts natura, qure apta eft ad alium ca. lorcm in alio gencrandum ; ica etiam vanum eft quaicre curlenfiles qualitates in medio, \& in organo fpeciern fitami producant; ctenim fuapte ma:ms funtaptzad fipeciem fuam multiplicandam: quum enim multo maius fit agere realiter, \& producere alind finile miteriale, quod ef B maioris entitatis, quam producere fpeciē fuam firititalem, qux minoits eftentutatis; fiquidem videmus qualitates, qquamaterinliter agunt, agere etiam fpiritaliter,multas aute margere fpiritaliter, quar realiteragerenequcunt; linonmiramur, quiomodo aliquereal iter agant, cur mirädum eitaliçuas agere fpiritaliteı ̀ium autem omnes penitusformatam fubtantiales, quam accidentales ciufnodi fint, it fpiritaliter agamt, \& feipfas multiplicent; quod videtur alferere C Albertus, \& alii, qui eius fententian fequuntmr; alienum eft a prafêti confidentione: fatis enin nobis eft, fi eiufmodi effe dicantur illa omnia accidentia, quะe per fe fenfilia funt; fiquidem nil alud eft fentiri per fe, quam fpeciem fuam in fenfiu producere: de reliquis vero accidentibus, ac de formis fubfrantialibus, qux non perfe fentiun'ur, hoc eff, non per feciem proprian, red per alicnam, certum eft nullam ab hts fpeciem fenfil $\mathrm{cm}$ produci; quum enim uihil fit fruftra in D natura, nulla eff ponenda fpecics fenfilis, qux nullofenfu fentiatur:quari folum de hispoflet, an fpeciem intelligibilem in intellectu producaut, quã omnia cntia fintentelligibilia; quamuis enim non per propriam fpeciem moueant fenfum, mouent tamen vt inuoluta fpeciei alienæ; quia vifus non folum videt colorem, fed rent totam coloratam; licet folum per fpeciem coloris, \& aliorum, quz per fe fenfilia funt;ideo fpecies hacad phantafiam delata mouet intellectim, \& imprimit in en fpecies intelligibiles etiam earum rerum, qua nullam fpeciem fenfilem produxerunt in lenfu; nam intellectus agêtis lumine colluftratis rerum fenfilium phantafmatibus apparent intellectui noftro etiam illa, qua non per propriam fpeciem, fed commifta, \& inuoluta fpeciei rei per fe fenfil is mouerunt fenfum:fed de hoc difputare ad nos in prefentia in on attnet; quum enim de eo tantum fit nobispropofita difputatio, an fenfiles qualitaF tesad producendam fpeciem fpiritalem egeant aliquo externo agente, fatis eft fi has folas confiderando dicamus cum Alberto eas nullum alind externum agens poftulare, fed fuapte natura fpeciem producere, quia funt multiplicatiux fui, \&acilux fpiritaliter. Dubitari tamen decoloribus poteft, qui egent lumine ad fpeciem in medio, \& in organo producendam; quare non funtper fe motui, proinde nec productui fpeciei, fed egent agente exterino. Ad hocrefpon-
Maines esis agere realiter quain fisirieales rer. -

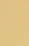
西

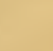


K. perfos det Albertus, lumen non requiriad calorem, fed A accidens fpiritale productum in medio tum idé elthers. admedium folum illuminandum, proindeco. Lorem effe fuapte natura aptum àd producen. dam Epecien fuam in perfpicuo, lumen vero non effe aecefarnam ad auxiliandum coloriagenti, ied ad pr zarandum perfpicusm recipiěs, solor enim vtagat, non indiget alio; fed quia agensnon agit, nif patiens fit aptum adrecipiendum, requiritur lum en propter medium reci-

piens, non propter coloremagentem. Sed hae Albertirefponfio difficultate non caret: nam $A$ - B rifrotel. in context.18-Libr. 3. de Anima ioquens de intellectuagente inquit, cius officium effe facercex potentiantelligibilibus a cu intelligibilia, quemadmodum lumen de coloribus poteflate facit actu colores; non poteft autem Ariftotel: confiderare colores fecundum fe pront colores funt, quia exiam in tenebris funt colores, fed folum prout funt vifibiles, \& motiui per. Ipicui; aferit ergo colores fieriactu motuuos à lumine, quum per fe nonfint motiui, nifi potethatejigitur ad cólores, vt agant in perfpicuum, inquit Ariftot. effe neceffarum lumen: fumitur etiã excodem loco vifum \& intellectum no differre in requirendo externum agens ad fpeGiem ab obiecto producendam. proinde ira ob. iectum vifus indigere externo agente, vt obicEtum intellectus.ad fpeciei productionem eget intellectuagente; idco non parua eftinter philofophos difceptatio de eo quod Albertus tanquam notum affumit an lumen requiratur ad colorem folum; an ad folum medium, an ad'vtrumq; illuminandum : qua derenon eft, quod in prafentia difputemus, ideo eam integram ad librum devifu remitrimus, vbi eam diligenter confiderabimus,atq; explicare nitemur. Ad pro-

zefporsse pofirum autem dubium fat effi in prafentia di. camus, cōcefla luminis aftione ad fpeciem fenfilem producendam, non ob id dari fenfum agentem in productione fpeciei, ficuti daturintellequs agens.in productione fpeciei intelligibilis;magnum igitur eft fenfus \& intellectus drfo erimen: datur enim inrellectus agens diftindus ab intellectu patiente;at non datur fenfus agens à fenfupatiente diftinctus, fquidem. Iumen non. eft fenfus., imoagit vt obicetum fenfile, nonvt fenfus: \& quamuis intelleetus quoque agens agar pocius vi obie Aum intelligibile, quam vt in rellectus, ficut alio in ioco declarabimus; is tamernon poteft effe nifi aiter intellectus, quia. ton porct co munerefungi,nifi firperfe intelli- I glbilis, orsncautem perfe intelligibile eft ctiã. yntellcetus:at lumen eft quidem per fe fenfile, \& in vifone fungitur officio obiedi fenfilis; inde tamen noninertur, quod fit alter fenfus, qui dicaturazens; neque quod prater obietcum vifus deturaliud agens, fiquidem lumen in vifrone mon alia ratione interuenit, quam vr obicotum; Tec hocin libro de vifu diligratius declìrabitur. iff stia bacin re funma annotitione dignum. numero dici poffe cum accidente materiali, à quo producitur, tun diuerfum ab illo : color enim in perfpicuo, fi fecundum fe ccifideretur, differt numero à colore materiali, \& fortaffeetiam fpecie, quum fit fpiritalis, illevero materia lis; fed quatenus imago illius eft, \& illum reprafentat, eft idem numero cumillo, ita vt oculus colorem fpiritalem recipiens dicatus videre illummet realem colorem, qui perillam fpeciem reprefentarur : fic conceptuslapidis in mente partim eftidem cum lapide reali, partimnon ideminam fi formaliter, \&fecundum fuam ua. turam confidererur, differtabeo \& numero, \& fpecie, \& genere, nam lapis realis eft in eatego. ria fubftantix, at concepius lapidis eft qualita in animo:quátenus autem eltimago'qux ipfum. reprafentat, eft idem cum illo, \& inrelle fus per ilum conceptum dicitur intelligere lapidem realem, qui ab illo conceptu reprafentatur: quac re omne dubium hac in se tollitur,f Latinorum moreioquenres hac diftinctionevtamur, formaliter, \& reprefentatiuej idem enim eft per rspralentationem, atnon idem formaliter. Hine colligimùs differre inter fe formam fpiritalem. \& formam realem, proutad formam producentem referuntur; nam forma realis producta ab a lia reali fimili, vt calor à calore, non efteius re. prafentatiua, fed penitus differt numero ab illa: ob id antea contra recentiores argumentando. dicebamus:; quodfirangibile in fenfum ageret materaliter folum, tactus non diceretur fentire illud ipfum obiectum tangibile, à quo pati dicitur, idque infolubile contra eos argumentum fuit, formavero fpiritalis differt modo aliquoà forma reali producente, fed modo etiam aliquo. eft idem, quodilla, quatenus eandemmet nu. mero reprafentat.

\section{Contrariorum omnium argumentorum folutio. Cap.VI.}

EEritate declarata, fupereft v̀t omniz, qux prius taca funt, dubia, \& argumenta, qua illi officere videbantur, foluamus. primoloco foluendum entid, quod huius difputationis occafio fuiffe videtur : obiectum eft qualiras naxterialis, ergo fpeciem fpiritalem producere non potef, quia fpiritale eft nobilius, ac pefectius materiali, nihil aurem agitfupra fuarum virium gradum. Ad hoc ego puto negandam efre confequentiam, \& ad probationem negandum effe fpeciem efle obiecto nobiliorem, in hoc enim conftiriffe puto multorum errore, qui omne fpiritale omni materiali nob1lius effe exiftimarut, quod tamen non eft vniuerfe verum;in fubftan. tis quidem verum eft, quia fubftanrix fpiritales materralibus nobiliores funt, \& materiales non funt caufa fpiritalium, imo potius fpirisales funt caufa materialium, ideo nulla ir iis 
oritu diffrcultas; at in accidentibus fpiritale ad materiale refertar, vt effectus ad caufam producente, \& eft minoris cntitatis, quam illud,ideo \& imperfertivis, deficit.n. ab integritate perfeAtınis illius, \& à natura eius fpecifica; lux enim Solis nobilor cit lumine ab caproducto in a ere, guod eft imago lucis, \& accidens fpiritaie: fic fpecies coloris, qua recipitur in perfpicuo,ignobilior eft colore ip fo reali, \& minoris entitatis; quamobrem color realis eam producens man agit fupra vires, fed infia vires, quia producit quodazin deterius \&ignobilius $f e$, quod vel eiuldé cfle naturx dicendü eft, cü defêtu tamen, a cafu ab illius naturæ perfectione, \& ita ab illo produsti tanquam abigente vniuoco, vel fi discre yelimus effe diuerfanaturx; t etiam dicere そoffumus, producitu à calorereali, tanquã ab agente xquiuoco,ageus aüt æquiubcū folet fuo effectu effe nobilius; reucra enim poteft modo aliquo vniuocim, modo etiam aliquo æquiuocum agens appellari, \& vtroq; modo eft nobi. lius fpecie fpiritali ab eo product. Alterum fuit addutum argumentum à fimili: vt fe habet obiectum intelligibileadintellectū, ita obiectum fenfile ad fenfum; at phantafma, quod elt obicAtum intellectus, nō poteft mauere intellectum sne ope intellectus agentis; ergo neq; obiectum renfilepoteft mouere fenfum fine ope alicuius externiagentis. Ad hoc neganda eft fimilitudo: id enim quod dicunt, vt fe habet intelligibilead intéllectum, ita fenfibile ad fonfum, verum qui- D dem eft, at non fecundumomnia, ideo nonlicet inferre eafdem prorfus conditiones requiri ad fenfile vt moueat fenfum, \& id intelligibile vt moueat intellectum; intelligibil equidè requirit suxilium agétis, qui alter intellectus eft, at fenfile non eget externo agente tanquam altero fenfu, qui dicaturagens: ideo fi de obiecto vifus concedamus quod egeat lumine, non tamen eget illo tanquam fenfu agente, fed tanquam perfectione conftitutrice obięti, ficuti alio in :6. de loco declarabimus:aliorum vero fenfuum ob iefta omni prorfus dubio carent, etenim nullo alio egent, fed per fe fola fpecies fpritales producunt. Ratio autem difcriminis fenfus, \& intellectus ết in hocpotiffimum cóftituta, quod obiectum, à quo mouetur intellectus, eft phantafma fingulare, \& Senfile, quod vt moueat intellectum, transferri oportet de gradu inferiore in gradum excellentiorem, de gradu fenfili ad gradum intellectilem; ideo quum nō fit aptum ad id propriis viribus præitandum, eget aliquo per fe intelligibili, à quo red datur actư intelligibile: at obiectúfenfus non eget vlla traductione de graduin gradum, fed iam per fe eft fenille, \& vtrale eft motiuum fenfus; in obiecto autem vifus requiritur lumer, non ad ipfum traducendum de gradu in gradum. quum debeat feruare gradü fenfilem, neq; ad al tiorem fit euehédum: fed obaliam rationem, qua in librode vifu con. fiderabitur. Ad verba autem Auerrois dicẽdura
puto cum aliis multis; Auerroem ibi non affeueranter, fed fub dubio loqui; id enim dicit tanquam difficultatem tangens, \& difficultatis caufam; \& eam infolutam dimittit: quod fl putaffet effereuera neceffarium in fenfu alique agens, vt in intellectu, certealio faltem m locoid declam fet, \& quodnä fit docuiffet; de hoc tanen nulloalio in loco aliquidamplius dixit; quare eius ip fe opinionis non fuit. Ad argumenta vero recentiorum probantium obicata quatuor fenfuum materialiter tantum agere, non eft difficile refpondere: quod enim de tangibilibus, ac de guftabilibus dicunt, ea non ageje, nifi carnem, \& linquam tangant, id nibil ef, quia iecundum A riltot.neq; caro eft inftrumentum taetus, neq; lingua guftatus, fedvtraq; eff mediü deferens obiectum 2 d organum, quod intimiti eft quare nihil nobis officit ifte cöa?tus; iquam certum fic etiam caloré tangere necclario me dium perfpicuum, fi debcat in ipfum, \& in organum agere: concedimus etian ntatuor primas tactiles qualitates materializer agere in carnen. \& imprimere reales fimiles qualitates, quis enim hoc inficietur: at nonobid fit $v \pm$ fpirtaliter non agant, dicimus enimeas \& materialiter \& fpiritaliter agere; nonenim facerent fenfio nem, fi materialitertantum, non fpiritaliteragerent, nam hoceffeneceffarium iam demonitrauimus: 1 deo etiam de faporibus dicimus, nil nobis officere quod materialiter agāt, \& imprimant in lingua faporem realem; hocenimetf dubium eft, nos tamen in prafentia condonamus, quiaper hoc non fat, quin agant èt fpiritaliter, \& ita faciant fenfionem. Illud vero, quod de fonis, ac de odoribus dicunt, aliqua contideCodarí. ratione dignu eft:nam fi concedamus, fonü effe realem motum, \& odorem effe vaporem corporeum, dicendum erit, cffe neceffarium concedere etiä fpiritales, per quos fenfiofiat, feu in meE dio,feu faltem organo fenfus receptos, neq; videtur negari pofic odoratum fieri etiam fine alicuins vaporis exhalatione, multa enim faciunt odorem per longum 2eris fpatium, qux taptam vaporis copiam emittere nullo modo pofent. Sed dicere etian polfumus, imo debemus, fpecies has fpritales, quxà fenflihns producun- Dantur tur, non ea ratione dicifpiritales, quodnon fint gredus resialiqua, fic enim effent nihil; fed resquadam accidēt funt, licet tenuis entitatis, \& imagines, quibus $3 \mathrm{~m} / \mathrm{p}$ aliæ res repræfentantur, ideo gradus habent, \& ritalı $\vec{x}_{2}$ aliqux magis, aliqux minus ad materialem na- $\mathcal{F}^{2}$ ali. turam accedunt, proinde magis, vel minus pen- $g a$ ma dent à materia, in qua recipiuntur : ideo conce-gis, alizdere poffumus aliquas effe, qua ad motum ae- quamiris modo aliquo commouentur, \& alias ma- zas ad gis, alizs minus : fonus igitur, quindaures de- natura fertur, videtur tum fpiritale quoddam, tum ma- materiteriaie effe, non eft enim talis motus aeris, qua- alem aclisfitflantibus ventis, vel quando $a b$ aliquo cedwnts

$$
\text { DD } 4 \text { pelli- }
$$


pellitur aed, non fuit enim acrin fono, fed fo- A lum trencere videtur nou matato loco, arque is tremor eft imaggo reprefentatiua illius motus, q ui eft verc fluxus aeris, \& ex corporum mutuo i.tuprimumfactus efí : ille namqi cf vere realis motus; 1lle velo, qui ad aures de ertur, videtur aliquantum ad firitalem naturamaccedere, quia fincacris fluxu partes ipfus ordinatim tre ount, dum via alterifum trimorem communicat: red ordo têporisaliquid denotat matorialis nature, quia non eodem tempore, quo fit, ad aures peucuir, fed aliquanto poleerius, idque necefiriun eft ( $\mathrm{st}$ ait Ariftor.) quạ nediun eft quātum,atq: diuiduแm:fignum autem fpiritalitaris in fono eft, quodnon penitus ad aeris agitationem mouctur, nam fertustur foni ad alures etiam contra venti fluxum \& fentiuntur, licet debilius:credendum autem eft fpeciem adhuc fpiritaliorem fieri in aere illo congeni 0 , qui auribusinclufus organu auditus efie exiftinatur.Idem de odore dicendum eft:mediim enim quoddam eft inter perfecte materialc, \&perfecte fpiritale, quod nullo modo pendet à materia; pendet enim modo aliquo à fubiecta materia, quia modo aliquo fequitur fubiesti aeris motum.I giturnon idem eft fpriritalitatis gradus in omnibus fpeciebus fenfilibus, fed in aliqua maior, in aliqua vero minor; maxime quidem fpiritalis eft fuecies coloris, qutm à nulloneris motu, \& ne a vchementifimo quidem vento

iredium disturistermateriale हु) moueri poffit; reliqua vero aliorum fenfilium fpecies videntur effe media intermateriale, apiritale, aliquidenin habent materialis naturze, red cum defectu çuodam, \& cafu à natura fpecifica, à qua producuntur, propter quem defetum, atq; (vtita dicam) entitutis imminutionem fpiritalis dicuntur, atque etiam quia funt imagines reprafentantes obiectum perfecte materiale: hocautem non absq; ratione fit; nam fi potcf accidens materiale producere accidens. tum fpiritale, tum perfecte materiale, poteftetiam producéte medium interv trum que, \& tum maiorem, tum minorem facerefpiritalitatem; quia fi poteft extrema producere, rationi confonum eft vt polfit etiam media. Defipitalium igitur fpecienm productione, qux propofita quaftionis prior pars fuit, hac dicta fint.

\section{De jentiendi actu, à quonamagente produ- catur, varicaliorum fententia. Cap. VII.}

Equitur altera huius noftrx difputationis Spars, à quonam agente producatur fenfio: quum enim aliud fit fpeciem producere, aliud fit facere fenfionem, quia in aereeft fpecies coloris ab obiecto producta, non tamen ibieft fenfio; ideo poftqnan confiderauimus, à quonan agente fpecics producatur, confiderandum etsons eft, àuonam producatur fenfio : quoniam enim operario qurdam eft, aliquod effe arens oportet à quoprodicaurisidquenecefle ef effe duotumalterum, aut fenfun ip fium, fi fenfum laberevim actuam fatcamur, aut obiectum, fi negenusfinfum agere, autcrian fimul vtruique: ideo varia hac de re fententia dite funt, quas nulti diffulilime examiunt, vt Io. Gindauenfis in lib.2, de Anima, \& Genun, \& alij recentiores cōplures; ideoquum totam hanc difputationem omnes legere in alı orü friptis porB lint, ego ftriztim, \& paucis verbis quid alii fentiant referam, ve ex eoruin difputatsone intelligatur in quonam liuufeerer difficultas confttuta fit, deinde in veritatis declaratione diligen tiusimmorabor. Primaeft Thomx opinio, qui in libr.2. de Anima, contex. 149, \& aliis in locis omnino neguuit effe in fenfualiquam vim actiuam. \& diyit fenfum fol. vi pafliua efle predi. tum, vt videtur vbiqueatlerere A riftot. qui fenper dicit fentire effe pati, \& operationem fenfus C confiftere in patiendo, \& nunquam tribuit fenfuivimactiuam; vnde colligitur ageris producens fenfionem effe folum obicetis per fpeciem mediam ab eo productam. Vtitur auten Thomas argumento tali : ratio, qux mouit Arift. ad ponendum incelledum agentem præter obieEumintelligibule, fuit, quoninm ages deber efe actu,ad obiectum intellectus, quodeft phantasma, non eft actu intelligibile, 1 deo indiguit irtellectu agente, à quo transfieretur de gradu in gradum, de intelligibili poteftate ad intell leactu; nā fi phantafima effet per feintelligibile actu, non pofuiffet Ariftot.jntellectum agentenI; atqui obiectü fenfile, quod extra animam eft, eft per fe actu fenfile, ergo fuperuacaneuseft fenfus agens; quum folum obiestum fufficiat ad mouendum fenfum, \& producendam fenfionem. Præterea idem agens, quod proaliqua for- secu iam illam formam producere; at obiedtum pro- twm. E ducit fpeciem in organo tanquan difpoitionem neceffariam profenfione, quam neceffario confequitur fonfio; ergo etiam fenforem producit: vel formerur idem argumentum fic:" agens dans formam, dat omnia confequentia formam, vt habemus in contex. 32. octaui $\mathrm{Ph}_{12}$ fic. \& in 2z. \& 25. lib. 4, de Collo; at obiectü fenfile producit in organo fpecsem, quam ex neceffitate confequitur temío; ergo etiam fenfio. nem producit. Ioannes aurem Gandaucrfis cö- opinis trariam opinionem fequntus cit, \& dixit fenfio. Io. Gai nem non ab obiecto produci, fed à folo fenfu, dasen, obid in fingulo fenit duas re dittmetas facultates pofuit, vnam agentem, \&aIteram patientem, ita ve detur vifus patiens, \& alter vifus agens in eodemanimal, \& ille recipiat folum, hic vero folum agat, \& fenfionem producat, fic eriam in alis fentibus; quare fecundum ipfum quinq; funtenfus actius, \& ali cuinq; paffrit. \& ficutiagen sproducens fpcciemin fenfum eft obicctuda. 
obicetum, ita recepta fpecic id, quod fenfionem .A producit, eftenfusagens, Testam fententium defendille videcur Scotus in 1 . Sentent. diftinet. 3. quxft. $7 \cdot$ quod fenfio à duobus funul agentibus producatur, nempe à potentia adiua fenfus tang̨uam ab agente primitrio, \&. sb obicdo tanquam fecundario, \& minus pracipuo, ia vt neutum fine altero tit totale agens lenfionem producens, fedvtrunque finul, ie vesung; proprian operam preifet in producenda fentione; hoc autin quomodo inteiligat, atque declaret Scotus, \& quibus argumentis tum hanc fententram probet, tumplures alias reprobet, in predicta ciusprolixa quaftione legr pote it; nolo enimpolixam illam difputationem in medium adducere, fed latis habui fententiam Scotı breuiter tetigiffe.

\section{Omnium dictarum opinionum con- futatio. Cap. VIII.}

GEdhxomesfententire magnis difficultatibus vigentui. l'rimum quidem aduerfus opinionem Thom x eft argumentum Ioan. Gandainenfis efficaciffimum, quod apud eum legere poffumus longo fermone expo itum; nititur enim quatuor fundamentis, vr ibi videle eft: fed einsargumenti visbreuiter collecta in hoc confiftit, quod fequeretur, obiectum externum, vel faltem fpeciem, qux ipfuni reprafentat, effe nobiliorem ferlu; cuius confequentis falfitas facis manifefta eft, quia fenfus eft forma fubftantialis cognofeens, \& valde nobilis, obiectum vero \& cius fpecies eft accidens ignobile, quod non eft dicendum effe nobilius fenfu: confequentiavero fic probatur: 1llud eft perfeCius altero, cuitus perfętifina operatio elt nob licr perfestirlima operatione alterius, nam operatio indicat erlentiams, atqui perfectifina $o$ peratio fenfus apud Thomam eft pati, \& 1 eciperefenfionem, 1pfe rinnq; nullam in eo concedit vim actium: perfectifima vero overatio obie$\mathrm{Et}_{1}$, feu fpeciei eft igere, \& prodicere fenfione nobiliusautem eft agere, quam pati; igitur obiectum erit nobilius fenfu : nititu tamen Thomas hocargumentum foluere in libro 2 , de $A$ nima loco pradicto, \& inquit nil aliud per hoc oftendi, nifi obiectum effe fenfu nobilius fecundum quid; nam quatenus obiectum eft actu tale, fenfus vero eft talis poteftate, earenus obiectum nobilius eft, quoniam actus eft poteftate nobilior, per hoc tamen non ftat, quin fubftantia fenfus, qux anima eft, fit abrolute nobilior óbicto, fiquidem fiequenter contingit vt aliquid fit abfolute nobilius aliquo, fit taméignobilius fecundum aliquani conditionem. Sed reuera argumentū per hoc non foluitur; quia in arguméto fumitur non folú operatio aliqua, qualifcunq; ea fit, fed operatio perfectifima, \& maxime pracipua:quoniam igitur præcıpua opera tiofenfuseffentire, \& adhane änatura dirigicurfenlus, \& cam ed it pariendo, obieftum vero ad cam concurrit vtagens, \& hac eft perfectiffina operatioobiceti prout fenfile clt, \& ipfius - fenfus quatcnus eft lenfus; prxecipua vero operatio decluat effentiam; ideo fequitur necellario obiectum elfe nobilius anima : quare argumentum Gundauenfis validiffmum elt. Sed ipfa quoq; Gandauenfis lententia difficultatem patitur: quum enim ponat fenfum agentem, \&

B fenfum patientem re diftinctos, quarendum eft, an ambo cognofcant, an folus patiens; nam fi ambo, ergo alier fuperuacaneus eft: \& praterea firmbo fentiunt, ergo ambo patiuntur, quia fecundum Ariftot. fentire eft pati; quare eciam fenfus agens patitur, ergo ab alio agente, \& fiç resininfinitun ibit: fi vero fenfus agens non cognofcit, fiquitur aliud abfurdum, facultatem non cognoficentem cffenobiliorem cognofeente, agens enim eft nobilius patiente, C quarefenfus agens, qui non cognofert, erit no. bilior fenfu patiente, qui cognofcit. Vidit Gan: daucnlis argumentum hoc, \& ipfum folui putauit, dicendo fenfim quidem agentem non cognofere, fed vtrunque effe fecundum quid nobiliorem altero variis rationibus; nam fenfusagenseft nobilior patiente quatenus agens, fenius autem patienseft nobilior agente quatenus cognofcens. Sedhrceuafio inanis eft: nam, vt Refponfero antcanducrfus Thomam dicebamus, ex perfe-nis tmp D Etifima operatione infertur maior perfectio ab-gnatio. folute, nec folum fecundum quid; perfectillima autem opecratio fenfus eft cognoicere. \& ea competit patienti, non agenti; ergo patiens eft ablolute nobilior quum autem talis fit, non poteft a natura dirigiad patiendum abaliquo agente iginobiliore. Illud pixierea adiernis iententiam Gandauenfis confiderandam elt, ipfum non feruare, vi feruare fe putat, proportioncm, feu finilitudinem fenfuscim intellectu, vt ficE atipraterintellectum patientem datui intelleEus agens re diftinctus abillo, ita detur fenfus agens re diftin tus à fenfu patiente; etenimalio in loco demonfrabimus officium intellectus a. gentis nonelfe fenfionem producere in intellectu patiente, fedfolum fpeciem producere: itaque fi fimilitudo feruanda fit, oportet fenfum agentem requiriad productionem fpeciei, non adfenfionem; vel prater intellectum agentem, qui fpeciem producit, darialterum intellectum agentem, qui fit caufa effectrix intellectionis : qua omnia vana funt. Scoti quoque opinio ad- Confutamittenda non eft, quia nullo modo a rerendum ticopinieft, obiectum efle caufam fenfioniseffectricem, arisscot: neq; vt primariam, neq; vt fecundariam, fic neque fpeciem; propterea quod fenfio eft forma. liter cognitio, obiectum veronnllä poteft vim habere efficiendicognitionem, licet poflit aliquid fenfuifubminitrare receffarumad fenfio$\mathrm{a}_{2}$ efícit enim fpeciem, fine qua fentionon ficDDS ret, fed

\section{Confuta \\ so opiss. dauenf.}

\section{$R e$ porrsto Ganda uenf.}


ret, fed iplus fentionis nullo nodo eft caufa of fectrix:ipfa vero fpecies in fenfione non habet locumagentis, fed folum forma genita, \& effectus producti, neque poteft agcrein organum; in quo tanquam forma in fubiecto recipitur, forma cnim in fubiedum fuum non agit. De ipfo quoque fenfu dubum eft, quomodo idem polfit efie actiuus, \& pallinus, quum nihil agat in feipfum: quood fidicatur diftinctus erle agens à patiente, tncidımus in opinionem Gandauenfis modorefutatam, \& in al iud præterea abfur. áum; quod eam infequitur, quod Ariftote!. in sractatione de fenfibus mancus ac diminutus efiet, quum de fenfu agente diftin eto à patiente *ihil vnquam dixerit, fed vnicum, qui patiendo - feratur, confiderauerit.

\section{Deatione fenfus, vera fententia. Cap. IX.}

$\mathrm{A}^{\mathrm{n}}$ D hanc difficulratem foluendam duoà no. bis decluranda funt; vnū, à quonam agente fenfio producatur; alterü, vero, quifnam fit huius actionis modus; hoc enim ignorato nil poffumus intelligere, quia multis dubiis perturbe-

Crasoris fentêtica.

rdemfersfus agit, Es patio. curfars. कis ratiosibus

Iudicare oft $\int$ enfionem prodasere. mur neceffe eit. Quod ad alterumattinet, fequendam efle arbitror Gracorum fententiam, quam paffim apud eos legimus in libris de Anima, \& apud Alexandrum in 1 . fuodeanma bbro in capite de intelle etu practico, \& fpeculatiuo, \& quä plures recentiores fequuri funt, quod eadem fit facultas fenfibilis, qux \& agat, \& pa. t1aturvariis rationibus: quum enim eademantma duobus muneribus iungatur; tum informet organum, quod fine ipsa non effer oiganum, nifi æquiluoce; tum organo à fe infor mato vtatur $2 d^{2}$ operandum: ratione plioris muneris patitur, proprium cnim organi officium eff fpeciem recipere, \& pati, ideo anima fenlibilis quatenus dat efic organo, conftituit proprium receptium fpeciei fenfilis, \& ad hanc receptionem seferturanimayt ratio recipicndi: facta autem receptioneanima v titurorgano dum fpeciem in eoreceptam iudicat: itaq; recipere eft organi animati, iudicare autem eft folius a nimz, \& ratione iuducii anima dicitur agerc, quia nil aliud eft iudicare, quam fenfionem producere : fimile huiceft id, quod Auerroes de motu elementorum dicit in Comment. 28. 1.b. 3. de Calo, forma elementi, vt eft forma mouet, moueturautem vieft in materia; nam quatenus materiam informans, \& conftituenstale elemen- $F$ rum, dicitur princıpiü paftium motus elemensi naturalis, 1 pla vero fecundú fe forma eft principium actiuum eiufdem motus. Hac eft Arift. fententia in contex. 127. lib, 2-de Anima, vbi dicit odorarenon efie folum pati, quia hoc dato fequercuracren odowaredum odores reciput, fed efle fentire: quaí dicat, odorare eft aliud quidnampreter pati, eft enim fentire, hoc aüt cft indrare, gevd cft agexe: Sic ctian in contex.
A 37. ciufdem libri aperte dicit animafn effe caufam effectricem fenfionis: quare non eft yerum id, quodà Thoma pro comperto affumitur, A. rifto t. nunquam dixiffe fentire effe.agerc, fed fn lum pati. Hoc idem fignificauit Ariftoteles in contextu 40. ciufdem libri dicens, actio vifus diciturvifio, fed actio coloris nomine caret; fie enim denotauit aliud effe impreffionem coloris fpiritalis in organo, quæ fit à calore materiall agente; aliud efle fenfronem iplam, qux diB citurvifio; fi namque vifio nilaliud effet, quam impreffio fpeciei, actio coloris effet vifio, quod ibi Arift. negat: hoc idem ex verbis Ariftotelis colligimus in contextu 16. noni Metaphyfico rum, ybi actionem immanentem diftınguen àtranfeunte dicit vifionem effe actionem immanentem, quia eft in ipfo agente: per hoc e nim differt actio immanens à tranfeunte, quod immanens eft in ipfoagëte, tran fiens veroeft in aliquo alio feparato ab agete, vt adificatio eft in

C externa materia, non in adificante: fic igitur vifoo eft actio immanens, quia recipitur in ipfometagente, nempe in anima, feu in corpore 2nimato quatenus eft animatum: quod fi nullum aliudagens haberet vifio, nifi materialem colorem, elfet abfque dubio actio tranfiens. quodibi Ariftor. negat; putąt igitur caufam vifionis effectricé cffe animam ipfam. Hoc idem coniprobatur argumento fatis manifefto fumptoab experientia : nam fape contingit.vt rem D coloraiam ob oculos pofitam non videamus, quia licet fatimprefio fpecici in oculo (nullo cnim exiftente im pedimento id negari non poteft) attamen anima aliis rebus intenta, - peciem illam non iudicat: non fola igitur fpeciei receptio eft vifio, fedetiam iudicatio; nam fi fola receptio eflet vifio, id quod dixımus, euenire non deberet; ergo præter receptionem fpeciei requiritur etiam animx actio, qua fpecies iudicetur, proinde neque obiectum, neque eius fpeE cics eft caufa effectrix vifionis.

\section{Demodo, quo fenfus infentiendo agit. cap. $X$.}

Q Voniam igitur przter actionem obiesti quaproducitur fyecies, necefle eft aliam efle ipfus anim actionem, qua eadem fpecies iudicetur,neq; proptetea duplex eft fenfus, vnu\& patiens, alter vero agens, fed vnus \& idem, qui variis rationibus \& fatitur, \& agit; teftat vt modun, quo hrcactió fit, confideremus : nam dicere fenfum iudicando agere, modum autem huiusactionis non declarare, eft fere nihil dicere, quum in eo animus ncn acquefcat, quia dubium nanet, quomodoidem poffit agerefimul, \& pati ratione eiufdem operationis, quoniam prérente obiecto ftatim, \& momento temporis fonfio fit. Hoc igitur eft à nobis in prxfentia confiderandum, quum ab aliis fatis declaratum c⿴囗十 non videatur, quup fol topa dixerint fenfum 
agere iudicando ; fed huitus actionis modiu non A declarauerint. Non eft approbandus modus à à Simplicio pofitus, quem apud cum legimus in context. 60. libr. 2. de Anima, vbi dicit animam fenfibilem habere fenfilia confubetantialia, quemadmodum anima intelleftiua habet inrelligibilia confubftantialia; hac enim negantur penitusab Ariftotel. qui putauit \& intellectionem, \& fenfionem fieri per folam receptionem specieiab obiecto externo; neq ; aliam fpeciem feufenfilem, feutintelletilem conceffic prater illam, qux ab obiecto materiali imprimitur. proterea neque fic declaratur quomodo fenfus agat; inquit enim Simplicius colorem agentein in oculum non imprimere fpeciem, fedexcitareanimam ad videndum colorem fibi effentialiter infitum, \& ita excitatam animamiudicare: at per hoc non tollitur dubium, quomodo aliquid agere polfit in feipfum; nam in illa excitatione patitur potius anima, quam agit, in iudicando autem nec agcre videtur, nec pati, quonian fenfilia illa confub tantialia $a b$ ipfa animæ fubftantia nö diftinguuntur; quomodo igitur idem fecundum idem poteft in eodem actu \& pati \& agere? Egoputo modum hunc polfe declarari perilla, qux de inrellectu dicunturab Ariftotel. in context. 8 . lib. 3. de Anima, \& in 37 .eiufdemde intellectu, ac de fenfu; inquit enim intellectum intelligendo fieri rem intellectam, \& fenfum fentiendo fieri.ipfum fenfile, ita ve vifus in videndo fiat color, non quidem materialis, fed fpiritalis:quemadnodum enim intellectus dum fpeciem receptam iudicat, fit resilla, quamreeipit; ita dum oculus colorem recipit, \& anima ipfumiudicat, dicitur anima fieri colorille, non enim cognofcit, nifi fiatres ipfa cognita: ob id aer, \& alia perfpicua recipiunt quidem colores firitales, fed eos non featiunt; quia non iudicant; non iudicant autem, quia non habent hanc vim vtfiant illud, quod recipiunt, hocenim non competit form immerf $x$ penitus in. materia,cuiufmodi eft forma res inanimat $x$;ed. folianimx, quzeft aliquantum elata fupra materiam, \& materiz imperat per cognitionem; magis quidem eleuatus-eft intelleaus, quam fenfus, quim in operando non vtatur aliquo organo recipiente, fed ipfefine organo tum recipia totum fiat illud quod recepit; eft tamë modoaliquo fupramateriam eleuatus etiam fenfus, vim enim cognofendi habet, \& quamuis fpeciem non ipfe recipiat, fed organum animatum,vt oculus;tamen non organumiudicat, fed anima ip $f a, \&$ in iudicando fit res illa, quamiudicat:hoc igituriudicare, \& fieri rem ipfam iudicaram, eft proprium anima opus, \& anima eft cius caufa effectrix, non tameriper veramactionem, qua mutatur patiens a b agente, fed per folam emanationem ; \& per hoc foluitur ominis. dificultas, fuxaliter folui non poteft, nam omaevere agens eget patiente, in quodagat, nc. que poteft idem pari, se recipere aliquidà femetipto:proptereailli,qui liæe duoagentia non diftinguunt, oftender c non poffurer, qunomodo idem fenfus patiatur, \& agat; nos vero dicentes fenfum per folam emanationem efficere fenfio. nem, omne dubsum tollin us: agens enim peremanationem non agitin aliud, fed neceffario in feipfum, emanatenim abillooperatio, \& in ipfomet remanet, ideo talis agentis aćtio nunquam eft trantiens, fed femper immanens; veri B autem agentis actio eft fempertranfiens, quoniam tali actione nihil potert agere in Ceipfum, fed folum inaliud extra fe, \& in hoc diftinguitur actio inmanens à tranfeunte. Recepta igitur in oculo coloris fpecie, cuius effectrix caufa eit color materialis externus, emanat ab ipfa natura anima vt in fua fubrtantia imbibat illam fpeciem, \& fiat fpiritaliter colorille, quem fentire dicitur : hoc modo anima eft fenfionis caufa effectrix per emanationem, \& hæc operatio ema. nat ab anima, recipitur autem tum in ipfamet anima, tum in toto oculo animato; quatenuse: nim anima eft, qux iudisat, \& fit fpiritalite? res cognita, catenus in anima fenfio fieri dicitur; fed quatenus fpecies in oculo animato recepta.eft, \&xanima quoque ipfa non extra oculum eft, fed in oculo, imo clt ipfa oculi forma, \& effentia, qua oculus eft oculus, eatenus in oculo fieri fenfo dicitur, \& ipfiattribuitur, ita vt oculuss dicatur fentiens vt quód, anima vero nonvt: quod, fed vt quo. Similis auté huic actionranima eft illa, qua alias diximus elémentũ moueri à reipfo, nam ea quoque eft actio per emanationem, proinde non trantiens, fed immanens eft, vi eo in locko cum diligentia declarauimus. per hxc autem, qux modo diximus, ratio facile affertur, curaliquando non videmus ea, qux.ob oculos habemus; tunc enim arima intenta eft confiderationi alterius rei, \& eft facta res illa, non poreft autemfimul fieri dures, ideo dum vnam fpeciem recipit,ac iudicat, non poteft fesi aliares:tunc igitur recipitur in ocule fpecies coloris, at non iudicatur, propterea quod anima cuius eft iudicium, tunc eft facta alia res, nec poteft fieri color hic receptus, nifi definat efferes illa aliạ: Exhis omn bus colligimus tria hæc in fenlionenotanda efle, quz Latini triainftantia appellarunc, ordinata, atq diftinata, fi non tempore; fal tem natura: primú enim ab actione obecti materialis fitin organo receptio fpeciei, vit: coloris in oculo; fecundo anima iudicium profert, \& ita agere dicitur; tertio recipituriudiciü. in toto compofito, nempe organoanimato, \& ita anima tanquam eius pars dicitur pati : primum quidem initans poteit etiam tempore præcedere reliqua; vt diximus deillo; qui re præfentes non animaduertit, poreft etiam non. pracedere tempore, fed folum natura; at fecundum non poteft procedere tertium rem: pore, fed atura tantum pracedit, quia vifio
In Y. Uth. dernoto grausuns Gi leus: sm. Cur alis quasde ea,ques presers. tia fune. zon Gide mssos

Piris is. fantis in fenjo ne. 
\& fimuliudicatio, feu actioanimæ, \& receptio oculi animati, quemadmodum fimul tempore forma elemeati eft monens quatenus eft forma, \& moia quatenus elt in materia, ita vtagcre fit folius animz, pati autem non folius, led organi animati : ideo Arift. quando effectricem caulam fenfioms confiderãu, eã refert in folam animam, non in compofis um animatum, vt in contex $\cdot 37$. lib.z.de Anima; quandoautem confiderat fubiectum recipiens tenfionem, \& cui fenfio attribuitur, id negat effe animā, fed dicit effe ipfum compofitum animatum, \& hac etiam ratione inquit fenfum pati, quia confiderat organuan animatum, quod reuerapatitur: defenfu autem loquens femper dixit ipfum patiendo opcrasi, quiafentire non eft folum iudicare, fed compiectitur omnia illa tria momenta, quorum primum \& vltimum pafiones funt organi animati, \& primum eft paflio facta exactione obicetiextcrni; ideotria illa in vnum colligendo, \& tanquam vnam operationem confiderando, ea re. fjectu fenfus vocata eft paffio, cuius actiuum principium eft obiectum externum, idco relpectu totius operationis fenfus dicitur patiens, obictum vero dicitur agens; pecr hostamen non ftat quin inter duo illa extrema momentaiertium medium intercipiatur, in quo fenfus agere dicitur, quemadmodum declaranimus.

\section{Quodargumenta aduerfus alios adducta} pradicte fententia non offciant. Cup.XX.

$T$ T Hiprobatur, quod eam fequentes illa ómnia
A. abfurda euitamus, quæ aduerfus alios adduxi- mus:nam fecunduni opinionem Thomæ agens effet ignobilius paticnte, quod iuxta fententiam noftrain non fequirur, quum fenfionis produEtionem totam animx, nullam fenfui attribuanus. Argumerium quoque allatum contra Gandauenfem nobis non olficit: nos enim non duos diftinetos fenfus ponimus, fed vnum, qui \& agat, \& patstur diuerfis rationibus, \& ita cognofat:fed caula erroris Gaudauenfis fuit, quia B non cognouit agens per emanationem; ideo, quum oitendere non potueril quomodo idem fenfus patiatur, \& agat, duos re diftinctos fenfus introduxit. Facimus etiam in huc fimilem fenfum intellectri i, quod vt fenfus fuapte natura fenfionem producit, ita intellectus nolter producit intellectionem, non intellectus agenș: qua in re decepti funt multi, ficut alio in loco demonfrabimus. Tandem nobis non obiunt illa, quice a duerfits Scotum dicta funt: nos enim in prodrictione fenfionis nullam obiecto actio nenuatribuimus, fed totam anim $x$ fentienti: deinde ira ponimus eundem fenfum agere \& pati, vt in nullam difficultarem incidamus, fiquidem actuum effe dicimus non actione vera,fed per folam emanationem; talen autem 2 ctionem fi negenus, nulla dabirur actio ummanens, quomam vera actione nihil poteft agere in feipfum. Non facimus etiam Arift. mancum in tractatione de fen/u, qua vnicu m-fenfum po. nimus, quem ipfe dixit operarı patiendo, fed "non omnino negauit eum agere, quemadmodum antea demonftrauimus.

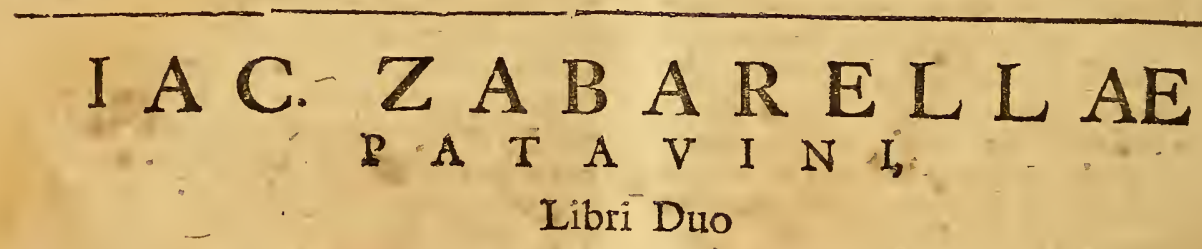

\section{DEVIS V. LIB ER PRIMVS.}

\section{Tropofitio ac partitio dicendorum. Cap. I.}

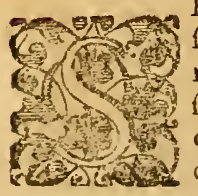

E N S V V M omnium nobiliffimum effe vifum, fatis inter omnes conftare videtur, nam \& ad fcrentias capeffendas vtilifimus ommium eft, \& ment1 etiam quam fimillimus; quod tum eius operatione colligi, tum cx hoc

rifasintellectui dignorci facile poreft, quod dicere non folemus mentem audire, vel olfacere, vel guftare, neque illiaures, autmres, aut linguam per
E translationem vnquam attribuimus; dicimus tamen oculos mentis, \& peradionis fimilitudinem infpicere, ac videre mentem dicere confueumus. Inftrumentum quoque huic fenfui pulcherrimum, \& artificiofifime fabricatum natura tribuit, ipfumq̨ue in fuprema corporis parte, vnde totius corporis faluti praefie, ac profpicere melius poffet, collocanit- Fuit preterea hic fenfus etian magna finmorum phi. lofophorum difienfione, \& controuerfia nobi-

F litatus, frilicet Ariftotel.Platonis, \& Galeni, qui de huius actione contrarias penitus fententias protulerunt. De hac igitur anima facultate; 


\section{7} de Vifu, Liber I. qua digna pra cxteris omniftudio, ac diligentia effe videtur, in prafentia dicendum, eiulque naturam, \& actionis modü diligentifine perfruiandum nobis properuimus; vt $c a$, qua ab Aritot.de hactun in libris de Anima, cum in paruis naturalibus dicuntur, declararc omnibus viribus noftris contendamus. Totam aūt hanc noftram difputationem in duas partes diuidemus: an quartumaltera $A$ tift.de vifu opinionem ita claram reddere conabimur,vt quantum fieri poffit optime incelligatur: in altera vero fenten- $B$ tiam Platonis, quam $G$ l enus enixe tutatus eft, confiderabimus, \& cun Ariftot. fententiaconferemus; \& veritate opinionis Arift. demonftrata, eam à Galeni obiectionibus vindicare nitemur. In ipfa autew Arift. fententia declaranda hunc ordinem feruabimus : quú enını ipfe exiftimauerit vifionem fierı per actionem obiecti in organum vifüs permediun per $\int_{p} i c u \bar{u}$, de his omnibus fingillacim agemus, \&eas, qux in fingulis orientur, dificultates foluenus; vt tar.dem quomodo ex eorum trium concurfu fecundura: Arift. vifio fiat intelligamus. Primum igitur de obiecto, qui color eft, iuxta Arift. przceptionem dicendumeit, vt eius naturam, \& generationem intelligentes, melius connofcere polfumus, cur, \& aquomodo à colore medium, \& organum fenfus afficiatur.

\section{De coloris natura, \& generatione. Cap. II.}

6. Vas coloris definitiones Arift. tradidife videfi. Ddetur; vnam in contex. 67. lib. 2. de Anines. ma, color eft motiuus perfoicui, quod fit adu; alteram in libro de fentu ce fenfilibus, cap. 3.color eft extrernitas perf́picui terminati; in libello autem Arift. adfripto de colorib. nulla calor 13 definitio traditurt, $v$ non in iuria fufpicari pofi1mus, librum illum ab Arift. foriptum nen fuiffe, licetaliqua etiam notatu digna in co legantur. de $\mathrm{Deprioretamen} \mathrm{definitione,} \mathrm{quz} \mathrm{tradi} \mathrm{in} \mathrm{fe-}$ cundo de Anima dicitur, ego lemper dubitaui. an fí deñnitio appellanda, quum verba illa non de- ad modum definitionis prolata effe videantur, inquit enim Arift. [omnis astem color] attamen in definitionibus afferendis dictio diftributiua. non conuenienter ponitur, fed potius articulus: nam diatione diffributiua fignificatur natura vt: distributa per particularia fuppofita; articulo autem fignificatur vt collecta, \& ad vnitatem. redacta; at in definition effentiam rei vt vnam fignificare, \& exprimere volumus, non vt diftributam: praterea vifibilitas eft accidens pofteriusipfa caloris natura, quod fignificauit Arift. in 10 . contex. 3. Phy fic. dicens colorea, 3 vifibile effe 1 dem fubieto, fed differre ratione; etenim noxen coloris notat naturaia quandā abfolutã, cui hxc aptitudo, \& hic ad vifurn refpecus fugeruenit, ve dicatur vifitilis, ideo ibiSim.
A plicius, ac Themifliusadmonent vifibilitatem effea:cidens coloris; intelligendum auten c accidens non quidem feparabile, aut commu Vifrbilsne, fed roprium, \& coloriperfe cópetens iuxta tus inest fecundum modum dicendiper fe: quoniam igi-perfecotur efle noriuum vifus competitcolori nó qua lorisnfetenus abfolute eft color, fed quatenus vifibilis, cindo ideo per hoc ipfa coloris natura non exprimi- mododitur;proinde videt ur potius $\Lambda$ rift. his verbis illam cendiper vt coloris preprietate proponere, quam vt co. $\int e$.

loris definitionem adducere: attamen quia ftatim fubiungit [G bacest ifficusnatura] in nuere videtar pofle per hane proprictatem definirico. lorem, non quiden abfolute vt color eft, fed vt vifum refpicit, a vifibllis dicitur; idro fi ea eft vocanda definitio, non eft talis definitio per quam abfolute fumpta coloris natura declaretur, fed eft defcriptio quxdarn tradita per pofteriora, \& pro oscaficne fufficiens; quumenim non alia ratione ibi de coloreagatur, quamad C declarandam ex fua operatione facultatem anima vifiuam, fatis fuir declarare nomen coloris, prout vifum refpicit, \& quatenus vifinilis eft; non eft autem alia ratione vifibilis, nifi vt eft motiuus perfpicui, quod actu perfpicumiz fit hoc eftilluminandum, lumen enim eft a ctus, \& perfectroperfpicui, vt eodem in loco Arifts. teles docet. At in libro de fenfu \& fenfilibus volens Ariftoteles exactiorem nobis notitiars vificnis tradere, intimius naturam coloris feriD tatuseft, ipfumetiam abfolute fumptúconfiderauit, acdefiniuit; quoniam eius cognitio non parum confert ad intelligendam cur col $\mathrm{r}$.
vifibilis fit, \& quomodo fiarvifio. Adillius igi-color dum tur definitionis intelligentiam dicendū eft bie-plex, reauiter de generatione coloris: \& quum dupiex $i s$, S ap effedicatur color, vnus, qui foletappellari rea- parens. lis, altervero, qui vocatur appatens, \& fpirstalis;: vtriufque generatio eft feoifum confideranda, quemadnodum. Ariftoteles quoque in eoden E liboofeparatim vtriufque colcrisgenerationem declarauit. Quodad reales coloresattinet, fant Decoloquidicant, ipfos, \& alias omnes qualitates, qua rum resfecund appellantur, generari exprimis, nem- lism gepe ex calido, \& frigido, \& humido, \& ficco; neratsoquod nos de coloribusnon omnino verum ef ne. fearbitramur : nam certum effccleftia corpora effecolerata, fiquidem luxip forum colo: eft. \& vifum mout quatenus color; 3 hocteftatur. Ariftoreles tum inillo tertio capite libri de renF: fa \& ferfilibus, tum in r: cap.libelli decolcribusprimæ tom en qualitates nullum in coelefti corpore locum habent: vnde colligi poffe videtur, quod etfí colorata inferioris mur di côf ant ex quatuor elementis, qua funt calida, frigi gia, humida, \&e ficcajnon tamen primo ex his cualitatibus colores proueniunt, idef, non yuatenuselementa funt calida; \& frigida, is humida, \& ficca, fed potius alia ratione, qux eadéin bis, \& in coleftibus locühabeat, faltem ficun ium quan- 
quandam fimilitudinem, \& analogiam; quum igitur \& cœleftia, \& inferiora corpora per̀́picuitate fint pradita, ego puto his omnibus colorem competereratione perfpicuitatis: quoniam enim perfpicuum illud eft, quod propter partium renuitatem tranfparet, nec vifum terminat, vnde etiam interminatum appellatur; neceffe eft fivt perfpicuum incraffetur, \& cödenfetur, ita ve definat tranfparere, \& vifum terminet, nec finat vlterius per intimam cius fubftantiam porrigi, tunc amiffa perf́picui ta te colorem loco eius recipiat in fuperficie, quo moueat ac terminet vifum : tale igitur perfpicuum ab Ariftot. vocatur terminatum, idq ; neceffe eft vt fit coloratum, nam fua fuperficie vifum termina. re eft effe coloracum, quia terminare vifum non poteft, nifi per colorem aliquem: color itaque oritur ex fola condenfatione perfpicui; quum enim ex condenfatione definit effe perfpicuum, fit coloratum,' \& per fúam fuperficien mouet vifum, tenim in fola fuperficie retinet perfjicuitatem, quam prius habebat in tota fua fub. ftantia: \& quum folum perfpicum fit receptiunm coloris, prius in tota fubftantia fua colores aliorum recipicbat, dum interm inatum erat; pofteavero factum terminatum babet folum in fuperficio perf́picuitatem, \& colorem proprium Ioco perSpicuitatis interminatz, quam prius haConders- bebatin totafubstantia. Cond nfatio autem ac futioper- terminatio perfpicui fieri videturduobus mo picuifit-dis. Vaus eft quando finealicuius alterius cor. duobus poris admifione ipfum folum perfpicuum cormodis.

pus in fe conftipatur, neque in alım naruram mutatur, praterquam quod fit denfum, \& definit effeperuium, \& incipit terminare vifum: qui modus locum habet in coeleftibus corpoMreterea ribus, ex vra enim \& eadem corporis $n$ tura Cali tota conftant coeleftia omnia, nec differunt, nifi per ef $e^{2} i n f l e \overline{~ m a i o r e m, ~ v e l ~ m i n o r e m ~ r a r i t a t e m, ~ f e u ~ d e n f i t a-~}$ *atwita. tem; \& quo denfiora funt, eo magis colorata funt, hoc eft, magis lucida; nullus enım alius eft coleftium color, quamalbedo fplendens, qua diciturlux, \& quodenfiora funt, eo magis alba aclucentia funt: ideo pars Coli rara pripicua eft, atq; tranfparens, aftra vero funt partes Coeli denfiores, quia non tranfparentes, fed luci$\mathrm{d} x$, \& coloratæ funt, minime autem omnium aftrorum denfaluna eft, quia minimum habet proprii luminis. Alter modus in folis inferioribuscorporibus locum habet, \& eft condenfacio perf́picui non per folam eius conftipationem, fed per admiftionem opaci; fic enim fit coloratum, quia definit effe peruium, fed alıa magis, alia minus, prout plus, vel minus opaci ha. ben: in lua miftione, vel etiam ratione modi miftionis,yndeetiam prouenit varictas fpecierum caloris ; quatu or enim elementorum tria funt perfpictia, ignis, aer, \&aqua, vna autem terra opaca, ideo cs admiftione terra definunt corpora elíe perficicua, \& fiunt coloratain fu-
A perficie variis coloribus; opponitur enim perfpicuitari opacitas, \& hx varias faciunt miftio. nes, proinde \& yarias colorum generationes. Quum autem tria elementa perfpicua fint, eft tamen inter ea difcrimen: a qua enim quia parum recedit à naturaterrx, minus eft perfpicua, quam alia duo, \& habet aliquid opacitatis; aer vero magis perfpicuus eft; fed maxime omnium ignis, ille fcilicet elementarıs , qui tenuiffimus, \& inuifibilis eft: cū his igitur admifta terraper

B fuam opacitatem impedimento eft perfpicuitati; admifcetur autem duobus modis, vel enim per folan compofitionem fine vera miftione, vel cum vera miftione, qux eft mutatio naturarum elementorum in naturam inifti : priore quidem modo fi elementa perfpicua condenfentur, fiunt alba, vel parum abalbedine recedunt, a qua enim condenfata albafit; fic etiam aer, vt inquit auctor libelli de coloribus in calce capitis tertii; non condenfantur autem a qua, a aer, nifi eisaliquid denfa materizadmifeeatur, neque enim aqua congelaretur, nifieffet commifta cum terra: ignis vero propter maiorem tenuitatem ac perfpicuitatem non mo. do fit albus, fi condenfetur, fed etiam lucidus, \& fplendens; non condenfatur autem nifi ob alicuius terreftris materiz adriftionem, ficenim fit vifibilis, qui perfeperfpicuus, \& inuifibilis eft; flamma enim cft ignis commiftus fu. Fla mo terreftri, \& in coconftipatus. fed propieri]- qui

D liusfumi raritatem alba eft flamma, maxime vero in parte fuperiore ellychnii ardents, vbi magis eft conueıfus furr us in ignem, \& à circumftante aere frigido condenlatus; in parte autem inferiore, qux prope ipfum ellychnium eft, fumus eft magis integer, necdum bene in ignem inutatus, jdeoibi magis turbida eft flamma, \& minusalba, \& ririor: in carbone autem, $\&$ in ferro 1 gnilo meft ignis commiftus materiz crallifina ablque vera miftione, ideoproE pierma eria crafiticm eft minus albus, ac minuslucens; habet ta!nen neceffario aliquid lucis, ina fenuar uribi integranatura ignis, quem ex lila condenfatione fplendentem fieri neceffeett. Quandoautem fit vera elenentorum mi$\mathrm{ft}_{10}$, in qua non leruatur elementorum natura, fed wutantur in naturam mifti, ignis non ampliusf fendet, quia definit effe ignis, quare mittum adipifcituicolorem non fplendentem: contingit tamen in aliqubus, vt licet veram F habeant miftionem, tamen aliqud lucis retineant ex igni commifto, cuiurmodifunt oculi quorundam animalium, \& noctiluca \& alia, quorum mentionem facit Ariftot. in contex. 72. $11 b .2$ de Anima, qux, quum noctu luceant, videntur in tencbries in talibus enim parum eft opaci terrefris, \& plurimuma qux, cui commifus ignis, licet defieritefle ignis, aliquid tamen fui fplendoris reliquit, quoniam aqua nó tant ü impedimentum affert luciditati ignis, quantum affert 
affert terra, qua fine vlla perfpicuitate eft opaciffima; non eft tamen in talibus multum lucis, fed parum, quod offufcatur à maiori lumine al- dici,ideo interdiu non videntur. Ex his colligimus, eiusdem effe natura lucem, \&albedinem, \&perfpicuitatem, quum perfpicuum interminatum, fi condenfetur, fiat album, idquevel fplendens,vtignis, vel non fplendens, vtaer, de aqua ; propterea neceffe eft etiam tenebram, \& nigredinem cffe eiusdem natur $x$, ita vt id, quod in interminato vocatur tenebra, in terminato dicaturnigrum, fiquidem albedini nigredo opponitur, \& luminitenebra; vt igiturlumen, \& albedo funt eiusdem naturz, ita oportet, tene- bram quoque, \& nigrum effe eiusdem natura: $\&$ hocclare a pud A riitotel.legimus in capite $3.1 \mathrm{ib}$. de fenfu \&e fenfilibus: quenad modum igiturtenebra eft priuatioluminis, ita dici potêft nigr $\vec{u}$ effe priuationem quandam albedinis; ita vt ficutivideridicuntur tenebra, quando nihil videtur, ita etiam nigrum videri tunc dicatur, quando nullus colorvidetur: \& hoc apud Ariftotel. apertelegimus in 3.libr. Meteorol. in tractat. de $i_{\bar{u}}$ Iride,vbi inquit [ nigrum est Geluitinegutio, 2 deo enim appare: rigrum, quia defictt Gufus] ciusdem igitur rationis effe videtur vifio nigri in corpore terminato, 2 vifio tenebrarum in corpore interminato, licet magis videri dicatur nigrum, qua tenebræ, quia id, quod eft terminatum, eft perfe terminatiuum vifus, \& per fe vifibile; interminatum yero non eft perfe vifibile, quia non eft terminatiwum vifus. Illud quoque mi hi videtur poffe colligi exiis, qux dieta funt, vt albedo eft proprius color trium elementorum perfpicuorum, fiquidem perfpicuitas per condenfationem migrat in albedinem, ita nigredinem effe proprium colorem terra, cuius propria eft opacitas, qua opponitur perf́icuitati : iccirco non affentiorauthorilibelli decoloribus, qui dicit omnia elementa effe naturaliter alba; quam enimillemet fateatur album \& nigrum effe colores fimplices, credendum eit vtrumq; effe proprium fimplicium corporum, \& ad hocprobandum poffumus ita argumentari : id, quodalicui competit per participationem, deberalicui cō. petere per effentia m; at colores extremi, album, \& nigrum, \& medij omnes ex his conftartes competunt miftis corporibus per participatio. nem elementorum, crgo neceffe eft vt colores. fimplices competant elementis effentialiter, \& per fe,quum per elementa competant miftis, \& quum ex elementorum commiftione oriantur in mift is omnes colores medij; eft igitur naturale terra nigrum, ficut etiam opacum, quum fis aliis naturale album, \& perfpicuum : confirmatur hoc ex opinione Parmenidis à Grzcis interpretibus declarata in primo Phyficz aufculta. tionis, cont. 41. dicunt enim Parmenidem fatuiffererum principia ignem \& terram, qua aliis nominibus cals dum 2 \& frigidum appellauit ${ }_{2}$ \&
A al:is etiam noniribuslucem, \& tenebras : Parmenides jgitur ter1 $x$ tribuit tenebras, rroinde \& nigredinem, quia eiusdem natur $x$ funt tenebr $x$, \& nigredo, atq; etiam opacitas, quam manifeftum eit effe natural em terrx : itaque terra pura debet effe nigra, quum fit naturaliter opaca, \& caufa opacitatis ornibus corporibus miftis; opacitas autem opponaturperfpicuitati, quz eft de natura albedinis. Hre igitur eft illorum colorum generatio, qui folent appellari reales, alB bum enim \& nigrum funt proprij colores elementorum, \& per elementa competunt miftis tum ipfimet colores extremi, tū omnes medij, qui ex elementorum reali commiftione oriuntur in miftis. Alterum datur colorum genus, qui Degene. vocari folent apparentes, feu fpiritales, \& horum ratione quoquegenerationem declarat diligenter A ri . ftotel. inillo 3. cap. libri de Senfu \& fenfilibus: ficutenim extaliftatuta miftione albicum nigro fit rubeus colorrealis, ita fine reali miftiocolorums apparen. tism. nealbi cum nigro fiet idem rubeus color, fi fola fpeciesillorum fpiritales commifceătur in medio; hocautem fit, quando per eandem rectam lineam fertur vtriusque coloris fpeciesad ocklum,vt quum Sol fit naturaliteralbus, fi eius l us. men tranfeatperaerem atrum, \& plenum terrea. exhalatione, fert ad oculum fpeciem miftam, quz rubeum colorem pra fe fert:quamuis enim corpora illa non commifceantur, neque reales ipforum colores, commifcentur tamen illorum colorum fpecies in medio, dum pereandem rectam lineam feruntur ad oculum tanquam color vnus medius : isque non ideo dicitur apparens, quia falfa fit illa apparentia, nam vifus non decipitur, dum iudicat fe rubedinem recipere, rubedo enim reuera eft quærecipitur, \& eit genita ex commiftione fpecierum, quemadmodum diximus : quod fi iudisaret ex ea vifione Solem effe rubeum, vriq; deciperetur, quia non eft in Sole colorille, fed generatarinaere ex cöE miftione luminis Solis cum aereatro, \& participatione tū opacitatis, tum perfpicuitatis. Sic ét quando radij Solis percutientes collum palumbx reflectuntur ad oculum, adiiciunt proprio pennarum reali colori albedinem fpiritalem, \&c ita generant colorem medium, qui magisad albedinem vergit, quam folus realis illarum pennarum color; ideo fi quisiudicet, talem effe reipra colorem pennarum, decipitur; at fi iudicet effe colorem prouenientem ex vero pennarum

F colore, \& albedineluminis, non decipitur, quia talis reuera eft color. Differt autem realis color à fpiritali, quia real is pendet omnino à fubiecto, in quo eft, \& ad eius motum mouetur, vt color vini, \& color lactis, \& color fanguinis; at color fpiritalis pendet ab agente, à quo producitur, nec moueturad motum fubie et, in quore. cipitur, vecolor in linteo panno produstus à colore vini in phrala exiftentis; ad motumenim ghiala mouetur, fed non ad motum panni

\section{Diferis. menco- Loris rea- lis ac $\int p t$ ritalu.}


lintei : in hos autem exemplo patet coloren fpiritalem, quando recipitur in corpore aliquo terminato, pofle in méedio fpeciem fuam producere, \& per fe videri, ficenim fit per feterminatinusvifus. Perhxcvidecurfatis effe declarata definicio illa coloris ab A rifot. tradita in libro de Senfu \& fenfilibus, color eftextremitas perfpicusterminati; fumit enim perfpisuum in definitione caloris, tanquam proprium cius fubicatum, quia vbieftcalor, ibj neceffe eft effe perfpicum: perficum quidem interminatum, giando eft actu perficurum, habet calores alianm rerum; fi vero fiat terminatum, habet calorem proprium in fuperficie. Ex his colligerepoffumus, non effe veram illorum fententiam, quidicunt colorem generari ex commi. Stione perfpicui, \& opaci; patet enim Arifotelem in definitsone coloris non nominare opacum, fed folum prefpicum; quia iam diximus, ex fola condentacione perfoicui eriam tine opaco generaricolorem, dum ies loço perfpicuitatis iufcipit terminationem; admiftio aurem opaci variat quidem colorum fpecies, at nen eft zçuata ratio generationis coloris, fed folum quatenus facit condenfari perfpicuum. Non eft zutem ignorandum, definitiousem hans partim dici poire caloris abfolute confiderari, partim ad vifionem relati:ip fa namq; fecundum fenullum refpectum notat, nam dicere extremitatcm peripucui terminati, non ef retiperevifum; dicitur tamen ea ratione definiri cum refpectu, D quarenus calorabfolute fumptus non minus in profundo effe videtur, quam in fuperficie,vt albedo non minus in profunditate fubftantiz Ans, qus ${ }^{\text {atctis, }}$ quam in cius extremitate; attamen non - st in pro eft vifibilis, nifi colur fuperficiei; buncigitur fofundisa. lum definit ibi Arifoteles: quum enim ibi in re, d $z$ - fenium confideratione verfetur, ad eum non sentws pertinebat definirealium colorem, quam eum, colir. qui vifibiliseft definit ergo colorem vilibilem, fed defuit ipfum fecundum fe, a abfolute E confideratum, non tamenalio confilio, quarn gratia vifus; quocirca eft modoaliquo definitio refpectiua, \& dicere poffumus notari in ea refpectun ad vifum, fed refpectum remorum; in illa vero, qux in fecundo de Anima traditur, notan refpectum proximum, ita vt bac fitdefinitio coloris vifibilis quatenus eft vifibilis, illa verocoloris vifibilis quatenus eft color.Sed dicere ctiam poffumus (neque erit ab A riftaliena fententıa) non effe actu colorem, nifillum, qui eft in fuperficiejeum vero, qui eft in profundo, potefta ie tantum effe colorem, quatenus enira poteff fierifuperficialis, eatenus poteit euadereactu calor : quu m enim co confilio à natura conftitutus color effe videcur, vt vifum moueat ad vitam anin:aliun conferuandam, \& in homine adrerum fcirntiam adipifcendarn, ille folus eft attu color, qui apcus eft per fe operam fuam praftare, hic autern eft ille foluca, qui in fuperfi-
A cie eft quia etiamfi conting?t ve fit in tenebriss tamen apestudinem per fe habet mouendi vifum, licet mouere nequear ob defectum luminis in perípicuo: nifi enim hoc dicamus, non erit color zquatum obie fum vifus, fiquidem dareturcolor, quifecüdum propriam naturam non cft vifibilis,nempeis, qui eft in profundoneque Ariftoteles per dufinitionem pradictam declararet naturans colorís, fed eam traderetper accidentalia; nam fi non minus color in profundo B effer, quam in fuperficie, effe accidentale colori effein extremitate. Sed aduerlus hoc oritur dubium, quodtangiturà Ioanre Grammatico in contextu 66. fecundilibri de anima, videtur enim efle coloretiam in profundo, imo \& actu vifibil is ; nam in clectro, multisquelapidibus tranfparentabus in eft, quando que intrinfecus concretum aliquodatimal, yrmuica, vel etiara folium aliquod, idque à nobis cernitur, licet fit in profundo illius coiporis, fic etiam viC demus colorem numari in fundo aquax, \& colcrem ipfius vafis. Scd hocà Ionne coptine folui- sols tur; inquit euim neceftarium efievt proprius elcatris color velfit intenfior coloreanimalis inclufi, vel $x_{\text {que, }}$ yel minus intenfus : fi igiturintenfior fit, aut etiam aqueintenfus, folus vide. bicur, \& occultabit colorem animalıs inclufi, qui non videbıtur: fi vcro intenlio fit color illius animalis, videbitur quidem, fed nois vecolor eleetris, fed v colur rllius animalis, proinde $v t$ in 1 lius anirnalis fupe: ficie, non vt in profundo elestri; quod enim appareat in profund tace fubftantix electri, hocnibil eft, quia tunc electrun fugitur off cio medij perfpicui , cuiuf. modieft etiamaer; ficigiturelectrun tan quam perpicuum medium defert ad oculos colorem exitientem in fuperficieillius anmalis in eo inclufi; quarenullas color videtur, nifi quiin fuperficie eft. Caufa autem dubitationis, \&e erroriscit, quoniam huiufretaodi lapides funt fimul \& colorati \& perf picul; participant enim aliqua opaci iat:, qua eos facit effe coloratus, fed non omnino tollit in eis perfpicuitatem : ideo quia fertur vifus per profundum lapidis ob eius perfpicuitaten, credimus vifibilem effe eriam illum colorem, qui eft in profundo; non tamea ficeft, fed quacenus coloraius, ac vifibilis eft lapis, eatenus à nobis videcur fecundum propriati ipfius fuperficiem; quatenus vero perfpicuus eft, transfert ad nos tanquam meF dium colores aliarum rerum, vt colorem ani. malis inclufi, velinclula herbx, fed non tanquam coloratus : itaque \& color exiftens in fuperficie animalisinclufi tranfitad oculos per electrum tanquam perfpicuum medium; \& ip?e quoque proprius ele tri color, qui in ipfius eft faperficie, mouet vifum, \& ita cernitur electrum vt coloratum. Patet 1 gitur non efle vifibilem alium colorem, nifillum, qui in fuperficic eft, imo \& eum folum effe actu colorcm; fic enim 
refte iprum definiuit Arift. dicens, colorem ni- A lores advifum, à duas his partibus conftitui, à hil alıud effe, quam extremitaten, hoc eft, lu. perficiem perfpicui terminati.

\section{De Perfpicuo. Cap. III.}

H Ec de obięto dikta fint: fequiturvt de meHio,quod perfpicuun eft, dicamus: huius duz funt partes; vna tanquam materia, qux apta eft recipere \& lumen, \& tenebras; altera vero vt forma, eaque eft lumen : de vtraque igitur dicendum eft. Quod ad partem materialem atcinet, ea nil aliud eft, quam corpus, aptum recipere in fua fub tantia \& lumen, \& aliarum re. rum colores;praftare autem hoc non poteft, nifi lit peruium, idque eft $x$, quod vocamus perfpicuum fiue tranfparens; peruium autem effe non poreft, nifi habeat firb itantix tenuitatem, ve per eam poffit lumen intima penetrare, nam tenuitati opponitur craffities, ac denfitas, qux impedimento eft receptioni luminis, \& coloris introrfum, quia facit terminationem, \& colorationem in fuperficie : ideo redte notat Albertus, clfe quidem neceffarium vt perfpicuum materiale habeat fubftantiam raram, id tamen non fatis effe ad faciendam perf́picuitatē , fed requiri etiam fubtilitatem fub ftantix; vult enim per hoc denotare perfpicuum non in illa raritate. confiftere, quz fignificat diftantiam partium, non fubftantiz tenuitatem, \& eft de categoria fitus,fed in illa, quze eft de genere qualitatis, \& fignificattenuitatem fubftantix, hac enim facit perfpicuitatem; inde etiam perfpicuorum differentia oritur; prout enim alia tenuiorem alia minustenuem fubftantiam habent, maiorem etiam, aut minorem habent perfpicuitatem. Eftatitem animaduertendum, poffe duo- bus modis confiderari perfpicuum; vno modo abrolute, \& fecundim propriam naturam; altero modo refpectu vifus: abfolutequidem confideratumnö complectiturlumen, fed talem ha. bet naturam, qux eft aptarecipere introrfum, \& Jumen, \& tenebrasiquemadmodum etiam prima materia nullam in fua fubitantia formam haber, fed aptaeft cum formam, tumpruationew recipere: quarevt natur $x$ primz materix extranea eft tum forma, tum priuatio ;ita naturæabfolutx ipfius perfpicui extraneum eft \& lumen, \& tenebra; proinde naturam fuam abfolutam retinet perfpicuum tam fub tenebris, quam fublumine: at refpectùvifus continet lumentanquars formam, à qua conftituitur, \& hacrationenon elt actu perf́picuum, nifi fir illuminatum, quia non eft aptü fungi officio fuo, nificuriumine:eft enim ei of ficium moueri a coloribus, \& eos recipere, vt ab illis vifus moueaturjluren igitur tanquam forma conftituit ai perfpicuars astu fumptum hocfecundo modo, idert, actureceptium colorum : ideo diximus, perfpicum quatenus eft medium deferens cocorpore teluli tanquany materia, do à lumine $t \vec{a}$ quain forma; \& hocrefpexit A rift. in contex. 69. lib.z.de A nima, quandolumen fic definiuit, lumen eft afus perfpicui quatenus eft perf́picuũ, nam fecundo modo perf́picuum accepit, nempe refpectu vifus, non primo modo; quia fecüdum fe, \& abfolute fumptum retinet naturam fuam, \& fuam tenuitatem etiam fine lumine, fed vt eft mediū inferuiens vifui, non eft actu perfpicuum

B nifi perlumen:propriam vero perfpicuinaturam priori modo acceptam confiderauit Ariftot. in Decharacontext.7r.eiusdem libri, quando dixiteandem tro cont. eius naturam quandoq; cum lumine effe, quan- 71 . lib 2 . doque cum tenebris, non effe tamen fecundo do Ansmodo aetu, nifi quando habet lumen. Aliud ma. quoque magni momenti codem in loco notan. Omne dum eft, inquit enim Arift. perfpicuum effe in- inuifobiuifibile; nec folum pradicat hoc de perfpicuo, le gis mo vtalij arbitrantur, fed afferit hoc cum perfpicuo do fie per C reciprocari, \& idem effe inurfibile, quod perfpi-Jpicsum. cuum; hoc enim fi intelligatur, veriffimum eft, licet ab aliis non animaduerfum: dicimus igitur Inuifts s. pofle duobus modis aliquid appellari inuifibi- le dicile: yno modo negatiue, qua ratione Deus, \& o- tur duomnes fubitantix incorporez funt inuifibiles, \& busmenullam habent aptitudinem vevideant ur; quare $d \dot{x}$. ita accepcum inuifibile latius patet, quam perfpicuum:altero modo priuatiue, nempe quod habetpriuationem vifibilitatis, cum aptitudine tamen aú eam adipifcendam, hoc autem eft iprummet perfpicuum; vifibile nam q; colcreft, perfpicuitas viro eft de natura coloris, quia eft eius priuatio in fubieto apto colorari, \& eft losocoloris in lisiedto perpicuo:ideo fi perfpicuum condenfetur, \& fiat terminatum, euadit coloratum, \& perfpicuitas migrat in colorem :in genere igitur vifibilium perfpicuum eft, quia perfpicuitas notat priuationem coloris, \& vifiE bilitatis cum apticudine, quofit, vt folum perfpicuum fitreceptiuum coloris : quamobrem in genere vilibilium folum perfpicuum eft in uifibile, \& ita omne inuifibile priuatiue eft perfpicuum. Si quis vero obiiciat:coloratum valde di. Obiectio. ftans inuitibile"eft, quia propter diftantiam non poteft viders, nectamen eft perfpicuum; quare in genere vifibilium datur aliquod inuifibile, quod non eft perfpicuum: dicendum eft, colorem cum hos, vel quouis alio impediméto poffe quidem inuifibilem dici,nō tamen per fe, fed F peraccidens, fiquidem eff perfe, \& fecundum propriam naturam vifibilis, licet ei accidat, vt ab aliquo viderinequeat; idec etiamfi conuenienteralicui propinquus, videri tamenab illo nō poffit propter illus vifus debilitatem, id fitper accidens, quia per hoc non itar, quin fuapte nat ura fit vifibilis, \& ab ali quo eriam alio vid eatur, fi nö ab homine, faltem à lynce; nullus enim per hoc defectus notaturin coloris vifibilitate, vt confideranti patet. Dum igiturloquimur de illo EE tan- 
tantum inuifibili, quodper ft inuifibilefit; hoc A à luce produciturin perfpicuo, eftalio modo viduplexeft ; vumeft per fe inuifibilenegatiue, vt Deus; alterum vero priuatiue, quia poteftasem habet recipiendi colorem, \& vilibilitatem. idque eft folum perfpicuum, vt Arift. ibi fignificat; hoc enim tum ea ratione eft vifibile poteltate, quatenus fi incraffetur, \& condenfetur, fit coloratum, \& vifibile; tum etiam quatenus feruata in es perfpicuitate recipit aliorum colores, non quidem realiter, fedfpiritaliter, repugnat enim perfpicut ti color realis, \& eam imminuit, autetiam penitustollit. Hacigitureft natura peŕ́picui, quarn ibi declarategregic Arift. perfpicuilas enim notatpriuationem realis coloris, qui non ineft nifi in corpore habente temınation em perf picuitsti oppofitam; proinde notat etiam pereftatem tum patiendi à reali colore, \& recipitndi fpecicm erus fpiritalem feruata perfpicuratr, tum eriam reciptēdi realem rolorem, fi cundenferur, \& fat ex perficu o terminatum.

\section{Deluminis, ac lucis difcrimine.} Dap. $1 \mathrm{~V}$.

$\mathrm{D}$ E formali autem perficicui parte, qux luinen eff, maior nos difficultas manct; fed ne anbiguitate laboreanus, intelligendus i:sprimis eft quid nomine luminis intelligamus, \& quid interfit inter lucem, \& lumen: lux proprie diciturilla, qux eft in corpore lucido, vt in Sole, \& in aliis aftris, \& in flamma; lumen veroeft id, quod à luce producitur in perfpicuo, ita vt in Sole fie non lumen, fed.lux, in a ere autem non lux, fed lumen:eft enim lunen imago, \& fpecies lusis; namà luce corporis lucidi gencratur in peripicuo lumen, quemadmodum reales rerum colores producunt in perfpicuo fpeciem fuam.

Euxef color, E. Sed magnum eft lucis, acluminis difcrianen reest 6 if ipectu vifus, ad hanc enim variis modis refe. is 6,203 runtur; duplxenim eft vifibile: vnum proprie Ticitur vifibile vifun terminans, diciturque Lumen vifibile ve quod, cuiufmodi eft color, fub quo esf pecs- lucem contineri,manifeftum eft; lux enimeft es lucis. color, quia vifum terminat, \& videtur tanquam $Y$ fibils albedo quadam quod aperte afferiturab Arift. auplex, in libro de Senfu \& fenfilibus \& in libello de Gt quod Coloribus, \& in calce capitis 4 libr. I. Meteorol. 8 Gr quo vbi Solem vocat album, quum fit lucidus; resq; per fe ranifefte eft, videmus enim flammam non effe pruiam, fed denfam, nec transferr per ipfam ad nosaliarum rerum colores, fed in ipfa. terminari vifum; quare continetur fub obiecto: vifus $x$ quato, $\boldsymbol{g}$ ì vifu iudicatur, \& eft vifibile vt quod \& tanquam fpecies quadam coloris, vt fignificauit Ariftotcl. in 2. lib. de Anima in cap. de Vifu, quando dixitonne visibile effe colo. rem; quum enim lusida corporafint vifibilia, ve ipfeibidéconticetur, \& ve perfe manifeftum eft, pacet lucem effecolorem, imoeft primum vifibile, yt posterus dicemus. Luunen yero, quiod. fibice. non enim vi quod fed vi quo;eft enim ratio vifibilitatis colorum, fiquidem non funt vif:biles, nifi in lumine, at ipfum per fe non mouet vifum, nec dicitur videri, nifi per accidens, dum enim rerum colores videm us, ex ea vifione iudicamus perfpicuurs medium effe illuminatum, quare non videtur lumen perfe, fed cognolsitur per vifionem colorum, eft igitur vifibile folum vt quo, non vt quod, dum confideratur in $B$ perfplcuo interminato: tamerfi in corpore terminato receptum fit etiam vifibilevt quod, non. tamen quatenus lumen, fed quatenus fubiens. rationem coloris, ficenim migrat in cólorem. vt Jumen à Sole protucturn in a crénon eft vifibile, fed idem in pariete receptum $m$ grat in solorem, \& fit obiectum vifioile vt quod, nam fimul cum colore corporis recipientis movet vifum tanquam color vnus ex viroque conflatus. Naucigitur dimiffa luce, quu un apeliatio. ne coloris conprehendivolumus, quum perfe vifum moueat, siudicencur vi quod, de folo lumine verba fasiemus; hoc enim elf llud, quod ab iriftutele vo atur perfet o \& actus, d formaperfpicui; nam lux non eft actus perfpicui, nific utaliter, lamen vero. formaliter : \& hoc refpexit Ariftotel.indefinitioneluminis, definiuit enim ipfum vt formam, ficuretiam in eiufdem libri initio definiuerat animams quum enim forma nil aliud fit, quam perfectio, \& aCus, quo aliquid tale êt, nilaliud efanima. quam actus, quo corpus viuens eft viuens; \& lumen nil aliud eft, quam actus, quo perfpicumm eft perfpicuum, id eft, qui conftituitipfum perficuum, \& facit effe medium acts: idoneum vt inferuiat vifui.

\section{Quod lumennonfitcorpus. Cap. T.}

E VMINIS. naturam declarare non facile Left, necparuum eft in eo difficultatis indicium, quod de genere quoque ipfius multi $P$ hilofophidubitarunt, ac varia fenferunt: Ariftot. enim cenfuit lumen effeaccidens, alij:tamé fuere, qui putarunt lumen effe fubftantiam, \& alij quidem corpoream, alijincorpoream, fed in bac dıfputatione nobis immoranúum nōeft, quum \& ipfe Ariftot. validis acmanifeftis argumentis fententiam illorum reiecerit, tum in $2.13 b$. de Anima,tum in libr. de Senfu \& fenfilibus, \& praterea plures etiam habeamus interpretum hac derediffutationes, vt Ioannis Grammaticion 2. libr.de Anima. in cap. de Vifu, \& Latinorum tum ibid.tum in 2. Sentent. diftinct. 13. \& Tho $m x$ in I. part. qux it. 7.7.arricul. 2.ac3. N. nc igiru faus fit argumenta Ariftrtelis paucis referre, \&diff cultatem quandam, qua multos turhare poffet, dernedio rollere. Duobus po- Lasn tiffimum argumentis probat Arift. Iumen non non effecor us. Vaum fumitur ex eius.fubita dif- corg

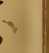


fufione pertotum Hemifpharium : nam fi effet $A$ producit in aere, nec ob id dicimus colorem carpus, non polfet fubito ad ortu ad occafum tranfire, fed neceffario in tempore; corpus enim per fpatium plenum moueri non poteft, nifi in tempore, ob me dir corporis refiftentiam; quum igitur lumen Solis orientis totum illud fpatium fubito, abfque tempore peragat, non poteft eft corpus Alterum argumentum eft : $1 \mathrm{i}$ lumen effet corpus, fieret corporum penetratio: quum enim nulla penitus fit perfpicui pars, qux non fit luminofa, feruetur autem integra tam luminis, quam perfpicui corporis natura, necefle eft vt lumen penetret omnes partes perfpicui; nam ha non cedunt partibus luminis, fed eas in fe recipiunt; quare fi lumen effet corpus, penetratio corporum fieret, quxpenitus impoffibilis eft: hinc itaque intulit Ariftoteles, Jumen in perfpicuo ineffe non ad modum corporis, fed ad modum formz: qua eaderi ratione etiam in contextu quarto ciufdem libri oftendit animam non potfe effe corpoream, quia quum omnes penitus viuentis partes fintanimatz, fieret penetratio corporum. Sed qui plura de hac re videre cupiunt, legant pradictas interpre, tum difpurationes, in quibus diffufe oftenditur, lumen non effe corpus, neque omnino fubltantiam:non eft. n. nobis tempus conterenöū in recehfendis aliorum dictis, fed tollenda cit difficultas quzdam, qux huic veritati maxime om mium videtur officere, eaque eft quodlumen " \& moueri, percutere, defledi videtur: nam lumen Sclis ad tion tranfit, \& folida corpora percutit; terram enimpercutiens, \& refiftens generat in aerecalorem, \& percutiens fpecilum ad multa llluminanda refictitur : qux omnia indicare videntur lumen efle corpus, quum folis corporibus competant, accidentibus vero competere nullo modo poffint. Ad hec igitur dicimus, effe quidem in vfu pofitum, vt hxc per quandam fimilitudinem luminiattribuantur, \& dicamus lumen moueri, \& percutere, \& frangi $\gtrless^{2}$ refledtifedreuera nihil tale competere lumini; producitur enim lumern à prafentia lucidicorporis in perfpicio, \& quia non eft corpus, neque habet contrarium pofitium, quod illirefinat, producitur fubito in omnibus perfpicui partibus: nec ramen ita producitur, vt habeat effe fixum, ac permanens, \& recedente lucido, à quo eft genitum, adbuc in ipfo perfpicuo maneat; fed recedente lucido perfpicuum ftatim definit effe luminofum : quăre ipfius natura cõfific folum in fieri, tamdiu exiftit in perfpicuo, quamdiu perfeucrat produci à prafentia lu. cidi: \& quia coipora folida, acfolita percutiens lumen reddit illa apta per receptum lumerad alia illuminanda, ideo videcur reflecti, \& moueri lumen; non tamenfic eft, fed abeisilluminatis generatur lumen in aliis: quod radem de coloredicimus, nam color producit in fpeculo firitalem colorem, \& fpeculum fimiliter colorem moueri \& reflecti, quum certum fit colorem effeaccidens: non eft igitur credendum, idem numero lumétranfire ab vna aeris parte ad aliam, neque aliquod idem recedere à Sole, \& ad acrem progredi, fed in omnibus perfpicui partibus fubito, \& in temporis momento generatur lumen fiue directe, fiue per reflexionem id fieri videatur; non enim illud idem lumen, quod in vB na parte eft, ad aliam tranfit, fed in omnibus, in quibus eft, generatur continue, tiue ab ipfomet lucido corpore immediate, fiue ab alio, quodab illoillaminatum illuninet alia.

\section{Varia fententia delumine, an fit cns reale, an intentionale, \& quid fit inten.}

$$
\text { tio. Cap. VI. }
$$

c A Liud ct deluminenonteuedubium à LaAtmis interpretibus maxime egitarum, an lumen, quum fit accidens in medio perfoicuo, fit acridens reale, an intentionale. Thorras in opinjo prima parte Summa, quzeft. 77 -artic. 3 . nititur Thoma. oftendere lumen in medio non habere effe intentionale, fed reale tantum. Contra Egidius opinio in fecundolibro de Anima, in cap. de Vifu, pro- Apgraja. folum intentionale. Inter has duas extremas fententias eft tertia media qued lumen in me dio habeat fimul eflereale, \& intentionale; häc requutilunt Scotus, \& Tonnes Bacronius, \& Openio Durandus in 2. Sentent. dift. 33. \& alii complu- Srots, $\mathcal{G}$ res; eamq; ego veram effe exiftumo, \& Auerrois Barcoquoque \& Alberti fententiam fuife: imo et- nü, हु iar Caietanus in fuis Commentariis in Tho-Durads. mam loco pradiato volens iprum tueri ab ar-Caieragumentis Scoti, ita ipfum defendit/vt tranfeat nus. manifefte in opinionem: Scoti; quum tamenneque ad cam trahi, acque modo vllo defendi Thoxas meo quidem izdicio pofit, quia negat lumen in perficus habereffe intentionale, \& confundit lumen cum lise, quam tamen aliud fit lux, aliud lumen, vtpradixinas, habeatpenitus effe reale, lumenvero in perficuofituntentio, \& imagolucis, necaliter, qu' colorin perfpicuo ef 1 mago, \& intentio coloris realis. Mitto hic conliderare argumenta, quz tum à Thoma, tum ab Ægidio addaccuntur,quum in hac difputatione non fit nobis inmorandum, \& quum llla apud eos in locis pradictis legere quifque poffit: fed Columi nitar. ipfam rei veritatem breuiter declarare, \& paucis argumentis que validiora effe videbuntur, comprobare. Ante omnia intelligendum eft, quid Intentse lit intentio, feu $\mathrm{ns}$ intentionale. Latini quidern gusd fato huius vocis etymologiam confiderantes, dicunt intenticnem rocari id, perquod targuam per rationem formalem anima tendit in obiequm cognefcendum, vide omaes fpecies tam fenfiEE 2 les, 
les,quam intelleatiles vocanturintétiones: qux ety mologiz cōfideratio fatis crafta eft, \& quamuis fortaffe ad rectum fenfum trahi polfet, non eft tamen in ea tempus conterendum. Ego dico intêtionem nil aliud effe, quam attentıonem, ac diligentiam animz in alıcuius rei confideratione, quo fit, vt intentum etiam fumamus pro attento; hrc eft vereLatina huius vocis fignificatio, fed traducta poftea à Philofophis noftris hxc vox eftad omnem animi conceptum fignificandum, etiamfiabsq; diligétiafiat, \& omnem fpeciem, fiue fenfil tm, fiue intellectilem; hacenim, quatenus eff fpecies fpiritalis reale obieAtum reprafentans, dicitureffe illius intentio, id eft,imagoin anima:hincorta eft diftinetio iila, qua omnesvtuntur, prinarum, \& fecunda: Prim $\dot{e}^{-}$rumintentionum :primasenimintentionesvoE' fecun camusillcs onunes conceptus, qui rem immedia inter. diatereprarentant; vt conceptum lapidis inatisnes. nimo, \& fpeciem coloris in oculo: fecundas vero intentiones vocamus illos conceptus, qui non rem immediate, fedalium priorem conceptum reprafentant; vt conceptus generis dicitur fecunda intentio, quia reprafentat conceptus animalis, \& plantx, \& alio rum eiusmodi à quibus imnediate reprafentantur res. Sed poftea traducta eft huius vocis fignificatio etiā extra animam, vtid, quod eft imago alterius repr $x$ fentatiua, etiamíi non fit inanima, dicatur ens. intentionale; huiusmodi eft fpecies obiecti fenTiIs in medio, vi fpecies coloris in aere, fiue etiam in folido aliquo cerporé recepta, ficuti $f x$. pevidemus à lumine per phialam vino plenam transeunte produci f peciem, \& imaginem coloris vini in panno linteo fubiecto: illa enim rubedo, qua in vino eft color realis, \& mouetur ad motum vini fubiecti, eft in panno linteo co. lor intentionalis, qui non mouetur ad motum fub ecti panni, fed ad motum vini, \& ad motum. luminis, à quo producitur.

\section{Declaratio, ec comprobatio veritatis de: naturaluminis. Cap.VII.}

Iverabac funt, \& intentio eft id, quod mo$S$ dodiximus, non video quomodo Thomas.

puodlio men ba- negare poffit, lumen in medio babere effe intenbeat effe tionale ; nam produciturà lucelucidi corporss, intentio ve inquit Ariftot tanquam a b obiecto reali, cunale con-ius eft reprafentatiuum : \& videmus lucem tanra Tho- quam colorem quendam, quod fieri non poffets. mam. nifi fpecieslucis, qua ipfam reprafentet, ad o. culura ferretur, quemadmodum etiam fpecies: coloris realem colorem reprafentat; ergo neguod lu- gare lumen in perfpicuo habere effe intentio. men bas nale, eft negare rem manifeftam, quum manifebeat offe ftum fit, ipfum produci à luce, d ita eius intenrealecon tionem effe: Exaltera etiam parte non debuit rraAe. negare Egidius lumen in aere habere effe rea. gidswm. le, quim reales effectus producat, vt Thomasi a) gumentatur,patet enim lumen producere co-
A lorem, qui eft effectus realis; patet etiam lu. men vehemens deftrueretemperiem oculi, qui fimiliter eft effectus realis : fed caula esroris multorum fuit, quod putarunt non poffe aliquid effe fimulinientionem, \& rem, quum potius è contrario fefe res habeat, \& hoc negare fit pugnantia dicere; nam fi aliquideft intentio alicuius, ergoeft resaliqua, quomodo enim effetintentio, fi effer nihil? ideo optime inquit $p$ Scotus in loco pradicto de figno, \&e re : quando ls $B$ enim diftinguimus remà figno, non propterea $f_{\varepsilon}$ dicimus fignum non efferem, fic enim effet ni- $\mathcal{E}$ hil, proinde fignum appellari non poffet; fed $t_{i}$ quum rem à figno diftinguimus, nil aliud fignificare volumus, quam aliquid efferem tanıum, non fignum, aliquid vero efle \& re rei : ficigitur (inquit) diftinguunturres, שै intentio; aliquidenim eft res, \& non eftintentio rei,aliquid autem eft intentio, \& resfimul, quia non poteft effeintentio rei, quinfit étiarses a-

C liqua, \& ita habeat effe reale. Huic fenten:a Scoti ego omnino fubfcribo; non folim eniy illas intentiones, qua extra animafe furt in medio fenfus, fed etiam eas, qua funt in ar, a, puto effe aliquid, \& efle res : eaque $\Delta$ rific... is fententra fuit, quiin libro Categoriarum, : tapite de qualitate fciētiam poraic in gesu is qualitatis, nil autern aliud eft fcicosin is, min! $\boldsymbol{x}_{\text {. }}$ quamintentio \& inagoreicognise, repulentans rem, qux extra anmam eft; hxigitur a$D$ pudAriftotelem eftens icale, quum fit qualitas. Poffum etiàm ratione id confirmaı e nam cognofcimus etiam cognitionem noftram tanquam remaliquam poficiuam \& confideramus quid fit cognitio, quare tali noffrz cognitioni reipondet cognitio ip fa tanquam res cognita: fic etiam diximus, colorem intentionalem incidentem in corpus aliquod folidum producereadhuc intentionem fuan in perfpicuo, \& videri ad modum rei. Sed pluribus caufa erro-

E. ris fuit, quod illa, qua fpiritalia funt, ipfi putant effe nihil, quum tamen fint res : ficut enim dantur fubfantiz incorporex \& fpiritales, qux verifime funt fuboftantix; ita dantur etiam ac. cidentia fpiritalia, qux veram habent entita. tem, licet minorem, quam accidentia materia: lia, à quibus producuntur : nam (vt ait Duran- $b$ dus in loco pradiato) ifte (pecies habent ef - no fe debile, quia deficiunt à perfetione propria $t ;$ fpeciei, \& eo magis deficiunt, quo magis diftant $q u$ F à prima caufa: Auerroes quoque in duobus $t e$, poftremis capit. libri de Senfu \& fenfilibus inquit fórnas in anima babere effe fpiritale purum, in materia vero extra animam habere effe materiale purum, at in medio habere effe me- $b$ dium inter materiale, \& fpiritale; quare fecun- $\int e$ dum Auerr.negari non poteft, lumen \& colores $\mathrm{x} n$ in medio habere effereale, \& magis, đั in anima ter fpeciem, quod etiam hocarguniento cōfirmari Ef poteft: id, quod habeteffe, feclufa omni opera- tal tione 
tione anim $x$, habet effe reale; at lumen in me- $A$ dio habet effe, ctiam feclufa omni animx operatine; ergo de ipro manifeftius elt quod habet efíc reale, quam de intentionibus, qux funt in anima : \& quod delumine dicimus, id de colore quoque obeandem rationem dicendum effe arbitramur: ideo deceptus eft Thomas, negaus colorem in medio habere clfe reale, quod de lumine conceffit; quamuis enim lumen fit efficacius ad reales effectus producendos, non obid negandum eft colorem habere effe reale, nam rerum quoque matcrialium multx funt, qux non funt actiux, nequeper hoc ftat, quin habeant effe reale. Illud verohac in re maxime annotandum eft, has fpecies, feu intentiones, quas diximus, \& in anima, \& extra animam efre aliquidreale, \& intentionale fimul, habere hoc le duplex efie duabus rationibus, yt recte notat Ioannes Bacconius in fua quæetione: nam re- fpectu obiceti materialis, quod reprefentant, io \& cuius dicuntur fpecics, habent effe intentionale: at refpectu fubiecti, in quo inhirent, hapinteffercale, vtlumenin perfpicuo, \& licienfru lin anima, quod quidem ex hoc difcrimine cognori poteft, quia lapis in anima tum fubftantia eft, tumaccidens ; nam fecuñdum fe formaliter eft accidens de genere qualitatis; \& eft fubftantia per reprærentationem; mouere autam animam dicitur, $\hat{\alpha}$ cognofci, non fecundum fuum effe formale, fed fecundum efferepræfentaım : quando enim cognof cimus lapidem, fubitantianı cogrofcimus', quæ perillam fpeciem reprefentatur, non ipfam fecundum fe qualitatem illam; dicimus enim videri realem colorem, non fpeciem ipfam; immo idiotxhomines non concederent yllam coloris fpeciem in medio productam, quia propriam illam realem fpecieientitatem ignorant, \& nilaliud fatentur, quam realem coloremà fevideri; illum igitur vident per eius fpeciem, quam ignorant, non enimillam cognof cunt, fed colorem, folus enim realis color vifum terminare, ac videri dicitur. Per hoc foluiturargumentum quoddam Egidii, qui inquit: fil lumen in medio haberet effe reale, fuperpofitus oculo, aerilluminatus impediret fenfionem, attamen patet lumen tangens oculum facere fenfionem, ergo non habet effe reale:Nos autem dicimus, fententiam illam Ariftotelis, fenfile pofitum fupra fenfum fenfionem non facit, effe intelligendam de obiecto reali terminante fenfionem, non de eius fpecie, quinimo neceffe eft fpeciem ad contactum vfq; organi peruenire, fi fieri fenfio debeat: lumen. autem in aere eft, non vt obiectum terminatiuun vifionis, fed vt fpccies ipfum reprefentans; \& quamuis habeat etiam fecundun fe effereale, tamen non eft vifibile fecundum fuum effe reale, fed fecundum illud, quod ab eo reprærentatur; quare tangens oculum non impedit vifionem. Hoc autem eodernargumento, quo abu- fus eft $x$ gidius, rectevfus eft Scotus, dicens : fí Argumeé lumen non effet intentio, fed folum liaberet ef- tum sien fercale, crgo fuperpofitum oculo non faceret topti, vilionem: eft enimargumentum validum, dum mum. ftatuimus lumen mouere oculum; quia finon mouet ve intentio alterius, fed ve res fecundum fe, ergo eft obiectum terminatiuum vifionis; ta le autein tangens oculum impedit fenfionem, quoniam inftrumentum fenfus debet pati à fpecie obiccti immcdiate, non ab ipfomet obie. B Etoreali.

\section{Deinfrumento vifus. Cap. VIIX.}

Equitur vt de organo dica mus, quod quidem Sbreuiffime praitabimus, vt Ariftotelem potius, quam Galenum imitemur: Galenus cnim tum de vifione, tum de plerifque aliisrebus fcribens, nef́ciuitartem medicädiftinguere à naturali plilorophia; quum cnim plurima ad C naturalem philofophum attinentia conftituere potius, quam exquifite tractare debuiffet;corum tamen confiderationem diligentiffimam cum medica arte cōmifcuit, quod ab aliis quoque Medicis Galeni in fcribendo artificium oe ptime edoctis factum frequenter effe animaduerti:apud Ariftotelem vero nihil tale notarea. liquis quantumuis liuidus aduerfarins eiuspoteft; qui femper à rebus alienis abftinuit; \& non modo illa, quxad aliam difciplinam, fed etianD quxad alium eitifdem difciplinæ libruru pert. nent, tractare veritus eft: quod quidem eft manifeftifrmum in tractatione ab eo facta de viru, \& de facultate vifiua ; diligentem enım oculi, \& confruction is cius declarationem apud Arifotel.nullibileginus, licet oculus ex pluribus humoribus, \& pluribus tunicis, aliisque partibus mirabili ftruetura, atque artificio conftitutus fit;nihil denim aliud de oculi fabricaab eo fcriptum habemus, nifí eum aqueu n effe debuifie, E nō quidem aquam purnm, fed excefu a queum: quum enim in primo cap. 2 libri departibus a nimal. dixerit organa fenfuum debere effe fimi . laria , totus autem oculus fit corpus diffimilare, Ariftoteles præcipuam oruli partem refpexit, qux eft hum or cryftallinus, in quo tanquam in vero vifus inftrumento fpecies coloris recipitur, \&rabanimaiudicatur: huncigitur confiderare fatis habuit, \& dicere organum vifus effe corpus aqueum; reliquas oculi partes Medicis F confiderandas reliquit, quum illarum officium non fit videre, fed inferuire cryftallino, vt in eo fieri vifio poffit, aliæ namque ad ipfum protegendum, alix ad nutriendum, alix ad mouendum totum oculum pertinent. Nos igitur Ariftotelem imitati, non totam oculi ftruEturam confiderabimus, fed quafdam tantum partes, quæad id, quod in præentia quærimus, conferre poffe videbuntur; reliqua apud

EE $\frac{1}{3}$ Gale- 
Galcnum lcgi potcrunt in libr. 10. Vfu partium, \& in librociadferiptod: Oculis, \& apud Fes by-Anerocm in 1. Collicturam, cap. 17. Din 2 . mores \&n lib.caps.s. Subitantian ocilitribus humoribus - crsla. "cóftarecertum ef, quorí medius, E interduos riquos collocatus cryfta!linus eft, durioralits, \& fimilis glaciei, fédluciditrmus, non quiden propria lince, fed lumine extrinfecis recepto; port hunc pofitus cit in parte oculi pofteriore hunortitrcus, quimollior eft, \& fubftantiam liabet minus confiftenrem; \& multo maiore ft cryfallino; nam ve cgoiudicare videns potui, eft fortalie quaduplo, vel ctiam guintuplo maior; fed maxime clarus, \& albus, \& in hoc maError nifeftifimum eft, deceptum effic Galenum, gui Galen in libr.19. deVfu partum dixit huius coloren debsme- effelubniğum, velurifi quis parum nigri cum re Sutreo multoalbocommi cteritegoenim apertifime vidi vitreum hunc humorem nihil habere nignedimis, nec minus cryftalino album cfie, non tamen ita folidum; led molliorcm, \& fuentem, vnde appellatus eft vitreus, ad fumilitudinemvi. triliquefacti; deceptus etiam in eo eft Galenus, quod dixit huius humoris officium efre, vtex eo cryftallinus nutriatur; hocenim falfum effe oftendemus loco fuo. In anteriore autem oculi parte eft tertius humor vocatus aquenz, feu albugineus, qui vna cum fpiriu miffo à cercbro per opticos nertos impletanteriorem pupilla partem, \& cryftallinum defendit, prohibetque contactu corner, qua fua duritic ipfum ladere potuiffet. Tunicas tres habet oculus, quarum extima ob fuam duritiem Grangó tur, fed in anferiori parte ocull vocatur cornea, quz durior quidem eft, fed trärparentior, vt per cani lumen ad humoresoculi ingredi poffit: $f e-$ cunda tunica vocatur $\chi$ ergoeidis \& colorata eft colore fubnigro, \& in partc oculi anteriore vo, cacurvuea; nectotam pupillam operit, fed in medio pupilla loco eft perforata, vitper illud feranciningredilumen \& colores poflint: teria, \& intima runsa retina appellata,confare videtur ex ipfamet cerebri fubftantia, nec totum oculum circumdat, fed definit in maximo cryftallini circulo, vbi degenerare videtur it tenuem illam \& luminofam membranam, arancam telam vocatam, qux totum cryftallinum operit, \& feparat tum in parte anteriorc ab aqueo humore, tum in poiteriore à vitreo. Dehis, ac de aliis ad oculiftructuram pertirentibus fi qui's plura videre cupiat, legat Galenum, \& Auerroem in memoratis locis: nunc enim fatis nobis eff ftatuife folum cryftallinum effe vcrum inftumentum vifus, cateras vero ocúli partés cins miniftras clfe, quárum aliquas poftea confiderabimus, quum de modo, quo vifio fit, verba faciemus, nempe illas, qua adremfacere videbuntur, reliquas rerodimittemus.
A Animancequiratur admedium, and coloocmilluminundum, opinio Aucm-

$$
\begin{gathered}
\text {, } a c e s, ~ d a r g u m e n t a . ' \\
\text { Capp. IX. }
\end{gathered}
$$

II I declaratis, conliderandum nobis ptopohitur id, de quo interpretcs $A$ riftotel.ma$x_{i m e}$ controuerfantur, qux fit lumin is neceffitas invifionefecundum Ariftotelem : quum enim fieri vifio nequeat fine lumine, quaritir

$B$ cuius gratia fit necefiarium lumen, an ad lluminandum perficuum medum, an ad illum inandum obiectum colorem. Fuit opinio Aucm paces, quam confiderat Auerroesin Commen tarió fexagefino feptimo libri fecundi de Anima, quodlumen fit neceffarum, nonpropter medium, fed propter folum colorem, vt laciat colotem effe actu motium perfpicui, quiañon eflet afu motiurs, nifi efiet illuminatus; quam eandem Sententiam twetur Auscenna in 6. Na-

C eural. Nitebatu Auempace, vtreferr Auerrocs, tali argumento: lumen, \& color pecienon ditfunt atqui omne recipiensabet barere pto, tgo perfpicuum àebens recipere colasen debet carerelumine, igitur moneriperfeicum eftillumin.uri, \& illummari, éf colorari; itaque fi color fitlliminatus, eft actu motiuus peripicui, \& imprumitin eo colorem quatenus ipfum illuminat: ideo dictum illud Ariftotelis, color eft mctius perficui, quodeft actu, fic ab AD uempace intelligebatur, color eft aptus ducere perfpicuum de poteftate ad actum, \& zeddere actu perfpicuum; hoc enim facit, dum fimul ipfum illuminat, \& colorat: quod fi prius illuminatus ctic aer ftatuatur, non poterit à colo. re monei, quum color fit de natura luminis, \& nihil recipat fe. Alia quoque ratione hoc confirmatur, quam eoin loco tangit Albertus: obiectum cuinique fenfus debet reduciad aliquam communcm naruram, fectrs enim non E effet obiectum vinum, proinde nec fenf́tis vnus; patet autem effe vitibile \& lumen, \& coloren; ergoduo hxc vel reducuntur ad pnam terisan communem nauram, vel inum ad alterum; primum dicinonpoteft, vt manteftumeft, ergo fecundum : aiqu mon reducitur lumen ad colosem, equix non detiritur lumen per colorem, ted prorus color perlumen;ergo reducitur color ad lurien, \& eft vitibilis ratione luminis; fic 1 gitur vita cif abtura vilibilis, nempe natriF raluminis, aci quam reducitur color; eryoad conftituend.im colorem vifibilem eft necefiarium lumen. Confirmatur hæc opinio ab Auicena per experientram; fi quis enm fit inaliquo obicurifimo loco, vifit foramen, vi. det per toramen illud externos colores, illi igitur trantenur per acrem tenebrofum, quare non requiritu lumen ad medrum illuminaisdam, led latis ett ficolores ipfi in lumine tint; fis cnim fun nobis vifibiles etian per aerem tene- 
tenebrofum. Addit etiam Auerroespro Auem- A pace aliud argumentum aceepun ex verbis $A$.

7.8. riftotclis in contcxtu 18. lib. 3. de Anima, vbi intellęum agentem comparat fumini, \& inyuit efe neceflarum propter phantalinta, vecalaciat aetu intelligibilia, ficuri lumen lacic colsreseffe a tu colores id ett,aEtu motiuos ferlpicuifaflerit ergo Ariftot. Iunien requiri proper colores ad mouendum perfpicutim.

\section{Anerrois, Al Albertifententic, \& argu- menta. Copp. X.}

$\mathrm{E}$ $\mathrm{X}$ altera parte Auerroes contrariam fententian fequens inquit, lumé cllèecéfirium, non propter colores, fed propter medium folum, \& in eam induchus efie videtur precipue à verbis Ariftotelis, nui in fecunito libro de Anima incapite deViri, definiens colorem di.it effe motiuum perfpicuilluninati, \& definiens lumen dixit effe actum, erfpicui quatenus eft perfpicum, non dixit eic actum coloris; cenfinit igitur necelfurium efle lumen propter folum inedium, non propter coloren. $\Lambda$ ddit etiam rationem Anerroes ad hoc comprobandum : colorfecundum Ariftorelem eft per fe vifibilis in fecundo modo dicendiper fe,ergo non accipit à lumine vifibilıtatem, fed eam habet $c x$ fua natura; nam fi à lumine fieretvifibilis, \& motinus perfpicui, non effet per fe vifibilis, fed peraliud. Albertus vero etiam fententiam fequutus eft, \& putauit lumen efle necelfarium propter vtrunque, ita vt neque medium poflit à colore moucri, niff fitilluninatum, neque color poffit movere medium, nifilluminatus : \& quiade medio clara eft fententia Ariftotelis, qui dixst lumen efle actum perficui, ipre de colore declarat hac diftinctione : color habet duplex effe, vnum materiale, alterum formale: efie materiale fit per materix mutationem à quatuor primis qualitatibus, quæ varios in fuperticie colores producunt, licet ipfa qualitates non fint de cfienua colorum, \& ad tale coloris efle non requiriturlumen; eft enim color etiam in tenebris, non eft tamen aptus ad mouendum medium : elle autem formale habet color à lamine, quatenus lumen mugitur fuperficiei, \& facit colorem actu motium perfpicui, quia fine lumine non moueret. Sic igiturnecefialum eft lumen etian propter colorem vt motilum perfpicu, , Idque videtur fignificaffe A riftoteles in contextu decimooctauo terij libri de Anima, quem antea pro Auempace confiderauimus: idco id, quod Ariftoteles dicit, colóren effe mouuum perfipicu, înterpretās Albertus inquit effeintelligundum de colore fecundum effe formale,icenim eft motiuus peripicui. Ex his igitur patet, rem hanc non carere magna difícultate:iequitur ve ratione duce quid lenticndum fit, inueitigimus.
Verafintentia, or eiusdeclaratio, accomprabatio. Cap. XI.

T hac controncria'ergo puto lumen effeneLecllarium, non modo propter medium, \& prolicr colorem, yt fenfit Albertus, fed ctiam propecrorganum, quod credo non negaffe Albertum, quurn aperte ab Arifotele proferatur, vt mox confiderabo: Ioannes etinm Gandauenfis in fecun to librode Anima, dum pro Aucräoe $B$ demonftrarenititurlumen non requiripropter colorem, fed proptermedium, fatetur tanicn requirtctian propter organum. Quum igitur wriahac, de quibus antea diximus, in vilione contideicutux, obiectum, medium, \& organum, in his omnibus requiri lumen exiftumo, fi vilio iceridebeat; hocenim facit tum colores ef Quod lut fe attu motiuos perfpicui, \& organi, tum ocu- men fat lum, \& medium effe rcceptium coloris : orga- necefftnim enim obeandem rationem debet effeillu- rism 6 F minatum, ob quam ô medium; nam fi medium propter coloresrecipit (vt Ariftoteles dixit) non quate mélrum, nusaer, nec quatenits aqua, fed quatenus per- 6 pro. fpicuum, noneftautem actu perficutum, nifl pter orper lumen; oculus vero, vi colores recipere pof - gansm. fet, debuit efle perfpicuus, vt Ariftotelez docet in libro de Senfu \& fenfilibus, capite ficundo; necefiarium eft non minus oculo lumen, quam medio, pröinde oculus non recipit colorem, nifi recipiat lumen : huic fententiz atteftatur D cryftallini humoris natura \& conditio:ipfum enini elle pracipuum vifusinftumêtum omnes confitcntur, eft autem maxime perfpicuus ac fplendidus, quia eff de genere illorumperfpicuorum, quxlumen quidem ex fe non emittunt, fed fi extrinfecus recipiant lumen, fplendida fiunt;imo aliqui etiam funt oculi, qui in tenebris emittunt ex fe aliquidluminis, vt óculi leonum, \& pardorum, \& catorum ; fed onnium oculorum communis conditio eft, vt eatenus

E lucidi fint, quatenus ob externi luminis receptionem fiunt fplendidi, hoc enin eft propisum illorum perfpicuortim; qua aliquam habent denfitatem, \& conffientiam, qua retinent receptum lumen, \& ex eius conftipatione redduntur lucida tanquam alieno lumine. Quoniam igitur oculus debuit effe perficicus perfpicuitate aquea, vt lumen recipere, acretinere, imo \& intenfius redderepoffet, \& talem effe humorem cryftalinum manifeftum eft, negari non poteft $F$ datamefféorganoperfpicuitatem, vt per receptionem luminis poffit recipere aliarum reium colores; eft enim communis con um perfpicuorum, vt à lumine fianr aciu ferficua, \& quatenus talia funt, à coloribus patiantur:igitur quando Ariftoteles dixit colorem effe motium perfpicui, quodeftactu, \& quando dixit lumen efte a eft perficulim, ablolute perificum conliderauit: quare hac non foli medio competere deE E 4 bent, 
specillo - fpicumeft. Hoc idem confimatur ex vfu perü lius videamus, nıfi qua faciunt vt plus luminis tecipiant oculi, \& ita meliusetiam recipiant colores:oculi enim feu propter prouectam ætatem, feu etian quandog; propter natiralem temperiem habent fubftantiam terreftriorem, ficcefcunt euim oculi fenum, vtait Arift.in s. lib. de Ortuanimalium,cap.ı.quo fit,vt minus recipiāt luminis, \& ob id egeant auxilio fpecillorum, in quibus ob vitricautatem vnitur, \& concentratur lumen tanquam in puncto, \& ita vnitum, ac validum oculospenetrat, \& lucidios es reddit, \& aptos ad melius colores recipiendos. Legimus autem hanc fententiam clareapud Ariftotelem in libro de Senfu, \& fenfilibus, cap. 2. vbi dicit. [Bidetur autem focut exterius non fine lumine, it a Es interizes] \& \&paulo poft inquit [quare ne-

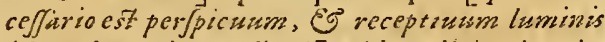
idquodenterius oculiest ] ix idem dicit etian? in libro 2. de Partibusanimalium, cap.13.Itaq; fententia Ariftotelis eft, oportere non modo externum, fed internunı quoque oculi perfpicuum illuminari, fi fieri vifio debeat; fic enim vtrunque grod lus- fit aetu perfpicuum, \& aptum vt à coloribus pamen fit tiatur, quale non effet line lumine. De colore neceffari oftendendum manet, quodipfum quequíe illuwum et- minari oporteat, fi debeat effe motiuus perfpisam pro. cui; hoc quidem fatis per expertentiam manipter colo- feftum effe videtur;nam fi totus intermedius aer rem. illuminatus effe ftatuatur, \& color fit in tenebris, non videbitur; contta vero fi color fitilluminatus, videbicur ab oculo in fpelunca in tenebris exiftente, \& per multum quoq; aeris medii tcnebrofi: num autem hocargumento oftendatur, folam colorisilluminationem effe neceflariam, vt putauit Aluempace, ita vt abfque medii illuminatione vifio fieripofit, póftea confiderabimus: nunc fat eft demonfirare vifionéabfq; illuminatione coloris fiert minime poffe, quod quidem pradicto argumento a perte oftenditur : neque eit quodaliquis dicat fieri non pofie, vt toto medio aere exiftente lumin ofo, color folusin tenebris fit; hoc enim effe poffibile non: conftituo in præfentia, fed cx mentali tantum abftractione argumentum fumo: dum. enim fta tuimus totlim medium effeilluminatum,coLorem veroeffe tenebrofum, manifeftuin eft vifionem non fieri: dicere autem. hoc effe imporfibile; \& pofito medio luminofo efre neceffa- $F$ rium vt color quoq; fit illuminatus, noneft argumentum foluere, fed eft fateri neceffitatem. illuminationis coloris, \& vifionem fieri tōo por-. Argume- fe, ea fublata. Sed res clinior fict, ficognof catur aйfume ptum is satura coloris. ratio curita effe oporteat; haxc.autem limitur à natura coloris, quamantea declarauimus: nam abfolute fumptus color oritur ex condenfatione perficui, fed color mon fplendeins, de quo in: præfentia loquimır, ontur ex ea perfpicui con-
A denfatione, qux fitperadmiftionem opaci, cuiufmodi eft niiftorum corporum color, qui fir quidem ex commintione elementorum quatenus funt perfpicua, \& opaca, imo etiam lucida. ignis enim eft lucidus, aer perfpicuus, terra opaca, aqua \&: perficuitate \& opacitate participans, attamen q̨uia elementa per miftionẽ proprias naturas amıttunt, ignis quamuis in nifto fit condenfatus, definit effe fplendidus, velfiquid fplendoris exigni feruatur, id exiguum eft B quale eft inillis, qux nootu fplendent; ure ig:tur hi omnes colores vocantur offufcata lumina, feu extincta per admiftionem opaci, qux facit ne luceant, fed fint abfolute colores. Quoniam autem primum vifibile, \& per fe vifibile eft lux, qux eft color fplendens, color autem non fplendens viribilis eft per participationem lucis, proinde fecundario vifibilis; omne autem fecundario tale, eft tale poteiftate, nec ducitur ad actum, nifiab éo, quod eft actu tale; color C tanquam fecundario vifibilis eft poteftate vifibilis fine ope lucis, ficut etiam phantafmata funt poteftare intelligibilia abfque ope intellectus agentis, qui eft primum intelligibile, vtalio in loco oftendemus: colorigitur non eft a âu vifibilis, nifi talis fiatà lumine, quare vt fit aêu motiuus perfpicui, requiritur lumen tanquam fpecies, \& imago lucis, qux eft primum vifibile: neq; fatis eft idd, quod aliqui dicunt, colorê conftare iam ex lucido \& opaco, proinde in fua 112. tura habere lucem, ne q; externo lumine indigere: hic enim eft cauillusmanifeftus, color enim deficit à natura lucis; \& luminis, \& ab his fpecie differt, licet oriatur ex lucido, \& opaco, neque poteft appellari lux, vel lucidus, nificum additione lux offufcata, feu lux extincta, qux non. amplius fplendet, nec poteft amplins fungi officiolucis, quum defierit cffelux, \& in colorem nonlucentem degenerauerit; eget igitur lumine producto à lucido actual $i$, fi debeat mouere E perfpicuum, namaetuale lucidú eft per fe motiuım, \& alia omnia funtmotiua perillua. Pr $x-$ tereacertum effproprium coloris fubiectũ effe ipfun perfpicuī: nam in perfpicuo interminato recipiuntur colores fpiritales, qui funt fpecies colorum realium : in perípicuo autem terminato reales colores recipuuntur, nó enim haberent colorem corpora; nifi experfpicuo conftarent; ergo eiufdem eft rationıs vtrumq; perfpicuum: \& ficuti interminatum non poteft SpiF: ritalem colorem recipere, nifi fit illuminatum; ita neque terminatuns poteft habere colorem motiuü perf́picui, nifi iuretam labeat lumen : hoc autem confirmatur, quoniam maius, ac no. bilius eft agere, quam pati, \& plura requiruntur v.taliquidpoflitagere, quam vt poffit pati; ergo fi perfipicuum interminatum requirit lumen vt fiat receptiuum colorum, magis debet perfpicuum terminacunì requirerelumen, ve per fuum. colorem polit moucre perficuum intermina. 
tum; itavt tum interminatum perfici la lumine $A$ oportcal, ve a calosepati pothit, tum color, qui

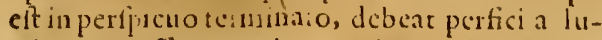
mine, ve polfit agere in perfpicuum internumatum. Ex his igitur patet neceflarium effelumen \& propter mediun, \& propter orgatum, vt hxc tanquam perfipicua colores recipere polfint; \& maxime ctian proptcr colorem, ve pofit nouere perlpicumn: quia id quod eft mocium per naruram alterius, quod in eo genere eft prinü, non potelt mouere, nili ope illus. A lia multa ad plenam luuiuferei declarationcm diconda effent, fed ne eaden frultra repetantur, hac poftea in argumentorum folutione opportunius confiderabuntur.

\section{Solutio argumentorum pro Auempace ad- ductorum. Cap. $X I I$.}

$\mathrm{R}$ Eliquím cit, ve ad maiorem veritatis declarationéconfideremus, quantum roboris hab ant argumenta omnia prius adducta, tum pro Auempace, \& Auicenna, tum pro Auerroe. Primü erat Auempaces argumentii ab Auerroe relatĭ, quod deducebatur ex eónindame èto, lumen \& color fpecie nō differüt. Ad hoc refpondens Auerroes non fatis habetid fundamentum negare, fed ét efficaciter probatlumen; \& colorem differe fpecie. Primum quidem fumit argu-mentum ab experiettia ; videmus enim in tranfitunubium parietes colorari colore herbarum, quod non fieret, nifi prius in aere colorille reciperetur; at qui iam erat prus illuminatus aer, ergo lumen nō eft color, quia fi eff́t color, non poffet aer illuminatus recipere alium colore $\overrightarrow{\text { : }}$ fic etiā lumen Soles tranfiens per vitrum coloratü colorat parietem illo eodem colore, quare prius in aere lumin ofo color ille recipitur: hoc aüt $\mathrm{A}$ uerroisargumentūprobat contra Auempacem tum inexiftens in aere lumen non impedire receptıonem colorū,tum differrefpeciecolorem, \& lumen; quia obiętī receptibile, licet in fuo receptito receptum: vt aduentitiumnonimpediat receptionem alıorū eiufden generis, nam: prima materia habensformas el ementorum re. cipere animam non prohubetur, tamen non po-. teft ita in 1 llo inefle, vt fit ratio recipiendi; quum cnim non inficietur Auempace coloré vnituerfe fumptum effe adæquatum receptibile refpectu perfpicui; imo hoc dicere cogatur; dum ait lu-e men \& colorem effe idemfpecie, ideo dium per. experientiamoftendimus aerem illuminatü ita. recipere colorem, vt lumen fit ratio recipiendi, quia non reciperet aer colores, nifï effet tlluminatus, demonftramus non effe: 1 dem fpecie $e_{\downarrow}$ lu men \& colorem; quiafi effent idem, fequereturaliquid efferationērecipiẽdi feipfum, quod nullo modo effe poteft. Quioniam ergo falfum eft affumptum illud, color, \& lumen funt idem fpecie, non fequiturid, quod inde colligebat Auempace, aerem recepturum colores debere ca: rereluminc: imo exhuius confequentis faifita teclarilima per experientian cognofeiturfalfitas illius aflumpti. Probat ctiam Auarroes hoc idcm argumeno fumpto à definitionibus: illa enim qux diucrias habent definitiones, fpecie, at ; cllentia differunt; at color de finirur effe extrcmitas perfoicui terminati, lumen veroadus perfpicuinteminati,differütergo fpccie. Exhis crgo infert Auenroes, non oportereillud, quod moueturà colore, effe nö luminofum, fed opor-

B tere efie non coloratū, quia nihil eft ratio recipiendife; \& in hocreate fenfit, \& eius folutio mco quidem iudicio oprima eft. Aucmpace veroesrauit, putans lumen requiri propscr folum coloreni, non proptermedium, ideo neq; reete eftinterpretatus definitionen coloris ab Arıft. traditam; non enin dixit Ariftot. colorem ducercperfpicuum de potcftate ad actum, \& facereactuperfpicuum, fed dixit effe motiuum perfpicui,quod iam fit actu; eft igttur prius actu perC fpicuumper lumen,pofterius vero vel tempore, vel faltematura ft mobile à colore. Ad recundum argumentum ab. Alberto adductū refpondeant Aueroiftx, qui negăt lumen requiri propter colorem : ego eninu arbitror totü effeconcedendum, \& aflero primum vifibile effelucem; ideog; omnes non lucentes colores fieri vifibiles per lumen, quod eft ïmago, fëu fpecies lucis; vt prædiximus. Ad tertium, quod Auicenna Ad torfumebatab experientia, dico probari quiden tirm.

D illo argumento, neceflarium effe lumen propter colorem, quia iam conceffimus non poffe perfpicuum mouteri à colore non illuminato. at non probari ipfum non requiri propter medium; dico enim eam effe luminis naturam, vt receptum in fuperficie corporis terminatifubeat quodammodo conditiones lucis, \& illuminet perfpicuum medium: quando igitur color eft illuminatus, videtur $a b$ aliquo exiftente in fpelunca tenebrofa, quialumen illud coloriad E: iunctun illuminat to tum illum teremad:ıfos vique oculos videntis: quanquam enim non ita illuminat, vt faciat aliorum colores videri, tamen tantum illumirat, quantum fatis eft ad: vifionem illius coloris, cui iunctum eft; fic etiam illa noctu lucentia, de quicus ld quitur. Ariftoteles in contextu 7.2.lib.2.de Anima, vt oculi: catorum, \& Iconum, \& noctilucæ; \& alia huiufmodi, ideo videntur noctu; quiailluminant ae= rem fatis pro jpforum vifione, lilet nó fatis pro F: vifione aliorum circumftantum colorum: ideo annotandum fummopere eft, A riftotel. in memorato loco fatis pingui Minetua illa noctu lucentia confiderare : quum enim vera ratio curnoctuvideantur fit, quia illuminant fibiaerem; tamen:Ariftot.concedit eaviderin tenebris, \& Declarafine lumine; quoniam non erat ibi cius confi- tiotex. lium exquifite docereilla; qua ad vifionen qer- 72. lab.3. tinent : fed quantum fasis era: ad facultatem vi- de Anifiuam declarandam; ideo fat is habuitibifume- ma. 
$r e$, colores faltem fine lumine videri non poffe, $A$ quafilux nófit color, id.n, fecit, ne lumen cum colore confunderet, ita vt ide clie crederctur : at in libro de Scuftu \& foufilibus, vbi exquifitins de vifione loquitur,aperte dicit lucem videri yt colorem. Adargumentīigutu Auicennx diconcrem illum, qui in fpel unca eft, effic quidem tenebrofam rationcalionĩ colorum, qui funt ibi in tenebris, quia non eft in co tantü lumunis, quantum ad illosilluftrandos requireretur, fed vocari poffe 1 lluminatum ratione illus tantum coloris, qui extra fpeluncāilluftratus effe ftatuitur: quoniam acrille ab illoupfo colore illuminato illuminatur; \& quamuis colorills,\& humen illi innclum moueat täquam obiectum vnü; tamen fecundum uaturam prius mouet illuminando, polterius y erò coloris fpeciem imprimêdo; quia ficutnatura lucis naturam coloris pracedit, ita in perficuo luméprecedit natura fpeciem colorisjnunquam igiturvidetur colot fine illumimatione perfpicui, quod inter coloré, \& oculos

Adgsar- mediumeft. Quartūargumentun nobis nó ofsain. ficit, proinde ominino concedédum eft; co enim nilaliud oftenditur; quam coloren non poffe Refporfzo motere nifi fit illuminatus, \& hoc afferit apertè Auerrois Ariftinillo contex.18.lib.3.de Anima. Auerroes tamen, qui omnıno negat elle neceffarium lume propter colorem, nititur hocargumentum foluere, \& inquit, cóparationem illam intellectus agentis cü lumine in vifione non efie intelligend $2 \mathrm{~m}$ fecundü omnia, fed in hoc folum, quod ficuti neceffarium eft lumen ad vilionem, ita necefrarius eft intellętus agës ad noftram intellectioncm; in eo autem (unqut) funt diffinilia, quod intellectus agens eft necellariusad illuminunda plantafmata, at lumen non eft neceffariú ad illummandos colores, fedad folum mediñil-

$\boldsymbol{R} e$ pöfo- luminandii. Hsec tamen A uerrois folutio vana ws umpert, quoniam Aritt. non modo dicit neceflarium gration cffe intellectum agentem ad intellectionem, ficutilumen ad vifionen, fed modĩ etiam exprimit, in quo hanc fimilitudinem confiftere arbitratur:dixèrat cnim dari intclestum, qui omnia fir, \& darialterum, qui omnia facit, nam intelleEtus agês facit de inteliigibilibus poteltate actu intelligibilia, \& ita apertè inquit eius officium in obıetıs phantalmatıbus efíe cōftitutum; deinde vero hoc declarans ait [Gt babitus quadiom, quale eft lumen, facit enim lumen oteficite exifiezes colores, act us colores] afferit ergo intcllectü agentem iung1 phantalmatibus rauguam formā, \& habitu, \& in hoc dicit ipfum effe fimilen lumini, qura lumen quoq; eft habitus, \& forma, qux iuncta coloribus hacit eos effe actu, qui prius erāt poteftate, qui enim erant potellatc motiui, funt åu motiun non debet er go in hoc Ariltot. de coloribus, ac delumine falfum dicere, quia ion visur eo exemplo tanquam ficto ad reidcclara $10 n e m$, ied tanquan vero: aneueräter enin hoc de colore pronunciat, \& nili de co-
A lore ferum fitsuon declaratur illa comparatione, quomodo intellectus agens facit intelligibilia: argumentum igituretivalidum, \& folutio Alerrois vana eft.

\section{Solutio argumentorum Aucrois. Cap. XIII.}

X X pendenda manent dio Ancrrois arguLimenta, quibus of enderenitcbatulumen non prepterculorem, fed propter folum me. B dium requiri, qua difficiliafint, \& magnü negotium faceffere vidcntur. Alterīfumebatur ex Aritt. in 2. lib. de Aaima, in cap, de Vifu, vbi defincns lumen vtad vifionem cóferens, nil alind dixit, quā cfleactum per f icui quatenus eft perfyicuum; non dixit effe actum coloris, quo perficintur color, imò etiam colorem definiens dixitefie motium perfptcui actu, mull a facta luminis mentione; centuir ergo colorem effe per fe motium perfpicui abfạne ope lummis. Ad

C hocargumertum varia dicuntur à fectatoribus cōtrarizopinionis. Quidam dicunt lumen propric iungi pérficuo, non colori : nam perfpicuo qusor iungitur formaliter, quia imbiliturin tota eius fubitantia tanquam formaredaens iofum aktu; coloriautcmingiturnon formaliter, fed obieciuc;non enimlacit colorem effe colorem, fiquidem etiam m tcubbriscft color, fed facit elfe obiceum motiun perf́picui : ob id Arift.lumen in folo peripicuo, non in colore confideraut,

D Sed hacrefponfio mihi non atis fecit,neq; dif- $R e$ f ficultatem tollit. quum cnim Ariftotel. ibinon nis is alio modo colorem confideret, quam vt vifibi-gnat lem proinde fub ratione obectiua, quum ipfum definiens dicat efle motiuü perf́picui; ad conftituendam añt in colore ratione ubięiunm requiratur lunen, e:go declaransquomodo color fit motiuus perfpicui, debuit omnino facere luminis mentione, fi eft motuus per lumen. Prxterea negarinon poteft iungi lumen colori for-

E maliter: quamuis enim lumen in colore habeat rationë obickt motiui refpectu perfpicui, quiz conftituit obicetum motiuum; tamen répeêtu ipfius coloris non habet niî formationem: quicquid enimalicui iunctum conftituit ipfum in tali efie, id facit vt formaillits quatenus talis, hoc enim eft ofícium formx; lumenatem sun. Eum coloriconftituit iplizm in effe obicetuo; ergo ef forma illius cöfiderati fecundumillud elle obic Etuü: hoc afferuit aperte Arift. tım de

F iprolumine refpectu colorum, tum de intellectu agente refpectu phantafiratum, quê locum antea confiderauinus: mulla igitur ratio apparet, curnon debuerit Ariftot. dicere lumen efle necerfarum colori, ve color fit motiuus perficui: quareargumentum viget. Rectior efle videtur $R e f$ Alberti refponfio, qui dicit Artitotelem ibi fu- Albc mere colorem fecundum etle fomale, \& vt vifibils eft, idcoque ftatuere iplum iam illuminatum, fic enim et motaus perficui:quan fente- 
tiam videntur fequentia A riftot. rerba fignifi- $\Lambda$

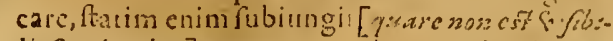
lis fone lumine] quar magis videntur ad colorem referr, quam ad perfpicuum; de colose namque colligit Arithotel. ipfum non elfe motiunm finclunine, \& videtur clieillatio à pofterore ad prius, ex eo cnim quod eft motius erfipicui, intert conditioncm ci necellatiam ad mumen: duni quafi dicai, eft motiuus perfficui, eı gn debutelleilluminatus. Attamen quia Arift. occafionem inde fumit lonuendi de lumine, \&de- $B$ clarandi eins naturan, \& fatim ipfum definens vtad vifionem rela: um, in juit efie adum perfpicui quatenus perfpicum, neque dicit efleaetum coloris ve vribilis, neque vllam coloris mentioncm facit,nonvidetus hac Albertifolutio, nifi quidaliud ei addamus, difficultatẽ tollere. Ego igiturdicam, in quo huus argumenti colutionem conftitutam clíe exiftimem. Cerng zo tum êt, Arifot.có in loco per lumen non intelwa. ligere lucem ipfan, qua meft in corpore lucido, quum hanc in context. 69. tetigerit vt caufam liminis an perfpicuo: nomme igirur luminis nilaliudintcllexit, quam id quod a luce producirui in perfipicuo; hocan ten eft necelfarium medio, quodiupponitur effe perlpicuum interminatum, led non eft necefiariun colori a mple accepto, \& prour color eft, nam color quatenus cft color, \& vifibslis vt quod, amplectitur etiam lucem, \& haceft moviua perfpicui absque cxterno lumine;at peripicuum femper eget lumine externo, quo illuminetur, vel ab piometcb. iefto colore, vel ab alio lucido; illuminaturau. tem à colore, tum quando eft color lucens, tum quando non eft quidem lucens, fed eft ab alio illummatus, ve quando alicuius rei color à Sole illuftraicus cernirur ab aliquo exiftente in frelunce obtcurifima, quia color ille illumenatus illuminat fibs medium, ficut ante dicebamus: quoniam igitur non omnis colur eget iliuftratione externa, fiquidem lux nullo illuminante indiget, non poluit Arift. lumen in definitione coloris: \& quoniam ita acceptum lumen eft neceffarium omni perficuo, li periplum vifio fieridebeat, 2 ipfi quoque lumani eft neceliarium perfpicuum tanquan proprium eius fubieetum, in quo folo recipitur, coloriauteni adharet vt luxpotius, quan vt lumen, quia in corpore terminatoreceptun lumen fit in ttar lucis vifibile vt quod, \& fungitur officio lucis, quum illuminetmedium; ideo Ariftot. Lumen defiriuit per F perfpicuum tanquam per eius fibiectum, non per colorem : attamen dum fratuimus colorem elfe tenebrofum, ita vt neque ex fe lucear, neq; ab alio illuminetur, manifeftum eft,ipfum non ele vifibilem, nec notiuum perfpicui : ideoreEte Albertus dicit Ariftot. in detinitione coloris accepifecolorem fecundum effe fornale, hoc af, lucentem vel exie, velab alio; nifienim eiusmódi fit , nō est motiuus: ho a auten iplemet
A Arifect declarat, quando cx definitione coloris. collogit iplum non clic motium fine lumine, de fubiungitomnem cuiusque rei colorem in lu. mine vilibilem elfe, quodeftinfere conditionem necefiaram advifibilitatem coloris, nec potent intelligere uifi conditionem ipfius coloris; quareaceperat colorem fecundum efic formale, fecus cnim non poffet inferre non elfe vifibilim finclumine : nec poteft aliquis dicere, A riftotel. id colligere, nonvt conditionem coloris moucnus, fed folius perfpicui patientis: tenim paticntis apritudo eft quidenu neceffaria mouentivt molteat, fed nonvt 'it motiuum; ignis cnum non vrit, nifi rem aptam vij, attamen cft per feveftiuss, etiâfi nihil ei adfit, quod vratur; Arift.autem ibi non confideratcolorem vt aciu mouentem, fedvtmotiuum, quia fi confideraret ve mowentem, vtique dicerepofremus, iplum nó poffe mouere, nifi perfpicuum aptum moueri, loceit, illuminatum : fed quum confideret vemotium, non eft ei necefaria patientis conditio, quia etiam fune hac nondefinit moucns effe fecundum fe motiuum, etiamfi nihil ab eo moucatur; itaque non confiderata condstione patientis, coll igit Ariftot. conditionem in colore requititam, fi debeat effe motiuus; quare accipit colorem fecundum effe formale, \& illatio, quam facit, eft à pofteriori ad prius, ex eo enum quodeft motiuus, infertipfun efle in lumine, tauquam conditionem, per quam eft moti-

D uus. Solutioigiturargumentieft in hoc conftituia : lumen accipi poteft duobus modis; vel e- potest nim vt communiter ampleetrur tam lucem, accipe quam fumen, hoc eft, vt eft vifibile feuvt quod; duobus feu vi quo; velfolun vt vifibilevt quo, \& ratio modis. vilibihtatis à colore difín ta : priore quiden modo eft 11 celiarum \& medio, \& colori ; quia color ron poteft mouere perfprcuim, nifi luceat velluce propria, vel lumine accepto abalio; vt quando lunen Solis in pariete receptum fit viE fibile \& vt quod, \& vt quo, quum \& ipfum per re vifum moueat, \& laciat vt color moucat : recundo autem modo acceptum foli medio eff necef. farium, tale namque lumen, quod non fit vifibile, nufi vi quo, lion datur nifi in folo perfpicuo interminato; Ariftotautem in 2.lib.deAnima, in c.deVilu, troc folum répexit, quoniam ad declarandan per fuam operationem facultatem vifituan voluit triailla diftinguere, obiectum, medium, \& organum; ideo confiderans lumen colori adueniens fubire rationem coloris, \& fiesi vríbile vt quod, nempe vt coloreni quendam, quia onne vifibile eft color, accepit ipfum tanquam vifibile tantum modo vt quo, \& vtactum perfpicui, proinde vt conditionem perfficui, ne jplum ctum colore confunderet; hocenim fat faculatem anina vifuam : per hoctamennon ftat, quin abfolute fumprum lumen fit neceffarium colori mam color lle, qui non eft lux, 
non poteft monere perfpicuum, nifiab aliquo $A$ lucidoilluminetur. Alterum Atterr. argumentum erat: fi color fieret vifibilis per lumen, ergo non eflet per fe vifibilss, quodaduerfatur Arit. \& communiomnium opinioni, qui dicunt colorem effeper fevifibilem uxra fecundum modum dicendi per fe. Ad hoc ego puto negandam elie confequentian : poteft enim aliquidalicui competere perfe, id efteflentialitur, non tamen absq; auxilio \&opealterius, vt eclipfis competit Lunx perfe fecundo modo, per terra tamen interpofitionem tanquan caufan, \& hocidem in pluribus accidentibus notare poffumus, quæ fubiectis fuis infunt per externas cáuas, tamen infuntperfe, \& in fuis definitionibus fubiecta accipiunt. Piæterea Arift. in 2 . lib.de Anima dixit, lenfilia communia effefenfilin per fe, quum cnim fenfum moueant per lpeciesproprias, dicunturperfe fentiri ; non nonent taméfenfum, nifiaxilio fenfilium propriorum, hoceft, nifi colum fpecies cum fpeciebus fenfilium propriorum coniunctrad organum fenfus deferantur,quia necefiariū eft, vt fenfilia propria prius moueant faltem natura : ergo dicendo aliquid alicui per fe competere, non excludimus omne extcrnum auxilium. Ad huius autem rei veritatem plene declarandan plurimum confert diftinctio illa duplicis primitatis, qua Logici yti
Propofi: tiodiciturprimadisobus nuodis. folent in libris Pofterioribus Analyticis : dicunt enim propofitionem poffe duobus modis dici primam, \& immediatam, yno modo primitate fubiect tantum, altero modo primitate cauf $x$, quahabet neceffario conıuctanetiam fubiecti primitatem; quare maior primitas, \& immediatio haceft, quam rationefubiedi tantummodo:conclufio enim demonftrationis eft prima,\& immediata ratione fubiecti folum, quia fi fumitur atiectionis fubiectum primum, nullum eit fubiectum prius, cui illa affectio infit ; at razione cauf $x$ non eft immcdiata, neq; prima, quia

A caufam mediam habet, perquam demōftratur: principia vero demonftrationis funt vtroq; modoprima, \& immediata, vt in libr. noftris de l'ropofitiunum necellitate dcclaraumus: fi hac vera funt, igitur competere aliquid aticui per caufam mediam, non facit quin cómpetat ei per fe, quum accidentia propria cōpetant fuis fubicetis perfe, tamen per caufam mediam, \& plura etiam perextcrmam; ino apud A ristot. neq; ali. cui competere peraliud fubiectum mediun, cui B prioricomperat,impedit quin competere polit perfe, fiquidem fenfilibus comnunibus perfe competit ve feufilua fint, funt enim fenfilia per $f e$, tamen non fentiuntur nifi per fenfilia pro- pria, quibus prioribus fenfilitas competit : ergo multo magis per fe fentiri dicetur illud, quod non per fubiectum aliquod prius dicatur fentiri, fed folum peralud tanquamper caufam, \& rationem fenfilitatis; tale autem eft color refpectu C luminis; dicinús énim colorem effe vifibilem per lumen, non tamen vi per fubiectum prius, id eft, quod prius fentiatur, conftat enin lumen non elle per fe vifibile, dum fumitur vt à colore diftinctum, fed folum efle rationem vifibilitatis, id enim quod viderurvt quod, eft coior, non lumé ; quinimo 1 famet lix, fi eft vifibilis vt quod eft, quatenus color, \& ipfimmet lumen in corpore terimato iunctum colori fit vifibile vt qued, quatenus fubit rationem coloris; illud D enin quod proprie dicitur videri, \& vifum terminare perfpeciem propriam, eft color; quare dicendo colorem efle vifíbilem per lumen, non tollimus, quin colot fit per fe vifibilis, color enim eft primú fubiectum vifibilitatis vt quod, lumen vero prout à colore diftinctum confideratur, non eft per fe vifibile vt quod, fed eft folum ratio vifibilitatis: fic igitur patet non tantum roboris habereargamenta Auerrois, quantum habere videntur.

\section{A C. Z A B A R E L L AE $\mathrm{P} A$ I A V I N I, $\begin{array}{llllll}D & E & V & I & S & V\end{array}$} LIBER SECVNDVS.

\section{se modo quo fiat vifio, opinio Democri-} ti, $\dot{G}$ eius confutatio. Citp. 1 .

Tenes Minia qux hactenus dicta funt, ad (1) declarandam Ariftotel de vifione Q 0 - fententiam pertimuerunt : fequitur $\Rightarrow$ vtaliorum quoq; hac dere opiniones perpendamus, \& cum Arift. fententia con-
E feramus, \& eam ab aliorum obiectionibus vindicare nitamur. Certum eft, 1 debcat fierivifio. oportere rem vifam cum vidente coniungi, vt etiam Gal. confiderat. in 7.lib. de placitis Hipp. \& Platonis : oportet igitur vel aliquid ab oculo egredi, \& ad rem vifam tranfire, qux llaton. \& Gal.opinio fuit; vel aliquid à revifa procedens ad oculū progredı, \& in eo recipi, quæ fuit Anft. opinio à Galeno efficaciter impugnata : videtur 
ctiam adhunc modum rediginpinio Democriti, quam refellit Aritt. in lib. de fenfu \& fenfilibus, cap. 2. qux nunc à nobis breuiter confideranda eft. Putauit Democritus vifioné fierı per op- receptionem quidem fpeciei in oculo, non tamen in ipfa oculi fubftantia introrfum, fed in fuperficic, apparet en im in oculo impreffa imago alrerius tanquarn in fpeculo: quum enim fuperficies oculi-lit laurs, ac terfa, recipit imagines rerum præfentium; quo fit, vt quifq: cernat imaginem fuam in oculis alterius: dicebat ergo Democritus, nosiden videre, quia habemus aliai í rerum imngines in fuperficie ocuterum.

grna Hanc fententiam impugnat Arift. confiderando quid fit illa imago, quam in oculis aliorum intueri folemus;ea nam que niml aliud eft quam refractio fpecies tanquam in fpeculo, quoniam fuperficies ocultisftar fpeculi terfá ac laeuis eft: hancigitur imaginem (inquit A rift.) in oculo habere non eft videre, fed videriab alio, nonenimille vider, quiin oculis habetimaginen, fed alius, qui imagine in oculoalteríus intueturs refacta enimimg : in oculo illius reflectitur ad oculum alter ius. quiita eam videre dicitur tanquam imagintm fuem à fupeficic oculialterius. refiactan : quoditefrangi in oculo imaginem efiet tā videriabillomet, in cuiusoculorefrangitur, fequeretur (inquit Arift.) omnizterá, ac Ixuia, 11 quibusimagines refrag gntur, effe videntia igtturetiam fipeculí viderer, fi becmodo vifio ficri diceretur, Quinobrena dicendirm eft, eam reuera non effe re eption é fpeciesin oculo, federfe feciei refractionem à fuper ficceculi : vera autem fpeciei receptio eft 1 lla, qua ab. Ariftet pontur, quidicit fpeciem recipi in ip a oculi fubttantia intrinfecus; ea namqueaquta: eft, \& perfp cua, \& aliquantum denfa, ita vt reciperefpeciem coloris, ac retineri poffit, it ab inexiftente faculiatc a nim $x$ iudicetur, \& ita fentiri, \& cognof́ci dicatur: hac enim eft Ariftotel. opinio, qua in pracedentelibro fuit à nobis diligenter confiderata, \& declarata.

\section{Argimenta Galeni contra fententiam: Ariftot. Cap. I 1 .}

Alenusvero \& in 7. illo de Hippocr. \& $\mathrm{Pl} 2$ -

Itonis decretis, \& in 10. de vfupartium, \& in libro ei adfcripto de oculis, aduerfus hanc Ariftot. opinionem acriter inuehitur, \& pluribus viturargumentis, quorum primum eft: fi vifio fieret perreceptioné (peciei in oculo, non pofferrerum magnitudo videris quum enim per foramen pupillx debeant omnia vifibilia in oculum ingredi, $i d q ;$ fit valde paruum, quí fieri potef, vt: per illud magnitudo magni mótis ingrediatura: (4ndü Irxierea (inquit Galenus) eadem montis ma- gnitudo videtur fimul à pluribus, ergo oporteret eandem tranfire eodem momento adóculos. innumerabilium animalium, quod ne excog:-
A rabilt quidem eft. Sumit etiam argumentum ex Tersion ca vifiune, qua in lpeculis fit, \& inquit: dicere argumequidem poteft Ariftot. colorem refrangi in fpe- tum. culo, \& ad videntis oculum reuerti; at magnitudo \& figura, quomodo videnturinfpeculo? dicere namq; eas refrangi vanum eft, quianö porfunt ha frangi in fpecula, \& ad oculum retrouerri, quum confiftant in quadam concinnitate partium, \& integritate totius, quam frangi nec - dicere, nec imaginari poffumus. Vutur etiam Galenus ipfamet Ariftot. confeffione, qui in 3. Meteorolog. dum agit de area, iride, parellis, \& virgis, inquit fieri refraetionem vifus, feu radiorum vifualium, \& ita fatetur vifionem fieriper radiorum emiffionem ab oculo ad rem vifam: \& ibi in cap. 3. rationem afferens cur Antiphon quidam cernebatante fe imaginem ruam in aere tanquam in fpeculo, caufarn effe inquit, quia

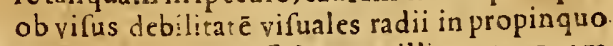
aere frangebantur, fiebatque illi aer tanquam. C fpeculum, à quo rajii vifuales ad eum reflete. bantur: in his igitur omnibus declarandis $($ inquit Galenus) Ariftoteles fua dimiffa opinione vfus eft opinione Platonis, quia fuam tueri non eft aufus. Notat etiam Galenus Ariftotelem ibi dicerenihil referre, an dicamus vifionem fieri. per egreffum radiorum ab ocuload rem vifam, anfer progreffum fpecici à re vifa ad oculos: quodidemnoslegere apud Ariftotelem poffumus in calce 1.cap.lib. 5 . de Generat. animal. quum enim aliqua ad vifum attinentia confideraffet, poftea fateturnihil referre, an egreffione radiorum ficri vifionem dicamus, an receptione fpecierum : inquit ergo Galenus, Ariftot. vidiffe fuz opinionisabfurditatem, \& cognouiffe eam defendi non poffe, nequeillis, qux apparent, accommodari;ideo que nos hoc cauillo elufifte, dicédo nihil referre an hoc modo, an illo vifionem fieri dicamus; quippe opinionem mutans, \&adalienam fententiam confugiens, illaque vtens, nectamen fateri volens fe mutare fententiam. Hxc funt, quz à Galenoaduerfus: Ariftotelen adducuntur.

\section{platonis ô Galeni opinio, é èius decla- ratio. Cap. III.}

Sam autem hac in.re fententiam proferens: Galenusinçuit vificnem fieri per radiorum: emifínéab oculoadrem vifam, qua Platonis. in Timzoopinio fuit, \& eam declarare multis verbis nititur: ego tamen fateormeillam plene: affequi mente nunquam potuiffe, nullum enim eius fenfum inuenio, qui non fir abfurdus, \&.0mnino abfonus rationi; referam igitur quid exGaleni verbis colligere de eius fententia potuerim, poftea fenfus omnes, qui ill atribui poffunt, diligeter confiderabo. Inquit Galenus primum totius fenfus inftrumentum effe cerebrü. \& abeo vim fentiendi cum aliis partibus com.

\section{Quarter} argumetums.

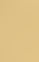


municari per neruos, qui ab ipfamet cerebri fubftantia deriuari tanquam propagines quxdam videntur, fed in duriorem materian aliquancum degenerare : neruos autem vifioni inferuientes, qui optici vacantur, in hoc differte inquit ab alie omnibus quod optici molliffire omnium funt, \& omnium etiam maximi, quippequi foli iater omnes neruos caui, \& perforati efle debuerunt : quod quidem ampliorem magnitudinem poftulauit, quia per hos oportet fpiritus animales à cercbro ad ocules deferrijper alios vero fenforios neruos ipfa quidem fenfibilis facultas ad alia membra transmittitur, at non ipfamet animalium fpirituum fubitantia, 'fedper folos opticos : hinc colligi ait magnam huius fenfus nobilitatem inter omnes alios, quiu in eotantum Atudiū natura pofuerit, eiq; tot, \& tantas prerogatiuas largita fit : de horũ autē neruorum tunicis, \& quomodo in ingreffu oculi dilatat $x$ migrent in tres oculorum tunicas, quas antea confiderauimus, recenfere prarerco illa, q̨ux à Galeno dicuntur, quum apud eum diffufe fcripta legi poffint in libro 10. de vfu partium; per cauitatem igitur neruorum opticorum pr $x$ dictam inquit Galenus magnam fpirituum animalium copiam à cerebro ad oculos transmitti, nec folum ad hure orem cry ftallinum, quem effe pracipuum vifus inftumentum confitetur, fed etiam ad anteriorem pupillæpartem, ita vt totum illud fpatium, quod eft inter corneam, \& humorem cryftallinum, plenum fit non modo humoreilloalbugineo, fed etiā fprritu animali, qui copıofusilluc à cerebro mittitur : quü ergo a magna fpirituu animalium copia oculus fiat lucidus, ac iplendidus, emittitur (Inquii) fplendor illeaboculo ad externum aerem, \& adres coloratas., \& ita fit vifio per extramiffionem, ad banc conferre dicit medium pupilla foramen, perillud enim emittutur ab oculo internus fpiritusad aerem externum; ob hanc eandem caufam inquit extimam illam pupillatunicam,quä vocant coniunctıam, non operire totam corneam, quiafi totam operiret, eam fpiritus perforare, \& extramitti non poffer. Videns autem Galenus magnamillam abfurditatem, quodoporteret ab oculo ad cœlum vsque emitif piritum. fubitu, quum aftra momento temporis intueamur; ve hanc euitaret, inquit, non emitti lumen ab oculis ad aerem externum, neq; cum eo commifceri, nifi ille fit illuminatus, \& ita fieri vtaer externus illuminatus ita commifceatur fpirituiab oculis emiffo, vt eusdat tanquarn internum nobis, \& cognatum membrum ad vifionem idoneum, iam enim aer externus recepitaliarum rerum colores, quippe qui aptus na. rura eft ad cos recipiendos: quum ergoaer iam in fe réeperitlumen, \& colorem aitrorum, fpiritus vifuus non ad colum v fque protenditur, fed folum ad circum it antem aerem imbutū coloribusaltrorum, \& cum eo commiftus reddit
A iffum fibifimilem, ita ve vnum fiat corpus ex ambobus, perquod tanquan perinitrumétum animal videt \& aftrorum, \& aliarum rerum colores, tanquam in circlimitante aere iam rece. ptos: \& hocidem apud Platonem in Timzo a. perte legimus; inquit enim ex igni ab oculis exeunte, \& acre externo illuminato ab aliquolucido cerpore, vnum corpus fieri, quod eft inftrumentum vifus; hocergo idem afferit, \& declarat Galenus, \& putat pulcherrimam efle bãc

$B$ ordinarionen, \& colligantiam omnium partium vifui inferuicntium, quod quum vis vifiua fit ingertbo radicata, cerebrum mittit neruos opcressadoculum, a per eos tranfmittit fpiritusauimales, \& his vt inftrumentis ad videndum vitur; ita pefea oculi quoque ad externum aerem mitcunt fpiritus animales, \& finiliter externo aere vtuntur tanquam inftumento ad videnduro, ficut cérebr um viturneruis opticis; nam commift cum aerefpiritis vifuiconC uer unt ipfiam in fuarnaturam, \& inftumentuma ad vifionem ap pū crnftiturunt; ita vt quemadriodurn nerai à cerebro emiff fupplementum faciunt cerebro, ita aer externus lupplementurti oculo faciat: fed notat efficacitei Galenus fe non ita intelligere osulum vit externo aere tanquam infrumento, vt intelligebant Stoici, q̨ui dıçbant ita vti,vr manus baculo vtiturad mo uendum; fiquiden manus veitur baculo vtinitrumento externo, śalieno à fua na$D$ ra, cuifitrefifentia abllo, quod mouctur extra: at foritibus anmalsbus ad aerem emsfis commifius ipfe aer fit inftumentum cognatum, ac veluti internum, cui nulla fierefiftentia. Hoc igitur pacto puracit Galenus fe magnam illam difficultatcm liubfulifie, que modo tanta poffit firitum copia oculo fippeditari, ve ad omnia circumflatia corpora, \& ad Colum quoque videndum diffundantur : inquitenim non cffe neceflarium, ve fpiritus animalis ad E rem vique vifam extendatur, fedadaerem folum exrernum, qui cum illocommiftus eius vices futit, \& illi fupplementur: facic. Singula' quoq; elementa fingulis fenfibus accómodans G. lenus (quod \& Ariftor. facit) aliterramen, quam Aitit. perfenfus eleméta diftribuit, quam enım Ariftot. inttrumentum vifus dicatefieaqueuin, ipfeignem effe afferit, tanquam rplendidum, \& lucisum propter fpiritus, yุuod Plato quoq; in Timacdixit inam fi comodo, quem F expofuimus, vifio fieri dicatur, oportuit ocu. lum elfe igneum, vtlumen, \& radios ad externuni acrem emittere poffet, folus enim inter elementaign s horfacete aptus eft.

Sententia Galenidevifione confutatio.

$$
\text { Cap. IV. }
$$

F E Galeni fententia, quanquam facilliLima impugnatu cit, ve qua eft omnino ab. Ionarationi, tamén propter varia \& pugnancia 
Galeni difa magnum nobis negotium faceffit, quum eam plene inte!ligere non facile effe videatur; quo factum eft, vt eam plures Mediciad varios fenfus, vt iptain tuerenrur, extorferint; nam fi $G$ ilenum pralentem haberemus, quem interrogare; \& viciffim refpondentern audire nobis liceret, magiseius fententiam affequi, \& affequuti reprehendere, atque impuguare facilius poffenus:quarendum enim à Galeno eflet, an ipiam fpirituum animaliun fubftantiam $e$ gredi ex oculo putet, an folum lumen, quod eft accidens, \& rurfusan id, quod exiit, ad oculos iterum vna cum coloribus, ac rebus vifis reucrtatur, its vt in ipfis vculus fentiatur, an poitus non remeare amplius ad oculos; red in externo acreremanere, \& ibivilionem abfolui at itretur : fed quum Gilenumauduehxedeclarantem non liceat, magnum fubire laboren cogimurcuncta hac feparatim confutandi, pratertinı quum ea omnia apud Galenum legantur, pugnareque ipte cum feipfo frequenter videa. tur; itaque aduerfus omnes lenfus, tum quos $M$ :dicı verbis Galeni attribuerint, tum quos attribuere poffunt, eft robis in prrentia difpuum tandum. Inprimis quum Galenus ex vifione men magnitudinis aduerfus Ariftotel. argument um on-fumat, ex eadein nos argumento irrefragábili falfam cffe Galeniopinionem oftendemus:nam fi vifus, vt ipfe ait, adreimagnitudinem videndam extra porrigitur, ergo in qualibet diftantia candem débet magnitudinem 1udicare, vbicunque enim ea fit, iple eam amplectrur vti eft; attamen non ita euenit, nam propinquum homi nem videmus vt maiorem, remotum vero ve minorem , \& aftra iudicamus multo minoris quantitatis, quam reuera fint, At.fecundum Ariftotelem inanifeltam afferimus huius difcriminisrationem;na ma eadem res, dum eft propinqua, obtufiorem, \& ampliorem angulum lir. nearum vifualium in oculo facit, dum autem eft remota, acutiorem, f ftrictiorem; obid propin. cqua ma or videtur, remota vero minor : at fi per egrefium radiorum vilio fieret, deberet in qualibet diftantia quantitas eiusdem rei eadem videri. Praterea quum radij vifuales ab oculo ex* tra mittantur, dicere Galenus deber,an extra oculum fiat rei vifa iudicatio, an in oculo, vtrum horum fenferit, ego quidem nefcio, quia vtrumqueafferuiffe videtur, fed verouis dato often. dam eius fententize abfurditatem;iudicationem autem confiderandum accepi, quia ibi effe rem vif́m oportet, vbi iudicatur, fiquidem vifio debet effeconiunctio facultaris vifiux, cum re vifa, feu elus znutatio in rem vifam; quare vel in re vifa recipitur facultas vifiua, vel contra in iffa facultate. feu in organo res-vifa resipirur: Galenus quidem in libr. 10 , de vfu partium dum cryAtalini humoris conditiones declarat, inquit ipfum effe album, clarum, ac fplendidum, quia fic aptus eft ytà coloribus immutetur:: qutat eso-
A gocolores in cryftallino recipi, \& ita vifionem fieri per fpeciei receprionem, immutari namq; eft pati, \& recipere, agens enim non immutatur, fed immutat, patiens vero immutatur:ideo qui: dam Medici ita Galeni fententiam interpretati funt, vt Galenus putauerit vifionem \& emifione, \& receptione fieri, nempe lumen-ab oculis emittiad aerem iam lum inofum, \& cum illo zerislurnine commifceri, deinde fimul iunctum vtrum quelumen vna cum colore ad oculum re meare, \& in eorecipi, ac iudicari: in libro quoque de oculis inquit Galenus, cryftallinum effe album, acfplendidum, vt cito colores recipiat :\& in feprimo de Hippocratis, \& Platonis decretis dicir aerem tunc maxime à coloribus affici, quando eft purus, \& lucidus; ex quo infert eriam inftrumentum vifus lucidum, acperf picuum ef$f e, v r$ à coloribus alterari pofit : concedit itaque oculum à coloribus pati, \&huius veram caufam adducir, cófirmans eriam exemploaeris, quem

$c$ ideorecipese in fe colores dicit, quia luminofus, acperfpicuus eft; omne igitur perf́picuurn eft receptiuum color um, fubftantia autem oculi peripicua eft, \& luminisreceptiua, quare etiam colorūiureigitur illi ad hoc confugerunt, quod etiam fecundum Galenum fit receptio coloris in ocurlo, \& eiusdem iudicatio. Attamen hoc pugnat cum aliis Galeni dictis, \& nulla videtur ho. rum efle poffe conciliatio: nam infeprimods placitis, dum aduerfus Ariftot.argumentatur, hoc fratuit, fenfus vifus, \& aliorum fen fuum difcrimen, quod alif fenílıad fe venientia expectant, vifus vero peraerem medium ad colores videndos porrigitur; negat ergo colores a docue lum remeare, quiafic quoque vifus fenfilia ad fe venientia expectatet: qund etiam clarius exaliis $\mathrm{Gal}$ eni verbis colligitur, nam poftea inde infert, folum vifum magnitudinem fui obiecti vna cum obiecto ipro comprehendere, quia ( vt aperte ibi dicit) fieri non poteft vt magnirudo re i E in paruam oculi pupillam ingrediatur, quo argumento (vt prædiximus) ibi aduerfus Alift. turur: quoniam ergoferundum Gal. ita videtur color, vt videtur etiam magnirudo rei colorat $x$; magnitudo autem ingredi cculum non poreft., igitur color quoque extra oculum videtur; nams fi ad-oculum remearet, etiam magnitudo cum: eo rencaret, proinde ruerer argumeńtum Galeniaduerfus Ariftotel. quod fumebaturà magnirudine, quam nullo modo in paruz pupilla recipi poffe Galenus exıftimauit ; igitur color queque extra oculum viderur, ac itudicatur, idque confiteri eo in loco Galenus cogitur. Hac. igitur omnia Galeni dicta quicquis perpendins non fateatur manifeltan elle, \& iniolubilemiprorum inter fe pugnantiam, vel cocus, vel proteruus,acpertinax eft. Sed oftend mus, vtronis horum daro. Galenum defendinon poffe. P.imum quidem ti cum illıs Medicis cicamus Ga. lesum reuera putaffe colorem yas cura vtroque 200\%4ndam Modicorum fentëtia de mente Galens.

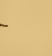

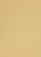


lumine ajoculum remeare, " 2 in eo recipi, iam receftione vifienem fieri Galenus confictur: vode etiä colligimus fola receptione fieri, non cxtramistione, quia natura nonabundat in fupertacaneis, neq̨; facit perpluraid, quod æque poteftabroluere perpauciora; igiturnon opus eft emitu lumen ad externum aerem, vt iterum adoculunı reuertatur: nam fatetur Galenusaerem perípicuum, \& luminofum iam mutatum effe à coloribus, \& eos in fe recipiffe; fatetur etiă oculü effe eiufmodi, vt queat colores recipere; poterit ergo pati oculus ab aere ita colorato, imoneceffariü eft vt patiatur, quia patiens aptü ad patiendum, \& à nullo impeditũ, neceffe eft, vt Ssolserfu abagentis contactu patiatur, Illud veroad quod gium ali- aliqui confugiunt áicentesvifionem non intringuorkm fecus in oculo fieri, fed ia contacku \& fuperficie pro Galc- oculi, ita vanum eft, ve confutatione quoque inno.

dignum effe videatur; fic enim non in oculo tit vitio, fed extra oculum, \& exrra corneam: quare

Confuin. nondefenditurid quod Galenus dicit, receptio120. nemcolorum in cryftallino fieri, neque ea dicetur remeatio luminis ad ocuium, fed estra oculum nianer lumen, nifipertanfeatiterum corncam, \& ad hum orem viqueciyftallinum perueniat; non enim de propinquitate, vel remotione externiluminis quaftionunceft, fed de emifione extra oculum, vel receptione intus in oculo: quare aque extra oculum effe lumen dicitur, fi fit in extima tantum fuperficie curnea, ac fi ab ocuio remotiffimum fit. Itaque fi vere ad oculum remeare lumen dcbet, in ipfia oculi fubftantia spum recipi oportet, vbi etiam infita eft vis iudicatiua: quare emiffio fuperuacanea fuit. Si vero extramitri tantū dicunt lumen, necremeare, fed manere extra oculum in aere yna cum colore, ibique fieri vifionem, in maius abfurdum incidunt, fic enim non erit animal videns, fed aer, fiquidem núlla in anirsali vilio fit, fed extra animal in aere : dicereautem colorem non recipi in oculo, fieri tamen in oculo vifionem, eft omnino abfonum rationi : quoniam omnis cognitio eft conitinctio cognofcentis cum cognito, \& ipro queque Galenoconfitente necelfe eft in vifione vel colorem accedere ad oculum \& in eo recipi, vel contra ab oculo porrigi vifum ad rem videndam extra oculum: quonsan igitur facultas vifiua, qua animal videns dicitur, in animals effe deter, non extra, nulla fit vifio manente colore extra oculum; vel folus aer, non animal, ea rationediTertim ceturvidens. Praterea experientia docetemifarghimsn fronem luminis à re lucida facere forius vtea swn. videatur, quam vevideat; illa cnim qialucent, vi.ibilia funt quarenus lucent, ideoetiam oculicarcrum, quatenus noktu l.cent, edteniss 4 i. fibiles à nobrs elle dicontur, at non videntes; nuticaricne, gra fignificatur illam oculifubAtantameferalis ocilis lucideren, prondeaptioremad.eripienjos, \& ad videndos coivres.
A Hoc etiam manifeftefenfui repugnat, ab cmai. bus cnim oculisilluminareturnocurnusaer, fi lumen omnes oculs emitterent; nulla tamen apparet illuminatio facta ab oculis noftris noctu. At vero fi tanta fit aduerfariorum pertinacia, vt affeuerare contendant emttii ab oculis noftris lumen; negareid faltem non poffunt, dabile ad modum lumen effe, cur ergo huic lumini noftro non euenit id quod aliisomnbus euenire manifeftum eft ? omnia namque parua lumina à B magnisluminibus offufcantur, idcircointerdiu non lucent, noctu autem lucent, \& videntur, quia tunc à nullo maiori lumine opprimuntur. Galenus tamen de oculoram lumine, quod de. bilifimum eft, aferit contrarium : interdiu enim dum externus aer à sole illuminatur, inquit emittiab oculis noftris lumen, \& externo luminiiunctum reddereacem vilus inftrumentum jdoneum; quum tamen turcaulium deberet emittiab oculis lumen, quun ¿ebilialucida pra-

C Sente aliquo vehementer lueraie, lumen non emitrant : neetu vero dum à nulloalio lucido illuminaturaer, deberent cosuif nofrilumenemittere, \& vifibiles aliis reddi ${ }_{2}$ guia tunc eorum lumen à nullo maiori lumine offufcatur; fice. nim videnus debilia lucida noctu effevifibilia, qua incerdiu videri ron poffunt;attamen Plato, \& Gialenus dicunt nullum aboculis lumen noctu emitti, at certe emitti deberet, faitemtanturz, quod faceretoculsm vifibilem abaliis, fi $D$ nonvidenturalia: ratiosutem, quam huiufce rei Plato inTimreo a Jducit, inan is eft, \& abA rift. refelliturin hibrode fenfü \& fenfílbus, c 2. Plato enim dicit ersifu ab oculis lumen noctu extingui à circum fufis tenebris; hos antem inquit Arift vanum effe, quoniam ignis non extinguitur, nifi hunido, aut frigido; hac enim funt contraria politiua, qua extinguere ignem poffint;at tenebra nullam agendi vim habent, quum fint mera priuatio luminas; in omnibus aliis lumi-

E nibus experimur triā debilia lumina à nocturnis tenebris nen extingui q quod li cōcedaturab humidıtate, vel à frigore nocturniaeris ignem, fenlumenaboculis emiffum extingui, curmon extinguitur etian interdia, dum pluuia ela in aere, \& dum aerfrigidinimus eft, \& dum magna glacies exiftit; fi ergo tunc non exinguitur, nequo noctu extingui deber, \& quum ab his contrariis, qua maxime extinguere ignem poffunt, non extinguitur, vanum eft dicere iplum extin. F guià tenebris, quum teneb:z fint nihil, proinde agendivim non habeant. Elt praterea confiderandum, andicat Galenus allquid corporeum exire ex oculo, vt ignern, vel firitū animalem, an lumen, quodeft accidens: dicere quidem aperte videtur corporeum aliquod egredi, refert enim Piatonis fententiam, ac verba in Timzo, qui dicit ignem egredi ex osulis, \& cum aere iam luminor citaconiungi, vt vnü ex ambo'bus corpus coalifiatineseffe eft igiturivt fecundum Plato- 
Platonem id, quod exit, corporeum fit, quia non fit tertium corpus ex duobus, nifilla fint corpora, ax aere enim \& aliquo accidente vnum corpus, fieri diccre vanum cfiet: l'latonis crgo fententiam quum ad vinguem fequatur Galenus, debet ipfe quoque dicere id, quodegreditur, corporeum efic; idque ipfe aliis fatis claris verbis afferere videtur, nam in illo feptimo lib. de Hipp. \& Plat. decretis modum, quo vifio fit, declaransinquit, fpiritum animalem ad circumfufum aerem egredi, \& cum co commifceri, \& eum fibi fimilem redderc: inquit etiam, noftram viforiam aciem fpirutalifubftantia praditam emitti ad externum aerem, \& iprum totum alterare, atque in naturam fiam mutarc; fpiritum autem animalem apud Galenum conftat effe corporeum, \&ipfe etiam aperte dicit effe fubftantiam fpiritalcm, id eft, tenueın; quare hac videtur Galeni fuiffe fententia, corporeum efleid, quod exit: in libro auttem de oculisrationem afferens, cur extima pupillz tunica, quam contunetiuam vocant, non totam pupillam operiat, inquit, fi totam operiret, , fprritus egrediens eam perforace non porfet; ego quidem non video, cur ob eandem rátionem non videat Galen, etıam corneam debuifie perforatam, vt fpiritus egredi polfit; dura enim eft, nec poteft à fpiri tu corporeo perforari; fed hasc difficultatem ego medicis confderandam relinquo; fatis mihi nunc eft ex hac Galeni ratione colligete corporeum effe id, quod exit, non folum accidens, nam lumen pro accidente acceptum eo tunicæ foramine non indiguiffet, fed facere natura potuiffet vt coniunctua toram pupillam operiret, ficutetiam cornea to!am operit, nam fatis erat eam facere perfpicuam, \& tranfparentem, cuiufmodi effe etian corneam manifeftum eft. Egoigitur credo hane fuiffe Galeni fententiam, quod oculus animalem firitum ad fe à cerebro mi ffum ipfe foras ad aercm mittat, fic enim maior apparetratio cur externum aerem cognatum fibi reddat per continuatam fpirituum egreflionem, \& commiftionem cum ipfo aere, fic enim cum externo aere magis continnatur, \& coniungitur oculus per egredientes fpiritus. Ve. rum hæc fententia magnis, \& infolubilibus dif. ficul tatibus vrgetur : nam fi corpus eft id, quod emittitur, cur non pellit, acmouet aerem loco, quum duo corpora eundem locum occupare non poffint ? cur etiam emiffus fpiritus non mouetur flante vento? moueri certe deberet, \& ita vtà vento impediri vifro,quod tamen non conringit. Præterea experiuntur medici, quanta virium eneruatio, atque imbecillitas tiat ex emufione, vel confumptione fpirituum; patei hoc in venz fectione, patet maxime inacu Vonero: quamuis igiturnon ad colum vf-
A que, fedad circumfufum aerem expandaturemiffus fpiritus, magnam omnino ipfius quan. titaten, \& copiam emitti nccelTarium eft,atque etiam durante vifione continuam emı fionem fieri: quemadmodum igiturin aliis omni. bus modis emilfionis fpirituum contingere vi. demus, ve durante duas horas continuas effufione, concidant omnes vires, vitaq; fimal cum. fangunc effundatur, ita in vifione contingere deberet, continua namque fpirituum ab ocu-

B lis effufione totum corpus debilitaretur,ac tandem etiam non magno temporis interuallo interiret; hoc tamen non cucnit, nam exmagna, vel longa infpectione oculus quidem, ac vis vifiua debilitatur, fed corpus totum nullam virium imminutionem fentit. Quodfi Galenus dicat effundi quidem in vifione animalem $r$ piritum, at non vitalem, ideo que virium debilitacionem fieri . vaniffima hre refponfia, elt; quonam fecundum Galenum firitusanima- Confutat

C les generaintur continue in cerebro ex vitalibus tro. co inceffanter miffis à corde, quare neceffe eft $v$ animalium fpirituun confumptio fitetiam confumptio vitalium : validum itaque argumentum eft, oportcret enim magis periculo fam, aclethalem effe continuam diarum horarum infpectionem, quam immoderatum coitum, qu frpein vitæ difcrimen adducere homines folet: praterea experimur perlongam, \&affiduam contemplationem corpus ob animalium fpirituum confumptionem debilitari, multo autem maior eorundem confumptio in vifione fieret, quare abfque dubio deberent ex longa infpectione totius corporis vires debilitari, atque concidere. Neque etiam dicere $\mathrm{Ga}$ lenus potef, non continuan fpirituum emiffionem in vifionefieri, fed femel emitti ftatutam quandam fpiritus quantitatem ad propinquim aerem, \& durare vifionem cefante emiffione: etenm fluxilem efle fpiritumillum

E credendum eft,nec diu in aere feruari poffe; neque etiam patet, à quonam detineatut, nec continue ab oculis exeat: praterea fingere quidem, \& affeuetare hoc pertinaticer poteft, dum animal in eodem loco manet immotum, eandem querem inceffanterintuetur; at quando ad varias partes, variaque loca progreditur animal, in fingulis locis noum fielifpirituum emiffionem neceffe eft; nifi fortafle dicere audeat, in loci mutatione oculum reF ceptui canere, \& emiflos iam fpiritusad fe iterum re:locare, quale figmentum fi diceret, ego quidem non mirarer. Hæc omnia plures Plurium Medicos dicere coegerunt, Galenum non pu- Medicotaffe emitti ab oculis fpiritum ipfum anima - rum fublem, neque corporeum aliquid, fed folum lu- terfizgize men, quod eftaccidens: hi tamen debent Ga-pro Gale. leni verba, quxiam confiderauimus, intei- Confuta. FF pre-tio. 
pretari, quibus corporex fubftantix emifio manifefte fignificaluit. Sed hor quoque maximas dificultues coniun tas habet, quarum vna, qure exn ytura luninis iam à nobis declarata defumitur, infolubilis elt; dixinus enim lumen non efle aliquid exiens à corporelucido, fed elle accidens Ipiritale in perfícuo productum à. profentia lucidi, lumen enim Solis in acre exiftens, nequic eft pars aliqua fubftantize Solis, neque accidens ciusaliquod, quod à Sole adaeremtranfmiflum fuerit; non poffet enim accidens migrare de fubiecto in-fubiectum, fed'eft accidensfpirtale in acre genitum à luce Solis prafente: hoc fi verum eft, vt certe eft verifî-. mum, non pofunt Medici, \& Galen. fi hoc intellexerint, vtinomine extramifinonis, quia fic emittiab oculis lumen, non eft egredialiquid aboculis, fed eft produci ab eis luméin circumftante aere:quomodo igiturex hacaeris illuminatonc dicere audent animal fierividens? fic enim nilla fit coniuntio videntis cum re vifa; \&: nihil ex oculo ad acrem egreditur, quo dici poliit oculum fier1 videntem, fed potius aer, quod lımen illum recipit, redditur videns : ob id in magnum etiam ablurdum incidunt, dum dicunt limen cuin colore adoculos remeare; quum enimlumen, vt antea diximus, nullo modo moucatur, vt vanum eft dicere lumenex aculis cgredi, itaeftridiculum dicerclumen ad oculos reuerti. Præterea experimur in omnibus ahis lucidis, quæ lumen generant in perfpicuo, quodlibet eorum per hane illuminationem fieri quidem vifibile, at non videns; quare enittiab oculis lumen non eft eos effe viden-

Dezanis argums. twin. tes, fed potius vifibiles alis reddi. Sed poffumus tandem contra Galenum argumentari ex ipfufmet dictis, quibus yeritatem inutus confiteri vifus eft: nam in feptimo illo de decretis inquit, cerebrum effe omnium fenfuum prie mum inftumentum, \& hoc munete fungiper neruos ad omnes partes miffos tanquam eius propagines; fic enim fenflis omnes ad natliram vnam vniuocam reducere videtur, \& advnum operandi modum, qui.prouenit ab vna primiinftrumenti temperie, ac facultate; eiufdem ergo rationis effe debet ommium fenfuum operatio; quare fialii fenfus operantur patiendo ab obiectis, debet etiam vifus patiendo operar1; quod etiam inficiarinon eft aufus Galenus: nam in libro decimo fexto devfu partium vniuerfe de omni fenfu loyucns, \& ipfam fenfus naturam confiderans dixit, fenfun in patiendo confiftere, \& in decimo ețiam libro particulaviter de vifu loquens dixitorganm vifus debuife effe album, ac fplendidum, trà coloribus pati, \& ímmutari posfite.
A Alia adierfus Galenum argumentatio ab oculifubfantiu. Cap. V.

$\mathrm{E}$ $\mathrm{X}$ ipfa quoque artificiofinima oculi ftu ctura magnum pro Arift.contra Galeni fen. tcntian argumentum funitur: nam fi abque receptione per folam emiflionem fitvifio, non poteft autem extramitti lumen, quia accidens non migrat de fubiecto in fubiectum, fed folus fpiritus, certe ad hunc emittendum fatis. B erat fine oculoneruas opticus, ta vt cerebrun. tanquam commune inftumcntum eovteretu* ad vifionem, deinde etiam aere externo tan: quam initrunento proximo. Sed aliquas præcipuas oculi partes confidereraus, vt tum ex toto oculo, tum excius partibiss cogrofcamus, cum adreceptionem luminis, \& colorum, non advllius rei extramiffionem directum effè natura : primum quidem confiderandum accipio. humorem cryftillinsm, quem \& philofophi, \&: Medici præcipuum efre videndi organum concordes tatentur; hunc afferit Galenus folidum efle, ac durum, \& praterca album, \& fplendentein, \& perfpicuum; fed abfque Galeni conferfione hrc omsia func manifefta ex anat one , \& infpectione contructionis osuli; nam in eius. medio tanquam princeps politus eft cryftallinus, \& inparte anteriore habet aqueum humorem, in pofteriore autem vitreum; \& fubitantiam habeit ta folidam, vt fublata etiam aranea tela, qua totus inueftitur, confiftentiam ha, beat, \& figuram fuam retineat, nec modovllo fluat; non eiufmodifunt alii duo humores, extunicis enim educti non confiftunt, fed Hu. unt: albus etiam maxime eft, \& fplendens, fed quo fplendore ?an tali, vt ex fe propriam lucem habens illuminet alia ? nequaquam, \& hoc affererepertinacifimi hominis effet, \& negantistes fenfur manifeftas; fed fplendens ef E alieno lumine, quod receperit: idque etiamin cryftallo. \& aliis folidis perfpicuis cernimus, receptoenin alieno lumine fiunt lucentia, fed in tenebris omri prorfus lumine deftituta funt; fit autem fplendor talis in perfpicuis folidis, ac denfis, quia propter perfpicuitatem recipiun: lumen introrfum, \& propter denfitatem retinent, atque vniunt : \& intenfius reddunt; fa* Atusigitur eft cryftallinus aptus ad.lumen recipiendum, nonad emittendum; \& huiusratio F. abeins temperie fumitur, aqueam enim fub. fantiam habet, ea autera eft aqua conditio. vtper fuam perfpicutatem recipiat lnmen, \& per foliditatem \& craffitiem retineat, \& intenfius effe faciat, \& adhuc magis $f$ condenfetur, \& congeletur; vt in cryftallo euent: ad esmittendum autem lumen aqua ex feapta nor eft, nam quantumuis denfata nunquam fit lu, aida; nes dico cryftallinum effe puram a quam. 
red dico effe corpus miftum, in quo eft aliquid ignis, \& aliorum eleinentorum, exceffit tamen aqueum; eft etiam in aliquibus oculis plus ignis, quam in aliis, quo fit vt noctualiquid lu. minis emit tant, non tamen ob td exceflu ignei funt, fed aquei, quia femper alis elementis prxualet aqua in miftione cryftallini : fed illud non omnibus oculis competit, quare confideratione dignum non eft, nonenin in ea e- miffione confiftit vifio, fed folum indicitur melior vifio propter maiorem cryftallini luciditatem, quefacit vi colores melius, 1 ecipiantur. Patet igitur cryftallinı officimm non effe lumen emittere, fedlumen \& colores recipere; quod etiam ipfius figura confirmat, gibbolam enm aliquantum habet vtranque fuperficiem, magis tamen interiorem, qua inficus eft vitreo,exterior enim planior eft. vt plures recipere radiospofit:interioris autem fuperficier nıior gibbofitaseanden caulam habet, quam \& ipte vitreus humor, in cuius officio alfignando orGa deceptum fuifie Galenum ita maniteftum cit, de vt ninilelfe polfit clanus, \& hocintellecto pazore tebitreceptione vilionem fieit, non emiffone. co. Iń it Galebu , nulluin elle alud vitre hamoris oficium, fiue vfum, quam nurrire cryftallinum, \& hac vitur ratione: cryltallinus omni-no egebat nutritione, nutriri autem fanguine immediate non oportebat, quoniam à calore, \& craffitie fanguinis vitiata fuiffet luciditas, \& albedocryftallini; natura igitur voluit vt fanguine prius nutriretur vitreus, deinde vitreo cryftallinus aleretur; ideo inquit vitreum efle minusalbum, ac minus lucidum, \& effe veluti fi quis multoalbo parum nigri commifcuerit, aliquid enim nigredinis accipit à fanguine, quo nutritur. Sed hæc Galeni fententia aduerf́aturfenfui , \& rationi : nam fenfui patet humorem vitreum cryftallinominus album noneffe, eft quidem minus folidus, fed nihil penitus nigredinis in eo apparet, quim fit albiffinus vt cryltallinus, nutritur tamen fanguine, vt Galenus afferit: quarevana eft eius ratio, cur non debeatcryttallinus fangune ali; fi enim vitrei albedo hac nutritione non vitiatur, pariter nequecryftallini albedo vitiabitur; hoc etgo non facit, quin ali fanguine cryftallinus poffit; idque confirmatur ex alis, quxalba funt, licet fanguine nutriantur, hususmodi enim funt neru1, \& offa: femen quoque \& lac alba funt licet ex fanguine fint genita, quia mutatur in ea generatione color in colorem conuenientem rei generand $x$, vel nutriend $x$, quod praftare fagaciflima natura, quando ita expedit, facile poteft. Eft étiam abfonum rationi, quod tanta moles, quanta eft humor vitreus, cryftallino ad eius uutritionem tradita fit: nam multo maior eft cryftallino vitreus, ac fi fenfui credi-
A mus, eft quadruplo, \& fortaffe quintuplo maior, videmusautem in onmibus alumentum ef- Alimen. fese nutrienda longe minoris quantitatis, 1d- tum doqueomnino necelfai ium eft : quia, quum ali- bet effe mentum in principio fit contrarium, \& cum re malto me alendapugnet, fi maius efiet, opprincret eim nus rea. potıus, quamaleret, tanquam validius, quo- lenduo niam in maiori corpore vis maiorine?t; potius igitur natuia cryftalliui in naturam vitres mu. taretur, quam è contrario. Hancigitur Galeni

B fententiam ego prorfusreiciendam puto, \& aliud effe virre humoris officium, quan cryftallinum alere, idqueinfpicientibus ac diligetuer confiderantibusita manifeftum eft, vtuihil cla- Argumë. rius effepollit : \& hinc validum argumentum tisn ex fumiturad oftendendum receptione fierivifio-' Sitreibis nem; quum enim neceflatumafit, vt per cry- mores of ftallinum tāquam perfpicuum tran feat himen, ficio. \& color receptus, certe nifi aliquis alius humor in parte pofteriore inter runicas, \& cryftal-

C lnum interceffiffet, lumenillud ad tunicas in illa par te peruenillet, \& quum foleat Jumen a folidis corporibusrefecti, fuiffetiterum reflexum à tunicis ad cryîallinum vna cum colore tunicarum, cit autem fecunda tunica colorata colorefubnigro, ideo imbutus fuiffet perpetuo cryftallinus colore illo, quod quidem vifioni maximumimpedimentumattuliffet; nam vifus omniaillius coloriseffciudicaffet, quemadmodum etiam ictericis contingerc folet fuit erm go neceffarium, vt inter tunicas \& cryflallinum in pofteriore oculi parte humorvitreus poneretur, isque magnus, \& magnæeprofunditatis, vt in eitus mediopoffet linearum vifualium angulus fieri, \& inde earum conus exinaniri, neq; ad tunucas pernenire, ne ab earum colore cryftalínus per reflexionem luminis coloraretur : hoc eft abfque dubio vitrei humoris officum; nam experientia docet, lumen tranfiens per vitrum aliquod caumm vniri in illa cauitate, \& permeans E vltra vitrum in quadam certa ab eo diftantia facere conum, in cuius extremitate intenfifimum lumen apparet, fed minimx quintitatis inftar milij, nempe fi in illa certa ditantia ponatur corpus aliquod folidum, id̀ quodangulus impingat; nam fi propinquius vitreo corpusilludponatur, maior eius parsillaminabitur, \& eo maior, quo fit propinquius vitreo; at fi paulatim remoueatur, niructur cõtinue, donec ad minimam fuperficiei illımınatæ quantitatem perueniat, ideo in illa minima quantitate ita eft vnitum \& validum illud lumen,vt etiam accen:dat, \& vrat, quoniam ibi definitconus, \& angulus à concurfu radiorum productús; ideo fiadhuc magis remoueatur corpus sllud, nullum amplius lumen ab illo vitro ad ip fum peruenit, fed eftexinanitum, quia quum ad conum, \& à d acumentendat, won pratergreditur quod dam 
detcrminatum punftum : cgo igrtur in oculorum fectione vidi cryftallinum ab alis humoribusfeparatum, cui quum accenfa candelula apponeretur, totus fiebat lucidus, \& fplendens tanquam candela lumine imbutus ob fuam perlpicuitatem, \& transtotam cryftallini fub. ftantiam meabat lumen, \& in. pofteriore cryftallini parte tranfibat in conum, \& in actrmen, non multo poft intimam cryftallini gibbofitatem, ita vt acumen illud, \& linearum concurfus parum diftareià cryftallino,imo ipfum fere attingere videretur; ideo certum eft, illius coni acumen exinaniri un humore vitreo, qui magnan habet profinditatem, ideoque ad pofteriores tunicas peruenire non poffe. Ad huncergovfum natura humore vitreum magnæ quantitatis poft,cryftallinum collocanit, vt in illo perfpicuo, \& incolorato corpore fieret radiorum percryftallinum tranfeuntium coniunctio; ne ad pofteriores tunicas peruenirent : \& hanc eandemob caufam credendum eft factam effe à natura maioremíllam in interiore cryftallini parte gibbofitatem, neproculà ciryftallino ra. diorum coniunctio fieret, nam gibbofitas illa maiorem luminis vmonem facit, ita vt in puncto propinquiore radij à cryftallino prouententes congrediantur. Hoc igiturfi eft vitrei humoris officium, necefle eft non emiffione, fed. receptione vifionem fieri;nam fi emilfione fieri. ftatueretur, non, opus effet humore vitreo. congreffum radiorum recipiente; quarefuper- D uacaneusille humor effet, ficut \& aliamulta in. Argumé. oculiftructura fuperuacua effent. Quarendum.
tü a colo-preterea eft, quomodo ad vifionem, vel ad ocure suea. Ii falıtem conferatcolor vuex, à quo oculum, \& vim vifuam roborari fatetur Galenus, hoc enim diccns veritate coactus fuam ipfe fententiam euertit:nam inquit, oculum lædi abalbo. \& à luce, contra vero à colore fubnigro, \& $c x-$ ruleo roborari, \& inde fieri, vt oculus fatigatus claudifoleat, tanquamad naturale remedum confugiens, vt ab illo circumftante tunica colore roboretui. Hoc quidem à Galeno veriffime dicitur: attamen nulla fieri roboratio poteft, fivifio per emuffionem radiorum, non pes: receptionem fiat; yt è contrario manifefta roboratio poteff, fi per. receptionem fieri ftatua-. Alb: ma: tur: albi namque magnaeft actio in oculum, gna est a ideo exercetur maxime, \& fatigatur oculus inctio in o- fpectionealbi ; contra vero nigri vel nulla, vel owlum. parua eft actio, quianigrum tanquam priuatio albi eft; ita yt nigrun videre fit nihil videre, vtaperte ait Arift.in 3.Meteor. cap. de.1ride: quod. finigrum in luminevidemus, id fit; quia illi ad. iefum lumen remittitillā nigredinem, \& conftituitquëdam medium colorem motiuum vi.. fus pofitiuc: colores 1taque ad nigredinem vergentes parum agunt in vifum, \& paruad excrce-
A turvifus in eorum vifione: itaquefireceptione colorum fit vifio, in promptu eit ratio cur vifus à colore vuex roboreturjat fi emiftione fit, nulla effe ratio poteft : nā fi ip f fpurituum fubftantia emittitur, colorille non cohibet fpititus ne egrediantur; fimiliter filumen folumenutti dicatur, non prohibet color vuex ne per foramen emittatur lumen; imo neque per huius modi e. miffionêluminis debilitari oculus poteft, guan. doquidem ian diximus eam proprie eniffio. B. nem non effe, fed productionem luminis in extremo perfpicuo; lucidum autem in. lucendo, \&illuminandoalia non íatigatur: quare fi ita fit vifio, neque vlla egebat o :ulus roboratione, neque fi indigeret, à colore vuez vllum recipere fui laboris remedium, aut roborari poffet. Alias quoque oculi partes confiderarepoffemus, \& ex iis quoque fententiam Artfot. conirmare; huic enim, omnes atteitancur, \& fuffragantur: fed pracipuas confiderare latis fit, reliquas iu. diciolis viris, \& libero animo philoiophantibus. confiderandas relinquimus.

\section{Confutatio Sententid Guleni de oculo, quod. fit igneus. Cap. Y. I.}

$\mathrm{E}$ $\mathrm{X}$ his que hactenus dich funt, colligere poltumusalium Gajer errere, qum confiderare,ac demonitra:e,anitro mfle dro alieArg: mumnonerit, fed poritisadipfim non arum ni.

D conferret;ing it enis Galenus oculum noneffeaqueum, vt Aritotci placuit, fedigneum, vt ex esus luciditate conijcipotct. Attamen huic: fententra difecrio sculi, \& Senfusipfe refragatur.; nam, vt Ariftoteles notat wn. cap. lib. de. fenfu \& fenilibus, fecto oculo apparet totam. cius fubftantiam aqueam efie, \& idnegare pro-. teruiadmodum, homnis eft:argumentum au- Solwt tem ab oculi luciditate fumptun nullam habet. efficacitatem; nia quomodo lucidus oculus fit . $_{3}$ E iam diximus;noneft enim lucidus luccpropria. qua in tenebrisilluminet aerem, \& per,fe vifibilis fit, fed limine aliunde recepto, quemadmodum etiam vitrum, \& cryftallus; talem ergo habetluciditatem, qux aqueū potıus effecculum denotet, quam igneum, nä filluceret luciditate ignea,lu ceret in tenebris, quod non de omnibus oculis verum eft. Alio quoq; nititurfundamento Galenus ad hoc comprobandum, nam plenus oculus eft fpiritu animali a d eum transmif- ment. F foà cerebroperneruum opticum, de cuius fpiritus emiffione paulo ante difputauimus : quoniam igitur fpiritus animalisigneus eft, \& Plato. quoq; in.Timxo eum vocat ignem, ideo rationépirituum oculus dicēdus eftignens. Sed hoc: quoq; leuffimum argumentum êt. Primü quidem, quia nos non inficiamur fpiritum anima-. lem ì crrebro ad oculos fluere, fed non ob id fit 
vtoculusfitigneus, etiamfi igneum effefpiritum A de, quifons \& radix caloris eft; \& nullibifirgiconcederemus; etenim huiufnodi appellatio fininitur ab excefiu, cxcedit autem humor aqueus, non fpuritus, ve per fegmanifeftum eft, ictque optime declaraturab Ariftorel, in libr. 2. de Partibus Animalium, cap.4.vbi dicit lubltantiam oculi efle frigidam \& humıdam, \& efle hamoris cerebri partem putifinam, qux fectrnisur, \& ad oculum nitrirur: q̨uenadmodum ıgitur etiam incerebro infunt fprtus tum in aricriis, tum in ipfifmet cerebri ventrirulis, neque per hoc ftat, quin ab omnbus cirbrum membrortum omnium frigidufinum, \& humidifimum effe dicatur; ita in oculo infunt fpiritus animales, ipfa tamen oculi fubitantia aquea eft. Sed preterea etrami fpiritus animalis in oculo excederet humorem aquum, non ob id oculus effet igneus appellandus, quia fpiritum animalen vocare igneum vaniffinum eft, vt facile eft vel ex ipfufnet Gal.difts demonutrare; fpiritum enim animalem putat Galenus in cerebro generari, vitalem vero in corde, \& hunc perarterias ad cerebrum deferri, \& ibià tacultate cerebriin animalem conuerti: fpirtus autem vitalis, fi bene confideremus, calidus eft \& humidus, proinde aereus, non igneus, vitales enim hx dir qualitates funt, calor, \& humiditas : quod etiam ex eo patet, quia generatur ex ranguine tenui, \& purificato in corde, fanguis autem tenuis non potef verti nufi in vaporem aercum, quia eft fpiritus vitalis : preterea fpiritus vitalis non eff fumme calidus, ergo non eft ignetrs, non eft emm ignis, nifi fit fumme calıcius; afrumptum manifestum eft, quia calorigneus deftructiuus potius vitx eft, quam conferuatiuus, vt ait Ariftoreles in libro fecundo de ortu animalium, cap.3. praterea fi calor fpitituum fimmus effet, nonpoffet intendi \& augeri ; augetur tamen, quoniam accenduntur fpiritus in tebri, \& fiunt calidi fupra modum naturilem ; per fe igitur funt mediocricer calidi, qua eft aeris natura; quocirca \& ex graducaloris, \& ex humiditate vitales fpiritus non igneos, fed aereos effemanifeftumeft: minusigitur fpiritus animales porfunt ignei appellari, hi namque ex vitalibus generantur in cerebro per refrigerationem; quia neceffe eft, vt in loco trigidinimo, atque humidiffirno, quale cerebrum eft, obtundatur vitaliū fpirituum calor, \& itâ ex vitalibus iuxta Galeni fententiam animales generentur: fi ergo in corde loco calidilimo fpiritus non funtignei, fed aerei, multo minus in cerebro dicédi funt ignei, vi multo minus habent caloris quamin corde, imo potius dicendum videtur, eosad aqua naturam accedere, \& efleinftar vaporis, qui eit medium quiddam inter aerem, \& aquam; vel faicem efleacrios compactiores, \& minus calidos, nullibs enim funt calidiores, quam in cosdiores, qum in cerebro, fic enim ad cognitionnem , \& aul contemplationemaptiores funt, ficutalio in loco oftendimus. Sed ipfemet Gialenus in unito iibri decimi de vfil partium veritate coafus confitetur pupillam effe plenain fpiritu areco, ac fplendido; quum ergo acreum elli:affirnet, non etk ocuius a firi uigneusappellandus, neque poteft ex eo fpiri uitalucere, vt rlluminct alıa, quonian aer noulucet luce B propria, quemadmodum necaqua, fed folum aliena per fuam perfipicuitatem recepta. Si vero Galen. dicat fpritum vitalem nercum efle, fed mutariin animalem igneum, hoc manifefterepugnat rationi, quonım hæc mutatio fit ince. reb:o, quod quun firigidifimum fit, non poteft vertere aerem in ignem: imo etranfi fpiritum vitalem in corde propter magnum calerem vellemus igneum appellare, cogeremurtanenanimalem vocarcaereum, quum in eofitpluriC mum remiflus, atque imminutus calor. Qund veroaliqui adducunt verba A riftotel. in poitremo problemate particula $3 \mathrm{I}$. dicentis oculim effe igneum, id parui momenti eft: nam con effe igneum, id parui momenti eft: nam con prob.parfiat Ariftotel. in problematibus populariter lo- tic. 31. qui, \& frpe aliorum opiniones fequi, prefertim quando ad id de quo loquitur, nullum momen- Solutı. tum afferunt; quam eandem ob caufam etian in 3. Meteorolog. loquens de iride $y$ fus eft opinione platonica de vifione, vt mox in argumenD torum folutione confiderabimus : quoniam igitur in illo problemate quarit, cur non ita difierant oculi intel fe, vt manus inter fe diferrecernuntur, refpondet id contingere, propterea citod manus eft corpus miftum, ideft, heterogeneum, oculus vero non eft miftus, id eis, non heterogeneus, fed fimplex, id eft, homogeneus, fiquidem igneus eft, hoc autem idem dixifiet ftatuendo oculum aqueum, ideo non curauit Ariftorel. ipfum aqueum potius, quam igneum E appeliare, dum ado fimplex, hoc eft, homogenets elle tratueretur; nonet autem credibile Arifotel qui in lib. de fenfu, \& fenfilibus, cap.z. opinionem Platonis oculum igneum efle aflerentis efficaciter improbauit, ibi ex animifententia cótrariumaffrmare dicéclo efre igneum: ideo perfãpe debilia effe folent argumenta, qux ex Ariftotel. verbisin aliis locis extra propriam dealiqua re trabtationem fumi folent;ipreenim extra proprium locum de re ali qua loquens, $v$ titur frequenter opinionibus aliorum tanqua m manifeftioribus, nepropria opinione vtens dubiam redderet propofitz rei declarationem; fed id tamen nunquam facit, nifi quando ad id, quod ibi propofuit, declarandum, nihil referit, an propria, an aliena fententia de aliquare vtatur. $\mathrm{FF}, 3$ Non-

$$
\text { FF, } 3 \text { Non }
$$

Obiectio exblt. 
Nonnulionum conciliatio Platoris, coralc- A

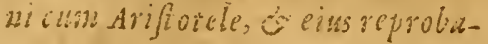
tio. Cup.VII.

C Olingere cx his poffumus quorundam recentionun errorem, qui putarunt fe Ariftotel.cum Phatone \& Galcno, tum de oculi tempeConcilis- ric, tum de vifione optime conciliaffe: primum tio de scrió. quidem de oculo per:hanc diftinetionem : oculus duobusmo dis confiderari potefts yno modo fumi poteft pro illo corpore, quodperanatomen fenfu confpicitur, fic autem a queus eft, patet enim sry fallinum hunorem efle aquenin; fecundomodo pro calido innato, quo ve inftrument o cryftallinus vticur, nempe profpirituasimali illuc rniffo à cerebro, \& hac ratıone ocuConfuta- lus entigneus, ideo Ariftot. vtrumque refpiciens tio. varic Joquutus eft. Sed vana eft hac confideratio, quoniam Ariftot. in lib. de fenfu, \& fenfilibus oculum fumit animatum, atque perfectum, fiquidem anima deftitutum negat efre oculum appellandum, fedillum folum, qui facultatem videndi habent; hic autem non eft fine fpiritibus, \& calore innato, eunt tamen Ariftot. negat effe igneum tam ibi, tum in libr. s. de ortü animalium, cap.s.\&aperte afferit efeaqueum, fciliset ratione exceffus, quia aliqquam ignis quooque porticriem in cryftallino effe quis negare poteft, fis eryltallinus eft corpus miftum, \& perfectum miftum?num eftergocredendum Ariftot alibi ex propria fententia loquentem appellare oculim igneum : adde quod de omnbuscorporis. partibus boc dicere poifemus", vt carnem effe terream ratione terræ puraalentis, qualem eam effe fenruiudicamus, fed effe igneam ratione caloris innati, quumergo hoc abfurdum fit, vanü eft à fipiritibus appellare, fet iudicare alicuius Concilia membri temperaturam. Quod vero ad vifionem trode bi- attinet, dicunt eam poffe dwobus modis confifroze. distari,vno modo prout eft vifio ab folute; altero modo vt cum alia vifione comparatur, \& melior effe dicitur, quam illa : priore igitur modo dicüt fatis poffe vifionem fieri per folam colorum receptionem in oculo ; qquia q̨uım aer externus recipiat fua perfpicuitate fpecies.colorum, fieri non poteft quin oculus vt perfpicuus casdera fpecies recipiat, \& receptasiudicet, \& ita videat; vit igitur frat abfolute v1fio, non eft opus erniffione radiorum, fed fufficit colorum receptio in oculoà contiguo aereilluminato: \& hoc refpicit A11ftotel. quando improbat Platonis fentenzianı de extraniffione, loquitur enim tunc abfolute de vificne, non de meliore vilione; \& hos idem à Galeno \&s i Platone conceffum fuife ar. ferunt.Si vero confideremus, quomodo fiat melior vifio, melior certe fit pet extramifionem, son quidem firituum, id enim imporibile efle
A confitentur, fed radiorum, \& luminis, quodeft accidens; emittuntur entm ab oculo radij; ficut etiam à fole, non quidem ad pem vsque viram, qquod etiam Galenus notauit, fèd ad çircumftātem aerem illuminatum, in quo iam receptus eft rei vidend $x$ color : quare lumen cum color e in. acre exiftens obuiam fit lunini cmufo ab octslo, \&- timul commiftum verumquelumentemeat cum colore ad oculum, \& in eo recipitu, ac iudicatur,eaque optima vifio eft, nee fit extra B oculan, fed in oculo : \& hanc dicunt non modo 1'latonis \& Galeni fententiam fuife, , fed enam Ariftot.cuius verba citant in particul.3r. problematun variis in locis, vbi concedit extramiffionem, quia de meliore vifione loquitur, \& in quinto de ortuanımalium, cap. I. vbı dicit, corneam oportuiffe non clle nigram, quia debet effe translucida, nigrum enim non translucet, quire eciam laterne, fi ex nigra cute conficiantus, non transhucent: vult igitur Ariftotel. ita extramitrilumenaboculis, vt ex laterna lumen foras emittitur, comparat enim oculum cum laterna. Sed hanciententiam veritati repugnantifímam $\in$ flé, fatis patet ex præcedéte noftra aduerfus Galenun difputatione : ram enim.oftendrmus, nec ipfam fpiritum fubftantian poffe extramit ti, qquod ifti quoq; concedunt, nec lumen tanquam accidens, quodidem ex oculo ad externum aerem egrediatur, proptercá quod accidens non nigrat de fubiectoin fubiectum, fed generatur inperfpicuo lumen à corpore lucido: quapropter omnia, qua ab his dicuntur de egref. ful luminis ab oculo, \& de eirsdem regreflu ad oculum, vanıffima funt, quoniā einsmodi motus lumini attribui nulla ratione potert. Vana igitur effilla, qua vtuntur, duplicis vifionis diftuntio; fiquidem nihil reuera ab oculo emıttitur, dum lumen emitti ftatuimus, quoniam illu. minare non cft enitterealiquid, vt antea oftenfum eft. Sed praterea reprobatur eorum fenten.

E tiaper dictum illud Ariftat.2. Topicormun,cap.4. vt fimplıciteradfimpliciter, ita magis ad magis: nam fi vifio fimpliciter in receptione confintit, \& receptio efiratio, qua fimpliciter vifio fit; oportet nelioren vilionem in mcliori receptione confiftere, nonin extramifione: ino Topica laxc regula in prafentia euadit demonftratiua; nam fi ratio vifionis abrolite confiderata. non in emifione confitit, fed in receptione, iameffentialis efl vifioni receptio ipecrei, accidétalis vero extraniffio luminis, quum line hac fieri vifio poffit, non fine receptione; ex eodem. igitur fonte liaurienda eff comparatio vifionis cunvifione, quavia melio: dicatur, \& altera deterior, ex quo abfoluce fumitur ipfa vifionis liarura; itaque melior vifio in meliorireceptione conftituenda eft, fiablolnte fumpta vifio in 
fio in receptione confiftit: \& huic fententix at- A teftatur experientia, nam fenes deterius vident, quam iuuenes, non propter animæ imbecillitatem, fed propter impuritatem organi : nam, vt in jutit Ariftoteles in particula 65. primilibride Anima, facultas animæ iudicatiua, \& anima ipfa per fenium non debilitatur, fed folum orgauum corporeum; 11am oculus in fene factus eft terreftris, ac minus perfpicuus, proinde minus aptus ad lumen, \& ad colores recipiendos; oflicium enim organi eft recipere, \& officium animzeft 1 udicare, ideo inquit ibi Ariftoteles, fi fenex acciperet oculum suuenis, ita vidcret, vt iutenis: in fenibus igitur $\&$ in imenibus patet meliorem, ac deteriorem vifionem in nulloalio confiftere, quam in meliore, ac deteriore luminis receptione. Ip fa igitur fecundum fe horum fententia ablurda eft: fed adhuc abfurdius eft eam Ariftot.attribuere, qui vbique fententiam hāe de excramiftione refellit, \& ab ea abhorret, multo autem magis abhorreret ab hoc difcri- $C$ mine vifionis, \& nelioris vifionis, quum fit rationi repugnantiffimum: quod autem in problematibus vtatur fententia Platonis de radiorum extramilfione, hoc nihil eft; eadem enim vtitur etiam in tertio Meteorologicor. in tractatione de iride, fed de hoc poftea in folutione argumentorum dicemus: quando autem ibi nominat meliorem vifionem, certum eft eum non ita loqui; quia comparat extramiffionem cum rcceptione abfque eniffione, nam ridiculum eft hoc dicere; fed vnum \& enndem vifionis modum confiderat, qui varietur fecundum magis, \& minus, idque ibi ita manifeftum eft, vt de hoc difputare vanum fit. Quod vero dicunt de comparatione cum laterna, quæ habetur in primo capite libri quinti de ortu animalium, id nullius roboris eft, quoniam Arift. ibi comparat oculum cum larerna ratione folius tranfparentix cornex, fed non ratione modis per corneam enim tranfire lumen oportet, ficuti per lat ernam, non tamen eodem modo, quia per corneam träft ingrediendo, per laternam cero egrediendo; quare non eft in omnibus accipienda illa fimilicudo, \& res per fe manifefta elt.

\section{Solutioargumentorum Galeni.}

\section{Cap. VIII.}

$\mathrm{T}$ Andem fuper eft vt ad argumenta à Galenoadducta refpondeamus: quorum primum, quod Galenus, \& Medici tanti faciunt, à magnitudinis vifione acceptum, nullius penitus momenti eft? poflumus enim primo illud hunc in modum retorquere : in phantafia, qua paruof fatioin capite honinis concluditur, recipitur mont is magnitudo inaginamur enim magnitudinem montis quanta reuera eft, qui ergo fieripoteft, $v t$ magna montis moles in pur-
A uohominiscapitecontineatur? vel, $f_{1}$ in plaítafia hoc non inpoffibile efle Galcnus iudicat, cur in oculo impothibile efle indicat? Dicimus igitur, fi oculos recipere iplammet mont is maguitudinem materialem diceretur, vti q: per forancn tam parum quantum pupillaceft, cain iigrediminme pofficd quxm non ipfarealis magnitudo, fed cius imago, \& fpecies, qux (piritalis ct, recipiatur, id fine vlla abfirditatc hicri; nam inagomaguitudinis eft quidem maB gnitudo, \& quanta perreprefentationem, gisua magnitudinem reprafentat, ipfatamen fecu 1dum feformaliter accepta non eft quanta, fed eft indiujlibilis, \& recipitur induifibiliter, ne?; perhoc ftat quis per eam cognof aturr rei ma-
guitudo modoampla, modo anguta, pro obguitudo modo ampla, modo angutta, pro ob-
tufitate, velacumine anguli viinalis inoculo, ficut antea diximus: hoc fignificauit Ariftoteles ipfe in contextu 1z. librifecundi de Anima, quando dixit omnes fenfis eflereceptiuos fpecierú fine materia, nam quantitas naturam primæ materiæ infequitur, vt al ias in lib. de materia often dimus, ideo extramaterian nil potert efle quantum:fpecies igitur quantitatis fine fua materia nō eft quantitas, licet quātiatıs repræxfentatiua fit, fed eft indiuifibilis, \& tum in oculo, tum in medioindiuifbiliter recepta, quiain quolibet puncto mediitcrminatur angulus coni, quo magnitudo illa videri poteft: confrmatur hoc ex confideratione colorum, nam per $D$ eunden aerm medium fimul eaien momento tranfe unt cótrariı color s, qui tamen in ipfo acre non commilcentur, neque vnus altertim vitiai, quialune fpiritales, \& funt materia; nam polunt in eodem aere duo homines effe, quorum vnus videat rem aliquam nigram, alter veroaliam rem alban, ita vt per eudem acrem fimul tranceant dur illa fpecies, abique vila fua lafione, vel commiltiones quare aryumentum leuifimüeft, vt patet exconfidentione phan-

E tafmaium in inagmatiua, quemadmodú nodo diccbannuss; eadem enim virobiqueratio eft; velenim fimiliter in oculo' fpecis quantitatis montis recipi poteft, vt in hantafia recipitur, vel, fi in oculorecipi non poteft, fimiliter dicendum eft non pofe tccipi in phantafia Secudum Galeni argunentum erat, quiomodo poteft eadem numero magnitudo eodem temporis momento ad oculos diuterforum tranfire, \& finul in iis onnibus recipi? hoc quoque contertce contra ipfum pofumus hoćniodo: quomodo poteit eadem numeromagnitudo recipifimul in phantafia diuerforum honinun? ricipitur tamen, quia multieodem temi poris momento eandem rei magnirudinem imaginantur, \& eadé eftrano vtrobique; nam fi in lenfuid tierinó poteft, is plantafia quoqque no notelt fieriant fi in plantalia poteft, vanum eft negare id in fen-

\section{specres}

Ciratalis non est quandis formaliter, fed Glismrepix $\operatorname{con}$ torizue. -.

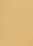


fu fici poffe. Dicimus isgitur magntudiacm res matcriatem, neque ad multorum hominum, neque ad vllius alicuius oculos poffe tranfire, quoniam ascidens idem numero non migrat de fubiecto in fubiectum; fed multiplicare tamen fociem fuam, atọue ad totum circumitans perfpicum diffundere poteft, ita vt recipiatureodem momento in oculis mulrorum hominum; itaque de obiedto materiali totum Galeni argumentum concedimus,ac: deobiefti fecic fprritali nullius momenti eft, quia hon eff aburdum id, quod Galenus abfurdum elle arbittratur; quod oftendo per ea, quæ ab ipfomet Galeno dicuntur: concedic ipte prerervifumalios fenfus per receptionem operari, zonucigitulidem numero fonus reciprtur fmul is arribus plurinoum hominum? cur ergo non \& idem numero color, \& cadem numero magnitudo poteft eodem mométo recipin eculis diuerform? etenim non ipra materialis magnitudo, neque materialis color ad oculos tranfit, fed fpecies fpiritalis, qua vildique diffufaperaerem adeft in quolibet aeris punco, \& inquolibet æque vifibilis ef: patet igitur nil eflevanius his Galeni argumentis. Tertium eius argumentum fumebatur à vifione magnitudinis, \&figura in fpeculo;resenim qux xctro, vel trans parietem funt, vidcre reetâ non potiumus, in obiato tamen fpeculorefractas videmus; fed colorem quidem in speculo frangi, ad oculosrefleatidicere poffumus at figurā, os magnitudinem refrangi in fpeculone imaginari gutuempofumus; confiftitenin figura in quadam partum harmonia, quam peralem refrationem tolli, ac deftui necefle eft quomodoigiturpoteftintegravideri, fin fpeculo fraêt ad oculos reflectirur? ego vero hoc magis dubitoiuxta Galeni fententiam, quam fecundum: Ariftotelis opinionem; quomodo enim radi ab o:ulo exeuntes frangi in fpeculo pofunt, \& refectiad rem videndam, quz twans parietem eft pofita? curenim non in quolibet alio corpore, quod nou fit fpeculum, franguntur fumiliter radivifuales, \& ad rem videndam refle ctuntur? aporteret etiam fecundum hanc opinionem rem illam viders vt in eo loco exiftentem, inquo teuera eft, non vrinfpeculo; nam fi vifus à fpeculo refratus ad eam vique porrigitur, ita deberet in loco fuo wideri, vt in eo effeci ederecur; \& bui us apparentrarnila afferri ratio potef, cur ces.videatu; in fpeculo effe, non vbi reuera eftat fecuncuronpinionem Arifotelis facile eft huius rationem afignare, dicimus enim fpeciem reivifibilis ad fpeculum vfque protendi, $\hat{\alpha}$ in cofrangi, ideoque videri effe in fpccuin: dum enimafierimus, obiectum ad vifun deferri, res clara cit, \& omnidubio caret; fed dim dicimus Eera vifibilem in lo so fuo ismotam manceso \&
A vifum adillam progredi, infolubili difficultate nos vrgerinecefre ett. Solutio igitur argumenai huius ex eodcm fonte fumenda eft, ex quo alix quoque accepta funt; frangi enim ip fa quiden. materialis figua non poteit, quin partium co:zcinnicas, in qua confiftit, deftruatur, fed eius. fpecies, qux fpiritalis, \& indiuidua eft, refrangi fine figurx deftructione poteft; imago enima qua figuram, \& qua magnitudinem repraferttat, in lpeculim terfum incidens reflectitur ad.

B oculum, \& ei figuram ac magnitudinem illius rei reprafentat: euenit tamen, vt propter obiecti à fpeculo diftantian maiorem, vel minorem nö eadem eiufdem rei magnitudo iudicetur, quia quando-remotior eft, per acutiorem angulum infpicitue, quando autem propinquior, per ob. cuforem; \& huius quoque valictatisuullum afferremionem Galenus poteft : elenit etiam vt propterfuperficiem fpeculi inzqualem quantiC tas vel maior,vel minor appareat: \& figura etian: vitiata, \& deturpata reprafentetur, ideoque cum de magnizudine, tum de figura prauum iudicium à vifu frat; non eftenim inconueniens, fo dicamus, fenfum quandoquein rebus iudicano dis decipi ob aliquam perturbationem medii, ir: quo fpecies viticrur, prafertim vero in iudicandis fenfilibus communibus; in his enim magis euenire poteft, vt fenfus decipiatur. quam in iudicandis propris : ob id non decipimur in iudicando colore in fpeculo, decipimuramen in D iudicanda magnitudine, vel figura ob paruam fpeculiconfticutionem, qua eft viriatio qua. dam, feu deturpatio medii : \& hoc quoque ma. nifefte refragatur opimioni Galeni ; nam fecundum ean deberemusvidére, ac iudicate \&. magnitudinem, \& figuram vti reuera eft, non deturpatam, feu vitiatam, proinde nunquam. decipi; nam fi radii vifuales in fpeculum incidentesad rem videndam reflectuntur, eam attingere deberent vt renera eft. $\mathbb{A} d$ poitremum E Galeui argumentum fumpurm ex Ariftotelis teftimono in tertio Meteorologicorum dico Galenum abuticonfelione Ariforeis, quoniam Ariftoteles confreuit vti aliorum opinionibus, de aliqua re ad aliud aliquid declaran. dum, quando fint vulgariores, \& notiores, \&e adid declarandam nihil.refert hac vel illa opinione vri, prafirtm vero quundo de illa re nondumaliquid docuit fictindum propriam opinionem, vt in fecuncio Putteriom AnalytiF corum docerevolensen, qua ad dimontrationempertinent, vitur falfis aliorum opmionibus de rebus naturalibus, quas exempli gratia adducit: inquit enim cauram cullumen tranfeat perlaternm, effe, quia vitrum illud, vel cortu literna eff perforatum, \& ita per poros ampliores lunen, quod icnuius eit, pertranfir:;

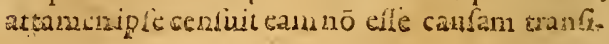


rus luminis, neque illa corpora effe perfornta, $A$

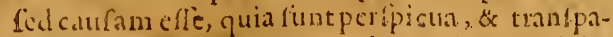
reutia: at quia vtroque modo caufa materialis addicitur, \& nullum momentum ad declarandam demonftrationem facit hac potius cpirione vti, quam illa, qua aliorum l'hy lofophorum fuit, \& illa etiam vulgatior erat; fatis habuit Ariftot. exempli grata vti opinioni aliorum : fic etiam in codem. libro accipitexempli gratia towitru effe fonum factum ab extinctione ignis, quoniam ibinihil relert hanc potius, quam aliam veriorem caufan adducere, qum ille non fit idoneus locus, in quo id declanctur. In tertio igitur hbro Meteorologicormm Ariftoreles modum, qio vilio fit, nondum declarauerat; ideo ad iridem, \& alia declaranda vi maliuit opinione Platonis de vifione, qux vulgatior erat, \& quan fequi vulgares etian hommes vidertur, quan opinione pespria, liest reriore, propterea quod ad illa, qua ibr tra fantur, decla. randa, nithil referebat boc potius modo, quam illo ficri vilionem dicere: non eft ergo verum id, quod. Galenus ait, A riftotelem vin alionum featentia de vifione, quod eam $\bar{v}$ eriorem effe cognouerit; fed quia vidic cam effe propria fua opinione vulgatiorem. \& quia vtro modo dicamus, nihul reicrebat adiridem deslarandan; fed. hoc ipfemet Arift. clare in ea parte nos admonet, fubiungit.n. nihilinterefle, an emiffione, an receptione vifionem fieri dicamus; hoc enim non variat eam doefrinam, qua ibi de itide traditur; ideofi co in loco Auerrocm legamus, videbimus cú illa omnia declarare iuxta Ariftotelis fententiam de vifione, non iuxta opinio nem Platonis, licet A riltoteles hac vt euidentioifice-re vri maluerit. Sed.aliud preterea artificiam ibi Ari.in Arifotete notare poffumus, quod Galenus non animaduerterit, \& quóiplein libris vti nefciuit : nam fiin iride declaranda vfus effet propria fua fententia de vifione, dicere aliquis potuiffer infirmam eam doctrinam effe, vt quæinfrmis fundamentis nitatur, nimiúm opinione
A Ariftotelis de vifione, proindenonfimiliter vera fore ea qux 1 bi de iride dicuntur, fi aliorum de vifione fententian fequamur; fic igitur ne. gatovificnis modo, qui ab A riftotcle ponitur, omnia illa, qua ibidciride, ac dealiis dicumtur, in dubiumeflentreuocata: Arstoncles igitur cum artificio volust ad iridem declurandam voi aliorum fententia de vifions, nec diffieultatemaliquam in iride, aliifque rebus; qqu ibitradantur, poneret: fed voluit eriam nos adB monere,vtcunque vifio tiendicatur, nihil referre ad iridem declaraidam, quia verunque dica-. tur fieri, eadem de iride fententia immutati, atque illala manct. Idem notare apud A riftotelem polfumus in cap. 1. 1.b. si de Animalium ortul, vbi docet cur aliqui acute cernant, fed non procul, contra aliquiprocul, fed non acute; deinde fubiungit nhil leferrc an emiffione, an receptionefieri vifio dicatur, rnm vfus quidem. propria ofinione, fed norale fo fea volut idem effectam fecunduin Platonis fententiam de vifione, vt firmior ratio abipfo adducta videretur, qua fimiliter iuxta omnitum opinionem locum haberet. Admirar1autem in hoc debemusingenium Arnfoselss qui omnia locis fuis tradautt; \&.fi quid vinquam extra proprium locum con: fidelauit, fats habuit pingui Minerua ac leuiter illud tangere, neque voluit tractationes com: milcere, nequealienas; atque intempeftiuas alicubi inftituerc. Num auten Galenus hocartificio fuos libros fcripferit, dubium eft; nam prater alia multa, qua ab ea intempeftiue tractata notari poffent, hoc vnum volo in prefentiaconz fidcrare:citat ip fa perfapelibros à fe fcriptos de demonftratione, \& $\mathrm{ill}$ is fe de fenfibus diligen: tithone lo quutum efre afferit, ideoq: de illis, qux ad fenfus perinent, nos al cos libros remitit, quodlegere trequenter poílumusin 7. libro de placitis Hippocracis \& Platonis, $111 \mathrm{~m}$ autem in E Logica contieniens fit ex quifite de fenfibus agere, \& an tale alıquid fecerit vaquam Ariftoteles, aldis cotafiderandum relinguo.

\section{FIACO}




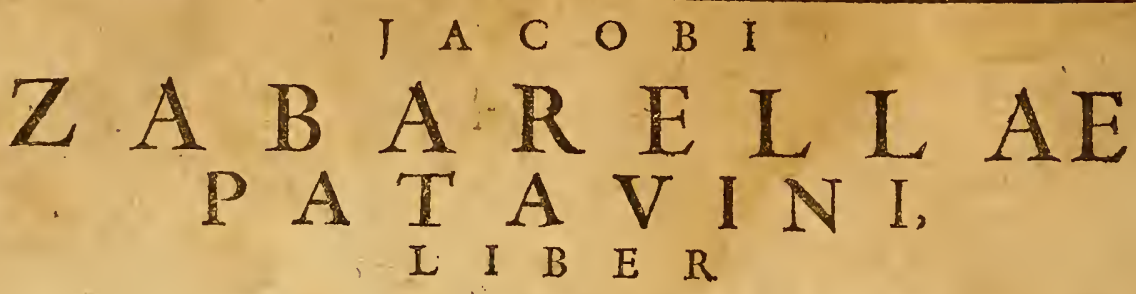

$D E \quad M E N T E$

Proamium. Cap. I.

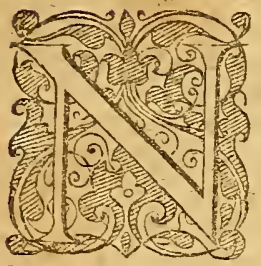

Vlla res eit, cuius notitiam illi, qui rerum fcientiam inquirunt, \& fapientes euadere cupiunt, magis indagare, atque en:xius perueftigare deberent quamilla animæ praitantiffima pars, qua homines fimus, \& quam folam hominem ipfum effe plures Pphilofophi exiftimarunt : cur enim non fatui potius, quam fapientis hominis effe fateaniur ad coeli \& elementorum, \& rerum a. liarum cognitionem adifpicendam omne ftudium conferre, feipfum autem ignorare? ego igitur ne huic crimnime obnoxium redderen, poftquam de rebus aliis naruralibus plura feripfi, de hac quoque fcribendum mibi effe indicaui, nequealio confilio, quam vt Ariftotelis hac de re fentētiam, fi fieri poffet, declararem; hunc enim vnū totius huius fufceptæ prouinciæ fcopì mihi propofitum effe aliấs protefatus fum, vt quum in hac latauina Academia Ariftotelis publice interpretandi officio fungar, non folum voce, fed etiam feriptis operam hanc praftando magis poffem obfcura Ariftotelis fenfa auditotibus meis plana, ac manifefta reddere. Hic autem, quam propofumus de anima humana difputatio, cum ipfa per fe dignifima eft, in quam fumma cum diligentia incumbamus, fiquidem res noftra agitur, quum ad nos ipfos coennofcendos hxc maxime emnium pertinere videatur; tum ob ipfins difficultatem; \& magnam, quz ex A riftorelis difts oritur, interpretum controuerfiam non omittenda; etenim Ariftoteles de mente liumano, quam \& animam rationalem; i intellectum poteftate, feu patientem appellauit, tum ex profeffo in tribus de anima libris, tum obiter in alis pluribus ita ant varic, ac dubie, aut faltem obfcure loquutus eft, vt ad diuerfas, imo etiam conttarias fententias à grauioribus quoq; intcrpretibus eius verba di1tracta fint; nec defierint. qui cum ancipitem frifle, a nihil certi has de fefriaifeafimare anfi fint. Illud vcro, quod potrfime condideran-
A dum in prafentiafufcepimus, eft humanæmentisnatura, \& quidiffalit: \& quia omnis anima principium eft animati corporis, \& ab A rif. in libris de Anima non alia ratione, quam vt principium confiderata eft, nomenautem principii notar refpectum ad illa, quorĩ eft principium; ideo ex hoc refpectu omnis animæ natura fitit ab Arift, declarara: Duorum antem principium eit anima, corporis animati tanquam forma, \& operationum tanquam effectrix; ob id in initio B 2.l.b. de Anima A Fiftot. vinituerfæomnis aninz naruram \& ellentian declarauit per refpęum, quem habet ad corpus, cuius cet anima; deirde in contex. 33. eiufdem lib. propofuit in tota fequente erus operis parte fingularum anim $x$ faculratum naturas ex operailonibus declarandas, \& poft diligentem \& vegetantis \& fentientis partis declarationem, quxin eo z. lib. habe. tur, fimplitin 3. lib. declarandù quid fit humaC na nens, refpectuoperationis tantum, non reffectu corporis; quid enon refpectu corporis fit, iam in mitio z. lib. de omni anima vniuerfe docuerat, neq; aliquid aliud de fingulis declarandum relinquebatur: ac refpecu operationum nihil vniuerfe de omni anima dici poterat, nifi valde rude \& imperfętum, quia non eodé modo omnes partes animr fuas ednnt operationes, fed hocin fingulis confiderandam erat, ideoque proponitur ab Ariftor. in illo contex. 33 . lib. 2. Nos igitur Ariftot. quem interpretari volumus, initat1, humanæ mentis naturam vtraq; raione declarabimus, vt tandem ex viroque refpectu perfectam eius definitione colliganus. Quaftio, an anima rationalis fit forma bominis, or quaftionis declaratio. Cap. II.

Lludigitur, quod primo loco confiderandü nobis proponitur, eft, an anima rationalss fit forma hominis, \& quia de hoc interuretes A. riftot. non confenferunt, ideo ve id, quod quxrimus, intelligatur, notä da eft diftinctio formæ, qua oés vtuntur. Forma dnplexeft: voa materiam infornans, \&-dans effe fpecificin, \& ré con-daplex ftruens tanquam difierentia adicena generi; de qua forma egit Alift. in lib. Phyf. aulcul. tanquam de terio principio.rernatural. \& eande in 2. $11 \mathrm{br}$. 
2.libr. vocauit naturam; cuiufcunque cuim rea natura dicitur ill. fola forma, qux unformat materiam habentem potcutian ad effe, \& 11 ftatuta fperie collocat. Altera eft forma, quxe non datcife, fedipfi reiiam conftituta, \& habenti efle lpecificum fuperuenit tanquam preftartius quaddam, \& dat folum operationem, ad quitm res illa poteftatem quidem habet maturalem, fed eam edere propris viribus fuis non poteft, ideo eget opealicuius nobitioris, quod eius nuturam, \& conditionem exeedat; ab co igitur non recipit effe, ied recipit operationem, nıfi dicamus, vt aliqui dicune, eapn recipere quoddam the nobilius, \& eminentius, quam fit proprium eius elfe fpecificum. Exemplis res. clarior fiet: nauis habet fuam formam, qua eft nau is, eaque eft figurailla ex lignorum co mpofitione prouteniens, quxe dicitur forma inlormans; per hane emm natus infpecie conttiuitur, \& line hac non effec mais : naui autem ita conititut $x$ fuperuenit 11auta, quinondutill vt fit nau is, iamenmeft, fed dar quoddameffe eminentius, \& aetun nauigand, qui nauisconditionem excedit, quia manis lecundum fenon haberni aptitudinem ad nanigationem, actum autem naugandià léplanon habet, fed à quodam liperueniente, \& nutusnaturam excedente, quı nauta eft:figura ig:tur nauis dicitur actus informans, matuta vero diciur actus alfitens, fed non materiam informans, nec dauseffe fpecificum ; aduenit enim naui iam habenti elle completum, \& datilli folam operatonem. Sic dicimus de fecuri, qua exempli gratia Aritzotel. quoque vfus eft; nam figurailla, \& acumeneft forma dansefie, \& materiam perficiens, \& conftituensfecurim, quafine illa non effer fecuris; homo vero vtens fecuridatilli folam operationem, \& eft tanquam actus afítens, ficuri nauta in naui. Tales funt etian coleites intelligentix refpectu orbium; orbis enim iam habet ex fe fuum effe completum, neque illud recipis ab intelligentia, illa igitur materiam illam noninformat, neque orbem in fpecie conftituit, fed folum datoperationem, quæ eft motus in orbem, adquein eft quidem corpusillud naturaliter propentum, fedipfum fe mouere non poteft; illa igitur dicitur forma affitiens tantum, quafi a th ansad regendum, necfolum dicitur feparabilis, fed feparata \& abiuncta abilla materia propterea quod non dat illi efle:quemadmodumnanta etram quando eft in nari, dicitur à. $F$ nau feparatus, quia eft extra jpfam nauis effentiam, quofit, vt poffit effe line naui, \& habeat etiam operationem propriani prater nauigationem, hoceft, operationem:noncum nauicommunicatam, nam \&in naui, \& exira nauim potelt multas edere operationes nihil ad num pertinentes: huius enim ratio manifera eft,pra-
A pterea quod nauta, \& nauis funt duo entia pertecta in tha fpecie, \& habentiaduos diftinctos aetus lpecificos, neque vnum recipit effe abaltero: : fic intelligentia, ấ orbis funt duo diftineta cntia perfecta, neque orbis recipit actum fpecificum abunelligentia, fedipfum habet ex fe, \&e intelligentia prater operationem mouendi or. bem habet etiam operationem propriam non communicatan cum orbe, neq; vllo modo ab eo pendentem, nam contemplaturfeipfam, \&e B inceffanter intelligit abfa; vilo or bis interuentu. Quoniam igirur anima ntonalis humaia eft forma quadam exiftens homini, quxrimus nunc, qualínam forma fit an informans miteriam habentem potentiam ad effe, confituens humanam fpeciem fub animali generetäquam differentia diuidens iprimgenus, ita vt homo peream fit homo, \&abfque illa ronfit homo: an porius fit folumafiftens, ita ve homo peraliquam a lam formam fit homo, \& ipfi iam con-

C ftituto, \& habenti fuum efle fpecificum fub animali genere, hec tanquam praltantior quædam torma fuperuenat, quanon det illi vt fit homo, fed folum vt fit quoddam eminentius homine, nempe det illi folam operationem 110 . bilem \& praftantem, qualis eft intellectio, adeo vtfitforma actu feparata, \& abiuncta à materia, illi aute $m$ affiftens ad regendum, ficut intelligentia coleftis âfiftit orbi : \& vt vno verbo dicam, quxitioeft, an anima rationalis fit forma

b hominis, vt figura nauis eft forma nauis, an po: tius fit in homine tanguam nauta in naui. Vtraque pars fefatores habuit grauifimos, ac fummæauthoritatis viros, inter quoseft de has reacerrima controuerfia. In hac igitur difputatione nos hunc ordinem feruabimus: primo loco $\%$. tramque contrariam opinonem reueremus, ac declarabimus; deindeargumenta præcipua, çuibus vtraquefects fententiam fuam comprobare folet,ac poreft, in mediim afferemus; poftea E vero veritatem declarare, ac manifeftam redderenitemur; \& pofmodum omna; qux veræ fentenrix aduerfari videbuntur, argumenta foluemus:vr his peractis ad talia, qupe ad, mentem humanam pertinent, confideranda tranieamus.

\section{Declaratio opinionis Auerrois, of aliorum dicentiun animan ratianalem non effe formam bominis. Cap.III.}

A Nimam rationalem non effe formam hominis, qua homo fit homo, fed effeformam afiftenten, ficuti orbicceleftiaffitit intelligentia; exiftimauit Aucroes,vilegere apud eum poffumus in Commentar. quinto libri terii de Anina, vbidicit nomen actus de animatationali, \& deali s partic us anina diciler- 
mexquiroce, quoniam de anima fentiente, \& de veguante figuificat formam informantem, de rationali vero fignificat non informantem, fed affitentem folum; \& ad huus fententia confirmationem adducit verba Ariftot. in contextu indecimo \& duodecimo libri fecund de Anima, qux poltea loco luo a nobis confiderabuttur : \& quia necefie eft omne corpus natumle haberc propriam formans, qua informando nateri.smipram in fpecieconitituat; homo autem eft corpusmaturale, \& fpecies animalis, ideoque oportet elle in homine aliquam huiufmodi formam informatem, quz det homini elle fpecificum fub genere animali, hanc in quit

Cogitati- Ancrocs efle cogitaciuam, ita ve per hanchoPis. mofit homo, non perintellectum, loquiturautem de hac Auerroesetiam in commentaris $\sigma$. 20, \&3 3.eiufdem 3.lib. \& in 63. Jibrifecundi, \& aperte dict cogitatiuam elfe formam hominis, qua eft homo, \& gencrationi \& interitui obnoxius: videtur autem in dietis locis eam diftin- $C$ gucre à phantafia : verum quia de hac animx tacul tate diftuneta à phantafia A riftotel. ne verbun quiden inlibris de anima facit, ideo multi Aueroiftavt Auerroem tucrentur, dixerunt, hanc Auerrois cogitatiuam efle reuera phanrafram, de qua loquuruseft Ariftoreles, fed Auerrorem nomine cogicariuze fignificare voluifie phantafiam humanam ditirctam à phantalia bruorum, \& illa multo pertediorem, qua fit supremus gladus ipfis facultatis imaginatiux, inmo \& iotils partis an:ma fenticntis, confttuens homineninfpecie fio animaligenere, 3 iplusi a crerisanimalibus diftingucn? Homisi igitur formaio ab hac perfecta maginatiua dicunt fuperuenire animam rationalem, quæ dat homin quoddan efle eminentius, \& fupergredicns humanam naturam, non quod ponat hominem in alia nota fpecie, fed qua infpecie humana dat ei nobilitatcon, qua eft fupra hominem, ad quam recipiendam habet humana natura aptitudinem naturalem; ideo fecundum Auerr.ımaginatiua in homine eft ficuti figura nauis in naui, qux conftruit nauim tanquă iorma materiam informans; anima vero rationalis eft ficutinauta, quifuperuenitnai ian conftitutx, \& dat hornini operationem preitanifirmam, qua eft costemplari, stintelligere, quemadmodum nauta naum regens datilli ačum nauigationis. Hxe certe Auerrois opinio fuit, \& miror quod Achllinus in tertio quoúlibeto, dubio quarto contrarian opinionem Aucros attibucrit, nempe quod putauerit animan ratomalem effetormam hominis, qua homo elt homo: arguncuta vero quibus ad hoc probandum vatur Achillinus, potms oltendunteam effreitertarem, \& abfolutei- credendun efe, quan hane tuifie Auerrois
A opinionem, vtea confiderantibus manifefum eft: quod autem dicat Achillinus Auerroem quandoque dicere rationalitarem efle hominus quidditatem, \& difficentiam conltituentem, quod quidem apud Auerroem legimus in commentaris v ndecumo \& duodecimo libri feptimi Metaphylicosum, hoc certe nihil cft, quonian Auerrores exempl gratia loquitur, \& eit apud Whilofophos vulgatifimum, vexcmpli gratia fumant anmal rationale tanquam $B$ honinis defimtionem, ita verationale fignifi. cet formm, \& differentiam diuidenten animal genus, \& conftituentem humanam fyeciem; exemplorum autem non eft exquirenda veritas, fed lolum rei propofitedeclaratio:posfunt tamen Auerroifte eriam veriatem huius exempl deiendere duobus modis: primo qui. dem dicendo Auerroem perrationale figmaricare cogitatiuam, tainquam difcurentem, \& ratiocinantem in pasticularbus, quain etram in contextu vigefimo libri tertii de Anima putat vocari ab Ariftotele intellectum paffium; quippe qux poteft appellari anima rationalis, \&intellectus, guatenus propinpua illi ett, $8:$ ei miniftrat, \& ext apia obedire animx rationali: altero autem modo dicendo Auerroem fignificalfe anmam rarionalem proprie fumptam, \& hanc disille effe hominis quidditatem, non quidem illam quidditatcm, qua homo in fpecre conftituitu, fed perquam adipifcitur præftantifiman quandam operationcm, \& quoddam elle eninentius, quod eit vltimumac fupreaum hominis complementum, ad quod aflequendum habet homo poteftatem naturalem, tanquam ad quoddam humana natura excellentius: hrec quidem confona efle doetrinæArrfotelis in ca. reptimo Metaphylicorum ego nunc non aifero, folum dico Auerroem, qui pradictam fententiam pertinaciter tutatus eit, alterum horum inciligere potuiffe : fententia E namque Autrois illa reuera eft, quam diximus, \& quancetari omnesilliattribuunt, Eandem opinionem Temiftius fequutus eft, it legere apud cum polfumus in contextu vigefimul1br.3. de Anima, putauit enim intelledum pationtem vium numero efle in tota humana fpecie, ficut eriam Autroes; ideo prater hune pofuit in homine aliam humanam aninama multuplicatam, perquam homo, fignilicans 1maginatiuam humanam, $\%$ hanc di..it habere poreniam recipiendi intellectum tanquam fupremam bominis perfictionem: quare non putauit Themiltius intellectu efle formam hominis, \& hoc itaclarum eft in memorato loco, vt mirandum fit, quomodo Themas in ofulculo 16. contrariam fententiam Themiltioaturibusrit, nempe quod dixerit intell ectum effe veram bominis formâ, gुue \แb genere animali huma- 
nam fpeciem conftituat. Videtur eriam liuins fententix !uifle foannes Grannancus; nam in fua Prafationen fecundum librum de Anima, \&.in declaratione I. contex, eiusdem libri aperte dicit animantationalem nōetre actun corporis fecundum fubstantian, fed folum fecundum operationem, cuitusmodi eftnauta in naui;alias veroanimas effe actus etiam fecundum fubftantiam : negat giruranimam rationalem effe forman in ormantcm, \& alferit effe folum afliftentem, \& dantem operationem, non dante. effe fubfantiale.Iden tamen Ioannes in primo contextu libru tertij de Anima inquit, animam rationalem dare ellc homini, \&: hominem conftituere:quare vil dicendum eft, ip fum fibimet aduerfari, velillud intellexiffe, quod ctian $\mathrm{A}$ ucrroifłx exiftumârunt, animain rationalem dare homini effe emmentius, quod fupra hominem eft, quemadmodum antea declaraumus.

\section{Aliorum contraria opinio, quod animara-. tionulis fit vera bominis forma. Cap. I V..}

A Lteramvero contrariam fententiam, quod A trima rationalis lis vera forma hominis, qua informando mareriam contriuat hominem in elf fpecifico fub animaligenere, tutati funt La ini icreomnesnec folum tanguam abfolutevoram lententiam, vtreucra oft, fidet- D iam vi Arítot orinionem, grod ipfiefficacicx. oftenderenixifunt, prefertim D..I hemas in 1. - par. Summe, quaft.7.6. \& in opufculo 1ó. it ibi. videre eft. Fuit etiam eius fencentra Aiexander, licet enim ip fe in al ıo à Latınorum icncentia, \&à veritatediffenferir, in hoctamen, de quo in prafentia loquimui, non diflenfit, ied exittimauitanimamrationalem efleformain hominis, quæ materiam.informet, \& fub animali genere humanam fpeciem:conftutuat.. Hanc eandem tribuit Ariftot. Olympio dorus in interpretatione Phædonis Platonis.. Plotinus quoque cenfuit hancfuifeopinionem Ariftot.nam. in.lib.r. Ennead. cap.4. \& s.eum reprenendit, quodin contex.s.libr.z. de Anima dixerit, animam effe ficut acumen. in fecuri, quod eit po-nereeam effe formam informanten ; \& fimiliter refert Ariftotelis verba in contex. 64. libri $i_{0}$ deAnima, quando dixit. operationes anim $x$. omnes effe coniuncti, non effe folius anim $x, \&$. perindeefre dicereanimam cogitare., vel inf ci, acdicere animam texere, vel redificare: in principio etiam 2: lib: 4 . Enneadis refert verba Arioftotelis in definitioneanim $x$, nequeadmittit a-

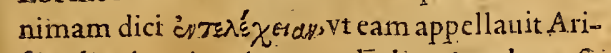
ftoteles, inquit enim non declarariper hoc efCentiam anime. Hancigitur Ariftotelis fenten:-
A tian finille Plotinuspradicta omnia Ariftot.dictar ecenfendo conftan er affirmat; fed quum Ariftot. in hocreprchendat, videtur contrariam opinionem lequs, quum præfertim in co t.lib.r. Enncadis, cap.4. dicat, anmmam rationalem effe forman fejaratam, \& in 2 . libro 4. Enncadis dicat aninam non recte ab Ariftotele appellari

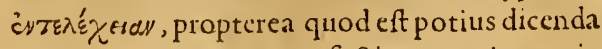
vtens corpore, quam perfectio corporis; quia dum dicitur perfectio corporis, dicitur in fepa-

B. rabilis a materia, dum autem dicitur.vtcns, dicitur domina, \& feparabilis. In tertio etiam libro 4, Enncadis inquit, animam non effe in corpore vtin loco, neque vt in vale, neque vt formaeft in materna,neque vt pars in to to, neque vt totum in partibus: igitur ncgare videtur animam effe formam corporis, imo \& rationë addit, diccus, ellet enım infeparabilis, \& ipfo corpore pofterior, propteren quod materix iam c prius exiftenti aduenit forma : fed dicendum potıus eft. (inquit) corpus effe in anima;anima. enim tanquam domina corpus complectirur: qua in re nos fenfirs decipit, corpus enim videmus, anmam non videmus, ob id credimus animanu effe in corporesat fi animam quoque videremus, corpusin anima effe cognof ceremus, \& animam compleeti, \& regere corpus, \& ip fo vt inftrumento vtr. Attamen hæc Plotinus non ideo dicit, quodneget hominem conftitui per animam rationalem, fed folum vt oftédat eam à materia non pendere; \& ab illa feparabilem effe:imo Platonici omnes non folum affirmant nos havere effe ab. animarationali, fed dicunr: nos effe animamipfami: quad certe non dicerent, nifi putarent eam effe formam: qua.homo eft homo : negârunt.igitur. eám. elfe fornam immerfam materiæ, \& ab ea infeparabiolem, non omnino negârunt effe formam hominis.. Ideo. Marfilius Ficinus in prinum librum Marf primx Enneadis Platini, cap. 2 inquit; fenten- liws Ficitiam Platonis effemediam inter Auerrois \& A - nus de lexandri opiniones : nam Alexanderputauit ef- opinione fe folum formam informantem, \& dantem ef- Platonis fe; Auerroes vero affiftentem folum, \& vten. tem corpore: at Plato virumque fimul afferuit, animaın \& perficere corpus, : \& ipfo à fe perfecto it : quomodo.autem dicant Platonicianimamperficerecorpus, legere poffumus apud. Plotinum in toto primo libro primx Ennea: dis, vbi etiam docet hominem efre animam iF pram. Illud tamen quod Marfilius de. Alexandro dicit, mihn videtur non omnino velum ef- error fe; fortaffe enim fententia Platonis dici poteft mediainterduas prediatas, atnon ea modo, quem Marfilius ponir: etenim Alexander non negaut: animam, rationalem regere corpus, \& ip fo vti : eft igituralia potius ratione media , quatenus fecundum Auerroem eff fe pa..- 
satà̀ corpore, nee dat cffe homini, fed ipfum A secit folum: fecundum Alexandrum veroregit quidem, fed nequic eft liparata à corpore, neque ferarabilis: at ficundum Platonem non ita eft abiun Eta a materia, vt non det the homini, fed eatenus eit abiuncta, quatenus continet, $8: 1 \mathrm{~m}$ perat, \& eft à corpore feparabilis : faicurur crgo Platonici informationem, nontamen eo mo- do, quem itatuit Alexanderifed eopotins modo quem D.Thomaspofitit, ipfi namque po- nunt in ormationem cum feparabilitate. l'atet Simpli- autem hoc, confiderantibus ea, qux à Simplicio ciuss. dicuntur, quiin ommibus 1'latonicortun fentenrias defendere nifus eft; ipfe enim non negat anman rationalem effe formam honinis, \& informate matcriam, vtapudeum legere in, multis locispoffunus, præe fertin in primo libro de Anima, contex. \$3.63.66. S6.87. 36 in 2.lib. Dugere contex'4. \& 10. Red videtur cum l'latonicis dira form cere duo elle genera formarum materiam inforrè mate-mantium : \& aliam ita dare effe materix, vt niram in- hil aliud fit, quamatus talis rei, pısinde infeforman- parabilem effe ab eo, cuius eft acus : alian vetius fecun -ro effe formam, cuius eflentia non in hoctandumpla--tum eft conftituta, vt fit actus alterius, fed ipfa varicos. quoque fecundum fe eft alıquid eo refpectuabfolutum, proinde poteft effe fine illo, cuius eft forna ; talem igitur effeputatitanimam rationalem humaram : ideo duas ei vires atrribuit, vnam informandi corpus, alteram vtendi corporeiam à.fe informato, etenimilli dominatur, 2. ab eo feparabilis eft:ideo Simplicius; \& Plasonici fententiam Auerrois non admittereut, quod homo confituaturin fpecie perimaginatiuam, feu per alian formam prater animam rationalem; fed clara eft eorm lententia, quod anima rationalis fola fit illa forma, per quam

Galenus. homo ef homo. Galenus qiuoque in hbro 11 o, quod mores animi fequantur temperaturam eorporis, hanc fententiam tuetur, quod anima rationalis firforma hominis, \& fere materiam informans: \& eanden inquit fequutumefleAn-

Astrori dronicum thodium, \& eam Ariftoteli attricass Rho- buit, idemg; exiftmatreait eundem Andronidizs. cum. Hrefunt aliorum fententix à me breuiter relatæ: fequitur ut argumenta, quxab y traque fecta affermutur, confiderenus.

\section{Argumenta pro opinione Auerrois, qued a- aima rationalis non fit forma bo- mirits. Cap.V.}

\footnotetext{
A Verroes, \& illi, qui eius fententiam fequuncu, eam mulus argumcentis, 11 sque primum poifine ex variis a pud Ariftotelem locis deargusmon fumptis comprobare nutuntur. Primuna argntwrm.
}

A Eto: cognito vniuerfalium fit cum abstractione à materia; ergo non conuenit nifi facultati à materia abiunetx : igitur anıma rationalis humana, quum cognoficat iniuerfalia, eft abiunta à materia, proinde non dat efre homini. Secundo fumunt alıqui argumettum ab intellestu agente:intellectus patiens eft vna \& eadem fubftantia cum intelleetu agente, at inrellectusa. gens confenfione omnitum eft forma abiuncta a materia , crgo ciufmodi eftetiam intellectus

$B$ patrens, qui elt anima noftrarationalis. Tertio conficerant verba Aritotelis in contex.92، libri primide Anima, vbidicit, ne tingı oquidē polre quan corporis partem occupet intellectus;vult igitur emm non ethe formam corporis, proinde elfe abiunctum à materia. Quarto adducūtzerba Ariftotelis in fecundo lib.de Anina, contex. ir.vbi aperte dicit aliquam animæ partem $n u l-$ lius effe corporis a tum, fignificans rationalem 2 . partem, \&ftatim fequentibus verbis inquit eam $m$

C. itaefle actum corporis, vt nauta cft actus nauis; afferit ergoeam non effe formom informätem fed affiftentem folum. Quint o perpend unt verba Arrftotelis in contex.21. eiufdem libri, vbi aitintellectum effe ahud animægenus, \& eum folum potfe feparari; nonvultigitur ipfum effe actum corporis, cuiuf no di funt alix partes animæ, fed à corpore feparatum. Sexto lumunt $\mathrm{Se}$ argumentum ex Ariftotele in 3. Irbr. de Anima, contex.4. \& 6 . vbidicit intellectum humanum effe immiftum, hoceft, non cómiftum cum materia, quase negateffe formam informantem. $m$. Septimo vtuntur teftimonio Ariftot. in so.libr. $\sigma$. de Moribus ${ }_{2}$ cap. 7 . vbi dicit, intellectum refpe- $S e$ ctu hominis effe quoddam diuinum; proinde arc hominem, quifecundum intellectum viuat, \& tu vitam contemplatiuam traducat, non quatenus $x O$. hominéita viuere, fed quatenus diunum quid- $c a$ dam in ipfo ęt: ideo hæc verba fubiungit [ non oportet ('it quidam monent) Gnumquem ${ }_{3}$, quum $\mathrm{E}$ fit bomo, humana, E quum fit mortalis, cogitare mortalea, jed quatenus licet, immortalem fe red. dere,omniaq efficere vt expraftatijsamo omniü. gua in eo funt. Grtam traducat] his igitur verbis figuificat Ariftoteles hominem non perintellectum efle hominem, fed inrellectum effe quoddam anima humana diuinius, quo homoadipifciturnon quiden efle fpecificum fub genere animali,neq; effe humanum, fed quoddam effe nobilitus humana natura. Ostauo F adducunt verba Ariftotelis in quarto libro de Partibus animalium, capite 10. qux fint liæc [ folns homo eredtas omnino est, guonzant eirs na-

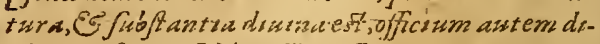
uins est fapcie, Es intelligere] non vocaret enim Ariforcles hominem diuinum, nufi nens hit 10. mana efiet forma diuina, \& leparata à mate- No na. Nono pergendunt ea, qux dicuntul $a b$. trifto- 
A riftotele in libr.12.Mctapluyfic.concext. sí. vbi A quum deprino intellectu docniffet, idem in ille effe intelligrens, \& intellectum, \& intellectionein, quiseltionen fubiungit an ille intelletus ficcompolitorum, hoc eft untelligat compolita : quia fi ellet cốpofitorum, requi sideretur iprum intelligere ordinatım partes cuiusque compo: fiti, \& modo vnā, modo aliam: fic ıgitur in cius inteflctione effetaliqua mutatio, dum tranfiret'ab vna partead aliam intelligendam. Soluit Ariftoteles, dicens primum intellectun cfle a materia abiunctum, proind e indiuifibilem, quia omne abiunatum àmateria ef indiuibibile; idcoque cus intelleationem indiuifibilem efe, \& totam limul, non partem poft partem:idque declarat Ariftoteles, exemplo fumpto ab intellectu humano, \& cius verba funt hxe [an omne non habcns matctiam eft indruifible, quemadmodrum bumanus intellectus ] patet igitur Ariftotelem afferere intellectun humanum nō haberc materiam, quia non polfet efle iudiuifibi$\vec{u}$ lis,nifictfetà materia feparatus. Poltiemo ad-

$\bar{c}_{-}$ducunt verba Ariftotelıs in z.Jibr.deGeneratione animalium, cap.3.\& is locusita difficiiis effe - exiftimatur,vt Auerroiftx putent argumentum 3i. demonftratiuum \& infolubile indé pro Auerroe inmu: Ariftoteles ibi quum quxftionem propofuillet de partibus anim $x$, an omnes extrinfecus adueniant, an nulla extrinfecus, an aliqua extrinfecus, \& aliqua non extrinfecus; poftea ad quxitionem refpondens inquit, folam mentem extrinfecus accedere, cam q; folam diuinam ef$f e$, quia nihil cum eius actione communicatactio corporalis;quum igituraperte dicat Ariftoteles humanam mentem extrinfecus accedere, afferit eam effe formam non informantem, fed abiunctam à materia \& affiftentem folum:iden confirmāt alıa fequentia verba in eodem loco, nam paulopoft inquit mentem humanam effe diuinum quoddam, fignifican's eam non dare effe homini, fed excedere humanam naturam. Alia quoque tum Ariftotelis loca.s tum argumenta, quibus Auerroiftx vtuntur, adducere poffemus; fed ea tanquam leuiora confulto omifimus, fatis effe arbitrantes, fi pauca hæc, qux validicra, \& magis præcipua ab ijs habentur, diligenter confideremus.

\section{Dict e ententia confutatio; Goltrerisis: contraria comprobatio..}

\section{Cap. VI:}

$\mathrm{H}$ Anc Auerois fententiam ego $\&$ abfolute fecundum ipfam rei veritatem, \& fecundum philofophiam Ariftotelis falfam effe exiatimo yeram autem alteran illorum qui di- cunt animan razionalem lumanam vere formam hominis cfle, qua liomo cut isomo, de in fpeciciontituntur:ad huius giturveritatem, \& alrerius fallitarem demonfraudam arzunent is prius vtar, deindeconfideratione verbortum $\Lambda$ ruforclis, quafententix nofte manifentifime atteftantur, opintoni autem Aucrois refiagantur. Prinum vtorargumento D. Thom $x$, quod Frimum ab eo adduciturin contextu feptimo libri tertij arguméde Anima,\& opuctalo decimo fexto: fi anuma tum.

B rationalis nö daret homini effe fpecificum, homonon diccretur intelligcns; quali intell cetus cft in homine vt forma feparatia à materia, \& ficutinauta eft m naui, crgo quemadmodum nauta quum fit fecundum fubftantiam feparatusà nail, fpeculaturin naui, neque ob id nauis fpeculari dicitur, ita intellcetus in homine intelligeret, neque ob id homo diceretur 1atelligens; igitur quo modo homo intelligat, oftendinullo modo pollet. Si quis vero pro Au erroe dicat Refponfió intellectum iungi homini per phanalmata, \& ita fieri, yt intellectu intelligente homo intelligat;hoc(inquitibi Thomas) nihil eft : dume- Confutanim poniturintellectus fecundum fuam effen- tio. tiam a natura humana feparatus, nihil facit illius coniunctio per phantafmata ad reddëdum hominem intelligentem, quia phantafmata funt quidem humana, fed refpectu intellectus non habent nifi locum obiedi mouents, \& rei cognitr,at non cognofcentis; itaigitur per fua phantafmata homo non fit intellıgés, vt paries per fuum colorem, quo mouetoculum, non fit videns: immo neque illa poteft vocari coniunctio, neque iungitur intellectus phantafmatibus; phantafmata enim funt in phantafia, nec recipiuntur in intelleetu, fed producunt in intellectufpeciem intelligibilem, \& hæc iungitus intellectui, non phantafma ipfum, ficuti neque realis color iungitur oculo, fed fpeciem fuam in oculo producit;vel ficum aliis dicamus nullam E fpeciem produci in intellectu, fed folum excitarià phantafmate intellectum ad intellectioné, ip fum certe phantafna ommibus confitentibus non iungitur intellectur : patet igitur vanum prorfuseffehoc fubterfugium, quia dicere intellectum iungi homini per phantarmata, perinde eft ac dicere oculum, feu facultatem vifiuam.iungi parieti per colorem, dum ftatuimus intellectum non efle hominis formam, fed efle à natura humana feparatum fecundum fubitātiam : quod fi etiàm concedamus hanc, qualis cunque fit , pofle vocari coniun tronem quandam intellectns cum homine, quatenus. homo offert intellectui phantaimata à quibus moueatu, lta vt ifte refpectus intellectus ad obieEtum poffit vocari coniunctio, ficut etiam relatio vifus ad obiectum conumitio quxdiam appellari poteft; ea faltem non eft talis, qua faciat. 
hominem effe intelligentem, aut rem colora- A tam effe videntem, fed folum facit hanceffe rem vifam, \& hominem, yel phantafmata effe rem int cllcetam; fed folus int cllectus, non homo, dicctur intelligens, quim fit fubftantia qurdam feiuneta à natura hominis : hoc igitur Thome argumentum ego efficaciflimum adAliormon refponfio. uerfis Auerroem efle arbitror. Aliqu ramen funt; quilicet Auerroem non fequantur, purant argumentum hoc parum habere efficacitatis: dicunt enim Thomam non animaduertiffe Auerroem dicereintellectum iungi homini nö folum perphantafmata, fed ctiam pernaturam; secunda. iungitur enim homini ftatim vt genitus eft, nec contun- tamen iungitur tunc per phantafmata, quia chio in- nondum poteft fuam edere operationem, fed zellect.cus foliadulto iungstur per operationem, proinde homise tunc folum dici poteftiunctus perphantafmafecundü ta, infantiautem non perphantafmata, fedper Awer - natúam tantum; qua de re legere Auerroem rocm. poffumus in commentar. 20. lib.3. de Anima: quamobrem ad argumentum Thomærefpondere Auerroes pollet, aliam elfe maiorem coniunctionem humanæ mentis cum homine, quam per phantafimata, proinde co argumento non oftendi hominem non effeintelligentem. Ego vero puto argumentum Thoma efie demonftratium, quod fic oftendo: Auerroes inquit ita coniungi intellectum cum homine, vt vniatur cum illo, vtitur enim nomine vnionis ; confiderandum igitur eft, quidnam fit vnio illa, quam vocant vnionem per naturam: vnio certe diciur, quando ex.pluribus fitvnum, nec fatiselt duorum congregatio, \& vnius pirfentiarefpeetualterius, vt vnirl dicantur; fi namque ponatur aliquis homo in naui, qui eam non moueat, non dicetur vnitus naui. licetilli infit; eft enim, veluti filignum lapidi apponeretur : \& huius ratio eft, quia non fit $v$ num ex duobus actibus fed ex poteftate, \&actu: cx nauta igitur \& naui non fit vnum fecundum effe, fediolum fecundirm operationem, quarenus fit vnum nauigabile conftans ex poteftace \& a atu; at fecundum effe funt duo entia actu completo, ex quibus non fic vnum : fic igitui quando ponitur tntellectus in infante antequam lit per xtatem aptus adıntelligendum, nulli fit vno, fi intellcctus non dat elfe homini; fed eft folun prafentia intellcetus ipfi homini iam per cogitatiuam conftituto, \& perfeeto in fpecie humana, non fecus ac homo in naui non nauigans dicitur prefens ipfi naui, non tamen illi vnius : quum enim homo habeat luum effeactu perfectum per cogiratiuam, intelleEtus non vuicur alli fecundum efie, quia non facit elle hominem; reftat igitur, vtper folam opeiationem dici pofit vniri, quam vocant $\nabla-$ aionem per phantafnatá ; nulla cuim teuera*
A eft illa vnio quam yocant per naturam. Sedid, quod multos decepit, \& fecit apparentiam quandam vnionis, fuit, quod intellectus eft incorporeus, quare eius à corpore diftinctio non cernitur, qualem Anerroes ftatuit, ficuti cernitur diftinetio naturæ à naui dum exiftit in naui, quo fit, vt etiam ftatuendo ipfum non efle formam hominis, non videaturà corpore feparatus fecundum fubftantiam, fed potius illi vnius tanquam facultas quxdam infita toti

I corpori, qux tota eft in toto \& tota in qualibet parte, ficut ipfi dicunt: attamen dum ponitur non informare materiam, non poteft dici vintus corpori per naturam, quia ex his non fit $r$ num, quemadmodum diximus; fic enim idem prófus effet, quod enenit in homine dæmaniaco; dxmon enim in eo exiftens non eftilli vnitus, licet illi affiftat \& membra etiam mouere ftatuatur: quemadmodum igitur dxmone illo intelligente homo illum habens non intelC ligit, ita fi comodo fitmens humana in homine, vt non det effe homini, eaintelligente nemonon intelligit, quo circa argumentum D. Thom , fi eius vis bene perpendatur, validiffimum eit: at ftatuen do intelle hominis, qua eft homo abfurdum hoc non iequitur; quum enim ipfo tanquam forma homo fit homo, \& corpus ad ipium referatur tanquam materia ad actum, materia inquam ha. bens potentiam ad efe, ita vt folus intellectus D Jocum habeat actus, inteliefum inteligere. elt homincm intelligere; idco Ariftoteles dixit hominem elfe intelligentem vt quod, intelleetum vero non vi quod, fedvt quo. Aliqui etiam pro Auerreis defenfione vtuntur exemplo luminis in perlpicuo; lumen enim aduenit aer extrinfecus, neque cit eius forma, eft amen ratio recipiendi colores, \& receptio attribuitur aeripropter lumen; fic igitur intelle etus, etii non eft forma hominis, E fedhomini extrinfecus accedit, eft tamen ratịo; qua homo dicitur intelligens. Sed hre comparatio congrua non eft, quoniam aer non quatenus eft aerrecipit lumen, fed quatenus perfpicuus; lumen autem eft fotma perfpicui, \& iplum côtituit quatenus perfpucuum eft, neque in ioro lumine recipiuntur colores, $\mathrm{fed}$ in corpore perficuo; lumen enim non eft receptiuum colorum, fed eft ratio reciplendi, ideo iurc attubuitur receptio aeri perf́picuo : at

$F$ intellectus fecundum Auerroem non eft formahominis, vtlumen eft forma perfpicui, \& recipit ipfe fpecies linc vllo viu corporis in recipiendo: nam fi ad recipiendas fpeciès vteretur corpore, iam effet organicus, quod Ariftoteles negat cont ext. 6. lila. 3. de Anima: vndecolligit folum intellectum che locum fpecierum, non fenfina : loci cain efr recipere. 
fenfus autem non recipit, fedorganum recipit, idco nonipfa anima fenfibilis elt locus fpecierum, fed organ um eft locus; aft anima rationalis dicitur locus fpecierum, quia nullum habet organum, quod fpecies recipiat, fed ipfa rnetrociptt: quocirca non ręte comparatur cumlu. mine, quod eft form a perfpicui, neque eft recipiens colores, fed folum ratio recipiendi; quo fit, vt iure attribuatur receptio aeri: non fic intellectio potest attribui homini, quia neque intellectus fecundum Auerroem eft forma hominis, neque in homine fit receptio fpecierum, fed in, folo intellectu. Prxterea fi intellectus non eft forma hominis, \& ex operatione intellectus homo dicitur intelligens, intellectio eft actio tranfiens; at hoc falfum eft, quia omnium confenfione intellectio eft aetio immanens; confequentia aurem probatur peripfanmet comparationem, qua aduerfarij vtuntur, intellectus cú nauta : aćtio enim, qua nauta mouet nauim, eft abfq; Jubio tranfiens, quũ nauta nö fit forma nauis, fed fit fubftantia diftinfta à fubftantia nauis; ficactio, qua intelligétia cœleitis mouet orbé, eft actio trā iens: firsiliterigitur f́ ex actione intelle etus homo diciturintelligens, illa eft actio tranfiens; attamē eft immanens, vt oinnes' concedunt; ergo ex ea homo non poteít dici intelligens, nifintellectus fit forma hominis, hoc enim negato, non video curnonidem de intellectu fit concedendum, quod \& denauta, \& de incelligentia coleltimanifeftumeft: nam fi fumatur aliqua natz operaio immanens, vt contemplatio, velloquutio, eaneque cum naui, neque cum toto coniunto communicatur; loqaenre enin nsuta neque nawis, neque totum coniun tu m dicitut loq tia contemplante feipfam, nequeorbis dicitur contrmplans, neque rozum coniunctum, quod ex intelligentia \& orbe conftat, fed Tola intelligentia dicitur contemplans, quemadmodum lolus nauta dicitur loquens; fie igitur folus in. tellectus diciturintelligens, non homo,cui affiftere dicitur. Nequealicuius momenti eff illud, quod aduerfarij dicunt, intellectum pendere à corpore bicetiue, quatenusà phantarmatibus humanispendet vt ab obiecto, à quo mouetur; nam,vt recte Thomas confiderat, hoc facit potuus hominem intelligi, quam intelligere;quod ex-eadem comparatione manifeftum eft; ram fi ftatuam mas nautam videre nauim, \& ab ea moueri, vtab obiecto; non ob id nauis dicitur videns. fed vifa folum, neque totum coniunetum dicitur videns, fed folus nauta; fic fi intelligentia ftatuaturintelligere orbem, non ob id orbis dicetur intelligens, fed fola intelligentia; quamuis ergo intellectus moueatur à phantafmate, vt ab obiecto, non tamen ob id homo eft intelligens, fed eft tanquam paries habens colorem, quo mouetur vifus; quare ficuti paries non eft videns, ita homonon eft intelligens. Noneft
A etiam admittendum id, quod dicit suerroes de Tertiwn cogitatiua; omnino enim contiteri cogitur ho. minem infpecie conftitui, \& à brutis diftingui per formam aliquam fubotantialem: veligitur. cogitatiun eft forma fubftantialis dıftincta $a b a$. nima fenfibili, vel eft folum facultas quxdam anim $x$ fenfibilis, quarum neutrum dicipoteft; primum quidem dicinon potest, neque id diceret Auerroes, quia de hac forma diftincta fecundum fubftantram \& ab anima rationsli, \& fen-

B tiente Ariftoteles nilil vnquam dixit:fed neque fecundium, quia fic honıo diftingueretur à brutis, non performam fubftantialem, nequeper animam, fed perfacultatem anıma, quare non diftıngueretur abeis fpecie; quim enim facultates anim 2 fint qualitates, vtalias oitendimus, perfacultatem diftıngui eit fola accidentali differentia diffngui $P$ xterea velifta cogitatiua Quarsm. eft illamet imaginatiua, de qua loquitur Ariftoteles in calcelecundilibride Anima, vel alia;

C fi eadem eit, homo à brutis fpecie non differt, quam etiambruta habeantimaginatiuam : nec refert dicere eam effe perfectiorem phantafia brutorum, quia magis \& minus nen variant fpeciem, \& Ariftateles ibiagens de phantafia, nullum in eadifcrismen confiderat, fed de eaagit communitr, prout omnibusarimälibuscompetit: fi vero eft alia, non poteft hominem cont7ituere, \& àbrutis feparare, nififitalia forma fubitantialis: cur ergo A riftoteles de haceffenD tialiterabalis duftincta phantafia nihil vnquam dixit? Sed hac omniafabulas the manifeftum eft, quoniam Ariftoteles in 3 . libr. de Anima aperte docuit propriturn elfe foliusanma rationalis difcurrere, \& affirmare, \& negare; ideo hoc alicui alij parti anima attribuendum non eft : quum igitur homoenuntiet, acratiocine tur, id perımaginatiuam facere non poteft, $\{\mathrm{ed}$ per folum intellefum : obid poffumus ita argumentari;idque eitargumentum firmiffimum E \& tum Aritoreli, tum veritati abfolutemaxime confentaneum: per illam anima partem fpecies humana conftituitur, \& à brutis diftinguitur, per quam lyomo enuntiat, \& ratiocinatur, at per folam animam intellectiuam hac prattat, ergo hac fola eft forma humanam fpeciem confrituens, \& eam à crteris anirsalibus feparans: immoeft ipfiufmer Arifotelis argumentum hor, quiin eo contextu vigefimo quarto libri fecundi de Anima probare volens animam effe formam corperis, ira argumentatur: anima eft id, quo primo viuimus, fentimus, mouemur, \& ratiocinamur; ergoanima eft forma viuentis, fentientis, mouentis, \& ratiocinantis : quoniam enim manife ftum eft hominem ratiocinari, \& intelligere, exhoc infert animam, per quam hoc agimus, effe formam, à qua confituimur. $* *$. 
Quodpradiarafententia Ariftotelis fuerit. Cap. VII.

$\mathrm{H}$ Anc fententiam A'riftotelis fuife non eft difficile demontrare, côfiderandoilla,qua ab ipfo in libis de anima ad aninze effentiam Duspro- declarandam traduntur. Clarum hoc erit, fi duas postio- propofitiones oftenderimus: vna eft, Ariftotepis. Jem in toto r. lib. de Animadum ex mente antiquorum de anima loquitur, \& in 2. lib. dum loquiturdeanima fecundum mentem propriam abinitiolibriadcontextum vsque 4 r. ampliffime animam fumere prout omnes animx partes complectitur, etiam animam rationalem, de qua agit poftea in .libro:altera eft, Ariftotelem docuiffe omnem mortalium animam nulla excepta effe formam vere informätem materiam. \& conftituentem animata corpora fub genere, Freoris corpore nacurali. Prior propofitio facile depropoft monfratur: quod enim ad primun librum attion is de tinet, mânifeftum eft Ariftotelem in toto eoli. - laratio. bro recenfentem antiquorum de anima fententias plurimum fermonem facere de mente humana; immo in contextu 7. reprehendit antiquos, quodinagendo de anima folam humanam animam confiderauerint, quafi omnes a. nima fint eiusdem fpeciei, \& fola detur anima humana: quare tantum abeft vt fermo in s. lib. factus de anima fit cum exclufione animx rationalis, vt potius antiqui de anima loquentes hanc vinam refpexiffe videanturjob id carpit eos Ariftotel. quod non vniuerfe omnem animama cófiderarint, fed folam ferme humanam, quum deanimalium anima parum loquutifint, plantarum veroanisnam vel ignoraffe penitus, vel tanquam nomine anim indignam fpreuiffe videantur': propterea in vltimo capite eius libri probat ftirpes quoque effe animatas, quoniam aggredi ftatim yolens tractationem de anima iuxta mentem propriam, redigere prius facuit ad genus anima omnes animz partes, vt tractatio integra, a perfecta effer: nullamigitur animam ab antiquis confideratam ipre à fua traAtatione exclufit, fed potius adiecit animam ftirpium, vt anima confideratio pniuerfalis effet, \& omnes prorfus animas complecteretur. Quum igitur in 2. libr.incipiat ex animi fententia de 2nima loqui, neceffarium eft, vtomnem animam comprehendat, pracipue vero rationalem; quia fi hanc exclufiffet, multo maiorem, quam antiqui, errorem ipfe commififtet : nuando quidem illi plantarum animam neglexerunt, qux viliffima eft, \& vix aliquod animæ veftigium habere videtur; aft anima rationalis nobiliffina, \& maxima omnium pracipua, nullo pacto pratermittenda erat. Sed res per feclara eft: quum enim in eo 2.libr. Ariftoteles de illa anima loqui incipiat, de qua in primo prifcorum fentencias expenderat, \& illi vel folam rationalem, yel hancpracipue refpexerint a neseffeeft
A vttrątatio Ariftotel. rationalemanimam complectatur;idque ita effe, multifariam oftendere poffumus, ea confiderando, qua in illo z. libr. dicuntur: nam in ipfolibri initio inquit, poftquam antiquorum de anima fententias recenfuimus, videamus quid fit anima, \& qux fit cōmuniffima eius definitio, certe fuperlatiuo $\nabla$ tens fignificat nullam animam à fe omittendam effe : deinde in context.7. concludens definitionem anima dicit [ f quid commune onni anims

$B$ dicere oportet, erit Gtique actus promus corporis naturalis snftrsmentalis ] \& poftea in contex. 8 . inquit [Gniwerfaliter igitur dictum quidfst anima] quare cum toties admoneat, feomnem animam nulla prorfus exclufa confiderare, ac definire, absque dubio animam rationalem ea definitione complexus eft. Hoc idem teitatur diuifio, quampo ftea facit: nam in context.13. diuidit animam latifime fumptam in quatuor partes, vegetantem, fenfibilem, locomotricem, \& intelligentem ; prius igitur nomine animi.late accepto etiam rationalem animam complexus erat; poft eum autem locum de illis quatuorvitz gradibus multa diçit, \& \{emper ab aliis tribus diftinguit intelle

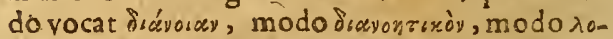

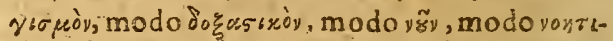
xoy ; his enim omnibus nominibus eundem quartumanima gradum intellexit de quo etiam in 3 . libr. diligentiflime pertractauit, vt ip fa eorum librorum feries indicat; agit enim ordis: natim de illis omnibus gradibus, in lib. 2 . de vegetante, as de fentiente, in 3. autem de intelligente, ac de mouente fecurdum losum, quare dubitandum non eft, intellectum, de quo agitur in 3 . libr. effe illam ipfam quartam anima partem, quam in z.lib. in ipfa animæ partitione is omnibns, qux commemoraumus, nominibus a ppellauerat: quod etiam affirmat ip femet Ariftoteles in context. 5. libr.3. quando declaE rans quisnam fit ille intellectus, quem ibi confiderandum fibi propofuerat, inquit [dico atstem

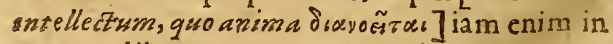
x.parte z.libr. quartum vitæ gradum vocauerat. fixvort ixò, \& ita etiam in 3. libr. fape eum vocat, dum de ipfius operationibus loquitur; Latinusautem interpres earn dictionem conuertens. modo dixit cogitatiuum, modo intellectiutum,

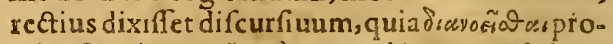
priéeft ratiocinari, \& à notoad ignotum dif́curI sere. Manifeftum igitureft, Ariftotelem in initio fecund. lib de Anima ita ampleacceptam animam definiuffe, $v t$ animani rationalem ea definitione, totaque illa natura anima declaratione complexus fit ; quare de priore propofia tione dubitandum non elt. Sequituraltera pro pofitio declaranda, quas fuit, Ariftotelem do-prop cuiffe eam efle omnis anim naturam, vtomnis tio. anima, nulla excepta, fit forma vere materiam införmans, \& dans effe animato corpori, \& in 
fpecie collocans fub genere corpore naturali: A primum, non actum fecundum, eft autem actus hane demonftrare multifariam poffumus, quoniam omnia Ariftotelis verba ita clare huic fententix atteftantur, vt pertunacis admodum hominis fit eam inficiari. In primis volens Ariftoteles communem omnis anim $x$ definitionem inueftigare, promittit in 2. contex. illius z. libri diuifionem fubftantix in materiam, formam, \& compofitum; vt horum aliquod acciperet, fub quo tanquam fub genere animam collocaret:eft igitur confiderandum, quam materiam, \& quam formam ibi Ariftoteles fumat; certe non fumit aliam formam, quam informantem, nequealiam materiam, quam habentem potefta. tem ad effe, \& hoc recipientem à forma; nam dicit materiam fecunduin fe non effe hoc aliquid, fed effe ens poteftate, \& à forma fieri hoc aliquid: quum igitur hoc aliquid ibi fignificet effefpecificum, \& determinationem in fpecie, negari non poteft, materiam ibi fumicum poteltate ad effe, \& id à forma recipientem; quare formam quoque talem intelligit, qua informet materiam, \& tribuat effe fpecificum; a perte etiam dicit formam facere hoc aliquid, quod ingnificat dare effe, \& in fpecie conftituere; nam de forma, qua folum affiftat, hoc dici nullo mo. do poteft; fi namque coeleftem orbem confideremus, \& ad intelligentram illi affiftentem réferamus, certenonrecipit effe abilla, fed eft hoc aliquid fecundü fe, \& habetdeterminatam naturam, neque habet poreftatem ad efle, fed ex fe eft a li quid actu fine ope intelligentiz: fic nauis fecundumfe eft actu hocaliquid fine nauta: \& homo quoque fecundum Auerroem percogitatiuam formatus iam eft hoc aliquid, \& ha. bet actum fpecificum etiam fine anima ratio. nali, iam enim eft homo, \& à cogitatiua in fpecie humana conftitutus fub anımali genere: quamobrem neque orbic celefti, neq; naui, neque homini ita formato conuenitid, quod ibi Ariftoteles de materia dicit, proindeneque forma affiftenti conuenit id, quod dicit de forma: nec dicereaduerarij poffint, hominem non effe hoc aliquid, fed habere poteftatern ad effe, dum confideratur prout refpicit formam nobiliorem, àu a recipit quoddam effe eminentias : etenim has fabulas reip ciunt verba Ariftorelis, qui non dicit materiam non effe hoc aliquid refpectualicuius forma, , fed dicit materian fecundum feipfam ron effe hocaliquidjtalem ergo materiam confiderat, qua fecundum fe nullum habet efiefpecificum, \& illud à fola forma recipit:proindenonaliam formam fumit, quan informantem, \& in pecie conftituentem: neque etiam dici poteft Ariftotel. tribue materip potentiam non ad effe, fed ad operari; etenim hec aliquidnonfignificat operans, fed habens fratutum effe fpecificum, preteres ingut formam facere hoc aliquid, \& efe setum a

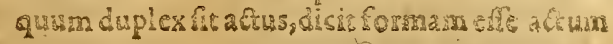
fecundus operatio: non igitur fumst formam ve tribuentem operationem, fed vt dantem effe, hoc enim fignificat actus primus; ideo neq; $\mathrm{ma}$. teriam fumitcum poteftate ad folam operarionem, fed ad efle. Hocidem oftendamus ex confideratione actus, quem ibi loco forma accipic Ariftoteles; inquitenim formam effe actum, \& ftatim diuiditactum in primum \& fecundum, \&e dicit formam non effe atum fecundum, fed a-

B ctum primum: fciendum igitureft, duo effe vocabula apud Gracos, qua fignificantid, quod non åtum vocamus, vnumeft cंv́ggete, alte-

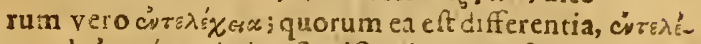

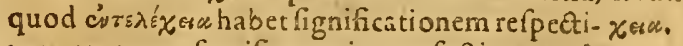
uam tantum, fignificat enim perfectionem alrerius, \& praterea dicitur tum de forma, rum de operatione, quia \& forma \&e operatio dicitur a. Etusalterius, \& complementum alterius: conǵ cośgrese. yesce vero habet fignificarionemabrolutam, fed C frictiorem, quiafignificarfolam operationem. nam cisegreñ eft operari; ideo vbi forma abo. peratione tanquam ab aćidente difringuitur. non poteft vocari cóg $\gamma \in \xi \alpha$, fed fola operatio diciturcukgyes; àt vbi operatio idem eft, quod fubftantia, ibi etian iṕa fubftancia dicitur cuésrero, quarenus eft idem, quod fua operatio; ob id fubitantize à materia abiundta vocantur cuésYEG, \& Ariftoteles in contextu 19 libri tertij de Anima, de intellectu agente loquês, dixitipfum

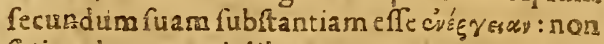
frcin rebus materialibus,nam eperationem quidem ignis vocare poffumus cuégyeav; yt eam vocat Arifoteles in contex. 32. libri oftaui Phy. ficorum, fedipfam forman ignis fubfantialem nunquam vocaremus čécy $\gamma(a)$, quia dietio hac folam operationem fignificat, nec poteft attri. bui form ; nifiquando forma eft idem, quod fua operatio, cuiusmodi eft omnis forrajper effentiam abiuncta à materia; ob id nos quoqúc

talem fórmam folemus intelligentiam appella. re, quia nomen hoc proprie fignificat operatio. nem, qua vocatur etiam intellectio. Non reete a utem fubftantix à materia abiun ctx vocarentur civs $\lambda \varepsilon^{\prime} x \epsilon_{e}$, quia funtactus abrolute, non funtperfectionesalterius: Ariftoteles tamen in conextu 42 . libriduodecimi Metaphyficorun

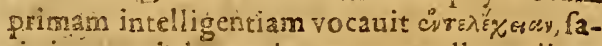
tis impropria loquatione, neque vllum alium locum iniseniemus, in quo dieto hac fubfan-

F tiis ̀े nateria abiuntis ateribuatur: neque absque ratione ibi Ariftotel. ita log̨ uitur, nam pìmam intell ligentiam ibidem vocat appellatione refpectua primum quod quid ef, quia eam cö. fiderat vt modo quodam perfectionem vniuer-

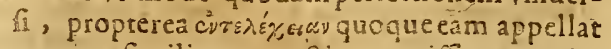
romine fimiliter retpeciuo, ceriffimum enim en, buius vocis fignificatignem effe refpeatwam Arinoteles ibieam famit, vtad propuin-

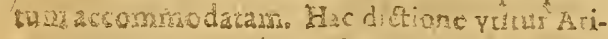

$$
\text { GG } 2 \text {-ftwit- }
$$


Atc teles in principio fecundilibrideAnima, cum A diuidustum 11 prumum \& fecundum, \& poftea definiens animam dicit animam effe $\dot{\varepsilon} v \tau \delta \dot{\varepsilon}-$

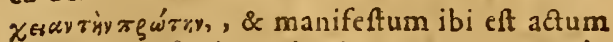
fitmi properfectionealteritis, non pro astu abfoluto, quum Ariftoteles dicat actum corporis naturalis organici, quod videns Themiftitusre-

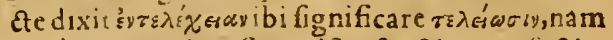
$\tau \leftarrow \lambda \epsilon^{\prime} \omega \sigma \iota s$ non lignticat nifirefpectiue perfectionem, \& complementum alterius: quod etiam confirmaturteltimonio Plotini, qui in initio fe-

plotinus cundilibri 4 Ennead. carpit Ariftotelem, quod

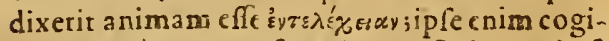

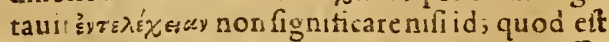
perfeetioalterius, \& quod non habet aliud effe, quam hoc, vt fitalterius complementum; hoc tamen negat Plotinus de anima rationali, quia putat animam rationalem effe etiam aliquod abfoluturnabsq; vlla relationead corpus: quod fi crgnouifict nomen hoc fignificare polle aEtum abolutum, certeappellationem hanc Ariftotelis non reprehenditter; cognouit ergo Plotin!s fententis $m$ Ariftotelis fuiffe, qued omnis anima fit forma corporis, qua verc materiam informet. Hucidem coiligimus ex ipfa diuifioneaktusinprimum \& fecundum, nam form à materia abiunet $x$ non conuenit appellatio primi,neque f́cundiafus; \& $1 l l i$, qui putántetus. modi forman efle actum primum, decipiuntur: dicitur enim abfolute actus, red non primus, neque fecundus; quia operatio non diftinguitur à fubftantia ; actusautem primus dicitur sefpętu fecundi, qui diftingtiatur à prino: propterea non dicitur actus primus nif forma materialis, qua à fua operacione diftinguitur; \& fignificat formam dantem effe, quia res materialis duas habet diftinctas perfectiones:vna eft proprium effe fpecificum, quod habet à forma, ideo forma dicitur prima perfectio corporis naturalis, ad differentiâm fecundx per. fectionis, qua eft operatio; ve actus primus ignis nihilaliud eft, quam forma pér quam eft ignis, hrcenim eft prima perfectio, qua rei effentiam fignificat, afcendere autem eft fecunda ignisperfectio; res enim non habet fuam integram perfectionem dum eft otiofa; fed quarido edit fuam naturalem cperationere. Ex his igitur patet, formam, qux non informet materiam,fed folum affiftatalicui corfori,non poffe dicillius actum, necprimum, nec fecundum; nam intelligentia non eft primus actus or bis, quum orbis iam exfeipfo fit a ctu, \& habear effe fpecificum fineopeintelligentix; non poteft etiam diciactus fecundus, quia licet orbi detactum fecundum, ip ra ramenper fe non eft 2 ctus. fecundus : formaigiturafifitens non poteft dici perfectio alterius, nec prima, nec fecunda, fed folum abfolute dicituracius, ficut anteś dicebamus. Quum igitur Ariftotèles aninam vniuerfe fumptam dicat cllic actum primurn cor. poris naturalis, non poteft fignificare, nif for.

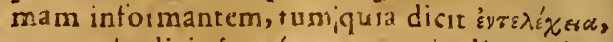

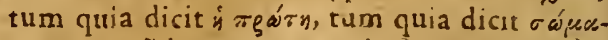

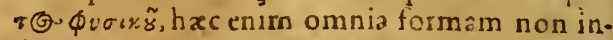
furmantem excludunt, vt quif̧; judiciolus vir ea, qua dixinus, confiderans cognofcere facile poteft. Eandem fententiam fumimus ex iss, qua in eodem 2. lib. poftraditam anıma definitionem ab Auftotele dicuntur, nam in contex. 7. inquit, non effe quarendam, an ex corpore, \&e B anima vnum fiat, ficuti non eft quarendü, quo. modo fiat vnum ex cera, \& figura, quoniam ex poteftate, \& actu non fiunt duz res, fed vna; eadem enim, qua prius erat poteftate, po ftea eft âu : ergo loquitur Ariftoreles de forma informante, non de afliftente, quia de hac id minime verum eft, a duent enim enti perfecto, quod nö habet poteftatem ad açu $\mathrm{tum}$, à quo recipiat effe; non fir autem vnum exduobus actibus, fed ex poteftate \& actu: exenplumetiam Ariftotelis C eft de formavereinformante, figura enim thatux eft forma informans ceram, \& faciens effe ftatuam; quarevult Ariftoteles animameffe in corpore vt figuram in naui, nö vi nautam in naui. In contex. autem 8. Arittotelesita clare loquitur, vt nullum reling̨uat fubterfug ıend cū inquit enim fe vnucife dixiffe quece hit anima. de ftatirn fenfum definitionis alis rerbis ieferens clariorem fubiungit (estenim füb/atnisa, quafecsond m rationem.idest, guod aruid oft talis corporis) qua veiba form $x$ alfitenti aptari non poffunt, fed flam fignificantinf imantem, fumitenım ibi soía proeflentıa, a dicit animam efli illam effentiam an mati corporis, qu $x$ per definitionem fignificatur; quod adbuc magis declarans dicit, id eft, quod quid eft talis cerporis: at forma affiftens nun fumitur in definitione illius, cui affitit, nec dicitur eius effentia, feu quod quid eft, nam intelligentianon fumitur in definitione corporiscoleftis, nec eft eius quidE ditas, itanequenatura nauis, neque auriga currus, vt manifeftum eft: nam etiain quando genera caufarum enumerat, vt in lib. 2. Metaphyfic. \& in z. Phy ficor. \& in 2. Pofterior. non alize formam in caufis numerat, quam informantem, quia femper eam vocar effentiam, \& quod quid eft, \& hanc folam dicit effe rei naturam in co 2. Phyf. lib.nam forma affitens non vocareturnatura: quod etiam ex eo patet, quod in 2 . lib. non alian formam vocat naturam, quam il. F lam, de qua in primo lib:o loquutus erat, tanquam de tertio principio rerum naturalium; autem eft forma dans efie materix, \& terminus ad quem generationis: fic igitur declarat Ariftoteles, quod in definitione animx intellexerit per actum prim $\bar{u}$ \& afferit fe intellexife effentiam, qux fecundum rationem, \& quod quideft corpois naruralis organici. IJem fignticat in eodem cōtextu, dun cóparat corpusanimatum cum ficuH, \& andwam cum figura, \& acumine 
fecuris : non enim dicit animam elfe $v t$ hominem vtentem fecuri, vel venautam vtentem naui, fed effe vt figuram, qux eft quod quid eft ipfius fecuris \& nauis. Similiter in conrext. 9 . \& 10. dicit ita fe habere animam refpectu totius corporis animati,vt fe habeat facultas vifiua re. ipectuocul, hac autem eft effentia,' \& quod quid eft ipfrus oculi, \& forma dans effe oculo, fine qua non effet oculus, nifi aquiuoce:quemadmodum igitur facultas vifiua non eft forma affiftens oculo vt nauta naut, fed forma dins effc osulo, ita anima eft forma dans effe toti animato corpori. In hoc itaque declarando laborat Ariftoteles ab cius libri initio ad eum vsque locum, \& nihil dicit, quod non manifeftiflime informationem fignificet; inulti tamen funt inuentiita pertinaces, vt hoc negare aufi fint. Ex Ir. autem contextu poffumus noftre fententiz confirmationem fumere, fed quia aduerfarij eum locum profe adduxerunt, ideo illum poftea in argurcentorum folutione confi- $C$ derabimus. Ex iis quoque, qux ab Arifotele dicuntur in context. $24 . \& 25$. hrefententia manifeftiflime comprebatur : nam oftedere ibi volens animam effe formam corporis, hoc fundamentum ftatuit;id, quo aliquid dicitur tale, duplexeft, vnum vt materia, alterum vt forma; dicimur enin fani tum corpore vt materia, tum fanitate vt forma; primario tamen quodlibet diciturtale per formam , fecundarto autem per materiam: quod quidem fund amentum patet intelligi non poffe nifi de forma informante, hac enim eft illud, quo primo res dicitur talis, 3 k conftituitur, vripra quoque Ariftutelis exempla declarant:hocigitur iacto fundamento facit 1 bi Ariftoteles fyllogifmum talem:anima eft illud, quo primo dicimur viuëtes, fentientes, moti,\& intelligentes;ergo anıma eft vt forma, \& ratio animazi corporis, non vt fubietum \& materia : medius terminus absque dubio fignificat informationem; id enirn, quo viuens eft viuens, \& quo fentiens eft fentiens, eft forma dans effe; quare conclufio Ariftotelis non poteft nifi de tali ferma intelligi:quod etiam per fe manifeftū eft;dicit enim animam effe formam, \& rationé, id eft,effentiam, ac definitionem, quod quidem de forma affiftente dicinon poteft; ficutantea notauimus in cont.8. eiusdem libri: deinde vero in contextu 25. repetit fubftantiz diuifionem, quam in 2. contextu fecerat, in materiam, formam, \& compofitum, \& inquit animä effe fubftantiam ve formam, quare eandem formam itgnificat, quam in 2.contextu, f cilicet informantem. Tandem hoc colligimu s ex cont. $36 . \& 37$. eiusdem lib. \& eft loçu sclarifimus : ibi namque Ariftoteles dicit animam efle caufam viuentis corporis in triplic1 genere cau f $x$, nempe vt effectricem, vt finem, ik vt formam, necpoteft a. Jiam formam fignificare, yuam illam, quam in libro fccundo Phylicz aulcultationis in caufis
A numerauerat, haecautem non éf nifi forma däs effe; quod etiam in pradicto loco expreffe afferit, inquit enim animan effe caufam vt formam, \& hoc declarans fubiungit, id eft, vt effentiam anumatorum corporum : poftea vero dicit, $i d$, quod eft caufaipfius effc omnibus, effe eorum effentiam, animam vero effe caufam ipfus effe omnibus viuentibus, ideo effe ipforum viuentium effentiam; ad quod etiam confirmandum fubiungit, quoniamanima eft actus eius, quod B erat poteftate:exprefle igitur afferit animam effe formam dantem eñe corpori animato, \& perficere materiam, quz habebat poteftatem ad effe. Quoniam igitur anima fecundum Ariftotelem elt formadans effe corpori animato, \& hoc docens Ariftoteles, complectirur nomine animxe etiam animam rationalem, negari non poteft hancfecundum Ariftotelem effe formam. qua homo eft homo 2 in fpecie sonftituitur ful animaligenere.

\section{Varia Auerroiftarum euafiones, of arum imprgnatio. Cap.VIrI.}

C ET ERVM guamuis hac omnia ita cla. ra fint, vt nullum fubterfugiendi locum relinquere videantur, tamen fectatores Auerrois aufi funt variis modis verba Áriftoteles extorquere, ac fubterfugere. Primum quidem Prima multiad hoc confugerunt, quod quartus ille ewafo. gradus animz, quem A rifoteles in tota illa fecundilibri partevariis ílis, qua recenfuimus, nominibus appeilauit, non eft animailla ratio$n \mathrm{nlis}$, de qua in 3 . libro A riftoreles agit, fed eft preftantıfirea illa hominis prepria imaginatiua, qux ab A uerroe cogitatiua vocata eft; \& ad hoc afferendum snani argumento ducti funt, quod Ariftoteles in contextu 18.\& 29. illius \{ecandilibri ( $v$ in Latinis Codicibus legimus) E quartumillum gradum vocat cogitatiuum : ridiculum certe argumentum, propterea quod vbi Latinus Codex habet cogitatiuum, Gracus Confute. habet $\delta_{6}$ cyonssxìv, quod fignificat difcurfuum, seio. \& ita vocauit Ariftoteles in contextu trigefimo Jibri-tertii animam intellectiuam vt à phantafia diffinctam, vt ibi videre eft, \& ibiquoque $\mathrm{Lati}$ nus Codex habet [cogitasizesistem anima] ne. mo tamen eft, quipon fareatur, verba illa fignificare intellectum diftinctum à phantafia, quum Ariftoteles ibi dicat cogitatiuam animam ita moueri à phantafmate, vt mouetur fenfus ab obieftoexterno. Sedilla omnia, qux antea łiximus, quisquis bene confideret, 60 . g loicet negarinon poffe quartum illum vitx gradum effe animam rationalem, qua eriam voca ia eft intellectus, \& insertio libro diligentiffime ab Ariftotele confideratur: iam enim dixumus Ariftotelem in primolibro multa de in. tellectu fecundum antiquos, ac de eius excel- 
lentia, \& duinitate dixif̂e, quze nemo fanz men- A tis referret ad imaginatıum humanam; illam igitureandem anim $x$ partem poitea in fecundo libro nomine anima complexus eft, quod etiam progreffus A riftot.ac verba teftantur; quum cnim animam in quatuorillos gradus diuififfet. cos poftea fumitfingillatim, \& ordinatim confiderandos; dicant igitur, vbinam confideretur Adser- ab Ariftotele illa humana cogitatiua, nullus e-
foscogi. nimapparet locus in libris deanima, nam in satisum Awerrosis. poftrema quidem fecundi libri parte agit de phantafia, non tamen vt de hominispropria, fed vt de facultate omnibus animalibus communitercompetente: $e a$ igitur non eft quartus ille ani naz gradus, qui folius hominis proprius eft, vt afferuit A riftoteles in contextu 29. eiusdem libri;figmentum igitur eft hac bumana cogitatiua, de qua Ar! ftoteles nusquam aliquid dixiffe comperitur: fed quum in tertio libro accurate agat de humano intelle $\{u$, omnino dicendum eit eurn efie quartum illum vifa gradum, quem in prima parce fecundilibricuas aliis connumerauerat. Praterea in context. 22 . quartum gradum vocatopinatiu $\mathrm{sm}$; atqui in calce fecundi libri feparat manifefte opinionem ab imaginatione, \& vult eam fub intell ctu contineri:ergo non poteft per opinatiuum fignificare imaginatiuam. In contextu etiam 32. quartum

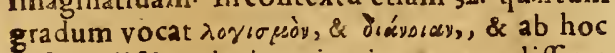
poftea diftinguit imaginationem ampliffime acceptam, vt etiam fecit in contextu 29. quare per quartum vitx gradum non poreft imaginatiuam fignificare: adde quod folus intellectus vim ratiocinandi,ac difcurrendi habet, vt Arift. aperte afferit in tertio libro, neque hoc eft phantafiæattribuendum:quum igitur in prima parte fecundi libri quartuen vitz gradum vocet $\delta$ oś-

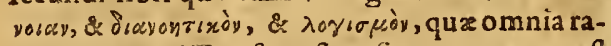
tiocinium \& difcurfum fignificant, non poteft per hac phantafiam fignificare. Sed quid dice.

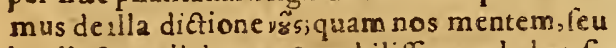
intellectum dicimus, \& nobiliffimam habet fignificationem, \& hoc nomine cocleftes quoque intelligentias, ac Deum ipfum appellare folemus;abfonum enim eft rationi phantafiam appellare intellectum, neque vnquam Ariftoteles ita eam appellauit: quederim multidicunt de cointextu vigefimo tertij libri, ita vanum eft, vt nib:l vanius, patet enin de quo intelleetu loquatur ibi Ariftereles, qumo pauloante duos inteiltotus diftinxiffet, vnum agentem, \&altexun patientem;qua nam autem fit vera eius lo ci incepsetatio, nen ff hic opportunum confiderare : in contextu eriam iss. fecundi libri videtur Ariftotrles phantafiam vosare intelleEtum, ledibipatet eum id dicere iuxta id, quod apparet, non expropriafententia; inquit enim incclingere viocrialiud efic imaginationcm,aliud exiftimationcm, vtitur enim vesbo, videsur, quod fignificatrem dubiam, \& apparentcm. nec omnino veram; nam videntur valgares ho. mines exiftimare omem internara anima facultatem, prefertim abfente obiecto nperan. tem, effe intellectum; id co Ariftorel. hanc conmunem opinionem accipiens diuidit faculta. tem animz internam cognofcentem abfente obiecto, in phantafiam, qux eft reuera facultas animx fenfibilis, \& exiftimationem, qux eft vereintellectus, de quo in tertio libroagitur; led nunquam Ariftoteles comperictur phantafiam B abfolute intellectum vocaffe: quare prima hac aduerfariorum euafio vanifima ef; quum enim Ariftoteles in diftinguendis quaruor gradibus vitx quartum fxpe vocet y ÿy non po:elt fignifi. care humanam imaginatiuam. Ideo bac alii Auerroift $x$ confiderantes, ad aliud figmentum confugerunt, ad diftinctionem dupl:cis hominis, dicentes vnum effe hominem, quieft fpecies animalis cunftituta per phantafiam humanam ab Auerroe vocatam cogitatiuam, quam C dicunt fignificarı per rationale, quando diuid:musanimal perrationale, \& irracionale; dicicur enion rationalis, quia eft apta ad fufcipiendam animam rationalem, \& ad obediendum rationi: alteram aurem effe hominem disinum, qui per intellectum conftituitur, \& coniftat ex homine illo, qui eft fpecies animalis, \& intellectu fuperueniente tanquam dinina quadam forma : priorem igitur hominem dicunt effe in genere lubftantix, vt fpeciem anımati corpe-

$D$ ris; fed alterum pofteriorem effe eminentiorem, \& fupergredi tot3m fubftantiz categoriam, vtpote formarum diuina potins forma, quam naturali, eamque effe in homine ve lumen in perfpicuo: ideo inquiunt diuinam banc formam dici poffe modo quodam informan. $t \mathrm{~cm}$, \& modo quodam non informentem; informat enim, quat en us dat effeilihomini eninentiori; non informat autem, quia non perficit materiam, quz habeat poteftatem adeife, E fed aduenit honini iam perfecto per imaginatiuam, ficuti nauta aduenitnaui iam conftitutre, atque completa; quare nen conftituit hominem vt fpeciem animalis, néque modo vllo ipfun collocat in aliqua noua fpecie, fed folum diuiniorem redditillum ipfum hominem, qui in categoria fubftaniz eft fpecies animalis: quam fentenciam nituntur colligere ex Ariftotele in 10. libr. de Morib. capit. 7. quem locum nos poftea perpendemus; tuncenim fatis eft, if à rio.

F definitione anima ab Ariftoteles tradita non recedenes oitendamus huius commenti vanitatem, ex iis enim quas in verbis Ariftotelis confiderauimus, manifeftum et hec omnia idem fignificare, dare tfie materiæ, informatc, confituere in fpecie, facerehoc aliquid, \& effe actun primum talis corporis; igitur fi onima rationalis non confituit horancm in fpesie, non facit boc aliquid, non dat effe, non eft actus primus corporis naturalis organici, pro- 
inde fub definitione animx non continetur; horsanen falfumeft, \& contrarum priorifundaníento à nobis iacto \& comprobato; Ariftoteles enim in contextulibri fecundide Anima, fubitantian diuidic in materiam, \& forman, \& compofitum, \& intelligit illam materiam, qua fecundum fe non eft hocaliquid, fed habetpotelfatem ad elfe, proinde \& iilam formam, qua facit hoc aliquid, \& rem in fpecie collocat; quare fub tali forma tanquam lubgenere animam fumit, \& vult omné animam effe forman danten effe fpecilisum: deinde in tertio contextu disidit corpus naturale in habens vitam, \& non habens vitam, ve colligat animam efe formam conftituenterc corpus illud naturale, quod habet vitam:alferitergo animam fub genere corpore naturali fpeciem conftiruere: poftea in contextu quarto probat animarn non effe corpus, co quod corpus non eft in fubiecto, anima vero eft in fubicetn: vult igirur omñern animam effe formam verc informantem, quia forma af. fiftensefle in fubiceto non dicitur; nam intelli. - Gentia affiftens orbi non dicitur in eo effe vt in fubiecto, eft res manifentiffima: quoniam igitur poitea mutat nomen talis form in nomen actus primi, quem diftinguit ab actufecundo, putat idem fignificari per actum primum corporisnaturalis organici, quod prius in 4 . contextufignificauerat per formam corporis naturalis viuentis; \& viuens in contex. 3 . dixerat fe intelligereillud, quod nutritionem, \& accretionem habct, \& eft vere in categoria fubftantia: ergo ncgari non poteft, Ariftotelem cenfuiffe omners a nimam effe for acam vere dantem effe, \& fub naturali corpore in fpecie collocantem, proinde figmentum illud eftab Arıftotele alieniffinsum. Hec igitur omniz alıqui Auerroiftre confideranies, \& cognofcentesita manifefta ef$f e, v t$ negarinon pofint, ad hoc tandem confugeiūr, quod reuerzomnia illa, que ab Ariftotele dicuntu in principio fecundilibride Anima, et fi profesutur dé anima late accepta, \& omnes anima partes complectente, tamen proprie cōueniunt aliis partibus animz prater rationalem, ipfi autem rationali nonomninoaccommodantur; proinde non eft mirum, fi ea qua $a b$ Arrftorele dicuntur in definitione anirsza, atque in eius definitionis declaratione, refpiciunt actum informantem, proprerea quod Ariftoteles precipue confideravit alias animæ partes prercr rationalem: huius autem rationem effe dicunt, quia nomen anim $x$ eft commune analogum, \&aliomodo competit anima rationali, álio cateris partibus, obid Ariftoreles répicere ynlust alias partes animz tanquam pracipunrs analogatü, nec per hoctanten ftat, quin confiderctur anima in communi cciam ad racioné: é; quia quando confideratur aliquod $c \bar{Q}$ -

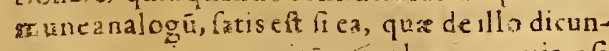
tur, conueniant pracipuo analogato, etianfi
A cateris non comperant. Sed quam inane fit hoc Confuta fubterfugium, quifque fan mentis intelligere tio. poteft. Primum in eo peccant, quod fi anima eft commune analogum, rationalis porius, quam reliqux, vocanda eft pracipuum analogum, tum ratione dignitatis, tum quia continet ac perficit aliâs, tum enam ratione familaritatis: quia anima noftra eft \& nobis maxime omniū rerum familiaris, omnes ob caufas nomine animx dignior, quam reliqux: hanc potifime 8 refpexerunt antigiui Philofephi de animadiferentes, vt Ariftot. ait in context. 7. lib. de Anima, \& vt totum jllumlibrum legentibus minifeftum eit: nulla igitur eft ratio, curreliqua partes animz dicanrur presipuum analogatum, \& cur Aritzotel. in declaranda animze effentia eas potius, quam rationalem, refpicere debuerit. Prxterea bac dicentes, \& Atifot. \& fibi aduerfantur, \& eft in corum dietis repugnantia nonifeffa : nam fi definitioanimx, \& ca qux poftea

C ad cius declarationem dicuntur, rationali parti non competunt, quonododicunt Ariftotelem definire animam in cormmuniad omnes anima partes, etiam ad rationalem? dicere igitur ea non competere anima rationali, \& dicere Ariftotelem ea proferre communiter de omnibus, etiam de rationali, eft implicare contradictionem: attamen patet Ariftotel. aperte dicere definitionem animx competere ómni anima, \& hoc fxpius repetere, \& animam late fumere ve D quatuorillos gradus complectentem : maniféftum igitur eft ipfum exiftimaffe definitionem illam competere etiarr animærationali, ideo hx fabulx dimittantur.

\section{Solutio argumentorum pro Auerroe addu- Ctorum. Cap. IX.}

$R$ Efrat vt argumenta, qux pro Auerroe ad- $\$ d$ pr. ducta funt, foluamus. Ad primum fum- mism. ptü ex cognitione vniuerlalium dicimus hane E effe propriam intelletus operationem, \& cum abftratione fieri, proinde in ipro quoqueintellectualiquam abitractionem poftulari, non tamen fecundum effe, fed fecundum operationem, ea enim ratione eft abftrafus, quatenus in operando eft abiunetus ab organo, \& hoc fatiseft vt polfit intelligere vriuerfalia: quando igitur dicunt, intrliectus cogr ofcit vniuerfalia, ergo eft abiunctus à rs:ateria; li intelligant abiunctionem ab orgsno in operando, $F$ eoncedimus omnia at fi intelligant fecundum efte, negamus confequentiam; quia ex abftractione vniuerfalium nil ahud inferri poteft, quam intellectum non effe organicum, nam organum refpicit operationer. Ad fecun- -tdfecüdum negamus intellectum agentern, \& intelle- dism. ctum patientem elfe vrams \& candem fubitanriam; quare, licet intellectusagens fit forma ab. iuncta penitus a materia, quod \& nos exfententia Aristot-afferimus, non ob id fit ve etiam inGG \& tclle- 
tellectus patiens fit forma inmaterialis: fed de A intellectu agente quid fit, \& quomodo ad nofram intellectionem conferat, poftea fufius lo5is lib. de quemui. Ad tertium acceptum ex context. 92. mrel.a. lib.r.de Anima, facilis eft refonfio: dicensenim Ariftot.intellefum non occupare al iquam corAdter- poris partem, nil aliud fignificat, quam non effe tiam ex organicum, quod quidem nes concedirnus; at cont.g2. fi indecolligant, ergo non dat effe homini, nelib.z. de gandaeft confequentia, \& Ariftot. fi hocfignifiantm. tum ex. con ${ }^{*} r x$. dib.20.de. corm.
Adquar care voluiffet abfurde loqumtus effct, quia formainformans occupat totum corpus, ideo inepta quxfioeffet, quam corporispartem occu= pet informanda; fed congrua eft quaftio de parte, quam occupet in operando, quar effet de organ o quaftio; ideo inquit Arift intellectum: nullam corporis partem tanquam ipfus proprium organum occupare. Ad quartum acceprum ex context.11. lib.2. de Anima, refponfia fumitur ex veraillius loci intelligentia, à qua aduerfarijlongiflime abfunt: tres in eo context. funt partes, in prima inquit Ariftot. manifertum. effe vel omnem animam, vel aliquas eius partes effe à corpore infeparabiles; \& rationem affert, quia funt actus partium corporis, in fecunda dicit nihil probibere, quin aliqua partes fint fe. parabiles, quia nullius corporis funt actus; \& cum ipfis aduerfariis affirmo Ariftotel in prima parterefpicere animam vegetătem, \& animam fentientem, in fecundavero rationalem:in tertia demum inquit, nondum effe manifeftum, an animafit itactus corporis, vt nauta nauis: Ad prima igitur, ac fecunda partis veram intelligentiam, fciendura eft, Ariftot. ibi velle fatisfacere vulgaizilli, \& optatz quzftioni, an anima. fit à corpore feparabilis; non quidem quodeam plene ibi foluere fatuat, id enim fieri minime poterat; fed folum confiderare, quid hac de re per illa, qua eo in loco manifefta erant, dici poffit: duo autem ibi erant manifefta, vnumiam in definitioneanim acreptum, quia erar om anima communis conditio, animam efle actum. corporis, hoceft, formam dantem effe viuenti corpori: alterum vero quod alique partes animafunt alligata propriiscorporeis organis, finequibus nullam edereoperationem poffunt aliqua vero nulli organo funt alligatz; de 0 . mibus enim vegetantis, ac fentientis anima facultatibus tremo eft qui ignoret eas per proprias quasdam corporis partes tanquam per infrumeta fuas edere opezationes, neq; vaquam: Ariftot. hocdeclarauit, quiadeclarationenon. indiguit: dubitare quidem potuit, quodnam 2ficuius facultatis organum fit, aut quomodoa. liqua per fuum organum operetur, fed an ha\$eantpropria organa, nunquarn dubitauit, quia: resper fe manifefta omnibus eft; rationalem aurem animam nulli proprio organo in operando. effeaddictam, manifeftum efo, inquit enim Ari- fotelcs in contextu 2z. libri . de Anima, ne fin- gerequidem facile effe quam corporis partem orcupet intellectus : hac igitur d so manif́cíta. erant, fed fecundum in derinitione anima poni non peterat, quum in co non conucniantomnes animz partes, \& alia organum babeat, alia vero non habeat. Quodigitur a danimz à corpore feparationen arcunet, nibil expriore communi condition e colligi manifefte poterat; ex eo enim quod anima eft forma vere mateliam informans, non licuit Arifotel. inferre omnem animam effe à corpore infeparabiles; non enim manifefta fuiffet illatio, quia quicquidipfe hac de re fenferir, id alii plures negaffent; quemadmodum etiam fecundum rei veritatem negandum elt ornem animam informantem effe à corpore infeparabilem: quoniam igitur exactu accepto in definitione animx nihilmanifefe colligipoterat, Ariftoteles id colligere voluit ex altera conditione, hoc eft, ex coniundione curs organo: videamus igitur, C quidex haccolligiponit, certe fi beneremiconlideremus, ex eo quod forma fit organica, neceffario inferaur eam eñe à cotpore infeparabilem, fed ex eo quod non habcatorganum, nithil neceffario colligi potef, hor eft, neq; feparabilem, neque infeprabilem effe : prioris dici ratio clara eft, quis nihil effe poteft in nalita otiofum, \& carens propria operatione; forma igitur, qua ita organoaddita eft, ve fine illo operarinon poffit, fi à corporepenitus fepararetur, $D$ non poffet operari; facultas ensm, vifiua fine oculonon videret, neque ambulatiua fine pedi. bus ambularet; omnes igitur animz partes, qua certis corporis partibus addıcta funt in operando; funt à corpore prorfus infeperabiles: alterius aurem dictiratio eft, quia licet nullum extet organum, quod feparationem prohibeat, aliquod tamen aliud effe potef, quod prohibeat; nam forma elementinullum habet organum, neque ob id efta materia feparabilis, quia

E licet aborgano non impediatur, quin feparetur, impeditur tamen à propria fua natura cui effentiale eft $v t$ fit forma talis materix, nec fine illa exiftere poffit: clarumigitur eft quid dicat Arift tum in prima, tum in fecunda parte illius. contex. in prima enim dicit, efie de aliquibus. faltemanima partibus manifeftú eas effé cor. pore infeparabiles, \& affertrationen, quia illarumąus eft jpfarü corporis partium, boc eft, quia actus, qui de illis pradicatur, efraddictus certis partibus corporis, nempe tanquam inffrumentis: nam quura dicat Ariftot. ipfas corporis partes, non potefteas confiderarenifi vt inftruméta partium animz in operando; quare accipit quidem a ctum pofitum in definitione $2-$ nion $x$, fed ve addict unftatuta corporis parti, qua: vt inftrumento vtatur; hxc jgitur eft manifeftiffima ratio, cur partes anim $x$, quz organis funt alligatz, à corpore infeparabiles fint : \& hanc eanden rationem legimus claciorem ab Arift: 
addusam in libr. 2 . de ortu animalium, cap. 3 . A quem locum poltea in argumentorum islutione confiderabiraus, \& huic confonüetre offendemus; ita vtexillo hunc, \& exhocillum interpretari polfinus, ac debeamus. In z. vero parte eiufdem contex confiderans Ariftot. illas animx partes, qux organo addicta non funt, cuiufmodi eft folarational is, non poteft aliquid de his certi colligere, fed folum dicere eas ab organo non prohiberi ne feparari pofint, quum nullum organum habeant; per hoc enim non fit vt absolute feparabiles dici poffint, quum alia conditio effe poflit prohibens ne feparentur: ideo quando rationem fubiungens dicit [proptereaquad nullius corporis funt act ws] non poteft intelligere rifi vt organi, vt haec verba pracedentibus exaduerfo refpondeant, \& perinde fit, as fi dicar, quia nullius partis corporis funtaktus; nonafferit ergo ibi Arifot. eas effe à corpore feparabiles, fed folum dicitnon prohiberiab organo quin feparari poffint, quam nullum orgarum habeant;ideo optina eft illorum verborum interpretacio, quam Alexander Aphrodifienfis adduxit, dicens Ariftot.ibi de intelleetus feparabilitate non affeueranter, fed fub dubio loqui. Nullumigiturargumentum ex eo loco fumere Auerroiftx poifunt: quia quando Arrftot.negat intellectum effe alicuius corporis actum, non negat vt informantem, fed folum vt organicum, idque affetieranter profert, feparabilitatem vero fub dubio; adeo vt fiuefeparabilem à corpore, fiue infeparabilem effe anissan rationalen A riftot. exitimauit, pro neutratamen parte colligi angumenta pofir. Quod autem extertia quoq; illius contex. parte argumentum aduetfari fumant, ridiculum eft: quum enim $A$ anfot. dicat immanifoftum ero fe an anima fit ita actus corporis, vt nauta nauis, non magis affrmare ipli poflunt animam effe vt nautam quam nos negare; ídeomirandum centeft, quomedo inde fumere audeant Ariftot.afieueranter dicere animam effe vt nautam, quam iple aperte dicat hoc non effe manifeftum: imooftendo efre in Ariftot. recundum corum interpretationem, repugnantiam infolubilem, nesefre enim eft omnem animam effe actum comporis.velvtinformantem : vel yt affiAtentem, etgo fi parsaliqua animx non fitactus informans, nuanifeftum efe deber earn effe aEum affiftentem, itag; fi fecundum eos przcedentibus verbis Ariftot. affeueranter dixerat,a. nimam rationalem non effe actun informantem; quomodo dicere poftea poteft nö effe manifeftum an fit ita afus, vt nauta nauis? Dicere enim potius debuifet effe manifeftum eam efic aftum afiftentem, qualis eft nauta. in naui: patet igitur eos in eius loci tntelligentialonge abefie ab Arritot.mente. Nos igitur veram Illius loci interpretationem afferamus, quaplurimo. rum errorem patefaciets eamyjita claram; ve fi
A primus ego eam inueniffem, afferere auderē id folum Arift. voluife, \&'alics onanes fuiffe dece. ptos; eam tamen ego non inuen $i$, fed apud Sımplicium in codcm locolegi, tamque ftatim veriliwam effe cognoui: dico igiurnautam ad nauim referri duobus modisivno modo quatenus non dat effenaui, \& ab illa abiunetus eft; altero modo quatenus eam gubernat, \& mouet: multi igitur putant Ariftot.comparare animam cum nauta, quatenus nàuta non dat efrenàui, $B$ in hoctamen decipiuntur; quia in en non confifti Ariftot. comparatio, neque in to anima eft firilis nauta, fed in eo tartum, quod regit corpus, ficut nauta regit nauim, de hoc animaregimen non eft contrarium informationi, fed fimul eft cum informatione; quocirca ratione informationis anima eft difinilis nautz: ratione autem regiminisenfrailis, \& hoc iantum Ari-ftoteles refpexit: her fuit Simplicii, \& Platonicorum opinio, qui dixerunt animam \& infor-

C marecorpus, de ipfurm regere, vc nauta nauim regit, ipfoquevti ve inftrumento, ficuti nauta vtıtur naui: hoc igitur refpiciens A.riftot.ibifignificare vult fe dixifie quidem animam efle aEtum corpóris vt informantem, \& dantem effe corpon viuenti, fed nibil dixiffe de gubernatione ideoque immanifeftum effe : an anima preterquam quod eft acius informans, fitetiam actus gubernars, ficuti nauta dicitur actus nauis; huius veritaris argumentum clarifimum eft, quod Ariftoteles non de fola anima rationali hoc dicit, fed deanima vniuerfe; dicit enim effe immanifefunz, an anima fit ita actus corporis, vt zauta nauis; reuera enim hoc competit ciam anima fentienti, qua ef forma conftituensanimal, \& eft vt nauta in naui, quia regit: corpus, \& iplotanquam infrume e vtitur: hoc: idem legimus apud Arifotelem in contex. 28. odaui Phyfic. vbi fimiliter animam comparat cumnata, \& corpus cum naw, necloquitur de

E. Sola animararionali, fed de ornni animalium anima, vt ipfi quoque aduerrarii non negarent, quia.ibi ét manifertfimum-; inguit enim animam mouere corpus animalis, \& ita animal diuidi in partem zaoventem: \& partem motam ratione quarum dicirur à feip fo moueri. Si quis autem quzrarybinam poftea Arifrotel declarat an animafitaEtus vi nauta in naui, cestum. eft id nullibi ab Ariftotele expreffe declarari, colligi tamen facile poteft ex illis, qua definF: gulis anima partibus poftea dicantur; aniraa enim regere corpus, \& imperare illi dicirur pe cognitionem, vt afferitipfeArifoteles in contexta 4. libri 3. de:Anima, omnis igituranima cognofcens dicicur regere corpus, \& illi imperaretanquam nauta: ideo fmilis eft nat nimafentiens, tum anima rationalis, quia, vtraque cognoficiua eft; anima' vero vegetalis, quum cognitione careat, nö̉icitur fimilis naz tai nequeingerans: corpori: Aruftoteles 1 gitun 
nullibi docet expreffe animam elfe vt nautam, quia ex eo quod \& anima fentiens, \& anima ıntelligens funt cognof centes colligere quilque peteft veramque ipfarum inftar naura regere cotous Hincetiam lumitur ratio, cur Ariftocel. ibi dicateffe immanife ftum an anima fit venauta, se cur hancconditionem in definitione animxnon pofuerit; ratio enim eft, quia non competit omni animx, non enim aninix vegetanti, quia non cognolcit: obid quum in eo contextu 11. abfolute de ornnianima quxrat abtquevlla diftenctione, an fit ita actux corporis, ve nauta nauis, iure dicitefle immanifeftum, quianon omnibus animz partibus competit; vel latis eft fi dicamus Ariftotel em per immanifeftum nil aliud fignificarevoluiffe, quam non expreflum in definitione animx propter ratione prx dictam.

ad 5. $x$ Adquintum argumentum, quod ex contextu consex. 2i. ciufde in fecundi libri fumebatur, refponfio $z r$. libr. colligitir ex ipfis Ariftotel. verbis in eodem lo2. de -1- ce: duo namque ibi funt Ariftotelss difa, qux mssirid. nos confiderare oportet: vnum ell [ de sntelle ct u astem, ES pecularicice fucultate n. bsladhuc manuffefum $\mathrm{e} t \mathrm{t}]$ alterum viroelt, quod ftatim fequitur [ fed sidetur altud genus arzome effe, G boc folwry offe foparari, tangwam perperusm al corruptıbil: ] patetautem \& pracedétia, s fequen. tia confiderantibus Ariftotelem de feparatione partiumanimix loqui, hanc igitur vtraque hac dictajrefpiciunt:idec fi vtraque ab Ariftotele affeuerantervt vera proferantur, eft in iis verbis manifesta, \& infolubilis contradictio; nam fi de

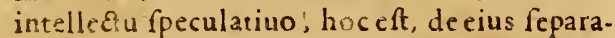
tione nil adhuc manifeftum effe alferit, quomodo potcft requentsbus ftatim verbis afletleranter dicereipfun eflealiud animz genus, $\&$ formamabilinetam à materia? quum prafertim in promptu fitratio curnihil de illomanifefum firjnondam enim de ipfo aftum erat, fed agendum iu certio libro relinguebatur: ad rollendamigittir $\mathrm{in}$ dictis Ariltot. repugnantiam, fateri rogumul non verunque dietum afincianter, of es animi fententia proferri ab Ariftutele, fed vinum affeueranter, \& fecundura menzem prupram, alterum vero dubium, \& i uxia alloum, vulyarium prafertim opinionem; ita

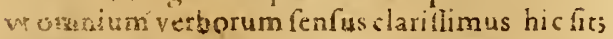
Seistellectu altem fpeculatiuo, nempe de cius feparacloneà corpore, fi fecundurn rei veritarem louvi velimus, nihil athuc manifetiun eftath leguamurid, quod alis apparet, multis wdezur if tuas efie ahudanimegenus v vizur e13 ma ibi Ariftoteles verbo (bisictser) yuod ligni-

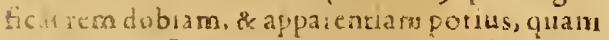
propren ýlus ofinonem; hancenim ad a-

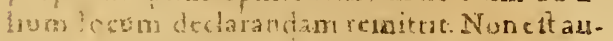

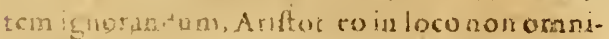

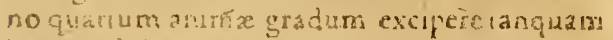

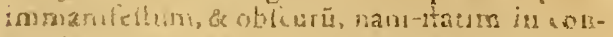

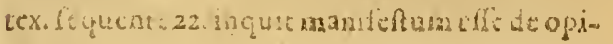

A natiuo, neq; aliud perhosfignificat, quam eum ipfum quartum gradum; quanquam ibi non amplius loquitur de feparaticre à corpore, fed de feparatione partium anima fecurdum locos iuxta Platonis opinionem, dequasniealoquebatur, cuius methodi rationem non eft hîc opportunum confiderare: in contex+u igitur 2 . folum excipit intellectum fyeculatium, hoc eft enndern quartum gradum v exercenteppraftantillimam fuam operationem, qua eft foc-

B culariefientiasrerum, \& vaiuerfalı; quan: anim hoc facere non poffit, nifiopeintelietrus agètis, qui eft forma vereabiü ta a materia, a deo ve ex veroque intelleetu conftare quodammodo videaturintellectus fpeculauuus, ideo non abeque ratione fit vt hicvideatureffealiudaninaz genus, \& forma abiú cta à maceria, euenit enim hoc prepter interuentum agentis; \& $A$ ue:roes quoque dicit intelieetum fpeculatiuum conftate ex intelledu portibili, \& pharitarma-

$C$ tibus, \& intellectu agente: hanc igitur ob caufam Arifloteles, \& 1 illo context11 21. \& poltea in 32. excipit intellectum fpecula iuum, tanquam sllum, de quo mihilibi manifefumerat, quoniam ratione intellectus agentis non continetur reuera fubanima defintione, neque eft actus corporis : at rarione aliarum ignobiliorum operationum Ariftoteles nunquam excipit intelle etum, neque dubi at ne fub animz defintione contineatur, fed pro comperto ha$D$ bet eum effe formam viluentis corporis, \& fub anim $x$ difinitione non minus, quàm alias anima partes contineri; nam in cuntextu 22 . inquit rullum dubium effe de opinatiuo, in co

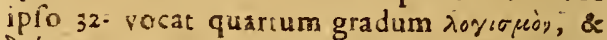
fióvorav, neque vilum dubium de illo effe dicit; ied ftatim fubiungit, de intellecturpeculatiuo al:am effe rationcm, \& effe pofterius confiderañdum: de inteliectu igicur fpeculatiuo, tota dubi: ratio prousnat ab inrellectuagente, E qui eft aliud arim geris, neque eit actus corporis, ve Ariftoteles poftea in libro tectio declarat. Ad fextum argumentum fumptum ex contexur quarto \& fextolibritertide Anima, dicimusintellęum dici poffe coinmıftum corpori, vel imrairium duobus modis; vno modo fecuncum effe, altero modo fecundum operationem: o hoc adhucduobusmodis; vel enim ratione ebiecti recupiendı; vel ratione corporis, quo viatur ad recipiendum, adeo ve tribus mo dis dici poffit inrellectus commiftus, vel immiAus : red primus modus non fuit ab Ariftotele confideracus in lihrotertio de Anima, quoniam ibi propofult fibi confiderandam naturam intellectus refpectu operationss tarium, nam fecundum fium effe ia in dixerat in principio libri 2. vannem anman efle actum primum curpo. is maturalis organcs, hoce ct, for ina informantcm: quate necille et intellectü hac ractous elfe cum conore commiltum, non quidem vera mi- 
ftione, qux non eft nifi corporis cũ corpore, fed A ctiua non vtitur organo corporeo in recipiendis illa, qua competere poteft incorporeo cuin cor. poreo, nam forma corpus aliquod conftitucns infinuat fe in omnes partes materiz, in qua ineft, \& ita dicitur comifceri cum materia; ficigitur intellectusfecundum fuum effe non eft immiftus, fed potius commiftus cum corpore, prout nomine comroiftionis nil aliud denotamus, quain veras materix informationem, \& conftitutionem fpeciei. Ratione autem opiectorum recipiendorum intellectus eft immiftus, quia in fua natura non habet aliquod ex obiegtis recipiendis, nam intusapparens prohibetalienum, vt inquit Ariftoteles in illo context. 4. lib.3. quarefi in ip fa effentia intellectus continereturaliquod ex obiectis recipiendis, prohibereturalia recipere; quemadmodum materia prima, fi in fua natura formam aliquam haberet, nullam poffet aliam recipcre: de bactantum immiftione loquitur Ariftotel.in eo contextu 4. libr. 3. vt manifcitifimum eft, neque exilla poteft inferri immiftio cum corpore fecundum efrc, quoniam etian cuilibet fenfui competit talis immiftio refpectu fui obiecti; organum enim vifus recepturum colores debusit effe fine colore, \& organuts auditus debuit elfe fine fono, \& fic dealiis; attamericertum ef fenfium effe formam materialera, vereinformanten materiam; quare ex eo 4 . contextu aullua poteft afgumentmm pro Auerroc fumi ad probandum inrellectum non effe formas informantem. In 6 . autem context. loquitur Ariftot. dsaltera immiftione refpectu operationis, nempequa opponitur illi commiftioni, ex qua inferretur intellectum effe organicum:quam enim Aritotel.prius docuif-

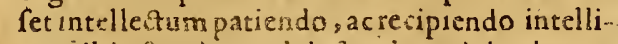
gere, ibi oftendere vult iplum in recipiendo non efle commiftura cum corpore, hoc eft, non vi minifterio corporis in recipiendis obiects, fed ipfummetrecipere, ad quod probandum hoc argumento vtitur, quia fi in recipiendo effet cum corporecommifus, iam extaret aliquod eius organum in humano corpore, properea quod fi in recipiendo egeret corpore fumul recipien. te, iam poftularet certam aliquatu corporis temperaturam idoneara ad resipiendum, proinde ftatutamaliquam corporis partem, in qua hrc receptio fieret, quod eilet ipfum effeorganicum; nullum enim aliud eft officium organi fenfus, quan reciperefpecies : quoniamigitur nullum apparet organum proprium, quo vta. tur intellectus in recipiendis obiedtis, dicendum eft eum in operande non efle cum corpore commiftum, Ted ipfurnmet recipere fpecies; vndepoftea colligitulam animam intellectiuam dicipofle locum fpecierum, locus enim recipit locarum, anima autem fenfibilis non recipit fpcies rerim fenfilitu, fed organum anmontum eas recipit, proindenon anima ipfa, fed organum eflocus ipecicurn: anima vero intellefpeciebus, fed ipfarecipit, ideo reete vocaturlocusfpecierum. Quum igitur talem immiftionem tribuat ibi A riftot. intellectui, qua folum refpicit operationem, nullum inde fumereargumentum Auerroifte poffunt : nam fi hine colligere velint immiftionem cum corpurectians lecunduns effe, negamus confequentiam. quia lıcet intellectus in recipiendis fpeciebus non vtacur aliquo proprio corporeo inftrumenB to, per hoc tamen non ftat quin fit for homi. nis, \& hominem in fpecie conftituat fub animalis genere;nam ex eo quod aliqua forma non habeat organum proprium, non licet inferre cam non effe formam informantern, fed abiunctam à materı. Alia multa ad illius loci declarationern, \& ad huiusargumenti vanitatem oftendendam pertinentia dicta à nobis funt in illius libri interpretatione, qua hic recenfenda nonfunt. Ad feptimum, quod fumitur ex cap. 7.libr. 10. Ethic. dicimus horninem apud omies Philolophos effe medize naturæ intermortalia, \& immortalia, inter terrena, \& diuina: pluribus euim falul tatibus præditus eft, quarum alix faciunt eum fimilem brutisanimalibus, \& rebus ignobilioribus; aliz vero reddunt eum fimilem diuinis, vt intellectus, prafertim fpeculatiuus : inter qua duo extrema datur medius quidam ftatus, fecundum quem homo nequead inferiora vergit, neque ad fuperiora, \& huiufrodi $D$ eft vitafecundum intell ectum practicura; ideo dici folet, hominem, fi viuatfecunduto fenfas, viuere, vtbeftiam;fi verofecundum intellecturn fpeculatiuum, viuere vt Deum; fivero fecundum intellectum actiuum, viuere ve hominem; fed tamen quando Philofophi ita loquuntur, non propterea negant vitam contemplatiuan homini competere quatenus eft homo, fedid dicunt comparatione illius vitzmedia, fecundurs quarn homo neutri extremorim fimilis. E effe dicitur; fic enim per comparationent vocatur fatus illefupra humanus, ab folute tamen: non eft fuprahumanus, fed eft penitus hutsanus; quicquidenim eft in homine, humanun ef, a co humanius, quo magis proprium hominis eft; quocirca contemplatiua hom in is vita eft maxisue humana, idque afferit ipfe Arift. clare in calce eiusdem capitis, dum ait ( quodnature bnoufcusufyue est accommodatum, idpre frenijßimum, aciucundißsmumbnicsiqg est, ergo d.l $>.2 x$ ro. Etk. c. 7 . F etiambominibsta, qua.exintellect w tradscitsor, figuidem maxime id est homa) vult igitur abfolute loquendo incellectum effe humañ narura maxime accommodatum, \& hominem per eum maxime effe hominem : dum enim abfolute quid natura humana fit confideramus, eam effe dicinus, pei quam hota maxirne confticuitur, a abalis diftinguitur; conftituiturautem, z diftinguiturperid, quod eft fumian iplius perfectio; fumisia autem perfe-

\section{Vitacoses templati. wa $e f t$ maxime bsmana} ही: 
tio cuiufque fpeciei ef praftantiffimx eius partis operatio, qualis eft in homine contemplatio; hac igitur nuhil in homine humanius eft, dum abfolute homirem confideramus; dum autem nomine hominis non omnes humanas vires, \& operariones intelligimus, fed aliquas tantum ignobiliors, tunc vita contemplatiua dicirur efle fupra hominễ, non quidem abfolutefupra hominem, fed fupra hominem ita conQuomo- fideratum; quia homo eft quidem naturæ medabomo diz, ficuti dictumeft, non tamen perveram exfis ne- tremorum parricipationem, fed folum pereodises in- rum fimilitudinem : ideo nominc hominis quãrer diu:- doque perfectionem, \& nobilitatem fignificare na Ëter volumus, quandoque imperfectionem, \& ignorena. bilitatem; denota mus enim nobilitatem, quando dicimus hominemeffe animal praitantiffmum, a adimaginem Dei effe factum;imperfectionem vero, quando excufare alicuius errorem volentes dicimus, homo eft, \& quando dicimus, humanum eft pecsare, \& memento homo quod cinis es, \& alia huiurmodi. Quando igitur Ariftoteles dicit vitam ex intellectu non efle humanars, fed diuinam, non ab folute negat effe humanam, fed folum prout humanum notat imperfectionem, neque vult effe proprie diuinam, quum propriefit humana, fed per quandam fuperioxum fimilitudinem, \& cum inferioribus comparationem; non eft enim eiufdem generi mens, \& intellectio in homine \& in fuperioribus, habent tamen quandam fimilitudinem : ob id homo refpeau ignobiliorum vocatur diuinus, abfolute tamen nihil eft in homine, quod humanum non fit, as nihil in eo humaAd sex nius eft mence, zicque intelligentia. Ad oftaum 4.dspar. argum entum, quod fumirur ex capire decirao anersal. libri quarti de Partibus animalium, dicimus dec. 20. bilemeffe rationem, qux fumitur à fola appellatióne diuini, nam in contextu $8 \mathrm{r}$. H. $\mathrm{r}$. Phyfic. aufcul tationis Arntotel. omnem formam naturalem vocat diuinam \& optroam; \& in libro fecundo de ortu animalium, cap.z. dicit, quamlibetanim $x$ facultatem participare diuino quodam corpore praterilla, qux elementa appellantur, neque propterea putat omnem formam naturalem, vel omnem animam efie à materia abiundtam; quod igitur mentem humanam wocet diuinam, nullius momenti eft ad oftendendum eamnon effe formam informantem, fed abiunctanì materia. Ratio autem, cur $A$ riftot. omnesanimx partes, \& omnes formas naturales appellauerit diuinas, eft 11 la, qua ex cius verCur for- bis fumitur in contextu roo. l bri t. de:Colosibi ma ab A- enin dicitrebus omnibusà Deo communicari rifto: Go- effe, \& viuere, his quidem clarius, illis vero obcetsr di-fcurius; quxlibetenimres illud quod eft, eft per sina. parcicipationem perfectionis diuina; fed ea participatio eft inzqualis, quoniam aliz res.magis, alix minus ad diuinas perfectionem accedunt: quoniam igitur efle cuique rei tribuiturà for-
A ma, qualibet forma dicitur diuina, quatenus eft inrago alıcusus gradus perfectionis diuinx;ideo non male à Platone dictum eft, omnia exduobus principis conftare, ex ente, \& non ente; per ens enim Deum fignificabar, pernon ens vero primam materiam, quafi ex materia \& forma conftare, fit conftare ex materia \& Deo. Solet etiam Ariftotel.aliquid appellare diuinum comparatione rerum ignobiliorum, vt in $\mathrm{r}$. Phyficor. loco pradictio formam vocat diunam etiam reB fpectu materize, à qua appetitur; \& in cap. 3.lib.2. de ortuanimalum omnem animz facultarem diuinam vocat refpectu elementorum, \& rerum animx experrium : maxime igitur hornini bae appellatio conuenit, quia omnium fublunarium corporum preitantifimus eft, \& proxime omnium ad Deum accedit: quid igitur mirúm, fi Ariftotel. dixit fubftantiam hominis effe diuinam, \& officium diuini effe fapere, \& intelligere? appellatio enim diu ini apud Ariftot.non de-

C notar abiunctionem à materia. Ad nonum ex context. sI duodecimi Metaphyficor. refponfio fumitur exipfis Ariftotel.verbis in eociem loco, \& ex Alexindrinterpretatione, quz plana, \& faciliseft: aduerfari namque verba Ariftotelis tum mutilata in medium afferunt, tum perperam interpretantur; citant en im verba hæc [an omnenon hubensmateriam eft indisifibils, quenadmodum bumanus sntellectus] a fubticent fequentiailla [ sut qui compofotorure est, sn alsquo D tempore fe habet ] dicoigitur Ariftotel. his verbis primum incellectum cum humano non in eo comparare quod careat materia, fed in co qu od intelligat obiectum totum fimul, \& indiuifibuliter; neque dicere humarim intellectum ita femperfe habere, fed aliquo tantune tempore, adeovt talis femper fitprimus intellectus, qualis aliquo tempore eft intelledus humanus: quod fi putaret Aritorel. humanum intelleEtum effe formam abiunctam à materia, vt illi E volunt, certerion dixiffet ipfum aliquo tantum tempore ralem effe, fed omni tempore, qui fi non dat effe, eft femperà materiabiunctus, $1 i$ cet corporiaffiftat: eft igitur fenfus verborum talis: omne non habens materiam eft indiuifibile, quemad modum humanus intellectusaliquo temporefe habet;eft enim quandoque eius intell :etio indiuifibilis, nempe quando intelligit obiectum totum fimul, non per difcurfum à partead partem : verba autem illa [ ast quicomF pofirorsin est ] ad maiorem declarationem ab Ariftotele adiciuntur, \& hábent fenfum vni-uerfalem, vtinquitibi Alexander, ita vt fenfus fit, quemadmodum fe habet aliquo tempore humanus intellestus, aut vniuerféloquendo. omnis intell cetus, qui compofita intelligat, $f$ sliuspræter humanum datur, quifit ciufanodi : dicit ergo humanum intell ectum effe compofitorum, proinde intelligere quandoque cum difcurfu à parte ad partem, nec femper intel- 
ligere indiuifibiliter, fed aliquando, imo râro; A loco contrarium colligimus; nam fecundum Ahoc enim euenit, quaido ad pesfectionem duEtus eft, \& fruitur telicitaie ccintex platius, hise eft, omnia nouit, qua hom ni in hac vita mortali cognofcere datum eft, tunc enim intelligit etiam intellectum agentem, proirde rem indiuifibilem \& indiuifibiliter: quod ipfemet Ariftoteles declarat, quando fubiungit [ nöenimfemper babet id, quod bene est, in boc, aut in sllo, fed in toto quedam ad, quod optimum est, illud ab eo exifens ] qua verba Auerroiftx fic interpretantur; intellectus humanus nō habet fuam perfeaticnem in hoc, aut in illo indiuiduo, vt in Socrate, velin Platone: fed hac interpretatio ab Ariftotele alienifima ett, nequead id, de quo ibifermo fit, vllo aiodopertinet; nam Ariftuteles ibinec de indiuiduis, nec de fperie loquitur, fed docere vult Deum incelligere feipfun indiuidue, $*$ id declarat per humanum intellectum: quemadmodum. n. humanus intellectus quandoque intelligit indiuifibiliter, nense quando ad perfectionem peruenit, \& intelligit intellectum agentem; ita $D$ us femper feipfum indiuifibilirer intelligit; hoc igirur fignificant verba llla Ariftotelis, \& ecirum fenfus hic eft: perfectio buman intellectus non femper confiftit in intellectione diuilib $l i$, qux eft quando partibiliter intelligit moda hoc, modo illud, \& comparat hoccumillo, \& difcurrit ab hoc ad illud, quod qadem ei euentr in ipfa habitum acquifitione; fed quandoque $h$ bet in toto quodam, 'D hoc eft, in tempors momento indiulfibili id, quod eft optirnum, id eft, cognitıonem intellectus agentis, qui ef diuerfum quiddam ab ipfo, \& ei iungitur tanquam forma extrinfecus adueniens: ficlocum illum interpretatur $\mathrm{Al}$ exander, nam momentum temporis vocaturtotum quoddam, quia quum partes non habeat, eft totum finul, \& indiuiduam : tunc igitur intelleetus humanus in mom ëro intelligit, fed quan. do intelligit difcurrendo ab hoc ad illud, tunc intelligit in tempore. Quandoautem fubiungit Ariftot. [ fic awieni fo babet spfa fusipfiussontelleFio to to azo] profert hac verba de pumo intellectu, \& fenius clarus eft : ficut enim fe habet quandoqque, \& raro bumanus intellectus, videlicet quando indiuifibiliterintelligit intelleelú agentem, ficfe habet Deus in tota xternitate, nam feipfum femper intelligit indiuifibiliter. Patet igitur nullum argumentum contra nos ex coloco fumi poffe, imo ridiculus effer Artfot . fij vellet, quodilli Auerroifta attribuunt:ham docere volens primum intellectume efe abiunCum à ma teria, non bene faceret hoe declarans. per intelle dum humanum; non enim ita immaterialis Deus eft, vt humanus intellectus, \& teiulto euidentius eft immaterialem effe Deurs. quam intellectum humarua; quocirca Arif. declararet notius per igno:ius, s per id quod cit difinaile, tanquan per waile: is so nos ex eo rillot, ozine carens mal eria eft femper indiuifibile, \& indiurfibiliter intelligens; ergo humanusintellectus, quum nun femper indiuifibiliter intelligat, fedraro, non eft abiunctus à materia. A d poftrem um, quod fumitur ex libro fecundo de ortu animalium, cap. 3. fectatnres $A$ - Adio.de lexandri variis modis refpondent. Simon Por- 2. de Gotius in librofuode mente huakiana traxit verba neras.dillaAriftot.ad onerationem refpeetu intellectus nom: agentis, \& dixit effeintelligenda de a tu fecun-cap.s.
do, operatio enion intellektus dicitur extrinfe- Porrö cus accedere, quatenus pendet ab intellectu a re/ponfso. gente, qui exrra eft, \& fine quo non fit intellectio.Sed aliipofteriores Alexandraifententiam ConfutrPortii non receperunt, quia reuera verbis Ari- tio. ftot. accommodari non poteft: Ariftoteles enim ibi quzftioné proponit de ipra animz fubftantia, de actu primo, non de actu fecundo, quxrit enim de facultatibus anima, an extrinfecus C adueniant, nec ne; nomen autern facultatis apud Ariftotel. feaper fumitur pro anima ipfa, nunquam pro operarione, nequepro intellectu. agente, hic enim non eft pars animz noftra, vt alio in locodemonftrauimus, proinde facultas animze appellari non poteft. Przterea fi dictum. iliud Arift. fic iatelligatur, falfum eft, quia non. folius intellectus operatio ratione mouent is extrinfecus accedit, fed etiam operatio fenfus. nam ctiam vifio fit per actionem obiecti exter$\mathrm{ni}$ in oculum, \& praterea ad eamneceffarium eft lumen externum, quod proportione refpondet intellectui agenti fecundum Ariftotelem, quare non minus vifio extrinfecus ad uenit, qua intellectio. Ideo alii hac refponfione relieta cō- Alioriz fugerunt ad intellectum fpeculatiuñ, \& de hoc refponfor. dixerunt effe intelligenda verba Arifotelis qui eundem exceperat in contextu 21 . \& 32. lib. 2 . de Anima, \& diftinxerat à quarto gradu vitæ: hic e. nim dicitur extrinfecus accedere ratione intelE lectus agentis, qui in eo comprehenditur, ficut antea diximus. Sed hi mihi videnturin eafdem difficultates incidere. in quas Portius incidit: nam dicere incllectum fpeculatium nilaliud eft. quam dicere praftantifimam intellecus o. perationem; tunc enim dicitur fpeculatiuus , quando effentias rerum actu fpeculatur: quoniam igirur disentes hunc extrinfecus ascede. re, refpicimus vel intellectum agentem, vel $O$ : perationen vt pendentem ab intellectu agenF te: refponfiohacin idens cadit cum refponfione Portii, nec conuenitcum verbis Ariftot. qui eo in loco de folis facult atibus anim $x$ loquitur; quare nomine mentis nil aliad incelligere poteft, quam mentern bumanam; qua yocari foletintelle etus poreitate, de quo in prefentia difpu:amus: idqu confrmatur ex requentib: Arift. verbis quibus ration êfiferens dicit [ribslemsm

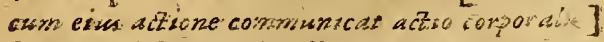

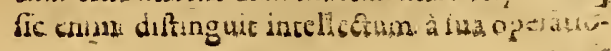


ne, \& cur extrinfecus accedat, hanc rationem adducit, quoniam in fua operatione corpereo infrumento non vtitur: hxc auten ratio pro. bat de ipfa fubftantia intell \& \&us poffibilis, hune igitur Ariftoteles refpicit, quare neutra horum folutio recta eft, \& difficultas integra manet, quomodo Ariftot. dicat folam inter an m $m$ partes humanam mentem extrinfecus aduenire. Petrus Pomponatius meo quidem iudicio proxime omnium ad Ariftotelis mentem, \& ad veram argumenti folutionem acceffit, eam tamen non perfecte affequutus eft, quia ipfam quidem veritatem iuxta Ariftotelis mentem optime declarauit, fedad illa Ariftotelis verba, in quibus aduer farii maximam vim faciunt, nihil refpondit: nam in libro 1. fuz A polog. cap. 7. locum illum declarans, inquit Arift. afferere non ipfam mentis fubftantiam extrinfecus accedere, fed folum prinsipium effectiuum, quod externum eft; hoc enim ibi paulopoftab Arift. aperte dicitur. Attamon queniam Ariftoteles eo in loso non folum intellectum, fed quamlibet etiam aliam animapartem dicit habere principium a. ctiuum cœlefte, ac diuinū, quod nobilitate excellit naturas elementorum, difficultas manet, quam Pomponatius non foluit, quomodo prius dicat folam métem hac ratione extrinfecus ad-

Pomporatii defectus.

\section{Tera re-} Sponfio. uenire. Vt igitur nos veram huius argumenti folutionem, quam nemo vidit, afferamus, declaranda funt verba, \& confilium Ariftotelis eo in loco; his enim intellectis, non modo difficul. tas omnis tolletur, fed etiam validum pro nobis argumentum inde fumctur \& co validius, quo abinterpretatione ipfurmet Auerrois in eo iṕo loco non recedemus; adeo vt mirandum profecto fit, quomodo Auerroiftz loco illo sanquam Achille pro Auerroe aduerfus fententiam noftram vtantur; illius tamen interpretationem, quam ibiaffert Auerroes, non animaduertant. Quum in primo eius libri capite Ariftoteles docuiffet femen maris obiectum in fceminam, nonefle materiam animalis, neque fieri partem vllam ipfits, fed folum agentis officio fungi, fanguinem autem menfrum fomina efle totam materiam aninalis generandi, \&e poftca in 2. cap. de ipfus feminis natura logu u. tus effer, mox in inıtio tertii, çuod nobis confiderandum proponitur, tresquartiones foluendas in medium affert, fed propofita prima ftatim fubiungit foluendas prius effe alias duas $f e-$ quentes, etenim earum folutioad primam foluendam conferebat: prima quaftio eft, quum femen maris non fit pars aliqua ipfius conceptus, neque habeat locum materia, in quodnam eins corpulentia conuertatur, guum certum fitipfum non poffetranfre in nithil: fecunda ef, an fanguis menftrus fomira, qui eft materia cóceptus, accipiataliquid à femine maris : tertia demum eft, an in femine, \& in conceptu infit anima, qua anima eft animal. Hanc
A tertiam quaftionem fatim primoloco foluit, quia cognouit eius folurioncm ad fecundx folutionem conferre, \& folutio in hoc confiftit, quodomnes animx partes in conceptu nondum feparato ab vtero, infunt prius poteftate, quam actu, quia in materia apta ad formam recipiendam neceffe eft $v t$ forma prius infit porefrate, quamactu; fciendum autem eft hoc poffe intelligi tum de primo, tum defecundo actu; nam embryumantequä accipiat animam, haB bet poreftatem refpectu actus primi, ea vero recopta habet poteftatem refpectuactus fecundi, ma pot. quoniam anima illa nondum vtitur inftumen- foste. tis propriis, quia his non incipit vti, nifi poft feparationen conceptus ab vtero; quare antequam feparetur, viuit illudanimal inftar membri illius focmina: non enim nutriturfumens ore proprio cibum, nec proprioventricul o concoquit, fedper vmbilicum recipit à matre fanguinem, ficut alia membra omnia illius fœmiC $n \pi$, \& hacratione dicicur habere animam poteftate, quoniam eius anima nondum poteft per propria organa operari, quum imperfecta atq; imbecilla lint. ita vi conceptus̀, dum eft in vtero, dicatur habere animam poteftate folum, no actu, id eft, non actu completo. Hac igitur ad rertia quaftionis folutionem ab Ariftotele ibi dicuntur, \& alia etiam multa, qua non refero, quia ad nos in prafentia non attinent. Poftea veroquando dicit [ fed aut omnes contingere, qun anie non fuerint, necefje eft] multi putant nouā aliam quaftionem difcucuendam proponirelictisaliis duabus, fed hi confilium Ariftot. non penetrant, quum enim non mul to poft, quando dicit [ corpus aurem geniture, in quo femest animalss proncip ÿ contentum bna prowenit ] foluat primam quaftionem de femine, in qundnam eius corpulentıa coóuertatur, necêffe eft vt prius fecundum foluerit; vult igitur aliis predıctis verbiseam foluere, fed id facit proponēs aliam E nouam quaftionem; quod quidem alios decepit, vt crediderint non fecundam quaftionem ibifolui, fedaliam nouam, qua ibi proponitur: nos autem dicimus proponi quidem quaftionem nouam, \& folui, fedeam effe fecundariam, \& ab Arif́totele eo confilio proponi, ve ex eius folutione fecund $x$ pracipux quaftionis folstionem colligamus; \& nifí hoc dicamus, nullus alius apparet locus. in quo fecunda illa quaftio folustur, qua fuit an fanguis mentrus foemiIn accipiat aliquid à femine maris, an nihil, hancigiturvt foluat Arift. aliam nouam quz. ftionem proponıt, eaq; eft, quum in conceptu nondum feparato anima pro actu primo accepta infit prius potefate, quam aetu, vndenam adueniam actu; \& ftatim tria membra difcutienda proponit, ve declaretur, quodna m iHor afferendu fit: neceffe.n. eft vel omnes illas anima facultates prafuiffe, \& foftca illi materix

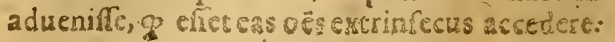

\section{Quamo. do $\sin c$ ceptes i it ani-}

\author{
(1)
}


vel omnes in illa materia innafci, quumante non fuerint, \& ita nullam extrinfecus aduenire; vel tandem aliquas innafci, quum prius non fuerint, aliquas vero induci, quum prius fuerint: non eft autem ignorandus verus fenfus quaftionis-huius, inquo manifeftum eftplurimos fuiffe deceptos; cognofcere enim oportet quid ibi fignificet extrinfecus accedere : certun eft quaftionem illam non proponi de anima fecundum fpeciem, quia nullidubium eft eandem fecundum fpeciem prafuiffe, fed proponide eaden numero anima an prrextiterit, \& extrinfecus materix inducta fit, ita vt prius extra matetiam generationis fuerit, \& illi poftea in dueta fit; certe in hoc fenfu accipit ibi Arift. extrinfecus accedere, quo fit vt tum fecundum fenten-. tiam Ariftotelis, tum abfol ute fecundum rei veritatem nulla prorfus anima hoc modo extrinfecus accedat, fed omres nulla excepta in ipfa generationis materia innafcantux, cum hoc tamé discrimine, quo $d$ cæteræe prater rationalem ita in illa materia innafcuntur, vt de illius poteftate educantur, \& hac ratione $\mathrm{ab}$ agente natu. rali dicantur attingi, hoc eft produci; anima verorationalis ita in materiainna fcitur, vtab agēete naturali non attingatur, neque de materize poteftate educatur, fed à Deo creetur; non enim ita creari animam humanam dicendum eft, vt prius extra corpus à Deo producatur, deinde sreata inducatur in corpus, fed vt in ipfomet humano corpore à Deo immediate creetur, \& eodem momento creata, \& infufa dicaturjagentis vero naturalis opera in eo tantum confiftere intelligatur, vt materiam difponat, ac praparet ad eam recipiendam; hoc dicofecundum reiveritatem,nam quid hac de re Ariftoteles fenferit, \&s an talem creãtionem cognouerit, dúbium eit, idque difutere ad propofitam nobis confiderationem non attinet; hacautem dicere volui, vt omnes intelligerent, nullam animz partem, neipfam quiden rationalem extrinfecus accedere, proutibi ab Ariftotele fumitur extrinfecus accedere, nempevt ita præextiterit, vt potuerit ante ingreffum corporis operari. Hac igitur quaftione, \& iis tribus me ebris propofitisantequam Ariftotel. exanimi fententia eam foluat difputationem, vt plerumque facere folet, prasmittit : nam etiam in cap. 1. Irb. 1. de partibus Animal.quum quaitionem propofuifet, an de omni anima agere ad Philorophum naturalem pertineat, antequam eam folueret, voluit dubitando argumentari; hocidem igitur etiam in $c 0$. loco facit, quod quum alij non viderint, omnes deceptifunt, putantes Arift. ftati in foluere diffisultatem propofitam, \&exanimi fententialoqui, quum tamem hoc facerenon incipiat niff ybi in Latino codice ita legitur [ fed entmomnisanume fucultas] adeo vtomnia pracedentia verba difpuratiua int, \& nihil sn is ab A riftot certi

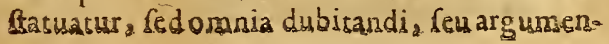

A tandigratia dicantur : argumentatio autem talis eft: quum Arift.tria vt prad simus, membra propofuifet, voluit vnum ex eis tantummodo impugnare difputandigratia, nempeillud, quo dicebatur omnes partes animz extrinfecus accedere, hoc enim falfum effe oftendit; a quiavniuerfalis affirmatiua fatis euertitur per probationem contradietoriæ, quæeft negatiua particularis, fcilicet, aliquas animx partes extrinfecus aduenire non poffe; ideo hanc probat, Arift.

B \& argumentum fumit ab illis, qux organica funt, \& per propria organa operantur, hunc in modum: fi ha extrinfecus accedunt, vel cum corporealiquo adueniunt, vel fine corporejnon. fine corpore, quia quum fint organic $x$, operari fine corpore non poffunt, proinde neq; fine corpore effe, quia fic effent otio $r a$, \& fine operatio- ne; quod dicendum non eft; eas igitur extra corpus fine vllo corpore prafuiffe impolfibile eft. quum fine corporeo organo non operentur: fed c nequecũ corpore extrinfecus aduenire poffunt. quia nullum aliud corpus apparet, cum quo aduenire dicantur fanguini menftuo, nififemen. maris, cum hoc tamen aduenire extrinfecus nequeunt, ergo cumnullo! affumptum patet per fundaraentum modo ia tum:tales enimanima. partes effe non poffunt fine corpore habente organa quadam ftatuta, quæad fingulas requir útur, vt facultas ambulatiua non poteft efie fine pedibus, nes vifiua fine oculis; at femen non hu. D iufmodi corpus eft his inftrumentisprzditü, fed eft fimilare quoddam, imo eff excrem entum vltimialiméti ex cibis geniri, igıtur ha facultates neque fine corpore, nequecum corpore aduenire extrinfecus poffunt: haceft Ariff argumentatio, in qua notare manifefte poffumus Arift. fumere extrinfecus accedere pro eo, quod eft prefuiffe extra corpus, isa vt ante corporis ingreflum operari potuerint, deinde in corpus indici; patet enim Arift. ex eo quod extra corpus

E non polfunt operari, probare cas extra corpus non extitife. Hanc argumentationem tatin ${ }_{e}$ quuntur verbailla [ reftat igitur Gimens fola extrinfecus acce dat, esque fola diuina fit, nibil enim cin es sus actione communicat adto corporalis I quas abfq; dubio in difputatione comprehenduntur, \&nihil certi fatuunt; fententia nam q; Arift hac elt, ös anima partes extrinfecus accedere impolfibile ef, nā multæ funt organicæ,idenq; extrinfecus ascedere nequeunt, fed fola rel inqui-

F tur mens, qua extrinfecus accedere poffit, ac di. uina efie dicatur, propterea $q$ in fuz operatione. nulló corporeo inftrumento veitur; quali dicat Arift. quantŭ attinetad vim rationis huius, qua ab organis fumitur, ex ea non probatur de intellectuquod extrinfecus ascedere non poffit, etenim non habet organum, exquo argumentari, vt de alis poffimus: fed fatis eft, fi dereliquistacultatibus probetur $\not$ extrinfecuś aduenire non poffust; hos enina iuffiticad impugnandamil. 
lam vniuerfalem, qua dicebaturomnes exerinfecus aduenire: igicur manıfeftü eft id, quod antca dixirnus, maximam effe huius loci confonantiam cum context.r.lib.z. de A nima, vbi de feparabilitate fermo crat; exillis enim anima partibus qua propriis inftrumentis vtuntur, A. riftot. vtroque in loco argument um fumpfit; ex illis vero, qua non funt organicx, vtrobique dixit nullum poffe argumentum fumi ad prebandum quod feparari non poffint, \& quod nequeant extrinfecus aduenire, nam ex organis quidem probatur aliquas animx partes accedere extriniecusnon poffe, at ex organi defectunon probaturaliquas extrinfecus accedere, fed folum eas à nullo organo prohiberi quin extrinfecusaccederepoffint; per hoc tamen non ftat, quin ab aliquoalio prohiberi polfint, quemadmodum in eo quoque 11. contextu confiderauimus. Haceft absq; dubio rententia Ariftot.co in loco, eaque in Græcis verbis mulro manifeftior eft, nam errorem in Latinis notaui non parui

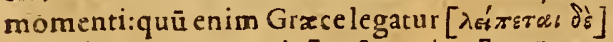
Theodorus Giza vertit [reftar sgitur] quū vertere debuerir [reftat autem] quare verum nō eft id quodalijpro comperto fumunt, Arift. ibi ex dictis conclufionem colligere, qua propriam fententiam proferat; fed vutur dictione aduerfatiua, qux nil aliud fignificat, quamid, quod modo dixımus, non poffe ex intelleftu idem argumentum fumi, quod exalis animx partibus fumptum erat, propterea quod iple non eft crganicus; adeo vt dubium deipfo máneat, an extrinfecus accedat, necnr. Sic interpretatur $A$ uerroes ibi verbailla in fua paraphrafi ; nam eorum loco, de ad ea interpretanda ipfe hac ponit [de intellecturamen dubiumest; quum eizsoperationon Gileatur communicarecum organncurforeo] cognouit enim Auerroes verbailla ab Ariftotele fub dubio effe prolata, \& recte vfus eft dictione aduerfatiua [tamen] ideo \& admiratione, \& rifu dignum eft, quod A uerroift $x$, dum Auerrois fententiam tuenivolunt, ita illis Arift. vesbis innitantur, \& ita inflati incedant, vt putent fe demonftraffe, neque animaduertant $i$ pfiusmet Auerrois interpretaticnem huic eorum fententix refragari ; pacet igitur nullum prorfusargumentum inde fumi poffe ad probädum mentem humanam non efle formam hominis, quum neque dicat hoc Ariftotcles, neq; omnino informationem, vel informationis negationem refpiciat, quum huius confideratio ab illis propofitis quxitionibus fit penitus aliena. Quiodautem prædicta verba non fint abArift.exarimi fententia prolata,fed fub dubio, \& in parte difputatuua contineantur; nö id folum, quod antea diximus, declarat, nempe quod falfum effet Ariftot. dictum, quia non poteft mens cx́trinfecus accedere eo modo quo ibi fumitur extrinfecusaccedere: verum etiam illa, qux ftatimfequuntur, apertiffime demonftrant : nam
A quaftionis folutio, ac propriz fententix determinatio in iis fequentıbus verbıs incipit [ fedenim omnis ansmef facultas] [ed in en rum qiioque conuerfione errauit Theodorus $G_{z z}$, quu

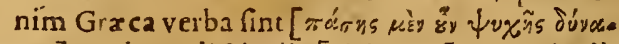
$\mu 6 s]$ non bene dictin 111$]$ [falonsm ]retcrevimil.

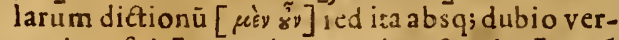
tendum fuit [omnso igst ur arima facultas] certu autem eft, foteft $q$ ab Ariftotel. frequentilime obleruari, diationem, ชั๊y, tunc poni, quando cō. B cludere, \&exdiatis colligere aliquid vult;fed $\mu$ s̀t žv,tunc dici, quando aliquid, qund antea profofuerit, aggredi, atque inciperevult, \& raro comperietur Ariftotel em in concludendo dicere, $\mu$ év siv;fed frequentius in aggrediendo, feu incipiendo: incipit ergo ibi quxitione foluere poft pramiffam difputationem, \& folutic manifefta eft; quum enim quxitio propofita effet de partibus - anima, an extrinfecus accedant, feu omnes, feu aliqux,cognofcens Ariftot. nullam extrinfecus C accedere in eofenfu; vtipfa anim $x$ fubftantia dicatur prius extra corpus exiftere, \& operari, poftea in corpus induce, alium modum in medium affert, quo dici poteft, non folum aliquam partem, fed etiam omnes exirinfecus accedere, nempe ratione caula efficientis : formz namque inanimatorum de materia educunturaba. gente elementari; nam calor elementais in generatione miftilocum habet agents in educenda forma mifti de poteftate materiz, vt alio in loco declarauımus; fed anima non poteft à facultate elementari produci; quare principium actiut:m haber exteinum, nempeccelefte, atgus diunum;itaquecaufam agentem in produetione on uum partium animarefert Ariftotel. in faculatem coletem an quas etiam inquit inter fe difideremaiore, ac minore nobilitate, prout etiam anime rodum cendre nobilitate difcrepant, \& funt alize alis nobiliores, aden véa facultate coelefti nobiliòre E nobilioretiamanina pars produci dicatur: in hanc ig:tur caulam agentesa refert Ariftotel. product onem animarum; nam animalia, qua ex putri materia generantur, ibidem afferit à talicol efti puncipı generari;illa véro qua per propagationem, \& exfemine gignuntur, inquit habele in feminibus facultaiem gencratricem à coleftubus corporibus inditam, quam dicit effe calorem, non quidem clementarem, \& i-Calorce gneum, fiquidem calrr igneus non eft produ- celefti F Etiuus viuentis, fed calorem coleftem, \& à coe- $d s / t s n-$ lo impreffum, proinde referentem na:uram alusab quinti elementi . quod eft clementum ftella- elemem. rum;calor enim vitalis, qui in femine eft, locum ters. tenet illius quinti el ementi, quum ab co proueniat, \& tanquam illius inftumentum eft productiuusanimalis: poftea vero alis fequentibus verbis inquit duas in feminibus viresinef. $f e$, vnamabipfis feparatam, alteram vero non feparatam; agitenim femen, tum virtute pro. mine. 
pria tanquam agens proximum, tum etiam vir- $A$ tute coleftitanquam infrumentum cocleftis a. gentis, \& hac rationedicitur in femine ineffe principium actiuum ab eo feparatum, hoc eft refum, \& guberuatum ab agente feparato, vnde dicifolet, Sol, \& homo generant hom inem; propria autem ipfius feminis virtus non poteft effealia, quam elementaris, quum femen exelementis conftet;nam hac quoque virtus fuam actionem contribuit, fed ad animalis generationem nullius momentieffet fine altera, quam fe- B men à Colo accipit. Hoc igitur modo inquit ibi Ariftotel, omnes partes anima extrinfecus accedere, non quidem ratione fuz fubfantix, fed ratione principij agentis, quod non eft elementare, fed colefte. Hoc autem Ariftotel. dictuns, vtcunque ab ip fointellectum fit, de quo in prefentia non difputo, verum etiam abfolute eft, fi fano modo intelligatur: nempe vi dicamusalias partes animz prater rationalem ita produci abillo caleftiprincipio, vt ipf $\boldsymbol{x}$ de poteftate materize educi ab illo dicantur; animam vero rationalem,à folo Deo immediate creari in corpore, penderetamenipfam quoque à colefti principio nobilıfimo, quod materiam tantummodo praparet, \&idoneam reddat ad ip fam recipıendam, fed iplanmet ammam non producar. Qurdautem Arif́otel. pradictis verbis dicat, folam mentem cfiediuinam, id nullius do-momenti eft ad probandum eam effeà materia Go- asiunftam, quia ibi diuinam vocat conftituens eam extrinfecus accedere; nam fi extrinfecus adueniret $e$ modo, quem antea declarauimus, vtique diunum quiddam abfolute effet, maxime vero compuratione aliarum partium animajideo etiam paulo poft eam vocat Ariftotel. diunam quippe hanc comparationem refpiciens, \& ibi mentem ipram exempli gratia nominat, quando disit [ qualis est, quse mens apjellatur ] id enim, quod ibi dicit de pendentia abagéte externo, verum effe prius dixerat de omni. bus animz partibus; fed qua de intellectu ef manifeft fimum, quum fitparsomnium nobililisma, ideo ipfum exempl grata nominare voluit:quod autem qualibet pars anima nobilo or refpectu ignobilio ris dici poffit diuina, infemet Auerroesiapeafierit:nam in Commentar. 59.lib.2 de Anima,animam quoque fentientem duinam appcllat, inquit enim Arifotel exifimafle in fenlibus actum prinum produci ab 1ntelligentıa agente, \& à diuino principio, \& citat Arist. 1n libris de Animalibus innuens caput illud 3.libr.2. de Animaliam generatione: fimiliterin Comment.3r. feptim Metaphyf. \& in r8. duodecimi loquitur Auerroes de hacomnium partium aniare diunirate fecundum Arift. \& cirateundem locum. Pater gyitur cur Arit. mentem humanam, \& ibi, ealis in locis diuinam acpellet:ac nus, quiverorem philofopham fectamur, alian quoquerationem affermus, sur intcromnes animx partes fola humanamens dicatur diuina ; eft enım diuina non comparatione aliarum, fed etiam quia fola eft à Dco inumediate creata, alix vero partes non fic, fed permedia agentia naturalia de materix poteftate educt $x$ funt.

\section{Auerrois ac Themiftï opinio de intellectus vnitate, \& eorum argumenta. Cap. $X$.}

I ICET perea, qux hactenus ditta funt, 2 . L liud quoque Auerrois dogma fit reproba. tum, nempeid, quod dixit, mentem humanam vnam tantum numero effe in tota humana fpecie : quia fieft forma materiam informans, \& qua homo eft homo, neceffe eft vtiuxta nume. rum indiuiduorum hominum fit multiplicata: attamen ad vbrriorem huius erroris confutationem, \& vt argunentorum quibus ad hoc probandum Auerroes vfuseft, vauitas manifeAta fiat, libet aliqua feparatim de hac re fcribere. Fuit itaque Auerrois, atque etiam Themiftij fententia, quam poftea multi pofteriores fequuti funt, animam rationalem humanam, qux ab Auerroevocatur intelleotus poribulis, non effe iuxta hominum numerum multiplicatam, fed vnam tantum numero in tota humana fpecie, \& elfe incelligentiam omnium infimam, cuiaffignata fit tota humana ipecies tanquam pro. prius, \& illizquatus orbis, \& qua intereunte aliquo homine nonintereat, fed in reliquis hominibus eadem numero maneat; vt apud eum legere poffumus in Comment.5. libr. 3. de Anima,\& apud Thenifitum in context.20.eiusdem teitij, \&in fex gefino primi.Casteri veroomnes Ariñotel. interpretes Grzci \& Latini putarunt eameffe multiplicatam; vt non modo frcundú Arritoteiem, fed etiàm fecundum veritatem afferendum eit. Videtur quidem Simplicius in 2.

E context.illius libr.3. dicereanimam rationalem fecundum fe vnara elfe, per fuam assem in corpus progreffonem multiplicari : fed ho: aiis pluribus Simplici figmencis annumerandum eft, multa enim dicit, qua fimul efle nequeunt, \& manife Ram repugnantiam habent, yeluti animam eationalem totam elfe in femanentem, \& perfectam, \& totam effe lapram in corpus, \& imperfectam; eanque vnatn numero effe fecundum $\mathrm{fe}$, in hom inibus autem effemulapliF catam, \& alia ciusmodi, cuz neque effe, neque cogitatione comprehendi à nobis poffunt. Ideo his omnibus dimiltis, fatis nobis erit illam Simplicij confeffionemaccipere, quod anima rationalis in hominibus multuplicara numero fit, non vt Auerrocs, ac Themiftius voluere, vaa numero in crabus. Hac igitur de re fermonem habituri, ante ornniain raedium afferemus Themifij \& Auerois argumenta, poftea veritatera demonitrare, \& omnia illa H argu. 
rrsmum argumenta foluere nitemur. Primum quidem argumé- hoc argumento ambo vtuntur; quamuis enim rsm a- Themiftiusillud adducatad oftendendam rniuerros, tatem intellectus agentis, idem tamen aptari E. The poteft ad patientis quoque vnitatem demonmysf 20. . frandam, ficut co vfus eft $A$ uerroes, necminus roboris iuxta corum fententiama habet in intellectu patiente, quam in agente; argumentum autem tale eft: Si anima rationalis effet iuxta hominum numerum multiplicata, effet forma materialis : confequentia fumitur ex A riftot. in context.49.duodecimiMetaphyf.vbi dicit multitudinem indiuiduorum fub eadem fpecie à materia prouenire : confequentis autem fálítas ita probatur: ompe materiale eftpoteftate intellectum, vt ait Arrit. in context.16. lib.3. de Anima,omne autem pote ftateintellectum eft obiectum motiuü intelle etuspatibilis ; ergoidem intelicetus eftobiefum fibiipf, \& mouer feipfum, \&recipit fe, vel intelicetus non eft intellectus, fed eft folummodo obiectrm intelleetus; quum igitur hac firt abfurd2, id quoque, ex quo deducuntur, ábfurdum eft; quare intelleftus noneft forma uaterialis, proindeneque

secundü argumétrsm. multiplacatus. Secundum argumentum in pradieto loco affert Auerroes t* le: fi intellectus patibilis multiplicatus eft, ergo etiam intelle tiones funt nultiplicata, hoceft, intellectio ciufdem reimea, \& tua funt penitus diftinetz numero; hoc autem dato fequitur, rem intellectam habere rem intellectam, \& illam adhuc habererem intellectam, \&: fic in unfinitum : cōfequens eft abfurdum, confequentia vero ita probatur: fingularia funt intelleda poteftate, vniuerfale auters eft 2 ctu intellectum, idco fingularia dicuntur habere remintellectam, quarenus habent vniuerfale, quod eft actuintelligibile; fingularesigitur intellectiones habebunt fum vniuerfale tanquam actu intellectum, quum ipf $x$ fint potefaictantum intellect $x$, nam intellecto communiter accepta de illis pradicabitur, vt vniuerfale de fingularibus; hanc igitur intellectus intelligitvtrem vniuerfalem: $2 t$ qui intellectioipfa intellectionis cfintellectio quxda $m$ fingularis, quia eft in animo huius hominis fingularis; igiturfi plures fingulares homines intelligantintellectionem vniuerfalem, erunt plures fingulares intellectiones intelleAtionis vniuerfalis; ergoadhuc habebunt rem intellectam, nempe aliud vniuerfale eas comprehendens, \& fic in infinitum: dicendum igitur eft (inquit A uerroes) tuam intellectionem, \& m ram non effe penitus numero diftinctas, fed effealiquo madoplures, \& aliquo modo vnam; plures enim funt ratione diuerforum phancafmatum, va autem niumero rationeintellectus, Tertium qui eas recipit, quia vnus numero eft. Tertio Aargume-- uerroes, ac Themiftius in pradictis locis 1ta artพร).
A intellectu, non poffet magifter in animo difcipuli fcientiamproducere; quum enim fcientia non fit qualitas actiua, non poteftaliam numerofcientiam in alio generare co modo, guo ca lor ignisproducit in alia realium numerocalorem; igiturfateri cogimurvnum \& eundem nu. mero effeintellectum magiftri, atque difcipuli, \& difcipulum eandem, quam magifter habet, fcrentian acquirere, quaniam à magiftro excitaturad eandem, qua in animo magifrieft, reB cipiendam.

\section{Pradicta fententia confutatio. Cap. XI.}

D huius fententix falfitatem demonltranA daro fatis eft (vtpauloante dicebsmus) illud vnum argumentum, quod deducitur expre demonftratis: nam fi anima rationalis elt forma dans effe homini,ficut oftendimus, neceffe eft vt fit multiplicata; quia fi effet vnanuméro in o. mnibus, omnes hom ines effent vnus homo fin. gularis, vel ego effem per effetui, \& tu clies per cffe mei, qux vtraque abfurda, \& inex́cogitabilia lunt:confequentia autem manifefta eft, \& ab Auerroiftis conceffa; quia neceffe ef: formam hanc fingularem côftituereindiuduum vnum. quare vel omnes homines effent vinus homo, vel fi plures, vnus effet per elfe alterius, \& vnius conftitutio effet oranium conftitutio, quz omnia funt abfurda, \& implicant contrudietio$\mathrm{ncm}$. Solus tamen Achillinus hanc confequentiamnegareaufus eft in Quodlibeto3. dubioz. inquit enim animain rationalem effe formam vere informantem, \& effe vnam numero in tota humana fpecie, non multiplicatam; negat autem pradicta abfurda fequi , quia putat 0 m nem tolli difícultatem dicêdo vnam quidem effe, diuerfa tamen indiuidwa conftitucre, \& dare diuerfa effe pro diuerfitate cogitatiuarum, qua in diuerfis hominbus funt, quia propter,

$E$ has fit v teffe meum non üt effe tuus, nec frmus omnes vnus homo, nam ab eadem forma nu. mero recipimus diuerfa effe, quatenusilla cft coniuncta cum diuerfis cogitatiuis ; fic ig:tur fumus multiplicati, \& numerodiftinguimur, li cet ipfa vna \&̀ eadé numero maneat. Sed A chillinifentētia eft omnino bfona rationi; quia vel à forma pendet fingularitas, vel à materia : fi à forma, ergo vna numero forma vnum numero fingulare conftituit, proinde valida eft confeF quétia noftra:fi vero à materia, fiue (quod idem eif) à conditionibus materialibus, neceffe eftab hıs formam indiuiáuari, \& fierihanc, rrumeroq; diftinctam à forn:a alterius;prorfus enimneceffarium eft formam aut ındiuiduare, aut indiuiduari à materia, in qua eft, \& quam informat; quia.vt inquit Arift. in 2. Phyfic. materia, \& forma inuicern referuntur, \& ad a liam formam refertur alia materı; qquo fit vt quicquid eft in hoc indiuiduo, ex necefitate fit hoc, \& numero difo

\section{Pris

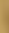

gumentantur: fintellectus hutus hominis effet penitus numero diftinctus ab alterius hominis 
tinctum ab aliis eiusdé fpeciei. Eft et am rationi confentaneum, vt form vltima reftringat, \& determinetalias, fed noa ipfaab vlla illarŭ determinetur, ac reftringatur: quare dicendum potius eft animam rationalem determinare, \& coarêtare imaginatiuam; quam ab illa coaretari. Ex his igitur patet, efficaciffimum effe argumétum noltrum, neque recipiendan effe Achillini folutionem in Arittotel.philofophia, imo neq; abolute in philofophia. Cognouit hoc, atque confeffrs eft Auerroes ; videns enim poni fimul non poffe vnitatem numeralem anira rationalis in tota humana fpecie cum informatione,negatit eam informare materiam, quū vnawa numero in omnibus effe exiftimaucrit; quoniam igitur nos demōltrauimus eam effe formam vere informantem; valida eft Auerroe quoq; confitente hac confequentia, intellectus eft forma, qua homo eft homo, ergo eft mul tiplicatus, nec poteft effe vnus numero in tota humana fpecie. 3. $\vec{u}$ Ad hocidem demonitrsndum efficacifima eft nen ratio ab Auerroe aducrfus feipfum adducta in predicto loco, necbene foluta, quzab operatione fumitur, \& talis eft : aftus fecundus, nempe ipfa intellectio, multiplicatur iuxta numerum indiuidaorum, ergo eriam actus primus: patet confeçuentia, quia diuerfitas operationum indicat diuerfitatem formarum : affum. tum autem manifeftum eft, quia mea intelleEtio non eft tua, \& me intelligente alij homines : ors 50 non exnecefitate candem rewas intelligunt. Sol. I rrois uit hoc algumentum Auerroes confugiens ad diuerfitatem phantafmatū, ex qua inquit prouenire diuerfitatem intellectionum; quia licet vnus fit intellettus in pluribus hominibus, tamen quum phantafmata in iis diuerfa fint, of fine hishowo non intelligit, diuerfas quoq; effe jomfio intellectiones neceffe eft. Hanc Auerrois euaunp fionem euercere nititur Tho cas in I. part. Sum. tio. quæat. 66.artic.3 \& in opufculo I6.vana enira reuera eAt, quoniam phantarma, vt recte Thomas confiderat, in intellectione habet locum rasouentis, non forma vtperperam Auerroes accipit, fed Incura form kabet fpecies intelligibilis à phantafmatein intellectu producta; quemadmodum etiam color realis refpectu oculinon habet forma locum, fed mouentis, fpecies autem coloris recipitur in oculo ad locum forma: igitur phantafma quidem huius hominis non poteft efie illius, quia phantafia huius differt numero à phantafia illius, fed fpecies intelligibilis neceffe eft vt vna 2 eadem in omnibus fit; quum enim vnus numero intellectus in omnibus hominibus infit, neceffe eft ve quicquid in eorecipitur, in omnibus fimiliter recipiatur : d $\vec{i}$ igitu: phantafma, quodin me eft, agit un incellectum, neceffe eft omnium hominum intellectü ex ea actione pati , ¿x intelligere, gqu ėdmodum fivnus numero efet oculus omniu hominum, neceffe effet, vt co patiente à quolibet colore omnes fimul homines illum colorem viderent. Nonnullitamen hoc Thomxargumentum par-Aligreoui momenti effe putant, \& dicunt folui duobusrum op:modis poffe: Primo quidem negando fpecies in ziso. intellectu impreffas, vt ipfieas negant: nam dicunt nullam reuera fpeciem in intellectu im. primi, fed fatis effe phantafma prefensad pro. mendam intellectionem, per eius enim prafentiam intellectus fit illametres, \& ita dicitur intelligere; negata igitur impreffione fpeciei, B argumentum inaneredditur. Secundo, conceffa etiam fpecie impreffa, dicunt argumentum folui dicendo, imprimi quidem in intellectu fpeciem, non tamen candem numero in intelleEtu omnium, fed eandem fpecie, num ero autem differentem, proinde neque eandem numero in omnibus fieri intelle etiónem. Igo tamen puto solutroinfirmam effe veramque folutionem, \& argu- nis smp w mentum Thomze firniffroum, atq; infolubile gnatso. effe. Quod enim ad priorem folutionem attinet, nos quidem poftea oftenfurifumus, non poffe absq; fpeciei impreffione intellectionera fieri: fed mitłamus hoc, fine imprimatur fpecies, fue non imprimatur, argumentum efficaciffraum eft : quia fi intellectus ex prafentia phantafmatisfirresilla, cuius eftphantafma, \& ita eam intelligit, idemẵ numero eft omnium horrinum intelle cus ergo oranium intellectus eodem momento eft facus res 1112 ; \& eam intelligit, etenim ne imaginabilequilem eft fieri in alıquo homine intellection é, quin fimul fiat in omnibus, fi intellectus pariendo intelligit, \& idem numero in omnibus ef. Altera quoq; folutio inanis eft: nos eni m in prafentia non confideramus varia diuerform hominum, aut etiam eiusdem hominis phanrafrata, qua diuerfas nusacro fpecies, aut intellectiones in intelectuproducant; fed vnum \&idern phàntafma, quodi moucat intellectum, \& dicin us vnam numero fpeciera imprimi ab vno phantafmate in $E$ intell cauvnofecundun numerum, proinde ex neceffitate eandera numero in omnibus hominibus incfre. Sed age, concedamus ex vnius phantafratis actione non eandem numero fpeciern, \& intell, ationem produci in intellectu omnium hominum, fed eandem fpecie, numcro autem plures piopter corum hominum diuerfi: tatero; quid hocad nos? fatis enim nobis eif, fi oftendaturneceffarium effe vteodem tempore omnes homines eandem rem intelligane, ct-

$F$ iamfi diuerfan num ero fpecies atque intellectiones fieri dicantur. Argumenturs igitar Thoma Tersum efficacifimume th, \& de cius efficasitate plura argumen legi poffunt apud Gregarium Ariminenfem in twm. libro fecundo Sentent. diftinct. 16. \&:17. qusef. 2. Alio quoque argumento hosidem confirmare poffum us: fi vnus numeroeffet intellectus in cmnibus hominibus, in codera fimul ineffentopiniones contraria de'eadem re, quod-eftpenitus impofibile, hic enim homo putat mundum

$\mathrm{HH} 2$ effe 
effexternum, alius veronon effexternum; hic $A$ animam mortalem efe opinatur, ille vero immortalem, \& fic de pluribus aliis rebus. Sed AAchilli- mortlinus lanc quoque rationem folui putauit so. dicendo, non poffequidem in eodem fubiecto recipi duo contraria fecundum effereale, at fecundun effe crignitum, ac fpiritale recipi duo contraria absque ylla abfurditate poffe: quod confirmauit dicto illo vulgato, contrariorum eadem eff fcientiajidem enim homo, qui cognofcit calidum, cognof́cistiam frigidum, \& qui cognofitalbum, cognofcitetiam nigrum. Sed Keffonfio in hoc quequedeceytuseft Achillinus, \& hac $n \dot{s}$ imp w folutio vim argumentinon tollit; quia aliud eft gnatio. cognitio contratiorum, aliud eft cognitio conAliwdef traria : contrariorum enim cognitio in eodem crgnitso intell tequ contrarietatem in fe non habet, \& in côtrarjo. hoc fenfu verum eftillud Achillini dictum, con$r \bar{u}$, alsud trariafecundum effe fpiritale poffunt effe in coest cogni dem, quia funt quidem reprafentatiua rerum tso con- contrariarum, fed ipfa fecundum fe non funt trarka. contraria : at contrariz opiniones habent inter fe veram contrarietatem, quia non eatenus habent contrarietatem, quatenus funt reprafentatiuz rerum contrariarum, quum potius de eademrefint, fed quatenus fecundumfe confiderantur vt qualitates reales in animo inhstrentes; ideo iure dicuntur contraria, nes paffunt fimul effe in eodem, cuemadmodum quisque in feipfoexperitur; non poteft enimidem homofimul opinarieandem rem eodem tempore effealbam, \& effe nigram fecundum eandem partem, nec poteft fimul credere animam hu. manam effemortalem, \& immortalem. Quod igitur in animo eiusdem hominis impolibile eft, non minus eft impoffibile in tors fpecie, $f$ idem numero intell causeft in tota fpecie hu. mana \& id, quod Achillinus dicit, quum in vno \& eodem homine locum non habeat, falfum abfolute effe deprebenditur; nam fi contraria deeadem re opiniones non funt retiera contrariz, \& taliquam fpiritales poffunt fimul effe in codem intellectu, cur non poffunt fimul effe in codem homine? ficutigitur in eodem homine fimul effe non poffunt, ita neq; in eodem intel. lectu, fi vnus num ero eft in tota fpecie; quare argumentum eft validiffimum, \& Achillini foluAlo re tio vana eft. Si quis vero dicat foluiargume extum
Sponfis. hos perphantafmatum diuerfitatem, nempe dicendo poffe in eodem intelleetu contrarias opiniones recspi ratione diuerforū phantafmatum, quz in diuer fis hominibus funt : hre quoq; folutio vana eft, quia phantafmata (ficut antea dimompzen cebamus) in incellektionenon habentlocum nifi dio. mouentium, intelle ctus autem recipit fpecies, \& intelligitiat impoffibilitas tota in recipient e cōfifit, aulla in agente; poteft enim contingere, vt duo contraria agentia, vnum calidum, alterum. frigidum fimul'agantin idem patiens'; at nō potefidum numero paticnsrecipere fimul codem temporecalorem, \&: frigus tanquam diftindes qualitates cōtrarias: quernadmodus igitur hic diuet firasagentium, \& contrariarum actionum poffibilitas non tollit irpoffibilitatem, qux in fubiecto eft, recipiendi fimul duas contrarias qualitates; itaneque direrfitas phantafmatum mouentium, quam quidem nos concedimus, non tollit impoffibilizatem recipiendi contrarias opiniones in intellectu patiente.

B Solutioargumentorum Themiftü, \& Auerrois. Cap.XII.

A Rgumenta vero à Themiftio, \& ab AuerA roe adducta facilefoluuntur. Primum erat: Sintelle etus of multipicatus, ergoeft forma materialis, ergoef poteftate intellectum, ergo eft obicetum libimet, \& mouet feipfam. Nos vero hac omnia concedere poflumus, dummodo per formam materialem nil aliui iatelligamus, quam formam informantem mateC riam, \& dantem efferei naturali, hoc eft, prout materialefumitur vt oppofitumilli, quod eft abiunctum à materia ; intellectum ăutem intel. ligere feipfum afteruit clare A riftoteles in context.8.libri 3. de. Anima, ita tamen vt intelligamus eum non primo fejplum intelligere, fed fecundario, \& per intellectionem aliorum; dum enim alia intelligit, potefsanimaduerterc fuam intelietionem, de eam, arque feipfum cognofcere : difum autem illud Arifotelis, in$D$ tus apparens prohiber alienum, intelligendum eft de folu obiceto primario, non de fecundario; oculus enim recepturus colores tanquam obie- ales ctū primarium, debuiteffeabfcolor, quia sclor fat ob oculo naturalicer inexifténs eum prohibuiffet $c z=m$ receptionealiortamcolorum; at propria oculi mari quantitas non impedit osulum, nealiarū rerum quantitares recipiat, ac videat, quia quantitas non eft obiectura primarium, fed fecundarium, quod igitur intellectus dicatur efe fibimet ob-

E iectumfecundarium, nihilabfurdi efit quare totum argumentum concedi poteft.Sed quoniam a duerfarij, dum 1 ta argumentantur, videntur obięū primarium intelligere, ideoaliterrefpondemus: a quando dicunt, ef forma materialis, \& ef poteftate intelligibilis, ergo eft obiectum fibimet, negamus hanc confequentiam: dicimus enim obiectum primum seadaquatum intellectus nō effe mareriale quatenus materiale, nec poteftate intelligıbile quatenus poteftate intelligibile;fed quoddam nominecarens,nempe omne ens quatenus eftens, vno excepto ip fo intellectu;quicquidenim eit prateripfum, continetur fub fubiecto eius primo, ipfeautem fibi cme eft obiectum fecundarium; quare ex co quod ens. fit poteftate intelligibllis, non inferturipfum effe fibi obiectum primum, quia obiectum eius prinum nó eft omne poteftate intelligibile, fed omne, quod eft prateripfum; argumentum ergo nibil roboris habet;de iplo autem intellectus. obicka. 
obicto nosalibi accuratius loquemur. Ad fecundum argumentum refpondere duobus modis poffumus. Primo dicimus, intellectionem noftram poffe dupliciter confiderari, vno modo fecundum fuum effe formale, altero modo fecundum effe reprafentatum : formaliter acce. pta omnis noftra intellectio eft fingularis; $\mathrm{ctt} c$ nim qualitas hacfpiritalis in animo huius hominis induidui;at per reprafentationem poteft effe tum vniuerfalis, tum fingularis, fcilicet vel rei vniuerfalis, vel rei fingularis; nam fi intelligam equum vniuerfalen, hac mea intellectıo eft vnucrfalis per reprafentationem, ipfatamen fecundum fe formaliter elt vna intellectio fingularis : fi vero intelligã equum fingularem, eft inteliectio vtroque modo fingularis: fic dicendum eft de intellectione intellectionis, nam fi intelligam intellektionem vniuerfalem, mea hre intellectio eft fingularis formaliter, fed eft vniuerfalis per repræfentationem, quia reprafentat intellectionem tanqquam rem intellectam vniuerfal ern. Ad argumentü igitur dico omnem intellcetionem effe fingularem, \& hacratione dici pofre poteftatc intellestam, etiam comprehendendo intellectionem intellectionis vniuerfalis, nam hac quoque formaliter accepta fingularis eft; habet igicur rem intelleetam, loc eft, intellectionem vniuerfalem tanquam rem, quare omnes intellectiones conpleatitur, ip fa vero intellectio vniuerfalis, quatenus eft vniucrfalis, non habet amplius rem intellectam, quia fi ha- $D$ bet, habet vtfingularis, non vt vniueralis, \& dum fumitur formaliter vt fingularis, eft poteftateintellecta, \& continetur fib intelleatione vniuerfali repraentata, tanquam indiuiduum fub fpecie; non procedimusigitur in infinitum, fed gradum fiftimus in intellectione vniuerfali, quia non habet amplius rem intellectam, fiquidem folum fingulare dicitur habere rem intellectam. Sed refpondere etiam aliter polfumus, negando intellectionem dici poffe poteftate intelle ctam, quod enim dicitur,omnefingula re eft poteftate intellectum, verum eft de fingulari tantum materiali, quod perfenfum ad phantafiam tranfiens ab ea offertur intellectui; vt lapis in intellectu, licet fit conceptus hic fingularis, non eft tamenres poteftate intellecta, fed eft res a fu intellecta, quia eft fine materia : idem igitur de intellectione dicendum eft; intellectu enim intelligente vnum fiunt hxc tria, intelieetus, \& res intellecta, \& intellectio: quareficutires initellecta eft fine mareria, intellectio quoque dicitur effe fine materia, \& ipfe quoq; intel lectus, etfi efterma dans effe materiz, in hac tamen fuz operatione eft fine materia.Hancrefponfionem ego defendi polfe arbitror, quod fi quis conftanter affirmare velit, intellekionem fin. gularë efepoteftate intellectarn, \& habere rem intellectam, eo etian conceffo fallax argumentwo eft, \& priorerefponfione oprime foluitur.
A Poftremum argumentum poteft contra aduer- $\Delta d$ lem farios ita retorqueri : aliqua animalia bruta di- $8 \mathrm{smas}$. fcunt multa ab hominibus, vt pfittacus vocem humanam audiens cam imaginatur, \& in memoria figit, \& mirabiliter imitatur, quidigitur? dicemusne eandem numero effe phantaliam in aue atque in homine? Ad argamentum auter dicimus intellectum magiftri differre numero ab intellectu difcipuli, \& fcientiam, qua eft in animo magiftri numero differre $2 b c 2$, qua in 2 B nimodifcipuli gignitur; \& eam efficerc;quam autem obiicitur, fcientia non eft qualitas a ctiua, dicimus non effe quidem actiwam actione ma. teriali, qua cum vera alteratione fit, qua ratione aetiuus eft calor:nihil tamen prohibere quo minus agerepoffic actione fpiritali : quod quidem de aliis eiusmodi pluribus negari non poteft; nam quantitas non eft attiua realiter, agit ta. men fpiritaliter,quiaimprimit in oculof eciem fuam, \& inde in phantafia , ac demum in intelle. ctu : quemadmodum igitur videns aliquis colo. rem, \& quantitatem, poteft bac imaginari, ac demum intelligere, \& horum cognitionem per vifum acquirere, cur non ctiam per auditum audiendo voces ha rum rerum fignificatrices à przceptore loquente? huius igitur ationis modum confideremus, Q videamus nihil in ea contingere abfurdi pofita intelleetus noftri multiplicatione, anima enim ínformata rerum cognitione poteft conceptus fuos exprimere voce per media corporea in itrumenta: \& quia voces funt figna non folum concepturm, fed ctiam obieftorum realium quorum conceptus funt; fignificant enim res per medios conceptus; ideo difcipulus audiens vocem apprehenditrem ab ea figntficatam, quia perillam vocem illi reprafentatur illud idem obiectum reale, cuius conseptus in animo magiftri eft: quemadmodum igitur obieftum reale potelt in fenfu producere fpeciem fuam; \& ad mentem víque per phantaE fismperuenire;ita potefridem à magiftri voce reprafentatum producerefpeciem fuam perauditum in mente difcentis. Tantum igiturabeft, ve ex doctrina \& difciplina vnitas intellectus humani offendatur, vi potius contrarium fignificetur;quia fi idem numero effet intellectus in magifro, scin difcipulo, iam non opus effet fcienciam imprimere in intellectu difcipsuli, effet enim iam imprefia cqum ergo habente eam praceptore difcipulus non habeat, poftea vero F acquirat, inde colligitur differre numero intel. lectum viriusque.

\section{Quid fit bumana mens ratione fus opera- tionis. Cap. XIII.}

Q Vid mens burasna fit refpeetu corporis, exiis, qua hadtenus dieta à nobis funt, fatis udnife fum effe arbitror:nam fi communem animx definitionemin 2, de A nima lib. ab A rift. 
traditam fingulisanima partibus ( vt confilium Ariftotelis fuit) aptare velimus, nil aliud eft animavegetans, quam aetus primus viuentis, hoc eft, forma, qua viuens eft viuensinil al iud eft anima fenfibilis, quam actus primusanimalis, id eft, forma, qua animal eft animal, nilaliud eft anima rationalis, qux mens humana dicitur, quam actus primus hominis, feu forma, qua bomo eft homo:aliud quoque, quod ex hoc deducitur, declarauimus, nempeipfarm effenon poffe vnam numero in tota fpeciehumana, fed iuxta induiduorum hominum numerum effe mul tiplicatan. Supereft vtrefpeetuetiam operationis naturam eius declaremus, quod facere fibi propofuit Ariftoteles in 3. lib. de A nima; fed ita obfcure, vt parsilla raximeomnium ambigua effe, \& incerpretatione indigere videatur, quum propter multa, \& magna interpretum diffidianon fatis liqueat, quid de hacanimbe parte doceat ea traetatione Ariftotel es. Nos igitur, dimiffis aliorum fententis, quum in carum confiderationenimium temporis effetinutiliter conteréndurn, dimifis etiam in præfentia multis ad hanc anim $x$ partem attinentibus, qua ibidemab Ariftotele tractantur, de quibus poftea feorfum differemusillud folum, quod ad inftitutum hoc noftrum attinet, breuiter, ac ftatim declarandum fumemus, idque eft, quænam fit anima rationalis natura, quatenus principium eftoperationis. Hanc Ariftoteles ibi in duplici Drsplex smmifso intelle-

arus. immirtione confiftere docet, feu in altera priore, quam poftea altera ex necefítate infequitur; vna eft cum obiectis intelligendis; altera vero cum organo: ad has declarandas ita progreffus Declars- eft,ante omnia hocfundamentum fatuit, inteltio cont. lectum fimilem in hoceffe fenfui, quod patien2.in 3 . ls. do intelligit, ficut etiam fenfus patiendo fentit: de Ani- quum enim in nobis ipfis experiamur, nos quämas doque effe aftu intelligentes, quandoque non actu, fed poteftatefolum, nulla autem res pofiit feipfam ducere de potefrate adactum, neceffe eft intelieetumab alio pati; non poteft autem pati, nif abipfifmetobiectis intelligendis, id enim quod eft poteftate tale, fit actu tale ab illo, quod iam fit aetu tale; fic enim etiam fenfușab obiectis fenfilibus patitur, vtiam docuerat ADeriera rift in 2. lib. Qunniam igitur patiendo, \& recipitio cont. endo obiecta intellectus intelligit, hinc intert

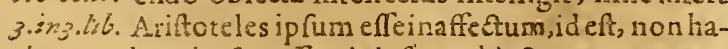
de snz- bere in fua elfentiaipfam obieftorum naturam 303\% fed poteftare folum, quiali actu haberet in feipro naturam fui obiecti, non poffet illud resipere, in hos quoque finilem effe dicit intellectum fenfui: quodficut fenfus non habetactu in reipfo obiceta fenfilia, fed poreftrtem ea recipiendi;ita neque intelledus habet afu obiecta inteligibilı, fed folam recipiendipoteftarem; ita vitquemadmodum fehabet fenfus ad obieEta fenfilia, itafe habeatintellécus adobiccia intelligibilia. Verum quia per has nulitum $8 \mathrm{em}$ -
A fus, \& intellettus difcrimen apparebat, fed fola fimilitudo, ideo Ariftotel. Atatin declaratin hoc ipfo eorum dillinilitudinem, ac differentiam, qua in hoc confiftit, quod obiectum cuiufque fenfus non eft omne ens, fed folum quadam ftatuta fpecies entis; vifus enim dirigitur ad recipiendos folos colores, audicus ad fonos tantummodo, olfacus ad folos odores, intelectus veroad resomnes, eft enim cinnium rerum coB gnofcitiuus: ob $1 d a l i o$ modo debuit effe inaffeẼus, \& immiftus ratıonec bıcetorum, quā fenfus: nam fenfuseft inaffectus, atque immiftus non omnino, \& abfolute, fed (vt aiunt) fecundum quid, hoc eft, non ratione omnium retum, fed folum ratione fui obięti, quod nó eft orane ens, fed itatutum quoddam entis; genus; quum enim vifus per proprium corporcum organum operetur, debuit quidem illud effe fine colore; debuit enim effe perfpiculım, hoc autem fine colore eft; not non debuic effe finelapore, 3. fine C taetilibus qualitatibus; quare vifus non eft penitus immifus refpecurerum omnimm, fedeft nauraliter affectus cerrs qualitatib. quas cum. aliis rebus communes haber:at intelleetus, quia res omnes cognofcere aptus eft, debuit omnino \& abjolute, a refpectu ornnium effe inaffectus, \& cum nulla alia re quisquam baberecmmune; eft igiturabiolute, \& penirus immifrus cum aliarum rerum naturis, vteasomnes incelligere. poffit; quia nifi talis effet, non cognofceret omnia, cognof cit enim recipiendo, nihil autem recipitid, quodiam habet, quia intus apparens prohibetalienum:hacigitureft prior immifio, quam colligit Ariftoteles in context 4. libri terti) de Anima, hocmediovtens; quoniam intellectus omnia intelligere aptus ef, \& pariendo intelligit, ficut antea dixerat: vnde fumere poffumus, quidfecundum Ariftotelem dicendum fit de obiectointellectus, ipfius namque obiectum eftens omne prater ipfum inteliefum; E non dicit enim Ariftoteles, quoniam omnia marerialia intelligit, fed abfolute dicit [ qusonits omvadastelligit ] nifi enim omnia penitus intelligeret, non poffet inde perfectam illam \& vniuerfalem intellęus 1 mmiftionem deducere, quam ibi deducere valt, fed folum fecundum a lingud, vt cuique confiderantimanifeftum eft; talis autem immiftio imperfecta etiam fenfui competit ratione fui obiceti, ficut dictum eft. Non eftautemignorandum, poffeduobus mo-

F dis confiderari obiectum intelketus; vel enim illud obiectum refpicimus, à quo intellectus mouetur,velillud, quo intellectusaptus eft recipere, \& intellıgere;ill tid quidem, à quo mouetur, non eft ens omne, fed folum phantafma, quod, quum per fenfus tranfierit, non poteft of fenifrer materialis; fed quia inellecus phantafma intuens nonfolum ip rum intelligrte ap:us eft, fed etram alia, qux in ipro phantarmate $v t$ illuminatio ab inteliectu agente relu. 
cere poffunt, nempe \& effentias \& quidditates A operandn, qutemadmodum vifusoculum, \&aurerum; qux perphanta fmata reprafentantur, \& cauras quoq; as cffectibus abiunctas tanquam in ipfis relucétes, ideo ex motione facta à pliantafmate immaterialia quoque intelligere aptus eft: à folo igitur phantafmate materiali moue. tur, per eam tamen motionë intelligere omnia poteft; \& hac ratione dicimus obiectum intellectus effe illud nominc carens, quod omnia prater ipfummet intellectum entia complecti-

lara. tur: ficigitur inquit Ariftoteles ipfum nilil habere cum alis rebus commune, fed efle quiddam abomnibus diftinctum; \& omnium receptiuum, proinde effealia onnia poteftate, fed nihil eorum actu, \& tta efle penitus immiftum rationefui fub eqti, quod eft ens omne prater ipfum intell cenum. Alteram quoque immiftionem tribuit Arst. intellefui in contex. 6. eiufdemlib. quam exillapriore deducit, eaque eft refpeetu corporis, in quo exiftit, ita tamen ve hac qunque intelligatur refpedu c perationis, nöalia ratione; quam en $m$ intelligat recipiendo cobicela, necefle eft, th in hac receptione non v tatur corpore, in quo eft, ha $\in$ eft, vt if fe fit recipiens, noi corpus neque vlla corrorfs pars: quad Ariftoieles eo argusa en to oftenditiqua fi corpus ili iu recipiendo oputularetir, iam intellefus eflet qualis, \& haberet organ $\bar{u}$, qua vraquefalfa funt; effeautem qualeibi tigniticateffenaturaliteralligatum determmatio natus $æ$ \& certæ temperiei piimarus qualıtatum: nam fi in corpore receptio fieret, ftatuca aliqua in 11 lo qualitatum remperies poftularetur, ficut in fenfibus videmus; non enim quodlibet corpus eft aptum recipere quodlibet fenfile, fed aliquod vidémus effe aptum recipere colores, nonodores, ali quod vero odores, non colores, horumenim fingulum requiritcertam quandam naturam ex quadam ftatuta elementorum miftione prouenientem; quo fit, vtfingulus fenfus fit naturaliter qualis, quoniam in corporeresipiente requirit certam quandam qualitatem atque naturam : quoniam igitur intellectus nilsil habet cum aliis rebus commune, \& cum nulla earum natura commifus eft, neq; cum corpore, in quo ineft, poteft effe commiftus in recipiendo: praterea fi ita cum corpore effet commiftus, haberetaliqued organum proprium, attamen nullü eius organ ü aparet,quoniam, vt in context. 92. lib.1.de Anima dicitur, ne fingere quidem poflumus quam corporis partem occupet intellectus in recipiendis feciebus : confequentia vero ita declaratur;quoniam fintelle etus in recipiendo fpecies minifterium corporis poftularet, ftarutam etiam recipientis so: poris naturam, ac determinatam quandam temperiem, vtmodo dicebamus, requireretjat non omnes vicentis corporis partes eandem habent elementorum miftonem, idemq; temperamentum; aliquam igitur determinatam corponspartem occuparctin ditus aures, id autem effet habere organum proprium; nil enim aliud eft vit proprio organo in cognofcélo, quam habereftatutam aliquam in corporeanimato partem, cuius officium fit obiediuum cognofcendorum fpecies recipere. Ex eo igitur quod intellc etus res omnes cognofcereaptuseft, Ariftot.vtramq; eius immiftionem collegit; neque enim cum obiectis vllam naturecommunionem haberedébuit, fiomnia re-

B cepturus erat, neq; vlla corporis parte vti in recipiendo, quod fuiftet proprio organe vti : hinc autem Ariftot. ftatim eodem in loco in: uilit folum interomnes anima partesintelle? poffe locum fpecierĩ, locus enim per metaphoram appellatur, quia recipit' ideo anima fen $\tilde{i}-$ bilis apud Ariftot.non eft vocanda locus, quia non recipit ipfa fpecies rerumf cnflicun, fed organumanimarum, anima vero rationalis in recipiendo non vitur organo, quia ipra fine orgaC no fpecies recipit, proinde iure vocktur locus. $\mathrm{N}$ eq; exiftimare ob id aliquis debet, folum intelletum, nos tsominem effe intelligentem; nam hoc quidem fegueretur, fi cum Averroe diceremus, intellectum non effe formam, qua homo eft homo; fed quum afferamus ipfuns of fe forman hominis vere informantem, \& hominem illohominem effe, neceffeeft ve intelleatu intelligente homo dicatur intelligens, imo vt folus homo fit intellgens vt quod, intelle. D Etus vero non vtquod, fed ve quo, jdq; co argumento confirmare poffumus, quod etiam anima fenfibilis, liset in fpeciebus recipiendis organo.vtatur, tamen ipfaiudicat, \& iudiciü non orcano, fed foli a nimas ttibuitur ; nęque per id ftat quin animal dicatur fentire, queniam illa efforma, qua animal eft animal. Neq; etiam exeoquod intellesus in recipiendo non vtitur organo, inferre aliquis poreft, ip fum effe formam à corpore abiunctam, nec danté effe corF pori: quoniam aliud eft confiderare intellectum fecundum fum efe, alind fecundum operationem; tara fecundum fum effe eft forma corporis, ievere materiam informat, fecundumoperationcm vero eft eleuztior à materia, quam catera partes anima, $\&$ in fpecierum receptiorenon vtituraliqua corporis parte recipiente, fi debeat ita efie immiftus, ve poffit omnia intelligere. Inoperando igiturpatet intelle ctuta neq; cum alicuius reinatura, neq; cum vlla corporis

F partetanquam oigano effe commifum, \& ita effe vtroq;immifum in โua operatione.

Error D. Thome, \& Sectatorum Alexandri de intelletu confiderato in 3. lib. de A-

$$
\text { nima. Cap. XIV. }
$$

Cognofere ex his poftur us D. Thomes, $C$ se plurium alwrum errerm, atque er$r \cdot t i s$ csuram, qui dixerunt intelle atum ab Arftutele in rewo de Anim 7 lingo confideratim 
non efe animam ip fam rationalem, qua forma hominis eft, fed facultatem tantum, feu potentiam ipfiusanima; hac enim Thom fententia fuit: qui confiderans ea, qua ab Aucrroe in 3. libr. de Anima aduerfus Alexandrum dicuntur, nititur Alexandrum defendere, nempe in co, quod ei Aucroes attribuit, quod dixerit in. telleetum, de quoin eo l: broagitur, non effeanimsm ipfam, fed folum praparationem, \& àptitudinem anima ad omnes rerum fpecies re- B cipiendas, \& cognofcendas : inquit enim Thomas Alexandrum in hoc optime fenfife, quia fignificarevoluit intelled ü elie potétiam çuanAlexan- dam anima, non animam ipfan; ideo rectato. dreorwm res quoque Alexandri hanc eandem fententiam opinro. enixe tutati funt: in hanc autem inducti hi omnes videntur ex eo, quod Arifoteles in contex. 5. eius libri dixit, iniellectum nihil efreanu eorum, quafunt, \& nullam ffe aliam eius naturä, nifi hanc, quod poteftate êt: at (inquiunt) fi effet anima, \& forma fubftantialis, id minime verū effet:iam enimcertam, ac ftatutam, eamque praftantifimam naturam haberet : quamobrem dicens Ariftotelesipfumnihil effe actu, fed effe folam poteftatem, fignificat fe non deanima ipfa hac dicere, fed de faculta teanima intellectiua: hrc enim non eft forma, fed folum facultas, ac potentia humanx forma. Hanc fententiam vifus eft fignificare Alexander in 1. fuolib. de Anima, in cap. de Intellectu fpeculatiuo, \& in 2. lib. in cap. de Intellectu materiali, vbi confiderans id, quod ab. Ariftotele dicitur in contex.14. libri 3. de Anima, intelletum effe vt tabellam abrafam, in qua nihil defcriptim fit, inquit intellectum melius fortaffe comparari $\tau \tilde{\omega}$

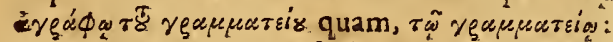
quoniam recpruczeñov eft aliquid actu, at intelCorsfiura-letus non eft actu, fed eft mera poteftas. Ego so. vero fententiam hanc fequi nunquam potui, cam queab Ariftotele alieniffimam effe femper exiftimaui; omnia enim, quæ in eo libro dicun. tur, fignificantanimam, non folam facultatem vt diftinctam abanima; etenirn facultas non patitur, nequerecspit, fed eft ratio patiendi, ac recipiendi, quemadmodum etiam id, quod materiales formas recipit, non eft potentia prina materiz, fed materiaipfa potens, potentia vero. eft ratio recipiendi: quum igitur Ariftoteles ibi dicat intelle etum pati, \& recipere, abfurdü hoc effet, fi de aptitudine ac facultate animx diceretur: \& in contex. s. dicit intellectum effe $\delta v v c_{-}$

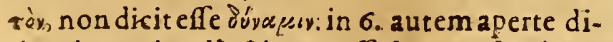
cit animam intellectiuam effe locum fpecierü, non dicit ip fam facultatem effe locum: quoniamigiturillud ex dictis colligit, neceffe eft, vtper animamintellętiuā fignificet illudidê. quod prius nomine intellectus, quem pati, \& recipere dixerat, ex eo enim quod fine corporis: minifterio recipit, infert ipfum effelocum formarum: buicfententix confona funt ca. qua in
A 3. contex. leguntur, ibi enim non dicit A rifotelesincellectum ita fe haberead incelligibilia, vt fe habet fenfus a denfilia, fed yt fe habet fenftiuum ad fenfilia, attafnen fi iasultates tantum fignificare, atque inter fe comparare voludifet,

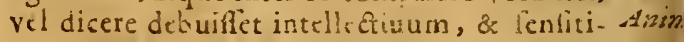
uum: vei intellectum, \& fenfum': quoniam igiturde receptionefpecierum ibi loquitur, recte dicit fenfitiuum, vt fignificet organum fenfus, quod poteftatem habetrecipienzi ipecies, fed non habetillas actu; idenim, quod recipir frecies fenfiles, eft abfque dubio organum fenfus: fed quia intellectus non habet organum, idco non intellectium dicit, fed intellectum: inquit igitur ita fe habere animam ipfam intelleftuam ad intelligibilia, vt fe habet organsm fenfusad fenfilia, nempequodrefpectuillorumeft

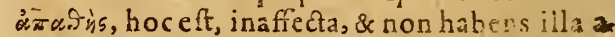
ctu, fed poteftace:id igitur, qued fecundum Ariftotel. refpicitfpecies, \& eft locus fpec es $\overline{1}$, eit C anima ipfa, non facultas anima. Piater:a in contex. 8. \& in 18. inquitintellectum intelligendo fieriomnia, aptitudo autem recip?endi non dicitur fierialiquid, red rubiectum potens, a aptum fitillud, quod recipitur; fic fHan t.sam prima materix potentianon dicirut therilapis, vel homo, fed materia iffa per recef icnem for. marum diciturfieri modo res hzc, modnilla. Sed fi totam illam partem legamus, \& beneperpendamus, videbirnus omnia Arifotelis dicta D illifententizrefragari, \& aperteanimanipfam, non facultatem anima ibi confiderari, quum etiam quandoqueanimam nominet, vt ibi legere eft. Maximevero hoc confirmaturex con!ideratione illorum, qua dicuntur ab Ariftutcle in contextu 37. \& 38. eiufdem libri, vbi epilogum faciensomnium à fe dictorum de vesaqueanimaparte cognofcète, defenfu, ac deintellectu. inquit animam effe quodam rnodores oés, quia per partem intellectiuam fit res omnes intelleE. Eiles, perpartem vero fenfibilem fit reson nes fenfiles: quod igitur in contextu 8. \& 1 \$. dixerat intellectum fieri omnia, hoc in $37 . \& 38$. dicit animam fieriomnia; quare ibi nomine intelleftus animam fignificauit, quoniam hoc non recte de facultate dicitur, fed defola anima. Tandem vero Ariftoteles hoc apertifine dicit in contextu illo trigefimo otauo, quando concludes inquit intellesum effe formam formarum, \&enfum effe formam fenfilium; fic F enim teftatur intellectum effe formam, camque talem, qua omnium formarum eft receptiua; non eftigitur fola aptitudo, \& facultas anim $x$, fed eft anima ip $\{a$, quxeft forma hominis. Illud vero, quod illos in errorem traxit, fuit, quod non animaduerterunt Ariftotelem ibi confiderare animam rationalem refpectu. fux operationis circa intelligibilia, ideo putấrunt non animam. fed facultaten confidera$r i ;$ \& videntes Ariftotelem dicere, intellectum. 
lard- nibil cffeact: ex entibus, fed effe omnia poteent. ftatc, dixerunt intelletim non effe formam, z lib. quia fi effer forma, iam effet ali juid actu: at1no-tamen, dum hoc attribuimus animze rationali refpectu operationis omne dubium tollitur, \& eorum error patefit, vt primzemateria exemplo declarare poffumus: materia namque duas habet cntitates; vnam proprian, qux eft eius propria effentia, eft enimaliq̨uid, \&: eftens diftinctum à forma; alteram vero, quam arquirit ex receptior efornra, à ciat fit hoc aliquid, nam recipiens formam hominis dicitur fieri homo, \& recipiens formà equi dıcitucfieri equus: quando igitur dicimus materiam primam non elfe acu vilum ex entibus, fed omnia poteftate, non obid afferimus eam fecundum fe nihil effe;neque hos dicimus de ipfiuspotentia \& aptitudine, fed de ipfamet miteria refoectu fecund $x$ tantum entitatis; prafupponendo enim propriam matesia entizatem, nec tamen ean refpiciendo, fed alteram folan, qua fitres omnes per receptionem formarum, dicimus eam nihilefre actu, led omnta poteftate. Ita igitur etiam intellefus duas haber entitates, vnam propriam, alteram acquifitam, nam fecundum le eft forma corporis, \& nobiliffima gquidem forma; fed refpectuoperationis, \& quatenus eft aptus omnia fieri, quia intelligendo rem aliquam dicitur fieri res:1la fpiritaliter; fic dicitur fecundum fe efle omniapotefate, \& nihil actu: recte igitur hoc dicit Ariftotel. de anima rationali corfiderata refpectu operationis, quare non oportetid ad facultatem anima referri, fed ad animam ipfarm; eanque tuife Arifotelis mentem teftantur verbailka nuper a nobis relata, quando in contexrutrigefimo etauoillius libri inquit intellectu effe formam formarum; fic enim illum intellectum, qui formarum receptiuus eft, formam effeafferit, nec folam format aptitudinem: Ad hunc fenium ctiam $A-$ lexandriverba, guibus folam aptitudinem figuificarevifus en, redigipore videntur; ipfe enim ita loqui voluit, vt Ariftotelem initaretur, atqueinterpretaretur, \& nullam intellectui eatiatem tribieret, fignificaretque ipfum nihil effeatu, fed omnia poreftate, ficut etiam Ariftoreles dixit, nempe prout refpicit operationem circa obiecta intelligibilia, fic enim ipfum confiderans Alexander, voluit eius entitatem extenuare, vt fignificaret eum ita confideratum nihil effe anu. Quemadmodum igitur ducti claris Ariftotel.teftimonis eius verba a d retum. fenfum trahimus, iia Alexandri quoque verba ad eundem fenfum trahenda funt, fi ipfum tuen, \&à magna abfurditate vindicare volumus. Quod fi ea fuit ipfiusfententiz, quam ei: Auerroes, \& alij attribuesunt, paruin refert ipfum: indefensum relinquere, atque eius opinionem refutare..

$$
\pm_{x_{r}} *
$$

A Anime rationalis perfect a fecundum Ariftotelem definitio. Cap.XV.

I anim $x$ rationalis perfectam definitionem $S$ affignare velimus, qualein Arifut. nobis ex fuis dictis colligendam relıquit, debemus per vtrung̨; refpectum naruram eius exprimere hoc pacto;intelledus eft forma hominis, qua quum
nullum ex entibus fit aetu, ea omnia recipere fpiritaliter, \& cognofcereapraef: immiftionem B vero cum organo in definitioneponerenonoportet, quoniam hac necelfric alteranimmiftionem fequitur tanquam proprictas. qua:e fupervacuein definitione poneretur. Hac eft bumanzmentis natura apud Arif. quam ip fe par. timininitio 2. Inbri de Anima, partim in 3- lıb. deslarauit, \& quà etiam epılogocollegit in contex.38 eius 3.116 . in quo non pofium no maxime mirari ingenium \& artificium Arift. qui quum in 37. propofuifer colligenda epilogo ea, qua de Cerfu, ac de intellectu dixerat, non tantum recéfere debuit, qua de fenfu tradiderat poft an n rwm. tex.5o.lib.2. Eqqux de intellectu in tertio ad eum vfqilocum, fiquidem ea omnia folam operationem refpicicbant, fed cum iis etiam illa coniungere, quar prius in fecundi libri initio de omnia. nima vniuerfe dixerat, dum eam refpectu corporis confiderauit: adeo in context.38: id quod: propofuerat , perfeete 3 artificiofe exequendo. duabus tantum dißtionibus exquifite naturam intellectus cum vtroq; refpectu fignificauit, du dixit intellectum effe formam formarum, formam refpectu corporis, formarum vero refpeCtu operationis; ideo vt formam dicens colle. gerit vnico verbo naturam intellectus, vedeclaratam in 2. libro, dicens autem, formarum, vnico finiliter verbo collegerit intelle fius naturam vt in 3. libro declararam; ex hbro enim 2. habemusintellectum effe formam, qua homo eft homo, ex tertic aute cognof́rimus eamefle E ompium formarum receptiuam Sicigitur definitionen intellectus omnibus numeris abfolutam, quam noz modo pluribus. verthis protulimus, Ariftot.duobustantummodo, ac friftim exprefint, dum dixit ipfum effe formam formarum. Idem de fenfu dicendum eft, fimiliter enim ex dictis in initio fecundilibri collegit fenfum effe formam : ibi enim docuerat omné:animam effe viuentis cosp oris formam'; poftea dixit, fenfilium, hoc colligens ex iis, quxpolt contextum: F so.eilisdem fecundilibridocuerar; fenfus enim fenfilia recipiendo operatur; non dixicautem. abfolute, formarum: quia vt antea dicebamus. fenfus non cognofit omnia, fed fola fenfilia, \& formas quidéline materia recipit, froinde formarum ip fe quog; receptius efi, non tamen omnium, fed fenfilium tantum;, reete igitur Ariftot dixit fenfum effe formam fenflidum, intellectum vero effe ablolute formam formarum. HES 5 I $\mathrm{ACO}$.

\section{Arifi- cium A- riftot. un decendo intelle- atsmefse formis}

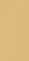




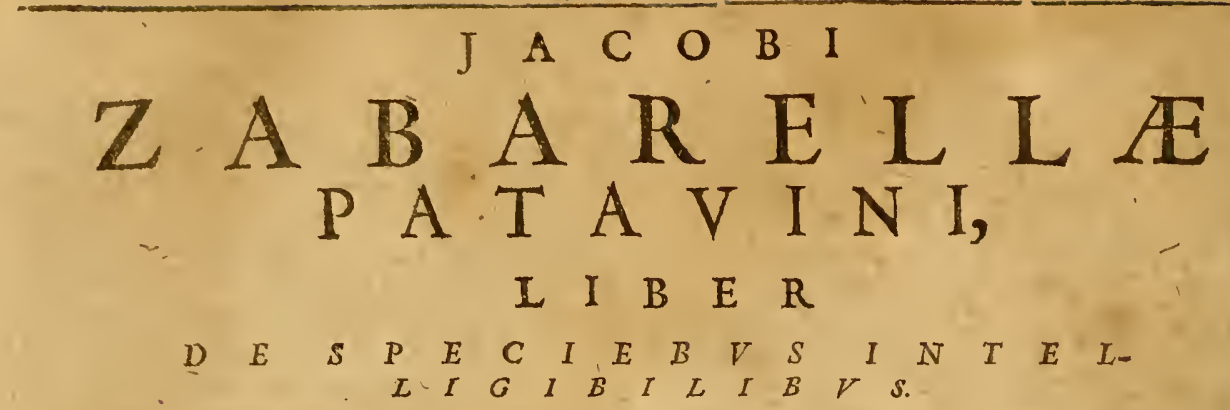

\section{Propofitio dicendorum. Cap. I.}

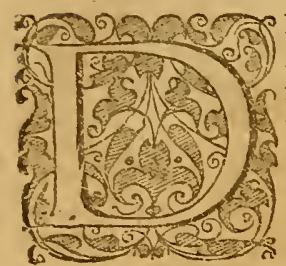

E mente humana agens Arift. in 3. de Anima libr. frequenter fpecierum in. telligibilium mentionem facit; dixit enim ipram ef[elocum Specierü, ita tamen venon habeat eas actu in fua effentia; fed poteftatem folum recipiendi, resipiat autem ipras à phantafmatibus. Hoc quomodo fe babeat, non ita clarum fuit, vt magnas interpretū controuerfias atque alrercationes non excitauerit; non folum enim dubitârunt, quodnam harum fpecierum officium fit in intelletione, verum etiam an reuera dentur, imprsmanturque in intelleêu fueciesvllz: idque etiam aliqui prorfus negare aufi funt, \& aliud alıquod excogita. re, quod Arifot. nomine, fpecieruos intelligere fotcerit. Praterea vero cim has difputatione alia non parui momenti, \& explicatu dignifima coniuncta eft, quidnam fintin intellectu illi, qui habitus vocari folens, vnde appellatur intellectus in habitu; quum nulaliudeffe videantur, quam hx fpecies in mente humana impref$\{z$, atqua ita firz, vt non facileamoueri queant. Sambit- Nos igitu hac de refecundum principia philocis op:- fophiz Ariftnt difputaturi, ante omnia Simpli380. cii, \& Platonicorum fententiam tanquam Ariftoteli manifefte aduerfantem reiicimus, \& ab hac noftra difputatione penitus excludimus; quippe quum nimis longa oratione opus eftet ad Ariftetel. de mente humana, eiufque operatione fententiam cum Platonis opinione conferendam: quum enim illi dicant animam rationalem habere infe rationesidealesin fe naturaliter infitas, \& confubftantiales, non vt extrinfecus impreffas, proinde nihil à phantafmatibus recipere, fed folun excitari ad contem. plandas in fe rationes ideales, qua tunc tanquam è tenebris in lucem frodeuntesincipiunt vocari babieus; huicfententia aduerfatur aferte Arifioteles, dicens intelledum elfe prorfus immi\{tum, neque vllum intelligibilitin habere atu infeipfo, fed omniapotetate, proinde ta
A recipere ab obie $t$ is externis. Hane igitur Ariftotelis fententiam veram effe ftatuentes, quum eam in dubium atque in difputationem reuocare nullum operz pretiun fore videatur; de eius tanturnmodo intelligentia difputandum, \& aliorum hacin re altercationem expendendam in prafentia nobis propofuimus. Referemus igitur inprimis contrarias multorum fententias, \& aigumenta, quibus viuptor, ve intelligatur, in quorism husufce rei difficultas B conftituta fit; deinde noftram hac de re fententiam proferemus, tanden que 11. , qux nobis adwerfari videbuntur, alıorum argunsenta foluemus.

Dua Latinorum contraria fententia, \& earum declaratio. Cap. 1 .

Vum Ariftoteles fpecies rerum intelligiwhum tanquam as intelletu nem necelfalsumanifeltepofuerie, Launiomnes tum in earum concetione confenterune, tum etram in eo quod fpectes in re ab intellectone dittinguantur, tra vtaliud fit fpecres intelligsbilis, aliudintellectio, quum p zertim etian temporefecund sin eos diftinguantur, \& detur fpecies intelligibis abrque intell ctione, vt porea de. clarabunus; fed quidnam fint fpecies intelligibules, a quem in intellectione locum habeant, difenferunt:prinum enim in duas peni. prior tus contrarias fectas diuifi funt, alii namque cte. fpecies intelligibiles in intellecus imprimialieruerunt; alii vero eas conitanter negârunt, \& folum extra intellectum fpecies concefferunt, $q$ ias ob id fpecies expreflas nominârunt; $v$. tramque igitur fententiam prius declarabimus, poftea veriufqueargumenta referemus. Illi, qui priorem fententiam fequuntur, dicunteas effe quiddam intelleotui fuperaddutum, \&dffe ac. cidencia fpiritalia à phantalmatibus in intelleEtu producta, qua \& pracedunt tempore intellectionem, \& post eam feruantur in intel. lectu, vnde eas imprefias appellârunt: fecundum hos facile eft ollendere curintell ifus vocetur in habitu, \& quidnā fit hic habitus; gquandoenim impreflas habecrerum intelligibilium fpecies, quas contemplari poteft quando vult, 
quum poft intellectionem fixæ in intelketu maneant, tunc dicitur in habitu, quia nil aliud eft habitus, quam fpecies impreffa, \& ita fixa, $v$ telerivix poffit. Sed hi in modo difcordes fuerunt, \& adhuc in duas feetas diuifi funt. Alij namque dixerunt has fpecies refpectu intellectus habere locum obiectitcrminantis intellectionem, quia intellectus eas habens contemplatur quando vult, cuius fententia fuit Gregorius Arrmirenfis in 1. Sentent. diftinet.3. qux th.x. \& clarius in 2.diftinct.7. quaft. 3.eandema fequutus videtur $S$ cotus in 1 . Sentent. diftinct. 3. quart. 6. vbilongo fermone of endere nicitur darifpecies intelligibiles in intelleetu ante intellectionernimprefias, tanquam obiecta ipfius intelleÊs, exquarum multiplisata intellectione firmiorimpreflio fiat, ita vtappellentur habitus, quos intellectus puteft contemplari quando vule; habet enim obiectum prafens, quum fpecies in intellectu maneant poft intelicet ionem: confutat etiamibi Scotus opinionem Henraci, \& alioram negantium fpeciesimpeeffas, \& ponentium tantim expreffas, vtibi legerc poffumus. Alij vero dicunt, fpecies imprefias non habere obiecti locum, fed format tantum, \& actus primi, quia per eas ita operarurintellectus, vt ignisperformam fuā, qua dicitur actus primus refpectu operationis, qux eft actus fecundus: fic igiturfuecies intelligibulis impreffa in in e!lequ eft ratio formalis, qua intellectus operatur;non operatur autem, nifià phătalmate mo- D ueatur, ideo phantafma locí haber ubiecti mouencis, fpeciesautem impreffa non obiecti lo. cum habet, fedform $x$ babitus reddentis intelletum propenfum, \& aptum ad operandum: hac fuit Thomz opinio, qua apud eum legitur tum in context.8.libriterrij de Anima, tum clarius in r.part.Summ.quan.85.articul. 2. eamque Scotus impugnat in dicto loco quaft.7. fed opinionera Thomafequi videtur Zimara in theo. remate 82 . vbrafferit fpeciem in intellectu impreftam effe principismeffectum intelle dionis, hoc eft, rationem formalem, qua intellectrs qui poffibilis dicitur, eft intellectionis produ. čiuus. Non eft autem ignorandum, non app?rere per ea, quz diximus, differentiam vllam inter Thomam \& Scotum; nam etiam dicendo fpeciem impreffam habere locum obieti, dicimusipfarm effe principım effectium, \& mctiuum, quia officium obiefti eft mouere, \& agere; ideo plures recentiores philofophidum hoc tatumdicentes putant fe Thomæ \& Scoti difcrimen,ac difidium tetigife, meo quidemiudicio decipiuntur, quanullumadhuc eorum difcrimen apparet. Dico igitur difcrimen veriusque fententia in hoc confiftere, quod Scorus dicens fpeciem imprefiam tenere iocum obiect negar intellectury phantafmate monente tunc indigere, quia fpecies ipfa imprefla obiecti cfficio fungitur: Thouas yero \& Zimara dicunt obisA etum effe phantafma, nonfpeciemipfam im-
preffam, ideoq; femper requiri phantafma mouens, \& excitans ad intellectionem ; intellectus enim habens impreffam fpeciem tanquam habirum, à hantafmate excitatus fratim intelleCtınem producit, quia fpecies eft ratio produ. cendi intellectionern, nec producesethancintelle etus, nifi fpeciem haberet; idsirco in altero quoque diffentiunt, quod Thomas pulat fpeciem impreffam effe totam rationem producédi B intelledionem, Scotus autem dicit, neq;intelleetum,nequefpeciem effe rationem totam intellectionis produetiuam, fedvtrumque fimul, a deo v tex ambobus confliruatur ratio a drequataintellectionis productiua; eft enim tum ipra fpecies imprefra, tum etiam ipfa intellectus natura:ideoind.quaft. 7 . impugnat Scotus in hos opinionem Thoma, vt ibilegere poffumus. Sed Caietanus inr.part. Sum.quaft. 79.art. 2, aliam Thom $x$ fententiamattribuit; inquit enim $T$ t omam non dixiffe fpecies imprimi in intelledu, fed intellectum ficrires ipras, \& imbiberequodam nodo totum obiectum: ideo videtur Caietanus accederead opinionem pónétium fpecics expreffas, de qua poftea dicemus, ideog; aliquu i eam fequentes approbant hoc Caictani dietum. Attamen apud Thomam in memoratis locis eam fententiam legimus, quam nos prius expofuimus, \& quäei omnes atribuuat. Ioannes autem Gardauenfis in 3.l1b.de Anima, quaft. 11. \& Gandis. 17.tuetur quidem fpecies impreffas, tum prace- wenfas. dentes, tum fequentes intelleøionem, fed negat eas effeintellectionis effętum principium, \&e probarenititur cas effe principiun receptiuum tantum, id eft, rationem recipiendi intellectionem, non quidem reseptiuum przcipuum, hes enim eft intelleclus, fedreceptuum praparatiuum, ficut in dictis locis legere poffumus. Hac funt; qua ab illis dicuntur, qui fpecies imprimi afferunt, \& corum inter fecontrouerfia ea eft,

E quamnos breuiter retulimus. Contratiam ve-secund. ro fententiam, quod nulla in intellectu fpecies fecta. imprimatur, fed fola fpecies exprefia fatis fit ad intelletronem producendam, fequutus'eft Henricus, quam Scotus confutat in dian fua Heariquaftione: \& eam magno conatu defendit Io- cirs. aunes Bacconius 2. Sentent. diftinct. $\sigma$. quaft. Ioa. Bac1. articul. 3. quam eandem tuentur his tempori- conises. bus omnes terc Philofophi resentiores; fpecies autem expreffa apud hos fintipfa phanafinaF ta, quando ab intellectu agente illuftrata funeactu inteliggbiliz, \& actu mo:iua noftrintelteEtus; quenadmodum enim lumen Solis iunEtum coloribus conftituis eos in effe claro, \& expreffo, \&actumotiuo ipfus vífus; ita phantaforata abagente inrellectuilluftrata funt clara, \& motiua intelleceus, \& ita dicuntur fpecic 3 expreffic, quez ad intellectionem in intellcctr producendam fufíciunt ab́sque vlla foecier imprefione, guia sibil in intellecu imprimitur 
tanquam illi fuperadditum. Eftutem esiam A ita argumentantur: intelleatio eft vnio intelleinter hos dillidium aliquod: nam Ioannes Bacconius dicit hanc fecciem excitare intellectum, deinde ipfinn ita excitatum promere ex feiplo intellectionem: quareapud eum intellectio formalicer eft folum a tio ipfius intellectus, quia iple in promenda intellectione agit, non patitur; fed antecedenter eft $\mathrm{paffi} \mathrm{J}$, quia excitatio praceflit, qua eft pafíio qux dä intell ectus à phanralmate. Sed recentiores quidam in reliquis Bicconij rententiam requentes, id tantum non $B$ receperunt, intellectionē effe intellectus ackionem rantummodo; nam aduerfus hoc fententım A riftotel.adduxerunt, qui clare dixitintelligere effepati, \& modum etiampaffionis expreffic, dicens intell ectum fieri res ipras, putauit ergo Ariftot.intellectionem effepaffionem non modo andecedenter, fed formaliter, adeo vt fit fimul actio \& paffio;actio ratione iu dici, , fiquidem iudicare cft agere; paffiovero quatenusintellectus imbibit quodammodo totum obieEtum, \& in ipfum transformatur, nihil tamen recipiendo tanquam fibifuperadditum; imbibere enim \& transformari eft pati quoddam. Hi autem fuam hanc fententiam declarantes dicunt neque intellestum, dum intelligit, formam vllam in fe recipere, neq; perfpicuu mà coloribus informari, fed vifum fieri rem vifam, \& intellectum fieri rem intellectam, abfque vlla fpeciei receptione : quemadmodum enim quum columna ex dextra fit finifra, id non prouenitex aliqua nouz forma receptione, qux in columna fiat', fed exfolo refpectu vnius reiad aliam; ita per folam prafentiam corporisluminofi, \& refpectum perfpicui ad ipfurn fie ipfius perfpicuitluminatio, quum nulla in eo fpecics recipiatur, fic etiam in oculo non recipiunt ur colorum fpecies, neque fit vifio per receptionem colorum, fed per prarentiam colorati corporis in perfpicuoilluminato, \& refpectum oculi ad colorem prefentem:quo fit, vt muteturvifus quo. dam mado in colorem, \& hacratione pati cicatur, non quod fpeciem al iqua m recipiat; non enim colorper medium perfpicuum adoculum tranfit, fedvltra perfpicurmapparet oculo, \& infpicitur, quum nihil in oculo imprimat: ita phantafmata, quando lumine intellectus agentis funtilluitrata, \& conftituta in efie claro, \&e exprefro, apparentintelle fui, \& nibil in eo imprimunt, fed intellectus fit resilla, quarm incelligit, \& brediciturintellectio: quamfentenciam F colligunt exverbis Alexandri, tum in $\mathrm{r}$ tum in 2. lib. de Anima in cap. deVı fu, tum etiam in lib. de Seniu \& fenfilibus.

Prioris fecte argumenta ad probandum species imprejfas. Cap. I11.

Contrariis fententiis ita declaratis, vtriufWue argumenta confideranda funt. Illi qui$\mathrm{dem}$, qui tucntur fpecies imoreffas, primum Etus cum incelligibili, ergo neceffe eft vt intelligibile in intellectu fpiritaliter imprimatur; nam quomodo erit vnio, fi intelligibile maneat extra intellectum? Secundo, danrur habitus intelleEtuales diftinctiab habitibus partis anima fenfibilis, ergo dantur fpecies in intellectuimpref$f x$, \& poftintelle ationem feruatz: confequen-t tia clara eft; quia ifti habitus non poffunt effe aliud, quam foecies ipfr rerum intelligibilium manentes in intellectu poft intellectionem, \& ante inrellectionem impreff $x$ affumptum quoque manifeftum eft apud Arift. in 6.lib. de Moribus, vbidicit intellectum, fcientiam, fapienriam, prudentiam, \& artem effe habitus intellectuales, \& effe actu in anima; in libroetiam categoriarum dicit hos habitus effe qualitates prima feciei in ipfa anima inhærentes, \& diumanentes, \& xgre feparabiles: hocetiam confirmatur per ca, qux dicuntur ab Arift. in context.

C 8.libr.j.de Anima;ibi enim inquit nos per tales habitus reddi aptos ad operandum quando vo. lumus; vult igitureos effe in anima fixos, \& poft operationem permanentes, nam operatio labiliseft, nec diu durat; quare fi fimulcum ea defineret habitus, quomodo aptiores ad operandum effemus, quam prius? certe fcientia rerum naturalium acquifita in animo Philofophi na. turalis feruaturin eo etiam dum nil contemplatur, \& dum dormit;fimiliter feruatur ars medica in animo Medicietian dormientis; in quanam igitur animx parte feruari has difciplinas dicendum eft? feruantur vtique in parte cognofente, atqui non in parte fenfibili, quia hac non recipit vniucriâlia, hi autem omnes habitus funt vniuerfâles, quare non poffunt feruari in memoria, qua elt facultas anima fenfibilis , \& fola particularia, qua à fenfibus recipit, feruare poteft; reftat igirur ve in intellectu feruentur, \&ea ratione, dicantur babitus, quatenus eliam poft

E intellectionem, \& diu quidem, in intelleetu remanent. Tertio, rationi confentaneum eft, adumprimum pracedere actum fecundum; at fientia eft aftus primus, acontemplatio eft aEtus fecuadus, vt inquit Arift.in initio 2 libr.de Anima, \& in context. 8. lib. 3.ergo habitus fcientix debetpracedere intellectionem: \& nifi hoc dicamus, fequetur intellectum femper habere poteftateax xac propinquam ad operationem, - neq; oftendere poterimus, quomodo nunc ha-

$F$ beat potefatem propinquiorem, quamprius; quoniam poteftas non poreft effe facta propinquior, nifialıquid in intelleftu imprefrum, \& illi fuperadditum remanferit : fed neque oftendere poterimus, quomodo intelleetus in habitus fit aptus ad opcrandum quando vult; curenimeftaptior, quamante acquifitionem habitus, fi nullus remanet habitus, à quo aptior reddi poftit ? dantur ergo fpecies irapreffx, \& pofincclleqionemi feruatx. Prxterea cöfirma-

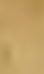


tur hxc fententia teftimonio Ariftot. in mult is locis: nam in 2. contex. 3. lib. de Anima dixit intelle etū pari ab intelligibilibus, atqui nithil patitur fisereceptione:ergo vult intelle ctum ab ob. iectis recipere fpecies : deinde in contex. 3. clare dixit intellicetum effefufceptiuú fpecie, at non potef fpeciem fuffipere, nidi fpecies in ipfo imprimatur: pofta in contex. 6. dixit intelle etum effe locuni format um, ai nulla efict cum loco fimilitudo, niff fipecies effet in intellsofis, qum etiam locaz un fit in loso; nam fi fpecies effent extrasintelloctum, quomodo intelleclus diceretur locus fpecierum? A uerroes quoq; cí locum interpretans inquit differieanimam intellecti. uan a locoproprie fumpto, quod locus recipit locatum, nec tit illud, anima vero recipit fpe. cies, \& fit illanet fpecies, quam resipit; porit ergo Auerroes receptioncm fpeciei in intelleatu, \& vnionem intcll etus curn fpecic in rellig!bili : in contex. criam 37 . \& 38 . dicit Ariftoteles animam modo quodam fieri omuia, nam per ferfum fit omnia fenília, per intell âm vero fit omia intelligibilia, non poteft autem fieri res ipre, nifi fpccies rerum infe recipiat.

\section{Argumenta pofterioris fectead probandum non dari fpecies impreffas. Cap. IV.}

nzm A Ltera vero fęt, ģua fpecies imprimineimé. Agit, argumentatur pracipue verbis Ariftot. in contex. 5. lib. 3. de Anima, vbi dicit intellectum nitil effe a tu corum qua funt, antequam intelligat; atquintelligere eft operari,etgo negat anteoperationem effe in intellectualiquam (peciem intelligibilem; quia pofita fpecie issprefia ante intellcctionem, tunc intellecus effet faetus aliquid antequam intelligeret: idem etiam legimus apud Ariftot. in contex. I4. ciufdem libri, vbi inquit intelleçu antequam intelligat, efé ficut tabellă, in qua nihil deferiptum lit; non vuli igitur Ariftot. aliquam fpeciem in intellectu pracedere intellectioni. Se-

ndü. cundo fic arguraentantur : fatis faluaturintelletio per folam fpeciem expreffam, hoc eft, per phantafma illufratum, \& actu motiusm, ergo. fuperuacaneũ ễ ponere fpeciem à phantafmate in intellectu imprefiam, fruftra enim fit per plura, quod per pauciora aque fieri poteft: antecedés part; quoniam prafentia obiecti ad mouend um apti poteft fine alicuius auxilio produ'sum cereintellectionem, fi nihil impediat. Tertiovtuntur argumento tali: fi concederentur fpecies impreffie, \& poftintelle cxionem feruata, daretur memoria intellectiua : confequentia clara eft; quia nullum eft aliud memoria officium. quam fpecies poft coguitionem fertare, quare fpecies poit intellectionem in intellectu fervarentur tanquam in memoria; confequens aduerfâtur Ariftot. qui in libro de Memoria, \& re-
A minifcentia dicit memoriam effe per fe primi fenfitiui, peraccidés vero effe intellectiui, nempe quate nus inrelle đus nō intelligit fine phantafmate; nullam igitur memoriam cōsedit, niff vnam, qua eff facultas animx fentientis, \& per fe inferuitphantafia, qu'um idola resú tantummodo particulariü feruet, \& fit plantafize tanquam apertus liber; per accidēs vero, \& per medianoliantafiam inferuit Et intellectui, quate. nus illemouetur à phantafmate. Quartoaliqui $B$ ita argumentantur: fnmanon potcitefle fubie. Eumascidentiutu, intellęus autem formate \& fpecies funt accidentra, ergo intellectus recipere fpecies nó pote?t. Adduntıidem hocaliud argumentum: fubftantia zterna non eft capax accidentiú mutabiliu'm, intellectus eft fubftantia zterna, fpecies vero funt accidentialabilia, ergo intellectus recipere fpecies non poteft.

Errorvtriufque fecte, do qund neceffarium: C fit, species in intellectu imprimi à phan-. tafmatibus, contra pofteriorem $\int e$ ctam. Cap. V.

$\mathrm{G}_{\text {Goin hac difficultate neutri opinioniadhæ }}$ Erendum puto, red mediam quandam viam: teuendam, per quam vt mihi videtur, omnia dubia, \& argumenta facile foluuntur.credo intelleftionem fierinon poffe fine imprefione fpeciei intelligibilis in intellectu, quz fit quiddamdiuerfun tum à phantafma te producente, tum. à fubftantiaintellectus recipiente; \& in hoc puto pofteriorem fectam fuifie deceptam, priorem vero rectefenffie; fed bains quoque in co erraffe, quod pofuit fpeciem hancimpreffan'pracedere inteliedrioni, \& poit intellectonem manere in intellectu; ego enim arbitrortam diu feruarin intelledufpecien, quam diu intellectus: intelligit a Etu, qua pito foeciem in intellect us. E reseptam, \& intelleetionem reipfa idem effe: proinde errafe in hoc omnes; qui fpecies impreffes re diftinftas abintellckione pofuerunt: ob idpofterior fecta in hoc bene ienfit, quod: nihil in intelledts pofu it prater intell êtionem. in co tamen rsale, quod dixic nullam à phantafmate fpeciem in intellectu imprimi \& intelleċumabfquevilius forme. receptione intelligere: in eo quoquehi defecerunt, quod in incelleEu intelleationem ponentes negarune fieciem. proirde diuerfum quiddam efie putarun fpeciem abintellectione; cuodetiam aperte:proatulerunt, dum phantafma illuftratum expreffam fpeciem appellarunt fic enim etiam fubiecto difingui fpeciem, \& intcllectionem afferuerunt, fcilicet vnam in phantafia elfe, alterams vero in intellectu. T'ria igitur à nobisdernonfranda funt. Primum aduesfus pofferiorcm fefam, quod non fuffsiatphantafma fine-fpecic impreffa, fed neseffaisum fit imprimi in intelleEtupe
Qeares.
Quivtin.

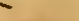


cunfreciem à phantafnate. Secundum veroad. uerfuspricrép Ann, qued feccies imprelfa non pracedartempore intellectionem, neq; poit intelle ctionem feruetur. Tertiü demum cur intellectus dicatur in habitu, \& quid fit ifte habitus, qui poft intelle etionem in intellectu manēs fau cie vt intellectus polfit contēplari quando vult, \& ve dicatur refpectu operationis habere potétiam propinquierem, quam prius habuerit. Primumprobatur efficaciter arguin êtis prioris fe.

_. Et $a$, nempeillis, qua folam impreffionẽ demõ. ftrant: nam illa, qua ad probandum permanentiamadducta funt, nihil roboris habere poftea demonftrabimus. Primuim quidem necelfe eft, ficur primo argumento oftendebatur, in intelleat one conunctionem fieri intelledus cum intellıgibili, hac aüt fieri non poteft, nifialiquid in intellectu recipiatur; hoc fignificauit Arifot. quando dixit intellectum fieri rem ipfam intellectam: at non poteft fieri res intellecta. itavt ab ea nomination em accipiat, nifi in fe recipiat aliquid noui, quodantea non habebat; fic enim etiam prima matcrianon dicitur factabomo, nifi Euafeo a perreceptione forma hominis. Illud vero,quod lıquorz̈. aliqui ad hoc dicunt, intellęum intelligentem ninil recipere, fed imbibere totun obictum, \& fieri illud, milsi quidem non modo vanum effe videtur, fed etiam iraplicare con radictionem: nam fi idem intellectus piius nihil inrelligat, Confuta- naftea vero intelligat equum, \& dicaturfactus sio. equus, quaro an fit idem intellectus, \& eadem res nunc, \& prius, an dux, fi idem, ergo ctiam anteinteilectionem erat equus, quod neq; aduerfarii concederent: fi vero non idem, neceffe eff, vt vel deftructa fua priore entitate fit facta alia entitas, vel ea manente alteram nouam entitatem reseperit: fi priorean fuam entitatem amifit, ergo destructus eft; quare intellect 10 erit deftructio ip fus iacelleceus, nec licebit amplius dicere, humanus intellectus incelligit, fed potius dicendum erit, equus inteiligit, quonian tunc ita elt factus equus, vt non fit amplius intelli. Aus: fi vero manente priftina fua entitate, al ceram quoq; entitatem acquifiuit, necefíe ê, vt aliquam formam receperit, non poteft enm dici factus equus, niff forma equi illi accefferit vi eius fubftätix fupperad dita, îc enim recte dicemus, factameffe vnionem inteilcetus cum re incellig,bili; non enine dicitur vnıri, \& coniungi res vna eum femetipfa, fed plures effe oportet, ex quarum coniundione vnum fieri dica. tur: oportet igitur fpeciem in intellectuimpri$m i, \&$ ita vnü fierı tanquam ex $r$ ateria $\&$ for$m a, n$ mipie in recipiendo tenet locum materix, vnde vecarifolet int ellectus materialis, fececies ayters impreifa tenet losum formz; \& quia nomuatio fit à forma, totum dicirur factum vnum, \& voratur equus, non quidem materialis, fed Spiritalis : hoc modo inteligendus eft Arift. quando dicitintellectum feri íngulă; nö enim
A quum videmus factum vnum, debenus negare eius conftilutionem ex párte rnateriali, \& parte formali; perinde enim effet ac fi quis videns hominem effe vnum negaret ipfum exmateria \& forma conftare. Sed id, quod cos decepit, fuit, aquod vnio intellectus cum intelligibili, quum fitfpiritalis, eft maior, quam vnio materiæcum forma materiali, idco partium coniunctarum difcrimen non confpexerunt: imo veritate coacti ita loquuti funt, vt infcii in noftram fentenB tiam vencrinr; negarunt enim intellectum recipere, fed dixeruntipfum imbibere potius obiect:sm, \& fieriillud, quareidemaffirmant, \& negant; negant enim in tellęum recipere fpecies, id tamen cŏce dınt, dum dicunt imbibere, quia imbibere cft recipere, \& nil aliud eft hre imbibitio, quam magna vnio; quum enim fit rerum fpiritalium, eft maior, quam vnio form materalis cum materia:ideo hanc eorum appellationem non modo non refutamus, fed maxime ap. C probamus, quia receptio fpecieruse in intelleêu conueniêtifíme vocatur imbibitio, nec poteft cósenientius nominari. Praterea alia ratione hoccōprobarepoffurnus, qua manifeftecau. fa erroris illorü declaratur : in ormini actione \& palione duas dariformaś neceffe eft vnä producentem, alceram produftam in patiente 3 at phantafma eft forma agens in intellectum, \&intellectus à planntarmate patitur; ergo neceffe eft prater phantafina dari aliam formatn ab ipfo D productam in incell, effet, quoniam \& ratione, \& experientia co gnofcicur effeverifinasfópus enim omnisagentis nullus alius eft, quam introducere in patiens formam fibi fimilem, namipfametagentis formanon poteti eadem nucaero migrareab agente ad patiens; ergo nil sliud eft agere, quam formam fibifimilem producere in patiente: idque per inductisnets manifefrumeft; ignis enimagit in igneum, non vt illi fuarnmet forma $\mathrm{m}$ numero ean élargiacur, çuia hoc fieri nullo modo poteft, fed ve in lignü introducataliam for. mam firilem, nempediam unmero formam i. gris, etenim fine huius introductione non fit actio, neq; preductio; non enim fisficit fola prafentiarignis agentis adfaciendam hanc produEtronem: quid enim producitur, fi ignis agens nullam formam producit? ergo ranatefum eft idem in omni actione dicendum efle; eft enim omnino neceflerium, vt à quolibet in aliud aF gēreforma aliqua in patiente producatur: quonam igitur phantafra in phantaria eft, necpoteft recipi in intellectu; \& eit agensrefpectu intelle etus, oportet formam aliquam abeo in in. trllectu ptoduci, quam iudıcans intellectus intelligat:quamobrern quu:n fit ( vt aduerfariidicunt) in elfe claro, \& exprefio, 1 ta vt fufficiat ad agendum, neçefe eft, vt formam producat In intellectu, hoc enim eftagere; ore hoc negato phantafima ad agendum non fufficit, qua non agit, 
nififueciem producas. Sedvidentur aduerforij A hoc concedere, dum dicunt phantalina produ- $A$ cere intellectioné in intellectu, etenim nil aliud He- eft intellectio; quam fpecies impreffa, vt afferit est apertiffme Arift.in cont.15.27.37. libr.3. de Anima, dum inquit fcientiä, \& fcibileidem effe, non quidem fcibil c materiale, quod extra anima eft, fed fcibile fpiritale, quod eft in anima; hoc enim fcibile ide eft ac fcientia, qux actu eft : vt actualis cognitio cqui eft equus ipre fpiritalis ; difcrimen eft folura fecundum rationem, hoceft,fecundurn diuerfas confiderationes: nam fi referaturadipfun intellectuan, in quo eft, \& à quo iudicatur, diciturintellectio; fi vero ad obiectum externum, vocatur fpecies, \& imago illius, feu illud ipfum fpiritaliter. Os id horum fententia prisculdubio ad veritate propius accedit, \& magis defendi poteft, quana altera: $n \approx m$ videtur Io. Bacconius, \&alij, qui eius fententiam fequuti funt, hoc folum refpexiffe, vt euerterent fpecies ita imprefis s,vintelledtonem pracedāt, \& poft intellectıonem feruëtur; at fpeciem inopreffam, qua 1 de cffi dicatur cum intellectione, certe (vt egoarbitror) nec Bacconius, nec alij negarent: quäobren fententia hac ad refum fenfum trahifacilepoteft. Hecfuit Auerrois opinio, quiin Comment.5.lib.3. de Ainima inquitintentiones intellectas habere duso fubiecta, vnum per quod funt entra, \& alterum per quod funt vera ; fubieEum enim per quod funt entia, eft intelle etus in quoinhxrent; fubiectum autem per quod funt vera, eft ip fum obictum externū; veritas enim eft rquatio conceptus cumre, cuius eit conceptusjafferit ergo Auerr. fpecies effe in intellectu tanquam in fubiecto, nec re diftingui ab intellectione, fed folum ratione, ficuti decla rauimus. Hocidem defpeciebus fenfilibus dicendum eft; nam color in oculo receptus, aciudicatus, fiad realem colorëreferatur, dicitur fpecies coloris, feu color fpiritalis; fi vero ad oculum, dicitur cognitio coloris, \& vifio, ita vtanima, dum iudicat, dica:urfieri colorille. Verum quia aliquiita ne. garunt fpecies imprefras, vt onner corum entitaten de medio tollere conati fint, \& oftenderenullius forma receptionem fieri fiue in fenfu, fiue in intellectu, fed cognitionem nilaliud effe, quam habitudinem, feu refpectum quendam ad obiectum præfens; ideo operæpretium eft fente tiam hancaliquantum confiderare, vt oftendamus fpeciem imprimi in fenfu e in intellectu, tanquam ens politiuum, \& abfolutum, \& veram fpeciem qualitatis, non vt meram relationem, vt ipfi dicunt.Inprinis illud nobis ftatuendum eft, quod ipfin non negarent, eandemefferationem \& f peciei intelligibilis in intellectu, \& fpeciei fenfilis in fenfu, ac luminis in perfpicuo; horum cnim omnium entitatem abfolutam ifti infici. antur: quodigitur de hormm aliquo oftendemus, id de aliis quoque oftenfum intelligatur. Primum pofiumus argumentum delumine fumere exiis, qua al ias fufius à nobis dicta funt in
libris de vifu.lumen in perfpicuo producit qualitatem materialem, nemperealem colorem, vt Arift. fxpe afferit inlib.r.Mereor.\& vtperfe manifeftum eft; ergolumen nó eft pura relatio, fed eftaccidensabfolutum : confequentia clara eft; quia mera relatio non poteft efficere qualitatem realem, \& multo minus talemagë tivim habere poteft id, quod ett purum nihil: nec dicipoteft colorem producià luce, quxe eft in Sole, non à B lumıne, quod eft in perfpicuo;etenim actio omnis fit per contactum, ve inquit A rift. in 3. \& 7. Phyfic.luxautem, qua in Sole eft, corpora hac inferiora non tangit. Confirmatur hoc exoculi lafione, qua fit $a$ b infpedione excellentis lucis, leditur enim ac de fruitur temperies oculi àma. gno lumine, vt ait A rift. in cont.123. \& 143. lib.2. de Anima, \& in 7. libr.3. deftruetro autem temperatura oculi ent alteratio realss, quz à pura relatione fieri non poteft; lumeñ gitur in per-

C. fpicuo non eft mera relario, fed eft accidens abfolutum, \& fpecies quadam qualitatis. Poliumusetiam à phantafmate fumere contra hos argumentum validifiusum : phantafma in phantafia non eft purum nitil, neque mera riclatio ad obiecturn pr $x$ fens, fed eft ens abfolucum; ergo etiam foecies obiekt in fenfu, \& intellectu eft ens abfolutum : confequentia claraelt, quia horum omnium eadena cit conditio; ab obiecto.n. externomoueturfenfus, à fenfu phantafia, \& à phantafia intelleatus; quare fi fpecses in fenfu nulia recipitur;fed eft mera relatio, nöpoteft in phantafiaproduciphantarma, quod fit ynaioris entitatis: antecedens aüt probatur multifariam: primo, quia, vt etiam aduerfarij confitentur, phantafrna mouetintellectum, ergoeftaliquid abfolutū, quia mera relatio non eft apta ad mouendum; pratereailluminatur ab intellectu agente, ergo eft elis pofitium \& abfolurum: przterea phantarmainharetactu in phärafia, eriam E won prafente obiecto externo, imo etiam deftructo obiezto, \& nulla etiam exiftente fpecie in fenfu externo; ergo non eft mera relarioadob. iectum, fiquidem deftruitur relatio per ablationem termini : fi vẻro aduerfarij ad parté memoratricem confugiant, dicentes memoriam feruare imagines obiectorum, \& has effe prafentes phantafia', \& pradictam relationem facere, incidunt in Scyllam dum volunt vitarc Charybdin: nam eaden difficultas manet de imagine in meF moria, qua eiusdean eft conditions, ac reliqua omnia pradicta : nam fecunduan eos etiam imago illa deberet effe mera relatio ad obiectum práfens, quum hacquoquefir eiusdem conditionis, ac reli qua pradicta; hoc tamen dici non poteft, quum nullum adfit obie etu m reale, quia memoria eft praterito?ura : igitur \& idolur in memoria, \& phaniz fma in phantalia; \& fpecies fentilis in o:gano fenfus, \& fpecies intelligibilis ia intelleहtu funt entia politiwa, * ablo. 
abfoluta. Confurmant hanc fententiam verba Ariftotel. in multis locis: nam in context.121.\& 133. Libriz. de Anıma inquit fenlum recipere formas fine materia, meram autem rationem ad obietum prefens non vocaret formam, igitur indicat recipialiquid politiuum; neque dicere poffunt obictumreale, vtrcalem colorem, ibi ab Arift. vocariformam; nam colorille eft forma in maieria, Arift autem dicit recipi formam fine materia: protereain 3. lib. dixitintelle tum effe immifum, vt poffit fpecies recipere, dixit effel ocum formarum, \& formam formarum; \&e fenfum dixit effe formam formarum fenfilium, qux omnia noftrx opinioniateft antur, vt con-

Auerro- fiderantibus manifefum eft. Auerroes quoque es. abfque dubiohocfenlit, quum in Commentario s. libr. 3.diserit intell ectum fpeculatiun conftare extribus, exporfibili, \& agente, \& phanrafmatibus, feu ex fpeciebus intellectis, quatenent locum formx, \& funt product à phantalmatibus; ergonon putauit fpecies effe męram relationem, quia relatio non facit compofitionem, necrecte vocaturforma : in Commentatio etiam 3o. eiufdem libriAuerroes dicit fpecies intellectas habere fubiecturn aliud à fubiecto phantaimatum, quare vult eas recipi in intell cetu; quīphantafmata recipianturın phan. tafia; non igitur putauit intellectionem effe folamprafentiam phäiafmatis extraintelledum, fed effe fpeciem à phantafmate productam in intellectu. Videturautem caufa erroris iftorum fuiffe, quodnon cognouerunt entitatem accidentis fpitital is; quaresdomne, quod materiale non fit, putarunt effenihil : qua de re diffufius Alesan- fripfimus inlibris de V:fu. Quodautem hi nider. tuntur in fuamfententiam trahere Alexandrum de vifu loquentem, \& in primo, \& in fecundoeiuslib. de Anima, id meo quidem iudicio vanum eft; trahinam q; verba Alexandriad verum fenfum facile poflunt, quoniam Alaxädernilalıud refpexit, hifi vtoftenderer obie ta non agere in crgana fenfuum prafertim colorem in oculum, actione reali, \& veraalteratione, qua realıs \&ululitas producatur; quare quando negat form $x m$ in intellectu, atuin fenfurecipi, negut folü formam realem, nonnegat fpuritalem, vt ex eius verbis manifefte colligimus: nam argumentum furrit exeo, quod formz non recipiuntur nui perverum motum in tempore factum, vifio aurem fit lubito; non igitur al am formam excludit, \& recipinegat, ఇuam formam materiaicm: excmplum autem columnx, quo Alexander $v$ titur, fano modo inrelligendum eft;non enim in omnibus ea comparatio confifit, fed in eofolum, qu od columna fic dextra ablque vllius materialis forma receptione, fiquidem nulla alia forma confideraripoteft, qua in columna recipratur, nifitorma materialis jin hoc igitureft fimalıs inftrumento vifus, in quuo fit vilio finealicuius materualis forma receptione: at fi fpirita-
A lem fortam confideremus, \& nomine formx comprebendamus, non eft amplius finilitudo: in oculo enimrecipitur forma fpiritalis, in columnaminime ; quod patet, fi huic exeraploaptemus modum loquendi Arift. de fenfu, acde intellectu; is enum columna, quxdextra fiat, minime conueñit: inquit A rift. Penfura recipere formas fine-materia, inquitintellectum patı, \& recipereformas, \& effelocum for sarum: at co. B lumna, quando fit dextra, nondiciturpati, neq; formamaliquam recipere; quare horum difcrimenmagnum, \& manifeftumeft. Poftet autem aliquis pro his nobis obiicere verbaArift. in cōt. 69 lib. 2. de Anima, vbi dicit lumen efle prafentiam corporis lucidi in perfpicuo: fed hrenobis non obfunt, quoniars propofitio illa Arift. non eft intelligenda formaliter, fed caufaliterinon enim dicir, nil aliud effe lumé, quam prafentiam lucidi,fed dicit lun é produci in perfpicuo à præfentia lucidi, idq̧; manife tum eft legentibus omn:a Arift verba in eo loco: \& hocidem de Alexādro dicimus, qui \& in r. \& in z. luo lib. de Anima, de vilu loquens inquit, lum effe frafentiam lucidi,fed hocipfemet declarans inquir lumen produci in perípıcuo à lucido tanquam à caufa. Hus idem apud Ausennam legere porfumus in libr.fuo, quivơcatur Compendium de anima: ibi enim dicitptzentiam lucidi in perfpicuo efiecauranc luminis, non dicit effe lumen D iplum: notare etiam apud Auicennam in eo lib. pofumus in s. $6 . \&$ 8. iffum exiftimafte fpecies in fenfu, \& in inrelleetu imprimi abobrects tanquamà caufis producentibus, \& elle entia abfoluta, non lolum relationes, ve ifti exiftimarunt.

$$
\begin{gathered}
\text { Oudod fecies imprefsenec pracedere intel- } \\
\text { lectionem pofsunt, nec poft cam feruari, } \\
\text { contra priorem jectam. } \\
\text { Cap. VI. }
\end{gathered}
$$

Equitur fecundum caput demonftrandum, $\checkmark$ juod Ipecies impreffx necpracedereintelle. Etionem tempore, nec poft eam feruari poffint; qua in re priorer fectas deceptam fuifie arbitror. Adhos demonftrandumnullume it efficacius argumentum illo, quod à $D$. Tho

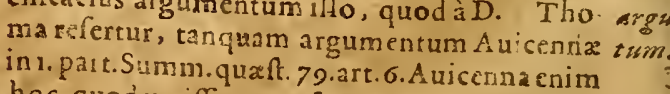
hoc, quod verifimumeft, cognouit, non poffe in intelle tu effe impreffam tpeciem fine intellectione, ideo hocargumento $v$ fuseft: $S i$ fpecies ad modurs habitus imprimeretur in intellectu, intellectus neceffario eam femper intelligeret: confequens manifente falfum eft : confequentia altem probatur, quia fpecies non poteft Imprimi in intellectu, nili abiun êta à materia, \& nudata conditionibus materialibus; at fecundum Ariftotelem in context.is. \& 16. lib. 3. de Anima, omne abiunctum à matcris eft act uintel-
Obie 
ligibile, imo ef a tu intcllcetum, imo eftidem quodintellectio; \& quod intellectusipfe; ergo fpecies in incellectu imprefla intellectio ipfa cit, idque afferitexpreffe Ariltot. in contex. is. 20. 27,37 . Lbri 3. de Anima, igitur ponere in intelleati fpeciem finc intellectione eft pugnantia dicere, \& implicare contradicionem, quia tantum abcet vi fpecies in intelleetu exfe poffit line intellectione, vt potius fir 1 pamet incllectio. Neque diccre aliquis potelt, requiri remper

30. phantafm 1 ; ptoinde foccien imprefam non ífficctea intellcetionem promendam funeaEioncphantafmatis; ercnin actio phantalina tis non alia ratione ad incelletionem confert, 8. quam imprimendo foccien. qüa eft intellectio nis. ipfa, quamobrem dum ponitur tam impreffafpecies, non eft amplius opus phantainate: idque adhuc manifertius eft fccundum cos, qui dicunt fpeciem impreffim habere locum obieEt , feu principii roductiti intellectionis, quæ deterrima omnium fententia cft; thin quianecelfarium omnino effet, vt intellectu femper intelligeret, quum ip fefit femper aptus ad intelligendum, \& haberet obiectum acturum femper prefens, nempefpeciem imprefiam potentem femperproducerentellectionem ; tun etiam quia forma ab agenteprodileta in paticnte non poteft habere locum agentis, nulla enim forma anitin fuam materiam in qua eft, fed habetpotius locum effecti, quam efficientis, vt forma ignis in ligno genita non habet locum effcientis refpectu illiufmet materia, fed folü formxeffectx. Quanquäetiam opiniodicentium fpecien imptellam habere locum forma, iofa quoq; eft abfona rationi, nam acquifita forma ceffat omnis morus, \& omnis a dio agentrsiquare, vt modo dicebamus, fiue fpecies impreffa efficientis locum habeat, fute forma, nullum eft opus phantafinate mouente poft impreliam fpeciem, fed necefrarium eft prafente fpecie in intellectu intellefum aecu intelligere, Ad huius autem veritatis confirmationem notandum eft artificium haturx in facul tatib. anim $x$ fentuentis : quum enim oportuerit duas in hac animx parte inefle vires, vnam cognofecndi, alteram reiinendi ac conferuandi imagines retum, natura non tribuit eidem facultati, neque eidem organo v tramq; vim fimul, fèd vo. luit memorian, qua confertratiua eft, non effe cognofitiuam \& imaginatiuam, qua eft cognofcitiua, non effe conferuatiuam : propterea quodneceffarium omnino eft, vtfacultas cognofcitulucognofcat actuilla, quxactu recepta habet; quarefi phantafia, qux cognofcitiun eft, conferuaret ctiam phantafmata recepta, \& memoria, quxeft confertatiua, $\operatorname{cog} n 0$ fceret etiam imagines in ea feruatas ; cognofeciermulta fimul codem momento, qrod pi-
A nitus impollisile ent; quonlam contemilari, Conten.

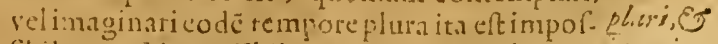
fibile, ve eft impollibilematersan fimul habere ingagize plures formas fpecificas:quemadmodum igitur ro plesice phastafia qum fit cognofcitilla, non potuit ef - fanzel ef: ic conferuatiua, umenoria, quun fit conferua- fe inzoftiua, nö poututefle comrofertua ; itaintellekins, fisile. quum fit cognof citiusus, non poteft efic confiruaciuus fpecicrun, idcontunquam plua limul intelligit, fed fempervnum, proindenon potelt B elle in eo imprefla fpecies line intellectione. Hocidem oftenditura:gumentis polteriors fectrantcarclaris, illis tamen crceptis, queimpreflionem tollunt; hrecenim poften oftende. mus nihilhabcre efficacitatis. Sed quia illa omuia often in argumentorum folutione confiderabimus, \& fingulorü vim expendemus, nunc fais fu vnum tantum confiderare. quod non partumomentieft, fibenentelligatur; eratautem tale : Si fpecies in intellectu port intellectioC nem fertarentur, daretur memoria intellectita. Cofiderantes argumentum hoc D. Thomas, \& Scotus in locis predictis, totum concedunt, proinde negant confequentisfalfitatem:adAriftot autem in lib. de momoria \& reminifcentia ftatuentem vnam tantum memoriam, quxe? facultas anim $f_{\text {fenfibilis, refpondent duplicem }}$ alfe memoriam; vnā, qua eff conferuatriximaginum rerun præteritaten quatenus præteritæ funt, dequaibi Arift: loquitur tanquam pertiD nente ad partem animæ fenfibilem : alteram vero, que eft folum conferuatrixfpecierum repræentantium obiecta fecundum fe abfq; temporis præteriticonfideratione, eaq; eft nemoria intellectiua, quam Arift. non negaret, etfi in eo lib. eam non confideret: fatentur igitur dari mcmorianintellectuam diftinctam abaltera memoria.quxad fentienten animam pertinet. Sed hoc dicentes non foluunt argumentum, neque tuentur.Arift. qui in cap. 1. enushb. afferit felo-

E qui de memoria prout inferuiente tam in elle. ctui, quam fenfui, proinde vniuerfe de maríloquitur, vram tamen tantummodo péni:, quam dicitinfertirepimo imaginatlix, fecul1dariọautem, \& per hocidens etiamintellectui; putat cnin-folum phantafna remanere fixum in parte meinoratiua poftimaginationem, fpeciem vero intelligibilem non manere in intellectu fixam polt intellectionem, dici tamen lllius memoriam confeuari, quaténus phantafna, à quo produici poteft, feriaturi npreffum in parte memotatiua, quod phantafia poteft iterum imaginari, \& 1 terum producere fpeciem eius in intellectu; hocmodo, non alio, cenfuitAriftoteles remanere in animo fcientias, ac difcuplinas omnes, ficut poftea; quum de hy bitibus agemus, deciarabimus. Przterea oftendo nullum effe harua duarum memotiarum II 
difirimen, grtodipfi fingunt: nam quando dicunt, memorian fenfitiuam efe rei preteritæ quatenus eft preterita, vel intelligunt ethenecellaria'ı conditionem recordaiionis, vel fimul cum ipfare etian deteminat temporis record'cmur, atque imagimem clum hac conditione in momorla conferuemus; vel dicuut non effe quidem necellarium vt iṇ̦ago rei prateritæ cum determinato tempore conferuetur, fedvt ea fit conditio obrecti tant um recordabilis, non. ipfius recordationis : prius qudem dici nullo modo poteft, quia falfum eit; etenm multa. particularia recordanur, quorum certum ac determinatum tempus nourccordamur; hacigitur non eft meanoria neceflaria conditio, neque hoc intellexit Ariftotel, quando dixit memoram efle prateritorum, fed fignificauitalterum pofteriorem fenfum, nempe quod tempus prat setitunn fit quiden conditio obreeti memorabilis, feduon ipfius recosdationis, fenmemoriæ, etenim feri recordatio poteft abfque vlla præteruti temporis conid deratione: quod quidé hoc argumento probare poflumus fumpto ex Ariftotel.in eodem libro; nam ibi inquit fenfum. elepræferim; menoriam veroprateritorum, vultigitur eandem efle tationemmenorix, ad pratericum, quxeft fenfus adpræfens; atqui fenfus non apprehendit tcmpus prafens, imo fentire etiam rem plafentem poffumus abfque vlla prefentis tenuporis comideratione; ergo vult Ariftotel. etiam præterita polfe memotari fine vlla confideratione prateriti: hoc igitur fi dicant, vt dicere omnino coguntur, non diftinguunt, vt putant, vnam memoriamabaltera, nam intellectus, vt alio in locodemonfirabi.

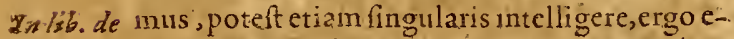
ardine tlampraterita, imo etiam vtptaterita; igitus intclli- tuncfaltem, quando intellectus conferuat pegenaio. ciemrei fingularis praterita, non diftunguetur memoria intellcetiua à fenfitiua, quoniametiā. intellectiua erit rei præteritz codem ptorfús. "nodo, quo me moriat fenfiriua ft præt eritorum. Hre igitur eft Arift. fententia: fac iltas imaginatiua , \& memorit accepta vt imaginum conferuatrix, funtfacultatesciuldem partis anima, nempe fenfibilis, \&ivtraq; eft organica, \&organü. vnius eft propinquil organo alterms, nam organum phantalire eft medius ventriculus cerebri memorize vero poftremus, phan afia quidem, vt ante diccbamtss, cognoficitila eft, at non $\Gamma_{p}$ ecierum conferuatrix, memoria vero eft conleruatrix, fed non cognefciti a ideonon potuitiden. organum vtrique acilitat1, \& tun cognitioni ${ }_{v_{1}}$ tum conferuarionimícruire, fed duo ditintra effe debuerunt, propinqua tamen, vt diximins quum refertin cognatio bumidius organum xequirat contentaio vero ficcius, atque etiann

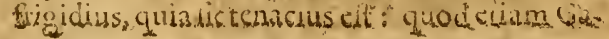

A len. afforit, licctalio nodofacnltates animx in cerebripartes diftribuat; medium enim ventriculun abfcribit parti rationi, quam nos cum Anftotel. organicam effencgainus, fed de hoc in prafentia difputandumnonef. A phantafia Igitur imaginante imprimuntur imagines memoria, \& ibi feruantur, ideoque propter propinquitatem phantañ dicitur habere prom pinquam memoriam, tanquan lib. apęrtum, in in quo multa funt feripta, qux legere poteft: $B$ quod fi vtrumque finul organum accipiamus vt valum, tunc dicimus illud habere vum imaginandi phantafmata, \& retinendi ac confer uandi ipfortum imagines; quo fit vt intelle que hac ratione dicatur 'habere phantaliam tanquam apertum libr. in quo multa legere. fuo arbitiatu poteft; quum enim ibi fint fixa. phantafmata illarim rerum, quarum fpecies intellectus prius intellevit, poteft ab eirden phantafmatibusiterumpati, \& eafdem fpecies c recipere; dum enim phan a ita renolat eiufdem phantafmati imaginationem, intellectus quoque eiufdem reintellectionem renouat, qua fit in iplo noua eiufden conceptus impreffio à phantâfnate: hacigiturviaratione vna \& ea. dem memoria fenditiua apud Ariftotel. per fe, \& primo inferuit anima fenibili, fecundarı autem rationali; quare dim propre menoria fumitur pro laciltate recipiendi rerum imagines, quzin ea fixæ ablque cognitione feruentur, nulla daturmemoria intellectiua; proinde Thom $x, \&$ Scotifententra de duplicimemoria ficaccepta aliena eftab Ariftotel. \& eam quoq; negare cogitur Ioannes Bacconius, dum 1pecies impreflas negat. Inalio camen fenfu memoriam intellectiuam à len itiua duftunetam etiano fecundum Ariftot. tueri polfumus, quem mox, quum de habitibus loquemur, declarabimus. Confirmatur pratcrea noftra hxc opmio auEtoritate Auerrois qui abique dubio huius fen-

E tentia fuit ; afferuit foecies in intellećtu imprimi ficutantea confiderauimus, \& ve pallim apud cum legere poffumas in libr. de auma, acion putauit eas manere fixas 11 in ellectu poft int cllectionem tanquam babitus : "nam in Commentar; 30 . Jibr. 3 . has apud eun verba leguntur Iformafisnt disobuswadis, funt enimf orma rerum thmextratimam, tum in intellectu: $\int \mathrm{c} d i 2$ intelicit ufunt frelusti res felocistrof molutationis. Enon fisa, extrasinimam vexo exiffunt in materiafonfals tanquam babitus in babere babituas Eresfuxain repatiente] itaque cognonit Atrer. formasintclligibile it a clle in intelletu, vt funt res fonbilesin jo ganolenf ts, nimiru prafente folum obleto; tan diu enim in eft 1 pecies colc ris in ocu o, quamdupsensentrealis color; a) hoc.n. penden infer, \& if coleruari: fictam

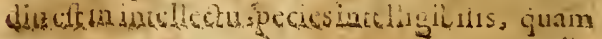


diu eft in phantafia phantafma aetu ; \& ceflantc phantafmate cefiat intellectio; \& foecies intelligibilis eunefeit, quoniam à plaanafmate pendetin elle, a in concicruari: quo fit ve intellectio fornaliter lit preelentia fjeciei in intellectu, caufaliter vero fit prafentia plantarmatis

sess- actu in phantalia. Hanceandem fententian de fpeciebusimprefis, fed pof́t intellecionem non feruats, uribuunt AuicennxD. Thomas, \& Scotus in memoratis loçis;licet, vt ibi Scotus ait, fatis obfcure ex Auicenne verbis colligatur : fed cnituscunque fit, vera eft, vt argumenta a nobis aducta demonftrant, qua quam debilitur à Gandauenle loluanturin quait.15. lib.3. de Anina, quisque apudeum legere, \& confiderare potelt;non eft enim operepretium, vi omnia, quæab ailis dicuntu; mu medium aiteramus.

\section{Confirmatio eiusdem fententia teftimonio Ariftotélis, or reicctio interpretationis scoti, of colleditio erroris omnition aliorum.}

\section{Cap. VII.}

Ententia hæcab Ariftotele manifeite poniStur in contex.3o.lib.3. de Anima, dum dicit animam inunquan intelligerefine phantafmate; \& in 39. eiusdem lib. dum inciuir neceffarium effe, vtintelligens fpeculeturphantafma aliquod; putauit enim nunquam fieri poffe intellectionem fine actionephantafnatis, proindenon feruari fpeciem in intellectu, quan poffit intellectus intelligere fine phantáfmate age $\overrightarrow{\text { - }}$ te. Sed Scotus qui exiftimauit fpecies in intelleetuimpreffas habere lociu obiedti mouentis, verba illa Ariftot.confiderans, \& fuam fententiam tueri volens, in quitit, conuerfionem intellectus ad phantafmata poffe duas ob caufas dici neceffariā, vnam ante acquifitionem habitüü, alteramyero poft antequam enim habeat habitus, neceffe eft vt ad phantafmata conuertatur, fi debeat intelligere, ficut onıne paifuum conucrtitur ad fuum proprium actiuum poftqquam autem acquifiuit habstus, non eget amplius phantafmatibus vt motiuis, eft tamen nezeffarium, vt dum ipfe intelligit, phătafia quoque innaginetur, propterea quod tanta eft propinquitas, \& coniunctio harum facultatum, vt vna operante al teram quoq; operari neceffefit, licet quandoq; neutra aiteri inferuiat; eft igitur neceflariü intelleftion phantafma, non tamen. femper vt caufa fed quandoq; vt neceliario cöfequens : ideo quando Ariftot dixit animam fine phantafmatenunquani intelligere, vtiamq; neceflitatem communiter complexus eft, nempe nunguam fine phantafmate vel efficicnte intellectionem, vel eam confequente. Attamenfi
A verbaArifteneconfideremus, videbimusen diccreintellectu in homine femper egereplsantafia ye mouches, \& obiedur fibminutrante; inquitenim un illo 39. contex. neceflaium efle ve intelligensphanafma aliquod fpeculetur: a:qui phantalia pecularino dicitur, fed lolus intellectus; quarenondicit Ariftot phanta:iam tunc inaginari, fed dicitintellectum fpeculari phantalina aliquod; hocautem non potcitaiso modo intelligi, nifi vt Arifot. dicarintelleztum $B$ inclligentem intueri necehario phantafma aliquod, \& ab illo moueri.Sedvana criam fecmdum fecltiila fecunda neceflicatis ratio, quam Scotus adducit:nam quando duo itafe habent inuicem, vt netutrum alterius caufa fit, nullus effe poteft inter illa effentialis refpe'ctus; feu neceffarius contextus, proinde feparari poffunt, \& vini exiftere fine altero; igitur fipoft habitum acquifitionem nequein ellectio eft caufa imaginationis, neq; imaginatio intelledionis, nulla eft neceffitas vt inrellectu intelligente etiam phantafia imaginetur: quod fi propter propinquitatem id contingere dicat, vt admittamus id polfe contingere, $11 u l l a t a m e n$ ratio adeft cur fit neceflarium ita femper enenire, quum in aliis facultatibus animx, quamuis propinquis, id fieri nonvideamus; dum enim fit vifio, non eft neceffarium vt auditio, vel guftat 10 fiat:quodfi dicat in fubordinatis tantum facultatibus ide-

uenire, adhuc fal fum eft; quia non eft necefia-

D 'riumvtphātafia imaginante etiam fenfus fentiat, quum poffit operam nullo operante externo fenfu, neque fenfu communi: neque adrem. facit exemplum, quo Scotus vitur, fenfus communis refpectu fenfuum extemorum;itia fenfus cōnunis eft veluti centrum omnium quinque fenfuum, neq;abill is re diftinguitur, quocirca non poteft operari nifr illis operantibus; abfente enim obiecto externo non operatur, fed prefente, \& mouente organum aliquod E fenfum externorum: at mrellectus non ita fe habet refpectuphantafix, fed eft facultas animaz feparata a phantafia, \& fecundum Scotum habetian fpecies impreflas tanquam obiecta motiua, \& fixas, neque eget amplius phantafia obiefum fuppeditante; quare nulla eft fimilitudo, proinde verba illa Ariftotelis manifefte adierfantur opintoni Scoti. Preterea alia etiam ì nobis fre notata loca apud Ariftotclem. noftrafententixattcitantur, \& Latinorum opinionem resiciunt, nempequando Ariftoteles dicit fpeciem intellectä $\&$ intellectionem idem effe; fic enim aperte dicitnon poffe in intelleetuexiftere fpecicm fine intcllectione. Colligere igitur ex dictis poffumus errorem illorum omnium, qui impreffas \& permanentes foecies pofueriit. Prinum enim faía eft Scoti feñtenia, qui dixit freciem in untellefn perma- 
nenten habere locum obiecti monentis; etenim moucns fecundum Ariftotelem if folum phantafma; fpecies veroineft in incellectn vt fomaproducta ab agente, non veageas. Emauitetian Thonas dicens fpecipm in intellectu ferturi tanquant raticnem operandi, qu!a fecundum Ariftotctem fpecies inintellectu eft operatioipra, non ratio operandi : ideo neque Gandancufis recte dixit, fpecres impreflas efle tanquam difpofitiones ad operationem; hoc enim dicens dicit aliquid efle praparation etin ad fenctipfum : quum igitur fpecies imprefia:ntellectio ipiafit, non fe praparatio ad intellectionem; quare manifeftum eft has omnes fententias pugnantia dicere, dum ponunt in intellcetu impretram foeciem fine intellectione. Errarte etian illi, qui amnino fpecierum impreffionem negarunt, quia horum quoque fententua, vt antea confideraumus, implicat contradictionem : dicunt phantaima efle agens, nihil tamenagere, quum mullan formam in patientefroducat; quum enim rec fpeciem vllam inprimat, necdicendum fit ipfum prodicereintcllectionem, nihıl agit, proinderft agens, \&

Dubirm, non eft agens. Sed aduerfus fentétiam noftram dubstare aliquis poflet : quiafi fpeciesimprefia idem eft, atque intelléctio, fequitur phantafma folum efie idoneum, ac fufficiens principium producendi intelleetionem; quum enim fuffi, ciat ad imprimendam fpeciem, \& fpecies imprefla idem fit, quod intellétio, certe fufficit ad producendam intellectionem; hoc tamen, vt pauloantedicebamus, falfum eft, \& comnuni, omnium confenfioni aduerfatur ; nemo enim dixit, folum phantafina effe aquatum principium productium infellectionis. Ad hoc dicimus fpeciem inteHligibilem non dici istellectionem quatenus folum recipitur, fed fimul etiam quateuus udicatur. adeo vt fpecies recepta \& iudicataidem fit quod intelle-

phanta- ctio:atquiphantama ad peciei iudiciun nıfrnasica hilconfert, fed ad impreffiouem folum : idco. producit dumhanc folam fpectamus, intelleaus patiintelle- tur tantum, phantafma vero agit; fed dum iuétionem. dicium refpicimus, ipfa intellectus natura eft principium actiuum intellectionis : quare adxquatum principipm intellectionis productiuum neque folumphantarma eft, nequefolus intellectus, fed ambo fimul, illudvt fipeciem. imprimens, hic vero vt iudicans; qux duo fimul codem tempore fiunt, fedratione \& naiu- F ra diftinguuntur; priór enim eft impreflio iudicatione, \& in indicatione procipue coní. ftit intelle Aio, quare precipum agens intellecticnem eft intellectus iple. Idcm prorfus de fenfibus dicendum eft : nam obiectum externum eft princicium productuium fenfioais quatenus fpeciemin organo imprimit fed
A facultasipfa renfibilis dicituragens, dum fpecien itidicat, qua ratione fenfionem producit, ficut aliàs declarauimus in lib. quem de fenfu agentefcripfimus.

\section{Quidfit baúinisistelledtus, à quio intel- lectus diciturin bubitu. C.tp. IIX.}

D Iclarandumreling̨utur, quid fintilli habitus, quifolent at?ribui intellefui tanG quam fixi, \& permanentes, ì quibus vocatur intellectus in habrtu; fienim poft intellectionem nulla in eo lpecies remanet, nihil apparet, quod pofit habitus appellari. Ego hac in refequendam puto nonullorimopinionem, cuins metion $=m$ facit $S c o t u s$ in dicta quxft. 5 . diftinct. 3 . lib.r. \& cam dıci: fuite à quibusdam Auicenin adfcrionan : attimen an Auicenna id voluerit, inquit Scotus, fe nihit certi habere; attribuit autcm illan AucenneThomas in contex.\&lib.

C. 3.de Anima, \& in r.part. Sum. qqueft. 7\%, artic. G. fed chiuscing; fuerit, cam ego veram effearbitror, \& Arift.verbisconfentaneam. Dico 1 gitur. acquiri in intelle di actibusquandan maiorem aptitudinem feu habilitacem ad easdem res incelligendas, quam non habebat prius, eaq; dicitur habitus acquifitus, nam mens nof?ranaficitur rudis, \& inepta ad rerū cognitionem ftatim capiědam, ideo neceffe eft vt laboret, \& inueftiget, vt difcat, \& in-

D ueniat; fedpoftquam.femelrem aliquā apprehen dit, fi du in eius contêplatione verfetur, acquirithabitum, id ef, habilitatem quandā, qua poteft, quando vult, rëilla m fpeculariabsq; exercitio, \& absq; labore:dicuntautem id ab Auicenna hoc pacto fuifie declaratum: intéllectus poifquam hanc habilitatẽ adeptus eft, cōıertit $\mathrm{re}$, quando vul $\tau$, ad quandam intelligentiam fuperiorem, quæinfundit eífpecies, quas ipfefine vllo laboretunc recipit. Sed hxc fententia apud

E Peripat. admittenda non eft : dicerepotius debemusintelle fum illam habilitatem adeptum conuerterefe, quand vult, ad phantafiam, \&e absq; vllolabore fieri hánerem, vel illam, quia Iam eft exercitatus in corundem phantarmatum infpectione, \& carundem rexum cognitione; quofir ye exphancafmatis oblatione inprimaturin eofittim fpecies intelligibilis, \& pro. maturintellectio, quod ante habitus acquifitionem non eueniebat; nam oiferebatur quisF demphantafmalumine agentis illuftratum,no tamen ftatim intelligebat, quia rudis erat, \& ad rccipiendum ineptus, \& labore, acconfiderąio-. ne indigebat, vt fpeciemreciperet, quum autem. femel recepit, aptior eft ad eandem rem iterum intelligendam, moxautem fialiquantum in illa exerceaur, fit aptus ad eam rem ftatim, \& fine labore in phantafmare infpiciendaw, quando 
vult. Hxc igitur aptitudo acquifita dicitur habitus quem prius intellectus non habebat, nec ta men eft fpecies intelligibilis,qux fixa maneat in intellectu poft intellectionem, ian cnim oftendimus fpeciem ceffante intellectione abo. leri; fed eft folum maior quxdam habilitas , quxpoft intellectionem fixa in intellectu manet. Hoc modo intelligenda puto verba Ariftot.in context. 8. libr.3. de Anima, quando dicit intellectum in habitu effe adhuc poteftate, non tamen ita, vt erat antequam difceret, aut inueniret; fignificat enim Ariftot. poteftatem refpeEtu operation is, femper enim intellectus non actu intelligens habet potentiam ad operationem; fed difcrimen eft, quoniam hxc potentia prius remotior erat, quando non habebat habitum, poftea veroacquifito habitu eft facta propinquior: ob id antea dicebamus, non onmino verum effe id, quod Ariftotel. quandoque ex. empli graria fumit, fcientiam in animo effeactum primún, fpeculationem veroelle actum fecundum; vtitur enim hoc exemplo non vt vero, fed vt apparente, \& ad declarandum prini ac fecundi actus difcrimen fatis accommodato; reuera enim intellectus habet potentiam ad fcientiam vtad a cum fecundum potius, quam vtad primum; quando enim poft ignorantiam açquirit fcientiam, nil aliud reuera acquirit, quam intellectionem \& fpeculationem, quxeft åtus fecundus; acquirit quiden etiam illam operandi habilitatem, ea tamen non eft actus primus, nifi improprie, \& per quandarin fimili. tudinem, fed actus primus eft ipfe intellectus. cuius,effe operatio dicitur: nam firlla habilitas effet actus primus, non poffet fieri intellectio, nifi profuppofita hac habilitate, quoniam actus fecundus præf uppont primum; hoc tamen ve. rum non eft, quia fit intellectio etiam anteacquifitionem huius habilitatis : igitur intellectus ipfe eftactus piimus, \& femper eft poteftaterefpectu asusfecundi, cum hoc tamen difcrimine, quodilla potettas, antequam acquirat habitum, remotioreft, poftea vero fit propinquior: quare habitum acquirere non eft acquirere actum prinum, fed eft potentiam ad fecundum actum fieri propinquiorem, quam prius erat. Hoc poffumus declarare exemplo facis claro : $m a n u s$ homïnis nafciturad feribendum apta, \& habet hane potentiam naturaleın, valde tamen remotam abactu fcribendi; in principio enim non poteff fribere, nec face- $F$ re illos motus, quibus charadteres formantur; at fi excrceaurur, \& laboret, difcit fcribere, \&e nunc dicitur habitum feribendi acquifiuiffe: quid igitur exillo exercitio manet in manu impretiom ? certe ea ceffante fcribere, nihil ipfiusactustn ip a impreffum manet; non enim alicuius characteris forma in manu remanet,
A sed fola habilitas, qux nihil aliüd eft, quama. ptituda, \& poteftas fribendi facta propinquions fic igitur de intelleatu noftro dicendum eft;nam in initio cum laboreaddifcit, aliqua tamen $f_{2}$ cilius al iqua difficilius, nec fine magno ftudio; nam prima principia, \& dignitates tacilius recipit (etenins harquoque à phantafia, \&à fen. fibus recipit) alia vero difficilius, \& cum exercitio, \& labore, \& difcurfu à noto ad ignotum; $\&$ is labor modo eft maior, modo minor pro $B$ rerum varietate; \& cognitio lllorum, qux facilius apprehenduntur, praparat intellectum ad recipienda alia cognitu difficiliora; \& aliqua etiam ita difficilia funt, vt ipfe perfe nullo difcurfu, nulloque ftudio illa addifcere pofht, fed do - Intellectore explananteindigeat. Ad huiusautem itus sm reiconfirmationem dignus annotatione efto- babitw cus aput Ariftor. in context. 59. libri fecundi de est $f$ Anima, vbidicit Senfum cffe naturaliter fimi- milis fexlemintellectui in habıtu: fenfusenim nafcitur fro.

C cumpeteftate operandii ita propinqua, vt nullo doctore, nulloque exercitio indigeat, fed ftatim fine labore fpecies fenfilium recipiat; ideo fi hanc habilitatem, quam fenfus naturalem habet, vocaremus habitum, fenfus accepiffet habitum à generante, non à doetore aliquo: non ficintellectûs ; non enim cum tali habilitate nafcitur, fed laborandum illi dis eft $\mathrm{t}$ camadipifcatur; talis igitur eft intelle fus poitquamacquifiuit habitum, qualis eft fenfus natura, proindecum eo tantum difcrimine, quodilla habilitas in intellectu eft acquifita, in fenfu autem eft nat uralis, fed ipfa fecundum fe confiderata habılitas eadem eit: quemadmodum igıtur in fenfunulla nafcitur impreffa fpecies obiecti, \& nihil illiusactus, quirecipiendus eft, fed mera habılitas, \& aptiıudo, \& potentia operationi proxima; fic in intellectu hic habitus nullam fignificat impreffam fpeciem, fed folam habilitatem, \& aptitudinem ad fpeciem ftatim reci- quidfot E piendam. Si quisautem quarat, quidnam fit babilit hæc habilitas, quæ vocatur habitus, ego arbitror effe qualitatem; - qua muis enim isriftotel. in 7. Phyfic. à 17. ad 20. vfque contextum dicat habitus effe relationes, tamen rei veritas eft, habitum notare naturam abfolutam, qux fimul effentialiter refpestum contineat; quocirca funt \& in categoria qualitatis, \& in categoria relatiuorum, alıa tamen \& alia ratione; id émm quod habent abfoluti, qualitaseft. In genere autem qualitatis, an ad primam fpeciem, an ad fecundam pertineant, non eft clarum; quum enim fint quxdam aptitudines ad operandum, videntur ad fecundam fpeciem pertinere, qux ef potentia, vel impotentia; attamen A. riftoteles omnes habitus inprima fpecie colosaffe videtur. Ego dicendum puto iales operandi habilitates. Iocatas effeab Arıftotel. par- 
tim in prima, partim in fecunda fpecie qualita- A tis; habent cnim hoc difcrimen, quod alix funt naturáles, aliæ vero acquifitæ: quạndó igitur funt naturales, Ariftotel. eas in feçunda fpecie colocauit, quam ob id vocauit naturalem potentian, aut impotentians : quando autem funt acquifit $x$, vocantur habitus, \& pertinent ad primam fpeciem qualitatis; ideo habilitas videndi, quæin oculo eft, licet fimilis fit habitui intelleatus, nō tamen vocaretur habitus, quia eft qua; litas connata, ideoad fecundam fpeciem qualipotentia tatis pertinet:potentia vero intell igendi in intelad entel- lectu duplex confideraripotert, vna propinqua, lectzosé alteraremota; \& illa quidem, quaeftremota, estow- pertinet ad feçundam fpeciem qualitatis, quia plex. connafcitur intellectui, fed facta propinqui or vocat ur habitus, quia eft habilitas per multiplicatos aetus acquifita, ideo hac fola a d primam qualitatis fpeciem pertinet; hac de habitibus intelleçus effe Ariftotel. fententiam arbitror, Recentzo peream enim omnes difficultates tolluntur.Sed rumop:- aliqui recentiores, quifpecies impreffas negaose. runt, \& illam quam diximus, habilitatem non. cognouerunt, ad phantafmata confugerunt; quoniam alium modum, quo habitus intelle-. ctuales feruarentur, inuenire non potuere; dixerunt enim eatenus feruari habitus quatenus phantafmatum imagines in memoria feruan-. tur, à quibus poteft intellectus intellectionem recipere quandocunque ad phantafiam fe conuertere vult. Sed hæcfententia recipiendanon eft, quia hoc dicentes non poffunt interpretari verba Arift. in cont.8.libr. 3. de A nim2, quando inquit, intellectum in habitu maiorem habere operandi poteftatem, quam prius:etenim fi nihil penitus in intellectu manct, qua eorum fententia eft, certe habet poteftatem $x$ que remotaim, ac prius habebat; quare nifi concedamus in intellectuillam habilitatem ex iterata operatione comparatam, neque interpretari Arift.poffumus, neque oftendere quinam fint habitus intellectuales, quia fecundum iftos nullus in intellectu habitus ponitur, fed folum in parte ani$m x$ fenfibili; quare nullam áfferre rationem poifumus, cur cognitio rerum naturalium fit magis in animo Philofophi non contemplantis actu, quam in anima hominis idiotx, quuma phantafmata rerum particularium æeque in $v$ triufque animo effe poffint; quamobrem nifi dicinus intellectun Phliofophi maiorem habere aptitudinem contempladi vuiuerfalia, \& 5 rerum effentias, quam intellectú hominis idio$r æ$, nullam afferre poffumus rationem, cur ma. gis ille, quam hic, habeat in animo fcientiam naturalem fixam tanquam habitum. Præterca. hoc illi dicentes nullam intelle ctui memoriam. attribuere poffunt, quum nos aliquam etiam fecundum Ariftotel. intellectiuam memorian concedamus; habitus namque illi aptumintellectum reddunt ad rem oblatam fatim abfque vllo labore intelligendam, vt quum fixi in intellectu fint, nomine memorix appellari polfint: ita enim celerem, \& facilem efleoperationern intellectus habitibus praditi certum eft, vt inftar conceptus imprefre effevideatur, necalio modo, quam hoc, Ioannes Bicconius memoriam intellectiuam in homine concedere po. teft, quum fpecierum impreffionem omnino

B neget. Si quis autem quxrat, quanam memoria animæ humanx feparatze attribuenda fit, de hoc nihil prorfus enunciare iuxta A rift. poffumus, quumipfe animan humanam à corpore feparatam nüllibi confideraffe comperiatur, ita vt non abfque ratione dubitauerint multi, an talem feparationem cognouerit. Secundum verițatem autem Theologos confulere oportet; certum quidem illud eft, aliim in eo ftatu effe intellectionis modum \& quemadmodum tunc C non amplius à phantasmatıbus obiectum recipiendo intelligit, neque vllas fpecies recipit, qux fint accidentia diftineta ab eius fubfantia; ițaperennem rerum memoriam ipfum habere credendum ent, qu $x$ ab intellectione nondiftinguatur:attamen hoc ftatuere inftituti noftri non eft, ideo rem hanc vtà propofito alienam ad Theologos noftros integram remittinus.

\section{omnium vtriufque fect a argumentorum confideratio ó Jolutio. Cap. IX.}

Spereft vt omnia vtriufque fectx arguOmenta perpendamus, \& quantum roboris habeant,confideremus, \& quantum roboris Ad priquo prior fect impreffas fpecies oftend totum eft concedendum; quoniam eo nilaliud probatur, quam fpeciei impreffio, quam \& nos concedimus, at non oftenditur eius permanentia poft intellectionem. Ad fecundum fumptum Ex habitibus intellectualibus neganda eft confequentia:iam enim diximus habitum non effe fpeciem impreflam, fed effe habilitatem, \& aptitudinem operandi facilius, quam prius; dicimus enim fcientiam naturalem eatenus feruaritanquam habitum in animo fcientis, quatenus feruatur illa aptitudo cognofcendi ftatim res naturales in phantafmatibus in memoria feruatis, \& intellectui oblatis à phantafia imaginante:ideo feient1a vniuerfalis non remanetactu in. animo vt vniuerfalis, fed poteftate maxime propinqua in fuis caufis, quia feruantur in memoria imagines particulares, \& in intellectu aptitudo abitrahendi conceptum vniuerfalem absque vlla difficultate; hanc.n.fignificauit Ariftot. in cont.8. lib. 3. de Anima nomine habitus, per quem intellectus eft aptusad operandum quando vult. Ad tertium negamus fcientiam feu $\mathrm{d} d \mathrm{kem}$ babi- riaint.
lestusa
cundisi
Arijt.

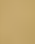

$-$


habitum predictum effe actum primum, \& operationem effe actam fecundum refpectu habitus; hoc enim verum non eft proprieloquendo, fed folum per quandam fimilitudinem; ip fa enim fubftantia intellectus eft actus primus, contemplatto autem, \& fcientix acquifitio eft actus fecundus; Arift.autem hoc exempli gratia fumfit, \& craffa Minerua confiderauit, quoniam exemplorum veritas exacte quxrenda non eft. Sed hoc etiam conceffo nullius roboris argumentum eit, quia non êf neceffarium, vt actus primus pracedat tempore actum fecundum; nam anima vegetans fimul incipit efle, \& operari;grauein fublimigenitum quo momento incipit effé, codem incıpit deorfum ferri; ignis finul atque eft genitus, calefacit: itaque adeo, validum eff argumentum, vt cius v traque quar propofitio neganda fit. Ad teftimonia autem 2. Ariftot. in pluribus locis nulla opus eft refponfiode, quia per illa non oftenditur fpecierum permanentia poft intellectionem . fed fola oftenditur impreflo, quam nos concedimus. pri- Pofterior vero fecta primum argumentibatur m po- ex verbis illis Ariftot.in context. 5.lib. 3. de Anima [intellectus nibslest attu corum, quafunt, anrequam intelligat] quxingnificant nullam fpeciem pracedere intellectioni, quare hocargumento non impugnatur impreffio fpeciei, fed fola praceffio: videtur tamen folui poffe dicendo Ariftot, ibi confiderare primam apprehenfionis originem, qux fit in puero; puer enim prius intelligendo acquirit habitus, qui poitea in eo feruantur, \& precedunt alias fequentes intellectiones, nonillam primam. Sed revera argumantum contra priorem fectam efficax eft, quia fecundumillos fpecies impreffa ante intellectionem requiritur vel tanquam obieetum mouens, vel alio modo tanquam caufa; fic enim intellectio fieri non potelt, nifi impreffa iam fpecies effe ftatuatur, impreffa autem fpecie factus eft intellectusresilla, vt Ariftotel. afferit in contex. 8. eiufdem libri, quare antequam aliquid intelligat, eft aliquid eorum, qu'e funt, quod in eo context. 5. Arift.negat. Serundum argumentum erat: fufficit fpecies expreffa; ergo fruftra poniturimpreffa : hoc dirigitur ad impugnandam fpeciei impreffionem, \& facile foluitur; perinde enim eft, ac fi quis dice. ret, ignis agens fufficit ad vrendum lignum, ergo fruftra poniturin ligno generarialiam formam ignis : inefficax enim argumentum eft, quum potius contrarium ex eo colligatur, nam fi ad lignum vrendum fufficit: ergo in eoproducitaliam formam ignis ; nifi enim producat, certe vel non agit, vel non fufficit : fic igitur dicimus phantaima illuftratum fufficere ad mo
A uendum intellectum, ideoque prodicere in eofpeciem; quia hane non producere effet nihil agere, vel non fufficere: ideo repugnantia ineft in hoc argumeuto, fi benc perpendatur; fed deceptio in hoc confiftit, quod putant fpeciem in intellectu poni tanquam caufam intellectionis, vt eam alii ponebant, aduerfus quos fortaffis efficaxargumentum eft: nos vero fpeciem in intellectu ponimus tanquam effeetuin à phantafmate productum, non tanquam intelB lectionis caufam, quin potius tanquam intellectionem ipfam; quareargumentum contra nos inane redditur. Tertium argumentum erat: $f_{1}$ darentur fpecies in intellectu impreffe, daretur memoria intellectiun: ad hoc quid refpondendum fit, iam diftum eft fuperius; validum euim eft aduerfus ponentes fpecierum permanentiam poft intellectionem, fic enim proprie intelleftiuam memoriam omnino negamus fecundum Ariftot. qui memoriam fumptam pro imC preffrone imaginis non conceffit, nifi in parte /animx fenfibili: "fed aduerfus fententiam noftram de habitibus nullius roboris argumenrum eft; nam fi quis dicat, his habitibus pofitis daretur memoria intellectiua, nos hoc concedimus, quoniam fic acceptam memoriam ipfe quoque Ariftotel. non negaret. Ad quartum; quod impreflioni refragari videtur, dicimus formam nori effe quidem receptiuam accidentis materialis, fed effetamen receptiuam fpiriD talis, fornam fcilicet informantem materam, \& conftituentemaliquid in rpecie fub corpore naturali, qualis eft in hom ine aninıa rationalis; nam deforma abiuncta à materia cöcedimus eä nullius accidẽtis fubiectū effe poffe.- Poftremū argumentum nullus prorfus momenti eft, nititur enim fundamento inter Philofophos maxime controuerfo, \& abomnibus folui facle poteft: Alexander enim \& illi, qui eius fententiam fequuntur, minorem negarent: fed alii inE terpretes Ariftot, qui animam rationalem et. iam fecuudum Ariftotel. immortalem effe affirmant, negarent maiorem: dicerent enim fubftantiam quidem xternam, \& ab omni materia abiunetam, accidentia mutabilia recipere non poffe; at fubftantiăm æternam vt corpori caduco alligatam, \& ab eo pendentem (vt aiunt) obiectiue, cuiufmodi eft anima rationalis hu. mana, poffeabfq; vlla abfurditaterecipere acci: dentia caduca, \& mutabilia, quum enim mo. ueatuì à phantafmatibus tanquam ab obiectis, \& phantafmata musabiliafint, ipfa quoque $a b$ eis recipitaffectiones nouas, atque mutabiles propter mutationem agentis, à quo producuntur: quareargumentum iuxta omnium fententias debile eft.
Adter. tions. Ad quar tism. If
Adquin.
trom. . 


\section{A \\ Z A B A R E L L $\mathbb{E}$ \\ P A T A V I N I, \\ L I B E R.}

$\begin{array}{lllllllllllll}D & E & M & E & N & T & E & A & G & E & N & T & E .\end{array}$

Propofitio, ac difpofitio dicendorum. Cap. $I$.

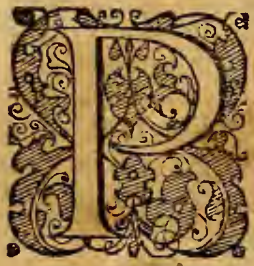

Ræter humanam mentem' quxe patibilis dicitur, cen luit Ariftotel. neceffariam effe alteram mentem agentem, fine qua nequear in homine intellectio fieri, ea ductus ratione, quod vbieft aliquod patiens; quod in aliquo genere omnia recipere, \& omnia fieri aptum lit, neceffe eft $v t$ illi refpondeat agens, quod iliius generıs omnia facere poflit: quoniam igıtur humana mens patiendo intelligit, \& apta eft omnia intelligere, proindeomnia pati, \& omnia fieri ; neceffe eft aliquod illiagens refpondere, quod omnia intelligibilia faciat, idque non effe nifi mentem: quo fit vt d ux in humana intellectione mentes confiderand $x$ fint, vna patiens, de qua nos in alis libris egimus, altera vero agens, de qua in hoc libio agerdum nobis propofuimus; etenim tum ob eius dignitatem, tum obfummam difficultatell1. tum etinm ob ipfius in humana intellectione neceffitatem digniffina res eft, quáaccura è trątetur $r_{\text {p }}$ ac declaretur. Duo autem funt in quibus tota eft huiufce rei difficultas conftituta:vnum, quid fit hxc mens agens, an fit pars aliqua animx noftrx, necne, \& qux fit eius natura; alterum vero, qquenam fint eius officia in noftra intelleEtione; nam ipfequoque Ariftoteles hac vtraque de mente agente in 3. de Anima librotraEtaffe comperitur; \& quamuis ordine nature dicendum prius effet deipfius effentia, poftea verode officiis, tamen in hocquoq; Ariftot. imitati de officiis prius ageñus, deinde vero de eius natura ; progrediendum enim femper eft à facilioribus, \& ab iis, qquorum cognitio ducere nos facilius in aliorü notitiam poffit ; coğnitis enim huius intellectus officiis, facilius quid ipfe fit indagare, atque inuenire poterimus, quod etiàm Airiftor.mouit, vt prius deipfius in humana intellectione officijs, poltea vero de effentia loqueretur. Id tainen ante omnia proteftari veلım,mehacde refecuudurn principia tantū phi.
A lofophix Ariftot. effe difputaturum, quum non aliud in his omnibus libris confillum meum fit, quam quid fenferit Ariftoteles, inueitigare, \& eius fententiam, quantum in me eft, planam, \& manifeitam reddere.

\section{De officiis intellectus agentis varia opi- niones. Cap. II.}

CErtum eft, officium mentis agentis efre agere, hocent, trahere de poteftaread actüm, fed in quodnam agere dicatur, \& quonsodo, ob. fcurtlima res eft, \& maxime controuerfa: alii namq, dicunt ipfam agere in phantafnata, non in mentem patibilem:alii in mentem patib le $\vec{e}$, non in phantaŕnara : alii vero in ambo fimul. Prima fententia Latinorum fuit, prafertim $D$. Thomx, qui in libr. 3. de Anim.?, \& in r. part. Sum. quxeft. 79.art. 3. \& 4. \& in qua ftonib. difputatis de fpiritalibus creaturis, artic. 10. \&de anima, artic. 4. \$. 5. quibus in locis fufifimede hac re loquitur, afferit rationem agentis in hoc effe conftitutam, vtagat in phantalinata: eiufdem fententix eft Ioan. B.cconius in r. Sentent. quxft.2. prologi vbi dicit officium intellectus agentis effe propterphantafmata, \& totam eius actionem in phantafmatibus terminari, neque vlterius progredi. Pro hac opinionc videturargumentum iumi ex verbis Ariftot.in contex. 18. lib. 3. de Anima, vbi declarans officium intelle- Argun ctus agentis inquitipfum effeficut lumen, nam tzym ith lumen facit colores, qui poteftate funt, efíe actu rum. colores: quemadmodum igiturlumen non agit in oculum, fed in obiectum colorem, \& ipfum ducit de poteftateadąum; ita intellętus agēs agit in phantafmata, non in intelleclum patibilent, ideo poteft indecolligi argumentum tale; officium omnis agentis eft trahere de poteftate ad actum; fed Arift, hocofficium rribuit intellectuiagenti ratione obiętorum, facit enim de intellectis poteftate actu intēlleeta: ergo in phātafmata agit, non in intell êt su patibilem. Con tra vero Simplicius videtur ei totam aAtioné tribuére refpectu intellectus patibilis; putat enim vtram q; efle vnam \& eand $m$ fubftantiam, \& vnum intelleetum, qui vt in fe manens dicatur agens, \&vt pregreffus dicatur patibilis; quoniam 
ipfevt in fe manens feipfum vt progreffum du- A cit de poteftatead actum, de imperiectione ad perfectionem. Hanc fententiam Anerroes in Comment. 5. libr.3. de anima Theniftio attribuit, attam cn non fatis liquet The miftium fuifian- fe huius opinionis. Hanc eandem fequiturloannfos. nes Gandauenlis in quaft. $24: 2.5$. lib. 3. de Ani-

- ma, vbitotam actionem intellectus agentis inquit efe in intellcetum patibilem, non in phantafmata, \& ipfum in intellectu patibili producere actum intelligendi. Pro hac fententia fumirurargumentum ex Ariftot. in contex. i7. eiuldem lib. vbi ex eo quod detur intell cetus patiens, infert dari ctiam intellęũ agentem, proptetea quod omni patienti refpondet aliquod agens: vult igitur Arift. intelle ctum agentē dari proptcrintell.etū patientem, \& vt agat in eum; rationanıqueilla vana eflet, nifi agensageret in illudmet patiens cui ref ödere drbet; hocidem Arillot. exempla declarant; inquit enimintellectum agentem ita fe habere adintellectú pa- C tiblem, vt ars ad niateriam fe habet, ars autem in materiam agit; ita materia prima eft patiens, in quod agunc omnia agentia naturalia; quare etiam intellectus partbilis dicitur patiens refpectuntellectusagentis \& nomen quoque iprum hocoltendit; non enim pharitalmata vocauit patientia, fed ipfum patibilem intellectum: in hunc itaque voluit agere intellectum agentem. Auerroes autem va:ius furfe videtur quandoq; enimafferit actionem intellectus agentis requi- D ri propterintellect:m patibilem, vi iplum ad actun ducat, atque perticiat; quandoq; propter phantalmata, vt ea transferat de gradu in gradum, hoc eft, de matciinlibus faciat immaterialia, \& de intellectis poteftais actu intellecta: quare videt urAuerroes exiftimalie officium intelledus agentis requiri propter vtramq: actio$\mathrm{n} \in \mathrm{n}, \overline{\mathrm{d}}$ : Ctus fortafíe vtrifq; argumentis ex verbis Ariftot. fumptis, quibus duas priores fectas vias efre diximus, nam Arift. in contex i7. lib. 3 . de Anima dicere videtur intellectum agentem agere in intellectum pátibilem, deinde in $18 . v i$. deturafferere ipfum agere etiam in phantafmata. Ideo fententiam hancnonnulli recentiores fequuti lunt, qui eam magis declarantes dixcrunt, intellectum agentem effe idem re cum intellectu patibili, \& effe cognofcentem, \& eatenus in illum agere, quatenus tribuit illi cognitionem, vt hac ratione dicatur intelleationem. producere, quia intellectui patibili tribuit cognitioné, quã ipfe agens prius habcbat. Hæc funt qux $\mathrm{ab}$ aliis dicuntur, à me breuiffime collecta.

\section{Dictarum opinionum confutatio. Cap. III.}

ifuta- TOs vero aliornm errores patefaciendo fiopini- Nunul ipam rei veritatem iuxta Ariftatelis menté declurabimus. Inprimis à veritate prorlus abcrrant illi, qui dicunt intellectum agentem agere in phantafmata: quoniam, vt modo alios confideraffe dicebamus, Arift. in ellectum agêtem inuenit propter intellcctum patibilem, \& vtin elim agelet tanquam patientem. Sed ob. ftare nobis videntur verba Ariftot. in contex. 18 . quando intellectum agétem cum lumine comparat, \& fignificat ipfum agese in phantarnata : iis tamen verbis bene intellectis tolletur omnis B difficultas, \& ipfa rei veritas manifefta fiet. Sciendum igitur eft, quandodicimus aliquid facere de tali poteftate tale actu, verbum illud [ $\mathrm{fa}$ - Facere cere ] ambiguum effc, \& poffe intelligi duobus alıgusid modis; poteft enim facere vt forma, poteft et- Gelfunim iam facere vt agens; forma enim humana adueniens materia, facit de homine poteftate hominem actu, neque ob id eft agens, quia facit hominem ad modum form $x$, non ad modum agentis; homo vero generans alterum hominem, diciturfacere hominem tanquam agens: differentia igitur eft in hoc cóftituta, quod ignis generat alterum ignem, \& facit de igne poteftate ignem actu,producendo in illa materia alteram formam ignis fibifimilem; illa vero altera forma producta facit de igne poteftate ignem actu, non tamen producendo aliam formam, fed vt formaipfa, quia non id facit vt agens; iungitur enim iplirei; at agens generans externum eft, neque cum materia coniungitur. Quando igiturArift oteles dicit intellectum agentem fácere hantafmata actu intelligibulıa de intelligibilibus poteftate, non ob id declarat ratione agent1s, quia non id praftat vt agens, fed vt forma; iùngitur enim phantafmatibus lumen intelleCusagentis tanquam fornia, qua redduntur actu motiua, \& actu intellıgibilia ; ficuti lumen iungitur colori táquam forma, \& perfętio, qua redditur actu vifibilis; \& actu motiuus vifus, néquediciturlumen effeagens refpectu colorum; E quia nitil in eis producit vt agens, fed eisiungiturvt forma, per quam totum hec cöiunctum, color illuminatus, conftituitur in effe obiectiuo; \& fit actum motiuũ vifus: hoc fignificauit Ariftot. in eo ipfo loco, dum dixit intellectum agentem facere omnia tanquam habitum quen-dam; habitus enim forman denotat, non caufam effectricem.quia efficiens eft à patiente difiun $\mathcal{E} \bar{u}$, forma veroiungitur materia recipienti, \& habitis rei habenti habitum; fic lumen coloribus hxret vt forma, \& perfectio; neq: ad cos fe: habet v.t agēes ad patiens. Non eft igitur verú id, quodprima fecta dicit, intellectum agenten agere in phantafmara, \& argumentū eorum nullius roboris eft. Decepti etiam funt illi, qui pu-

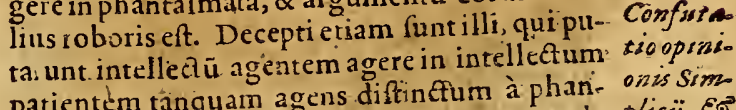
tafmaubus quod extra phantafmata agenda plicü E IJ. $s$ perí-
Rhem. E Encro Sulutio argism. tur ad $\bmod$ for me, Gel admodis agentis.

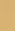


perficiat intellectum patientem, \&ipf tribuat $A$ intellecionem; hoc enim dato fequeretur intellectum patientem poffe etiam fine phantafmatibus intelligere, nempe fumendo cognitionem immediate à folo agente; id tamen Ariftot. aduerfatur, qui in contex. 39. libit tertii de Anima aperte dicit, fieri nunquam poffe vt intelleetus intelligat, nifi phantafmata aliquod fpeculando: quare fecuñdum Ariftotelem omnis noftra in. tellectio fit ex motione facta à phanta matibus. Intello- Imonon folum falfumeft id, quod dicunt, inctus agés tellectum agentem tribuere patienti fuain conon agit gnitionem, fed neque ea ratione, qua eftagens, gusate- eft intelligens; quanuis enim neceffario confenisintel quatur vefit mens aliqua, \& actu intelligens, taligens. men ea ratione, qua eft agens, nihl formaliter intelligit, fed folum effeetiue; quatenus in homine intellectionem producit: quomodo alltem id faciat, poftea declarabimus, \& oftendemus intellectum agentem effe quidem femper intelligentem, agere tamen non vt intelligencem, fedvt intelligibilem : falfum id quoq; eft, quod Gandauenfis dicit, intellectum agentem in intellectu patiente producere actum intelligendi: poftea enim oftendemus intellectum patibilem fufficientem fibiefle ad promendam intellectionē fine ope intellectus agentis. Quocunque igitur modo dicatur intellectum patibilen pati abintellectu agenté, tanquam ab agente diftincto à phantafmatibus, \& tanquam à cognofcente, falfum eft, \& ab Arift.alienum, Quum autem vtraq; hæc fecta errauerit, errauit etiam tertia, qua vnum cum altero errorem coniunxit, yt confiderantibus manifeftum eft.

\section{Vera Sententia de acione intellectus agentis. Cap. IV.}

$\mathrm{D}$ $E$ actione igitur mentis agentis ego hanc effe puto veritatem iuxta Ariftotelıs opinionem; vtagere dicatur in intellectum patibilem, non in phantafmata, fed phantafmatibus iungatur vt forma conftituens obiectum motiulum intellectus patibilis: clarum hoc eft confiderantibus argumentum Ariftotelis in contextu 17.eius libri; ibi nam que conftituto intellectu patiente colligit mentis agentis neceffitatem, quia nihıl imperfectum, \& tale potefrate vult in fua imperfectione manere, fed ad perfectionem ducatur neceffe eft; non poteft autem femetipfum perficere; ergo requirit agens, à quo perficiatur, ducaturque de poteitate ad aatum; agit ergomens agens in mentem patientem, non in phantarmata, fed eis iungiturvt forma. Vnde colligimus, quomodo agitin intelle fum patibilem : non enim agaț vt folus, \& v.t agens diftinetumà phantafmatibus, tũ quia fequeretur poffe abfque phantafmate intelle-
Etionem fieri, tum etiam quia agit vt habitus, \&e forma phantafmatum: agit igitur vt iunctus phantalmatibus, ita vtex vtrifque vnum conftituatur obicctum perfectum, \& potens in intellectu patibili fpeciem producere: quare $v$ num tantumeftagens, ipfum phantafma, lismen vero intellectus agentis non eft agens feparatum, fed eft perfectio phantafnatis, qux confituit obiectum perfeetum, \& potens mo. uere intelle乞tum patibilem. Ideo recta eft illo- Inte. B rum fententia, qui dicunt intelleetum agentem ctus effe agentem vt intelligibilem potius, quam vt afit intelligentem; quia fi debet reddere phantafma intet atu intelligibile, oportet ipfum per fe effeactu bilis. intelligibilem, quemadmodum etiam lumen, quatenus eft perfe vifibile, non quatenus videns, reddit colorem a ctu vifibilem: eft quidem neceffarium, vtipfe quoque fit intellectus aliquis, quia omne actu intelligibile eft intellectus; non in hoc tamen confiftit ratio agentis, C fed in eo quod fit actu intelligibilis: hoc autem nonita accipiendum eft, vt dicamus ipfum ita intelligibiiem effe, vt à noftro intell ectu intelligatur fecundum propriam naturam, \& quatenus eft quadam fubftantia abiuncta à materia; hoc enim fortafte eft vltinum, quod à nobis cognof citur: fed eatenus dicituragere vt intelligibilis, quatenus eft ratio intelligibilitatis aliorum, id eft quatenus eft actus, \& perfectio, qua catera redduntur intelligibilia; proinde diD citur intelligibilis, non quod ipfe intelligatur, fed quod peripfum alia intelligantur; fic enim \& lumen vna cum colore locum habet vnius obięti vifibilis, \& mouentis; non enim quod ipfe Sol, feu eius lumen videri feparatim dicatur, fed quia eft ratio, qua colores funt actu vifibiles. Facultas igitur paffua intellectus patibilis nonrefpicit aliud agens, quam obieatum phantafma; fed hoc non poteftagere, nifiab intellectu agente perficiatur, \& fiat obiectum aE Etu motium: quare intellectus agens eft for$\mathrm{ma}$, qua obiectum fit actu obiectum, proinde refpicit obiectum vt forma, patibilem vero intellectum vtagens, non quidem agens feparatum, fed vt forma conftitutiua agentis. Hac eft abfque dubio fententia Ariftot. quam ipfe magno cum artificio fignificauit: nam in contextu illo 17. docuit rationem agentis effe refpectu intellectus patibilis, deinde in 18 . modum actionis declarauit, ne intelligeremus effe agens diF ftinctum ab obiectis; comparauit enim vtrunque intellectum cum obiectis dicens, hic fit omnia, ille vero omnia facit, id eft, facit effe actu intelligibilia, facit autem vt habitus quidam. id eft, vt ferma \& perfectio, qua obiectis iuncta conftituit obiectum actu, \& perfectum, quemadmodum declarauimus. 
An Intellectus agens iungatur phantafmatibus in phantafia exifientibus, an in in* telleciu patibili receptis.

Cap.V.

Q Vxtio explicatu digna hic oritur, quum intcllectus agens iungatur phantafinatibusveforma, an eis iungarur in phantafia, an poftquam in intellectu patibili recepta funt. Dicuntaliqui non in pliantafia hanc conituntionem fieri, led lumen agentis phantafmatibus iungi, \& en perficere in ipfo intellectu patibili: quod probantargumento tali: officium intelleEtus agentis requiritur propter quidditates, qux im in phantafmatibus latent; has enim facit actu zen intelligibiles; ergo fi in phintafia phantarmati-. bus iungeretur, phantalia cognofceret quidditates, \& vniuerfalia, quod nemo vnquam dixit; non poteft igitur intellectus agens munus hoc exercere, nifi in phantafmaribus 1 am in intelleEtu patibili receptis. Confirmant perilla, qux $\mathrm{ab}$ Ariftotele dicuntur in contex tu ro. libri teriij de Anima; ibi enim inquit, intelle Aum à folo fenfititio recipere carnem, id eff, totum compofitum fingulare, absque vilo auxilio íntelleêtus agentisjergophantalmata funt perfe ipfa fuffcienter prafentia intellectui patibili : vt ab eo apprehendantur tanqua m confuf $x$ quædam cöceptiones fingularium, per eas tamennon apprehenduntur quidditates, quia non apparent; fed illis confufis conceptionibus adueniens lumenintellectus agent s refoluit eas in quidditatem, \& quidditaten à qu1dditate diftinguit, \& facit quidditates de intellectis poteftate actu intellectas, qux funt verum obiectum intellectus patibilis; quum igitur requiratur intellectus agens propter obiectum, hoc eft, propter quidditates, vt eas apparerefaciat, \& hx non cognofcantur nifi ab intellectu, oportet lumen agentis iungi phantafmatibus in intellectu, non in phantafia. Vtuntur etiam ad hoc declarandum exemplo tali : fi velimus in ftatua cernere aliquas minutiffimas lineas, apponimus ftatuam lumini, vtilluftretur, nec quærimus vt illuminentur oculi, quoniam oculinon eg ent lumine, fed obiectoilluminato, vt il ta qux confufa erant,appareant, quia absque illo lumirre videret quidem oculus ftatuam, at minutiffimas illas lineas non cerneret : ftatua igitur poteft per $\int e$ imprimete in oculo fpeciem confufam, neque lumen illud requirit, fed folım requiritur propter lineasillas, quibus proportione refpondent quidditates latêtes in plantafmatibus. Hxc feniuta- tentia mihi probari nulla ratione poteft, quum per eam tollatur to:ta ratio agentis:fi enim intellektus agens iungitur illis confufis conceptinnibus iam receptis in intellectu patibili, iungitus
A potius veforma, quam vtagenș, guod ctiam illi concedere videntur, fatentui enim intelle agentem refpeetu obicetorum non habere locum agentis, fed formæ tantumimodo; attamen neque refpectu intcllectus patibilis poteft habere locum agentis, hoc caim non poteft effe alio modo, nili quodilla conceptiones ita illuminat $x$ agant in intellectum patibilem, quod nullo pacto dici poteft, iam enim inhxrent ipf intellectui tanquam formæ; quare etiam intellcecus agens illis iunctus habet locum forma vna cum illis, at forma non agit in fubicetum, inq uo recepta eft; quare intellectus agens nulla ratione haberet locum agentis iuxta illorum opinionem. Miror etiam, quomodo hoc dicere potuerint; quum omnino negauerunt fpecies in. intellectumprimi; id enim fi verum eft, quomodo poffunt phantafmata, \& confuf $x$ illæ cäceptiones in intellectu recipi ? fic enim reciperentur in intellectu tanquam fpecies diftinct a C pliantafmatibus, quod ipfinegant, dum negant fpecies impreffas. Egoigitur sogor multorum fententiars fequi, qui dicunt int ellectumagen$t \vec{e}$ iungi obiect is nond $\vec{u}$ in intellectu patibili receptis; fed in phantafia exiftentibus, quia hos modo feruatur vera ratio agentis; phantafmata enim fine lumine agentis effent quidem apta. ad imprimendam in intellectu patibilı conceptionem reifingularis, at non imprimerent fpeciem quidditatis, nifi efient illumisata ab intelD lectuagente, quidat eis vim motricem, \& produetricem Epeciei quidditatis; facit enim vt in phantafmatibus diftincte appareant omnes natur $x, \&$ quidditates, ficuti lumen Solis in ftatua facit vt appareant diftincte omnes minutiffim $x$. linex, \& vt ftatua fit apta ad imprimendum in oculo non folum totam imaginem confufam , fedetiam omnes partes, \& omnia exilia lineamenta : ideo fimilitudoab illis adducta manifefte cötra ip fos facit,nä minutifimæillæ linex in

E ftatua non indigét lumine eas illufrante, quando iam in oculo recepta funt, fed extra oculum \& in ip faftatua; ipfienim fatenturoportere fatuam illuminari, non oculum : fic igitur optime feruaturatio agentis, nam agens debet effe externum, vt poffit agere in patiens, id vero, quod: in ip fo patiente recipitur, non eft vocandum agens, led forma. Ad argumenta autem illorum facile eft refpondere. Primum erat; fi iungeretur. plantafmatibus in phantafia; ergo phanta-

F fa êflet intelligens, \& apprehenderet vniuerfaPrimum argumétzmo. lia, \& quidditates: ad hoc neganda eft confequentia, \& ratio negationis. fumitur tī à phantafia, tūabobiecto ipfo : à phantafia, quoniam ipfa nō êt apta cognof cere vniuerfale, \& quidditarem ;-quare etiam fi haberet in feipfa ipeciem vniuerfalem, non cam cognofceret, , quia non eft talis facultas, qux ad hane operationem: 
nem idonea fir; non poteft enim abftrahere vni- A verfale, \& iplum transferre de gradu in gradum: hocpoflumus confirmare exemplocoloris, \& luminis; lumen enım facit vt color parıetis fit aEu vilibilis, paries tamen habens colorem illum illuminatum non eft videns, quia vim cognolcendi non habet; quare eft quidem color ille vifibilis, non tamen à pariete, in quo ineft, fed ab oculo, cuius motiuus eft: fic etram in phantafia funt quidditates in phantafmatibus 1lluminatx, proinde intelligibiles, non tamen à phantafia, quoniam ipfa hanc vim non habet. Idem oftenditur ratione obiecti : phantafina enim quan:umuis ab intellectu agente ill uminatum non eft formaliter intelligibile, ideo fi fieri poffet vtidem formaliter acceptun adintellea $:$ m poffibilem transferretur, non intelligereturabeo; quia phantafma illuminatum vocatur quidem actuintelliģibile, nō tamen formaliter,fed obiectiue, nam fi ipfummet in intelleAtu poneretur, non fieret intellectio; fedideo vocatur intelligibile, quia poteft producere in intellectu poffibili fpeciem intelligibilem, qux dicitur intelligibilis formaliter, quia ipramet recipitur in intellectu. Hocquoque confirmatur codém exemplo luminis, \& coloris : nam color realis, qui in pariete eft, licet fit actu illuminatus, \& ita attu vifibilis, non elt tamen vifibilis formaliter, fed folum obietiue; quia fi $\mathrm{i}$ demmetrealis color 1 luminatus poffet in oculo poni, non videretur ab eo : ideo actu vifibile fumi poteft duobus modis; nam coloris fpecies Spiritalis in oculo recepta dicitur vifibilis formaliter, fed color realis illum inatusvifibilis d1citur obiectiue, fed nońformaliter. Leuitas igitu argumenti manifefta eft, quia neque phantafia eit apta intelligerequidditates, neq; phantafna illuminatū in phantafia eft actu intelligibile formaliter, fed eft formaliter imaginabile; intelligibile autem obiectiue, quatenus eft obiectum potens extra phantafiam producere in intellectu fpeciem intelligibilem. Alterum argumentum fumebatur ex cont. 10. lib.3. de Anima,vbi Arift. dicit intellectum recipere compofitum confufum à folo fenfu fine ope intellectus agentis : vult igitur phantarmata in phantafia exiftentia non egerelumine agentis,vt fint a cu motiua, fed effe per fe motiua abfque illo, proinde lumen agentis non requiri nifi poftquam illud confufum in intelle etu patibilireceptü ef, nempe vt in eo quidditas elucefeat. Ad hoc dicimus obiectun illud poife duabus rationibus diciactu motnumm ; nempe vel ita motiuum, vt totius tant um confufi fpeciem imprimat; vel ira notiuum, vt imprimat etiam fpeciem quiddttatis latentis in eocnntulo : priore quidem modo inquit ibi A rift. phantafna effe per femotiuum untellectus noitui abfque lumine intelle- ctum agentis, fed non fecundo modo; non eft enim ex le ita motiuum, vi poffit quidditatēimprimere, nifi illumineturab intelleetu agente: vult igitur Arıft.phantafma illuminari in phantafia, \& it a lluminatum imprimere in intelletu fpeciem quidditatis: quare per hoc argumétum non oftenditur obiectum illuminari in intelle. lectu red potius in phantafia ; hoc enim demonftrat comparatio, quam ibi Arift. facit cum linea flexa ; dicit enim cognitionem quidditatis fimiB lem effe linex Hexæ, quatenus lumen agentis fertur prius ad obiectum in phantafia, deinde cum eo ad intellectum reflectitur.

\section{Deauftractione, an fiat ab intellectu patibili,an ab agente. \\ Cap. VI.}

Ignum confideratione hîc eft, à quonam hat abitratio, anabintellectu paribuli, an abagente; hoc enim cognito, erit plene cognitum oficium intellectus agentis: plurium fententia eft abltractionem fieri ab intellectu agente; nam Latinorum plures hoc dicunt, \& Auerroes quoque aperte id afferit in Conment. $18 . \mathrm{lib}_{3}$ de Anima, \& in calce.20.vbi dicit Arift. fuiffe coactum ponere intcllcetum agente propter abftractionem, quia eius actio eft abftractio;abftrahit enim à phantafmatibus vniuerfa. le, \& ipfum denudat omni materiali conditione;ideoque intellectio intell ectus patibilis nilaliud eft, quam receptio huius vniuer al is ita abftracti abagente; 2 actio ipfius agen is nilaliud eft, quam abftractio vniucralium ab omniconditione matcriz, vt moucre porfir incellectum patientem illudigitur, quod vocari folet, facere deintellect is poteftate actu intellecta, apud $\mathbf{A}$ uerroem eft abftahere, proinde abftrahere eft officium folius agentis: ciratetian Auerr. ditum Alexandri, quod apud eum legimus in lib. 2. de Anima in capit e de intellectu agente ;ibi enim Alexander dicit, non folum elre necellariam in anima intellectiua vtra mque vim, vnam agendi, alteram patiè udi, fed etiam melius declarari naturam intellectus peragere, quam per pati:quod declarans Auerroes dicit intellectum per patinon differre à fen fu, fed folum peragere, quia non daturfenfus agens, fed daturintcllestus agens, qui fabricat intelligibilia, quod dicitur abftrahere. Hac fententia recipienda noneft, \& impugnatur efficacilfrne argunento Ioannis Gandaueníis, licet ipfe ad sliud demonftrandum eo abutatur ; nam probare volens intellectum agentem non agere in phantafma \& eis nihil tribuere, ita argumentatur: intellectus agens, fi phantafmata illuninat, xque onnia in eis exiltentia illuminat, xque omnia intelligibilia facit, nec potelt vnum expo. 


\section{7} de Mente Agente, Liber.

expoliare alijs, \& ab eis, feparare, á facure vt v- A num fite alio intelligatur; quemadmodum lumé piçuram alıquam feriens facit æque omnes eius colores efie vifibiles, iequicomnes illuftrat, neefacit yt ynum videatur tine alio; ergo intellectus agens nihil phantafmatibus tribuit, \& nihil in ess operatur. Sed hæc confequentid reucra inefficax eft, \& Ioannes falliciam commit tit. à fecundum quid ad fimpliciter; quia hoc argnnentum probat quidem intellectumagentem non feparare, feu abftrahere yaum ab alio, quoniam aqueilluminat totum phantalina, \& omania, qux un co funt;proinde eft eficacifimum ad probandum quod intelledus agens non polfit facere abtriactioncm; qui nihil alitid fit abftractio, quanì feparatio vnius ab alijs, \& acceptio vnius non acceptisalits : at non probat intellectum agentem nil prorfus in phantafmatibus operari; operatur enim aliqud necefartum pro abfiratione, . licet non faciatipre abluractionem, vtmox declarabimus: quando enim

rem aliquam ab alia reabftrahere volumus, \& eam fumerenon fumptailla alia, certum eft necefiarium effe vt vnam ab alia diftinctam habcamus;quia ficonfufx \& commifte fint, id faceré ninime pofumus; $v$ t fi nobis offeraturaqua vino commifta, noreit in noftra facultatè accipere vinum non accepra aqua, quod dicitur abftrahere;quod fi quispiam aliquo artificio vinum ab aqua feparares; itavt v́traque diftineta infpicierentur, tacilenobis effet $v$ fium accipere relifo alcero : duo igitux actus confiderandi funt; vnus eft actus diftinguendi rem à re, ve difincte appareant; alter eft actus accipiendi ynam dimıfiis alijs:qui duo aeus ad eundem intellefumpertinerenompoffunt, fed vnus ad agentem, alterad patientem; quia fi abftahere eft acciperevnum dimifis alijs, certenón intellectus agentis officium eft, fed fatientis, hicenim quidditatem intell git in phantafmate ewicantem, \& eam accipit absque conditionibusmatcrix, \& absquealijs, qux in co phain. tafmate funt, \& fic eâ ab alijs abftrahere dicitur: at facere id nō poffet, nifi prius omnia in phantafmare diftuncta apparcent, quxi diftinctio eft opus infellectus agentis; huius enim lumen phantarmati adtueniens onunia, quæin co funt, aque illuminat, \& facit ve diftinete omnia ap. pareant, vtiuphantafmate equi facityt diftinEtc apphreantnal ura corporis, natura viuentis, natura animalis, natura equi, nat ura quantitatis, \& natura qualitatis, \& ficalionumaccidentium;hæc enim omnia in eophantafmate confufa, \& indiftinata erant, fed ab agente llluftrata offeruntur patibili intellectui clara, atque diftineta, vtipfeea omniaintuens poffit contemplariid, quod vult, tam totum confufum, quam fingulan quididisatem in eo emicatem, \& cam. omm thatijs intelligere : hoc idem in coloribus eucnir; quando enim debile eft in aere lumen, vidcmus confufe picturam tot: $1 \mathrm{~m}$, fed colorum diftinctionem non videmus; a duenientc autcm Solis lumene diftincti apparent onanes colbres, \& ommes tenuillinre linex, nosque liber fitmus, \& aptiadintuendum in ea pietura quicquid volumus dimifis alijs: nani primo loca totum confufum inf picimus, poftea ad lingulas. particulas conucrtimur, \& intuemur modo hảc fincilla, modoillam fine hac, \& lioc vifus ip facit, nonlumen, fiquidem lumen illuftrat folum, arque diftinguit, vifus vero infpieit hane partem fineilla, \& illam fine hac: ca tamè à philofophis abtractionon appellatur; quia vt di- que dz catur propricabitratio, non fitis eft fi vnares tur a phi fine alia accipiatur; fed oportet etiam vt de or- lofophes dinsin ordinem transferatur: quod in vifione abfranoineuenit; oculus enim rem hancaccipiens vi- etro. dendam fine alijs non obid eam transfert adalium ordinem rei cognof cibilis, quia ibiomnia: fenflia funt, tam totum, quam partes;atintelle-ctus abftrahens transfert rem de ordine inordinen, feupotiustalem translationem factam. prafupponit 2 , fitlamen re vera translatio hac ab agerte, qui illuftrans facit rem è fenfilinintellccilem, deinde patibilisintellectus eam accipit, \& ita abfrahere dicitur: in hoc igitur differt intellectus agens à lumine, quod lumen non: transfert colores adalium gradum cognofcibilitatis., at intellèctus agens fạcit è fenfiliintelle. atle. Ex his igiturpatet error Auerr. qui putauit abitractionem effe minus intelle otus agentis : patet etiam error. Ionnis Gandaucnfis, qui ex hoc colligebat intellectum agentem nil tribuere phantafmatibus; tribuit enim reuera lumen diftinguens, fed nullamelectionem facit; hre enim fit ab intelleeturariente, diciturque formaliter abftractio, quum actio intellectus, agentis non fit abitractio,nifi antecedenter, quia. E. neceflario pracedit abftractionem.

\section{Solutio dubï aduerfus ea qua dicta funt. Cap.VII..}

Ed aducrfus hac dubium oritur; fi enim abOfrahere eflet munus intellectus patibilis, er-go efret part, quia officium intellectus patibilis eft pati;id tame videtur effe falfum, \& repugna:re proprix huins vocis fignificationi, nāabitractio actionem potius, quam paffionem fignifi. cat:quodargumentu mihi midetur Auerroem mouilfead dicendum abfrabionem effe operationem intelle etus agentis. Ad hocdicimus, ve- Intellerum quidem illud elle, quod ex vi vocabuli fu- cäus nomitur,abitrationem effe actionem', fed negan- fer in co dum effe, patibilis intelledus officium effe fo- gnofcerslum $\mathrm{gari}$; quia licet Arift. dixeritintelligere efe do agt. gati, 
pati, quia fecundum originen eft pati , \& facilius ad cognofcendam cius naturam ducimur perpati, quantper azere, tamen intelligère eft ctiamagere; nam cognofcere non in fola fpecierum receptione, qux paffio eft, confiftit, fed etiam in receptarum iudicatione, qux eft actio; quare patibilis intellectus fpecien quidem recipiendo patitur, fed eam iudicando argit, \& ita agendo diciturabftrahere, quo fit, vi intellectio dicaturactio immanens, quia fit ab ipfo patibili intellectu, \&ipfometrecipitur. Hoc fignificare voluit Alexander in loco ab Auerroe citato, quando dixitintellectum humanum magis declarari per agere, quam per pati; hoc eft, eius naturam rationeoperationis magis in actione, quam in paffione efle conftituam: quem locum non intelligens Anerroes traxit ea ver-

Anerroiscrror.

Intellectus agés non producit aatis intel ligendi. ba ad intellectum agentem, quafiAlexander dicere voluerit intellectum agentem obtinere in antma humana precipuum locum, \& paribili intelleetui antecellere, non quidem tempore, fed dignitate, quia nobilius eit agere, qua in pati. Attamen Alexanderibi nō de illa actione loquitur, que attribuitur intellectuiagent1. led de illa, qux eft propria intellectus patibilis, \& eff fpeciei receptx iudicatio; vult enim ijs verbis fignificare cognitionem magis in udicatione, quam in receptione confiftere: nam fircceptio tempore iudicationem pracederet, vtiqute clarum elfetintellęionem effe formaliter 1udicationem, non recéptionem, nifi antecedenter ; fed quum fimul tempore receptio, \& iudicatio fiant, dicimus intellectionem effe fimul paffionem, \& a tionem, fed magis in actione, quam in paffione confiftere. Ex his colligimus errorem illorum, qui dicunt officium effe intellectus agentis producere in intellectu patibıli actumintelligendi; hoc ensm falfum eft, quoniam actus intellig ndiproducitur ab ipfomet intelleetu patibili, dum receptam fpeciem iudicat; agens vero non iudicat, nequeiudicium producit, fedid folum praftat, quod antea diximus;iunetus enim phantafiratı ipfiim aptum reddit ad Speciem quidditatisin intelleetu patibili imprimendam:propterea fi intellectio effet fela receptioin intellectu patibili, absque dubio dicēdum effét ab intelleetu agente vna cum phantafmate ptoducrafum intelligendi in in. tellectu noftro, quum fpecies impiet î idem fit, quad intellectio: fed quoniam intellectio non eft folareceptio, fed etiam iudicatio, imo eft præcipue iudicatio, \& hæc fit à folo intellectu patiente, fiquidem ipfe ad iudicandam fpeciem eft fibi fufficiens ex propria fua natura fine ope intellectus agentis; ideo non dicimus intellectumagentem producereintelledtonem in $1 n-$ trelleetu patiente, hoc enim neque folus facit, seque phantaimatibus inatus, nifi yt caula re-
A mota, \& antecedens; caufa enim proxima, \& xquata eft ipfemet patibilis intellectus, qui ex fua natura fpeciem receptamiudicat.

\section{Collectio officiorum intellectus agentio, septem propofitionibus. \\ - Cap.IIX.}

$B$

Q VE igitur fint officia intellectus ages tis in noftra int ellectione, fatis ex iis qua diximus, manifortim eft: vtautem omnia qua haetenus declarauimus, breuiter colligamus. tota rei veritas iuxta Ariftot. fententiam in his feptemaffertionibus iam à nobis fatis huperque demonftrantis conftituta eft. Prina affertio eft: intellęus agens refpétı obiectorum non eft agens, fedperiectio, \& forma, quæ ipfisphantafmatibus imncta perfecit póa, \& facit vi lint obiectumactu, hoceft, idoneum ad moucndum intellectum patibilen.' Secunda eft : intellectus agens iungitur obiectis extra intelleEtumpatibilem ${ }_{3}$ videlicet vt in phanaila exiftentibus. Terta eft : intellectus agens dicitur agens refpectu intellectus pat1entis, g guid in iplum folumagit. Quartaeftinic intelledus, non ita agit in intelleftum patioilem, vt fis agens diftnctum, \& feiuncum à phantaimatibus, led viofis phantaimatum, iะa vt es phantafmatibus, \& intellectuagonte contituasur $\mathrm{y}-$ num agens imprimens in miellectu patibili fpe. ciem viniucraiis, \& quidditatis ; quia phantafmata ropriis viribus non efient apta adimprimendam aliam fpeciem, quani fingularis confufi. Quinta, quex hac quarta deducitur, eft: intellectus agens eft agéns vt intelligibilis, nonvt intellectus, \& agit ad modum obiect; quare quatenus eft agens, non eft formaliter intelligens; quanquans ex hoc infertur neceffario ipfum efie alterum intellectum , quin omne aE Etu intelligibile eftintellectus. Sesta eft : intelleatusagens non producit in intellęu patibili actum intelligendi, fedipfemet patibilis intellectus hunc aftum producit, dum receptam fpeciêm iudicat. Septima eft: officium abftrahendinon eftintellectusagentis, fed eft proprumintelle etus patibilis; ita tamen, vt abitraEtio ex neceffitate profupponat operam intelleftus agentis, qui phanta mata illuftret, \& claraš,atque confpicuas efle faciat omnés naturas, \& quidditates, qux in phanta nuatibus in funt vt portea patibilis intellectus accipere poflit id, quod vult, \& alia dimittere, quod vocatur ab. ftrahere:quare abftractio formaliter fumpta elt opus folrus intellectus patientis, fedantecedeńter eft opus etiam intcllectus agentis, cuius operam abftractionem pracedereneceffarium eft.

(n)


1021

Ouidfit intellecus agens, varia alio-
rum fententia.

Cap. IX.

OOgnitis officis untellectus agentis eft quoque eius natura confideranda; quod. etiam Ariftotel. fecit, fed ita breuirct, \& obfcu$r e, v t$ per cius dicta non fatis liquere videatur. quifnam fit apud eum intellectus agens; quo factum eit vtinterpretes ad varios, \& inter fecontranos fenfusverba Arilio el traxerint: non igitur aliorum fententias fumma breuitate conplectendo ratione dure perueitigabımus, quifnam fit apud Aiiftotel. intellectus agens. Neceffe eft intellectum agentem vel elic eundem fecundum fubftantiam cum intellectu patiente, vt mulsi arbitrantur, a deo vt non lint duo intellectusefientialiter diftincti, fed vnus, qui folá ratione diftinguatur; vel diftinctum efle effentialiter $a b$ inrellectu patiente, \& duasefie formas, non vnam, qua etiam plurium fententiafuit. Qui dicuntintelle tum agentem, \& inteliectum parienterinon efie duas formas, fed vnam, qux fola ratione ditinguatur in duas,varïsmodis id afferuni; Simplicius dicitvnam etre humanzimentis fibitantiam, qua diciturporfibilis quatenus eft piogrefla in corpus, \& dicitur agens quatenus in fe manet; quam eandem fencentiam Theftimio quoque \& A uerroi multi poiteriores attribuunt; egotamén puto The - D miñum \& Auerroem fatuiffe intellectum agentem diftinatum eflentialiter à patiente, ita vt fint duæ formæ, \& duxintelligentiz diftin. ex $x$, ambx humanx; hanc enum fententiam legere apud Temiltium poffumus in context. 20. lib. 3. de A inima, \& apud Auerioem in Commentar. 4.5,18 20. eiufdem libr.vbihos duos intelle tus vocat duas fubftantias æternas, \& alia multa dicit, quæ ignificant ipfum exiftimafle duas effe fubftantix, non vnam: quod fi The- $E$ miftıus'\& Aucr. quandoque dicere videantus xnum effeintelle aum, confideranda funt vir1ufqueverba: naun vnum appellantid, quod ex eis tanquam ex materia, \& forma conlatur: nunquam enim dixerunt eos effe eflentialite vnum co modo, quo Simplic. exiftımauit. Alii fuerunt, eaq; fuit antiqua opinio relata, \& confutata $\mathrm{T}$ Them. in loco prædicto, qui dixerunt $\mathrm{va}$ num elte intellectum fecundum fubftantiam; qui dum eft in mera 1 otefrate, \& bmpi co gnitione caret, pofíbilis dicitur; dım autem habet habitus dignitatem, quæ funt prima principia: perfenota, vocaturagens, quía horum principiorum cognitio ef atílumm principiuni lcientiacuncillionum : in quam fenteniam ducti fun ob Ariftotel. verba in context. 18. ib. 3. de

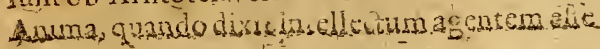

A habitum quendam;-videtur enim non potuife alium habitum fignificarc, quam habitum principiorum.' Ab hac fententia parum receffit loannes Grammaticus, qui putauit eun dem patibilcm intcllectum, quatenus habet habitusnon moda principiorum, fed etiam conclufionem, vocari agentem, quoniam dum habet fcsentiarum habitus acquifitos, poteit agere quando vult, quemadmodum Ariftotel. dixit, ideoque vocaturintellectus agens, quira poteft arbitratu fuo exite in atum: \& in hanc opinionem ipfe quoque loannes incidit ob illa Arift. verba, quibus intellectum agentem dixit effe habitum quendam. Demum D. Thomasputauitintel- Thoras. Jectumagentem, \& intel! ectum patientem non duas formas effe, fed duas facultates eiufdem animæ rationalis, qux ratione potentix paffux dicatnt intellectus poffibilis, \& ratione potentix actiux dicatur intellectus agens : quare apud eum non funt dux partes animæ, nifi pröutnoC menpatris fro facultate, feu potentia fumitur; ideo eius fententia iure numeratur in opintonibusillorum, quidicuntintellectum agentem, 8 intellectum parientem non effe duas fubftantias diftinctas, fed ynam, qux fola ratione diftınguatur.

\section{Confutatio omniam opiniorum eorum, qui dicunt intellect um agens, co intellect un. paticutem effe vnam or eandem fulfrantiam. Cap. $X$.}

T omnes fententix, quibus ftatuiturhos falfe funt, \& cum principiis Alift. minime conuenire poffint: quod prius comm uniteraduerfus omnes ofteridemus , poftea vero etiam fingillatim eas confiderando proprios cuiufq; errores patefaciemus. Impi imis certum eft, Anif. exiftimafle nullum fimplex poffe mouere leiprum, fed quicquid mouetur, ab alio moleri ; hoc enim legimus ab eo fufe demonitratum in: 7. \& 8. Phytridq; in ipfa quoq anima impoffibire effe docuit in 1 . libr de Arima, quando confutauitillorum fententiam, qui dicebantanimam mouere fempam : non poteft igitur eadem harmanæ mencis fubftan ia, quü fit forma timplex, efie fimulagens, \& patiens répectu fui:pfius; rec fatıs eit drituncto fecundum rationem, quia: fi hoc fufficeret, de omnire implici hocidemi F dicere poffemus, eam habere facultatem agéndi, \& facultatem patiendi, \& ita agere in eipiam: ratione ditierfarum virium; hoc tanen abiurdum eft, nec lecundum Ariftot. concedendun : ergo fimliter in intellectu eft abfurd:s $m$, qui quiunfitimplex, non poteit fimul effe perfeCus, \& imperiectus, poleftate \&raêtu, \& in féip fuj agerc, \& feipfun cincersule poteftatead actup 
ciun, deimperfectione ad perfectionem : pafet autem Ariftotelem in contex. 17. libri 3: de Ansna inueniffe intellectum agentem propter paitientem, \& vt in ipfam agar, ficut antea de mon* frauimus, iergo non polint efle vinus \&idem intellectus fecundum fubftantiam; poteft quidem eadein res habere \& agendi. \& patiendi facultatem refpectu diuerforum, ita vt ab vno patiatur, \& in aliud agat, fed non refpectu fui-ipfus, nempe vtin fe agat, \& à fe pattatur, nifi habeat in fe ipfa partesfecundum fubstantiam diftinctas', qubus hæ duæ contrariæ vires attribuantur. Exempla quoqueab Ariftotele adducta in contex.17, \& 18. libri 3 " de Anima hoci. dem demonftrant, in tota enim natura videmus femper agens diftinctum effe fecundum fubftantiam à patiente, fic omnis ars agens difruncta efiefientialiter à materia patíente ; Ariftoteles autem dixit intellefum agentem ita fe habere ad intellectum paticntem, vt ars fe habet ad materiam, ergo voluit eos fecundum fubftantiam efte diftinctos: hoc idem fignificat exemplum luminis; lumen enim efteflentiali ter diftinctum \& à colore, cuirungitur \& à vifu. in quem agit; putauit autem Aritoteles quem locum habet lumenin vifione, eundem habere intellectum agentem in intellectione; cenfuit igitur hunc efle diftinetum eflentialiter \& ab intelleetu patiente, \& ab obiectis intelligibilibus. Ip ra quoque ratio, qua Arifoteles ad oftendendum intellefum agentem yfus eft. hoc idem demonitrat, probat enims dari intellectum agentem, eo quod datur intelleetus patiens, eosigitur ftatuit tanq̨iam duos, non tanquam vnan fubftantiam, quóniam argumento illolyoc non oftenditur : nam fi Ariftotel.id, quod ift comminif cuntur, oftendere voluiflet, proba. re non debuifet dari intelleetum agentem, quia deturintellectus patiens, fed folum oftendere eundem intellectum patientem, de quoantea loquutus erat, actiuam quoque vim habere, ratione cuius dicitur etran agens : hoctamen neque dixit, neque lignificauit modo vllo $A$ riftotel. fed omnia, quxibi dicit, contrarium indicant, yt modo dicebamus. Hoc idem declarant illa, qux ibidem dicuntur poftea ab Arrftotele in contextu 19. \& 20 - inquit enim agens effe honorabilius patiente, inquit intelleaum ageritem effe ationem fecundum fubftantiam; inquit ipfum nilailud efe, quam id, quodeft, nempe puram quidditatem, \& prium actum, imo ipfirmmet cffe; at in contextu s. dixerat intellectum patibilem nilil cfle, nifi puram poteftatem; quomodo 1 gitur funt effentialiter idem, fi alterius natura, \& efrentia eft actus purus; ita vt fit idem eflentialiter cum fua opcratione, altcrius vero eft pura poteftas? dixit etiam intellectuma agen-
A tem femper intelligere, patientem vero non femper, quod maniefre denotauit eos effeculus diftinctas fubftantias, nam cadem fubitaniia dici non poteft fimul inteliigens, \& non inceiligens. Quoniam igitur Aritot. nihil vnquam divit, quod fignificare potuerit vnaṇ elje horum duorum intellefuum fubftantiam, immo onnia eius verba denotant eorum differentian fubfantialem, \& ratio quoque Arifo t. hoc demonftrat, vanx-\& falfx itunt onines fententix; B quibus quouis modoftatuatur vrian \& eandem horum duor:nin intellectum effe fubfantiam. Si vero fingulas predictas opiniones feorfum confiderare velimus, opinio simplicii ab A:iftotelealicnifima eft : nam fecundum Simplicium non eft clientialeintellestui efre poteftace, fedid per accidens ei concingit, nempe quatenus progreditur in corpus; Ariftotel. tamen vultillud ei efientiale efle, inquit enim nullam effe aliam eius naturam, nifi meram potettaC tem; at fi fequamur Simplicium, intellectus cifentialiter eft purus actus, per accidens veroeft pura poteftas: igitur hæc feritentia elt contraria opinioni Ariftotelss, \& eft potius Platoni$\mathrm{ca}$, quam Peripatetica ; vnde colligere poffumus, eam nec Theniftio, nec Aluerroi adforibendam effe; hi namque in Ariftotele interpretando non folent rtl dogmatibus llaton:coruin, quod Simplicius vb que fecit. Alia quoque opinio eorum, qui dixe unt intellecrum agentem effe ipiummet intellectum fatibilen, vt habentem principiorum babitus, veletiam habitus-conclufionum, ve Ioannes Grammaticus exiftimauit, non eft opinio Ariffoctss: quoniam Ariftoteles intellectum in habitu manifefte difinxitab intellectu agente, quum de vtrifque feparatim egerit, \& ntellectum in habitu conliderauit, in ipfo tractatu, qui eft de intellectu patibili : dixit etiam irtellectum in habitu non femper efle antu intelliE gentem, fed quandoque etiam poteitate, agentem vero dixit femper effe intelligentem: denique fi illa omna, qui intellectu agente in contextu 19. \&20. dicuntu, conlideremus, manifertifimum eft ea non polfe ac commodari intelleetu in habitu; illud prxfeitim, quodixit, intelleĉum agentem efle per effentinm fuam actionem; nam intellecus in habitu, qumi quandoque non intelliligat actu . non eft per effentiam fia operaF tio: alia quoque multa in ea parte diclintur ab Ariftot. ex quibus hoc oftenditu, qux miffafacio vtin re manifefta. Neque fulfiagantur huic fententia yerba Ariftotelis in contertu 18. dicentis intellectum agentem elie habitum quendam : non enim quemlibet háahitum fignificauit, neque illum, quem iffi refpexerunt, fedtalem, quale eft lumen; Ju- 
men vero non eft habitus ip fe videndi, neque eft $A$ fpecies coloris in oculo recepta, fed eft quoddam externum, ab externo principio adueniens, diftınctum \& à vifione, \& ab obiectis; \& à facultate vifiua, \& ab ipfa habılitate videndi : talis $\mathbf{i}$. gitur habitus eft int ellectusagens, qui extrinfecus accedens producit in intellectu patibili fcientiarum habitus, à quibus ipfe patibilis intelleetus vocatur in habitu: quare intellectus agens non eit talis habitus, à quo dicatur intelleetus in habitu. Opinio quoque D. Thom $x$ non eft Ariftoteli confentanea, \& proprias patitur diff. cultates : nam quum in intellectu patibili co. gnouerit \& vim patiendi, \& vim agendi, in ambiguitatem lapfus eft, credens vim actiuam, quam patibilis intelle ctus habet, effe intellectum agentem, quod minime verum eft; quia incellectus agens debetagere in intellectum patibilem, \& antea demonftranimus; igirur fi effet vis illa actiua, quam habet intell ectus paribilis, idemageret in feipfum , quod minime dicendum eft. Nos vero iam diximus, qua fit vis aEtiua, quam habet intell ectus patibilis, eft enim vis iudica tiua obictti recepti: quæ non eft dicenda intellectus agens; quia non eft vis agendi in ipfummet intellectum patibilem, fed potius in obiecta quodammodo, dum ea iudicat. Thomasigitur non in hoc errauit, quod pofuerit in intellectu patibili vim paffiuam, \& vim actiuam, hoc eft, \& vim recipiendi, \& vim iudicandi, etenim nos quoque veramque concedimus; fed in co errauit, quod putauit vim hancactiuam ab Ariftotele voca ri intelle etumagentem: fed mox oftendemus D.Thomam proxime omnium ad mentem Ariftotelis acceffiffe, neque in ipfa re, fed in fola ferme appellatione aberraffe.

\section{ouod neceffarium fit, intellectum agentem effe formam abiunctam à materia per effentiam. Cap. XI.}

Q VONIAM igitur nullum dogma fecun. dum Ariftotelem defendi poteft, quo dicaturutellectum patienter, \& intell ectum agentem effe vnam \& eandem fub ftantiam; reftat vt fint dux fubftantix effentialiter diftinctr, qux abfque dubio fententia Ariftotelis fuit. Hoc autem fi ita eft, fequitur neceffario inellectum agentem effe formam immaterialem, \& à materia prorfus abiunctam, quod facile oftendo argumento fumpto ab intell ctu patiente : is enim vel eft forma feparata à materia, nec dans effe hominı, vt Auerroes exiftima uit, vel eft forma materiam informans, \& hominem conftituens, vt Alexander, \& Latinz omnes arbitrantur: fi eft forma abiunota à materia, multo magis oportet intellectum agentem effe à materia feparztum, quum fit nobilior patiente : fi vero intellectus patibilis eft forma conftituens hominem, agens, quipatiente preftantior eft, nŏ poteft effe forma informans materiā; quia fi inı ellectus patibilis eft forma fpecifica, qua homo eft homo, ergo omne illi fuperueniens in hom.ne, \& exccllëtius ipfo, excedit humanam naturam, nec poteft effe forma informans, quia nulla forma informans nobilor, poteif vltim ac fpecificx differentix fuperuenire, fed ita fuperuenict, ve nauta fuperuenit naui iam conftitut $x$ \& form at $x$ : omnsbus $B$ igitur modis fateri oportet intellectum agentem non effealicu.us corporis formam, fed effe fubftantiam penitus immaterialem. Hoc etiam fignificarunt omnes conditiones intelleatui agentiab Ariftotel.attributx in 3. Lib.de Anima: nam in context. 19. dixit ipfum effe feparatum, \& immiftum, \& impatibilem; \& has conditiones probauit ex eo, quod eft fecundum fuam fubftantiam actio, id eft quoniam per effeniam eft fua operatio; hac enim non eft quarta conditio, vt multi Grxcx lingux ignarı arbtrantur, red eft probatio; \& medius terminus, per quem rres ill $x$ conditiones oftenduntur, vt in $\mathrm{G} x$ cis verbis manifeftum eft, qua funt hac [ $7 \tilde{n} \dot{\delta} \sigma i \alpha \omega^{\prime \prime}$ ciéģ⿻心㇒ hic enim loquendi modus apud $G^{\prime} z-$ cos prebatiuus eft, vt etiam notare poffumus in context. 14 libr. 4. Meteorolog. \&pluribus aliis in locis, \& fignificat, quum fecundum fub tantiam fuam fitactio, cyégrese enim eft operatio, \& in omnibus formis materialibuseft diftincta ab effentia, in formis vero à materia abiunctis eft idem quod effentia, ficut in libr. de Mente humana declarauimus: quoniam igitur fecundum fuam effentiam eft fua operatio, A riftotel. inde colligit eum effe à materia feparatum, non commiftum corpori modo vlio, \& prorfus im. patibilem; nam patieft propter materiam, qua. re omne carens materia expers eft omnis paffionis: quod autem ferundum elfentiam fit actio, fatis habet ibi oftendere Ariftoteles à pofteriori, argumento fumpto ab intellectu pati-

$E$ ente, nam ipre quoque, dum actu intelligit, fit idem quod resintelleeta, \& quod fua oqeratio: quum ergo hoc notet perfectionem, \& competat intellectui patienti, deber etiam agenticompetcre, imo \& modo praftantiore, quum agens fit patiente nobilius : quoniam igitur patienti intellectui competit ve fiefua operatio ; quia aliquando folum, non femper eft fua operatio, nempe tuns, quando a tu intelligit; fed ei com. petit per aliud, à quo perficitur, neceffe eft vt $F$ agenti competat per elfentiam ; idenim, per quod aliud tale eft, per fe tale efferdebet: hac eft illius loci vera interpretatio, non quam multi putant, qui dicunt verba illa [bonorabilius est enimagenspostiene] \& alia quriequuntur, dirigi ad probindum, quod incellectui agenti competant tres illa conditiones, feparatus, immiftus, \& impatibilis; probationem autem talem effe, competunt intellectui patienti, ergo etiam agenti, qui honorabilor eft : fed de. $\mathrm{K}$ K cipiun.
Declare. tio cont. IJ. in 3 leb. de $A$. rima. 
cipiuntur, quoniam verbailisertinent ad proband́a proxime pracedentia, non ills, quaremotiorafunt, non enialprobat Ariftot.tressllas conditiones, fed probat medium, nuo illas oftẻerat, quemadmodum feries verborum manufe ite demonf rat : imo neque oftendere poterat 1 llas cres conditionesayenti competere ex eo quod com petantpatienti, ficusilli cóminifcuntur; quia ratio effet fallax, \& aquiuoca, quum illa conditiones alin modo agcnticompetant,alio parienti, neque devirceguein eadein fignificarione accipiantur: ne min context. 7. Arift. intelledum paticntem vocaucrat feparatum, fcilicet aborgano, ve pracedentia verba à contrario fenfu demonftrant; at in 19. ageniem vocat ieprarat um penitus à maceria : \& incellectum patientem vocaucrat in cont. 4 . non miffum cum obiectis, \& in 6 . non miftum cum partealiqua corporis in recipiendo fpecies; at in 19.agentern vocatnon miftum cum corpore, aut cum vlla alia re vllo modo, tam fecundum effe, quam fecundum operari, quum in eo operatiosb effentianondiftinguatur: \& in contex. 3 intelle etum paticntem vocauterat $\dot{\alpha} \pi c i \tilde{n}$, hoc eit, non affectum naturis fuorum obictorum, camqi conditionem abfque dubio adduxit, ve cummunem intellectui cum fenfu: quunian id, quodaliqua eft recepturum, nō debetilla habei cactu in iua efientia, fed poreftacem folum recipiendi; atin 19. intellectum agentem vocat $\dot{\alpha} \pi \propto 2 \tilde{n}$, hoc eft, impatibilem penitus, patet enim Grxcum no-

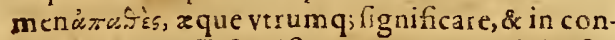
texr.3. non poffe fignificare impatibile; fed affectionem carens, in 19. autê fumi pro impatibili: nec mirum, fin alio, \& alio fenfu hac illis attribuantur, quuns ex diuerfis med sis ab Arift. colligantur, neq; eadem rationevtriq; intelle etui competant: nam patienti competunt, quatenus eft mera poteftas, \& inferuntur ex eo quod pa. tiendo inielligitsagentiautem competunt, quatenus eft purus actus, \& inferuntur ex eo g̨uod agit, \& eft per ellentiam fua actio: quomosio $\mathrm{i}$ gitur pollunthite conditiones de viroq;intellectu idem fignificare, li ex oppofitis mediis de vtroque colliguntur? igitur deintellectu agente fignificantefarationè àmateria, quum ex hoc mediodeducuntur, quodfecundumefientiam eft iua operatio, qux condirio intelledui patienti non competit, falté prout hamano corpore fumitur, fiquidem non alıo modo ab A rift. vnquim confideratan fuifte manifeftum eft. Praterea in context. 20. inquit Ariftot. intelleetuciagenicm efle feinperincelligentem, \& effe idquod th, lioceft, effeden purum, \& ipfammetcnitatem, vt in fequentibus declarabimus: qua cmnia figntifant mentem à nateria abiun ta mercificntian', Adde quod fi in cont. 12 . triàlla attributadducerentur veteadera, qua frituz intelle ctui patientiadfcripta erant, debuiflet Ariftot. conumctione vti dicendo [ $E$ bo
A gisog:se intellcatus fouratus, im miftss, ES smpatibilis attamen inquitabiointe [e hiconecllest aes] yui loquendi nodus cenotat ca addusi vt propiraagencis.

Quod intellectus agens nö posit effe vlia intelligentia, preterillas, que mouent caleftesorbes. Cap. X 11 .

B Vum igitur intellectus agens fit fuhltan. tia abiuneta à materia pcr effentiain, \& noususe intelligentix appell anda, necefe eft, vt vel fit aliqua ex intelligentiis fuperioribus, guz coelos mouent, vel alıqua a lia illıs inferior forma, qux vel Angelus, vel'D amon, vel Intelligentia appellanda effe dicatur, \& fit hominis propria, \&ad perficiendam humanaxi mentem peculiariter applicata, \& illi copulabilis, ve forma iungitur materiziquz fuit $A$ uerrois, acThemiftii fententia, quam etiam Marino Plotinus C attribuit. Qundnam igitur horum affern um fit, ratione duce inueltigemus. In primis id no. bis firmum, \& indubitatum fundamentur ftatuendum eft de fubftantiis per effenti:m à materia abiunctis loqui, non effe munus l'silofophi naturalis, fed folius Metaphyfici : teftatur hos Ariftotel. in r. cap.r. lib. de Partibus anima?. dicens non effe officium Philofophi naturalisa. gere de intellectu, \& hanc rationerg adducens; quia ad Naturalem Philofophum non attinet $D$ loqui derebus à materia abiunctis, intellectus autem à materia abiunctus eft: Auerro ft trefiicaciter tueri contendunt Ariftot. ib lo loqui de intelle etu humano, quod quidem nos eis condonamus: quicquid igitur eft in anima humana abiunctam à inaterna, fiue fit patibilis intellect us, qui dicatur nō effe forma corp oris, fiue in tellectus ag ens, certum eft illud non pofle à Pisilofopho naturaii fecundum effentiam cognofci, fed folum refpectu humani corpons, quod

E quidem Auerroiftxon negant,id enim eft munus folius Metaphyfici, vi afferit Arit. eo in lo-

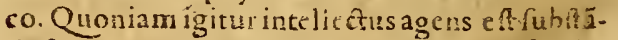
tia feparata, certum eft declarationemeffentia ipfius non ad Naturalem pertinere, fed aú Metaphyficum, Naturalis enim confiderare į̧ tum non poteft, nifiprost eft agens refpeetu humani intellectus. At obicict aliọuis, quomocio igi. tur potuit $A$ rift in context 19. \& 20 . libr. 3.de. nima, cófiderare eius condıciones ad effentiaru

F ipfiusabfolute funptam fertuncntes? ex hriius dubii folutione artilicium Arifotelis, os eilus de intellcetu agentefententia manifefta fiet : fertinebat quidem ac naturalem Phil ofofhurn iola confideratio officiorum intellecius agentis, quoniain hac refpeEtum notat ad intelleetum humanim : fed videns Arifotel. nos in hac acquicturos norsuiffe, \& fe animos noftics dubios, \& fufpenfos reliquife, nifide ipfo inielleciu agente quidnam fecusdum fe fit aliqua 
ibi fubiunxiffet, ideo dicerealign breuitervn-A luit a deins chentiam attinent1a; fod ita breuiter, á oblcure, ve fatisaperte fignificauerit fe ea tangeretanquam aliena à naturali philofonhia: folet en im vbique Ariftot. quando ex profello alicuius rei definitionem, feuefientiales conditiones proponit, eas diligentifime declarare, vt in pluimislocis quifque notare poteit, ibitamen de praftantifima, atque ignotifima loquens quafdam effentiales eius condiciones in medium profert, abfquevlla earum declaratione; vt eas leuter tangendo, necdeclarando, fignificaret earū, \& iplîs intelle etus agęetis conliderationem ad eum locum non pertinere; ideo notarecoin loco, \& in aliis quoque poltumus, non effeabrurdum, fi in difciplina aliqua quandoque tangatur id, quod ad aliam difciolinam percinet: imoillud interdum necefiarium effe: quum enim res omnes magno inter feordine, \&e nexu coniundtz fint, fcientias quoque contemplatiuas ita inter fe coniuntas effe oportuit, vt vna attingeret aliquando ea, qua funtalterius; hocenim non eft ablurdum; fi leuiter, \& cum moderatione fiat; quemadmedum co in loco facitiriftoteles: quod etiam alıâs notauimus de potiremo cap. lib. 8. Phylicor. in quo a git de primi moteris impartibilitate ; qua ad Metaphyficum porius, quam ad $\mathrm{N}$ turalem Philofophum pertinebat. Ex ca igitur obfcura, \& imperfeera confideratione conditionum intellectus agentis ranifefte colligimus, ipfum tanquam lub tantian à mareria abiunctám per effentiam nó ad Naturalem Philolophum, fed ad Mctaphyficum pertinere : idque etiamalio Ariftot. teftimonio comprobatur; nam in 7. Metaphy f. contex. 6. inquit effe pofterius confiderandum, an prater fenfles fibftantias aliqua alia deturab. iuncta à materia, an non detur;idem etiam in contex.29. lib. 12. inqurendurs proponit, is enim proprius locus eft, in quo Ariftot. ex profefio de talibus fubftantiis accurate pertractat: hocigitur proponens in dictis locis Ariftot. denotat non effe ante libros Metaphyficos nobis cognitamaliquam fubftantiam à materia feparatam. Videamus igitur, quas fubftantias à materia sbiunctas conlideret Ariftot. in eo 12. libr. certe nullas alias confiderat pratèr illas, qux iga d-Cœlos mouent; docetenim tot effe intelligentias, qunt funt orbes motinec dicere aliquis poteft, intelligentiam humanam vna cum coleftibus ibiab Ariftotele fumi, \& in orbibus motis numérari etiam fphram humanam, ve aliqui dicere aufi lunt: nam legentibus contex. 43 . \& mefura- 44. illius 12. lib. patet Anitot. dicererot effe fubftantias à maicria feparatas, quot funt orbes; quet autem fint orbes, furs eis ci efeex Altrologia; atqui Aftologus non contidesat notben

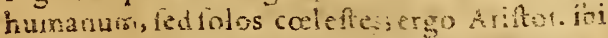
nuliamaliam inelligentiancotide illas, qux mcuent orbes caleftes. H de Ariftot.certifimum eft, ipfum nee dxmones cognouife, neque formam vllam à niateria abiunctam inferiorem int:lliger tis, qua mouent colos: quare fi intellc etus agens eft forma fepa. rata, non poteft fecundurn Anftot. clle dzonon alıquis, neq; intelligentia percul iariter homini applicata inferior cocleftious, \& fuperuenicns formx informanti, qua homoeft homo. Reftat igitur, ve non pofrit eife alia fubftantia abiuncta à materia, guam vnaex cis, qua mouent fpheras coeleftes, quū prater cas nullam aliam fubftariam feparatarn Ariftot. in libris Metaphyficis confideratit. Alinui tamen dicere aufi EHafto funt: folis quidem coleftes intellgentias ex. Aupropreffe ibiab Ariftot. nominatas fuiffe, implicite aftarum. tamen eadem tradatione comprehenfam effe etiam inumanam intelligentiam; quans enim eiufder generis lint, id, quod de illis dicitur, de humanaquoq; ditum incelligitur. Sed hos va- Confutanum eft; non enim objectionem noftram effu. tio.

C giunt, quum Ariftot. de folis illis intelligentii, qua mouét orbes, feagereaffirmet: ad de. quod huic humanz incelligentia non cōpetunt conditiones ab Ariftot. cœleftibus attribatz; casenim primo loco inuenit ex terno motu, \& eas primum cognouit vt fempermouétes vno continuo motu; humana vero, fi datur, non femper orbem fuum vno continuo motu mouet, quare fub eam tractationem rouci sinime potcf; non eft igitur verura $i$, quod illi dicunt, de in. telligentia humana effeintelligendailla omnia, qux de coleftibus ab Ariftotele declarantur. proinde fi dehac quog;ibiagere voluifer, eam abfque dubio nomiare feorum, \& eius pro. prias conditiones, perquas à cceleftibus difcrepat, expreffe declararedcbuifit. Manifeftüigitur eft,nnllas alias fubfantias àmateria abiunEtas A rifloteli cognitas fuilie preter incelligen. tias color ü motrices, gquas dari ex æterno motu demonftraust, \& hec omnia ita frmis nituntur E fundamétis, vr nullum certe fubterfugiendi,aut cauillandilocum relinquant: igitur Themiftia Auerrois fententia de intelle tu agente non ef Arifotelis, $n$ eq: vlla ratione defendipotef.

\section{Ouod Intellectus agens non poßsit effe aliz intelligentia, nafi onnium prima. Cap. XIII.}

$F$

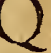
Vum igiturmensagens non poffit effe nifi aliqua colellum mentū, quz calos moucrit, qua namex eis ert intellefus agens? an fuprema, qua Deus eft, an aliąua exalis qua fecund a intelige $\mathrm{e}$ iz appellantur? atio nos cogit vrifam primem hoc inumere fungijofe fateamur: etenim reliçux oés fint virtutes particulares, exad mouendos lingula picprios crbes peculiarter applicaia, neqj; habers virn vniuerialemi cua au resu omnium regimen extendatur: $\mathrm{KK}$ \& fo!a 
fola prima eft ciufnodi:quia nó folum primum orbem mouet, fed to:un finul coleftem giobum, imo \& mundum vniuerfum, \& eft prima omniū rerum caufa, cmnia gubernans, omnia perficiens, omniaconferuans virtute fua diffufa per omnia; hac enim quama is vbique fit, \& 0 mnibus rebus adfit, non omnibus tamen intelligëdifacultatem prebet, fed homini foli: quod optime declaraturab Alexandro in 2. fuo. lib.de Anima, cas. 4. inquit enim humanum intelle¿tü, qu pofíbilıs dicitar, effe veluti inftrumentumintellectusáiuini ad intellectionem in homine producendam; folus enim humanus intellectus a prus eft recipere lumen intellectus diuini, \& fieri intelligens: res autem alız talem naturam non habent, vt poffint inftrumenta fieri diuini intellectus ad producendam intellectionem : ficut etiam videmuslumen Solis, quum idem fit, penetrare vitrum, at non parietem. propter diuerfas horum corporum naturas; fic calor Solis lurum indurat, ceram vero non indurat, fed riollit; agens enim non agit, nifi in pitensidoneum adrecipiendum: in hocigitur mundo inferiore nulla eft natura fuceptiua intellectionis, nifi natura intellectus noftri patibilis, qui forma hominis eft; quo fit, vt eo in-

Argumé

$\checkmark$ is Alex andri. telligente homo dicarur intelligens. Ad hoc comprcbandum habemus argumentum doCtiffimum, \& vere peripateticum ab Alexandro adductum in x. fuolib. de Anima, cap. de Intellectu agente: inquit ibi Alexander, in omni genere, in quo fit aliquid per $f e, a c$ primo tale, \& aliqua fecundario talia, necetiar una effe vtilla, qua fecundario talia fant, ab jllo primo habeant vt fint talia, proinde fint talia propter illud: hoc poffumus inducti oné in rebus omnibus comprobare; nam fubltancia eft primum ens, \& maximum ens, accidentia vero funt fe. cundario entia: fic inter omnia vifibilia primum vifibile eft lux, \& maxime omnium vifibile eft So is lux, ab hac; gituralia funt vifibilia : fic eriam omniabonz dicunturbona per primiboni partucipationem. Quum igitur res potertate intelligibiles debeant $a b$ intellectu agente reddi an intelligibiles, non poteftintellectus agens effe aliud, quam illud folum quod primum intel igibile, \& maximeorraium intelligibile eft; ab hoc enim, \& à nulloalio poffunt alia reddi intelligibilia; maxime autem omnium intelligibilis Deus eft, \& eft prirnum in genere intelligibilium; ergo nil aliud ftatui poteft intellectus ag ns, nifi folus Deus: hoc fuit argumentum efficacifimum Alexandri. Sed hocidem argumentumegoapud Platonem notauiin fine 6 libri de Republica, \& miror quod ali hanc fententram trquentes locum illum nom aninad. ueiterint: Plato ibi hanc fenfuum differentian confiderar, quod prater vifum alii, vi fenriant, fatis haberit obicto prafente; at vifus, ie videat, nonlaus habet piaferua culons, fid alro
A quodam eget diuerfio \&à calore, \& à vifu, \& ab oculo; idquc eft lumen; deinde quarens quam potiffimum affignareluminis origrinem debeamus, inquir eamefeillud, ąuod maime onniü lucidurs eft hicautem eft Sol, qui neque eft celor, neque vifus, neque oculus, fed diuerfum quiddam, à quo babet color, \& vtfit, \& vt vifibilis fit; \& vifus ab eadem habet vt fit, \& vt videat; eft enin Sol tanquam parens, \& genitor omnium rerum corporalium, à quo \& vifus, \& B colorrecipiunt effe, \& abeodem vt primo vifibili vifibiliratem adipifcuntur: deindefubiun. git Pla o solemeffe ipfius boni fitium, nempe Dei, qui ipfurr in rundo fenfili principem fixtuit, vr in es tereret eundem locum, quem ipfe obtunet in mundo intell:gibili; ipfenamqueer primum intellig!bile, Sol veroeft primum fentfile: quo fir, vequersadmodum in rrundo intelligibili Deris ad incellectum, \& ad intelligibilia fe habet, ira in mundo fenfili le habeat Sol ad C vifum, \&advifibilia; hicenim eft caufa genera. tionis vifus, \& rerúm vifibilium, \& eft caufa vt vifus videat: \& vt vilibiliafint vifibilia, quum faciat ea $\&$ abfolute effe; \& vifibilia effe, ille vero eft caufa ve intelledus fit, \& ve res omnes fint \& vtintellectus fit intelligens, \& vt resomnes fint intelligtbiles : manifeftumigitur eit Platonem exiftimaffe Deum effe intellectum agentem, \& eum cum lumine comparaffe, ita vi ciedi polfit Ariftotelemid à Platone accepiffe: hoc dePlatone teftari videtur etiam loannes Grammaticus, qui interp:etans primum contextum tertii libri de Anima, attribuit Plutarcho, quod iuxra Platonis opinionern dixerit frientiam noftram effe reminifcentiam, \& quod dixeritintellefum agentem effe Deam: deinde inquit, Ammonium reprehendiffe Plutarchum de reminifcenta, quod Plaionica dogmata Ariftot. attribuerit: videtur itaque tiam in altero Plutarchus adhafiffe Platoni, nempe quod Deus fit E irtellectus agens. Hac abrque dubio fententia sinftotelis fuit; qui tli fatis breuiter, \& obfrure tetigit intellectus agentis naturam, tales tamen conditiones illıatribuir, ex quibus colligi poffit, ipfum non effe nifi Deum; hoc enim denorat eius comparatio cum lumine, qua etiam Plato vrus eft: nam fi reeta effe compalatio debeat, oportet, ficut lumen eft primun vifibile, ita intellectum agenters efle primum intelligibile, vtargumentum ab Alexandro, \& à F Platuneadduktum ácisionfirat: ita vt, ficut illuminatio colorurn nil aliud eft, quam coniunctio reifecundario vifibilis, \& per participationem cum vifibili per fe, \& primo vifitili; colores enirn funt participata lumina, quia conftant ex luminoto, \& opaco, quare, vt vifum moueant, iungi dabent lumini puro, à quo perficiustur \& vm motricem recipiunt; ita \& phantafmatum illumanationil aliud lit, quam cóiunctroreifecundano miciligib blis cü primo intel- 
ligibili, \& rei poteftate intelligibilis cum ıeper. A fe intelligibili actu.Hocidem lignticat id, quod de intelleatu agente in cont. zo. illius libr. Arift. dicit,ne mpe iplun ene id quod eft; fic enim de. notat eum effe entitatem ipfam, \& ipfummct ef fe; hxcautem eft propria Dei conditio, vt D. Thomas oftendit in 1.part.Sum. quaft.3.art.4. in omribus enim aliis rebus effe diftinguitur ab effentia, folius autem Dei eft ipfummet fuum effe.

Pradictesententic confirmatio teftimonio D. Thoma. Cap. XIV.

$A$ $D$ hujus fententix confirmationem libet il ${ }^{-}$ laconfiderare qux à $D$. Thoma hac de re dicuntur, tum in 1.par.Sum mxe, queft. 79 9. artic.4. tum in quaftionibus difputatis de Spiritalibus creaturisart. 10. \& de Anima, art.s. Ip fein dietis locis confiderandam fumit illorum fententiam, qui dixerunt intelleetum agentem effe fubrtantiam ali quam feparatam, quxenon fit forma hominis; fed ean diuidıt in duas, \& viram que feparatim impugnat: inquit enim aliquos dixiffe intelleetum agentem effe quandam fubftantiam à materia abunntam inferiorem Deo, aliquos veroexiftimaffe Deum ipfium effe intelleatum agentem. Pricrem fententiani inquit effe Catholicx fidei repugnantem, \& magnum eam fequi abfurdum: quum enım cuilusque rei perfe¿to in nobilifima eius operatione confiftat; nobilifima autem noftra operatio fit coniunEtıo animæ noftræ cum illo, à quo lumen-recipit, effet perfect to noftra conftituta in coniunEione cumalio preter Deum, quodabfurdum atque impium eft : in hoc igitur Thomas nobis confentit. Alteram vero fententiam, quod fit intellectus agens, non dicit effe Catholicx fidei repugnantem, imo afferit quorundạm Catholicoitian ententiäm fuiffe; Catholicos enim certe non nominaret, fi impram, \& Catholicx fideiaduerfantem effe eorum opinionem arbitraretur. Thom antem verba funt hxc [qurafides Catbolices Deum, non aliquasm aliams uubftantiam Separat wm natura, EF anzmabus noft ris operantemponat, ideo quidam Catboluct of fuerunt Deitm saceilecitum ajentem, qui eft lux Sera, qua elluminat omnem homine Gerientem in hunc mundsum ] imo tantum abeft, vt opinionem hanc repugnătem Catbolicax fidei effe dicat, vt etiamaliqua ex parte earn approbat; inquit enim effe neceflarium, vt fupranumanamanimam fit ali quid à $F$ quo cius intellectio pendeat, \& quumid non politr effe alia intelligentia præterDeum, omnino dicendĩ effeillud effe Deum : \& ad hoc proban:ln!n vitur argumento Alexandri, quod validinimun effe diximus, nempe qua id, quod eft talipernarticipationem, necelfario pendet ab alionerfetali, \& fit tale perillud. Sed in eo foiur ab illis Thomas diffentit, quod negat Deum ob id effe vocandum intelle 2 tum agen- tem, hac vtensintione; quia Deus eft carfa vniuerfalis, non adxquata humanæ intellectioni, de qua loquimur, quocirca requiritur præter Dcumaliacaufa particularis, quxe fit hominis propria, \& pars, fcu facultas quxdam animx humanx, dicaturque in homine intellętus agens: ad quod confirmandum vtitur Thonias exem. plisnaturalibus; Sol enım generat animal tanquam caufa vniucrfalis, fed non fine caufa particulari, quxeft visinfita in feminc illius aniinalis: accommodat etiam huic fententir com. parat tonem, qua Arift. vtitur, intelleetus agentis cum lumine, \& inquit lumen referriad Solê, ta:ıquam eff:ctum ad caufam, A riftotel. antem coniparare intellectumagentem, non cum Sole. fed cum lumine, ad denotandumipfum effealiquid à Deocreatum in homine, non effe Deum ipfum, quemadmodurn lumen non eft Sol ipfe. fed effectusà Sole productus : ideo concludens dicit, illud, quod in nobis facit intellıgibilia aetu ad modum luminis creati, effealiquid animxe noitrix, \& effe multiplicatum iuxtanumerum animarum, \& hominum, \& vocitum effe ab Ariftotel.intellectum agentem; illud vero, quod facitintelligibilia ad modum Solis illuminantis, effe vnum tantum \& \& Ceparatum, quod eft folus Deus, nec vocari intellectum agentem. Hæc funt, qux à Thoma dicuntur: in quibus eorum, quxe vera funt, confeffionem eius accipio, qua puto fententiam noftram maxime comprobari ; in reliquis facile oftendam eum à mente Ariftotelis aberraffe. Imprimis ipfe fatetur Quid reDeum tanquam caufam prinam facere omnia cte dexeintelligibilin, quod quidem verum eft, imo rit Thoetiam neceffarium; quum enim fit primum in- mas. telligibile, abeo folo polfunt alia reddiactu intelligibilia : conceditetiam in noftro intellectu preter vim paffiuain etiă vimaetiuam, tan quam eius facul tatem, quam nos quo o; diximus fateri neceifarium efle, eamque Alexandri fuife E fententiam.Sedin ẹo à nobis diffentit, quod pu- Quid tat vim adiuam noftri intellectus effe intelle- non recte ctum agentem, \& tanquam caufam fecundam dixerit à Deo creatam facere phantafmata asti intelli- Thomars: gibilia lioc enimnos negamus, \& falsum effe iam effe oftendimus, qua facultas actrua hùmanx mentis non poteit facere actu intelligibilia, proinde non eam vocauit Ariftoteles inrellectum ageatem, neque cum lumine comparas uit: hocoftenditur argumentis fuperius adduQtis; primum enim falfum eft id, quod Thomas fumit,actionem intellectus agentis effein phan. tafmata, iam enim oftendimusipfum agere in intellectum patıbilem, non in phantalmata. neque eft quod in re manifefta eandem demon. ftiationeni reperamus; hocautem fi verun eft, \& intelleetns agens inxta ipius Thomx fententiam elt facultas quadam animæ noftre rationalis, neq; fecundum fub trantiam diftinguiturab intellectupatibili, quomodo poteft idem $\mathrm{KK}_{3}$ agere 
anere in feipfum? quomodo poreft idem efle lumineplenus, \&illuminas, \& limul omnilumine, omn ique cognitione carere, \& illuminari à femetipfo? at condonemus ipfum agere in phantafinata, licet idomnino falfum, \& ab Ariftot.alienum fit, idem tamen abfurdum fequitur;quod vidit quidem Thomes, \& nixus eft explicare, fed fruftra laborauit; nam debet intelleAus nofter pati à phantafmatibus, vt Arift. aperte dixit,quomodo igitur agere in eadem poteft? fic enim effet fimulagens, \& patiensrefpectu ciusdem, \& fecundum ideni, quod eft onmino abfonum rationi ; nam agens naturale in agendo repatitur quidem ab eodem in quod agit, non tamenfecundum eandem qualitatem, fed fecundum contrariam ; calefacieus enim non calefit vicifim ab eodem, fed refrigeratur; at intellectus nofter quatenus agens nil aliud iuxta Thom $x$ ententiam agit in phantalmatibus, nifilluminationem, qua redditea intelligibilia, \& ipfe quoq; ab iis ita illuminatis illuminationem recipit,qua redditur intelligens; at certe, fi iam in feipfolumen habebat, non debuitillud tribuere phantafmatibus, vt idem ab eis poftea reciperet. Præterea minime conueniens eftilli præter Deum facultatem attribuerefaciendiactu intelligibilia; folum enim primum intelligibile id facere aptū eft : \& quemadmodum Deuts cum nulla creatura vim fum c:eandi communicat, ita neque vimilluminandi; fed ipfe folus eft lux vera, quæ, vt illi Catholici dicebant, omnem hominemilluminat. Argumentum autem Thomæ nullius efle efficacitatıs, poftea oftendemus, quum dubia \& aliorum argiımenta, ศiı fententiæ noftræ officere videntur, foluemus; Idem enin argumentum etiam à Ioan. Grammatico contra Alexandrum adductum eft, ad oftendendum non effe Deum intèlleAum agentem.

\section{Dubia, \& aliorum argumenta, que predi- ctic cententic videntur officere. cap. $X V$.}

T E $\mathrm{C}$ fententia, quam haftenus \& ratione; 1 \& Ariftanthoritate dem onfrauimus, manieftiorac firmior reddetur, fi dubia quædam. \& argumenta, quibus eam demolirialiu contendunt,foluerimus. Primum obijciunt: fi intelleAtus agehs Deus effet, intellectio non effet in moftra poteftate; confequens falfum eft, intelligimus enim quando volumus : confequentia probatur; quoniam illa acrio in noftra poteftare elle dicitur, quie pendet à principio noftroformali, quz vero pendet ab exter no principio, ea in poteftate noftra effe non potef ; Deus auter eft principiurn externum 5 igitur fi ipfe effet intellectusagens; intellectionon effet pofita in noftrapoteftate, fed vel femper omnia intelligeremus, vel ea folum, \& tunciolum, qu s, \&
A -quando Deus vult.Secundo obiicinnt, \& eft ar- secusn gumentum Thomx pradictum : caufa debet offe zqualis efrectui, illi ex equo refpondere, vt Ariftot. docet in 2. Poiter. $x$ in 2. Phyficor. effectus enimcommunis caula deber elfe communis, \&effectus particularis cau a particularis; fed Deus cftcaufa maxime vniuerialis, nofra autem intellect 10 eft effectus particularis; quia eft propriahominis operarı : ergo Deus non poteft effe intellect is agens, fed requiritu agens particulare, \& effectui adxquatum, quale fign1ficaut Ariftotel.in context.17.libr.3. de Anima, quando dixit cuilibet pariendi refpondere agěs, à quo patiatur; fignificauit enim agés proprium cuilibet patienti. Tertio dicunt: Deus lecundum Arift. nihil agit immediate in his inferioribus, fed omnia per motum, \& lumen coeleftium corporum, \& per caufas fecundas; ergo non potelt effe intellectus agens, quia hoc daro ageret in homine immediare absque vlla caufa fecunda: hoc quoque argumento videiur vfus effe D. Thomas, vt pridiximus. Quarto confiderant verba A riftot.1n context.17. libri 3. de A. nima, ubi intellectum paticntem, \&intellectum agentem vocaut animæ noftr differentias, voluit ergo vtrumque elie aliquid humanum, \& animæ humanæ partem; at Deus non poteit vocari differentia, vel parianimæ inumanæ : id que confirmant contiderando verba Arift. in 1. cont. eiusdem libri, vbi proponit agendum de parte animæ, qua cognoicit anma, fapitiomns igitur intellectus, qui in eo libro conideratur, pars animx eft. Qirinto argumentum iumunt $c x$ verbis Ariftotel. in contek.is. eiusdein libri, vbi dixitintellictum agenten effe- habitum quendam, \& eflevt lumen : at Deusnon potef habitus appellari; quoniam habirus dicirurid, quod eft polterius effentia, \& notat aptitudinem ad operandum, qualishabitus non eft Deus: non E poteft et,am Deas cum lumine comparari, quia. lumen non dat coloribus vt abfolutefint, led. fólum vt fint motiur; Deusautemabfolure res effetacir, quia omnia producit; quare elt potils cum Solecomparandus, qui eft fons, \& caufa liminis, quam cum lumine ipfo:hoc facirargumentum Ioann. 'Grammatici aduerfus Alexan'drum, \& eodem vfuseft D. Thomas, vtantea diximus. Sextoargumentantur ex iis, qua dicur. turab Ariftotel.in cont.20. eius 3. libri, \& eit argumentum Themiftijcontr.a Alexandrum : Ariftoteles ibi de agente intellectu loquens inquit, hunc folum effe immortal tm, ergo nor putat cum effe Deum; quia hoc polito drctum. Arift.fallum effet, quum non folus $D$ equs fit inmortalis, fed etiam alia coleftes mentes, ino \& cole itia corpora fecundum Arift.æeterma fint. Tandem dicuntaliqui : fintellestus agens effet. Dens inon opus erat Arift. eo in loco oftendere eum effeimmortalem, quia Deum effe immortalem null us homo ignorat.

Dictá 
1037

\section{Dictorum argumcntorum folutiv. Cap. XVI.}

ipri- Hecigiturargumenta folucre nitendum no-

$\mathrm{H}$ bis eit. Ad primum dicimus fore quidcm illud efficaciffimum, fi Deus aliquando nobis fuam operam recufaret, nec femper ad nos effunderet lumen fuum; fic.n. nos nö quando volumus intelligeremus, attamen non ita fefe res habet, nam cius lumen femper nobis adeft, immutabile, \& nunquam deficiens; ideo intelligimus quando volumus, dummodo habitumacquifiuerimus, nam ante acquifitionem habitus non eft in noftro arbitrio conftitutum intelligere quāndo volumus: quemadmodum enim fi it atueremus. Solem à noftro hemifphærio nunquam recedere, femper lumen prafens haberemus, quare fi calorem quoque haberemus prafentem, in noftro arbitrio effet infpicere quando volumus, fic de noftro intellectu dicendüm eft, habet enim femper prafens lumen agentis: quia, vi D. Thomas oftendit in $x$. part. Summx, quxit. 8. artic. I. \& 3 . Deus eft in omnibus \& per potentiam fuam, \& per prafenciam, \& peref. fentiam, non quidenı peripfarum terum effentiam, ita vt ipfe fit pars effentixillarum, fed per fuammet effentia m eo modo, quod agens dicitur effe cum fúo effectú: \& hoc necellarium eft, quia Deus ipfe fibi hanc neceffitatem iniunxit, quemadmodum etiam ex necefitate animam creat in qualibet humano corpore, quod ab a. gentibus naturalibus fit conuenienter preparatum; ipfe enim libera fua voluntate ftatuit hoc effe neceffarinm: fic igitur nunquam par ipfum ftat quin intellectus noiter intelligere poffit, ftat quidem aliquando per defectum lia bitus ne valeat intelligere; quandoqite etiam per defecum organi phantafix, quod in aliquibus eft ita rude \& incptum, vt propter phantafmatis impurita rem, etiamfi adfit lumen intellectus agentis, nil tamen intelligere polfint.Secundum argumentum validum quidem eft in aliis agentibus, namagens vniuerfale non agit nifi per agens particulare adxquatum effeetul, fed in Deo nuhil habet efficacitatis; poteft enim immediate hominem producere fine al iqua caufa fecunda, quem Sol fine altero homine agente producere non poteft. Praterea dicimus magnum effe fenfilium, \& intelligibilium rerum difrrimen : nam fenfilia quidem efficit Deus vt caufa vniuerfalis, nec fine caufis fecundis, quia $F$ ipfemet hanc rebus legem prafcripfit; at in mundo intelligibili ipfe abfq; caufis fecundis. immediate agit, poffumusq; hoc Thom a argumentum aduerfus ipfun infolubiliter retorquire: Deus animam humanam creat, \& eft agens vniuecrale, \& vinuerfalis creator rerum omnium, \& mundi vniuerfi ; ergo requirttur alia media caufa creata, \& homini adxquara, per qquam creat animam humanam : qquoniam : igi-
A tur Deus, et $f i$ eft creatorvniuerfalis, animam tamen humanã immediate creat line vlla caufa media, fic immediate eadem illuminat, necrequirituralius illuminatorcreatus : dicere etiam poffumus diuinum lumen per omnia diffufum effe quiden caufam maxime vniuerfalem; fed iunctum phantaimatibus, qux funt noftri intellectus obiectum propiium, reftringi, \& fieri proprium agens, \& quodammodo obiecti proprii rationem fubire : quod exemplo luminis B Solis confirmari poreft : nam Sol per lumen fǘ eft omnium rerü fublunariun viniuerfalis cau$f_{2}$, attamen quatenus jungitur colori, qui eft proprium obiectü vifus; reftringitur, \& fit caußa propria refpectu vifionis; fubiten im rationem obiceti vifibilis, qua ratione non refpicit alium effectum, nifi folam vifionem. Ad tertium refponfio patet ex iis, quxad primum dieta funt; Deus enim per motum, \& per lumen cocleitium corpcrum effectus materiales producit, fed in C mundo intellectuali agitabfq; collorum lumine, \& motu, atque omnino abfq; fecundis caufis. Ad quartum dicimus, non eam effe A riftotelis fententiam, quam ipfi comminifcuntur; non enim dicit intellectumagentem, \& intelleEtum patientem effe duas animx noftrx differentias, fed folun dicit, oporrere in anima effe has differentias agentis \& patientis, hoc eft, dari agens \& patiens: nam fi Deus vbique eft, \& eius lumen phantafmatibus iungitur vt perfeD etio, eft vtique in anima noftra; non tamen vt anima noftre pars, fed vt extrinfecus adueniens: hoc manifeftum eft confiderantibus argumentum, quo ibi Ariftoteles vitur; nam illa verba, quxitti pro fe adducunt, funt conclufio fyllogimi, quo Ariftoteles colligit effe in animas has differentias ; is ergo eft elus conclüfionis fenfus, qu eo fyllogifmo colligitur; is vero eornm verborum fen lus effe non poteft, qui ex iilis propofitionibus non infertur:eft autem fyllogifmus A riftorelis talis : vbi datur patiens, ibi datur agens illi refpondens, atque datur in nobis intelleetus patiens, ergoilli debet agens aliquod refpondere : quarendun igitut $a b$ ad uerfarus eft, quomodofit maior propolitio intelligenda; an ita, vt cuilibet patienti refpondeat tale agens, quod fit eiufdem nature, \& im ternum, an abfolute cuilıbet patienti debeat agens refpondere, à quo ad perfectionem ducatur : certe prior fenfus falfus, \& abfurdus effet; non enim cuilibet patienti refponder tale agens, quod fit eiufdem generis, vt exempla, quibus Ariftoteles id declarat, aperte demonftrant; ars enim refpectu marerix patientis eft agens externum, \& conditionis longe diuerf $x$; fic in natura elementa funt materia refpectu Ca$\mathrm{li}$, quod in ea agit continue; quomodo igitur poteft in conclufione colligi fenfus talis, qui non eft acceptus in propofitionibus, imo neque accipi potuit, quia falfus eft? dicere etiam
Adter

$t+12 m$.

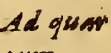

trum. 
poffemus, Dellm non effe quidem anima noftre partem, fed tancin quateus eft inteilectus agens; fieti modo quodam partem anima noftrx ; nempe quatenus eius lumen aniniæ noftr $x$ iungitur; quanquam ad hoc confugere minime cogimur, quoniam prior folutio ita vera \& manifefta eft, vt nuirandum fit cur aduerfarios non pudeat eo argumento vti. Ad verba Arift. in 1 . context. illus lib. dicimus partem animæ ibi fignificare folum intellectun patientem, qui folus per fe confiderandus erat; de agente autem uihil propon1, quia non per fede ipfoagendum erat, fed folum quatenus confertad operationem intellectus patientis. fic in I. context. lib. 8. Phycor. Arift. non proponit agendum de xterno motore, quia hunc non propter fe, fed propter æternum motum erat confideraAdquin-turus. Ad quintum dicimus intelleetum agentum. tem non propriehabitum appellari, prout fumitur habitus proaptitudine ad operandum, qux ex multiplicata operatione acquiritur, \& ponitur in prima fpecie qualitatis: fed fumi eo in loco ab Ariftot. habitum pro forma, \& perfectione, nam intellectus agens iungitur phantafmatibus vt perfectio conftituens obiectum intelligibile, \& hactantum ratione vocatur ab Arift. habitus. Quodvero D. Thomas \& Ioan. Grammat. dicunt Deum rectius comparari cum Sole, quam cum lumine, quum lumen fit effectus. quidam à Sole productus, vanum eft ; decipiuntur enım, dum à rebus materialibus ad inmateriales argumentantur: nam ip femet Thomasafferitin rebus materiaibus potentias effe res diftinctas ab effentia, ita vt in anima quoq; humana, quum forma hominis fit, potentiz ab, ipfa a nimaeflentia diftinguantur; at in feparatis à materia fecus eft, potentia nanq; idem eft quod effentia; nec dicendun eft Deum per fuam potentiam res creaffe tan quam per effectum aliquem, \& per rem ab ipfo diuerfam, fed potius tanquam perfemetipfum, nam potentia Dei Deusipiceft:fic igitur de lumine dicendum eft, lumen à Soleprodiens (inquit Thomas) eft quiddam à Sole diuerfum, \& ab eo productum, efto, at dicmus, non eiufmodi effelumen Dei; non eft enimaliquid creatum, fed eft Deus ipfe, qui ficuti quatenus intelligens, faprentia ipfa. eft, ita quatenus intelligibilis, \& fumme intelligibilis, vocaturlumen, quo omnia redduntur intelligibilia :obid videturin hoc Ariftot. fatis prope ad Chtiftianæ fidei veritatem accefliffe, fedinaliquo tamendefeciffe: quemadmodum enim nos per fidem afferimus mentem noftram a folo Deo, quem hac ratione Sanctum. Spiritū vocamus, illuminari; ita Ariftoteles dixit nos à Deo, quatenus eft intellectus agens, \& primum intelligıbile, intellectionem recipere: fed veritatem non plene afequutus eft; putauit enim per folam phantafmatum illuftratiomem peruenire ad miemtem noltram Diuinum
A lumen; nos vero ex diuina reuelatione acrepimus polle Diuinum lumer non modo inferne per phantafiam, fed etiam fuperneabfque illuminatione phantafmatum ad mentem noitram accedere, ita vt etiam abfque phantafinatum vfu poffità Deomultarum rerum fcientianentibus noftris infundi per Sancti Spiritus immiffionem, quod Ariftot. diuina reuelatione deftitutus cognofcere minime potuit. Adde quod lumen, quod in aere eft, non à Sole, fed à Solis luceproducitur, \& modo quodam tion eft diB. uerfum alıquidaluce, quatenus enim eft eius imago, \& eam reprafentat idem potius dicendumeft, quia naturam lucis, qux primum vifibile eft, nobis repræfentat. Dicendum igitur omnino eft Ariftot. non ea ratione intellectum agentem cum lumine comparare, quatenus Itrmen eft effectus quidam lucis; vel enim non eft effectus, vel non fumitur vt effectus, neque ea ratione fimilis ei eftintellectus agens, quum aliud fit lumen fenfile, aliud fit lumen intellectC le; hoc enim non habet caufam, fed eft ipfummet primum intelligibile, à quo omniareddunturintelligibilia:cumipfoautem Sole vediur rfo à lumine fuo non recte comparans eflet intellectus agens; quia ipfa Solis fubftantia non iungiturcoloribus vt perfectio, fed cins lumen tantummódo; at intellectus agenselt talis Sol, qui à fuo lumine non diftingurtur, finuidem Dei lumen Deus ipfe eft: neque etiam neceniarium eft, vt proptercomparatione in Arifotelis D. lumen debeat etiam abfolute colores producere, quia non in hoc coinparatio 1 lla confiftit, fed in eo folum, quod tanquam forma conftituit obiectum vifibile, \& fimiLterintellecus agẽs tanquam forma \& perfectio contituit obicctú. intell lgibile. Sextum argumenrum, quod Themiftii erat contra Alexandrum, poteft contraiprum Themiftum reiorqueri, imo \& contra onnes, qui dicantintellectum agentem effe partem anim $x$ humana, vel aliquam aliam inE telligentiam inferiorem prima, fequitu enim eam folam effe immortalem, reliqua vero omnia, qux in mundo funt, caduca effe, \& Deum quoque ipfum effe mortalcm: qua igitur refpofione \& Themiftius, \& alii omnes vti coguntur ad fe tuendos, eadem nos quoque in prafentia vtemur: dicimus enim Ariftotelem non confiderare co in loca Deum abfolute vt Deus. eft, fed folum vt refpicithominem tanquam: F intellectus agens, à quo prouenit in homine: intellectio:quando igitur dicit ipfum effe immortalem, confiderat ipfum quatenus eft factus quodammodo aliquid animx noftræ, \& fic eum comparat folummodo cum reliquis. animanoftre partibus: ita vt fenfus fir, nihil in homine eft inmortale, nifi intellectus 2. gens: fiquis vero obiiciat, ergo apud Ariftotelem intellectus patibilis mortalisef, ad hoc interpretes variis modis refponderent, prout: 
varrefunt eorü fententix de intelleetu huma- A no. Alixandier quidem totum soncederet, quosiam putauit humanü intellectum apud Arift. clie murtalc. Thomas vero dicit caverba proferri non de folo agente, fed eriam depatiente, fiquidem vna apud eum eft corum tubftantia, caq; immortalls : catzmen intcrpretatio verbis Arift. confentanea non clt, vt coniderantib.patet, A riftot.cinim profert verballla de folo agentc; \& nosfuperius demonftraumus, non poffe elle candem iubftanuam intellectuspatibilis \& agentis. Prubabilior eft quorundam sliorum in teipretatio, qui dicunt intellectum parientem mortalem elle, non quidem fecundum fubitantiam, fed ranmm rationc fux imperfectionis, \& patibilitatis ; catenus enim interire dicitur, quatenus definit efie imperfectus, \& recipere obieetū à phancafia. Vtcunq; fit, de hoc enin, \& de eius loci interpretatione nunc nō difputo, fatis.
A eft oftendiffe argumentum hoc Themifti fecundum onnium fententias nullius effe efficacitatis. Poftrenum quoque argumentum, quo aliqu recentiores vtuntur, vaniffimuni eft:nam fortaffealiquid roboris haberet, fi prius manifeftum fuilletintellectum agentem effe Deum, mortalem; fedè contrario feie res habet, ignotum enim eo loco eft, quifnam fit intelle tus a gens, idquc Ariftot. voluit ex inmortalitate, \& aliis fimul cius conditionibus effe colligendü: Præterea etiamfi clarum fuiffet eum effe Deum, reprehendi quidem Ariftot. potuifiet, fi demonftratione aliqua ad Dei immortalitatem probandam vfus effet : fed fimpliciter \& abfque vlla probationeafferere Deum effe immortalem, quid abfurdi fit, non video: quum in vfu fit apud omnes homines, etiam fapientes, yt Deum vocent immortalem.

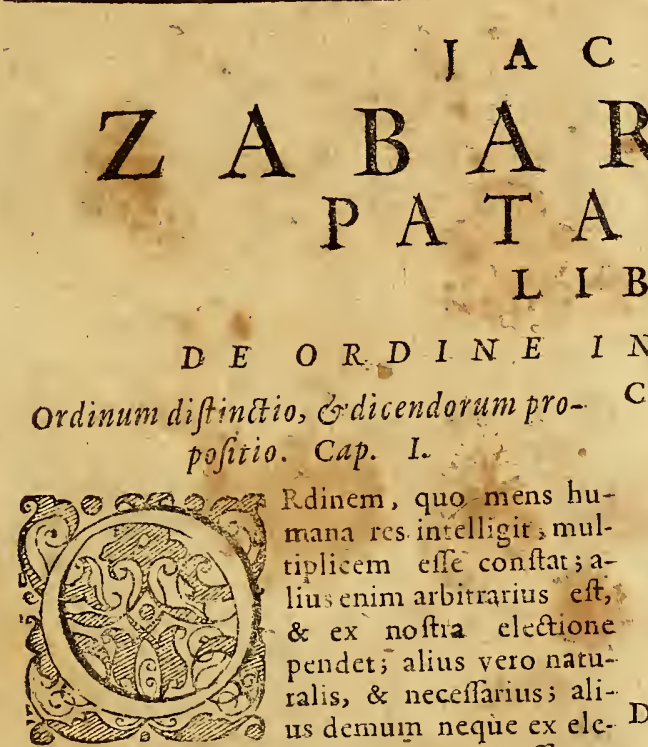

ctione, feu arbitrio noftro, neq; ex necaflitate, fed omnino peraccidens, vt fi quis equum prius nouerit, quam afinum, quim potuerit priusninum nouiffe, quam equum: hic nulla confideratione dignus eft, ideo dimittatur. Arbitrarius wes prio- vero eftilla doctrinz ordo, de quo nos alias in tb.libris libris Logicis plura fcripfimus : eius enim conLe Metho fideratio ad Logicum pertinet, quum fit Logil.,$E^{\circ}$ in cum inftrumentum, \& exarbitrio noftro fabrispologia carum; quod fi effet naruralis, atq; abfolute neceffarius, non effet quod Logicus de ipfius vfu. pracepta tradere niteretur : dici tamen pöt neceffarius ex conftitutione finis, quira fi rei fcientiam in fuo genere perfectam acquíitur fumus, vel faltê racilurus acquifituri, ftatuto quodam ordine vtamur neccffe eft. Alius demum. neceffarius prorfus, ac naturalis eft, ideoq; eius.
B I
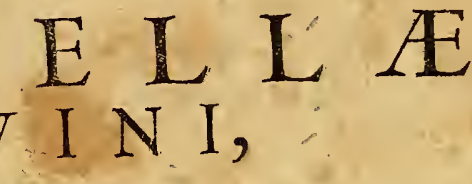

\section{,}

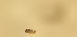

$\begin{array}{llllllllllll}N & T & E & L & L & I & G & E & N & D & I\end{array}$.

C confiderationonad Logicum, fed ad Natura lem 'hilofophum attinet, quum eiufmodi ordo naturam mentis noftrx infequi neceflario videaturideo illud horum ordinum difcrimen effe videtur, quod etiam habituum mortalium, \& facultatemanimx; quü enim habitus non fint menti noftræ naturales, fediex noftro arbitrio pendeant, \& ex arbitrariis actionibus comparentur,folx autem facultates, quibus eos acquirere apt fumus, natural es dici poffint, de folis facultatibusagere debuit Dhilofophus Naturalis, de habitibus verononipfe, fed alius, vt Moralis: fic doctrinx ordo arbitrarius eft, nequeeft menti noftræ naturalis, fola autem facultas. procedendi ab hoc ad lllud naturalis eft;ideo de facultate differit Philo fophusNaturalıs de ipfo auté ordine loquitur Logicus, à quo de eo tanquam de re arbitraria regulx \& pracepta traduntur: at fi quis fit mentihumanænaturalis. ordo, ita vt non ipfa tantum facultas,ipfum que vtendiarbitrium fit einaturale, fed ipfentet ordo, cuius variandi null un nos arbitcium habeamus, de hoc agere naturalis. Philofophi officium eft, ad plenam cognitione natura humani: intellectus, \& eorum, quxillam neceffario cnnfequuntur: talem autem ordinem potifime in fimplicium rudi, \& contufa apprehenfione exiflere nasifeftum eft, nö.ita in cognitione com$\mathrm{KK} s=$ plexo- 
plexorum, neq; in cognitione diftincta, atque perfecta, cöponere enion \& enunciare hoc prius quam illud, arbitrii magis, quam natu'æ elle vi¿etur apprehendere autem in phantafinate rem hanc piius, illam vero pofterius, fit primam rudium habituum acquifitionem fpectemus, non eft arbitrii,fed naturæ:rudium autem dico,quia diftinct $x$ cognitionis ordo in noftro arbitrio pofituseft, nec diftinguiturab illo doctrinx ordine, quem à Logico cōfiderandum effe diximus; at ordo notitix noftr confufx, quam à fenfibus accipimus, aliquis prorfus naturalis, ac neceffarius e?t, eumq; confiderare ad Naturalem Philo hophum attinet. Hicigitur, eft de quo nüc fermoncm facturi fumus, nempe naturalisille, ac neceffarius ordo, quo mens noftra fimplices rerü conceptus ruditer, \& confufe primum apprelandit; duoq; funt, qua fub prafentem confiderationécadunt, \& de quibus eft robis propofita difputatio; vnumo de ordine cognofcendi fingulare, \& vniuerfale; alterum vero de ordi neintelligendiupra vniuerfalia; quoniam enim offertur menti noftræ phantafma rem fingularem reprafentans, in qua ineft etiam natura communis, \&ipfum vniuerfale, confiderandum primo loco eft, virum prius à mente noftra cognof catur, an fingulare.anviuuerfale; deinde verointer vniuerialia an prius apprehendantur vniuerfaliora, quam minus vniuerfalia, an è contrario bxc prius, quam illa.

opinio, or argumenta illorm, qui negant fingulare ab intellectu cognofici.

Cap. II.

$\mathrm{D}$ E ordine intelligend fingulare \& vnituerfale difputari non poteft, nifiprius conftet intellectum noftrum cognofcere fingularchoc igitur, quumà multis negetur, eft à nobisante omnia confiderandum. Illi, qui finguiare ab intelletu cognofe polle inficiantur, his potifi- $E$

Prom mumargumentis vti folent. Primumargumenargumë- tantur plures Auerroifte ex abiunctione intelswr. letus à materia:intellectus non eft forma corporis, fed eft forma feparata à materia, forma. autem feparata non poteft intelligere, fingtrlare intellectusigiur fingularia non cognofit: $\mathrm{mi}$ norcm verà ltatuunt, iuxta Auerrois fentêtiam, quam fequuntur; maiorem it. probant; quicquidrecipiturinaliquo, recipitur ad modú recipientis,ergo forma immaterialis immaterialiter tantum aptac ft recipere, fingulare a utem eft wateriale, \& conditionibus materialibus alligatum, quia eft forma commifta nateria, vt ait Arift, in costex. 92. lib. 1, de Colo, igitur forma immaterialis non poteft cngnofere fingularia.

nosowdis Secundo, dimina etian illi Auerois opinioue, putant ex fola intellectus abiunctione ab organo idem dens onftrari:qutun enim intellectus ip operandonon vtatuc organo corporeo, ficut
A omnes concedunt, eft faltem in fua operatione immaterialis, ergo ob eandem rationem non poteft intelligerefingularia. Præterea fi intellectus fingularia intelligeret, non diftingueretur à fenfu, qui folū fingulare cognofcit; quioniam igitur oportet intellectum à fenfu diftıngui, \&e id, quod ab vno cognofcitur, ab altero non cognolci, dicendurn eft proprium effe intellectus cognofcere vniuerfale, fenfusautem cognofceie ingulare. Confirmant authoritate Ariftot. in

$B$ I. Phyfic context. 49. \& 2 . de Anima 60, \& 1 . Pofter. $134 . \& 2$. pofteriorum, cap. vlt.vbi per hoc diftinguit intellectum à fenfu quod intellectus vniuerialia cognofcit, 'fenfus vero fingularia; negat igiturintelleitum fingularia cognofcere, quum dicat fenfum per eorũ cognitionem difíngui ab intelleetu, Præterea Ariftot. in contex. Is. \& 16. lib. 3. de Anima inquit, omne actu intelligibile effe fine materia: materiale vero non elleactu intelligibile, fed potefate folum; C fingulare igitur, quum fit materiale, non eft apud Arift. intelligibile a tu, fed folum vniuerfale, quodà fingularibus \& à materia ab trahitur, eft actu intelligibile. In contex. quoq; 37 . eiuf- sestres dem libri Arifot.diuiditea, qux funt in fenfibllia, \& intelligibilia igitur nó tunt fenfibilia effe incelligibiliajat fi fingularia efient intelligibilia, omnia entia effent intelligibilia, nec darentus fenfibilia diftineta ab intelligibilibus.

\section{Dicta ententia confutatio. Cap. III.}

$F^{\text {Go cum alis pluribus arbitror intellectum }}$ Eiloftru etiam fingularia cognofcere, \& hoc potifimumargumento ad hoc afferendum ducor, quod in taculratibus animze fubordinatis necefle eft, it quicquid cognofit facultas inferior, cognulcat etiam fuperior, \& vt vbi inferior façultas definit, illic fuperiorincipiat; hoc enim negato, tollitur ordo partiumin animali, \& ipfius animalis vnitas: hoc autem manifeftumelt in phancafarefpectu feníum externo rum; ipfa enim poteft illa omniaimo poffunt illi fentire; diffem fus externi non fentiunt obiesum, quia ten-porsor. folum prafens, phantafia vero im abiens, led iam abientia : hxctamen differentinaginatur etcipiendaef, vt dicamusfenfis fentire fola pra fentia, phantafiam v ro fola abfentia, filfum e F nim eft, fed vt fenfus fentiat fola prafentia phantafia vero \& prafentia, \& abfentia: fic enira diftinguenda eft facultas animx fitperior $a b$ in feriore, vt poffit omnia cognoficere, qua cogna feit inferior, \& alia preterea. Quoniam igitus $v t$ fenfus ad phantafiam, ita phantafia ad intelleatun dirigitur, eiulinodi debetefle diferimen intelle dus, \& phantafix, \& fenfuum omnium, vt intelledtus cognofcere illa omnia poffit, qua phantafia \& fenfus coginofcunt. \& alia quoque 
preterilla, quoniam igitur phantafia \& fenfus $A$ cognofcun tingularia, debet inclleatus quoq; fingularia cognofcere, \& preterea vniticritia, qux nec phantafia, ncefenlus cognofcit. Significaus hoc Ariftot. in context.3. \& 4.1.b. 3. de Anima: nan in context.3. dixit finsilem elle intellectum fenfui, quatenus non eft miftus cum fuis obictis; fedfatim in context.4. differentiam fubiunxit, dicens intellectun efle abfolute \& prorfus immiftum relpectu rerum on nium; propterea quodomnia cognofit; dicens enim - mnia, nihil exclulit, \& pei hoc feparautintel. lectum à fenfu : jenfus enim quun fit alligatus organo, non potelt omnia cognolcere; proinde non eit, prorfits iminitus; at intcll ctus quum nulli orga no fit addictus, eft abrolute immiftus, \& poteft omnia cognofrere fic igiturixorgani defict 1 , ex quo aduer fari argumentum lumpferunt, nos contrarium oitendimus; tacultas cnim oryanica, quum fit organo addreta , quod eft deterninare nature, non poteft omniaco- C gnofcere; facult as vero non organica cognofcere omila poteft, nullo excepro, quia non habet organum, a quoad łeterminaram ăliquam naruram reftringatur. Confirmatur hæc fententia ex ratiocinio, \& difcurfu in pattucularibus, fint enim mult fyllogifm partictiare colligé:es in omuibusfiguris; rat ocinari autem, \& dricurrereeft proprium incllectus, vi at Ariltot. clare in terio librode Anima;ideovana, ck ab Arrit. aliena eft defenfio, qua aduerfarii viuni ur, dum ad phantafiam confugiunt, \& eam dicusitratiocurari in particularibus. " $A$ d dequed non fit fyllogifmus nifi es altera faltem popofitione vniuerialı, quam cognoficere hanta ia pon poteft, quod Auer roifteal qui animaduertentes dixerunt in fyllogismo particulari propofitionem vniueralers ab intelletu cognoici, altcram vero particularem a phantafia, $x$ ab eaden colligi conclufionem;icd hoc ridiculum eft;oporter enim abvna \& eadem animx.parceeundem dif- curfusm fieri, quum diftunctarí pantium diftinetæoperationes hint, \& viderenon fit a udire,neque img inarifit intelligere; quomodo enım phanta colligerepoteit conclufionem fi pro. pofitionem vniuerfalem ignorat? abintellectu igitur, non à phantalia, cogno! citur propofitio particularis, quum rafertim folus intellectus apud Ariftorel. affirmare, acnegare polfit:adde quod in minore fyllogifmi purticularis predicaturvnuerfale de pasticulari, idque ab Arift. in primo capite primi Póftriorum vocaturinducere, fcu inferere particulare fuo vniuerfali: quomodo igitur phantafia, qua vniuerfale non cognofcit, poteft particulare inferere vniuerlali:vana igitur \& prorfus abiiciēda eorum refponfroeft. Yoflumus preterea ficargumentari: intellectus fuam intellectionem cognof cit, om nis autcm incllectio eft particularis, ergo quando. cognolcitfe nunc rem hancintelligeie, cognafcitintellectionem particularem : at fecundum
adueriarios non poffer ab vlla animx facultate cogolci hac intellectio particularis; non enim gularia coznofcere; non à phantafia, neq ab firla alia animx fenfibilis facultate, quia fenfus nonpoteft cognofcere intelle tionem. Præterea eit rationi conlentane um, ino oneceffarium, yt fi intelleftus cogpofcit vniuerfale per abftractionem à fuppofitis, cognof cat etiä fingularia fuppolita a quibus abitrahit: quomodo enim coguofcere porett vniuerfale, \& eius vnuerfalitatea, nifi cognoficatíngularia, de quibus prædicatilr? quosiodo pót compararé v niucr fale curx fingulari, \& corum conuenicntiam ac differentian cognofcere, nifi vtrum q, feorfun cognofcat? neceflaritim enim eft, vt qui duo inter fe comparat, vtruinque cognofcat. Quomodo po:éft cognofcere quiddinaté. nifi cognoicatid, cuius eft quid ditas?quidditates aut é funt resum fingularium, quæ exira animam exiftunt, quare necellarium ett, vt cognofcatingularia : folus etiă intelle êus cognolcit fingularitatem, quum fit quidditas reílingularis quatenus eft fingularis, ergo cognoficit enãfingulare; quîenim fieri pōt, vit.fingularitatem cognof cat, fi omnia protfus fin Jularia 1 gnoret? Aui horitate quog; Arift. Declaramaniteita hre jententia comprobatur, qui in' 3 . tro cont. lib.de Anima cont. 9. \& 10. inquit intell ectú co- 2. Eे 10. gnofcere \& carnem, \& carnis efle, nil aliud no- ins.libr. inive carris fignificans, quám fingulare, ficuti de Aniefle camis ibi ugnificat effentiam \& vniuerfale, ma. quemadmodum iplemet Arift, ibidem declarat dicens carnem efle cum materia, effentian vero carnis elle fine materia; etenim in cont.92. lib.1. de Colo, dixerat vniueriale efre formam, fingulare autem efle formam cum materia miftam: reliqua etiä, qux in eo cont.ioab Arift.ad id declarandum dicuntur, hoc magis cófrmant; docensenim modum, quo intellectus \& carnë, \&z

E carnis eflèritia cognofcit, inı̧ùit ipfum cognofere carnem ope loluus fenfus, ne epe phantalix, qua elt faculias antma fenfibilis;effentiam vero carnis non ipfirs fenfus ope, fed alterius fepa. rati,feu etram ipfius qquidem fenfus, aliter tame fefe habentis; denotare per hac volens mentem. noftram ad fingulare cognofcendum non egere intellectu agente, fed folo phantafix minifterio illid cognofcere, tanquam torum quoddam ri1de atq; confufum, hoc enim ab intellectu comF prehcnditur etian fine ope intell ęus agentis; ledad intelligendam rei effentiam indigere alio, fcilicet intellectu agente confufum illud illuminante; feu (quodidem eft) eodem fenfu: aliterfe habente, hoceit, phantafia ab intellequagente illuminata, nam phantafma a b agente illuitratum imprimit in intellectu etiam ipeciem uniuerfalis, \& effentise rei ideorede comparat Arifotel. cognitionem fingularis cum linea rect 2 , vuiuerfalis autem \& eflentix cîlinea.

fexa. 
flexa, feufracta; n am fingulare à phantafia ad $A$ intellectum tanquä per rectam lineam protenditur, vniuerfale verò, \& effentia rei tanquam perflexā ; qua lumen agentis primò ad phantafiā porrigitur, deinde $a b c a$ ad intellectü reflectitur:hæc ef illius locivcra interpretatio, ex qua apertè fumitur $A$ rift. cenfuifle intelledtū noftrì cognofcere lingularia; inde etiă fumitur phantafmata à menteagéte illuminari in phantafia, nò vt in intellectu recepta,fic enim lumēagentis frä gitur quodãmodo in phātafra, quod nullomodo frangidiceretur, fi recà ad intellectū noftrü mitteretur. Praterea in contextu vigelimo fecundo, \& trigefimotertio eiufdem 3 . libri Ariftoteles afferit intellectum cognofere partes temporis, præteritam, \& futuram; \& res, quæ in eis fiunt, fimul cum tenspore, in quo funt; \& i! a deliberare conferendopræterita cum præfentibus : vult igitur intellectuth cognofere fingularia; quia 1lla, qux in ftatutis, ac diftinctistemporibus fiunt, fingularia tạntùm funt; nam vniuerfalia femper funt, nec magis praterito tempore, quàm itituro; quare folis fingularibus competit appellatio præteriti, \& futuri: noftrum igitur intellectum fingularia cognofcere fecundum Ariftot. negari non poteft.

\section{Contrariorum argumentorum folutio.} cap. IIII.

Adprimumar

gumentนm.

Adfecun drum. Voniam igitur confiderantibus fatis mâ-
nifefta hæcreseft, intendum eftargumenta loluere, qux veritati tenebras offendsrevidebantur. primum erat:forma abiuncta a materia non intelligit fingulara, intellectus eft forma abiuneta à materiá, igiturfingularia non intelligit: vaniffirnü certeargumensum, cuius vtraq; propofitio falfa eft: falfam qudè effe maiorem, certiffimum eft; jam quicquid fen ferit Arifotel. credere nos, \& conftaner affir mare Chriftianx fidei veritate compeilimut, Deum habere prouidêtiam fingulariun. \& 111 a cognofecre, proindeformam a materia abiunctam cognofcere fingularia ; cur igitur huriana mens cognofcere fingularia non potett? fed dimifla propofitione maiore fatis in prafentia eft niegare minorem ; aliâs cnim oftendimus mentém humanam in honine non effe formam à matetia abiunctan, vtilli fumunt abiunctain à materia, prout opponitur informanti ; fed effefor-" mam, qua homo eft homo, \& in fpecie conftituitur: quare etiam fi concederemus formann à $F$ materia lepuratam non poffe fingularia intelligere, argumentum tamen nobis non obeffet; quia mens humanain hominenon eft talis for$\mathrm{ma}$, froinde hac ratione fingularia cognofere non prohibetur; quare nullius roboris argime $\vec{c}$ tum eft. Validuis effe videtur fecundum, quod funebatur ex abiunctione ab organo : abiunctus enmm eft incellectus in fua operatione ab argano corporeo, quare non videtur polfe fin-
A gularia, qux naterialia funt, intelligere; quicguid enim recipiturin aliquo, ad modum recipientis recipitur. Ad hoc dicimus negandam effec confequentian:quod verò ad probationem attinet, digna quidem confideratione eft propofitio illa, quicquid recipitur inaliquo, recipiturád modum recipientis, multi nam que ea ad cauillandum abuti confueuerunt; fed vtcunque intelligatur, nobis non obcft: fingulare enim, quod extrannimam exiftit, matcriale eft, neque recipi in insellectu poteft, imò neque in fen fit, quum A rift. dicat fenlorium recipere fpecies fine materia; fpecies autem ipfius fingularis non eft marerialis, fed fp rital s: nihil igit ur prohibet quin eiurmodi fpccics in intellectu recipi poffit, fic enim diciturrecipiad modü recipientis, quoniam intellectus habet aptitudinem naturalem recipiendi omnia fpiritaliter, etiam fpeciem fin. gularis, \& quum ipfe in operando fit immaterialis, quatenus uon vtitur organoad recipien $\rightarrow$ dum:fpeciem quoque fine materia recipit:nam fi organum fenfus, quod curporcum eft, recipit formas fine materia, nulio magis de intellectu idafferere debenus, im nò credenduin eft ipeciem in phanta elfe fpiritliorem, quän in fenfu, in intell cetuatem effeadhuc piritalio$\mathrm{rem}$, quám in plianiafia ; neque nobis officit quod fit fpecies rei materialis, nam etian quiddita eft quidditasrei mateiajis; \& licèt perreprefentationem fit materialis, quia rem materialem reprafentat, tamin ipfa fecuñdum fe fpecies formal iter fumpta fpiritalis eft, poteft is gitur in intellecturecipi: fi verodicant peciem fingularis confufi effe quidem abiunctam à materia, at non à conditionibus materix, veriffmum hoc quidem eft, at vndenam acceperint, noin poffe intellcetum noftrum cognofere etiàn condiciones mai eriales? nos enim dicimus intellectum foffermnia intelligere, etiam con ditiones materiales, \& remicum conditionibus materealibus; femper tamen per receptionera fpeciei formaliter immacrialis, licetrem ma. teriali $m$, vel materialis conditionesteprefen tât is : ideo fano modo in elligendaeft differen tia illa, quain muli ftatunt inter has animx fácultates fubo:dinaras, dicunt enin fonfum cognofcere abitrahendo à mareria, fed non à condıcionibus materix, neque à prafentia materiz; phantafiam yeroabftrahendo \& à materia, \& à pix cntra materix, fed non à conditionibus mites ix, qux funt accidentia(vrvocant) indiuiduantia; at intelleçu abftrahere å à materia, \& à prafentia materix, \& à conditionibus materiæe hoc enum,vià plerifiq; intelligitur, falfumeft, nempertnceeffrium fit intellectíab his omnib abitrahere, fed verumeft, if itaintelligatur, vt \& intelleetus, \& phantafia, \& fenfus frub ab

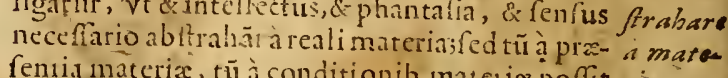

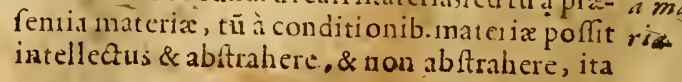


vtctiam fine his duabus abfraetionibus porfit $\mathbf{A}$ intelligere, ficenim etiam phantafia imaginari poteft \& cumi abfractione à profentia materix, oc absque hac abfraenonejeft enim rationiconfentaneurn vt intellectus polfit id, quod inferiores faculiates pofiunt, $\&$ al iquid preterea, ita vt \& rem prafentem, \&e materiales cōditiones co. gnofcerepothisquoderiam al a facultates porfunt, fed ab his et omnibus vniuerfale, \& quidditatemabfrabere, $g$ aliz non potfunt, ex qua operatione nomiratu: intelle etus fpeculatiuus, quia proprie fpecularieftrerú eflentias cognofcere. Seddubitarchicaliquis non absq: ratione poteft de cognitione prim $x$ materix : fi namque necefiariurs et vt oếs facultates anima abitra- hant formam à materia, videturprimãm materian non porte modo vllo cognofrs, quuin non polfitabitiahi àfeipra. Ad hoc dicendum eft abftractionem à materia hic nen intelligi à prima materia, fed à materia fingulari fenfili, qux extra animam exiftit; hancenim vocamus fenfilem, quia eft obiř etú potens mouere fenfurm, \& fenfus recipit eius fpecié non recipiendo ipfammet realem materiam, \& ita dicitur abftrahereà materia,fic etiä phantafia, \& intellectus: ideo etiam prima maceria, quū nec fenfum, necphantafia mouere poffit, à folo intellectu cognofcirur, \& per abftractionem à materia, non quidé à feipfa, fed à materia fenfili, in qua abfcondita eft, imo magna ét ab tractione indiget, vi intelligi poffit:quum.n.fit minima entitatis, inftar tenu fima linex, qua vix difcerni poteft, maxime omnium eget lumine intellectus agentis, vt à noftro intellectu eius natura infpici queat, \& maximo êt noftri incellectusacumine, \& exercitatione in rebus contẹplandis, "z maxima phantafmatü puritate. Ad tertiū argumétum fumen. da eft rêfponfio exiis, que modo diet a funt;non enim per hoc diftinguirur intellectus à fenfi, $q$ nó poftir intelligere fingulare, fed per cognitionem vniuerfalis:nōeft enim neceffrium, vteas, qux inter fe differunt, in omnib.differant: cöueniunt igitur fenfus \& intellectus in cognizione fingularis, fed difinguuntur per cognitione vnidquar uerfalis, cquz folius intellectus propriz eft. Sim:liter ad quartú dicim us Arift. in iis omnib. locis tribuere intelle etui cognitione vniuerfalis, quia eit eius propria, fed nunquam dicere intell ectü cognof cere folum visiueriale: adde $q$ pracipua operatiointcllectus eft cognitio vniuerfaliù, \& ad hanctanquam ád finẹ dirigitur cognitıo fin. gularium, quia roo pófet intelligere vaiuerfale, nifi etiā fungulare cognof ceret;rede ig tur cōltituitur operatio intellectus in cognitịne vnuerfalium, quia haceft pracipua, \& finalis eius operatio,quum cognitio fingulanum fir potil. medium quodala neceffariü, fine quo ad vniveríad quin liū cognitionem peruenirenon poffet. Sicetiam ad poitrem um dicend $\bar{u}$ et ; quande enim srift. inquit, omne habens materiadid efe poreftace intelligibile, carens aŭt materia effe actu intellibile, fi per carés materia fignificet omneabiunctù à reali materia, ergo fpecies coloris recepta in oculo eritactuintelligibilis, quum fit forma abiuncta ì fuareal materia; hoctamen dicendü non cit, quoniam Arift dicensactu intelligibile, fignificare vult aliquod à folo intellęu cognofcibile, quareper cares materia ibi fignificat folum vniueriale, \& quidditaie, caret enim materia penitus, quatenus eft fine condixionibus ma. B terix, cui üruodi non eft fpecies in fenfu, neque phantafraa in phantafia: fingulareautem vt abiunctura à reali materia nö minus côt fenfibile. 乌̆ intelligibile, \& partim ef̂f fine materia, quatenus eft fine reali materia, parcim cunı matcria, quatenus eft cü conditionibus materiz: refpiciens igitur Arift. vniuerfale, $\Phi$ eft vere, \& propricintelligibile, \& cuius cognitio eft propria intellectus, a finalis, as pracipua cius operatio, hoc folü vocauitaktu intelligibile; quamuis .n. C intelligat ét fingulare, hoc tamen ei datū eft tăquam praparatio quadam neceffaria ad cognofcendï vniuerfale, non vt in 1 p fo fingulari quiefcat, ideofingulare ibi non vocaturaetu intelligibsle:hoc fignificat in eocontext. Is. Ariftoteles, quando dicit [ fientzafpeculatisa, EF fibile idem est] ípeculatio enim non vocatur nifi vniuerfalium cognitio, \& contemplatio quidditatum: quare de hac fola fibi Arift. loquitur, quix hac fola eft propria operatio intellectus. Sic ad $A d$ Jecrz$D$ poftremum argumentum dicendum eft. Diftin- dwm. gutens enim Arift.intelligibilia à fenfil ibus, przcipuur, \& proprium intellectus obiectum refpexit; hoc enim à fenfunō percipitur, red à folo intellectu, proinde vocatur proprie intelligibile: fingularia vero; qux fub fenfum cadunt, licet cognofcátur etiamab intellę̂tu, maluit tamen appellarefenfilia, quam intelligib lia; quia in his proprie verfatur fenfus, intelletus vero proprie in illis, qua non percipiuntur à fenfu: E pernde ergo eftac fi Arift. diceret, eoum, çuz Cunt, alia fub fenfum cadunt, alia non cadunt, \&e hac inrelleatus cognofcit: pottrat quidem dicere cmnia effe intelligibulia, fed meliss effe iudicauit vt fingulana fenibila fencui attribueret, quam intellekui, reliqua vero intelleEtui, qua fenfupercipi nequcunt. Adde quod, etfi fingulara fun \& fenfilia \& inteligibilin, non tamen ex rasore mefenfilia, qua junt inrelligbiliainoues : erinifenfan ve iuncta rea-

F limaterı, incellectum verovt faça fpiritalia in phantalia, ab uf fo eniu realiobiecto non parererur intellectus; fic igitur fenfilia, vt fenfiliz, non funt intelligibllia.

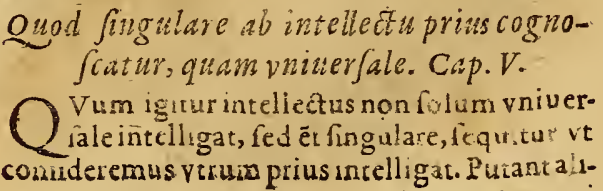


omnia cognofceret intelledus, fi modurn fin- A gularis, quofingularea feulucognolicita, iple nera. nonin:elligeret. Eift pratereaindictis Iauelli reffio on pugnantia manifelta:nam in quaftic n.is.quinti ctis la- Mctaphy r. ipfe opinionem D. Thom requens 4i. deprincipiofingularitatis afierit ipfum effe materiam ; crgo fecundum hanc cus jententiam dicere quakenus fingulare elt dicere quatenus materiale, nam dietıo illa, guatenus, nota rationé formalem; ingulare, igitur, fi eftint ligibile quatenus fingulare, eft intelligibilequatenus materiale; quomodoergo aficut cfie intelligibilevt fingulare, \& negat effe intelligibilc vt materiale? Argune éta quoyj ipfus facileioluun-

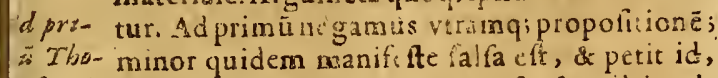
- farä. quod probandun erat, nempe fenfumabintellectudifferre per hoc quod prinuo cognofcit fingulare; dicimus enim non perid feníum differre ab intellectu, fed per hoc, qquod lenfus in fingularigradum fiftit, \& iffum folun coginolit, intcllectus vero in eo non fifit, fedprogrediurad vniuerfale ranquam ad pracipuum, \& finale obiectum: fic enim nec phantalia per hoc differt à fenfu, quodnon incupıat ab imaginationerei prafentis, à qua fenfus incipit, fedincipit ipra quoque à ccgnitione rei prafentis, \& differtà feriu non per hoc, fed quia imaginari poteft tetiam ress abfentem; gucd veroad maiorem attinet, quando dicit, illudelt primo intell gibile ab intelleçu, quo piimoditinguiturintellectusà fenfu, quumbisponat ean diktionem, primo, confiderandum eit quomodream fumat; velenim vercbique intclligit primitate originis, yt intellgere deber, quia de has tantum loquimur, \& hacratione maior eff falfa; nonenime intelecus differt ì renif perid: quod pumo int lligit primitate onginis, imo in hoc conuenit cū enfu; fi vero vtrobiaue accipiat primitatem piricipalitatis, vera efitmaior, fed ad remnonfaci, differe namque intelkctum à feníu concedimusper cognisionem vniserfalis, quodprimo,

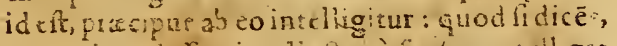
quoprixo difertintelletus a fentu, intell gat quo pracipuo, dicens aurem, illud efprimo intelligble, arteligat fecundumorginem, falia fic queque en maier; naim pracipucutinguitur intelletus a fonfupcrognitionem vniucriahs, non tamen hoc primum cognofit fecundum originem; quumenim hac fie pracipua, of fina. lis opesatio, debetefle poltesor cogutione fingwlars, quoniam illa, qua ad fnem diriguntur, ddfecun debent ipfifinanteire. Ad fecundum poliumus negare cosict quentiam, quia perticton, \& actuatio intellectus nen confitit in cognitione fingularis; quod fi tueri etiam conrendat hanc efie afuationem aliquam, poffumus cotum conce-

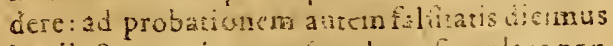
intuilecum ad cognoferdum fingularenon indiguifie intellefu agente, fedpropter abitra- etianem vniuerfalis; quoniam igiturcognitio vniserfalium cot pracipua, \& proptia epcraico intellectus, fuit ei nectfls:ia opera intellcc?us agentis, 3 hoc pronuntiatur clare ab Ariftotele in eo cont.10.lib.3.de Anina : ideo arguincutum quogue, quod inde I.nellus fumit, vanume fr, \& nititurprax eius !oci interpretationi, Aritt. enim cognitiontm lingularis ibi compusticum linearects, noncesm obliqua, proirde vulefingulare primo intelligi, non yniuerfale. Plurs bac

B dt: relegi pohinnt apid Gregorium Ariminen fers 1. Sent. dittinet. 3. quatr. 3 .

\section{Declaratio quafions deordme intelligen- di vniuserfulia Cap. VI.}

$\mathrm{H}$

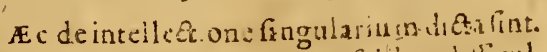
Multo maior nos de vniucrfalibus diticultas manet: quura eaimalia magis, alia mirus y. niverfaliafint, dubium eft vtrum priusabintelC lectu orgnofcaiur, ais magis vniueriale, ain mi. nus ; vt an prius in minte hofira tsprimaturcóceptus corporis, deinde concepus viue ex deil-
deanimalis, deindehominis, \& equi, \& aliarum fpecierum, an è contrario, primum cognof́carur fpecies, deingenusp o, inquius, deinde alia rimotiora, \& poftremo omnium id, $q$ fupremum eft: lonuimuratem detemporis tantum atque originis ordine, \& defolacognitione cenfufa, ho eft se primarudi horum timylicium conceptum intrefione in nobis ; etenin diftinea cognitionis ordinem al bitran mone iam diximus, ideoq; de ip fo pracepta a Logscorradinec vllus vaquan dubitauit; quin in adipilcenda difincta rerü notria neceflarium fit phiusviniterfalioracogrofiere, quä minus vniuer falia, qua nequeñe has perfecte cognofoi, ajiblla linespfecte cognitajeftenin gerus de cirnua lpecisi, proinde uon potet perfecte cognafici pecies ignorato genere; igitur necefie claprius uatu-

E iäcorporis intelligere, quam naturatri vintentis, whanc prius, quata naturam animalis, in hase prus qua naturas proprias fpecienm : hoco:dinc traditan ab Ariftere naturalem philofophiam nos in libr. nontro de Natanalis licntix confitutionedemóltramus, eumo; ordinem in 4 cont. lib. 1. Phy raufcult ab Arift propoficu efle arbitiamur. De hoc igisui diftinde congitionis ordine, nos in przintria éo lo quinur, icd. deordine cognitionis confula, quë cognofcere F potius nosoportetverenaturalem, ße nue is no1tr $x$ propmetaterr quaniam cognitu diginam. quam vlla de lroc presepta trajere; quádoguidemilla, quænon in nostro arbitrio poíta, ied naturalia, \& necelaria hut, fub fcientiam yotius, quam fub praceptiones noftras cajerevidentur. Pizicrea neq confufa notitiz noftra curs dift: 2 a comparationem v!lam in preten-

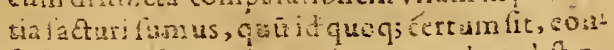
furam cuibque rei notiam prasedere diftn. 
etre cognitionieiufdem rei : dimifa igitur peni- A lare, \& illipropinquior eft fecies, quam genus; tus cognitione diftincta, folum confufam con. fideraturi fumus, \& rationeduce inueftigaturi, an cognitione confufa prius origine, ac tem p.o. re cognofcatur à noftro intelleetu magis vniueriale,an minus vniuerfale.

\section{Scotiopinio \& argumenta. Cap. VII.}

T Arix hacdere opiniones extiterunt, quarum dux extrema, \& contrarix funt, vna Thom $x$, altera Scoti, alize veromedix. Scotus in 1 . Sentent.diftınct. 3.q.2.aferit minus vniuerfale, hoceft vltimam féciem, efie primú cógnitum ab intellectu noftro cognitione confufa, \& ad id probandum tribus argumentis vtitur. Pri-

Primum mum, quod à $S$ cotiftis validifimum efie cenfeargumé. tur, tale eft : agēs naturale fatis propinquum patwm. tienti fufficienter praparato, atq; idoneo ad recipiendum, feclufo omni impedimento, producit effectum perfectifimum, quem producere poteit; proponaturigitur cognof cendus homo in diftantia debita conftitutus, qui pofit mouere, \& cognofici is vt corpus, \& vtanimal, \& vt homo, obiectum hoc eft agens naturale conuenienter propinquum, necimpeditum, intellectusautem nofter eft naturaliter aptus, ac praparatusad omnem concep tum recipiendí; ergo prius imprimetur in intellectu conceptus hom: nis, qui aliorum perfeetiffinus eft; potentia năq; imprimendi conceptum hominis tanquan validior praualebitaliis, Ccilicet potentiæ imprimendi conceptum corporis, \& conceptum animalis ; itaque prius cognof cetur homo, quam a-

secundü nimal, \& corpus. Secundo ita argumétatúr Scotus: fi primum cognicum effer magis vniueríale, diuina fcientia effet omnium prima fecundum ordinem noftrum cognofcendi; confequęs fal. fum eft, yt eius inferiptio declarat, infcribiturenim $\mu \varepsilon \tau \dot{\alpha} \tau \dot{\alpha} \phi v \sigma i \dot{\alpha}$, hoceft poft naturalem fcientiam addifcenda : patet confequentia; quia fubiętum Metaphyfica eft ens prout ens eft, quod eftomnium amplifimum, quere eftet et-

Tertium lam ncbis omnium notiffimum. Tertio fic: fi primum cognitum effer magis vniuerfale, maximun tempus interponereturantequà à fummogeneread fueciem infimam peiueniremus, quia tranfeundum eft per omnia genera media, quorum aliqua funt ignota, vt ait $A$ rift. in cont. 28. feptimi Métaphylicorum, vbi dicitignora-

Quartü. ri proximum genusatini, \& equi. Quarto:dem fic confirmarepofiumus: ita fe habet fpecies ad genus, vr fingulare ad fpeciem; vt enim fingularefub fpeciceft, \& ea de ipfopradicatur in quid, itafpecies eftub genere, qued de eain quidpracicatur;atquindiuduurn cégnoliturabintellectuprius quarm ffececs, ficut ante oftéium eft;

Quintü. ergoctan ipecies prius, quam genus. Pisterea resiudicantura agis, vel minus tales exmaiore, vel minore propinquitatead primum talejarqui id, quod primum omnium intelligitur, eft finguergo prius ab intellectu cognofitur fpecies, quam genus.

Thome opinio orargumenta. CAp. VIII. 7 Homas vero in procmio r. Phyfic. \& in r. 1 part. Summ. quaft. 85. contrariam fententiam tuetur, primum cognıtum cognitione cōfufa effe mag!s vniuerfale; eamque probat auEtoritate Ariftot. in proœnio L. Phyfic. qui eam $B$ manifefte pronuntiare videtur, dicens à magis vniuerfalibus ad minus vniuerfalia progredicn. dum efre tanquamà notioribus nobis: probat etiam hoc Ariftotel. ibidem hoc pacto: omne totum cognofcitur prius, quām partes, tum à fenfu,tum ab intellectu; at magis vniuerfale refpectu minus vniuerfalis eft totum quoddam, quedetiam Porphyrius afferit in capite de Spe. ciejergo prius ab intellectu conofcitur id, quod magis vniuerfale eft, quam id, quod minus. $V$ ti-

C tur praterea Thomas tali agrumento, quo buiufce rei rationem, \& caufam ad ducere videtur: mens noftra, quando nafeimur,eft ficuti tabella abrafa, in qua nihil defcriptum eft;n on poteft igitur à perfecta ignorantia ad perfectam fcientiam tranfire, nifi per media; atqui perfecta cognitio eft cognitio infima fpeciei, cognitio verovniuerfalium eft confufa, \& potentialis, quia cognitio animalis eft hominis cognitio poteftate, \& confufe; debet igirur aufpicari ab vniuerD falioribus, quorum cognitio confulior atque imperfectior eft, deindeper differentias defen. dere, donec plenam, \& perfeetsam vltimarum fpecierum cognitionem adipifcatur, harumenim perfecta cognitio eft finis noftr $x$ contenplationis. Experientia quoque hoc compro- Terti: batur: nam multorum animalium, ac multarum ftirpium fpeciem, \& naturam propriam ignoramus, genus tamen cognofcimus, \& inter genera illud magis cognofcimus, quod comE muniuseft: cuiusnulla alia effe videtur ratio, quam quod facilius cognitu eft genus, quã fpecies, proinde etiam privs cognoffectur ; nam id, quod facilius cognitu eft, prius tempore cognofcitur, quum cognitio noftra à facilior bus incipiat. Pratereaidem confirmatur exemploillo vulgaı animalis à rem oto loco venientıs : primum enim non cognofcitur, nifi ve corpus, quia difcernere adhuc non poffumus an fit animal, an corpus aliqued inanimatum; poftea vero propinquius factum cognofcitur efre animal, at non difcernituran fit homo, an equus, an afinus; poftea vero cognofcitur etian vt homo: quoniă igitur ex fentione intellectiofit, eodem ordine deber intrllectus vniuerfalia intelligere, quo a lenfu ingulariafentiuntur;à fenfu autem illud cognofcitur primu m vt hoc corpus, dein. de vt hocanimal, tandem verovt hichomo; fi. militer ergo ab intellectudebetprimum concipi corpus, deinde animal, tandem vero homo. 
Horum autem argumertorum vis, \& efficacitas poftea quum huiufce rei veri tatem declarabimus, diligentius expendetur.

\section{Genus opinio, \& predictarum opinionum conciliatio. Cap. $V$.}

T. As duas contraras Thom $x$, \& Scotifententias M. Antonius Genua preceptor meus putauit media quadam opinione polie conciliari : dixit cnim diftinguendam cfle cognitionem, duplexenim eft; vna aetualis altcra habitualis; aetualıs cognitio eft quxlibet prialis, ma cuinfque rei appichenfio ex phantafinate uid oblato inclleetui, \& ipfum mouenteatu; hatua- bitualis vero eft quædam naturalis aptitudo, \& cun- propenfio tum rerum cognof cibilium, vt ordiqlios. ne quodam ab intellecturecipiatur, tum ipfius intelleceus ad eas ordinatim recipiendas: hac diftin Atione conftituta dicebat Thomam \& Scotum concordes cfie, quum ambo dixcrint coguitione confufa actuali primum cognitum effe fpeciem infimam, coginitione autem confura habituali promun cognitum effe id, quod eft maxime vniucrfale : hanc Scoti fententiā fuifre facile often debat confiderando ea, qua à Scoto dicuntur in pradiata fua quattionc; ibi namque Scotus dicit, fi confideremusaptitudinem? feu habilitatem intellectus vtab obiectis perficiatur, \& ipfaxum quoque rerum apticudinem vtipfum perficiant ordine quodam, is ordo talis cft, vt prius communiores eonceptus fint imprimendi, quam minus communes, natura enum in omnibus progrediturab imperfecto ad perfectum : at qusando accedit intellectus ad atum ipfum apprehendendi; \& cognofendi, perturbatur hic ordo, \& impeditura ácultate motrice infimæfpeciei, quæ validior eft, quum eius fingulare validius moueat fen rum; proindefaciat vt prius in intellectu imprimatur rpecies q lam genus: quare dubitandum non eft vtrunque dienum manifefte à Scoto fuiffe prolatum. Quod vero eriam. Thomas vtrumque protulerit, oftendere nitebatur cöfiderando ca, quæabipfo dicuntur in prædictio procemio I. Phyfic. nam ibi in cont. 5 . Thomas aflerit hoc nomen, homo, notius nobis effe quam partes definitionis, animál, \& rationale; quas e conce. dit hominem effe nobis notiorem.cognitione confura, quā animal, refpicitenim actualem cognitionem, quan etram Scotus refpexit : quando autem dicit vniuerfalius effe nobis notius, refpicit habitualem cognitionem, non amplius åtialem, vecius verba declarant; inquit enim incellectum tendentem ad perfectionem a dipifcendam aufpicau primum à cognitionererun yniuerfaliorum, cquimperfectiores funt; $8 \mathrm{ab}$ is ad minus vniueriales tranfife, doncc ad infimam ipeciem queperfe Qiffima eft, peruenit; fic autem Thomas denotat cognitionem habitua:em, quun cófide et natuatemillan mete-
A leetus habilitatem vt ordine quodam diuerfos habitus auipifcatur, quxe confentanca ctian eft ipfi naturx, qux in operando procedere Temper folet ab imperfectioribus ad perfectiona Sed hæc dicens Genua videtur potius in omnibusad vnguenrfequi opinionem Scoti, \& nitiad cam Concilia. trahereverba Thomx, quam aliquidmediun, tsonis coquoilliconcilicintur, adducre: Scotusenim in futalio. illa fua quaftıonc tum vtitur illa ipfa diftinetionenotitix actualis, \& habitualis, tum hxe tria $B$ dictaprobat; cognitioneactuali confufa primü cognitum effe minus vniucrafale; cognitione actuali diftincta primum cognitum efle magis vniuerfale; cognitione habiuali promū cognntum efle magis vniuerfale; qux omnia fequens, Genuanitiurea Thom attribuere. Attamen primum dictum à fententia Thomx alieniflimum eft, qui abfque dubio putauit cognitione actualı confufa primum cognitum elfe magis vniuerale: dicens enim mentem noftram naici $v t$ tabellam abrafam, in quanihil fociptum ert, \& aufpicari à conceptibus impcrfectioribus; non folam aptitudinê refpicit, fed actum ip fum apprehendendi, hüc enim vult effe aptiudini confentaneum, itavt, quo ordinc aptus eftintellectus res apprehendere, \& quo ipierint apre apprehendi, coipfo apprehendanturabint ellectu, neqg; vllam impedimentimentioné facit:contra vero Scotus inquit actu aptitudini contrarinm effepropter impedimentum illatum à magna vi motrice fpeciei, quod quidem neque à Thoma dicitur, neq; videtur enle côfentaneum rationi, quia natura ni h1] fruftra facit; quare non debuit mentinoftratribuere hancnaturalem aptitudi. nem vt certo ordine res çognof cat, fi nuinquam feruandus hic ordo erat; fed potius contrarius; fic enim propenfio illa naturatis nunquam ducereturad actum, quod dicendum effenon vi. detur. Neque verba Thom in concex. s. primi E Phyfic.id, quod Genua cxiftimauit, fignificare poifunt: ibi namque \& Thomas, \& Ariftot. fiecrem confiderant tanquam totum definibile, quod dicunt notius etfe patribus definitionis, hocautcm dicere nihil alind eft, quam dicere -speciem prius cognofci confure, quam diftinete, yuod quidem clarum eit, \& à nemine vnquam negatü : ideo anmaduertendmm eftanimal refpecru hominis pofle duobus modis confiderari ; vno modo vt eius pars effentialis, qua F ratione homo vt totum cońrufum notius eft animali vt parte, idque ibilignificare Thomas volust, vt legen ibus manifefrum ett: al cero autem modo vt totum potentıale continens hominem vt partem in quo fenti ibi no accipıtur: pars. fed putauit Thomas genusita acceptum vf totum quoddam confusum effe priuscognitum cognitione confufa, quam fpeciem, quod 1amen Scoils negatic; noc autem eit, de quo nunceit nobis pióforì difpuratio: q'areT Tomas, \& Scoius hac in re concordes nun ium.
Animal refperis bomrais ejt $\Theta^{2}$ to t.m उु

$$
\text { LL Zima- }
$$




\section{Zimare, A Achilliniopinio. Cap.X.}

M Arcus Antonius Zimara, \& Alexander Achillinus prædictis argumentis moti in mediam quandim fententiam incidetît; quam utiflmam efie exiftimarunt : dixerunt enim \& Thome, \& Scoti opinionem vniuerfe fumptam vtram q; falfam efle, veram tamen effe vtramq; vt particularem, quin in quibusdam notũ prius eft magis vniuerfale, in quibusdam veio minus vniueriale, proinde nullam certam vniuerfalem regulam de primo cognito tradi poffe:idcoque errafe Thomam dicétem in omnibus primum cognitum effe magis vniuerfale, errafle etiam Scotum putantem minusvniuerfale in omnibus efle primum cognitum; quanquam(dieınt) minuserratit Thomas, quia fapius euenit vt magis rniuerfale fit primum cognitum, quam vt minus viniuerfale. Quodautem vtrumque contingat, probant fic : multi cognofcunt id, quod offertur, effe herbam, fed quanam herba fpeciesfit ignorant; \& cognof cunt aliquod effe animal, qux vero animalis fpecies, ignorant; tunc igitur eft illis prius cognitum magis vniuerale, quam minus vniuerfale, quandoque tamen contrarium contingit;nam Arift. 7. Metaphyf.cont.28. inquitaliqua genera meçia ignorari,vt proximum genus equi, \& afini; tunc igitur notior eft fpecies, quam genus, quum fipecies equi, \& afini cognofantur, proximum autem eortim genusignoretur. Huius diuerfitatis caufam refert Zimara in fenfum : omns enim intellectualis cognitioà fenfu pendet, fenfilia: vero quæ per fe, \& proprie fentiuntur, accidentia funt, deo ex horum varietate prouenit in intellectu hac diuerfitas; quando enim accidentia gencris funt magis fentilia, quam accidentia joeciei, tunc prius cognof citurab intellectu genus, quam fpecies; quandoautem magis fenfilin funtaccidentia fpeciei, quamaccidentia generis, prus cognolicitur ab intellectu fpecies, qum genus; magisenim fenfilia funt accidétia frop ria equi \& aini, quam al cidentia proximi eorum generis, ideo prius cognitæ funt intellecuil: foccies quam illud genus. Hæc fuit ho, numfententia qua quantum in fe veritatis ham Lcat,yofteare cognita intclligetur.

\section{Nofrracognitionis diffinctio: Cap. XI:}

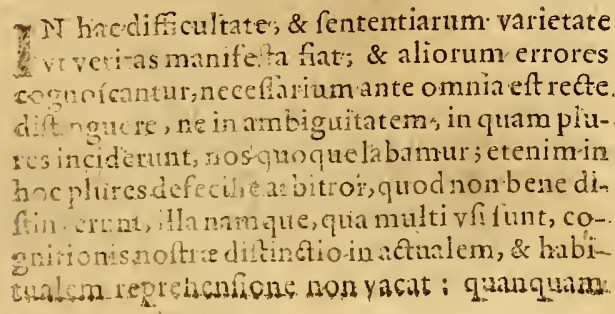

A enim nominum impofitiones, \& appellationes arbitrarizeffe videntur, conuenit tilmen à proprijs vocabulorum finnificationibus non recedere, quod illifecerüt,dum cognitionem habitualem impropric admodum ab eis acceptam ab actuali diftinxerunt: quemadmodum enim potentia acquirendi habitum non recte habitus nominatur, ita neq; aptitudo intellectus ad habifus ordinatim comparandos recte appellatur cognitio habitualis, quum neque adhuc cogni-

B tio lit, neq; habitus vllus in intellectu infit, red reatus potentialis appellaretur; fic enim opponi polfet cognitioniąuali quoniam actui non habitus opponitur, fed potétia:qux autem proprie fit vocăda habitualis cognitio, poltea corrfiderabimus : nunc dicimus nil a liud fua illa diftinctione eos fignificaffe, quä noftram cognitionem vel actualem effe, vel potentialem, conftat enim eos pro potentiali habitualem accepiffe: vnde alium ipforum errorem colligimns, C quod de vtraque hac cognitione duo contraria dicta protulerunt, quum tamen idem de vtraq; afferendum fit; quoniam, vt pauloante dicebamus, nulla naturalis aptitu do poteft effe fruftra, aptitudo autem noftri intellectus ad res certo. ordine intelligendas non poteft efle potentia. Logica, quum infit intellectui etiam nobis non. cogitantibus: proinde ad actúm ducenda eft, ita: v. $\mathrm{t}$ cognitio a $\mathrm{etualis} \mathrm{eodem} \mathrm{ordine} \mathrm{acquiratur,}$ quo naturaliter apta eft acquiri, \& debita feruetur confonantia in rebus natura;idem ergoeffe debet ordo cognitionis atualis, \& cognition is. potentialis, quamilli fatis.mproprie habitua 2 leappellarunt:propterea nos dimiffa potentiali folan actuale confiderabimus; quum de vtriúsque ordine idem fentiendum fit, \& hanc oporruniore partitione ita diuidemus: omnis noftra aetualis cognitio vel confura eft, vel diftincta; qua autem vtraque fit, docet $A$ rift. in initio lib. 2.Pofter:Analyt.nam rei fimplicis cognitionem $D$ iffin habemusconfufam, quando cognof cimus is ctio co pram effe, \& ignoramus quid fit; diftincalan ve-gritio, ro quand a etiam quid fit cognof cim us; rem au- noftrou zem complexam confufe sognof cere eft ignorata caufa noffe folum quod ít, diftincte vero eft cognofcere propter quid : vtraque hrc adhuc duplex eft \& hac diftinctione omnem tollidifficultatem arbitror : fed etiam in fola confufa notitiaconfiderare fatis ef? quumide hac fola fit nobis propofita difputatio; eandèn enim diftinctionem etiam diftinct $x$ cognitioni accommodare quisq; facile poterit : certum ent actualem noftram confufam rei fimplicis noiitiam duplicem efle, velerim eft prima reiapprehêfio, quamantea nuaquả cognouimus; vel eftactualis cognitio rei etiă prius cognitæ; quădo enim mathematicusà fomno excitatusincipit contemplarialiquod theorema nathemancum, eft quidem illa actualis cognitio illius rei, nou eft tamen prima cius apprehenfio, quiailie: 
iampridem theorema illud apprehendit, \& eam rem frepius alias intellexit : prima autcm conceptuum imprefio magna ex parte in pueritia fit: ordinatim cnim res, quxà fenfibus intelleetui offeruntur, apprehendere incipimus, quas prius non cognoueranus, licet eum cognofecn di ordinem in illa atate non animaduertamus; in fingulo enim noftrum neceffe eft aliquando primum fuiffe impreffum cōceptum animalis, conceprum equi, conccptum bouts, \& alios omnes, idque vt plurimum in pucritia factū eft; euenit tamen vt etiam adultis,acfenibus offenrantur resaliqux eis antea prorfus incognitx proinde confufi earum conceptus tunc primü in illorŭ animis imprimantur, quum prius nullam prorfus earum notitiam habuerint. Quum ergo ita rem fefe habere manifeftum fit; liceat nobis hanc diftinctionem proponere tum rei, tum rocabulorum fignificationi maxime confentaneam : cognitio noftra anualis confufa duplexeft. vina originalis, altera vero habituaIis ; rectius enim habitualis appellaturilla, qux fit ex habitu iampridem acquifito, vt quando ego equum actu intelligo, cuius notitiam iampridem in pueritia acquifiui, quam mera aptitudo ad habituscomparandos;intellectus enim poftquă contraxit habitus, poteft res actu contemplari, quand o vult; ideo eam actualem cognitionem, qua fit ex habitu, voco in prefentia cognitionem habitualem:fed quando primum conceṕi anim o equĭ, illa fuit prima origo impreflionisillius conceptus, eamquc in præentia appello cognitionę originalem: quare actua lem nó accipio vt ab habituali dittinctam, ficut eam Scotus, \& alii acceperúnt, fed vt communem originali, \& habituali, quum vtram que actualem effe manifeftum fit; nec dubito quin omnesiudiciofi viri noftram hāc \& habitualis, \& actualis notitix acceptionem tanquam maxime propriam, \& rei, ac vocibus ipfis conuenientem approbaturi fint.

\section{Quodnam fit primum cognitum cognitio- ne actuali originali confusa. Cap. XII.}

Fi Ac diftinctione confituta puto totam huiufce rei veritate tribus affertionibus contineri, quarū prima de cognitionc originali talis eft: primum cognitione actuali originali cōfufa eft maxime vniuerfale, vt recte fenfit $D$. Thomas, \& cum eo Auerroes, \& Greci omnes, quam féntentiam deféndit etiam loannes Gandauenfis aduerfus Scotum in fua quastione in proemio i. Phyfic. Probatur affertio hæc multifariam: primum quidem auctoritate, \& ratione Ariftot. in co prooemio, quam fuperius quoque confiderauimus; fed ea nunc acciratius eft perpendenda : Ariftot. enim co in loco in quit, à magis vniuerfalibusad minus vniucrealia ptogrediendum efle tanquamà ào ioribus nobis
\& rationem adducit, quonizm omne totum, \& confufum notius nobis cft, qumm partes. Non latuit Scotiltas locusille, qui relpödciunt $A$ riftot.ibi loquide ordine cognitionis difin $2 x ;$; ponjio. quam in ea fcientia traditurus crat, proinde locum illum Scutonon obeffe, quum criam Sco. tus fateatur cognitionc diftineta prius efic cegnitum magis vniuerfale, quam noinus xniuerfale;fed de cognitione confufa nihil ex co loco B colligi,quüdcea ibiAriftnonloquaius: At hoc dicentes fignificant fe Arist.\& cius artificiū nem intelligere, quod breniter declaro. Aritt. ibi in 4. contex.proponensab vinuerialibusad particularia progrediendü efic, viiq: fignifacar ordinem cognitionis dirtinctx: proponit enim ordi nēferuandü in tractundis reb. naiuralibus quarum cognitioné tradendan fibi porpolut tnon coofulam, fed diftinctum; hanc enim nosadhic nō habemus, fed eam ex leçione librorī Arift. adipifcimur. l'oftea vero probās Arilt.illà cconclulionem afiumpfit eam minoré, vniuerfalius eft nobis notius quā tribus argumentis confirmauit,nec potuit intelligercalio moco notius quă cognitione contura, quod maniféftü eft in tribusillis argumentis : totum entm eft notius fenfui, quam partes cognitione confú́ : 1 one "eft nobis notius, quä definitio, cognitione confufa, vt etism expretfe ibi Arift.teltatur,dum in quit nomen fignficat totūi quoddam confufe: prima quoq; pueronū cognitio quando omnen $D$ virum vocint patrem, ¿omnem fominam matrem, eft cognitio confufa : ita q; fi conteniens, \& valida efle debentilla triplex ninoris propofi tionis probatio, non poteft min or illa intelligi, nili de cognitione confufa: præterea dicens ibi Arift. in contex.4-vniuerfale effe totum quod. dam. \& multa continere vt partes, cōfufam cognitionem denotat; id enim quod accipiturvt totum confufum, \& prius notum, quam partes, non eft nifí confúfe cognitĭ, quū ad huc cignoE rentur partes: in ordine autë cognitionis diftinctæa animal genus nó modo vt totū cognof́citur prius, quam fipecies, verum etiam ve tingularü fpecierun pars effentialis; quod quidéArift.ibi non confiderat, quia fumit totum commune vt confufe tantum cogn itum. Patet igitur Ariftot. probanteni ex ea minore concluionem pofitä in initio illius 4. contextus, argumetarià cōfufa nofra cognitione ad diftinctam, quam in ea fcientia tradere vült; ordinem enim feruandü $F$ in tradenda perfecta fententia rerum naturaliũ confirmat ex ordine cognitionis noftr $x$ confufx, tanquam ex ordine noftro addifcendi naturali prob.ıns ordinéartificiofum:nam; quemadmodum initio dicebamus, ordo, quodiftinctann rcrum notitiam comparamus, artificiofus, atque arb!trarius eft, ordoautem, quo à pueritia perfenius cognitionem rerum confufam acquirimus, naturalis eft: qumiam igitur hic confurf cognitionis ordo eiufmodieft,

$$
\mathrm{LL} 2 \text { vtprius }
$$
io. DC cías isto inj.lii. Pbyeco ,

Conjutice contex. fo 
vi prins cogroformus ea, qua magis vniuerfalia lint, poitea veroilla, qux funt minus vniuerfalia; ex lioc infert Ariftot. talemeffe deberectiam ordifem diftincte cogniticnis', quem in ca feientia fertaturtus erat: voluit autem ea ratione fignificare, artem debere in hoc naturam imitari,nempevt ordoas tificiolus, quo ad rerum fcientram adipifcendaus vtamur, lequatur mentis noftra propenfionem naturalem; ita vt eo ordine ad retum feientiam capeffendam progrediamur, quoipfo naturaliter, acfine artificionoftro res apprehendit:fic enim ordinem doftrinefequi ordinem rerum natwralium docuimusaliâs in libris de Methodis:quodautem Ariftotabordine cognitionis confurie ad ordiLib. 1 . c.10. nem diftinct $x$ cognitionis argumentetur, ex eo etiam patet, quod diftincta cognitione \& magis vnıuerfalia, \& minus vniuerfalia eo in loco incognita effe ftatuuntur: quando ergo inquit Ariftot. vniuerfalioraefie nobis notiora, non.

secundü poteft intelligere nifi cognitione confufa. Alio argume- quoque argumento hrc prima noftra affertio sum. confirmaripoteft, quod à Scoto adducitur in fua quaftione pradicta ad fuam tuendam opinionem, nec vidit Scotus illud contra ipfum facere, \&D. Thom $x$ opinioni fuffragari; imo cgo arbitrol hoc efle validifimum onnium argumen:orum, quxaduerfus Scotum pro fenteiltia noftra adduci poffint , etenim vers huius noftreaffertionis ratio, \& xquatacaufa eo argumento adducitur; Scotusita argumentatur: illud eft faciliorisintellectionis, quodeft facilioris abftraftionis; fpecies eft facilioris abftiaationis, quam genus; ergo fpecies eft facilioris intelleetionis, proinde eft prius cognita, quam genus; in eo enim confenture omnes videntur, quod ea quifaciliora cognitu funt, priusetiam cognofcantur, idg̨; vcriflimum eft, vt poftea dicemus ; maior propofitio clara eft eo fundamento confitituto, quod vniuerfalium intellectio eftabftraciio quxdam, yel non fit fine $a b$-. ftractione; minore ita probat:illud facilus abftrahitur, quod à paucioribus feparatur; at fpecies à paucioribus feparatur, genus vero à pluribus;crgo fpecies facilius abitrahitur, quam genus : maior manifefta effe videtur, minor probattirquia fpecies abiungitur mentea folis accidentibusindiuiduantibus, genusvero feparatur \& ab eisdem, \& ab jpfa quoq; fpecicinaiura, \& quanto fuperius in-caregoria genus fuerit, tanto à pluribus feparabitur, nempe ab omnib. coinfcrioribus;corpusigitureft dificillimaab. Nofacs: ftracionis, homo vero, \& equusfacillimæ. Hoc maior fit Siouargumentum manifcte ipfiadueriatur, \& ficcictab nirorquodmulticins fallaciam non-animadforticio, ucrtcrint; nam in peciefunt aggregateplures g*at'gene conditiones, a comiunetx plures difircnite, ris:prom quaningcn:re, omnes cnim conditiones, $q ! x$ de deffici- acturuntmaninali, funterianin homine, \& lios. alia pratercas idcoli animal ab homine ab-
A frahere velimus, oportet ve conditiones hominis proprias relinquamus, reliquas vero communiores accipianus; quare fpecies maiorem habetcounpofitionem, quan genus, \& genus eft fimplicius fpecie:quo uiam igiturabftrahere eft aliqua accipere dumifis aliis, certtm elt difficultatem abftractionis confifterein accipiëdo plura, relinquëdo pauca, nōn accipiendo pauca, relinquendoplura: proindein abftractione B fpeciervlima verum clt id, quod Scotus dicit, pauca relinqui; fed hoc nö fac1t abftractionéfaciliosem, vt ipfe frnnit, fed potius elifficiliorem, nam fi pauca relinquuntur, piura fumuntur: quonsam igitur in infima fpecie funt coniunctæ plurimia differentix, \& conditiones, in fupremo autem genere paucr, ideo difficillima eft abftretio infima fpeciei, fummi vero generis facillima:in co 1 gitur deceptus eftScotus; quodex paucitateiudicans abltrationis facilitate, paucitatem accepit corum, quarelinquäur, qum, eorum, qqux fumütur,accipere debuerit; fi namque aceruus lignorum proponatur, ex quo fint aliqua accipienda, \& alíqua relinquenda, certú eftacilitatem auferendi confiftere in paucitate eorum, quæaccipinntur, uon eorum, qux relin. quũtur; nam facilius eft pauca ligna auferre relinquendo multa, quam aufere multa, reliriquendo pauca. Videtur autem Scotus hoc argumento vitens ftatuiffe fundamentü hoc, quod. intellectus abftrahës hoc ab aliis debet cogno. D fcereilla alia,à quib.abftrahit; fic enim videtur abftractionis difficultas confiftere in multitudine eorum, quæ relinquuntux: fedid minime ve. rū eft, \& aduerfatur propriæ nature abftactionis, \& fignificationi huius vocis, abftrahere; nil. enım alud eftabftahere, nifrapprehendere vnum non apprehenfis aliis, vt abfrrahere animal ab homine nil aliud eft, quam folam animalis naturam in homine contemplari, propria hominis natura non confiderata; eft igitur necefE fariabltractionis conditio, vt in ipfo abftra-hendiadti reliqua non cognof cantur, \& id folum, quod apprehenditur, intelligatur; quia fi in illo actu aliaquoq cognof́cantur, nulla fit abfradio.Ideofi accepta maiore propofitione argumenti Scoti, minorem.illiveriorem fubiungamus, fietargumentumefficaciffmum ad eius lententam oppugnandam, noftam vero, acD. Thome deimontrandam:illud eft faclioris in.tellectionis, quod eft ticilioris abetrnetionis; at: F genus eft faciliorisabftractionis, quam species; ergo eft facilioris intellectionis, proinde prius; cognofcitur, quam fpecies. Vidstur etiam ferrtentia hacconlona efle opiniont omnium anty quorum philofophoum, omnes enin putarit facillimum cfererū conuenicutiam cognofcere, ciricrentias autem difficilimum; qui cnim

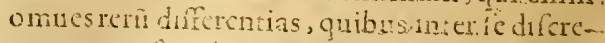

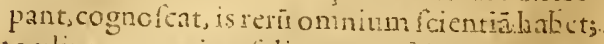

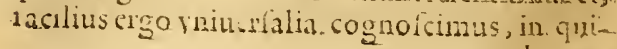


bus ies conueniunt, quam propria, quibus differunt : idque etiam quotidie experi unur, man ego aliquando vidi pilcem quendam quem putaui elle auratum pifcem, tamen pifcatores dixerunt non effe pifcem auratum, fed aliam quisdam fpeciem; ego igitur folam conuenientiam illius pifcis cum aurato animaduerti, differentiam auten non animaduerti : fic pueri conuenientiam afini cum equo, \& mulo cognof́cunt, fed cortum differentias nô difcernunt : nos qquoque adulti cognofcimus ex loco valde remoto conmenientiam equi, \& afini, \& muli, differentiam vero confpicere non poffumus, nifi propinquiores fimus; facilius igitur conuenicntia cognofcitur', quam differentia. Poffumus proxven terea argumentum fumere ab oldine fentiendi; quoniam enim omnis noftra intellectio à fenfu originem fumit; neceffe eft vt qualis eft lentiendi ordo, talis fit etiam ordo intelligend, præfertin cognitione confufa, de qua nuncloquimur: iciendum itaque eft illa, qua proprie, ac per fe fentiuntur, accidentia effe, lubftantiam autem non fentiri perfe, fed pet accidens, vt ait Ariftotel.in 2.libr.de Anima; exiftunt autem accidentia omnia un fubftantiis indiuiduis, \& quia in eisdem latent etiam naturæ omnes commues, ideo accidentium quoque hoc eft difcrimen, quod al:a inle quuntur naturam communiorem, alia naturam minus communem:nutriri enim \& aageri competit omni viuenti, proinde huic homini competit quatenus habet in fe naturam viuentis; fentire autem omni anima$\mathrm{Ji}_{i}$ \& huic homini quatenus habet anmalis naturam; loquivero homini tantum, \& huic homini quatcnus eft homo: conceptus igitur confutus rei vniuerfalis in intellectu non fit nifi ex fenfione accidentium illius vniuerfalis à fenfu facta: videtur autem omnis natura communis in fingularibus latens habere necefiario aliqua accidentia fenfilia eam infequentia; neque dicendum eft dari genus aliquod, cuius nillum fit in fingularibus fenfile accidens, ve fignificat Ariftotel.in libr. 2. Priorum Analyt.cap.vit. ibi namque videcur innuere naturam omnem relinquere aliquod in corpore veítigium fui, per quod cognofcatur; effet eninı reprehendenda natura, fialiquam communem naturam in rebus fenfilibus pofuiffet; quxnullam haberet fenfilem affectionem, per quam confufe iali em cognofcipoffit : argumento effe poteft anima nottra rationalis, quæ maxume omnium formarum materian informantium elata eft flipra materiam, feafiles tamen habet operationes,per quas in homine cognofcitur, vt docere, \& loquir, \& manibus ad pl urima opera vit ; iunt enım manus organum intellęus, non quidem ad cognof cendum, fed ad agendum : ipla quoque prima materia, quamuis à fenfibus remotiffina, iisque maxime abfcondita, habet taven in corporibus aligua renfilia accidentia
A vt quantitatem, \& mutabilitatem, pet qua mab A riltotel.demonftrata fuit: hinc colligimus fingularia non folius infim $x$ fpeciei fingularia ef1e, fed omnium quoque fupcriorum generum; Socrates enim non folum eft hichomo, verum etiam hoc anmal, \& hoc viuens, \& hoccorpus; omniaigııur fingularia, quæ in aliqua natura communi comm niant, necefle eft vt aliquibus etiam conmunibus accidentibus participent, quxillam infcquantur, \& fint sanquam fenfilia B illius figna, atque veftigia. Hæc quum ita fefe habeant, laion confonum, imo ctiam necefla. rium eft, vt ascidenti. vniucrialiorum facil us fentiantur, proindc etiam prius, quam accidentia nınu: vniuerfalium; quo fit vt etiam incelleAui prius offerantur magis vniuerialia quam minus vniuerfalia:hoc aucen probatur tum extenfionem, tum intenfionen motionis confiderando: extenfionenı quidem, qua illud magıs mout, quod rapius mouct; atqui accidentia

C corporis iapius offeruntar fenfui, quam accidentir animalis, \& accidentia animalis $f x p i u s$ quam accidentia equi: nam accidentia corporis offeruntur fenfui in omnibus corforibus tam animatis, quam inanimatis, accidentia veroa. nimalis in folis animalibus, fed non minus in cquo, qua in cane, \& in leone $\&$ in aliis, accidentia vero equi in folo equo; patet autem in omnibus exiterata, \& muluplicata actione prodirealiquid, quod ex vnico actu prouenir enópotêt, nam multæ guttæx cauant lapidem, quem neque vna, neque pauciores cauarent; itaque accidentia rerum communiorum magis agunt in fenfumakione extenfiua, quamaccidentia rerum minus communium; proinde conceptus viniuerfaliores $x_{1}$ sus offeruntur intellectui, \& magis ipfum mouent, quan cōceptus minus communes; quamobren fi tot aciuales motionesad imprimendum conceptum requirun : ur, quibus pauciores non imprimerent, neculle eft vt prius E conceptus communiores quam minus communes in int ellefu imprimaniur. Dico praterea accidenia reı um communior un magıs agere in fenfum antenfione actionis, quam accidentium minus comn un ium; propteren quod accidentia vniuerfalion um fimpliciona iant, \& pauciores differentias continent; accid $2 n: 12$ vero minus communium plures differentias comprehendunt, etenim ex neceflitate continent omues differentias vniueria'ion F renta, qua diftinguisur animal à planta, comprehenditur ab ea difercntia, qua d ft ngui.ur equus ab afino: ideo qu cegnoscit accsdentia, quibus differt equas ab a ino, necufe eit vtlimul cognof cat accidentia, qu. by suiffert animal à lanta; non tamu è cur rario, ytia poteft in equo dilcerni differentia, çna diffirt à planta, \& 1lla ignorari, qua differtabafi:10.quod id.m intellectui contirgere neccfiariü $\in$ ft: nam consepcus ammalis fimpicior eft, guam con- 
ceptus cqui, is cfic poteft fincillo; at conecptus cyui maiorem haber compofitionem, quum: necefiario contincat afu conceptum animalis; fiquidem equus elt eflentialițer animal; ideo conceptus inferiou ū in categolia, vt ctiam Scotus aferit, in fuperiorum conceprus refolumnrur: quonam igirur facilius appuchendicur vnum, quam duofimul, neceffe eft vt facilus cognofcaturanimal, quam equus; animal enim eftanimal, \& non eft cquus, equus vero eft actur \& equus, \& animal : hocautem experientia manifeste comprobatur; nam pueri prinum non diftingunt equum ab afino, neque à boue; fed cos ommes eodem nomine boues vocant, quia rudemill.m animalis figuram, \& motum confpicantur, videntque illud commune accidens, quod hi omnes currum trahunt; at particularia lineamenta figur $x$ fingulorum, \& particulares motuum conditiones nondum difcernunt, hæ namque differentix continent iHas, quare maiorem iudicandi vim in fenfrurequirunt, vt dgẽs in- videantur. Hinc fumi poteft ratio erroris Scoti; dicatur ipfe enim iudicabat agens validius adagendum Salidizs ex maiore eius perfectione quod quidē verum acnex noneft; fedagens validius efle iudicatur ex magrsaiore iore eius proportione cum patiente, hoc eft, $\mathrm{ex}$ perfectio maiore conuenientia potentix actux cum pore. fed maiore troportionecü patiente tentia paffiua patientis; in mitio autem totius noftracognitionis omnes animi noftri facul tates ruides, \& potentiales funt; ideoilla, qux funt andia, \& potentialia, facilius in animo imprimuntur, quia maiorem habent proportionem, \& conuenientiam cum facultate recipientis., \&e quia facilius eft vnum imprimere, quam plura; fic eiim videmus etiam ignem calidiffimum agentem in aquam ron ftatim imprimere o. mnes finul gradus caloris, fed vnum, deinde alium, donec imprimat omnes: huius autem: difficul tatis ratio fumitur ex iis, quæalias de intelleftu, ac de fenfu diximus; cognof cunt enim non folum patiendo, fed etiam agendo, hoc eft, receptam fpeciem iudicando: vis autem iudicatrix in principio debilis elt, necpoteft illa ftatim 1 ducare, qux plures differentias continent, fed prius udicat fingulas differentias, \& per gra dus peruenit ad̀ cognitionem perfectam, qua omnes fimul differentias comprehendit; nihi enimaliud eft cognofere primo corpus, deinde viuens, deindeanimal, deinde equum, nif ordine quodam vitin his omnibus conceptibus, qui in equofunt, apprehendendis, dones omnes int apprehenfi ; nam apprehendere ve corpus, eft apprehendere folum conceptum corporisabiunetum abaliis, apprehendere autem animal eft apprehendere fimul corpus, \&

\section{Argumë} animal, \& hæc abftrahere à natura equi; fed sum ab apprehenderevt equun eft omnes fimul appreenimals hendere, quoniam equus eft effentialiter \& corproculbe pus \& animal. Demonftratur maxime huiusce pitate.
A plerisqucfatisintellecto, quod fumitur ab ho: mine procul veniente; primum enim cognofciturvt hue corpus, deinde vt hoc animal, tandem vero vt hic homo; fenfus ergo prius difeernitaccidentia communiorum, deinde accidentia minus communium, quare mens quoque in intelligendo eundem ordinem fertuat. Multi tamen putant argumentum hoc debile effe, \& facile folui dicendo, fenfum ob nimiam ditantiam tunc decipi, ideoque non effe fumendum

$B$ argumentum ab hoc exemplo, in quo anima in iudicando decipitur, fed ponendum effe obie. ctum in diftantia conteniente, vbi non decipia: tur; quia ıunc manfeftum erit illud idem mo. uere primum vt hunc hominem, non vt hoc corpus. Sed qui hocdicunt, huius argumenti vim non pescipiunt, quod $\mathrm{f}$ bene intelligatur. in folubile ett, \& eft demonftratio à pofteriori: ipfi autem decipiuntur, dum dicunt in prædicto exemplo fenfum decipi; decipitur cnım quan$C$ do exiftimatur effe aliquid, quod non eft; in hoc autem exemplo quădores illa prumum iudica. tur vt corpus, fic creditur effe id, quodeft; non eft ergo deceptio, fed eftimperfecta, \& confura cognitio : vt autem huiusargumenti efficaciras intelligatur, ita argumentor: id quod validius mouet fenfum, prius etian ipfum mouet; atqui accidentia corporis validius fentum mouent. quam accidentia animalis, \& hominis, ergo accidentia corporis prius fentiuntur:maiorem neDare nemo poteit, Scotus quoque hac eadem vitur: minorem ita probo: quando pluribus agentibusidem offerturimpedimentum, à quo vnum ex eis non prohibetur neagat, cætera ve* ro prohibentur, id, quod prohiberinon poteft, validius agit, etenim fuperat vim impediments, quam fuperarealia non poffunt; ille autem homo mouere fenfum poteft \& vt hoc corpus, \& vt hoc animal, \& v thic homo, nimia autem illa diftantia eft vnum \& idem impedimentum his E omnibus oblatum, ab eotamen non poteft impediri quin moueat v.t corpus, impeditur autem ne inoueat vt animal, \& vthomo; ergovalidius agitytcorpus, quam vt animal, vel vthomo; \& huius ratio iam declarata eft fuperius: argumentum igitur efficaciflimum eft, \& folui. non pateft.

\section{De primo cognito cognitione babituali confufa. Cap.XIII.}

$F$ Filla vero actuali cognitione, qux fit 1 ex habitu prius acquifito, aliud eft arferendum, hxcautem fieri duobusmodis po1eft : quum cnim in intellectu nullus maneat: impreffus conceptus, ficut alibi demonftrauimus, non poteftuntellectus intelligere actu. nifi à phantafmatemoueatur; phantafma auen vel eft productum ab obiefto externo præfente, vclab imagine prius imprefia in memoria absque prafentia externi obicti : itak- 
qua fi externum obiectum abrens efre ftatustur, \& intelleetus iam habens habitum intelligat ex motione facta à phantafmate iam feruato in memoria, profero hanc affertionem, quxe extribus propolitis ordine fecunda eff : de hac luffo. liabituali cognit tone nihil certi pronunciari poteft, fed cum magis vniuerfale, tum minus vinuerfalepoteft cfle primum cognitum; huius ratio in promptu eft, quia intell cétus iam ftatuit ur contraxiflc omnes habitus, tam communiores, quam minus communes, \& poteft cos contemplati quando vult, \& co ordine, quo vult, ideo vir fapiens poftquam à fomno excitatus $\mathrm{ctt}$, poteft ftatim naturam corporis contemplari, veI naturam animalis, vel naturam equi, \& aliam quamlibet, cuius contempland habitum jam acquifiverit. Tertia demum aflertio eft : $\operatorname{cog} n i-$ tione habituali, qux fiat ex oblatione obiceti materialis externi, primum cognitum eft minus vnutuerfale, cuius accidentia mouere fenfum polfint; ve fiftatuatur me iam pridem cognouiffe \& corpus, \& animal, \& hominem, \& mihi in diftantia conueniente offeratur homo, ita vt fenfum mouerepoffit, \& vt corpus, \&ut animal, \& vt homo, monebit primum vt homo, quod cft dicere, mouebit fecundum hæcomnna fimul : quod fi diftantia tanta fit, vt mouere poffit vicorpus, \& vt animal, non tamen vt homo, mouebit primum vt animal, \& ita quodlibet externum obicetum, quod fenfui offera- tur, femper mouebit primo fenfum, \& per fenfum etiam intellectum fecundum conceptum minus communem inter illos, fecundum quos mouere poffit. Ad hanc demonftrandum non poteft efíicaciusargumtntum adduci, quam illud, quod primum à Scoto allatum eit; id enim reuera nullam habet efficacitatem de primaa ctuali cognitione, quam nos originalem appellamus, fed de habituali, prout nos in prxfentia habitualem fumimus, eft efficacifimum, \& taleeft: Agens naturaleapplicatum patienti bene $E$ prepararo, feclufo omni impedimento, producit effectum perfeatifimum, quem producere. poteft; agit enim fecundum omnes fuas vires, \& patiēs iam eltita preparatum, vt tantundem ftatim recipereaptum fit, quantum agens agere poteft: igiturfi obiectum potestillico mouere \& vt corpus, \& vtanmal, \& ve homo, mouebit ftatim vt homo, quia conceptus homınis perfeEiffimus eft, \& alios omnes continet; ipfe aultem intellectus eft optıme praparatus, quia iam $\mathrm{F}$ prius contraxit habitum \& corporis contemplandi, \& animalis, \& hominis; homine igitnr oblato omnes fimul apprehendit, dum apprehendit vt hominem: \& hoc experientiâ manifefte comprobatur; cuilibet enim cognofeenti corpus, \& animal, \& equum fi offeratur equus, itatim dicet effe equit:ideo Scotiftre dum huiufmodi exemplo, \& argumento predicto vtuntur, non animaduertunt fe decipi, quum putent
A. re probare de primanoftra originalicognitione, probetus tamenuon de origmali, fediolum deilla, qux lit ex habiu antea contracto: etcnim de prima originali cognitione lecus eft. tunc enim intellextus notter rudis, \& ineptus eft, nec poteft fimul totam reiperfetionem apprehendete, fed pes gradus, \& paulatim eam apprehendit; quare incipit à communioribusconceptibus reioblat $x$, quemadmodum antea declaraumus. Errarunt etiam ob ciufmodi cx-Alioru cmpla alii nönulli, qui propriā de primo cogni- error. to fententiam proferentesdixerunt, cognitione aduali confura magis vniuerfale vel prius cognofci, quam minus vniucrfale, vel fimul cum illo,pofteriusautem nunquam, propterea quod cum concepturei minus vniuerfalis coniuncti funt alii omnes conceptus communiores. Scd ifti nonanimaduerterunt, cam non effe primam acualem cognitionem, fed effe habitualem: C quando enim fimulomnes cognofcuntur, ca non eft prima origo cngnitionis noftrx, led eft cognitio ex habitu, quæoriginalem præfupponit, in ipfa autem originali necefle eft cum ordincm effe feruatum, quen diximus, vt prius acquifiti fuerint conceptus cómuniores, quam minus communes, idque fit potiŝimum in pue. ritia, \& nobis non anma ducrtentibus. Notandum autem eft, poffe in homine adulto contingere, vt, licet nō omnes habitus acquifierit, fed folos communiores, fi illi offeraturaliqua noua fpecies non ei cognita prius, ftatim imprimatur eius conceptus confufus in intelleatu; hoc enim fiet propter prxparationem factam à conceptibus communioribus, qui iam funt impreffi : nam fi mihi offeraturaliquodanimal nousm, quod nunquam amplius viderim, porfum primo afpectu non difcernere adhuc proprias differentias, quibus differt ab aliis, fed folum infpicere communia quxdam accidentia, in quibus conuenit cum aliquo alio animali; quod nobis frequenter euenit in auibus, \& pifibus; \& tunc non cognofcimus illam fpeciem fecundum propriam ration cm, fed folum fub ratione generis nobis ansea cogniti : poffum etiam primoafpeetu notarepropria illius animalis accidentia, quibusdiftinguitur abaliis, quæ nunquam in alio vidi, \& fatim dicere hanc effe nouam fpecicm animalis mihi antea non cognitam; tunc autem imprimiturin animo meo conceptus confufus illius fpeciei, etiam finomen ignorem; neq: ob id fequitur fpeciem primo cognofci cognitione originali, etenim genera iam pridem cognoui in aliis animalibus, fi non in illo, hanc autem fpeciem nune primum; non enim tunc imprimeretur conceptus illius feciei, nifi haberem priuscontractos habıus generü fïperiorü, qui intellectum preparárunt, \&ad huius fpeciei cognitionem aptī reddiderunt:illa igitur eius fpeciei cognitıo erit fecundū fe prima originalis cognitio, quam LL 4 pracer 
pracefsèretempore cognitiones originales generum fuperiorum; rationeaurem cóceptuum commuño um poteftilla cádem cognitio vocari habitulis, quoniam ex poffeffione labisurm vr uerialion un potuit itatim conceptus illius licerici confulus in intell ctu imprimi Ilxc, de habituali cognitione diximus a fententia Thom a aliena non funt, neq; illi adverfantur; ipfe enim dicens efle primo cogniti magis snimen fale, folam originalem cognitionem rifpexit; quare id, quod ac habituali diximus, iple non negaret, vt cuilibet cius yerba conlide. Jinti maniseftum effe poteft. Sed aducrfus $\mathrm{Sco}$ tum de cognitione originali contuia puto effe demonftratum; magis vniucrale femper efie primum cognitum; fimiliter contra Zimaram, \& Achillinun, qui dixerunt primunu cosnitü. c) guandoq; magis viniuer fale, quindoq; minus vninerfale. Sed veritas manifefturina redderur, fi folutis omnibus iftorum argumentis omirem hac in re difficultatem iutulerimus.

\section{Contrariorum argumensorum sointio.}

\section{Cap.XIV.}

Slyenda funt argumenta, quæ \& Scoti \& $\checkmark$ recentiorum opinioni fuffragari videbantur. Primum Scoti quantum roboris habeat, iam diximus: validum enim eft de cognitione
Adprimum gumenWm. Scozz ar -

habituali, at non de originali, in qua mens noftra pariens non eft adhuc bene preparata, vt rccipere pofit totam actionem agentis: quod vero Scotus dicis; eam habere aquam potentiam recipiendi omnes conceptus, verum aliquo modoeft, fed aliquo etiam modo non verum; nam etiam prima materia potentiam habctatque omnas formas.recipiendi, non tamen cas recipit, nifi conuenienter praparetur; \& ad alias recipiendas maiorem proparationem poftulat, ad alias vero minores; \& aliquæ funt formæ; quarum tanta eft perfectio vt recipi in materia non porfint, nifi priusali imperfectiores receptæ fint : quod ergo dicitur, materiam habere æquam potentiam recipiędi omnes forPriphers- mas, verum eft refpiciendo folam priuatiuam. tic mate-praparationem, fed non eft verum de pofitiux, vicalia prisutian materia præparatio eft, yt æque oeftpriua- mnibus formis careat, fic enim xque omnium tiwa, ali- eft receptiua ; at pofitiua præparatio non $x$ qua ad omnes formas requiritur,ied adalias maior, ad alias minor, neque præparationem hanchabet materia ex fua natura, fed eam recipit ab alio: idem prorfus de mente noftra recipiente dicendum eft; rudis enim nafcitur, \& aque amniunı receptiua : fed pretcr hanc priuatiuam pı sparationem requirit etiam aliam politiua, qux non xqun refpectu omnium conceptum eft; quare fine hac non poteft ftatim quemlibet conseptum recipere: ratio autem huius eft
A quamanteatetigimus, quia natura (vt dicitur) non facit ialtum a pura potentia, cu umma im. perfectione ad inpremamperfestionem, led per media tranfit, donecad vlimam periectionem perueniat. Hæc autem tum per ie manifefta funt, tum manifeitiora redd uniur, fi argumentum hos Scoti contra ipıum retorquamus: nam fi agens naturale non impeditum producir ltatim efiectum pertectiflimum, quem producere poteft, ergo oblaia intellectui upeciesa-

B liqua vlrima, vt equus, deberet ftarim producereconceptum fuum diltmetum, quia difincta sognitio eit pertectior, quam conrula; confequens tamen ipfi quoque Scoto aduerfatur, qui putat primum cognitum cognitione diftincta efie magis vnuterale. Scotiftæ tame aliqui hoc animaducitentes, Scotum tucri nituntur eius verba perpendendo: quum enim ipfe dicata. gens naturale producere ftatim effectum pertectifimum, quem primo poteft, perpendunt ipli cam dictionem, primo, \& dicunt fpeciem vltimam non poffe primo producere conceptum diftinctum, fed folum contufum; quia ditinctus maiorem laborem, ac difcurium requirit, nee primo imprimi poteft. Sed per hoc Scotus. non defendit $L \mathrm{r}$ : hoc enim dicentes tatentur non effe vniuerfe veram illam Scosi propoítionesn, agens naturaleproducit itatim eftectum perfectilinmum, quim producere poteft, led debitam paientis præparationem requiri, Quod fi dicendo, quem primo potest, reipicimuspraparationem patientis, vt refpicere debemus, vera eft propoitio: íed vltima ipecies non poteft producere primo, nifi conceptum $v$ niuerfalem, quoniam ad alios particulares recipiendos nondum eff mens noitra bene praparata.Secundum Scoti argumentum erat: fi primum cognitum cognitione confufa efiet magis vniueriale, fequeretur Metaphyficam inter cmnes icientias effe primam refpectu noftiæ cognitions. Hoc quioque contra Scotun retorqueo: quxro an fientia fint difponend in:ter fe iuxta ordinem cognitionis nolt $r$ diftinctax, an confula: fi diftinctx, ergo ímiliter metaphyíca quoad nos eft prima, quia etiam a: pud Scotum magis:vniueriale ett primo cognitum cognitione diftincta, quare argumentum: eriam contra ipfumlacit: fi vero confula, crgo libri de Calo, \& libri de Animalibus funt anteponendi libri Phyfica aufcultationis, fos minus vniuerfale eft nobis primo notum cognitione confuí, vt Scotus putat; nam fubie. dtum librorum Phyfica aufcultationis vniuerfalius eft, quam proprium dictorum librorum. fibrectum. Ad argumentum autem multe. folent afferri. refponfiones, fed aliis dimifi. hanc ego turtifimam \& optimane effe puto: 1 netaphyisa non alia ratione dicitur vltima qua ad. nosa \& polt naturalem fcientiam attingenda, oifi ratsone patris in ea maxime gracipus: 
in qua agitur de fubftantiis à materia abiunctis pereffentiam, qux quum finta fenfibusnoft rem. tintmx, \& mobis ignotiln $m$, nec poflunt cognofa, nifi prius cognira fint qux.lam, qux declarantur in naturali philo ophis: Metaphyfiea igituz pott noturalem foientiamaddicenda elt, quia ordo inclioris noftræcognitionis hoc requirit. Sed adverfus hanc refpunionem argumentabatur: dupliciter $M$. A intonius Ge. nua. Pimo, quia pars Mctaphyfica, quxett de abiunctisi matera per clíntian, parus, \& minima eft refpectu illius partis, qua cft de ente, prout cns cit, \& deillis, qux vocari foleutabitracta per indificrentiam, hæc enim maxima eft: quum igitur fcientia à parte maiore fit nominanda, viget ar gumentum Scoti, Metaphyfca enim prima quo ad nos crit, non vltima. Secundo, quia fe pueretur ficandam effe Metaphyficam in duas partes; qux. un altcra, qunz. eft de ente, prout ens est, ante naturalem legen daeflet, vtargu nentum Scoti demonftrat, altera ver o, qux eft de liub tantiis à materia feparatis, legenda effet poit maturalem $\mathrm{H} x$ tamen obiediones contra noftram refponfionem non fint alicuius momenti. Non prior, quia pars illa Metaphyfic. quae eft de diuinis, quamuis mole parta fit, tamenpraftantia, ac dignitate eft maxima, nam multo pluris:x timanda eft leuis, ac breuistractatio de rebus nobiliffimis, quam diligens, \& prolixa de rebus ignobilioribus, vt ait Ariftoteles in r. lib:-de Pas t. bus animalium, cap. vltimo. Confirmatur hoc ex com. muni illius dif iplinæappellatione; tolet enin vocari fientia diuina, neque ob aliam caufam, nifi, quia præcipuum eius fubiectum eft. Deus, \& res dituinz: ergo fi a parte minima nominatur diuina, quoniamea pars nobilifima,ac maxime pracipua eft, poteft etiam appellatı ob

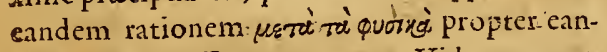
- dem præftantiffimam partem: Videmus præterea Ariftot. in Procmio Metaphyficafumniislaudibus eam fcientiam extollere, \& vere fapientiam appellite, neq; ob aliam rationem, nifi quod primas cauras confiderat; etenim ratione entis, prout ens eft, diceretur potius ignobilifima, quoniam ens cömuniffimum omniü eft; \& quanto aliquid in predicando communius; tanto elf ignobilius. Altera quo que obicctio friuola eft, nec fequitur fecandem effe Metaphyficam in duas partes; quia fi ipfam rerum naturam fpectemus, quatenus nobis confidefind $x$, \& cognofcenda proponuntur, oportuit ¿e abiunctis à materia per effentiam, \& de abiunctis per indifferentiam, non duas effe difciplinas; fed vnans, \& eandem: ea autem tota legêdà̀ aobis cf:poft naturałem philofophianı, fumendo huius ordinis rationen à parte eius: precipua, qux nō folum ignotiffima nobis ent, dedetiamneceflario requicirit, vt prius cognita fit fcicntia naturalis itag; naturalis ordine doctrine pracedir Metaplyficam, quia fine cius cognitionc pars Meta liylicx precinua intelligia nobis non poílet. Terlum aig.mentum Seoti Adtorsie erat:Si mags vinituerialc ellet primo cog ritum, $u m$. maximum tempus interponeretur, ancequam à fumuno generead inlimas fecies perueniremus, quia plura intermedua genera v!cimis fpecicbus proxima ignorantur. Hoc qitog; contra scotumconturni poteft:fmiliter enim dicam, fi. B vlimafpecies eflet primum cognitum, maximum tempus interponeretur, antequam abea ad fuprenum genus pertenirenus; quoniam illa media genera, per qua tranfeundum eft, funt incogritia. Si vero dicat Scotus, non effe necellarium vt afpecie ad fuperiora afcendentes tranfeamus per omnia media, ita nos quo. que foluerc eius argumentum poffumus dicen. do verum. quidem de cognitione diftineta effe id, quod Scotusait, fed talfums effe de confufa;

C nam dif́tincta cognitione a fiperioribusadin. feriora defeendentes necclle eft, vt omnia me. dia cognof camus, omnia namque de fpeciebus in fims eflentialiter prædicantur; quare nullum eotum ignorandum eft, fifpecierum diftincta, \& perfecta cognitio habenda fit; fed in ordine cognitionis confulænon eft neceffarium; yt:amnin-media cognolcamus, guia poteftépecies confule cognol ci ignorato penitus aliquo eius atributo ellentiali; ficambulantem pertotam

$D$ fori longitudinem neceffe eftab vna extremitate ad altedam peruenire, at non eft necelfarium: vt pedibus tangatomnes intermedios lapides: neque ob id fit, vt fententia noftra de primo co-gnitofit vera folum vt particularis; quod exifti, mauitZimara, eft enim vuiuerfe vera; quia in Ad $z$ omnibus cognitio noltra coniufa incipit a ma- marara xime vniverílibus, nunquam abinfima fpecie: nunquam enim non cognofitur genus proximumafini \& equi, tamen latis eft iiante cognira Luperiora genera, vtcorpus, \& viuens, \& animal, ab his enim incepit cogiaitio noltra, non à proprio fpeciei conceptu: lic igitur in omnibus primum cognitum est maxime vaiuerale, nunquam fpecies vltima. Quod autem argumentum Sçoti debilifímum tit, ex eo patet, quod quemadmodum ipre dixitaliqua g-nera ignorari. quum fpecies cognofcantui, ita nus obiicere.illi poflumus, multas fpecies vltimas igno, rari, quum plura earum genera, ea præiertim, qux ampliffima funt, cognofantur, fic enim oltenditur, velnon efle intimam fpeciem primum cognitum, vel faltem non in omnibus, proinde iententiam Scoti non cfie vniuerfe veram:at fententiam noitram vniuerte veram effe ex.eo oftéditui, quod femperante cognicionem fpeciei cognof́cuntur remotiora genera. licetaliqua proxima ignorentur. Alio qlioque modo Alea fo. foluere hor argumentum poffumus, perpen- lat LL 5 dendo 
dendo verba Ariftot. in eo contextu 28 . libri 7. A Metaphyficorum :ibi namque non dicitgenus proximū equi \& afini effe penitus incognirum, fed effe innominatum non eft autem illatio efNor om- ficax, llomine carct, ergoeft penitus incogniwe smo- tum; poteft enim res cognof ci confufe, etiam fi minat $\vec{u}$ nomen ignoretur; vt patet in mutis \& furdis, \& ef incog - in infantibus, qui abfque vila nominum intelliwitum.

gentia confufe res animo concipiunt peraccidentia earum fenfilia, quxà fenfibus intellectui offeruntur : id enim quod dici folet, cognitionem nominis efle principium omnis no ftræ cognitionis, verum eft de illa notitia, quam addiIcédo acquirimus, nempe vel aliquem audiendo,vel alicuius fcriptalegend o;nifi enim nomina intelligamus, nihil difcere poffumus:at non eft verü de cognitione in nobis naturaliter acquifita per fenius, fic enim poffumus etiam nominibus ignoratis res in animo confufe concipere; imoprimi homines prius confufe res cognouerunt, poftea illis nomina impofuerunt; dico igitur proximù genus afini, \& equi, quamuis nomen non habeat, notius tamen effe afino, \& equo; communia namque accidentia, in quibus conueniunt, faciliora cognitu funt, quam ptopria, per qux diftinguuntur; $\mathrm{l} x \mathrm{c}$ enim \& in fenfu, \& in intellectu maiorem iudicandi virn requirunt, quod patet in iis animalibus, quan do proculafpiciuntur:quum enins videamus animal hominem portate, vel currum vehere, \& cömunem quandam figuram infpiciamus, cognofcimus effeneceffarium vt fit vel equus, yel mulus. vel afinus, fed quodnam horum fit adhurc ignoramus: tunc igitur cognofcimus acci. dentia illius generis innominati, propria vero illorum animalium accidentia non infpicimus id antem, quod diximus, confirmarur per illa, quæ dicunturab Ariftotele in libro Categoriarum, in capite de Relatiuis, vbiad recte faciendam reciprocam relatiuorum relationen pracipit vtalteri, quod nomine careat, nomen im- E ponamus, \& dicamus caput effe capitati caput: fignificat ergo nomen folum effe ignotum, non iplam rem: quia fi rem quoque ignoraremus, non poffemus illi nouum nomen imponere:idque in eo exemplo manifeftum eft, quia antequam capitati nomen fingamus; cognofcimus quid fit habere caput, ideo nom en illi imponere pofumus. Hanc igitur refponfionem fi fequamur, dicemus ante fpeciei cognitionem cognita efie confufe omnia fuperiora genera,licet $F$ corum aliqua nomine careant. Vtramque folutionem ego ad diluendum Scoti argumentum optimam effe cenfeo: prior enim ad hominem iufficientifina eft, hæc autem pofterior, vt ego puto, veriffina : qua etiam vtebaturM. Antomius Genua, quilicet Scotifententiam fe- queretur; tamen confeflus eft, nullam habere efficacitatem argumentum hoc, quod fumitur ex contextu 28. lib. 7. Metaphyf. quem locum eo modo, quem nunc diximus; interpretatus eff. Corruit etiam hac folutione argumentum $A d Z$; Zimarx, quod ex eo loco fumebarur, ad pro- rum. bandum nö effe vniuerfe veram fententiam noftram:fed folum in parte:nos enim oftendinus primum cognitum femper effë id, qnod yniuerfalius $\mathrm{c}$ f, \& nunquam effe infimam fpeciem.

B Quartumargumentum erat; vt fe habet fingu- $\Lambda d q u$ lare ad fpeciem, ita fe haber fpecies ad genus tum. nos vero hoc negamus; quamuis enim aliqua adift fimilitudo, habenttamen etiam magnam differentiam, qux in prærentia magni momenti eft: dum enim à fingulariad fpeciem afcendimus, tranfimus ab ordine ad alium ordinem. nempe à re fenfili ad rem intellcctilem; atdum à fipecie ad genus tranfimus, non variamus rerum ordinem, quia ambo funt intelligibilia; $C$ hinc fit, vt fingulare, quum fenfile fit, \& a fenfu primum oblatum, fit neceliario primo cognitum, de fpecieautem hoc dicere non poffumus, quia hæc non poreft nifi perabitractionem cognofci, quemadmodú etiam genus; ideo quum genus fit faciliorisahftractionis, quam fpecies, prius etiam cognof citur, quam fpecies; fingulare vero tali abitractione non eget, quace eft abfolute primum cognitum. Advltimum argumentum, quando dicebatur fpeciem efiè indiuiduis propinquiorem, quan genus, dicinus verum quidem hoc effe fecundum ordinatio. nem Categorixà Logico factam, at fecundum rei veritatem non ita lefe rem habere; qua non minus genera, quam fpecics, habent fua indiuiduajnam hic homo eft etiam hocanimal, \& hoc corpus, \& ita propinquum eft corpus huic cor. pori; vt homo huic homini.Vti praterea poffumus eadem refponfione, qua precedens quoque argumentum foluimus; nam propinquitas $\mathrm{E}$ indiuiduorum nullius momenti eft, dum rerü ordo variatur:fr enim de his, qua eiufdem ordinis funt loqueretur, vtiq; efficax argumentum eflet, oporteret enim id, quod primo cognito propinquius eft,prius cognofci: at dū ordinem rerum variamus, \& à fentilıbus ad intelligibilia tranfumus, propınquitas hæc, quæ ̀̀ rei communitate fumıtur, nullins momenti eft, imo $\mathrm{ex}$ ea contrarium colligitur; fpecies cnim ea ratione propinquior elt inditiduo, quam genus, quia plures differentias continens contiaftior cit, \& totam indiuidui fubftantram compleetitur, genus vero eam non totam, fed partem; facilius äutem cognofcitur pars rei aliqua, quam

omnes partes fimul, ob rationem fatis à nobis in pracedentibus declaratam. 


\section{INDEX L OCVPLETISSIMVS RERVM \\ OMNIVM NOTATV DIGNARVM, QV IE in hOC VOLVMINE contincutur.}

A.

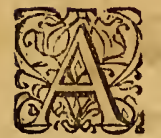

B entia forme bumand non est prewatio, fedpotius negatto $\quad$ s5o.6 Abfoimin fine alvo eje potest $x>7 . x$

Abfoluti effertia nullum habet refpectumadaliud $\quad 180.6$ Abfratio an fiat ab intellectu patibili, anabagente 1010.f quedicatur aphilofophis 10r.8. 6

sn Abfractione qua fint confideranda.

1017.6

Accidens aliquod formam pracedere nequit $203 . d$ non cogruocitur nif 1 per fuam caufam demonfretur $3 \sigma$. non est aptum fubfantia effentiam conficuere zis. $c$ nullum pojJe ftatw principium fubfantic fingularis 379 .f nullum potest effe de effentia alicusussfobftätice 100 . fiproprium est re infeparabile afub.jubiecto $1 \mathrm{C}_{3}$.f. Accidens quid 300 a fine fubiecto exifferenequist 2 r.\%.d Accidens piritale fo $^{\circ}$ idem numeroest cum accidente reali, En nonidem 843.4 Accident is tractatio in quibus cöfiftat

ot.a

Accidentia eterna que Ariftotela igg. 6 conuenientia formageneranda non debent de materiapelli

197.a

Accidentza dro eivedem. Jpeciei numero difincta. non poffisnt frmul effe in codem fubresto. 550.6

Accidentia Es principiagua in libris phyfece aufcultatinin is. tract antur, coppetunt omnicorporinaturali $\quad$ \$.C. Accidentia formam: confequentiafunt duplicia 325 .e babere gubiectum. fenfile E. ens actu ArG.e habere fubiedumfenfile, quomodo (at intelligendum a.250
Accidentia natura pofteriore confituta 775.6 fubiecto 18.a item fubfrantïs Accretronis Galiarum mutatiosoo.c naturalua cognefientur aphilofopho neturals $\sigma . a$ non dicuntur babere naturam, fed effe inaturas s. dquomodo dicantur efjefecundum naturam $242 . d$

Accidentia nan polfe conftutuere fingulartatem 375.6 non poffunt effe caufat fingularistat is 3.7 G.e pluraformain necefjario infequuntur 248.6 propriacur Gocentur effentialia rjo.a propria generis peciebus non attribuenda

18.6

Accidentia qua ratione entia 25. efpecier duplicia 03.d fibffantüseuidentiora

217.6 Accidentaum fpiritalium gradus 8 a. f. fubiedtum efje ens actu, EF ex materia $\mathcal{E}^{\circ}$ forma conAans 10r.f. traggenerain animalibus $9.7 . d$. inter Accident 1 a $\mathcal{E}$ formas fubfantiales perfectas funt forma fubftantuales imperfecte. $4.75: 6$

num, qua cum illa coniuncte funt, non dem est fubiectum $72 \pi . a$

Accretionisfinis 820 . e forma 830. 6 materia $i b i d$. Accretionis pofereria códitio quo modo intellyatur 806.a ratio quod fimatur aúunima $824 . e$ feretresconditiones 760.6 $a^{*}$ Accretionem quomodo fe babeant alia mutationes que in eafiunt 790.6 in Accretione alia extenfio fit, alasinfpongia $787 . a$ quomodo pofteriores conditiones ferwerntwe $805 . d$ Acetum quod non pofit dici mediocriterputrefactum $680 . f$ Acetiqualitates $682 . f$ inter Acetigenerationem ESputredinem fimilituda $68^{1} . d$ differentia ibiai de Ace to $\mathcal{G}$ de Sini putredine propofita difficultatis folustio 078.6

Achilloni de element is liber 173.6 .

de Accidentibus reinonest necef- Adtio à debsliore in Salidus fier: farium prius agere quam de "non potest 428 :f cur dicatur. ipfa reagatur $\quad 1.8 .0^{\circ}$ Accretio ad quam raritatem tê.

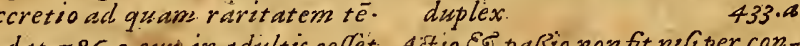
dat $780 . c$ cur' in adiultis ceffet Aitio ES pal3io non fit nzfiper con$772 . d$ cur post aíolefcentiam ceffet $774 . a$ est motus continisus.781. din Siuetibuspotest. portbusfiant for 732.2 Acmplacter confiderari 781.d Actro etiam datur fimilis in fimito cum quomodo desn for Jubiecto cum nutritione $780 . d$ quomodo in Giuentibus fiat, $\mathcal{F}^{2}$ quamutationes ad eam faciédam concurrant 707.6 quot modisfumatise, Eq queconditzonses ad accretzonem proprse dictam requerantur $750 . a$ tri$766 . a$ actio omnisfit per contacti 353.9 plex est mifie 5.80.a magis tribuendas est primario agenti quam $f e$. cundiario 439 . d' nonfit nifzab aqualifuperante $435 . d .445 .6$ non fit nifiab activ $319.5^{\circ}$ actioper emanationem femper est Accretionis caufaeffictens. 820.e actioomnis naturalis per conta-

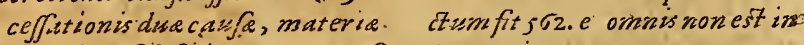

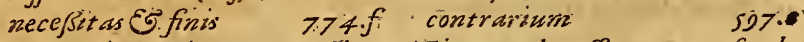
Accretzonis definitzo 830: a eflen- Actioguando ceffet 435.a. Snde:

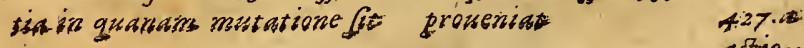
adtion 


\section{$I N D$ D X}

ationis modus quo dud actiuen- wer cur non fit fomme calidiss stz gunt in disaspaßsuas 505.0

ationem feri a proportione masoris incqualitat is, quomodo Gerumfit $433 . c$ nonfierinifi $i$ froperante $448 . f$

ix actione omni duxe forme cons 2 derantur

$787 . \mathrm{C}$

actionum duogenera $\quad 448.4$ actiuc qualutates quandopajsius is dominentur $\quad 587 . d$

actiusurum qualitatum dornenin in dseaspasisuas quomodo fit intelligendum

586.6

at7us alsus non datur, prater formalen

177.e.181.d

actus duplex 38 r.e entitatuus quid $177 . f$ eizs reprobatio $177 . e . f^{\circ}$

aitus formalis refpondet sirique potentie $18 \mathrm{dr}$ d incompletus nunguam à potëtia ferungitur 172.f maxime est in categora fusbfiantic 150.6 nullus competit materiafecundum fisam waturum 189 . a per Se cognofcutur, potentia Gero peractiom:so.e poteftate est principaliór 426.2 quempotentia refpect, nullus alizes est, nifi motus ipfe

$322 . a$

attus quid 38 1.e fumitur mult fartam 185.6

aites birtualis 80 potentia formalis nonfufficit, or popist aliquidmutare ferplism $442 . a$ exzfendi non est forma, fid offecturforms

I85.c

attus nomen quomodo fumstus ibid.e.187.6. Sis in quo conftipute

$r \neq 0 . C$

- cius fingulopropriepotentia iespossdet 173.6

acisum babere nal dacimus, nifaid quod ex materia 0 formaccnftat 271 . f purums poje fulliftere,non aistem proram potentsi IfI.d

ó AdZu fini argumentume efjcacisivimum

156.a

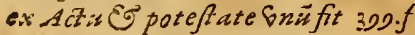

- itus duo apudAriftotelem 170.9 fubfifferntes nullam babent relationemadpotentzum 141.6

- $x A B$ abs disobus ron fit Enism,

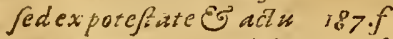

actusum motus proncipisem guid fit $\quad 2 \neq 0 . a$

dditio fit folous wateria non foras

$8+4.6$ demleuitas $\quad 527.6$ $f$ curnon Srat ibed. elementum agitabile in fuo loco $3 \neq 0 . f$ rarius aqua 422 de est tarda actionis $537 . d$ bumidior aqua si8.f igni denfior siz.a aer inferior bumiduspropter $6 a-$ poress $+6 . a$ dupliciter calidus $553 . c$ bumidus duplice bumiditate ibod. qua ratione debileorem calorem habeat, quam medius 552.6 aer medua regionis quomodo poßnt efe frugudus 5 4.6.c comparatione aliorum est frigidus ssod. aer minus igne caledus st2. $d$ nat.uraliter defcendit in igne, $\mathcal{E}^{\circ}$ afcédit in aqua 350 .f no mower graue defendens. fidpotsus cedat graus defcendenti $3 i 5 . f$ nunquam bumiditate caret s24.f propenquus terraminus est lewis quam aer fuperzor $3.37 . e$

aer yuomodo poßnt effe perpetwo frigidus, fiest naturaliter cuslidus 54 f. a quonodopolst fo mulculefier ab igni, Eo refi-i. gerariab aqua 4 40. a quomodoputrefcat

$648 \cdot f$ er quaido putvefcere dicatur $\sigma_{3} 7$. $c$ quomodo transeat in nostura igniss 8o.f Jupera regionescur calidiss $\sigma^{3}$ ficcus 5 iz.a duplici calore calidiss

545.6

aeris calor ab ignis calore qua differentiadifinguatur 533.6 minor quam ignis sil.f potest zotabiliter iniende Ef remitti absó villaisatenfione 405.0 aers हैं tgnis leuitatem non effe eirusdemperiers33.c nonersaerishumiditas $\quad 70.6$ aers in ignem mutatio quomodo fiat $5=2 . f$ aerisinfima regioqualis sso.d neits locus igni est prater nuturam $30+d$ d Aeris mot $\overrightarrow{1}$ etian iffurm grawe moueri $3+9 . a$ eris mediaregio,est idonea cauwiessze efrigida $200 f$ aeris medis regions refrigeratio finde 5 4 4.aregiofsupera a motus caldia redditurs 50 a regeones differunt quantitatsbuico qualicatibus 542.6 guot 5 Agerequid $432 . f$ est forme, pat: guales Stin veromaterise eris ficcitas bnde \&85 c Juprema regionis caliditas Gnde $5 \neq 1 . d$ deris Gna est of fomplex natior s5o.e

de Aeris qualitatibus Gera fententia declaratio $\mathcal{E}^{\circ}$ comprobatso

550.2

aeriquis caloris gradus fit conue. niezs

sio.e

Aerem confare ex materia $\mathcal{E}$. forma $273 . d$ frigidum efle, Suaprenatura Stoicz dixeruns s $47 . d$

ad Aerem confituendum non $\int a-$ tis est bumiditas, ed etiam calor requirstur $5+0 . f$

in Aere cur omnia mifa putrefant ryo.d

aerem calorem mutare in ignem facilius est, quam calorem in frigus

520.6

Affectrones anima effe st originis qusd

125.0

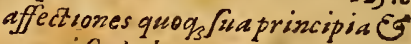
caisfas habent I25.a qua agart 5 non repatiantur $447 \cdot d$

Agens apatientequomodo fat difinctum 247.a aquinocum est natura prius agente Gniuoco $235 . a$ non est contrarism patierti

so7.d

gens alt erans an alteretur modo aliquo ipstiente $\quad 42 \sigma . c$ agens an Gucusim a patiente patiatur $+2 \sigma . b$ cur non poffit bocari caufa fre qua nos 426.a

gens diuplex

322.6 formule 3 ry.c formale non potest agere infet fum $3 x>\cdot d$ gëneranseit cauja generationus equata 424.6 naturale non est cauf af forma, $e d p r o d u-$ ctionisformis $S_{34}$. d nonlergitur multitwdinem fed perfenem fonul est cum effectss 224 . cperfe an ab eodem repatiatur $42 \sigma . e$

agens omne in agendo repats 428 .

$d$ per eminuationem equinocis $33) .3$

-eiss quando a nullo probibetur, neceffe exfubitam fieri mitiationem 320.e quandoque inag's ripatitur quam agit +37.4 veromaterias $\$ 32 . f$ ctionem 182.a" per emanatia. 


\section{$I \quad N \quad D \quad E \quad X$}

agens quod nungusm pofist per focte alsmilare fibi patiés, cur falfum \& st.a remosum non cst curepretsense coniundtum 435 . $f$ birtuale $316 . d$ poreft absgne Glld repugnatiotid agere infeipfim ibude Gude iudicetur balidres

$1067 . \mathrm{C}$

Agent is per emanatione actio est immanens327.6 Galadum intenfine ${ }^{\circ} \sigma \mathrm{t}$ agentis validiu exicnfaue difcrimen $\quad 070 . a$ in Agente per emanationem qualis diffinctzoneceffuria 328 .f. Agenda 0 recipiendi eadem. ratio

320.6 Alberti Magzi de mineris libri $45: a$

Albertifententivartificiofa oj $_{3}$.f Albi indeginate est actio in oculuns $237 . e$

Aichimifie exficcis of aridis olessm edscunt 035.2 Alexandrit fenrentia de fibiedzo librorum de ceelo. $\quad 42.6$ Alimentum debet efe. multo minus realenda:

$202 . a$

Alimenti quantitas an c $\vec{u}$ cyuantitate aiendi corporis uncorporetur.

giz. $f$

Alteratio previanonft in matereanuda. fed in materia forma ta: $420 . e$ Alterationis $\mathcal{F}^{-}$accretionis. dif crimen: $783 \cdot d$ - Altcrationem eleméti efferrutaxionem naturalem $4 \$ 6.6$ qua. lem Arifiot. in definitione mifionis intellexerit $47 . a$ animaprincipizas animaliz. $120 . \alpha$

in Altetatione fola accidentia. mutantur.

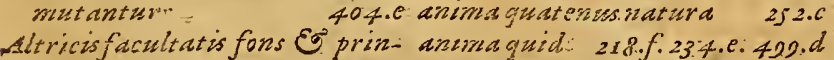
cipinmest cor $7.43 . b$ anima gisomiodo dicatur corpori Ambiens qwod fuo calore corpora. putrefaciat, quodinam fit intel. ligendiums

$625 \cdot f$

Anfit $\sigma^{\sigma}$ quidft declädre, einfdeme efjè difciplins.

- Anaxugcrachaos. einf- os

Aizulogiz etian ad exifientian a materico cognolcendam. Gtilis antmationalis an fit formatso est.

analogiaquid

139:e: minis

$337 . e$ anima rationalis quod fit. Etra

analogiani conferre tum atie fjentiam tum adexifentiam mot- anima re difind a forma mi-. teriacogrofendam I 41 f: finnis:

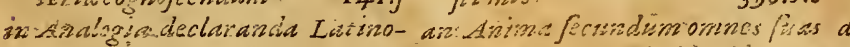
rumerion:

aszalogumquid.

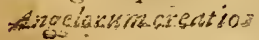

24.437 .0 137.28
$25 \cdot c$

227.6 adagwari 813. d quomodo ba-
beat affeciones $125 . a$ quomodo beat affectiones 125. a quomodo 390.b.c

- facuitutes fit in fingulature nime finfolitis facultatum: 0 7.60.f mintimecolicizio.

$724 . a$
215.6

anima fenfobilis fungitur officüs arumabegetances $\quad 357.6$ anma fenfibilisnonest re difinataisegetante 357.0 unimir totuquid $70 \sigma$. d quidbem. parsanzms

$357 d$ anima begetans 205. fest forma aque a planta atg ab animali participata 128 . d propriafor masiucntis I26.d

animas bere addita formis elemétorysme $372 . a$ $x .28 .6$

anima bt principium fubickidefrnitur, non St subicdum 12-f.f Anime a notura definctio 250.6 affectiones guib. modis intelligenderas.e cognitio curquaratur 122.f qua in Giucntibus confideraripofjunt $\quad$ - 105.6.e anima conditiones $121 . \mathrm{c}$ con/ideratio 120.f.123.4. 684.acreatio 227.6 definitio 11g. 6 duo minera: 736.4

ab Aizma effentia an facultates difingivatur, opinio Scott 6 Greg.Ariminenfis: $\quad$ 6.85.C anima: humane- smmortalitas. $250 . d$.

anime facultatï inter $\int e$ difino ctio.

animemedicina.

00.2 animamiftionisggna . $\quad 267 . a$ anome motricis interitus $256 . d$ animanatura: $\quad 708.6$ anime operationes toti animato corpori attribuenda; non ansmes.125. 6. $c$ operationum difcrimen:

III.C.

in Anime parte intellistiwa; an fitmemoria: $\quad 7.25 .6$ de Animepartium difrebutione, Plitonis opinio, G eius confutatio

$\overline{7} 30 . d$.

animapartitio fecundum jucuntitates 753.6 plures operationes: 111.6 productio duplex est 120. b.c.

anime rationalisfacultas' $725 \cdot a$ : perfecta definitio fectundum $A$ rifiotelem:

978.4 st Anime receffum monere aliquandiu formam: mifizonis $400 . e$

a Aninue feic Galcni error

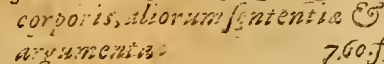
de ani- 
de Anima Gegetantis facultati- ansmalis Gnitas pendet à corde animatorumpropriwm est mouebusdubia 7 Traf 706.e riafcipfis 250 . animam dicerc fubiectum, abfur-animal fgnificase formä in ma-antiperiftafis quids 44. fquomodum $124 . a$ effe actum illum, teria 220.6 dofrat guo corpus naturale organi- in Animali duofunt diftinctina-Antonius Trapolinus Pomponacum conftitustur 252.2 non turalesinotus 306.d tüpreceptorsgs.a Profeffor oreffe siaturam $235 . c 236 . c$ non in Animals triapartium genera dinarius ingymnafio Patauthabere omnes condationes, que rej.a 113.e no itid. in fubiecto fcientia reguirun- animalia caftratacurpinguefcät $M$. Antonius Genua Zabarello tur $\quad 124 . a \quad 774 . e \dot{a}$ feiplismoueri239.f a preceptor $1 / 2 . a$ extra Animänullum daturcor- fenfubabent, fo fint animalia Appetitius antmalis infequitur

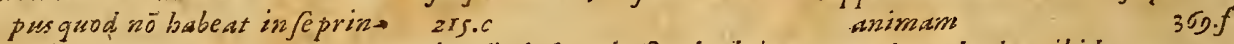
cupium motus $\quad$ o.e aninaliababere infeprincipium appetitus duplex ibid.e mate-

animamfenfibilem conftituere fuimotus i237.e animal 130.6 vegetalem confir animalia infecta E planta cur tuerefiuens, ibid. post diwifionem butuant $735 . e$

ab Anim cognofcente non dict-animalua fola mouere feipfa $307 . e$ turemanare inanimalimotus tam diubiuunt, quam diure$235 . f$

de Anma librorum Arifotelis fopissiro.b.c cur principem locum teneant inter omnes libros de animantibus $104 . c$ exo. tericinonextant $38 . d$ inficibuntur ab intentione, non à fubrefto 121.e quomodo abalits fecernantur 124.a fcientiales potius at $\hat{q}_{3}$ auf cultator $\ddot{j}$ funt appellonds $38 . d$ de

Le Animalibris nullapars respodetinhiftorïs $\quad 103 . d$

de Animatractatio exquifitabiforia $\quad \therefore \quad 103 . a$ Animanibilprafiantius 130.6

de Anzmarzm multtudine Latinorum opinio Go.e

nimal cur ex motw calefatso.f duo habet partium genera ad Animalium partium noti$33 . a$

animal हु cadawer fpecie differunt 407. dgenus refpicit contingentor fecundum from effentiam igo a in bomine quare fit tanquam materia $220 . c$ per propriam definitionem diffincte cognofcitur 33.6 quatenus genus $\mathcal{G}^{2}$ materiazzi.e repeitu bominis est है totum EF $^{\circ}$ pars

$1058 . e$

in Animalis interitu nibil generatur $\quad \mathbf{1 2 . a}$

onimalis materia que partes fint 115.e motusnon itaintimus natureest, Gt fenfus. g) $8 \cdot a$ naturanibut intinuius eff fenfs 27.cpartes, inferumenta animod ad Gertas edendas operatrones

23.a

ad Animalisperfectam notitium guidre justratur

444.6 fpirare $E^{\circ}$ expirare pofjunt פg.d

de Anemalium commuse motzlis. bro nulla propria tractatio in bifior:js refpondet $\quad 104 . e$ de Animalium incejfitiber $93 . d$ arimalium motus 309.6 infequiturnon ampliues niaturam abfolute acceptam, fed naturam animalis 67.6 gralis $357 . f$ de Animalium motu cōmuni cur Ariftot. librum foreferit III.C Gbi-Arifioteles agat $\quad$ rio.a de Animaizum ortu librosquo in loco ponendos effe nonnulli putarint - ${ }_{13}$.d.c aximalizm partes caufam babent finalē, cuisugratiafunt $103 . e$ effepropter animam ibid.f tiam habendam dwo neceJjaria D3.e. ria quid 16o.e naturalis proprï loci est grawitas $6 \overrightarrow{\text { lewitas }}$ $350 . e$

appetitiuafacultas $\quad \mathbf{7 2 3 . d}$ Aqua à re calidapotest per condenfationem generari $554 . e$ cur exmotunon calefiat sai.e est menus grauis quam terra $372 . e$ ignimaximecontrari 420.a non est fumme frigida 512 equiefcens eft calidior quä motasoz.c quandoputrefcere dicatur $\sigma_{37} \cdot a_{47}$. f refifut o. minicalefacienti $433 . \pi$ iqua calefactio quatenus generatio dicatur 15 a quatenus motus alterationis ibid. forma quomodo dici potest conditio necejJariamateria ad recipiēdum calorem 4IDd generatso s36.d in ignem adto celerrima $537 . c$ fna est 5 femplex natzora

351.6 agram aque fimplici motu moueriacterram372.e ejfe aere bumidiorem SI8.dpuram nö dari 74.6

de Animalibus libri anteponends in Aqua $E^{\circ}$ terracur omnia pulibris de plant is ga.e librorum oprizizm dewifio है ordo iuxta ab Aqua cur facilius feparetur propriamopinionem jo.d frigus,quambumiátas $525 . e$ de Animaibus tractatio in tres Araneus propter aliguem finem partesdivifa 110.6 telamitexit 230.0 Sinmaibus que Ariftoteles Architedonica artesquanam diconfoderare confitucrit 24.6 I27.f qua conftant ex contra-Ariftoteles de eadem re fapius $a$ rijs naturis, daripoteft alteratis git

$\log f$

animatum idem quodorganicum $252 \cdot a$

inanimaticorporis nulla alia est forma, nifi forma mificionis qor.e

animata augerieuidentrusestomolb. queturnanimeates 237.6 ordincforipilis.d labrorsm
ordo g.e foln nuiriuntur $\mathcal{E}$ angentur in Arifotelislubis interpretan$z^{i} z, d$ dis firi preclarifuimi ctatem
congum. dis Giri preclarijsimi etatem
congum. decendo intellectum c/fe forma formarum $077 . d$ confilium in odtaus libro quid fit $36 . c$ interpretum fuperiorabus temporibiss differigro of librequa ordincforipinis.d librorum 
11

'onfsupferunt

I.C

Ariftotclis libros ordinandi ratio Gnde fimendis.

Ariffotelis mos

8r.e

$100 . d$

in Ariftorel. Gerbic cur nulla re pugnantia

II 2.d

Arifiotelinfientia rerum naturalium nemo comparandus $x . C$

Aritbmetica' demonflratio quid Arifoteli

260.6

Ars medica inde partem illam que Phyfrologuca dicitur, fumate

D2.e

Ars non dicitur, nis qua cum ratione eft 10x.e non est arte factorum principium pajisum, fedactiuum folum

$$
240 . f
$$

Artis medicefcopus.

$100 . e$

Arteria in omntus membris pro corde eff, Gerocerebro neruus. $7 s x \cdot f$

Afracelerrime mosent ur nan ideo calefacere guodignea fint

Afrorum motus qualis Auerroes de feptima libro quid Senferit

\section{ors.f}

C.

$I N \quad D \quad E \quad X$

Adauer cur Gnum corpus fileamus appellere $40 x . f$ est plurzim corporum cogeres ibid. non est corpus. Snum $736 . x$

Cadisucres forma 406 . a non datur $40 x$. d quomodo fit noud forma $461 . e$ in Cadasuere quomodo dicatur genitanaisaforma 412.e Garic fint mifionis forme $401 . e$

Calcfaciens quomodo refrigeretwr $430 . d \neq 40 . f$

Caictani ficntide confutatio $380 . d \mathrm{~m}$

Calcdum ì frugido quomodo recte fepurctur $498 . \mathrm{cum}$ ficco magnam agendi Sim babet 442.6

Cals dum Eg frigidum maximam agends Gimbabent 660.6 . 0 lemactiua. $40 \mathrm{r}$.a

Calidum beterogensper accidens congregat 486.6 $35 . a$ Calidnm quid 407.e quomodo ab Arifotele definitum $498 . a$ Summe non laditurfolum a frogido,fedetiam istetids 304. a Iuperarefrigidum, Co wrigido superari aptum effe. Gndeproducatur:

538.6 ibid.6 o.f Socet

A- Calidi definitro $+83 . d$

Auerrois argumentum contra $A$ uicennam inualedum

$464 . c$ Calidi 6 frigidi actio celerrima

in Aiserrois dictis nulla repugnantia $235.6 \mathrm{c}$

Auerrois refponfo ad Ariftotelem inpreducamentis - $\neq \sigma_{j} \cdot e$ Aserrois fententia declaratio $\mathcal{E}^{2}$ confirmatio

IDS.e

in Auerrois folutione qua confideranda

sog.a

auerroi praus fenfus a nonnullis attributi reprobatio 108.5

Auicenne 8 aliorum de materia demonf tranda error $138 . d$ quod. augetur, quomodo idem numeromaneat

7or. $f$ Aturum abigni non abjumi $572 . f$ Aurigeneratia.

Go6.

\section{$B:$}

Ioan.: Docconius philojophius

Benedicti Pereriide principiis liber

$287 . a$

Brutorum animemortiales 25G.e

Burles argumentum contra-reaGisnema
524.6 est rarefacere $\quad 484 . a$

Calor ambientis non putrefacit, nifle lente agat $6 \sigma 0 . d$ caleftis ab e'ernet aridifindzus st tod

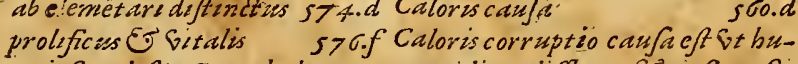

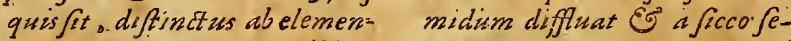
turs ibidee paretur 623.d

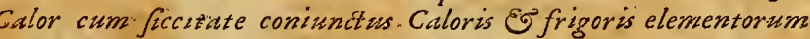
nonpoteft diciaereus $70 . a$ du- caufa sitice

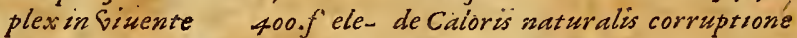
mentarisnōcorrumpitwr, nifi Alberifententia $\quad \sigma_{32} 2$ perputredinem 300.a Gita dt-- Calort alia competunt focundum fructums.

$577 . a$

Calor eft caufararitatis, non raritas calorie sor.a est pri-

mum anime. inffrumentum Calorem coeleftem difingui ab e$7 \div 1 . f$

Calor हु frigus agunt हैं mowent, nechabent in feprinci- Calorem $\sigma^{2}$ frigis in element is piums.c nonpoffint finul cxi.. fere in eodem jubicito. sos.f qua ratione adtiue qualitates. 40.1.f qualitates actine Calorem in elementis a motucie-

489.e: feconfiderato, alia btestini frumentum primariiagenti. 530.6 lementari, dicentium opmio 589.

efe duplicia 544.6 E raris tatem $\int_{\text {f }}$ miutuoconfequuntur 550. $f$ :

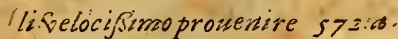

az\&ia. Calor extranews quornodo in cot Calorem; omnemitam fimplicium 
quam mifforsm corporkm effe perfeevusdempecie; $533 . e$

- aloresdivo in animali 743.4

calores medï differunt jpecie ab extrenis

$48 . f$

Caput cur relatiuns $\quad I \& 4 . C$

dc Cafu $\mathcal{C O}^{3}$ fortunatrad atio, annexa est tractation de canges $30 . \mathrm{C}$

Categoria qualibet diuditur in potentiam 5 actum $358 . f$

Caufa alicuins rei abjolute qux dicatir $\quad 42 \sigma . a$

canfu effedtrix Ariftoteli principiummotus $223 . f$

caufa formalus dupluciter fumptur $248 . f$ caufe definitionis perfectio $\sigma_{\sigma}$ coplementum $\quad \sigma_{i z} .6$

arufam effeiticem Ariforeles appellare folet principium motiss

250.6

- Caufapriuatiua non poteft prodire effectis pofitiws fine blla caufipofititus

$5 \& 6.6$

de Caufaloquiquatenus est caufaquid

37.4

caufa externa finis $\mathscr{E}$ efficiens 302.c

caufarum confederatio qua infe. cundo phyficorü babetur qualis 20.6 generuquanam in demonftrationibus locum babere pojsint

$30 . d$

de Catefrumgeneribus quomodo Ariffoteles in fecundo pbyfica aufcultationis agat ibid.

aufarum tractatio qualis $30 . \mathrm{C}$ du.zbabetpartes $30 . d$ non ad natiralem phalofophis, fed ad metapbyfacumpertinet . 30.6 canfas alicuius rei abjolute confiderare, 6 aguatum citafum quarere differunit - 423.6

canfis rerum abditas penetrare quomodo aptifimus

quomodo apti fomiss $\quad .6$

Cera ${ }^{\circ}$ piciscommifio $\quad 270.0$

Cerebrum est omnium membrorü frigidifimum $\quad 7 \neq \sigma . d$

cerebrum quomodo dicatur fuo frigore calorem cordos modera$r i$

Cerebriprafintia

Chaos Anaxagore

$748 . c$

Cinis eupulusisquid

IDブ.d

Ciuiles difciplinaiog legislatori.e gremododefierent . rorf

Colum aliquondo efje interiturum 257.f cawfa effectrix in. feriorum corporum 25.6 cuinsnam elementum Socari pojist $41 . f$ cur corruptibile $277 . a$ curelementum focetur 50,6 cur incorruptibule 272. e cur indiguerit externoprancipio, quo moverctwr 200.6 curnon Sideat ur babere-naturat $285 . a$ curmiforum refpectu elementum dicinonpoliut $\quad \mathbf{2 . 6}$ Coclum duobus modis accipi $281 . a$ clementum cur Socetur so.d est animatum 27 . a est indzuiduwn act uexiffens 285 .a ef matcria formalis $\sigma$ forma materialis $285+6$ est Geluti animal quoddam magnum 306.6 colum $G$ boc colum differunt $380 . f 392.2 \%$

colum ${ }^{2}$ quatuor clementa quomodo fimslicia corpora dicantur $40 . c$ exclementis conftare $25 \sigma . c$ ex mite:ia $\boldsymbol{C}^{\circ}$ forma itumex quo fit aligusd 270.6 busprincipijs conflet 23 .f ex crusdemnatura

s50.6 quibusprincipüs genutum non. de Calemareria, Gracorum opi$\sqrt{i t}$

calum hanc inferiorem mate- $2>1.6$

riam calefaciendo generat ele - cole motss $10 . d$ ad terram us yue mentacalida $577 . e$ boc efje peruenit *. sage formam cum materiamigam caí moiss cur bere naturalis 386.6 internaturalia corpora $286 . f$. 200.6

primum locum fibi Gendicat coelimotis fimplex i 200.6 24.c in bacinferrora non age- cali motum non effe natuialcm

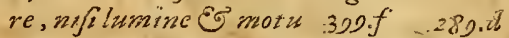

materice ${ }^{\sigma}$ forma conditiones calomotu in bis inferiorib. calor redolet $20^{\circ}$.d neque materiam curgeneretur $558 . a$ habereneg, contrarism 282.2 cceli naturam quid Ariftoteles nobulizs est inferiombus cor- Gocet $280 . c$ pofitionis differenporibus $\mathcal{G}^{2}$ natura privs $40 . a$ tia 40. f fubied um pracipum aelum non continerifib defini- $40 . d$ fubfantia immutabiles tionenature 280.2 szon babere $273 . d$ fimplicisma $\quad 282.6$ principia 42.c. so. d nun- in Cale tractatione quem ordiné quam elfe genitum, fedfemper Arijotelesfequet $\quad 40 . b$ abfolutum $\mathcal{G}^{2}$ perfécum exti- colinatura definitionem cur $A$ tiffe

$2>5 . c$ rift.aptare Golicerit

26.6 calum omium corporum nobi- in Calo eundem efe anime EGnalifsimumz-dper calorem gc- twremottm 28\&.f nerat animal $5>7 . f$ per mo-in Calo effemateriam Arafoteles tum calefacere 562 . dperpetuo moseri 2546 aperte negat $2 \& 0 . c$ columpromunio Gniuerfo fumitur 40 . a quaratione elementum bocetur 50.6 qua ratione immobile

$44-5 . c$ colum quid 302, equomodofimatur + r.d.e guogo effe anumatis. Ii 8.6 quomodo per motum cale faciont

SS. A.A in Calo efe naturam $\mathcal{G}_{\text {int }}$ innü principiummotus $\quad 287.2$ in Calo est privatio ratione lose $280 . e$

in Colo materiam effe diwerfe rations a materia inferiorum $281 . \mathrm{e}$

in Colo non est principizm mor us atziunrs $288 . d$ calum repectu mundi elemen- in Calo non efe naturam 


\section{$\begin{array}{lllll}\boldsymbol{I} & \mathrm{N} & \boldsymbol{D} & \boldsymbol{E} & \boldsymbol{X}\end{array}$}

nulla materia nijzloco mobilis 282.6

in Calo nullam efje potentsam patiendi, nifs refpeitus mot us localis

$282 . c$

in Colo nullam materiam efje, nificorbem ipfum 280.e que materia concedenda 280 . e qualis natura $398 . \mathrm{c}$ quatenus propria natura $14 . d$ quomodo natura infit 286 . f quomodo fit natura 287. cralis natura, cus competat definitionatura ibi. colum Arifotelesfepe Socat pri- Color duple mumelementum $41 . e$ 858.d

inter Colum $\mathcal{E}^{\circ}$ boc calum qua an Color frt diccndus is qui est in fit differentia. $377 . d$ profunditate $804 . d$

de Colo curpriss agatur, guam coloris definitiones dua $857 . \mathrm{cna}$ de elementis $40 . f$

de Calo Eु de generatione librorum ordisis ratio, difficultatumq folutio Gi.e.f

de Calo luber guem locum infoi- colorum apparentium generatzo entianaturaluobtineat $39.6 \quad$ \$Oz.brealiumgeneratio $807 . f$

dé Calolabrorum diuifio 30. a Combuftio ab externa tant ü caufubiedtum ibid.

de Coelo tertit libre qualis fit tractatio

dc Colo librorum cum libirispby/ ca aufcultationis conexio $30 . d$ de Colo tractationis ordo $\quad 4 r .6$ calorum motores debent effe fine materia $274 . d$ calefte corpus nullum babere fub.
iecturis

cicleftis corporis effentialium conditionum declaratio $\quad 123.6$ celeftia corporacur calorem effictant s05.c non egent loco 395 . $e$ quant int perfections ibid. quod fuo motu E lumine agant in bac inferiora, ad gia amphilofopbixpartem pertineat con-
fiderare GG.e.f coleftia corporanyomodo bac inferuaracale faciat 558.6 regere peraccidess bec inferiora $205 . c$ celeftium corporumfinis ibid.e calica naturacur fub natura definitione non contineatur $20 . e$ Cognitio abfoluta quando debeat Concoctio ì calido, inconcoctio pracedere refpectuam 62.6 a- . autem per $/ e$ a frigido fit $590 . f$ itualis quid fit, EJ quid babitualis 1057.6 contrariorum Ecognitio contraria differunt 967.6 cuing $q_{3}$ rei exprincipiorum fuorum cognitione acquiritur 45 .e frigidum organums poftulawit $748 . d$ noftra bel sit originalis, Gel habitualis Contemplari $\mathcal{E}_{5}$ imeginariplura confufe cognofcere 33.4 confufum cognofcere confufe है indifincte quidfit ibid. confiderari id dicitur, cuius prin cipia $E S$ caufaguarunt ur $35 . d$
confiderandi modus $x 4.6$ debet ef

fimulest impojubile $\quad 983.6$ Continuitas in motw a refigtentuaprouenit 318.5 contsnum accidens commune corporisnaturalis $34 . d$ Contradictionum non pendet is fuo contradictorio is o.f Contrarium agere in fuum contrarium 400.c.d contrariagua Ariffotele $\begin{array}{r}\text { 400.c.d } \\ 135.6\end{array}$ contrariorum conditzo $149 . a$ Cor non recte dicitur organum effentuanima 736 . Gitefos 25 . d cordis primates 735.6

Corpus alio modo est genus generalisimum, alio modo est prima materia $213 . a$ animatum Specues corporis naturalis $120 . f$ fubsectum librorum de anima 11D.e

corpus colefte est materia exsRensperfe 285 . a quaratione nec formam nec materiam habeat 282.e quomodo habeat formam $283 . a$ corpus cur nec finitum nec infinitum $213 . e$ de categoria quanti non potest exiftere fine corpore de fubfantic categoria $218 . d$ de categoria fubftantie duobus modis accipitur 226.a de generefubftantioquid $206 . d$ lenta cur dicatur alo.c biolentusinteritus $614 . d$ corpus duplex

218.4 iustaid 72.f 75.4183 .2 e- corpus est generalijimum 215.a iuspabulum - G8.f. E corporeitas differunt 220.6 cometam non recte appellari i- corpus miftum cur fimplaci motse non pofsit moueri 364.6 qued $364 . d$

Compofitum a materic forma- corpus mobile fubiectum naturatione quomodo diftinguatur $327 . e$ quomodo Es quaratione augeatur. $823 \cdot 5$ tam naturis componentium 340.6 de omini duas formas confrderari $387 . d$ Cöclufio Eo medium ciufdem generis effe debent 25 .e non demonftrat, fed demonfiratur $205 . a$

lis philofophic $12 . a$ motus fubictum, $11 . d$ naturale alterabile cum corpore generabile reciprocatur 56.c. commune. fubiectum totius cientia naturalis 16.e cur mobile sz. fnonest Grituocum 16.d non est absno, fedanalogum 25.f quod non fit commune Gniuocum, fedanalogum 24.d fubicctum in totafientia naturali $47 . d$ fubieltum libroriu pbyfice aufoultationis rg.e Gocandum est commune analogum 26.6 naturam babens, fubiectum phyfices 39.4 tribus modis accipipotest Ig.d.e corpusnullum interit, quatenus corpus $215 . e$ primum de categoriafubftanticquale 217.0 quid dicatur is $15 . e$ quibusmo$M$ MS dis 


\section{N D E X.}

Lie cosfiderabile o. d fientic corpora naturalia an caduca, an nat is alisfubiectum 21.c quaregenus fnituocum. $\quad 22.4 .6$ aorpus fimplexicur non fubiectum

librorum de calo 43 ididicere meliuse effe, quam mundus 79 . d. est commune analogrm jo.e. quatenus mobile $52 . d$ quomo- corp do duos motus maturales ba: berepojit

351.0

aorpus fupremum cur genus proximsimprimamateria $221: 0^{\circ}$ Gniuerfe fumptum que corrplectatur

$f$ cospora aternds. o.e cur loco fint mobilia 2G.f ex materia. Gorma conftare 23,6 quatenzs confl- Denfitatis cauf.a est frigidism derandat. $40 . f$ 550.f.

est medum हु conclufionem ad eandem fientiam pertine264 . corporanaturalia quomodo con-Determsnare हु actuare est fofiderentur. DD.f. insesforma officium $381 . f$ corpora qua in fientia naturali deterininatio nulla à materia: jubiectilocumbabeant 14.6 prouenirepotest a 196.6 corpora quomoán matbematicus determinatio omnis fit a forma:

corpus Gr fit Sinisiocum, oportet Gna Go eadem ratione omnia corporum. naturalium proprium dicicorpora $2 \pi \cdot f$

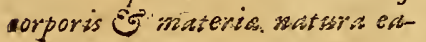
derm 21 R.R:

corporis form non ef parsaligua. foriss bamanis

corporis mijti migfus. est- motses: $3 \sigma_{2} f$

corporis naturalis cognitio qua- on Corporib. miffis quot fint motenus imperfecta a.e.

corporisnaturalis plisimaspecies de.Corporious naturaliús eter20.6 prencipia externafimpli- nis aginalabris de colo Ga.f: ciora: funt internis principits corruptibsle cur omne excontra133.b. fubiectum librortump by- rits conftans. $607 . d$ ficeasfcultationis. $\quad 37 . d$ corruptionaturalisque oxpoc corporis naturalis prima diwsigo Eryfallbibumorisofficium 200.C. 30.d tractatio gromodo di finguenda $18 . d$ triplex.acceptio.

I.g.e

corporis nomen praciphe dimenfronesfyrificat $217 \cdot d \cdot 3$

corporis nomine figntican materiam - qualis effé debcat. corporis nulla forman dist: 215.0 corporis phyjzologia fabiecti ab alusmum. ficentsirum frobicetis fepariztio:

4.c. corporis comfiderentia modis 4.C. per Corpus generationi $\mathcal{G}$ inter: suiobnosism quid antelligendum:

so.d.

in Corporenaturali perpetuss $\mathcal{G}$ incefabilis exiftit motus: 3.0.c.

in Carpore ; Got commsni genere. consersurequidfit: $217: a$

de Corpore nativrali-tractiatio.in quibusconfifix:in fitimedio 264.Q. $2 x \cdot a$.

corporaccelefica in hoc insundo.inferiore caloxem praducunt $y \geq 7$. finonfuntin locasozud cur mobelia" 8. di cur nutwaliter an futsm locum ferantur,jog.b. in 205: 0 in libro de Calo quece. G4

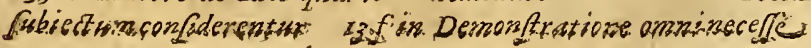
contempletur 4.e folatphilofophice naturalis fubiectum nowinat Ariftot.

4.C. Deus amallopendèt, Esest omni-

Efinitio accidentis trio parm Defibus confare debet o,2r.f eitifiemfontfpecies $\quad 528 . d$ $4.93 . e$ ing iefinitionis Galeni cum Arifiotelis definitione collatio. Spg.c manus 48 q e omnespartesegle formass

227.6 omnis prowentt a forma: $243 . e$

zimprimism

253.4

1033.2 perfectissmum jubjgytens $14,1 . a$ Deinatura. $\quad 238.0$ Deipotentia est ip $\int$ Deus 180. at. in Deo efle adeam primamiteria $224: 3 ?$

Differétiacofititutiua 2z2.e diuifiese abid. andiuidurlis quíd? $388 . \mathrm{c}$ fecundum magis $\sigma_{6}^{\circ} \mathrm{mL}$ nus now Gariat peciem. IS5: Dimenfonesin corporibus perfect is effe accidentia, fed in ipje materia eflejubfiantiam 227. fi interwinata cus diccniw. ng8.e materie internisinatios. non c/fe actuales, fedpotentiax les ig8.d quafunt in frmirse. interminata.

tbid.c

Difiplina naturalis quid 3.6 difiplina morals accruilis actegis latoriam refpedtiss ror.f Difciplina qua methodo fi: progrediendum

$30 . \mathrm{C}$ Difcurrere est proprium folius $1 n$ sellecas jo $4 a, b$ irum rezlatentem: $138 . e$ Definitione Gateni defectus rat. 520 ;

Goge

Demonftratio cur non ämedio, $f(d: \dot{d}$ quefto fit nominandis 257f formari" ab: eo dicitur, cuiverest quefotsins. $258: a$ quod. Demonffratio nominandi? demonftratio omnis di:medio noninatur 25 .e onnis mestiabere: debet reales. temminos. ato.b:

dèmonftrationis ppofitiones quat. leseffe debeant: 26.2. demonfizarionem it olónedia denomisour:$2 \sigma 0 . d$ Difputatio eadern dè prima librosum naturaliumpartitione, de de jubiedto-odto iibrorum phyfice aufultationi:

Diftucte cognofiere. ig.6.c. Diuifibile quid Gocemus $204 . \mathrm{C}$ effepropriam quanth $\quad 37.6$ ¿wúupus quidfgnificet $408 . f$ .

$\mathrm{E}$ Clip/is quid $623 . e$ eius effers. tiainguo confiftat $364 . d$ Effect us dim exiftit', neceffe est" curifarm quoq of fimulcodem modo cxijteres 32. f emanans 6 fit ab efficierstediftinctus., ne-

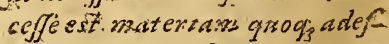
Le $322 . a$ ex cauja pendet, nox sAu bumano quatenus dici poßsint Disifionem है diuifbilitaiem 


\section{$I N D E X$.}

-aufa ex effectu t3o. $_{3}$ idem ab Gna caufa, Ej eodé modo agenseprousenits 20.f non nifiper fuas causfas cognof cuntur 12 r.e

- quandofat poreftate isz.e preteriti causam effe proteritam 3rz.e.f

effectum effe in potented paßius materis

180.6

effectibus quomodo potentua tribuatur $\quad$ ISA.d

Efficuers duplex 225.e

efficiens in corporib. naturalibus est forma refpectu accudentiä ibid.f iure socatur canfa bnde matus ibi. principium onde motus 225 . e requirut neceffat riopatiens diueiffom ibid.

Element um à fexplo maiseri, Scosifententia $297 . e$ adfusumlocum monetur, St conferuetur so8.e calidruf fit frigidü à motu soo.e corpusfenfile $40 \sigma . c$ cur à fe non mosseat tsr $3{ }^{1} 3$. f dividis in motorem EG motum 327. fitem inpartem mouentem Eै parte motam 310.6 elementum dominams $37 x .6$ frzgidism, fit calidum a mot $18500 . e$ graue babet Gbigs naturam gratuis

$342 . f$

elerrentum ignis radix formalis omnis caloris in hoc mundo inferiore igg. 6 in miftis duobus modis ioffe dominari 371.6 mowere per accidens $236 . a$ moueriperfe à generante $313 . f$ nullum in mifto aptum est per femoweri343.f primum quid Socet Ariftoteles 4 4.c quando in fuo loco est, non mouet ur. $\int e d$ quiefcit

elementum quid 300.f

elementusr auando ì generante moueatur. Es quomodo a fua forma 270 . a quomodo a fe momeatur $313 . a$ quomodo moueatur áfeipfo $320 . c$ quomodo dicatur in fesplo habere principium motus है actiusm है paßsurum 313 . f qù magis appropinguat fuo loco, eo magis roboratur

335.c.d

elementi dominant is forma non potest effe motrix $244 . \mathrm{C}$ element iforma eft agens aquizsocum 316.e est natura 3ir.e mouet Gt forma 244 . a है mouetur $6 t$ in materia $327 . d$ sabturafimplex $36 \sigma . e$ non po- test diciprimus motor respects fii motses $235 . c$ grauitas Gel leuitas quaido augeantur 326.6 motsus naturalis que ratione tardior in fine effe debeat, gut $\vec{T}$ in principio $338 . d$ in Element: mots refiftentia externafolum 2jo.e clementi mutatio $246, c$ inatura fimplex eft 345 .a naturam effe princopium actiusus fui motus xat 3 ralis 325.6 nomex refpectiuum , \$1.f. $\mathrm{G}_{3} .6$ de Elementi in Sacuo mot ts, nsnnullorism opinio $3 \times 8 . d$ elemëto cur tribuatur bt fit generabile Es corruptibile 64.6 in Elemento duplex potentia ad motum 310.6 graus qualitas afecolendi potefias jar.e qualibet an anibe qualutates fint fumine, anpolstt altera cfjercmijja.

$507 . e$ elementa a fuis formis conftitui 450.f ad formam mijti quam rationem babeant $352 . c$ adfua locemoueri 3c2.f elementa calida a motu cecli haberecaloreme 205.e conferuantur àmotuc circularizor. deffe calida à mot uc cali 400.6 habét calorem ìmotu $\quad 562.6$ èlementa confiderare fo partes mundi quid apud Auerroem qu.b.c conftutusentsorpropter mifta s05.f cur inaturaproductatig.c curinterfecontrarias $10 . d$ cur magis dicätur materia mifi, guam miftum mifti $4 \sigma_{2} . b$ cur putrefcant $53^{5}$ f cur fimplicie corporaAriftot. Sape Goces 214 .d effe miforwm est quadam illoruin corporum proprietas 85.c E़ calism cuizes ordinis effe Gideantur $12 . f$ in fientianaturali fubied lociu habent

44.6

elentêta Es mifta inanima Snam tant um formam babent 305.d ex niateria Ef forma confare 19D.a externum tantum baberemotorem dicentium opinio, EF eius comprobatio $370 . a$ elementa frigida conferwari per immobilitate 303 . a habere in feprincapium motus non altiusum fedpaßsum is $4.4275 . e$ indigent forma aligua conti-

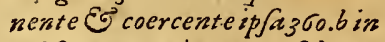
mifto manere integra, EF pro- prias edere operasiones difins. ct as ibid. intendi Es remitti cumbariationejpeciei, Auerroisfentètia 4 Gs.d mifto priora607. a mifforume carese 25. principia i 44.6 moncri a prow prÿs formis dicentium op: 10. ES eiss comprobatio sir.e moweri ad locum furm tanquam ad formam 301.e non habere figuram aliquam propriam 454 .a non feparantur a miffo cadem numero, qus prius erant $4>1 . c$ non funt aptainterfe agere Es pati, nifi per qualitates alteratrices s.d omniagraxitatem habent excepto igni s20.C omnus in fuis locis aliguam babere grawitatem proter ignem $341 . e$ qua ratione aterna $\sigma_{2}$ a item caduca ibid. qua ratione dicantur imperfeita mifta jr:a qua in libris de coolo confiderantur, effe indiwidua aterna $\sigma \sigma . e$ guatenus fimplicia corpora appellentur 230.d quateniss fint mitAt: materia 423. o quatuor babere principia so.e quomodo aternasc. $f$ quomodo generentur $\mathcal{G}$ inuicem mutentur, ignoramus $\sigma_{4}$. $d$ quomodo in mifto maneant, $\mathcal{E}$ quomodo intereant 359.6 quomodofint zn mijito $\quad 472.16$ quomodo fint materia miftorum 477.6 recipere qualitates icclo 4yg.a folalocum Gere babent 50j.d perfe funt mifeibilia $478 . c$ funt corporanaturalia 53.6 snat at tism forme conftare $305 . d$ St materia müdi confiderantus

elementorum abfolute tract defideratur in forentza naturalisz.d actualem inutationeconfiderare quid fot $65 . c$ affectiones librorum meteorologicorumfubiectum $73 \cdot f$ elementorum alterationes $245 . f$ $43^{\prime} . c$ non effe mutationes naturales $240 . c$ Snde proweniant $247 . a$

ad Elemëtorum cognitionem quse pertineant $6 \sigma . \alpha$ ex Elementornm cömiftione quomodo $6 n \bar{u}$ in mifto remaneat principium notuum fecundumnaturam $352.6 . c$ 
clementorum confideratio $\quad 33.4$ $4 . c+6.6$

in Elementorum contrariorim congrefjus duas qualitates interire opinio Alexandri 539 .

clementoris cum materia cur non it couneniens compuratio 144 . $f$ due diftincteconfiderationes s7.f duomunera 68.a duo qualitatumgenera ibid.

- olementorum EF primarum qualitatum duplex confideratio $s+\sigma . f$ forme an in mifto ferwetur $453 . c$ incognit a so. f nobiliores griolibetaccidente 47 g.f non pojunt in mifo fimul coneftere

$353 . a$

clementorum forms quomodo intenfionem $\mathcal{E}$ remijsionem recipiant 470 . a quomado fint media $470 . a$ funt qua-
litatum caufa finales so4.d. tenent in mifto bocum materie 357. a formis attribuitur intenfo Eु remisia 477 .a for mas aliquo modo ferwari in mifto 4 o8.c effeprincipramotws actiua

elementorum infientia naturali duplex confideratio $\quad 142 . a$ 17 Elementorum locis qua it conferuatrix facultas $503 . f$ ad Elementorum mifionem non conferre grauitatem $\mathcal{E}$ leuitatem

57.6

clementorum mutatio mutua 379.f mutationes Gnde $547 . a$ omnium Gnus Eं idem motus naturalis- 243 . a perfecta cognitio in quibus confffat 482.c quam tradtationem pofulet - $\sigma_{4}$ 'd precspus operatio qua 4DI. $d$ propria conditiones que 371.6 proprietates loco formarum accipuunturso.f qualitates à celo produci

215. $f$

inElemëtorwm qualitatibus duos ejfé erdinesinter fe contrarios $438 . e$

lementorum fingulorumpropria est duarum qualitatum coningatios3r.e fubfantiales forma priores natura omnibus qisalstatibus $\sigma_{3}$.d.e Girtutes quomado fint intelligéda $468 . \mathrm{c}$

clemientis cur duas contrarias coditiones natuxa dederit so.f

in Elemèt is in alteraqualitatum

\section{N D E X.}

tranjatusex bno in aliud, quä gnificationembabeant $888 . f$ in babentibus ftramgue con- Thome Erafi de putredine difputrariam s34.e.f tatio

SDs.c in Element is omnibus debent oês Efje ád effentiam quomodo comqualitates effe furma s;r.c in Element is triagenera accidetıum paretur $3 \$ 2$. eper feip ism quid it 1oof fecundum quid nunquam est prius, quam effe fimpliciter

$203 . e$ bus tertï elementigcneratio- effendiprincipianonfunt nifi renemfieri 536.6 rum caducarüprincipia $27 . f$ de Elementis quo ordinesififote- elfentia materiacojfituta in ip $\sqrt{a}$ lesagat sid ex Elewentis duobus contrarys tertium medium generaris 29. c $537 . a$

ex Elementis qua generitur, differwnt efjentialiter ab elementis

353.6 inter Element a $\sigma^{\circ}$ mifa nullum difcrimen

351.6

Empedocies elementa in miftoponebat, feruantiafuas naturas integras

$360 . a$

Empedoclis fententia rations abfona.

300.6

Empirica curars nominarzin non poßst mam recipiendam dirigutur. $1>0.6$

effentia motus est forma fuens. $768 . \mathrm{C}$

efjentia $\mathcal{E}_{0}$ forma rerum neceje est iot fint fupperaddit s elcmie$t$ is

$353 . d$.

efentiāmateria quatenus quaintitasinfequatur. $\quad 204.6$ ad Efentiam tribuendam plura. requiri,quam adefentiam $\overrightarrow{0}_{-}$ fituendam: $184 . f$ effentiale eft duplex Is 8.ffumitur duobusmodis

ibid.

Enunciure $\mathcal{G}^{2}$ difcurrere est proprium folzus intellectus $732 . a$ Ens acceptum pro re confiderata latius patet, quam ens acceptuni pro modo confiderandi io. 6 dum progenere rerum ornutis Jumitur, efjentiam fynsficat $184 . e$ est actuperformam 188 6. est metaphy/ica. confiderationis

$258 . e$

ens mobrle quid Auerroes appellet.

10.a

ens non est analogum

20.6 ensperpotentiam $\mathcal{G}_{\vec{G}}$ actum diutditur $1>8$. guomodo reftringat ens 10.ff fimstur dupliciter. $268 . a$

ex Ente $G^{2}$ non Ente omniaiconfare Plato afjexuit os 2.4 entia abfract a effe aternos motores metaphyficus cognof cit $38 . f$ fubjantzababunct a a materia $39 . c$

entiñ diuinorum attributa quatenus ad Metaphy/icum pertineant

3.D.C entitashominis , nilaluwdqwam homo 177.6 materiequad 7 G.f. indiuidualis habet locum materis $388 . a$ fumitur $\mathscr{G}$ pro exiffétia, Eg pra effentia I $44 . E$

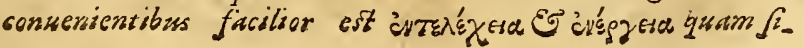
duas-habet caufas politiuas $\sigma \neq 0.6$ bumidi est quoddam cöfequens exitum calorisnatwralis.

Gij.e

Euclidis libri cur elementa. Gocentur 132. c quanto artificio fripti

832.4

Eudemus cur feptimum librum Qt. fuperuacaneum, dimferit. 32.e.

Exemplis quibus. Arffoteles $f i t$ Sfus. $\quad 479.6$ exiftere nibilpotest, cuius non fit determinatinatura. I80.a exiftentia eft actus additus effentia 382. est quoddam additum effentid I $8+7$.f infequitur formam praftantem, $\mathcal{G}$ perfectam 210.d nondemenfratur nifia Philofopho natwrali 267.6 xiffentiam adtu tribuere maius est, quam efjeniam rei confiz tuexe382.c effe quidaddumm efentic $300 . d$. ad Exiftentiam plura requruncertenature I80.f 806.6 E.

Hacere aliquid, Selfumitur ad modxim form $e_{2}$ Selad modis agentis roro Fackb tur, quam ad determinatione 


\section{N.D E X.}

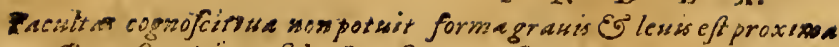
effe conferwatiua, Eo ecouterfo caufamotus 325 . a hominis ri28. finferior quicgus d cognofist, id cognofit Eु fuperior $1045^{\circ}$. dmaterialis nullapotefs mowere perpetso 202. $f$ fine operatione quomodo non fot frum fira $716 . e$

facultates omnes infingulaparte infunt originaliter, at non 346 icctive $7 \sigma_{3}, d$

focultatsim ordo 713.6

per Fatü quidintelligendz̈ ox\&. febrilis calor differt jpecie à calovenaturals s27.e Figura quid IDS.C

figuram propriam quid dicamus babere , tbid.

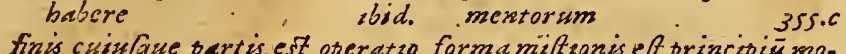
ppria Go proprizimisnus 23.1 fris mosser efficiens ad agendum 230.d

finitiad infinitum nulla est pro-

portio
Flaxmaquid
fuminumgeneratio
Fat rs generatio
fonsquid

$320 . f$ G.d forma moret, quatenus est in G.6 materia $243 . e$ nonest aterna go8.f 200.d necefjaria est materia 73.e ad exiffendum r8g.e non eft fontizm generatio og.d formatad exiftendum eget materia 38 ij alceraparscopofizizs5 $f$ appctibila rón.a cur ab $A-$ rifotele diuina vocetur g5I.f curtotum boceur $403 . f$ dat terminos extéfroni materiaigy c dicitur actus ab agendo 372 . adomina estexiftentia 383.6 duplex $283.2380 . e$ diplices terminos preftat 106.6 elementiprincipium motuspaßsiuum 332.f ë̈ adtionisprincspissm, materia Gero omnispaffronis $317 . d$ eft caufa formulits corporis naturalis $327, c$ eft illa gue tprie dicxtur nuturez 44 $f$ est principium motus adtisum, Es eadem eft etiamprincipiumpaßiurm $\quad 274.6$

forma ED effentiam \&o exiftentiam tribsit 3826

forma $E^{\circ}$ omnes eirs partesquomodo maiores fiers dicantur 813.6

forma Eq quaddit as differunt ratione 380.6

forma generalis dat quidem aitum, fedimperfectuin $218 . C$ officio materia fungitur $398 . d$ generations: Gel alterationis verminas

II. $f$ fibilitatis caufa 327.6 materiafenfitis 387 . fimaterialis est cömunrcabilis, abftradta Gero incommunicabalis 38 . fmatc. riam prefupponst, Grpotenatuea priorem 220. fmiftianfis addita formis elementorum in mifto 354 . a contsnet infe formas elementorum, EG cdiro. perationem elements dominas. tis $357 . e$ est formis elcmentorumfuper addita 353.6 in $\sqrt{e}$ continet formam elcments dominant is 357 .dpartim addita, partion non addita formir eletus dominanti elemento conuenient is 350.6 in viuente est genersca, in cadatsere bero $\oint_{p}$ cifica 408 . a quomodo intereat $397 . d$

tiwam wafiure prescipesse molus 2 f G.a guaterase res of fentia $382 . f$ quid $x 51.6385 .0$ quod non for tantum activa, guant üreffeitisa \& 4.6 gruomodo aे matcria है compofito difinguatur $282 . e$ quomodo dsferentiappecifice E' individualis 390.6 quomodo extra agat 328.6 quomodo faciat reiffentiam, aliorum opinio 440 a quomodo non moncatur 12.4 guomodo st principinm motus pastrum 242.a quomodo Sub. iectum Snisserfitatis 392.2 formaireinatura 27: drempotius Gniuerfalem fignificat, quan particularem 377.6 fingulari. tatis caufa $385 . c$ folaper feef natura 242.4 forma Specifica dat actusm perfectum $208 . d$ non factr abfolute corpus $23 \sigma . d$ fubftantialis cur non intendatur 337.6 duple.s 217.6 est mediatrix inter accidens Ef materiam $421 . f$ pracedit natura accidentalem 415. $f$ quatenus indiusidua $477 . c$ perfepatibilis, fed yuaterses eft in materia 418 anon poteft ef - forma cerminimotus

I2. 6 fepars materis, in qua rectpi- forma bana eft, que non form. tur $353 . e$ non potest efjè ratio patienden 210.6 materia 245.6 nullagenerica potest dareexiftentiam $183 . f$ nulla mareriam informans potest femputérno mots mosuere 270.6 omnis eft jui multzplacatiua 841 . domnis EF qua for litas est extra materia effentiam $153 . a$ omnis informans forma contrarium $150 . a$

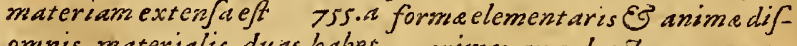
omnis materialis duas haber crimens57.d estagere,mateconditiones 825 a omnis ma- raberopati $242 . f$ terialis interitui eft obnoxia forma $\sigma_{5}$ materic nomine qud 200. $C$ omnis materiam informansest natura $252 . f$ omnis naturalis per materiam deft-forma officium $243.6358 . d \mathrm{mu}=$ nienda $386 . f$ quomodo in fub- nusproprium 181.6 $311 . f$ noiecto" 152.6 omnisnon dat exi- mendupliciter accipitur 228 . ftentiam,jedfolappecificar 85.e dfanemateria cofideratio $2 x 7$. formupartis Es cotius $387 . d$ per ffpecsficeduplex operatio 720 . fe induidsia est, $\sigma_{0}$ anni quatutate carens $42 \pi .6$ perfepati non dic itur, fedratione materus $3 x$.f que differunt specie differunt 377. f qualiot locum b.tbet prisationis refpectu for- forma omnibus partibus quómome adwenture $150 . d$ guantitatis caufa igs.a quatenus a- $f$ Gires dise $440 . e$ forma cuilibet propream opponi prisuationem 140.6 non potest alia forma siperuenire 398.6 doaddetio frat 825 .dfoil poten tinativantriónitur $x>96$ $M . M 3$ for 
I. N D E $\quad$ X.

fornews effe. cua fucit boc aliqued $381 . a$

forinum Es materiam fobimustu. operame prefture $\quad$ so G.d

forman mijlicfje quid additum, Selquid difinaction af ormisclemestorums

$36 x \cdot d$

formam mifi non effe additam formiselementorum $353 . e$

formam nullamputasit Awscen-frigus Gnde producatur $5 \neq 8.6$ do actum frocamus, quidfigni- 540.6

ficemiss 585.6 quomodo Ariftot. frigiditas est fecundum duas fpeconfideraust

$382 . e$ cies

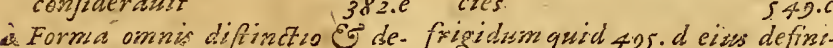
terminatioprowenit. 387.6 tio ma duplici, Ge duplici ma- frigidi est condenfare 485. teria, Ev de principio fingula- de jrigidi adione bera fententia ritatis, Scotiopraizo 387.6 sol.6

forma imateria abiuncte omini- fregidifima of calud sima diffno impatibules 161.6 dus a feci- cilusputrefere fics nonpoffunt fimule fje in ed- fislgurumgeneratio dern materia 40 s. f elementa- fulminis motus qualis rescur intendi $\mathcal{E}^{\circ}$ remittipof fulninum generatzo fint quG.a elemext orum ingeneratione mififisut terminus a q2:0.473.6 in inajto non feruaiur $4 x_{3} . d$ non poffiut remutti, rificum Buriatione peciei 254 fronfunt eparabiles a mate- Galent error de Gitrec kimore ria.

352.f 875.6

forma materiales per accides pa- Generare fibifinile quomodo fit tiuntur $1 \sigma_{1} . c$ fubftantiales ab propuiumaniniatorum $707 . a$ accidentibus quomodo diftin-ganeraridicimus id quodnon est gisantur.

423.9135 .6

formarum duo genera matcriam generari ${ }^{2}$ feri quando proprie informantusm $023 . c$ recupien- dicatzr darum idem est or do, ac mate-generari Binterere dicimus prcriarecipientir 315.6 formarum fubfantialium है accidentzum difcrimen 415.f generariquidu35.d quod proprie formas elementorum alaquamodo manere in mifto integras 354 . a effe medias uxicer fubf atian gerans ad element $220 . f$ EFaccidens

$450^{\circ} . f$

formas elementorum Es agere, $E^{2}$ refiftere per medias qualitates 445.6 non efje in mifto penitus poteftate, Alexandri opinio 7.70 .6 remanere inmifo integras, Anicenna opinzto 453.d fufcipere magis $\mathrm{BO}^{2}$ minus

in Earmicisquisfat ordo $\$ 17 . d$

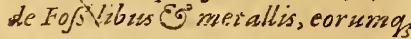
tractatione

$8: 2 e$

Irigus est prinatio caloris sig.e s03.f in generatione mijtica exinéperse babst ratione prean wice alrerateress 582 a angis aget cium bumido, quane cum Sicco 442. a non est Gera prireat lo catoris, fedqualitas pofitima 543 .e non bavet carsiam agriuocumpofitiwam 548.6 qua ratione astutum 590.6 funimus non potest exiftere cumbumiditate priefubftantias, mon acciden-

624.2 est ilterus rei coirts ptio $83.6 \mathrm{eft}$ animulis operutio adextra

105.d

generatio $\mathcal{F}^{2}$ interitus quomoda elementis competat $\quad 00 . d$ generatzo. Ev morus in quo conseninat $413^{\circ}$ a in quo differans ibid.

genteratiomifiest interituselementorum 474.6 non est aiterinsputrefactio $583 . d$ generatio naturalis que GID.e Siolenteoppofita ibid. generationoxz disitur nefz aliqua. nowa forma adiseniat materia 403.6 zon omnino competite lement is 64.2 quatenus est de pofitiuo 453.a guid 135.a quomodo competatu corpori nuturali caduco g7.d buxentis qued fit $717 . a$ brizs an Eo quomoda fit altetias corruptzo 393.6 3 T4.e generationis a motu diffrnctio.

G.c $135 . e$ canfa efficiens $423 . d$ finalis est forma generanda 585 . comrinis definitio $403 . d$ cuussqg rei duo effe cōtraria prin cipia 134.6 definutio cur ingteri. tum gisog compleciatur $410 . f$ definitio bbitradatur G.73.f in Generationis definitione quad Ariftoteles denotare Soluerit $404 . d$

generationis duplex confideratio. 500.f duplexmateria $\quad 422 . f$ generationis $\mathcal{E}_{0}$ unteritus caufse. $23 . e$ \$22.6. e exdem definitio. $408:$

generationis finis 424 a forma 422.f perpetuitas ${ }^{5}$ eiusdem. perpetuabilitas differür. $425 . a$ dicitur, non est forma, fedco-de-Generationis perpetuitatis pofatum. $\quad 226 . f$ coufor dubruis?. 424.6 quam rationem babeat 325 . a dans element o formant, no dat eadem actione motrm. : $326 . e$ quomodo fat motor grauium है lezsinu.

$325 \cdot f$ quamproductioforme motio, ginerabilitas 65 generatio diffo runt $b_{3}$. $d$ ad interitum quomodo fo babeat $412 . c$ competit elementis for maieria 60.6 cur mutatio natisules $24 \sigma .6$ curfor ferpetua 424.6 data est elcmeatis proptermifia 52.6 dipititer fumitur generationis quomodo materiafit. aquata canfa, Eq quomodo nom. fit tbid. quodnam primum fit fubiectusa $423 . d$ deterós termiausest duplex $\quad 413.6$ generationira alio modo refpacere. naturä Snuerfalerr, alioparticularem o8.d effemuteition natursiem

247.6 generatzonem $\sigma^{\circ}$ interitum non tribur forma. fed toticompofitos 40.4.e

in Generatzonemsfi dua sctius. qualitates funguntur officio. agentis 622. C omvi griatssor terizinos in confoderationem. 
$I N \quad D \quad E \quad X$.

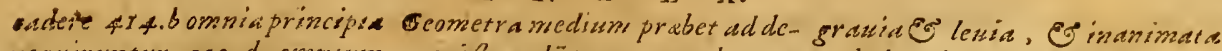
reguiruntur 15z.d omnwm móprandüpropter gistd 258. . corporum naturalum triare- Geometre non liccre demonftraguin: 211. $f$

de Generatione ac eius caufis agere quid $165 . c$ animalium libricur ante libros de anima fint ponendi

II qua

de Generatione librifunt libris de anematopateriores $\quad 115 . a$

de Generstrone animalium librorum. opinio $113 . d$ tractatio maxme frentialis 100.d libros efje de principizs, aliquorume error

II U.a reconclufionem metapbjyficam $26 \sigma . d$

Geometria ad metapbyfacti quomodse babcat $2 \pi z i a$ geomctricum nullum effe theorema, cuius demoftratlo cx libris Euclidis non hasuriatur 132.6 Gradus cuens libet mutatio est fpecscibariatio 4.76 .6

de Generatione animalium $b b t$ Gracorum errorinfatuendis liAriffoteles ayist $\quad 94.6$ bris deprincipiis

3r.f bubere in fiprincipzum nuotes passiunt 23 s. grawio $\mathcal{G S}^{2}$ lewia moucri perfe gencrante $324 \cdot f$ nin monc. $i$ ij ${ }^{c} 32 . c$ quem motorcm bubeant $315 . c$ belocines ferri in fine motus, quam in principio $333 . d$ grauium Eु lexium appellatione quecomprebendantur $308 . e$ conditio 331.6 motus 308.6 $343^{3} \cdot d$

dc Grautum EF leurum motores antiquorumfententia $305 . a$ 227.c generalejsimum nass dat definitionem 210.c, inferius in categoria nobslius $\mathcal{E}_{\text {g per- }}$ fcitius est genere fuperiore 321. a logice potius quam $2 a-$ turaliter ab Alexandrofumiter 22t.d non extat nifi in fuis peciebus 87.f omne du-
plici ratione confufum $33 . a$ phy/scusm quid 224.c predicabsle non potest bocarl. Snisocum ibid.e quomodo differat imateria 223.C quonodononfot actu injpecie 700.e totum fubiectum debet fuo receptiuo effe extranewm 210.4 Garits modis forma ${ }^{5}$ compofitum dicipoteft 220.0 gencris cognitio jine cognitione fpecicrum imperfecta . 20.d adGeneris $\mathcal{E}$ materiacoucnientiam 6 bi Arift.refpexit 222.6 generis forma quomodo exiftat fincformaspeciei $\quad$ aptee ad Generis perfectam notitiam quidrequiratur , 32.6 generis phyfaci ES logici difframen $224 . c$ ratione cur maltacompetant, qus repugnent in Grat ratione peciei $716 . c$ Gritas ad fubueti $E_{5}$ ficntis Gnitaitem confrituendam fufficat 20.6 genert quscrompetunt, nöfunt de jpeciebus demonftranda ibid.a quod competit, debet ët cuilibetpecieicompetere $\quad$ fóo. inter Genus Ef materiam differentia $123 . \overline{8}$

genera effe compofita zig.f quatenus inter fe dijfonguaiur 21.6 fubalterna omialunt compofita ibid.d immunem nonferueuit 2ig.c Ariftotelis de calo opinzonem impugnawit

$282 . \mathrm{C}$

Grando qued 73.a 75.a Sidetur babere conditiones terre E aque

grundinisgeneratio $\quad$ G.c

Graue ipprimo ad bltineum quomodo moucatur $328 . d$ a jezpfomoueatur, E per accidens 3is.f actudiccrequid $316 . f$ curfurfumfereatur 320.6

graue Eु lewe a folo generante mowert $314 . e$ babere infe princifinm motus pafiraum ron actuwum 333.s non habent in je principium affectiusem motus $320 . e$ fimplici motumouers

grase in fuo loco non grauitat $345 . c$ non potef aerem moue$r e$, nifi ipfum motupriore moueatur $3 i 0.6$ perfe exiftens infuo loco mon grawitat $348 . f$ quat enus ef graue, non aficndit 322. a yuomodo dicatur potefatem babere adnaturaliter afcendindum 310.6 Graus $G$ leus displexpotentia 121.d -

rauta cur defendant 300.d ball grawia E lewia a propriis for-
mismoweri $339 . c$ afuisformis moneri 313 . d abanimalibus gremsdo difinguantur 311.e aliquo modo babere in fe actiuumprincipium fuimo tus maturalis 248 . e ferriad bifortaliber decimus noninteger proprasm locum 200.c babere 2 en $\int$ ip is principzism motus pajsium tantwm, no actiuwn 31106 turaliguidrequiratur 327.6 grauitas 6 lewitas non funt acius Got.d proformiselewentorumfumuntur 41.0 grait as prograwitatione quando fumatur 343. dquid $_{3}+1, e$ quorefpectubarietur ibid.a Simutur dupliciter $3 \neq T . d$ graxizs magis fuperat refoftentiam medü, quatm idquouest minusgraue $373 . d$ Hr

Abitus mielledtis quid fit, it quo intelledtus dicitur in babitu $1000 . a$ quidefer 1002.ereifnus 135.6 babitus animi cognofcere cuivs fit roi.e Hacheitas fingularitat is principiurs. $\quad 387.2$ Halitus accenfusquid $74 . d \mathrm{~cm}$ nibil bumiditat is habeat 72.6 miftaimperfecta 70 ol qua ratione dicantur mifa imperfectaibidaagrid $73.2 x$ quomodo ex agua G $^{2}$ terrage nerentur $68 . f$ ficcus cislorem fummum cur non babeat 72.6 Gtergue calidus,non tamenfumme 72.4 alitus duo bitient locum fibiecti in tribus libris meteorologicis 80.d diso materiacorum que in trubus libris metcorola gicis trabzantur

E).c Hiftorra de anima quafientia $104 . a$

I06.c

de Hiforia animalium libromem cum religuis libris de animalibuscomparatio $\quad$ 102.d.e

citur $\quad \neq 0.6$
tium ad medium diin Grusium Eु lexium motu $n a$ MI $M$ 
$I N D X$.

qua ratione nö fint parjfcicn- bumidum Eo frcum cuiusg mifi:

tianataralis 102.f

biftoriarum liber dacimus curli-

bris degeneratsone non anneet $\bar{c}$ dues $107 . \mathrm{cnec}$ hifaricus nec

fcrentialissab.f medicinalis. potoss quam noturalis 106.f biftorici qui libri iure appellati g2.6

Hippurchi de motu opinio

Hoc aliquisid duo figneficat

Hurundo propter aliguem nudum focit

333. $f$ $185 . d$. $235 . \pi$.

Homo adtu $\&$ poteftate est in fubftanti.e catcgoria 205 .d ominium animalium praftantiffimus 780 . a poteftate nibil aliudest, nifitpfamet materia $x>0 . c$ quomodo definiendus 384 . d quomodo fit mediess. in terduina Eo terrena $272 . a$

bominis definitio. $283 . \mathrm{C}$

kominis generationis proprium qua $4 \sigma_{3} . h$ quidditats nibil. aliud in rebus refpondet, ni/2 Idem non potest mouere feipgism bomo itfe. 283.6

ad Hominis effentiam copftetsendam quaconditiones requer atur 364.c Iecur quodnullum babeat priact-

bominem ex elementis generari 481.f effe in potentia abiecti- Iecoris officum principe indignü. a Hominem generandwm qua Ignis à colo infuo naturali fiat requirsutis $36,4 . c$

in Homine quat funt format, tot etzamin bruto 707.e

bominum diuerfapotentia $2 . d$.

Homogeneum omue non cfje elimentum

a.f

Husmanitatis equata ratio qua 25.2

Humiditas aquea magis humeitat quam aerea sst. d. aques coniunct a eft cum frigare s32.f cur neque cum fumo calore, negue cum fummo frigore effe poßit $210 . a$ E calorem Ef firigus obtundit.

512.6

bumidstas Ef ficcitas qualitates paßsiue 400.c quar ratione qualitatespapsius

$491 . d$

Gumiditas facele feparatum ab aere, fed non facile ab aqua siG.c. non pateft cum fummo frigore exiflere $013 . d$ requiritur ad compactionem Eo conticuationem partium j16.6 aecea ignem nou exringuit, fed sutrite

at $\leqslant .0$

\section{1.f}

bumidum $E^{\circ}$ vincere feccum potest, EG abea Genci 538.6 non est fine ficco, nec ficsum fine - bumido 70. $e$ omne est refolu822.d

524.6 :

bumidi in mificone pracipuum munus. Humido duplici opiniones $\sigma>\sigma$. d. $820 . d$

Humor cryfallinus precipuum Gidendiorganum goo.a bumoris Gitreiofficium g01.c bumores in animalibus quomocio putreficant. I

G.6.a 649.d

Amblici liber de myjacriis Aegyptiorum 281.6. 30y. $f:$

idem qua funt alicui tertio, funt idem interfe confersaturper motson 300.0 ignis abfolute non quiefeit 303.6 ignis agit $\mathcal{E}^{2}$ patitur.

\section{$252 . e$} igniscaloris fubiectum. $302 . e^{\prime} 325.6$ bile i calore $\$ 88.6$ 491.a de ignis elementxpartibus dubiü. $408 . f$ compafitifit idea. $224 . f$ :

$206 . d$ poum $742 . d$ 327.6 in Igne duplex calor

Ej eiusfolutio $571 . d$
gnis formareftringit potentiam

EG einsfolutio $571 . d$
gnis forma.reftringit potentiam. qualitatum remificonem 464.2 ginis accretio qualss fis $76 \sigma .0$ afcenfur quanda proprie dicatur $304 . c$ item defcenfiso ibid.d

aéris calor requirit humiditate. $527 \cdot d$ materic paßzuam ad motum a media 243 . $d$ genus prima materia 222.f in aquam satia celerrims $537 . d$. in or. bem wotus 301. a motus circa medium non est fimplex , fed miftus 206.c. motus in orbem curpotius fupra, naturaim quä. fecundum naturam Gocetur 301. a medius inter naturalem Eviclentum 305 .e naturalior. quam mot us rectus 301.6 quath lis.

303.e ignis motuss Grolentus $E_{0}$ perp.eturs $201 . \mathrm{cmotus}$ inde $132 . \mathrm{f}$ Ignisoperatio tranzlens. abia.f. gni contrarianest agyn 1 T. f.non. competitimminntio $236 . f$ gnem E aerem a tota omnizm Sphararum congerie mouer: sor. $f$ Eु terrain babere funmamficcitatem. $515 . e$ igaem in fora loca refrigerari E defcendere $572 . d$. nutrive quid 532.6 foio motu a crelo conferwari 300 . a fub polis con feruartnon pojfe. $572 d$ son cesto terminaze requirere, neq bu- celsio.

3.20 .28 miditatem S33.d. Insago a pictore leuiter adumbras ignis cur in concasso calí confer- ta quomado differat ab up a abwetur s03.e curnon putrefcat folute. 19 g.f. 3o. e cur fub cale conferuetur Imaginatiuaresquoque abfentes 309.e cur fuperum locumpetat imaginaripotest. $720 . d$ Imminutio quid. $77 x \cdot d$ ignis elementum cur minime a- Immobilitas primi motoris denomnsum propellatur 30g. $d$ to- tat abfructionem. is materis tum a motu coli conferuatur. $248 . e$. sGu.k Eterrajuman babent Impedimentum guad Gjoatur reficcitutem 72.6 in fua fibe- fiftentia brideproweniat 438.6 ra non proprie dicitur afcen- eiuscaufa 441.6 dere, Gel defcendere 305 e nifl Imperare eft primarÿagentis, no moueatur, perit 400. d. pex fecundarÿ $356 . f$ formam agit $435 . d$ perpetuo Inanimatum omne bomogenewm fertur circa maediuns 290.6 est. $401 . d$ potius fot calidus, quam. Gt de lincefu animalium liber nul. ficcus, inmifionem Genit 480 . Lam certam babet in bifforÿs c quampartempetat $36 \mathrm{~g} . \mathrm{C}$ for refpondentem partem 103 . Gixaliquam admittitfwarmos e fequitur quatworlibros de. 


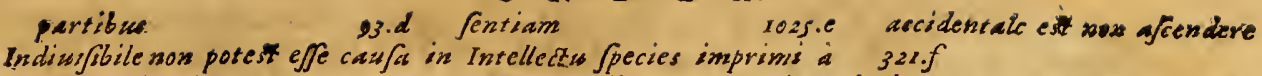

diwifabilitatis. 194.f pbantafmatibus, neceflarium. lewium nootus à medio dicitur

Indiusidurtmab ailys omnsbus est g86.c

40.6.

fisunitum. $380 . c$ intelligibile eliquid dicitur Gel Libri de biftorse funt prapara..

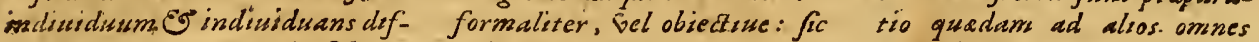

ferüt $385 . c$ ex materia Ef for- etianswifibile I015.6

maconflut $39 x . a$. boc abillo Intclligcrisacum orbe conueniéquomodo diftinguatur $393 . e$ 30 . than $288 . f$ est nifi per formam $385 . e$ Intends $\mathcal{F}^{\circ}$ remitit latius patet,

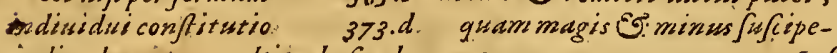

indiusduoriom multisudo snde re promentiat 381.6 intenfo G remigizo fit dupliciter

Inductionis demonftratizse. Gis 4 Gr.a 136.f. Intentiofeuens intétionale quid.

Inferior a cur corruptibilia 272.6 \& $>0 . f$ de.inimalibus libros g, $f$ octo pbyfice aufcultation quomododiftingwantur $\mathrm{r}_{23}$.d quz fint proprie animalium D7.f: Inferiora cur corruptibilia 272.6 870.f ralefomplex $23 . e$ dari $34 . c$ quomododetur in ibid. rebus naturalibus: $\quad 33 . e$ Interire quid/fit foo.f librorum de anima cum libris de partibus difcrimen 240 de animalibus ordo, go.e de caelo fubiedtum, corpus natumantur.

118.0

Innominat um non omne eft inco- Interitus gencrationt contrarius. gnitum: $\quad 875 . e$ fop.e naturalus biolento oppoab Inforiptione argumentumi cur fitus. Gig.d: nullius roboris $\quad 121 . a$ interitus quid $c_{3}$ T. 6 quot modis. inftrumëtinaturaoptime exeius: fumatur $\sigma_{24} d$

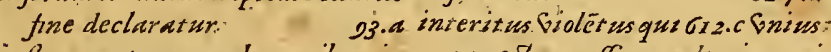
inflrumentorum ordo, quibus in rez est neceffarso alterivs. rei eadem operaitione añima bti- generatio. $408 . d$ tur. $\quad 7.46$.f in Interitu mifi quomodo dica-

Intellectio estpecies ifaimpref- turgeneraricadawor 407.6 .

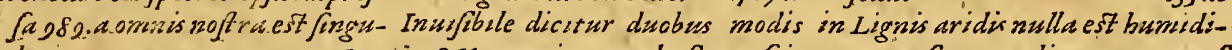
laxis: 200 .a!" "8Ga.comni quomodo fit perfpi-

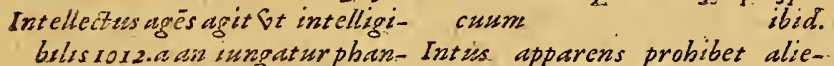
bolus 1012.a an iungaturphan- Int is apparens probibet alie-
tafmaribus in phantafia exi-. num, f fot obiectum primum. fientibus, an intellectu pati-. $273 . d$.

bultacceptis 1012. $C$. non agit Iudscare est fenfionem producere: quatenus intelligens $1000 . d$ 8jx.e non producit actum intelligen- Inrisprudentialegislatoriâigno: di 1010.dquidfit 1020.e quod bilior. son pojsit efje Glla intelligentiapraterillas qua mouent or- T Aetamenis aceruss in prinbes ealcftes: i 1014.c Dcipiopistrefactionis quätum inteltectuscum bomine cöiundt:o incalefcat a $30 . d$. fecundim fukeroem: 027.6 Lapis cur per aquam tardius

Intellectuss dsplex immsfiogyi.d. quam per aerem. defcendut disas habet entitates $977.4 \mathrm{2n}$. $342 . f_{5}$.

babit us est fimilis fenfui 1002.6 lapis proiectus tardius mouetur. nofter in cognofcendo agit 1018 in fine quam in principio $339.6=$ f praiticus EF peculatiusu an. furfumproiectusper Sim,äquo fint dicepotentia $7.25 . e$ quomo. moueatur $\quad 324.0 . f$ do dicatur abjuabere amate- lapidumgeneratio $\quad 3.4$. ricu 10 4. 8. folus est fpecierum Latinorum error de genere logico. locus

220.A deffincto à genere pby 21002240. intellectus agentis officia roo8.a. copineo defubiecta librorum de. intellectus displex obiectum 07.f. ganeratione 5.4 .6 immslzo triplex confiderari Legislator bonus deber callere. poteft 948 .e obiectum est omne philofophiammoralem. 102.f poteft 948 .e obiectum.est omne philofophiammoralem" 102.f 503.a.

tas, ne in naturalis: $13 . f$ Linea. ES Juperficies diuidus funt , non tamen corpora 8.6 qua à centro mundi ducitur. est brewifima 367.6 rect a ad centrum protenta, fimplex est 371. fimplex-quanam fis $364 . f$ Libris de animalibus tracta$r$ onznia, qua Giuentibses calo agi de fimplicibus corporibus 43 . c. de biftorradinimalium duarum tractationum diftenctio notanda 103. a pbyficorum qued.tractetus. $38.4 \%$

Ligna arida cur non facile putre.inea in mundo fimplex fitus $366 . d$

Locatrm cur non dicatur acquirerelocusm, fed potius locatio-. nem.

Locus Arifotelis: mendofus: 110.5

locus conferuat renusn fua nat uraliconfititutione $299 . c$ dat ws. est corporibus ob corum imperfectionem 209.6 res externa: qua non potest bocariforma rei moters.c quatenus infar forma fit 209. b. quid st. d refpectu motus localis habet rationem: caufe finalis 34.6 . Bnus. Snus nature est conferwator 340. E losi sonditiones.

$202 . a$ Lewe 121 wo
intellectum agentem effe formam 3.48 .f

phinnstapa a materia per ef- bewi extra locнm fuwm exiftenti: alienum 12.aeffepriorems locato. 
$I N D E X$.

de Locolisrom de anima Latinorsm opinio. $G$ esus reprobatio 107.4

locadiuerfa raturalia, diucreis mift is effe alsirnata $35 x .6$ au $\vec{a}-m$ do fecundizin naturam locita effe dicantur

$3+9.2$

Logica cur iphilofopbis producta 2.48.e ficnticesi inuturale doArincordinepracedit IIZ.f

logicarum regularum duogenzera 29.6

logicus ad particulares 6 proprias fingshlarum fientsarun conditiones defcendere non debet ibid.f

Lumiè an requivatur ad medoum $\mathcal{E}$ ad colorem illuminandum 85.a anfit ens reale ens intentionale 870.6 cur extenuet aerems 57.0 csispecies lucis 877 . b.effe seceffarism, ES propter medzum Es propter organism 870.6

lumen Gु $^{3}$ calor pecie differunt $882 c$ non est carpus 868.6. $f$. lumen poteft accipi duob.modis 886.d qua ratione caufa caloris 57.4 .d quomodo calefaciat 574.6

laminis $G$ liscis differentia $8>6$.f luminisnatura $574 . f 87$ I.e Luree motuss $78 . d$ Lurne orbis nullius caloris est capax $\quad 5 \sigma_{2} f$ lunanu lumine crefcētem calidio-

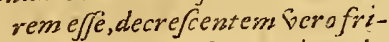
gidzorem 574 . dmoueri a Sole, fed a motoreproprio 564.6 Lux est primum bifibile 880.6 est colorEgeftifibitios $877 . d$ $M$.

Agnotudinis siditio quaIV modo ominibus partibus eius quod arngetur, fiat $707 . a$ maris Ef farmine officta in generatione

$7 x>f$

Mathematica difipina perfects in Euclidis libris continentur $132 . d$

Neiteria abiuncta à formis qualis 7 is.e an perfe fit corpus 174.daptitsdinem habet naturalem recipiendi ommes formas 248 . a comparata cum fingula forma, potest exsftere Sine illa 177. as corpustrina Zimenfoni fibiectum 228.6 cur debeat effe affect 231.6 cur dicatur casis ar fine quat non 426.a cur non fit effentispars materia non fuit create, fedcont 3\&6.acur per fe non moneatur r.e curfustatem numeralem trabuere nequeat $\quad 383.6$ ateria déset efje affecta, E⿱ ${ }^{2}$ non affecisus $2 . f^{\circ}$ dicitur, quead formam recipienduin dirigatur ànaturaised diftindta tum a formit, thin à potentia $x g^{\prime} \cdot 6$ dus as babet entitates 977 $c$ dupliciter fumitur refpects forme" 8 G.dest caufa multitudrnis indzuiduorum, fed formotest caufe difintionis illoruss interfe $381 . \mathrm{C}$ est dimern fo magnitudinis igo. a est onsniviper analogian $38.6 \mathrm{eft}$ exiffentix caufa. St fine qua non $383 . c$ est libera $\mathcal{G}^{2}$ apra ad contrarios notus recipiendos 2,2 a es: natura prior ominibus formis $88: f$ est ineceffarta conditio forme ad extifendsum. 48 - b est propter alia, non propter êroy.ecit ratio corporei-

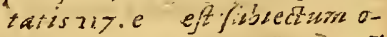
misism fornarum 4i8. $\bar{c}$ est fublsantio

$143 . e$

materis ${ }^{\circ}$ forma cur vocentur eícnerutea an a mobiles dicunturbarj̈smodis I. a quomodo dicinatura 275.6 quomodifit natuina $2+1 . d$ materia etiam fumitur pro fubfantia demonflata 28 a.b extēditur ad extenjisnem forme, E forma ad extenfionem materic $228 . f^{\prime}$ formam aliquam recipere non porest, nifi pins ad eam recupiendam preparetur $17 . \mathrm{c}$ habetpotentian naturalem recpiendi formas articificiofas 2.77 .6 babet propriam effentiom diffinctam ab effentia forma

$188 . d$ materiaidem poreftate, quodformaactu 244.6 inprimafua notione est a babet potentiam ibid. non babet priuationem, fed negatione tantum $x$ as.a materiainterminat a non differt numerocterninata 200.6 materia ipfsus cópofitipars $387 \cdot a$ materia magis appetit formam fubftantialem, quam accidentiu igr.d moles quedam indifinct ibid. neque mouens dici potest, neguepcrie mota 387.6 cresta i8z.e non modo cors porea est. fed corpus iffisim 217. a non potest effe principinat motues nefi pafsisurum 233. ' non potest exiftere fune (orma iso.d nullis certesterminis alligutos 2:3.e nunguam est fene poten. tias

160.2

materia omnis pafsionis rades $3: 7 . d$

materiapartis $\mathcal{G}^{5}$ totias $387 . f$ peraccidens mowetur 12.'e per fe nonest natura, fid per for main 244. f prim sm fubiectus exquoresfiunt 67. a potefia tem habet aque recipiendi formam acpriwationem if 2.0 materie prima an fecundis fisam nat wra act um alıquem haverst $174 . d$ anfit curpsss de genere

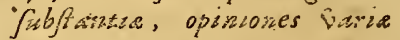
205. $f$ debrist effe ätro: 153. a dicitur principing nastirale 8.e efincorpus de categorta fwbintintix ziqf fin fis

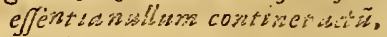
fedfolam potötam 186. f multis modis ab Arijotcie mazifeftata137.b ribil alikd givam corpus de categorias fis bit antice 206.d nobilior quam form as is compofitum $479 . e$ non patest nuda exifferefine forma $408 \mathrm{f}$ per quasm analogiam cognofiatwri37.of quem actumbubuerit.cum primum a Deo fiut productailo.a qusiadscognofeatur pèr abjtraitzonem 10.48.6 guomods frat disidua 205.a quomodo fe babeat ad jisffantiam compofitam isg.e quomodo fit in rerume netura 167.6 quodfet trinut ijs dimejor, argumenta loaw. Gram. matici $211 . d$ quorrodofitfubiectum accidentis:31 320 . d radix.omnespopabilitatis $1 \sigma 1 . d$ fecusndü fe penitus incorpores IDIf. Sisbfiantia totius pars 40j.e Gna cum alïs rebus a Deo creata 182. d promum principium corporsum natw ralium 2 I 4 .d pristectioninecefjaria propter gencrationem is2.d prizisrecipit formus 6 niverfules, poste vero particulares $208 . \mathrm{C}$

materiagua corpus fone act $218 \mathrm{ge}$ 
apaterat qualis naturat is Deo creata 184.6 qua rerione ens 1;2.a itemnatura 245.6 gua "ivicone principium molus parfistem ibid.a materia gisatenus corpus decatur $225 . e$ quatenzes de compofito pradicetur 222. q quatenus moles $G_{G}^{3}$ non molcs ro7.f gruatenus rerumprincipium, eatenus potentiade effentiatmateria

$102 . \mathrm{c}$

mosteria quare dabust habere potentiairecipiendiformas $2-4>6$ materiaguid 137.c 167.0274.d maticrias quidditat is Gehiculum $385 . \mathrm{C}$

miatersal quomodo it nobis cognofatur 130.d 143 . f quomodo ab Arifiot ele confiderata $1: 44$ $e$ quomodo confideretur it principium generationis corpor is naturalis $170 . d$ quomoslo informis 228.e quomodo Lacetur in media linea categorusfubfantise $22 \sigma . d$ quomiodo fecundium fo babeat formant G affertionem $228 . d$ qromodo $\sqrt{2 t}$ natura $244 . c$ quomodo fibfraxtictur perpoffe. I62.a materiaefentia cognstio $122 . d$ materia radix prina, ac funda- ad Materia effentiam cognofenmentum omnispajionis $\quad$ II.d receptuculum omnium for- ma marum 418 e rei effentia 2.65 .6

austerufecundum fe corpus infinitsom 220. as est prorfas unformi: ig3.d nullum reSpicit determinatum motum $288 . a$ quatenus. informis $198 . \mathrm{f}$

materiaferuatur inregenita,nec Gnqueminterit $\quad$ I52.C an Materis fen potius forma $f i t$ reinatura. $26 . d$

materia fignate quid fignificet $378 . e$ fingularitatis. caufa 277.a fone forma non potest appeliarinatura $28 \sigma . f$ fola in rebus inferioribus aterna est 212.c folet etiam caufa Gocarifinequanon Go.c. wateria fuapte natura eft libera Gु indeterminata $i>1 . d$ item est quanta $\mathscr{V}$ extenfa I.07. 6

wateria fubectum omnium 16T.a tota EG maiores partes: gisomodo augcalatir $\quad$ s 0.6 propenjio $153 . a$

de Materia cognitione Gere fententia declaratio

materiaconfideritio

$142 . \mathrm{C} 143 . \mathrm{C}$ damanalogianos ducit 139.6 augeatur 8og. e natura conficitutaest in potentiareceptiua omizum formarum है prinationum 162 .f natura $E^{\circ}$ ef: Sentra qua. Lizanotificatu $138 . f$ per negationem, non per primatzonem declaratur $150 . e$ naturaquaibid.d

materianaturam difficile est af seque . ID7.e effe: corpus de categorta: fubftuntia $22 \div f$ nulla determinatio potest infeque 165.6 materie nomine aliguando ia tfim compofitum intelligi
$1 N D \quad E \quad X$.

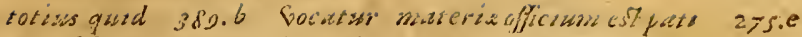

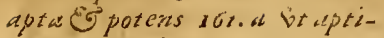
iuderiem babet ad ommes for-

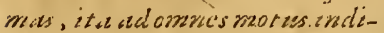
firnite recipiendos $\sigma_{1} \sigma . e$ rrateri.e accretio cur non fecundism ompespartes ficridicattr ssof ad forma indefferens eft potentia 159. $e$ adformam naturalis

$159 . e$

1.) 2.6 materie prime udres ormes que. 1.40.6 ratio 139.2 ad Materice prime cognitionem quibusmodis ducamiur 137.6 claratioper negstionem qualis maieriaprima demiflratio 135.6 138.e definutio 143. cperqualé de Materia prima duabus notioanalogiam cognita $139 . a$ nibus 142.6 materic dimenfiones IDI. c cur materice primu idea $1 \delta 3 . e$ inm potentiales $290 . e$ duonomma wentio $136 . a$ 145.6 entitas quid 178.6 efjen- ad Materic primse notituam qua tia aformanöpédet $178 . e \int e_{\text {n- }}$ Siaperuenirepoßumus $138 . e$ tianbjoluta $1+13$.f cognofcutur materiaprimanulla actus appelperanialogiam $138 . f$ indeter- latio conwenit $\quad \mathbf{8 7} 7.6$ minataproreft quamefjentia de Materie prima quantitate guantitatis indeterminate Auerrois opino Ino 203.e. $\quad$ materiaprima quatuor confiderationes 167 . a nibil magis propinguizs, quam generaliffroum 223.4 materice effentiam qua ratione materice nullim tribui pojje asimpliciass declaret rig.e ctionem 233.f quandogue nomine potentia materia primam notionem nulGginicari $\quad$ loo.f lamdari $142 . f$ maicia efjentialis conditio 27,6 contra materia primam notio-

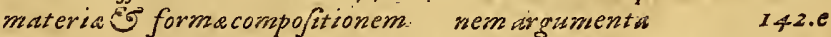
in rebss cognofimus z10.e de Materiaduplicipotentia 158:e confideratio duplex $\quad 14.6$ materiafgnatafignificatio 377.6 materia minima pars quomodo materiam confideramus antequi $330 . d$ quid Arjzoteles in- 248.0. iclligat. 32r.f ficare, cum difriminetamen resipiat formam $153 . f$ dicere efje quid diuerfum ab ommbus quid.

160.6

materiam. efje actu principium quedfit dicere 188. a efje cau-

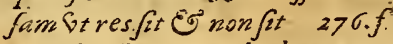
2.79.f éffé corpus duob us modis intelligi 223.6 efje cortars indetermunatum., quomado Simplicius probet 2I8. d effe corpus gna ratione. Auerroes nonneget 223. f efje pofje per feipfan, formam sero non pof fe 177.6 10r.e effe fubiedums. teceptiuum omnium catego-
riarum
248.2 atersam $\mathcal{G}$ formam idem fgrniact 3 int 
a nus idem effé re, fed ratione difingui $222 . f$ Materiam frequëter appellat $A$ riftotelesprincipium 250.a wateriam babes's cur fit corruptibile 278 .f babent diuerfam, qua murentur 280. $e$ habere potentiam ad omniaquid $1 \sigma \sigma$. - in rebus naturalibus effe principzum motus paßiuum, formam beroactium $240 . \mathrm{c}$ magzs refpicere formas jub. ftantiales quam accidentales $798 . c$

per Materiam nuilla res ab alia differt

379.6 at eriam nuillä fubftantial formis fubrectam Gracos cognowiffe $28 x .6$ nullam babere act um I 87. f non ejfe Gllo modo ens act w 186. a non effe sllum ex entibus determinate natu- Mediciofficium sonperformam cugnofici 1 q0.6 bent perfe babere dimenfones inde- Medicorum error

147.8 terminat as

materiam primam dari quo medio ofiendatur $139 . e$ effe corpus per formem corporeitatis aternam dicentium argumēta 204 . $f$ ex $\sqrt{e}$ bajere esje fimpliciter non at arma 203. a per formam cozin fir $137 . d$ quemodsphiofopbias naturalis cognofcat dúj.a fecundsum $\rho$ e eféc corpus 206.6 G noneljecorpus 212.6 $234 . e$

materiams quomodo Ariftoteles definiat

I $\sigma_{3} . d$

d Materiam gisomodo priuaito Jibabeat

IS $1 . C$

maperiam fecuncin je cfe incorpoream Go guarzita:em rom ba

bere In7.e efje natusam 247.0

wateriom fine quarztitate cirsiduars dicinon poffe $\quad 205.6$

in Masteria cum quantitate determinat a configiti jingularieas 370.6 que conueniwnt, neceffe est bt muttsointer fe pathantur EF egant 278

in materia primanullä effe quátitatem aternam fopus iniuerfalis natur of fuerit 248 . a femper rewanet poteft as Es propenfio ad alias forteas 159.6

do Materin prima contratiajenrave cit tasconfideret minorfiat fieri ftere dicebant acorde gnofitiua difputatio cogiacfounes tentic, an fit perfequantalgr. met allorna gexeratio

$f$ quonzodo predzcentur res o- Metapby/zca, divimafcientie \$2.e mnes, Er negentur $\quad \mathbf{r} \%$.d ex Materia Ef forma resfiunt है conftant 20 f.cextrinf ccus acredente, quomodo idquodaugetur, maiorem quantitatem Eo maiorem locum acquirat 76 .apriuatafit, quidquidfit 147.6. nuda nibilpotest gene-

153:b Meteorologiaquid $259 . a$ lem diffenda

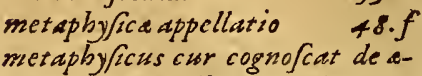
ternis motoribus quid fint 37.0 Gerfatur in fubfantia immo bili

$256 . e$

$6 \sigma . d$ 76.6 materialia ab immaterialibus meteorolog.liber quartus eur per quomodo differant, $218 . e$ materialster agere quid $\$ 38 . e$
Medicinafolam effectionem re $p$ i,

102.6

Medicineparspbyfologica $02 . f$ redicus bonus debet efje philofophus naturalis $102 . a$ in quo incipiat IDg.cprincipium acturuts Sanationis 138 . f quatenus plä-

I2D.C rox.e fenonmeteorologicus $\quad 80.6$ meteorologiciguartinfinfriptio 8 a infriptionis ratio cur non approbanda 80.6 meteoralogicilibricur ftatim $\sqrt{e}$ quantur libros de ortu 6 in teritu

68.

meteorologicorum libri quomodo fint de imperfuctis mifis $6 \& . f$ meteorologicorum librarü infiriptio 40.6 Sndefumpta $70 . d$ meteorologicorum librorumordinis 6 inforiptionis ratio 75.6 fubiedum

68.2 .6

Medium cur demonftret conclu fonie $2 \sigma$ 4.f eft materia ex qua confrustur demonfiratio 250.f ex metaphy/cea pojje accipi ad demonfrandam conclufionem geometricam 260.c inter extrema est duplex $305 . e$ inter materaie $\sigma^{2}$ pirita'e $847 . d$ per participationem dupltx eft 400.dproprie gierdibid. quatito applicarequidfit z6G.e medï refiftentia cur maior bel

$337 . e$

Meтźopor

Michael Ephefus Alexandrife. czator

281.0

Migratioguaimpokibzlss $801 . f$ Minera non est miftum imperfe. ctumjedperfectum $\$ 3.0$ manera ad metcorologicos libros nos përtnent on.d ex duplici balitu intraterra fisnt $77 . \alpha$ ex quamateriageneretur $82 \pi$ de Mineris libri diligenter $\mathcal{G}^{2} e-$ gregie fript;

85.4

de Mineris nunquid Ariftot. fori. pferit, preter Gltimum ceput tertij meteorologuci \& 4. a qua traciatio requiratur $82 . \mathrm{f}$ quatenis Arifiagat $7>.6$ Garias demonftrationis species

260. Megaricinullam patentiam exi-

If 4.2 Membrorum omnium pendentia

$749 . f$

Menzoria intelledtua fecundum Ariffotelem $1004 . a$ non est ca-

720.4

de Memoria ${ }^{3}$ reminifcëtianullafeparata ttactatio in libris de hiftoriarefpondet rof.d Mens bumana cur diutna boceturgor.c quidfit ratione fue operationis ibid.c Arch. Mercenary de putredsne

sog.a Metalia diplicibalitu intraterrayifieri>7:b putrcfere Gnde

Gas.6
Minimum abjolute non dore 4aj.a

Mifibilia manere in miflo, de folis elementis inielligendum cft 450.c non interive, icd ferwars 453.6 non prorfus interimere fe mutuo 472.0 gisomodo jant mifibiitum quafit ratio $4.43 . f$ Mifizo eft corportim, non qualitatum $52 x .6 \mathrm{ef}$ mutatic guadan ine interitu 470.6 est rerum Speeie diwer farum $3 \sigma 5.0$ mifso $\mathcal{G}$ generatto mifire idem funt $4>3.6$ mijo है mifte dijolutio est m;tatiofubltartialis $\quad 470 . f$ miftio potefiate in mifio ibid. 


\section{$1 N D E$ X.}

Aio So mifiz generatio in quso differant 5Do. $f$ reipfal idem sDg. $e$ fit ex diutsone mifcibilium in partuas partes $538 . a$ frev non potest fine readtiones fecundum eandem contrarietatem 429 .f non pracedit generationem mifis cos.c non requirtt duifionem in monima 4 G.a onnis est elementorum.

miftio quid $344 \cdot 0.340 . f \cdot 453 \cdot f$ cor.6.

miftiogromodo conferuetur $\sigma_{10}$.f qüo fiat 470.6 G.66i $488 . a$. miftronis conditiones quibus exéplis declarentur 470.6 quomodoferuentur.

$458 . d$ miftionis definitio voof $\mathcal{G}^{2}$ difficultates gucexipfa oriuntur 453.C. forma non potest in toto. corpore anterire 400 . f nullam babet in materaprecedentem formam $371 . f$ qua ratione produci decatur. . $\quad 4$ Iz.d miftionis natura $4>6$ a inpluriza fubfantiarum Gnione confffits. so8.e.f nomenelementarefpi. cit. 613.6 mificiöeimperfect à fequitur duratzonis brenitas o8.e ominem. effegenerationemmifit 607.c in Miftione Es generatione duo termini confiderandi cos.a formalitates clementorum intereunt, Ev producitur nowa formalitas 47 i.a. non exiftere aroplius aliquod mifcibilizm... fedquouldam medium $354 . f$. omini Gnum. elementum alys dominari $444 . f$ oportet fieri mifcibilium disifioszem in minutaspartes $493 . a$ quid requiratur co8.d.tres Gniones fiunt. $359 . d 604.6$;

miftum ifua forma naturalitermouetur $340.6351 \mathrm{f}$ ab ele-mifigenerationiscaufa Glo.f dementisppecie differt 361.6. finitio584.e.f finis ibid.

miftum aguale non dari $360 . e$ an in Mufigeneratione dwas actiuas
duobus modis interire poßit. qualitates edere ommes operaputredine $\mathcal{E}$ combuftione G11.. cconftat ex quatuor.elementis. $583 . f$ tiones:

sos.e

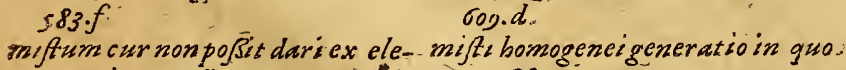

ricos.6imperfectum metcorologicorum librorum fisbiedtum 72.dquid

$\sigma 8 . c$

proualens 348.f: $371 . e .472$.f non duct ex elementis aqualitor conftars $360 . f$ non pofje moueri ad eundem locum, ad quem mouetur elemëtum fimplex.

miftum perfectum quid 68.6 potizus conftare ex viribus elementorum; quamex elersenmentisfat co3.e quod motu fuo naturale tardius mossatur in fine motus, quam in mouseatur in Sacse qram in plenaibid.e quomodío ex clement is conftet $352 . e$ - giscriodo
generetur oro.b quot modis in-. terirepolit

ibid.f

corrumpi $\mathrm{C}_{32} 2.6$ confideratio $358 . e$

motus 372.6 . corruptio gus putrefaczio dicitur, quomodo fiat cog.a formatanfit fuperaddita formis elementorum. $352 . a$ non potcf conflare ex. formis elementorum j52.equid. $4 \sigma_{3} a$ re à formis elemeniorum $d t-$ uerfat.

352.6 . mamre diftinctam a quaticor forrnis elemétoriz fradzis $352 . e$ generatzo Ginteritus. $582 . c$ fint sos.d. Goz.b, non est, nifiex element $\sigma_{10} \sigma^{2}$ b non fit fine mificone mifti $\sigma_{0} \sigma . a$ guid $602 . a$. Miftigeneratione E interitw confffat miffum fus natura, non ali- mifti inanimati forma qué no-ter quam per putredunem in-. tum efficiat serire 618.6 E. Giuens quo miffinteritus quidh $\sigma_{24} .6$ - qua-mobilutas est accidens corporis difcrimine disideant's84.ef modofiat Gog.a naturalis so.a sx quatuor elementis genera- mifti interitum cur Ariftoteles. mobulitatis caufa 8. 6 nomine

non exprefferit $6.5 . c$ materia fisnt quatwor elemonta $583 . f$ motus naturale Gride pueniat $358 . e$ comper eft mifius $370 . d$ mific natura configfit in inditifisbili350.f media est inter formam clencentı $E$ animam 308 effrilleor est nature elementi dominants, quam naturis aliorum.

$350 . d$

miffi naturalis propenfio ad putredincm: o.ig.f

migfiproprus interitus qui $\sigma_{1}$.d Giolentus. interttus quomodo fiat G12.c. Gnanatura. 348 .f motusnaturalis $352 . c . d$ mifro fimilari accidit ex duplici babitufieri: $\quad 82.6$ in Miftoingenito frigus agit per $\int e_{352 e}$ snanimusto vna tantum forma inest 305 . d non funt elementa aitu $349 . c$ guafit caufaieffectrix motas. 350.6 guolibet aliguod elementum caterispromalere. $308 . f$ mifta habent locum ratione fimplicium.367: d: grausa non minus quam eleruenta per finplacemlineam defcenderes $3>1.6$.

mifta ornia effe putrefcibilia 620. $f$ non perputrefactionem interive ibid.c quomodomoueantur $308 . c$. Fnde conftent. 40D. $a$.

mifforum corporum materia 320.4 miftos effe motus $3 \sigma_{3} . f$. motus fimplices effe non poffé. 373.6 .

mifforum formaguid $\quad 462.6$ mifforum inanimatorum motus 367 . alocus $45 . f$ motus ex dominante elemento prodit $350 . d$ motus gualis 308.6 amnitum non cominunis interitus

620.d.

Miftus calores fpecie differwnt s27.e

mobile.ad formam quid fat $54 . d$ cur.refiftat. fus forma mouento sIg.c omne diusidusum s.e quididicatur $11 . f$ quomodo confiderandum 8.c fubiectum philofophicanaturalis 14.0 probile quid Ariftoteles in- 


\section{$I N D E X$.}

quidintelligesdum R.d motores aterni quomodo à pbyjeco

modus confiderands debet effe aqualis reiconfiderata g.e tenet locum forma

10.6 moralis philofopbue, animimediciss

Morbies quis roI.d ror.a

morborym caufas diftingucere at medicumpotius qusin ad phelofophum naturalem pertixet 101.6

Mores Garö diserfis namalibus inaturaditi roG.a

morü animalism nulla effectrix. caselafferripotest

100.f

Mors naturalis qua GIg. a item
fiotenta ibid.6 quid $357 . d$ Motor eternus immobulis à metspbyfico Ep phyfico qromodo cognofatser $6 \sigma$. a non confideratur à naturali, nifs st princupium है caufa eterni motus $38 . a$

motor immobilis non est confiderationis pby/aca 36 a inmobilis Gniuerfanfit aternus an corruptibilis

256.6 motor per emanationem non potest esfeprimus . $\quad 235 . a$ motor primus a materia abiżctus 37.6 eternus mouet Ef e.t inmobilis $4 . e$ cur arernus 257.6
est motor Gniuergals 307.6 est totius globi motor 300 .f immobriscurnon babeat in fe principism motw, non est conjiderestionis playfice Gtgisbiectum phyfoum 57.5 Eniwerfaternus $255 \cdot d$

ad Motorts aternicognitioné quomodoperuenire poßsimus 254 . d motoris aterni qualis fit demonfretio

262.6

motoris cum motuproportio $28 \mathrm{~g}$. 6 primiconditio quomodo confideretur

$\sigma 6 . c$

motorem aternum probare ad folum naturalempertinet $25 \mathrm{~g} . \mathrm{h}$ dus II.f'cur Gelocior fiat $33 \sigma . f$ immobilem efje ipfius coeli for-motus datperfectioné calidozor.6 mam 281. fin elemento efje formams 2.4 nullumper emanationempofje aiciprimim $333 . \mathrm{C}$ primum smmobilem efje jubfantiam

260.4

a Motore per emanationem non potesit aternusmotiss effe $333 . \mathrm{C}$

deMotoremifi Lacisorum ac so- motus igniscirca medium qualss misalium opisio

$34 \cdot f$ dicitur acsidens nat urale $8 . e$

- est calidiperfectio $301 . b 562 . f$ factusfecurdum proualés elemotusgrawium 0 lewiurz curfit
Gelociorinfine, quam in principio $3,33 \cdot d .349, c$
dium qualss de Motore primo aliquorum opinso36. a tractatio qualis 37 . f motus in fine cur Gelocior
$304 . f$ $338 . e$ localis Latifime acceptis $6 b_{i}$ tractetur 33.al latißime omniñ patet 55. d non est ad formane 54 . a non recipit appellatione generationis,nifimproprie 15 . a eiusfpecres quomodo intelligeizda

352 motus medius ixter neturale $\varepsilon_{G}$ Siolentum 20z.aperparticipationem extremorum non potcf efeperpetuss 200.6 medius qui $203 . \%$ motus miftus $365 . c$ Gndeconfer $3 \sigma \cdot c$

4.f en Motus mifts factus fecurdurn preualers elementum fit fimplex,anmifus $\quad 3$ ri.e motus mifti naturalis cws fimplexfit 3 jo.c mififecrsdum pranalens estfimplex $\quad 3 \sigma_{3} . a$ motus naturalis 372 . d ab appetitufit $36 \mathrm{~g}$.e dicstiur duobus modis $249 . c p r i m e$ qued in pbys. cis 23. quidfet $3 I I . C$ motus nullus Gerus datur in $\int u b$ fantia 476.6 omnis est i terminoadterminü 410.6 est de Subiecto infibiect $\bar{s} 413 . d$ qua ratione naturalis princip $\ddot{p} p a f-$ firi $240 . a$ Gelest fecundü na. turam fel contra naturam 2) $4 . a$

snotus planetarzmi non est mifus 332.d precedens cur fit caufa masoris Gelocitatis motus fe. quentis $338 . d$ motus principe- locü tenet inter accidentia corporis naturales ar.c

motus principiü habens in feipfo corpusest g.cprimus est motor totius $300 . f$ motus proprie de mots locali dicitur II.f quarü rerü caufafinalis $110 . f$ guiest ad locis, cur ab alys omnibus difinguendis 15.d

motus qui elementis naturalis 3or. C quipreternaturä est, quomodo posit efje perpetums 302.42

motus qusi Socari poßit gereratio

I5. motus guid $308 . f$ quomodo generet caloré $550 . a$ q180modo in animalibusfiat nir.f gronrodo in definitione natu re fumendus $3 \sigma_{3} . d$ rapidiffirnus quantä Sim habest 300 . a fimplex circularis 305.6 morns 
worus non potest effe medius inter naturalem ${ }^{\sigma}$ cont rarium natura 200.c non potest medio modo fe babere $208 . e$ proprius est corporis fimplicis $0 \sigma . c$ fimplex rectus 365.6 Giolentus gris fat $3 \sigma_{-7}$.d Jubicczi affectio 122.d Gbo fit $770 . f$ talis est, qualis coft natura, qui ab eo producutur

362.6 motwes Giolentus $371 . d$ cur infinetardior, quam in principio 400.at

motus 6 t calefaciat, qua conditionesrequarantur $\quad 70 . a$ motus cognitio bnde pendeat $34, d$ : in mot us cuinfog principiamotus caufa attenderide.

oro.a

motus diurni a motibiss planetarum difinctio zoo.f infpharis errantibus, $E^{2}$ motiss ignis in orbemconcitioqualis 507.6 localis divifio

motus maior Gelocitas Gnde proueniat $342 . f^{\circ}$ principium a fiusm internum in colo nutlum est 2\%8.d pasiuum non efje folum materian: , fed etsam formam 24j.d principium quadname fit in corpore naturali 242.6 guodinfe non babet, non est phyfica confidemationis 5 a propriwm est facerecciorem

3.0.c.

motus fimplicis caufa natura fimpiex $48 . a$ effentia in quo confiftat $3^{\sigma} 4.6$ effectrix caufa. sor.e

motus fimplacioss binde tudicetur $3 \sigma_{7} \cdot a$

ad Motus fimplicitatem que con: ditionesnequirantur 364.6

de Motus fpecicbus cus in quinto libro agasun

3.1.e.

motus fubiectum s44.e fubrectum quale, talis eft motus ipfe 362.e tratatio fine temporis notisia terjecte cognofi non poteft

de Motus, tractiatione distum $35 . e$.

motws Gelocitas cur continue cre feat 338.6 femper augetur, $\mathcal{G}^{2}$ infine est maxima:340.d igni 6. in" were: Snde prosseniat" so8.f Giolenti divifio $\quad 203 . d$ motwme cur à remotiore loco z13-. cboemus 338:C effe materiam: formatoman

$300 . f$

317.4

Ad DIatbin elementi non effe ne$3 \sigma 5 . e$
$I N \quad D \quad E \quad X$.

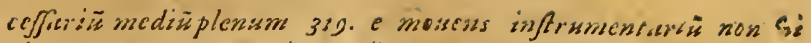
clementorum naturalem efje propriamouet $35 \sigma . e$ omne est illum, gui in orbemfit 301.4 motune zgnisorbcm efjé perfeconruptibilem zoj:f mifí fuct in fecundiu prausilens clementiz eje rïfum

$3>4 \cdot .2$

demotutradatio, caliguogmotis
compleditur
$10 . e$

motum precedentem effe cauf.im rudioris Gelocitatis motus fequentis 338 'a prater $z a t i s a m$ non pofje effeperpetuum 303: d producere $\mathcal{E}^{\circ}$ rem producere cummotudifferunt $\quad 320.6$ ad Motum fimplicem producen320s-a dum, quacaufepofutertur moucri quidfit $32 x \cdot d$ tribuitur $364 \cdot d$ foliforme 300:5 motis terminare non estmoneri moweri, gcnerari, $\mathcal{G}^{2}$ feridiffe$x$ s.e Sinde inferiora corpora runt

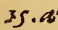
patianius

sof.e mowetur id, quod actu exslte motugnoratonecefe est ignorari $280 . c$ naturam

$31 . e$ quod Mouetur quo difcrimine fe-

a Motu call prodisctus calor per tot $\tilde{u}$ infertore mundz̈ diffunditur. paretur ab eo, quodgeneratur. 3 ig. C

ditwr $\quad 715.0^{\circ}$ or quicquid coniunitum msaltitudinis numeralis caufa est eft, effemobile, in eptum 11.f materiat 3846

de. Motu elemention 6aciso, Art- Mundiss cur aternus 44.4 est

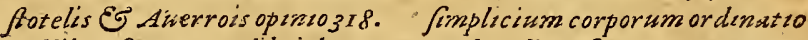
e:flibriufequuntwrlibrideger sx.dex diuerfarumnaturarum neratione animalium 25.e corporibusconflatus $43 . f \mathrm{ex}$ de .Motu mifto aliquorum error nibilo creatis rys.d ex quibus 305.f Gera opinio j06.c plune- conftet $41 . d$ non a folis.jimplitarum diurna dubism $305 . d$ ciăuscorporibus diciturperfa an ex Motu aterno polsint demon- etiss, fedetian a mifis omnia fruarifibjtantisamateria at: bus fr.f omnsumnaturalum iuncte

351.2 ex Motu foladuci.pofjumus incoriaabiunctarism. $\quad 351 . c$ in Motw elementi non poffe divifioncm fieri in partem per $\int$ mowesté, Epartëperfemotí. $320 . d$ grawis $\mathcal{E}$ lewis orda. 32 o.e. naturali non fufficit gerans $334 . a$ Juccejsio Ginde prozeniant $3 \div 8 . e^{\circ}$ corporum aggregatio 48.6 omnixm/pecierum cögeries $45 f$ mundus primo: modo acceptus quid 45:C qiiaratione perfedius dicatur 4 f.e si. a quid $45 . c$ ratione quantitatis $\mathcal{E}^{2}$. extenfionts perficitur quingue fimplicibus corporibus $44 . e$ fimpliciü corporis tratatio $q$. a fubiect $\vec{u}$ non fimplican corpora $4 \mathrm{x} \cdot \mathrm{d}$ jomi potest diptzceter

4.4.C ternoprincipiopa/sizo $240 . d$ mundiaccidentia so:c atersitas motus firiplices non poffunt cfje? trrecipue in coli aternitate coniff naturales, , Gel conitrariz. nature.

303.c. fifit 280.4 cognitio 4 sie confldératio? 45.6 . motus per eccentricos mifi funti Mundi elementarus Girtis a caleftimotwgubernatur sos.c inferioris: Girtus a calefibles: corporibus regstis: 550 : Misndinteristus $256 . c$

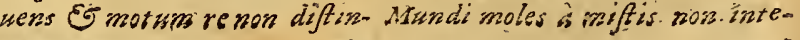

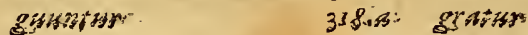
$44 . e$ ad Nusto 
$I N D E X$.

ad Musdi modis intugritatem folafomaliciapertincnt $\quad 45 . a$ musadinomen equirsocum $48 . \mathrm{c}$ isnificat quiddan perfectum. EF abjolutum 4 4.d 48 .dperfectio quatenus conftituta 43 . a qualis confoderatio requiratur

si.c

de Mundo tractatio Gbi habeathr $43 \cdot d$

mundum confiderarest conftantem ex fimplicibus corporibus. E confiderare fimplicia corpora, Gt Junt partes mundi, $i$ nuturalatiuspatet, quam anima dem cst

46.c 251.6

mundum dicere fubiectum quid natura mift a quando faciat moibid. ibid.
mumdum fumplacem in potentia obie- naturamotus caufa 30.f 37 prin. ctum $175.6180 . f$ habere principia, negandwm omnino est so. $c$

mundum inferioreng gubernare est finis coeleftium corporum $25)^{-d}$

Fundo attribuere potentiam obiectisam refpectu opificis, Ganum 180.6

in Mundo boc inferiore nibil asernuin, nifi prima materis. 212.6 duplex perfectio notari porest

$44 . d$

de Mundoloqui 45.c non egtfe Ariftotelem in libris de colo 44.6

Mrutatio in accidentibus Socars potest $\mathcal{F}^{\circ}$ mot ws, $\mathcal{G}_{\text {generatio }}$ Gariis modis 135.d mustatio miftiansmati. $400 . e$ un animati $390 . c$ omnis est ab oppofito ad oppofitum
abaliquo agente fit

mutationisplurespecies $42 \sigma . e$ fecundum locum cur Ariftoteles nullam faciat mentionem Is. $f$

mutationi nonconuenire Gerbum freri, aut generari ibid. mutationes cur tres tantum decantur ad formam $4 . d$ natujales Gnde fint $N$.

247.6

$\mathrm{N}$ Atura ab arte quid differat sos.e anfit principium motus actiusum, an paßsuum 233. $c$ communis babet in ondiui dus accidentia tpfam infequentia 10G. e cuingue naturalis corports, motus prinsipiz 47. $d$ cusuguc rei dicitur propria cius forma $280 . d$ eadem tur s.e forma potius, quam que est principism motus, est etiam principium quietir 347 6 est caufa motus. Ev in eodem Es inalio fonantia $4 r 7.6$ prima rerusm materia $244 . d$ in Nature rebses Jumma est constura est internumproncipium itemparticularis ibid. motus 2o.f naturam agerepropter fine 230.4 natura EF effentia rei quomodo $239 . d$ cognofcatur at ura etiam pro effentia fumi-

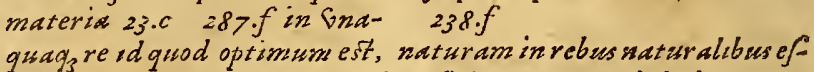

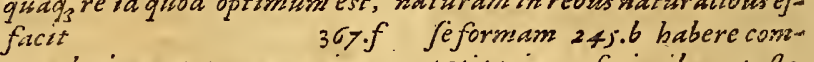
petit prizes inferioribus, pofte. rius coelo 26.6 est accidentale quiddam fubfantis, ro.e cipium 4.023 .628 .6 principism motus palsium, nonacitiusm nond- fium $234 \cdot f$ motus Eq quietis 53.0253 .5 effe principium notus actiusure aturam rangis effe form $\vec{a}$, quam materiam 243.A non cfjéprtrcipiur motus actius, fedpaffinum natura quidgutd agit, propterfinemagit naturaguid fit $218 . e 233 \cdot a \cdot 36$. $f$ natura realis quomodo i mate-prot radiftingwatur $221 . c$ femper est in fisbiecto $28 \sigma . c$ fimplex cotra cur fimplicem motum efficut naturam fuam inagueque tres $270 . a .308 .6$

naturafimplex quafit $36 \sigma . e$ fimplicis motus caufa 4 g.d Ginum tantum motum efficere apta est

301.4 natura fingulo animali Gnum tantum infrumertum dedit $441 . d$ quando babeat $242 . c$ femper efje infubiecto $225 . d$ in Natura quomodo aliguid fio fruftra $7 \sigma_{3} \cdot f$ i. Natura mifta non potest nifs miftus motus prouenire 370.0 i Natura fimplics cur motus fomplexproueniat $\quad 367.6$ quod Natura fitprincipium mo- de Natura tractationem effe de tus, tum actiusm, tum pasi. elemëtis, rationirepugnaiz20.a Hz 230.f naturalis philofophia perfect a ab Ariftotele forpta 132.f qua ratione perfecta $13 r . f$ quatenusperfecta $132 . c$ ab artedifinctio $\quad 234$.d naturalis philofophic fubiecium atura.coli cum naturainferio- S.f 0.a.b $12 . e$ runefimilitudo, ac dißimulitu-naturalis Variafignificatio $0 . c$ do 200 a naturalemphilofophiam difere naturedefinitio 0.d $28.6233 . d$ cupiens mullo nifz Ariftotele cur communis omnibus naturalibus corporibus i G.e compe- naturales effectus feri ex matetit ctian colefticorport 1G.e ricnecefstate $30 . e$ in Nuturs definitione quid Ari-naturale dicitur triplaciter s.e fotelespectarit 20.c prizs est omni accidentals ad Natura intelligentiam quid 207.d requiratur 23.6 naturale quid 233.6398 .f quonatur.e motus caleft quoque mo- modofumatur s.e tuz communis 27 . a nomen non naturalia babët in feip/ss princicöplecte nifo formas naturales pium actiuum motus $240 . f$ materiam informantes 252.e maturalia omnia ex materia $\mathcal{F}^{3}$ natureproprium 233.2 formaconftare. $281 . d$ in Natwice rebus nibil obfoursus naturalia moweri ab interno 


\section{$I N D E^{-} X$.}

principio ativo

saturalia ousefint

in Naturalsom corporism interith non dimenfiones ipfas interive, fod rerminos tantum $227 . f$

in Naturaliumverum confderat sione Gerfaturo quid ante omnia cognofcendum

aturalsum rerim traprincipia $r_{3} 4 . e$

ece/stas in rebus naturalibus cur tribuendamaterix $30 . e$

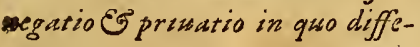
rant $i \neq \sigma . c$

neruorum fubfantia à cerebro ef 747.4

Nigredo ect proprizes color terre 8 ri:a

aigrum fidere, est nullum colorem videre

801.6

ibilexifit, nififingulare 383.6

wisis generatio

Go.c

Nominatio omnis fit ab actu 417.2

Nubes a frigorecogi $\quad 542 . e$ de Ordine intelligendisniuerfa-

- st fubiect materia

34.f patiens nore ef abfolute nominan. Opacumcur in alcinutronc coloris non ponatur, jed folum perfpidum agens,' fed folum reagens exum operationesnon funt fines animic $104 \cdot f$

802.f Perfiscuum, lux Eु albedo funt Oppofitione priuatiza non est perfpicui condenfatio fit duobus pendentis reciproca

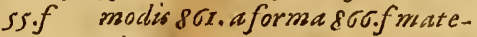
Orbis colefis corpus fmplex $200 . e$ ria s68.a qualem babeat naturam 'G' ef- Phantafma non producit intellefentiam 205.6 dionem 1000.e orbis cur non Gideatur appcllari Pbilofophianaturalis quid $10 . f$ natura $2 \& \sigma . f$ dicutur materia, philo fophienaturalis propriü fubquanon habet potentiä adcfe iectum 3.6 fedfolumadbbi 270.f Philofophus naturalis in quo deordo artificiofus est, ab Gniuerfalibus ad particularia progrefSus $43 . f$ ordo Ariftotelis in libris naturalibus $43 . e$ in aliquibus necefCarims in aliquibus non ordinis ab Arifotele ferwati ratio 34.1 compofitui conditio 133, a librorum de colo ordinis quo confiftat $135^{\circ} \mathrm{C}$ ratio 43.6 Philofopho naturali de fantote deratione berfetwe 3.e quomo. do agere debeat de fanitate $\mathcal{G}$ morbo 10.2. d quomodo corpora costempletur

4.c

Philofophus quatenus plantas cöcideret 1 atemus plantascofideret

29.6 umeros non fufcipers magis 6 minus 1054.6

EF egritudine fripturo duo offe obferwanda

Ioo.e

sutritio in bonsine + um ab anima Gegetante fit, tum is rationali $708 . f$

nutritioguid

So.7.e org.

ordinandi ratio Grade fumatu 33. $f$

Phyfica aufaltationis libror $\vec{u}$ diuifro 20.f fubiectum 17 . d 10. a in Organisfenfum quomodo ope-in Pby/ace anfeultation is libirs rationesfiant .. III.e quidArifotelesdoceat . I8.e

utritionis definitio 830.6 finis

820.f forma 3 8. f marcria $\varepsilon^{3}$ Oßsis officium efficiens

ibid.c

O. ganica forma i corpore infepa- phyfice aufcultationis libroriu inrabilis est

$P$.

P. 156.a foriptio $38 . c$ 25.f in Pbyfice dictione confiftut difinctio octo librorum ab alïs

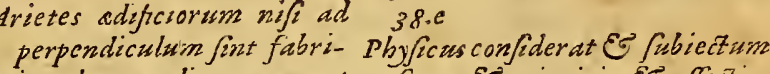

O Biestum potentia creatiue Dei nunquam fuije materiam, fedformam 183.6

- biectum reale est nobilius jpecie pat
aleproducta
$844 . f$

-biectifenfus $\mathcal{G}^{\circ}$ intellectus differentia $845 . e$

-buetza non poffe fimul ofe fentiétia $\mathcal{G}^{2}$ intelligentia in illomet actu 428.6 cati: durare diw nequeunt fuwm, Ev principia, G affectio$371 . a$ nes s.d partes generationi inferwientes Pbyfici $\sigma^{2}$ Metapbyfici in confidenon babent locum materia iss. ratione abfaractorum difcrime a non funt animalis effectrices $36 . e$ canfe

rio.a Pbyficorum Ariftotelis librorum artesintegrantes nö difinguz- ordinisratio 23.d.e tur re atoto, fed funt idéquod Phy/acorum duo libri quomodo illud 46.f

Oculus aquess est, fecundum $A$ - in Partibus omnibus ea Giget rariftotelem:at ignews, fecundum tio, è quibus totum actu conPlatonem 8D2.f ftat

I) 4 .f fint de prancipÿs 27. a primivs liber miro artificio ante fecundum ab Ariftorelc collocatus $22 . e$

oculitres bumores $\$ 75$. e tres tu- Paruinaturales 95 a cormm ordo nice $874 . d$ 95.C

Odoratum etiam fieri fine alicuius Vaporis exhalatione $8 \neq \sigma . f$

oleum quomodo fuffocet, 6 ex-

$$
\text { apina }
$$

tis imm tinguat ignem

- leinatura s32.e.f paßsutsm

mut cibiliores fint, quam 525.e

- lei Sna st natura aue ip 6o.d fat 240.6 aqwa afcendere facit Ej. re defendere

$\therefore$ Omsibse, que finnt, necefjaria $* 1$ ia

350.e paiciess agenti quomodo refffat connexucumfecundo 2 r.f byfacor liber fecundus initivm fienticnaturalis $\quad 75 . a .33 .6$ byjicorum eptimus liber preparatio est ad octaunm 34 .eliber octauns cur poftremus omnism efje debuerit $35 . d$ Pbyficorum libri quo nomine ab alïs Ariftotelis libris difingututur

$N N$ Quer- 


\section{$I N D E X$.}

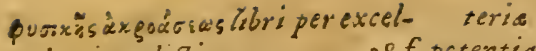
Lertiam dicti

38.f potentia

Planetafingulus in die naturali rix totsmecircuttumperagit 304.6 potentiaduplex

planetarism moins naturalis to- 321.6

tises caelefis glabz 206.a motus potentis effentiolis qus.e dicatisr proprates ac nat:uralis qui 305 . ibid.e

in Planetarsm motis diurno declarado muliorssm error 305.6

357.4

potentianöeft casfa médie $502 . \%$ potentia est effectus per emisnationem Gor.f est folum conditioneceffiriamaterise IGg.6 planetas duobus fimul motebus potentia $e^{-}$actus complecturur oferri ibid.

planta ab animali gua forma differat 1350.6 nines categorias 157 . e opponun turprisatiue 156.6 quomodo ineoderngersere 158.6 plantuqualibet duss animas ba-potentia F $^{\circ}$ priuatio funt idem bet $707 . f$ re, G differuntratione $150 . \mathrm{C}$ plantam ab animale differre per potewtia babet cöiunatampriuasropriarnformam 130.6 isomem 157 . a materia adfor de Platarum duslici colore leniopinio

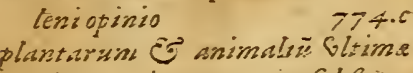
differentic acpropria fubficintiales forma igrorantir $130 . e$ libricur equintur libros de a- por nimalib. 130. e natura finspliciorquam animalisms $80 . d$ plant.aresn tractatio $128 . f$ plantarum îies eq proprietates niedico erphilolopho cognofcéde $\quad$ I00.f 129.6 in Plantis find tantum concoctio fit 775 .e de Plant is duo efjec cofiderande I20. .6 librorim $A$ uerrois opinis

00.6

Platons de materia prima fenfentias $128 . a$

Ilotinierror in non difinguends negatione ipriustione 150.5 aduerfus driffotclem dsfyutiztio inefficus

Plssica qued

Flusiageneratio 5) 2.8 Poriobduas canfasfinat $770 . f$ potentia actiuaguid $32.2 . d$ refertur aioperationem 79.6
.

cotentia ad actum refertur, fed. ron actusad potentiam $258 . a$ adizatellecturié eft duplex $101 \div$ e admateria efjentiamfignificandam ftilis, non tamen ne-potentiagratenusprizatio 50.6 mas babet giadres

321.25 $24-7 \cdot f$ potentia materiequomods is sub. otentiamateriedutes 15 \& f potest efjequilitas

T58.d qualitatis 158.d trer trer. 155.2170 .4 obsectisa reprobatio

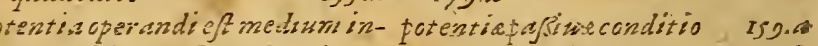

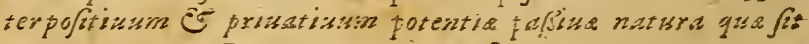

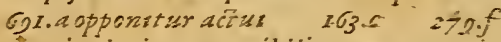
particslasiscomuptibilis $I 72$ potentia ratio est natura prios a cum priuatune conisusta ratione principü materialss

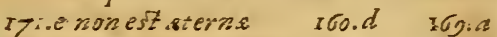

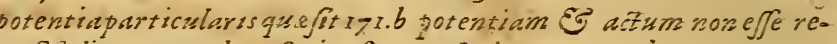
Edicatur IGo.bper Gnizesfor- latina - I5s.e mxaduentum adimpleturi 4 potentiam impropriefumit Auerequaraticne osponatur actui roesproiflamateria taia

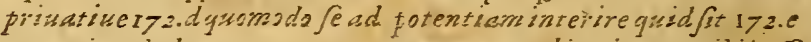
materiambabeat $\quad$ ipo.e. Fotentiam obicaziusm rihil effe

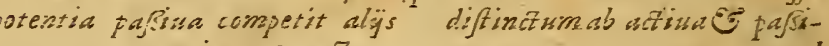
propter materianciot.cest potentiacontradictionis 230.4 274 a esforincipiun St res tranfmufetur ab alio quate. nus est alizd - $27+6$ otéticz afsua quonedo fiat mul-

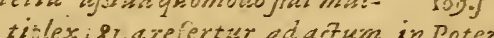

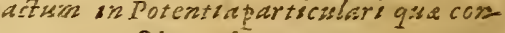
primism $\quad 170 . a$ fideranda. 1.1.e otentiopatiendi est ratio forma fine Potentia dicere quidem lisfrincifömaterialis rag.c fofiumus, quid materianon

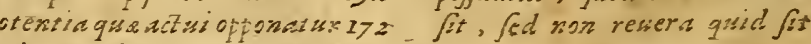
$b$ quead actun refertur, gus $:-0 . b$

fit $\quad 3-3 . a$ totentre dus a cisd arifoteler

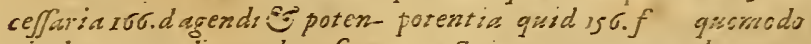
tia bene agendi erusdem fun: generis 155 .d nonest idem at $\sigma_{3}$ agereacts 437.6 .

torentio

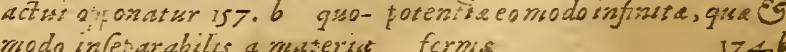
$163 . a$

totentis continui nunquam ad patentios recetius non expletur

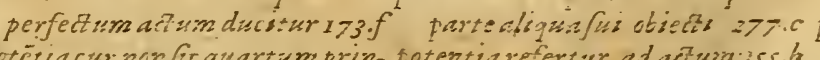

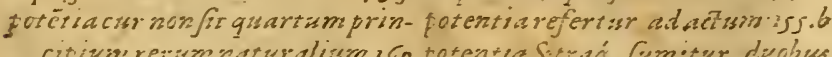

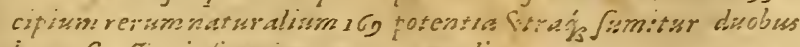
b cur fo eferstiajis trima ma-

reodis

II $3: 0$
170.4

itemaindScotum । 175.6 forms $\quad 1746$ potentis abiectiua fistima forst effeitibus atribute I8vec preatias purtickines efie quiden infinttas,nsn tamen frmul omnes exsfere in caderiz mate215 


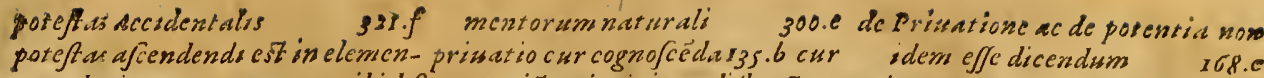
toleui ibid.f tertiü principium diflinctum priuationes cum formix cötraräs

poteftas effentialis $321 . e$ effentialiteramatcria 169.6 funt coniuncta

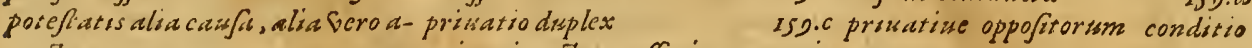
ituss $\quad 424 . e$ priuatio est neceffaria materie $155 . e$

Precognitionum exprejso quan- propter generatzoncm IGD. $c^{2}$ Prociniumprolixum cur libris de do defpicratur $120 . f$ estauodummodoforma 147.6 parcibus animalium appofit is

Pradicamentatraabfolutas $4 . c$ estanquamaccidensmateris p2.f

Prafentiaquafunt, cur aliquan- 152.6153 .6 Progresioguid $\quad 30$. dononsudeamus. $854 . d$ prisatio 5 potentia materiant-progrefsonispecies ibid.d

Iremens quomodo reprimatur tributa 14r.f Proicitum guomodo ab acremo447.6 prisutio forma bumane est for- weatur $324 . d_{328 . f}$

Principisofficium $743 . a$ mabumanifeminis 147.6 non proiectorum motustardior infize

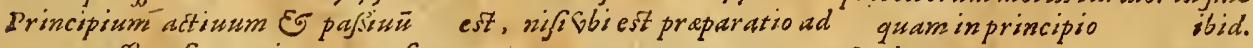
nonpoffiunteparari $243 . f$ cam $\quad$ I50.C Prolegomena 3.6

principium motus in colo palsi-priuatio formam connotat 140.d Propofotio dicitur prima duobus uum $288 . d$ prissatio in aduentu forme rece- modis 794.4

principium motus in fe babess, dot. usz.d propria quandog fumi loco difcorpusest 12.c fubiedum fcié-priuatio neceffariaproptergenet ferentiatum ad rei effentian

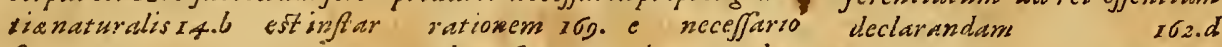
forme $\quad$ 4.e aliam formam cöiunctam ba-Putredo cur nuturalis dicatur,

principium pafiusum quomodo. bet 153.6 non est de effentia Vicomercatiopinio Git.a - intelligendum $243 . c$ materia $151 . e$ non est effen-putredo imperfecta cur bocatafit principÿ nomen refpectiuum est tialiter forma, fedper comi- feparatio inatura 054.6 in \% $06 \cdot f$

principü

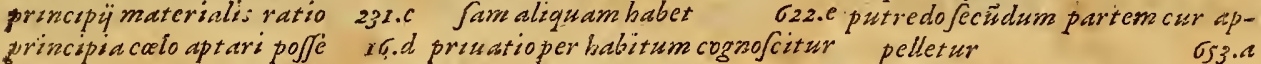
dwoeffe mouentia phyfice $2 \sigma \mathrm{r}$. a effendieffe etiam cognofcen-pric definitur. 150.f an Putredofecundum partom fit di $27 . f$ in primo physco- prisatio propriam ratione prin interitus forma, an fit mera di $27 . f$ in primo physco- cepybaber 232.6 alteratio 050.6

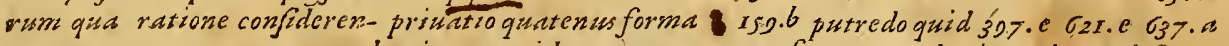
tur. $55 . d$ priuatioquid $137 . f$ quomodo $\dot{a}$ Galeno definat a princrpia monentia quot s. f pre- priuatio quodammodo forma ES G.4.e quapododecatur interifantfibimutuñoperam 16D.f natura If4.f tus naturalis 6II.6 quomodo propref fumpta non nifz rebus priuatio quomodo fit neceffaria fiat ibid.c quomodo tum a caceduciscompetunt 14.6 materie $152 . d$ lovealicnorumià propriofrigoprincipia que motui locali no ac- priwatiofemper babet formam a- refieridicatur $0_{27} .6$ commodentur Itaf lam coniunctam IAG.d fola putredinis alia ab alüs adducta principia rerumnaturalum cur mereturnomenprincipä $23 x a$ definitio, cizesque reprobatio iprincipüs foientic naturalis priuationecbonum,nec appctibi- Gor.d difincta 27 c EG primácau- le est. ISD.f putrediniscaufaque G23.f a Eproprie elementa bocan-priuatio tertium generationis putredints caufam effe remotionetur $28 . f^{\circ}$ principium a materat diftung caloris 020.5 prancipiafubiecti que dicantur ctum . 552.6 putredinis definitio ojo.f est de124.C prisations definitio Isof monftratiofitudifferens $625 . e$

principiorum cognitio adnatura- priwationis dreplicis error 140. in Putredinas defintione Arifso-

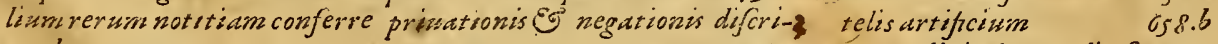
231.6.c men. I\%G.a an Putredinis detur aliafpecres,

principio:um confideratio $14 . e$ prizationis necefsitas in quo fit a quafub definitionepradictang principioruin incoplexorum pro- $1 \sigma_{\mathrm{g} . c}$ contineatur $\sigma_{3} \sigma_{0} b$ priums. $\quad 124 . c$ de Prisationisncesitate aliquo-putredinis effentia que $\sigma_{23} . e$ exprincipiorumnotitia omnisa- rum error abid.d effentiam non effe aliam quam

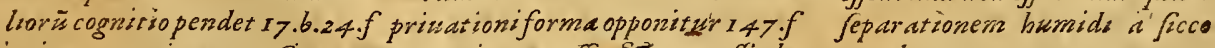
principonum trium necefitatem priuationem effe $\mathcal{E}^{2}$ non efje de $\sigma_{3} 0 . d$

onde Ariftot.colligat ist.c effentia materia isi.e putredinis imperfectepluresfunt de Proncipijsagere quidfit $20 . d$ priuationem innateria interire gradus $053 . e$ de Principüs duobus contrarÿs Iq G.C putredinis Gnampeciem Artizo-

134.6
Prifiorsmferentia de motue cle- prizationem appetat telis omnes interpreves agnowijfe Godentur $0_{3} 7.6$ $N N 2$ pustren 
putredinispecies dua 612.6638 .6 qualitates contrarias non poffe fi- qualitatum fymbolarü dus diffede Putredinisfpeciebus aliorum mulexiftere 585.f rentice s31.b.c opinio

in Putredine natureordo $631 . a$ mum agens in miftione $431 . f$ quidobferuandum G22.a. qualitates elementorum an fint de Putredine fecundum patrem, aliorum fententia, Ev earum confutatio

S20.c

in Putredine tria or dinat a $624 . f$ putrefactio cur ad differentiam combuftionis dicatur naturatlis, Albertiopinio Gis.e putrefactiopartim est naturalis, purtim Siolenta

o1s.c qualitates non funt forme eleputrefuctio qua ratione dicatur mentorum $483 . d$ omnes effe ratuturalis - abad.f putrefackio quid G12.a $\sigma_{37 . a}$ quomodo dicaturinteritus naturalis $0_{13}$. e quomodo fiat 031. e.f quomodo nuturalis Ev Vicolentia G1G. fquomodomifo naturalis $\sigma_{17} . \mathrm{C}$ finde fiat c3i.f

in Putrefactione calorem internum cooperari calori externo

in ewocundo bumido ors.e.f
putrefcibile non est, nifsid quod est. buridum GiG.a putrefcere quando rem dicamus $624 . d$

que Putrefcüt, calidiorafieri adfititio calore, proprio autem firigidiora

$\sigma .33 . e$

(Veftio entis accepti proge1 nere, metapbyfica est $208 . a$.

quaftionem omnem, effe quaftionemcause 291. $f$ gut

Qualitas aliqua in elemétis quomodopoßit efjè remijJa. sis.f gralitas natira pofteriox quantitate

104.6. qualitates fymbolas fpecie differ-per mnes quomodo fint forme elementorusn

qualitatespajius cur non patiä-

tur ab aituis, nifi coniunct e 493.6 difficilius auferuntur, quam actius j2a.d qualitatespajsuas in omnib. element is efféfummas s2r.e iudicariexactiuis - $513 . a$ qualitates psims cur elementis tribut 40 9 d qua rationt elementafocentux 483.24 in Qualitatibus actiwis onde remißio proueniat sio.d idem inpajsiuis "ibid. ¿Qualitatibus Symbolis ÿdem effectusprouersiunt S3I.f Quantitas curusque reiterminata.lgs.f cur formam infequattur ig7.e duplex. 379. $d$ quantitas interminata cumprima materia est comparanda 2g.c eadem numero cum ter. minata 100, a nunguam perit 192.f

quantutas non est generabilis 102. $f$ non est guartum generationisprincipium 204.4 non babet contrarum 195. a non potest exiftere absg fubiecta fubftantia.

$320 . d$

quantitas per accretionem acquifit a act us quidam est 158.6 potest mète abfrabi ab omni for. ma naturale.

104.9 quantitas quomodo formam infequatur 124.6 item materian abid.

qualitates prime quomodo defi- quantutas terminata377.e indenienda 497.6 quomodo fe terminata ibsd. baberint adelementa $7 \bar{\gamma}_{2} . d$ quantitatistermini a forma praguopodo fint elementus natu- fribuntur. 195.a.6 rales, E a colo proueniant quatitatis terminiduplices 107.6 $504 . e$ funt formis elementorum quantitate infequi natura mate-

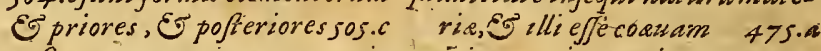
a funt preparatinnes materia quätitatem interninatam comad Garias formas recipiendas. parare cum compojito, Ev illo $530 . \mathrm{c}$

qualitates quomodo formas ele- $202 . \mathrm{C}$.

priorem dicere, abfurdim mentorum confequantur sor.f ad Quantitatem interminatam funt principia elemientorum comprobandam arguméta pro 6o.6.

Auerrae

ig3.f

qualstatis remijzo guad sig.al re,nonnullorumopinio j27.a

fit per admifionem contraria 507.6 .

qualitatsminterstus, est productio contrariarum $\quad 530.6$

in Qualitat is fecunda fpecie cur qualitatumprimarum ackio alia. Ariftot non exprefjerit, nifipotentiamberne agendi iss.c.

ad Qualitatem omnem tranfitus non eft alteratio $\quad 787.6$

qualitates actius in element is

medÿs funt remijse gro.e non efficiunt fecundas qualitates, nifo per medias primas sos.e quibus fint fummo, Eु qubus remij]e s10. a actuales $\mathcal{E}^{2}$ Girtuales $032 . f$ alteratricesnaturafunt priores motracabus

662.6 fnimoca, alea equiuoca 493.6 quantum quid

prititatem materia fit diusfbilis,poteftate remota 205.6 de Quantitate intexminata Thoma aduerfus opinionem Auerrois argumenta. DD2.C de Qualitatum primarum caufis quantum fgnificare certam ac in elementis, aliorum opinio, Eeius reprobatio. $499 . \Omega$ terminatam rei quantitatem 1D3. e. folumperfe diuiduum. rg. 2.6

ualitatum primarum definitiones $484 . e$ differentia s30.c. malitatum primorum duplaces operationes $534 . d \quad 487 . d$ operationes primasfemper efjes contrarä in contrarium s07.6 operatzones quales $597 . e$ quomodo dus dicantur actiuce, ह5 dirapaluitue

$420 . \mathrm{C}$

Quiddites an $a b$ eodiftingsatur, cuius eft quidditas 283 . a hominis quad ibed.b omnis est snim werfalis. 388.2 quidditatem efe $E_{5}$ kabere differunt 229.6 Quies quomodo fit caufafinalis inotuse $30=. f$ Ratica. 


\section{$\begin{array}{lllll}I & N & D & E & X\end{array}$}

R. regiocalida sbidee post Rei interitum ci aliquate.

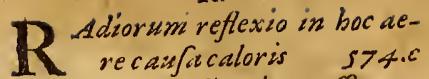
in Radiorüduplicatione effe magrum difcrimen

radios Solis in boc aere inferiore caloremproducere $5 \% \sigma . c$ recti proiectos aliquid caloris efficere $5>5.6$.

Raritus duplex $>84 . a$ in elementisesteffectus caloris $500 . \mathrm{c}$ raritatis $\mathcal{S}_{\text {tenutatis caufa of }}$ fectrix calor.

soo.a

Ratio animalis 2IG.a apnd Arifot. formam Ggnificat $377 . e$ corporis im quonamconfituta 215.6 diftinctionis trattationis de miftione, ac de generatione mafi $\sigma_{20} c$ bominis $21 \sigma$.a. ratio Gnimocationis debet efjefim piex

ratio Giuentis

$210 . a$

ibid.

ratione qua difingunntur, eadifinctas defintiones habët 608 .f rationabilitas, caufa effectrix riflilitatis in bamine '322.f rationalitas $\mathcal{G}$ bumanitas non funt duaforms $\quad 388 . a$

Reactio cur fit neceffaria $43 x . e$ pofitiua quafit $432 . d$ primatiua quafit zbid.quamdiu duret $435 . a$ quando efjèt ibid.a quid 420.6435 . $d$ quomodo in motis lacalifiat

$447 . d$ Repajsio gusd

reactioni qua argument irefragentur $427 . f$

reactionem fiericurfit nece fariz $435 . d$.

reactionem nullam dariinter illa queinmaterianö conueniunt $432 . d$

de Reactione in motw alterationis

- quidfentiendum ft $\quad 432.6$ resquelibet actu exiftens exiftit reagere $\mathcal{G}^{\circ}$ repatz dicitur dupliciter.

Realiter differrequid Gos.f realuter ageremaims est, qua $\int p i-$ ritaliter $8<0 . f$ realis $\sigma^{2}$ pirifalis coloris difcrimen

realitas formarum elemëtarium eadem in elementis ${ }^{5}$ in mifto *6\%. $f$

Regio infina aftiuo tempore maior est quam tempore byemis s42.e.f. eizs finisibid.f

regio aeris media qualus ssx.e est maiax byeme, minor autem aftate 547.6

regio aeris Juprema

numerus $4,1.6$ finguluriu quätitas

$5+1.6$

sinoli fine fuo correlatino $\times 80.6$ pendet afuocorrelatiua iss.e rei Gnius luna debet è natura, relatiui tola effentia confifit in nonplures $.242 . d$ relatione ad aliud $\quad 189.6$ rei bnius Gna forma zonplures elatiua fecundum dici qua fint 403.6 snusestatu. $242 . e$ is7.dfunt duplicia $\quad$ I57.C rei bniuscuius $\hat{g}_{3}$ ab is perforrelatiuabereque ibid.c mamdifindtio a.dropria $\sigma_{0}$ elatiuorum conditio 155 .f defi- peculiarisnatura 241.6 nitio. $144 . d$ rem quamlibet cöfituaj ua for relatiuorum effentiapofita est iu majubfantiali,non qualitarelationead aliud $157 . d$ tabus $402 . d$ Remi/suo form.e elementaris non rem fimplicem confufeognofcere potest fiexi, nificum ipjius ele - qued $2 \sigma_{3} . \mathrm{c}$ mentinteritu $\quad 444 . C$ resnaturales ab.Arift ole numeema Bo forme femper est cü ele- rantur z.equomodo gnofcëda mentionteritu $\quad 4 \sigma_{4} .6 \quad \mathrm{r}_{3} . \mathrm{d}$

emijso formarum elemët arium res non differunt per iateriam 6 qualitatis differunt $4 \mathrm{C}_{3} \cdot \mathrm{e} \quad 130 . \mathrm{a}$

emissio luminis fit fine commz- res qua fole abfolute

xo.d ficonecontrary

so.e rerum ab alÿsper format difinmisio nonfit, nifiper admiftio- ctio. nem contrarie qualitat is $5 x$.f rerum cofferwatio est fous preciomnis an fiat per adrificionem pwusnature oniwerllis $452 . c$ contrar $\ddot{y}$ 71.a 72.a. rerum naturalium anonaturaremussio qualstatü elemétartum. libus diftinctio $\mathbf{4}$.a.b in muftione quomodo fiat 431 .f rerumnatwalium Ecmituonis emisionem omnem fieri per ad- eademprincipia 27.cion Gnus mifionem contrarÿ $518 . f \quad E_{\sigma}$ zdémotus naturas $242 . a$

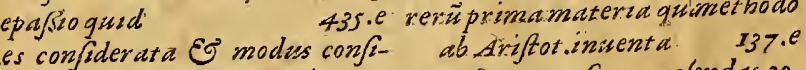
derandi debét effe aqualis am-res efjeper caufas cognolendas 22 . bitus

I0.c $c 280.2$

res cófderata loc ü obtinet mate- resinterire tribus modi natura riaibid. eadem nöpoteft froul fatuit . $118 . f$ effe mifum छे eleméra 474 . a Reffétia à realitate dijert 440 res $\sigma_{6}$ intentio aliquidesjepotest fin motu elementi zaturali duplex3ig.c internisnmotu elementiz 42.6 ominifit abactus:

320.f res qualibet facilius mouetur per: refffentiaper accidens non potef mediü quiefcensquam perme- babere locum, nifin medio pleduum aduerfomotulatis $340 . a$ no 320.0

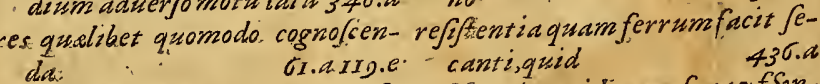

GI.aIIg.e. - canti,quid

$436 . a$ res qualibet quomodo eadem fit reffentiaquid $437 . f 440 . f$ in -

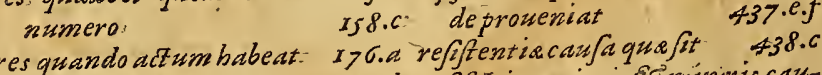
ressbifit definienda $\quad 604 . b$ refifëtia maioris $G^{2}$ mininis caurei alicuius nominatio. Snde fu faque fit

442.6 208.a. refiftentiam äforma promenire cicuiuslibet princ̈̈pia: efje duo 432.6 .

contraria $\quad 135 . a$ refftere quid Fomponatio $430 . \mathrm{C}$

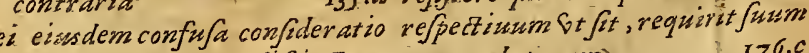
debet pracedere difindtam correlatiuwm $1>0.0$ 670.6

de Refiratione fermo cur coniun- 


\section{$I N D E X^{*}$}

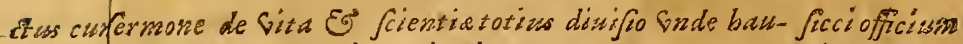
430.4 morte 29.6 rienda r7.a Signa non dicuntut, wifilita qua

Rorisgenetio

Anguaptexir 6.c. fientiatotius ED partis non zdem manifefiafunt fubicstum rg.f stmilare corpus quid $\sigma 26 . f$ .

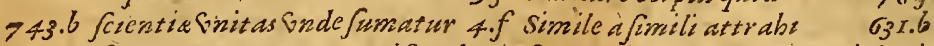
$78 . f$ 101.a fientiam tot $x$ cur Arifoteles a fimplex EF nature $E^{\circ}$ cogristion is Anitamid fanitatis morbi cuufa non o- primalibroaufpicetur $23 . a$ ordine mafopracedit $02 . \Omega$ pholofoum roc.c rari de Sants Es morbo qualis de- Scire quzdfit Go.c fimplex naturaquafit in 350. 36.f fimplex natura que dicatur ibid.

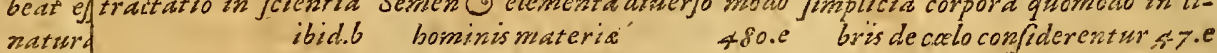

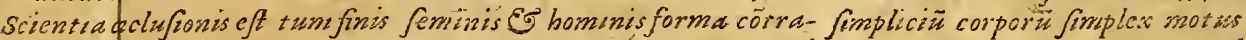

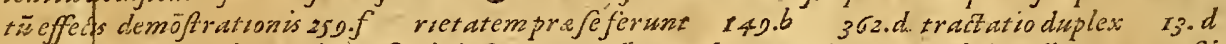
fcientiactieplatiua à principys feuinis formucur dicatur buma- singulare ab intellectu coonofi Eaffionib.diftinguitur 2.6 naformecontraria ibid.f negantium argumentai0 $42 . d$ Cientia hturalis est de corpore feminis forma disobus modis con-fingulare quid $3>6 . f$ quodprisus

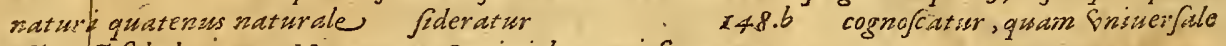
est 7.05t fubalternat a Meta-cum Seminis humani forma qua- $1054 . C$

pbyfic $205 . f$ in corporibus daqualitates coniuncte $160 . e$ fingularitatis principium 380.6 Serfatr 4.6 100. a qualis in Semme duebires $\quad 060 . f$ quanafitinterna ratio 377.0 $30 . c$ farum rerum additione in Seminubus effe principium Gt- ratio ibid. quafit Scoto $387 . d$

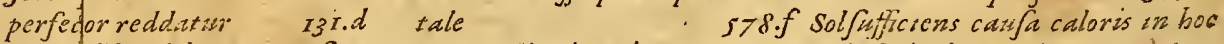

fiêtiaq qlibet debet proprÿfub- Senectus estexiccatio 821.6 . inferiori mundo per motums sectigidditatem cognofcere fenes cur deterins videant 009.9 s58.e motufuo calorem gene-

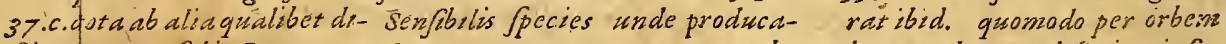
fingulur per fubiectum 123.c - tur 832.d.e fietian naturalis in duasprin- fenfoles fpecies habent effe in fieri, lasna medsum calefaciat inferioreminundum sci2.d

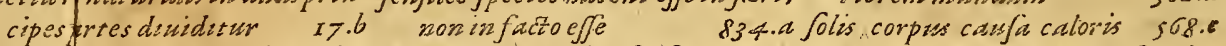

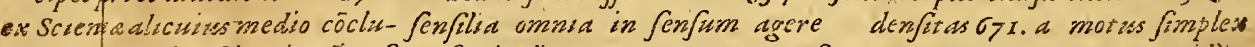
fonenalteriwsfientianö pof Sptritaliter $838 . f$ 36G.c

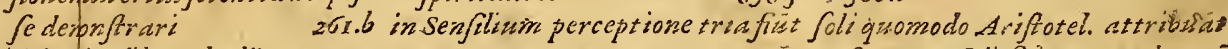
fcietiectizeslibet abalïs permo- $722 . c$.

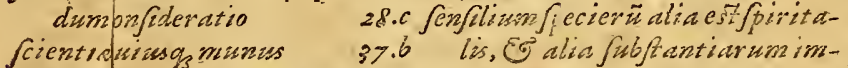
Gim mozedi Ë atterendiacrö s67.b.c

in Sciensainitio quedeclaranda materializm $835 . f$ $28 . d$

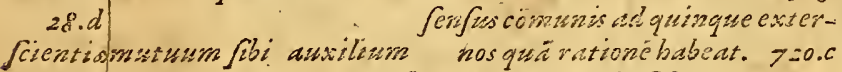

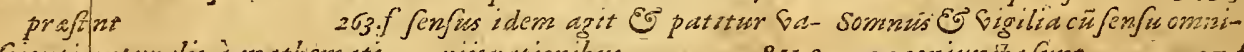

folem conficlerare Gt agens quoddaméparatum quid ibid.d per torridam zonamferris $>^{3}$ a recederequidfot s;o.f

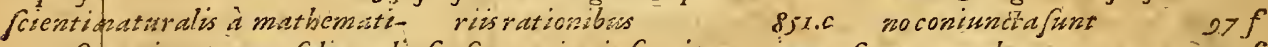

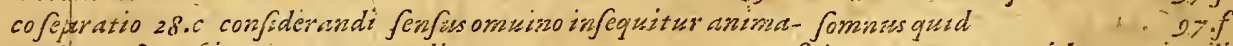

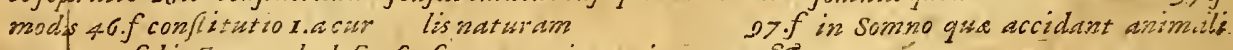

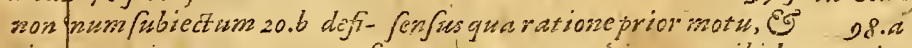
nitudac partitso .. 10.f motusgeneratione. ibid.c diffictio $18 . d$ ordo compofiti. infeguitur or.a wres 33 a perfectio $131 . b$ quod de Senjiss adione, fora fententia initum conuenientius $22 . c f e-852.6$.

cundē alios partitio 89.6 f:0- fenfies nomen fumutur Ef pro anipus p.6jubiectum ibid.6 maEG prooperatione o7.e

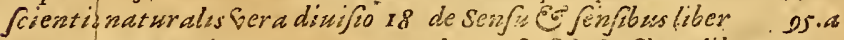
d Sorumbitium 22.C de Senfâ Eु fenfibus librum cur

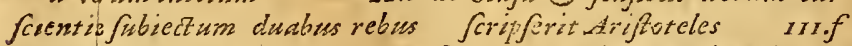

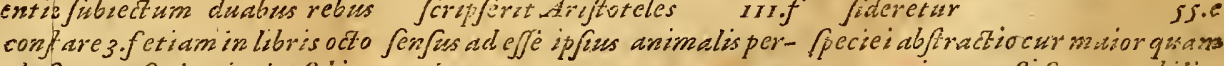
pbyjea aufoultationis fibie- tinent ctune efe ftatuendum ID.d fenfurm difindz:a $\quad 837 . e$

in Scientiafubiecto que poftulen- fenfum internorxinumerus 720 .

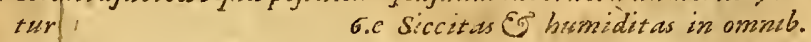

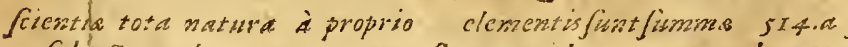

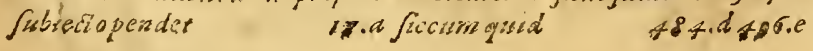

species in medio babet efje miediz matermateriale है forritales s72.f maiorem hábet compofitionem, qwam gensis 210.6 perfecte cogrnofin mon potest, ignorato genere 86.6 quelibes

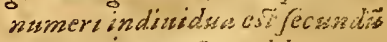
effentiom 4 so.f qualubet corporis naturalis qramodo confideretar 5s.e generis ${ }^{0} \mathrm{O}_{3}$. $f$ forma nobilior quam formatgener is $\quad 130.6$ propria conditzo csth, quaceccidentalisgeneri $\quad 83 . e$ feciediferre quidfat, $\quad 530.5$ gaid differant 32a.e Grume 


\section{I. $N \quad D$}

Terminus al"gucm, non est aluses, de Vacuo tractutio quam mo:ks ip $\int e$ termino adusniente cefjat motus

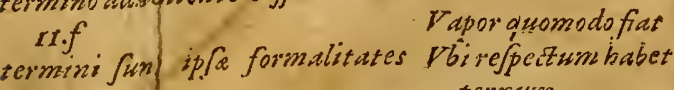
efle debwerit tr. co

:

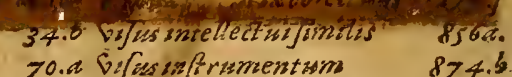

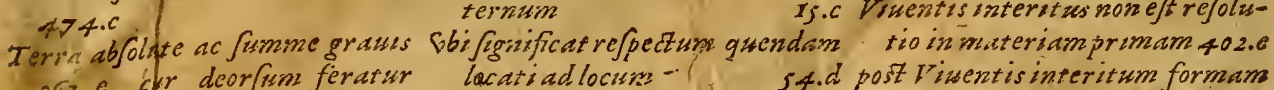
ternum $\quad 15 . c$ Viuentisinteritus non eff refolu-

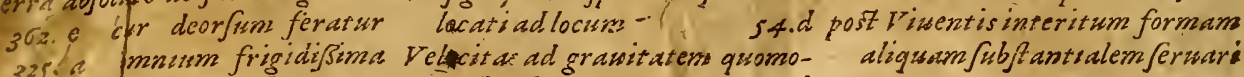

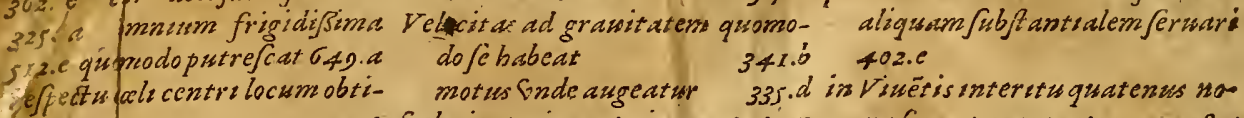
motus Snde augeatur $335 . d$ in Viuet is sntertuquatenus no

qu.e Gelocitatis in motuincrementum waformacqusratur 708.1 terif confextatso in quso conffiftat 1, 30.9

\section{Gnde}

Venarumorigo

rery eadep est caufa motus ad $347 . \vec{b}$

crramotuseneratio

cerra parts calefacta quomodo rareficm $E^{\circ}$ in fumidam ex-

balation me Gertantur

terreaerchtrarius

6.6 $5 \times 7 . a$

is Terradifilius ficcitas aufertur, quich frigus

Theodorustaz decimum bifio. ris librm conwertere noluit ro6.6

Theophray los tor Theophralu lib.decimus imperfe-
ctus
tag.d

Theophrafilib. de bifioria planiarsins

Theriacason habet Geri miffionem

Theriaca $7>6 . f$

Thomadorincipïs rernm naturalusm Gera opinio . $27 . b$

Thomift. romefententia de cnte mobils

I1.

Trabium accenfarum generatio Go.c

Tractar Not principia, est tractarisluerugratia $13 . d$

tratiatilominis a quo nominetur III.a.:

Tranfersts est vitiofus in omn: Speciedemonftrationis $2 \sigma x . d$

Tranfparens Eै coloratum potest aligus d fomul efje

Trenorin ebrÿs Fnde

Turbinis mot us qualis

$$
V \text {. }
$$

$\mathrm{V}$ Acusm in
datur $804 . d$ 633.d Vita contemplatiua est maxime Sniverfaliain doctrina-funt par303.6 bumiane $V$. Situra sullism gui mnsum altifismus

Ventimotusqualis. $334 . f$ in
744.2

$\mathrm{SO}_{3} \cdot \mathrm{a}$ $3 \sqrt{3} \cdot d$

oj.c waforma acqusratur 708. .
in Viuéte an aliqua materiapars fit, qua non fluat $818 . e$ duplew calor 400 . f due facultares generatrices 750.6 nonfunt dut caloresnumero, fed Gnuspen.dens à düobusprincipüs 580.0 Videre nigrum, est nibilvidere in Viuete omini plures funt formo Do3.f

Videndi pracipum organum bu- Giuentium alia diutius, alia bremorcryftallinus $000 . c$ inum E piper babere frigus actwale, fed calorem Girtualem 633.4

Ginum non poirest calefacere feiplum

Giniputreds

330.6 Vnvo in defritione mifionis 89.6 femperfeciora 821.6 omnisim accidentiaque $\quad 08 f$ de Viuentibustractationts diuino 675 .f bnü dicetur quatuor modis $383 . e$

648.6 tageneratzonéfynificat 603.

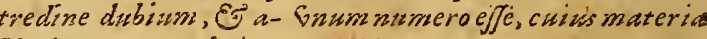
liorwn folutiones earumis im $388 . e$ pugnatio $672 . c$ Snum numeroquid $376 . c 380.0$ in Vino du calores $\sigma_{7} \sigma . c$ duc bu- Enum per accidens fieri ex matemiditates $677 . f$ ria.E quantitatcintermuaViolentum cur nequeat perpetudta $203 . f$ ri2. c c cst coinumniss quam Snumperjuäformameffe $384 . e$ contranaturam 290. a esz du- Snius rè quomodo Gnum fit effe, plex $202 . e$ nullumcurpoßut Eg quomodoplura 308.6 effe perpetum 200.6206 .0 Gnitas indiuidus ab Snitate $\int p e-$ $304 . e$ cieiquomododiftinguatur 305 Giolentumper accidenspoteft per- "b/pecieimotus iudicatur a finc peizari 203.f 35x.e.

iolentum nature contrarium Gnitatisfcientienaturalis ratio 20.4. $c$ quando perpetuum 201. $f$

Giolentum quid

$293 . c$ orta $a$ ft

Vnumquods sis side appellandum iolentum motum lata fignifi- Vniuerfale ED fingulare diwerfis catione fumi proomne motu, qui fiat ab externo principio modis ad mut teriaje babét 386 . a quomodo materiam complectatur ibid. Gacui nomen quid frgnificet 34.6 Gifisilitas inest per fe colori infe-Vulnera orbuculate cardius fain Vacro nulle elementificri poffe motym. 2. 8.6 g50.e ticularibus anteponenda 85.0 extin- Gniwerfalitatis fubiectum form $579.6 \quad 377 . e$ 8ú.d Voluentas quid

nantwer

$$
\text { F I X I S }
$$


leaned \& Oiled

Noverisen 



\section{0}

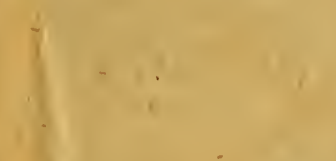

$+\cdots$ 
